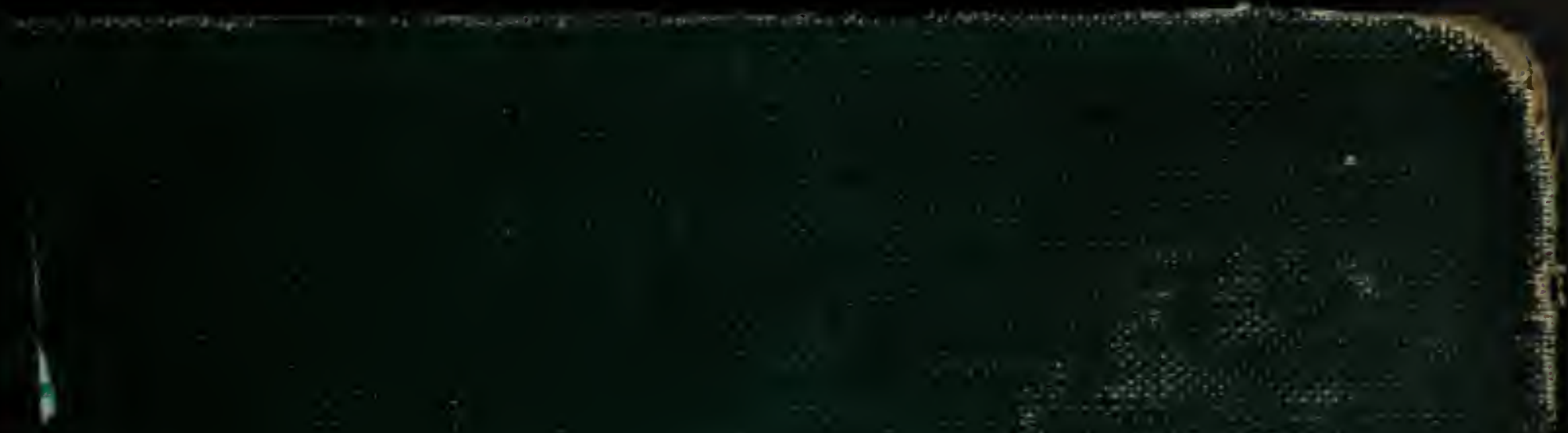

1

$\therefore=8 \pi^{2}$

18.
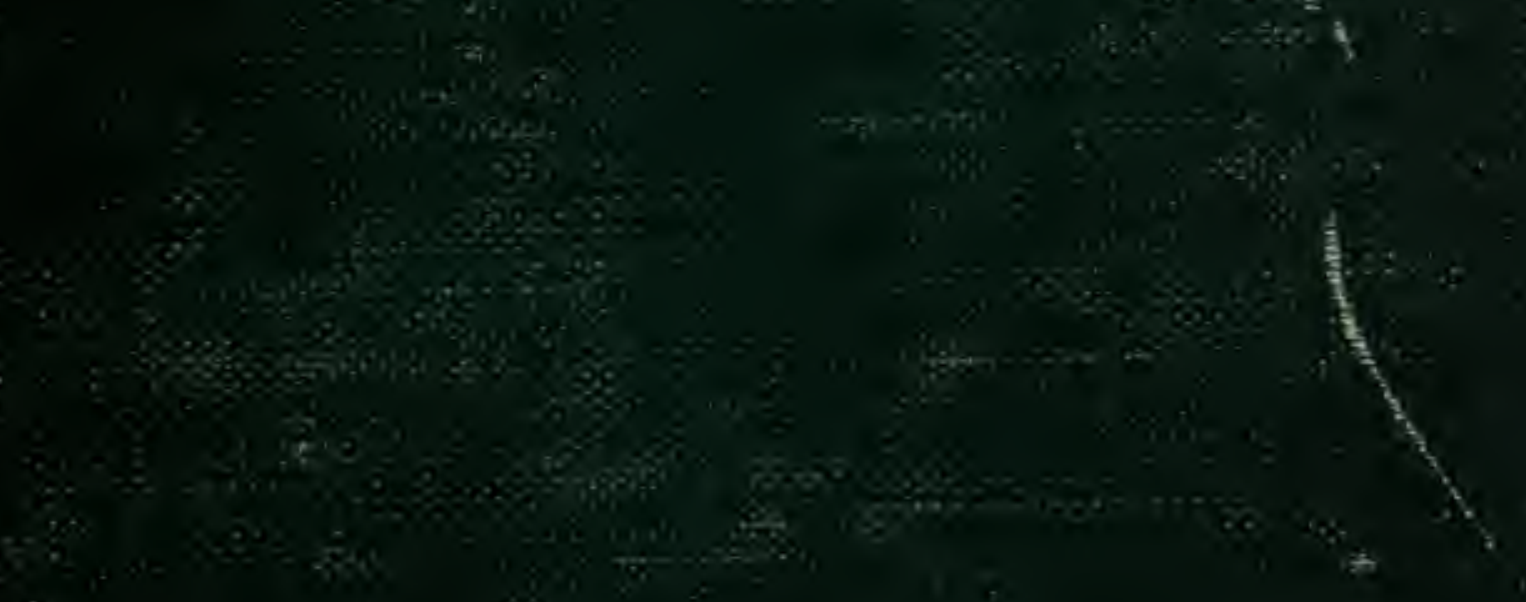

है

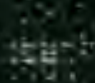

\%

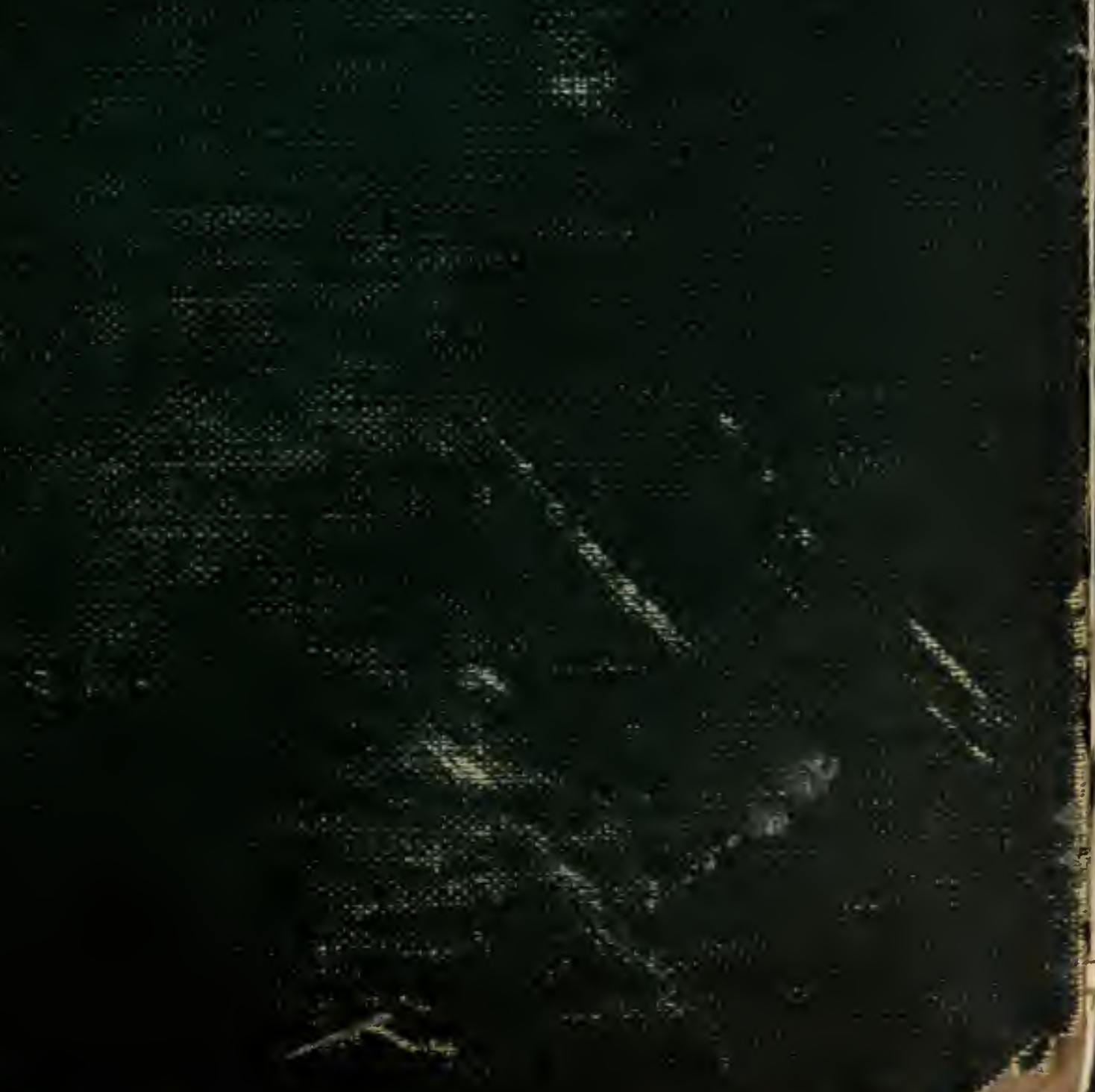




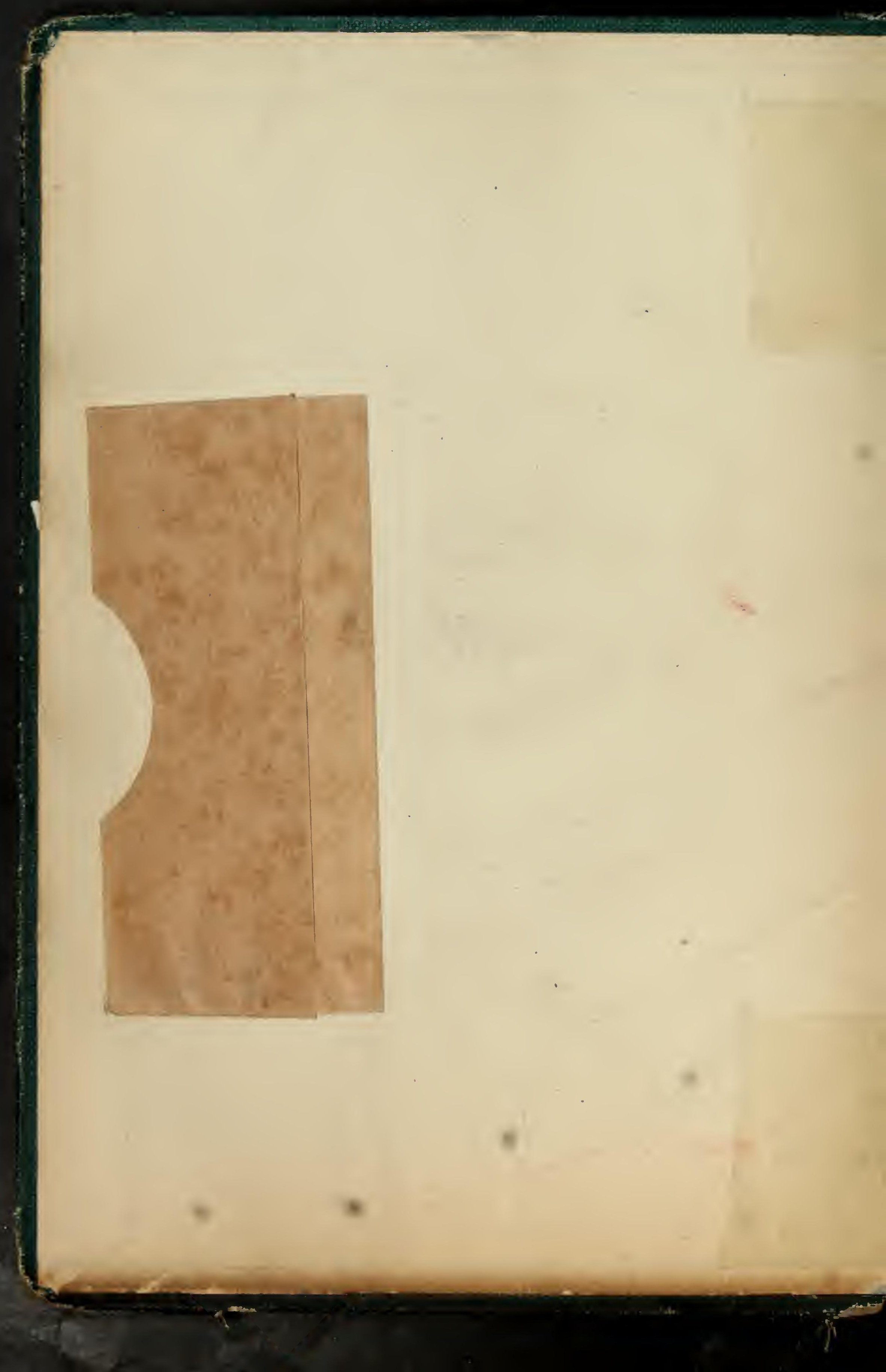


NORTH AMERICAN BIRDS.

\author{
L A N D BIRDS.
}

VOL. I. 


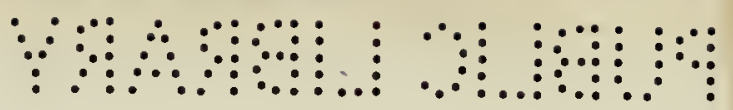

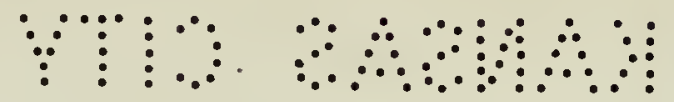 \\ :}




\author{
A \\ H I S T O R Y
}

oF

\title{
NORTH AMERICAN BIRDS
}

BY

S. F. BAIRD, T. M. BREWER, AND R. RIDGWAY

\section{A N D B I R D S}

ILLUSTRATED BY 64 PLATES AND 593 WOODCUTS

VOLUME I.

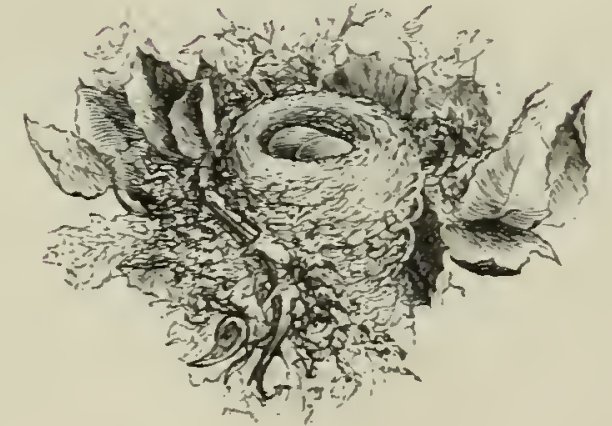

B OSTON

LITTLE, BROWN, AND COMPANY 1874 
Entered according to Act of Congress, in the year 1574 , BY LITTLE, BROWN, $\Lambda$ ND COMPANY, in the Office of the Librarian of Congress, at Washington.

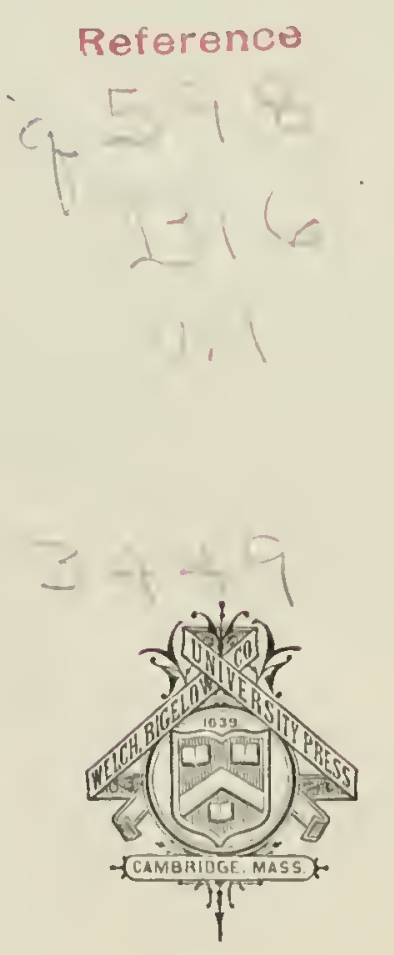




\section{PREFACE.}

THE present work is designed to meet the mant, which has long been felt, of a descriptive account of the Birds of North America, with notices of their geographical distribution, habits, methods of nesting, character of eggs, their popular nomenclature, and other points connected with their life historr.

For many years past the only srstematic treatises bearing upon this subject have been "The American Ornithology" of Alexander Wilson, finished br that author in 1814 , and brought down to the late of 1827 by George Ord ; the "Ornithological Biography" of Audubon, bearing date of 1838 , with a second edition, "Birds of America," embracing a little more of detail, and completed in 1Stt; and "A Mammal of the Ormithologr of the Lnited States and Canada," by Nuttall, of which a first edition was published in 1832 ? and a second in 1840. Since then no work relating to American Ornithology, of a biographical nature, has been presented to the public, with the exception of some of limited extent, such as those of Giraud, on the "Birds of Long Island," in 18t1; De Kar"s "Birds of New York," 184t; Samuels's "Ornithologg and Oölogy of New England," 1S68, and a few others; together with quite a number of minor papers on the birds of particular localities, of greater or less moment, chiefly published in periodicals and the Proceedings of Societies. The reports of many of the gorernment exploring parties also contain raluable data, especially those of Dr. Nerrberry, Dr. Heermann, Dr. J. G. Cooper, Dr. Suckley, Dr. Kennerly, and others.

More recently (in 18-0) Professor Thitnes, Chief of the Geological Surver of California, has published a very important rolume on the ornithology of the entire west coast of North America, written br. Dr. J. G. Cooper, and containing much original detail in reference to the habits of the western species. This is br far the most raluable contribution to the biography of Americar birds that has appeared since the time of Audubon, and, with its typographical beauty and numerous and excellent illustrations, all on rood and manr of them colored, constitutes one of the most noterrorthy publications in American Zoülogy.

Lp to the time of the appearance of the work of Audubon, nearly all that was known of the great region of the Lnited States west of the Missouri Piver was the result of the journes of Lemis and Clark up the Missouri and 
across to the Pacific Coast, and that of John K. Townsend and Mr. Nuttall, both of whom male sonse collections and bronght back notices of the comntry, which, howerer, they were unable to explure to any great extent. The entire region of Texas, New Mexico, Colorado, Arizona, Nevada, and California was unisited, as also a great portion of territory north of the United States boundary, including British Columbia and Alaska.

A work by Sir John Pichardson, forming a rolume in his series of "Fauna Boreali-Americana," in reference to the ornithology of the region corered by" the Hudson Bay Company's operations, was published in 1\$31, and has been much nsed by Mr. Audubon, but embraces little or nothing of the great breeding-grounds of the water birds in the neighborhood of the Great Slave and Bear Lakes, the Lpper Iukon, and the shores of the Arctic coast.

It will thus be seen that a third of a century has elapsed since any attempt has been made to present a systematic history of the birds of North America.

The object of the present work is to give, in as concise a form as possible, an account of what is known of the birds, not only of the United States, but of the whole region of North Anerica north of the boundary-line of Mexico, including Crreenland, on the one side, and Alaska with its islands on the other. The published materials for such a history are so copious that it is a matter of surprise that they have not been sooner utilized, consisting, as they do, of numerous scattered biographies and reports of many government expeditions and private explorations. But the most productive source has been the great amount of manuscript contained in the archives of the Smithsonian Institution in the form of correspondence, elaborate reports, and the fieldnotes of collectors and trarellers, the use of which, for the present work, has been liberally allowed by l'rofessor Henry. By far the most important of these consist of notes made by the late liobert Fennicott in British America, and received from hin and other gentlemen in the Hudson Bay Territory, who were brought into intimate relationship with the Sinithsonian Institution through Mr. Kennicutt's efforts. Anong them may be mentioned more especially Mr. F. MacFarlane, Mr. B. R. Ross, Mr. James Lockhart, Mr. Lawrence ('lark, Mr. Strachan .Tones, and others, whose names will appear in the course of the work. The especial value of the communications received from these gentlemen lies in the fact that they resided for a long time in a region to which a large proportion of the rapacions and water birds of North America resort during the summer for incubation, and which until recently has been scaled to explorers.

Equally servicealile has been the information received from the region of the Yukon River and Alaskia genemally, inchuding the Alentian Islands, as supplied by Messrs. Pobert Kennicott, William H. Dall, Henry M. Bannister, Henry W. Elliott, and others.

It should he understond that the remarks as to the alisence of general works on American Ornithology, since the time of Audubon, apply only to the life 
history of the species, as, in 1858 , one of the authors of the present work published a systematic accomnt of the birds of North America, constituting Vol. IX. of the series of Pacitic Railroad Reports; while from the pen of Dr. Elliott Coues, a well-known and eminent ornithologist, appeared in 1872 a comprehensive volume, entitled "A Key to Nortl American Birds," containing descriptions of the species and higher groups.

The technical, or descriptive, matter of the present work has been prepared by Messrs. Baird and Ridgway, that relating to the Ruptores entirely by Mr. Ridgway; and all the acconnts of the habits of the species are from the pen of Dr. Brewer. In addition to the matter supplied by these gentlemen, Professor Theorlore N. Gill has furnished that portion of the Introduction defining the class of birds as compared with the other vertebrates; while to Dr. Coues is to be given the entire credit for the pages embracing the tables of the Orders and Families, as well as for the Glossary beginning on page 535 of Vol. III.

Nearly all the drawings of the full-length figures of birds contained in the work were made directly on the wood, by Mr. Edwin L. Sheppard, of Philadelphia, from original sketches talien from nature; while the heads were executed for the most part by Mr. Henry W. Elliott and Mr. Ridgway. Both series have been engraved by Mr. Hobart H. Nichols of Washington. The generic ontlines were drawn by Anton L. Schönborn, and engraved by the peculiar process of Jewett, Chandler, \& Co., of Buffalo. All of these, it is believed, speak for themselves, and require no otler commendation.

A considerable portion of the illustrations were prepared, by the persons mentioned abore, for the Reports of the Geological Surrey of California, and published in the volume on Ornithology. To Professor Whitney, Chief of the Surrey, acknowledgments are due for the privilege of including many of them in the present History of North American Birds, and also for the Explanation of Terms, page 526 of Vol. III.

A few cuts, drawn by TVolf and engraved by Whymper, first published in "British Birds in their Haunts," and credited in their proper places, were kindly furnished by the London Society for the Diffusion of Christian Knowledge; and some others prepared for an umpublished rolmme by Dr. Blasins, on the Birds of Germany, were obtained from Messrs. Vieweg and Son, of Braunschweig.

The volume on the Water Birds is in an adranced state of preparation, and will be published with the least possible delay.

SPENCER F. BAIRD.

Surthsoniax Ixstitution, Washington,

January 8, 1874. 


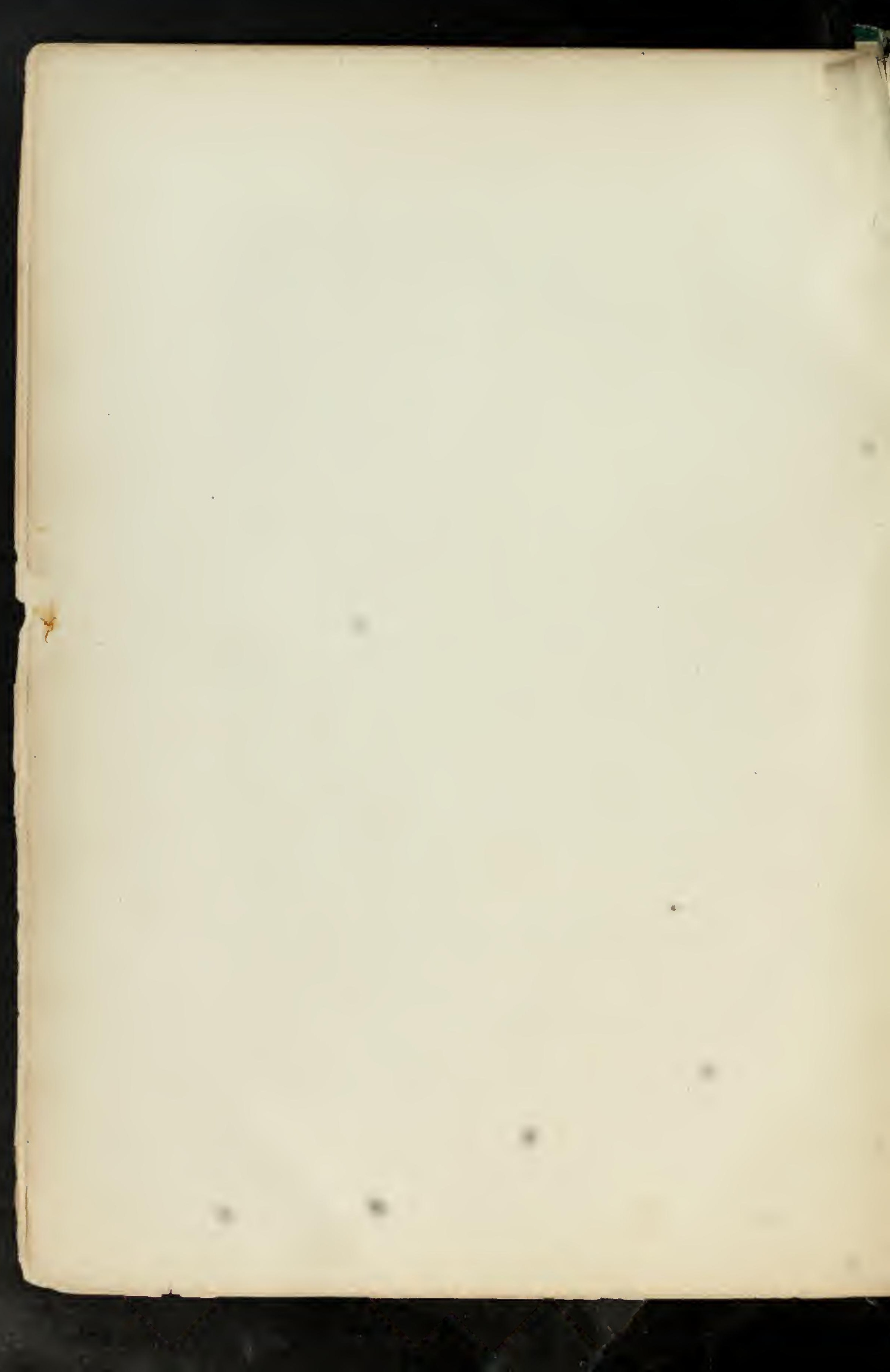




\section{CONTENTS.}

Preface

Introduction .

Family Turdide. The Thrushes

Subfamily Turdixe

Subfamily Muñe

Family Cinclin.. The Dippers

Family SyLyind. The Sylvias . . . . . . . . . . . . 69

Subfamily Srlunise

Subfamily Reguline $. \quad . \quad$.

Subfamily Polioptiline . . . . . . . . . . . . 77

Family Chamidade. The Ground-Tits . . . . . . . . . . 83

Family Paride. The Titmice . . . . . . . . . . . 86

Subfamily Patinet

Subfimily Sitrixe . . . . . . . . . . . . 113

Family Certhinde. The Creepers . . . . . . . . . . . 124

Family Thoglodytide. The Wrens . . . . . . . . . . 130

Family Motacillide. The Wagtails . . . . . . . . . . 164

Subfamily Motacilline

Subfamily Avтhise

Family Sylvicolide. The Warblers . . . . . . . . . . 177

Subfamily tricoline . . . . . . . . . 179

Subfamily Geothlypise . . . • . . . . . . . . 279

Subfataily ICTeriane

Subfamily Setophagine

Family Hiruxnmide. The Swallows . . . . . . . . . . 326

Family Vireonide. The Vireos . . . . . . . . . . . 357

Family Amperide. The Clatterers . . . . . . . . . . 395

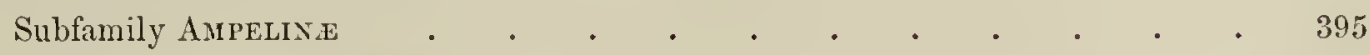

Subfamily Ptilogoxatise . . . . . . . . . . . 404 VOL. I.

$b$ 
Fumilr Lanne: The Strikes

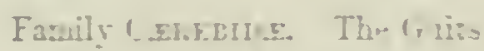

Fanily Taxd Hos Th-Tamer.

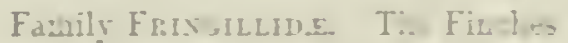

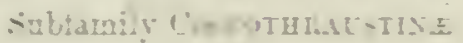

Subfamil Pro, ITISE

Sularily SPIZLLIX

INIEX TU THE P'LIE.

PLITE $1-23$ 


\section{INTRODUCTION.}

The class of Birds (Aves), as represented in the present age of the world, is composed of very many species, elosely related among themselves and distinguished by numerous charaeters common to all. For the purposes of the present work it is hardly necessary to attempt the definition of what constitutes a bird, the veriest tyro being able to decide as to the fact in regard to any North Ameriean animal. Nevertheless, for the sake of greater completeness, we may say that, compared with other classes, ${ }^{1}$ Birds are abranchiate vertebrates, with a brain filling the cranial cavity, the cerebral portion of which is moderately well developed, the corpora striata connected by a small anterior commissure (no corpus callosum dereloped), prosencephalic hemispheres large, the oltic lobes lateral, the cerebellum transversely multifissured; the lungs and heart not separated by a diaphragm from the abdominal viscera; aortie arch single (the right only being developed); blood, with mucleated red corpuscles, undergoing a complete circulation, being received and transmitted by the right half of the quadrilocular heart to the lungs for aeration (and thus warmed), and afterwards returned by the other half throngh the system (there being no eommunication between the arterial and venous portions); skull with a single median convex condyle, chiefly on the basi-occipital (with the sutures for the most part early obliterated); the lower jaw with its rami ossifying from several points, connected with the skull by the intervention of a quadrate bone (homologous with the malleus); pelvis with ilia prolonged in front of the acetabulum, isehia and pubes nearly parallel with each other, and the isehin usually separated: anterior and posterior members much differentiated; the former modified for flight, with the humerus nearly parallel with the axis of the body and concealed in the muscles, the radius and unn distinct, with two persistent carpal bones, and two to four digits; the legs with the bones peculiarly combined, (1) the prosimal tarsal bones coalescing with the adjoining tibia, and (2) the distal tarsal coalescing with three (seconr, third, and fourth) metatarsals (the first metatarsal being free), and forming the so-called tarsometatarsus; dermal appendages developed as feathers: oviparous, the egrgs being fertilized within the body, excluded with an oval, calcareous shell, and

1 We are indebted to Professor 'Theodore N. Gill for the present account of the characteristics of the class of Birts as distinguished from other vertebrates, parges $\mathrm{XI}-\mathrm{xV}$. 
hatched at a temperature of about $104^{\circ} \mathrm{F}$. (generally by the incubation upon them of the mother). ${ }^{1}$

Such are some of the features common to all the existing species of bircls. ${ }^{2}$ Many others might be enumerated, but only those are given which contrast with the characteristies of the mammals on the one hand and those of the reptiles on the other. The inferior rertebrates are distinguished by so many salient characters and are so widely separated from the higher that they need not be compared with the present class.

Although birds are of course readily recognizable by the observer, and are definable at once, existing under present conditions, as warm-blooded rertebrates, with the anterior members primitively adapted for flight, - they are sometimes abortive, - and corered with feathers, such characteristics do not suffice to enable us to appreciate the relations of the class. The characteristies have been given more fully in order to permit a comparison between the nembers of the elass and those of the mammals and reptiles. The elass is without exception the nost homogeneons in the animal kingdom; and anong the living forms less differences are observable than between the representatives of many natural orders among other classes. But still the differences between them and the other existing forms are sufficient, perhaps, to anthorize the distinction of the group as a class, and such rank has always been allowed excepting by one recent naturalist.

But if we further compare the characters of the class, it becomes evident that those shared in common with the reptiles are much more numerous than those shared with the mammals. In this respect the views of natmralists have changed within recent years. Formerly the two characteristics shared with the mammals - the quadrilocular heart and warm blood - were deemed evidences of the close affinity of the two gromps, and they were consequently combined as a section of the rertebrates, under the nume of Warm-blooded Tertebrates. But recently the tendeney has been, and very justly, to consider the birds and reptiles as members of a common gromp, separated on the one hand from the mammals and on the other from the batrachians; and to this combination of birds and reptiles has been given the name Sumropsida.

I Dr. Cones, in his "Kory to Torth Ameriean Birls," gives an able and extended auticle on the general characteristic's of birds, and on theis internal and cxternal anatomy, to which we refer our readers. A paper by l'rofessor E. S. Morse in the "Annals of the New York byeeum of Natural IIistory" (X, 1869), "On the Carpus and Tarsus of Birds," is of mueh seientific value.

2 ("ilus and Gerstaceker (Handbuch eler Zoologie, 1868, 191) puesent the following elefintion of limis as a cliss :-

Aves. Skin covered wholly or in part with feathers. Anterior jair of limbs, converted into wings, generally used in llight; sometimes rulimentary. Oeciput with a single condyle. Jaws encaserl in horny sheaths, wheh form a hill ; lower jaw of several clements and articulated behim] with a distinct qualdate bone attached to the skull. Heart with double anrele and domble ren-

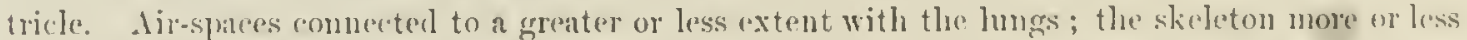

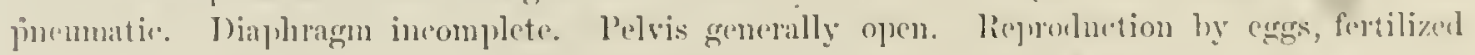
within the body, and hatelied externally, cither by incubation or by solar heat; the shells cal. careous and hark. 
As already indicated, the range of variation within this class is extremely limited; and if our views respecting the taxonomic ralue of the subdivisions are influenced by this condition of things, we are obliged to deny to the groups of living birds the right which has generally been conceded of ranking as orders.

The greatest distinctions existing among the living members of the class are exhibited on the one hand by the Ostriches and Kiwis and the related forms, and on the other by all the remaining birds.

These contrasted groups have been regarded by Professor Huxley as of ordinal value; but the differences are so slight, in comparison with those which have receired ordinal distinction in other classes, that the expediency of giving them that value is extremely doubtful; and they can be combined into one order, which may appropriately bear the name of Eurhipidura.

An objection has been urged to this depreciation of the value of the subdivisions of the class, on the ground that the peculiar adaptation for flight, which is the prominent characteristic of birds, is incapable of being combined with a wider range of form. This is, at most, an explanation of the cause of the slight range of rariation, and should not therefore affect the exposition of the fact (thereby admitted) in a classification based on morphological characteristics. But it must also be borne in mind that flight is by no means ircompatible with extreme modifications, not only of the organs of flight, but of other parts, as is rell exemplified in the case of bats and the extinct pterodactyls.

Yor is the class of birds as now limited confined to the single order of which only we have living representatives. In fossil forms we have, if the differences assumed be confirmed, types of two distinct orders, one being represented by the genus Archopteryx and another by the genera Ichthyorn is and Apatomis of Marsh. The first has been named Scururer by Hrckel; the second Ichthyornithides by Marsh.

Compelled thus to question the existence of any gromps of ordinal value among recent birds, we proceed now to examine the grounds upon which natural subdivisions should be based. The prominent features in the classification of the class until recently hare been the divisions into groups distinguished by their adaptation for different modes of life; that is, whether aerial or for progression on land, for wading or for swimming; or, again, into Land and Water Birds. Such groups have a certain ralue as simply artificial combinations, but we must not be considered as thereby committing ourselves to such a sistem as a natural one.

The time has scarcely arrived to justify any system of classification hitherto proposed, and we can only have a sure foundation after an exhaustire study of the osteology, as well as the neurology and splanchnology, of the various members. Enough, however, has already been done to convince us. that the subdivision of the class into Land and Tater Birds does not express 
the true relations of the members embraced under those heads. Enough has also been adduced to. enable us to wroup many forms into families and somewhat more comprehensive groups, detinable by osteologrical and other characters. Such are the Charadrimorphe, Cecomorplix, Alectoromorphre, I'teroclomorpha, Peristeromorphie, Coracomorphie, Cypselomorphæ, Celeomorphe, tëtomorphe, and several others. But it is very doubtful whether the true clew to the afthinties of the gromps thus determined has been found in the relations of the romer and contiguous bones. The fanilies, too, have been probably, in a number of cases, especially for the passerine birds, too much circumscribed. The progress of systematic ornithology, however, has been so rapid within the last few years, that we may be allowed to hope that in a second edition of this work the neans may be furnished for a stricty scientific classification and sequence of the families. (T. N. G.)

A primary division of recent bircls may be made by separation of the (r) Rotite, or struthious birds and their allies, - in which the sternum has no keel, is dereloped from lateral paired centres of ossification, and in which there are numerous other structural peculiarities of high taxonomic inport, from the (b) Carinate, including all remaining birds of the present geologic epoch. Other primary divisions, such as that into Altrices and Precoces of Bonaparte, or the corresponding yet somewhat modified and improred Psilopuedes and Ptilopacules of Sunderall, are open to the serious objections that they ignore the profound distinctions between struthious and other birds, require too numerous exceptions, cannot be primarily determined by examination of adult specimens, and are based upon physiological considerations not necessarily co-ordinate with actual physical structure.

In the following scheme, without attempting to indicate positive taxonomic rank, and without committing myself funally, I present a number of higher groups into which (arinate birds may be divided, capalble of approxinately exact definition, and apparenty of approxinately equivalent taxonomic value. Points of the arrangement are freely drawn from the writings of various anthors, as will be perceived by those competent to judge without special references. I am particularly indebted, howerer, to the late admimble and highly inportant work of Professor sunderall, from which rery many characters are directly borrowed. The armangement, in effect, is a modification of that adopted by me in the "Key to North American Birls," upon considerations sinilar to those herewith implied. The main points of difference are non-recognition of three leading groups of aerial, terrestrial, and natatorial hirds, - groups without morphological basis, resting simply upon telenlogical modification; a general depreciation of the taxmonic value of the several aroups, conformably with the considerations preventet in the precenting pages of this work: abolishing of the grmp Cribllutores; and recognition of a primary group Sphrisisci.

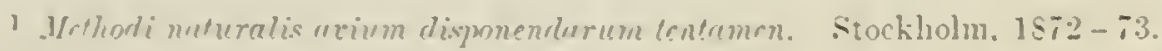

2 This gruup is insusceptible of definition. The wading bird., as usually allocated, do not 
A. PASSERES.' Hallux invariably present, completely incumbent, separately morable by specialization of the flexor hallucis longus, with enlarged base and its claw larger than that of the middle digit. Neither second nor fourth toe rersatile; joints of toes always $2,3,4,5$, from first to fourth. Wing-corerts comparatively short and few; with the exception of the least corerts upon the plica alaris, arranged in only two series, the greater of which does not reach beyond the middle of the secondary remiges. ${ }^{2}$ Rectrices twelre (with rare anomalous exceptions). Musical apparatus present in greater or less derelopment and complexity. Palate regithogmathous. Sternum of one particular mould, single-notched. Carotid single (simistra). Nature highly altricial and psilopædic.

a. Oscines. ${ }^{3}$ Sides of the tarsus corered in most or all of thieir extent with two undirided horny plates meeting behind in a sharp ridge (except in Alaudida; one of the plates imperfectly divided in a few other forms). Musical apparatus highly dereloped, consisting of sereral distinct pairs of syringeal muscles. Primaries nine only, or ten with the. first frequently spurious, rarely orer two thirds the length of the longest, nerer equalling the longest.

b. Clamatores. ${ }^{4}$ Sides of the tarsus corered with divided plates or scales rariously arranged, its linder edge blunt. MLusical apparatus weak and imperfect, of few or incompletely distinguished syringeal muscles (as far as known). Primaries ten with rare exceptions, the first usually equalling or exceeding the rest.

B. PICARIA. Hallux inconsiderable, weak or wanting, not alwars incumbent, not separately morable by distinction of a special muscle, its claw not longer than that of the middle toe unless of exceptional shape (e. g. Centropus). Second or fourth toe frequently rersatile; third and fourti frequently with decreased number of joints. Wing-corerts for the most part larger and in more numerous series than in Passeres, the greater series reaching beyond the middle of the secondary quills (except in many Pici and some others): Rectrices commonly ten (eight to twelve). Primaries always ten, the first only exceptionally short (as in Pici). IIusical apparatus wanting, or consisting of a muscular mass, or of not more than three pairs of syringeal muscles. Palate desmognathous or agithognathous. Sternum of non-passerine character; its posterior border entire or donbly notched or fenestrate. Carotid single or double. Nature completely altricial, but young souretimes lratched with down ${ }^{6}$ (e. g. Caprimulgida).

possess in common one single character not also to be found in other groups, nor is the collocatiou of thei claracter's peculiar.

1 Corresponding closely with the Limnean aud earlier Sundevallian acceptation of the term. Equivalent to the later Oscines of Sundevall.

2 As remarked by Sunderall, exceptions to the diagnostic pertinence of these tro character's of hiud claw and wing-corerts taken together are scarcely found. For, in those non-passerine birds, as Raptores and some Herodiones, in which the claw is enlarged, the wing-corerts are otherwise disposed; and similarly when, as in many Pici and elsewhere, the coverts are of a passerine character, the feet are highly divelse.

3 Laminiplantares of Sunderall plus Alaudide.

* Scutclliplantares of Sunderall minus Alawdide.

5 Nearly equivalent to the Linnean Picc. Equal to the late (1873) Volucres of Sumlevall.

6 A polymorphic group, perfectly distinguished from Passeres by the abore characters in which, for the most part, it approximates to one or another of the following lower gromps, from which, sererally, it is distinguisud by the inapplicability of the characters noted beyond. My divisions 
a. Cypseli. Palate segrthogmathous. Wingz lengrtened in their ter-

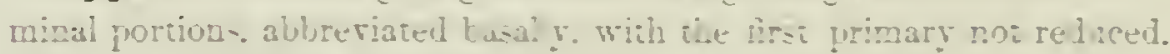
Ta.l of ien rectrices. Bill tissireiral or ienuirvetral. Feet never zygodactrle nor smlacivle. small. weak, scarcely futed hor locomoiju:

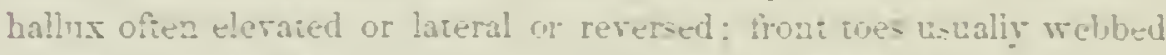
ai ba-e, or with ainormal ratio of phalanges in length ani number, or both. Siernum deen-keeled, u-naly entire or the doubly noiched or ferforate. Stringeal muwele not more than one prair.

b. Cuculi. Palate de-mognations. Wing tor reculiar in bresity of pruximal or lengrin of dital portions. and with first primary not reduced. Tail of eight to twelve rectrice. Bill of indeiterminate form, nerer cered; tongue not extensile. Feet rariouly modized ty rersatility or retersin of either firsi. seconl. or lourth ines or by cohesion for a greai di-iance of third and fonth. ur ky abence or rudimentary cuadition of trs or second : often highy cansorial, rarely amiviatorial. Srringeal mis les iwo pairs ai mo-t.

c. Pici. Palate "exhihiving a simplincotion and de eradation of tie regiti grathous strucure" (Huxles): wing bearing olat this paserine afini-y in the conumon redugion of the first prinary and the restriction of the ereater covers. Tail of itn perfect recirice and woully a sunplenentary pair. Pusrum hard, straigh, narrow. subequal to lead. with conmouly exiensile aud vermiform bui not furcate iongle. Feei highly scansorial. Fuurth toe yermanenily reversed : basal rolalanges

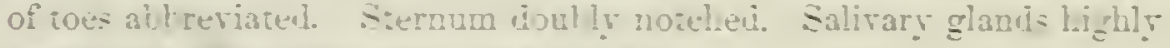
developerl. Hroidean apparatu- pecular.

C. PSITTACI. Bill enomoun thich, Alort high, nuch arched from the base. the uprer manuible sirongly hootel at the end. cered at bust. and

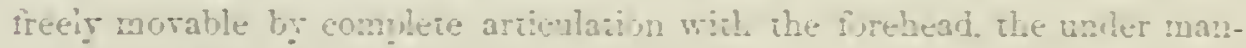
dible with thort, broad. imincaie smphynis. Feer permazentl zroriactrle by rever:on of the fourh tne, which artichlates by a double iacet. Tarsi reticulate. Syrinx peculiarly constructed of three plairs of in rinsic muscles. Tongue hort thick. Alent. Sternum entire or teactrate. Clavicles weak. defective. or wating. Orbit more or les completel ly approaek or union of posiortital proces and lachrymal. Alricial: p-ilopedic.

D. RAPTORES. Bill ravally powerfin, a dapted tor tearing tes strungly decurved and hoterl at the end. firnihed with a cere in which the rm-iritopen. Feet strongly texile, wh large sharp muco curvel claw gra litalty narrowed srom bare io ip, convex on ibe sides, that of tle wond we larger than that of the furt' toe. ald the hin ler not smaller than the second one. Fee: neter rermusuently zyendantyle. though fourth to oten rersatile: anierior toes eummonly with on hasal wet, lallux com-ilerable and completely incumter. (except rintirtida). Legs feathere i in the suffrazo or beruad. Rertrices iwelve (wi-b rare excention=1: primaries sinuate or emarginate (with rare exceptim:). Stemum singly or dushly notedel or fenezirate. Palate desmognathus. Caroils double. Srrinx wantints or develoned with only one pair of mus les. Altricial; the young being weak and helple.. ve fill perolic. leing lowny at birth.

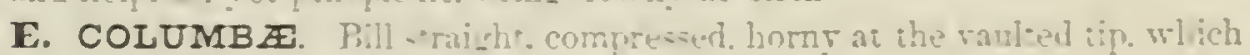
is separatel by a matricion frum the oft meml ranous ta-al portion. Nus-

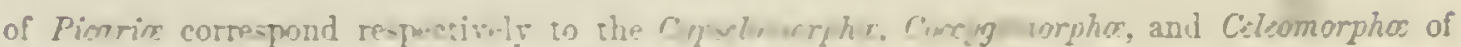
Huxley, from whom many of the chara ters are borrowed. 
trils beneath a soft, tumid ralve. Tomia of the mandibles mutually apposed. Frontal feathers sweeping in strongly convex outline across base of upper manclible. Legs feathered to the tarsus or beyond. Hallux incumbent (with few cxceptions), and front toes rarely webbed at base. Tarsus with small scutella in front, or oftener reticulate, the envelope rather membranous than corneous. Head very small. Plumage without after-shafts. One pair of syringeal muscles. Sternum doubly notched, or notched and fenestrate on each side. Carotids double. Palate schizognathous. Monogamous, and highly altricial and psilopredic.

F. GALLIN $\nexists$. Bill generally short, stout, convex, with an obtuse raulted tip, comeous except in the nasal fossa, and without constriction in its continuity. Nostrils scaled or feathered. T'omia of upper mandible overlapping. Frontal feathers forming re-entrant outline at the base of upper mandible. Legs usually feathererl to the tarsus or beyond. Hallux elerated, with few exceptions (e. g. Cracida and Megapodidce), smaller than the anterior toes, occasionally wanting (as in the IIenipods). Tarsus, when not feathered, generally broadly scutellate. Front toes commonly webbed at base. Claws blunt, little curred. Wings strong, short, and concaro-convex. Rectrices commonly more than twelve. Head small. Plumage usually after-shafted. Carotids double (except Turnicide and Megapodidee). No intrinsic syringeal muscles. Sternum very deeply, generally doubly, notched. Palate schizognathous. Chiefly polyganous. Precocial and ptilopedic.

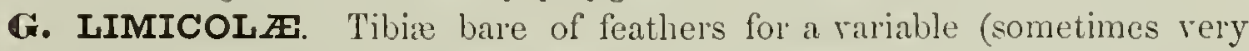
slight) distance abore the suffrago. Legrs commonly lengthened, sometimes excessirely so, and neck usually produced in corresponding ratio. Tarsi scutellate or reticulate. Toes never coherent at base; cleft, or united for a short clistance by one or two small morable basal webs (palmate only in Recurvirostra, lobate only in Phaluropodida). Hallux always reduced, obriously elevated and free, or wanting; giving a foot of cursorial character. Wings, with few exceptions, lengthened, pointed, and flat; the inner primaries and outer secondaries very short, forming a strong re-entrance on the posterior border of the wing. Tail shorter than the wing, of simple form, and of few featlers, except in certain Snipes. IIead globose, sloping rapidly down to the contracted base of the bill, completely feathered (except Phitomachus ठ). Gape of bill short and constricted; tip usually obtuse; bill weak and flexible. Rostrum commonly lengthened, and more or less terete and slender; membranous wholly or in great part, without hard cutting edges. Nostrils narrow, placed low down, entirely surrounded with soft skin; nasal fosse extensive. Palate schizognathous. Sternum usually doubly, sometimes singly, notched. Carotids double. Pterylosis of a particular pattern. Nature precocial and ptilopxilic. Comprising the "PloverSnipe" group; species of meclium and small size, with never extremely compressed or depressed body; more or less aquatic, living on plains and in olen places, usually near water, nesting on the ground, where the young run freely at birtl.

H. Herodiones. Tibiæ naked below. Legs and neck much lengthened in corresponding ratio. Toes long, slender, never coherent at base, where cleft, or with movable basal webbing. Hallux (as compared with that of the preceding and following group) lengthened, free, and either perfectly incumbant or but little elevated, with a large claw, giving a foot of insessorial character: Wings commonly obtuse, but broad and ample, without marked re-entrance on posterior border, the intermediate remiges not FOl.. I. 
being mueh abbreviated. Tail short and fer-feathered. Head narrow, conieo-elongated, gradually contracting to the large, stout base of the bill; the loral and orbital region, or the whole hearl, naked. Gape of the bill decply fissured; tip usually acute; tomia hard and cutting. Bill conico-clongate, always longer than the head, stout and firm. Nostrils small, placed ligh up, with entirely bony and horny, or only slightly membranous, surromelings. P'terylosis nearly peenliar in the presenee, almost throughout the group, of powder-down tracts, rarely found elsewhere; pteryle very narrow. Palate desmognathons Caroticls double. Altricial. Comprising the JIcrons, Storks, Ibises, etc. (not Cranes). Species usually of large stature, with compressed body and very long S-bent neck; perehing and nesting usually in trees, bushes, or other high places near water; young hatching weak, searcely feathered, and reared in the nest.

I. ALECTORIDES. ${ }^{1}$ Tibix naked below. Neck, legs, and feet much as in the last gromp, but hallux reduced and obvionsly elevated, with small claw, the resulting foot cursorial (natatorial and lobate in Fulica). Wings and tail commonly as in IIerodiones. Head less narrowed and conic than in the last, fully feathered or with extensive baldness (not with dehinite nakedness of loral and orbital regions). Bill of varions shape, usually lengthened and obtuse, never extensively membranous. Rictus moderate. Nostrils lower than in Iterodiones. Pterylosis not peculiar. Palate schizognathous. Carotids double. Nature precocial and ptilopadic. Comprising the Cranes and Rails and their allies; the former agreeing with the Herodiones superficially in stature, ete., but highly direrse in the schizognathous palate, precrocial nature, etc.

J. LAMELLIROSTRES. Fect palmate; tibin feathered (cxecpt Phonicopterus). Legs near centre of equilibrim of the body, its axis lorizontal in walking; not lengthened except in Phrnicopterus. Knee-joint rarely exserted beyond general skin of the body. Wings moderate, reaching when folded to, but not beyond, the usually short and rounded (exceptionally long and cuneate) tail. Feet tetradactyle (execpt sometimes in Phonicopterus); hallux reduced, elerated ind free, often independently lobate. Bill lamellate, i. e., furnished along each commissural edge with a regular series of mutually adapted lamine or tooth-like processes, with which correspond certain laciniate processes of the fleshy tongue, which encls in a horny tip). Bill large, thick, high at base, depressed towards the end, membranous to the broad obtuse tip, which is ocempied by a horny "nail" of various shape. Nostrils patent, never tubular; nasal fosse slight. No gnlar pouch. I'lumage dense, to resist water. Eyes very small. Ileal high, compressed, with lengthened, sloping frontal region. Palate lesmognathons. Reproduction precocial; young ptilopedic. Frgs numerons. Carotids double. Stermm single-notelied. Comprising Flaningoes and all the Anserine birts. K. STEGANOPODES. Feet totipalmate: hallux lengthened, nearly incumbent, semilateral, (ompletely uniter with the seconcl toe by a full web). Tibise feathered; position of legs with reference to axis of hody rariable, but generally far posterior; knce-joint not free. Wings and tail rariable. Bill of very variahle shape, never lamellate, wholly corncous; its tomia often serrate; exlernal mares very small or finally ahortive. A prominent naked gular pouch. Tarsi retienlate. Sternum entire or nearly so; furcu-

1 Groups G., H., and I. are respectively equal to the Cheredriomorphe, Pcleryomorpha, and Geranomoryiha of Huxlcy. 
lum confluent with its keel. Carotids double. Palate highly desmognathons. Reproduction altricial: roung psilopædic or ptilopædic. Eggs three or fewer.

L. LONGIPENNES. (To most of the characters of the group here given the genus Halodroma is a signal exception, though unquestionably belonging here.) Feet palmate. Tibire feathered. Legs at or near centre of equilibrium, affording horizontal position of axis of body in walking. Knee scarcely buried in common integument; tibia sometimes with a long apophysis. Hallux elerated. free, functionless: rery small, rudimentary, or wanting. Rostrum of rariable shape, usually compressed and straight to the lhooked end. sometimes entirely straight and acute, commonly lengthened, always comeous. without serration or true lamelle. Tostrils of rarious forms, tubular or simply fissured, nerer abortive. No gular pouch. Wings rery long and pointed, surpassing the base and often the end of the large, well-formed, few-feathered tail. Carotids double. Palate schizognathous. Reproduction altricial; young ptilopædic. Eggs three or fewer. Habit highly rolneral.

M. PYGOPODES. Feet palmate or lobate. Tibiæ feathered, often with a long apophrsis. alwars buried in common integument nearly to the heeljoint, necessitating a more or less erect posture of the body on land, where progression is difficult. Hallux small, elevated or wanting: feet lobate or palmate. Bill of indeterninate shape. wholly corneous. never lamellate or serrate, nor with gular pouch. Yostrils not abortire. Wings vers short, reaching scarcely or not to the base, nerer to the tip, of the short, sometimes rudimentary, tail. Palate schizognathous. Carotid usually double, sometimes single (in Podiceps and Jergulus). Nature altricial or præcocial; young ptilopredic. Highly natatorial.

N. SPHENISCI. With general characters of the last group, but distinguished by unique ptilosis and wing-structure, etc. Plumage without apteria, of singularly modified scale-like feathers on most parts; no dereloped remiges. Wings unfit for flight, insusceptible of perfect flexion or extension, rery short, with peculiarly flattened bones and stable articulations. Skeleton-non-pneumatic. Manr bones, terete in ordinarr birds, here flattened. Metatarsal bone flattened transversely, double fenestrate. Hallux elerated, lateral, minute, free. To free pollex. Two anconal sesamoids; patella from double centres: tibia without apophysis; a free tarsal ossicle. Sternum with long lateral apoplyses. Pelvic connections unstable. Carotids double. Comprising only the Penguins. Confined to the Southern Hemisphere.

Haring thus presented and defined an arrangement of the higher groups into which recent Carinate birds are susceptible of dirision, I next proceed to the consideration of the Nortl American Families of birds which the authors of the present work hase prorisionally adopted as suitable to the end they had in view. Professor Baird urges the caution that the scheme is intended merely for the convenient determination of the Torth American species, aware that in many instances diagnoses or antitheses of entire pertinence :n such application would fail or be negatived by consideration of the exotic forms. The arrangement of the families here adopted is essentially that presented in 1858 in Professor Baird's "Birds of 
North America," modified somewhat in accordance with more recent views of Professor Sundevall and others. But before proceeding to the analysis of the families, I will introduce an artificial clew to the preceding higher groups as adopted, so far as they are represented by North American species.

\section{ART'IFICIAL KEY TO THE FUREGOING HIGHER GROUPS,}

By means of which any North American bird may be readity referred to that group to which it is held to betong.

1. Toes 3 ; 2 in frout, 1 behind .

II. Toes 3 ; all in front. Toes eleft or semipalmate .

(Piei) Picanife.

\section{Toes jalnate. Nostrils tubular.}

Nostrils not tubular

III. Toes 4; 2 in front, 2 behind. Bill cered and hookerl - Psitraci.

IV. Toes $4 ; 3$ in front, 1 behind.
1. Toes syndactyle
2. Toes totipalmate (all four full-wehbed)
3. Toes palmate. Bill errved up
(C'uculi) Picaria. STEGANOIOOES. LIMICOLE. Bill not curverl up ; lamellate not lamellate; hallux lobate. - LaMeldinostres. hallux not lobate LoxGIPExies.

4. Toes lobate. Tail rudimentary Tail perfect. A horny frontal slield

PygOPODEs. No horny frontal shielel.

ALECTOHIDES. LIMICOLE.

5. Toes scmipalmate; joined by evident movable hasal web $(\mathbf{A})$.

6. Toes eleft to the lase, or there immovably coherent (IB).

A. Hincl toe elevated above tle level of the rest.

Tibire naked below. Nostrils perforate Nostrils imperforate. Tarsi reticulate. Head hald . Heronioxes. Ilead feathered LInICOL.E. Tarsi scutellate in front . . LIMICOLA.

Tibix feathered below. Nostrils perforate Raprones. Nostrils imperforate. Gape reaching below eye. (Cympsli) PICArix. Gape not reaching below eye . Galitin.

A A. Hind tor inserted on the level of the rest. Tibix naked below

Tibie feathered below. Bill ceres and looked Bill not ecrecl. Nasal membrane soft and tumid . Coursus. Nasal scale hard and flat . . . Gatulina.

B. Hind toe elcrated ahove the level of the rest.

Gape reaching below eyr . . . . . . . . . (Cyjseli) Picaniz.

Gape not below eye. First primary emarginate or ahout cinal to $2 d$. Linicolds.

First primary not emarginate and much shorter thin 2d, ALECTOIIDEs.

BB. Hind toe inserted on the level of the rest.

Nostrils opening leneath soft swollen membrane . . . . . . Colvmis:

Nostrils otherwise. Bill exret and hooked

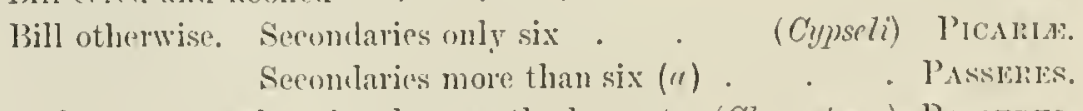

(a) Primaries 10 ; the 1 st more than as long as the longest. (Clamatores) PAsscres. P'rimaries 10: the 1st not $\frac{2}{3}$ as long as the longest. $\}$ (Oscincs) . PAsserus.
Primaries 9. 
Recurring now to consideration of the North American Families of the foregoing higher gromps, I take up the latter in the natural orter in which they have been presented, giving under head of each such group an analysis of the North American families by which it is represented, reiterating the caution that the characters are drawn up only with reference to the North American genera, and are, consequently, not necessarily or always applicable upon wider considerations. These analyses are made as nearly natural as the state of the case permits, but I seize upon any obrious external characters which may be afforded, without regard to their morphological significance or taxonomic ralue.

\section{Aratrsis of THE FaURIEs OF PASSERES.}

A. Oscines. Musical apparatus highly dereloped. Back of tarsus undirided, or formed of a few seutella distinct from those lapping orer the front. First primary wanting, spurious, or at most not orer two thirds the length of the longest.

a. Each side of tarsus corered with a plate undirided in most or all of its leugth, and meeting its fellow in a sharp ridge behind.

b. Primaries only nine.

c. Bill triangular, depresved, about as wide at hase as long: the gape trice as long as the culneu. reaching to about opposite the eres: tomia straight or rently curred. No obvious rictal bristles. Tarsi not longer than the lateral toe and claw. Wings long and pointed, the first primary equal to or longer than the second. Central tail-feathers not half as long as the wing . . . Hivndinida. cc. Biil rariously conico-elongate or slender; or. if depressed, with long rictal bristles: gape not nearly twice as long as culment : tomia straight or gently curved. Tostrils not obriously nearer culmeu than tomia. Tarsus longer than lateral toe and claw.

Biil rers slender. acute; culmen rather concare at base. Longest secondary acuminate. nearly or quite equal to the primaries in the closed wing. Hind claw little curred. about twice as long as the middle clar. Hind toe and claw longer than middle toe and claw . . . . . . . . . . Mo

Bill rariously conico-elongate and acute; culmen not concare at base. Longest secondary not acuminate. falling far short of primaries in the closed wing. Hind claw well curved. not nearly twice as long as middle claw: hind toe and claw not longer than middle toe and clarr. Gape ample; tongue slightly bifid or brusby, if at all .

Syluicolide.

Bill lengthened, rery acute, eren decurred. Tings and feet as in the last. Gape constricted; tongue generally deeply biful or brushy . . . . . . . . . . Curebidce. ccc. Bill more or less truly conic. usualle short. thick: commissure usually more or less evidently abruptly angulated near the base. or with lobe or tooth further fortard. Nostrils obviously nearer culmen than tomia. Tarsus longer than lateral toe and clarr.

1 In the true conirostral or fringilliform genera the under mandible has high strong tomia. bent at an angle near the base: the corresponding portion of the upper mandible is deep, so that the 
Bill stout, tumid, conrex in nearly all its outlines; tomia not angulated, but with one or more lobes or nicks in advance of the base. Nostrils placed very high. Other characters much as in Sylvicolida. Colors chictly red and yellow. One genus of Tanagrida.

Bill truly conic, much shorter than head, usually with the angulation evident; no lobe along midale of tonia, but usually a notch at end. Nostrils placed rery high. Rictal bristles usually obrious

Fringillida.

Bill conic, but lengthened, little if any shorter than head; the angulation of the tomia erident; no notch at end. Nostrils high. No rictal bristles

bb. Primaries ten.

Otherwise with characters much as in Icteride

Icterida.

a. Nostrils concealed with antrorse bristly feathers (except in Psilorhinus and (rymnokitta). ${ }^{1}$

Base of bill shcathed with antrorse bristly feathers, having lateral branches to their very ends; its tip mostly notched. Basal joint of milllle toe united only laalf-way to the lateral. Sicles of tarsus occupied by a lateral groove, mostly filled in with small plates. First primary more than half as long as second. Large, - orer seren inches

Base of bill with two tufts of bristly feathers, ending in simple filaments withont lateral branches. its tip mostly unnotched. Basal joint of middle toe mited nearly all its length with the lateral. Sirles of tarsus ungrooved. First primary less than half as long as second. Small, - under seren inches. Paride. ${ }^{2}$ dd. Nostrils exposed.

e. Tail scansorial, with rigid acute feathers. Whole bill slender, compressed, acute. decurved, unnotehed, unbristled Outer toe much longer than imner · · · · ·
ee. Tail not scansorial, graduated. First primary not less (generally more) than half as long as the second, and inner toe mited to the midklle by at least one half (usually more) of the length of its basal joint.

Tarsus with few obseure scutella. Rietal bristles present. Bill stont, lut not toothed nor hooketl. Wing excessirely rounded (fifth, sixth. and seventh primaries longest). much sloorter than the long graduated tail. Size small. Plumage brown, unbanded . . . . . . . . C Chen

Tarsus distinetly sentellate. Nostrils wholly exposed,

nostrils are nearer the eulmen than the tomia. The whole bill is more or less bent in its axis from the axis of the cranial hase, so that the palate curves fown, or is excavated or, as it were, is broken into two plunes mecting at an angle, - one plane the anterior hard imperforate roof of the month, the other the hack jalate where the internal nares are situate (Sumler:ill). The single North

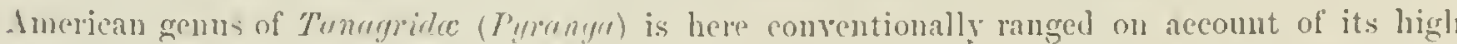
nostrils ame conic bill, althongh it does not show angulation of the tomia. The Icteride, with olvious]y angulated tomia, shade into the Fringillide in shortuess and thickness of bill, and into other families in its length and slemlemess.

1 These two enenera, Psilorinus and Gymnolitle, of the family Corvide, have naked nostrils, as under dil, but otlerwise slow the chliatacters of "orvider.

2 With the Perrine the anthors of this work inclute the Nuthatehes as a subfomily Sillina, which I prefer to dissociate and plice as a group of equal grale next to Certhiide. 
scaled. No rictal bristles, but loral feathers with bristly points. Bitl slender, not notched nor hooked. ITings: and tail moderately rounded: neither rery much shorter than the other. Size small. Color brown, etc., the wings and tail barred or undulated

Tarsus distinetly scutellate. Tostrils orerhung (not concealed) with bristly feathers. Rictal bristles present, strong. Bill powerful. compressed, strongly notehed, toothed, and hooked. Wings and tail moderate. Large. Colors black. white, and gray

eee. Tail not scansorial. First primary less than half as long as the second. ${ }^{1}$ or about laalf as lone. in which case the imer toe is cleft nearly to it: base ( $f$ and $/ i)^{\prime}$ ).

f. Basal joint of midlle toe uniteci some distance with the inner, and for half or more of its length with the outer toe.

Basal joint of middle toe shorter than that of inner toe, and wholly adherent to both inner and outer toes. Tarsus longer" than midlle toe and claw. Gonys more than half the length of the lower jaw. Bill stout, high, compressed: notched and abruptly hooked at tip. Tireonidce.

Basal joint of midulle toe not shorter than that of inmer toe; united to the outer for about two thirds, to the inner for about one half, its length. Tarsus not longer than the middle toe and claw. Gonys less than half the length of the under jarr. Bill triangular, much depressed at base, moderately notched, and hookerl at tip ${ }^{2}$. . . . . . Ampelidce.

Basal joint of middle toe shorter than that of the imner toe, united to the outer for about two thirds, to the inner for about one half, its length. Tarsus longer than middle toe and claw. Gonss more than half the length of the under jaw. Bill rery weak and slender. little deenwed or notched at tip. Tery small, - under six incles: long. (Tarsi booted in Regutus, distinctly sentellate in Polioptita.).

ff. Basal joint of midule toe quite free from the inner, and not united with the onter more than half-war.

Nostrils linear. low. "No bristles or bristly points whaterer about the mouth. Wings short. rounded, concaro-consex. Tail rery short, nearly concealed by its coverts. Tarsi booted

Nostrils oral. Bristles or bristly points about the month. Wings very long and pointed, reaching. when folded, berond the middle of the short. square. or emarginate tail. and one and a half times or more

1 In the genus Ampelis and part of the Tirconirion it is so extremely short as to appear absent, and is displaced, lying concealed ontside the secontl (apparently first) primary, like one of the mimary corerts; howerer, it may always be detected on close examination, differing from the corerts with which it is associated in sume points of size and shape, if not also of color.

2 In $A$ inpclis there is tendency to sublirision of the lateral plates; in .ryiadestes the anterior scutella are obsolete. 
the length of the latter; tip formed by secoml, third, and fourti quills: onter secondary reaching only about two thirds way to end of longest primary: spurious ynill very short. Tarsi booted . . S S Nostrils oval. Bristes or lorintly points about the mouth. Wings moderate not reaching, when foldeet. beyond the mictlle of the tail, and nut over one and a thiret times as 1 ng as the latter; tip formed ly thirel to sixth quill: outer secontary reaching in closen] wing three fonthe or more the length of the lengest primary. Spurius y pill lunger. smmetimes one loalf the second. Tarsi scutellate in MFiminc, booted in Turdina $\cdot$. $\cdot \cdot \cdot \cdot \cdot \cdot \cdot \cdot \cdot$

aa. Ontside of tarsis coveren with two series of scutella, - one lapping ('ntirely arome in front. the other entirely around belind, and meetine at a groove on the inside; lind edge blunt. Firs primary spurious or apparently wanting. Hind claw much lengthened, searcely curved. Xn-irils with antrore bristly feathers. Bill conico-elongate

B. Clamatores. Outside of tarsus covered with a series of plates variously arranget, Japlung entirely around in front and helind, to meet at a groore on the inner sille.

First primary lengthened. often longest, at least over two thirds as long as the longest. Bill broad at the base. much depresed, tapering to a tine point. Which is abruptly decurved; culmen rounded or flattened; gonss flattened: rommisure straight, or nearly so. to the tip. Nostrils small. circular, basal; overhung. but nut concealed by bristes. Mouth capacious, with broad and decply fissured rietus, beset with numerous long strong birites. Feet small, weak. Tail of twelve feathers

Tyramide.

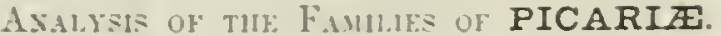

Eecondaries only six.

Bill temuirostral, longer than head. nearly evlindrical. Gape con-tricted. Tongue filiform, extensile, li-tubular. Wing long in terminal portion, abbreviaterl moximally, achte. Phmage compact, of metallic sheen. Size smallest of all hirdi. (IImuning-Birel..) . . . . . . Trochilide. Secondarics mure than six.

Feet syndactrle hy connation of outer amb midlle toes.

Ouber tue mind, lonere than the inner, united fur half its length with the middle. forming a broal sule. Tibia naked ledow. Isill longer than lueat, straicht. acute, with hard cutting extgen and ample rictus. Tomence rudimentary, fixml. Wing-pointed, mud longer than the short squar tail. Tail-feather- twolve. Plumage compact, oily. (Kingfis $\rightarrow$ hr.r.s.)

Ireclinidu.

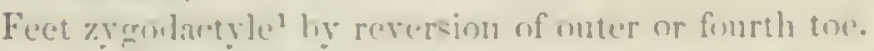

Yot cansonial: tail of eichlt or ten lune suft fenthers. Bill with decurved tip. not fitted for hanmmering: rietns ample. Tungue not ex-

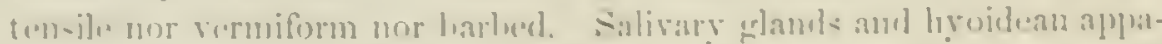
rats- met peruliar. Su masal tufte of feathers. Arboreal and terrestial. (C'uchoo-.).

livepring Pisnite. in whi h the trun hind tos (hallux) is wanting : the outer or fourth toe b ing, however, revereal as ustul. and taking the place of the hind toe. 
Highy scansorial; tail of twelve rigid acuminate feathers, whereof the outer pair ale short and spurious, concealed between bases of' next two pairs. Bill stout, straight, with the tip truncate or acute, not decurved, - an efficient chisel for hammering and boring wood. Tongue verniform, extensile, and barber. Salivary erlands lapere; hyoidean apparatus peculiar. Nasal tufts usually pesent. Arboreal. (Woodpeckers.) - Picide.

Fect neither syndactyle nor zyoulactyle.

Feet semipalmate, of 120 mual ratio of plalanges. Anterior toes connected at hase by movible webling. Hind toe rery small, elerated, scmilateral. Midlle toe produced, its larece claw pectinate. Bill lissirostral, with very small, triangular. (lepresserl horny part and immense rictus, reaching below the ryes. fumished with bristles. Rather lauge. Plumage soft and lax, much rariexnted . . . . . Caprimulgide.

Feet seasecly ol not semipalmate, of frequently abuolnal ratio of phalanges (mildle or outer toe, or both, with fewer joints than usual amoner birls). IIallux rery small, elevated, frequently lateral or rersitile. Mirldle toe not podineed nor its claw pectinate. Bill much as in the last, but rictus unbristled. Sinall. Plumage compact, of few simple subdued colors

Cypsetide.

\section{FAMiLY of PSITTACI}

To characters of Psittaci add: Cere feathererl, concealing the nostrils. Fect granular, rugose. Trings pointed. Tail cuncate. Plumage coarse and dry. Head feathered. Colors green, with yellow and blue . . . . Psittacido.

\section{Axdlysis of Fumlies of RAPTORES.}

Feet highly raptorial, with large, strong, sharp, curverl, contractile claws, adapted for grasping. IIallux perfectly incumbent, lengtliened (more than half as long as the fourth to(), with large claw. Front toes with slight basal welhing between outer or midlle ones, or none; onter toe often reversible. Nostrils imperforate. Bill short, stont, not notably contracted in its contiunity, with strongly hooked tip; tomia often once-twice toothed or lobed. Heal feathered wholly or in greatest part. Lower larymx dereloped with one pair of muscles. P'lumage with ol without after-shafts. Coeea present, as a rule, if not alwars.

Physiognomy peculiar by reason of grent lateral expansion aud lengthwise shortening of the cranium, causing the eyes to be directed forward. Eyes surrounded by a dise of radiating bristly featlers, in front closely appressed to and hidling the base of the bill, elsewhere bounded by a rim of differently formed feathers. Tomia never toothed or lobed. Nostrils usually at the edge of the cere. Outer toe completely rersatile, shorter than the innel toe. Basal phalanx of middle toe not longer than the second, and much shorter than the next. Legs commonly feathered or hristly to or on the toes. Plumage peeuliarly soft and las, without after-shafts; flight perfectly noiseless. Cranial walls willely separated by intervention of spongy diploë. Sternum commonly douhly notehed. Chicfy noeturnal . . . . . . Strigida. Physiognomy not peculiar in any lateral expansion of the cranium; the ejes lateral in direction. No complete facial disc; base of bill not hidden by

1 Excepting Sphyrapicus, in which the tongue is not more protrusible than in ordinary birds. 2 Our species falls rather in a restricted family Arida, as distinguished from Psittacida proper. rOI. I. 
appressed bristles. Nostrils wholly in the eere. Onter toe rarely versatile, exepte I'tundion, ete; not shorter than the inner. Basal phalanx of midede toe longer than the second. Leere commonly naked and sentellate or retienlate in some portion of their length; toes always bare and sealy. Plumage compact, usually with after-shalts; flight andible. Cranial walls with little diphö. Sternum commonly single-notched or fenestrate, sometimes entire. Dinumal

Feet searedy raptorial, with lengthened, litt!e cumed or contraetile, weak, short claws. Hallux elevated, shortened, not more than half as long as the fourth toe, with small clan. Front toes all weblued at base; miclile toe lengthened ; nuter not reversible. Basal phalanx of middle toe longer than either of the succeeding. Nostrils perforate. Bill lengthened and compraratively weak, little hooked, contracted in its continuity; tomia not toothed or luber. Ilend naked of leathers in erreatest part; sparsely bristy. No lower larmx developed. No cerait. After-shafts absent

C'athavida.

\section{Family of COLUMBA.}

With characters essentially as in Columbe (exclusive of those peenlian to Diduncudide and Didida). Plumaere withont after-shafts: the feathers with thickened, spongy thathis loosely inserted in the skin. Heat small, completely feathered, execpting sometimes a ciremorhital space. Tarsi naled or only feathered a little way above. T'ail of twelve feathers, or lengethened, cumeate, and of fourtcen. (IIallux not perlectly incumbent in strmemas.) . . . Columbidre.

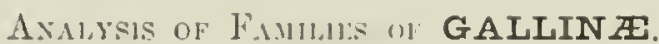

Itind toe lengthencel, insistent. Thil-fenthers twelse. Sides of head and throat with maked spaces. Color greenish . . . . . . . Craciele.

Hind toe shortened, elevated. 'latil-feathers usually fourten or more. No green.

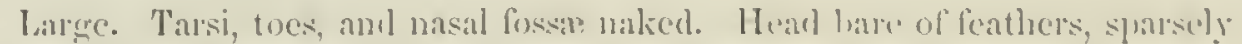
bristly, with wattles and carmuldes. A pectoral tult of bristly leathers. Tarsi usually spurred in the male. I'lmage irileseent . . . Melengrididu. Mredium. Tarsi wholly or in great part, sometimes also the toes, and always

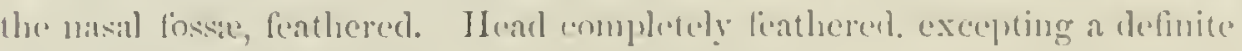
papillate strip orer the eve. Tail-ferithers sixteren or more. Sides ol neck

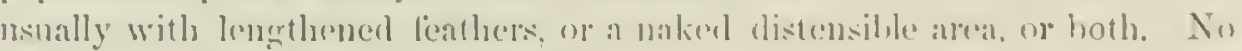

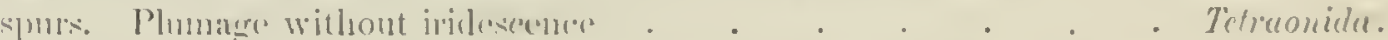

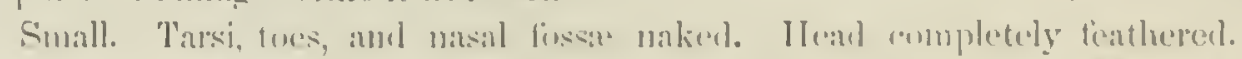

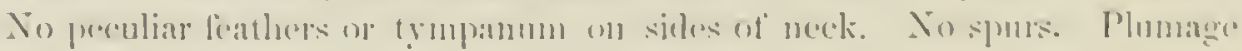
not iridescent

Prerdicide.

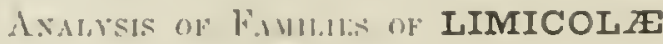

T'oes not lubate. T'arsi not motilly compreseorl.

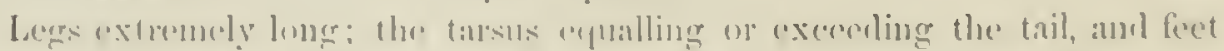

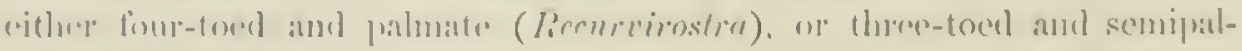
matr. (Jlimantepus): with the hill mush lonerer than the head, rery slender,

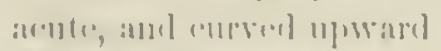

lícurivostrider.

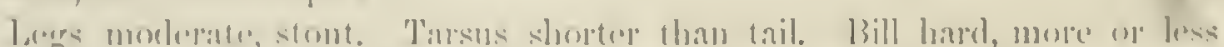

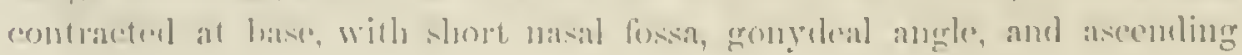


gonys, the tip either compressed and truncare or depressed and acute. Feet three-toed and with basal webbing (Homatopus). or four-toed and cleft (Strepsilas)

Hcemalopodida.

Legs moderate. Tarsus shorter than tail, reticulate. Hind toe wanting (except in squatarola, where very small. and in Aphriza). Bill short, straight, - not excceding the head (generally shorter), - shaped like a pigeon's, with short, broad, soft nasal fosse separated by a constriction from the enlarged. obtusc. hurny terminal part. Head large. globose, contracting

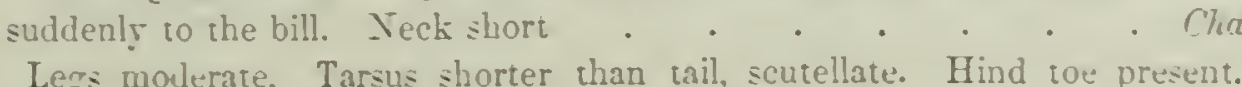
Bill long, - equalling. or oftener exceeding. frequently sercral times longer than, the head: softish and membranous to the rery tip. without constriction in its continuitr: straight or rariously curred . . . Scalopacida. Toes lobate. Tarsi notably compresed.

General characters of Scolopacictc. Body depressed; the under plumage thickened, duck-like. Habits natatorial.

Phalaropodidee.

\section{Araltsis of FaulliEs OF HERODIONES.}

Hallux lengthened, perfectly incumbent. with large claw. Tarsi scutellate. Middle claw pectinate. Bill perfectly straight. tapering, acute. Loral region definitely naked. continuous with corering of the bill. Head narrow. elongatc.

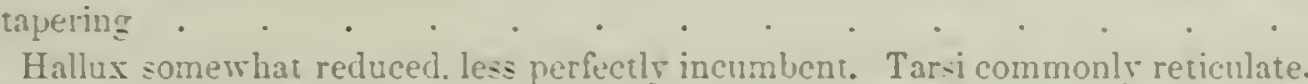
Iriddle elaw not pectinate. Lores. cular space and usually more of the head. naked. Bill rariously curred or with expanded tip. (Genera Tantalus. Ibis. J(ycteria, and Platalea.) .

Tantalida.

\section{A.MLYรI OF FAMILIE of ALECTORIDES}

Of great stature. with extremely long neck and legs. Part or all of the hearl bare. Toes much shorter than the tarsi: with basal webbing. but without lobation: hallux rery short, highly ele raterl. Bill equalling or exceteding the lieat, compressed, perfectly straight, contracted about the middle. with enlarced acute terminal portion; nasal fosse wide and deep. with large perforate no-trils

Gruidce.

Size moderate and small: nech and legs comparatirely short. Ilead completelr fearhered. excepting, in the Coots and Gallinules, a broal horny frontal plate. Toes equalling or exceeding the tarsi, simple or lobate. Bill not constricted in the middle. wher shorter than the heal. straight and quite stuut: or much longer. regularls slender and decursed, with long nasal fossa. Nustrils incompletely or not perforate

Rallida.

\section{ArALTSE OF FivtLIF OF LAMELLIROSTRES}

Of great stature. with extraordinarily lengthened neck and legs. Bill of unique shape. bent abruptly down from the middle. Tibie naked below. Hind toe minute or absent. Tings rounded. Ped the chief color . . . Phrenicopterida. Of moderate size: the neck short, or. when lengthenerl, not accompanied by co-ordinatels lengthened legs, these heing always shorter than the wing. Bill straight. Tibire feathered below. Hind toe present: weil dereloped anil functional, though short . 
xxriii

\section{ANALYSIE OF FuHLHE of STEGANOPODES}

Bill rather longer than head. cleft to eyes. very stom at base. tapering to the deenrred, but not hooked, tip. Nu-tril abortive. Frular sac moderate. naked. Wing rather long, pointed. Thil long, stitl, euneate, twelve to fourteren feathered. Feet nearly beneath cente of eppilibrium. General contiguration gonze-like. . Bill sereral times longer than head, slemder hut strong., depresenl. perfectly straight, with small distince hooked uail at emel. No-trils very small. Fular sar. enormoti. Jandibular rani menting only at tip. Wing axtromely long. with upwarl of torty remiges. Tail short. roundetl. of twenty or more feathers. Lees beneath centre of etpilibrim, extremely short and -inut

bill about as long as heal. stont, straight, scarcely tapering, strongly horiket]. Fostrils abortive. Gular sac moderate, but erident: mostly nakeol. Wines short. Tail large. fan-shaped. wan-orial. of twelve to fourteen broal-tiff fe-ath-

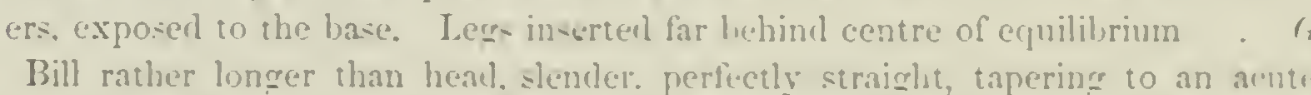
tip. Gular sac small. Nostrils minute. Wings aml tail, and general configuration, as in the last

Sulider.

Bill much longer than hearl, straight, stont, strongly looket. Xustril- very small. Gular sar well developed. Wings excectlingly lung. strong. and pointed. Tail excedingly long. deeply forket. Feet extraordinarily short; tarsi partly feathc.rinl

Tachypetirle.

Bill about as long as head, straicht, stout, tapering to an acute tip. Tostril. small. Gular sac rulimentary. freathered. Wings moderate. pointed. Tail sher. but with two central feathere extraordinarily prolongerd and filamentons. Feet small, beneath centre of equilibrium

Phethontide

\section{ANALYSE OF FAMULES OF LONGIPENNES.}

In-trils not tuhular. lateral, perforat. Bill with continuous covering. or only broken ly a sort of cere, houted or straight to the end. Ilallux small and eleratel, but alwars pre-ent

So-ril- tubular, digioned and lateral, or oftenest superior and united in one double-barrellew tube. Coveriug of lill in several pieces; till always hooket. Hallux miunte, rudimentary, rir alieent

Priscrllariille.

\section{ASALYL UR FAMHLE OH PYGOPODES.}

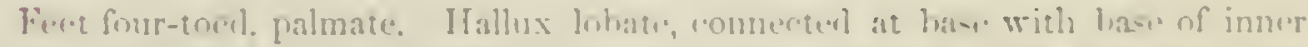

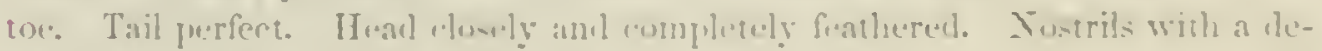

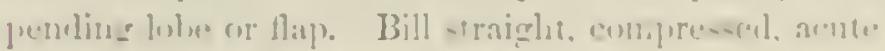

rolyminills.

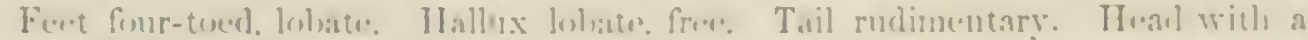

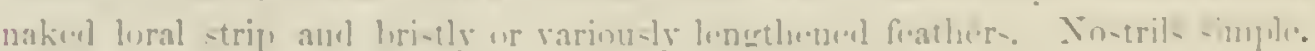

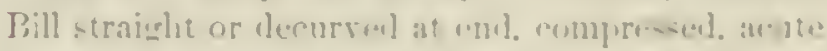

Pulicifiuion.

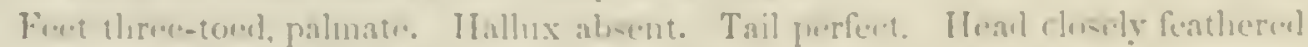
or varionly ere-tedl. Tostrils simple. Bill of indeterminate slape . . . Aride. 


\section{NORTH AMERICAN BIRDS.}

\section{Fanily TURDID平. - Tie Thrusines.}

THe Turdide, with the Suxicolide and Cinclider, form a group closely related, by common characters, and appreciably different from the other Oscines with slender bills and specially insectirorous habits, having, like them, ten primaries (the first much shorter than the seeond, but nearly always appreciable), and the nostrils meovered. The great fanily of Sylricolide, with similar characters of the bill, never present more than nine primaries. The most striking of these common characters is seen in.the deeply cleft toes, of which the outer is united by the basal joint alone to the midlle toe, while the inner is separated almost to the very base of its first joint. The frontal feathers extend, with rare exceptions, to the very nostrils. The bill is elongated and subulate, moderately slender, and usually notehed at tip; the culmen moderately curved from the base, and the month well provided with bristles, except in a few cases. Usually the scutellie covering the front and sides of the tarsus are fused into one continuous plate, or else scareely appreciable, except on the imner edge only; in the Nocking Thrushes they are, howerer, distinctly marked. The lateral toes are nearly equal, the onter rather the longer. With these as some of the prineipal characteristics, they may be distingnished from each other as follows: -

Note. - In the present work the length of the tail is mensured finm the cocerx, incirle of the skin, and not, as usually the case, from the base of the quilts at their insertion. The wings are measured from the carpal joint, with dividers.

1 In a perfectly fresh specimen of Turtus mustelimus, the basal hatf of the first phalanx of the inner toe is connected with the first joint of the midlle toe by a membrane which stretches across to within two fifths of the end of the latter ; there appears, however, to be no ligamentous alliesion. The basal joint of the outer toe is entirely adherent, and a membrane extends from nearly the basal lalf of the second joint to the listal end of the first joint of the midcle toe. When this connecting membrane becomes dried the division of the toes apjpears considerably greater.

When the toes are all extended in line with the tarsus, the hind elaw stretehes a little beyond the lateral and seareely reaches the base of the minllle claw.

The plates at the upper surface of the basal juints of the toes are quadrangular and opposite each other. 
A. Nostrils oval. Loral aud frontal feathers with bristly points or interepersed with bristles: rictus with longer or -hurter bristhes.

Saxicolida. Winge very long and much pointel, reaching beyond the midelle

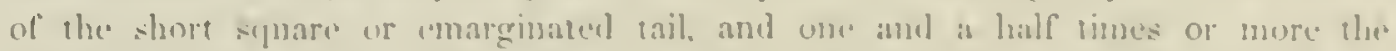
leneth of the latter. T'he spurious primary very short. the smoms quill longere thin the fourth. In the elosent wing the onter secondiaty reaches only about two thirds the length of longest prmatiry.

Turdida. Wings mexlerate, more munded, not reaching leyomel middle of the

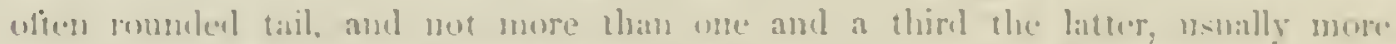
mearly expal. Spurions prinary sometimes lalf the length of seome quill; the scoond quill shorter than the fourth. In the elened wing the outer second:sy reaches three foumlis or more the henere of longest primary.

B. Tourril: linear, in lower enlege of masal memhrane. Loral and frontal fenthers soft and downy, and mo lorixtles or bristly points whatever ahom the mouth.

Cinclida. Budy very short and hroal. Wings short, rounded, and eoncave.

The American sylvide are in some respects very closely related to the

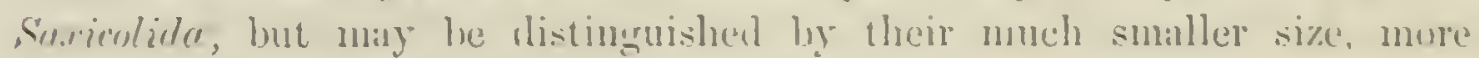
slemder and depresied hill, more strongly hristled rictus, ete. ; on which aecomnt they are more strictly "fly-catchers," taking their prey in great part on the wings.

Of the three families, the Turdide contain a and exhibit widely diflement chatmeters, remlering it excexdingry difficult

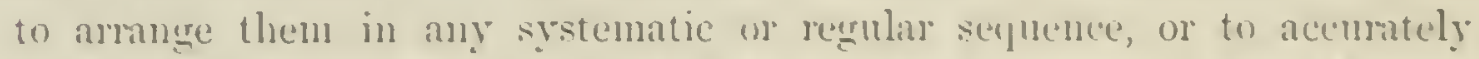
define their hommlaries. In the birds of Sorth Amriece, the Mocking Thrushes were placed ammer the Wrens, on acenut of the listinct tarsal sontellar, and wher chinacters. We are now, huweres, inclinenl to helieve,

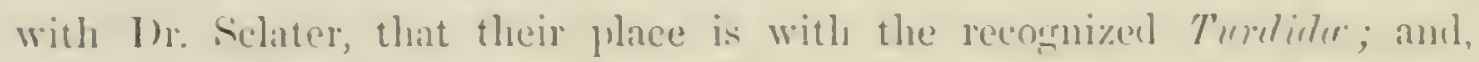

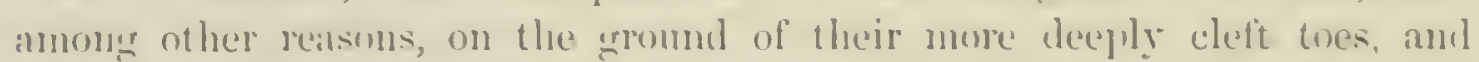
erreater extension forward of frontal feathers. The following symplsis of the North Amerian forms will serve the purpose of determining the erenem, even if these are not arrangeel or comblined in a strictly natmal mamer.

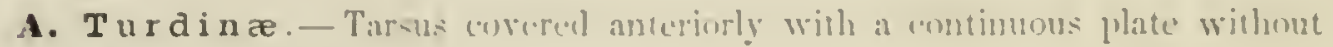
scales.

Winge deciderlly Innger than the tail, which is nearly even. Bill considleralsly shorter than the leanl.

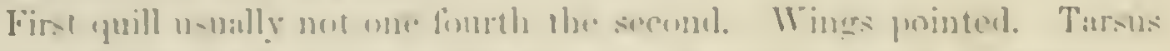

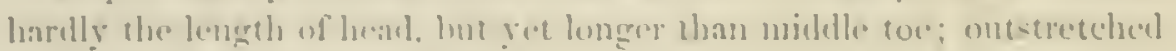
toes falliner slurt of tip of tail

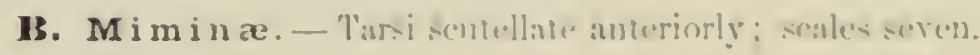

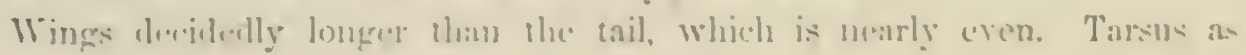
longe os 1120 lec:ul.

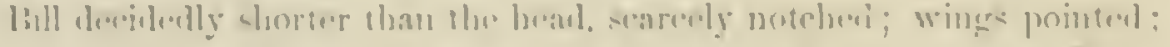

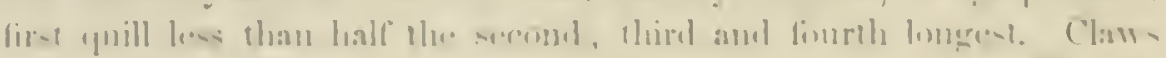

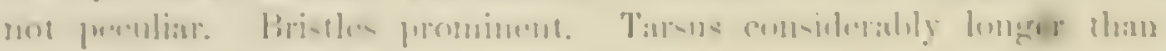
milllle lan and r.liw. 
Wings dectiletly shorter than the tail, which is considerably graduated; first quill half or more than halt the second.

Bill notehed at tip, shorter than head; straiglat.

Scutella very distinct; gony's straight, or even declining at tip. Jimus.

Scutella more or less obsolete; gonys convex, ascenling at tip. Galeoscoptes.

Bill not notelied at tip, lengthened; sometimes muels decurved. Harporhynchus.

Note. - In the Reriew of Ameriean Birls, I., May, 1860, 409, I have adranced the suggestion that the X. Aneriean genus. Iryiadestes, nsually placed under the Ampeliek, really belongs under Turdicle in a group. Mryiadestinc. The relationshipls are certainly very close, as is shown by the characters giren below.

Commos Cunneters. - Tarsi without regular tmusperse seutella, exeept at lower end. Wings acute, pointerl, as long as or longer than tail, which is but slightly graduated. First primary rarely half second, which excends the secondaries. Base of yuills butli vellow, as are inner edges. Tail spottech or varied at the end. Youmg birds with many light spots. Very meloulious singers.

Myiadestinæ. Bill short, much depressed; month deeply cheft ; width at base about equal to the distance from nostril to tip, or greater ; commisinge more than twire distance from nostrifs to tip of bill, and nearly two and a half times length of gonys. Legs weak; tarsi rather longere than middle toe and elaw. Tail feathers tapering slightly from base to near tip, giving a slightly" cuneate appearance to the tail.

Turdinæ. Bill stonter, more lengthened; narrow at base and more comnresset; wilth at balse less than distance from nostril to tip; commissure not more than twice distance from nostrils to tip of bill, and alrout twiee length of gonys. Tissi stonter, longer than midule toe and claw. Tail feathers widening slightly- from base to near tip', giving a parallel-sided or slightly fan-shaped appearance to the iail.

'The Jimine difler, as alleady mentioned, in the seutellate tarsi : more rounded wings, etc. S. F. B.

\section{SubFinir T U R DIN 仺。}

There are several American genera of T'urlince not found north of Mexico as yet, although it is not impossible that one of these (Cuthumes) may hereafter be detected within the limits of the United States. The species of C'uthurus resemble the North American wood-thrushes (Hylocichlir); but the spurious or first primary quill is longer (from one half to one third the second quill), the wings are rounded, not pointed, the tarsus is longer thin the head, and the outstretched toes extend beyond the tail. The species to be looked for are C. melpomene and occidentalis. ${ }^{1}$

The North American species of Turdinue, while retained under the single genus Turdus, yet constitute several distinct groups, which we may call subgenera.

\section{GENUS TURDUS, Lisxets.}

Turdus, Lixaxus, Syst. Nat., ed. 10, 1758, 168. (Type, Turchus viscironus of Europe.) Baind, Rev. Am. Birts.

Gex. Crar. Bill conical, subulate, shorter than the head; the tip gently decurved and notched (except in Hesperocichla); the rictus with moderate bristles; the wings rather

\footnotetext{
1 See Baird, Review American Birds, I, 1S64, 7, S.
} 
long and pointed, with small first jrimary (hes than one fuurth the second); wings consilerably longer than the tait, which is firm. nearly evest, with brual diatluers. Tarni variable, seldom on long as the skull, the scutellir linet into a continuens plate, only in rare indivilual instances showing imlieations of the lines of selparation.

The genus Turdus is rery cosmopolitan, occuring nearly throughut the globe, excepting in Awstial and conblaces species of highlest perfections as singers. In the large number of species known there are many variations in external form, but the transition from one to the othel is so inalual as to renter it very diflicult to sepanate them into different genera. The sections of the group we adopt are the following:-

$$
\text { Seres similar. }
$$

Bylocichla. Sinallest sprecies. Bill short, lrual at base; mneh depressed. Tari long and

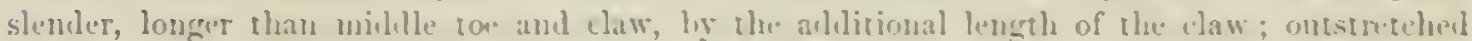
legr, reaching marly to tip of tail. Benly slender. Color: above ulivacens ur redilish, lneneath whitisls; loreast - prothel: thruat withont spots.

Turdus. Bill stouter and higher. Tarsi stont anl shurt, searewy longer than mildle tor and

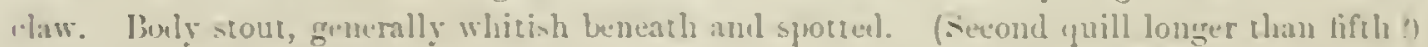

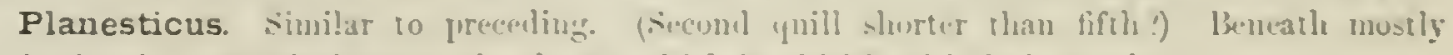
uni-colored; unstreaked excejt the throat, which in whitish with dark streaks.

$$
\text { Sexes divinilur. }
$$

Merula Similar to Turdus. Male 11 -nally more or les. lolak, encecially on the head; females brownish, often with streatienl thruats. lbill distinctly mecherl.

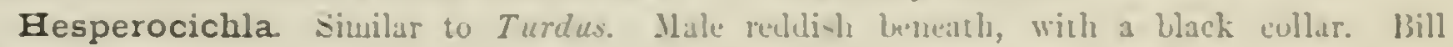
without notch.

\section{SiBGEIts H}

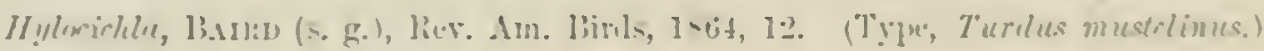

The essential characters of Mylocidlu have already heen griven. The

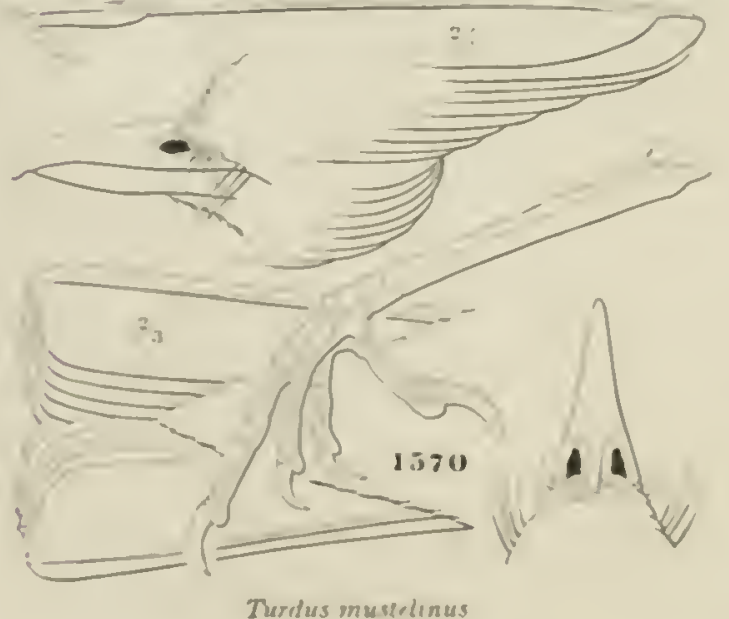
sulyenus includes the small North Aneriean species, with Thidus musflinus, lim., at the head as type, which are closely connected on the one sile with Cotharus, hy their lenerthened tarsi, and with Turelus lix the shape of the wing. The bills are shorter, more depressed, and liroader at hase than in typi(al Tworlus, so much su that the species lase frepuently been deserilned nunder Musingum.

It is not at all inprobable that natumalists may ultimately conchule to consiler the group as of generic monk.

In this group there apprears to lee five well-natrked forms or "sprecies."

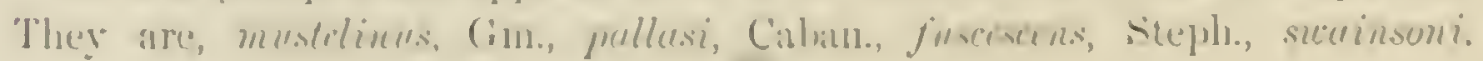


Caban., and alicia, Bairl. The first-named is totally mlike the rest, which are more closely related in appearance.

In stulying carefully a very large series of specimens of all the speeies, the following facts become evident:-

1. In autumn and winter the "olive" color of the plumage assumes a browner cast than at other seasons; this variation, however, is the same in all the species (and varieties), so that in autumn and winter the several species differ from each other as much as they do in spring and summer.

Of these fire species, two only (pallasi and swainsoni) inhabit the whole brealth of the continent; and they, in the three Fammal Provinces over which they extend, are modified into "races" or "varieties" characteristic of each region. The first of these species, as the pullusi var. pallasi, extends westward to the Rocky Mountains, and migrates in winter into the South; specimens are very much browner in the winter than in spring ; but in the Rocky Momtain region is a larger, grayer race, the viur. auduboni. This, in its migrations, extends along the central mountain region through Mexico

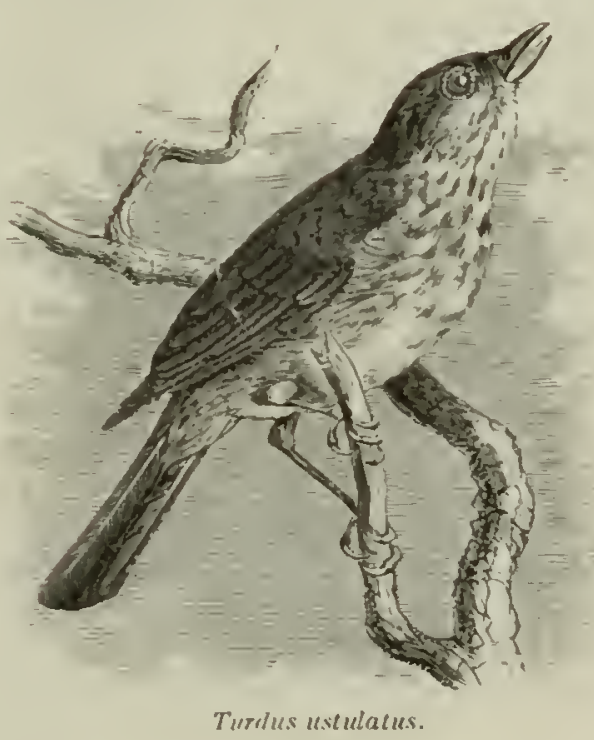
to Guatemala; specimens from the northern and sonthern extremes of this range are identical in all the specific characters; but the sonthern specimens, being in the fall and winter dress, are browner in color than northern ones (spring birds); an autummal example from Cintomment Burgwy, N. MI., is as brown as any Central American specimen. Along the Pacific Province, from Kodiak to Western Mexien, and occasionally straggling eastwird toward the Rocky Mountain system, there is the var. numus, a race smuller than the var. pallasi, and with much the same colors as var. anduboni, though the rufous of the tail is deeper than in either of the other forms. In this race, as in the others, there is no difference in size between specimens from north and south extremes of its distribution, because the breeding-place is in the North, all Southern specimens being winter sojourners from their Northern birthplace.

The T. swainsoni is found in abundance westward to the western limit of the Rocky Nountain system; in the latter region specimens at all seasons have the olive of a clearer, more greenish shade than in any Eastern examples; this clearer tint is analogous with that of the Rocky Mountain form of pallasi (auduboni). In precisely the same region inhabited by the pallasi var. nanus the sucinsoni also has a representative form, - the var. ustulatus. This resembles in pattem the var. sucainsoni, but the olive above is decidedly more rufescent, - much as in Rocky Momntain specimens of 
T. fuscesecne; the spots on jugulum and breast are also nurower, as well as haudly darker in color than the back; and the tail is longer than in liocky Mountain sectinsoni, in which latter it is longer thain in Eustern examples. The remaining speeies - mustelinus, fuscessens, and alicia extend no fauther west than the locky Mountains; the first and last only towarl their eastern base, while the second breeds abundantly as far as the eastern limit of the Great Basin.

The T. fusersecus, from the Roeky Momntains, is considerably darker in color ahove, while the specks on the throat and jugnlar are sparser or more obsolete thin in Eastern birds.

In T. mustelinus, the only two Testern specimens in the collection (Mount Carroll, Ills, and Fort P'ierse) have the rump of a clearer grangish thin specimens from the Atlantic Coast; in all other respects, howerer, they appear to be identical. Some Mexican specimens, being in winter plunage, luare the breast more buffy than Northern (spring or smmuer) examples, and the rufous of the head, ete. is somewhat mighter.

In uliric, no difference is observed between Eastern and Western birls; the reason is, probably, that the breeding-ground of all is in one province, though their migrations may extend ores two. There is, however, a marked difference between the spring and antum plumage; the clear grayish of the former being replaced, in the latter, by a snuffy brown, or sepia tint, — this especially noticealle on wings and tail.

The following synopsis is intended to show the elanacters of the different speeies and rarieties.

1. Spots benenth rounded, covering brenst and sides.

A. Rufous brown above, becoming much brighter towad the bill, and more olivecous on the tail. Benenth white; whole breast with rouneled spots. Yust oll tree; egres pale Bhe.

1. T. mustelinus. Buncath nerrly jme white, with romded blateish spots over the whele lneast, sides, and mpler part of ablomen;

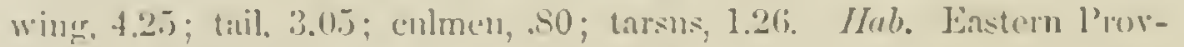
ince Uniterl States, soutl to Guatemala and Honduras. Cuba and liermucla of 1 eset Inelies.

\section{Spots bruecoth triangutur. on breast only.}

13. lintirely uniform in colur above, - olivaneous. varying to redelish or

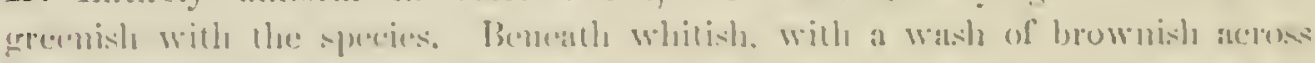

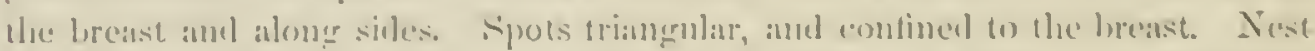

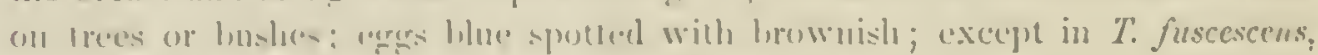

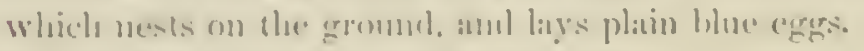

a. Vu comspriruous light orbitul ring.

2. T. fuscescens. Vollowish-rufous or nlive-fiulinus alose; a strong

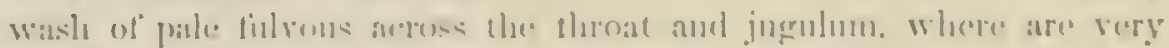

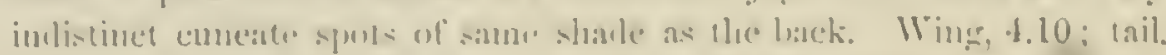

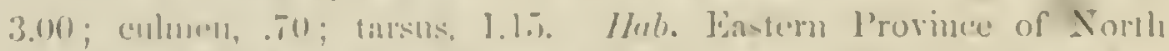

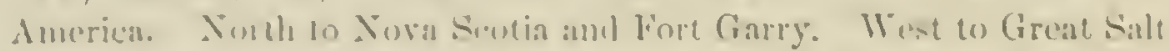

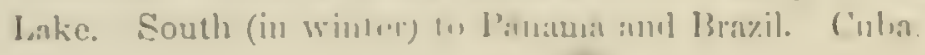


3. T. aliciæ. Gravish elore-brown ahore; breast almost white, with broal, blackish spots: whole side of head unilorm grayish. Wing, 4.20; tail, 3.20; culmen, .iT; tarsus, 1.1j. Ihub. Eastern Province North America from shore of Arctic Ocean, Furt Yukon, and Kodiak to Costa Rica. West to Missouri River. Cula.

b. A conspichous orbital ring of butf.

4. T. swainsoni.

Greenish-olive abore, breast and sides of head strongly tingerl with bunf. Spots on breast broad, distinet, nearly black. Length, 7.00; wing. 3.90 ; tail, 2.90 ; culnen, .6.5; tarsus, 1.10. Hub. Easteru and Middle Provinces of North Linerica. North to Slare Lake, soutl to Ecuador, west to East Humboldt Mountains . . var. swainsoni. Brownish-olive abore, somewhat more rufeseent on wing; breast and head strongly washed with dilute rufous. Spots on breast narrow, scarcely darker tluan back. Wing, 3.S.j; tail. 3.00; eulmen, . 0 ; tarsus, 1.10. Hab. Pacific Province of Lnited States.

Guatemala . . . . . . . rar. ustulatus.

C. Above olivaceous, becoming abruptly more redilish on upper tail-coverts and tail. Spots as in sucuinsoni. but larger antl less transwerse, - more slarply definel. An orbital ring of pale buff. Nest on ground; eggs blue, probably unspotted.

\section{T. pallasi.}

Olivaceous of upper parts like ustulatus. Reddisls of upper tailcorerts invading lower part of rump; no maked difference in tint between the tail and its upper coverts. Flanks and tibia yellowish olive-brown; a faint tinge of buff across the breast. Eggss plain. Wing. 3.80 ; tail, 3.00 ; culmen, .70; tarsus, 1.20 . Hub. Eastern Prorince of Cnited States (onyy?) . . Var. pallusi. Olivaceous of upper parts like surainsoni. Recldish of tail not invading the rump, and the tail decillely more castancous than the upper coverts. Beneath almost pure white; searcely any buff tinge on breast; flanks and tibia grayish or plumbeous olive. Size smaller than sucuinsoni; bill depressed. Wing, 3.50; tail, 2.60; culmen, .60; tarsus. 1.15. Ilab. Western Province of North Ameriea, from Kodiak to Cape St. Lucas. East to East Humboldt Mountains . . . . . . . var. nanus. Olivaceous above, like precelling; the upper tail-coverts scarcely different from the back. Tail yellowishrufons. Bencath like nunus. Size larger than swainsoni. Wing, 4.20; tail, 3.35; culmen. .80; tarsus, 1.30. Hab. Rocky Mountains. From Fort Bridger, south (in winter) to Southern Mexico. . rar. auduboni.

\section{Turdus mustelinus, GMelix.}

\section{THE WOOD THRUSH.}

Turdus mustclinus, Gyetrs, Syst. Nat. I, 1788, S17. - Audubox, Orn. Biog. I, 1832, 372, pl. 73. - Iв. Birds Am. III, 1S11, 24, pl. 144. - D'Ore. La Sagra's Cuba Ois. 1840, 49. - BA1ro, Birds N. Am. 185\$, 212. - IB. Rev. Am. Birds, 1864, 13. - Sclatfli, P. Z. S. 1856, 294, and 1859, 325. - Joxes, Nat. in Bermuda, 26. - Guxulaci, 


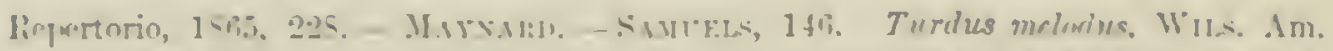

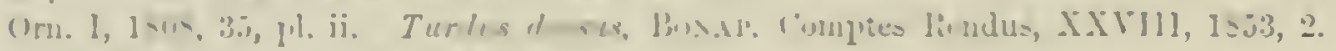

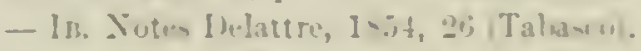

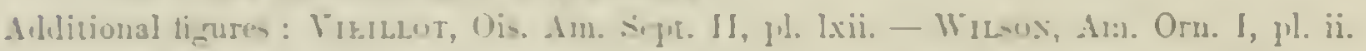

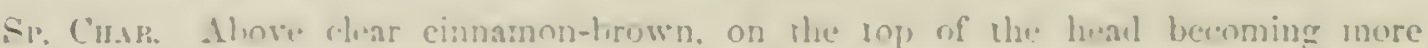

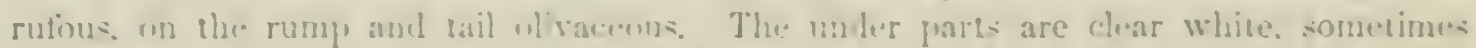
timgerl with buft on the hereat or an rerierly, atul thickly markenl be seath. except on the

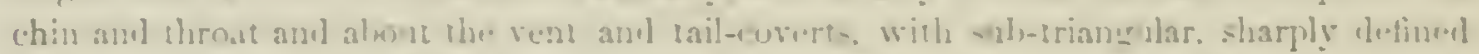

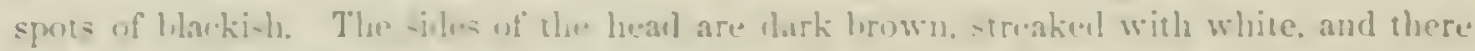

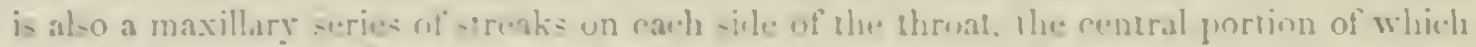

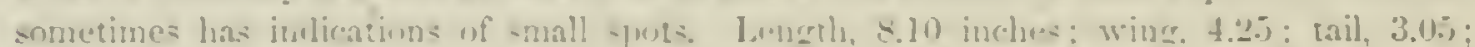
tarsus 1.26. Yome liri simihr lo aduh, but with rn-ty yellow triangular -pots in the ents of the wing curerts.

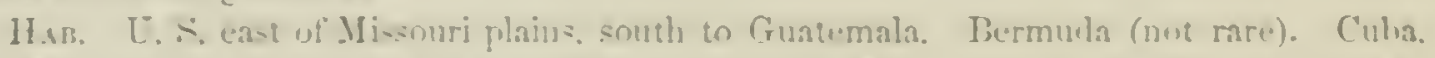

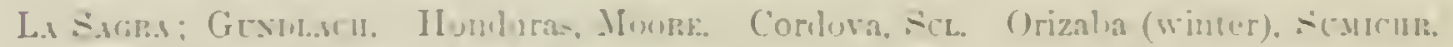

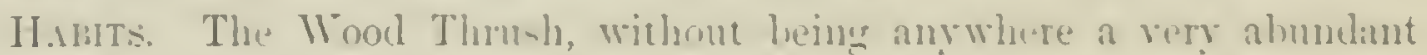

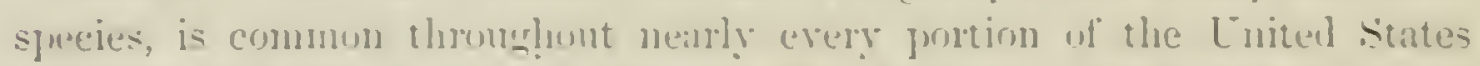

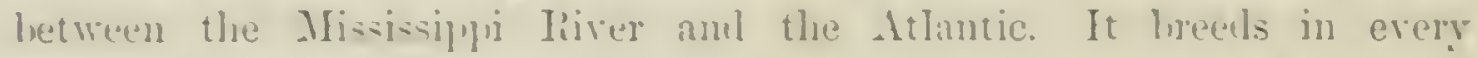
gnotion of the sinne extented area, at least as far as (ieurria on the sunth aml Masidelunetts on the north. Beroml the latitnamed state, it rarely, if ever, lneetio on the const. In the interior it lans a higher range, nesting around IIanilton, ( .11 . So far as I am aware it is unknuwn, or very rare, in the States of Vermunt, New Hamplere, nud Maine.

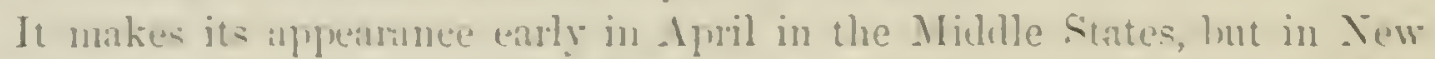

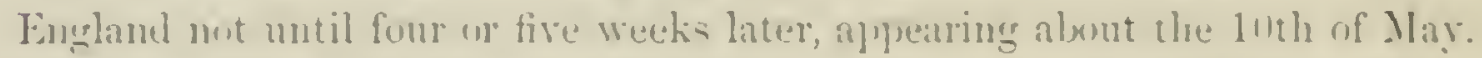
Their migrations in fall are usose irrerglar, leing ajgarestly determined hy the ahmulanee of their fimel. At tines they degrart as early as the first of September, lut sometimes unt mutil the lat of Detuber. It winters in Cintral Imerioa, where it in quite almulant at that seatson.

The farorite luealities of the lloul Thrush are the borders of dense

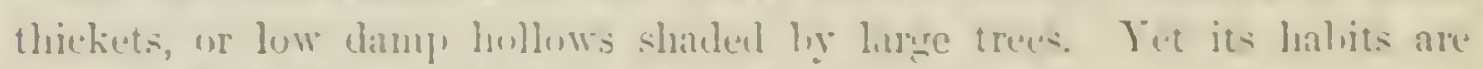
ly no neans so retiring, or its nature so timid, as these places of resurt

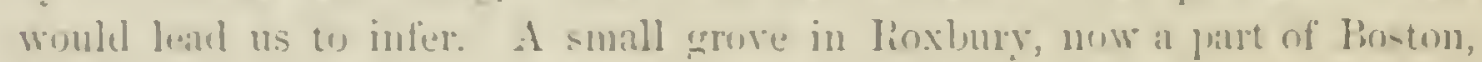
in elove proximity in a dwelling-bunse, was for many years the faverite

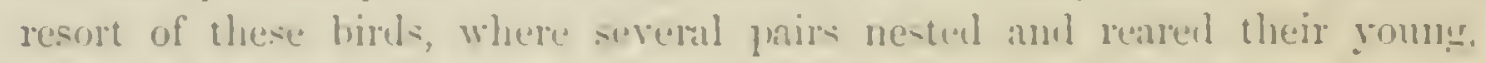
rately even leaving their nesta, which were muty in low bushes, wholly unmindful of the curion- ehildren who were their freptent visitus. The

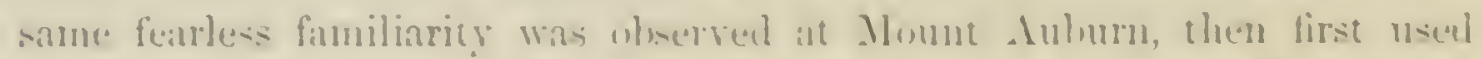

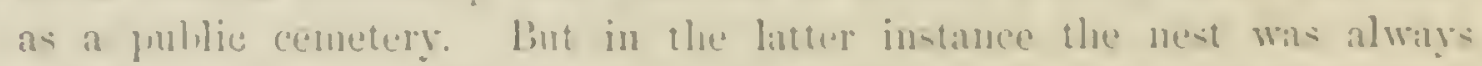

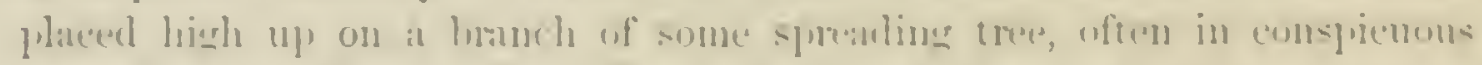
places, but ont of reach. Mr. . . . . Mllen rofere th several similar instandes

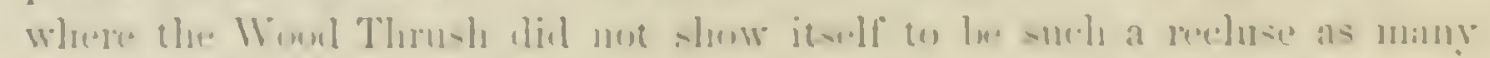

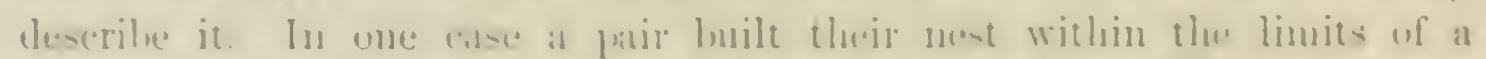

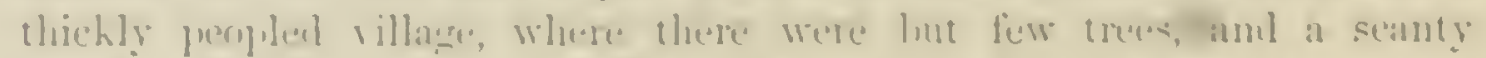

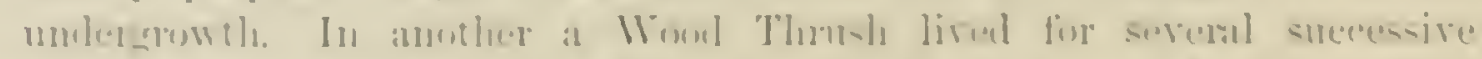
summers annung the elons and majeles of court siputre un the city of 
Springfield, Mass., undisturbed by the passers by or the walkers beneath, or the noise and rattle of the vehicles on the contignous streets.

The song of this thrush is one of its most remarkable and pleasing characteristics. No lover of sweet somuls can have failed to notice it, and, having once lnown its source, no one can fail to recognize it when heard again. The melody is one of great sweetness and power, and consists of several parts, the last note of which resembles the tinkling of a small bell, and seems to leave the conclusion suspended. Each part of its song seems sweeter and richer than the preceding.

The nest is usually built on the horizontal branch of a small forest-tree, six or eight feet from the ground, and, less frequently, in the fork of a bush. The diameter is about 5 inches, and the depth 33 , with a eavity averaging 3 inches across by $2 \frac{1}{4}$ in deptl. They are firm, compact structures, chiefly composed of decayed deciduous leaves, closely impacted together, and apparently thus combined when in a moistened condition, and afterward dried into a firmness and strength like that of parchment. These are intermingled with, and strengthened by, a few dry twigs, and the whole is lined with fine roots and a few fine dry grasses. Occasionally, instead of the solid frame of inpacted leaves, we find one of solidified mud.

The eggs of the Trood Thrush, nsmally four in number, sometimes five, are of a miform deep-blue tint, with but a slight admixture of yellow, which imparts a greenish tinge. Their average measurements are 1.00 by .75 inch.

\section{Turdus fuscescens, firephexs.}

\section{TAWNY THRUSH ; WILSON'S THRUSH.}

Turdus mustelinus, Wisox, Amer. Onithology, V, 1S12, 9S, jl. 43 (not of FMrur.').

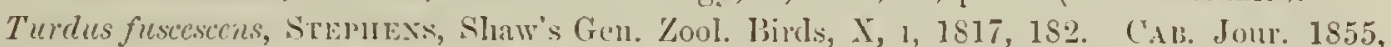

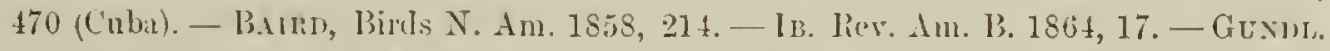
liepertorio, 1865, 225 (C'uba, not rare). P'ik\%t:k, Orn. Bras. II, 1868, 92. (Sam

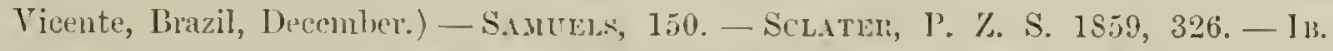

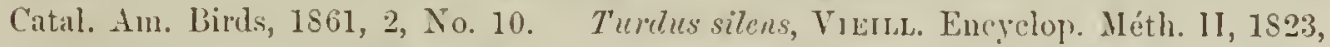
$6+7$ (based on T. mustclinus, WiLs.). Turlus uilsonii, Bon. Ons. Wils. 1825, No. 73. Turdus minar, D’Ori. La sagra's Cuba, Ois. $1840,47, \mathrm{pl}$. v (Cuba).

Sr. Cirsr. Above, and on sides of hearl and neck, nearly uniform light redelish-brown, with a faint tendeney to orange on the crown and tail. Beneath, white; the fore part of the breast and throat (paler on the chin) tinged with pale brownish-yellow, in decided contrast to the white of the belly. The sides of the throat and the fore part of the breast, as colored, are marked with small triangular spots of light brownish, nearly like the back, but not well defined. There are a few obsolete blotches on the sides of the breast (in the white) of pale olivaceons; the sides of the body tingerl with the sane. Tibire white. The lower mandible is browish only at the tip. The lores are ash-colored, the onjoital region grayish. Leneth, 7.50; wing. 4.25; tail, 3.20; tarsus, 1.20 .

IIAB. Eastern Nortl, America, Halifax to Fort Bridger, and north to Fort Garry Cuba, Panama, and Brazil (winter). Orizaba (winter), Sumemkast. 
H.nBts. This species is me of the common hirds of New England, and is probahly abmulant in eertain localities throughout all the country east of the Rocky Momntains, as far to the north as the ioth parallel, and possibly as lire as the worled comntry extends. Mr. Maymard did not meet with it in Nonthem New IIampshire. Mr. Wm. G. Winton ohtained its nest and eages at Ilalifix, N. S.; Mr. Boardman found them also on the Gulf

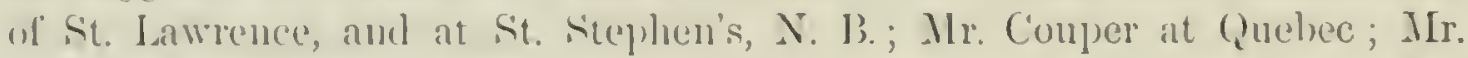
Krieghoft at 'Three livers, ('anada; Domald Gum at Selkirk and lied liver; and Mr. Kumlien and J)r. Hoy in Wisconsin. Mr. Mellwrath also gires it as common at Hamilton, West Caunda. It breeds as far south as Pemnsylyuna, and as far to the west as Ctall, and occurs, in the breeding season, lnoughout Maine, New Brunswick, Nora Scotia, and Cinada.

Mr. liderwar found this thrush very abundant amoug the thickets in the valleys of the I'rovo, Weber, and bear rivers, in Ctah, and rery chanacteristic of those portions of the comntry.

It arrives in Massachusetts early in May, usually with the first blossoms of the peatr, lamging from the ith to the 2oth. It is strictly of woodland hablits, foumel alnust cutirely among clumps of trees, and olitaining its food from among their hanches, or on the gromed among the fallen leaves. It moves sonth from the 10 th to the 2.jth of September, rarely remaining till the first week in Octuber.

It is timid, listrust ful, and retiring; delighting in shaty ravines, the edges of thick cluse wools, and oceasionally the more retired frats of gardens: where, il mumolested, it will frepuent the same locality year alter year.

The somp of this thrusl is quaint, but not mumusical; varialole in its rlanacter, changing from a prolonged and monotonous whistle to ynick ancl almost shrill notes at the close. Their melody is not moneruently prolongerl mutil quite late in the evening, and, in consequence, in some portimss of Massachnsetts these bids are distinguished with the name of Nightumgale, - a distinction che mathere to the season than to the high quality

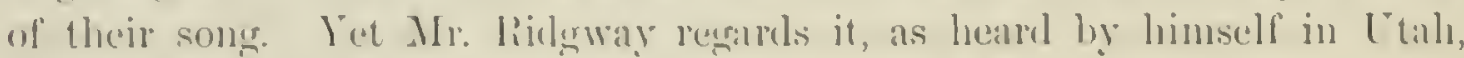
as superion in some resperets to that of all others of the gemus, thongh far

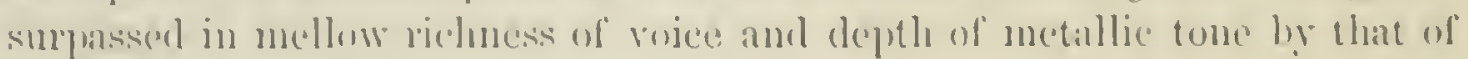

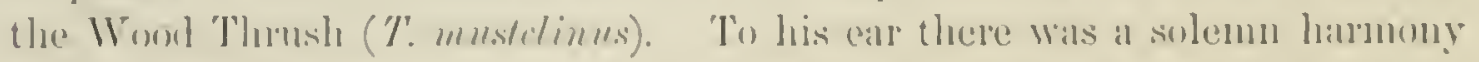
and a heantifnl axpession which comblined to make the song of this surpitss that of all the other Anerican Whod Thustes. The heanty of their notes

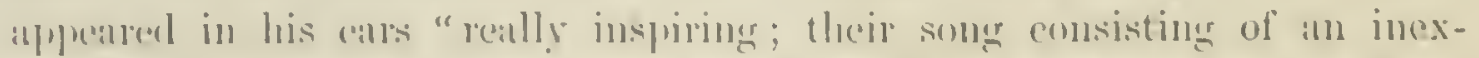

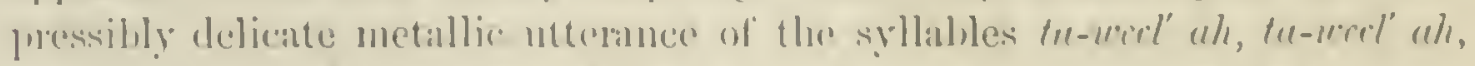

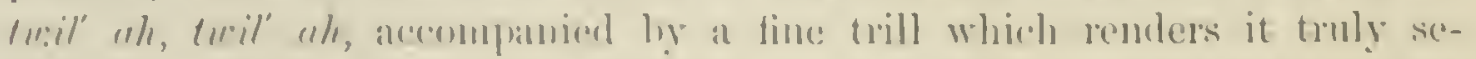
duretive." The last two noter alle sind to le mttered in a soft and suludued

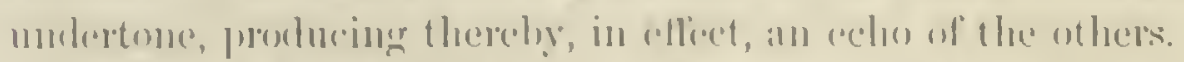

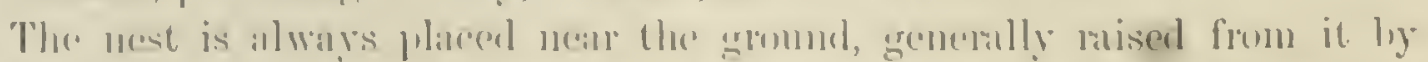

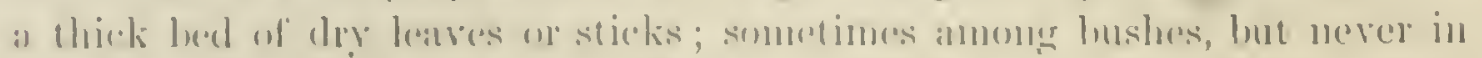
the forle of a hush or tren, or if so, in rery ratre and rexpeptional cases. 
When incubation has communced, the female is reluctant to leave her nest. If driven off she utters nu complaint, but remains eluse at hand and returns at the first opportunity.

They construct their nest early in May, and the roung are hatcherl in the latter part of that month, or the first of Jnne. They raise two lroods in the season. The nest, even more loosely put together than that of the (iroum Siwnp Robin (T. pullasi), is often with ditheulty kept complete. It is ahout 3 inches in height, th in diameter, with a carity 1 这 inches deep and z̈ in width, and composed of dry lark, deal leaves, stems, and woody fibres, intermingled with grasses, caricas, sedges, ete., and lined with solt skeleton leares. A nest from Wisconsin was composed entirely of a roarse species of sparyanem; the dead stalks and leares of which were interworen with a very striking effect.

The eggs, usually four, sometimes five in number, are of a mitoru green color, with a slight tinge of blue, and arerage .yt by .66 of an inch in dianeter.

Turdus aliciæ, Batrn.

\section{GRAY-CHEEKED THROSE; ALICE'S THRUSH}

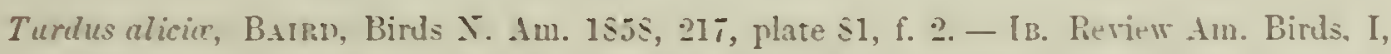
1ミot, 21. - Curke, Pr. Ac. N. Sc. Aug. 1\$61, 217 (Labralor). - 1в. Caral. Birds of

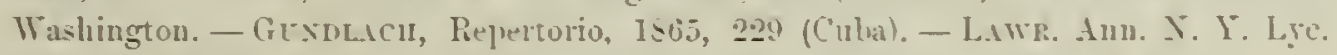
IX, 91 (Costa Riea). - Dall and Basister, Birds Alaska. - Rungwr, lieport.

Sr. Cinf. Above nearly pure dark olire-creen: sides of the head anthray; the ehin, throat, and unler parts white; purest behind. Siles of throat and acros the breast winh arrow-shaped spots of dark plumbenus-brown. Sides of hody and axillaries dull gratisholisaceous. Tibie plumbeous; legs brown. I.ength, nearly 8 inches: wing. 4.20: tail, 3.20: tarsus. 1.1.5.

HAB. Eastern North Ameriea to shores of Arctic Ocean, and along northern coast from Labrador to Kollak. breeling in immense numbers between the months of Mackenzie and Coppermine. West to Fort Yukon and Misouri Rirer States. Winters south to Costa Riea. Chiriqui, Saltra; Cuba, Gexdach.

As originally described, this species differs from surninoni in larger size, longer bill, feet, and wings especially, straghter and narrower bill. The back is of a greener olive. The breast and silles of the head are entirely destitute of the buff tinge, or at best this is very faintly indicated on the upper part of the breast. The most chancteristic features are seen on the side of the head. Here there is no indication whatever of the light line from nostril to eye, and scarcely any of a light ring round the eye, the whole region being grayish-olive, relievel slightly hr whitish shaftstrealis on the ear corerts. The sides of bour, axillars, and tibice are oliraceous-gray, without any of the fulrous tinge seen in suminoni. The bill measures . 40 from tip to nostril, sometimes more; tarsi, 1.21; 


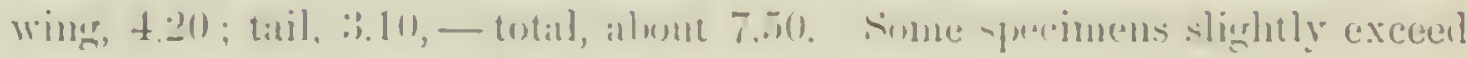
these dimensions; few, if any, litll slust of them.

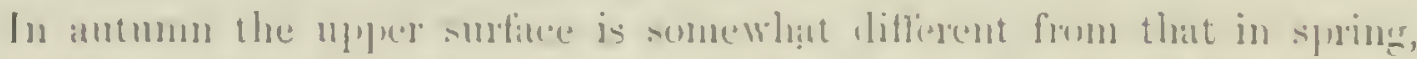

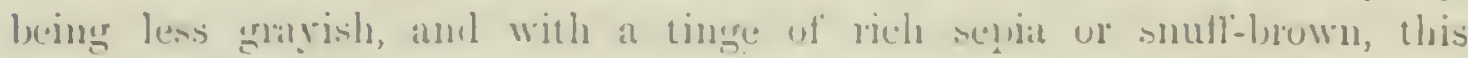
leceming gradually more ilplectalle on the tail.

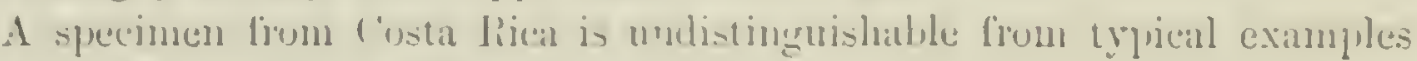
firm the ditstern Enited states.

Hants. This specos, tirst described in the ninth volume of the Pacitie

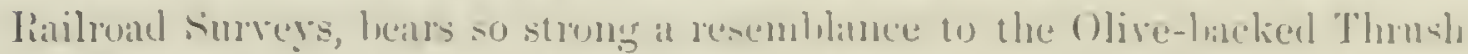

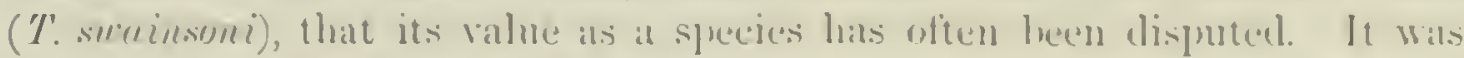
first net with in Illinois. Since then numerms specinens hate been ob-

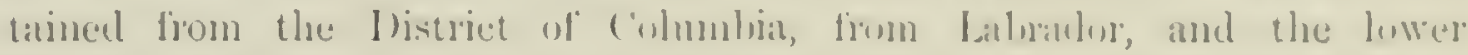

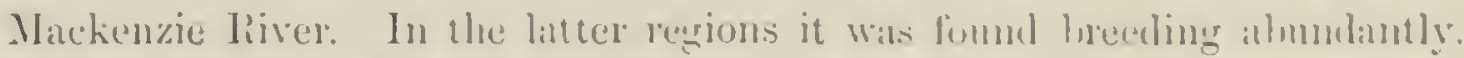
It was also foumd in latere mmber's on the Amlersun liver, hut was rare on the Jukon, as well as at Geat Slire latke, wecorring there only ats at

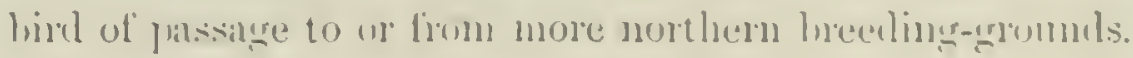

In regand to its general latbits lut little is known. 1)r. (onses, who

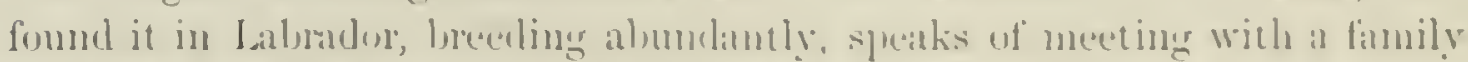
of these linds in a leep and thickly womed rasine. The gounger wore just

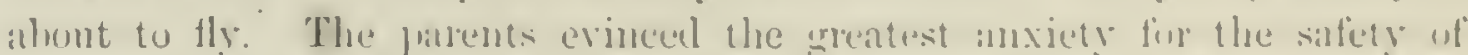

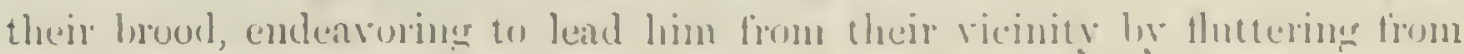
bush to bush, comstantly utcoring a melmeholy flungl, in low whistling tome. He mentims that all les saw utered furedsely the sime note, and

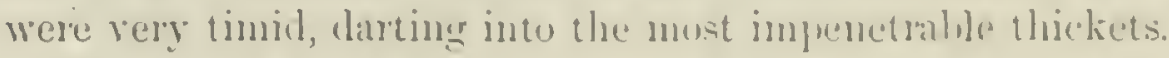

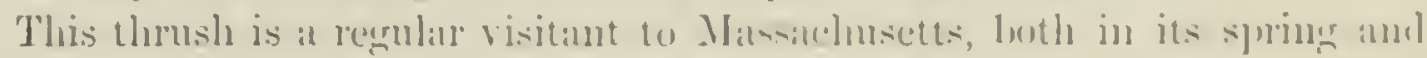
in its fall migration. It arrives lom abont the first (n the milllle of Maly.

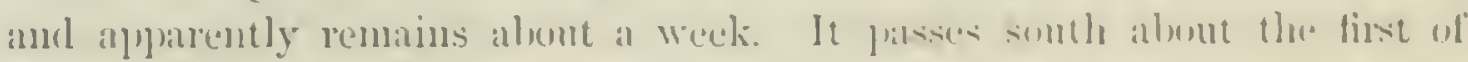

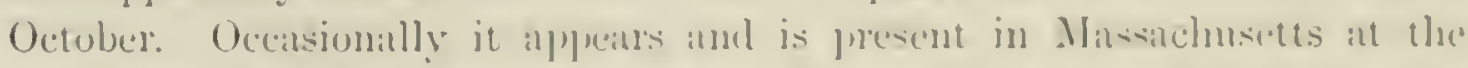

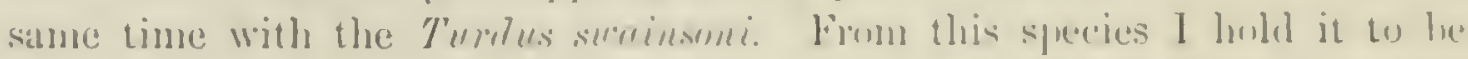

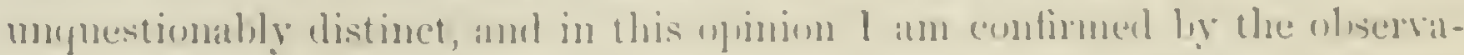

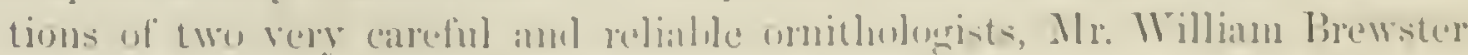

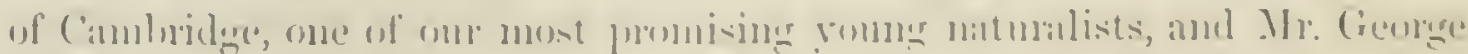

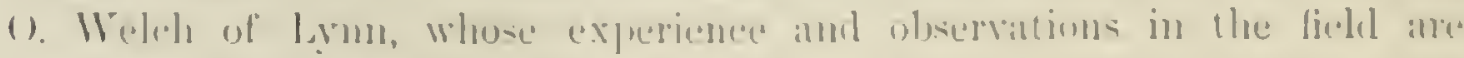

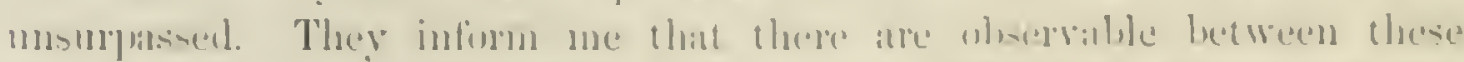

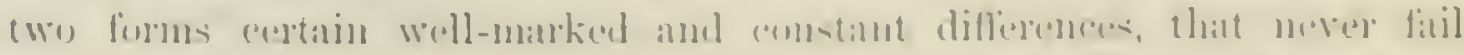

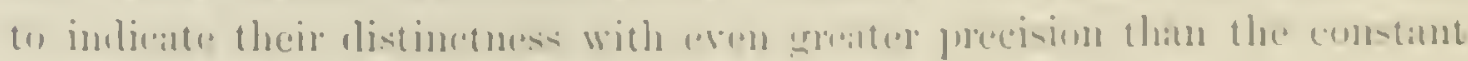

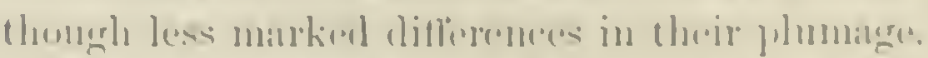

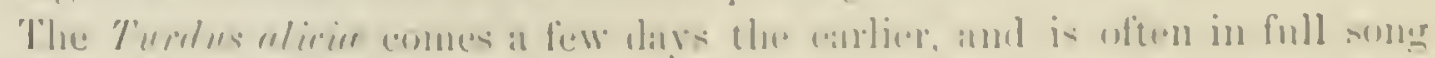

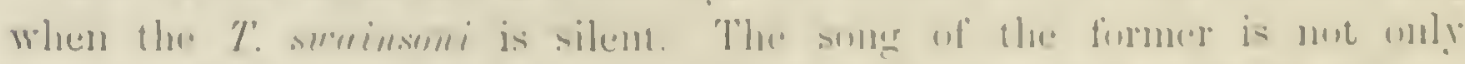
fotally ditherent from that of the lattere fut also from that of all wur

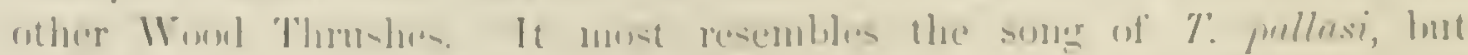

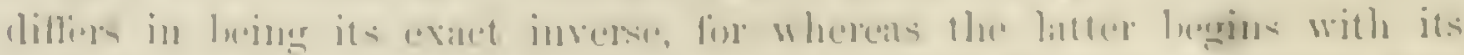

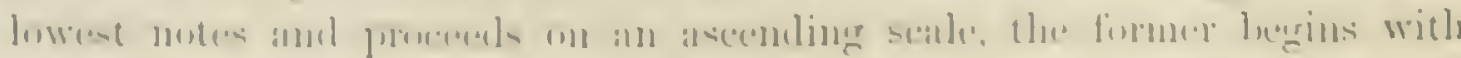

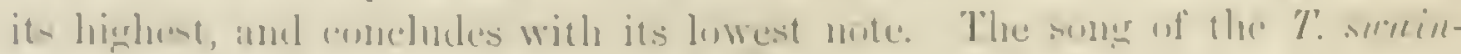


soni, on the other hand, exhibits much less rariation in the scale, all the notes being of nearly the same altitule.

I am also informed that while the T. surinsoni is far from being a timid species, but may be easily approached, and while it seems almost invariahly to prefer the edges of the pine woods, and is rarely observed in open gronuds or among the bare deciduous trees, the habits of the T. alicice are the exact reverse in these respects. It is not to be fonnd in similar situations, but almost alwalys frequents copses of hard wood, searehing for its food among their fallen leares. It is extremely timid and difficult to approach. As it stands or as it moves upon the ground, it has a peculiar erectness of benring which at once inclicates its true specifie character so unmistakably that any one once familiar with its appearance can never mistake it for T. succivisoni nor for any other bird.

The nests measure about $t$ inches in cliameter and $2 \frac{3}{4}$ in leeight. The earity is 2 inches deep, and its dianeter $2 \frac{1}{2}$ inches. They are unusually compact for the nest of a thrush, and are eomposed chiefly of an elaborate interwearing of fine sedges, leares, stems of the more delicate Équisetucce, if dry grasses, strips of fine bark, and decayed leares, the whole intermingled $\xi$ with the panienlated inflorescence of grasses. There is little or no lining other than these materials. These nests were all found, with but few exceptions, on the branches of low trees, from two to seven feet from the gromnd. In a few exceptional eases the nests were built on the $f$ gromil.

\& Occusionally nests of this species are found constructed with the base $M$ and sides of solid mul, as with the common Robin (Turdus migratorius).

$M$ In these, as also in some other cases, their nests are usually found on or near the gronnel. So far as I am aware neither its oceasional position on the ground, nor its mud franes, are peculiarities ever noticeable in nests of T. sucuinsoni.

- The egrys were nsually four in number. Their color is either a deep

$>$ green tint, or green sliglitly tinged with blue; and they are marked with spots of russet and yellowish-brown, varying both in size and frequeney.

6 Their mean length is 92 of an inch, and their mean brealth .64 . The

- maximum length is .94 and the minimum 88 of an inel. There is

(1) apparently a constant variation from the eggs of the I'. succinsoni; those of the alicice having a more distinetly blue ground color. The nests are also quite different in their appearance and style of structure. The Hy/mum $\infty$ mosses, so mirked a feature in the nests of T. suminsoni, as also in those of or T. ustulatus, are wholly wanting in those of T. alicia.

This bird and the robin are the only speeies of our thrushes that cross In the Aretie Circle to any distance, or renel the shore of the Arctic Ocean. It occurs from Labrador, all round the American coast, to the Alentian $\sigma^{b}$ Islands, everywhere bearing its specific character as indicated above. It is extremely abundant on and near the Aretic coast, letween the mouth of 
the Mackenzie River and the ('oplermine, more than 200 specinens (mostly with their eggs) having heen sent thence to the sinithsmbian Institution hy Mr. Mactinlane. In all this number there was mut a single bird that had any approach to the chanacters of $T$. sucuinsoni, as just given. From the slave Lake region, on the other hand, T'. suminsoni. was received in nearly the same abmulance, and mumixed dhring the lireeding season with 7 ? uliciu.

\section{Turdus swainsoni, ('AßNIS.}

\section{OLIVE-BACKED THRUSH; SWAINSON'S THRUSH.}

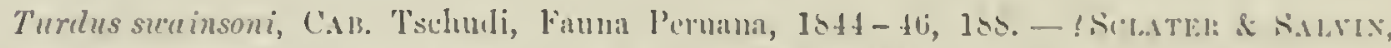

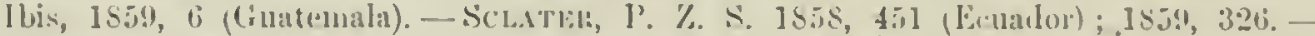

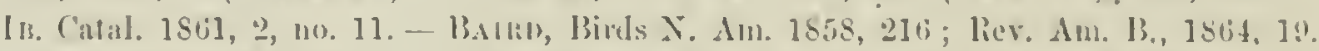

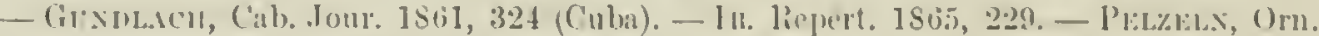

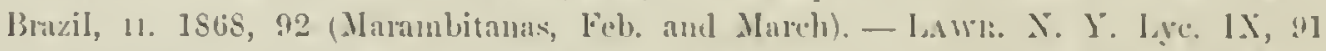

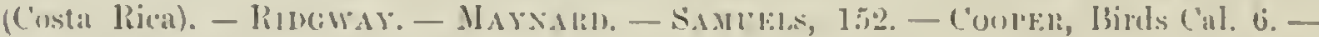

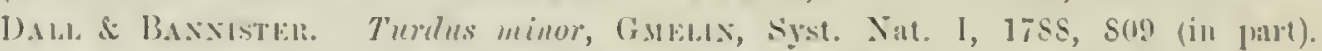

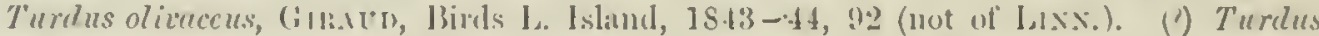

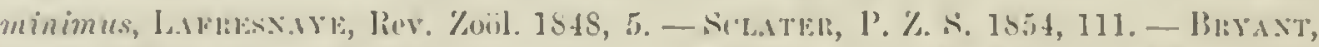

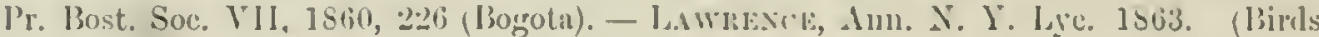
P:uama, IV, no. 3S.1.)

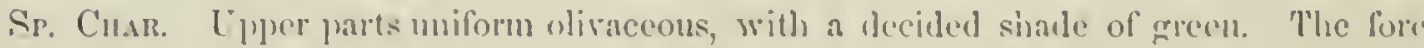
part of heast. the throat and chin, pale hrownish-ycllow; rest of lower parts white: the sides washed with bownish-olive. Silles of the throat and fore part of the luenst

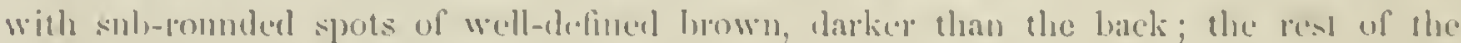

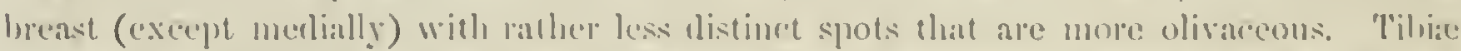
yollowish-lnown. Broad ring rommd the rye, lobal regrion, and a general tinge on the

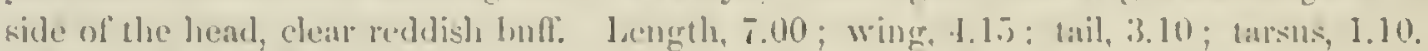

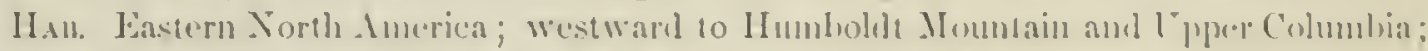

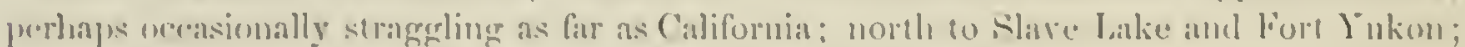

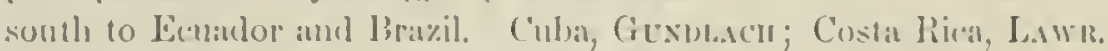

Specimens examined from the morthem regrons (Great Slave Lake, Matekenzie liver, and lukon) lo (inatemala; from Atlantic states to bist Jumbolit Momntans, Nevarla, am from interrening localities. The extremes of ratration are the bromenish-olive of eastern and the chan der\%

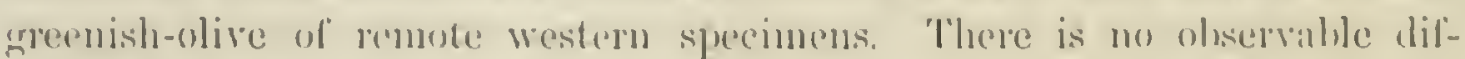

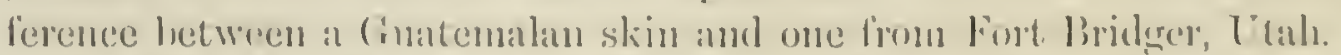

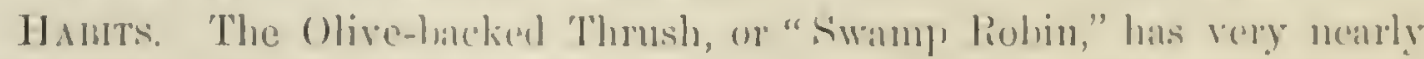

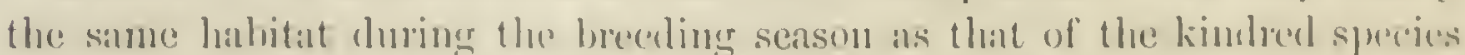

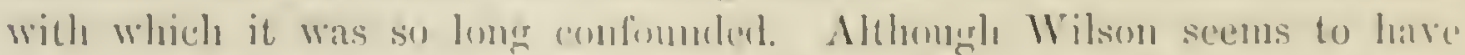

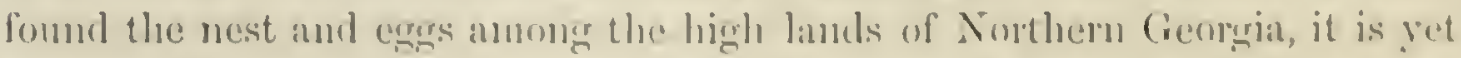

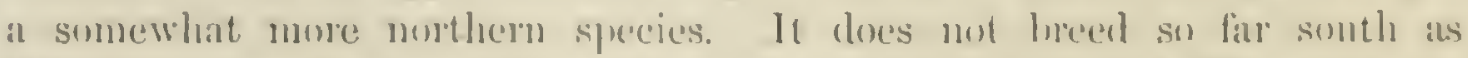
Massachusetts, or if so, the calses must he exeeptionil and rery rare, mol even in Western Mane, Where the "(imond swanp) liobin" (T'. pullesi) is

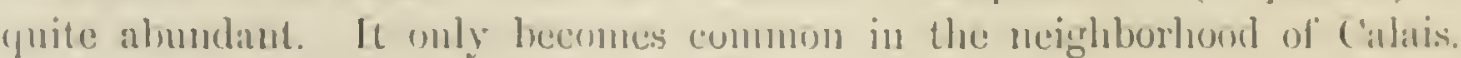


It is, horrever, most wilely distributed orer nearly the entire continent, breeding from latitude $t t^{\circ}$ to high Arctic regions. It winters in Ginatemala and southward as far as Ecuador and Brazil.

In its habits this thrush is noticeably different from the T. pallasi, being much more arboreal, frequenting thick woods; rirely seen, except during its migrations, in open ground, and seeking its fool more among the branches of the trees.

Mr. Ridgway found this species very abundant among the Wahsatch Ifountains, where it was one of the most characteristic summer birds of that region. It was breeding plentifully in the cañons, where its song could be heard almost continually. It inhabited an intermediate position between $T$. unduboni and $T$. fuscescens, delighting most in the shrubbery along the streams of the cañons and passes, learing to the T. auduboni the sechuded ravines of the pine regions higher up, and to the T. fuscescens the willow thickets of the river vallers. He did not meet with it farther west than the East Humbollt Mountains. The song, in his opinion, resembles that of the Wood Thrnsh (T. mustelinus) in modulations; but the notes want the power, while they possess a finer and more silvery tone.

The song of this species has a certain resemblance to that of $T$. pallasi, being ret quite distinct, and the differences readily recognized by a familiar ear. It is more prolonged; the notes are more equal and rise with more regularity and more gradually, are richer, and each note is more complete in itself. Its song of lamentation when robbect of its young is full of indescribable pathos and beauty, haunting one who has once heard it long after.

When driven from the nest, the female alwars flies to a short distance and conceals lherself; making no complaints, and offering no resistance.

These birds, in a single instance, have been known to reach Eastern Massachusetts early in April, in an musually early season, but they generally pass north a few weeks later. They make no prolonged stay, and are with us rarely more than three or four days. Their return in the fall appens to be, at times, by a more inland ronte. They are then not so numerons near the coast, but occasionally are abundant.

Their nests in Nora Scotia, wherever observed, were among the thick roods, on horizontal branches of a forest-tree, usually about five feet from the ground. Those observed in the Arctic regions by MIr. Kennicott were frequently not more than two feet from the ground.

The nests arerage about four inches in diameter and two in height, the cavity being three inches wide br about one and a half deep. They are more elaborately and neatly coustructed than those of any other of our thrushes, except perhaps of T. ustulatus. Conspicuous among the materials are the Hypnum mosses, which by their dark fibrous masses give a very distinctive character to these nests, and distinguish them from all except those of the T. ustulatus, which they resemble. Besides these materials are found fine sedges, leares, stems of equisetaceous plants, red glossy regetable 
filmes, the flowering stems of the Cludonirn monses, lirhens, fine strips of larki, ete.

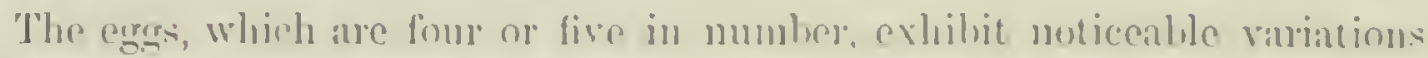

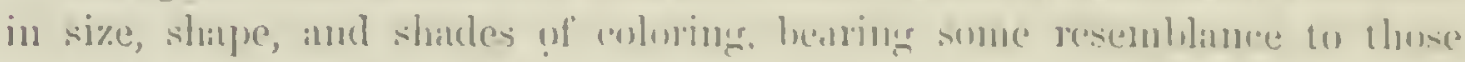

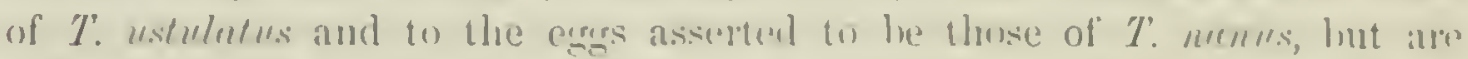
sufliciently distinet, and are still more so from those of $T$. alicir. Thes.

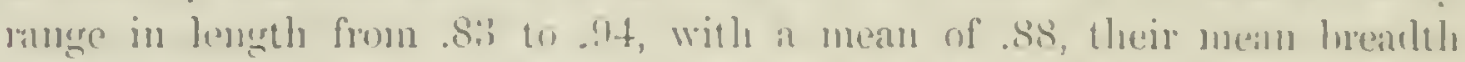

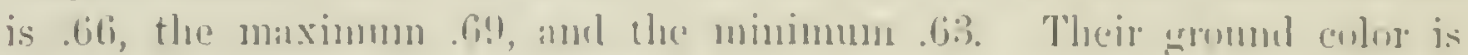
usnilly bluisht-grten, sometimes light blue with harlly a timge of erren,

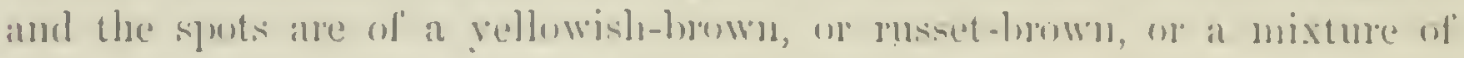
both colors, more or less contluent, wilh marked vartitions in this respect.

Turdus swainsoni, var. ustulatus, N'TT.1L..

\section{OREGON THROSH}

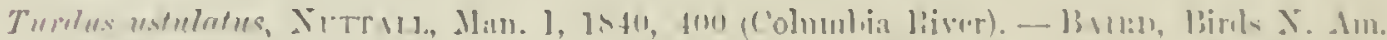

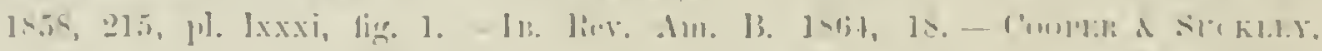

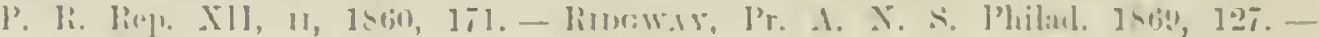

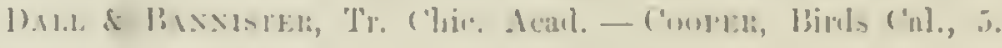

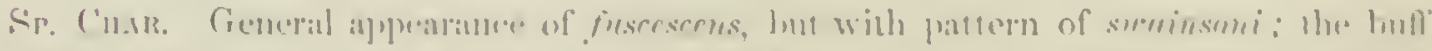

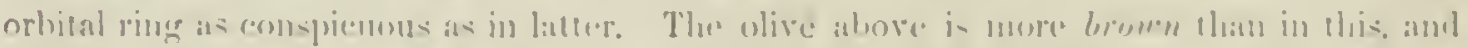

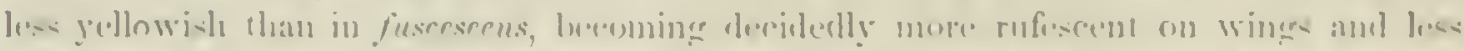

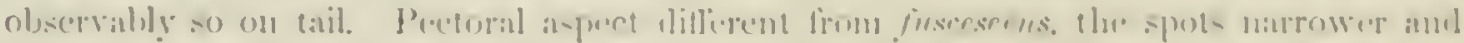

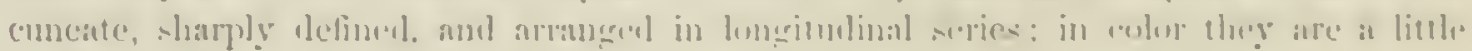

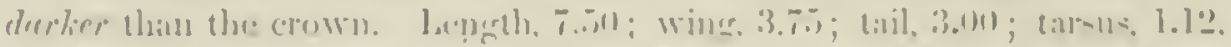

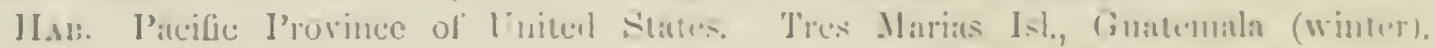
II Is. s. I.

This well-marked race is to les compared with sminsont, not with

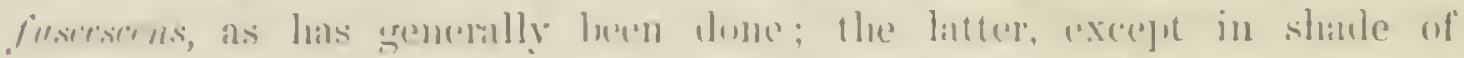

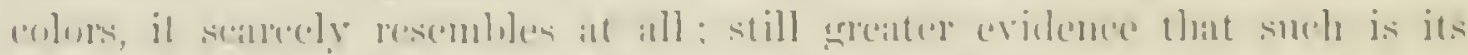

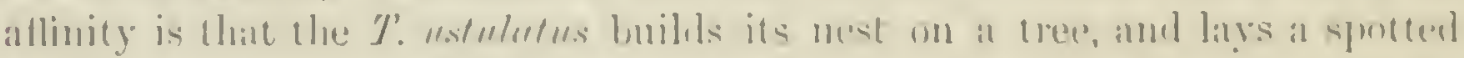

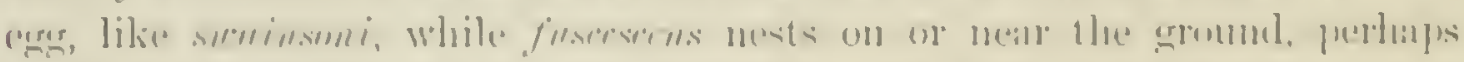

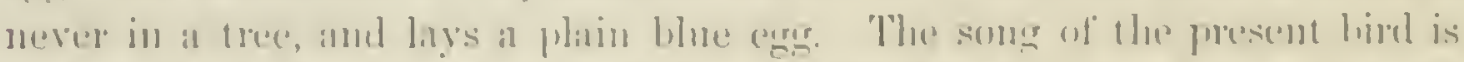

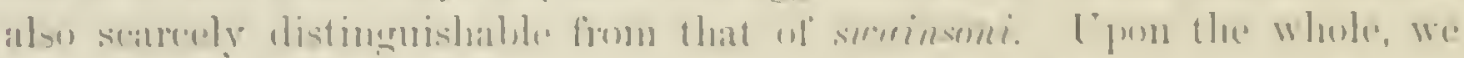

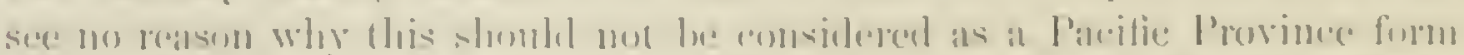

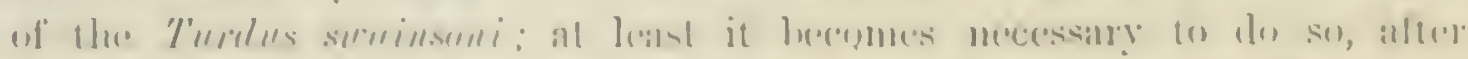

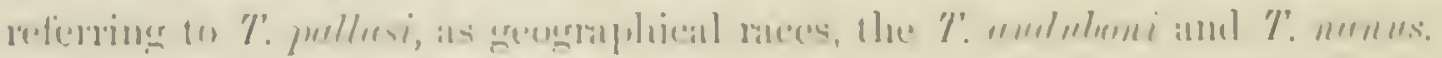

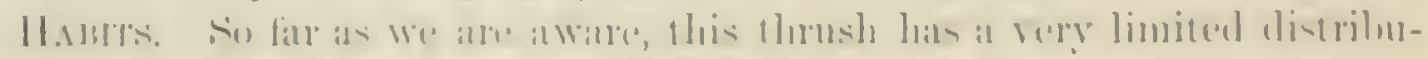

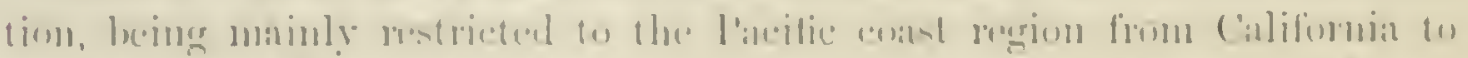

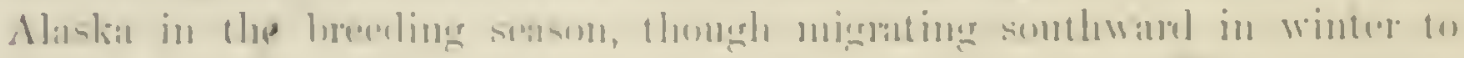

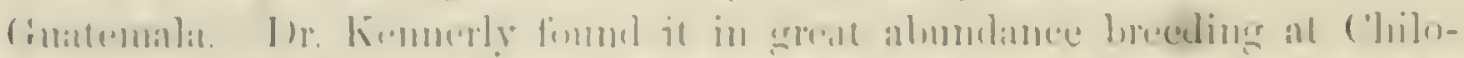

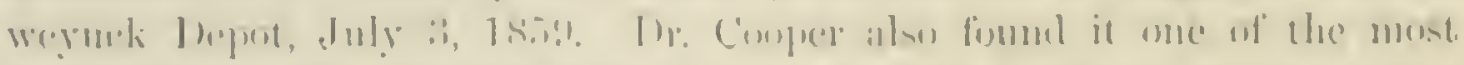
alumblant of the summer residents in Wishington Territory, artiving there 
in May and remaining until the beginning of Septemher. Three specimens of this thrush were obtained at sitki, by Mr. Bischofl. Mr. Rilgway met with only a single specimen east of the Sierra Nevada, though on that range he found it an abundant summer bird.

In its general appearance it has a marked resemblance to Wilson's Thrush (T. fuscescens), but its habits and notes, as well as its nest and eggrs, clearly point its nearer affinity to Swainson's Thrush (T. suminsoni), its song being scarcely different from that of the latter species. Like this species, it frequents the thickets or. brushwood along the momntain streams, and, except just after its arrival, it is not at all shy. In crossing the Sierra Nerada in July, 1S67, Mrr. Ridgway first met with this species. He descrilues it as an crquisite songster. At one of the camps, at an altitude of about 5,000 feet, ther were found unusually plentiful. He speaks of their song as consisting of "ethereal warblings, - outbursts of wild melody." "Although its carols were heard everywhere in the depth of the ravine, scarcely one of the little musicians could be seen." "The song of this thrush," he adds, "though possessing all the wild, solemm melody of that of the Trood Thrush ( $T$. mustcimus) is weaker, but of a much finer or more silrery tone, and more methodical delivery. It is much like that of the $T$. sucuinsoni, but in the qualities mentioned is even superior."

Dr Cooper found its nests with egos ahout the mildle of June. These were most usually built on a small hnrizontal branch, and were rery strongly constructed of twigs, grusses, roots, and leares, usmally corered on the outside entirely with the bright green Hypmum mosses peculiar to that region, which in the damp clinate near the coast continue to grow in that position, and form large masses. The number of egrgs is usually five.

Dr. Cooper states that these thrushes sing most in the early moming and in the evening, when numbers may be heard answering one another on all sides. They do not affect the darkest thickets so much as the Hermit Thush, but are often seen feeding in the gardens in the open sunshine.

Dr. Suckley, who found them quite abundant in the neighborhood of Fort Steilacoom, on the edge of the forest, and in swampy land, describes the song as a low, soft, sad, and lively whistle, confined to one note, and repeated at regular intervals. Mr. Nuttall, the first to describe this form, speaks of it as shy and retiring, and as in the habit of gathering insects from the ground. His ear, so quick to appreciate the characteristics of the songs of birds, which showed a close resemblance between the notes of this bird and that of Wilson's Thrush ( $T$. fuscescens), enabled him to detect rery distinct and easily recognizable differences. It is much more interrupted and is not so prolonged. The warble of this bird he describes as resembling wit-rit t'villia, and wit-uit, t'villia-t'villia. His call when surprised was wit-wit.

All the nests of this species that hạve fallen under ny observation are large, compact, strongly constructed, and neat. They measure about is inches in their external diameter, with a depth externally of 3 ; the carity 
is immamtively shallow, heing burely :2 inches in depth. The external portions are constructed almost entirely of $H_{y p}$ mum muses, matted tofether and sparingly interwoven with dry leaves and fine fibrous roots, and are lined with finer materials of the same kind. These nests most wearly resemble in their matterial and in their prostion those of swainson's Thrush.

Mr. Hephurn fouml these lind very ahumlant alusut Victoria. It dues unt nsully hreed there before the lite of May, thongh in une exeeptional instance he found a nest with young hirits on the 2 th of that month.

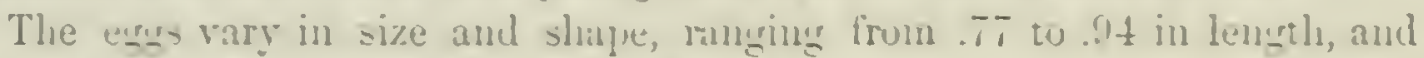
from . 6.5 to $.194 \mathrm{in}$ loreatth. They also vary in their ground color and in the tints of the s[ots and markings. The eround colur is light gereen or light Whe, and the markings are varjunsly velluwish-brown and lilac, or dark bruwn ind slate.

Mr. Ginvarn fund this thrush very abundant in the month of Jamuary; in the thickest of the whels, in the islinds of the Three Marias, on the Parific const of Mexico. They were very timil and shy, more sio than any hind that he saw on those islank. It freyuently uttered a low plaintive whistle, and seemed solitary in its habits.

\section{Turdus pallasi, Cabaris.}

\section{RUFOUS-TAILED THROSH; HERMIT THROSH.}

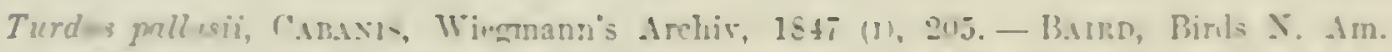

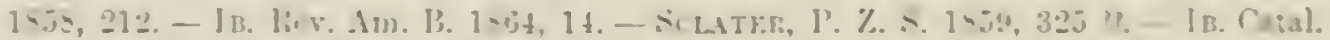

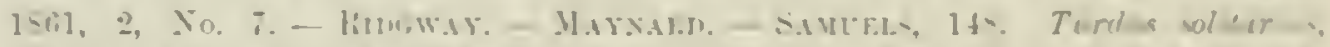

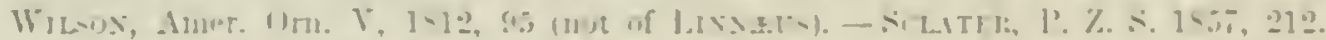

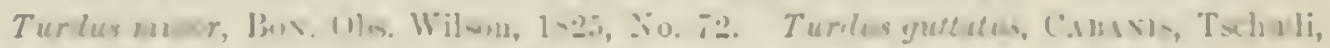

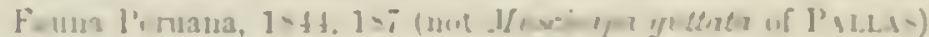

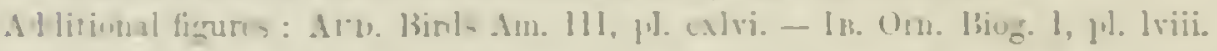

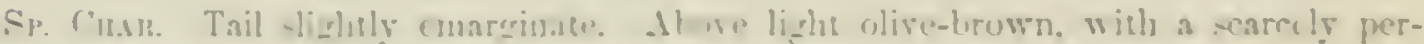

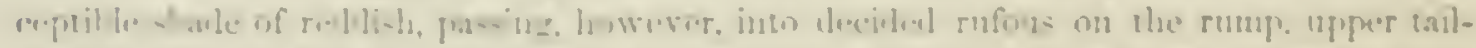

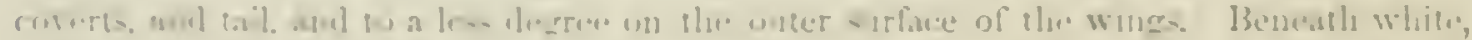

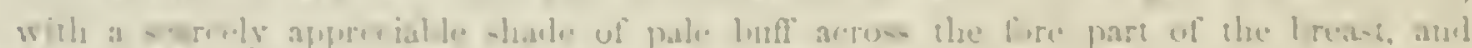

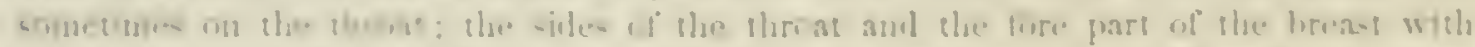

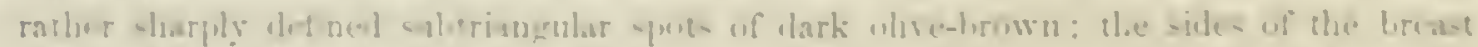

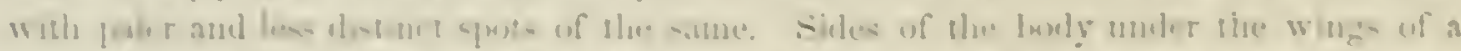

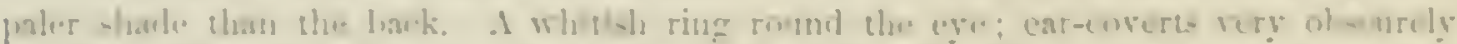

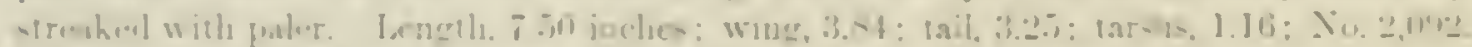

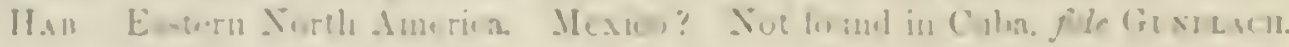

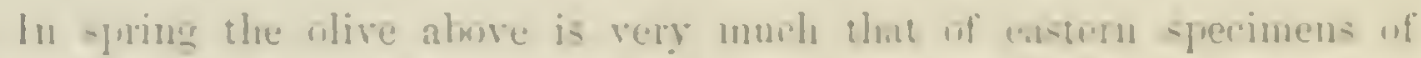

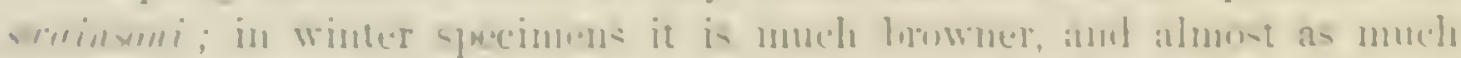

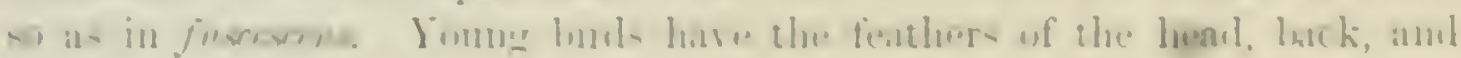

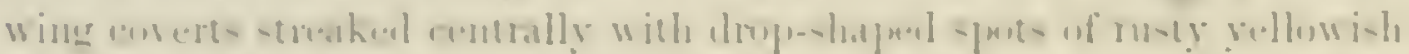

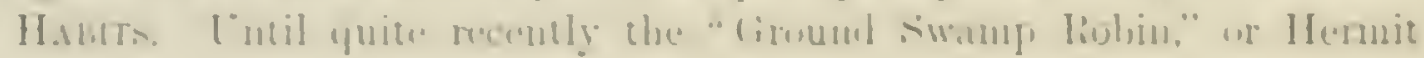


Thrush, has not been distinguished from the elosely allied species $T$. swuinsoni, and all accounts of writer's lave blended both in singular confusion. My colleagne, I'rofessor Baird, in the summer of $184 t$, was the first to smygest the distinctness of the two species. By the common people of Maine and the British l'rovinces this difference has long been generally recognized, this species being lnown as the "Gromnd swamp Robin," and the other as the "Swamp Robin."

The present species is found throughont Eastem North America to the Mississippi, and breeds from Massachusetts to higl aretic regions. It is only occasionally found breeling so far sonth as Massachusetts; through which State it passes in its spring migrations, sometimes als early as the 1uth of April ; usually reaching Calais, Mitine, by the 15th of the sime month.

It is a very almudant bird throughont Maine, where it begins to breed during the last week of May, and where it also probably has two broods in a seasoll.

The greater number appear to pass the winter in the Southern States; it being common in Florida, and even occasionally seen during that season as fur north as latitnde $38^{\circ}$ in Sonthern Illinois, according to Mr. Ridgway.

It rarely, if ever, sings during its migrations; appears in small straggling companies, frequents both thickets and open fields, and is unsuspieions and easily approached.

The song of this species is very fine, having many of the chancteristics of that of the Wood Thrush (T'. mustelinus). It is as sweet, lias the same tinkling somnds, as of a bell, but is neither so powerful nor so prolonged, and rises more rapilly in its intonations. It begins with low, sweet notes, and ends abruptly with its highest, shamp ringing notes.

Talien from the nest they are easily tamed, and are quite lively and playful; but their want of cleanliness renders them very unlesirable pets. When their nest is visited they make no complaints, but retire to a distance. Not so, however, when their matural eneny, the liawk, appears; these they at once assail and seek to drive away, uttering lond and clear chirps, and peculiar twittering somm.s.

The nest of this thrush is always built on the gromnd, most generally either mnder low bushes or in the open gromd, rarely, if ever, among thick trees, and for the most part in low swampy places. Both nest and eggs closely resemble those of Trilson's Thu'ush (T. fuscescens). In Parsboro, Nora Scotia, I found one of the nests built in the very midst of the village, close to a dwelling, though on a spot so marshy as to be almost unapproachable. The nests are 3 inches in height and 5 in dianeter, with a cavity $3 \frac{1}{4}$ inches wide by $1 \frac{3}{4}$ deep. They are composed of decayed deciduous leaves, remmants of dried plants, sedges and grasses, intermingled with twigs, and lined with finer grasses, sedges, and strips of bark.

The eggs are of a miform bluish-green color, and range in leugth from .88 to .94 , with an arerage of .63 of an inch. 


\section{Turdus pallasi, var. nanus, Atrisus. DWARF HERMIT THRUSH.}

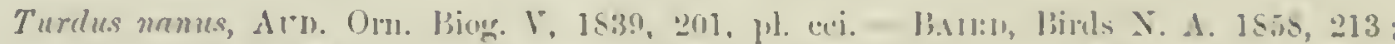

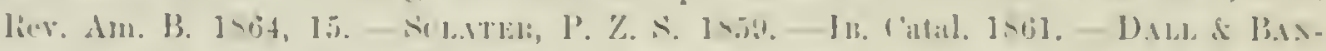

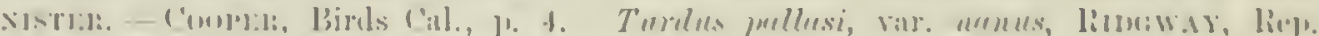

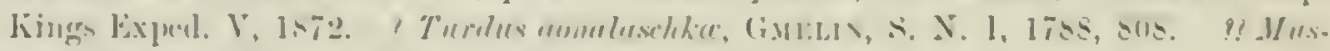

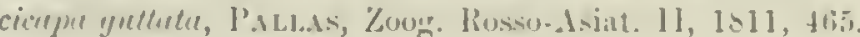

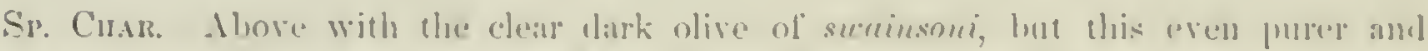

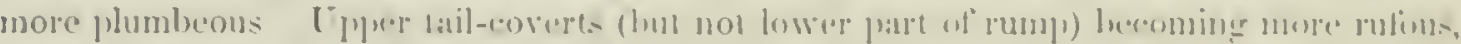

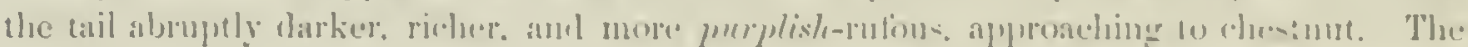

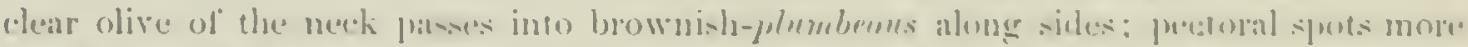

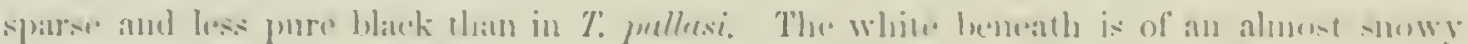

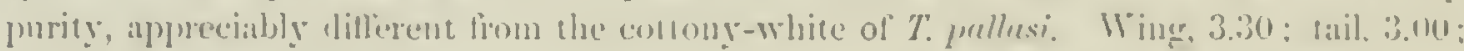
bill, .36; ; 1.กเ:1s. 1.07.

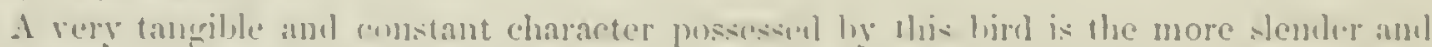

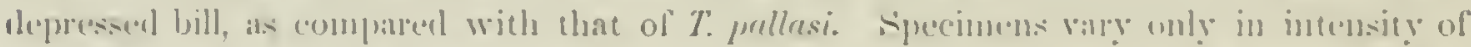

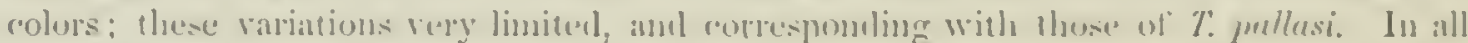

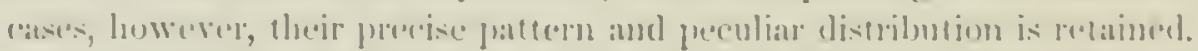

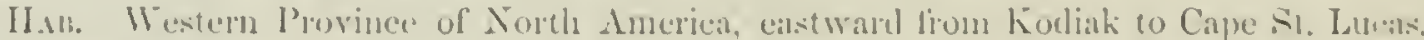
Arizona, cortis.

Habits. This small race of the Hermit Thumsh was first noticed hy ly: Pickering, and deserilned by Mr. Andubon from an imperfect skin. It

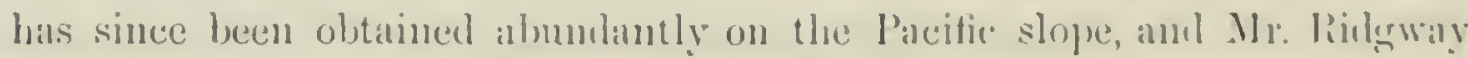

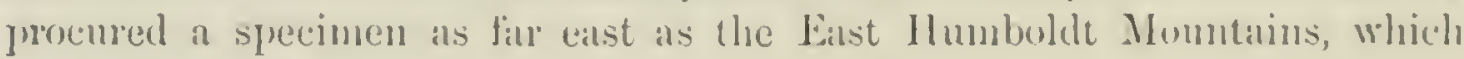
Je considers its citstern limit.

In its labits it is said to be, like T. pullusi, almost exclusively terrestrial.

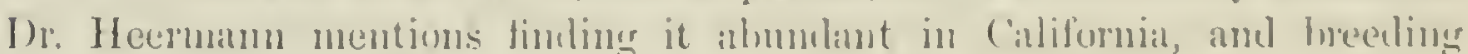

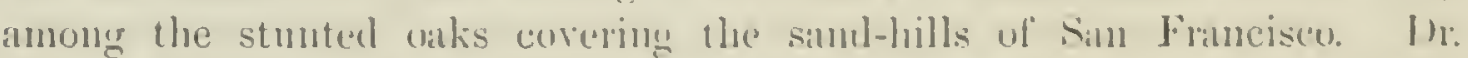

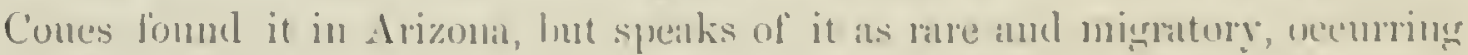
chiclly in spring and antumn, and as a shy and retiring species. 17r. Conper,

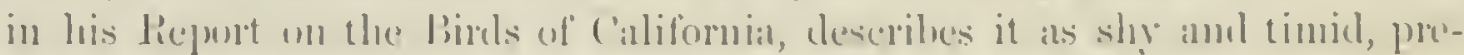
ferring dark and shouly thickets, feeding chielly on the gromul, ruming

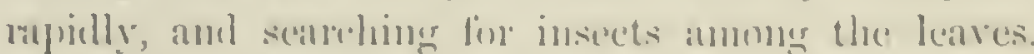

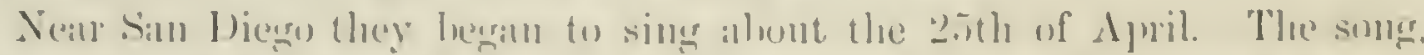

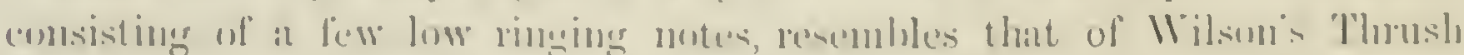

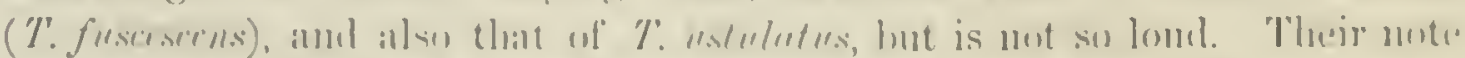

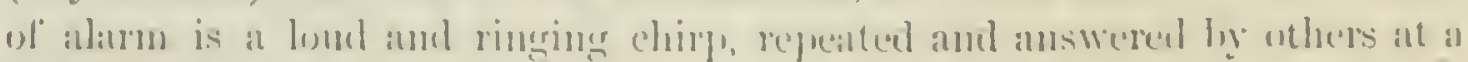
long distinnce.

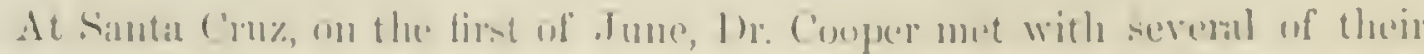

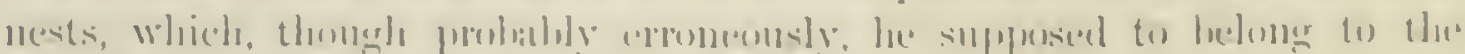
Dwart Hermit Thrush. They were all built in thickets moter the shande

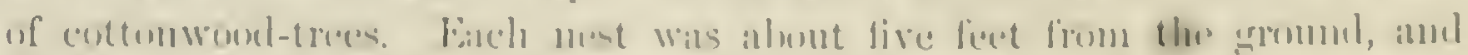

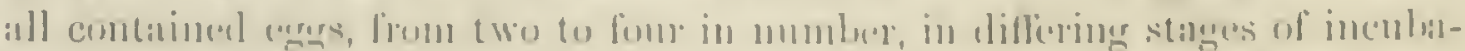

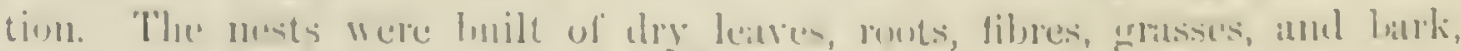


withont any mud, and were lined with deeayed deaves. Their height and ex: termal dianeter measured 4 inches. The diameter of the carity was $2 \frac{1}{2}$ inches and the depth $2 \frac{1}{4}$. The eggos measured $.90 \mathrm{by} .70$ of an inch. They are of a pale bluish-green, speckled with cinnamon-brown, cliefly at the larger end.

The nest, supposed to be of this species, supplied by Dr. Cooper, is large for the bird; constructed of a base loosely made up of mosses, lichens, and coarse filures of plants. It is a strong and compact strueture of matted leares, put together when in a moist and decalying condition; with these there are interwoven roots, twigs, and strong fibres, surrounding the nest with a stout band and strengthening the rim. In fact, it corresponds so well - as do the erges also - with those of T. ustulatus, that it is extremely probable that they really belong to that species. The only observalue difference is the absence of the Hilymum mosses characteristie of northern ustulutus.

Dall and Bannister mention in their list of Alaska birds that the species is not common there. It was also taken at Sitka and Kodiak by Biselioff.

The fact that this thrush builds its nest above the gromud, and lays spotted eggs, if rerified, would at once warrant our giving it independent rank as a species, instead of considering it as a loeal race of pallasi.

\section{Turdus pallasi, var. auduboni, Batrd.} ROCKY MOUNTAIN HERMIT THROSH.

Turdus auduboni, B.ın, Rev. Am. Birds, 1564, 16.-Ringwar, P. A. N. S. 1569, 129.Eldiot, Illust. (fig.). Merulu silens, Swaxsox, Philos. Mag. I, 1\$27, 369 (not Turdus silens of Vieılot, EncyeI. Métl. II, 1S23, 647, based on T. mustelinus, W1Ls. $=T$,

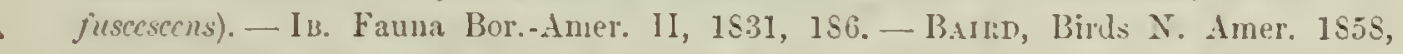
213, and 922. - ScldTEK, I'. Z. \$. 1S5S, 325 (La Parala), and 1859, 325 (Oaxaca). IB. Catal. Am. Birds, 1S61, 2, no. 9.

Sp. Cuır. Colors much as in Turdus nanus, but the upper tail-coverts scarcely different from the back. Tail yellowislı-rufous. Length of wingr, 4.1S; tail, 3.60 ; bill from nostril, .45 : tarsus. 1.26 .

HaB. Rocky Mountains, from Fort Bridger south into Mexico. Orizaba (Alpine regions), Simichrast.

This is a very distinct race of thrushes, although it may be questioned whether it be truly a species. It is, howerer, sufficiently distinct from the eastem and western Hermit Thrushes to warrant our giving it a place of some kind in the systems.

The young plumage differs from that of pallasi as do the adults of the two, and in about the same way. The olive is very much purer, with a greenish instead of a brownish cast, and the tail is rery much lighter, inclining to dull ochraceous instead of rufous; this rellowish instead of rufous cast is apparent on the wings also. The yellowish "drops" on head, back, etc., are very much narrower than in pallasi, while the greater coverts, instead of being distinctly tipped with yellowish, merely just perceptibly facle in color at tips. 
H.nits. At puesent we have hut little knowlenlge of the habits of this form

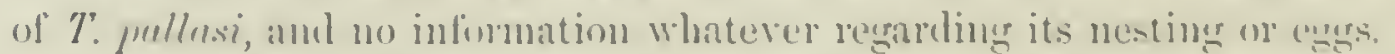

In its distribution it is contined we the central landere of momutains from Fort liridger to sunthern Mexico. This species, there known ats "Solitario," is common in the Alpine rexion of Vera ('ruz (as well as in all the cherated regions of (entral Mexien), frephenting the pine wools in the distriet of

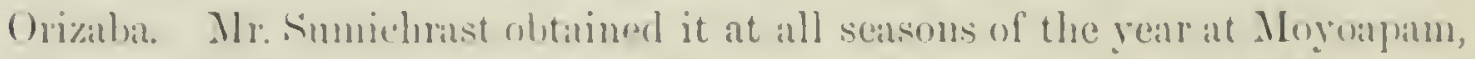
in that vicinity; a locality the height of which apploximates 2, not metres. It is also fomel at a height of 1,200 metres, near the city of Orizaba.

Mr. Rickway calls this hirel the "Rocky Mountin Hermit Thrush." IIe states that he found it common in the Wilssitch Mommains, but that, on accomnt of its retiring habits, it was seldom seen. It there lives whetly in the deep ravines in the pine renion, exhihiting an attachment to these solitudes rather than to the thickets along the wittercourses lower down; the latter it leaves to the T. smansoni. Owing to the reserved mammers of this hime as well as to the great difliculy of reaching its aborle, there were few opportunities presented for learning much concerning its habits, nor did he hear its song. In its flight the pale ochraceous bind across the hases of its quills was a very conspicums feature in the appeaname of its species, leading Mr. Iidgrway to mistake it at first for the Mymelestes formsinulii, - also an inlabitant of the same localities, - so much dict it look like that bird, which it further resembled in its moiseless, glicling flight.

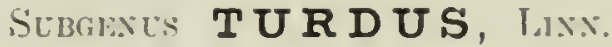

Of T'urelus, in its most restricted sense, we have no purely American

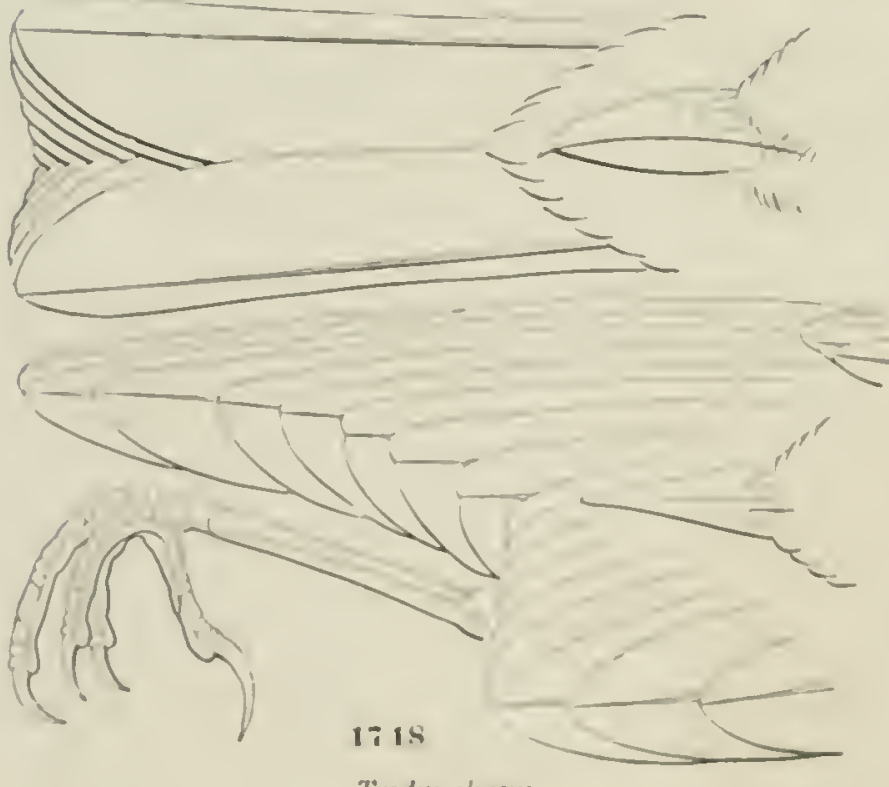

Turdess ilueves. representatives, although it helomgs to the fimma of the New World in consenuence of one sprecies acemring in Cirenlamb, that meeting-erroment of the limets of America and linope; which, howerer, we incluste in the present work, ats related much more closely to the fommer.

This (ireuland speries,

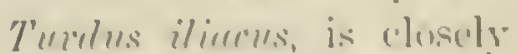
relaterl to T', risciomes, the type of the andus, and comes much closer to the

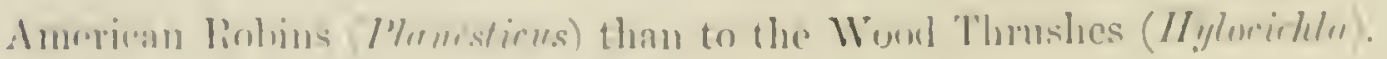


Turdus iliacus, Lrs:

\section{REDWING THRUSH.}

Turdus ilincus, Lrxx. Srst. Nat. 10th el. 17.s, lós, and of European authors. - Rerx.

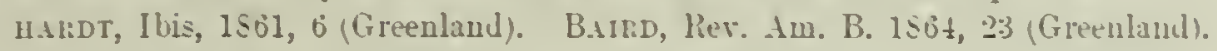

Sp. Canto. This species is smaller than our Robin ( $T$. migretorins), but of a similar grayish-olive abore, including the heal. The under parts are white: the fuathers of the lower throat and breast streaked with brown. The silles. axillars, and inner wing-covert are reddisl-cimamon. A conspicuous white strak orer the eye and extending as far back as the nape. Bill black. rellow at base of lower jaw. Legz pale-colored. Second quill longer than fift. Length. about \$.2.; wing, 4.64; tail, 3.45; bill, from gape, 1.0T: from nostril. .t4; tarsus. 1.16: middle toe and claw. 1.1.j. specimen deseribed: 18, 18 , d. a British specimen received from the Royal Artillery Institution, Troolwich.

Hab. Greenland, in the Iew Trorld.

The occurrence of this well-known European species in Greenland brings it within the linits of the American Faun. Two Greenland specinens are recorded by Dr. Reinhardt: one of them shot at Frederichshaab, October 20 , 184.5 .

Hibits. The Redwing can probably only claim a place in the fauna of North America as an occasional visitant. Of the tro specimens observed in Creenland, one was shot late in October. It is not known to breed there.

This species, during its breeding season, is found only in the more northern portions of Eumpe; only occasionally, and rery rarely; breeding so far south as England It makes its appeanance in that kinglom on its sonthern migrations, coming in linge flocks from Northern and Northenstern Europe, and arriving usually before the end of Octoher. During their stay in England they frequent parks and pleasure-grounds that are ornamented with clumps of trees. During mild and open weather they seek their subsistence in pasture lands and moist meadows, feeding principally on worms and suails. In severe winters, when the ground is closed by frost or covered by snow, the liedwings are among the first birds to suffer, and ofteu perish in large numbers.

During the winter they extend their mignations to the more southern portions of Europe, to Sicily. Malta, and even to Smyrna. In early spring they retum to the more central portions of the continent, and leave in May for their more northeru places of resort.

They nest in trees in the moist woods of Sorray and Sweden. Their nests resemble those of the common Fieldfare, $T$. pilaris. The outside is composed of sticks, weeds, and coarse grass, gathered wet, and matted with a small quantity of moist clay. They are lined with a thick bed of fue grass.

The Redwing is said to possess a delightful note, and is called the Nightingale of Norway. Linnæus, speaking of this bird, claims that its high and raried notes rival eren those of that far-famed rocalist.

During the summer the Redwing advances to the extreme north, visiting 
the Faroe Islands, Iceland, and Northern liusia. The :eneml character

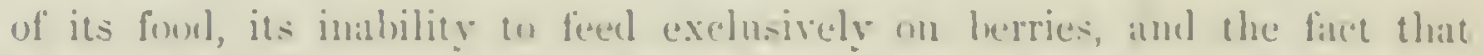
it perishes from starvation in severe winters, would secm (o) prove that its

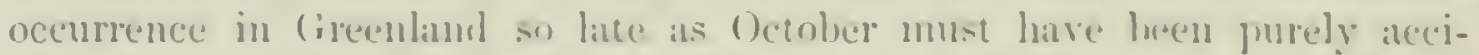
dental. It is not probalile that its presence in Sorth America will be found to be a coumusu event.

The enges measure 1.116 inches in length by .S1 in breadth. The ground colur is a light green with a bluish tinge thickly covered with russet or realdish-lirown sprits, confluent at the larerer end.

\section{SUmGars P I A N ESTCUS, Boxir.}

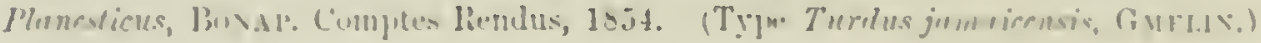

This section of the Thrushes is well representen in Ameriea, especially in

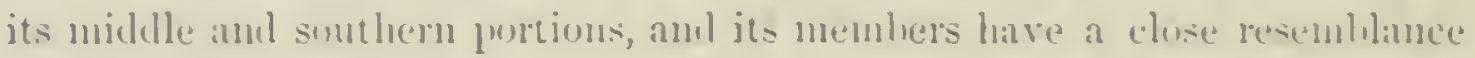

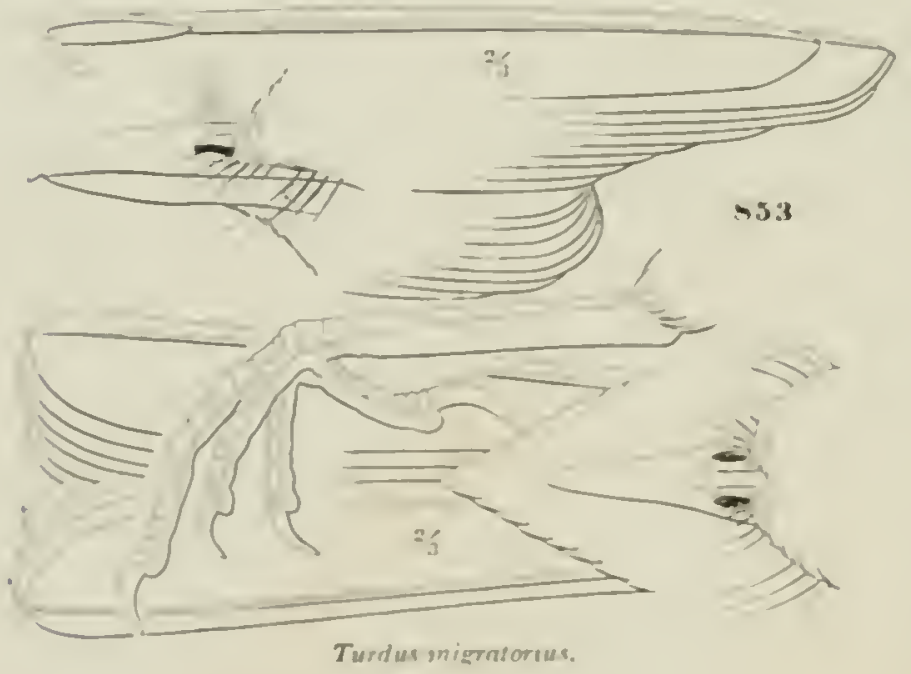

to the trpical Furupen sprecies in the full form. stout leurs, rotc., as alrearly stated. The sputs wh the throat, and their alisence elsewhere on 1 le under part of the lumly, are sufficiest to distingui=h them.

O) the two North Sumericills species me is the well-known lioling, the where al chosuly mited form from ('ilpe st. Lncis, which indeerl is jumblily

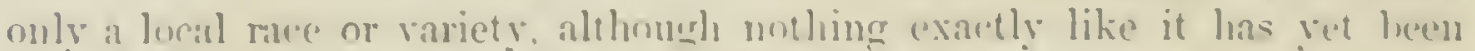
fomml away from Inwer ('alliformia. The following diagnosis may serve to distingnish the two hirds: -

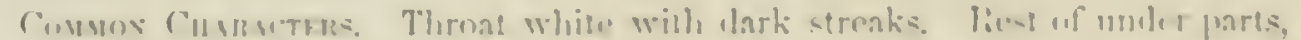

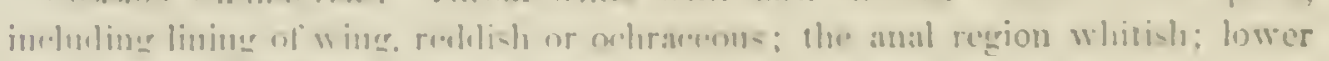

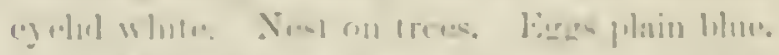

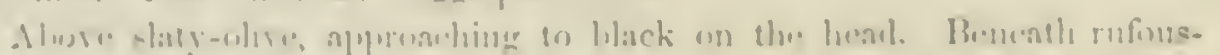

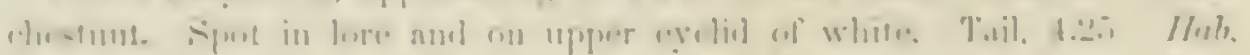

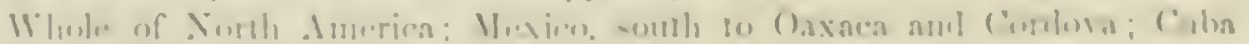

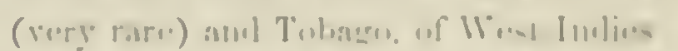

var. minrelorius.

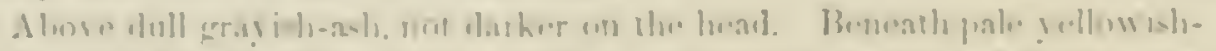

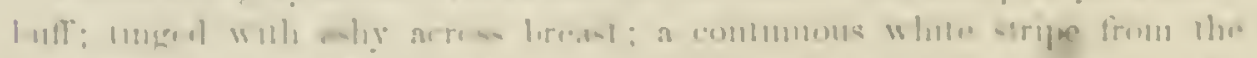

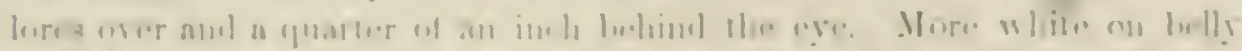

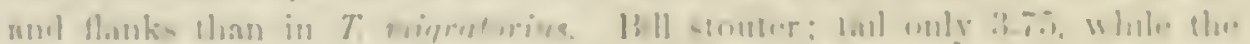

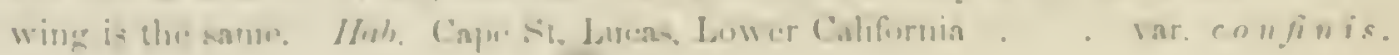


Turdus migratorius, var. migratorius, Lזx.

\section{ROBIN; AMERICAN REDBREAST.}

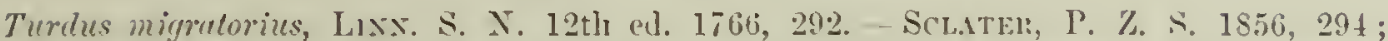

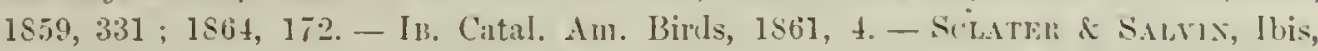

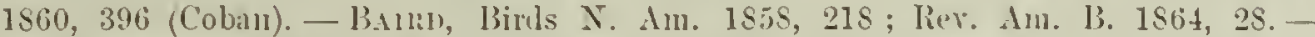
COopel: \& Scckiler, P. R. R. R. XII, 11, 1559, 172. - Dliesslil, lbis, 1565, 475 ('Texis, winter). - Cot Ls, Pr. A. N. S. 1S66, 64 (Arizona). - DAll \& Bansisten (Alaska). - Coopen, Birls Cal. - S.t.uress, 154.

Fignres: Vienlot, Ois. Am. Sept. 11, pl. Ix, Ixi. - Wilsox, Am. Orn. I, 1808, pl. ii. Dougnty, Cah. N. H. I, 1S30, pl. xï.-Avprbos, Birds Am. Ill, pl. exIii ; Orn. Biog. 11, pl. exxi.

Sp. Cп.ır. Tail slightly romded. Abore olive-gray; ton and sides of the head blaek. Clin and throat white, streaked with black. Eyelids, and a spot above the eye anteriorly, white. Under parts and inside of the wings, chestnut-brown. The under tail-coverts and anal region, with tibia, white, showing the plumbeons inner portions of the feathers. rings dark brown, the feathers all edged more or less with pale ash. Tail still darker, the extreme feathers tippen with white. Bill yellow, dusky along the ridge and at the tip. Length. 9.75; wing, 5.4.3; tail, 4.75; tarsus, 1.2.5

H.us. The whole of Torth Amerien; Ifexico, Oaxaen, and Cordora; Guatemala; Cuba, very rare, Guxdu.ıen; Tobago, Kırк; Bermula, Joxis; Orizaba (Alpine regions, breeding abundantly), Stuncurust.

Young birds have transrerse blackish bars on the back, and blackish spots beneath. The shafts of the lesser corerts are streaked with brownishyellow; the back feathers with white.

There are some variations, both of color and proportions, between eastern and western specimens of the Robin. In the latter there is a tendency to a longer tail, though the difference is not marked; and, as a rule, they slightly exceed eastern specimens in size. The broad white tip to the lateral tail-feather - so conspicuous a mark of eastern birds - is scarcely to be found at all in any western ones; and in the latter the black of the head

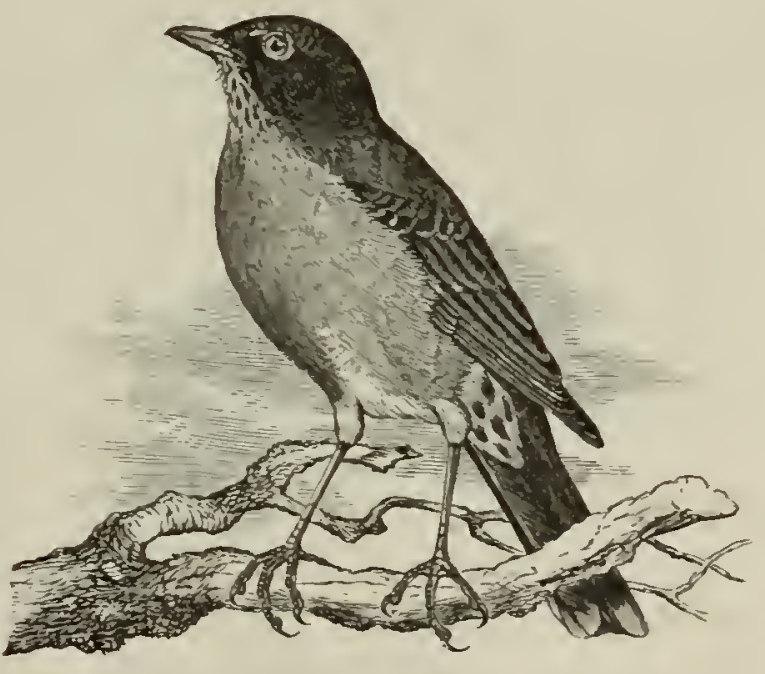

Turdus mioralorius. is very sharply defined against the lighter, clearer ash of the back, there hardly ever being a tendency in it to continue backward in the form of central spots to the feathers, as is alınost constiuntly seen in eastern examples; of western specimens, the rufous, too, is appreciably lighter than in eastern. As regards the streaks on the throat, the black or the white may either largely predominate in specimens from one locality. 
In autmm asm winter each pufous leather beneath is bordered by a more

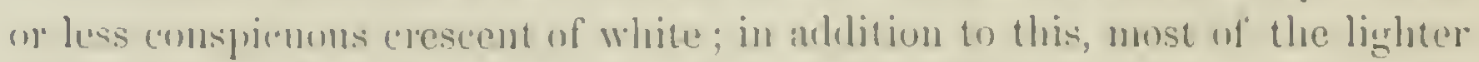

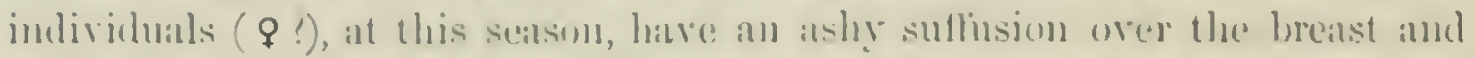

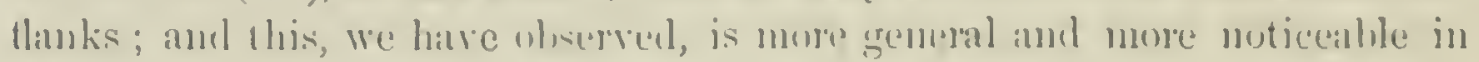
western than in eastern specinens. In fill and winter the color of the bill, tur, changes, beenming at this season cither putially of wholly lusky, instean

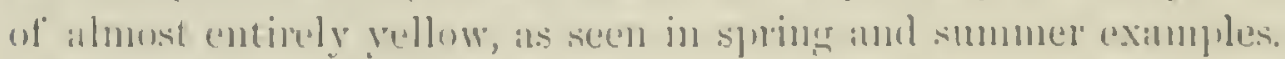

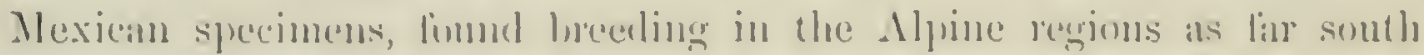

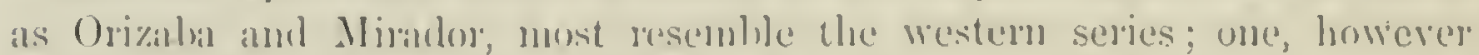
(No.:38,1208, Orizabi1), but in the antumual pilmmane, ant therefore very possihly a migrant from the Sorth, is hatrly distinguishable from

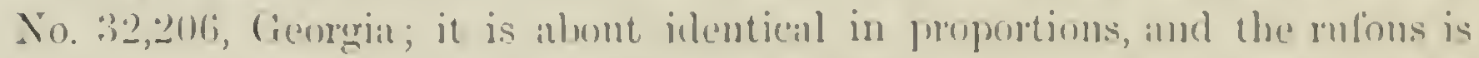
of a castaneons sharle, like the deepest coloned eastern examples; the white tip to the outer tail-feather is as broad and conspicuous as is crer seen in the latter.

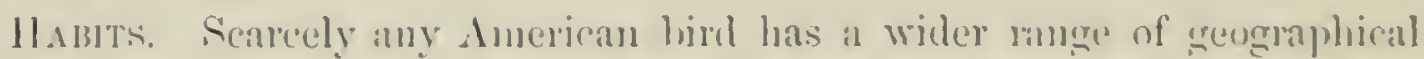
distribution, or is more munerous wherever fomme, than this thonsh. Fom (iremlind on the extreme northenst to the platean of Mexien, and foum the Allantic to the Pacifie, the lirhim is everywhere a very abundant species.

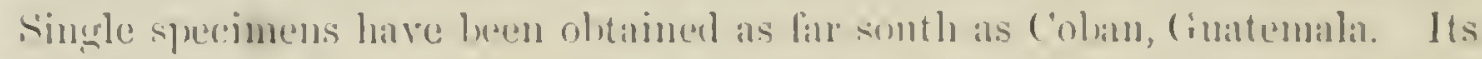

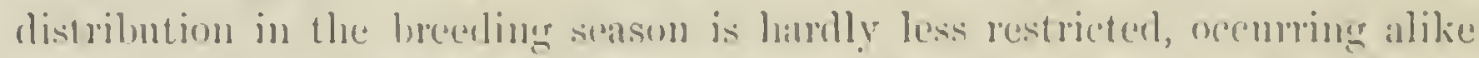

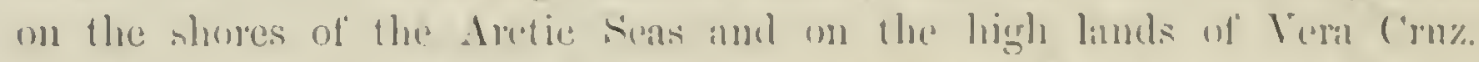
In the winter montles it is most almumbunt in the sonthens states, while

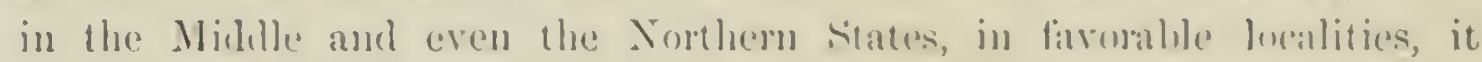

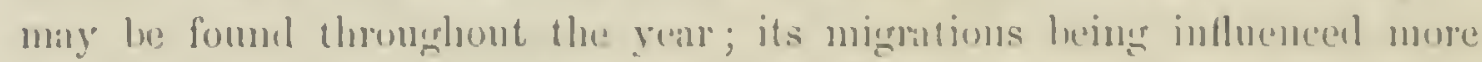

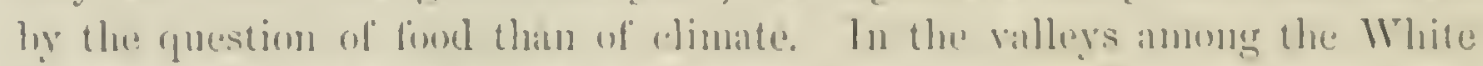

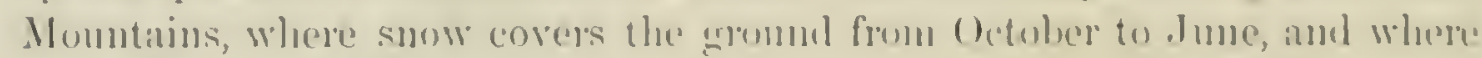

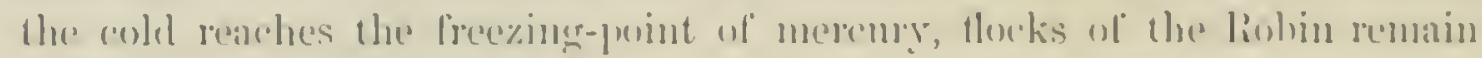

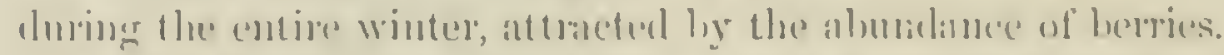

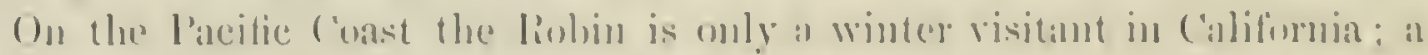

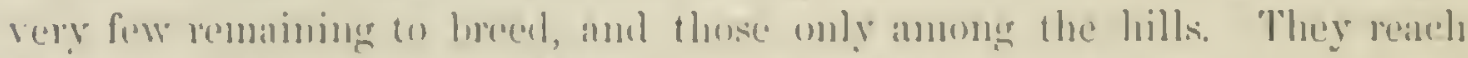

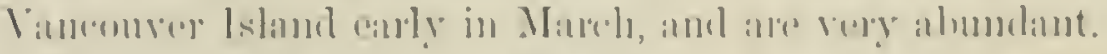

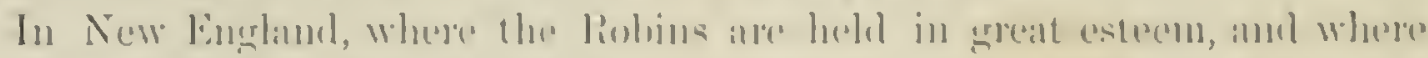

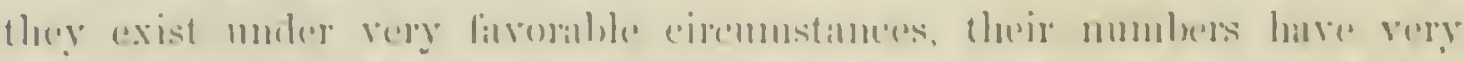

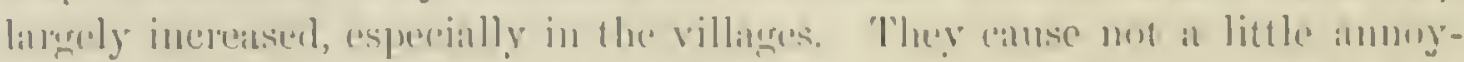

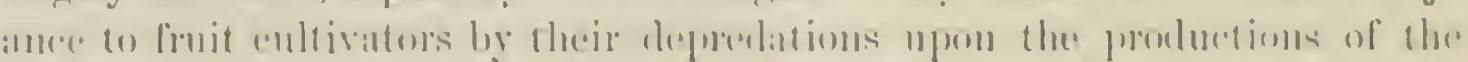

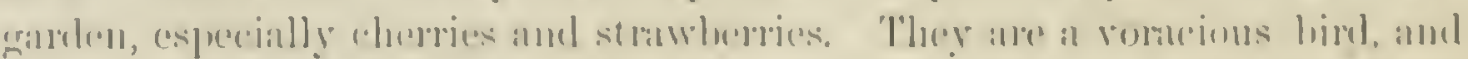

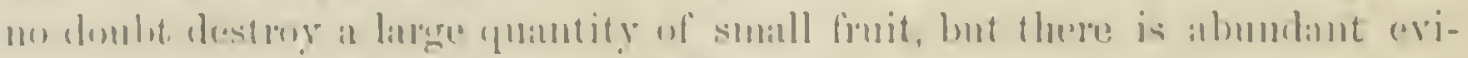

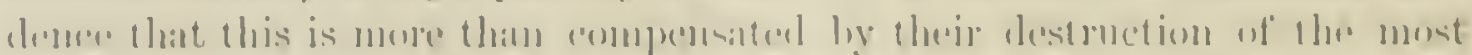

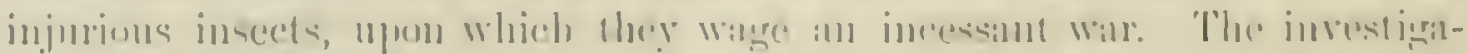

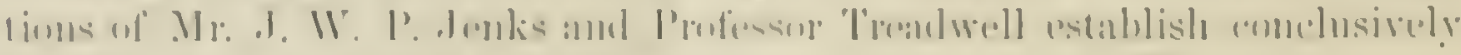

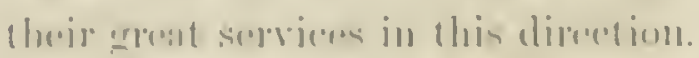

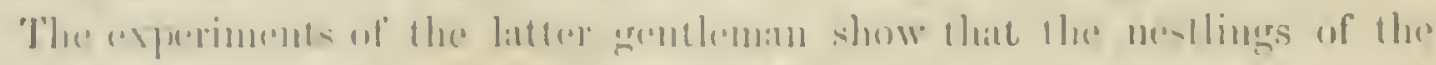

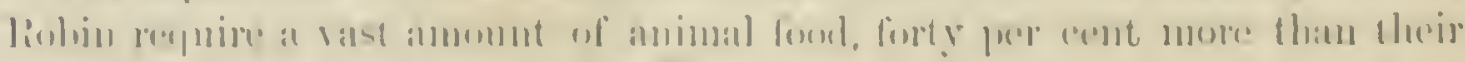


own reight being consumed by the young bird within twenty-four hours, and, what is more, demonstrated to be necessary to its existence.

In Irassachusetts a few Robins remain throughout the year, hut the greater proportion leave early in Norember, retuming late in February or early in March.

The song of the Robin is deservelty popular. While many of our birds possess far superior powers of melody, and exhibit a much greater variety in their song, there are none that exceed it in it duration or extent. It is the first bird in spring to open and one of the last to close the great concert of Nature. Their song is earnest, simple, and thrilling, and is sail by Audubon to resemble that of the European Blackbird, Turdus merulu.

The Pobin, when taken roung, may be readily tamed, and soon becomes contented and accustomed to confinement. They are devoted to their young, watchful, attentive, and provident. They herin to construet their nest in early spring before the trees put forth their leaves, and often in rery exposed positions. The size of the nest, in fact, makes concealment impossible. These nests are sometimes placed in quite remarkable positions, such as the beans of a ship partly fuished, and where the carpenters were every day at work, and similar situations indicating a great familiarity. Their farorite place is the horizontal branch of an apple-tree, about ten feet from the ground.

The nest of the Pobin is a large and coarsely constructed combination of rucle materials. It is composed of a base of straw, leares, mosses, stems, and dry grasses, upon which a cup-shaped fabric of clay or mud is built. The whole is lined with finer dry grasses and regetable fibres. They avenge 5 inches in height and the same in diameter. Their cavity is $2 \frac{3}{4}$ inches deep, with a diameter of $2-\frac{1}{2}$ inches.

The egrs of the Pobin, which are usually five and sometimes six in mumber, are of a uniform bright greenish-blue color, lialle to fade when exposen to light, but when fresh exhibiting a very distinct and bright tint. They vary in size from 1.25 to 1.12 inches in length, and in breadth from . SS tu

.75 of an inch. Their mean measurement is $1.15 \mathrm{by} . \$ 1$.

Turdus migratorius, var. confinis, BAIRD. CAPE ST. LUCAS ROBIS.

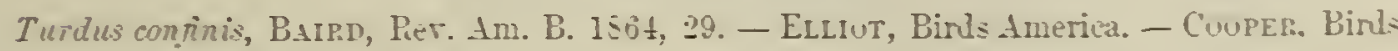
Cal., $\dot{a}$.

Sp. CHap. No. 23,-s?. Entire upper parts and sides of head anil neck uniform grayi-bash. with perhaps a faint tinge of olivaceous. less than in eastern specimens of $T$. migratorius. The central portions of the feathers of the iop of head are rather darker than the elges, though almost inappreviably so. and not imparing a general lushr appearance. The chin and throat are white. streaked with ashy-brown. The jugulum and breast are 


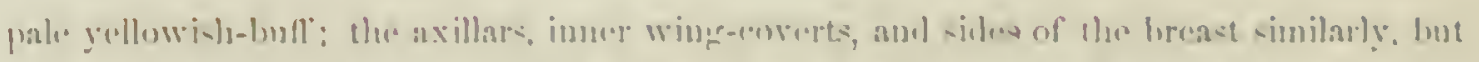

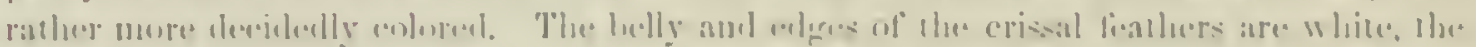

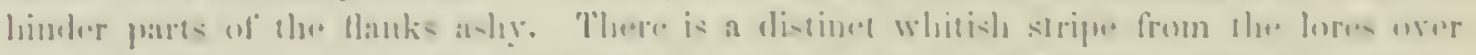

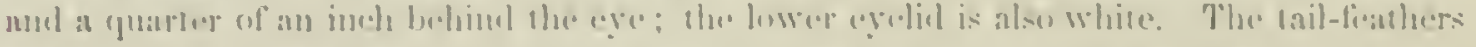

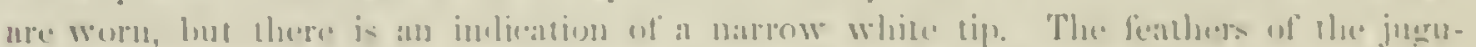

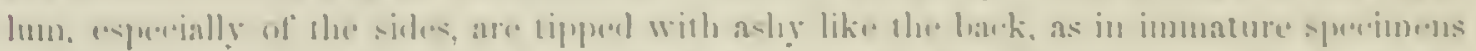

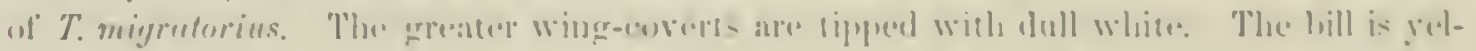

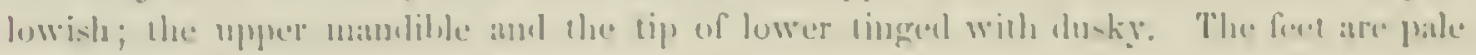
hrown.

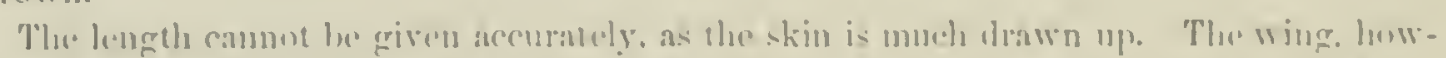

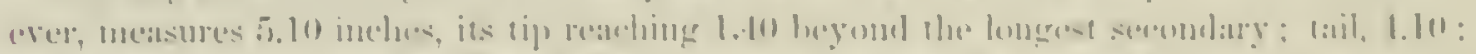

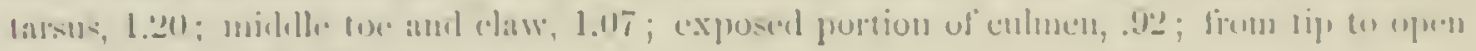
portion of nowitil: . (it).

Hab. Tulus sintus, Cape st. loneshs.

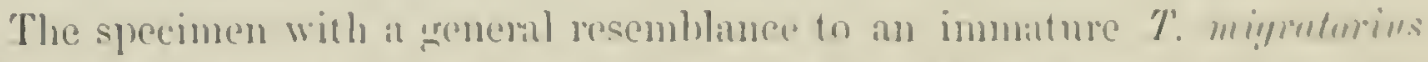

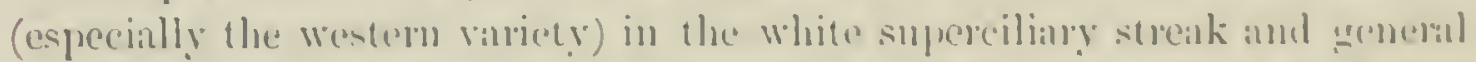
markings, is smed lighter bencith than in any of the many skins of $T$. mi-

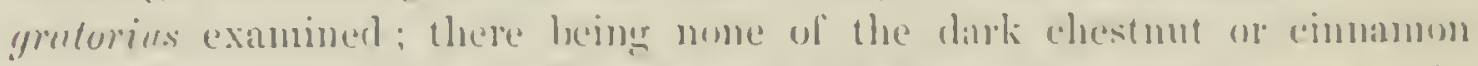
shacle, but rather a light lufl; the helly and flanlis atre much more purely white. The supereiliary strije astends forther lechind the eye: inderd, in

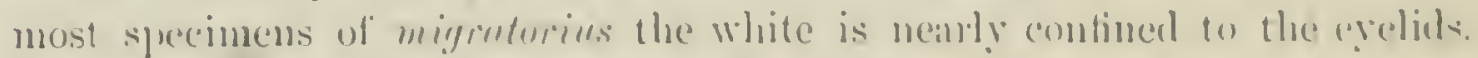

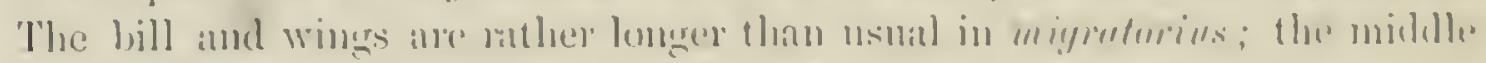

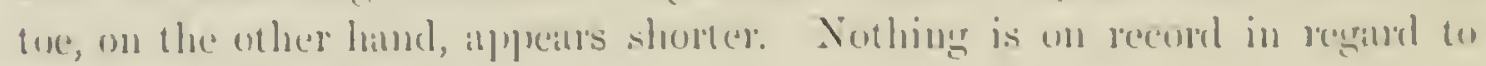
the habits ul this bird.

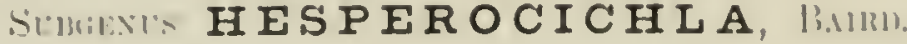

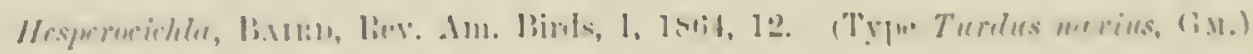

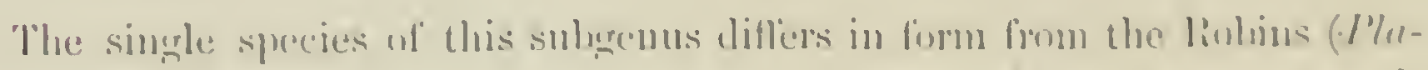

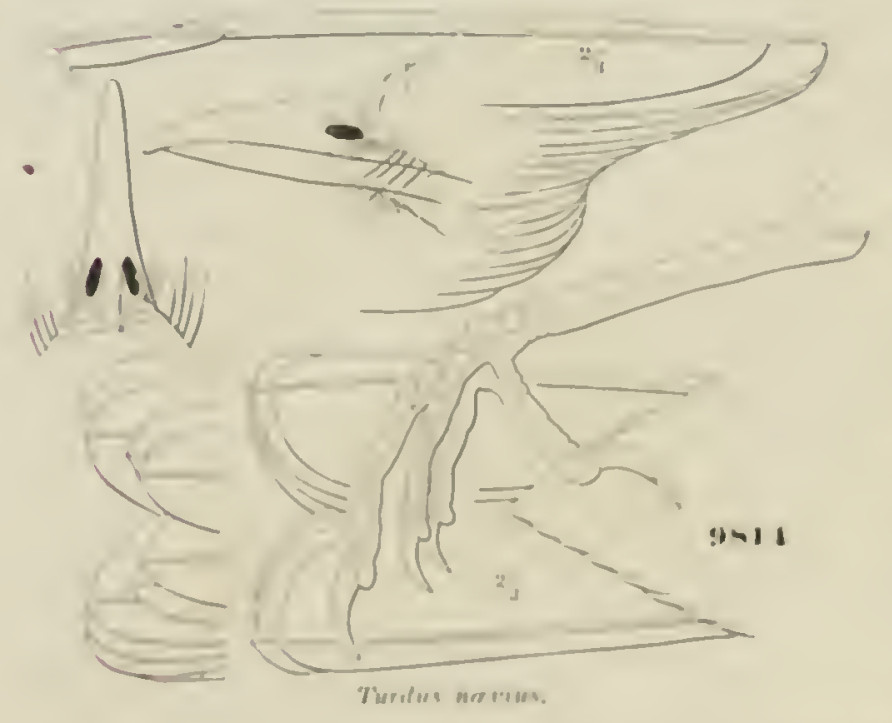
mevticus, in the muse atwl-

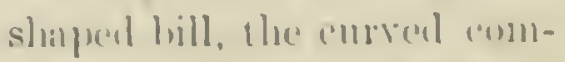
missure, and the alsinge of a moteh at the end: the lomig('r. stomlerer, and stmightere (linws; and in llow disimi-

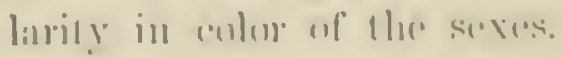
In the latter resperes it

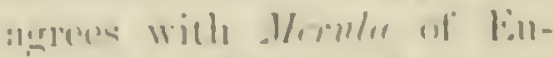

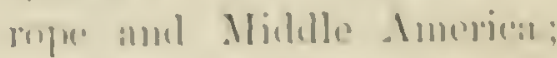
in which, herwerers, llac hill is di-limetly notehed, amel lese attembatcrl. The tail is shorter and hroider thats in

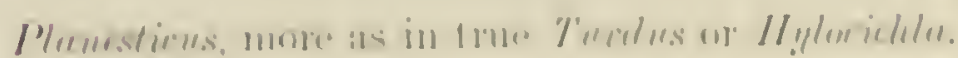


Turdus nævius, (BMEL. OREGON ROBIN; VARIED THRUSH.

Turdus navius, Gu. S. S. I, 1758, \&17. - SuLAtel, P. Z. S. 1857, 4; 1859, 331. BArd birls X. Am. 1Sjs, 219 ; Ruv. Am. B. 1sit, 32, - Coober \& Stchley, P. R. R. R. III, II, 1859, 172.-Corrs, Pr. A. N. S. 1866, 65. (Quotes vecurrence on (olomdo Iiver, above Fort Mohave, as exceptional.) - Marsan (Massalehusetts !).

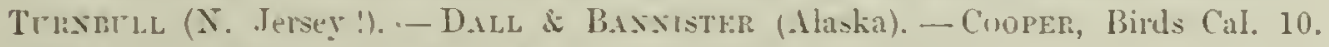
Orpheus meruloides, heı. F. B. A. II, 1£31, 1\$7, pI. xxxriii.

Other figures: Vieldut, Ois. An. Sept. II, 1S07, pl. lxvi. At'D. Orm. Biog. IV, 183S, pI. ccclxix, and cecexxiii. - I B. Birds Am. II, Il. cxliii.

Sp. Cuar. Tail nearly eren; the lateral featler slorter. Above, rathel dark bluish slate; muler parts generally, a patch on the upper eyelicls continuous with a stripe belimd it along the siele of the head and neck, the lower eyelicls, two bands across the wing coverts and thr elges of the quills, in part, rufous orange-brown: midule of belly white. Sirles of the lrearl and neck. contimons with a broad pectoral transwersc band, black. Most of tail feathers with a terminal patch of brownish white. Bill black. Feet yellow. Female more olivaccous abore: the white of the abdomen more extended; the brown beneath paler; the pectoral band obsolete. Length. 9.75 inches; wing. 5.00; tail, 3.90; tarsus, $1.2 \mathrm{~J}$.

Foung (45.897. Sitha, Aug. 1866: F. Bischoff) Exactly rescmbling the adult female, having no spots other thau secn in the adult plumage; but the pectoral collar is composcd only of badly defined blachish transwerse cresents, and the upper parts anterior to the rump are of an umber brown tint. The markings about the heal and on the wings are precisely as in the adult.

This species dues not appear to be liable to any noticeable variation.

H.tB. West coast of Sorth Ameriea, from Belning Straits to California: straggling to Great Bear Lake. Accilental on Long Islanu (Cab. G. N. Lawence). Tew Jerser (Cab. Dr. Sammel Cabot), and Ipswich, Mass. (Cab. Boston Society Natmal History); Iowa (ALLE).

HABITS. The accidental occurrence of a few specimens of this wellmarked bird in the Eastern States is its only clain to a place in that fauna, it being strictly a western species, belonging to the Pacific. Coast. It was first discorered by the naturalists of Captain Cook's expedition, who met with it as far to the nortl as Nootia Sound. It is only very recently that we hare become possessed of reliable inforluation in regard to its breeding and its nest and eggs. Sir John Richardson was informed that it nested in bushes in a manner similar to that of the common robin.

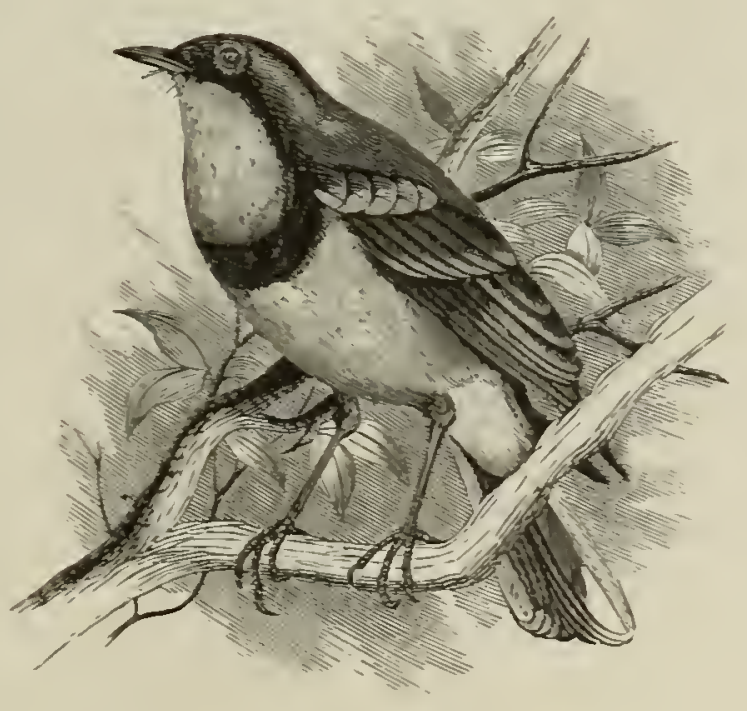

Turdies novius.

Nuttall and Townsend found it abundant among the western slopes of the 


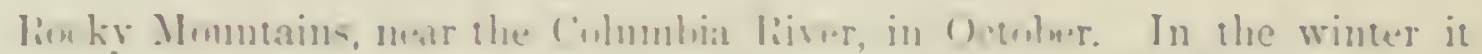

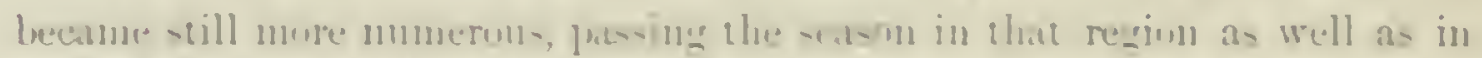

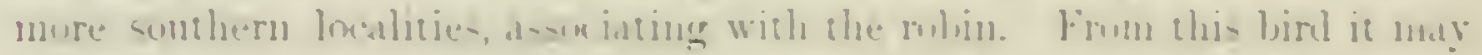

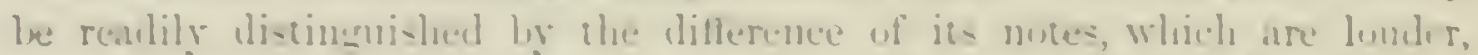

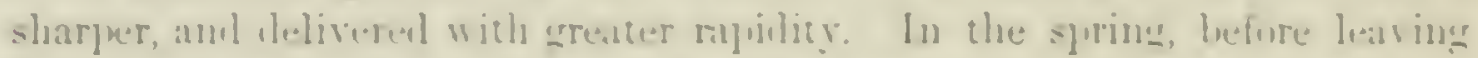

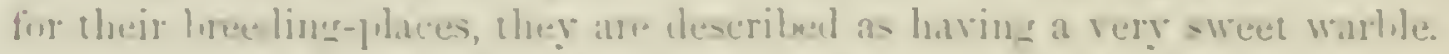

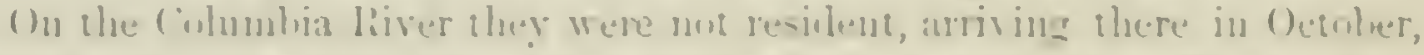
continume thronghont the wimes, and leavine enly in May. Inume their

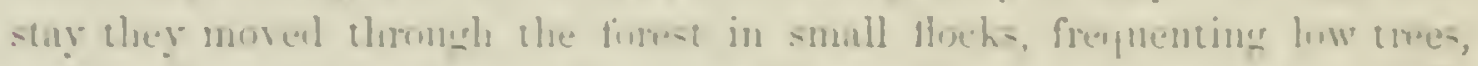

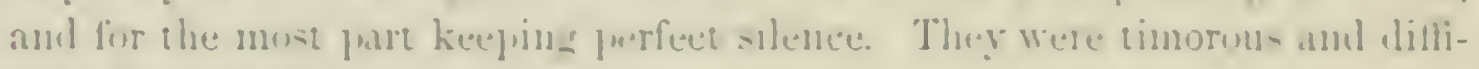
eult of appruach.

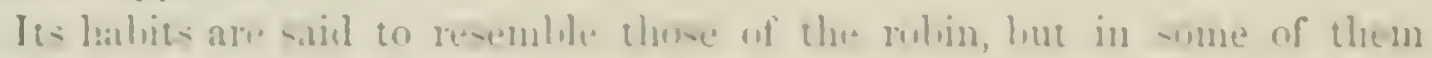

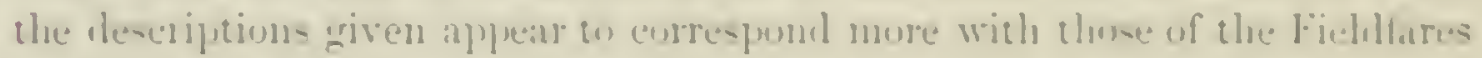

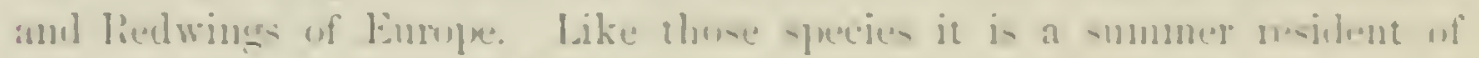

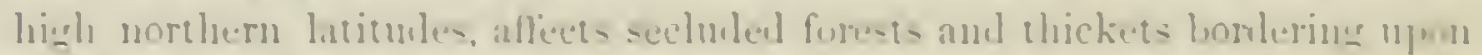

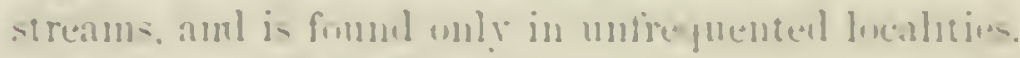

Dr. Cinger was uf the "piniom that a few of thee thrusles remained in

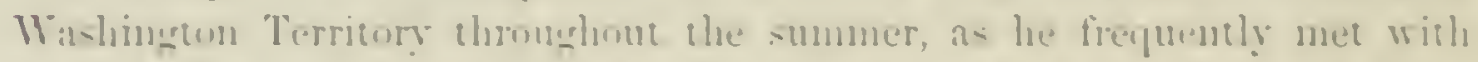

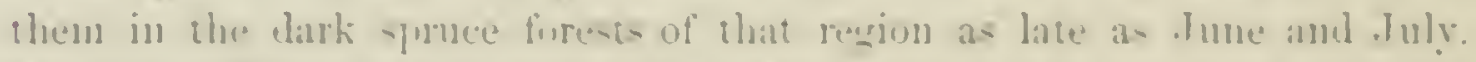

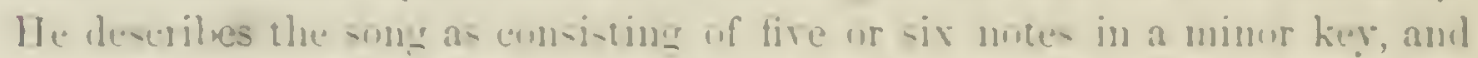

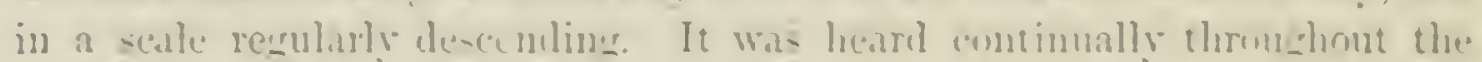

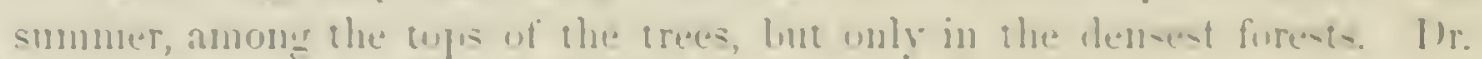

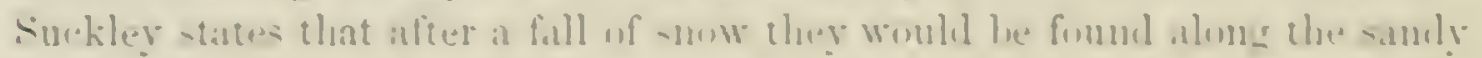

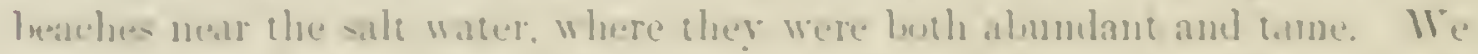

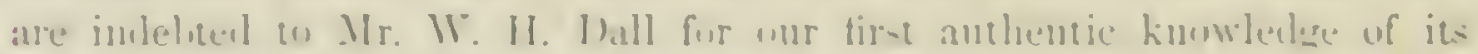

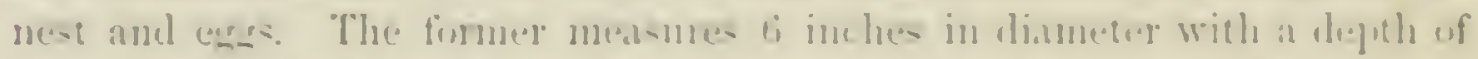

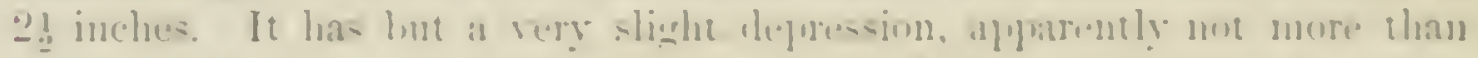

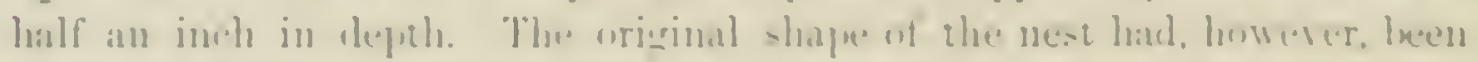

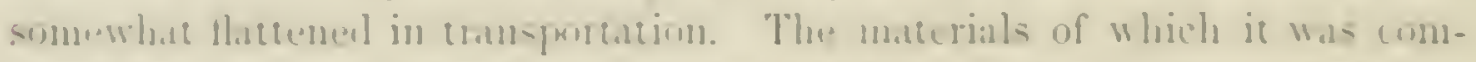

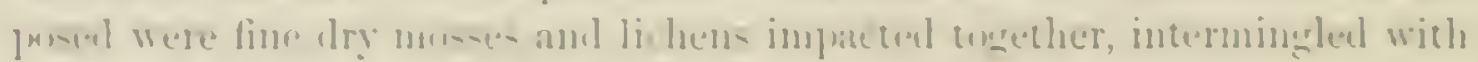

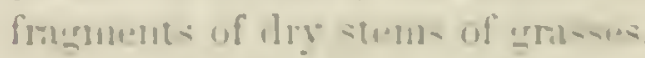

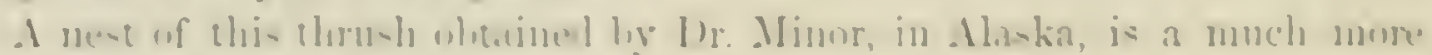

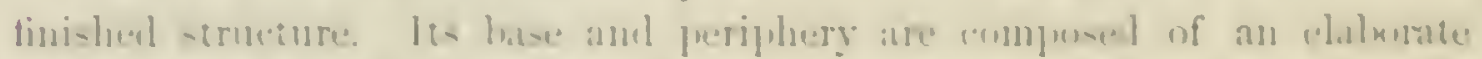

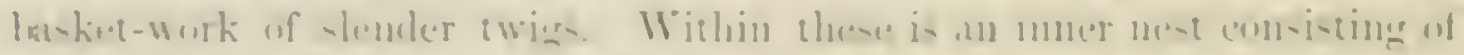

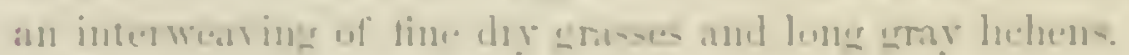

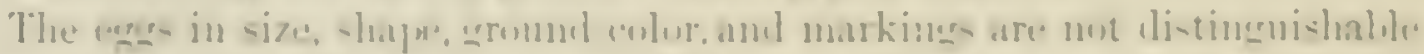

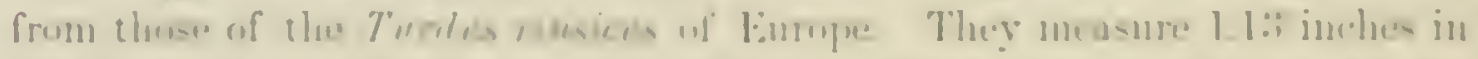

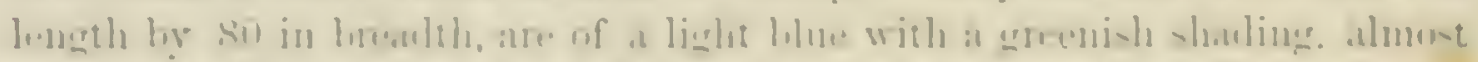

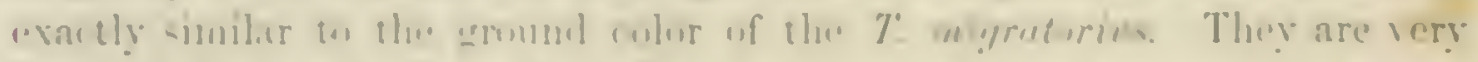

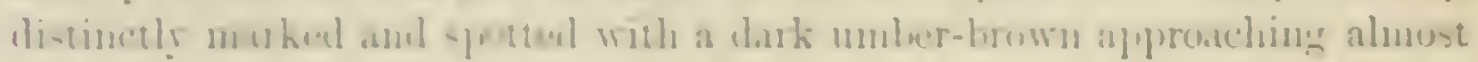
(1) lilekine..

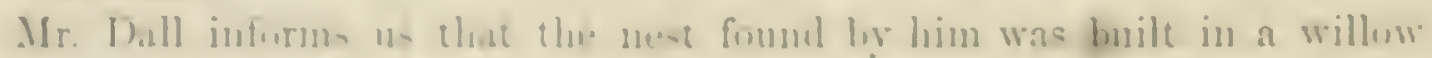

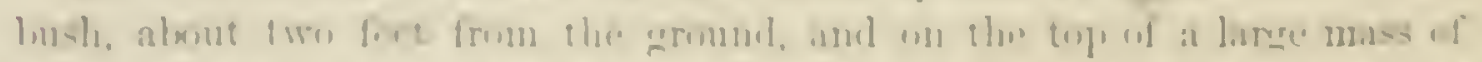

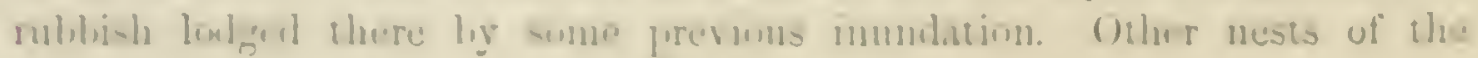


same species were met with in several places between Fort Iukon and Nulito, always on or near a river-bank and in low and secluded localities.

They arrire at Nulato abont May 1j, and prefer the vicinity of water, freyuenting the banks of small streans in retired places. MIr. Dall states that he has seen the male bird on a prostrate log near the nest, singing with all his might, suddenly cease and rum up and down the log for a few minutes, strutting in a singular manner, then stopping and singing again; and heepiug up this curious performance. Specimens were received from Sitka, Kodiak, Cool's Inlet and Admiralty Islands.

\section{SubFhILl M I M I N Æ.}

Birds of this section have a somewhat thrush-like appearance, but (except in Orescoptcs) with longer, much more graduated, and broader tail; short concare wings, about equal to or sloorter than the tail, usually lengthened, sometimes decurved bill without notch, and strongly marked scutellie on the anterior face of the tarsus. The loral feachers are soft, and not ending in bristly points. The colors are dull shades of brown, gray, or plumbeous. Most of the species, in addition to a melodions mative song, possess the power of innitating the notes of other birds; sometimes, as in the American Mocking Birl, to an eminent degree. All are peculiar to the New World, and the species are much less vagrant than those of the Turline, - those of the United States scarcely going beyond its northern boundary; others, again, restricted to small islands in the West Indies or in the I'acific Ocean.

\section{GEXUS OREOSCOPTES, BAIRD.}

Oroscoptes, Bairn, Birds X. Am. 1S5s, 3t6. (Type Orpheus montanus, Tow:s.)

Orcoscoptes, Banlin, Rev. Am. Bircls, 42 .

Sp. Cuar. Bill shorter than the head, without distinct notch. Bristles prominent, their tips reaching beyond the nostrils. Wings pointed, equal to, or a little longer than the tail. First quill not half the second, about two fifths the longest; third, fourth, and fifth quills equal and longest; second between sixth and serenth. Tail but slightly grarluated; the feathers narrow. Tarsus longer than middle toe and claw by an additional claw; scutellae distinct anteriorly.

Of this genus only one species is at present known. This belongs to the Middle and Westem provinces of the Cnited States and extends from the Pacific coast eastwarl to Fort Laramie and the Black Hills

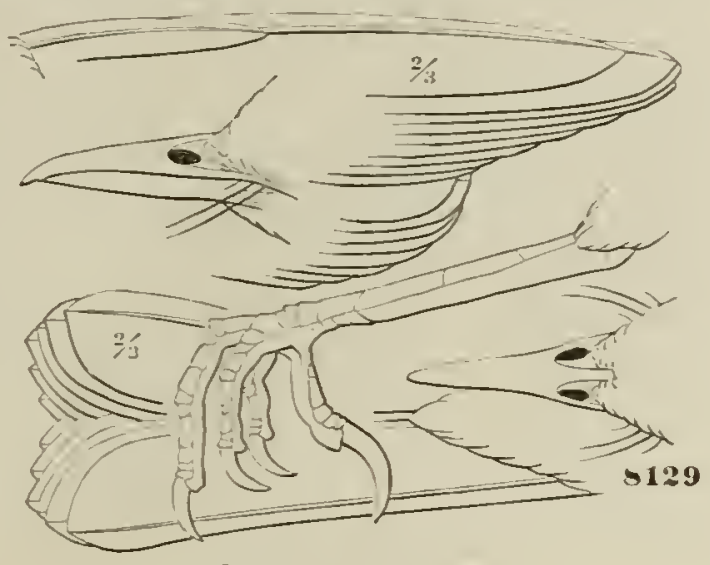

Oreoscoptes montanus. (in winter to San Antonio, Texas); soutlı to Fort Iuma and Cape St. Lucas. 


\section{Oreoscoptes montanus, lin1:1\%.}

\section{SAGE THRASHER; YOUNTAIN MOCKER.}

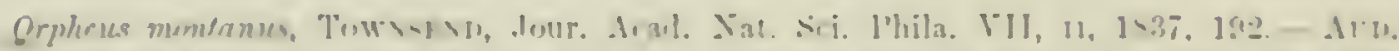

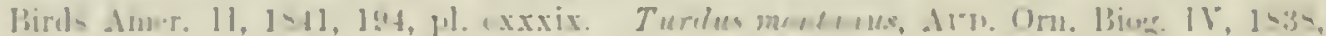

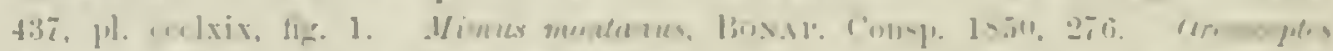

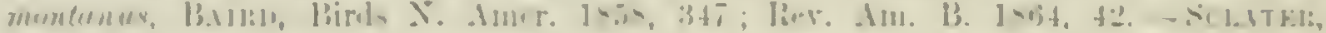

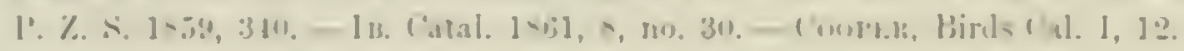

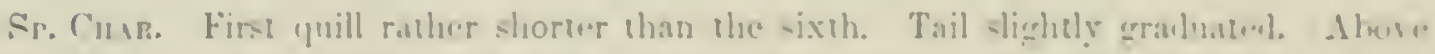

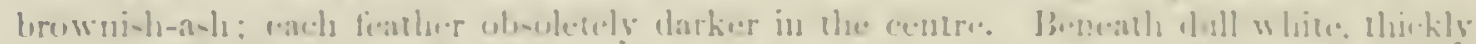

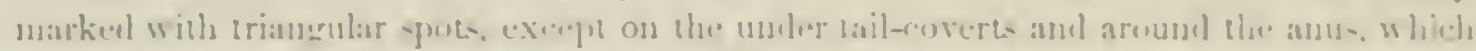

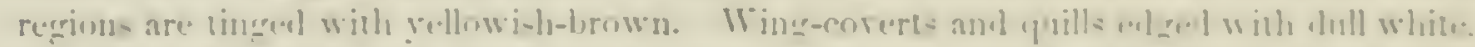

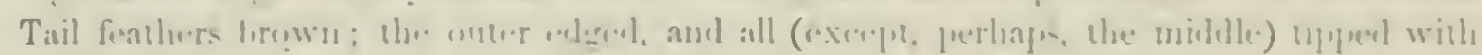

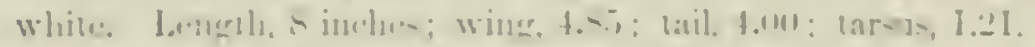

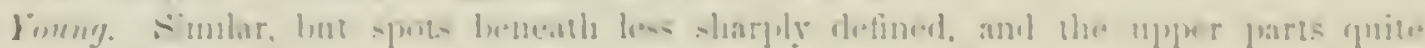

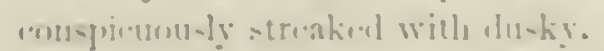

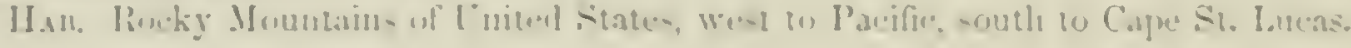

The careful olservations of Mr. Roluest libleway have led him to the com-

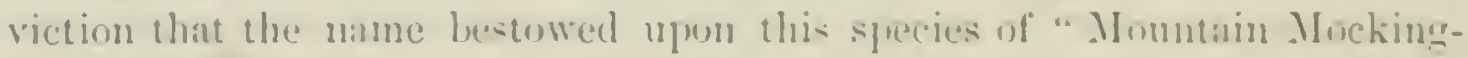
Himl "is doubly a misnomer. It is not at all initative in its motes, and it is

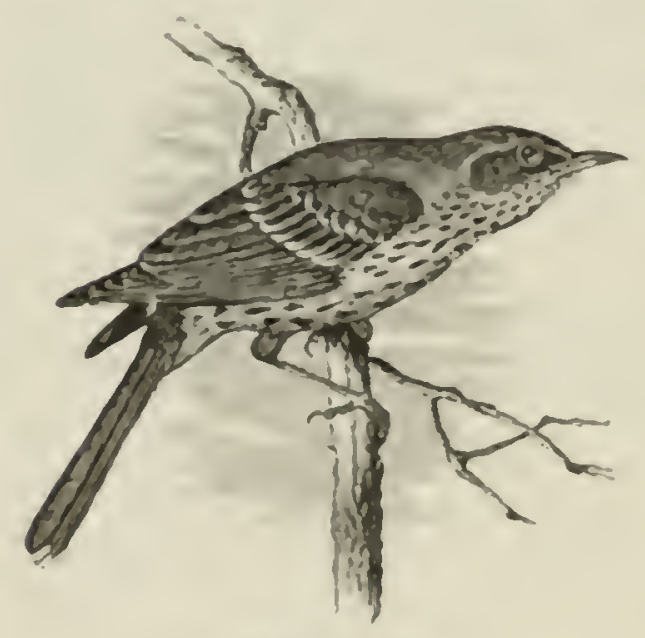

()roesepes momtanus. almont exclusively a resilent of the artemisia platus. It seems un In (Michly confuned to the erreat antral plistenn of Sinth America, frum Mexien alumen to

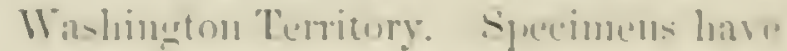

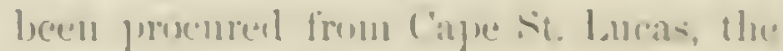

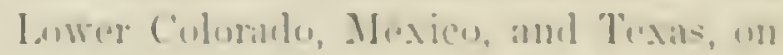
the somth, and Nutall met with it meanly as far morth as Willa-Malla. It publiably acempies the whole extent withe (iverit biasin.

1). kemerly, whon met with it while

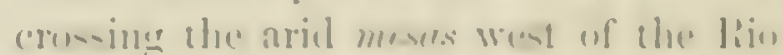
cimmese sity that while singing it wat

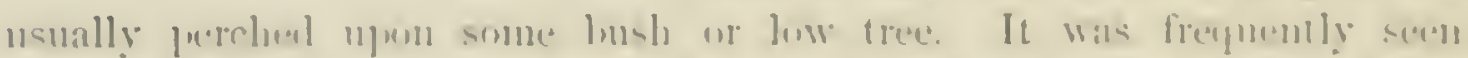

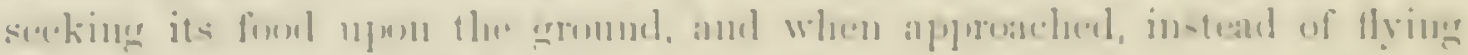

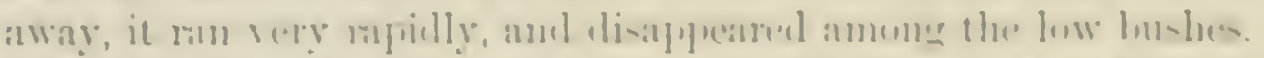

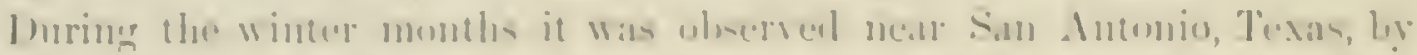

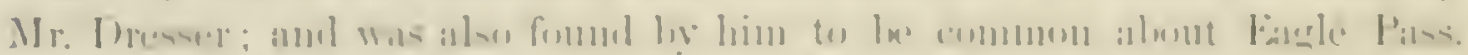

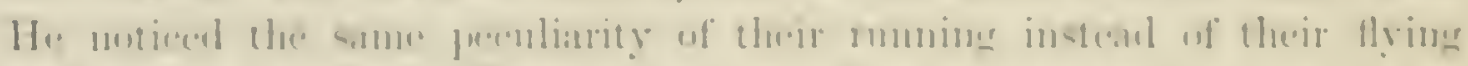

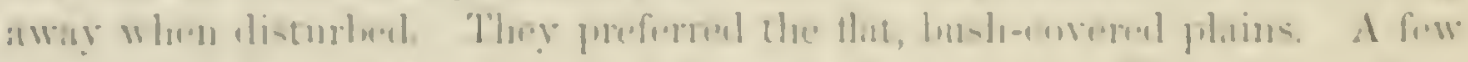

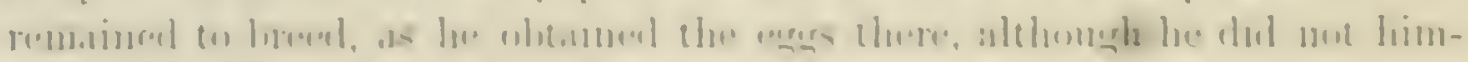

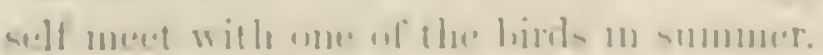

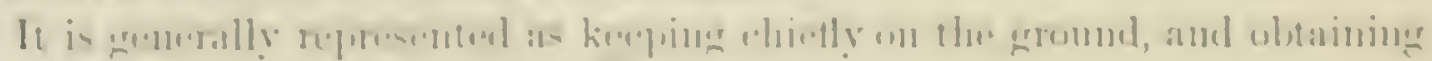


its food in this position. General Conch speaks of it as Sparrow-like in its labits.

Mr. Nuttall describes its song as cheering, and the untes of which it is composed as decidedly resembling those of the Brown Thrush (Harporhynchus rufus). He clains for it some of the imitative porrers of the Mocking-Bird (Mimus polyylottus), but in this he is not supported by the observations of others. He met with its nest in a wormwood (Artemisia) bush on the border of a ravine; it contained four egogs of emerald green, spotted with dark olive, the spots being large, rounclish, and more numerous at the larger end. The nest was eomposed of small twigs and rough stalks, and lined with strips of bark and bison-wool. The female flew off to a short distance, and looked at her unwelcome visitors withont uttering any complaint.

The nests of this bird, so far as I have seen them, are all Hat, shallow structures, with very slight depression, and loosely and rudely constructed of an intemingling of strips of bark with rootlets and the finer stems of herbaceous plants. Their eggs, usually four in number, do not vary essentially in size, slape, or marking. They measure 1 inel in lengtl, and from .73 to $.75 \mathrm{in} \mathrm{breadth.} \mathrm{Their} \mathrm{ground} \mathrm{color} \mathrm{is} \mathrm{a} \mathrm{bright} \mathrm{greenish-blue,} \mathrm{marked} \mathrm{with}$ deep olive-brown spots, intemingled with blotehes of a light lilac. There are slight variations in the proportion of green in the shade of the gromud color, and also in the number and size of the spots, but these variations are mimportant.

The following are Mr. Ridgray's observations upon the labits of this species. They are full, valuable, and very carefully made:-

The Orcoscoptes montruns is a bird peculiar to the artemisia wastes of the Great Basin, being a characteristic speeies of the region between the sierra Nevada and the Rocky Mountains. It is exclusively an inhabitant of the "sage brush," and is partial to the lower portions of the country, though it is not unfrequent on the open slope of the momntains. A more unappropriate term than "Momntain MLoking-Bird" could hardly have been chosen for this species, as its predilection for the valleys, and the fact that its song is cntirely its own, will show. In my opinion, the term "Sage Thrasher" would be more appropriate.

In the neighborhood of Carson City, Nevada, these birds arrived about the 24 th of March, and immediately npon their arrival began singing. At this time, with the Sturnella neglecte and Poospiza belli, they made sweet music in the afternoon and early morning, in the open wastes of "sage brush," around the city. The birds when singing were generally seen sitting upon the summit of a "sage" bush, faintly warbling, in the course of the song turning the head from sicle to side in a watchful manner. Upon being approached, they would dart dowmarl, seemingly diving into the bush upon which they had perched, but upon a close search the birl could not be found, until it was heard again singing a hundred yards or more in the 


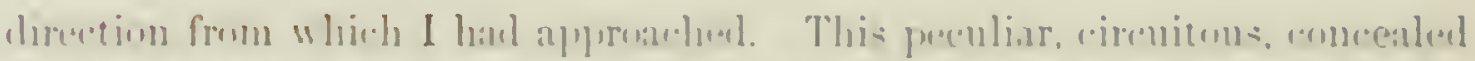

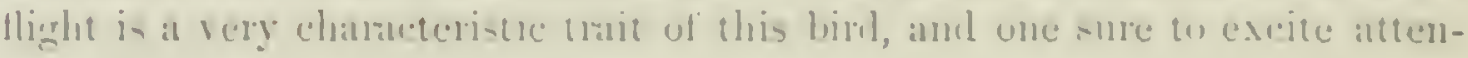
tivin.

As the seisson antranced, or allout the loth of $A$ pril, when the grairing

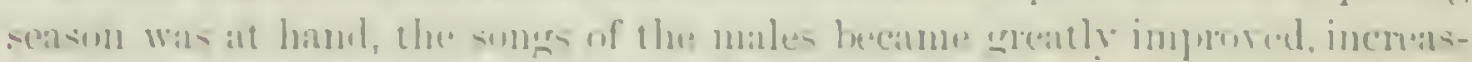

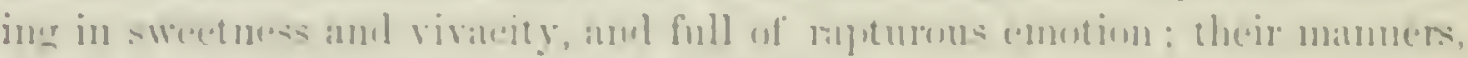

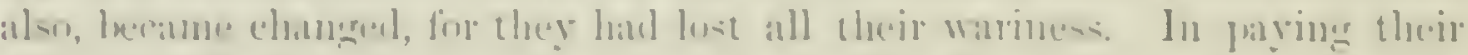

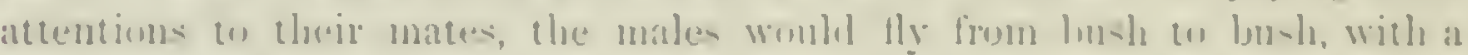
perenliar, tremuloms fluttering of the wings, which, when the himl alighted,

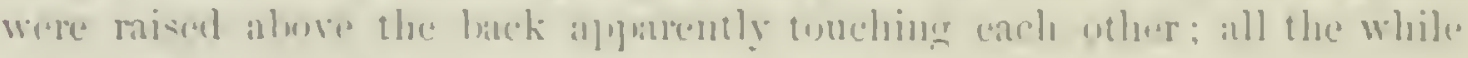
vibuting with the enotion and ecstasy that agitated the singer.

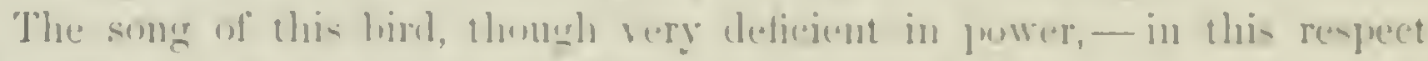
equalling no other species of Mimine with which 1 am aryuainted, - is

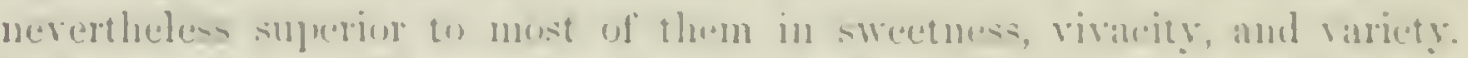
It has a womlerful resemblume (1) the beautiful subtle warblime of the

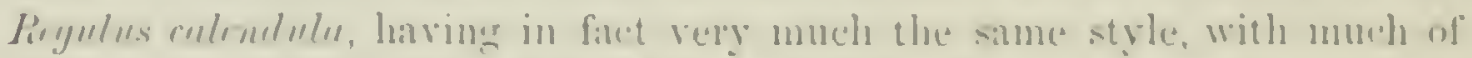

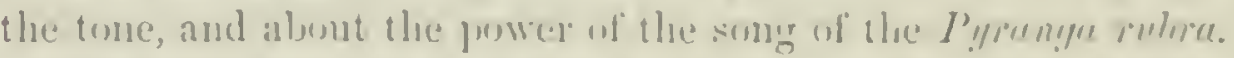

When the hirds are (nigared in inculation, the males hecome very silent, and one not familiar with their haligt; eartier in the seasom would think they

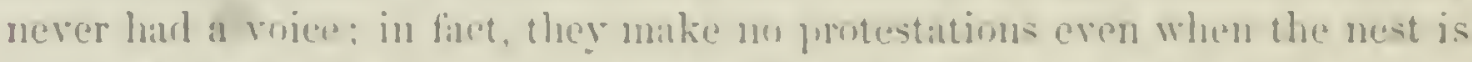
di-turbed, for, while howing the ereres, I have hat the patrent hirds ruming aronml me, in the manner of a rohin, now and then halteng, stretehing forward their leats, and evine me in the nnot anxions manner, lout remaining

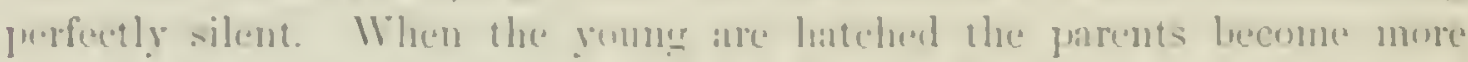

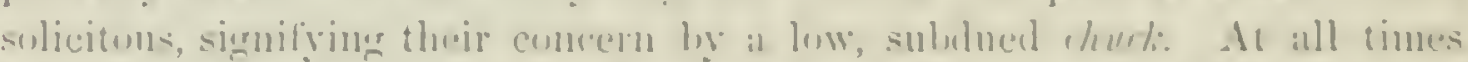

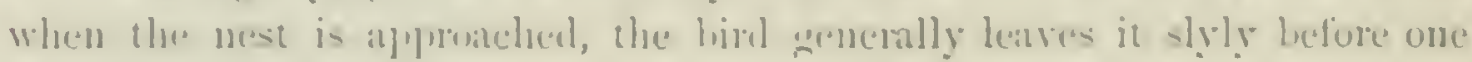

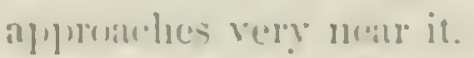

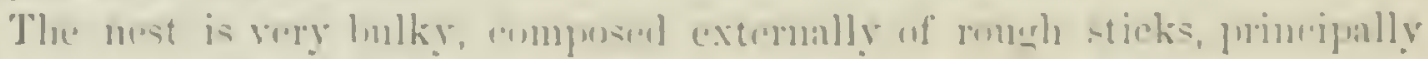

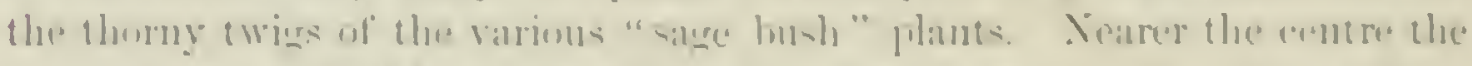

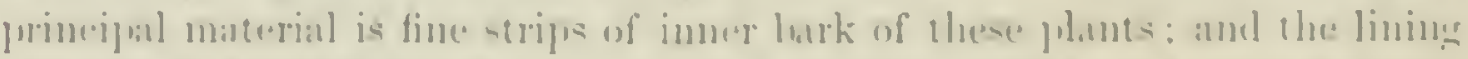

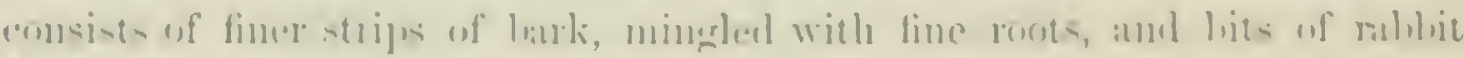

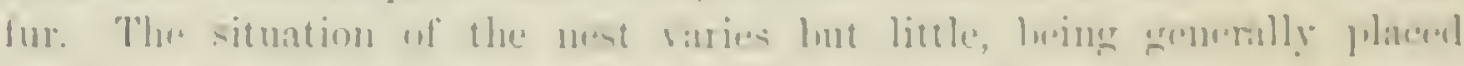

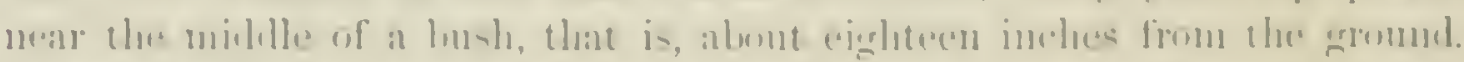

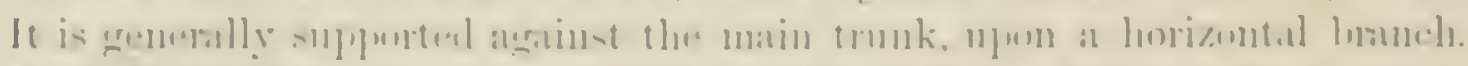

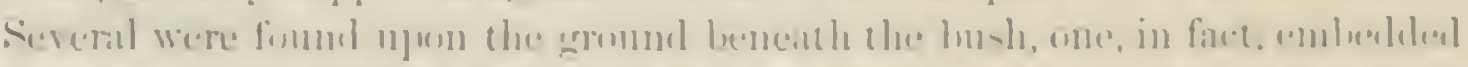

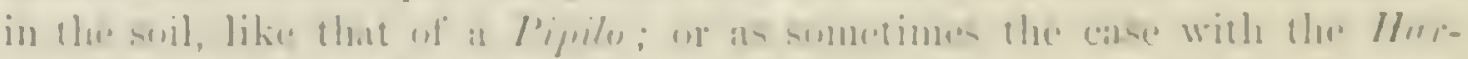

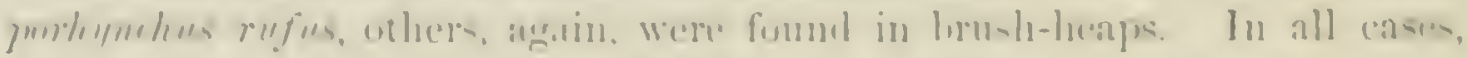

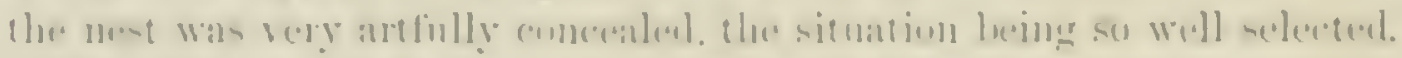

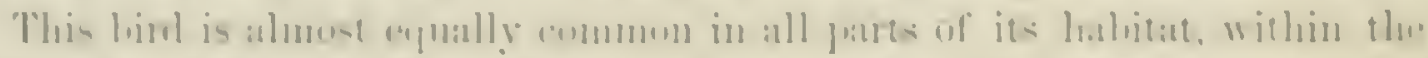

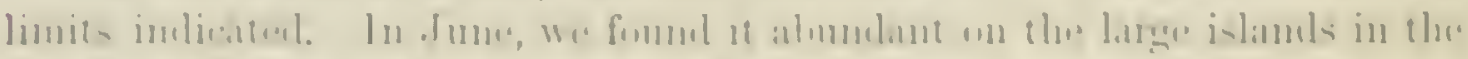
Great silt bahe, where many mests were finmul

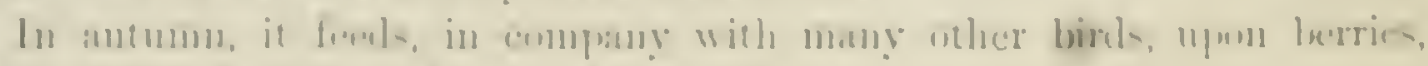

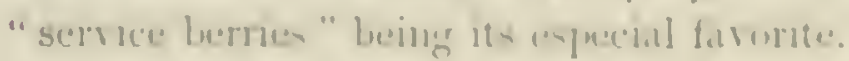




\section{GEN'S HARPORHYNCHUS, CABMIS.}

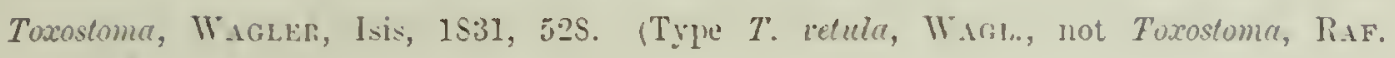
$1 \$ 16$.

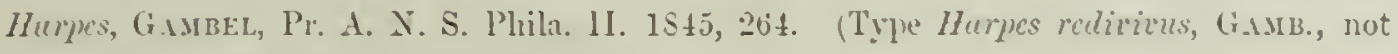
of (iolnFt's, 1539.)

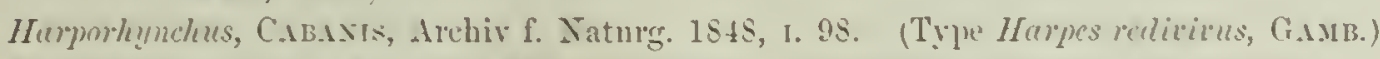
Methriopterus, REucir. Ar. Syst. Xat. 1S50, pl. ir. (Type said by (iraly to be H. rufus.)

Gex. Cuss. Bill from foreliead as long as. or much louger than the luead; becoming more and more decmerel in both jaws as lengtlened. No indication of a notch. Rivetus with the bristles exteudiug heyond the nostrils. Tarsus long and stout. appreciably cxceeding the micldle toe and claw, strongly sentellate anteriorly. W"ings considerably shorter than tail, much roumeled; the first quill more than half the second; fourtlı or fifth longest. Tail large, much graduated ; the leathers firm.

The species of this genus are all of large size, in fact, embracing the largest of the American slender-billed os-

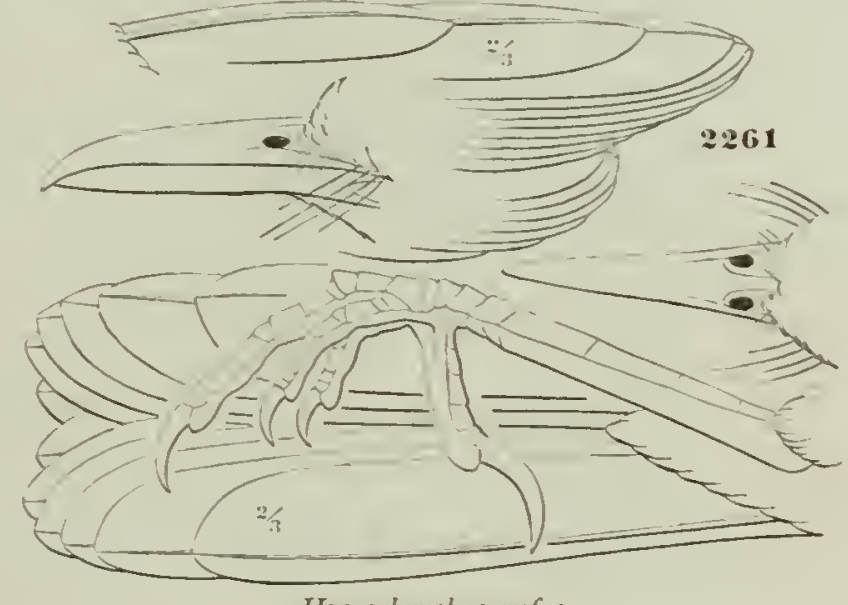

Harporhynehus rufus. cine birds. All the species differ in structure, varying especially in the length of the bill, as above stated.

It is useless to attempt a division of this genus, for there is such a gradual chain of characters between the two extremes of form (mufus and crissalis),

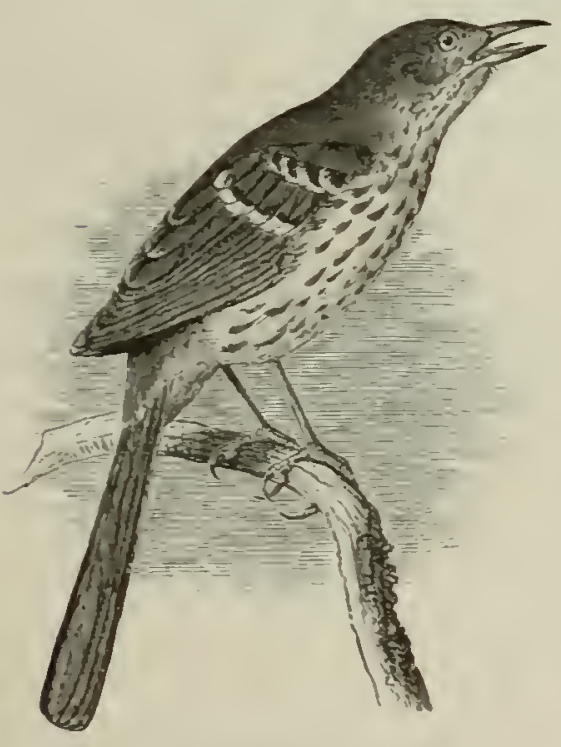

Harporhynchus rufus. that they even seem almost one species, when the mumerous intermediate forms, shading so insensibly into each other, are considered. Howerer, as this riew would be rather extreme, in view of the really great difference of form between the species mentioned, we may consider the following as grood species, several of them with one or more varieties: rufus, with longicanda. and longirostris as rarieties, the former scarcely appreciahly different, the latter ranking as a permanent race; ocellatus, cimerews, curvirostris, the latter with one wellmarked rariety, paluncri; redirivus, with most probably lecontei as a well-marked variety, and crissculis.

The seasonal differences in the plumige often make it difficult to determine these sereral forms; but if the following facts are borne in mind, the 


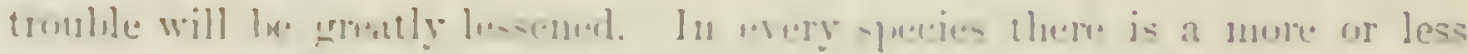

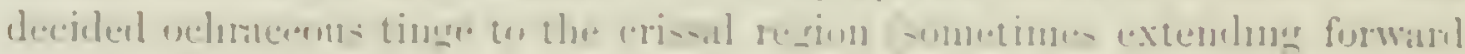

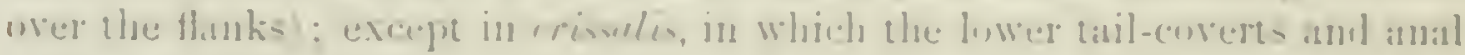

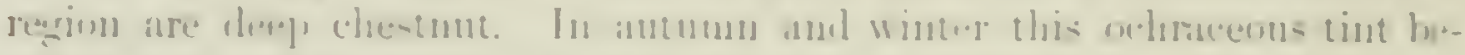

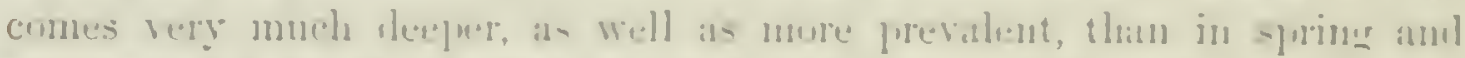

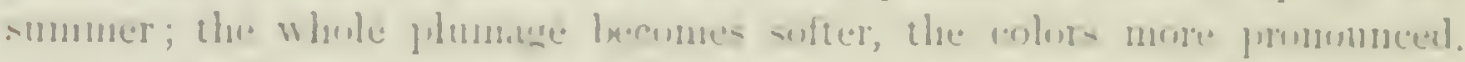

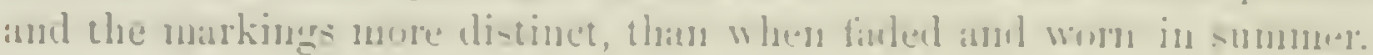

\section{Synopsis of Species of Harporbynchus.}

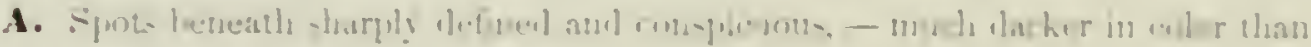
ilee upuner prart:

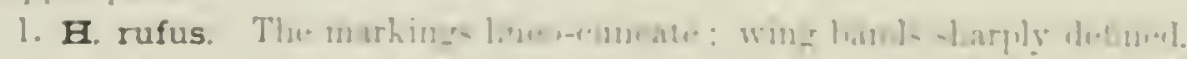

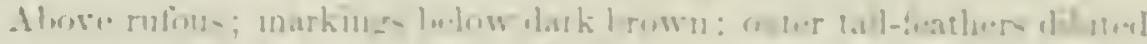

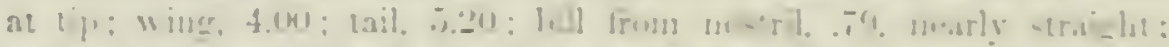

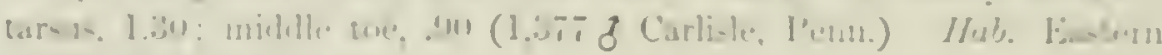

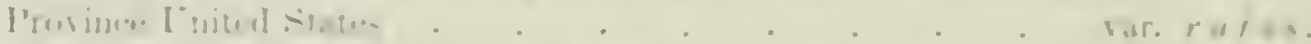

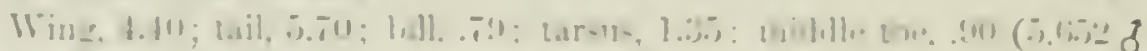

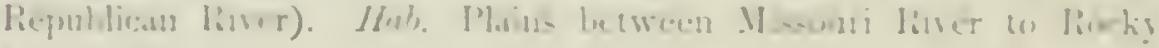
Mrantain

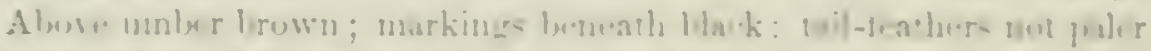

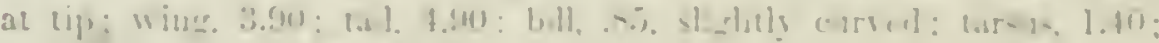

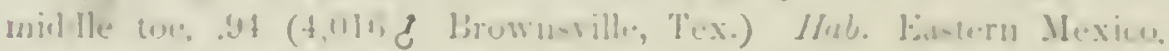
north on lis rirande of The nas

var. longirastris.

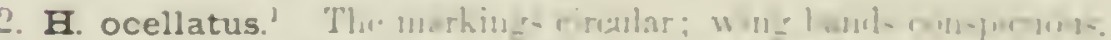

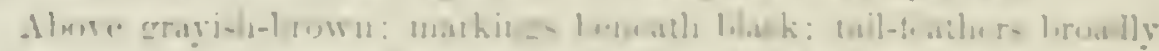

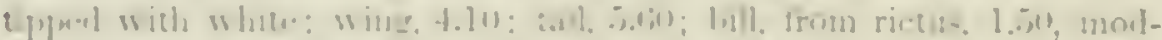

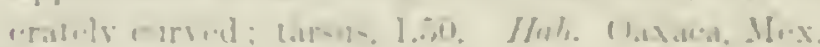

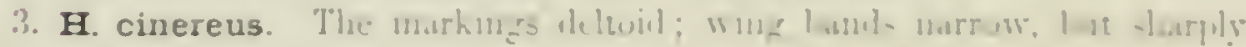
definect.

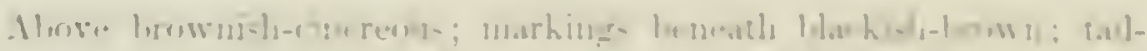

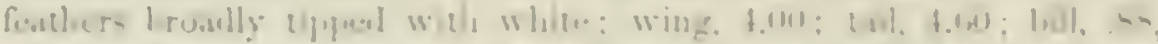

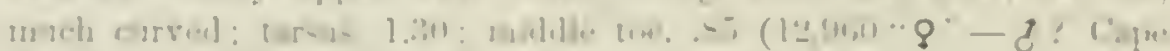

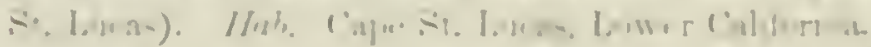

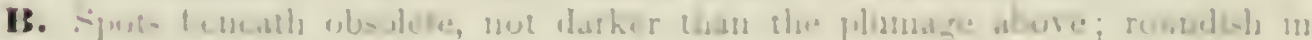
Lersus.

\section{H. curvirostris.}

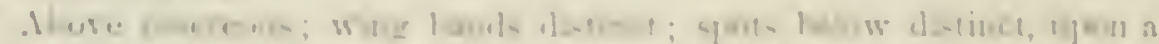

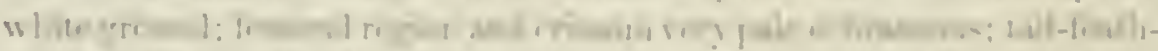

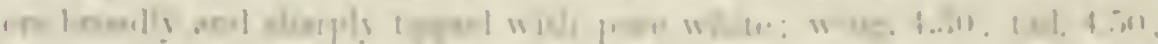

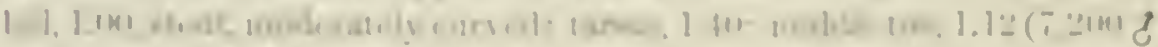

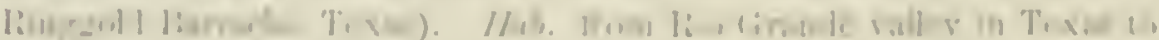

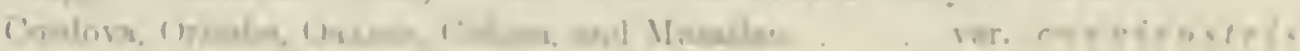

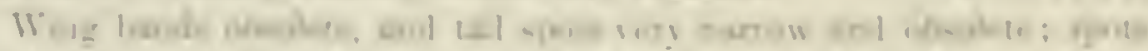

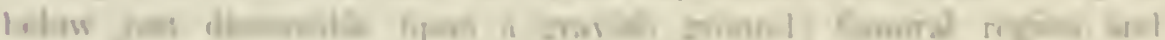

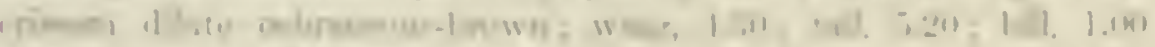

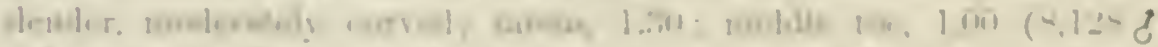

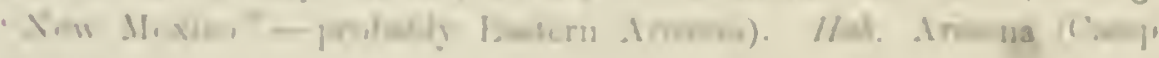
(iisen)

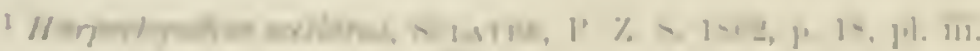


C. Entirely imspottel beneath.

5. H. redivivus. Anal region and lower tail-corerts light ochraceous.

Ahore sott brownish-cinereons, tail considerably diarker; wing bands almost obsolete, and tail-feathers merely diluted at tips. Bencath paler than abore, - ahmost white on throat and abdomen; anal region and lower tail-coverts yellowish-ochnaceous. A distinct "bridle" formed by the hair-like tips of the featluers, bordering the throat; maxillary stripe white with transverse bars of dusky; wing, 3.90 ; tail, 5.25 ; bill, 1.05 , slender, moderately curred; tarsus, 1.25 ; middle toe, $.86(40,718 \delta$ 20 uniles from Colorado livere, 1sear Fort Mojare). Mab. Arizona (Gilit River, Fort Fuma, and lort Ilojare) . . . . . var. lecontei.

Above aslyy drab, tail darker and more brownish; wing bands inconspicuous, and tail-featluers hardly diluted at tips. Beneath, the ochraceous covers the abelomen, and the throat inclines to the same. No "bridle." Checks and ear-corerts blackish, with conspicuous shaftstreaks of white; wing, 4.30 ; tail, J.60; bill, 1.40 , stout, very much bowed, - the arch regular; tarsus, 1.55 ; midlle toe, 1.00 (3,932 $\mathrm{d}$, Callifornia). Itub. Const region of California . . var. redivivus.

6. H. crissalis. Anal regrion and lower tail-coverts deep chestnut.

Abore, brownish-ashy with a sliglat purphsh east, tail not darker; no trace of wing bands; tail-feathers diluted, and tinged with rusty at tips. Beneath, of a uniform, paler tint than the upper plumage, not lighter medially; throat white, with a conspicuous "brille "; from this up to the eye whitish, with transwersely angular bars of dusky; wing, 4.00 ; tail, 6.50 ; bill, 1.25 , very slemler, bowed from the middle; tarsus, 1.30 ; midlle toe, .90 (11,53:3 \& liort Iuma). Hub. Region of Gilit Rirer to Rocky Mountains; north to Southern Utah (St. Georoe, breeding; Dr. Palmer).

Harporhynchus rufus, Cabasis.

\section{BROWN THRASHER.}

Turdues rufue, Lixx. Syst. Nat. 10th ed. 1758, 169, based on CATrsBr, tab. 10. - IB.

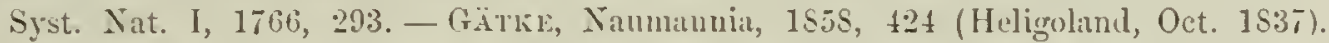

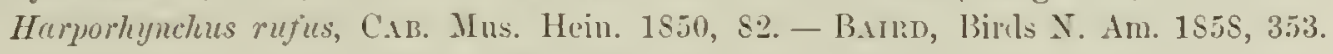

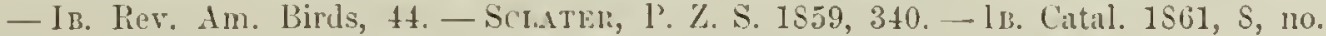
48. - Santels, 163. Jimes mufus, Pr. Max. Cal. Jonr. 1858, 180.

Figures : Vieillot, Ois. Am. Sept. II, pl. lix. - Wilsus, Am. Om. ll, pl. xiv. - Aen. Orn. Biog. pl. cxri.

Sp. Crus. Exposel portion of the bill shorter than the head. Ontline of lower mandible straight. Abore light cinnamon-red; beneath pale rufous-white with longitudinal streaks of dark brown, excepting on the chin, throat, middle of the belly, and under tailcorerts. These spots anteriorly are reddish-brown in their terminal portion. The inner surface of the wing and the inner edges of the primaries are cimamon; the concealed portion of the quills otherwise is dark brown. The median and greater wing-corerts become blackish-brown towards the end, followed by white, producing two conspicuous bands. The tail-feathers are all rufous, the external oncs obscurely tipped with whitish; the shafts of the same color with the ranes. Length, 11.15; wing, 4.1.5; tail, 5.20; tarsus, 1.30 .

HaB. Eastern North America to Missouri River, and perhaps to high central plains United States, east of Rocky Mountains, north to Lake Wimnipeg. 


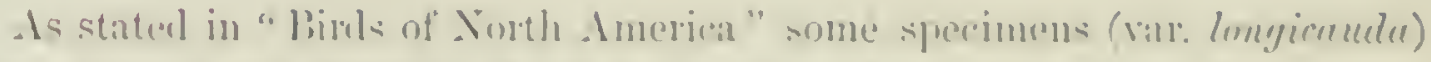

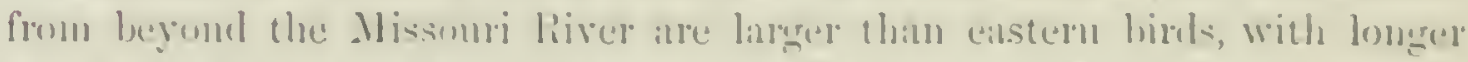

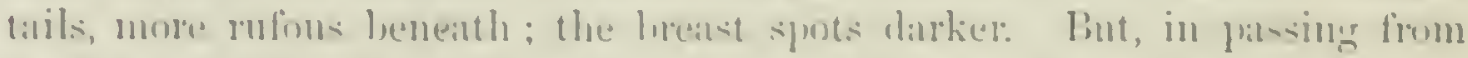
east to west, the change is so insemsihle that it is inpossible to divide the series.

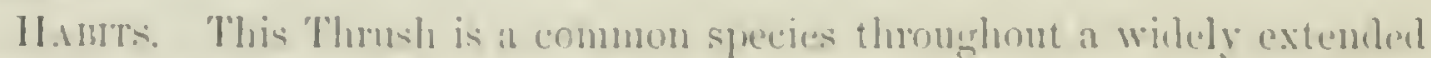
area, from the locky. Menutans to the Aclantic, and from the Reed River

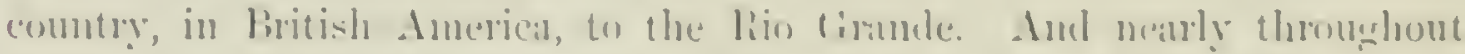
this entire territury it also resides and lneeds, from lexas to the itth prarllel of littitule.

It resches New England enty in May and lenves it in the latter part of

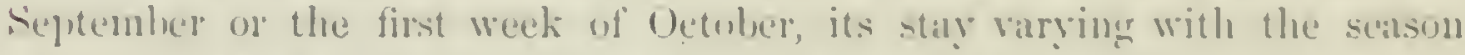

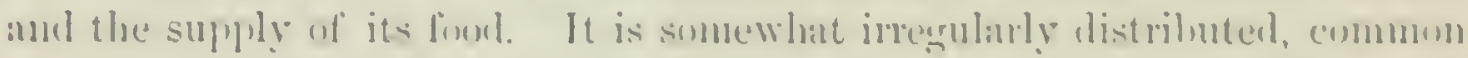
in some portions of this section, and rare or cren wnknown in others. It is not found near the seal-cuatst leyond Massalehects. It passes the winter in the somtlern stattes, even as for to the morth as Virginia, and is in foll

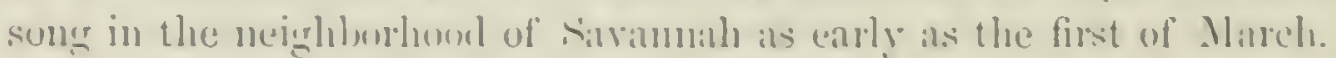

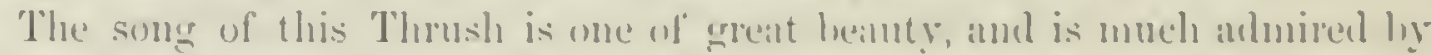
all who appreciate woolland melody of the sweetest not liveliest type. It

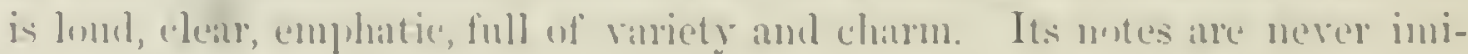
tative and cannot be mistalien by any one who is familian with them, for

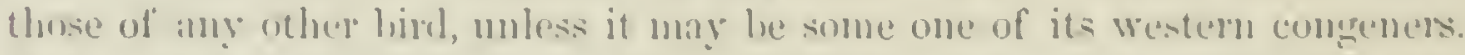
It is a very steaty ferformer, simging for hours at a time. Its motes are

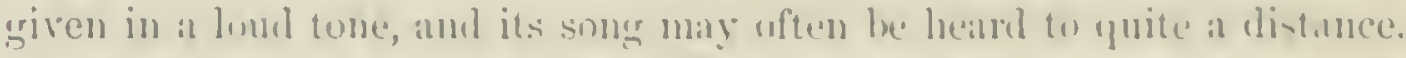

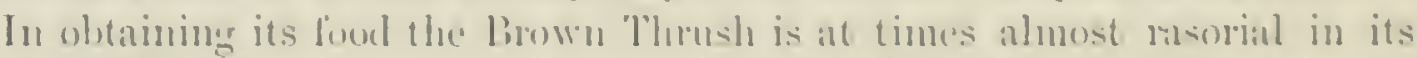
habits. In the early spring it seratteles ammong the leatres of the forest for Worms, coleopterous ermbs, and other forms of insect food. by some it

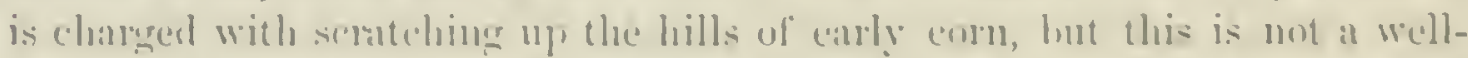

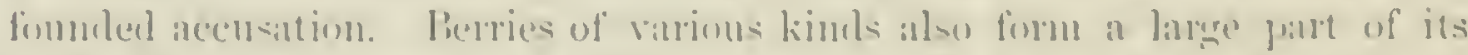

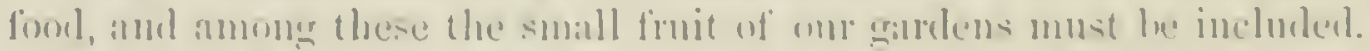

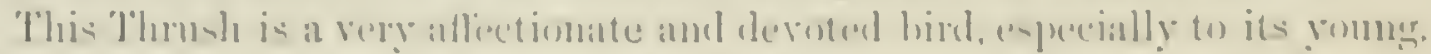
It is also prompt in ending to the assistance of others of its species when in

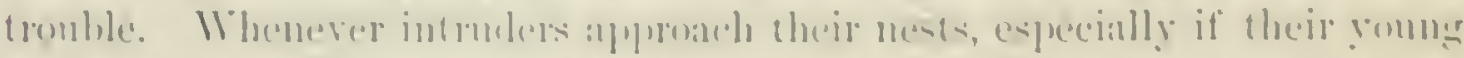

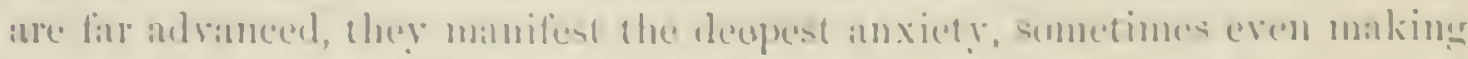

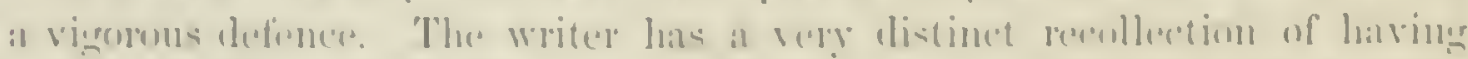

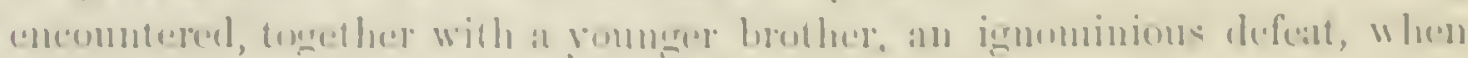

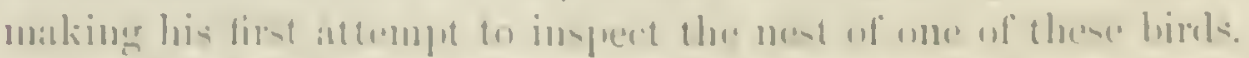

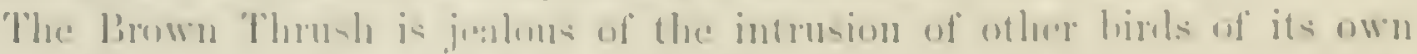

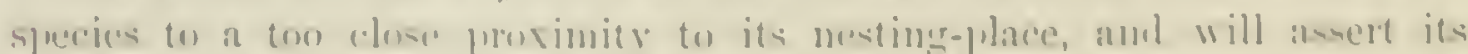

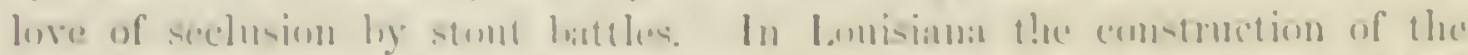

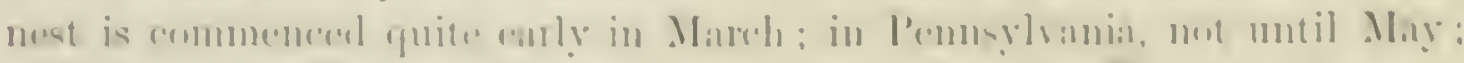

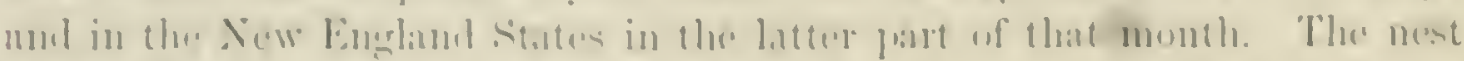

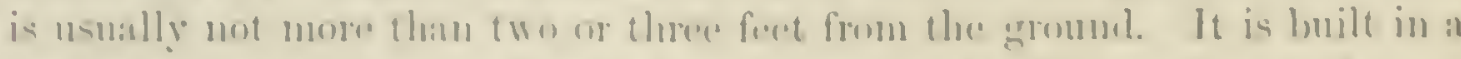

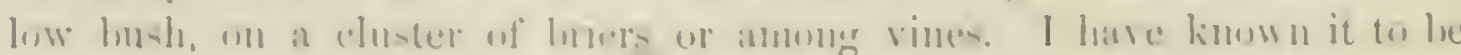


placed in the interior of a heap of brushwood loosely throm together. I have never met with the nest built upon the ground, but in sipringrield, and in other dry and sandy localities, this is by no means. an meommon occurrence. These nests are frequently placed in close proximity to houses, and sometimes in the rery midst of villages.

The nest of the Thrasher is large, and romghly but strongly built. The base is usually made of conrse twigs, sticks, ant ends of buanches, firmly interworen. Within this is constructed an inner nest, composed of dried leares, strips of bark, and strong black fibrous roots. These are lined with finer roots, horse-hair, an occasional feather, ete.

The eggs are usmally four, sometimes five, and rarely six, in number. They vary both in the tints of the ground color, in those of their markings, and slightly in their shape. Their length raries from .99 to 1.1 . inches, with a mean of 1.05 . Their breadth ranges from .76 to .87 of an inch; mean breadth, .81 . The irround color is sometimes white, maked with fine realdishbrown dots, confluent at the larger end, or forming a broad ring around the crown. In others the markings have a yellowish-brown tint. Sometines the ground color is a light green.

\section{Harporhynchus rufus, var. longirostris, CAвнг.}

\section{TEXAS THRASHER.}

Orpheus longirostris, L.afr. R. Z. 1835, 55. - In. Mag. de Zool. 1839, Ois. pl. i. Torostoma lonyirostre, CAB. Wiegm. Arels. 1S47, 1. 207. Mimus longirostris, ScLatrer, P. Z. S. 1\$56, 294 (Cordora). Harporhynchus longirostris, CAB. MLus. H(in. 1550, \&1. - B.Mrd, Birls X. Am. 1858, 352, pl. lii. - IB. lier. Ht.-ScL.1TEr, I. Z. S. 1859, 339 ; Ів. 1864, 172 (City of IIex.); IB. Catal. 1S61, $s$, no. 47.

Sp. Cuns. Similar to H. rufus, the rufous of back much darker. Wings much rounded: second quill shorter than the secontaries. Exposed portion of the hill as long as the head: the lower edge decidedly decurved or concare. Abore rather dark browni-h-rufous: beneath pale rufous-white; streakerl on the sides of the neck and body, and across the breast, with rery dark brownish-black, nearly uniform throughont, much darker than in rufus. Two rather narrow white bands on the wings. The concealed portion of the quills dark brown. Length, 10.50 ; wing. 4.00 ; tail, 5.00; tarsus, 1 t0.

Hıв. Eastem Irexico; north to Rio Grande, Texas. Cordora, Scl. Orizaba (temperate region), Scmicurast.

Specimens from the Rio Grande to Mrirador and Orizaba are quite identical, with, of course, differences among individuals. This "species" is not, in our opinion, separable from the $H$. rufus specifically; but is a race, representing the latter in the region griven above, where the rufus itself is never found. The relations of these two forms are exactly paralleled in the Thryothorus ludaricianus and T. berlcundieri, the latter being nothing more than the darker Southern representation of the former.

The Texas Thrasher appears to belong only to the Arifama of the South- 
west. It first appears as a biml of the valley of the lion fimule, and extends

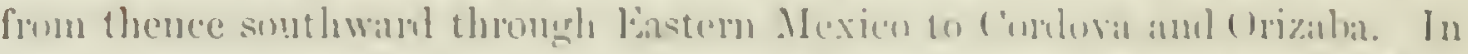

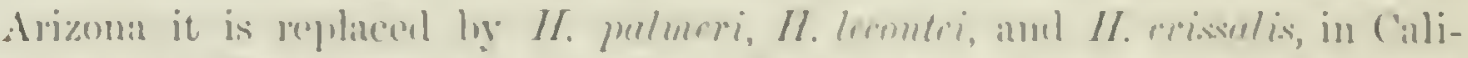
fornia hy II. velirirus, and at ('ape st. Incas hy $I$. rimmos, while in the

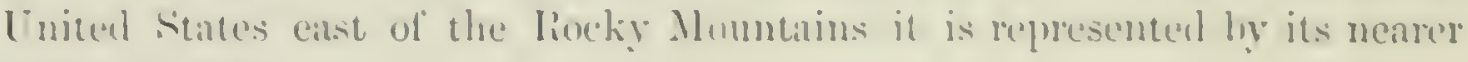
ally H. rufus.

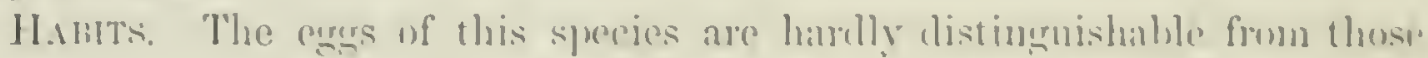

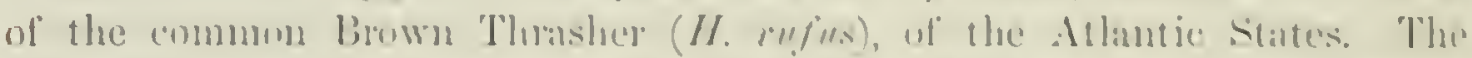

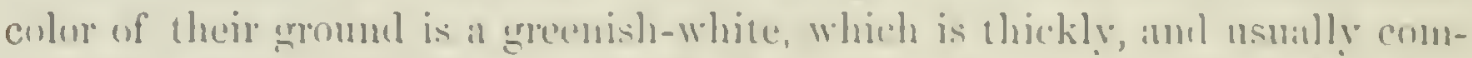

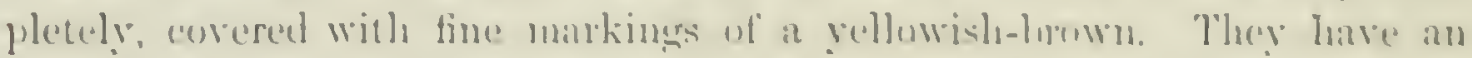

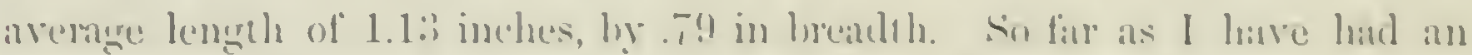

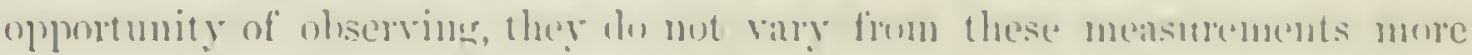

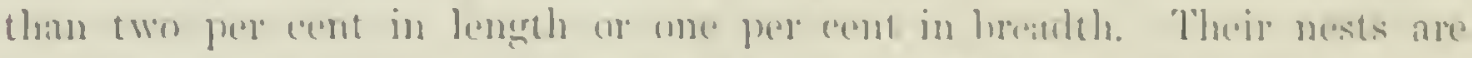

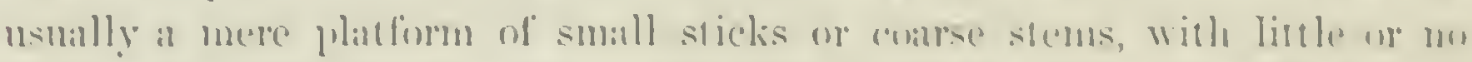

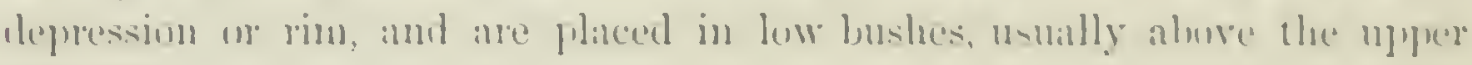
hinaches.

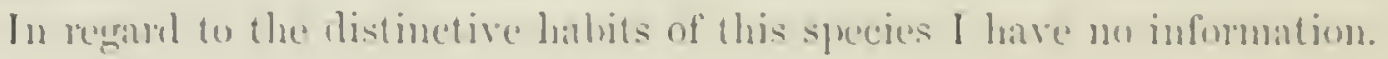

\section{Harporhynchus cinerous, Xistrs.}

CAPE ST. LUCAS THRASHER.

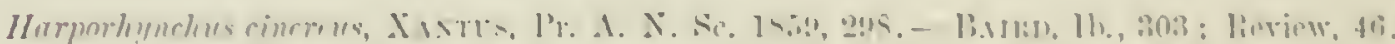

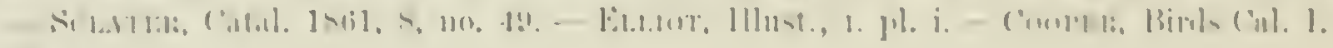
$1 ! 1$

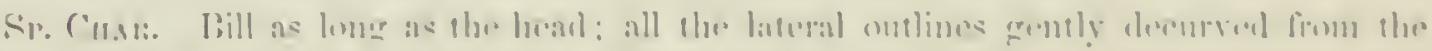

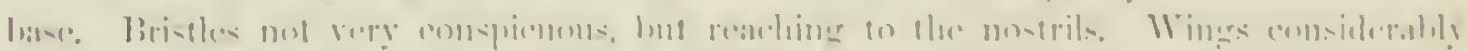

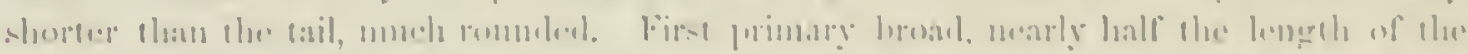

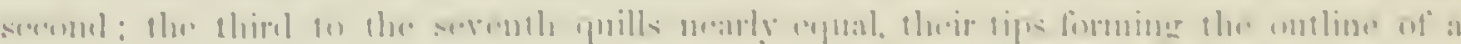

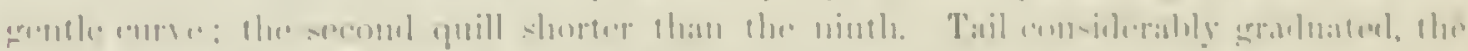

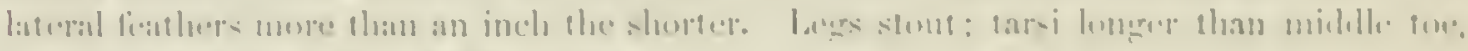
linimenly :

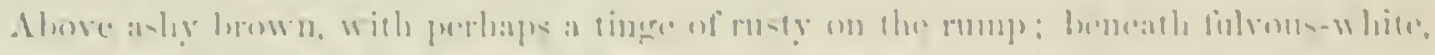

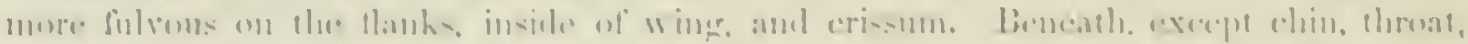

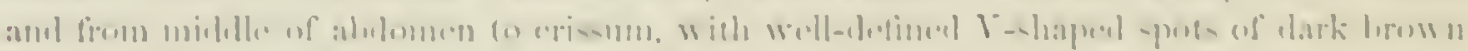

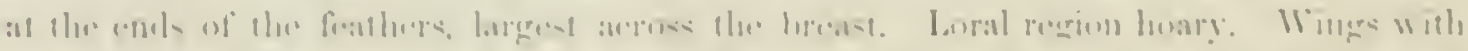

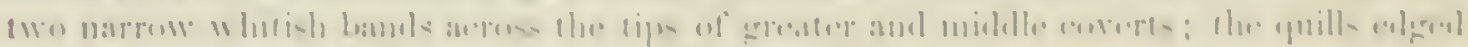

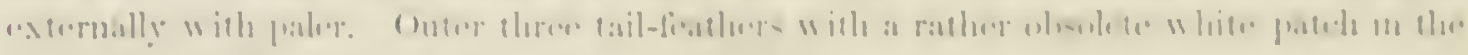

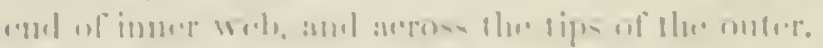

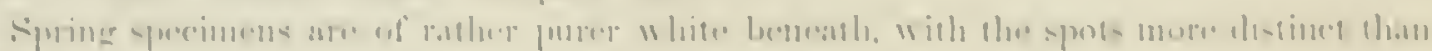

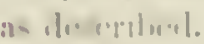

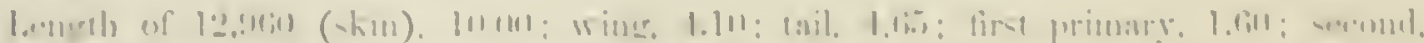

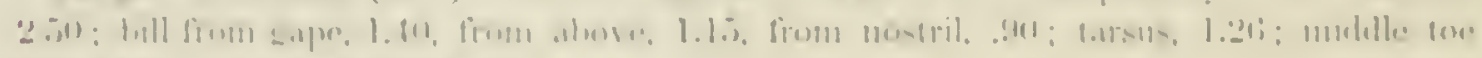

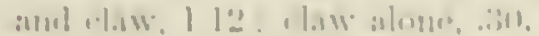

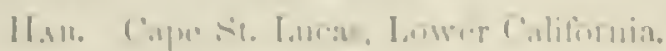

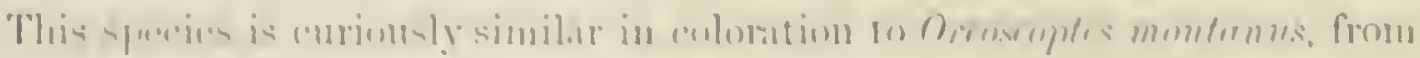

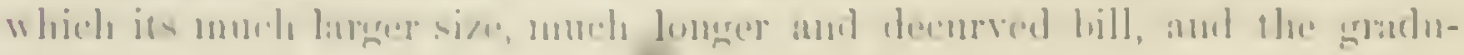


ated tail, of course rearlily distinguish it. It agrees in some respects with $H$. rigus and $H$. longirostris, but is stnaller, the bill longer and more curved; the upper parts are ashy olivaceous-brown instead of mifuns, etc.

H.sits. So far ats is at present knuwn in regarl to this species it appears to he confined exclusively to the peninsula of Lower Califurnia. It has, at least, been met with nowhere else. Mr. Sautus found it yuite numerous in the vicinity of Cape St. Lucas, in a region which, as he descriles it, was singularly unpropitious. This was a sandy shore, extending about a quarter of a mile inland, whence a cactus desert stretched about six miles up to a high range of mountains. Throughout this tract the ground is covered with a saline elthorescence. There is nu fresh water within twenty-eight miles.

Mr. Aantus speaks of the habits of this bird as leeing similar to those of the Oreascoptes montanus. It was a very aluudant species at this cape, where he found it breeding amoug the cactus plants in large numbers. He mentions that as early as the date of his arrival at the place, April $t$, he found them already with full-flectged roung, and states that they continued to breed until the middle of July.

He was of the impression that the egges of this species more nearly resemble those of the common Mrocking-Biru than any others of this genus. The aggravatingly brief notes that accompanied his collections show that the general position of the nest of this species was on low trees, shrubs, and most usually, cactus plants, and in no instance at a greater clevation from the ground than four feet. Their nests were flat structures, having only a very slight depression in or near their centre. They were about 5 inches in diameter, and were very little more than a mere platform.

The eggrs vary somewhat in their ground color, but exhibit only slight variations in size or shape. Their greatest length is 1.13 inches, and their average 1.12 inches. Their mean breadth is . 7 inch, and their maximum .79 inch. The ground color is a greenish-white, profusely marked with spots of mingled purple and brown. In others the ground color is a hluishgreen. In some specimens the spots are of a yellowish-urown, and in some the markiniss are much lighter.

Harporhynchus curvirostris, CABAI.

\section{GRAY CURVE-BILL THRASHER.}

Opphus curcirostris, Swarsos, Philos. Mag. 1\$27, 369 (Eastern Merico). - M'CALl, Pr.

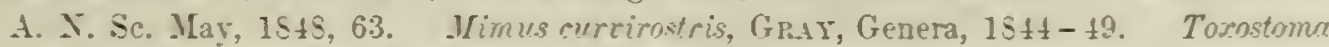

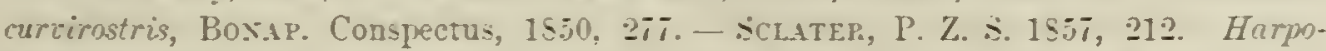

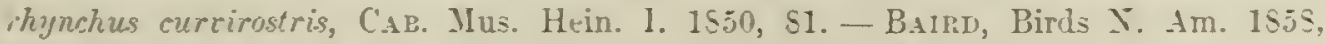

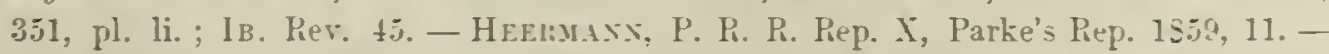
SClate\%, P. Z. S. 1559, 339: If. Catal. 1561, 7. no. 40. - Dreserk. Ibi Pomatorhinus turdinus, TeMu. P1. Col. 41 . ? Tocastoma retula. WAGLË, Isis, $1 \$ 31$. 239. 


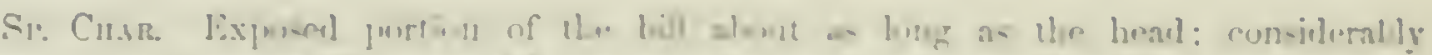

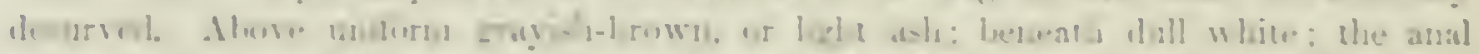

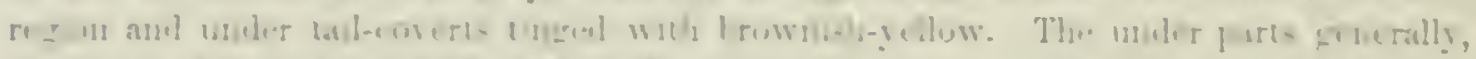

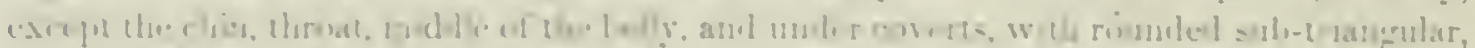

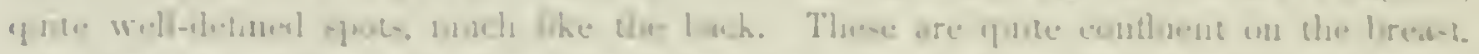

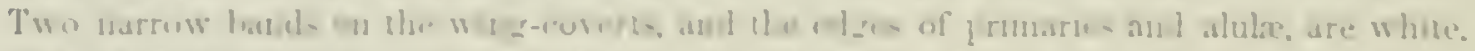

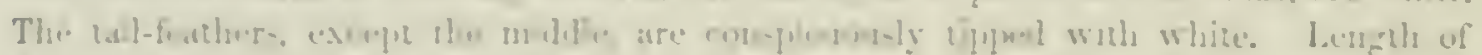

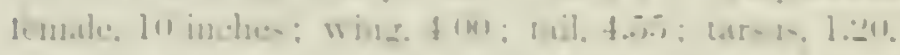

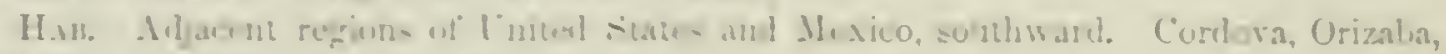
Il raulor; Maza'lon, Colima, Taxana.

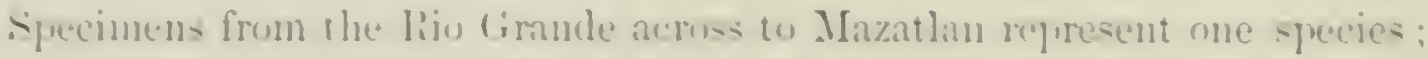

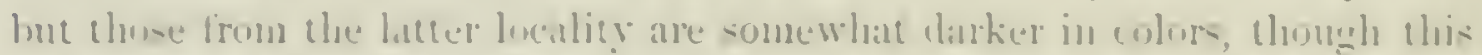

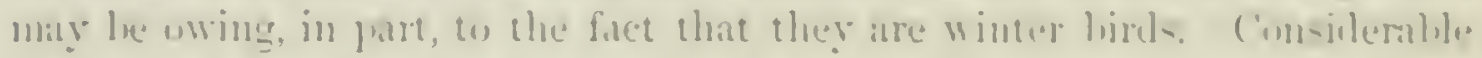

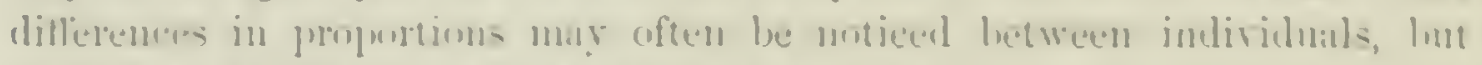

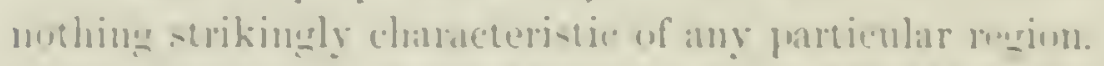

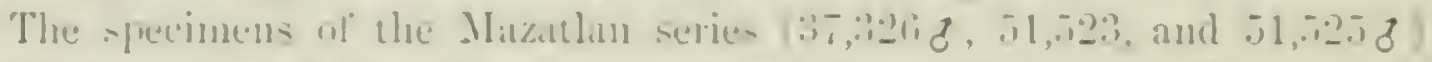

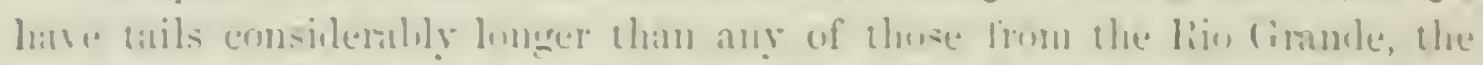

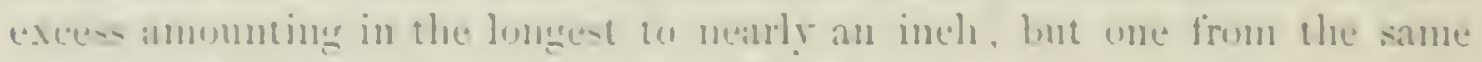
lueality has it oluerfor than any of the Texids speceimens.

In its perfect plumil--e, this species las buth rows of coverts distinctly

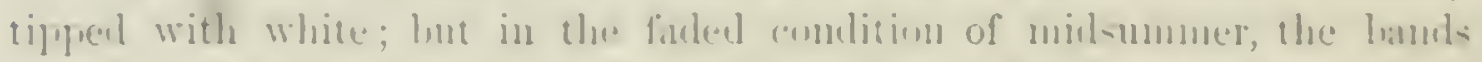
thus probluced are hardly disecrnible, and the sputs below become very obsulete.

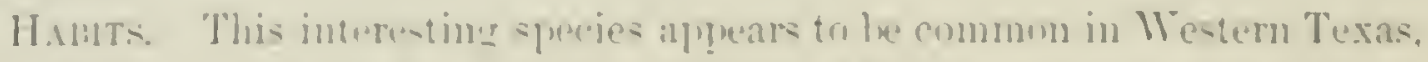

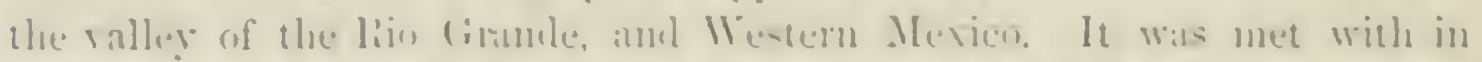

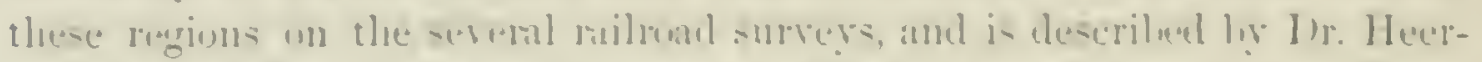

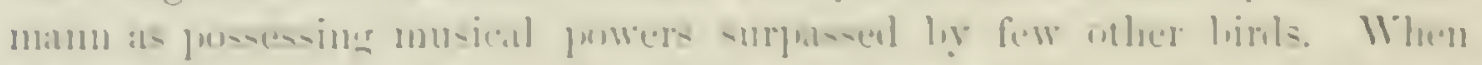

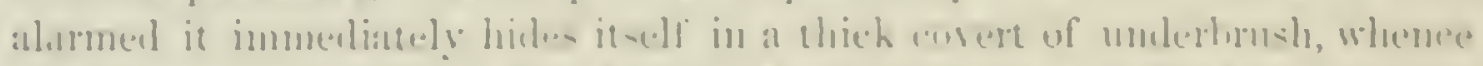

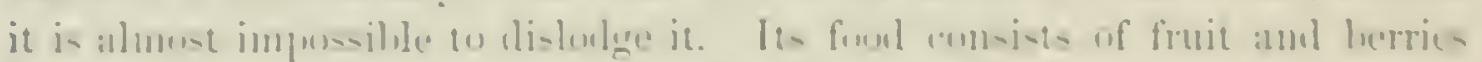

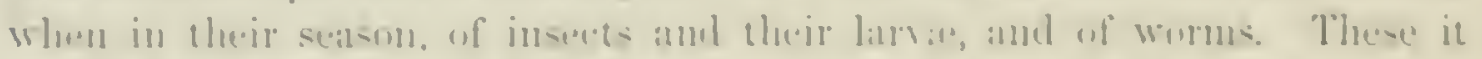

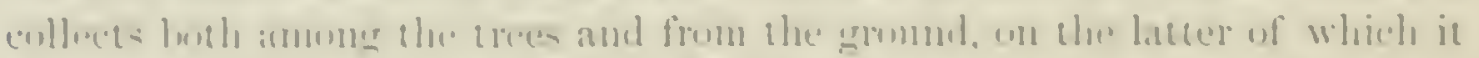

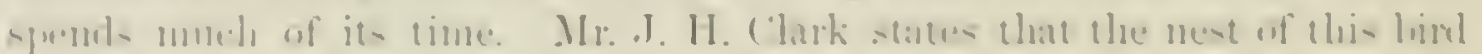

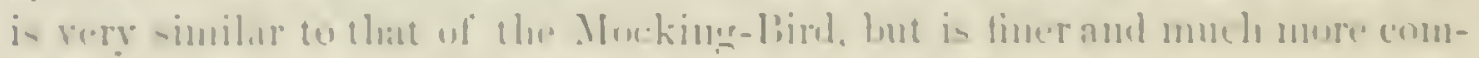

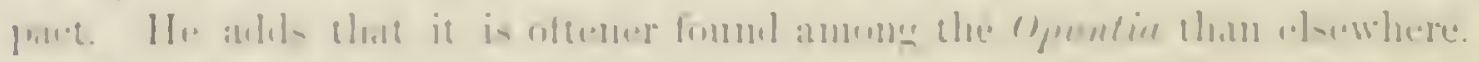

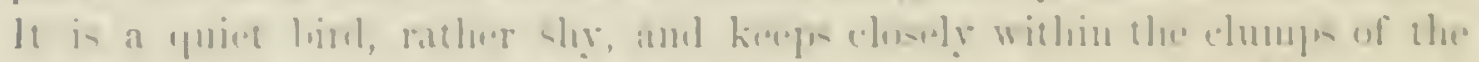

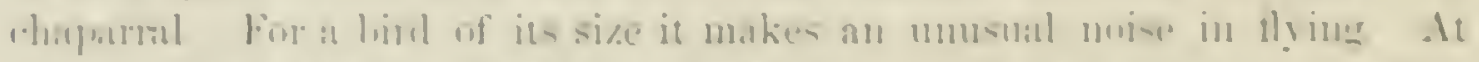

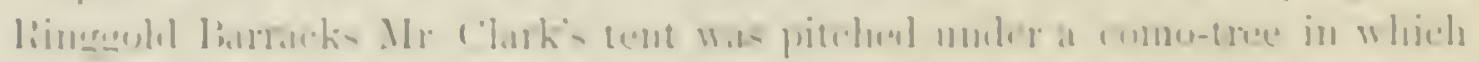

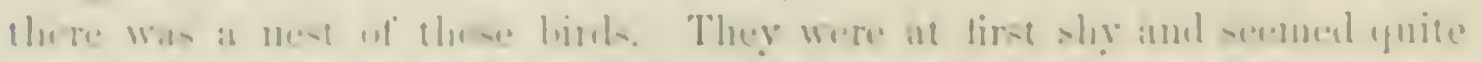

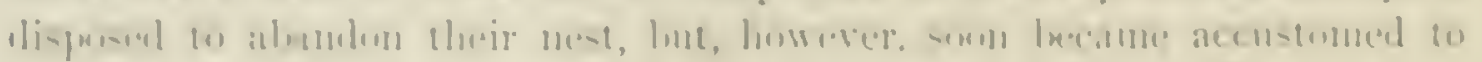

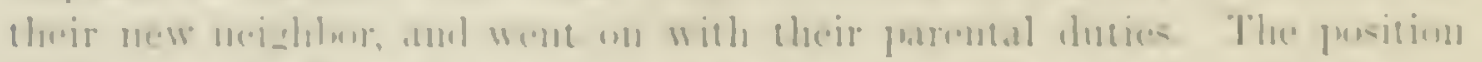

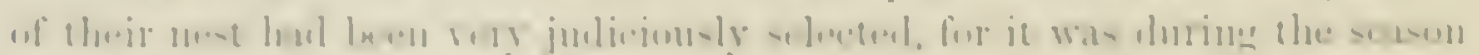

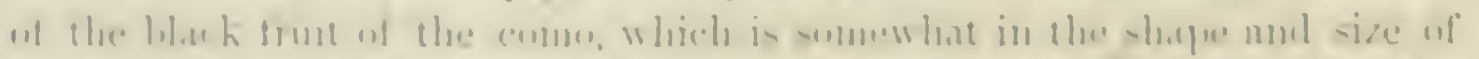

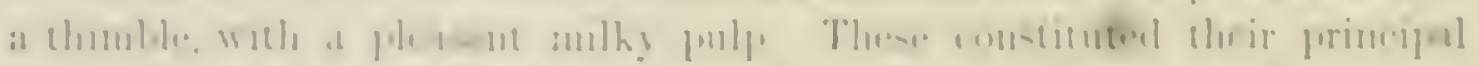

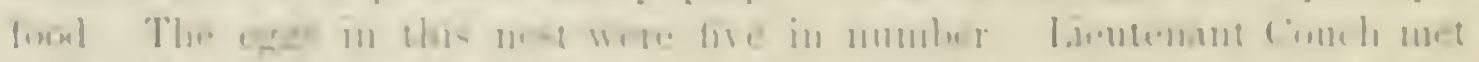

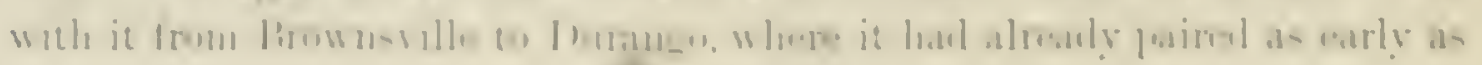


February. He describes it as exceedingly tame and gentle in its habits, and with a song remarkiably melodions and attractive. P'erched on the topmust bongh of a fluwering mimosa, in the presence of his consort, the male will pour forth a volune of must enelanting music. Their nest is generally very nearly flat, measuring nearly six inches in eireumference, and searcely more than an inch in its greatest thickness. It hats hardly any distinct cavity, and hollows but very slightly from the rim to the eentre, its greatest depression having barely the depth of half an inch. The nests are composed of long eoarse fibrous roots, rulely, but somewhit complatly interwoven. The immer framework is constructed of the same materials intermixed with the finer stems of grilsses.

MIr. II. E. Dresser states that in the vicinity of Matamolas these lirds are fond of frequenting small villages, and that he frequently found their nests within the gardens and court-yards of the honses, and nen the road.

The egrgs of this Thrush vary considerably in size, ranging from 1.20 to 1.03 inches in length, and from $8 \pm$ to .77 of an inch in brealth. Their mean length is 1.12 inches, and their arerage breadth 80 . They have a light green ground-color, generally, though not thickly, covered with fine brown spots.

Harporhynchus curvirostris, vill. palmeri, lingiws.

\section{PALMER'S THRASHER.}

II arporhynchus curvirostris, var. pelmeri, lingwar, Report King's Expedition, V, 1872.

Sr. Cirar. Bill slender, moderately eurred; fifth quill longest; fourth and sixth just pereeptibly shorter, and equal: sceoncl equal to ninth; first 1.55 shorter than longest. General plumage uniform grayish-umber, paler below, becoming almost dirty whitish on the throat and abdomen; lower part of the breast and abdomen with a rery fow just diseernible irregular specks of a darker tint; lower tail-corerts dilute isabella-brown, more ochraceous at their margins; anal region and lower part of ablomen light ochraceons. No bands on wings, and tail-feathers only diluted at the tips. Mixillary stripe whitish with transwerse bars of dusky. "Iris orange."

$\delta($ No. 8,128, "New Mexico"= Arizona, Dr. Heermann): wing, 4.30; tail, 5.00; bill (from nostril), 1.00; tarsus, 1.30 ; middle toe (without claw), 1.00. $\$(49,723$. Camp) Grant, Tueson, Arizona, March 12, 1867; Dr. E. Palmer; with egrs) : wing, 4.15; tail, 4.5 .5 ; bill, .95; tarsus, 1.25 ; mildlle toe, .90 .

Haв. Eastern Arizona (Tucson).

This rery curious race seems to unite the characters of currirostris and lecontei; in fact, it is so exactly intermediate between the two, that we are alnost in doubt as to whieh it is most nearly related. Having the stont form and larger size, as well as the spots on the abdomen, of the former, it has also the uniform colors and general appearance of leconte $i$. Were it not that the nest ancl eggs, with the parent accompanying, had been received from Ir. Palmer, we might be tempted to consider it a hybrid between these two 


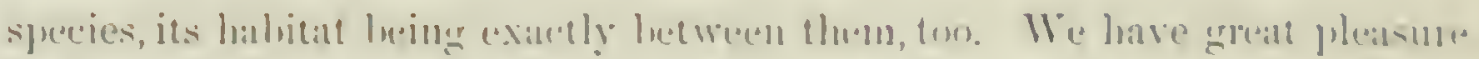

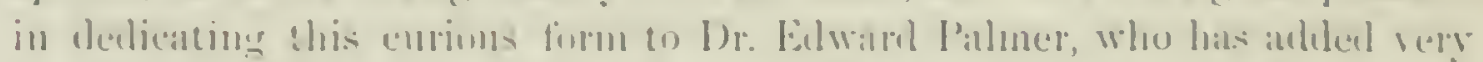
much to on knowledige of the Natural Historg of the interesting rengin "lete the juentut limb is fonml.

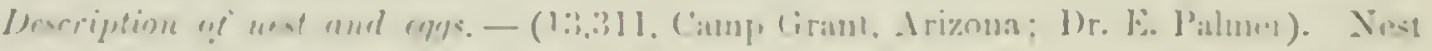

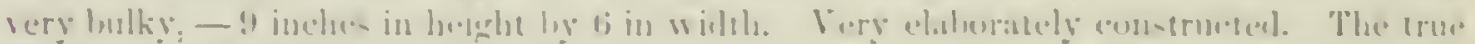

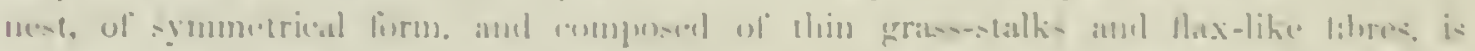
(')

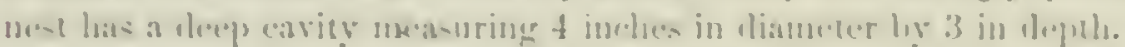

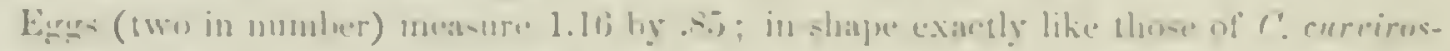

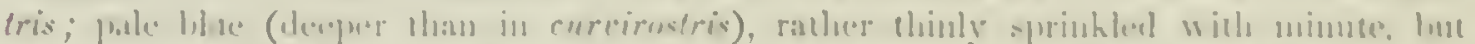

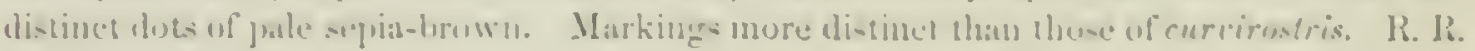

The nest was situated in a cactus-bush, four and a half feet abore the grominl

1)r. Palner renembers nothing special concerning its habits, except that the himl was very shy, and kept nuteh on the ground, whele it was seen ruming bencath the bushes.

\section{Harporhynchus redivivus, var. lecontei, Bux.l. LECONTE'S THRASHER.}

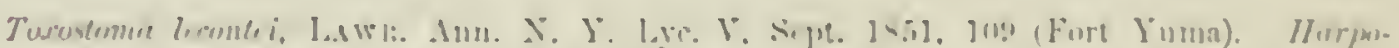

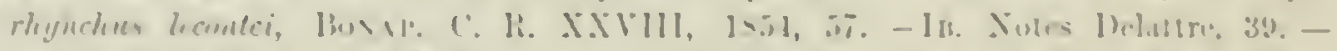

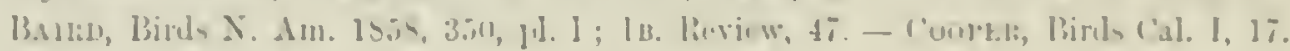

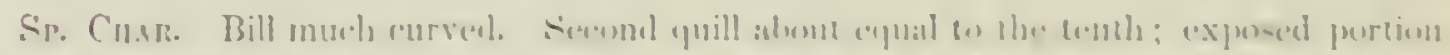

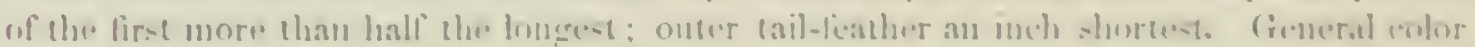

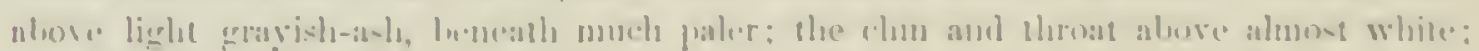

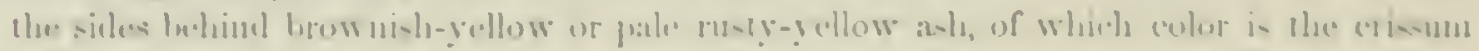

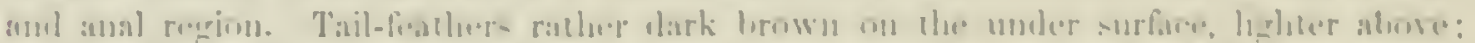

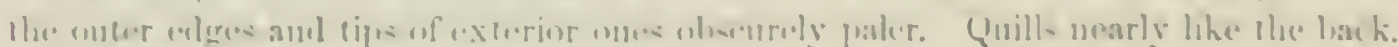

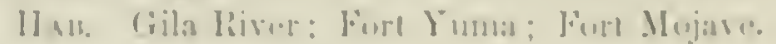

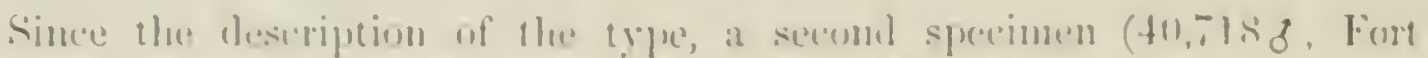

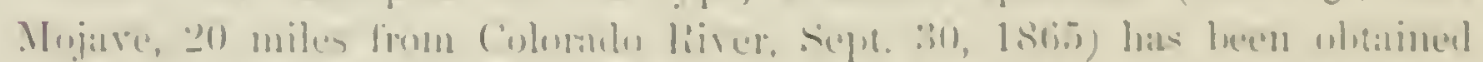

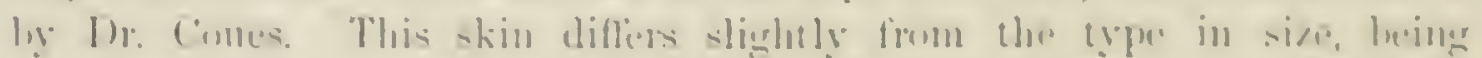

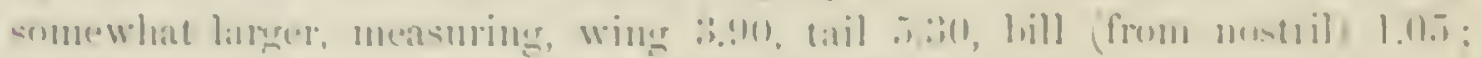

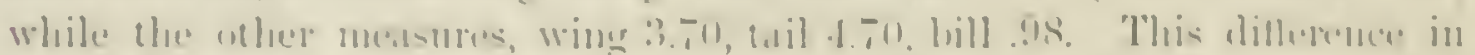

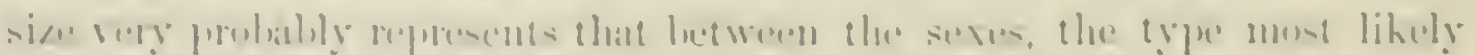

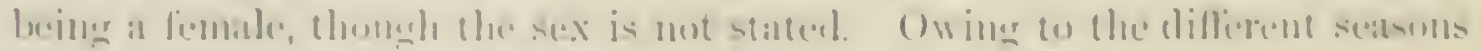

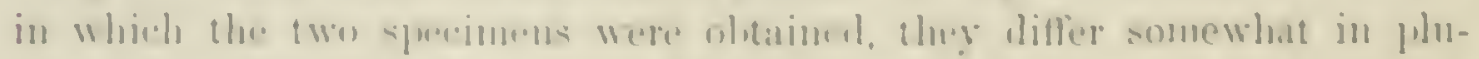

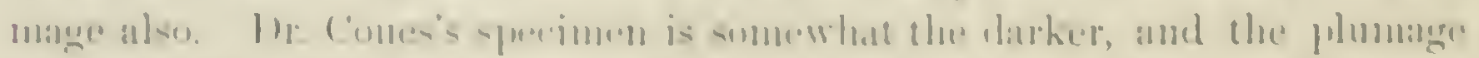

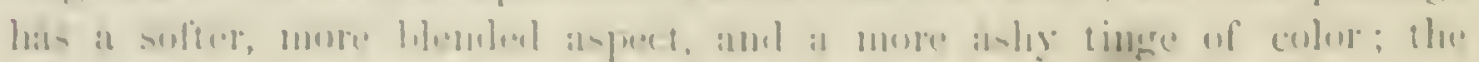

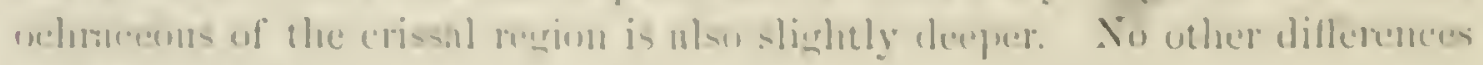

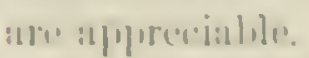

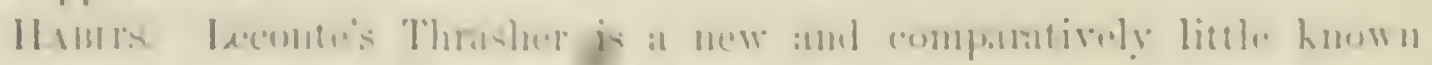


species. A single specimen was obtained by Dr. Leconte near Fort I'uma, and described by Mr. Lawrence in 1851, and remained mique for many years. In 1861 Dr. Cooper presented a paper to the California Acalemy of Sciences, in which this binl is given among a list of those new to that State. He then mentions that he found it common abont the Mojare River, and that he procured two specimens.

Dr. Cones, in his valuable paper on the birls of Arizona, speaks of obtaining, in 1865 , a specimen of this rare species on a dry plain covered thickly with mesquite and eactus, near Fort Miojare. This bird was rery shy and restless, fluttered hurriedly from one eactus to another, until he at last shot it where it seemed to fancy itself hidden among the thick fronds of a large yncea. Its large stont feet admirably adapt it for its partially terrestrial life, and it apparently spends much of its life upon the ground, where it runs rapidly and easily. Its flight he clescribes as swift but desultory, and accompanied by a constant flirting of the tail. He considers this species as inhabiting the whole valley of the Colondo and Gila, and thinks that it does not leave the vicinity of these streams for the monntains.

Dr. Cooper found a nest of this species, but without eggrs, built in a yucea, and similar to that of $H$. redivirus. In his Report on the Birds of California, Dr. Cooper speaks of finding this bird common on the deserts, along the route between the Colorido Valley, wherever there was a thicket of low bushes surrounded by sand-hills. Its notes, habits, and general appearance were like those of $H$. redirivus.

\section{Harporhynchus redivivus, C.вьк. CALIFORNIA THRASHER.}

Harpes redivira, frumel, Pr. A. X. S. II, Ang. 1S45, 264. Toxostoma redivira, Gambel, J. A. N. Sc. 2l ser. I, 1847, 42. - CAssix, Illust. I, 1555, 260, 1l. xlii. Hrarporleyn-

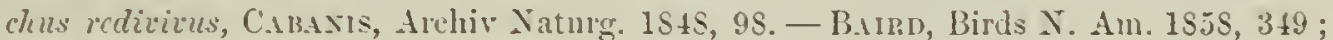
Rer. 4S. - Sclater, P. Z. S. 1S59, 339. - Cuoper, Birds Cal. 1, 15.

Sp. Cnar. Wing much rounded; the second quill shorter than the secondaries. Tail much gracluated. Bill much decurved, longer than the head. Above brownish-olive. withont any shade of green: beneath pale cinnamon, lightest on the throat, deepening gradually into a brownish-rufous on the unler tail-coverts. The fore part of the breast and sides of the body brown-olive, lighter than the back. An obscure ashy superciliary stripe, and another lighter beneath the eye. Ear-corerts and an indistinct maxillary stripe. dark brown; the shafts of the former whitish. Ends and tips of tail-feathers obsoletely paler. Length, 11.50 inches: wing, 4.20 ; tall, 5.75 ; tarsus, 1.55 .

H.ı. Coast region of California.

H.siTs. The California Thrasher appears to have a somewhat restricted distribution, being confined to the coast region of California, where, however, it is quite abundant. It was first met with by Dr. Gambel, near Monterey. The specimens were obtained on the ground where they were searching for 


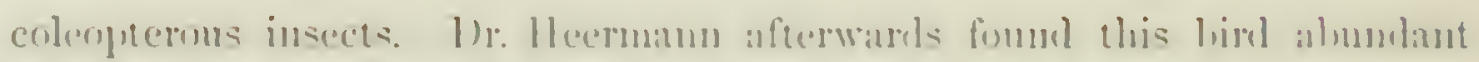

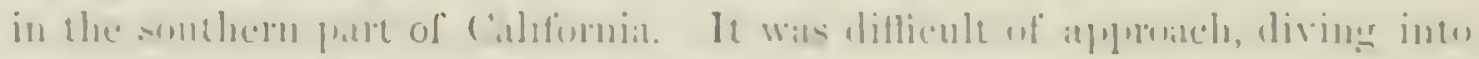

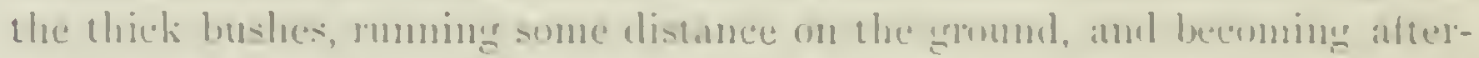

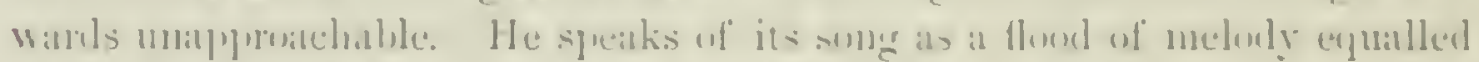

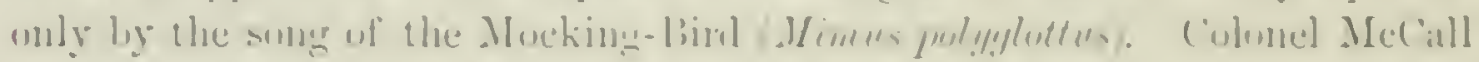

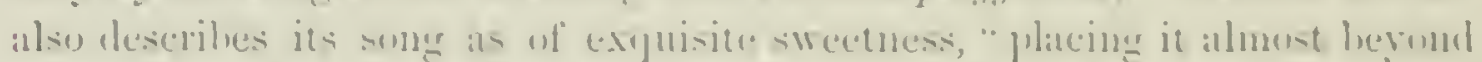

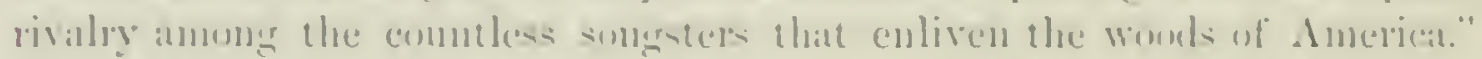
He alos states that it is as retiring and simple in its mamers at it is hrilliant ill sillis.

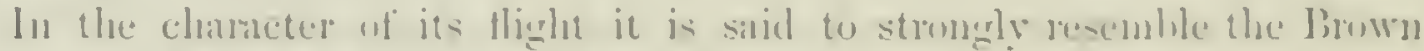

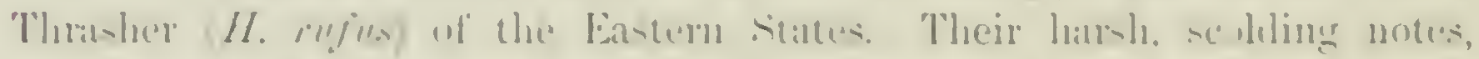
when their nest is applobitchel, their motions and attitules, alle all very

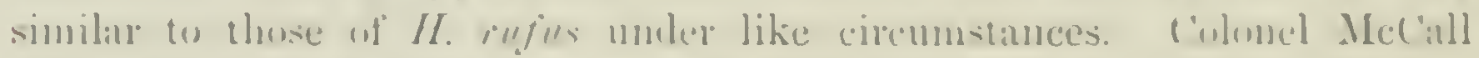

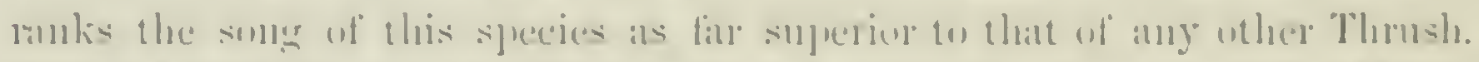

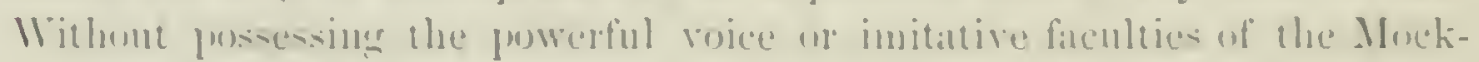

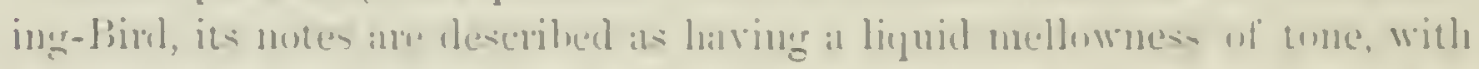

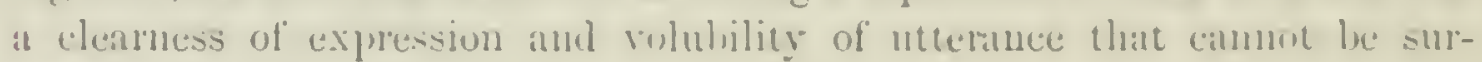
paramel.

I nest of this hird lomml by Dr. Ileemnann was composed of conse twigs, and lined with slender rents, and not very andefilly constructed. Mr. Ilep-

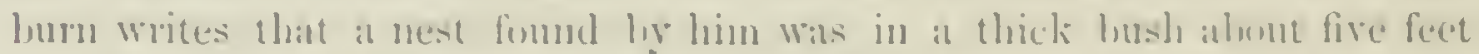

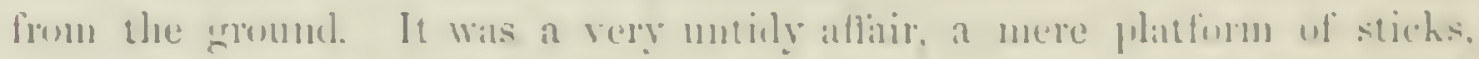

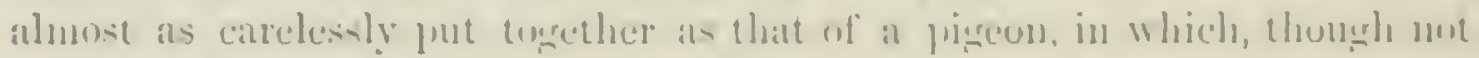
in the centre, was at shallow dejersion alome + incher in dimeter, limed

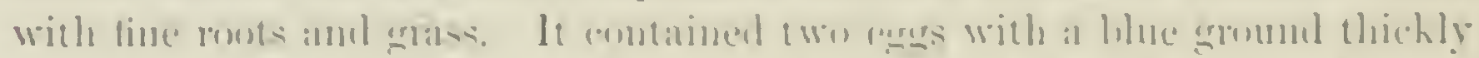

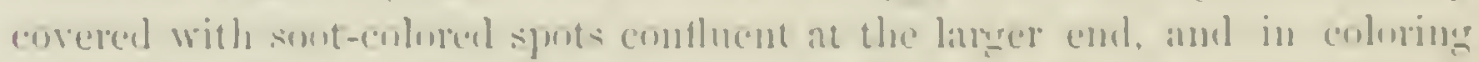

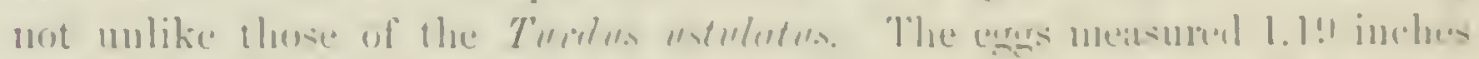

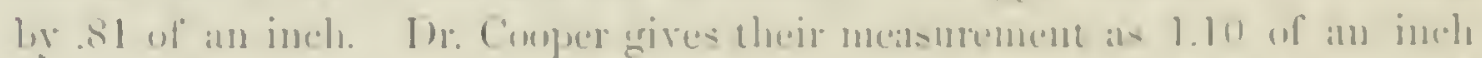

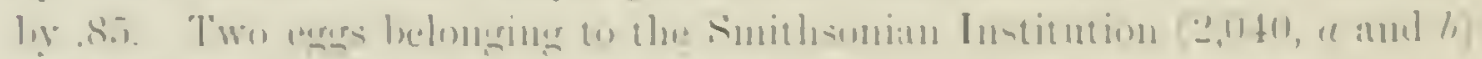

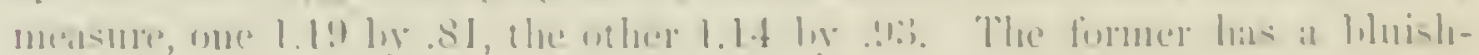

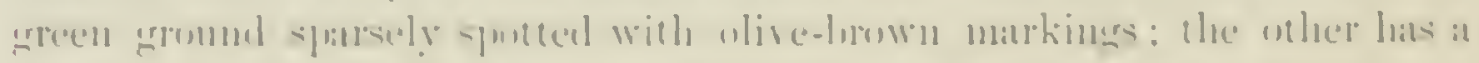

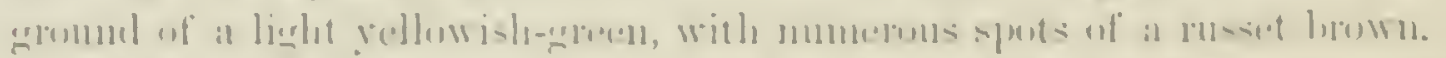

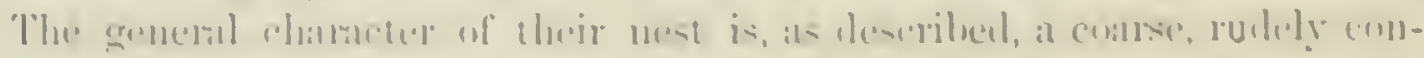

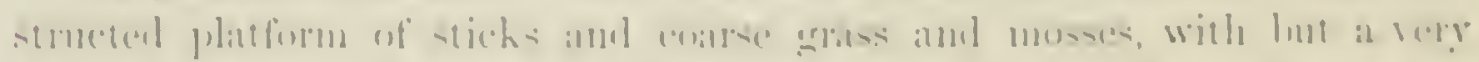

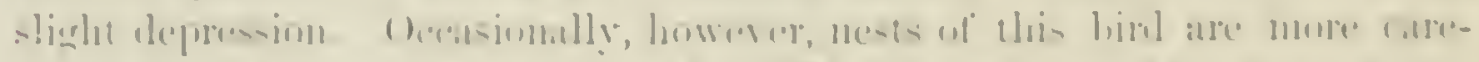

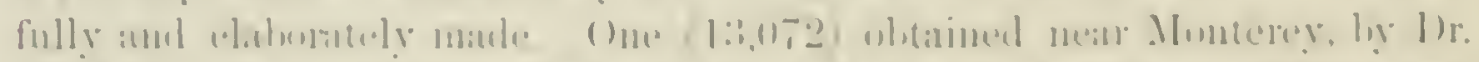

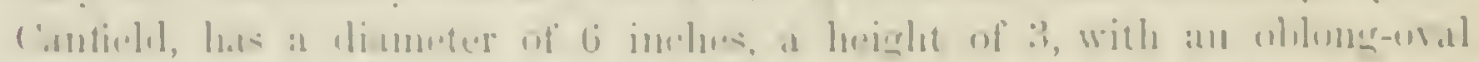

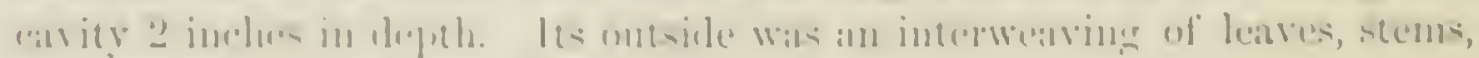
:

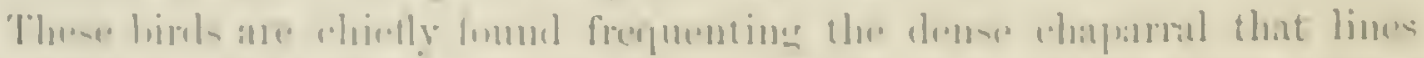

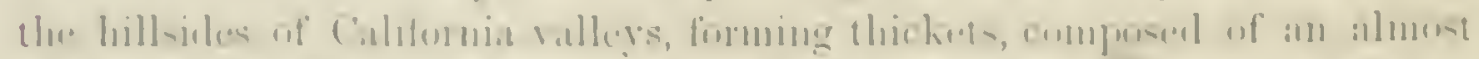

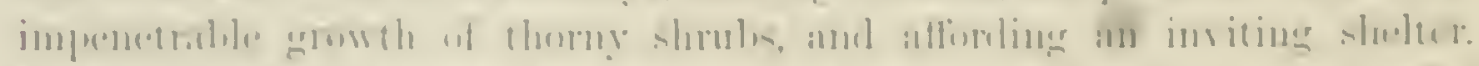

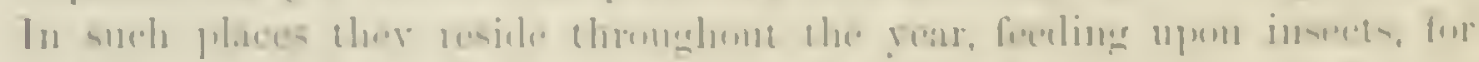

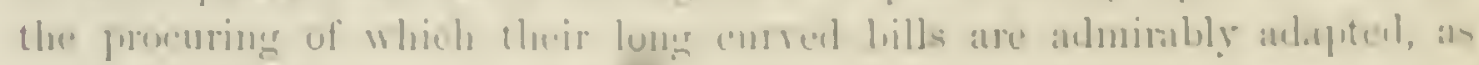


also upon the berries which generally ahound in these places. Their nests usually contain three egyrs. Dr. Cooper states that their loud and raried song is frequently interningled with imitations of other birds, though the seneral impression appears to be that they are not initative, and do not deserve to be called, as they often are, a mocking-bird.

\section{Harporhynchus crissalis, HEXr:}

\section{RED-VENTED THRASHER}

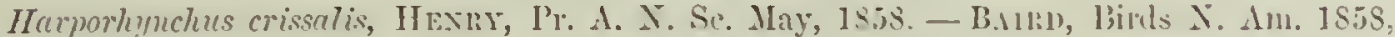
350, 1. Lxxii ; lieview, 47.-Coupler, Birds Cal. 1, 18.

Si. Cunr. Sccomel quill about as long as the secondarios. Bill much curred; longrel than the lead. Shove olive brown, with a faint shate of eray; bencath nearly uniform brownish-gray, much paler than the back, passing insensibly into white on the chin; but the muder tail-coverts dark brownish-rufous, and abrupty ledined. There is a black maxillary stripe eutting off a white one abore it. There do not appear to be any other stripes about the hear. There are no bands on the wings, and the tips and outer erlges of the tail-feathers are rery inconspicnons]y lighter than the remaining portion. Length, 11 inches: wing, 4.00 ; tail, 5.80 ; tarsus. 1.2.

H.us. Rergion of the Gila River, to Rocky Mountains; Southem Utah (St. George, Dr. I'almeric).

A second specimen $(11,533)$ of this rare species is larger than the type, but otherwise agrees with it. Its dimensions are as follows:-

Length before skinning, 12.50; of skin, 12.50; wing, 3.90 ; tail, 6.50; its graduation, 1.45 ; first quill. 1.50 ; second, .41; bill from forehearl (chord of enrre), 1.65 , lrom gnpe, 1.75, from nostril. 1.30 ; curve of culmen, 1.62; height of bill at nostril, .22; tarsus, 1.30 ; middle toc and claw, 1.12.

The bill of this species, thongh not quite so long as in redivirus, when most dereloperl, is almost as much curved, and much more slender, - the depth at nostrils being but .2.2 instead of .26 . The size of this specimen is equal to the largest of redivivus $(: 3,9: 32)$; the tail absolntely longer. The feet are, however, considerably smaller, the claws especially so; the tarsus meisures but 1.30 , instead of 1.52 ; the midlle claw .29, instead of .36 . With these differences in form, however, it would be impossible to separate the two generically.

A third specimen (No.60,958 \&, St. George, Utah, June 9, 1870), with nest and eggs, has recently been obtained by Dr. Palmer. This specimen, being a female, is considerably smaller than the type, measuring only: wing, 3.90 ; tail, 6.00 ; bill, from nostril, 1.15 . The plumage is in the burnt summer condition, and has a peculiar reddish cast.

HABITs. Of this rare Thrush little is known. So far as observed, its habits appear to be nearly identical with those of the Californian species (H. rerlivims). It is found associated in the same localities with $H$. lecontei, which also it appears to very closely resemble in all respects, so far as ob- 


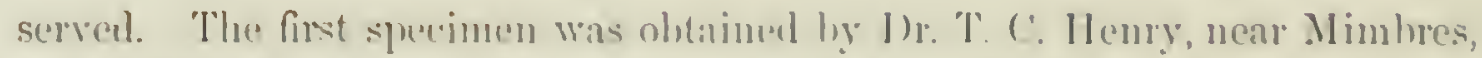

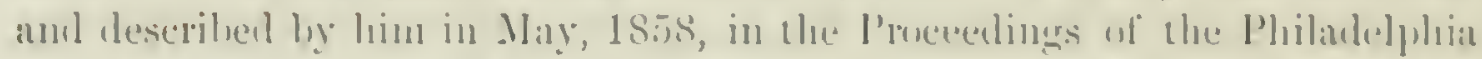

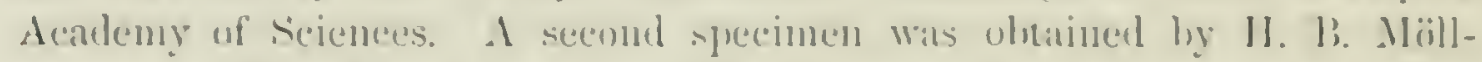

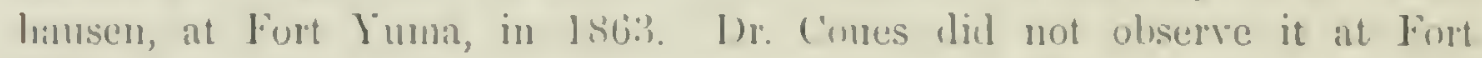
Whipple, lout thinks its range illentical with that of $I T$. Lemeri.

1). ('ooper fomnd this speedes quite common at Fort Mojale, hut so very sly that he only snceceded in shomting one, alter much watelung for it. Their song, genemal halits, and nest he spenks of as being in erery way similar to these of $I I$. moliricus.

The egrgs remained unkmown until Dr. E. Jaluner land the crood fortune to find them at St. (ieorere, foutlem Ltall, Jume 8,1871$)$. The nest was an

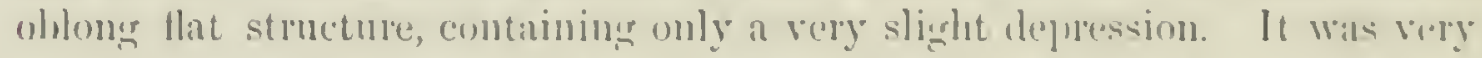

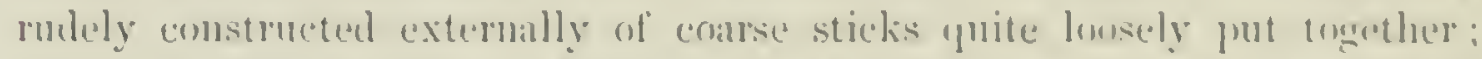
the inner nest is mate of finel materials of the same. The hase of this

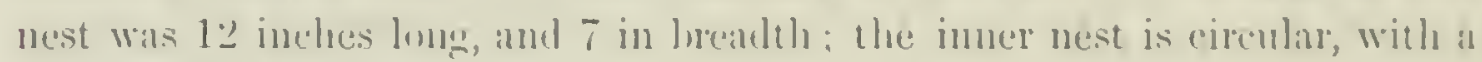
dianeter ol to incles.

The coress are of an ohlung-oval slape, one end being a little less ohtuse

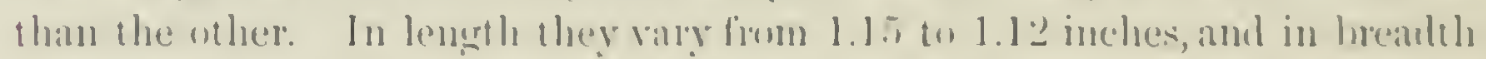
from st to .82 of an incls. Ther are of a uniform hlue andor, similan to the

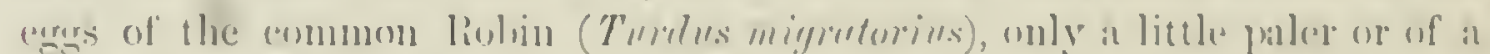
lingter tint. In the total absenece of matrings they ditler remarkably from those of all other species of the gemus.

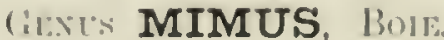

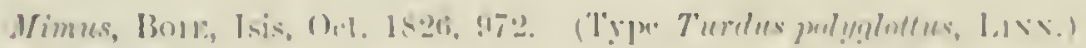

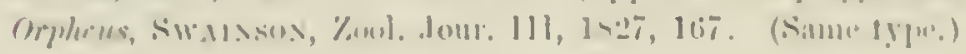

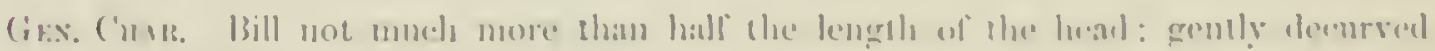

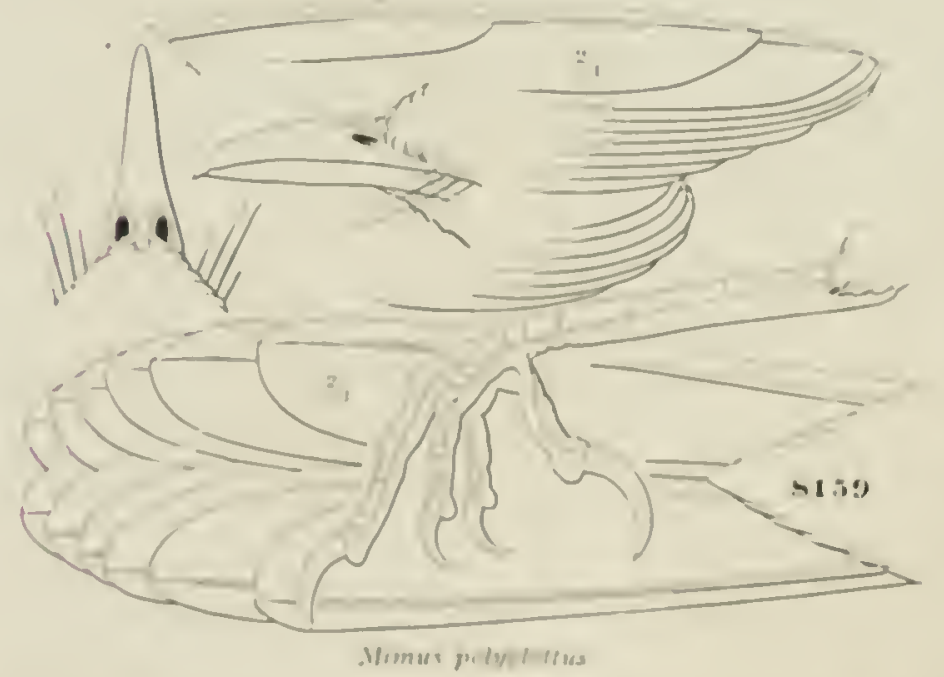

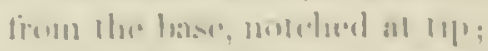
nommim-nare rumenl. liums struight, or slighty tomenser.

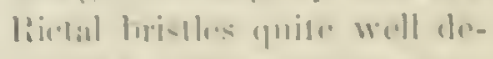

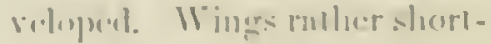
('r llan tle lail, birs primary

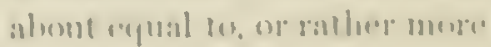

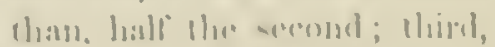
fommls, and tifth pulls marly

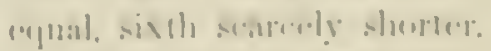

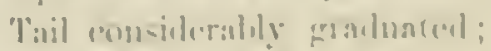

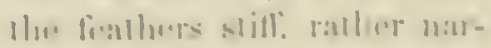

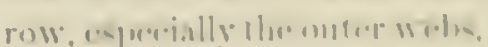
latreral liatluers nlumb tlun.

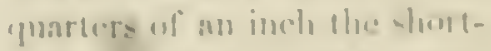

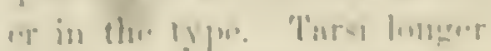

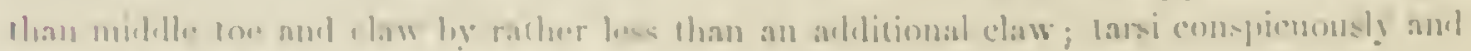

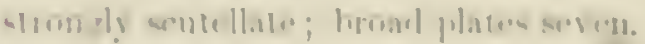


Of this genus there are many species in America, although but one occurs within the limits of the C'nited States.

The single North American species . M. polyylottus is ashy brown above, white beneath; wings and tail black, the former much raried with white.

\section{Mimus polyglottus, Bore.}

\section{MOCRING-BIRD.}

Turdus polyglothe, Lixx. Srst. Yat. 10th ed. 1758, 169; 12th ed. 1700, 293. - Vimus

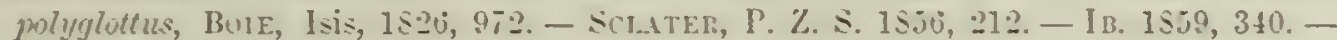

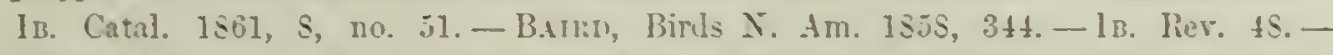

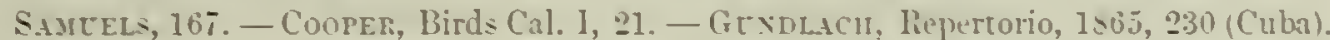
-Dresser, Ihis, 1\$65, 230. - Cotes, Pr. A. I. Sc. $1 \$ 006$, 05 (A1izona). ? Orphous levemiterus, Yignns, Zool. Beechey, 1 \$s?

Figures: WiLsos, Am. Om. 11, 1\$10, pl, x, fig. 1. - At'D. Orn. Biog. I, 1S31, pl. xxi.I B. Birds Amer. II, 1S 41, pl. 137.

SP. Chur. Third and fourth quills longest: sccond about equal to eighth; the first half or more than half the second. Tail considerably graduated. Abore ashy brown, the feathers rery obsoletely darker centralls. and towards the light plumbeous down basal portion (scarcely apprecialle, except when the feathers are lifted). The uncler parts are white. with a faint brownish tinge. except on the ehin, and with a shade of ash across the brenst. There is a pale superciliary stripe, but the lores are duskr. The wings and tail are dark brown, nearly black, except the leser wing-coverts, which are like the back; the niddle and greater tipped with white. forming two banls: the hasal portion of the primaries white: most extended on the inner primaries. The outer tail-feather is white, sometimes a little mottlerl: the second is mostly white, except on the nuter web and towards the base: the third with a white spot on the end: the rest. except the middle, very slightly or not at all tipped with white. The bill and legs are black. Length, 9.50; wing, 4.50 : tail, 5.00

Young. Similar, but distinetly spotted with dusky on the breast. and ohsoletely on the hack.

H.s. Torih America, from about $40^{\circ}$ (rare in Massachreetrs, Samuels), south to Mexico. Said to occur in Cuba.

The Mocking-Birds are closely allied. requiring careful comparison to distingruish them. A near ally is .Y. orpheus, of Jamaica, but in this the outer featler is white, and the 2 $d, 3 d$, and th tailfeathers are marked like the 1 st, 2 d, and 3 of polyglotus, respectively.

The have examined one hundred and fourteen specimens, of the present species, the series embracing large numbers from

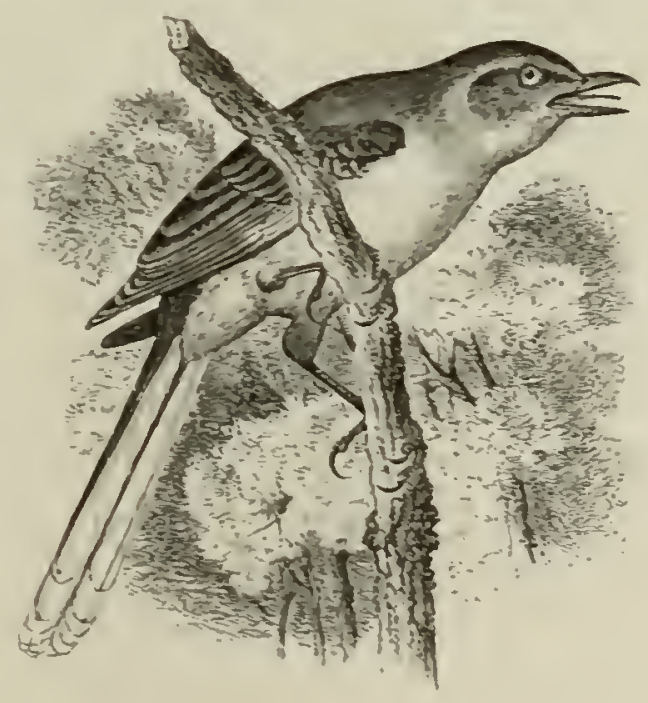

Mimus polyg!otus

Florida, the Rio Grande, Cape St. Lucas, and Mazatlan, and numerous specimens from intermediate localities. The slight degree of rariation 


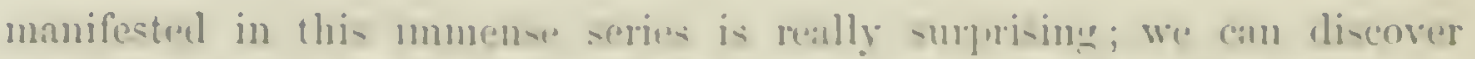

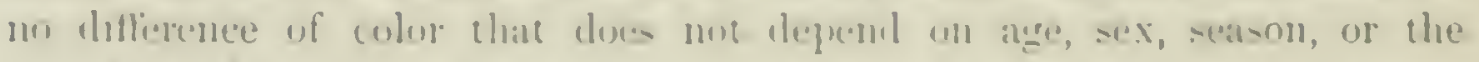

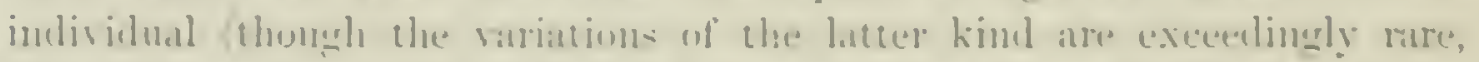

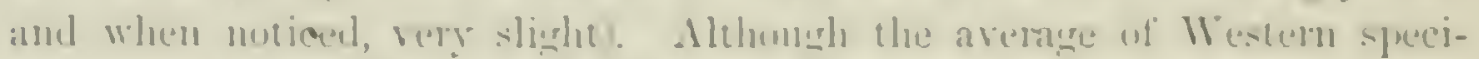

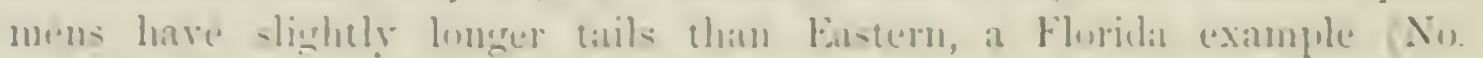

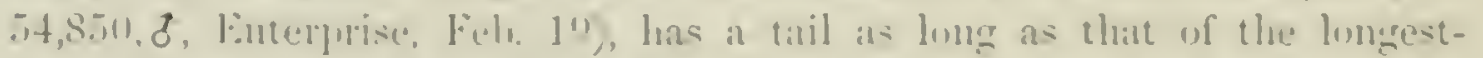

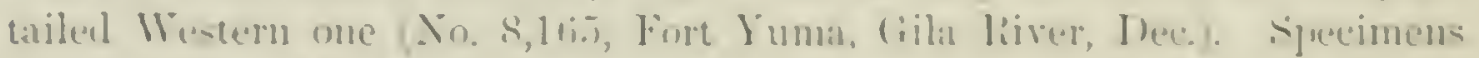
fron Colima, Mirador, Mrizalsa, and Mazatlan are quite jelentical with Surthern unes.

Habits. The Menetine-lirel is distriluted un the delantic const, from

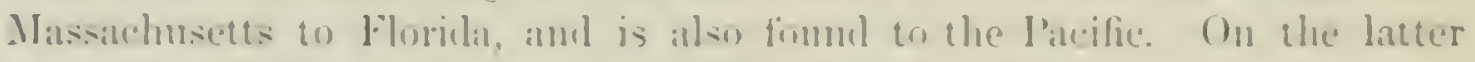

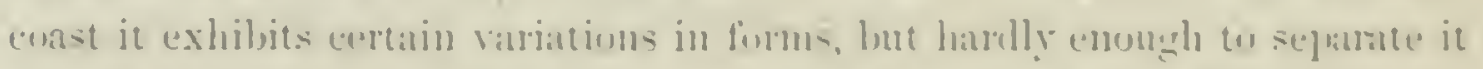
als a distinet sprecies. It is he me means a common him in lew lingland,

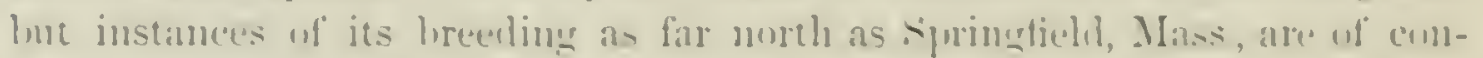
stant occurrence, and a single judividual was seen ly Mr. Boardman near (alais, Me. It is met with every year, more ur less fremently, on Lomg

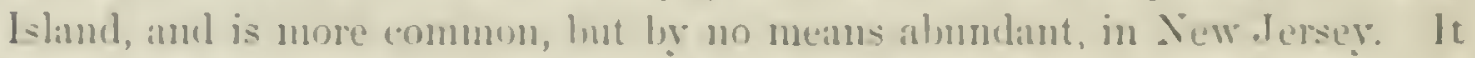
is found alumdanty in erery somblern sitate, and thronshont Nexien. It las also becen taken near (irinnell, Iowa.

A warm climate, a low country, and the vioinity of the sea alplear to be most congenial on their nature. Wilson fimml them less numerous west of

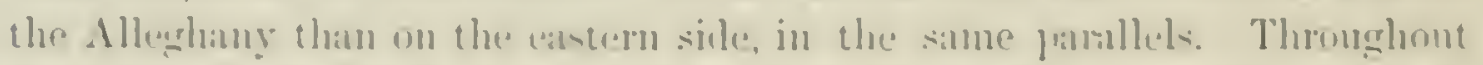

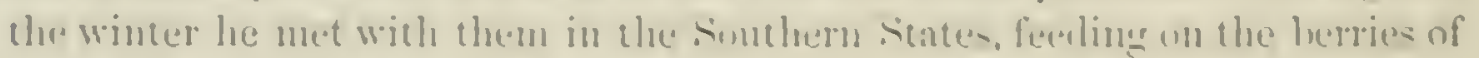

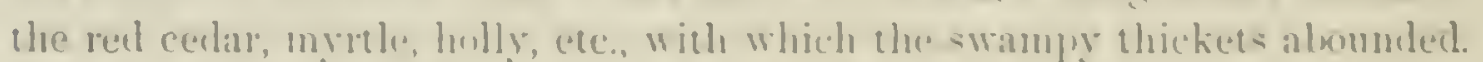

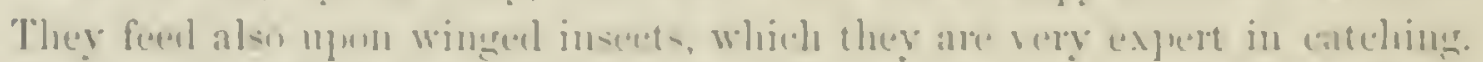

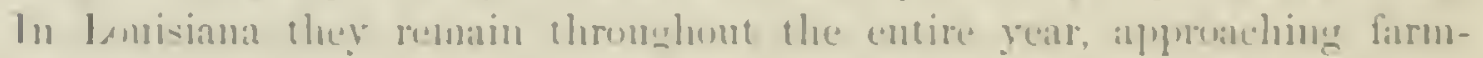
buses and plantations in the winter, and living alumt the gramlens and out -

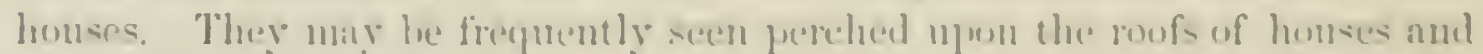
on the chimmer-fojo, and are always full of life and animation. Whlun the

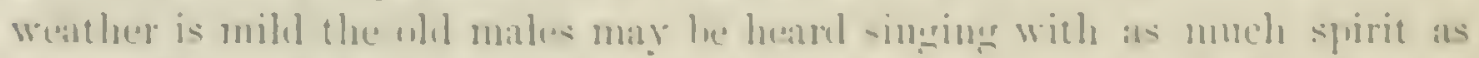
in the spring or summer. They are much more fandiar than in the mere

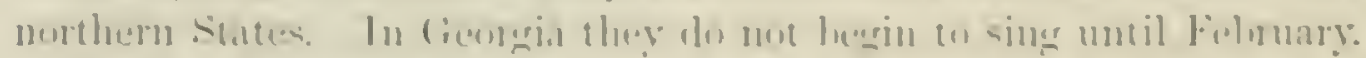

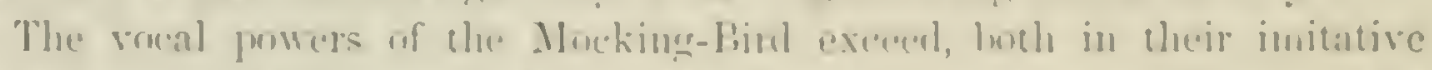

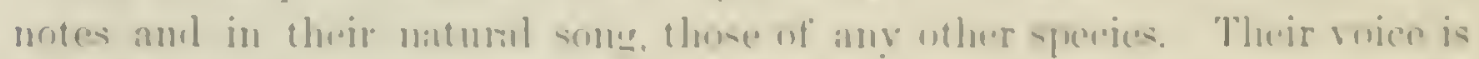

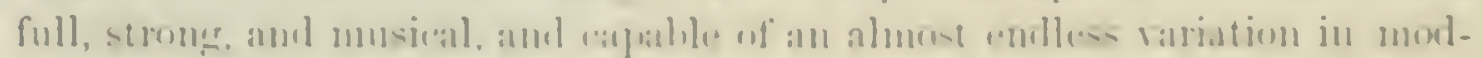

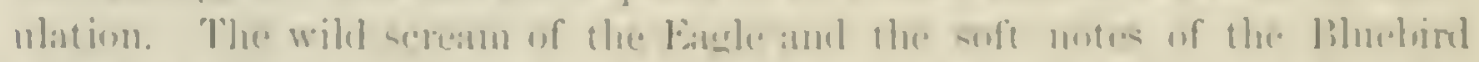

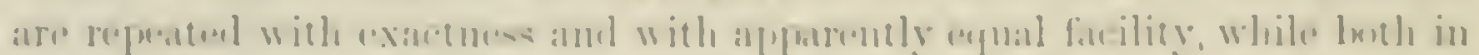

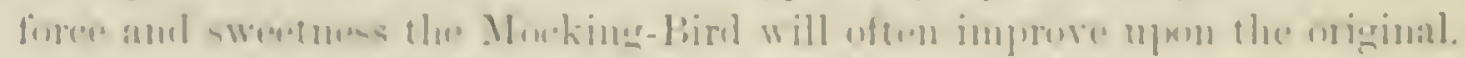

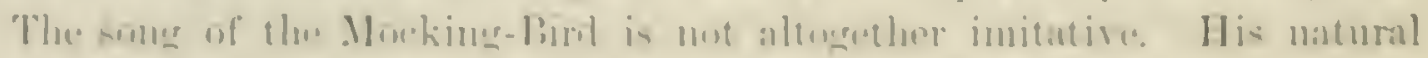

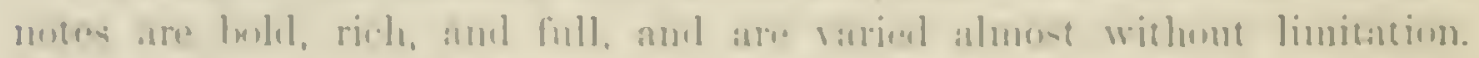

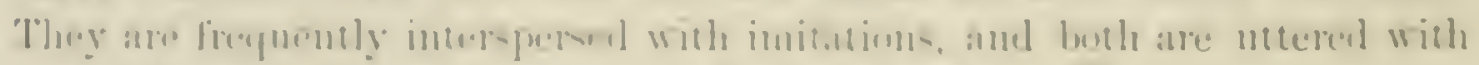

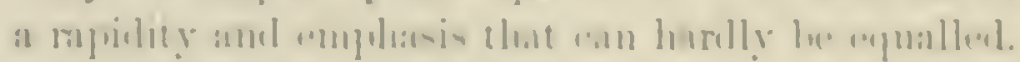

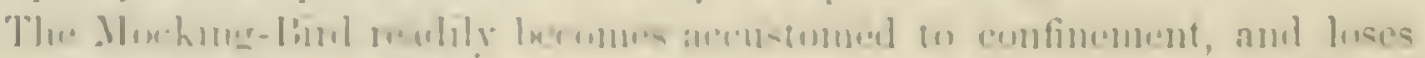

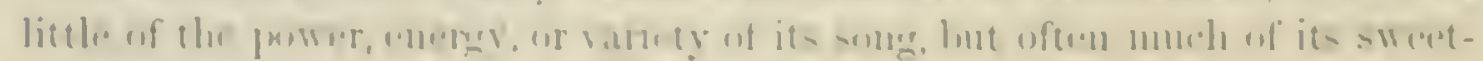


ness in a domesticated state. The mingling of ummusical somnd, like the crowing of cocks, the cackling of hens, or the ereaking of a wheelbarrow, while they add to the variety, necessarily detracts from the beanty of his song.

The food of the Mocking-Bird is chiefly insects, their larrie, worms, spiders, etc., and in the winter of berries, in great variety. They are said to be very fond of the grape, and to be very destructive to this fruit. Mr. G. C. Tarlor (Ibis, 1862,1$) .130$ ) mentions an instance that eame to his knowledge, of a person living near St. Angustine, Florida, who shot no less than eleven humbed Mocking-Birds in a single season, and buried them at the roots of his grape-rines.

Several successful attempts lave been made to induce the Mocking-Bird to rear their young in a state of confinement, and it lias been shown to be, by proper management, perfectly practicalble.

In Texis and Florida the Mocking-Bird nests early in March, young birds appearing early in April. In Georgia and the Carolinas they are two weeks later. In Pennsylvania they nest about the 10th of May, and in New York and New England not mntil the second week of June. They select various situations for the nest; solitary thorn-bushes, an almost impenetrable thicket of brambles, an orange-tree, or a holly-bush appear to ba farorite localities. They often build near the farm-honses, and the nest is rarely more than seven feet from the ground. The base of the nest is usially a rudely constructed platform of coarse sticks, often armed with formiclable thorns surrounding the nest with a barricale. The height is usually 5 inches, with a diameter of 8. The earity is 3 inches deep and 5 wide. Within the external barricade is an inner nest constructed of soft fine roots.

The eggs, from four to six in number, viry in length from .94 to 1.06 inches, with a mean length of .99 . Their breadth raries from . 81 to .69 of an inch, mean brealth .75. They also exhibit great variations in the combinations of markings and tints. The ground color is usually light greenishblue, varying in the depth of its shade from a very light tint to a distinet blue, with a slight greenish tinge. The markings consist of yellowish-brown and purple, chocolate-brown, russet, and a very dark brown.

\section{Gent's GALEOSCOPTES, Cabinis.}

Gulcoscoptes, Cabavis, Mus. Hein. I, 15.50, 82. (Type Muscicupa carotinensis, I.)

Gex. Char. Bill shorter than the head, rather broad at base. Rietal bristles moderately developed, reaching to the nostrils. Wings a little shorter than the tail, rounded; secondaries well developed; fourth and fifth quills longest; third and sixth little shorter; first and ninth about equal, and about the length of secondaries; first quill more than half the second, about half the third. Tail gracluated; lateral feather about. .0 shorter than the middle. Tarsi longer than middle toe and elaw by about an additional half-claw; scutellate anteriorly; more or less distinctly in different specimens; scutellie about seven. 


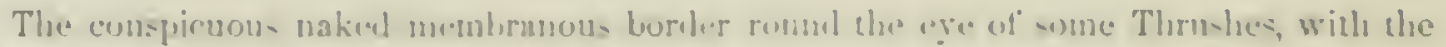

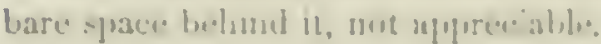

There is little diflemence in form between the single sperejes of (irrlen-

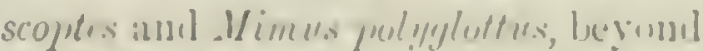

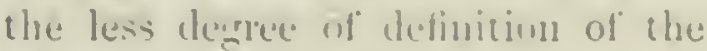
tarsal plates; and but fir tlue difference in colurition xunifinm plumbeous insteat of errily allove and white beneath), we would hardly be inclined to distinguish the two atenerically:

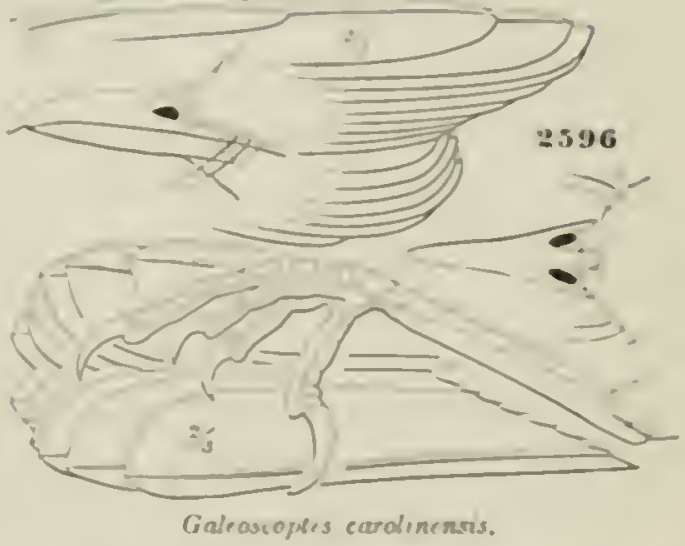

The single species known is lead-eolured, with black cap, and chestuntred miler tilil-coverts.

\section{Galeoscoptes carolinensis, ('.1...}

\section{THE CATBIRD.}

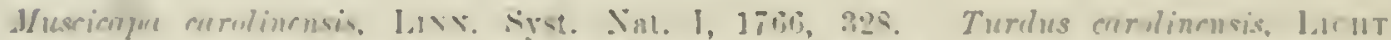

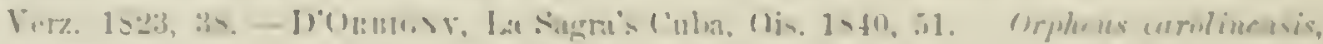

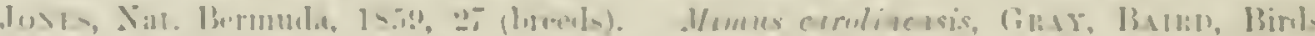

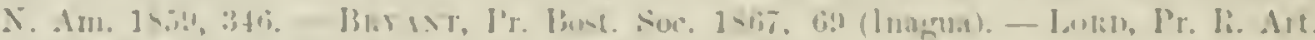

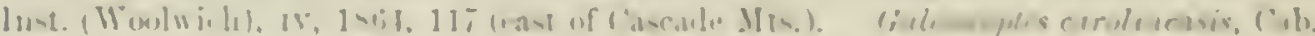

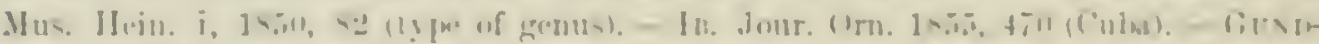

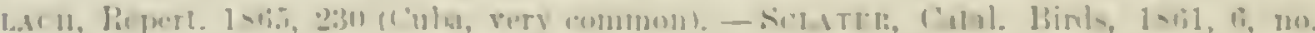

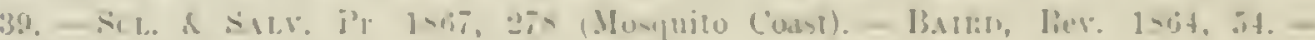

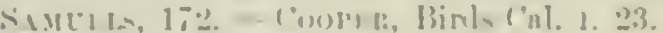

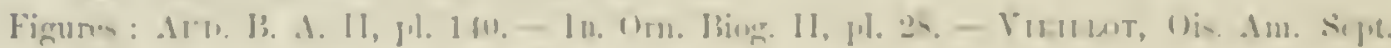

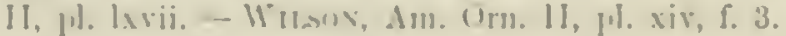

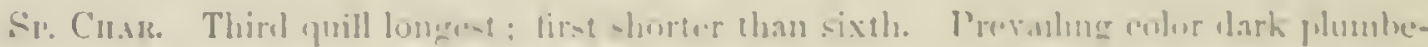

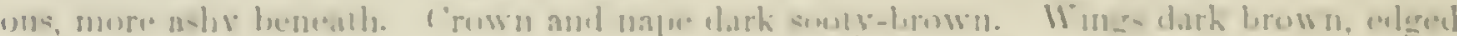

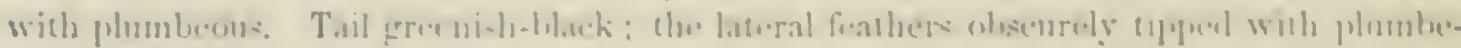

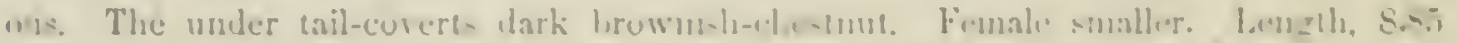

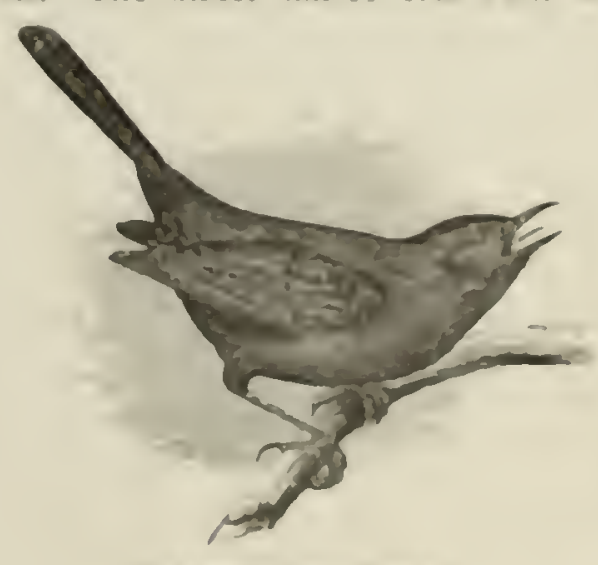

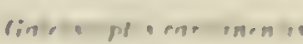

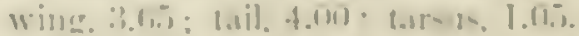

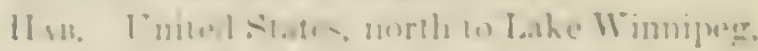

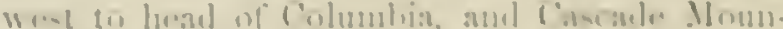

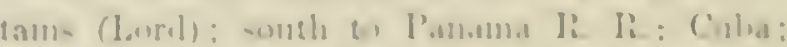

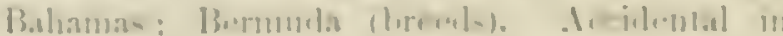

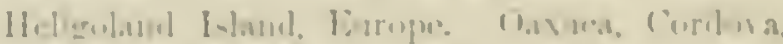

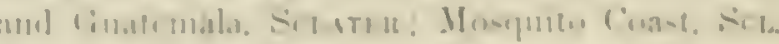

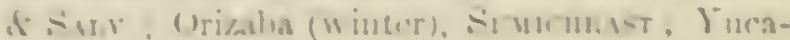
ใ.113. I, I 118 .

Mistern sprecinems linse not apprecinhly longer tails than lablem. Contmel American evimpless as a ruls', hisve the

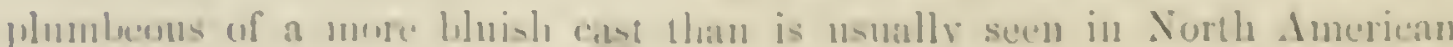
shills 
HABITs. The Catbird has a very extended geographical range. It is abundint throughout the Atlantic States, from Florida to Maine: in the central portion of the continent it is found as fur north as Lalie Winnepeg.

On the Pacific coast it has been met with at Panama, and also on the Columbia River. It is occasional in Cuba and the Balımas, ancl in the Bermudlas is a permanent resident. It is also found during the winter months abundaut in Central America. It breeds in all the Southern States with possibly the exception of Florida. In Maine, according to Professor Verrill, it is as common as in Massachusetts, arriving in the formel place about the 20tl of May. about a week later than in the ricinity of Boston, and beginning to deposit its eggs early in June. Near Calais it is a less common visitant.

The Northern migrations of the Catbird commence early in February, when they make their appearance in Florida, Georgia, and the Carolinas. In April they reach Virginia and Pennsylvania, and New England from the 1st to the 10th of May. Their first appearnuce is usually coincident with the blossoming of the pear-trees. It is not generally a popular or welcome visitant, a prejudice more or less wide spread existing in regard to it. Yet few birds more deserve kindness at our hands, or will better repay it. From its first appearance among us, almost to the time of cleparture in early fall, the air is vocal with the quaint but attractive melody, rendered all the more interesting from the natural song being often blended with notes imperfectly mimicked from the songs of other birds. The song, whether natural or initative, is always raried, attractive, and beautiful.

The Catbirl, when once established as a welcome guest, soon makes itself perfectly at home. He is to be seen at all times, and is almost ever in motion. They become quite tame, and the male bird will frequently apparently delight to sing in the immediate presence of man. Occasionally they will build their nest in close proximity to a house, and appear unmindful of the presence of the members of the family.

The Catbirl's porer of mimicry, though limited and imperfectly exercised, is frequently rery amusing. The more difficult notes it rarely attempts to copy, and signally fails whenerer it does so. The whistle of the Quail, the cluck of a hen calling her brood, the answer of the young chicks, the note of the Pewit Flycatcher, and the refrain of Towhee, the Catbird will imitate with so much exactness as not to be distinguished from the original.

The Catbirds are deroted parents, sitting upon their eggs with great closeness, feeding the young with assiduity, and accompanying them with parental interest when they leave the nest, even long after they are able to provide for themselves. Intruders from whom danger is apprehenderl they will boldly attack, attempting to drive away snakes, cats, dogs, and sometimes even man. If these fail they resort to piteous cries and other manifestations of their great distress.

Towards each other they are affectionate and deroted, mutually assisting 
in the construetion of the nest; and as inculation prongreseses the female, who rarely leatres the nest, is supplied with ford, and entertaned liron his exhatustless vocahulary of somg, by her mate. When amuered by an intruder the ery of the (at bird is loml, harsh, and mupleasant, and is supposed to resemble the ontery of a cat, and to this it owes its nane. This note it reiterates at the approach of any whjeet of its dislike or fear.

The food of the (atbird is almost exelusively the larve of the lawger insects. For these it searehes both anomer the branches and the fallen leaves, ats well as the furrows of newly plonghed fields and cultivated gartdens. The henefit it thus conlers upon the farmer and the horticulturist is very great, and can hardly be overestimated.

The Citthird can with proper prinstaking be raised from the nest, and when this is suceessfully accomplished they become perfectly dumesticated, and are very anmsinto pets.

They constrnct their nests on clusters of vines or low bushes, on the edges of small thickets, and in retired places, though ilmost illways neall cultivated ground. The usual materials of their nests are dry leares for the base, slender strips of long dry bark, small twins, herbaceous plants, fine roots, and finer stems. They are lined with fine dry arrasses, and sedges. Their nests average 4 inches in lieight by 5 in dianeter. The diancter and depth of the carsity are $3 \frac{1}{2}$ inches. The eggs are of a miform deep bluishgreen, and measure $97 \mathrm{in} \mathrm{length} \mathrm{and} 69$ of an inch in breadth. 


\section{Family CINCLID无. - The Dippers.}

On page 2 will be found the characteristics of this family, which need not be here repeated. There is only a single genus, Cinclus, with four American species, and sereral from Europe and Asia.

\section{Geives CinCLUS, Bechsteis.}

IHydrobala, Vieillot, Analyse, 1816 (Ag.). - Baird, B. N. A. 229.

Cinclus, Brohsters, Gemein. Naturg. 1802. (Not of Moehring, 1752. Type Stumus cin-

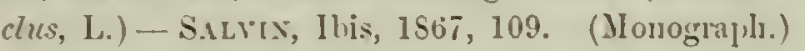

Grx. Cursr. Bill without any bristles at the hase; slender, subulate; the mandible bent slightly upward; the cuhnen slightly concave to near the tip, which is much eurved

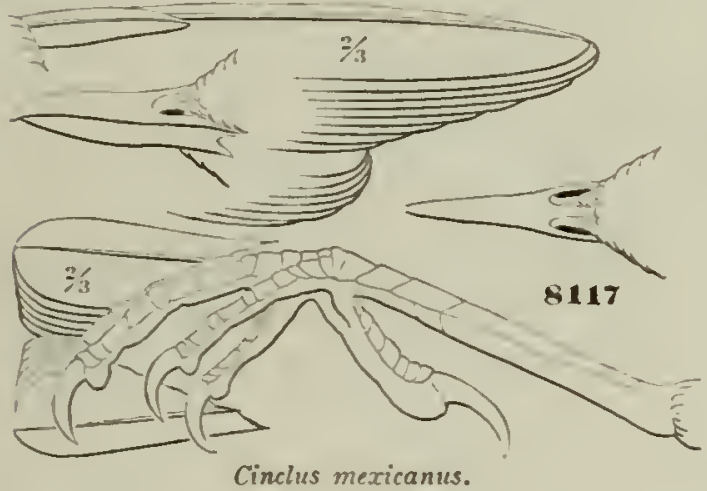

Cinclus mexicanus.

and notehed; the commissural edges of the bill finely nicked towards end. Feet large and strong, the toes projecting considerably beyond the tail; the claws large. Lateral toes equal. Tail very slort and even; not two thirds the wings, which are concare and somewliat falcate. The first primary is more than one lourth the longest. Eggs white.

The slightly upward bend of the bill, somewhat as in Anthus, renders the culmen concare, and the commissure slightly convex. The maxilla at base is nearly as high as the mandible; the whole bill is much compressed and attenuated. The lateral claws barely reach the base of the middle one, which is broad; the inner face extended into a horny lamina, with one or two notches or pectinations somewhat as in Caprimulgide. The stiffened sub-falcate wings are quite remarkable. The tail is so sliort that the upper coverts extend nearly to its tip.

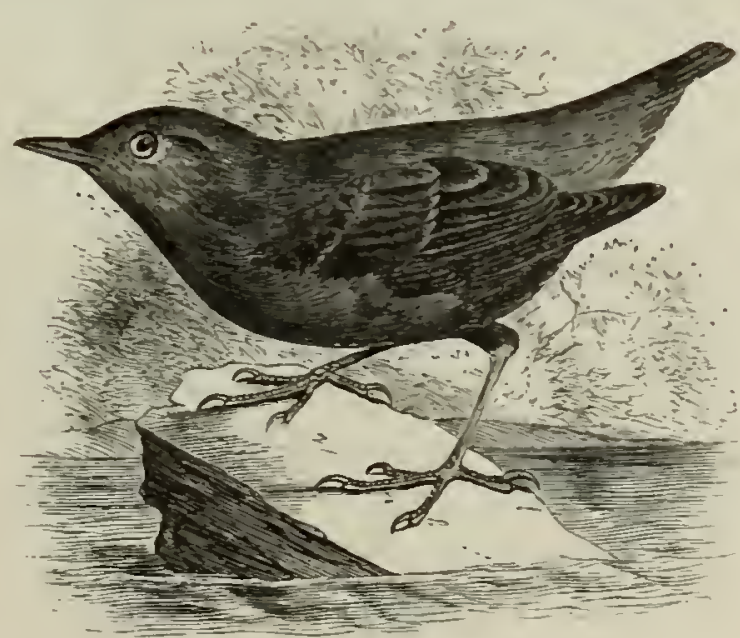

Cinclus mexicanus.

The species are all dull-colored birds, usually brown, sometimes varied with white on the head, back, or throat. They inhabit mountainous subalpine regions abounding in rapid streams, and always attract attention by their habit of feeding. under water, searching among the gravel and stones for their insect prey. 
The only other species at all allied to the simele North American one

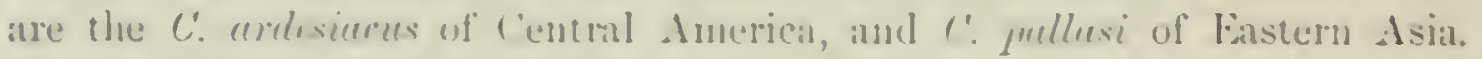
They may be easily distimgusised ly the followiug chancters -

Plumage buneath searcely lighter than that ahove; heal and neck brownish,

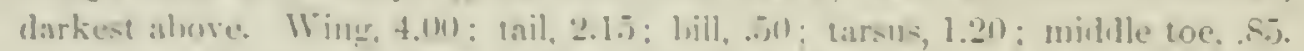

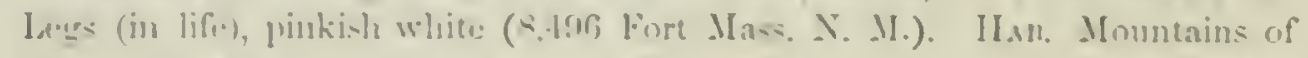
Miellle l'resince from Sitka, suth un Guatemala var. ne sicanus. Plumage benesth much lighter than that above, - very light along the meelian line: heal not brownish, the contrast in shale helween mper ant lower sur-

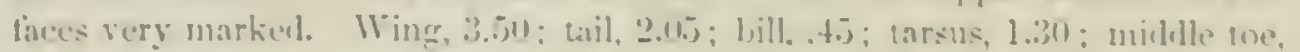

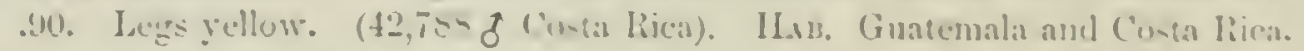
lar. $\|r\|$ siurus.

I'lunage uniform dusy-brown, middle of belly backish: lnak and rump styumated with bluck; wings and tail hlackish-hrown. Total length. S.un: wing,

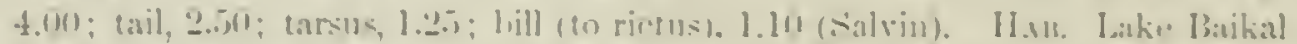

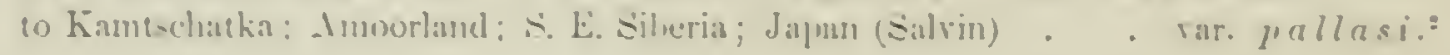

\section{Cinclus mexicanus, swass.}

\section{AMERICAN DIPPER; WATER OUZEL.}

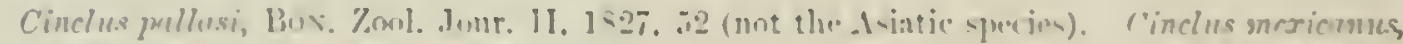

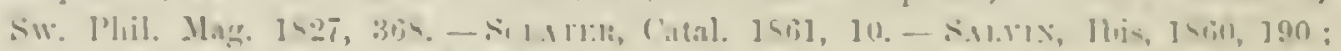

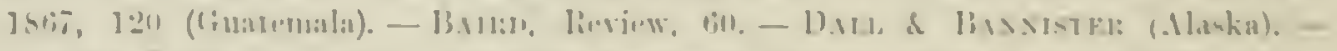

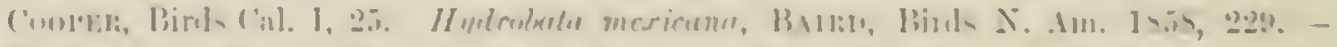

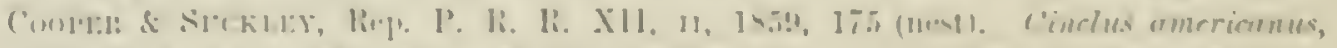

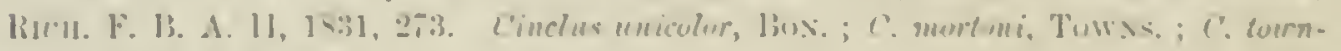
seneli, "Aln." Twws.

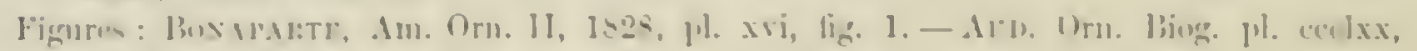
43.i. In. librls . Imer. 11, pl. cxxxvii.

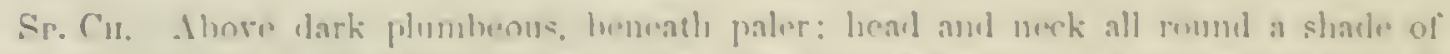

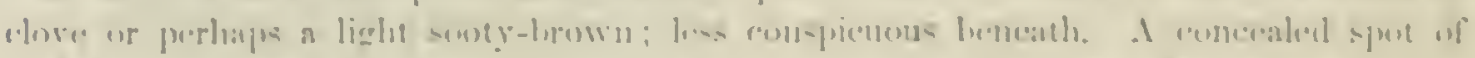

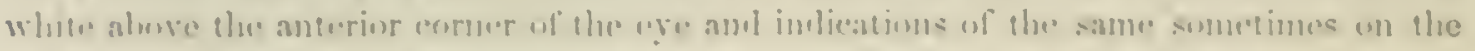

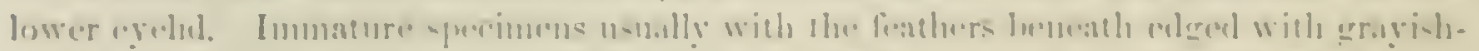

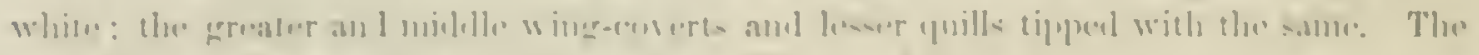

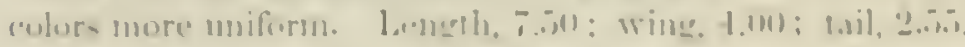

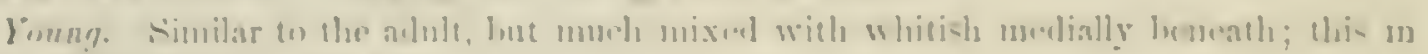
furm of lousunulinal - แfiv-jus.

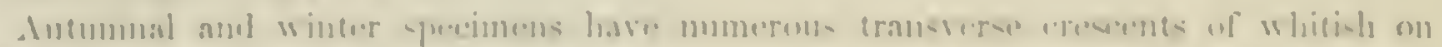

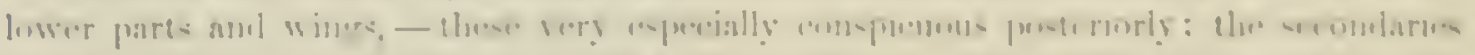

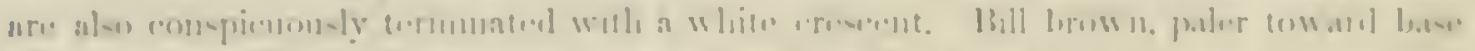

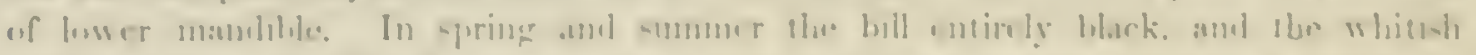

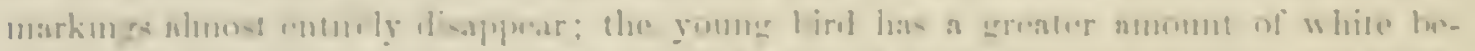

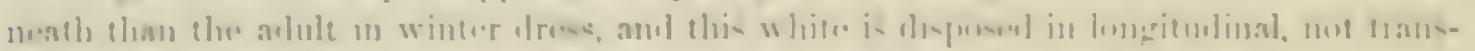

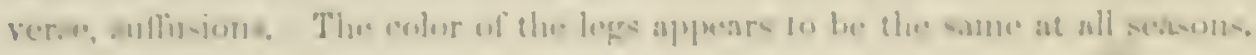

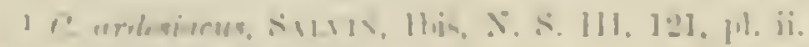

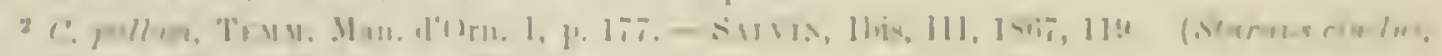

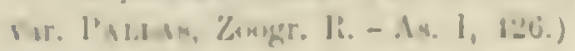


Specimens, of any age. from the coast of Oregon aud the Casieale Mountains, have the head nore dereply brownish than those from other regrion:

IIAB. Found through the mountainous region of the central and western part of Jorth America, from Fort Halkett south into Mexico aud Guatemala. Orizalua (Alpine region) Stancu. Sone received from the coast region of Calitomia. Abundant on the N. IV. coast, Laranie Peak and Deer Creek, Neb.

This species has a wide range along the mountainons region of North and Middle America. Mexican specimens are darker.

HABITs. This interesting bird inhabits exelusively the mountainous portions of North America west of the Mississippi from Alaska sonth to (iuatemala. It does not appear to have been obtained on the coast of C'alifornia, nor in the ralley of the Mississippi. In the British l'ossessions specimens have been procured on Fraser's River, at Fort Halkett, and at Colville. It the latter place Mr.J. K. Lord states that a few remain and pass the winter. They are found among the mountain streams of Tera Cruz, and probahly throughont Mexico, and no doubt may be met with in all the highlands between these extreme points. Dr. Newbery met with it in the rapid streams of the Cascale Mountains. He describes it as flitting along in the bed of the stream, from time to time plunging into the water and disappearing, to appear again at a distant point, "up or down the stream, skipping about from stone to stone, constantly in motion, jerking its tail and moring its body somewhat in the manner of a wern.

Dr. Cooper observed this species both on the C'olumbia and its trihutaries, and also among the monntain streams of the Coast liange west of Santa Clan. At the latter place he foumd a pair mated as early as March 16th. At sumset he heard the male singing very melodionsly, as it sat on one of its favorite rocks in the midlle of the forming rapids, making its delightful melody heard for quite a long distance above the sound of the roaring waters.

"This bird," adds Dr. Cooper, "combines the form of a sandpiper, the song of a canary, and the aquatic habits of a duck. Its food consists almost entirely of aquatic insects, and these it pursues under water, walking and flying with perfect ease beneath a depth of several feet of water." He also states that they do not swim on the surface, but dive, and sometimes fly across streams beneath the surface; that their flight is rapid and direct, like that of a sandpiper; also that they jerk their tails in a similar manner, and genemally alight on a rock or log.

Dr. Cooper on the 5th of July found a nest of this bird at a saw-mill on the Chehalis River, built under the shelving roots of an enormous arbor-vita that had floated over, and rested in a slanting position against the dam. The floor was of small twigs, the sides and roof arched over it like an oren, and formed of moss, projecting so as to protect and shelter the opening, which was large enongh to admit the hand. Within this nest was a brood of halffledged young. The parents were familiar and fearless, and had become 


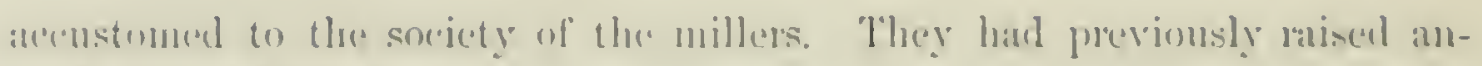
(1) Horel horoul that seatsint.

The same olservant matumlin, some time afterwats, in May, found the

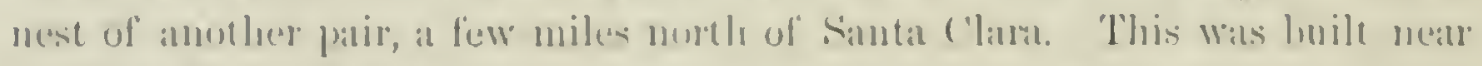
the fiot of a mill-tam, resting un a slight bedge under an werhanging rock,

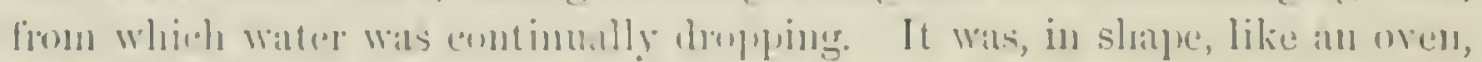
with a small denewaty, and it wais built externally of green muss, which, being still living preventent the easy disenvery of the nest. It was lined with soft

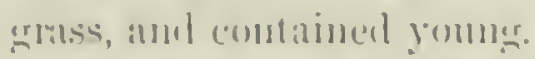

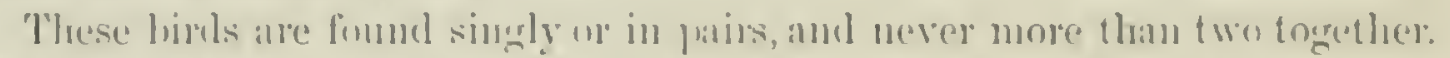
They are never fomml near still water, and frepuent only wild monntainstreans, cascenles, culdies, and swift currents.

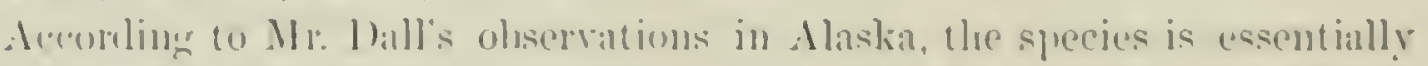

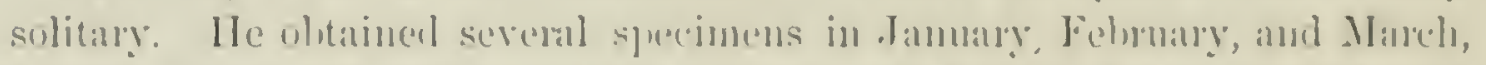

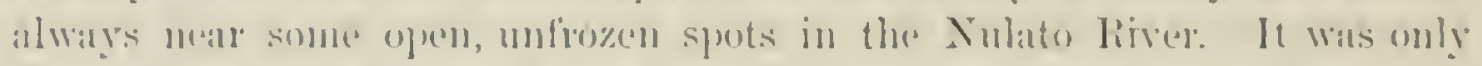
found in the most retired spots, and almost invarialy! allone. When disturlect, it would dive into the water, aren in midwinter:

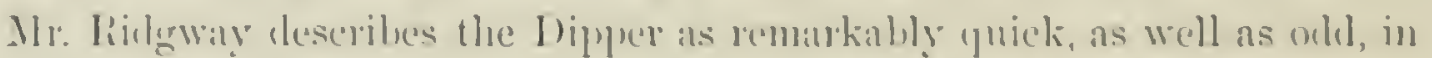
its morements, - whether walking in the shallow leed of the stream, or

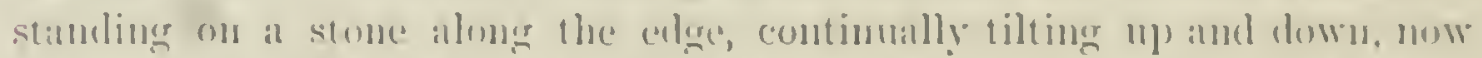

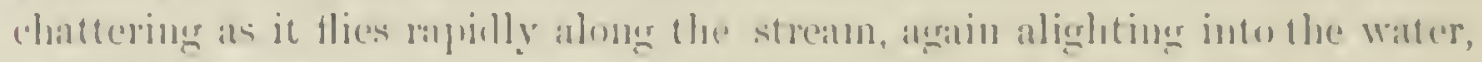
in which it wades with the grentest facility. Its flight is remathishy swift

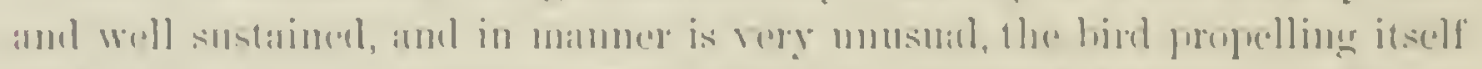

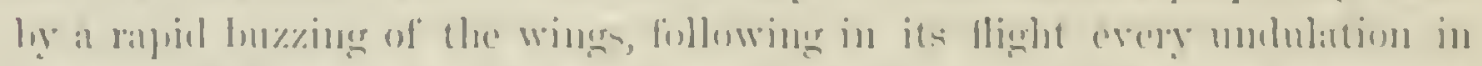

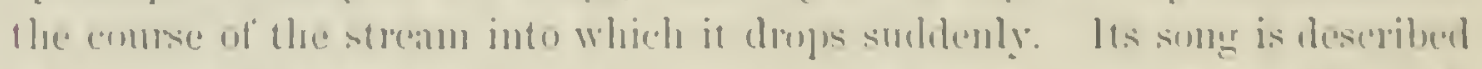

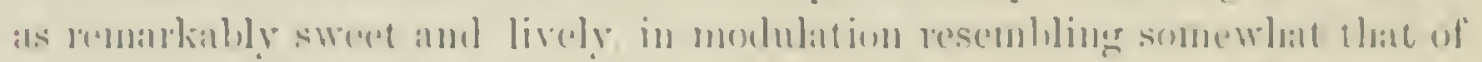

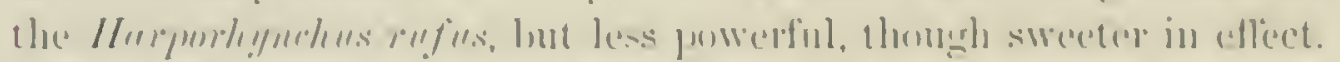

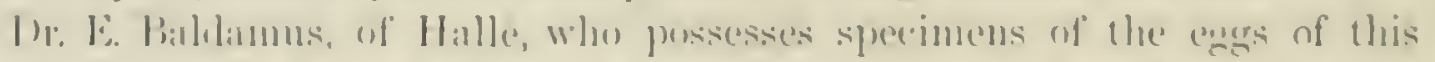

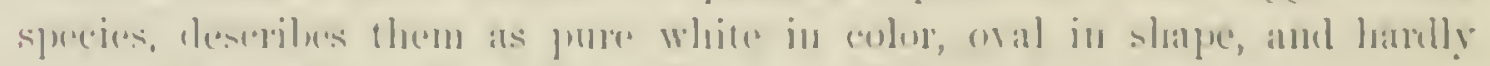

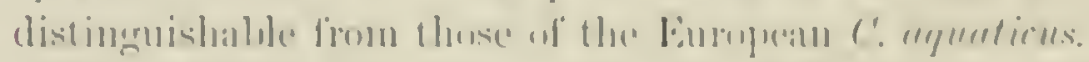

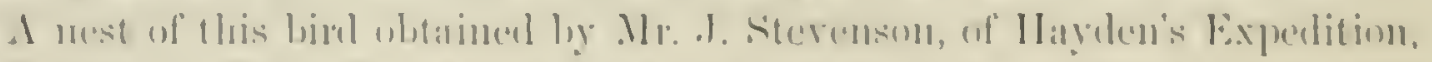

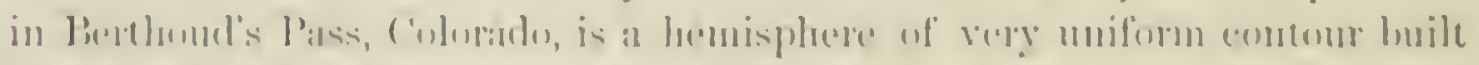

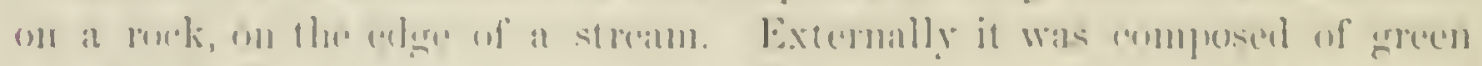

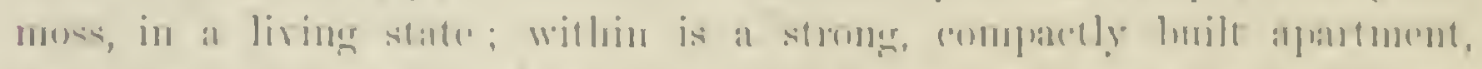

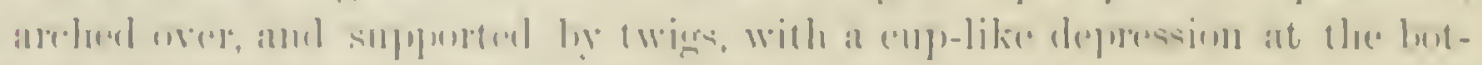

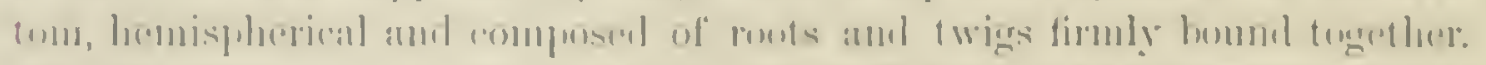

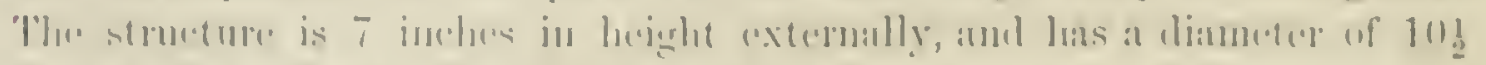

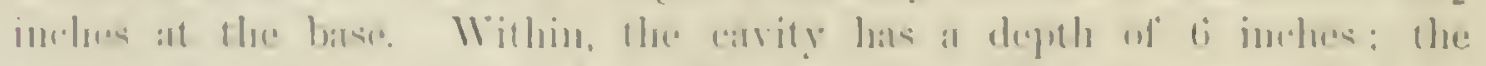

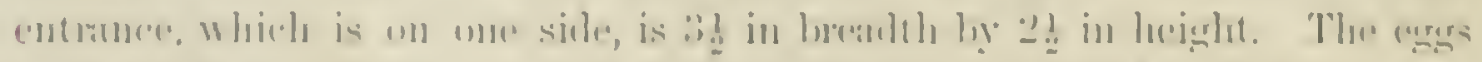

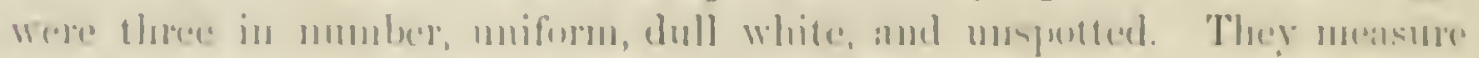

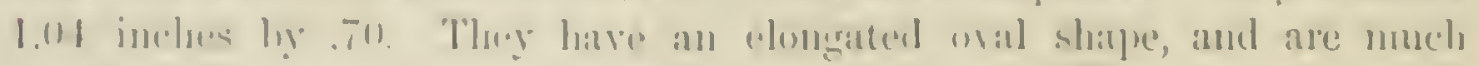
pinted at une end. 


\section{FANILY SAXICOLID年, - Thf, SAXICoLAS.}

The general characters of this family have already been given on p. ?, as distinguished from the Turdide. The relationships are very elose, however, and but little violence would be done by making it a subfanily of Turdide or even a group of Turdince, as was done in the "Birds of North America."

While the group is very well represented in the Old World, America has but one peculiar genus sublin, and another sumblu, represented by a single species, a strurgler, perhaps, from Greenland on the une side and siberia on the other. The diagnostic characters of these are as fulluws, including Turdus to show the relationships of the three genera:-

Turdus. Tarsi long. exceeding the milltle toe: wings reaching to the midtlle of the tail, which is about four fitths the length of the wings. Bill stout: its upper outline convex toward the base. Second quill shorter than fiftl.

Saxicola. Tarsi considerahly longer than the midhle toe. which reaches nearly to the tip of the tail. Tiil short. eren; two thirds as long as the lengtheneet wings. which reach beyond the minllle of the tail. Siccond yuill longer than fifth. Bill artenuated; its upper outline coneare towarls the base.

Sialia. Tarsi short; about equal to the midule toe. Wings reaching beyond the midule of the tail. Bill thickened.

Gexts SAXicola, Bechotels,

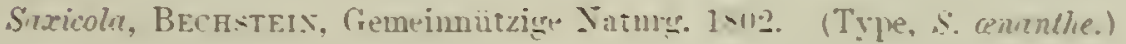

Gex. Cutsp. Commisure slighrly curred to the well-notched tip. Culmen concare for the basal halt, then gently decurving. Gonrs straight. Bill slender. attenuated: more

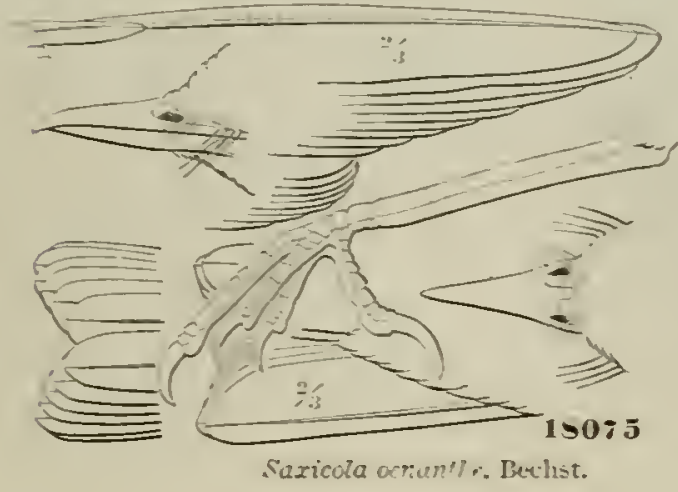
wings, a stripe through the eye, and the middle of exposed tail-feathers black. broarl. eren. Legs considerably longer than the head; when outstretcherl reaching nearly to the tip of tail. Thiril yuill lnngest: second but little shorter. Claw: long. slightly curred: hind toe rather elongated.

As already stated, America possesses but a single member of this aroup of birds, so well represented in the Old Trorld. The color is bluish-oray, with

than half the lengrh of heal. Tail short. 
Saxicola œmanthe, PEANST. THE WHEAT-EAR.

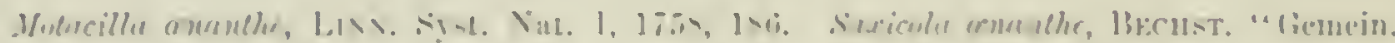

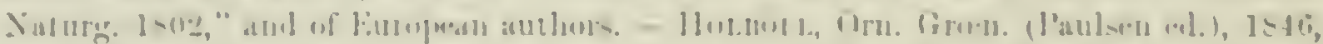

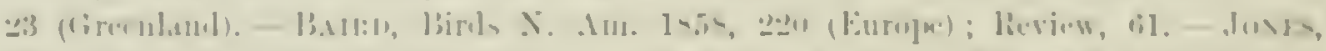

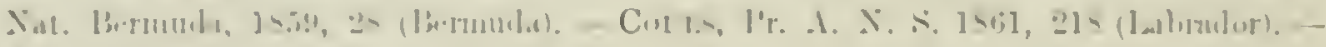

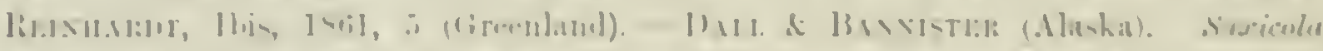

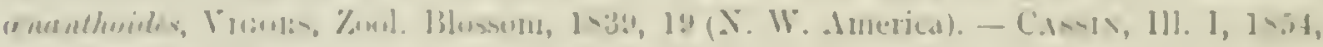

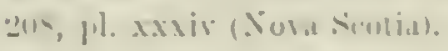

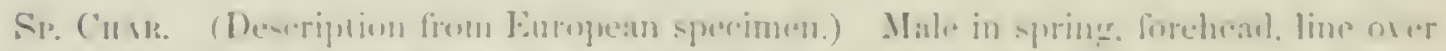
the

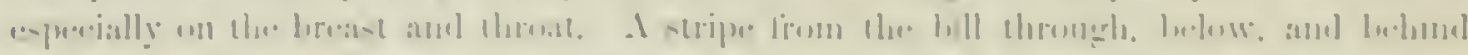

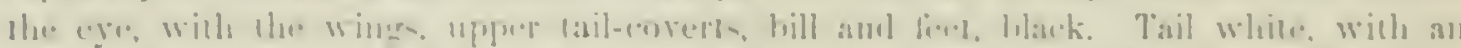

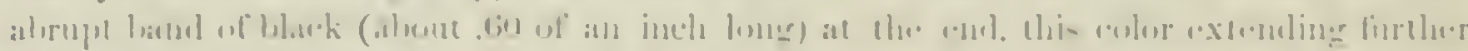

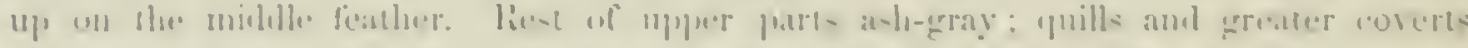

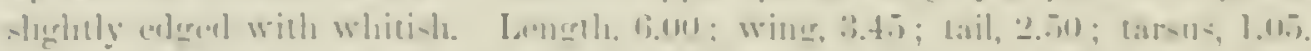

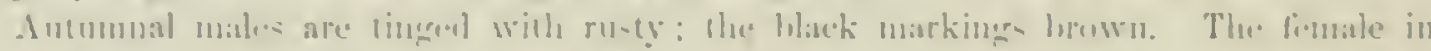

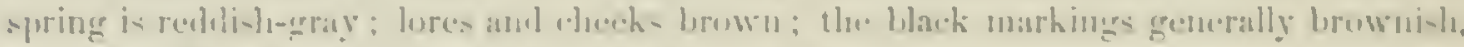

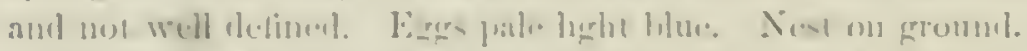

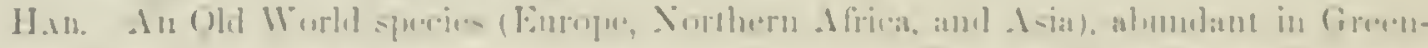

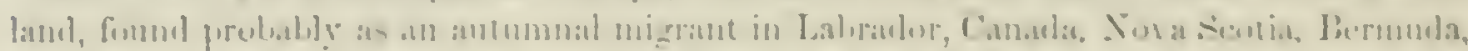

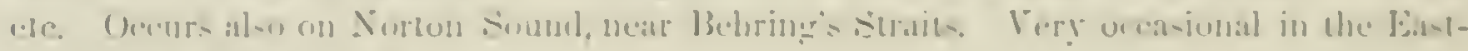
1.ru siatles: lone I-lamul.

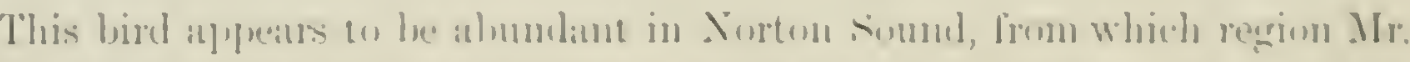

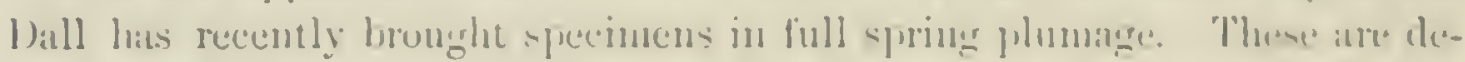

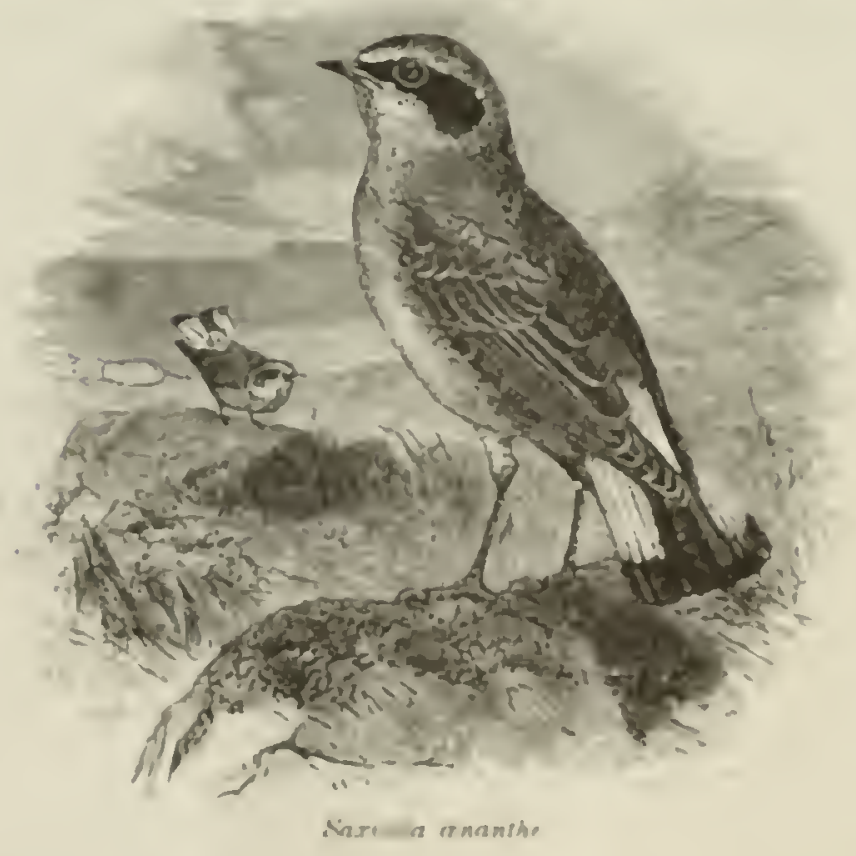
ciskolly smaller than hirks from lablualor and cirrentland, hut not distinguis-lablike,

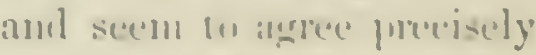
will skins from ('untral burojue.

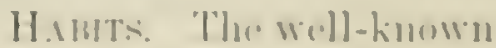

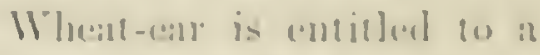

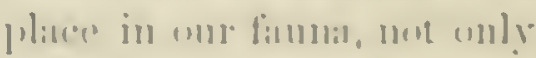
: :

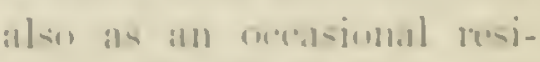
dent. In. II. Ii. Stentrer, ol

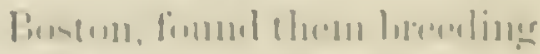

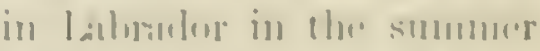

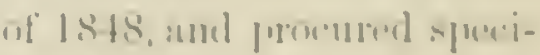
mens of the youme lime which were fully inlontified

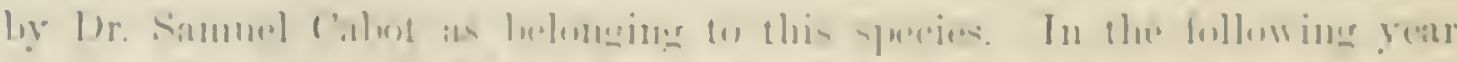

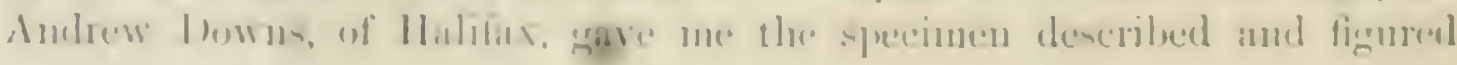


by Mr. Cassin. This was secured late in the summer near Cape Harrison, Labmelor, where it had eridently just reared its brood. In 1860 Mr. Elliott Cones obtained annther specimen on the 2.jth of August, at Henley Harbor. It was in company with two others, and was in immature plumage. Its occurrence in considerable numbers on the coast of Labrador is further confirmed by a writer ("W. C.") in "The Field," for June 10, 1871, who states that when in that region during the months of May and June lie saw a number of "White Ears," the greater proportion of them being males. He inferred from this that they breed in that comntry, the apparent scarcity of fenmles being due to their occupation in nesting. Mr. Lawrence has one in his cabinet from Long Island, and the Sunithsonian Institution one from Quebec. Specinens lave also been obtained in the Bermudas.

Holböll, in his paper on the fauna of Creenland, is of the opinion that the individuals of this species that oceur there come from Europe, make their joumey across the Atlantic without touching at Iceland, and arrive in South Greenland as early in the season as it does at the former place, the first of May. It reaches Godharen a month later, at times when all is snowbound and the warnth has not yet released the insects on which it feeds. It is found as far north as the 73d parallel, and even beyond. In September it puts on its winter dress and departs.

Mr. Dall states that several large floeks of this species were seen at Nulato, May 23 and 24, 1868, and a number of specimens obtained. They were said to be abundant on the dry stony hill-tops, but were rare along the river.

The Wheat-ear is one of the most common birds of Europe, and is found, at different seasons, throughout that continent as well as in a large portion of Western Asia. It breeds thronghont the British Islands as well as in the whole of Northern Europe and Asia.

Its food is principally worms and insects, the latter of which it takes upon the wing, in the manner of a fly-cateher. The male bird is said to sing prettily, but not londly, warbling even when on the wing, and hovering over its nest or over its partner. In confinement its song is continued by night as well as by day.

The Wheat-ear begins to make its nest in April, usually concealing it in some deep recess beneatl a huge stone, and often far beyond the reach of the arm. Sometimes it is placed in old walls, and is usually large and rudely constructed, made of dried bents, scraps of shreds, feather's, and rubbish collected about the huts, generally containing four pale blue eggs, uniform in color, and without spots, which measure .81 of an inch in length by $.69 \mathrm{in}$ breadth. 
Grixl's SIALIA, Minssos.

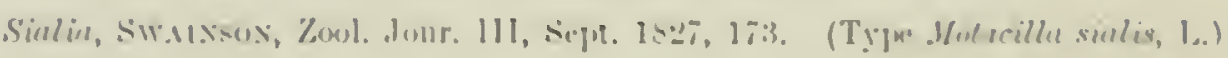

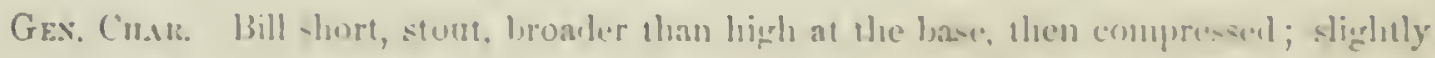
notched at lip. Rictus with short h,risl $:$. Tarsi not lomgerer than the midille toe. Claws

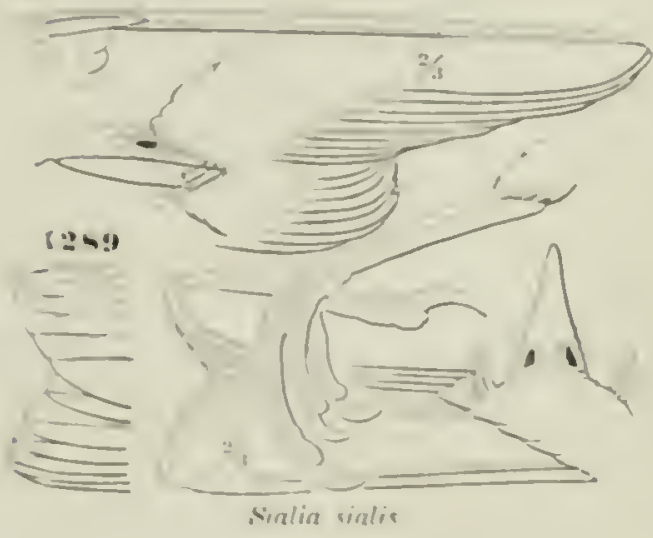
collsiderally onrved. Wings much longer han the tail: llue tirs furmary smorions, not one

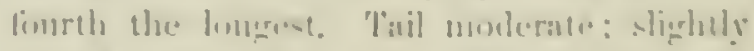

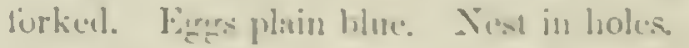

The species of this agentus am all well marked, ant inlult males ane rissily distimguishable. In all, blue forms a frominent featture. 'Three well-mintienl species are known, with a fomth less distinct. The fermales are duller in color than the males. The young are spotted and strested with white.

\section{Synopsis of Species.}

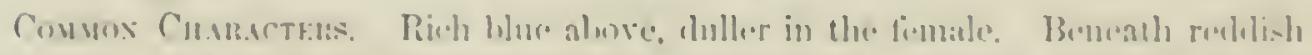

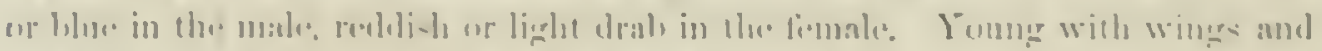

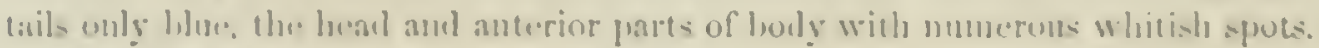

A. Brenst rentish, ar chestunt.

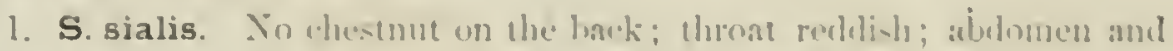
rrivinu while.

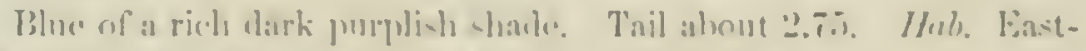

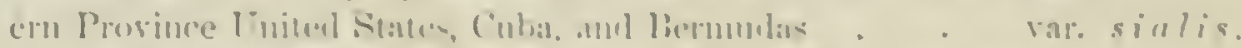

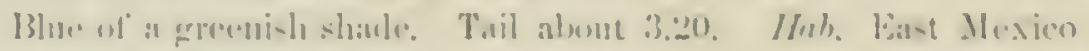

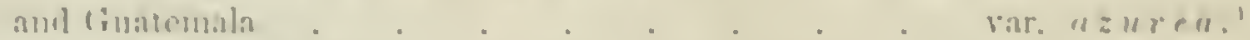

2. S. mexicana. (")

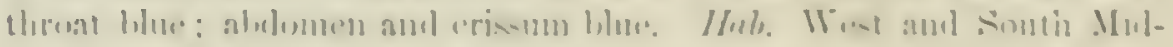

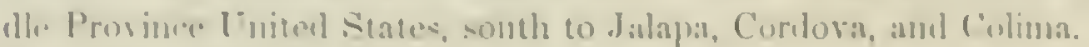

1E. Cirenst blue (light drub in \&).

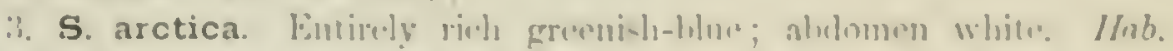

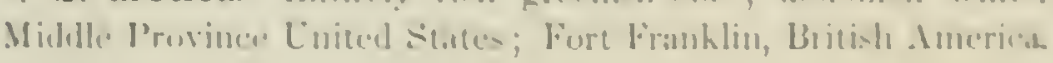

Sialia sialis, Pimin.

\section{EASTERN BLUEBIRD.}

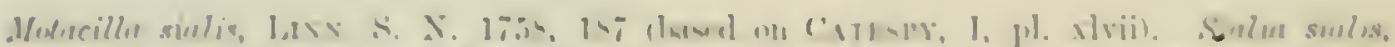

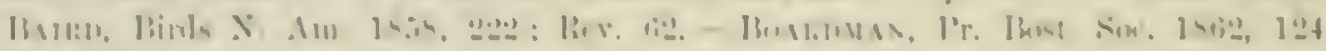

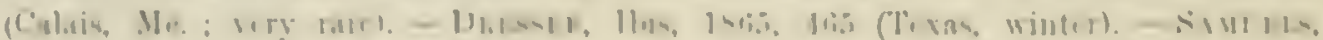

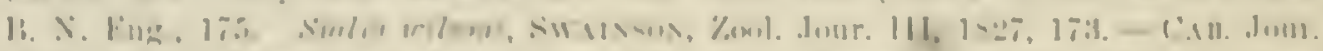

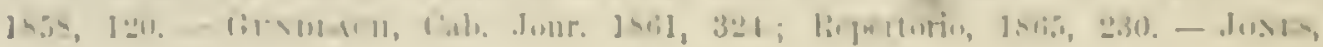

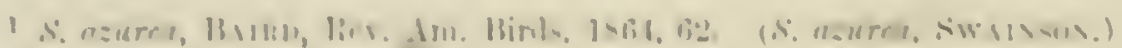


Sat. Bermuda, 155?. 2S, 66 (resident in Bermuda). Sylvia siulis, Latur. Amprlis sinlis, Ẍtт. : Evyllerace vilsoni, Sw.

Figures: Vieılot, Ois. Am. Sept. II, pl. ci. cii, ciii. - WiL. I, pl. iii. - Ard. Orn. Biog. II, pl. cxiii. - IB. B. A. II, pl. cxxxis. - Dotoury, ("ab. I, Il. xiz.

SP. Cuır. Entire upper parts, including wings and tail, eontinuous and nuiform azureblue; the cheeks of a duller tiut of the same. Beneath redelish-bromu; the abelomen, anal region, and under tail-corerts white. Bill and feet black. Slafts of the quills amb tailfearhers black. Fenale with the blue Lighter, and tinged with brown on the head and hack. Length. 6.7.5: wing. 4.00 : tail, 2.90.

Foung. Iales of the rear dull brown on head and bach: and lesser coverts streaket, except on head, with white. Throat and fore part of breast streaked with white. Tertials elged with brown. Rest of coloration somewhat like adult.

II. Fistern Inited States; west to Fort Laramic, Milk Rirer: worth to Lake Winnipeg; resident in Bermuda; Cuba (rare). Grxolacu.

A specimen from Cinatemala $(50,+11 \delta$, Van P'atten) referrible to the var. azurea is mulistinguishable in color from Sorth American examples: the wings and tail are longer, however, meatsuring respectively 4.20 and 3.00 .

HABITs. The Bluebird is abundant throughout the eastern portion of North America, breeding in nearly every part, from Georgia and Lomisiana to the Arctic regions, with only this exception, that near tlie seaboard its migrations do not extend so far to the north as in the interior. It is rery muly to be met with beyond the Penobscot, although Professor Verrill mentions it as rery common in the western part of Maine. It is found throughout the year in the Bermudas, and occasionally in C'uba.

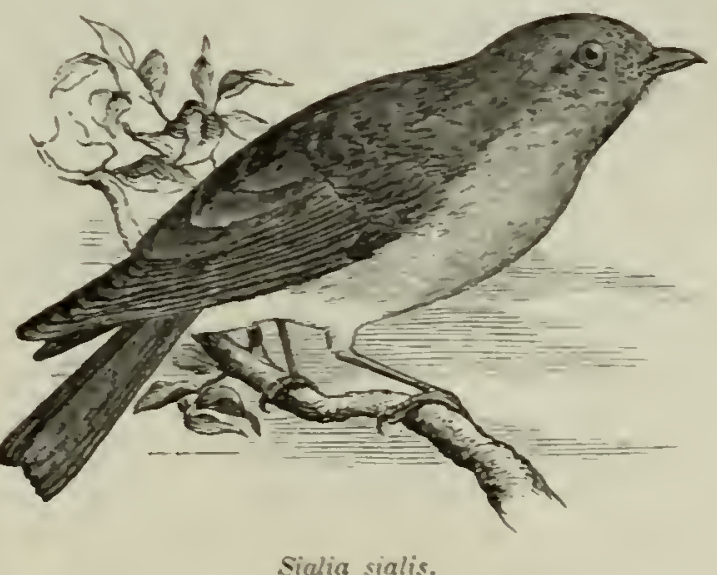
The Selkirk Settlement is the most northern locality to which it has been traced. It is not known to occur farther west than the lighlands west of the Mississippi.

Through all the Eastern States the Bluebird is one of the most familiar and relcome of the earliest visitors of spring, usually making its appearance as early as the first of March. In mild seasons they come in the latter part of February, long before there is any apparent relaxation of the severity of winter. In 1957, in consequence of the unustal mildness of the season, Bluebirds appeared in large numbers as early as the 15th of February, aud remained apparently without suffering any inconvenience, although the weather subsequently became quite severe. In 1869 their first appearance was observed as early as the 2Sth of January, the earliest period of which I can find any recort.

In the Middle States, with every mild winter's day, the Bluebirds come 
out from their retseats, and arain disilpear on the weturn of severer weather.

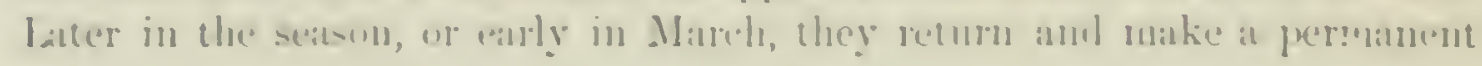
star:

When well treated, as the liheliris almus miversally are, they return year after year to the sane hox, coming always in pais. The mirkent atten-

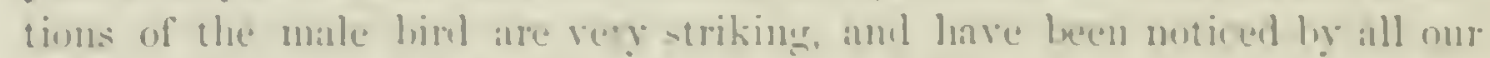
writers. He is very jealues of at rival, driving ofl every intruder of his own

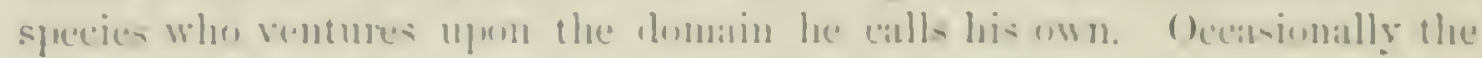
pair suther great anneyance from vexations interferences with their dumestic arrangenents ly the hone wren, who unceremonimaly enters their homesteatd, despoils it of its carefinly selected matterials, and departs. It other times the wren will take pussession of the premises and harricale the enttrance, making the return of it rightful owners impusible.

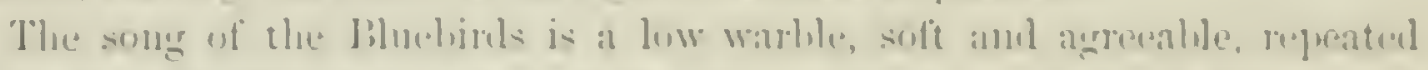
with ereate constinny and earnestness, and probured until yuite late in the seasmi. Just hefore their departure, late in Octoher, the sprightliness of

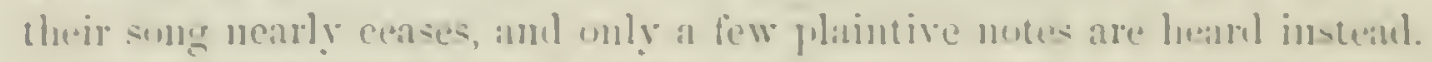

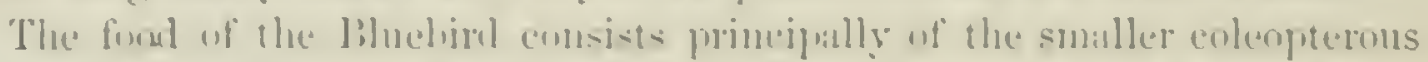
inserets, ahen of the larrite of the subiller lepindoptera. In the early springr they are very lmo turning over the dre leaves, exannining the trunks and

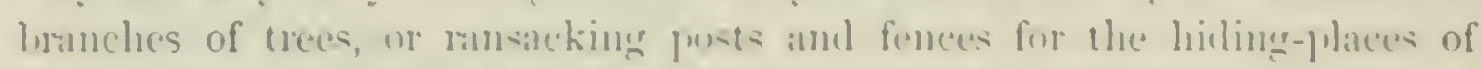

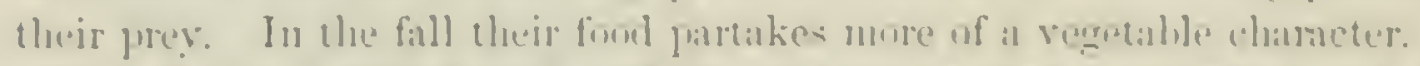

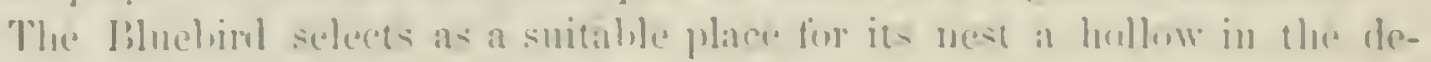

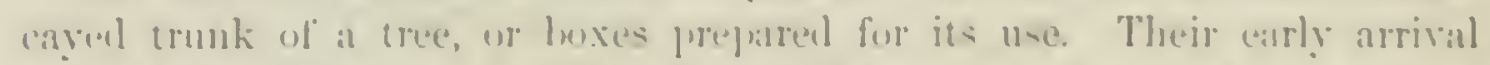

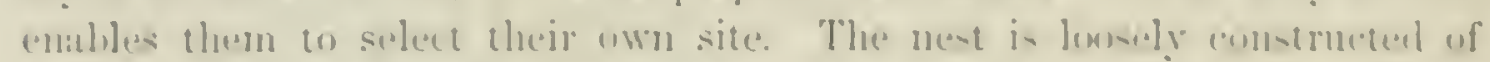

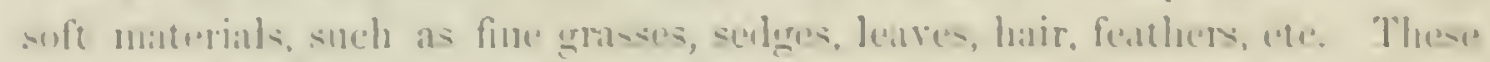

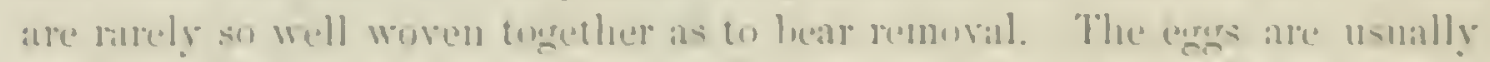

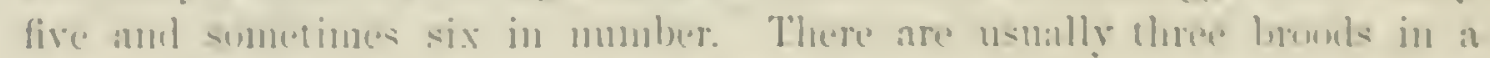

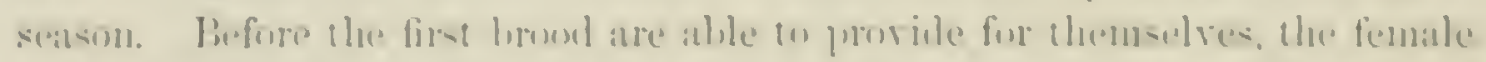

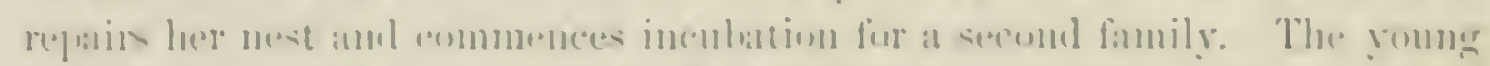

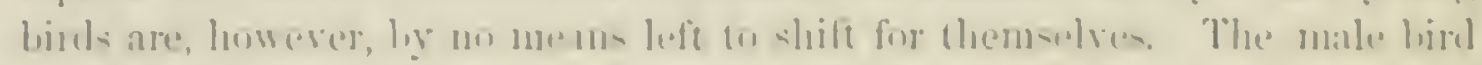

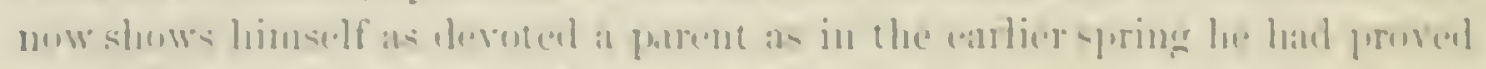

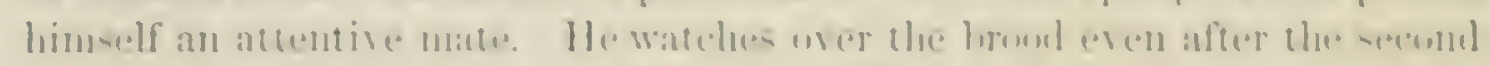

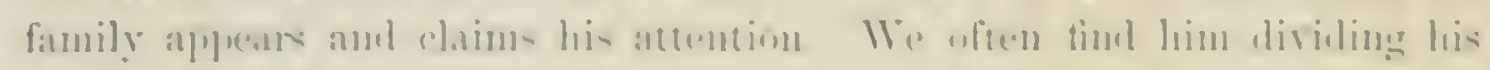

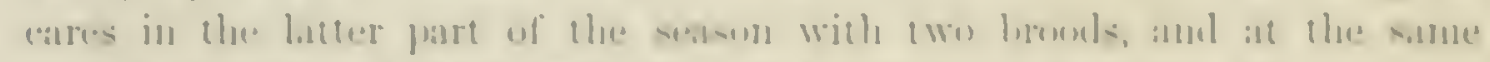

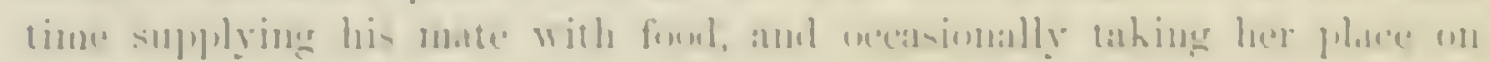
the mist.

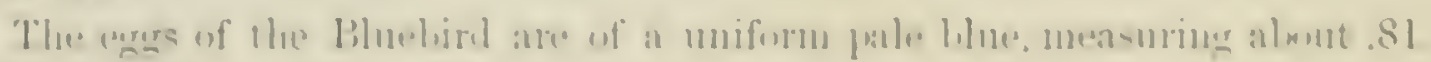

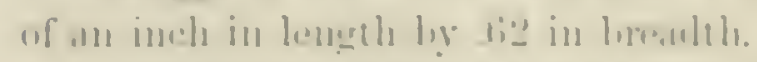

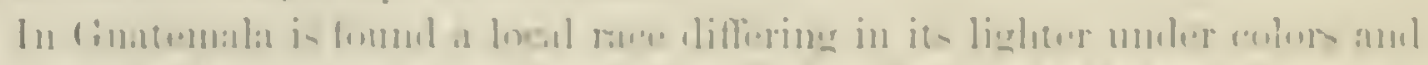

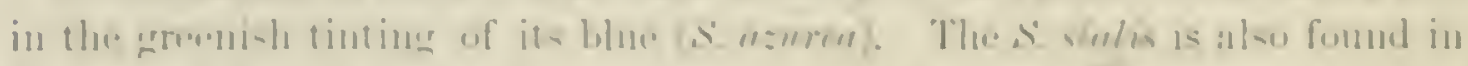

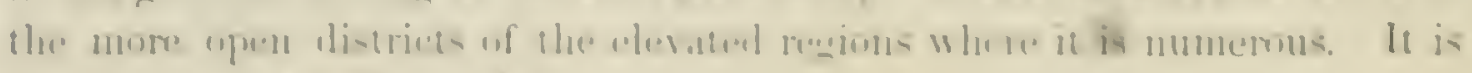

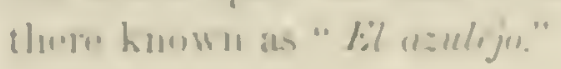


Sialia mexicana, SWALs.

\section{CALIFORNIA BLUEBIRD.}

Sialia mexicana, Sw. F. B. Am. I1, 1\$31, 202. - ScLATEL, P. Z. S. 1856, 293 (Corlora);

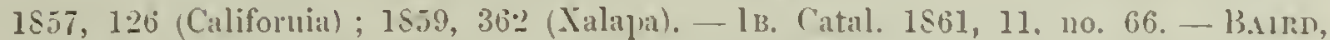

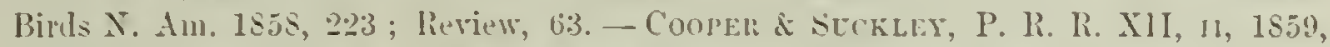

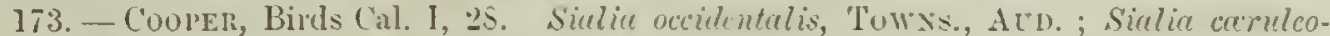
collis, Vigolis.

Figutes: Atrn. B. A. II, pl. exxxy. - lB. Olı. Biog. T, pl. ccexciii. - Vigors, Zoöl. Beechey's, Voy. 1\$39, pl. iii.

SP. Cusr. Bill sleuler. Head and neck all round, and upper parts generally bright axure blue. Interseapular regions, sides and fore part of the breast. and sides of the belly, dark redhish-brown. Rest of under parts (with tail-coverts) pale bluish, tinged with gray about the anal region. Female duller above: the back brownish; the blue of the throat replaced by ashy-brown. with a shade of blue. Length, 6.j0; wing. 4.25; tail, 2.90.

Young. Tail and wing as in adult; head, neck, back, and breast, dull brown; each feather, except on the rrown, streaked centrally with white.

HAb. Western Lnited Siates. from the Rocky Mountains to Pacific. Not noticed on the Missouri plains. Central British Imerica, or at Cape St. Lueas. Found at Xalapa and Cordova, Mex., Schitel. Popocitapetl (Alpine region), Stmuculast.

As in the others, the colors of this species are much duller in fall and winter: No. 53,319, \& (Carson City, Nevada, Feb. 21) differs from others in the following respects: there is hardly any chestnut on the back, there being only just a tinge along each side of the interscapulatr region; that on the breast is interrupted in the middle, and thrown into a patch on each side of the breast, thins connecting the blue of the tlroat and abdomen; the biue of the throat is unusually deep.

Habirs. This Bluebind belongs to westem North America, its proper domain being between the Rocky Mountains and Pacific, from Mexico to Washington Territory. Mr. Nuttall first met with this species among the small rocky prairies of the Columbia. He speaks of its habits as exactly similar to those of the common Bluebird. The male is equally tunefinl throughout the breeding-season, and his song is also rery similar. Like the common species he is very deroted to his mate, alternately feeding and caressing her and entertaining her with his song. This is a little more varied, tender, and sweet than that of the Eastern species, and differs in its expressions.

Nuttall describes this as an exceedingly shy bircl, so much so that he found it very difficult to obtain a sight of it. This he attributes to the great abundance of birds of pres. Afterwards, in the vicinity of the village of Santa Barbara, Mrr. Nuttall again saw them in considerable numbers, when ther were tame and familiar.

Dr. Cooper states that these Bluebirds seem to prefer the knot-holes of the oaks to the boxes provided for them. He does not confirm XIr. Nuttall's description of its song, which he regards as neither so lond nor so sweet as 


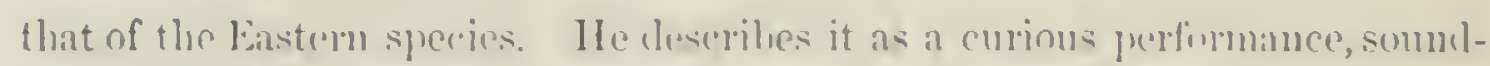

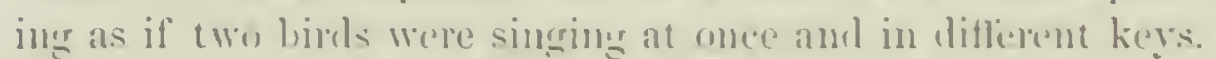

Many of this species remain in Washington Turitory dumes the wintere,

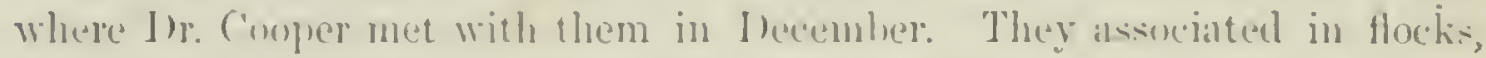

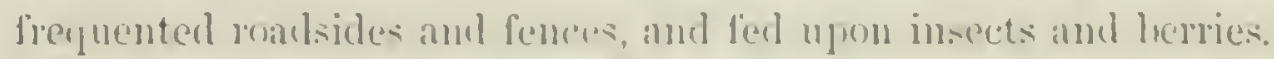

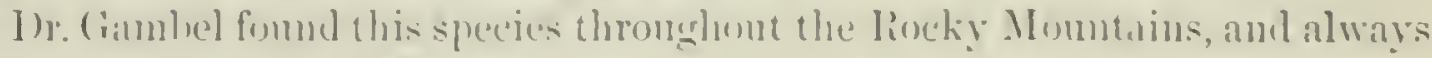

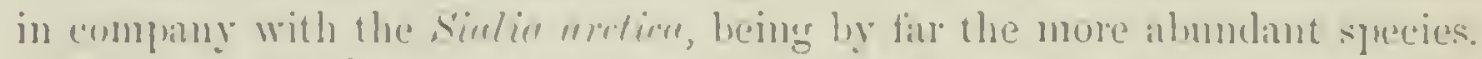

I) Kennerly mentions finding this species very abmolant during his

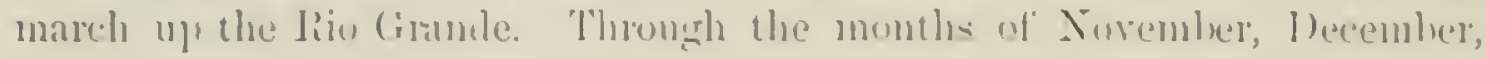

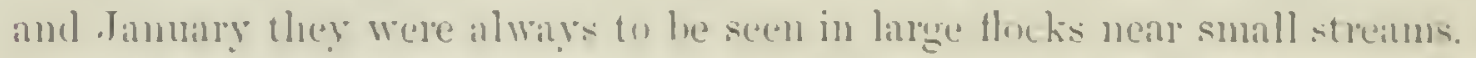

The Westem blucbird consturets a nest nsually of very fonse malterials, consisting chiefly of line dry grases. These are mot woren into an clabonate nest, lut are simply used to line the hollows in which the exress are deprosited. Sear Sian Franciscu Mr. Hephurn found a grir making use uf the nest of the

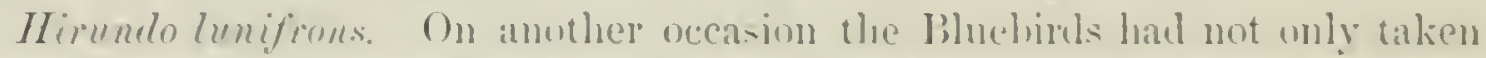
joscession of the nest of this swallow, hut antmally envered up two fresh expess with a lining of dry ensases, and haid her own aluse them.

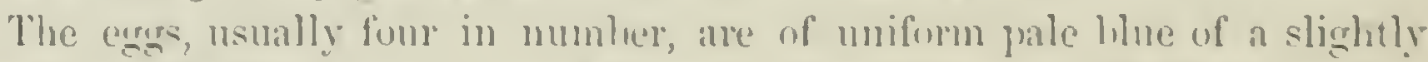
deeper shate than that of the s. sirlis. They measure st at an inch in lengrth ly .69 in luesulth.

Dr: (iveper's sulseguent olseprations of this species in Califomia enabled him to ade to his aceoment of it in lis repert on the lime of that state. He fomm it almulant in all the worded districts, except high in the momtains,

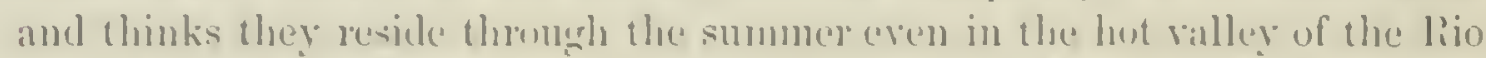

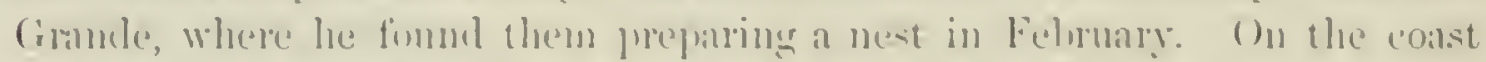

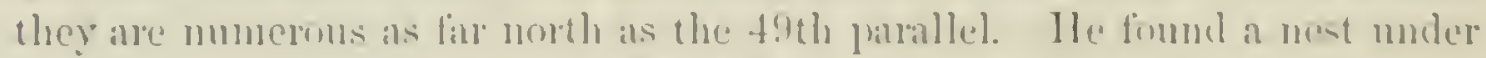

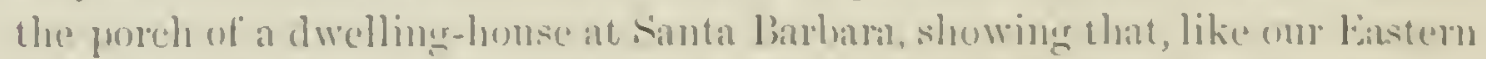

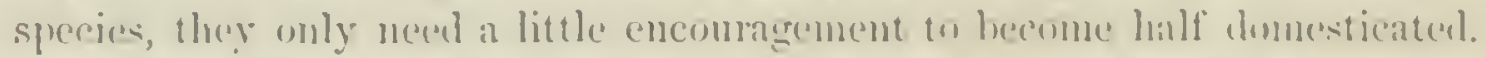
They nise two hrouls in a season, the first heing hatehed early in . Ipril.

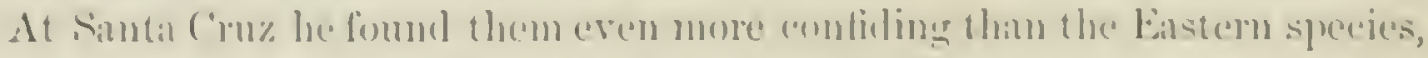

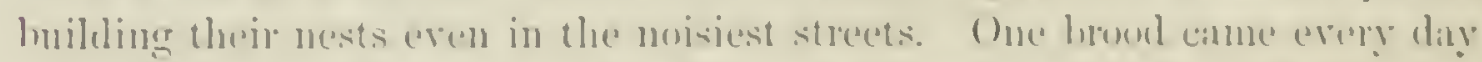

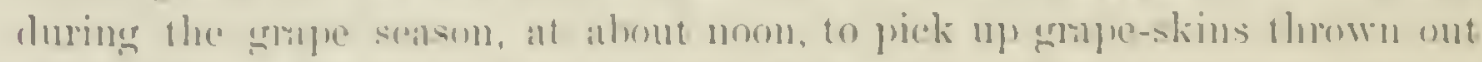

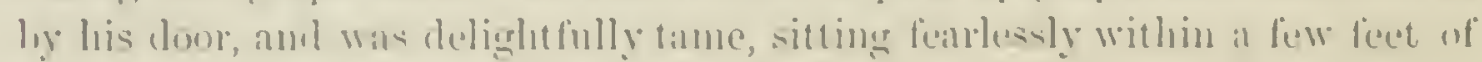

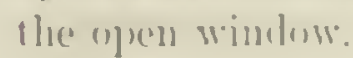

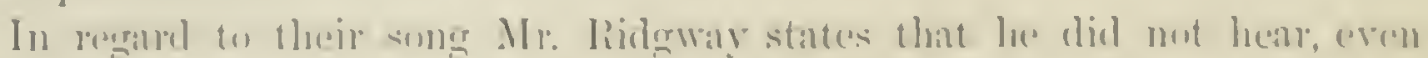

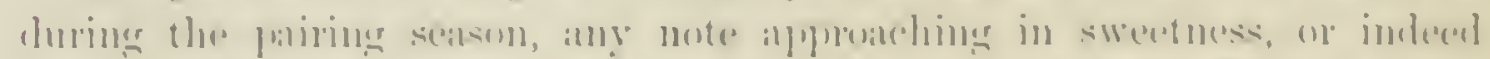

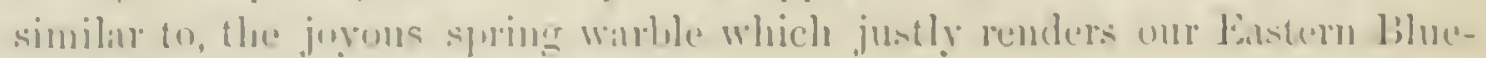

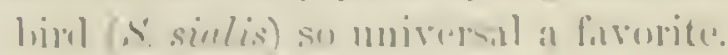

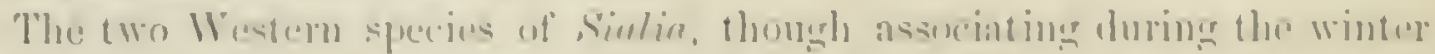

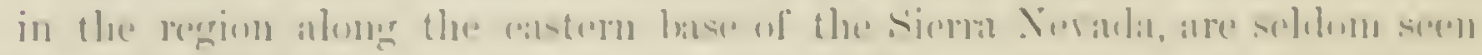

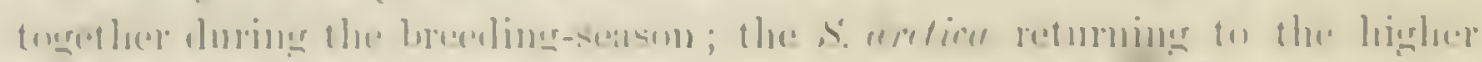

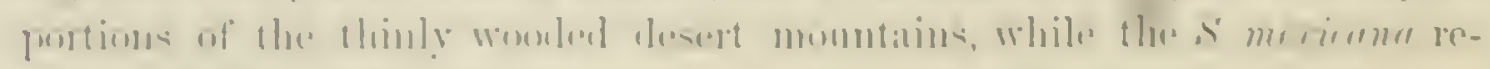

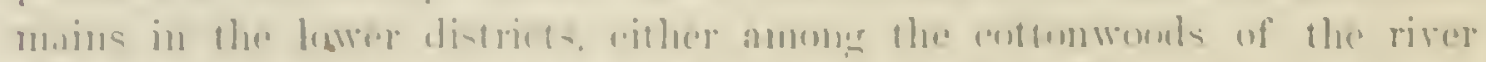

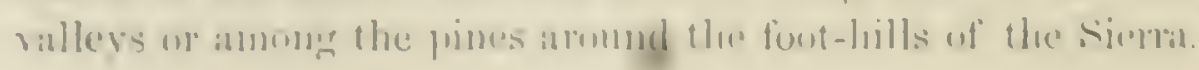




\section{Sialia arctica, Swaxs.} ROCKY MOUNTAIN BLUEBIRD.

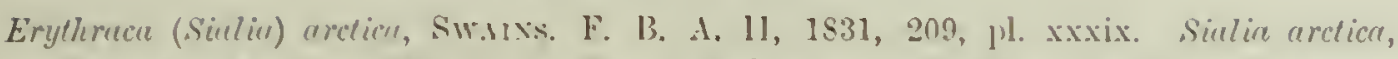

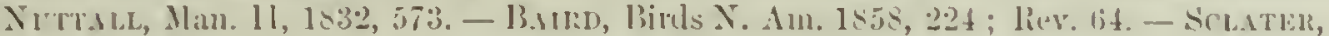

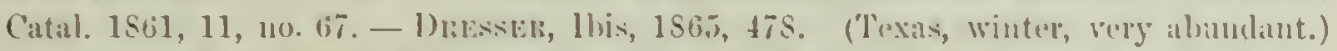
- Cooper, linels ('al. I, 29. Siulie anceroplere, listro, Stansbury's liept. 1S52, 314 (larger race with longere wiugss).

Sr. Cusr. Greenish azure-blute above and helow, brightest alowe; the belly and inder tail-eoverts white; the lattere tinged with blue at the ents. Female showing blue only on the rump, wings, and tail; a white ring romel the eye; the lores and sometines a narow front whitish; elsewhere repliteed by brown. Length, 6.25; wing, 4.36 ; tail, 3.00 . $(15 \% \bar{i}$.

Young. Male birds are streaked with white, as in S. siulis, on the characteristic groumel of the adult.

II.r. Central table-lands of North Ameriea, east to montl of Fellowstone. Onr individual collected at Fort Franklin, Great Bear Lake. Not common on the Pacilie slope; the only specimens received coming from simiahmoo, Fort Crook, and San Diego. Not recorded as fomm in Mexico. W. Arizona, Coces.

As already stated, the blue of this species is greener, more smalt-like than in siulis. The females are distingnished from those of the other speeies by the greener blue, entire absence of rufous, and longer wings.

In antumn and winter the blue of the male is much soiled by amberbrown edges to the feathers, this most conspienous on the breast, where the blue is sometimes almost concenled; the plumage of the female, too, at this season is different from that of spring, the anterior lower parts being soft isabella-color, much less grayish than in spring.

Hıbits. This Pluebird belongs chiefly to the Central fama, and oceupies a place in the Eastem only by its appearance on its borlers. It was first procured by Sir Joln Richardson, at Fort Franklin, in July, 1825. It is abundant throughout the central table-lands of North America, between the Pacific and the month of the Iellowstone, from Great Bear Lake to the lower portions of California. In the latter State it is not common.

Mrr. Nuttall met with this species in the early part of June, northwest of Laramie Fork. The female uttered a. low complaint when her nest was approached. This was constructed in a hole in a clay cliff. Another was found in the trumk of a decayed cedar. In one of these the young were already hatched. The nest was composed of dried grasses, but in rery insigrnificant quantity. Mr. Nuttall found them much more shy than the common species, and describes them as feeling in very nearly the same manner. He afterwards found a nest of the same species in a cliff of the Sandy River, a branch of the Colorado. Both parents were feeding their brood. The female was very uneasy at his approach, ehirping, and at intervals uttering a plaintive cry. He states that the male bird has a more plaintive 


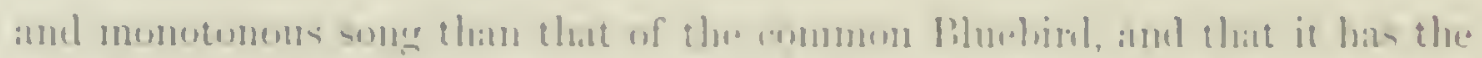

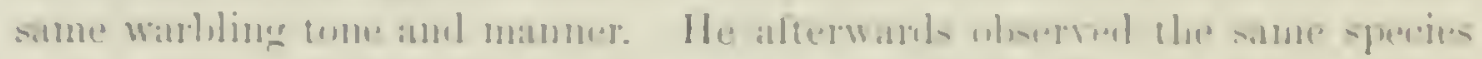

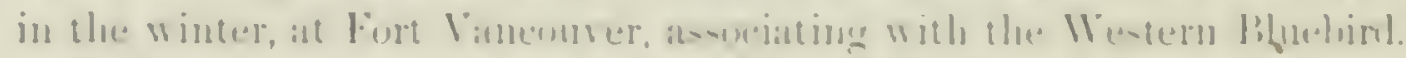

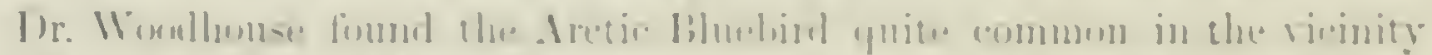

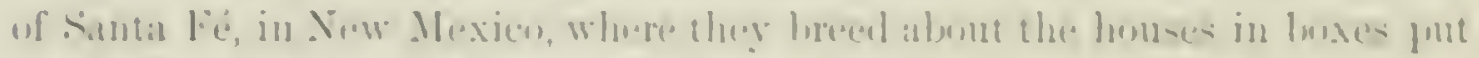

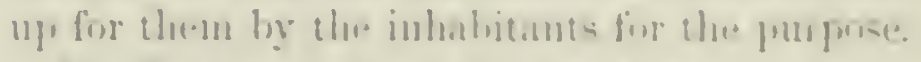

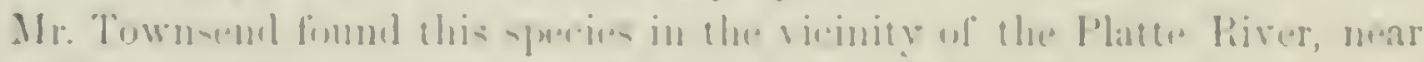
the black Ilills, and al-1 on the bunk of the Culumbit. Thee contined

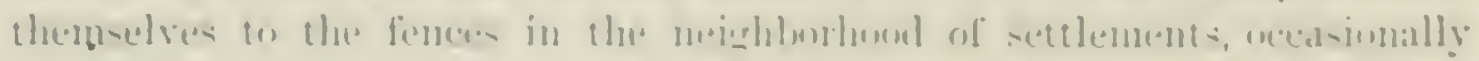

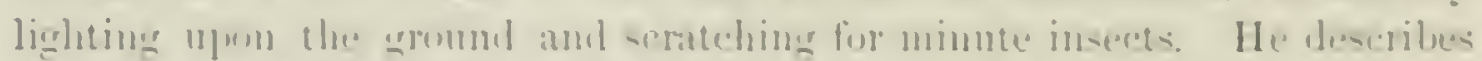

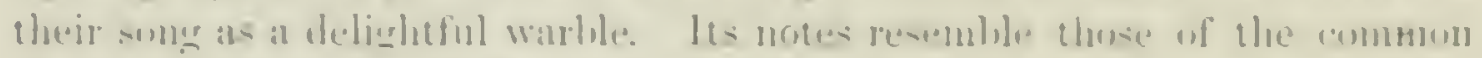

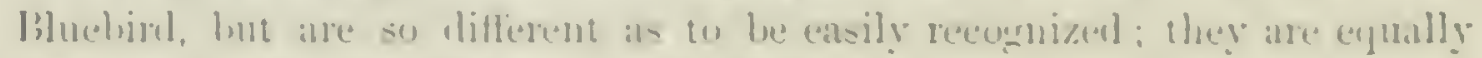

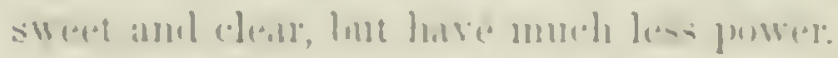

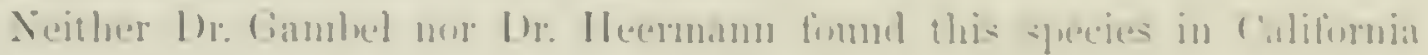
cexcepting during the winter, and were of the opinion that nome remain there (c) breeel.

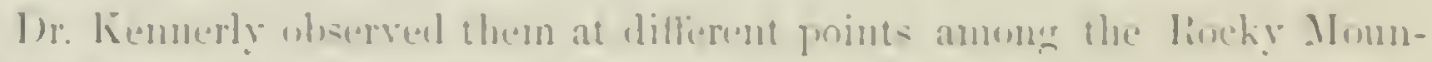

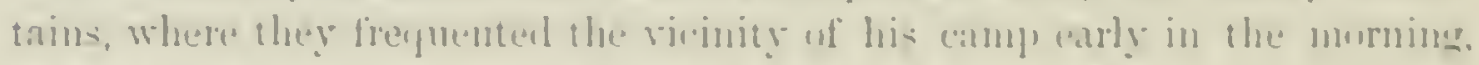
at some times in pairs and at oflurs in floctis of lour er five.

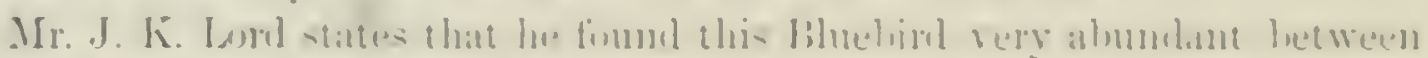

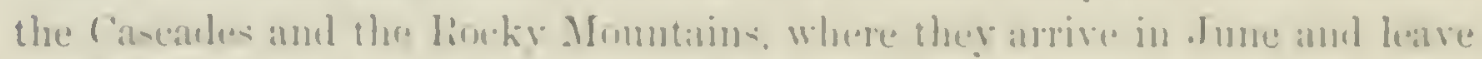

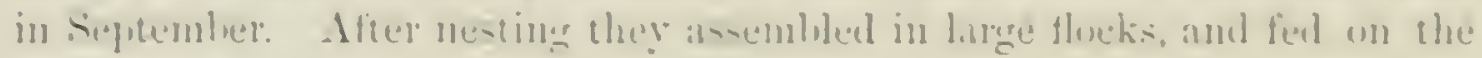
(1])en plitiss.

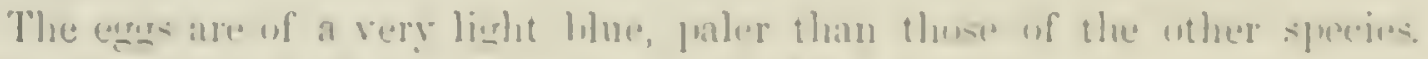

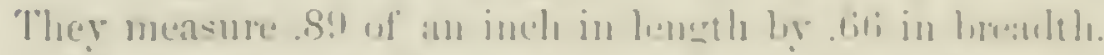

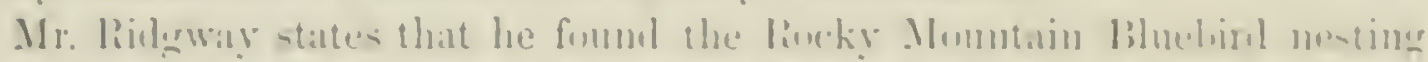

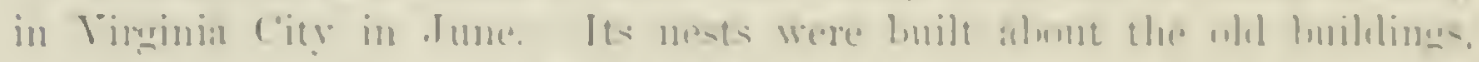

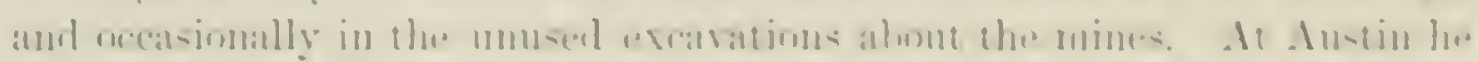

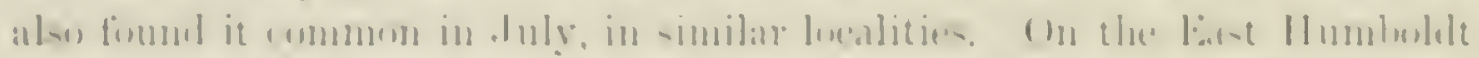

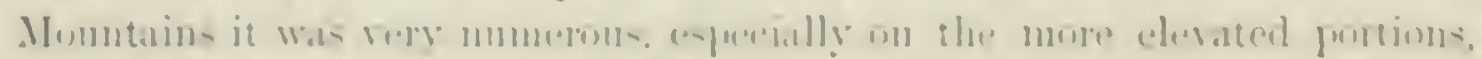

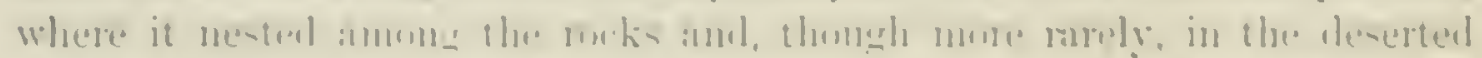

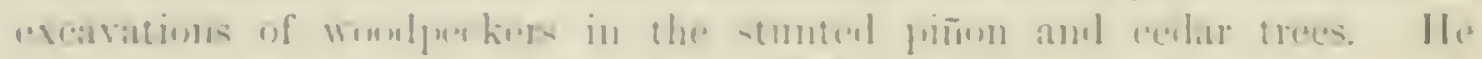

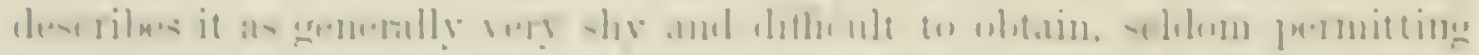

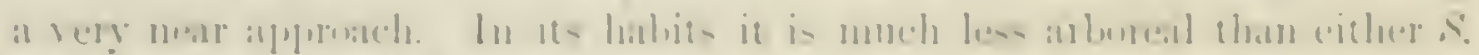

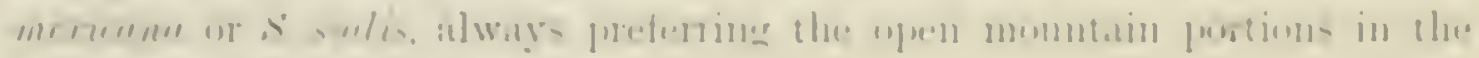

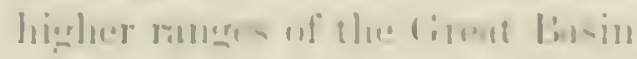

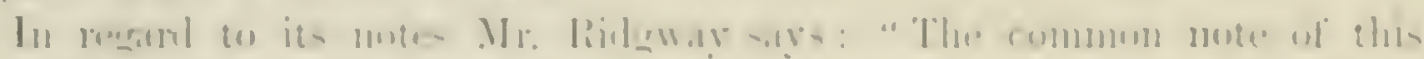

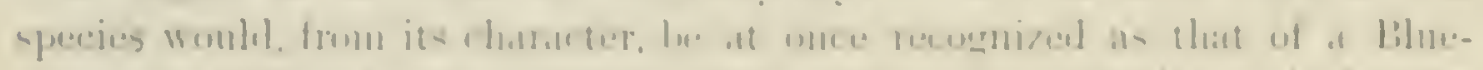

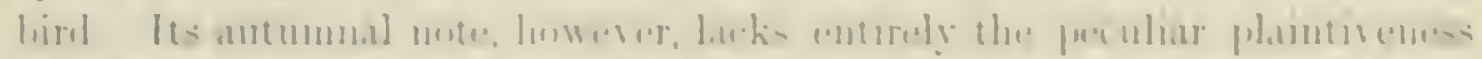

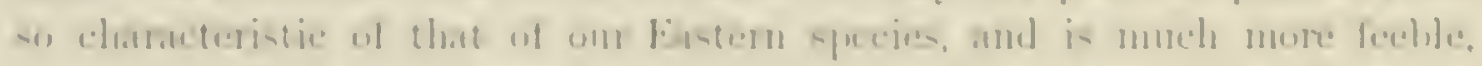

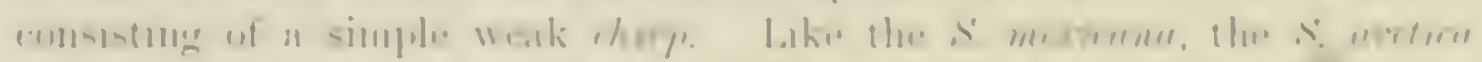

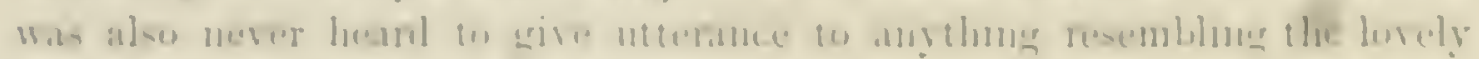

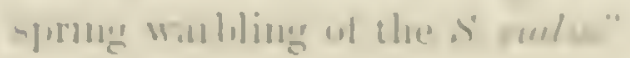




\section{Family SYLVIID卌. - The SYLVils.}

Crar. Bill much shorter than head, sleuder, broad, and depressed at the base, distinctly notehed and clecurred at the tip. Culmen sharp-ridged at base. Frontal feathers reaching to the nostrils, which are oval, with membrane abore, and orerhung - not concealed by a few bristles or by a feather. Rietal bristles extending beyond nostrils. Tarsi booted or seutellate. Bisal joint of middle toe attiched its whole length externally, half-way internally. Primaries ten; spurious primary about half the second, which is shorter than the serenth. Lateral toes equal.

The birds of this family are readily distinguished from the Parida by the slender bill, notched and decurved at tip; much bristled gape, sharp-ridged culmen, exposed oral nostrils, less acherent toes, etc. They are much sualler than the Turdide and Suricolide, with much more slender, depressed bill, longer rictal bristles, etc. The short outer primary, with the primaries ten in number, distinguish them from the Sylricolida.

The following symopsis will serve to characterize the American forms of their respective subfumilies. The species are all among the most diminutive in size with the exception of the Humming-Birds :-

A. Wings longer than the nearly eren and emarginate tail. Scutelli of tarsus scarcely or not at all appreciable. General color oliraceous abore. No white on tail.

Nostrils naked. Scutellie distinct on inner face of tarsus only. Ifead plain.

Nostrils orerhung by bristly feathers. Scutelle of talsus not appreciable.

Heal with a colored central crest. . . . . Regulina. B. Wings about equal to the graduated tail. Tarsal scutellie distinct. Above bluish; tail with white spots or patehes.

Nostrils uncorered. Head plain; either bluish or black abore. Polioplilina.

\section{StbF.MMLI S Y L VIIN 㞌。}

Cunr. Size and form of Syliculine, but with a spurious first primary about one thirc the second quill. Wings considerably longer than the nenrly even or emarginate tail. Feathers of frontal region with bristly points; but not covering the nostrils. Tarsi scutellate anteriorly, but indistinct externally (Characters drawn with reference to the American form.)

The introduction of this subfamily into the present work is required to accommodate a species of Phyllopmenste collected on the Yukon br the Russian Telegraph Expedition, the first known instance of the existence in North America of a group of birds characterstic of the northern parts of the Old World. Among the smallest of the class, they are eminently sociable, and feed entirely on insects, which they capture mostly on the wing, like fly- 
eatchers. The nest is placen on the gromml, and is of an oval or spluerical form with at ronnd opening on one side. The rexes are sinnilat, and the young difler very little from the patrents.

Gires PHYLLOPNEUSTE, Mrin of Winf.

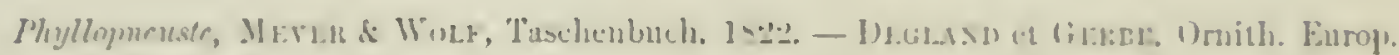
$1,1=607,5+3$.

Ges. Cuak. Bill shorter than the head; straight, slemler, and deprocaed, notihent

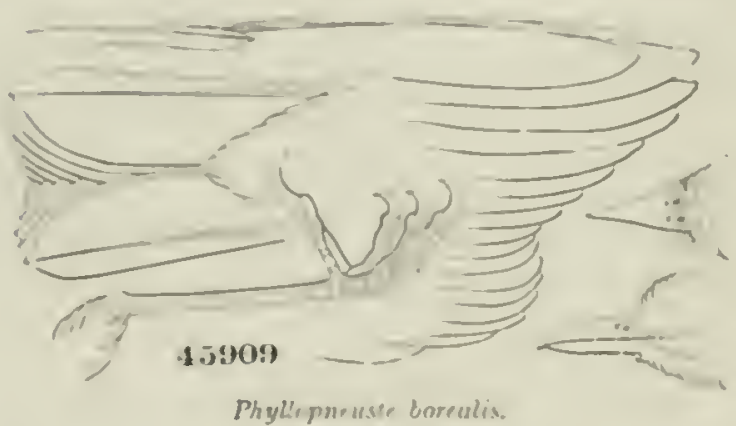

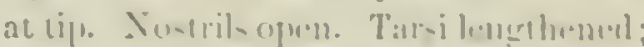
exceeding the middle for: sentellate anteriorly, hut with the platus indiesinct. claws =hort, much enrvel. Whing-puinterl. longer than tail. and reaching at least to it: mirlells: spurious ynill axtending firther than the ujper cotert. Tail emarerinate. (Olis:mens abse: yellowish or whitish lementh.

For the purpose of distinguishing this gemus from any other North Anerican, it is enough to say that, of the general appearance of the warblers, it has a short spurinus first primary, is in the Thrushes, and some Tirmuiller. The single sprecies foumd as yet within our limits resembles at first sight an immature limd ruime

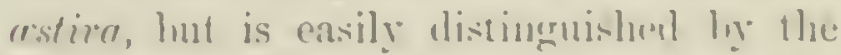
winer formula, the yellowish stripic over the eye, and the brown tail-featlecrs.

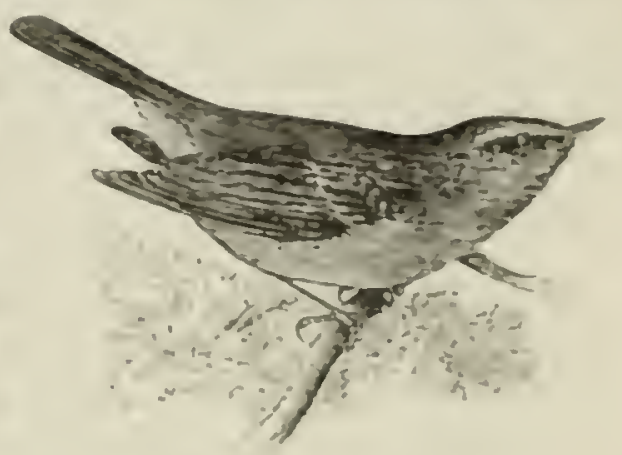

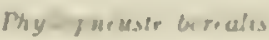

\section{Phyllopneuste borealis, lit..s.}

\section{ALASKA WILLOW WARBLER.}

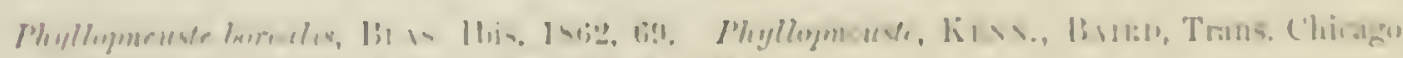

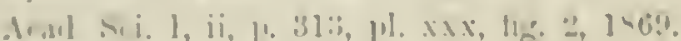

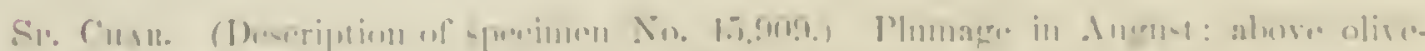

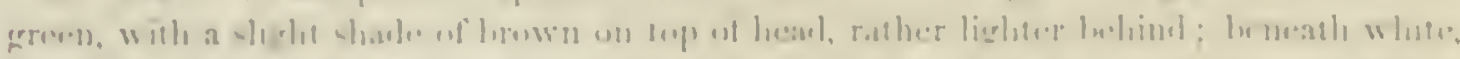

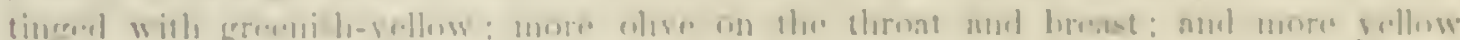

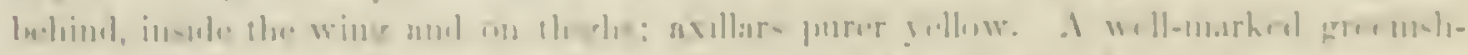

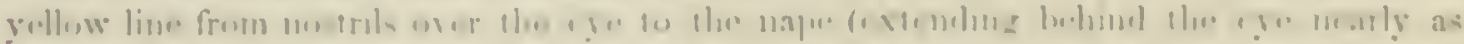

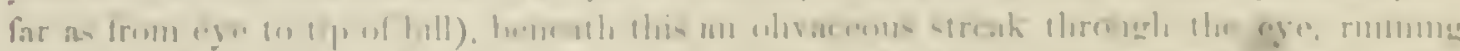

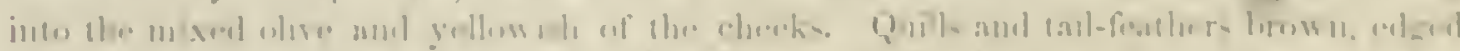

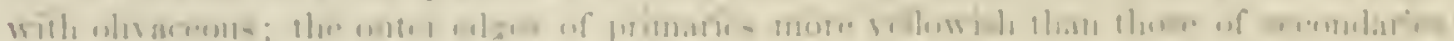

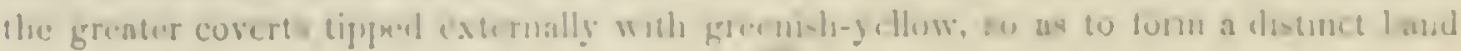


across the wing. Bill rather dark blown; paler beneath. Legs dark olive; toes not sensibly different. Nest probably on ground, and domerl. Eggs white, spotted with pink.

Spmrious quill in length about one fourth the second, which about equals the sixth, or rery slightly exceels it; third and fourth longest: tifth a little shorter.

Dimensions (fresl specimen before being skinned): total length, 4.75 ; expanse of wings, 6.00 ; wing from earjal joint, 2.j0.

Dimensions (prepared specinen) : total lenğth, 4.60; wing, 2.40; tail, 2.00. Exposed portion of tust primary, 0.42 ; of secourl, 1.56 ; of longest (uleasured from exposed base of first prinam), 1.85. Bill: length from above, 0.38; from nostril, 0.29; along gape, 1.5.). Legs: tarsus, 0.66 ; middle toe and elaw, 0.55 ; claw alone, 0.16 ; hinel toe and claw, 0.36 ; claw alone, 0.20 .

II.u. Northeast Asia (China, East Siberia); adjacent to Beluring's Straits aud Alaska.

This species, in general appearance, apparently contes nearer to $P$. trochilus than to any other of its congeners. It is, however, more olivaceous-green above, and more yellow beneath, and has a distinct band across the wing. The supereiliary light stripe is more distinet and longer; the bill and legs are darker, and the toes not sensibly different in color from the tarsus. The proportion of the quills is much the same, except that the interval between the tips of the fifth and sixth quills is greater, and the second is almost inappreciably longer than the latter, not reaching nearly midway between the two. The first or spurious quill is rather shorter.

A single specimen of this species was obtained Angust 16, 1866, on St. Michael's Island, in Norton Sound, Alaska, by Mr. Charles Pease. Mr. Bannister met with no other specimen in that locality, and from this it is inferred that this is not an abundant species there. It was described as a new species under the name of $P$. licnnicottii (Baird), but has been ascertained by Mr: Tristram, to whom it was sent for examination, (Ibis, 1871, p. 231,) to be identical with $P$. boreal is of Blasius.

Dr. Blasius also states (Nammannia, 1858, p. 303) that a specimen of this species has been obtained on the island of Heligoland, showing it to be also an accidental visitant to Westem Emrope.

Habits. Mr. R. Swinloe, who describes this among the birds of Formosa as $P$.sylicultrid, states it to be a smmer visitant to Southern China, passing in large numbers through Amoy in its antumnal migrations snutheastward, probably to the Philippine Islands, touching at Southwestern Formosa and Twaiwanfoo, where he found them abundant. This was for a few days in October, but he neither saw any before nor afterwards, nor did he neet with any at Tamsuy (Ibis, 1863, p. 307). The same writer (Ibis, 1860, p. 53) speaks of this bird as very abundant in Amoy during the months of April and May, but passing farther north to breed.

We have no information in reference to its habits, and nothing farther in regard to its distribution. As it bears a rery close resemblance to the Willow Wren of Europe, P. trochilus, it is quite probable that its general habits, nest, and eggs will be found to correspond rery closely with those of that bird. 
The Euroguan wablers of the erenus J'hyllegmenst are all insert-eating

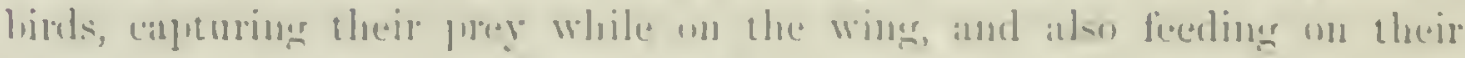

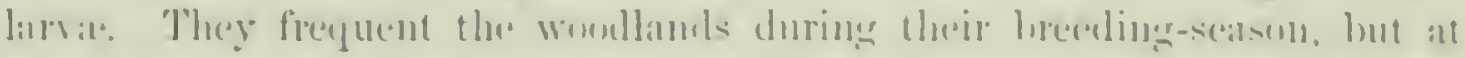

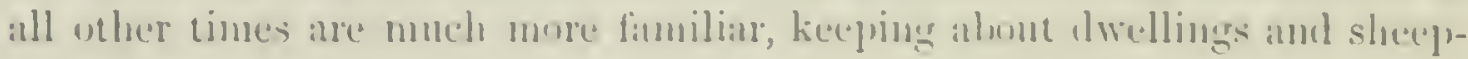
folds.

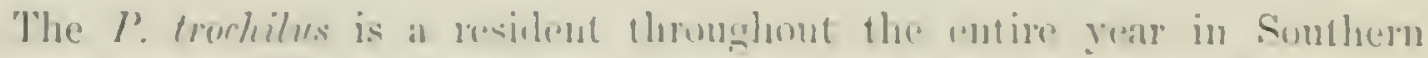

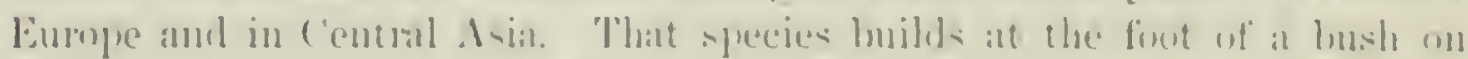

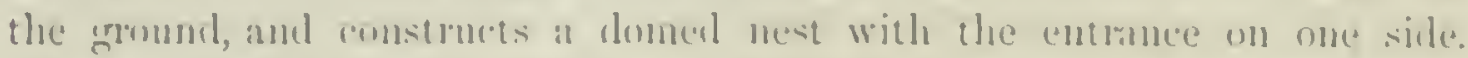

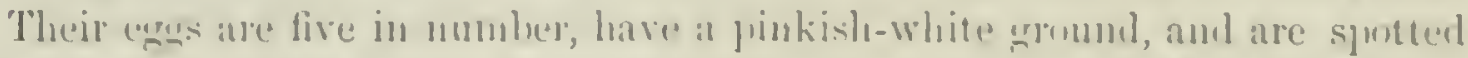

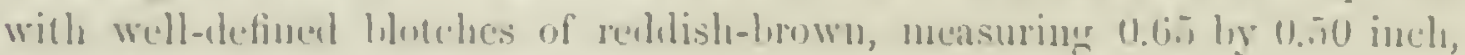
and ane of a romuled oval shape.

\section{Srifwuly REG U L I N 死。}

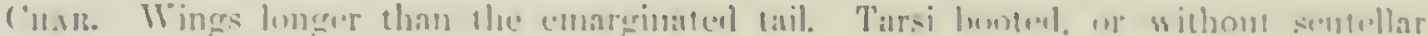
divi-ions.

This subfanily embraces lut a single well-defined North American gremils.

\section{liars REGULUS, l'v.}

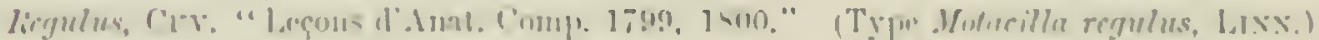

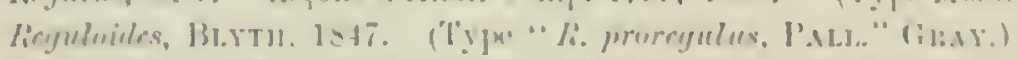

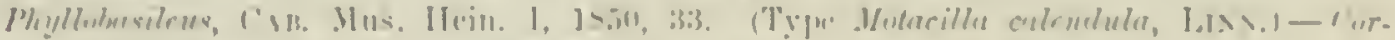

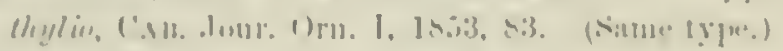

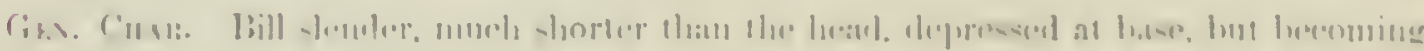

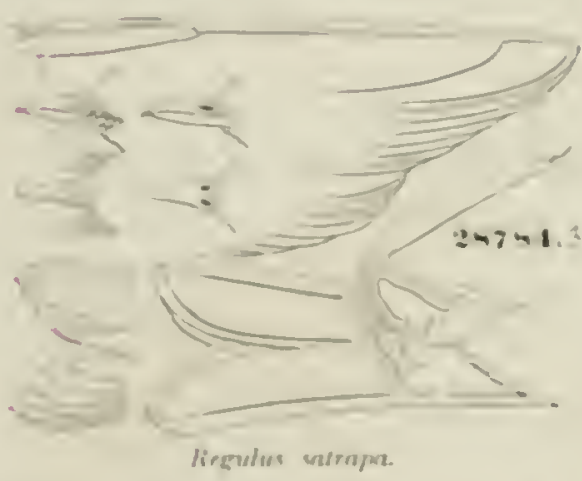

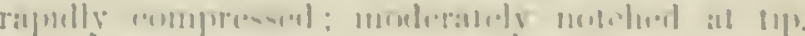

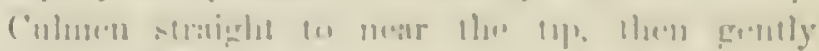

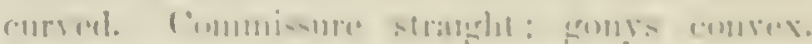

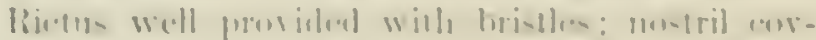

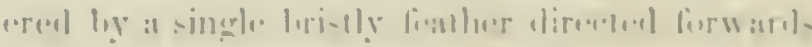

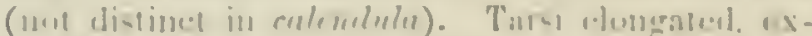

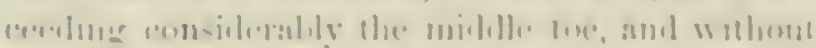

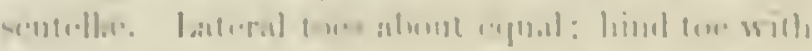

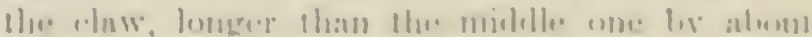

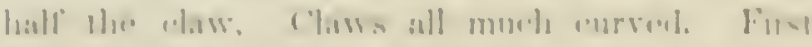

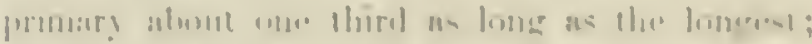

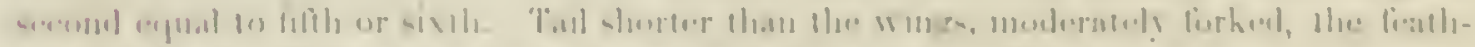

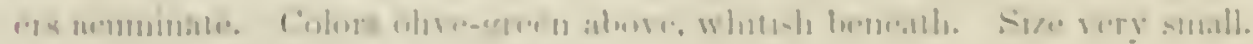

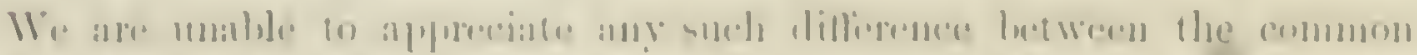

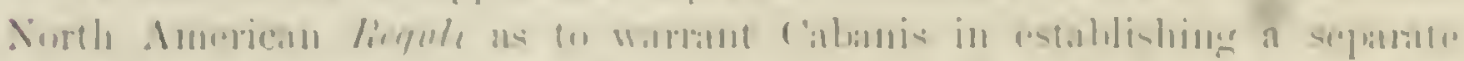

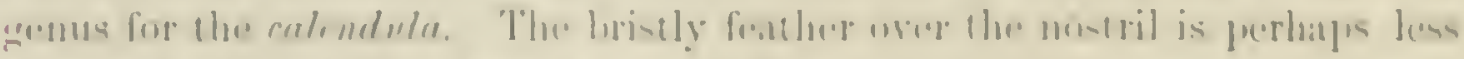

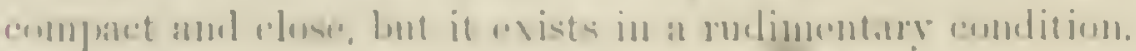


The following synopsis will serve as diagnoses of the species:-

Ifead with entire eap in adult plain olivaccons, with a concealed pateh of crimson. Hub. Whole of North Americar; south to Guatemala; Greenland . . culemelulu.

Ilead with foreheal and line orer the cye white, borlered inside by blick, and within this again is yellow, embracing an orange patch in the centre of the crown. Hab. Whole of North Ameriea

Head with forehead and line throngh the ere black, bordered inside by whitish, and within this again by black, embracing an orange-red patch in the centre of the erown. Hab. Banks of Schuylkill River, Pennsylrania

\section{Regulus satrapa, Licht.}

\section{GOLDEN-CROWNED RINGLET.}

Reguthes satrapa, LicuT. Perz. 1823, no. 410. - DaLi \& Barister (Alaska). - Lol:D (Vancouver Isl.). - Bund, Birls N. Am. 1S59, 2227; lieriew, 65. - ScL.rtek, P. Z. S. 1857, 212 (Orizaba). - B.edeker, Cab. Jour. IV, 33, pl. i, fig. s (exgrs, from Laibrallor).

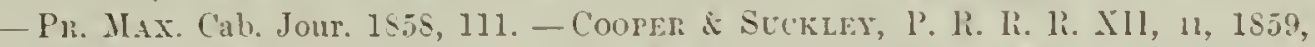
174 (winters in W. Territory). - Loln, li. Art. Inst. Wool. 1s64, 114 (nest?). Dlesser, Ibis, 1665, 476 (Texas, winter). - Sanutas, 179. - Cooper, Birals Cal. I,

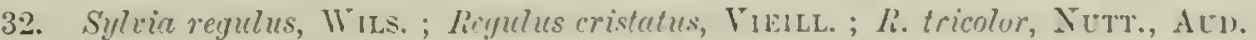

Figures: Aed. Birds Am. II, pl. cxxxii. - Iв. Oru. Biog. Il, pl. clxxxiii. - Vifint. Ois. Am. Sept. II, pl. cri.

Sp. Crur. A bore olive-green. brightest on the outer edges of the wing: tail-fenthers tinged with brownish-gray towards the head. Foreleat, a line over the eye and a space beneath it, white. Exterior of the erown before and laterally black, embracing a eentral patch of orange-red, eneircled by gamboge-yellow. A dusky space aronnd the eye. Wing-eorerts with two yellowish-white bauds, the posterior covering a similar band on the quills, succeded by a broad dusky onc. Lnder parts dull whitish. Length under 4 inches; wing, 2.2.5; tail, 1.80. Female without the orange-red central pateh. Young birds without the colored crown.

H.s. North America generally. On the west coast, not recorded sonth of Fort Crook. Orizaba, Sclater; IT. Arizona, Coces.

Specimens of this bird from the far West are much brighter and more olivaceous above; the markings of the face are also somewhat different in showing less dusky abont the eye. These may form a rariety oliraceus.

The Regulus cristatus of Europe, a close ally of our bird, is distinguished by having shorter wings and longer bill; the flame-color of the head is more extended, the black border is

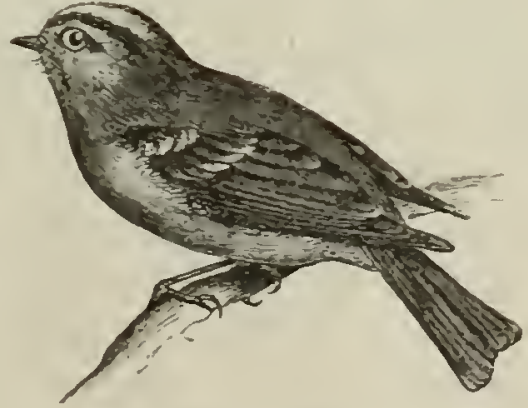

Regulus satrapa. almost wanting anteriorly. The back and rump, too, are more yellow.

Habits. The Golden-crested Kinglet, or "Wren, as it is often called, occurs over nearly the whole of the Nortl American continent. It is abnndant from the Atlaitic to the Pacific, and throughout the British Provinces, where 


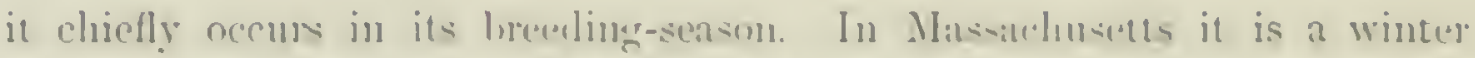
resident from (t)teluer mutil May. In Maine it is met with in sprims and

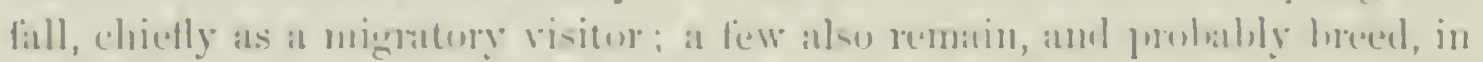

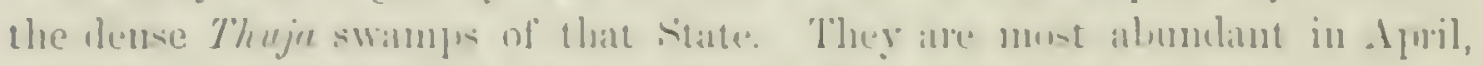

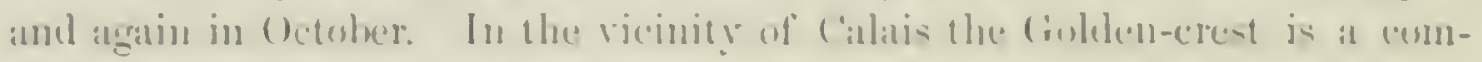

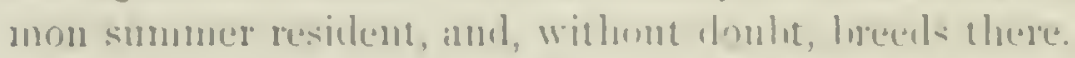

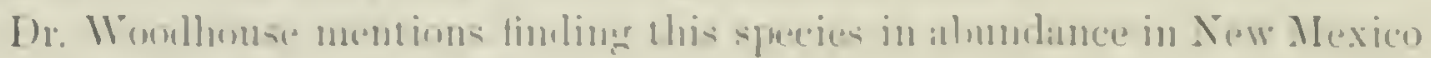

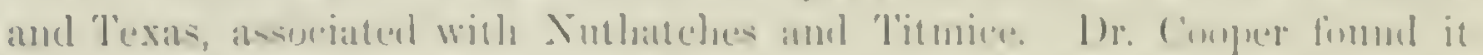

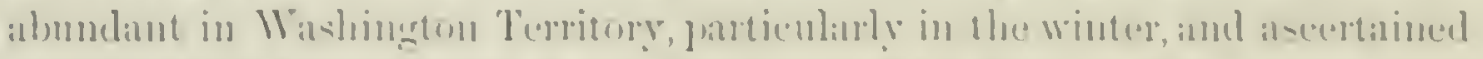

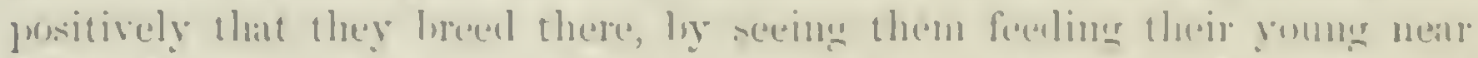
Puget Somed, in the month of Ambust. According to Mr. Ridgway it is

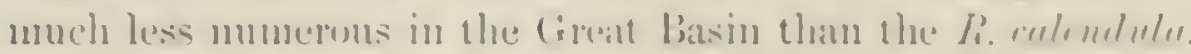

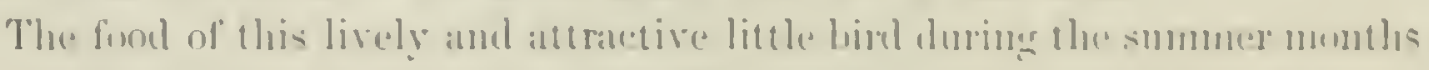

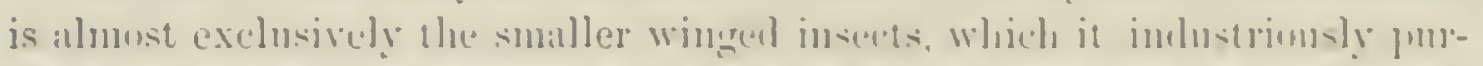

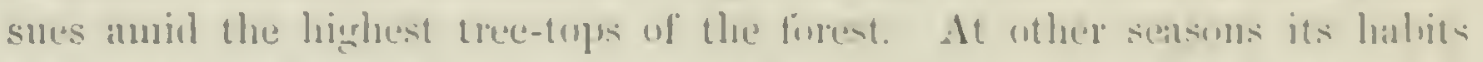
are more those of the titmice, neessity leating it to minsate the creviedes of the bark on the trmbs and latere limbs of the forcst-trees. It is an expert fly-cateleer, tatking insects realily njom the wing.

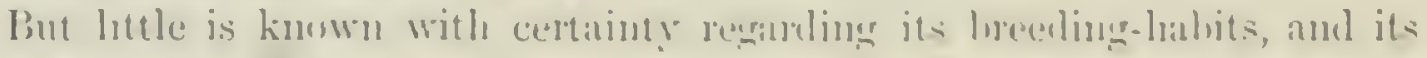

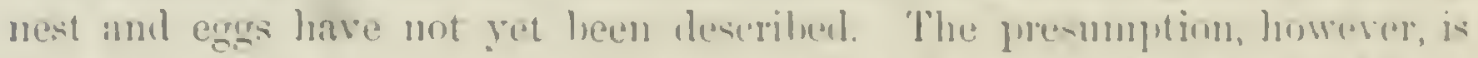

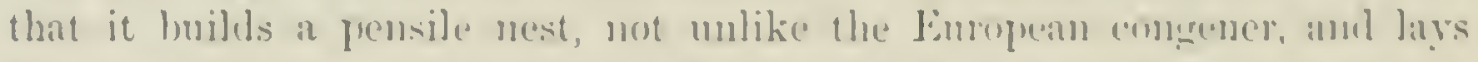
small eargs fincly sprinkled with bufl-colored dots on a white struml, anul in

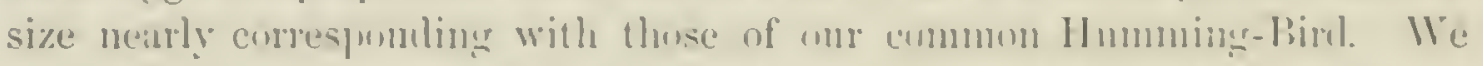
must infer that it rises two brools in al season, from the firet that it spends

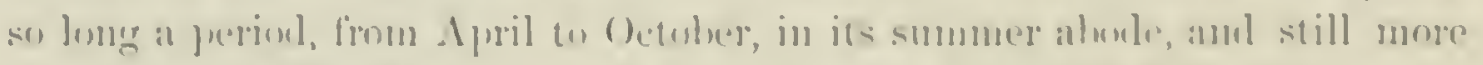

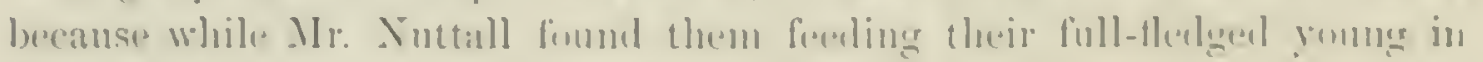

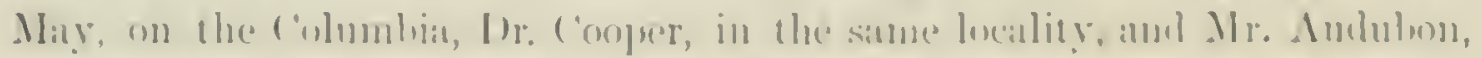

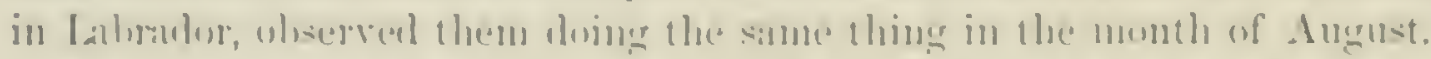

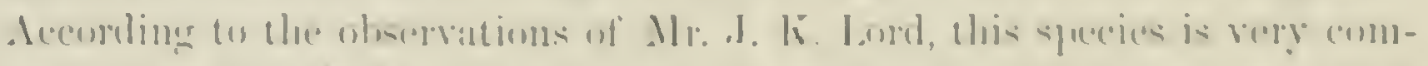

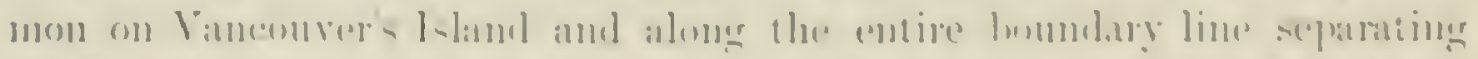
Washingtun Territore form liritish Columblia, where he met with them at an

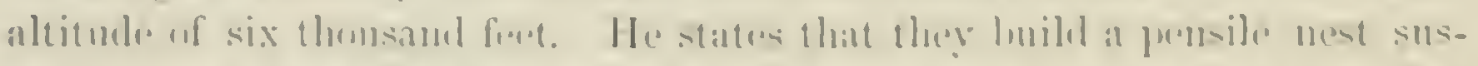

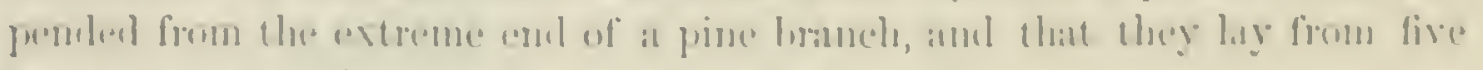

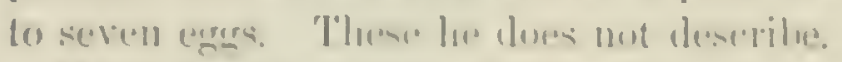

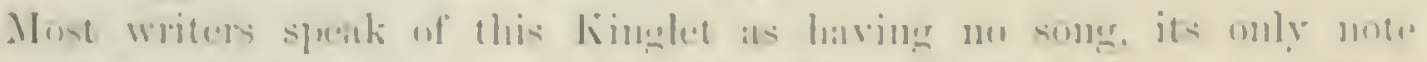

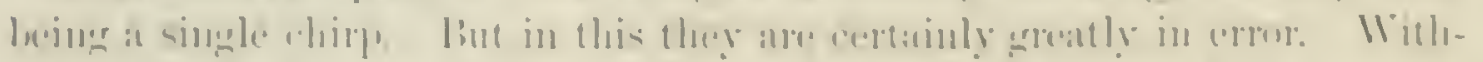

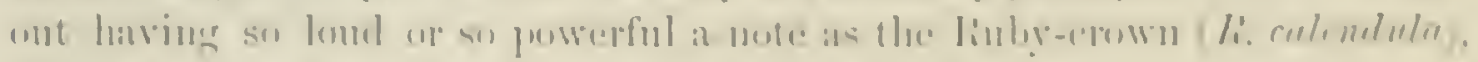

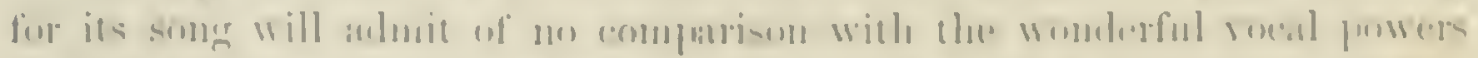

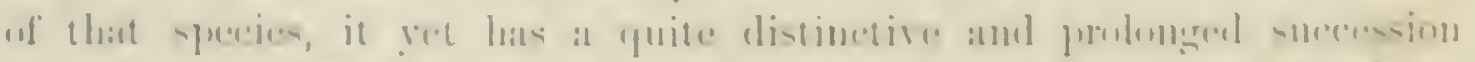

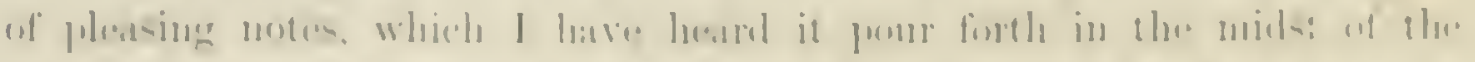

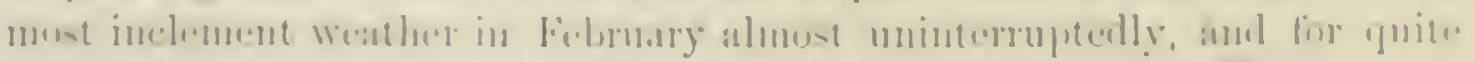
au intervial.

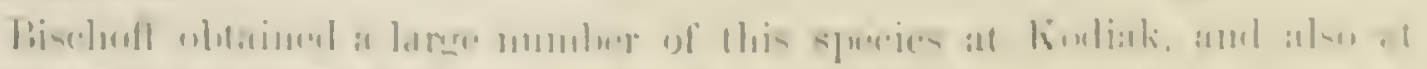

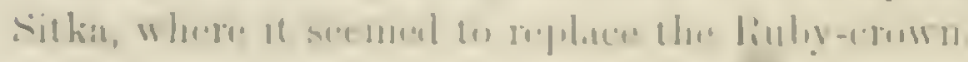




\section{Regulus cuvieri, Ain.}

CUVIER'S KINGLET.

Reguluscurieri, Atn. Orn. Biog. I, 1532, 2ss, pl. 1r, ete.-Ban:D, Birds X. Am. 1859?, 22S: Rer. Am. Birds, 66.

Sp. Cust. Size and general appearance probably that of $R$. satrapa. A black band on the forehead passing back, through and behind the ere, separatcel by a grayish band from another black bancl on the crown, which embraces in the centre of the crown an orauge patch. Length, 4.25 inches: extent of wings, 6 .

HAB. "Bauks of Schuylkill River. Penn. June, 1812." Arn.

This species continues to be unknown, except from the description of Mr. Audubon, as quoted above. It appears to differ mainly from $R$. satiou in liaving two black bands (not one) on the crown anteriorly, separated by a whitish one; the extreme forehead being black instead of white, as in satrapu. The specimen was killed in June, 1812, on the banks of the Schuylkill River, in Penusylrania.

\section{Regulus calendula, Licht. RUBY-CROWNED KINGLET.}

Sotacilla calendulu, Lrx. Srst. Sat. I, 1766, 337. Regulus culendula, Licnt. Verz. 1523,

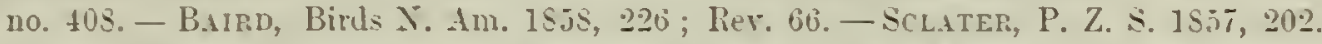

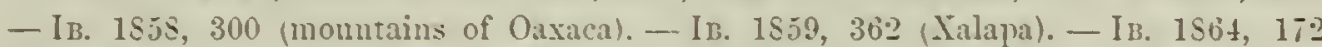
(City of Mex.). - SAMtELs, 17s. - DAll E B.risster (Alaska). - Cuoper, Birds Cal. I, 33. - IB. Ibis, I, 1Sj!), \& (Gruatemala). - Cuoper \& Stchler, P. R. R. XII, II, 1\$59, 174. - Rersirant, Ibi., 1Sỏ1, 5 (Greenland). - Dresser, Ibis, 1565, tĩ (Texas, minter). Corthylio culendulu, CAB. Jonr. Orn. I, 1S53, \&3 (ty]e of genus). Pernulus rubincus, Vienll. Ois. An. Sept. II, 1507, 49, pl. cir, er.

Other figures: Wils. Am. Oru. I, 1 sos, pl. r, tig. 3.-Docgntr, Cab. II, pl. vi. - At'd. Oru. Biog. II, pl. cxer. - In. Birls Au. II, Il. cxxiii.

Sp. Cris. Ahore dark greenish-olive, passing into bright olive-green on the rump and outer edges of the wings and tail. The under parts are grarish-mhite tinged with palt olive-yellow, especially behind. I ring round the ere, two bands on the wing-corerts, and the exterior of the inmer tertials white. Male. Crown with a large coucealed patch of scarlet feathers, which are white at the base. Female aud young without the red ou the crown. Length, 4.50 ; wing, 2.3.3: tail. 1.85.

HAB. Greenland: wholc of North America, and south to Guatemala. Oaxaca (high region, Norember), Sclıter. Ialapa and Guatemala, Sclater.

This species of Regulus appears to lack the small feather which, in satropa, overlies and conceals the nostrils, which was probably the reason with Cabanis and Blyth for placing it in a different genus. There is no other very apparent difference of form, however, although this furuishes a good character for distinguishing between young specimens of the two species.

Habits. Much yet remains to be learned as to the general habits, the 
mesting, and distribution during the meding-setson of the liuly-crowned

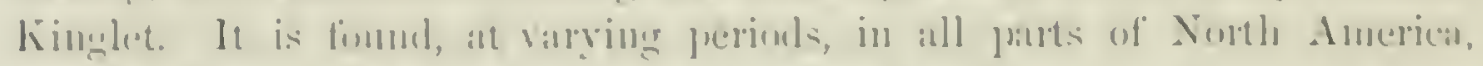
from Mexice to the sheres af the Aretic seas, and from the Atlantic (1) the

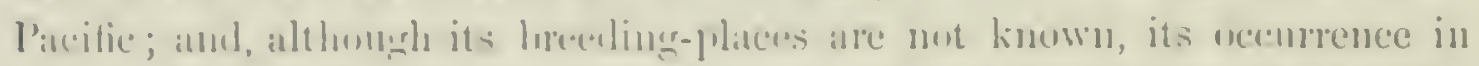

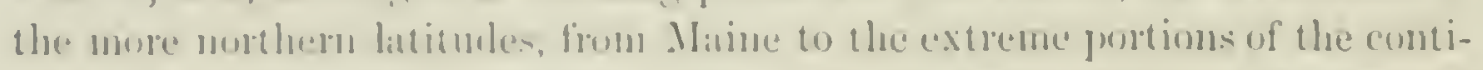

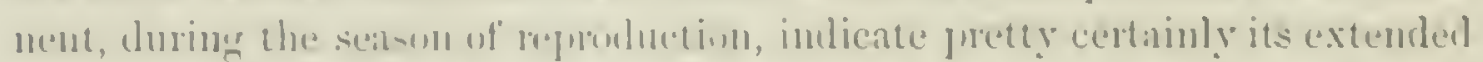

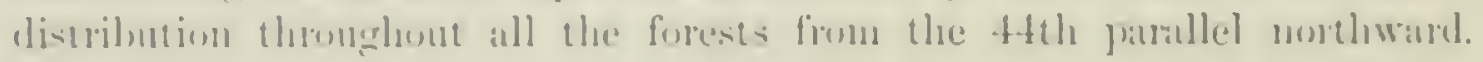
None of our American ormithulue ists ane known to have met with either its

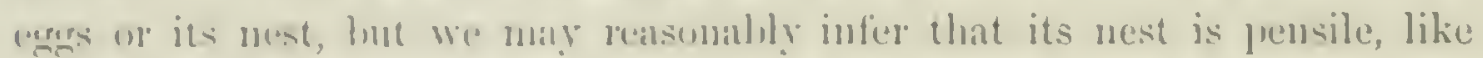

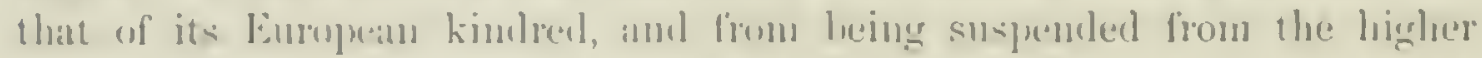
branclues, from its peculiar structure and position has thus far escaped ohservation.

In the Yew Eingland States they are most abundint in the months of

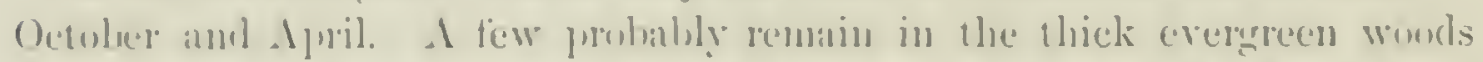

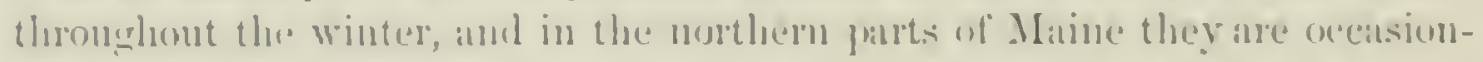
ally fonnd in the summer, and, without douht, heed there. In the damp'

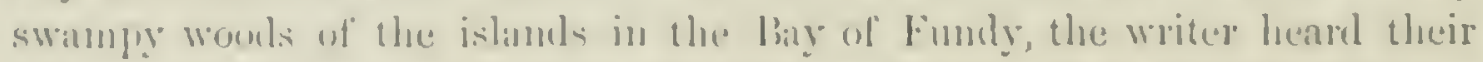

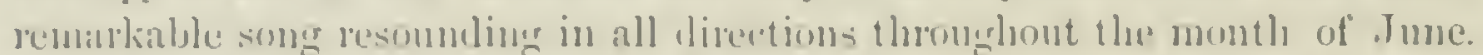

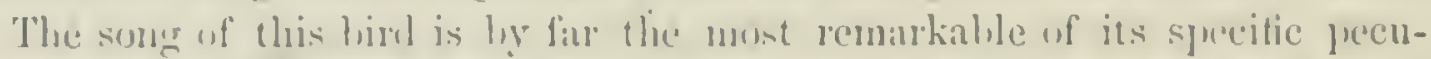
liarities. Its notes are dean, resonant, and hiph, and constitute a prolonged series, varying from the lowest tomes to the highest, terminating with the latter. It may he leatrd at quite at distance, and in some respeets bears more resemblinue to the song of the limelish skylark than to that of the ('amary, to which Mr. Amblahon complares: it.

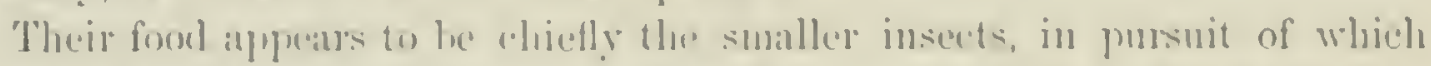

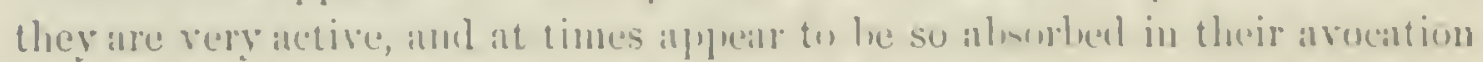

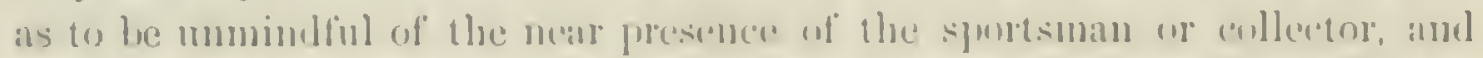

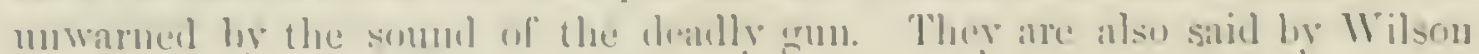

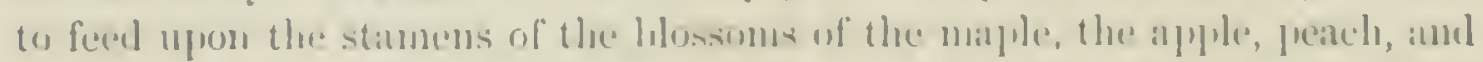

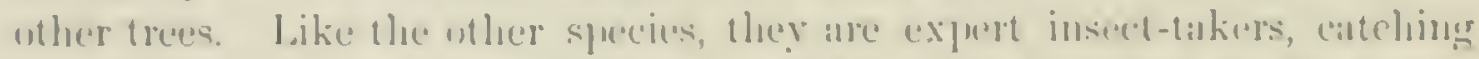

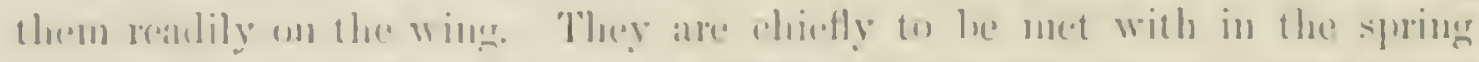

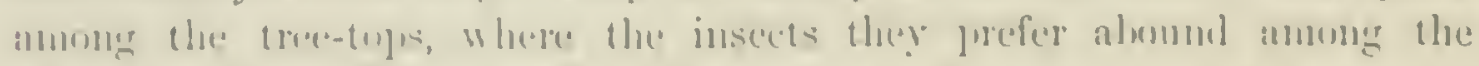

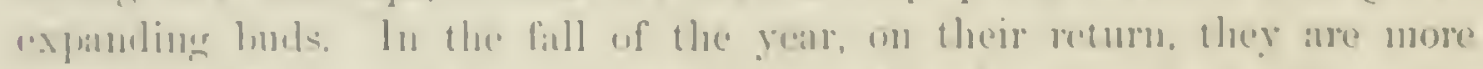

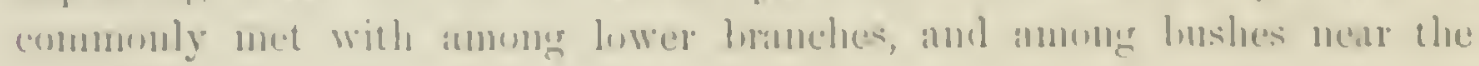
arromal.

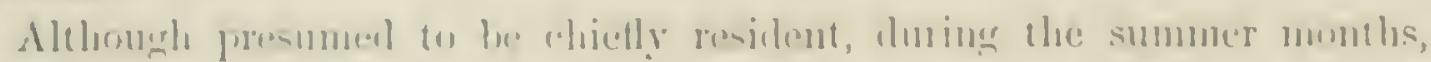

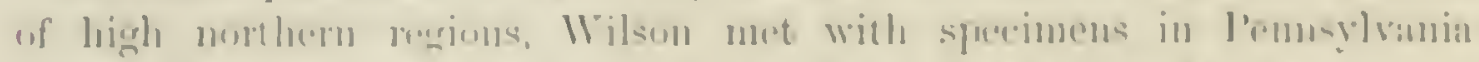

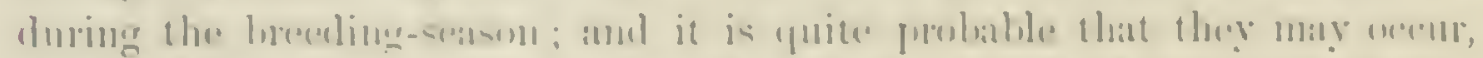

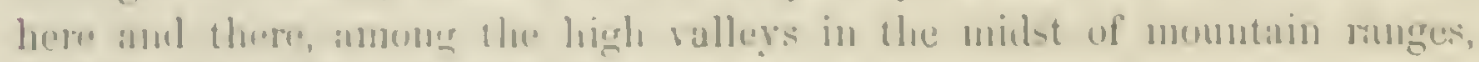
in ditlewent parts of the comutry

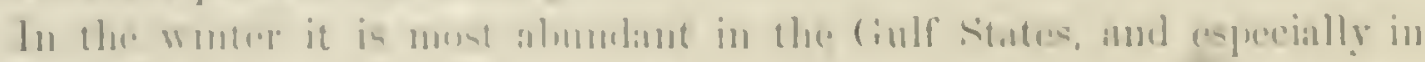

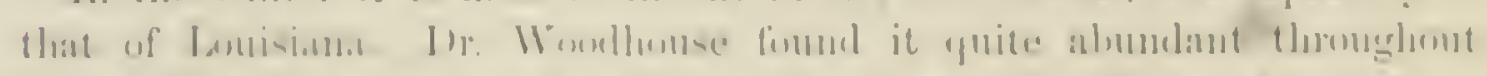

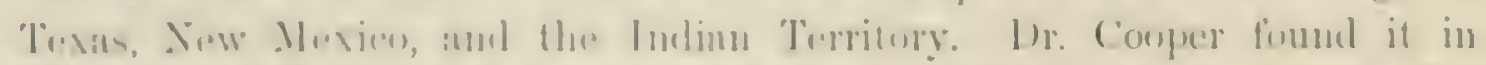
Washimaten territory, but did not there meet with it in smunnes. 1)r. 
Suckley, however, regarded it as a transient visitor, nther than a winter resident of that region, and far more abundant from about the Sth of April to the 20th of May, when it seemed to be migrating, than at any other time.

Dr. Kennerly found these birds in abmulance near Espia, Mexico, and afterwards, during January, among the Aztec Mountains, and again, in February, along the Bill Williams Fork. He describes them as lively, active, and busy in the pursuit of their insect food. They seem to be equally abundant at this season in California, Arizona, and Colorado.

Mr. Ridgway found them common in .June and July anong the coniferous woods high upon the Wahsatch Mountains in Utah, and has no doubt that they breed there.

Mr. Dall found this species abundant at Nulato, Alasha, in the spring of 1868 , preferring the thickets and alder-bushes away from the river-bank. They appeared rery courageous. A pair that seemed about to commence building a nest in a small clump of bushes tore to pieces one lialf finished, belonging to a pair of Scolecophagns forrugineus, and, on the blackbirds' return, attacked the female and drove her away. This was early in June, and Mr. Dall was compelled to leave without being able to witness the sequel of the contest.

A straggrling specimen of this bird was taken in 1860 at Nenortatik, in Greenland, and sent in the flesh to Copenhagen.

\title{
Subantig POLIOPTILIN 开.
}

The characters of this subfamily will be found on page 6.9.

\section{Gexts POLIOPTILA, Schit.}

\author{
Polioptile, Sclater, Pr. Zoöl. Soc. 1855, 11. (Type, Irolecille ccorulea.)
}

Curar. Bill slender, attenuated, but depressed at the hase; nearly as long as the head, distinctly notched at the tip, and provided with moderate rictal bristles. Nostrils rather elongated, not concealed, but anterior to the frontal feathers. Tarsi longer than the middle toe, distinctly scutellate; the toes small; the hinder one scarcely loilger than the lateral; its claw seareely longer than the midlle. Outer lateral toe longer than the inner. First primary about one third the longest; second equal to the serenth. Tail a little longer than the wings, moderately graduated; the feathers rounded. Nest fe!ted and eorered with moss or lichens. Eggs greenish-white, spotted with purplish-brown.

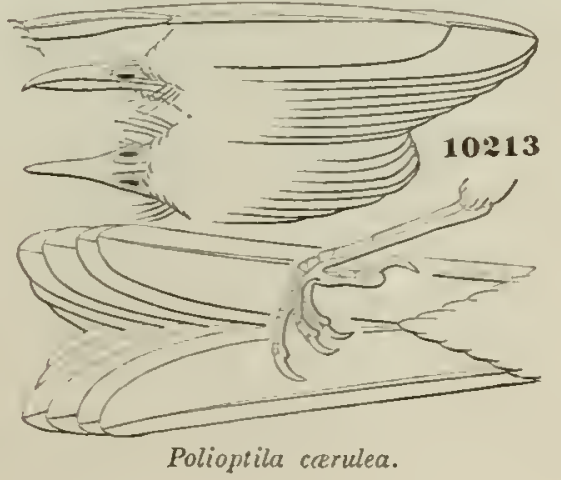

The species all lead-color above: white beneath, and to a greater or less 
cxtent on the exterion of the tail, the re-t of which is hack. Very thummtive in size (but little over tour inclues longer.

\section{Synopsis of Species.}

Tip! "y lecail plumberues.

Two outer tail-finther end rely who. A nanuw fromtal line, cxkending lack

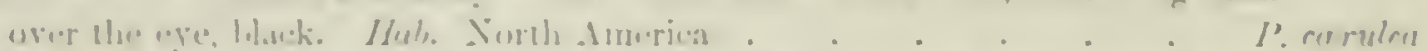

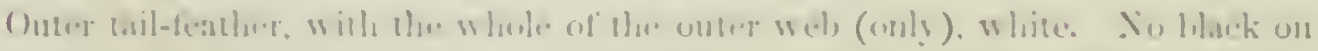

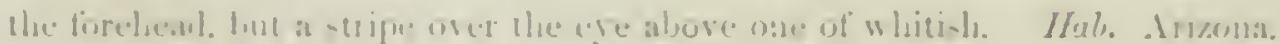

Tope "il herell bluck.

P. plumber.

Folere only of outer weth of onter tail-feather white. Eintire top of heal from the

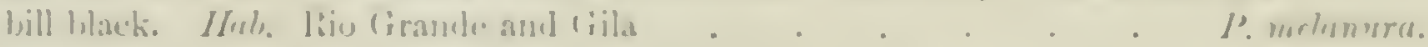

Siperes occur cover the whole of America. One, 1'. Iombryi, is peroliar to ('uha, and it close ally ol' I'. rermlice.

Polioptila cærulea, Sct.st.

\section{BLOE-GRAY GNATCATCHER; EASTERN GNATCATCHER.}

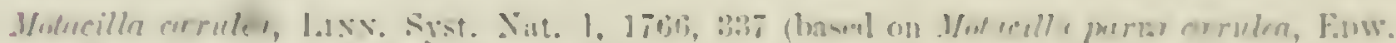

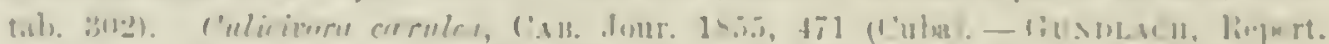

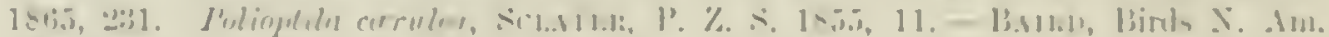

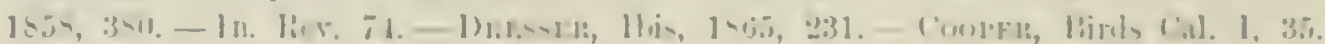

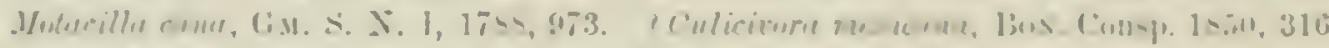

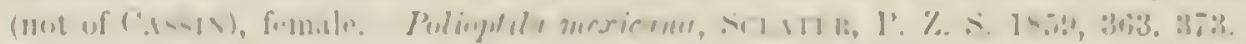

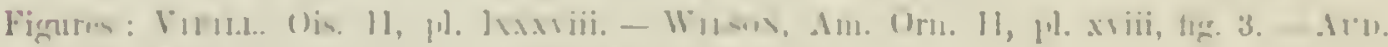

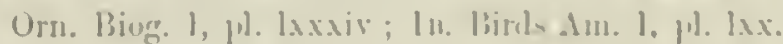

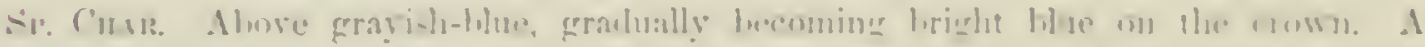

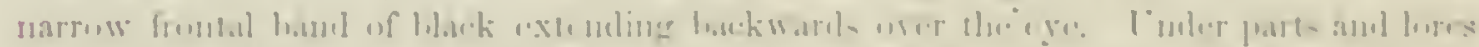

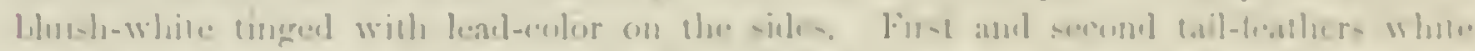

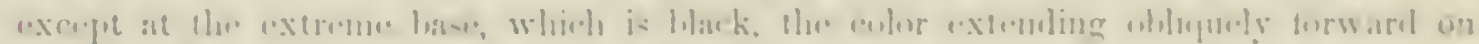

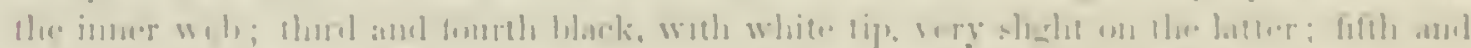

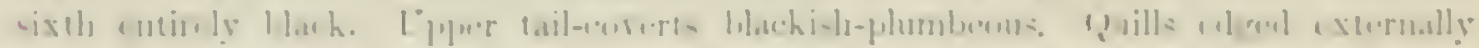

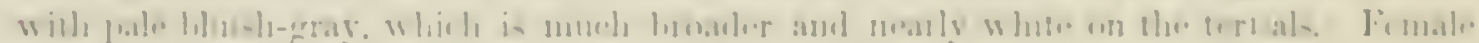

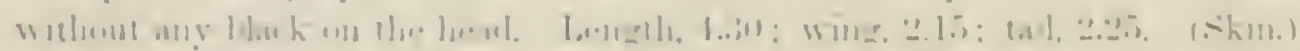

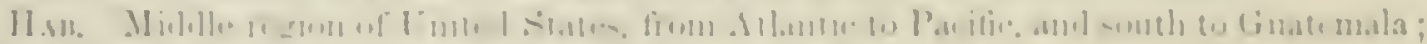

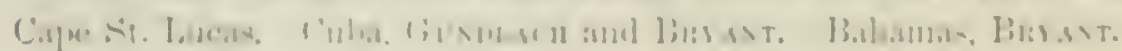

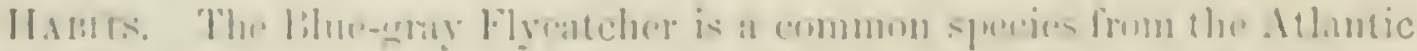

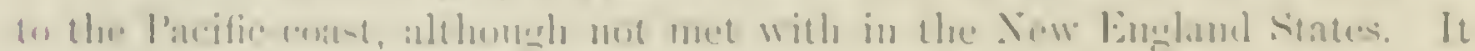

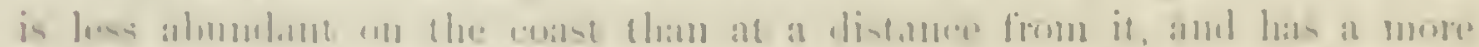

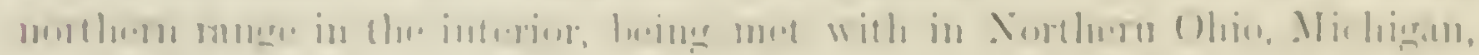

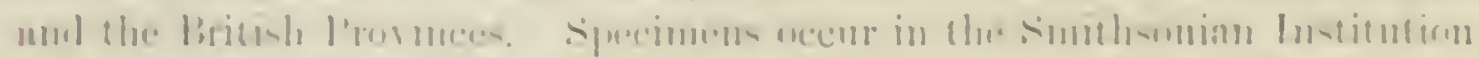

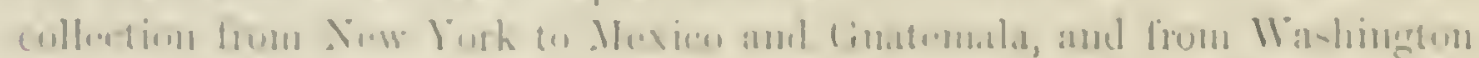
Territury u Collunni,

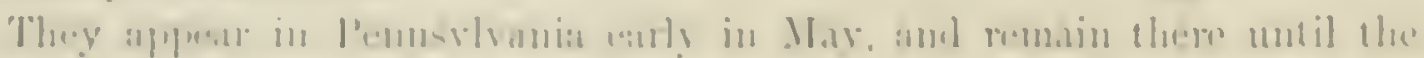

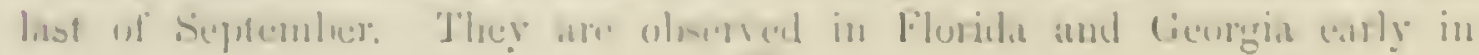


March, but are not known to winter in that latitude. All the specimens in the Smithsonian collection were obtained between April and October, except one from Southern California, which was taken in December.

Near Washington, Dr. Cones states the Blue-gray Guatcateher to be a summer resident, arriving during the first week of April, and remaining until the latter part of September, during which time they are rery abundant. They are said to breed in high open woods, and, on their first arrival, to frequent tall trees on the sides of streans and in orchards.

In California and Arizona this species oceurs, but is, to some extent, replaced by a smaller species, peculialy western, $P$. melanura. There they seem to keep more about low bushes, hunting minute insects in small companies or in pairs, and their labits are laudly distinguishable from those of Warblers in most respects.

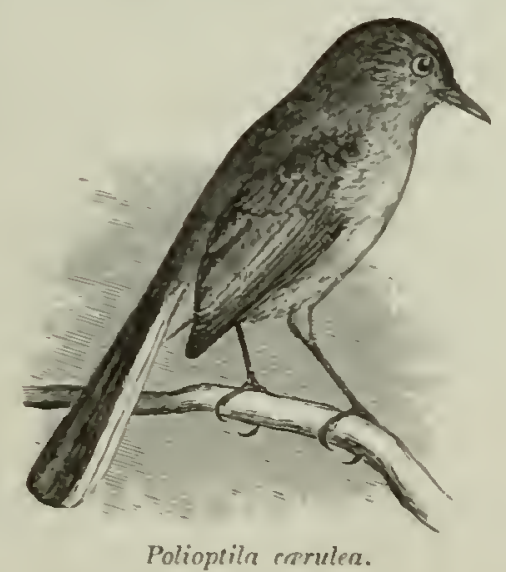

The food of this species is cliefly small winged insects and their larve. It is an expert insect-catcher, taking its prey on the wing with great celerity. All its morements are rery rapid, the bird seeming to be constantly in motion as if erer in quest of insects, moring from one part of the tree to the other, but generally preferring the upper branclies.

Nuttall and Audubon, copying Wilson, speak of the nest of this Gnatcatcher as a very frail receptacle for its eggs, and as hardly strong enough to bear the weight of the parent bird. This, howerer, all my observations attest to be not the fact. The nest is, on the contrary, very elaborately and carefully constructed; large for the size of the bird, remarkably deep, and with thick, warm walls composed of soft and downy materials, but abundantly strong for its builder, who is one of our smallest birds both in size and in weight. Like the nests of the Wood Pewee and the Humming-Bird, they are models of architectural beauty and ingenions design. With walls made of a soft felted material, they are deep and purse-like. They are not pensile, but are woven to small upright twigs, usually near the tree-top, and sway with each breeze, but the depth of the carity and its small diameter prevent the eggs from rolling out. Externally the nest is eovered with a benutiful periphery of gray lichens, assimilating it to the bark of the deciduous trees in which it is constructed.

Occasionally these nests have been found at the height of ten feet from the ground, but they are more frequently built at a much greater elevation, even to the height of fifty feet or more. They are made in the shape of a truncated cone, three inches in diameter at the bise and but two at the top, and three and a half incles in height. The diameter of the opening is an inch and a half. In Northern Georgia they nest about the middle of May, and are so abundant that the late Dr. Gerhardt would often find 
not less than five in a single day, and rery rarely were any of them less

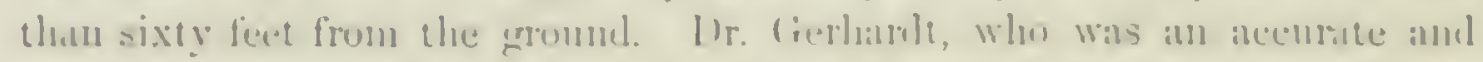
careful olserver, speaks of these as the bes built nests he had met with in this country, both in regard to strength and its ingernionsly contrived aper-

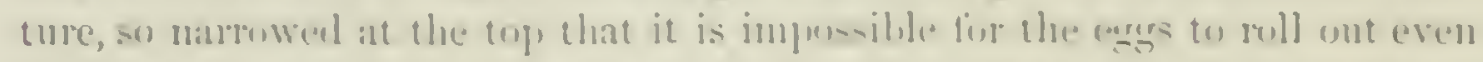

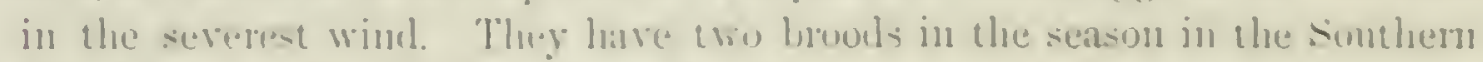
States, one in A pril and atrain in duly.

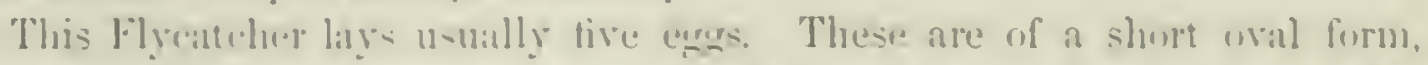

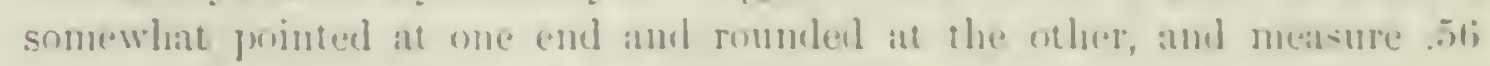

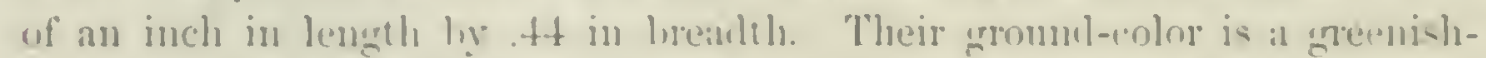
white, narkenl and drited with small blriches and swots of varying and

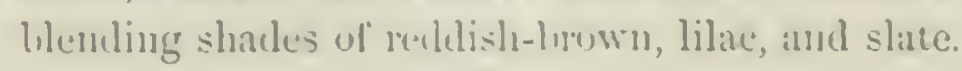

\section{Polioptila plumbea, B.ulin.}

\section{LEAD-COLORED GNATCATCHER; ARIZONA GNATCATCHER.}

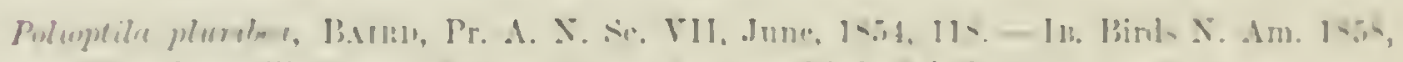

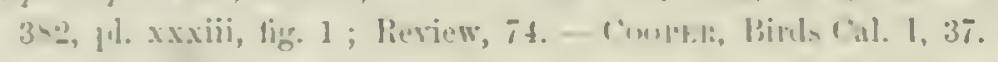

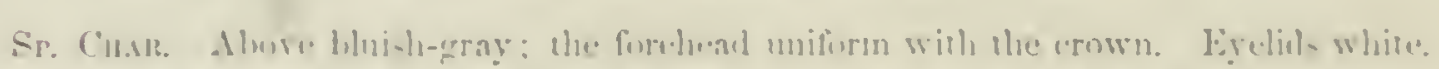

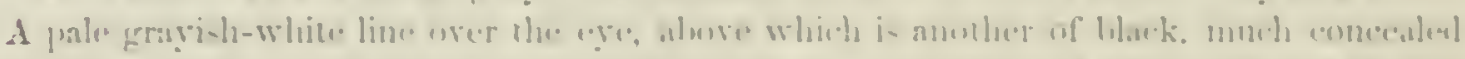

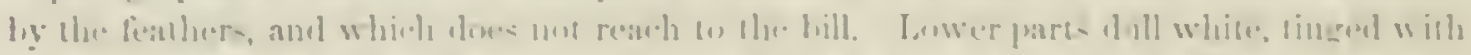

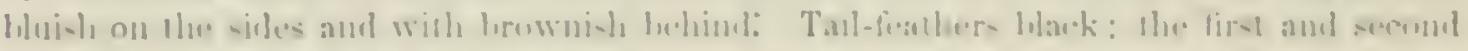

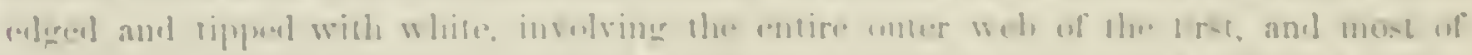

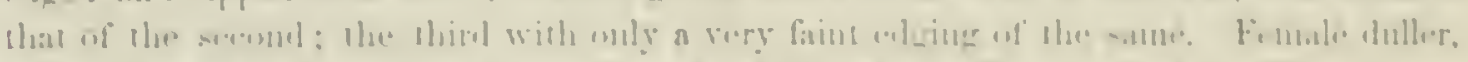

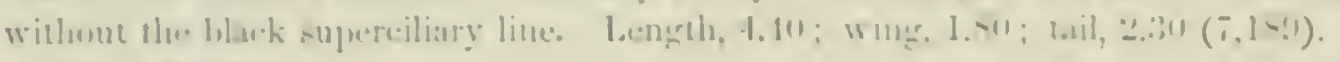

H.su. Irizuna.

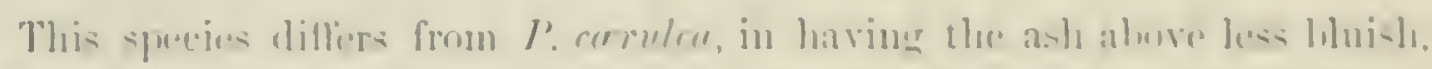

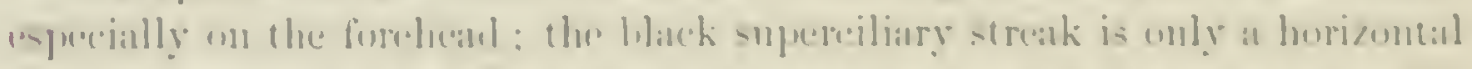

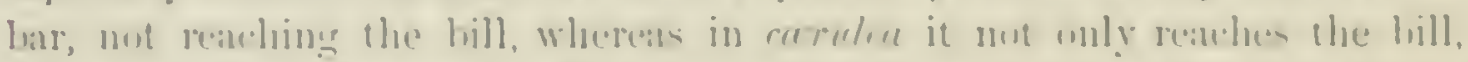

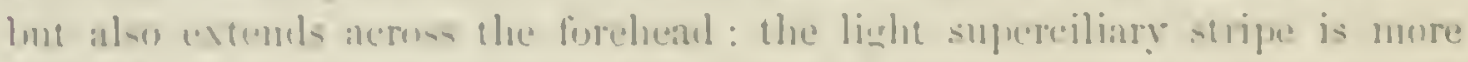

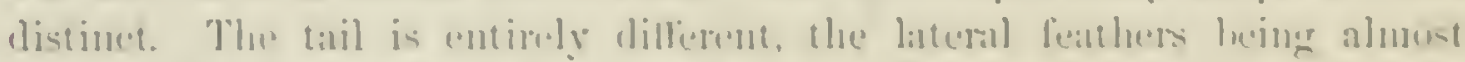
entirely hathe instent of the reverse.

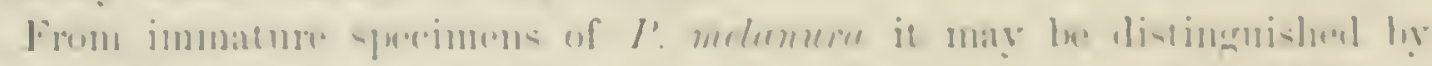

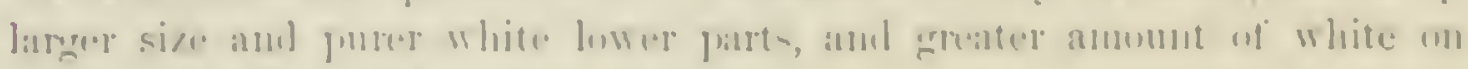

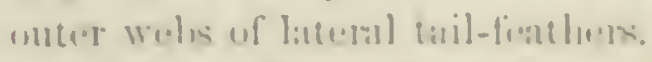

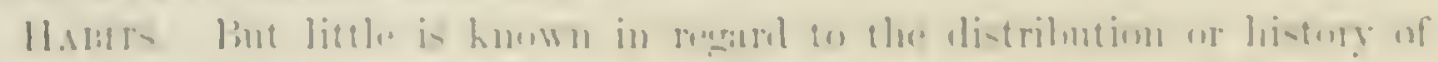

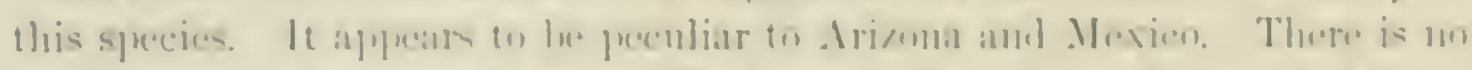

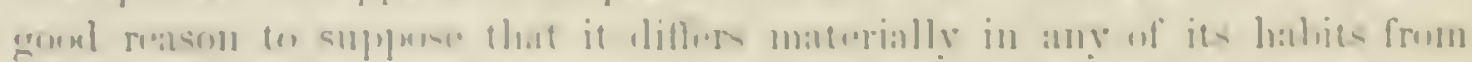

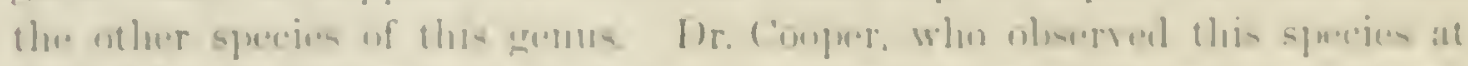

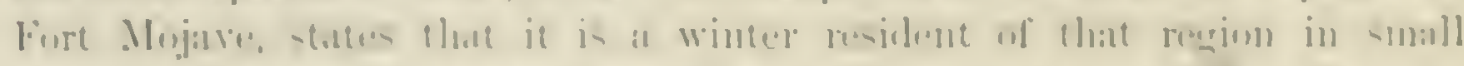

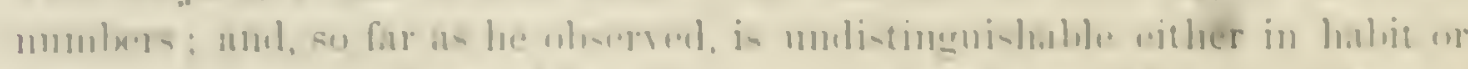

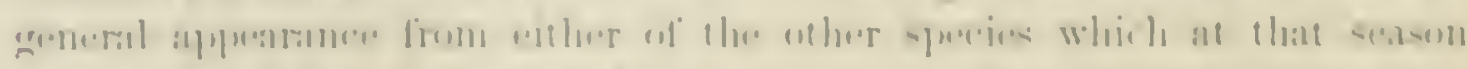

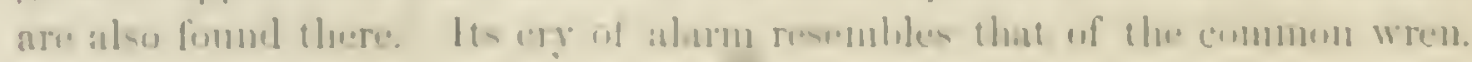




\section{Polioptila melanura, LAWR. BLACK-CAPPED GNATCATCHER.}

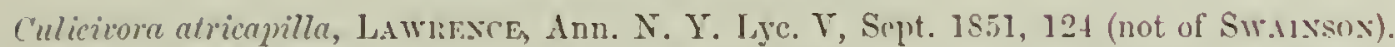
Culicivora mexicana, CAssis, Illust. I, 185 t, 164, pl. xxvii (not of box.). Polioptilu

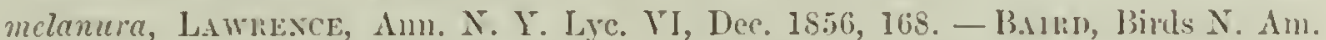
1558, 382 ; Review, 68. - HeEludsx, P. R. R. R. vol. I (Williamson), 1859, 39. CoOpeli, Birds Cal. 1, 37 .

Sp. Cuar. Above plumbeous-blue. Whole crown, to bill and eyes, with tail, listrous blue-black. Beneath pale bluish-gray, almost white on chin and anal region; the flanks and erissum tinged witl brown. Elge of eyelists, and margin and tip of onter web of first and second lateral tail-feathers, white. Female and young without the black of the crown. Length, 4.15 ; wing, 1.S5; tail, 2.10.

HAB. San Diego to Fort Ymua and Cape St. Lueas. Arizona, Cores.

Specimens of this species from Cape St. Lucas differ from those of San Diego described in the P. R. R. Report $(\overline{7}, 191)$ in luaving the whole of the outer web of the onter tail-featler white, and in a rather larger white tip. The colors beneath are a little less ashy, though not of a pure white. The ash of the back is rather lighter and purer. The lores are rather lighter. The first primary is a little larger and broader.

It is possible that the restriction of the white of the onter web of the exterior tail-feather to the onter half only is an unusual circunstance, as both Mr. Cassin and MLr. Lawrence, in their descriptions, speak of the entire onter web being white, - the second feather being of the former character. Under these circumstances there will be little specific difference between the tails of $P$. melanura and plumbea. The fomale birds will then be separated by the light superciliary line and much shorter tarsi of $P$. plumbea, - the latter measuring .63 instead of ncarly .70 of an incl.

HABiTs. This species was first noticed as belonging to the Nortl American fauna by Captain McCown, who obtained it near Ringgold Barracks in 1850. It has since been noticed at Fort Yuma and at San Diego, and obtained in greater abundance at Cape St. Lucas. It is also found in Mexico. Dr. Cooper says that it is common all winter both at San Diego and at Fort Mohave. It las been traced as far north as latitude $30^{\circ}$ in the Sierra Nevada. Its song he describes as a harsh ditty of five parts, something like a wren's song, with notes like those of a swallow, and also closely resembling the song of Vireo belli. Their scolding note is a faint mew, like, that of a cat.

The habits of this species appear to be not mlike those of the peculiar family to which it belongs. All its members are among our smallest birds, are almost exclusively inhabitants of woods, and resemble the Reguli in their restless activity in pursuit of the sinallest insects on which they feed. This bird is described as particularly active, quick in its movements, search- 
ing with great activity for its fond, and preferring low trees and lushes. At times it will dart about in the arr in jursuit of small inscets.

Mr. John Sintus fonnd these birds to be yuite almulant at ('ape sit. Luens, and olutaned seremal of their mests. They were genemally built amomer the interlacing temblrils of a wild vine (Antigonom leptopuss), and so clesely interwoven with the smaller hanches as on be insepanble. The nests, like those of all this family, are structures of great beanty and delieacy. They have a height aml an external diameter of ahont 21 inches. The colvity is 1 inches wide at the rim, and fully two inches deep. This great proportionate depth of the nest serms to be chamcteristic of this gemus. The extrual joution of this nest is composed of a composite blending of various vergetalule materials, fine lempen fibres of plants, strips of delicate lark from sualler shmuls, silken frigments of cocoons and downy cotton-like substance, all very closely impricted and felted torether, somewhit after the manner of the Humming-Birl. The whole is very softy and warmly lined witl a benutifully interworen and silky fabric composed of the soft down of rarious plants.

The walls of the nest, though of the softest matcrials, we so thick and so furmly impacted as to make it a structure remarkibly firm ambl secure agailsst aceidents.

The egrs, four in number, measure s5 of an incle in length ly .tis in brendth. They are of an whlomg-oval shatpe, their ground-eolor is a pale greenish-white sprinkled arer the entire surface with fine dottings of pupple, reddish-brown, and black. 
F.umi CHAMEAD五. - The Groctd-Tits.

Cras. Bill compressed, short, rather conical, aot notched nor decurred. Culmen sharp-ridged. Nostrils linear. with an incumbent seale. Rictal bristes reaching berond nostrils, which are scantily overhung by bristly feathes. Loral teathers bristls and directed forwands. Tarsi booted. or corered with a continuous plate anteriorls. with fain indieations of scutelle on the inner side. Basal joint of middle toe attached for about half its lengrth on either side. Primaries ten; sixth quill longest. Plumage rery lar.

We have found it impossible to assign the genus Chamea to any recognized family of American birds, and hare accordingly been obliged to give it independent rank in this respect, although it may properly belong to some old World group with which we are not acquainted. In its general appearance it approaches the Paride in loose plumage, bristly lores, want of notch to bill, etc.; but differs in the verr much bristled rictus, sharp-ridged

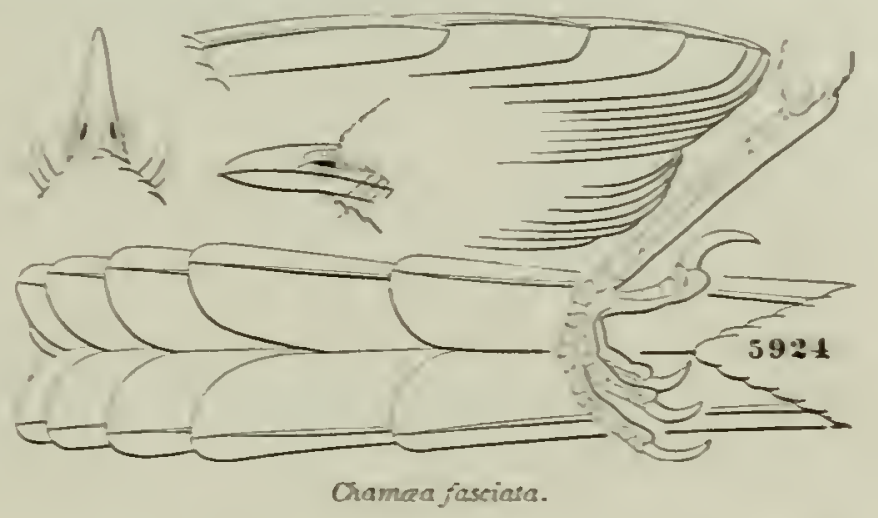
culmen, linear nostrils, booted tarsi, less amount of adhesion of the toes, etc.

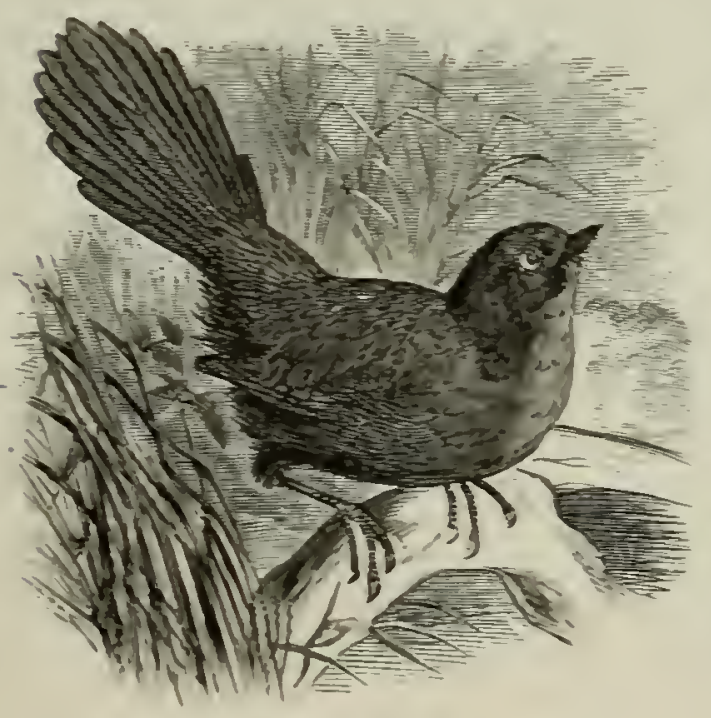

Crama fusciatc. It approaches the Sylriide in the sharp-ridged culmen and bristly gape, but is otherwise rery different. The excessirely rounded wing is a peculiar feature, the sixth primary being the lougest.

The family may, perhaps, be best placed between the sylriids and Paride.

This family has but on' representative (Chamea frasciuta), and this confined to the coast region of California. The characters of the genus are those of the family.

\section{GeNes CHAM EAA, GayBEL.}

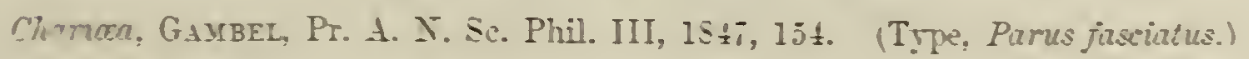

But one species of this genus has as yet been described. 


\section{Chamæa fasciata, (i.sis.}

\section{GROUND-TIT ; WREN-TIT.}

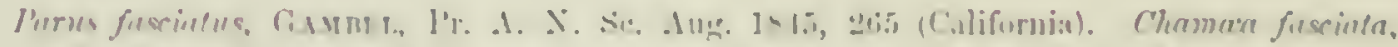

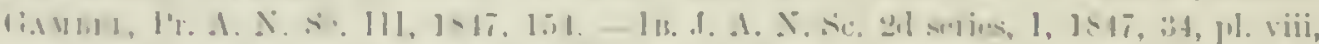
lig. 3. - 1'11:191, $111^{\prime}$

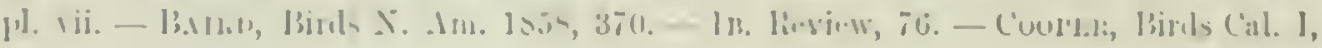
$3 ! \%$

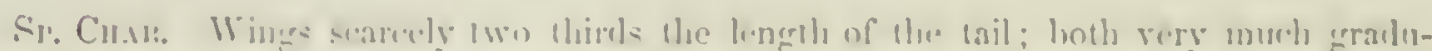

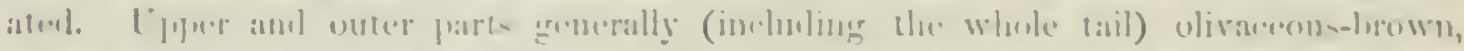

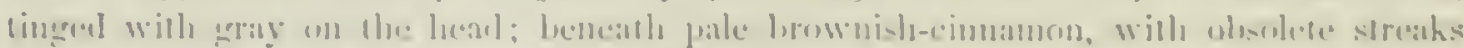

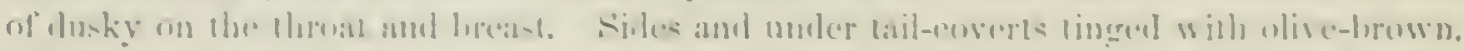

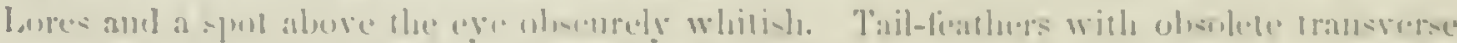

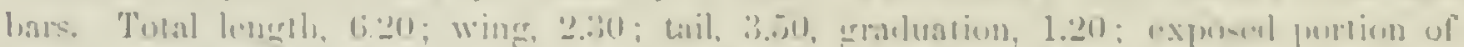

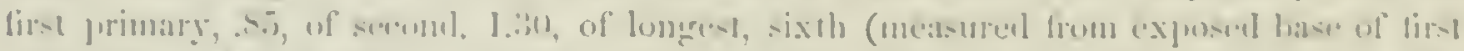

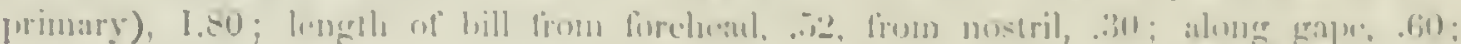

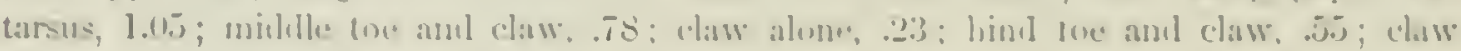

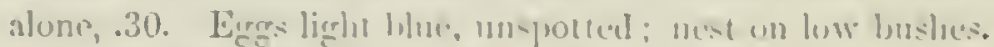

H.n. Coast reginn of Calilumia.

HABTs. This very interesting species, whirh seems to comhe within

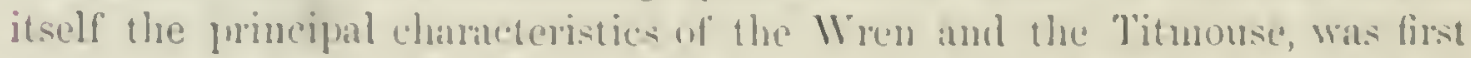
described hy the late In. (Sambel of Thilatedphist. Su far as is now known, it is confined to the cuast eonntry of Califomia, from Fent Tejom to the shome

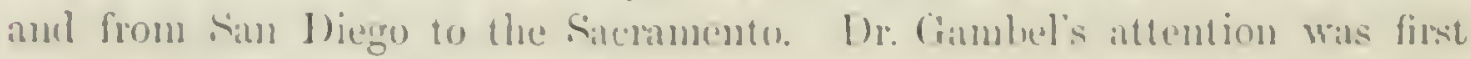

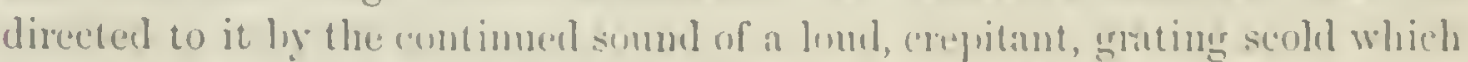
he was constanty hearimg in tiedds of deal musturd-stalks and other similar phaces. He at last distovered it to tee this spectes, whith from its perouliar

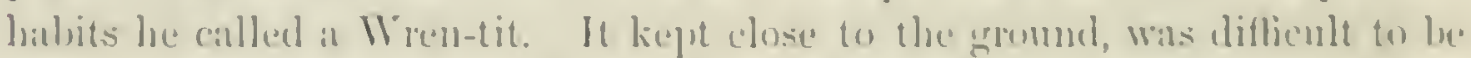
secen, and eluded pursuit ly diving inte the thickest hunches of weeds, nttering, when apprualded, its peculian grating wentlike notes. When quidly

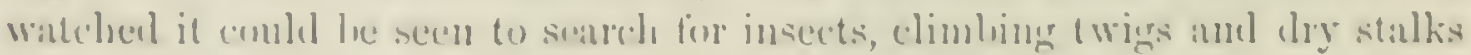
sideways, jovking its lomptrit, or helding it erect in the manner of a wren,

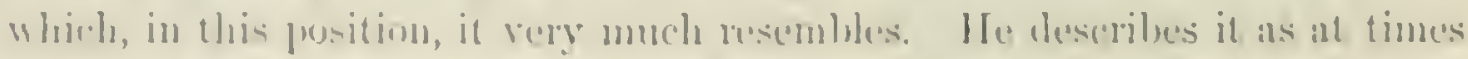

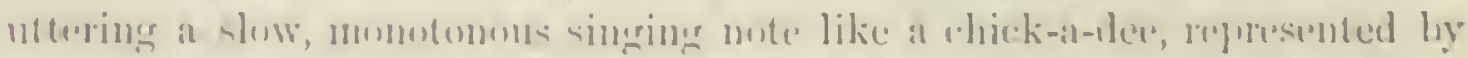

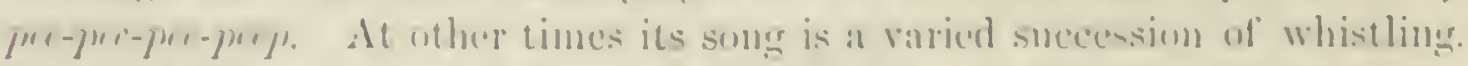
In spring it wak hearl, in pairs, calling and answeringe in a less solenum

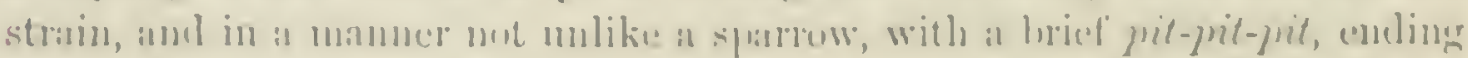

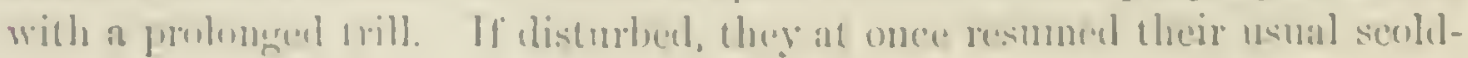
inter cries.

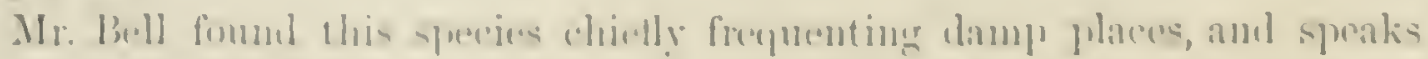

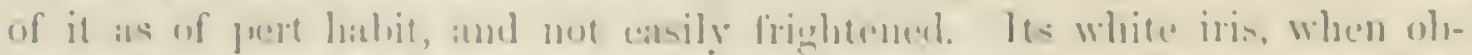

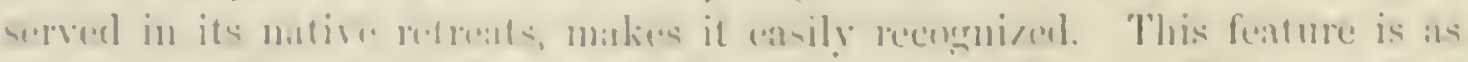

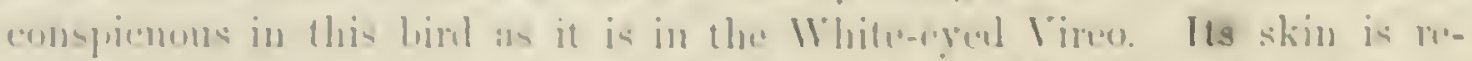

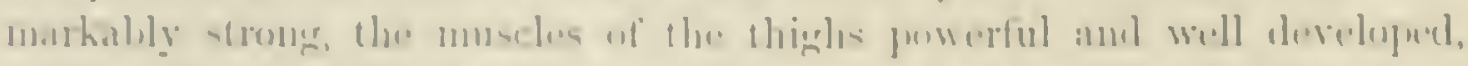

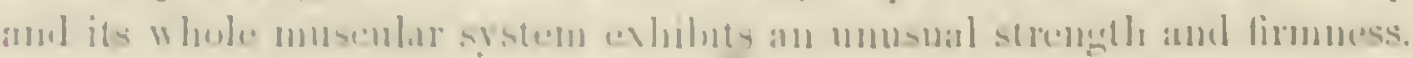


Dr. Cooper's observations in regard to this bird are a little different in some respects. He found it common everywhere west of the Sierra Nevada on dry plains and hillsides, among the shrubby undergrowth, but not in the forests. Instead of preferring damp places, he found it living where there is $n$ water, except occasional fogs, for six or eight months at a time. Their movements can be observed by patient watehing and keeping perfectly quiet, when they seem attracted by curiosity to such a degree as to approach one within a few feet, and fearlessly hop round him as if fascinated.

Dr. Cooper found their nests near San Diego built about three feet from the ground in low shrubs. They were composed of straw and twigs mixed with feathers and firmly interwoven. The cavity, about two inches wide and an inch and three fourths deep, is lined with grass and hair. The eggs, three or four in number, are of a pale greenish-blue, and measure .70 by .52 of an inch. 


\section{FaMILY PARID Fe. - THE: TITMICE}

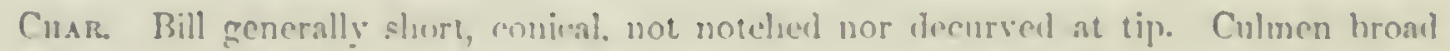

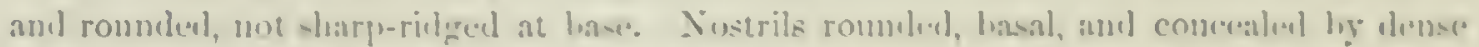

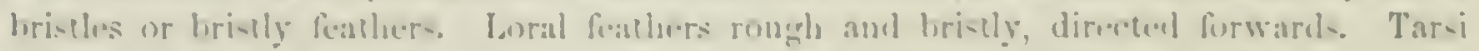

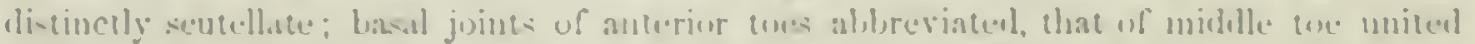

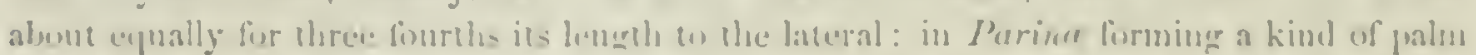

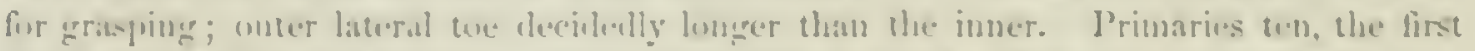

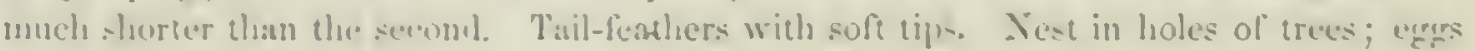
White, spotied with rendis.h.

With Cabanis We include the Nuthatehes in the same fumily with the Titmice, and lave preprared the above diagnosis to eudrace hoth gromps. They andee in having a conical bill, not notehed nor deenred, with much rombled culmen, and nearly straight commissure, aml romeded ustrils covered with dense bristles. These characters will readily distingush them, in connection with the tun prinaries, and tarsi with sentelle on the anterior half only (as compared with slumbler), from any other American Oscines.

The two subfanilies may he thus distimenished :-

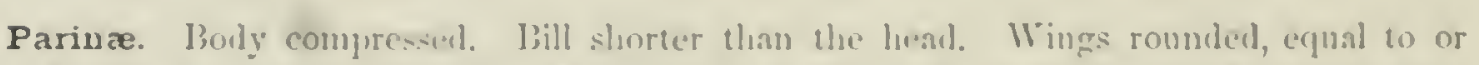

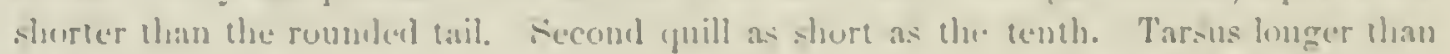
the middle toe and claw, which are about chual to the linder; soles of tues widened into a paln. Plumage rather sult and lax.

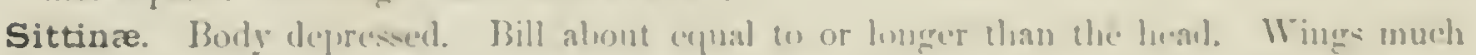

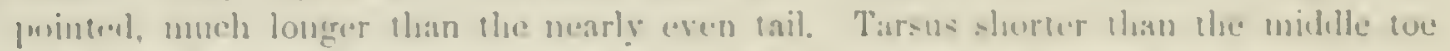
and daw, which are about cepal to the himeler. J'lumage more compant.

\section{Sенвамй PARIN 床.}

The characters of the subfamily will he fumbl sullicicutly detailed above. The gencera ate als folluws:-

$$
\text { bill with curverl untlines. }
$$

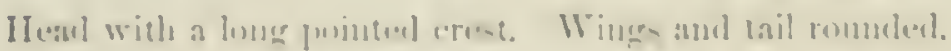

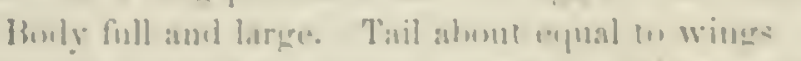

Lepplinpleeners.

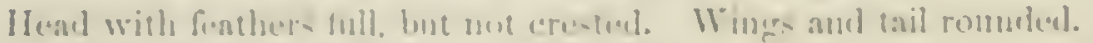

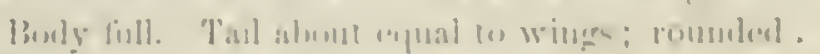

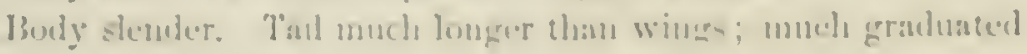

$$
\text { lsill with outlimes wrorly struiglt. }
$$

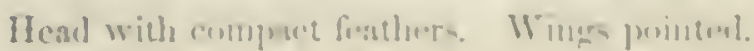

Buly slender. Tasl rother shorter than the wiugs: nearly even

\section{(i).. LOPHOPHANES, KiUn,}


Gex. Cirar. Crown with a conspicuous crest. Bill conical; both upper and lower outlines conrex. Wings graduated; first quill very short. Tail moderately long and rounded. Nests in hollow trees; eggs white with fine red dottings.

Of this genus there are several North American species, all agreeing in general characters. One of these, the $L$. wollweberi, is given by $\mathrm{Ca}$ banis as typical, while he separates the $L$. bicolor generically under the name of Bocolopturs, as having a rather different form of crest, stouter bill and feet, and longer wings. All of our species, however, vary in these characters, each one showing a different combination, so that we prefer to consider all as belonging to the same genus with $P$. cristatus.

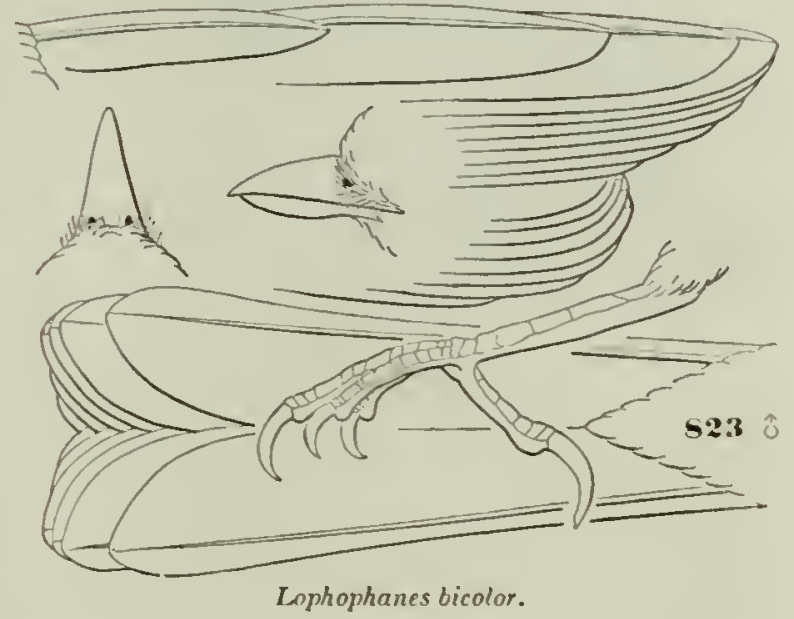

The species, all of which have the under parts uniform whitish, may be arranged as follows:-

L. bicolor. Abore plumbeous; forehead black; crown much like the back. Hab. Eastern Province United States.

L. atricristatus. Abore plumbeous; forehead whitish; crown black. Hab. East Mexico, north to Rio Grande.

L. inornatus. Above olivaccous; forchead and crown like the back. Irab. South of Middle and Western Provinces of United States.

L. wollweberi. Sides of head banded black and white; crown ash; throat black. Hab. S. Rocky Mountains of Lnited States; Mexico to Oaxaca.

\section{Lophophanes bicolor, Boxap.}

\section{TUFTED TITMOUSE; BLACK-FRONTED TITMOUSE}

Parus bicolor, Lisx. Syst. Nat. 12th el. I, 1766, 340 (based on Parus cristatus, Catesby, I, pl. Ivii). - Pr. Max. Cab. Jour. VI, 185s, 118. Lophophuenes bicolor, Box. List Birds Europe, 1842. - B.und, Birds N. Am. 1858, 384; Review, 78. - Sclatel, Catal. 1861, 14, no. 87. Bacolophus bicolor, CAB. Mus. Hein. I, 1850, 91 (type of genus). Lophophanes missouriensis, Batr.D, Birds N. Am. 1858, 384 (var. fron Missouri River).

Figures: Wilsox, Am. Orn. I, pl. viii, fig. 5. - Aud. Orn. Biog. I, pl. ccci; IB. Birds Am. II, pl. crxv.

Sr. Criar. Abore ashy; a black frontal band. Beneath dull whitish ; sides brownishchestnut, of more or less intensity. Length, 6.25 inches; wing, 3.17.

$\mathrm{H}_{\mathrm{AB}}$. United States, from Missouri Talley eastward.

Feathers of the clown elongated into a flattened crest, which extends back as far as the occiput. Bill conical; lower edge of upper mandible nearly straight at the base. Fourth and fifth quills equal; third a little shorter 
than serenth; seeond rather shorter than the secunlaries. Tail nearly even,

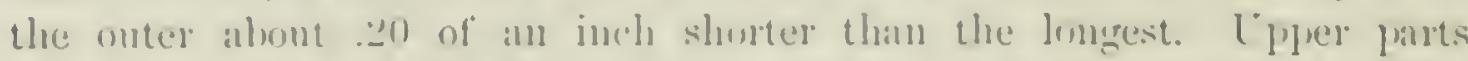
ash-color, with a tinge of olivaceons. Foreheal datrk souty-brown. The

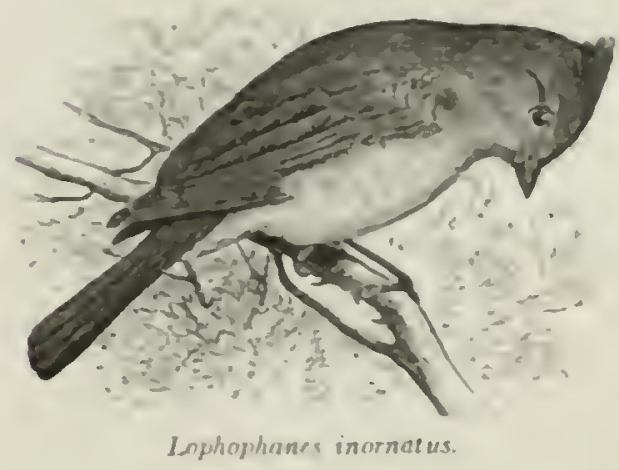

Iophophanes inornatus. feathers of the ulper past of the head and crest obscurely streaked with lighter.

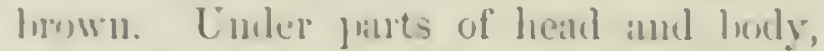
sides of head, including anriculars, and a narruw spance alduve the eye, dirty yellowish-white, tinged with lwown; purest on the side of heal, the white very distinct in the lomal region, and including the tuft of bristly feathers over the unstrils, excepting the tips of those in contact with the lill, which are blackish. The sides of the body and the under tailcorerts are tinged with vellowish-lorown. The quills and tail-feathers are edgect with the color of the halck, without any whitish. bill hlack. Feet learl-color:

sinecimens from the West are larger, the colors all more strongly mirlied.

Habtrs. The Tufted Titmouse is a common and well-known species in the Southern states, from the sealnard to the Renky Mountains. Its morth-

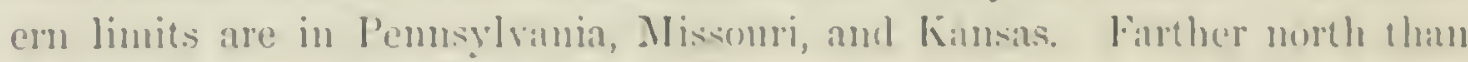
this its wecurrenee appears to be only occasional and accidental. The statement of Mr. Aululuen that they are foumd in the Northern states, even to Noval sontia, Was evidently a mistake. They do not oceur in Massachusedts, uor, so far ats I am aware, have they leen met with in any part of New Eninlind.

They are alumblant in Northem Genvia, where, aceording to the olser-

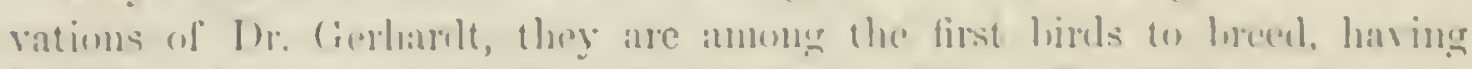

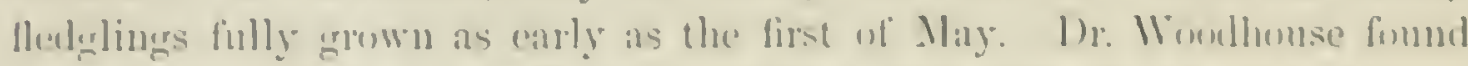
them very common in the Indian Territury lut none of the where explening fartion met with it farther west, where it is reldaced ly its kindred spercins.

It is perhaps the most abmutant birl in Southern Illinois, where it is resi-

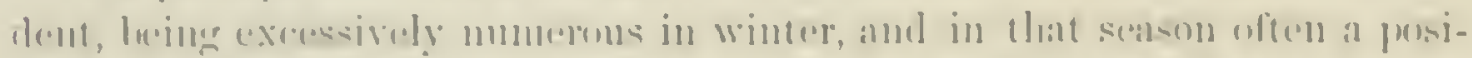

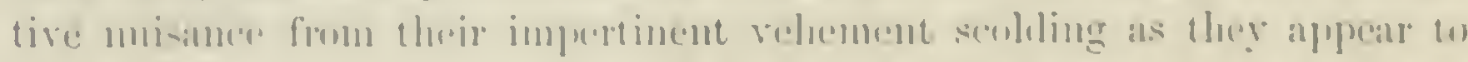

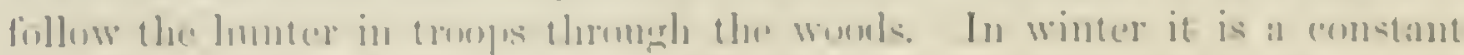

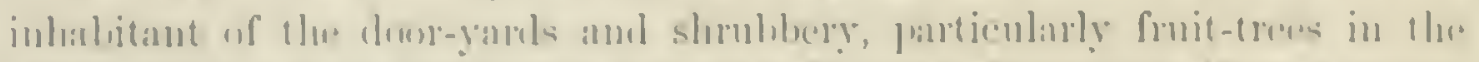

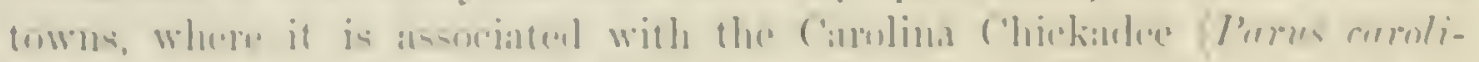

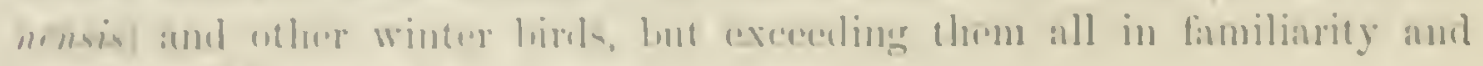
lolducas. (lidilgwiy.

Mr. Nintall, whe uerer met with this bird north of Pemeglvania, found

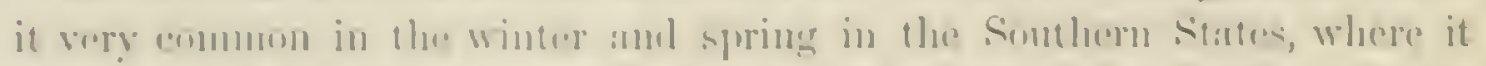
displityent all the lathits and nttored the usual notes of the family. In the 
dreariest solitudes of the Southern States these birds were his constant and amusing companions. Their sprightly morenents and their raried musical talents made it even more peculiurly interesting at a time when all the other tenants of the forest were silent. The notes of this bird, which, when expressed by this miter on paper, seem only yuaint and eccentric articulations, were characterized by him as lively, cheering, and varied, delivered with a delicacy, energy, pathos, and rariety of expression to which it was far beyond the power of description to do justice.

These notes, at times, eren partouk of the ligh-echoing and clear tones of the Oriole. The usual song of this Titmonse is presented by Mr. Nuttall

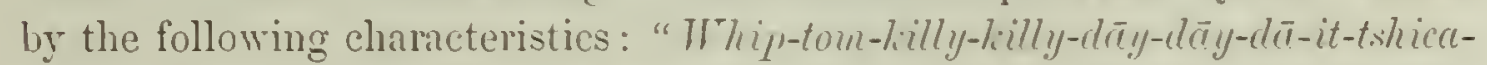
dèe-dec," varied with "höt-tec-did-didt-dill," ete., ete. Later in the season, under the milder influences of spring, these Titmice pursued the insects from branch to branch, calling restlessly and with loud and echoing voices, petopeto-peto, witl frequent (puaint variations too numerons to be repeated. Their song eren consisted of successions of playful, pathetic, or querulous calls, never exhibiting any trills after the manner of the Wrorblers, yet the compass and tones of their roice, their capricions variety, and their general effect are described as yuite as pleasing as the more exquisite notes of our summer songsters.

When wounded this Titmouse resists with great spirit any attempt to take him alive, but soon becomes tame and familiar in confinement, subsisting on seeds, broken nuts, etc. Impatient of restraint, it incessantly attempts to work its way out of its cage.

The general habits of these hirds correspond clusely with those of the large family to which they belong. They more usually in small flocks of from five to ten through the branches of trees and bushes in quest of insects, examine the cracks and crevices of the bark, hang on the uncler side of small branches, more sideways aromul the trunks of trees, probe the openings in acorns, pine-cones, nuts, etc., for its food, and retain apparently the family group until the spring, when they seprarate into pairs.

One of these birls kept in confinement by 1)r. Bachman of Charleston was in the habit of hicling its food in the corner of its eage, in a small crevice, and of creeping at night into a small box, where it lay doubled up like a ball till the first light of the morning, when it resumed its restless habits.

The Tufted Titmouse passes its nights and days, when the weather is inclement, in the hollows of decayed trees or the deserted holes of the woodpeckers. In such places it also builds its nests. It has heen known to exeavate a hole for itself even in hard somnd wool. Its nest is simply a rude lining of the selected cavity, composed of rarious soft and warm materials. In this are deposited from six to eight eggs. But a single brool is raised in a season. The young birds, as soon as they are fledged, hunt in company with their parents, and remain associated with them until the following 


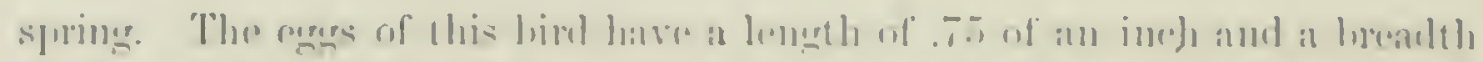

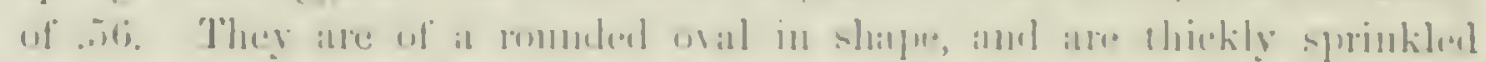

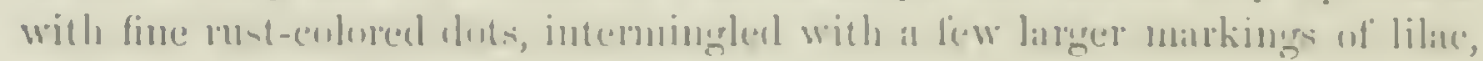
un a white groumd.

\section{Lophophanes atricristatus, (1.:-1) \\ BLACK-TUFTED TITMOUSE; TEXAS TITMOUSE.}

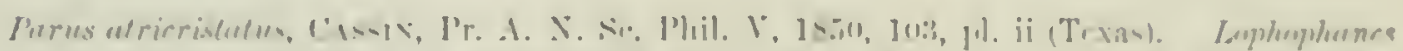

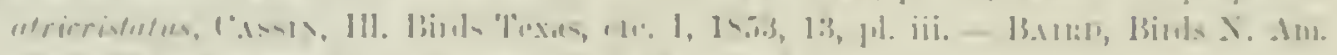

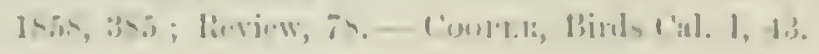

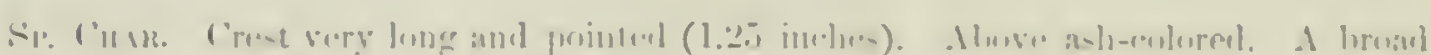

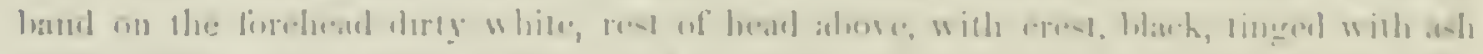

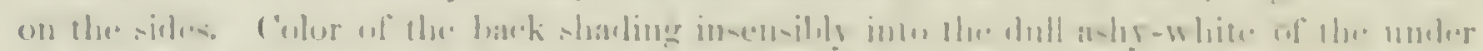

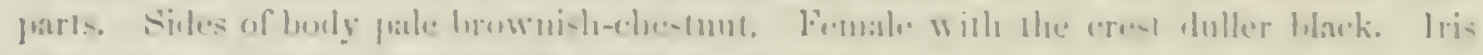

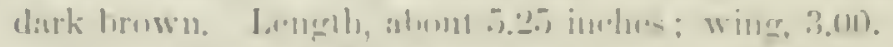

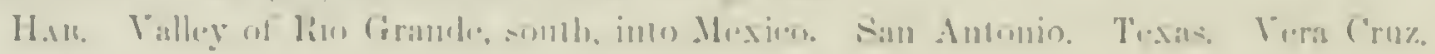
Siบ1.str.ll.

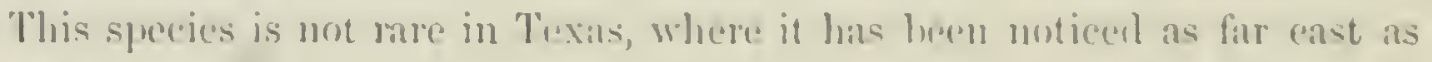
Sinn Antonio.

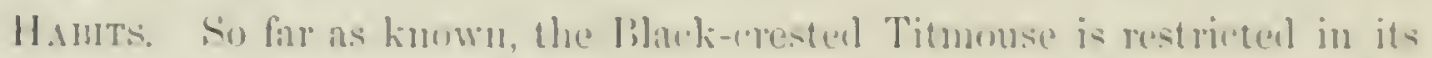

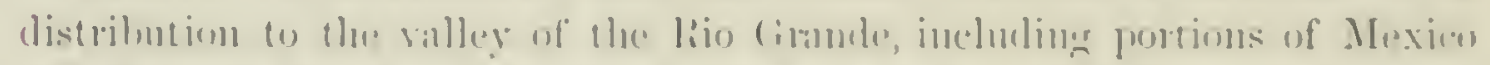

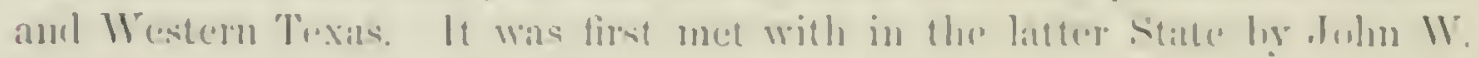

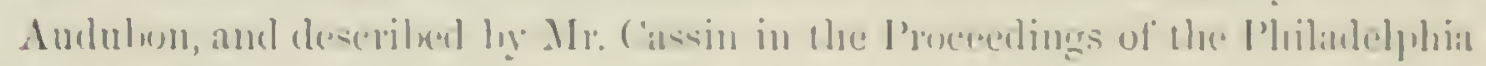
Acialciny.

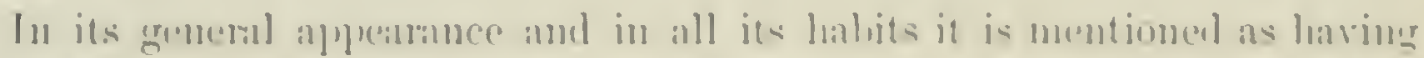

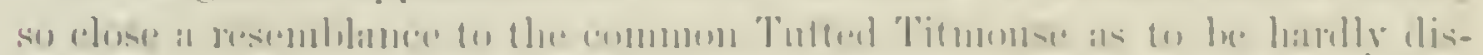

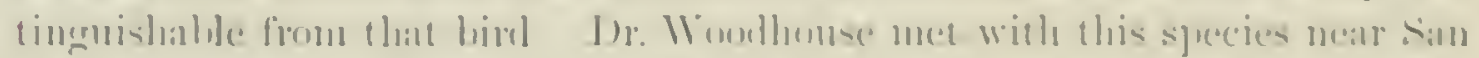

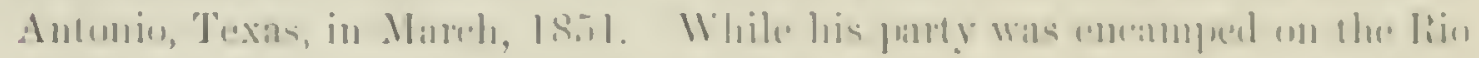

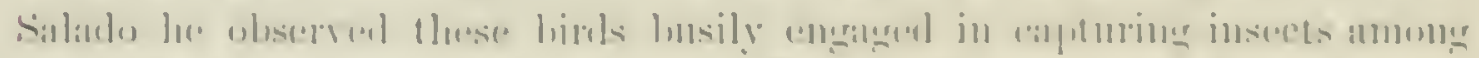

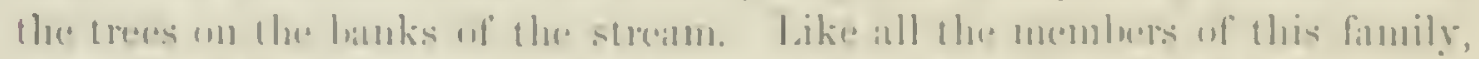

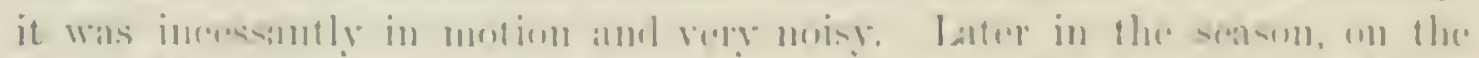

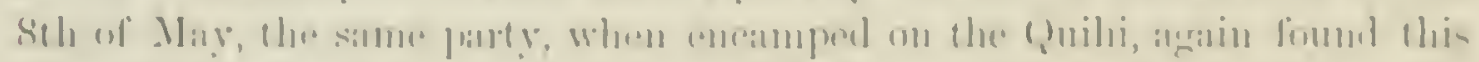

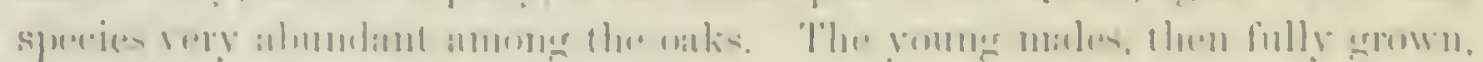

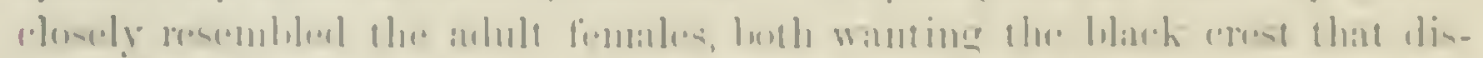

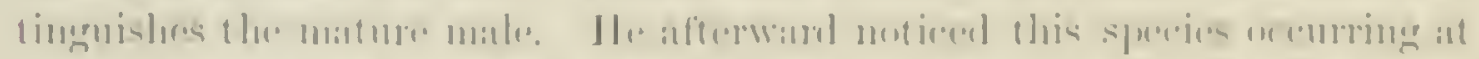

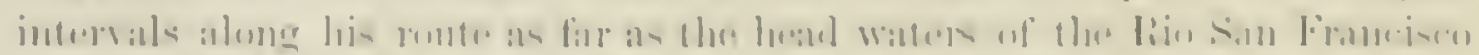

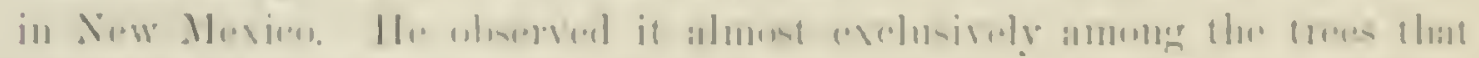

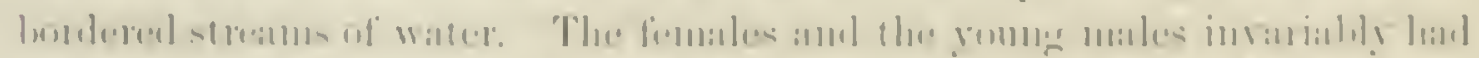

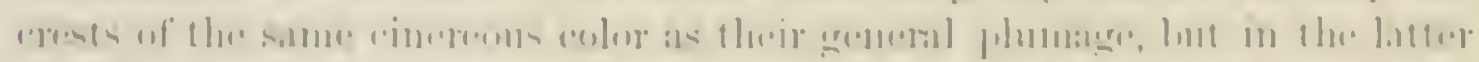

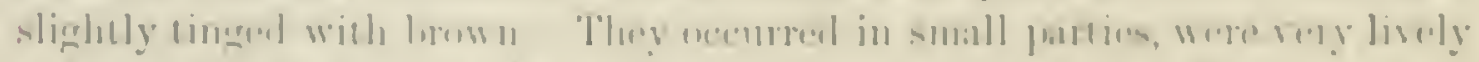

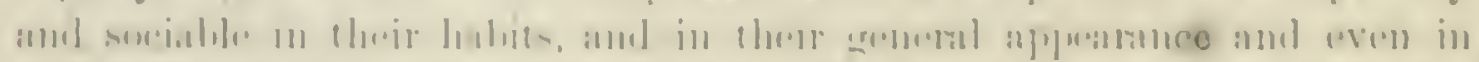

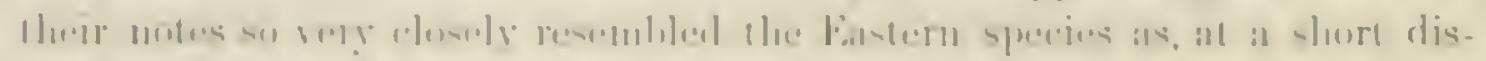

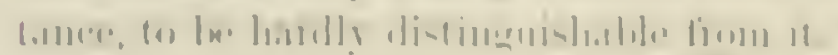


Dr. Heermann, in his report on the birds of Lieutenant Parke's survey, mentions having first observed this speeies near Fort Clarke, in Texas, where it was very abundant. He describes it as sprightly and active in its movements, searching with great assiduity for insects in the crevices of the bark and annong the branches of trees. While thus engaged it keeps up a chattering note, varied with an occasional low and plaintive whistle. Its liabits appeared to him to resemble most those of the common P'arus atricapillus. Dr. Heermann states that it builds its nest in the hollow of trees, and that it lays from twelve to sixteen eggs. He does not, however, say that he ever met with its eggs, nor does he give any description of then. The nest, he states, is composed of fine dry grasses, feathers, wool, mosses, etc.

General Conch's description of this species and its habits is very similar. He observed it in the province of New Leon, in Mexico, where he found it very abundant along the San Juan into the Sicra Madre. He describes it as a very lively birl, with a very perfect whistle of a single note.

Mr. Henry A. Dresser souglit rery diligently for its nest and eggs near San Antonio and Houston, in Texas, where he found the bird very common, and where he was sure many pairs remained to breed, but its nest was very hard to find, and the birds very wary. He succeeded in finding one nest, in a hollow tree, near the head springs of the San Antonio River, but it contained young. The nest he does not describe, nor does he inention the number of young it contained.

\section{Lophophanes inornatus, CASSIX.}

\section{GRAY-TUFTED TITMOUSE; CALIFORNIA TITMOUSE.}

Parus inornutus, Gaubet, Pr. A. X. Sc. Pliil. Aug. 1945, 265 (L'pler California). - IB. J. A. X. Se. new ser. I, 1847, 35, 11. vii. Loploplunes inormatus, C.ıssx, 111. 1853, 19. - Batrn, Birds N. Am. 1858, 3S6; Review, 78. - Sclaten, Catal. 1S61, 1t, no. SS. - Elliot, Illust. 1, pl. iii. - Cooper, Birls Cal. I. 42.

SP. Char. Crest elongated. Color above oliraeeons-ashy, bencath whitisll. Sides of body and under tail-coverts very faintly tinged with brownish, scalcely appreciable. Sides of head scarcely different from the crown. Forehead obscurely whitish. Length, 5 inches; wing, 2.5).

HАв. Southern United States, from Rocky Mountains to Pacific; Western Nerada (Ridgwiy). W. Arizona (Coues).

The bill and feet of this species are lead-color. The third, fourth, and fifth quills are longest; the third and eighth about equal; the second is shorter than the shortest primaries. The lateral tail-feathers are a little shorter than the others.

A specimen from Fort Thorn has the crest longer than in other specimens before me, measuring 1.35 inches from base of bill to its tip. This may be a characteristic of the male, the sexes being otherwise alike. 


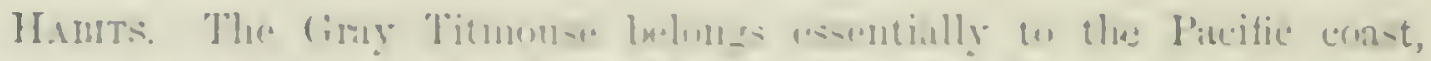

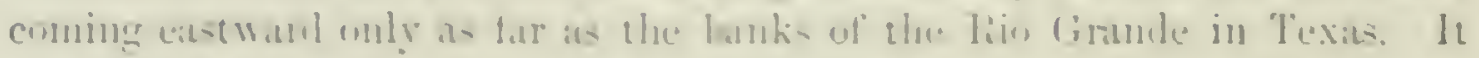

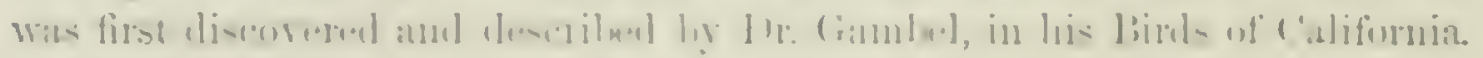

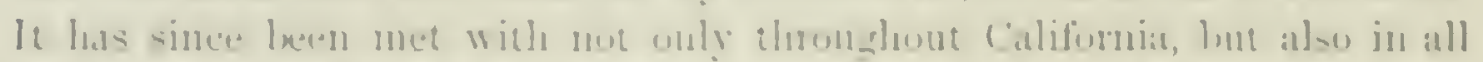

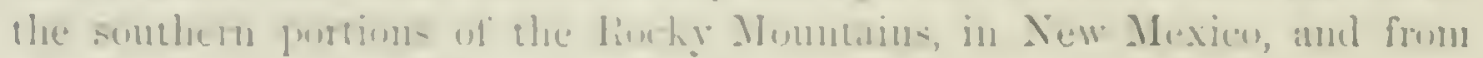
Mimbres to the líg Cirande.

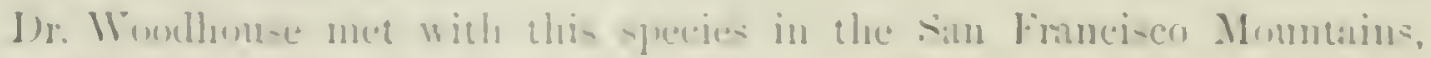

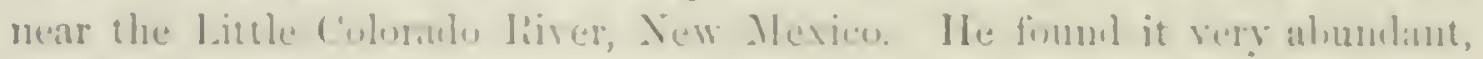

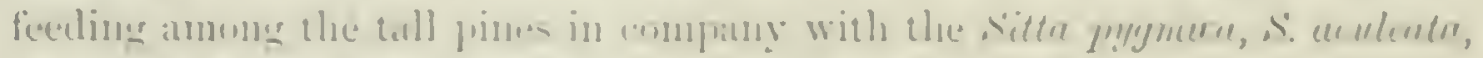
aud l'arus munlunus.

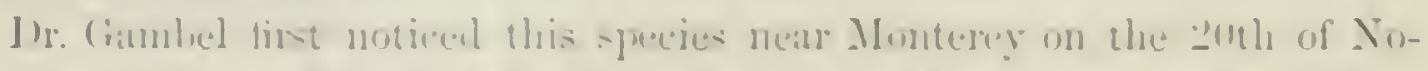

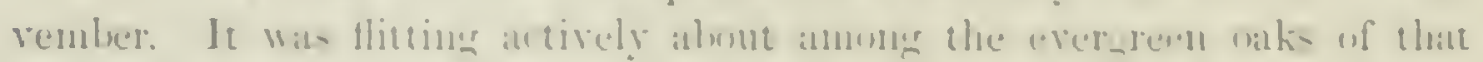

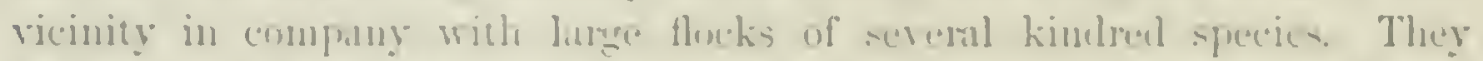

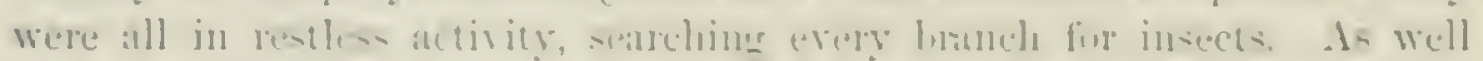

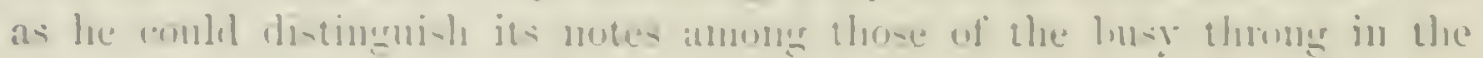

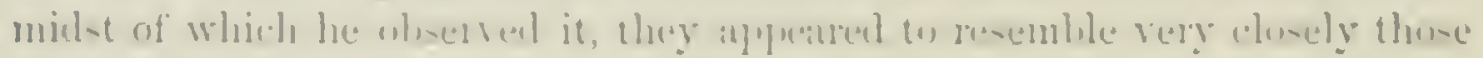
of the ernmmun $P$. afrimpillas. Ljun lis folluwing it up, it would utter a

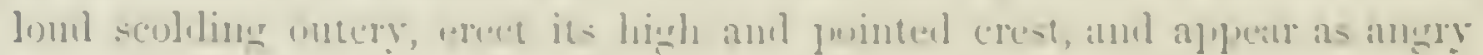

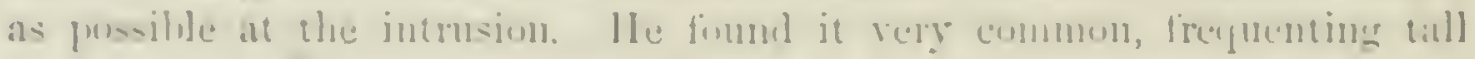

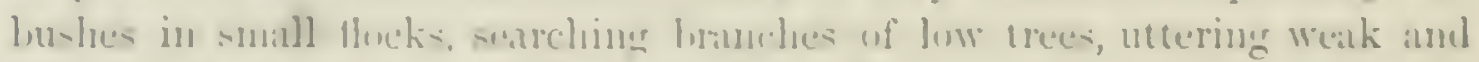

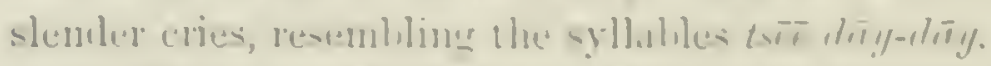

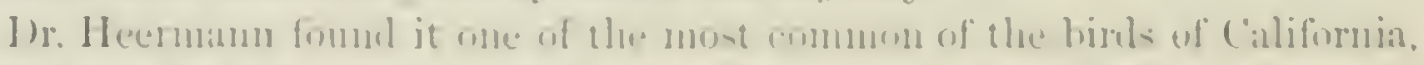

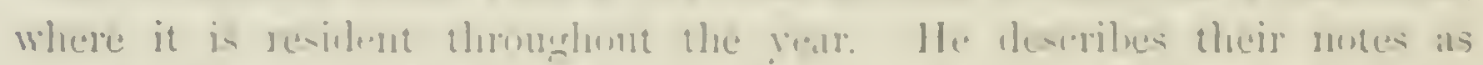

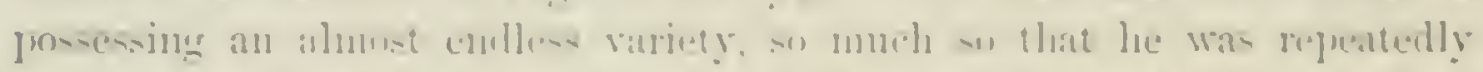

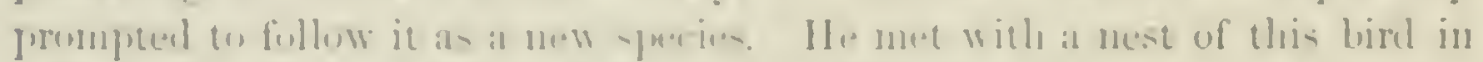

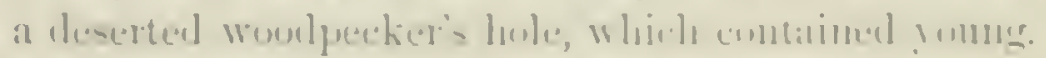

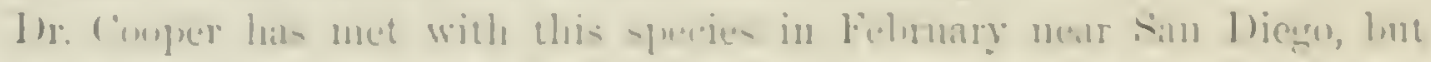

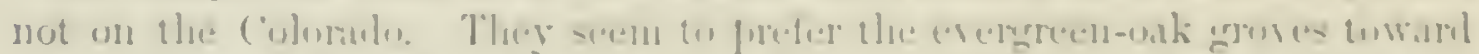

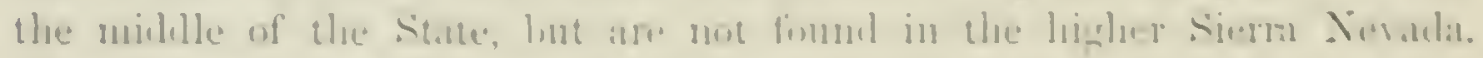

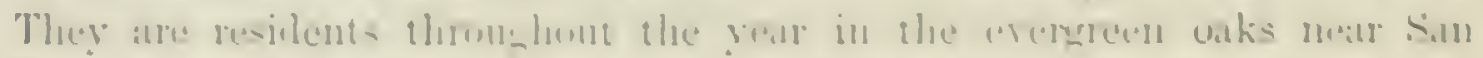

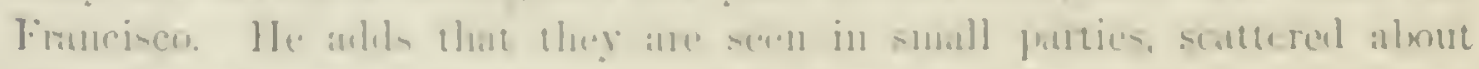

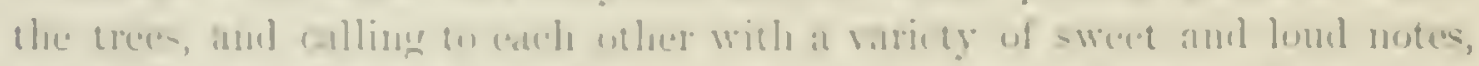

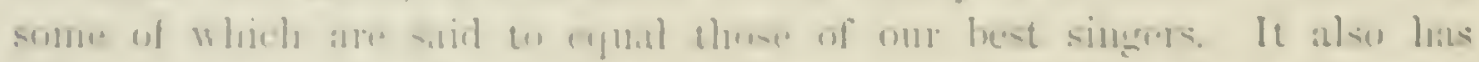

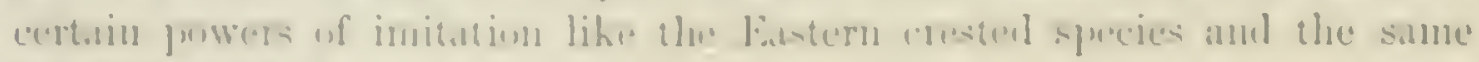

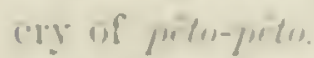

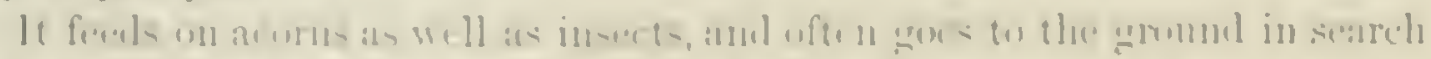

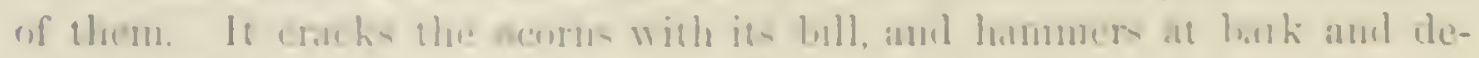

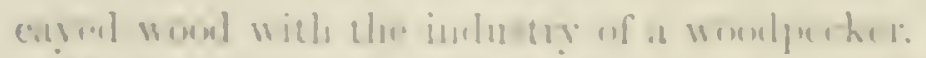

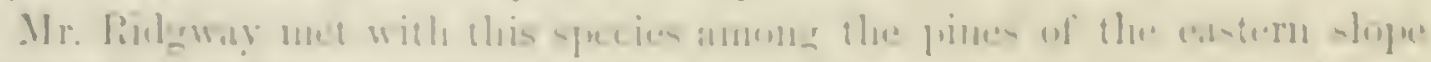

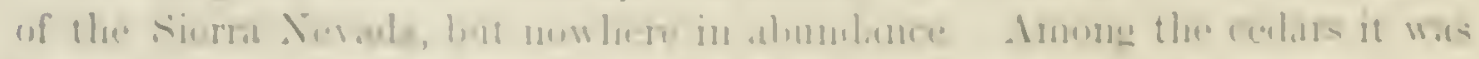

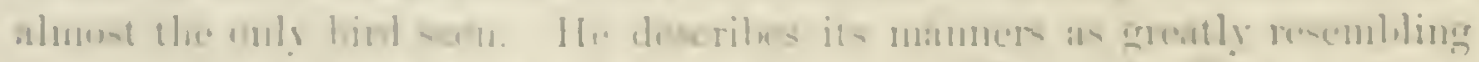

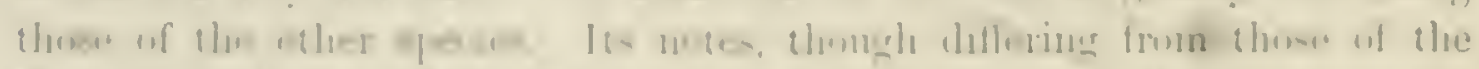

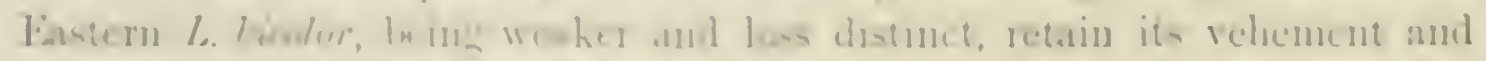

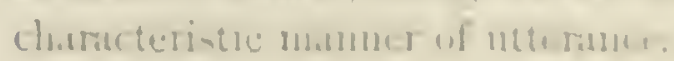




\section{Lophophanes wollweberi, Boxal'.}

\section{WOLLWEBER'S TITMOUSE; STRIPED-HEADED TITMOUSE.}

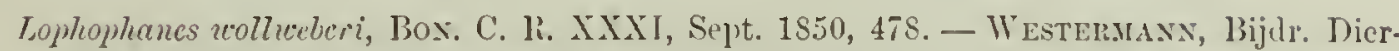
kunde, 1II, 1851, 15, plate. - BA11:D, Birds N. Am. 1858, 386, pl. liii, fig. I; lieview, 79. - Sclater, P. Z. S. 1858, 299 (Oaxaea, high lands). - lв. Catal. 1S61, 14, no. \$9. - Coorer, Birls Cal. I, 43. Parus anuexus, Cassix, Pr. A. N. Sc. V, Oet. 1850, 103, pl. i. Lophophanes galeatus, CAB.1sis, IIus. IIein. 1S50, 1S51, 90.

Sr. Cuns. Central portion of crest ash, encircled by black, commencing as a frontal band, and passing over the eye. Chin, throat, and a line from behind the eye and curving round the auriculars to the throat (bordered belind by white), as also some occipital feathers, black. A white line from above the eyc margining the crest, with the clieelis below the eye and under parts generally white. A black half-collar on the nape. Upper parts of body ashy, Length, about 4.50: wing, 2.50 .

H.s. Southern Rocky Mountains of Cnited States, and along tahle-lands tlurough Mexico, to Oaxaca (high regions, Sclaterz). Orizaba (Alpine regions, Sum.).

Habits. Wollweber's Titnonse, so far as its distribution is known, is a bird of Western Texas, the high table-lands of Mexico, and of the whole of New Mexico. It was described by Bonaparte and by Cassin nearly simultaneonsly, in 1850 . It bears a very close resemblance to the Lophophancs cristatus of Europe.

Although comparatively nothing is known in reference to the specific labits of this species, they may be very readily inferred from those of the other members of this genus, whose characteristics are all so well marked and so uniform. Dr. Kennerly is the only one of our naturalists who has mentioned meeting the species in its living form. In his Report upon the Birds of Lieutenant Whipple's Survey he states that he found it in the thick bushes along the Pueblo Creek. Wherever noticed it was constantly in motion, hopping from twig to twig in search of its food. He also found it annong the pines of the Aztec Mountains. No mention is made of its nest or egrgs, and its nidification remains to be ascertained.

\section{GeNus PARUS, LINAEUS.}

$$
\text { Parus, Lixxets, Syst. Nat. 1735. (Type, P. major.) }
$$

Gex. Cirsr. Head not crested. Body and head full. Tail moderately long, and shightly rounded. Bill conical, not rery stout; the upper and under outlines very gently aul slightly convex. Tarsus but little longer than middle toc. Hearl and neck generally black or brown, with sides white. Nest in holes. Eggs white, sprinkled with red.

In the group, as defined above, are embraced several genera of morlem systematists. The true black-capped American Titmice belong to the section Pecile of Kaup, and exhibit but three well-marked forms; one, P. montanus, with a white stripe over the eye; one, atricapillus, without it, with black 
heal; and on1, hudsonims, also without it, and with brown head. The sprecies mity be ammereel ats follows:-

\section{Houl and neck, abrere und benruth, blark; Hecir sides ụhite.}

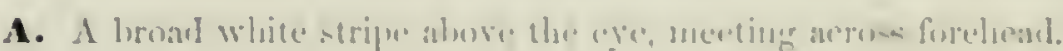

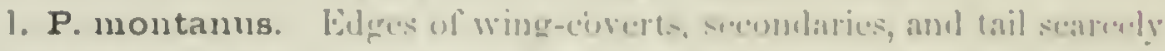

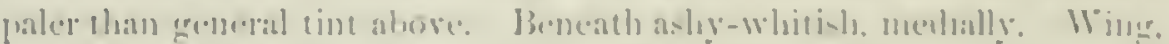

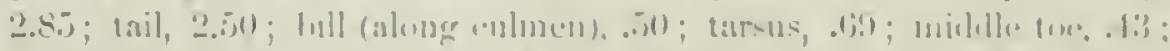
wing-formula, $4-i, 3=6,7,2$; graluation of tail, .1S. Jab. Moun-

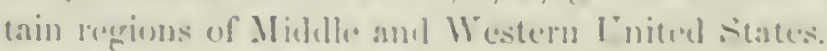

B. In white stripu ahove the eye.

4. Tat ats long an, or fonger than, wing. Conspicuous white edgings to wing-coverts, socomlaries, and tail-feathers.

\section{P. atricapillus.}

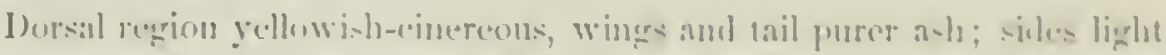

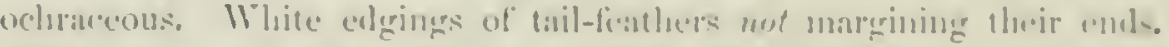

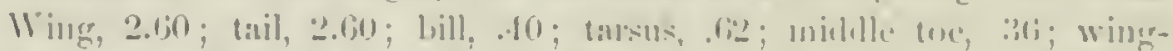

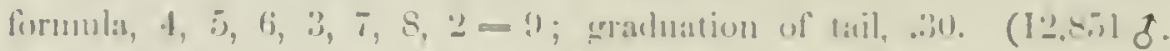

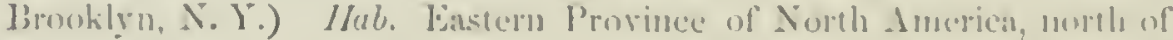
ahout $3 !^{\circ}$. . . . . . . . sas. atricupillus.

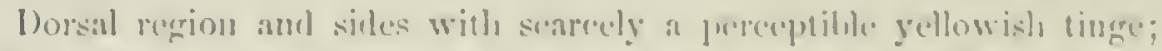
white edgings of tail-feathers paseing aromed thejr ands. Benesth

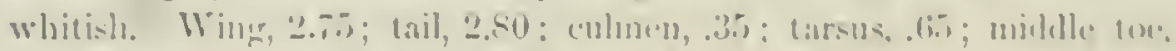

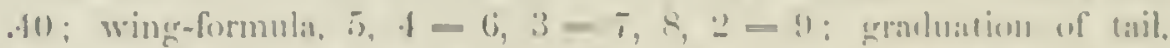

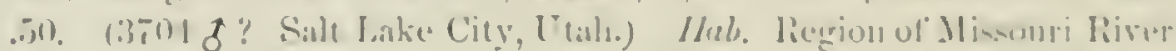

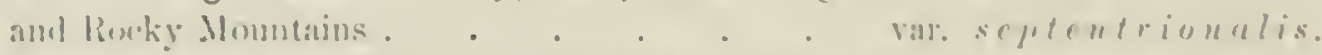

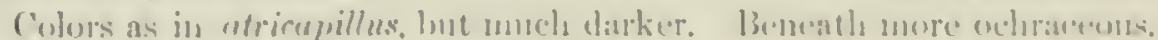

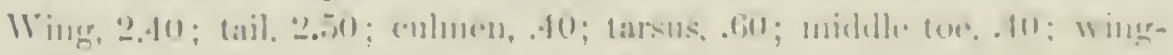

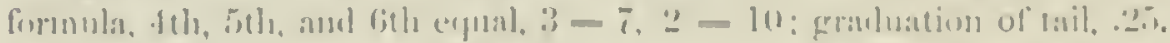

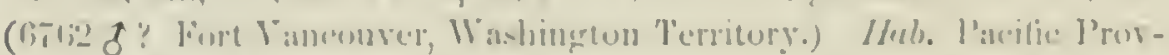
ince of Ninth Ameries
lar. oeridenlulis.

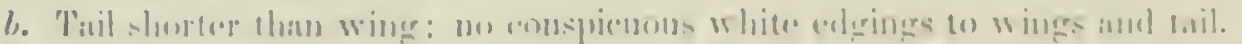

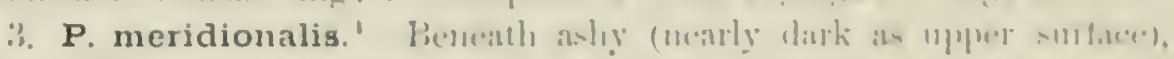

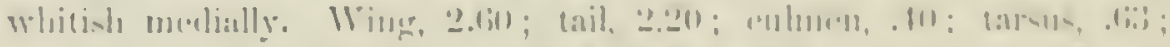

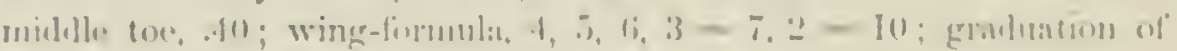

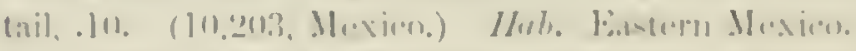

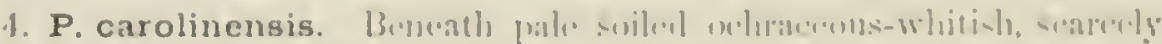

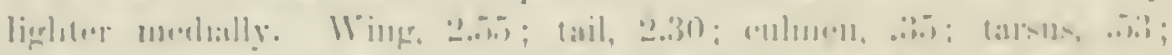

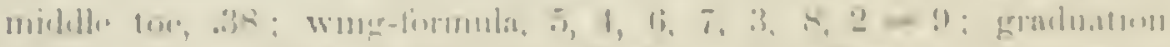

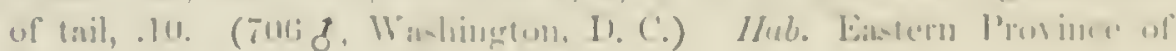

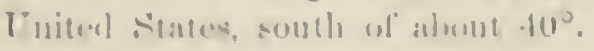

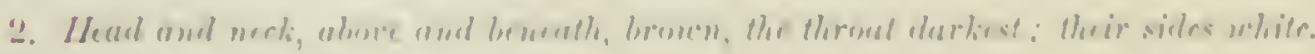

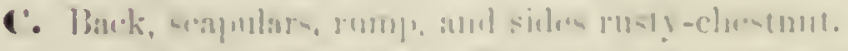

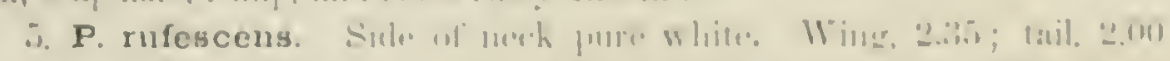

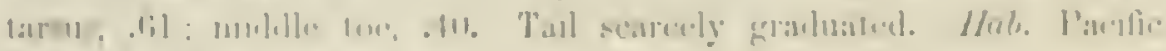

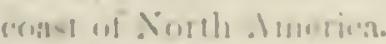

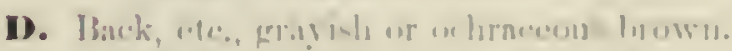

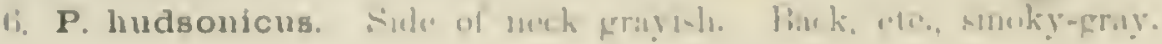

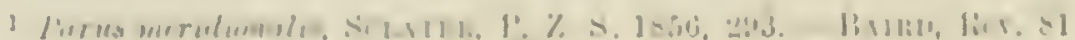


Sides dark rusty-brown. Wing. 2.45: tail. 2.45: tarsus, .f.2: middle toe. 3.j: graduation of tail, .30. (1\%,101. Halifax, X. S.) Hab. Aretic America: south to northern boundary of the ["nited States (except to westwarll).

7. P. sibiricus. ${ }^{1}$ Side of neck white. Back. etc., rusty ochraceousgray. Siltes rusty ochraceulls. Wing. 2..10: tail. 2.50; tarsus. .66: midule toe, .36 ; graduation of tail, .30 . Hab. Europe.

Parus montanus, Gaybel.

\section{MOUNTAIN CHICRADEE: WHITE-BROWED CHICKADEE.}

Parks montunus, Gasibfl. Pr. A. N. S. Phila. April, 1543, 259 ; Journ. A. N. Sc. 21

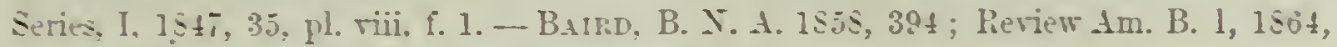
S.2. - Elliot, Illust. - C'onper, Birds Cal. I, 46.

Sp. Chir. Head and neck abore, with under part of head and throat. gloss black: forehead, stripe abore the eve and band below it, involring the auriculars, white. These stripes embracing between them a black band through the ere and confluent with the black of the heal. Abore ashr: beneath similar. but paler: the upper part of breast and middle line of belly" white. Length about 5 inches: wing. 2.60: tail, 2.40 .

H.Ab. Jountain region of Midule and Western Lnited States.

Habits. The Mountain Chickadee was first met with by Dr. Gambel in journering westward from Santa Fé, in New M[exico, and from thence was found in all the ranges of the Pocky Mountains nearly to California. Its notes and habits are said to closely resemble those of the common C'hickadee, but weaker and more raried. It keeps more in low bushes, where it mores from branch to branch with untiring activity, searching each minutely for small insects. It also frequently descends to the ground to pick up small seeds. While thus occupiecl it will occasionally stop, louk

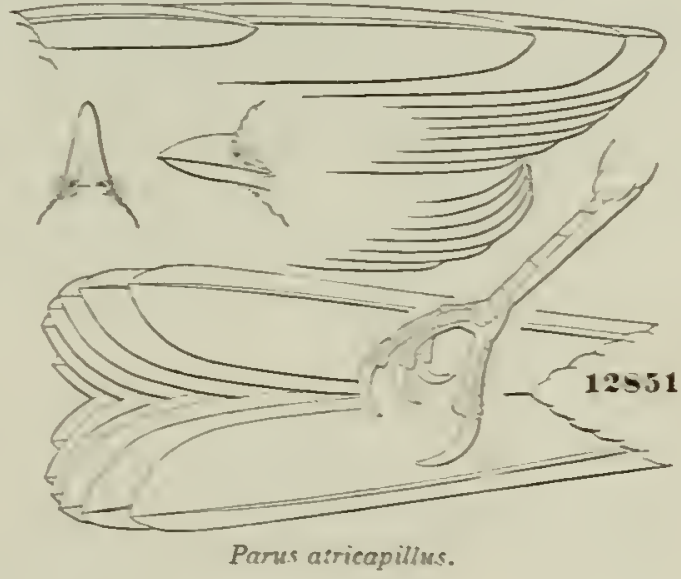
round, and, uttering a slender te-de-de, and then its nsual note, to- $l e-d e-d a i t$, will fly to another bush.

On the Rin Colorado they kept chiefly among the cotton-wood trees that grew along its banks, and its familiar notes were almost the only sounds heard. They were observed in larre and bus flocks along the smaller streams in company with the Least Tit and the Reguli. Dr. Crambel did not find them, hotrever, so abundant on the California sides of the ridge, where other species took their place.

Dr. Heermann found this Titmouse abundant among the mountains sur- 
rommline the Polsan in the sontleen mines, and sulsequently met with

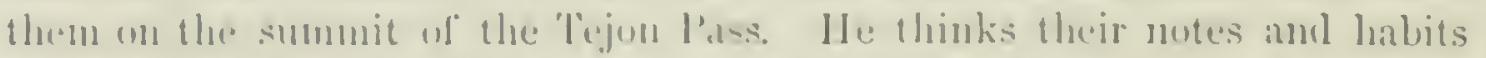

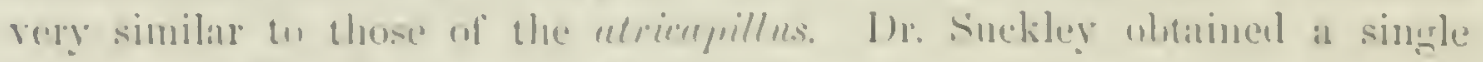

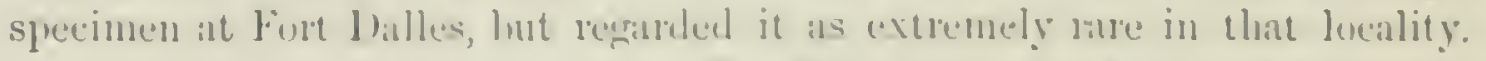

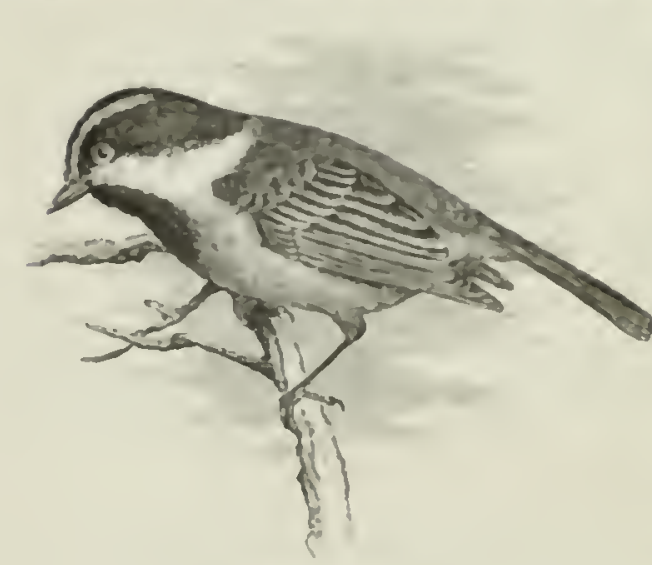

Parms mnneanus Dr. Wimollumse fimud it quite almulant in the sin Francisen Mlomitains of New Mexico, where it wits feeding among the tall pines in complany with kincleel species.

Mr. lidinway fouml this species in great atbundine amente the pines on the eartern shene of the siem Nerata Momutilins, ans wedl as in all the exten-

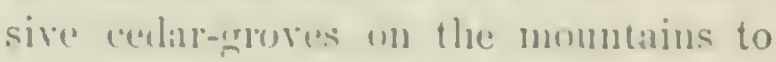
the east ward. Arount ('arson ('ity this speceies was fouml throughont the winter. In its manuers and notes, particulanly the latter, it was harlly distin-

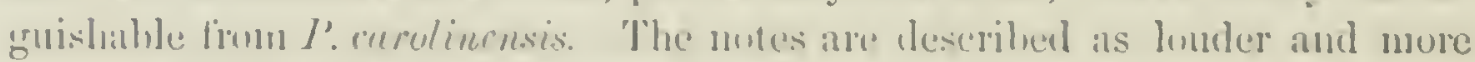
distinct, thongh their calls in spring atre mother less clearly articulated.

\section{Parus atricapillus, l.s.}

\section{EASTERN CHICKADEE; BLACK-CAPPED TITMOUSE.}

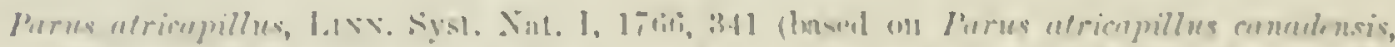

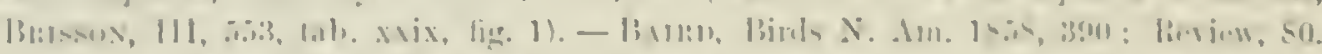

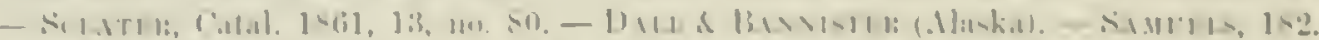

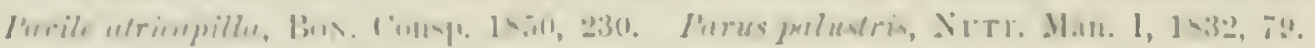

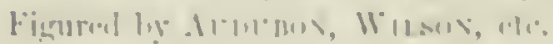

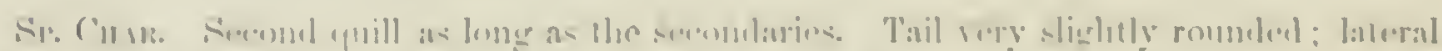

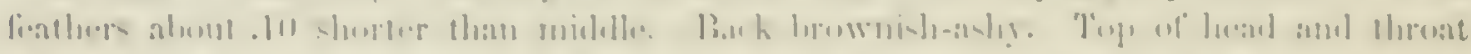

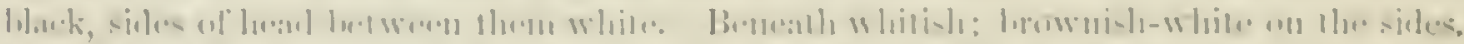

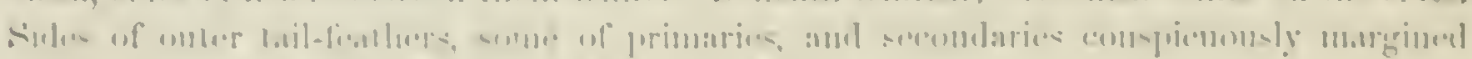

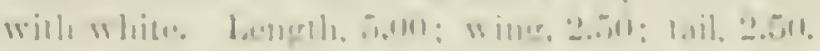

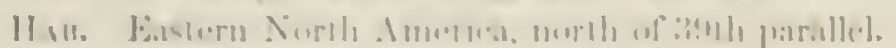

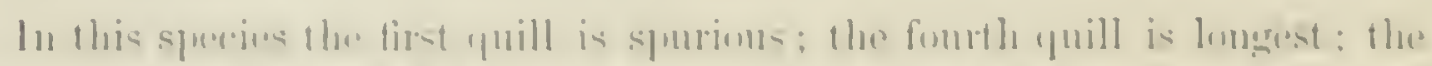

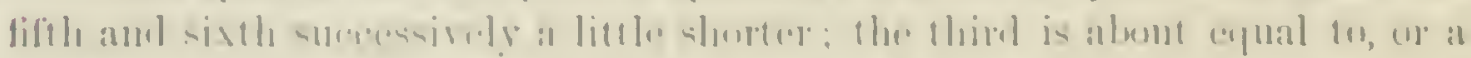

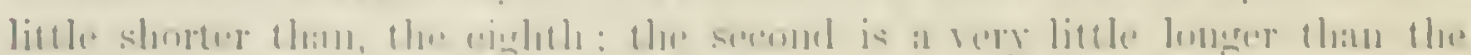

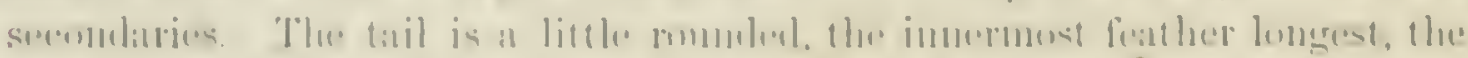

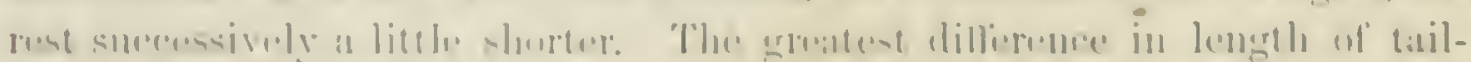

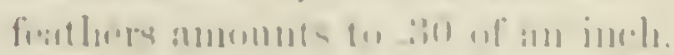

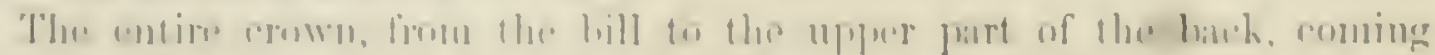

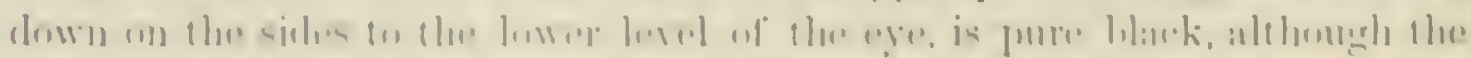

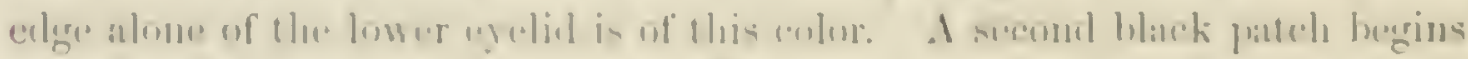


at the lower mandible and oceupies the entire unler surface of the head and throat, lut not extending as far back within a quarter of an inch as that on the upper part of the neck. The space between these two patches, on the sides of the head and neck, is white, this color extending along the black of the back of the neck as fiu as its tuncated extremity, but not borlering it behind. The midllle of the breast and belly, as far as the rent, is clull white, that immediately behind the black of the throat a little clearer. The sides of the breast anıl body under the wings, with the mnder tail-coverts, are pale, dull brownish-white. The bach, rump, and upper tail-coverts are of a dirty bluish-ash, washed with yellowish-brown, especially on the rump. The wings are brown; the outer edges of the thirl to the seventh primatries narrowly edged with whitish; the innermost secondaries more broadly and conspicuously elged with the same; laryer corerts edged with dirty whitish. Outer webs of tail-feathers ed.red with white, purest and occupring lialf the web in the external one, narrowing and less clear to the central feathers, the basal portions, especially, assuming more the color of the back.

Habits. The common Chickadee or Black-capped Titmouse is so well known throughout the greater portion of the Unitel States as to be generally accepted, by common consent, as the typical representative of its numerous family. Until recently it has been supposed to be universally distributed over the continent, and while this is now yuestioned, it is not quite cleal where its limits occur. In Eastern Maine the Parus hurkonicus and this species meet. In the Distriet of Columbia it crosses the northern limits of $P$. corolinensis, and in the northern Mississipni Valley it mingles with the var. septentrionalis. It remains to be ascertained how fir the species exceeds these bounds.

A few individuals of this species were observed by Mr. Dall, Necember 12, at Nulato, where, however, it was not common. They were also obtained by Bischotf at Sitha and Fodiak.

As in rery many essential respects the whole family of Poride are alike in their chancteristics of habits, their manmer of collecting food, their restless, uneasy morements, the similarity of their cries, their residence in hollow trees or brauches, and their nesting in similar places, with the exception only of a few species that construct their own ponch-like nests, we have taken the best known as the common point of comparison. Exce, in the variations in plumage, the points of ditference are never great or very noticeable.

In New England the Black-Cap is one of our most common and familiar birds. In the vicinity of Calais, Mr. Boardman speaks of it as resident and abundant. The writer did not meet with it in Nora Scotia, nor even in the islands of the Bay of Fundy, where the hudsonicus is a cummon bird.

It is a resilent species, nesting early in May, and having full-tledged nestlings early in June. While it seems to prefer the eliges of wools as best affording the means of fool and shelter, it by no means contines itself to 


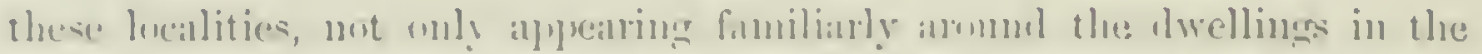

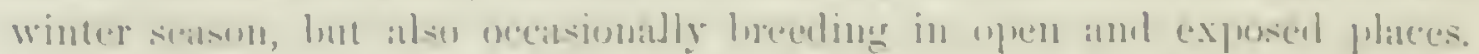

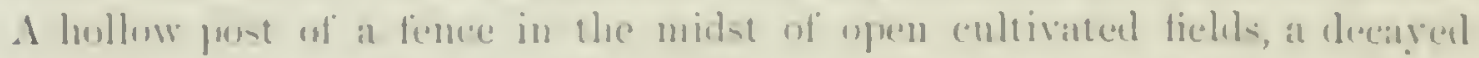

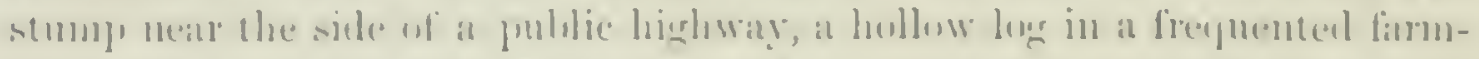

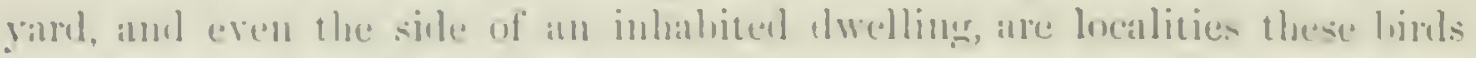

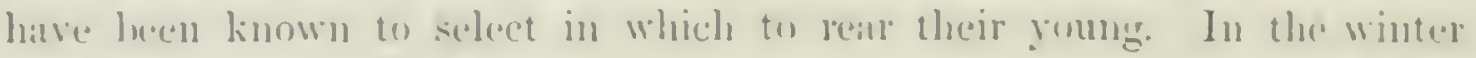

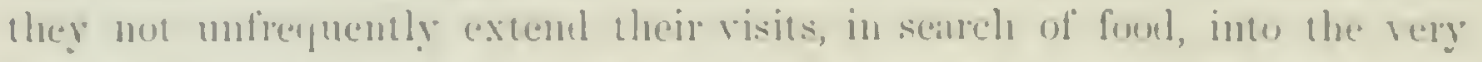

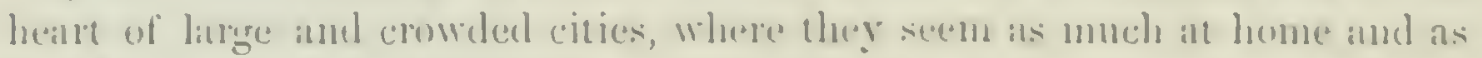

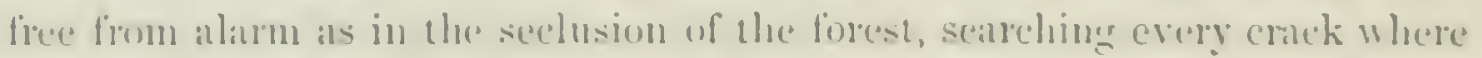

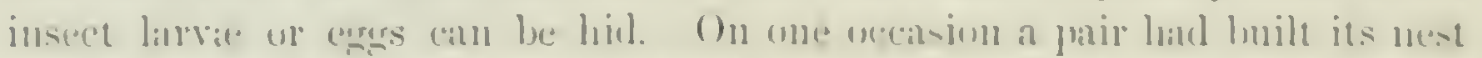

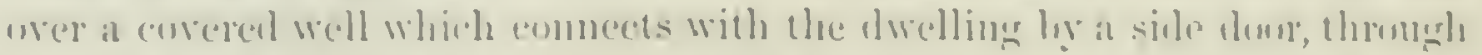
which watere was drawn at all homrs of the day he means of luchets and a

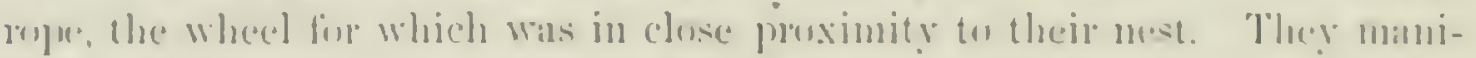

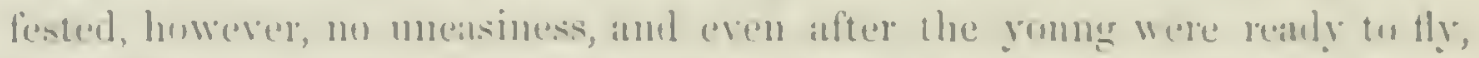
the whole finnily wemlel return to the plite for shelter at night and during imelenteme weilther.

Their eourage and devotion to their yomes is a rematrable trat with the whole race, aml with nome more than with the present species. On me

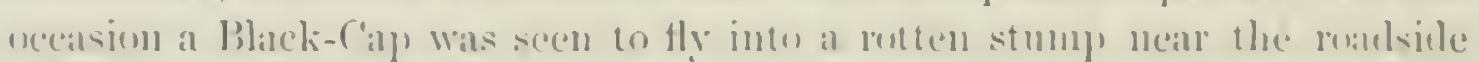

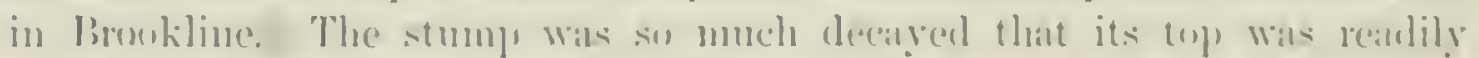

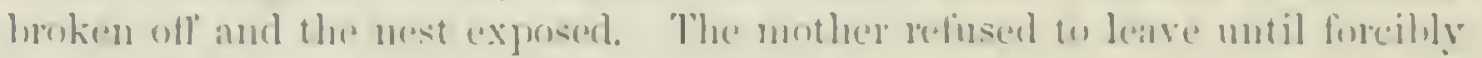

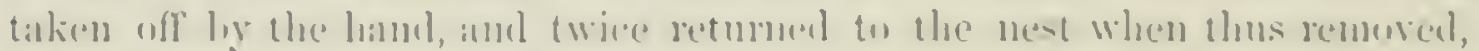

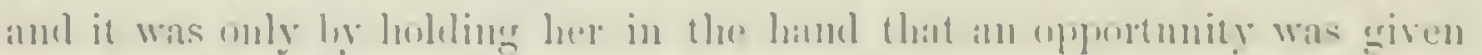

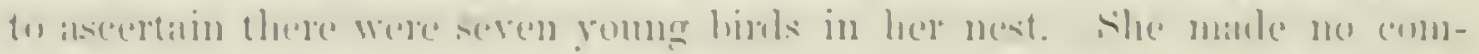

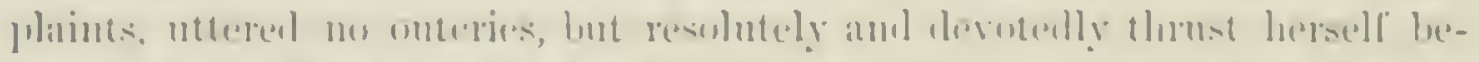

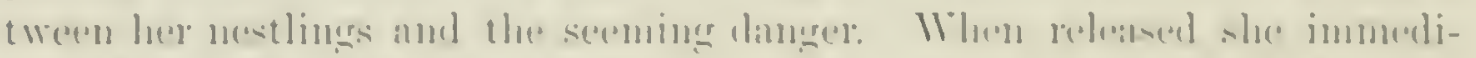

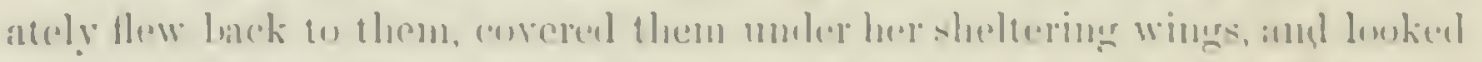

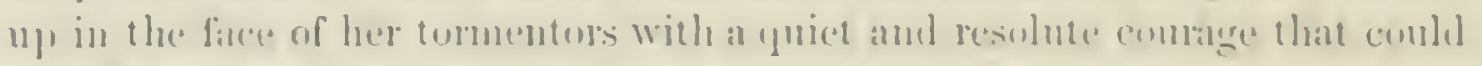

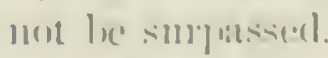

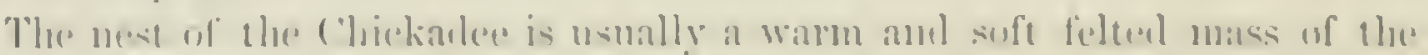

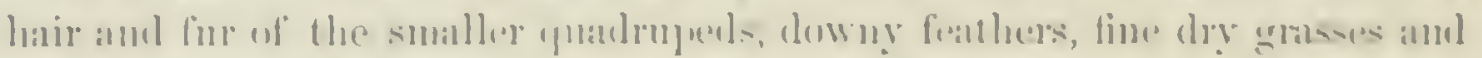

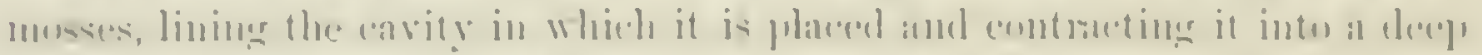

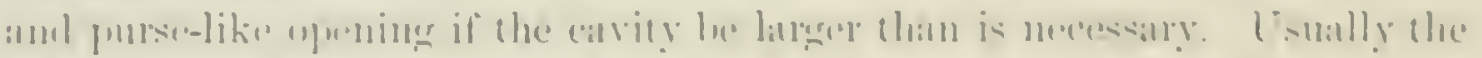

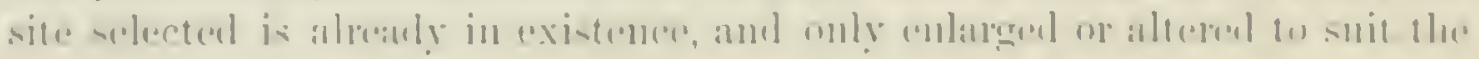

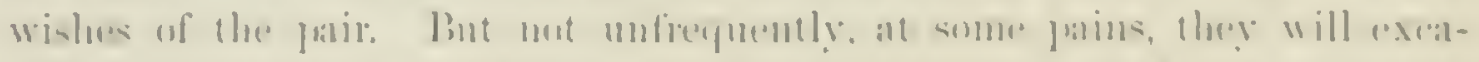

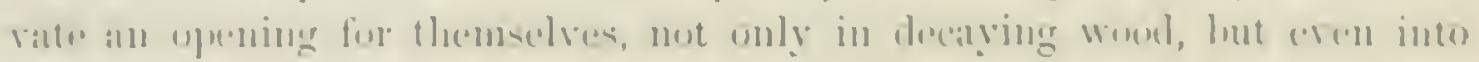

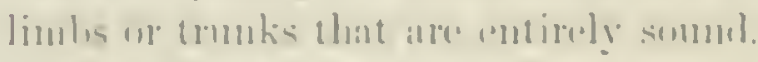

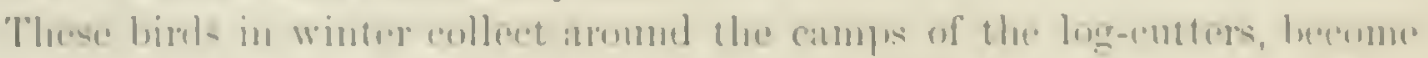

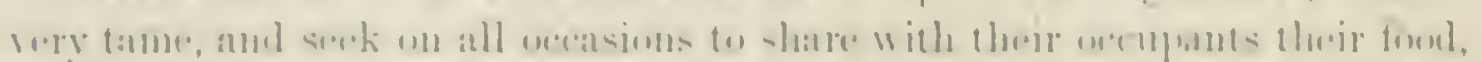

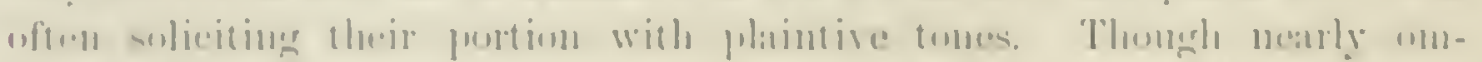

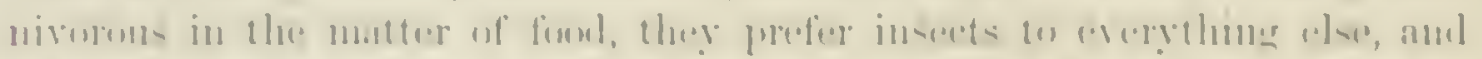

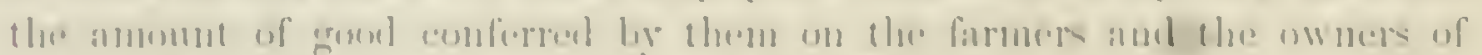

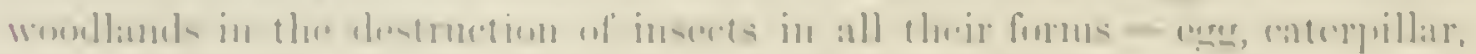

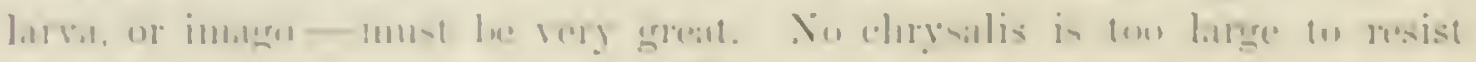


their penetrating lill, and no eggrs so well hidden that they cannot find them out. I have known one to attack and Hy off with the chrysalis of a "Woullybear" or salt-marsh eaterpillar. (Leveurctiu acrece). When thus foraging for their food they seem totally unconscions of the near presence of man, and unmindful of what is passing around them, so intent are they upon the object of their pursuit.

The notes of the Chickadee exhibit a great variety of sounds and combinations. As they roam through the country in small flocks in quest of food, their refrain is a continued and lively succession of rarying notes somnding like a quaint chant. When annoyed by any intrusion, their cry is londer and harsher. They are rarely thus disturbel by the presence of 'man, and even when their nest is approached by him they present only a passive and silent resistance. Not so when a cat or a squirrel is observed in unweleome vicinity. These are pursued with great and noisy pertinacity and hoarse cries of $d \bar{a} y, d \bar{a} y, d \bar{a} y$, in which they are often joined by others of the same species.

So far as we have observed them, ther are apparently affectionate, gentle, and loving to each other. We utterly discredit the accusation that they will treacherously beat out the brains of feeble birds of their own race. It is unsupported by testimony, and in the instance cited by Wilson he gives no evidence that this injury may not have been done by some other species, and not by one of its own kindred.

Their nest is usually near the ground, and the number of eggs rarely if ever exceeds eight. They are said to have two broods in the season, lut this statement seems to be contradicted by their continued presence after June in small flocks, eridently the parents and their first and only brood, who apparently remain together nine or ten months.

The eggs of this species vary somewhat in regard to the distribution and number of the reddish-brown markings with which their white ground is more or less sprinkled. In some they are chiefly gathered in a ring about the larger end; in others they are clistributed over the entire egg. Their eggrs are smaller and a little less spherical in shape than those of the septentrionalis, averaging .58 by.$t i$ of an inch.

Parus atricapillus, var. septentrionalis, HARris.

\section{LONG-TAILED CHICKADEE.}

Parus septentrionalis, HArris, Pr. A. I. Sc. II, 18 $45,300$. -CAssm, Illust. I, 1853, 16,

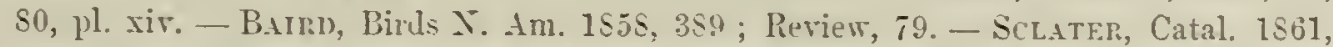
14, no. s2. Parus septentrionalis, var. allescens, Barn, Birds X. Am. 1s5s, xxxrii. ? Parnes atricapillus, Pr. MLx. Cab. Jour. VI, 1s58, 119.

SP. Criar. Length about 5.50 inches; wing, 2.70; tail about 3 inches. Hear abore and below black, separated by white on the sides of the head; back brownish-ash. Be- 


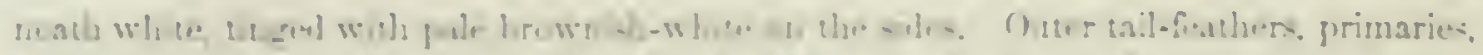

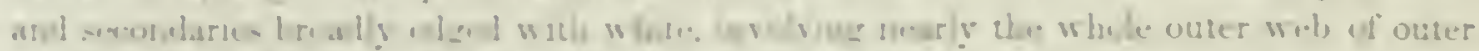

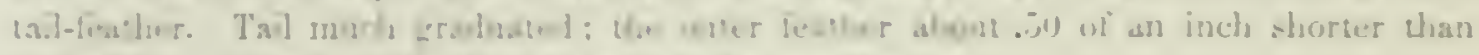

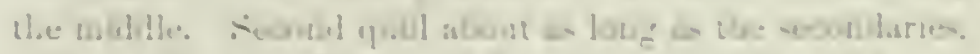

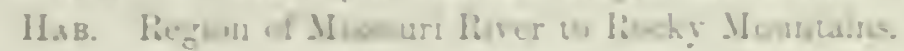

This race is very similute to the P. atrimpillus, lut differs frosn it

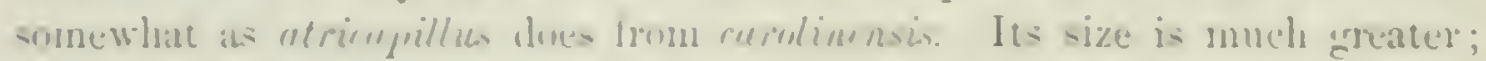
the tail profnetimully lonerer, and unth more eraduated; the white of wing and tail puret and more extendet. The lill aplentss to he stonter

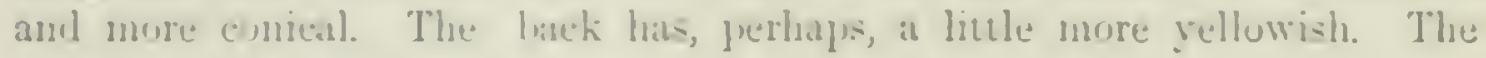
spurimon or tir-t printury is larger.

It will he a difficult matter to retain this as a species distinct frosn atrinpille, in view of the insensible sradation from one form to the other;

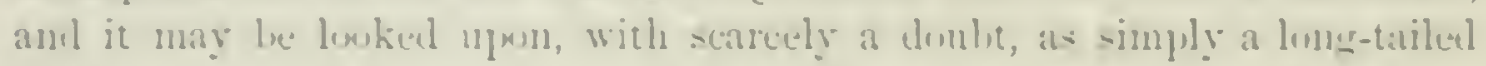

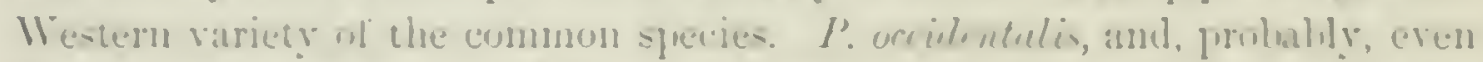
I'. curolinonis, may even tall moler the sane colterory, their freculiarities of color and size being jueciedy such as would " forimi be expected from their getengrajhical ili-tribution.

H.nBT:. The Lumg-tailed Titmonse appears to lave an extended distribution letween the Mll-i-ipgi Valley and the lincky Mumtains, from Texas

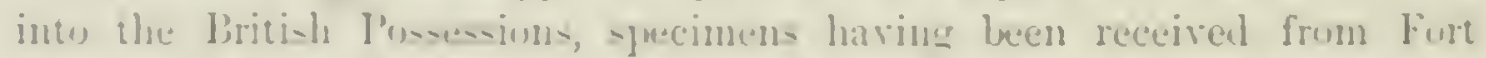

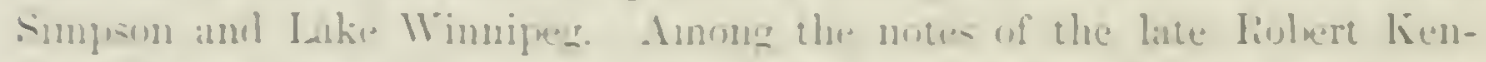

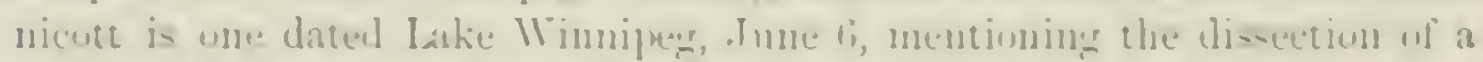
female of this specios foumd to coutain a full-sized ate. A menoramlum

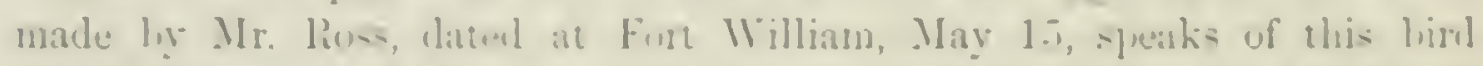
a abumlant at Fort Simpun, from Augu-e until Suventer, the last larring

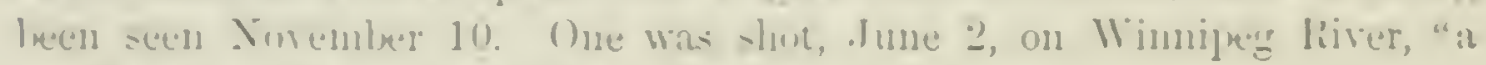

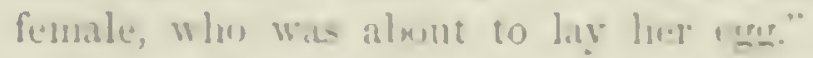

In rearl to it-distince individual hisery lut litele is as yet known. It

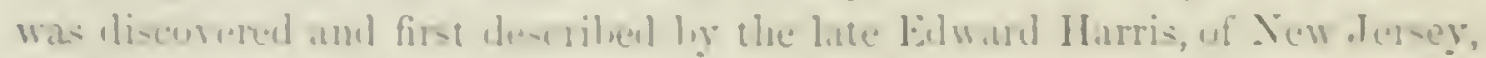

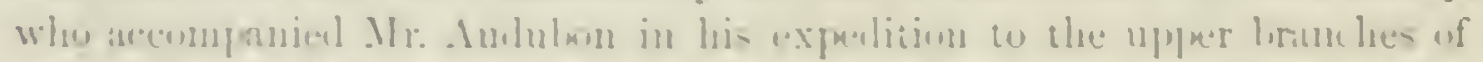

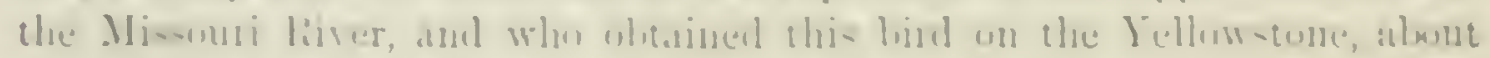

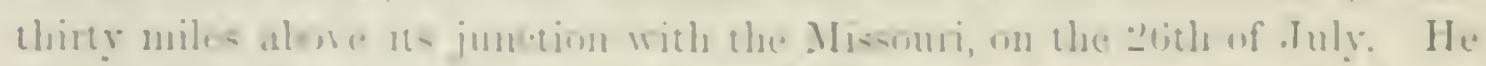

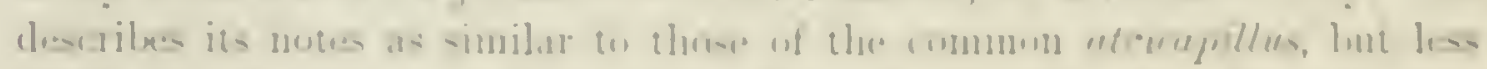

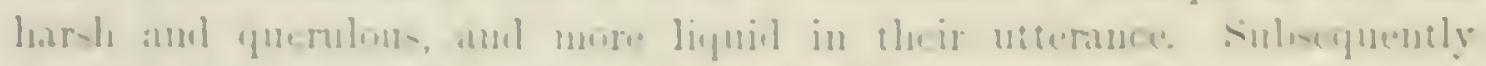

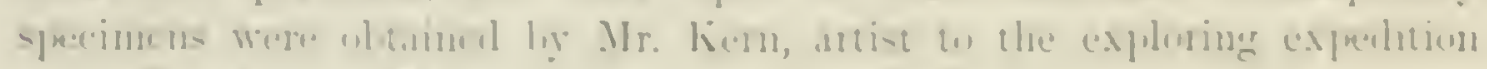
muler liremont in listi;

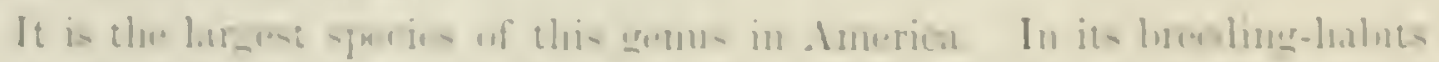

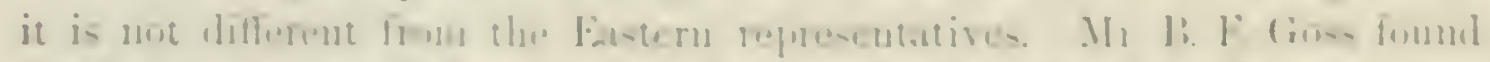

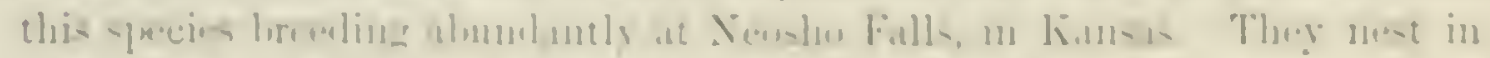

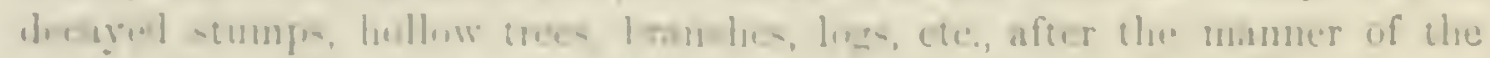

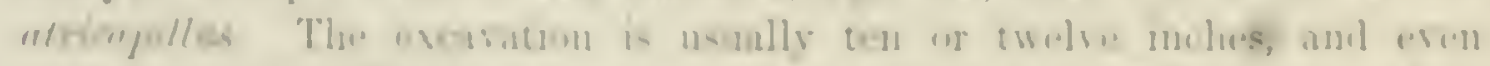

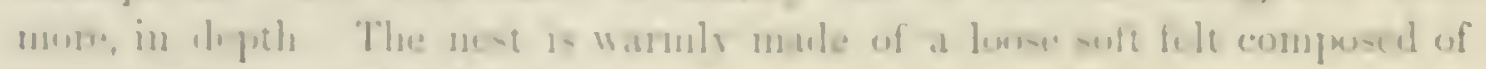

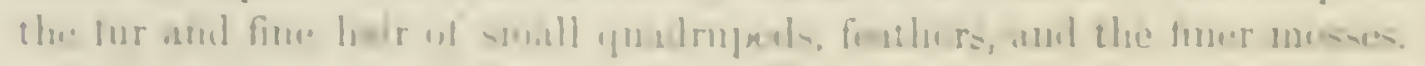


The eggs, usually five, occasionally eight, in number, are of a rommded oval shape, meatsuring .60 by .50 of an inch. They have a pure clull-white ground, and the entire eggr is very uniformly and pretty thickly eovered with fine markings and small blotehes of red and reddish-brown intermingled with a few dots of purplish.

Parus atricapillus, var. occidentalis, Bamb.

WESTERN CHICKADEE.

Parus occillentalis, B.un, Birds N. Am. 1S5S, 391 (W. Territory); Review, s1. - Scutris, Catal. 1S61, 14, 110. S2. - Elutort, Illust. 1, pl. viii. - Coopist, Birds Cal. I, 45.

Sp. Cuxr. T'arsi lengethened. Tail graduated; onter fenther about .25 of an inch shorter than the middle. Above dark brownish-ash; head and neck above and below black, separated on the sides by white; beneath light, dirty, msty yellowisil-brown, scarcely whiter along the middle of borly. T'ail and wings not quite so much edged with whitish as in $P$. atricapillus. Length about 4.5 ; wing, 2.40 ; tail, 2.40 .

Has. Northwest eoast region ol the Lnited States.

This race is of the same size as $P$. atricapillus, and resembles it in its markings; the ashy of the baek is, howerer, washed with a darker shade of yellowish-brown. The brown of the muler parts is so much darker as to cause the predominant color there to be a pale yellowish-lorown, instead of brownish-white. The fourth quill is longest; the tifth and sixth a little shorter than the third; the second is about as long as the secondaries. The tail is romded, rather more so than in most utricapillus, the difference in the lengths of the feathers anounting to about .25 of an inch. The anount of light margining to the quills and tail-feathers is much as in atricupillus, but rather less, perhaps, on the tail.

This seems to be the Pacific coast representative of the $P$. atricapillus, as septentrionalis belongs to the midalle region, corresponding in its differences with other IVestern representatives of Eastern species.

Habirs. Dr. Cooper, in his Birds of Washington Territory, says of this variety: "The common Black-capped Chickadee, so abundant in the Eastem States, is, in Washington Territory, represented by the Western Titmonse, frequenting the low thickets and trees, where it is always busily employed seeking food." He observed its nest near P'uget Sound, burrowed in soft rotten wood. Dr: Suckley found it quite abundant in the valley of the Villamette, and also at Fort Vancourer during winter. In habits it closely resembles the Black-Cap of the Eastern States.

It is chiefly found in Oregon and Washington Territory, visiting the northern part of California in winter, when it is also abundant near the Columbia River. At this season it is generally found among the deciduous trees along streams and oak groves, seeking its foud anong the branches. It feeds on seeds and insects, and is very fond of fresh meat, fat, and crumbs 
of loread. They mignte but little, remaining at the colmunhia hiver even

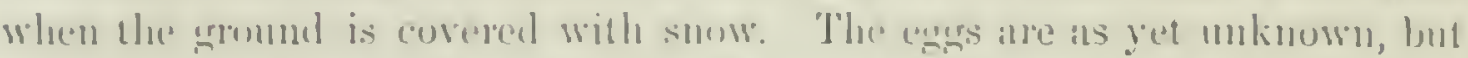
without doube they closely desemble those of the bistern species.

\section{Parus carolinensis, Iunuos.}

\section{SOUTHERN CHICKADEE.}

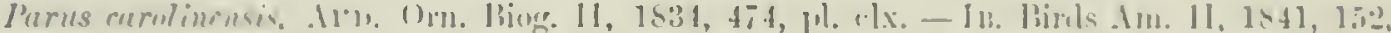

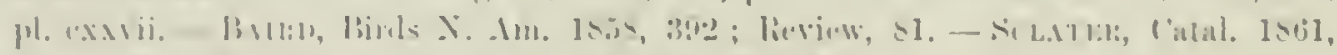

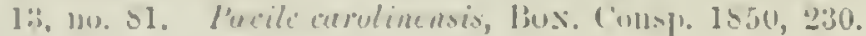

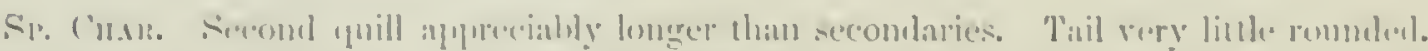

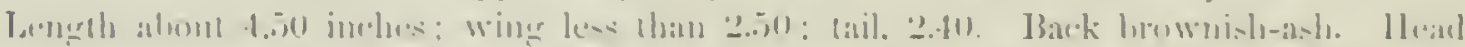

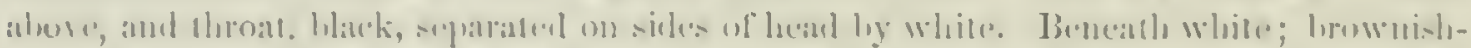

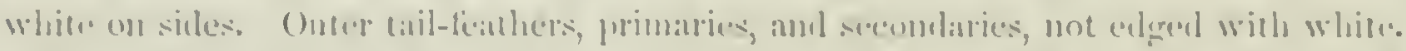

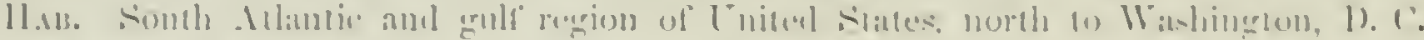

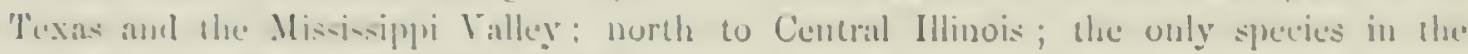
sonthern purtion of He latcer siate.

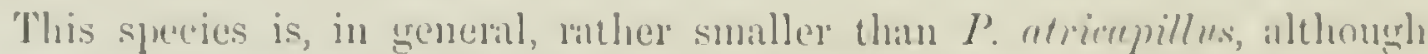

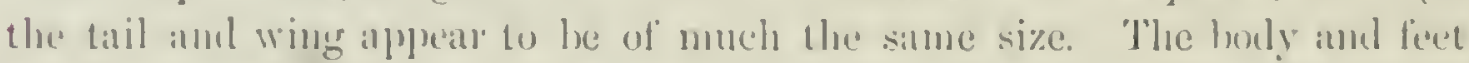
are, lumeror, smaller, and the extent of wing is three ynarters of an inch lesis. The libl is applatenly shorter and steuter.

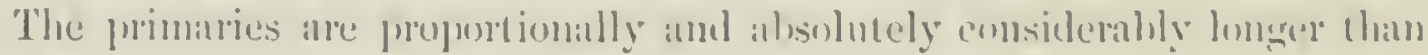

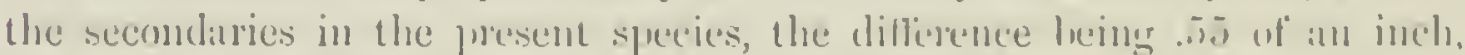

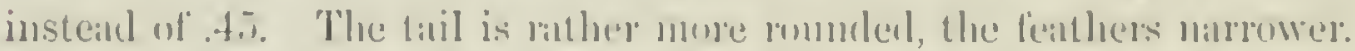

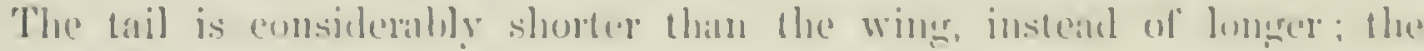

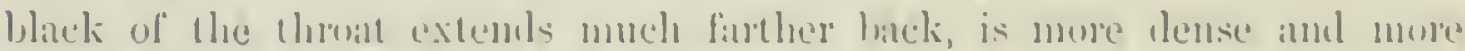
shanply elefined lehind, than in atrienpillus. Taking imb vien these dif-

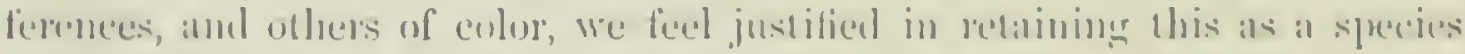

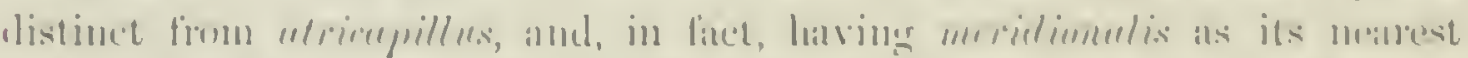

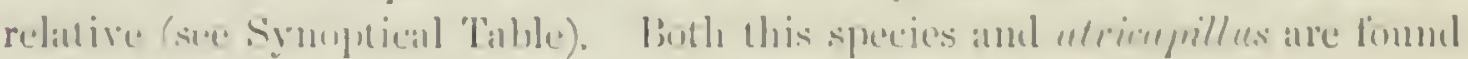

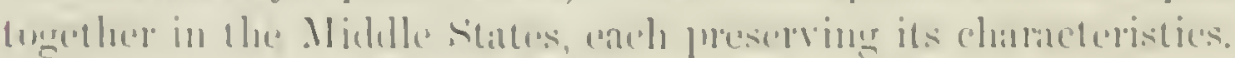

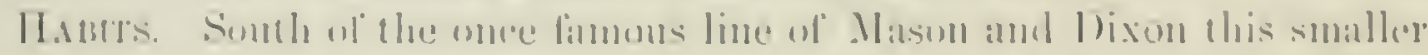

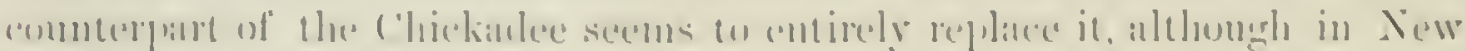

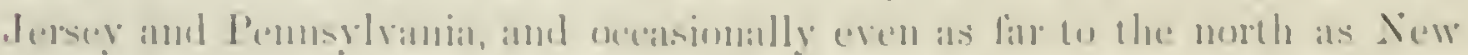

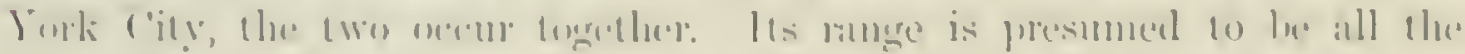

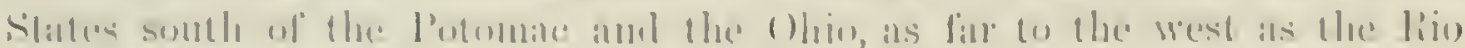

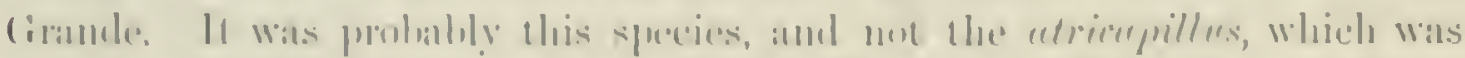

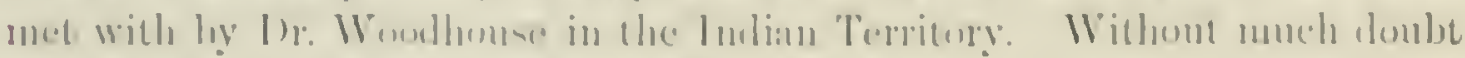

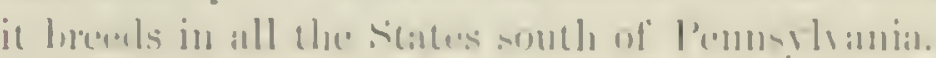

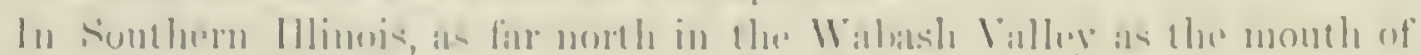

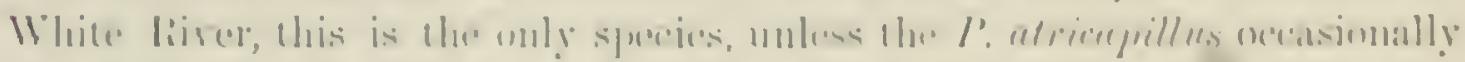

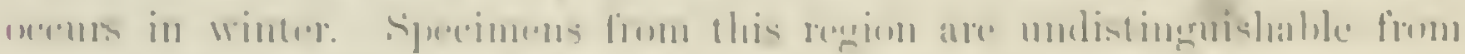

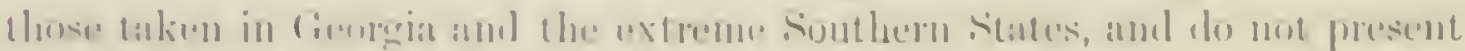

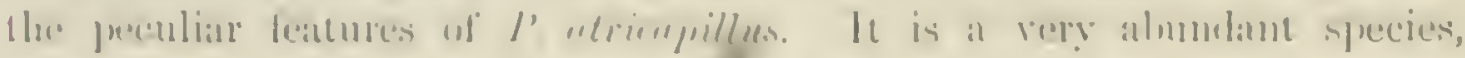


and resident, heing in winter one of the most common, as well as one of the must fanilinl birk, inhabiting ull localities, giving preference neither to swampy woods nor to door-yarls, for it is as often seen in one plice as anuther. It is never gregarious, though many may often be seen or heard at the same moment. It begins incubation carly in April, grenerally selecting the wild plum and red-bud trees in the wools. This species rery often constructs its own nesting-places, and the soft wood of these trees is rery easily excavated. The excavation is genemlly male in a lorizontal deat limb, with the opening on the under side; this is neat and renglatr, and as elaborate as those of any of the woolpeckers. Sometimes, however, a natural carity is selected, frequenty in a prostrate stump or "snar." The nest is almost always a rery elaborate structure, being a strong compact cup) or hech of "felt," whose main material is rabbit-fur and cow-hair.

In its liabits it seems to resemble more elosely the $P^{\prime}$. palustris of Europe than the utricupillus, being grenerally found only in the immediate ricinity of ponds and deep, markly, moist woods. It is also rarely found other than singly or in pairs, the parent birds, unlike most of this fimily, separating from their young soon after the latter are able to provide for themselves. It rarely or never moves in flocks.

Their notes are said to be less sonorous and less frequent than those of our Black-capped Titmouse. In the winter a portion retire from the coast in South Carolina into the interior of the State and into Florida, where Mr. Aulubon found them, in the winter of $15: 31$ and 1832 , nuch more abundant than he had ever seen them elsewhere. He found them breeting as early as February, occasionally in the nests deserted by the Brown-headed Nuthatch. A nest obtained by Dr. Bachman from a hollow stump, abont four feet from the ground, was in form cup-shaped, measuring two inches internally in diameter at the mouth, and three externally; with a depth of two inches. It was constructed of cotton, fine wool, a few tibres of plants, and so elaborately felted togetlee as to be of uniform thickness throughout.

Mr. Audubon was in error in regard to the eggs, which he deseribes as pure white. Their ground-color is of pure errstalline whiteness, hut they are freely and boldly marked all over with deep reddish-brown and red spots. These, so far as we have compared the egges, are larger, more numerons, and more deeply marked than are any ergs of the atricapillus we have ever met with.

According to the observations of the late Dr. Alexander Gerhardt of Irhutfield County, Georgia, these birds usually breed in holes that have been previously dug out by the Picus pubscens, or in decaving stumps not more than five or six feet from the ground. He never met with its nest in living trees. The eggs are from five to seven in number, and are usually deposited in Georgia from the 10th to the last of April.

The eggs of this species are slightly larger than those of the atricapillus, 
and the redilish-brown blntches with which they are profusely corered are much more distinctly marked. They are of at sphervidial oval in shate, have a pure white ground, very uniformly and generally sprinkled with

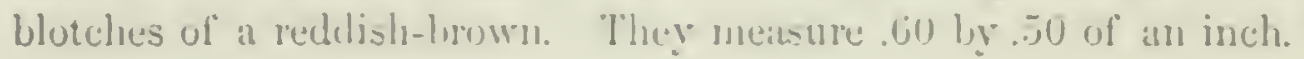

Parus rufescens, Twis. CHESTNUT-BACRED CHICKADEE.

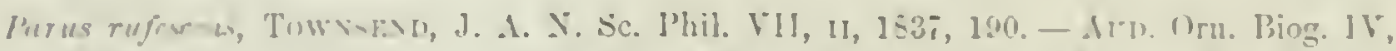

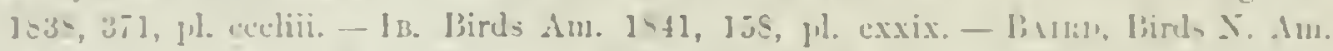

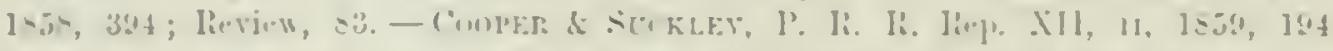

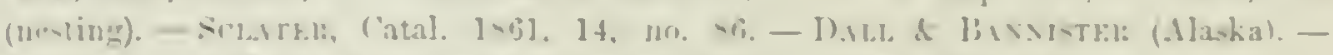

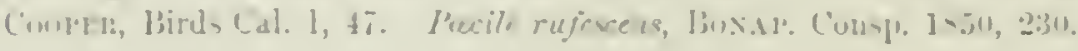

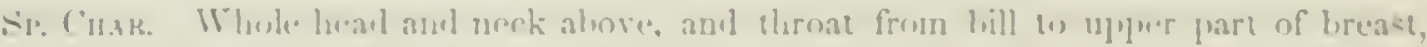

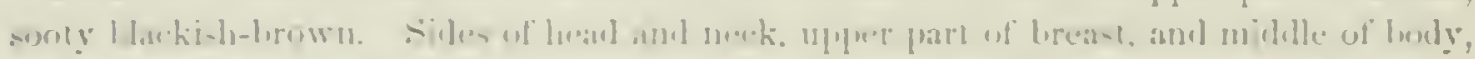

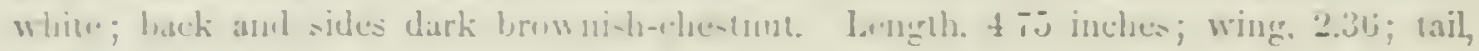
$2.11 \%$.

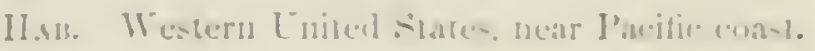

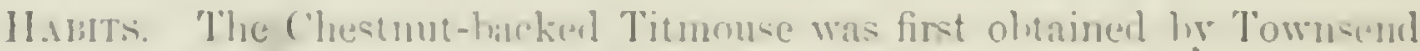

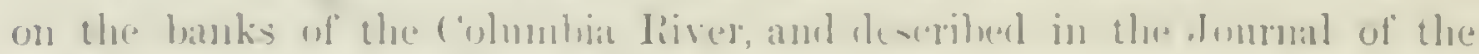
I'hiladelphia Academy. It is a reident, throughout the reatr, of the foresels

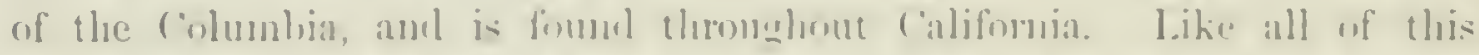
faniliar fanily, they may be seren in small tlocts, of all arees, in the autumn

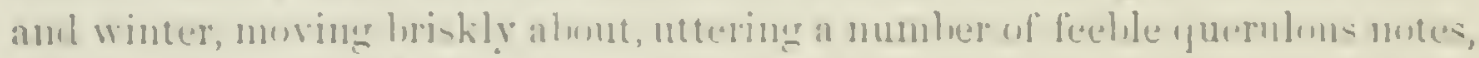
after the mamner of the utrimpillnes, but merer joining in anything like the

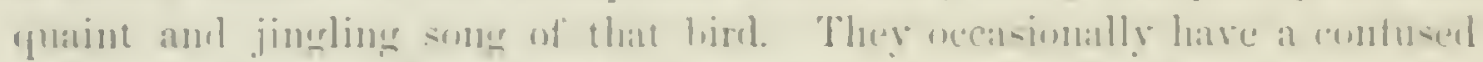

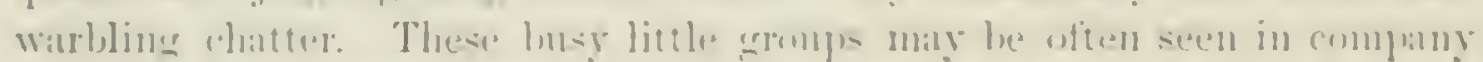

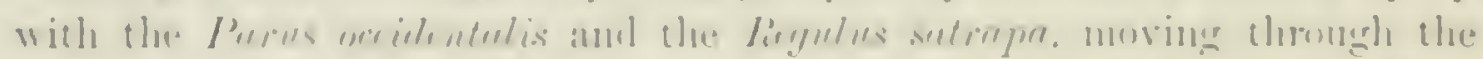

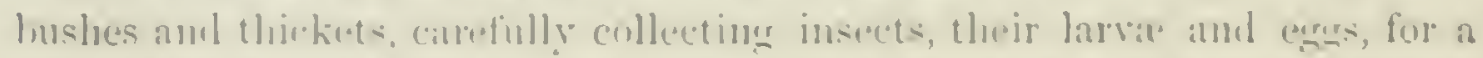

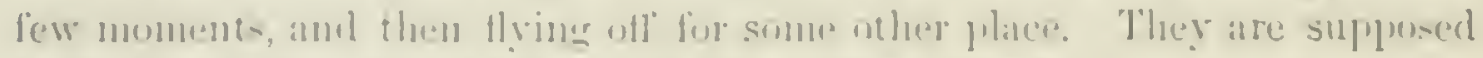

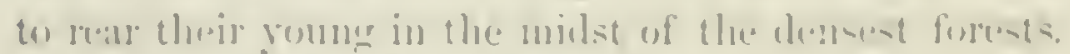

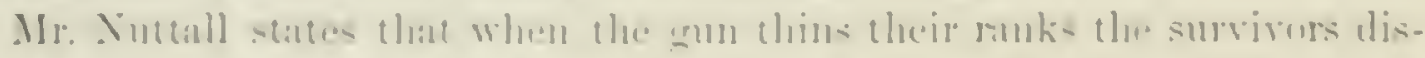

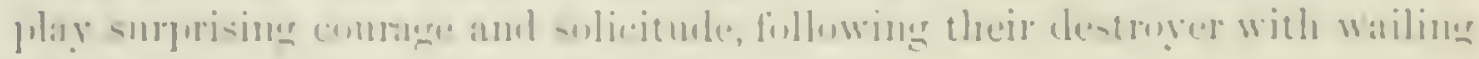

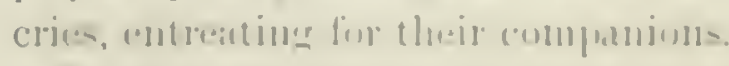

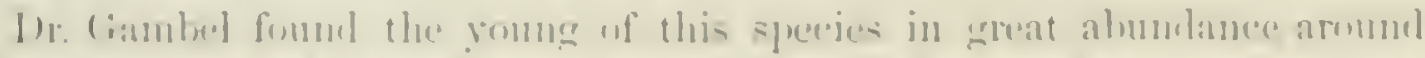

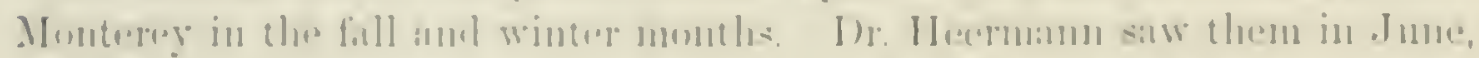

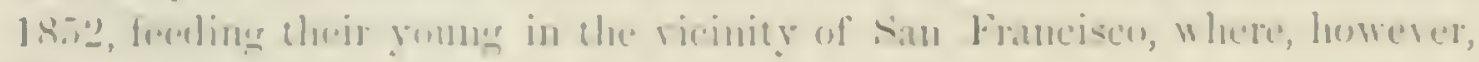
Hareg are nare.

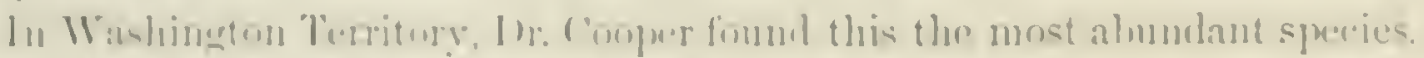

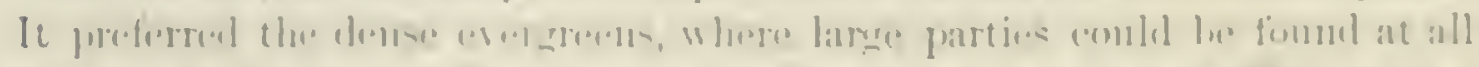

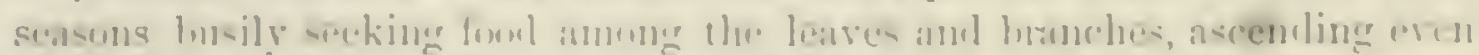

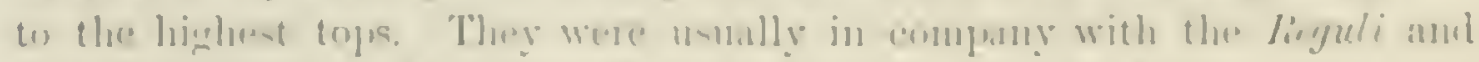

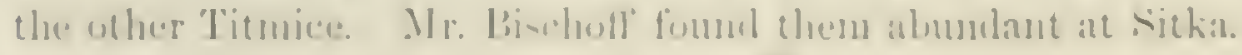


They nest, like all the otliers of this genus, in holes in soft decayed trunks and large limbs of trees a fer feet from the ground. Their egras are not as yet linown.

\section{Parus hudsonicus, Forst.}

\section{HUDSON'S BAY CHICKADEE; BROWN-CAPPED CHICKADEE.}

Parus hudsonicus, Fonster, Philos. Thans. LAIII, 17i2, 383, 4:30. - Al'1). Orn. Biog. II,

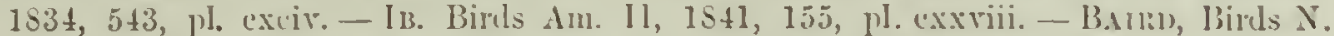

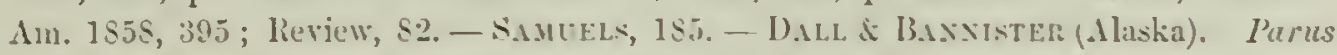

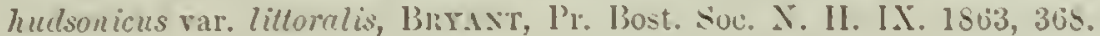

Sp. Culır. Above yellowish olivareous-brown; top of head purer brown, not rery dillerent in tint. Chin and throat dark sooty-brown. Sides of heat white. Beneath white; sides and anal region light brownish-chestnut. No whitish on wings or tail. Tail nearly even, or slightly emarginate and rounded. Lateral feathers about .20 shortest. Lengtlı about 5 inclues: wing. 2..40; tail, 2.66\%.

HAs. Northern pertions of North America, from Atlantic to Pacific.

Specimens from the most northern localities appear larger than those from Maine and Nora Scotia (P. litlorulis, BRYANT), with proportionally longer tirils (3.00 inches, instead of 2.40). We cam, however, detect no other difference.

The Purus sibirins of Europe is rery similar in coloration and characters to the P. hudsonicus. The principal difference is seen in the cheelis, which in sibiricus are pure white, this color extending along the entire side of the neck, widening behind, and extending round towards the back. In hudsonicus the cheeks behind the eyes and sides of the neck are ash-gray, the white being confined to the region below or near the eye. The smoky-gray of the upper part of head and neck in sibinicus is in a stronger contrast with the brighter rufescent-uray of the back, and is separated from it hy an obscure, concealed, whitish dorsal half-collar, represented in hudsonicus only by a dull grayish shade in the plumage.

HABits. This interesting species, one of the liveliest and most animated of its fanily, belongs to the northern and eastern sections of North Anerica. It is found in the eastern and northern portions of Maine, and probably also in the northern parts of New York, Vermont, and New Hampshire. In the heavily wooded mountain-ralley of Errol, in the latter State, Mr. Maynard met with this bird in the latter part of October, in company with the common atricapillus. In the same month he also obtained two birds in Albany, in the northwestern corner of Maine. A single specimen was taken at Concord, Massachusetts, October 29, by Mr. William Brewster.

Near Calais it is resident, but not common. It is more abundant in the islands of the Bay of Fundy, where it talies the place, almost exclusirely, of the atricapillus. The writer first met with these lively little wood-sprites 
in 1850, in the thick swanyy wools which rover one of the small islands

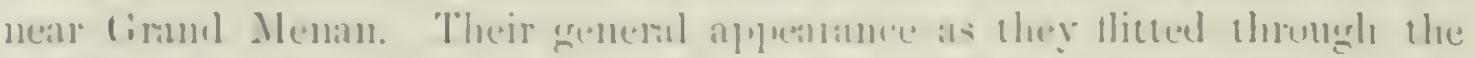

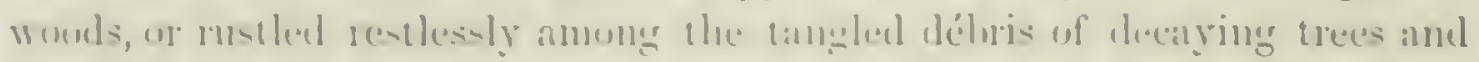

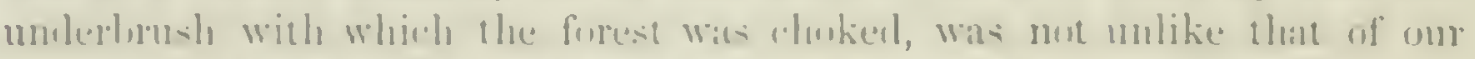

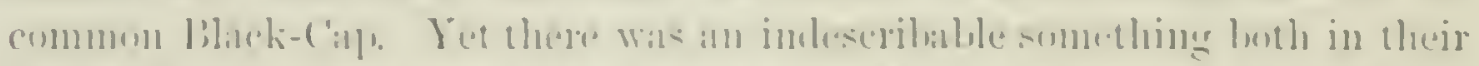

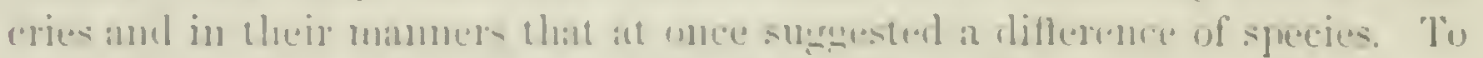

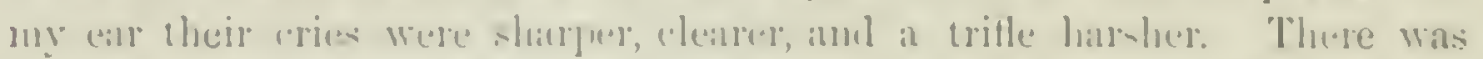

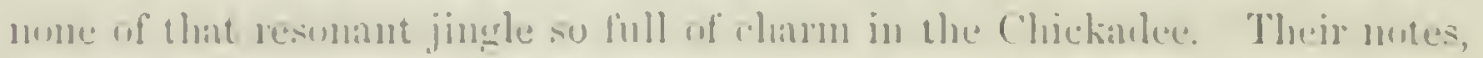

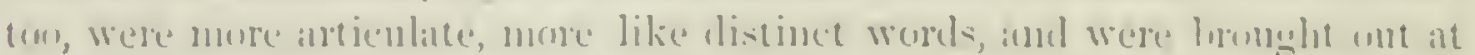
certain tintes with an emphasis the ellect of which was rery striking.

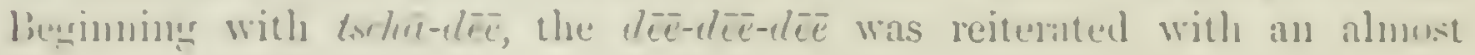
incersilnt volubility.

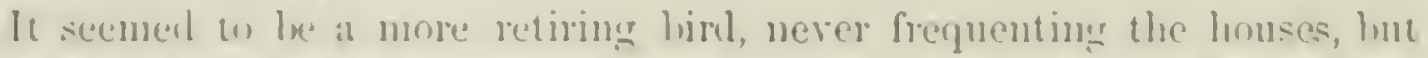
kecpung closely to thick and retired wouls. Vet it is nut a timid species, lint

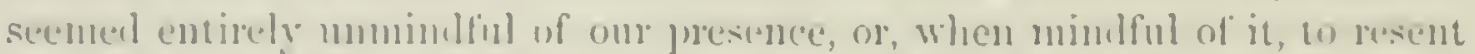

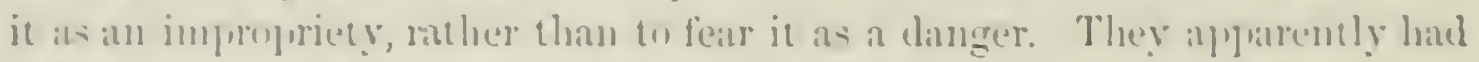

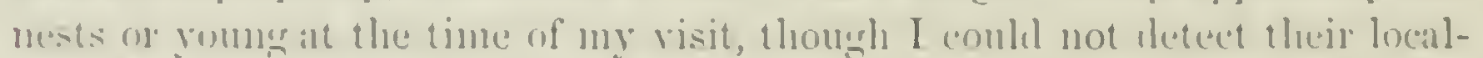

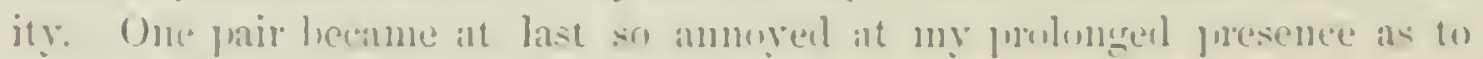

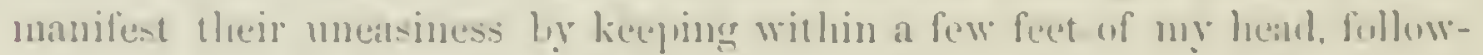
ins me wherever I went, and withnt ceasing from their eluse sureillance

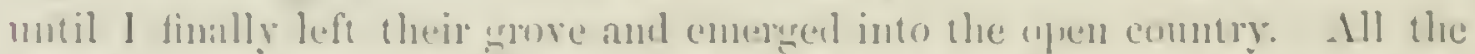
time they hromeln ont the cry of ate-tete with a clear, rimering emphasis that Was almust stantlines.

A few dity later, lueing at Jalifax, Mr. Amlww Jownes, the naturaliot.

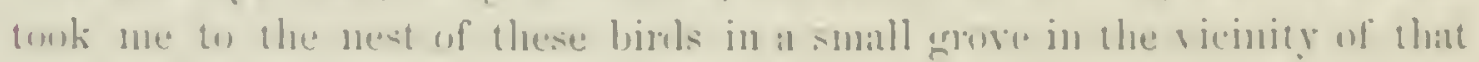

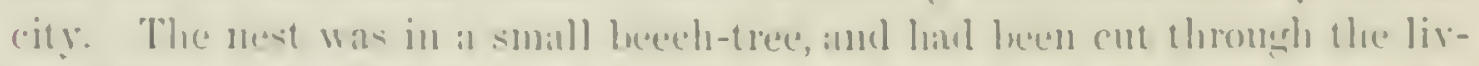
ing wonl. The excavition, which wats net more than iwn feet from the

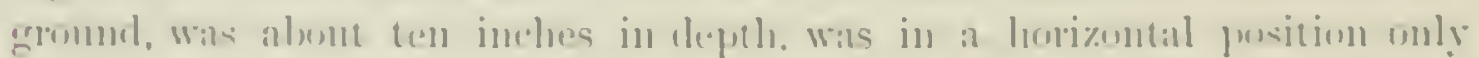

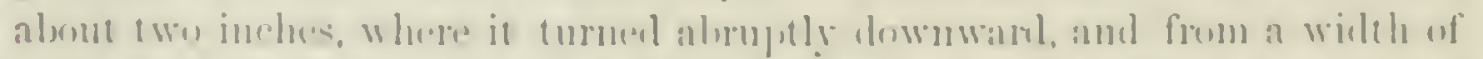

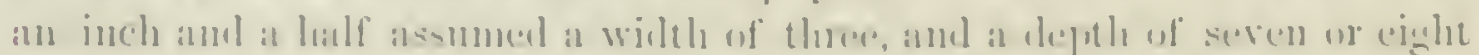
inches. This was wamly lined with feathers and sult four. The nest con-

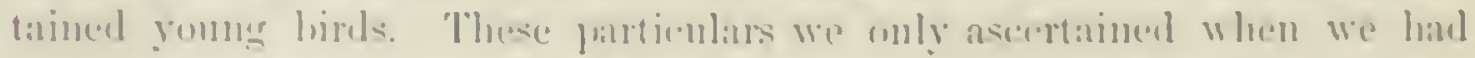

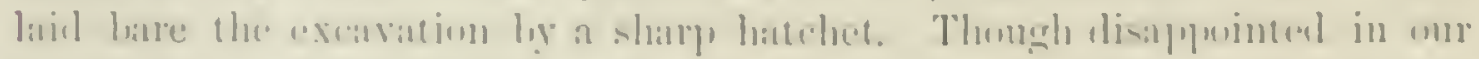

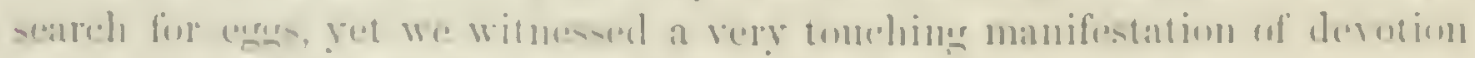

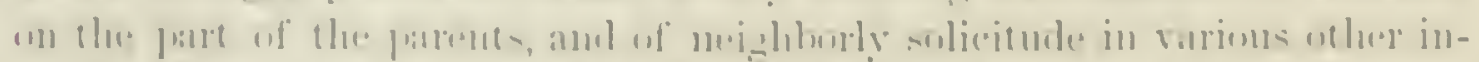

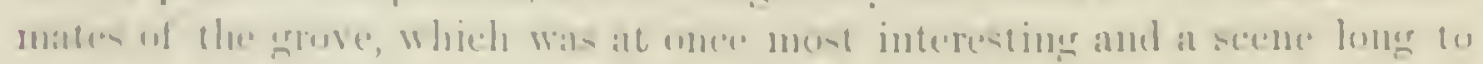

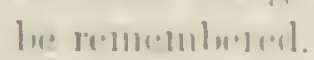

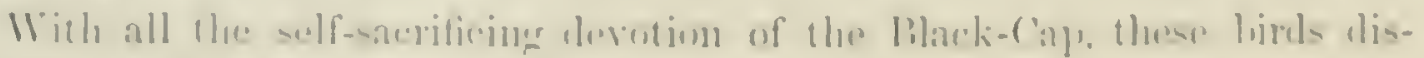

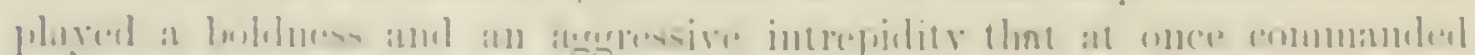

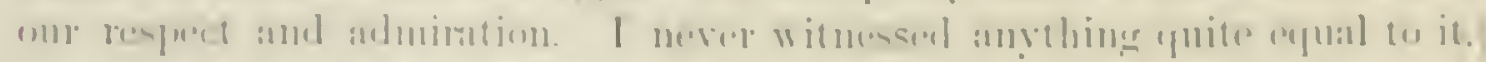

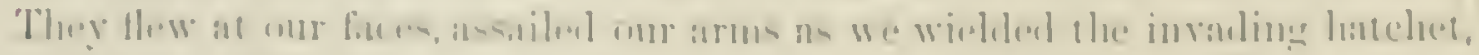

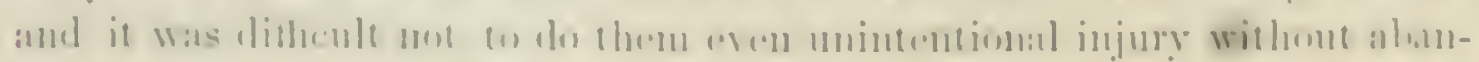

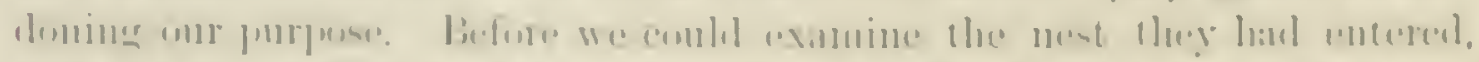

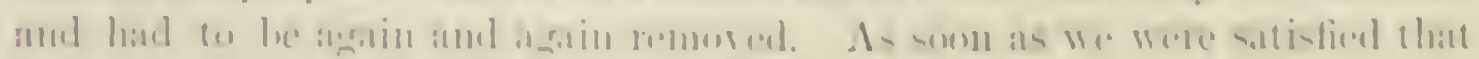


the nest of this heroic pair did not contain what we sought, we left them, and turned to look with equal admiration upon the indignant assembly of feathered remonstrants by which we were surromeled. The neighboring trees swarmed with a variety of birds, several of which we had never before seen in their summer homes. There were the lied-Poll Warbler, the Black and Yellow Warbler, and many others, all earnestly and eloquently crying out shame upon our proceedings.

1)r. Bryant, in his Notes on the Birds of Yarmonth, X. S., etc., mentions finding quite a number of this species on Big Mul Island, near that place. A pair of these birds with their young were seen by lim near Yarmouth on the $3 \mathrm{~d}$ of July: Their habits seemed to him identical with those of the Black-Cap. The young were fully grown and could fly with ease, yet their parents were so solicitous about their safety that he conld almost catch them with his hand. Their notes appeared to him similar to those of our common species, but sharper and more filing, and can be readily initated by repeating, with one's front teeth shut together, the syllables tie $\bar{e}-d \bar{e} \bar{e}-d \bar{e} e-d \bar{e} e$.

Mr. Andubon found a nest of this Titmouse in Labrador. It was built in a decayed stump about three feet from the ground, was purse-shaperl, eight inches in depth, two in diameter, and its sides an inch thick. It was entirely composed of the finest fur of rarious quadrupeds, chiefly of the northerm hare, and all so thickly and ingeniously matted throughout as to seem as if felted by the hand of man. It was wider at the bottom than at the top. The birds rehemently assailed the party.

Mr. Ross, in notes communicated to the late Mr. Kiennicott, mentions that specimens of this species were shot at Fort Simpson, October 13, in coinpany with $P$. septentrionalis, and others were afterwards seen towards the mountains. The notes he describes as harsher than those of the septentrionalis. The Smithsonian museum contains specimens from Fort Iukon and Great Slave.Lake, besides the localities already referred to. Mr. Dall found it the commonest Titmouse at Nulato, abundant in the winter, but not present in the spring.

The eggs of this species measure $.56 \mathrm{by} .47$ of an inch, are of a rounded oval shape, and with a white ground are somewhat sparingly marked with a few reddish-brown spots. These are usually grouped in a ling around the larger end.

\section{GEITS PSALTRIPARUS, BOIAP.}

Paltriparus, Bosal. Comptes Rendus, XXXI, 1550, tis. (Type, P. melanotis.) Agithaliscus, Cabaxis, Juseum Heineanum, 1551, 90. (Type, Purus erythocephalus.) Paltrin, C.ssis, Ill. ‥ Am. Birds, 1553, 19.

GFx. Char. Size rert small and slender. Bill rery small, short. compressed, and with its upper outline much curred for the terminal half. Upper mandible much deeper than under. Tail long, slender, much graduated: much longer than the wings; the feathers very narrow. Tarsi considerably longer than the middle toc. No black on the 


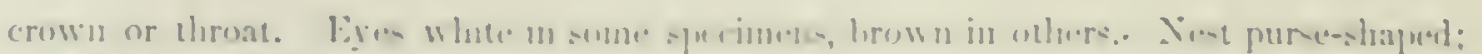
coges min-putteol, whute.

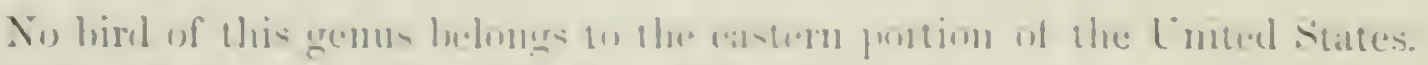
The three species male le defined as follow- -

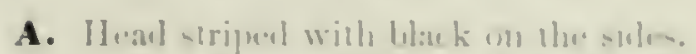

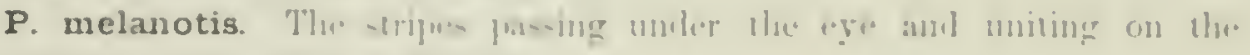

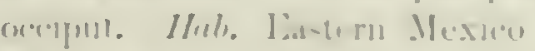

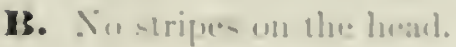

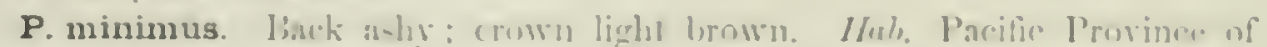
Thitulstates.

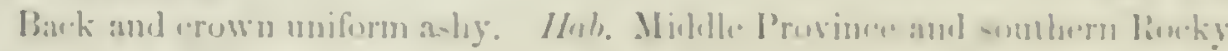

Moumtains of lisited state.

var. plumbeus.

\section{Psaltriparus melanotis, lisis. BLACK-EARED BUSH-TITMOUSE.}

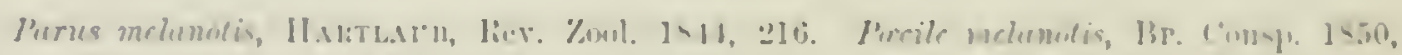

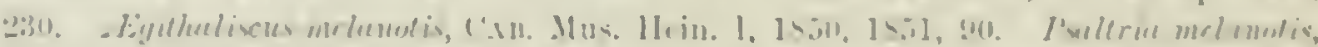

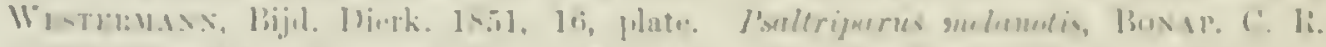

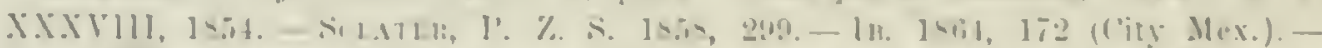

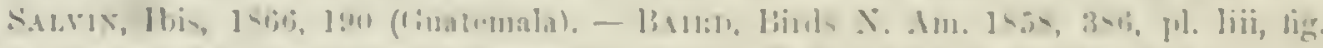

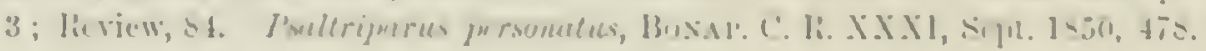

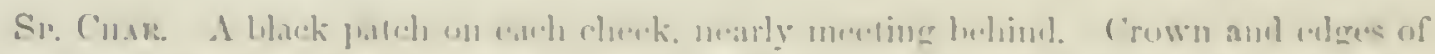

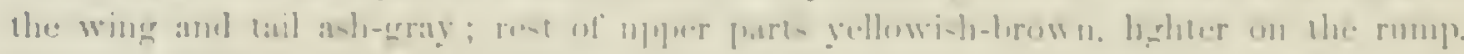

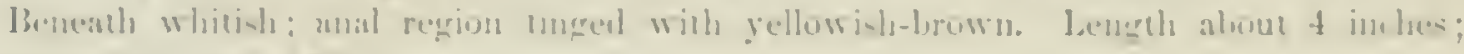
win: 1.6u; tail, 2..31.

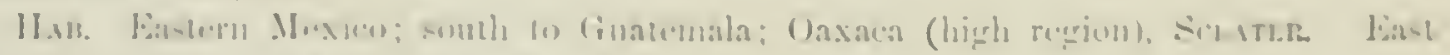

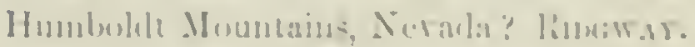

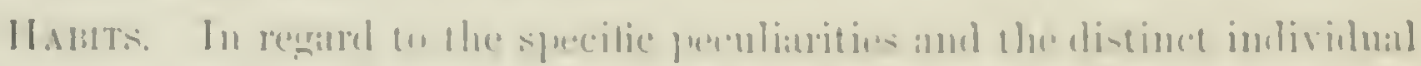

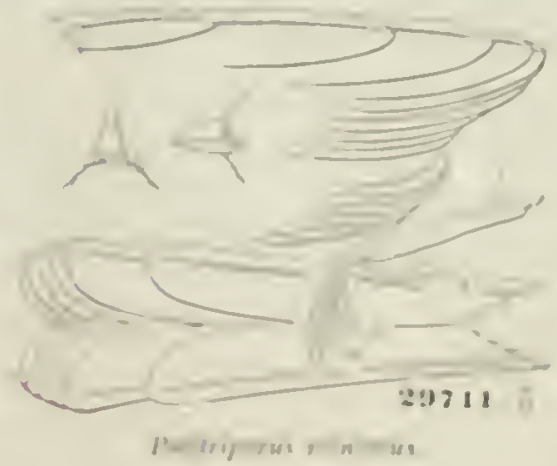
habits of the members of this probly little

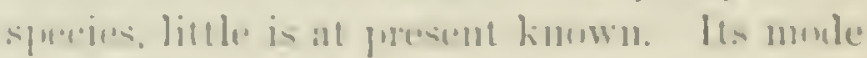
of mo-hing has not heen olmervinl, and no murution is makle, la Huse whu hance met with il, of it furuliatilies of solng, mor latse Wr. any infommation in regart on any af its

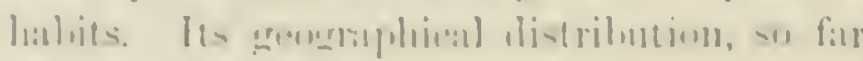

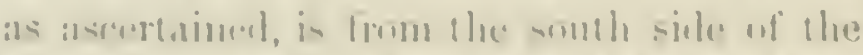

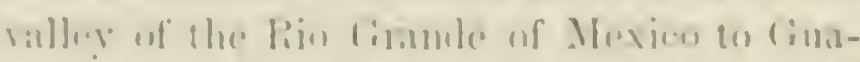

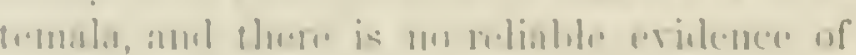

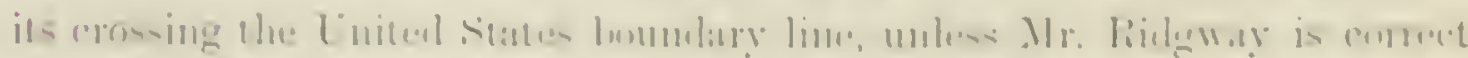

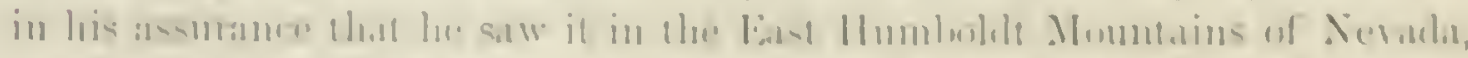

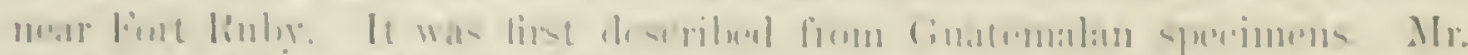

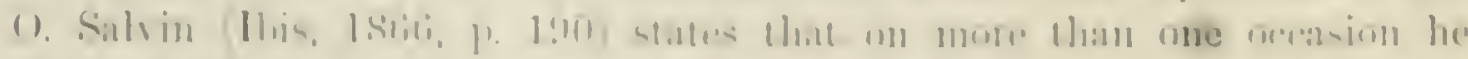

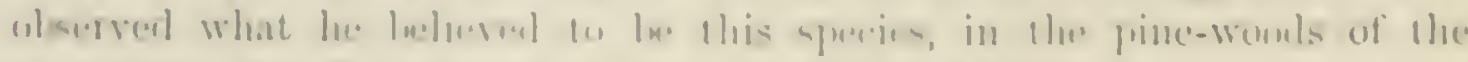

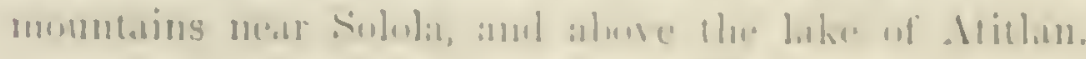


Psaltriparus minimus, var. minimus, Boxis. LEAST BUSH-TITMOUSE.

Parus minimus, Towsiswn, J. A. N. Se. Vll, It, 1837, 190.-Atn. Orn. Biog. IV, 1S3S, 35:, pl. cceldxxii, figs. 5, 6. - I B. 13irds Am. Il, 1S\$1, 160, pl. cxxx. I'cecile minima, Bus. Consp. 1850, 230. Psaltru minima, Cassis, 11lust. 1853, 20. P'saltriparus

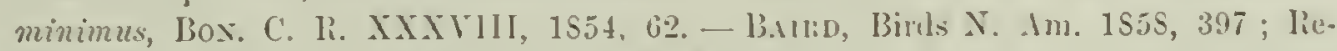

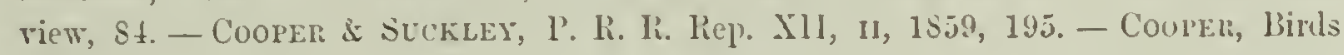
Cal. I, 4S.

SP. Cuır. Tail long. feathers graduated. Above lather dark olivaccous-cinereous; top and sides of head smoky-brown. Bencitle pale whilish-brown, darker on the sides. Length about $t$ inches; wing. 1.90 ; tail, 2.25 .

Hab. Paeific const of Lnited States.

There is quite an appreciable difference between specimens of this speeies from Washington Territory and California; the latter are smaller, the under parts paler. In the series before us, however, we see no grounds for specific distinction.

Hıвiтs. This interesting little species was first added to our fauna by the indefatigable Mr. Townsend in $18: 37$. It is abundant throughout the Pacific coast from Fort Steilacoom to Fort Tejon. Ir. Gambel found it exceedingly abundant both in the Rocky Mountains and throughout California. During the winter the otherwise cheerless woods were alive with the busy and noisy troops of these restless and industrious birds, gleaning their scanty fare in company with the Reguli, in every possible position and manner, from bush and tree. He describes their anxious solicitous search for food as quite curious. They kept up a continual twittering, and so intent were they in their employment that they appeared to lose sight of all danger, and it was by no means unusual to he so surrounded by a flock as almost to render it possible to catch them in the hand.

Dr. Cooper found this species abundant in Washington Territory, but never met with it north of the Columbia River. Dr. Suckley says it is quite common at Fort Steilacoom. He could not, however, detect any difference in its habits from those of other species of this family. He saw none in Washington Territory during the winter, and presumes they all migrate to the South, though the rnfescens and the occidentalis are found there throughout the winter. Townsend, however, speaks of it as a constant resident about the Columbia River, hopping around among the bushes, hanging from the twigs in the manner of other Titmice, twittering all the while with a rapid enunciation resembling the words thshish tshist-tsec-tuce. 


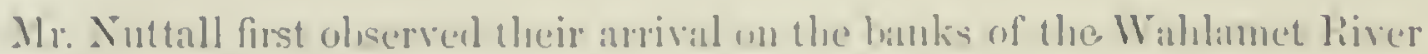

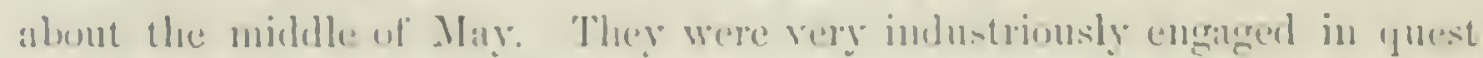
of insods, and wore ly un me:ass sly, lut kept always in the low bushes in the skints of the wouls. ()n one oceisiun the male bird was so sulicitums in

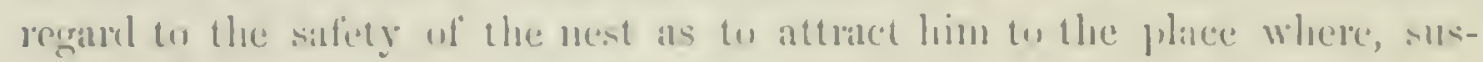

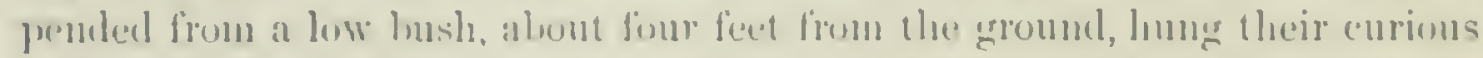
home. It was formenl like a long furse, with at rombl hole fin entrunce near the top, and nade of moss, hwom, lint of plints, and lined with feathers.

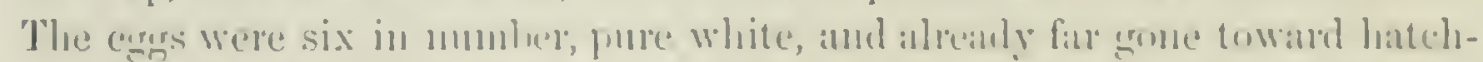

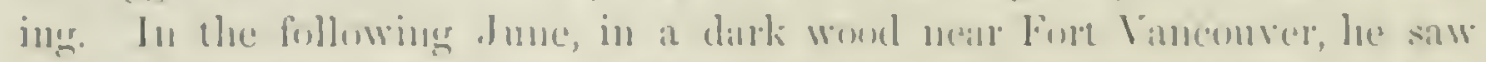
a flock of about twelve, wheh, he intating their chimping. he was alle to call aroumd him, and which liejt 10 an ine

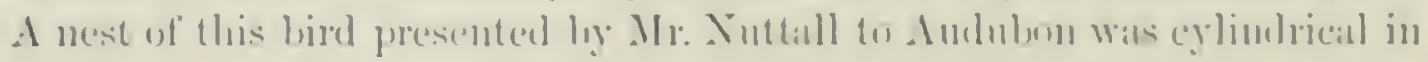
form, nine inches in lenerth and there and at half in diameter. It was sus-

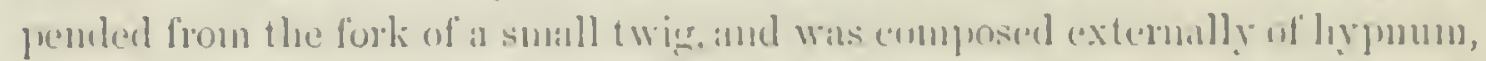

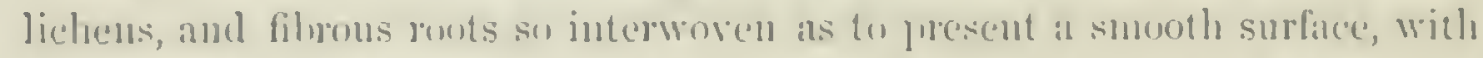
a few stems of grasses and feathers intermingled. The aperture was at the

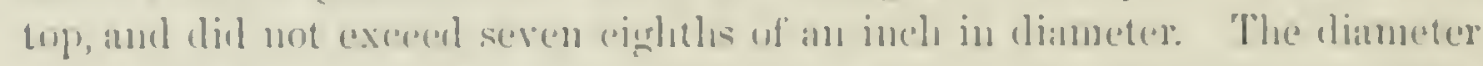
of the internal pasige for two thirds of its length was two incles. This was lined with the cottomy down of willuws and a vist yuantity of sult

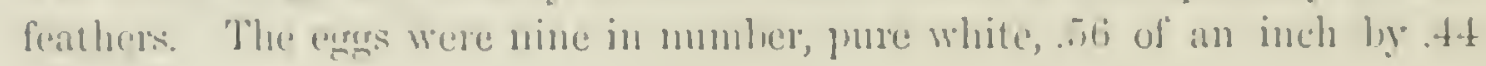
in their measurement.

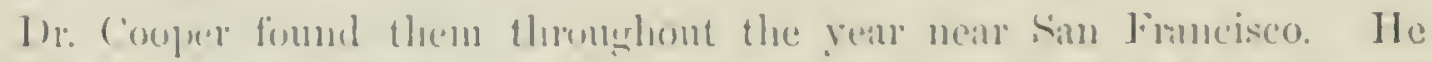

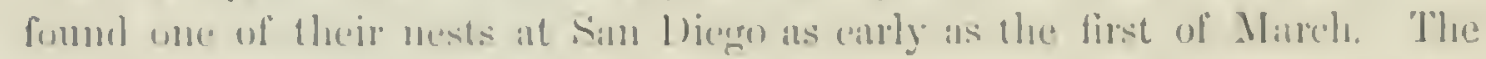

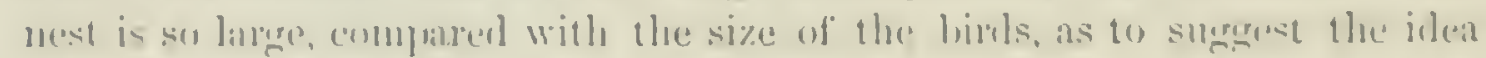
that the fleck unito to build it. Ho gives the meisurements as cight inches

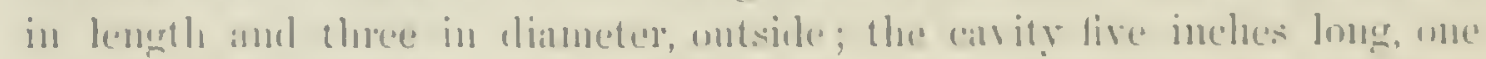

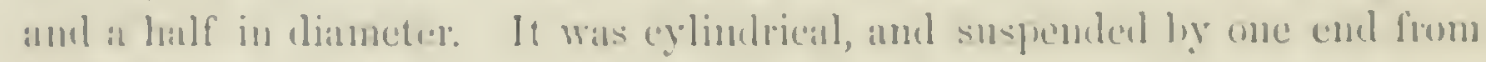
at lem lumanls.

When one of these limb is killed, Dr. Cooper silys that the uthers comme

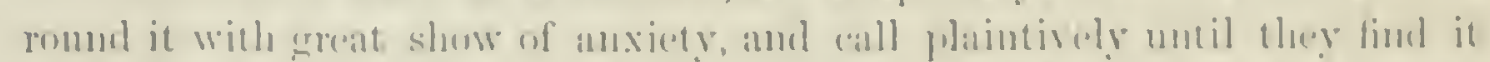

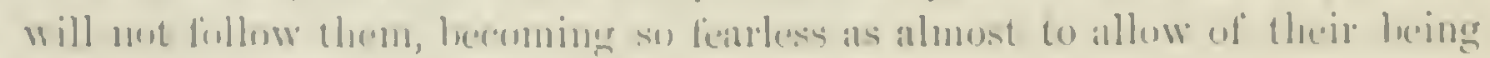
taken by the hand.

Psaltriparus minimus, var. plumbeus, linis.

\section{LEAD-COLORED BUSH-TITMOUSE.}

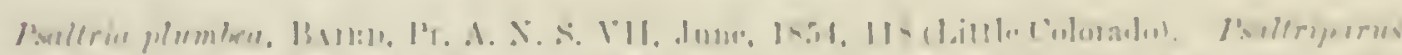

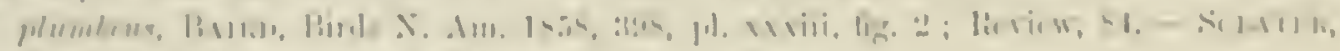

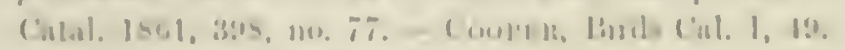

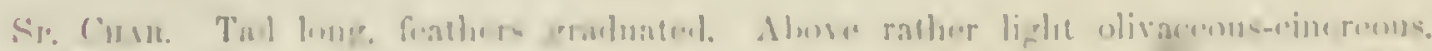

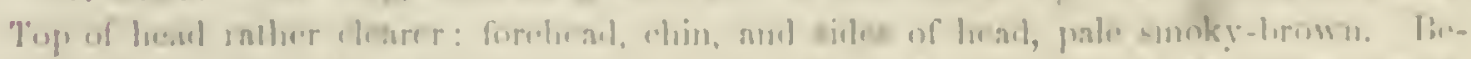

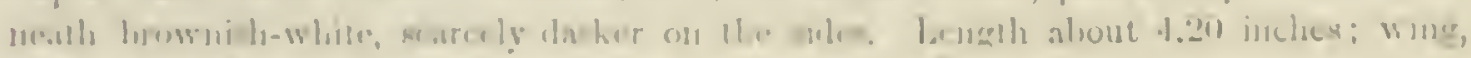
$2.15 ; 1.11,2.00$. 
HaB. Southern Rockr ILountan region of Cnited States, from mountains of West Arizona to Green River. Wroming; west to Carson City, Jerada (Rrdawar).

This variety is very similar to the Psaltriparus minimus of the west coast, which it represents in the Rocky Mountain region. It is, howerer; appreciahy larger, the wings and tail proportionally longer. The top of the head is phumbeous, uniform with the back, instead of smoky-brom. The back is a paler ash, the under parts darker.

H.tBITs. Of the history of this variety but little is knomn. It is found in the southern portion of the Rocky Momtain regions, within the United States, in Arizona and New Mexico. The extent of its area of distribution remains to be ascertained. Dr. Kemnerly met with it on Little Colorado Iiver, where he observel it among the scattered bushes along the banks of the river, occurring in large flocks. These passed rapidly from place to place, utteriug their short, quich notes. He afterward met with them along the lead waters of Bill Williams Fork, inhabiting the tops of the cotton-wood trees. When attracted to them by their notes, they could only be seen after a very careful search. He obtained no knowledge as to their mode of nesting, and no information, so far as we are arrare, has been obtained in regard to their egrs. It may, howerer, be safely conjectured that they are white, and hardly distinguishable from those of the minimus. Dr. Coues found them common near Fort Whipple, Arizona.

Mr. Rilgray met with this bird in especial abundance among the canons of Trest Humboldt Mountains in September. He found it also in all suitable places westward to the very base of the Sierra Nevada Mountains. It was met with principally in the thick brushwood bordering the streams, in erer-restless companies, continually twittering as they flew from bush to bush, in single rows. Mr. Ridgway describes these birds as remarkably active in their morements. If unmolested, they were exceedingly unsuspicious and familiar. During Norember he found them inhabiting the cedars, alrays associating in scattered flocks.

\section{GEILS AURIPARUS, BaIRD.}

Auriparus, B.in.d, Rer. Am. Birds, 1sut, sj. (Type, Egithalus flavicops, Srxd.)

Gex. Char. Form srlvicoline. Bill conical, nearls straight, and rery acute: the commissure very slightly and gently curred. Tostrils concenled by decumbent bristles. Wings long, litule rounded; the first quill half the second; third, fourth, and fifth quills nearly equal, and longest. Tail slightlr graduated. Lateral toes equal, the anterior united at the extreme base. Hind toe small, about equal to the lateral. Tarsus but little longer than the middle toe.

This genus is closely allied to Paroides of Europe, as shown in Birds of North America (p. 399), though suficiently different. It is much more sy-lvicoline in appearance than the other American Paridce. 


\section{Auriparus flaviceps, B.11:D.}

\section{YELLOW-HEADED BUSH-TITMOUSE; VERDIN.}

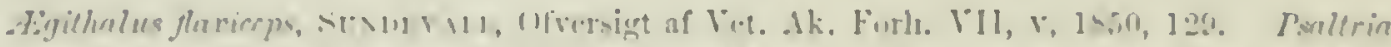

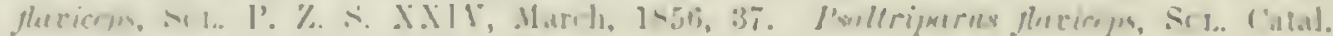

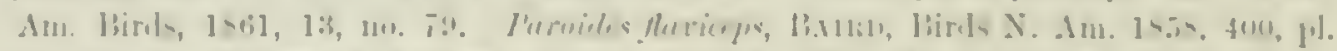

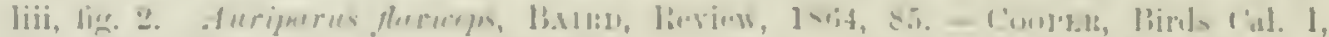

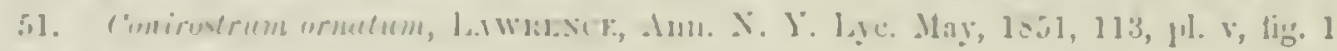
(T):xas).

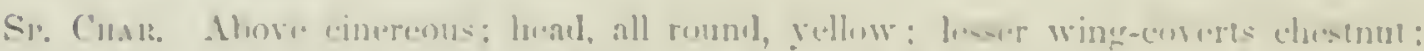

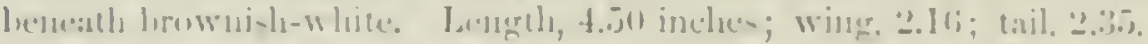

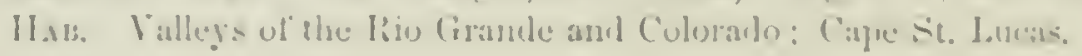

Ilouts. This new aud interenting little suedes was first alded to our

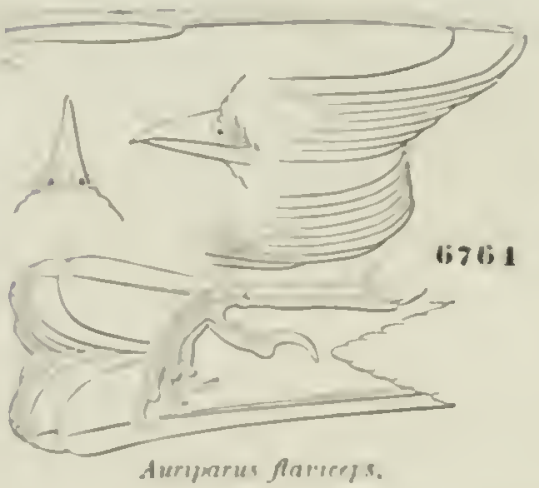

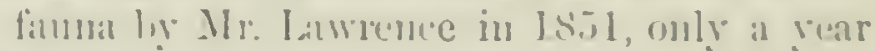
after jts firt drecription as a libd of Mexien.

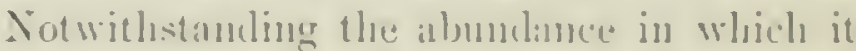
has heen in cortain localities, less has heen developed in resarel to its hislits and specilie chameteristica tham we seem to have had a right to anticipinte.

It was fimml in Western Texas, in Mexion, in the lewer valleys of Nell Mexieo and

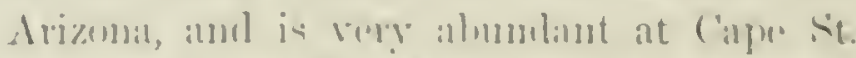

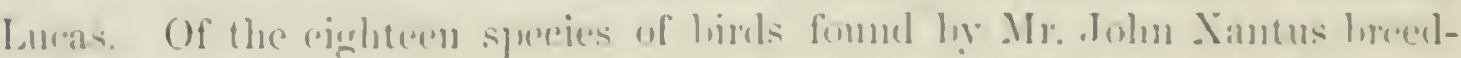

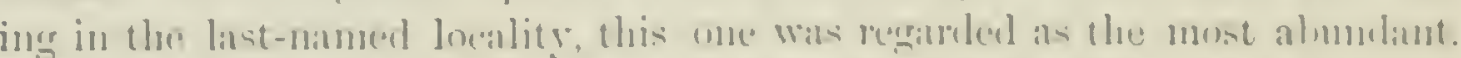

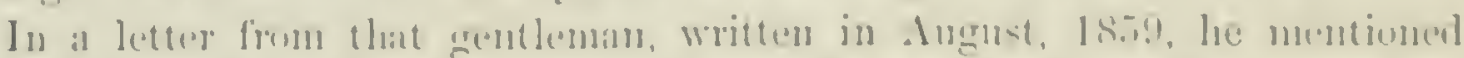

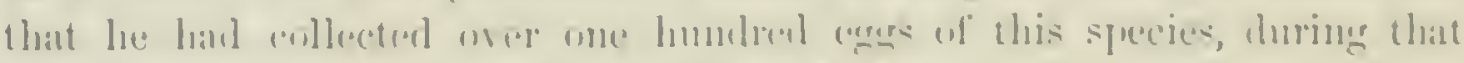

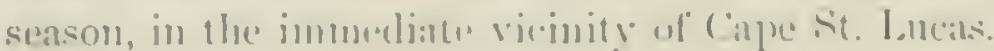

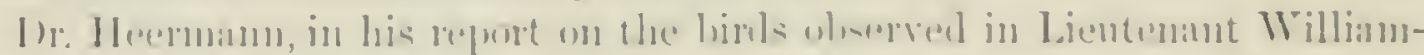

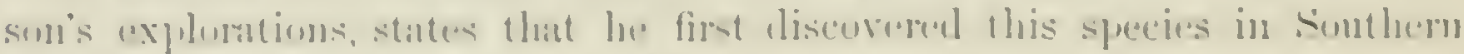
Califumia at the termimas of the Mhlate liver. Owing to their extrense willness. le was mat alle to ubtain any sporjumens. In scarrehimg lin their foul, he stattes that

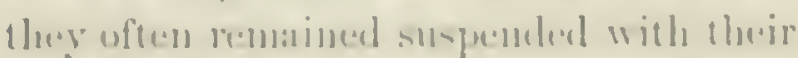
latek dewnward, aftere the mammer ut the Titmice. He fomml their meats quite

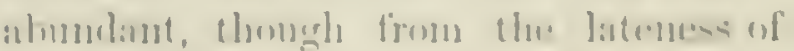
the season fow of the hirls were les-

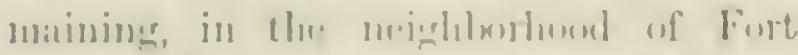

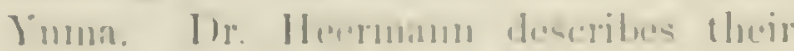

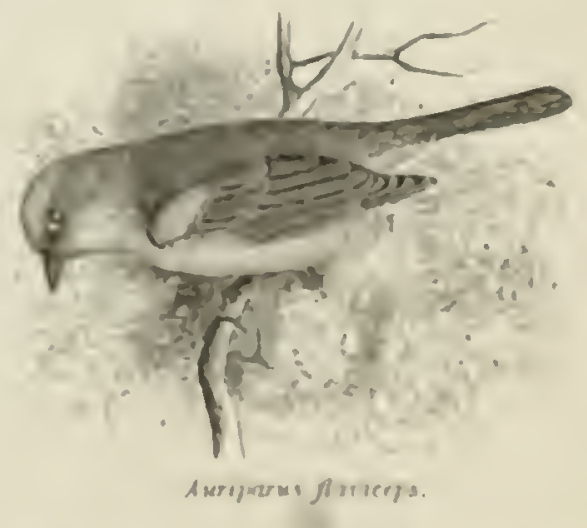

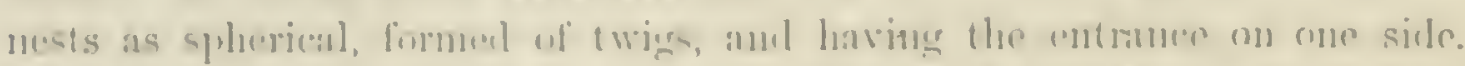

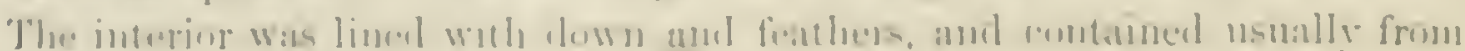


four to six eggs. These he describes as having, when fresh, a ground-color of pale blue, dashed all over with small lilack spots.

Dr. Kennerly, in his Report on the Birds of the Mexican Boundary Survey, states that he met with this species in the vicinity of the Rio Grancle. They were very wild, flew rapilly, and to quite a distance before they alighted. They seemed to frequent the low mezquite-bushes on the hillsiles.

Mr. Xantus found this species, when hie first arrived at San Lncas, on the th of April, with young birds already fully fledged, although others were still breeding and continued to breed until the middle of .July. Two fifths of all the eggs he collected that season, he writes, were of this species. This may, however, have been in part owing to the conspicuous prominence of their nests, as well as to their abundance. Xantus found the nest in rarious positions. In one instance it was suspended from a leafless branch not three feet from the ground, with its entrance nearly to the ground. In another instance it was on an acacia twenty feet from the ground. lor the most part they are hung from low acacia-trees, on the extreme outer branches. In all cases the entrance to the nest was from the lower end, or towards the ground.

Dr. J. G. Cooper, in his History of the Birds of California, speaks of finding a large number of this beautiful little bird during the whole winter frequenting the thickets of algarobia and other shrubs, and with habits intermediate between those of Titmice and Warblers, corresponding with their intermediate form. Their song resembles that of the Chickadee, and they also uttered a loud cry, as they sat on high twigs, with a triple lisping note resembling tzee-tee-tec. Dr. Cooper found a pair building on the 10 th of March. They first formed a wall, nearly spherical in outline, of the thomy twigs of the algarobia, in which tree the nest was usually built. They then lined it with softer twigs, leares, the clown of plants, and feathers. They corered the outside with thorns, until it became a mass as large as a man's head, or nine inches by five and a half on the ontside. The cavity is four and a half inches by two, with an opening on one side just large enough for the bird to enter. On the 27 th of March, Dr. Cooper found the first nest containing egg.s. These were in all instances four in number, pale blue, with numerous small brown spots, chiefly near the larger end, though some had very few spots and were paler. Their size he gives as .60 by .44 of an inch. In one nest, which he clnsely observed, the eggs were hatehed after about ten days' incubation, and in two weeks more the young were ready to leave their nest.

\section{Sebfamli S I T T I N 再。}

The characters of the Sittincr are expressed with sufficient detail on page 86. The section is represented in America by a single genus, confined mainly to the northern portion. 
lint- SITTA, 1.1.x.ti.

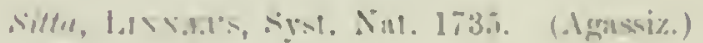

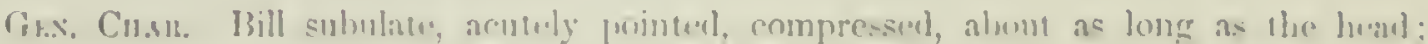

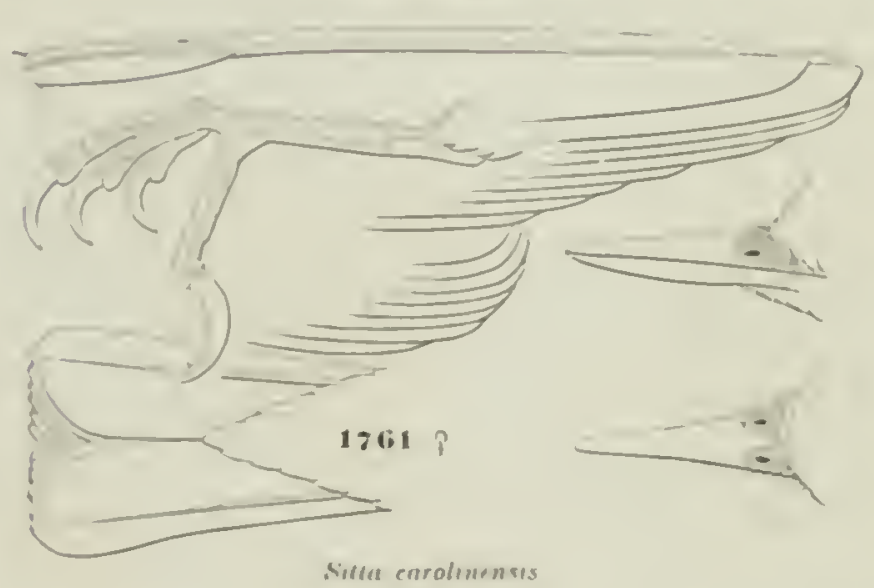

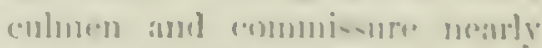

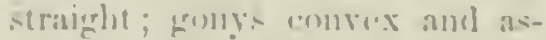
remliner: motril- covereal ly as

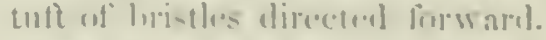

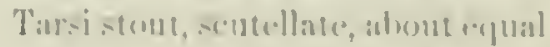
to the midalle tore museh shurtere

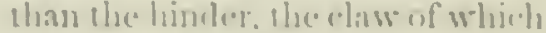
is half the total lemerth, Outer laters] toe mumh lunger than inmur, amel nearly a.jual lo the mildle. 'Tail sery short. irond, amel menty (.)

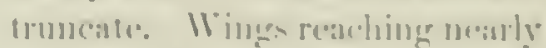
(1) the reml of the tail, Jolne :mel

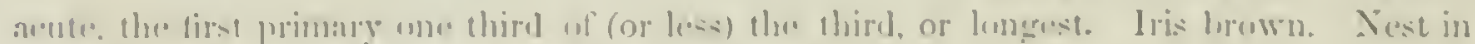

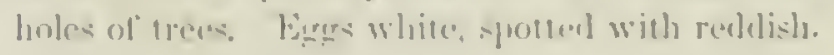

The North Ameringus species maty be amangerd as follows:-

1. ('mom lilark.

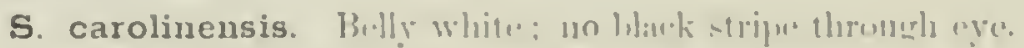

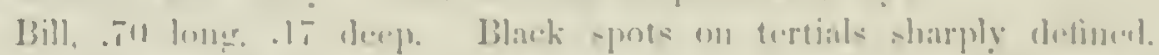

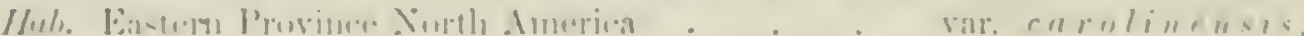

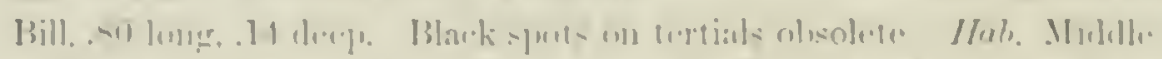

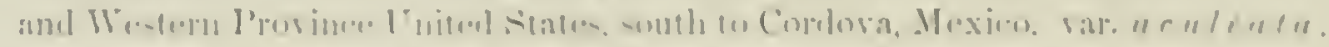

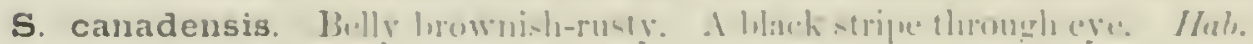

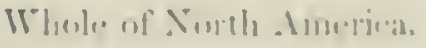

I3. ('rowll nes lilirek.

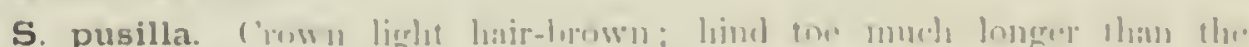

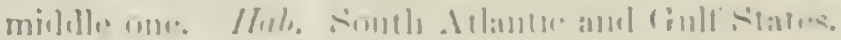

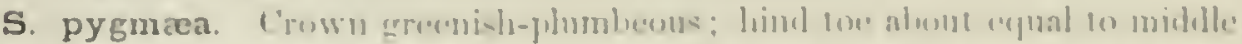

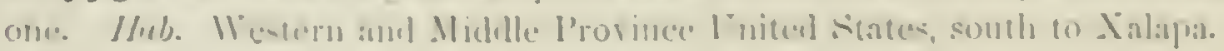

Sitta carolinensis, vir. carolinensis, L.rm. WHITE-BELLIED NUTHATCH.

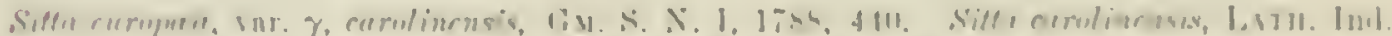

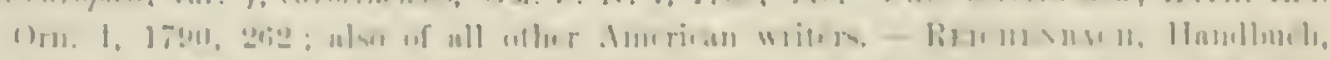

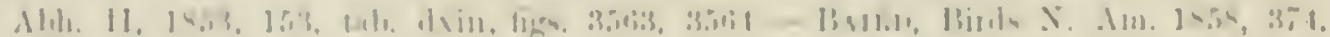

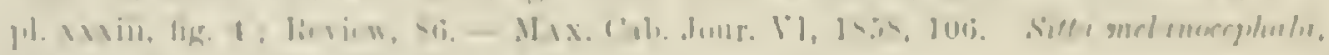

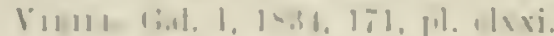

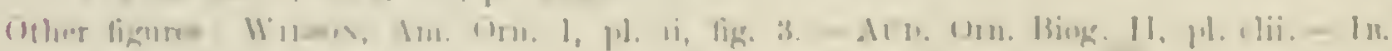

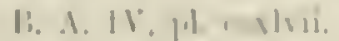

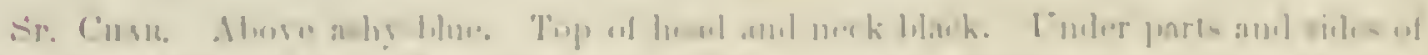

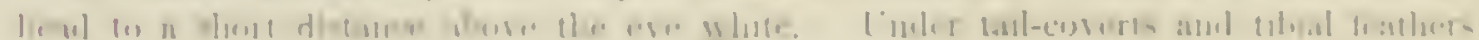


brown; concealer primaries white. Bill stout. Female with black of head glossed with ashy. Length about 6 inches; wing about 3.7.5.

H.ı. Lnited States and British Provinces; west to the Valley of the Misouri.

Habits. The common White-bellied Nuthatch has an extencled listribution throughout nearly the whole of Eastern Forth America, from the Atlintic to the Rocky Mountains. West of the great central plains it is replaced by the var. aculectu. It has not been met with, so far as I am aware, farther north than Nora sicotia. It is a resident of Eastern Maine, and is quite common in the sonthern and western portions of the same State. In Massichusetts it is rather common than abundant, and more plentiful in the western thin in the eastern portions of that State.

The habits of this and the other species of Nuthatches partake somewhat of those of the smaller Wroudpeckers and of the Titmice. Without the noisy and restless activity of the latter, they seek their foor

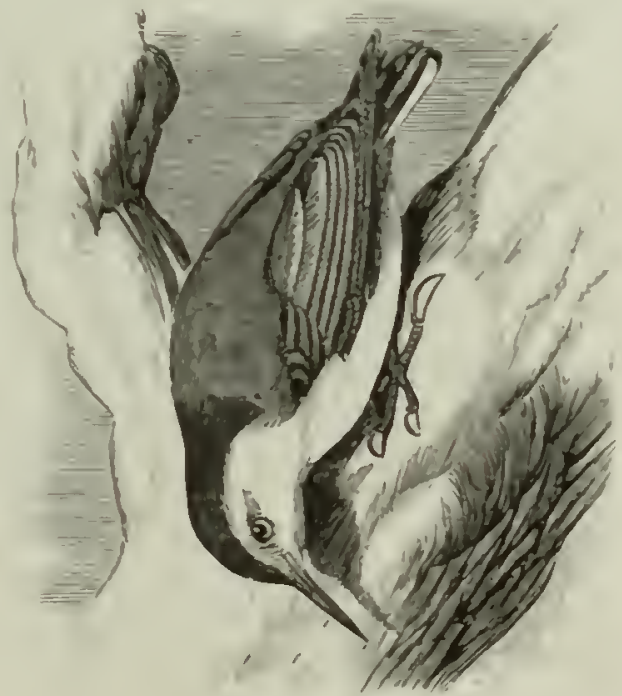

Sitta aculterta. in a similar manner, and not unfrequently do so in their company, moving up or down the trunks and orer or under the branches of trees, searching every crack and crevice of the bark for insects, larre, or eggs. Like the Woorlpeckers, they dig industriously into decayed branches for the hidlen grub, and like both Woodpeckers and Chickadees they industriously excavate for themselves a place for their nests in the decayed trunks of forest trees. Their nest, however, is usually at a greater eleration, often some twenty or thirty feet from the ground. The European Nuthatch is said to plaster up the entrance to its nest, to contract its opening and lessen the dangers of unfriendly intrusion. This habit has nerer been observed in any of the American species.

All our ornithological writers have noticed the assichities of the male bird to his sitting mate, and the attention with which he supplies lier with food. He keeps ever in the ricinity of the nest, calls her from time to time to come to the month of the hole to take her food, or else to receive his endearments and caresses, and at the approach of danger fearlessly intervenes to warn her of it. When feeding together, the male bird keeps up his peculiar nasal cry of $h \breve{o n k}-h \breve{u} h k$, repeating it from time to time, as he mores around the trunk or orer the branches.

Their farorite food is insects, in every condition. With this, when abundant, they seem content, and rarely wander from their accustomed woods in summer. In winter, when snow or ice covers the branches or closes against them the trunks of trees, they seek the dwellings and out-houses for their 


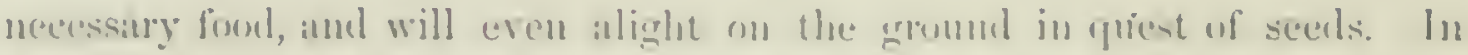

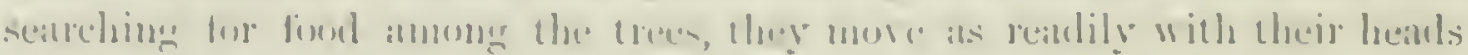

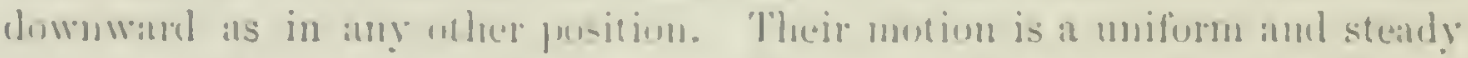

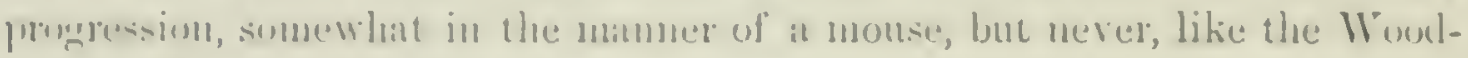

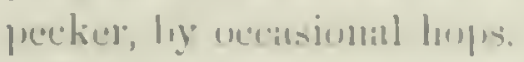

The linropean sprecies colleet and store away the fruit of the hazel and uther nut-bearing trees. Onl hirl hits been supposed to do the sinne thing.

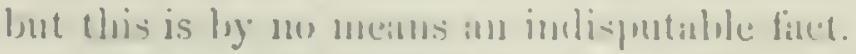

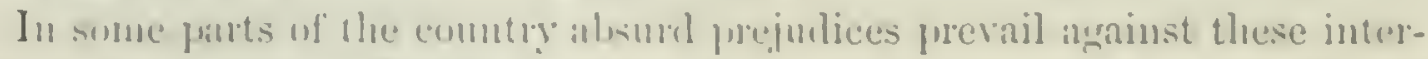

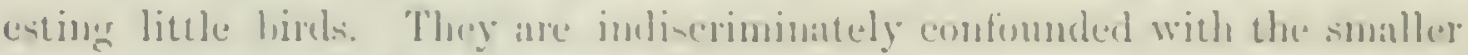

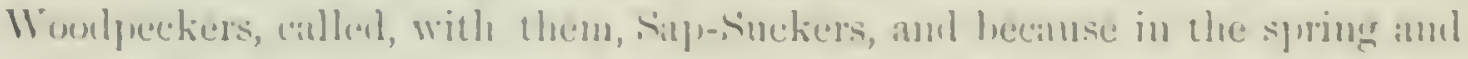

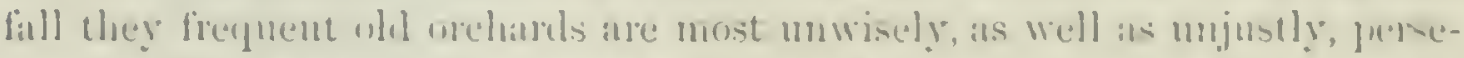

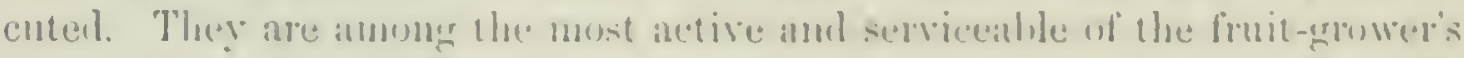

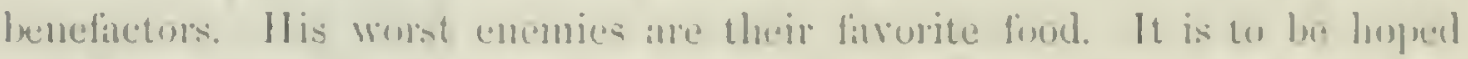

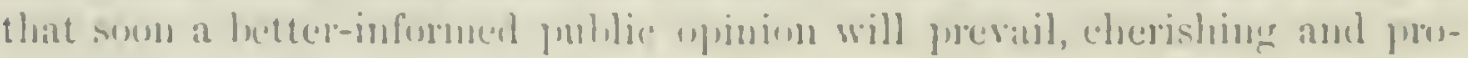
tecting, rather than seeking Lo destroy, this usceful, aflectionate, and attrative sjecies.

Interesting acenuts are given in Finglish works of the confiding tamentess

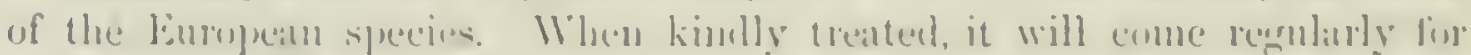

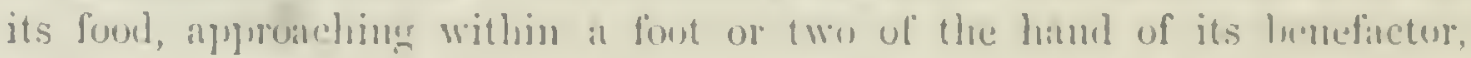
and catching with its hill the loul thrown to it hefore it call reatch the grommil.

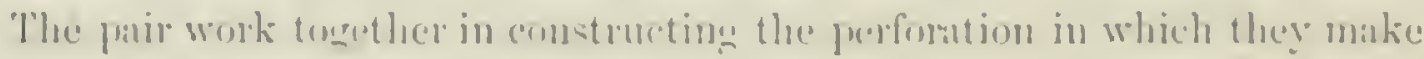

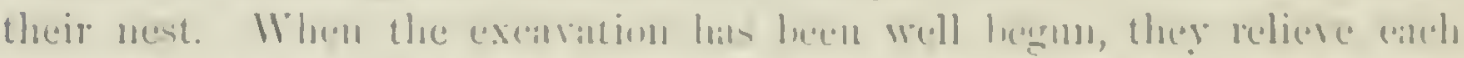

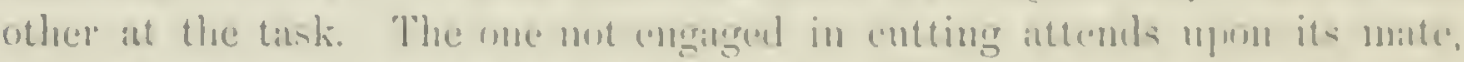

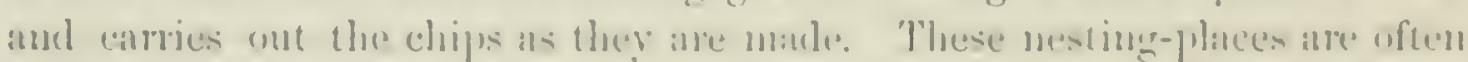

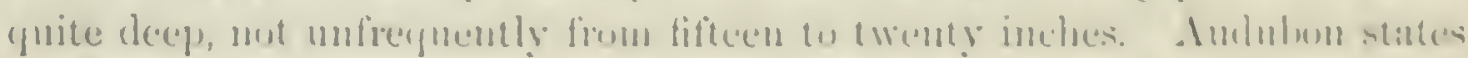

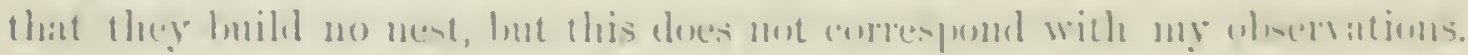

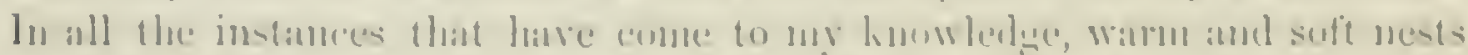

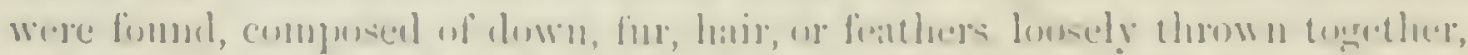

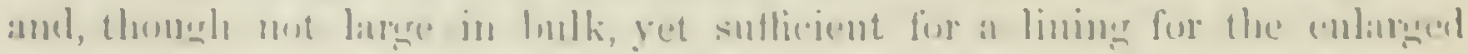

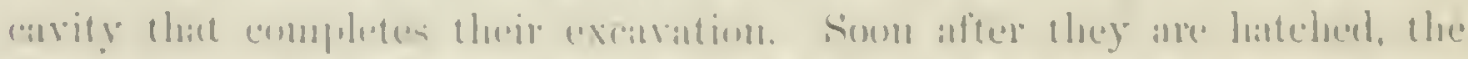

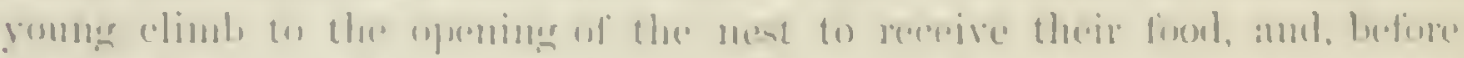
they are realy to tly, routure out 1]

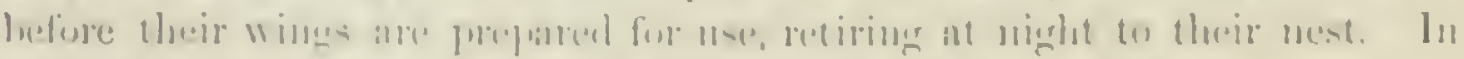

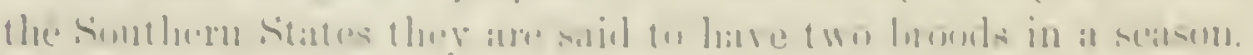

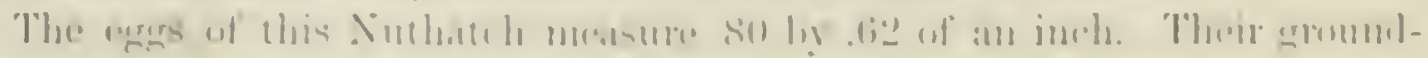

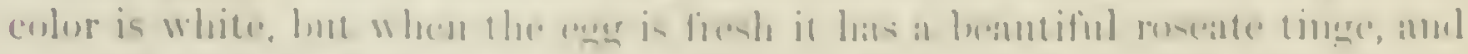

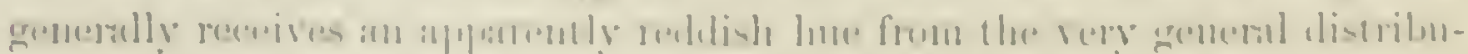

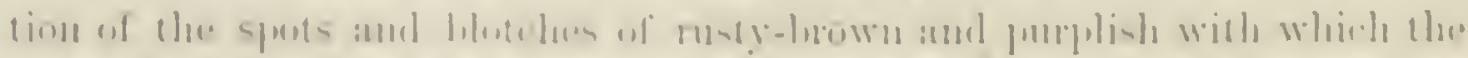
roges

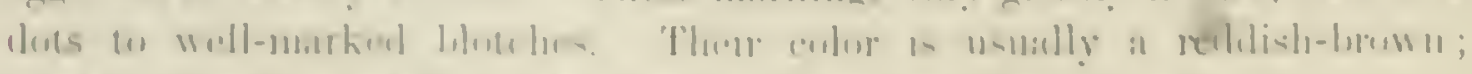

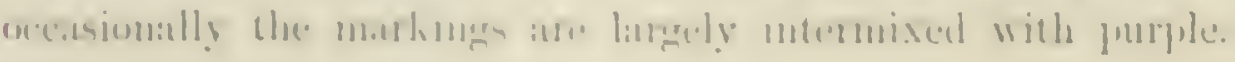


Sitta carolinensis, rar. aculeata, Cıs. SLENDER-BILLED NUTHATCH

Sittre aculentu, CAssix, Pr. A. T. Sc. VIII, Oct. 1556, 254. - B.ırn, Birds N. Am. 1S5S, 375 , pl. xxxiii, lig. 3 ; Review, \$6. - Coopen, Orn. Cal. I, 1570, 54. ? Siltu carolinensis, Sclater, P. Z. S. 1S56, 293 (Cordora); 1S5s, 300 (Oaxaca); 1859, 363 (Xalapa), 373 (Oaxaca)

Sp. Cinar. Tery similar to crrolinensis; lout upper secondaries with only obscure blackish blotches, insteal of sharply defned longitudinal spots of clear black. Bill slenderer and more attenuated.

H.ıB. Western and Middle Provinces of the United States, sonth to Cordora, Mex. Orizaba (Alpiue recions), Sumer.

The characters given ahove express the essential differences betreen this and the Eastern race of S. corolinensis. In the present form, the depth of the bill opposite its base is .14 , the width .17 , and .80 or more in length from the forehead; while these same measurements in rar. carolinensis are $.17, .22$, and .70 . The obsolete character of the black spots on the secondaries is a persistent feature in the var. aculcata.

HABITs. This bird chiefly differs from its eastern congener in its more slender bill. There appears to be no difference in regard to their habits, at least none have been noticed, and it is probable there is none other than trivial changes caused by its opportunities of procuring food, and the kinds upon which it subsists. It is supposed to he distributed throughout Western North America, from the British Possessions to Mexico, though Dr. Cooper thinks that it is not a common bird sonth of San Francisco, and only to be seen there in the coller months. It has been met with at San Diego in February. He did not observe any in the Coast Mountains, near Santa Cruz, but northward they are numerous in the summer, frequenting chiefly the grores of the deciduons oaks, creeping constantly about their trunks and branches in search of insects, which they also occasionally seek on the roofs and walls of houses. Their habits are similar to those of S. cancedensis, but their movements are said to be slower, and their note is a single harsh call, uttered occasionally, and responded to by their comrades. Dr. Cooper found them quite common in Washington Territory and at Puget sound. Dr. Suckley also mentions their great abundance.

Dr. Kennerly met with this species a hundred miles west of Albuquerque, New Mexico, and quite abundant among the pines of the Sierra Madre. He speaks of its note as being peculiar.

Mr. J. K. Lord states that this species remained about Colville during the winter, when the thermometer was $30^{\circ}$ below zero. He also mentions that he found them nesting, in June, in the branches of the tallest pine-trees, so high up as to render the obtaining their eggs almost an impossibility.

Mr. Ridgway found the Slender-billed Nuthatch abundant, throughont the 


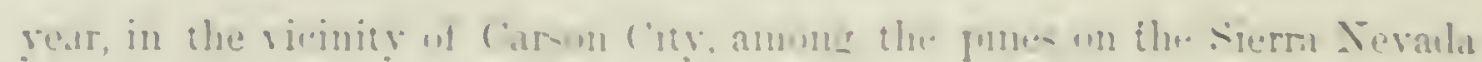

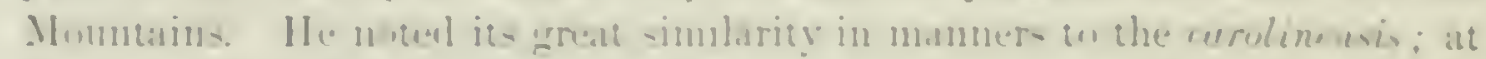

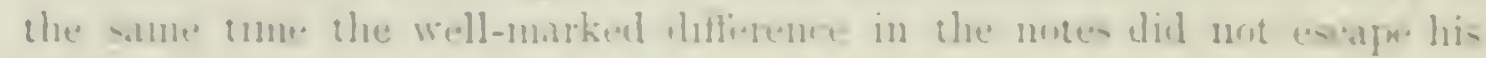
attention There nutes are innd weaker, and are uttered in a finer come, annl

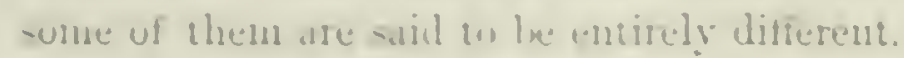

\section{Sitta canadensis, I.is:}

\section{RED-BELLIED NUTHATCH.}

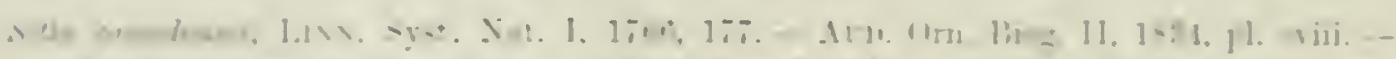

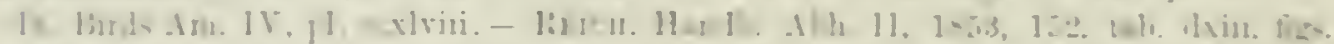

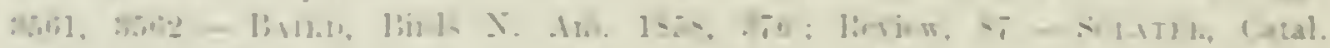

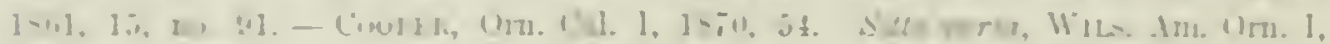
1, - 11, , 1. 11.

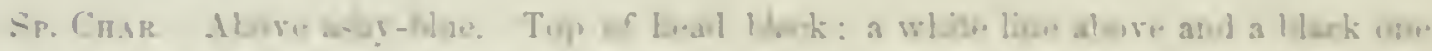

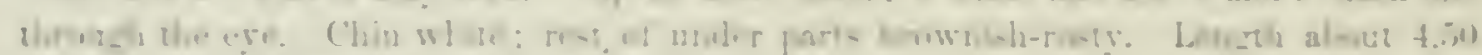

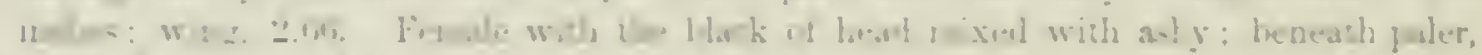

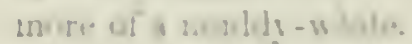

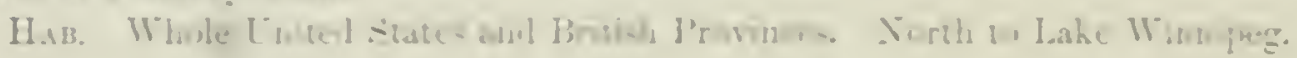

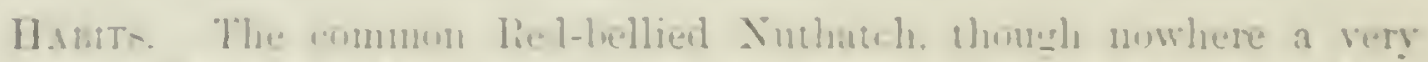

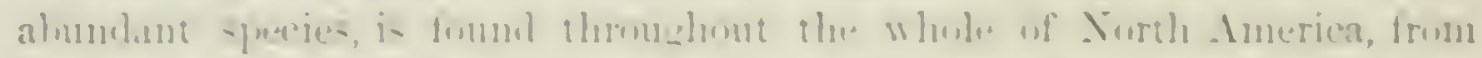

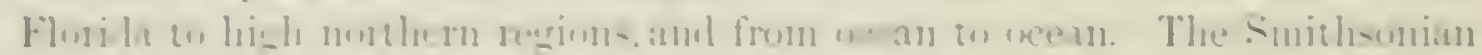

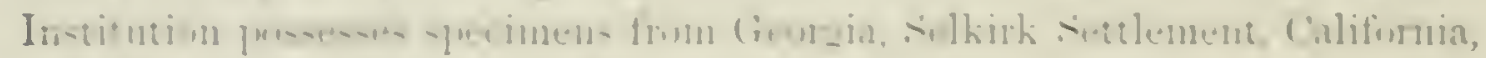

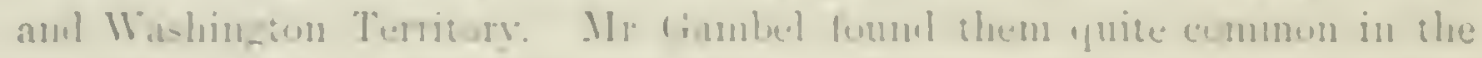

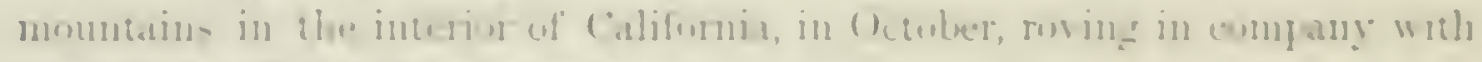

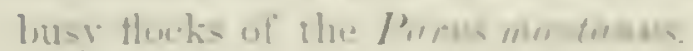

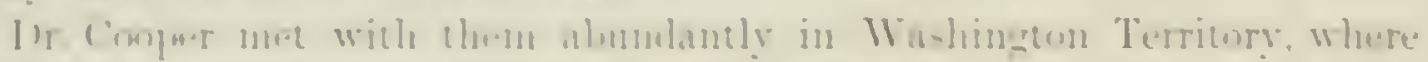

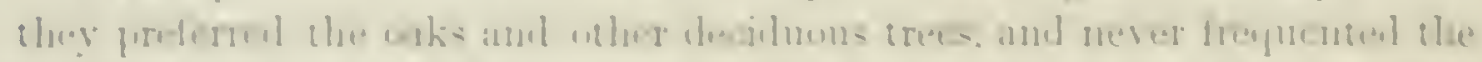

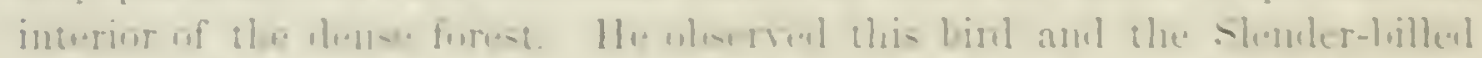

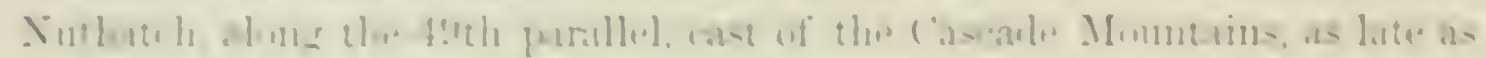

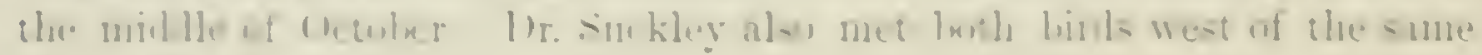
munutuin-

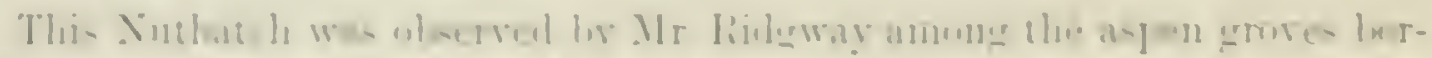

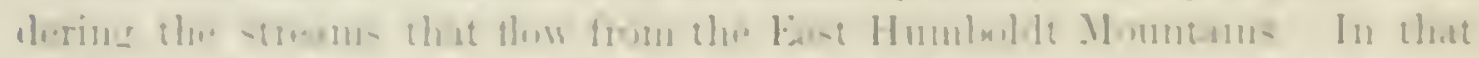

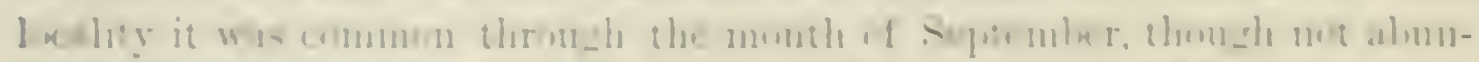

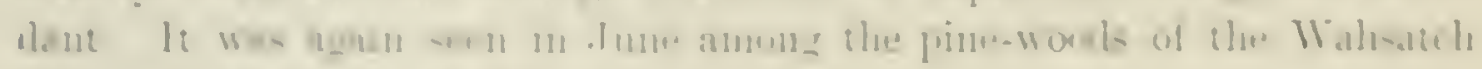

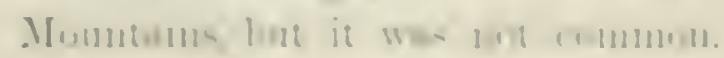

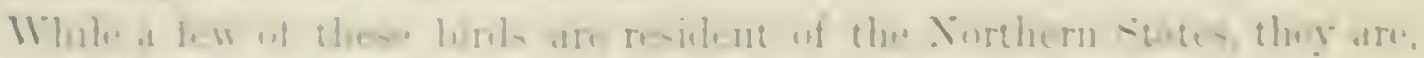

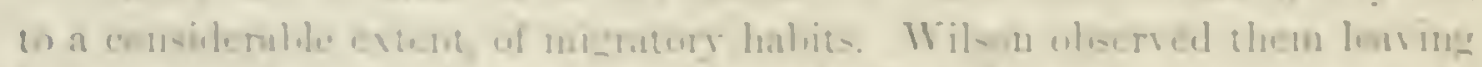

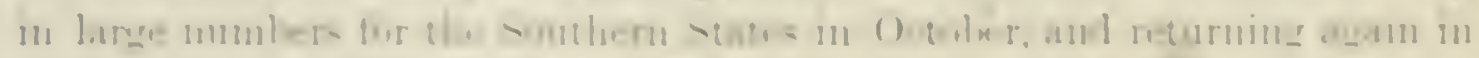

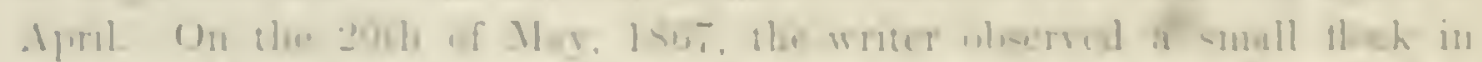

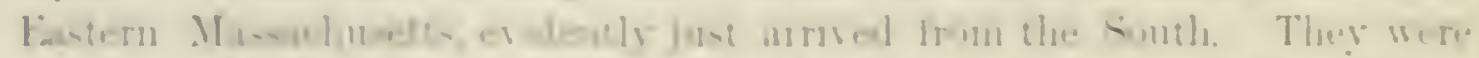

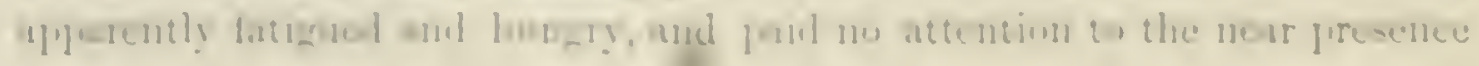


of workmen engaged in setting bean-poles. They visited and carefully examined each pole, and bored holes into several in seirch of hidden larvap, often within a few feet of persons at work.

While on the Pacific coast they are sail to prefer the forests of deciduous trees, and to be rarely found in the dark evergreen forests, in the Eistern States they seem to be particularly fond of the seeds of pine-trees, and in the winter are seldom found in the woods of decidnous trees.

They feed in pairs and clinb about in all directions, usually in company with the white-breasted species, Chickadees, and the smaller Woodpeckers. They are restless and rapid in their motions, and lave a voice at least an octave higher than any other of this fanily. The note is a monotone, and is ummusical. Mr. Nuttall represents their ery as consisting of three syllables,

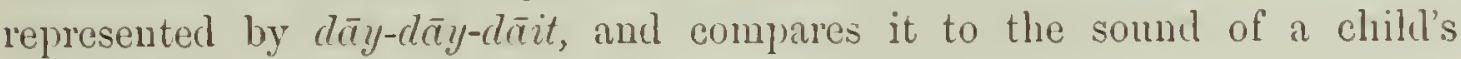
trumpet.

Those wintering at the North occasionally visit farm-yards and orchards, and examine the eares of outbuildings for food.

Andubon found this species more plentiful in the woods of Maine and Nova Scotia than anywhere else. He nerer met any south of Maryland, saw none in Newfomelland, and only met with one in Labrador. At Eastport he found a pair breeding as early as the 19th of April, before the Bluebirds had macle their appearance, and while ice was still remaining on the northern exposures. An excavation had been made in a low dead stump, less than four feet from the ground, both male and female birds working by turns until they had reached the clepth of fourteen inches. The eggs, four in number, were of a white ground-color, tinged with a deep blush when fresh, and sprinkled with reddish dots. They raise but a single brood in a season.

C. S. Paine, of East Betlel, Yt., found a nest of this species abont the middle of May, in a small beech-tree, the excavation liaving been made at the height of twelve feet from the ground. The hole was about as large as that made by the Downy Woodpecker. When first noticed, the bird was looking ont of the hole. Having been started ont, she flew to a limb close by and watched the party some time. When she flew back, she buzzed before the hole in the manner of a Humming-Bird, and then darted in. While Mrr. Paine was looking on, the male came several times to feed his mate, who would meet him at the opening with a clamorous noise, to receive lis bounty. The nest contained five eggs.

In Western Massachusetts, Mr. Allen speaks of this species as chiefly a winter resident, appearing the first week in October, and leaving the last of April.

The eggs of this species measure .62 by 48 of an inch, and are of an oblong-oval shape. Their ground-color is a elear crystal white, marked principally about the larger end with a wreath of purple and roseate markings. 
Sitta pygmæa, l"u.

\section{PIGMY NUTHATCH.}

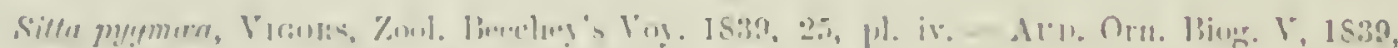

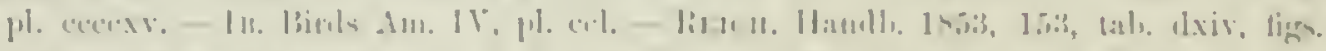

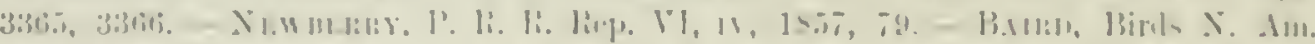

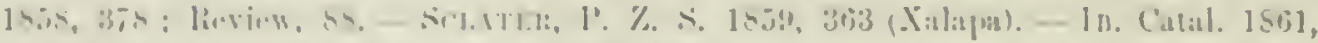

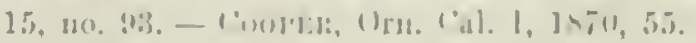

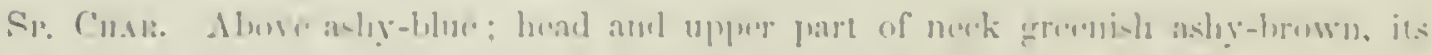

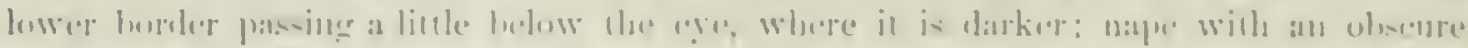

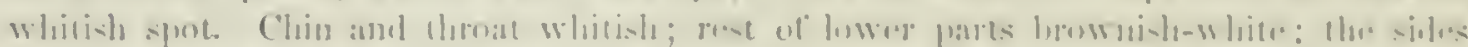

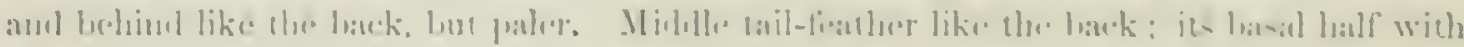

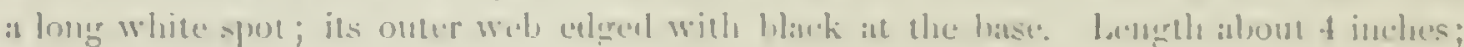
win!r. "2.111.

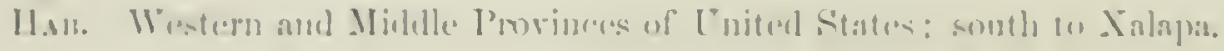

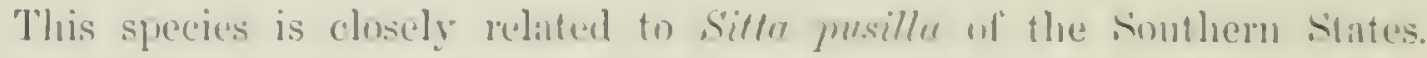

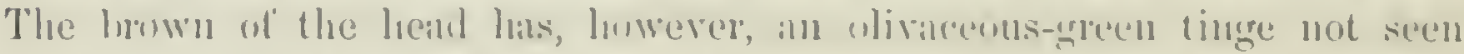

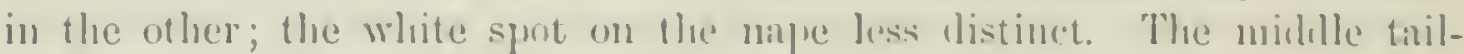

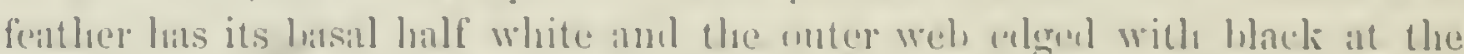
hatse. This black colging is never seen in the other, and the white gatch is

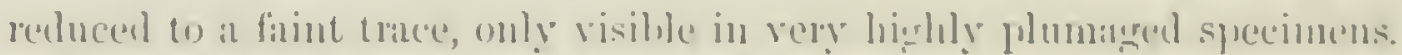

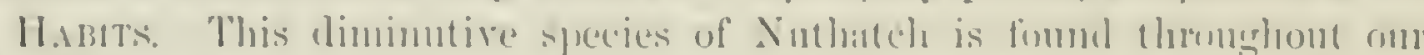

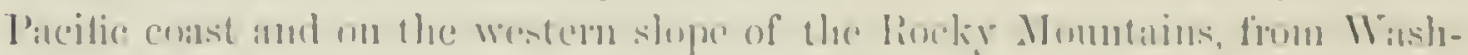

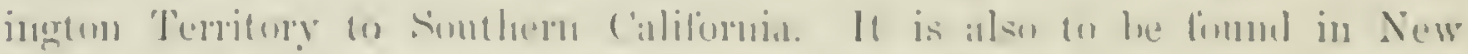

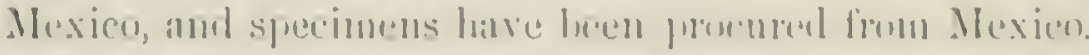

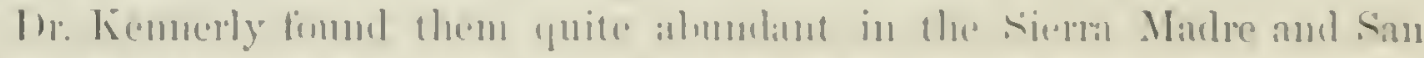

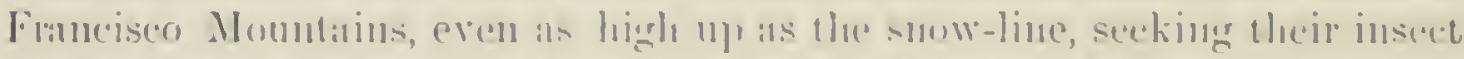

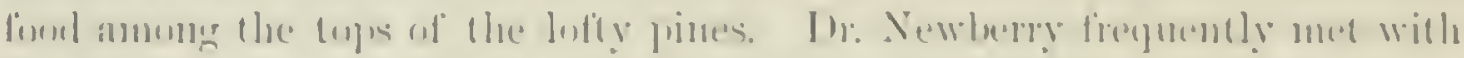

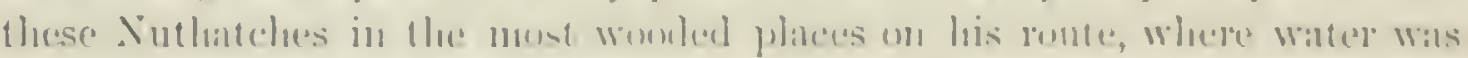

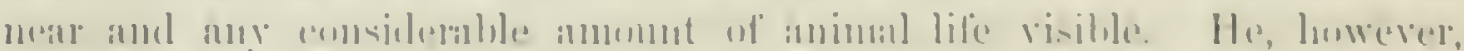

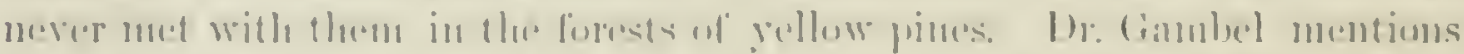

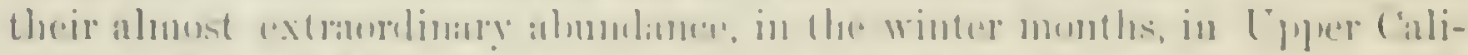

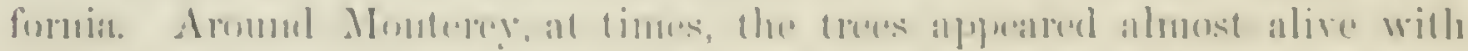

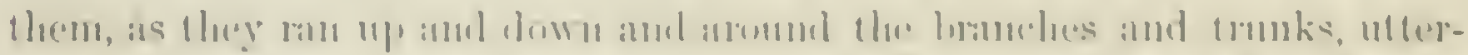

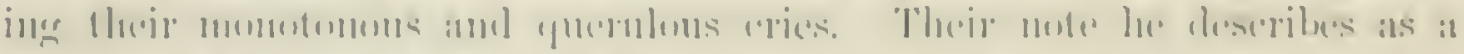

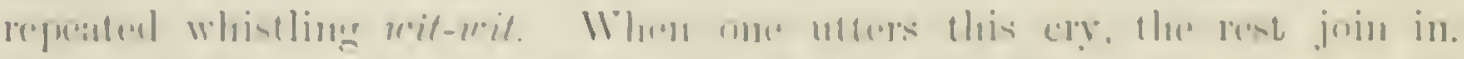

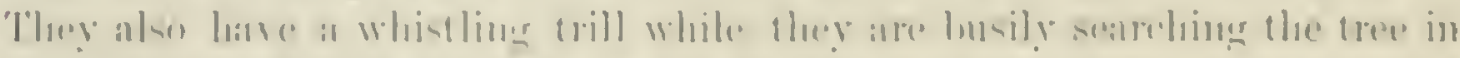

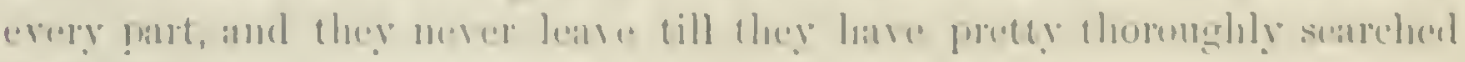

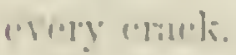

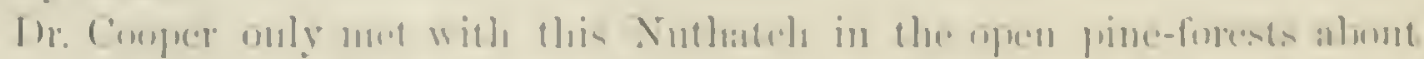

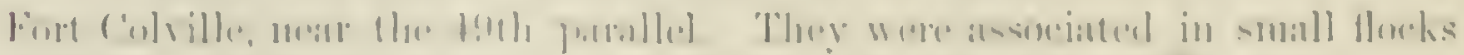

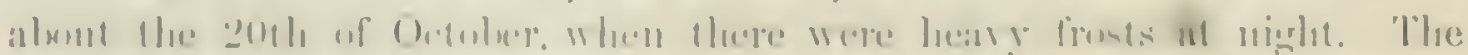

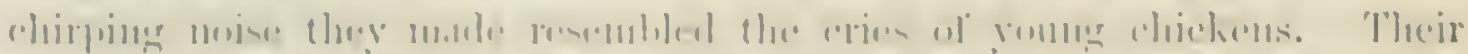

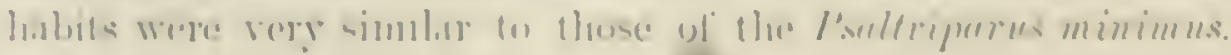


Mr. J. K. Lord found this Nuthateh an abundant bird along the entire length of the houndary line firom the cuast to the Rocky Mountains. It was also common on Vancouver Island. They were seen in large flocks in company with the C'hickalees, extept during the nesting-time, which is in .June. A few were winter resilents at Colville, but the greater number left in November. He describes it as a very active bird, always on the move. After nesting they congregate in lange flocks and move about from tree to tree, twittering a low sweet note as if singing to themselves, now climbing back downwards along the under sides of the topmost brunches of tall pines, searching into every crevice for insects, or, descending to the ground, clinging to the slender flower-stalks for other insects. They nest in June, make a hole in the dead braneh of a pine, and deposit their eggs on the bare chips of the wood. This account does not agree with the experience of California ornithologists, who have found a loose nest within the excavation.

Mr. Ridgway found this Nuthateh abundant among the pines of the Sierra Nerada, in the ricinity of Carson ('ity. They were found generally in pairs. Its note is said to greatly resemble the rociferous peeping of some of the small Sandpipers, being sharp, lond, and distinct, and rigorously and continuously uttered, whether climbing or flying. He found it exceedingly hard to discover this bird among the branches, or even when flying, owing to the swiftness and irregnlarity of its flight. When the female of a pair had been killed, the male bird was extremely loud in his lamentations. Diminutive as this bird is, Mrr. Ridgway states that it is also the noisiest of all the feathered inhabitants of the pines, though it is less active in the pursuit of insects than the larger species.

Nests of this bird obtained near Monterey appear to he as well made as those of any of this genus, lining the carity in which they are placed and conforming to it in size and shape, the materials sufficiently interwoven to permit removal and preservation, and warmly constructed of feathers, wool, regetable down, hair, and the silky efflorescence of seeds.

Their eggs, seven in number, resemble those of the s'cunudensis, but are of smaller size and a little more pointed at one end. Their ground-color is crystalline-white. This is covered more or less thickly with red spots, nost numerous at the larger end. Their measure raries from .65 by .50 to .60 by .47 of an inch. The first eggs of this bird bronght to the notice of naturalists were procured at Fort Crook on the Upper Sacramento of California, and not far from Mount Shasta, by Sergeant John Feilner, L. S. A., forming part of a very extensive collection of birds and eggs transmitted by him to the Smithsonian Institution. Promoted to a lieutenancy for gallant conduct, this gentleman finally attained the rank of captain of cavalry, and was killed by the Sioux during an exploring expedition into Dacotah under General sully. 


\section{Sitta pusilla, I, ith. BROWN-HEADED XUTHATCH.}

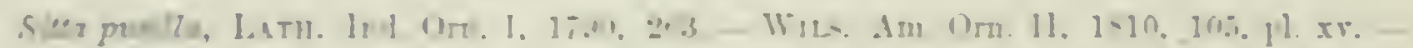

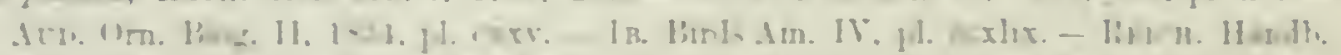

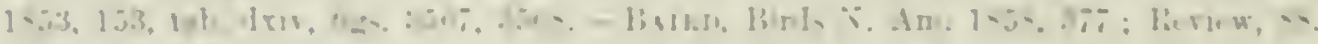
- Malk.1., Caid!. 1-1, 1j.

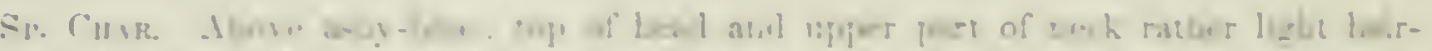

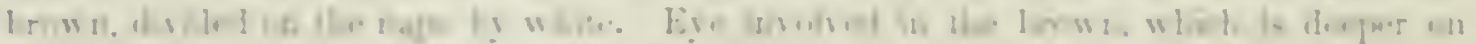

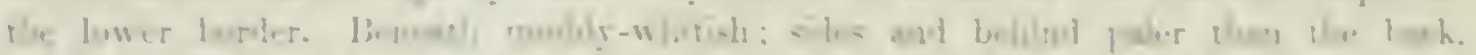

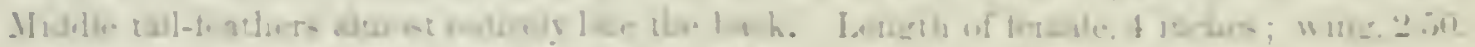

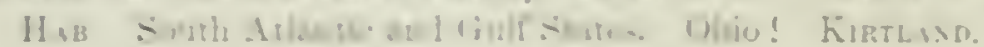

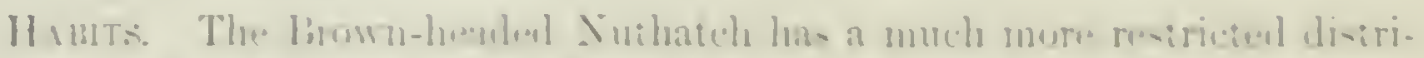

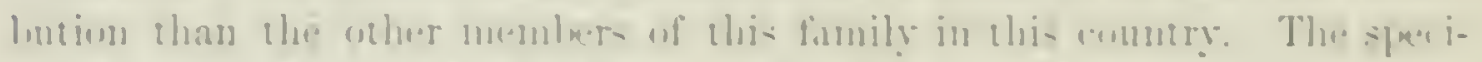

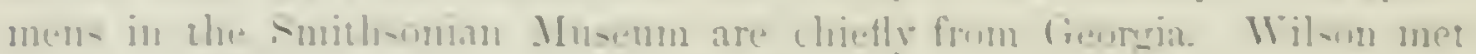

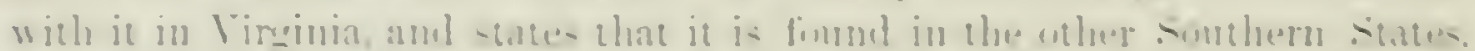

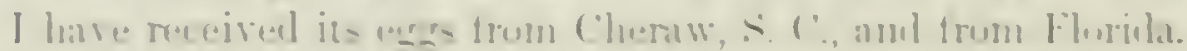

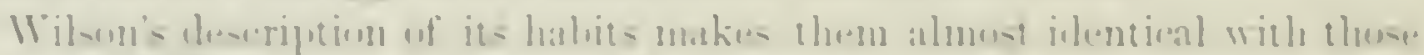

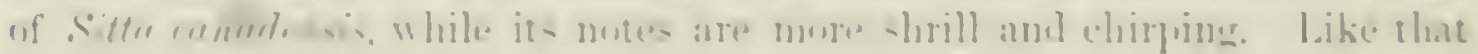

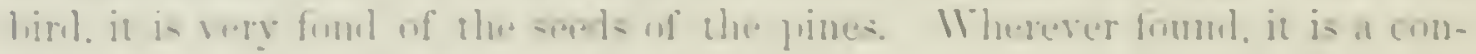

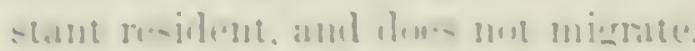

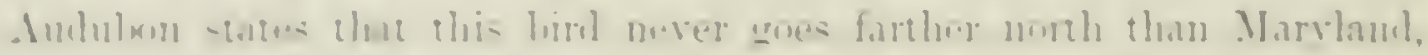

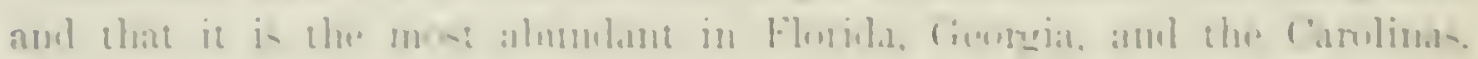

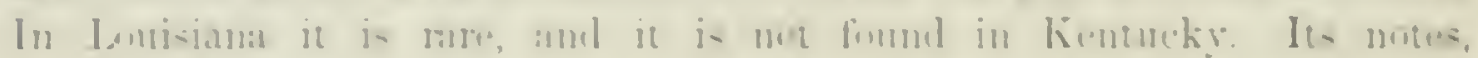

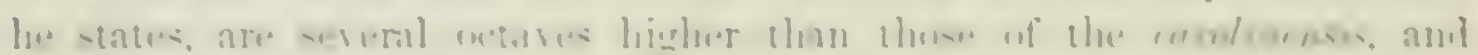

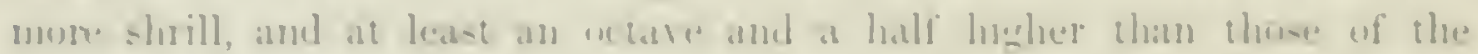
renuelensic

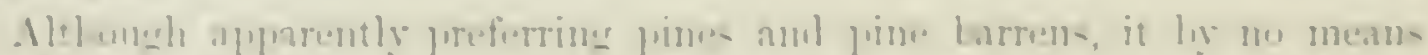

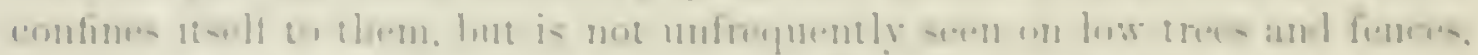

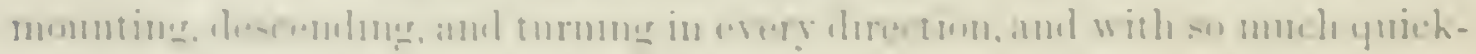

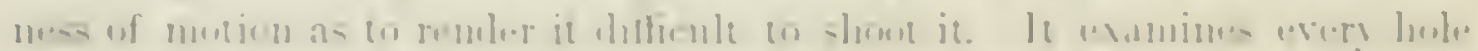

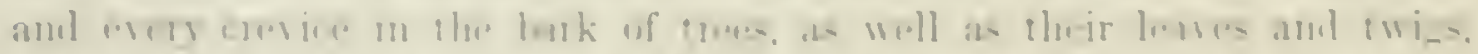

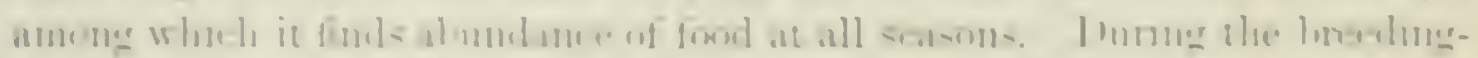

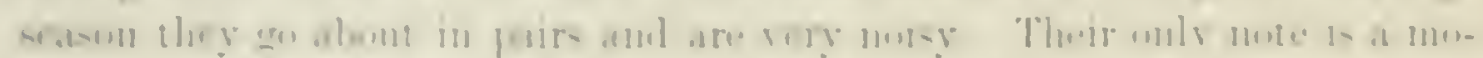

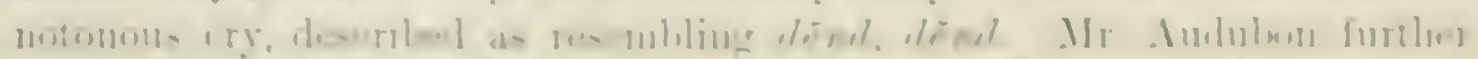

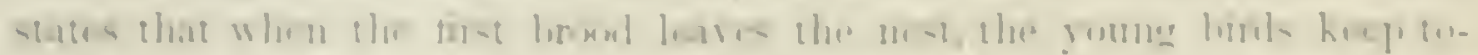

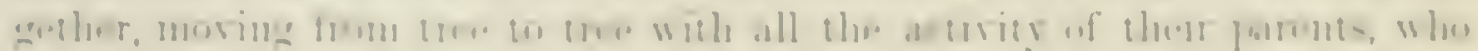

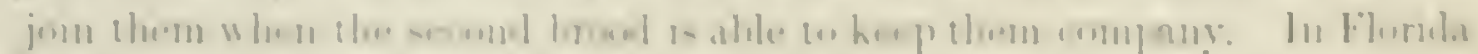

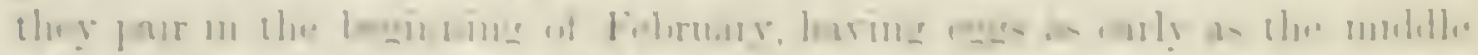

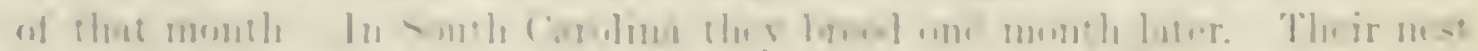

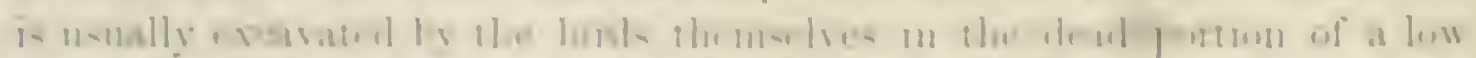

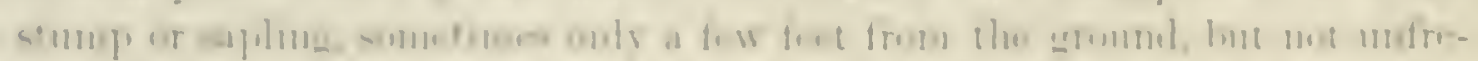

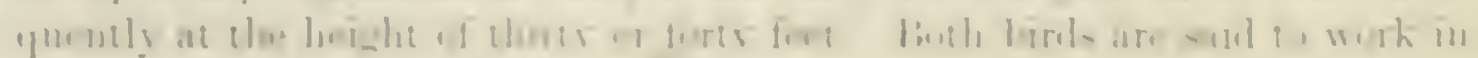


concert with great earnestness for several days, until the hole, which is round, and not larger at the entrance than the body of the bird, is dug ten or twelve inches leep, widening at the bottom. 'The eggs, according to Mr. Audubon, are laid on the bare wood. This, howerer, is probably not their constant habit. The eggs, from four to six in number, and not much larger than those of the Humming-Bird, have a white gromel, thickly sprinkled with fine reddish-brown dots. They are sail to laise two, and even three, broods in a season. According to the observations of the late Dr. Gerliarit of Northern Georgia, the Brown-headed Nuthatch breeds in that part of the comutry about the 19th of April.

The eggs of this Nuthatch are of a rounded oval shape, measuring .60 by .50 of an inch. Their white ground-color is so completely overlaid by a profusion of fine dottings of a dark purplish-brown as to be entirely concealed, and the egrg appears almost as if in uniform chocolate or brown color. 


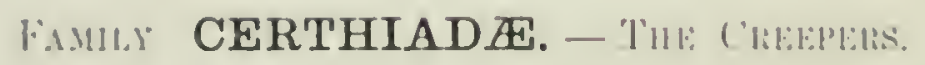

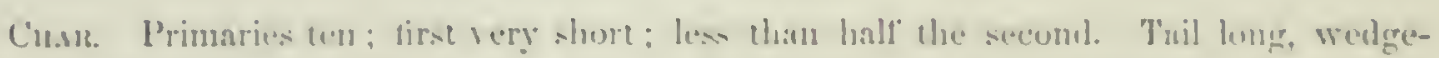

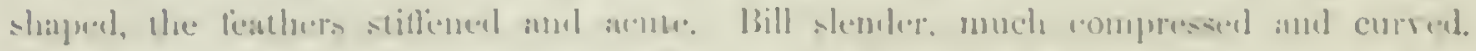

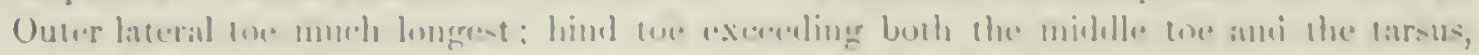

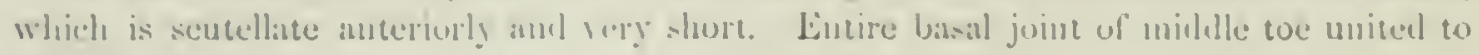
llac lateral.

\section{(iATP CERTHIA, LAS.}

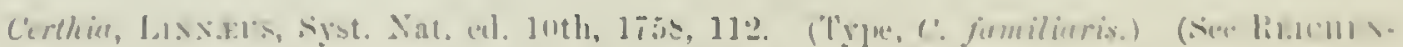

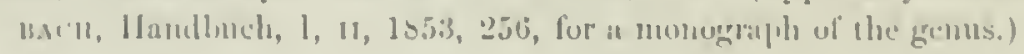

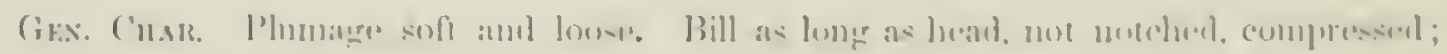

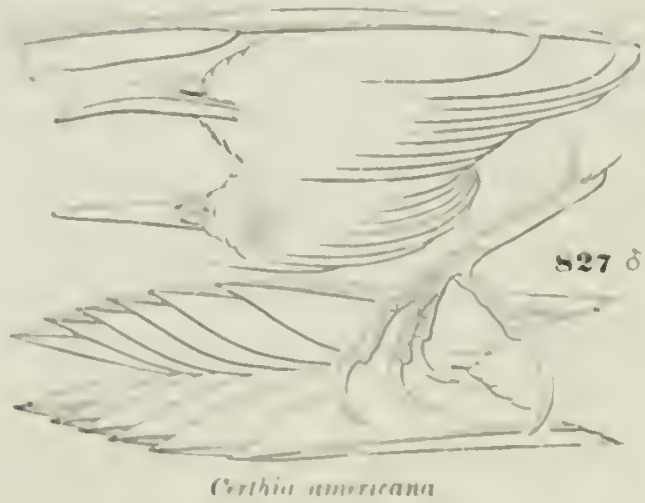

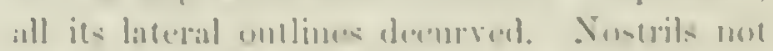

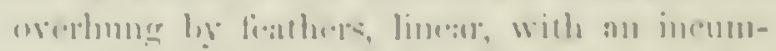

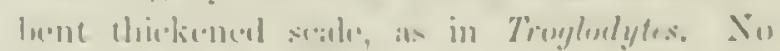

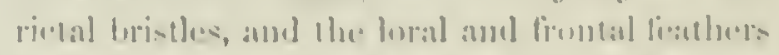
-meoth, withom bristy shaths. Tar:als sentele Inte antertionly, shorter than midlle tere. which

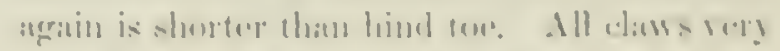

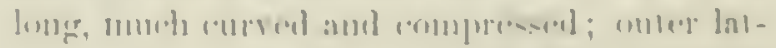

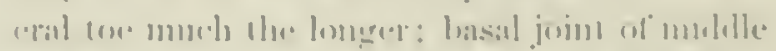

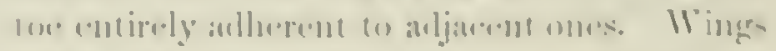
ratlour prointerl, alwout expand to the tail, the "istlerese of whiehs are mum juinted, with

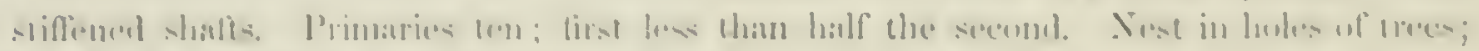

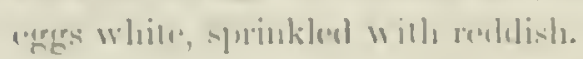

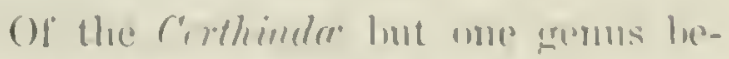
Jomers to Amerien, - Virthin. with its ome

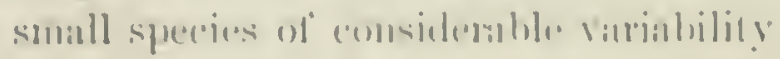

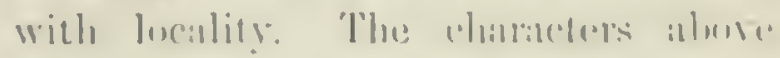

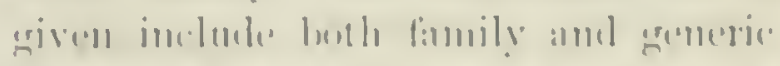

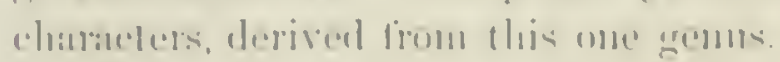

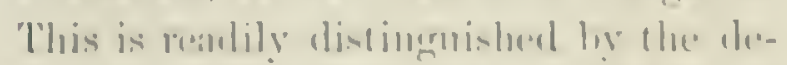

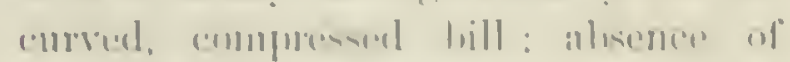

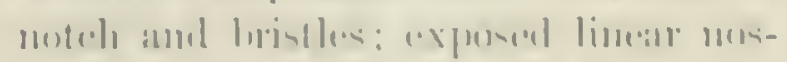

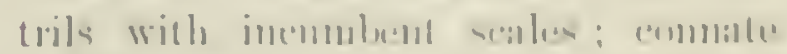

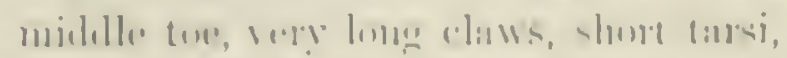

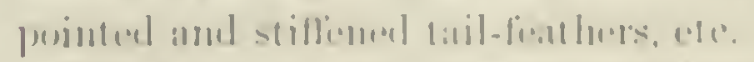

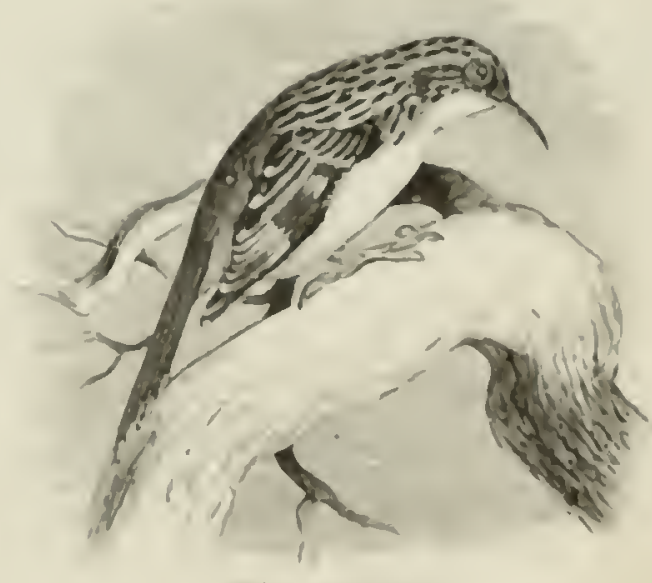

Cathist anterserina

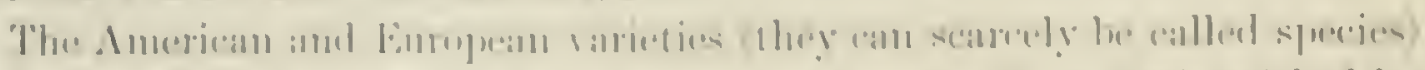

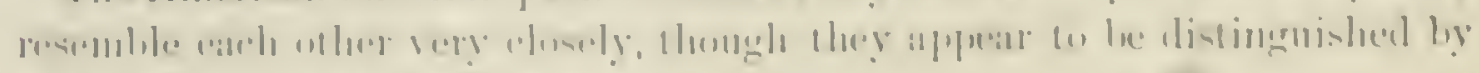

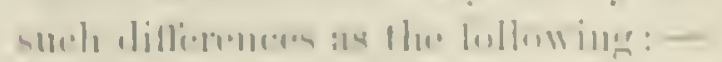

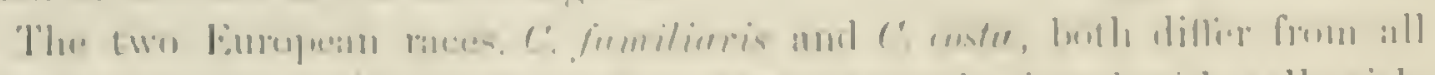

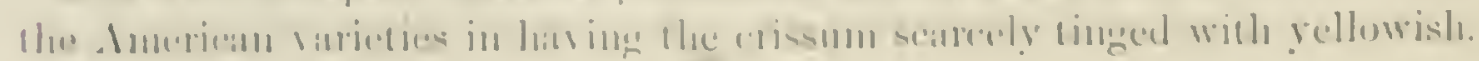


C. fumiliuris is more aslyy beneath than any others, and $C^{\prime}$. coster is purest white beneath of all. Neirest $C$ : fumiliuriz, in the Anerican series, as regarls tints of the upper parts, are the Picific enast specimens of $C$. "mminanu, while the latter are most like the Athutic region specimens of the same. C. mericana is to he compared only with the Forth American forms, though it is the only one ilpproaching fomilinris in the ashy lower parts.

C. familiaris is at once separated from the rest by having the tail shorter than the wing.

C. coster is almost precisely like Fastern specimens of $C$. nmoricuna in colors, but is absolutely pure white beluw, and withont the distinctly yellowish crissum of the American bird. 'The bill and claws, howerer, are considemably longer than in Eastern umericana, thomgh their size is almost equalled by those of Westem specimens; the color's are, howerer, more decidedy different.

There is never any deriation from the generic pattern of coloration; but the rariation, among indiriluals of cuch jorm, in length of the bill and claws, as well as the tail, is remarkable.

\section{Certhia familiaris, var. americana, Bnsap.}

\section{BROWN CREEPER.}

Certhiu jusca, Bastos; Fragments of the Latural History of Pemnsylrania, 1799, 11. Cer-

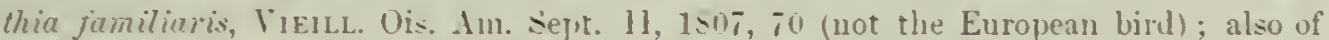

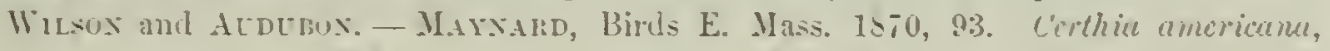
Bnx.p. Comp. List. 183:. - Reicir. Handb. I, 1553, 265, pl. dexr, figs, 4102, 4103. - Bann, Birls X. Am. 1858, 372 : lieview, s9. - Max. Cab. Jour. 1\$5\$, 105. Cooper S Stchlet, P. R. R. Rep. N11, II, 1959, 192. - H.1ylis, Pr. Bost. Soc. I. H.

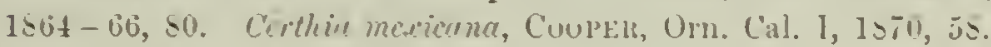

Sr. Cuar. Bill about the length of the head. thore dark hrown. with a slightly rufous shade, each feather streaked rentrally, but not abruptly, with whitish: rump rustr. lieneath almost silky-white: the under tail-covers with a faint rusty tinge. I white streak orer the ere: the ear-eoverts streaked with whitish. Tail-leathers brown centrally, the edges paler rellowish-brown. Wings with a transwerse har of pale reddishwhite across botk wehs. Length, 5.51): wing. 2.60): tail. 2.90. (No. 827.)

Fonng. (5045, steilatoom, W. T.: Dr. J. S. Comper.) Resembling the adult, but streaks above indistinct. and the feathers there tippred indistinctly with blackish: the rufous restricted to the upper tail-corerts. Breast and juguhm with rery minute blackish warings or indistinct bars.

H.B. Whole of Lnited States, to Red River Setulement.

Specinens from the far west are purer white beneath, much as in coster, but those from the northwest coast have the white tinged with light rustr. Though purer white below, these specimens are much bromer above than Eastern ones, - sometimes more so than in fumiliaris, but then there is the yellowish crissum never seen in this "species," and the proportions are quite different. Thus it will be seen the C. americana may always be dis- 


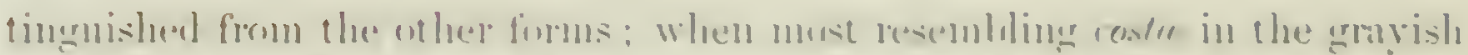

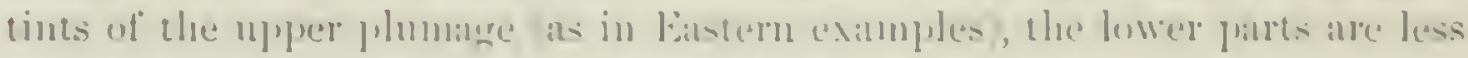
jurely white, and the bill amd elaws sualler: when like it in the propurtions

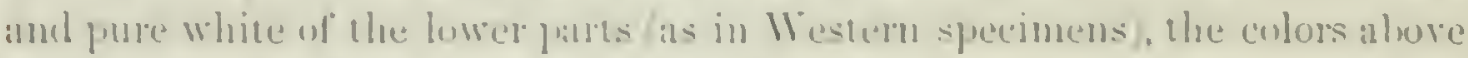
are allugether more hrown. The rellowish eristum of amerionnes will

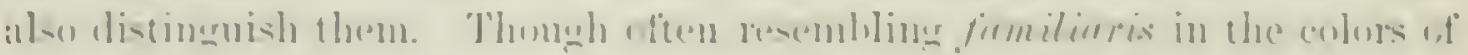

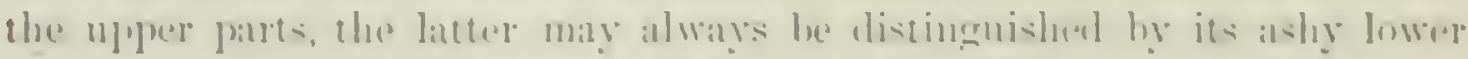
parts withme pellowish crisilm, the shurter tail, with its les- acute feathers, and struter hill.

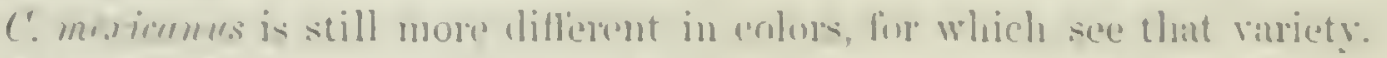

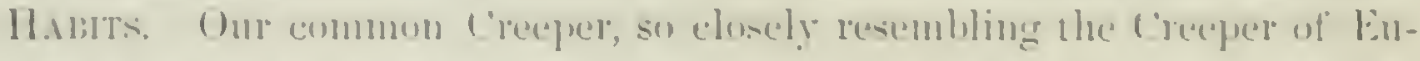

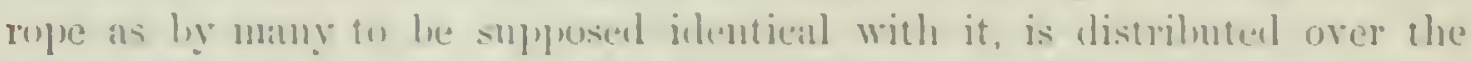

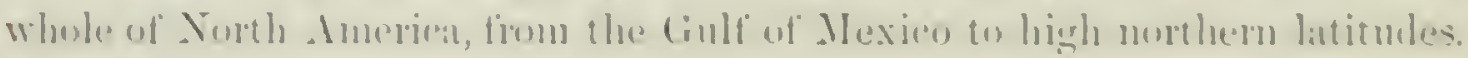

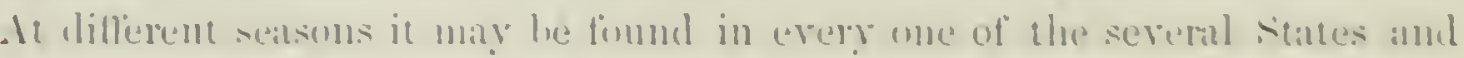

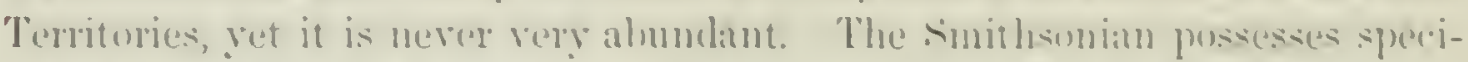

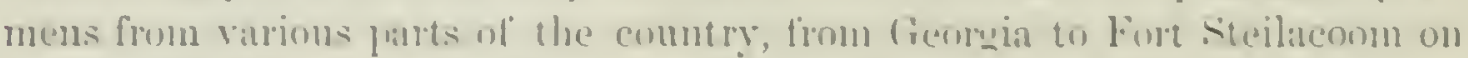

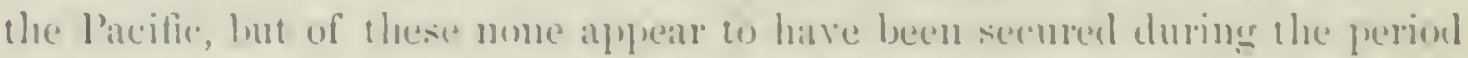

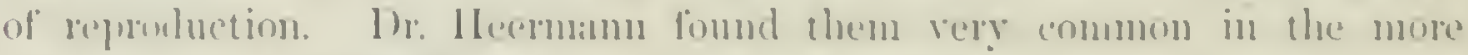

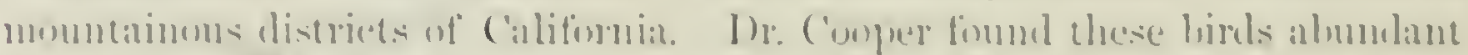

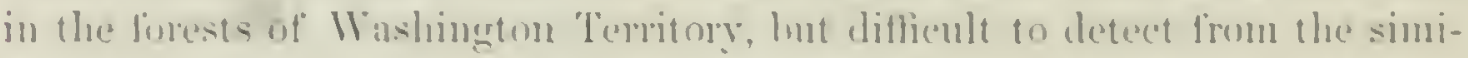
larity of theif colns to that of the hatk over which they erept. They were

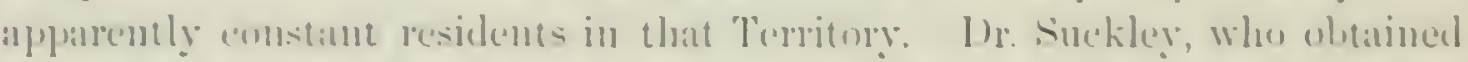

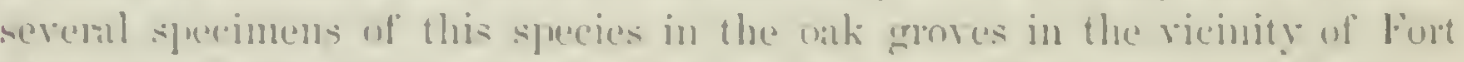

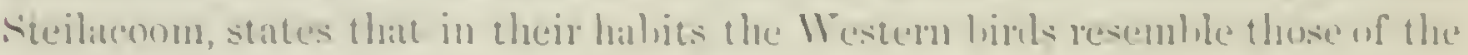
Atlintic sitite:

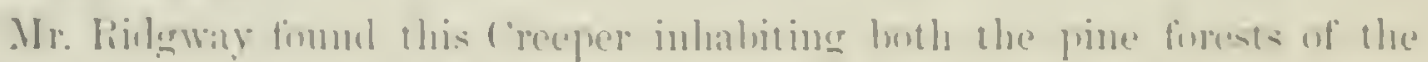

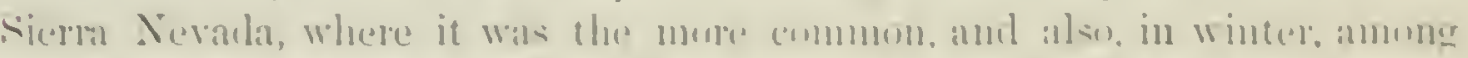

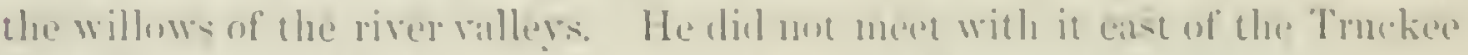
livere, mor until he haul reached the Walsateh Momutains.

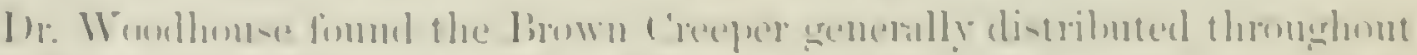

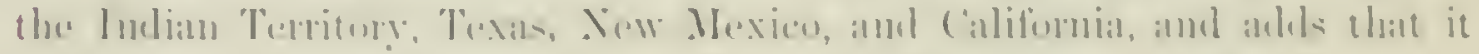

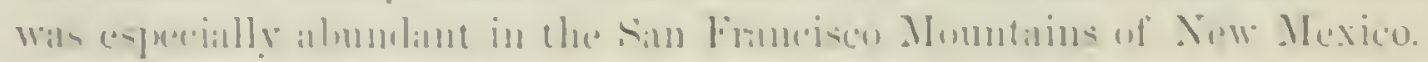

Dr. (imprel states that he has met with this fortu in the winter thronght-

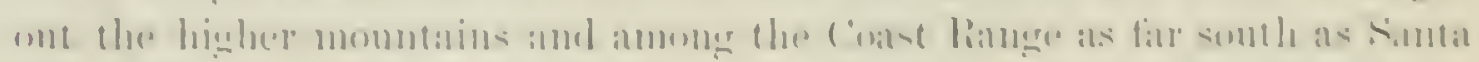

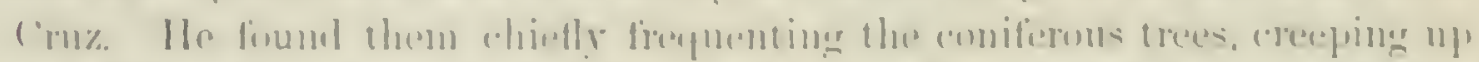

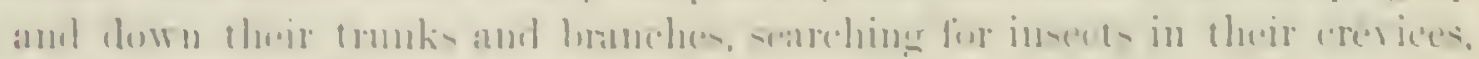

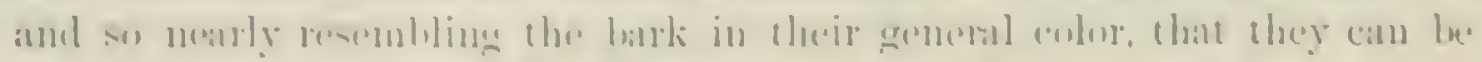

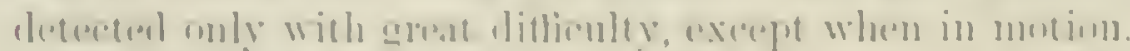

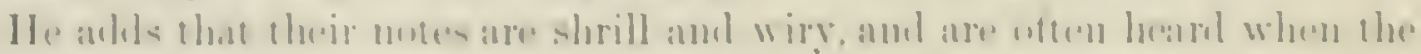

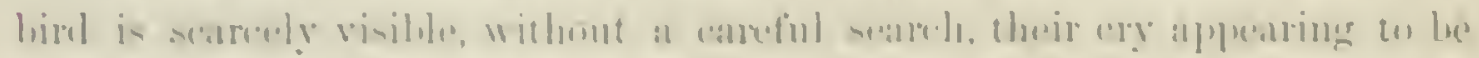

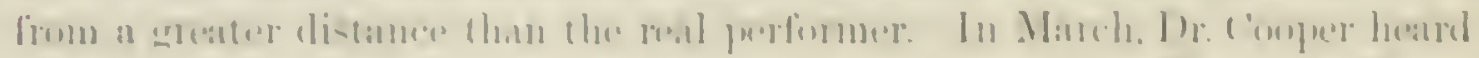

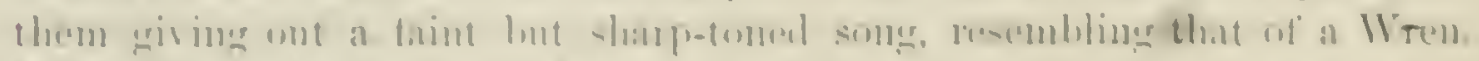

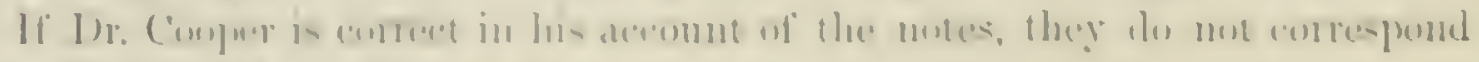
with thuse of oml lisklom lijul 
Dr. Kennerly, in his lieport on the birls observed by him near the 3.ith parallel, stintes that he found our common Creeper rery abundant among the rough-barked cedars in the Aztec Inountains. It usually attracted mutice, and its place of retreat was discovered, by his hearing its quick and sharp notes. A choe and careful search grenembly enalued him to perceive it proceeding leisuroly upward and downward, in straight or spinl lines, toward the top of the tree, clodging dexterously to the opposite side from the observer, and only resuming its ocenpation when assured of solitude and satety.

The ohsersations of Dr. Kennerly, it they are to be received as characteristic of the Wistern Creepers, do not correspond with those of our bistern birls, as far as we hare ohserved them. None of our hirds are more ensily approached, and when they are pursuing their search for foml, none are more rewallilless of observation. The statement that nur (reeper, when watched, mares to the opposite side of the tree from the lonker-on, has found a certain currency in our hooks. We are, howerel, of the opinion that this is owing to its restless activity, prompting it to constant changes of place and position, and not to its timidity or caution. We have miformly found them either unconscions or regardless of our near presence.

They are solitary in their habits, and freyuent, especially in the summer. deep wools, searching for their tarorite fond in high places where it is ditticult to reach them, but this is no neessary evilence of their shyness. They uften hunt for their food in very exposecl places, with eyual courage and recklessness. It is an active, restless bird, associating with Titmice and the smaller Woodpeckers, moving with great mpiclity from sile to side and from place to plice. They breed in hollow trees, in the deserted holes of the Woodpechers, and in the decayed stumps and hranches of trees. Their nest is a loose agsegegation of soft, warm materials, not interworen, but simply collected with regam to no other requisite than warmeth.

In the summer of $18.51 \mathrm{om}$ paty, in their visit to one of the smaller Fmond Menan Islands, was so fortumate as to meet with the nest of this bird. It was huilt in a decared birch-tree, only a few feet from the ground, and contained five egres nearly rendy to hatch. This was on the 2uth of . Tune. The nest was an intermingling of decared wood, the fur of small quadrupeds. and feathers, but with so little alherence or consisteney of form that it was impossible to retain the materials in pusition after remoral.

So far from evincing any timidity. the birds refused to leare their nest, and conld hardly be prevented from following it when remored from the wouds to a house on the island. One of our companions, returning to the roods in order to secure the birds for the sake of identification, found the pair still lingering round the place of their ritted nest. Lpon his approach ther began to circle round his head with reproachuful cries, and continued to keep so close to him that it was impossible to shoot one rithout mutilating it. At length one of the hirds alighted on a small branch held orer his head by a lad who accompanied him, and in this position was secured by shonting it 


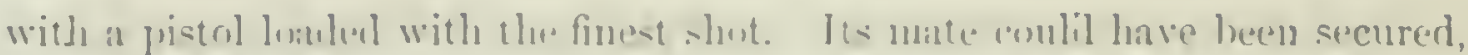

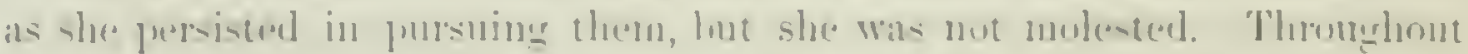
there was not a trane uf timblity on the part of either hirel, hut the most

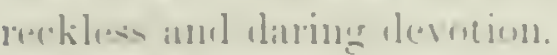

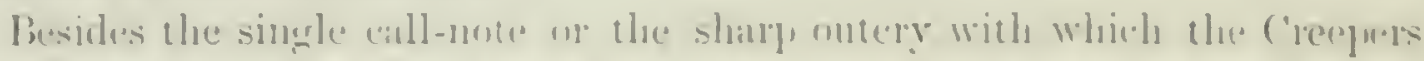

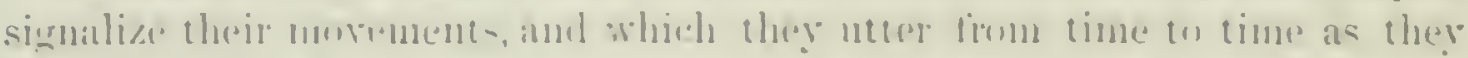

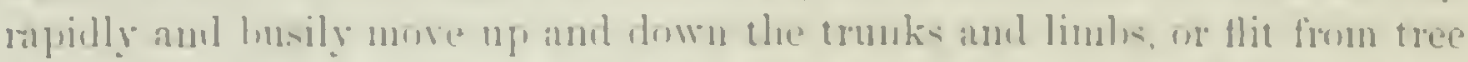

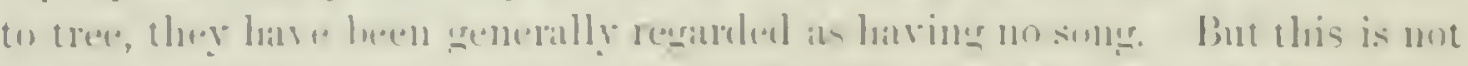

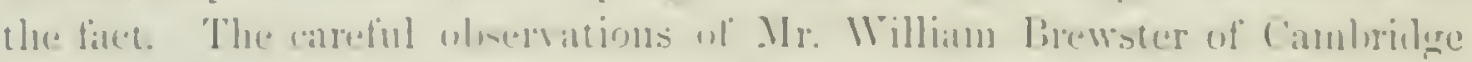

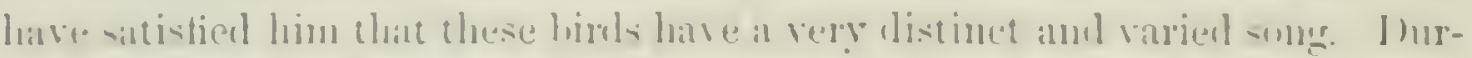

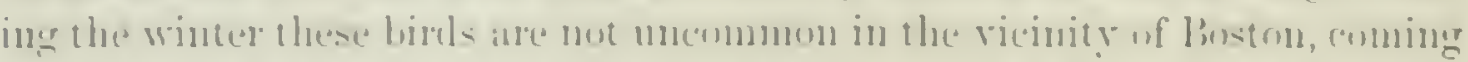

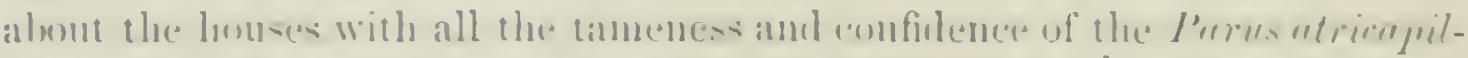

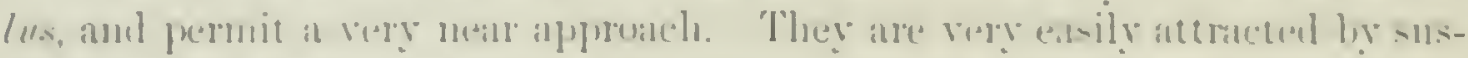

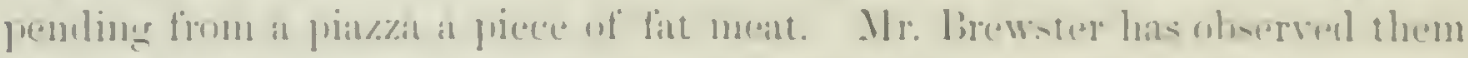

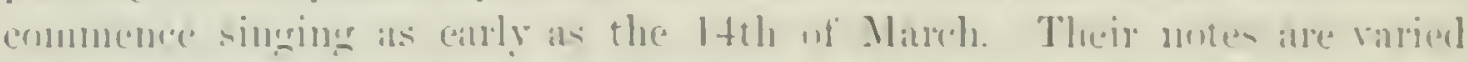
and watbling and somewhat confused some of them are loul, powertul, and

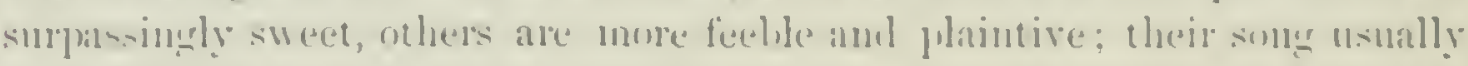

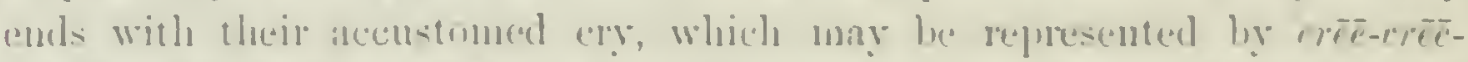

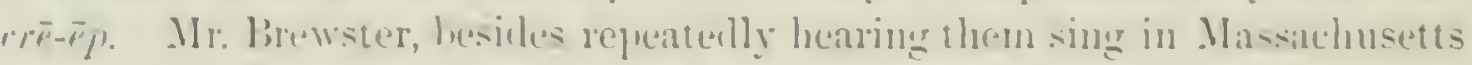
in the eatrly spring, lats alos histened to their song in Minine in the month of Jume.

Their enres are small in propmetion on the size of the hird, are nearly oval in shape, with a gavish-white gmomd, spiningly spunkled with suall, fine,

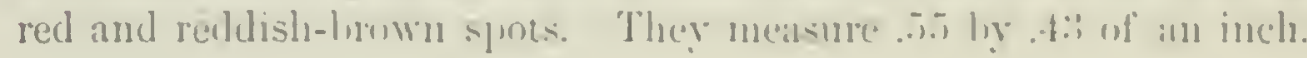

\section{Certhia familiaris, vir. mexicana, riur.}

\section{MEXICAN CREEPER.}

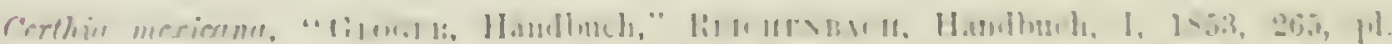

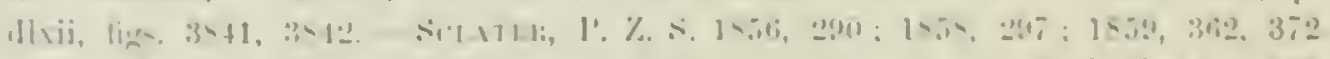

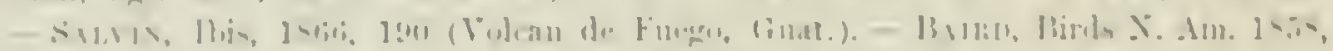

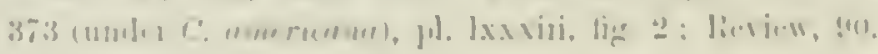

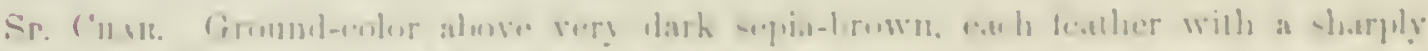

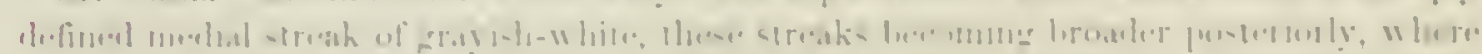

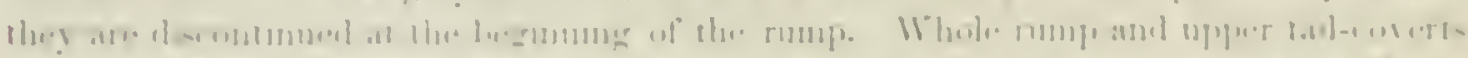

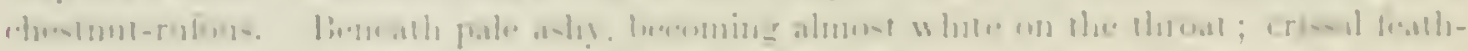

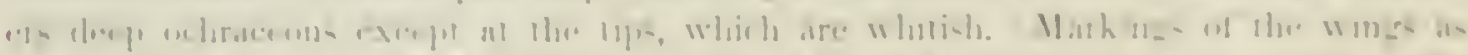

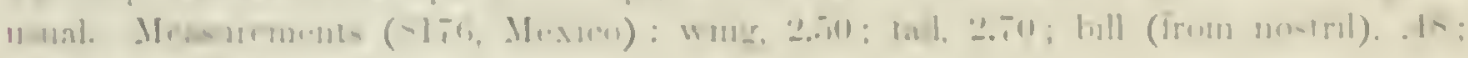

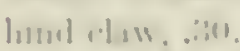

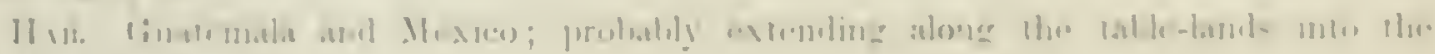

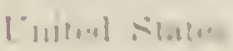

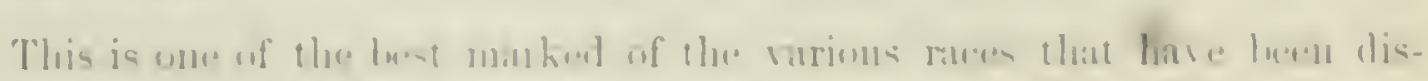

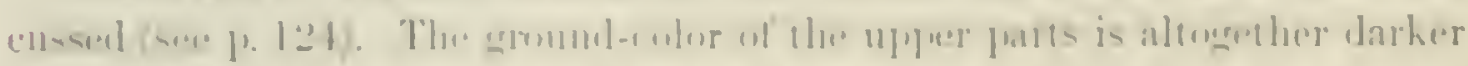

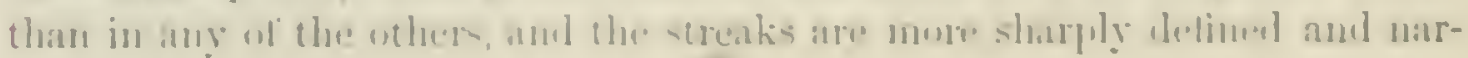


rower; the rufous of the rump is of a castanenus, instearl of yellowish cast; the wings appear more miform with the back, wing to the dark color of the latter, and their pale markings have little of that yellowish tinge so noticeable in the others. In the ashy tinge of the lower pirts there is a resemblance to fumiliaris of Europe; but the latter has not the ochraceous crissum so noticeable in the present bird. There is little resemblance to Western and Rocky Mountain specimens of the C. umericum; and if these are to he considered as separable from the Eastern (which, however, would not, in our opinion, be advisable) they must not be referred to merrana.

'The Mexican Creeper is introduced here on account of the probability of its occurrence in the Southern Rocky Mountains.

Habits. Mr. Salvin found the Mexican Tree-Creeper by no means uncommon in the pine forests of the upper zone of the Volcan de Fuego. He also observed it frequenting pine-trees in the district of Chilasco, Vera Paz, at about 6,000 feet above the sea. 


\section{FAMIY TROGLODYTID无. - THF, WHES.}

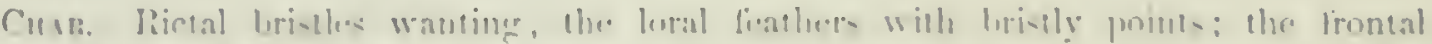

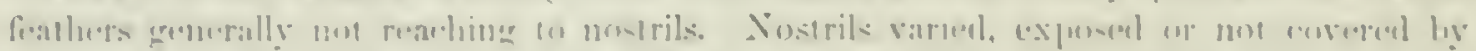

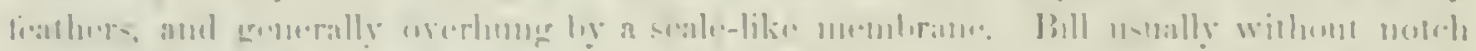

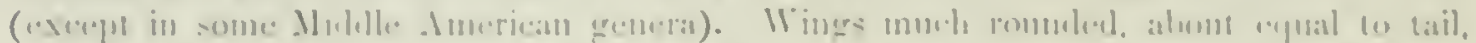

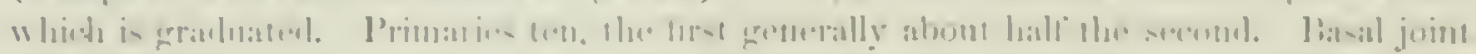

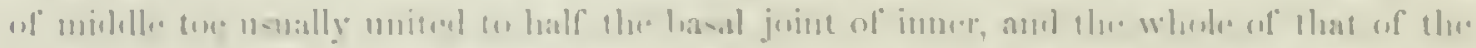

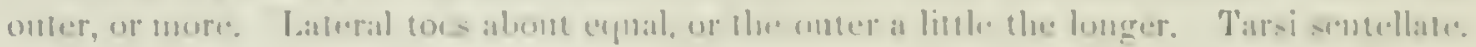

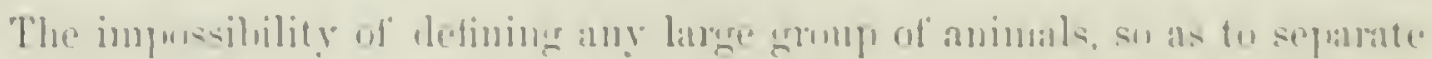

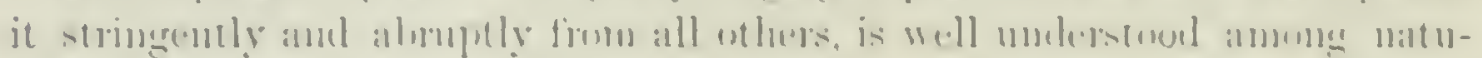

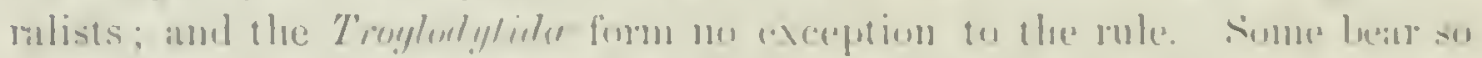

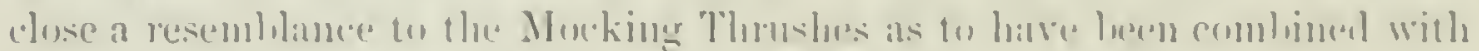

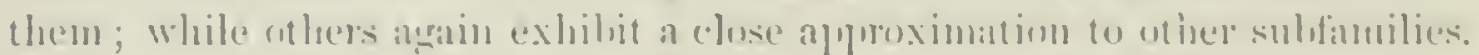

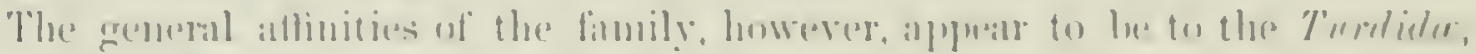

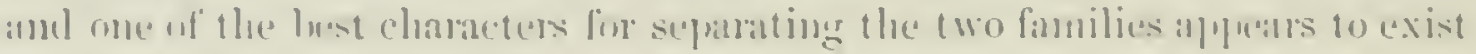
in the structure of the fiect.

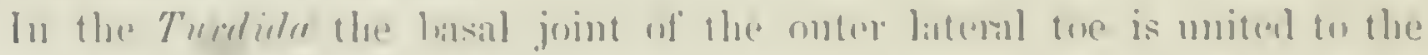

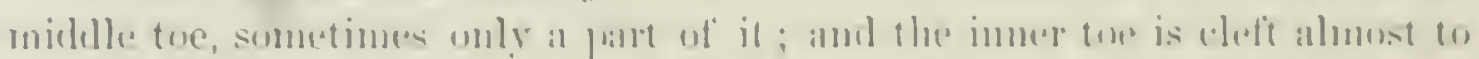

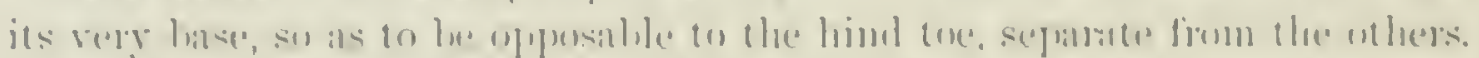

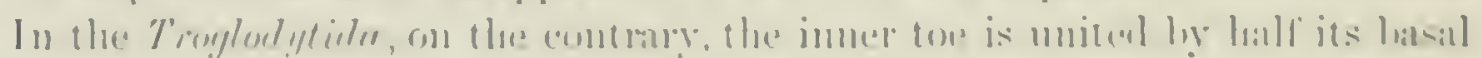

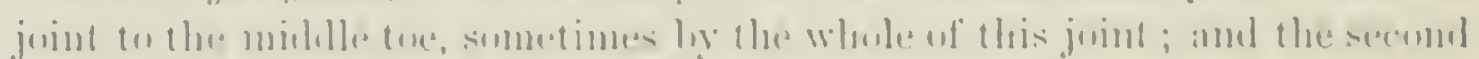

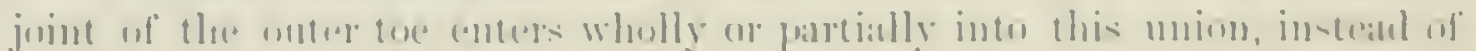

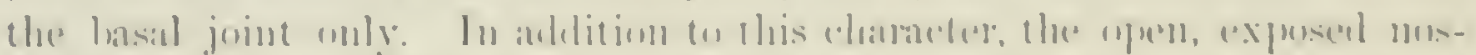

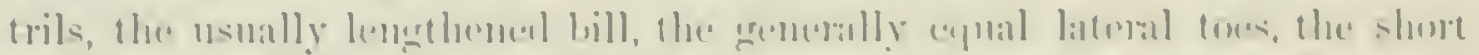

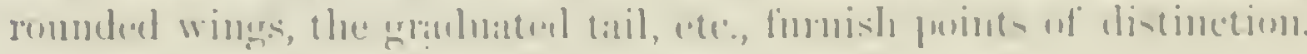

\section{Genera.}

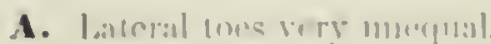

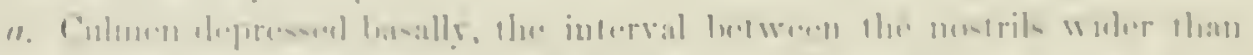

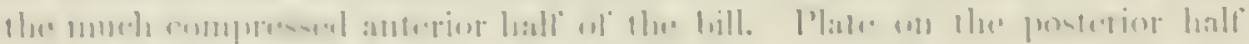

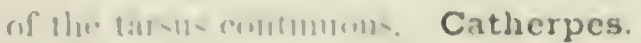

b. (1) (1)

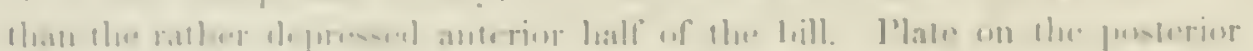

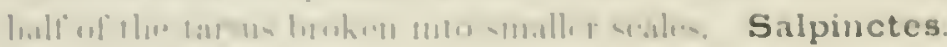

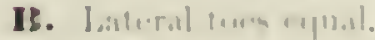

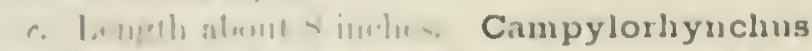

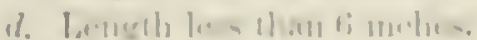

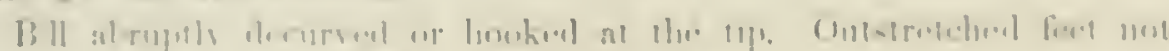

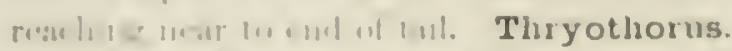

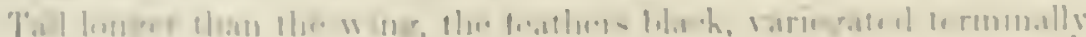

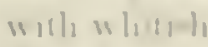

fillemenr $7 \%$ rym

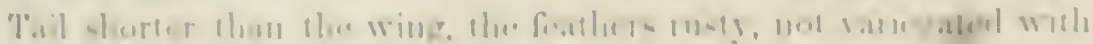

whitivis

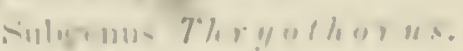

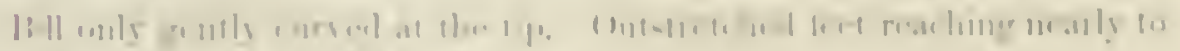

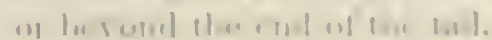


Back without streaks. No distinet supereiliary stripe. Troglodytes. Bill curred, sub-conical. Tail as long as wing. Subgemus Troglodytes. Bill straight, subulate. Tail much shorter than wing.

$$
\text { Subgenus . } 1 \text { north } 1 \mathrm{ra} \text {. }
$$

Back streaked with black and white. Cistothorus.

Bill short, stout; its depth eyual to one hall its length from the nostril; gonys straight or eren convex, ascending. Crown streaked; no distinet superciliary stripe. Subgenus C'is to thorus. Bill elongated, slender : its depth less than one third it: length from the nostril : gonys slightly coneare, declining. Crown not streakell; a conspienous superciliary stripe. Subgenus Telma to dy tes.

\section{GEXUS CAMPYLORHYNCHUS, SPIX.}

Campylorhynchus, Sprx, Ar. Bras. 1, 1S24, 77. (Type, C. scolopaceus, spix = Turdus variegatus, GMEL.)

Gex. Chur. Bill stout, compressed, as long as, or longer than the head, without notel or rictal bristles; culmen and commissure curvel; gonrs nearly straight. Nostrils in the antero-inferior part of nasal groove, in alvance of the frontal feathers, with an orerhanging scale with thichened elge, as in Thryothorus; sometimes, as in the type, reduced to a slight ridge along the upper side of the nasal groore. Lateral septum not projecting below or anteriorly into the nasal carity, hut concealed by the nasal scale. Tarsus a little. longer than midelle toe and claw; claws strong; much curvel, and rery sharp; mildle toe with basal joint adherent almost throughout. Wings

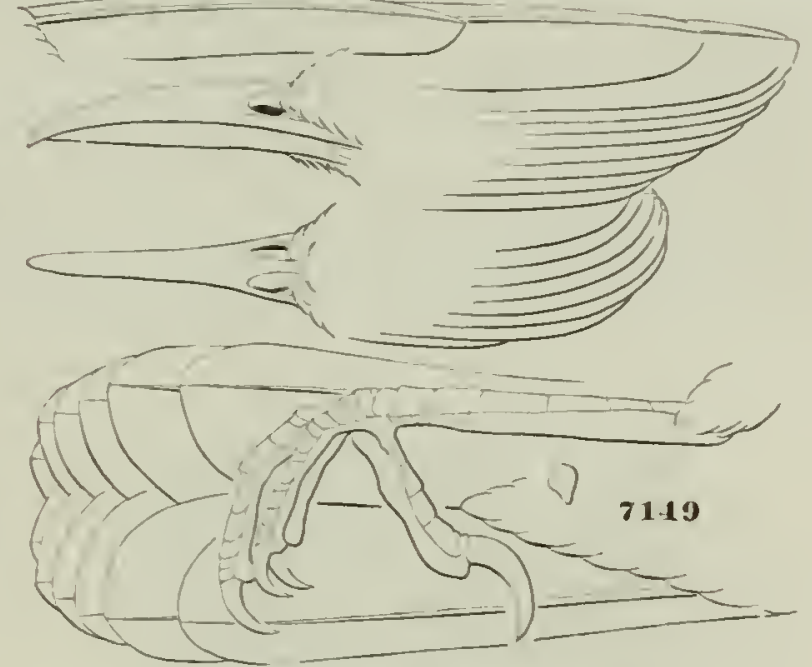

Campylarhynchus brunneicapillus. and tail about equal, the latter graduated; the exterior webs of lateral feathers broad.

This genus embraces the largest species of the family, and is well represented in Middle and South America, two species only reaching into North America, which may be distinguished as follows:-

Top of head and post-ocular stripe redclish-brown; back streaked longritudinally and linearly with white. All the feathers beneath conspicunously spotted. Crissun and flanks with rounded or elongated spots. Iris redelish. Xostrils inferior, linear, overhung by a scale. Nests large and purse-shaped; ergors white. profusely marked with salmon-colored or reddish spots.

a. Spots much larger on throat and jugulum than elsewhere. Inner webs of second to fifth tail-feathers (between middle and outer feathers) black, except at tips. Length, 8.00 ; wing, 3.40 ; tail, 3.55. Mab. Aijacent borders of United States and Mexien . . . . . . . brumeicapillus. b. Spots on throat and jugulum little larger than elsewhere. Inner webs of intermediate tail-feathers banded with white like the outer. Length, 7.50 . Hab. Caple St. Lucas 


\section{Campylorhynchus brunneicapillus, Gist:}

\section{CACTUS WREN.}

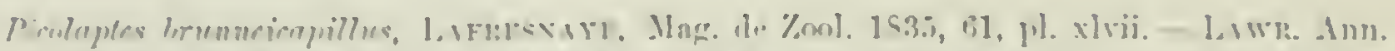

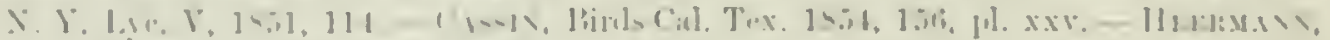

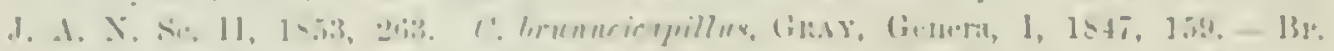

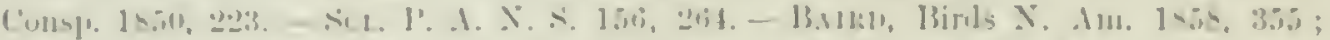

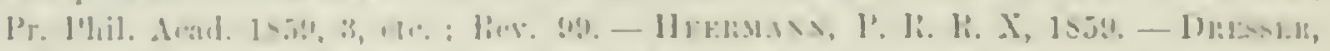

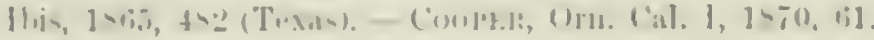

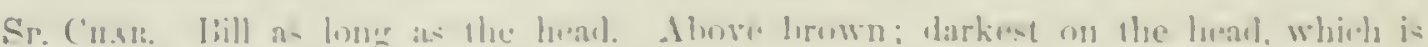

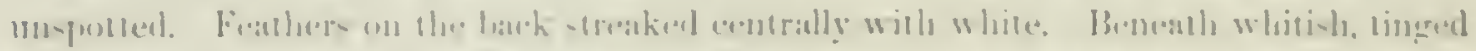

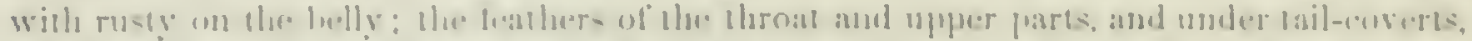

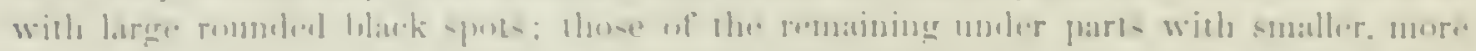

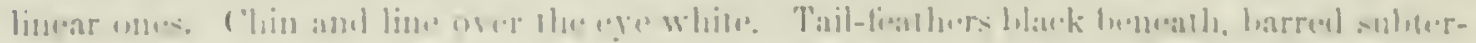

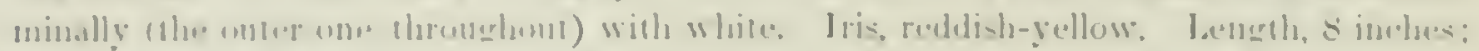

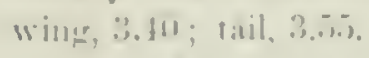

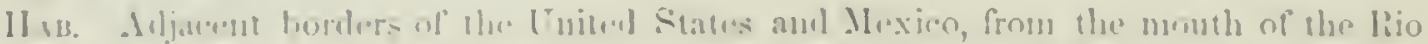

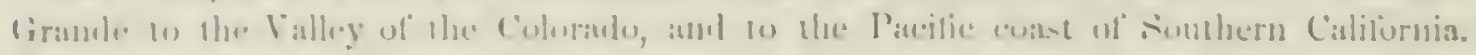

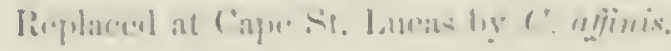

This speedes is foumd ahundantly along the line of tho lio frande and

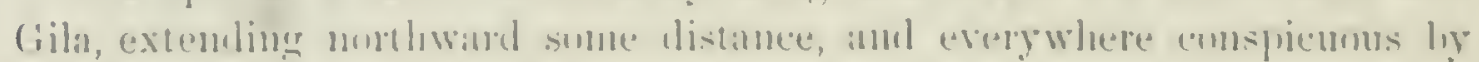
jts wren-like hallits and emormmus nest.

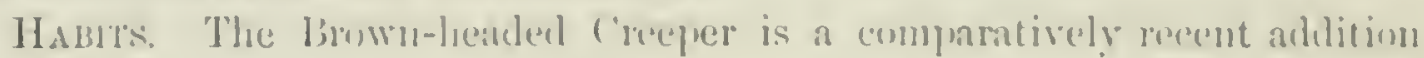

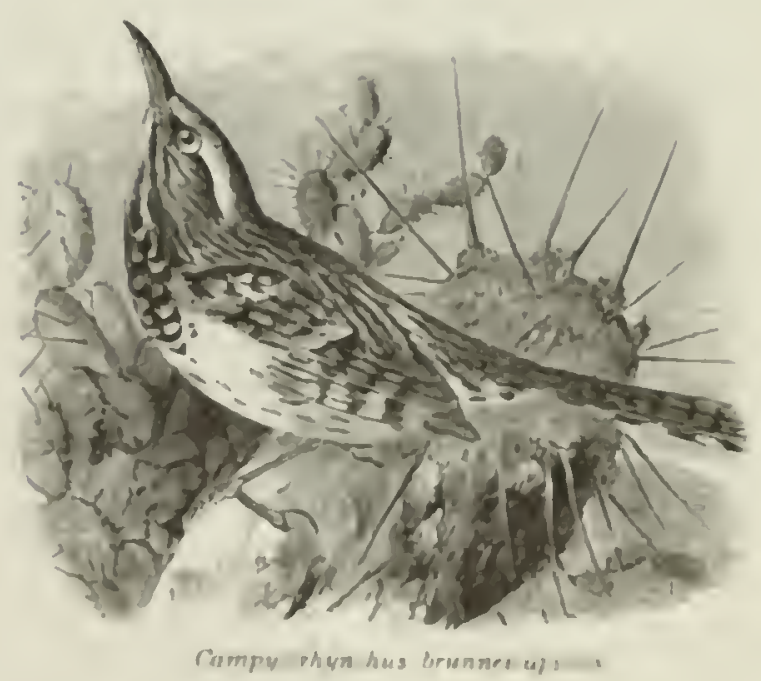

to the finum ol the l'nited States, lut : [?] the subllowextoru burlers of the louted statten, from the valley uf

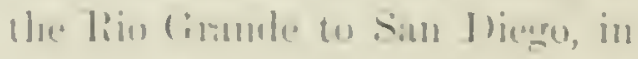

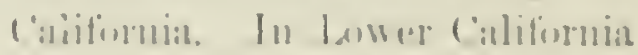

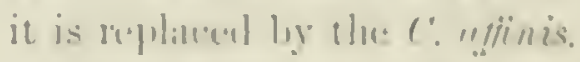

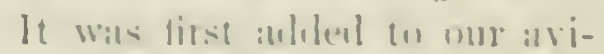
fimma hy Mr. latwreme in lsisl,

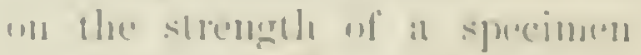
mbamel in Texis ly cintuin Th. (1)

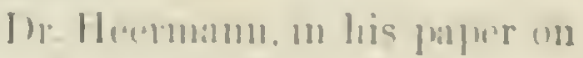

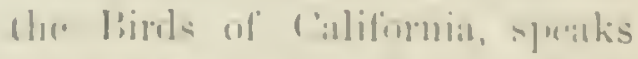

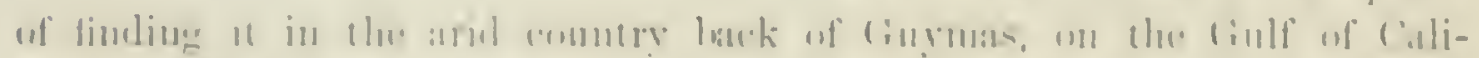

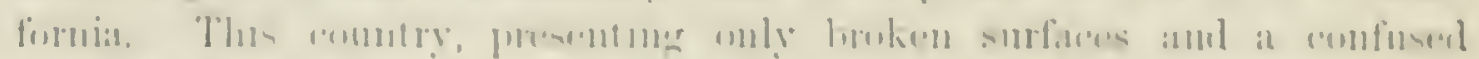

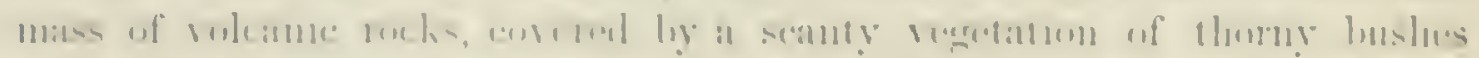

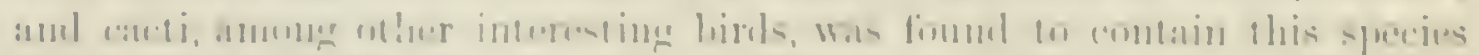

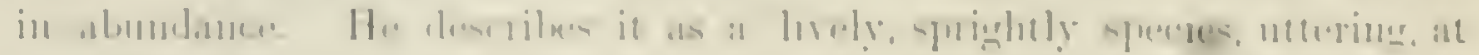

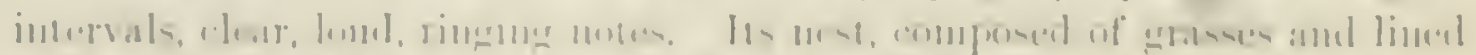

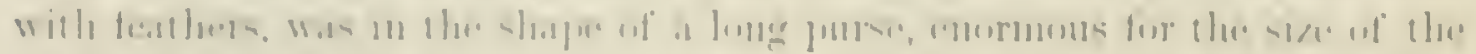

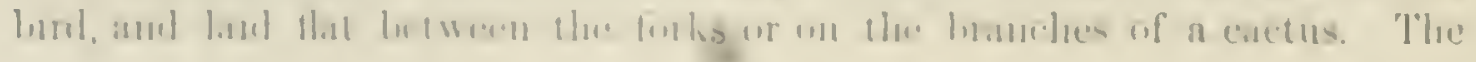


entrance was a covered passage, varying from six to ten inches in length. The egyrs, six in number, he deseribed as being of a delicate salnon-color, very pale, and often so thickly speckled with ash and darker salmon-colored spots as to give quite a rich cast to the whole surface of the eygr.

Lientenant Conch met with these birls near Monterey. He states that they have a rich, powerfinl song. Of the nest he gives substimtially the same description as that furnished by In. Heermatm.

The egrgs are of an oblong-oval shape, slightly more pointed at one end, and are so equally and generally covered, over a white ground, with fine salmon-colored spots, as to present a miform and almost homogeneous appearance. They vary in length from an inch to 1.02 inches, and have an average breadth of .68 of an inch.

\section{Campylorhynchus affinis, X.ıTus. THE CAPE CACTUS WREN.}

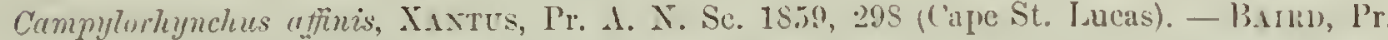
A. N. Sc. 1859, 303; liev. 100. - Sec. Catal. 1861, 17, no. 108. - Ellıur, Illust. B. N. A. I, N. - CUOPER, Orn. Cal. I, 1870, 62.

SP. Cuar. Cap of head reddish-brown; the concealed centres of fuathers dusky. Fiest of upper parts gragksh-brown, all the feathers of body and scapular's with broad central or shaft streaks of whitish ellgeel with blark: the streaks irregular in ontline, on some featlers nearly linear, in others widening at intervals along the shaft. Outer webs of the wing-fealhers crossed by about seren rows of whitish semicireular spots, with corresponding series of more cireular ones on the inner web. Tail-feathers black, all of them with a series of abont eight quadrate white spots on each wel, which are alternate to each other, not opposite, and extend from or near the black shaft to the eclgge; the extreme tips of the f'athers black; the two central feathers, however, more like thro baek, with irregular mottling of grayish and black. Cpper tail-coverts barred transversely with black.

Unche parts white, faintly tinged with rusty posteriolly; each feather spotter with black, exrepting on the immaeulate chin. These spots are rather larger and more (1tadrate on the jugulum, where they are sometimes on the sides of the feathers (on one or both sides); posteriorly, howerer, they are clongated or tear-sluped, and strung along the shaft, one or two on eaeh. On the erissum they are large and much rounded, three or four on each longer feather. Legs rather dusky. Bill lead-color, pale at the base below; iris reddish-brown. A broad white stripe from bill over the eye and nape: edged abore and below with black; line belnind the eye like the crown; cheek-feathers white, edged with blackish.

Immature specimens exhibit a tendency to a whitish spotting in the ends of the feathers of the cap. A rery young bird does not, howerer, differ materially, exeept in having the spots less distinet beneath, the white streaks less conspicuous above, the white of the wings soiled with rufous. Specimens vary eonsiderably in the proportional as well as absolute thickness and length of the bill; thus, No. 32,167 measures .80 fiom nostril to cond of bill, instead of .60, as given below for No. 12,965.

12,965. Total length, 7.50 ; wing, 3.30 ; tail, 3.40 ; its cradnation, .45; exposed portion of first primary, 1.42, of seeond, 2.15 , of longest, or fourth (meusured from exposed base of first primary), 2.45; length of bill from forelead, .90, from nostril, .60; along gape, 1.07 ; 


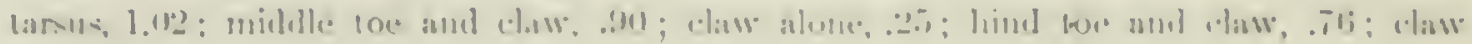
alom, ..in.

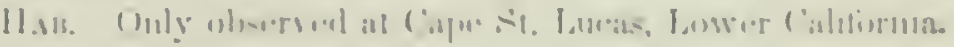

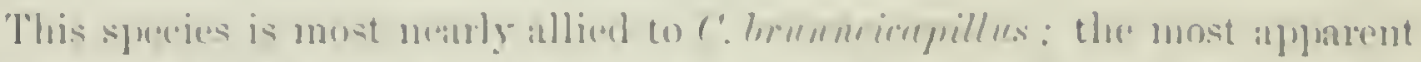

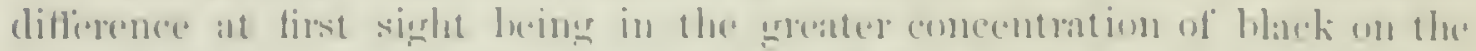

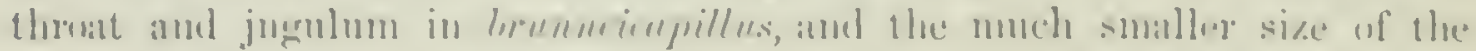

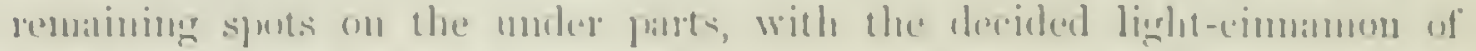

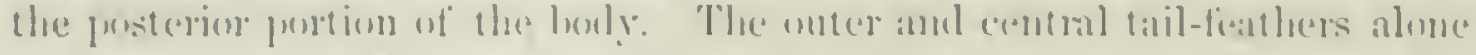
are marked as in C'. "ffintis, the intermediate ones being entirely libak, with the exectention of at white subterminal hamel.

This is onc of the most chancteristic birls constitutine the isulated faumil

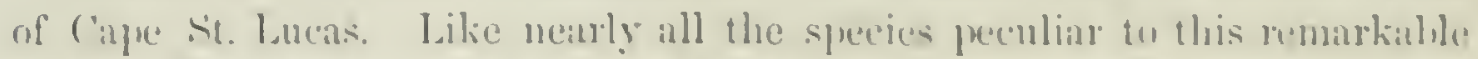

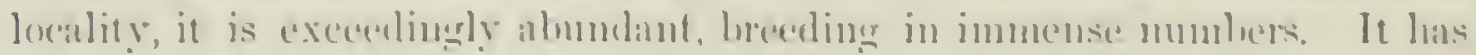

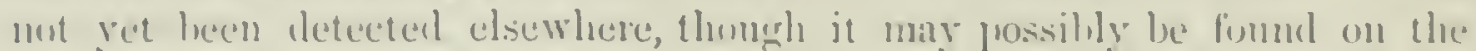
l.mwer' ('oluristo.

llablts. This recently described sprecies was fimst disenvered hy Mr.

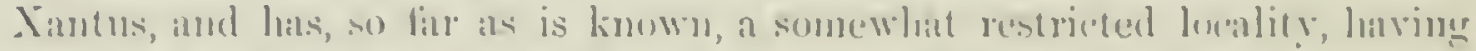
heen met with only at the somthern extremity of lower Califurnia, where it

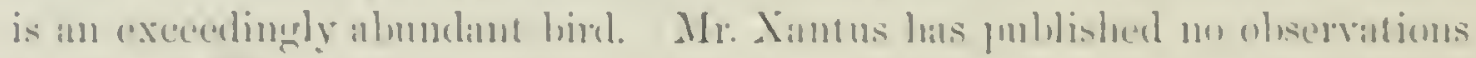
in rearal to its habits, which, howerel, are jubbibly rery nearly jelenticil with thuse of the more commmn species. Fom the indef momoramb given

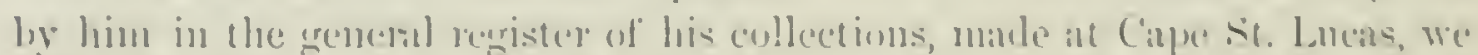

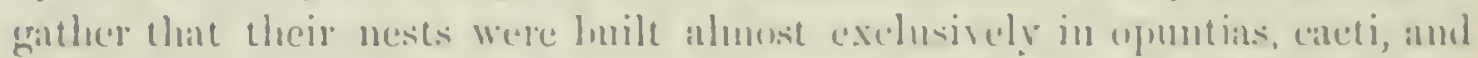

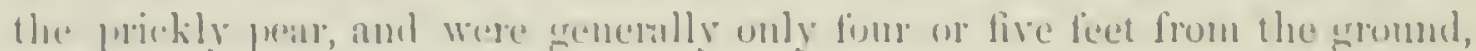
but oxessinnally at the haight af ten feet.

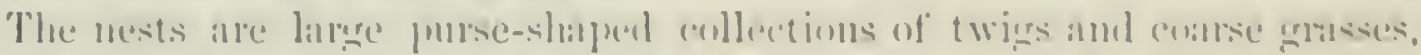

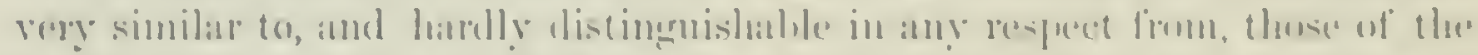

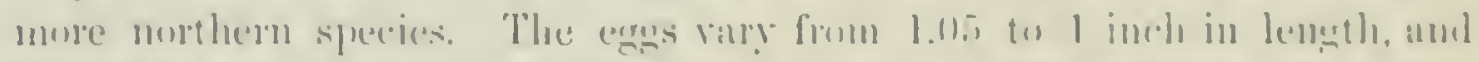

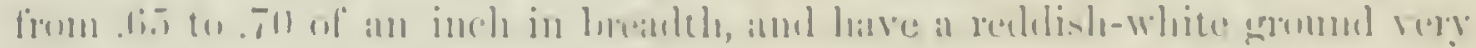

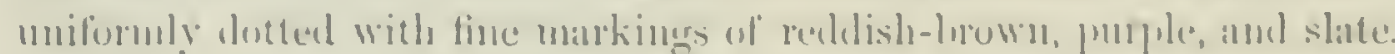

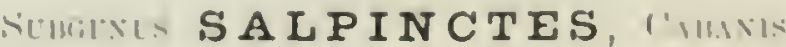

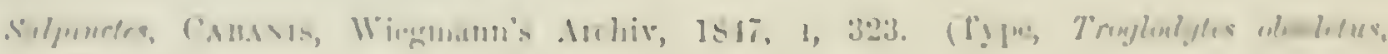
iㄴ.

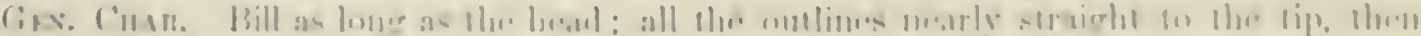

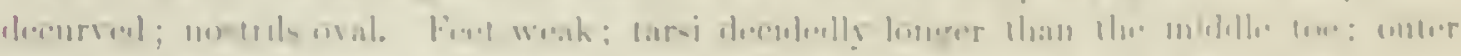

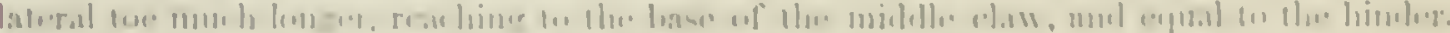

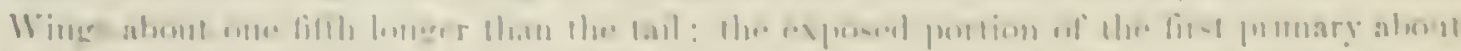

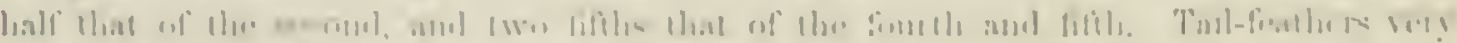

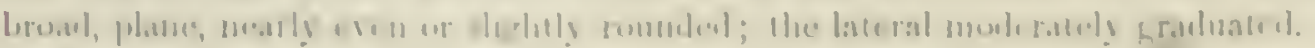

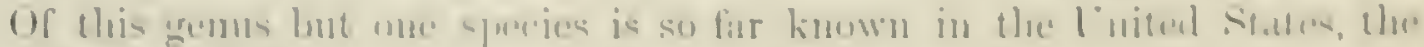

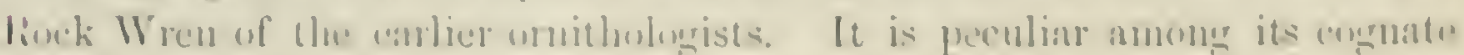


genera by having the two continnons plates on each side the tarsus divided into seven or more smaller plates, with a naked interval between them and the anterior scutellae. Other character's will be found detailed in the lieview of American Birds, p. 109.

\section{Salpinctes obsoletus, CABAN.}

ROCR WREN.

Tromlodytes obsoletus, SAY, Long's Exped. II, 1823, 4 (sonth fork of Platte). - Arn. Om. Biog. IV, ll. ceclx. - IB. B. A. II, pl. cxvi- - Newberri, l'. R. R. Rep. VI, Ir, 1S57, so. - Hefruax, P. R. IR. liej. X, 1S59, 41. Sulpinctes obsoletus, Cab. Wieg-

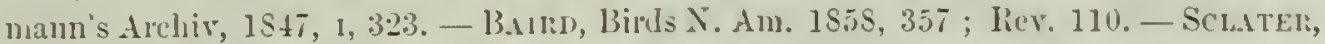
P. Z. S. 1S.59, 371 (Oaxica). - C'wopen, Orn. C'al. 1, 1570, 64. ? Troglodyles latisfasciatus, Licht. Preis-Verzeich. 1831, no. S2.

Sp. CHar. Plumage rery soft and lax. Bill about as long as the head. Upper parts brownisli-gray, each feather witl a centıal line and (except on the head) transverse bars of dusky, and a small dull brownish-white spot at the end (seen also on the tips of the secondaries). Rump, silles of the body, and posterior part of belly aud under tail-coverts dull cinuamon, darker abore. Rest of under parts dirty white; feathers of throat and breast witl dusky central streaks. Lomer tail-corerts banded broally witly black. Inner tail-fenthers like the back, the other's with a broad black bar near the end; the tips cimnamon; the outer on eaclu side alternately bancled with this color and black.

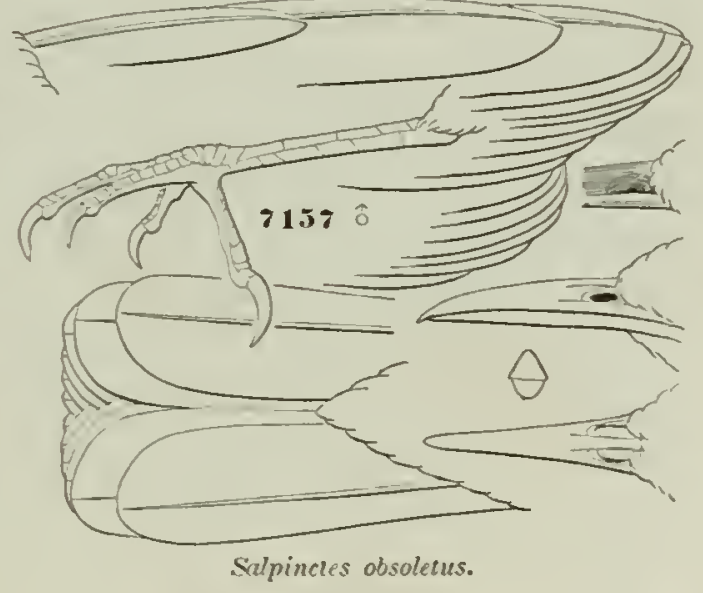
A dull white line above and behind the eye. Iris brown. Lengtl, 5.70; wing, 2.82; tail, 2.40. Foung not marked or bauded beneath. Egrs white, spotted with red.

His. Central regions of the United States, to Mexico, east to mouth of Yellowstone River. Cape St. Lucas. Not recorded from Pacitic slope. W. Arizona, Coces. Oaxaca, SCLATER.

Hamits. The Rock Wren, so far as its distribution is known, is principally restricted to the high central plains of the Rocky M[ountains, from Nelıraska to the coast ranges near the Pacific, and from Oregon to Mexico and Lower California. According to Dr. Cooper it is an abundant species throughout the dry, rocky, and barren districts of California, especially in the southern portions, where it comes nearer the const. They are numerons among the plains on both sides of the Rocky Mountains. Their farorite places are among the rocks, where they are alwars busily engaged in hunting for insects in the crerices. Dr. Cooper found nests at San Diego in cavities under the tiled roofs of houses, but they all contained roung as early as Mar. At Furt Mojare they began to sing in February, and their song continued thronghout the spring. They range to a high elevation among the moun- 


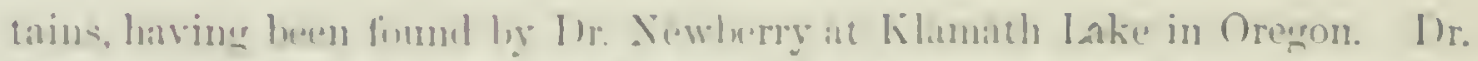

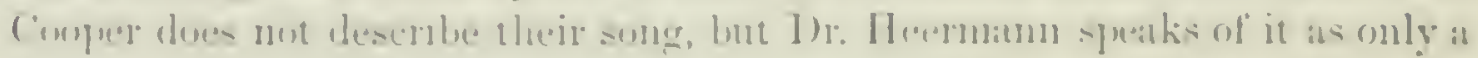
very weak trill. The latter met with them in the mentatinous districts of

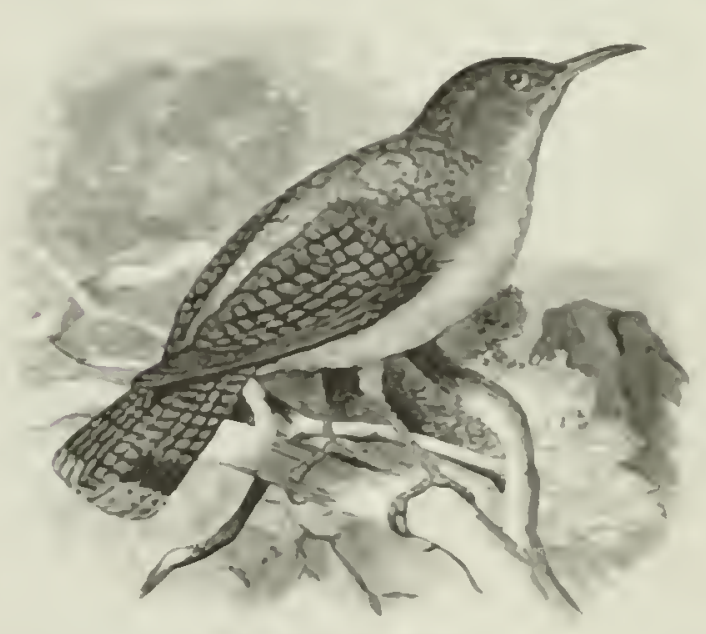

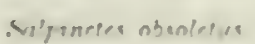
(itlifurnia, where they were searching fin their forml anmong the erevices of the rocks. He afterwatuls met with them in New Mexion and Texas. There were quite athumbant in the te-

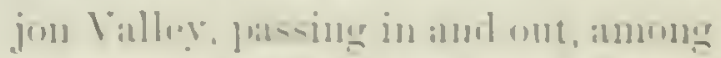

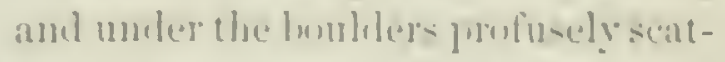
teres aver the momtains, searehing for spinters, worme, inul small in-ecte, in pursult of which they uttered at intervals at lond and yuirk note of at freculiarly thrilling chamater. I.ientenant cound found them in the simd-

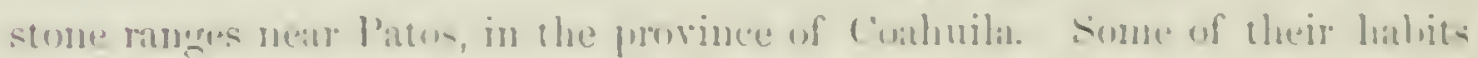
are spreken of as ejarrow-like, and, white they latve the manal wren-like

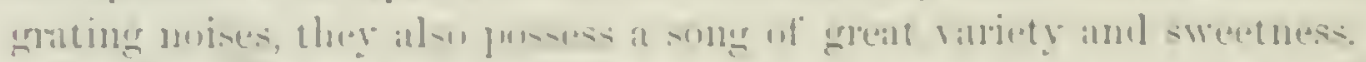

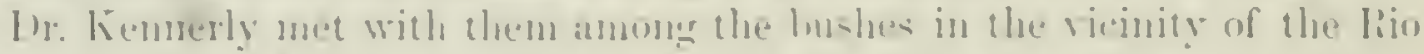

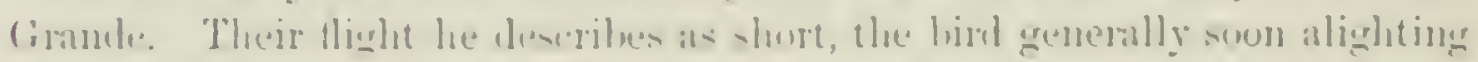

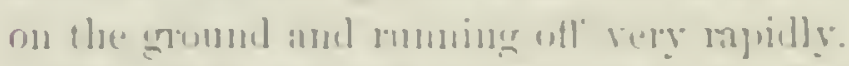

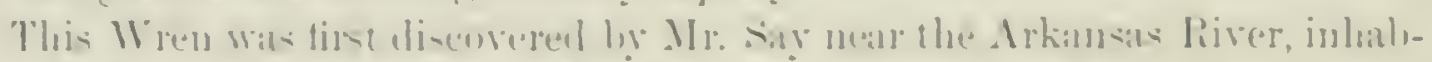

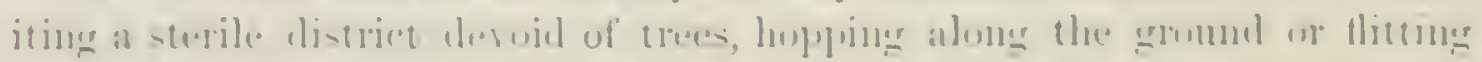
thrumeh the low, stunted junipers on the hank- of the riser, w- ually in small

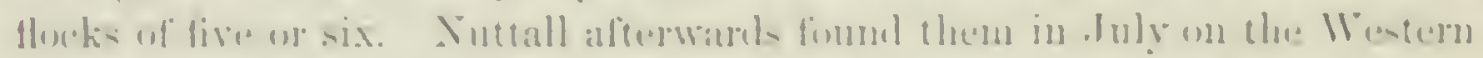

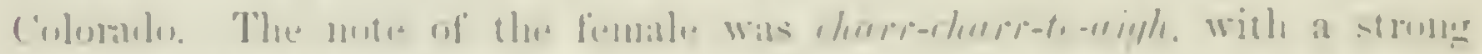

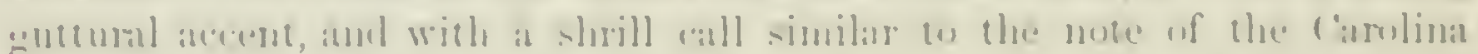

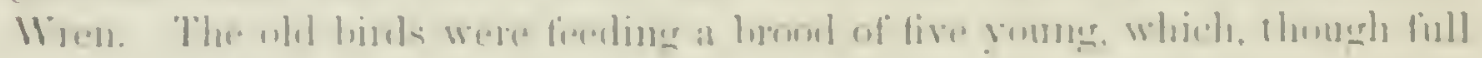

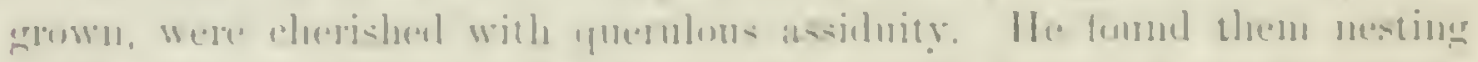

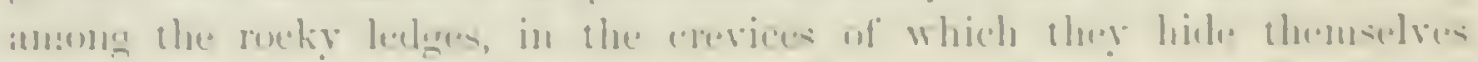

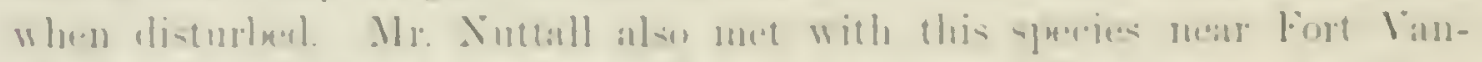

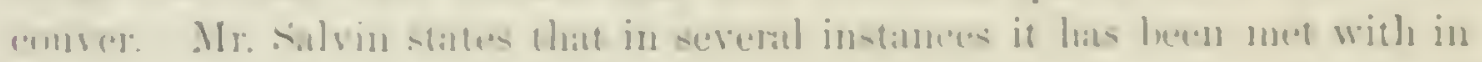
(intutemintitiv

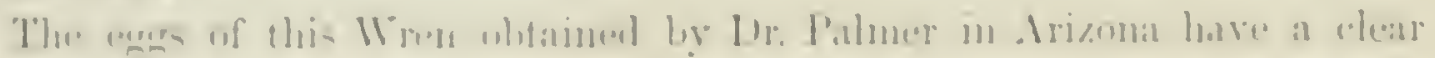

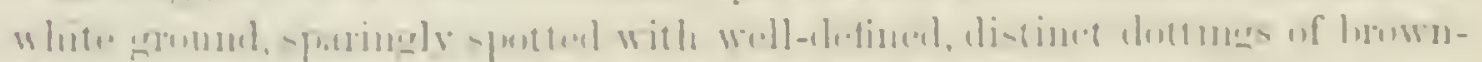

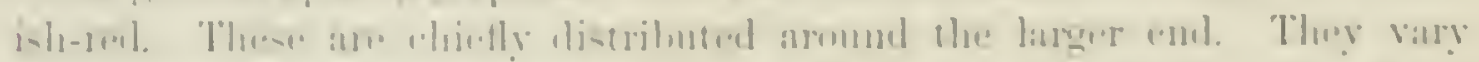

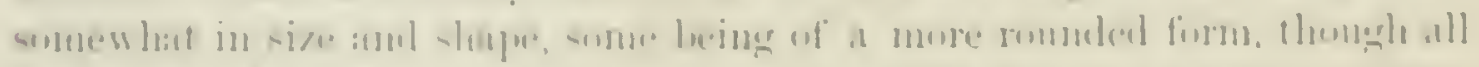

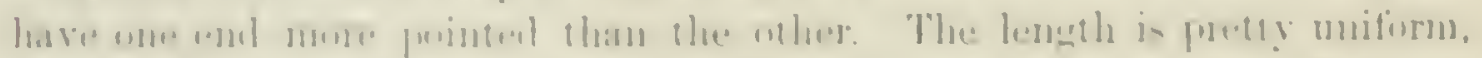

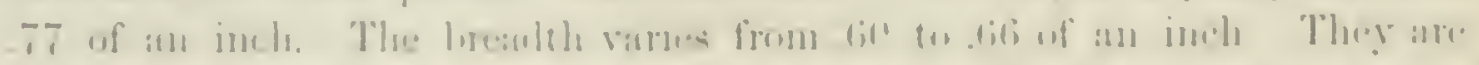

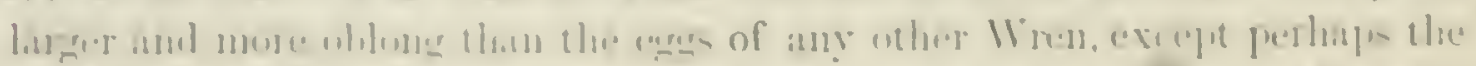

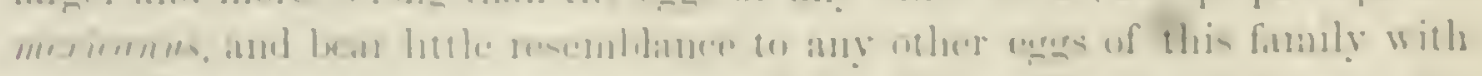

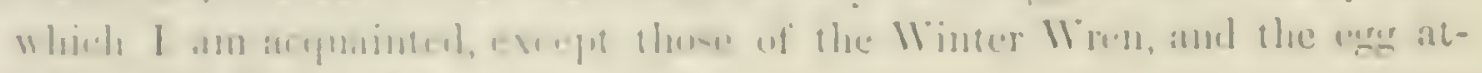

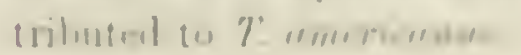


Tho nest $i_{3}$ homogeneous in structure, composed entirely of thin strips of redlish-colored bark and fine roots, interspersed with a few small bits of wool. It is distorted by packing, so that measurements of it wonkl be vilueless: its dimensions in its pressed eondition are: diameter, jinches; depth, 2- inches. The cavity is shillow and sancer-shaped.

From Mr. Ridgway we learn that from the summit of the Sierra Nevada enstward, as far as the party explored, he found this Wren miversally distributed. In the midlle prorinces of the Rocky Momutinins it was the most abmulant species of the family, but was not so abundant in the Walisateh Momntains. The general resort of this species was among rocky or stouy hill-slopes, though it was not confuned to such loealities. At Carson City he found it particularly partial to the rubbish of the decaving pine-logs. At Virginia City it was the only Wren seen frequenting the old buildings and abandoned mining-shatts, in its predilection for such places reninding him very much of the Thingothoms ludoriciunus, which in its manners it very strongly resembles.

Mr. Riclgway noticed a wonderful variety in the notes of this Mren. Its peculiarly guttural turee was repeatedly heard, and its song in spring had a shight resemblance in mochlation to that of the Carolina Wren, thongh altogether lacking the power and richness so characteristic of the superb song of that bird. Freymently its song was cluanged into a prolonged nonotonous trill, similar to the tremulous spring-call of the Junco hymemalis.

This species is not so wary as the Cutherpes mexicanus. Upon suddenly starting up an indiridual of this kind, he would fly to the nearest boulder, tm'n with his breast towards the party, swing ocklly from side to side, all the while ludicrously bowing and scolding the intruder with his peculiar sharp expressions of displeasure.

Dr. Cooper, in lis paper on the Famma of the Territory of Montana, states that he observed this hirl occasionally through the main Iincky Momntain chain to near the crossing of the Bitternot, but it was less common than among the cliffs and rocks of the barren plain along their enstern slope. Thongh he did not find it in the western part of Washington Territory, he las $n$ o doubt that it frequents parts of the rocky cañons of the Columbia Plain. A nest with nine eggs was found in a logreabin below Fort Benton.

\section{GeNes CATHERPES, BAIRD.}

Catherpes, Bdind, Birds X. Am. I\$5ฐ, 35\%. (Type, Thryothorus mexicanus, Sw.)

Gex. Char. Bill longer than the head, slentler; all the outlines nearly straight to the tip, then gently decurred. gonss lenst so: nostrils linear; tarsus short. about equal to the middie toe, which reaches to the middle of the midlle claw. Outer toe colsuilerably longer than the inner, reaching beyoud the lase of the middle clarr. Mings a little longer than the tail; the exposed portion of the first primary about half that of the fourth and 


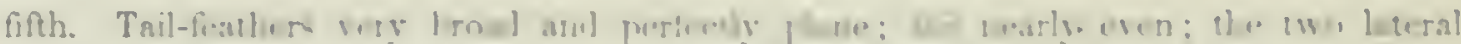

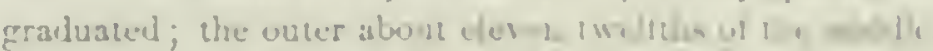

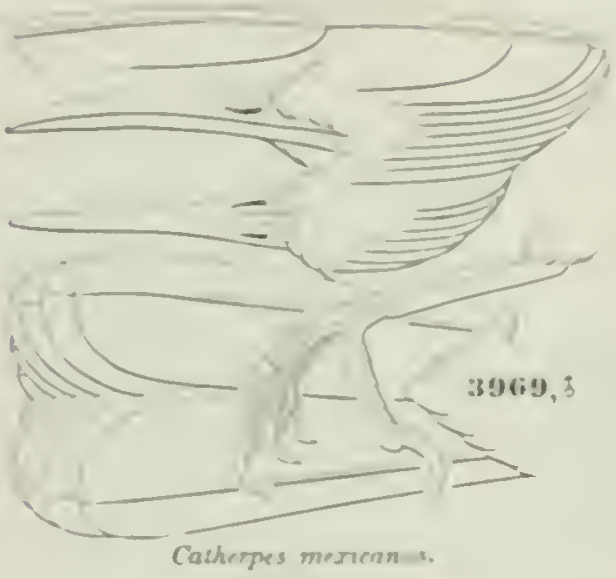

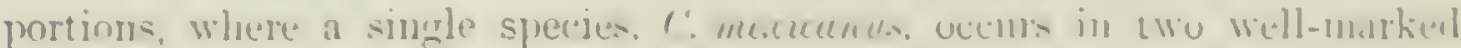
virleties:-

\section{C. mexacanus.}

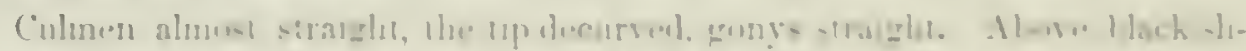

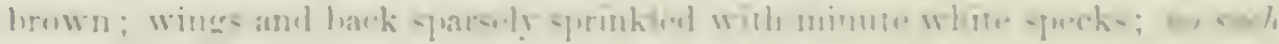

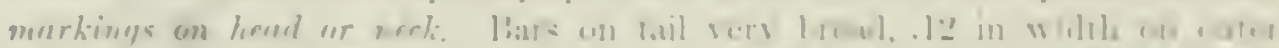

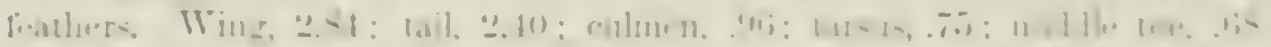

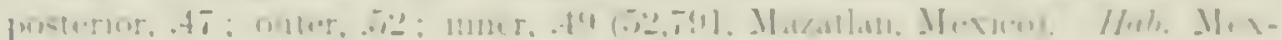
$11 \%$

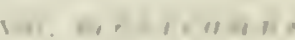

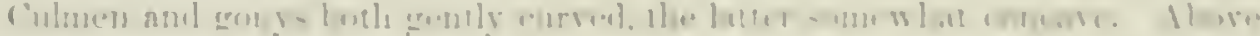

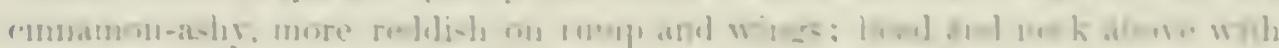

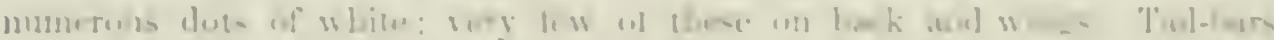

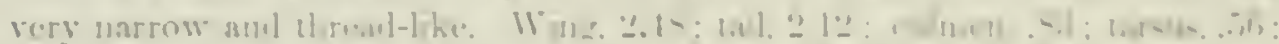

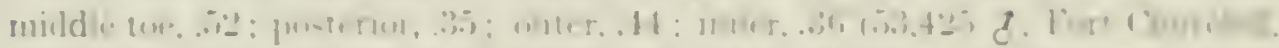

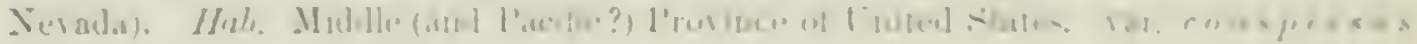

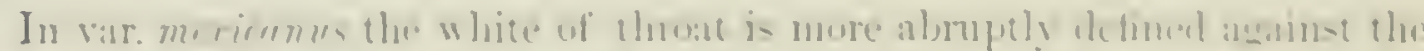
rufous of alulumen than in rar. courspervus, in which the tran-ition is very grmolual. The latter hak the seremblat-

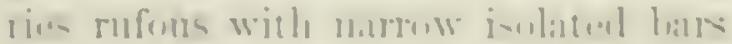
of liluk: the former has thern hath-

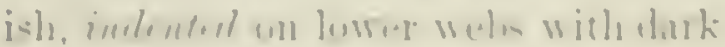

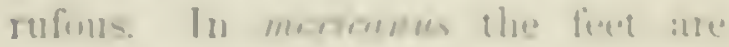

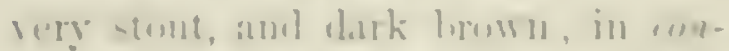
yoroms they atc much wrotier, and Menplilack.

All specinems Irom somth of the

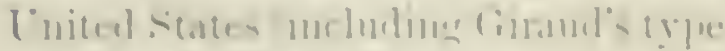

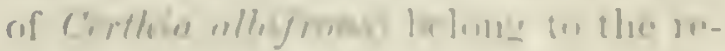

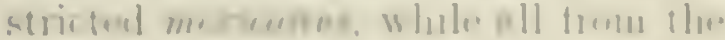

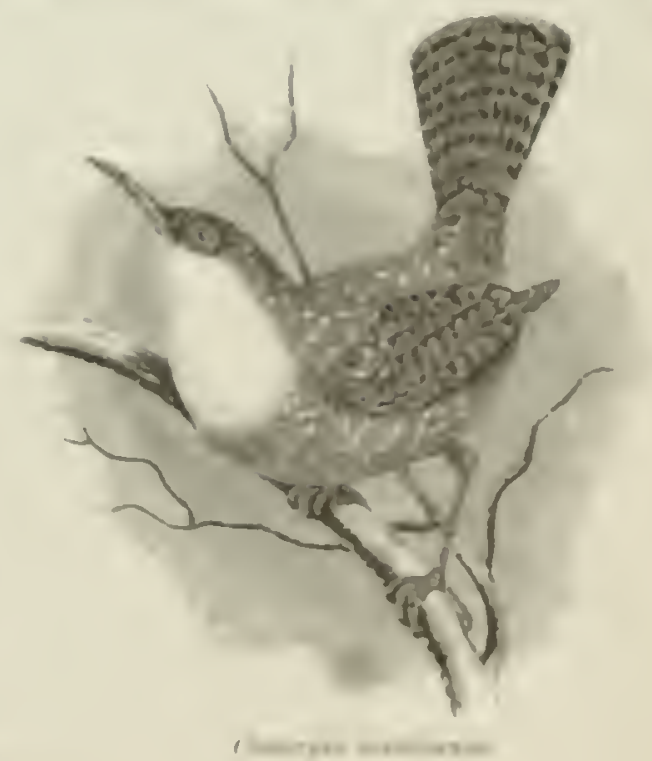

[intoll states ure of the rat 10 n pomata

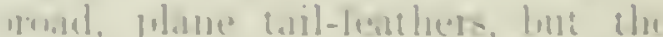

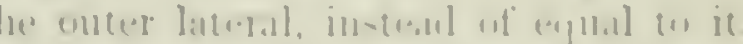

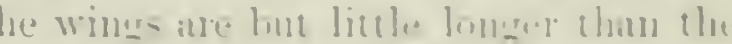

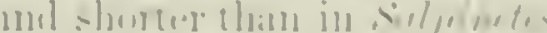

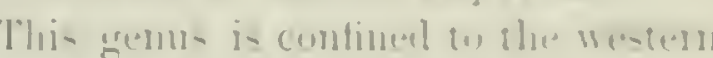

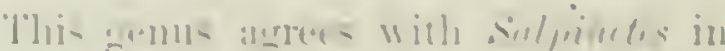


Catherpes mexicanus, var. conspersus, lingway. CAÑON WREN; WHITE-THROATED ROCK WREN.

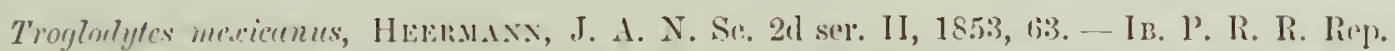
$\mathrm{X}, 18.9,41$ - C.Issix, lllust. Birds Cal. J, 1554, 173, jl. x.x. Cutherpes mexicanus, Bann, Birls X. Am. 1858, 356 (in jart) ; Rev. III (in part). - Cuoper, Onn. Cal. I, 1870, 66. Cullerpes mexicunus var. econspersus, Ridowar.

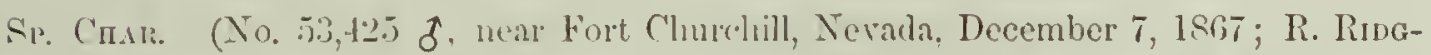
war). Alove, brownislashy on the anterior, and bright cimamon-mfons on the posterior half, the two colors shading insensibly together. 'The anterior, or graysh portion thickly sprinkled witl mumerons suall circular dots of white, each preceled by a smaller speck of dusky; a few of these dots on the rump). Wings with obsolete, lagreel, narrow, isolated bars of dusky, these most shapply lefined on the secondaries. 'Tail clear l'ufons, rossed witl ahout uine rery narrow, thearl-lik', somewhat zigang bats of black, - these about 02 wide on the midele, and .07 on the outer feather. Beneath, anterior thirel, pure silky-white, shading insensily into soft orlunceons on the bleast, this soon darkening into deep ferruginous, the (o)lor of all the posterior lower parts; the whole of this ferruginous surface, with very obsolete transwers spots of white, each preceded by a marower dusky one. Length, 5.75; extent of wings, 7.50 (fiesh); wing, 2.48; tail, 2.13; culmen, .83; tarsus, .56. Bill deep slate, paler, and with lilaceous tinge, at hase of lower mandible; iris nmber; tarsi and toes black (fresh colors).

HAB. Central region of North Inerica, fiom boundary of United States northwarl. Extends up Valley of Coloralo. Westem Nerada, resident; Runwar.

The above characters apply to all specimens of Catherpes from north of Mexico, as substantiated by a sufficient series in the collection. It is a remarkable fact that this northern race should be so much smaller than the Mexican one, especially in view of the fact that it is a resident lird in even the most northern parts of its ascertained habitat.

H.dBits. The geographical distribution of this race of the White-tlroated Wren, so far as known, is confined to the line of the United Sitates and Mexican boundary, extending northward up the Valley of the Colorado, as fin as ITestern Neracla. The corresponding Mexican race reaches some distance sonthward, but has not yet been detected beyond the linits of Mexico. The habits of hoth races, however, are quite similar, as far as known.

Dr. Heemann first met with this Wren in the spring of 1851 , on the Cosmmes liver. In the following year he procured three specinens on the Calaveras liver. He describes it as an active, sprightly bird, having a loud and pleasing song that may be heard a great distance, and which it repeats at short intervals. When found, it was ocenpied with searching for insects, between and under the large bonlders of rock that, in some portions of the river, are thrown together in confused masses, as if by some terrific convulsion of nature.

Dr. Kennerly also met with this species in similar localities among the hills bordering upon the Big Sandy, where the rocks are also described 
as piled mp thick and high. They were darting from rock to rock and

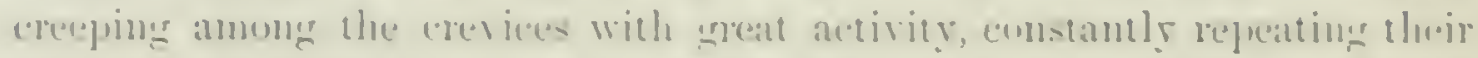

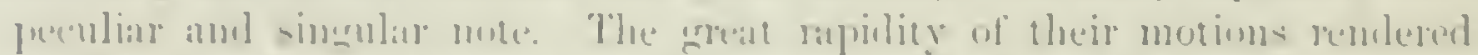

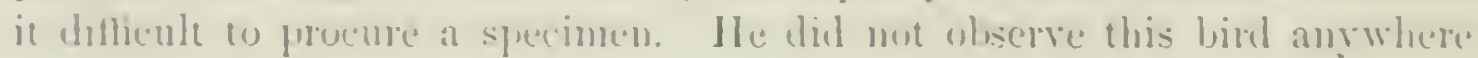
e.se.

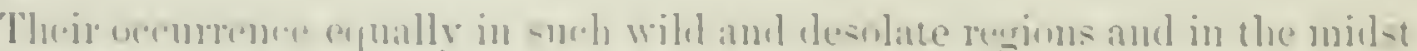
of crmmled eithes indieates that the ahmmlanee of their foud in either plater,

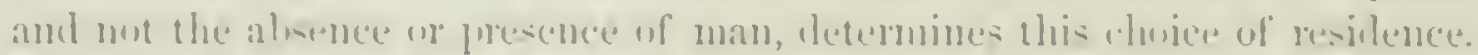

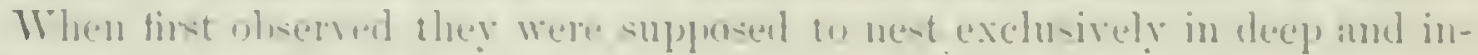
accessihle erevicen of meks, where they were not likely to lie maced. Mr.

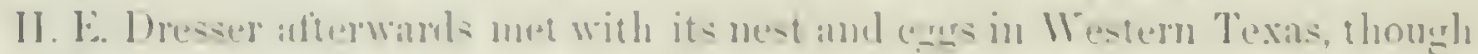

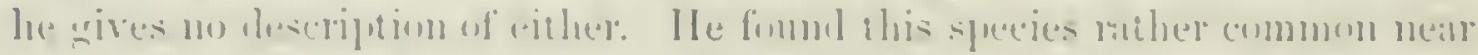

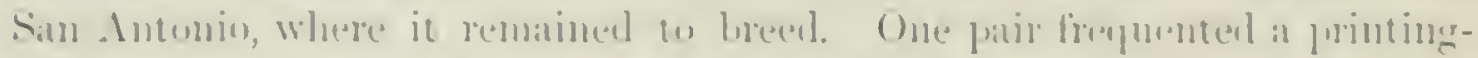

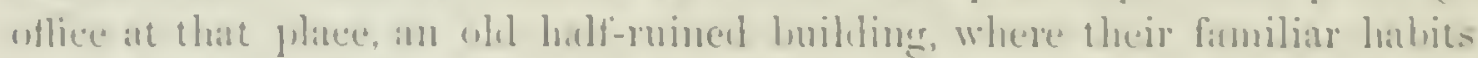
marle them erteit fitrorites with the workmen, who informed him that the

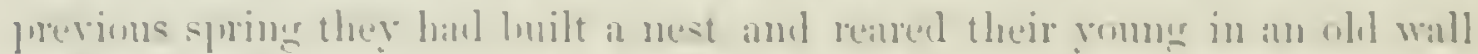

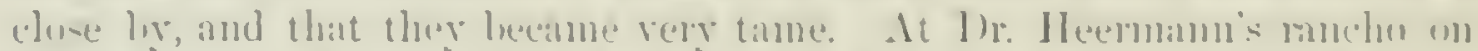

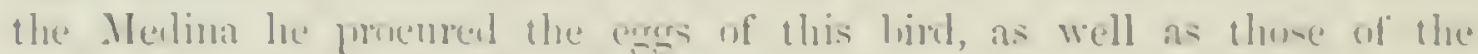

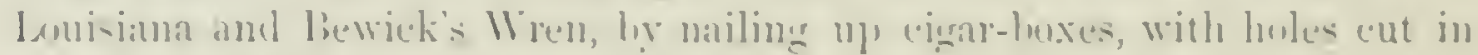
front, whererer these birks were likely to builel.

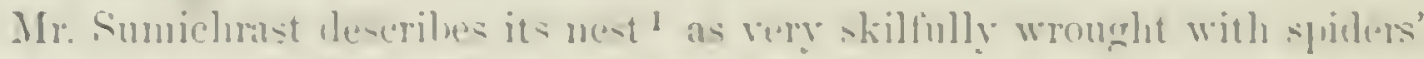

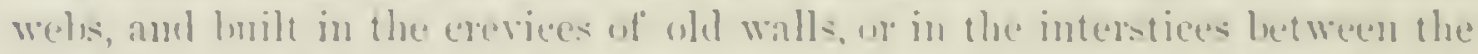

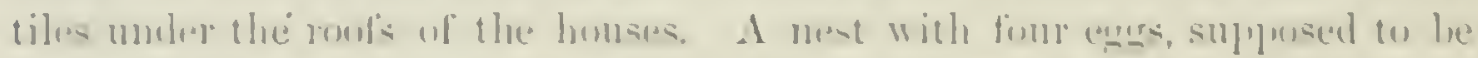

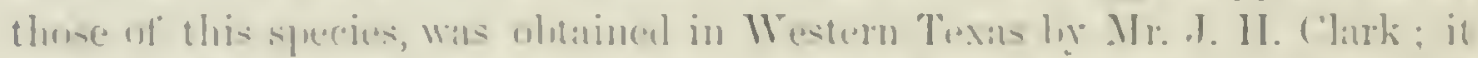

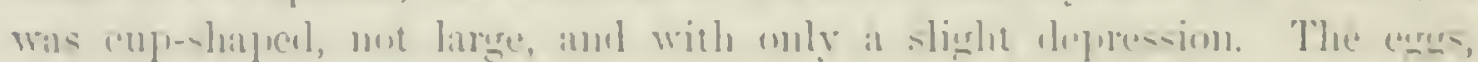

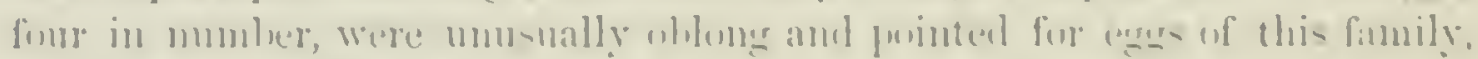

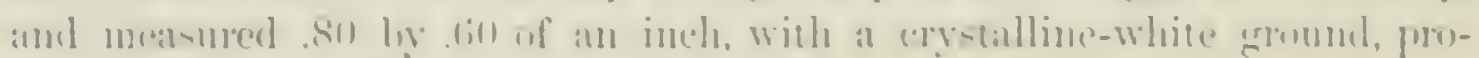

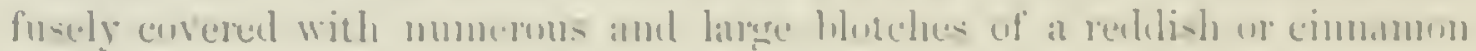
brawn.

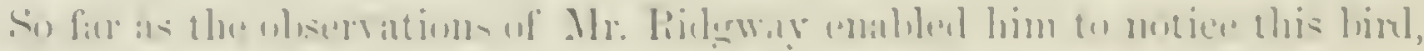

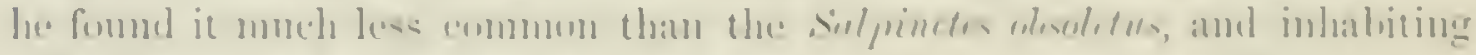

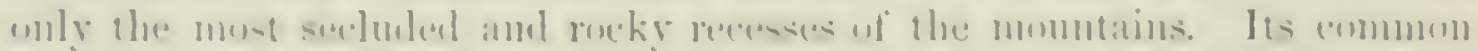

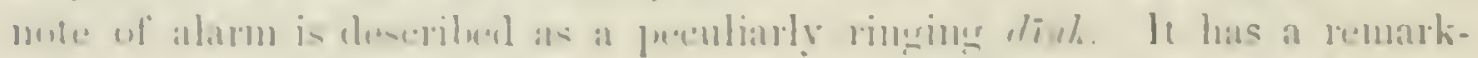

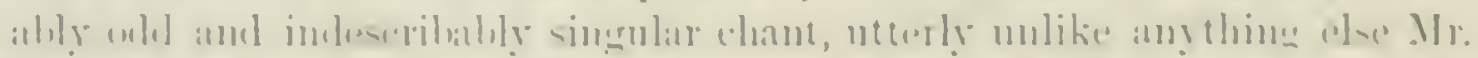

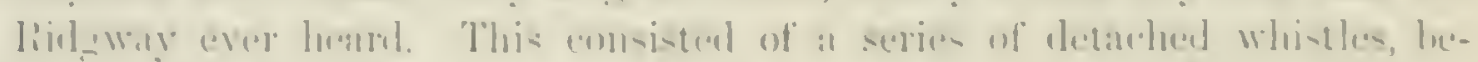

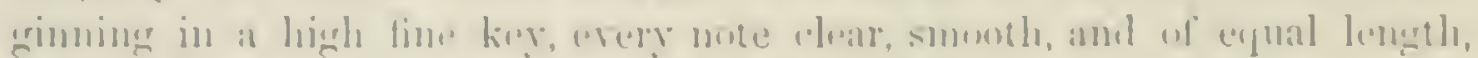

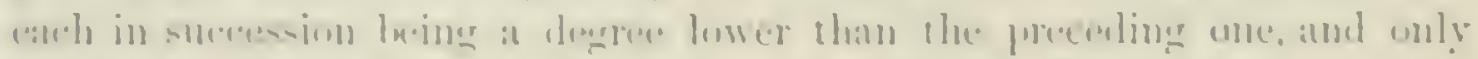

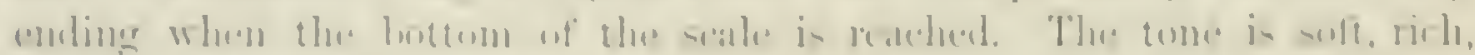

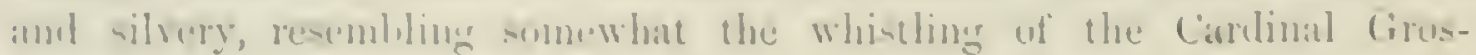
lin.ti:

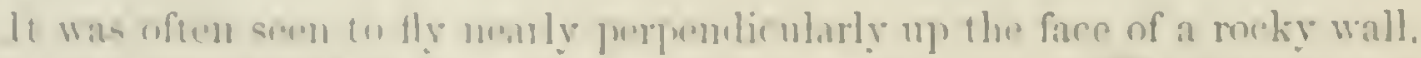
atml was al-o noticed to cling on the rout of a cave with atl the facility of a tme Lirieju.r. 


\section{GEXTS THRYOTHORUS, VIEILL.}

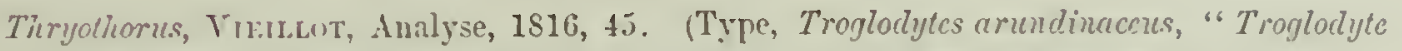

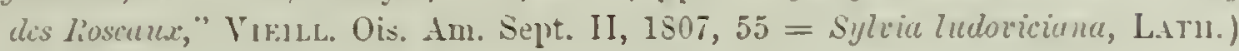

GEx. Crin. Bill compressed, rather slender; height about one fourth the length above. Culnen and commisure gently eurred thronghont: gonys straight; tip rery obsoletely notehed. Nostrils in the lower edge of anterior extremity of the nasal groore, narrowly elliptical, orerlung by a stiff seale-like roof of the thickened membrane of the upper part of the nasal groove, the crescentie elge rounded. The septum of nostrils imperforate; the posterior part of the nasal carity with a short septum projecting into it parallel with the central, not perpenticular as in Microcerculus. Wings and tail about equal, the latter moderately rounded; the first primary more than laalf the second, about half the longest. Tarsi rather short. scarcely exceeding milllle toe Anterior scutellat distinct, rest of each side of tarsi in a continuous plate. Lateral toes equal.

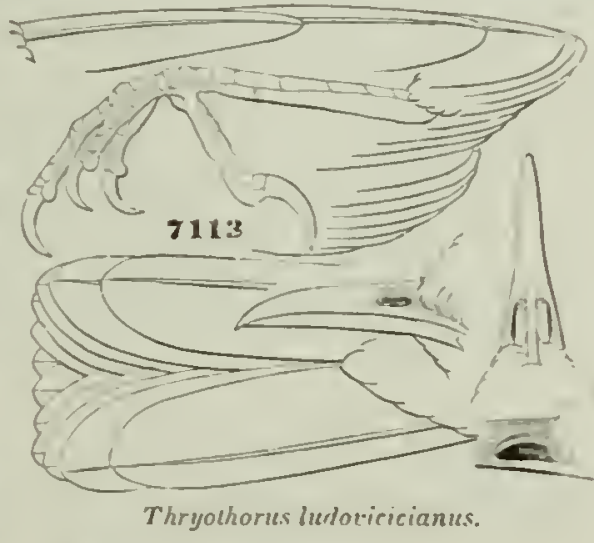

The diagnoses of the North American species are as follows:-

\section{Species and Varieties.}

Comos Citaracters. Head above, and back, of mucl the same color. Crissum barred transierely; rest of under parts plain. Lpper tail-corerts and exposed surface of wings barred. Iris hazel. Test in holes or with an arehed covering. Eggs reddish-white, spotted with red and purple.

\section{a. Thryothorus.}

T. ludovicianus. Tail-feathers reddish-brown, barred with black. Greater wing-corerts spotted with whitish.

Beneath yellow-whitish, washed ocrasionally with rusty. Sicles plain. Bill from nostril, .45. Length, 6.00. Hab. Eastern Province Lnited States. var. ludoricianus.

Beneath rufous; lighter on throat and along meclian line. Sides obsoletely barred with dusky. Bill fiom nostril, .j6. Length. 5.2.5. IIub. Lower Rio Grande. var. berla ndieri

\section{b. Telmatorlytes.}

T. bewickii. Tail-feathers, exeept central. black; the exposed surface and tips only rariel with white. Length, 5.jo.

Above dark rufous-brown; beneath plumbeous-white; flanks tingerl with brown. Rump and exposed secondaries distinetly banded. Quills and middle tail-feathers brownish-black. Length from nostril, .39; along gape, .70. Hab. Eastern Prorince Lnited States. var. beuickii Abore ashy-brown; beneath, including flanks. clear white; rump ashy, and, like secondaries, very obsoletely barred. Quills and midlle tail-feathers grayish-brown. Hub. Southern border of Lnited States, into Mexico . . . . . . . . . rar. leucogaster. Colors intermediate between the two last. Bill longer, from nostril, .50 , from gape, .81. Hab. Pacific Province . . . var. spilurus. 
Thryothorus ludovicianus, var. ludovicianus, Bwal.

\section{GREAT CAROLINA WREN.}

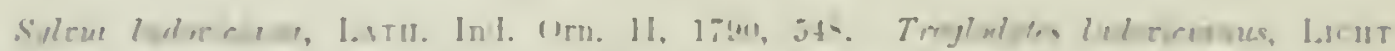

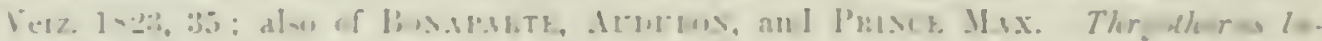

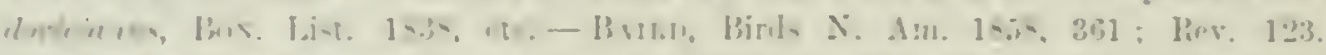

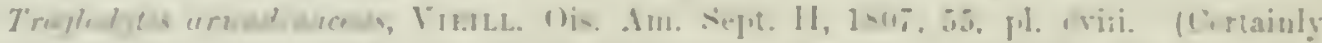

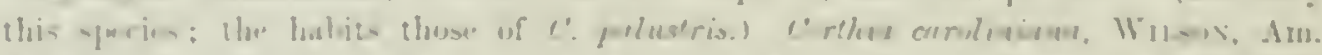

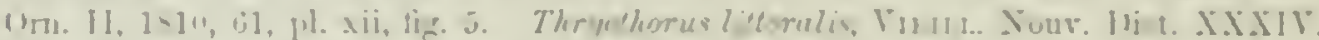

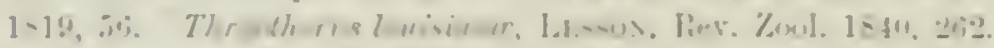

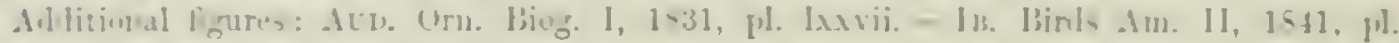
cxii.

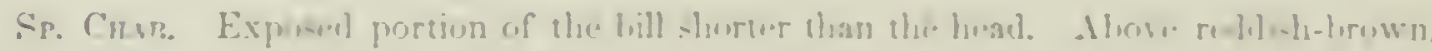

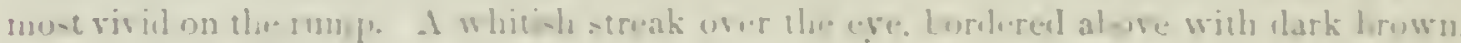

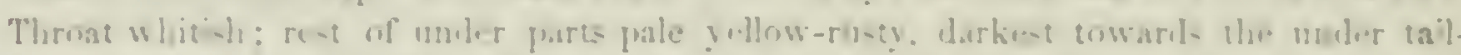

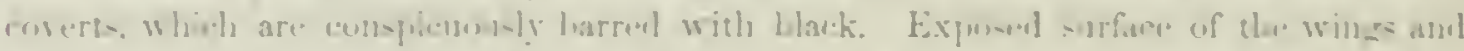

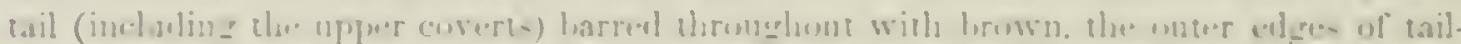

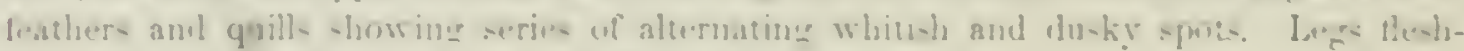

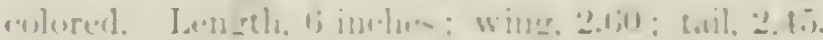

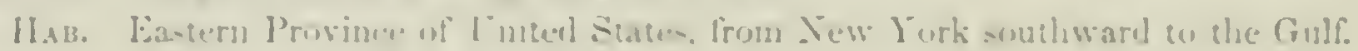

Honts. The Great Corolina or Mocking Wren is fonnd in all the simth-

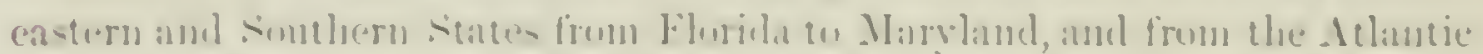

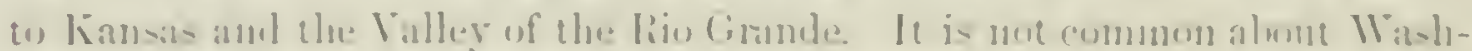

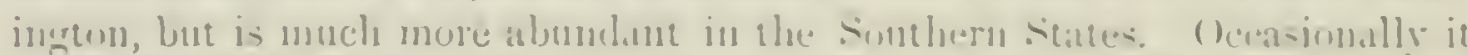

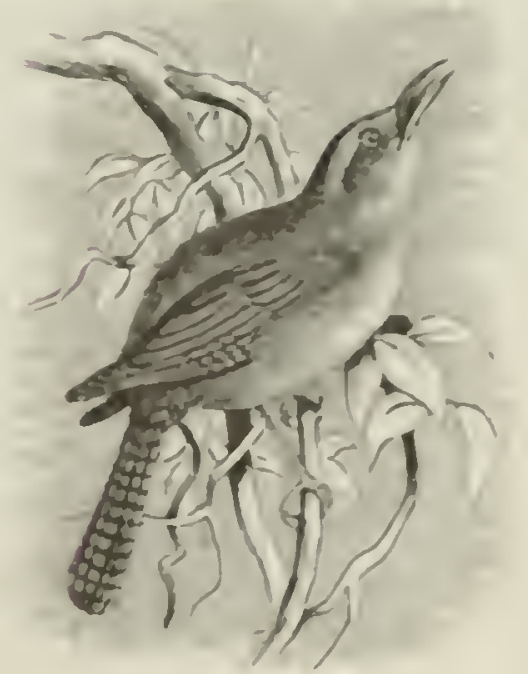

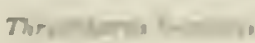
has been forment is far north as l'hiladelplia, and in one ur two instances near lew York, where Mr: Lallitence has iwice som it, and

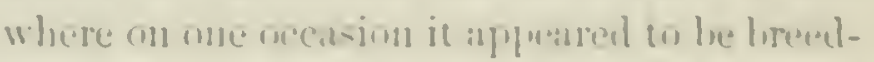
ing. [)r. Wiredhoure fomm it wery almudant throughome Texis and the Intian Territury.

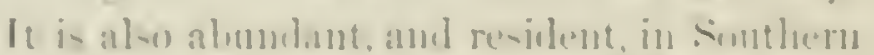

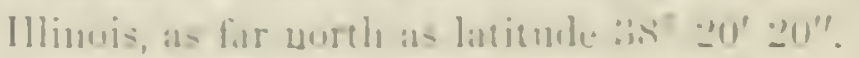

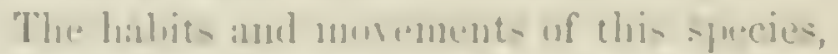
at descrilned he these whe hate had the

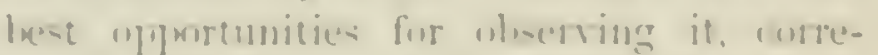

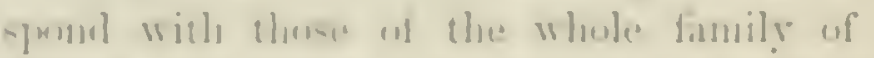
Wrens. It flight is monally only in thert

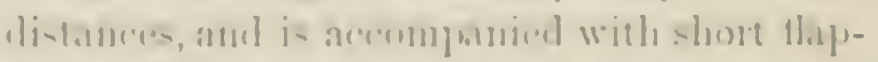
pines of the winges, ant rivelent juthings of

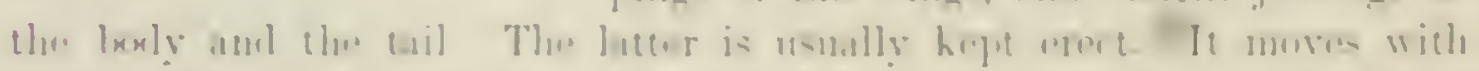

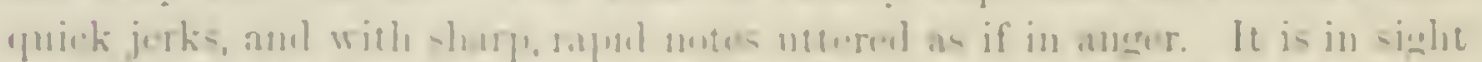

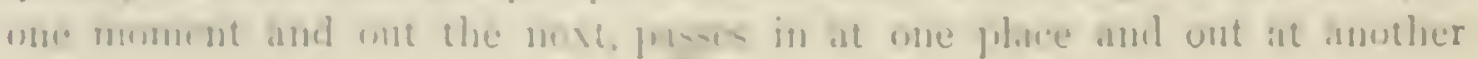


with the rapidity of thought. Mr. Audubon often saw it singing from the roof of an abundoned that-boat, near New Orleans, and wlen its song was ended it wonld ereep from one hoard to the next, enter an augur-hole at onc place to reappenr at another, catching numerons spiders and other insects all the wlile.

Occasionally its movements are like those of a Creeper, ascending to the upper branches of trees of a molerate lieight, or elimbing a griperine, searehing diligently among the leares and in the crevices of the bark for insects.

This species possesses a great variety and power of snng. It is also said to have and to exlibit remarkable powers of imitation, with a great rariety in its appropriated notes of other birds, giving, witl modulations, the hoarse rattle of the Kingtisher, the lively nutes of the Tufted Timouse, the simple refrain of the Ground Robin, with those of the Grikles, the Mearlow Lark, the Blnebird, and others. Like the common Wren, the Carolina generally builds its nest in the hollow of some tree or stump, or any other convenient eavity. At other times it constructs its own habitation without any other protection than the thick branches of a vine or shrub. In these situations they are long and deep, and have an artificial roofing, often separate from the nest itself. The materials employed in their construction are lay, grasses, leaves, feathers, horse-hair, and dry fibres of the long Spanish moss. They are softly and warmly lined with fur, hair, and feathers. The nest is not infrequently fire or six inches in depth, while the opening is not large enough to admit more than one bird at a time. They sometimes raise three broods in a season.

It breeds as far north as Philadelphia, Mr. Andubon having found its nest in a swamp in New Jersey, opposite that city.

Although seemingly studions of concealnent, and shy and retiring in its habits, Nuttall frequently observed it in Tuscaloosa and other large towns in Alabama, appearing on the tops of barns and out-houses, singing with great energy.

Dr. Cooper, who enjoyed a farorable opportmuity of watching these birds in Florida, in the spring and smmmer of 1859 , found a nest of this Wren in the middle of March. It was built in a small box on a shelf in a mill, and was about fom feet from the gromnd. It was arehed over at the top, though this was not necessary to shelter it. This covering was formed of shavings, with a few small sticks and straws. Four eggs were laid. The birds were very tame, and were not alarmed by the loud noise of the mill, nor by a cat almost always present. Another nest found by Dr. Cooper was built in a small hole in the trunk of a tree, not more than six inclies from the ground. This nest was not arched orer. Its close proxinnity to a dwelling-house alone protected it from wild animals.

The eggs of this Wren are usually six or seven in number, and vary in size and shape. They are for the most part of a spheroidal-oval sliape, though 


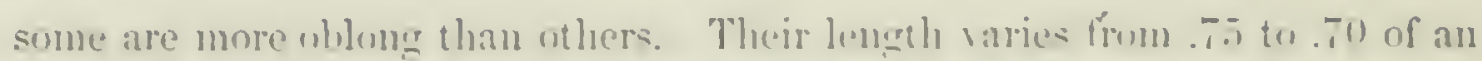

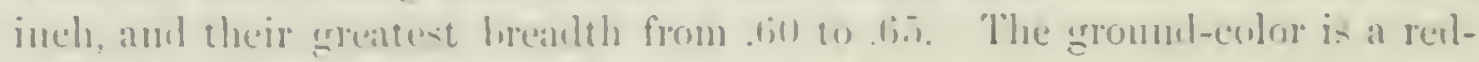
di-h-white, profisely covereel with hlotches of purjle, slate, redilish-brown,

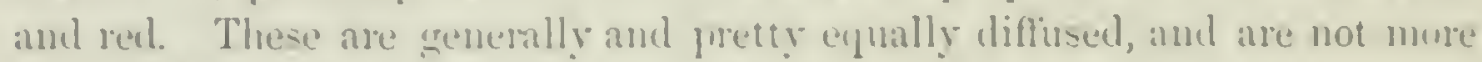
abundant at the latreer end than elsewlere.

\section{Thryothorus ludovicianus, var. berlandieri, ('rech.}

\section{BERLANDIER'S WREN.}

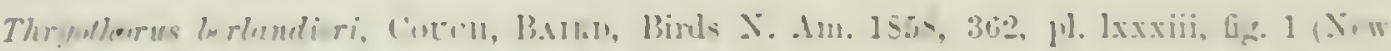
Loul1); line. 1:-1.

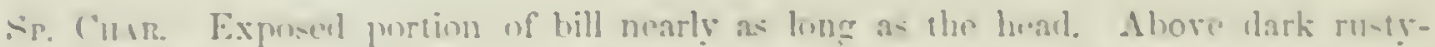

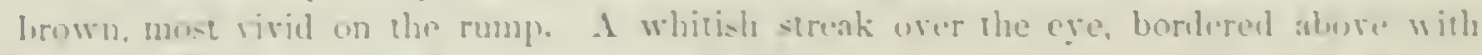

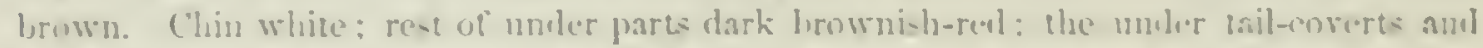

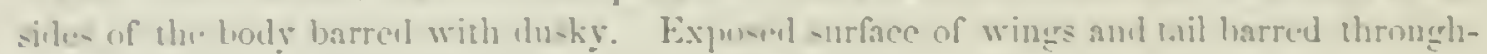

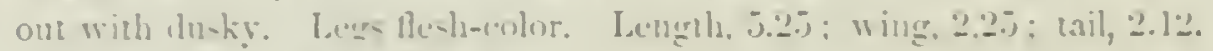

H.s?. Vallig of Riu Gramle.

The distinctive features of this race will be found indieated on page $1+1$.

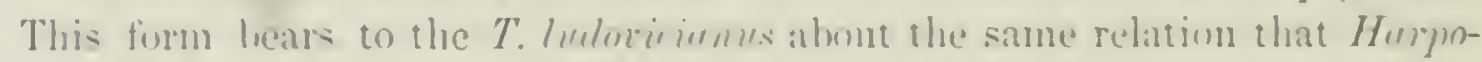

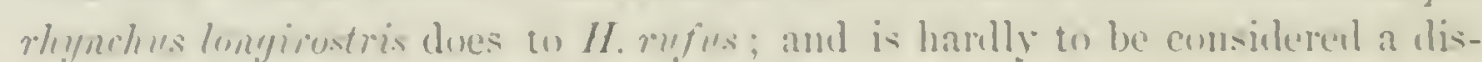
tinct "sprecies" from it. It slumlil be moted that in luth cases the length-

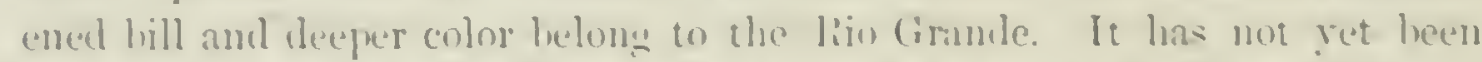
unet with north of the lifo cirande, lut donbtless extends into Texils. Nothing is kmwn of its labits.

\section{Simotes THR YOMANES, ShT}

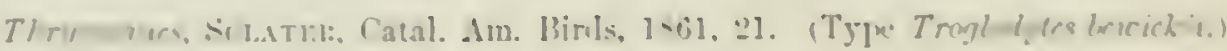

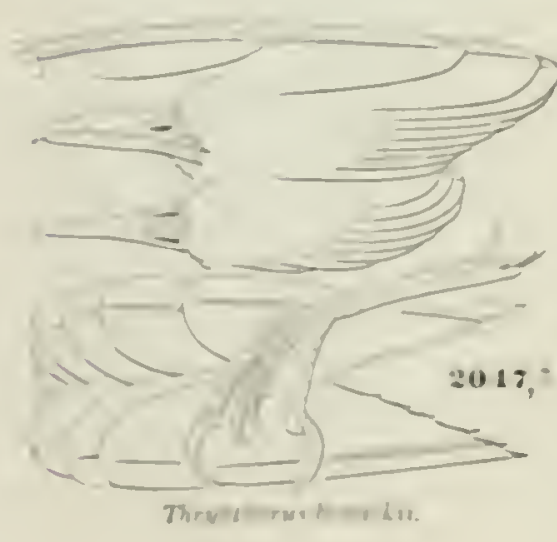

There are three strungly marked geostaphi-

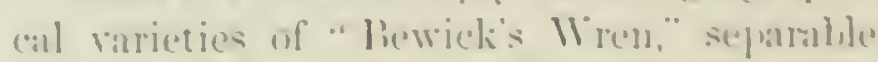
ly quite constant chameters. of these the

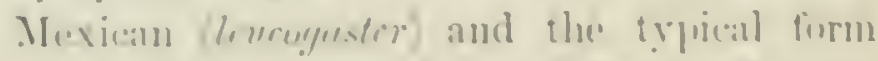

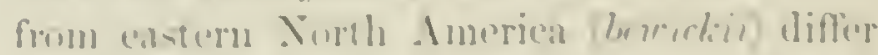
mot in mblomtion, while the western grilnrus is infermendiate in this reapert, hut witl a longer libll than in the other two. The pe'culiarities of the three forms are expressed (iil) 
Thryothorus bewickii, vil: bewickii, Bnxip. BEWICK'S WREN; LONG-TAILED HOUSE WREN.

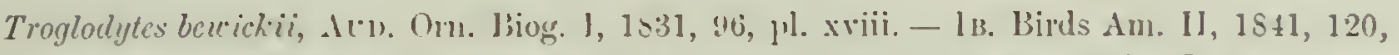

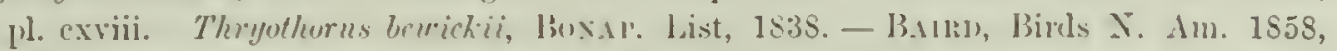
363. Telmutmlytes berichii, C.s1. Ilus. Heir. I, 1850, 7s. Thryothorns bevichii, var. beuickii, B.11:D, licv. Am. H. 1S6t, 126.

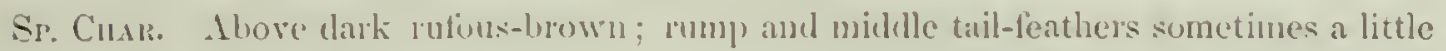
palere, and very slightly tinged with erraty, amb together with the exposed surface of sec-

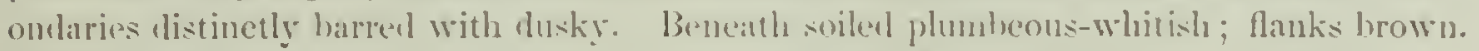
Crissum banded; ground-color of (puills and tail-leathers brownish-black. Length, 5.50):

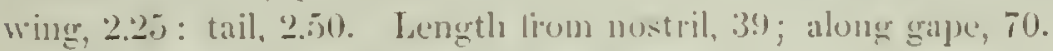

Hiss. Eastern Province of Inited sistex.

Habiss. This interesting speries of Wren wits first met with hy Audubon in Lonisiana. A number of indivilnals were olserved at the time, but nothing of its history was known for several years afterward. In shape, color, and habits it most resembled the (amlinit Wren, lut was less rapid in movement, and not so lively. Fonrteen vears later I)r. Bachman anain met witl birds of this species, in 18:3., at the salt. Sulphur siprings of Virginia. They comprised a fanily of two parents and five young, nearly full grown. Their notes were like thuse of" the Winter "Wren, neither londer nur nue connected. They seemed of restless habit, creeping actively among fences, stmups, and logs. One ascenderl an bali, nearly to the top, in the manner of a c'reeper. This species proved to be quite common in that locality, and to be the only Wren abmolant among the momtains. 1): Cribus detected it neau Columbia, S. C., and I)r. Trudeau afterwards foumd it yuite common in Louisituli.

It was first observed breeding ly l'rofessor bairel in Carlisle, Penu., in 184t. In all respects the nests and their locition corresponded with those of the common Wren. I)r. Woodhonse found it very abundant in the Indian Territory, and describes its hahits as similar to those of ofler Wrens. Lientenant Conch observed this Wren at Santa Rosalio in Mexico, early in March. It was seeking its food anong the low prickly-pents. He was informed that they deposited their egrs wherever they conld do so without making much of a nest, inside the eabins under the rafters, but in New Leon he found one of its nests ynite elabonately ennstructer in a thatehed roof. He describes the song as quite varied, and one of the sweetest that he heard in that comutry.

The late D1. Gerhardt of Vinnell's Station, Ga., met with this speeies anong the mountainons portions of Northern Georgia, where it generally nested in holes in stumps. In one instance the nest was constructed five inches in length, and four in diameter, with a cavity two inches in depth, and the walls of great proportionate thichness, made externally of coarse roots, 
146

NORTH AMERH:AN MHRS.

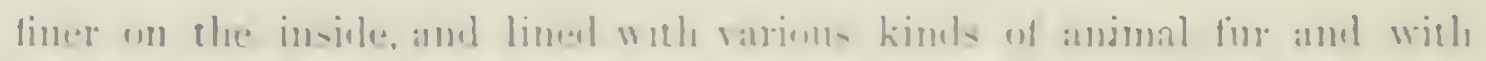

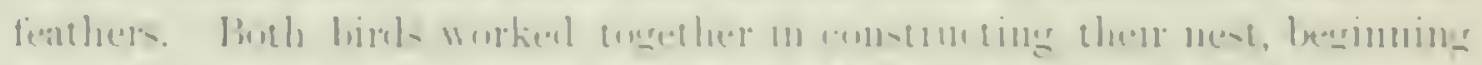

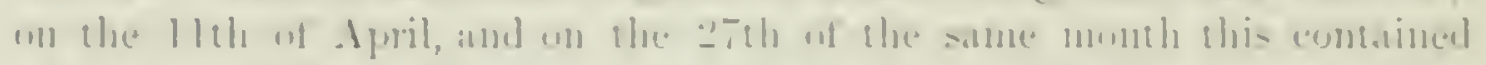

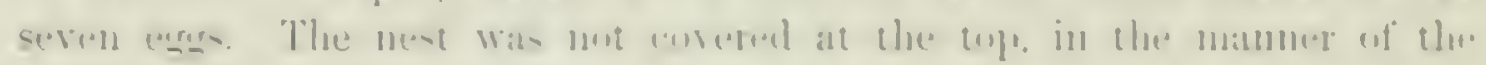

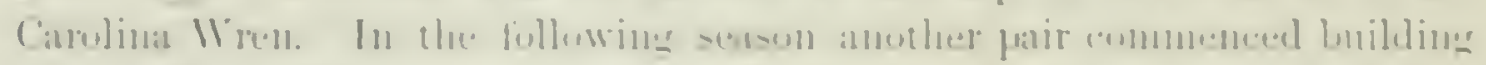

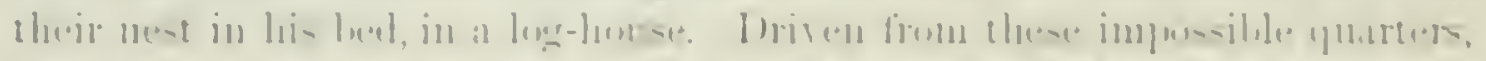

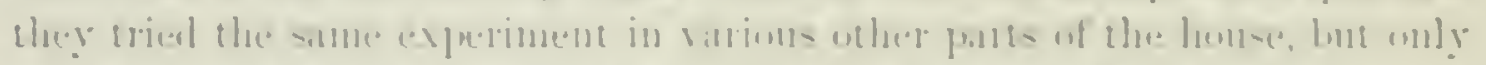

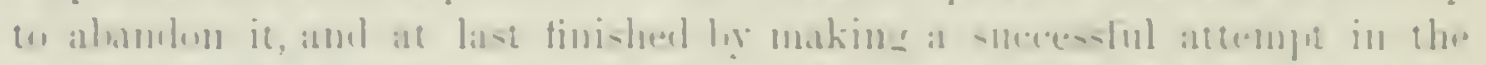

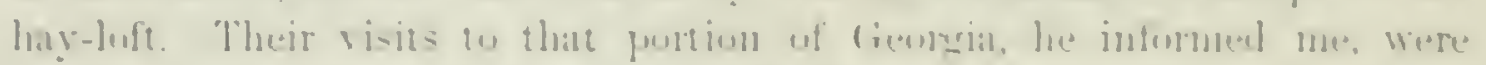

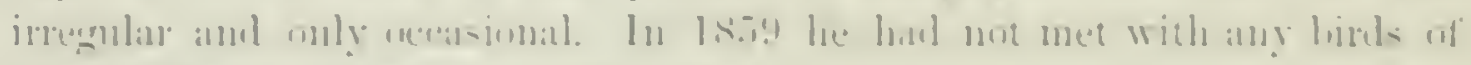

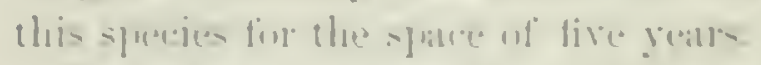

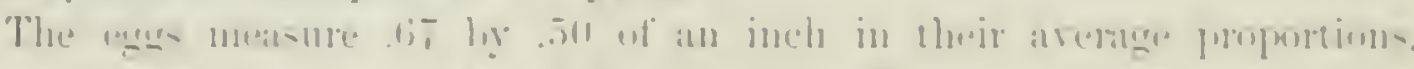

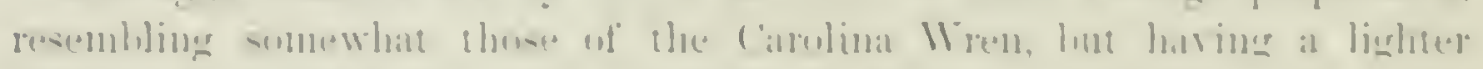

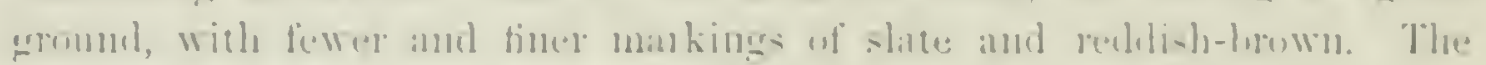

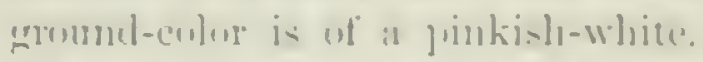

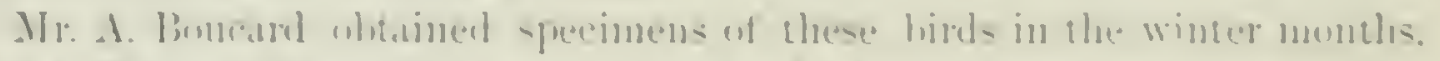

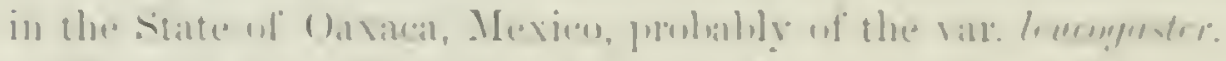

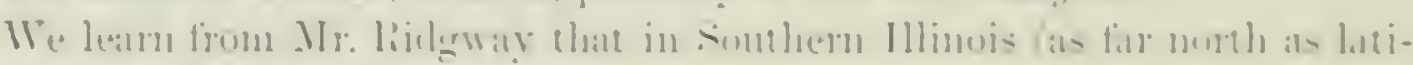
tmb. :

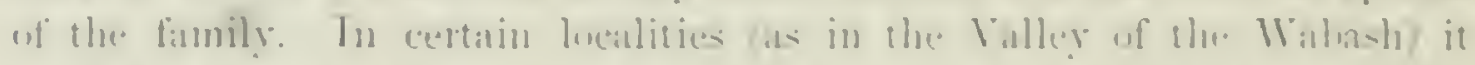

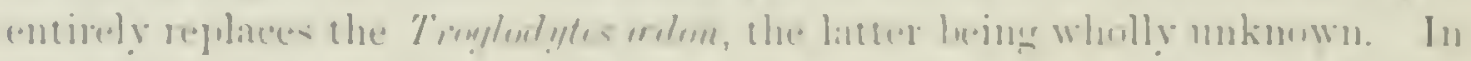

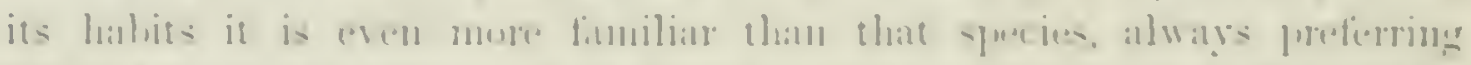

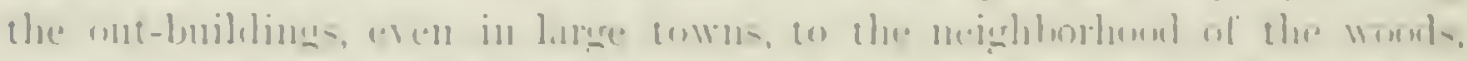

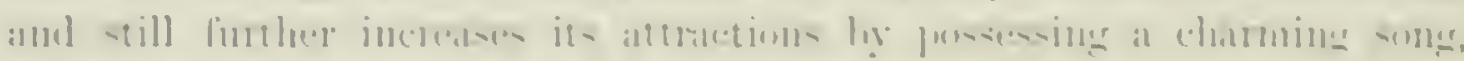

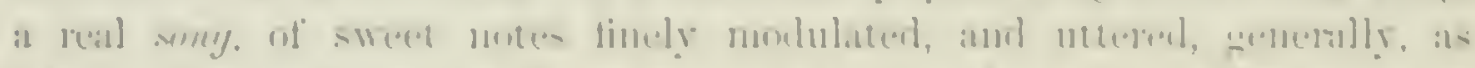

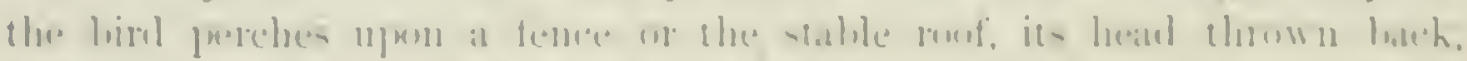

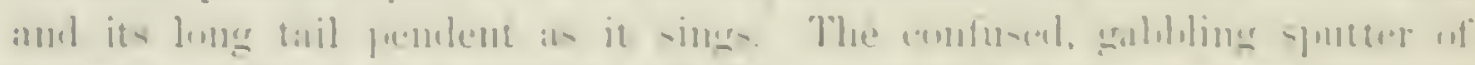

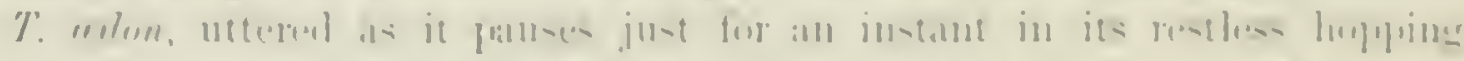

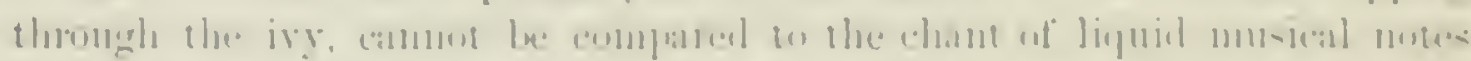

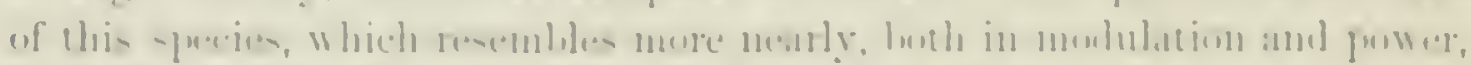

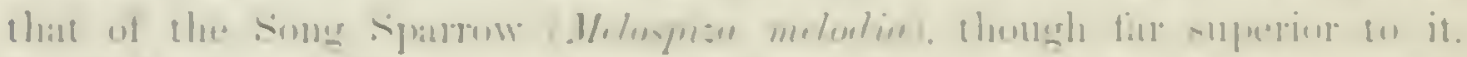

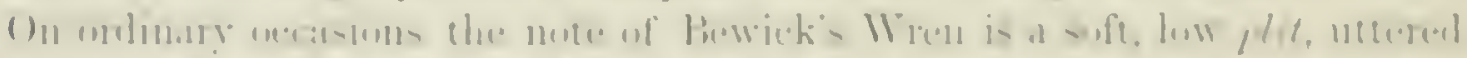

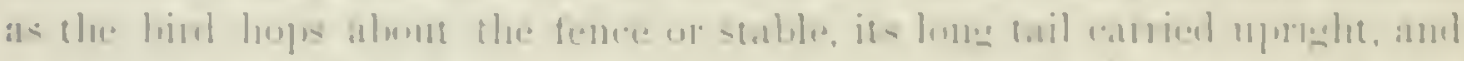

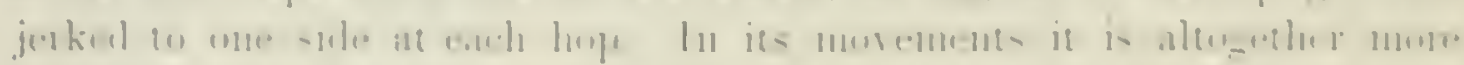

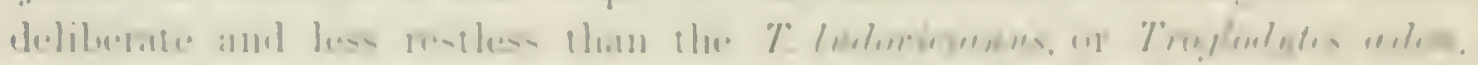

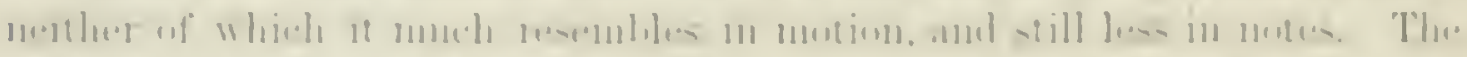

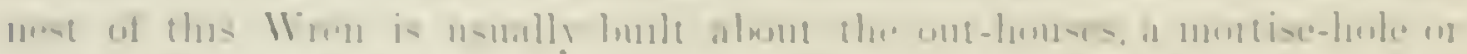

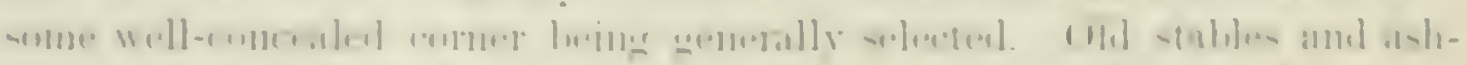

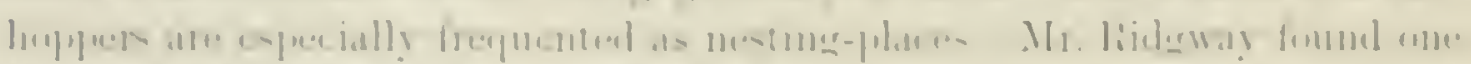

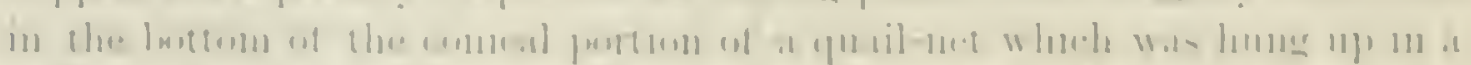

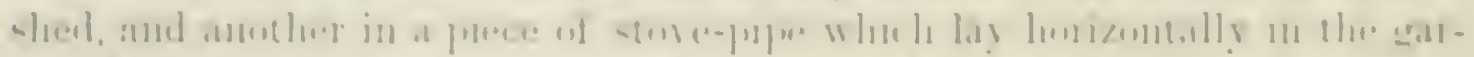

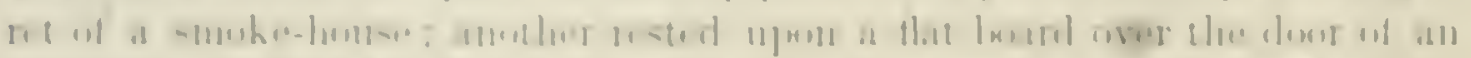

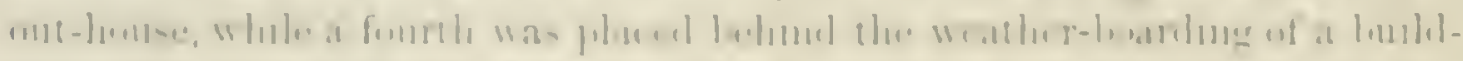

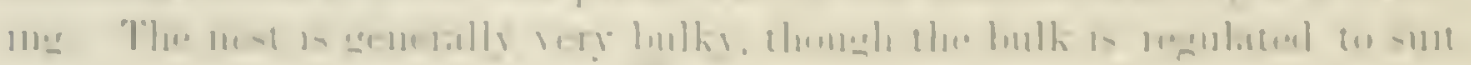


the size of the cavity in which the nest is placed. Its materials are usually sticks, straws, coarse feathers, fine chips, etc., exteriorly fastened together with masses of spider's-wels, the lining being of finer and more downy materials, generally soft spider's-webs, tow, and especially the downy feathers of harnyard fowls.

\section{Thryothorus bewickii, var. leucogaster, Goctn.}

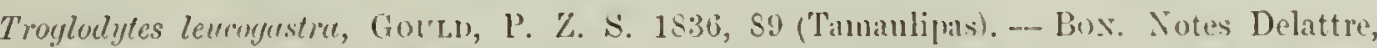

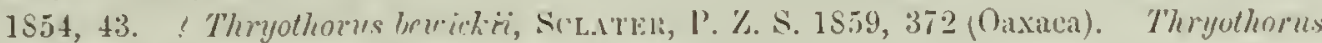
berickii, var. leweogester, H.111: L, Rev. Am. 13. 127.

Sp. Cusr. Above ashy-brown; rump and miclle tail-feathers brownish-ash, the former nearly pure ash; without apprecoblule bars; bars on secondaries obsolete. Beneath, including insile of winer, pure white, with little or no brownisly on the silles. Crissum handed; ground-color of the quills and tail-feathers graysh-brown. Size of rar. beurelii

HAB. Sonthern borkers of I'nited States, into Mexico.

Habits. Nothing is on record of the habits of this variety as ilistinguished from var. bruiclii.

\section{Thryothorus bewickii, var. spilurus, Vicors.}

Troglodytes spilurus, Vigons, Zöil. Beechey's Voyage, 1\$39, 18, pl. iv, fig. 1 (California)

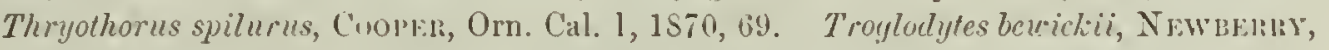

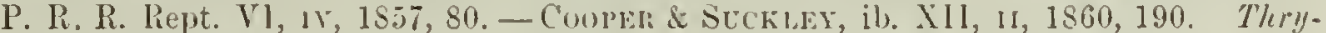
othorus beuickii, ScLatrli, Catal. 1S61, 22, no. $1 \pm 1$ (in part). Tliryothorns bewichii, var. spilurus, Banti, liev. 126.

Sp. Cirar. Similar to berichii in eolor, the bill eonsiderably lonerr. Leneth from nostril, .50, gape, .81, instearl of .39 and .70

Haв. Pacific slope of United States.

Young birds from all the localities differ from adults merely in liaving the feathers of the throat and breast very narrowly and inconspicuously edged with blackish.

HaBits. This variety of Pewick's ITren is exclusively an inhabitant of the Western coast. According to Dr. Cooper, they abound throughont the wooded parts of California and northwarl, frequenting the densest forests as well as the open groves. During the winter they were found in the vicinity of Fort Mojave, but left in April, probably for the mountains. They also winter throughont the mild regions towards the const as far north as Puget Sound. They are known as Mocking- Wrens, though Dr. Cooper thinks they do not really imitate other birls, but rather have a great variety of their own notes, some of which resemble those of other birds and are well calculated to deceive one unacenstoned to them. He was often led to search in rain for some new form, which he thought he heard singing, only to fiud it to be 


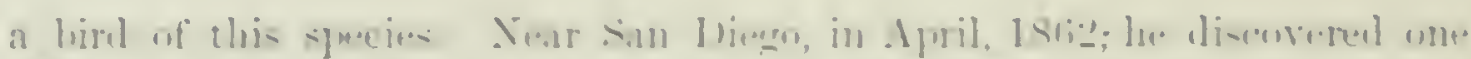

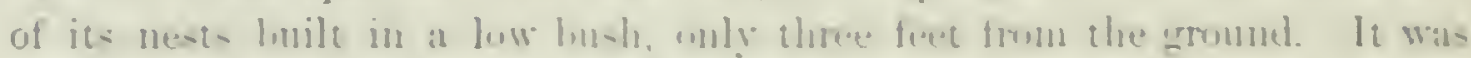

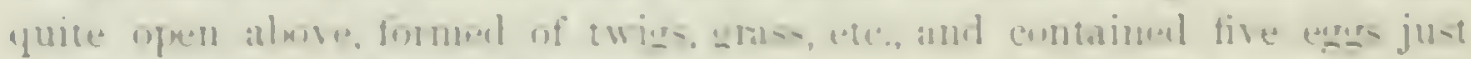

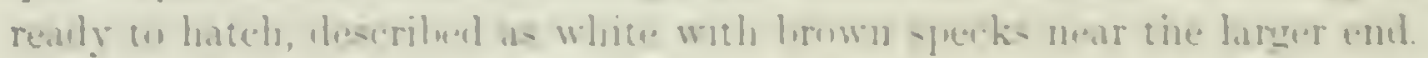

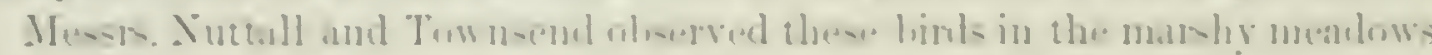

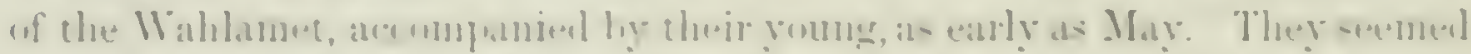

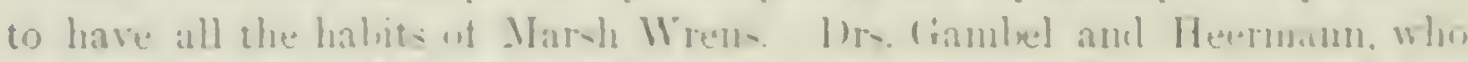

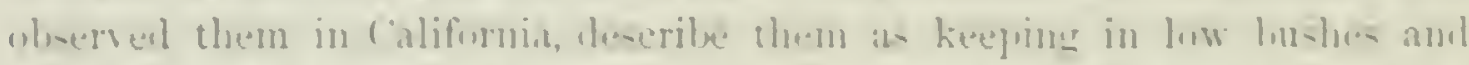

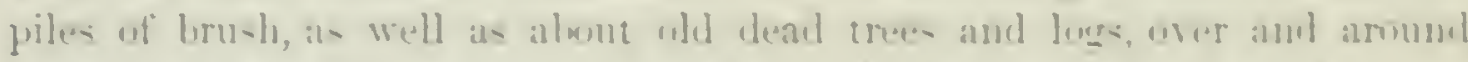

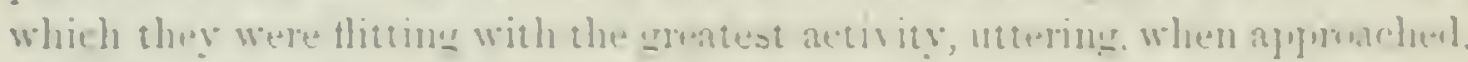
the misal grating reold of the 11 rion-

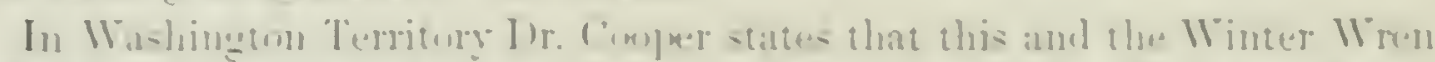

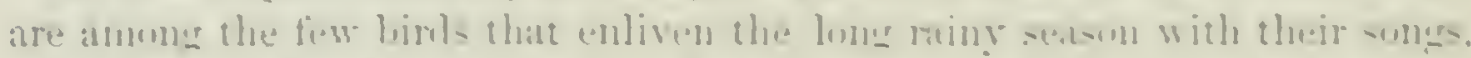

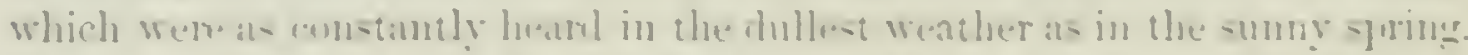

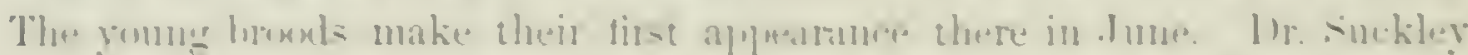

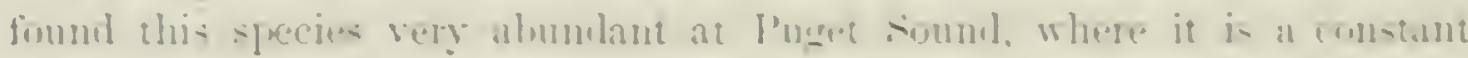

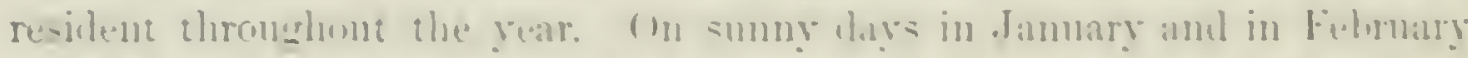
it was fond anong low thicket in complany with the smaller - jrecies. It this season they were very tane, allow ing a person to alprouch the-m without

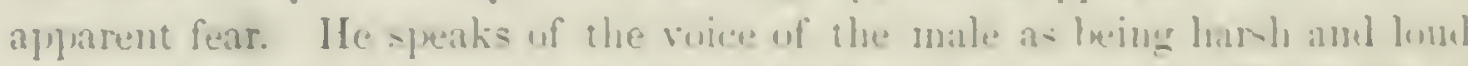
during the breeding-seasin, and not unlike that of the comnun Hutse Wren.

('FN- TROGLODYTES, VIFH.

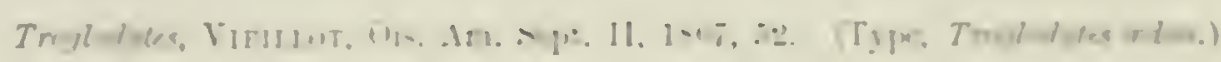

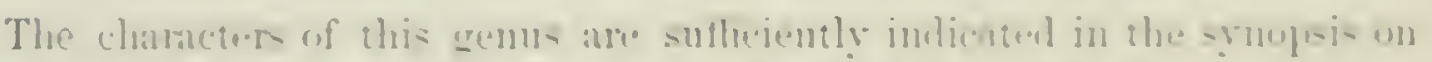

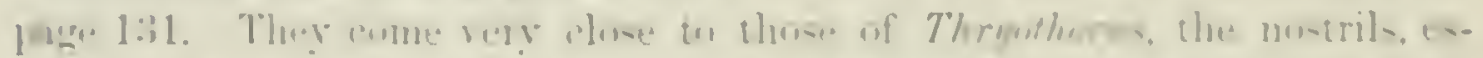

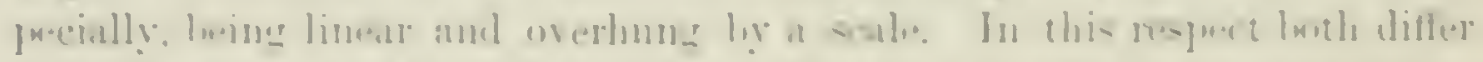

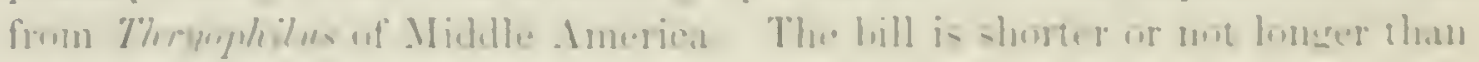

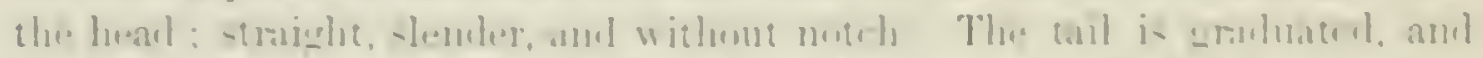

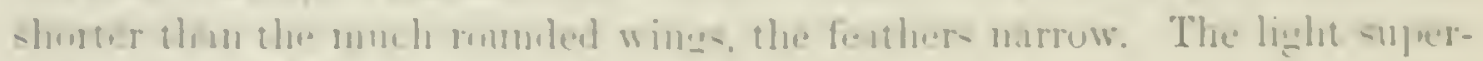
whary luse of Th ryothoms is ahomet entirely wantul-

\section{Species and Varieties.}

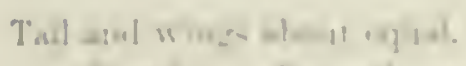

$$
\text { a. Thin'. }
$$

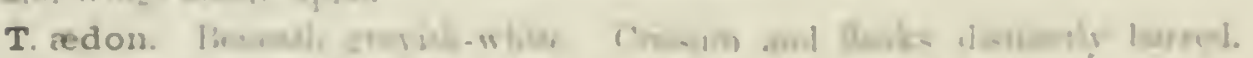

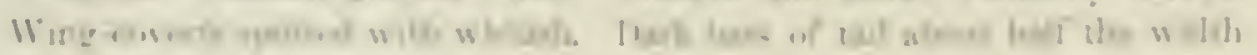

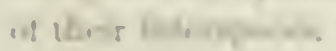

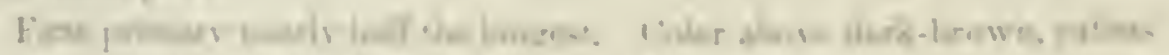

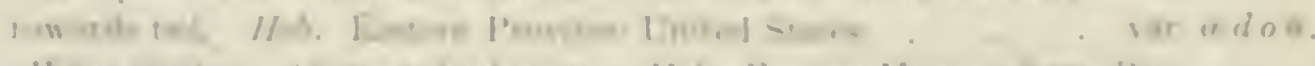

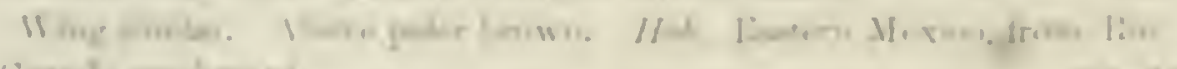
liranl. matimari

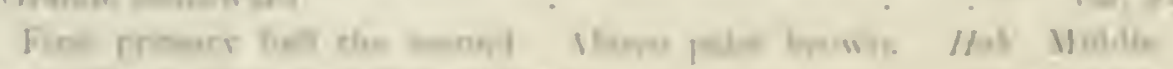

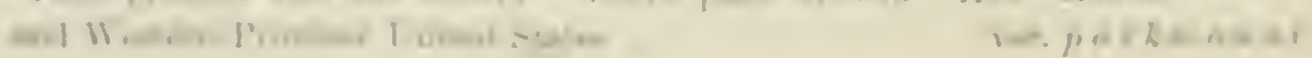


b. Anortherre.

Tail very short: only about two thirds the wing.

\section{T. hycmalis.}

u. size of udon exeept for shorter tail, wing ahout 2.00 ; eulmen very

straight. Ilub. Aleutian Islaucls. . . . . . var. "lusensis.

b. Much smaller than édon, wing about 1.75.

Pale reddish-brown; dusky bals of upper parts with whitish spots or in-

terspaces. Hab. Eastern Province Lnited states; Corlova? Vill. h y e malis.

Dark rufous above and below; upper parts with tew or almost no

whitish spots. Hab. Pacitic Province Tortl America. vill. pacificus.

Troglodytes ædon, Vieilit.

HOUSE WREN; WOOD WREN.

Troylodytes adon, Vıeıl. Ois. Alu. Sept. 11, 18n7, 52, pl. crii. - In. Nour. Diet. XXXIV,

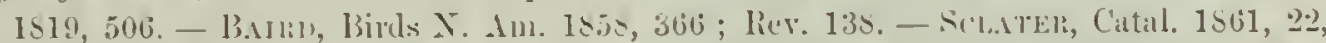

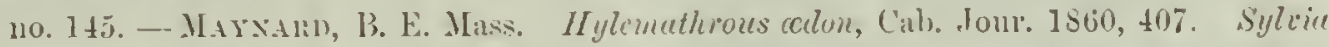
donesticu, Wilsox, Am. Orn. 1, 1s0s, 129, pl. vii. Troyludytes fulvus, NutT. Man. I, 1832, 422. ? Troglodytes americuuns, Avi). Olı. Biog. 11, 1834, 452; V, 1839, 469,

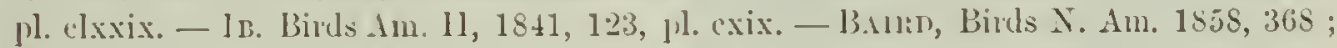
liev. 1, 141.

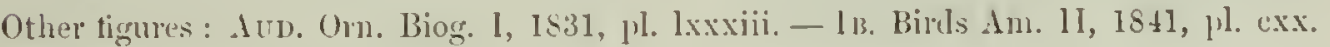

Sr. Cusk. Tail and wings about equal. Bill shorter than the head. Above reddishbrown, darker towads the head, brightry on the lump. The feathers everywhere, exeept on the head and neck, harred with dusky; ohscurely so on the back, and still less on the rump. All the tail-featlers barred from the base; the contrast more rivid on the exterior one. Beneath pale fulvous-white, tinged with light brownish aeross the breast; the posterior parts rather lark brown, obseurely banderl. Tulde tail-coverts whitish, with dusky bars. An indistinet line orer the eye, eyelids, and loral region, whitish. Cheeks brown, streaked with whitish. Length, 4.90 ; wing. 2.18: tail, 2.00.

Hab. Eastern Province of the Lnited States, from Mtlantie to the Missouri River.

In the Reriew of American Birds (p. 139), I have established a rariety, aztecus, to embrace specimens from Mexico paler than adon, and with a brownish tinge on the breast, and smaller size.

There can scarcely be any doubt that the T. americunus of Audubon is nothing more than this species in dark, accidentally soiled phumage (from charcoal of burnt trees, etc.).

Hubits. The common House Wren is found throughout the United States, from the Atlantic to the Rocky Mountains, though it is not everywhere equally abundant. Thus, while in some parts of Massachusetts it occurs in considerable numbers every year, in other portions not twenty miles distant it is nerer seen. West of the Rocky MLomtains it is replaced ly Parkman's Wren, which is rather a race than a dis-

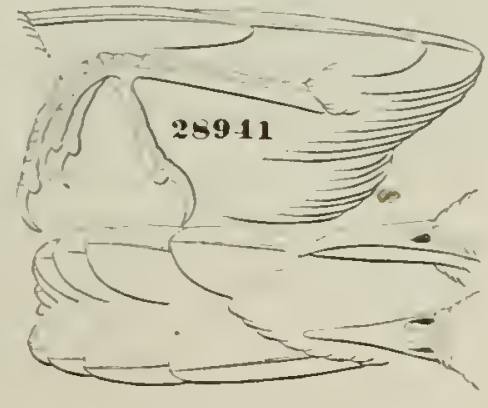

Trowlodyers adoun 


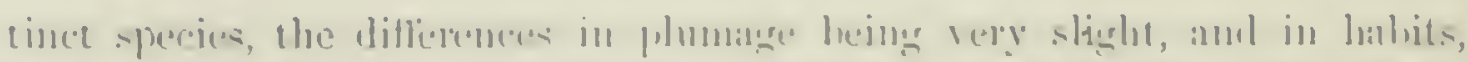

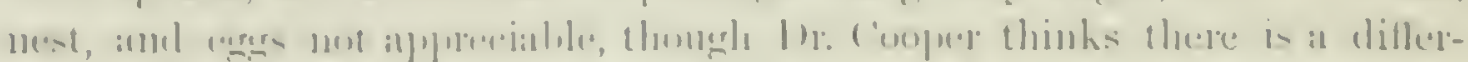

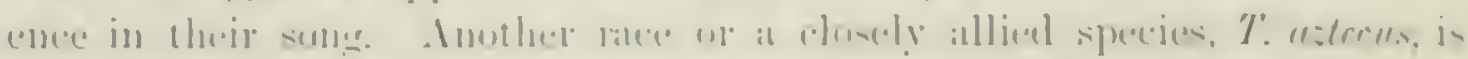

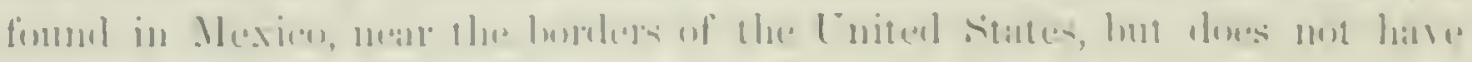

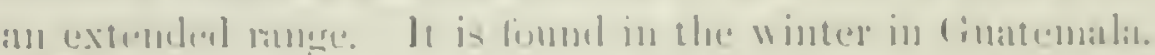

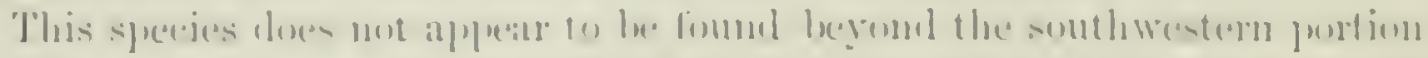

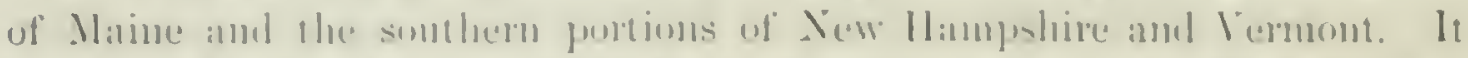

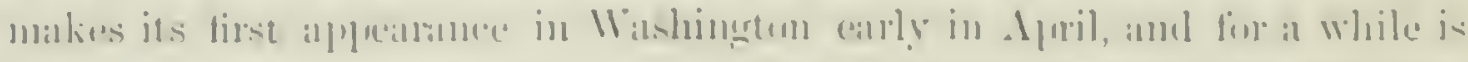

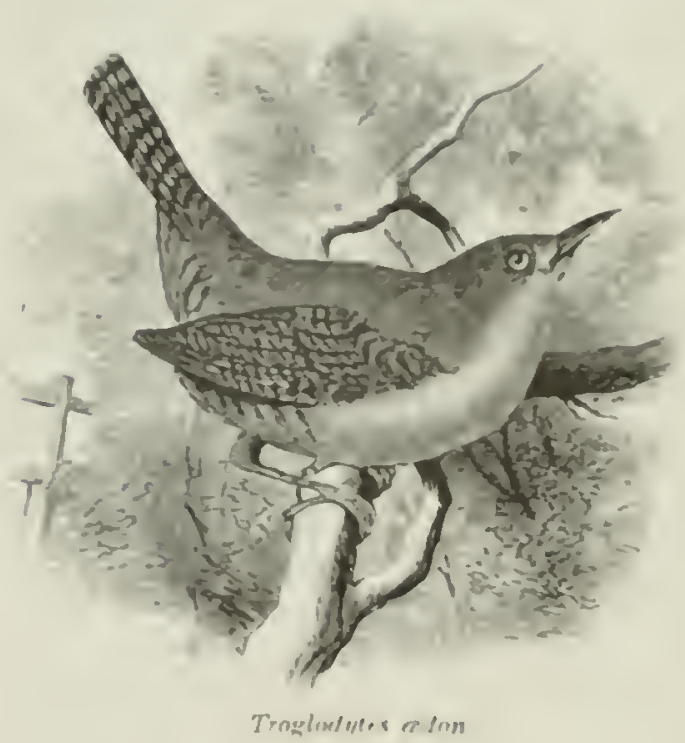

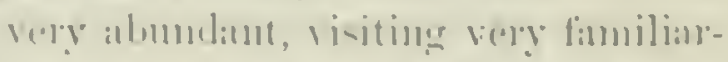
ly the pullic grommls of the ("ip)itul,

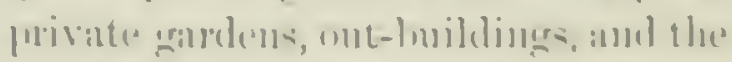
(aives of dwelliness. It does not al)pear in the Now Englannl states motil

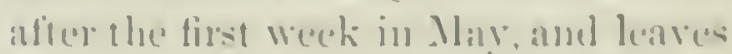

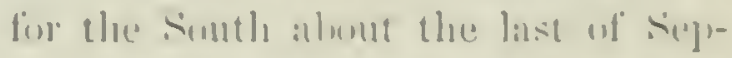
tomber. It is not obserrecl in any furtion of the Linited states alter the lisst wit Normber:

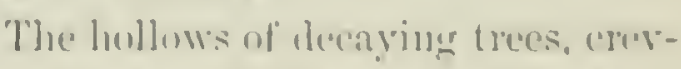
ieces in rocks, on the cerntre of meshes of interlateing vines, are theje mitumal renorts. There dhey mandily relimpuish

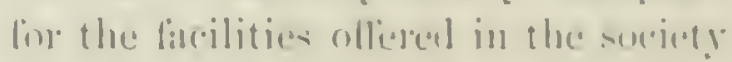
of man. They are lold, sociahle, confidine hirds, and will anter inte the

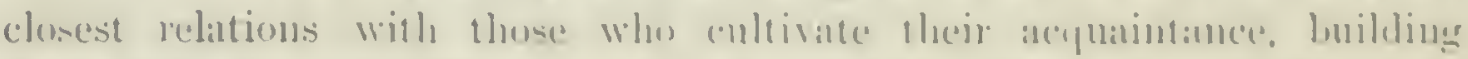

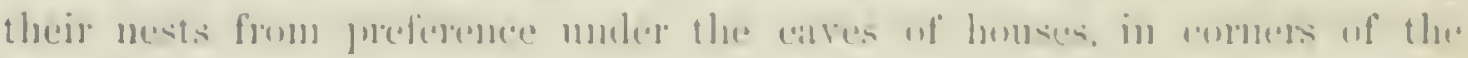

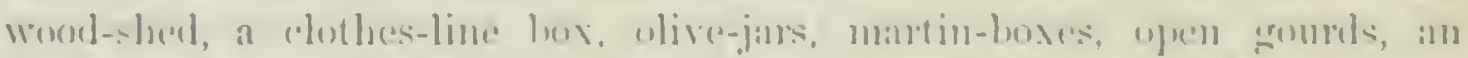

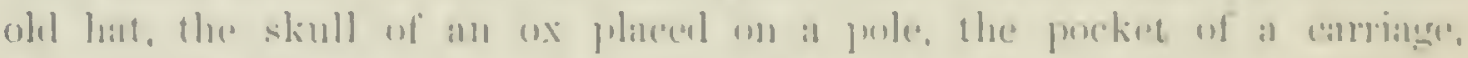

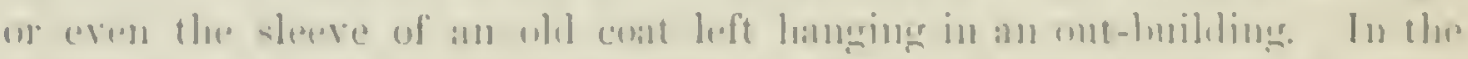

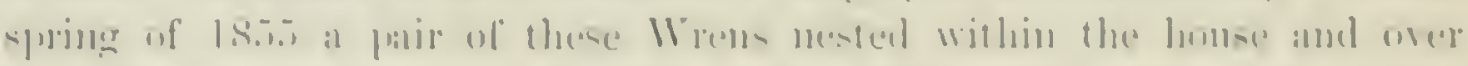

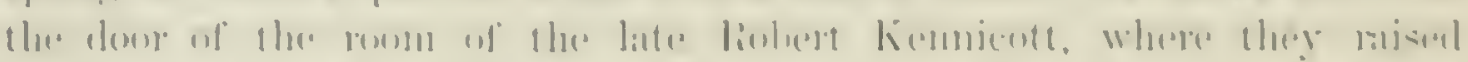

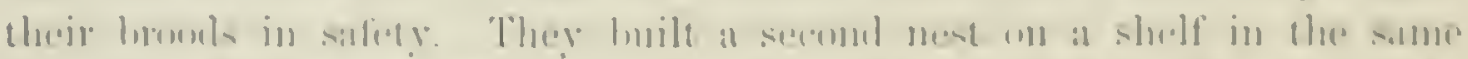

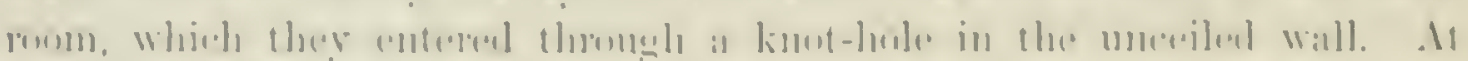

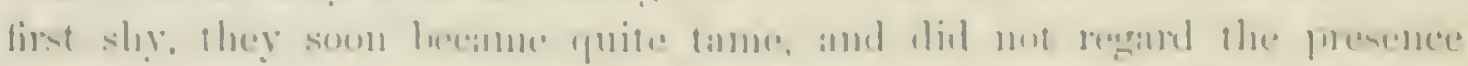

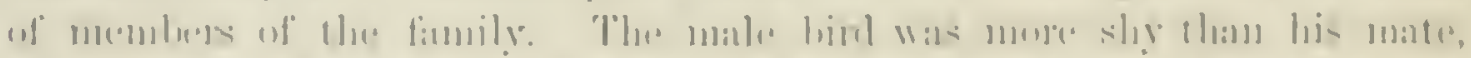

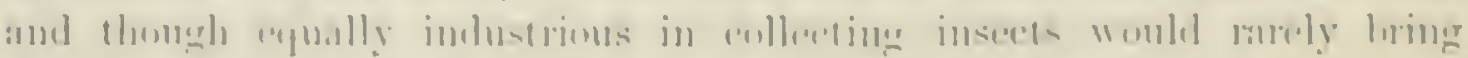

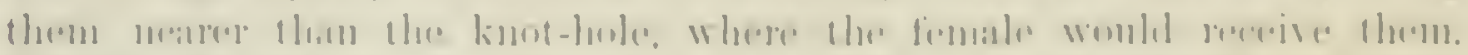

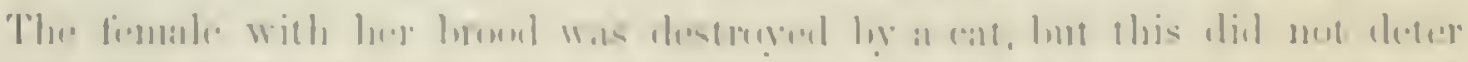

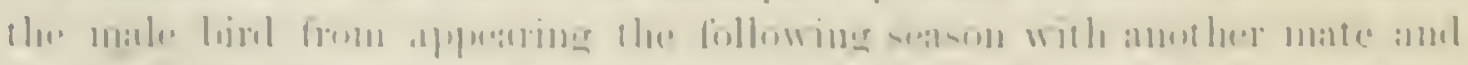

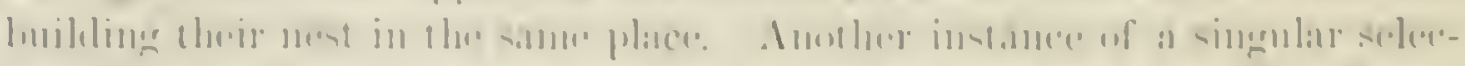

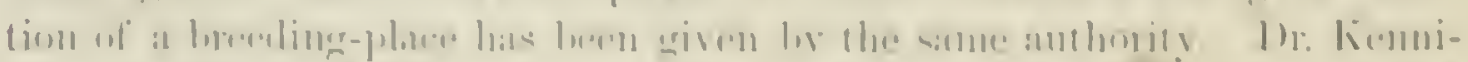

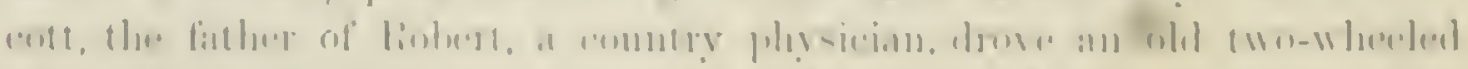

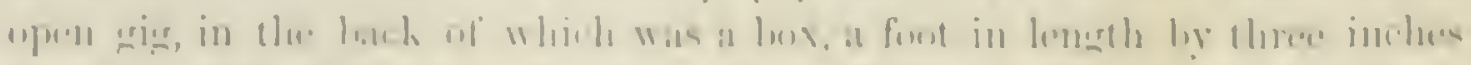

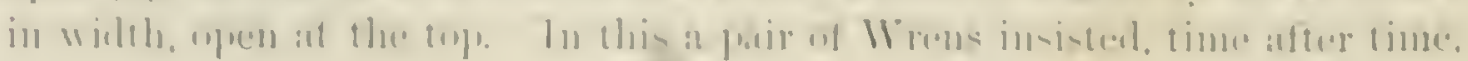


in building their nest. Though removed each time the rehiele was used, the pair for a long while persisted in their attempts to make nse of this place, at last even depositing their eggs nu the hare bottom of the bns. It was two or three weeks before they finally desisted from their vain attempts.

Sometimes this bid will build a nest in a large cavity, holding perhaps a bushel. Before the cup of the nest is completed the birds will generally endearor to fill the entire space with stieks and varions other convenient substinces. Where the entrance is unnecessintly large they will generally contract it by building abont it a barricalde of stieks, leaving only a small entrance. In the midst of these masses of mitterial they construct a compract, cup-shaped, imner nest, hemispherical in shape, composed of finer matterials and warmy lined with the fiur of small quadrupeds, and with soft feathers. If the eyrgs are taken as the female is depositing them, she will contimue to lay quite a long while. In one instance eighteen were taken, after which the birls were let alone and raisen a brood of seren.

During the months of May and June the male is a constunt and remarkahle singer. His song is lond, clear, and shrill, given with great animation and rapidity, the performer evincing great jealousy of any interruption, often learing off" abruptly in the midst of his song to literally "piteh in " upon any rival who may presume to compete with him.

If a cat or any nuwelcome visitor approach the nest, anyry vociferations succeed to his sprighthty song, and he will swoop in rathid tlights across the head or back of the intrucler, even at the apparent risk of his life.

Where several pairs occung the same garden, their contests are frequent, noisy, and generally quite amusing. In their figlits with other birds for the possession of a coveted hollow, their skill at harricading frequently enables the Wrens to keep trimmphant possession angainst birds much more powerful than themselves.

Their food is exchsively insectivorous, and of a class of clestructive insects that render them great benefactors to the farmer. MIr. Kennicott ascertained that a single pair of "Wrens carried to their young about a thousand insects in a single day.

The young, when they leave their nest, keep together for some time, moving about, an interesting, sociable, and active group, under the chinge of their mother, but industrious in supplying their own wants.

The eggrs of the Wren, usually from seren to nime in number, are of a rounded-oval shape, at times nearly as broad as long. Their yromd-color is white, but they are so thickly studded with markings and fine spots of reddish-brown, with a few oceasional points of purplish-slate, als to conceal their ground. Their shape raries from nearly spherical to an oblong-oval, some measuring .60 by .55 of an inch, others with the same breadth having a length of .67 of an inch.

Under the name of Troglorlyfes amerimnus, or Wood Wren, Mr. Aulubon figured and descriled as a distinct speeies what is probalbly only a somewhat 


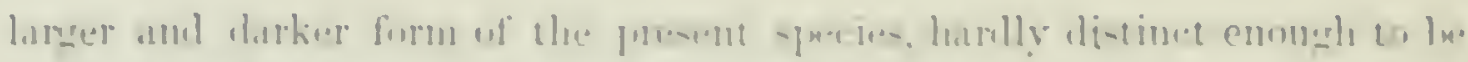

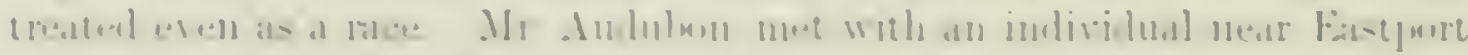

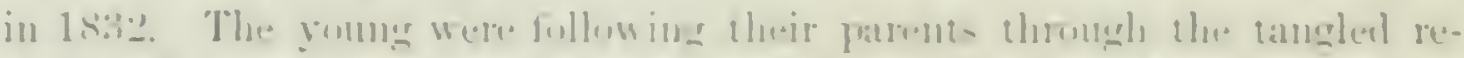

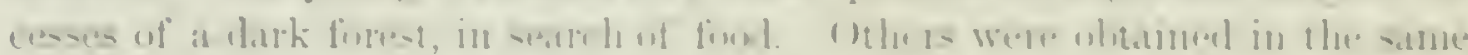

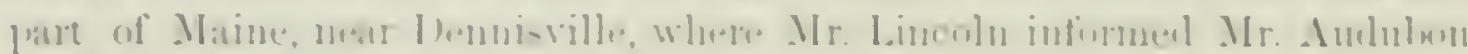

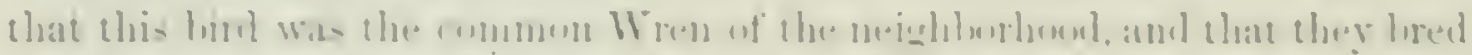

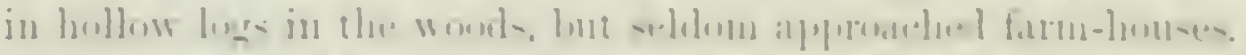

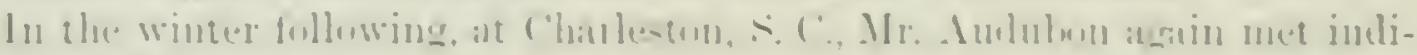

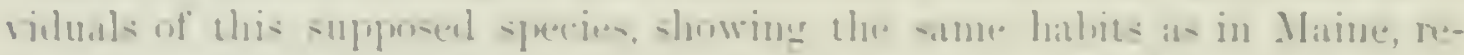

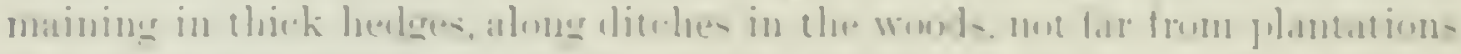

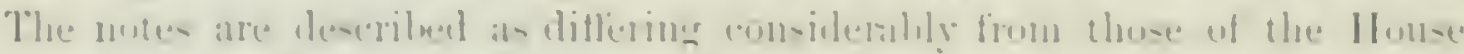

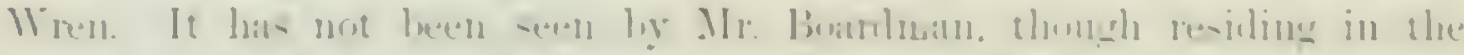

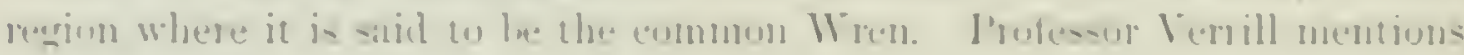

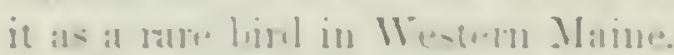

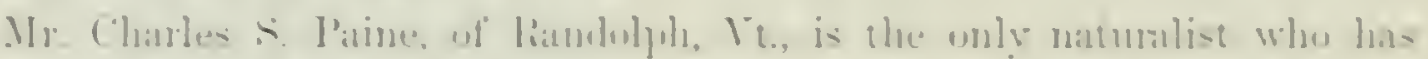

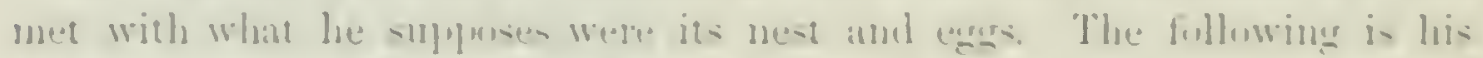

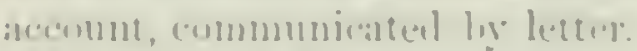

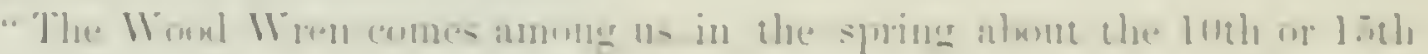

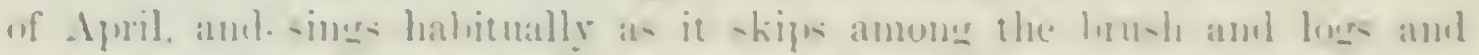

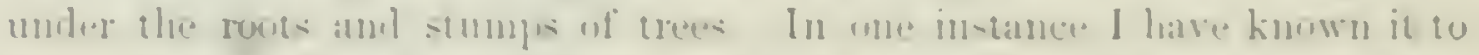

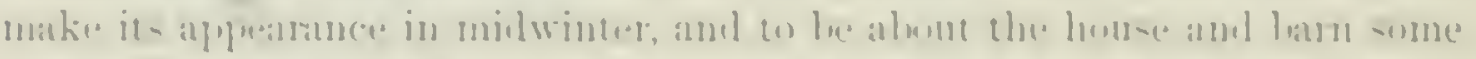

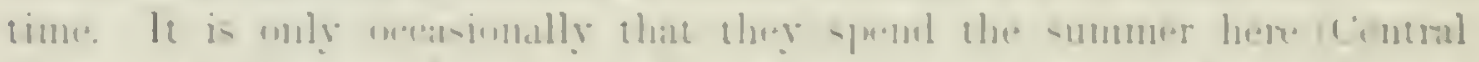

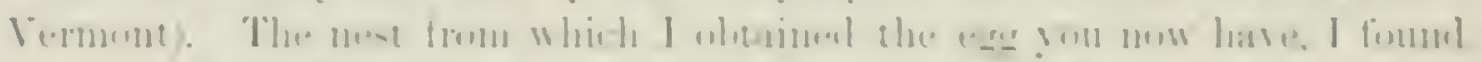

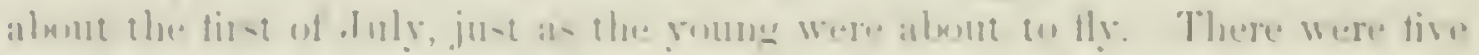

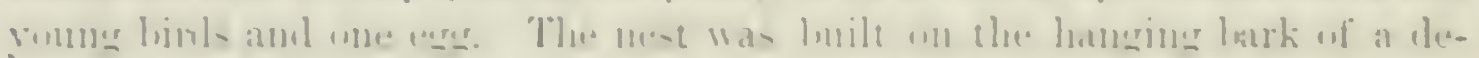

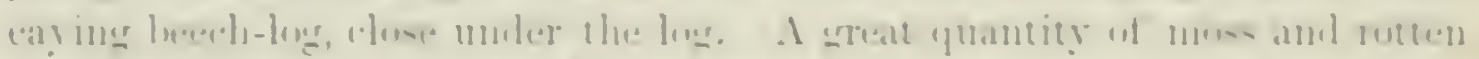

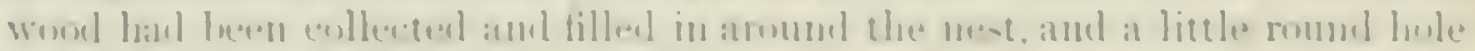

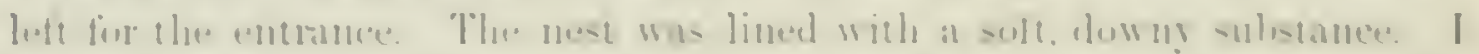

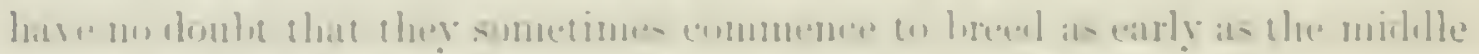

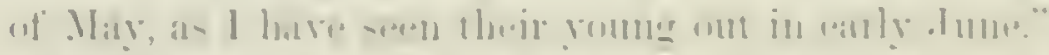

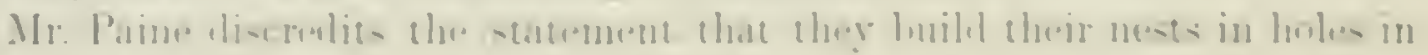

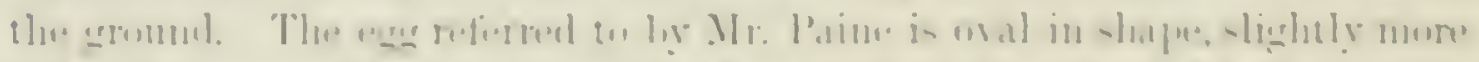

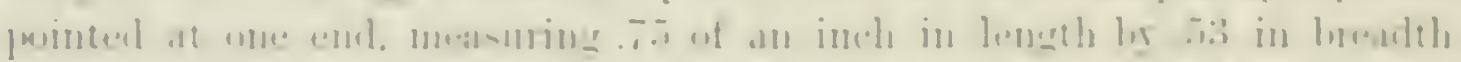

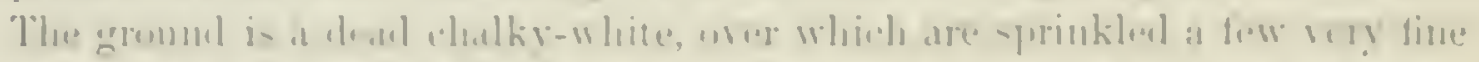

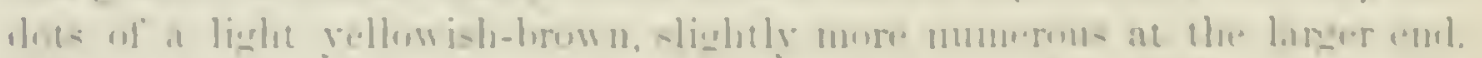

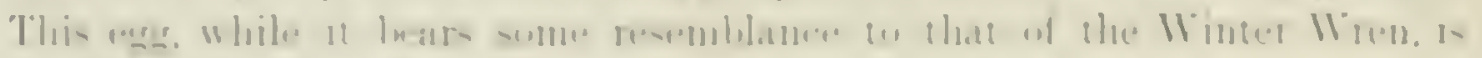
tutally mishe that of the House Mirill. 
Troglodytes ædon, rar. parkmanni, AUD.

PARKMAN'S WREN; WESTERN WOOD WREN.

Troglodytes parkmanni, Acw. On. Biog. T, 1839, 310. - Iв. Nynopsis, 1\$39, 76. - Im. Birls Am. II, 1S41, 133, pl. cxxii. - BArrn, Birls N. Am. 1858, 307; Fer. 140.-

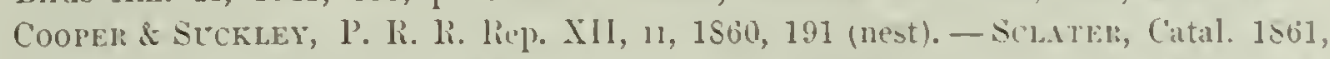
23, no. 146. - Cuoren, Orn. Cal. I, 1870, 71. Troglodyles sylecstris, fimmi:L, I'1. A. X. Se. III, 18t6, 113 (California, quotes erronteusly Alv. T. americunus).

H.ı. Western and Middle Provinces of L'nited States. East to the Missonri River. Westeru Arizona, Coues.

Althongh the differences between the eastern and western House Wrens, as stated in the Birds of North Anerica, are not very appreciable, yet a comparison of an extensive series shows that they can hardly be considered as identical. The general color of parmanni above is paler and grayer, and there is little or none of the mfous of the lower back and rump. The bars on the uplel surface are rather more distinct. The under parts are more alike, as, while cedon sometimes has flanks and erissum strongly tinged with rufous, other specimens are as pale as in T. parkmumi.

Perhaps the most appreciable clifferences between the two are to be found in the size and proportions of wing and tail. The wing in partimamin is quite decidedly longer than in adom, measuring, in males, 2.12 to 2.15 , instead of 2.00 to 2.05 . This is due not so much to a larger size as to a greater development of the primaries. The first quill is equal to or barely more than half the second in promrmani; and the difference hetween the longest primary and the tenth anounts to .3 .2 of an inch, instead of about $.20 \mathrm{in}$ celon, where the first quill is nearly half the length of the third, and much more than half the length of the second.

HaBITs. This western form, hardly distinguishable from the common Honse ITren of the Eastern States, if recognized as a distinct species, is its complete analogne in regard to habits, nest, eggs, ctc. It was first obtained by Townsend on the Columbia River, and described by Andubon in 18:39. It las since been observed in rarious parts of the comntry, from the Mississippi Talley to the Pacific Coast, and from Cape St. Lneas to Orecron.

Dr. Cooper, in his Birds of Washington Territory, spealis of this Wren as common about Puget Sound, where it appeared to be much less familiar than our common Wren, thongh its habits and song seemed to he verr similar. It there frequented chiefly the ricinity of woods and piles of logs, neither seeking nor dwelling in the ricinity of houses. It arrives there about the 20th of April. As observed about Tanconver in 1853, its song appeared to Dr. Cooper different from that of the $T$. adon. He found one of their nests built in a horse's skull that had been stuck upon a fence. Dr. Suckley, who observed these birds abont Fort Steilacoom, describes their voice as harsh and unmusical. 


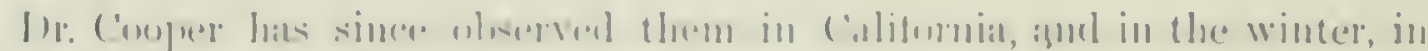

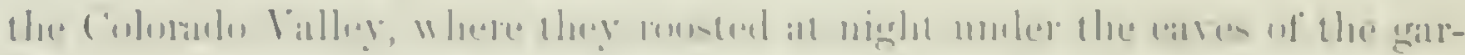

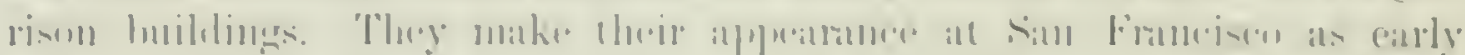

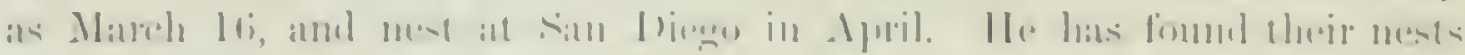

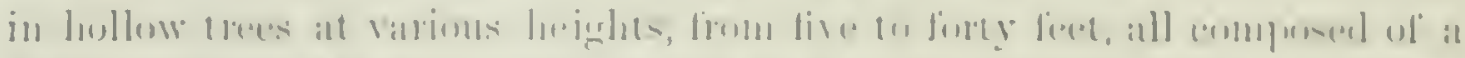

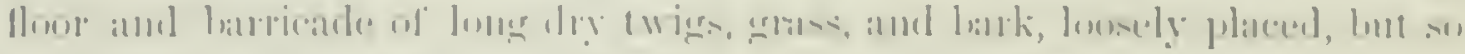

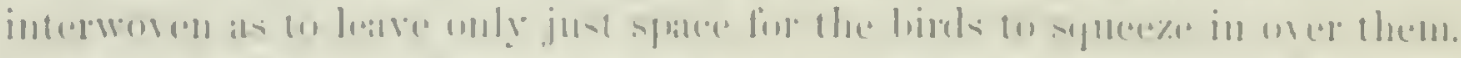

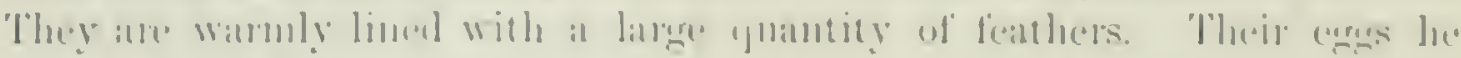

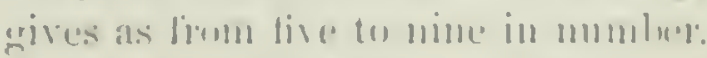

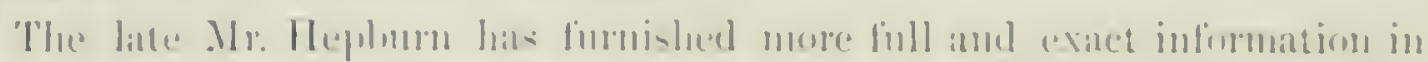

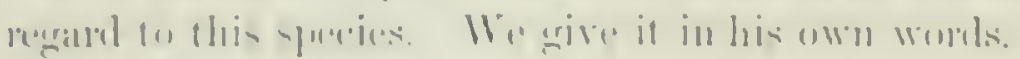

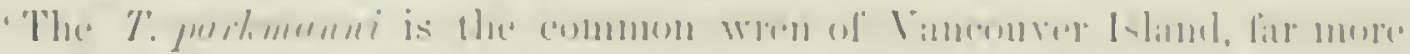

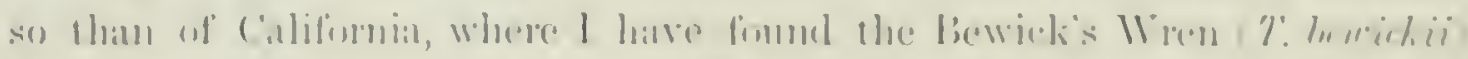

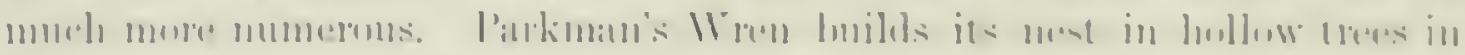

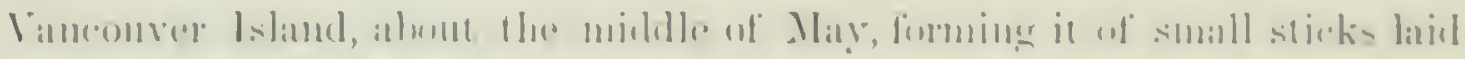

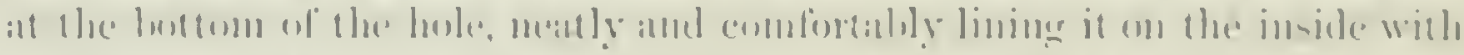

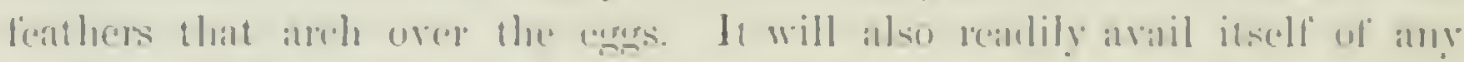

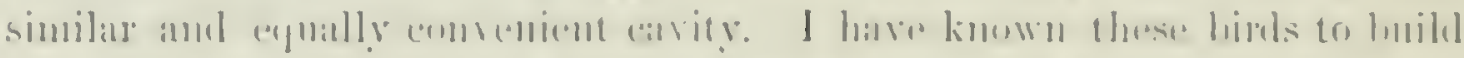

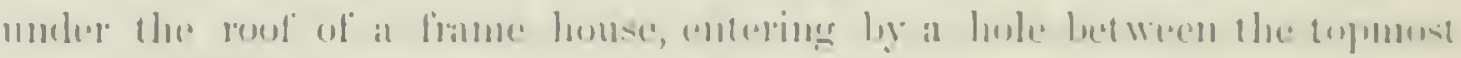

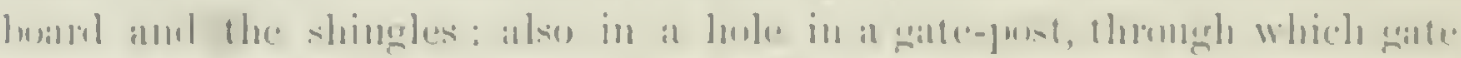

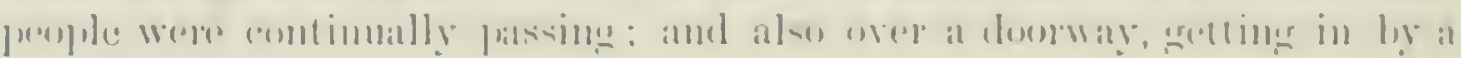

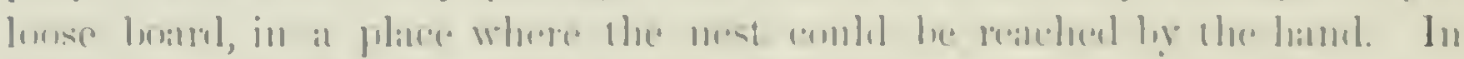

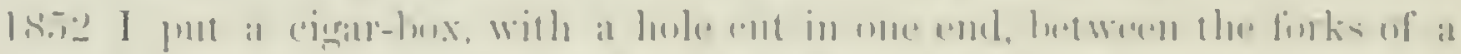

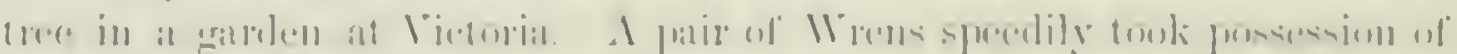

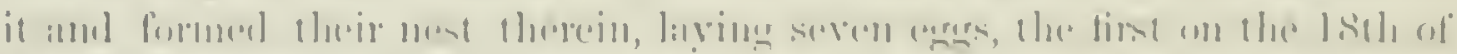

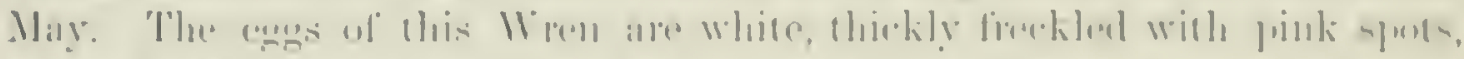

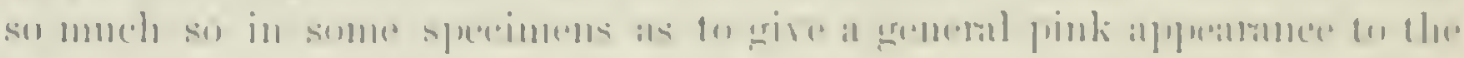

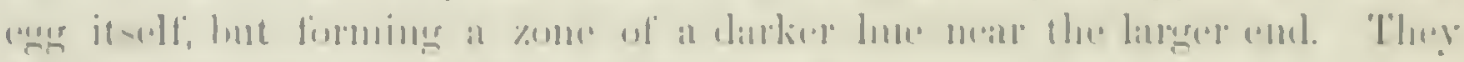

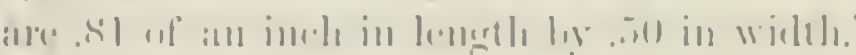

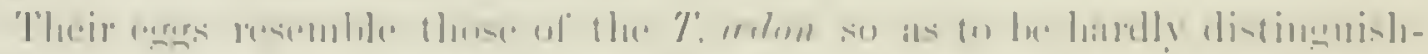

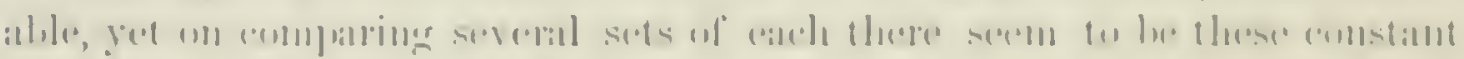

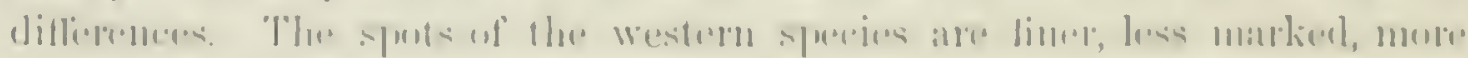

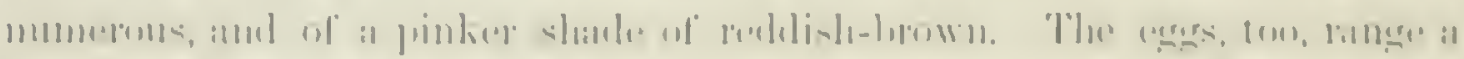

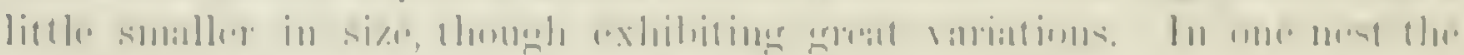

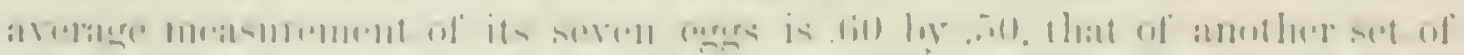

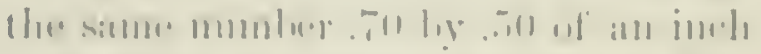

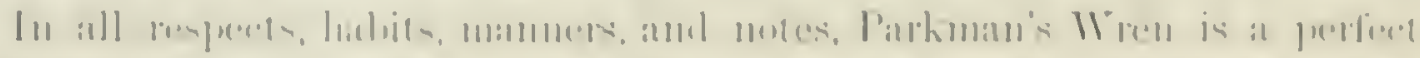

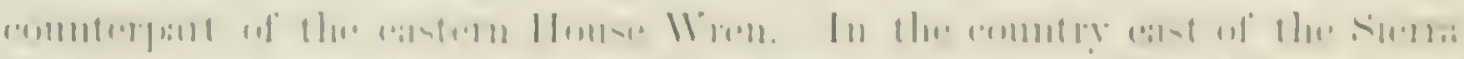

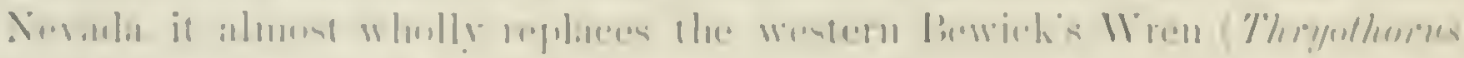

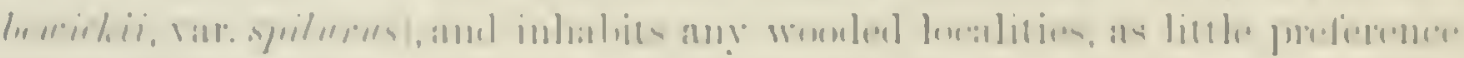

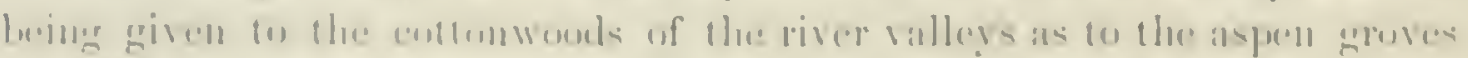
lingl, 11 , in the monntuins. 
Troglodytes parvulus, var. hyemalis, VieıLL.

WINTER WREN.

Syliu troploulytes, WiLsos, Am. Orl1. I, 1s0s, 139, pl. viii, f. 6. Tinglndyles hyemalis,

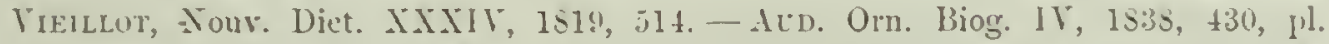

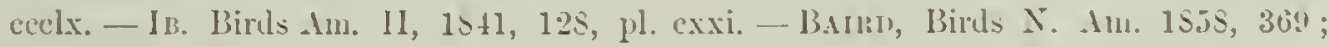

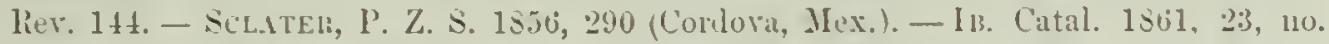
150. - Dirl \& Baxister (Alashia). - Cuoper, Orn. ('al. 1, 1870, 73.

Sp. Cur.r. Bill very straight. slemeler, anel conical; shorter than the lueal. Tail considerably shorter than the wings. which reach to its mieldle. [pper parts rerlishlebrown; becoming brigher to the rmup and tail; evervwlere, cxcept on the lead aml upper part of the back. with transicerse bars of dusky and of lighter. Scapulats and wing-coverts with spots of white. Beneath pale rudlish-brown. Uarred on the posterior half of the body with dusky and whitish, and spotter with white more anteriorly: outer web of primarics similarly spotted with pale l,row uish-white. An indistinct pale line orer the eye. Length, about 4 inches: wing, 1. (3) : tail, 1:26).

H.s. North America generally. South to Curdora, Mex.

Westem specimens may be separated as a variety pacificus (Band, her. Am. Birls, $1 S 6 t, 14.5)$, hased on the much darker colors and the almost entire absence of the whitish spots among the dark bars. The under parts are more rufous; the tarsi are shorter, the claws larger, the bill straighter and more slender.

The Winter Wren is very closely related to the common Wren (T.parmlws, Koch) of Europe, so much so, in faet, that the two almost seem to be varieties of one species. The differences, as shown in a large series from both continents, are the following: In T. parrulus there is a tendency to more uniform shades; and the prevailing tint anteriorly, beneath, is a pale yellowish-ash, almost immacnlate, instead of brownish-ochraceous, showing minute spechs and darker erlges to the feather's. In extreme specimens of 1. parvulus the bars even on the tail and wings (except prinaries, where they are always distinct) are rery obsolete, while on the lower parts they are confined to the flanks and crissum. Sometimes, however, specimens of the two are found which are almost undistinguishable from each other. In fact, it is only by taking the plainer European birds and comparing them with the darker American examples from the northwest coast, that the difference between $T$. parvulus and $T$. hycmulis is readily appreciable.

Habits. The Winter Wren, nowhere very abundant, seems to be distributed over the whole of North Arnerica. Hardly distingnishable from the common Wren of Europe, it can scarcely be considered as distinct. The habits of our species certainly seem to be very different from those assigned to the European bird, which in England appears to be as common and as familiar a bird as even the Redbreast. The suall size and retiring habits of our species, as well as its unfrequent occurrence, and only in wild places, combine to keej, its history in doubt and obscurity. It is supposed 


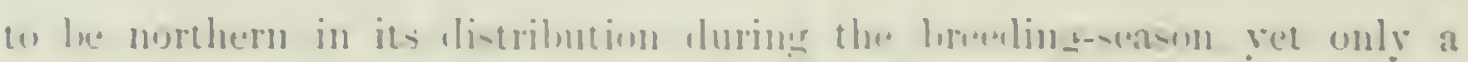

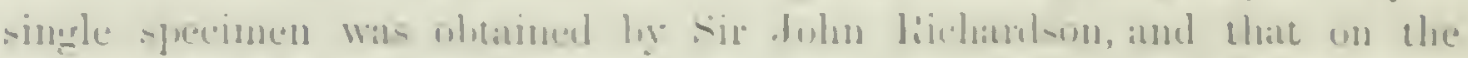

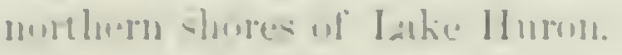

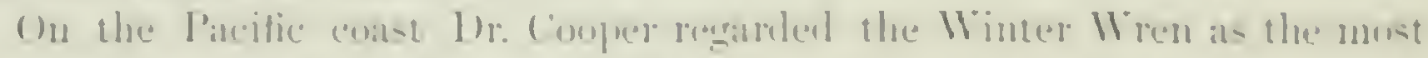

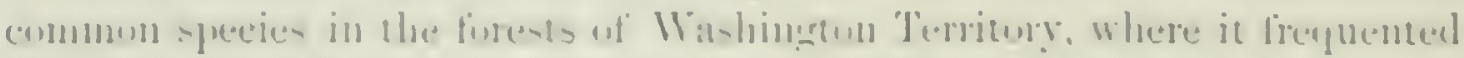
even the demest portions, and where its lively somg wor almust the only

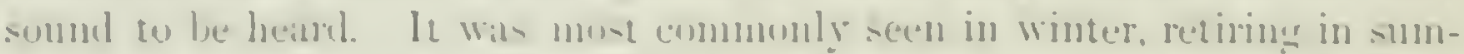
mer to the menutains to breed. He observed roung birks on the coast Mountisins in oluly.

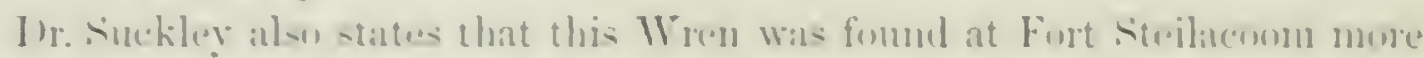

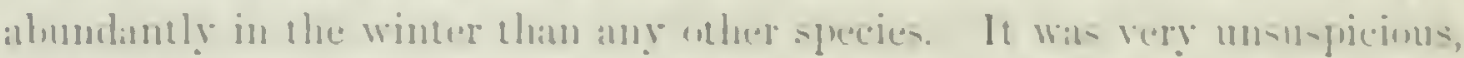

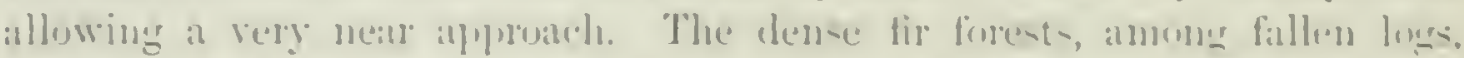

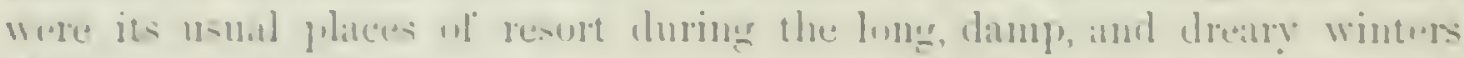

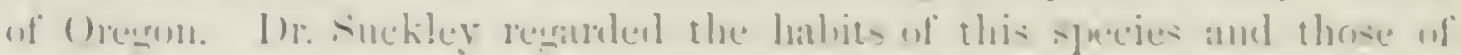

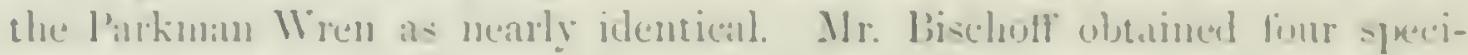
mens in sitkil.

Mr. Auduluon found this species at Eastpurt, on the !ht of Mays, in full

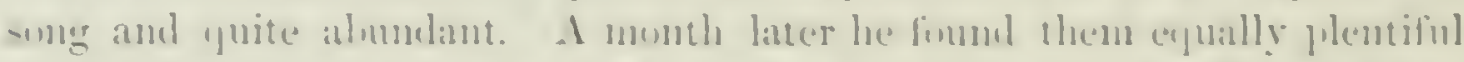

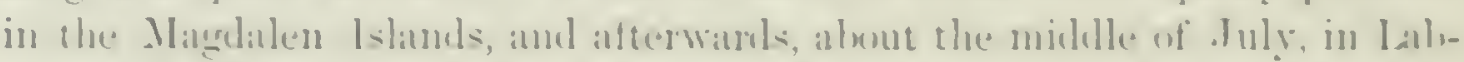

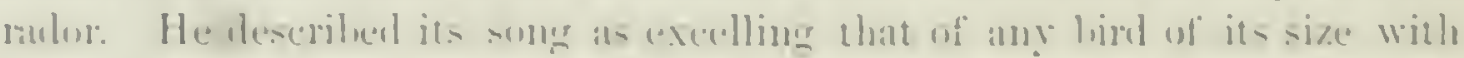

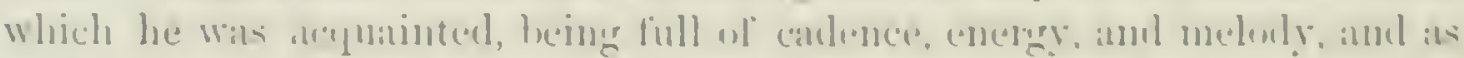

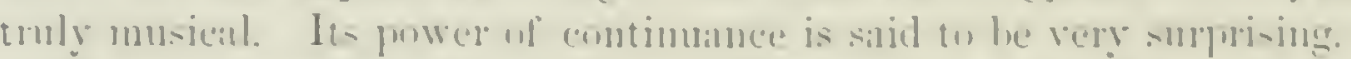

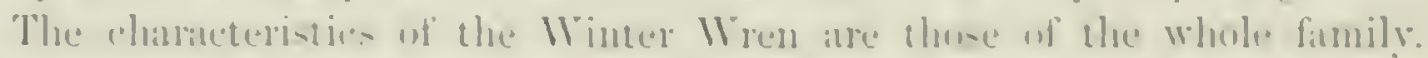

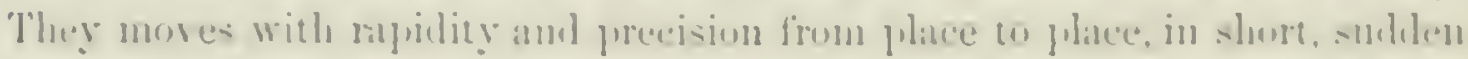

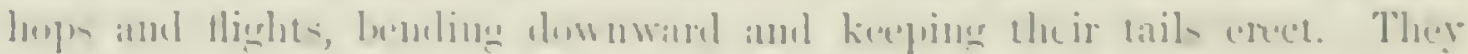
will run muder a linge reot, throngh al hollow stump or ling. ar lectween the

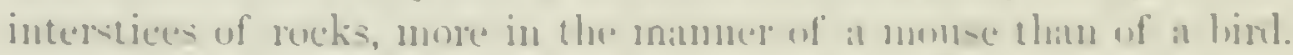

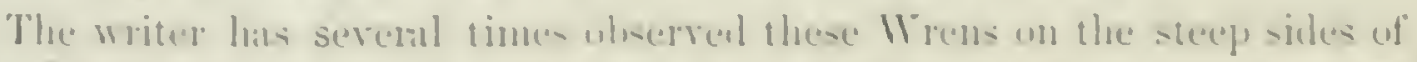

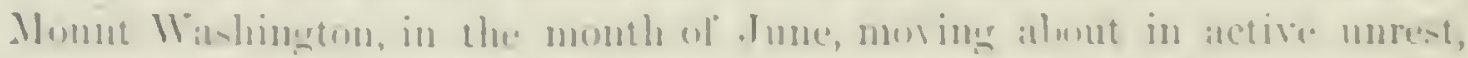

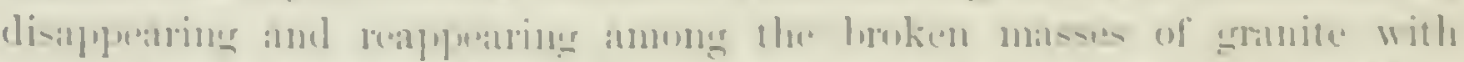

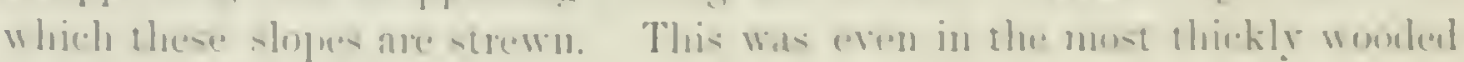

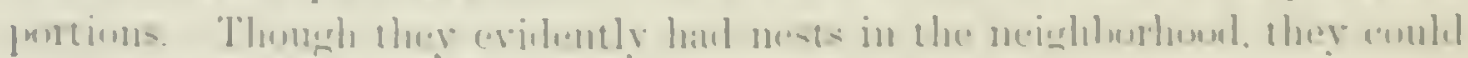

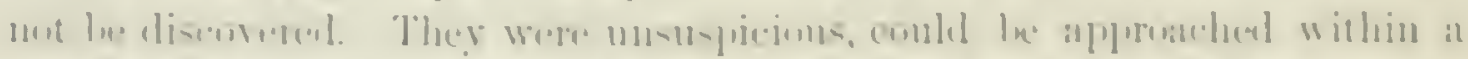

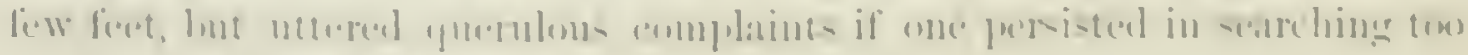
long in the plince they coterem.

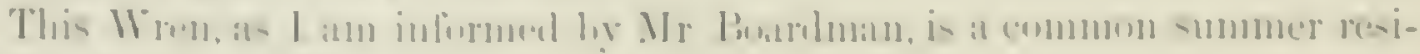
dent uns ('illats, .Me.

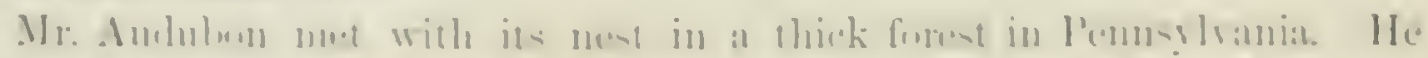

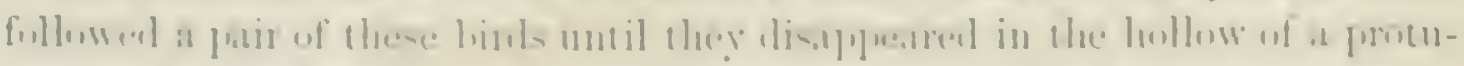

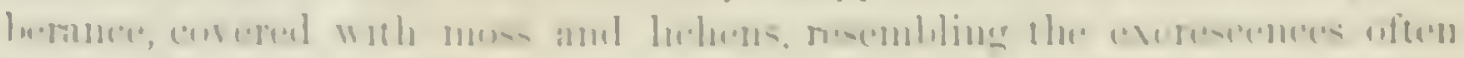

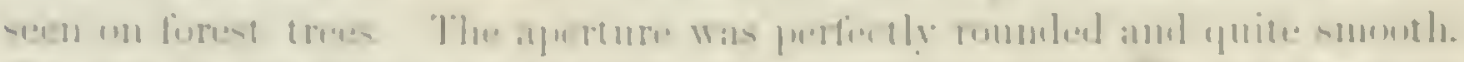

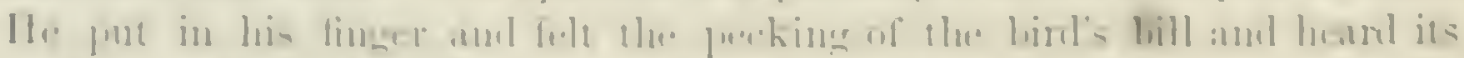

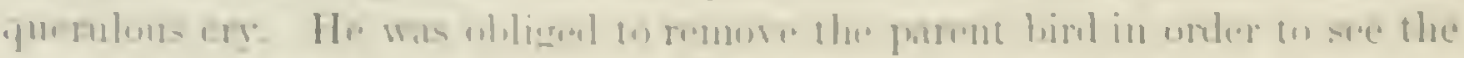

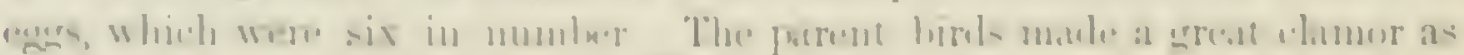


he was examining them. The nest was seven inches in length and four and a half in breadth. Its walls were composed of mosses and lichens, and were nearly two inches in thickness. The cavity was very wamly lined with the fur of the American hare and a few soft feathers. Another nest found on the Mohawk, in New York, was similar, but smaller, anch built against the sicle of a rock near its bottom.

Mr. William F. Hall met with the nest and eggs of this bird at Camp Sebois in the central eastem portion of Maine. It was built in an unoccupied log-hut, anong the fir-leares and mosses in a crevice between the logs. It was large and bulky, composed externally of mosses and lined with the fur of hedge-logs, and the feathers of the spruce partritge and other hinds. It was in the shape of a pouch, and the entrance was neatly framed with fine pine sticks. The eggs were six in number, and somewhat resembled those of the Parus atricupillus. Tlue female was seen and fully identified.

In this nest, which measured five and three quarters inches by five in brealth, the size, solidity, and strength, in view of the diminutire proportions of its tiny architect, are quite remarkable. The walls were two inches in thickness and rery strongly impacted and interworen. The carity was an inch and a quarter wide and four inches deep). Its hemlock framework had been mate of green materials, and their strong and agreeal,e odor pervaded the structure. The eggs measured .6.5 by . 48 of an inch, and were spotted with a bright redish-brown and a few pale markings of purplish-slate, on a pure white ground. Compared with the eggs of the European Mren their eggrs are larger, less oval in shape, and the spots much more marked in their character and distinctness.

Troglodytes parvulus, var: alascensis, B.ıIv.

\section{ALASKA WREN.}

Trogloclytes alaseensis, BAIrd, Trans. Chicago Aral. Sc. I, ii, 315, pl. xxx, fig. 3, 1869. Dall \& Baristen (Alaska). - Frıescu, Oruith. X. W. Amerikas, 1872, 30.

Sp. Cuıs. of ad., 61,329, Amaknak Island, Lnalaschka, Oct. 21, 1871: W. H. Dall. Above umber-brown, more rufescent on the wings, rmmp, and tail; serontaries and tailfeathers showing indistinet transverse dusky bars: primarles about equally harred with blackish and dilute umber or brownish-white: midlle-coverts tipped with a small white dot, preceded by a black one. Lower part, including a rather distinct superciliary stripe, pale ochraceons-nmber; sides, flanks, abdomen, and crissum distinctly barred with dusky ancl whitish on a rusty ground; crissum with sagittate spots of white. Wing, 2.20; tail, 1.60 ; culmen, .65; tarsus, .75 .

Hab. Aleutian and Pribylow Islands, Alaska.

The specimen above described represents about the average of a large series obtained on Amaknak Island by Mr. Dall. They vary somewhat among themselves as regards dimensions, but all are very much larger than 


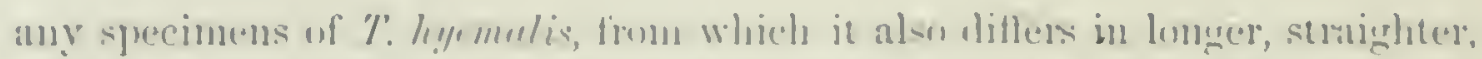

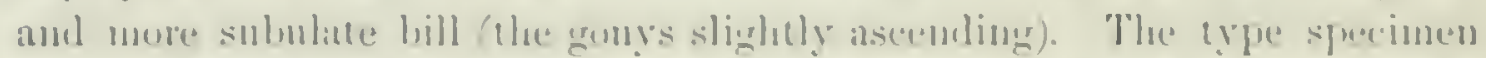

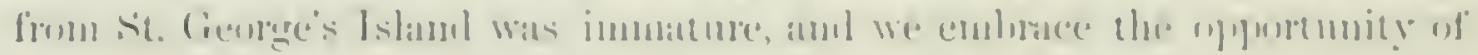

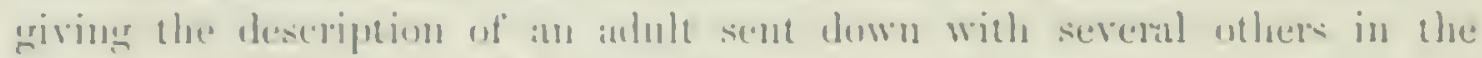

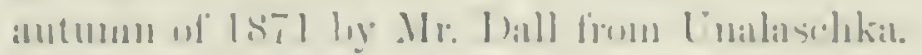

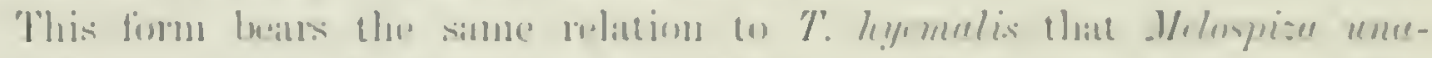

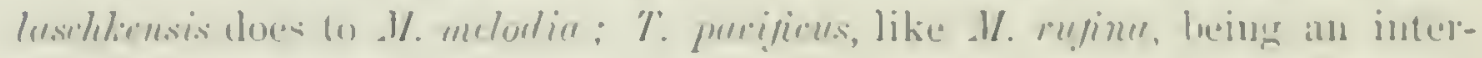
mediate linus.

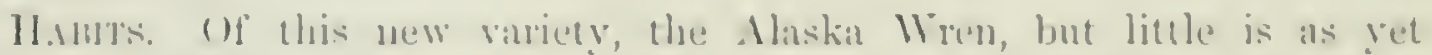

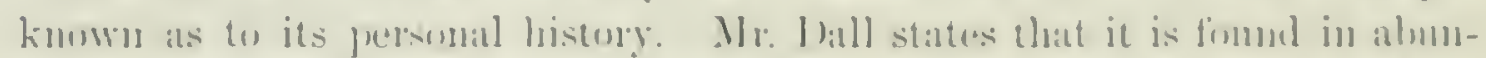

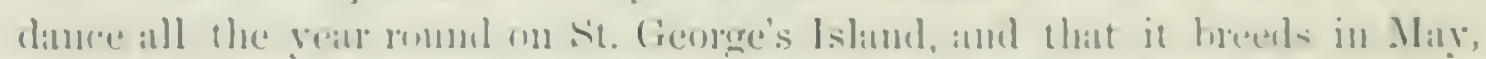

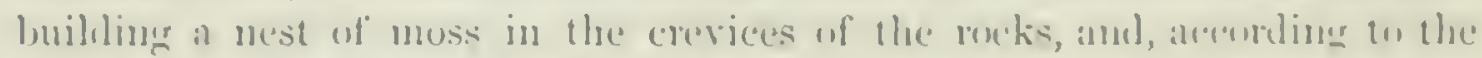

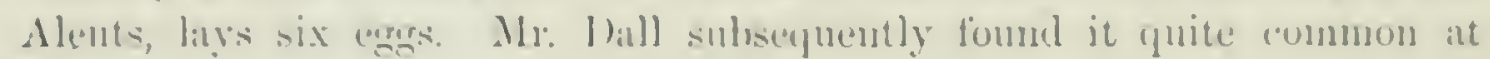

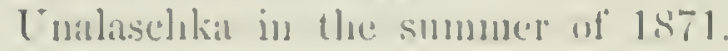

\section{(iris's CISTOTHORUS, ('sHA}

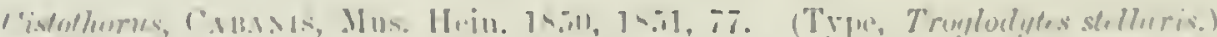

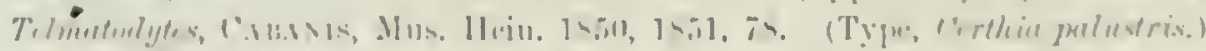

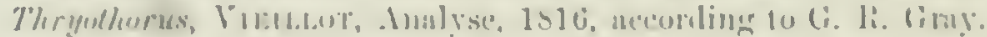

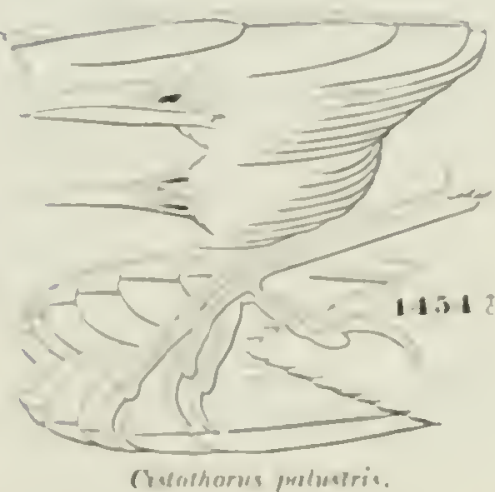

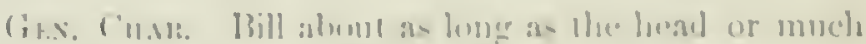

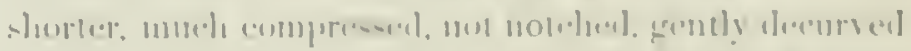

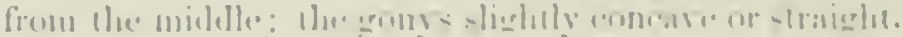

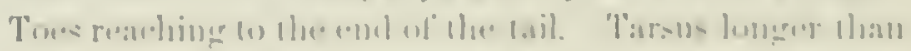

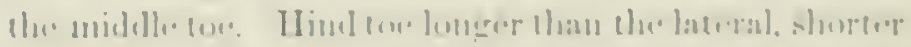

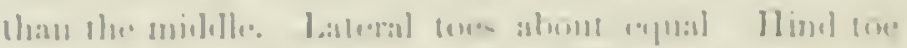

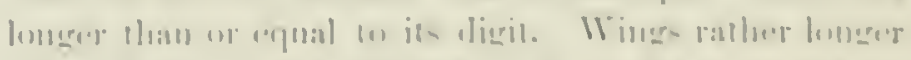

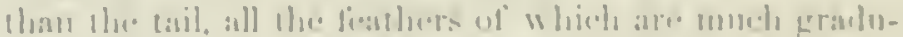

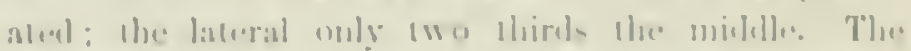

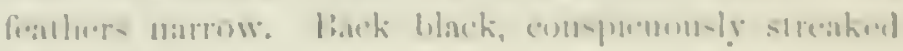
wills while.

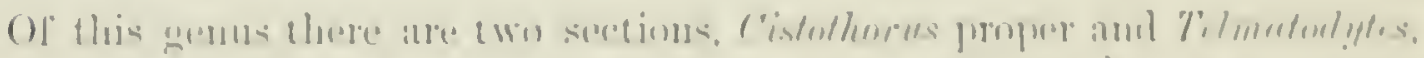

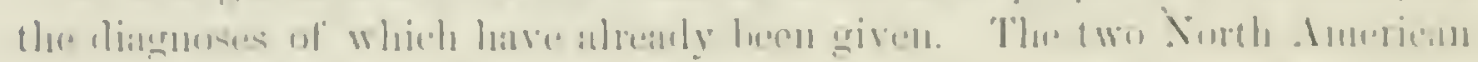

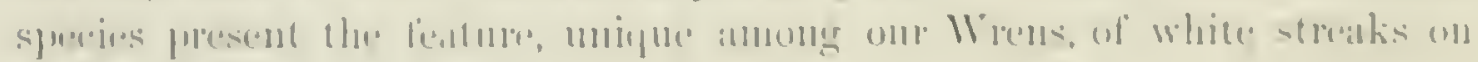
thir. hiuk.

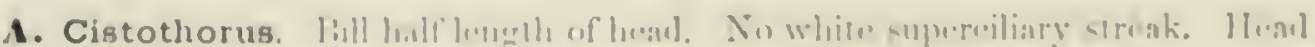

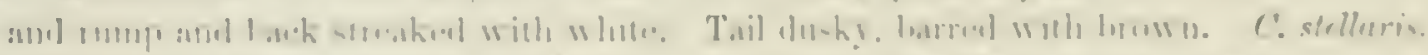

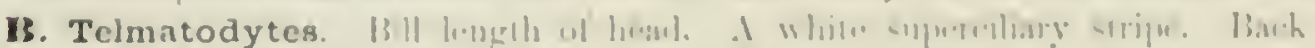

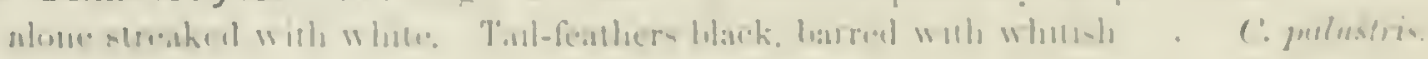




\section{Cistothorus stellaris, ('AB.I:}

\section{SHORT-BILLED MARSH-WREN.}

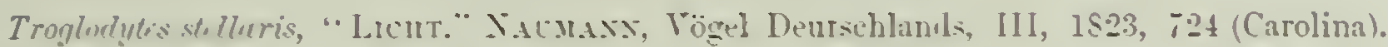
Cistothorus stollaris, Cab. Ins. Hein. ii.-Band, Birls X. Am. I\$5s, 365; Res.

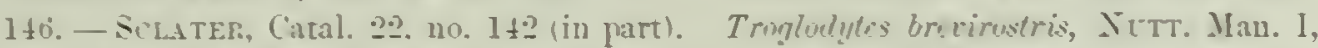

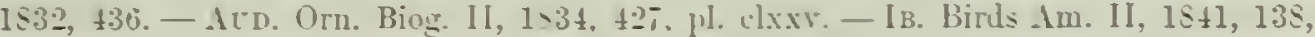
pl. exriv. C.eleynus, Silater is saluix, Ibis, 1s59, s.

Sr. Charr. Bill rerr short. scarcely half the lengrh of the heal. Wing and tail about equal. Hinder part of the crown and the seapulat and intersenpular region of the back and rump almost black, stre:aket with white. Tail dusky, the feathers barred throughout with brown (the enlor grarish on the under surface). Beneath white; the sides, mpper part of breast, and under tail-coverts reddish-brown. Lpper parts. with the exceptions monrioned. reddish-brown. Lenerth. 4.50) wing. 1.75: tail. 1.7.j.

Hab. Eastern Prorinee of L'nited States, west to Loup Fork of Platte.

There is a closely allied variety from Mexico and Guatemala ( $C$. clegans, Scliter of siltix, Pr. Z. \$., 1s.9, s) which litfers in the cliaracters stated below.

White dorsal streaks extending to the rump, which is conspicuously banded with * brown. and somewhat spotted with whitish. Benearh, including lining of wings. liglut cinnamon-brown; throat and belly paler, almost white; sides and crisum rery obsoletely barred with darker. and faintly spotted with whiti-h. Feathers of jugrulum like silles but with the color uhseured by the paler edgers.

Tarsus, o.j long. IIab. Eastern Prorince of Lnited States. . . C. stellaris.

Streaks on back confined to interscapular region: munp and upper tail-covert. almost plain reddish-brown. Beneath much paler than in stellaris, without any appreciable indication of bars or spots on siles and erisum, or of the fulvous of the jugular feathers. Insile of wings snowr-white. Tarsus. it long. Hab. Mexico and Guatemala: Brazil? . . . . . . . C. elegrnus.

The differences between these two rarieties are just barely appreciable when specimens of the two, of corresponding seasons, are compared. Two Mexican examples (clegans) differ more from each other than one does from Torth American specimens; because one (a typical specimen received from Salvin) is in the worn, faded, midsummer plumage, and the other in the perfect autummal dress. Besicles the longer tarsi of these Mexican birds, their tails, and even their bills, are longer than seen in North American skins. But while these differences between the North American and Mexican birds are just appreciable, there is one from Brazil $(j 1,017, \mathrm{Sr}$. Don Fred. Albuquerque) which is exactly intermediate between these two varieties in color, while in size it is even smaller than the North American ones, measuring as follows: wing, 1.60 ; tail, 1.60 ; culnen, . 45 , tarsus, .61 .

Even if recognizable as belonging to different rarieties, these specimens are certainly all referable to one species.

H.abITs. The Short-billed Marsh Wren is rery irregnlarly distributen throughont the Cnited States, being found from Georgia to the British 


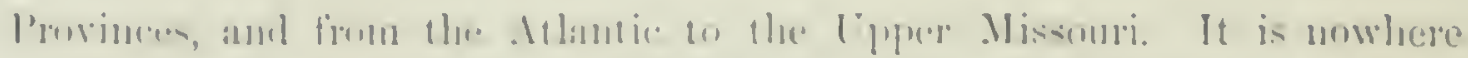

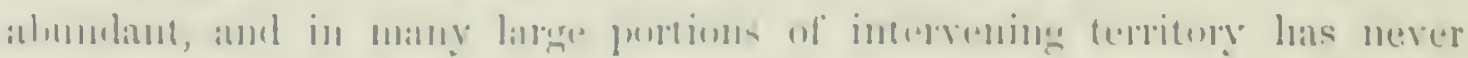
heroll fimml.

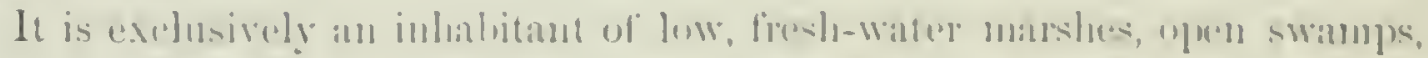

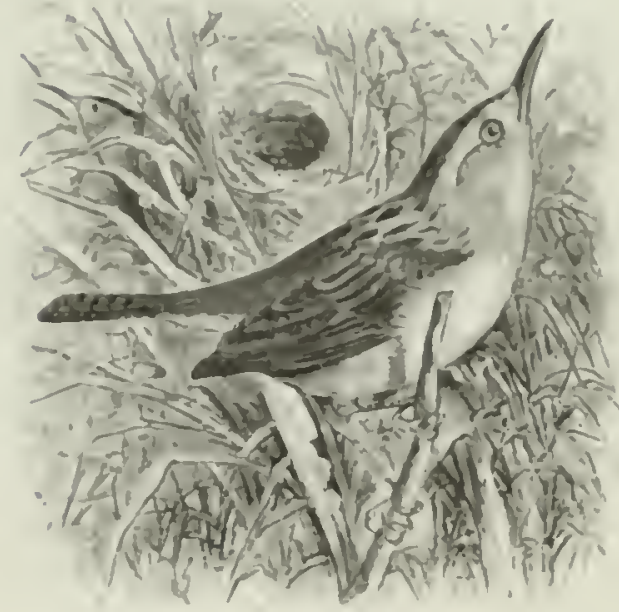

cistothornes painetris. and Im"almws, is mever fouml on liserl

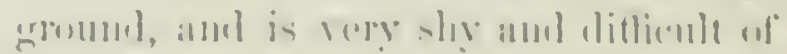

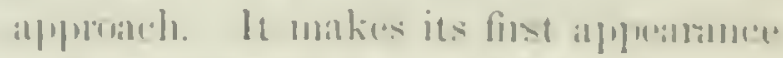

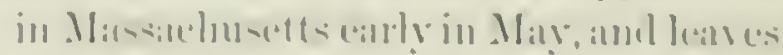
carly in sepplemblere. In winter it has lecen timmel in all the (inlf states, from

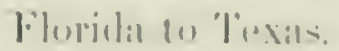

Arempling an Nuttall, this Wren has a

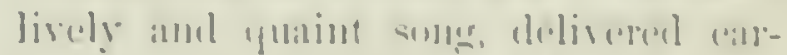
ne-1ly anml as if in haste, andel at shomt intervals, either from a tuft of sellese or

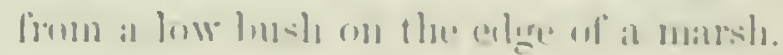

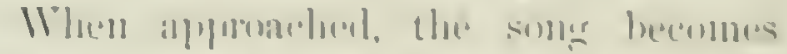
latgsher and more lumrienl, and rises

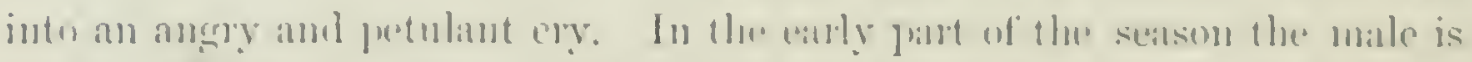

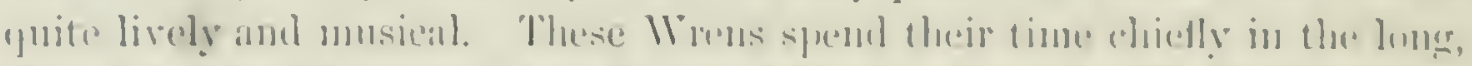

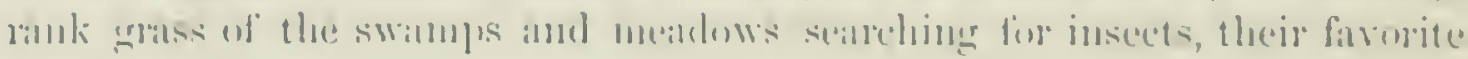
forml.

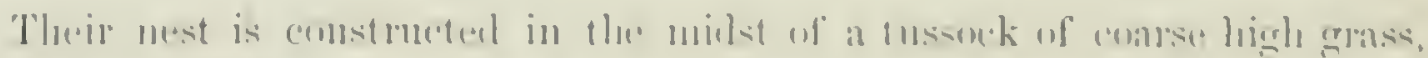

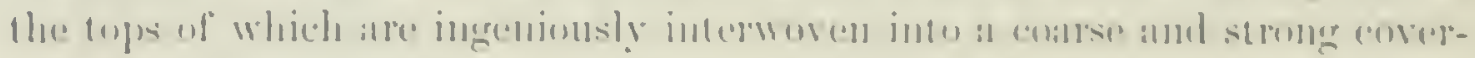

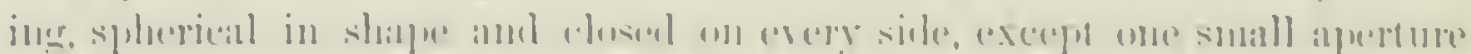

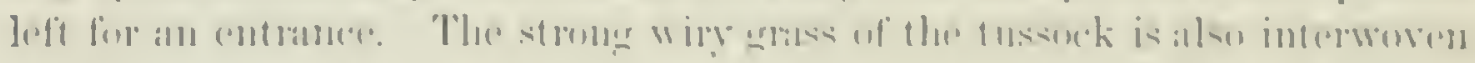

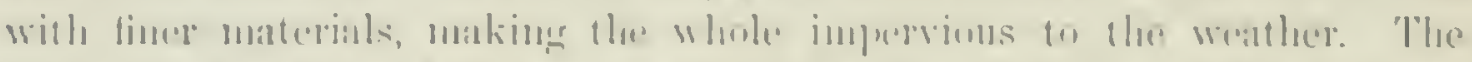

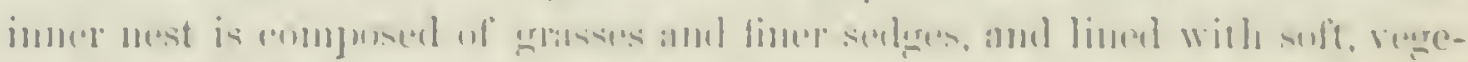

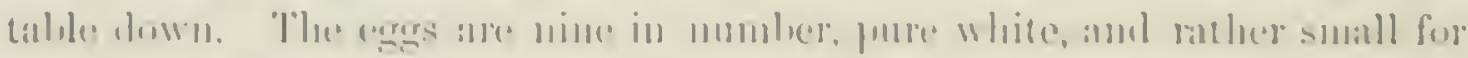

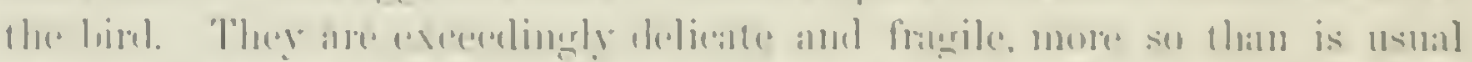

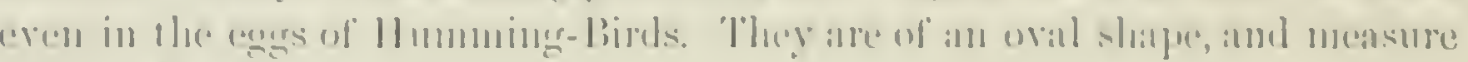

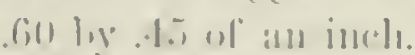

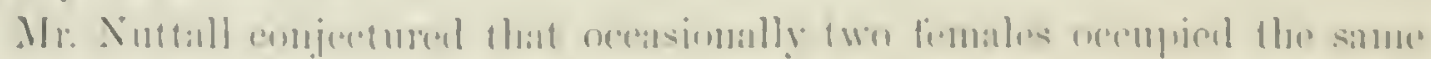

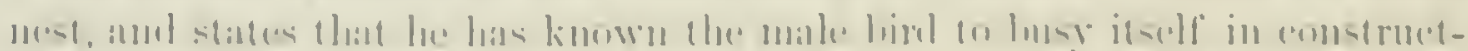

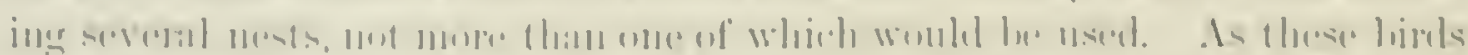

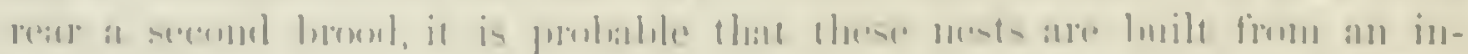

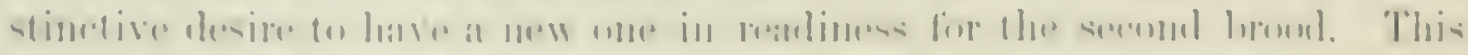

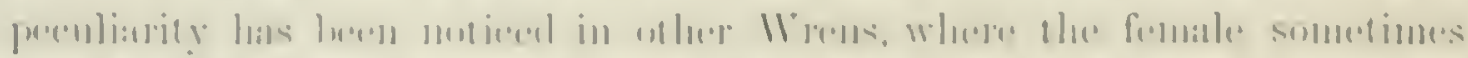

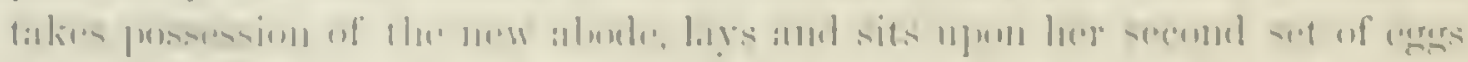

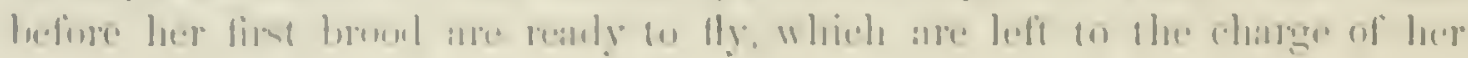
IIIII!.

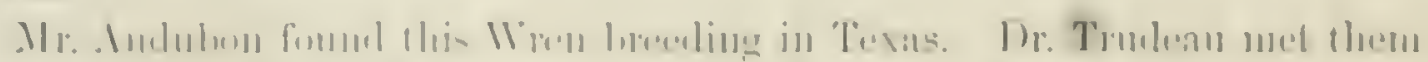

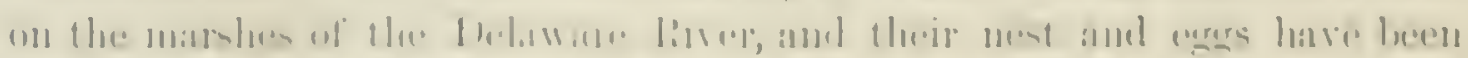

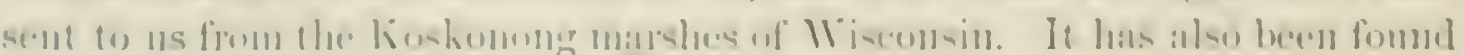


in the mashes of Connecticut River, near Hartford; and in Illinois Mr. Kennicott found it among the long grisses burlering on the prairie slonghs.

In Massachusetts I have occasionally met with their nests, but ouly late in Jnly, when the rauk grass of the low mealows has heen cut. These were probably their second brood. The nest being built close to the ground, and made of the living grasses exterually, they are not distinguishable from the unoccupied tussocks that surround them.

\section{Cistothorus palustris, BAIRD.}

\section{LONG-BILLED MARSH WREN.}

Par. palustris.

Certhia palustris, IIIsox, Alu. Orn. II, 1\$10, 5s, pl. xii, tig. 1 (Penua). Troglodyles pa. lustris, Bos. Obs. Wils. 1s:2t, no. 60.-AxD. Orn. Biog. I, 1s31, 500, pl. c.-IB. Birds Am. II, 1ミ41, 135, pl. 'xxiii. - Reırmant, Ibis, 1561, 5 (Godthatb, Greenland). Thryothorus pulustris, NiтT. Ian. I, 1530., 430. Cistothorus (Tclmatodytes)

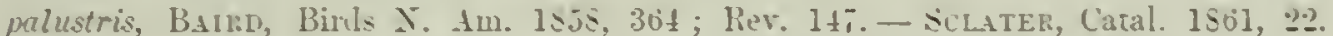

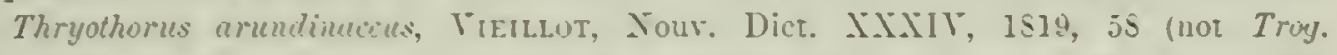

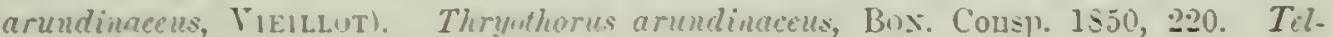
matodytes arundinuceus, C.1B. Mus. Hein. 1850, is.

HAB. Eastern Cnited States. from the Misouri hiver: Greenland? Reishardt: Mexico, and Guatemala? Cordora, sch.str.

\section{rar. paludicola.}

Cistothorus pulustrix, var. puluticulu. B.11:1, liev. An. B. 1sot, 1ts. Troglndytes palus. tris, IEWB. P. R. Rep. VI, IV, 1S5i, s0 (I'acitic region). Cistothorus pulustris, Cooper:

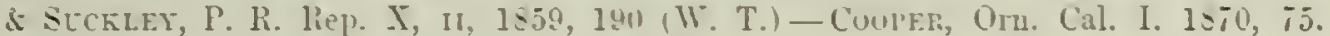
Certhia palustris, Lal:D. Pr. R. Art. Inst. IV. 11 T

Sp. Crar. Bill about as loug as head. Tail and wing rearly eyual. L pper parts of a dull reddish-brown, except on the crown. interseapular region. outer surface of tertials. and tail-feathers, which are almost black: the tirst witl a median patch like the groundcolor: the second with short streaks of $\pi$ hite. extending round on the sides of the neck: the third indented with brown; the fourth barred with whitish, decreasing in amount from the outer feather. which is marked from the base to the fifth. where it is confined to the tips; the two midille feathers abore like the back, and barred throughout with duskr. Beneath rather pure white, the siles and under tail-coverts of a lighter shade of brown rhan the back: a white streak over the ere. Length. 5.50: wing. 2.05; tail. 2.00. (1,4.j.)

H.18. Pacific Coast and Middle Province of Lniced States.

In comparing a series of Marsh Wrens of eastern North America with western, we find that they differ very appreciably in certain chanacteristics, which may be expressed by the following diagnoses:-

Bill lengthened, equal to tarsus. Tail-coverts above and below either perfectr plain. or with rery obsolete bands. reduced to obscure spots beneath. Band: on tail broken: scarcely appreciable on the midlle feathers. . var. $p$ alust $t^{\circ}$ s.

Bill shorter than tarsus. Tail-coverts distinctly bandel all aeross. Bands on tail quite distinct; appreciahle on the central feathers. . . . var. paludicola. 


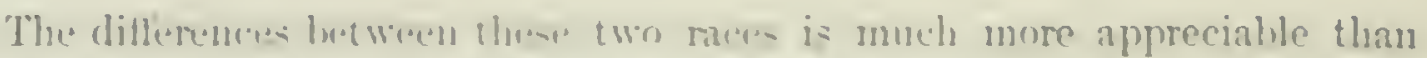

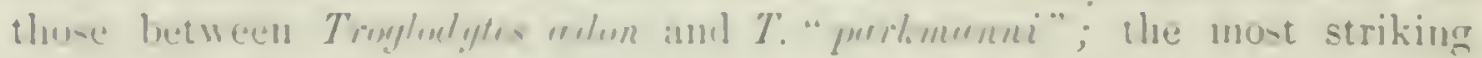

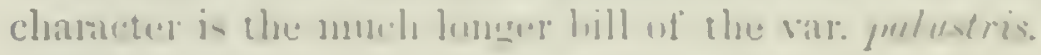

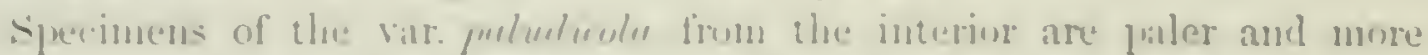

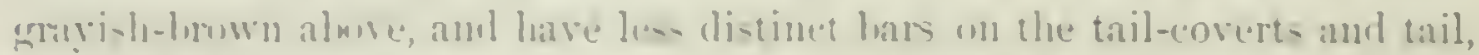

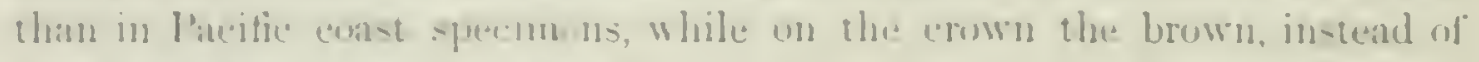

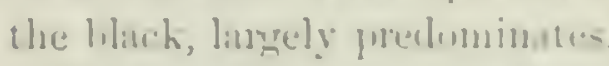

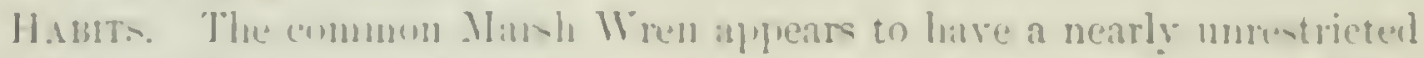

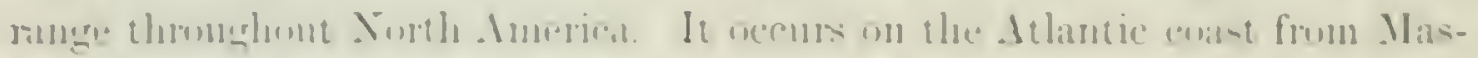

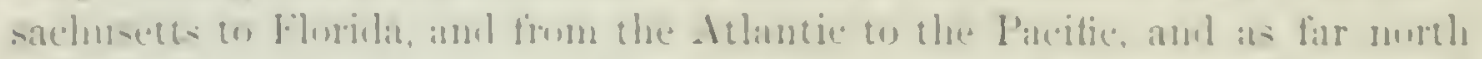

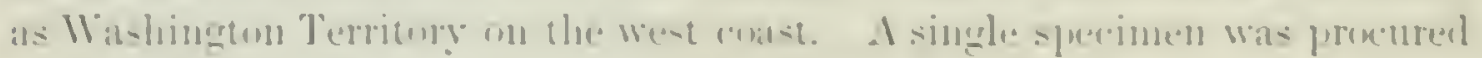

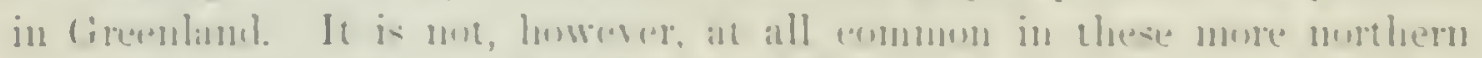

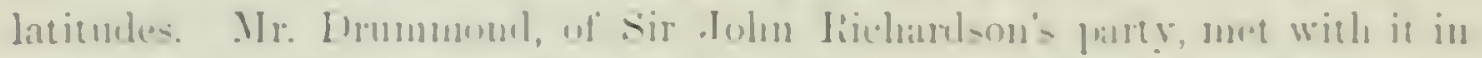

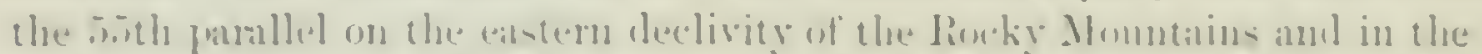

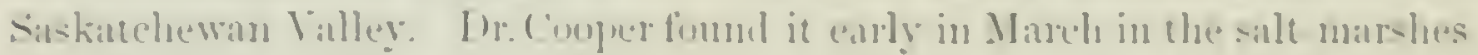
along the const of Wa-hingten Territury, and thinta it winters in that sect ion.

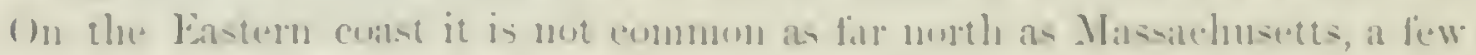

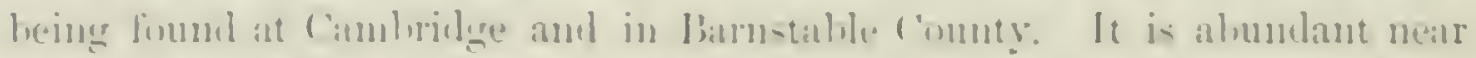

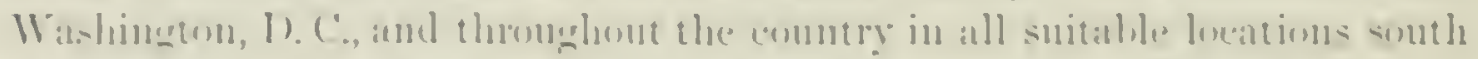

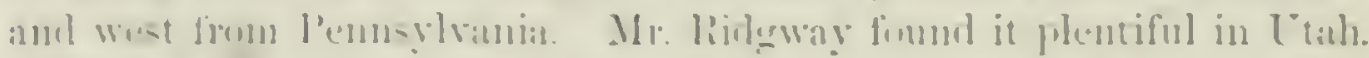

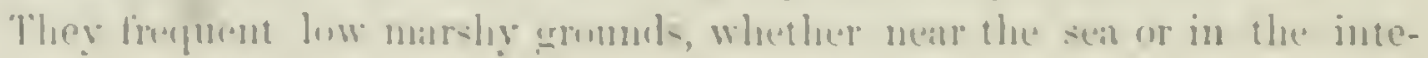

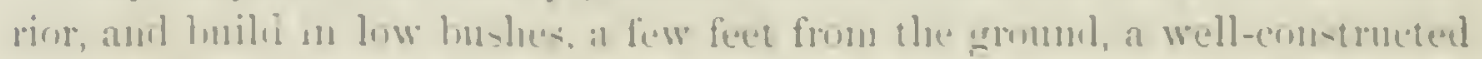

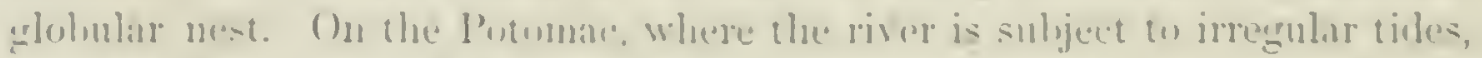

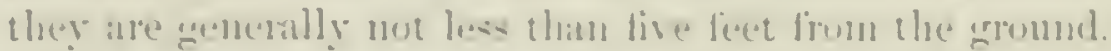

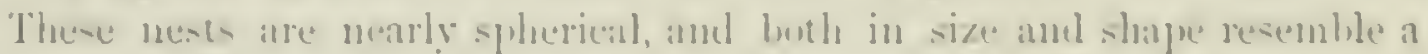

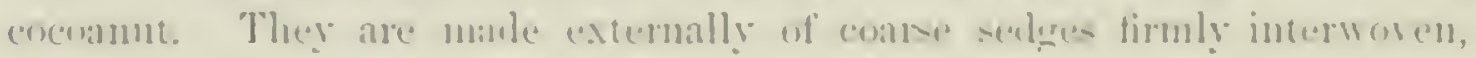

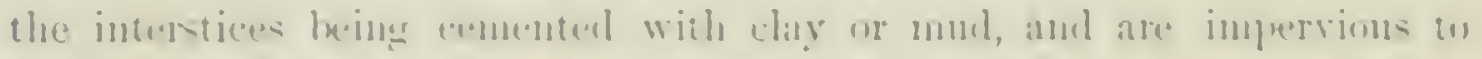

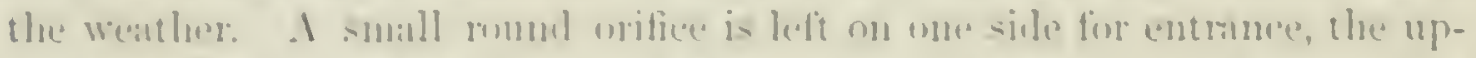

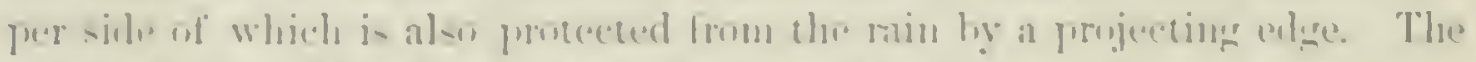

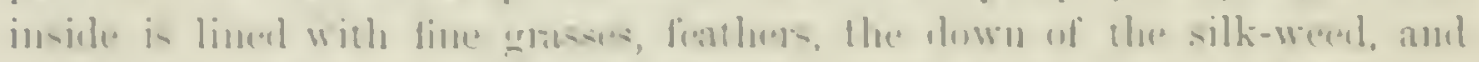

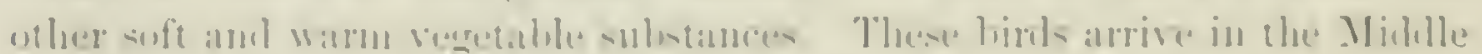

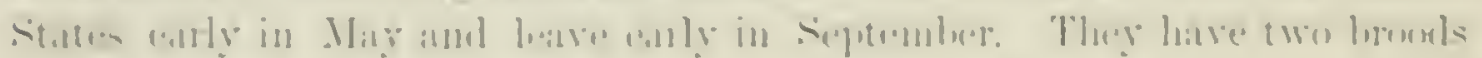

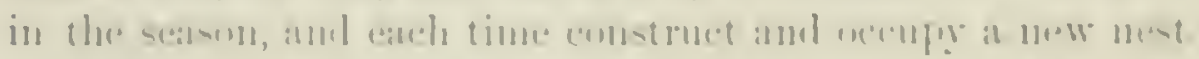

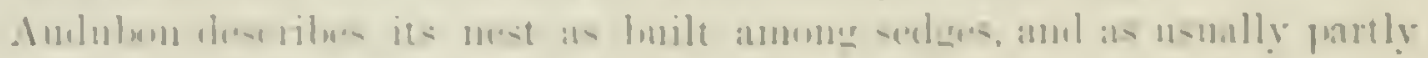

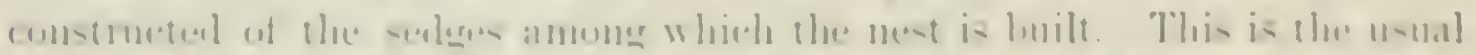

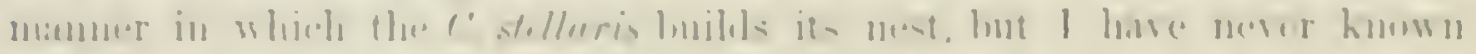

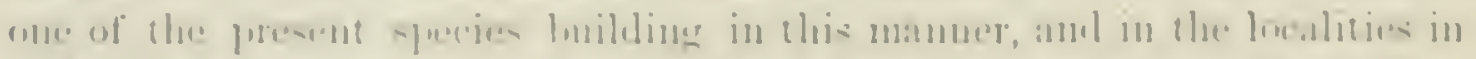

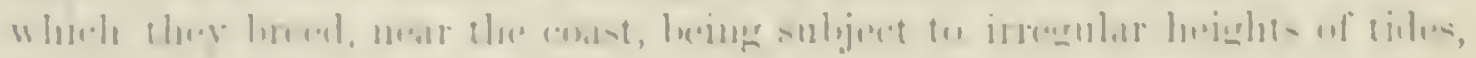

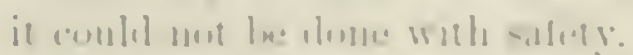

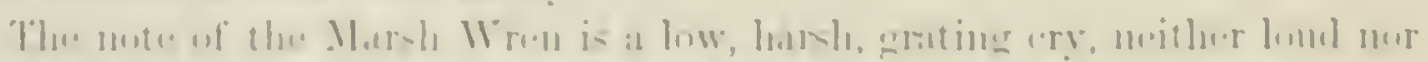

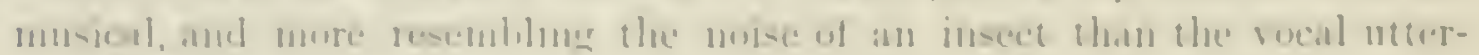
atscen of a lingl.

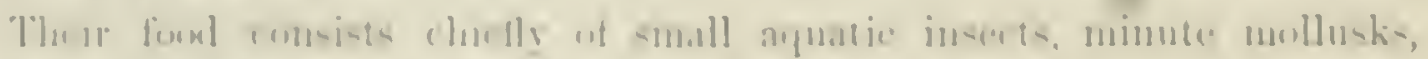

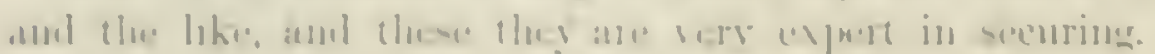


The eggs of this species average .65 of an inch in length and .50 in breadth. They are, in color, in striking contrast with those of the $C$. stcliaris, being so thickly marked with blotches and spots of a deep chocolatebrown as to be almost of one miform color in appearance. They are of an oral shape, at times almost spheroidal, one end being but slightly more pointed than the other. They number from six to nine.

In a few instances egurs of this species from the Mississippi Valley and from California are of a light ashy-gray color, the markings being smaller and of a much lighter color.

Te have thus completed the account of the Oscine Singing-Birds with slender bills not hooked at the end, and which have ten distinct primaries; the first or outer one, however, either quite small or else considerably shorter than the second. We now come to a series with only nine primaries, the first being entirely wanting, and the second, now the ontermost, nearly or quite as long as the third. In the prelininary tables of general arrangement will be found the comparative claracters of the different families of Oscines, but the diagnosis of the series referred to is presented here, as follows :-

Commox Cinsacters. Primaries nine: the first quill nearly as long as the second or third. Tarsi distinetly scutellate the whole length anteriorly. Bill conical, but slender or depressed, usually, except in Curebidce, halt' the lenerth of the head; more or less bristled. or notelied. Nostrils oval or rounded. Lateral toes nearly or quite equal. and shorter than the middle; the basal joint of the miclcle free nearly to its base cxternally, united for about half internally.

Motacillidæ. Bill slender. Culmen slightly concave at base. Less long; claws lut little curved. Hind toe considerably longer than the midhlle one; its claw much longer (twice) than the milllle claw; all the claws hut slightly eurvel. Innermost secondaries (so-called tertials) elongated, much longer than the ontel secondaries; and the fifth primary emarginated at enıl. Test on ground.

Sylvicolidz. Bill rather slender, conical, or depressed. Culmen straight or conrex. Hincl toe shorter than the middle: the claws all much curred. Hind claw not conspicuously longer than the midlle one. When the hinul toe is lengthened, it is nsually in the digit, not the claw. Tertials generally not longer than the secondaries. and not emargimated. Gape wide; tongue slightly split at end. Test varionsly placen.

Cærebidæ. Similar to Sylvicolider. Bill generally longer: equal to hear or more. Gape of mouth narrow; tongne generally much fringed at the end. Nest on trees.

The Tanargide, the Fringillide, and even the Icteride, come very near these families, as will be explained farther on, all agreeing in having the nine prinaries, and in many other characters. 


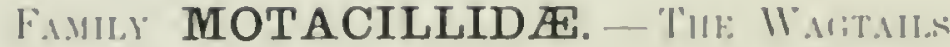

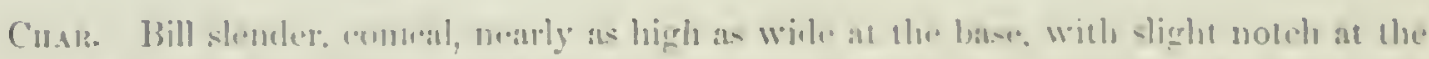

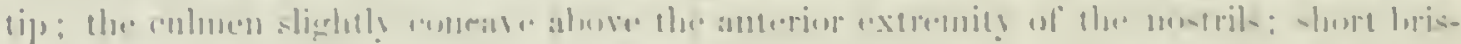

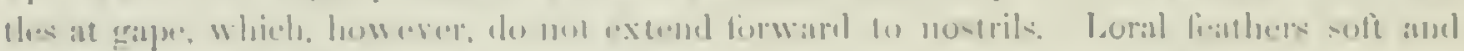

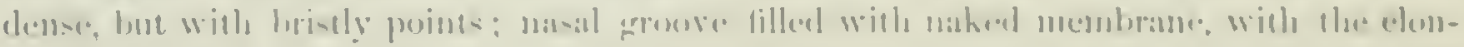

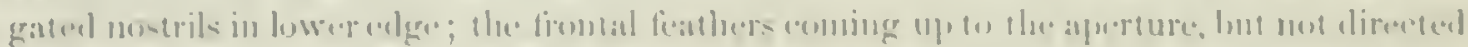

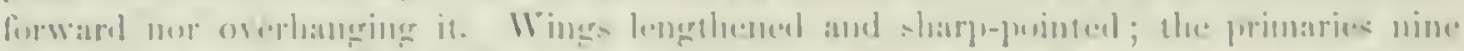

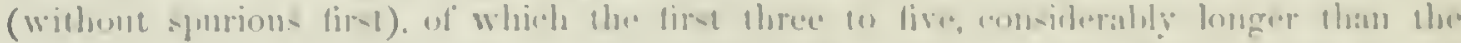

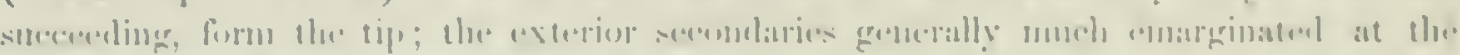

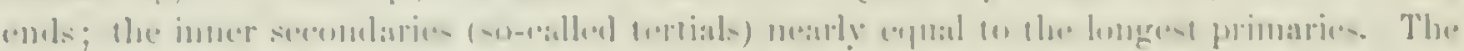

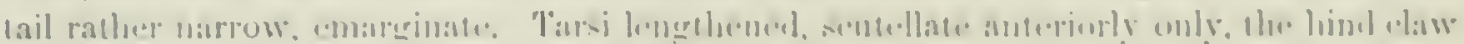

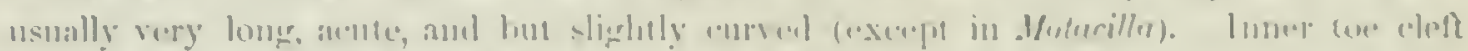

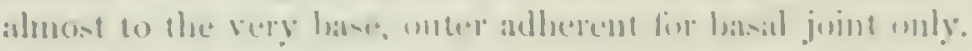

The comblinition of maked mostrils, wotehed hill, and nine primaries, with the tarsi scutellate anterionly only, will an mee distinguish the Anthine of

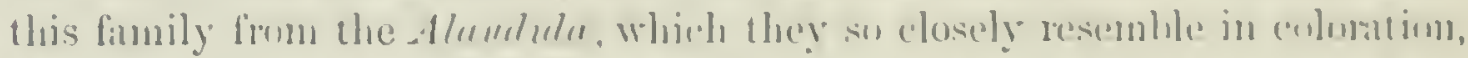

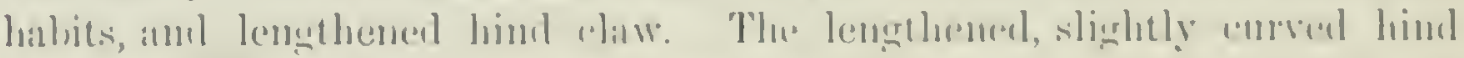

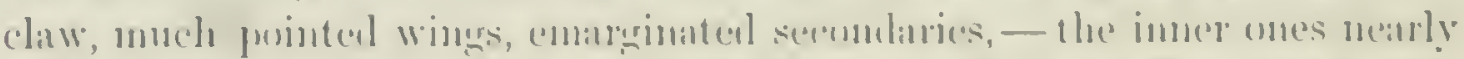
as long as the primaries, - distinguish the linnily from the sigltricolider, with Which also it hins uear relationshijus.

\section{Subfamilies and Genera.}

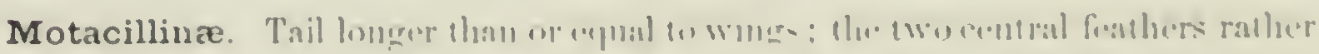

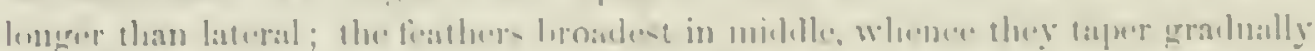

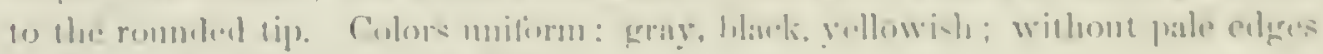

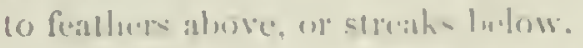

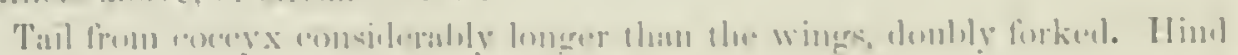

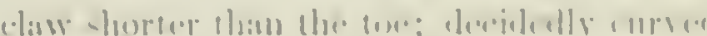

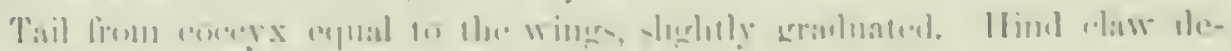

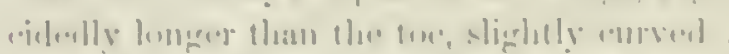

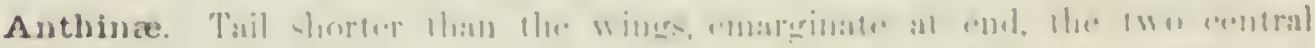

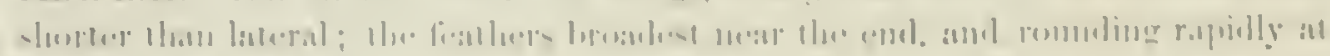

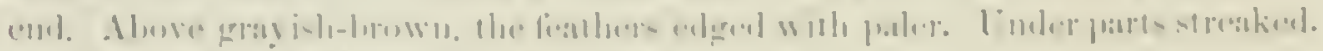

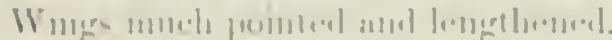

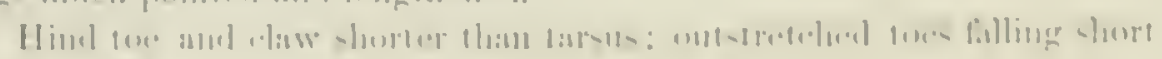
(1) (i) of hil

llind [ore :

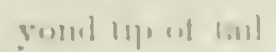

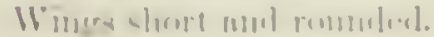

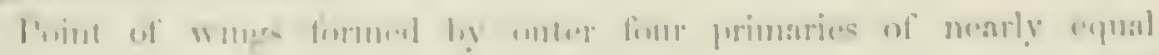

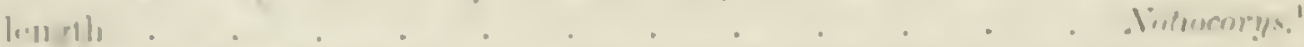

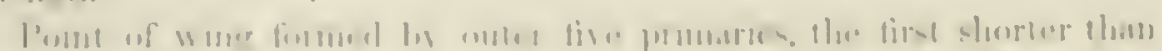
Ilı. Ilinil

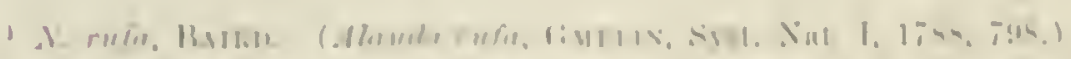

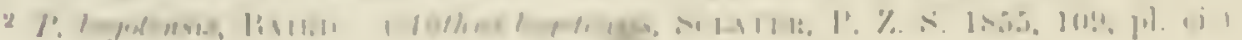




\section{Subfinll MOT A CILLIN 㞌。}

Gexts MOTACILLA, Lix:.

Motacilla, Lis: Srst. Sat. (Trye, Mohecilla alba.)

The diagnosis already given of Motucillu will serve to define it. The genus is an Old Torhl one, represented by several species, only one of which (M. alba) is entitlel to a place here from occurring in Greenland.

\section{Motacilla alba, Lisx}

\section{WHITE WAGTAIL.}

Sotacille alba, Lis: Srst. Yat. 12th ed. 17003, 331. - Kers. \& BLts. Wirb. Europ. 1S40,

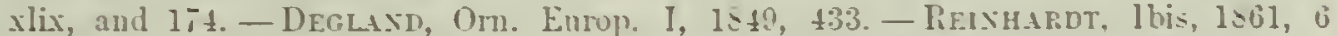
(Greeulaud). - Newtus, Baring-Gould" lcelaud, 1\$63, App. ("rather plentiful"). Barn, Ret. Am. B. 1stit. 1j2.

Figure: Gockn, Birls Europe. 143.

Sp. Curn. (9,410 ठ. Nüruberg). Forehead as far back as abore the eres, with sides of head and neck. white; the remaining portion of head and neck abore and below to the jugulum. black; the rest of under parts white. Cpper parts ashy-gray, including rump; the upper tail-corerts tinged with black. Wings with two conspicuous bands and the outer edges of the secondaries white. Tail-feathers black: the outer two white. edged with black internally. Bill and legs: black. Tip of wing formed by outer three primaries: the distance between the third and fourth about one third that betreen

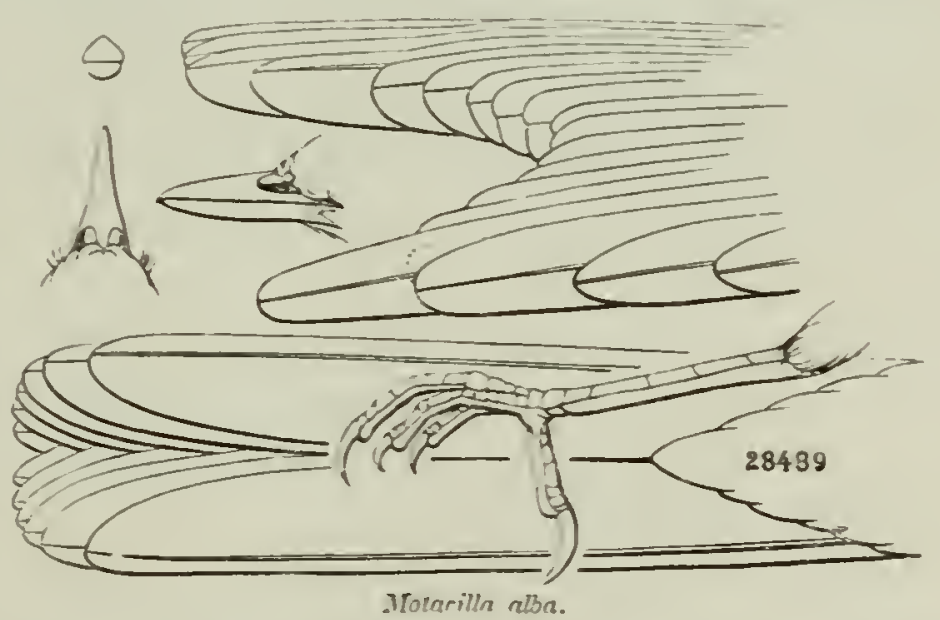
the fourth and fiftl. Tarsi lengthened; claw small: hind toe and claw shorter than the middle, its claw short, considerably curred. less than the toe alone: lateral toes nearly equal. Length, 7.30 : wing. 3.45 ; tail. 3.90 : bill from nostril, .37 ; tarsus, $.8 b$; lind toe and claw. .50.

Hab. Continental Europe. rarer in Encland; Iceland: Freenland (onlr two specimens seen); Siberia; Srria: Nubia. ete.

Motacilla yarrelli, a closely allied species, by some considered a rariety only, differs in having the rump black, the ashy of the back glossed with blackish, and with the black edging of the lateral tail-feathers broader.

Habits. The common White Wagtail of Europe claims a place in the 
North Ameriean fauna ats an occasimal visitant of (ireculand, where in two

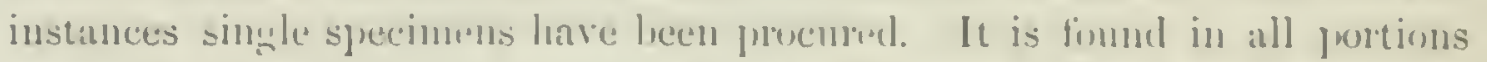

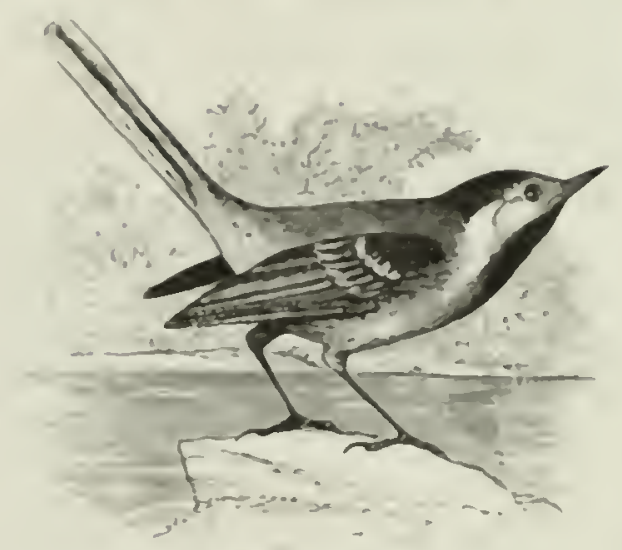

Mtotarilla alba. of the Emropean comtinent, frum the islands of the Mediterranean as far north as the Aretic regions. It appears in swe-

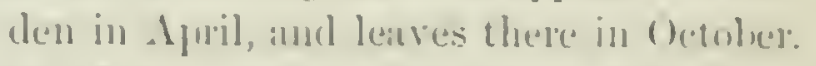
Mr. Gould states: allse, that it is finnd in the unthern portions of Africa, and in the highlatuls of Imelia. It also necurs, thongh les: freepuently, in Englant, where it is replaceet ly a licill noce, or an allied species, Deturilln yurrelli of Gould. The Moturille celler is sited ly Temminsck to inlathit menduws in the vicinity of streans of water, villages, and old houses. Its foul is clicelly insects in various stiges and of dilierent kinds.

It huilds its nest on the ground anomg the grass of the meinlow, in fissures in rocks or derenged buildines, amonge the ruts of trees, on the banks of streams, in piles of woud and fagots, or unter the arch of a bridge. The nests are somewhat coarsely constructed of interworen dre leent stems of

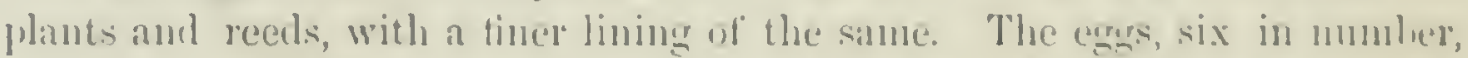
are of a huish-white grwnd thickly sprinkled with fine duttings, which are most usually of at blackish-bruwn rolor, sometinnes abhy-eray or rendishlorwn.

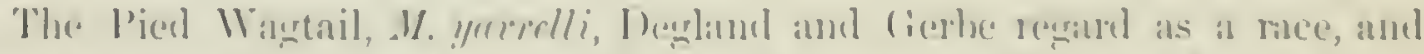
not a species. It has is limital habitat, contined tw Nompay, sweden, and the British Islands, in the latter of which it is a resident thronglumt the

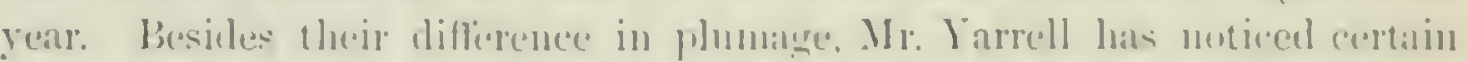

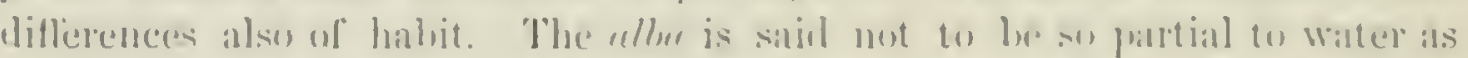

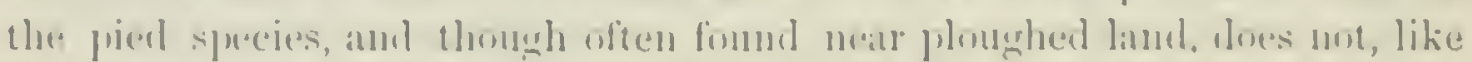
its limdrem speries, follnw the plongh in seareh of insects. Mr. Hewitson also states that it has a lovarser volece.

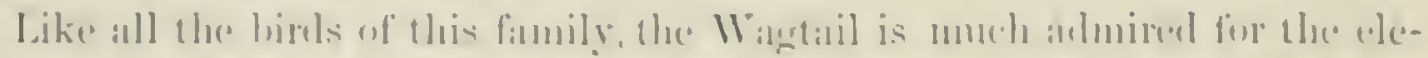

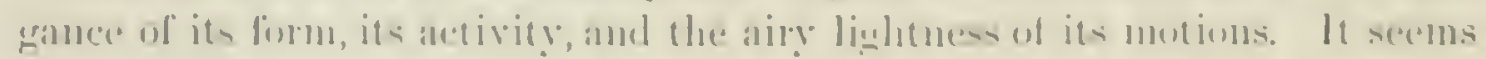

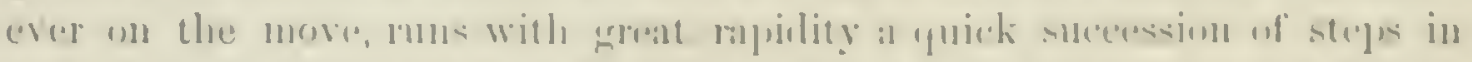

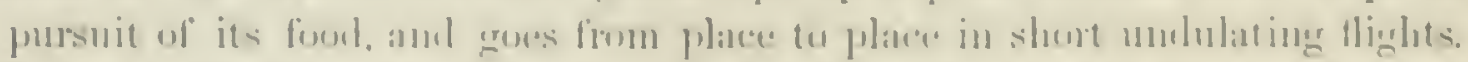

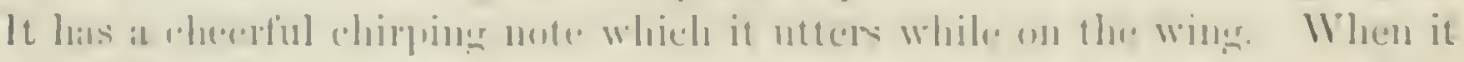
alights, it gises a graceful finning moseneme with its tail, from which it Merives its natulue.

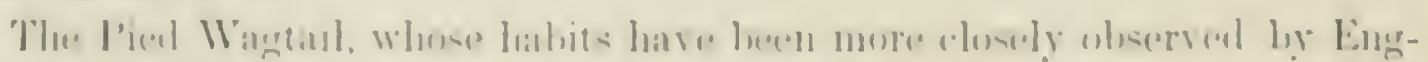

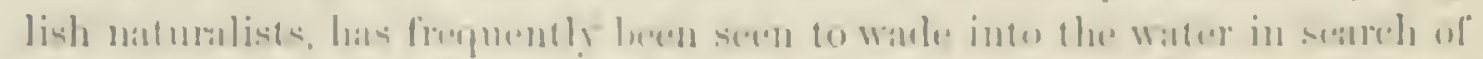

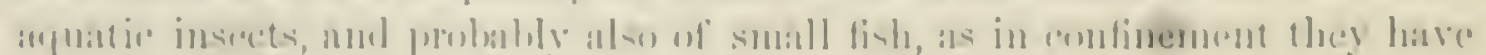

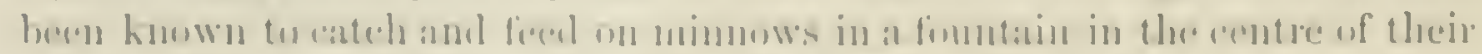
aviary. It is probulde that the hathis on the White Wantail are nut discimilat. 
They leave their breeding-places in October, collecting and moving in small flocks.

Their engs measure .79 of ai inch in length and .59 in breadth. The ground-color is of a gravish-white so thickly flecked with fine ash-colored and black dots as to give the entire eggr the eflect of a uniform dark ashen hue.

\section{GENL: BUDYTES, CUVIER.}

Budytes, Cuver, R. A. 1S17. (Type, Motacilla flava, Lixx.)

The recent discovery of a species of yellow-bellied Wagtail in Norton Sound, by the naturalists of the Russian Telegraph Expedition, adds another member of an Old World family to the list of American birds. Much confusion exists as to the precise number of species in the genus, some grouping together as rarieties what others consider as distinct species. There is an unusual degree of variation with age, sex, and season, and this, combined with strongly marked geographical peculiarities, ren-

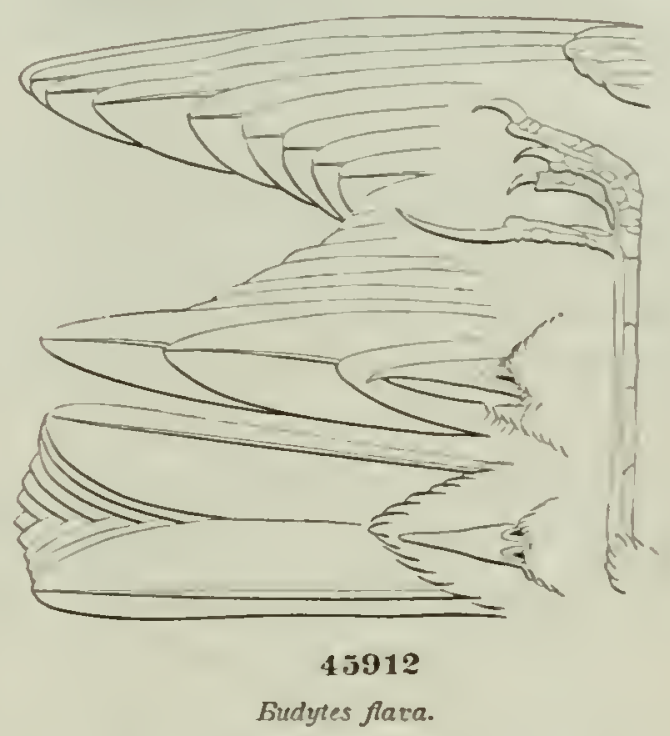
ders the proper solution of the problem impossible to any but those having access to large series.

Budytes flava, Lisx.

\section{YELLOW WAGTAIL.}

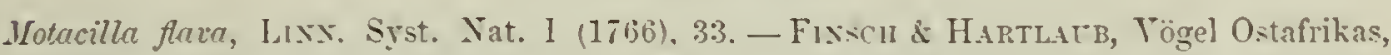

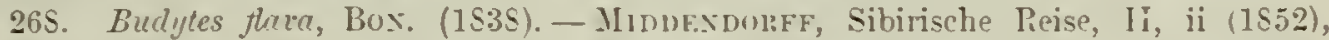
16S. - Deglasd \& Geribe, Omith. Europ. I (1£67), 376. - BArnd, Trans. Chicago Acarl. Sci. I, ii, [1. 312 , pl. xxx, fig. 1 : 1869. - DAll \& Barsister, Tr. Ch. Ac. I, 1869, 127. - Thistran, Ibis, 1Si1, 231. - Finch, 1872.

Sp. Char. Description of specimen No. 45.912, taken at St. Michael's, Norton Sound, June 6, I866, by H. M. Bannister. Abore, incluling edges of upper tail-coverts, rich olive-green, the top and sides of the head and neck pure ash-gray; chin and well-marked stripe from nostrils over the eye to the nape, white; all under parts rich yellow; tinged with olive on the sides. Strine from corner of mouth through the eve, and involving the earcorerts, blackish-ash. Feathers of wings and tail dark brown: the corerts and secondaries edged with olive (showing the obscure light wing-bars). the longest of the latter edgerl externally with white; innermost quills edgred cxternally with white. Outer three quills nearly equal and longest (the prolonged secondaries as long), the others graduating less. Outer tail-feathers and shaft white; the inner web edged externally with dusky, 


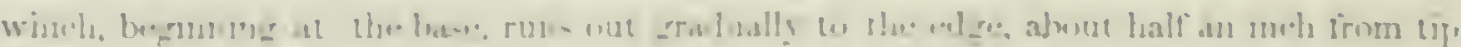

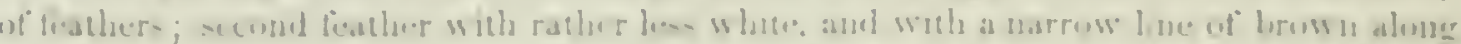

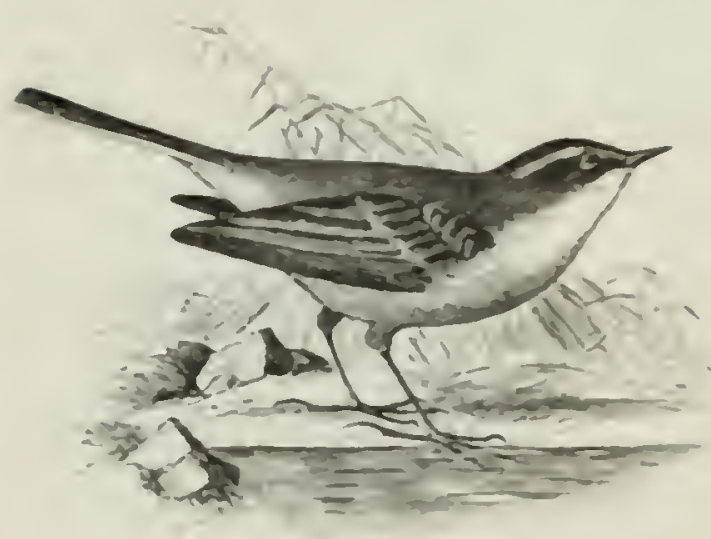

Fistules Alara

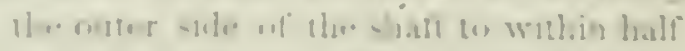

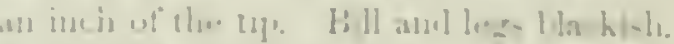

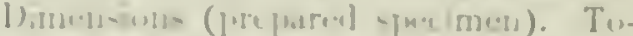

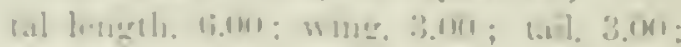
“xpman] portion of firot primars. "2.31).

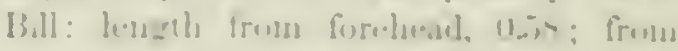

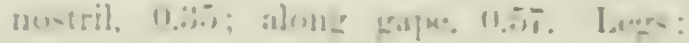

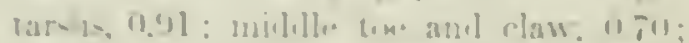

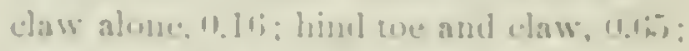

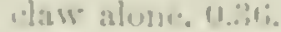

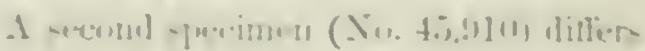

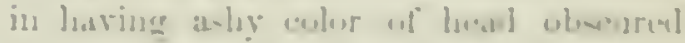
will olis aments--bown: and the rellus in hroes showing browni-h hase. The

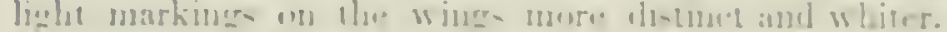

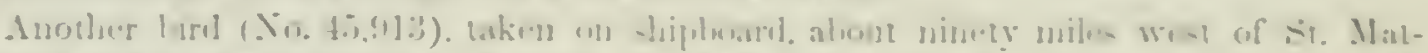

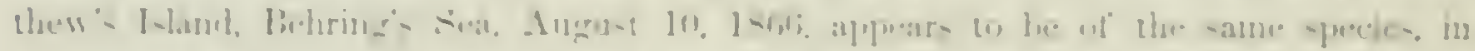

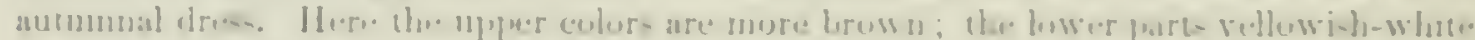

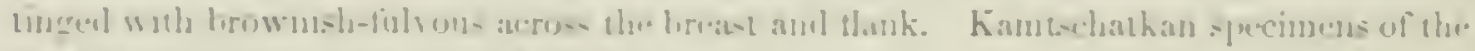

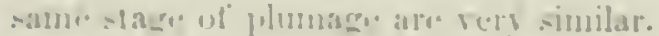

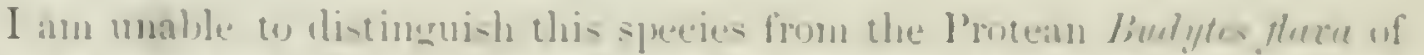

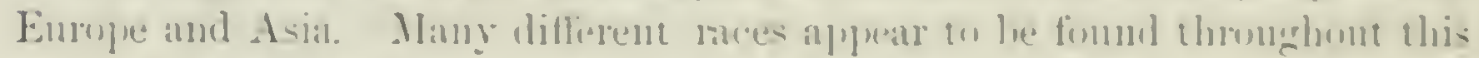
wide circle of distributions, many of them mure on lese local, lunt the propur-

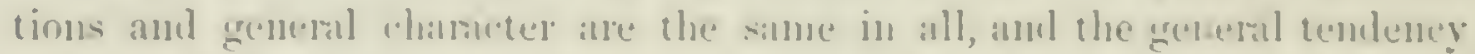

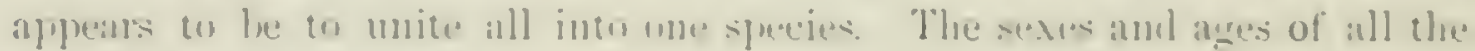

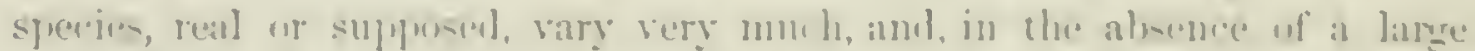

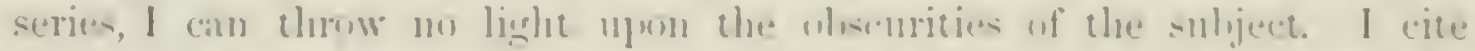

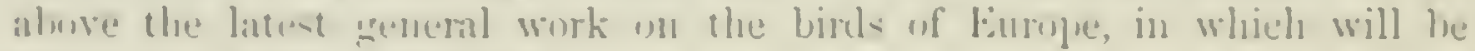
fouml the princijal symmynte.

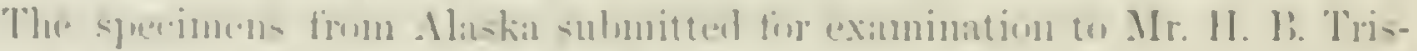

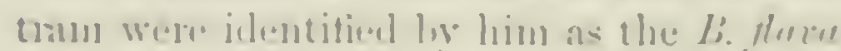

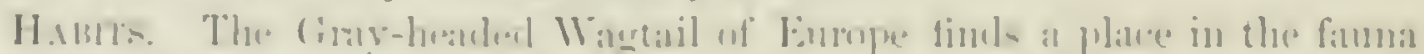

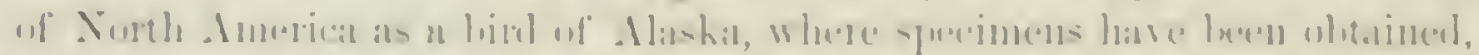

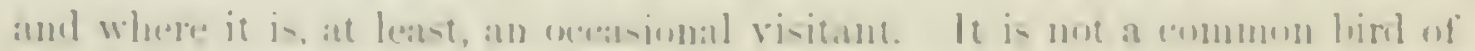

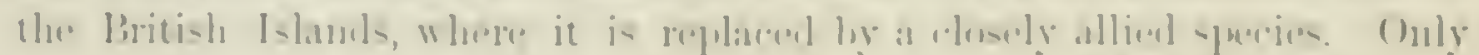

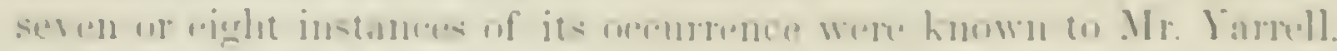

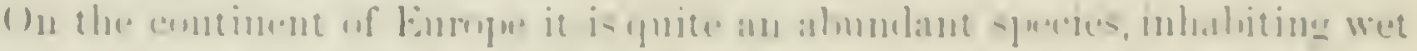

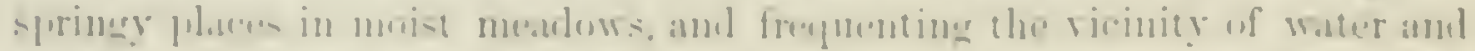

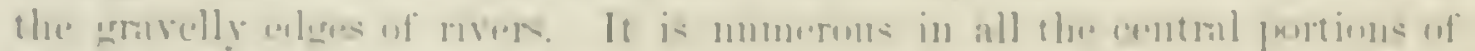

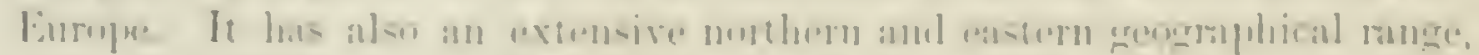

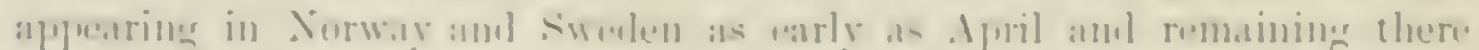

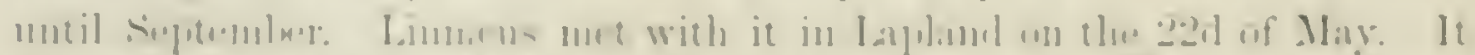

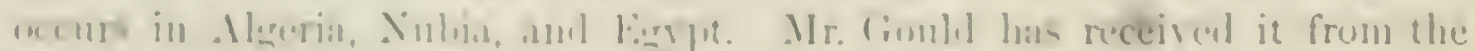

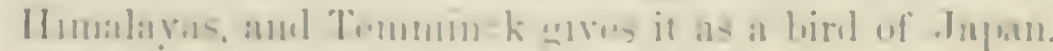

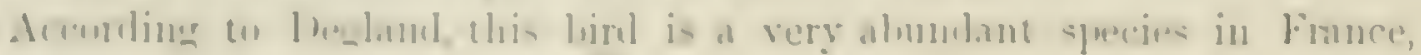


where it nests on the ground in the cornfields, in open fields, meadows, and anidst the standing grain. It lays from four to six eggrs, of a brownish-yellow on a reddish-white ground, profusely covered with fine dots of reddishgray, which are more or less confluent. A few zigzag lines of dark brown or black are found on the linger enct. They measure . i3 of an inch in length and .55 in breadth. Its food is flies, moths, small green caterpillars, and aquatic inseets.

Ray's Wagtail, recognized by some author's as a distinct species, is probably only an insular race, chiefly found in the British Islands and in Western France. In the latter place both birls oceur, and here also they have been known to mate the one with the other. Their nests and egrys are so alike as not to be distinguishable. The former are constructed of fine fibrous roots and fine stems of grisses, and are lined with hair.

These birds are remarkably social, collecting in small flocks soon after learing their nests, and until their antunnal migrations following the older birds in quest of food. They have two call-notes which are quite shrill, and are repeated in succession, the second being lower in tone. No mention is made by the naturalists of the Telegraph Expedition of their having any song other than these notes.

Mr. Bannister first observed this speeies at St. Michael's, on the 9th or 10th of June, and from that time until late in August they were among the nost abundant of the land-birls. During the month of June he observed them in flocks of twenty or thirty individuals. It seemed to be a rather shy bird. He deseribed its flight as like that of our common Goldfinch, rising with a few strokes of its wings, then closing them and describing a sort of paraboloidal curve in the air. The only note which he heard and identified as uttered by this species was a kind of faint ehirp, hardly to be called a song. These birds seemed to prefer the open comntry, and were rarely observed in the low brush, the only approach to woods found on the island.

\section{SubaMILY A N THIN 压。}

The characters of this subfamily have already been detailed. The American sections may be defined as follows, althongh whether entitled to rank as genera may be questioned:-

Commox Crunacters. Tail deeidedly shorter than the wings: less than half the whole length of bird; simply enarginate and rounded. Hind claw lengthened; only slightly curred. Feathers of back with paler edges; breast streaked with dusky. Nest on the ground; eggs finely mottled so as almost to be uniform dark brown (in North American species).

$$
\text { a. Wings much pointed, and lengthened. }
$$

Point of wing formed by four outer primaries, of which the fourth sometimes a little shorter than the third. Hind toe and claw as long as middle, shorter than tarsus, the claw alone winilly a little longer than the toe itself, 


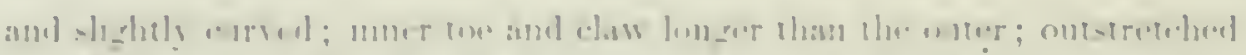

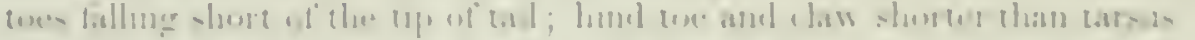

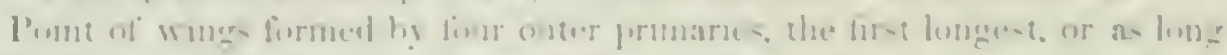
1 118), as.

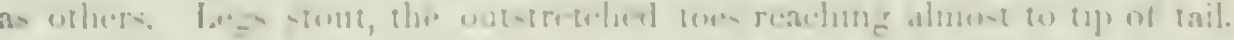

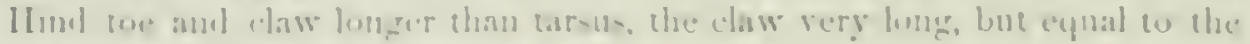
tien proper

\section{1. "ivings short, roluteled.}

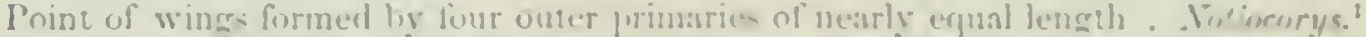
Point of wings lermed ly twe onter primarse-, the fir-t shorter than third

\section{(iENL: ANTHUS, BEMT.}

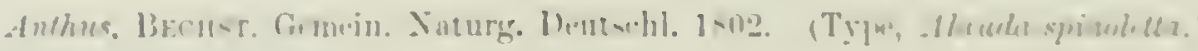

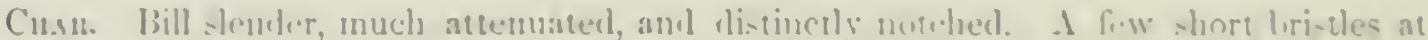

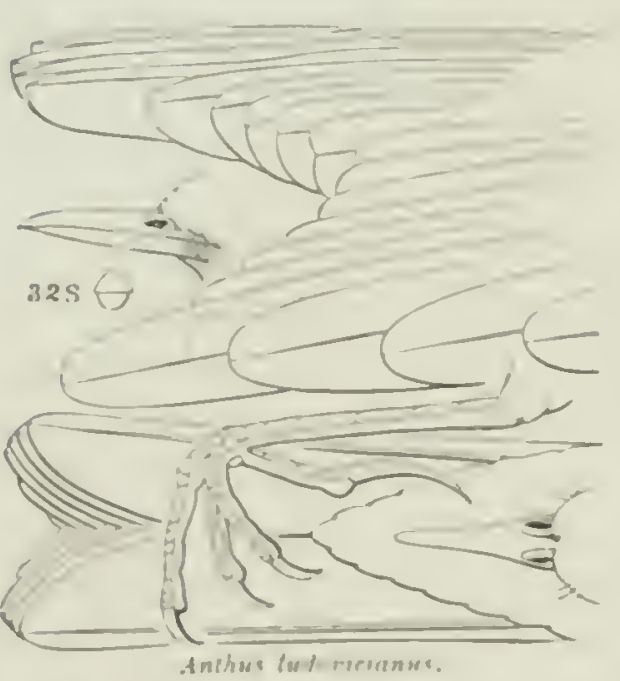
the lisa. Cubnen concase at the ba-c. Tar-i quite distinetly coutellate; lenger than the mulille.

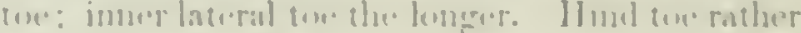
shorter than the tar-11. lout longer than the midtlle

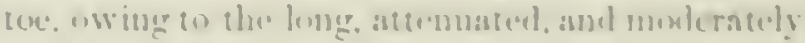

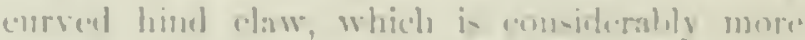
than hali the cotal hength of the tere. Tial rather

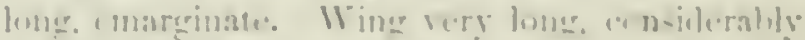

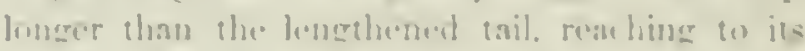

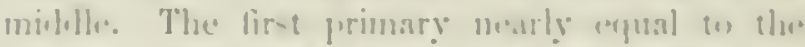
loneret. The tertal alenos as loule as the primaric..

lint the speedes of this grems helomers

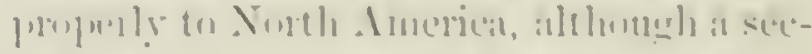
ond is accilental in Grenland and Mlaskat. The diannuses are as fullows:-

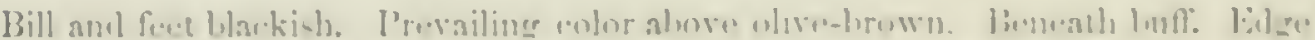

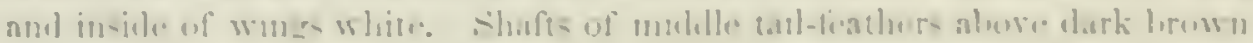

1. Iudw. irinnus.

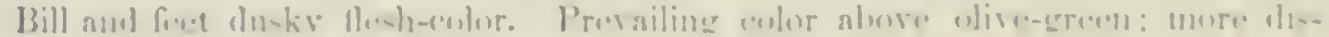

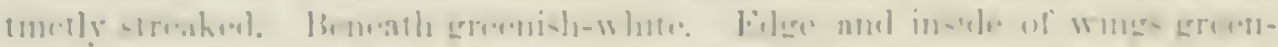

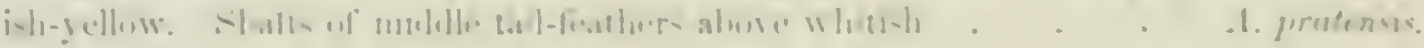

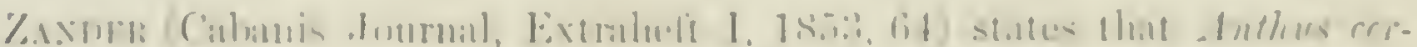

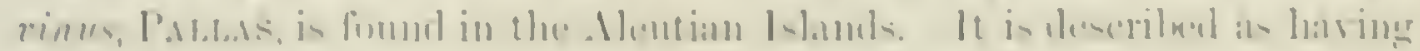

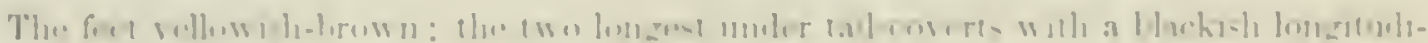

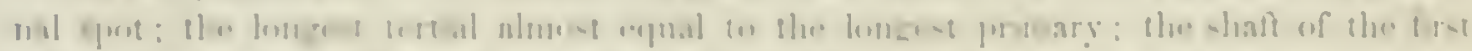

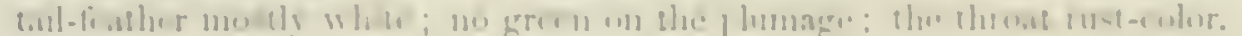

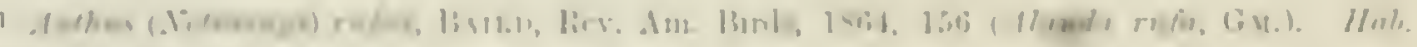
ln limus of l'an+wh

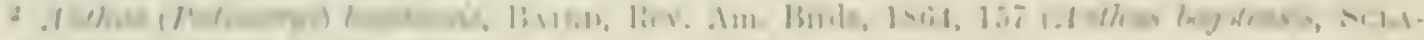

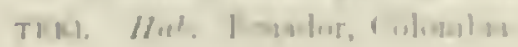


Baldants (Nammamia, 1857, 202) says he las received Anthus aquaticus and its eggs from Lahrador. This statement, however, requires verification.

\section{Anthus ludovicianus, Licht.}

\section{TITLARK; AMERICAN PIPIT.}

Aluuda ludoriciana, G.s. S. X. I, 17SS, 793. Anthus ludoricianus, Licnt. Verz. 1S?3,

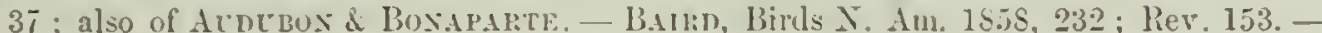
Coles, Pr. A. X. S. 1861, 220 (Labrador). - Sclater, P. Z. S. 18506, 296 (Curdora). —IB. Catal. 1561, 24, no. 153. ScL. \& SAlr. Ibis, 1859, 9 (Guatemala). - Juses, Nat. in Bermula, 1859, 29, antumu. - Blakistox, Ibis, 1862, 4 (Saskatchewan). - DALL \& BAsister, Tr. Chic. Ac. I, 1569, 27/.-Cuoper, Orn. Cal. I, 18j0, 7 s. Aluude rubra, G.r.; Alaudu meji, Wils.; Anthus spinoletta, Box., At'D. ; Aluuda ponnsylvenica, Briss.; ?Aluede pennsylvanica, Boss. Enevel. Méth. I, 1790, 319. ?.Hotucilla hulsonica, Latri. Ind. Orn. II, 1790, 503. - Vieilut, Encyel. Jlétlı. II, 1S23,

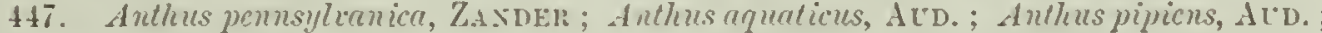
Anthus mebens, Ml:ki:eM; Anthus reinhareltii, HöLborl, l'tuma Grönlands (ed. Paulsen), 18 46,25 (Freenlanul).

Figures: Ard. Birds Am. Il I, pl. cxl. - Ir. Om. Biog. l, pl. lxxx. - Wilsox, V. pl. lxxxix.

Sp. Cплt. (Female, in spring.) Above olive-brown, each feather slightly darker towards the central portion; beneath pale dull-buff, or yellowish-brown, with a maxillary series of dark-brown spots and streaks across the brenst and along sides. Ring round the eye, and supereiliary stripe, yellowish. Central tail-feathers like the back, others dark blackish-brown; the external one white, except at the hase within: a white spot at the end of the second. Primaries elged with whitish. other quills with pale brownish. Length, 6.50 ; wing, 3.45 ; tail, 2.9.5.

HAb. Whole of North Ameriea: Greenland: Bermuda; south to Orizaba, Guatemala, and eren Peru? Heligoland, Europe. (Gïnк.) Not noterl in West Indies.

Spring specimens from Labrador, collected by Dr. Cones, have the upper parts ashy without any tinge of olive, almost bluish on the head; the lower parts deeper and more reddish-buff' than in autumnal and winter specimens. Tarsi black in spring, brown in winter; toes always black.

Habits. At different seasons of the year the Brown Titlark is found throughout the continent, and abundant for the time in the sereral parts of the country, chiefly frequenting the least cultivated portions and appar-

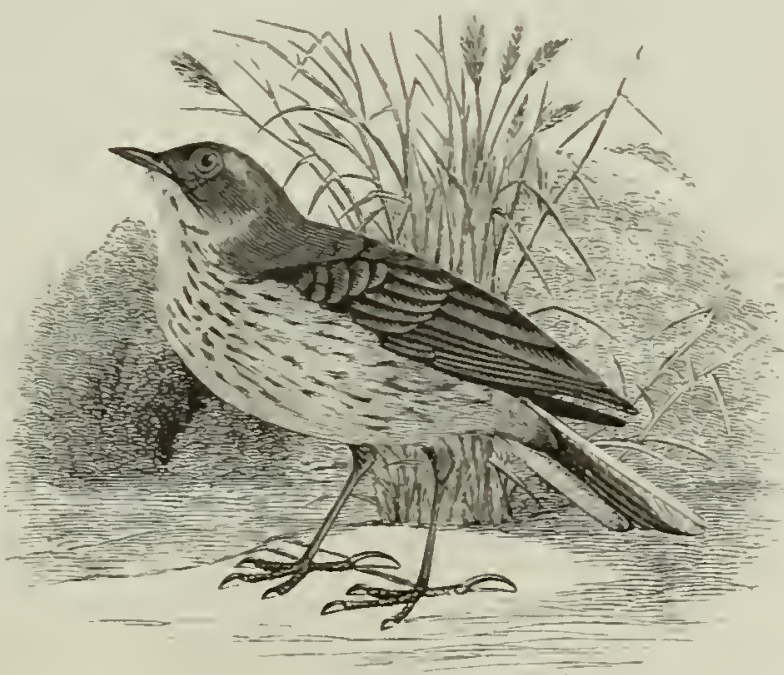

Anthus ludoricianus. ently preferring the sterile and least attractive regions. It is one of the most extensively distributed of all our North American birds, being found 


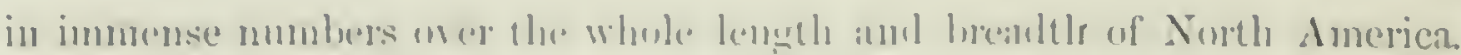

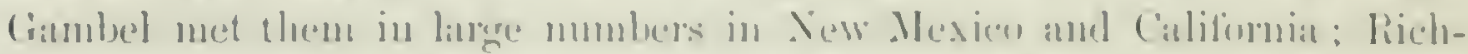

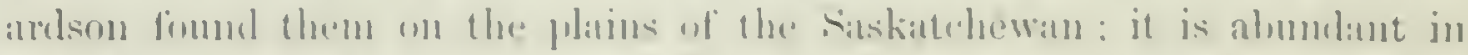

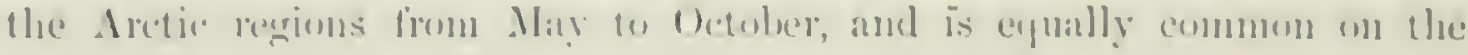

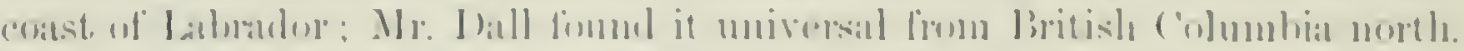

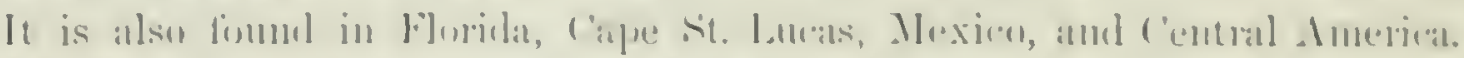

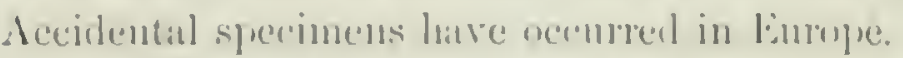

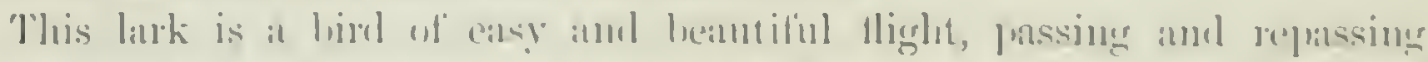

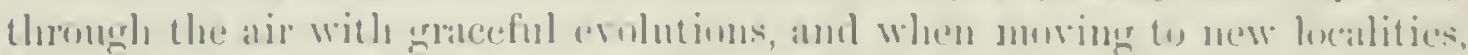
sweepring over the plate several times lefore alighting. It also moves rapilly on the groum and altere the manner of the true latks, jerking the

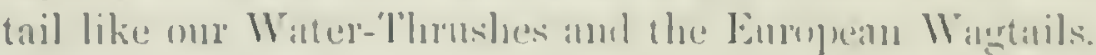

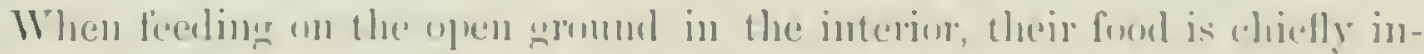

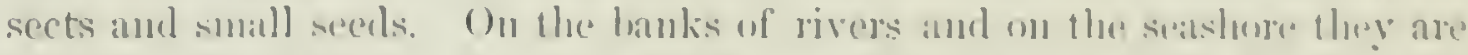

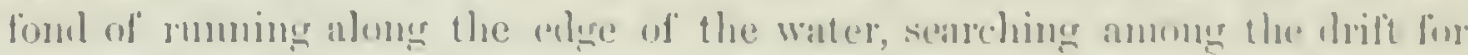

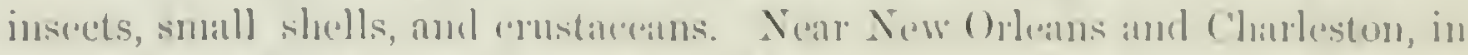

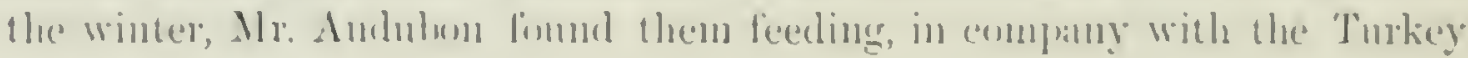

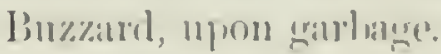

Dr. (ones fomml the l'it atrk almmlant in erory locality visited ly him in

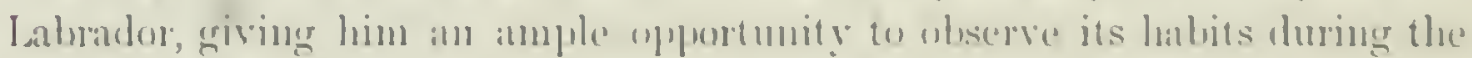

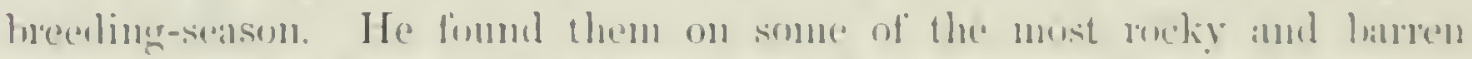

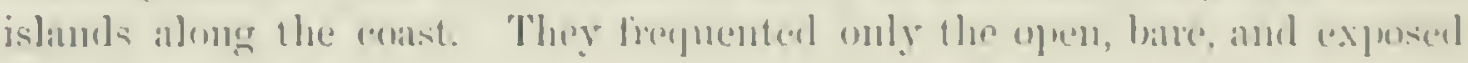

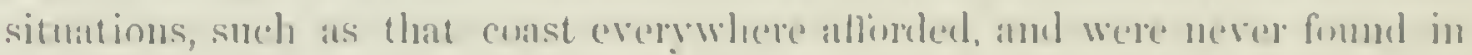

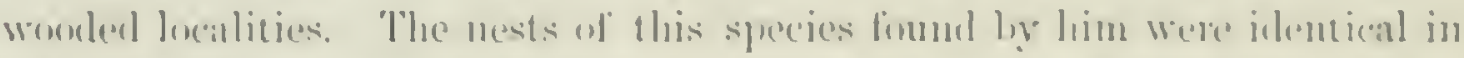

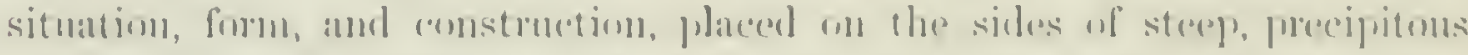

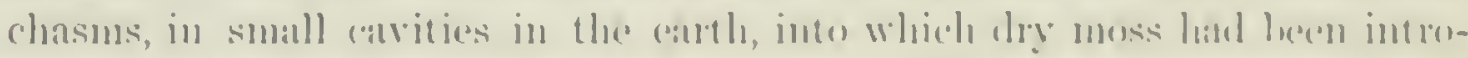

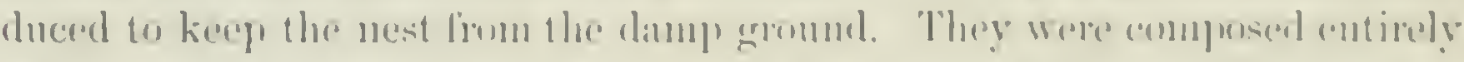

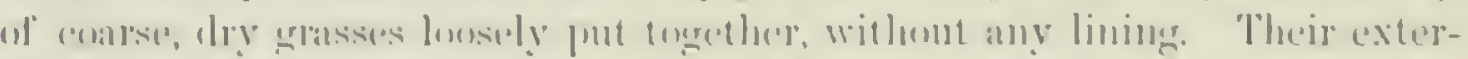

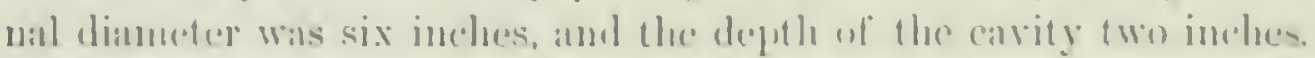

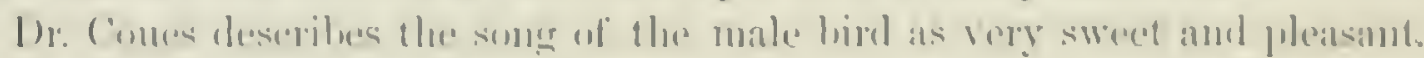

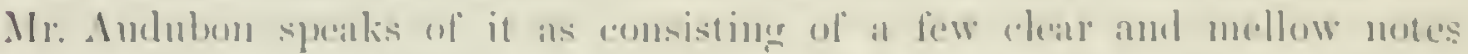

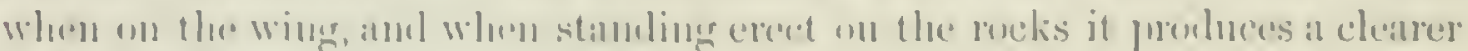
and lomelere simg.

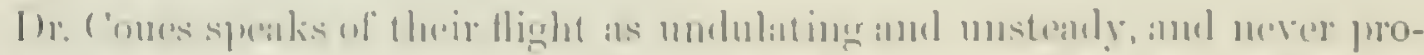

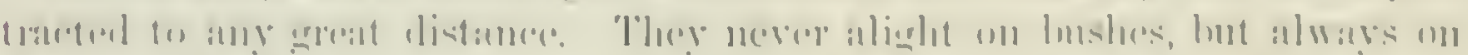

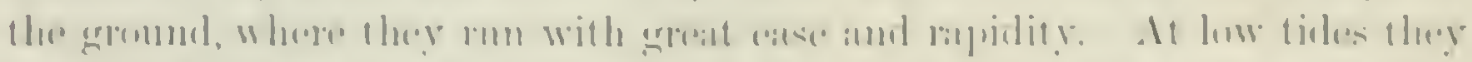

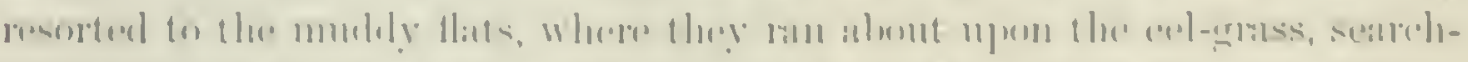

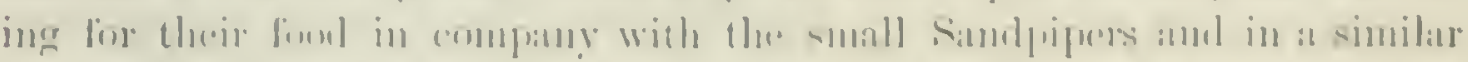

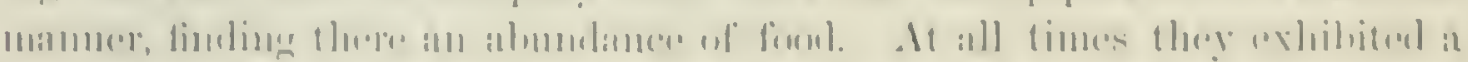

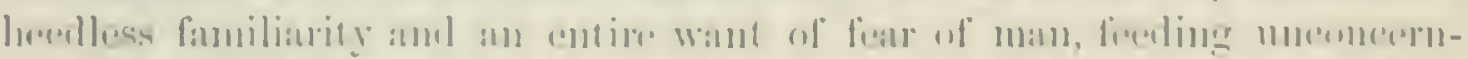

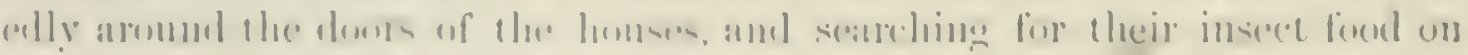

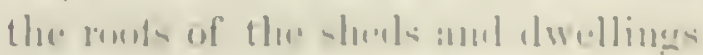

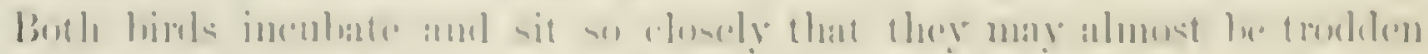

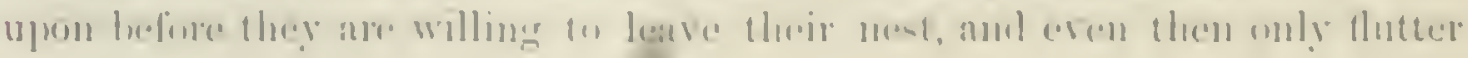


off to a short distunce, with lond cries of distress that soon bring the nate and other pairs of the same species to join in the lamentations. They horer orer the heads of the intrulers, at times approaching within a few feet, expressing their distress by the must plaintive eries, and even when the intruders withdraw following them to a considerable distance.

All the nests of this lark that I lave seen are remarkilble for the thickness of their walls, and the strength, compactness, and elahorate care with which the materials are put together, farticularly for nests built on the gromend. They are well snited to protect their contents from the cold, damp ground on which ther are flaced; and their "per portions are composed of stout regetable stems, lichens, and grasses strungly interworen, and forming a strong rim around the upper part of the nest.

I). Cones describes their egros as of a dark chocolate-color, indistinctly marked with numerous small lines and strealis of black. Audubon describes them as haring a ground-eolor of a deep reddish-chestnut, dinkened by numeruns dots of deeper reddish-brown and lines of various sizes, especiallytoward the linger end. Those in my possession, received from Labrador by Thienemam, measure from $i 5$ to. is of an inch in length, and from .59 to .62 in breadth, and have a light-hrown or clay-colored ground, so thiekly covered with spots as to he almost cuncealed. These spots are of a purplish chocolate-brown, with oceasional darker lines abont the linger end. In others the markings are bolder and larger and of brighter hues. Like the eggs of the Anthus crboreus of Europe, it is probable that those of this Titlark exhilit great variations, both in gromu-color and in the shacles of their markings.

\section{Anthus pratensis, BECHsT.}

\section{EUROPEAN PIPIT.}

Alaudu prateisis, Liss. Syst. Sat. 1706, 257. Anthus protensis, Bechst. Dentsch. Pügel,

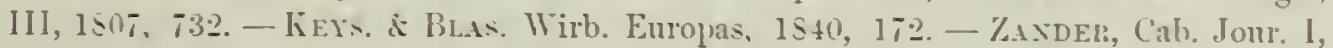
extraheft, 1553, 60.-PAllses, ed. Hölboll, Famn. Grünlands, 1846, 24. - lírs.

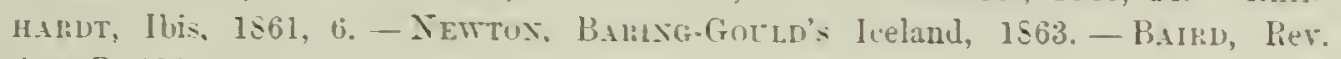
Am. B. 1Sơt, 155

Figures: Gotho's Birds Ëurope. pl. exrxvi.

HAB. Europe generally: : common in Layland: accidental in Greenland: st. Michael". Sorton Sounil.

This species in general form resembles the $A$. Iudoricionus, the fifth primary in both being abruptly and consiclerably shorter than the outer four; the bill and legs quite similar. The arerage size appears much the same. The upper parts are, howerer (especially the head and back), more distinetly streaked with dusky; the edge and inside of wing greenish-yellow, not white, and the upper plumage and outer edgres of the quills decidedly olivegreen. The shafts of the middle tail-feathers above are whitish, not dark 


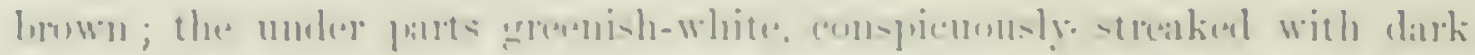

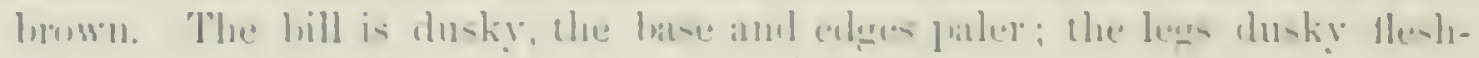
(m)lur, nut link linw?.

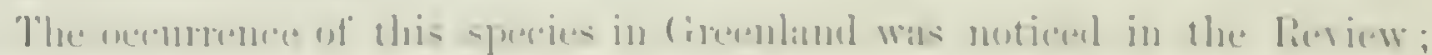

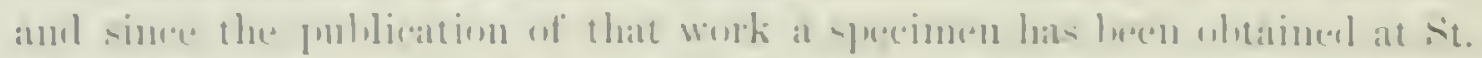

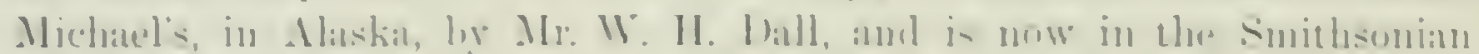

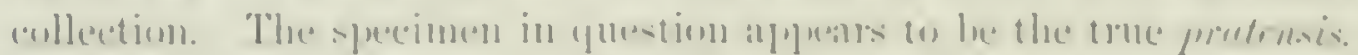

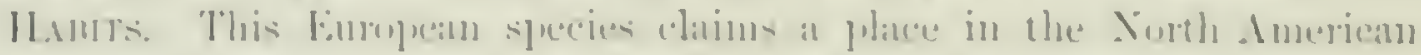
fitmat mo the

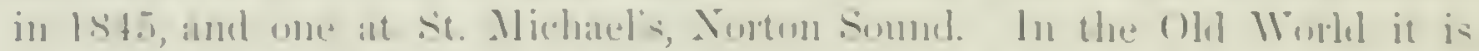

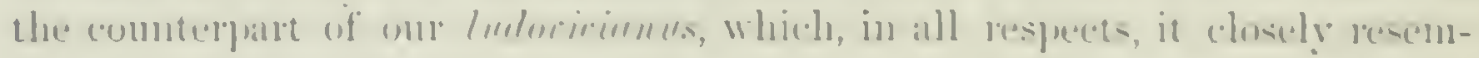

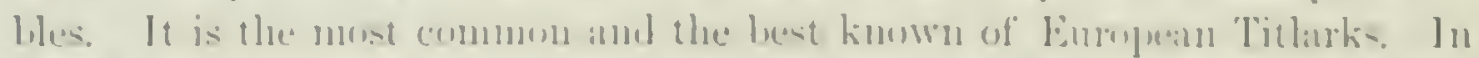

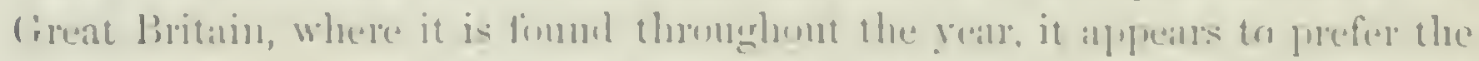
mucultivated districts, inholliting commons and waste lands, and in the more mothern pats frepuenting the mons. It is alon fomml in meatows ame

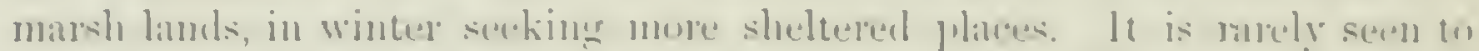

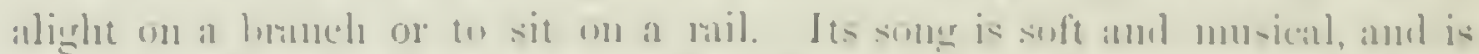

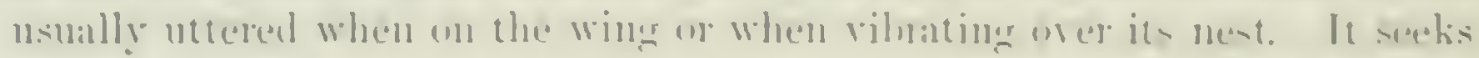

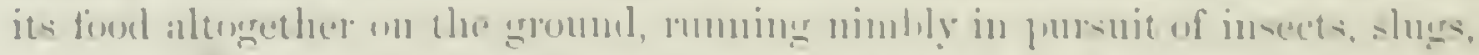

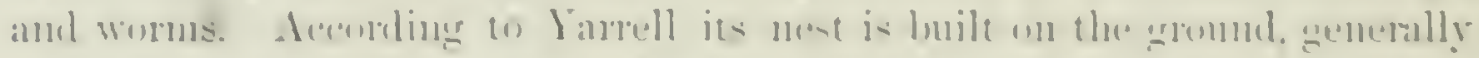

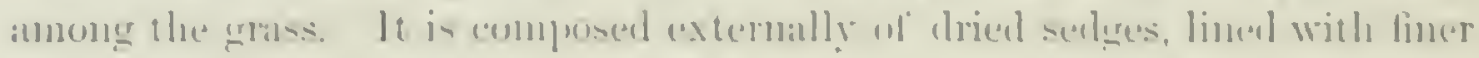

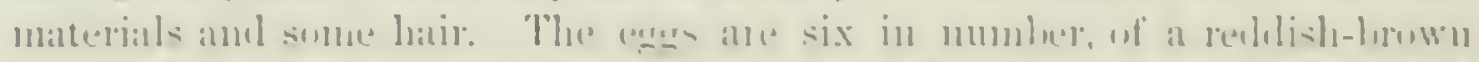

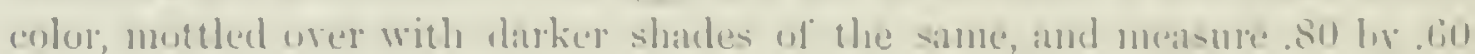
of an inch.

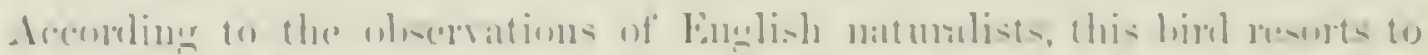

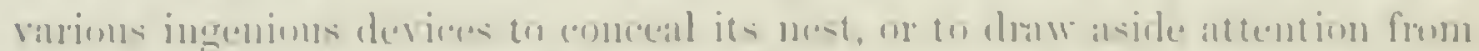

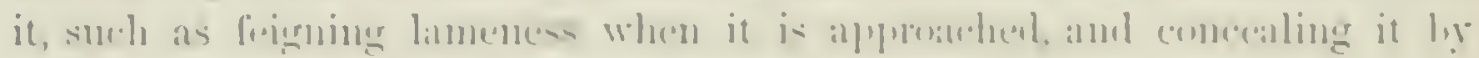

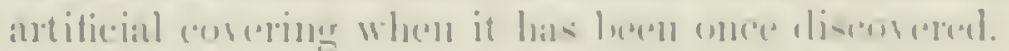

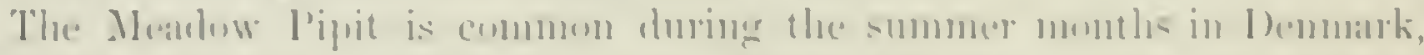

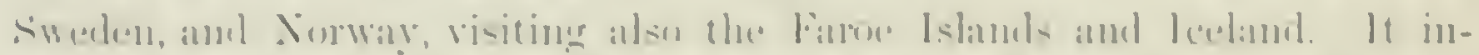

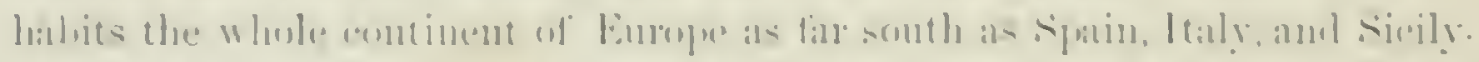

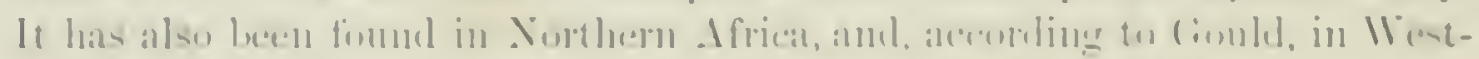

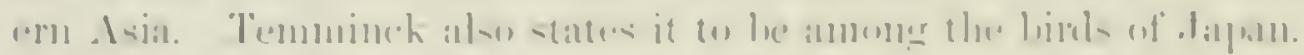

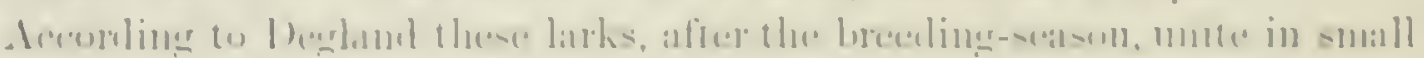

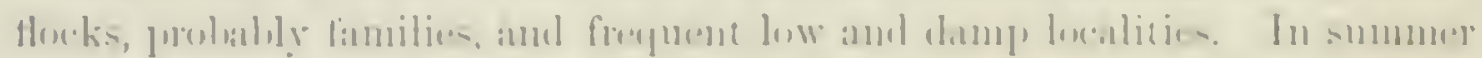

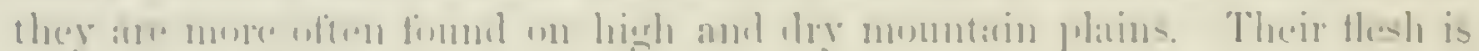
saicl in In aluleism

\section{(ii) - NEOCORYS, i117118}

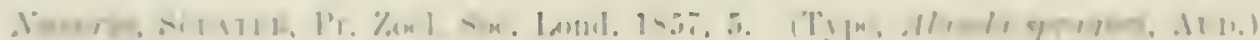

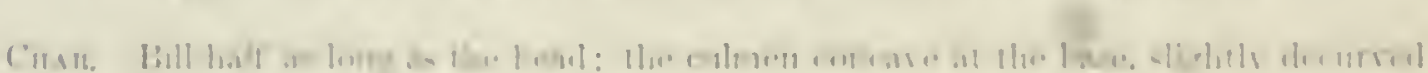

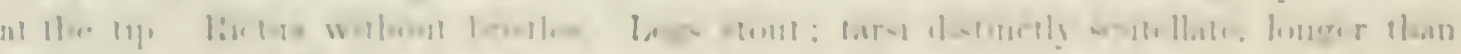

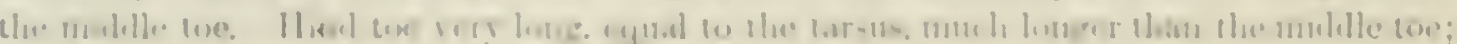


its claw but slightly curred, and ahout half the total length. Inmer lateral toe rather longer than outer. Wings much longer than tail; first quill longest. Tertials eonsiderably lunger than secondaries. Tail rather short, emarginate.

But one species of this genus is known, it being peculiar to the Western plains.

\section{Neocorys spraguei, S'LAt}

\section{MISSOURI SKYLARK; SPRAGUE'S PIPIT}

Alaudu spraguei, AtD. Birds Am. VII, 1843, 335, jl. cecelaxiri. Alyrodoma spraguci.

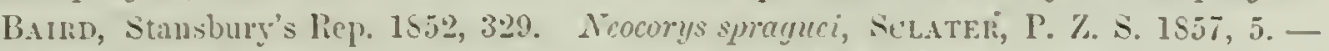

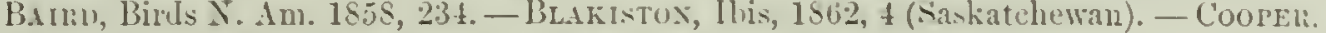
Orn. Cill. I, 1870, 30. Anthus (.Icacorys) spruyuei, B.tlut, Rer. 155.

Sr. Cuan. Above wood-brown, all the feathers edged with paler, especially, on the meck, where there is a brownish-yellow tinge. The under parts are dull white, with a collar of sharply defined narrow brown streaks across the forepart and along the sides of the breast. Lores and a superciliary line whitish. Tail-feathers, except the middle ones, dark brown; the outer one white, the second white, with the inner margin brown. The outer prinary is edged with white. and there are two dull whitish bands across the wings. Bill and feet yellow, the former brown above. Length (female), 5.7.j; wing, 3.35; tail, 2.50

H.ı. Plains of Yellowstone and Upper Missouri to Saskatchewan; Nebraska.

This little-known species has the general appearance of a Titlark, but is readily distinguished from Anthus ludoricianus by the purer white of its under parts, the much darker centres and much paler margins to the feathers above, the entirely white external tailfeather, and the vellow legs and bill, as well as by its generic peculiarities. In its song and general habits it approaches nearer the European Skylark than any bird belonging to our fauna.

Hibits. This interesting species was first described by Audubon, in the supplementary portion of his Birds of America. It was obtained by the party which

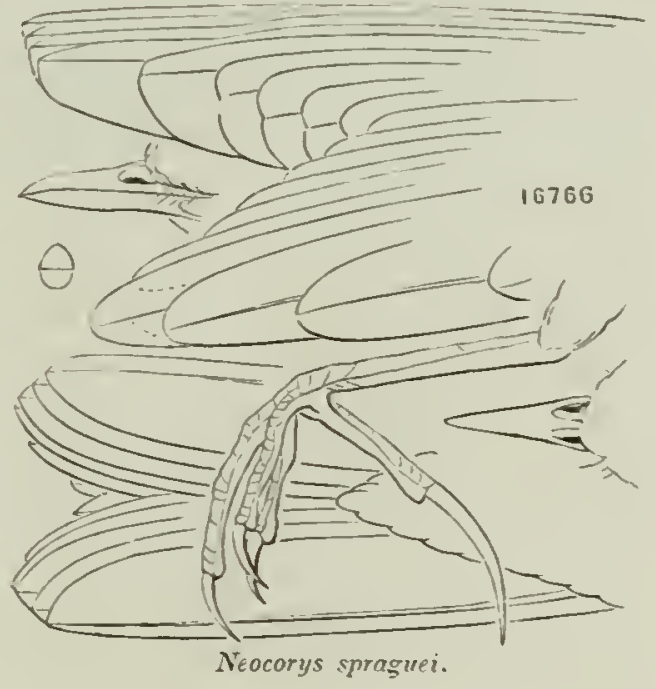
accompanied him to the Upper Missouri in 1843. It was first met with on the 19th of June near Fort Union, in Dacotah Territory. It has since been found on the fork of the Saskitchewan, but little alditional information respecting its habits has been obtained since its first discovery.

It seems to more nearly approach, in its habits, the European Skylark than any other of our Nortl American birds. Mr. Edward Harris was completely misled, at first, by the sound of their song, so that on several occasions he sought for them on the ground. Their voices appeared to come to 


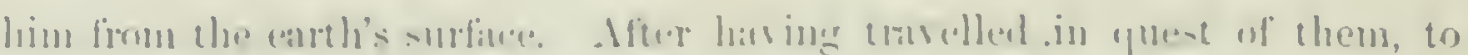

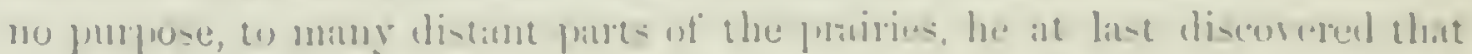
there smmols promented from someml

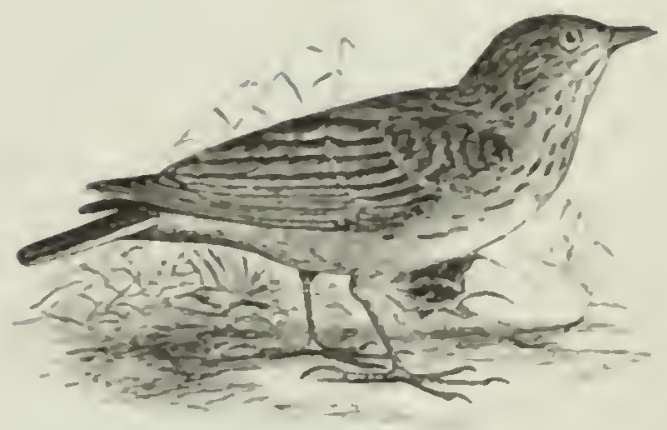

Brororys sprusues

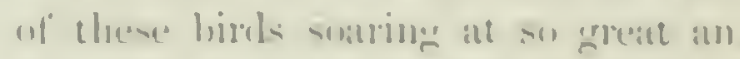
"letittion as to make them diflicult to

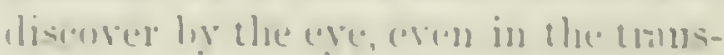

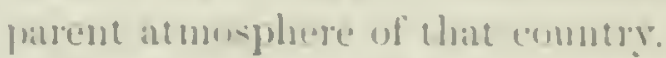

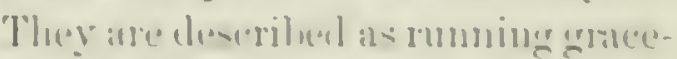
fully on the eromod, alt times squat-

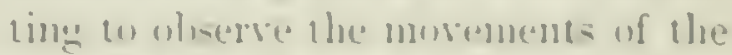
intrulers, and aytin elevitin= thrir herlices as it on meet their approbuh.

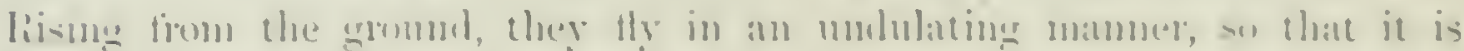

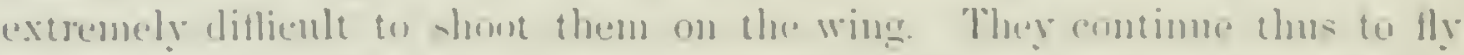

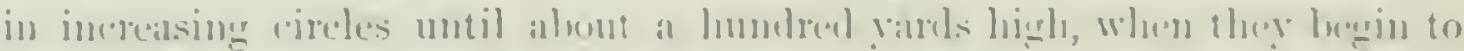

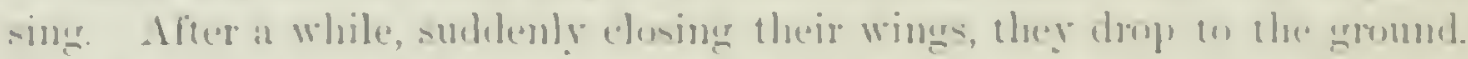

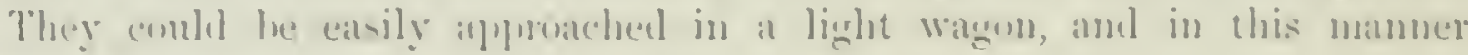
seremal specinens were ohtained.

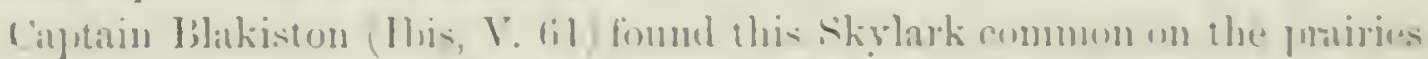

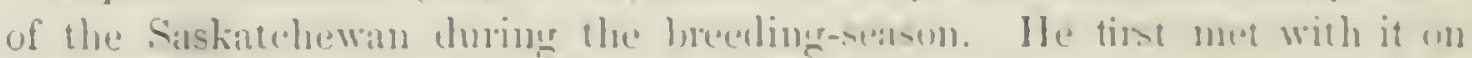
the bith of May, mear Fort carlen. When disturbed from the gratsis. its

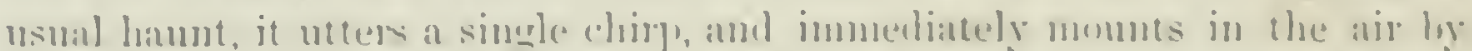

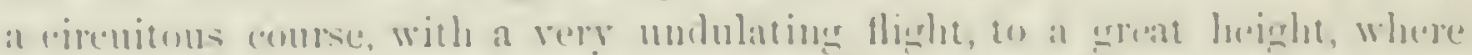

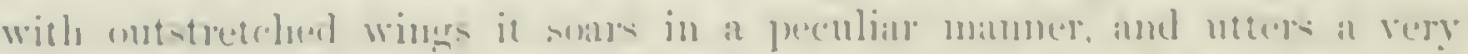

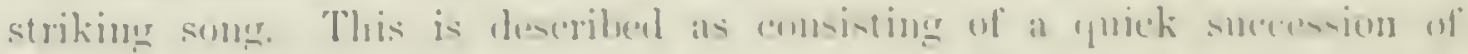

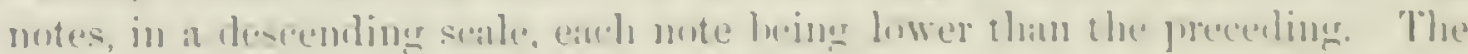

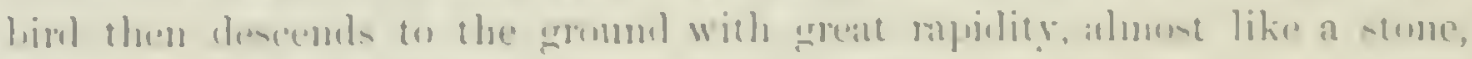

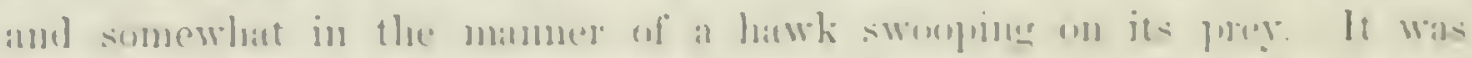

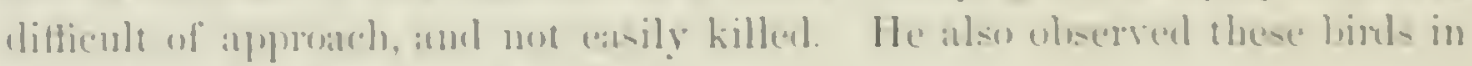

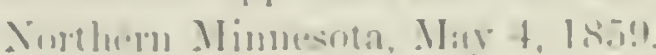

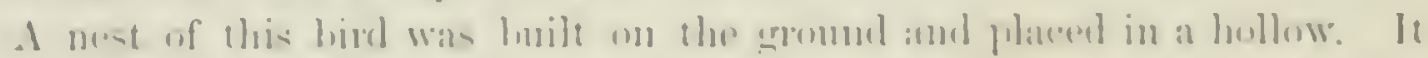

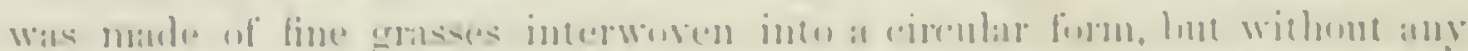

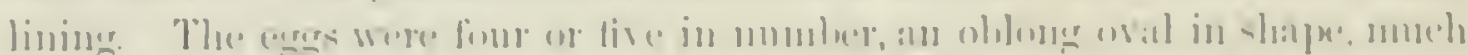

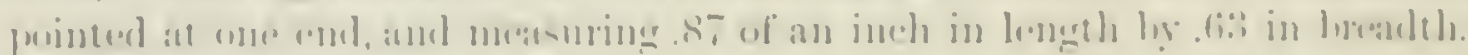

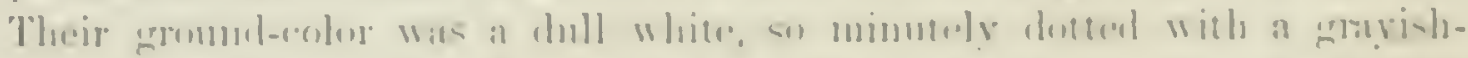

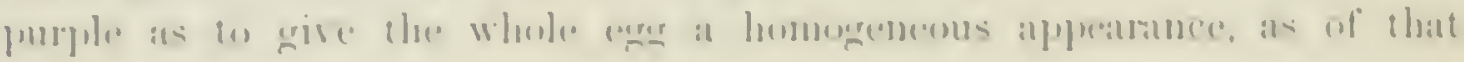
miform color.

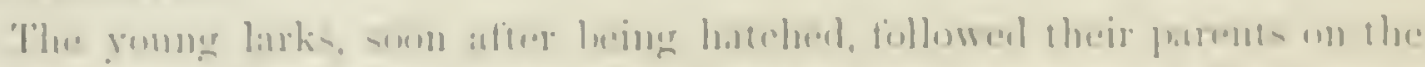

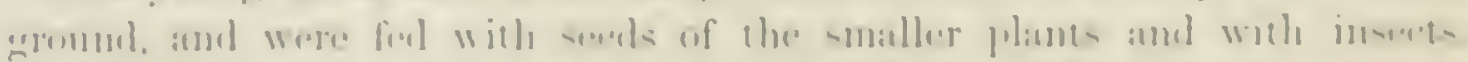

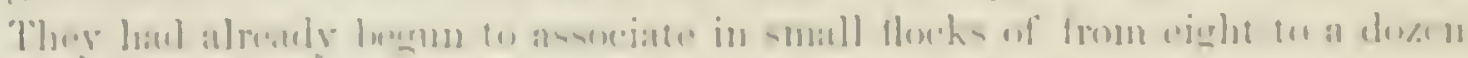

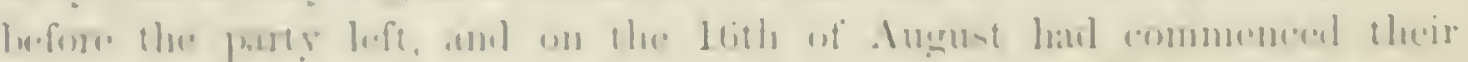
minthern minratum 


\section{Family SYLVICOLID丑. - The WARblers.}

The Sylvirolida are essentially characterized among the Oscines with nine primaries, by their small size, the usually slender and conical insectivorous bill, shorter than the head, without angle in the gane near the base; the toes deeply cleft so as to leave the immer one free almost to its very base (except in Mniotilte( ), etc. The shallow noteh at the end of the tongue, instead of a deeply fissured tip, distinguishes the family from the Carbidla', to some of which there is otherwise so great a resemblance. The absence of abrupt hook and notch in both mandibles separates it from such of the rirconila as have nine primuries.

The American Motacillide are distinguished from the Sylicicolide by the enargination of the outer and the great elongation of the inner secondaries, as well as by other funtures referred to under that family. Anthus, in particular, rliffers in the lengthened and slightly curved hind claw. There is little difficulty in distinguishing the Sylvicolida, however, from any families excepting the slender-billed forms of the Tanagrida, as Chlorospingus, Nemosia, Chlorochrysu, ete, and the conirostral Carbide. In fact, some ornithologists are inclined to include all three of the families thus mentioned in one, from the difficulty of marking their boundaries respectively.

In fact, we are of the opinion that no violence would be done by adopting this view, and would even include with the abore-mentioned families the Fringillide also. The order of their relation to one another would be thus: Fringillida, Tanagrida, Sylvicolide, Cardida; there being scincely any break in the transition between the two extremes, unless there are many genera referred to the wrong family, as seems rery likely to be the case with many included in the Tanumpida. The fringilline forms of the latter family are such genera as Buarmon and Arremon, they being so elosely relited to some fingilline genera by so many features - as rounderl concave wing, lax plumage, and spizine coloration - as to lie scarcely separable. Either these two families are connected so perfectly by intermediate furms as to be insepirable, or the term Tanugrida covers too great a diversity of forms. With the sinne regularity that we proceed from the Fringillicle to the typical forms of the Tanagrida (Pyranga, Tanagru, Culliste, etc.), we pass down the scale from these to the Sylvicolide; while between many genera of the latter family; and others referred to the Corchida', no difierence in external anatomy can be discorered, much less expressed in a lescription.

In the following symopsis we attempt to define the higher groups of the Sylricolide, although in the large number of species and their close relationships it is very difficult to express clearly their distinctive features. 


\section{Subfamilies.}

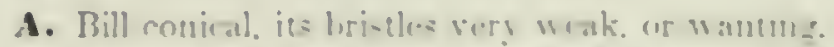

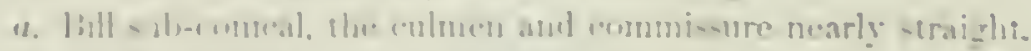

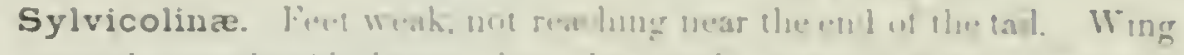

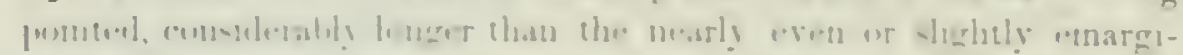

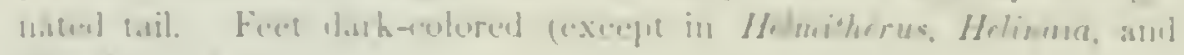

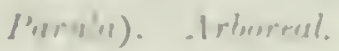

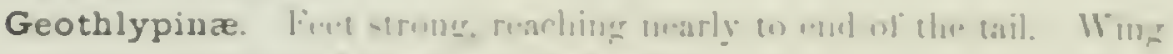
roumlenl. Fin punhinh-uhalla. Terrestrial.

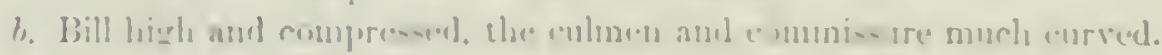

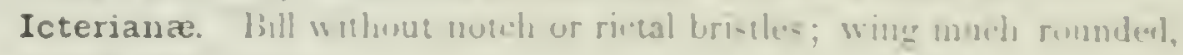
- Horreor ihan the iail.

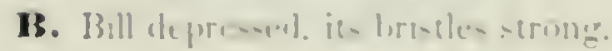

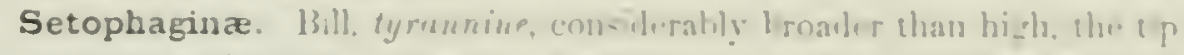

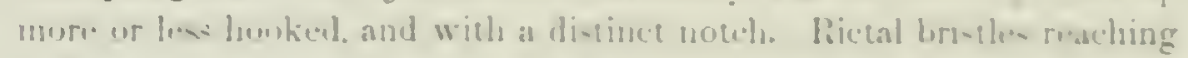
lati-way, or more, to the tip.

\section{Sections and Genera.}

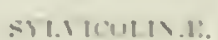

1. Muldhe pue, with elas, longer than tar-nk.

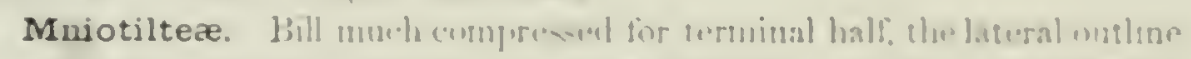

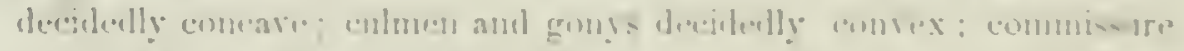

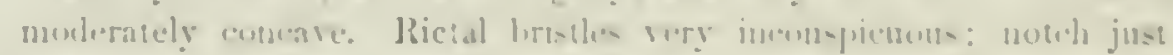

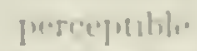

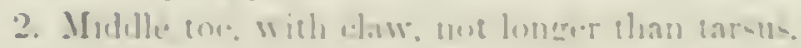

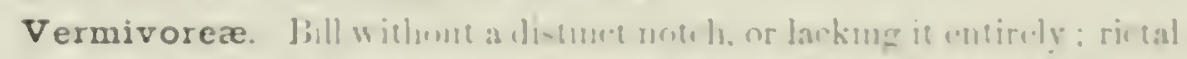

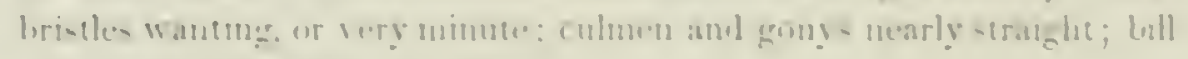

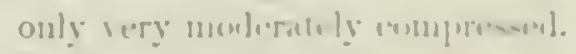

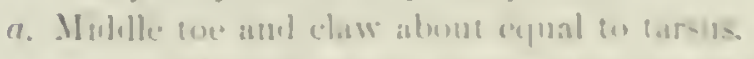

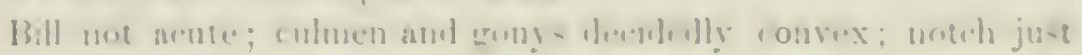

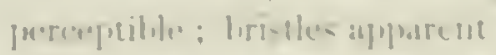

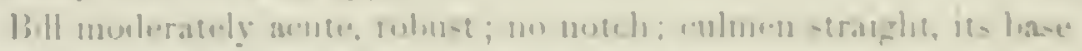

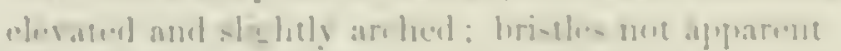

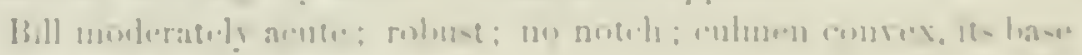

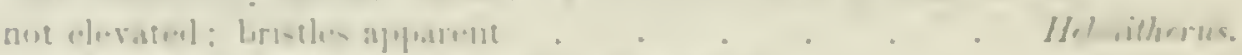

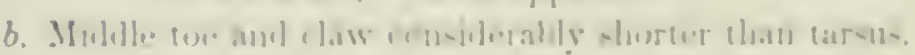

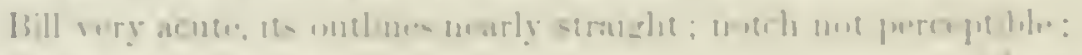

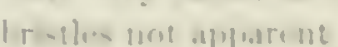

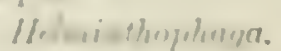

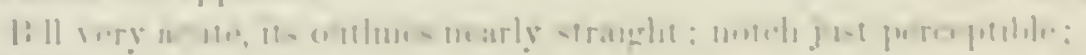

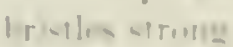

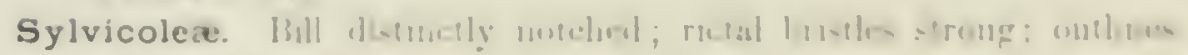

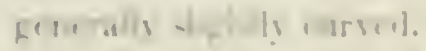

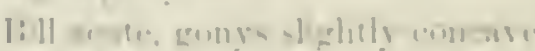

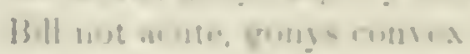

1.1 ".TIII ITI

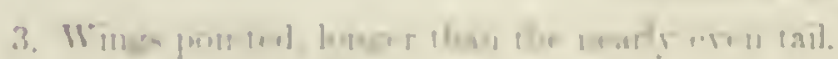

Sebureae.

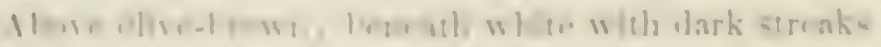

Srinrus.

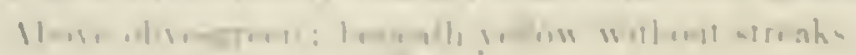

Ujurorivie 
t. Wings rounded, shorter than the graduated tail.

Geothlypeæ.

Above olive-green; beneath yellow, without streaks . . Geothlypis.

ICTERIAX.E.

5. Bill very deep and compressed; tail graduated; outer toe deeply cleft.

Icteriez.

Olive-green above; bright yellow anteriorly beneatlı. Upper man-

dible deeper than the lower . . . . . . . Icteria.

Plumbeous-blue above; red, black. and white beneatl. Ypuer

mandible not so deep as the lower. . . . . . Granatellus.

6. Bill slender, sub-conical. but curvel; tail nearly even; outer toe alherent for basal half.

\section{Teretristeæ.}

Above olive-gray; beneath whitish posteriorly, and yellow anteriorly

SETOPIAGLE.

7. Bill tyrunnine. Tail broad, equal to or longer than the wing, and much rounded.

Setophageæ. Colors mainly black, red, and white.

Tail not longer than the willy. Abore black, wing raregated Setophaga. Tail longer than the wing. Abure plumbeous, wing unrariegated Myioborus.

8. Bill sylviculine. Tail narrow; almost even; shorter than the wing.

Myiodioctez. Colors yellow bencath, olive-green ol ashy abore. Black markings about the head in the of . . . . Myiodioctes.

9. Bill somewhat parine. Tail equal to the wing, almost even.

Cardellineæ. Colors mainly red, or red, ashy, and white.

Bill weak, almost cylindrical; wings rounded, the quills broad and soft at ends. Tail slightly rounded, the fenthers soft. Colors mainly red.

Bill stout, the culmen and gonys very convex; wings pointed, the quills emarginated and hard at ends. Tail even, the feathers hard. Color ashy aborc; rump and beneath white. Head red and black.

Curdellina.

Of the above, Granatellas, Myioborus, Ergaticus, and Cardellinu belong to Central and Sonth America, Teretristis to Cuba.

\section{Stbfamliy S Y L V I COL I N 鹿。}

\section{Sectiox MNIOTILTEAE.}

Chrtr. Bill slightly notched some distance from the tip. Rictal bristles minute. Hind toe considerably developed, longer than the lateral toe; its claw decidedly longer than its digit. First quill nearly or quite as long as the second. Wings long, pointed; much longer than the tail, which is nearly eren. Tail-feathers with white spots. Bill much compressed for terminal half, the commissure and lateral ontlines decirledly concare; the culmen and gonys convex. 
Iso

.WITH .MHRIC.I BM IHS.

Gist: MNIOTILTA, Visit.

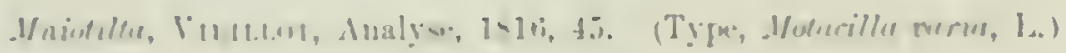

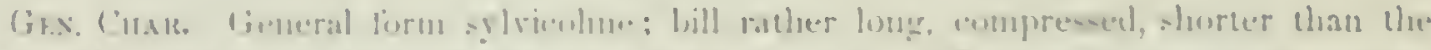

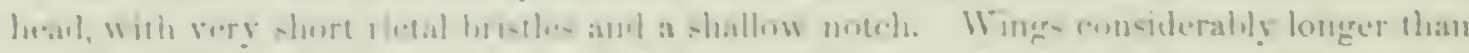

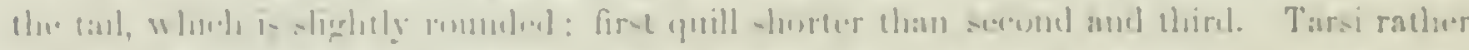

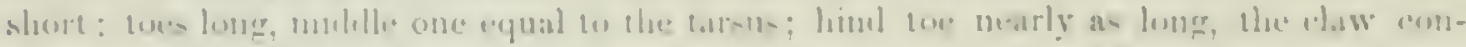

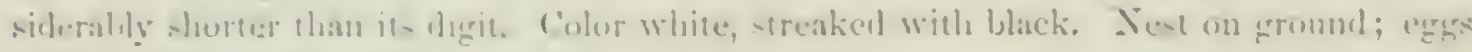
white, blotch end with real.

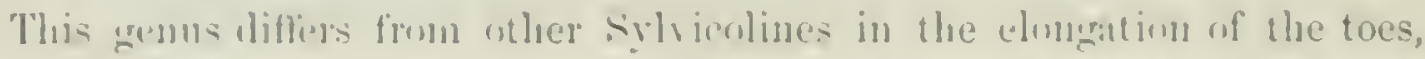

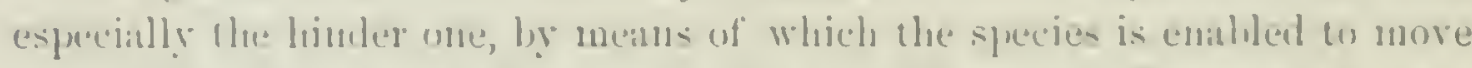
ul, and down the trunks of trees, like the true creepers. But none specie n is recognized as Ninth American, allonge Netball describes a secund.

Mniotilta varia, Vif.h.L.

BLACK AND WHITE CREEPING WARBLER.

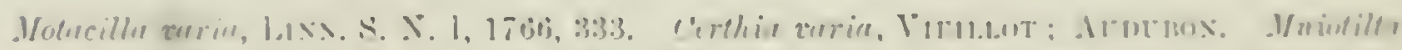

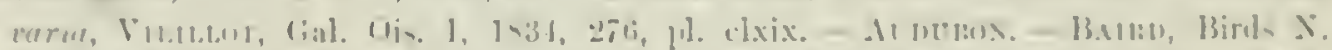

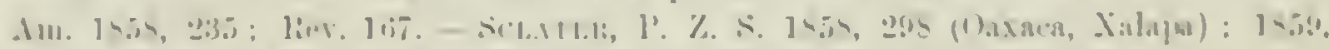

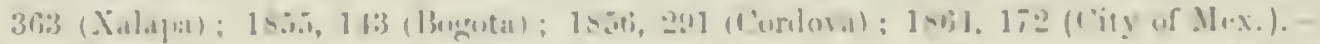

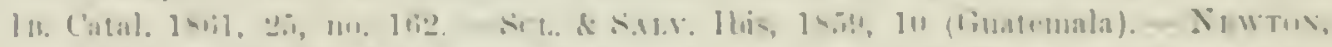

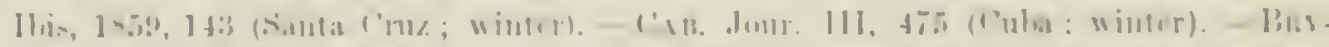

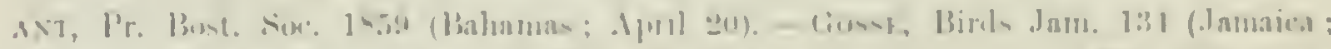

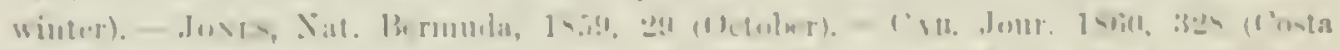

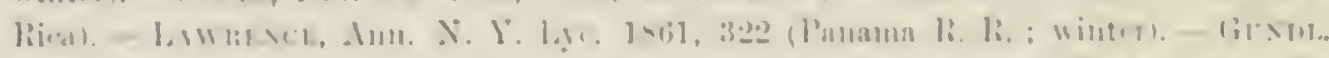

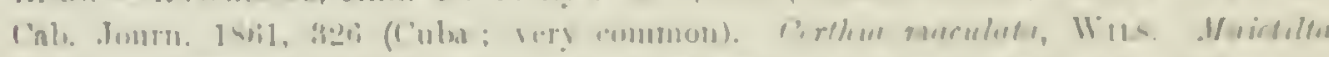

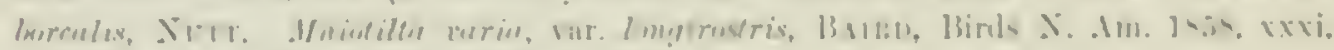

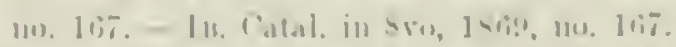

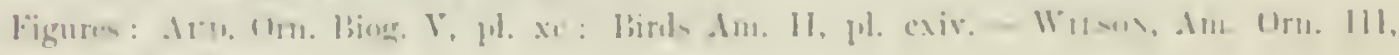
pl. xix.

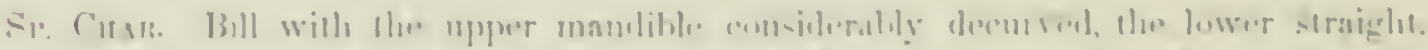

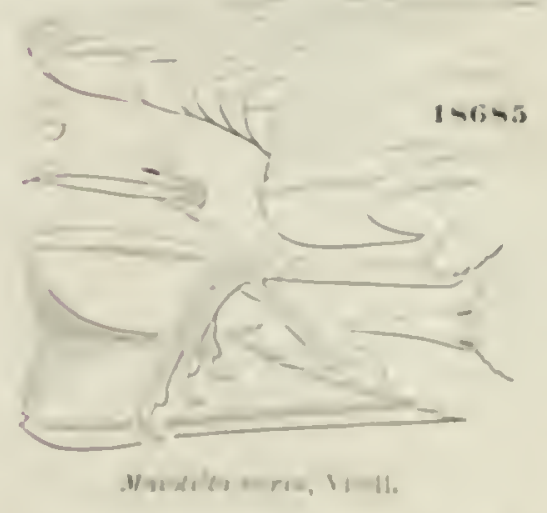

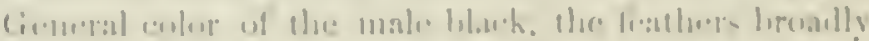

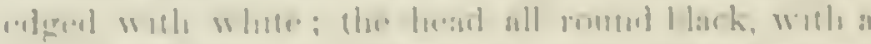
merlin -

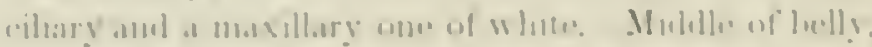

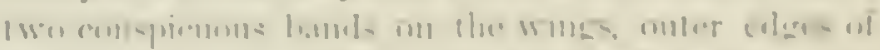

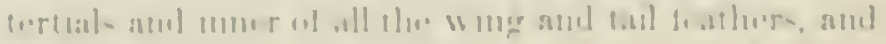
: 1 -

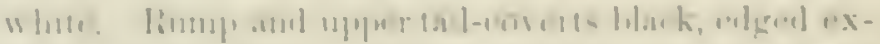

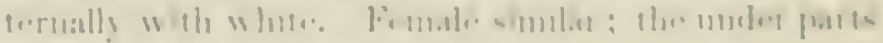

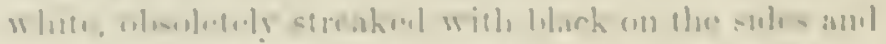

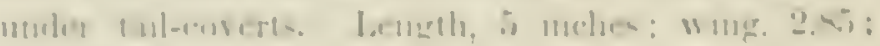
tail. ……

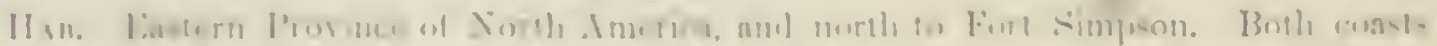

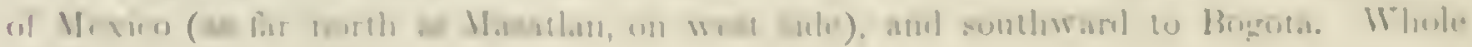

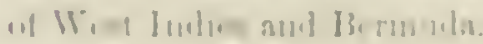


Localities quoted. Bahamas; Bermuda; Cuba; Jamaica; Santa Cru\%: West Indies; Corilova, Xalapa. Oaxaca, Mex.; Guatemala; Panama R. R.; Bongoti.

Specimens breeding in the Southem States differ in mather longer bill and less anount of black, but are otherwise undistingnishable.

In Brits. The Black and White Creeper, nowhere an abundant species, is met witl in rarious sections of the conntry. It occurs in all parts of New England and New York, and has been found in the interior as fur north as Fort Simpson. It has been met with on the P'acific coast only at Mazatlan, is common in the Bahanas and most of the ITest India Islands, genemally as a migrant. It has also becn found in Texas, in the Indian Territory, and in Mexico, and thronglout C'entral Anerica. In the last-named region Mr. Salvin states it to be pretty eyually and generally spread over the whole comntry. It is there migratory, leaving in spring. It was also detected in Colombia, South America, by Mr. C. W. Wratt. Mr. Newton also met with it as a wintel visitant in St. Croix, leaving that island at the end of Mareh. He regards this species as almost a thorough Creeper in habits. In Jamaica a few are resident throughout the year, according to the observations of Mr. March, and though its nests have never been found there, a son of Mr. Mareh saw a pair earrying materials with which to construct one.

Dr. Coues states that this Warbler is a very common summer resident near Trashington,

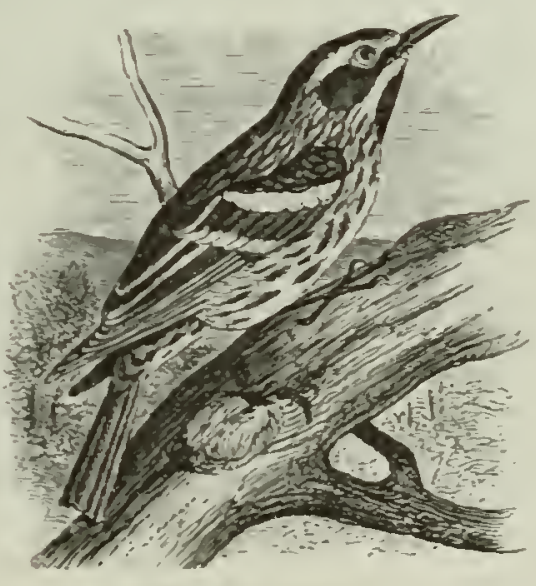

Mniorilla treria but is more abundant there in the spring and in the fall, the greater number going farther north to breed. They arrive in Washington during the first week in April, and are exceedingly numerous milil May. He ackls that they are generally found in high open woods, and that they "breed in holes in trees." This is probably an error; or, if erer known to occur, an entirely exceptional case.

Our birl is also a common summer visitant at Calais, arriving there about. the 1st of May, and by the 10th becoming rather abmulant. Mr. Boardman has frequently found their nests there, and always on the ground, in roeky places and usually under small trees.

It does not appear to have been net with on the Pacific coast north of Mazatlan, nor in any portion of Westem North America, beyond the valleys of the Mississippi and the Rio Grande.

In its habits this bird seems to be more of a Creejer than a Warbler. It is an expert and nimble climber, and rarely, if ever, perches on the branch of a tree or shrub. In the mamer of the smaller Woodpeckers, the Creepers, Nuthatches, and Titmice, it mores rapidly around the trunks and larger linbs of the trees of the forest in search of small insects and their larve. 


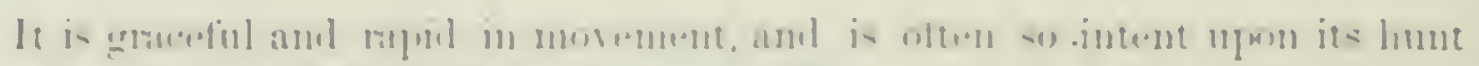

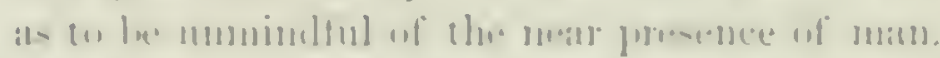

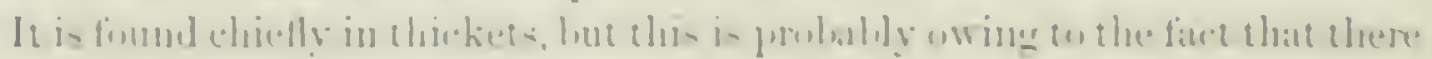

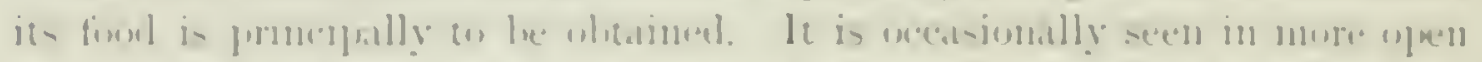

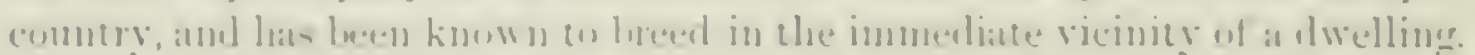

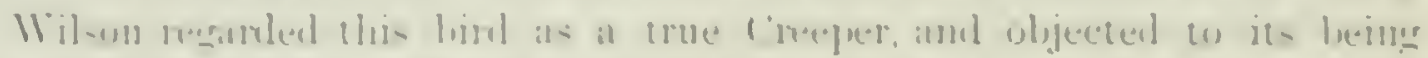

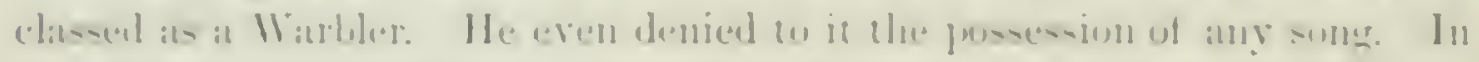

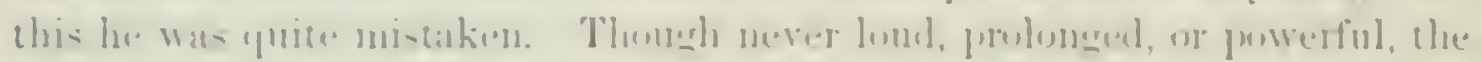
song of this 11 atrbler is very sweet and pleasing. It lewins w sing from its

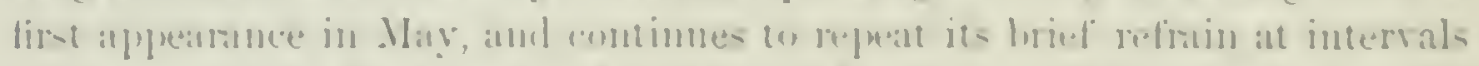

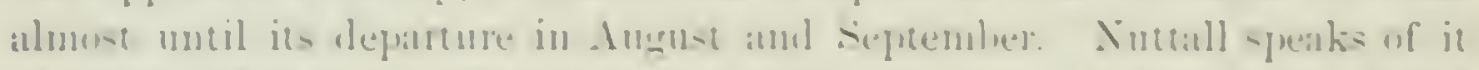

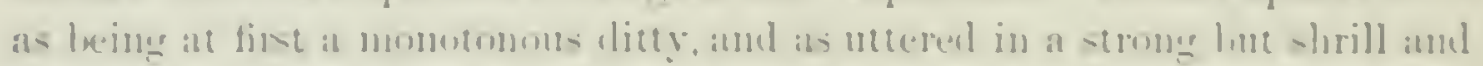

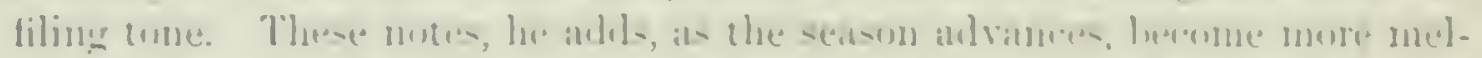

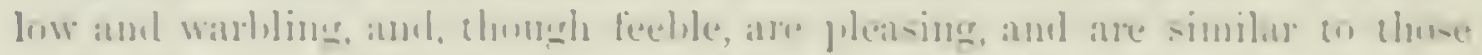

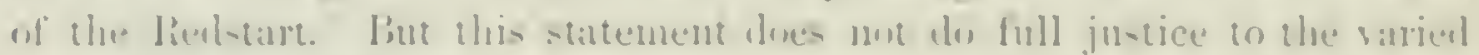

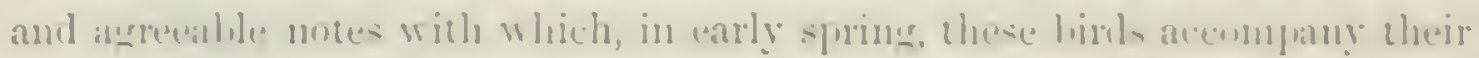

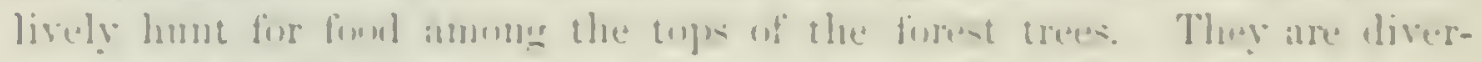

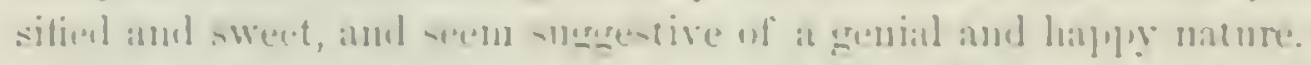

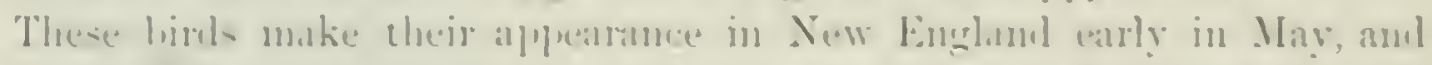

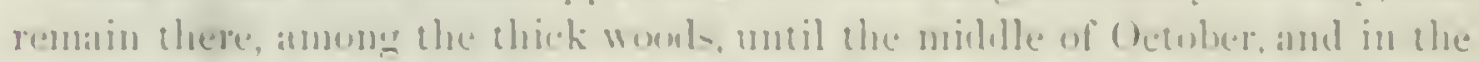
sumblerns stater motil thes berpe of winter.

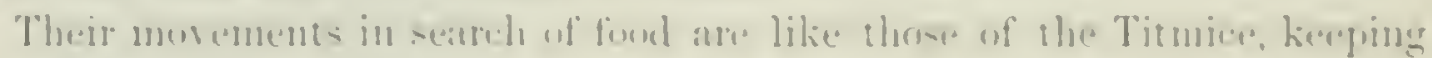

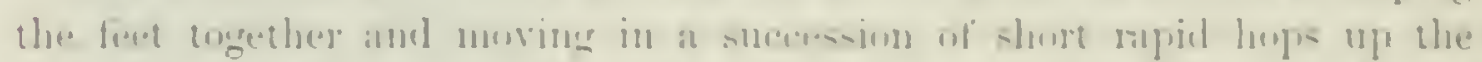

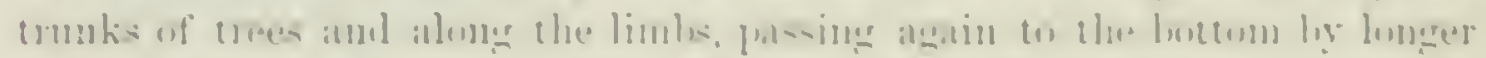

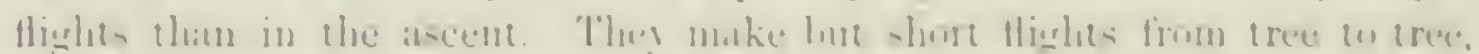

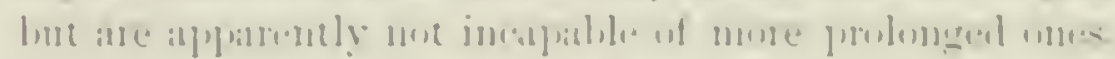

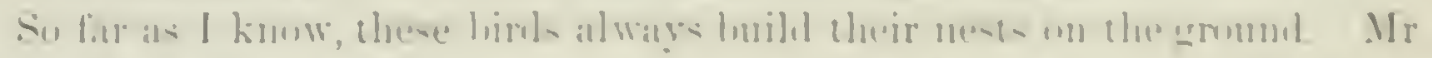

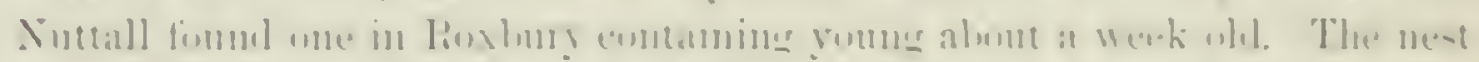

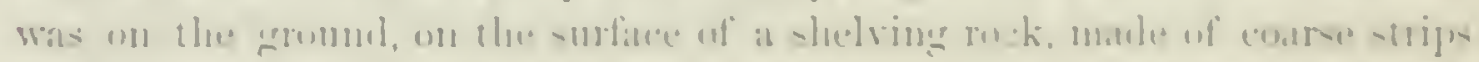

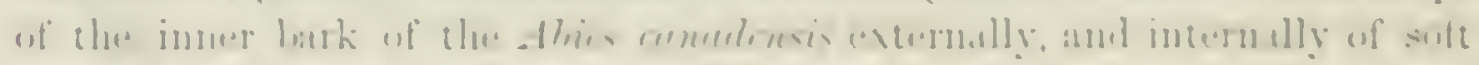

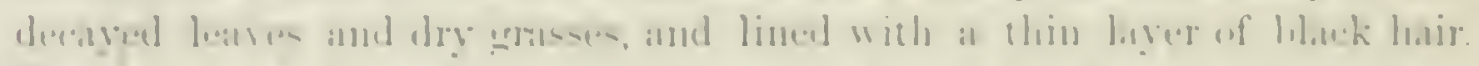

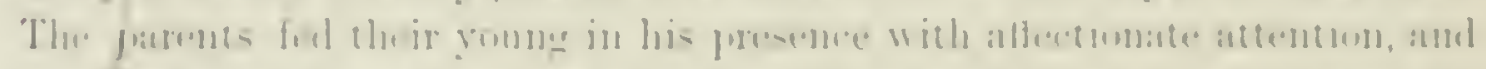

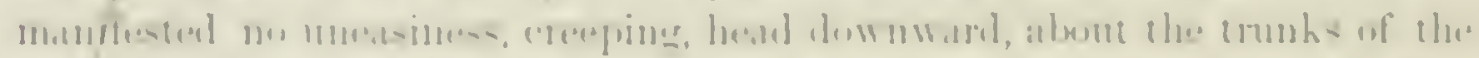

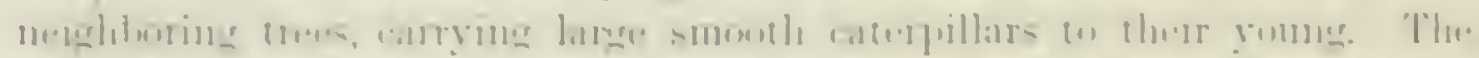

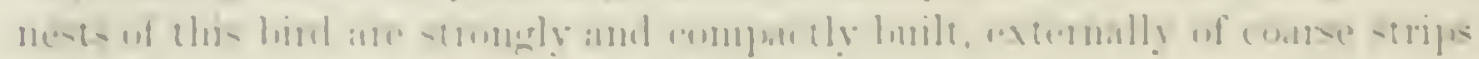

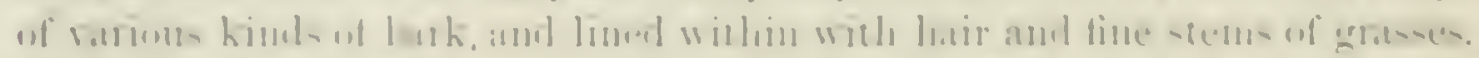

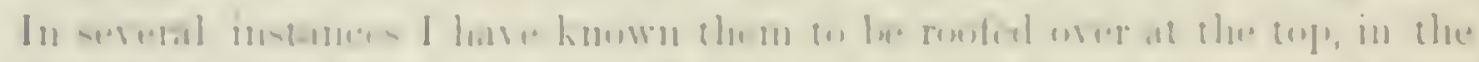

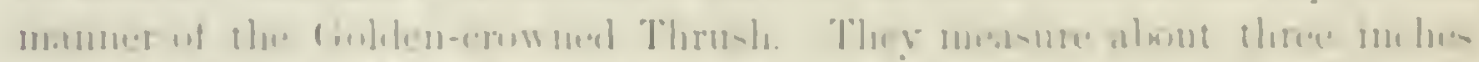

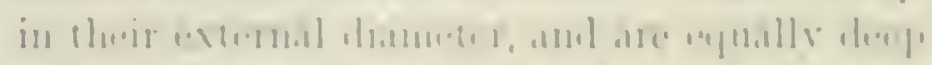

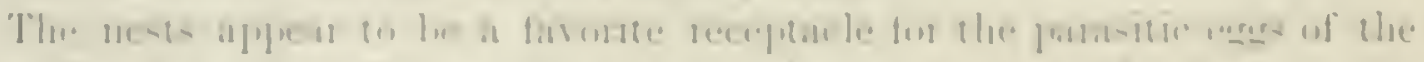

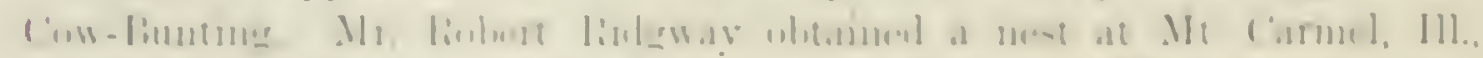

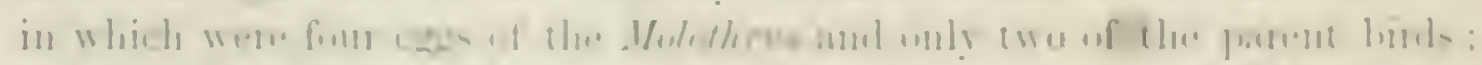

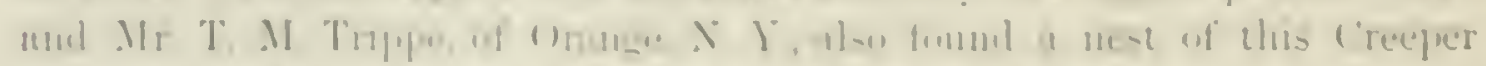

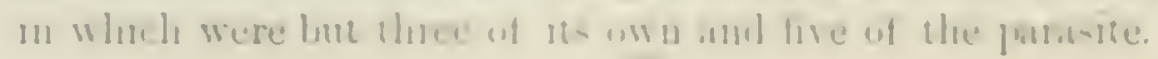


The eggs vary in shape from a rounded to an oblong ovil, and in size from .69 to .75 of an inch in lengtls, and firm .51 to .5:3 of an inch in breadth. T'heir ground-color is a creany-white, to which the deep red nuaking impart an apparently pinkish tinge. 'They are marked more ol less profinsely with bright red dots, points, and blotehes. These vary in number and in distribution. In some they are very fine, and are chiefly confined to the larger end. In others they are linger, more diffised, and occisionally there are intermingler marks and blotehes of slate-color. The effect of these variations is, at times, to give the appearance of greater differences to these eggs than really exists, the gromul-color and the shade of the red malings really presenting but little modifications.

The color of the young nestlings is elosely assimilated to that of the objects that usually surround the nest, and helps to conceal them. Mr. Burroughs once came accidentally upon a nest with young of this species. He says: "A Black and White Creeping Wirbler suddenly becane much alarmed as 1 approached a crumbling old stmmp in a dense part of the forest. He alighted upon it, chipped sharply, ran up and down its sides, and finally left it with much relnctance. The nest, which contained three young biris nearly fledged, was placed "pon the gromud at the foot of the stump, and in such a position that the color of the youm hamonized perfectly with the bits of bark, sticks, ete., lying about. My eye rested upon them for the second time before I made them ont. They hugged the nest very closely, but as I put down my hand they all scampered off with lond cries for help, which caused the parent birds to place themselves almost within my reach."

\section{SECTION VERMIVOREA.}

GENU: PROTONOTARIA, B.IRU.

Protonotaria, Barnd, Birts N. Am. 1858, 239. (Type, Ihotucillu citrea, Bupn.)

Gev. Cuak. Characterized by its long, distinctly notched bill, and long wings, which are an inch longer than the slightly grarluated tail (the lateral fenthers about .12 of an inch shorter). The under tail-coverts are very long, reaching within half an inch of the tip of the tail. The tarsi and hind toe are proportionally longer than in the true Warblers. The noteh and great size of the bill distinguish it from the Swamp Warblers. Nest in holes; egrgs much blotched with reddish.

The only North American species belonging to the group appears to be the old Sylvia protonoteria of Gmelin.

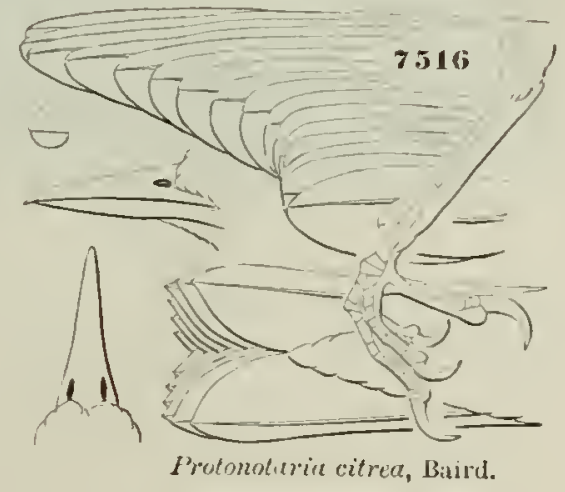




\section{Protonotaria citrea, li.usi. PROTHONOTARY WARBLER; GOLDEN SWAMP WARBLER}

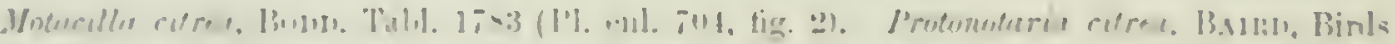

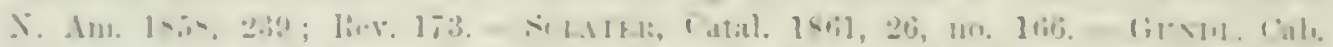

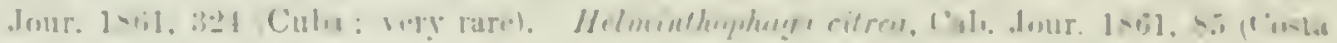

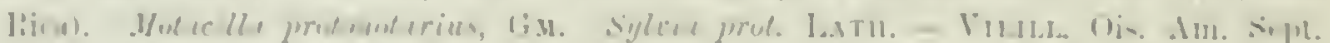

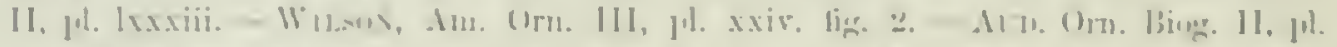

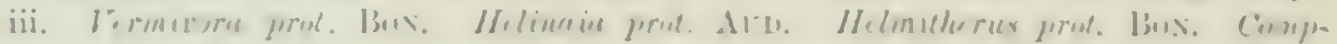

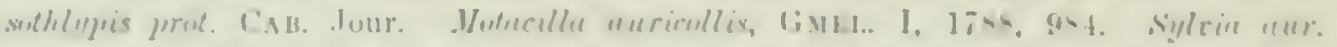

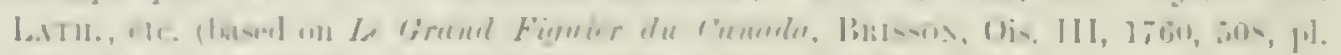

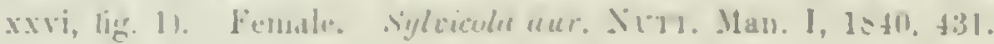

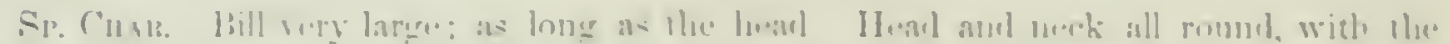

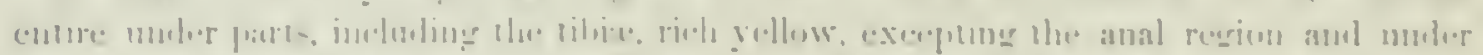

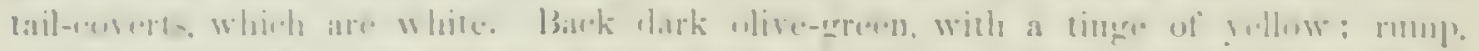

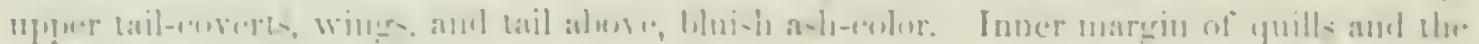

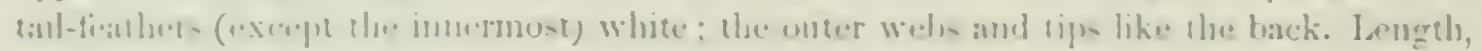

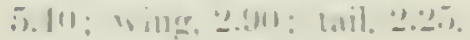

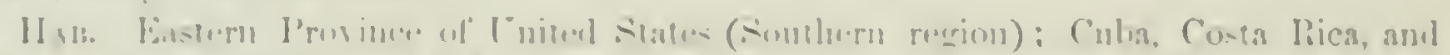

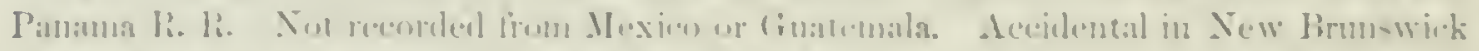

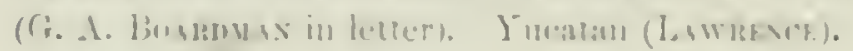

This is ane of the very hambenteat of American Withless, the rellow of the

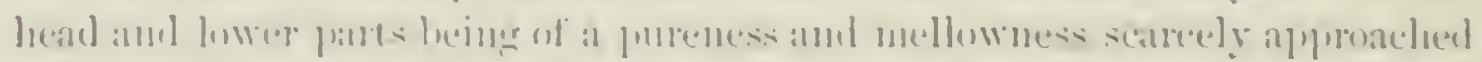

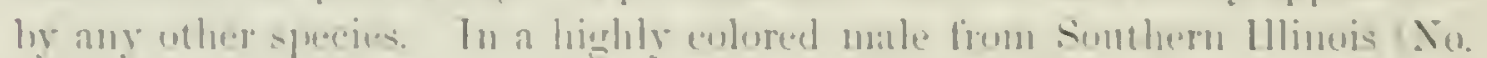

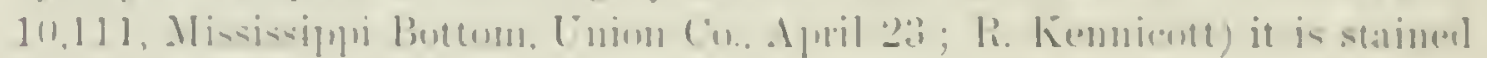
in sputs, farticularly orep the eyes and on the neck, with a lreantiful carl-

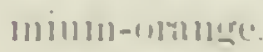

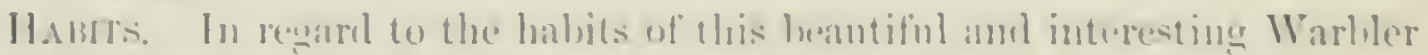

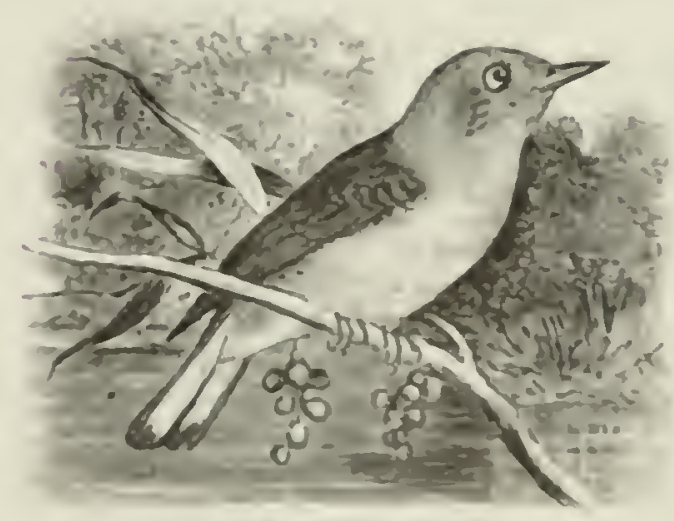

Be, an we receve lut litte light from the ohs.ro:

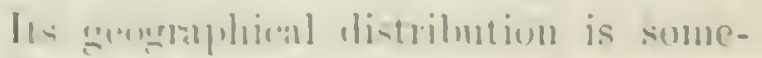

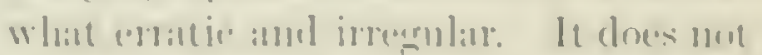

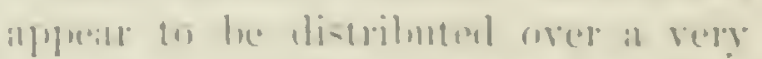

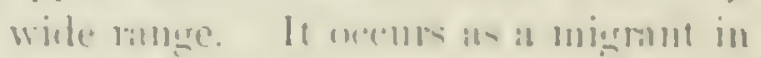
the Ilint [ntline and in Cintme Ameri-

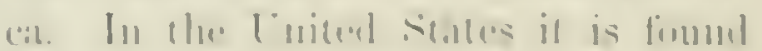
in the sumthern merion, hut farther west

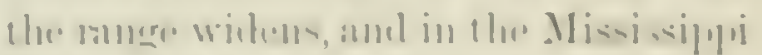

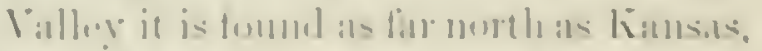

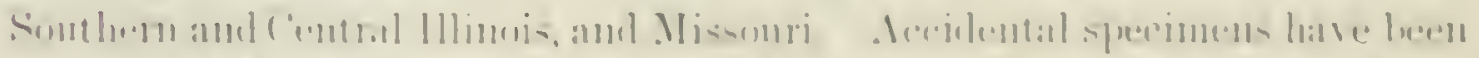

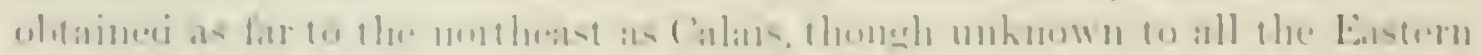

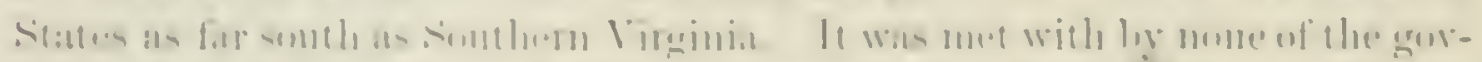

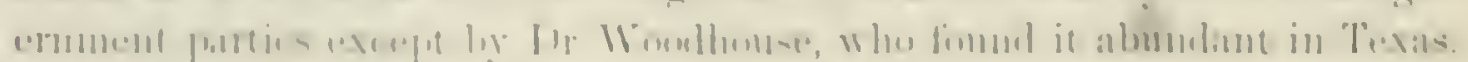

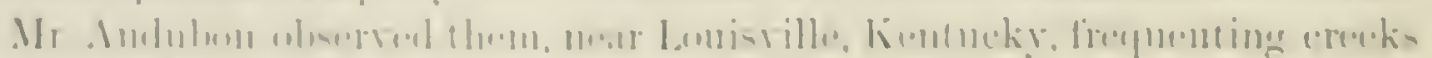

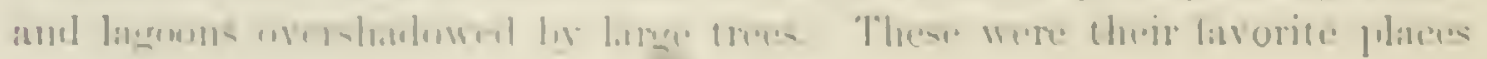


of resort. They also preferred the borders of sheets of water to the interior' of the forest. Ther return in spring to the Southern States eally in Mareh, but to Kentucky not before the last of April. They leave in October, and raise but a single brood in a season. Audubon describes their nest, but it it differs so essentially from their known node of breeding, that he was evidently in error in regard to his supposed identification of the nest of this species.

I)r. Bacluman, who often met then on the borders of smill streams neai Charleston, was confilent that they breed in that State, and noticed a pair with four young liris as early als. Tune 1 , in 1836.

Recently more light has been thrown upon thein habits by Mr. B. F. Goss, who, in May, 1S63, foum them breeding near Neosho Falls, in Kinsas. The nest was built within a Wrodpecker's hole in the stump of a tree, not more than three feet high. The nest was nut rounded in shape, but made to conform to the irreunlar cavity in which it was built. It was of oblong shape, and its cavity was deepest, not in the centre, but at one eud, upon a closely impacted base marle up of framents of dried leares, broken bits of grasies, stems, mosses, and lichens, decayed wood, and other naterial, the upper portion consisting of an interweaving of fine roots of wooded plants, varying in size, but all strong, wiry, and slender. It was lined with hair.

Other nests since discovered are of more uniform forms, circular in sliape, and of coarser materials, and all are built with unusual strength and care for a nest occupying a sheltered carity.

In one instance their nest was built in a brace-lole within a unill, where the birds could be closely watched its they carried in the materials, and the parent was afterward taken by hand by Mr. Goss from its nest. It was quite tame, and approached within two yarts of him.

Since then Mr. Rilgway has obtained a nest at Mt. Canmel, Ill. It was built in a lollow snag, about five feet from the glounc, in the river bottom. So far from being noisy and rociferous, as its name would seem to imply, Mr. Ridgway describes it as one of the shyest and most silent of all the Warblers.

The egrgs of this Warbler have an arerage Inearth of .5.5 of an inch and a length rarying from .65 to .70 of an inch. They are of a rounded-oral form, one end being but slightly less romded than the other. Their ground-color is a yellowish or creany white, more or less punfusely marked over their entire surface with lilac, puple, and a dark purplish-brown.

Mr. Ridgway states that it is always an abumlant smmmer bird in the Wabash bottoms, where it inhahits principally bushy swamps and the willows aromend the borders of stagnant lagoons or "pourls" near the river, and in such localities, in company witl the IIhite-lyellied Swallow (Himulo bicolor), takes possession of the holes of the Downy Wroodpecker (Picus mosserns) and Chichadee (P'urus rorolinensis), in which to build its nest. 


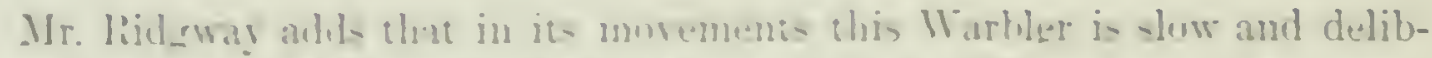

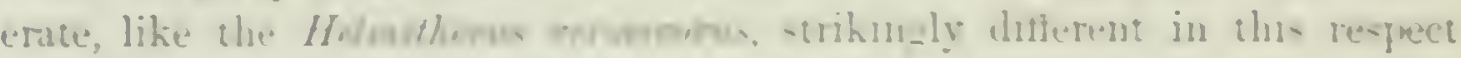

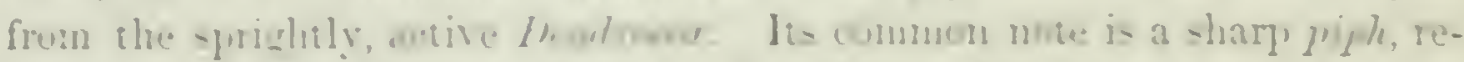

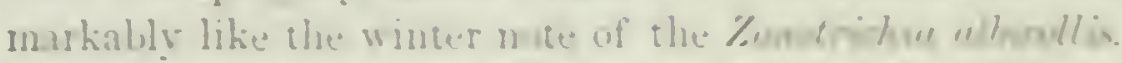

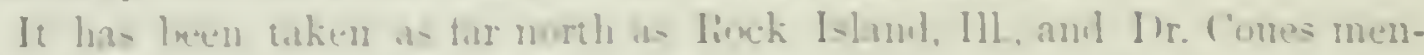

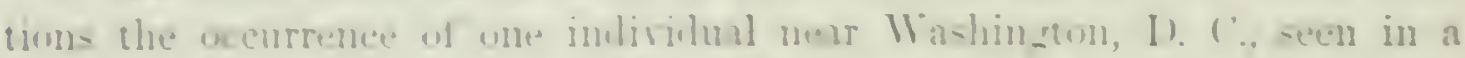

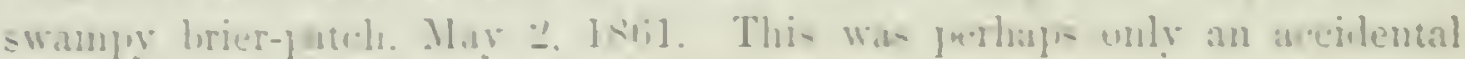

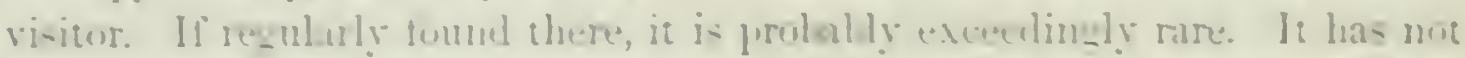

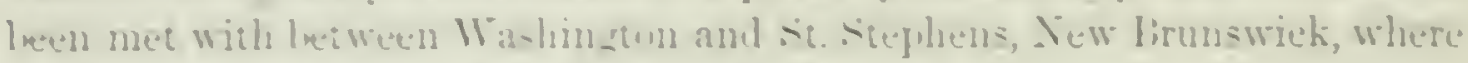
its ereurrence was unyuerionalily pusely acejelentenl.

\section{GEYT= HELMITHERUS, RAF.}

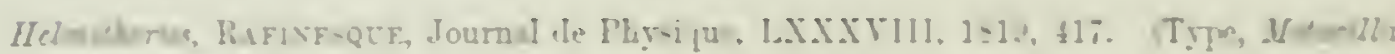
iemennam.1

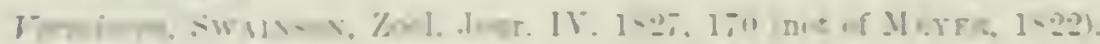

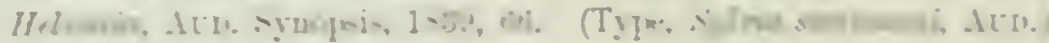

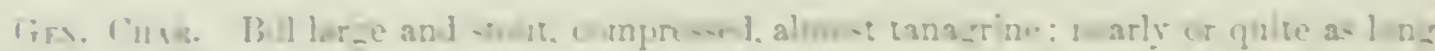

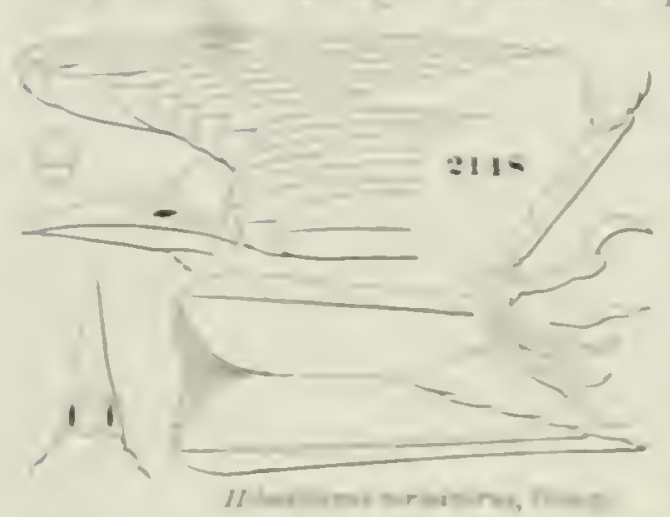

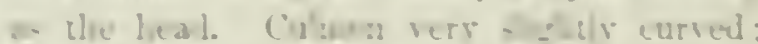

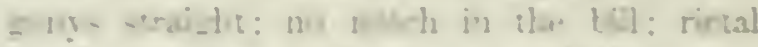

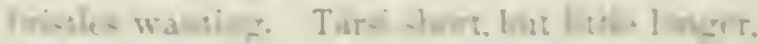

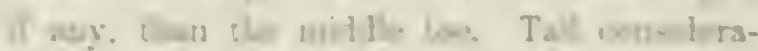

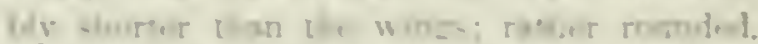

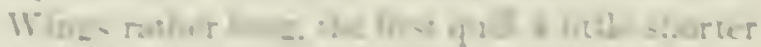

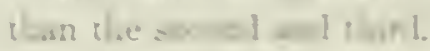

The tink of this divisinn are very pluin in their colms. mure $\rightarrow$ ihan any wher Amerienn Warller. There un

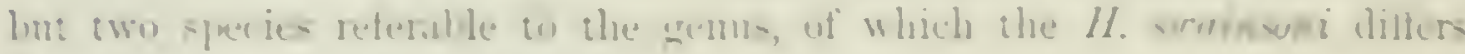
from the tye in havins a consilerally

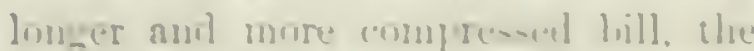

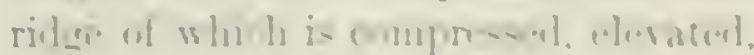
and apgean in escond lekwark on the fureleral, as well as to le in a stmight lime witl the uyger prut of the lomal. The wing an louger: the tul furhell. mo: numbel: the fouller

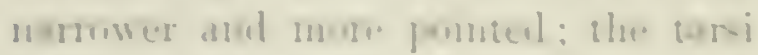

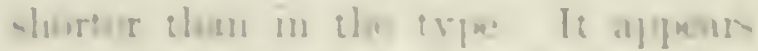
(1) Ine a l.

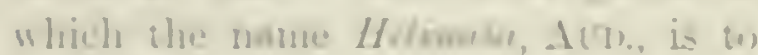
I= ayjlied.

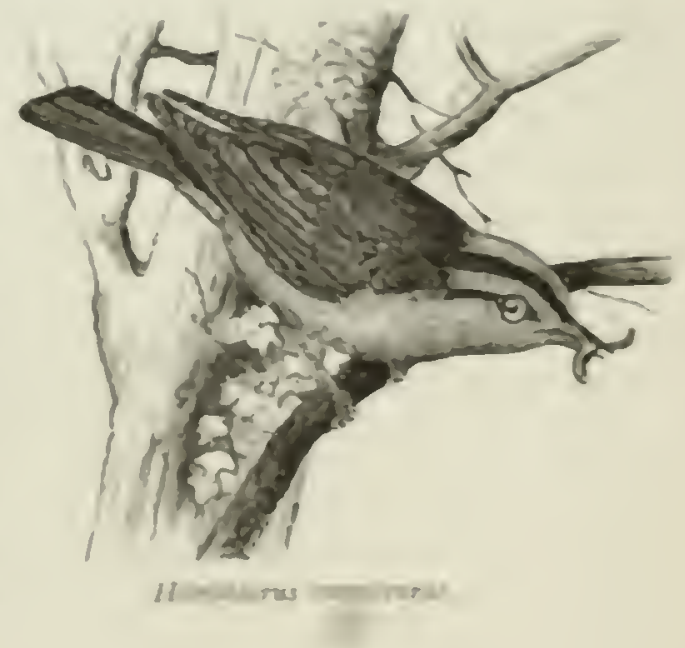




\section{Species.}

Commox Characters. Colors plain. Above olivaceous, beneatl nearly white. No spots or bands on wing or tail.

H. vermivorus. Above olive-green. Ifend yellowish, with a black stripe above and one behind each eye. Tail rommled. Tab. Listern P'rovinee of United States; south to Costa Riea; Culn. (IIelmitherus.)

H. swainsoni. Abore dull olive-green, tinged with brown. Stripes on the hend somerhat as in the last, but redelislu-brown; the median light stripe on the erown searely visible. Tail slightly forked. Hab. South Carolina and Georgia; Cıba (very rare). (Helinaia.)

\section{Helmitherus vermivorus, Bovap.}

\section{WORM-EATING SWAMP WARBLER.}

Motacilla vcrmirora, Gres. Syst. Nait. 1, 178s, 951. ? Syllia vermivoru, L.ıTit. Ind. Orn. HI, 1790, 499. - WiLs. 111, pl, xxir, fig. 4. - Al'T. Om. Biog. 1, pl, xxxir. Sylvicola

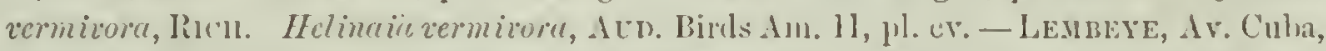
1850,35, pl. vi, fig. 4. Helmitherus ermiroms, Box.; (AB. ; Ballin, Birds X. Am.

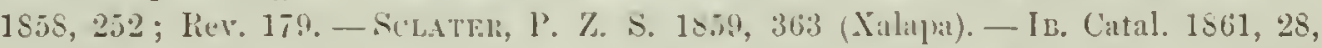

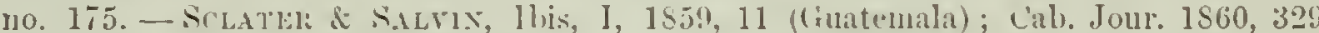
(Costa Riea); Ib. 1856 (Cuba). - Gưvinac'n, Cab. Jour. 1861, 326 (Cuba; somewliat rare). Vermivore pennsyluenicu, Box., G(1)si:, B. Jamaica, 1817, 150. Helmitherus migratorius, R.A. J. de Phys. S8, 1S19, 417. - H.ıтLAUb; Vermivora fulvicapilla, Swarsod, Birds, IJ, 1837, 245 .

Sr. Cran. Bill nearly as long as the heal: npper parts generally rather clear olivegreen. Head with four black stripes and three brownisli-yellow ones, namely, a black one on each side of the crown and one from behind the eye (cxtending, in fact, a little anterior to it), a broader median yellow one on the erown, and a superciliary from the bill. Under parts pale brownish-yellow, tinged with buft across the breast and with oliraceons on the sides. Trail unspotted. Female nearly similar. Length, 5.50; wing, 3.00; tail, 2.35.

In autumual specimens the liwht stripes on the head are deeper buff than in spring.

Hab. Eastern Prorince of United States (rather Sonthern); Southeastern Xexico; Guntemala; Cuba ; Costa Rica; Ve agua; Orizaba (winter, Stuncurast); Yucatan (Law waxce).

HAbITs. Much remains to be ascertained in regard to the history, habits, and distribution of this interesting species. So far as is now known it is hardly anywhere very conmon during the breeding-season. Yet its abundance and wide distribution as a migrant during the winter months in varions extended localities appear to warrant the belief that it must be correspondingly abundant in snmmer in localities that have escaped on attention. It has been occasionally met with in the Central and Sonthern States, as far west as Eastern Mexico, and as far to the north as Sontheastern New Iork. Specimens have been procured from Cuba, Mexico, Central America, and the northern portions of South America. It is a regular winter risitant of Jamaica, whither it goes in the autumn in considerable numbers, and is very widely diffused.

It reaches Pennsylrania about the middle of May, and leaves in September. Wilson noticed a pair feeding their young about the 225th of .Jne. 


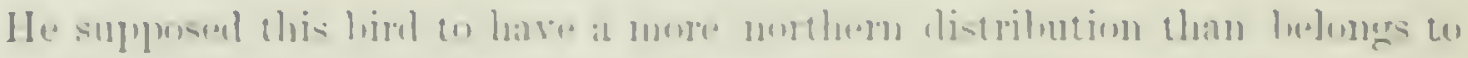

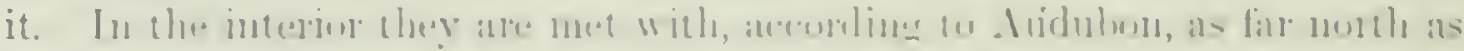

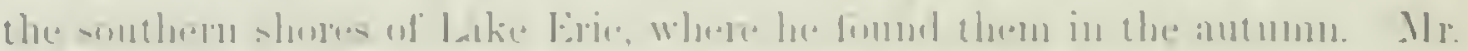

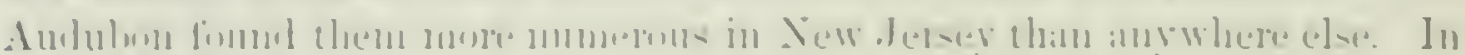

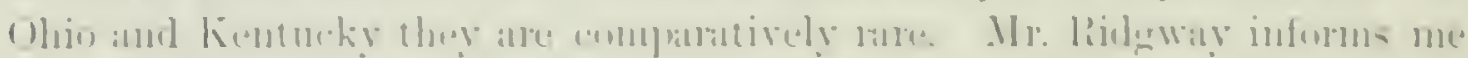

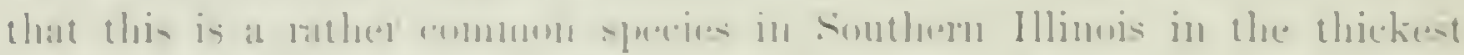

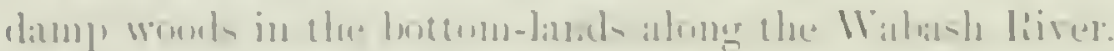

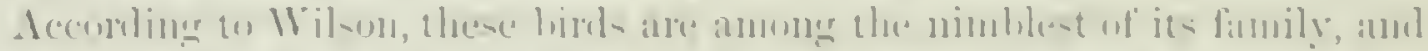

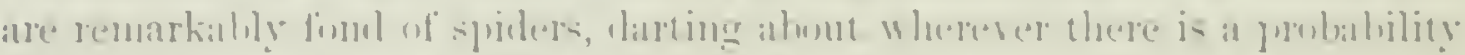

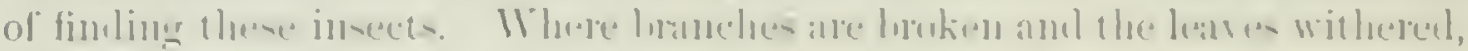

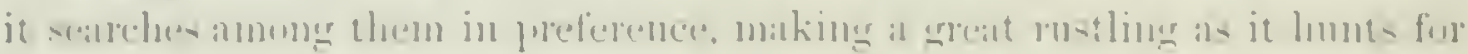

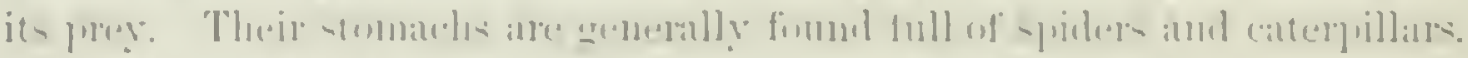

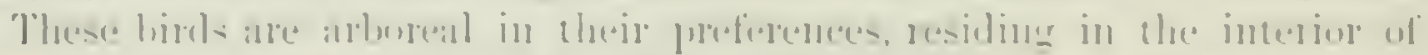

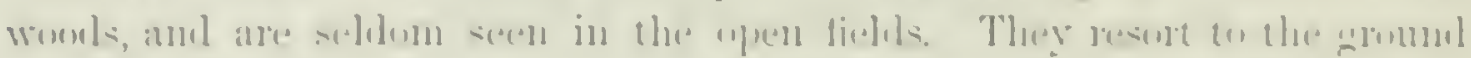

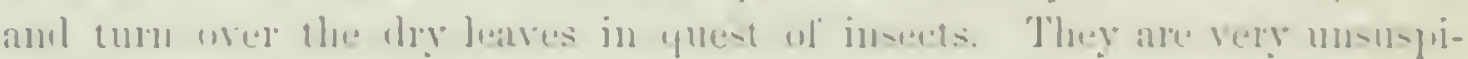

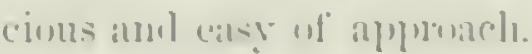

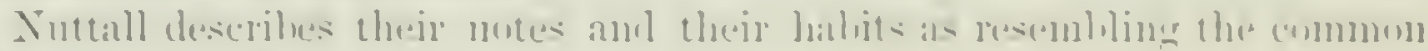

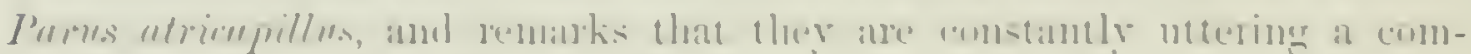

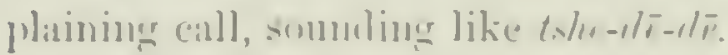

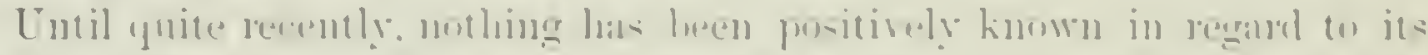

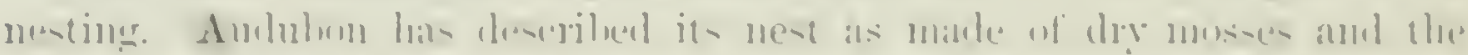

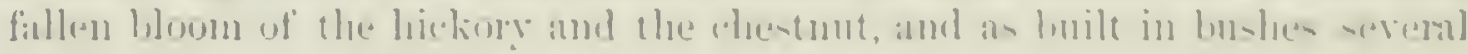

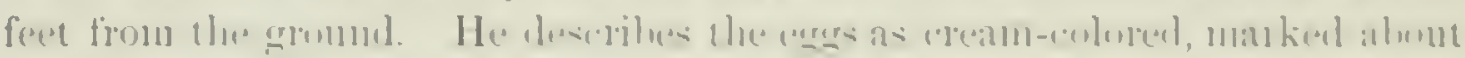

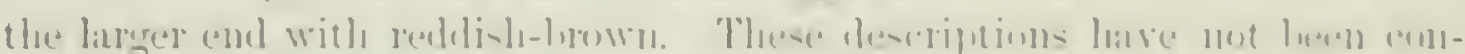

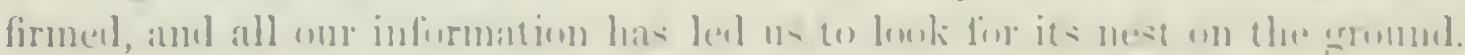

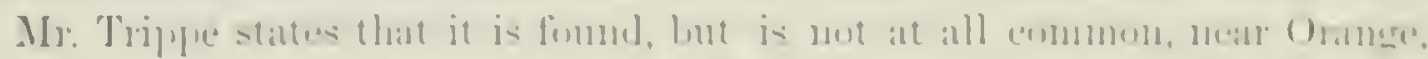

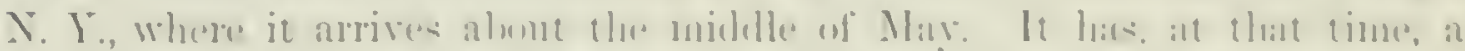

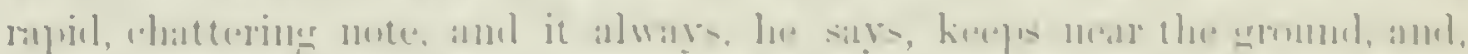

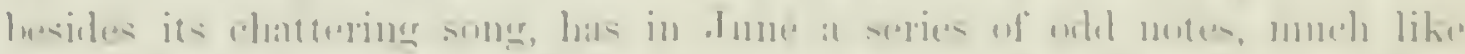

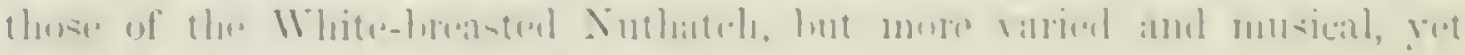

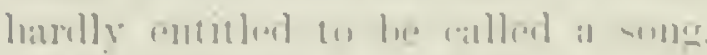

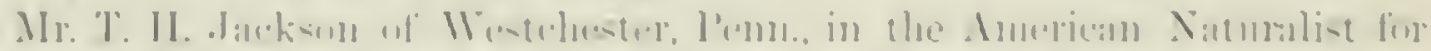

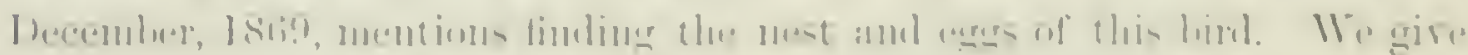

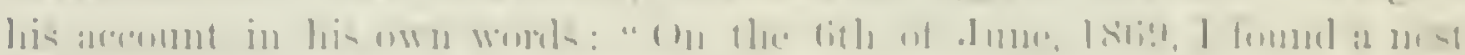

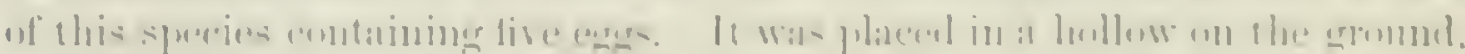

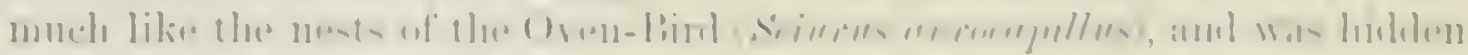

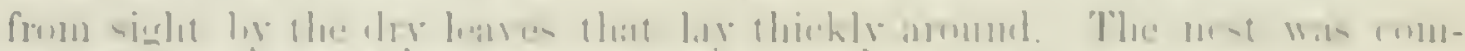

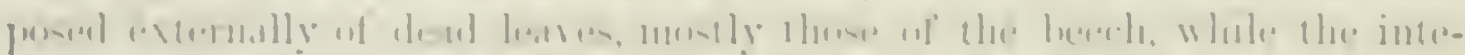

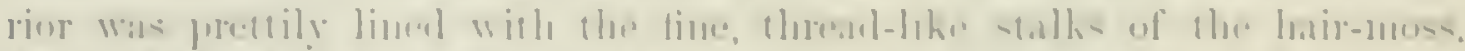

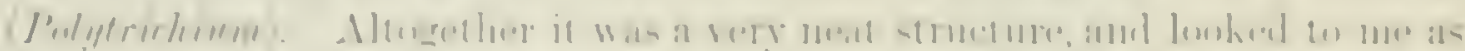

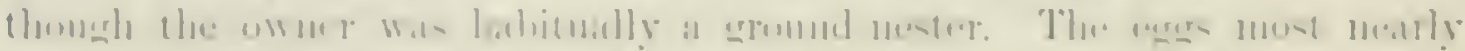

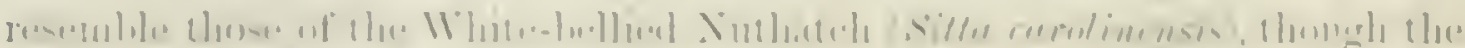

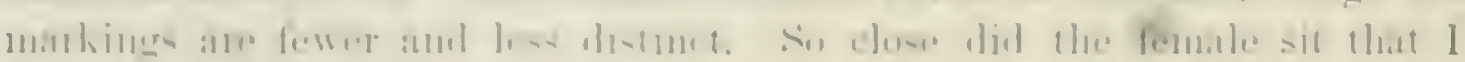

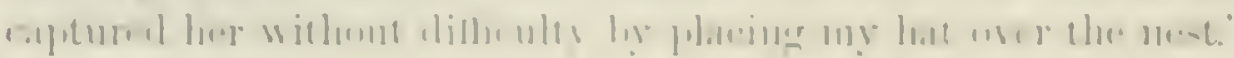


The same observing ornithologist informs me that this Warbler arrives in Pennsylrania early in May, and makes the most solitaly pant of the woods its home, outside of which it is rurely seen. True to its name, it is ever busy hunting out and devouring the worms that lurk anong the forest foliage, pursung its arocation in silence, with the exception of a faint note uttered occaliunally. This species is not as shy as many of our Marblers that frepuent the woods. Towards the latter part of May they commence constructing their nests. Mr. Iackson alds that the nest above referred to was found on a thickly wooded liblside, a few vals abore a rumning stream. So neatly was it embedded in the sround and corered with dry leaves, that discovery would have been improsible hal not the female betrayed its position. Both birds exhibited the greatest alarm at his presence, but on his retiring to a short distance the female returned to the nest, where she was easily captured. The base and peripliery of the nest were composed of dry beech-leares, while tle inner lining was made of fine hair-mosses (Polytivilim).

In the latter part of Jume, 1Si1, Mr. Jackison foumul another nest of this species, containing fire young birls about half grown. He was seated on a log, resting after a hard tramp, when a Worm-eating Warbler alighted near him, having a large green worn in its beak. Aftel at first manifesting much uneasiness, and scolding as well as she could, she suddenly beeane silent and flew to the ground. On his going to the spot both parents flew from the nest. It was in all respects, in regard to materials, mamer of construction, and situation, the exact comnterpart of the other. Both were placed on steep, wooded hillsides, facing the east.

Tro of the eggs of this Warbler thus identified hy MIr. Jachson, and kindly loamed to me by him, are of a somewhat rounded-oval slape, less ohtuse at one end. They lave a clear, crystal-white gromud, and are spotted with minute dottings of a bright red-brown. These are much more numerous in oue than in the other, and in both are confluent at the larger end, where they are beautifully intermingled with clondings of lilac-brown. These eggs measure, the one $.8 \mathrm{by} .60$ of an inch; the other, $.70 \mathrm{by} .56$ of an incl.

Another nest of this species, found hy Mr. Joseply H. Batty of New York, on the side of a hill near Montclair, N. J., was also built on the ground, in a part of the woods where there was no umlerbrush, and was placeel in a slight hollow, with dry oak-leaves collected around it, and partly covering it. The nest ras made of dry leares, and lined with grasses and fine roots. It contained four eggs, alike in their marking, and corresponding exactly with those obtained by Mr. Jackson. Mr. Batty nearly stepped on the bird without her learing the nest.

Dr. Cones found the Worm-enting Warbler a rather uncommon summer resident near Washingtou, breeding there but sparingly. It arrives there during the first week in May, and remains mil the third week in september. He describes it as slow and sedate in its movements. 
Helmitherus swainsoni, I $\mathrm{m}$.

\section{SWAINSON'S SWAMP WARBLER.}

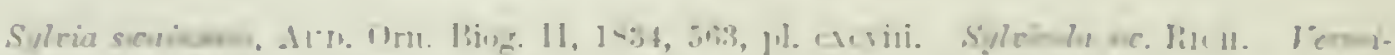

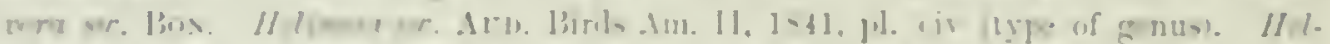

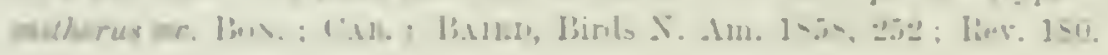

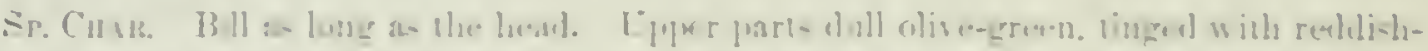

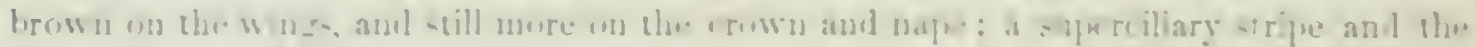

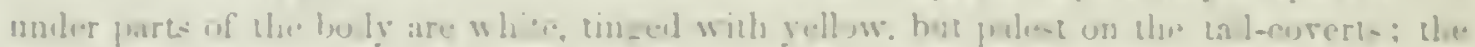

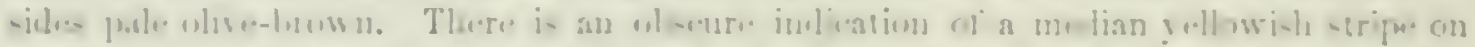

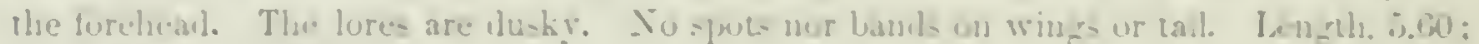
winz.....; : เal. 2.20 .

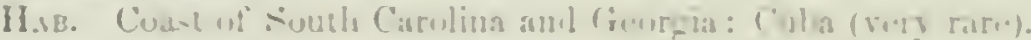

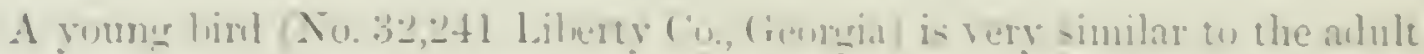
described, but ditlers in the following regrects: the lower fares have a de-

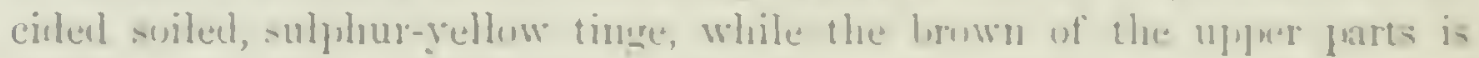
much more redilish, there beine no ditlerenes in tint Letween the erown

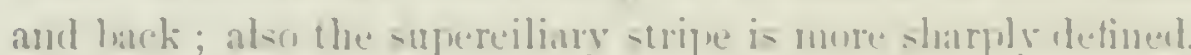

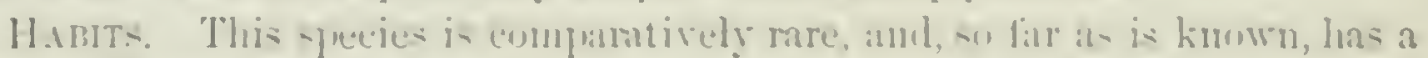

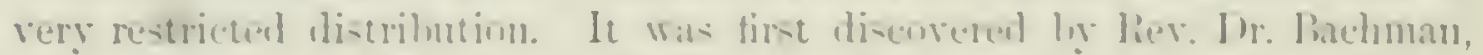

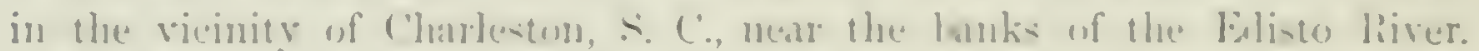

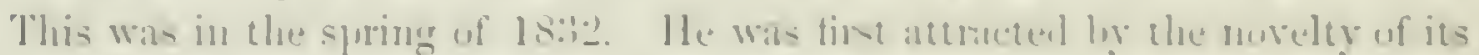

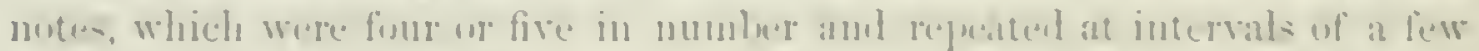
minutes. These notas were homl and clear, and unne like at whistle than a

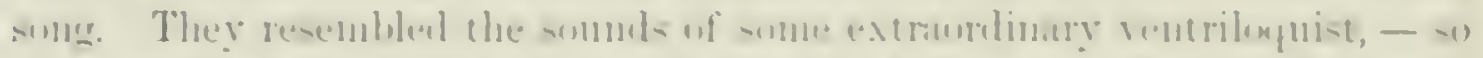

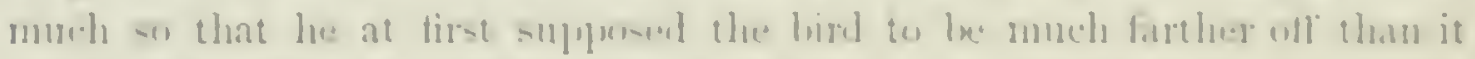

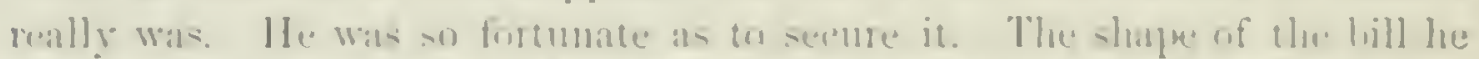

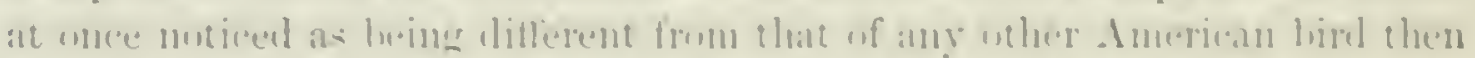

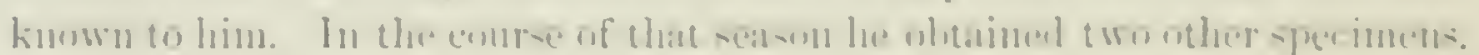

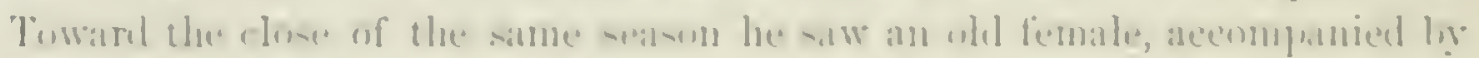
it: four rontue. One of the latter, which he forenred, thil mot diller materially from the aled himl.

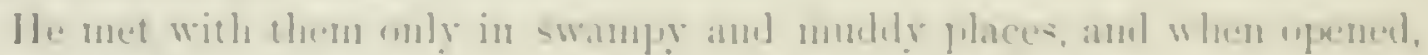

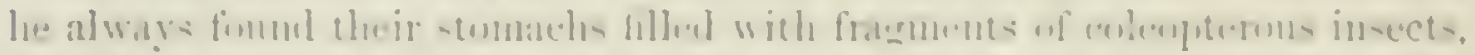

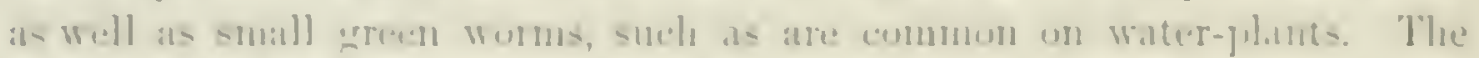

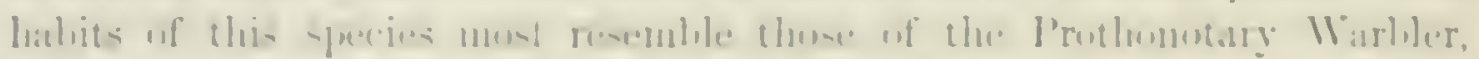

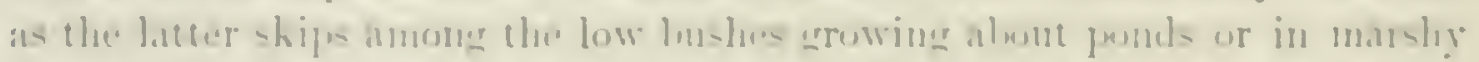

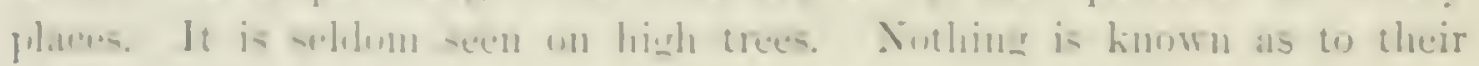
nesting ur exus 
Gexts HELMINTHOPHAGA, CAва.

Helminthophaga, Cabaxis, MIus. Hein. 1850, 1851, 20. ('Type, Sylvia muficapilla, Wils.)

Gex. Cutar. Bill elongated, conical, very acute; the ontlines very nearly struight sometimes slightly decurved; no trace of notch at the tip, nor of bristles on the rictus. Wings long and pointed; the first quill nearly or quite the longest. Tail nearly eren or slightly emarginate; short and rather slender. Tarsi longer than the middle toe and claw.

The species of this section are well characterized by the attenuation and acuteness of the bill, and the absence of any notch. There are, however, consiclerable subordinate

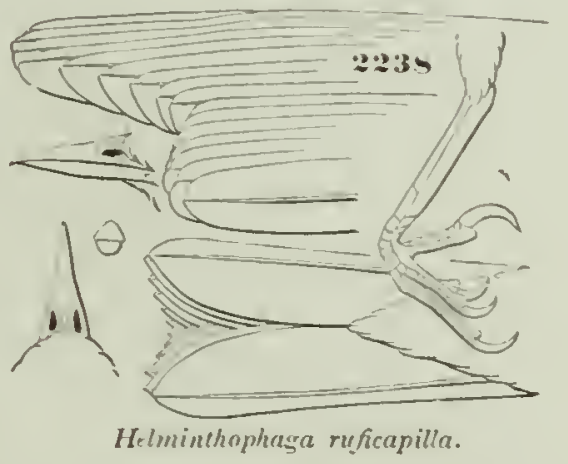
differences in the different species. In some the bill is larger and more acute than others; in one speeies, the $H$. peregrinu, the wings are unusually lengthened, the tail being only about seven twelfths as long.

\section{Species and Varieties.}

Commox Charactems. Iris brown. Length about j.00. Nest on the ground, in grass or dead leares. Egggs clear white, thickest at end, with uimte dots of brown of rarious shades and faint purple.

A. Tail with a conspicuous patch of white.

a. A black patch covering throat and breast.

1. chrysoptera. Above ash, beneath white. Forehead and a patch on the wing yellow. Hub. Eastern Province of United States, soutln to Bogota: Cuba.

2. bachmani. Above olire-green; beneath, with forehead, yellow; crown asl, bounded anteriorly with a black har. No yellow on wing. Hab. South Carolina and Georgia. Cuba in winter:

b. No black on throat or breast.

3. pinus. Above olve-green; beneath, with forehead, yellow; wings asl, with two white bands; lores blaek. Hab. Eastern Prorince of United States, south into Guatemala.

B. Tail without a conspicuous white patch.

c. Crown with a concealed patch of rufous (obsolete in $\$$ ).

4. ruficapilla. Above olive-green; head ashy; beneath continuous yellow; a light orbital ring. H Hab. North America (rery rare in Middle and Western Prorinces); Greenland. South to Southern Mexico (Oaxaea, Cordova, Orizaba).

Yellow of throat spreading orer cheeks, and staining lores and eyelids. Atlantic States. (Carisle, Penn., specimens.) var, ruficupillu. Yellow of throat confined within the maxilla ; lores and eyelids clear white. Jlississippi Talley. (Chicago specimens.) var. ocularis. Yellow of throat restrieterl to a medial stripe, leaving its sides ashy. Middle Province. (Specimen from Fort Tejon, Cal., and East Humboldt Mountains, Nerada.) . . . var. gutturalis 


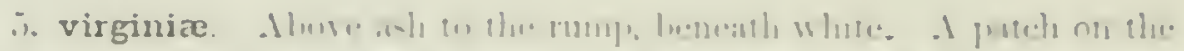

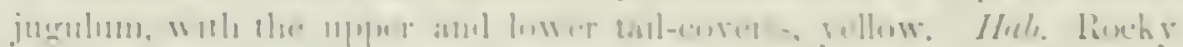

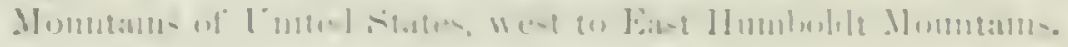

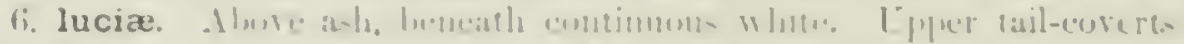

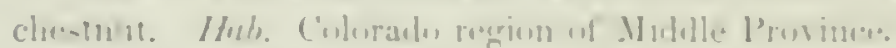

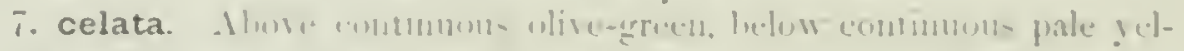
low. (Uringe on crown an d only?)

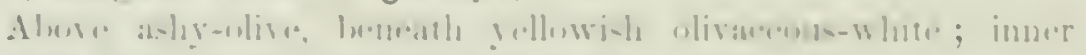

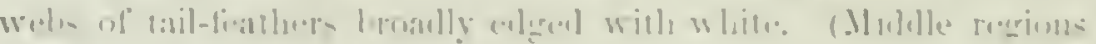

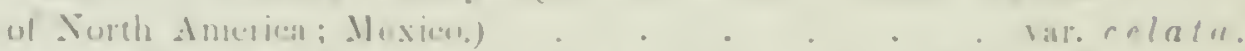

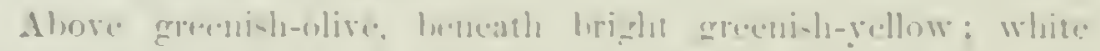

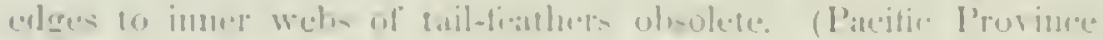

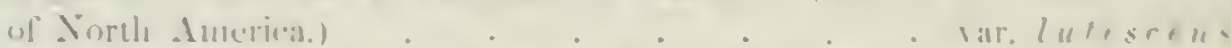

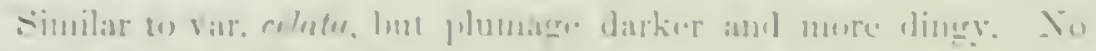

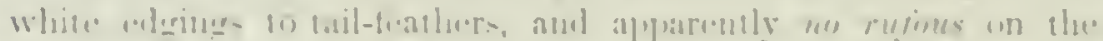

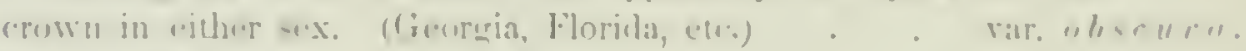
1. No rutins on เruwr.

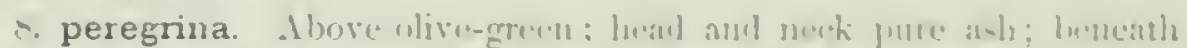

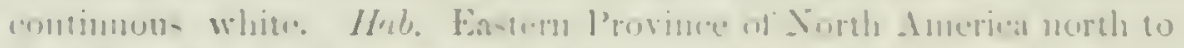
fort simpon, H. B. T' soutl to l'annma. ('uba (rare).

\section{Helminthophaga chrysoptera, ('in:}

\section{GOLDEN-WINGED WARBLER.}

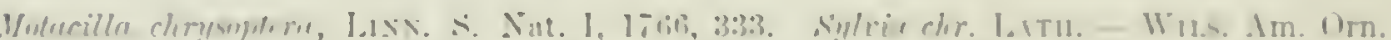

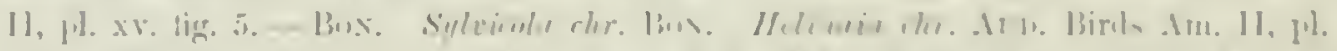

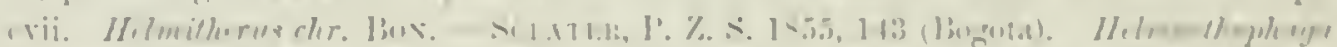

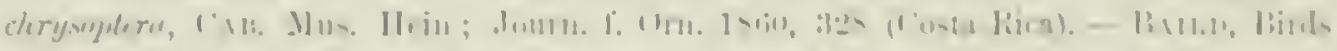

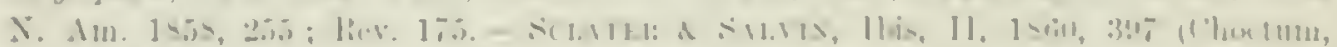

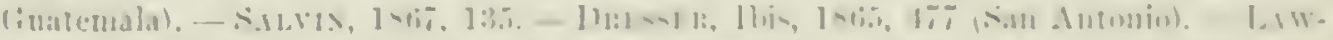

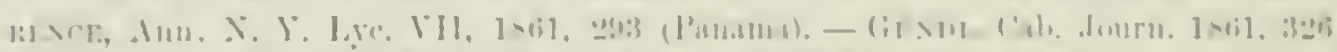

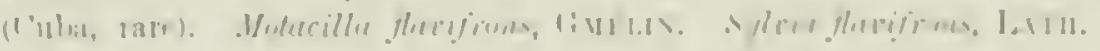

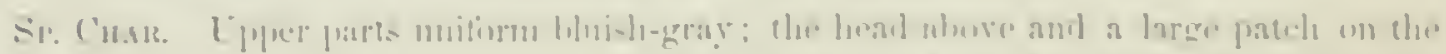

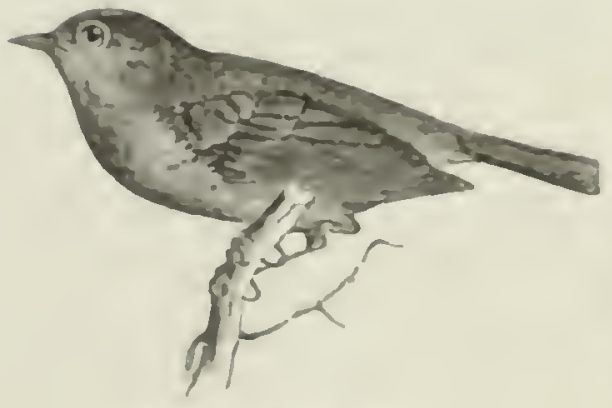

II Imemthon heger of Jin

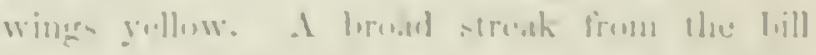

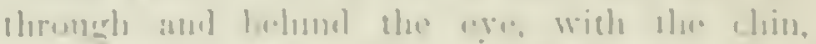

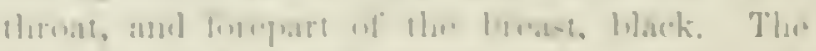

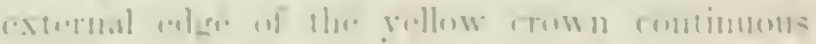

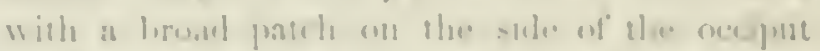

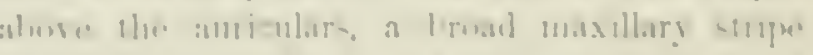

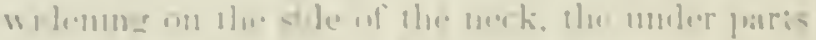

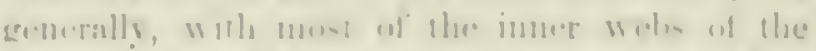

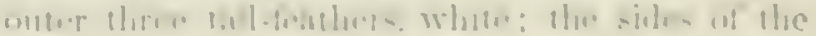

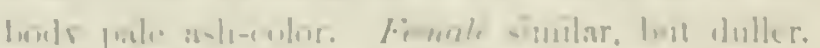

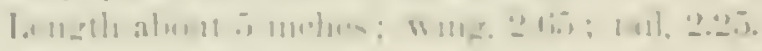

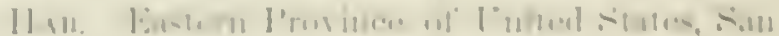

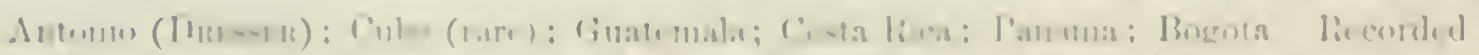

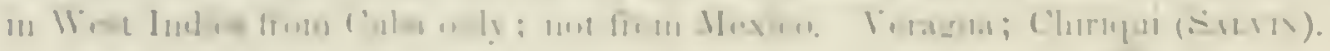

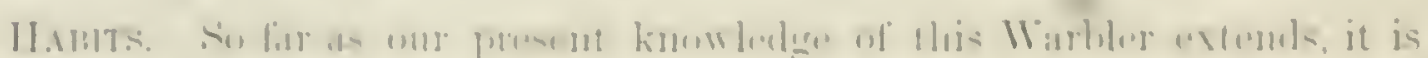

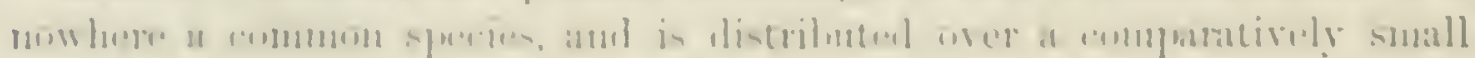


extent af territory. Wilson met with it in Pennsylrania during the last of April and the first of May, believing it to be only a migrant species on its way to more northern regions. Nuttall was sceptical of these conclusions, as he nerer net with the species in the New Englind States. Andubon observed these birk in their migrations through Lonisiana, which State they cntered from Texis in the montl of April. He procured several specimens in Lonisima and Kentueky, and one in New Jersey. He knew nothing as to its breeding, and seems to have accepted Wilson's inferences in regard to its northem migrations. He never met with this bird in the fill, when, if a Northern species, it should be returning south, and thence inferred that it migrated by night.

Professor Baird has obtained this hirel neal Carlisle, Pemm., in .July, rendering probable its breeding in that vicinity. W. S. Wood met with it near St. Louis, May 13, 1857, and two days previonsly in the same year Mr. Kennicott procured an individual in Sonthern Illinois. Occasionally specimens have been obtained in Massachusetts, and of late these occurrences hare become more frequent or more observed. It was first noticed near Boston by .I. Eliot Cabot, Esy., who shot one in May, 1838, near Fresh Pond. This was, he thinks, on the 20th of that month. Since then Mr. J. A. Allen has hnown of several speeimens taken within the State. Mr. Jillson has ohserved it spending the summer in Jolton, and evidently lureeding, as has also Mr. Allen at springfield, and Mrr. Bennett at Holyoke. In the summer of $1870, \mathrm{Mr}$. Maynard obtained its nest and egors in Newton.

The late Dr. (rerharelt found it breeding among the high grounds of Northern Georgia. It has also been taken at Iacine, $11 \mathrm{is}, \mathrm{ly}$ Dr. Hoy, and in Ohio. These data seem to show that it is sparingly found from Georgia to Massachusetts, and from New Jersey to Missouri and W"isconsin. Its western limits may he nore extended. It was not met with by any of the exploring parties beyond St. Louis, but its retiring labits and its sparse distribution may account for this.

Dr. Samuel Cabot was the first naturalist to meet with the nest and eggs of this bird. This was in May, 18:37, in (rreenbrier County, Ta. The nest was constructed in the midst of a low bush on high ground, and contained four exgs.

The late Dr. Alexunder Gerhardt found the nest and eggs of this Trarbler in the spring of 18.59 , in Whitfield Countr; Ga. It contained four eggs, and was built on the ground. It was very large for the bird, being five inches in height and four in diameter. The cavity was also quite large and leep for so small a bird, exceeding three inches both in depth and in diameter. The onter and under portions of this nest rere almost entirely composed of the dry leaves of sereral kinds of decidnons trees. These were interworen with and strongly bound togrether by black regetable roots, dry sedges, and fine strips of pliant bark, and the whole linerl with a close network of fine 


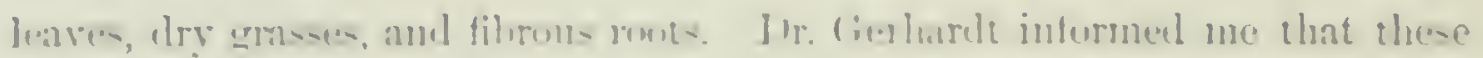

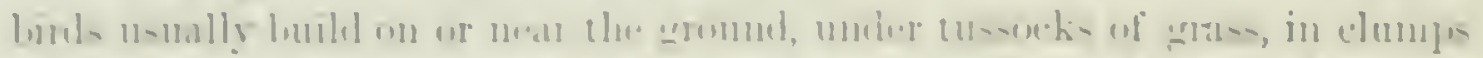

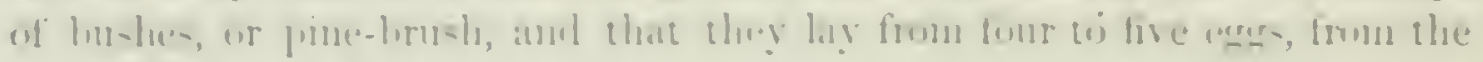
bith (1) the 1 inth of . May.

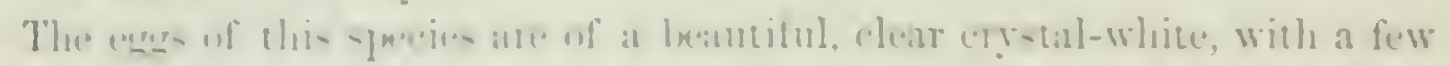

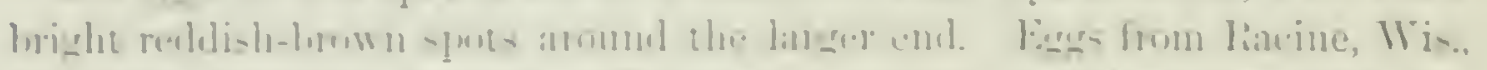

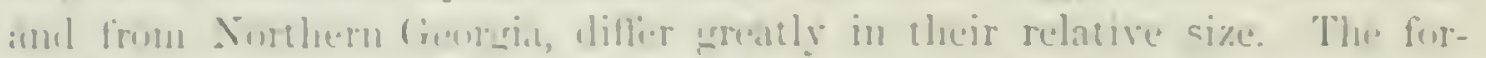

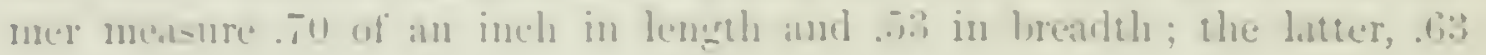
$1,5 .+4 !$

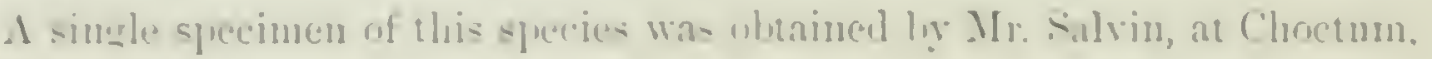
in (imatemala.

\section{Helminthophaga bachmani, ( BACHMAN'S WARBLER.}

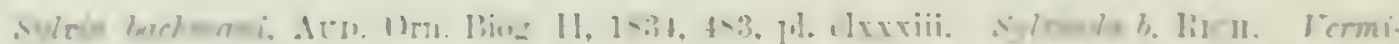

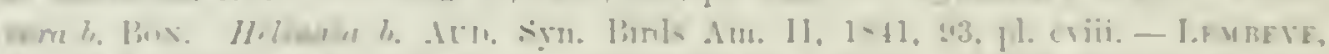

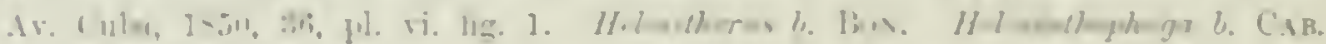

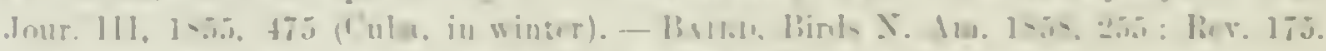

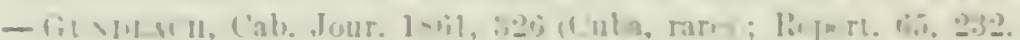

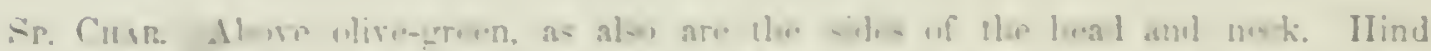

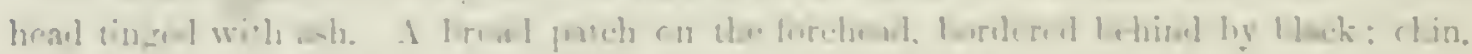

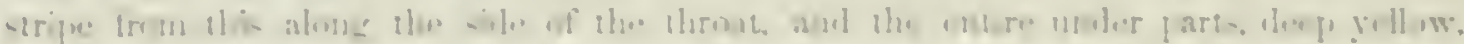

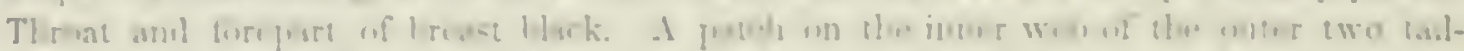

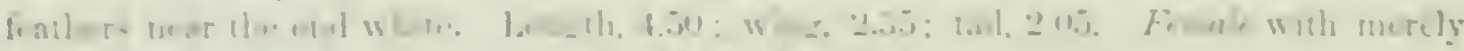

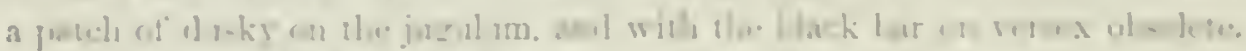

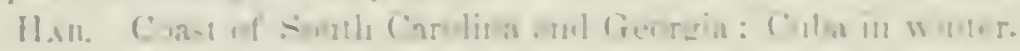

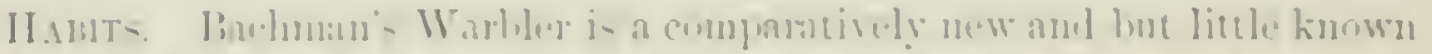

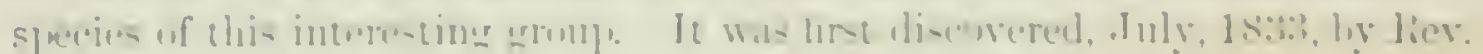

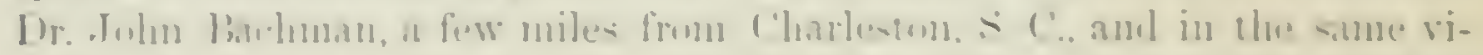

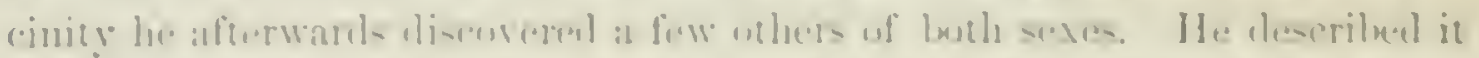

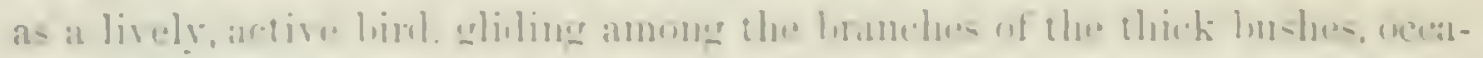

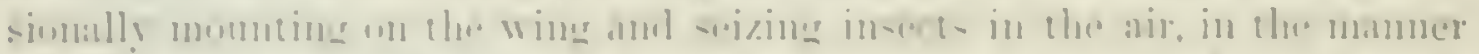

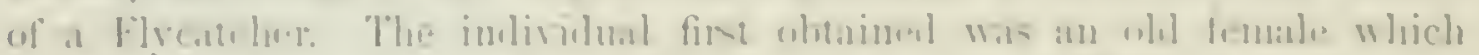

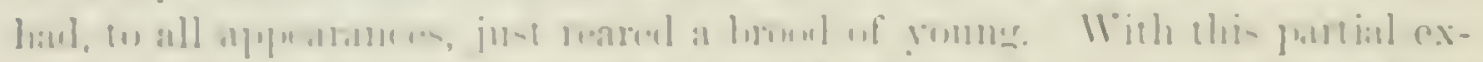

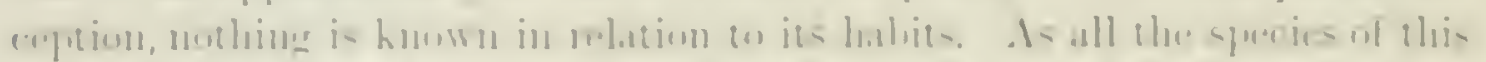

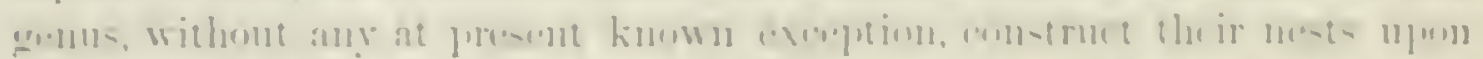

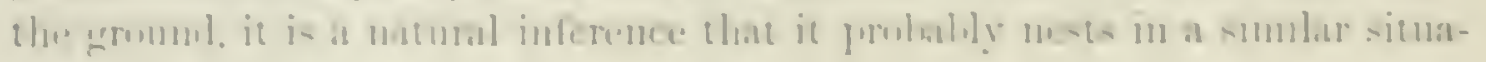
tiinil.

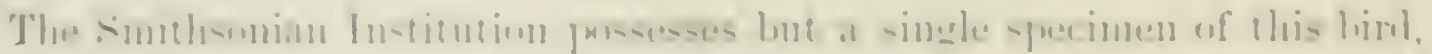

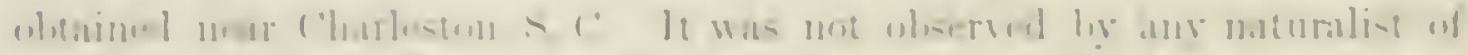
|l, - +.

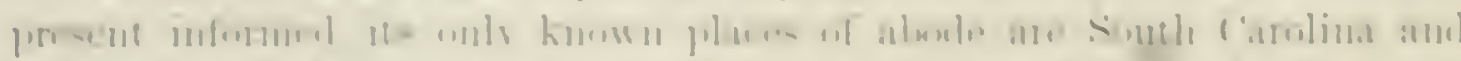

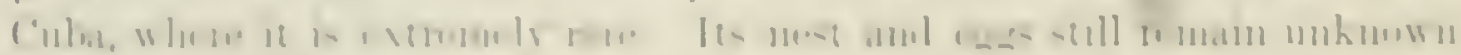


Helminthophaga pinus, Barro. BLOE-WINGED YELLOW WARBLER.

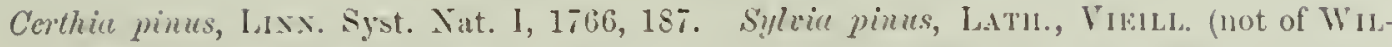

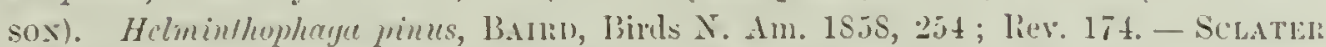

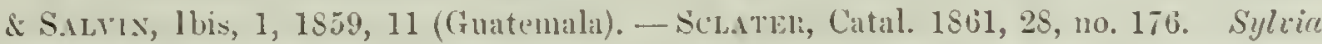

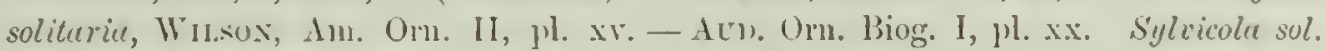
Ricir. Temmivore sul. Sw. Helineia sol. Acn. IBirds Am. 11, pl. exi. Helmitherus sol. Box. - SClateli, P. Z. S. 1550, 291 (Cordora). Helminthophuege sol. CAB.

Sp. Curn. Upper parts and cheeks olive-green, brightest on the rump; the wungs, tril, and upper tail-coverts, in part, bluisl-gray. In intenscly black patch from the blue-black bill to the eye, eontinued a short distance hehind it. Crown, exeept hehind, and the under parts generally, rich orange-yellow. The inmer wing and muler tail-corerts white. Eveliels, and a short line above and behind the eye, brighter yellow. Wing with two white bands. Two outer tail-feathers with most of the inner web, third one with a spot at the end. white. Female and young similar, duller, with more olivaceous on the crown. Length, 4.50 ; wing, 2.40 ; tail, 2.10 .

Hab. Eastern United States and Mexico to Guatemala (Cordora; Coban). Not noted from West Indies.

Habits. The Blue-winged Yellow Warbler is not known so far to the north as New England, and is rare even in Eastem and Southern New York. It seems to be distributed throngly the L nited States from Penusylvania to Florida, and from the Mississipui Valley eastward. It las also been taken in Central America. Mr. Trippe states that it breeds in the vicinity of Orange, N. Y. Mr. Aulubon found it alsundant in the barrens of Kentucky, and as far north on the Mississippi as St. Genevieve.

In regard to the song of this bird, Mrr. Trippe states that its notes are very forcible and characteristic. Once heard, they will always be remembered. He describes them as a rapid chimul resembling chüuchich, $l^{\prime}-a-r^{\prime} \boldsymbol{c}-\gamma^{\prime} r^{\prime} r^{\prime} r^{\prime} r^{\prime}$, uttered rery quiclily. Accorling to Mr. lidgway, they are wonderfully sminilar to the lude lisping chirrup of the Cotumiculus passerimus.

Wilson says that these Warblers come from the Soutl early in May, frequenting thickets and shrubleries in search of insects, which they seek in the branches. They are also fond of risiting gardens and orchards, gleaning for insects among the low bushes. They generally build their nests on the edge of sequestered woods. These Mr. Milson states to have been, in every instance observed by him, fixed on the ground, in a thick tussock of long grass, and built in the form of an inrerted cone, the sides being formed of the dry bark of strong fibrous weeds lined with fine dry grasses. These materials, he remarks, are not arranged in the usual circular manner, but shelve downard from the top, the mouth being wide and the bottom narrow. He describes the eggs as five in number, pure white, with a few faint dots of reddish near the larger end. The young appear the first week in June. The nests were always in an open hut retired part of the woods, and were all as thus described. 


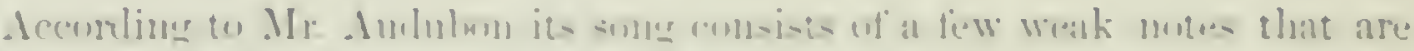

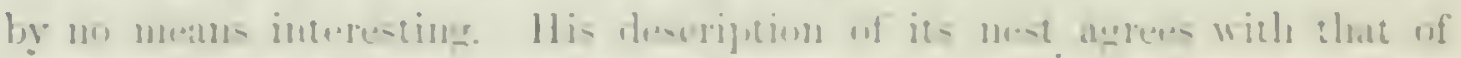

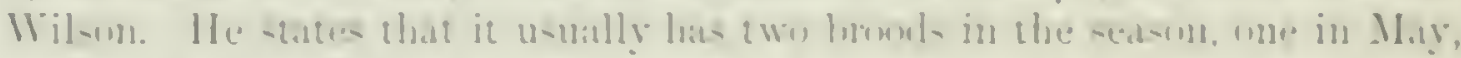

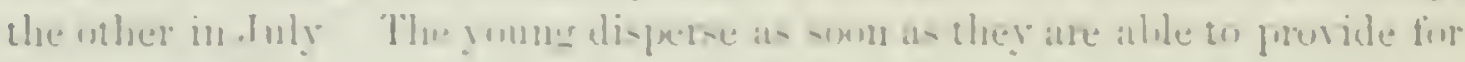
them-elsen

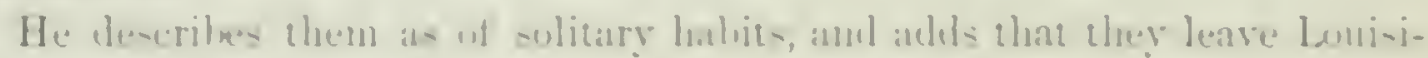

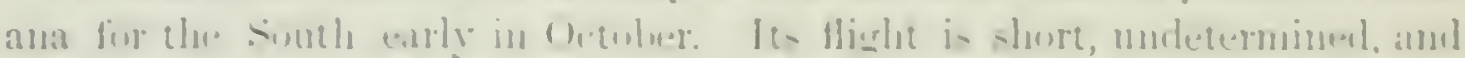

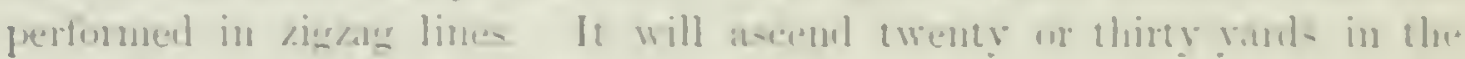

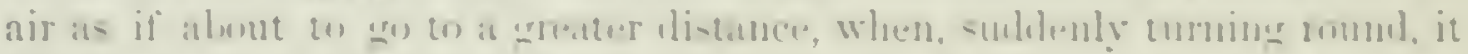

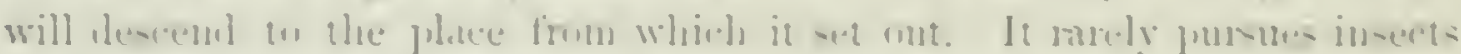

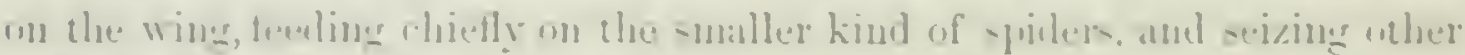
in-eets as they come within its reath.

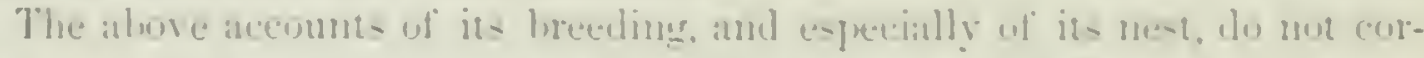

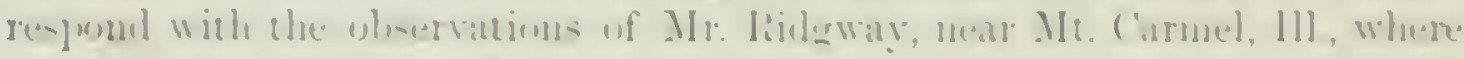

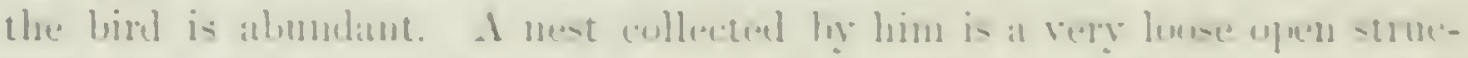

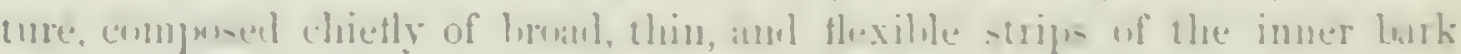

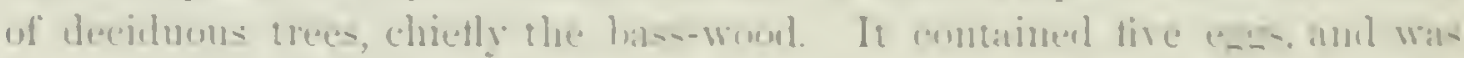

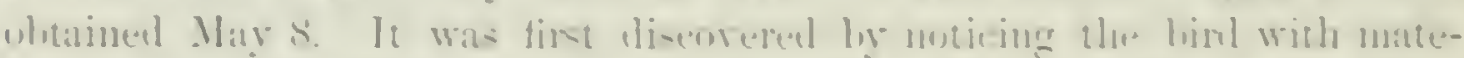

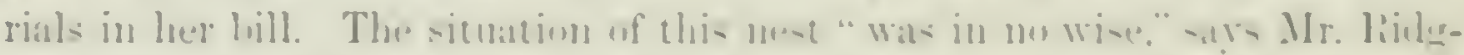

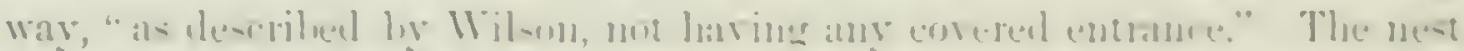

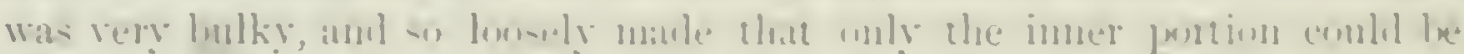

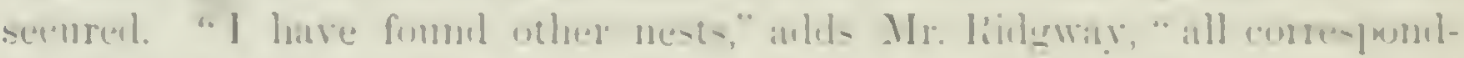

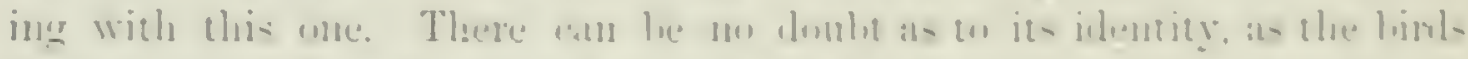

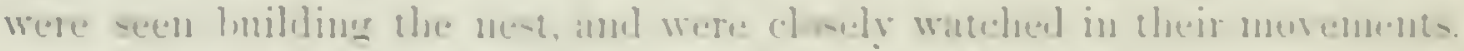

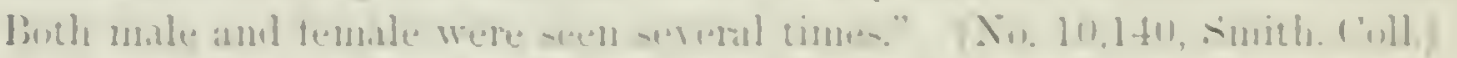

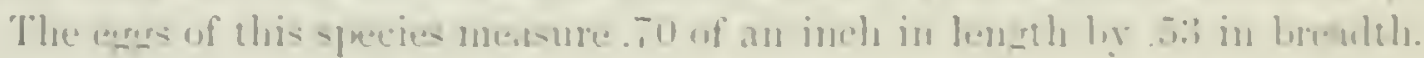

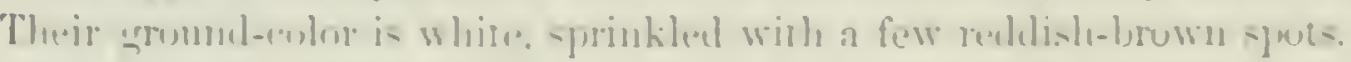

\section{Helminthophaga ruficapilla, Birlit.}

\section{NASHVILLE WARBLER.}

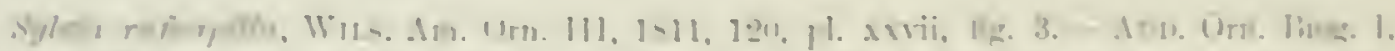

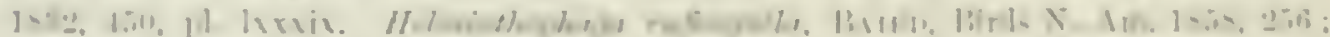

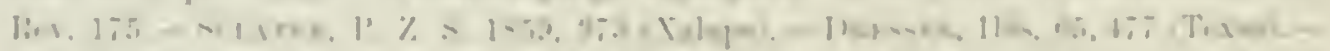

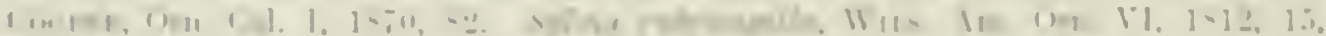

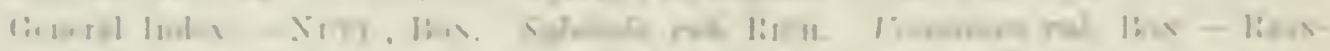

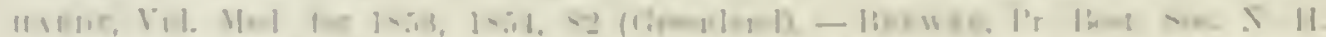

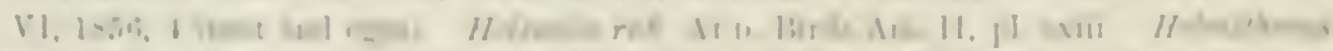

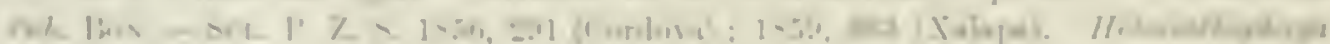

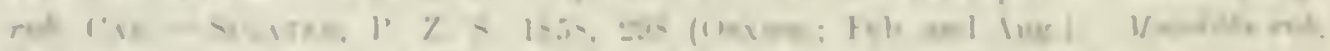

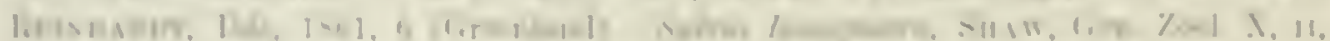

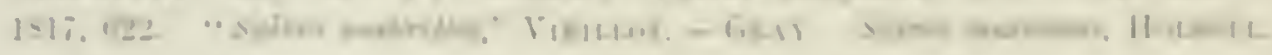

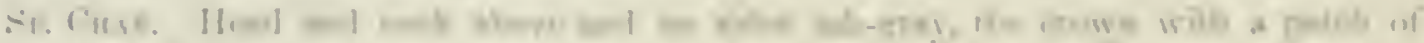

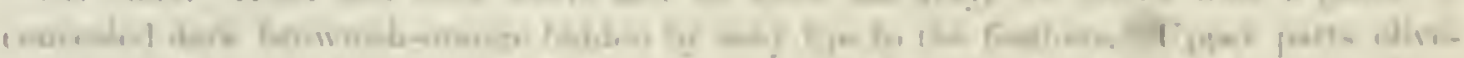

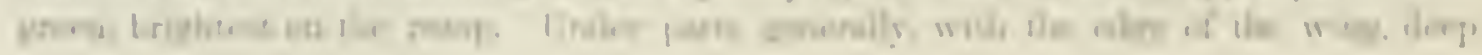


Sellow; the anal region paler; the sides tinged with olive. A broad yellowish-white ring round the eye; the lores yelluwish; 110 smpereiliary stripe. The inner edges of the tail-feathers margined with dull white. Femole similar, but duller; the under parts paler, and with unore white; but little trace of the red of the erown. Length, t.6.5: wing, 2.42; tail, 20.05 ,

IL.ı. Eastern Provinee of North Ameriea; rare in the Middle Province (Fort Tejon, Cal., and East IImboldt MLuntains, Ner.); Greenland (Rasumure); Oaxaca (February

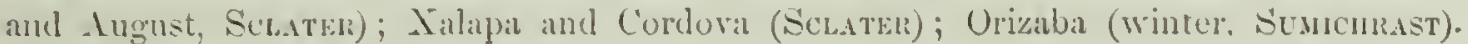
Not recorded from West Indies.

It is an interesting fact, that, in this species, we find in the yellow a tendeney to become more and more restrieted as we pass westwild. In adult spring mates from the Atlantic States this color invades the cheeks, and even stains the lores and eyeliels. In two alult spring males from Chicago it is confined within the maxilla', the cheeks being elear ash, and the lonal streak and orbital ring pure white; while in an adnlt male (antmmal, however) from the East IIumboldt Mountains (Nevada, No. 533,35t, U. S. (ieol. Expl., 40th par.) the yellow is restrieted to a medial strip, even the sides of the throat beng ashy; the ash invades the back too, almost to the rump, while in Eastern specimens it extends no further back than the nape. A male (No. 10,656, J. Xantus) from Fort Tejon, Cal., is much like the Nevada specinen, though the peculiar featmes of the remote Western form are less exaggerated ; it is about internediate between the other specimen and the specimens from ('hieago. As there is not, minfortunately, a sufliciently large series of these birds before us, we cammot sily to what extent these variations with longitude are constant.

Habits. The Nashrille Warbler appears to be a species of somewhat irregular ocemrence; at one time it will be rather abundant, though never very mmerous, and at another time comparatively rare. For a long while our older naturalists regarded it as a very rare speeies, and knew nothing as to its habits or distribution. Wilson, who first met with it in 1811, never found more than three specimens, whieh he procured near Nashville, Temn. Andubon only net with three or four, and these he obtained in Lonisiana and Kentucky. These and a few others in Titian Peale's collection, supposed to have been obtained in P'emsylyania, were all he ever saw. Mr. Nintall at first regarded it as very rare, and as a sonthern species. In that witer's later edition he speaks of it as a bird having a Northern distribution as fan as Labrador: Dr. Richardson records the occurence of a single straggler in the fur comntry. So far as known, it oceurs as a migrant in all the States east of the Missouri, and is a summer resident north of the foth parallel. It probably breeds in the ligh ground of Pennsylvania, though this fact is inferred rather than known. It breeds in Connectient and Massachusetts, and in Maine in the vicinity of Calais, being more abundant there than anywhere else, as fiar as has been ascertained.

Two individuals of this species have been taken in Greenland: one at Godthaab, in 1835; and the other at Fiskeniesset, Ingnst :31, 1840. 


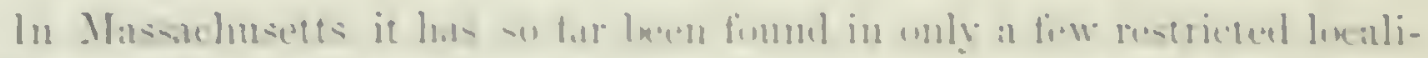
tres, Imloser, l.

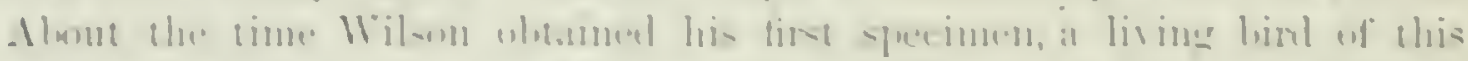

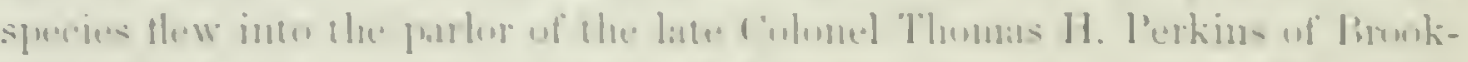

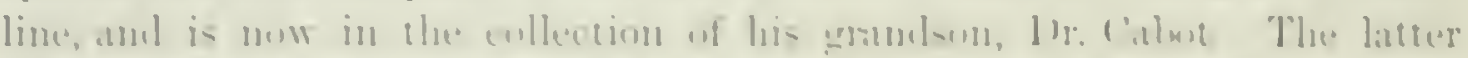

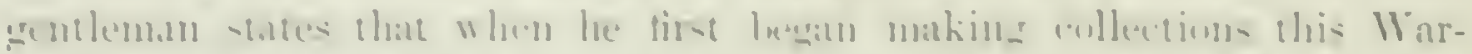

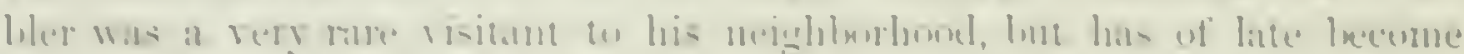

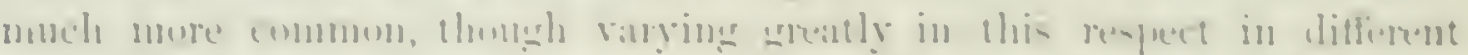

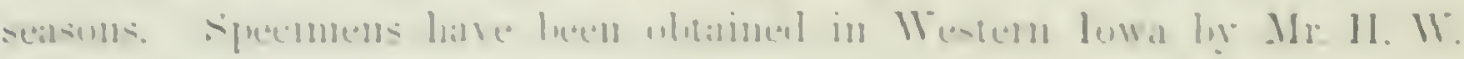
l'urher, of lirimell.

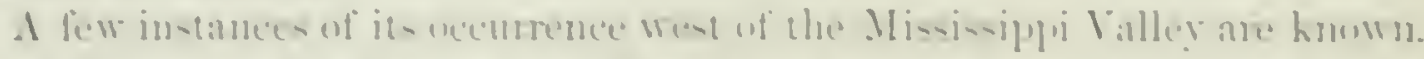

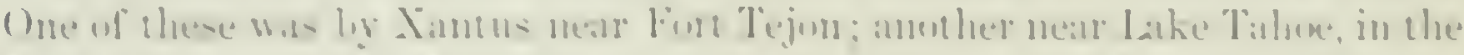

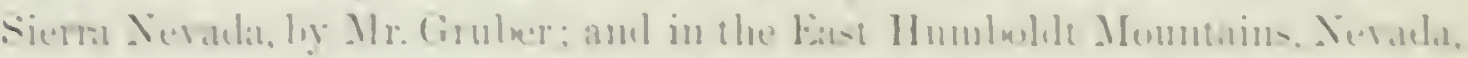

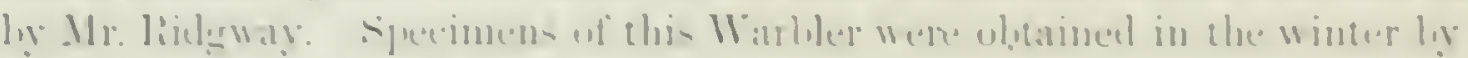

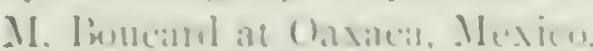

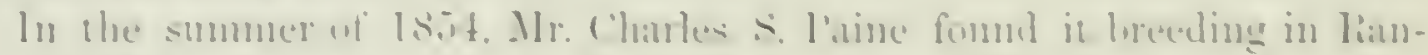

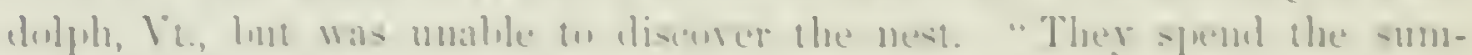

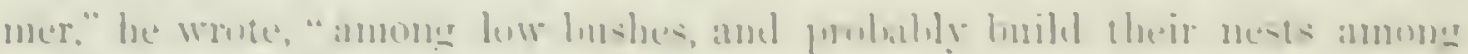

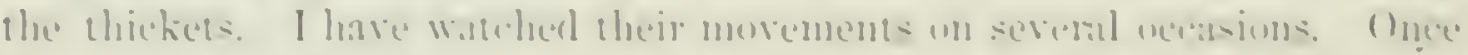

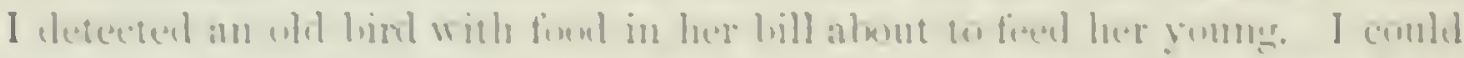

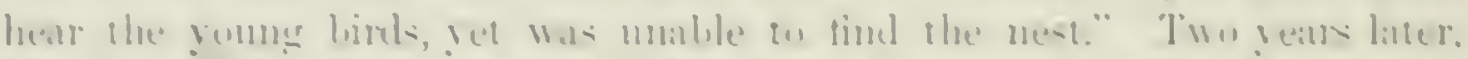

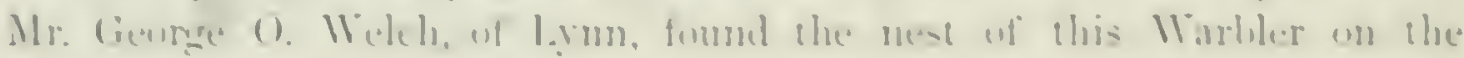

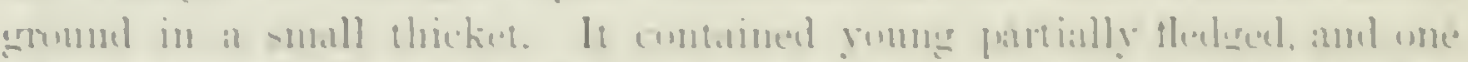

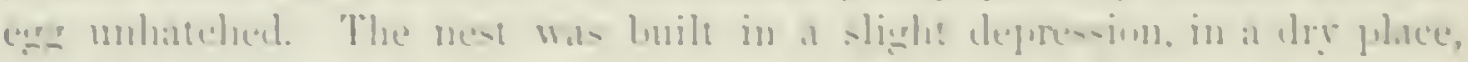

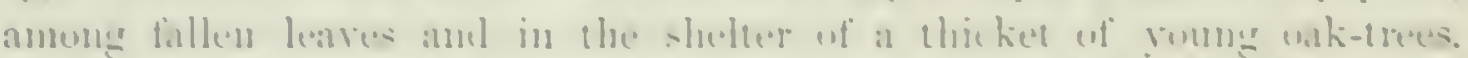

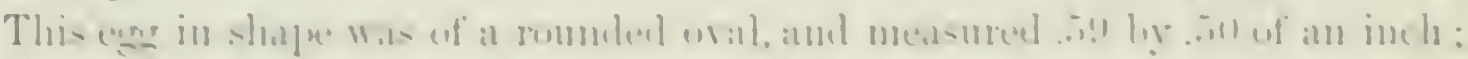

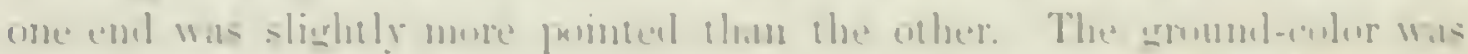

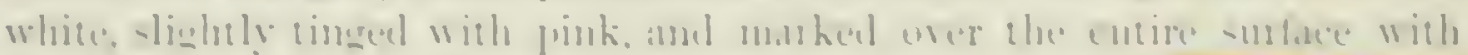

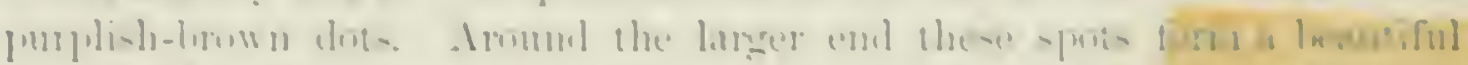

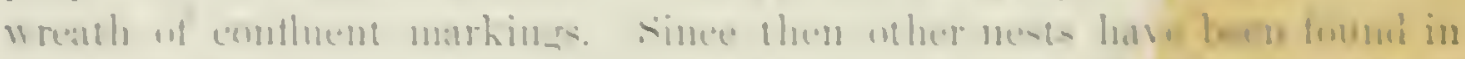

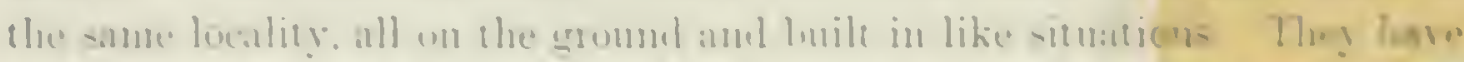

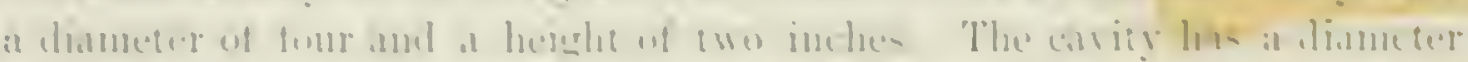

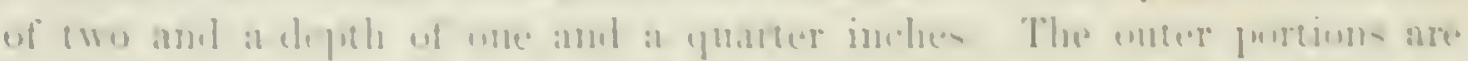

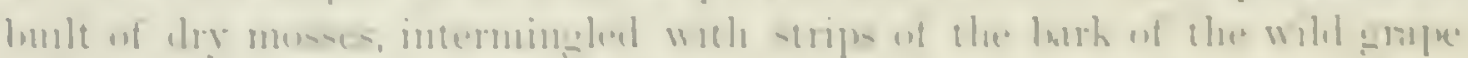

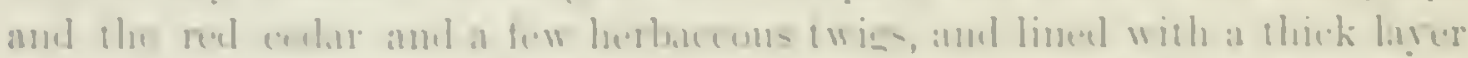

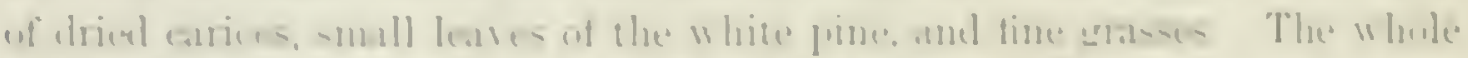

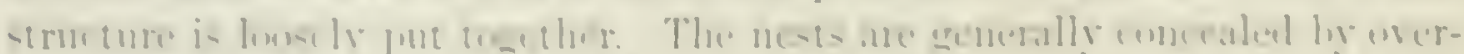

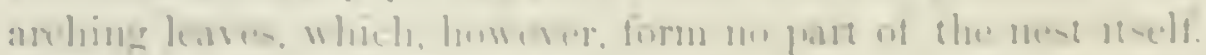

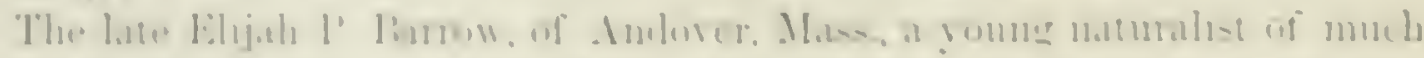

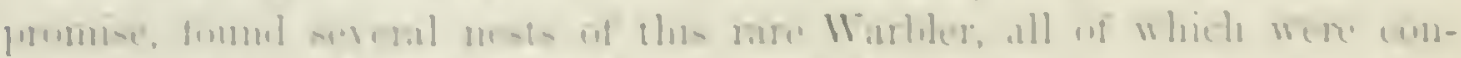

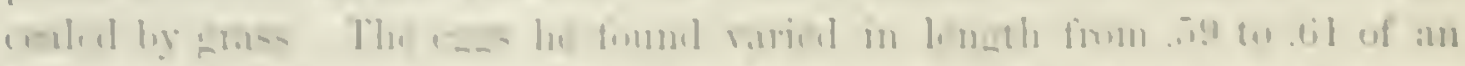

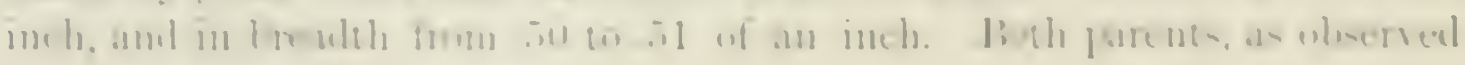
hs lim were entmeh -l, me

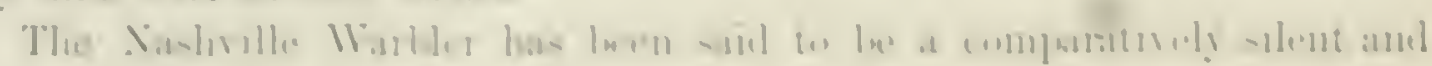


songless hird, rarely giving forth any somnds, and these are comprated lyy lor. lichandson to the creaking noise made by the whetting of at saw. W'ilson comprares these sounts to the cracking of dry twigs or the striking together of smill pebthles. MIr. I. A. Allen speaks of its song as being sinilar to that of the Chestnut-sided Warbler, which latter bird, as is well known, has notes so closely resembling those of the Sumner Yellow-bird that it is difficult to distinguish one from the other by their notes. Mr. T. M. Triphe states, also, that this Warbler has a very fine somg, resembling that of the Sunner Yellow-bird more nearly than any other.

These Warblus arrive in Massachusetts abont the first of May, and remain alout three weeks, when the larger portion move firther north.

More recently Mr. Paine writes me that the Nashville Warluler has of late years becone a common hire in certain localities in C'entral Vermont. They eome and keej company with the Canada Warbler, but are more restless than that species at the time of their first appearance. They always in the breeding-season take up their ahode in thickets, where there are also tall trees. Mr. l'aine adds that their song eonsists of repetitions of single notes, the last teminating somewhat abruptly. Their song ceases by the 10 th of June. After their young are ready to fly, they disperse about the woods and fields, and are then not readily discovered.

\section{Helminthophaga virginiæ, lB.ARD.}

\section{ROCKY MOUNTAIN WARBLER; VIRGINIA'S WARBLER.}

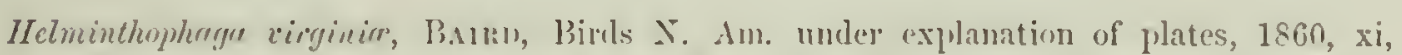
pl. lxxix, liğ. 1 (Fort burgwyn, N. M.); Rev. 177. -- Cooper, Orn. C'al. J, 1870, $8 \check{.}$

Sp. Cusw. Somewhat like II. rufierpilla. Mule. Top aud silles of head, hack, and wiugs light aslyg-plumbenus: quills aud tail-featlers l,rown, elgerl with pure ashy-plumbeous, the latter indistiuctly and narrowly margined with whitish internally and at the enel. liump, with ujper and lower tail-enverts, bright yellow, in vivil contrast with the jest of the horly. Crown with a coneealed patch of rich chestnut. Rest of under parts brownishwhite, with a patch of rich yellow on the jugulum. Insille of wings and axillars pure white. A white ring roumd the eye. Bill and legs dusky. The colors much duller in autumn.

Female, spring. Similar to the male, but chestnut spot on rown olsolete. the yellow jugnlar patch less distinct, the upper tail-coverts more greenish, and the lower less rich yellow.

Length, 5.00; extent. 7.2.); wing, 2.50 when fresh. Dried skin: longth, 4.90; wing; $2.50 ;$ tail, 2.20 ; tarsus; .67.

II.us. Soutliern Rocky Mountains (Mirhlle Province of Luited States); East Humboldt, Wahsatel, and Uintah Mountaius.

A young bird (No. 53,35.5, East Humboldt MIountains, Nevada, August 5) is olive-gray alove, becoming green on the rump and "lper tail-coverts; the midlle and secondary coverts narrowly tipped with pale grayish-luff, produeing two indistinct bandis. The lower parts are pale dirty-buff, except the 


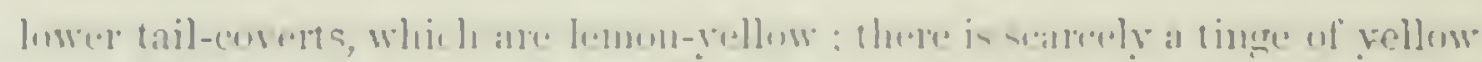

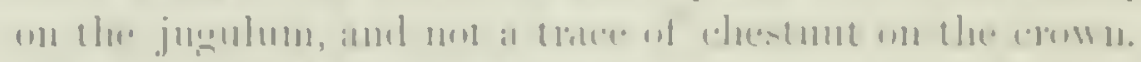

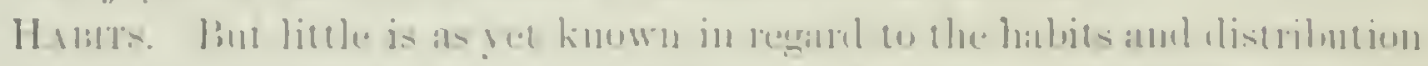

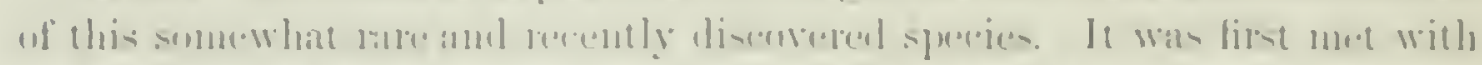

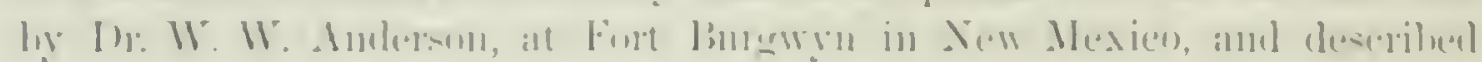

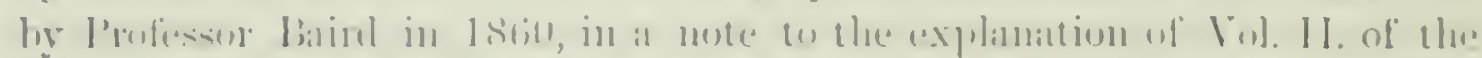

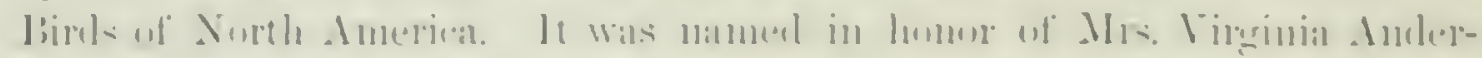

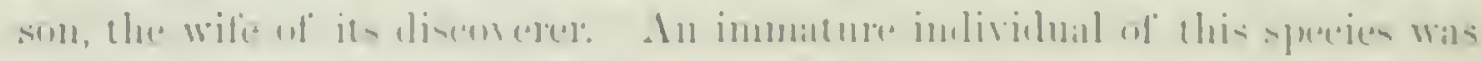

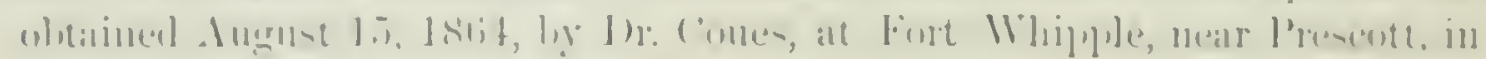

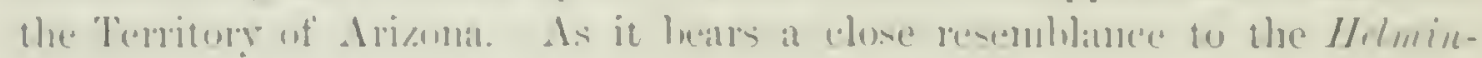

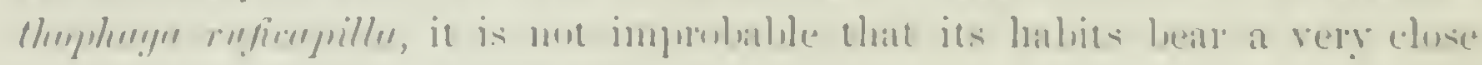
resimblinee to those of that spereies.

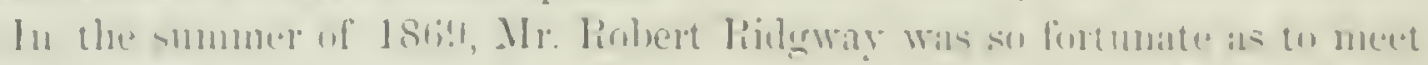

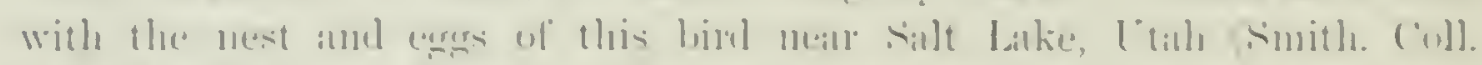

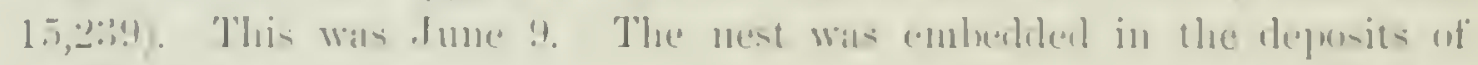

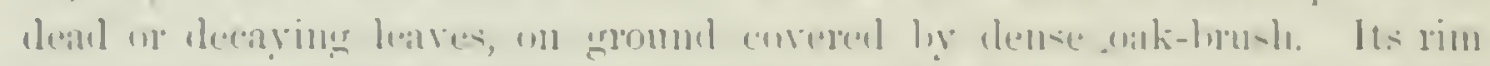

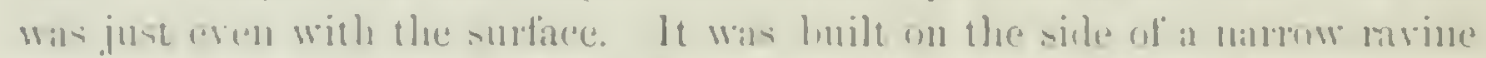

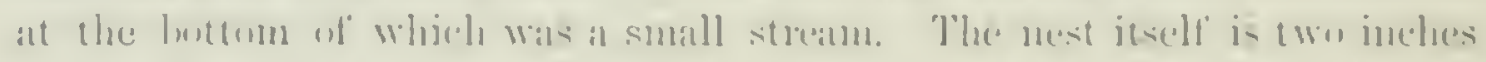

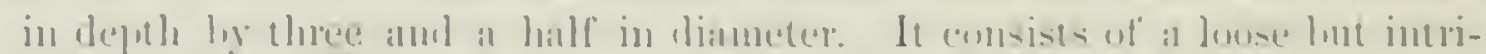

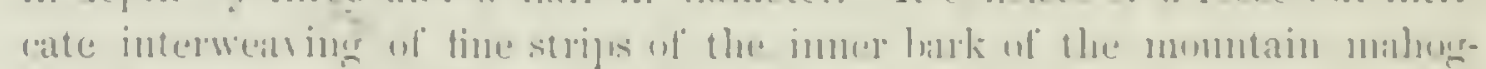

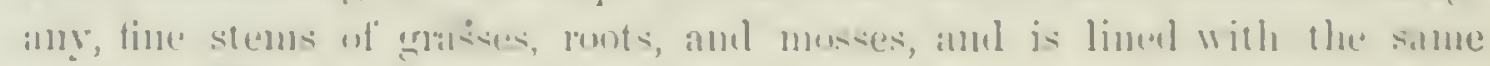
with the addition of the lin am hair of the sulallere animals.

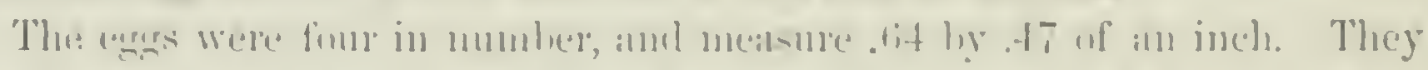

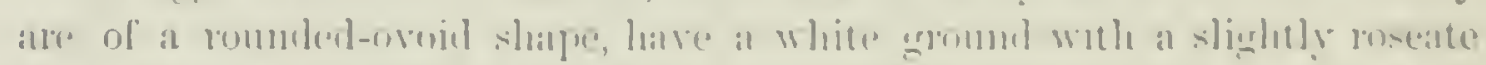

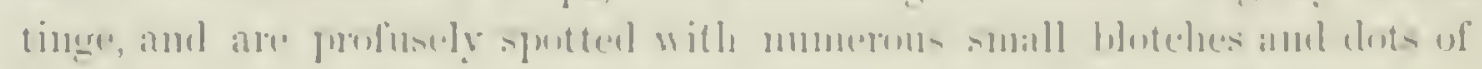
purplish-l,

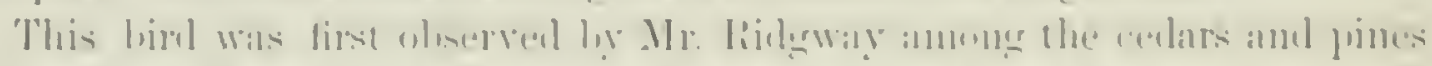

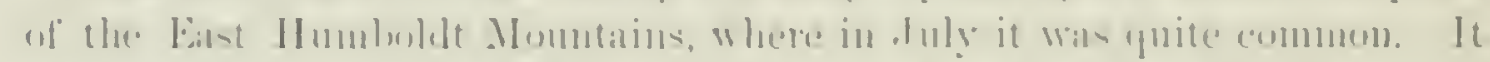

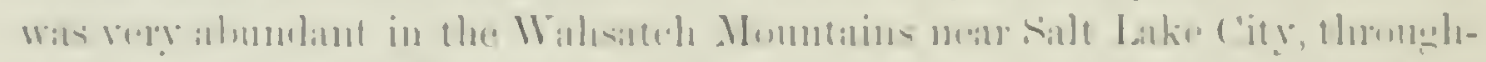

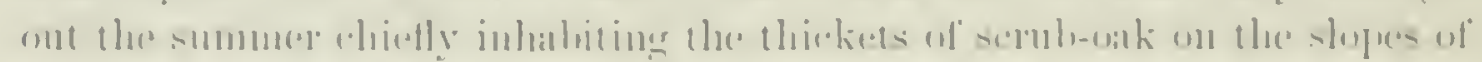

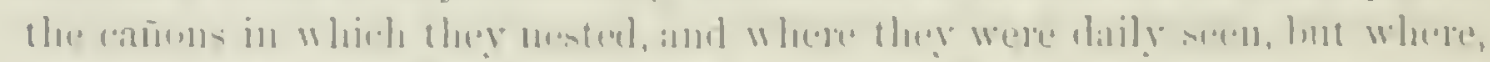

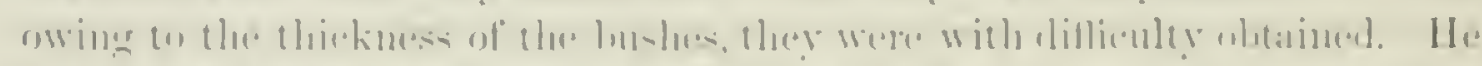

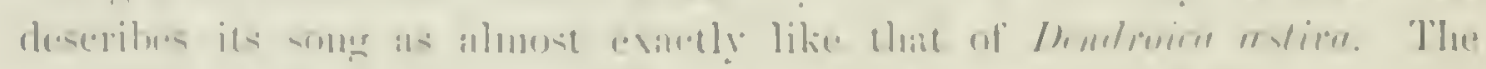

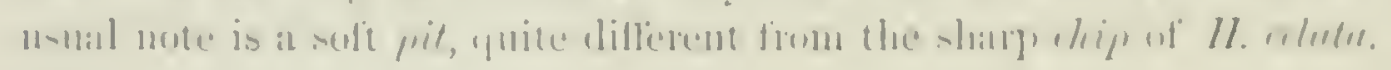

\section{Helminthophaga luciæ, cinosik.}

\section{LUCY'S WARBLER.}

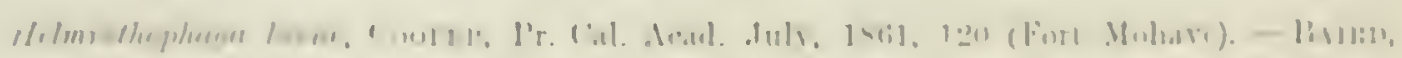

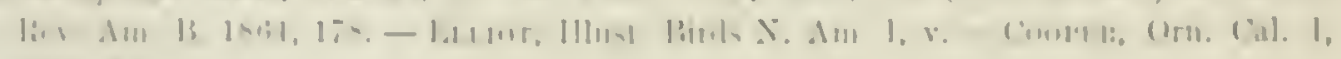
$1-71,-1$.

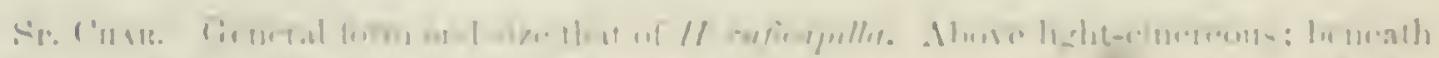

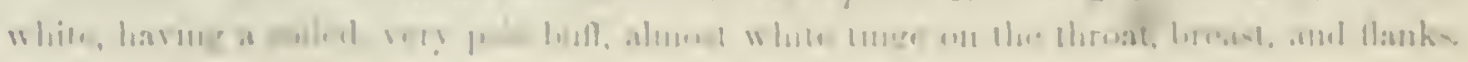


A patch on the vertex, as in H. Muficupilla, and the upper tail-coverts, dark chestnutbrown. Lores to nostrils and region round the eye, like the throat, in rather decided eontrast to the ash of the erown. Quills and tail-feathers brown, narrowly edged externally with gray. An obsolete terminal white patel on the inner web of the outer feather; this web in most of the other tail-feathers likewise narrowly edged with white. Axillars and inner face of wings wlite. Iris brown. Tarsi blue. Length, in life, 4.40; extent, 6.90 ; wing, 2.40. Length of skin, 3.90 ; wing, 2.33 ; tail, 1.86 ; tarsus, 64 ; mildle toe and claw, .50 ; bill above. 35 ; wape, .50.

IIAB. Fort Mohave, Colorado River (Middle Province of United States) : Fort Whipple, Arizona.

HABITs. This is also a new or recently discovered species of this interesting group of Warblers. In regard to its nest and eggs nothing is positirely ascertained, yet as all the birds of this genus are known to build on the gromnd, and to have i great uniformity in the characteristics of their eggs, it seems to be a matter of natminl inference that this species also is a gromud builder, and has eggrs similar to those of the Nashville Warbler. For the little we know in regard to its habits and distribution, we are indehted to the observations of Dr. J. G. Cooper of California, who first discorered it, and to Dr. Cones, who has since met with it in Arizona.

Dr. Cooper first observed this species near Fort Mohave, where it made its appearance about the last of March. His attention was called to it by its peculiar notes, resembling those of some Dendroice, 'but fainter. After considemble watching and scrambling throngh dense mezyuite thickets in its pursuit, he succeeded in shooting one, and found it to be a new species. Afterwards they became more numerons, frequenting the tops of the mezquite-trees in pursuit of insects, and constantly uttering their short but pleasing notes. About ten days after the first appearnee of the males, Dr. Cooper obtained the first female, and thinks that without doubt they are much later in their migrations, as is the case with other Warblers. He was not able to discover their nest, having to leave the valley late in May.

Mr. Holden obtained other specimens of this bird, near the 34th parallel, in March of 1863.

Dr. Coues met with three indiriduals of this speeies near Fort Whipple, where it is a summer resident. It arrives there between the 15 th and the 20 th of April, and remains until the latter part of September. It mates abont the last of April, and the young birds ajpear early in June.

Dr. Cones regards its habits as more like those of the true Ground Warblers than those of the other species of this group. It shows a decided preference for thickets and copses, rather than for high open roods, and is also an exceedingly shy and retiring species. To the extreme difficulty of observing or procuring it Dr. Coues attributes its having so long remained unnoticed.

It is described as exceedingly active in all its motions, and quite as restless as a Polioptila, to which class, in its colors, it also bears a close resem- 


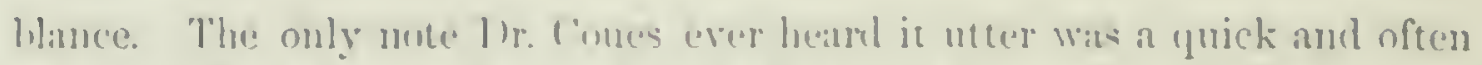

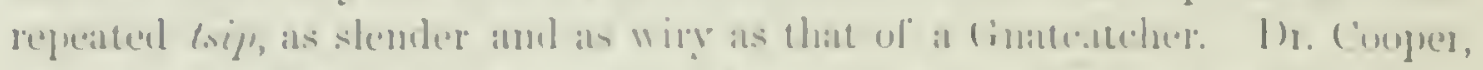

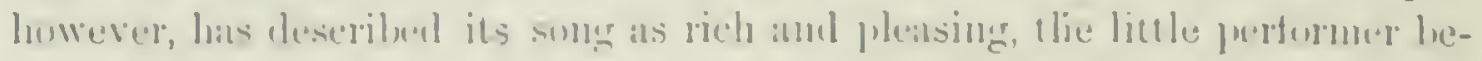

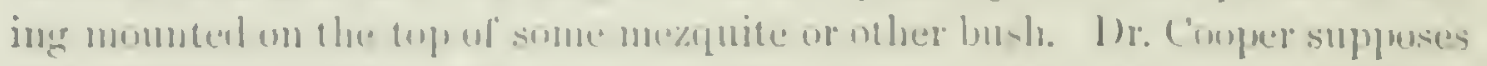

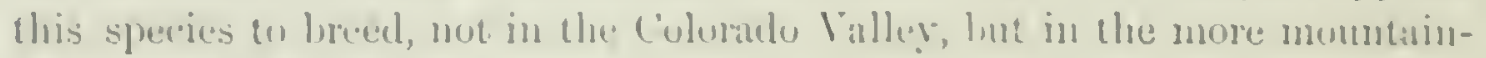
outs senions.

Wr. Cines hazards the conjecture that this him huids in low lushes. should it prove so, it would in this respect difler from all the of her members

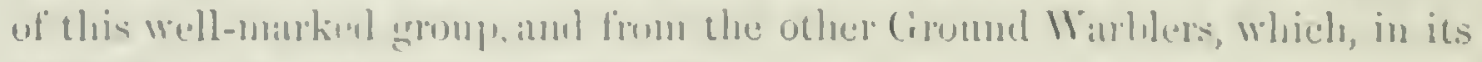
general habbits, it so mucli rescubles.

\section{Helminthophaga celata, var. celata, Iinris. ORANGE-CROWNED WARBLER.}

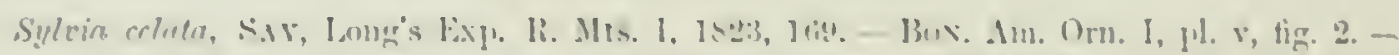

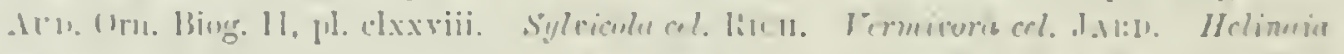

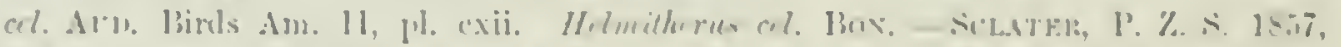

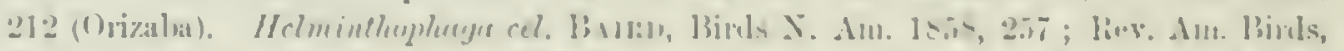

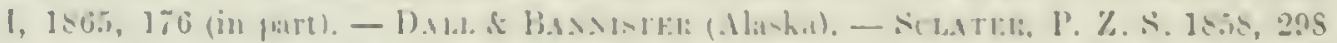

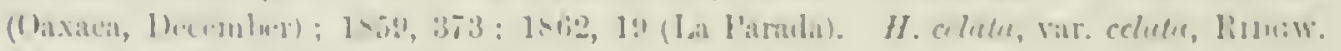

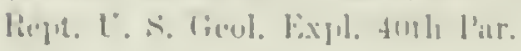

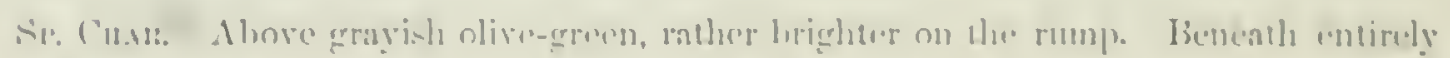

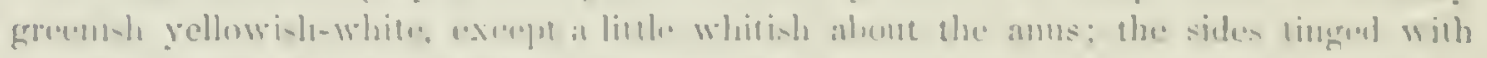

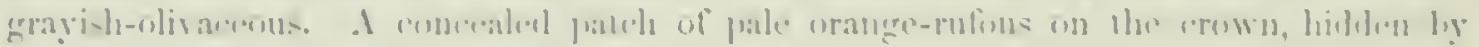

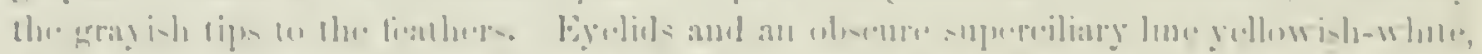

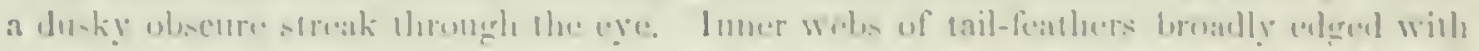

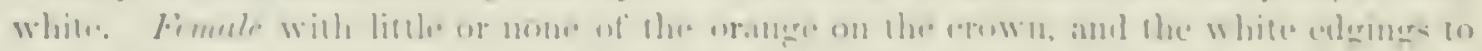

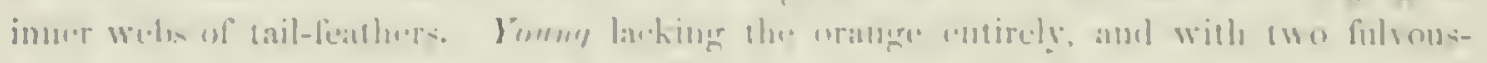

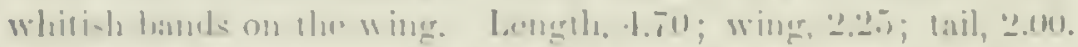

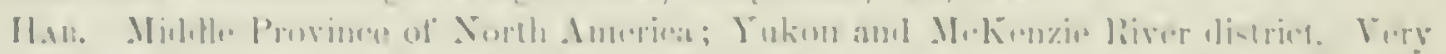

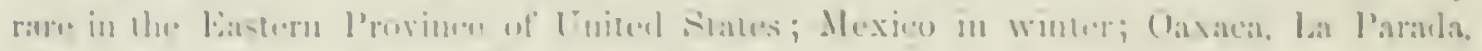

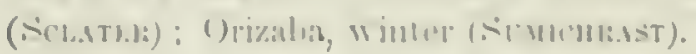

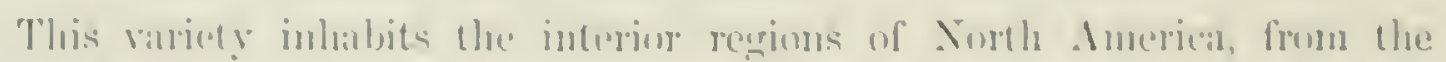

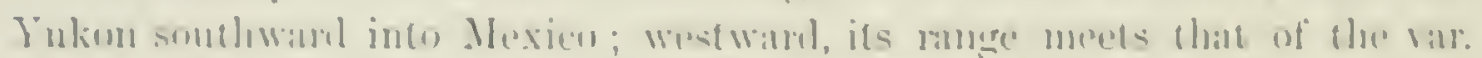

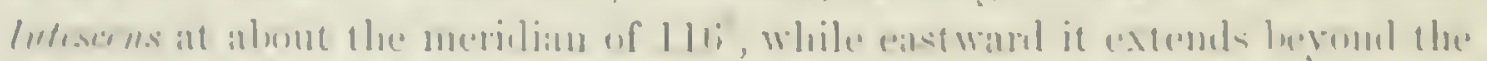

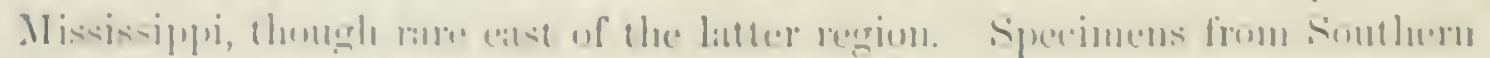

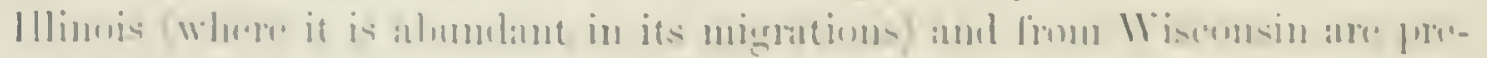

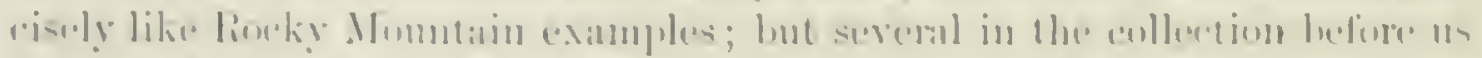

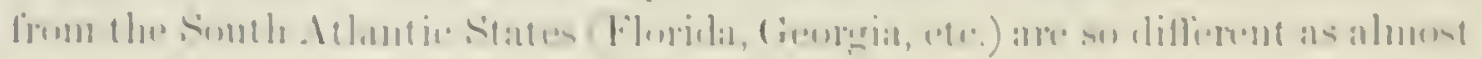

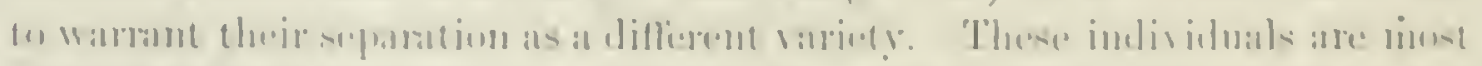

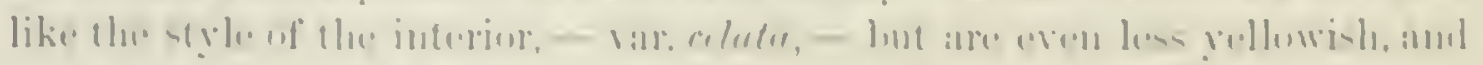

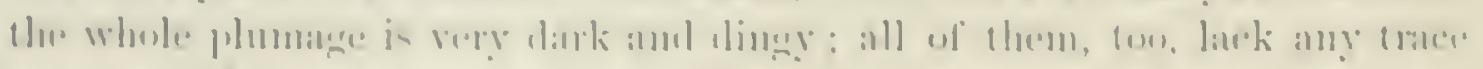

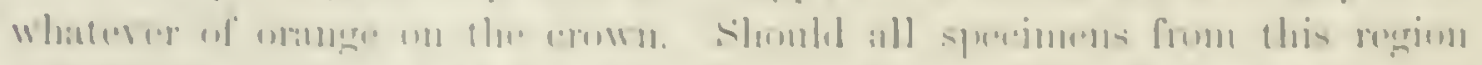

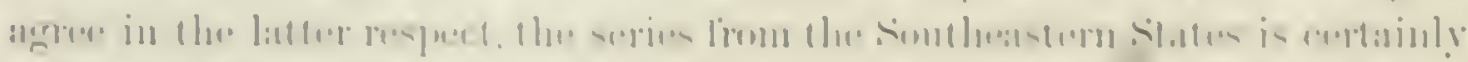

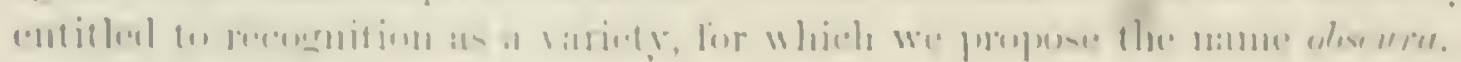


Hıbits. The geographical distribution of $H$. celata is involved in some doubt, owing probably to its irregularity of miglation. In a tew occisional instances this species las been olserred in the Atlantic states. Several have been obtained near Philadelphia. Мr. Audubon attirms to liaring seen it in the Middle States about the 10th of May, and in Maine later in the month. Beyond that he did not trace it. Mr. J. A. Allen procured one speeimen of this bird in Springfield, Mass., May 15, 1863. There were quite a number among the fruit-trees of the garden and orchard, then in hloom, and, mistaking them for Helminthophagu rufucapilla, he at first neglected to shoot any, until, being in doulot, he proenred one, and found it the Orange-C'rown. The group passed on, and one was all he obtained. It is not given by Mr. Turnbull as one of the birls of New Jersey and Pennsylyanla, nor by Mr. Boardman or Professor Verrill as occurring in Maine. I an informed by Mr. Ridgway that it is a regular spring and antumn migrant in Southern Illinois, and in some seasons is quite common.

It was taken as a migratory speeies at Oaxaca, Mexico, during the winter months, by M. A. Boucard.

Mr. Audubon's account of the habits and morements of this species must be received with much caution. His description of its nest is entirely inaccurate, and much that he attributes to this species we have reason to believe relates to the habits of other birls.

On the Pacific coast it seems to be quite abundant, at different seasons, from Cape St. Lucas to the aretic regions, where it breecls. Mr. Kennicott obtained several speeinens at Fort Fukon and at Fort liesolution, and Mr. Ross met with them at Fort Simpson. Santus obtained these birds both at Fort Tejon aud at Cane St. Lucas. It is common in Southern California during the winter, frequenting low hushes and the margins of streams. Ir. Gambel met with it in early spring on the island of Santa Catalina, where he had an opportunity of listening to its simple and lively song. This he describes as commencing in a low, sweet trill, and ending in tshe-up. It is sometines considerably varied, but is described as generally resembling er $r-r, r, r, r-s h \grave{e}-u p$.

Dr. Cooper speaks of this Warblel as an abundant and constant resident of California, near the coast, and found in summer throughout the Sierra Nevada. In Mareh they begin to sing their simple trill, which, he says, is rather musical, and audible for a long distanee.

Dr. C'ones met with this Warbler in Arizona, at Fort Tuma, September 17, at.Fort Mohave, October 1, and also at the hearl-waters of Bill Williams River. Lientenant Couch found it at Brownsville, Tex., seeking its food and making its home among the low shrubbery.

Dr. Suckley found it rery abundant at Fort Steilacoom, in Wrashington Territory, where it kept in shady places among thick brush, generally in the vicinity of watereourses. Dr. Heermann found a few pairs incubating near the summits of the highest mountains on the Colorado River. The nests of 


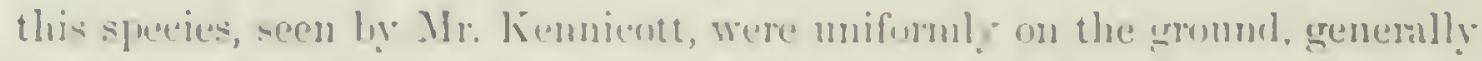

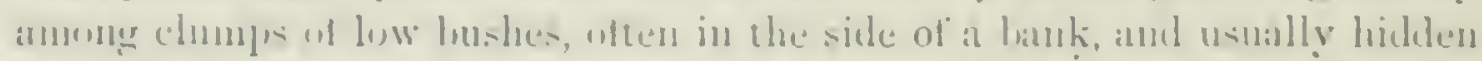

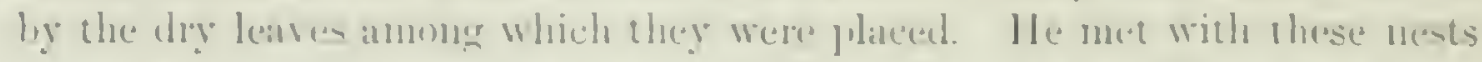

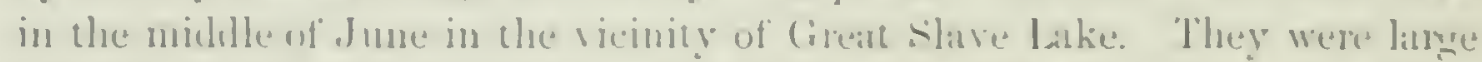
for the sime of the birl, having an extermal dianceter of lom inchess and a leveght of two and at hall, and alplearing ats if mate of two or three dis-

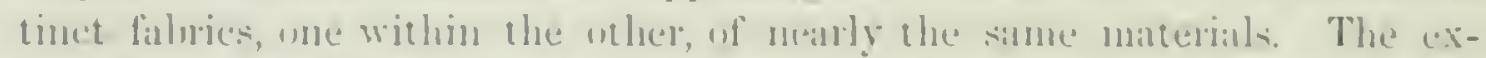

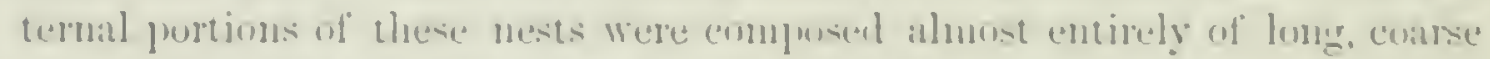

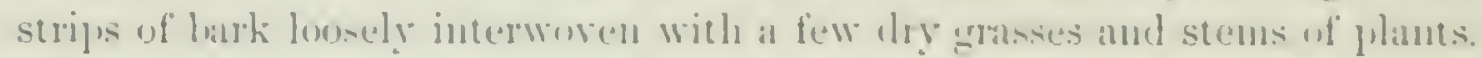

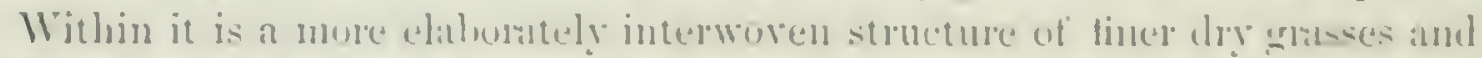
mosices. These ate soltly and warmly lined with hair and fur wi small animals.

Nests lonm more aretic leninus are of a diflierent style of stmoture, homo-

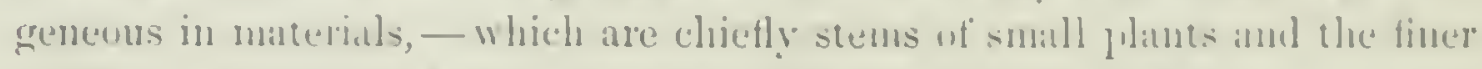
gratses, - imd ane of a more compact nuthe and smallep in sike.

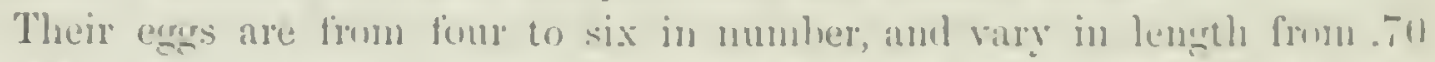

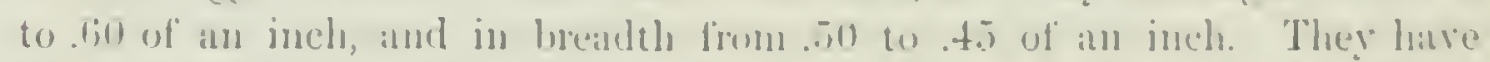
a clear white grouml, matied with spots and small henches of rehlish-

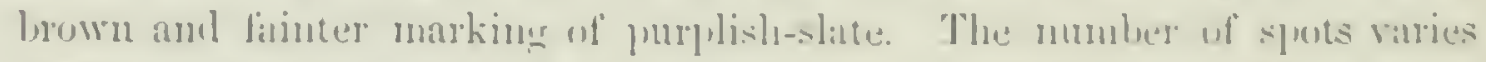

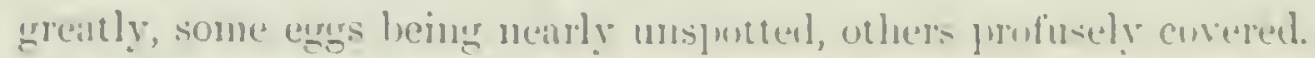

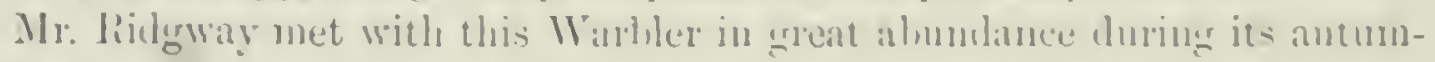
nal migration among the shrubbery along the streams of the siema Nevalia,

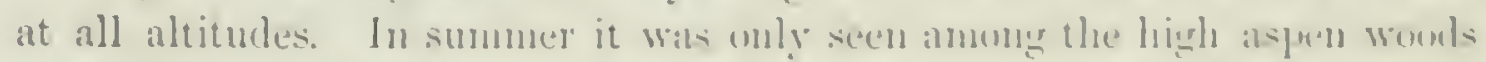

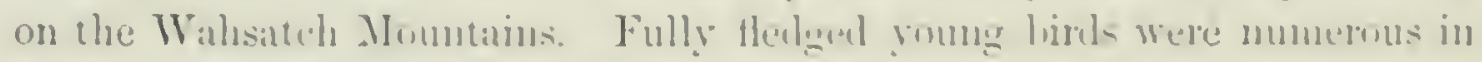

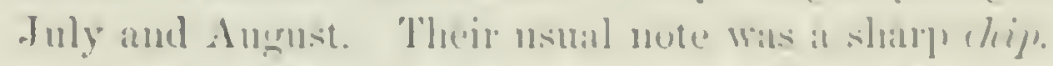

This birl wins found breeding neitl Fort Fiesolution, on the Fukon, at Furt liate, and at Fort Amblersun.

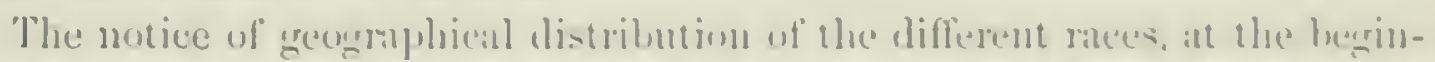

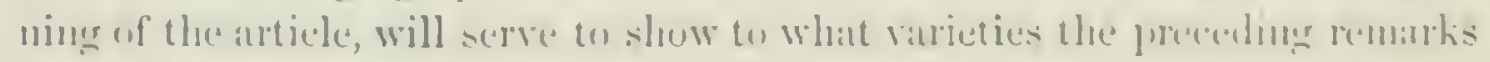
seremally lelong.

Helminthophaga celata, var. lutescens, hincwar. PACIFIC ORANGE-CROWNED WARBLER.

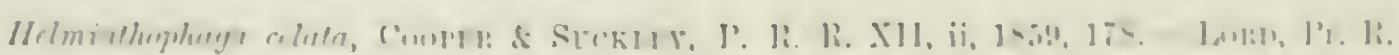

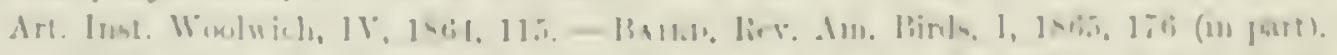

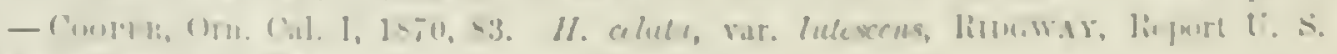

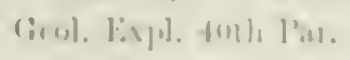

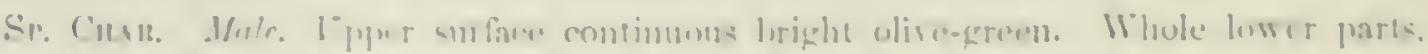

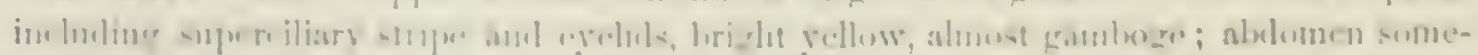

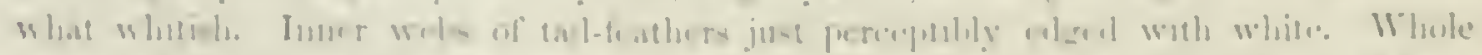

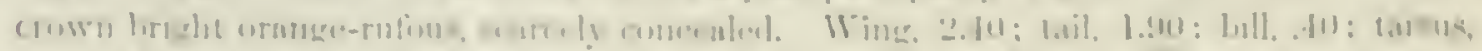

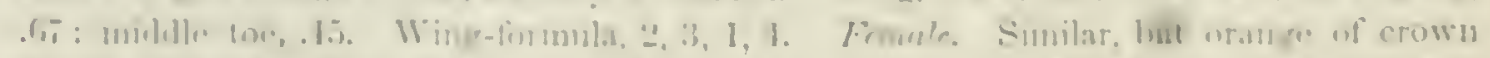

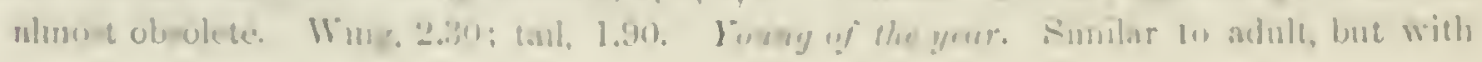


a brownish tinge above: middle and secondary corerts tipped witl dull fulvons, furry, inconspicuous bankls. No trace of orange on the crown.

Hab. Pacifie Province of North Ameriea, from Alaska to Cape St. Lucas. Straggling enstward to about the 116th meridian. Not found in Mexico?

The differences between the Pacific coast specimens of the $H$. cclutu and those from the interior regions - first pointed out in the lieview of American Binds - are very readily appreciable upon a comparison of specimens. The present bird is a coast variety, entirely replacing the true celutu (var. celat $($ ) in the region above indicated.

\section{Helminthophaga peregrina, CABAs.}

\section{TENNESSEE WARBLER.}

Sylvia peregrina, Wils. Am. Orn. 1V, 1\$11, \$3, pl. xxv, fig. 2. - Atv. Orn. Biog. I1, pl. cliv. Sylvicola per. Ricu. Fermivure per. Box. Melinaia per. Aun. Birds Am. 11, pl. ex. Helmitherus per. Bos. IIelminthophage per. Caв. Mus. Hein. - IB. Jour. Orn. 1861, 85 (Costa líca). - B.1111, Birds X. Am. IS5S, 25S; Rev. 17S. - Sclater

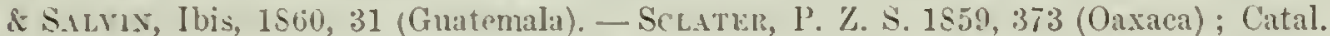

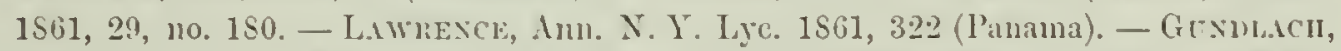
Cab. Jour. 1561, 326 (Cuba, very lare). Sylrie tennesseci, Vieıllut, Eneycl. Héth. II, 1823, 452. ? Sylvia missuriensis, Max. Cab. Jour. VI, 185S, 117.

SP. Crır. Top and sides of the head and neek ash-gray; rest of upper parts olivegreen, brightest on the rump. Beneath dull white, faintly tingel in places, especially on the sides, with yellowish-olive. Eyclicls and a stripe orer the eye whitish; a clusky line from the eye to the bill. Outer tail-fenther with a white spot along the inner edge near the tip. Female with the ash of the head less conspicuous; the under parts more tinged with olive-yellow. Length, 4.50; wing, 2.75; tail, 1.85.

H.ı. Easteru Province of North America; Calais, Me.; north to Fort Simpson, II. B. T.; Mexico; Oaxaca? Guatemala; Costa Rica; P'anama R. R. Very rare in Cuba. Veragua (S.lbvis). Chiriqui (Liwrexce).

Autumnal specimens and young birds are sometimes so strongly tinged with greenish-yellow as to be scarcely distinguishable from $H$. celata. The wing is, howerer, always longer, and the obscure whitish patch on the imer edge of the exterior tail-feather, near its tip, is almost always appreciable. In celuta this edge is rery narrowly and uniformly margined with whitish.

A young bird of the year, from Fort Simpson (27,228), lias two distinct greenish-white bands on the wings, and the forehead and cheeks greenishyellow. A corresponding age of $H$. celcte has the wing-bands more reddishbrown, the wings shorter, and no white patch on the onter tail-feather.

HABıTs. Like the Nashville Warbler the present species has received a name inappropriate to one with so northern a distribution. It was first obtained on the banks of the Cumberland River by Wilson, and has since been known as the Tennessee Warbler. But two specimens were ever obtained by him, and he regarded it as a very rare species. He found them hunting 


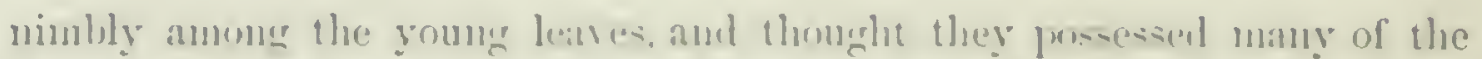

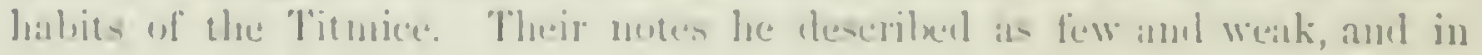
their stemache he fonmd, npon disecetion, small green caterpillars and a few winferl insects.

Mr. Aulubon also reganted it an a me species, aud only three specimens ever fell withon his olservatims. These were whatned in Lsusiana and at

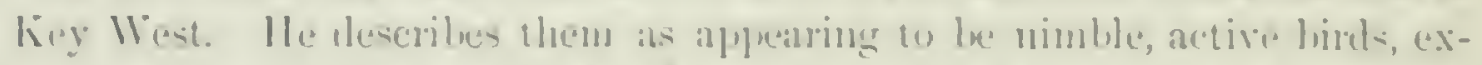

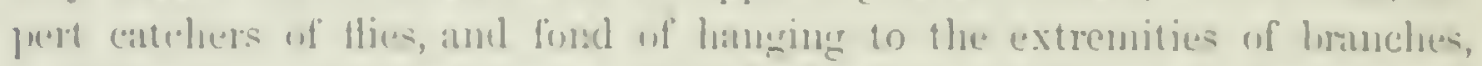
uttering a single mellow turat as they lly from branch to banch in search of foent, or while on the wing.

Mr. Nuthall ilperars not to have met with it. Dr. Richarden frocured

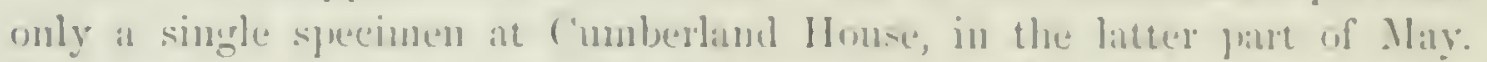
This was in a dense thicket of small trees, and wat flying about anmeng the lower lnanches. He wis mable to discover its nest, or to lann anything in regratrl to its halits.

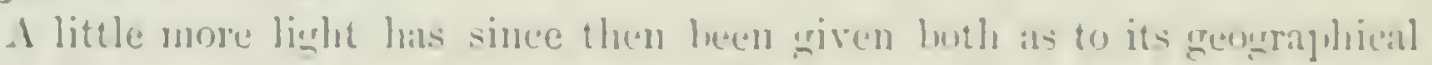
distrilution and its mole of nesting. Specimens of this species have lnen

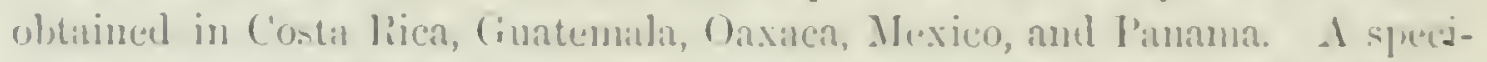

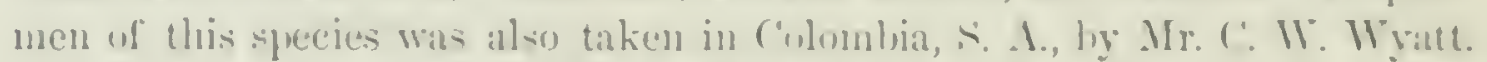

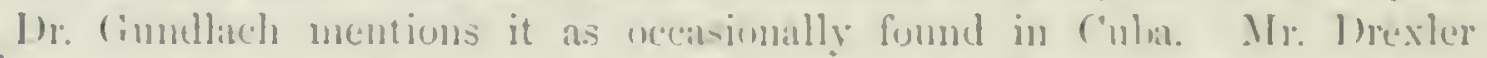

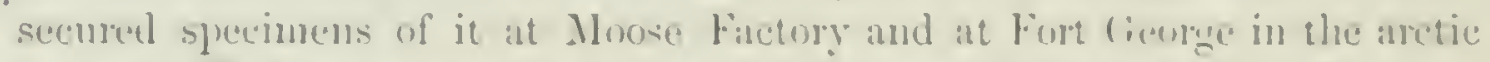

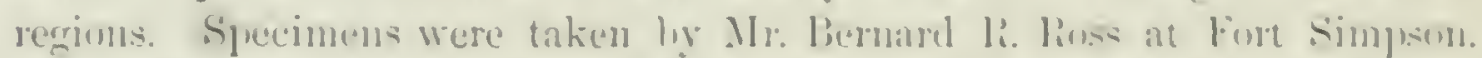
Ir: liobert kemicott net with it on the northern shores of latke llinni-

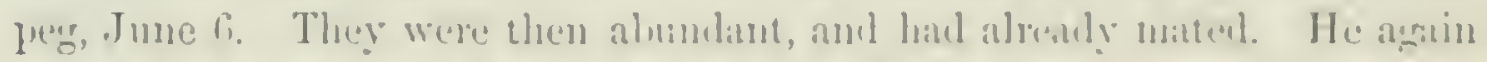
met with them at Fort liesulution, and .17r. Clarke found them at Fort Jian,

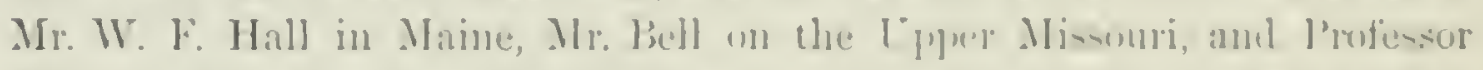

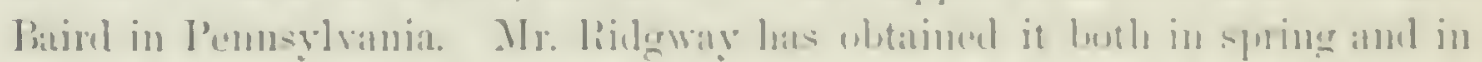

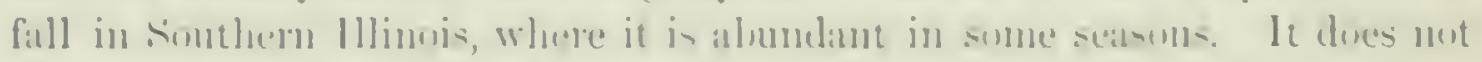

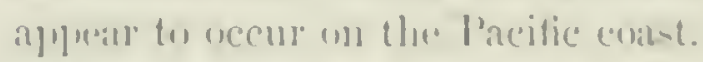

Mr. Jeardman writes that the Penmeste Warher is, in the summer time, quite a tommon livet in st. Stephens and vicinity. Its moter, he athe, re-

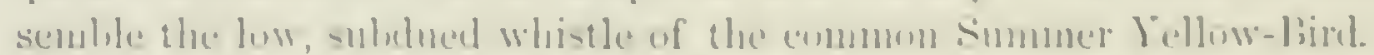

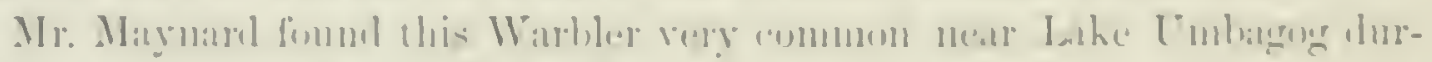

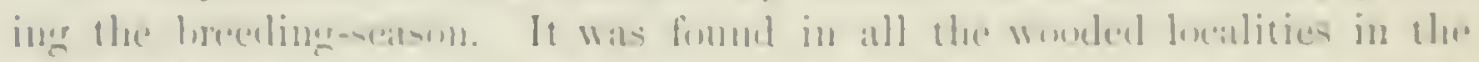

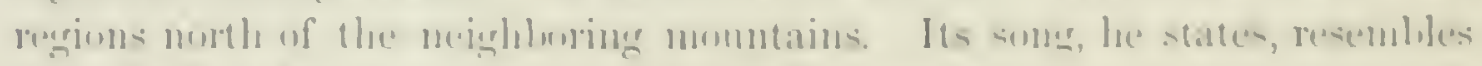

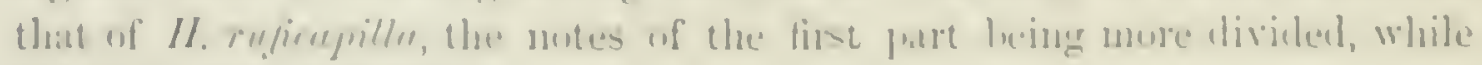
the l.ther prom is shriller.

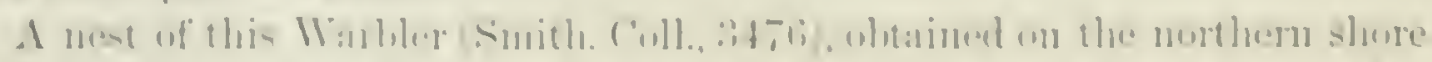

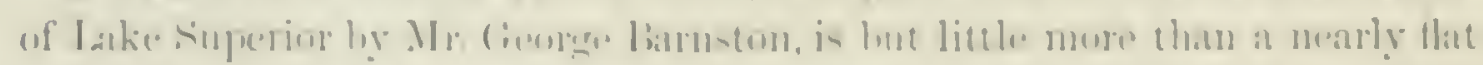

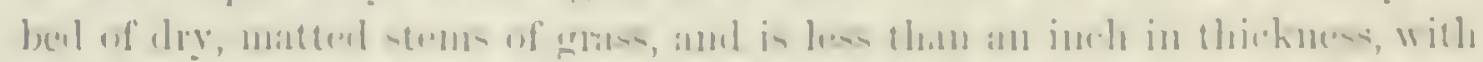

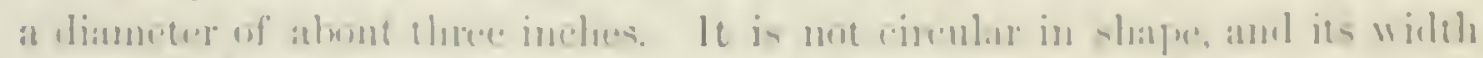

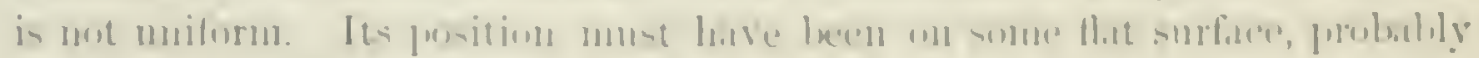

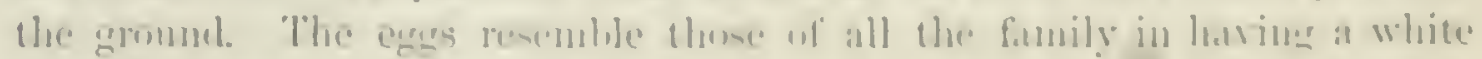

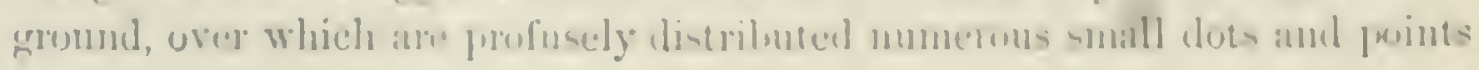


of a reldish-brown, and a few of a purplish-slate. They are of an oblongoval shipe, and measure 68 by .50 of in ineh.

A nest from near Springfield, MLass, obtained by Professor Horsford, the parent bird having been seeured, was built in a low ehmup of bushes, just above the ground. It is well made, woven of fine hempen fibres of vegetables, slender stems of grass, delicate mosses, and other like materials, and very thoronghly lined with hair. It measures two and three fourths inches in diameter and two in height. The carity is two inches wide and one and three fourths deep. The eggrs measure .60 by .50 of an inel, are oblongoval in shape, their ground-color a pearly white, marked in a corona, about the larger end, with brown and purplish-brown spots.

\section{Gexes PARULA, Borip.}

Chloris, BoIf, Isis, 1526, 972 (not of Iloehring, 1752). (Type, Parus americanus.) Sylricola, Swassox, Zoöl. Jomm. 111, July, 18:7, 169. (Not of Humplrey, Mus. Calonnianum, 1797, 60 ; geums of land mollusks.) (Sane type.)

Parnla, Boxar. Geog. \& Comp. Iist, 1838. (Same type.)

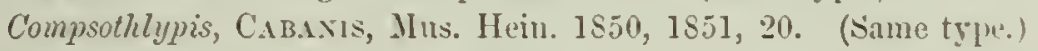

Gex. Crur. In the species of this genus the bill is conical and acute; the eulmen rery gently curred from the base; the commissure slightly coneare. The motch when visible is further from the tip than in Dendroicu, but usually is cither obsolete or entirely wanting. Bristles weak. The tarsi are longer than the midlle toe. The tail is nearly even, and considerahly shorter than the wing. Color, bue above, with a triangula pateh of green on the back; anterior lower parts yellow.

Two species - one with three rarieties - of this genus, as lately restricted, are known in America, only one, however, las as yet been detected within the limits of the United States. They may be distinguished as follows:-

P. americana. Eyelids white. Yellow beneath restricted to anterior half.

Two white bands on wing; a dusky collar across the jugulum. Hab. East-

ern Province of United States, south to Guatemala; Bahamas; Cuba ;

Jamaica; St. Croix; St. Thomas.

P. pitiayumi. Eyelids lusky. Fellow beneatl, extending back along sides to the crissum.

$$
\text { Two white bands on wing. }
$$

Abore plumbeous-blue; lores and erelids deep black. Abdomen wholly yellow. Wing, 2.20; tail, 1.75. Hub. Sontls Ameriea from Bogota to Paraguay . . . . . . . . . rar.pitiayumi.' Abore ashy-blue; lores and eyelids scarcely darker. Abdomen wholly white. Wing, 2.35; tail, 2.05. Hab. Tres Marias Islands, Mestem Mexico

var. insularis.2

1 Sylvia pitiaynmi, Tierlu. Nonr. Dict. II, 1816, 276. Parula nit. Sclat. Catal. 26, no. 165. - Batrd, Rev. Am. Birds, I, 1S65, 170.

2 Purrle insularis, Lawr. Ann. N. Y. Lyc. X, Feb. 1871. 


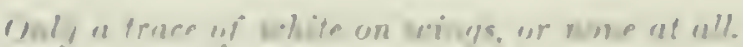

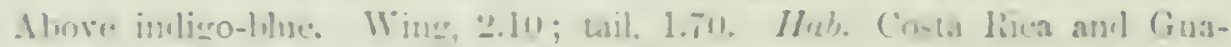

L.m:1n

rar. inornata!

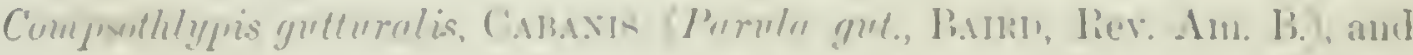

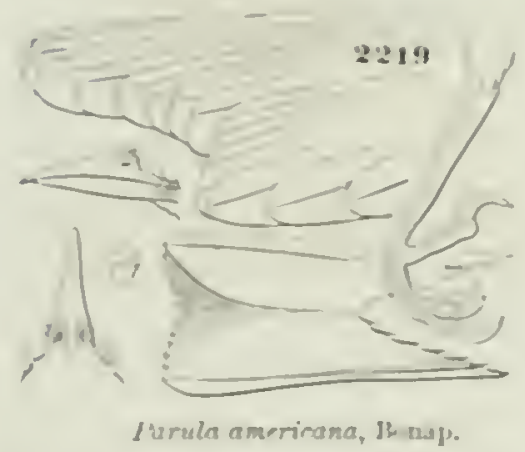

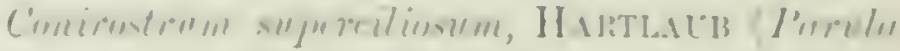

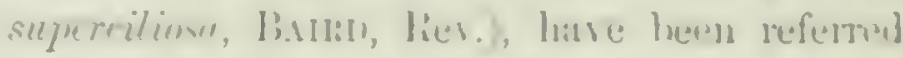
ly later systematists to this :-1mus: lnt they

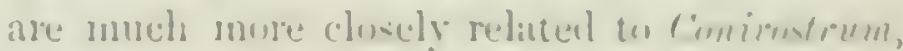

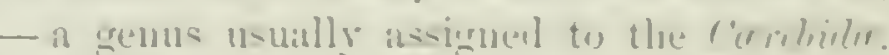
The "I?" gullumlis is confined un Custa Ficia;

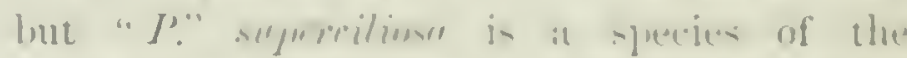
table-linds of Mexico, and likely w be detected in Arizuna or New Mexico. The char"1hters of this species are as follows:-

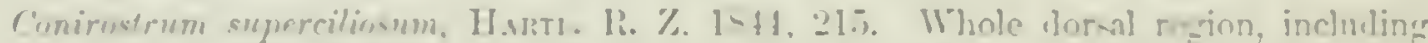

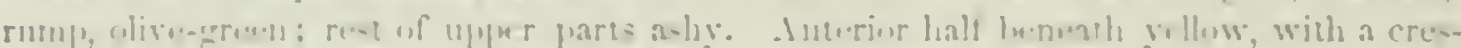

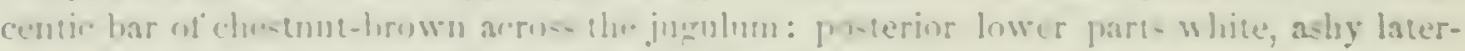

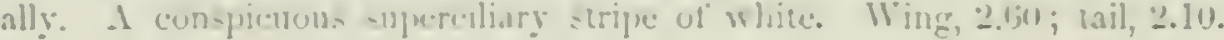

\section{Parula americana, Burip}

\section{BLUE YELLOW-BACRED WARBLER.}

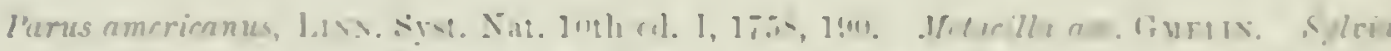

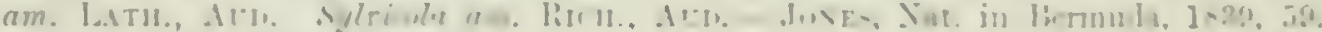

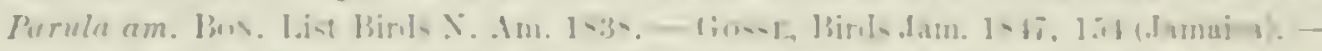

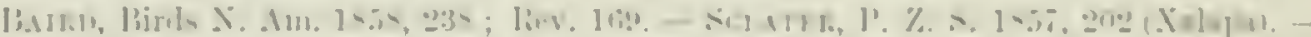

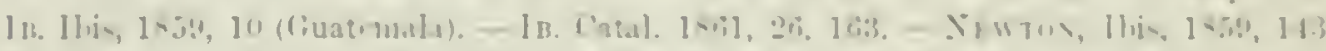

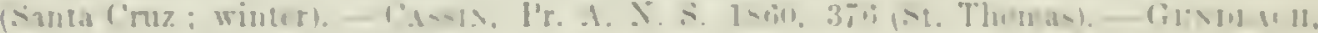

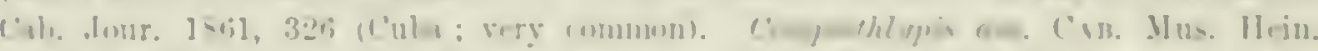

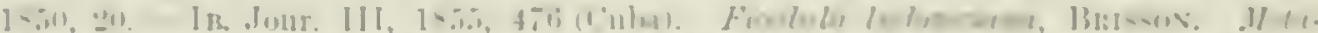

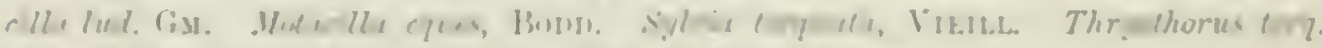

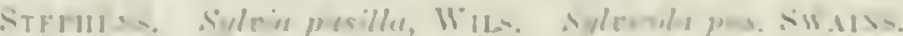

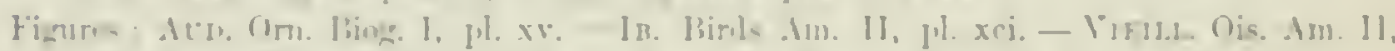

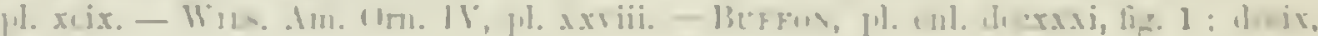
lig. 1.

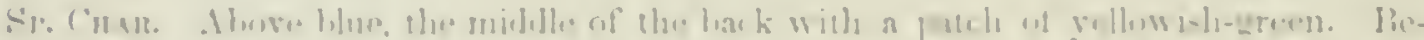

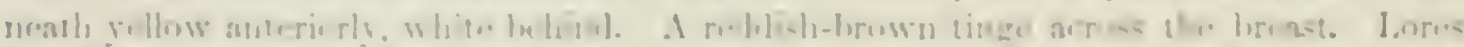

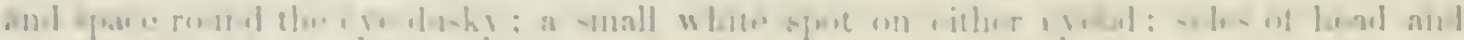

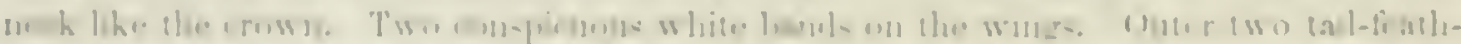

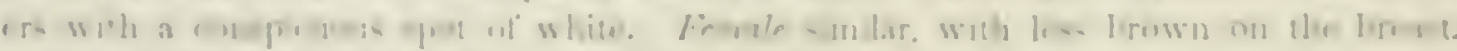

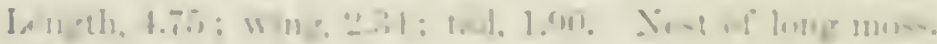

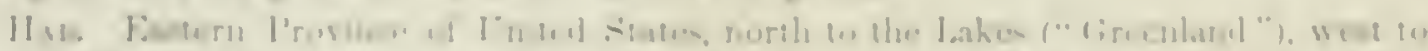

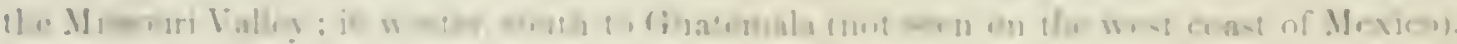

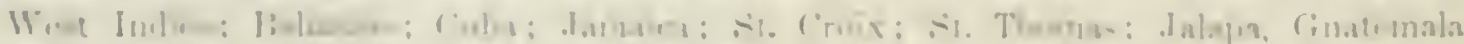

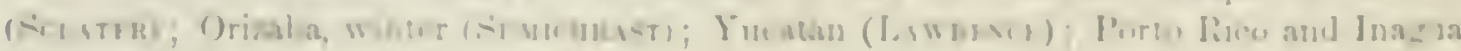
( 
Antumnal males are browner on the chin, yellower on the throat and jugulum. Head tinged with greenish; secondaries edgred with greenish-yellow. Autumnal females are light greenish-olive above, dirty-white beneath.

In very brightly colored spring males, there is frequently (as in 58,335 , Philadelphia) a well-clefined, broad blackish band across the jugulum, anterior to an equally distinct and rather broader one across the breast, of a brown tint, spotted with black, while the sides are much spotted with chestunt-brown; the blue

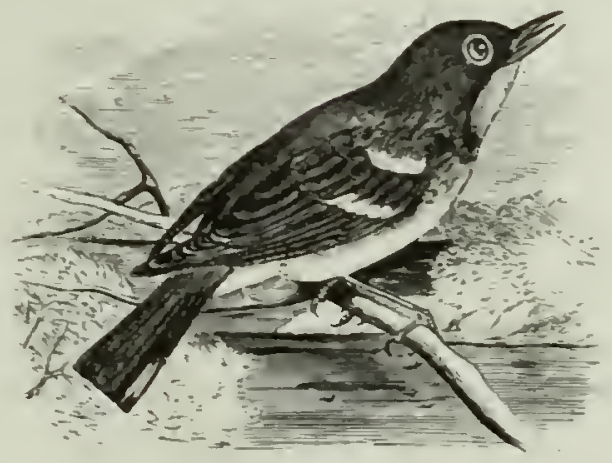

Parula americana. above is very pure, and the green patch on the back very sharply defined.

HaBIts. The Blue Yellow-Back is one of our most interesting and attractive Warblers. Nowhere very abundant, it his a well-marked and restricted area within which it is sparingly distributed. It is found from the Mississippi Valley to the Atlantic, and from Canada southward. In its winter migrations it risits the. West Indies, the Bahamas, and Central and South America. Halifax on the east, and Platte River on the west, appear to be the northern limit of its distribution. Dr. Woodhouse met with it in the Indian Territory during the breeding-season. Mr. Alfred Newton found this species, apparently only a winter visitant, in the island of St. Croix. Most of the birds left about the middle of March, though a few remained until early in May.

A single specimen of this species was taken at South Greenland in 1857.

This Warbler has been found breeding as far to the sonth as Tuckertown, X. J., by Mr. W. S. Wood; and at Cape May, in the same State, by Mr. John Krider. At Washington, I)r. Cones found it only a spring and autmmn risitant, exceedingly abundant from April $2 \tilde{j}$ to May 15. Possibly a few remained to breed, as he met with them in the first week of August. In the fall they were again abundant from August 25 to the second week in October. He found them inbabiting exchsively high open woods, and usually seen in the tops of the trees, or at the extremities of the branches, in the tufts of leares and blossoms.

Even where most common it is not an abundant species, and is to be found only in certain localities, somewhat open and swampy thickets, usually not of great extent, and prefers those well covered with the long gray lichens known as Spanish moss. In such localities only, so far as I know, do they breed.

This Warbler has also been ascertained to breed in Sonthern Inlinois, where Mr. Ridgway found it in July, engaged in feeding fully tledged young birds. It is there most common in spring and fall. 
A true Warlele in most of its attrilutes, this bird has many of the habits of

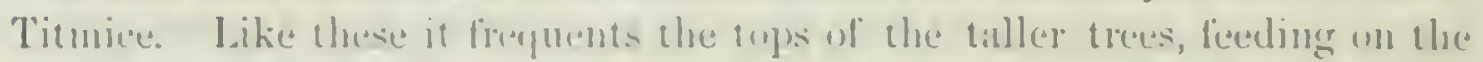

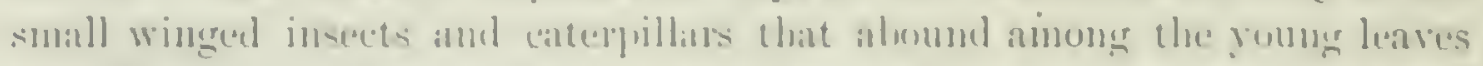

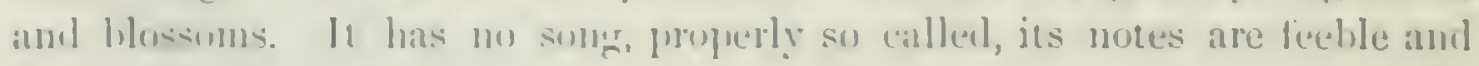
fow, and cam be heatril only at short distance.

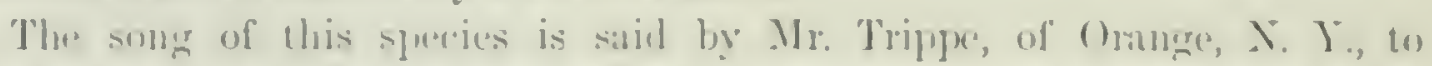

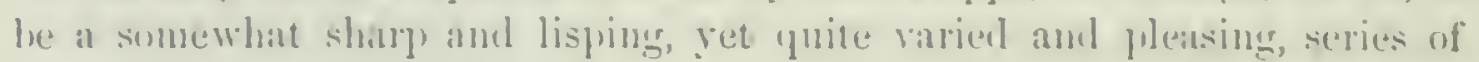
mites.

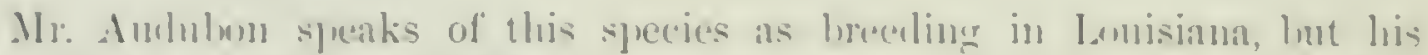

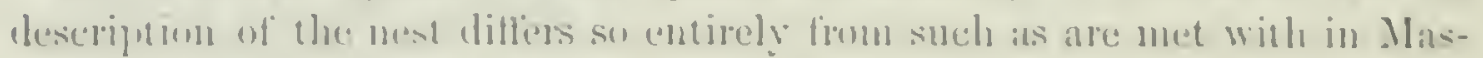

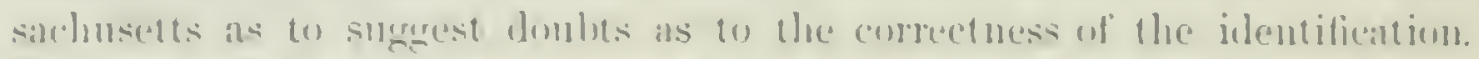
He describes them as Hitting orer diump places, the celges of promb and streams, and pursuing their juey with great activity. They resont to the. wools as semu ats the folinge appens on the finest trees, and gleam anmmg the leates fur the smatler winged inserts.

The mests of this Wabler, so lity as laks fallen muler my olservation, have always been nade of long gary lichens still attalled to the treses on which

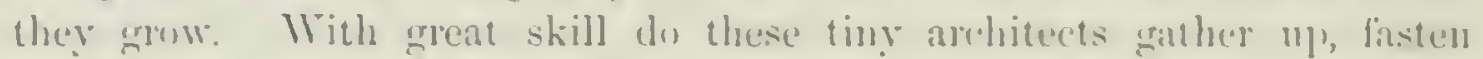
togethes, and interwetre, one with the other, the hanging ends and longer branches. By an elaburate intertwining of these long tihres they form the principal fart, sometimes the whole, of their nests. These structures are at once simple, beantitul, ingronions, and skilfully wrought. W'hen first made, they are somewhat rule and mutinished, but its their founily are gatheroul,

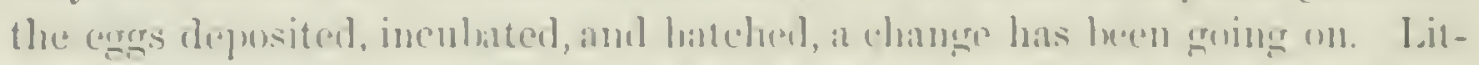

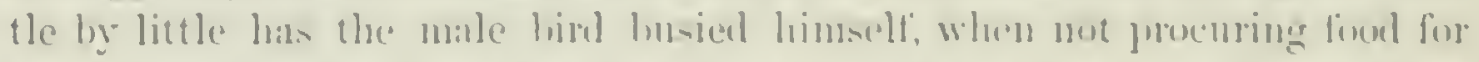

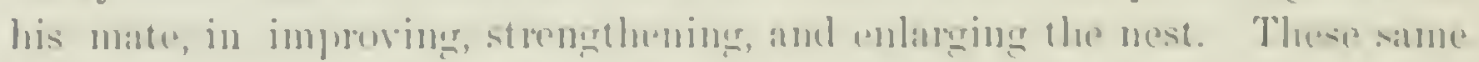
acte of improvement upon llace original nents are noticed with HummingBirls, Vireos, mel a few other livds.

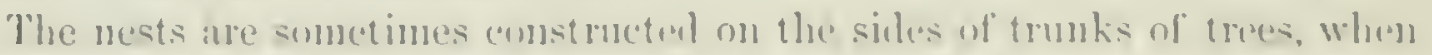

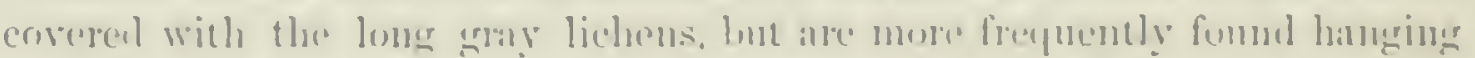

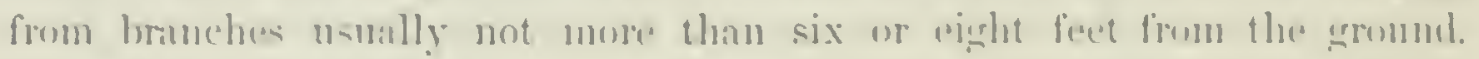

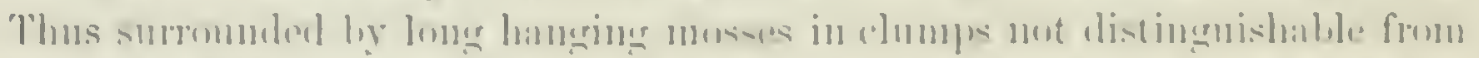

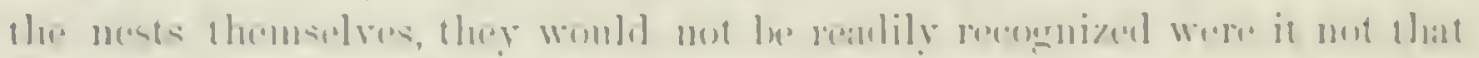

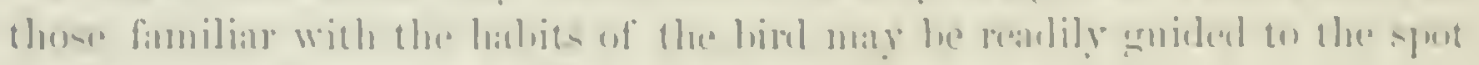

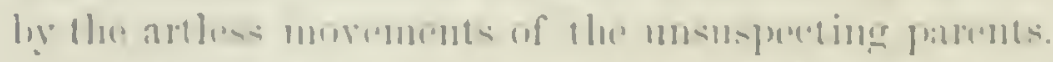

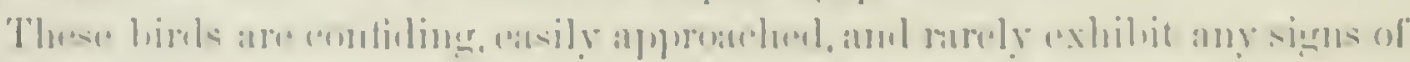

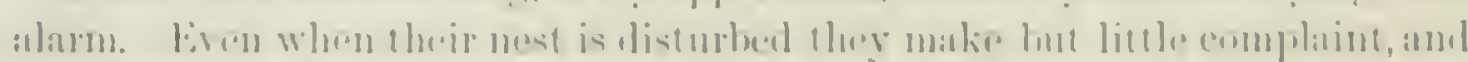

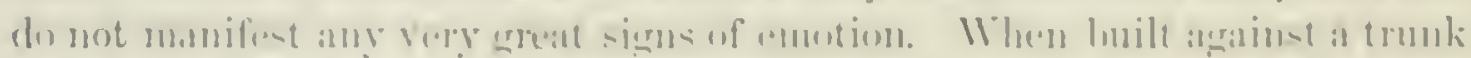

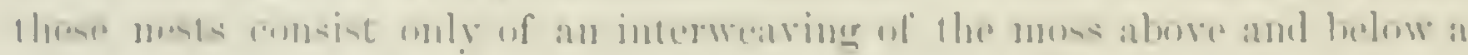

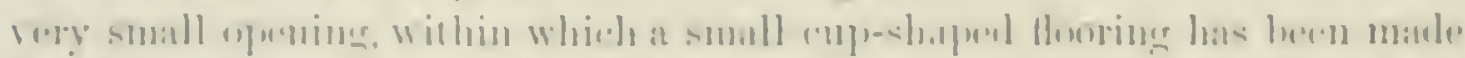

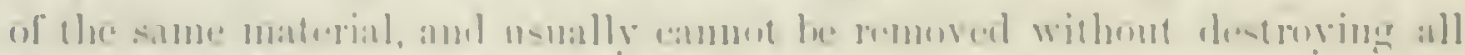

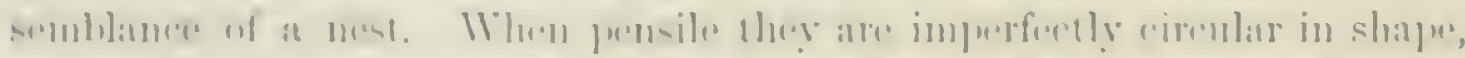

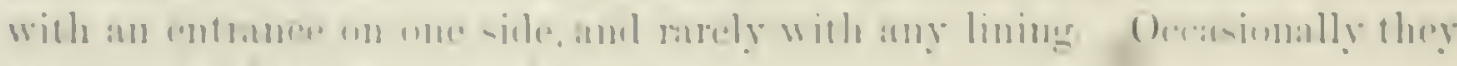

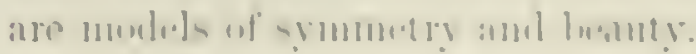


The egas, four or fire in number, have a clear white ground, and are sparingly spotted with makings of rechlish-brown, slate, jurple, aud lilac. In some the first predominate, in others the list three shades are more abundant, and usually form a confluent ring around the larger end. They neasure from .62 to .65 of an inch in length, and from .49 to .50 in breadtl.

\title{
SECTIOS SYLVICOLEAE.
}

This section has been already characterized as having a distinctly notehed bill, well provided with bristles. Of the two genera one, Perissoglossu, has the bill slender, acute, something like Helminthophuga, and with the tongue lengthened and much lacerated at end; the other, Dindroica, with less acute bill and tongue shorter, merely notched at tip, and a little fringed only.

\section{GENCS PERISSOGLOSSA, BAIRD.}

\author{
Perissoglossa, B.in:D, Rer. Am. Birds, 1\&61, 181. (Trpe, Motncilla tigrina, GM.)
}

Gex. Char. Form of Dendroira, but bill slender, acute, with very obsolete notch; the conmisire gently arched or curred from the base: the gonys also straight, or eren slightly concare. Tongne lengtheneul, narrow. deeply bitid (for one third), and deeply lacerated or fringed externalls at the end; the edre along the median portion folded orer on the upper surface, but not adherent.

The curvature of the bill in Periasoglossa tigrina is quite peculiar among the sillo icolide with notched bills. Some Helminthophagas (without notch) approximate this

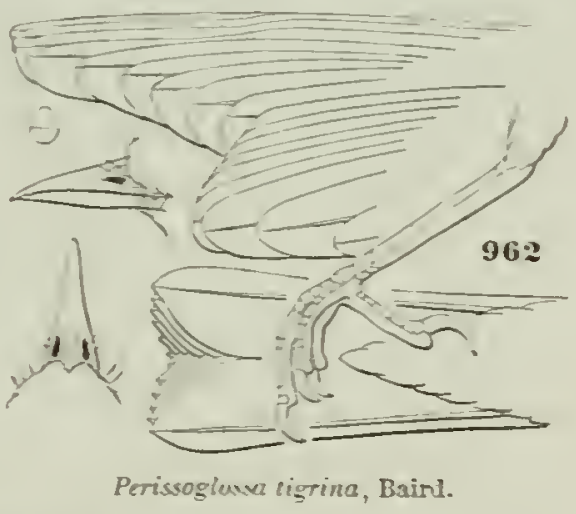
character, though in none, excepting $H$. bnchmoni, is it in equal amount, all the others having the gonys very slightly convex, instead of straight, or even slightly concave.

It is most probable that the Helinaia carbonata of Audubon belongs here, as it appears very closely allied to the type of this genus. The two species may be distinguished as follows: -

Commox Characters. Male. Top of head black. A bore olire becoming rellowish on rump. Head. neck, and lower parts bright sellow, becoming whitish posteriorls. Dorsal feathers with black centres; breast and sides streaked with black. A black streak through the ere.

P. tigrina. Large white patehes on inner webs of tail-feathers.

Sides of head and midule of throat tinged with chestnut. One large white patch on wing. corering both rows of corerts. Outer web of lateral tail-feather blackish. 


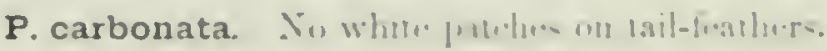

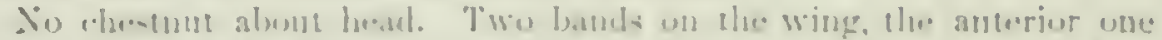

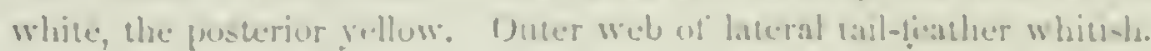

\section{Perissoglossa tigrina, lisıı. CAPE MAY WARBLER}

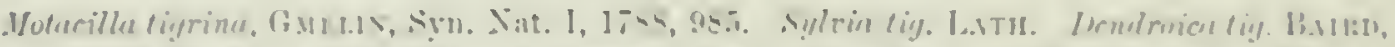

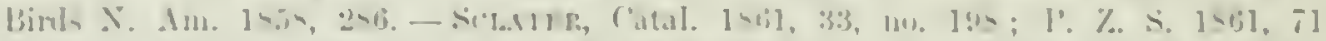

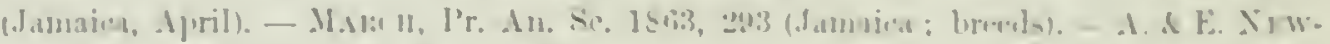

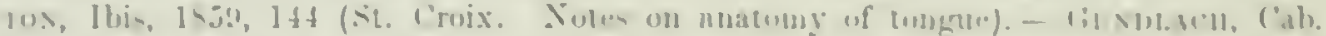

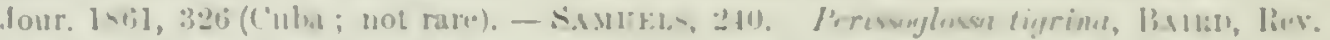

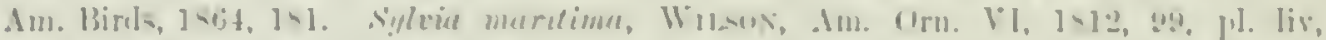

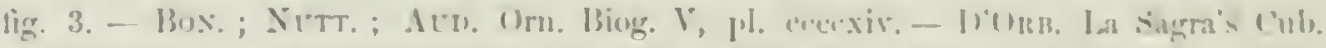

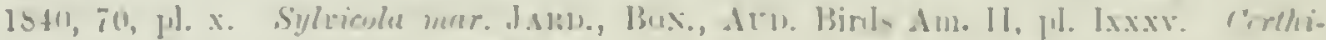

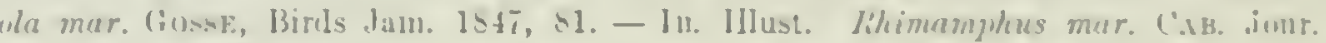
III, $18 j j$, tit (1'uha.)

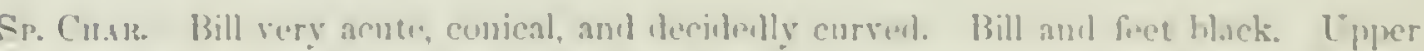

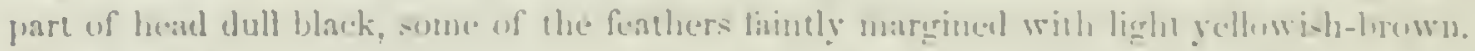

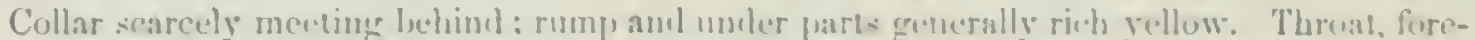

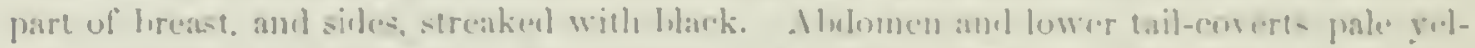

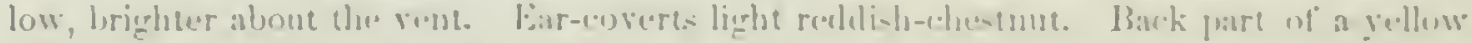

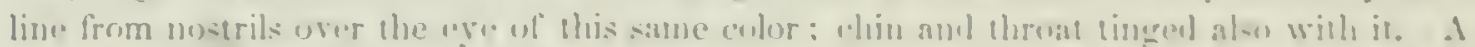

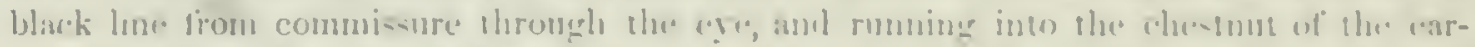

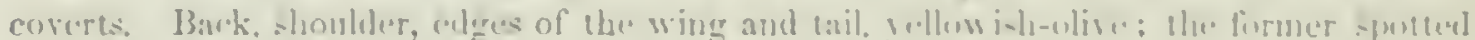

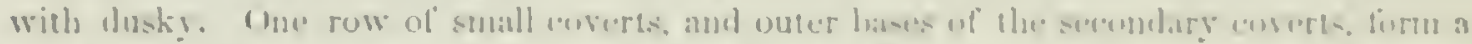

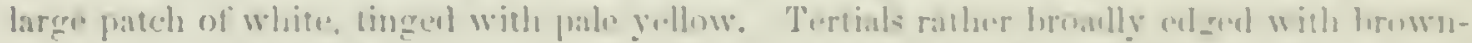

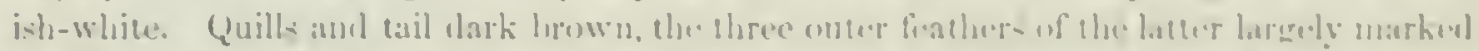

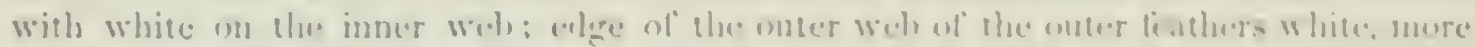

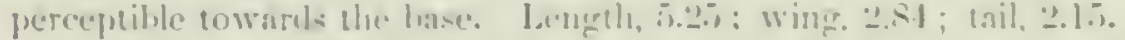

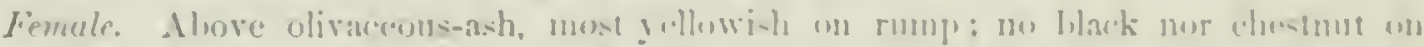

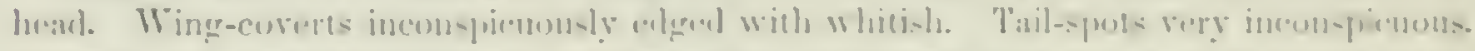

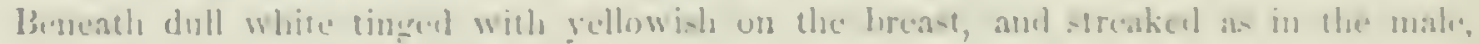

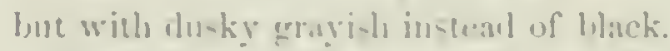

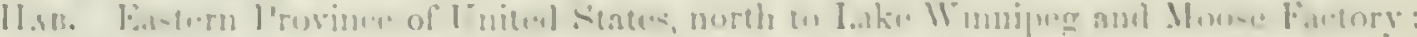

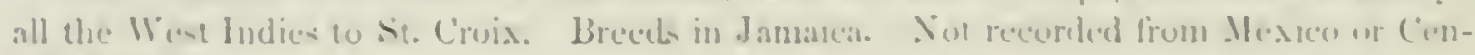
tral Anericis.

The rhestmut alumt the heal in adult males varies in amount with the

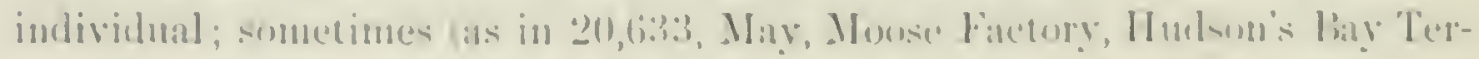

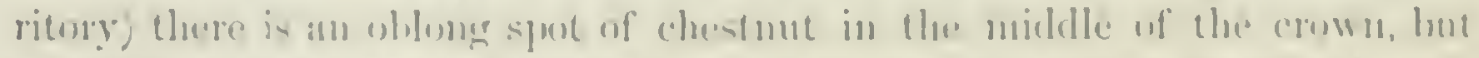

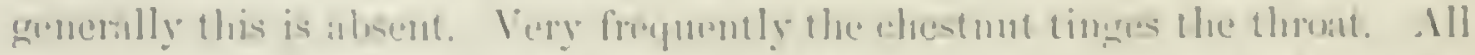

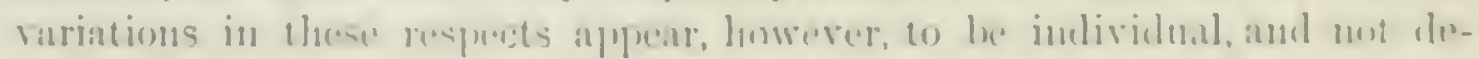

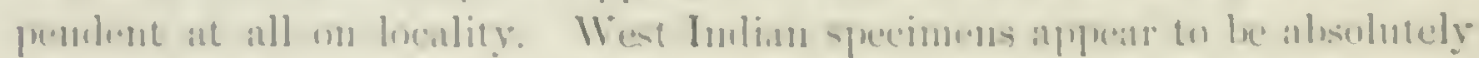
identical with thone from Sorth Amserivat.

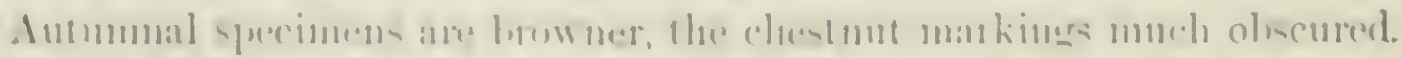

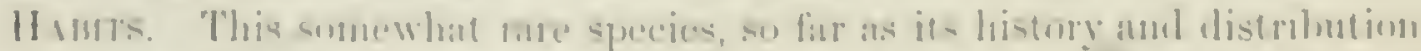

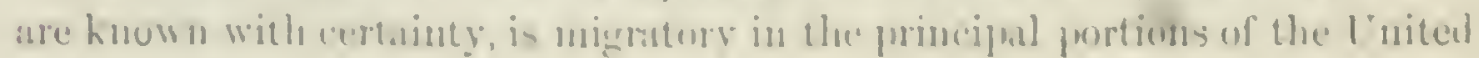


States, in the spring and fall passing to the north of the 42d parallel to breed. The first speeinen was obtained near the extreme southern point of New Jersey by George Ord, in 1811, and described and figured by Wilson. From this accidental circumstanee it derives its inappropriate name of Cape May Warbler. Wilson never met with a second specimen, and Mr. Nuttall was wholly macquainted with it. Mr. Andubon also never met with a specimen in all his wanderings, and was able to add nothing to its history. Those figured by him rere procured by Mr. Edward Harris, near Philadelphia, through which region these birds appear to pass rapidly in their northern migrations.

Mr. J. A. Allen obtained a specinen near Springfield, Mass., May 15, 1S63, and specimens have also been procured at East Windsor Hill, Conn., by Dr. Wrood. It was not met with in Western Maine by Mr. Terrill, but in Eastern Maine and in New Brunswick Mr. Boardman has found it a not uncommon summer risitant, though of irregular frequency. He has no doubt that they remain there to breel. They reach Calais as early as the second week in May, or as early as their appearance usually in the neighborlood of Pliiladelphia has been noticed. Mr. Kumlien has also obtained specimens from year to year, about the middle of May, in Southern Irisconsin, where they do not remain to breed, and Mr. Ridgway las taken them in the beginning of May in Southern Illinois.

It is also by no means uncommon in Cuba; was met by the Newtons as a migrant in St. Croix, and is not only one of the bircls of Jamaica, but is resident and breeds in the highlands of that island. It is not known to occur in Central America, Mexico, or rrest of the Mississippi River. Specimens were procured at Moose Factory about May 28.

Its nests and eggs have not been, witl certainty, obtained in the United States, thongh an egg obtained in Coventry, T't., in 1836, and attributed at the time to this bird, closely resembles its iclentified egrgs from Jamaica. Specimens of the bird, as well as its nests and eggs, have also been received from St. Domingo by Mr. 'Turnbull of Philadelphia. In the summer of 1871 a nest of this species was found by Mr. H. B. Bailey on the Richardson Lakes, in the extreme northwestern part of Maine. The nest was in a low spruce-tree, less than five feet from the ground, and when found contained only a single egg. Unfortunately it was left mintl more eggs were deposited, and in the mean while the tree was cut, and the nest and eggs were destroyed.

Mr. Wr. T. March of Jamaica, in his notes on the hirds of that island, states that this species may always be found, in its various changes of plumage, about the mangrove swamps and river-banks. During the summer months it was conmon about Healthshire and Great Salt Pond, and at other times very generally distributed orer the island. He also met with several specimens of its nests and eggs, but their position was not stated. The nests had apparently been taken from a bush or tree, were three and one fourth 
incles in dianeter ly 2 wo and whe half in height, witl cavities unusually

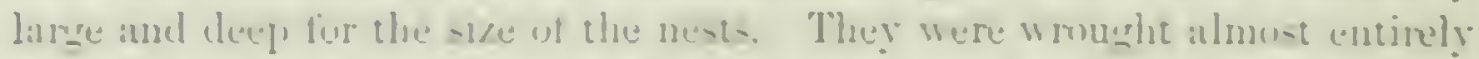
of long strips of thin tlesible burk, stongly and timily interworen. The

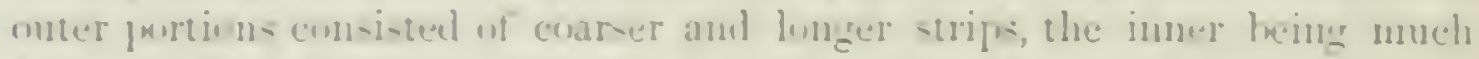
tiner and more delicate. With the outer portions were alou interwosen hits of moses, lichen-, and the wher lark of deciduons trees. The entire fabrice was a remarkinhle one.

The erges measure 70 b. . . . of an inch, lave a pinki-h-white ground, boteleel with purple and brown of batums slanles and tints. They are disprosed elitefly about the lavger end, usually in a ring. The enges are ural in shaje and slightly printed at one end.

\section{Perissoglossa carbonata, li.min.}

\section{CARBONATED WARBLER.}

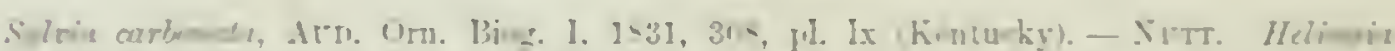

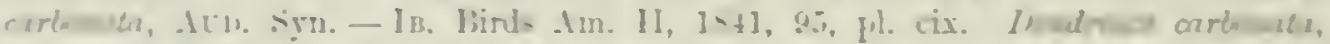

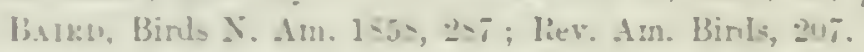

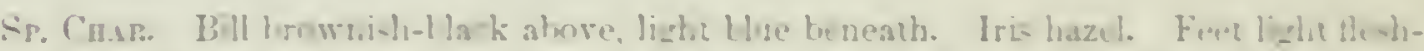

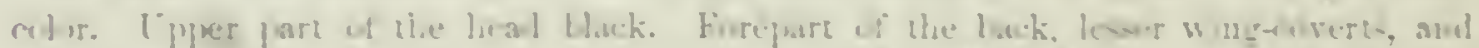

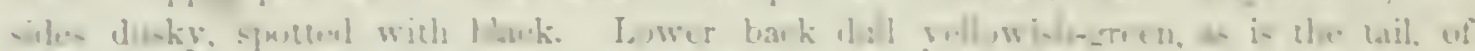

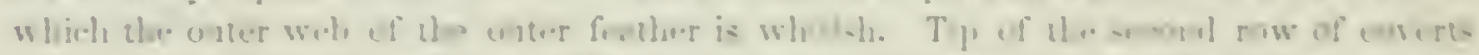

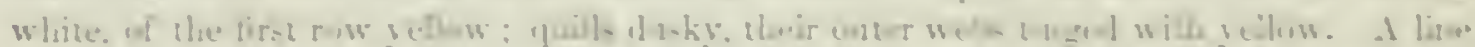

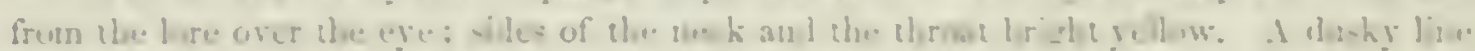

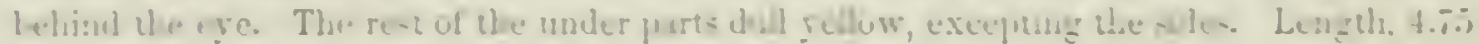

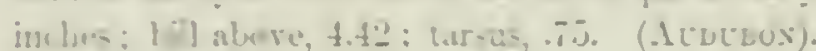

H.s. Kencuks.

This - grecies continues to be known only by the description and figure of dimlulnis.

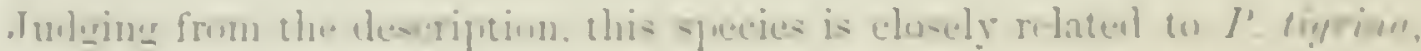

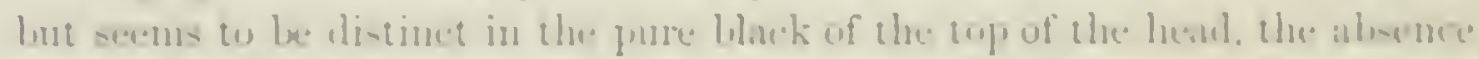

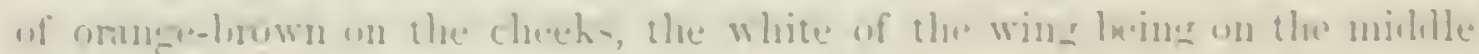
corerts instead of the ereater, and the tail-feathers lecine rellowi-h-ereen:

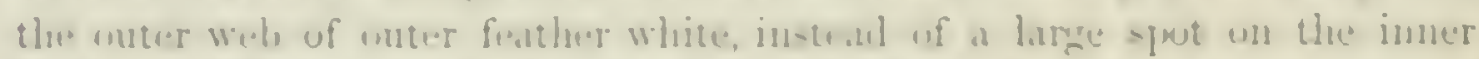

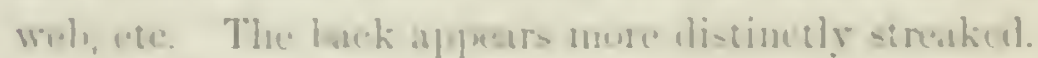

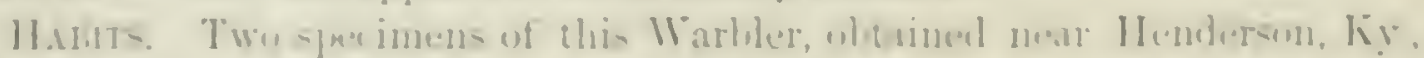

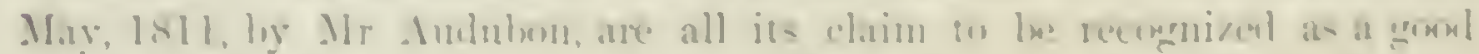

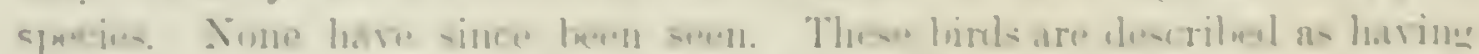

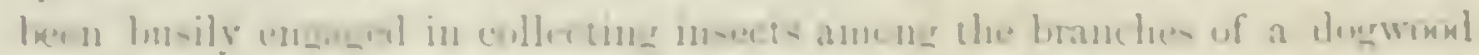
tree Their motions wom like thoee of other Warbors. This is all we an

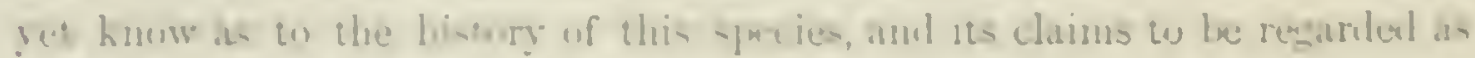
a gover and dotinet speces are insilvint in donbt. 


\section{GENES DENDROICA, GRAY}

Syleicoln, Grur, Genera Birds, 2d ed. 1541, 32. (Not of Humphreys nor Swainson.)

Dendroicu, Gistr, Genera Birds, Appendix, 1842, 5 .

Rhimamphus, Hantlavis, Rer. Zool. 1845, 342. (Not of Ratinesque, Am. Mouthly Mag. 1S1s, and Jour. de P'hyss. 1S19.)

Gex. Cunr. Bill conical, attenuated, depressed at the base, where it is, howerer, scarcely broader than high, compressed from the micldle. Cuhmen straight for the basal half, then rather rapiclly curring. the lower edge of upper mandible also concave. Gonys slightly conrex and ascendling. A distinct notch near the end of the bill. Bristles, though short, generally quite distinct at the base of the bill. Tarsi long; decidedly longer than middle toe, which is longer than the linder one: the elaws rather small and much curved; the hind claw nearly as long as its digit. The wings long and pointed; the second quill

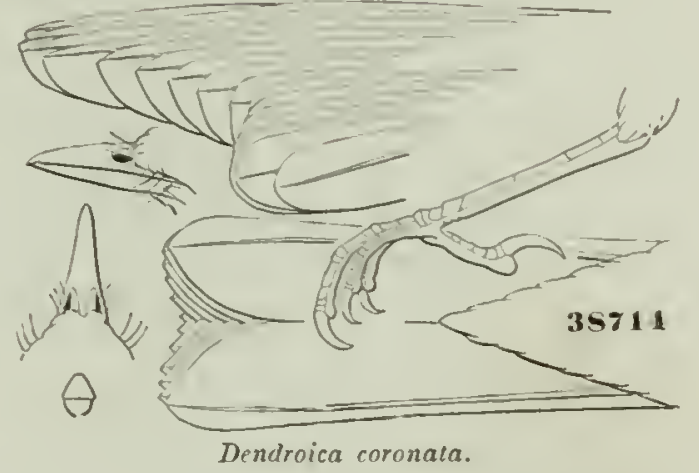
usually a very little longer than the first. The tail slightly romded and emarginate.

Colors. Tail always with a white or yellow spot; its ground-color never clear olivegreen. In $D$. astiva edged internally with yellow.

Eggs usually with a white or a bluish-white gromd, marked with purplish-brown and obsenre lilac; in some, mingled with rarying shades of siemna-brown. Nest, so far as known, in bushes and trees, except D. palmarum, which is on the ground.

The genus Dentroicu is one of the most extensive as to species of any in North America, and scarcely admits of any subdivision. There is a little rariation in the bill, wings, etc., the chief peculiarities being in $D$. castanea and pennsylvanica, in which the bill is broader, and more depressed, with longer bristles; in $D$. striata, where the bill is narrow with searcely any bristles; and in D. palmarum and lirtlandi, where the wings are very short, scarcely longer than the tail. D. palmarum has

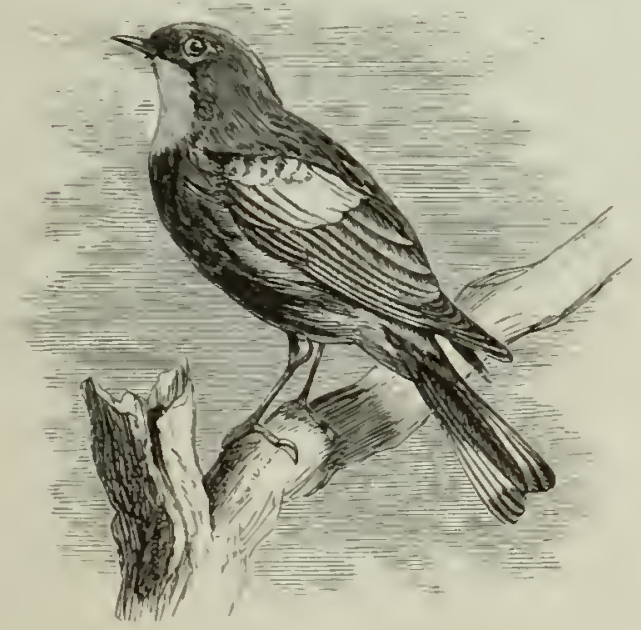

Dindrouca audirboni. the tarsus unusually long. The colors in all are strongly marked, and the species are among the most beautiful of all belonging to our fauna, and are the most conspicuous for their numbers and in their migrations.

The difference in manners between certain members of this genus is remarkable; thus, the D. palmamem is very terrestrial in its habits, walking upon the ground with the ease and grace of a Titlark (Anthus), and, like these birds, it las a wagging motion of the tail. On the other hand, the Dcndroiea dominica is as much a 


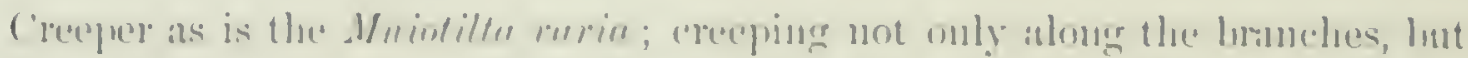

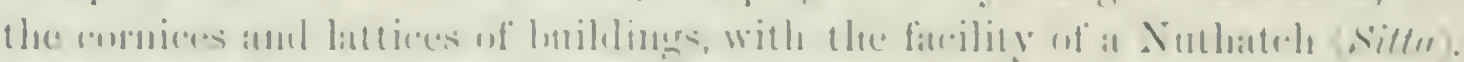

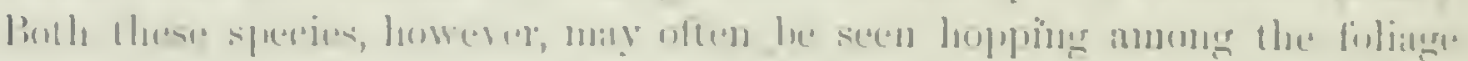

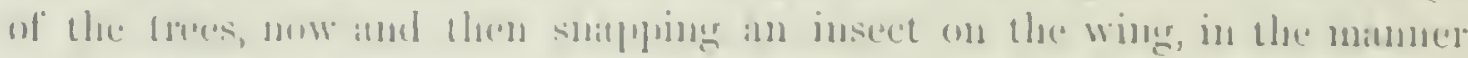
of other's of the funily.

\section{Species and Varieties.}

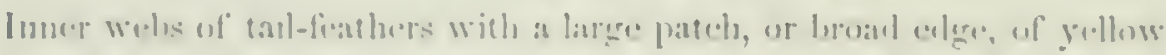

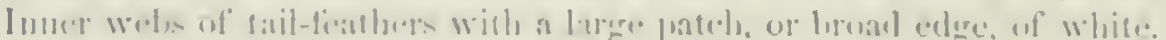

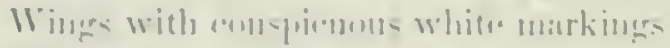

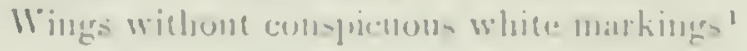

Finoter 1

(immol" li. (iliutor c

\section{Group A. - rivdelen Wintbles.}

limmp and reri-smu withum rulum: makkings

\section{Sirirs 1.}

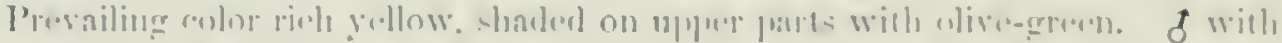

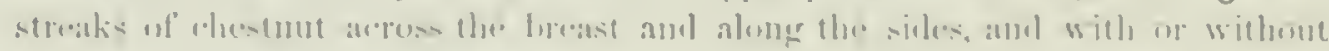

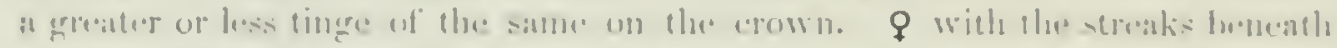

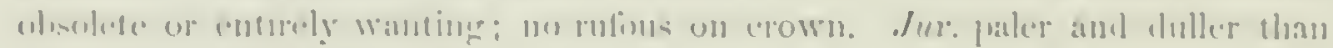

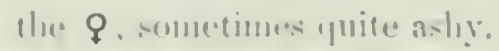

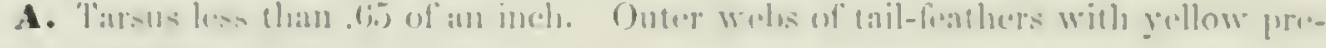
dlominatine.

1. D. xativa. Crown grompally pure yollow, sometimm with only :

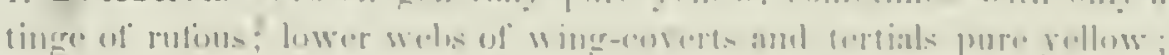

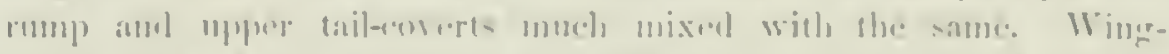

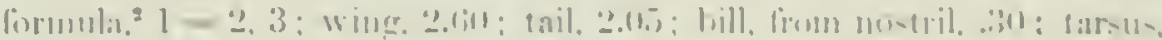

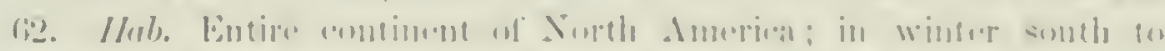

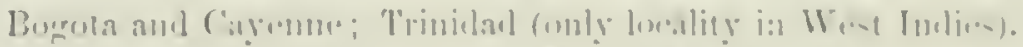

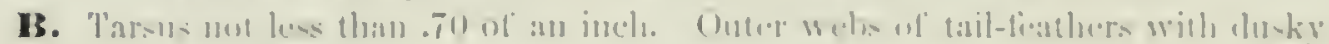
|remlamilualinge.

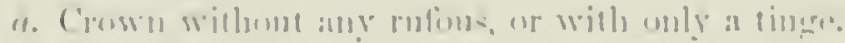

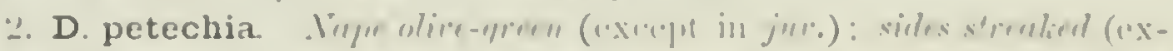

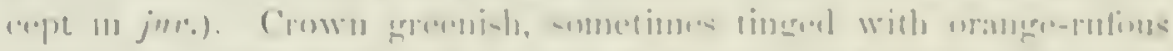

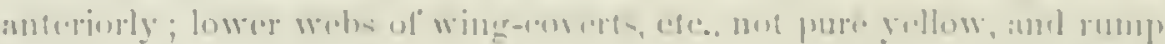
and

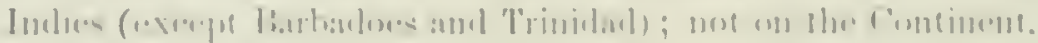

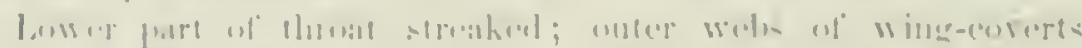

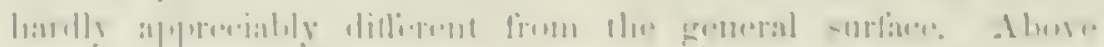

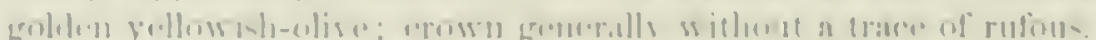

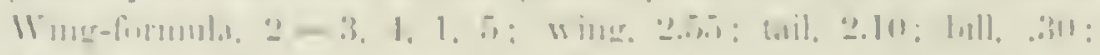

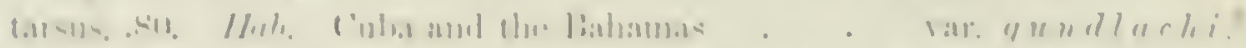

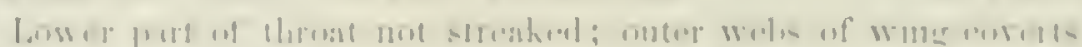

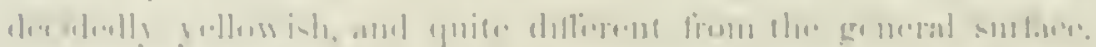

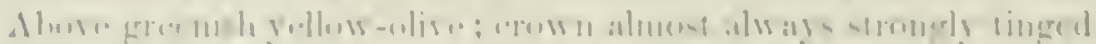

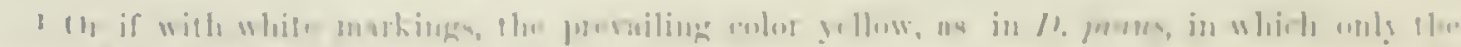

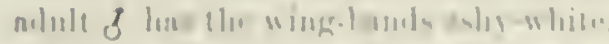

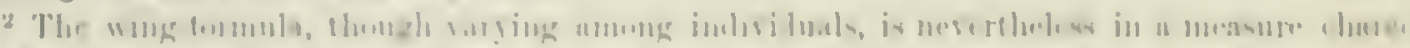

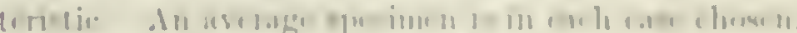

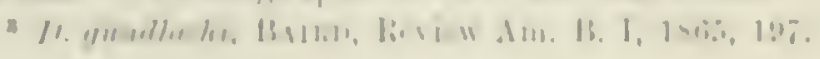


with rufous. Wing-formula, $4,3,2.5,1,6$; wing, 2.-7): tail. 2.25; bill, .3.5; tarsus, .79. Mul. Jamaica and Hayti? var. petechiu.' c. Whole throat sometimes streaked; back also sometimes with streaks of dark castancous; green above lighter than in var. petechin, the rump sometimes tinged with yellow. Wing-formula, 2,3 , and 4 equal, $\bar{J}=1$; wing, 2.50 ; tail, 2.00 ; bill, .3t: tarsus, .is. Hals. Porto Rico, St. Thomas, st. Croix, and St. Bartholomew.

virr. ricupilla.*

3. D. aureola. ${ }^{3}$ Tupe alucays ashy : sides nerer streatied. Abchomen, anal region. and axillars nearly white: foreheal and crown strongly tinged with rufons: nape dark asly. Wing-formula. 2,3 , and 4 equal, $5,1=6$; wing, 2.5.5; tail, 2.00; bill, .32; tarsus, . 7j. Mab. Galapagus Islands.

b. Crown with only at sharply defned orate patch of dark purplish-rufous.

4. D. capitalis." I broal superciliary stripe of pure yellow: wingformula, $3=4,2.1=5$ : wing, 2.30 : tail, 2.00) ; bill, .30); tarsus, . 0 . ( $q$ distinguishable from that of the rarietics of petechice by the distinetly yellow upper erelie, and considerably shorter tarsus.) Hub. Barbanloes Island, Wrest Indies.

c. Head all romd rufous.

j. D. vieilloti. ( 9 not distinguishable from that of other specie..) Hab. Continental Ifidule America.

Bienst and sides with broarl strealis of rufous; outer webs of wingcocerts and tertinls pure yellou.

Rufous of the throat witlu the posterior outline sharply defined against yellow of jugulum. Wing-formula, 3, 4. 2. 1, 5; wing. 2.75 ; tail. 2..10; bill, .34: tarsus, .7 .5 . Inb. New Granada (Carthagena, ete.) . . . . . . var. vieilloli.5 Rufous of the throat cosering the jugulum and hlending with the streake of the breast. Wing-lormulit, 3. 2. 4, 1, 5; wing. 2.45 ; tail, 2.05 ; bill, .27 ; tarsus, .64. ITab. Isthnuts of Panania.

var. $r$ uigula.6

1 Dendroicn petchia, B.trn, Review, 199. (ifutncilln petechia, 1.1x. 1766.)

A specimen from Port au Prince is -maller. measuring wing, 2.50; tail. 2.10 : lill, .31; tarsus, . 7 f. It is perhaps lighter green alore than Jamaican specimens. These features may only be chatracteristic of the particular individual.

? D. ruficapille, B.1lin, liev. ?口1.

A single specimen from l'orto licu differs in some lespects from the average of a series from the other islands named. The chief ditlerences are, less thickly streaked throat, and distinct shaft-streaks of dark chestnut on the hack. However, one or two specimens of true ruticupillu from sit. Thomas have the nyper part of the throat streaked, and une of them has the streaks on the back. In all probability other specimens from Porto Rico would be more like typical species of this race as seen in the majority of those from st. Thomas and st. Bartholomew.

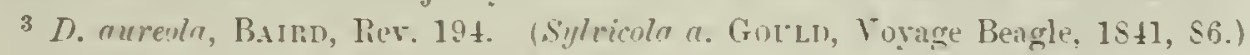

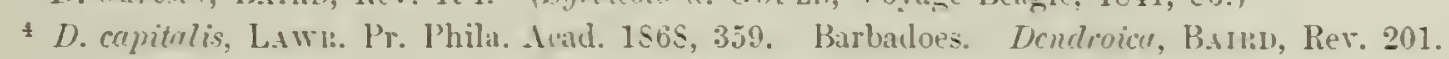

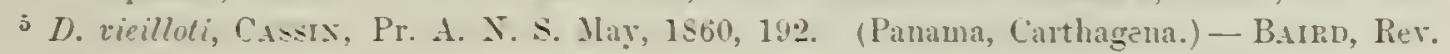
203

${ }^{6}$ D. rufiguln, Batn, Rev. p. 204. The halvitalt as Martininue, W. I., was there queried, but without any reason for so cloing other than that this was the locality of Vieillot's species, with which the type elescribed in Review nearly agreed. Should rieillot's species be really from Martinique, in all jubability the present bird will be found to be different, and therefore not entitled to the name here giren. Provided such is the case, the name "ruficeps," Cabanis, cannot with 


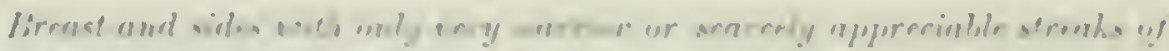

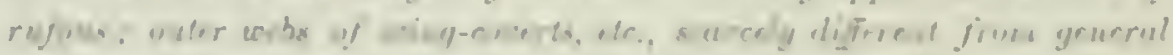
setgere.

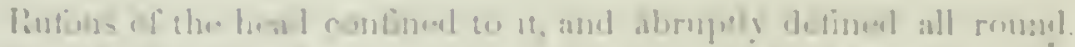

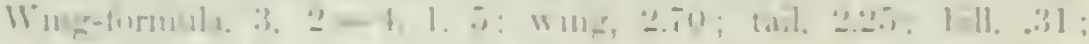

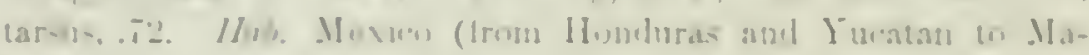
zatlati)

\section{Sirrios 11 .}

Prevalung rolur bellow: rown, rump, and , ri-em with spots of ruturs: a

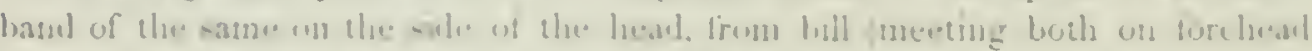

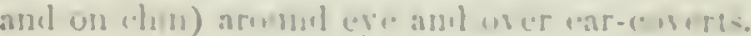

6. D. coa: Hub. Jamaina (1insa).

\section{Group B}

Base of primarse. with wite patuh.

Two wlite haml- an wh

Sirie 1

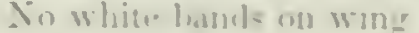

Sirs 11 .

Base of primaries without v]lite polteh.

Pesup vellow.

Crown with a vellow sot

"row a without a bellow - not

Sierin $/ 11$.

siries $111^{\circ}$.

Inimejp u(ot yollow.

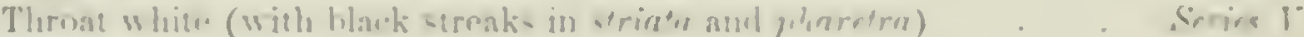

Throut yelluw ur urangere

srie 11

Throat Ilack, or musecl w 1 l] lilise

siejer $1 \%$

\section{Sirin 1}

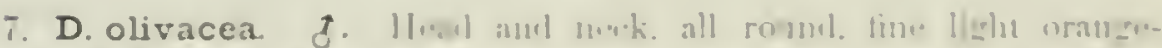

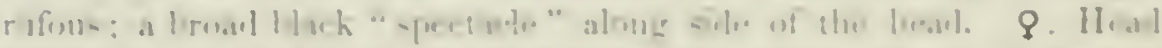

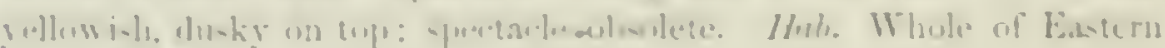
Hexin , Fuaremala.

$$
\text { Siries } 1 / \text {. }
$$

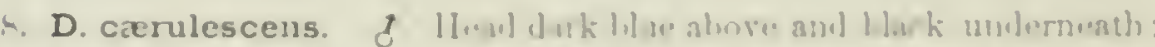

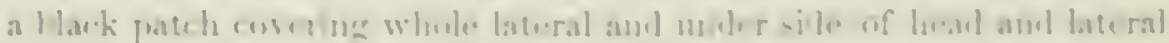

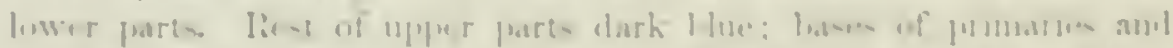

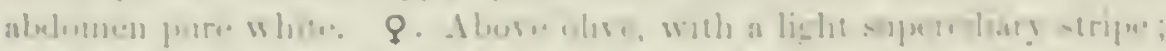

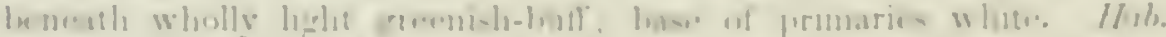

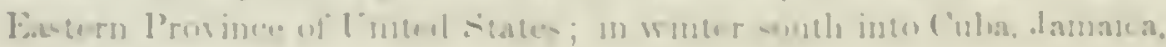
sunl $\leqslant$. D. Duin:os.

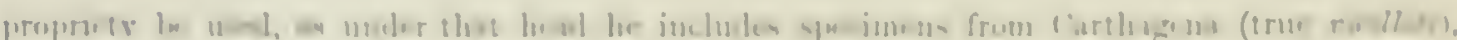

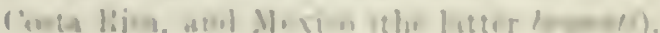

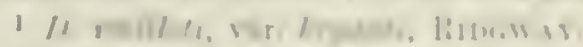

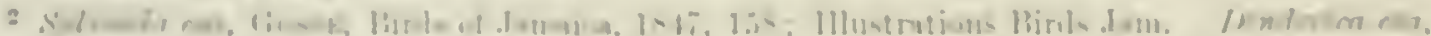

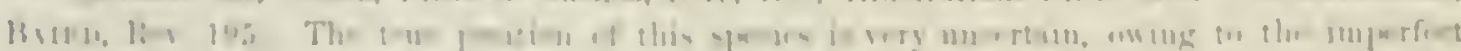

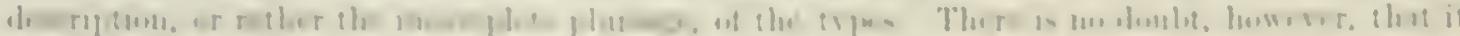

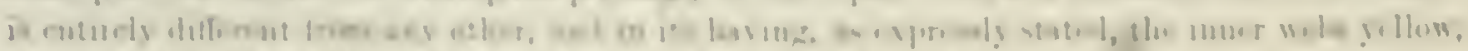

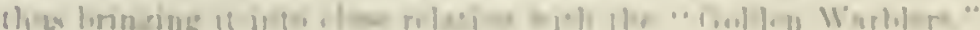


Series III.

9. D. coronata. A yellow pateh on each sicle of the breast; above ashy streaked with black; belly white. \&. Breast more or less bluck; upper parts ash with a bluish tinge. 9 . Breast only streakerl with black; ash of upper part grayish or brownish.

Throat white; a white superciliary streak; two white bands on wing. Ifab. Eistern Provinee of North Anerica, north to Alaska and Greenland; in winter south to Panama and West Indies (resi-

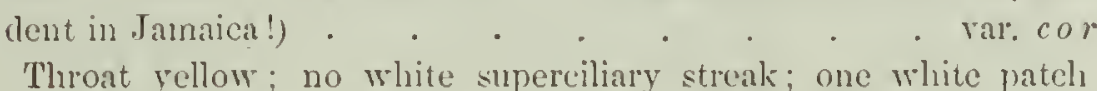
formed by the fusion of the two bands on the wing. IIab. Western Province of North America from Britisl, Columbia, south to Calpe St. Lucas and Jalisco, IVestern MLexico; east to Rocky Mfountains.

\section{Series II:}

var. a ucluboui.

10. D. maculosa. Whole lower parts bright yellow; black streaks across breast and along sides; crown ash; lores, auriculars, and back black. \& seareely different. IJab. Eastern Province of North America, from Fort Simpson to Panama; Cuba and Bahamas.

\section{Scries 1.}

A. Above ashy-blue, or soft bluish-green.

11. D. cærulea. Lower parts pure white or greenish-white; with or without an narrow band across the breast; abore fine ashy-blue, or soft bluish-green; if blue ( $\delta)$, the back and crown streaked with black; if green ( $q$ and juv.), these streaks olssolete. Hab. Eastern Province of United States (rare northward except in Mississippi Valley), south to Bogota in winter; Cuba.

B. Above not ashy-blue nor blush-green, but streaked with black upon an ashy greenish-olive or yellowish gromul, or else bright olive-green.

a. Sides more or less rufous, and withont black or dusky streaks on muder surfaces.

12. D. penusylvanica. §. Crown pure yellow; throat and auriculars pure white; $q$ ad. similar, but erown greenish, and more or less streaked. Jur. Above bright olive-green, nearly glinss-grcen, without strealis except on the back; side of head, and sides, clear ashy, the latter with or without a trace of ehestnut; eyelids and medial lower parts pure white. IIab. Eastern Province of United States, south to Panann; Bahanns.

13. D. castanea. 8. Crown reddish-cliestnut; throat and sides rufous; aurieulars black. $q$ similar, but erown thickly streaked, sometimes withont a trace of rufous; jugulum and throat only tinged with rufous. Juv. Above greenish-olive, streaks obsolete; beneath, including lower tailcoverts, pale greenish-buff, or whitish-buff, and without any trace of streaks on the sides (distinetion from $q$ of $D$. striata) the sicles usually with a tinge of chestnut. Hab. Eastern Province of North America, from Hudson's Bay Territory to New Granada.

b. Sides without any rufous, and with black or dusky streaks.

Medial lower parts not streaked; inner webs of tail-feathers with broad patch of white.

14. D. striata. J. Crown deep black; amieulars and lower parts white; throat with two series of black streaks, converging and forming an angle on the chin. Above ashy streaked with black. $\$$ similar, 


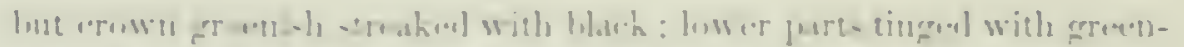

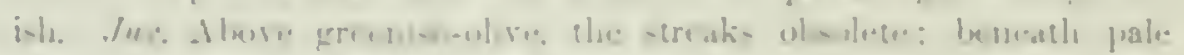

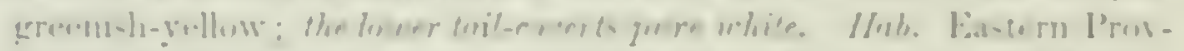

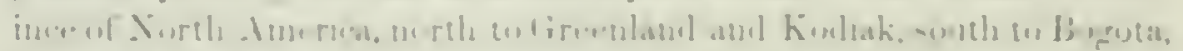
Cuba, and Bahama.

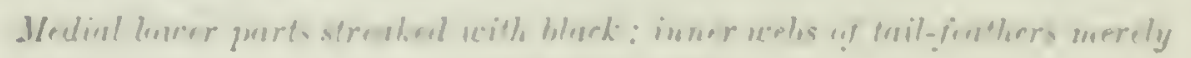
celygel with white.

15. D. pharetra.' d. Ahowe terarinh-w hime, with liroud - treahe of

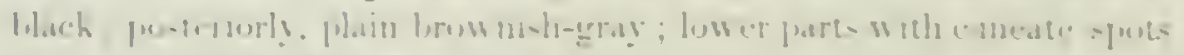
of blatk. Jlol, Jamaica.

Siriv $1 \%$

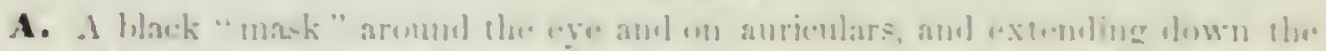

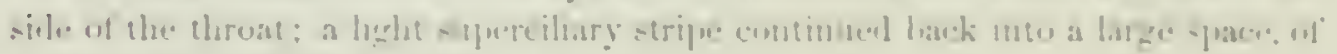

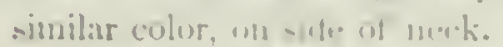

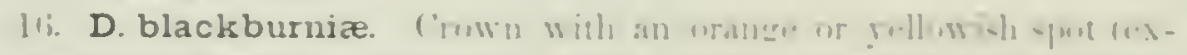

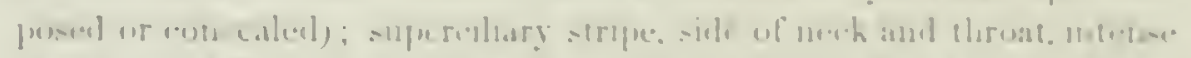

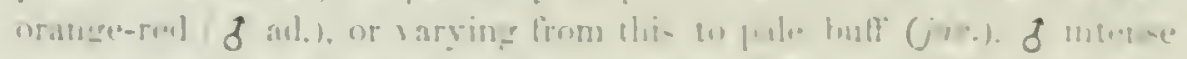

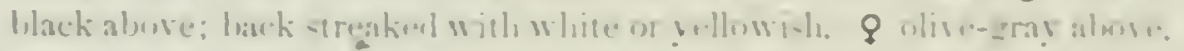

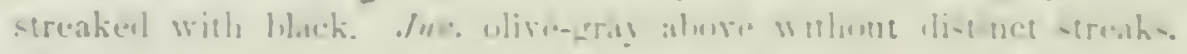

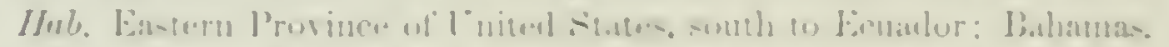

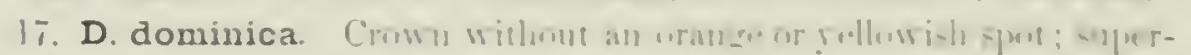

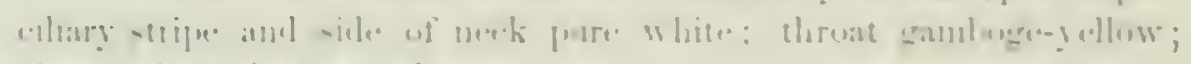

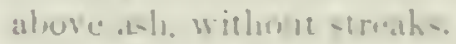

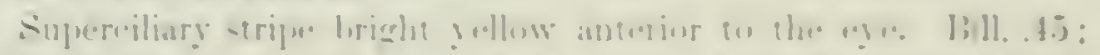

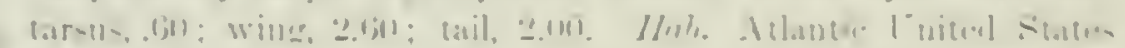

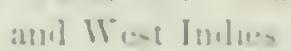

1.15. duniuicu.

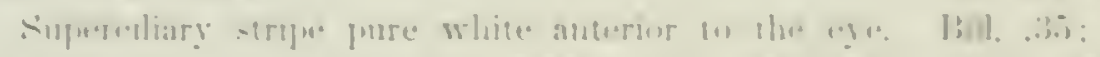

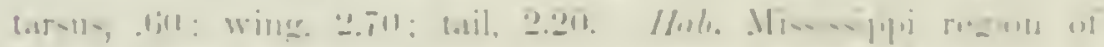

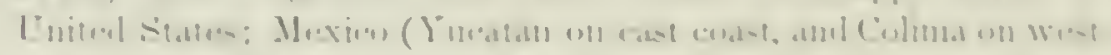

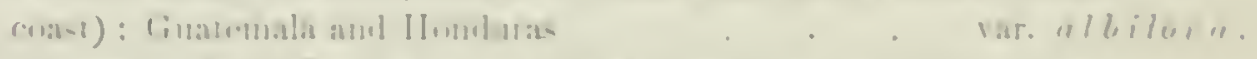

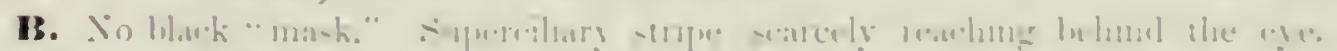

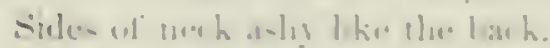

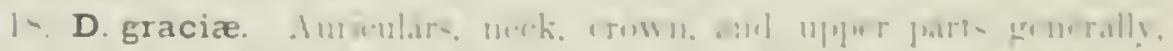

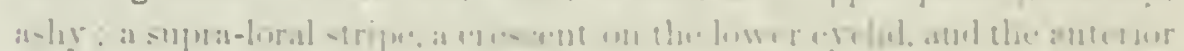

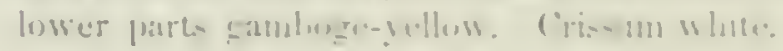

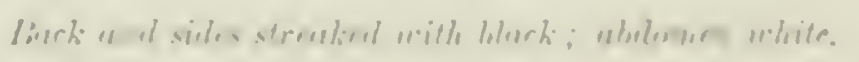

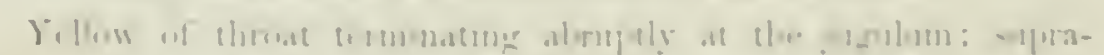

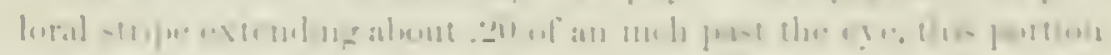

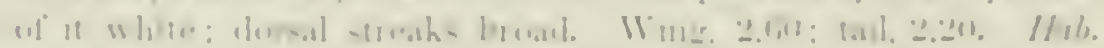
Arania (Firt Whiph).

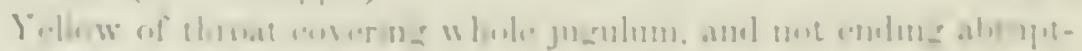

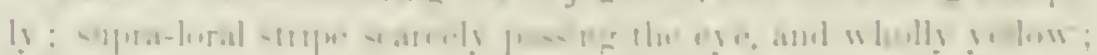

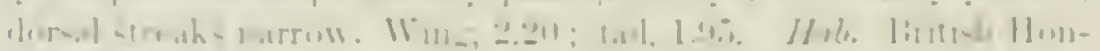
duran $(\operatorname{lin} \operatorname{lin})$

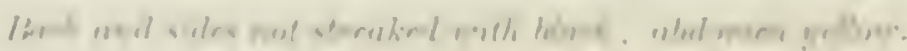

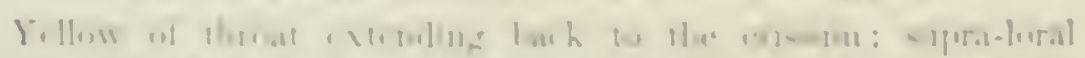

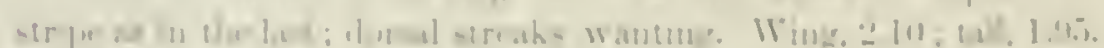
Heub. I'ort., lin,

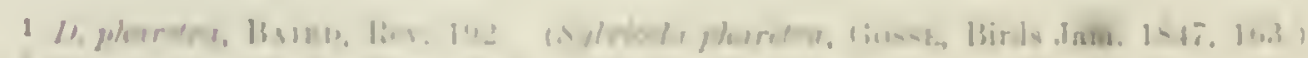

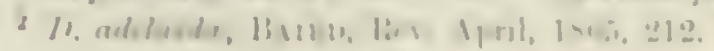


Series III.

Throat black in $\delta$. mixed with black in $q$.

A. Sides streaked: black of throat with its posterior ontline concare.

a. Sile of head white and black.

19. D. nigrescens. A small yellow spot over the lore; above asli; beneath white. J. Whole erown, uniform glossy black: back streaked with black. $q$. Crown ash streaked with black; throat mixed with white anteriorly. Jur. Crown and elnecks astyy; throat mostly white; batek without streaks. Hab. Western and Jiddhe I'rovinee of Lnited States. south, in winter, into IV estren Mexico (Uaxaca).

b. Side of heal yellow and black, or yellow and olive.

Black of throat corering jugulum; a hirdden yellour spot in middle of forehead.

20. D. chrysopareia. Black abure, pure white helow: no tinge of yellow bethind the black jugular patch. Hub. Eastern Mikdle Anserica, from Cruatemala to Texas (Ban Antoniu).

21. D. virens. Olive-green abore. the erown and back without streaks; beneath white, the breast and anal reerion tinged with black. Hab. Eastern Province of North America, from Greenlind to Panama; Cuba ; Oaxaca : Heligroland, Europe!

Black of throat confinal unterimly to the jugnlum: no yellow spot on fir he heal.

22. D. townsendi. Abore olive-green. the erown and back with wnspicuous black streaks; beneath yellow anteriorly, anel white posteriorly. 9 . black of throat mixed with yelhw: jur.. no black on throat, and streaks on back obsolete. Hab. North and Midklle P'rovince of Lnited States, somth, in winter. into Guatemala.

B. Sides not streaked: black of throat with its posterior ontline convex.

23. D. occidentalis. Above ash tinged with olive: benteath white. Head nearly all yellow. \&. Top of head yellow with a few small black spots; nape black; back streaked with black: siles pure white. ( 9 not seen.) Jux. Yellow of crown orerlaid by olive; above greenisklphumbeous, without any black on nape or back; throat yellowishwhitish; sides tinged with ashy. Hab. II estern and Jiddle Province of Luited States, south to Guatemala.

\section{Group C.}

A. Abore ash; no supra-loral stripe: erelicls not yellow.

24. D. kirtlandi. Above, inclueling side of head and neck. bluish-ash; (rown and back streaked with black: beneatla (except crissum) pale rellow: breast speckled, and siles streaked with black; lores and orbital regrion, black; eyelicls white. Hab. Eastern Province of Ĺnited States (Cleveland, Obin), and Baliamas.

2.5. D. pityophila. Abore, including side of head and neek, dull astr; the forehead and crown olive-green: crown and hack not streaked; beneath white; the throat and jugulum pellow; sides asly : no spectis on breast. nor streaks on siles, but a few along side of neck, between the ash and yellow. Hab. Cuba.

B. Olire-green or brown abore; a supra-loral stripe of yellow: eyelids yellow. a Above olive-green, without streaks; crissum white; sides of brealit with obsolete grayish streaks.

${ }^{1}$ D. pityoplilu, Ban:D, Rer. 20S. (Sylvicola p. Grxde. Ann. X. Y. Lyc. Oet. 1s5j, 160. 


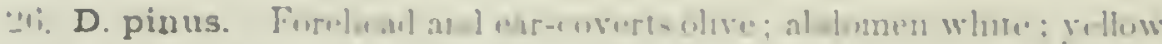

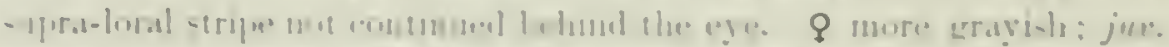

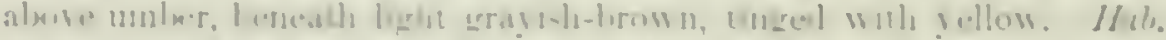

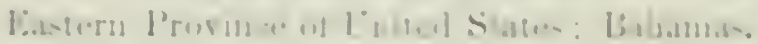

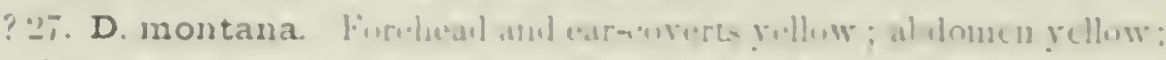

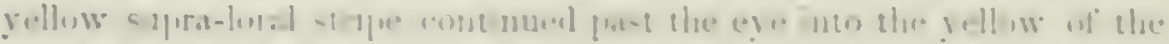

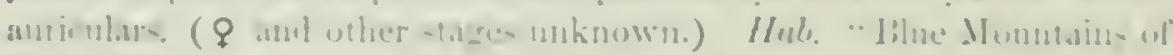
rireima."

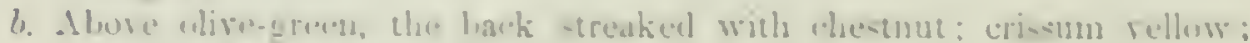

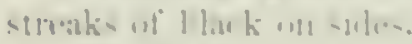

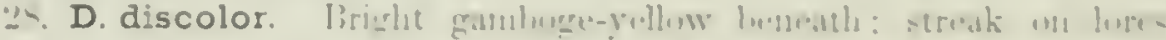

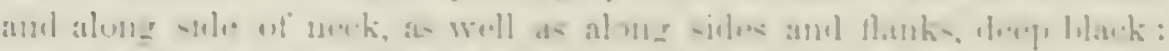

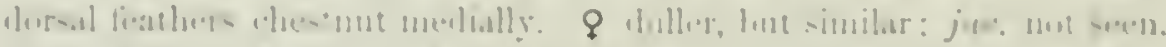

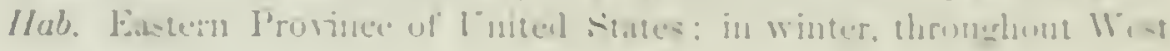
Inilier.

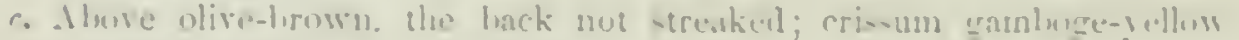

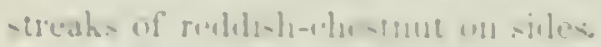

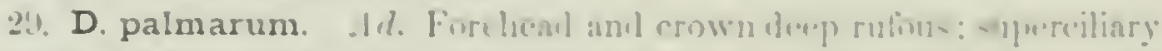

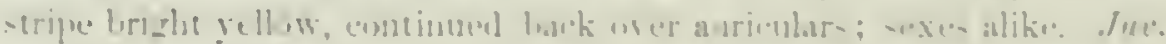

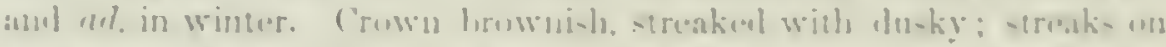

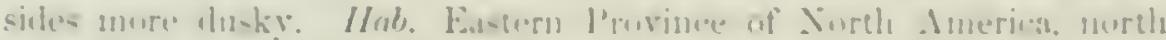

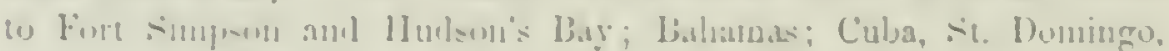
and Jamaica, in wimicl.

\section{Dendroica æstiva, l3..mp.}

\section{YELLOW WARBLER; SUMMER YELLOW-BIRD.}

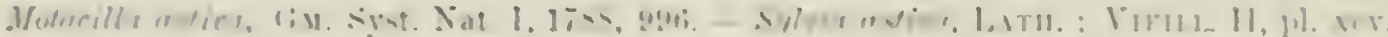

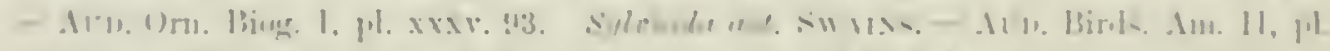

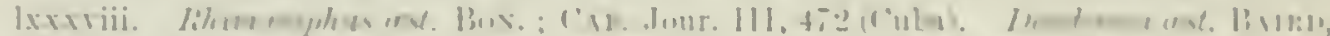

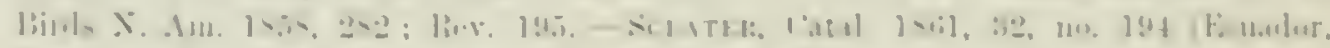

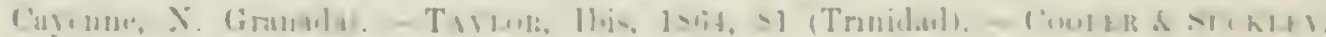

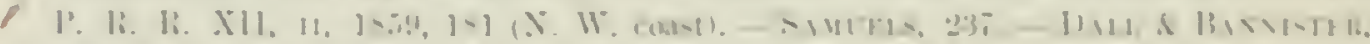

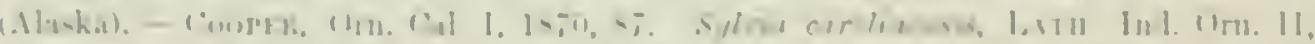

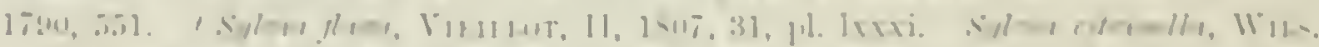

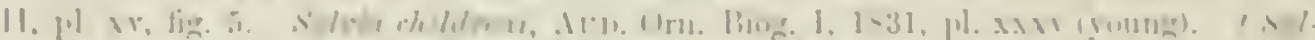

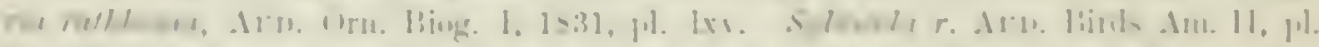

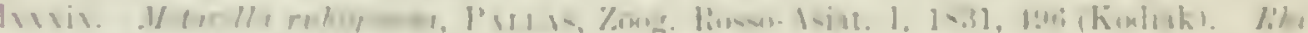

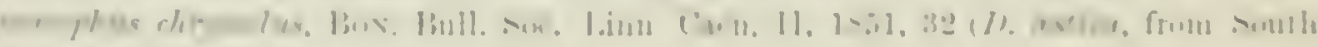

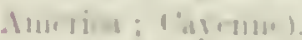

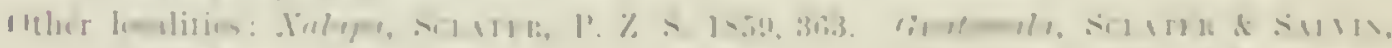

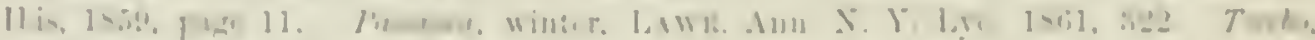

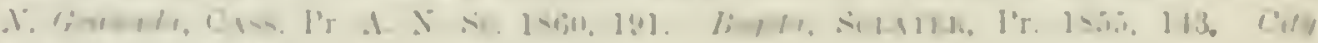
if Merti, In 1, ail, 1;:

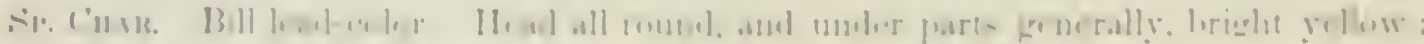

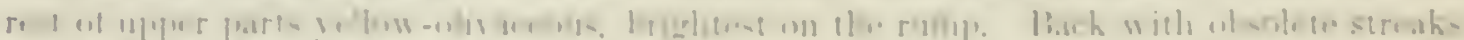

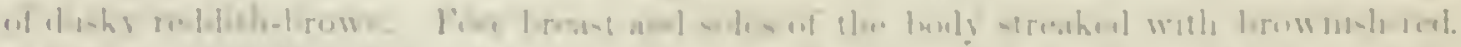

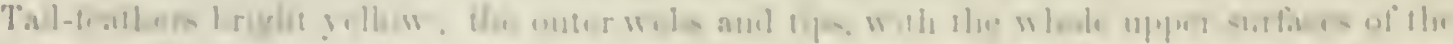
113.

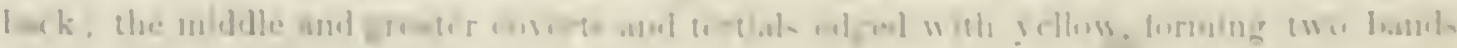

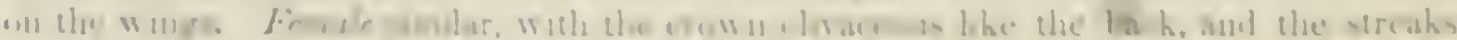


wanting on the baek, and muels restricted on the under parts. Tail with more brown. Lengtl of male. 5.2.5; wing, 2.66; tail. 2.2.5. ( (5o. 940.) Young. Dull brownish-olive above; pale ochraceous-yellow beneath, with the throat more whitish; the yellow of tail restricted to inner half of inner webs. The latter feature will serve to distinguisli it from any other Torth American species.

IAB. Entire North America, and in wintel into South Anerjea as far as Ecuador, Cayeme, and Trinidad. Fou recorded from West Indies, where replatced by allied species.

In the great abundance of this species and its wile range of distribution, there are many rariations in size and color, though none that are not readily understood. In young birds the yellow of the tail-featlers is more restricterl, sometimies confined to the elgre of the inner wels. In adults there is occasionally a tinge of orange in the forehead.

Sylria rathbonia of Andubon is described with even tail, and the tail-feathens brown, edged externally with yellow; the reverse of c'stiuc. It is generally, however, considered a synonyme.

Birds of this type ("Crolden Warblers") of six or eight additional species are known to occur in the West Indies, the Galapagos, and in Midclle Anerica; one of them, D. bryunti, possibly to be met with in Southern Arizona. (See Baird, Reriew Am. Birds, 19:3.)

After comparing a series of about one hundred and twenty Nortl and Central American specimens (the latter being winter visitors to the region where obtained), nothing really characteristic of any particular region can be detected. Specimens from the Pacific coast of the United States are perfectly identical in colors with those from the Atlantic States; and they agree in size and proportions, except of the bill, which is appreciably longer and broader in the Eistern thin in the Western birls. The most lighly colored examples are from the interior regions, along the Mississippi Valley from Louisiana to Northern Illinois, and over the plains north to Fort Simpson. The majority of the specimens from this region are just aplreciahly different from others, in having the yellow inore intense and prevalent, almost subduing the olive shades ahove; the crown more tinged with orange. Sometimes (as in No. 4,301, Calcasieu Pass, La.) the lump and upper tail-corerts are absolntely pure yellow, only a medial stripe on the feathers being olivaceous like the back. The orange-rufous tinge on the crown is deepest in Nos. 4,665, Fort Lookout, and 4,300, Calcasien Pass.

Three adult summer males from Alaski (Nos. 54,429, Kodiak; 54,425, Iukon River; and 27,267 , Fort Yukon), as well as one from Maine (52,378, Calais), differ from others in having the olive pervading the whole surface abore, even to the bill, the forehead being only tinged with yellow; and the edges of wing-coverts merely inclining to this color. The lower parts are much as in Sonthern specimens, though the yellow is less intense.

Females from Arizona (as 49,712, Camp Grant, May ; 40,664, Fort Thipple, May; and 34,3+0, Los Pinos, New Mexico, June) differ from other's in very bleached plumage, the lower parts being almost white, and the upper 


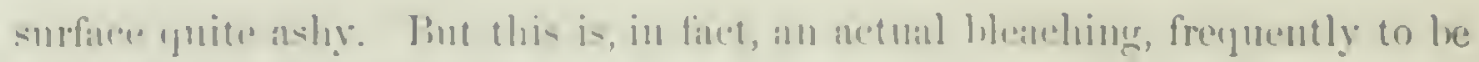

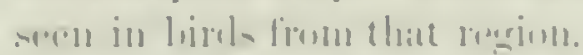

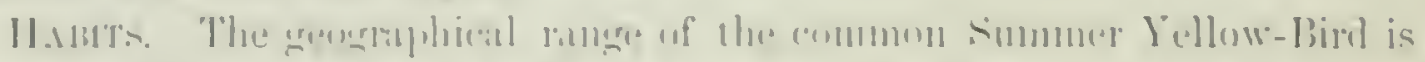

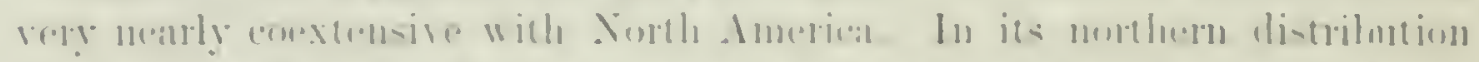

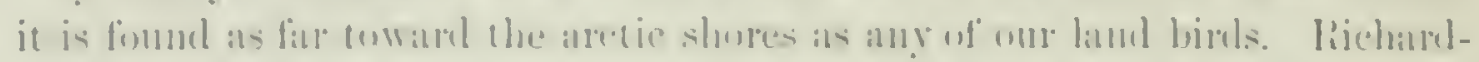
sun speaks of it as woll knum throughout the fur eountres as far as the

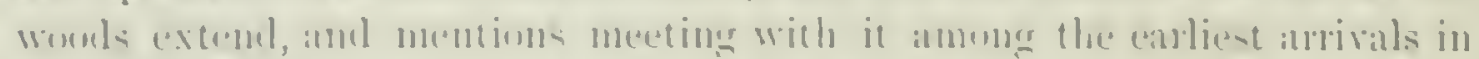

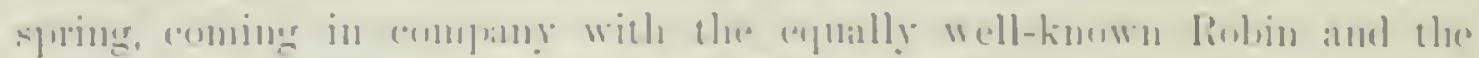

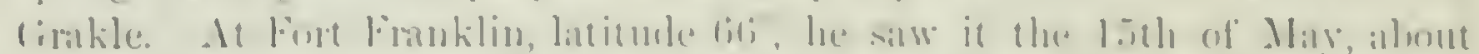

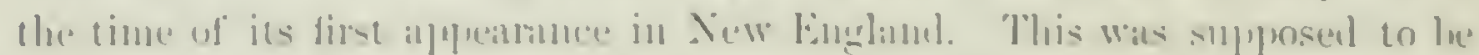

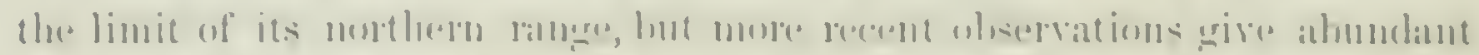

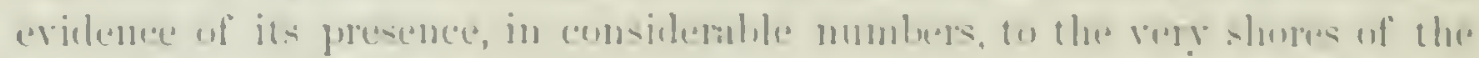

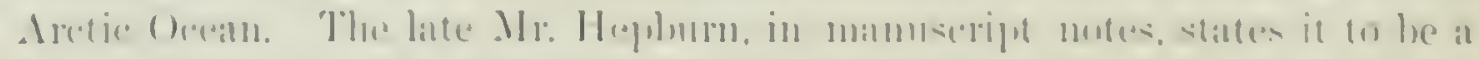

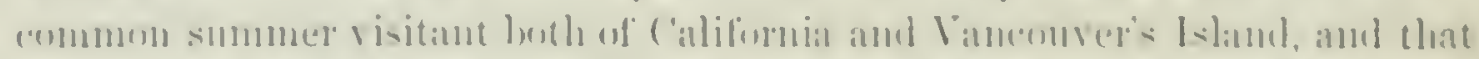

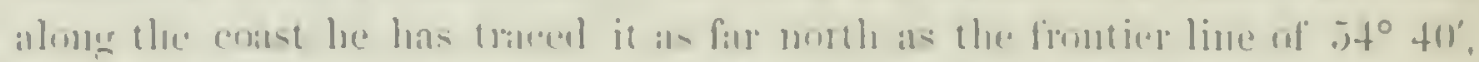

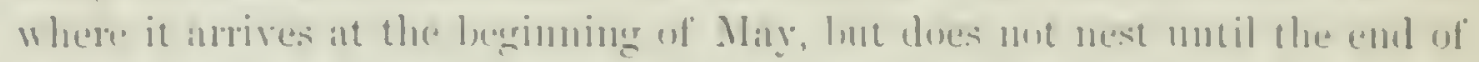
the mintl).

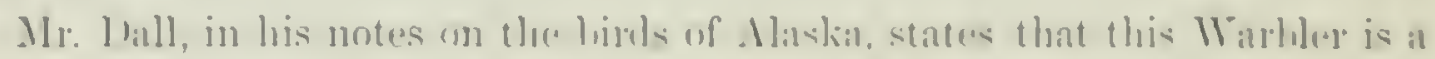

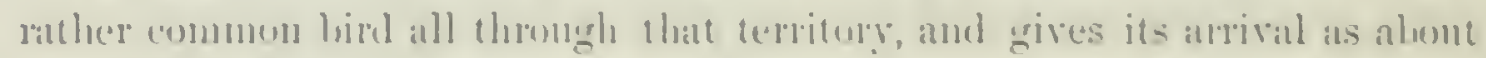
the 10th of . Maty.

Its extreme sonthelut linit is unt su dielinety traced, lut is at lenst as far

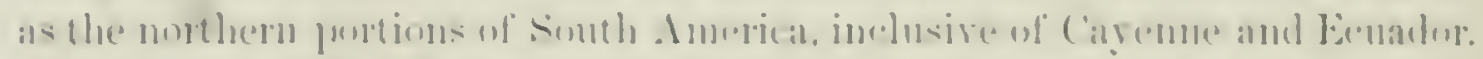

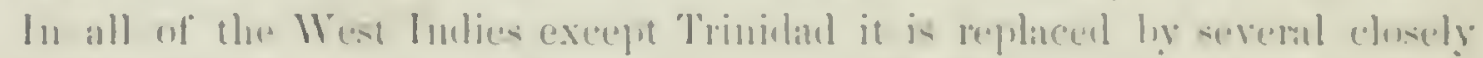

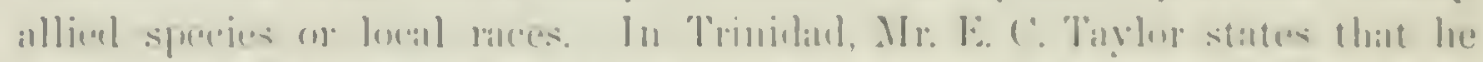

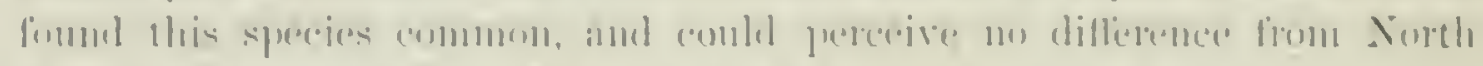

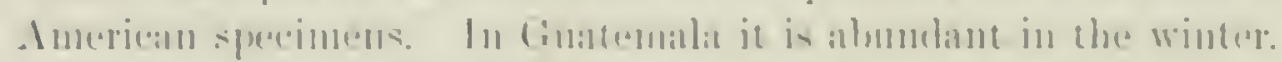

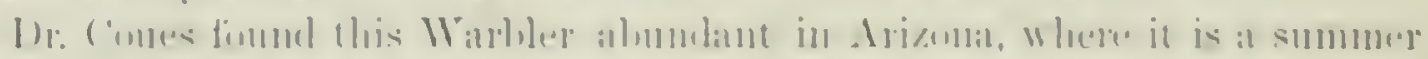

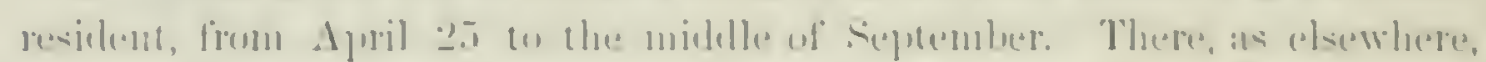

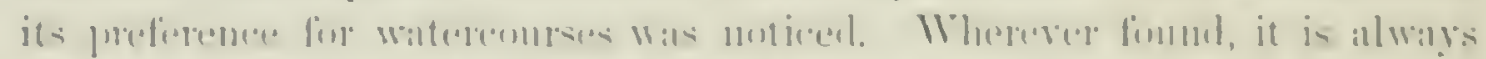

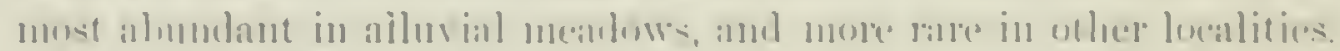

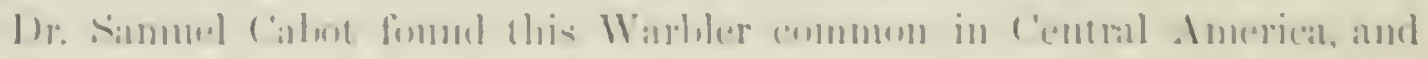

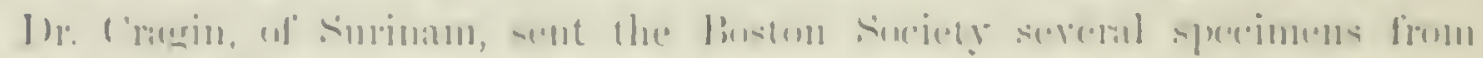

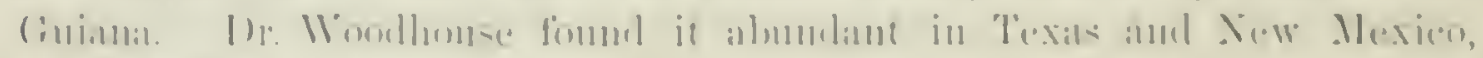

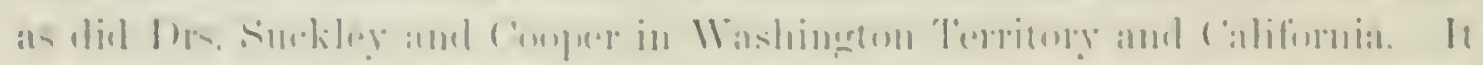

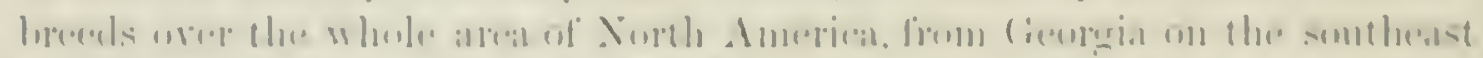

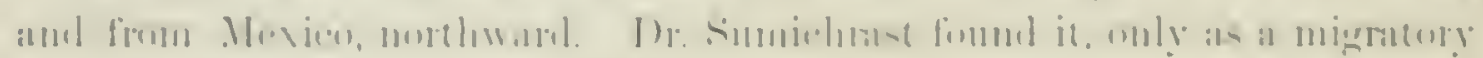

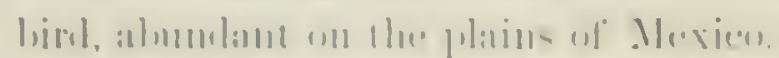

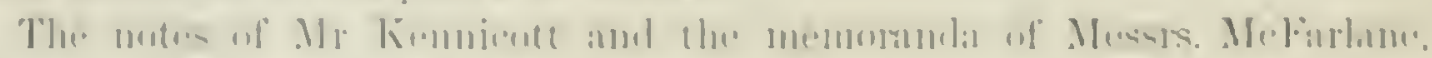

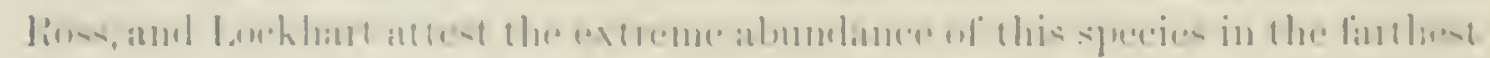

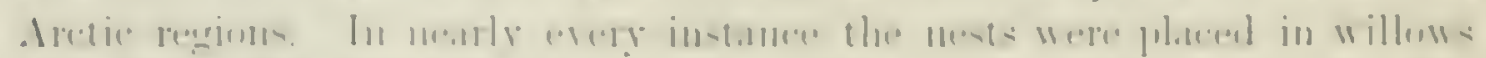

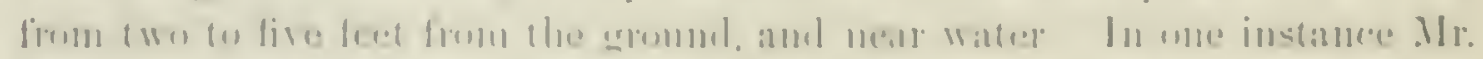

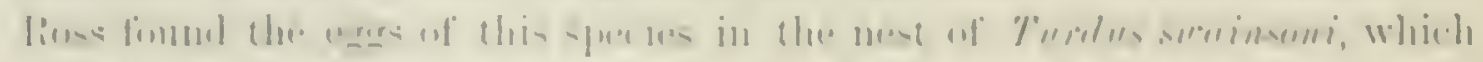

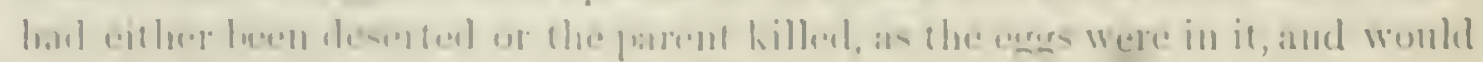

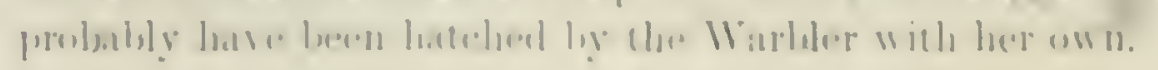


Dr. Cooper found this Wabler very abundant in Washington Territory, and noticed their arrival in large numbers at the straits of Fuca is early as April 8 .

The Summer Yellow-Bird arrives in New Enghand with great miformity from the first to the middle of May. Its coming is usually the harbinger of the opening summer and expanding leaves. Unlike most of its family, it is confiling and fandiar, easily encouraged, by attention to its wants, to enltivate the society of man. It confidingly builds its nest in gandens, often in elose vicinity to dwellings, and in the midst of large villages and cities, among the shrublery of frequented parks. This Warbler, soon after its arriral, begins the construction of its nest. It is usmally placed in low bushes, three or four feet from the gromnd. Occasionally very different positions are chosen. Hedges of buckthorn and hawthom, barberry-bushes, and other low shrubs, are their farorite places of resort. On one oceasion the nest was placed some forty feet from the gromul, in the top of a horse-chestnut tree orerlanging the main street of a rillage. Such high positions are, however, not very common.

The nest is invariably fastened to sereral twigs with great firmmess, and with a remarkable neatness and skill. A great rariety of materials is employed in the construction of their nests, though not often in the same nest, which is nsually quite homogeneous. The more common materials are the liempen fibres of plants, filrous strips of bark, slender stems of plants and leaves, and down of asclepias. Interworen with these, foming the inner materials, are the down from willow cathins, the woolly furze from ferm-stalks and the Eriophornm riminicum, and sinnilar substances. These are lined with soft, fine grasses, hair, feathers, and other wam materials. Cotton, where procurable, is a favorite material; as also is wool, where abundant. I have known instances where nests were built alnost exclusively of one or the other material. A pair of these birds, in $18: 36$, built their nest uncler a parlor window in lioxbury, where all their operations conld be closely wateherl. When discovered, only the frmework, the fastening to the supporting twigs, had been erecter. The work of completion was simple and mpid. The female was the chief builder, taking her position in the centre of the nest and arranging the materials in their places as her mate brought them to her. Occasionally, with outstretched wings and expanded tail, she would whirl herself round, giving to the soft and yielding materials their hemispherieal form. At intervals she arlested her revolutions to stop and regulate with her bill some myielding portion. When her mate was dilatory, she made brief excursions and collecter material for herself, and when the materials brought her were deemed unsuitable, they were rejected in a most smmmary and amusing mamer. The important part of the tail-feathers in shaping the nest and placing the materials in position was a striking feature in this interesting performance. The greater portion of the nest was thus constructed in a single day. 


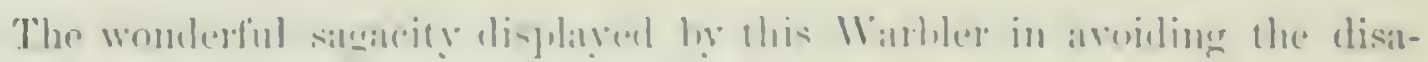

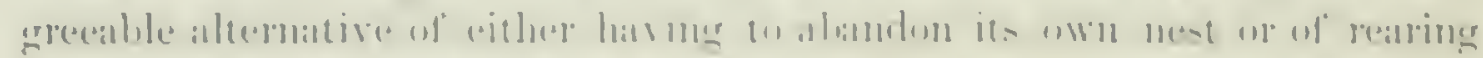

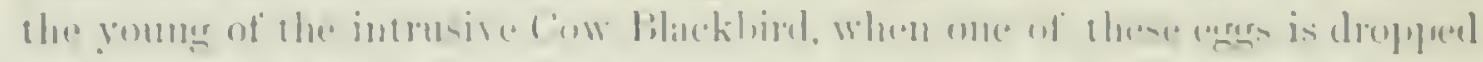

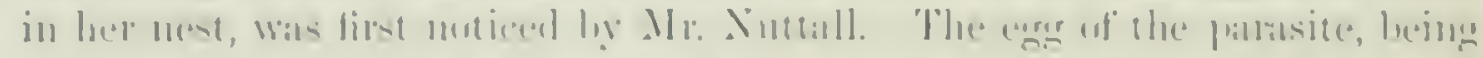

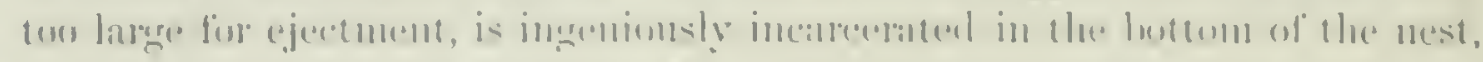

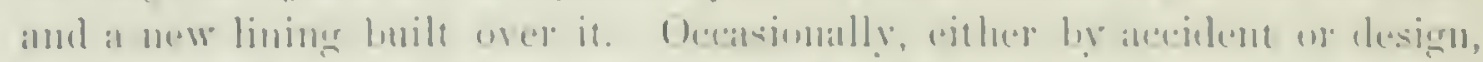

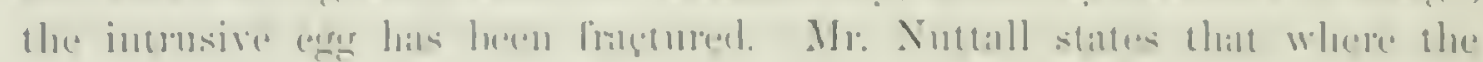

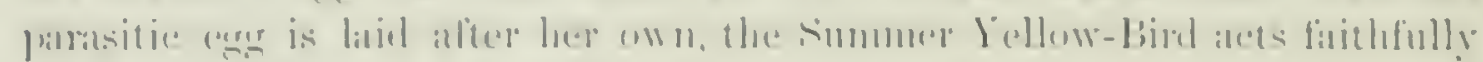

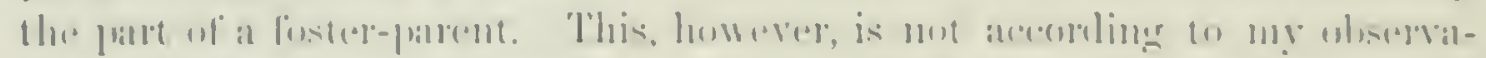

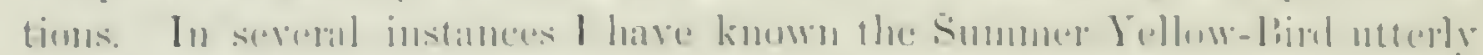

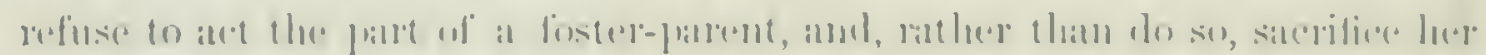

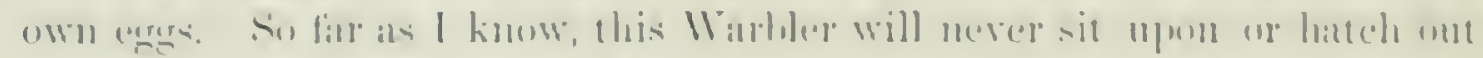

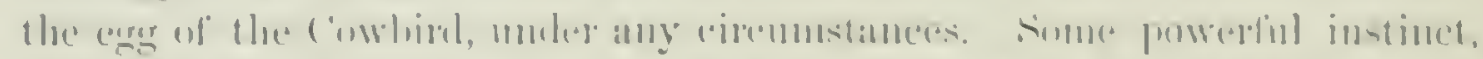

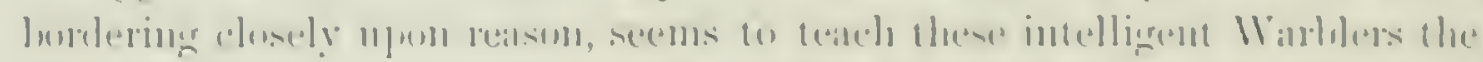

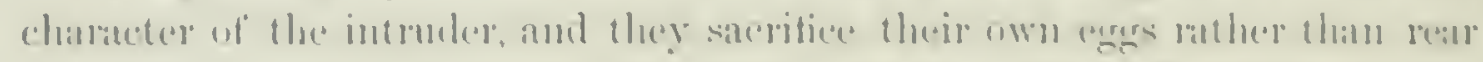

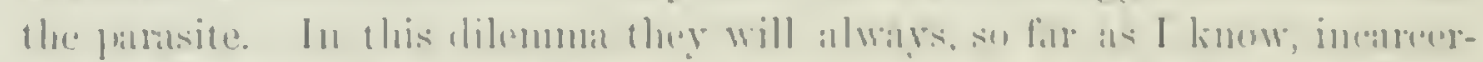

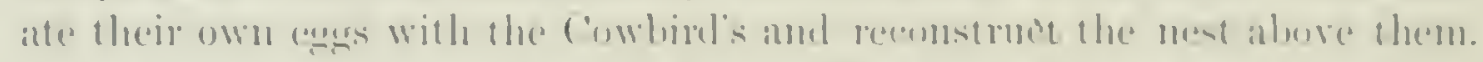

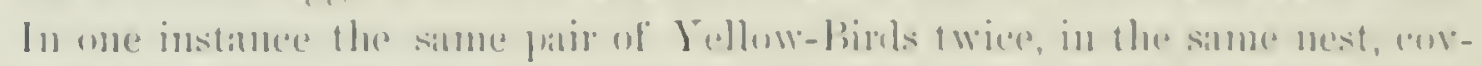

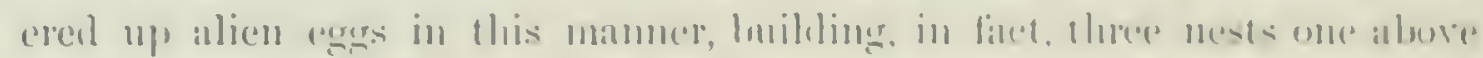

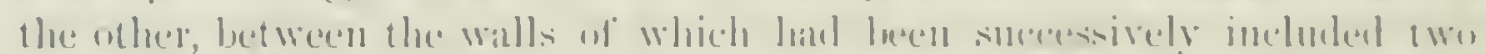

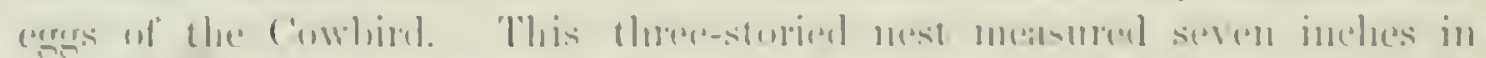

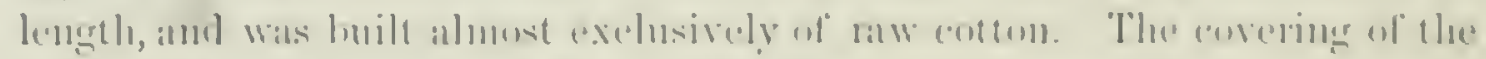

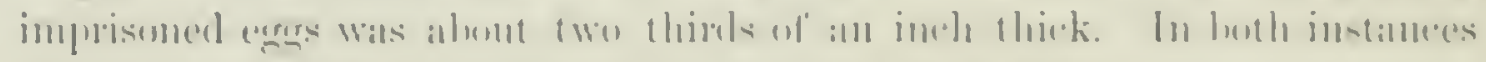

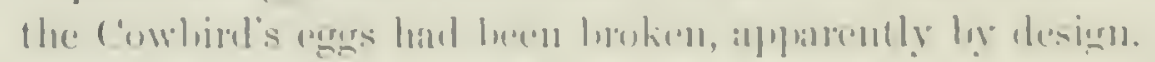

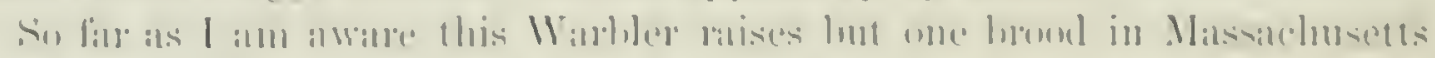

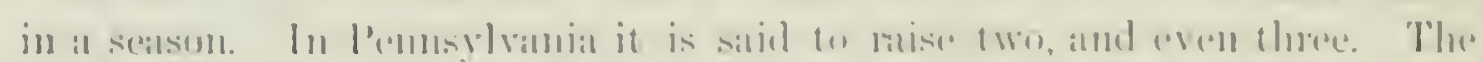

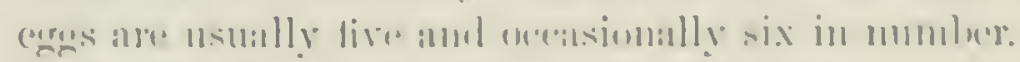

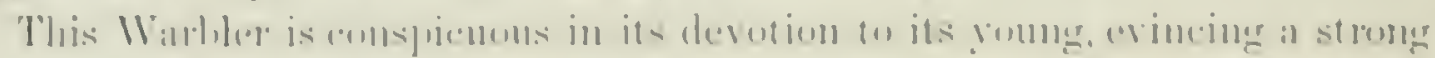

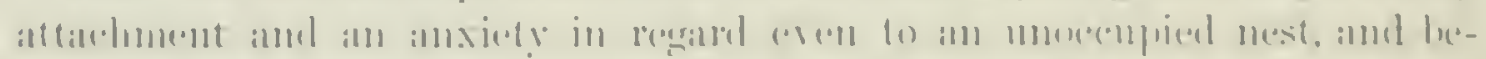

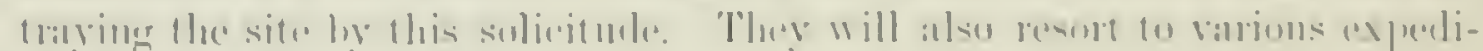

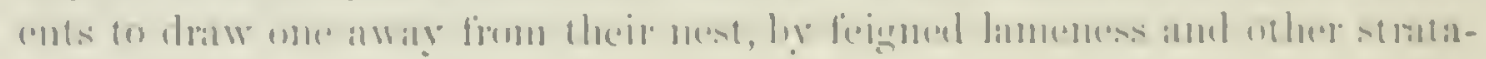

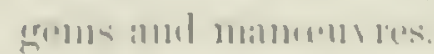

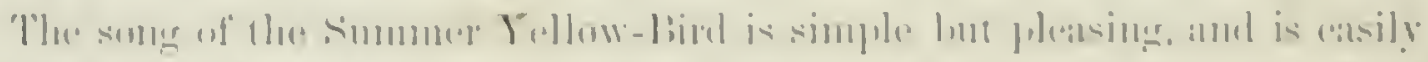

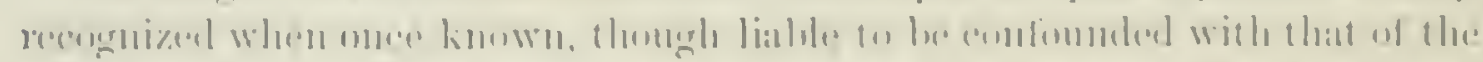

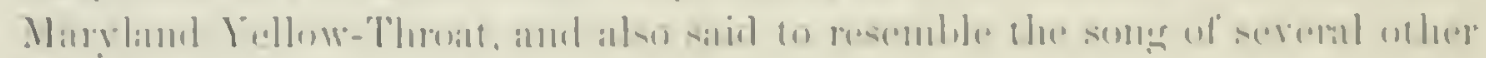
Wirlur.

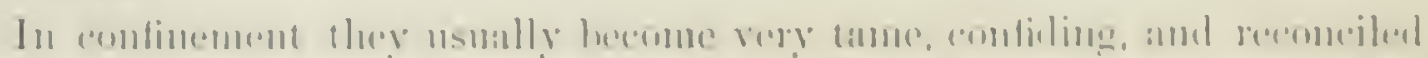

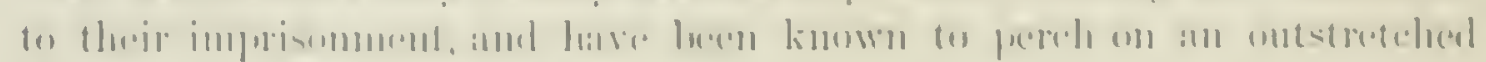
finewe, and to caltell flies in at roum.

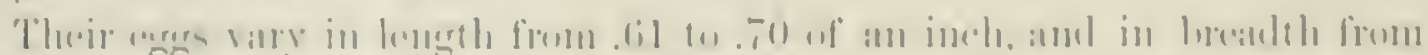

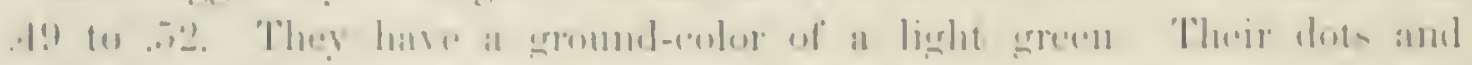

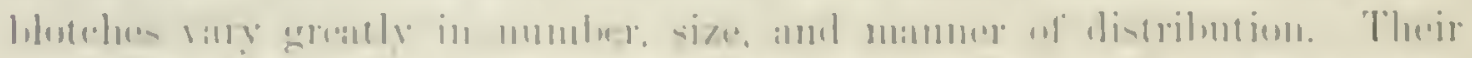

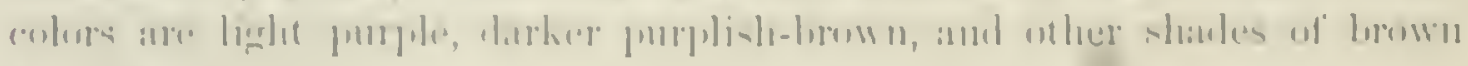
numl lila. 


\section{Dendroica coronata, CrRir.}

\section{YELLOW-RUMP WARBLER; MYRTLE WARBLER.}

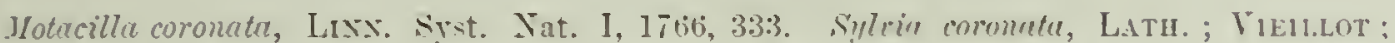

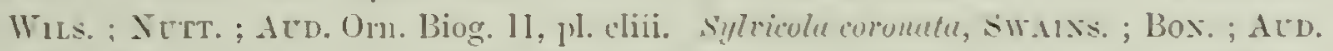
Birds, Am. Il, pl. 1xivi. - Juses, Tat. Bernula, 59 (abundant in ApriJ). I)endroieu

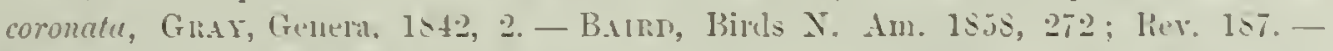

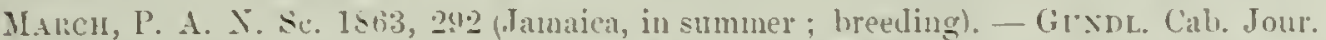

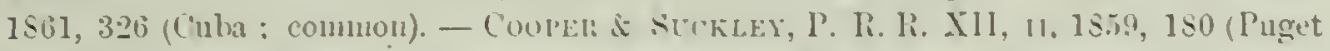

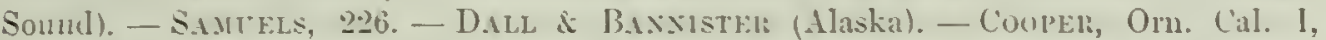
1570, s9. Rhimumphus cor. C.u13. Ionr. 1855, tis (Cuba). Molucillu conulcnsis, Lixx.

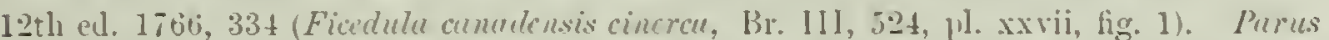

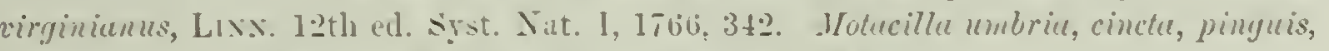

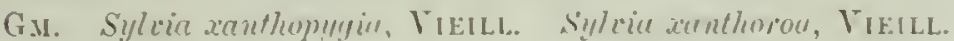

Localites quoted: S. Gremlemel, lisisuanur, Ibis, 1\$61, J. Cordova, ScL. P. Z. S.

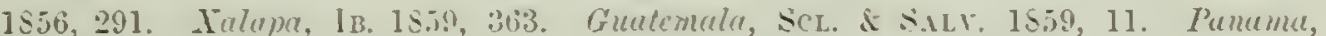
Lawr. Anu. Y. Y. Lye. Till, 6:3. Fube, winter, Cab. Jour. Ill, t73. Bahumas,

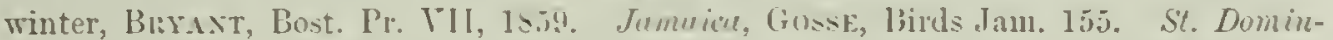

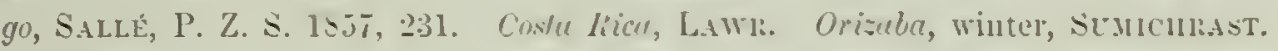

Sp. Crur. Above bluish-nsh, streakerl with lulack. Inder parts white. The forepart of breast and the sides black, the feathers mostly edged namowly with white. Crown, rump, and sides of breast yellow. Cheeks and lores black. The eyelils and a superciliary" stripe, two bands on the wing and spots on the nuter three tail-fenthers, white. Female of duller plunage and lorowner ahore. Length, 5.6.5; wing, 3.00 ; tail, 2.50 .

H.a. Eastern Prorince of North America, and northward, extending sparsely along Cnited States boundary to Pacife Ocean; Denrer City, Coloradn; Fort Yukon : Greenland; Eastern Mexieo to Panama R. R.; Western West Indies and Bermula. Breeds in Janaica!

Autumnal and winter birds are rery much duller and more obscurely colored, the upper parts of an umber cast with the streaks almost obsolete; the black of the breast wanting or but just indicated, and the yellow patches on crown almost concealed by the brown tips to the feather's, and those on side of breast quite dull.

A spring male $(52,283)$ from Washington is remarkable in having the adjoining series of feathers down the middle of the back with their imner webs broadly edged with vellow. In this respect it differs from all others that we have noticed.

Habits. The Yellow-crowned Wood Warbler is one of the most common species of this genus, as well as one of the most widely distributed. It is found, at different seasons, thronghout the eastern part of the continent, as far mest as the Great Plains, extending at the far north to the Pacific Ocenn. It has been found in Greenland, three specimens haring been taken within twenty years, and on the shores of the Arctic Ocean, and during the winter in the West India Islands, Mexico, and Central America. Specimens from Florida and Fort Steilacoom, Panama, Guatemala, and Jamaica, and from Fort Rae, Anderson River, and the Tukon, in the collection of the Smithsonian Institntion, attest its wille distribution. In .Jamaica, in the neighborhood of 


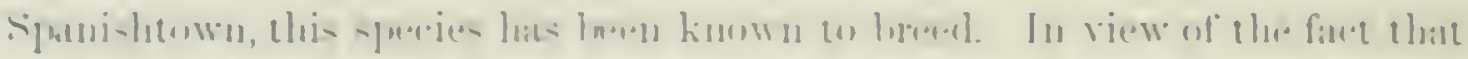

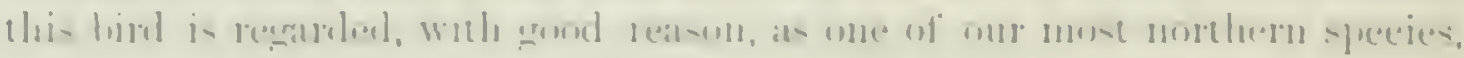

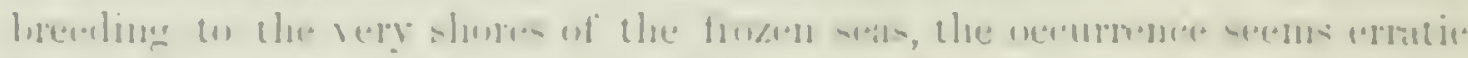

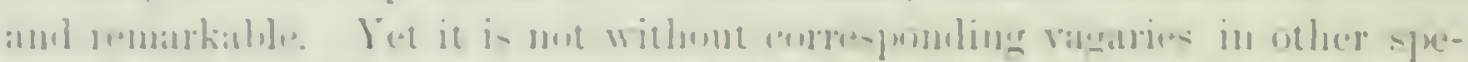

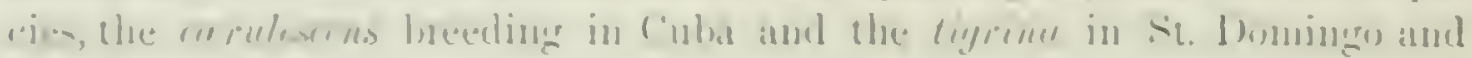
.I:แנricici.

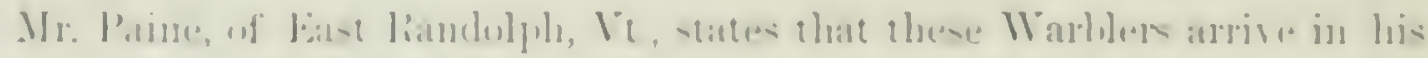

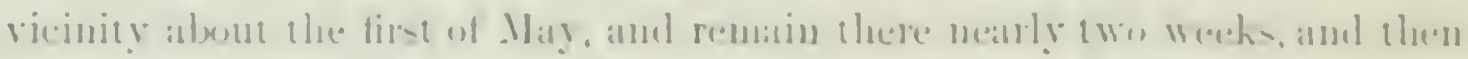

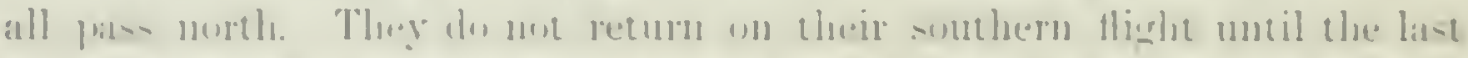

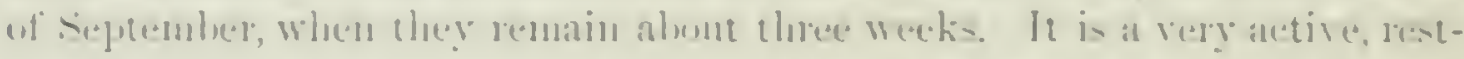

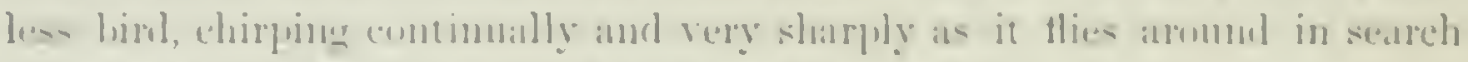

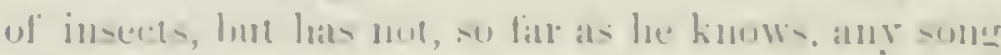

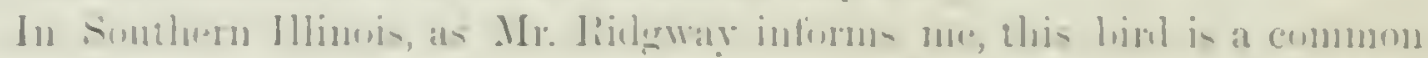

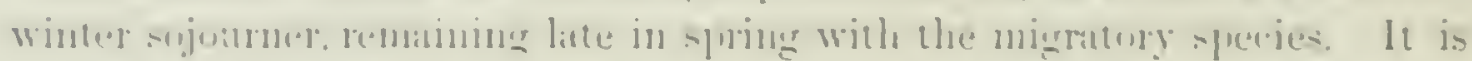

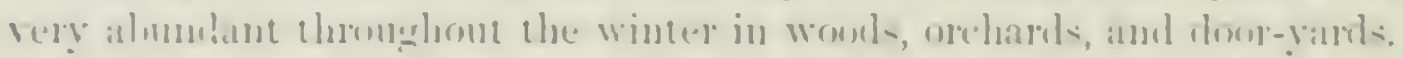

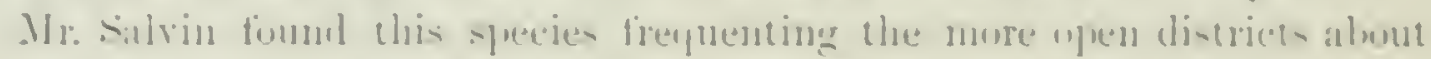

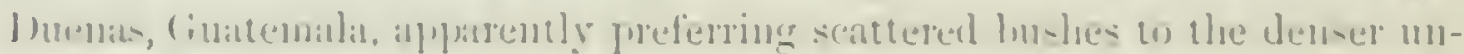

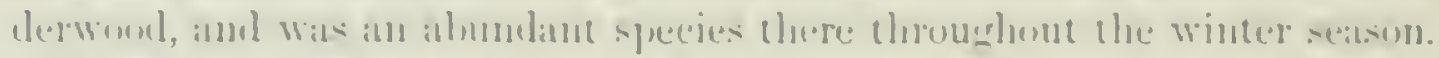

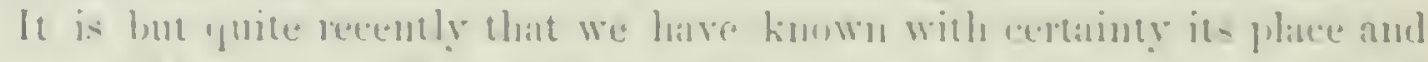

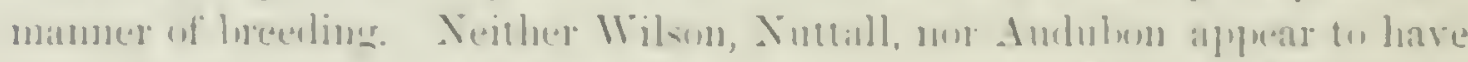

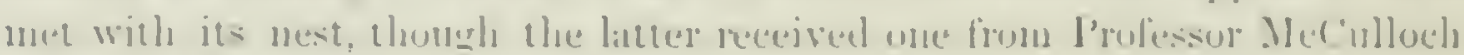
of Hillifix.

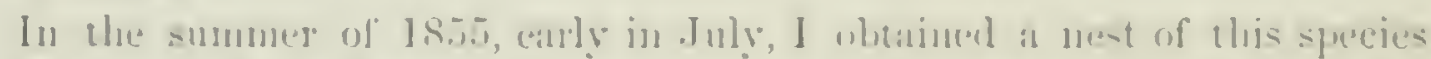

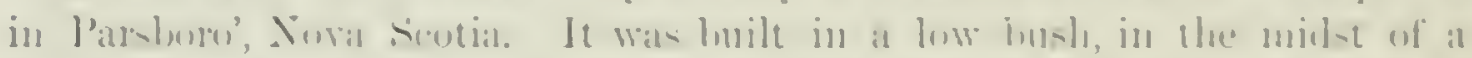

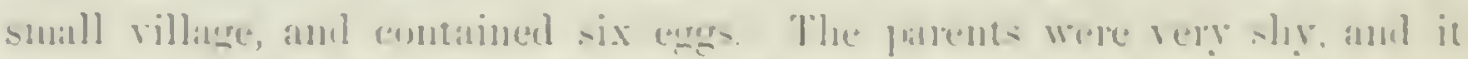

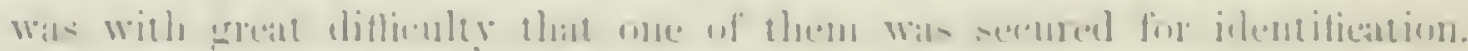

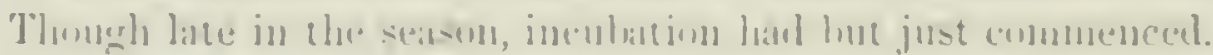

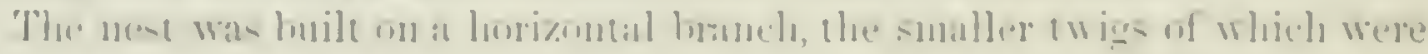

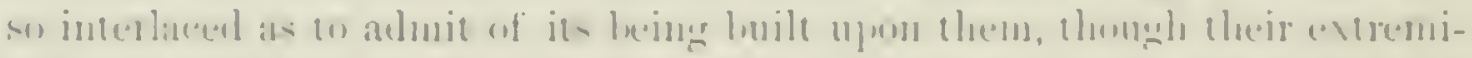

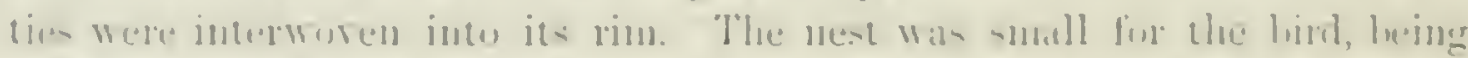

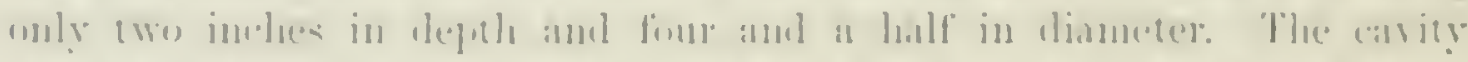

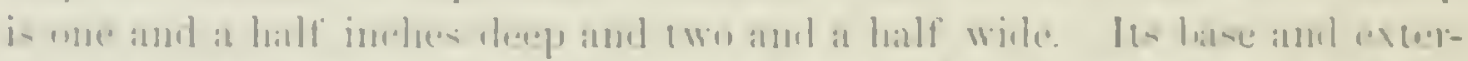

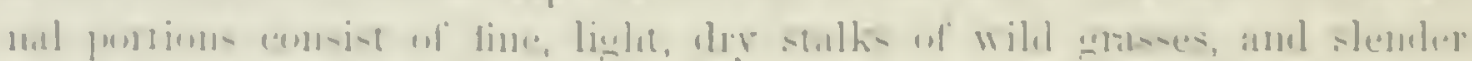

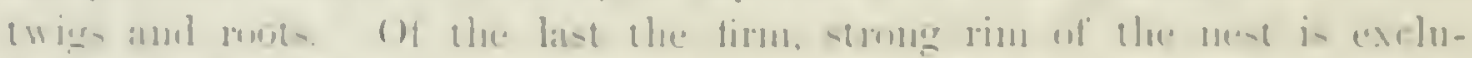

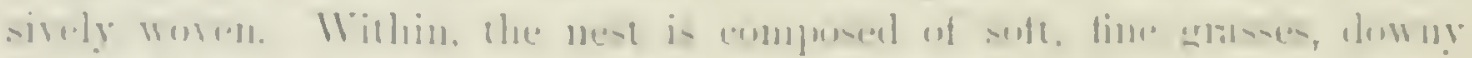

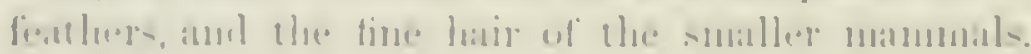

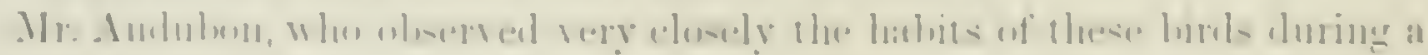

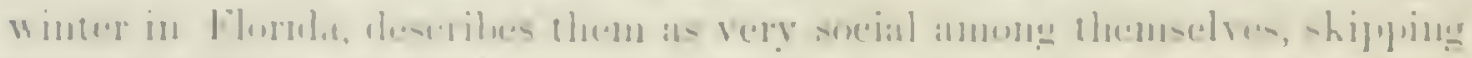

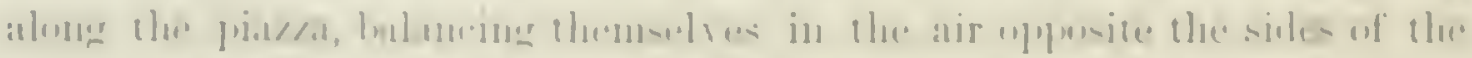

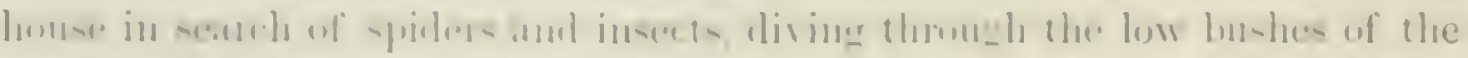

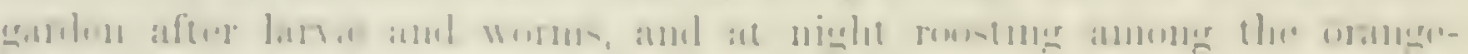

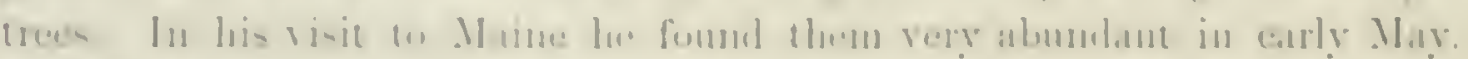

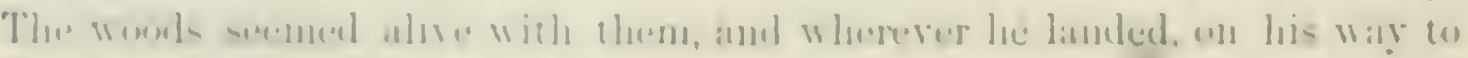

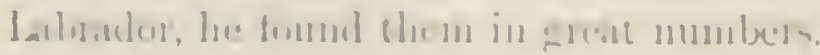


This Warbler is an expert flyenteher, feeds ehiefly on insects, and is a great dervurer of small caterpillars; but in the winter its food is lingely composed of berries, especially those of the Hypricu ceriferce. It will also feed on gritssseeds. In the warmer wintry days in Florida, when insects are abundant, Mr. Audubon states that these birds are particularly active in their pursuit, and the trees seem full of them. At this time they emit, at each morement, a single note, tueeett, so very peculiar that they may be at once recognized by the cry.

Wilson states that these Warblers appear in Pemsylvania, from the North, early in October, and stay there several weeks. Some of them remain in the Sonthern States all winter. They feed with great avidity upon the berries of the red cedar.

In Western Massachusetts it is a very abundant spring and autumn visitant, making but a brief stay in spring, but passing northward in linge numbers. In autumn it remains longer, and passes south more leisurely. Mr. B. P. Mann found its nest and egges in Coneord, but this was probably an exceptional instance. In Eastern Maine it arrives May 25 , and, as Mr. Boardman thinks, remains to breed. Both Dr. Suckley and Dr. Cooper met with this species in Wishington Territory, where it is very rare.

No writers have observed or noted the sung of this bird, except MIr. T. M. Trippe (American Nat., II. p. 171), who states that during its spring migrations it has a very sweet song or warble, uttered at short intervals.

It reaches the high northern latitudes late in Miny, ind leaves that region in September. The observations of Mr. Mrcinline show that the nests of this bird are moderately common at Anderson River, and are generally built in low spruce-trees four or five feet from the ground. In one or two instances it was placed on the gromend.

The eggrs of this Warbler vary from .72 to 80 of an inch in length, and from .50 to $.55 \mathrm{in}$ breadth. Their gronnc-color is white, often tinged with a bluish shade, and blotehed and spotted with reddish-brown, purple, and darker shades of brown. They are of a rounded oral shape.

Dendroica auduboni, BAIRD.

\section{AUDUBON'S WARBLER; WESTERN YELLOW-RUMP.}

Sylvin auduboni, Towsisd, J. A. N. Sc. V1I, 1I, 1S37. - IB. Narative, 1539, 312. -

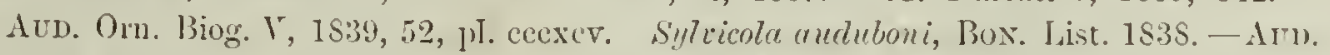

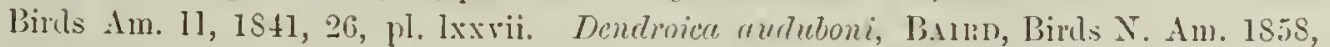
273 ; Rev. 1S8. - Sclateri, l'. Z. S. 1858, 298 (Oaxara; (Octoher); 1860, 250 (Orizaha). - Sclaten \& S.llyx, Ilis, 1860, 273 (San Geronimo, Guat.). - ('noper \& Stckley, P. R. R. liep. XII, II, 1859, 181. - ScLATE1, P. Z. S. 1S64, 172 (City of Mexico).Cooper, Orn. Cal. I, $1870,8 s$.

SP. Cirar. Abore bluish-ash, streaked with black, most marked on the middle of the back; on the head and neck bluish-ash. Middle of crown, rump, chin, and throat, and a 


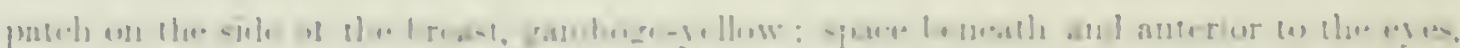

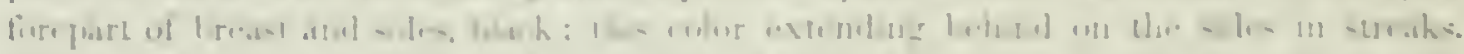

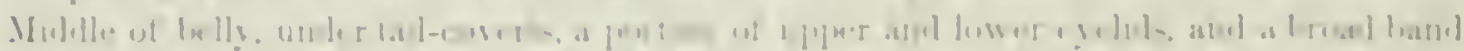

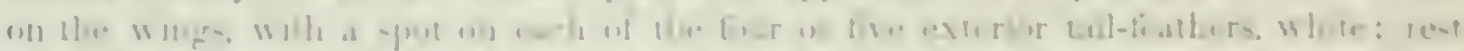

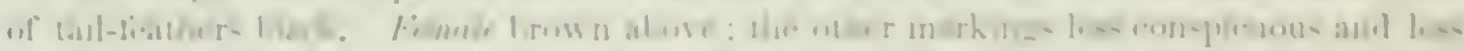

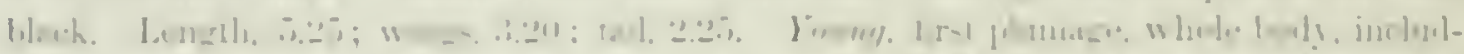

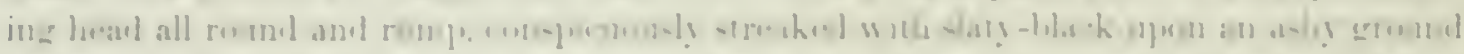

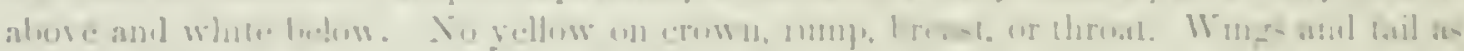

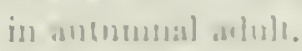

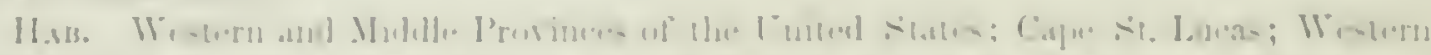

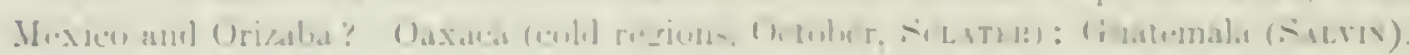

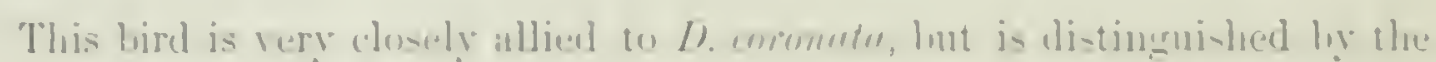

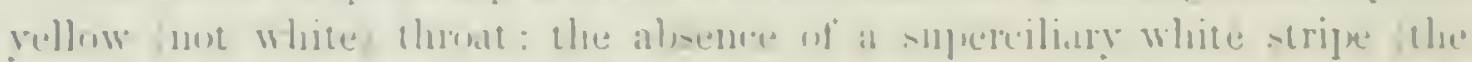
crelinls white, howerere: the restriction of the black of the hace to the lores.

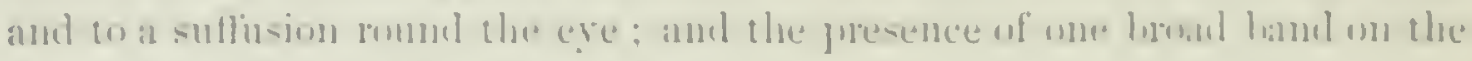
winers, insloitel of two natrow ones.

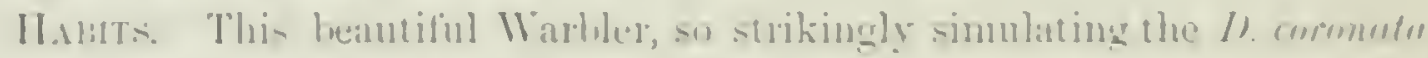

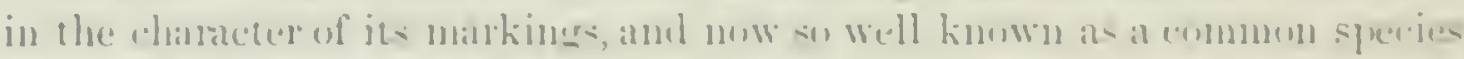

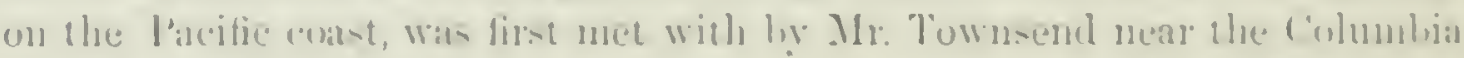

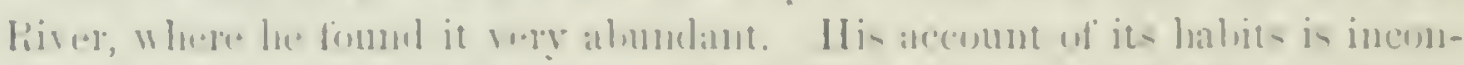

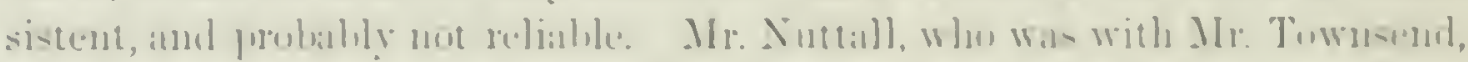

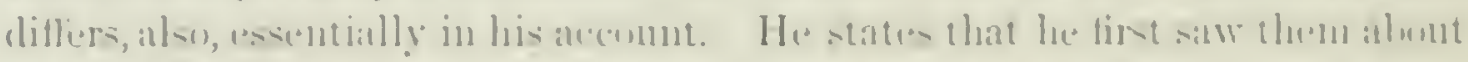

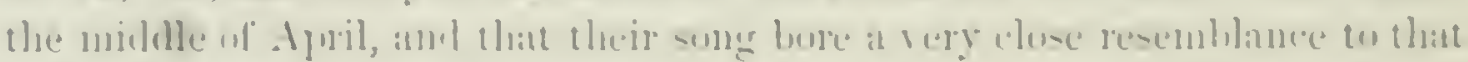

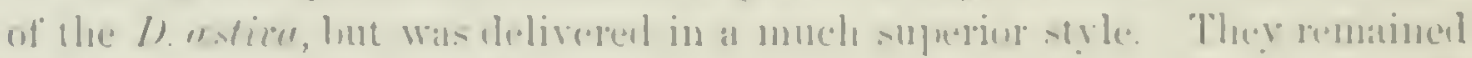

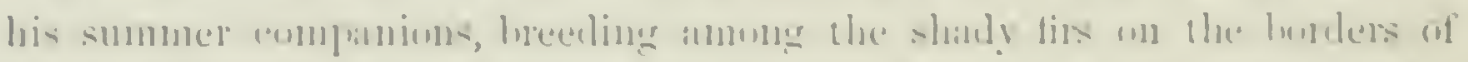

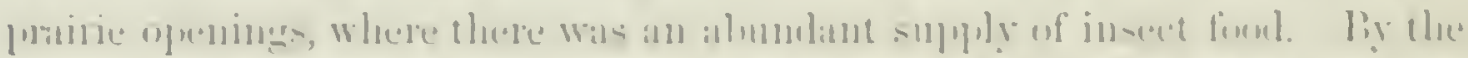

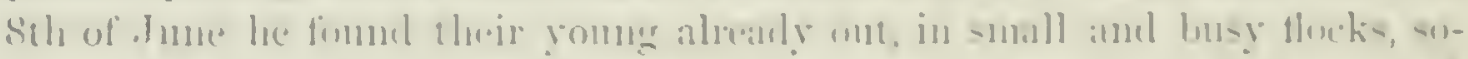

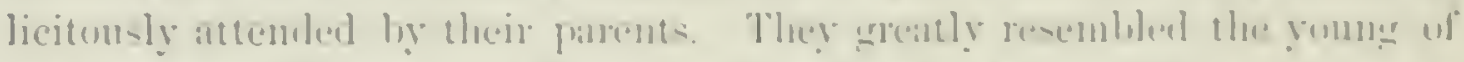

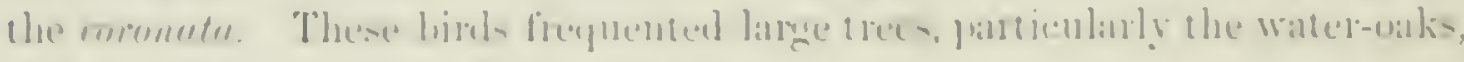

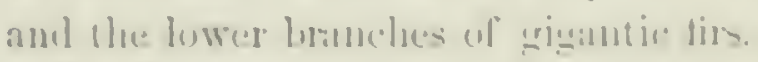

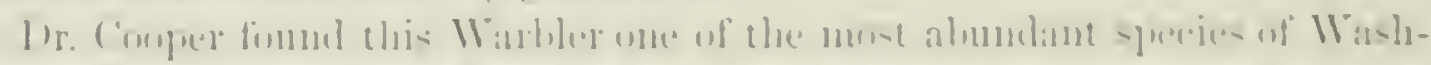

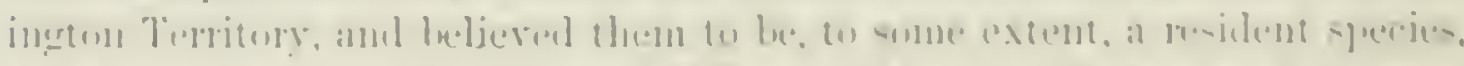

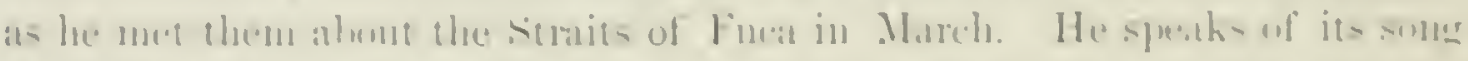

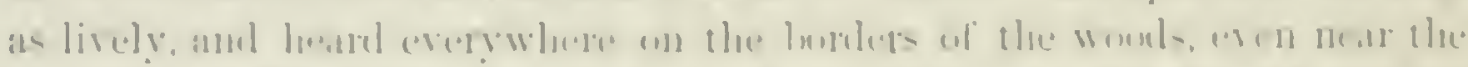

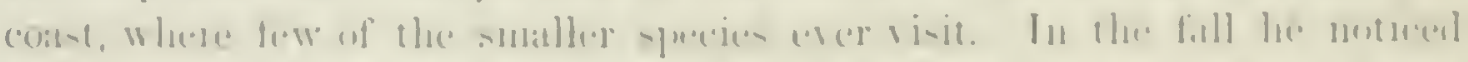

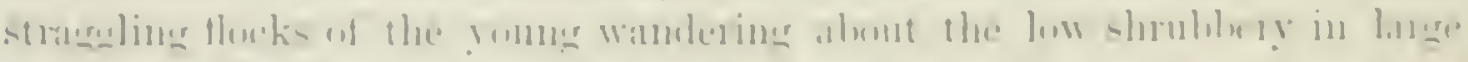

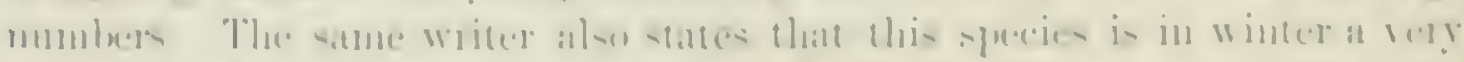

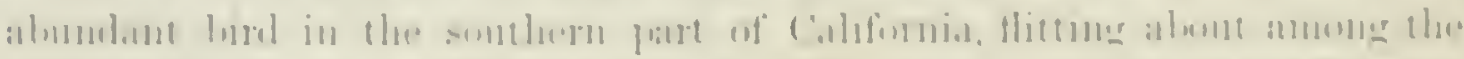

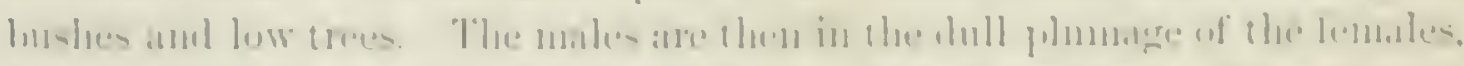

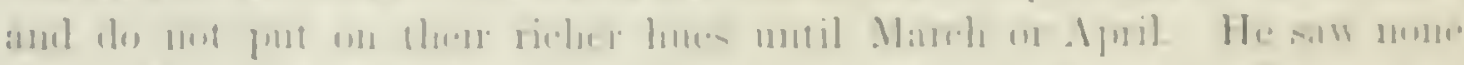

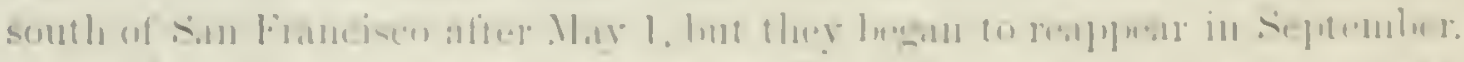

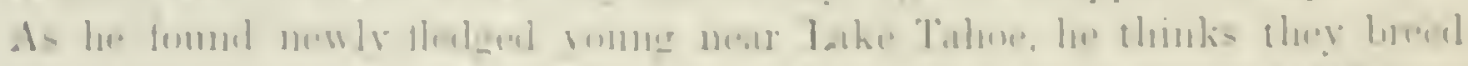

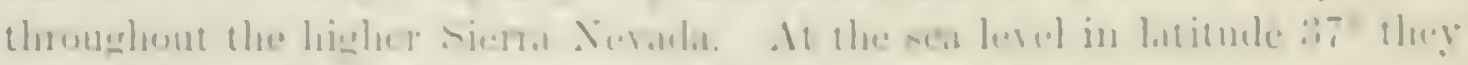

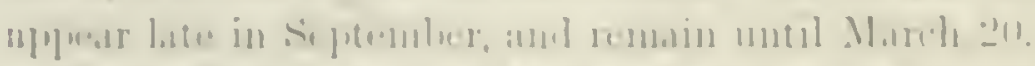

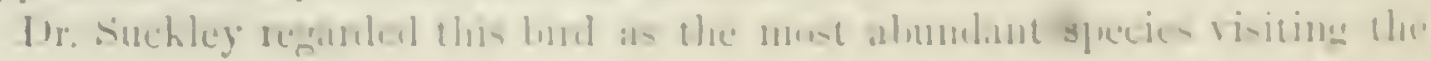


western portion of Washington 'l'erritory. Near Fort Steilacoom it was found principally among the oak-trees on the plains.

Dr. Woolhouse found it almudant in New Mexico, confining itself to the timbered and momtanous districts, and especially plentiful anong the San Francisco Mountains, feeding anong the tall pines. I)r. ('oues found it exceedingly common in Arizona, where some spend the winter, and a few possibly remain in the summer to breed.

Dr. Heerman foum them remining in the Sacramento Talley throughout the winter, and quotes Dr. Kennerly as finding these birds on the Boca Gramle and at diflerent points in Sonora. Mr. Cambel tomul these Warblers on all his route from New Mexico to California in great alundance, their habits greatly resembling those of the D. coronutu. They display a great deal of faniliarity, entering the towns, resurting to the gardens and helge-rows, and even the corrals of the houses, descending also to the gromel in company with Blackbirds and Sparrows.

This Warbler is thus shown to have a very extended distribution. It is now known to be found, at diflerent seasons, from Central America to British Columbia, and from New Mexico to the Pareific.

We are indebted to the late Mr. Heplum for all the knowledge we possess in reference to its nests, eggs, and breeding-habits. He procured their nests and eggs in Vancomer's Island. They were built in the forked branches of small shrubs. Aromul these the materials of which they were huilt were strongly bound, and to it the nests were thus securely fastened. They were quite long and large for the bird, being four inehes in height, and three and a half in diameter. The cavity is small, but deep. The external periphery of the nest is mate of conrse strips of bark, long dry leares of wild grasses, and strong stalks of plints, intermingled with finer grasses, pieces of cotton cloth, and other materials. The inner nest is also a singular combination of various materials, yet carefully and elaborately put together. It is made up of fine grasses, feathers, lichens, mosses, fine roots, etc., all felted together and lined with a warm bedling of fur and feathers. Mr. Hepolnu's observations, so far as they go, seem to show that this birl does not usually build in such lofty positions as Nuttall and others conjecturen.

According to Mr. Hepburn, they arrive in Vaneouver's Island in the middle of April, and generally frequent high trees, constructing their nests in the upper branches, thongh also frequently building in low hushes, a fow feet from the ground. The number of their eggs is four. These, lie states, lave a pure white ground, and are spotted, usually chiefly about the larger end, with red inarkings.

Mr. Salvin met with both this species and the $D$. coioncte at San Feronimo, November, 1859. They congregated together on the ground, where they principally ohtained their food.

Dr. Cooper, in his paper on the fauna of Montana, mentions this WTarbler as the only one of the genus seen by him between Fort Benton and Fort 


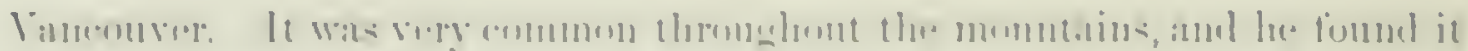

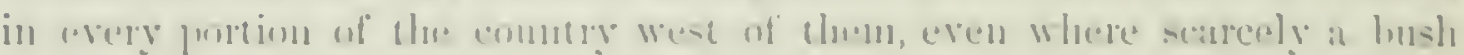

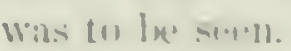

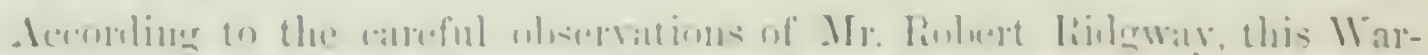

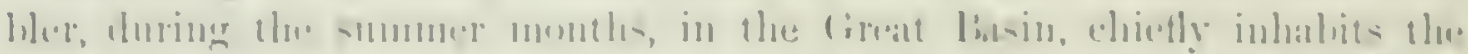

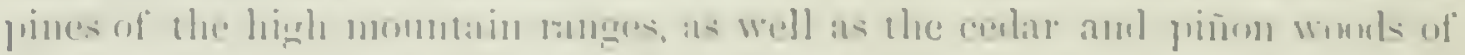

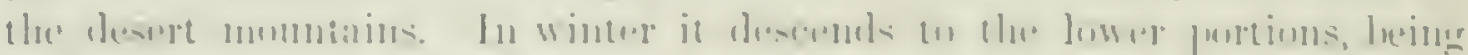

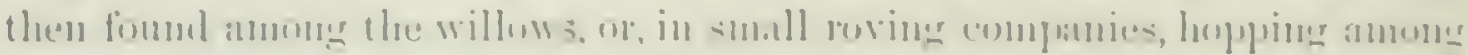
the tree-tops in the river villeys. In matumes it is sidel hy him to resemble

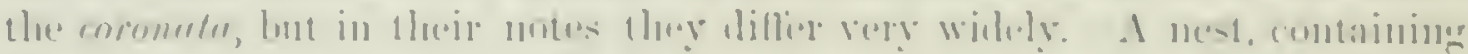

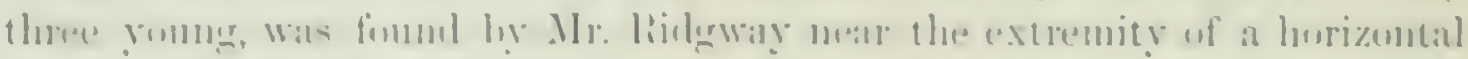

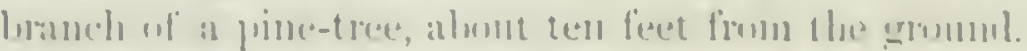

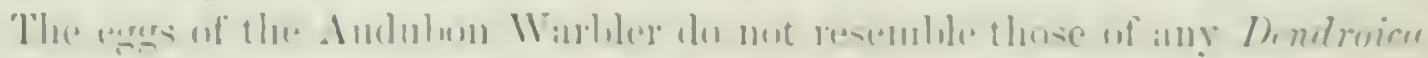

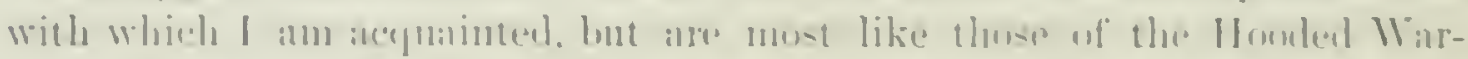

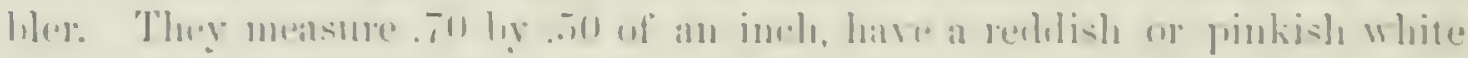

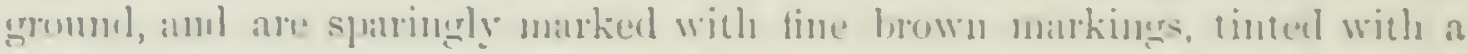
crimsin shitding.

\section{Dendroica maculosa, li.sur.}

\section{BLACK AND YELLOW WARBLER.}

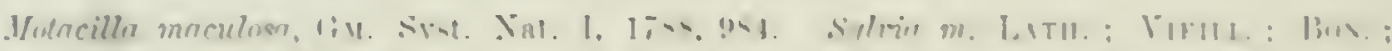

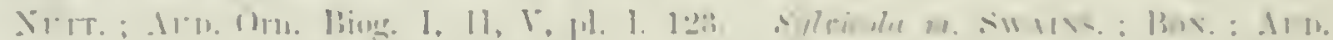

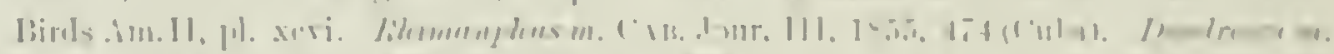

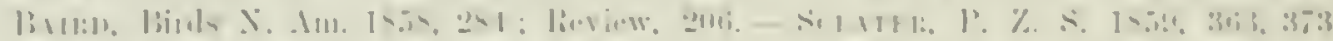

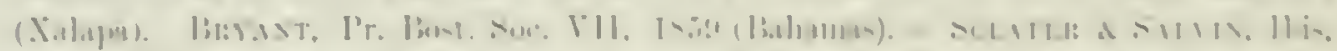

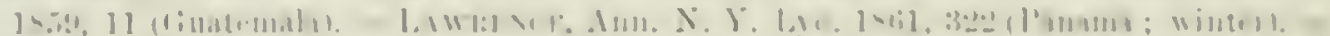

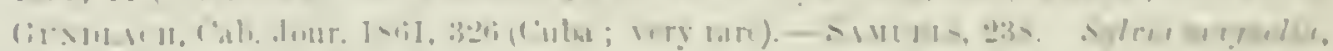
III- III. pl xviii. liz. :3.

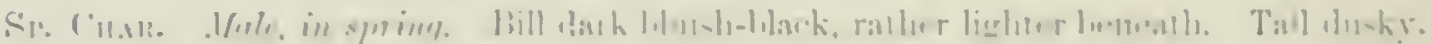

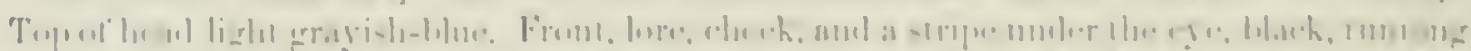

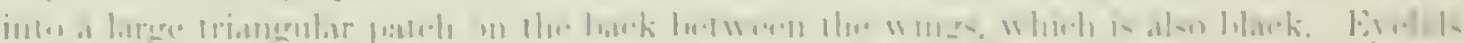

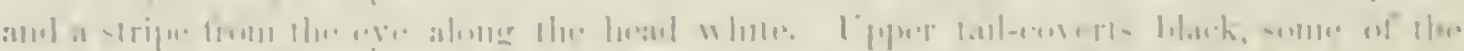

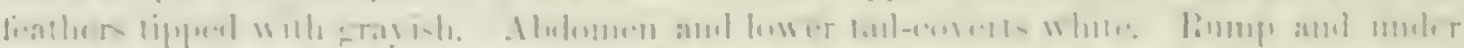

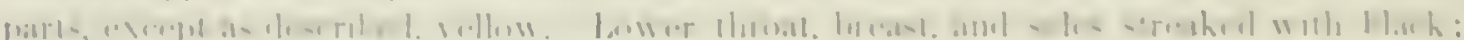

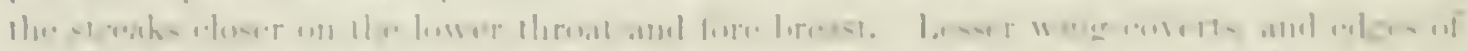

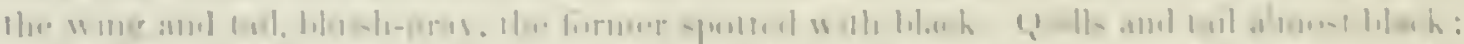

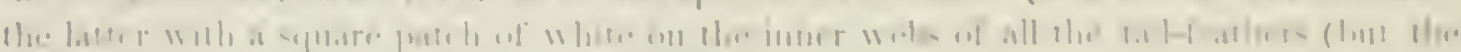

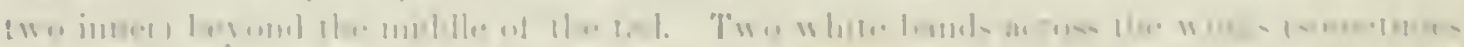

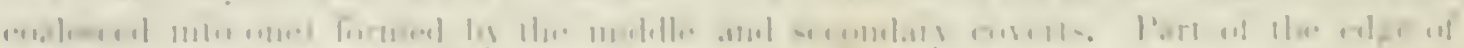

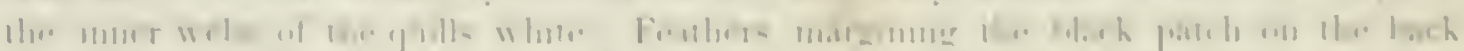

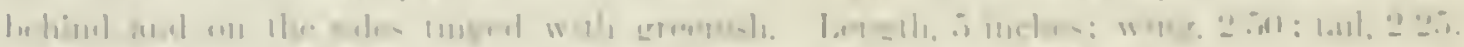

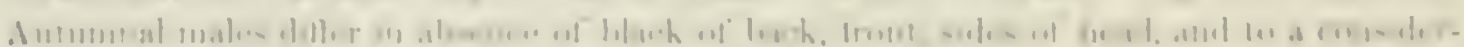

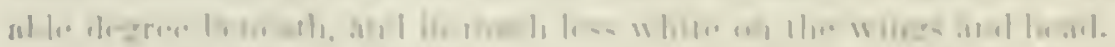

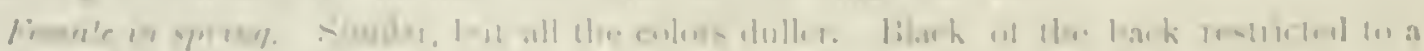

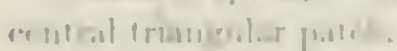

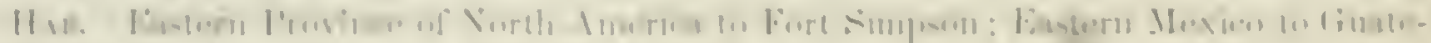

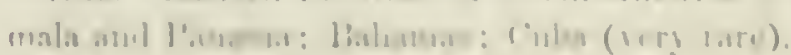


H.sits. The Black and Yellow Warbler, one of the most beautiful of this attrictive family, was supposed by our earlier writers to be exceedingly rare. Wilson nerer met with more than two specimens, - one in Ohio, the other on the Mississippi, - and spoke of it as a rery scarce species. In regard to its song lee was quite at fault, denying to it any notes deserving the name of song. Nuttall, who had only seen it occasionally in Massachusetts, in the middle of Mary, regarded it as rare, and was macquainted with its notes. Its history is now much better known, and neither its great rarity nor its deficiency as to melody can any longer be admitted.

At certain sensons and in particular places it is a rery common species. It may" be found during the breeding-senson throughont North America enst of the Great Plains, between latitude $4 t^{\circ}$ and Fort Simpson in the fur country. During its migrations it may be met with in most of the Eastern states, in Eastem Mexico, and the northern portions of Sonth America. It has been found in the Bahromas, and also in C'uba, where it is not common. Specimens have been received from Mexico, Gruatemala, and Panama, and from Fort Resnlution, Rupert Honse, and Fort Simpson, in Aretic America, and as far to the west as the moutl of Vermilion River. Dr. Bryant met with it in the Bahamas as early as the 15th of March, where it was quite common. II. Boucard fouml it at I'laya Vicente, in the hot portion of the State of Oaxaca, Mexico.

In Westem Massachusetts, Mr. Allen found it a common spring and antumn visitor, occurring in its northern flights from the mildle of MLar to the first of June, and in the autumm as late as September 20. Professor Verrill fonnd it in Westem Maine, but not common, both in spring and fall, but had no reason to beliere that it bred there. Mrr. Boartman does not include it in his list of Calais birds, and I did not find it among the islands in the Bay of Fundr. In the vicinity of Halifax, during the months of June and July, it is one of the most common of the Warblers, occurring in every direction.

Mr. Auduhon observed these Warblers in Lonisiana, in their migrations, as early as the midlle of Aareh; but its appearance there, as well in in Kentucky and Ohio, appeared to be occasional and accidental. In autumn le has met with then in large numbers among the mountains of Northem Pennsylvania. Ther were passing southward with their young. While on his way to Labmodor he noticed them in Amine, near Eastport, in Mny, very abundant along the roads, the fields, and the low woods, as well as in the orehards and gardens. The season was then not mlranced, the weather cold; and these birds sheltered themselves by night among the evergreens, and were often so chilled as to be readily taken by the hand. He also met them wherever he landed in the neighboring islands in the Bay of Fundy and at Labrador.

The song of this Warbler is clear and sweetly modulated, and surpasses that of most of this family. It seems to prefer the interior of low woods, where its notes may chiefly be heard during the early summer, as it sings 


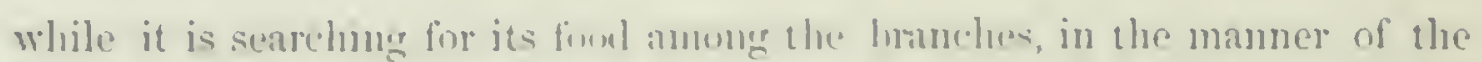
Virens.

Like nearly all the meminers of this family, in its search for foul it blends

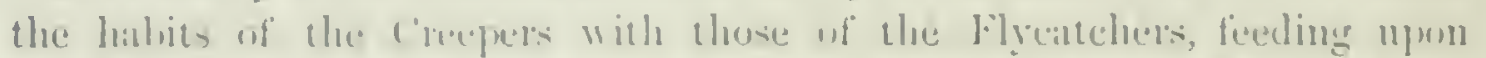
insects in their every form, ruming up and down the trunks for the ora,

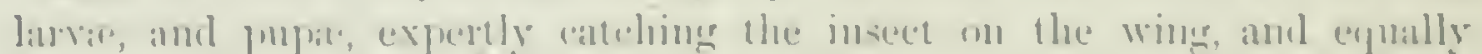

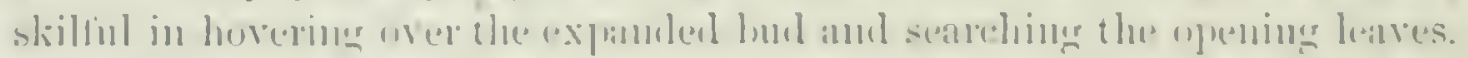

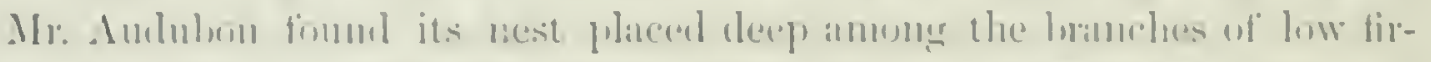

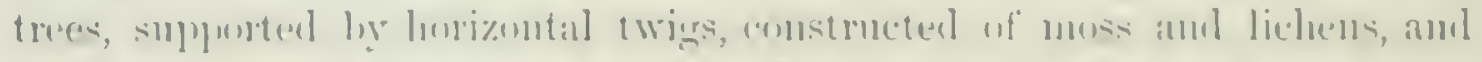

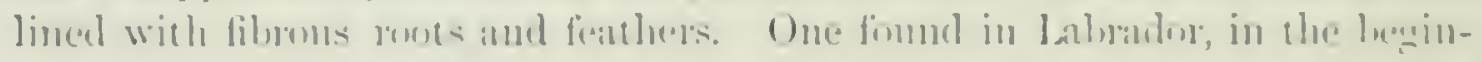

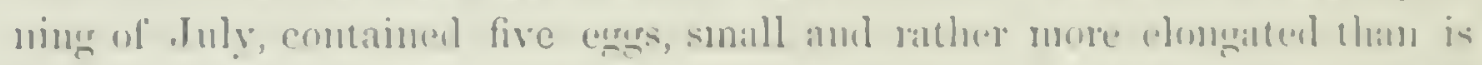
commun in this genns. They were white, and sprinkled with reddish dons at

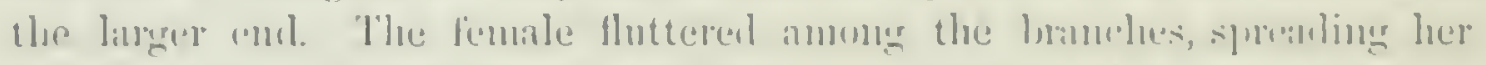
wings and tail in great distress, and returning to here nest ats soon ats the in-

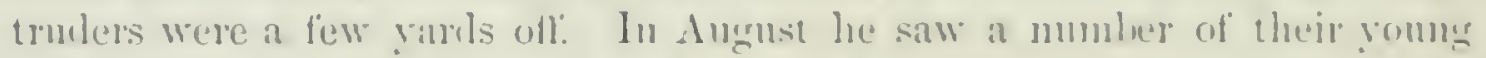
alrealy following their parents and moving somthwith. In his axpedition

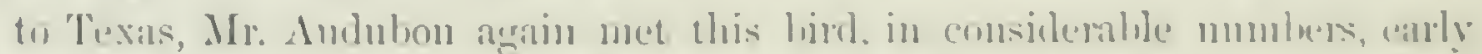

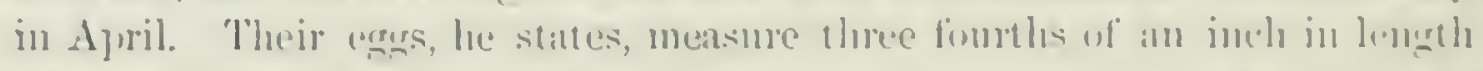
ly nine sixteenths in breadtly. In sume the ground-color, insteal of pure white, is of a yellewisli tinge.

The writer fomml this Warlder ahumdant near Halifix in the early sum-

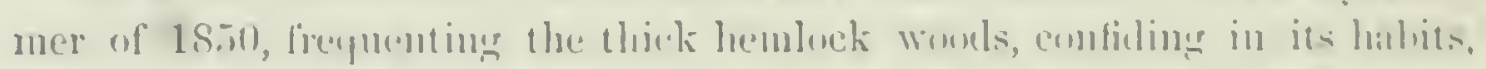

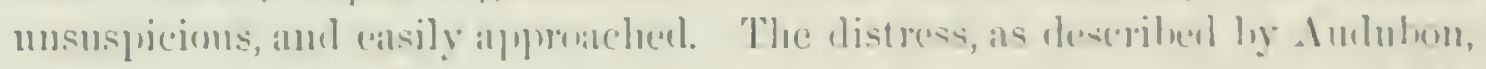

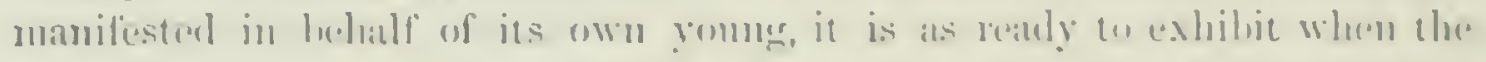

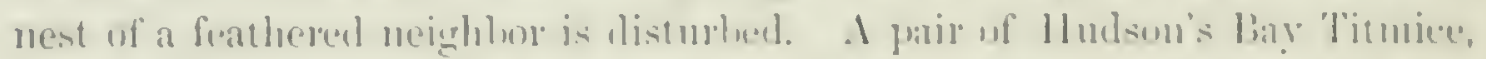

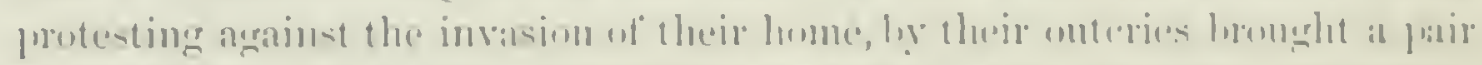

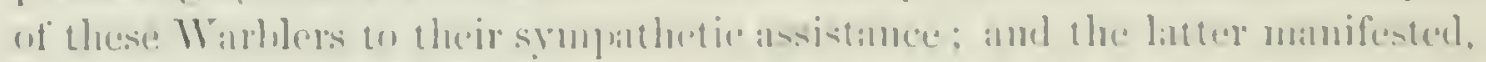

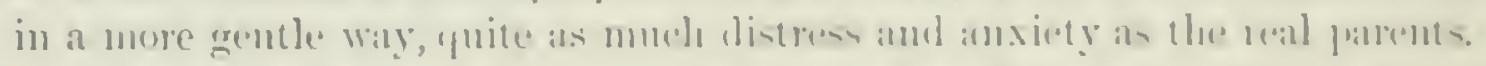

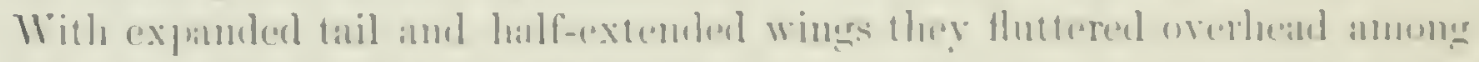

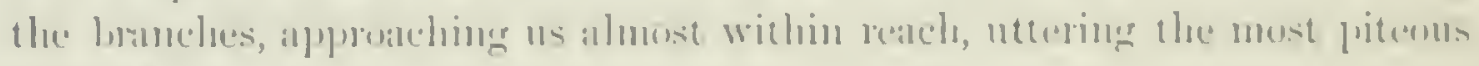
1mituries.

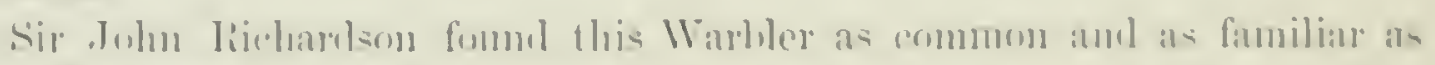

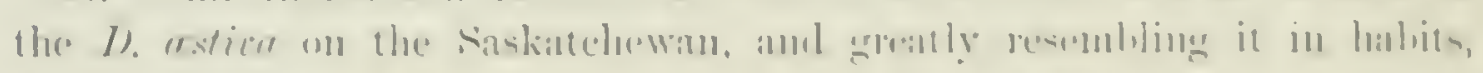

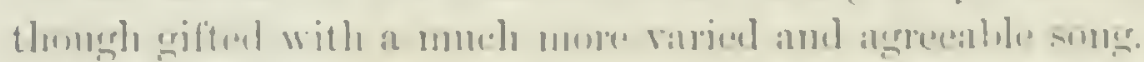

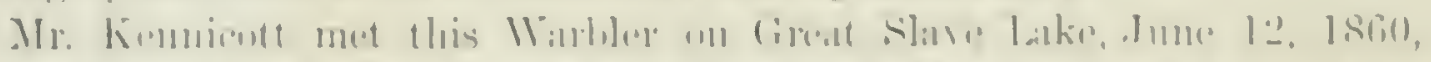

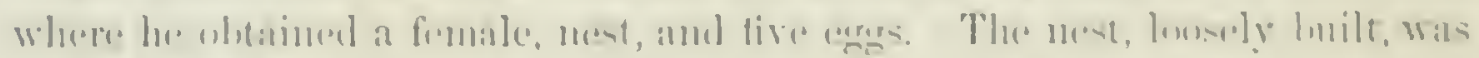

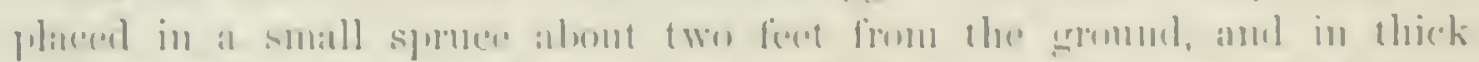

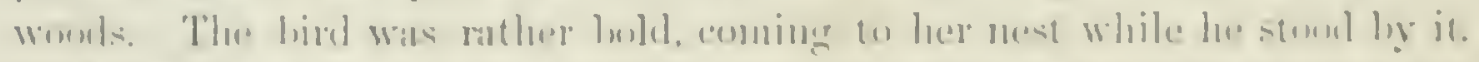

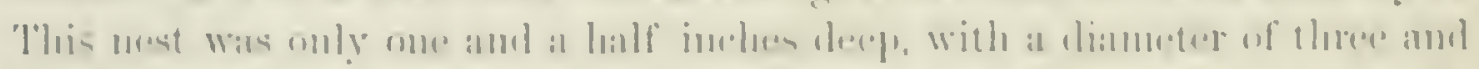

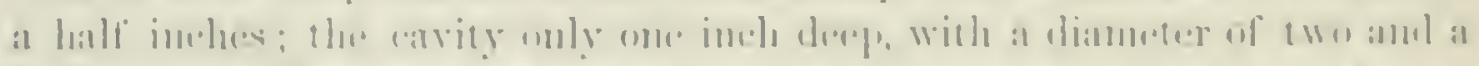

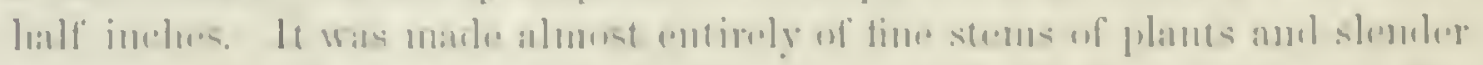

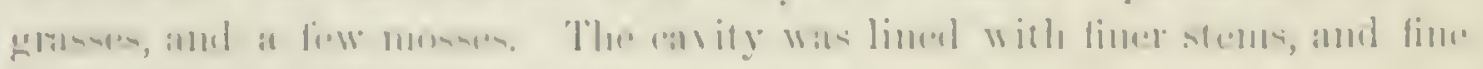

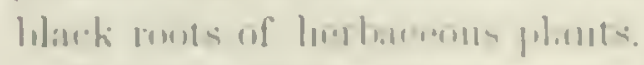

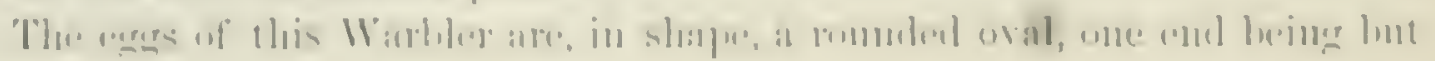


slightly more pointed than the other. They measure 62 of an inch in length and .49 in breadth. Their ground-color is a light ashen hue, or a dull white, and this is more or less sprinkled with fine dots and blotches of a light brown. Fur the most part these are grouped in a ring about the larger end.

Mr. R. Deane, of Cambridge, found this hird breeding near Lake Lmbagog. Its nest was in the fork of a low sprruce about three feet from the ground. The nest contained four egge, and was made of dry grasses, spruce twigs, and rootlets. It was lined with fine black roots, being a rather coarse structure for a Warbler. The eggrs were nearly spherical, averaging .62 by .51 of an inch. Their ground-color was a creamy-white, sparsely marked with a few large blotches of lilac and umber.

Dendroica cærulea, B.Irn.

\section{CERULEAN WARBLER; WHITE-THROATED BLUE WARBLER.}

Sylria carulca, WrL. Am. Orn. II, 181n, 1£1, pl. xrii, fig. 5. Syleicolu c. Swass, Jarn.

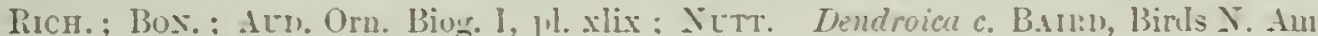

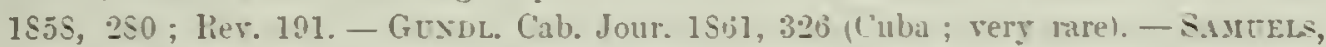

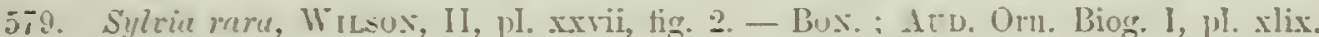
Sylein aะura, Steptl. Shlaw, Zü̈l. X, 1s17. - Box. Am. Orn. II, 1:2S, pl. xxrii (q).

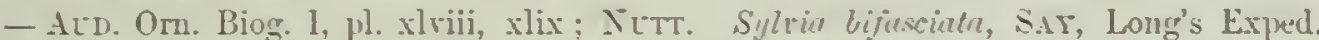

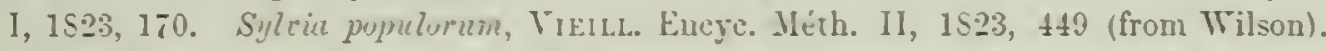

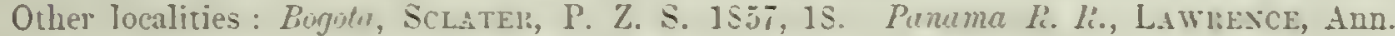

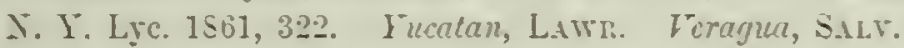

Sp. Crar. Mrate. Above bright blue, darkest on the erown, tinged with ash on the rump; midlle of back, scapulars, upper tail-coverts, and sides of the cromn, streaked with black. Beneath white; a collar aeross the breast, and streaks on the sides. dusky-blue. Lores, and a line through and behind the eve (where it is bordered abore hy whitish), duskr-blue; paler on the rheeks. Two white bands on the wings. All the tail-feathers except the imnermost with a white patch on the inner web near the end. Female, greenish-blue above, brightest on the crown; beneath white, tinged with greenish-rellow. and obsoletely streaked on the sides; eyelids and a supereiliary line greenish-white. Length, 4.25; wing, 2.6.5: tail, 1.90.

H.в. Eastern Lnited Stales, north to Niagara Falls: Cuba (rerr rare); Guatemala; Teragua, Panama, aud Bogota. Not recorded from Jexico (except Yucatan), or llest Indie: (except Cuba).

The autumnal adult plumage of both sexes is, in every respect, exactly like the spring dress. Young males in late summer are very similar to adult females, but are purer white belor, and less uniform greenish-blue above, the dark stripes on sides of the crown and black centres to scapulars being quite conspicuons; the young female, at the same season, is similar in pattern to the adult, but is dull green above, without any tinge of blue, and light buffyyellow below.

There is considerable variation in adult males, especially in the width of 


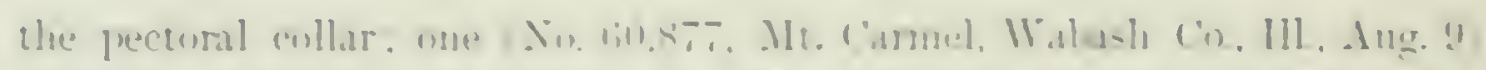

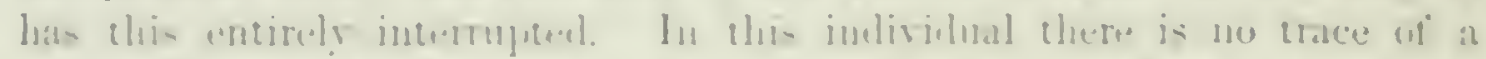

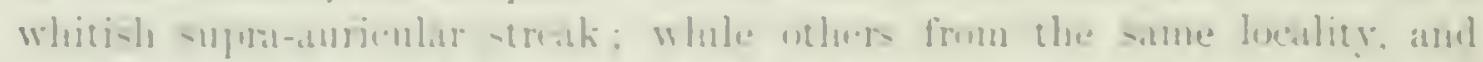

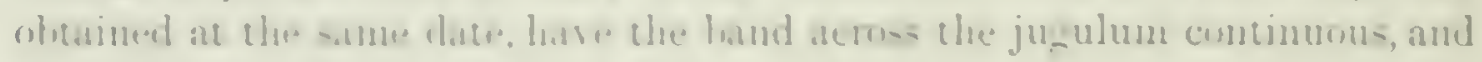

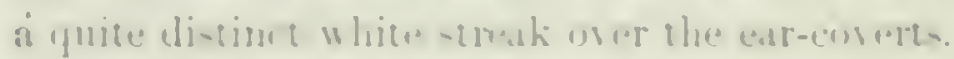

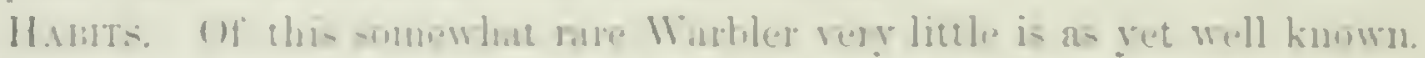

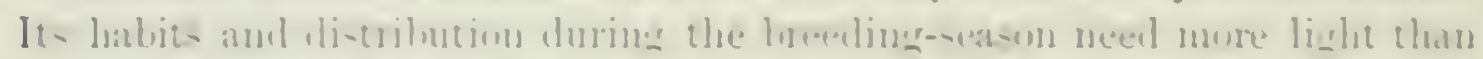

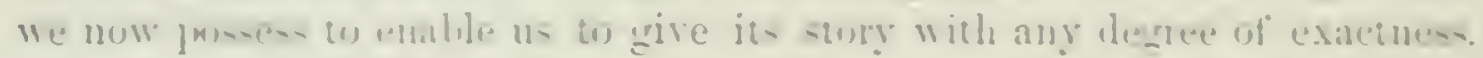

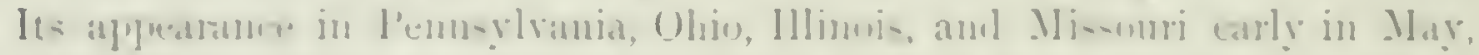

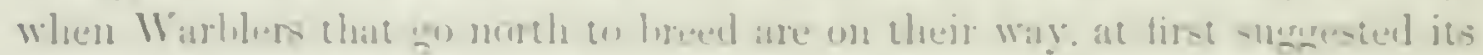

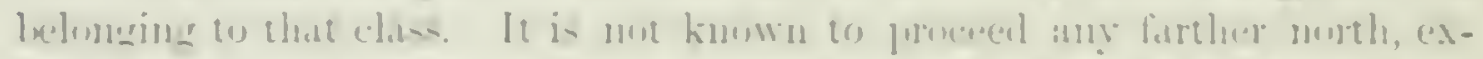

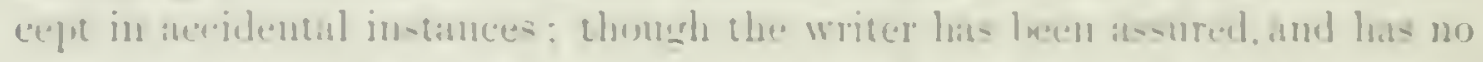

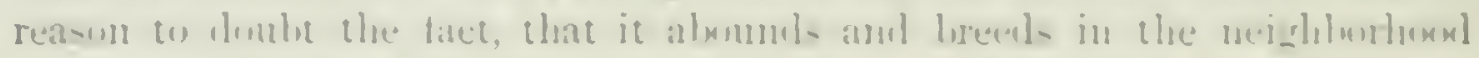

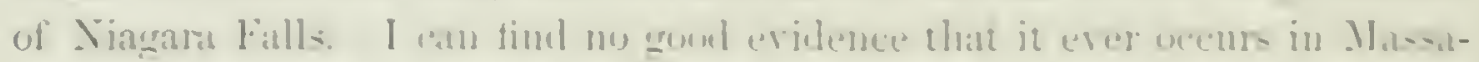

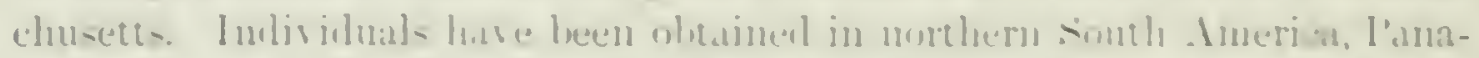

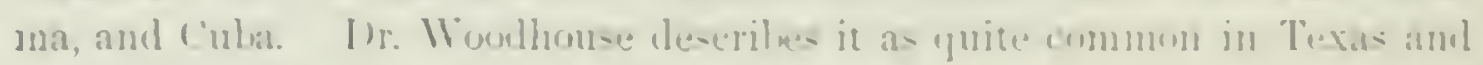
in the Indian Territery, where it breats, as he ohtained invils the ald and the roung birds. It was also almulant anume the timlereal lands of the Artinn-

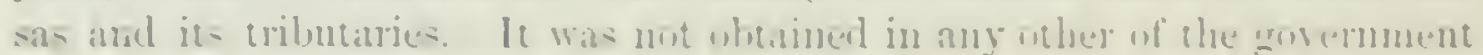

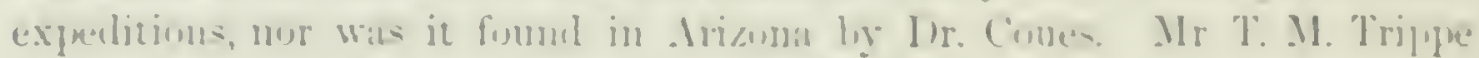

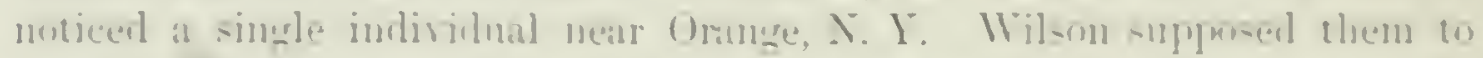

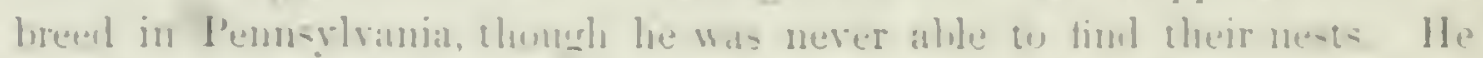

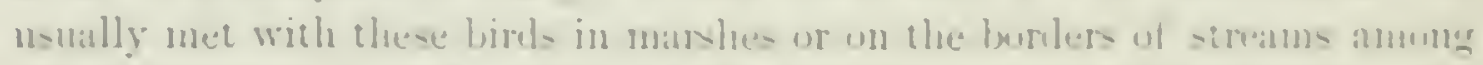

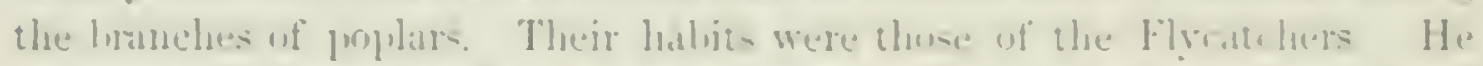

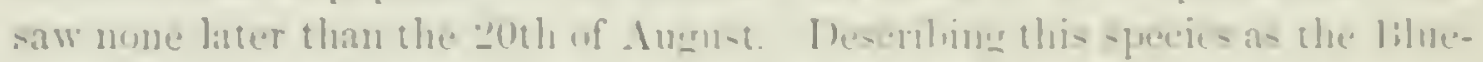

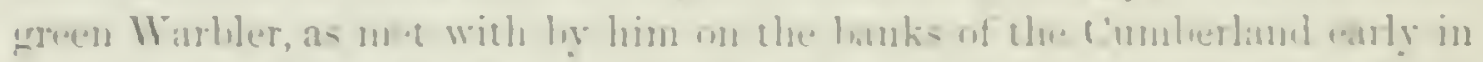

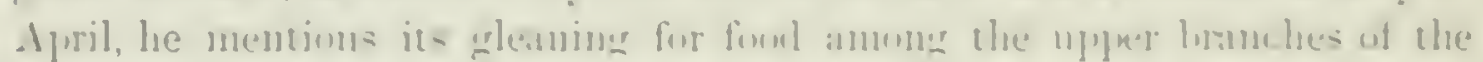

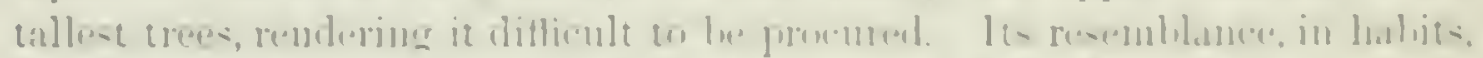

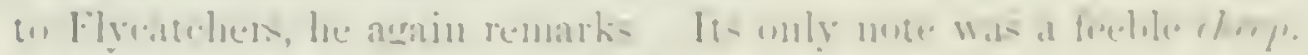

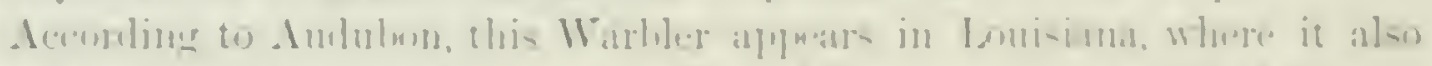

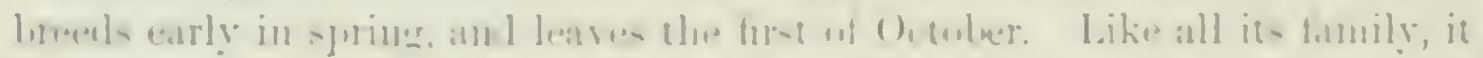

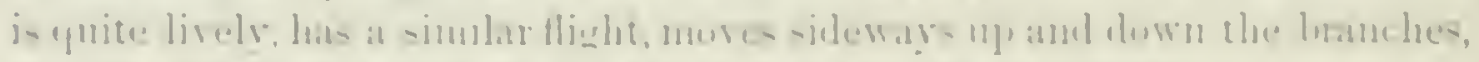
:

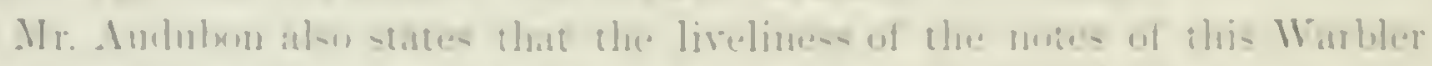

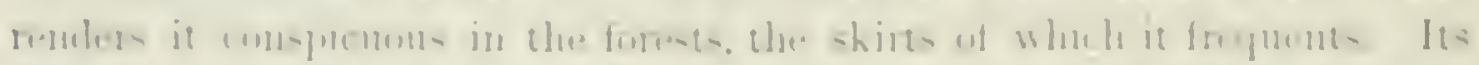

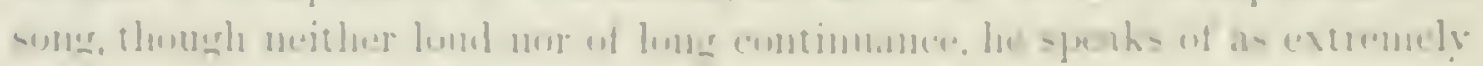

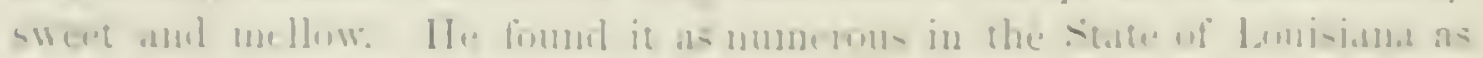

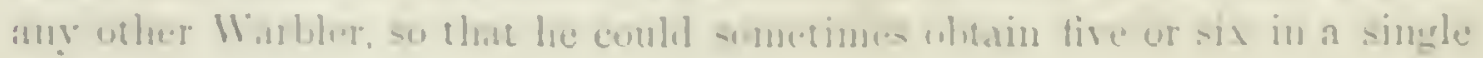
walk:

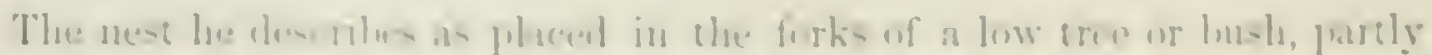

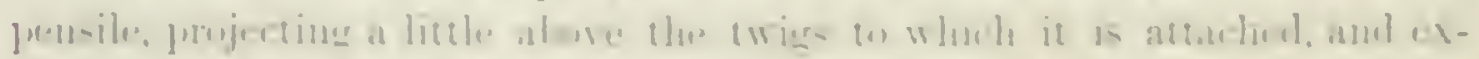

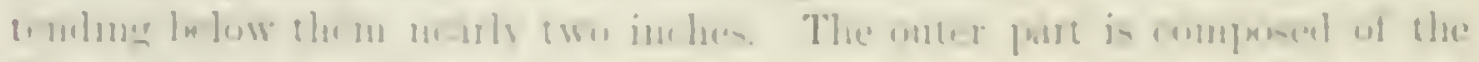

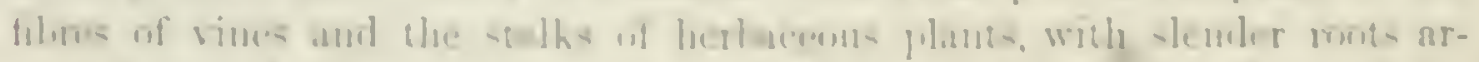

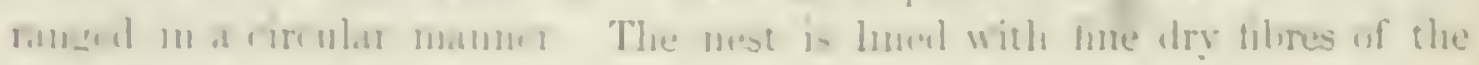


Spanish moss. The eggs are five in number, of a pure white with a few reddish spots about the larger end. When disturbed during ineubation, the female is said to trail along the branches with drooping wings and plaintive notes, in the manner of $D$. astirce. After the young lave left the nest, they move and hunt together, in company with their parents, evincing great activity in the pursnit of insects. They are also said to have a great partiality for trees the tops of which are thickly eorered with grapevines, and to occasionally alight on tall weeds, feeding upon their seeds.

In his visit to Texas, Mr. Andubon met a large number of these birds apparently coming from Mexico. On one occasion he encountered a large flock on a small island.

Mr. Nuttall mentions finding these birds very abundant in Tennessee. and also in West Florida.

In only a single instance has the writer net with this Warbler. This was about the midlle of June, at the Fairmount Water Works in the city of Philachelphia, where, annoug the tops of the trees, a single individual was busily engaged in hunting insects, undisturbed by the large numbers and vicinity of visitors to the grounds. It kept in the tops of the trees, moring about with great agility.

Mr. Ridgway gives the Crerulean Warhler as the most abundant species of its genus in the Lower Wabash Valley, not only during the spring and fall migrations, but also in the summer, when it breeds more plentifully even than the D. astixa. It inhabits, however, only the deep) woods of the bottom lands, where it is seldom seen, and only to be distingnished by the natmalist. Inhabiting, mostly, the tree-tops, it is an inconspicuous bird, and thus one that easily escapes notice. In its habits it is perlaps less interesting than others of its gemus, being so retired, and possessing only the most feeble notes.

\section{Dendroica blackburniæ, BAIRD.}

\section{BLACKBURNIAN WARBLER; ORANGE-THROATED WARBLER:}

Motacilla bluchbumice, Ganein, Syst. Nat. I, 1788, 977. Sylvia bl. Latir. ; Wissox, III, pl. xxiii. - Nutr. ; Arn. Orn. Biog. II, V, pl. cxxxv, eccxeix. Sylvicole bl. JAIn). ; Ricur. Auv. Birds Am. II, Il. Lxxvii. lihimamplus bl. CAB. Mus. Hein. 1850, 19. Dendroica bl. Batrin, Birts X. Am. 1858, 27t; Rev. 189. - Sclater \& SAlrix, Ibis, 1859, 11 (Guatemala). - Sclater, P. Z. S. 1859, 363 (Xalapal); Ib. 1860, 64 (Ecuador). - Iв. Catal. 1861, 30, no. 187 (Pallatanga and Namegal, Ecuarlor). - șduteds, 227. - Suxievall, Ofv. 1869, 611. - Drissen, Ibis, 1S65, 475. ? Lutucilla chrysoccphala, Guelix, I, 1788, 971 (Figuicr orangé et $F$. étranger, Buff. $V, 313$, pl. lviii, fig. 3, Guiana). Sylvia parus, Wis.. V, pI. xliv, fig. 3.-Aud. On. Biog. II, pl. cxxxiv. Sylricola parus, Al'D. Birts Am. II, pl. lxxiii. Sylvia luteralis, Steri. ? Motacilla incure, GMEL. I, 1788, 976. Sylria inerme, LATh. ; VIEILL. ? Sylvia melanorhoa, Vililı. Nouv. Dict. XI. 1817, 180 (Martini(ue). - Iв. Encycl. Métl. II, 44.

Localities quoted: Boyotr, Scrater, I'. Z. S. 1855, 143. Panama, LAwr. Anu. N. I. Lye. VII, 62. Costa Rica, CAB. Jour. 1S60, 32S. Bahamas, Brydxt, Bost. Pr. VII, 1859. Veragua, Salvix. Orizuba (winter; rare), Sumicilast. 


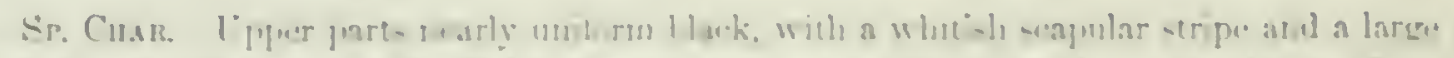

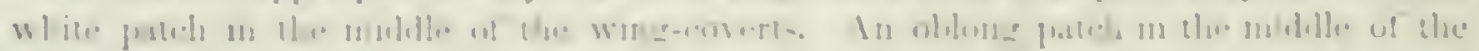

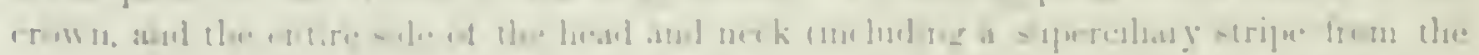

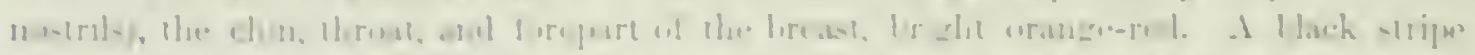

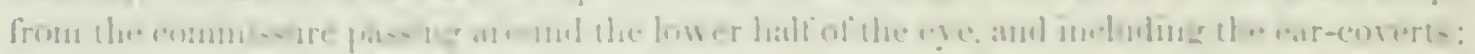

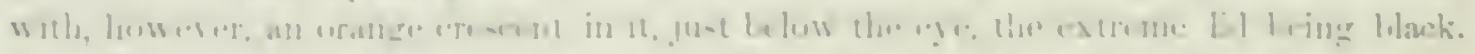

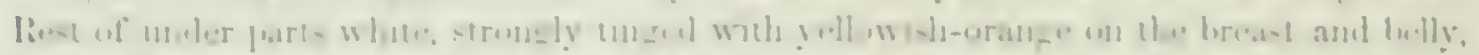

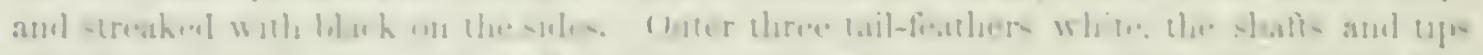

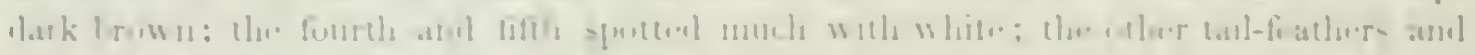

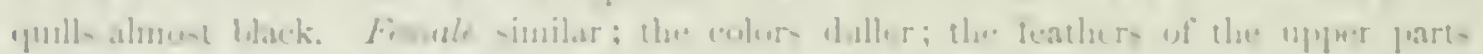

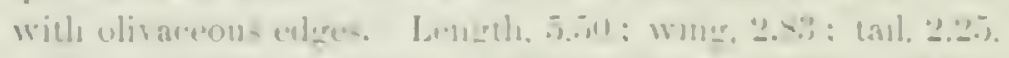

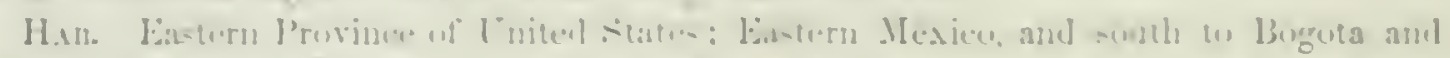
Ecuctur: buhansus alune of 11 ces Indien whe certainty.

Autumnal uales resemlite the females. Ther have two white hamb instead of ono: the batch stripes on the sides are larger: under jart yellowi-h; the throat gellewish, pasing into purer vellow hedimul.

Autumnal young birels have the sause pattern of colonition, but the dark

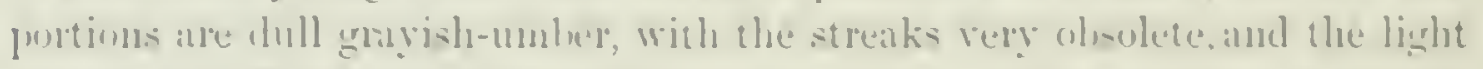
jarts dull butly-white, tinged with yellow on the jugulum: lhere is neither

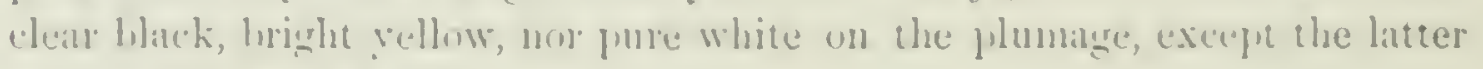
on the wing-hands and tail-pratches.

Ifabits. This somewlat rare and very hantiful Warther requires addi-

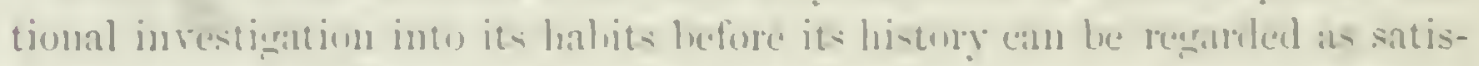

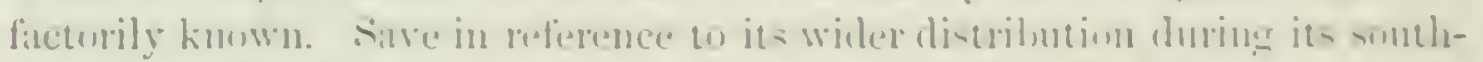

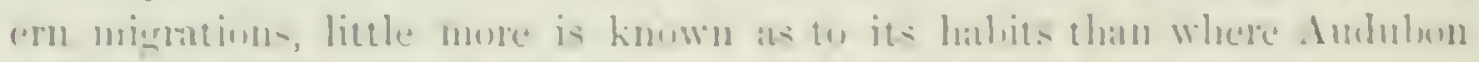
left it: history nearly thing years since. The sunthentian collection hat

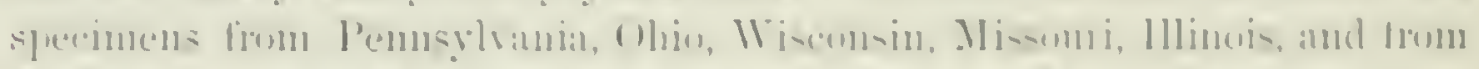

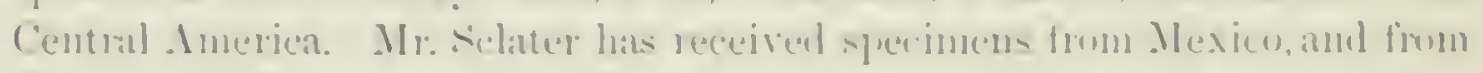

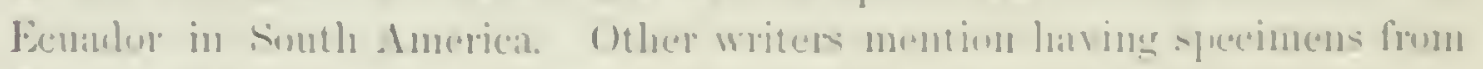

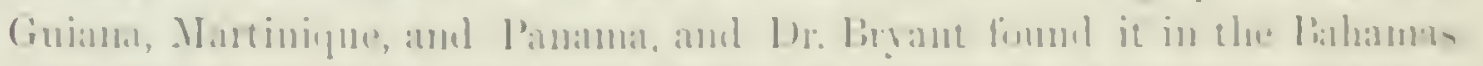
It is thes kumw to have a wide distrihution from the Allantie to the Mis-

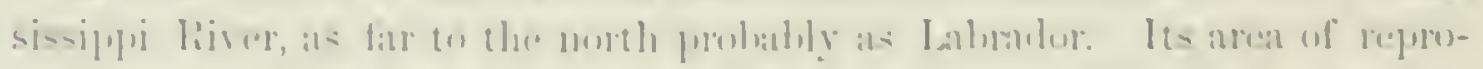

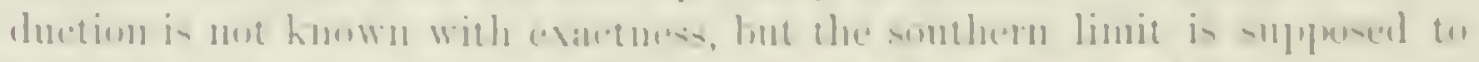

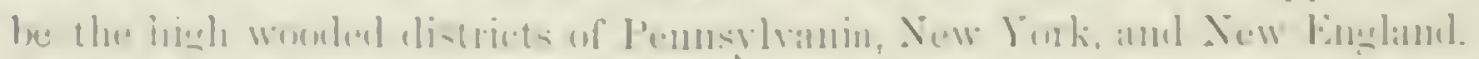

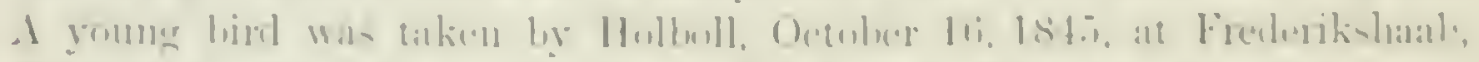

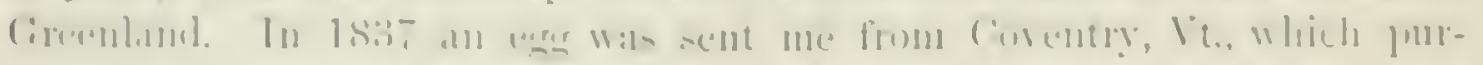

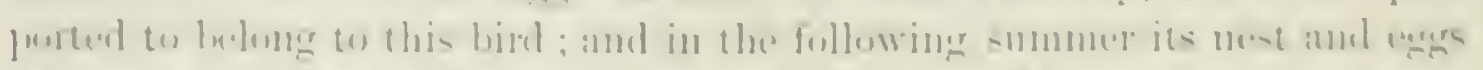

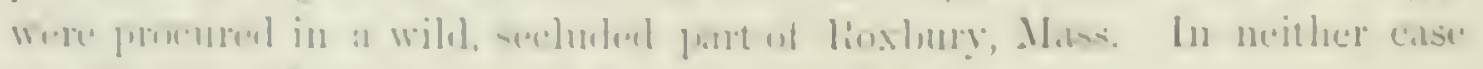
was the identileation entimly free trum dember

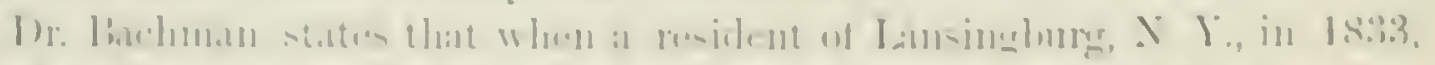

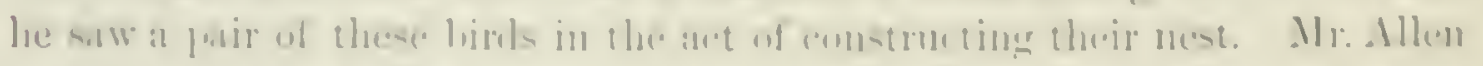

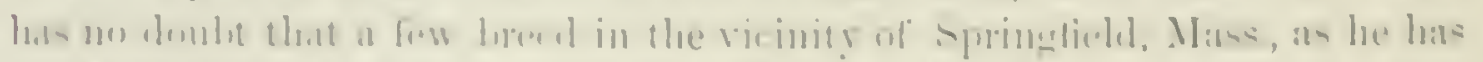

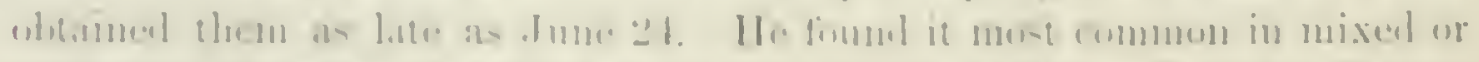

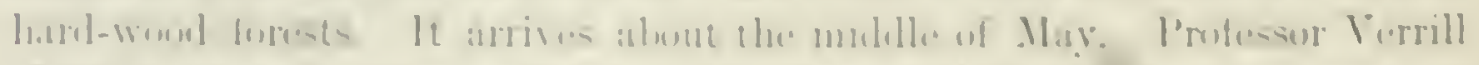

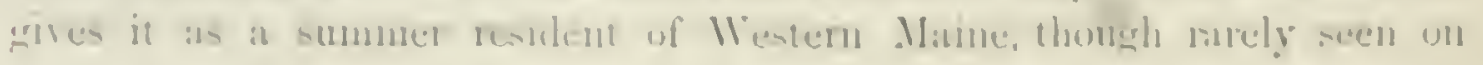


account of its liabit of keeping concealed anong the dense foliage. Mr. Buardman gives the same acconnt of its residence in summer in the neighborlrood of Calais.

Mr. Audubon did not regard this birl and his "Hemlock Warbler" as the same species, but gave distinct and different accounts of their hahits. We hatre therefore to receire with cantion these records of reculiarities. He found the Blackburnian Warbler breeding in Northeastem Maine, in New Brunswick, in the Magdaleine Islands, and in Lahmdor and Newfonndland. He states, correctly, that it has a very sweet song of five or six motes, much louder than seemed possible from the size of the birl. It pursues its insect prey among the branches of the fir-trees, moving along after the manner of the common Redstart.

Mr. McCulloch, of Halifax, gave Mr. Audubon a nest of this hird with three egrs. The nest was formed externally of different textures, lined with fine delicate strips of bark and a thick bed of feathers and horse-hair. The egirs were small, conical, with a white sround spotted with light red at the larger end. The nest was in the small fork of a tree five feet from the ground, and near a brook.

The nest obtained in lioxbury was in a bush, a few feet from the ground, in a very wild region of forest and rocks. Externally, except in its lengtl, which was less, it resembled a nest of the G. trichas, being made of coarse, dry grasses. Intemally it was much nore wammly lined with feathers and soft fur than is the case in nests of the Iellow-Throat. The egars were of a crystal whiteness, marked at their laruer end with dark purple, and but for their smaller size might have been mistiken for those of G. trichas. The position of the nest, however, was conclusive in regard to this point. The egg from Corentry was substantially similar, except that reddish-bruwn dots were mingled with the purple markings, in the form of a wreath around the larger end.

Wilson describes this Warbler as songless, but attributes to its counterpart, the Hemlock ITarhler, a rerr sweet song of a few low notes, - a rerr different account from that given by Audubon of the song of the Blackburnian.

Mr. Paine states that this species is resident during the summer months in Raudolph, Tt. It is, he says, a rery close companion of the D. rirens, nuriving at the same time with it eren to a day, or about the 10th of May. Its dry chipping song may then be heard in striking contrast with the sweet notes of the rircus. He ras not able to find its nest.

Mr. C. Wr. Wyatt met with this species as a winter resident at Alto, in Colombia, South America. Its upward range seemed to be terminated only ly the paramos. Among the oaks on the Pamplona road he found it rery commou just mder the paramo, the bright orange throat of the male making it a rery conspicnous bird. He was led to believe that they were not foum there at a lower elevation than five thousand feet. 


\section{Dendroica dominica, li.ull. \\ YELLOW-THROATED GRAT WARBLER.}

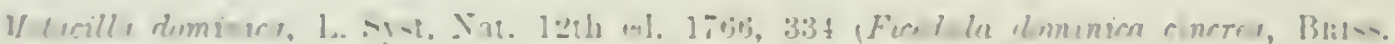

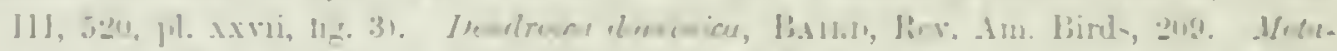

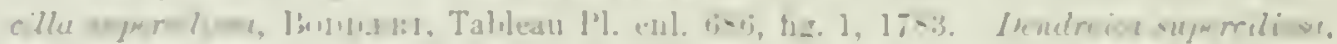

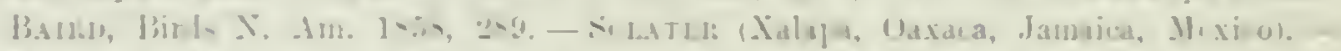

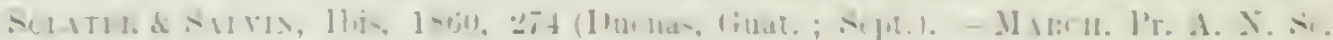

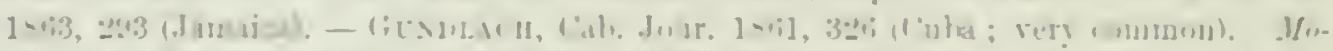

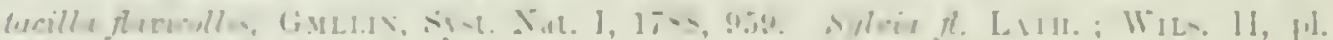

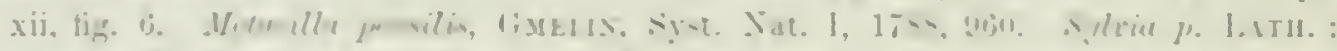

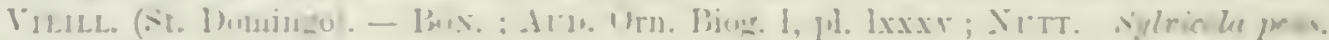

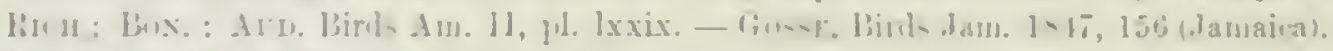
Iil a jow yous. CAL. Jour. III, tit (1'uba).

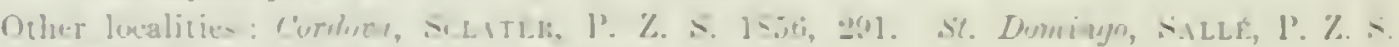

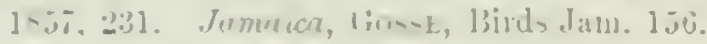

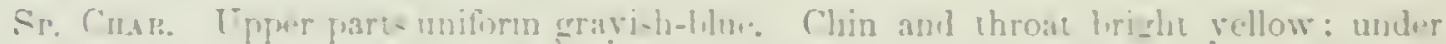

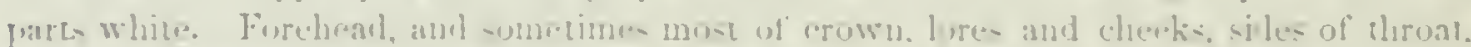

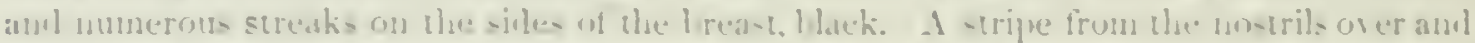

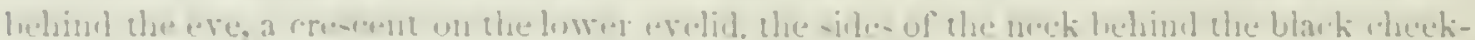

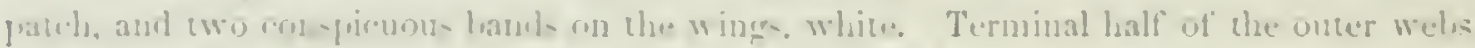

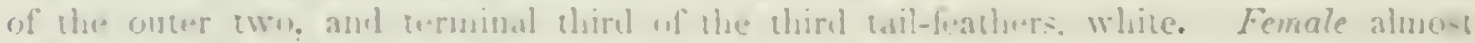

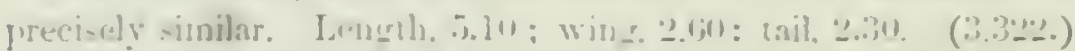

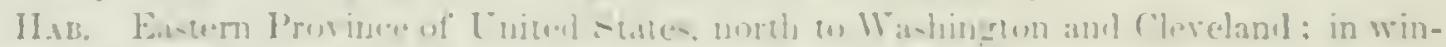

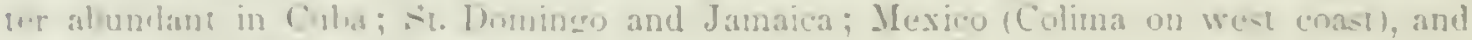
Guscemala, lievelent in Jamaica?

An antumnal mal, (No, 1,u!s, Wishimeton, D. (') has the buish-ash

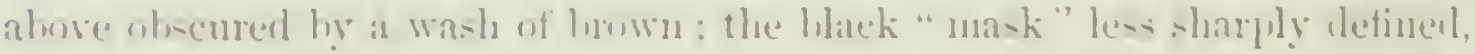
the streaks on forelsead wanting: the yellow galer and duller, and the white lesenth -riled with liownish.

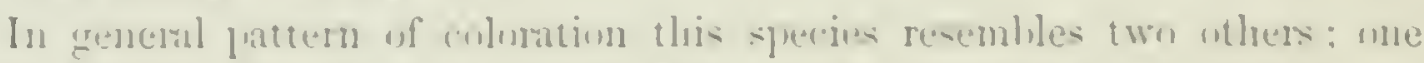
from Arizuna, the other from Portu Rien. The diallumes are as follows:-

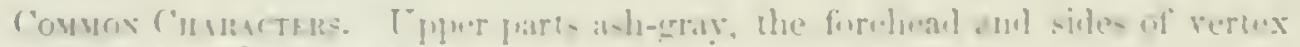

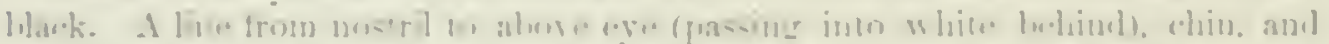

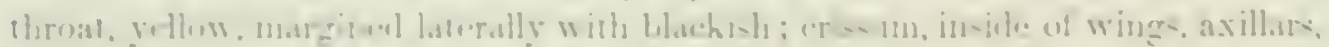

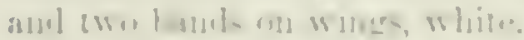

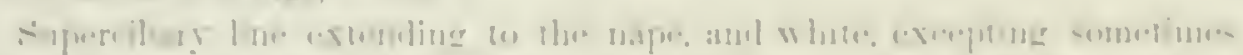

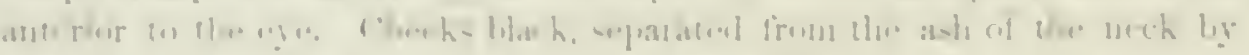

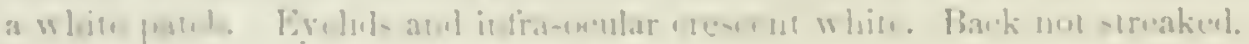
Bill I.

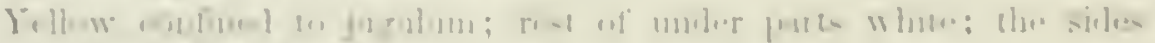

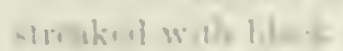

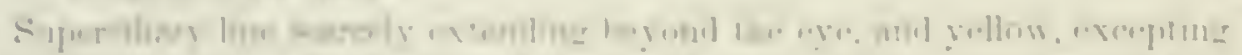

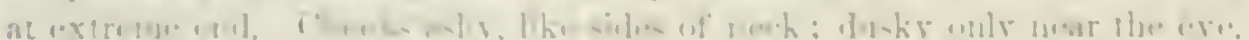

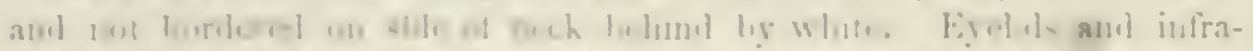

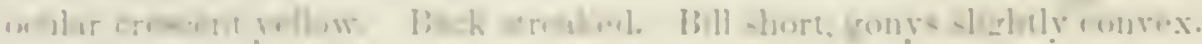


Yellow of muder parts contined to jugulum; rest of muler jants white; the sirles streakinl with blatek

Yellow of undel parts extending to crissum. Sides scincely stlealied.

In the Review (p. 209) several variations in this species are noted ; lut at that time there was not a sufficient number of specinens to warrant our coming to a conchusion as to their value. Now, however, we have better material before 115 , and npon the examination of about thirty specinens, including two series of nearly equal numbers, - one from the Atlantic States and the West Indies, the other from the Mississiply region and Middle America, - fund that there are two appreeiably different races, to be distinguished from each other by points of constant diflerence. All birds of the first series have the bill longer than any of the latter, the diflerence in a majority of the specinems being very ensidemble ; they also hitre the superciliary stripe bright yellow anteriorly; while anong the latter there is never more than a trace of yellow over the lores, and even this minimmm amount is discernible only in one or two indiviluals. The West Indian form is, of course, the true dominire, and to be distinguished as vill. dominire; as none of the synonymes of this species were fommled npon the Mexienn one, however, it will be necessiny to proprose a new name; accordingly, the term rar. albiloru is selected as being most descriptive of its peculiar features.

The following synopsis, tilken from typical specimens, show's the differences between these two races:-

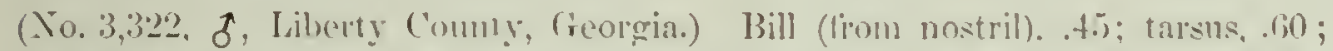
wing. 2.60; tail, 2..00. Supereiliary stripe. anterior to ege, wholly hright rellow; yellow of chim and maxilae extending to the bill. Ihub. In sumber, Atlantic: States of Lnited States, north to Waslineton. In winter, and possibly all the year, in ("uba. Santo Domingo, ant Jamaica. . . . var. dominiru.

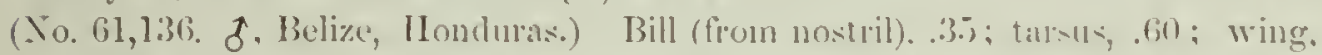
2.70; tail, 2.20. Supereiliary stripe wholly white; yellum of rhin and maxilla boldered narowly nest the bill with white. Hub. In summer, the Mis-issippi region of United States, north to Lake Eire: enmonon in Sonth Illinois. In winter, and possibly all the year, in Mexiro, sonth to Guatemala, Yucatan on the Atlantic, and Colima on the Pacifie side . . . . . var. elbilo i".

Habits. The history of the Yellow-throated Wirhler is very imperfectly known. Its gengruphical clistribution is irregular and apparently cocentric. Found occasionally, rather than frequently, in the Southern Atlintic and Culf States, it occurs irregularly as far north as Washinerton, New Tork City, Cleveland, O., Union County, Ill., and Kansas. In the last place it is supposed also occasionally to breed. West of this it loas not been traced in any portion of the United States. It was obtained in Tamaulipas, Mexico, by Lientenant Couch, and on the western coast MIr. Xantus found it at Colima. Mr. Sclater has also procured it from other portions of Mexico, and M. Bon- 


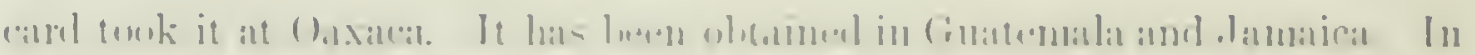

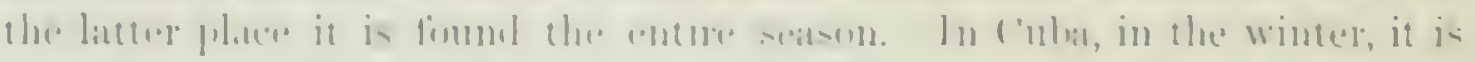

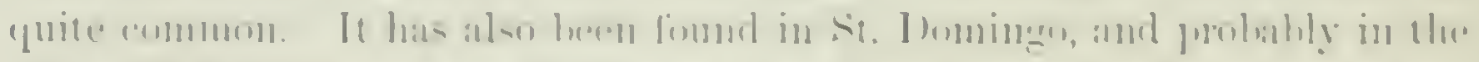

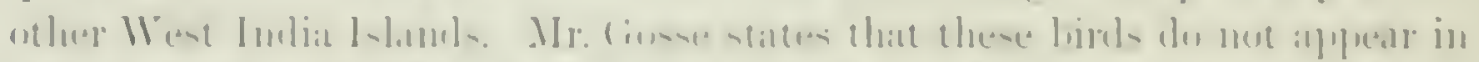

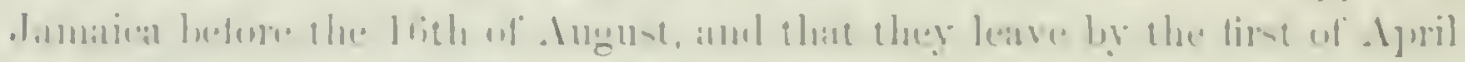

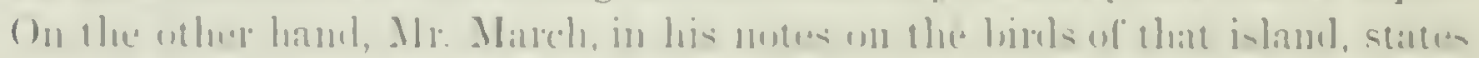

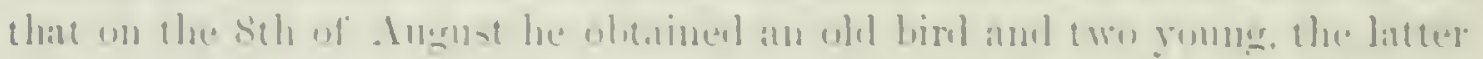

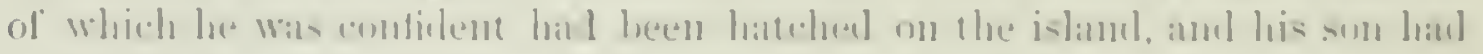

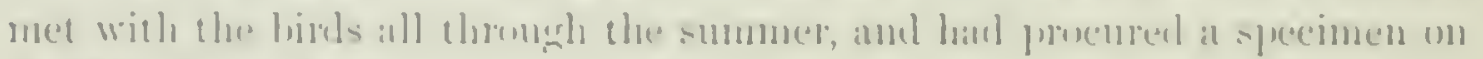

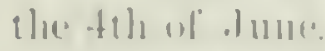

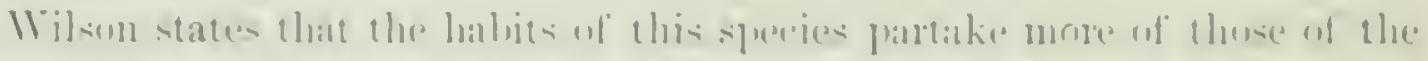

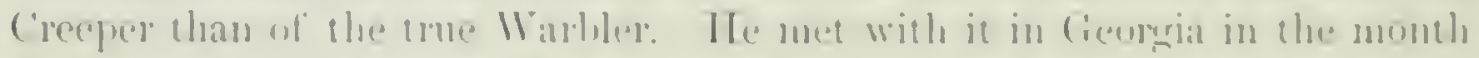

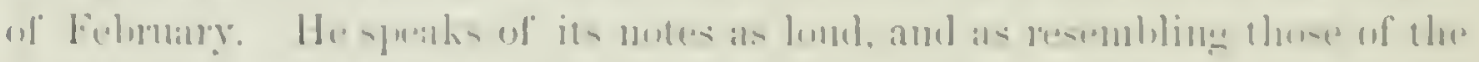

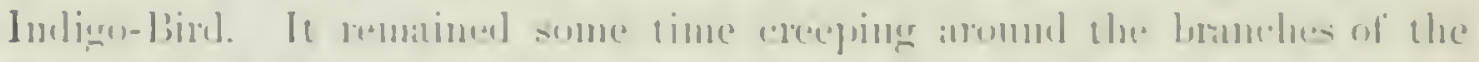

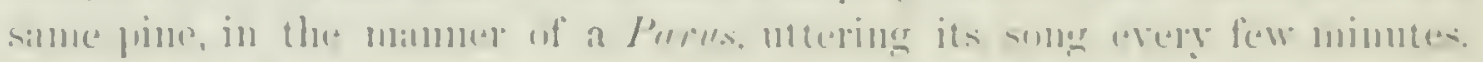

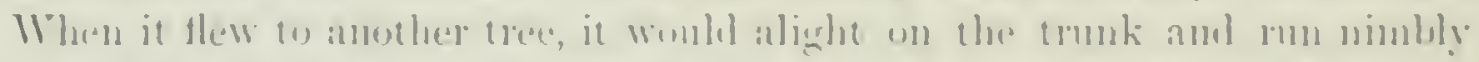

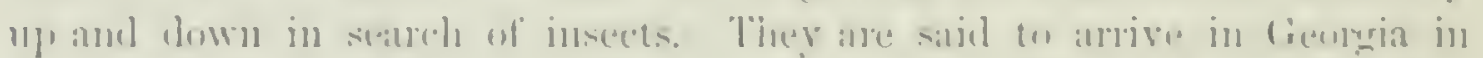

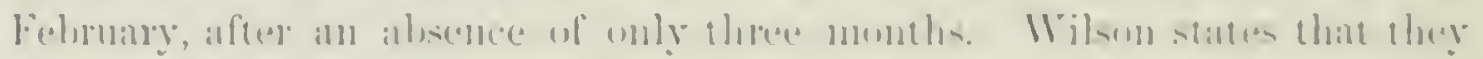

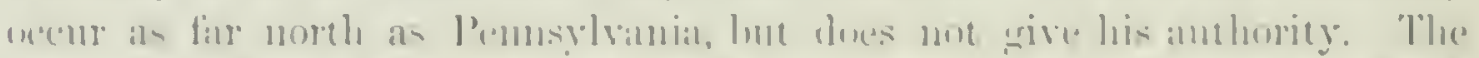

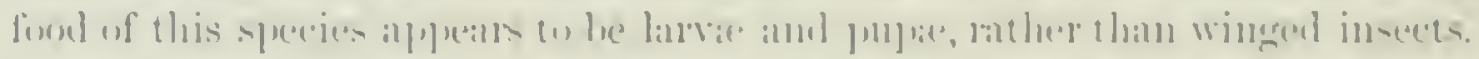

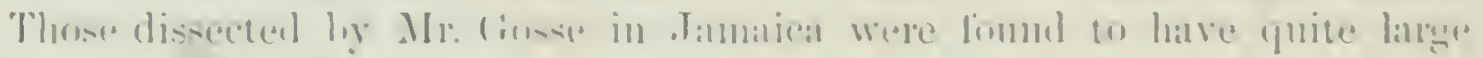

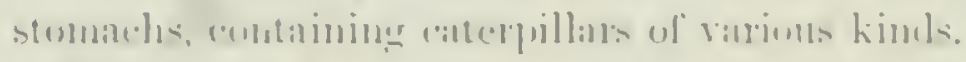

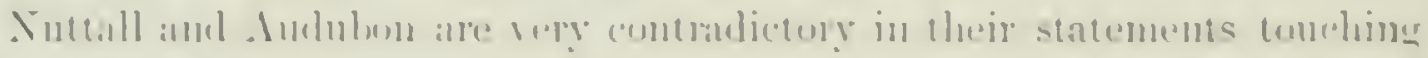

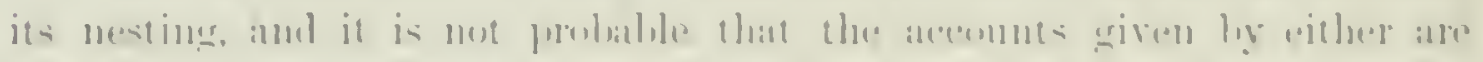

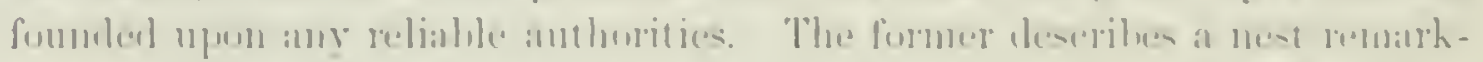

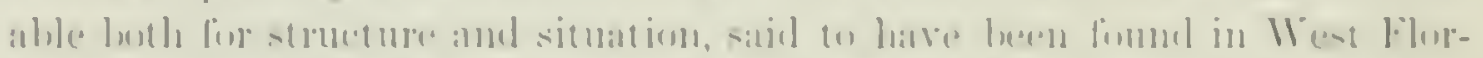

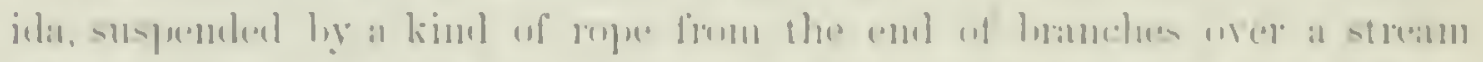

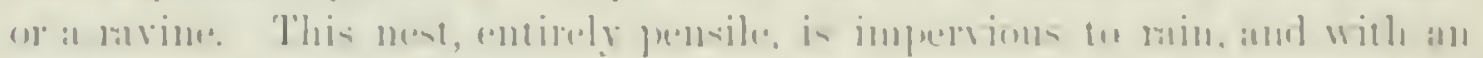

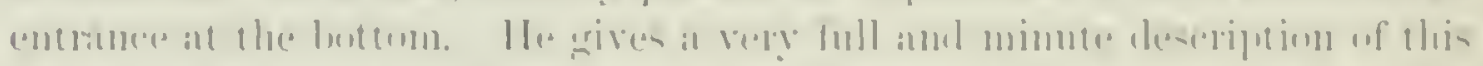
met, hut grive no

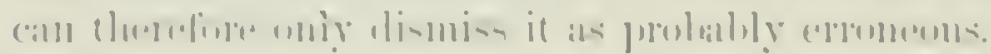

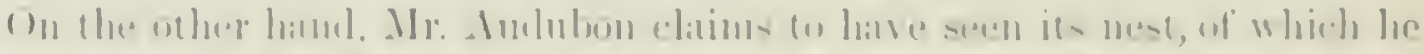

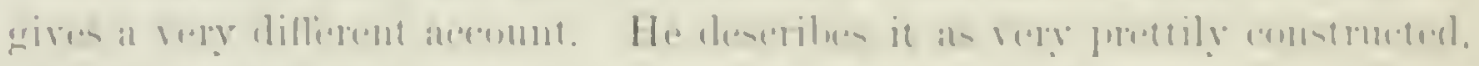

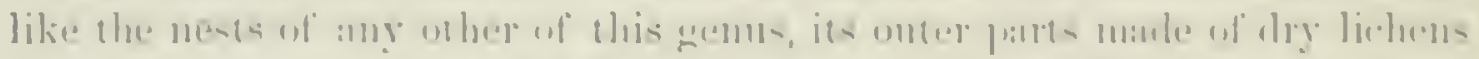

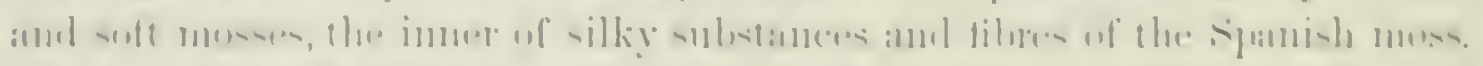

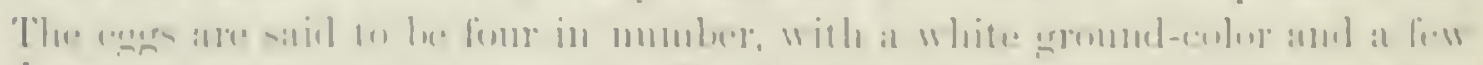

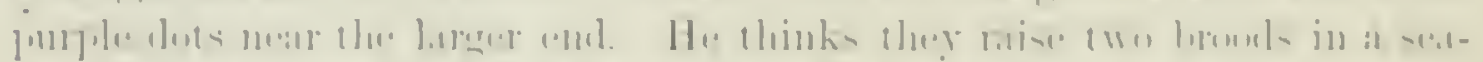

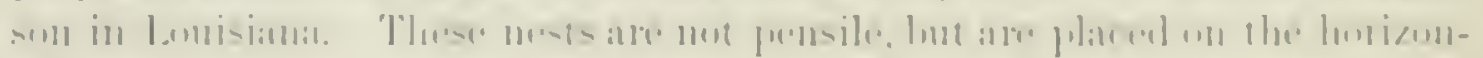

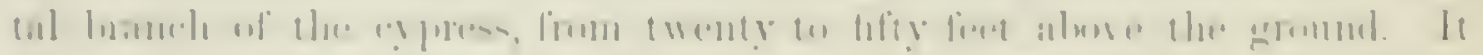

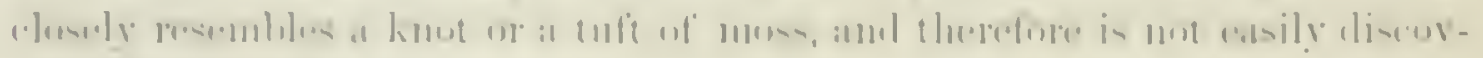

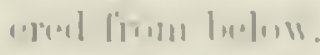

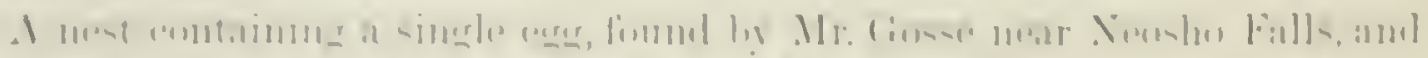
-

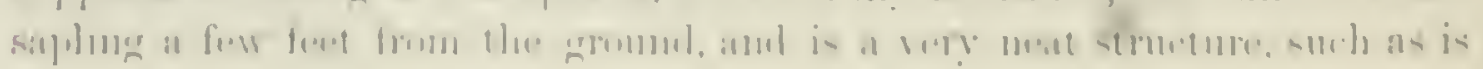


described by Auduhon. The egr is pure errstal-white, ohlong and pointed, and marked with purples and brown.

Mr. Ridgway informs me that in Sontlem Illinois, at least in the valley of the Lower Wabash, the Yellow-throated Warbler may he satil to be at least al regular, thongh not common, summer sojourner. Thongh it inhabits chiefly. the swanly portions of the bottom-lands, it makes frequent visits to the orchards and door-yards, less often, however, in the hreeding than in the migrating seasum. In its manners it is almost as much of a C'reeper ats the Mniotiltu rariu, being frequently seen ereeping not only along the branches of trees, but orer the eaves and cornices of buildings, with all the facility of a Nuthatcl.

Egrgs supposed to be of this species, taken near Wilmington, $\mathbf{X}$. (., by Mr. Norwood (riles $(16,199$, smitlı. ('oll.), have a gromul-culor of dull ashywhite, with a livid tinge. They are thickly speckled, chiefly arom the larrer end, with irregular markings of rufuns, and fainter ones of lilac interspersed witl a very few minute specks of black. They are broadly orate in form, and mensure. 70 by .j5 of an inch.

\section{Dendroica graciæ, ('心E.}

\section{ARIZONA WARBLER.}

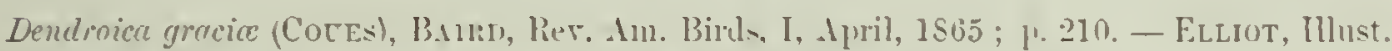
Birds . I. In. I, vi. - Coorlis, Orn. Cil. I, 1570, 563 (Alpendix).

Sp. CH.ır. Idult male (No. 40,680, May 1. Is15, Dr. E. Couss). Thole upper parts, including ear-eorerts and sides of neck, a-l1-glay; small cumeate streaks over the eromn. coalesced laterally into a broal stripe on cach sicle, with larerer cuncatestreaks on the interscapular region. and inconspicnows linean streaks on wpper tail-corerts. black. Two conspicuons white hands across tle wing, tomed by the tips of midelle and secondary coverts; secondaries passing externally into light a-h. Lateral tail-feather entirely white. cacept ahout the basal third of the inner web (the dusky lunning sone distance toward the end along the edge), and a broul streak covering nost of the temmal fourth of the outer web. which are clear dusty : the next feather lias the onter web exactly the same, but almost the basal half of the imner is dusky : on the next the white is confunel to an oblong spot (not touching the inner elge) on abont the terminal thirk. While the onter wreh is only erlged with white; the rest have no white at all. A supereiliary stripe uxtending alunt al of an inch behiml the ere (that portion hehind the ere white). the lower eyclid, maxillax, chin, throat. and jugulum purc gambore-rellow. Rest of lower parts, incluling lining of wing, pure white; the sides conspicuous!y streaked with black; lores. ant a few obsolete treaks along the junction of the ash and rellow, lnk ky. Wing, 2.60; tail, 2.20; lill (from nostril), .31); tarsus. .60. Adnlt female (40.(585). May 2t). Similar to the male. but colors duller, and markings less sharply defuned. Wing. 2.45; tail, 2.00. Yromg (36.992. August 11). Above brownish-gray withont strerks. Beneath ochlaceous-white, obsoletely streaked along the sides. Fellow superciliary stripe not well defined, and only a tinge of yellow on the jugnlum, the throat being grarish-white. Wings and tail nearly as in the adult. The young in autmmal plunage is similar. but the gellow ocenpies its usual area; it is, howerer, much duller. as well as lighter. than in the adult.

Haв. Fort Whipple, near Prescott. Arizona. Belize. British Honduras (var. decora). 


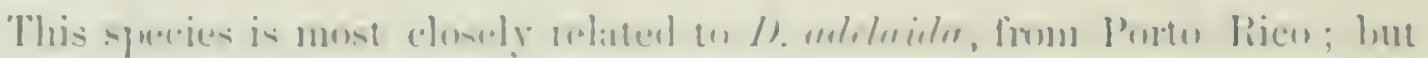

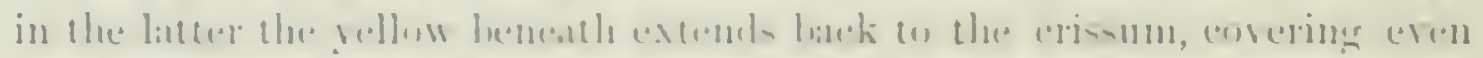

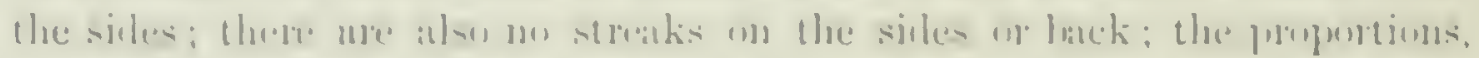

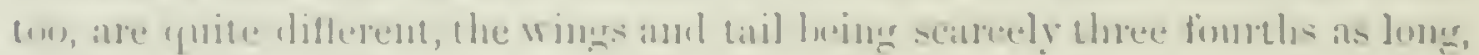

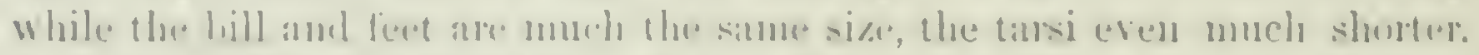

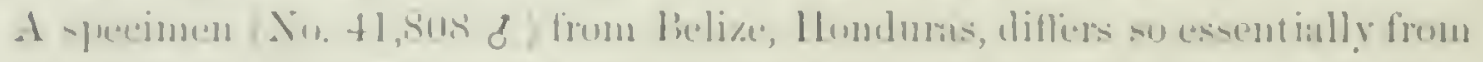

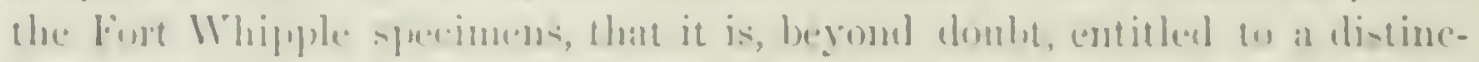

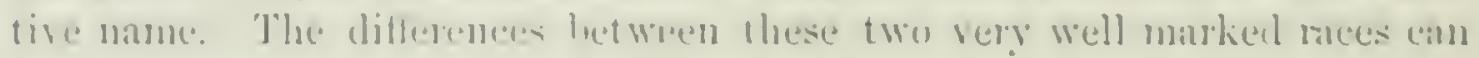

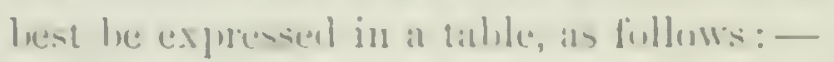

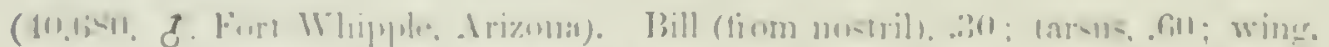

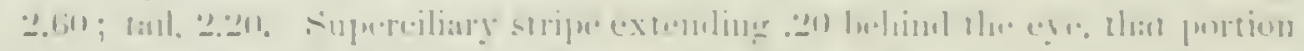

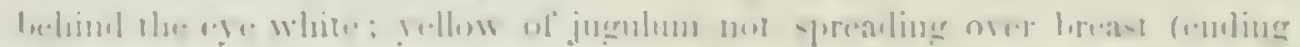

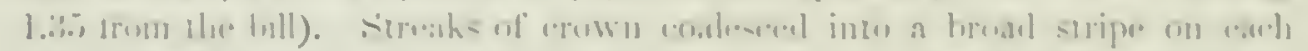

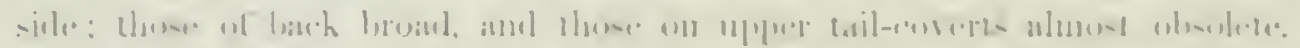

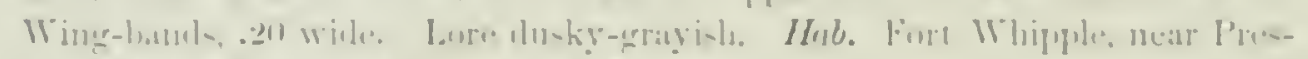

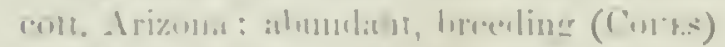

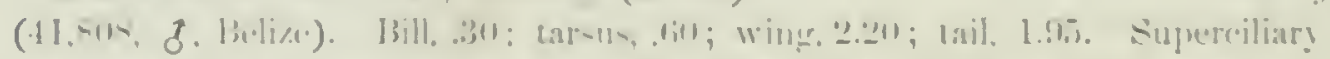

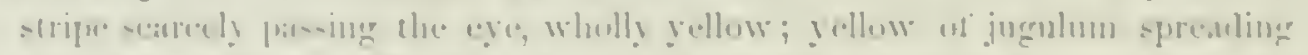

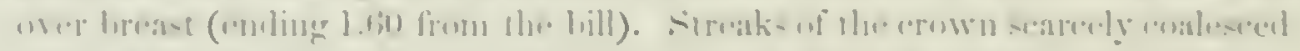

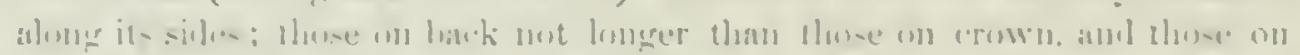

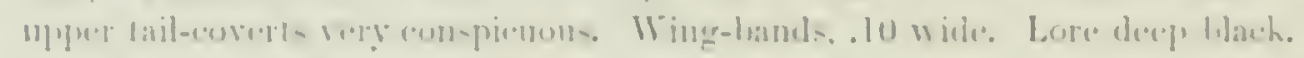
Hlil. Belize, Husmluris, revillent?

ial ipequa

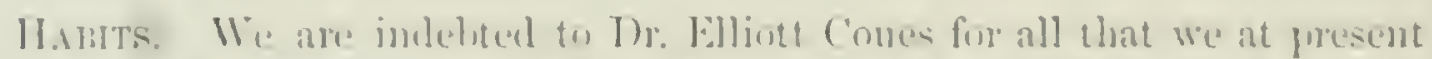

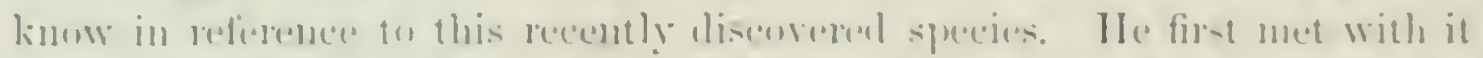

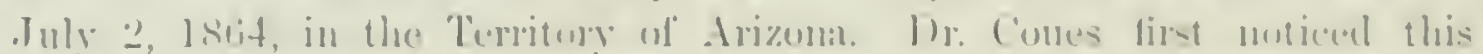

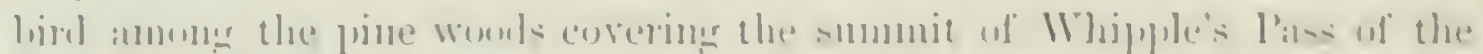

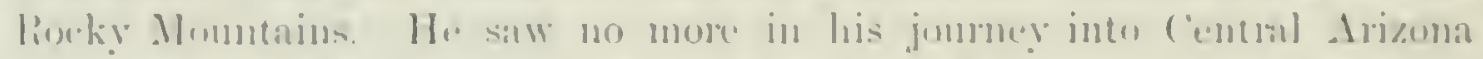

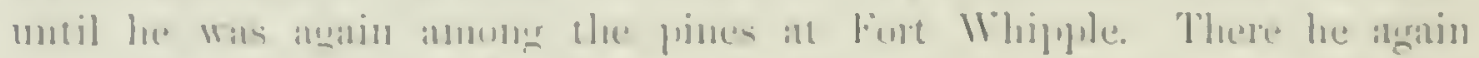

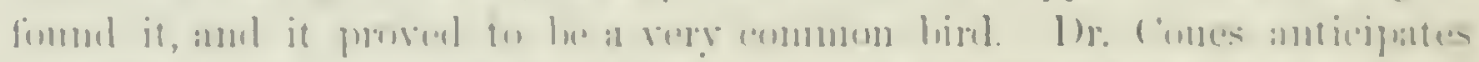

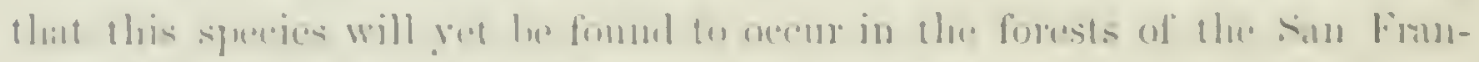

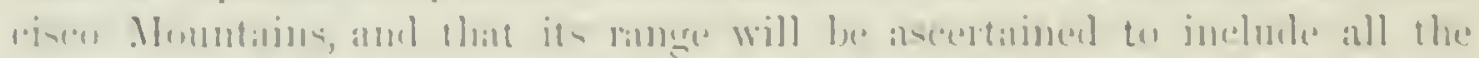

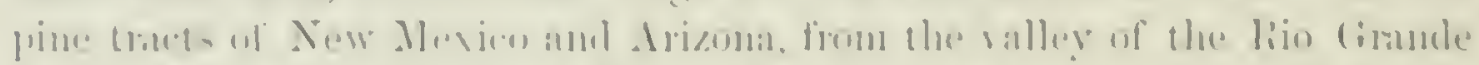

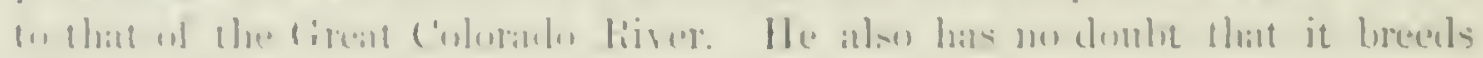

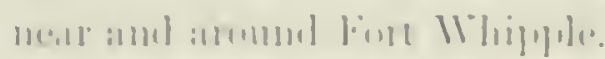

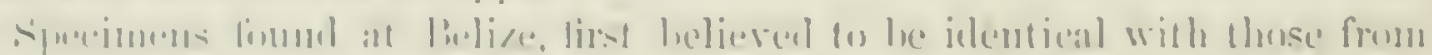

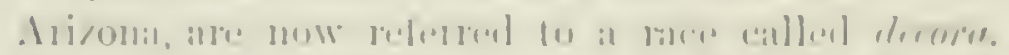

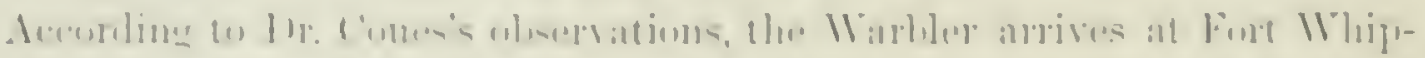

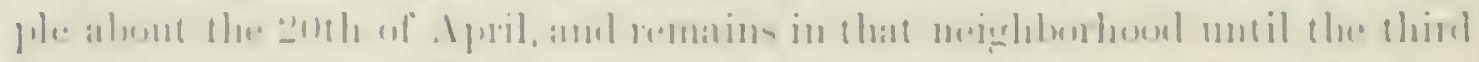

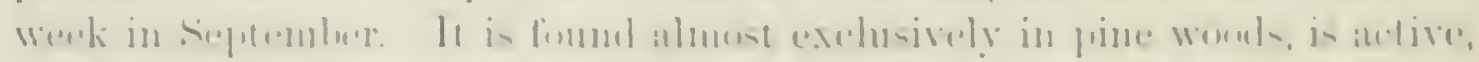

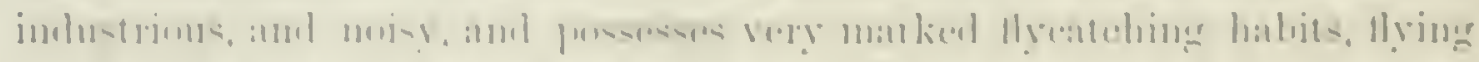

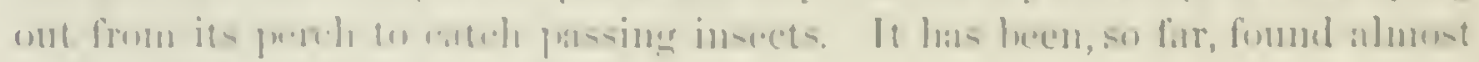

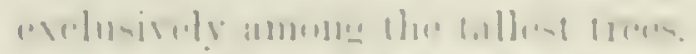

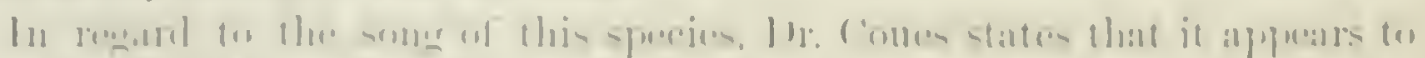

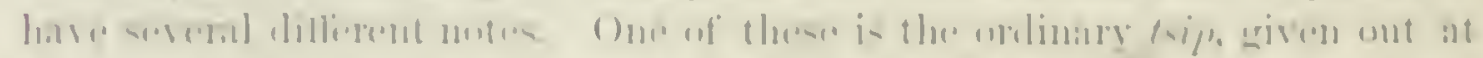

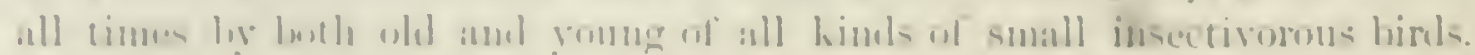


Its true song, heard only in spring, consists of two or three loud sweet whistles, sometimes slurred, folluwed by sereral continnous notes, resembling chir-r-r, in a wiry but elear tone. Their notes are of great power for the size of the bird. It also hias another and quite different song, which Dr. Cones thought greatly resembled the notes of the common Anerican liedstart.

As all the birds he noticed had mated by the first of May, he has no doubt that they raise two broods in a season; and the fact that he found newly Herged young as late as the middle of Angust seems to corroborate the correctness of his supposition. In regand to the egrgs, nest, or breeding-habits of this species, we have as yet $n$ information.

\section{Dendroica pennsylvanica, BarRD.}

\section{CHESTNUT-SIDED WARBLER}

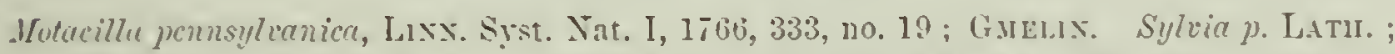

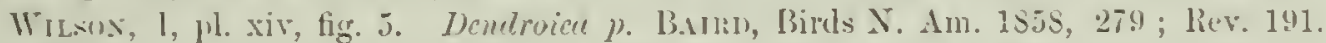

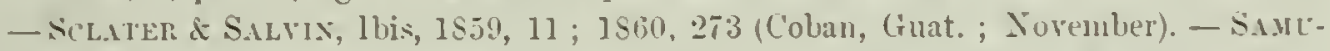
F:Ls, 231. Sylria ictcroceplula, LATII. Ind. Orn. II, 1790, 538. - VIEILL.; Bos.;

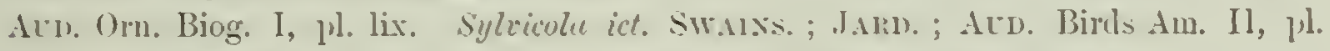
lxxi. Dendroice ict. Scl.ter, P. Z. S. 1859, 363 (Jalapa), 373 (Oaxnca).

Other localities: Bahamus, Bırı.st, Pr. Bost. Soe. VII, 1859. Costa Irica, C.1B. Jour.

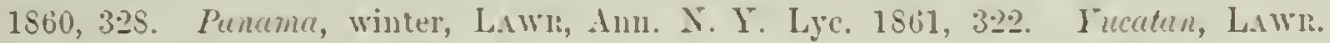
Verague, S.tLr.

Se. Crur. Male. [Tper parts streaked with black and pale bluish-gray, which becomes nearly white on the lorepart of the back; the midullo of the batck ghlosed with greenishrellow. The crown is continuous yellow, bordered hy a fontal and superciliary band, and behind by a square spot of white. Loral region liack. sunding off a line orer the eye. and another below it. Ear-coverts and lower eyelid and contire muler parts pure white. a purplish-chestnut stripe stating on each side in a line with the black mustache. and extencling back to the thighs. Wing and tail-feathers dark hrown, edgerl with bluish-erray, exept the secondaries and torials, which are bordered with light yellowish-green. The shoulders with two greenish-white bands. Three onter tail-feathers witl white patelues near the end of the inner wehs.

Female like the male. (xeept that the upper parts are yellowisly-green. streaked will black; the black mustache scarcely appreciable. Length, 5.00; wing. 2.50; tail, 2.20.

Hab. Eastern Province of the Luitul States: Bahamas; Guatamela to Costa Rica and Panama R. R. Tot recorded from Mexico proper or West Indies, exeept Bahamas.

The young in autumn is rery different from either male or female in spring. The entire upuer parts are of a contimuons light olive-green; the under parts white; the sides of the head, neck, and hreast asl-gray, slading insensibly into and tingeing the white of the chin and throat. No black streaks are risible above or on the clieeks, and the eye is surrounded by a continuous ring of white not seen in spring. In this plumage it lias frequently been considered as a distinct species.

The male in this plumage may usually be distinguished from the female 


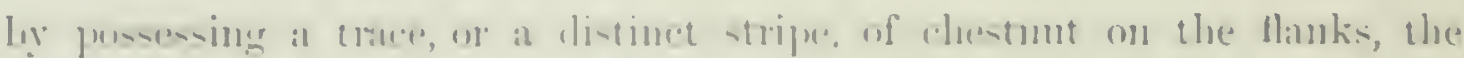

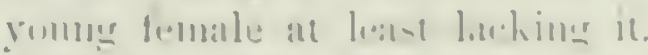

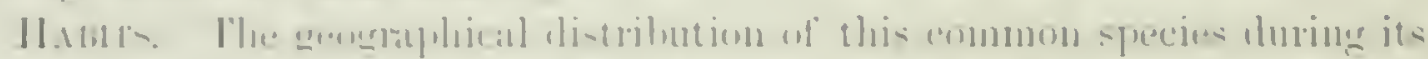

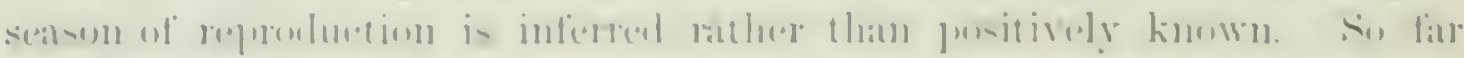

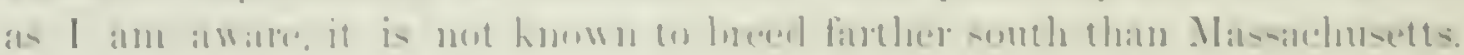

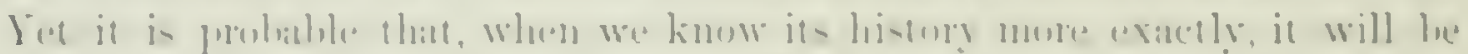

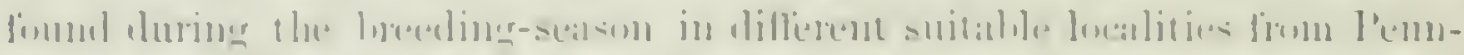

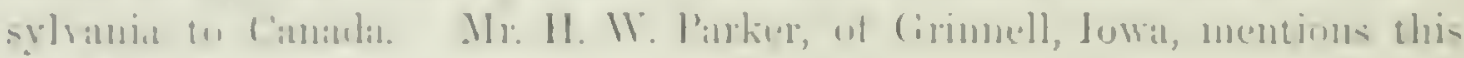

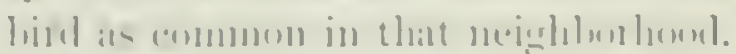

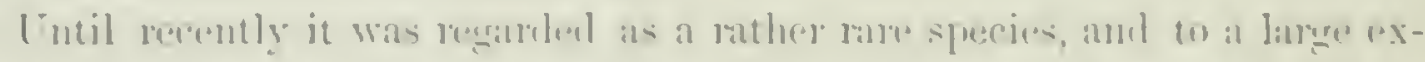

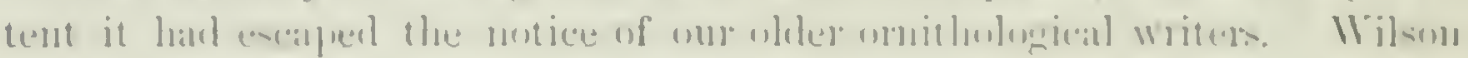

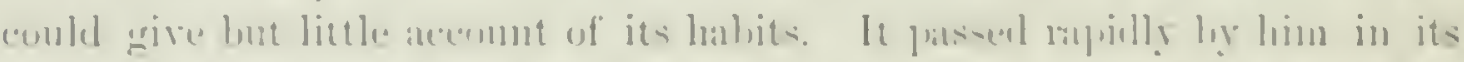

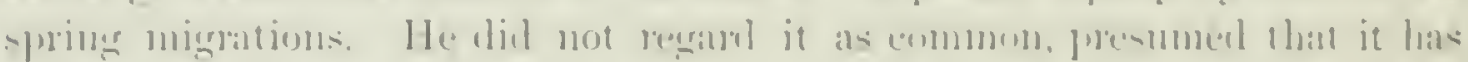

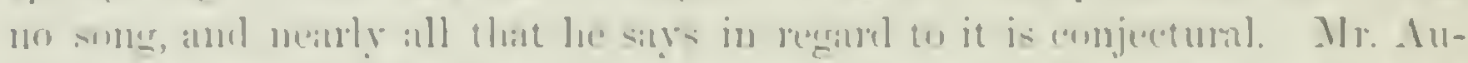

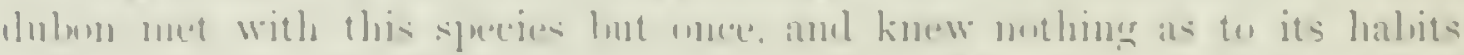

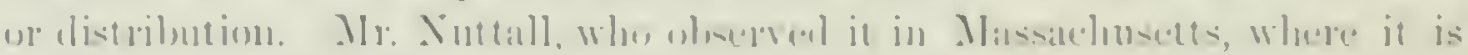

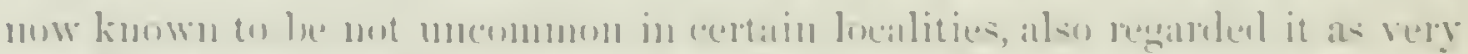

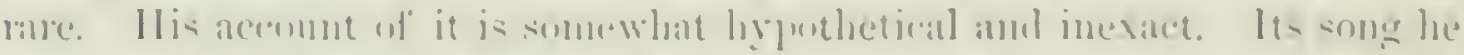

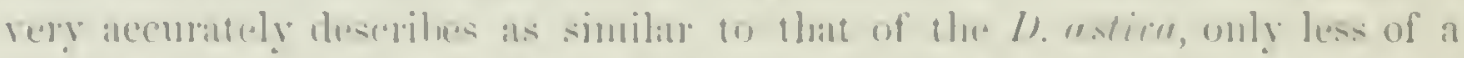

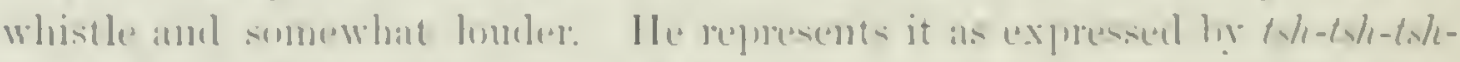

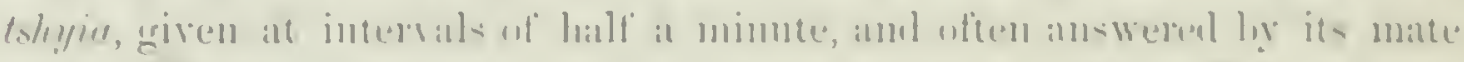

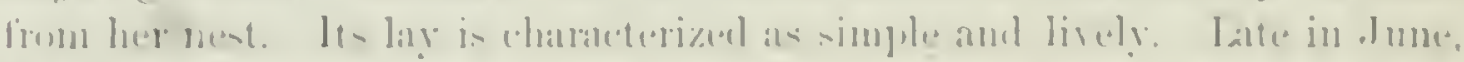

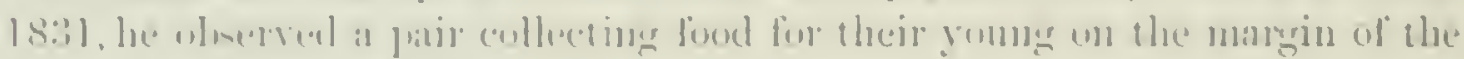

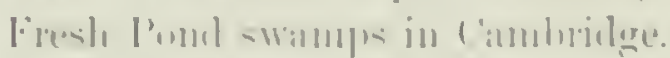

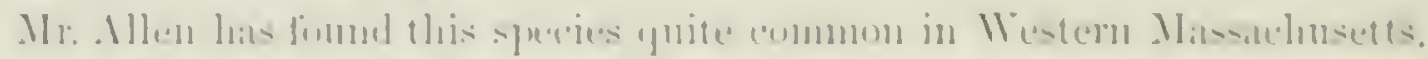

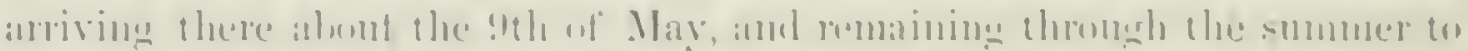

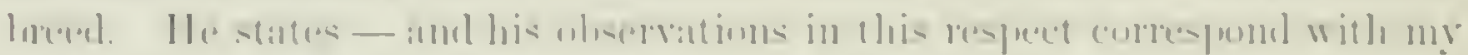

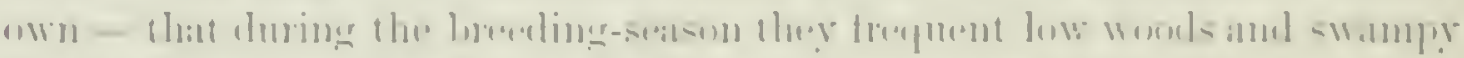

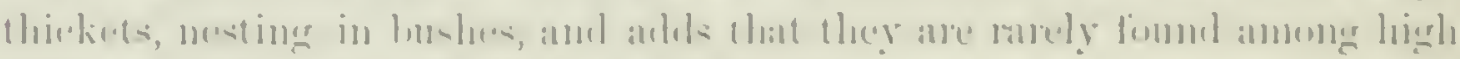

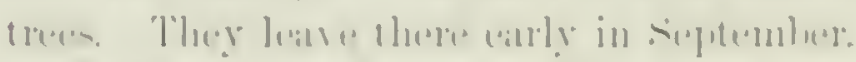

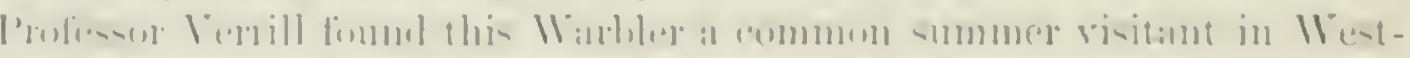

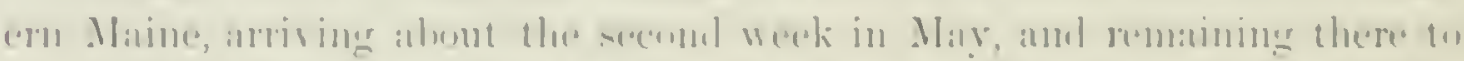

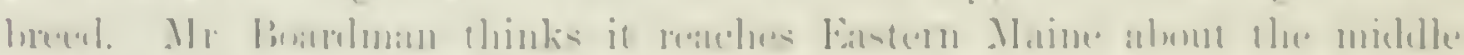

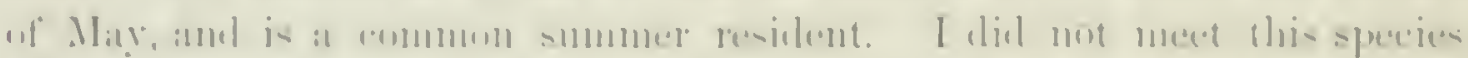

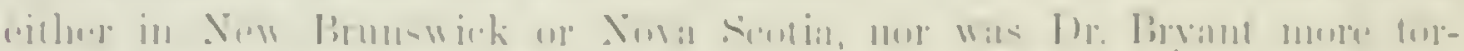

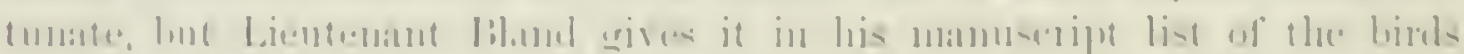

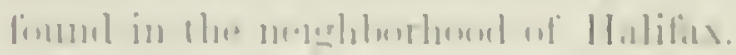

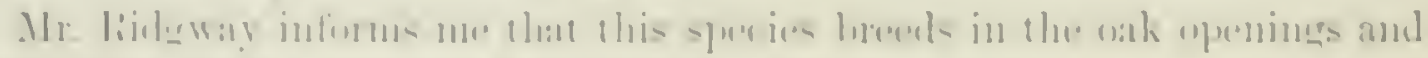

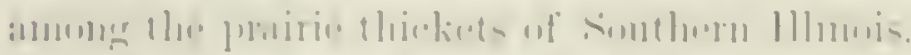

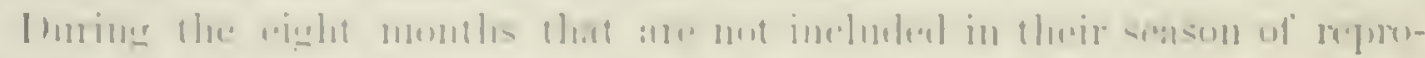

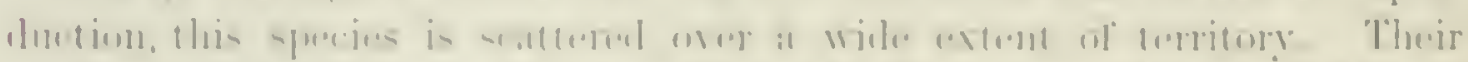

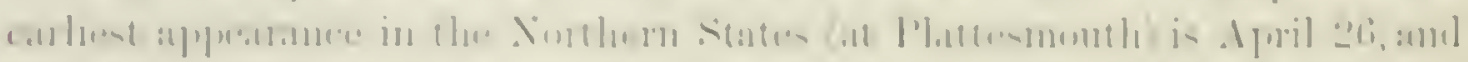

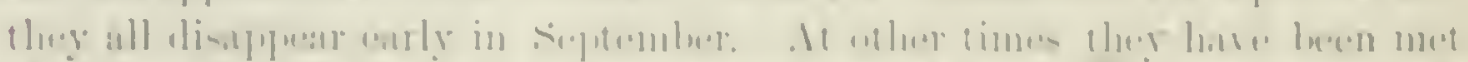

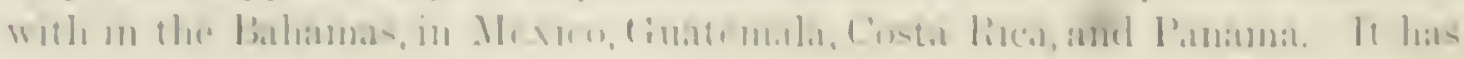


not yet been detected in the West Indies. M. Boncurd nbtained speeimens at Plisy Ticente, in the hot comntry of Oaxaca, Mexico.

In the neighborhood of Calais, Mr. Boarlman informs me that this Warbler is common, and that its habits resemble those of the Black-poll Warhler more than those of any other of the genus. It always nests in bushes or in low trees, and in the vicinity of swamps.

Among the memoranda furnished to the lite Mr. Kennicott by Mr. Ross is one to the effect that the Chestnut--sided Wirluler wals observed at Lake of the Woods, May 29. How common it is at this point is not stated.

Mr. C. S. Paine regards the Cliestnut-sided Wimler as one of the sweetest singers that risit Vermont. He describes it as very confiding and gentle in its habits It is chiefly found inhabiting low bushes, in the neightborhood of taller trees, and it always builds its nest in the fork of a low bush, not more than from three to five feet from the ground. He has seen many of their nests, and they have all heen in similar situations. They will permit a very near approach without leaving their nests. These are constructed about the last of May. Their song continues untii abont the last of June. After this they are seldom heard.

J. Elliot Ciabot, Escl., land the good fortune to be the first of our naturalists to discover in .June, 1\$:39, the nest and exgs of this Warbler. It was fixed on the horizontal forked luranch of an oak sapling, in Brookline, Mass. The female remained sitting on her nest mitil so closely alproached as to be distinctly seen. The nest was of strips of red-cedal hark, and well lined with coarse hair, and was compact, elastic, and shallow. It contained four eggs, the ground-color of which was white, orer which were distributed numerous distinct spots of umber-brown. These were of different sizes, more numerous towards the laryer ent.

In regard to their breenling in Pennsylrania, Mr. Nuttall mentions in the second edition of his work that he met them among the Alleghanies at Farranville in full song, and had no doubt that they were nesting there at the time.

The Chestmut-sided Warbler usually constructs its nest in localities apart from cultivated grounds, on the eiges of low and swampy woods, but in places more or less open. Quite a number of their nests lave been met with by $\mathrm{Mr}$. George O. Welch, of Lymm, Mass. Their more common situation hias been barberry-bushes. The nests vary from about two and a half to three and a half inches in external height, and have a diameter of from three to four inches. The carity is about two inclies deep. They are usually composed extemally of loosely intertwined strips of the bark of the smaller regetables, strengthened by a few stems and bits of dry grasses, and lined with woolly vegetalle fibres and a few soft hairs of the smaller animals. They are usually very firmly bound to the smaller branches by silky fibres from the cocoons of various insects. These nests were all found in open places, in low, wild marshy localities, but none far from a cultirated neighborhood, and the 


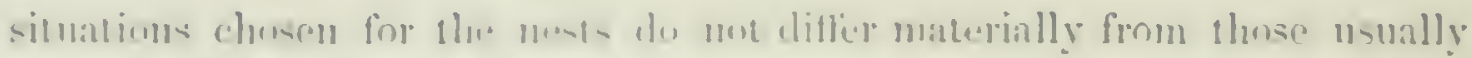

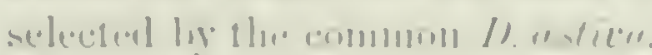

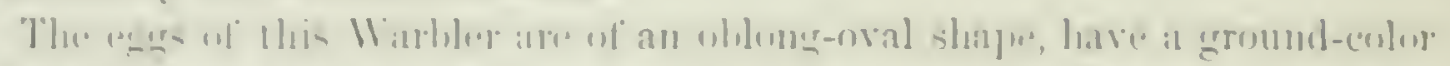

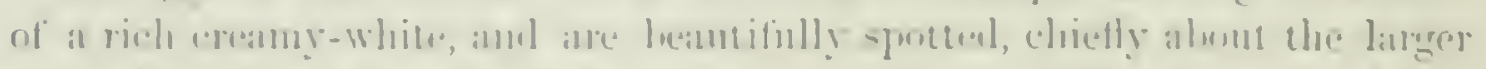

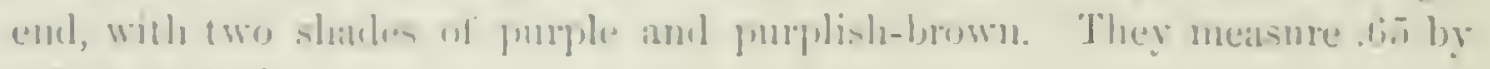
.4? 01 in inch.

\section{Dendroica striata, P.Mlli.}

\section{BLACK-POLL WARBLER.}

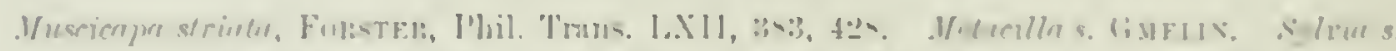

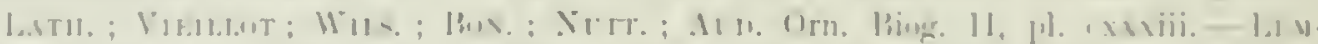

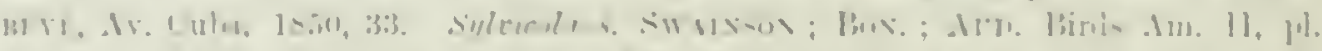

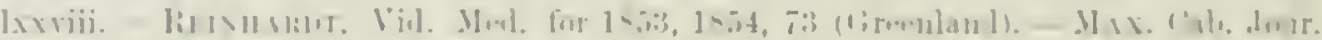

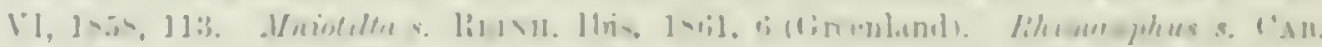

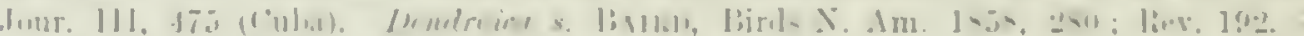

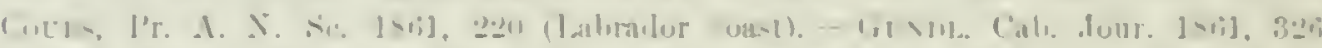

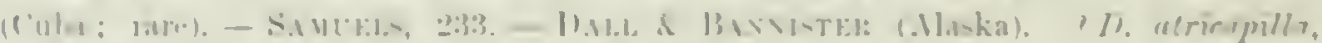

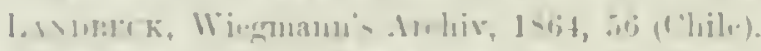

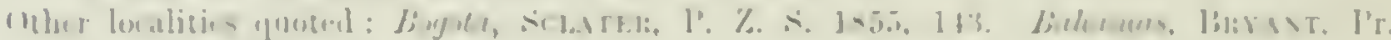
l'unt. Fir: V11, 1-3!?

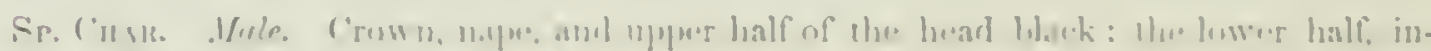

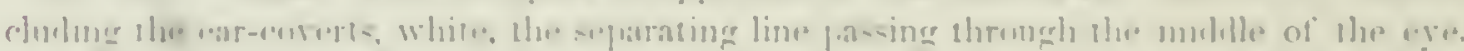

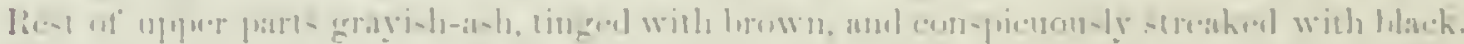

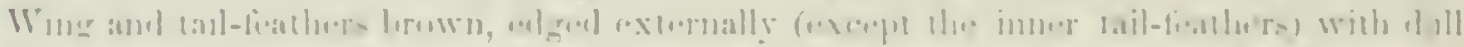

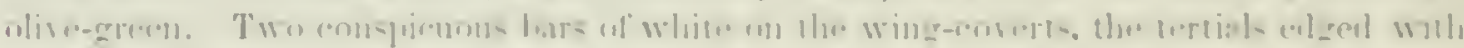

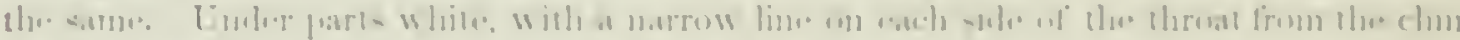

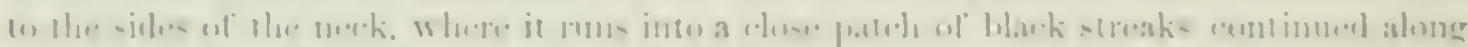

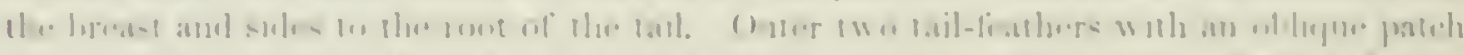

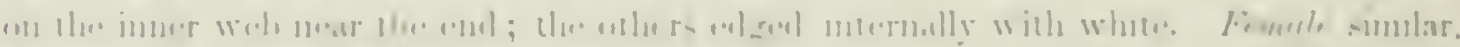

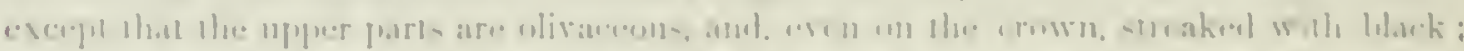

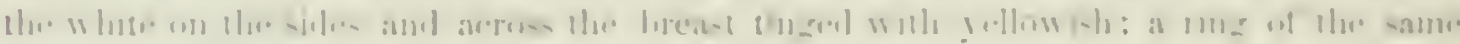

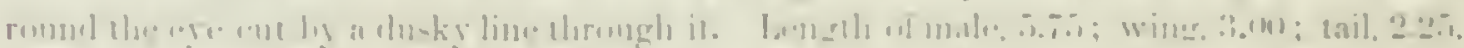

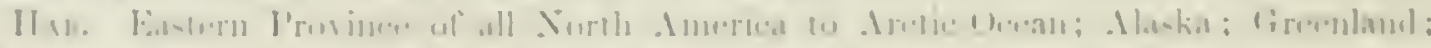

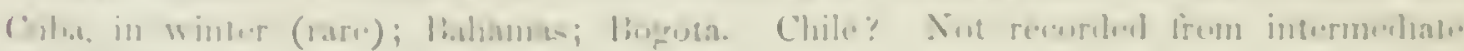
lim

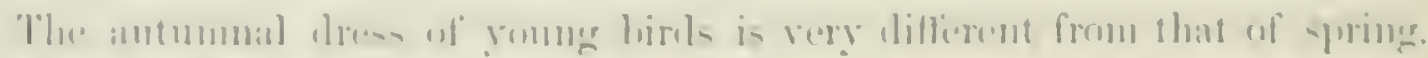

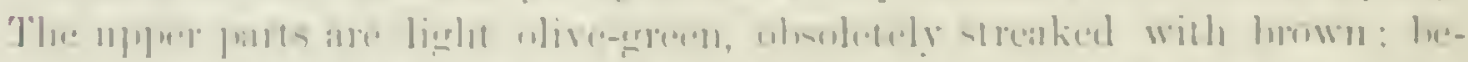

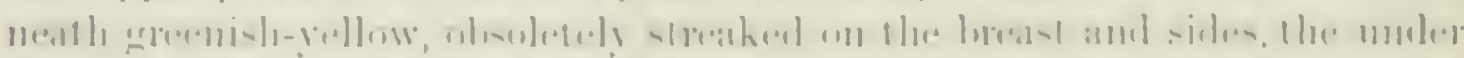

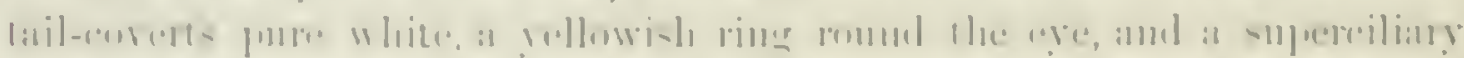

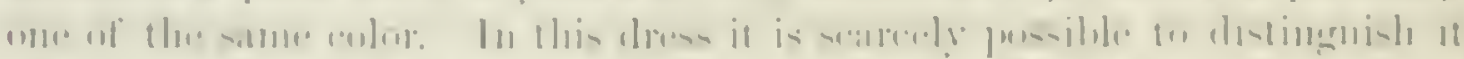

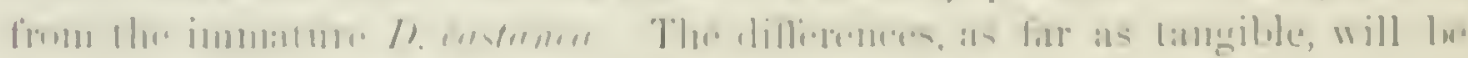

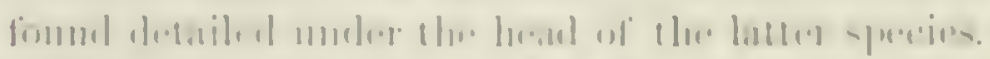

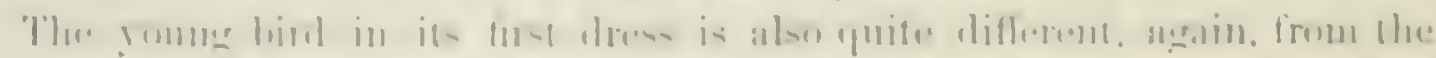
antmunal-

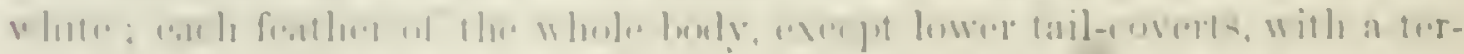

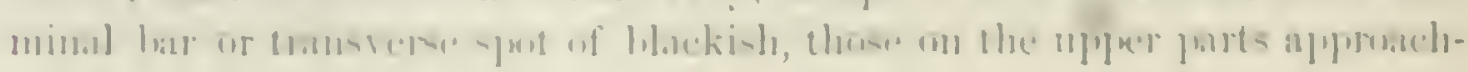


ing the base of the feathers along the shatt. Wings and tail mueh as in the autumnal plumage.

Habits. The appeannce of this beautiful and finniliar Warbler in New England is the sure harbinger of the summer. 'The last of the migrants that do not tarry, it brings up the rear of the hosts of hyperborean risitors. This species ranges over the whole extent of eastem North America, from Mexico to the Aretic seas. It has not been found farther west than the Creat Plains and the Rio Grande. Wherever found it is abundant, and its lively and attractive manners and appearance render it a pleasing feature. It is not known to stop to breed in Massachusetts, but it lingers with us till the last blossom of the apple falls, and until the Bluehird and the Robin have already well-fledged broods, sometimes as late as the 10th of June, and then suddenly disappears.

Dr. Woodhouse found it abundant in Texas and the Indian Territory, and individuals have been procured in Missouri and Nebraska. It has been found abundant in the Aretic regions, around Fort Anderson, Fort Yukon, and Fort Good Hope. A single specimen was taken near Godhaab, Greenland, in 18.53, as recorded by Professor Reinhardt. Dr. Bryant met with it in the Bahamas, in the spring of 1859 , where it was abundant from the 1st to the 10th of May. He describes its habits as similar to those of the Innotilta varia, climbing around the trunks of trees in search of insects with the same facility. Single specimens have been procured from Greenland on the northeast, and from Bogota and Cuba. I)r. Coues found it alundant in Labrador in all well-wooded sitnations, and describes it as a most expert Hycatcher, taking insects on the wing in the manner of the Contopus virens.

Mr. Allen has never noted the arrival of this bird in Western Massachnsetts before the 20th of May, nor later than the 1st of June. They again hecome abundant the last of September, and remain into October. In Eastem Maine Mr. Boardman reports them abundant, and as remaining to breed. They are there more numerous about open pastures than most Warblers. They nest in low trees, about swampy places.

In Central Vermont, Mr. Paine states, the Black-Poll is the last of all the migrant birds that come from the Sonth, and is seen only a few days in the first of June. It seldom stays more than a day or two, and then passes north. It appears singular that a bird coming so late should go yet farther north to breed. He states that its song consists only of a few low, lisping peeps. It may usually be seen wandering orer fields in which there are a few scattered trees, and seems to be a rery active, restless bird.

The writer also met with them in great abundance about Eastport, and in the islands of the Grand Menan group. It was the most common Warbler in that locality. The low swampy woods seemed filled with them, and were rocal with their peculiar lore-notes.

Wilson states that he occasionally found this Warbler in Pennsylvania and New Jersey, and was confident they would be found to breed in those States, 


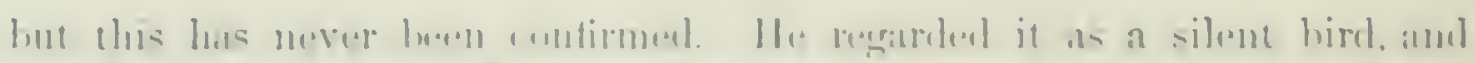

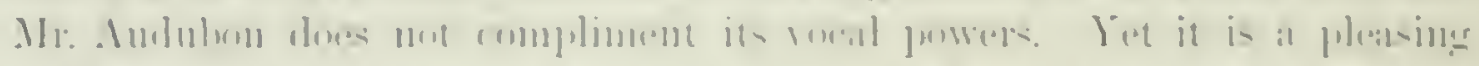

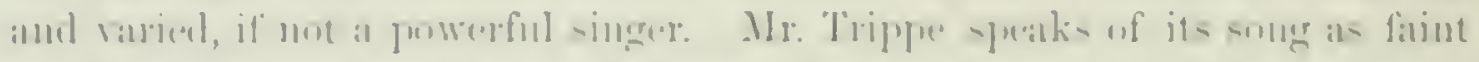

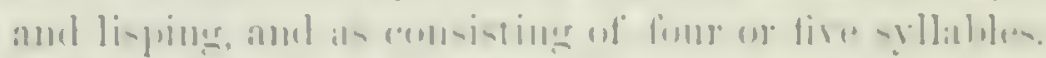

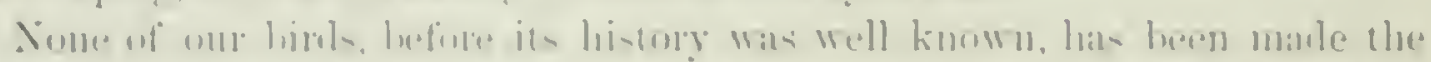

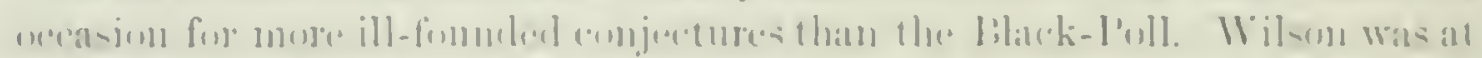

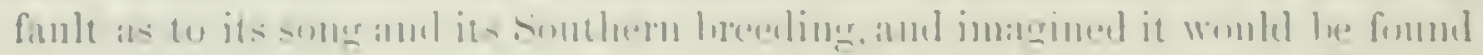

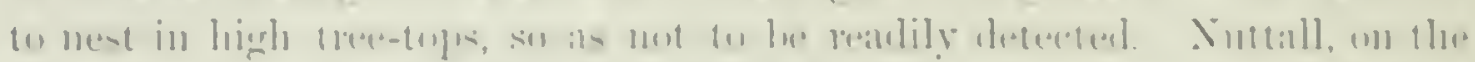

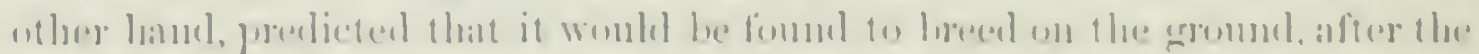

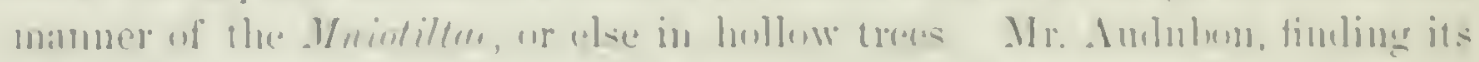

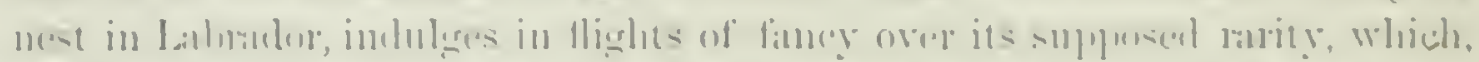

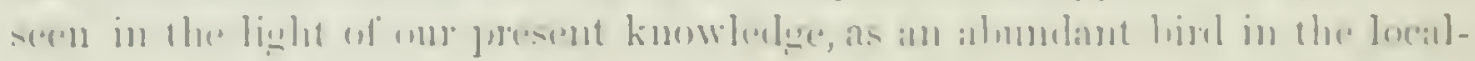

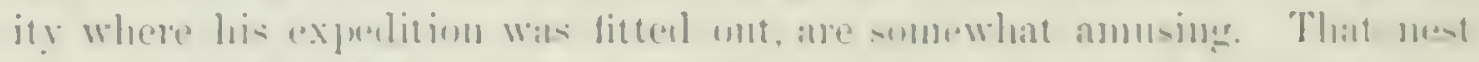

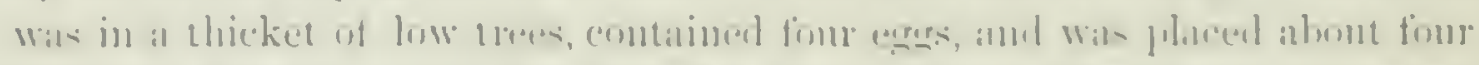

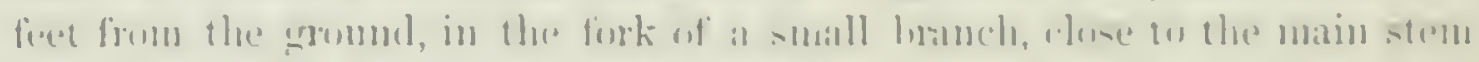

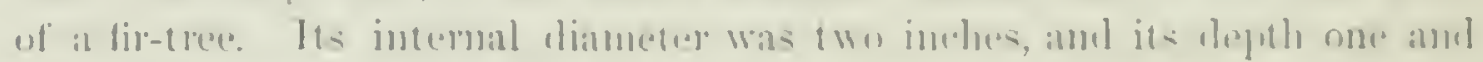

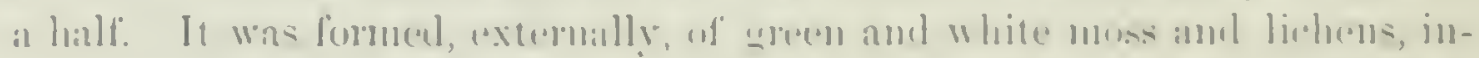

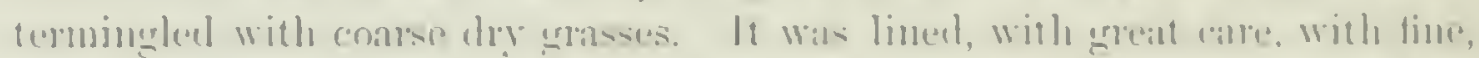

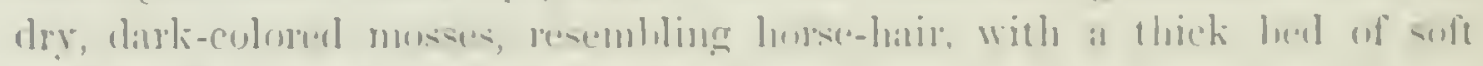

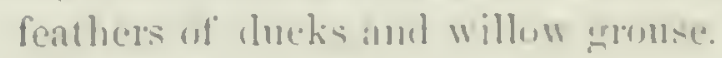

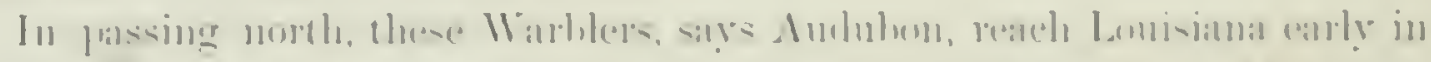

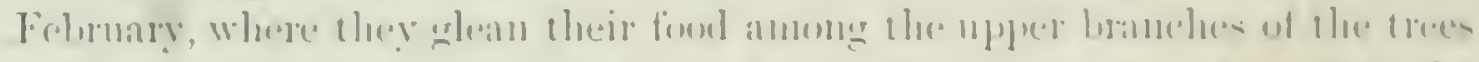

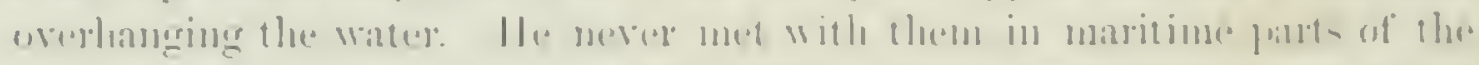

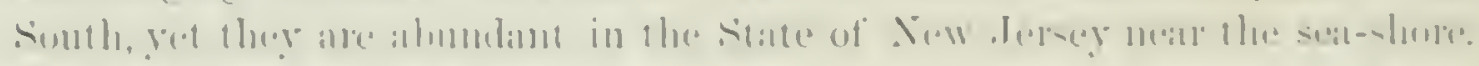

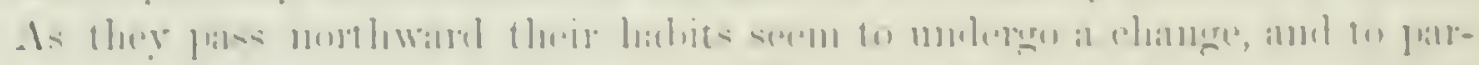

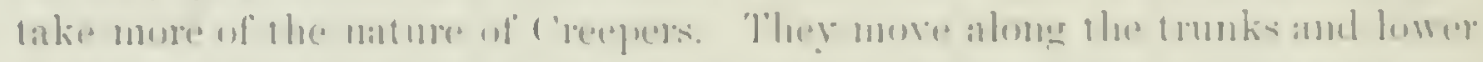

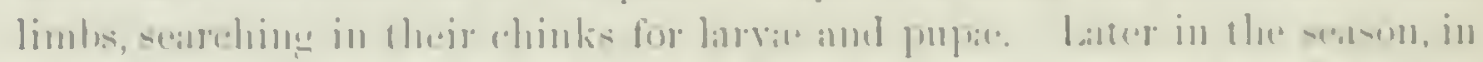

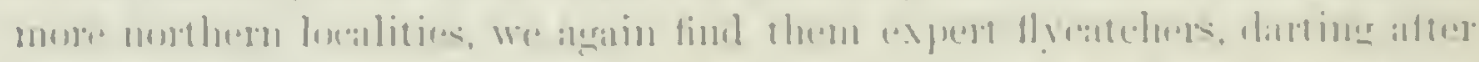

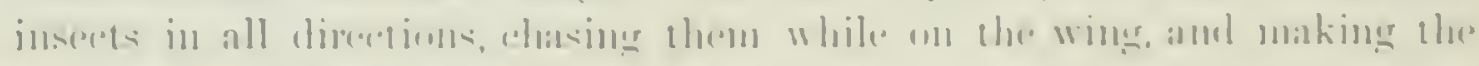

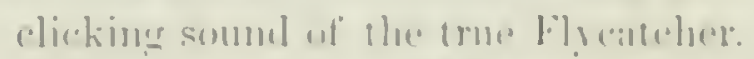

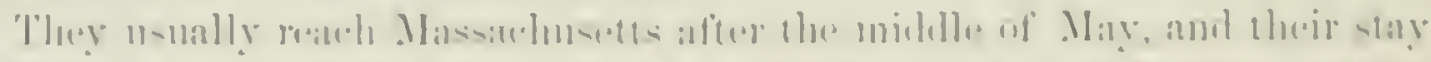

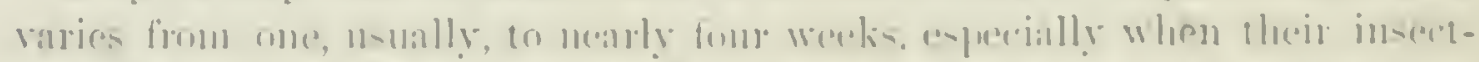

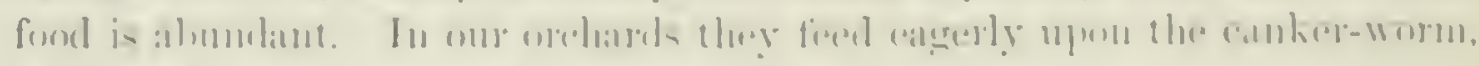

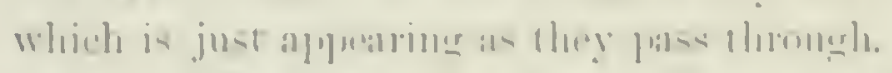

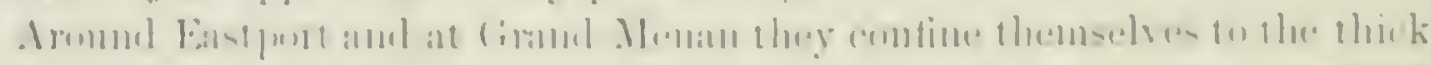

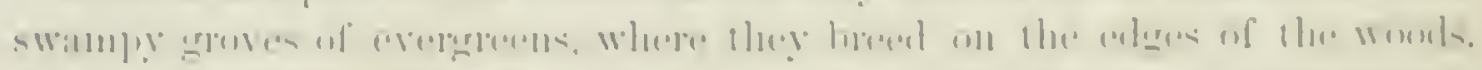

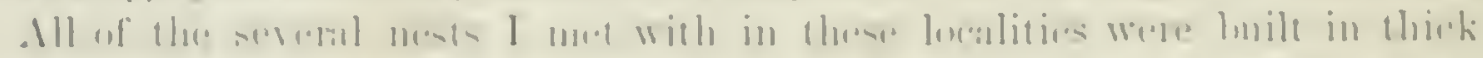

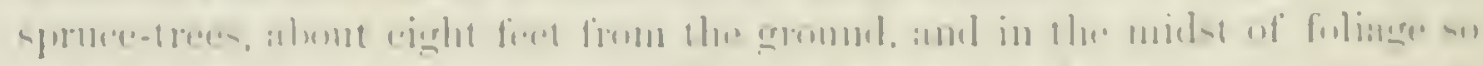

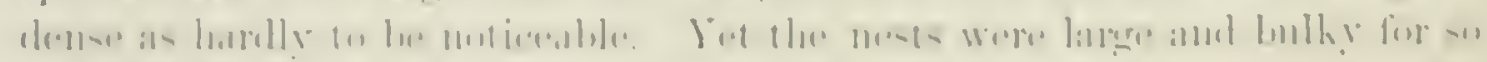

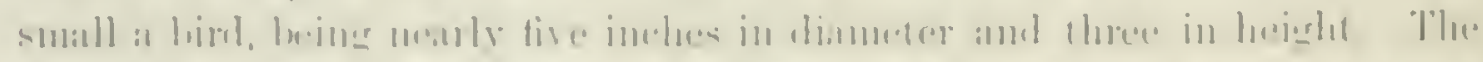

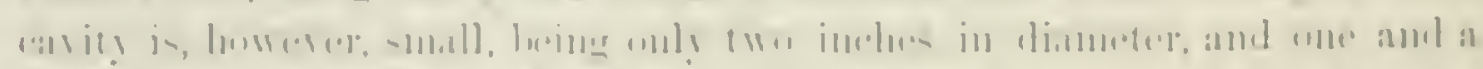

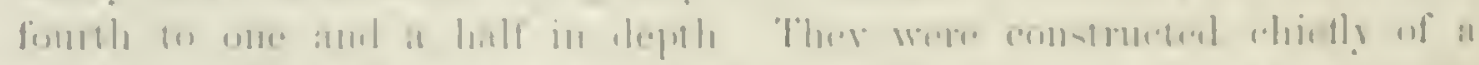

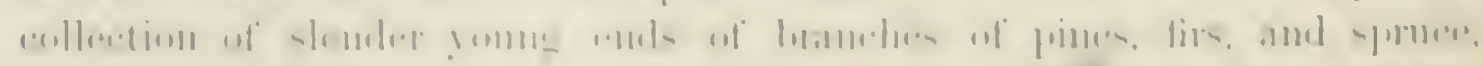

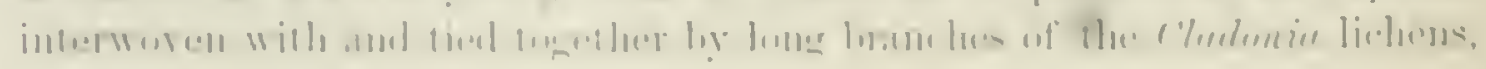


slender herbaceons rnots, and finer sedges. The nests were strongly built, compact and homogenemss, and were elaborately lined with fine panicles of grasses and fine straw. In all the nests found, the munler of egüs was five.

It is a somewhat noticeahle finct, that thomgh this specie's is seen in New England only by the middle of May, other's of its kind liave long betore reached high Aretic loealities. Lichardson records its presenee at the ('muberland Honse in May, and Engineer C'antonment by the 26th of April. Mr. Luckhart procured a nest and five egogs at Fort linkon, June 9. All the nests taken in these lucalities were of smaller size, were built within two feet of the ground, and all were much more warmly lined than were those from Grand Menan. In a few instances Mr. MuFarlane fomd the nests of this species actually built upon the gromel. This, however, is an abnormal position, and only occasioned ly the want of suitable situations in protected localities. In one instance a nest was taken on the first of June, containing well-developed embryos. Yet this sume species has frecunently been observed lingering in Aassachusetts a week or more after others of its species have alleady built their nests and begnu hatching

The eggs of this species meatsure.$i 2$ by .50 of an inch. Their shape is an oblong-oral. Their gromul-color is a beantiful white, with a slight tinge of pink, when fresh. They are blotched and dotted over the entire surface with profuse markings of a subdned lavender, and deeper markings of a dark purple intermixed with lighter spots of reddish-brown. The usual number is five, though six are occasionally found in a nest.

\section{Dendroica castanea, BAIRD.}

\section{BAY-BREASTED WARBLER}

Syleie crstance, WrLs. An. Onn. 11, 1510, 97, pl, xir, fig. 4. - Bos. ; Nutr. ; Atn. Orn. Biog. I, pl. Lix. Syylucule castenea, Swars. ; Jan. ; Ricu. ; Box. ; ALv. Birls Anı. 1I, pl. lxxx. Rhimenphus custeneus, ('-1в. Dendroicre castance, Balm, Birds X. Am. 1S58, 256; Rev. 1\$9. - SuLatil \& SAlur, Ihis, 1850. 11 (Guatemala). - CAssis,

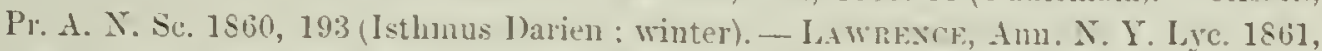

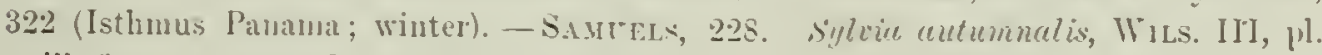
xxiii, fig. ‥ - Avv. Orı. Biog. I, pl. lxxrviii.

Sp. Cuar. Male. Crown dark reddisli-chestnut: forelsear and cheeks. including a space above the ese. black; a patch of huff-yellow hehinl the eheeks. Rest of upper parts bluish-gray streaked with blark. the erges of the interscapulars tinged with yellowish, of the scapulars with olivareous. Primaries and tail-feathers edged externally with bluish-gray, the extreme outer ones with white: rhe secondaries enged with oliviceons. Two bands on the wing and the edges of the tertials white. The under parts are whitish with a tinge of buff: the chin. throat. forepart of breast. and the sides, chestnut-brown. lighter than the crown. Two ourer tail-featlers with a patch of white on the inner web near the end; the others edged internally with the same. Female with the upper parts olive, streaked thronghout with black, and an occasional tinge of cliestnut on the crown. Lower parts with traces of chestnut, but no stripes. Length of male, 5.00 ; wing, 3.05 ; tail, 2.40 . 


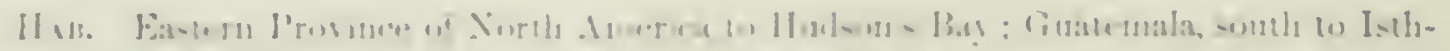

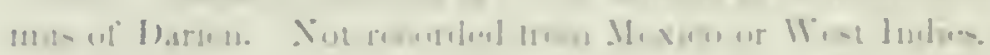

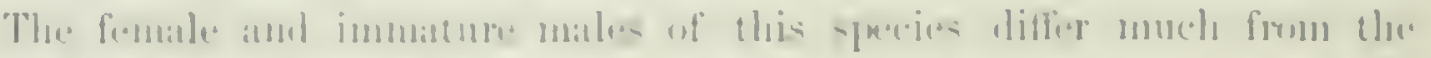

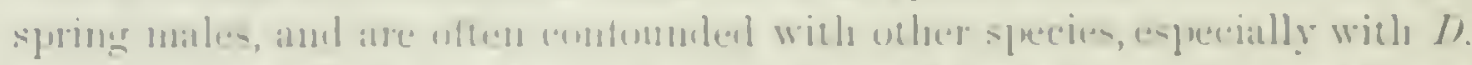

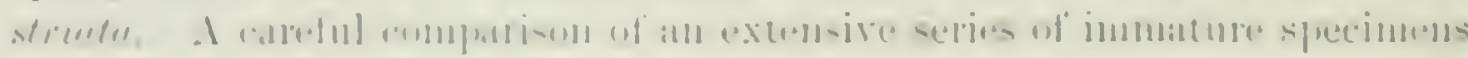

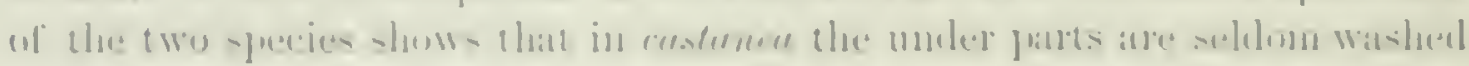

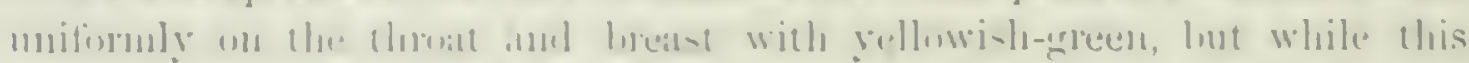

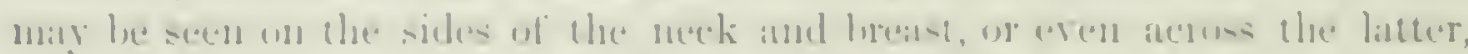

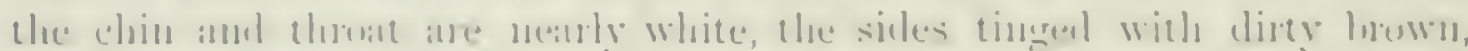

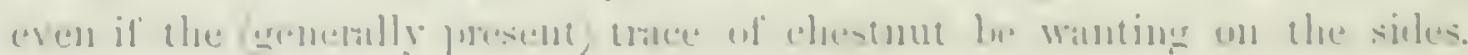

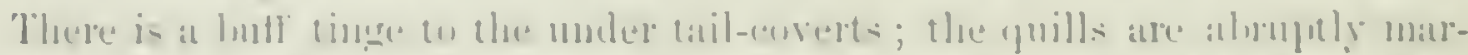

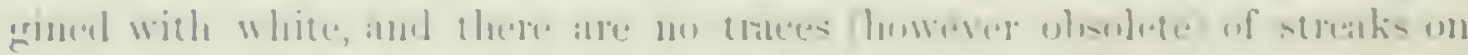

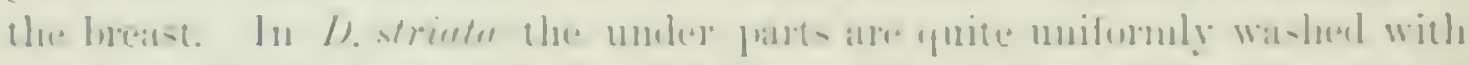

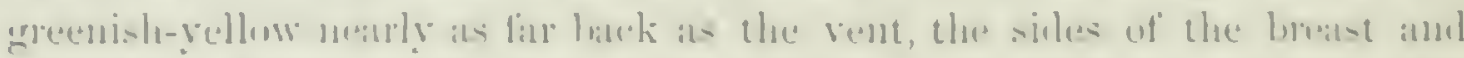

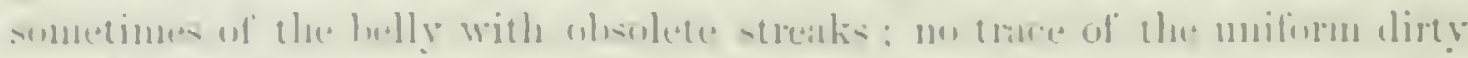

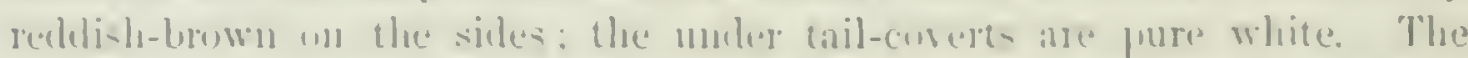

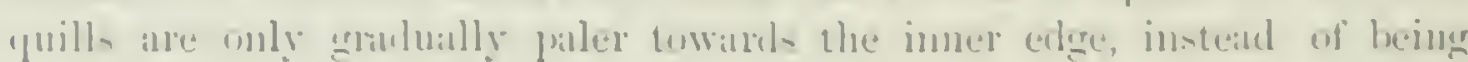
mather alnupuly white.

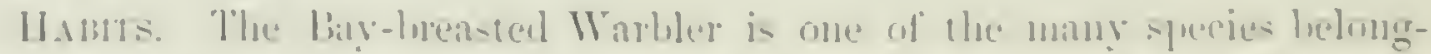

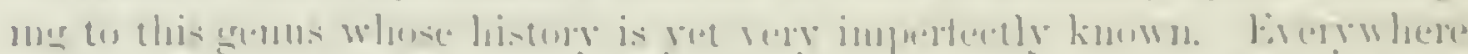

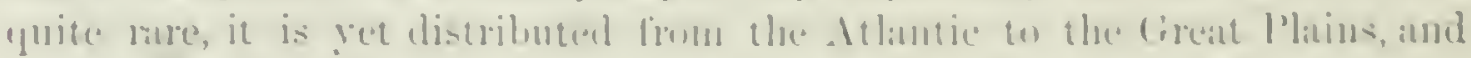

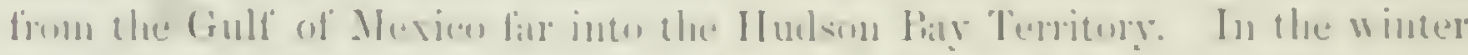

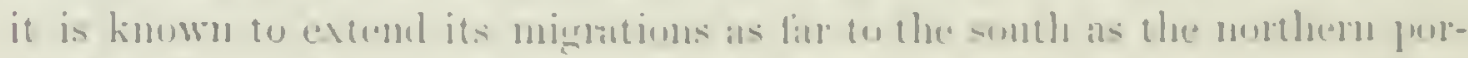

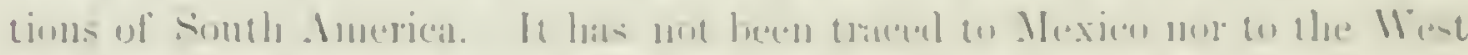

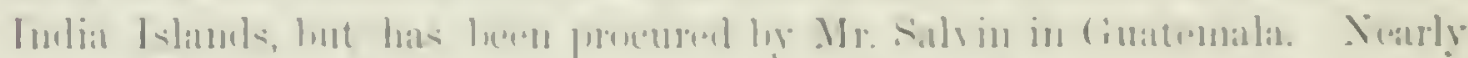

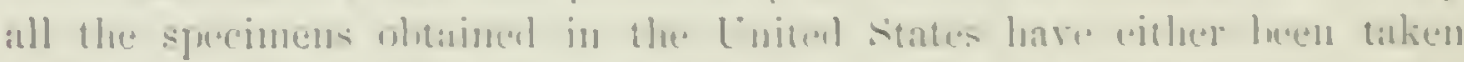

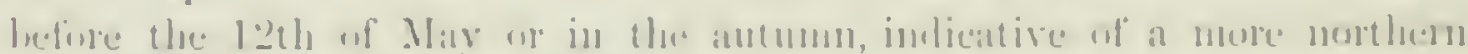

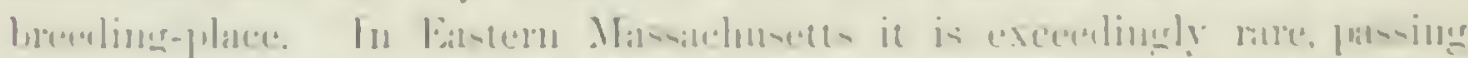

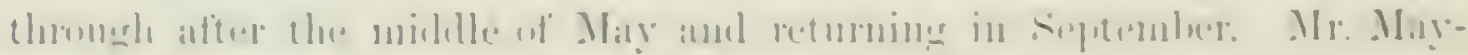

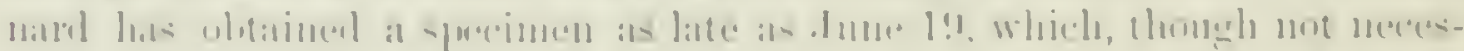

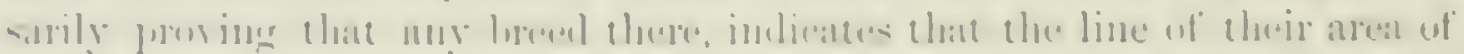

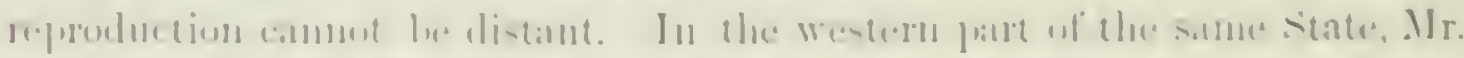

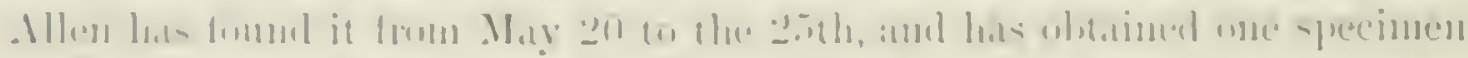

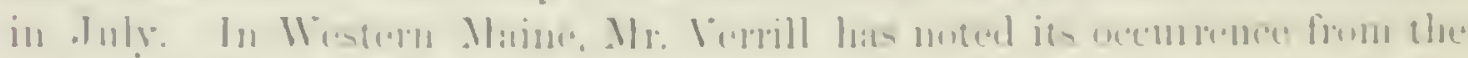

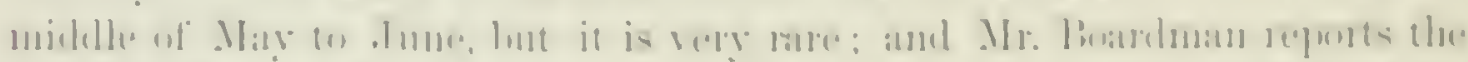

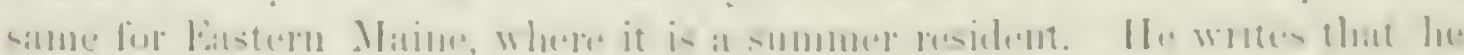

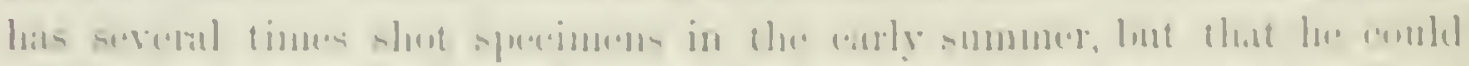

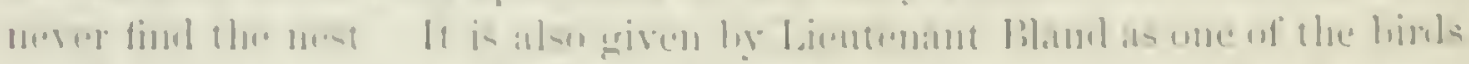

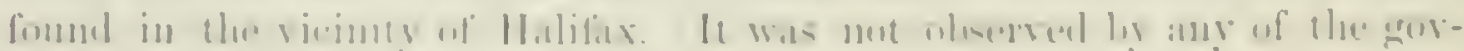

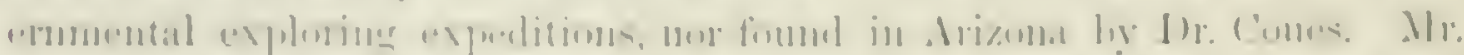

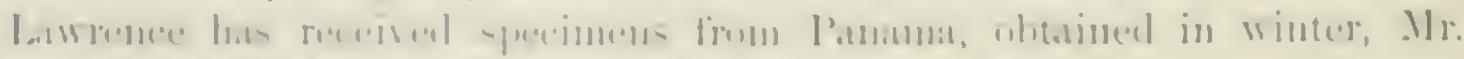

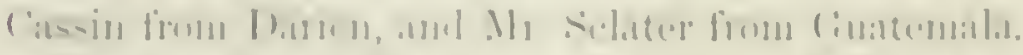

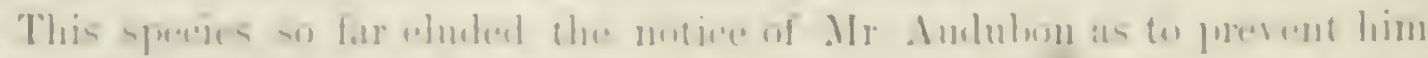

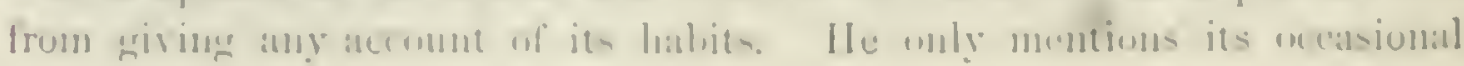


arrival in Pennsylvania and New Jersey early in April, and its almost immediate and sudden disappeannee. He several times obtilned them at that period, and yet has also shot them in Lonisiana as late as June, while busily searehing for food anong the blossoms of the cotton-plant.

Wilson also regarded this species as very rare. He reports it as passing throngh Pennsylvania about the middle of May, but soon disappearing. He describes these birds as having many of the habits of Titmice, and displaying all their activity. It hangs about the extremity of the twigs, and darts about from place to place with restless diligenee in seareh of varions kinds of larræ. Wilson never met with it in the summer, and very rarely iu the fall.

Mr. Nuttall noticed this species passing through Massachusetts about the 15th of April. He regarded it as an active insect-hunter, keeping in the tops of the highest trees, darting about with great activity, and hanging from the twigs with fluttering wings. One of these birds that had been wounded soon becane reconciled to its confinement, and sreedily caungh at and devoured the flies that were oflered. In its habits and manners it seemed to him to greatly resemble the Chestnut-sided Warbler:

Mr. T. M. Trippe speaks of this Warbler as one of the last to arrive near Orange, X. Y. Owing to the fact that at that time the foliage is pretty dense, and that it makes but a short stay, it is not often seen. He speaks of it ins not quite so active as the other Warblers, keeping more on the lower boughs, and seldom ascending to the tops of the trees.

Mr. C. W. Wyatt met with this species at Naranjo, in Colombia, South America.

Eggrs of this bird obtained by Mr. Creorge Bush at Coldwater, near Lake superior, are of an oblongr-oral shape, measuring . i. by .52 of an inch, and except in their superior size and fewer markings might be mistaken for eggs of $D$. astiru. Their ground-color is a bluish or greenish white. The markings are very few and fine, except those in the crown around the larger end, and there the hlotches are deeper and more munerous. Their colors are dark reeddishl-brown and purple.

Mr. Maynard found this species the most abundant of the Sylricolide at Lake Linbagog, where it hreeds. Two nests were taken in June. One was found June 3, in a tree by the side of a cart-path in the woods, just completed. It was built in the horizontal branch of a henlock, twenty feet from the ground, and five or six from the trunk of the tree. By the Sth of June it contained three fresh eggs. The other was built in a similar situation, fifteen feet from the wround, and contained two fresh eggs.

These nests were large for the bird, and resembled those of the Purple Finch. They were composed ontwardly of fine twigs of the hackmatack, with which was mingled some of the long hanging Usneu mosses. Ther were very smoothly and neatly lined with black fibrous roots, the seed-stalks of Cladonia mosses, and a few hairs. They had a diameter of about six inches, 


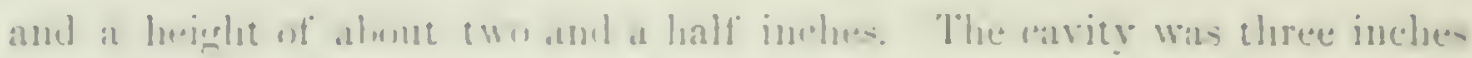

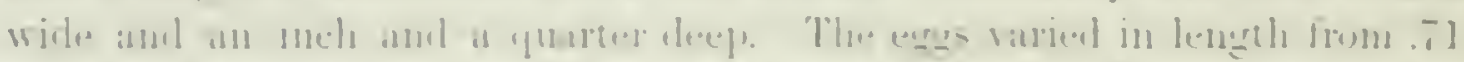

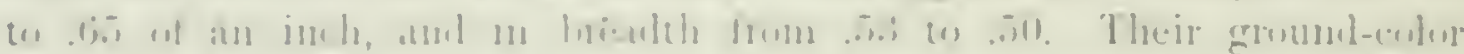

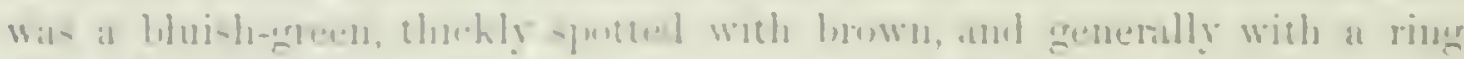

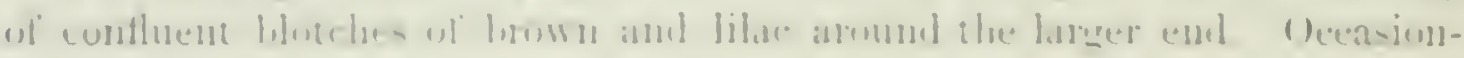

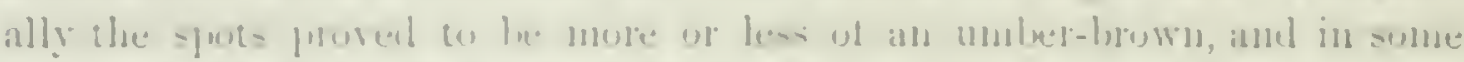

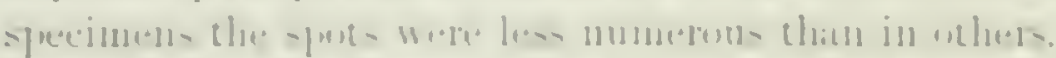

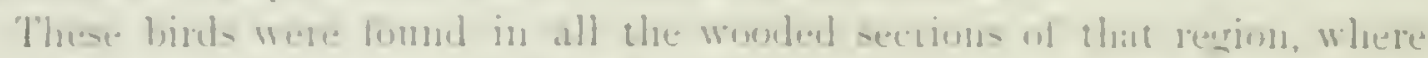

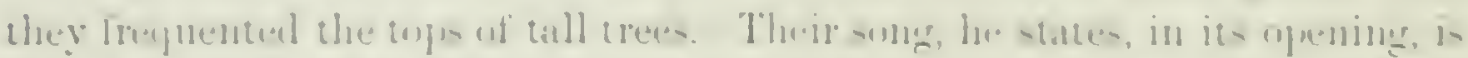
like that of the libati-l'ull, with a terminal wable similat io that of the liedsan, but gisen with leso enerery.

\section{Dendroica cærulescens, B.,1k1}

\section{BLACR-THROATED BLUE WARBLER.}

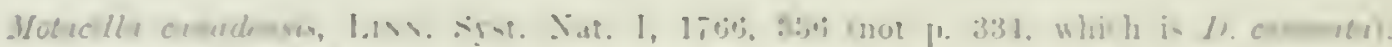

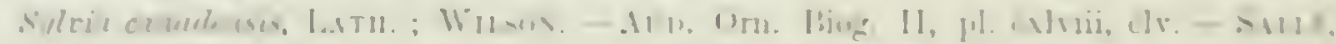

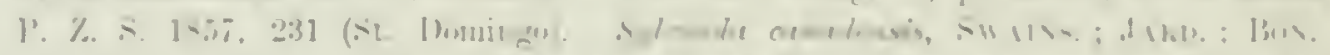

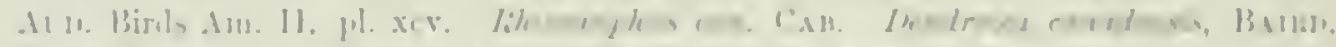

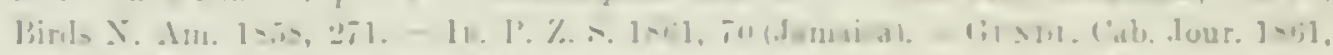

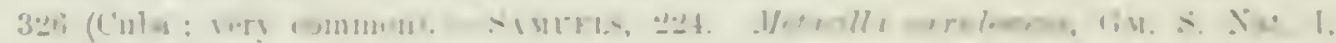

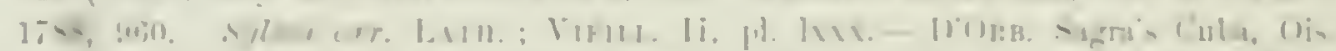

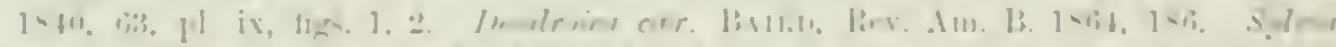

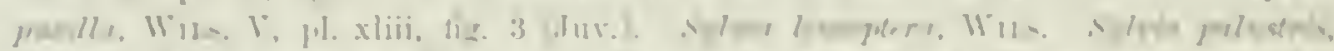

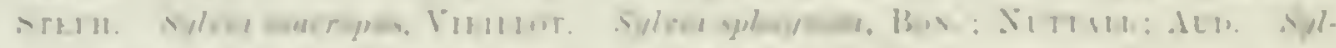

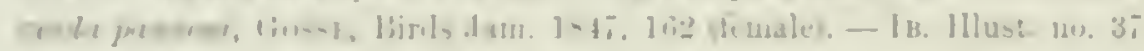

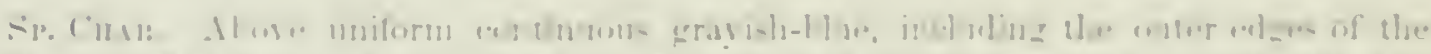

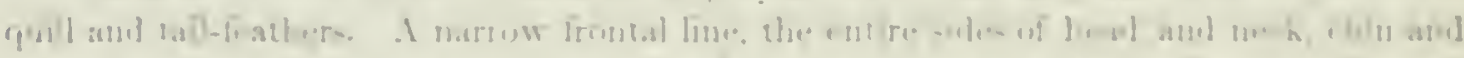

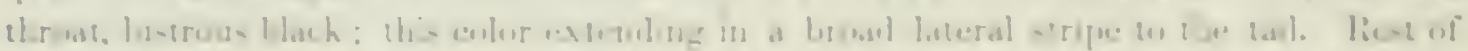

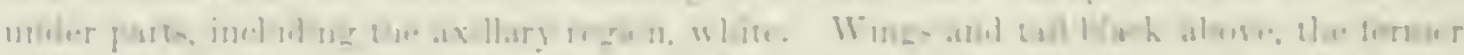

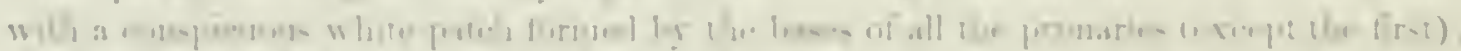

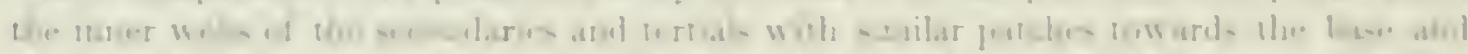

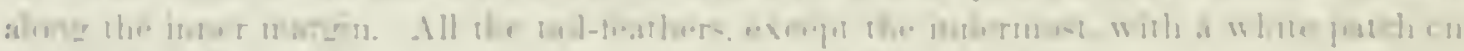

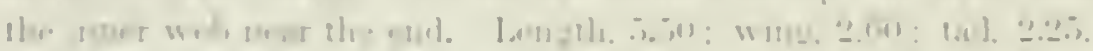

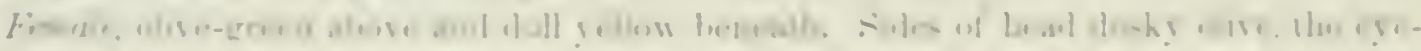

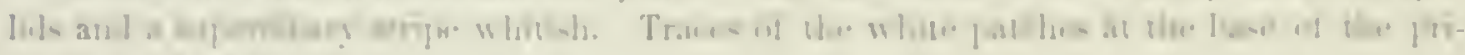
mare and i i, i l.

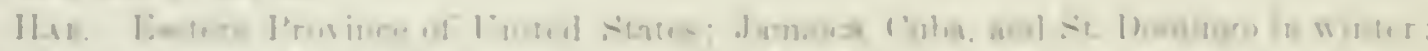

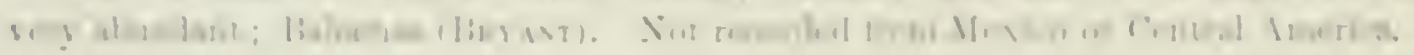

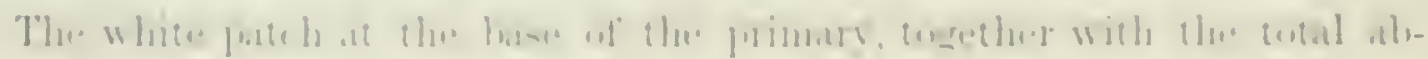

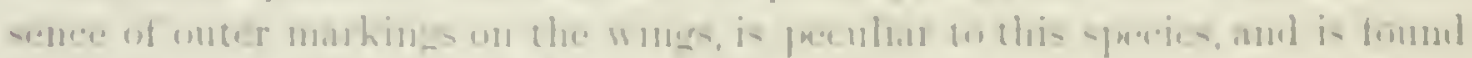

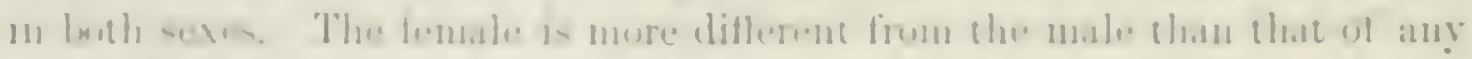
uther suecies.

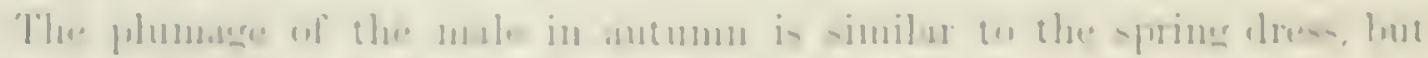

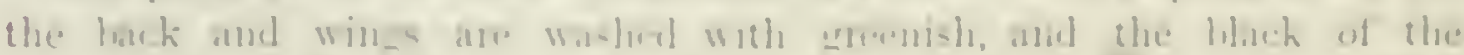

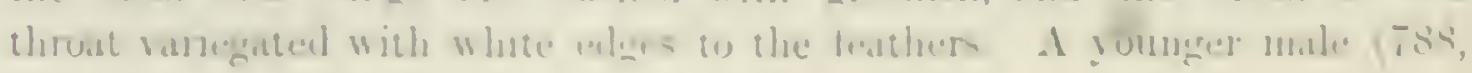


Octoher 10, Carlisle, P'enn.) differs in having the black appearing in pateles, the throat being mostly white; there is also a narrow white supereiliary stripe.

H.ıBITs. The Black-throated Blne Wrahler, at different scasons of the vear, is distributed over neuly the whole eastern portion of North America. Abundant in the West Indies in winter, as also in the Sonth Atlantic States in early spring and late in fall, it is foumd during the hreeding-season from Northern New Tork and New England nearly to the Aretie regions. A few probably stop to breed in the high prortions of Massachnsetts, ind in late seasons they linger about the oreharts until. Tume. They undoubtedly breed in Vermont, New Hampshire, and Maine.

Dr. Woollhouse stintes that he found it abundant in Texas; hut this is the only instance, so far as is known. of its oceurring west of the Mississippi Valley.

Towards the close of the remarkably mild wintel of 1866 , a pair of these birds were obserred for several days in a sheltered portion of buston. They were in excellent condition, and were rery husily employed hunting for the larrie and equs of insects and spiders in the comers and crevices of the walls of houses and out-buildings, evidently obtaining a full suplply. In Sonthern Illinuis, Mr. liilgway cites this Warbler as one of the least common of the spling and fall visitants.

Audubon found this species in nearly every Sonthern and Sontluwestern State during their migrations. They arrive in Sonth (anolina late in Mareh, are most abundant in April, and leave early in May. Ther keep in the deep woods, passing among the branches abont twenty feet fiom the gronnd. He traced them as far north as the Magrlaleine Islands, but found none in Newfoundland, and but a single specimen in Labrador. They breed in Nora Scotia, and a nest was given him found near Halifax hy 1)r. Mac(ulloch. These were said to he usually placed on the horizontal branch of a fir-tree, seven or eight feet from the ground, and to be composed of fine strips of bark, mosses, and fibrous roots, and lined with fine crinsses and a warm bed of feathers. The egas, fire in mumber, were white, with a rosy tint, and sprinkled with reddish-brown dots, chiefly at the larger end.

This Warbler is an expert catcher of the smaller winged insects, pursuing them quite a distance, and, when seizing them, making the clicking somnd of the true Flycatcher. So far as they have been observed. they lave no song, only a monotonous and sad-sounding cheep.

Nuttall, in the second edition of his Manual, mentions having observed several pairs near Farranville, Penn, on the Susquelnama, and annm the Alleghanies. It was in May, and in a thick and shady wood of hemlock. They were busy foraging for food, and were uttering what he describes as slender, wiry notes.

In Westem Massachusetts, Mr. Allen states it to be common from the 15th to the 25th of May, and again in September. They were found by Mr. C. W. 


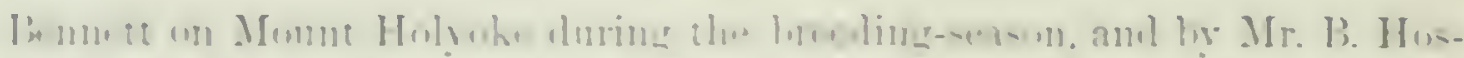

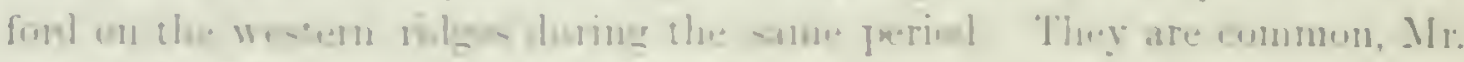

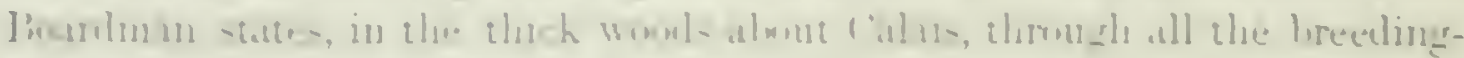
Seat -111 .

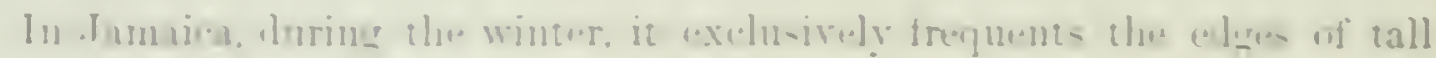

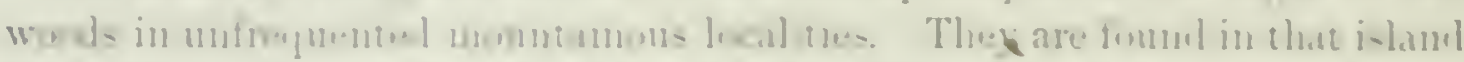

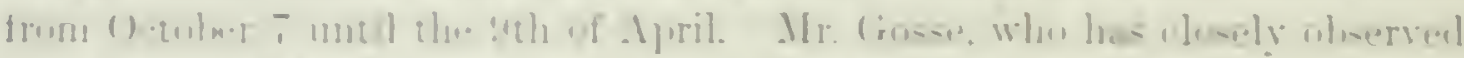

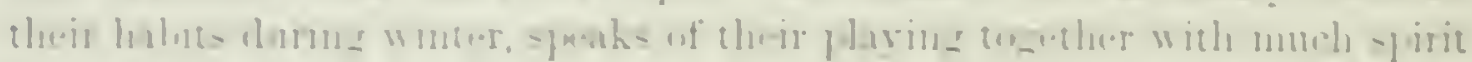

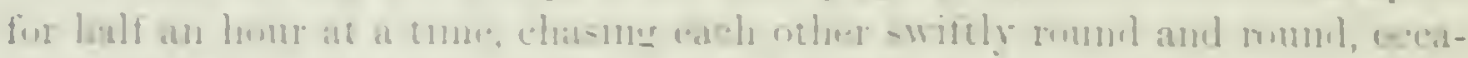

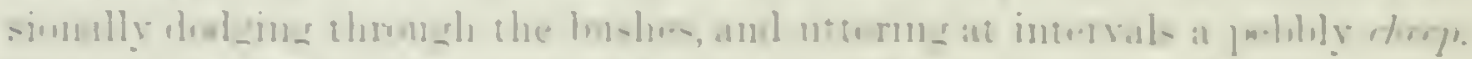

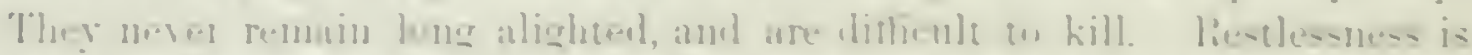

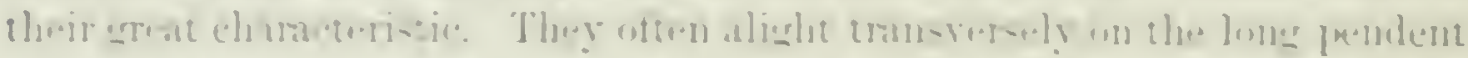

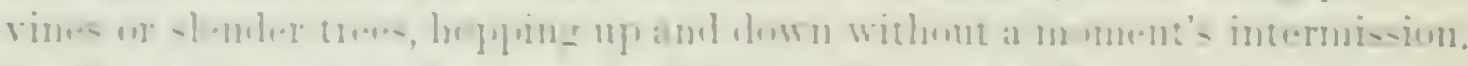

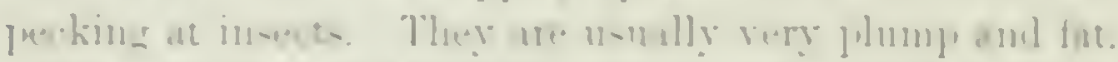

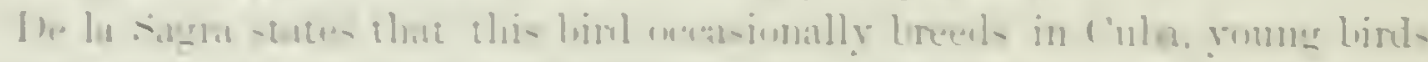

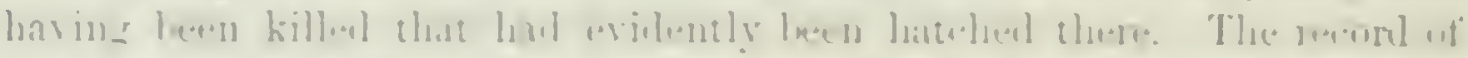

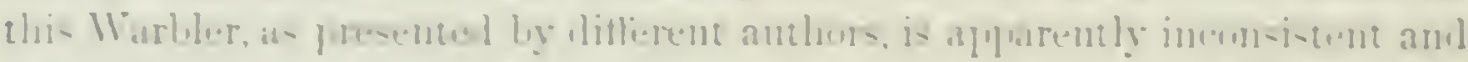

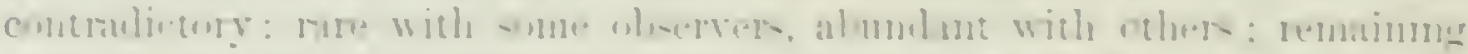

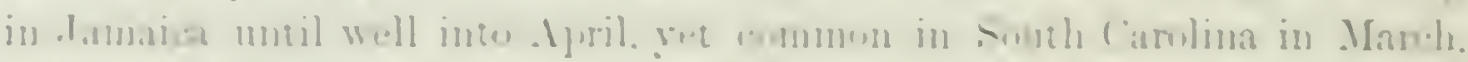

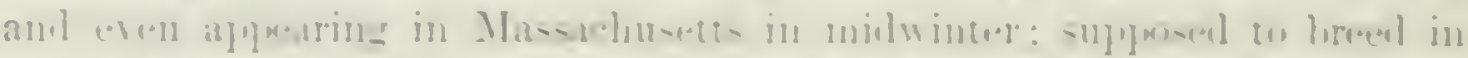

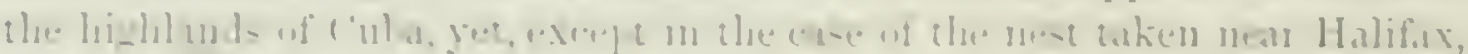

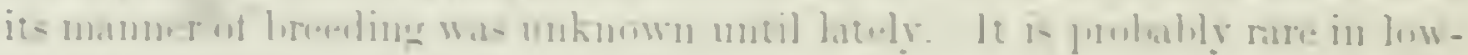

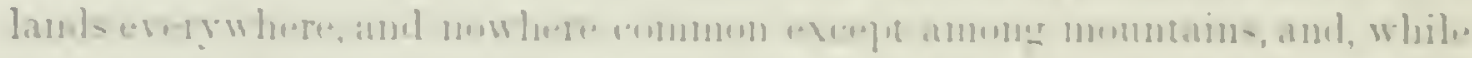

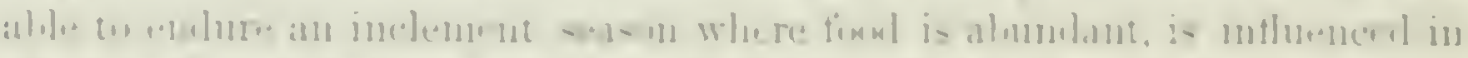

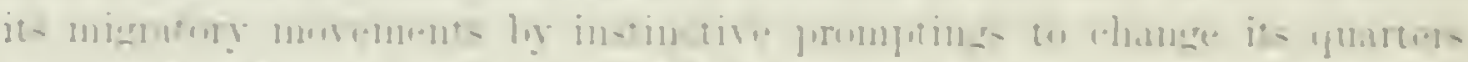

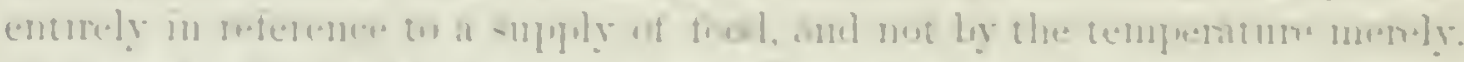

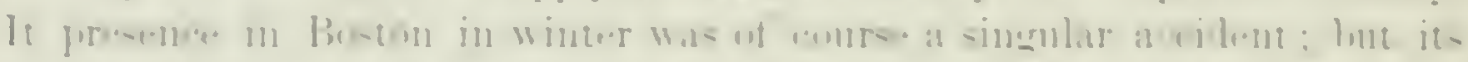

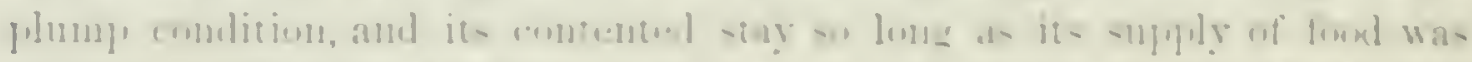

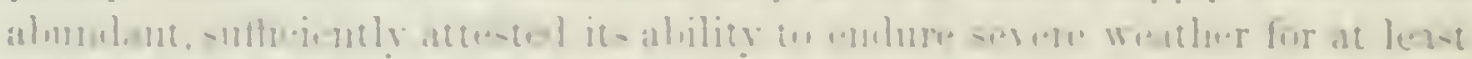

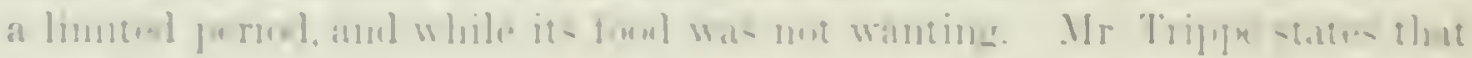

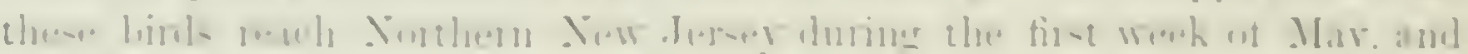

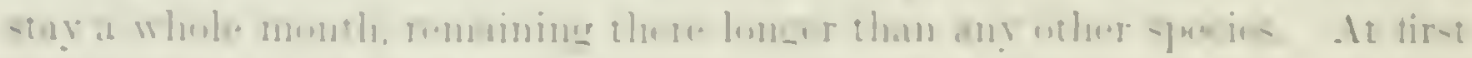

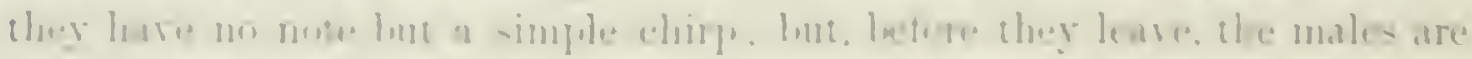

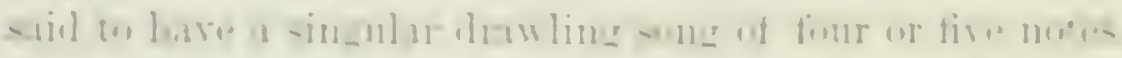

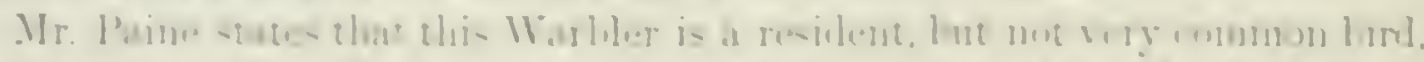

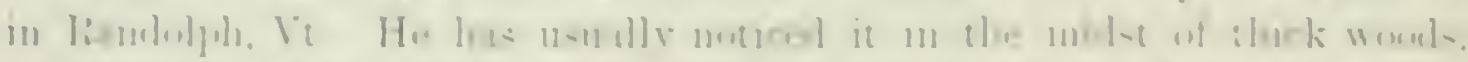

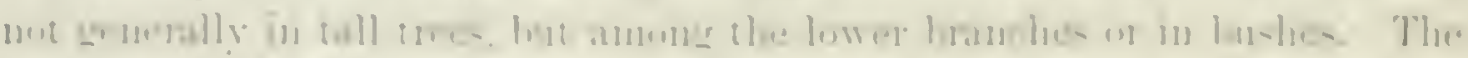

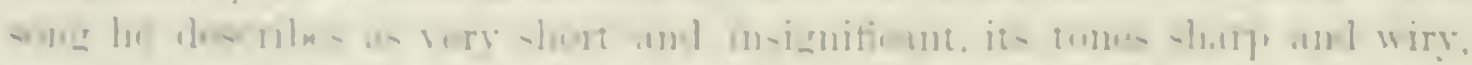

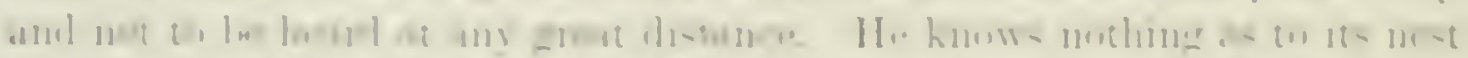

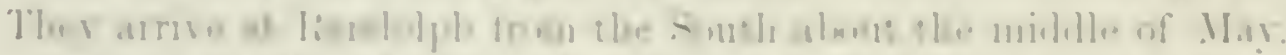

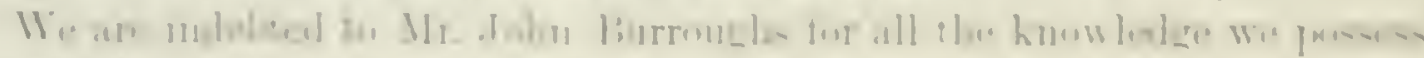

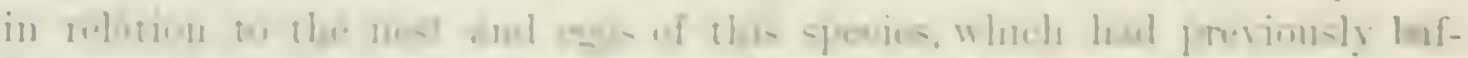

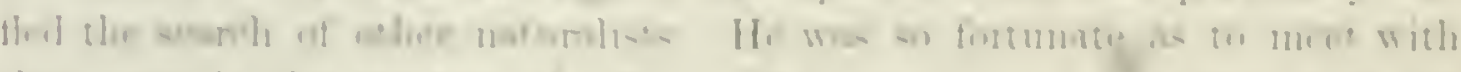

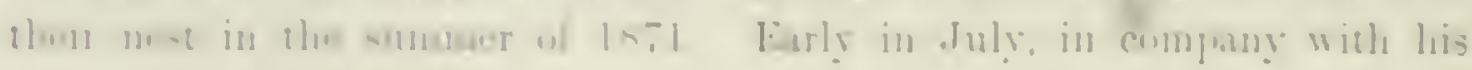


nephew, Mr. C. B. Deyoe, Mrr. Bumronghs visited the sime woods, in Roxhury, Detaware County, N. Y, in which he had in a previons year found the nest of the Mouming Ground Warbler. The trees were mostly hemloek, with an undergrowth of bireh and beech. They first noticed the parent birds with food in their bills, and then set abont deliberately to find their nest hy watching their movements. But the loinds were en nally vigilant, and watched them quite as determinedly: "It was dianond cut diamond." They were so suspicions, that, after loidling their heaks with food, they woukl swallow it themselves, rather than rum the risk of betraying the ir seeret by approaching the nest. They even apparently attempted to misleal them by leing very private and confidential at a point some distance from the nest. The two watched the birds for over in hour, when the mosquitoes made it too hot for them to hold ont any longer, and they made a rush upon the gromud, determined to lmut it orer inch by inch. The birds then manifested the greatest consternation, and when, on leaping over an old log, the youmg sprang ont with a scream, but a few feet from them, the distracted pair fairly threw themselves under their very feet. The male hird trailed his bright new plumage in the dust; and his much more humbly elid mate wis, if anything, more snlicitons and renturesome, coming within easy reach. The nest was placed in the fork of a small hemlock, about fifteen inches from the ground. There were four, and perhaps five, young in the nest, and one egg muhatched, which, on blowing, proved to have been fresh.

The nest measures three and a half inches in dianeter, and a trifle more than two in height. The carity is hroad and deepl, two and a third inches in diameter at the rim, and one and a half deep. Its base and periphery are loose aggregations of strips of deenyed imner bark from dead decidnous trees, chiefly basswood, strengthened by fine twigs, rootlets, and bits of wood and bark. Within this is a firm, compact, well-woven nest, made by an elabnrate interweaving of slender roots and twigs, hair, fine pine-needles, and similar materials.

The egg is oval in shape, less obtuse, lut not pointed, at one end, with a grayish-white ground, pinkish when unblown, and marked arom the larger end with a wreath, chiefly of a bright unber-brown with lighter markings of reddish-brown and obsenre purple. A few smaller dottings of the same are sparingly distributed orer the rest of the egg. Its measurements are .50 by .50 of an inch. It more nearly resembles the egrges of the D. maculosa than any other, is about five per cent larger, a little more oblong, and the spots differ in their rerldish and purplish tinge, so far as one specimen may he taken as a criterion. 


\section{Dendroica olivacea, : 4 T.}

\section{OLITE-READED WARBLER.}

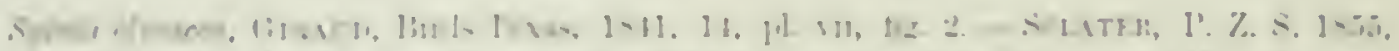

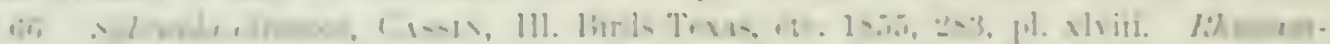

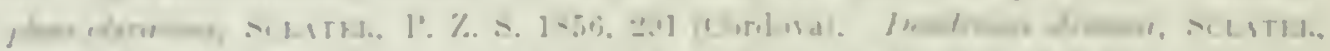

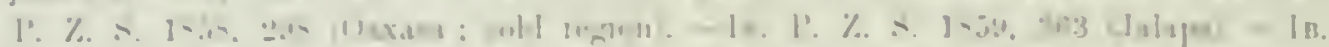

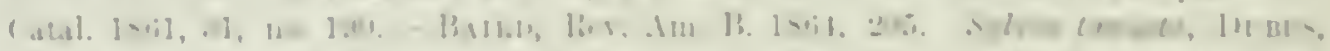

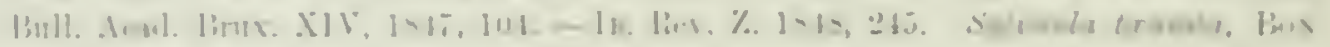

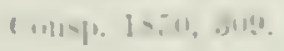

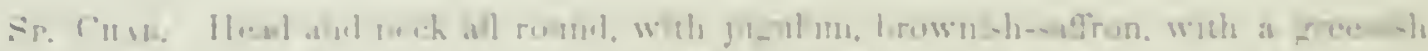

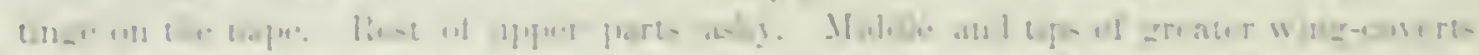

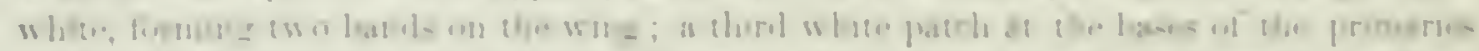

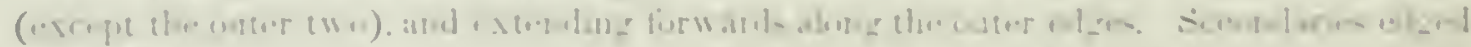

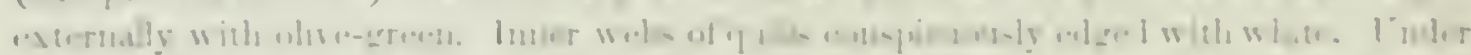

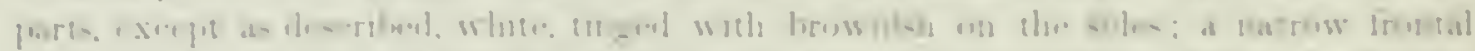

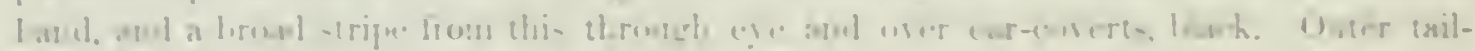

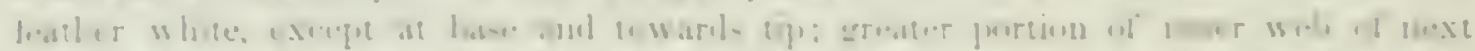

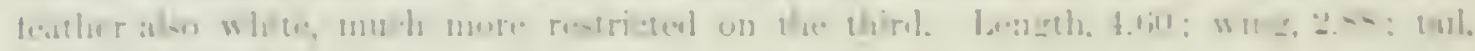

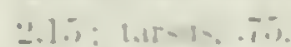

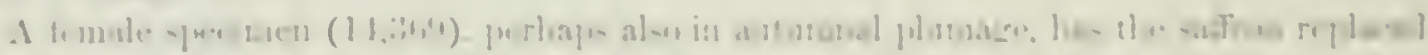

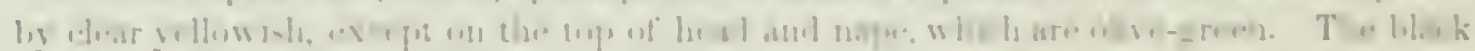

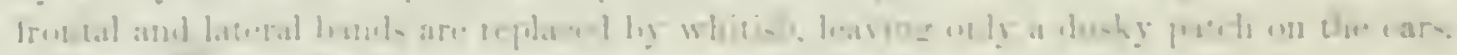

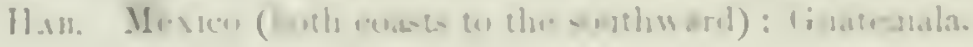

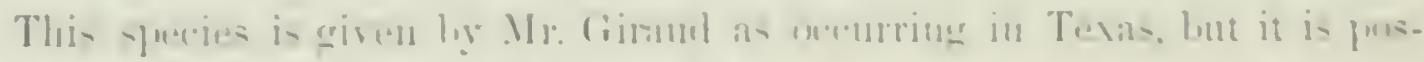

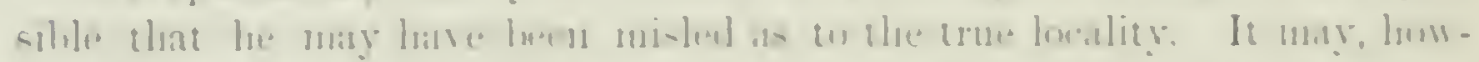

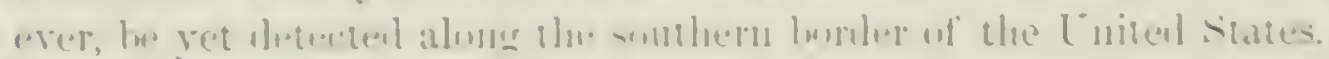

Nonlinge is known of it- lablith.

\section{Dendroica nigrescens, liwki.}

\section{BLACK-THROATED GRAY WARBLER.}

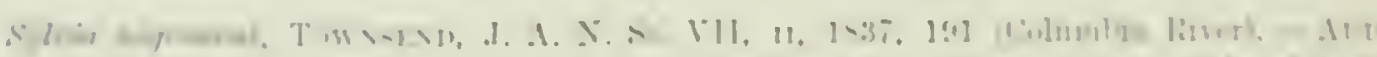

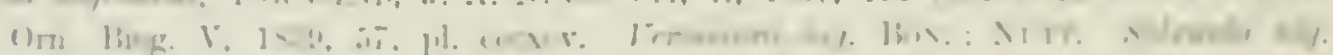

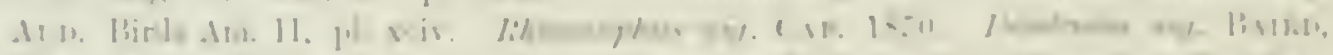

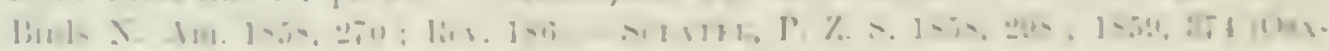

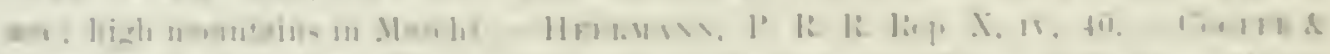

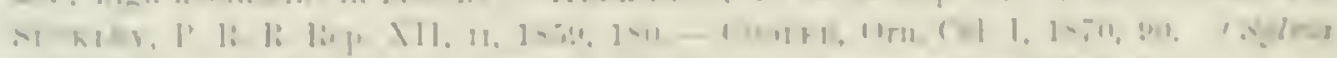

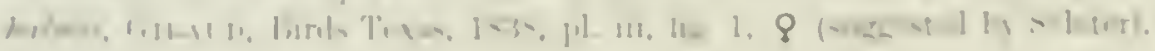

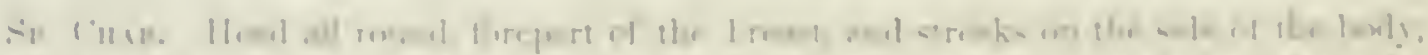

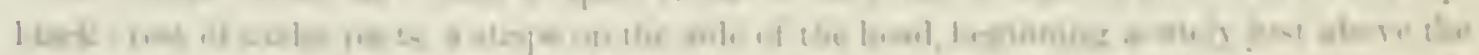

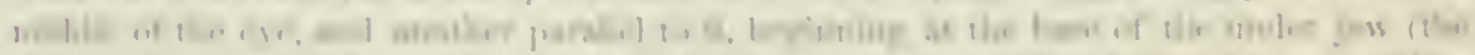

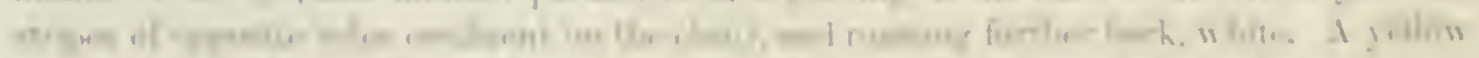

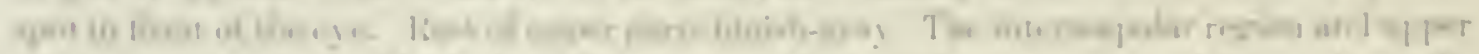

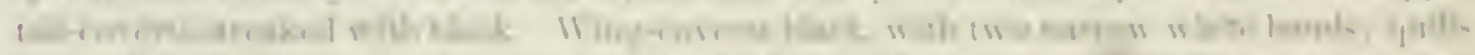

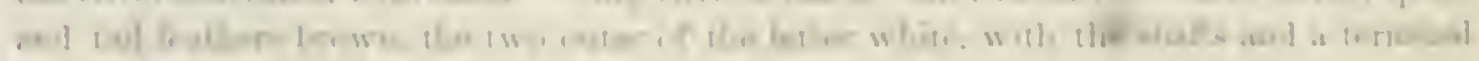


streak brown; the third brown, with a terminal narrow white streak. Bill black; fect lnown. Length, 4.70: wing, 2..30; tail. 2.10.

IIs\}. Western and Milllle l'rorinces of L'nited States. Migratory sonthward into Wrestern Mexico (Oaxaca); Orizalal (winter, semcumsts).

Female (5:3,37:3, East Humboldt Mountains, Ner., July 14). Similar to the male, but crown ash medially streaterl with black, instead of contimuous black; the streaks on back narrow and inconspienons; the black of the throat confined to the junnlmu, appearing in spots only on anterior half. A young female ( $N 0.53,376$, Eilst Humboldt Momntains, Angust 10) is plain brownish-ash above, lacking entirely the streaks on the hack, and those on sicles of crown extremely obsolete. There is no black whatever on throat or jugulum, which, with the well-defined supra-lonal stripe and lower parts in general, are soiled white, more hrownish laterally. The other features, including the yellow spot over the lores, with the wing and tail markings, are much as in the adult. A romm male (5:3,:37.), same locality and clate, cliffers from the last in having the sicles of the crown hlack, and the thruat-pateh almost complete, but much hidden by the broad white borders to the feathers. An adult autmmal male ( 7,690 , Calaveras liver) is like the spring adult, but the ash is overspread ly brownish, nearly obliterating the dorsal streaks, and diviling the black of the erown; the black throut-pateh is perfectly defined, but much obsemed by white borders to the feathers.

Husrr. The Black-throated (iray or Dusky Warbler, so far as is now known, belongs to the Mestern and Middle Provinces, occurring certainly as far to the south as San Diego, in ('alifornia, and as far to the north as Fort Steilacoom, in Washington Territory, penetratimg in winter into Mexico. The most ensterly localities in which it has been met with are in Arizona and New Mexico. The Sunthsonian İustitution has received specimens also from Columbia River, ('alareras, ('al., and Fort I)efiances.

This species was first obtained and described hy Mr. Townsend, who found it abmulant in the forests of the Columbia, where it breeds and remains mutil nearly winter. Its nest, which he there met with, resembles that of Parula americrna, only it is made of the long and filmous areen moss, or Usner, peeuliar to that region, and is placed ammon the mpler branches of oak-trees, suspented between two small twigs.

Mr. Nuttall states that it arrives on the ('olmmbia eary in Mar, and from the manner in which its song was delivered at intervals, in the tops of clecicluous trees, he had no doubt that they were breeding in those forests as eary as May 23. This song he rlescribes as delicate, but monotonous, uttered as it busily and intently searches every leafy bough and expanding bud for insects and their larra in the spreating oak, in which it utters its solitary notes. Its song is repeated at slort and regular intervals, and is said by Mr. Nuttall to bear some resemblance to t-shee-tshry g-tshnitsher, varying the feeble sound rery little, and with the concluding note somewliat slenderly and plaintively raised. Dr. Suckley speaks of this birl as morlerately abundant 


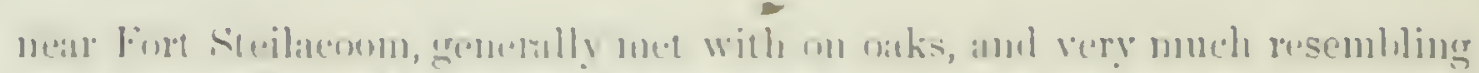

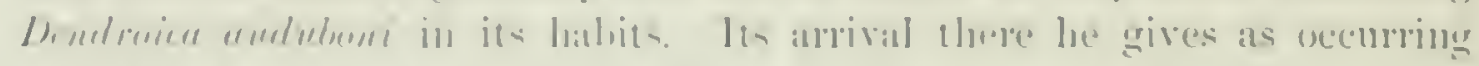

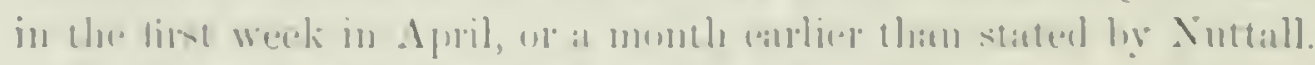

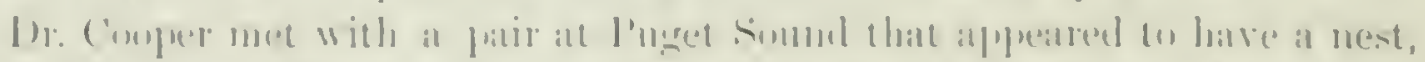

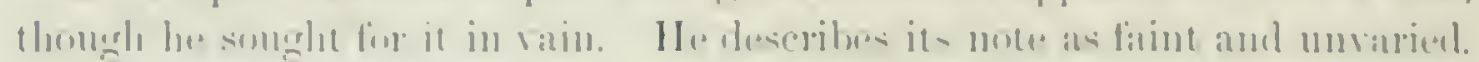

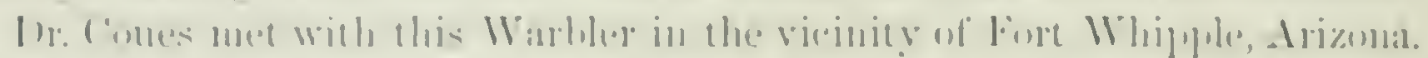

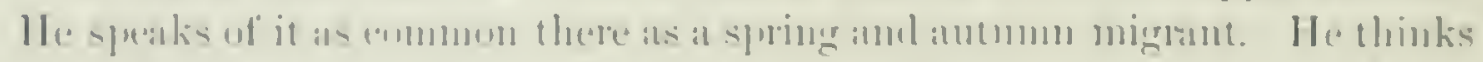

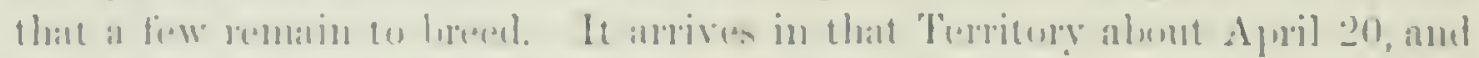

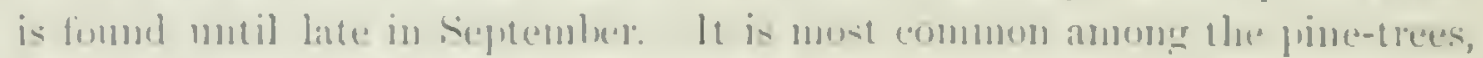

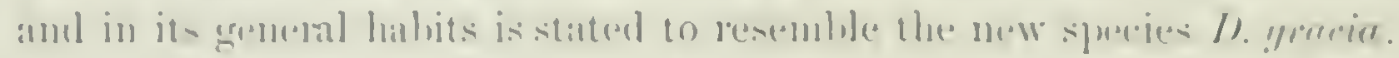

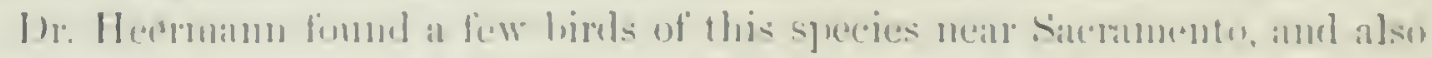

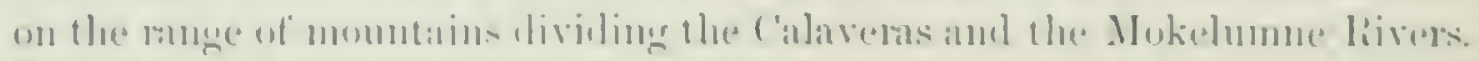

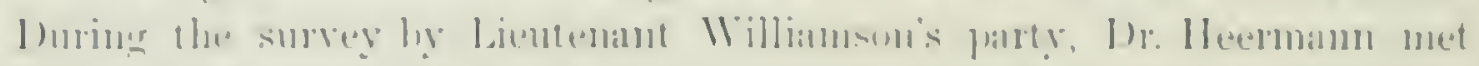

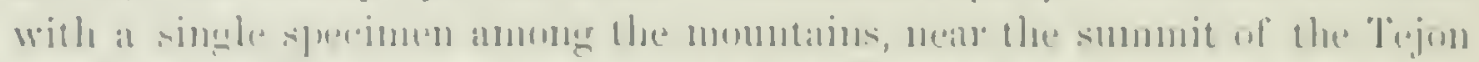

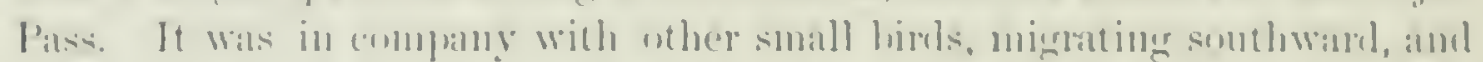

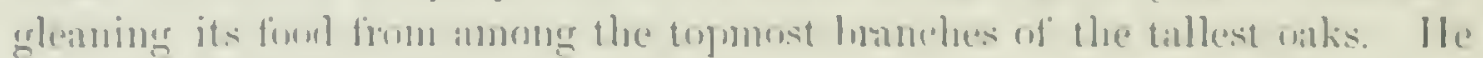
stalles that its motes chesely resemble the sommls of the lorenst.

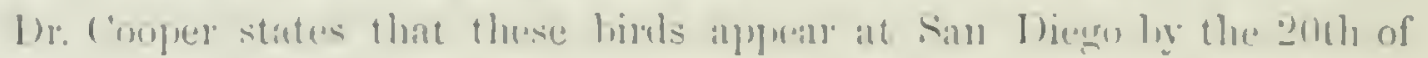

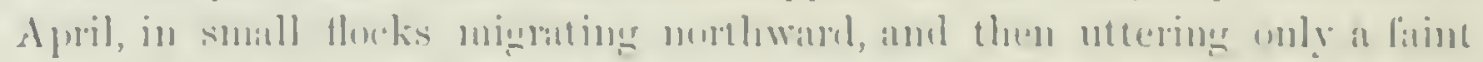

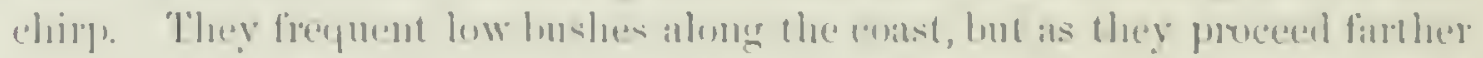

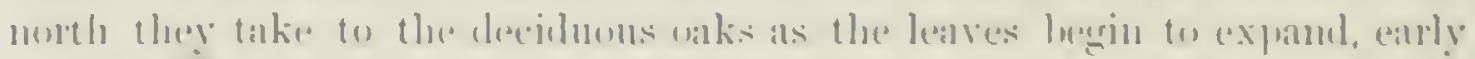

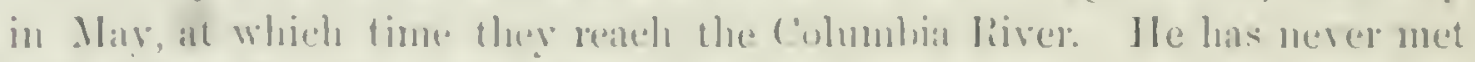

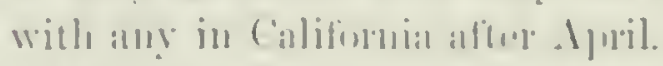

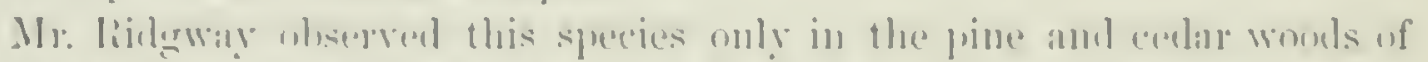

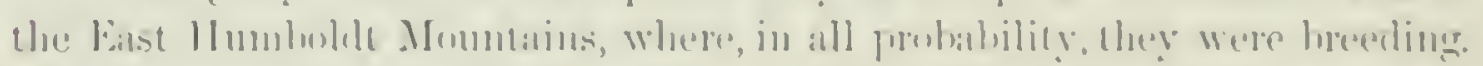

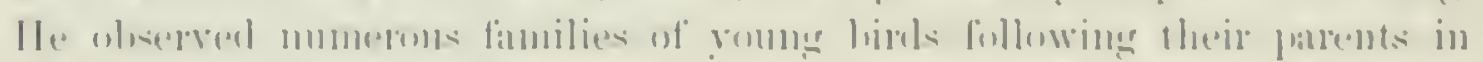

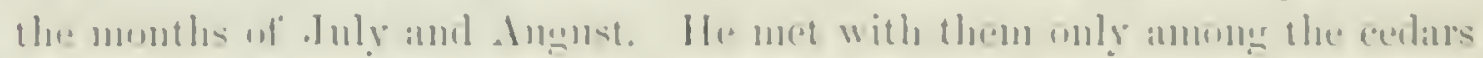

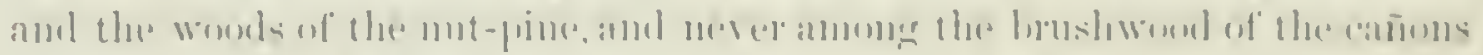

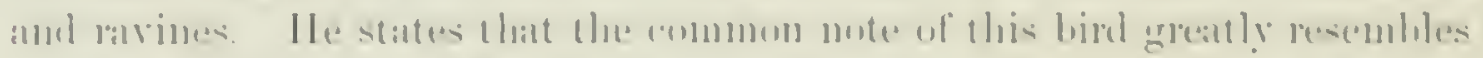

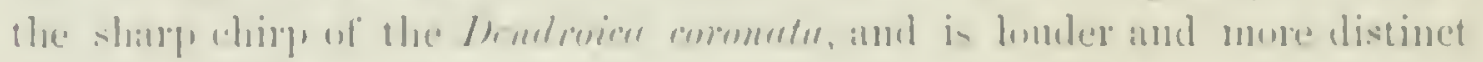

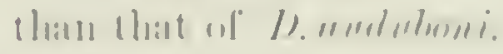

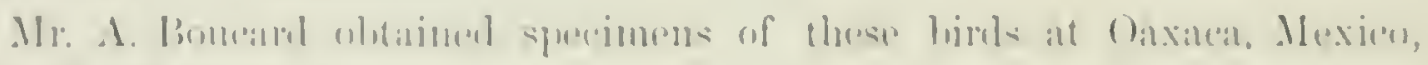
Jurim the winture mumths.

\section{Dendroica chrysopareia, Sil. it.in}

\section{YELLOW-CHEEKED WARBLER.}

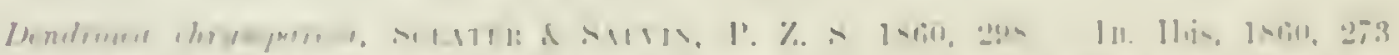

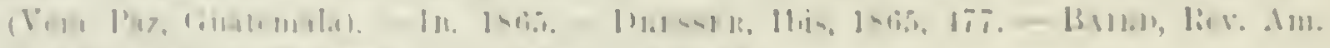

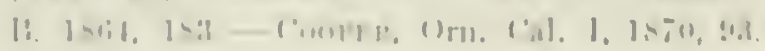

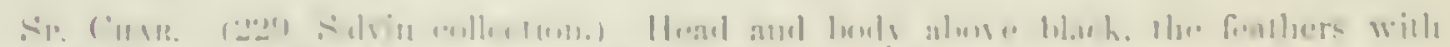

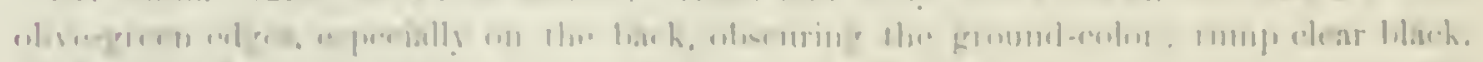

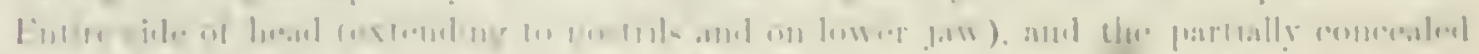

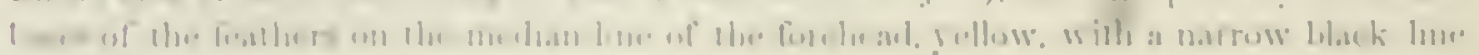


from lores, through the eye, widening behind, but not crossing through the yellow. Beneath, including inside of wings. white: a large patch of black covering the chin and throat, and oceupying the entire space between the rellow patches of the two sides of the heall and neck, ant extended along the sides in a series of streaks. Feathers of crisum wilh black centres. Wings above ashy, with two white bands across the coverts, the scapulars streaked with blackish; first quill edged externally with white, the rest with gray. Tailfeathers blackish, edged externally with ashy, the lateral with white at the base. Outer tail-feather white on the inner web, except a stripe along the shat near the end; second similar, but the white not reaching so far towards the base; third with a short pateh of white in the end. Bill and legs browni-h-black. Bill unusually thick. Length, 4.50; wing. 2.50 : tail. 2.40 ; tarsus. 2.75 .

H.ı. Tera Paz, Guateruala; San Antonio, and Medina Rirer, Texas. (HeErmax: and Dreserr.)

The capture of specimens of this species at San Antonio, Texas, by Dr. Heermann, and on the Medina River by Mr. Dresser, entitles it to a place in our fauna. The specimen described ahove is Mr. Salvin's trpe.

Habits. A single specinen is said to have been taken near sin Antonio, Texas, by Dr. Heermann. It is thought to be probably a bird helonging to the fauna of Arizona and New Mexico, and is griven hypothetically by Dr. Couper among the liris of California. In its appearance it resembles $D$. virens, $D$. tounsendii, and $D$. occidentolis. It was origrinally describen by Salvin from a single specimen obtained in Cruatemala. Another pair was afterward obtained by Mr. Salvin on the lighest point of the road between Salama and Tactic. In reigral to its habits. nothing is on record.

\section{Dendroica virens, BAIRD.}

\section{BLACK-THROATED GREEN WARBLER.}

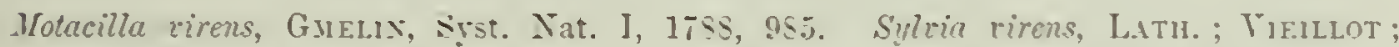

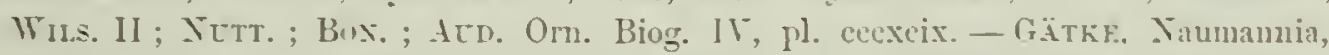
1558 , 423 (Heligolnul, Eurone, an originaI description). Sylviwle virns, sw. ; AtD. Birds Am. II, pl. laxiv. - Reishant, Vill. Med. for 15.33, 185t, 72, s1 (Greenland).

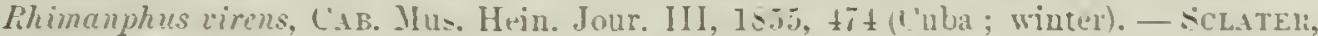

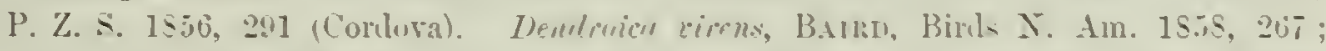

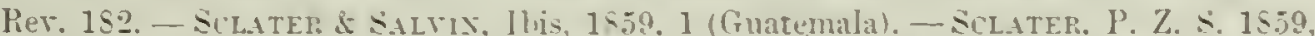

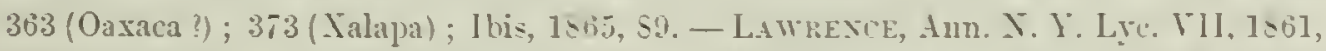

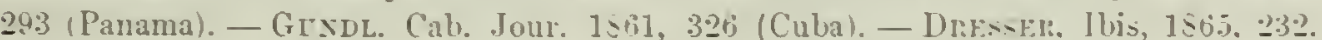

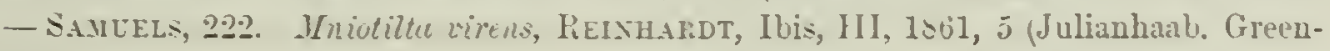
land).

Sp. Char. Male. Tpper parts, exclusive of wing and tail, clear rellow olive-green: the feathers of the back with hidden streaks of blach. Forehead and sides of head and neck. including a superciliars stripe. bright yellow. A dusky olive line from the bill through the eye, and another below it. Chin. throat. and forepart of the breast. extending some distance along on the sides. continuous black: rest of under pars white. tinged with yellow on the breast and flanks. Wings and tail-feathers dark brown, edged with bluish-gray; two white bands on the wing: the greater part of the three outer tail-feathers white. Female sinilar, but duller; the throat yellow; the black of breast unch cou- 


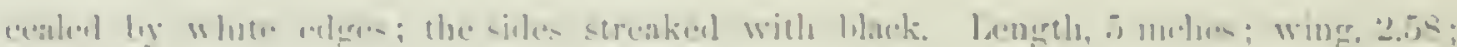
tail. 2...'11

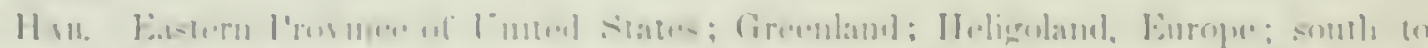

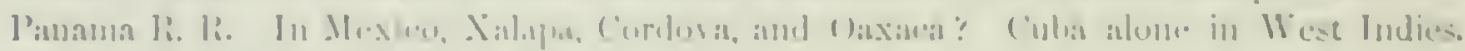

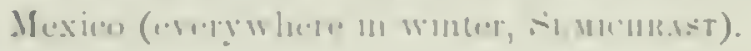

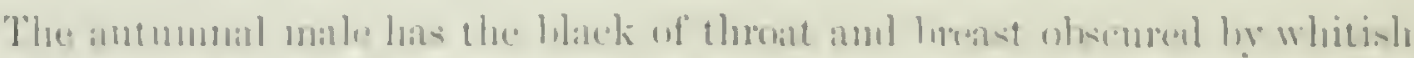

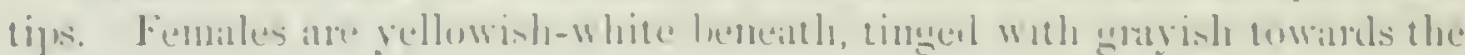
tail.

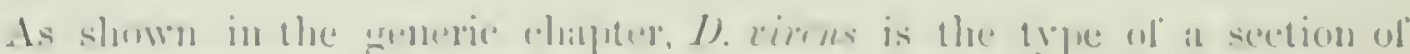

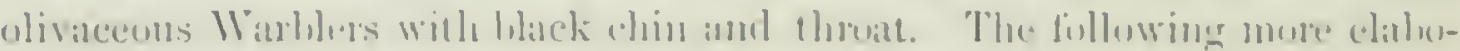

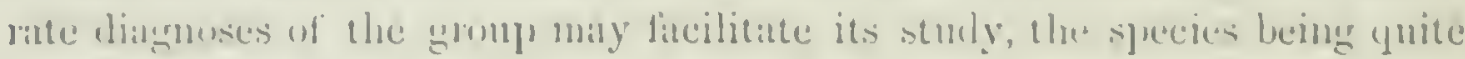
clusely reliterl :-

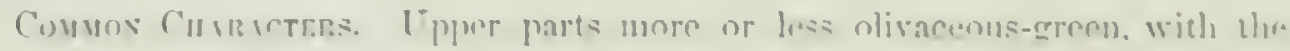

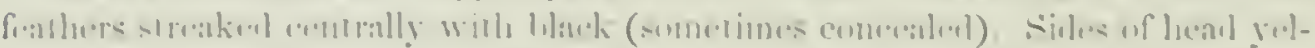

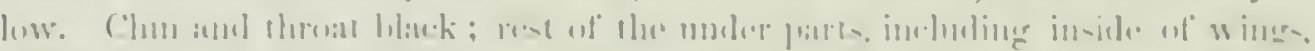

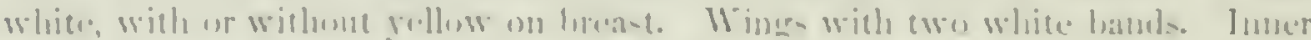

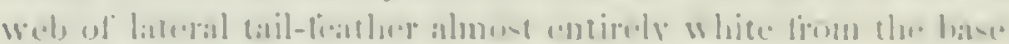

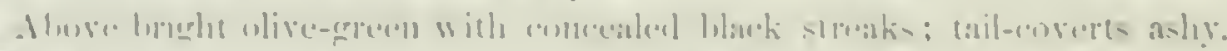

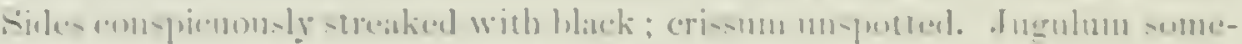

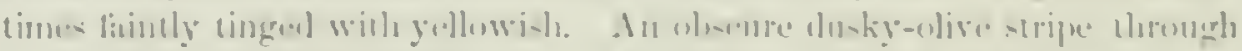

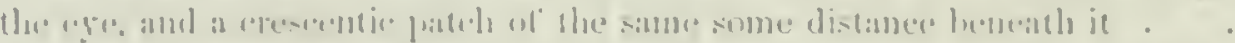

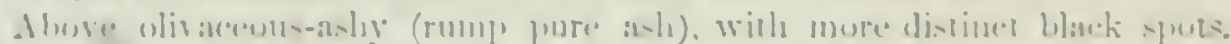

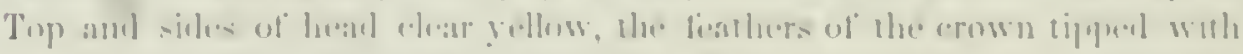

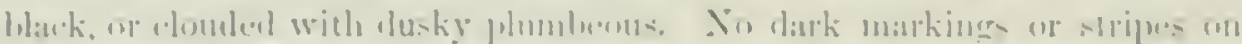

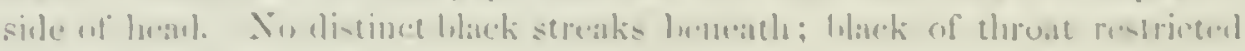
(1) froll of mik

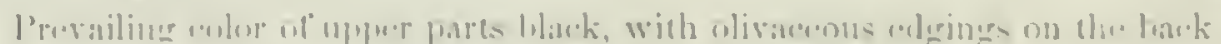

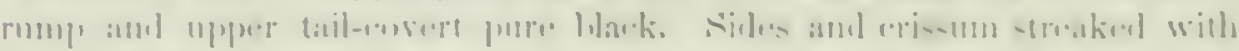

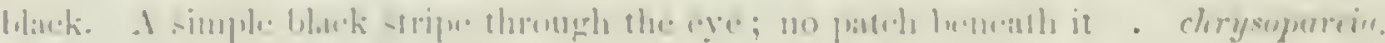

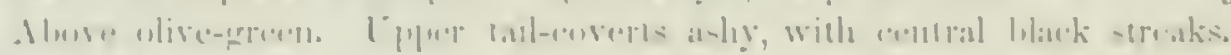

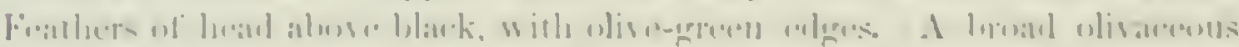

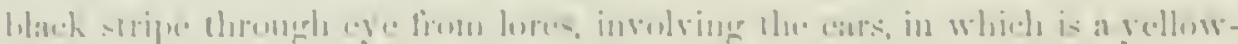

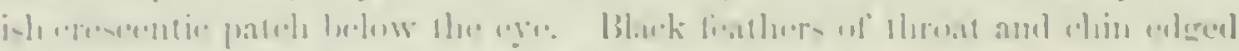

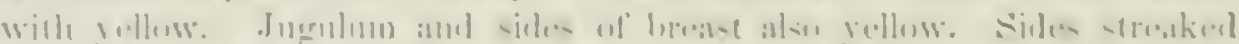
will back. No listiuct black struks an crinsum

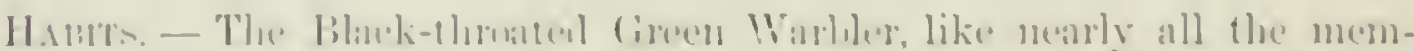

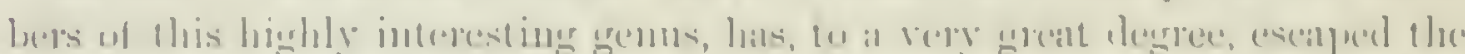

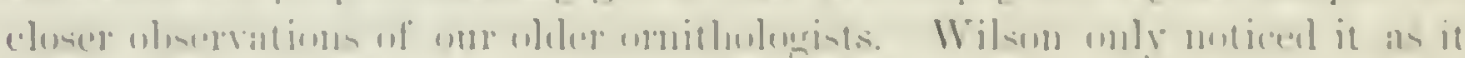

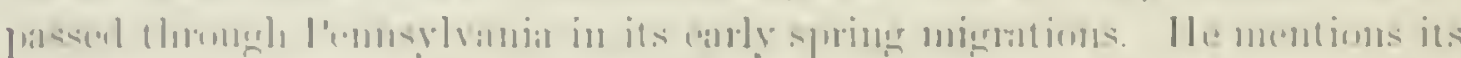

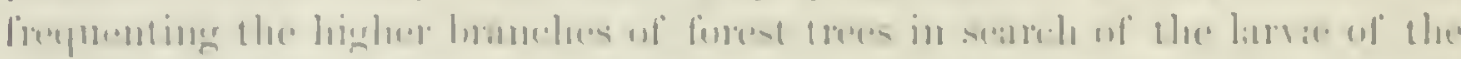
small

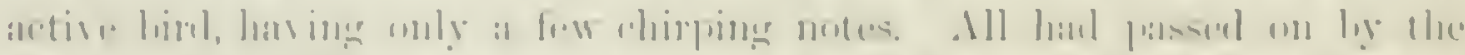

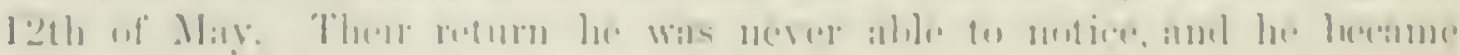

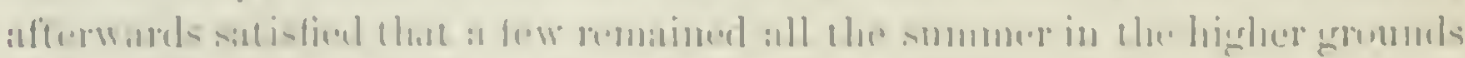

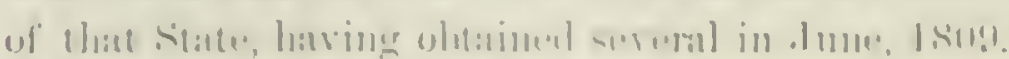

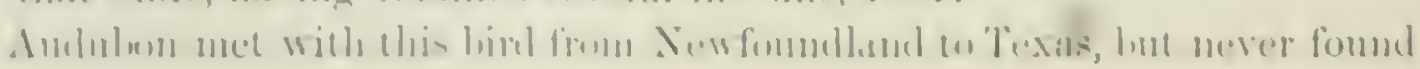


it breeding. Sowhere ahundant, there were large tracts of country where he never met with it, or where it was of rare occurrence. He found it most abundant in the ricinity of Eastport, Me. He also met with it during summer, in New England generally, Northern Pennsylvania, and New York, but not in Labuador. He describes its laahits as a mingling of those of the Wirlylers and of the Vireo, and its notes as resembling those of the latter. In its search for food he found it yuite regardless of the nean presence of man. In its spring migrations it passes through the woods usually in pairs, in the fall reappearing in flochs of six or seren. In breeding it occurs only in single pairs, and eath pair appropriates to itself a large tract of territory within which no other is usually found. After Octuber, all have prassed berond the limits of the United States.

During the winter months it appears to be quite common in different parts of Mexicn and Central America. In the large collection of (iuntenalin skins collected hy Irr. Van Patten, and purehased by the Buston Nituril History Society, this liril was one of the most aloundint of the migratory species. Specimens were taken by Mr. Boncard at l'laya Vicente, in the liut comntry of Oaxaca, Mexico.

Dr. Woothouse found this Warbler common in the Indian Territory and in Texils, and Lientenant Couch met with it in Tinnaulipas, Mexico, in Marrdh, 1853. With these exceptions it las not been observed in any of the grovernment survers, or fouml west of the valley of the litu Grante. Besiles the points named, it has been obtained in Olio, Inlinuis, Missouri, and in the West Indies, in C'entral and in the nurthern portions of sunth Anerica. Reinharelt gives it as accilental in Greenland. A single stray specimen was obtained in Heliguland, Emrope, Oetuber 19, 1s.is.

Mr. Paine, of Riandulph, Yt., notes the arrival of this lired about the 10th of May. He speaks of it as a very sweet singer, and as monally seen in the tops of tall trees, the hemluck being its farorite resort. There it chants its sweet sad notes through eren the heat of the dar. It continues in song nearly thrumghout the summer. Later in the season it frequents the open fields, in which it is seldom seen in the breeding-season. Its food, which it cattches on the wing in the manner of Vireos, consists of the smaller winged iusects, caterpillars, and other larve. In the fall, aceording to Mr. Audubon, it feeds upon various kinds of small berries.

It reaches Massachusetts the first of May, and is most numerous about the 1.5th, when the larger proportion pass farther north. In Western Maine, Professor Verrill states it to he a summer but not a common risitant; and near Calais, Mr. Boardman has found it lreeding, but does not regird it as at all common, though in the year 1865 he found it quite abundant in the thick woods in that neighborhood during its breeding-season. Dr. Bryant also speaks of it as one of the most common of the Warblers observed by him near Tarmouth, X. S. A single specinen was taken at Julianhaab, Freenland, in 1853, and sent to the Royal Museum of Copenhagen. 
In the vicinty uf linstom, e-precially in the high errommes of Norfolk and

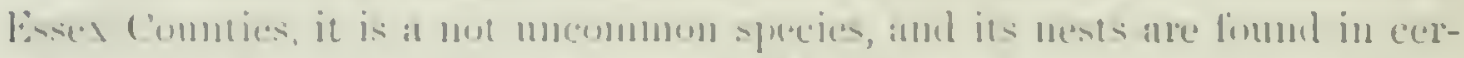

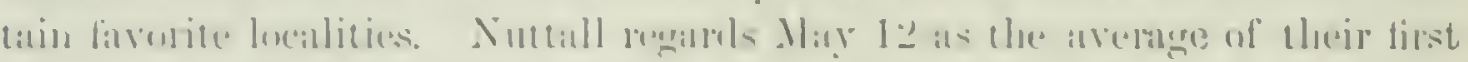

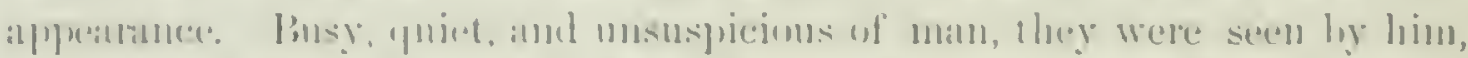

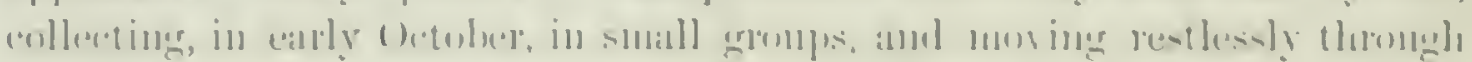

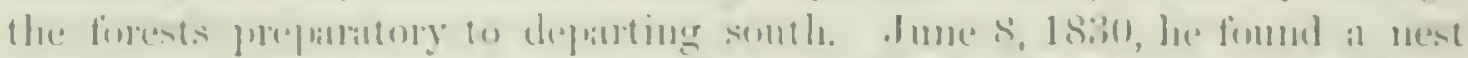
of this species in at solitaly simation amonge the lilue Milk of Miltom, Mass.

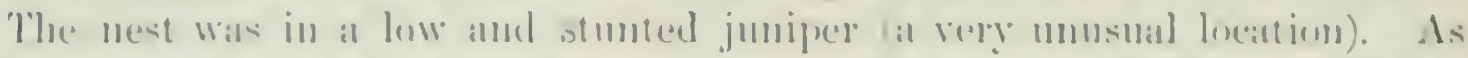

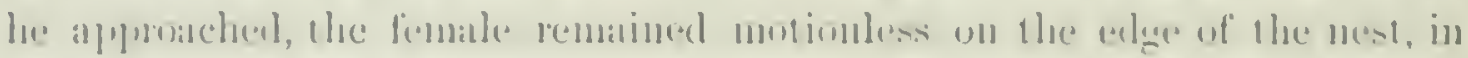

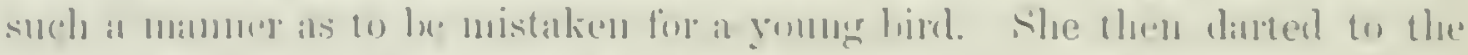

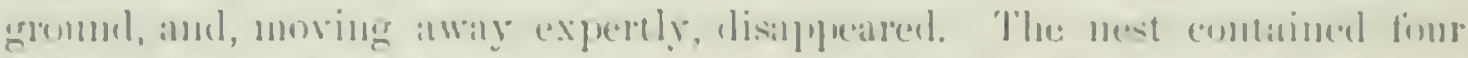

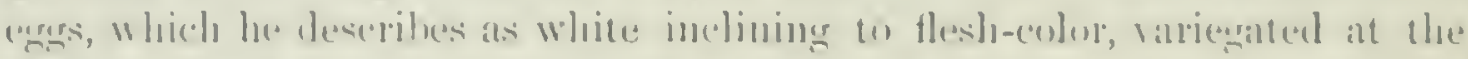

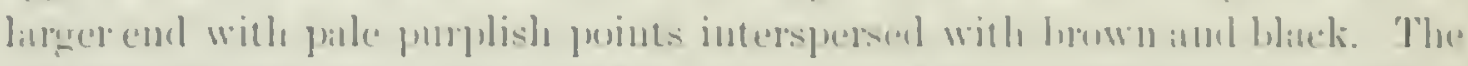

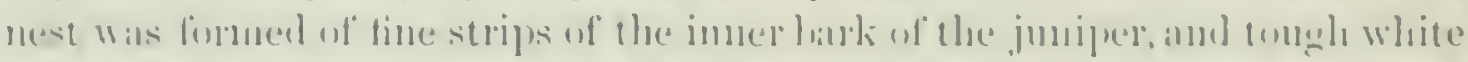

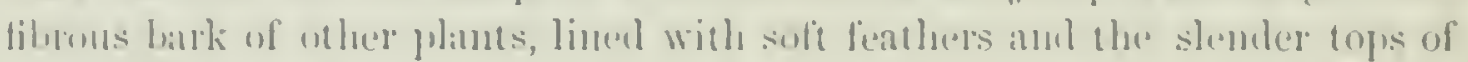

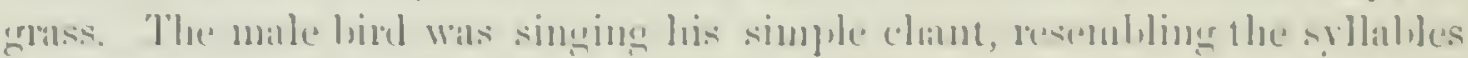

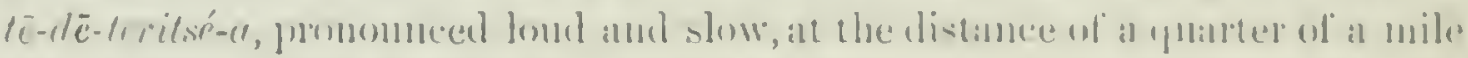
from the nest. Ile deseribes his song as simple, drawing, and phintive. Mu.

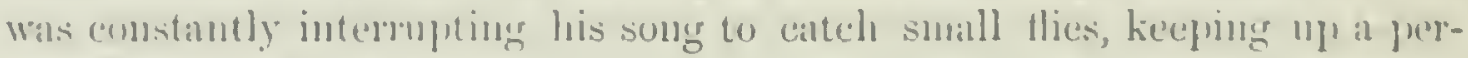
petmill smat'ping of his hill.

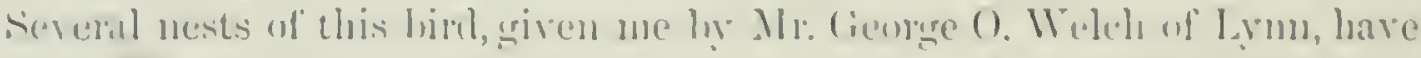
leen fomme by lim in high trees in thiek wouds on the western burders of

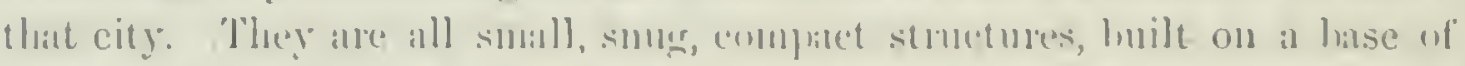

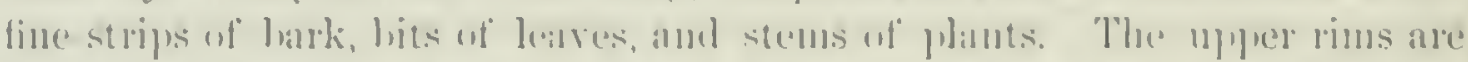
a circular intertwining of the slemeler twigs, interworen with a few fone

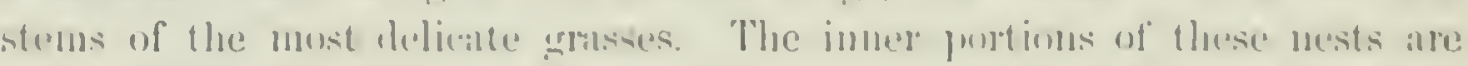

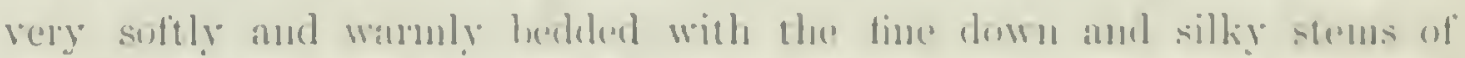

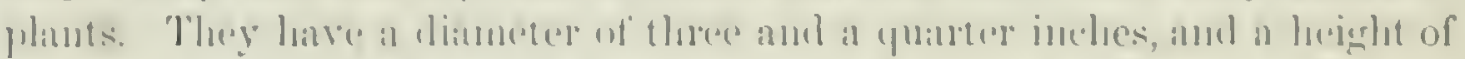

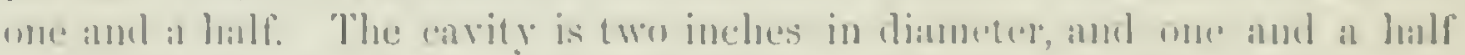

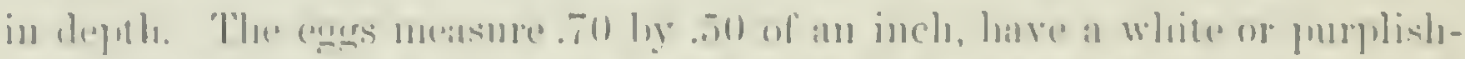

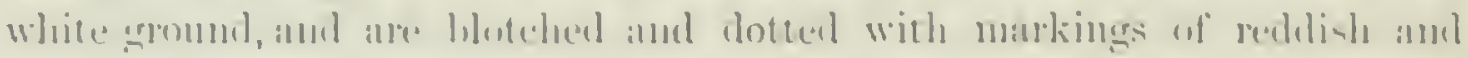

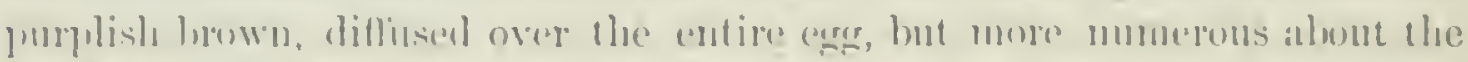

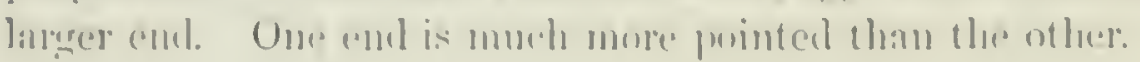




\section{Dendroica townsendi, Barin.}

\section{TOWNSEND'S WARBLER.}

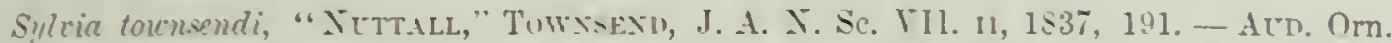

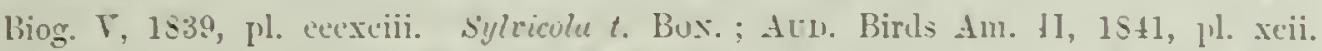

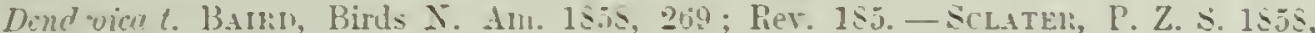
295 (Oaxaca; high lands in winter); $1258,37 \pm$ (Totontepee: winter) : Ibis, $1565,5 ?$.

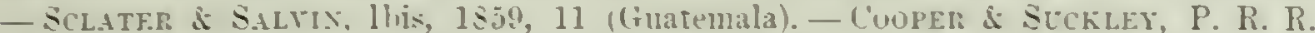

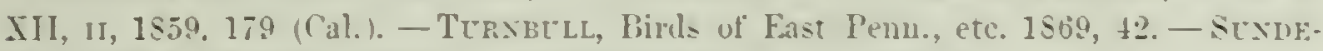
VAL, Otrers. 1s69, 610 (Sitka). - Cuupkl, Orn. Cal. I, 1si0, 41.

Sr. Cras. spring mate. Abore bright olive-green: the tiathers all black in the centre. showiug more or less as streaks, especially wn the crown. where the black predominates. Quills, tail, and upper tail-covert leathers dark brown. edged with bluish-gray; the wings with two white hands on the coverts: the two outer tail-feathers white with a brown streak near the end: a white -treak only in the end of the third feather. [nder parts as far as the middle of the holy. with the sides of heal and neck, including a superciliary stripe and a spot beneath the eye, yellow: the median purtion of the side of the head. the chin and throat. with streaks on the siles of the breist, tlanks, and under tailcorerts, black; the remainder of the unler parts white. Length, j inches; wing. 2.65; taill, 2.25

Sprivg female. Resembling the male. but the black patch on the throat replaced by irregular blotches upon a jure gellow ground.

H.в. Western Prorince of [nited states, north to Sitha; Mexico, into Guatemala. Migratory. Accidental near Philadelphia.

The autumnal adult male is much like the spring female, but the black throat-patch is perfectly dehined, though much obscured by the vellow edge: of the feathers, instead of broken into smill blotches. The roung male in antum is similar in general appearance, but there are no streaks above, except on the crown, where they are mostly concealed; the stripe on side of head is oliraceons, instead of black; and nearly all the black on the throat is concealed.

A fine adult male of this species was taken near Philadelphia, Pemn., in the spring of 1868 , and is now in the collection of the late W. P. Turnbull, Esq., of that city.

Habirs. In regard to the labits of this rerr rare Westem Warbler very little is as yet positively known, and nothing whaterer has been ascertained as to its nesting or eggs. The species was first met with by Mr. Townsend, October 28, 1835, on the banks of the Columbia River, and was named by Mr. Nuttall in honor of its discoverer. It is spoken of by these gentlemen as haring been a transient visitor only, stopping but a few dars, on its way north, to recruit and feed, previous to its departing for the higher latitudes in which it spends the breeding-season. It is, howerer, quite as probable that they disperse by pairs into solitarr places, where for a while ther escape observation. When the season again compels them to migrate, ther reappear on the same path, only this time in small and silent flocks, as ther slowly move toward their winter quarters. These birds also are chiefly to be found 


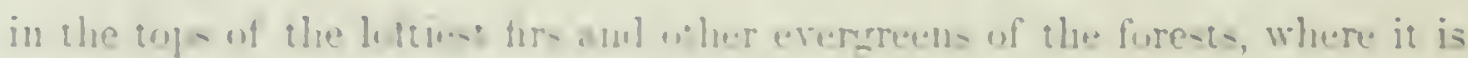

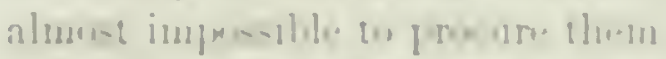

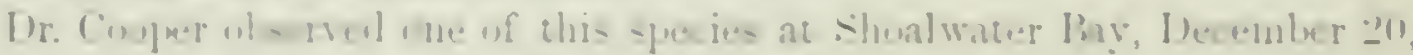

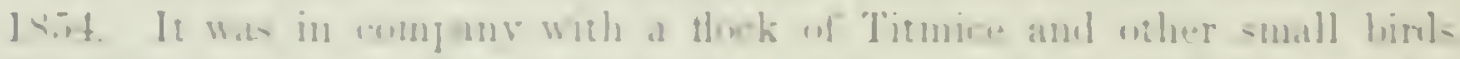

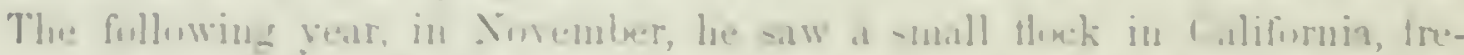

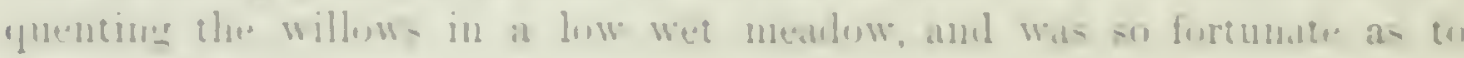
prence a pair

linl-way met with it in the Fan-i Humbulit Mountuin, where it was

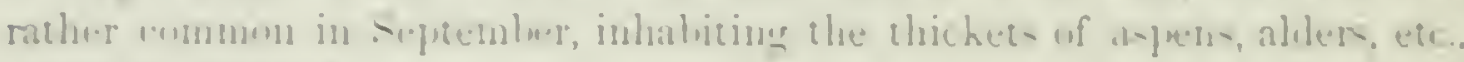
alon:- the strems.

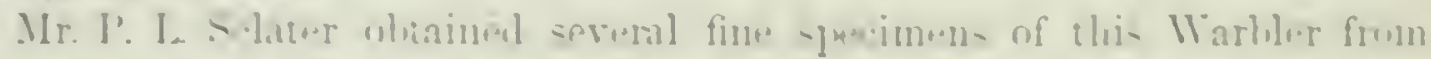

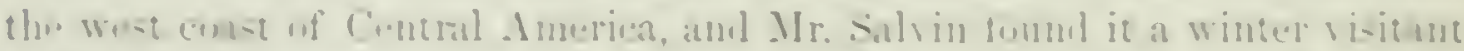

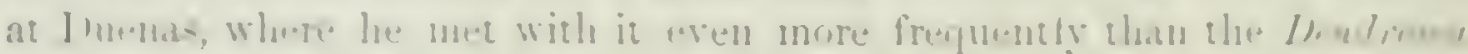

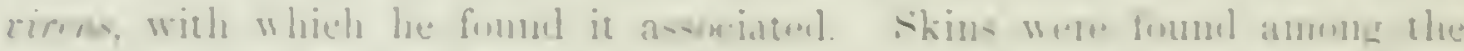

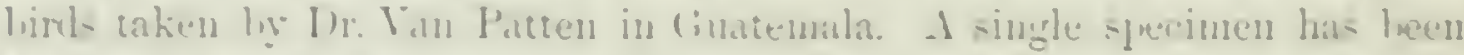
take'n in l'emmstrunia.

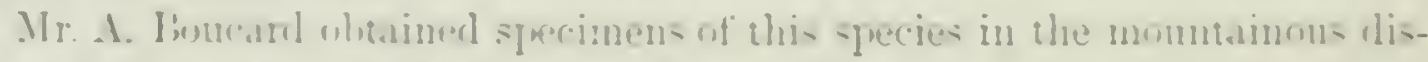

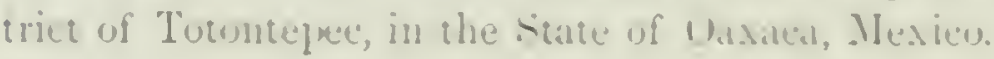

\section{Dendroica occidentalis, Bum.}

\section{WESTERN WARBLER.}

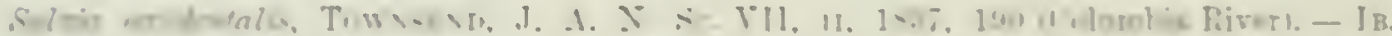

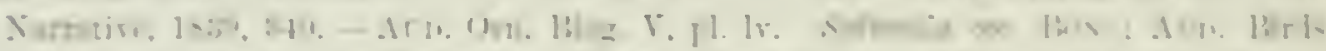

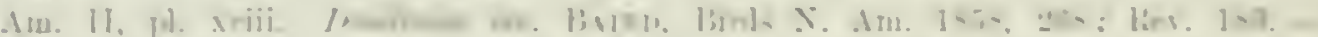

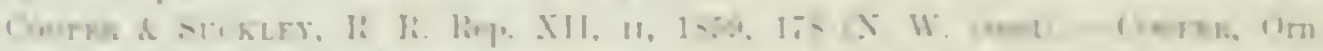

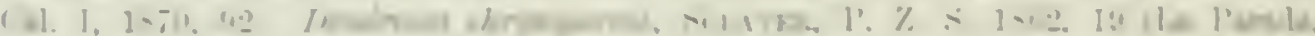

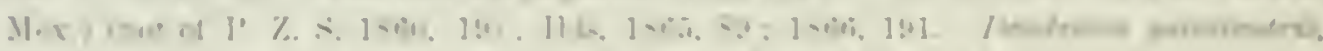

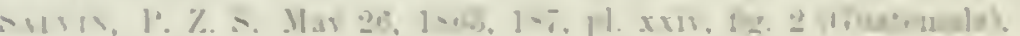

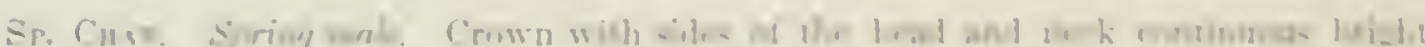

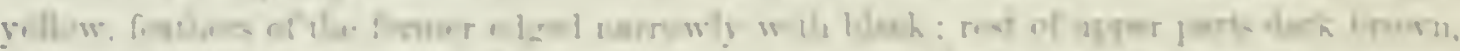

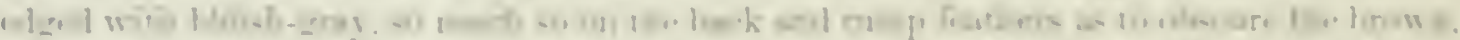

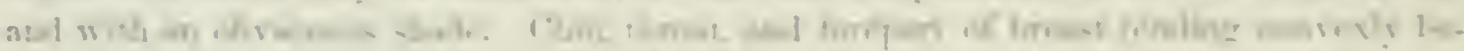

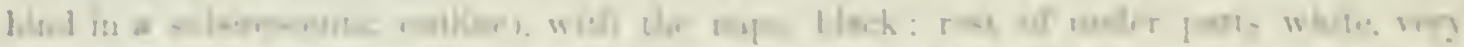

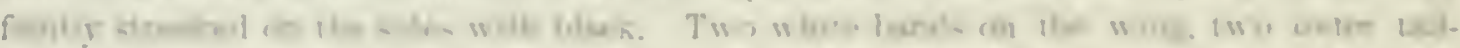

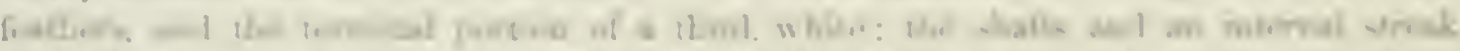

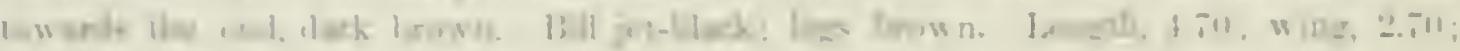
1.6. 2.511 .

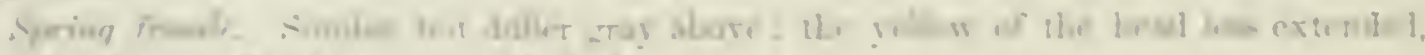

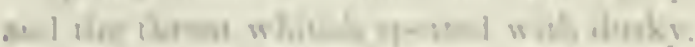

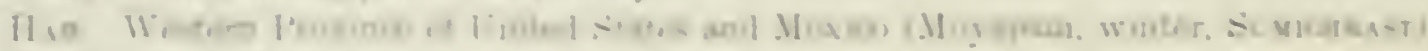

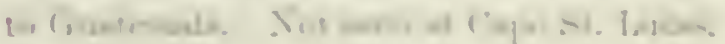

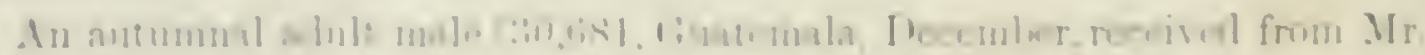

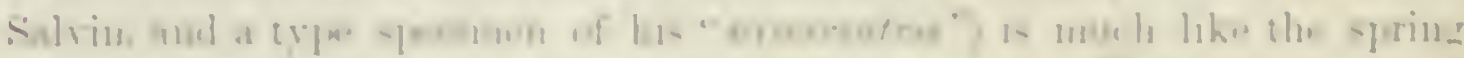

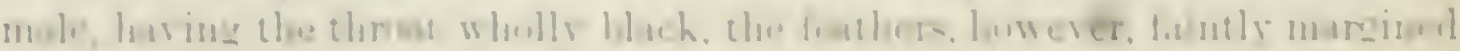


with whitish; there are no black spots on the crown, but, instead, an olivaceous stain; the nape is oliviceous instead of black, and the black centres to dorsal featlers more concealed ; the ash above is less pure, and there is no trace of strealks on the sides. A temale (antumnal !) - 38,1+1 - firm Orizaba, Mexico, is grayish-olivaceous above, inchding the whole top of the head, except beneath the surface; the fathers on top of head have conspicuons black centres, but there are none on the back; the sides of the lieal, and the bases of the fentluers on its top, are soiled yellow; the throat is dirty white, with the feathers disky beneath the surfice; the hreast and sides have a strong brownish tinge. Another femille, and an autumual one (probably of the rear), is more brown above, the specks on the top of the head exceedingly minute; there are also obscure strealis along the sides, where there is a strong brownish tinge.

Habits. The Western or Hermit Wood Warbler, so far as known, is limited in its distribution to the l'acifie coast from C'entral America to W'ashington Territory. Speeinens procured from Volean de linego, Mexieo, Arizona, and California, are in the collection of the Smithsonian Institution. But little is positively known as to its history ol habits. Nuttall, who first net with it in the forests on the banks of the ('olumbia, han no doubt that it breeds in the dark forests hordering on that river. He described it as a remarkably shy and solitary birel, retiring into the darkest and most silent recesses of the evergreens, and apparently living among the loftiest branches of the gigantic firs of that.region. In consequence of its peculiar habits it was with extrene difficulty that his party could get a sight of this retiring speeies. Its song, which he frepuently heari from these high tree-tops at rery regular intervals for an hour or two at a time, he clescribes as a fiunt, moody, and monotonous note, delivered when the bird is at rest on some lofty twig, and within envenient hearing of its mate.

Mr: Townsend, who was one of the sime party, shot a pair of these birds near Fort Vanconver, May 28, 1835. They were Hitting anong the tops of the pine-trees in the depths of the forest, where lie frequently saw them hanging from the twigs, in the manner of Titmice. Their notes, uttered at different intervals, he describes as very similar to those of the Black-throated Blue $W^{r}$ arbler (D. ccrulescens).

Dr. Suckley obtained, June, 1856 , two specinens at Fort Steilacoom. He also describes them as very shy, feeding and spending most of their time in the tops of the highest firs, so high up as to be alnost ont of the reach of fine shot. The species he regards as not at all rare on the Pacific coast, but only difficult of procuring, on accomnt of the almost inaccessible nature of its haunts.

Dr. Cones procured a single specinen of this species in Arizona early in September. It was taken in thick scrub-oak bushes. He thinks it may be a summer resident of that Territory, hut, if so, very rare.

A single specimen was also obtained at Petuluma, Cal., by Mr. Fmanuel Samuels, May 1, 1856. 


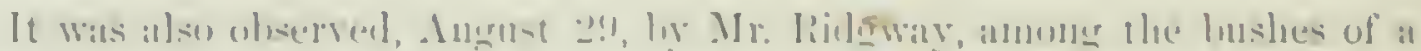

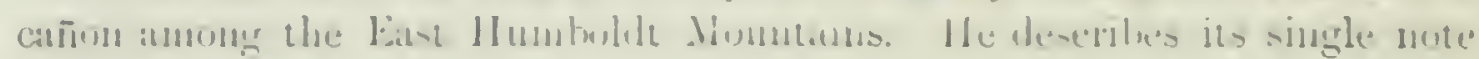

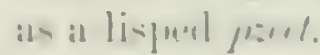

Three individuals of this strecies were collected hy . Mr. Loucard in southern

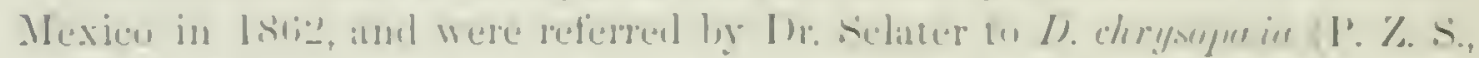

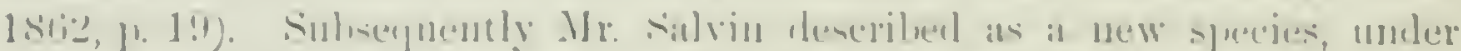

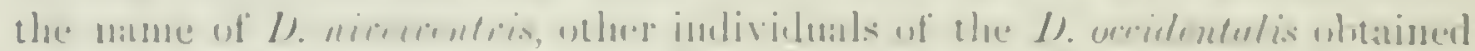

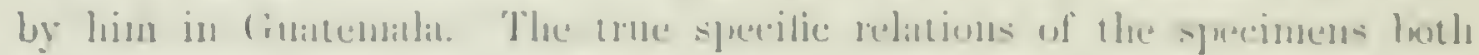

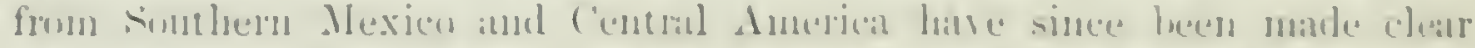

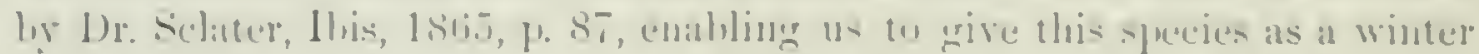

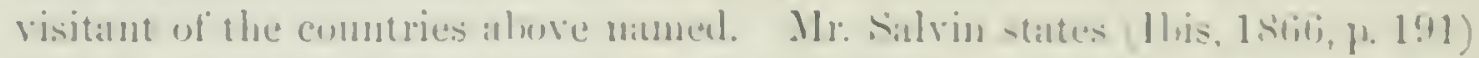
that these birls were fouml in must of the elevited districts where pines

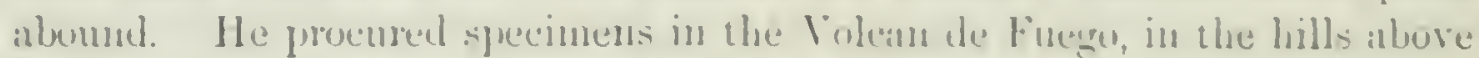

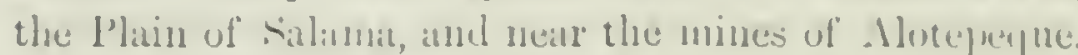

\section{Dendroica pinus, BatkD.}

\section{PINE-CREEPING WARBLER.}

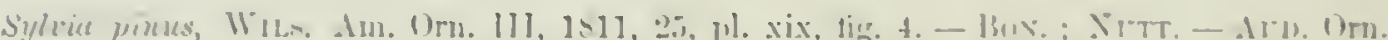

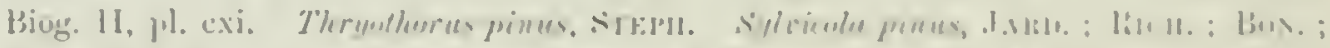

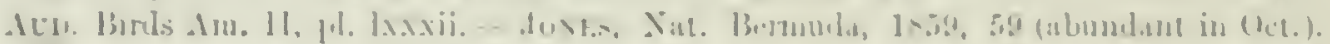

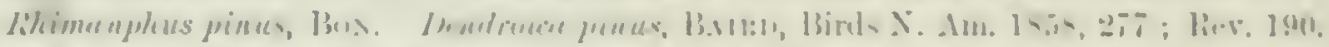

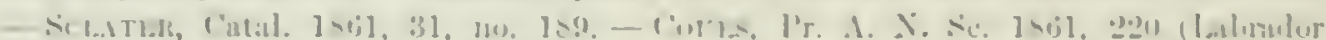

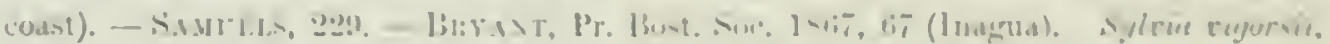

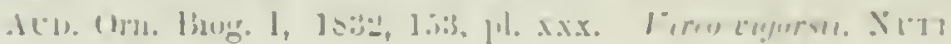

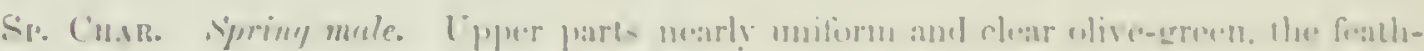

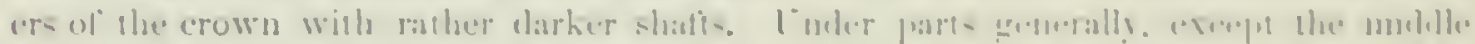

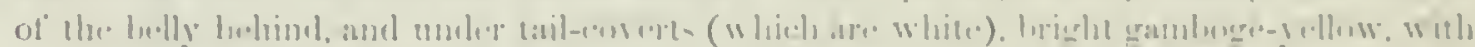

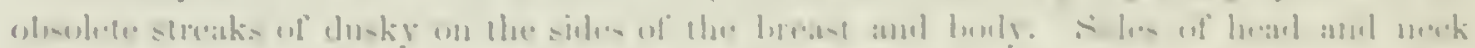

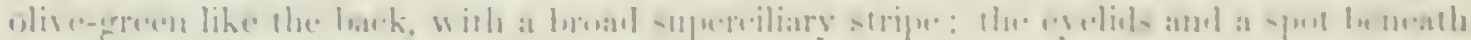

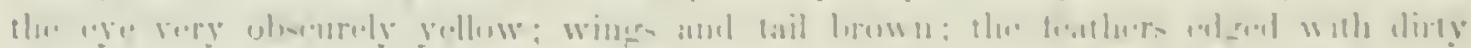

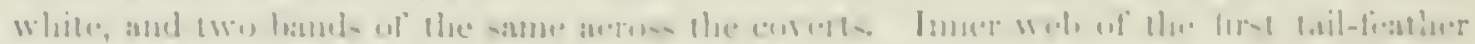

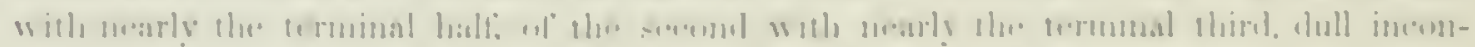

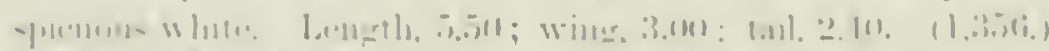

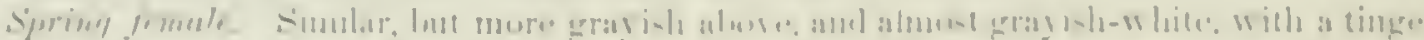

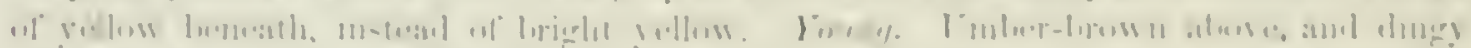

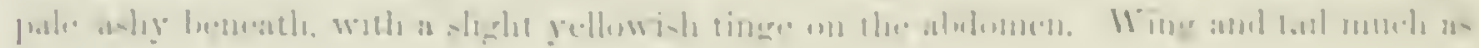
in lles autumual sulult

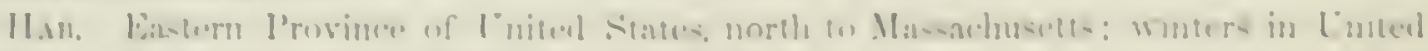

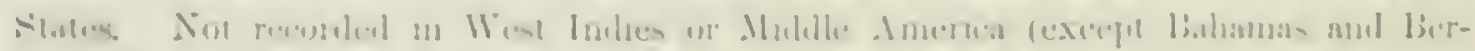
แuนda?).

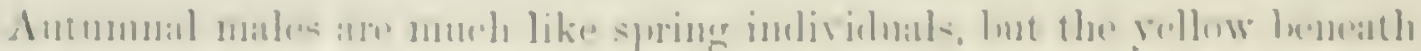

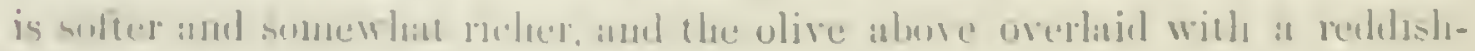
muluer tint.

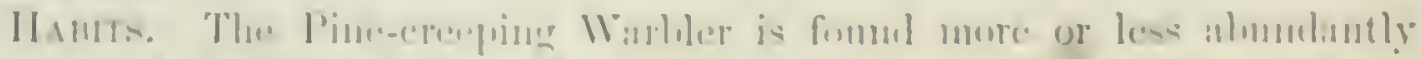

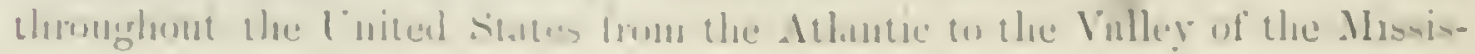


sippi. Dr. Woodhouse states that it is common in Texas and New Mexico. It wils not, however, met with by any other of the government exploring parties. Dr. Gerhindt found it (puite common in Northern Georgia, where it remains all the winter, and where it breeds very early in the senson. On the 19th of April he foumd a nest of these birds with neilly full-grown yomng. It has not been found in Inaine by l'rofessor Verrill nor by Mr. Boarduan, nor in Nura scotia by Lientenant Bland. Mr. Allen has found it breeding almudiuntly in the westem part of Minsachusetts, where it is one of the earliest Warlolers to anrive, and where it remains until Oetober. In 1861 they were abundant in the pine woods near springtield an early as April $t$, althongh the ground at that time was corered with snow. Ining the last weeks of April and the early part of May they frequent the open fields, obtaining much of their foorl from the ground in company with $D$. palmurum, the habits of which, at this time, it closely follows. Later in the season they retire to the pine forests, where they remain almost exclusively throughout the summer, chictly on the tops of the tillest trees. For a few weeks preceding the first of (October they angin come about the orehards and fields. In its winter migrations it does not anpear to leare this conntry, and has not been found in any of the West India Islands, in Nexico, nor in south or Central America. It loreeds sparingly in sontlem mlinois.

Mr. Jones fonnd these birls numerons in Bermula late in september, but they all clisalppeared a few weeks later. Dr. Bryant found them at Inagua, Bilhimils.

Wilson first noticed this Wirbler in the pine woods of the Southern States, where he found it resident all the year. He deseribes it as rumning along the bark of pine-trees, though occasionally alighting and feeding on the ground. When disturbed, it always flies mp and elings to the trunks of trees. The farther south, the mure numerous lie finnd it. Its principal food is the seeds of the southern piteh-pine and varions kinds of insects. It was associated in thocks. of thirty in the depths of the pine barrens, ensily recougnized by their mamer of rising from the ground and alighting on the trunks of trees.

Audubon also speaks of this lird as the most abundant of its tribe. He met with them on the sandy banrens of East Florida on the St. John's River early in February, at which period they alrealy had nests. In their habits he regarded them as quite closely allied to the Creepers, ascending the trunks and larger branches of trees, hopping along the bark searching for concealed larre. At une moment it moves sicleways along a branch a fer steps, then stops and moves in another direction, earefully examining each twig. It is active and restless, generally searehing for insects among the leaves and blossoms of the pine, or in the erevices of the bark, but occasionally pursuing them on the wing. It is found exclusively in low lands, never in momutainous distriets, and chiefly near the sea.

Its nest is usually placed at considerable height, sometimes fifty feet or 


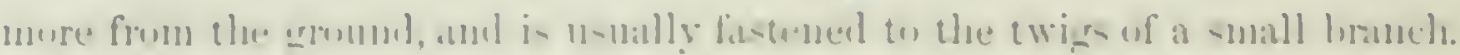

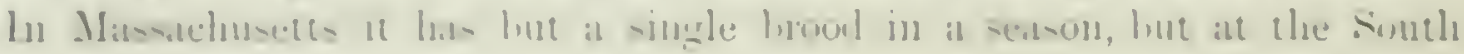
it is saisl (1) lasse three.

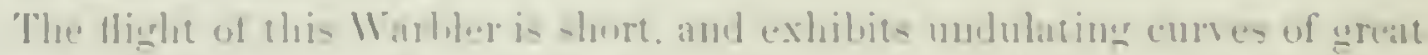

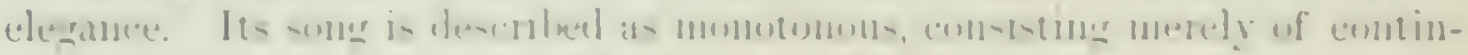

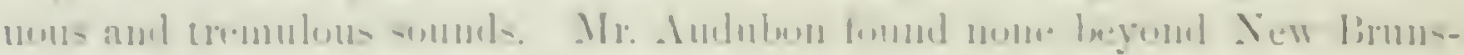

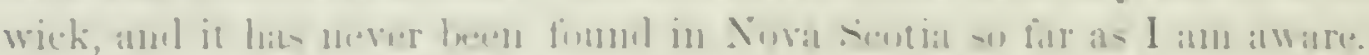

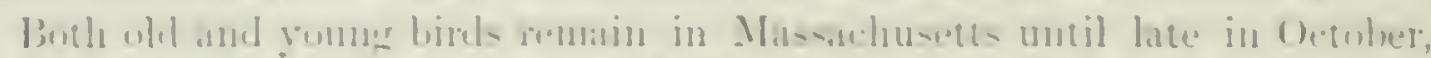

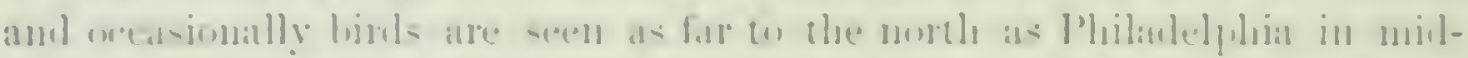

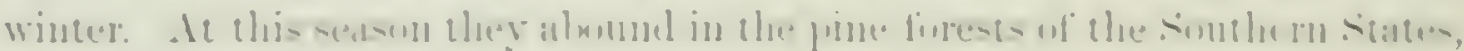

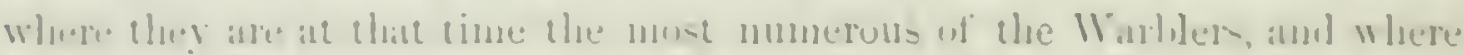

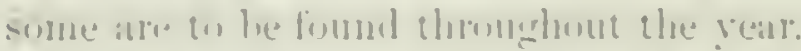

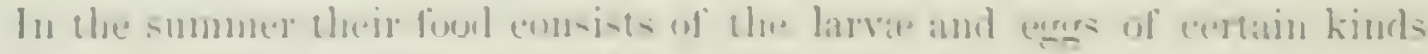

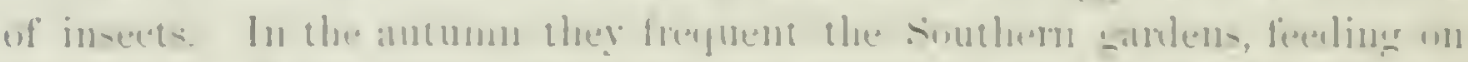

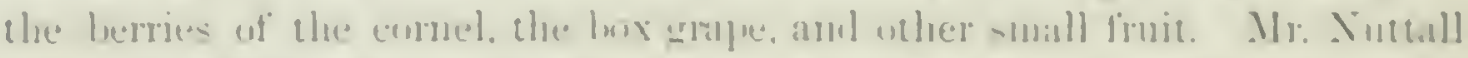

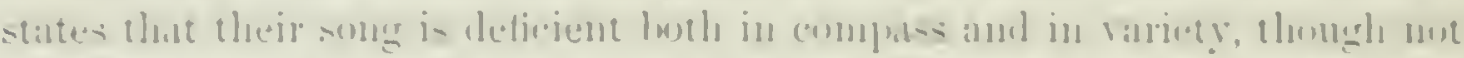

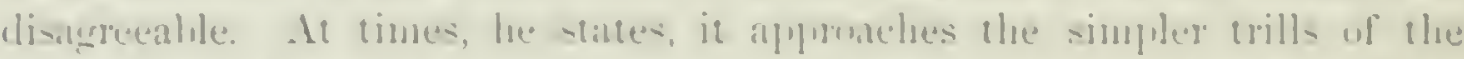

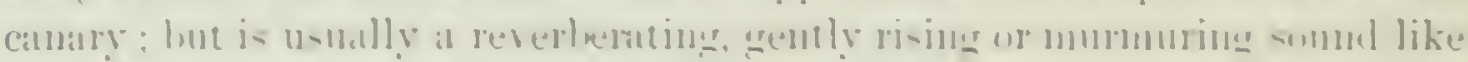

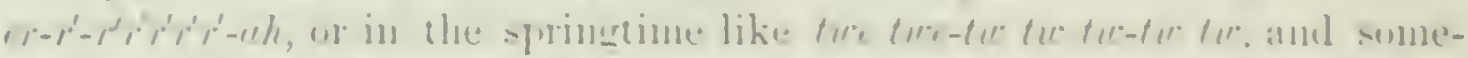

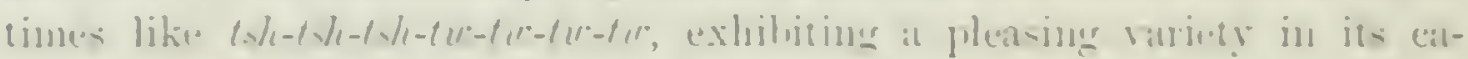
demes. The more of the female is nut unlike that of the libate and Whote ('renerer.

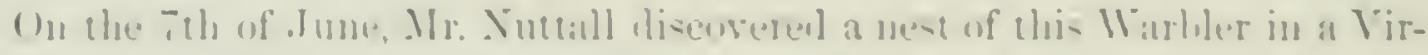

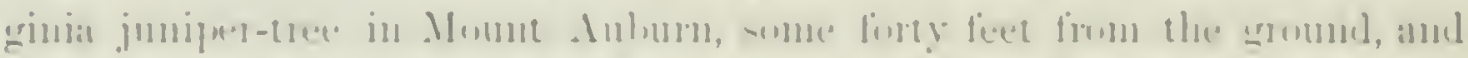

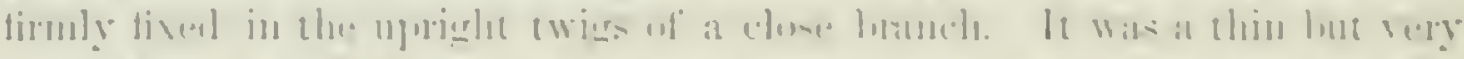

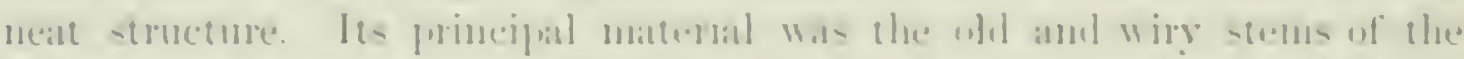

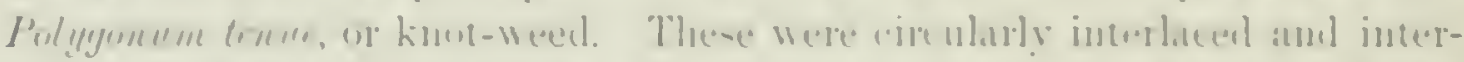

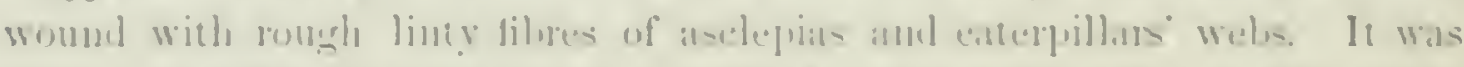

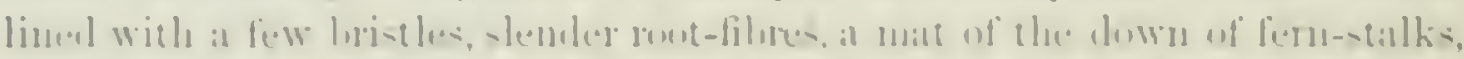

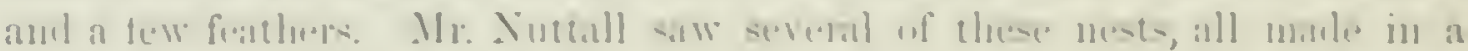

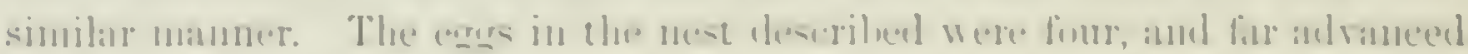

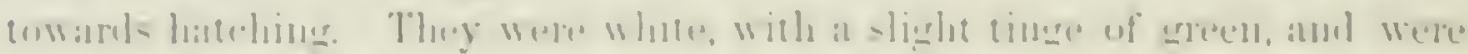

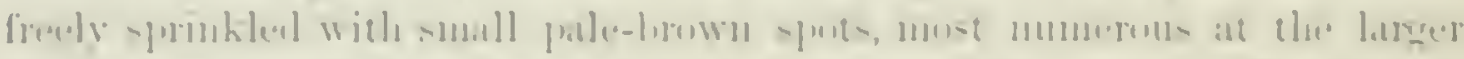

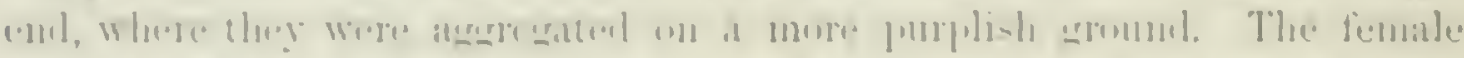

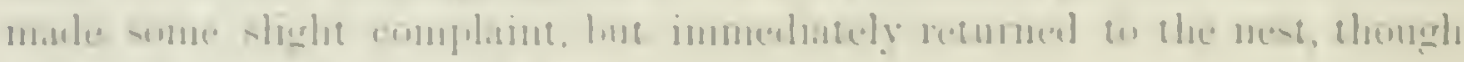

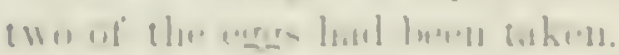

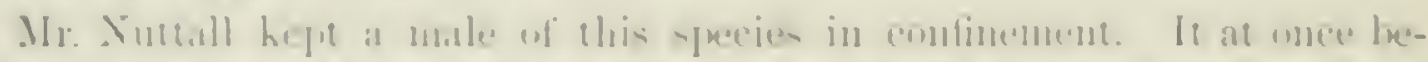

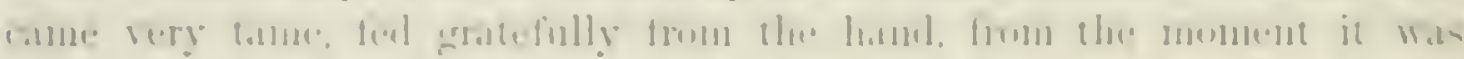

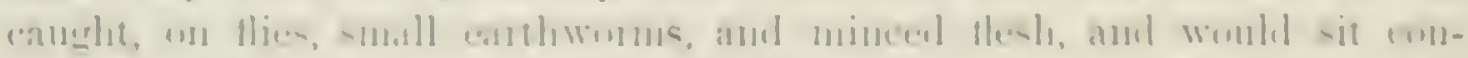

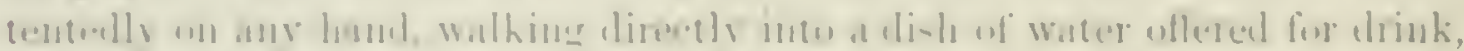

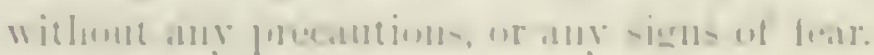

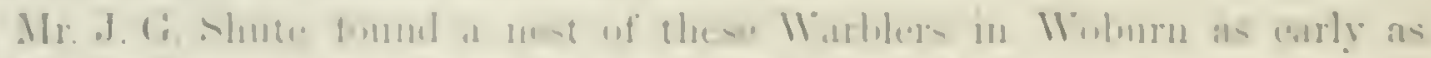

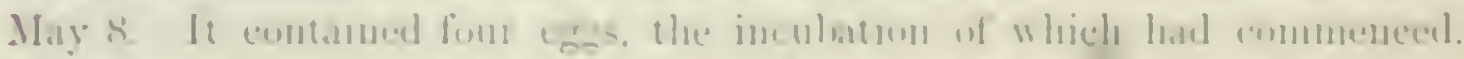

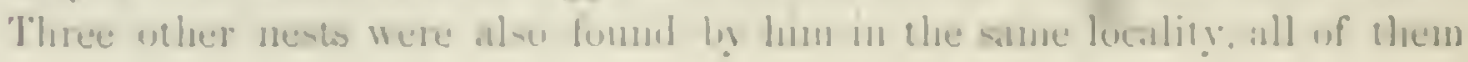


between the Sth and the "2th of Maty, and all built on branches of the red pine and near the top. Several nests of this Warbler, found in Lym, Mass. by Mr. George O. Welch, are alike in their mode of construction, and differ in their materials from other accomts. 'They are all somewhat loosely jut together, and are composed externally of fine strips of the bark of the red cedar, fine inmel bark of severnl decidnous trees, dry stalks of plants, the exuria of insects, and fine dry grasses. The carities of these nests, which are comparatively large and deep, were lined with the fur of the smaller mammals, the silky down of plants, and feathers. A few fine wiry roots were also intermingled. These nests are about two and a half inches in height and three in diameter.

The eggs of this Warhler are of a rounded oval shape, have an average length of .72 of an inch, and a breadth of .55 . They resemble in size and appearance the egrs of the $D$. castunea, lunt the spots are more mmerous, and the blotches larger and more generally distributed. The gromd-color is a bluishwhite. Seattered over this are sublued tintings of a fine delicate shade of purple, and upon this are distributed dots and blotches of a dark purplishbrown, mingled with a few lines almost black.

\section{Dendroica montana, Burn.}

\section{BLUE MOUNTAIN WARBLER.}

Sylvire montone, WiLs. An. Oln. V, 1812, 113, pl. xlir, fig. 2) "Blue Mountaius of Penn-

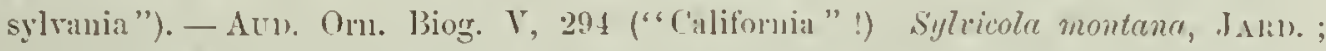

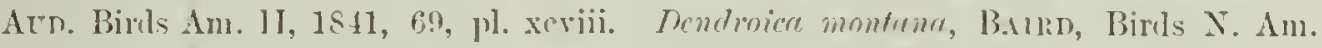

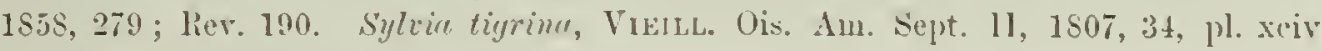
(U. S. and St. Domingo).

Sp. Char. This speries is four inches and three quarters in length; the upper parts a rich yellow-olive; frout, cheeks; and chin yellow, also the siles of the neck; breast and belly pale yellow, strealied with black or dusky; vent plain pale yellow. Wings black; first and second rows of coverts broally tipped with pale gellowish-white: tertials the same: the rest of the quills edged with whitish. Tail hlack, handsomely rounded, exged with pale olive; the two exterior feathers on each sicle white on the inner vanes from the mirlle to the tips, and edged on the outer side with white. Bill lark brown. Legs and feet purplebrown; soles yellow. Eye dark hazel. (Wilson.)

H.ı. "Blue Jountains of Tirginia." St. Domingo?

This speeies is only known from the description of Wilson, Vieillot, and Andubon, and we are not aware that a specimen is to be found in any colleetion. If described correctly, it appears different from any establisher species, although the most nearly related to D. pimus, which, however, difiers in the absence of a yellow frontlet, in having a greener back, less distinct streaks beneath, and in the white of the anal region.

HABits. Whether the Bhe Momtain Warbler is a genume species or an unfamiliar plumage of a bird better hnown to us in a different dress is a 


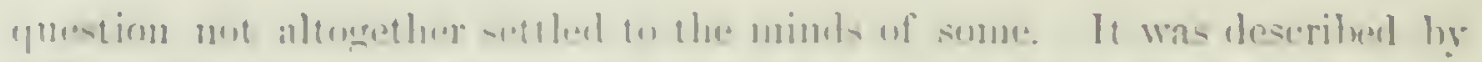

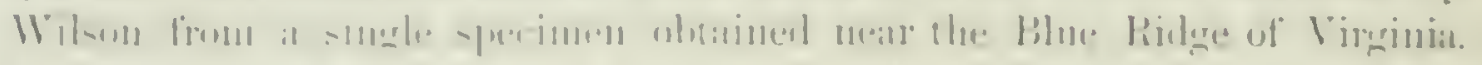

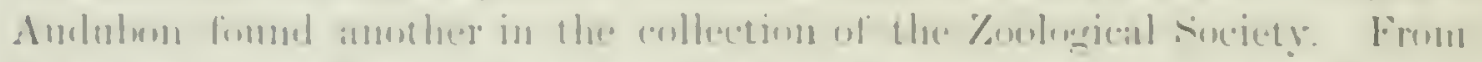

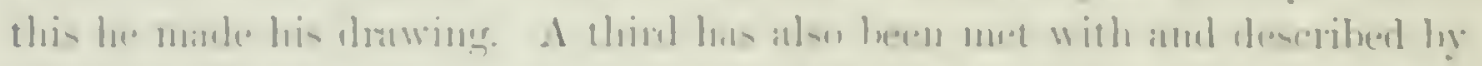

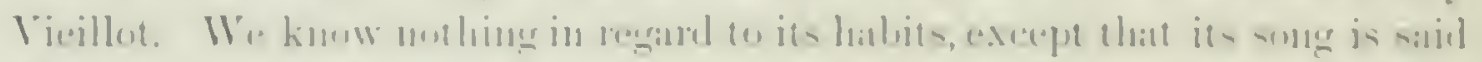

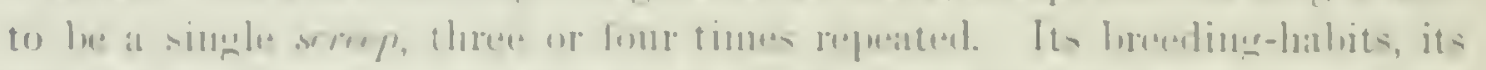

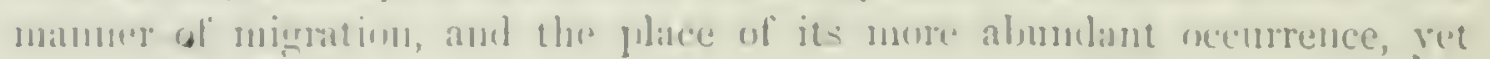
resuain cutirely unkuswn.

\section{Dendroica kirtlandi, Bairn.}

\section{KIRTLAND'S WARBLER.}

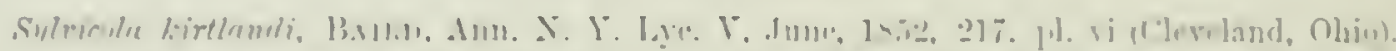

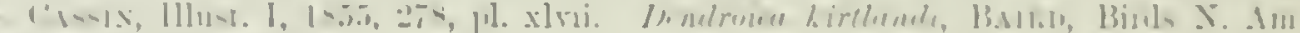
$14 ., 2$ anti: lier. : 2ulti.

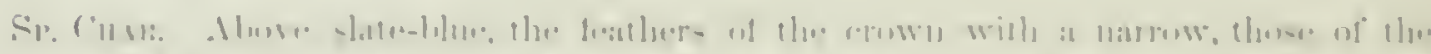

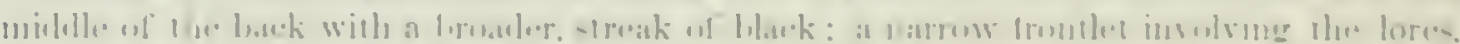

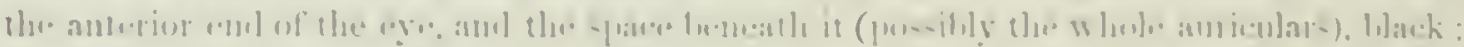

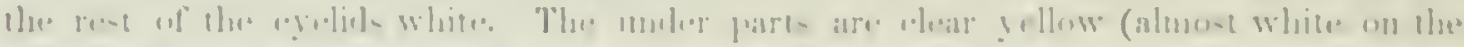

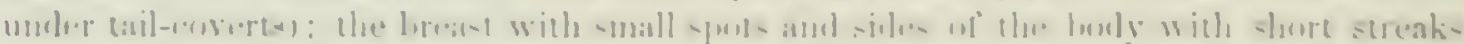

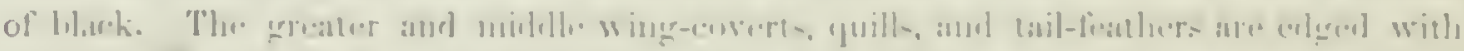

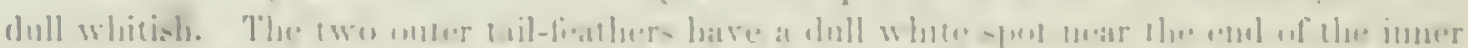

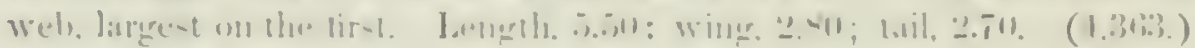

Il.us. Northern ()hio, and biahanna.

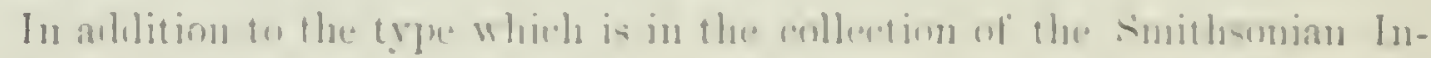

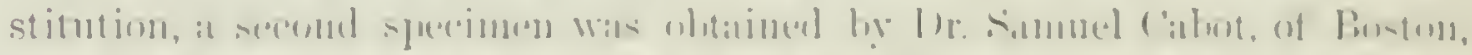

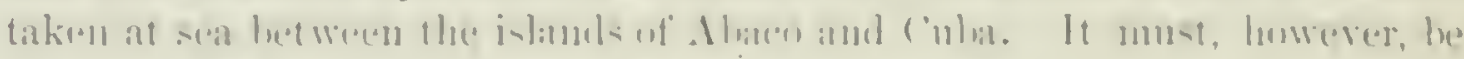

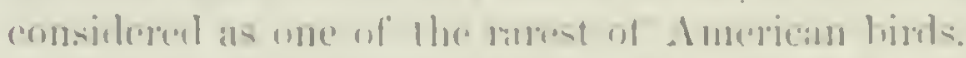

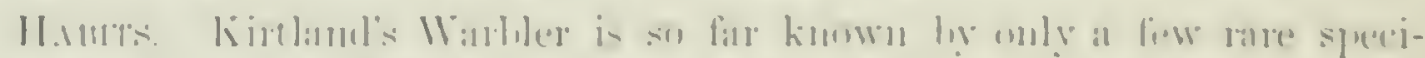

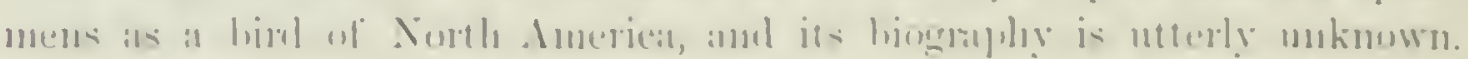

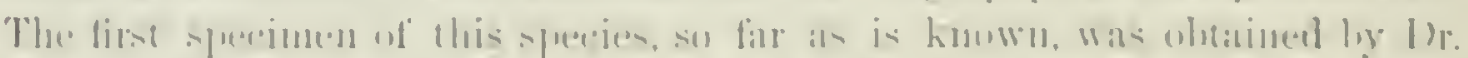

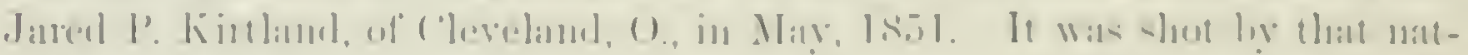

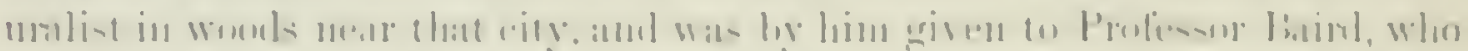

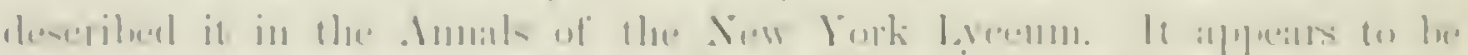

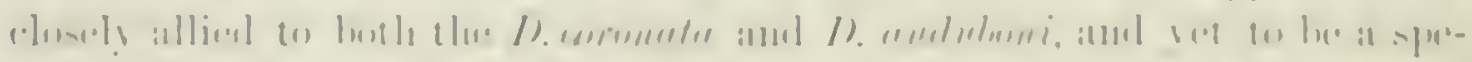

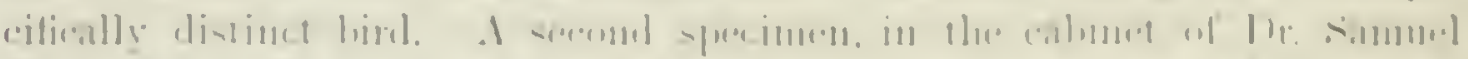

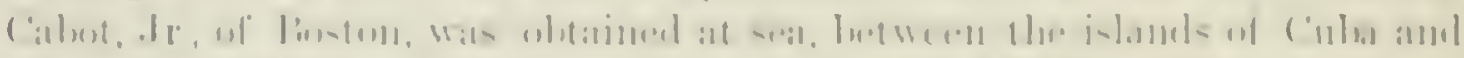

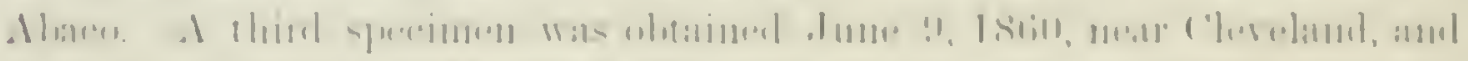

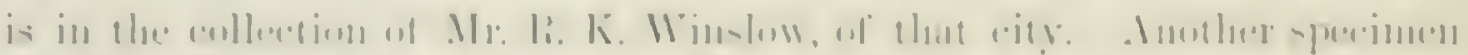

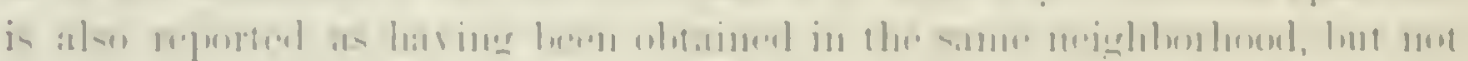

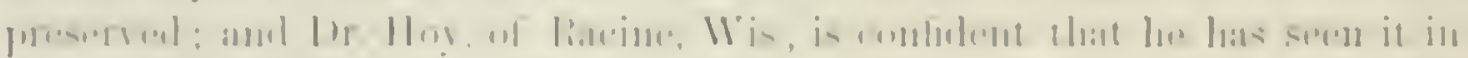

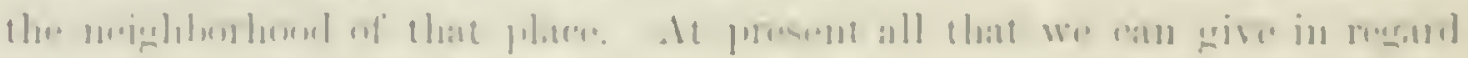

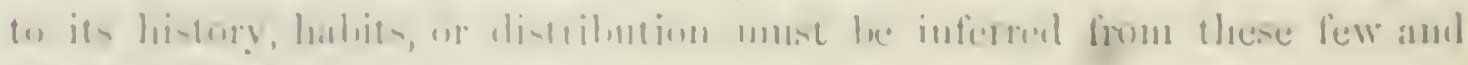
mestrine lintels. 


\section{Dendroica palmarum, BaIrD.}

\section{YELLOW RED-POLL WARBLER.}

Motacilla palmarum, GuEL. Srst. Iat. I, 17SS, 951 (based on Palm Warbler, Lathay, Syn. II, 1. 49S, no. 131, St. Domiugo). Sylvia p. Latu. ; Veılot, II, pl. Ixxiii. - Box.; D’Oıb. Sagra's Cuba, Ois. 1840, 61, pl. viii. Sylricola p. SALLÉ, P. Z. S. 1857, 231

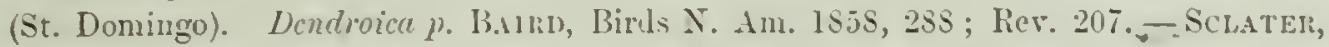
Catal. 1S61, 33, no. 199.-IB. P. Z. S. 1S6̈1, 11 (Jamaica; April). - Blixast, Pr. Bost. Soc. VII, 1559 (Ballamas). - Iв. 1§67, 91 (Hayti). - Brewer, P'r. Bost. Soc. 1S67, 139. - Grinlach, Cab. Jour. 1561, 320 (Cuba: rery common). - saulecs, 2240.

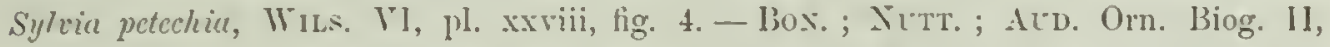
pl. clxiii, clxir. Sylricola petcchia, SwAss. ; AtD. Birds Am. 1I, pl. xc. Sylricola

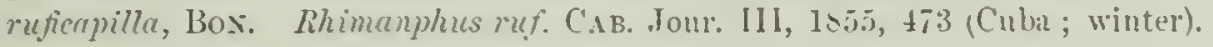

Sp. Crisr. Adult in spring. Head above chestnut-red: rest of upper parts brownish olive-gray; the feathers with darker centres, the color brightening on the rump, upper tail-coverts, and outer margins of wing and tail-fenthers, to greenish-yellow. A streak from nostrils over the eye, and under parts generally, including the tail-coverts, bright yellow; paler on the body. I maxillary line; breast and sides finely but rather obsoletely streaked with reddish-brown. Cheeks brownislı (in highest spring plumage chestnut like the head); the eyelids and a spot under the eye olive-brown. Lores dusky. A white spot on the inner web of the onter two tail-feathers, at the end. Length, 5 inches; wing, 2.42 ; tail, 2.2j. Sexes nearly aliki.

Autumnal males are more reddish abore; under parts tinged with brown, the axillars yellow.

Hıв. Eastern Province of North America to Fort Simpson and Hudson's Bay; Bahamas, Jamaica, Cuba, and St.Domingo in winter. Not noted from Mexico or Central America.

This species varies considerably in different stages, but can generally be recognized. Inmature specimens resemble those of $P$. tigrina, but differ in the chestnut crown, browner baek, less bright rimp, brighter yellow of under tail-coverts, smaller blotehes on tail, no white bands on the wings, ete., as well as in the shape of the bill.

H.ıBITs. The Red-Poll Warbler belongs, in its gengraphical distribution, to that large elass of birds which risit high northern latitudes to breed, passing back and forth over a wide extent of territory, from the West India Islands to the extreme northern portions of the continent. Speeimens lave been proeured from C'ula, Jamaica, St. Domingo, and the Bahamas, in fall, winter, and spring, where, at such times, they seem to be generally quite common. It has not been olserved in Mexico or in Central or South America. It has been met with on the western shore of Lake Michigan, but nowhere farther to the west. It has been found in the Red River Settlement, Fort George, Fort Simpson, and Fort Resolution, in the Hudson Bay Territory. It is not known, so far as I am aware, to breed south of latitude 44. Wilson and Nuttall both state that this bird remains in Pennsylrania through the summer, but they were probably misinformed; at least, there is no recent evidence to this effect. Wilson also states that he shot speei- 
mens in Ceorria, near Sarammal, early in Fobruary, and infers that some pass

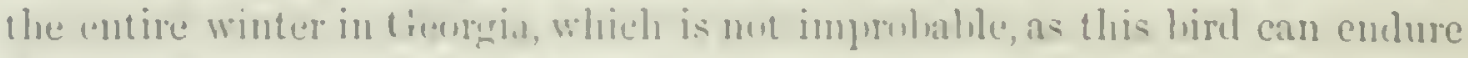
severe weather withent any applarent inconventence.

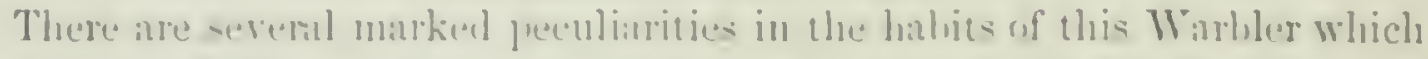

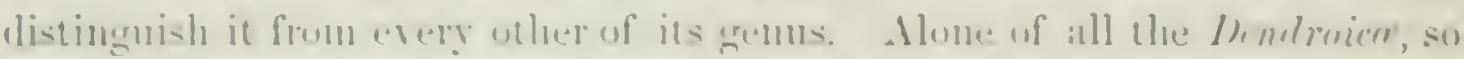
for as is known, it huilds its ne-t on the gromul, and is quite lerrestrial in its hahits, ant, motwith-tanding the statements of earlier writers, these are yuite different from all others of this gemus. It lase very little of the lablits of the Creeper and still lese of the Flyeatcher, while it has all the manners of the

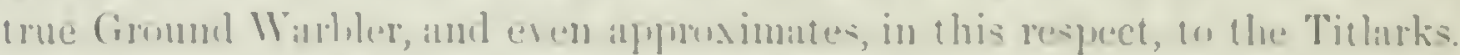

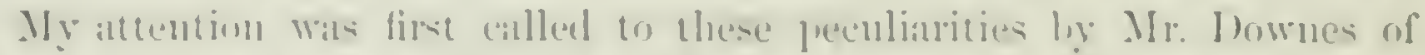
Ilalifix, in the summer of 18.1 ; amel I was surprial to find it nesting on the

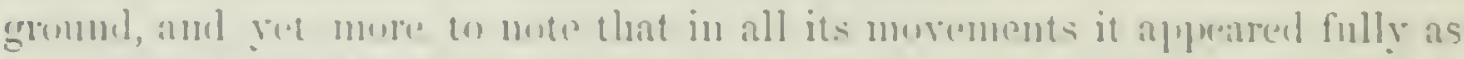

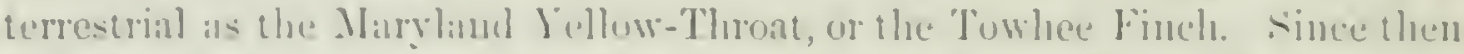

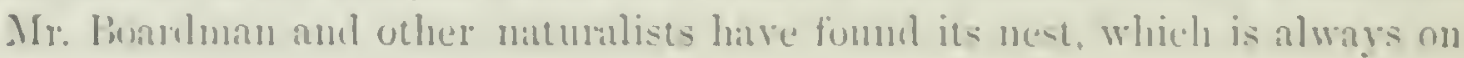
the sresund.

Mr. Macculloch, in the fourth rolume of the . Tommal of the lision Satnmal History Society, has given an interesting gaper ujun the termentrial

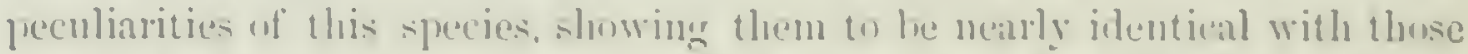

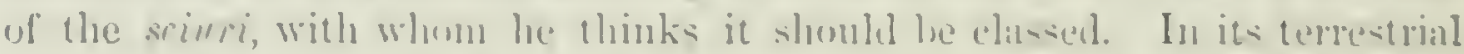
movements this hird is shown to be puite at home, while otler Wablers, when driven hy mecesity to feed upon the smound, are awkwiml, and manfest a want of adipltitiun.

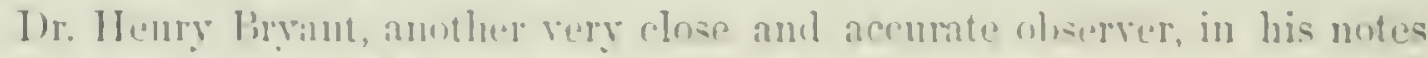

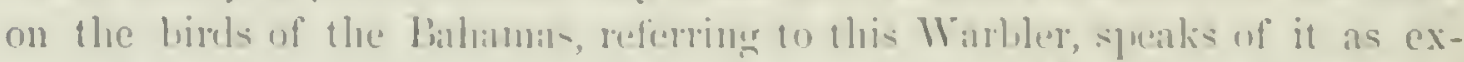

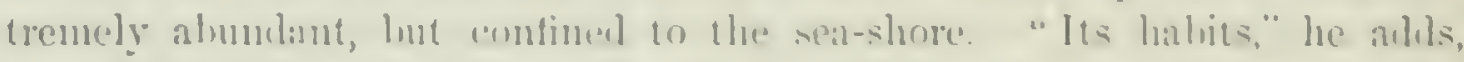

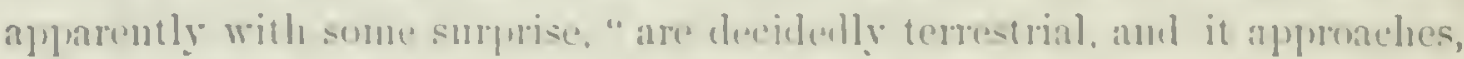

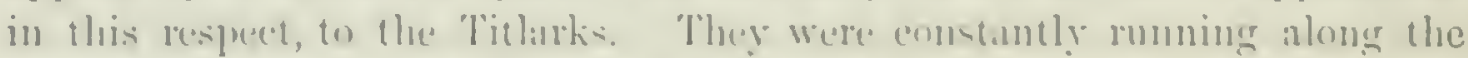

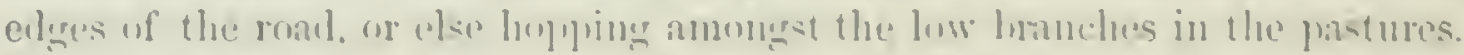
I diit not see a single indis idual sereking for ford amilst the large trees.

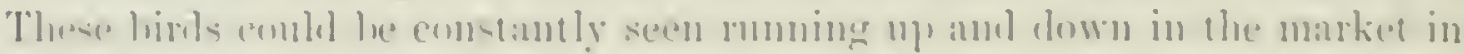

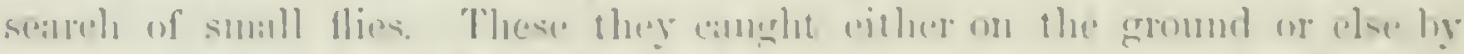

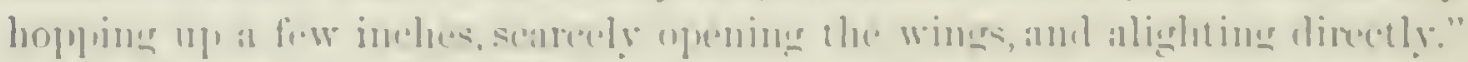

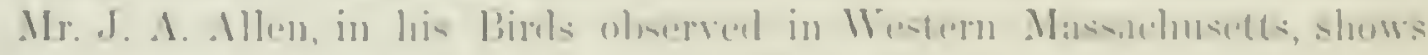

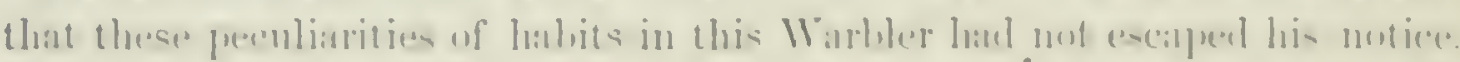

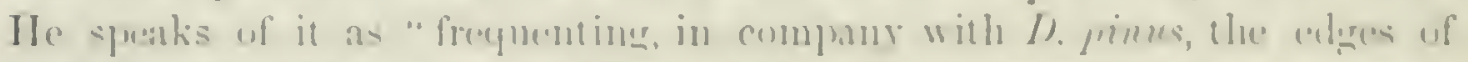

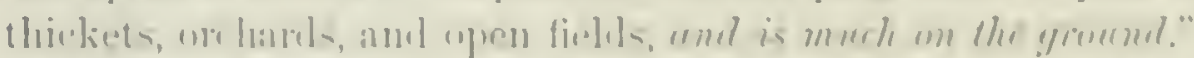

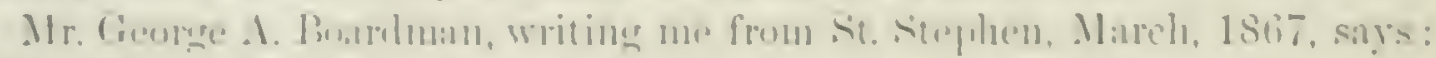

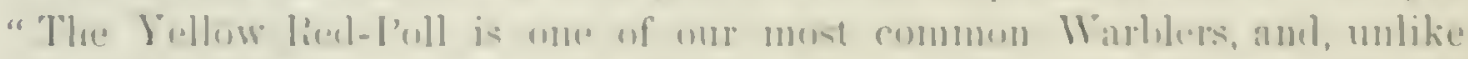

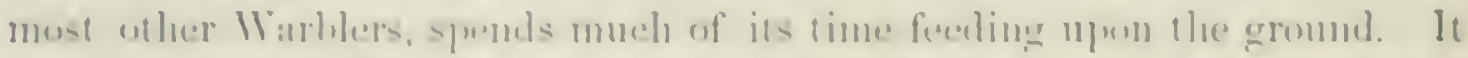

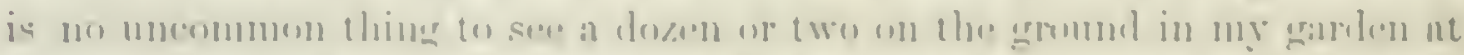

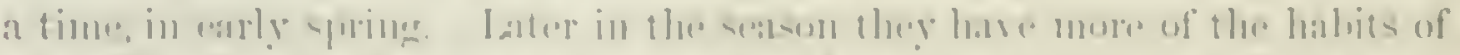

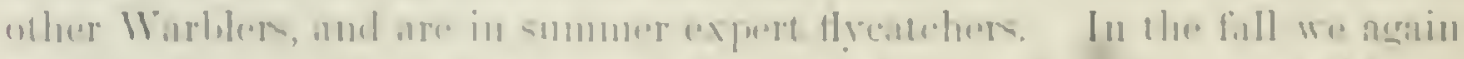

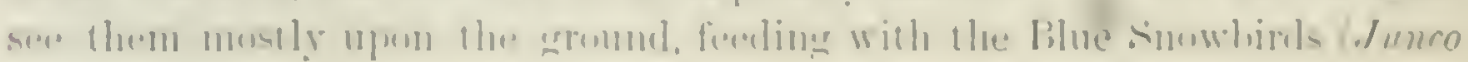


hyemalis) and the Chipping Sparrow. They breed in old brushy pastures, and very early, nesting alongsile of some little knoll, and, I think, always upon the ground. The nest is very warmly lined with feathers.'

Mr. MacCulloch, in the praper already referred to, states that during their autumnal migrations they seem invariably to exhibit the habits of true Sylvicolide, gleaning among branches of trees for the smaller insects, and not unfrequently visiting the windows of dwellings in search of spiders and insects.

In their migrations through . Massachusetts these Warblers are everywhere quite abundant in the spring, but in their return in autumn are not observed in the eastern part of the State, though very common in the western from September into November, remaining long after all the other Warblers are gone. None remain during the smmmer.

In Westem Maine, Mr. Verrill states, it is quite common both in spring and in fall, arriving in April, earlier than any other Warbler, and again becoming abundant the last of September.

I found it plentiful in the vicinity of Halifax, where it occurs throughont the summer from aray to September.

Mr. Ridgway gives this species as perhaps the most numerons of the transient visitants, in spring and fall, in Sonthern Illinois. It is very terrestrial in its habits, keeping mueh on the ground, in orehards and open places, and its movements are said to be wonderfully like those of Anthus ludovicianus.

In the vibratory motions of its tail, especially when upon the ground, these birds greatly resemble the Wagtails of Europe. They have no other song than a few simple and feeble notes, so thin and weak that they might almost be mistaken for the somds made by the common grasshopper.

The Red-Poll usually selects for the site of its nest the edge of a swampy thicket, more or less open, placing it invariably upon the ground. This is usually not large, about three and a half inches in diameter and two and a half in depth, the diameter and depth of the earity each averaging only half an inch less. The walls are compactly and elaborately construeted of an interwearing of varions fine materials, chiefly fine dry grasses, slender strips of bark, stems of the smaller plants, hypum, and other mosses. Within, the nest is warmly and softly lined with down and feathers.

Mr. Kennieott met with a nest of this bird at Fort Resolution, June 18. It was ou the ground, on a hummock, at the foot of a small spruce, in a swamp. When found, it contained five young birds.

Their eggs are of a rounded-oral shape, and measure .70 of an inch in length by .5.5 in breadth. Their ground-color is a yellowish or creamywhite, and their blotches, chiefly about the larger end, are a blending of purple, lilac, and reddish-brown. 


\section{Dendroica discolor, H.AliL.}

\section{PRAIRIE WARBLER.}

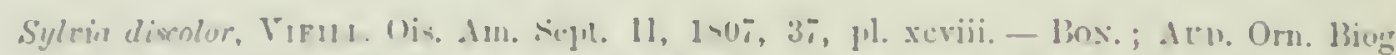

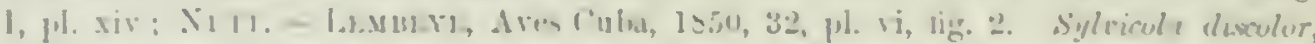

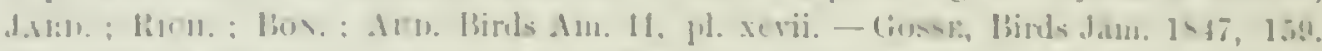

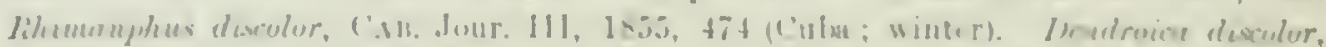

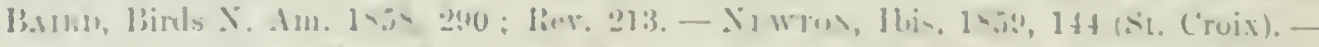

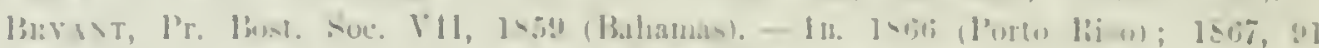

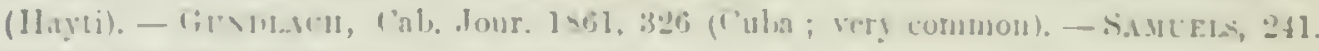

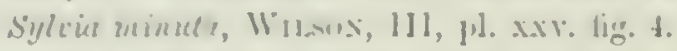

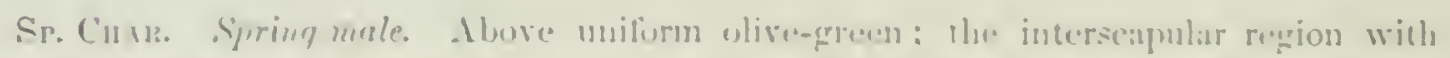

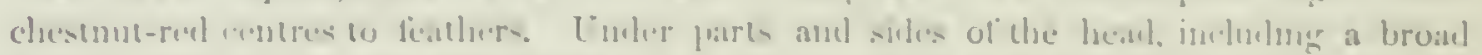

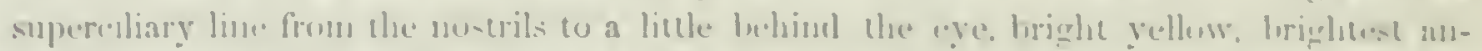

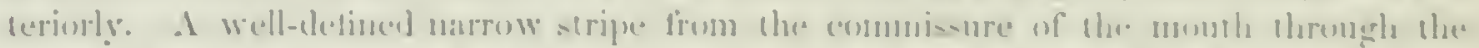

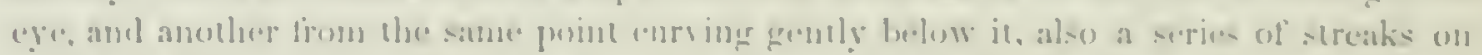

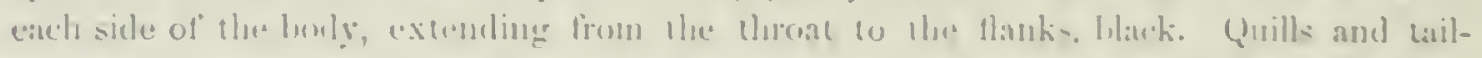
feathers brown, edgerl with white: the terminal halt of the inmer well of the first and

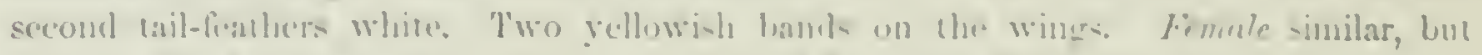
duller. The dorsal stresth= indi-tinel. Lengrth, 4.e(i; wing, 2.25; tail, 2.10.

First plumage of the youmer not seent

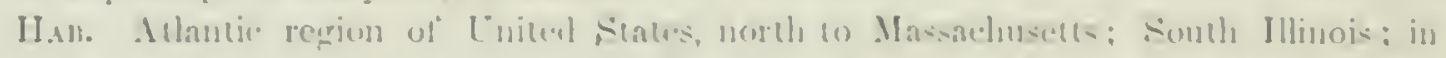

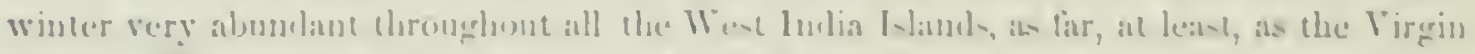
Islands. Not recorden from Alexico or Cintral Americit.

Autmmal specimens have the flumage more hlemleol, hut the markings

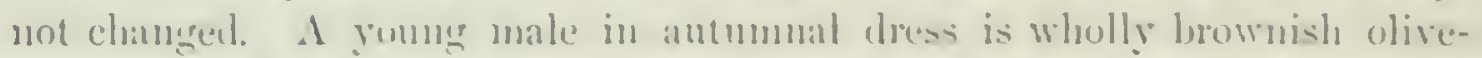

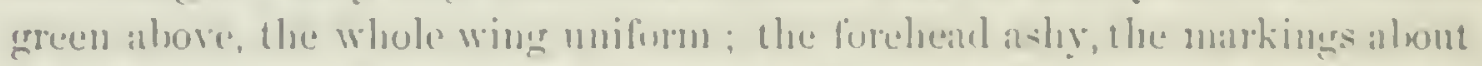
the hearl rather wholete, the chestmut spots on the back and the blick ones on the sides ne:irly entrecalled.

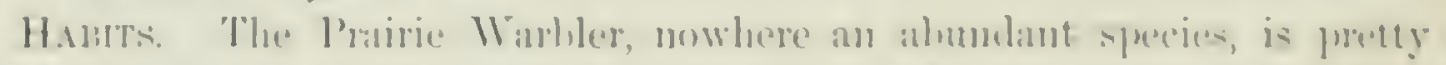

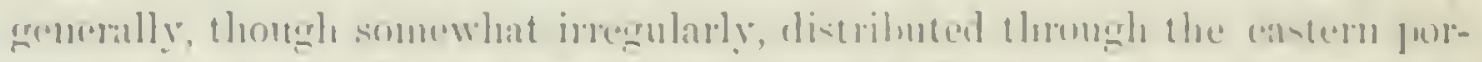

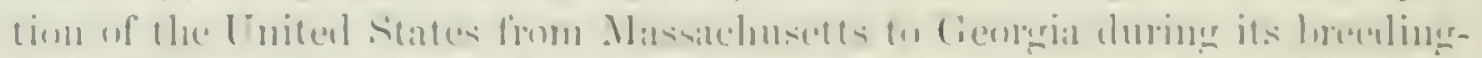

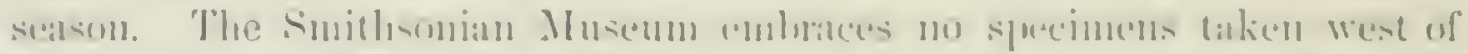

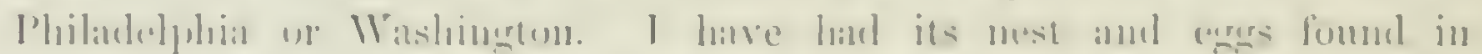

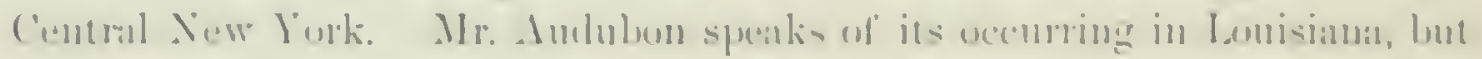

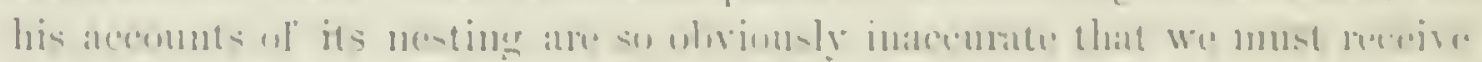

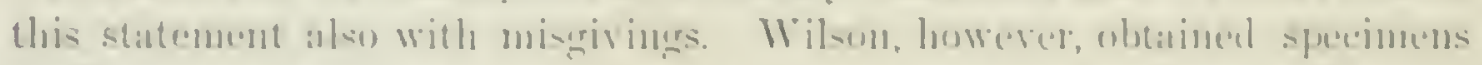

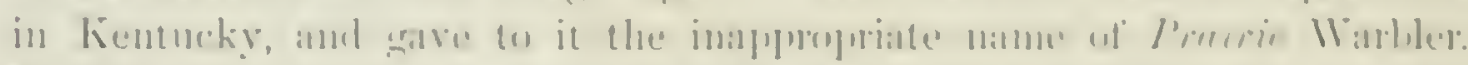

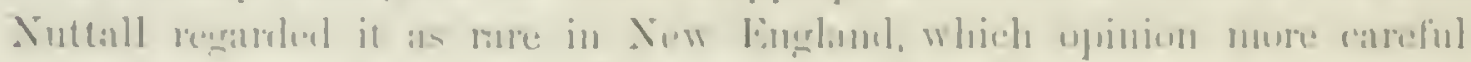

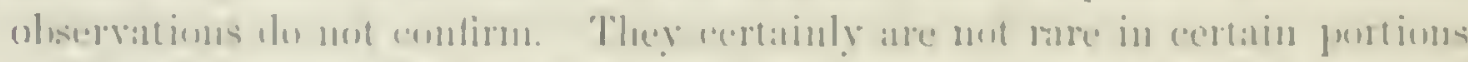

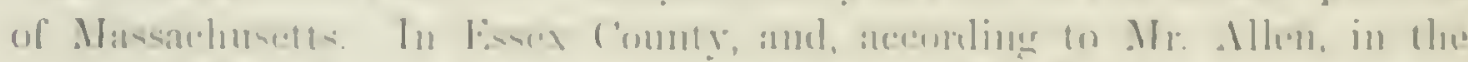

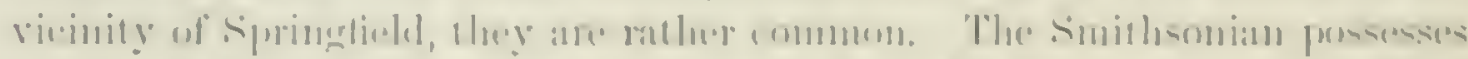

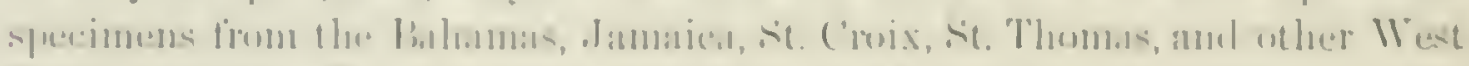

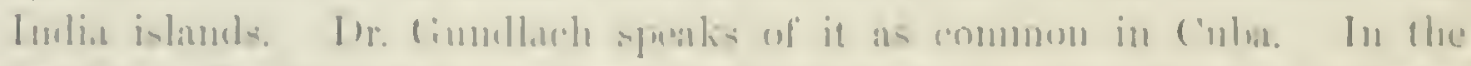

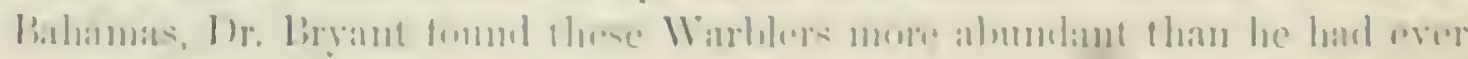
kuswn then in the linited states. In dannary all the males were in winter 
plumage, some not having changed by April to their summer costume. He regarded them as constant residents of those islands. They had all paired off by the middle of $A$ pril.

In the island of St. Croix, Mr. Edward Nerrton observed these Warblers from the 10th of September to the 27 th of March. They were present on the island about two thirds of the year, and while they were fomnd were very common.

In Jamaica, according to Mr. March, they are numerous throughout the entire year, though less abundant during the summer months. They were always plentiful in the gardens about the Malpighia glabru, capturing small insects from the ripe fruit.

Mr. Gosse, on the contrary, regarded it as only a winter visitant of that island, appearing by the 1Sth of August, and disappearing by the 11th of April. He observed them among low bushes and herbaceous weeds, along the roadside, near the ground, examining every stalk and twig for insects. Others flew from bushes by the wayside to the middle of the road, where, hovering in the air, a few feet from the ground, they seemed to be catching small dipterons insects. Their stomachs were filled with fragments of insects.

Wilson found them usually in open plains and thinly wooded tracts, searching most leisurely among the foliage, carefully examining erery leaf or blade of grass for insects, uttering, at short intervals, a brief chirr. They did not appear to be easily alarmed, and he has known one of these birds to remain half an hour at a time on the lower branch of a tree, and allow him to approach the foot, without being in the least disturbed. He found their food consisted of winged insécts and small caterpillars.

In 1855, Mr. John Cassin wrote me: "The Prairie Warbler certainly breeds in New Jersey, near Philadelphia. I have seen it all summer for the last twelve years, and have seen the young just able to fly, but never found the nest. It has a very peculiar note, which I know as well as I do the Catbird's, having often followed and searched it out. It frequents cedar-trees, and I suspect breeds in and about them."

Dr. Cones found the Prairie Warbler mostly a spring and antumn visitant in the vicinity of Washington, being quite abundant during those seasons. A few were observed to remain during the breeding-senson. They arrive earlier than most of this family of birds, or about the 20th of April. $\mathrm{He}$ found them frequenting, almost exclusively, cedar-patches and pine-trees, and speaks of their having very peculiar manners and notes.

Both Wilson and Audubon were evidently at fanlt in their descriptions of the nest and eggs. These do not correspond with more recent and positive observations. Its nest is never pensile. Mr. Nuttall's descriptions, on the other hand, are made from his own observations, and are evidently correct. He describes a nest that came under his observation as scarcely distinguishable from that of the D. cestiva. It was not pensile, but fixed in a forked branch, and formed of strips of the immer bark of the red cedar, fibres of asclepia, and caterpillars' silk, and thickly lined with the down of the Gnaphalium 


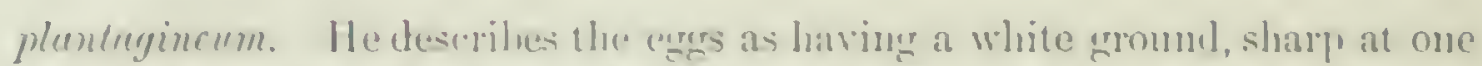

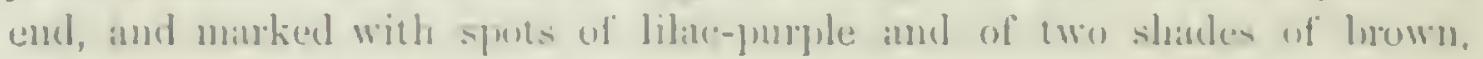
more numerons at the largere end, where they formed in ring. He speales of their note as stemeler, ans moticerl their arrival alout the second week of May, leaving the middle of september.

At another time Ar. Nuttall was attracted by the shemder, filing notes of

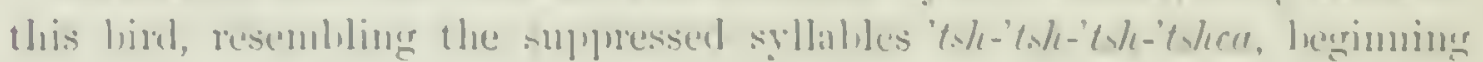
low and gradually growing lomber. With its mate it was lonsily omgaged

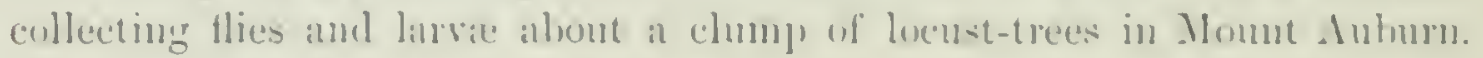
Their nest was near, and the founle, withont any frecantimns, went directly to it. Mr. Sutall removed two earse, which he afterwards replated. Fich time, on his withdrawal, she returned to the nest, and resurted to no expedients to entice him away:

Sereral nests of this Warher have heen ohtained he Mr. Welch in Lymu. One was built on a wild rose, only a few feet from the gromed. It is a smur, comneact, and cliburately woren strueture, having a leeight and a diameter of inbout two and a lailf inclies. The cavity is two inches wide and one and a half deep. The materials of which the onter parts are woren are chiefly the soft immer lark of small sluruls, mingled with dry ruse-leases, bits of vegetallese, wood, wondy fihres, decayed stems of plants, spinlers' weds, dete. The whole is boumd trgether like a web ly cotton-like filmes of a vegetalue origin. The upper rim of this nest is a marked feature, leing a strongly interlated weaving of vegetahle roots and strips of hark. The lining of the nest is composed of the regetible fibres and al few hurse-hairs. This nest, in its general mole of construtiom, rescombles all that 1 hate seen ; only in whers the materials vary, - in some dend and deenged leares, in whers remins

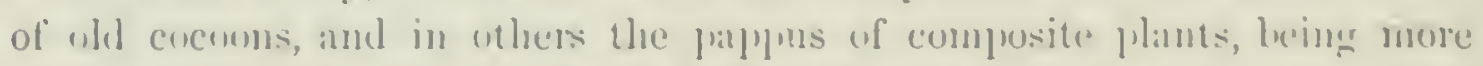
prominent than the fine strips of lank. The nests are noully within four

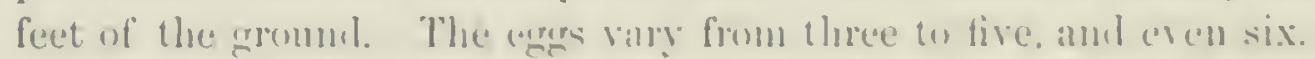

The late Dr. Gerthardt fomml this hird the ment common Wintler in Northeron Gengia. There its nests were similar in size, stmeture, and pusition, lout diflered mure or less in the materials of which they were mate. Ther

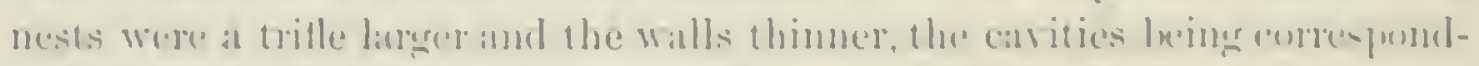
ingly lawger. The materials were mere invarially fine strips of inner bark

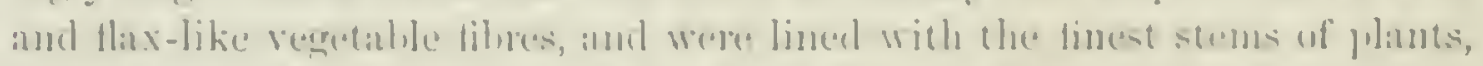

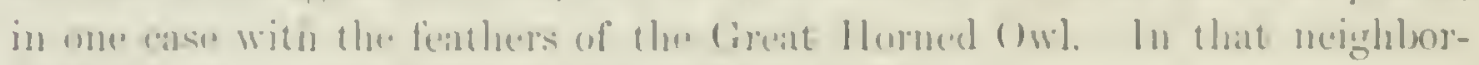

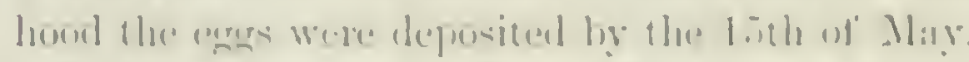

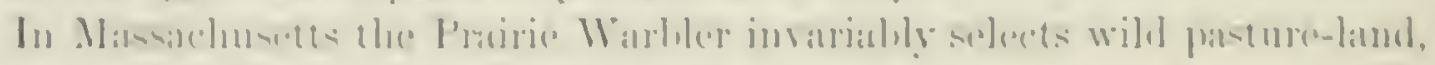

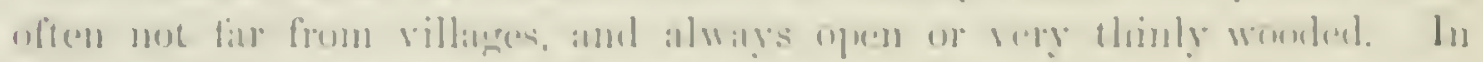

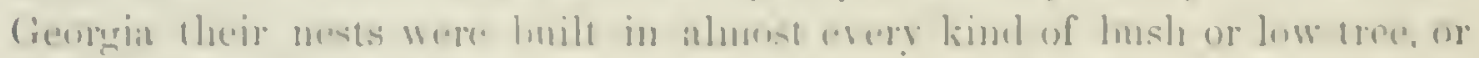

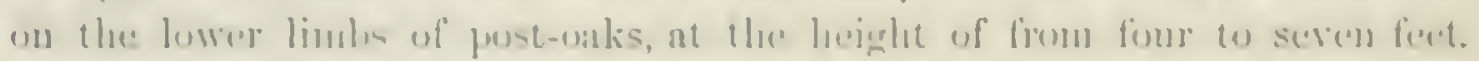

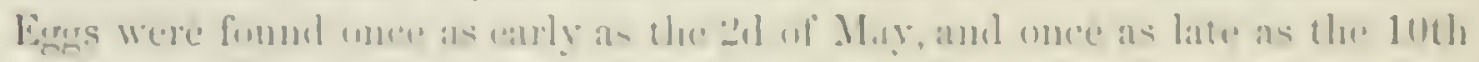

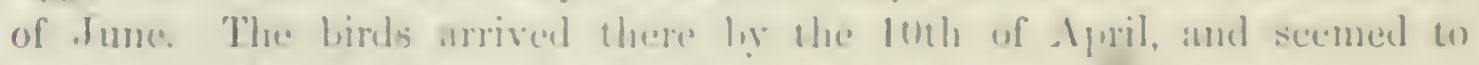

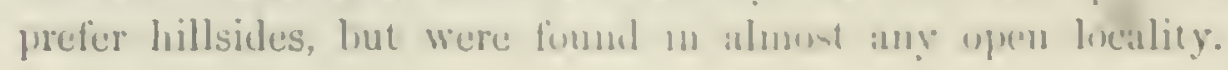


In Sonthern Illinois, Mr. Ridgway cites this species as a rather rare bird among the oak barrens where it breeds. He also met with it in orchards in the wooded portions, in April, during the northward migration of the Sylvicoirila.

The eggs are of an oval shape, pointerl at one end, and measure .68 by .48 of an inch. They have a white glound, marked with spots of lilac and purple and two shades of umber-brown.

\section{Stbandiy GEOTHLYPIN 王。}

\section{SECTIOX SEIUREAE.}

The diagnosis of the subfamily will be found on page 178. The Sciurce, as there stated, have the wings pointed, and rather longer than the nearly eren tail, which is unspotted. The genera differ in proportion rather than absolutely, Oporornis having longer wings and larger claws. The coloration, however, is always distinctive, as follows:-

\section{GeNus SEIURUS, SwaINSON.}

Sciurus, Swarssox, Zoöl. Jour. III, 1827, 171. (Sufficiently distinct from Sciurus.) (Type, Iotacilla aurocapilla, L.)

Honicocichla, Gris, List of Genera, 1540.

Gex. Cinar. Bill rather sylricoline, compressed, with a distinct notch. Gonys ascending. Rictal bristles rery short. Wings moderate, about three quarters of an inch longer than the tail; first quill scarcely shorter than the second. Tail slightly rounded; feathers acuminate. Tarsi about as long as the sliull, considerably exceeding the middle toe. Under tail-corerts reaching within about half an incls of the ent of the tail. Color above olivaceous; bencath whitish, thickly streaked on the breast and sides. Wings and tail immaculate. Nests on the ground, often arched or sheltered by position or dry leares. Eggs white, marked with red, brown, and purple.

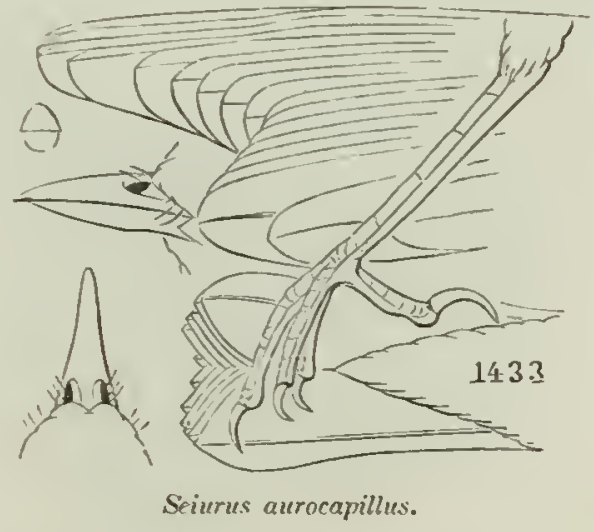

This genus is decidedly sylvicoline in general appearance, although the spots on the breast resemble somewhat those of the Thrushes. The three species may be grouped as follows:-

A. Middle of crown brownish-orange, bordered by blackish. No white superciliary streak 


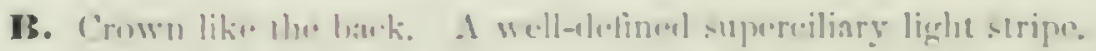

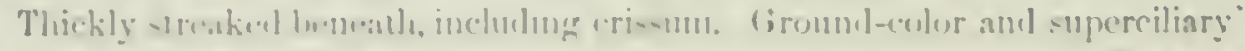
strun yelluwm. bill small

$\therefore$ noverburucensis.

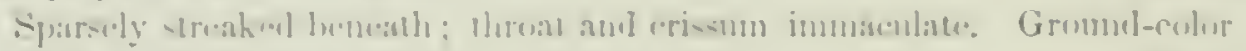
and supurenliary stripe " whe. IBtl very large

s. Induricinnus.

\section{Seiurus aurocapillus, swars.}

\section{GOLDEN-CROWNED THROSH.}

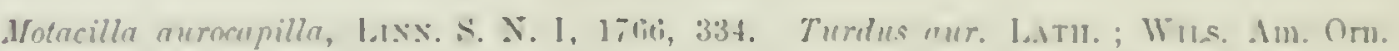

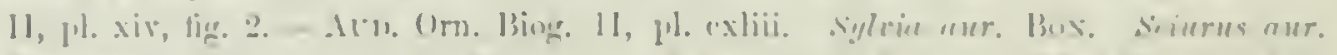

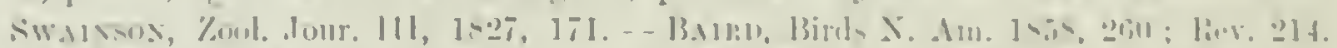

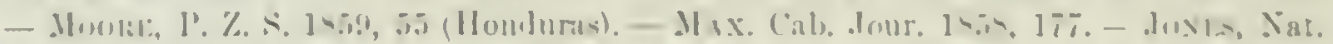

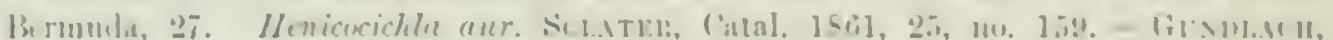

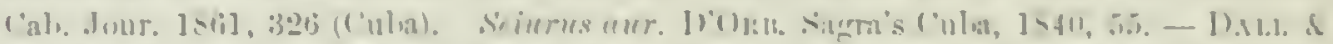

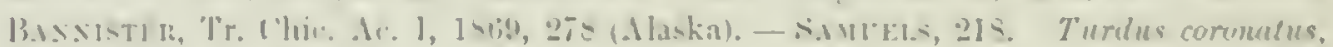
Vir.ll.1., 11i, 11. 1401, s.

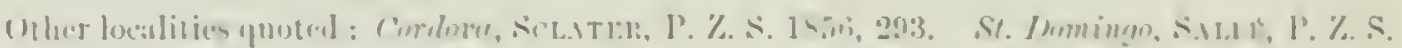

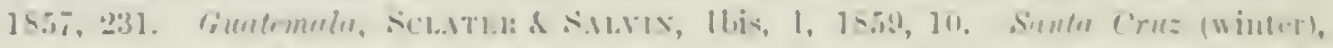

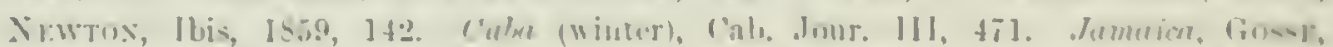

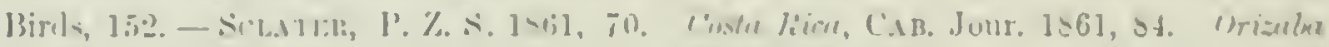

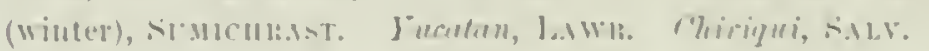

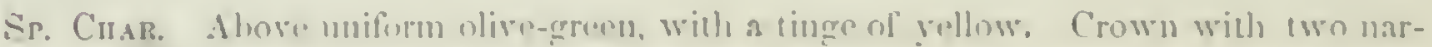

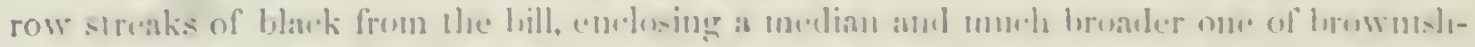

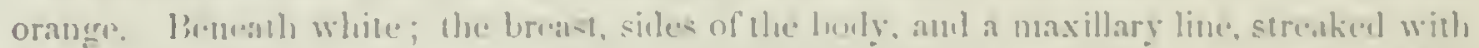

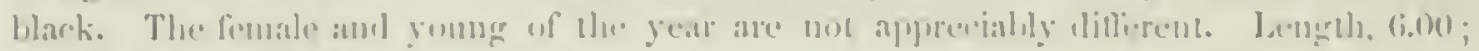
wiur, :1.111: |ail, 2..t11.

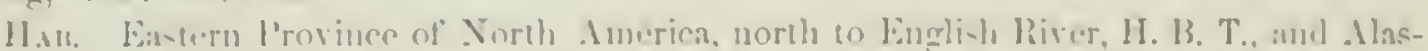

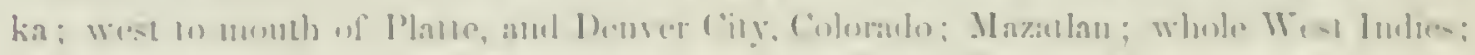

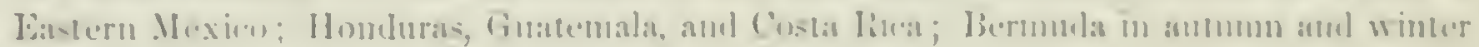
(lust:s).

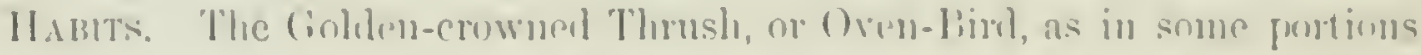

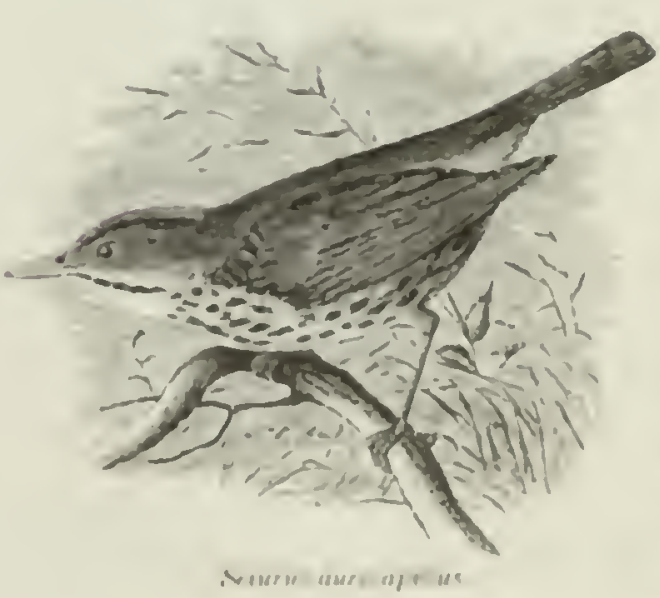

of the country it is exclusirny collewl,

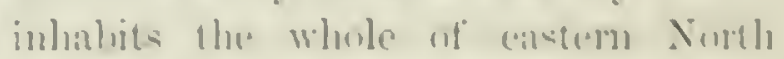

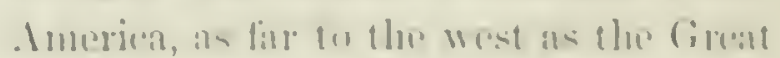

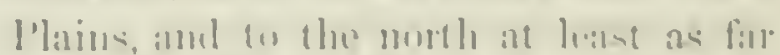
as Finglish livir. In the winter satson

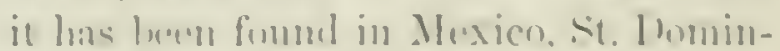

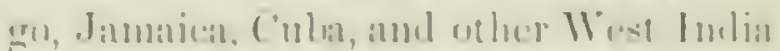

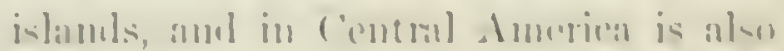

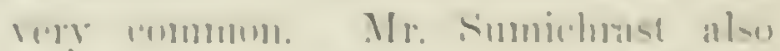

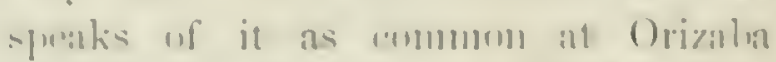

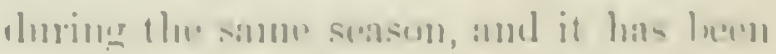

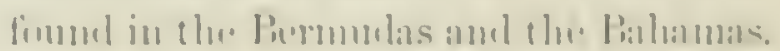

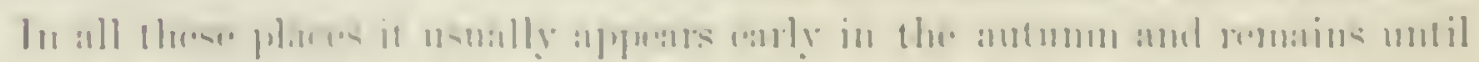

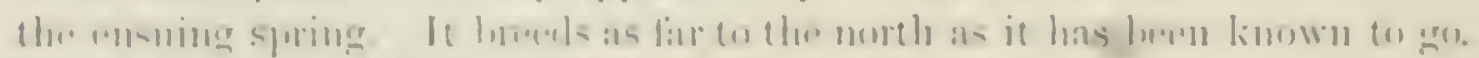

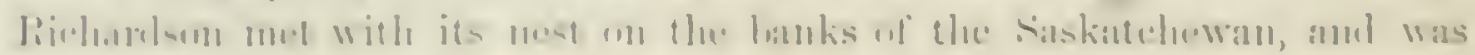


convinced that it bred at even still higher latitudes. Among some memoranda I reeeired from the late Mrr. Kennicott is one stating that lie met with this Thrush breeding near English River, July 15. These birds arrive in the fur comntry about the first of May. How far to the south they breed we have no positive information. I have never received its eggs from any point south of Philadelphin, nor did I ever meet with it or hear its notes in summer in the vicinity of Washington. Andulon was of the opinion that a few remain to breed even in Louisiana, and states that he found them abundant in Texas in the middle of May, but he may have confounded this species with the Lonisiana Thrush.

In Jamaica, where its habits have been carefully studied by Mrr. Gosse, it arrives in September and leares about the 20th of April. Mr. Würdemamn obtained specimens at Cape Florida, September 24 and 25. Mr. Audubon mentions their appearing in Louisiana as early as the first of March. Wilson never noticed it in Louisiana before the last of April, nor after September. The Smithsonian possesses no specimen obtained earlier than May 1, except some procured April 25 from the mouth of Platte River. Mr. Allen notes its arrival in Western Massachusetts May 10. Mrr. Verrill gives the early part of May as the time of its reaching Western Maine, and Mr. Boardman May 1 for the vicinity of Calais.

Though not found on the California coast, specimens of this bird have been taken in winter near Mazatlan, Mexico, showing probably that in their migrations they cross the mountains of Northern Mexieo, as do the Mniotilta varia and a few other of our Eastern species.

In Eastern Massachusetts it usually appears from the 1st to the 10th of May, just as the first leaves of the trees are expanding, and is to be found only in thick woods, often near their edges. Occasionally found perched on the low limbs of trees, it is quite terrestrial in its habits, keeps a good deal on the ground, rumning about among the fallen leaves, more in the manner of a small quadruped than a bird. Mr. Audubon speaks of its frequenting shady woods, watered by creeks and rivulets. I have found them rather more abundant in woods upon high and dry ground, usually upon slopes of wooded hillsides. In this respect it appears to differ in a marked manner from its near of kin, the Water Thrush (S. noveboracensis).

This bird, and indeed all of this genus, have the peculiar vibratory motions of the tail noticed in the Wagtail of Europe, and also observed in our own Red-poll Warbler, and in the Titlarks. In consequence of these peculiarities this species is known, in Jamaica, as Land Kiclup, and the noreboracensis as the Water Kickup. Mr. Gosse found in its stomach gravel, various seeds, mud-insects, caterpillars, and small turbinate shells.

The usual and more common song of this species is a very peenliar and striking one, unlike that of any other of our birds. It is said to somewhat resemble the song of the Accentor modularis of Europe. It is lond and elenr, enunciated with great rapidity, and uttered with great emphasis at its close. 


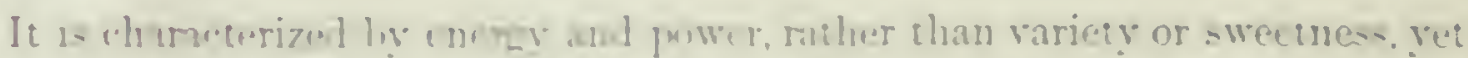

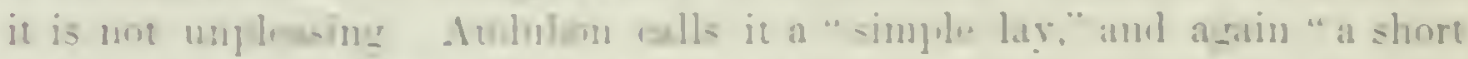

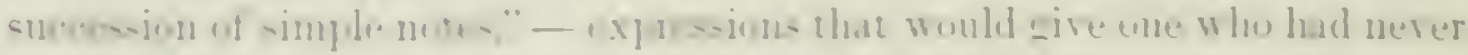

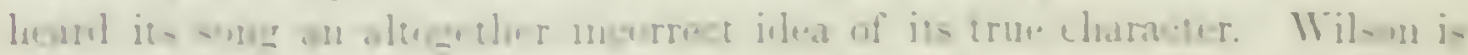

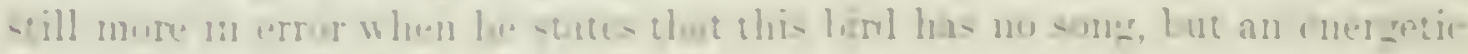
twitter, when, in feci. it has two sery di-inet smge, e.e.th in its way ressurh-

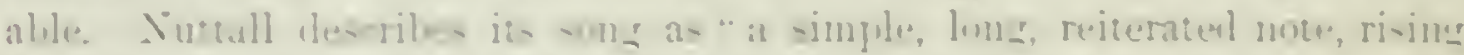

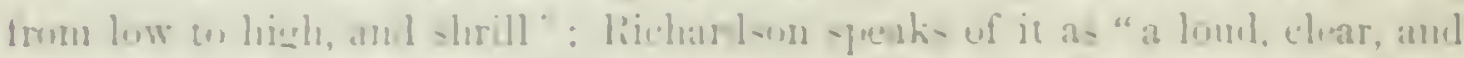

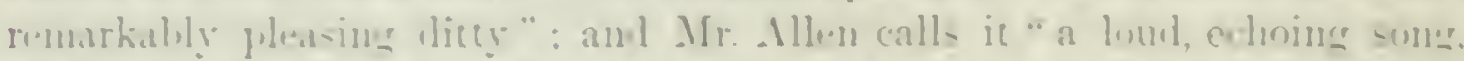

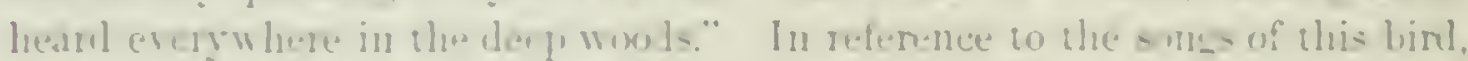

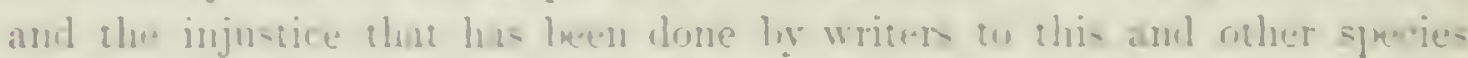

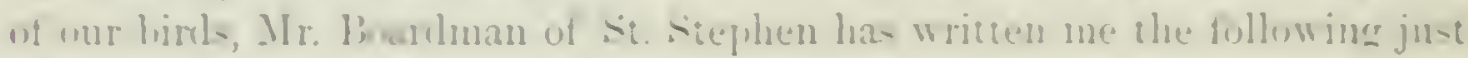
oliservations

"Mans uf our common Warlilers. Thrushes, and cither hink, hase mre somes ther re-erse fol -

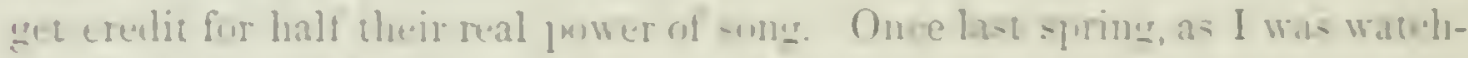

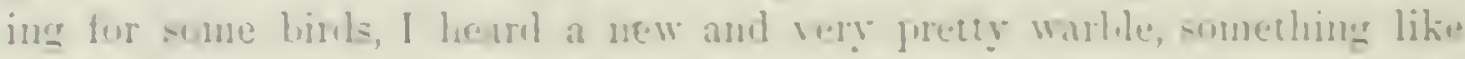

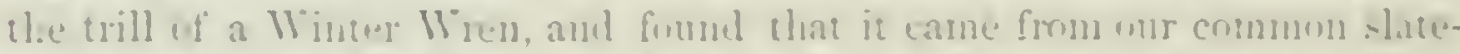

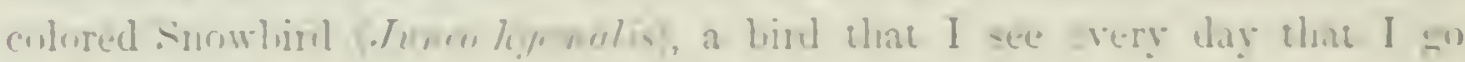

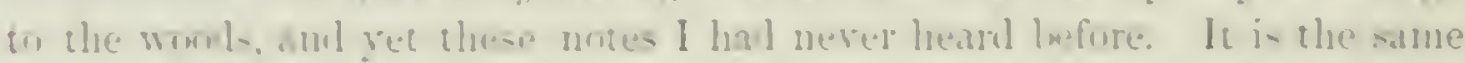
with the finhlen-ermwel Thru-h. When it gets inte the cop of a tall tree.

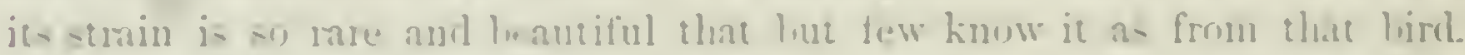
The sme is true of the Water Thru-h, and al-e of both Tomb gallesi and Torilu sumievmi."

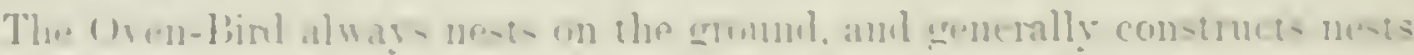

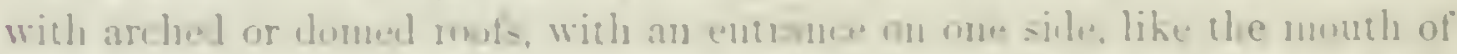

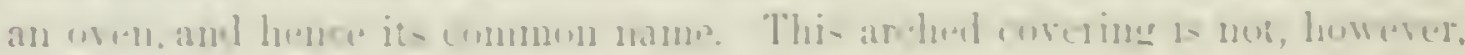
unis.rsil. For a site this spenies ustally seleten the wrolel slope of a hill.

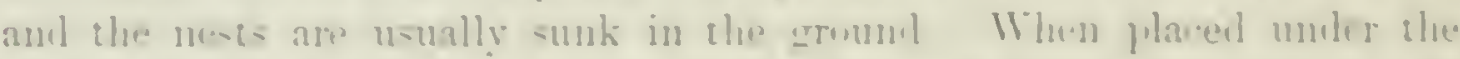

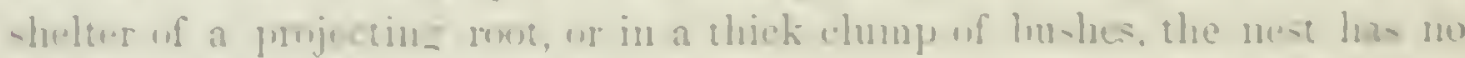

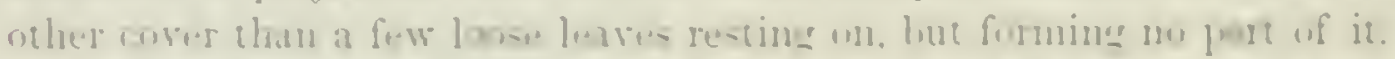

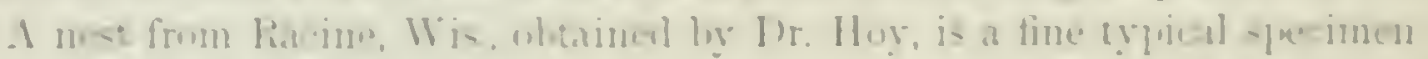

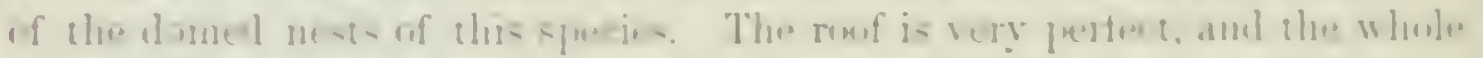

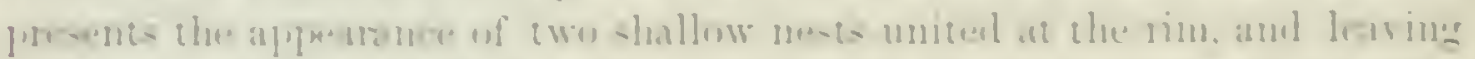

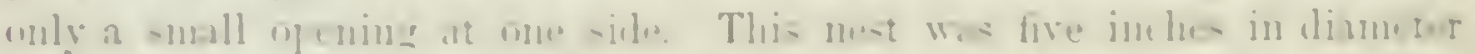

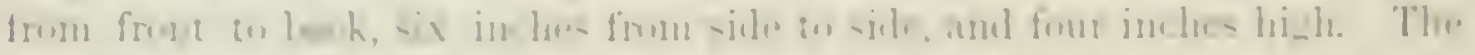

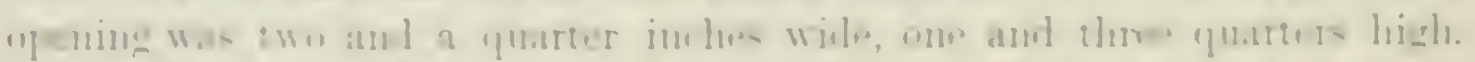

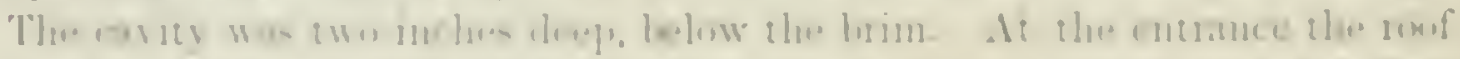

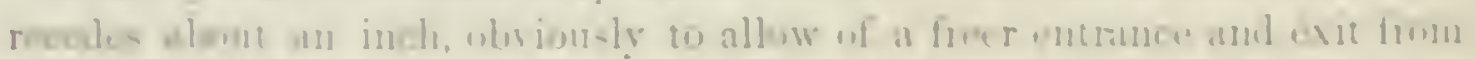

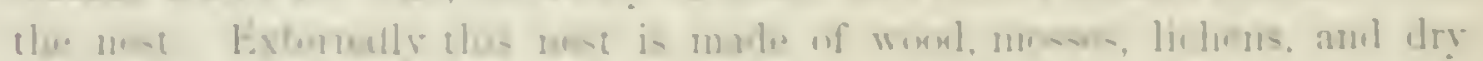

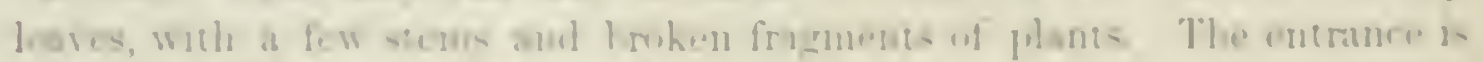

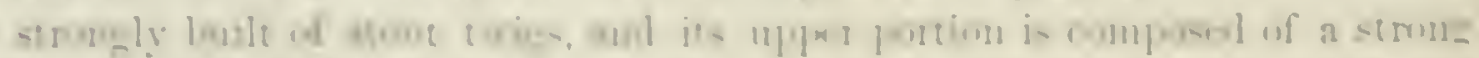

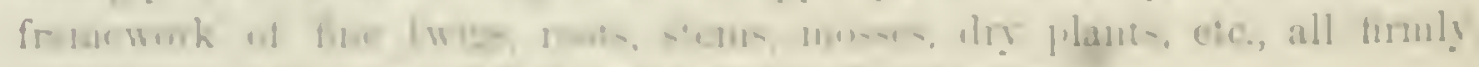

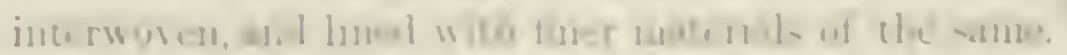


On the 7 th of June, 1858 , I came accidentally upon a nest of this bird of a very different style of structure. It was in a thick wood in Hingham. The nest was built in a depression in the gromul at the foot of some low bushes, and its top was completely covered by surrounding vines and wild flowers. It would probably have escaped notice had not my claughter, then a child of fom years, attempted to gather some wild flowers growing directly orer its entrance. This flushed the mother, who until then had remained quiet: althongh we were standing with our feet almost upon the nest, and the bird fluttered and tumbled about at our feet with well-feigned manourres to distract our attention. The child in great glee songht to catch it, but it elucled her grasp, and, rumning off' like a mouse, disappeared. The nest contained six eggs, was entirely open, and with no other cover than the wild plants that clustered above it. As to its identity there was no doubt, as the parent was afterwards snared upon its nest. This nest was somewhat loosely constructed of slieleton leares, dry slender stalks, grasses, and pine-needles, and was lined with a few slender grasses and leares. It had a diameter of six inches, and was two and a half inches deep. The cup had a diameter of three and a half inches and a depth of two, being very large for the size of the birch, probably owing to the shape of the carity in which it was sunk.

The nest of this bird seems to be a farorite place of resort for the Cow Blackibird to deposit its egg. In one nest, fomd by Mr. Vickary in Lymn, no less than three egrs of these parasites had been placed.

The eggs of the Golden-crowned Thrush are subject to considerable variations. Their markings differ in their colors and shades, and yet more in number, size, and mamner of distribution. The egrgs are oral in shape, one end being but very slightly smaller than the other. Their average length is .82 of an inch, and their breadth is .55 of an inch. Their ground-color is a benutiful creany-white. They are marked, usually principally about the larger end, with dots and blotches, intermingled, of red, reddish-brown, lilac, darker purple, and fermginous. Occasionally these make a beantiful crown around the larger end, leaving the rest of the surface nearly free from spots.

\section{Seiurus noveboracensis, NutT.}

\section{SMALL-BILLED WATER THRUSH.}

Matacilla noveboraccnsis, G.IELIx, S. N. I, 1788, 958. Sylvia nov. LATH. ; VIeIllot, Ois. Am. Sept. II, pl. lxxiii. Sciums nov. Nutr.; Box. ; Aud. Birds Am. III, pl. excix. - Ballid, Birds N. Am. 1859, 261, pl. lxxx, fig. 1; Rev. 215. - Max. Cab. Jour. 1858, 121. - DAld \& Baxister (Mlaska). - SAMtels, 220. Irnicocichla nov. CaB. Schom. Guiana, III, 666 ; Jour. 1860, 324 (Costa Rica). - Sclatel (Tobago). Guxdesch, Cab. Jour. 1861, 326 (Cuha). ISniotilte nov. Gliar. ? I Motucille fusces. cens, Grielin, S. N. 984 (hased on Ficedula jamuicensis, Brissox, III, 512, Jamaica). Turdus aqueticus, Wris.: ALn. O1n. Biog. 1839, 284, pl. cccexxxiii. Sylleir anthoidcs, Vieillot, Nouv. Dict. XI, 1817, 208. Scinrus tenuirostris, Sw. 1827; GAMB. Sciurus 


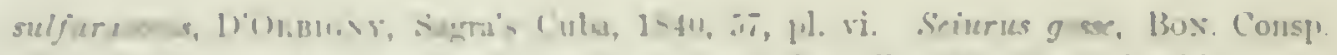

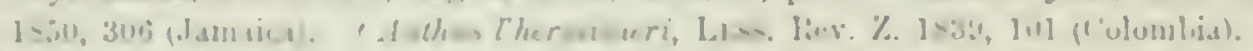

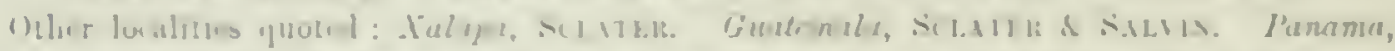

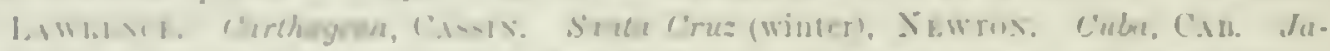

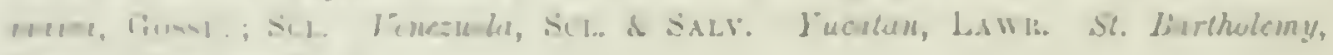
Sisu. Virmul, SiLs.

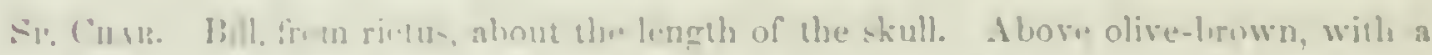

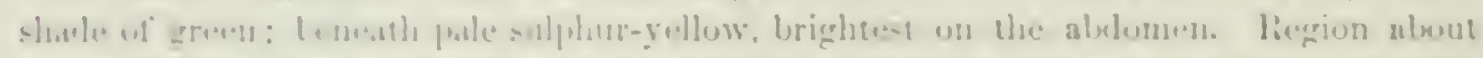

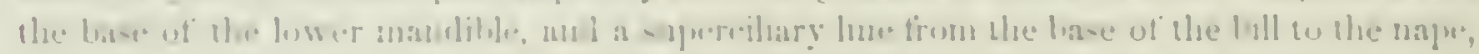

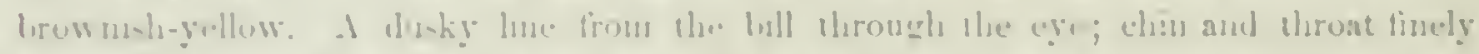

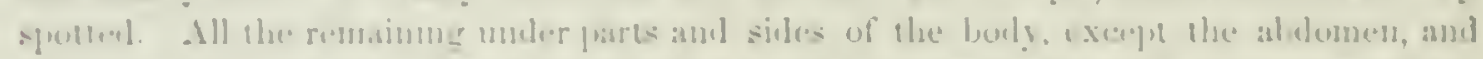

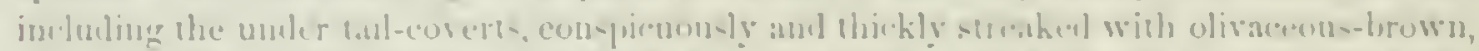

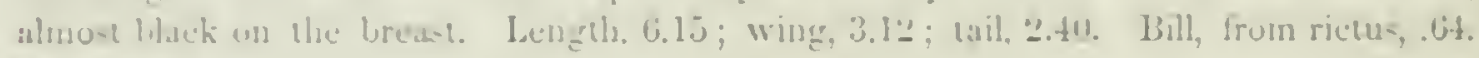
E.xus similar.

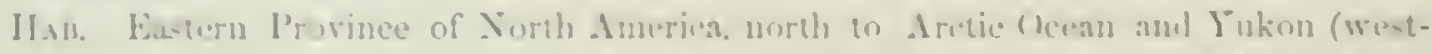

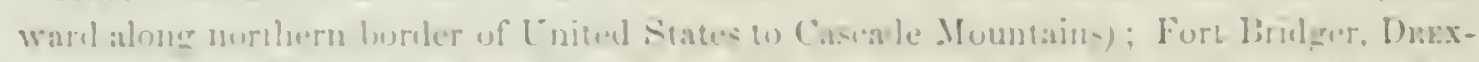

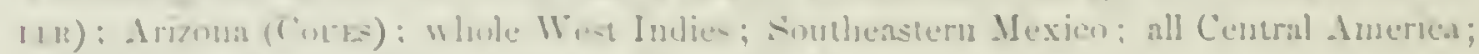

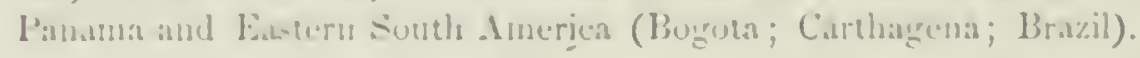

I rery young hird (20,619, Fort Simpson, Angust 10) is rery different from the adule in colloration. The upper parts are fuliginous-black, each feather with a broad terminal har of pale ochnceons, wing-criverts tipjed with the sanne, forming two distinet hands; streats beluw as in the adult, but limater and less sharply defined.

llabirs. This species hats a grentral distrilution, at certain seasons, thromehnut the whole of eastern North Ameriear as far to the north as the

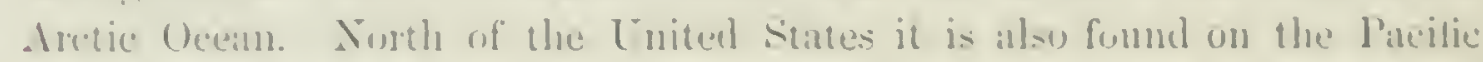

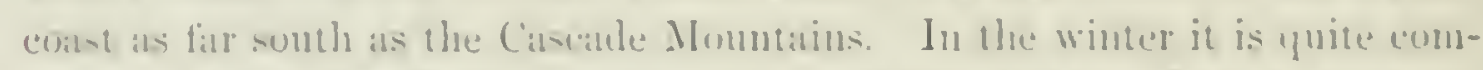
mon in all the We- India Islank, in Suntheastern Alexien, Contmal Ameriea,

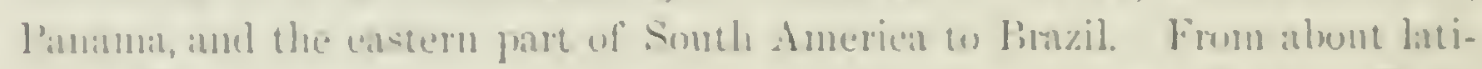

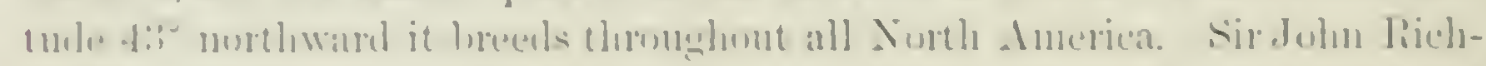

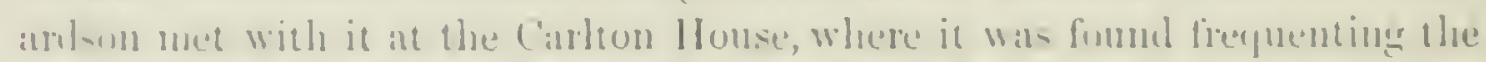

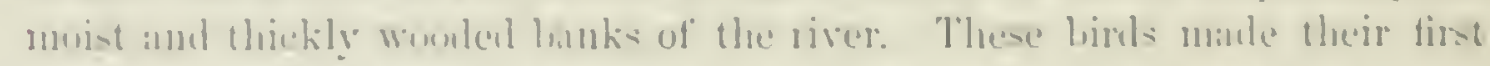

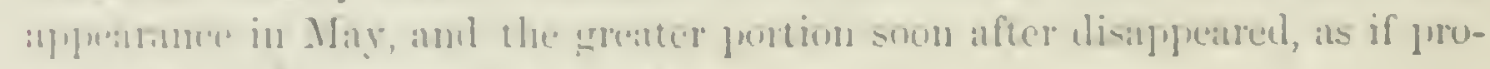

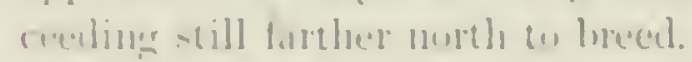

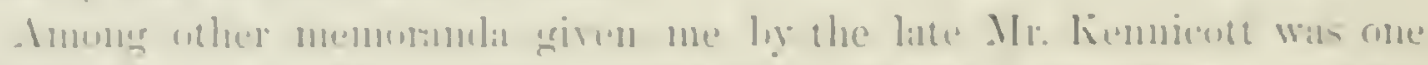

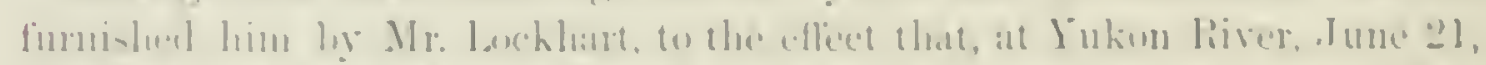

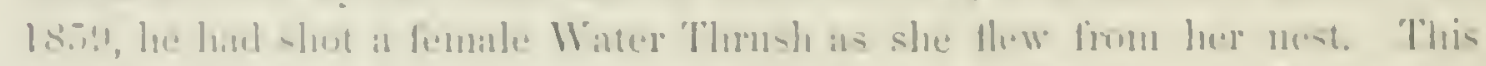

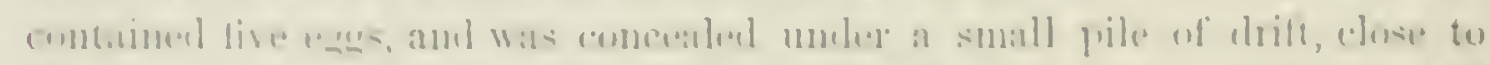

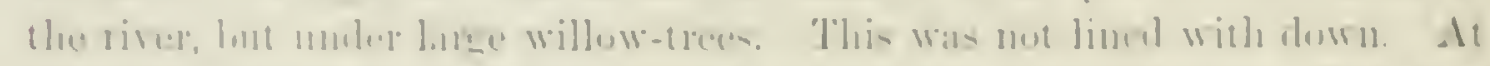

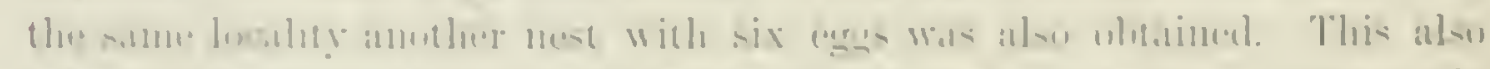
whs on the grominl at the fint of some willows near the water. It was mate

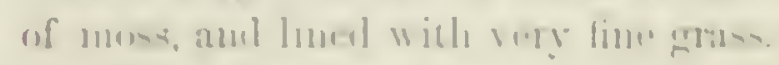

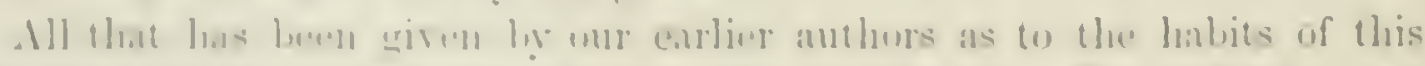

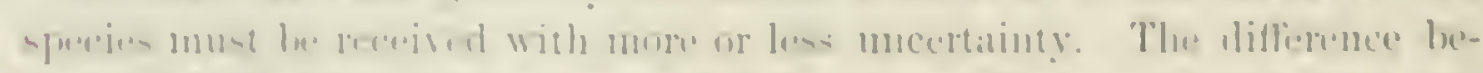

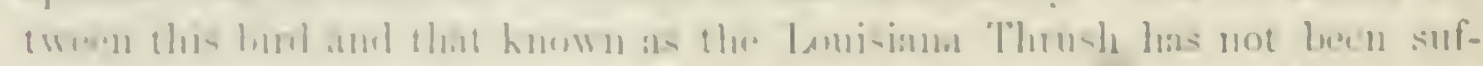

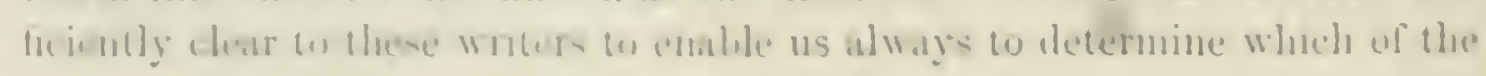


two they had in view. And even now the distribution in summer of the ludovicianus is hardly definable with precision.

Wilson describes the habits of those he observed in Pennsylrania as evincing a remarkable partiality for brooks, rivers, ponds, and the vicinity of water generally, wading in shallow pools in search of aquatic insects, and griving, as it moves it along, an almost continuonsly vibratory motion to its tail. He speaks of it as very shy, darting away with signs of alarm whenerer approached, and uttering a sharp cry. In all other respects his account of this bird probably refers to the Louisiana species.

This is also, without doubt, true of nearly all Audubon gives in connection with the history of this Thrush, which in all probability cloes not breed in Lonisiana, nor remain there through April, being at that time well on its way to more northern regions.

Mr. Gosse, in his notes on the birds of Jamaica, states that this bird reappears in that island about the end of August. He noticed them about the muddy margins of ponds, and they soon became abundant. Individualswere also to be seen rumning on the road, especially near the sea-shore, and by the edges of morasses. They ran rapidly, often waded up to their tibive in water, or ran along the twigs of a fallen tree at the brink, and now and then flew up into the branches of a pimento or an orange-tree. Whether running or standing, they were continually flirting up their tails, after the manner of the European Wagtail. During its winter residence in Jamaica it has no song, only a monotonous cry, a sharp chip. Its stomach was found to contain water-insects and shells. Mr. March has noticed their arrival in Jamaica as early as August 5. They all leave by the first of April.

Mr. Allen found these birds not uncommon both in spring and in fall in the vicinity of Springfield. He thinks a few breed there, as he has met with them in the months of June, July, and August, very sparingly however. They arrive about the 12 th of May. I have once, at least, met with its nest and eggs near Boston.

Dr. Coues says this bird is quite common, both in the spring and fall, near Washington, and breeds sparingly, having been found there in July. They arrire about the first of May, are eminently aquatic, frequent swampy thickets and thick dark woods interspersed with pools, where they associate with the Solitary Tatler.

In Sonthern Illinois this species, Mrr. Ridgway states, is found only during its migrations and in mild winters. He nerer met with it in the breelingseason, when the $S$. ludoriciunus is so abundant. But it returns early from the North, and he has shot numbers of them in August. During the whole fall they are common abont all swampy places, or the margin of creeks in the woods; and in mild winters a few are found in the swamps of the bottomlands, where the dense forest affords them comfortable shelter. On warm days in December and January, he has heard them singing with all the vigor 


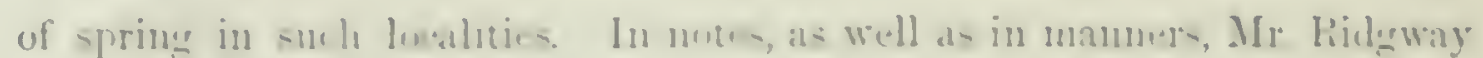

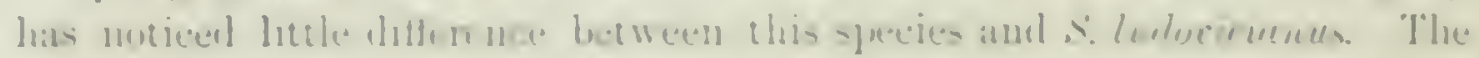

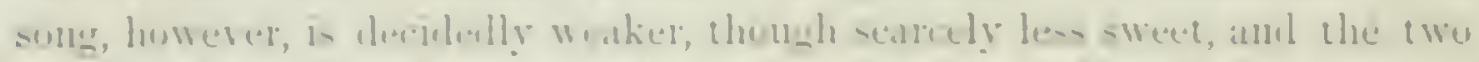

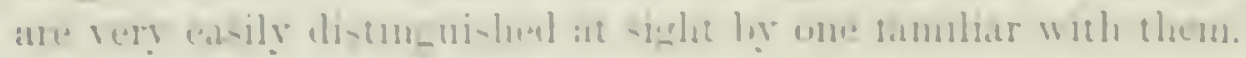

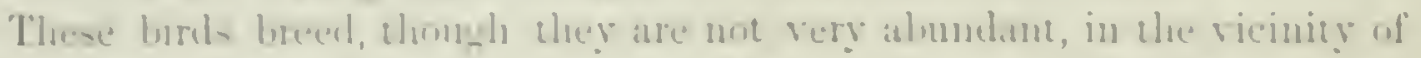

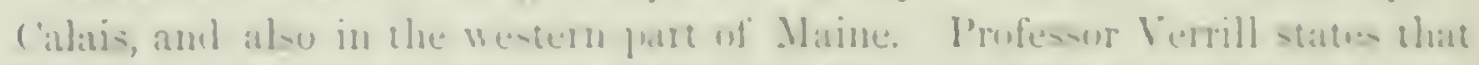

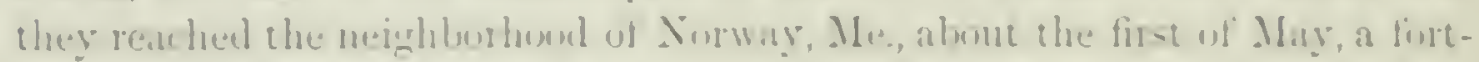

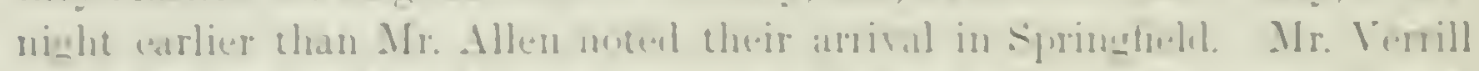

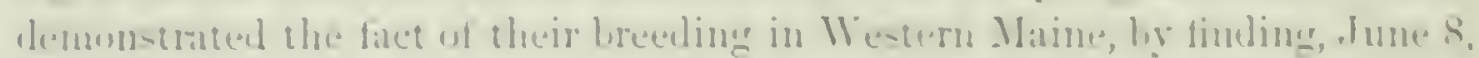

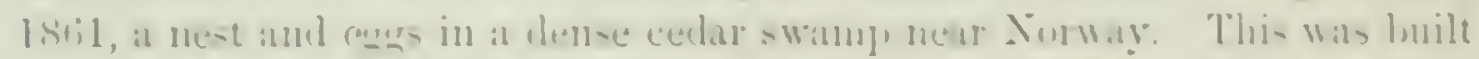

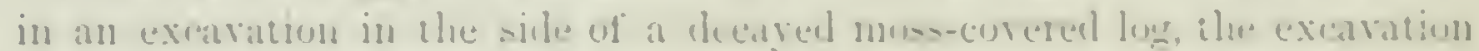
itself finming an ard wer the nest in the mamner of, yet liflerent from,

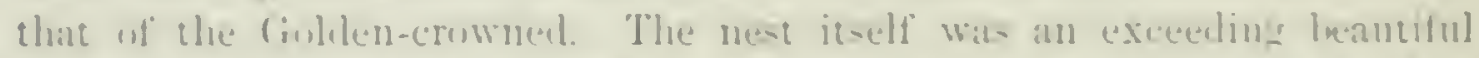
structure, four and a half inches in dlometer, but only an inch and a half in depth, heine very marly flat, the cavity only half an inch dee-fy. The entire base wats made of louse hypmun musece, interopersed with a few dend leares and stems. The whole inner structure or linins was made up of the fruitstems of the same mose, densely impacted. The outer ciremulerenee was

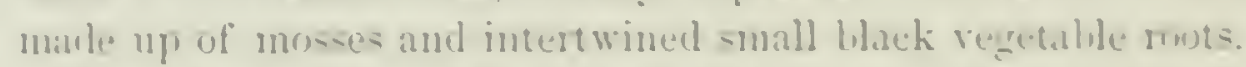

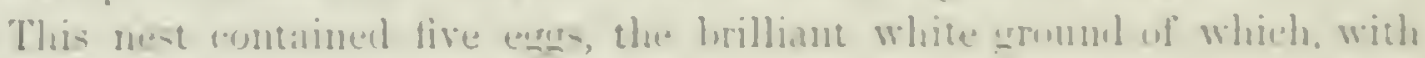

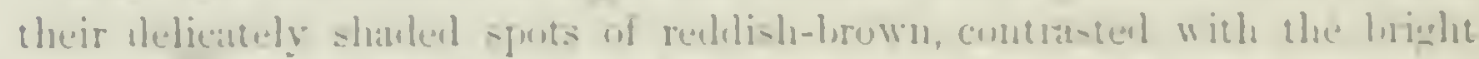

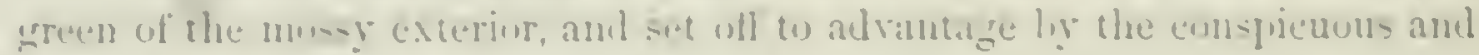
unipue lining, proluce al very latatiful eflect.

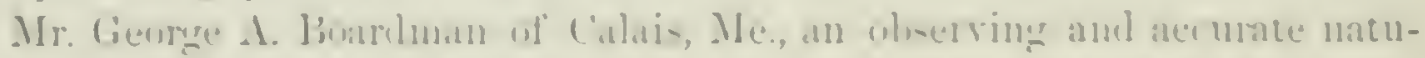

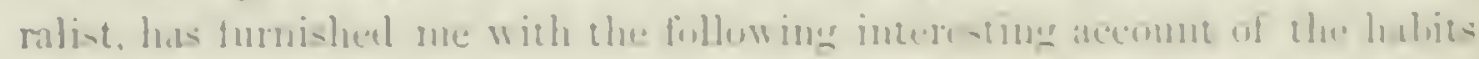

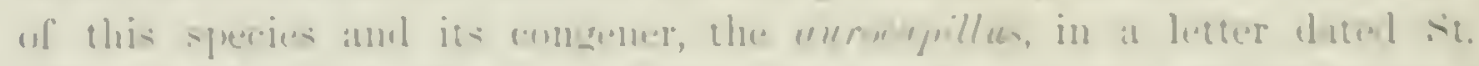

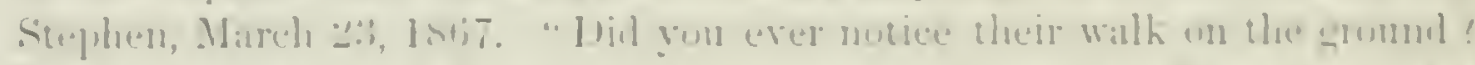

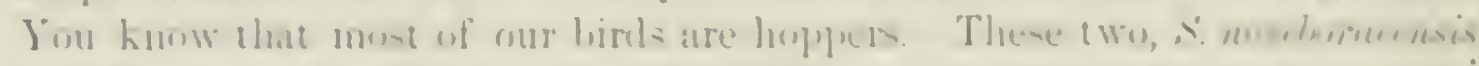

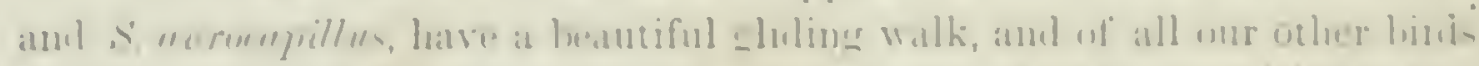

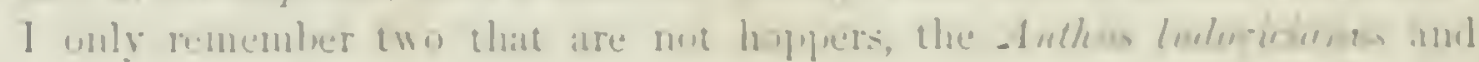

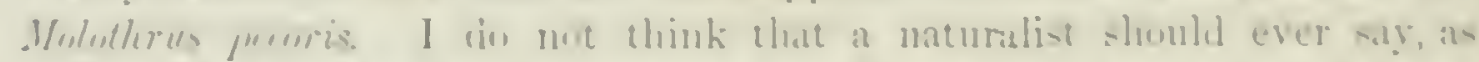

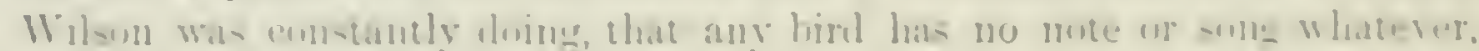

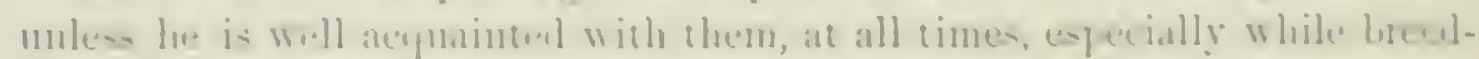

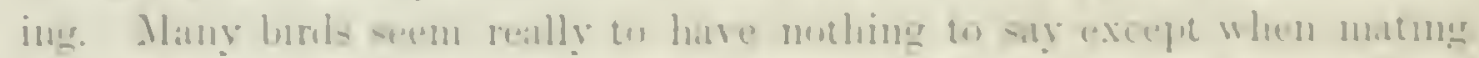

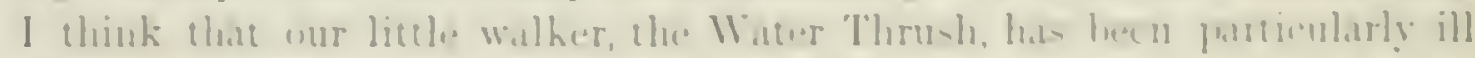
used ly writers in this res....9, for I reapl him at none of our lis cliest sing-

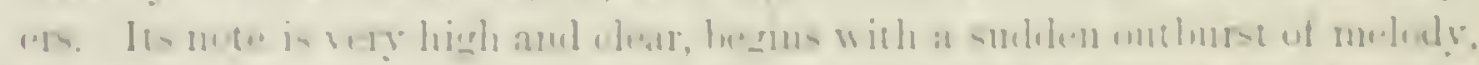

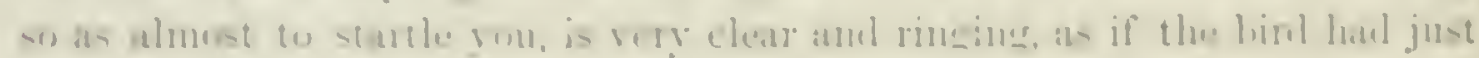

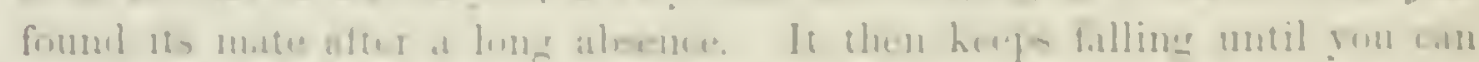

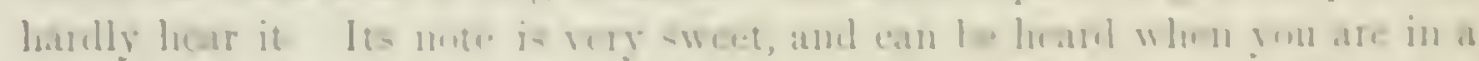

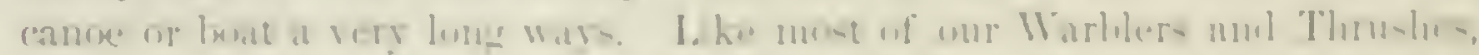

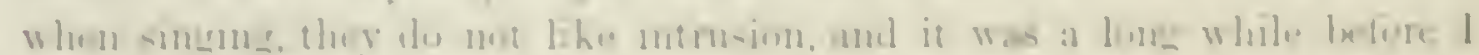

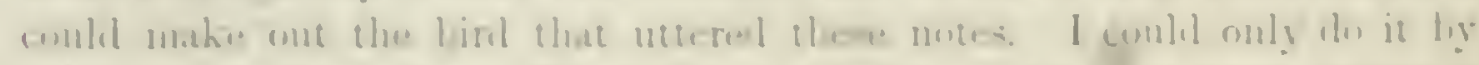

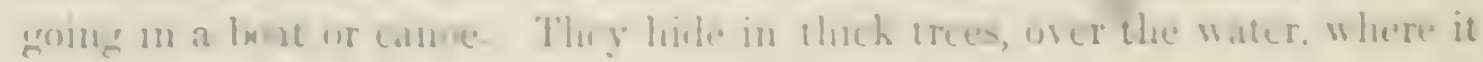


is impossible to walk up to them. I almost always find them on some island, in a river, that has been overflowed, and always very near the water."

Their eggs vary in length from . $\$ 1$ to .87 of an inch, and in breadth from .65 to .69 . They have an oblong-oval shape, tapering to a point at one end and rounded at the other. Their ground is a clear crystal-white, and they are more or less marked with lines, dots, and dashes of varying shades of umberbrown. These markings are more numerous around the larger end, and are much larger and bolder in some than in others, in many being mere points and fine dots, and in such cases equally distributed over the whole egg. In others a ring of large confluent blotches is cromped around the larger end, leaving the rest of the egrg nearly mmarked.

\section{Seiurus ludovicianus, Bovar?}

\section{LOUISIANA WATER THRUSH.}

Turdus ludoriciunus, Atn. Orn. Biog. I, 1832, 99, pl. xix. Sciurus ludovicianus, Bกx.-

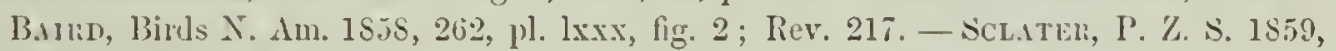
363 (Xalapa) ; 373 (Oaxaca) ; 1S61, 70 (Jamaica). - Sclaten \& SAlrix, Ibis, 1S60, 273 (Guatemala). - SAmliss, 579. Hcnicocichla lud. Sclatfil, Catal. 1561, 25, no. 161 (Orizaba). ? Turdus motacillu, VieiLl. Ois. An. Sept. II, 1S07, 9, 11. lxv (Kientucky). Seinrus motacilla, Box. 1550. IIcricocichla mot. CaB. Joul. 1555, 240 (Cubi).

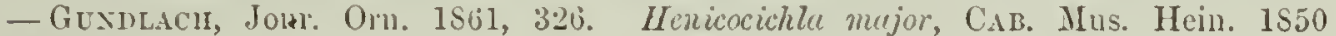
(Xalapa).

Sp. Cris. Bill longer than the skull. Upper parts olive-brown witl a shade of greenish. A conspieuous white superciliary line from the bill to the nape, involving the upper lid, with a brown one from the bill throngh the eye, willening behind. Under parts white, with a rery faint shade of pale buff behind, espceially on the tail-coverts. A dusky maxillary line; the forepart of breast and sides of body with arrow-shaped strealis of the same color. Chin, throat, belly, and under tail-corerts, entirely immaculate. Lengtl, 6.33 ; wing, 3.25 ; tail, 2.40; bill, from rietus, .75. Sexes similar. Young not seen.

HAB. Eastern Prorince of United States as far morth as Carlisle, Penn., and Michigan; Cuba and Jamaica; Southern Mexico (Colima) to Guatemala.

Autumnal specimens have a more or less strong wash of ochraceous over the flanks and crissum, and the brown above rather darker and less grayish than in spring birds.

This species is very similar to S. noveboraccnsis, although readily distinguishable by the characters given in the diagnoses. The differences in the bill there referred to are illustrated in the accompanying diagram.

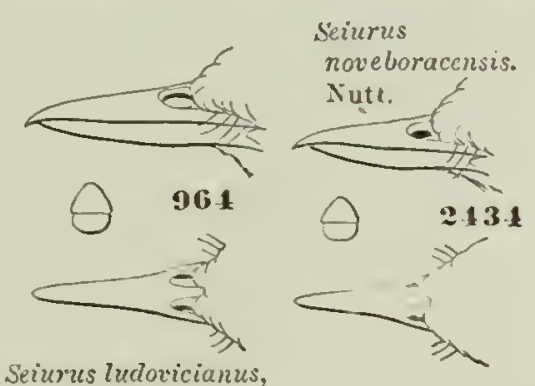

Bon:tp.

Habits. The Water Thrush described by Wilson as most abundant in the lower part of the Mississippi Valley, as well as that given by Audubon as the Iouisima Water Thrush, though its position as a genuine species was afterwards abandoned, are undoubtedly referable to a closely allied but ap- 
parently distinct seiurus, now kunw as the Louisiana Water Thrush. This

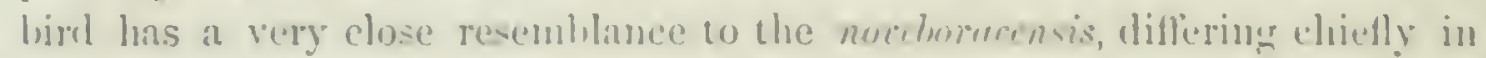
size and in having it lawer hill. Althomgh its distributim is mot yet fully

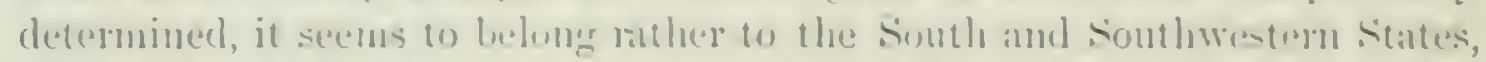

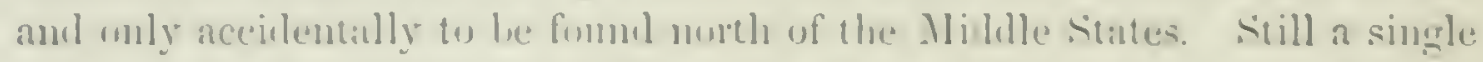
speeimen has been whatinel in Massachusetts, and it has heen several times foumel in Michigin and Missnuri. Speciuncens of this hird have alan luen

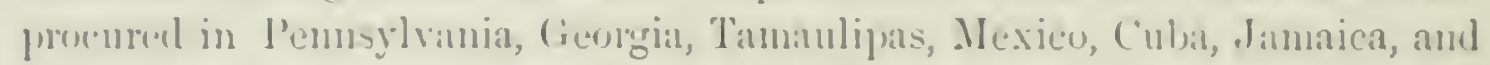
Guaterualat.

Its recungition as a distinct speejes from the common Water Tlumsh is so recent, and the two spereses so elosely resomble rateh wher, that an yot its

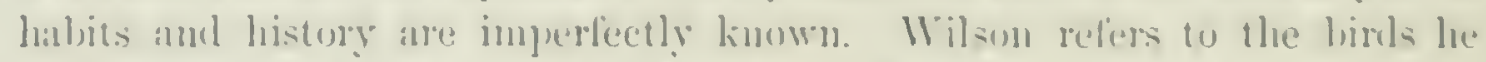

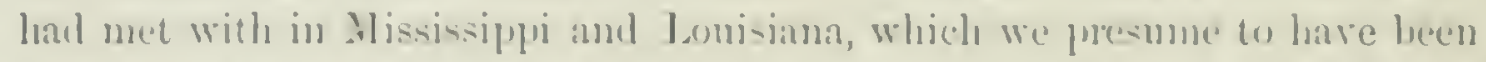

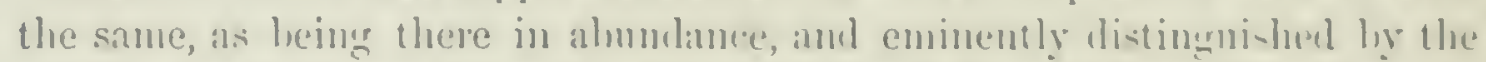
londness, sweetness, and expressive vivacity of their motes. These he deseribes as heximning very ligh and elear, and as falling with an almost imper-

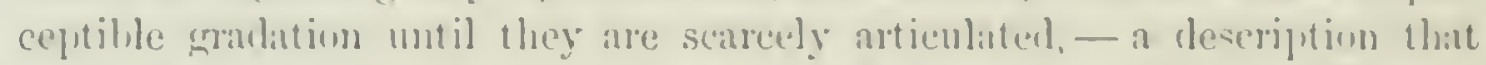
would also antwer very well for the song of the true llater Thush. I luring

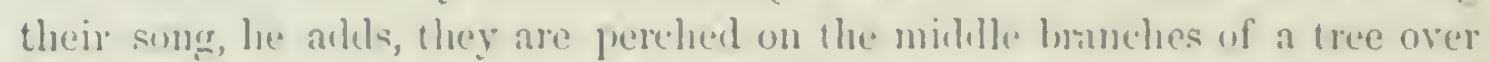

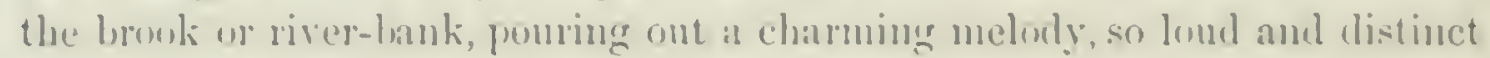
that it may he heard at the distance of nearly half a mile. The volece of this birl appeaned to him so exquisitely sweet and expressive that he was never tireel of listemimer to it.

It is alse funite probable that mearly all of Auduhon's necoments of the habits

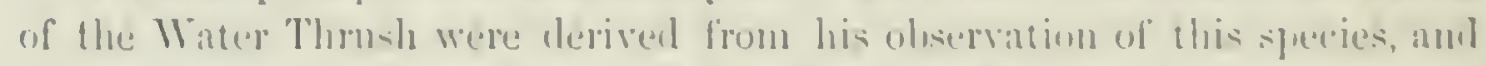

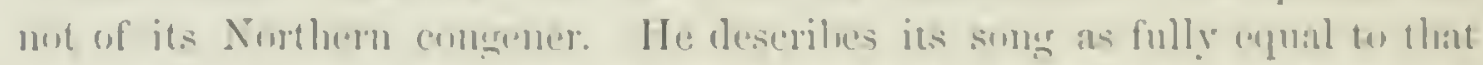
of the Nightingrile, its notes as juwerful and mellow, and at times as varded.

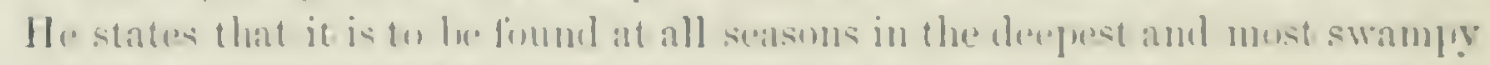

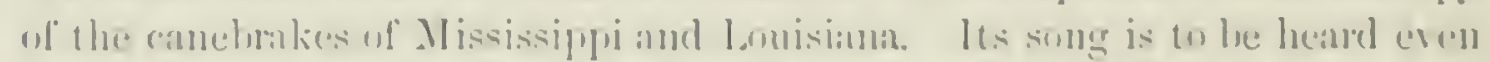
in the wintere when he weathere is collut and warm.

He describes its llight as easy and contimerl, just above the lorakes, or

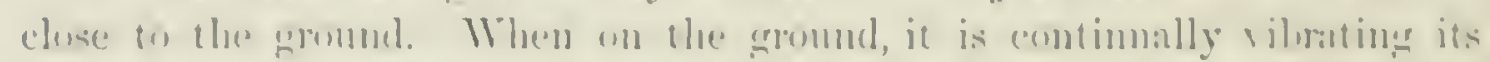
lunly, jerkingont its tail and llen clusing it agran. It walks gracefully alongr

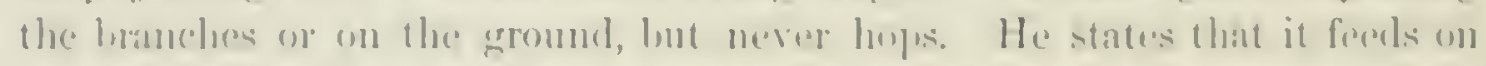

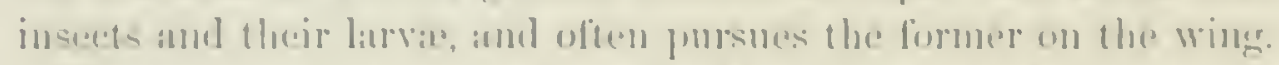

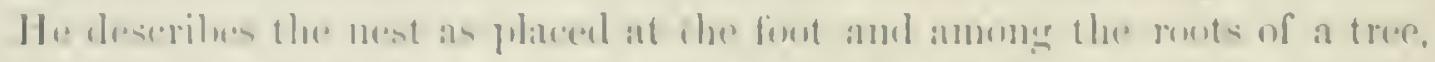

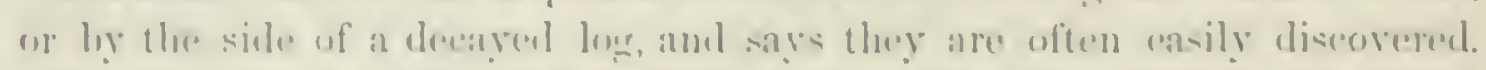

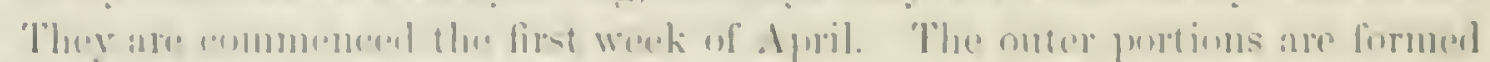

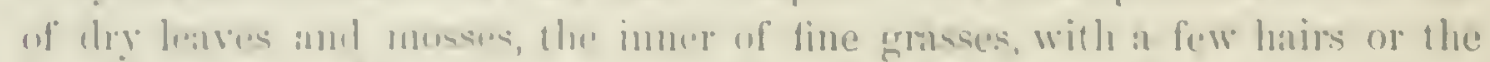
dry libes of lloe spaniale norses.

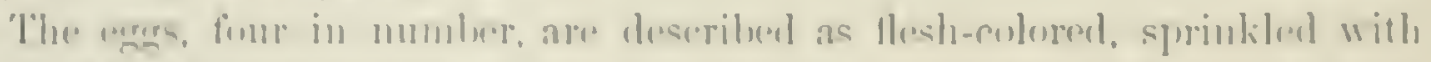

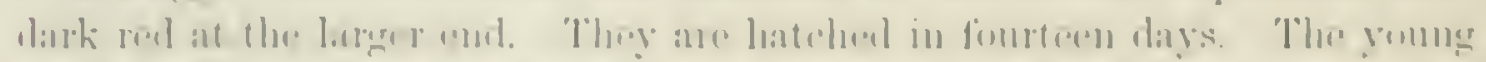

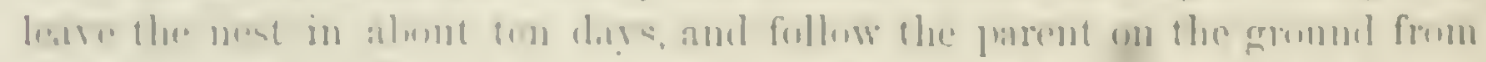

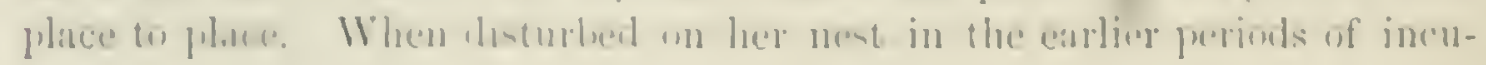


bation, she merely flies off; but later, or when she lias young, she tumbles about on the ground, spreads her wings and tail, utters piteous cries, and seems as if in the last agonies of despair. This species Mr. Audubon never met with farther east than Georgia, nor farther north than Hendersun, liv.

Of late years, or since attention has been mo:e drawn to the specitic difference between this species and the Water Thrush, it has apparently become more numerous, and has been obtained in considerable numbers in the ricinity of Washington. In that neighborhood, once considered so ralre, it was found by Dr. Cones to be not at all uncommon at certain seasons and in particular localities. From the 10th of April to the 201h of May it was always to be met with annong the dense laurel-brakes that border the banks of and fill the ravines leading into liock Creek and Piney Branch. He believes they breed there, but they were not obsersed in the fall. They were usually very shy, darting at once into the most impenetrable brakes, but were at other times easily approached. He always found ${ }^{-}$ them in pairs, even as early as the 20th of April. Their call-note was a sparrow-like chirp, as if made by striking two pebbles together. They also had a loud, beautiful, and melodious song, the singularity of which first drew his attention to the bird.

Mr. Ridgway informs me that in the Wabash Valley this bird, familiarly known as the "Water Wagtail," is an abundant smmmer sujourner. It inhabits the dampest situatious in the bottom-lands, the borders of creeks, lagoons, and siramps, living there in company with the Prothonotary Warbler (Protonotaria citrea). In its morements it is one of the quickest as well as the most restless of the Sylrirolide, though it is eminently terrestrial in its habits. It is usually seen upon the wet ground, in a horizontal position, or eren the posterior part of its body more elerated, and its body continually tilting up and down; if it fancies itself unobserved, it runs slyly beneath the brushwood overhanging the shore; but if startled, it flies up suddenly with a sharp and startling chatter. He adds that in early spring (from the latter part of February to the beginning of $A_{\text {pril }}$ its rich loud song may be heard before the trees are in leaf, for it is one of the earliest of the Warblers to arrive. When singing, it is usually perehed upon the lower branches of a tree orerhanging the water, but he has frequently seen it among the topmost branches. Wilson and Audubon have not exaggerated the merits of the song of this bird, for among all its family there is certainly not one of our North American species that compares with it. In richness and volume of its rery liquid notes it is almost unrivalled, though the song itself may not be considered otherwise remarkable.

Mr. Salvin met this species in different portions of Guatemala in the months of August, September, and Norember, 1859. A dry watereourse in the forest, or in the bottom of a barranco, seemed to be its farorite resort, while its near congener, the noveboracensis, was observed to seek rather the more open streams. 


\section{(iFin: OPORORNIS, BMm,}

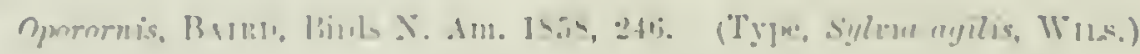

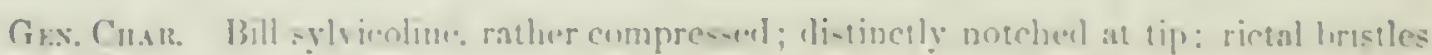

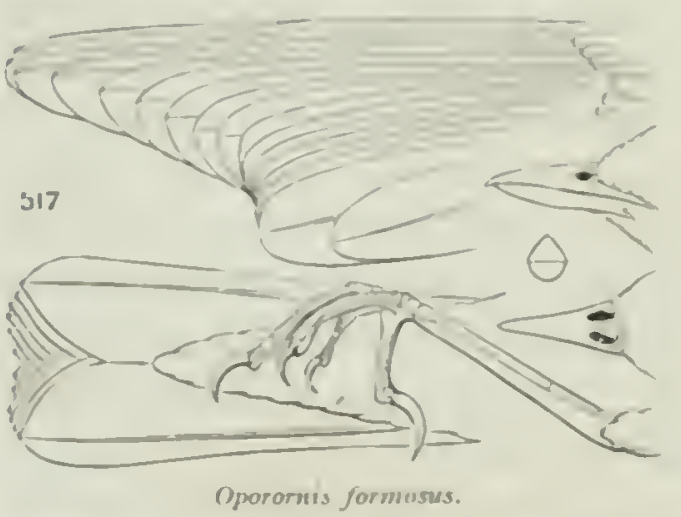

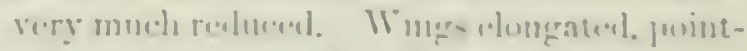

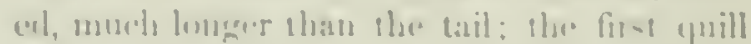

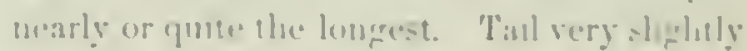

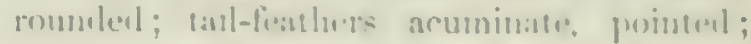
the muler rovert- rearling to whthin le- than lailt an inch of their tip. Tarsi elemeatuel.

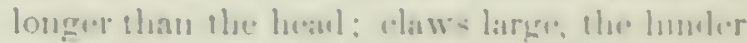
one as longer as it digit, and longer than the

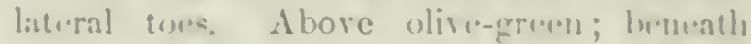
yollow; tail and wings immaculate. Lawyellow.

This group of American Warblers is very distinct from any other. The typical species is quite similar in color to crothlypis philudelphin, hut is at once to be distinguished hy much longer wings, more even tail, and lumer toes and claws. It is also very sinnilar to simms, differing chiefly in the longer wiugs, larger claws, and alsence of spots bencath.

Throat and crown a-h-eolor; a white rene rumml the cre. So hlact nu the sille. of 1 lue lical

Throat and superciliary stripe ! wlow; inp of the heoul and a streat hemeath the cye blatek

\section{Oporornis agilis, Ballin}

\section{CONNECTICUT WARBLER.}

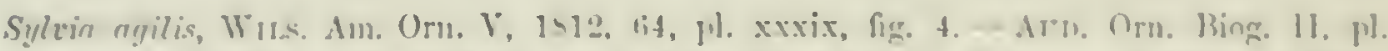

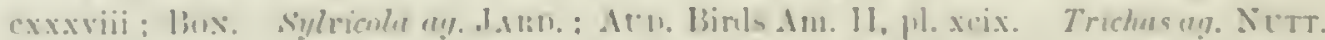

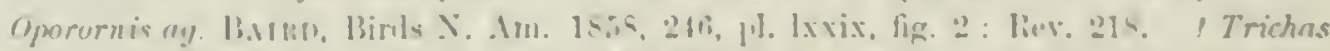

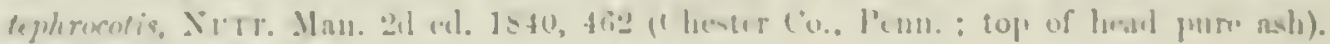
- S.MII.L, zus.

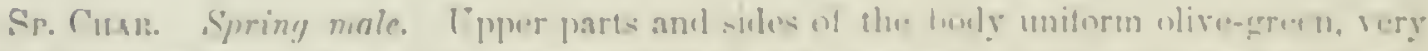

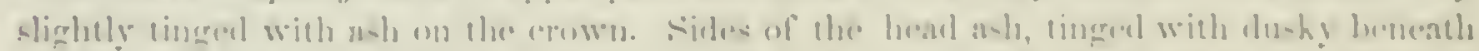

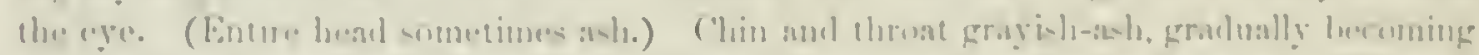

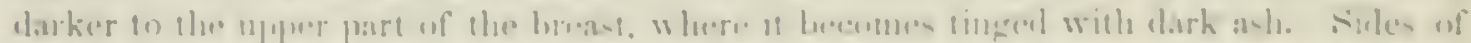

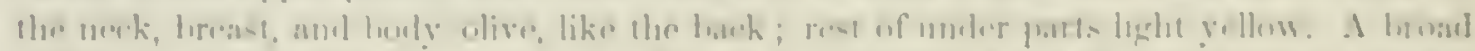

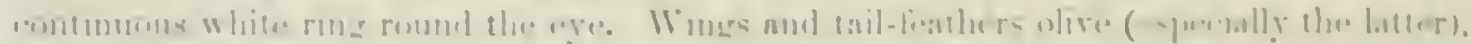

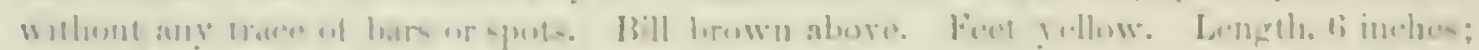

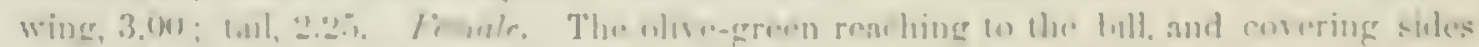

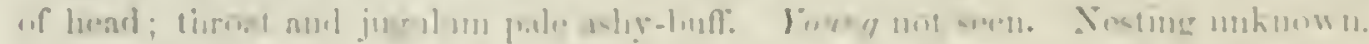

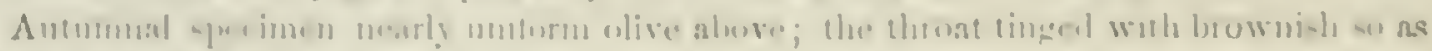

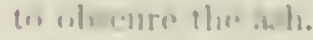

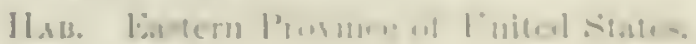


A specimen in the collection of the Philadelphia Academy, killed by Mr. Krider, has the darker ash of the jugulum of a decided sooty tinge.

A peculiarity in the history of this species is shown in the fact that it is quite abundant in Illinois, Wisconsin, ete., in the spring, and very rare in the antumn; precisely the reverse being the case near the Atlantic border, where only two or three spring specimens have been announced as captured by collectors. It is possible that they go north in spring, along the valley of the Mississippi, and return in autunn through the Atlantic States. Their summer abode and breeding-place are as ret unknown.

Habrts. Of the history of this rare and beautiful species but little is as yet known. It was first met with by Wilson, in the State of Connecticut, and he afterwards obtinined two other specimens near Philadelphia. Others have since been procured at Carlisle, Penn., at Washington, London C'ounty, Va., near Chicago, Racine, and in Southern Illinois. September 25 to October 1 , and May, from the 15 th to the 2Sth, appears to be the epoch of their fall and spring occurrence. They are more frequently noticed in the au-

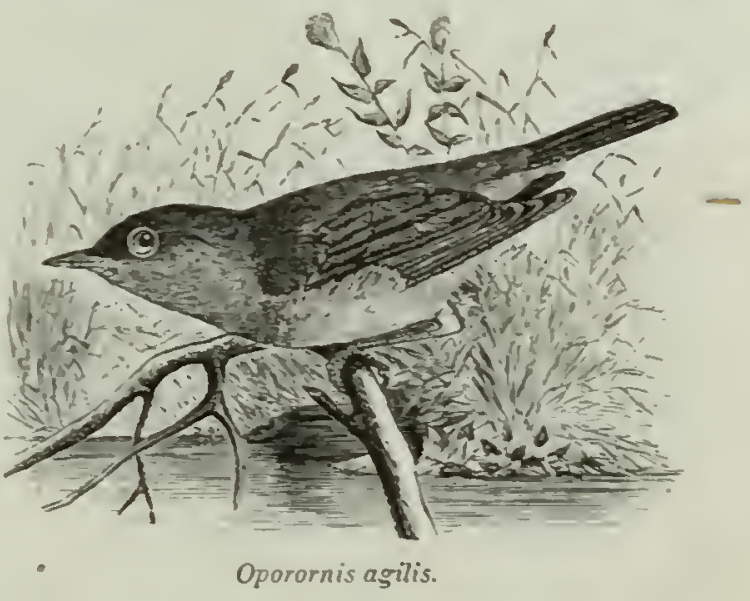
tumu. It is supposed to be a migratory bird, going north to breed.

It was found by Wilson, in every case, anong low thickets, and seemed to be more than commonly actire, not remaining for a moment in the same position. Mr. Aulubon obtained only two specimens, a pair, opposite Philadelphia in New Jersey. When he first obserred them they were hopping and skipping from one low bush to another, and among the tall reeds of the marsh, emitting an oft-repented twet at every move. They were chasing a species of spider that ran nimbly orer the water, and which they caught by gliding orer it. Upon dissecting them, he found a number of these spiders in their stomachs, and no other food. These two birds were not at all shy, and seemed to take very little notice of him, even when close to them.

Mr. Trumbull, in his list of the birds of Eastern Pennsylrania, marks it as a sumner resident of that State, which is probably not the fact. Mr. Lawrence includes it in his list of birds found near New Tork City. It is not given by Mr. Terrill or Mr. Boardman as occurring in any part of Maine, and has not been detected in Mestern Massachusetts by M[r. Allen, though it has been occasionally met with in the eastern part of the State by Dr. Cabot, Mrr. Marnard, and others. More recently, in the fall of 1870 , and again in that of $1 S 71$, this species has been found quite abundant in a restricted locality in the eastern part of that State. It was first observed by М $\mathrm{r}$. H. W. Henshaw, a promising young naturalist, in the early part of September, 1S70, among the Fresh Pond marshes in Cambridge. They appeared to be quite 
numerons, and seversl speeiness were obtuined. He communicated the dis-

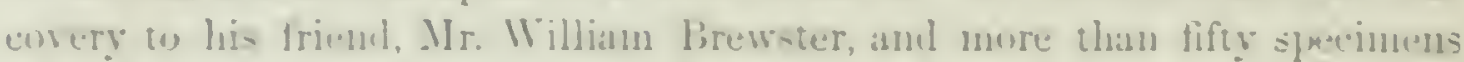

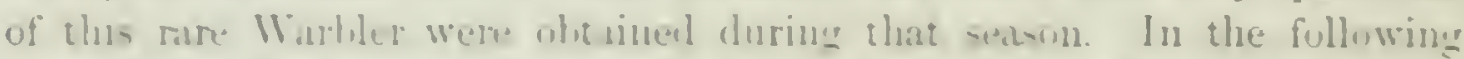

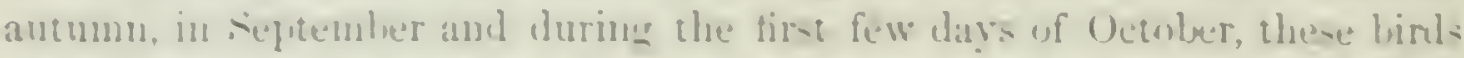
were nherred in the same lowality, apparently in erreater numbers, and mere - jes imens were whtabed.

Mr. Henshaw writes we that he tirst saw this speecien, september $7,15.0$,

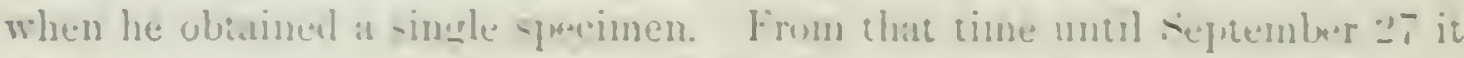
was very common throughout the Fresh l'oul swanps, w which loulity it

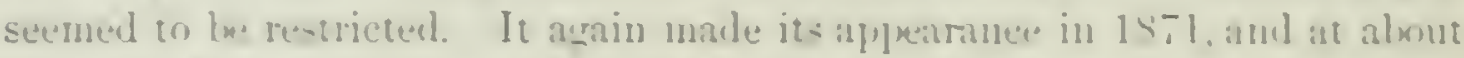
the same time, and remained until Cretolner 5 . It was in even omeater mumber- than during the preceding gear.

Their habie, while with us in the fall, ajpear to lo very diflerent frmm these of the individuals observel l, Wilon and Andubon, which were described as Inding of a remarkally lively di-gusition, and hemee the name of agilis. Mr. Henslaw found them alme- constanty engaged in seeting their

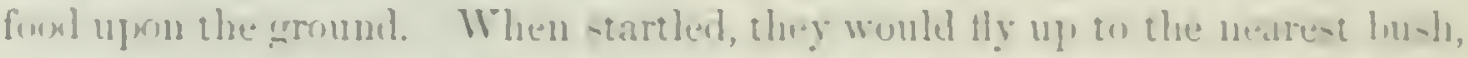

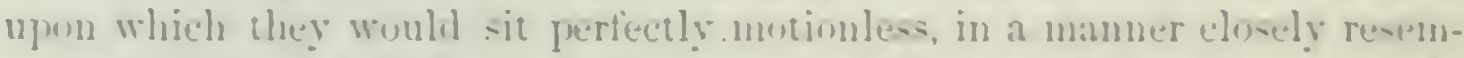
hing the Thrushes. If not further di-turleal, they immenliately returmed to the ground and resuned the search for ford among the leare. If greatly

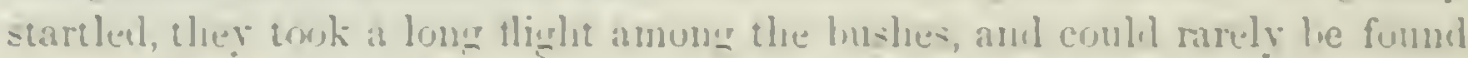
arain. The only nute he heard them uther was a single slarp chirp, emitterl wea-ionally, when surprised. They were all remarkably fat, su much so as to make it ditlienlt to obtain as somel specimen.

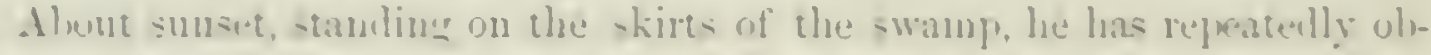

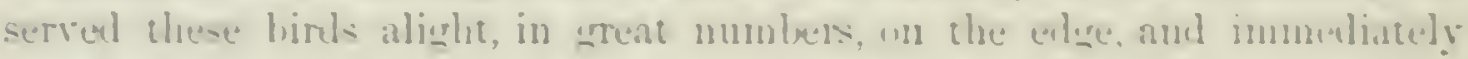
fade in. evidenty intending on remain there over night. He julged that they migrate entirely ly lay. On only nese or two recasions did he ol-

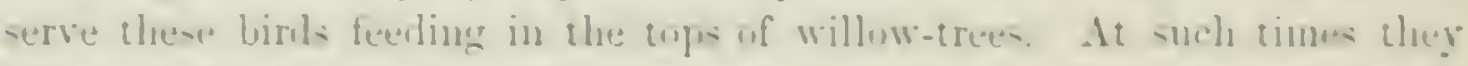

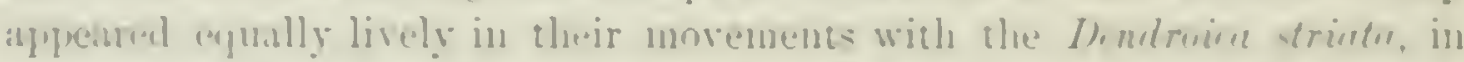

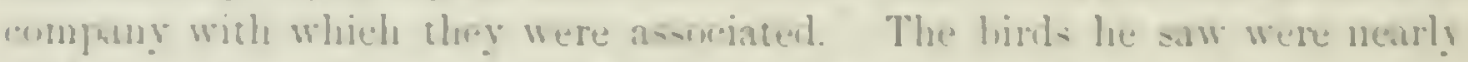

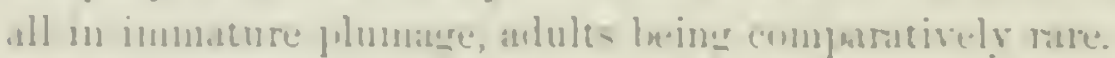

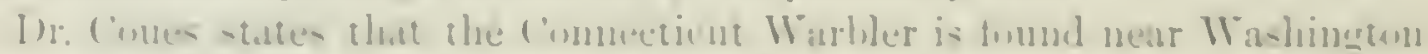

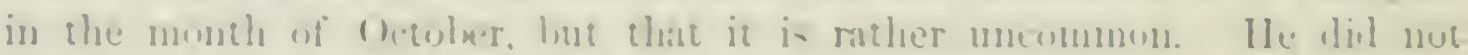

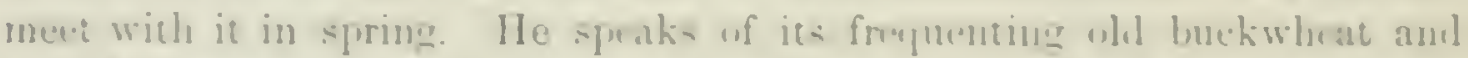

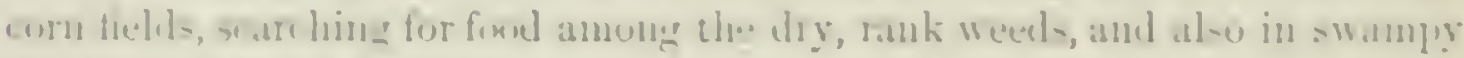
places annung lin thiekets. 


\section{Oporornis formosus, BanliD}

\section{KENTUCKY WARBLER}

2 Sylvia aquinoctialis, Vieill. Ois. Am. Sept. II, 1s07, 26, pl. Ixxi, Penn. (not of Guris). Sylvia formosa, Wils. Am. Orn. III, 1811, S5, 11. xxv, fig. 3. - NuTr. ; Aun. Orn. Biog. I, pl. xxxviii. Sylvicole formose, Jann.; licrr.; Bux.; Max. Myjodioctes formosns, Avv. Syn. - IB. Birls An. II, pl. lxxiv. - LlinBEvE, Av. C'uba, 1550, 37. Guxplach, Cab. Jour. 1861, 326 (Cuba). Oporornis furmosus, Barlid, lirds N. Au. 185S, 247 ; Rev. 218. - Schitri \& SAlvis, Ibis, I, 1S59, 10 (Guatemala).

Other Iocalities cited: Mexico, Schater. Isthmus Panama, LAwrixce. Vcragua, Sal. Costu Rica, Lawr.

Sp. Char. Adult male. Tpper parts and sides dark olive-green. Crown and sides of the head, including a triangular patch from behind the eje clown the side of the neck, black, the feathers of the crown narrowly lunulated at tips with dark ash. A line from nostrils orer the eye and encircling it (except anteriorly), with the entire under parts, bright yellow. No whita on the tail. Female similar, with less black on the head. Length, 5 inches; wing, 2.95; tail, 2.2.). Young not seen.

The adults in autmnn are exactly the same as in spring.

II.AB. Eastern Province of United States, north to Washington and Chicago; west to Republican Fork of Kimsas Rirer (Cocks). Cuba, Guatemula, and Isthmus Panama. Not recorded from West Intics except Cuba.

Habits.' The Kentneky Warbler is an abundant species in the Southern and Southwestern States, and has been found, though more rarely, as far to the north as Southem New York in the east and to Sonthern IVisconsin in the west. It has also been obtained at Fort Riley, in Kansas. Its nest and eggs have been procured near Cleveland, O., by Dr. J. P. Kirtland, and also in Chester County, Penn., by $\mathrm{Mr}$. Norris. It is a winter inhabitant in Mexico, Panama, Guatemala, and Cuba.

Wilson speaks of having met with this lird in abundance from Kentucky to the mouth of the Mississippi, everywhere quite common, but most especially so in the States of Temnessee and Kentucky. At the Balize he several times heard it twittering among the high rank grass of those solitary morasses. He found it frequenting low damp woods, and building its nest either in the middle of thick tufts of rank grass, in the fork of a low bush, or on the ground. The materials of which these nests were made were loose dry grass, mixed with the pith of wood, and lined with hair. He found the eggrs from four to six in number, pure white, sprinkled with recldish specks. He met with the female sitting npon her egrgs as early as May. These birds, he adds, are seldom seen among high branches, but prefer to frequent low bushes and canebrakes. In their habits they are very lively and sprightly. The song is lond, comprising three notes, and resembles tweedle-tweedle-dweedle. It makes its appearance in Kentucky from the South about the middle of April, and leaves the region about New Orleans on the approach of cold weather. Wilson was assured that it never remains there during the winter.

Wilson characterizes these birds as a reckless fighting species, almost always engaged in pursuing its fellows. 
Mr. Andubun states that this Wirluler is the mest common and abundant species that visits the state of Lonisianta and the whole resion alunt the

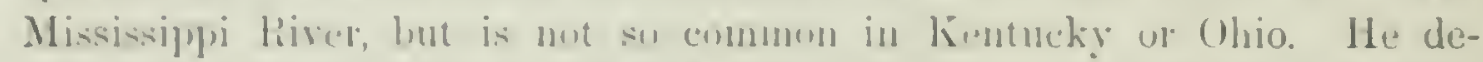
seribes it as an extrentely tively and active bird, found in all the low grounds

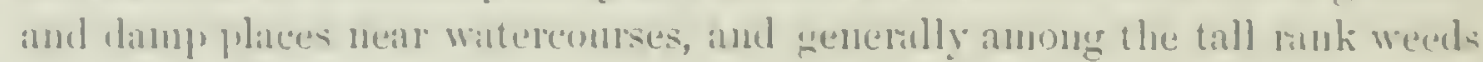
and low bushes srowing in rich alluvial soil. It is continully in motion, henping from stalk w stalk, and from twig to twig, preving npon insects, larrar, or small berries, ranely pursuing an insert on the wing. He deseribes its song ats agrecable and emphatic. He has never known this species fly firther than a few rards at at time. It: flight is low, and is perfurmed in a

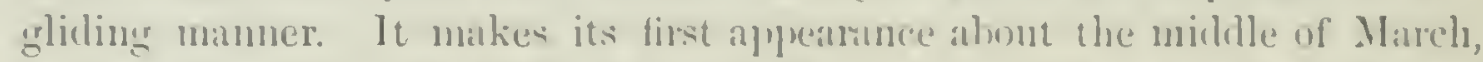
and remains until the midlle or lant of seprember. He states that it rears two brovels in a season. His description of its nest, as "small, leamtifully

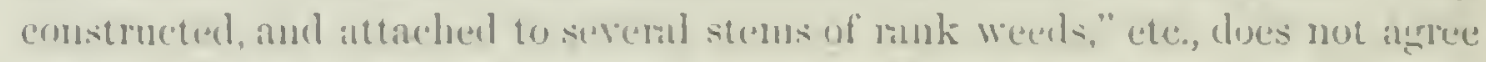
in position, size, or alprearance with any that I lave ereer seen.

According to Mr. Auduhon, it fecels langely upon spiders, which it ohtains by turning ower the withered leares on the gronnd. The young hirds resemble their unther until the fullowing setson, when the males attain the full beauty of their plumage. They remation with their parents until they migrate.

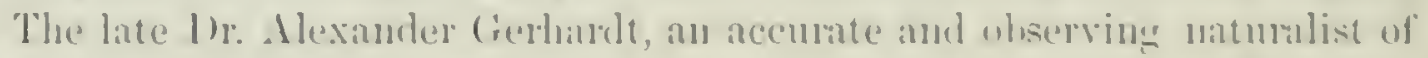
Northern (ienryia, informed me, ly letter, that the nest of the lientucky Warther is usually built on the ground, under a tuft of grass. often on a hillside and always in dry places. The earres are depmeited from the the the 15th of May. Nearly all the nests he met with were made extermally of a

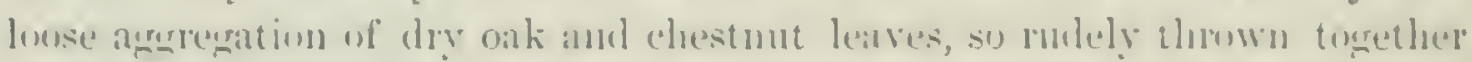
ats hardly to possess any collerence, and retpiring to he sewed to he kept in

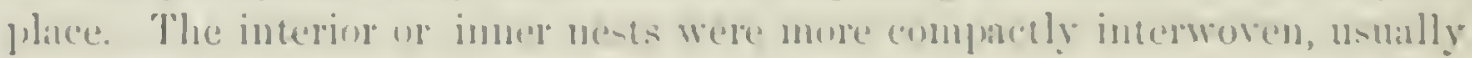
compused of fine dank-hrown rums. lusteald of heing small, they are lange for the hird, and ane inelenanty and clumsily made. They measure four inclese in their diameter, three in height, and two in the depth of the ir carity.

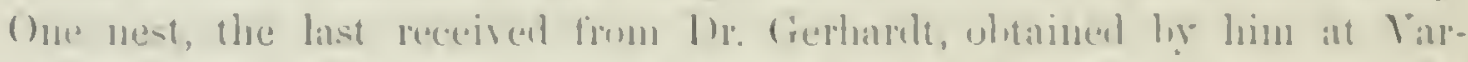
nell's Station, in Northern Georyil, June J. Lstio, is lange and preculiar in its

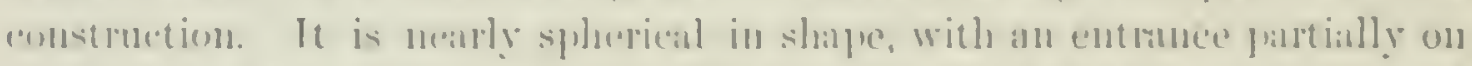

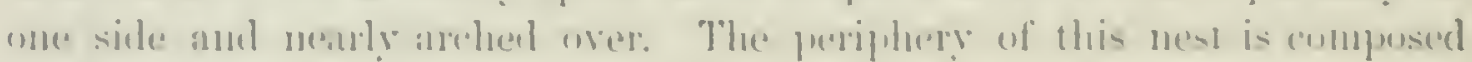

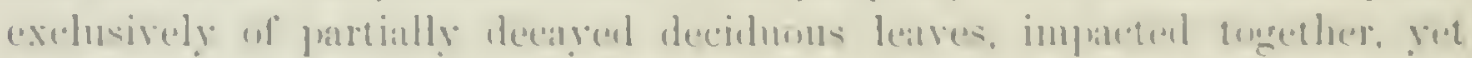

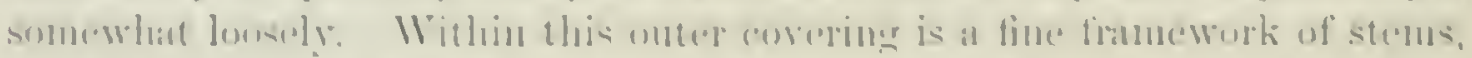

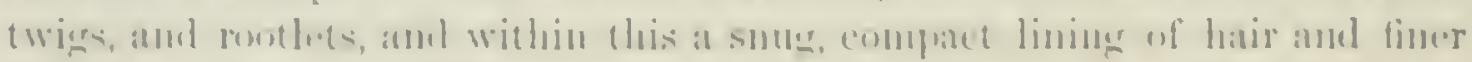

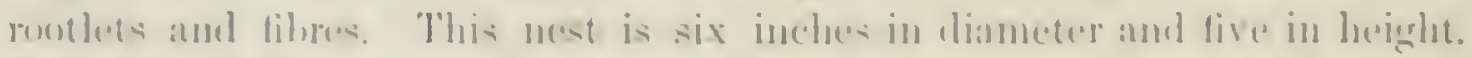
It conticined four cens.

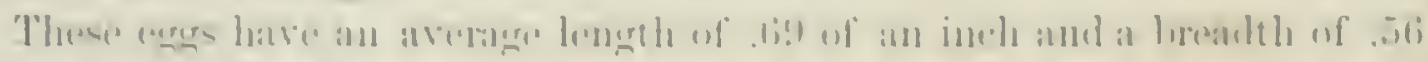

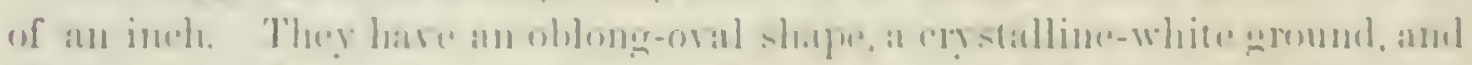

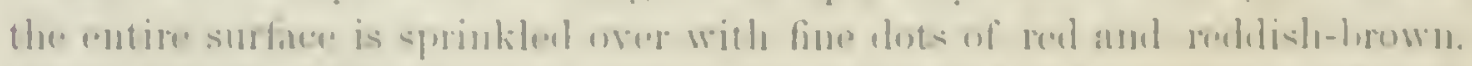

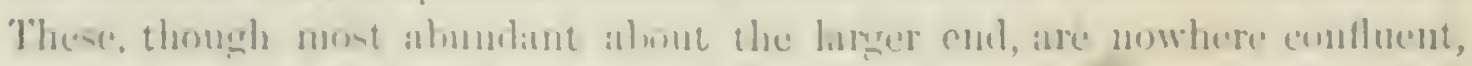
and de not form at crous 
A nest of this bird from Chester County, Penm., is a very flat structure, evidently built in a bed of fallen leaves. It has a cliameter of six inches and a height of only two. The cup is a mere depression only half an inch in depth. Its base is loosely constructed of dried leaves, upon which is interwoven a coarse lining of long, dry, and wiry rootlets and stems of plants. It was given to $\mathrm{Mr}$. J. P. Norris, from whom I received it, and it is now in the Buston collection.

Mr. Robert Ridgway furnishes the following valuable information in regard to the abmulance and general habits of this species as observed in sontherm Illinois: "It is a rery common summer bird in Sonthern Illinois, where it arrives in the Wahash Valley towards the last of April. It is a Wood-loring speeies, and of terrestrial habits, like the Seimrus unrocupill us, but generally frequents rather different situations from the latter bird, liking better the undergrowth of 'bottom' woods than that of' dry forests. In all its manners it closely rescmbles the Sciuri, especially the two anuatic specics, ludoriciunus and noreboracensis, having the same tilting motion of the body, and horizontal attitude when perching, so eharacteristic of these birds. The nest I have never found, though well aware of its actual situation. I knew of one somewhere among the 'top' of a fallen tree, but it was so well concenled that the closest search did not enable me to discorer it. In most cases the nest is probibly on the ground, among the rubbish of fallen tree-tops, or low brushwood.

"The usual note of this Warbler is a sharp tship, almost precisely like that of the Pewee (Sayomis fuscus), nttered as the bird perches on a twig near the ground, continually tilting its body, or is changed into a sharp rapid twitter as one chases another through the thichet. Their song is very pretty, consisting of a fine whistle, delivered very much in the style of the Cardinal Grosbeak (Curdinalis iringinianus), though finer in tone, and weaker."

Dr. Coues found this Warbler rare at Washington, and chiefly in low woods with thick undergrowth, and in ravines. They were very silent, but not shy, and a few breed there.

\section{SEctiox GEOTHLYPEA.}

\section{Gexts GEOTHLYPIS, Caban.}

Trichas, SwAxisox, Zoöl. Journ. III, July, 1527, 167 (not of Gloger, March, 1527, equal to Crinigcr, Temun.).

Geothlypis, CAs+sis, Wiegmam's Archir, 1sti, I, 316, 349.-Iв. Schomburgk's Reise, Guiana, 1StS.

Gex. Cust. Bill sylvicoline, rather depressed, and distinctly notehed ; rictal bristles rery short or wanting. Wings short. romded, scarcely longer than the tail; the first quill shorter than the fourth. Tail long; much rounded or graduated. Legs stont; tarsi elongated, as long as the head. Olive-green above, belly yellow. Tail-feathers immaculate. Legs yellow. 


\section{Synopsis of Species.}

Thronat yellow

\section{Siris $I$.}

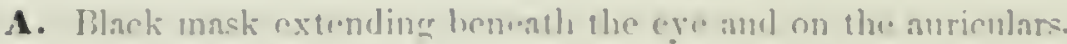

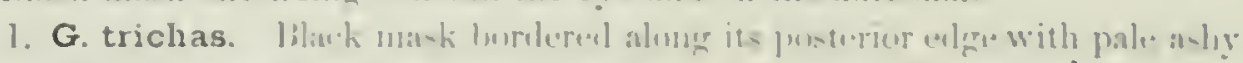

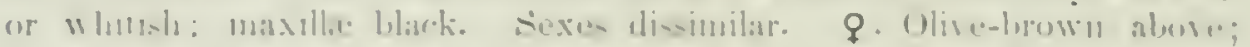

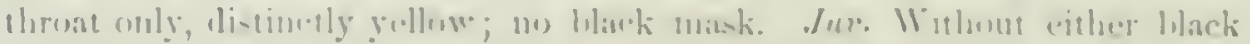

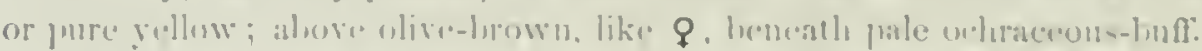

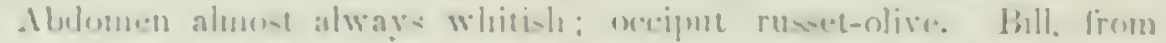

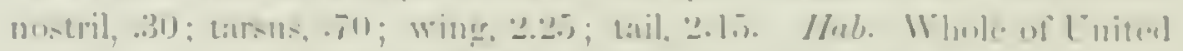

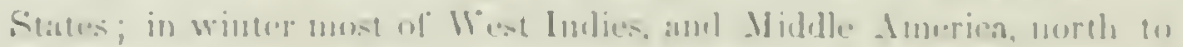
Gilistertiralit

var. trirlins.

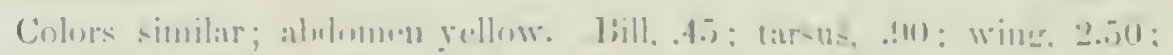

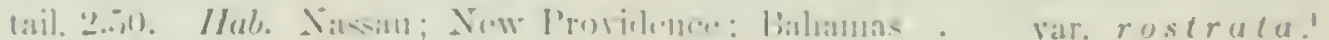
Aluhmon hright yellow; neciput whiti-h-a-htinged with vollow. Bill,

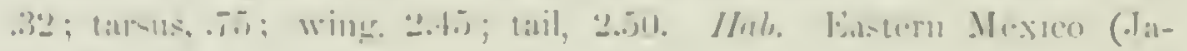

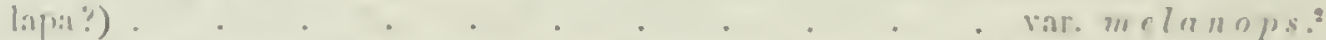

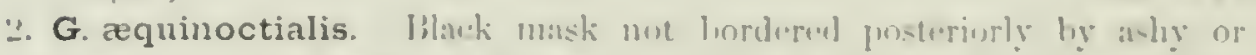

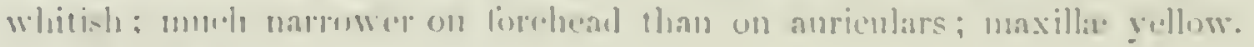
S.Xes similitr.

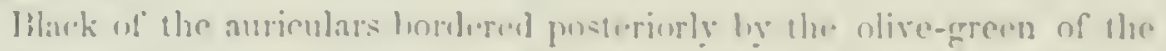

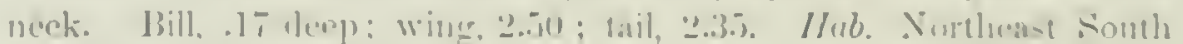

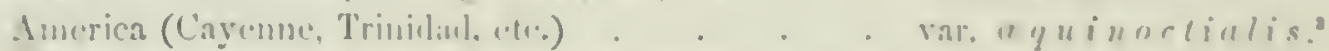

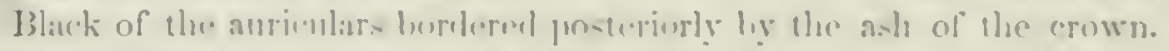

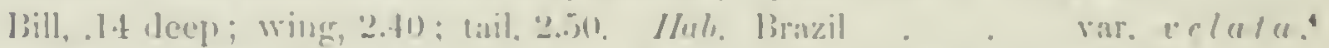

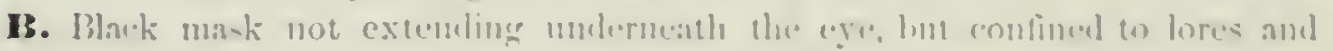
Irimell.1.

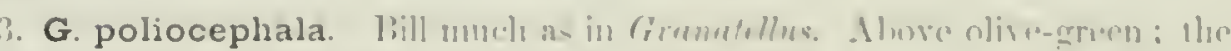

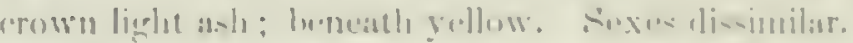

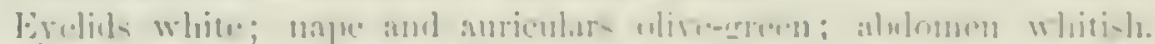

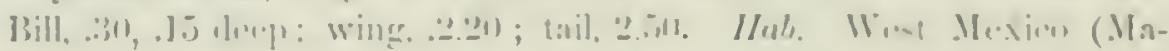

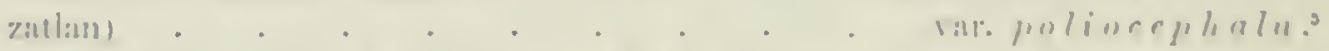

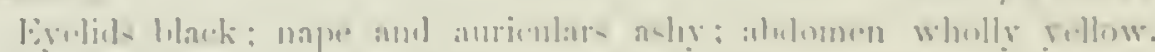

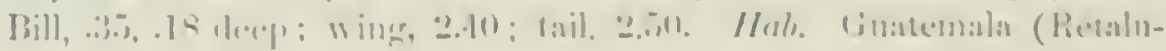
(1:11) var. ca niunclua? Sirrios 11 .

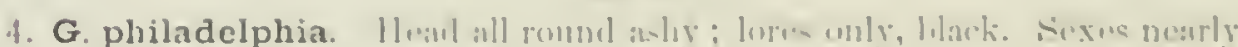
similir.

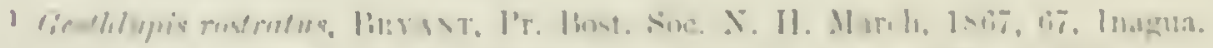

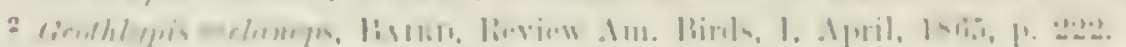

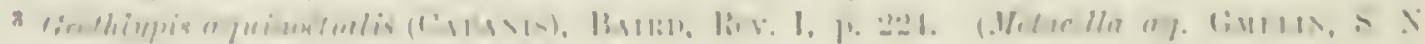
I. 1 - $19-2$

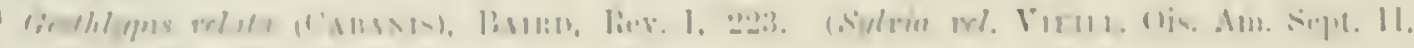
$141 \%, 2.2,10$. Iris.

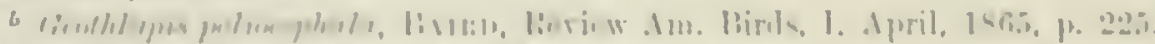

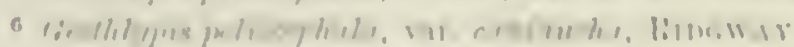

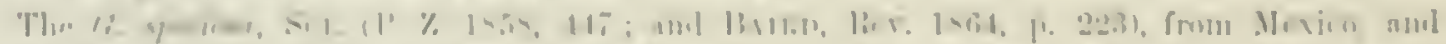

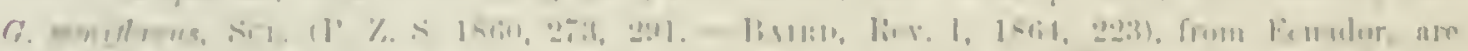

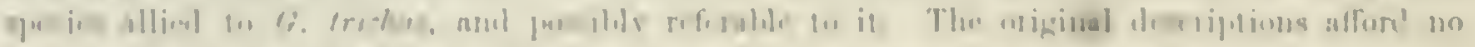

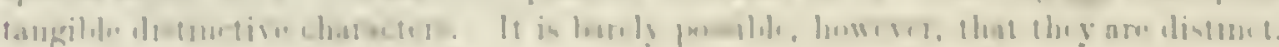


Evelids dusky (except in $\$$ ) ; a black pateh on jngulum of $\delta$. $\$$. Throat tingel with sellow. Hab. Eastern Prorince of 'Torth America: in winter south to lanama . . . . var. philadelphin. Evelids white; no llack pateh on jugulum. $\$$. Throat not tinged with sellow. Hab. Western and Middle Prorince of Lnited States: in winter south to Costa Rica (Western Coast) . rar. macgillivrayi.

\section{Geothlypis trichas, CABAs.}

\section{MARYLAND YELLOW-THROAT; BLACK-MASKED GROUND WARBLER}

Turdus trichns, Ltsx. S. I. 1760, 293. Sylvin trichas, LatrI.; AlD., etc. Genthlypis

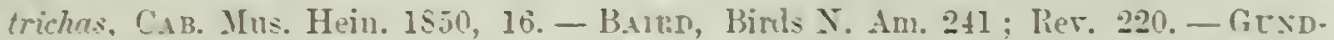
Lacil, Cab. Jour. 1861, 325 (Cuba). - Sclater, Catal. 1S61, 2i, no. 16i. - March, Pr. A. X. Sc. 1S603, 293. - Lor:D, Pr. R. Art. Inst. Woolwich, IV, 1864, 115 (I. W. Bomdery). -Joses, Nat. Bermuda, 29. - Sasitels, 205. - Cooper, Orn. Cal. I, 1570, 95. Sylria marilandian, Wilsox. Trichas mar. Box. Regulus mystacens, STEphexs. Trichas personatus, SwAlsox. Syltia roscoc, AtD. Trichas brachydactylus, swatss.

Other localities yuoted: Salapa, Daxaca, Cordora, Sel. Guatemala, Scl. \& S.ubr. Baha-

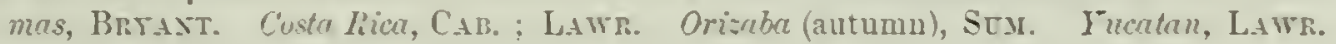

Figures: Vieill. Ois. II, pl. xxriii, xxix. - Atr. Orn. Biog. I, Il, V, pl. xxiii, cii, ccxl. - Wils. I, pl. vi, fig. 1. - Brffos, Pl. enl. 709, fig. 2.

S. Cr.tr. (No. $26.82 t \delta$.) Wings a little sloorter than the somerhat graduated tail. Bill slender, the deptls contained about two and a half times in distance from nostrils to tip. First quill about equal to serenth. Foreheal to abore the anterior edge of the ese, and across the entire cheeks, ears. and jaws, and ending in an angle on sides of neek. black. with a suffusion of hoary bluish-gray helius it on the erown and sides of neck: the occipital and nuchal region grayishbrown, passing insensibly into the olive-green of the upper parts. Chin. throat. jugulum, edge of wing and crissum riels vellow (the latter paler) : rest of under parts. witl lining of wings yellowish-white. the silles tinged

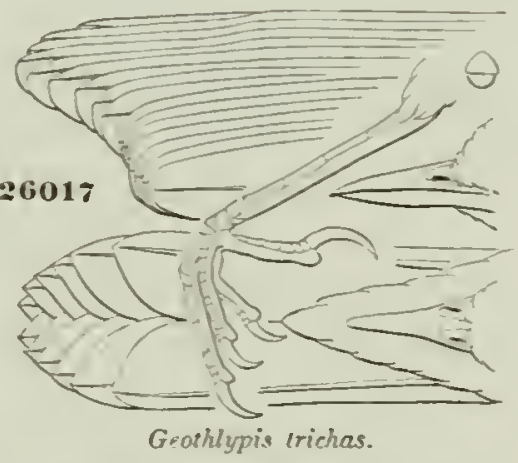
with brownish: outer primary edged with whitish, the others with olive-green. Bill black; legs rellowi.h. Total length, 4.40: wing. 2.15 ; tail, 2.30; graduation, .25: wilth of outer tail-feather, $.2 S$ : difference between first and third quills. .15; length of bill from forehead, .52 ; from nostril. .30 : along gape, .60; tarsus. . .5: mildle toe and claw. .66; claw alone, .IS: hind toe and claw. .t8; claw alone, 26.

Male in winter. anl the female. without the black mask: the forehead tinged with brown. the yellow of the throat less extended. the eyelids whitish, and a yellowish supereiliary line.

Hib. The whole Tnitell States, from Atlantic to Pacific, and south to Costa Rica ; Bermucla (October): Bahamas; Cuba ; Jamaica.

The roung bird is bromish-olive abore, becoming more rirescent on the rump and tail; evelids, and whole lower parts, soft light buft, with a faint tinge of yellow on the breast and lower tail-coverts.

There is very much variation manifested in a large series (containing more than one hundred and thirty specimens, principally North American), though 
lut very little that accurls with any distimetions of habitat. As a mole, howerer, those firm the Atlantic states are the smallest of the series, ami

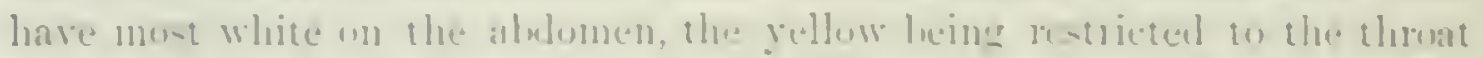

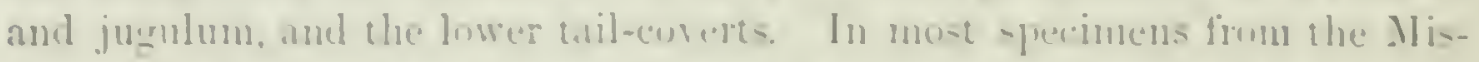

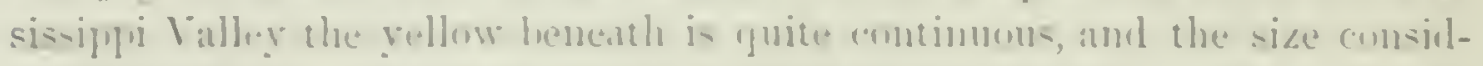

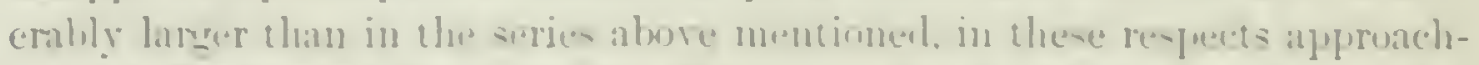

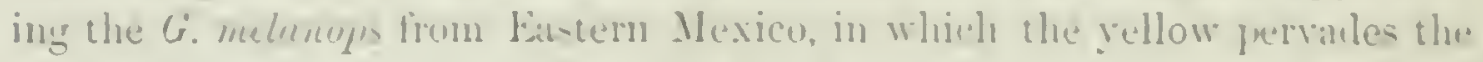

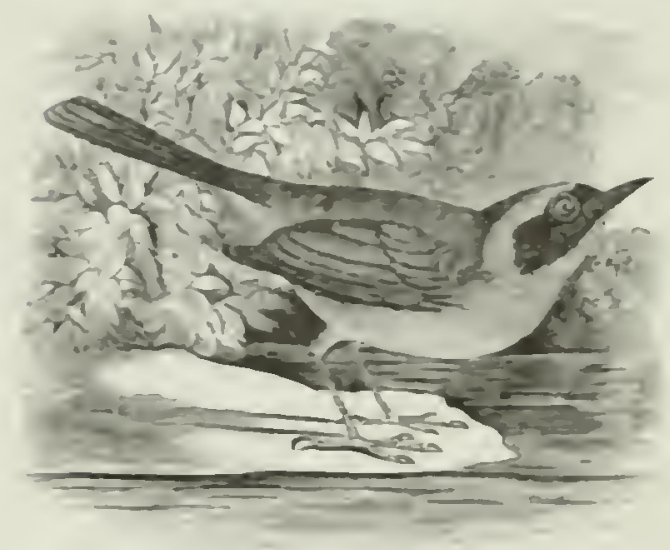

rie 2 thpis irichas. whole surface bencith: but in this the whiti-h lumler alume the hlaw mask is

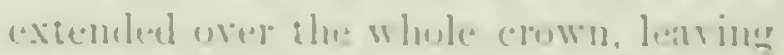
the male wnly distinctly hownish, and the size larred than the arerage of the erim allumeel 10. Ilowever, No.

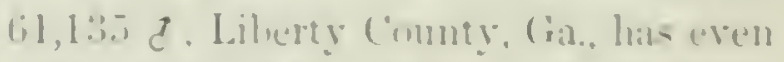
more white on topof the hestl, the whele nceipue leeinge of this color: while So.

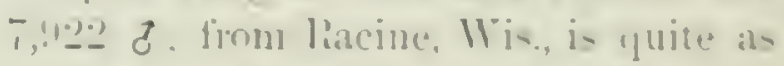
long as the tyge of molumeps the tail only. -lorier), and there is marly as much yellow heneath. The feorgia suecimen, howerer, in wher re-puets, is most like the dilantio strle. Squedusens from the l'acitic eoant have ju-t

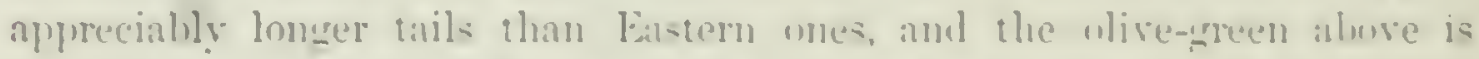

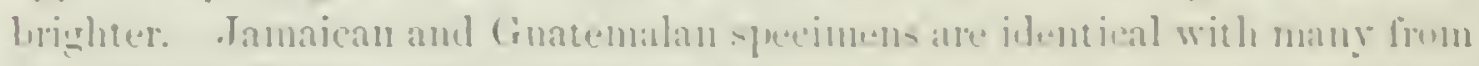

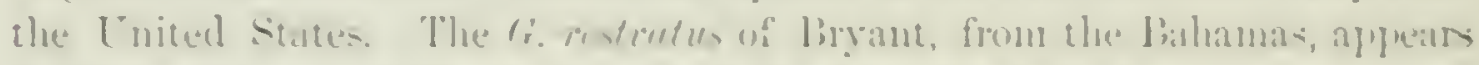

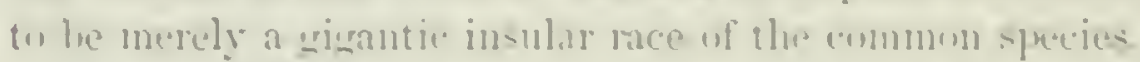

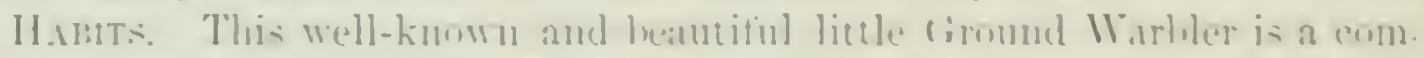

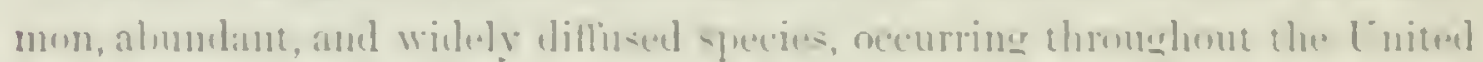

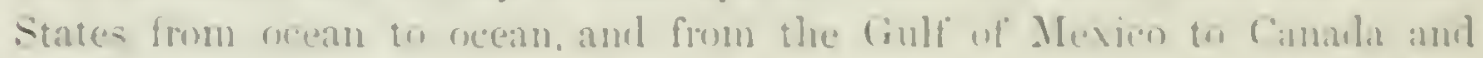

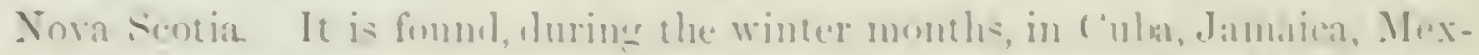
ico, Jueatan, Guatempla, Contal liven, the balauma, and, in the fall, in ling-

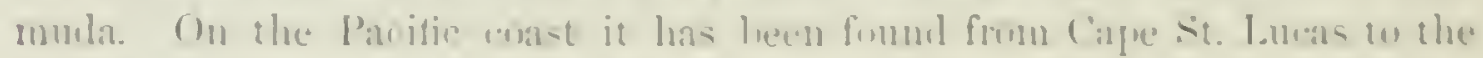

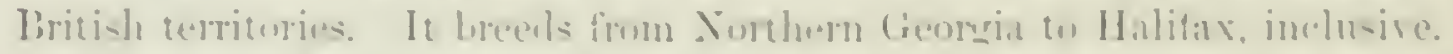

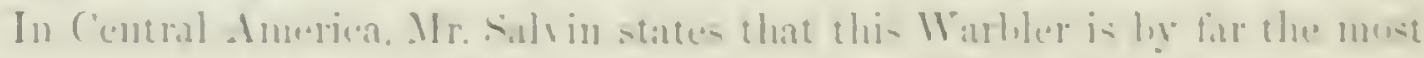

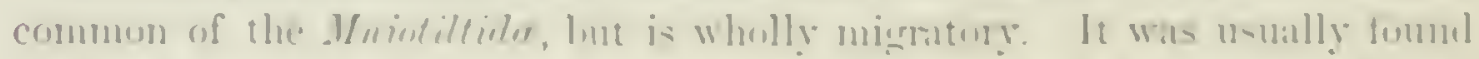

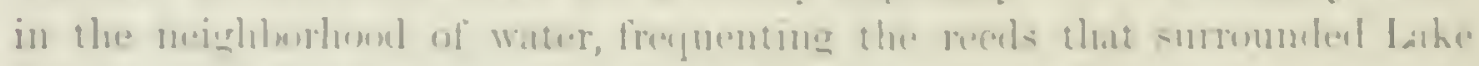

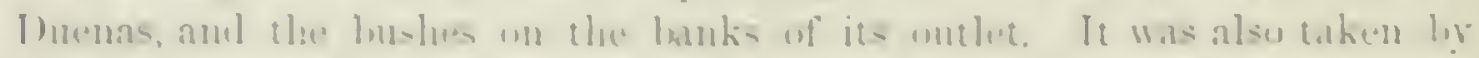

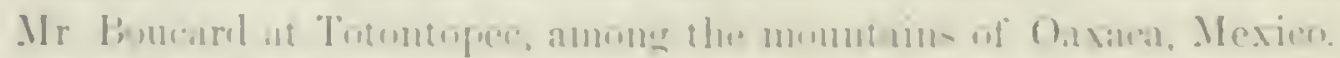

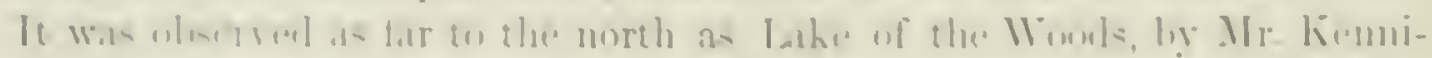

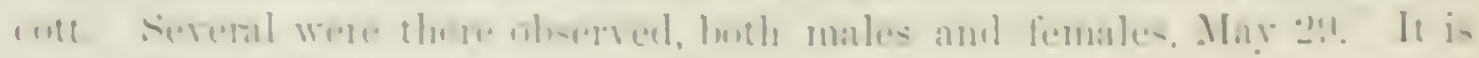

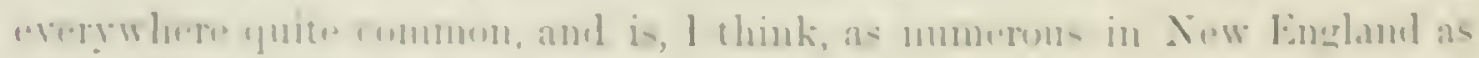

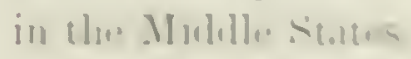

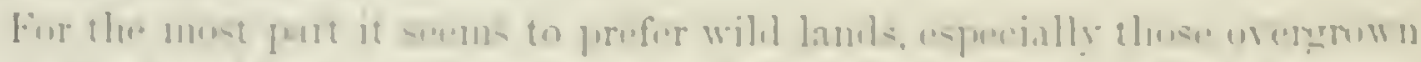

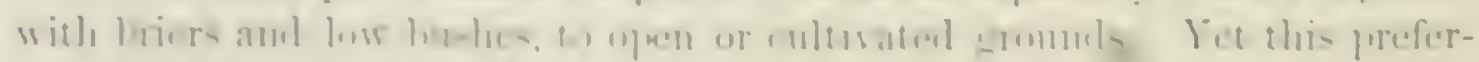

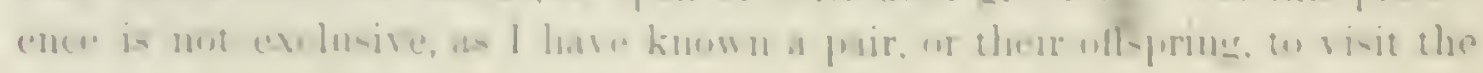


same garden nine or ten successive summers. It is also more generally found in low lands than in high, and is probably attracted to moist thickets of briers and underbrush by the greater abundince of its favorite food. 'This IV:urbler is eminently terrestrial in its habits, never being found among higher limbs, but always either on the ground or among the lower branches of bushes, vines, and weeds. It is a diligent rather than an active or nimble bird, is always on the move, and incessantly in search of its food. This consists of insects in all their forms, but more particularly of larve, small beetles, and spiclers. They are of great service in the destruction of several forms of injurious grubs, and but that their mode of life exposes them to destruction by prowling cats, I doubt not they would readily adapt themselves to living in our gardens. Occasionally they are found in fichs of grain, where their presence is due to the abundance of destructive insects.

The Tellow-Throat appears slyy and retiring because it prefer's to move back and forth anong low shrubs and brambles, where it most readily procures its food, but it is not a timid bird. They are unsuspecting, and will as readily permit as fly from the near presence of man. I have frequently had them approach within a few feet, especially when at rest; and even when in motion they will continue their lively song, as they move about from twig to twig. Though able to capture an insect on the wing, they are not expert flycatchers, and chieffy take their prey when it is at rest.

Their song is a rery lively and agreeable refrain, easily recognized, though exhibiting at times marked differences, and occasionally closely resembling the song of the Summer Yellow-Bird. The same brief series of notes, usually sounding like $u h i-t i-t \bar{e} \overline{-}-\bar{e} \bar{e}$, is constantly repented at short intervals, while the singer continues his perpetual hunt for insects.

The male is rery affectionate and deroted to botl mate and offspring. The pair are never far apart, and during incubation the male is assiduous in the collection of food, feeding its mate, and afterwards assisting in collecting for their young. They rely upon concenhent for the protection of their nest, and rarely show any open solicitude until it is discorered. Then they will make the most vehement demonstrations of alarm and distress, flying abont the intruder and fearlessly approaching him to within a few feet. In Massachulsetts they rarely, if ever, have more than one brood in a season. The young are able to take care of themselves carly in July. At that time the song of the male ceases, or is abbreriated to a single $u h i t$, and parents and young form a family group and together liunt in the more secluded thickets, the edges of woods, and otler retired places, for their food. Early in September they take their departure.

The Yellow-Throat is distributed, in suitable localities, orer a large area, and wherever found is apparently equally common. Dr. Gerhardt found it quite abundant in Northern Georgia. Wilson and Audubon thought it more common in the Middle States than farther north, but I have found it quite as numerous about Halifax and Eastport as I have at Washington. Dr. Cooper 
speats of it as "very commun" in Wishington Territory, thumgh not so

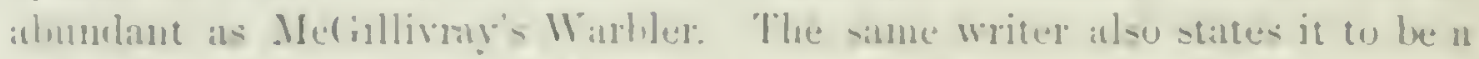

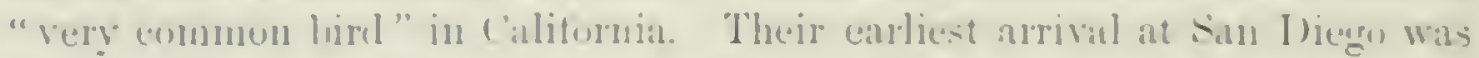
on the 1ith of Ipril, ahout the time they reach l'ennsylvania. There appear in Xew lingland eatrly in May.

Their nest is almost invariatily upon the ammud, ustally in a thich bet of fallen leaves, a clump of grass or weeds, at the ruots of low bushes or briers, or unter the shelter of at brush-pile. Oecasionally it las heen found amones high weeds, buile in a mathed elunter of hanchess four or five feet fron the aronnd. Sonnetines it is sunk in a depreajon in the armund, and often its top is covered ly lowse werlying leaves. I have never found this toj) interwosen with or forming any part of the nest itself.

The nest is usually hoth larese and deep for the size of the bird, its loose periphery of leaves and dry sedges adding to its size, and it often has a depth of from five to six inclues from its rim to its hase. The cavity is mally three inches deep aml two and a quarter wide. Cienerally these nests are constructed on a bite of dry leatres. An external lramework, rudely put to-

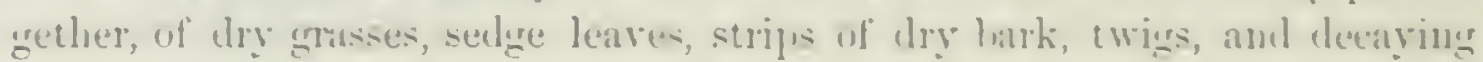
vegetables, covers an inner unest, or lining, of tiner materials, and more carefully woven. At the rim of the nest these materials sometines project like a rude pulisade or leedge. Lsually the lining is of tine grasses, without hair or feathers of any kind.

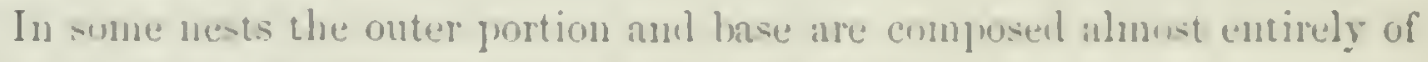
fine dry strips of the inner hath of the wild grape.

The egors vary from four to six in number, and alsu diller greatly in their size, so much so that the gluestinn has ari-ast if there are not two spectes,

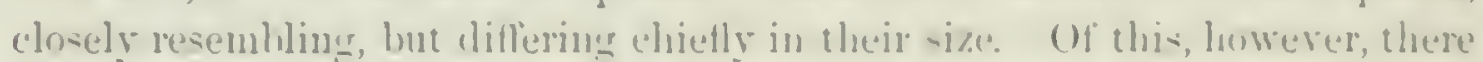

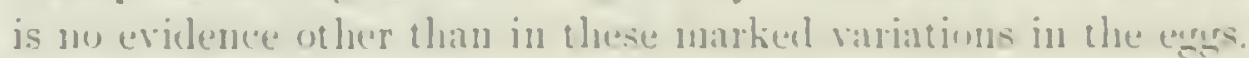

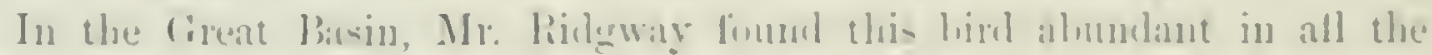
busly locenlities in the vieinity of water, but it was enntined fo the lower purtinns, mevere boing seen high up on the montain, ner even in the lower portions uf the munutain aturons.

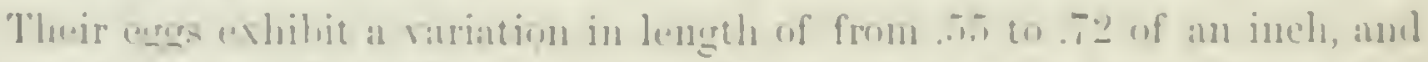

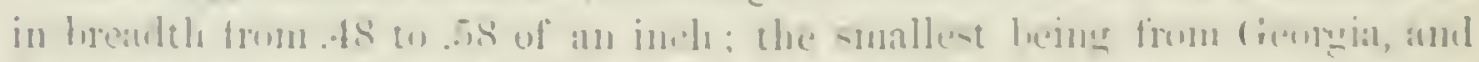

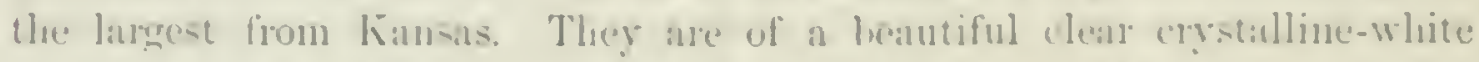

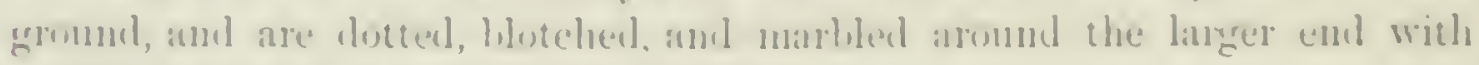
pur])le, redelislt-bruwn, and dark unber. 
Geothlypis philadelphia, Baris.

\section{MOURNING WARBLER.}

Sylvia philudelphia, Wils. An. Orn. 1I, 1510, 101, pl. xiv; Aln. ; Niтt. Triches phile-

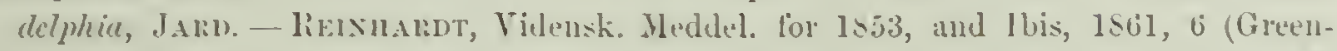

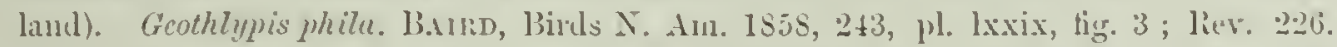

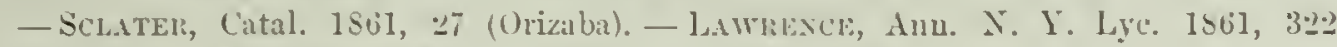
(Panama). - Sintres, 20\%. - Dresser, Ihis, 1s65, tiv.

Figures: Wils. Am. Orn. 11, 1l. xir. - Atv. Birds Am. I1, pl. ci.

SP. Cuar. Wings but little longer than the tail, reaching but little beyond its base. Adult meale. Heal and neck all round, with throat and forepint of breast, asli-gray, paler" beneath. The leathers of the chin, thoat, and fore breast in reality black, but with uarrow ashy margins more or less concealing the black, cxeppt on the breast. Lores and regron round the rye lusky. without any trace of a pale ring. I'pler parts and sides of the body clear olire-green; the under parts hright yellow. Tail-featlers uniform olive; lirst primary, with the outer hall of the outer web, nearly white. Female with the gray of the crowu glossed with olive; the chin and throat paler centrally, and tinged with fulvous; a dull whitish ring round the eye. Tangth, 5.50) wing, 2.45; tail, 2.25. Young not seen.

H.ı. Eastern Proviuce of [nited States to Britisl] America; Greenland ; Southeastem Mexico, Panama R. R., and Colombia. Not recorded from West Indies or Guatemala. Costa Rica (Liwr.).

Specimens vary in the amount of black on the jugulum, and the purity of the ash of the throat. The species is often confounded with Oporomis agilis, to which the resemblance is quite close. They may, however, be distinguished by the much longer and more pointed wings, and more even tail, shorter legs, etc., of ugilis. The white ring round the eye in the female philadelphia increases the difficulty of separation.

The adult male in autumn is scarcely different from the spring bird, there being merely a faint olive-tinge to the ash on top of the head, and the black jugnlar patch more restricted, being more concealed by the ashy borders to the feathers; the vellow beneath somewhat deeper.

H.rbits. The Ifourning Warbler was first discovered and described by Wilson, who captured it in the early part of June, on the borders of a marsh, within a few miles of I'hiladelphia. This was the only specimen he ever met with. IIe found it Hitting from one low bush to another in search of insects. It had a sprightly and pleasant warbling song, the novelty of which first attracted his attention. For a long while Wilson's single bird remained unique, and from its excessive rarity Bonaparte conjectured that it might be an accidental variety of the Tellow-Throat. At present, though still of unfrequent occurrence, it is by no means a doubtful, though generally a comparatively rare species. Audubon mentions having received several specimens of this Warbler, procured in the neighborhood of Philadelphia, New York, and Termont, all of which were obtained in the spring or summer months. He met with a single specimen in Louisima, and thinks its habits closely resemble those of the Maryland Yellow-Throat. 
Nittall met with what he presumes to have heen one ol these birds in the

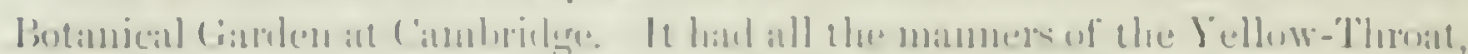

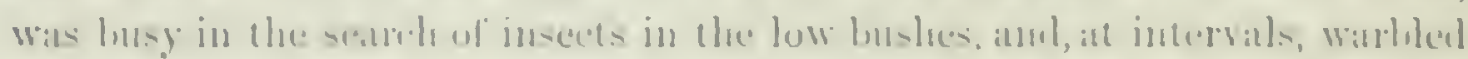

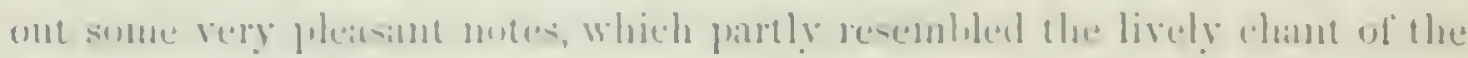

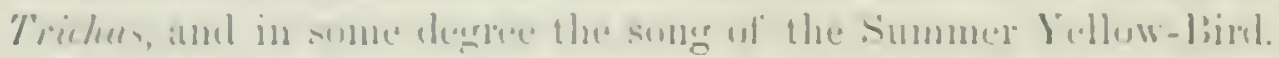

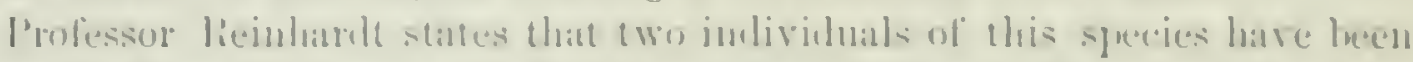

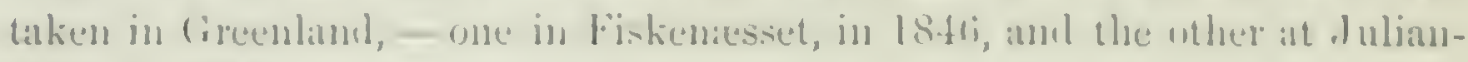
hash, in lis:o.

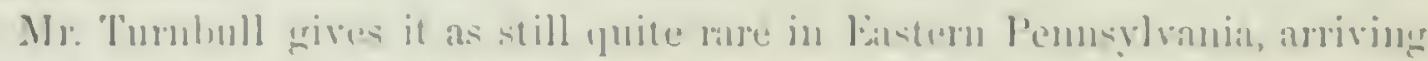

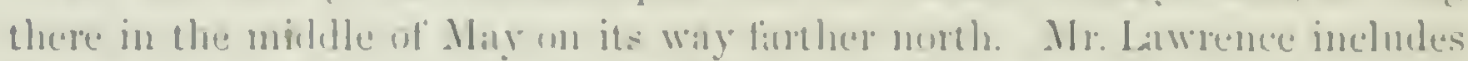

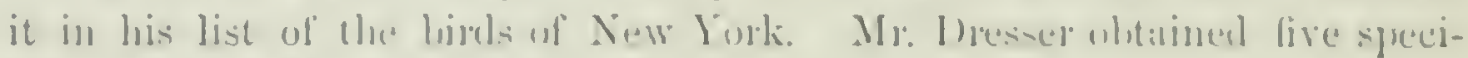
mens cinly in May, in somtlen Texils.

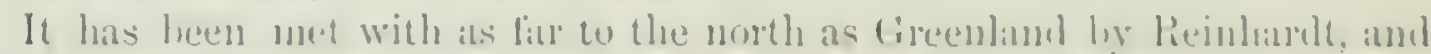

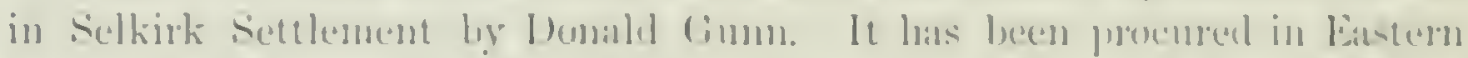

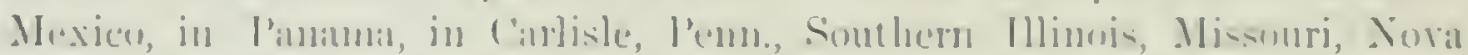

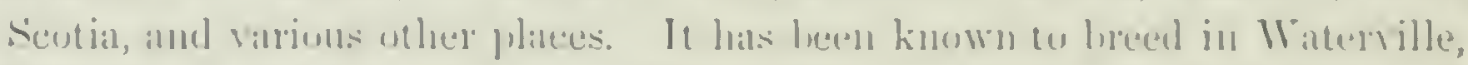
Me., and is not uncommon in Northwestern and Sorthern Now link. A

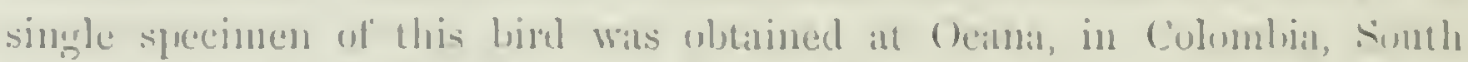
Americal, by Mr. ( 11 . Wyatt.

Late in May, Is:3s, I hatre a note of having met with this species in Mount

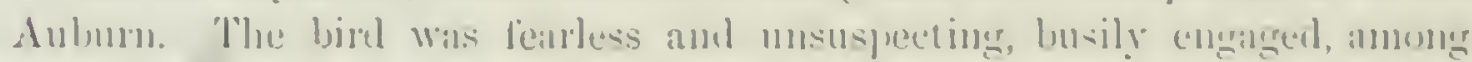

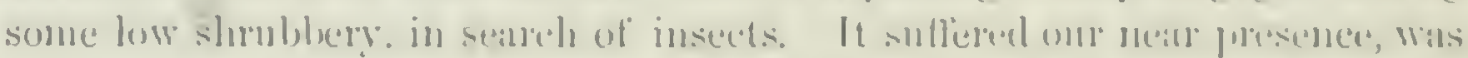
olten within a lew lect, and was sn readily distinguishable that my entmpan-

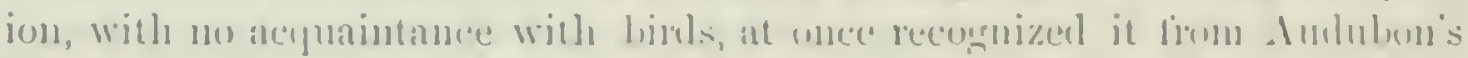
plates. Its habits were the exalct counterpant of these of the Jellew-Throat. We did mot motice its somer.

Mr. Marmart states that, May 2-1, Istib, Mr: Willian Brewster shot a male

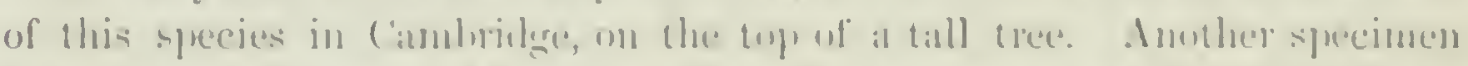

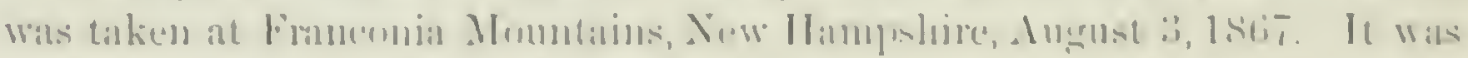

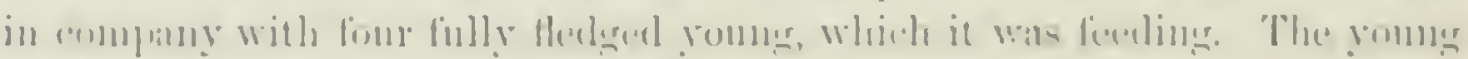

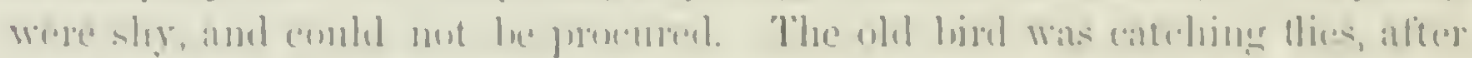

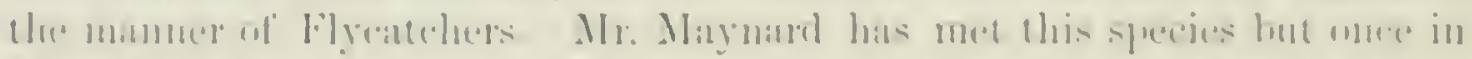

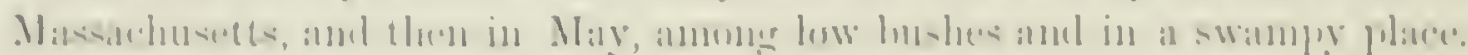

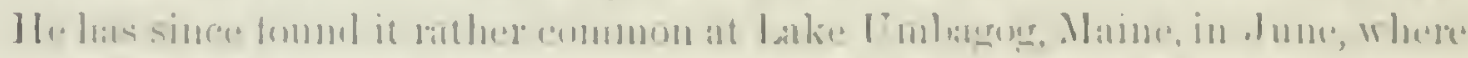

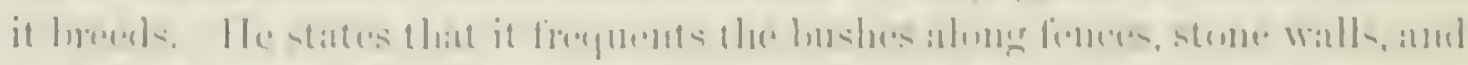

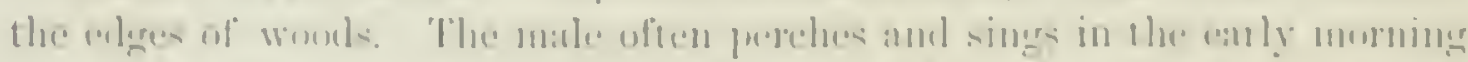

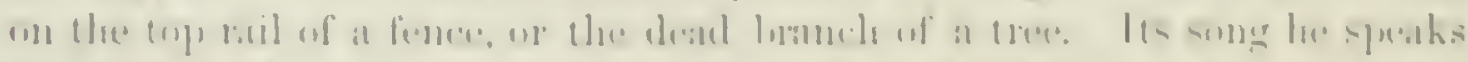

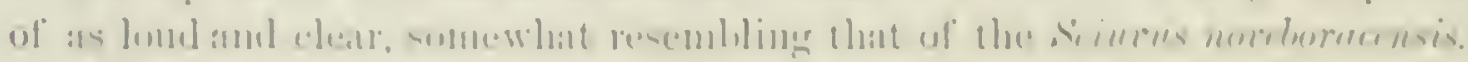

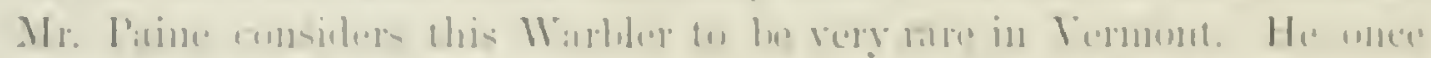

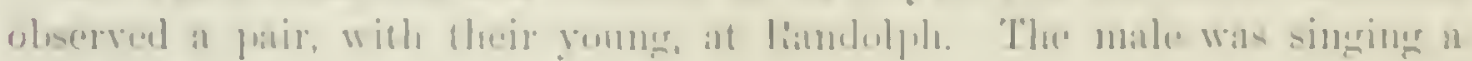

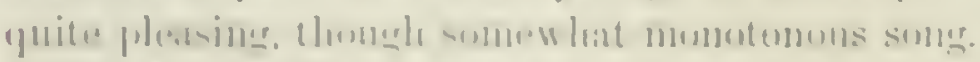

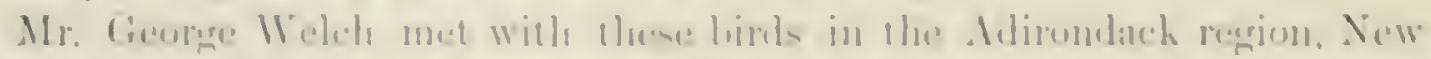

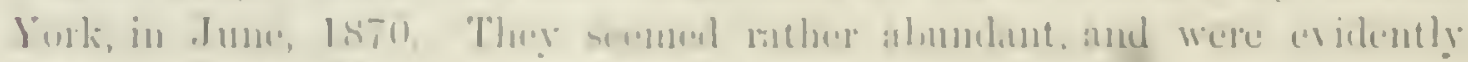

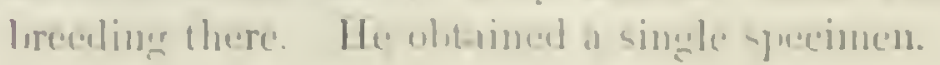


Mr. John Burrouglis, of Mashingtun, was so fortunate as to obtain the nest and eggs of this Warbler near the head-waters of the Helaware liver, in Roxbury, Delaware County, X. Y. "The nest," he writes me, "was in the edge of an old bark-peeling, in a lemlock wooul, and was placed in some ferns about one foot from the ground. The nest was yuite massive, its outer portions being composed of small dry stalks and leaves. The carity was very deep, and was lined with fine black roots. I have frequently observed this Warbler in that section. About the head of the Neversink and Esopus, in the northwest part of L'lster County, New York, they are the prevailing Warbler, and their song may be heard all day long. Their song sugrests that of the Kentuck Ground Warbler, but is not so loud and fine." Mr. Burroughs states elsewhere that "the eggs, three in number, were of light flesh-color, uniformly speckled witl fine brown specks. The carity of the nest was so deep that the back of the sitting bird sank below the edge."

Their eggs are of an oblong-oval shape, pointed at one end. They measure .75 by .5 .5 of an inch. Their ground-color is a pinkish-white, and they are marked with dots and blotehes, of rarying size, of dark purplish-brown.

\section{Geothlypis macgillivrayi, B.ıns. MACGILLIVRAYS GROUND WARBLER.}

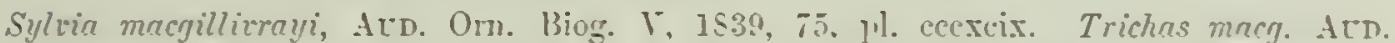

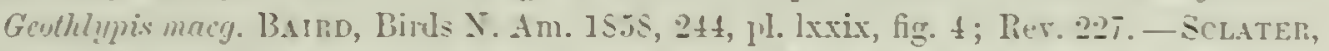
Catal. 1ミ6i1, 27 (Jalaja and Guat.). - IB. P. Z.S. 1559, 363, 373 (Xalaja, Oaxaca). -

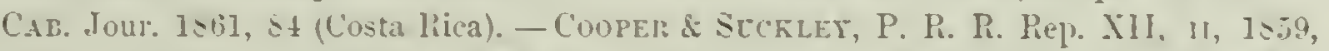
17т.-Cinopr, Orn. Cal. 1, 1siu. 96. Sylvicoln maey. Max. Cab. Jour. VI, 1s5s, 115. Sylria tulmiri, Towss. J. A. I. Sc. 1539. Trichas tolmiai, Nutr. Man. I.

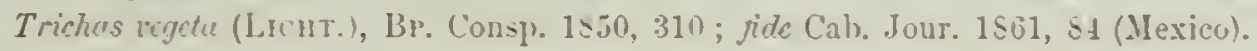

Sp. Crin. Adult male. Head and neck all round, throat and forepart of the breast, dark ash-color; a narow frontlet, loral region. and space round the ere (scarcely complete hehind), black. Tine eyelids above and below the eye (not in a continuous ring) white. The feathers of the thin, throat, and fore breast really black. with ashy-rray tips nore or less concealing the black. Rest of upper parts dark olive-green (sides under the wings palery; of lower, brigh jellow. Female with the throat paler and withont any black. Length of male, 5 inches; wing, 2.45: tail. 2.45. Foung not seen.

HAB. Western and Middle Provinces of Lnited States, to northern boundary; east to Fort Laramie; south to Costa Rica.

The white evelids of this species distinguish its males from those of $G$. philadelphia, in which there is a black jugnlar patch not seen in the present species. The females can only be known by the slenderer bill and more rounded wing, the first quill being intermediate between the fifth and sixth, instead of being considerably longer than the fifth.

The autummal adult male is as described abore, except that there is a faint tinge of green on the crown, and the ashy borders to feathers of throat and 
jugnlum l,ronder, eoncealing mure the biack. The adult fermale in autumn

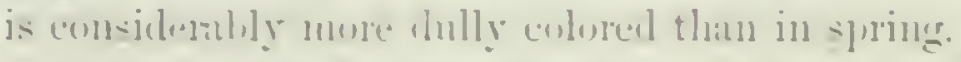

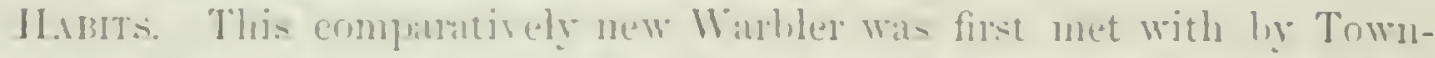

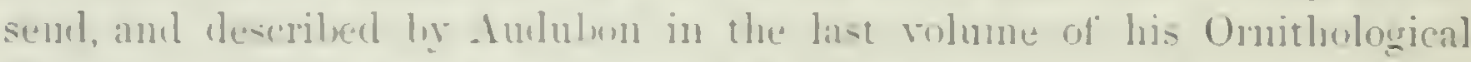

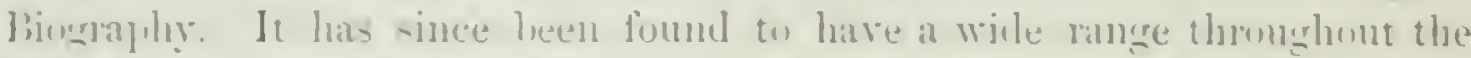
westem portion of Sonth America, from ('alue st. Lueas to british Ames-

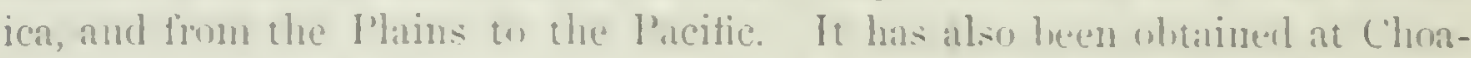
pan in the State of Orizala, Mexico, Ly Mr. Boncard, and in (Bnatemala hy Mr. Salvin, whu -tates that thrmishout the district hetween the voleannes of

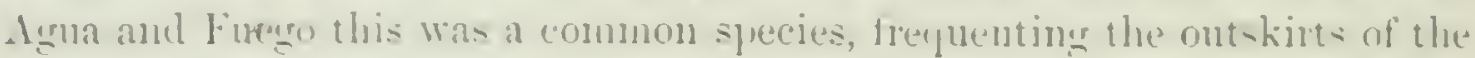

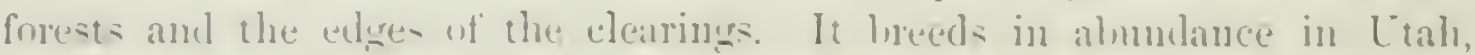
Montani, Wahw, Oregon, Washington Tenritury, and pmolnaly also in North(am California.

Townsend first met with it on the lanks of the Columbia. He states that it was mostly allitary and extremely wary, kepping chictly in the most inpenetrahle thickets, and grliding throngh them in a cantions and smepiecions manner. Sumetimes it might he seen, at midday. perched upon a deal twier, over its lavorite flaces of concealment, at such times warbling a very spujghtly and pleasant little song, raising its head until its bill is nearly vertical.

Mr. Nuttall iuformed Mr. Audubon that this Warther is one of the most

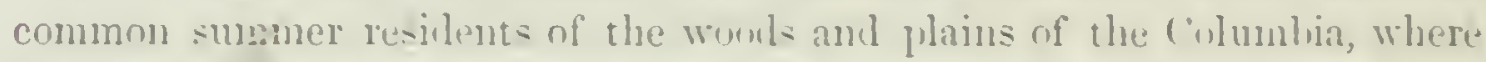
it appears early in May, and remains until the appwach of winter. It keeps near the gromul, and gleans its sulsistence among the low hushes. It is shy, and when surprised or clwely watelled it immediately skulk onl, often uttering a loud rlick. It a notes he states, resemble those of the simms

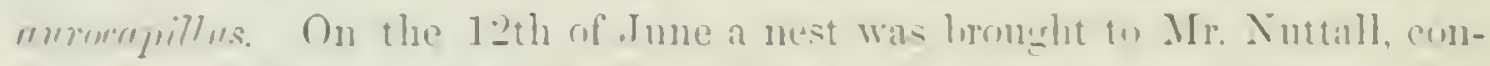
taining two romng hirds quite flectged, in the plumage of the mothers. The nest was chicefly mate of strijs of the inner hark of the Thuju orridentulis, linesl with slenter wiry stalks. It was lonilt near the ground in the dead,

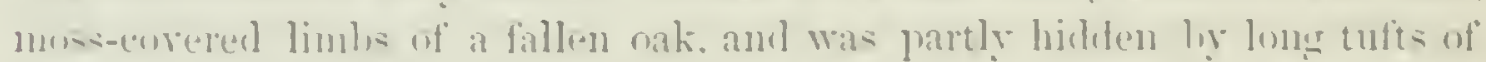
ushus. It was less artificial than the Yellow-Thruat's nest. But was of the simne general appearance. On his resturing the nest to its place, the parents

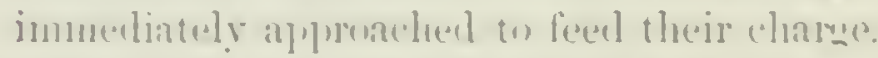

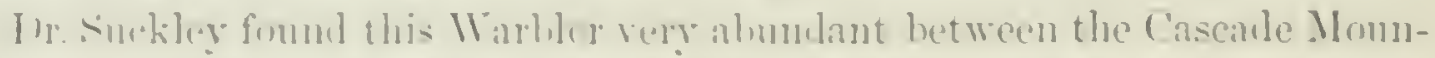

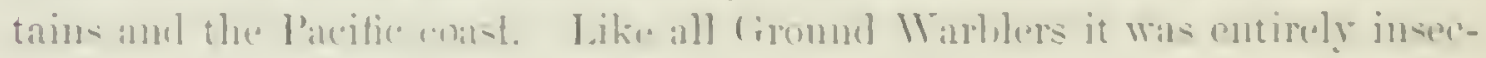

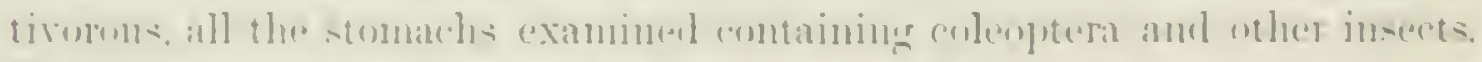

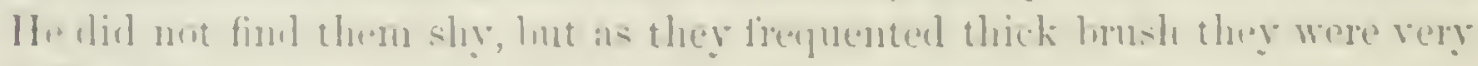
tiflinente to procure.

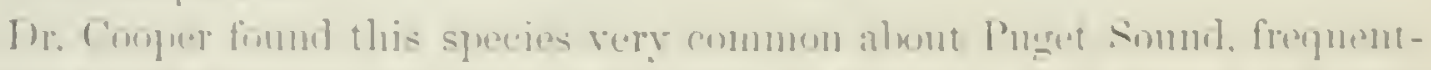

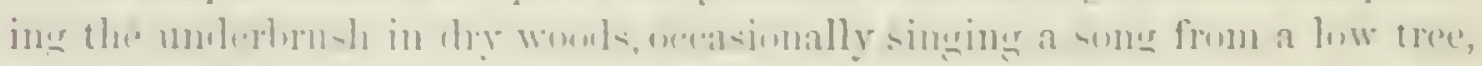

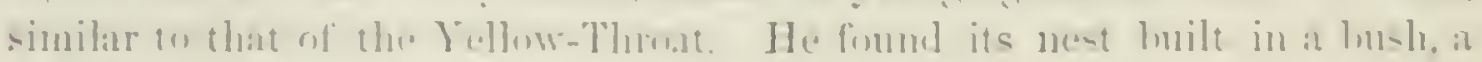

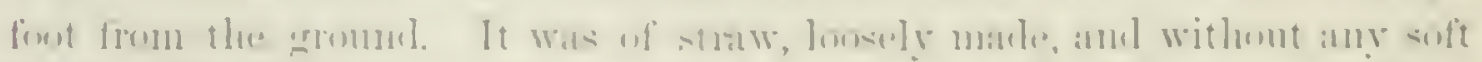

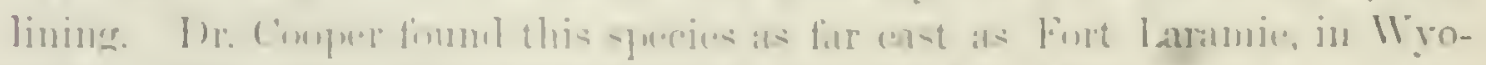

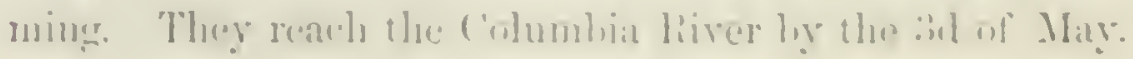


The same writer notied the first of this speeies at Fort Mrojave, Ipril :2t,

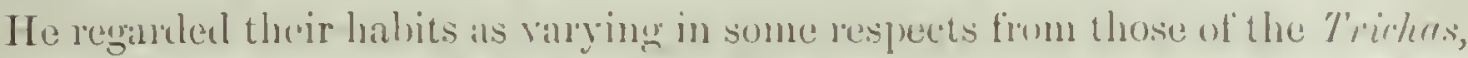
as they grefer ary locilities, and hunt for insects not only in low hushes but

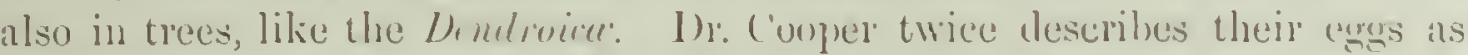
white, which is inaceminte. He thinks that some of them winter in the wamer portions of Califumia. He regints them ats shy, it watched, seeking the densest thickets, but lnemglit ont again by their curiesity il a person waits for them, and the birls will aplynouch within a tew feet, keeping up a scolling elinp.

The nests of this species ohtained by Dr. Kennerly from l'uget Somnd were all built on the oromme, and were constructed ilmost exclusively of beantifully delieate mosses, peeuliar to that country. They are shalluw nests, with a diameter of fom amb a leeght of two inches, the carity ocemping a lange proportion of the nest. Its walls and base are of mifonm thickness, averaring abont one inch. The nests ane lined with finer mosses and a few slemeler stems and filmes.

Mr. lidenay fomel these Warblers breeding in great numbers, fune 2:3,

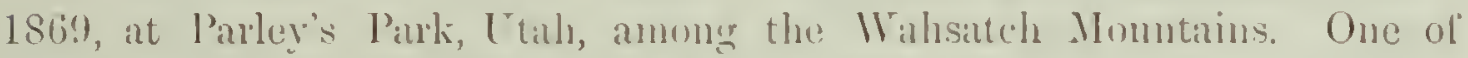

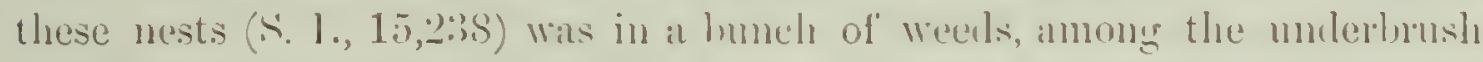
of a willow-thicket along a canon stream. It was situated alnout eight inches from the gromel,-is (mplike in shape, two inches in height, three in dianeter, and somewhat lousely construeted of slemler strips of birk, lecaryed stallis of" plants, hy grasses, intermixed with a few fine roots, ind lined with finer materials of the same. The eavity is one and a hall inches in depth, and two in dimeter at the rim.

The eggrs, four in number, are .7. of an inch in length and .jol in breath. Their gromel-color is a pinkish-white, mablerl and spotter with purple, like, reddish-hrown, and dink lown, appronching hlack. The hlotehes of the last color vary much in size, in one instance having a length of .21 of an inch, and having the appearance of hieroglyphies. When these spots are linge, they are very sparse.

"This species," Mr. Riderwy wites, "inhabite exrlusively the brushwool along the streams of the momitain canons and ravines. Among the weels in such localities numerous nesits were lound. In no wise were they on the gromen, thongh they were always near it; being fixed between upright stalks of herls, occasionilly, ferluaps, in a hrier, from about one to two feet above the ground. The note ol" the pratent hirl, when a nest was disturbed, was a strong chip, nuch like that of the Cymnospion remerun or $C$. "yanece." He also states that it was abmulant in the Fist Humboldt Momtains in Angust and in September, and also thrughont the smmmer. A pair of fully fledged young was caught on the 221st of July. 


\section{SHAML, I C T ER I A N 无。}

\section{SRTIO: ICTERIE}

In this section there are two American ardnern; one found in the Lnited States, the wher not. The diagnuses are as bollows:-

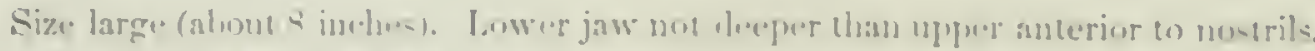

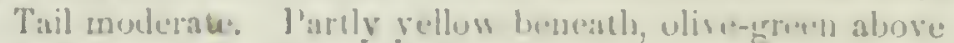

Interin.

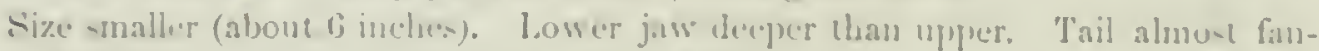

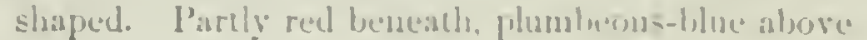

Giennatellus.'

\section{(HAT'S ICTERIA, VIFHL}

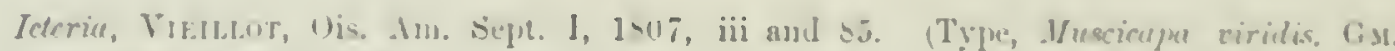
Turdus vircus, Liss.)

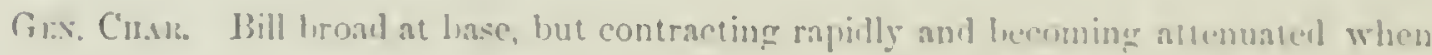

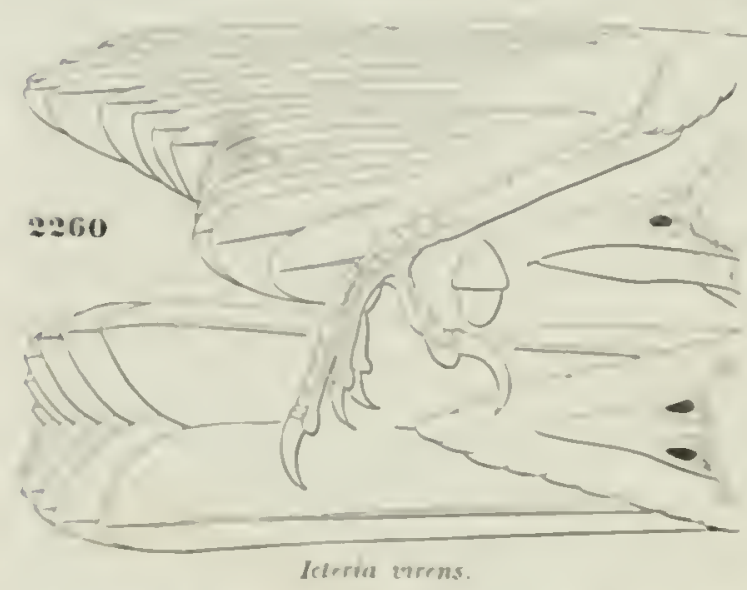

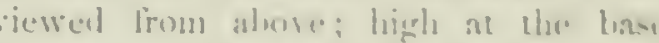

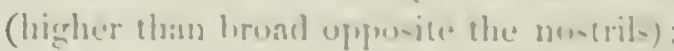

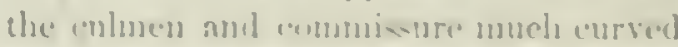

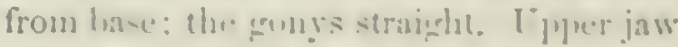
levener than bse hwor: bill w ithome not.h

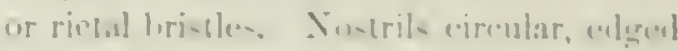

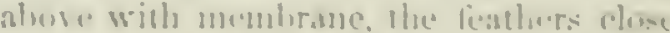
to eheir burders. Wime shorler than teil.

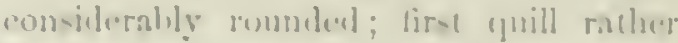
-horcer than the sixth. 'Tail mulurately

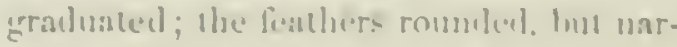
row. Milllle tor willume elaw alume

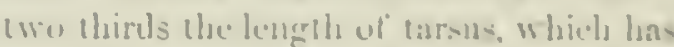
the scutelle fundel exlermally in part into one plate.

The precise spstomatic justion of the gemus leterin is a matter of much

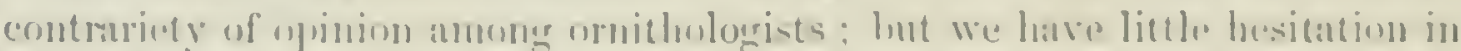

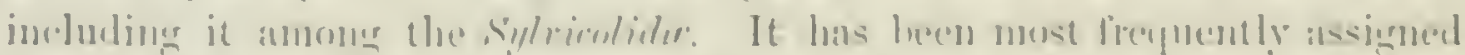

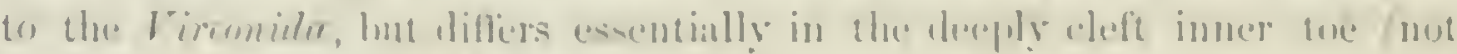

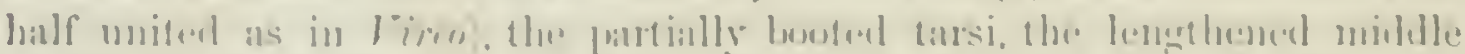

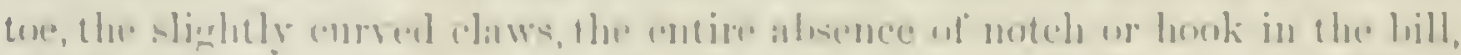

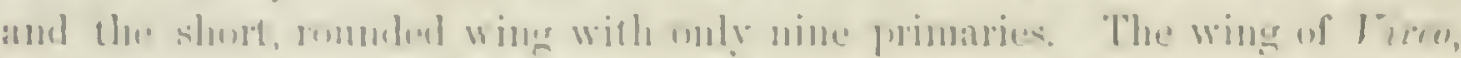

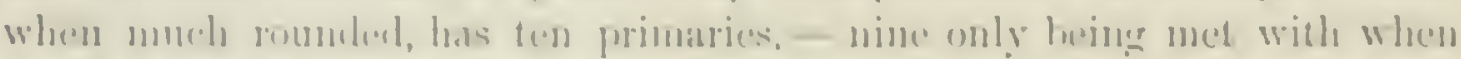

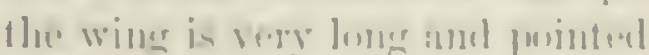

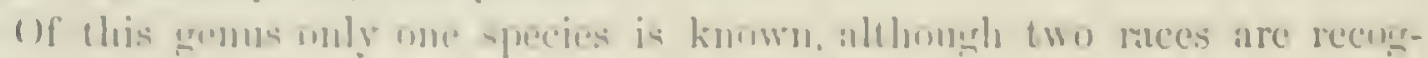

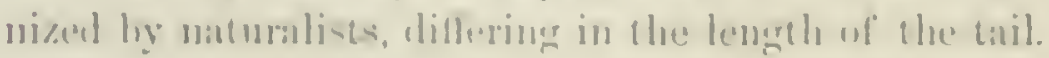

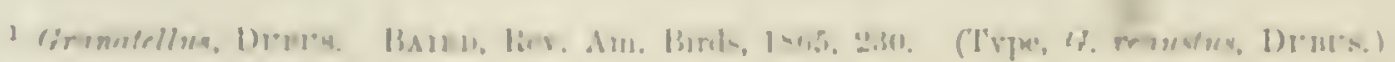


I. virens. Abore olive-green; beneath gamboge-yellow for the anterior half, and white for the posterior. A white stripe over the eyc.

Length of tail. 3.30 inches. Hab. Eastern United States to the Plains; in winter through Lastern Mexico to Guatemala rar. lirens. Length of tail, 3.70 inches. Hab. Westem United States from the Plains to the Pacific; Western Mexico in winter .

rar. longicauda.

\section{Icteria virens, BaIRD.}

\section{YELLOW-BREASTED CHAT}

Turdus vircus, Lixx. Syst. Nat. 10th el. 1758, 171, no. 16 (based on Euanthe americana, pectore lutco, Yellow-breasted Cliat, CatesBr, Carol. 1, tab. 50). Icteria vircus, l3aniI, Rer. An. B. 1S64, 22S. ILuscicupa viridis, GMELIx, Syst. Nat. 1, 17S8, 936. Ieteria viridis, Bux. ; Acn. Orll. Biog. II, pl. cxxxvii. - BAlnd, Birds N. An. 1858, 245. Ictevia dumccola, Vifull. Pipra molyglottu, WiLs. ! Icteriu vclasquczi, Bos. P. Z. S. 1S37, 117 (Mexico). - Schater \& S.1.Y. Ibis, I, 1S59, 12 (Guatemala).

Localities quoted: Coste Pial, CABax. Orizaba (winter), Srs. Irucatan, LAwr.

Sp. Citsr. Third and fourth quills longest ; second and fifth little shorter : first nearly equal to the sixth. Tail graduated. Upper parts uniform olive-green; under parts, including the insicle of wing, gamboge-yellow as fur as nearly half-way from the point of the bill to the tip of the tail; rest of nuler pants white, tinged with brown on the sides; the outer side of the tibia plumbeous; a slight tinge of orange across the breast. Forehead and sides of the head ash, the lores and region below the eye blackish. I white stripe from the nostrils over the eye and involving the upper eyelid; a pateh on the lower lid, and a short stripe from the side of the lower mandible, and rumning to a point opposite the hinder border of the eye, white. Bill black; feet brown. Female like the male, but smaller; the markings indistiuct; the lower mandible not pure black. Length, 7.40; wing, 3.25; tail, 3.30. Nest in thichets, near the ground. Eggs white, spotted with redlish.

Hab. Eastern United States, west to Arkansas; rare north of Pennsylvania ; south to Eastern Mexico and Guatemala. Not noticed in West Indies.

Both sexes in winter apparently lave the base of lower mandible light-colored, the olive more brown, the sides and crissum with a strong ochraceous tinge. It is this plumage that has been recognized as $I$. velasquezi.

Habits. The Yellow-breasted Chat is found throughout the Eastem Lnited States, from-Massachusetts to Florida, and as far to the west as Fort Riley and Eastern Kansas. Mr. Say met with it among the Rocky Mountains as far north as the sources of the Arkansas. It is not very rare in Massaclusetts, but a few breed in that State as far north as Lymm. It has been found in Mrexico and Guatemala, but not, so far as I am aware, in the West Indies.

Probably no one of our birds has more distinctly marked or greater pecu-

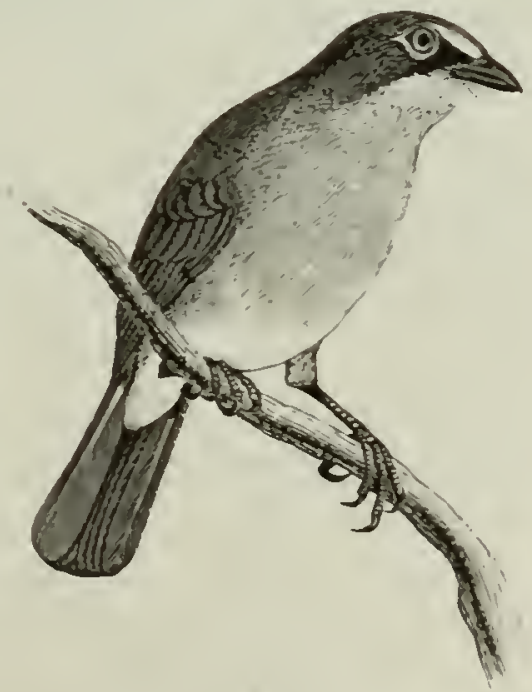

Icteria virens. 


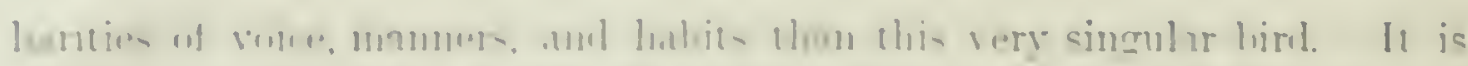

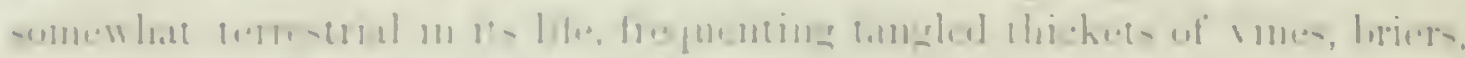

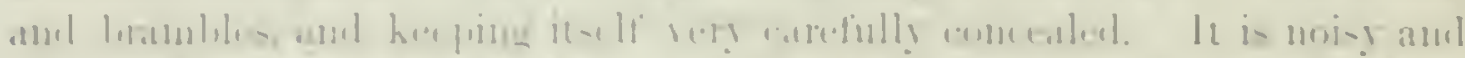

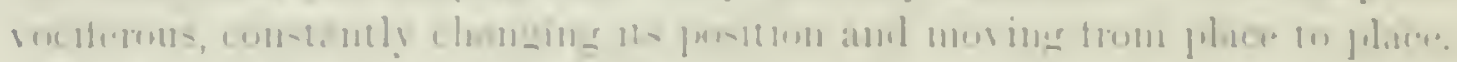

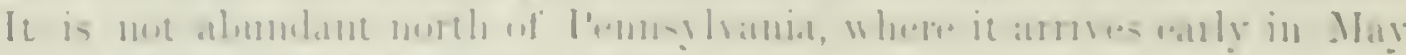

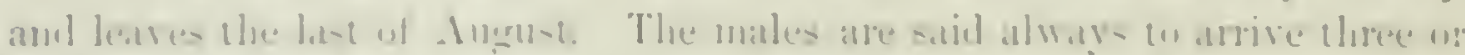

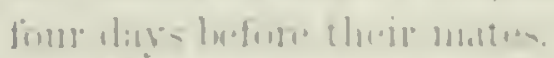

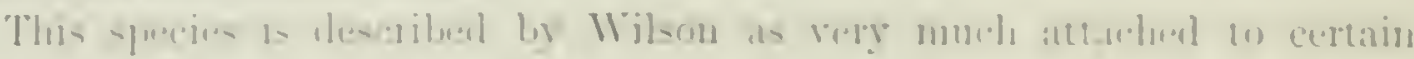

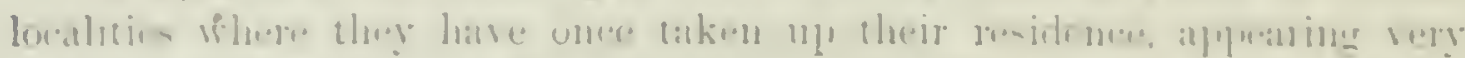

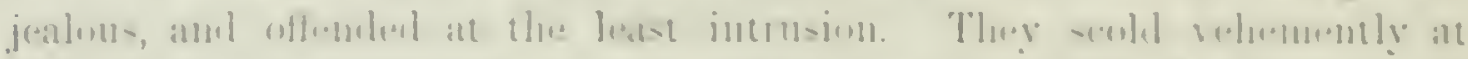

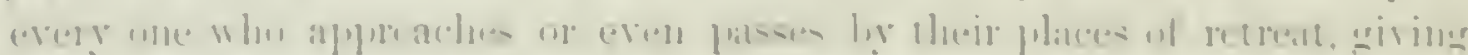

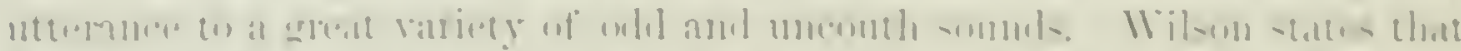

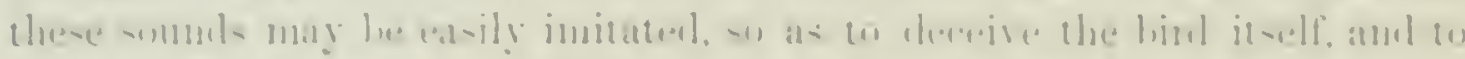

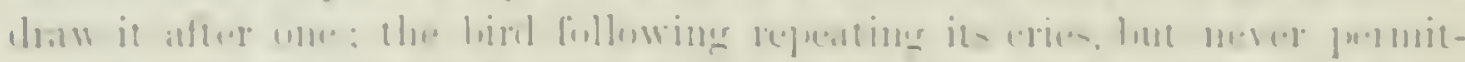

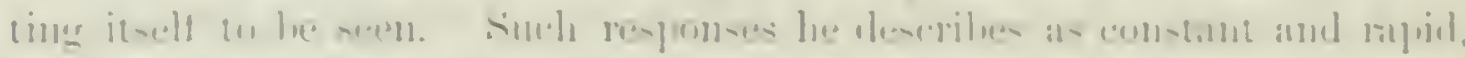

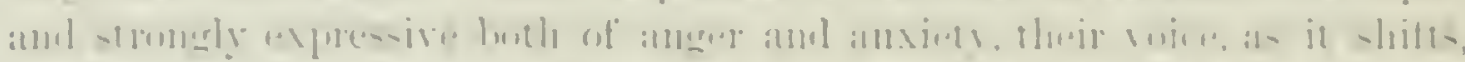

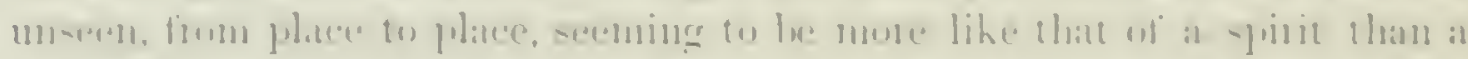

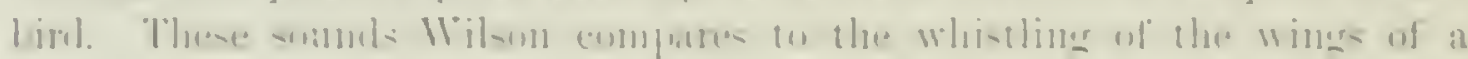

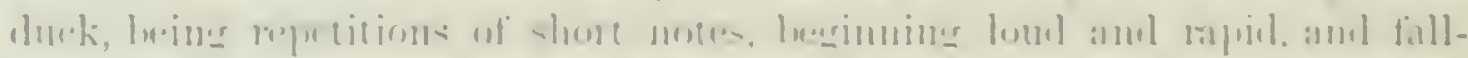

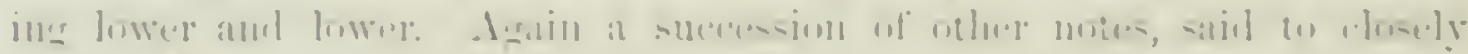

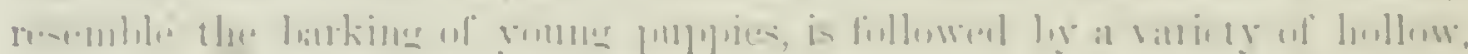

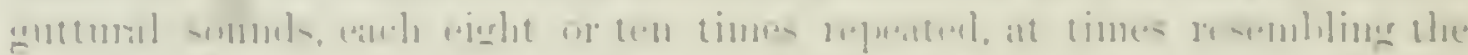

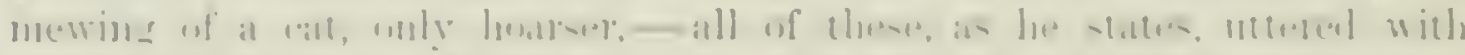

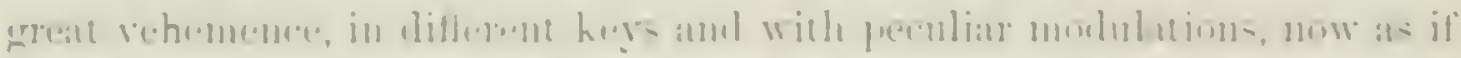

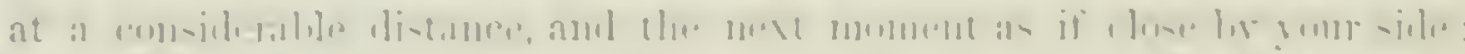

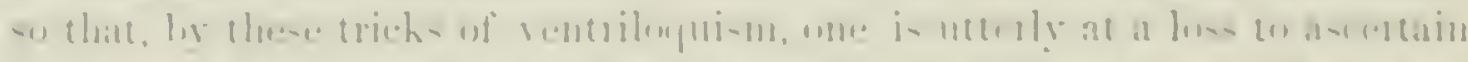

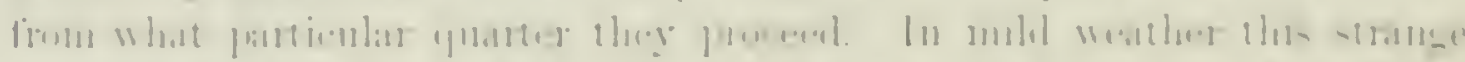

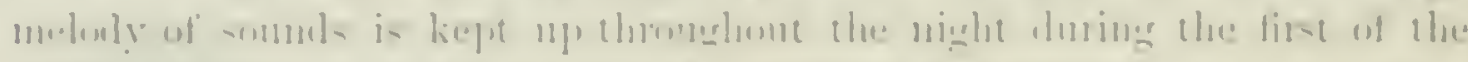

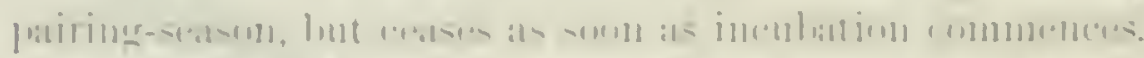

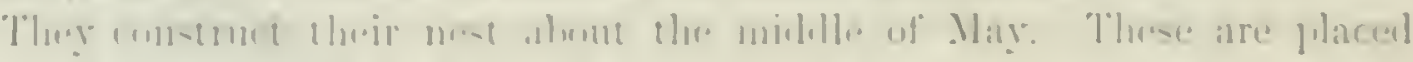

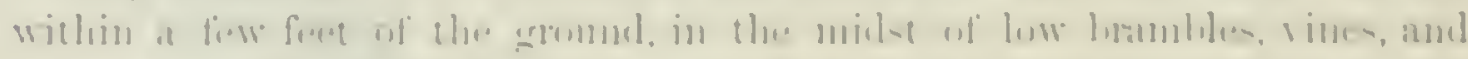

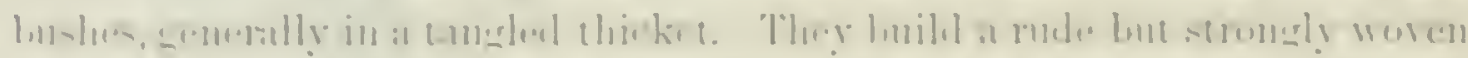

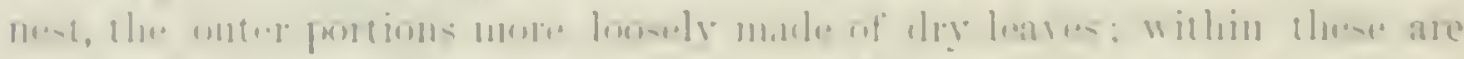

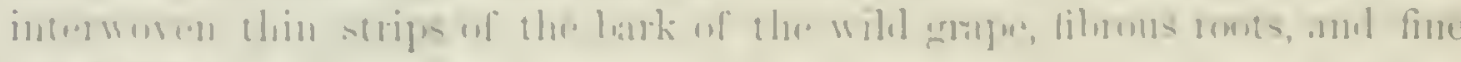

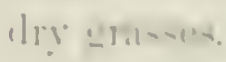

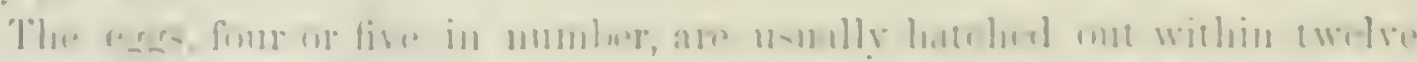

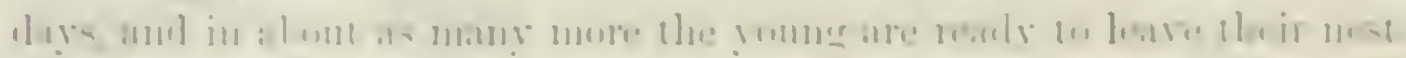

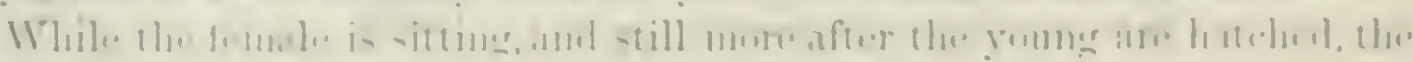

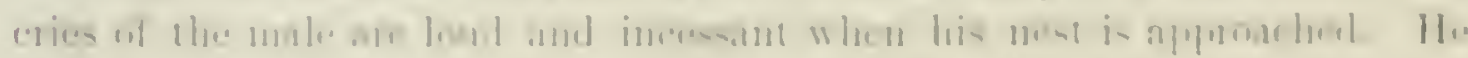

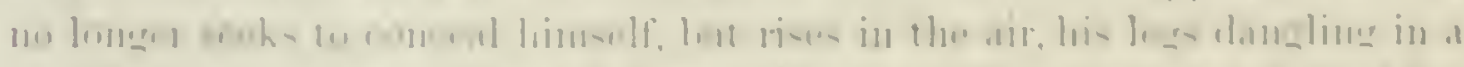

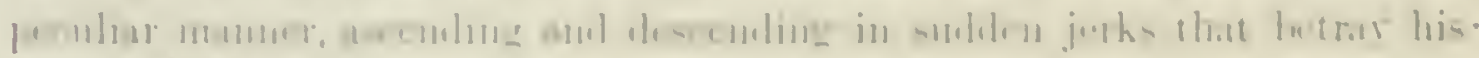

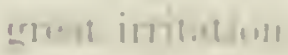

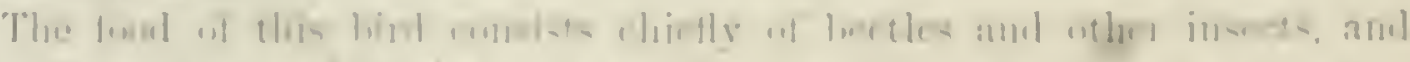

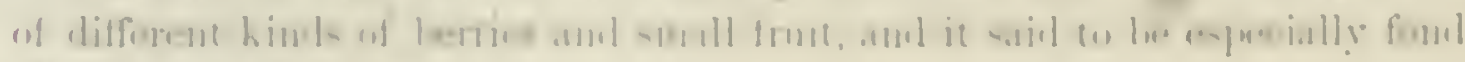

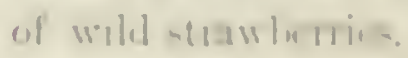


Audubon states that in their migrations they move from bush to bush by day, and frequently continue their march by night. Their flight at all times is short and irregular. He also states that when on the gromul they squat. jerk their tails, spring on their legs, and are ever in a state of great actirity. Although the existence of this bird north of Pemsylvania is generally disputed, I have no doubt that it has always been, and still is, a constant visitor of Massachusetts, and has been found to within a score of miles of the New Hampshire line. Among my notes I find that a nest was found in Brookline, in 1852, by Mr. Theodore Lyman; in Danvers, by Mr. Byron Goodale; in Lynn, by Messrs. Tickary and Welch; and in many other parts of the State. It certainly breeds as far sonth as Georgia on the coast, and in Lonisiana and Texas in the southwest. On the Pacific coast it is replaced by the long-tailed variety, longicauda.

A nest of this species from Concord, Mass., obtained by Mr. P. P. Mann, and now in the collection of the Boston Natural History Society, has a diameter of four inches and a height of three and a half. The carity has a depth of two and a quarter inches, and is two and a half wide. This is built upon a base of coarse slieleton leares, and is made of coarse sedges, llied grasses, and stems of plants, and lined with long. dry, and wiry stems of plants, resembling pine-needles. Another from Pomfret, Comn., obtained by Mr. Sessions, is a much larger nest, measuring five inches in diameter and three and three quarters in height. The cup is two and a half inches deep by three in width. It is made of an interweaving of leaves, bark of the grapevine, and stems of plants, and is lined with fine, long wiry stems and pine-needles.

Their eggs are of a slightly rounded oval shape, vary in length from .S5 to .95 of an inch, and in breadth from .65 to .70 . They have a white ground with a very slight tinge of yellow, and are marked with reddish-brown and a few fainter purplish and lilac spots.

Icteria virens, var. longicauda, LAwk.

\section{LONG-TAILED CHAT.}

Icterice longicauda, LAwrFxeE, Amn. X. Y. Lye. VI, April, 1853, 4. - B.tro, Birds N. Am. 1\&58, 249, pl. xxxir, fig. 2 ; Rer. 230. - Scudrer, Catal. 42, no. 253. - Fissrit, Abl. Nat. Brem. 1S70, 331 (Mazatlan). - Cuoper, Orn. Cal. 1, 1s70, 9S. ? Ictcria auricollis (Licht. Mus. Berl.), Bos. Consp. 1850, 331.

SP. Char. Similar to var. virens. Fourth quill longest; third and fifth shorter ; first shorter than the serenth. Abore ash-color, tinged with olive on the back and neck; the outer surface of the wings and tail olive. The under parts as far as the middle of the belly bright gamboge-yellow, with a tinge of orange'; the remaining portions white. The superciliary and maxillary white stripes extend some listance behind the eye. Outer edge of the first primary white. Length, 7 inches; wing, 3.20 ; tail. 3.70.

Young (8.841. Loup Fork of Platte, August 5: F. T. Hayden). Abore light grayish- 


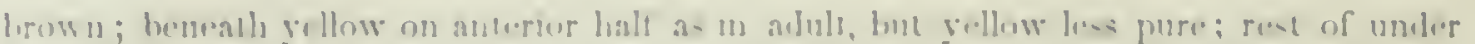

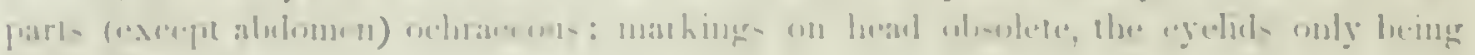
lis-linells whise.

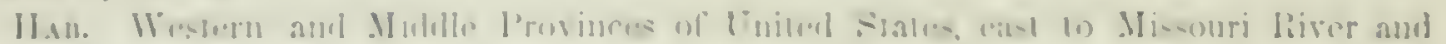

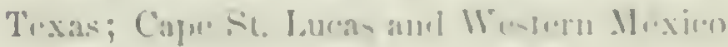

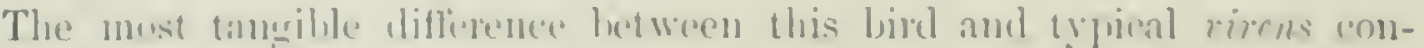

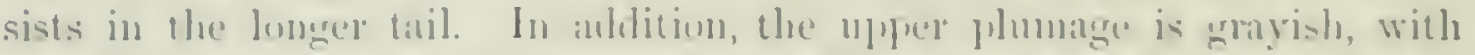

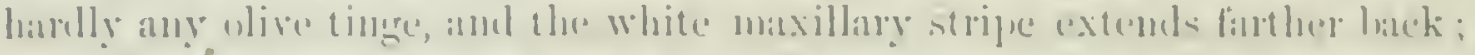

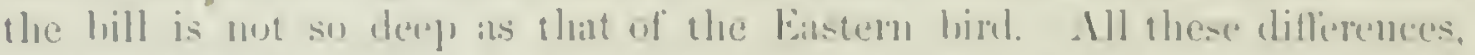

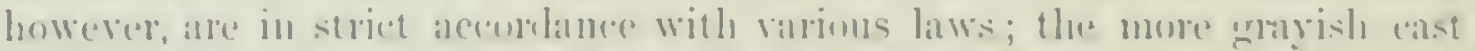

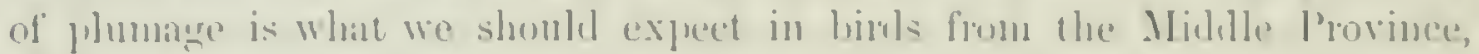
while the restrielion we the yelluw from the maxillar we ser alse in Mestern

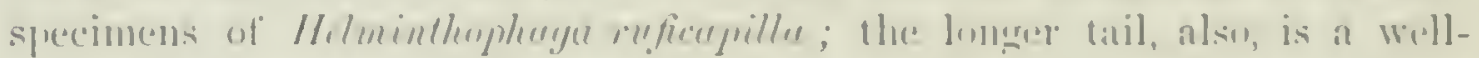

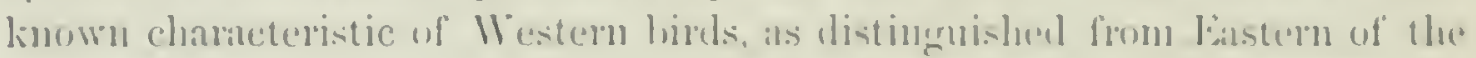
salue splecies.

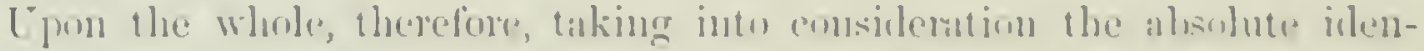

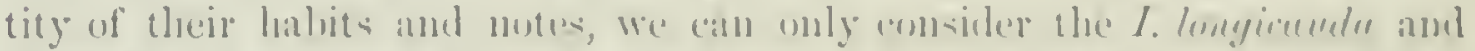

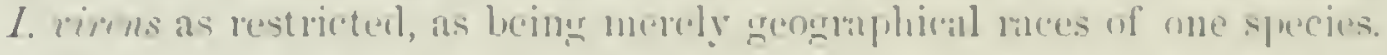

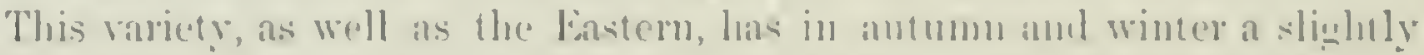

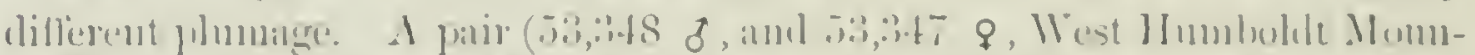

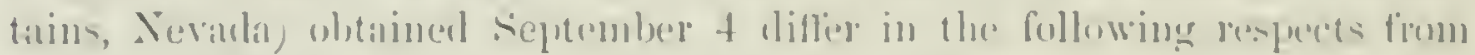

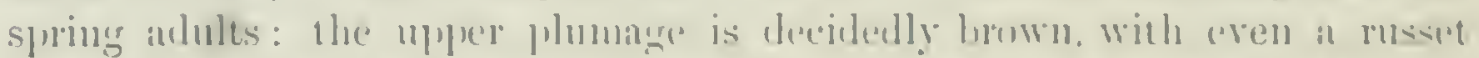

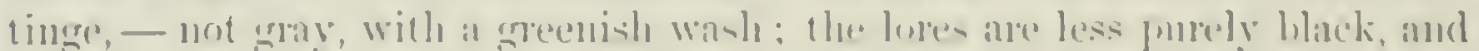

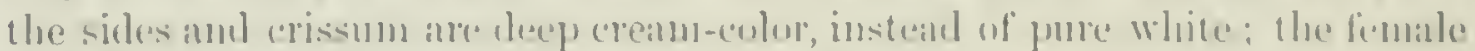

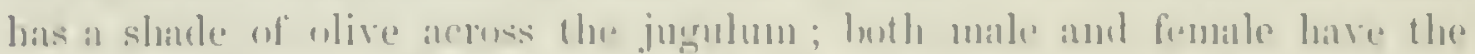
lower mamblibe almost wholly white, and the rommisene broadly ediged with thir sillte.

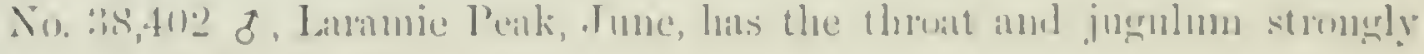

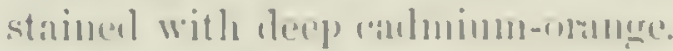

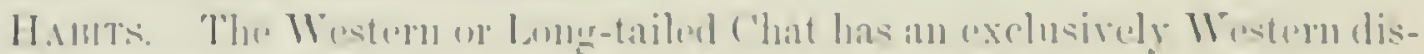

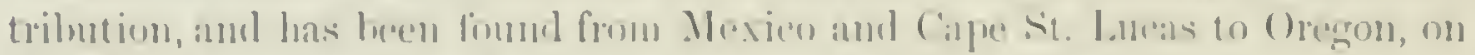

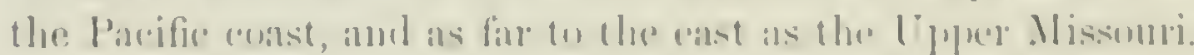

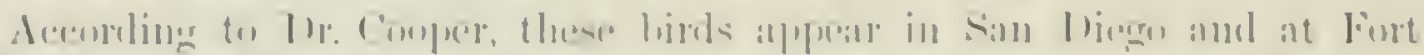

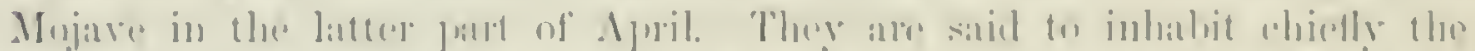

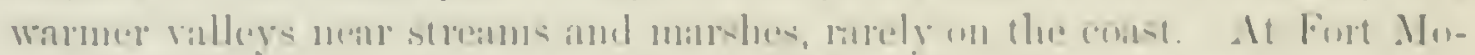

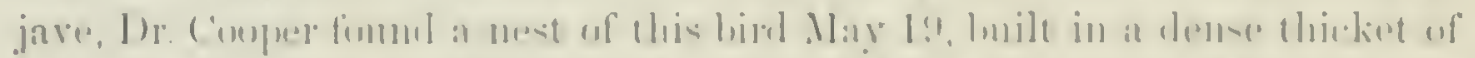

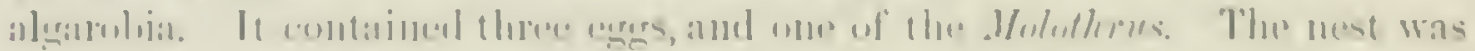

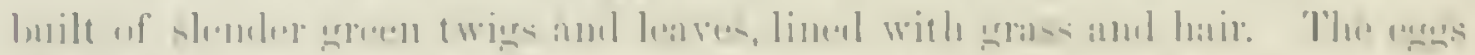

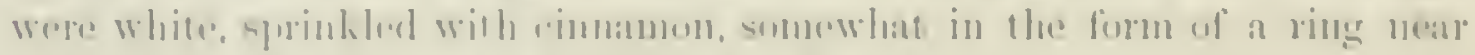

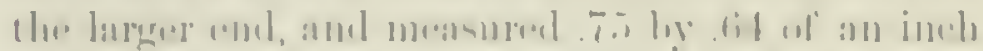

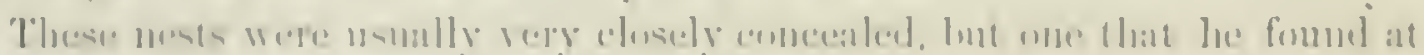

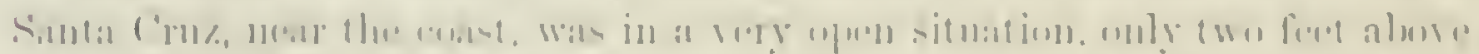

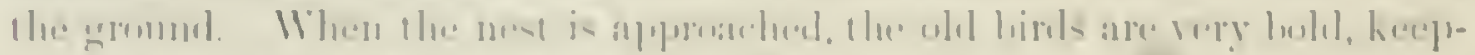

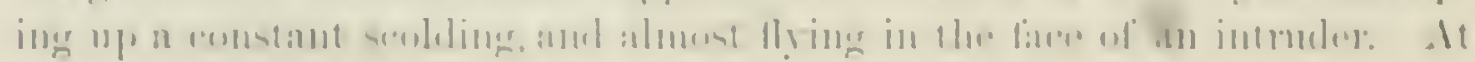


other times they are very shy. The notes and sounds uttered by the Western bird Dr. Cooper states to be the same as those of the Eastern species, and with the same grotesqueness. They leave the State of California on or before the first of September.

Dr. Gambel states that the Chat appears in California about the middle of April, resorting to the hedges, vineyards, and bushy portions of gardens to breed.

Mr. Xantus found a nest of this bird (S. I., 896) at Fort Tejon, California, in May. It is a very symmetrical and exactly circular nest, six inches wide and three in height. The cavity has a diameter of three inches at the brim, and a depth of two. It is built of soft strips of bark, large stems, and branches of dry plants, leares, twigs, and other regetable substances. These are very neatly and compactly interworen. The nest is elaborately lined with finer stems and flexible grasses. Another nest (S. I., 1816), obtained at Neosho Falls, Kansas, by MIr. B. F. Gross, is of irregular shape. Its height is four inches, and its dianeter varies from three and three quarters to five inches. It was built in a depression in the ground, and its shape adapted to its location. The base is composed entirely of leares, impacted when in a moist and decaying condition. Within these is interworen a strong basket-like structure, made of long and slender stems, strips of bark, and fine rootlets, lined with finer gasses and stems of plants.

A nest of this species from Sacramento is composed, externally, of fine strips of inner bark of the grape and of deciduous trees, coarse straws, stems of plants, twigs, and dried remains of weeds, etc. It is lined with finer stems and long wiry roots, resembling hair. This nest has a dianeter of four inches and a height of three. The carity has a diameter of three inches at the rin, and a depth of two.

In regard to this variety Mr. Ridgway writes: "In no respect that I could discover does this Western bird differ from the Eastern in habits, manuers, or notes. The mesting-liabits are exactly the same."

The eggs of this species are, for the most part, larger than are those of the virens. They vary in length from .95 to 1.00 of an inch, and have an average breadth of .70 of an inch. Their markings do not differ essentially in shadings from those of the common species.

\section{StbFanli SETOPHA GIN 仺。}

Gex. Char. Sylvicoline birds with the characters of Flscatchers: the bill notched at tip, depressed and broad at the base, though quite deep: the rictus with well-dercloped bristles reaching beyond the nostrils, sometimes to the end of the bill. First quill rather less than the fourth, or still shorter. Size of the species rarely exceeding six inches. Colors red, yellow, and olire.

The species of this section resemble the small Flycatchers of the family 
Tyrenniler in the structure of the lill, etc., and in the habit of cillturing insects more or less an the wintr. thungh they are more restless in their movements, seching their prey among trees of in bushes, mpidly chamerner

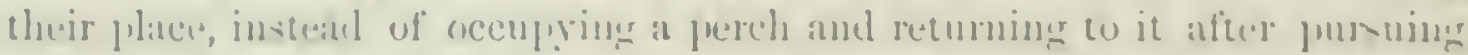
an insece throngh the ais. The yellow or orangere crown foumel in mang spe-

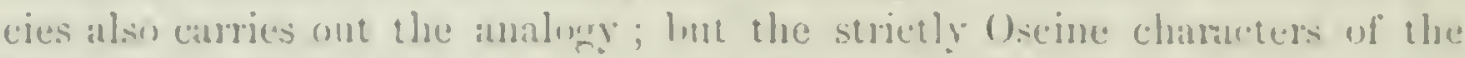
tarsal sentellie and the nine primaries will serve to distingmish them.

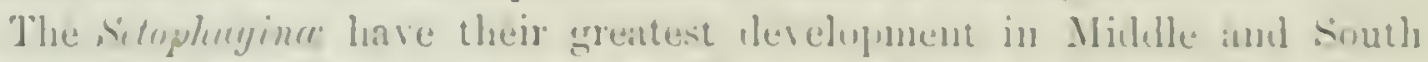
America, nu less than nine genera and sulugenera being on mend, uf whoh mily two extend into the Linted States. Of une of these, Silnghrign, we have unly a simgle species of the many described; the wher, Myiuliueles, hats no members other than those foumd in the Luited states.

The following diagnosis is prepared to distmonish our genem from the South American:-

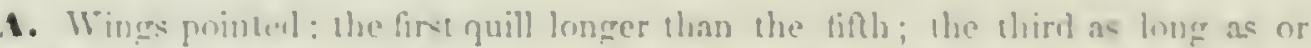

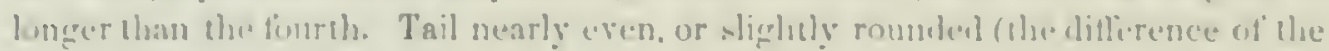

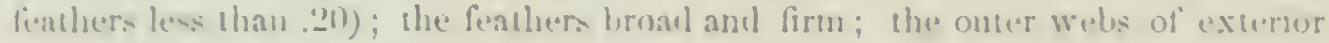

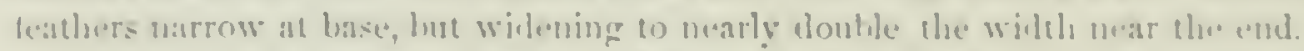

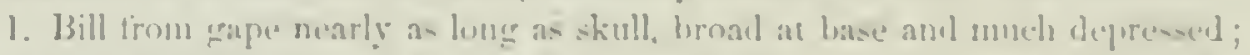

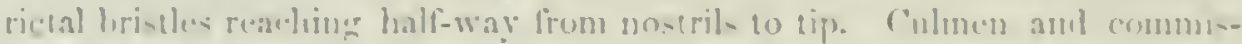
sure mearly straight. Winges aqual to the tuil. Tar-i long: toes short; mul-

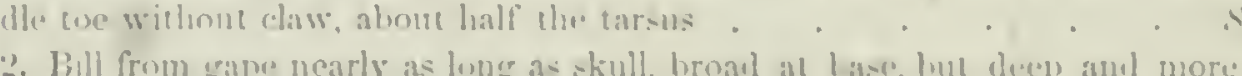

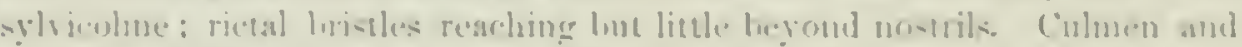

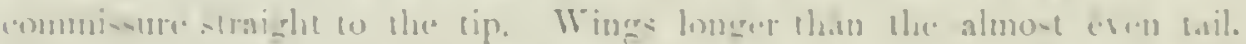

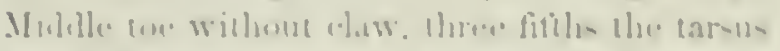

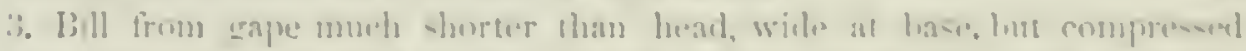

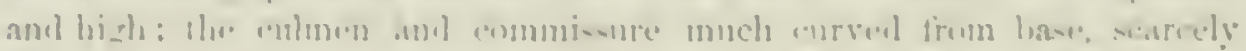

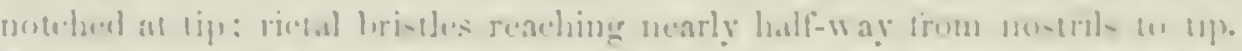

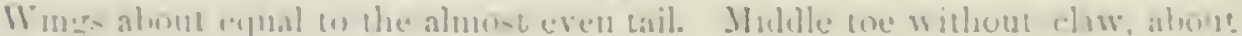

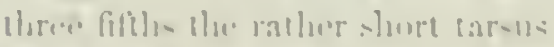

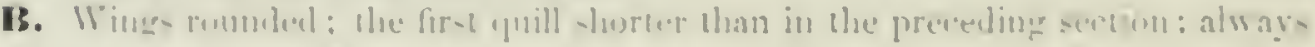

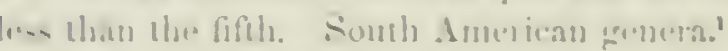

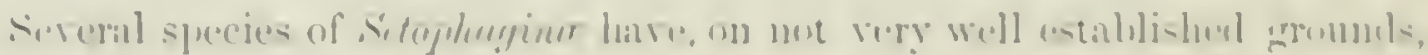

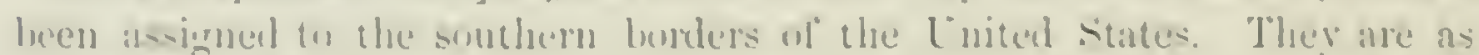
follows:-

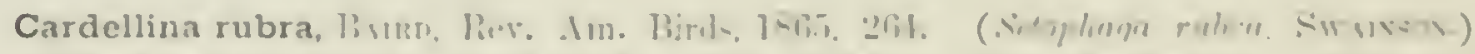

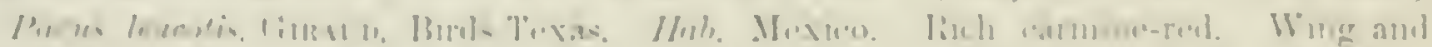

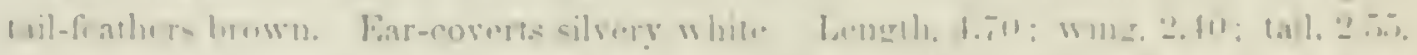

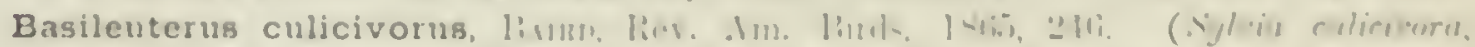

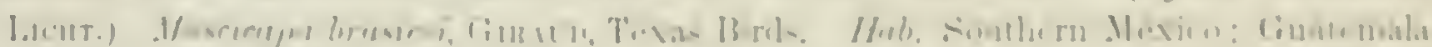

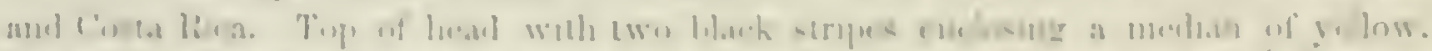

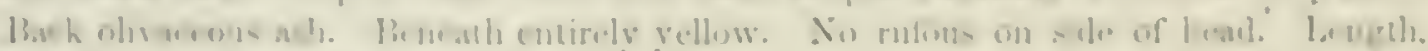
$4(4) ; \quad 111 \% 2.10 ;(n), 2.2 \%$.

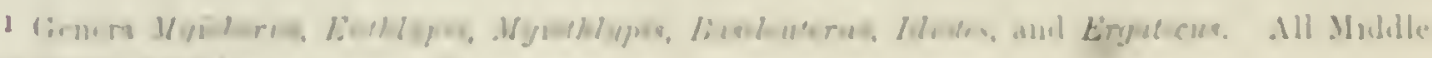
amel sunth Ane rina 
Basileuterus belli. Barnd, Rev. Am. Birds, 1S6j, 24i. Mnscicapa belli, Grratd, Texas Birds. Hub. II exico and Guatemalit. Top of head and face chestuut. A yellow superciliary stripe bordered above by dusky. Back olive; beneath yellow. Length, 5.10; wing, 2.28 ; tail, 2.50 .

\section{(iENT'S MYIODIOCTES, AtD.}

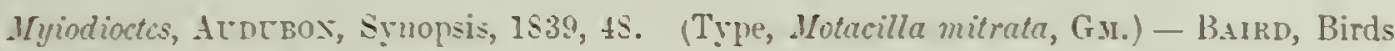
N. Am. 155., 291.

Mitsonia, Bositp. List. 1838 (preoceupied in botany).

Iyyiocionus, Cabasis, Mus. Hein. 1550, 18. (Type, Iotacilla mitrata.)

Gex. Crar. Bill broad, depressed; the lateral outlines a little concare; the bristles reaching not quite half-way from nostrils to tip. Culmen and commissure nearly straight to near the tip. Tostrils oral, with membrane above. Wings pointed, rather longer than the nearly even but slightly rounded tail; first quill shorter than the fourth, much longer than the fifth; the second and third quills longest. Tarsi rather lengthened, the scutellar divisions rather indistinct: the midule toe without claw, about three fifths the tarsus.

This genus is distinguished from Setophara mainly by stouter feet and longer toes; short-

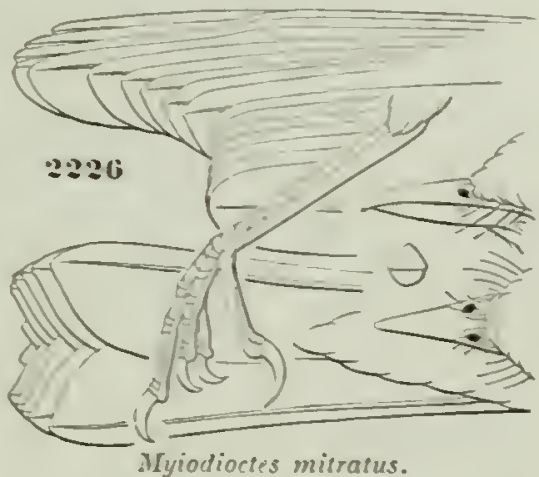
er and more even tail, narrower bill, etc. The species are decidedly muscicapine in general appearance, as shown by the depressed bill with bristly rictus. The type 1I. mitratus is very similar in chancter of bill to Dendroica castanea, but the wings are much shorter; the tail longer and more gradnated; the legs and hind toe longer, and the first primary shorter than the fourth (.15 of an inch less thin the longest), not almost equal to the longest. The species are plain olive or plumbeous above, and yellow beneath. They may be grouped as follows:-

A. Tail with white patches on the inner feathers.

1. M. mitratus. Head and neck black. Front. cheeks, and under parts rellow. Back olive-green. Hab. Eastern Province of United States, south to Panama and Test Indies.

2. M. minutus. Olive abore; rellowish beneath. Two white bands on the wings. Hab. Eastern United States.

B. Tail without white patel on the outer feathers.

3. M. pusillus. Crown black. Forehead, cheeks, and under parts rellow. Back olive.

Fellow of forehead without an orange tinge; upper parts dull olivegreen; pileum with rerr dull steel-blue lustre. Hah. Eastern Prorince and Rocky Mountains of North America, south to Costa Rica. var. pusillus.

Yellow of forehead with an orange cast; upper parts bright rellowishgreen: pileum with a bright steel-blue lustre. Hab. Pacific Prorince
of Sortls America, from Sitka to Costa Rica
var. pileolata

4. M. canadensis. Streaks on the crown. stripes on sides of head and neck. with pectoral collar of streaks, black. Rest of under parts, and line to and around the ere. rellow. Baek bluish. Hab. Eastern Province of Cnited States. south to Ecuador. 


\section{Myiodioctes mitratus, I(i)}

\section{HOODED WARBLER.}

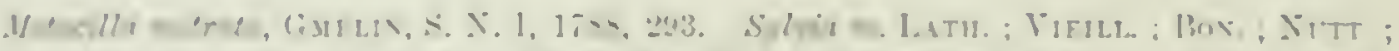

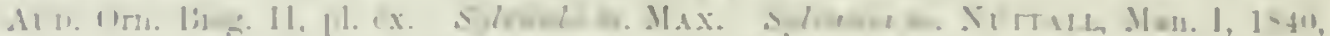
\&.s.3. $\therefore$ H

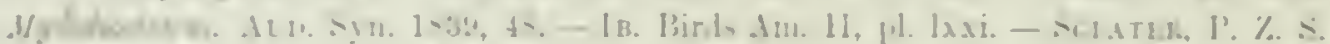

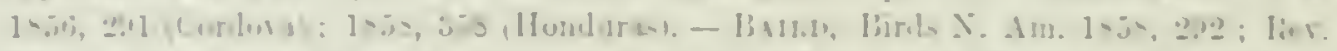

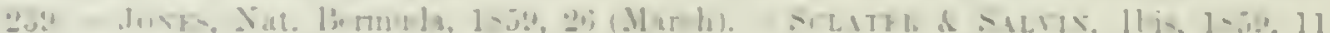

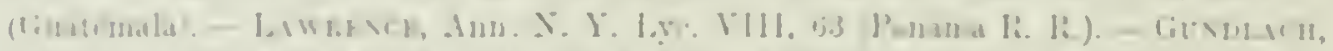

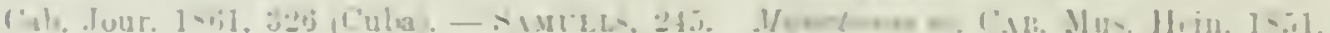

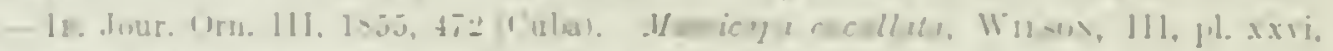

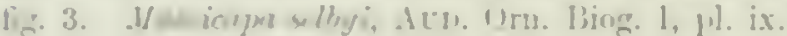

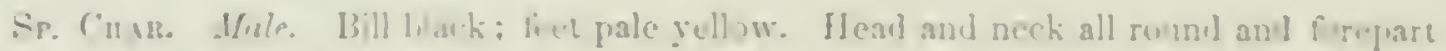

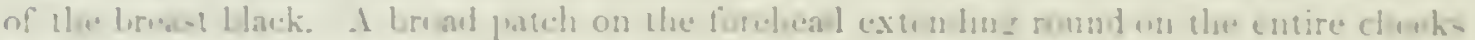

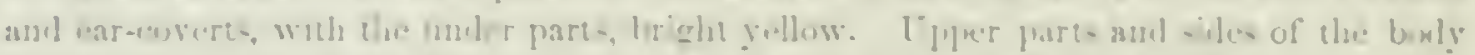

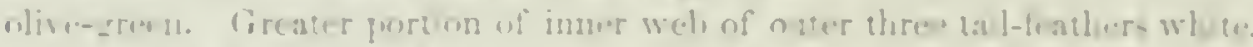

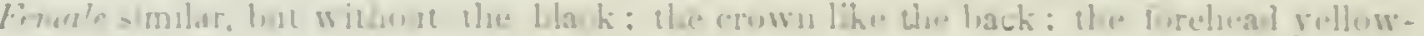

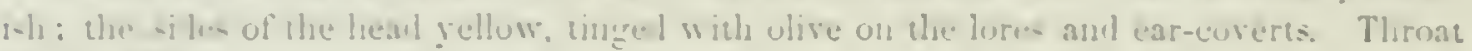
lisist rillow.

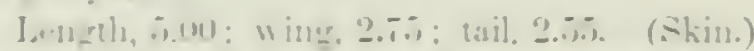

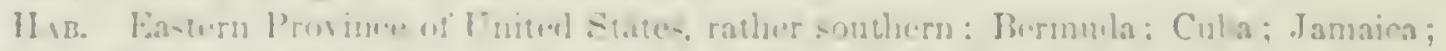

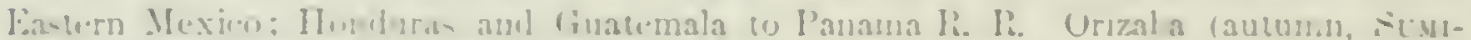
CHR.

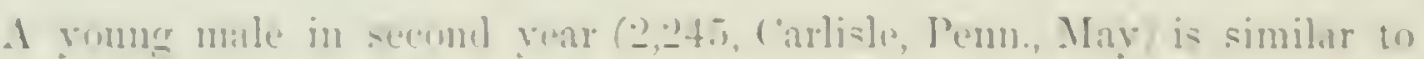

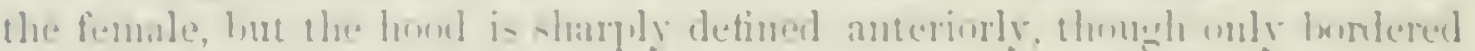

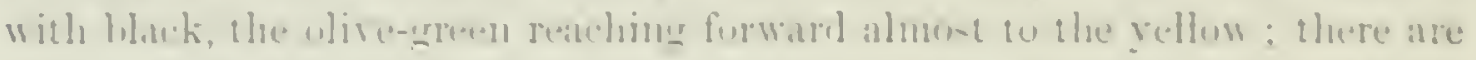
only very slight indientins of thach on the throat. Alprarently the male of

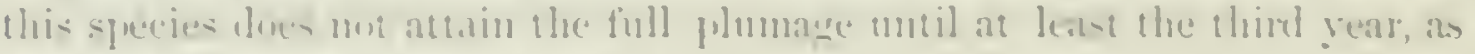
is the case with silmilum, rutirilln.

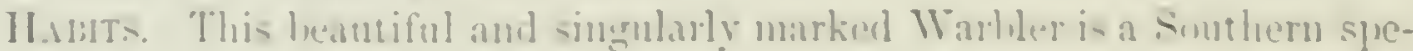

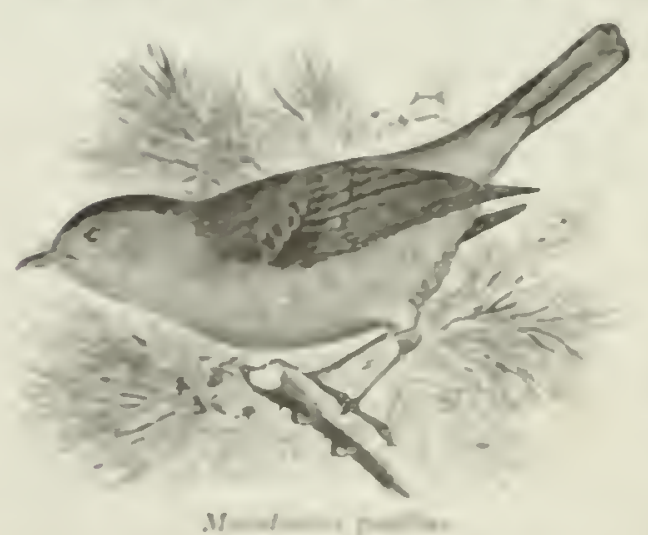

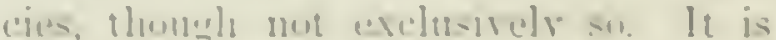

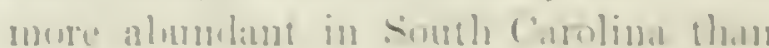

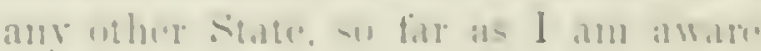

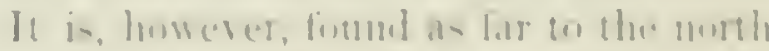

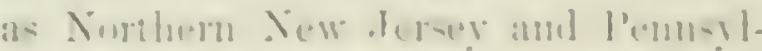

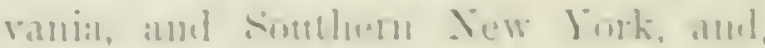

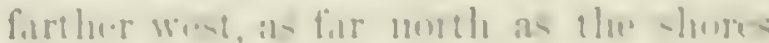

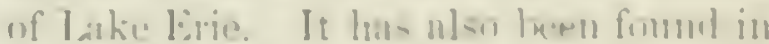

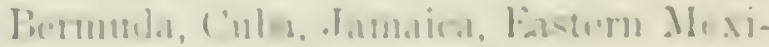

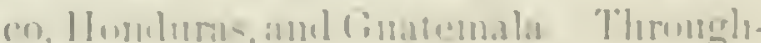

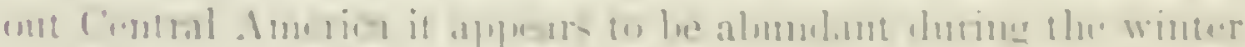

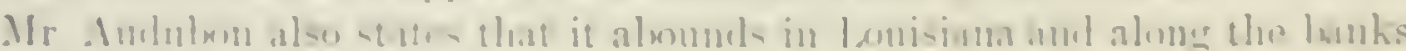

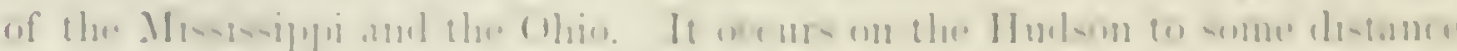

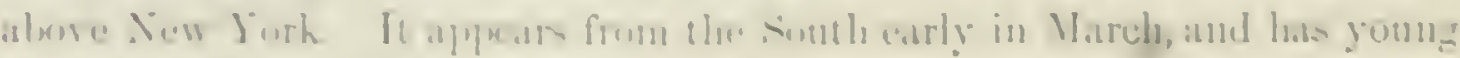

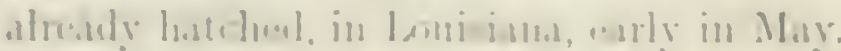


It is said to be one of the liveliest of its tribe, and to be almost constantly in motion. It is fond of sectuded places, and is equally common in the thick eanebrakes, both of the high and the low lands, and in the tangled undergrowth of impenetrable swamps. It has a peculiarly graceful numner of elosing and opening its broad tail, that at once distinguishes it from every other bird, as it gambols from tree to tree, now in sight, and now hich from the eye, but ever within liearing.

Mr. Audubon adds that its call-note so closely resembles that of the Spizce ciris that it requires a practised ear to distinguish them. But its song is very different. This consists of three notes, and is loud, lively, and pleasing. This song is said to be made of somnds resembling the syllables reet, wect, wcctèe. Extremely vocal in the early spring, it becomes nearly silent as soon as its brood is hatched. It resumes its song when its mate is again sitting on her eggs, as they lave more thin one brood in a season.

They are described as expert flycatchers, full of activity and spirit, flying swiftly after their insect prey, and catching the greater part on the wing. Their flight is low, gliding, and often protracted.

Mr. Bachman narrates a striking instance of its courage and conjugal devotion. While a pair of these Warblers were constructing a nest, a sharpshimmed Hawk pounced upon and bore off the female. The male followed close after the Hawk, flying within a few inches and darting at him in all directions, and so contimmed until quite ont of sight.

Wilson states that it builds a very neat and compact nest, generally in the fork of a small bush. It is formed of moss and flaxen fibres of plants, and lined with hair or featleers. The eggs, five in number, he describes as of a grayish-white, with red spots at the larger end. He noticed its arrival at Savamnah as early as the 20th of March. Mr. Aurlubon adds that these nests are always placed in low situations, a few feet from the ground.

The late Dr. Gerhardt, of Varnell's Station, Georgia, informed me, by letter, that the Hooded Warbler deposits her eggs about the middle of May, laying four. The nest is not unlike that of the Spiza eycunca, but is larger. It is constructed of dry leaves and coarse grass on the outside, and within of dry pine-needles, interworen with long yellow grasses and sometimes with horsehair. They are built, for the most part, in the neighborhood of brooks and creeks, in oak bushes, four or five feet from the ground. The female sits so closely, and is so fearless, that Dr. Gerhardt states he has sometimes nearly caught her in his hand.

In another letter Dr. Gerhardt describes a nest of this species as measmring three inches in height, three in external diameter, and an ineli and a quarter in the clepth of its carity. Externally it was built of dry leares and coarse grasses, lined inside with horsehair, fine leaves of pine, and dry slender grasses. It was constructed on a small oak growing in low bottom-land, and was three feet from the ground. The complement of eggs is four.

Mr. Pidgway states that this species is a common summer resident in the 
bottom-lands along the Inwer Wahsah, in southern Illinois, inhabiting the canc-bmbes and the margins of hushy swamp.

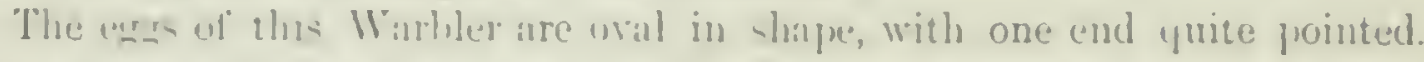

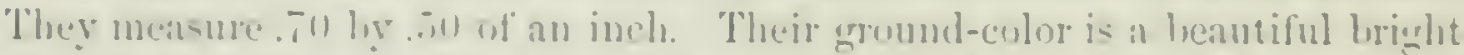
white, when the enge is freh, strongly timged with flesh-color. The spots are of a fine led, with a lew markings of a sublued purple.

\section{Myiodioctes minutus, hinlR. SMALL-HEADED FLYCATCHER.}

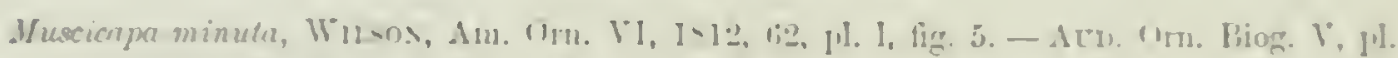

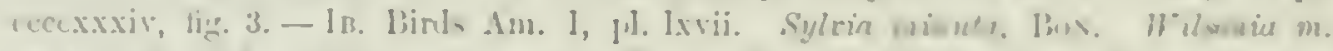

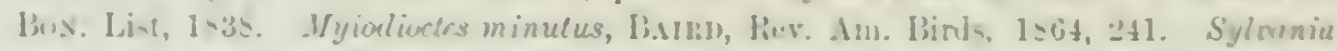
pumilit, Nitr. Man. I, 1=\$1, 3:34.

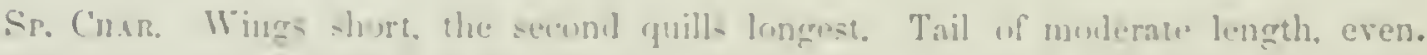

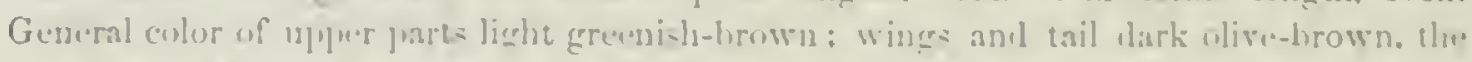

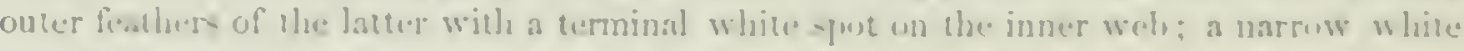

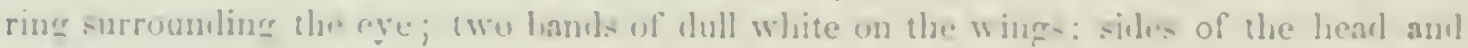

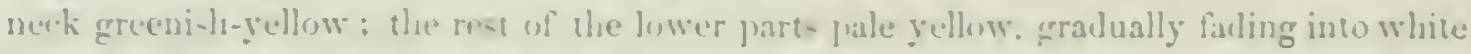

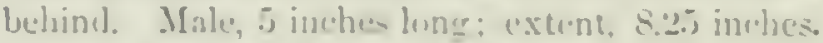

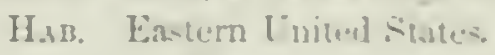

H.suts. All that ji known in reural to this species we receive from Wilson and Amblum, and there is a deediled discrepancy in their several statements. Wilson states that his tierure wis taken from a roumg male

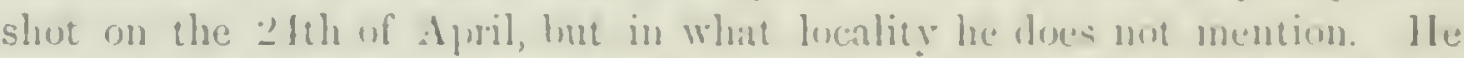
adels that he afterwards shest several individuals in varmo gants of Sow Jersey, partieularly in swamps. Ife foumd these in Iunce and has no doubt they lireenl there.

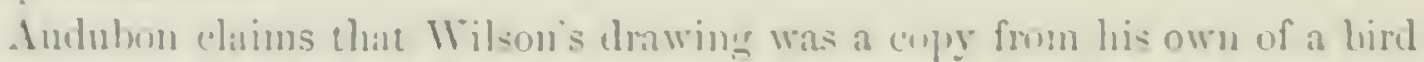

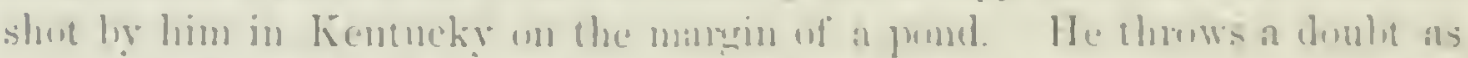
to the correctures of Wilson's statement that they hase heen found in New

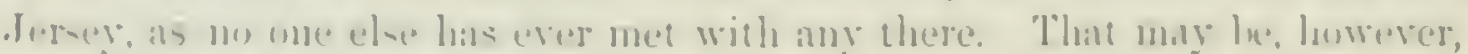

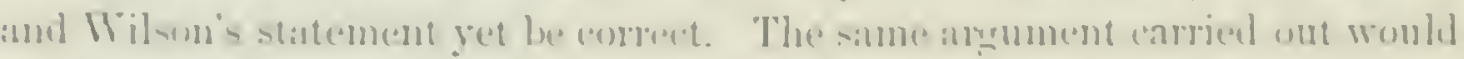

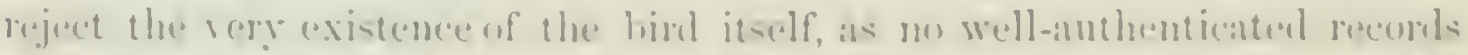

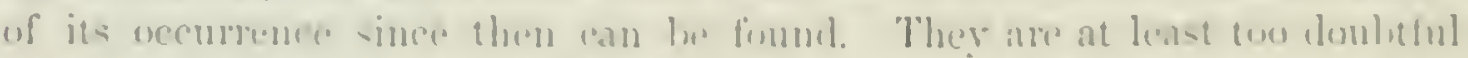

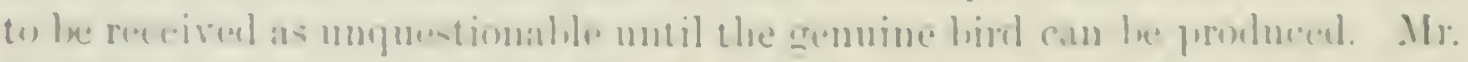

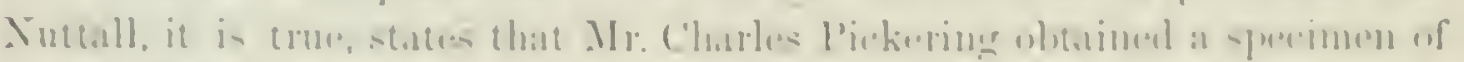

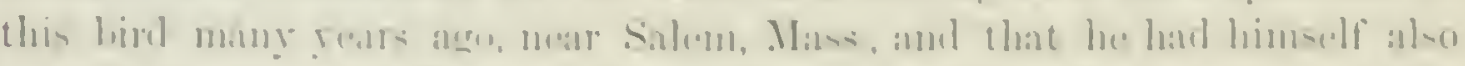

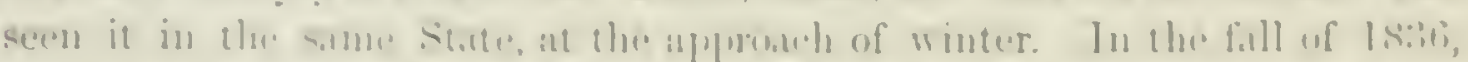

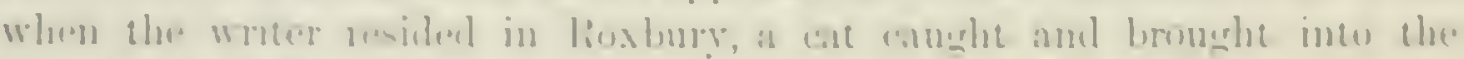

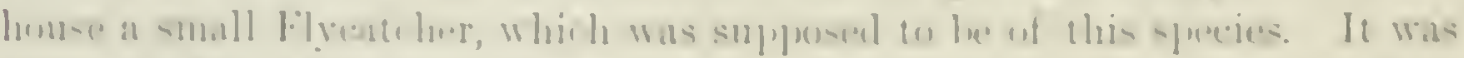

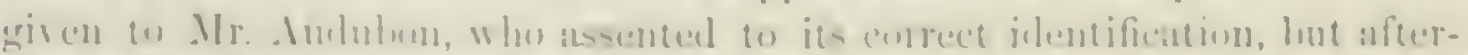
whals male mo mention of it. The presmmplim, therefore, is that we maty hatve beron mistikitn. 
In regarl to its habits, Wilson represents it as "remarkably active, rumning, climbing, and darting abont anong the opening buls and blossons with extraordinary agility." Audubon states that in its habits it is closely allied with the pusillus and the mitretus, heing fond of low thick coverts in swamps and by the margin of pools. He also attributes to it a song of rather pleasing notes, enunciated at regular intervals, loud enough to be heard at the distance of sixty yards. These peculiarities seem to separate it from the true Flycatchers and to place it among the Warblers.

\section{Myiodioctes pusillus, BoxaP.}

\section{GREEN BLACK-CAPPED FLYCATCHER.}

.Hescicapa musillu, Wissus, An. Orn. III, 1S11, 103, pl. xivi, lig. 4. Writsonia pus. l3ox. Sylvaniu gues. NtтT. Myiodioctes pus. Bux. Consp. 1850, 315. - Sclosteli, P. Z. S. 1550,291 (Corlora) ; 15j8, 299 (Oaxaca Mts. ; Dec.); 1559, 363 (Xalapa) ; 373. - lis. Catal. 1su1, 34, no. 203. - P.11ru), Birds X. Am. 1S5S, 293 (in part); lier. 240 (in

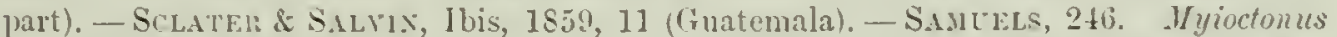
pus. C.1B. II. H. 1551, 1S. - IB. Jour. 1860, 325) (Costa Rica). Sylvia uilsomi, 131). ; NuTr. Muscicape wilsoni, AtD. Orn. Biog. II, pl. cxxiv. Setophage wilsoni, Jalın. Myiodioctcs wilsoni, AUD. Birds Am. 1I, pl. Mxr. Sylvia pclusndes, Licux. PreisTerz. $1 \$ 30$.

Sp. Cirar. Forehead, line over and around the eve, and under parts generally, bright yellow. Lpler part olive-green; a square patch on the crown lustrous-black. Sicles of hody and cheeks tinged with olive. No white on wines or tail. Female similar, the black of the crown replaced by olive-green. Length, 4.7.; wing, 2.2.j: tail, 2.30.

H.в. Eastern portions of United States, west to the Sualie and Humboldt Rivers: nurtl to Alaska, south through Eastern Mexico and Guatemala to Costa Rica; Chiriqui (SALTIX).

HaBITs. Wilson's Black-Cay is found throughont the Lnited States from ocean to ocean, and as far to the north as Mlaska and the Arctic shores, where, howerer, it is not common. Mr. Dall shot a specinen, Maty 30, on the Yukon River, where it was breeding. Mr. Bischoff obtained others with nests and eggrs at Sitka, and afterwards found it more abundant at Kodiak. On the Pacific coast Dr. Suckley found it rery abundant in the neighborhood of Fort Steilacoom, where it frequented thickets and small scrub-oak grores, in its habits resembling the Helminthophaga celatu, flitting ahout among the dense foliage of bushes and low trees in a busy, restless manner. He describes its cry as a short chit-chut call. In California, Dr. Cooper notes their first arriral early in May, and states that they migrate along the coast, up at least to the Straits of Fuca. At Sinta Cruz he noted their arrival, in 1866, about the 20th of April. They were then gathering materials for a nest, the male bird singing merrily during his employment. As they lave been observed in Oregon as early as this, it has been conjectured that some may remain all winter among the deuse slirubbery of the forests. 
'This bird winters in latre munbers in (entmi Americal, where it is alpar-

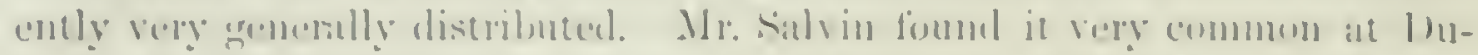

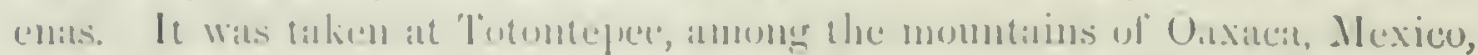
ly Mr. linmaiml.

Ir: lifigway foumd it very common doring the summer and antmum months anomer the willows of the lertile river valleys, and annone the rank

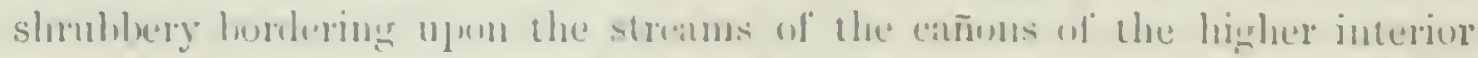

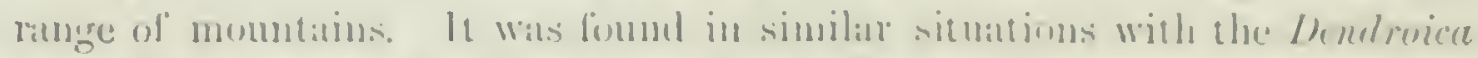

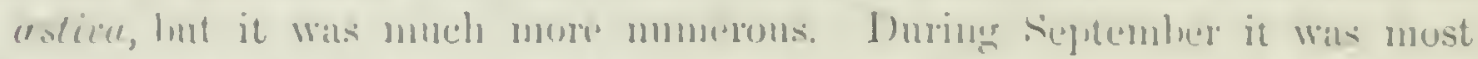

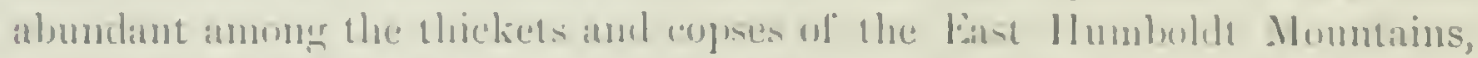

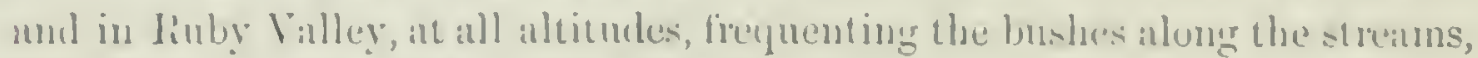
from their sources in the snow to the rilleys.

Wilson first met with and described this species from sperimens olnamed

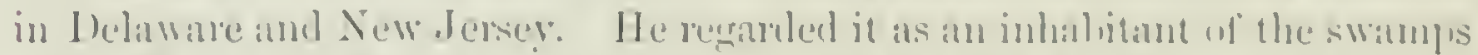

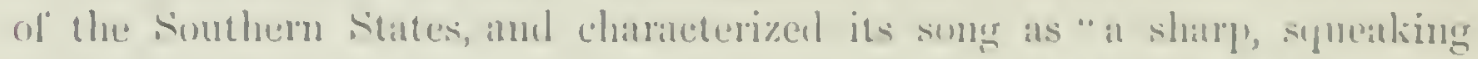
note, in mo wise musicat." It is sill hy him to leare the somblem states in ().tulere

Ambluon states that it is never fomed in the sunthern states in 1 he sum-

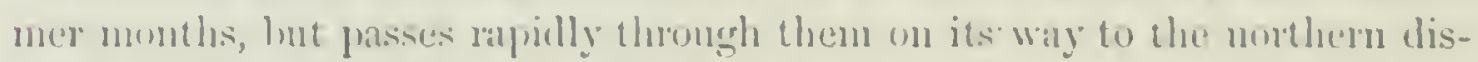

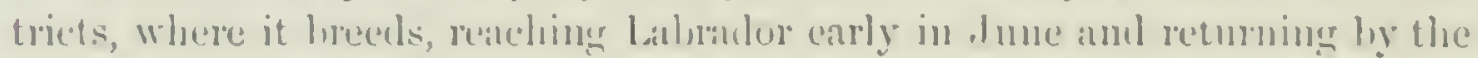
midille of August. He describes it ats having all the habits ol a trme l\%y-

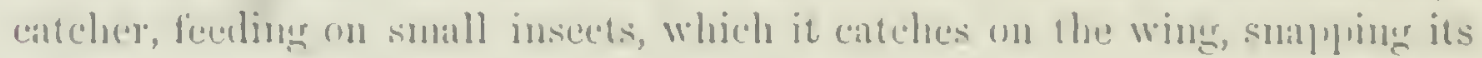
bill with a sharp elicking somml. It freunents the lurders of lales and streans fringed with low lushes.

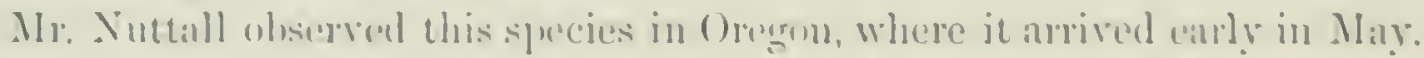

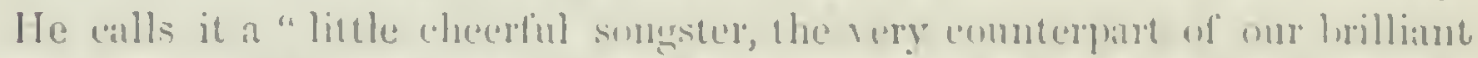

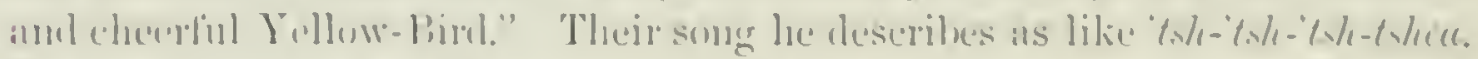

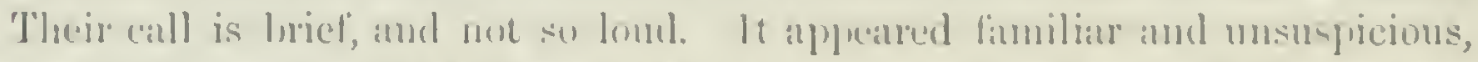

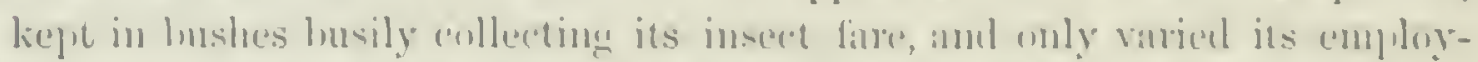

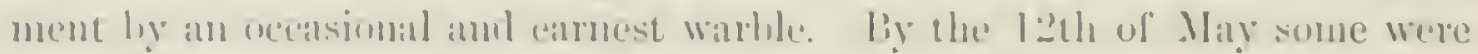

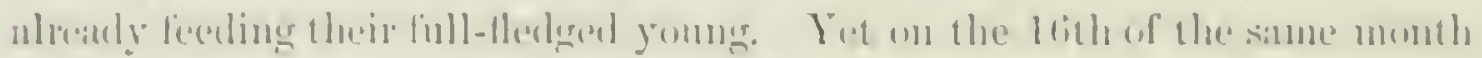

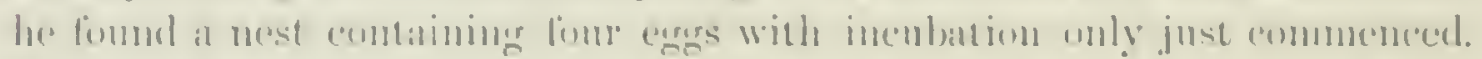

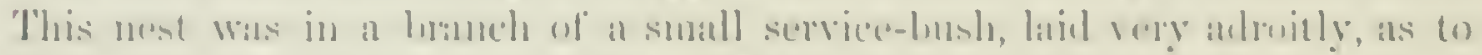

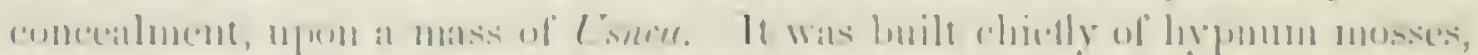

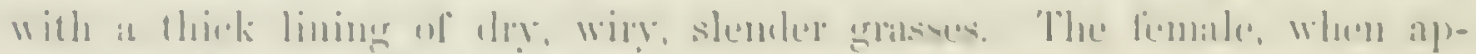

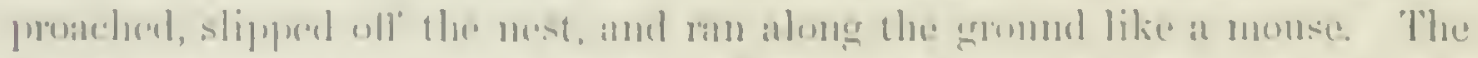

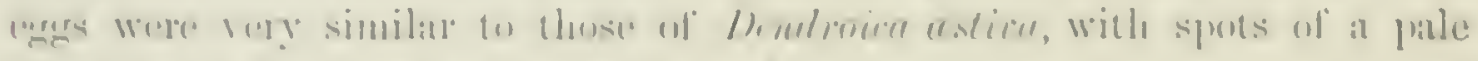

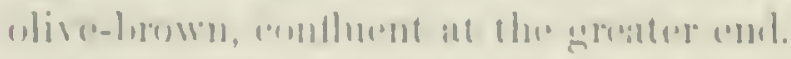

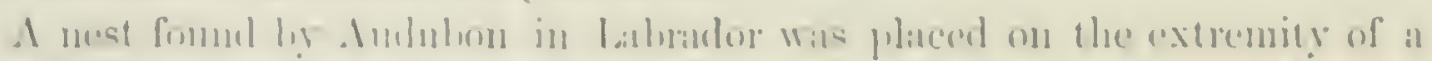

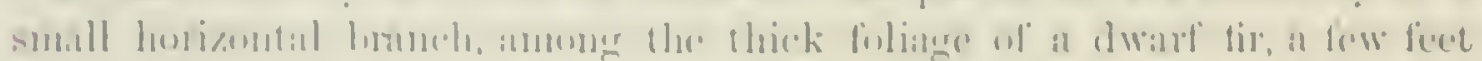

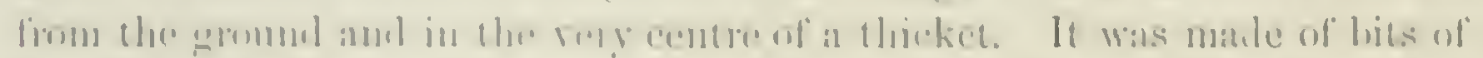

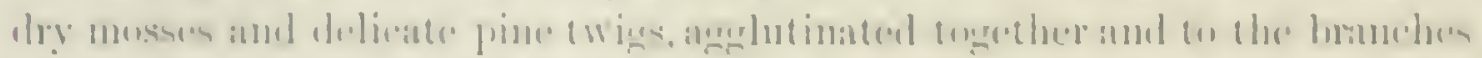

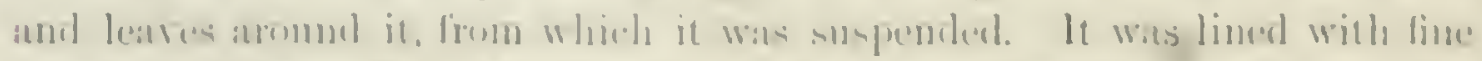

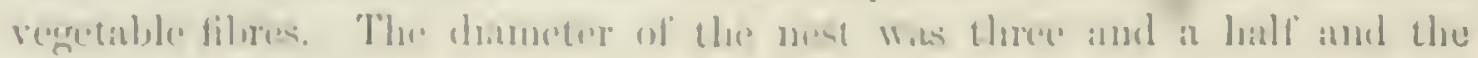


depth one and a half inches. He describes the eargs, which were four, as white, spotted with reddish and brown dots, the markings being principally around the larger end, forming a circle, leaving the extremity plain.

In this instance the parents showed much nueasiness at the approach of intruders, moring about among the twigs, snapping their bills, and uttering a plaintive note. In Newfoundland these birds had already begrun to migrate on the 20th of Augnst. He met with them in considerable numbers in Northern Maine in October, 18:\%. Mr. Turnbull mentions it as a rather abunlant birl of Eastern Pemsylvania, appearing there early in May, in transitn, and again in October.

Mr. T. M. Trippe hats observed this species at Orange, $X$. T., from the 19th to the 30th of May. It is said to keep low down in the trees, and is fund of haunting thickets and open brush fields. Occasionally he has heard it utter a loud chattering song, which it repeats at short intervals.

A nest of this species from Furt Yukon (Smith. Coll., 13,346), obtained May 20, by Mr. MeDougal, contained four exgrs. These raried from .60 to .63 of an inch in length, and from . 45 to .49 in breadth. They were obovate in shape, their ground-color wis a pure white; this was finely sprinkled round the larger end with brownish-red and lilac. To mention is made of the position of the nest, but it is probable this birl builds on the gromel.

\section{Myiodioctes pusillus, var. pileolatus, RIDGWAr.}

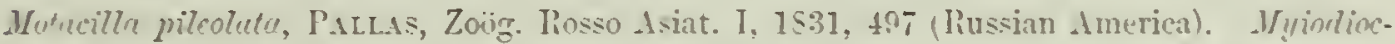

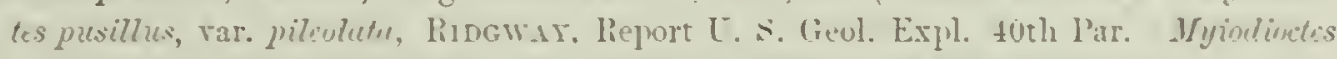
mesillus, At'T. (all citations from Pacific const of Nolth and Ylihlle America). - Lon D, Pr. R. Art. Inst. Woolw. IV, 1Sủt, 115 (Br. Col.). - D ill \& B.sisster (Alaska). Cuoper, Oru. Cal. I, 1\&70, 101 .

Sp. Cuır. Similar to var. pusillus, but much richer rellow, scarcels tinged with olive laterally, and deepened into an almost orange slade on the front and chin. Above much brighter and more sellowish olive-rreen. The black pileum with a brighter steel-l,ue gloss. Bill much narrower, and deep. light brown above. insteal of nearly black. Measures (t.2.22 d. San Francisco. Cal.), wing. 2.15: tail. 2.00.

HaB. Pacific coast region of Forth America, from Kodiak (Alaska): south through Western Mexico (and Lower California) to Costa Rica.

This is an appreciably different race from that inhabiting the eastem dirision of the continent; the differences, tested by a large series of specimens, being very constant.

A Costa-Pican specimen before me is almost exactly like specimens from California.

HABITs. The remarks in the preceding article relatire to specimens from the Pacific coast belong to this variety. 


\section{Myiodioctes canadensis, $1 \times 1 \%$}

\section{CAXADA FLYCATCHER.}

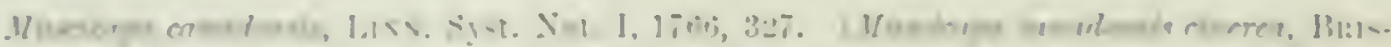

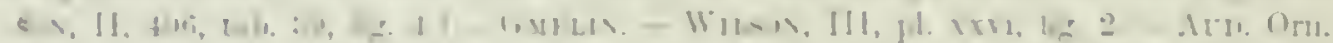

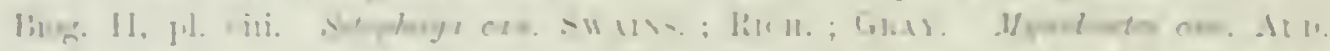

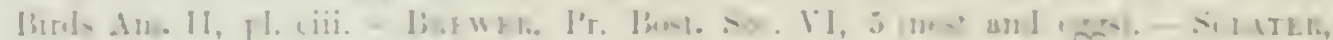

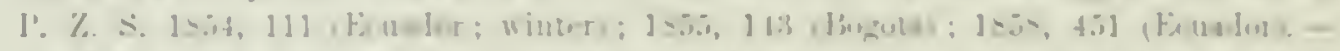

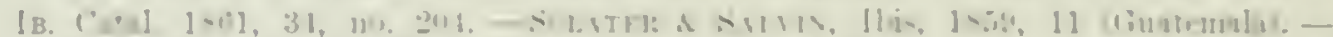

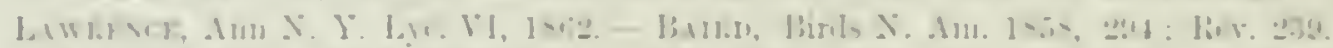

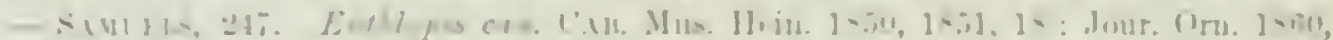

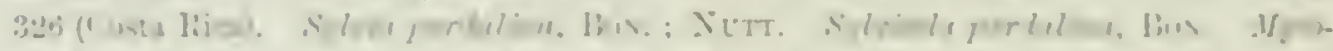

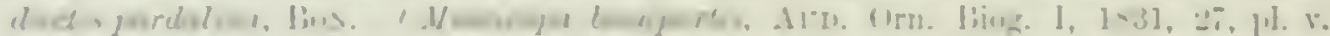

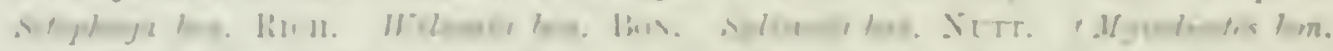

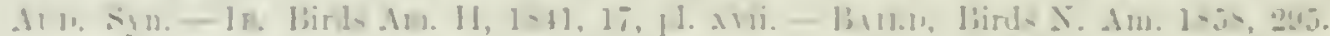

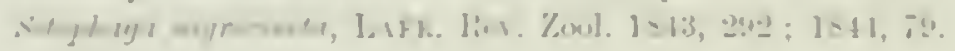

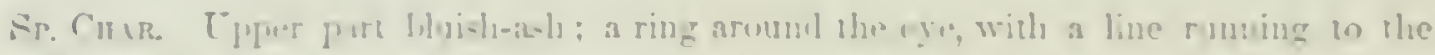

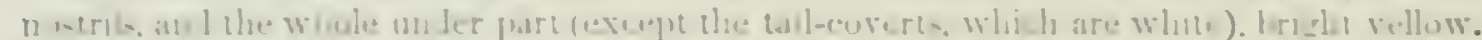

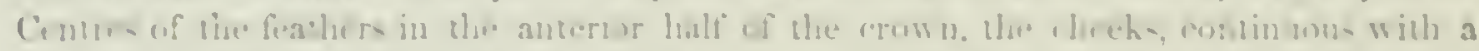

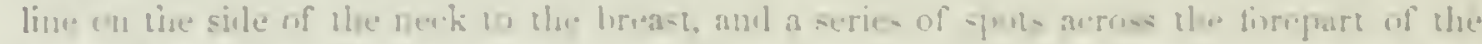

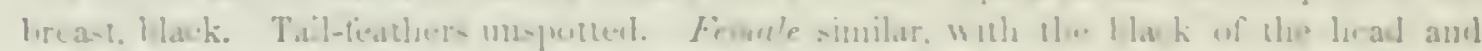

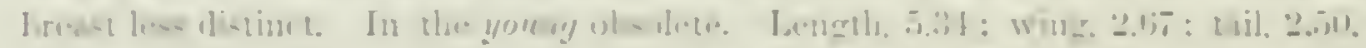

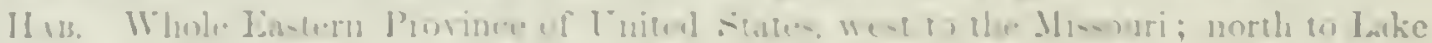

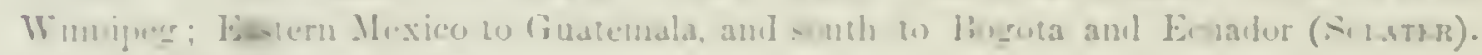
Not noted irom 11 ins lulin.

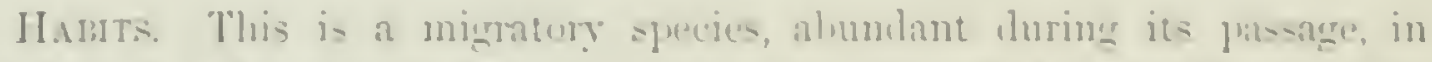

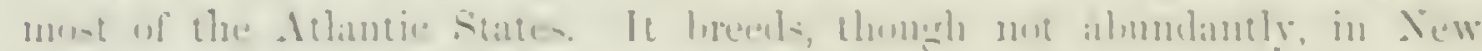

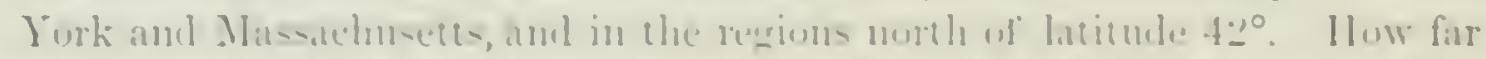

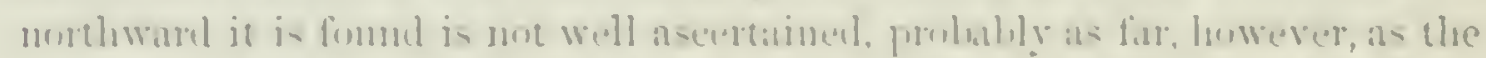

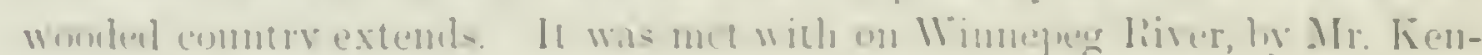

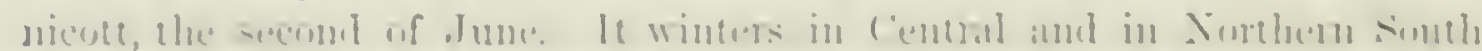

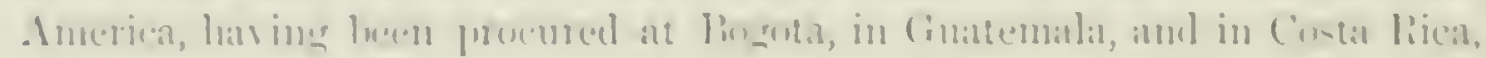
in Jure mumluers.

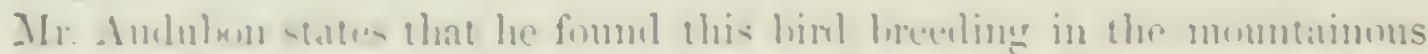

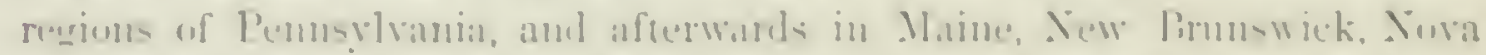

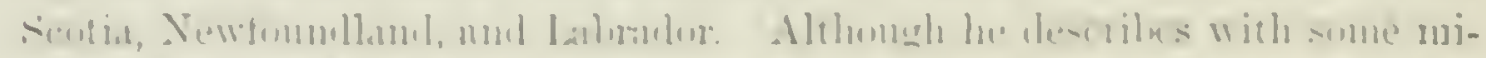

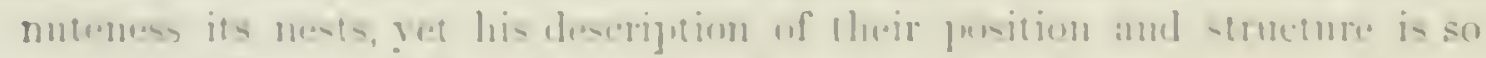

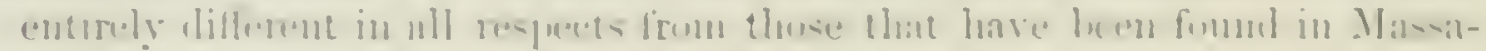

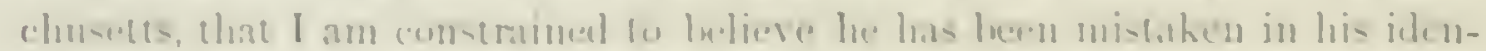

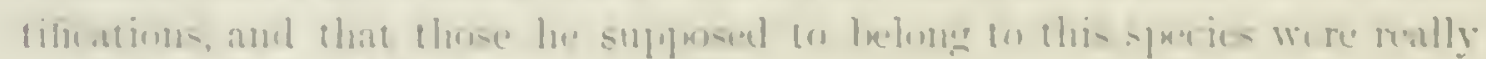
the mast of a lillerent lim

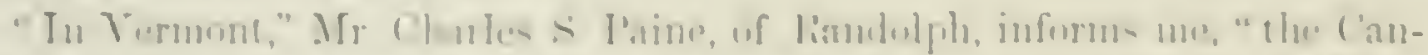

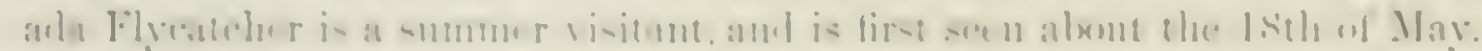

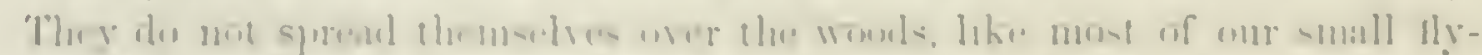

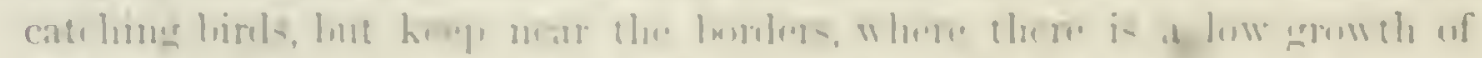

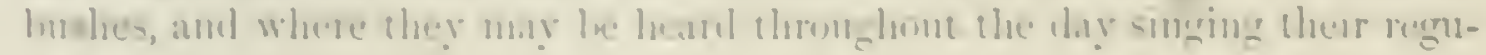


lar chant. A few pairs may occisionally be found in the same neighborhood. At other times only a single pair can be found in quite a wide extent of territory of similar chanacter. They build their nests, as well as I can judge, about the first of June, as the young are hatched ont and on the wing about the last of that month, or the first of July. I have never found a nest, but I think they are built on the ground. They are silent after the first of July, and are rarely to be seen after that period." The song of this bird is a rery pleasing one, thongh heard but seldom, and only in a few localities in Massachusetts.

Near Washington 1)r. Cones found the Canada Flycatcher only a spring and antumnal risitant, at which seasons they were abmulant. They frequented high open woods, and kept mostly in the lower branches of the trees, and also in the more open underorowth of marshy places. They arrive the last week in April and remin alout two weeks, arriving in fall the first week in September, and remaining until the last of that month.

The first well-identified nest of this bird that came to my linowledge was obtained in Lyun, Mass., by Mr. Georue O. Welch, in June, 1856. It was built in a tussock of grass, in swampy woods, concealed by the surrounding rank regetation, in the midst of which it was pliteed. It was constructed entirely of pine-needles and a few framents of decayed leaves, gripevine bark, fine stems, and rootlets. These were so loosely interworen that the nest could not be remored without great care to keep its several portions together. Its dianeter was three and a half inches, and it was very nearly flat. Its greatest depth, at the centre of its depression, was hardly half an inch. It contained four young, and an mulatched egg.

Another nest found in. Junc, 186 t, by the sime observing naturalist, was also obtained in the neighborhond. This was built in a tussock of meadow-grass, in the midst of a small boggy piece of swamp, in which were a few scattered trees and bushes. The gromul was so marshy that it could be crossed only with difficulty, and by stepping from one tussack of reedy herbage to another. In the centre of one of these bunches the nest was concenled. It measures six inches in its larger diameter, and has a height of two and a quarter inches. The carity of this nest is two and three quarters inches wide, and one and three quarters deep. It is rery strongly constructed of pineneedles, interwoven with fine strip)s of bark, dry (lecichous leaves, stems of dry grasses, sedges, etc. The whole is firmly and compactly interwoven with and strengthened around the rim of the carity by strong, wiry, and fibrous roots. The nest is very carefully and claborately lined with the black fibrons roots of some plant. The eggs, which were five in number, measure .72 of an inch in length by .56 in brealth. Their ground-color is a clear and brilliant white, and this is beantifnlly marked with dots and small blotches of blended brown, purple, and violet, varying in shades and tints, and grouped in a wreath around the larger end. 


\section{(i:LL: SETOPHAGA, SWAN:}

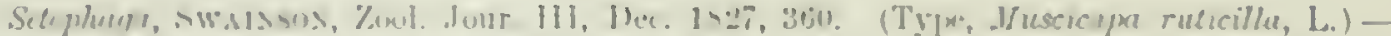

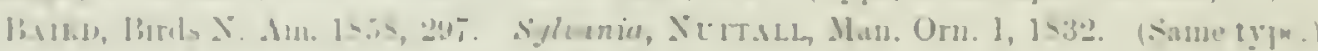

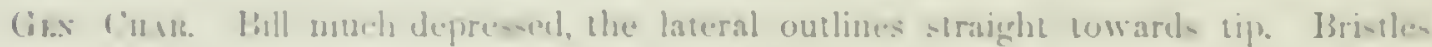

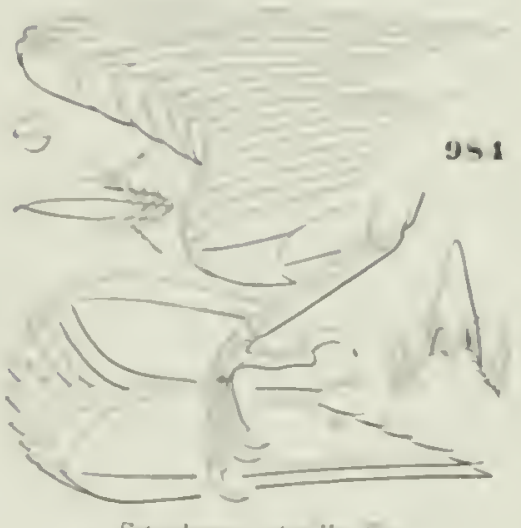
reatll lalf-way trom nostrl of tip. Culmen almust

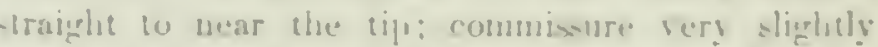

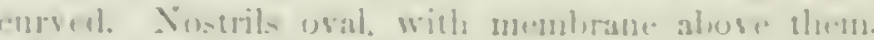

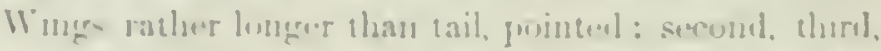
amel fourth quills mearly mplual: tir-t intermediate

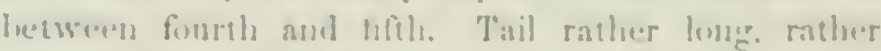
roumberl: the foathers broml, and willemug at end. the onter wel, narrow. Tarsi with smutellur disis-

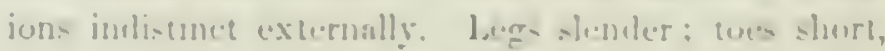
inner eleft netarly (o) hate of tir-t jublut, unter with tirst joint allierent: mblille toe willout claw, not

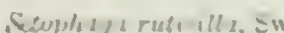
yuite lalf the tar: 1 =

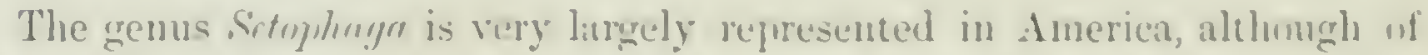
the many speciess satrely any anree exactly in form with the type. In the

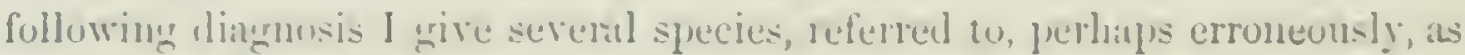
vecurring in Texis

Belly whitu. Ful uf lateral tail-fenthere bluk. Sexus elikimilar.

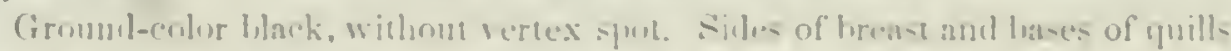

and tail-feathers redeli-h-orange in mule, bollow-h in timale.

ruticillı

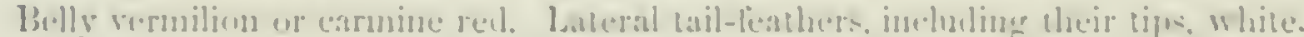
Scexes -imilar.

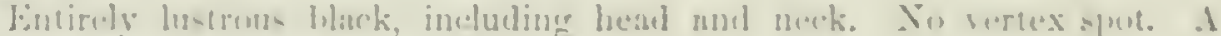
whil. pituls un the wings

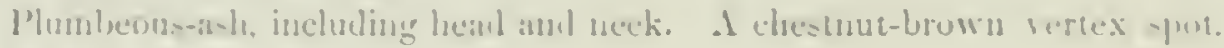
Su white un wings:

\section{Setophaga ruticilla, silsixs.}

\section{AMERICAN REDSTART.}

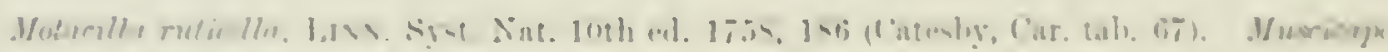

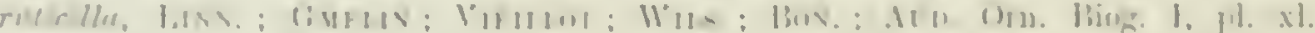

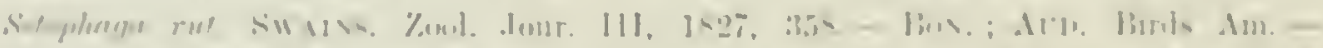

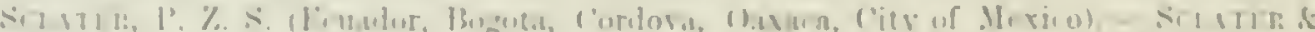

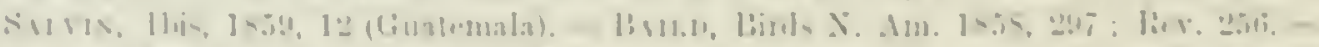

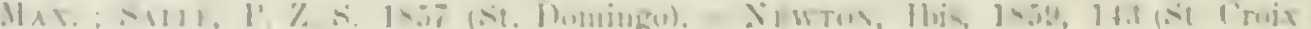

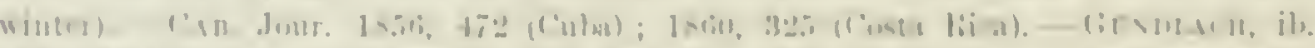

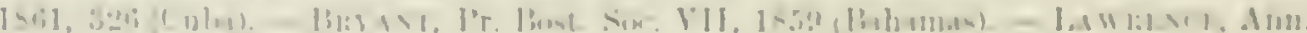

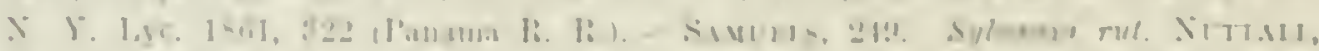

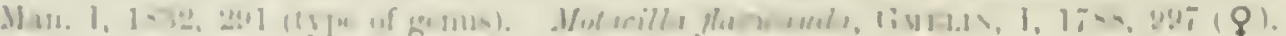

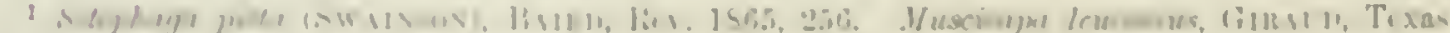

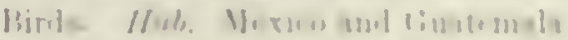

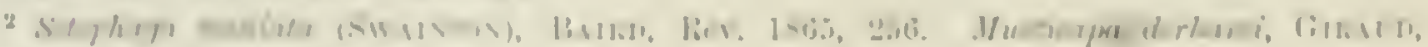

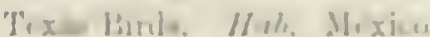


Sp. Cuar. Male. Prevailing eolor blaek. A central line on the breast, the abdomen. and under tail-corerts white; some feathers in the latter strongly tinged with dark brown. Bases of all the quills except the inner and outer, and basal half of all the tail-feathers except the middle one, a patch on each side of the breast, and the axillary region, orange-red, of a vermilion shade on the breast. Female with the black replaced by olive-green above, hy brownish-white beneath, the red jeplaced by yellow; the heal tinged with ash; a grayish-white lore and ring round the eye. Length, 5.25 ; wing, 2.50; tail, 2.45 .

Hab. Eastern and in part Middle Provinces of Nortl Americia to Fort Simpson, west to Great Salt Lake: Fort Laranie; Denrer City; most of the West Indies; Mexico to Ecuador.

The young male in early autumn greatly resembles in plumage the adult female, but has the upper tail-coverts and tail deep black, sliarply contrasted with the olive of the rump, instead of having the upper tail-corerts olive, the tail simply dusky; in addition the back is more greenish-olive, and the abdomen and crissum pure white. The male does not obtain the perfect adult plumage mutil about the third year.

HabITs. The so-called Redstart has an extended distribution from the Atlantic to the Rocky Mountains, and from Florida to high northern latitudes, having been found breeding at Fort Simpson by Mr. Ross, and at Fort Resolution by Mr. Kennicott and Mr. Lockhart. It is genernlly abundunt in suitable localities, and probably breerls wherever found north of the Potomac. It winters in large numbers in cruatemala and in other parts of Central Anerica, as well as in the West Indies. It is common in St. Croix in the spring,

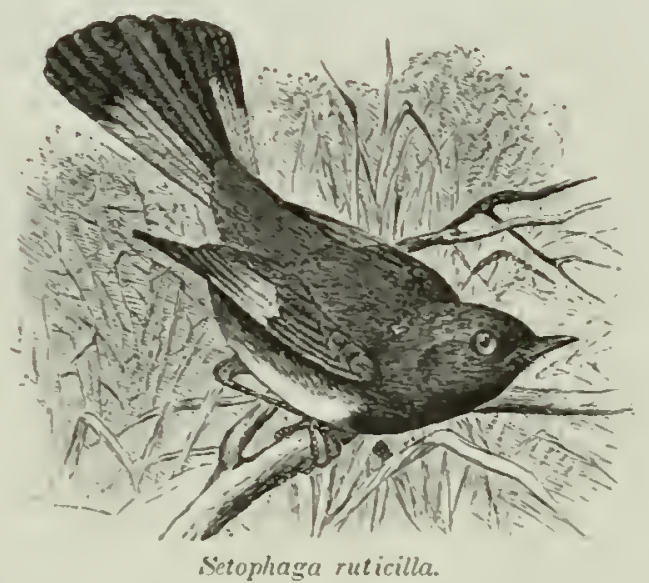
and is especially seen about houses, according to Newton. It remains there until the end of April.

Richardson found this species abundant on the Saskatcheran, as far to the north as the fifty-eighth parallel. It appeared there the list of May, and left early in September. He found it frequenting moist, shady lands, flitting about among the moss-grown and twisted stems of the tall willows that skirt the marshes. It was easily recognized by the red lining of its wings as it flitted throngh the gloomy shades in pursuit of mosquitoes and other winged insects.

Amoug the memoranda of the late Mr. Kemnicott, we find two to the effect that on the 26th of May he found both males and females of this species common near Rainy Lake, and that on the 6th of June he also observer these birds near Lake Wimnepeg. June 14, at Fort Riesolution, he ohtained a female Redstart with nest and four eggs. The nest was built in the fork of a willow, in a thick but low wood of alder and willow. It was entirely unprotected by leaves or branches. The female was taken on the nest.

The Newtons found this a very common species in St. Croix, in the spring 


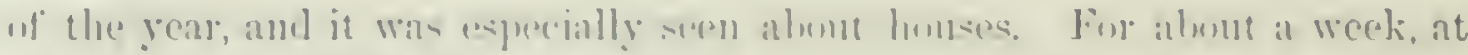

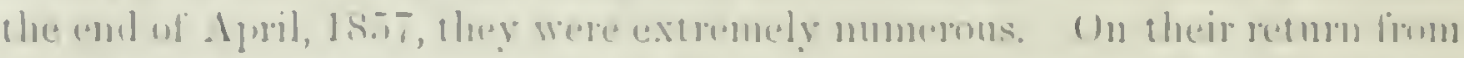

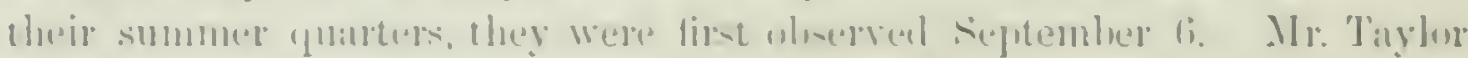

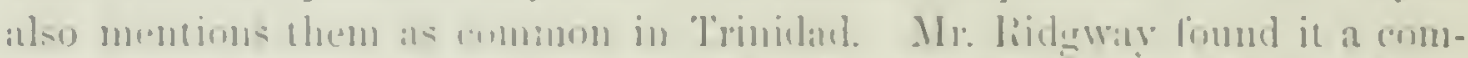

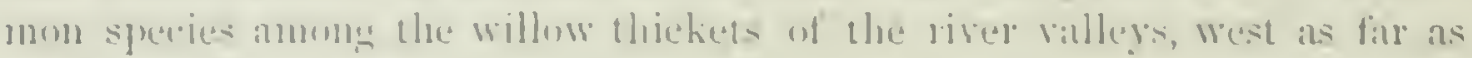

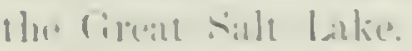

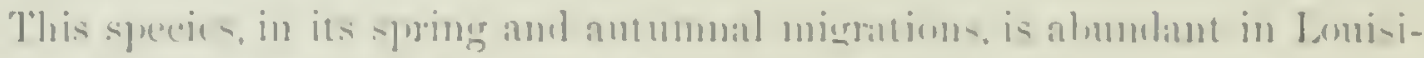

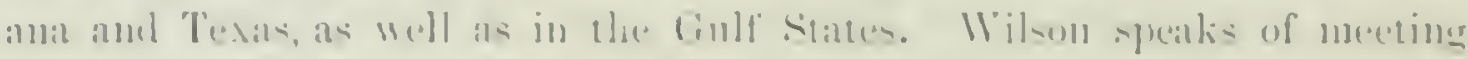

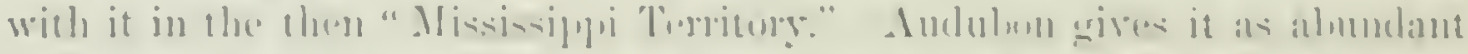

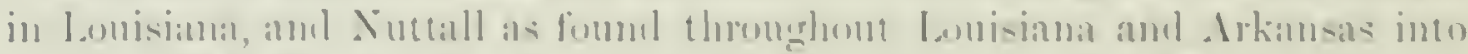

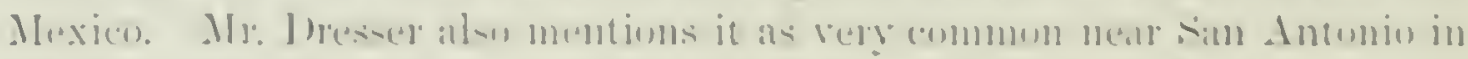
the spring and atutumu, alrising on the Medina the 27th of Aprit.

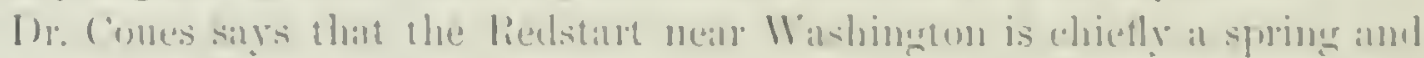

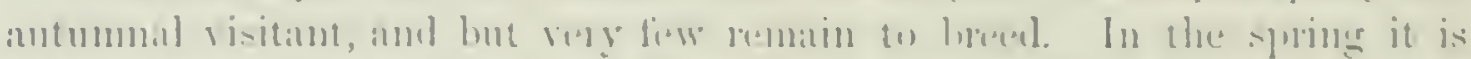

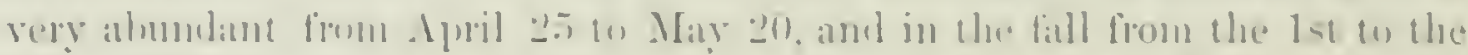

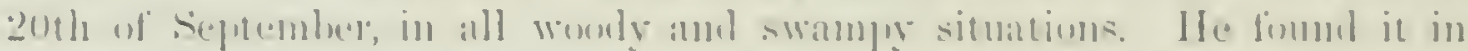
the hahit of rumning along slemeler twies, sinleways, and hoving a mote very similare to that of $D$. "sstirn.

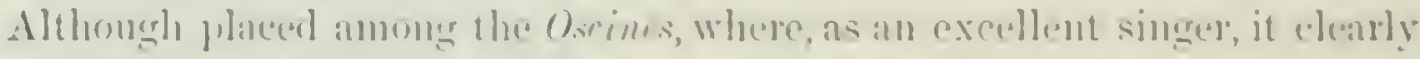

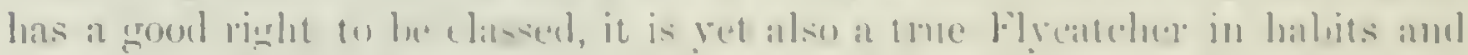

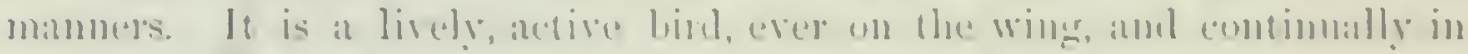

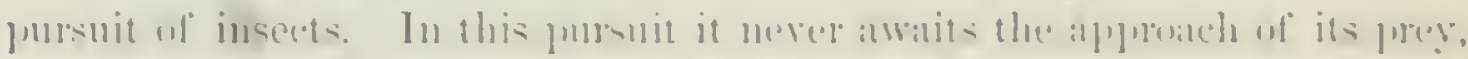

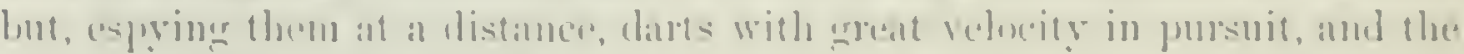

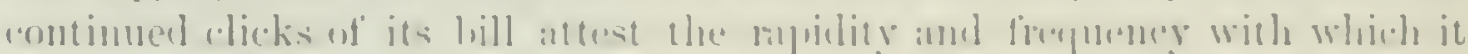

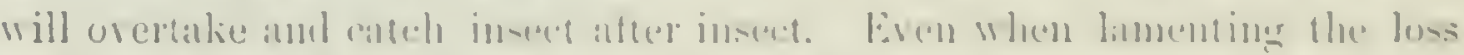

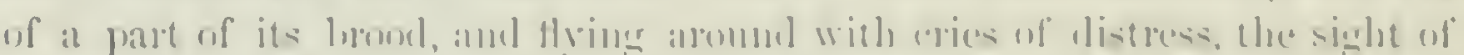

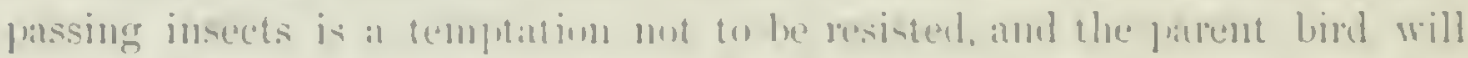

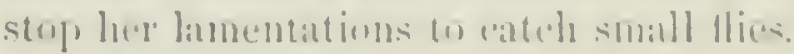

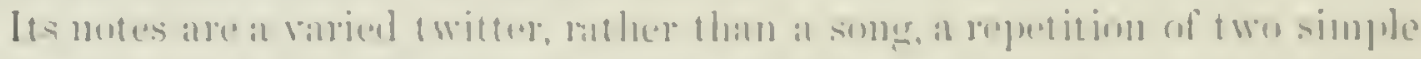

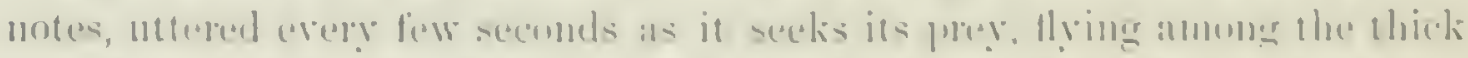

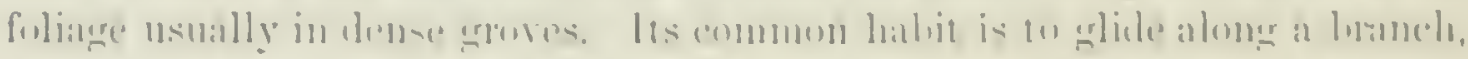
between its smaller twigs, at times dorting forth into more n]

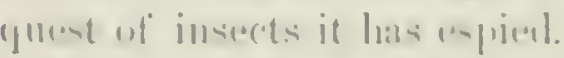

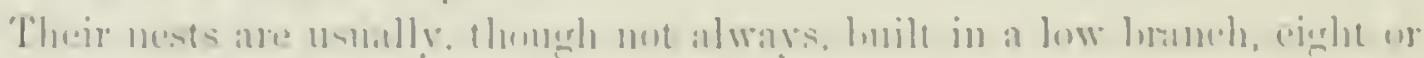

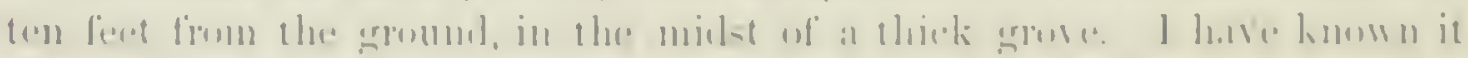
(1) bulle in :

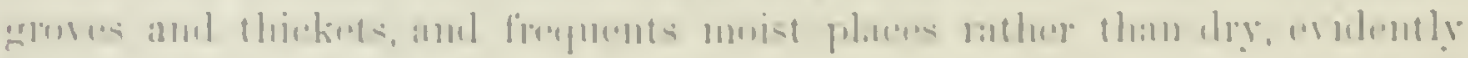

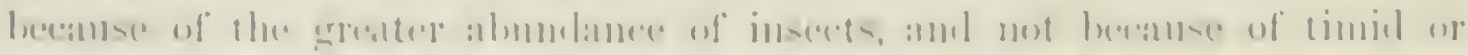

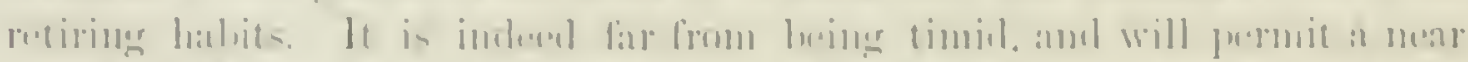
:1p]puach 11 th

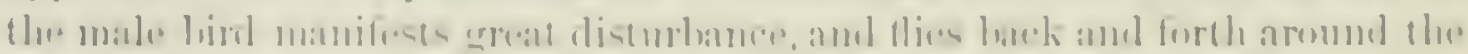

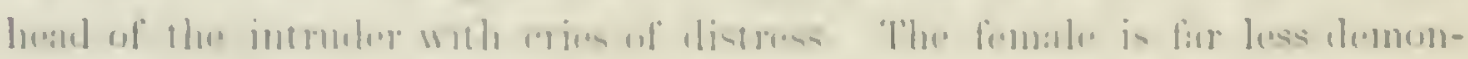

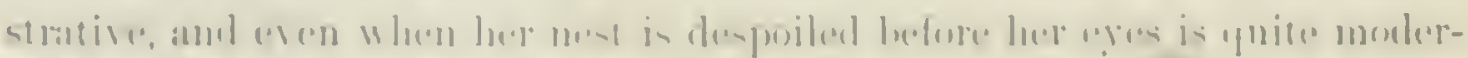

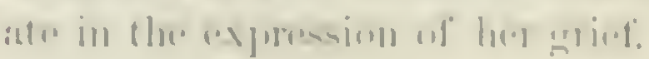


Its flight is graceful, ensy, and rapid, varied by circumstances as it glides in its intrieate course among small interlacing branches, or darts rapidly forth into more open space. As it moves, it is continually opening out, closing, or flirting from side to side its conspicuous tail, the white spots in its expanded feathers constantly appearing and disappearing.

In the construction of the nest there is a general uniformity of character, although the materials differ and the localities are far apart. They are never pendent, but are placed anong three or more small upright branches, around which it is firmly woren with regetable flax-like fibres. A nest obtained in Lrnn, by Mr. George O. Weleh (S. I. 3,778), in June, measures two inches in height hy three in diameter. It is a small, conpact, and homogeneous nest, compred almost entirely of shreds of sarin-bark internixed with solt rexgetable wool. Within are loosely intertwined minute regetable fibres and strips of bark, and a lining of horsehair, fine pine leares, and dry grasses. The nest contained tour eggs. Another nest found in Grind Menan, June 24,1851 , was rery similar in size, structure, and materials. It was in the centre of a thick, swampry thicket, fire feet from the ground, and containecl five eggrs.

Another nest of this hird, obtained in Lynu by Mr. Welch, is only a reconstruction of a nest hegun by a pair of Dendroicn astizn, and either abandoned by them, or from which they had been driven. Above the original nest of the Warbler the liedstarts had construeted their own. The base is composed of the downy covering of the nuller silles of the leaves of ferns, mixed with a few herbaceous stems and leaves. Within this was built an entirely distinct nest, composed of lonic and slender strips of bark, pineneedles, and stems of grasses. These are firmly and elaburately interworen together.

A nest found in Hingham, lunilt in a tree in an open space near a dwelling, was seven feet from the ground, and of the usual size and shape. In this the more usual strips of bark were rejlaced hy hempen fibres of vegetables, thistle-down, bits of newspaper, and other fragments. Within is a strong lining of hair and fine stems of grasses. In this nest there were two young, about half fledged, and two egers nearly fresh. The latter were taken, the female parent being present and making only a very slight protest, stopping, from time to time, to catch insects.

The eggrs of the Redstart rary consilerably in their size and in their general appearance, but resemble somewhat those of the common summer Yellow-Bird. They vary in length from .55 to .68 of an inch, and in their breadth from 4.5 to .53 . Their ground-color is a grayish-white, blotehed and dotted witl purple, lilac, and brown. 


\section{FMMY HIRUNDINIDE. - THE SWALLNW:}

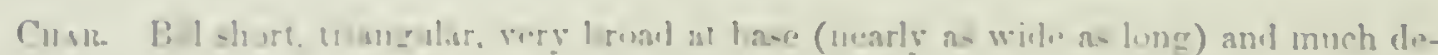

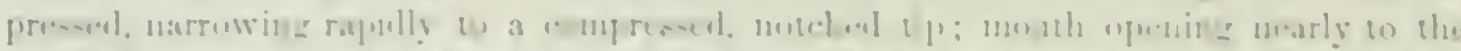

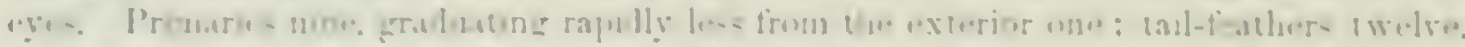

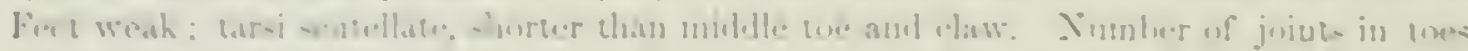

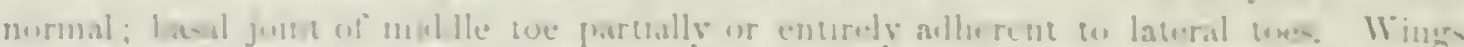

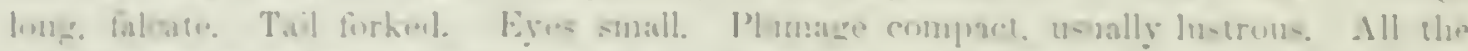

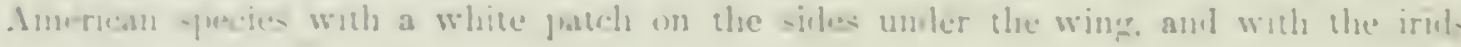
hazed or l ruwn.

Th. Mirundinilde form a rorg well mathed group of birls rasily distingui-hed trom all others. They whibit a close resemblance, in external apr-

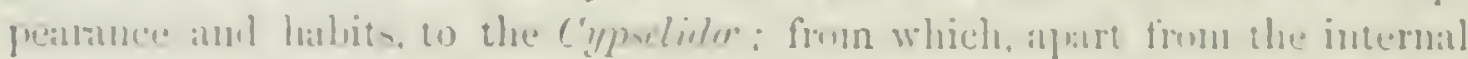

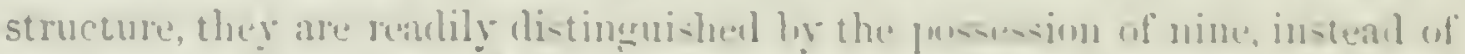

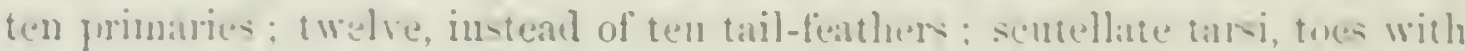

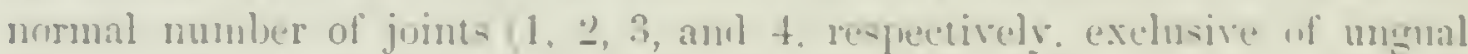

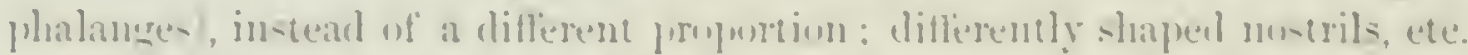
In huth limilies the wings are developed to an extromedinary deugree: the

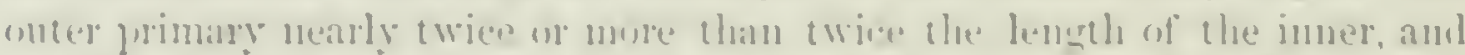

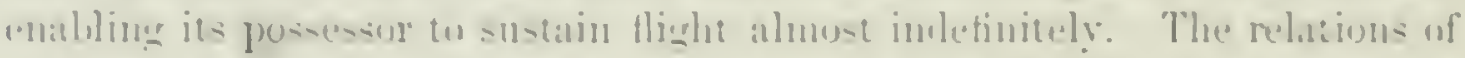

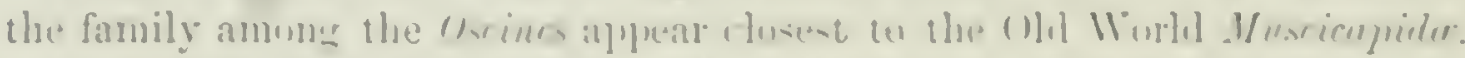

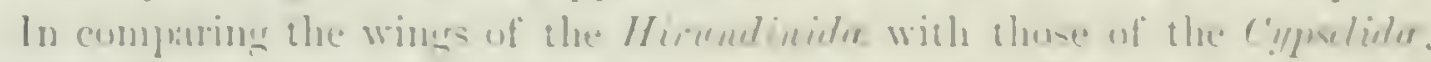

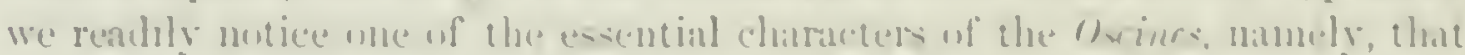

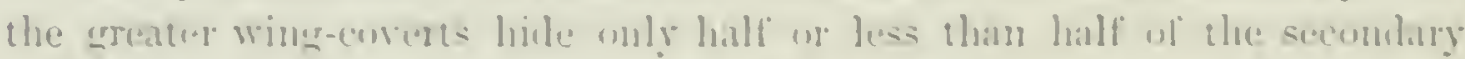

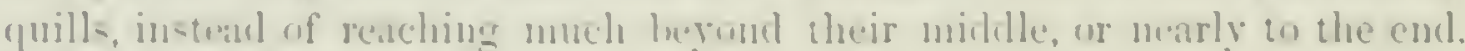

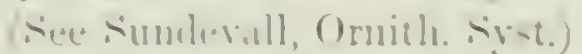

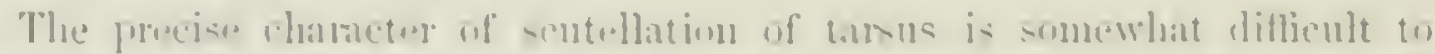

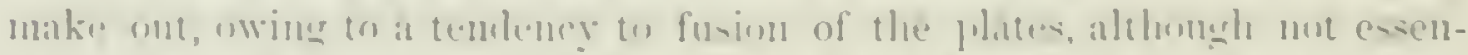
tinlly dillegent from most Wrinas. There is a series of sombllie aloner the

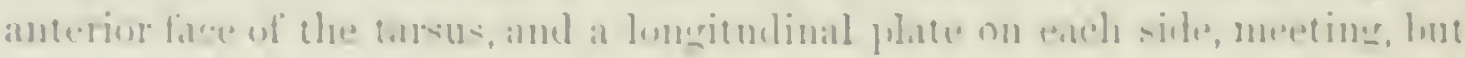

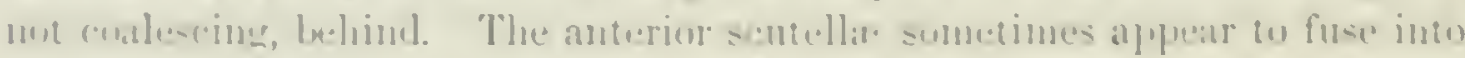

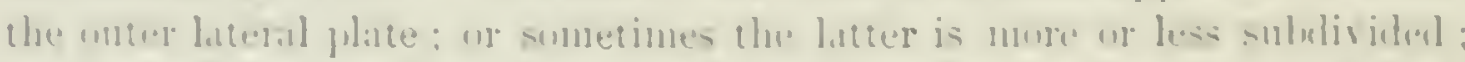

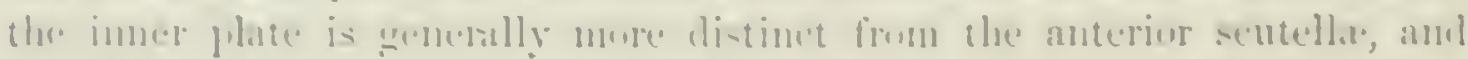

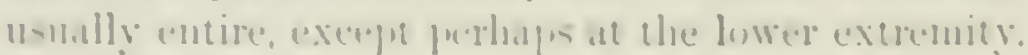

\section{Gener of North American Hirundinidx.}

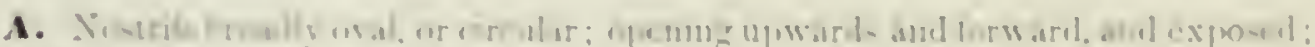

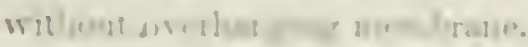

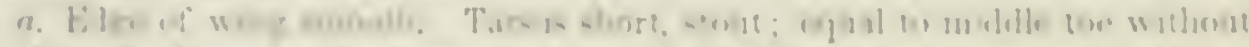

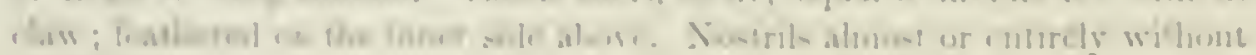

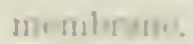

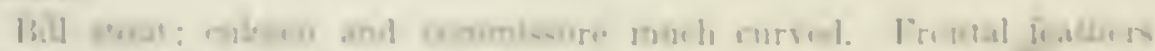

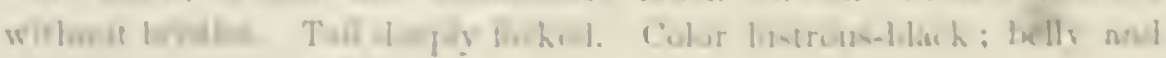
1 Trensu : 1.1 
Bill rather weaker; commissure and culmen nearly strajglit to near tip. Frontal feathers bristly. Tail nearly eren. Throat, rump, and erissum. and usually forehead, rufous: belly white . . . . Pctrochelinlon. b. Edge of wing stmooth. Tarsus longer than in last; equal to middle toe and half the claw. Nostrils bordered along posterior half by membrane, but not orerhung internally. Bill rers small. Tail forked. Crissum dusky except in Veochelidon jucati. Various genera aud subgenera, none Yorth American, as Atticora, Notiochelidon, Neochelidon, and Pygochelidon.

c. Edge of wing armed with stiff recurved hooks. Tarsus as in preceding (tarsus and toes much as in Pygochelirlou). Bill larger and more depressed. Tail emarginate only. Crissum white . . . . . . Silelgidopteryx. B. Tostrils lateral; bordered behind and inside, or orerhung by membrane, the onter edge of which is straight, and directed either parallel with axis of bill or diverging from it.

a. Tarsus short; abont equal to middle toe withont elaw. Tibial joint feathered; feathers extending along inside of upper end of tarsus.

Tarsus bare at lower end. Lateral claws reaching only to base of mildle.

Tail rery deeply forked, much longer than elosed wings; lateral feathers linear and rery narrow at end, twice the length of central. Upper parts and pectoral collar steel-blue; front and throat, sometimes under parts, rufons. Tail-feathers with large spots . Hirundo.

- Tail with shallow fork, not exceeding half an inch, shorter than closed wings. Feathers broal. Color blue or green abore, with or without white rump; white beneatl. Tail-feathers without spots . . . . . . . . . . . Tachycinela. Tarsus with a tuft of feathers at lower end. Lateral elaws lengtheuet, reaching berond base of middle claw.

Tail slightly forked. Color dull-brown abore; benenth white, with brown pectoral collar

Cotyle. b. Tarsus long; equal to middle toe and half elaw : entirely bare. Tait considerably forked, about equal to elosed wing. Color green abore; white beneath

Callichelidon.

\section{Gexts PROGNE, BoIE.}

Progne, Boif, Isis, 1526, 971. (Trpe, Hirundo purpurea vel subis, L.)-BaIrd, Birds X. Am. $1555,314$.

Gex. Cuar. Body stont. Bill robust, lengthened: lower or commissural edge of maxilla sinuated, decidedly convex for basal half, then as concave to the tip, the lower mandible falling within its chord. Nostrits superior, broally open, and nearty cireular. without any adjacent membrane, the elges rounled. Legs stout. Tarsus equal to middle toe without claw; the joint feathered: lateral toes about equal; the basal joint of the middle toe half free internally, rather less so externally. Claws strong, much curred. Nest in hollow trees. Eggs white.

The species of this genus are the most powerful and robust of the Swallows. Some are entirely glossy-black, others whitish below. The following

1 Ifirundo (Callichclidon) cyaneoviridis (Briast), Bann, Rer. Am. Birds, 1565, 303. Bahamas. This species may yet be detected on the Florida coast. 


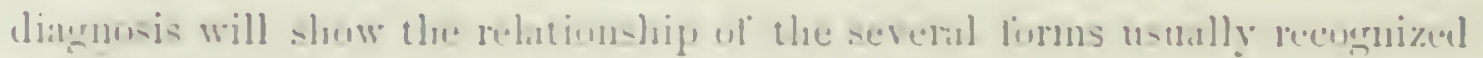
ats distuset - precter :-

\section{Species and Varieties.}

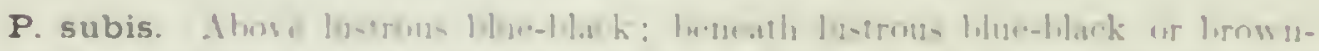

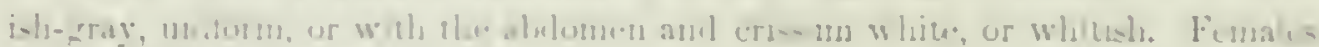

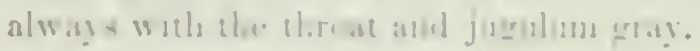

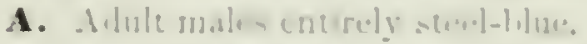

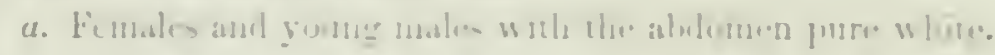

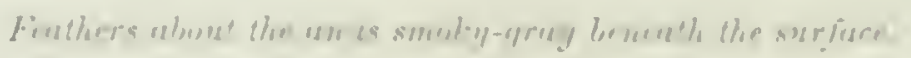

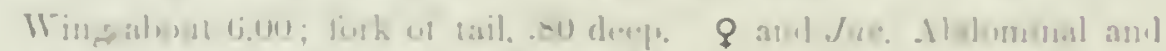

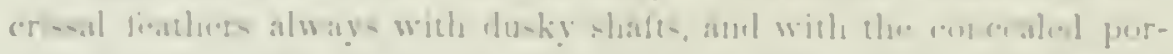

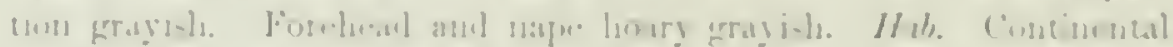

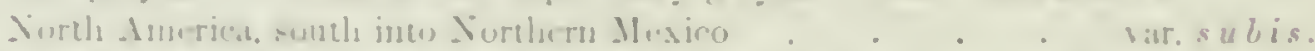

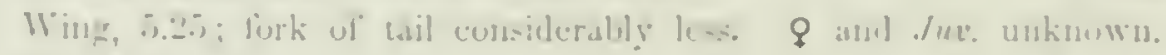

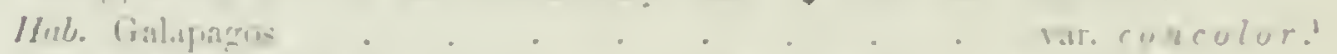

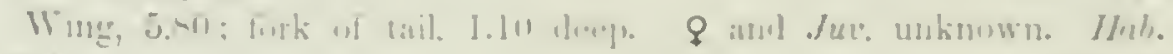
Chilj

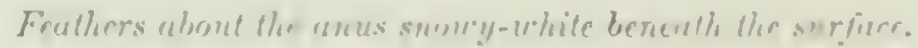

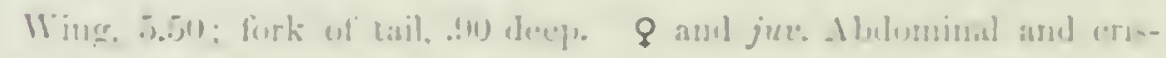

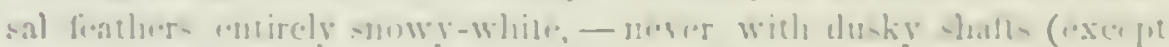

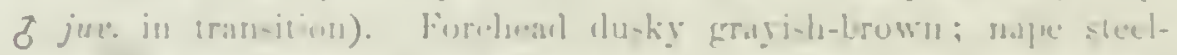

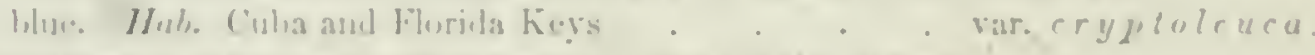

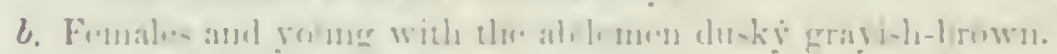

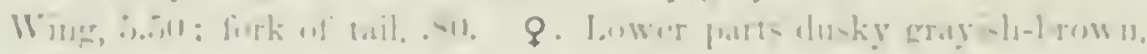

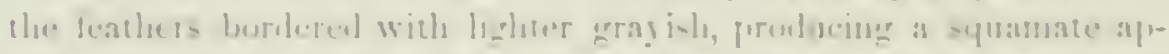

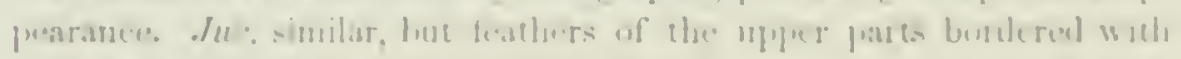

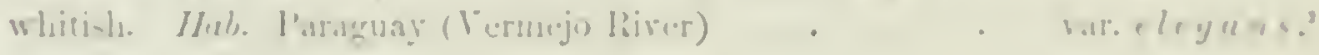

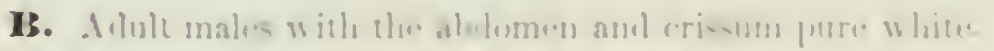

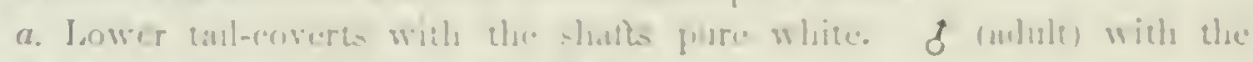

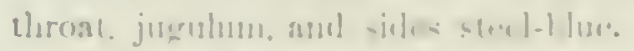

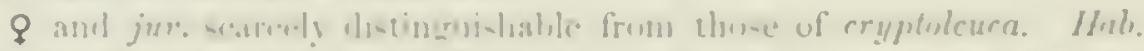

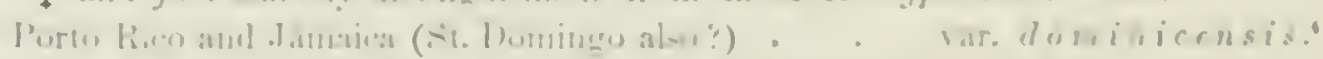

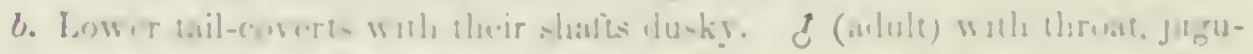

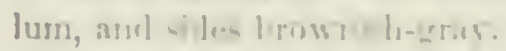

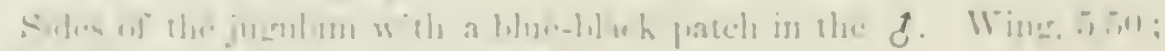

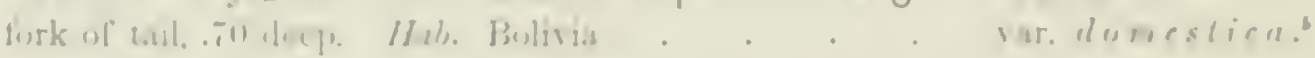

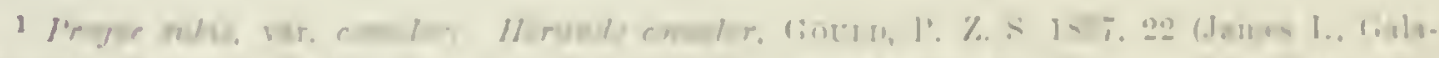

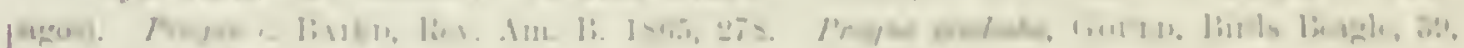

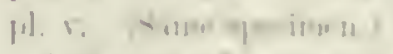

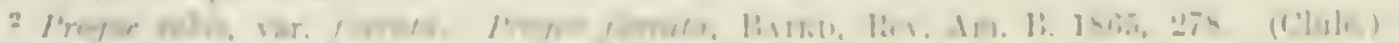

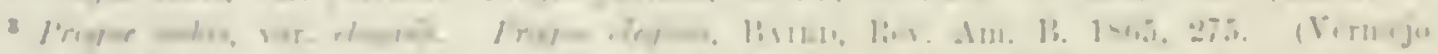

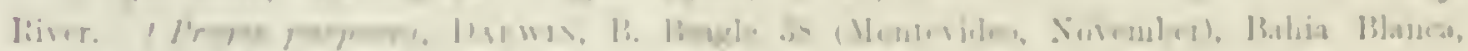

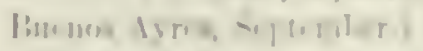

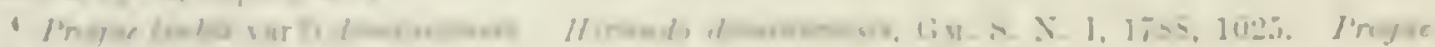

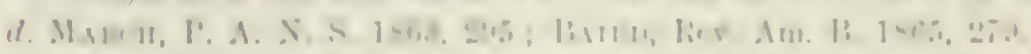

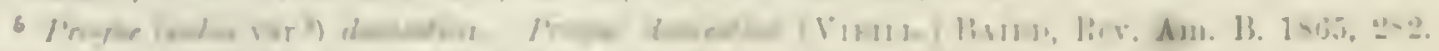

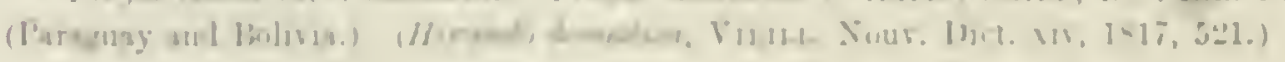


Sides of the jugulum without a blue-black patch in the 8 . Wing, 5.20 ; fork of tail, .55 deep. IIab. Widdlle America, from Southern Mexico to New Granada

rar. lencogaster.

\section{Progne subis, Baird.}

\section{PURPLE MARTIN}

Hirundo subis, Lixx. S. N. 10th ed. 1758,192 (Hirundo ccemlca canadensis, Enwards, Ar. tab. 120, Hudson's Bary). Promne sulis, Banlin, lier. An. Birds, 1864, $274 . \quad$ II.

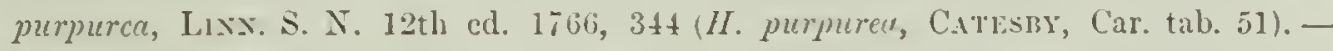
Alv. Orn. Biog. 1, pl. xxiii. - lis. Birds An. I, pl. xlv. - Yalitele, Br. Birds, ll, 232, 2 it (England and lreland, Sept. 1S42). - Joxes, Nat. Bermuda, 34 (Sept. 22,

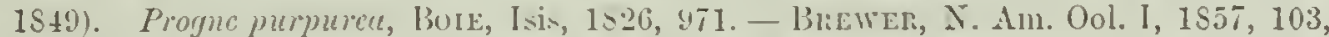
pl. ir, fig. 47 (eggs). - Batid, Birds N. Anı. 1sis, 31 4. - Coopeli \& Suckler, P. R. R. Rep. Xll, 2, 1S6 (Fort Steilacoom). - Bukistux, 1bis, 1863, 65 (Saskatchewan) Cooper, Orn. Cal. I, 1S70, 113. - StuleLs, 200. Hirundo violucea, Gs. H. ccorulea, Vielle. H. versicolor, VIeiLL. H. lutoricianu, Cly.

Sp. Cmar. (No. 1,j61 ठ.) Entirely lustrous steel-blue, with a purplish gloss; the tailfeathers and the wings, except the lesser and mildle coverts, and edge inside, dull black,

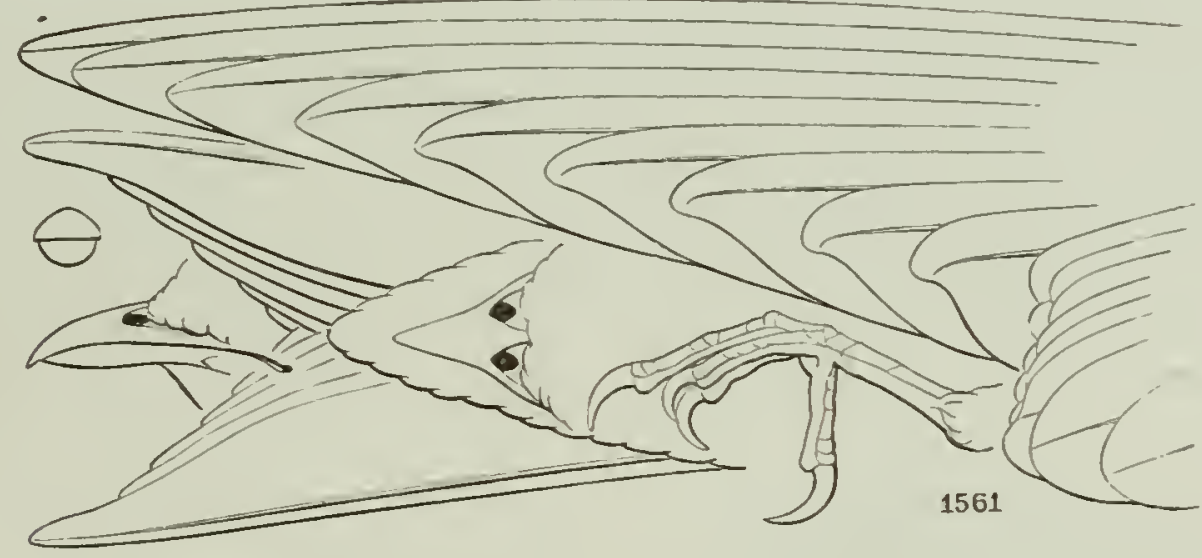

Progue subis.

scarcely glossed. Tibire dark brownish. A concealed patch of white on the sides under the wings. Concealed central portion of anal feathers light whitish-gray.

(No. 1,129 9.) Above somewhat similar, but much duller. Beneath smoky brownish-gray, without lustre, paler behind, and hecoming sometimes quite whitish on belly and

${ }^{6}$ Progne, (subis rar?) lcucongaster. F'rogue lcuconyuster, B.Amn, Rer. Am. B. 1S65, 280.

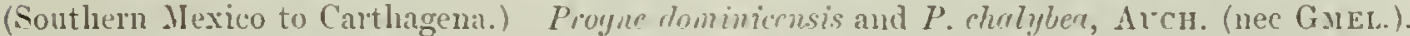

From a careful examination of specimens of the above forms, the opinion that they are all local differentiations of one primitive tyje at once presents itself. The diflerences from the typical subis are not great, except in the white-lrellied gromp (dominicensis and its allier), while an approach to the white helly of these is plainly to be seen in $P$. cryptoleuca; again, sone specimens of dominiccnsis have the crissum nixed with blackish, while others have it wholly snowywhite. While the male of cmptolcuce is scarcely distinguishablc, at first sight, from that of subis, the female is entirely different, but, on the other hand, scarcely to be distinguished from that of dominiconsis and lcucoryster. Adult males of the latter species are much like actult females of dominiccusis, while Florilan (resident) specimens of subis approach very decidedly to the rather unique eharacters of clcgans. It is therefore extremely probable that all are merely local modifications of one speeies. 


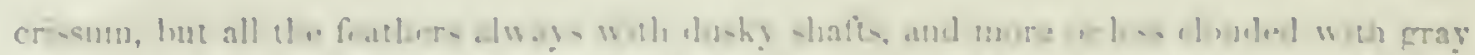

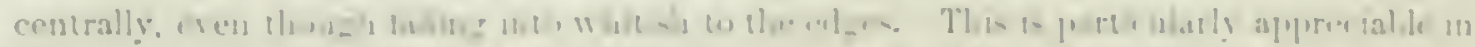

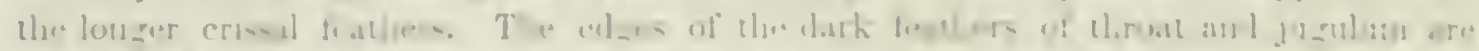

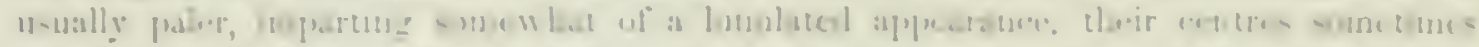

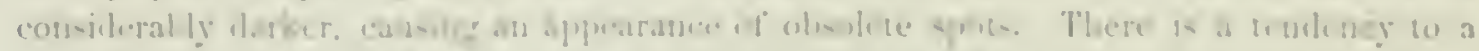

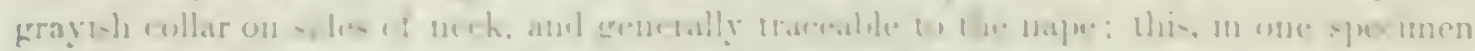

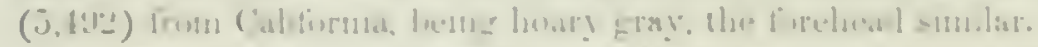

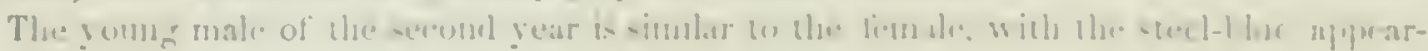

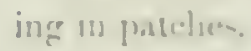

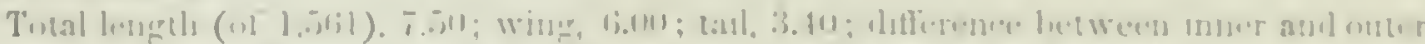

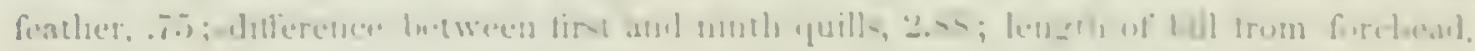

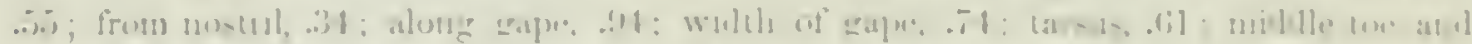

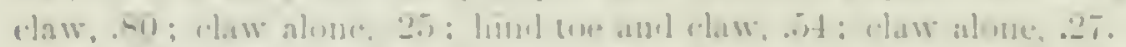

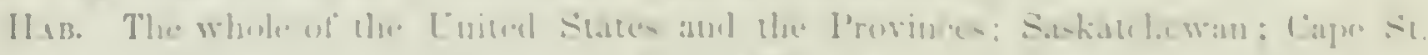

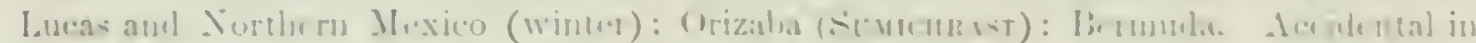

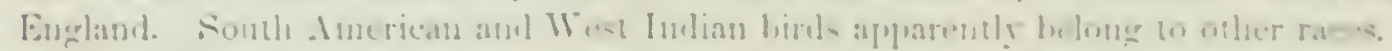

Many Weatern anlult males are cunsideraluly less viulacenus than any bast-

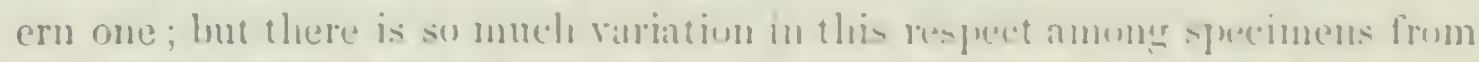
one Incality, that this dillerence in lustre does not seent of muth importance.

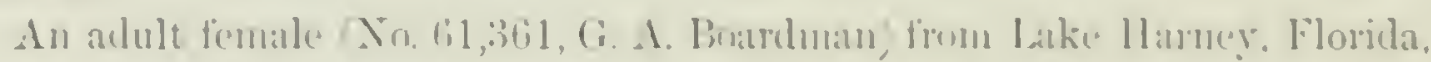

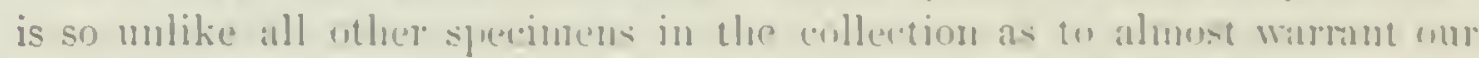
considerine it as reprecenting a distinet locenl ratee. It ditlers from females

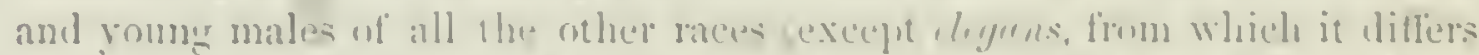
in other striking particulars) in the following sespects: . 1 luse, the lustrous

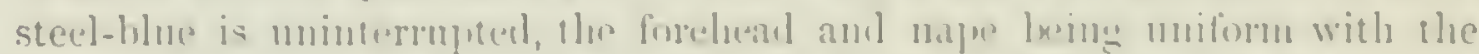

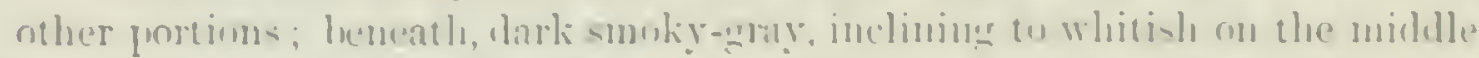

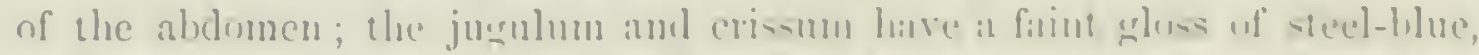

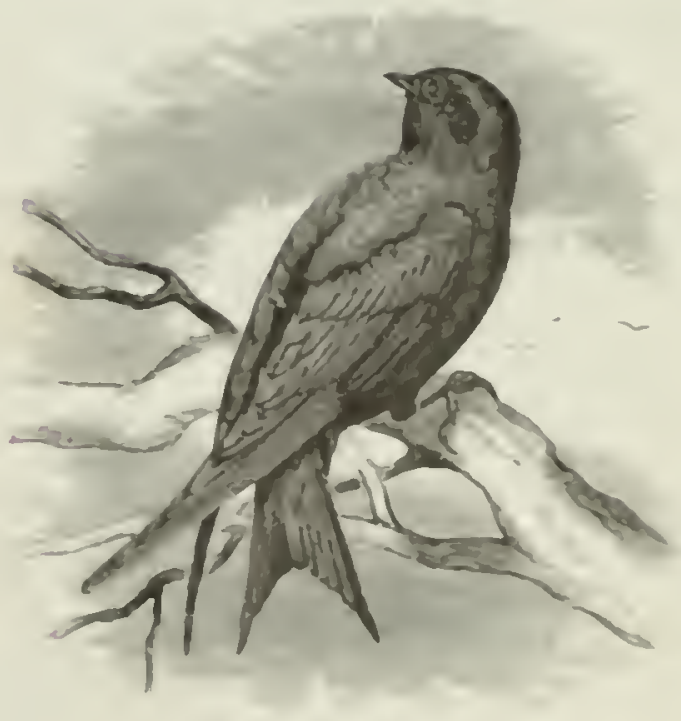

$r=$ ne 13 the laitlures of the latter burlereal with gray-h-white. The chice ditler-

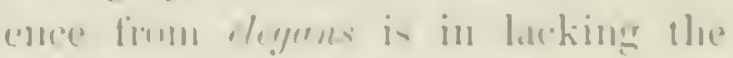

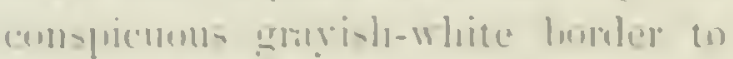

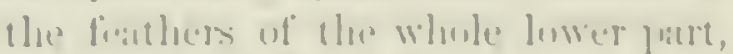

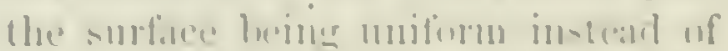
('m)

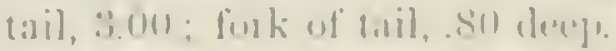

H.mers The Puпple Mantm is 1011 phat bally a hisel common to she whole

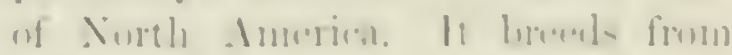
Floribla a high northern latitules,

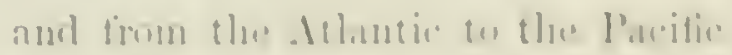
It is wrealumlum in Flurida, as it

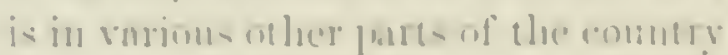

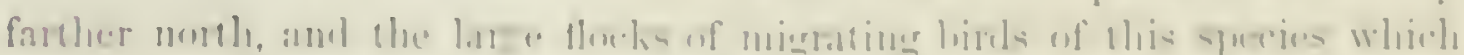

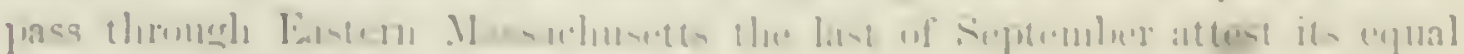

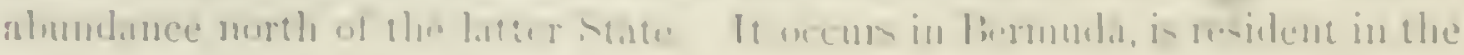


alpine regions of Mexico, and is also found at Cape St. Lucas. Accidental specimens have been detected in England and in Treland. It is abundant on the Saskatcheran. Burmeister states that this species is common in the vieinity of Rio de Janeiro, and that it is distributed in moderate abundance through the whole of tropieal South America. Ton Pelzeln also cites it as occurring on the Rio Negro and at Manaqueri through the three winter months, nesting in old buildings and in holes in the rocks. It is, however, quite possible that they refer to an allied but distinct speeies.

In a wild state the natural resort of this species, for nesting and shelter, was to hollow trees and crevasses in rocks. The introduction of civilized life, and with it of other safer and more comrenient places, better adapted to their wants, has wronght an entire change in its habits. It is now very rarely known to resort to a hollow tree, thongh it will do so where better provision is not to be had. Comfortable and convenient boxes, of various devices, in our cities and large towns, attract them to build in small communities around the dwellings of man, where their social, familiar, and confiding disposition make them general favorites. There they find abundance of insect food, and repay their benefactors by the destruction of numerous injurious and noxious kinds, and there, too, they are also comparatively safe from their own enemies. These conveniences vary from the elegant martinhouses that adorn private grounds in our Eastern cities to the ruder gourds and calabashes which are said to be frequently placed near the humbler cabins of the Southem negroes. In Washington the columns of the public buildings, and the eaves and sheltered portions of the piazzas, afford a convenient protection to large numbers around the Patent Office and the PostOffice buildings.

The abundance of this species varies in different parts of the country, from causes not always apparent. In the vicinity of Boston it is quite unusual, though said to have been, forty years since, quite common. There their places are taken by the $H$. bicolor, who occupy almost exclusively the martin-houses, and very rarely build in hollow trees.

Sir Joln Richardson states that it arrires within the Aretic Circle earlier than any other of its family. It made its first appearance at Great Bear Lake as early as the 17th of May, when the ground was covered with snow, and the rivers and lakes were all icebound.

In the Sonthern States it is said to raise three lroods in a season; in its nore northem distribution it raises but one. Their early migrations expose the Martins to severe exposure and suffering from changes of weather, in which large numbers have been known to perish. An occurrence of this kind is said to have taken place in Eastern Massachusetts, where nearly all the birds of this species were destroyed, and where to this day their places have never been supplied.

Within its selected compartment the Martin prepares a loose and irregular nest. This is composed of various materials, such as fine dry leares, straws, 


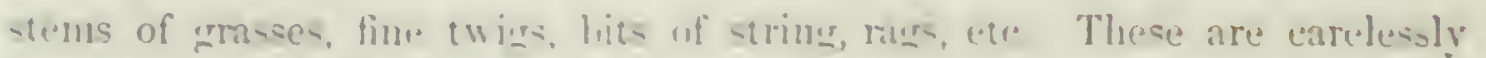
thrown together, and the whole is nsually warmly lined with feathers or other soft material. This ne-t is ancupled year atter year hy the sane pair,

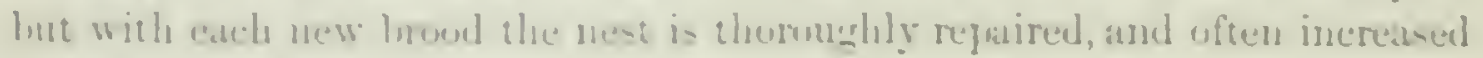
in size ly the aneumulation of uew materials.

The Martin do sot winter in the Lnited states, but enter the extreme

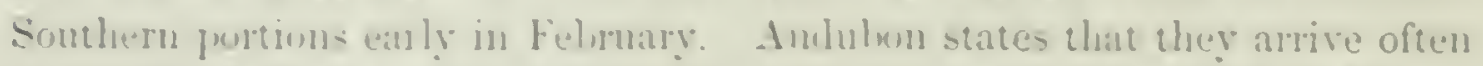

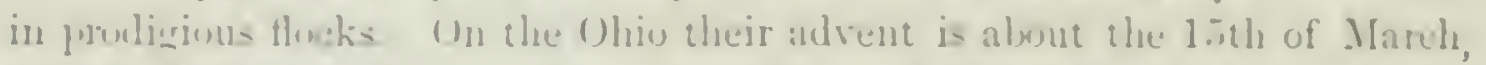

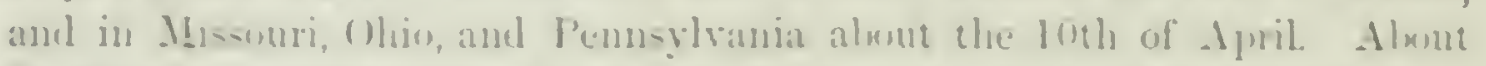

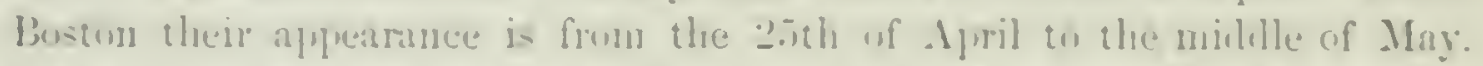
Mr. Auchumen states that they all return to the Simuthern States about the

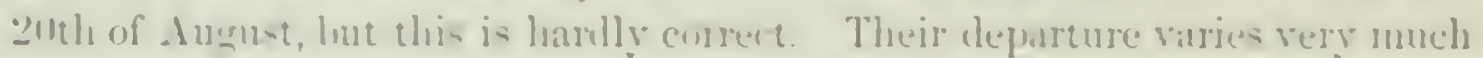
with the senson. In the fall of $18 \mathrm{~S} 0$ they were to be found in large flocks, slowly moving sulthwarl. but often remaining several dlys at a time at the sane place, and then proceeding to their next halt. The-ir farvite place for such stops are usually a high and uninhahited hillside near the sea.

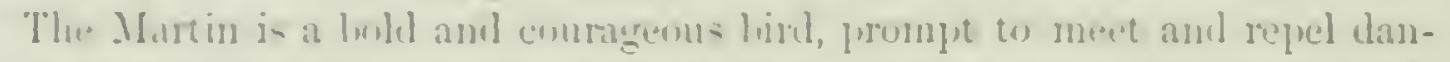
gers, eprecially when threatened by winged enenics. never hesitnting to at-

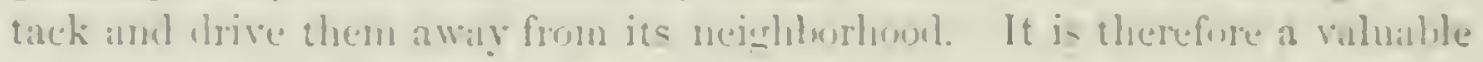
protection to the hanyard. Its food is the laryer hinds of insects, eapecially

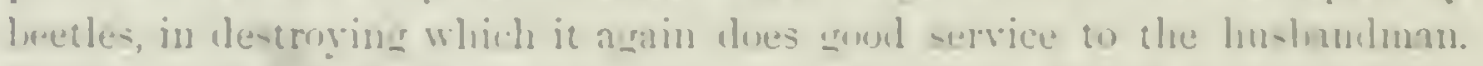
The sme of the Martin is a snece-ion of twittels, which, without Ixeing musical, are far from leing unpleasmt they leegin with the earliest dawn, and eluring the earlier gerionls of incolnation are alumet incesantly repeated.

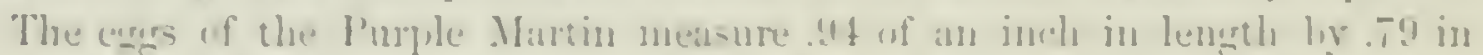

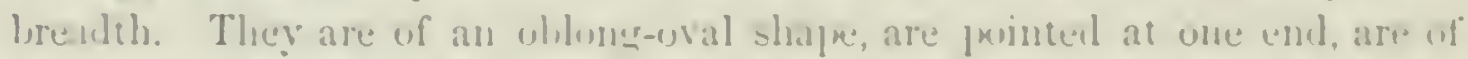
a uniform creamy-white, and are never spoted. They ane yuite unifom

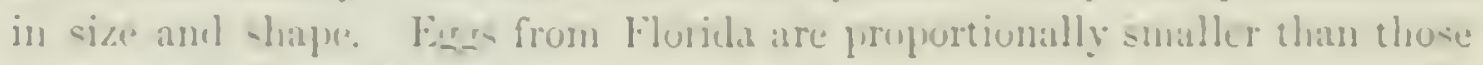
from the Sortlesu States.

\section{Progne subis, var. cryptoleuca, Bimb.}

\section{CUBAS MARTIN.}

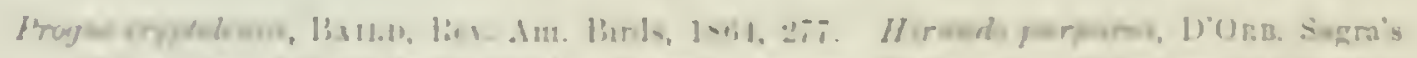

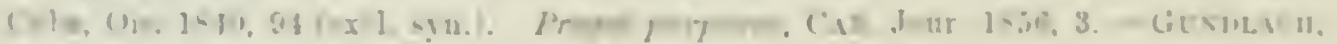

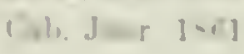

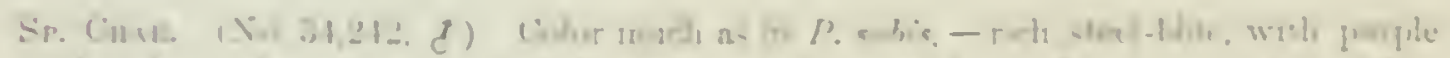

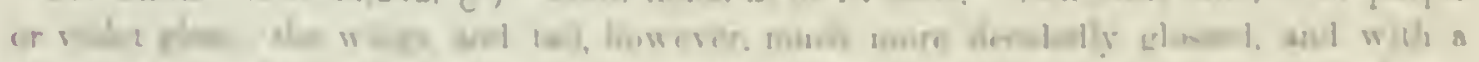

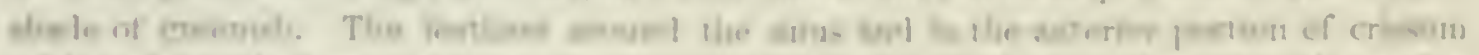

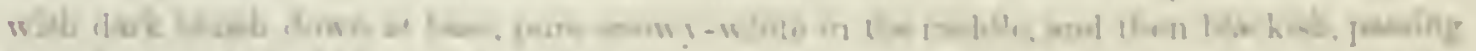

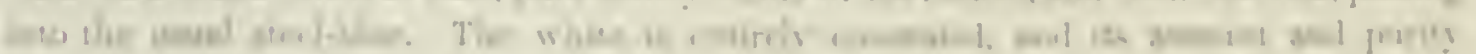

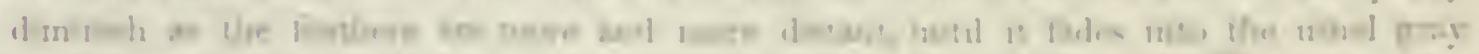

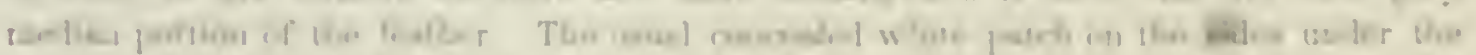

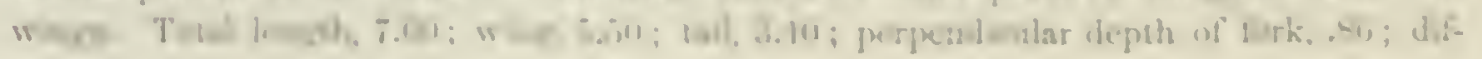


ference between first and ninth primary, 2.75; length of bill from forehead, .55; from nostril, .34; along gape, .86 ; width, ..58; tarsus, .53 ; middle toe and claw, .59 ; claw alone, .24 ; himl toe and claw, .52; claw alone, .25.

Female (17,730, Monte Ferde, Cuba, Mary 2; C. Wright). Abore steel-blue, less glossy than in the male, and becoming lustreless dark smoky-brown on the forehead. Heat, laterally and beneath, with jugnlum and sides, uniform brownish-gray (without darker shafts or lighter borders to feather's, as in subis); whole abdomen, anal region, and crissum snowy-white, including the shafts. Iring, i.t0: tail. 2.80; fork of tail, 70 deep.

Young male (10,36s, Cape Florida, May 18, 1858; G. Wurdemamn). Similar to the female, but the steel-blue abore more brilliant and contimons, the forehead and wings being nearly as lustrous as the back; throat and jugulum mixed with steel-blue feather's. and crissum with some feathers of steel-blue bordered with whitish. Wing, 5.40; tail, 2.90 ; furk of tail, .so tleep.

Hab. Cuba, and Florida Keys? (Perhaps Bahamas.)

This species has a close external resemblance to $P$. subis, for which it has usually been mistaken. It is of nearly the same size, but the feet are clisproportionately smaller and weaker; while the wings are shorter, the tail is as long and more deeply forked; the feathers considerably narrower, and more attenuated (the onter 40 wide, instearl of .46 ). The colors above are more brilliant, and extend more orer the greater wing-coverts and lining of wings, while the quills and tail-feathers have a richer gloss of purplish, changing to greenish. An apparently good diagnostic feature is the concealed pure white of the feathers about the anal regions, replaced in subis by grayish, rarely approximating to whitish.

A Progne collected by Mrr. Wricht, at Monte Verde, is duller in color than that from Remedios, but has still more concealed white below, in the median portion, not only of the anal feathers, but of those of the entire crissum and of the belly. A female bird, which I presume to be the same species, can scarcely be distinguished from the female of dominicensis, except in the brownish shafts of the longer crissal feathers, and an almost imperceptible tinge of brownish in the webs of the same feathers. It is almost exactly like the $P$. leucogaste of Mexico and Central America.

This species is included in the Nortl American fauna in consequence of the capture of a specimen (No. 10,368 o jur., May 18, 1858) at Cape Florida, which is with scarcely a doubt referahle to it. This specimen is a young male in its second year, so that it is difficult to ascertain positively its relationship to the two allied species; but as it agrees perfectly in its proportions with cryptoleuca, and its plumage differs from the corresponding one of subis in essential respects, we have little hesitation in referring it to the former.

Nothing distinctive is recorded as to the habits of this bird. 


\section{(ivin PETROCHELIDON, ('MANIS.}

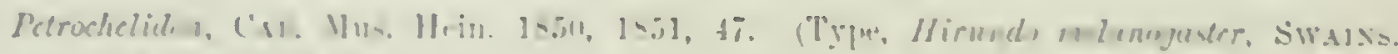
- l'. siaxe, sirl.

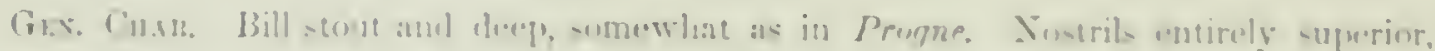

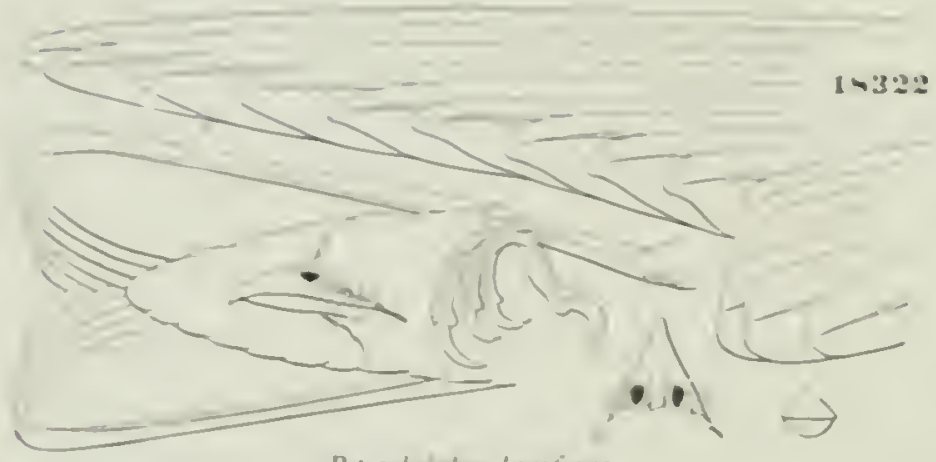

opwn, withos overhangerise membrane on lase insuer (or "lplet) side. lout somewhat

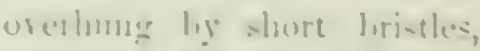

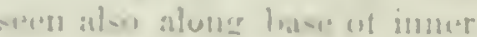
mambille and in thin. Leess -tout: the tar-i hort, not i.x-

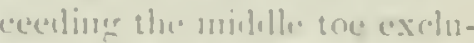
sive of its rlaw : Feathered all romul for lasal third or fourd. thenghts no lindlers are incertwh on the po-terior lice. Thal

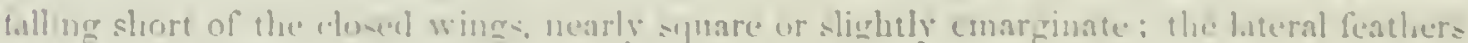
broal to near the ands. and mot antelunatenl.

Of this grenus as gestricted we have hut one species in Sorth America, althmuh several others necur in the We-t Indies and the southern parts ut the continent. All have the back steed-blue, with concealed streaks of white; the sump, crissum, and a natrow nuchal band, and usually the forchead, chestumt.

\section{Petrochelidon lunifrons, Batrin.}

\section{CLIFF SWALLOW : EAVE SWALLOW.}

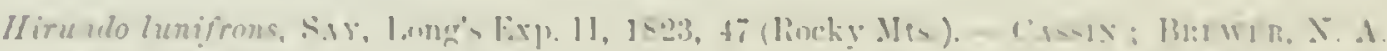

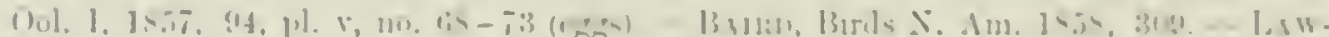

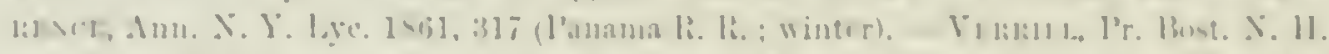

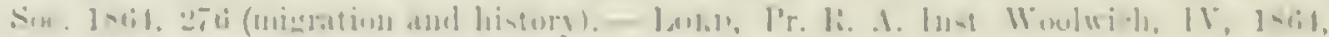

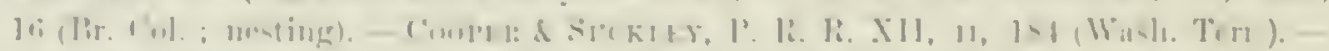

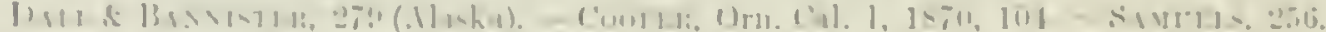

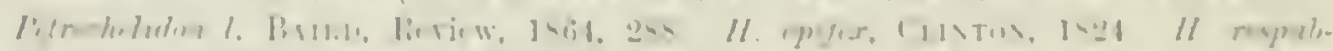

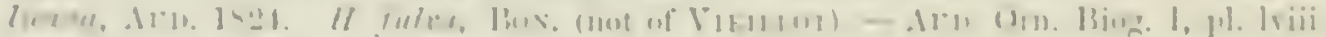

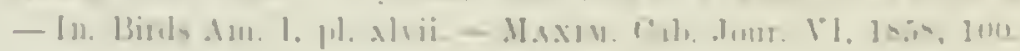

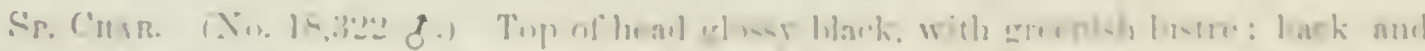

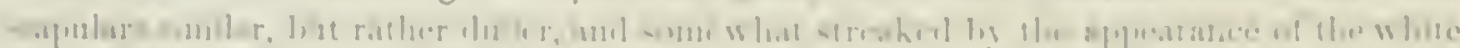

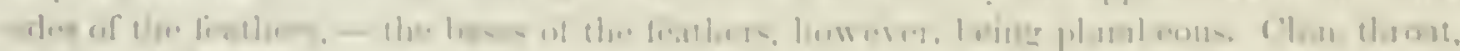

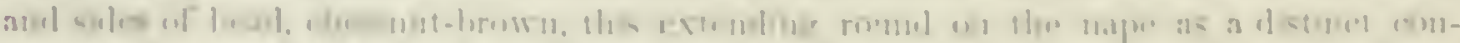

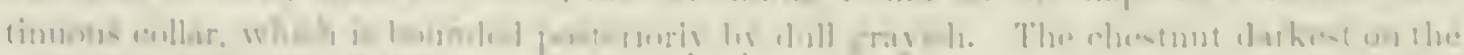

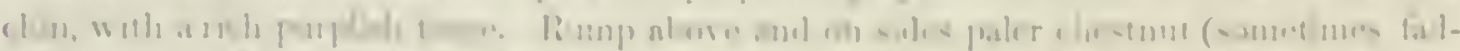

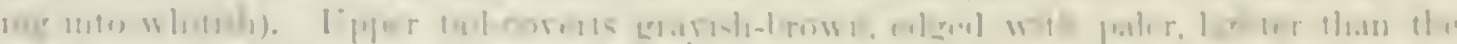

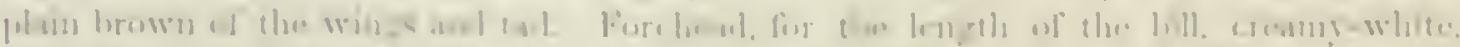

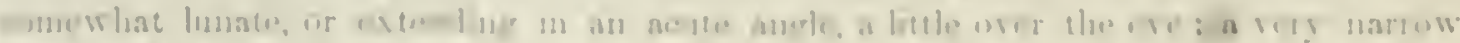

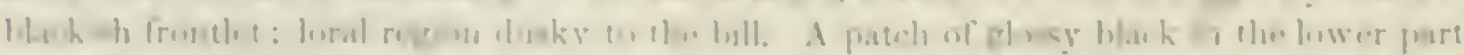


of the breast, and a few black feathers in the extreme ehin, the latter sometimes searcely appreciable. Under parts dull whites tinged with reddish-gray on the sirks and inside of the wings. Feathers of crissum brownish-gray, edged with whitish, with a tinge of pufous anteriorly (sometimes almost inappreeiable). Nest of mud, lined; huilt against rocks or beams: opening sometimes cireular, on the side; sometimes open above; eggres spotted.

Total length, 5.10; wing, 4.50 ; tail, 2..40, nearly eren; difference of primary quills, 2.10: lengrtlı of bill from foreheal. .38, from nostril. .25, along gape, .60, wilth. 50 : tarsus,

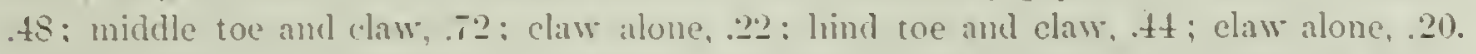

Hab. Entire L'nited States from Atlantic to Pacitic, and along central region to Aretic Oecan and Fort Yukon: Panama in winter. Not noted at Cape St. Lucas, in Ilexicu, or in West Indies.

There is no difference between the sexes, but the young bird is rery different from the adult in the following particulars: the steel-blue above is replaced by a lustreless dusky-brown, the feathers (except on head) being mangined with a creany tint; the neek merely tinged with rufous; the throat has only a dusliy suffusion, and the chin is much mixed with white; the fromtal patch is obsolete.

A closely allied species from Mexico, P. surinsoni (see Baird, Rer. Am. Birls, 1865,290$)$, possibly yet to be found near our southern horder, differs as follows :-

Frontlet rechlish-white, with narrow hand of black along upper mandible . lunifrons. Frontlet chestnut-brown, without black at base of upper mandible. Size smaller.

suainsoni.

Sometimes (as in 11,027 $q$ and 11,02.7 $\delta$, Fort Bridger) the black patch extends npward, somewhat hroken, however, to the bill.

H.sits. The early history of the Cliff swallow must always remain inrolved in some obscurity, so far as concerns its numbers and chistribution before the first settlement of the comntry, and even duwn to the early purtion of the present century. Its existence was unknown to $\mathrm{Mr}$. Wilson, and it was unknown to other naturalists until obtained by Say, in Longr's expedition to the Rocky Mountains in 1S20. It is now linown to occur nearly throughout North America, and to breed from Pennsylvania to the Aretic regions, and from the Atlantic to the Pacific. Yet to many parts of the country it is a new-comer, where, a few years since, it wa wirely unknown. It seems to be probable that at first this speeies was to be found only in certain localities that offered farorable places whereon to construct their nests. Where high limestone clitfs abound, these birds may have always occurred, although escaping ohservation.

In the same rear that Long discorered this species among the Rocky Mountains (18:0), Sir Joln Franklins party also met with it between the C'umberland House and Fort Enterprise, and on the banks of Point Lake, in latitude $65^{\circ}$. In June, 18.5, a number of these birds marle their first appearance at Fort Chippewran, and built their nests moler the eares of the house. This fort had then existed many years, and trading-posts had been in existence a century and a half, and yet this was the first instance of its 


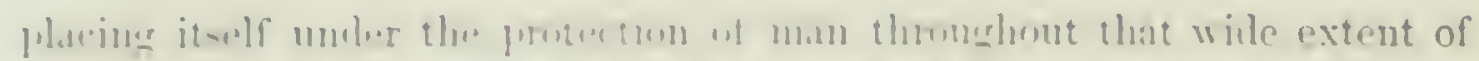

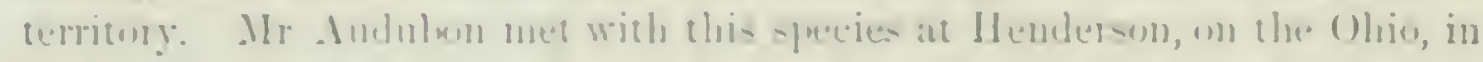

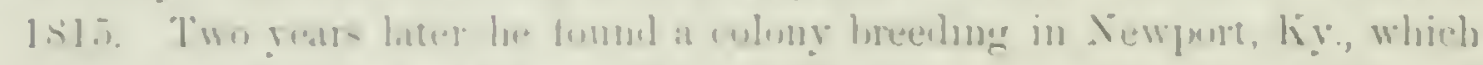

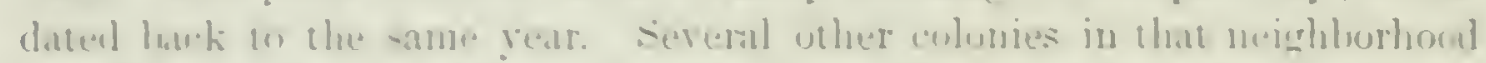

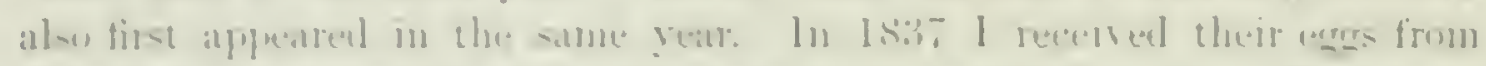

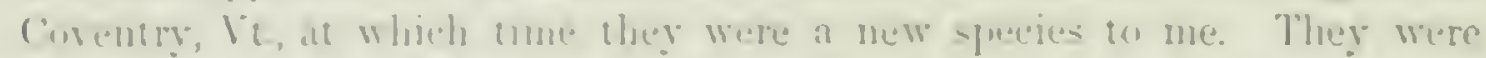

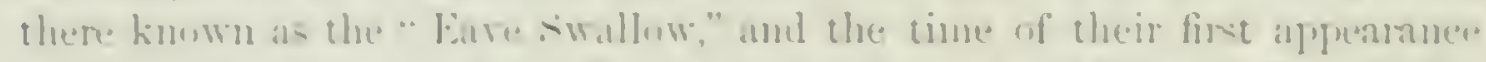

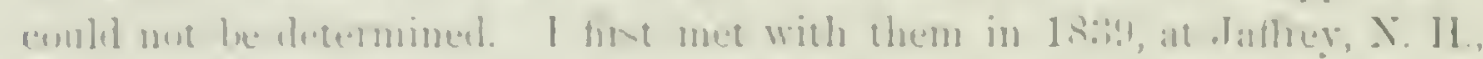

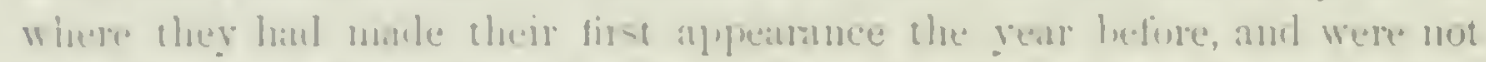

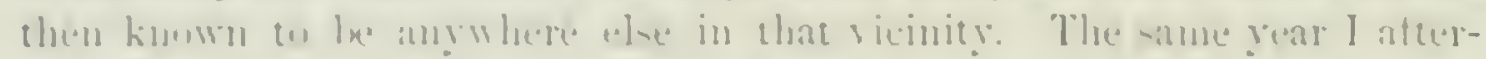
wards fouml them in limlinglon, li, whese they haul been known muly for

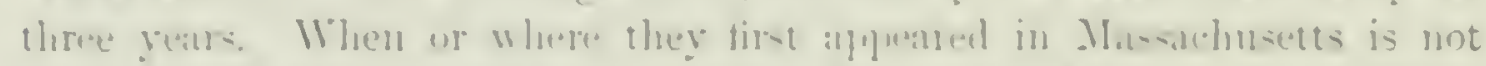

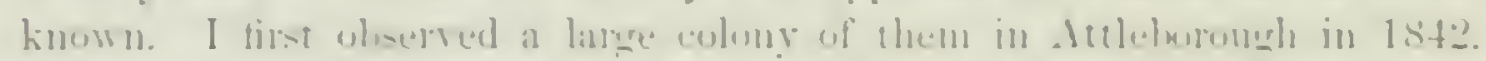

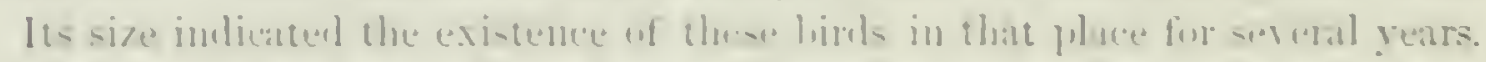

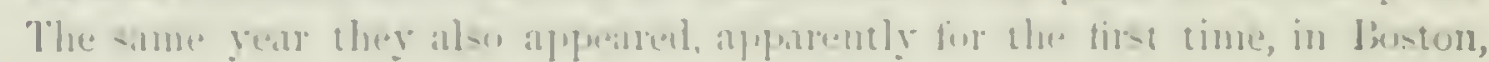

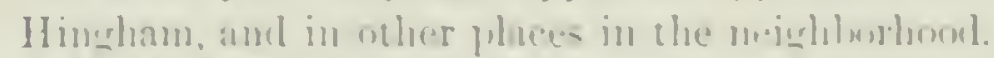

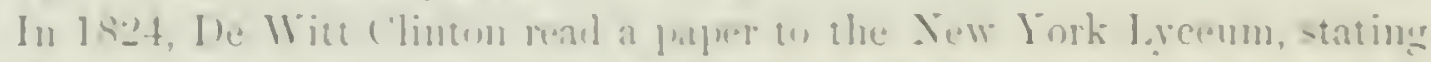
that le haml met with there himls at Whitehall. X. Y., at the wimthen end of

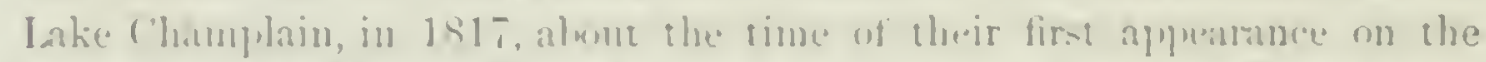

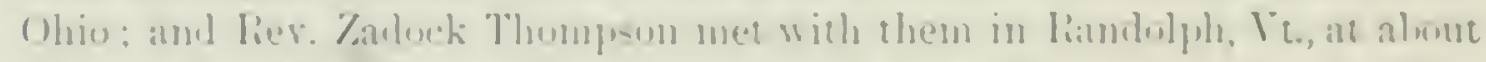

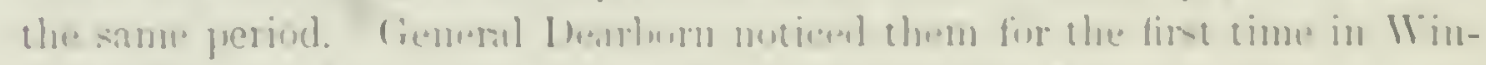

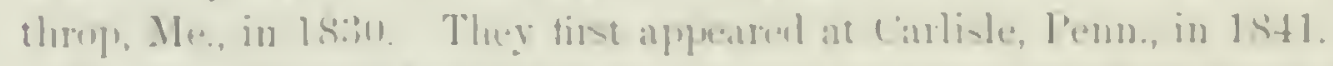

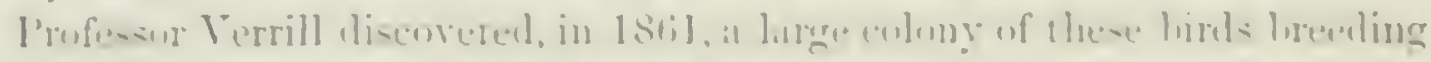

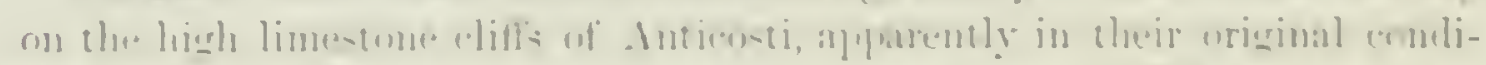

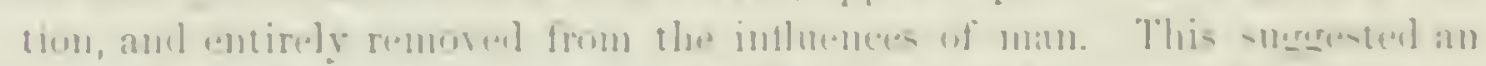

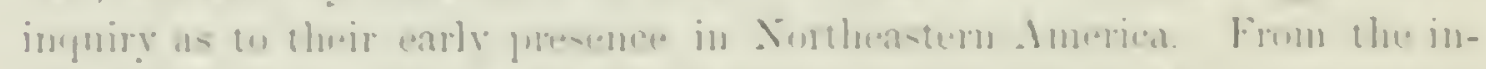

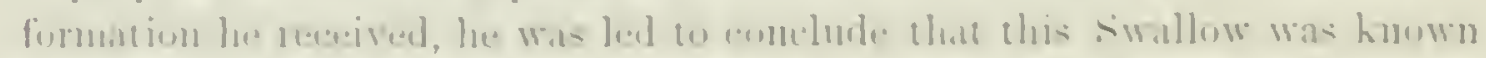

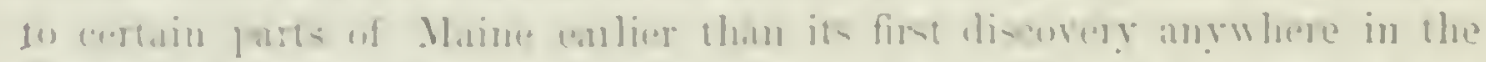

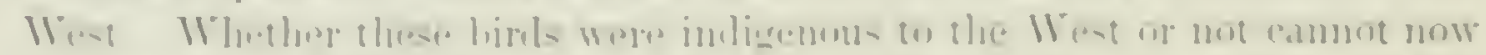

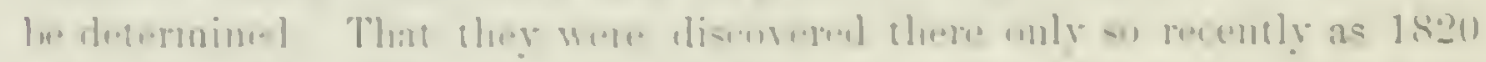

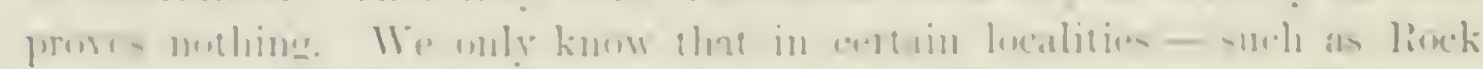

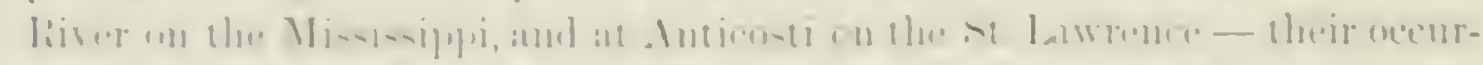

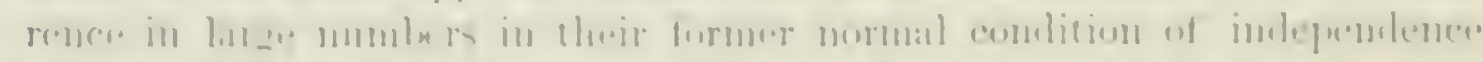

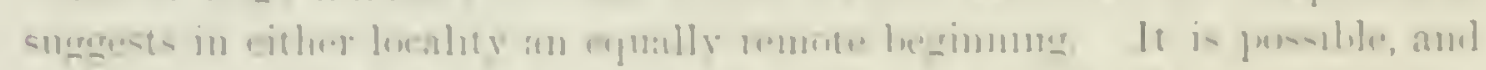

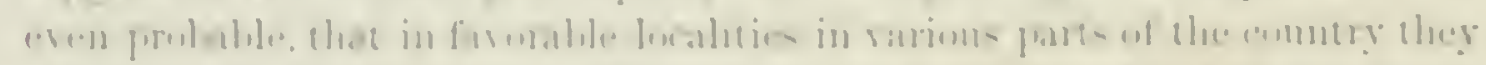

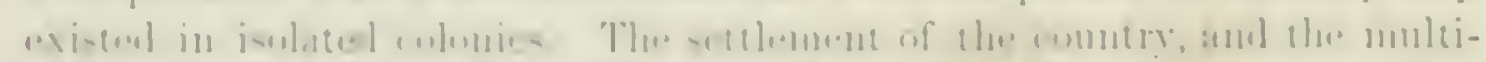

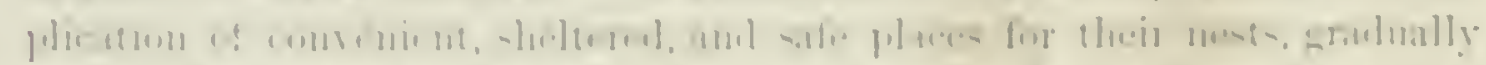

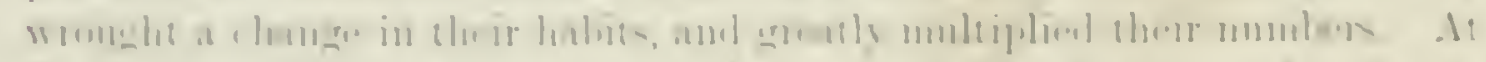

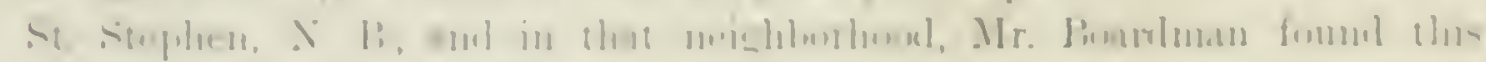

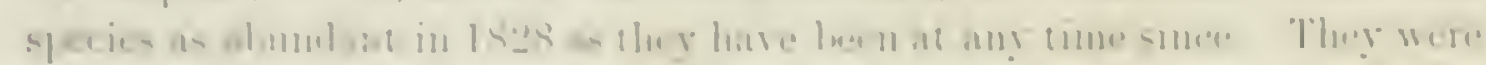

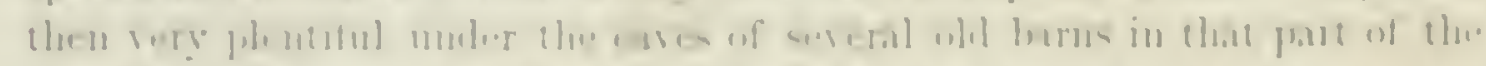

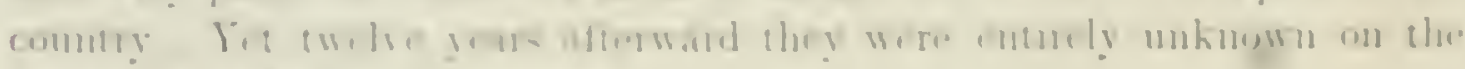
lower kinumlet.

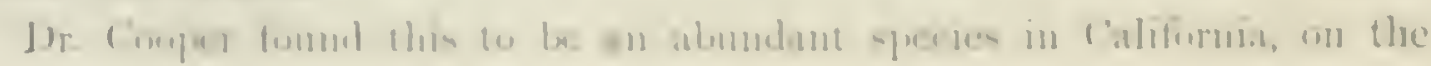


coast, where they breed on the cliffs, and have all the appearance of being indigenous. They appear at San Diego as enrly as March 15, a week before the Barn Swallow, and do not leave until October. They luild even in the noisy streets of San Francisco. Dr. Cuoper observed them catehing young grasshoppers, which is certainly musual food for Swallows, and one that has proved fatal to young Barn Swallows when fed to the latter in confinement. At Santa Cruz they bred as early as April 12, and had second broods July 5.

The nests of this Swallow, when built on the side of a eliff or in any exposed position, are constructed in the shape of a retort, the larger portion adhering to the wall, arehed over at the top and projecting in front, with a covered passage-way opening at the bottom. The normal original nest, in a state of nature, is an elaborate and remarkably ingenious strueture, sheltering its immates from the weather and from their many enemies. Since they have sought the shelter of man and built under the eares of barns and houses, the old style of their nests has been greatly changed, and the retort-like shape has nearly disappeared.

In building and in repairing their nests they work with great industry, and often complete their task with wonderful celerity. Where they exist in a large colony, it is not an uncommon thing to see several birds at work upon the same nest, - one bird, apparently the female owner, always assisting and directing the whole. After the work of construction has gone so far as to permit the occupation of the nest, it is often to le observed that the task of completing and improring the structure is kept up by the male. In a large colony of these Swallows, whose nests were built under the projecting roof of a barn in a small istand in the Bay of Fundy, every nest was as open as are those of the Barn Swallow: These birds had been enconraged to build by the owner, and boards had been placed above and below their nests, of which they at once took advantage to build an unusual nest. These nests are made of varions linds of adhesive earth and mud. They are neatly and warmly lined with fine dry grasses and leaves, intermingled with feathers, wool, and other soft, warm substances. It has been thought that the mud of which these nests are composed is agghutinated by the saliva of the birds; but of this I have never been able to detect any evidence in the nests themselves, the crumbling nature of which when dry is against this supposition; and the birds themselves are often to be seen about puddles of water, apparently gathering materials.

When the nests of a large colony are invaded, the birds manifest great mneasiness, collecting in a swarm over the head of the intruder, wheeling aromnd in circles, uttering lond outeries, and even flying close to his head, as if to attack him, with lond snapping of the bills.

The song of this Swallow is an mmmsical creak, rather than a twitter, frequent rather than loud, and ocensionally harsh, yet so earnest and genial in its expression that its effect is far from being unpleasant.

The ground-color of their eggs is white, and they are marked with dots, 
blotches, and points of reldi-h-hrown. Theoe marking vary greatly in size.

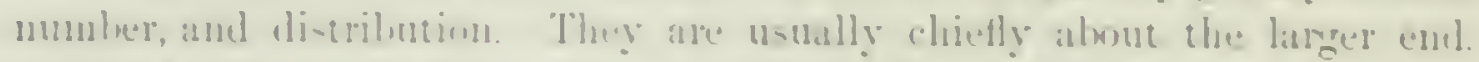

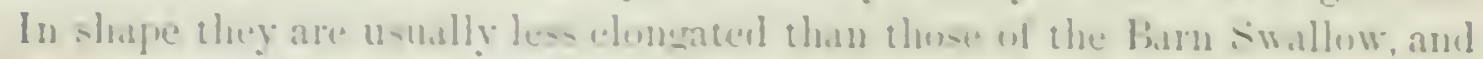
their markings are latger. This s not, howerer. imvarialle. and the two kinds are unt always detinguishable. In kenth they vary frum s.t. of an

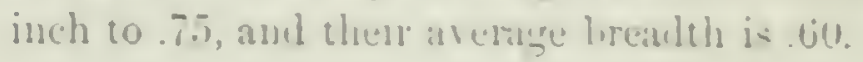

\section{(iFN- HIRUNDO, lWX.}

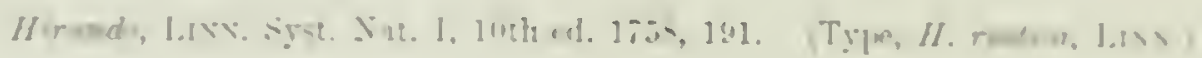

Unler the eneneric lead of Hirumlo I lopose to combine aeveral group

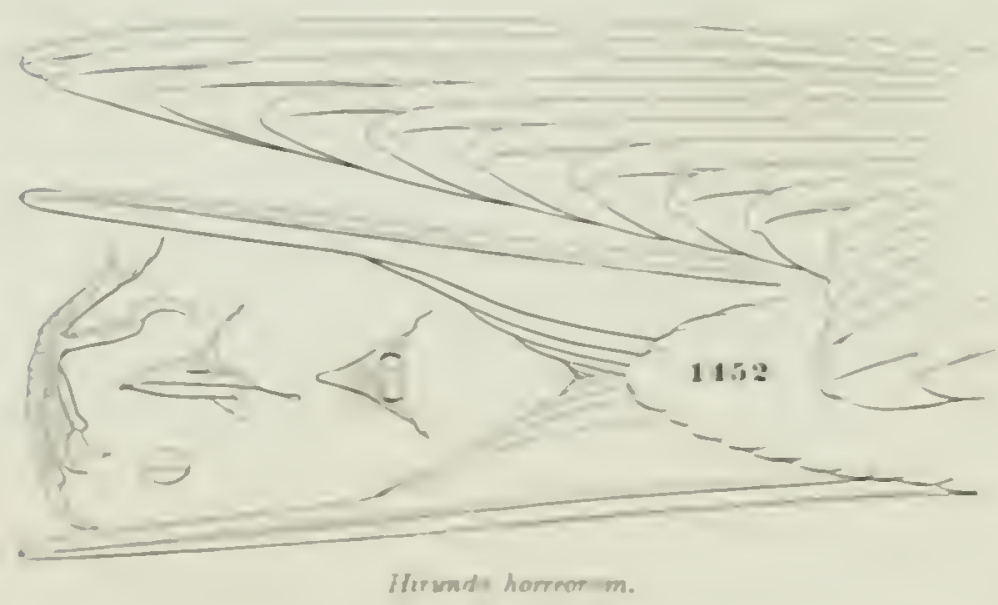

of Anericun swalluw: andering in moderate. depressed bill, with

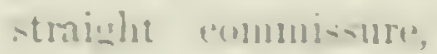
and litteris nusirils werhume by menhane; the tari fenthercel only at the mpler end, or elep entiriely Lare; the lateral claws moterate, not extemi-

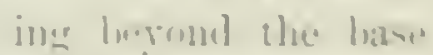

of the median: the elee of the outer primary without lomks: the tiil raria-

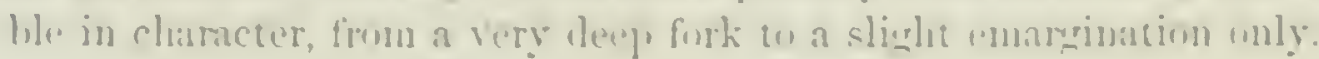

\section{Subgenera.}

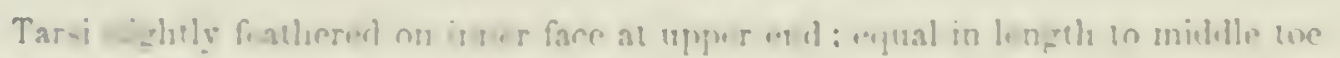
willonst , law:

Tal bery dien ly firkmi

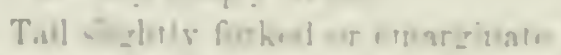

Irirend.

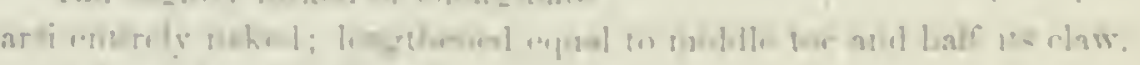
Treligrions,

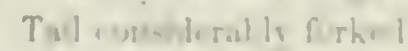

Pitirialin =

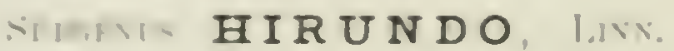

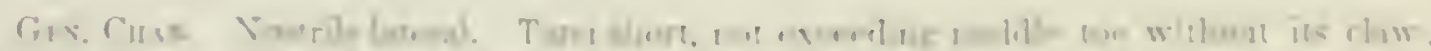

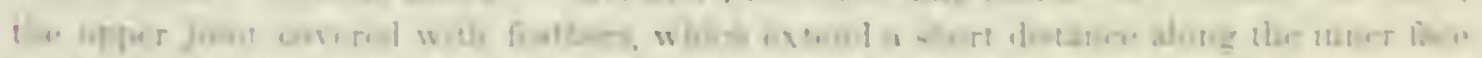

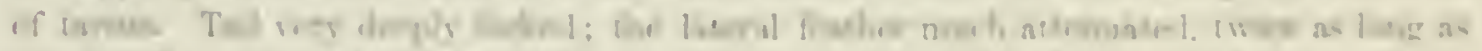

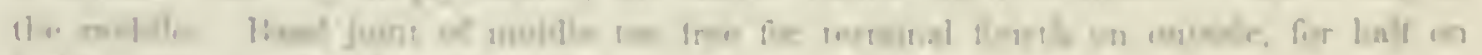

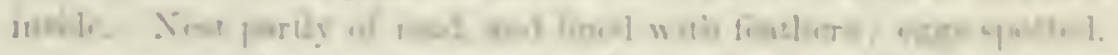

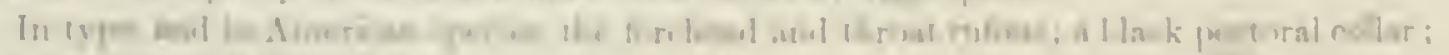

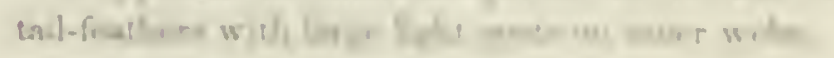

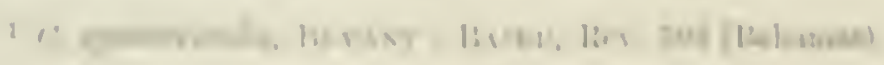


But one species, so far as known, of this subgenus as restricted, belongs to America. There are, however, quite a number known in the Old World.

\section{Hirundo horreorum, Barton.}

\section{BARN SWALLOW}

Hirundo horreorum, Bastox, Fragments N. H. P'enna. 1799, 17. - B.1nD, Birds N. Am. 1858, 308; Rev. 294. - A. \& E. NewTox, lbis, 1859, 66 (Sta. Cruz; transient). ScLatele \& Salyin, lbis, 1859, 13 (Guatemala). - Sclater, P. Z. S. 1864, 173 (City of Mex.) - Lawrexee, Ann. N. Y. Lye. 1861, 316 (Panama), - Couper \& Suckley, P. R. R. Rep. X'Il, II, 18t (south of Columbia liver). - Dald \& Baxxistels, 279 (Alaskil). - Cooprir, Om. Cill. I, 1870, 103. - Sanueds, 254. Hirundo rufu, Vieill. - Cassis, Hll. - Brewer, N. Am. Ool. J, 1857, 91, pl. v, fig. 63-67 (eggs). - CaB. Jomr. IV, 1856, 3 (Cuba; spring and autumn). -- Peisnarist, lbis, 1861, 5 (Greenland ; two specimens). - Guxidach, Cab. Joul. 1861, 328 (Cuba ; common). Hirundo americana, Whlson; Rich; Lanbeve, Aves de Cuba, 1850, 44, lan. vii, fig. 2. Hirundo rusticu, Aud. Orn. Biog. II, pl, elxxiii. - I s. Birds Am. 1, pl. xlviii. - Jones, Nat. Hist. Bermudi, 34 (Bermudas; Aug. and Sept.).

Sp. Cuns. Tail very deeply forked; outer feathers sereral inches longer than the inner, very uarrow towards the end. Above glossy blue, with concealed white in the midale of the back. Throat chestnut; rest of lower part reddislı-white, not conspicuously diffirent. A steelblue collar on the upper part of the breast, interrupted in the middle. Tailfeathers witl a white spot near the miclule, on the imner web. Femalo witls the outer tail-feather not quite so long. Length, 6.90 inclies; wing, $5.00 ;$ tail, 4.50 .

Haß. Whole of the Uniterl States; north to Fort Rae, Slare Lake; Greenland; south in winter to Central Aneriea and West Indies; Pananna (L.ıwr.);

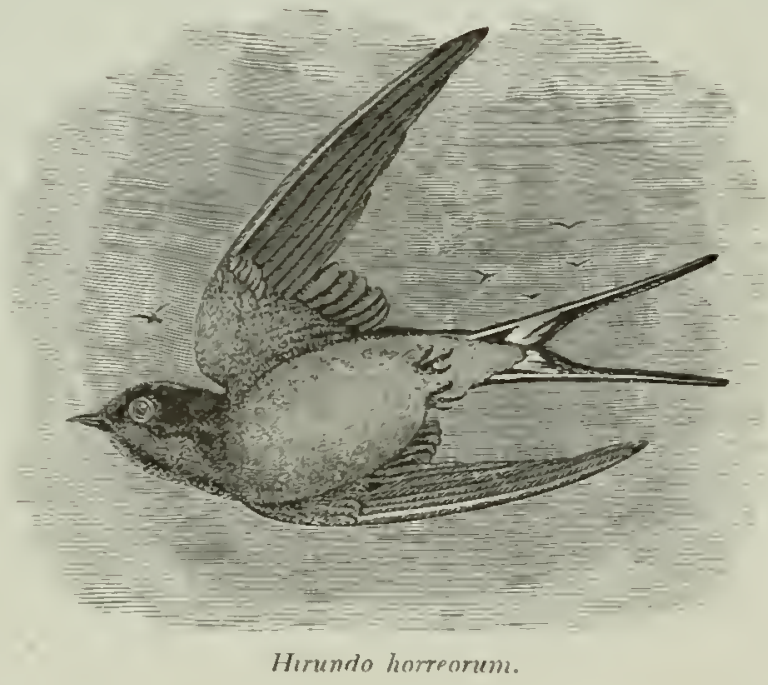

Plateau of Mexico (breeds, Sumcirast); Teragua, Chiriqui (Sıwix). Not found at Cauje St. Lucas. South America?

In young birds, the frontal ehestnut band is smaller and less distinct.

It is still a question whether a South American resident species (H. erythrogaster) is identical or not. The only two specimens of the latter $(21,007$ and 21,008, Vermejo, Feb., 1860 ; C. Wood) have a very much less violaceous upper plumage than North American examples, the blue above having even a greenish tinge. They are moulting, unfortmately, so that they cannot be satisfactorily compared; except in the respeet pointed out, however, they appear to be identical with North Ameriean examples.

The European H. mustica is perfeetly distinet, though closely allied. It differs essentially from the American $H$. horreorum in unuch longer outer 


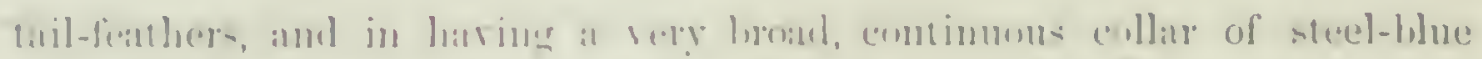

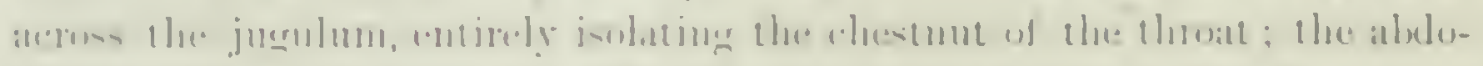

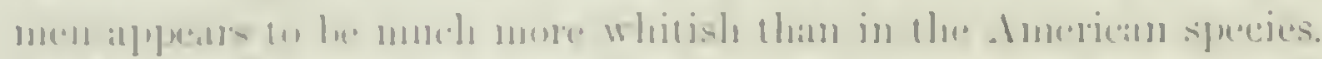

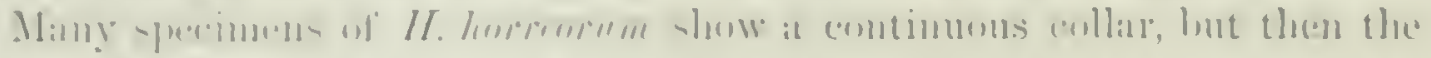

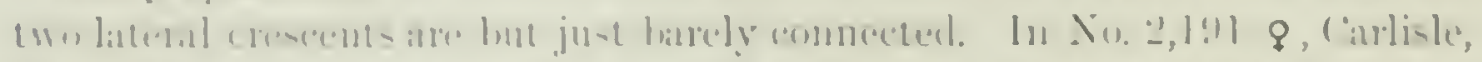

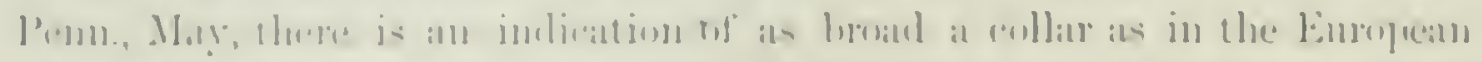

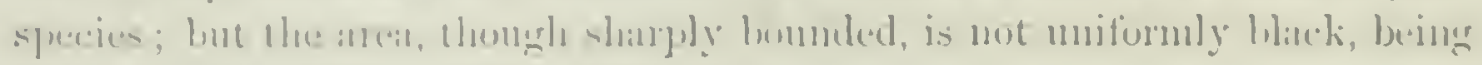
murl, miserl a.mblally with light rufous.

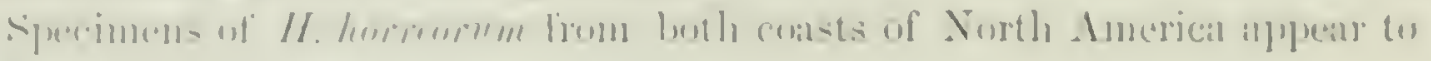

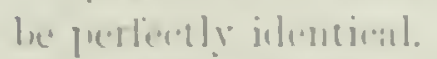

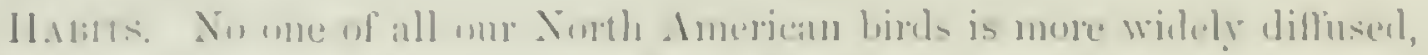

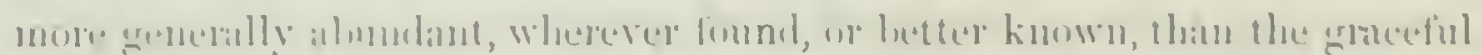

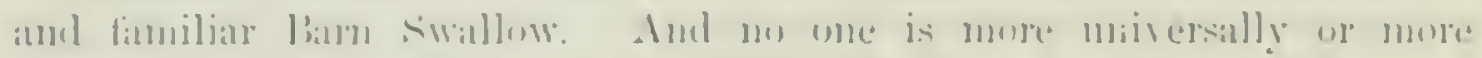

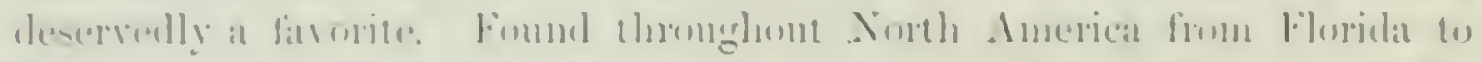

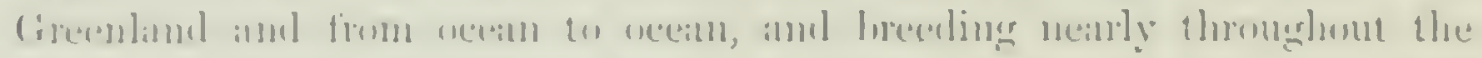

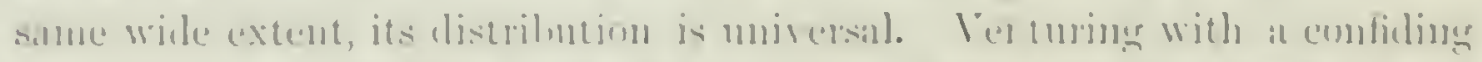

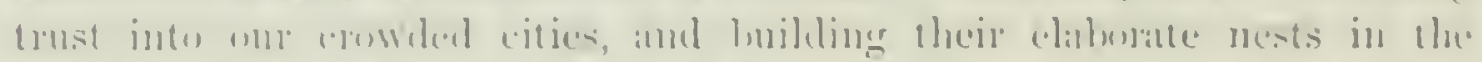

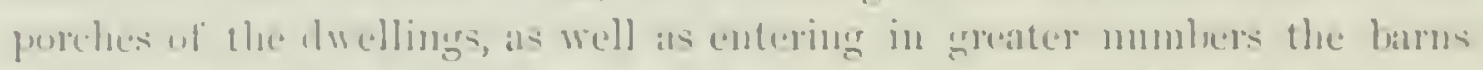

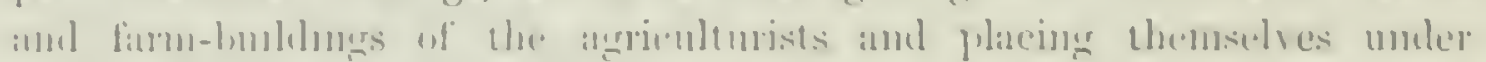

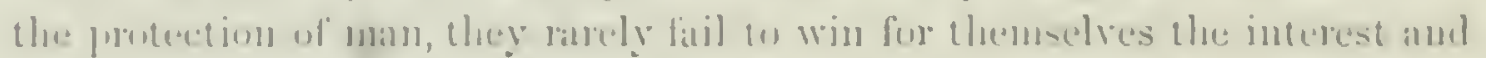

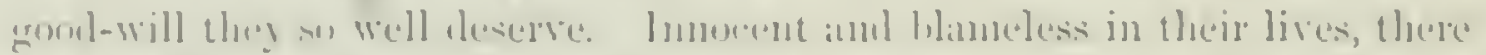

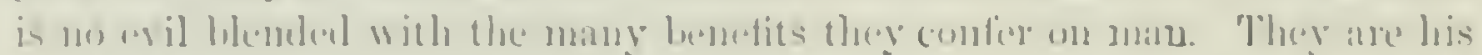

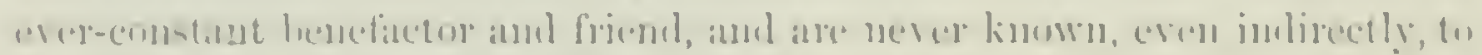

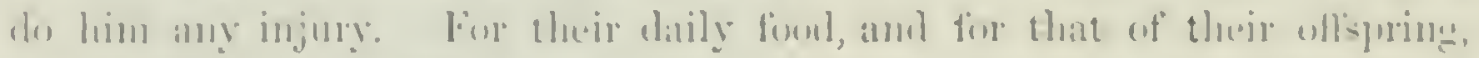

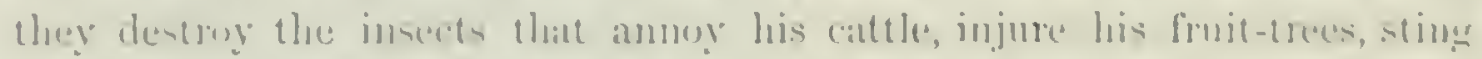

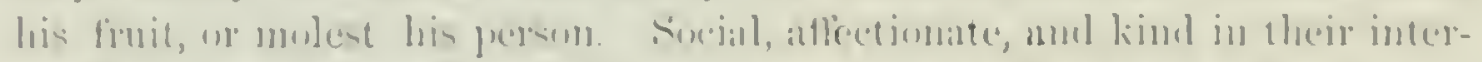

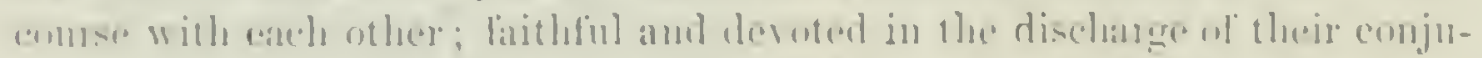

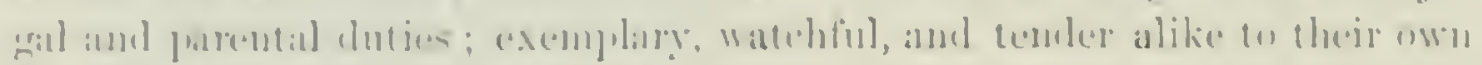

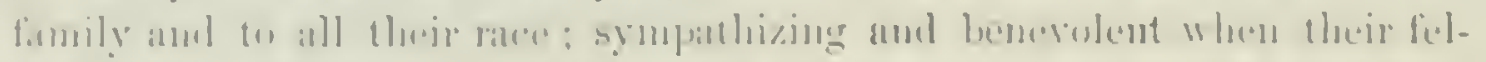
Ju1- an in

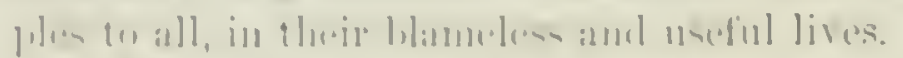

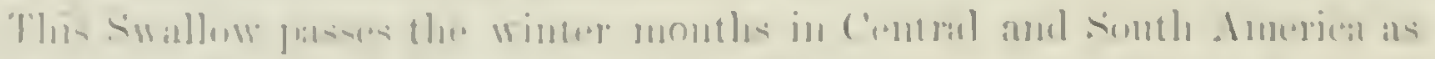

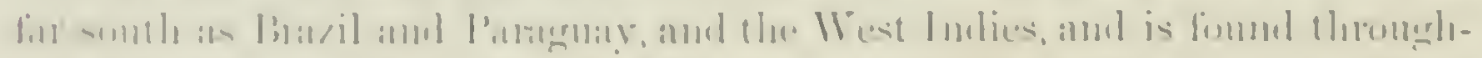

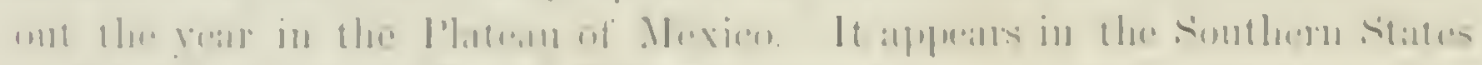

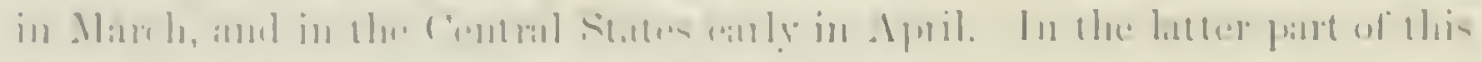

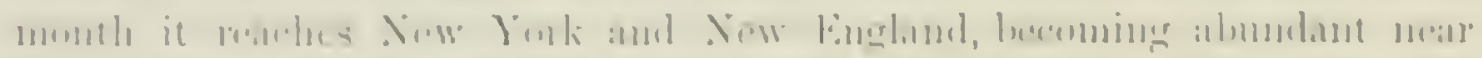

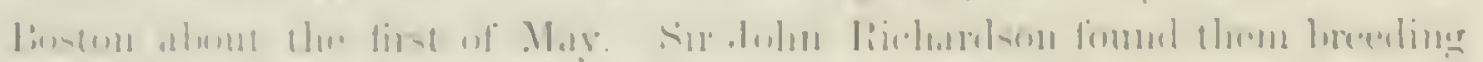

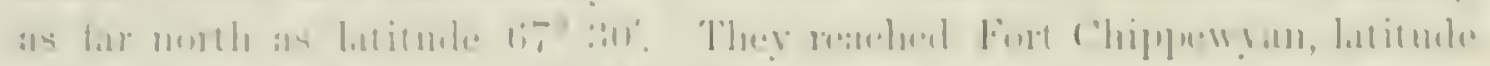

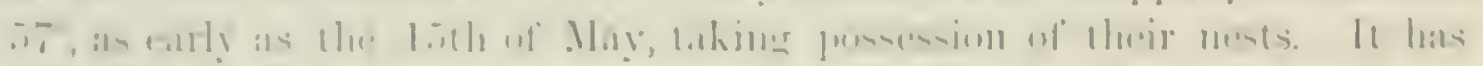

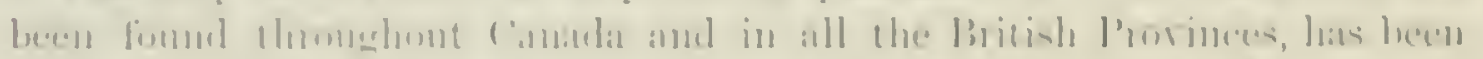

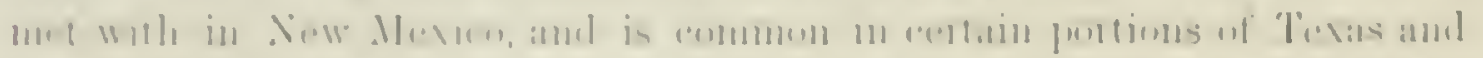

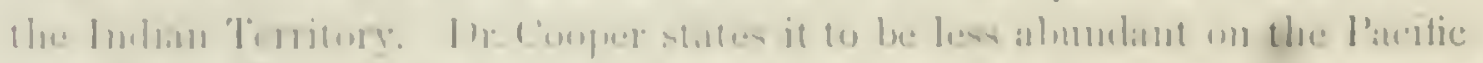

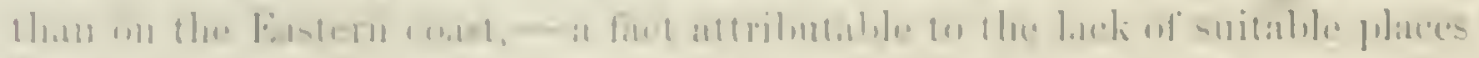

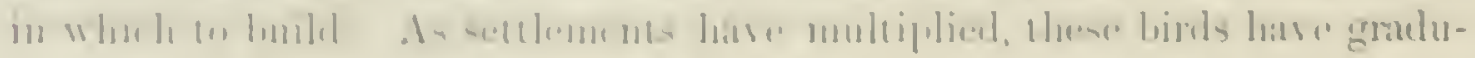


ally increased about farms near the coast. In the wild districts they build in the cares that abound in the blufts along the sea-shore from San Domingo to Columbia River. Dr. Suckley found them-also moderately abundant about the basaltic cliffs, near Fort I)alles, Oregon. They are $\cdot$ much more abundant about the coast than farther inland.

Mrr. Rilgway found this Swallow a very common species in all the rocky localities in the vicinity of water, but not so numerous as the lunifions.

In May it was particularly numerous in the neighborhood of I'yramid Lake, where its nests were built among the "tufa domes," attached to the roofs of the caves. It was seldom that more than one or two pairs were found together.

In July lie found a nest that contained young, in a care among the limestone cliff's of the canons of the East Humbollt Mountains, at an altitule of about eight thousand feet. Many of their nests were found in May, in the caves of the tufa rocks, on the shores of Lyramid Lake, as well as on the islands in the lake.

Mr. Hepburn writes that he found this Swallow widely diffused along the Pacitic coast, as far to the north as Sitka. In California he found it very local, common near the coast, rare inland. Its earliest appearance is March 26, the great bulk leave in Angust, and the last stragglers are gone before the last of September. They breed in cares and crevices of rocks, and also nnder the sides of the wooden bridges that span the gullies at San Francisco. Two broods are hatched in a year. The earliest egg was found on the 30th of April, but they are usually a fortnight later. The second laying is about the first of July, and no eggys were found later than the th of Angust. It is at all times quite common to find nests with fresh egrgs close to others with half-grown young.

Mr. J. K. Lord publishes an interesting account of a visit made by a solitary pair of Barn Swallows to his party when encamped at Schyakwateen, in British Columbia. A small shanty, locsely huilt of poles, and tightly roofed, was in constant use as a blacksmith's shop. Early one summer morning late in June, a pair of Swallows perched on the roof of this shed, without exhibiting the slightest fear of the noise made by the bellows or the showers of sparks that flew all around. I'resently they entered the house and carefully examined the roof and its supporting poles, twittering to each other all the while in the most excited mamer. At length the important question appeared to be settled, and the following day they commenced building on one of the poles immediately over the anvil. Though the liammer was constantly passing close to their structure, these birls kept steadily at their work. In about three days the rough ontline of the nest had been constructed. Curious to see from whence they procured their materials, Mr. Lord tracked them to the stream where, on its edge, they worked up the clay and fine sand into a kind of mortar with their beaks. They worked incessantly, and in a few days their nest was finished, the mud walls having 
finally heen wambly limel with seft dry armases and the featlers and down

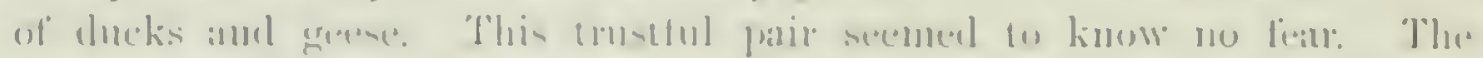

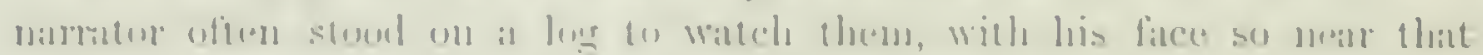

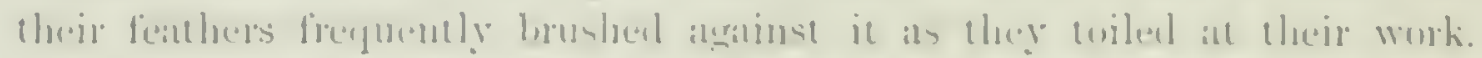

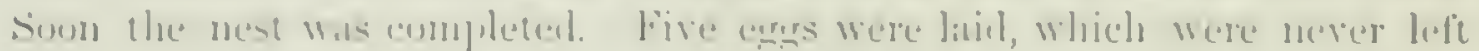

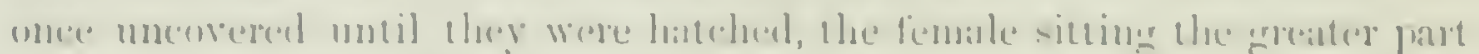

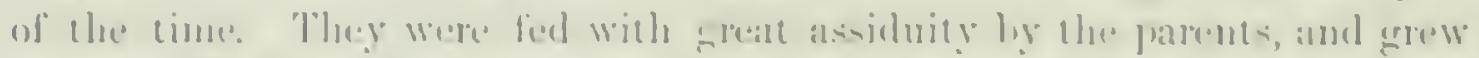

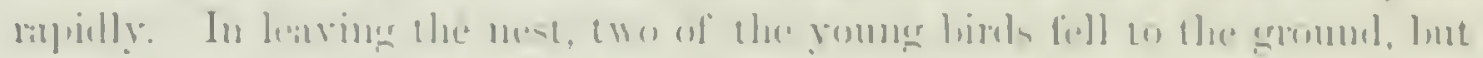

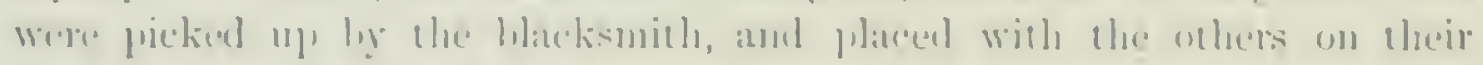

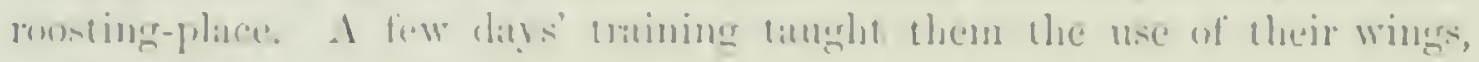

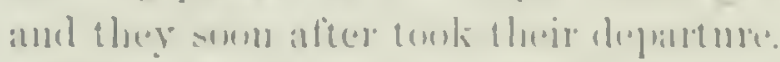

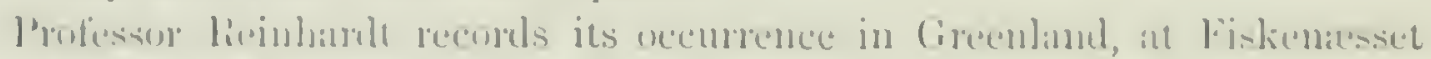
amel al Nimematilik.

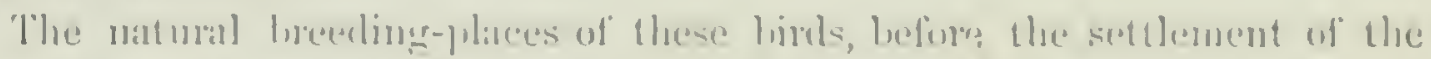

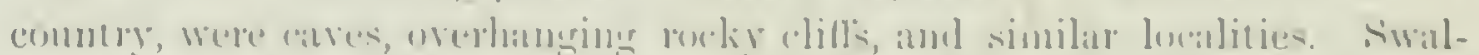

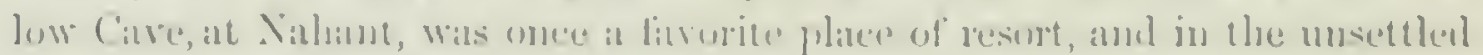

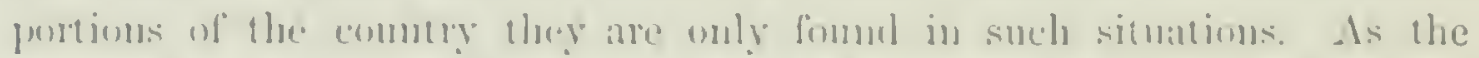

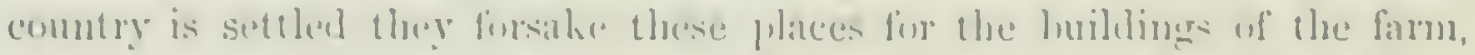

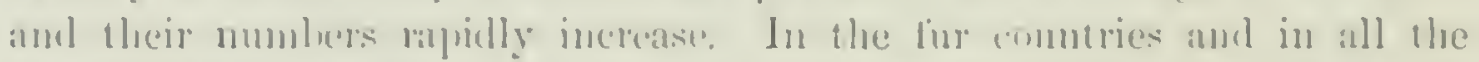

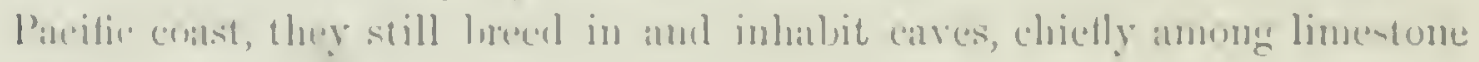
rockis.

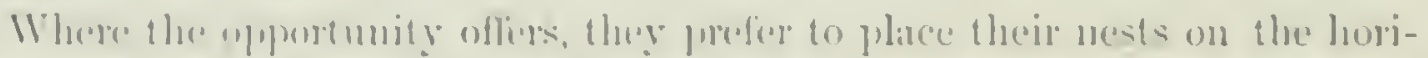

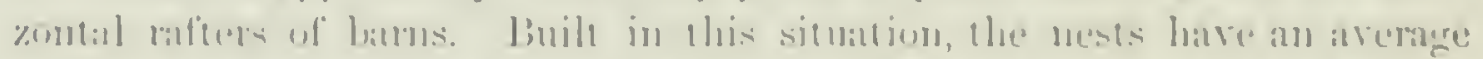

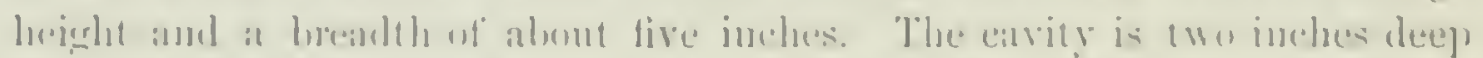

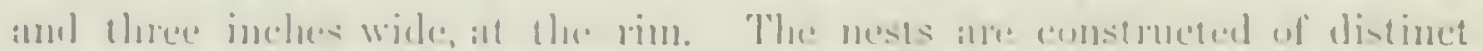

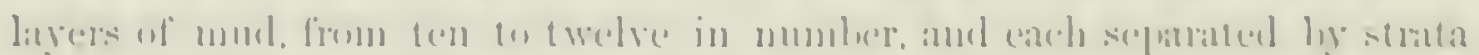

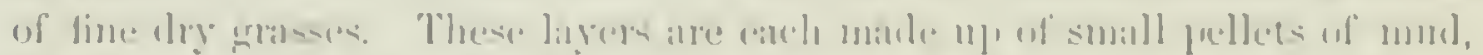

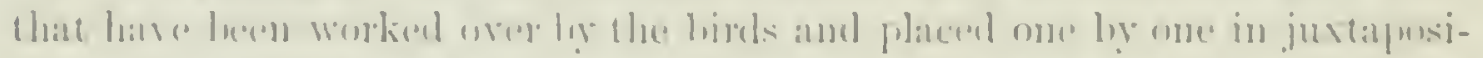

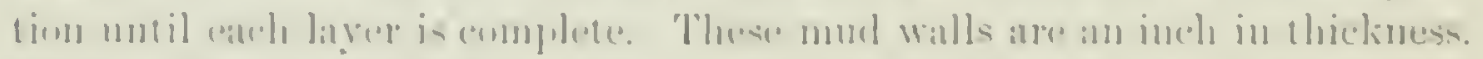

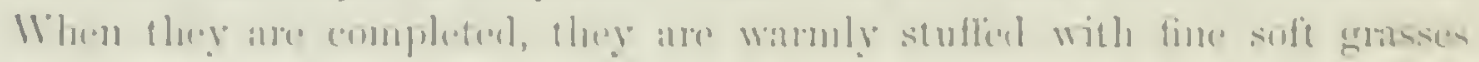

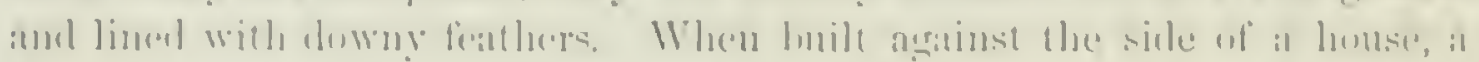

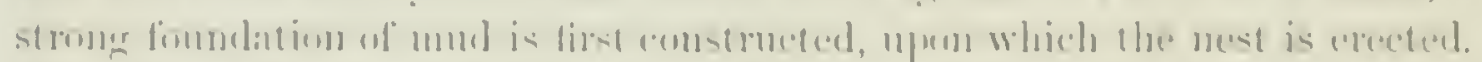

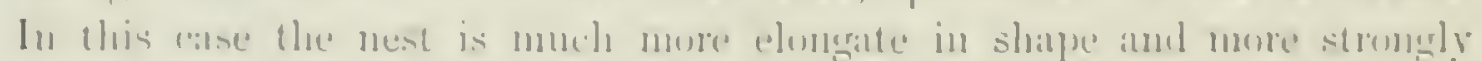
[1]:11?

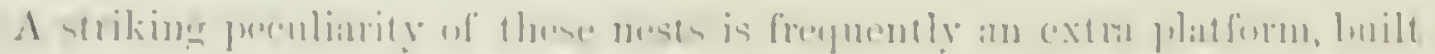

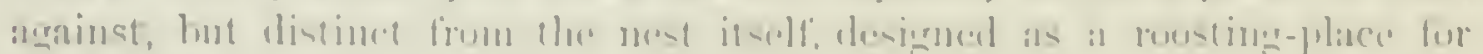

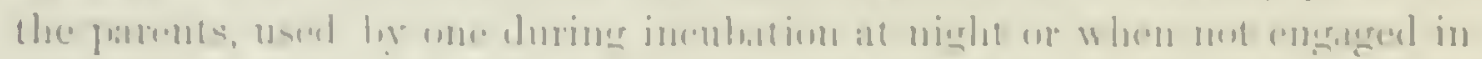

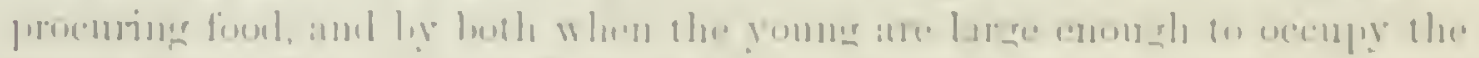

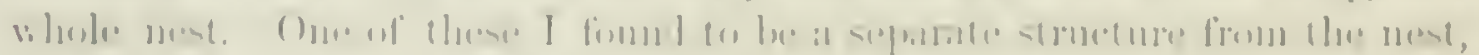

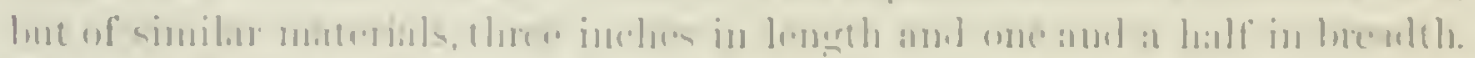

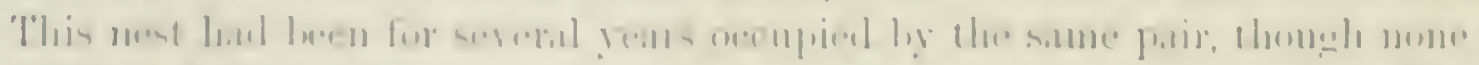

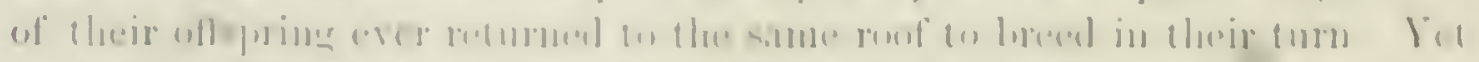

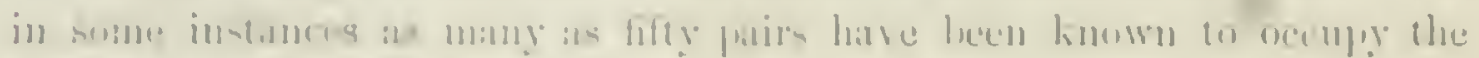
rallets of the sirue bitn. 
In one instance Mr. Allen has known a pair of these Swallows to take possession of the nest of a pair of ('liff Swallows, placed under the eaves of a barn, driving off the rightful owners. The next rear they built a nest in the same place, the old one having fallen down. But such instances are rare, and the attempt is often a failure.

The wonderful activity of this bird, its rapidity and powers of Hight, are too striking a peculiarity of this species not to be mentioned. During their stay with us, from May to Sejtember, from morn to night they seem to be ever in motion, especially sn before incubation, or after their young lave flown. The rapidity of their tortuous evolutions, their intricate, involvect, and repeated zigzag flights, are altogether indescriballe, and must be witnessed to be appreciated. Wilson estimated that these birds fly at the rate of a mile a minute, but any one who has witnessed the ease and celerity with which they seem to delight in orertaking, passing, and repassing a train of cars moring at the rate of thirty miles an homr must realize that this estimate is far from doing full justice to their real speeil.

The song of this swallow, especinlly when on the wing, is rery pleasing and sprightly. It is a succession of twittering notes uttered with great rapidity and animation. When alighted, their notes are delivered more slowly and with much less animation.

The attention of these birds to each other when sitting upon the nest, and to their young when lhatched, is unremitting. The estimated numbers of small insects they collect for their own consumption and that of their nestlings is almost incredible. When the young are old enough to leave their nests the manceurres of the parents to draw them out. and their assistance to them when practising their first short flights, are among the most curious and interesting scenes one can witness in his ornithological experiences. : but space would fail me were I to attempt their details.

The number of the young is from four to six, and there are often tro broods in a season. As soon as the second brood can fly, or early in September, ther all prepare to leare. Ther usually collect in flocks of from one to sereral hundred, and depart within a few dars of their first assembling. Targe Hocks pass along the coast of Massachusetts, from the north and east, early in September, often uniting as they meet, and passing mpidly on.

Their eges have a ground-color of clear white. with a roseate tint when unblown. They are marked with spots of reddish and purplish-brown, varying in size and number, and chiefty at the larger end. Ther are smaller and more elongate than those of the lunifrons, and the markings are usually finer. Their orrentest length is .94 of an inch, their least. .5 , and their mean .is. Their mean breadth is .56 of an inch, the greatest .6:2, and the least .50 . 
Simple TACHYCINETA, (N)

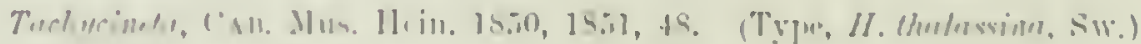

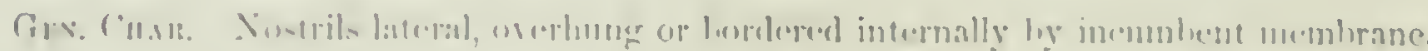

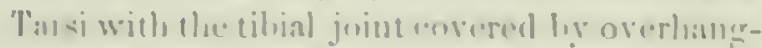

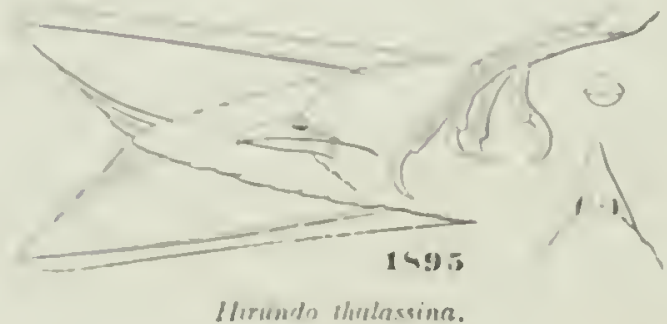

blirundo Ihutassinn.

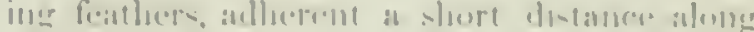

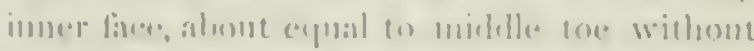

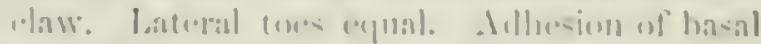

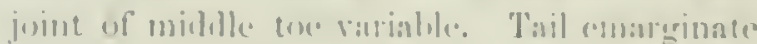

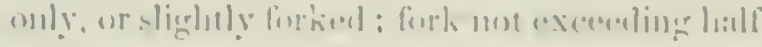

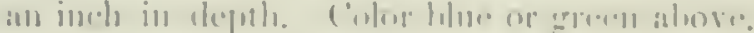

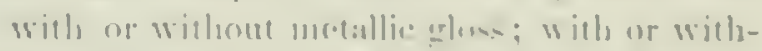
ont white rmus. Fontirely white leementh.

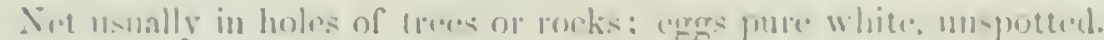

Of this section there are two North Amerion species, differing as follows, both being sreen alwie and white leneath:-

\section{Species.}

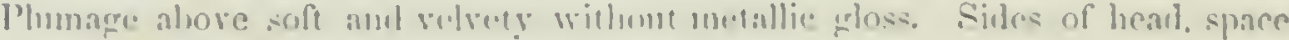

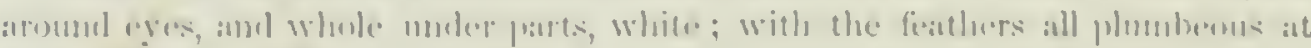

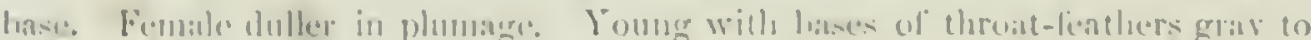
routs.

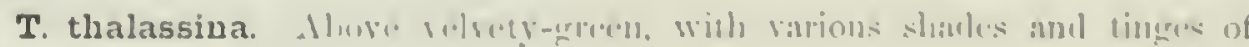
visket surl purple.

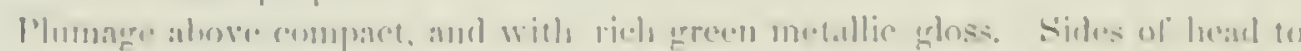

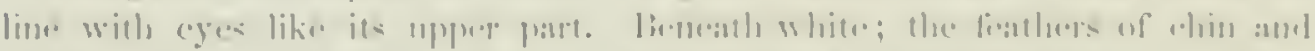

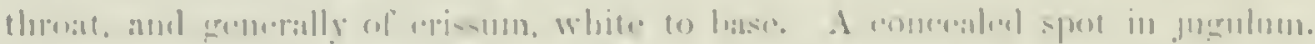

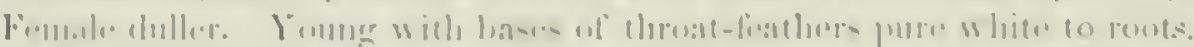

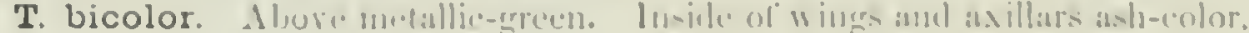

\section{Hirundo bicolor, Vistl.}

\section{WHITE.BELLIED SWALLOW}

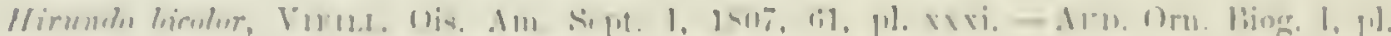

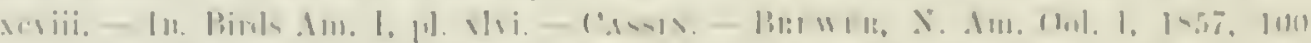

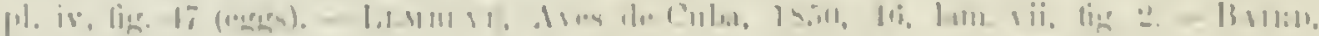

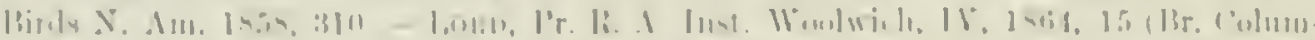

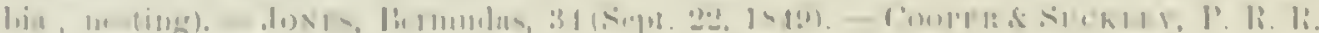

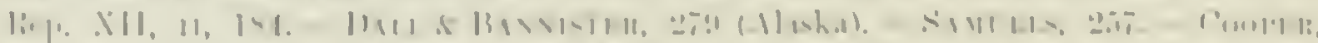

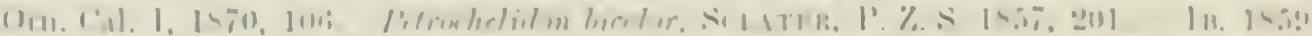

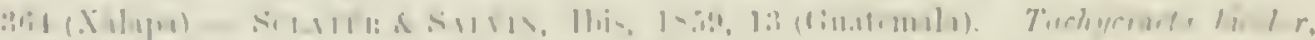

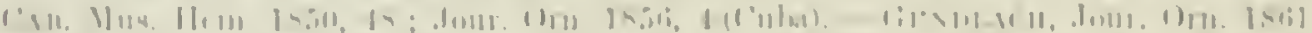

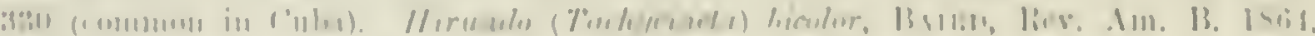

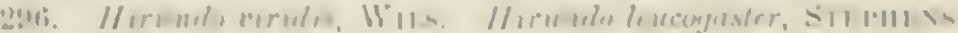

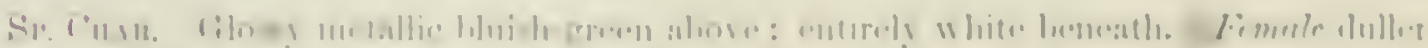

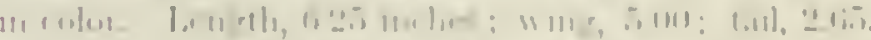

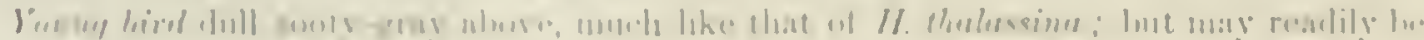


distinguished by the feathers of the throat being pure white to their roots, instead of hasing the concealed bases grarish as in that species.

HAB. Whole Cnited States, and north to Slave Lake, south to Guatemala; Bermuda; Cuba, common in wiuter. Breeds on table-lauds of Mexico.

H.ıBIs. This Swallow has quite an extended distribution. Found throughout Forth Anerica in the seasons of its migrations, or breediug, it is only a little less restricted in its area of nesting than the preceding species. It breeds from latitude $3 \mathrm{~S}^{\circ}$ to high Aretic regions, and is also resident throughout the rear in the Plateau of Mexico. It is abundant in winter in the West Indies, in Central America, and in Northeru South America. It is a common bird about Boston, where it replaces the Purple Martin, and is even more abundant in the British Prorinces. D). Cooper also found it a very common species in the western

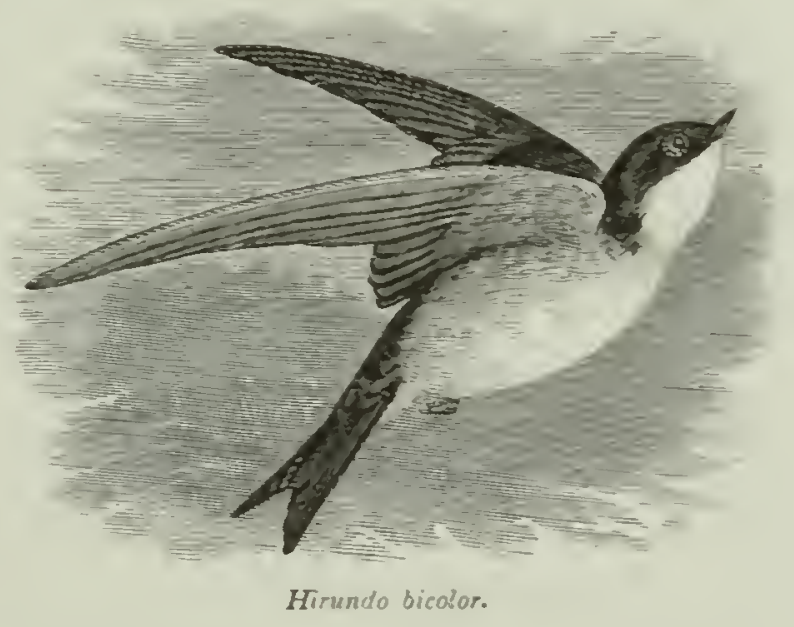
portions of Washington Territory, where it was invariably found to breed in hollow trees. In California he stittes it to be a more or less constant resident, a few wintering in the southern portion of the state. He met with it both at San Diego and at Stockton, in February. He regards them as the hardiest of the Swallows, preferring the coast and the mountain-tops for their residence in that state. At Santa Cruz fire or six pairs in 1866 were resident through the winter, where he saw them in Tanuary during the coldest of the season. They roosted in the knot-holes in the houses in which they had previously raised their young.

This swallow, in the more thickly settled portions of the country in which it breeds, exhibits a marked departure in many of its habits from those observed in wilder regions. In the latter places we find it a comparatively wild species, aroiding the society of man, and breeding exclusirely in hollow trees and stumps, and deserving the name hy which it is know in the Pritish Provinces, of the "Wood Srallow:" In the islands of Grand Menan, in 15.51 , where repeated attempts had been made to induce these birds to build in martin-boxes, the endearor had been entirely unsuccessinl. Tet the birds were so abmulant that hardly a hollow tree or stump, on certain of the smaller islands, could be found, that did not contain a nest of this species. This is still the case on the Pacific coast, though not exclusively so. It was not until after the publication of his Ornithological Biography that Audubon was a ware of any departure from this mode of nesting on the part of this Swallow, although it had not escaped the notice of Wilson.

In Eastern Massaclusetts these birds have undergone an entire change of 


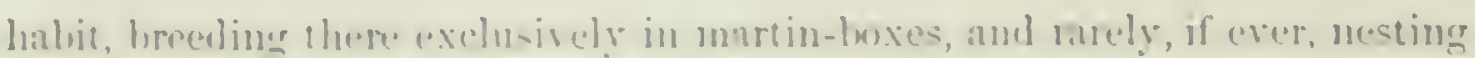

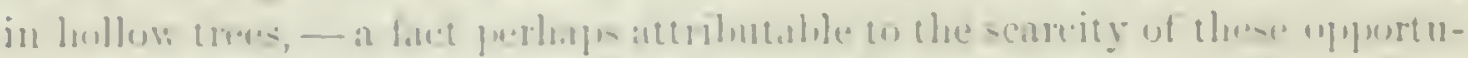

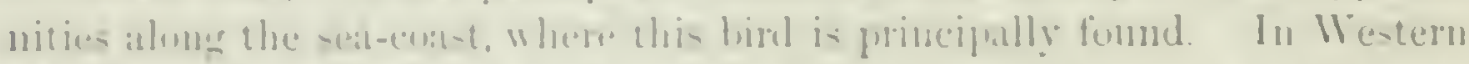

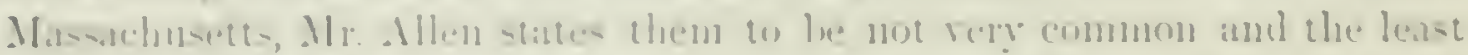

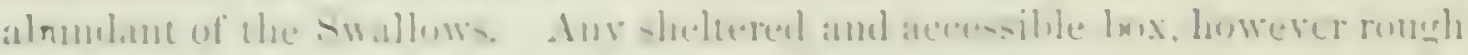

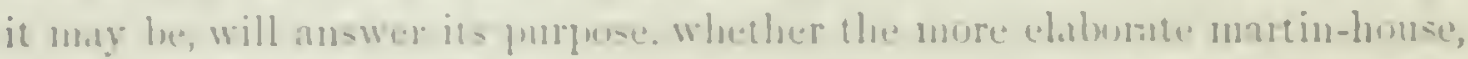

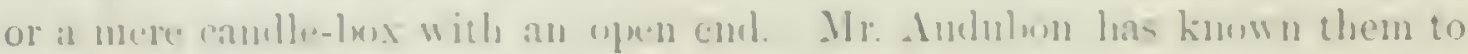

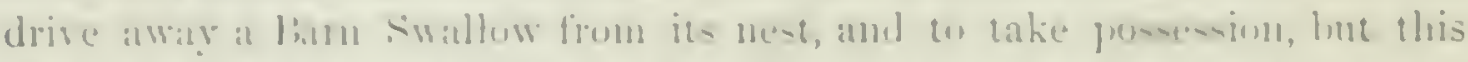

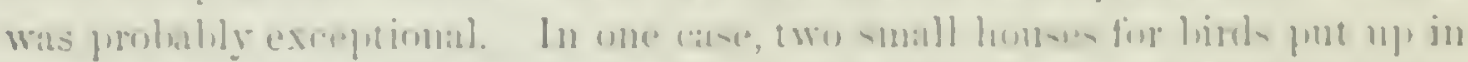

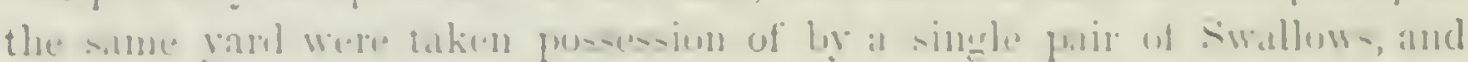

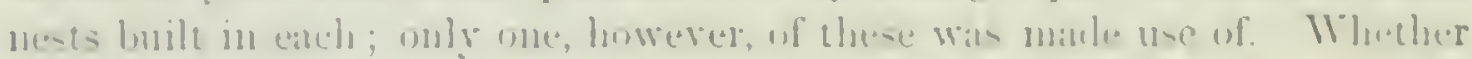

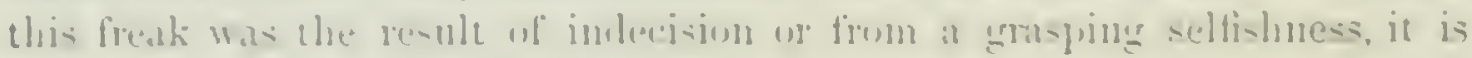
not pusible we comeluble, hut appancenty the former.

In the pural di-triets. I.

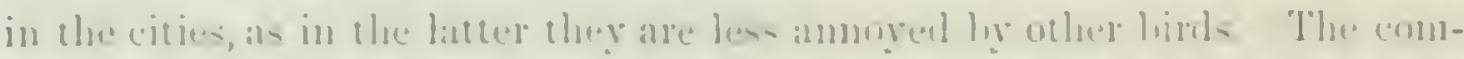

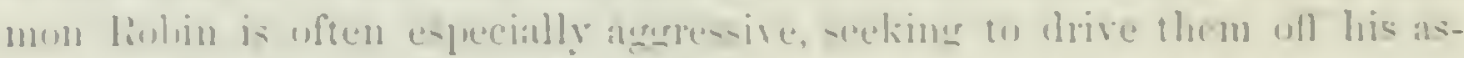
smmenl premises. In one imstance the linhin has leen known to station him-

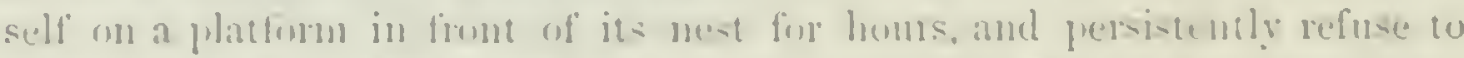

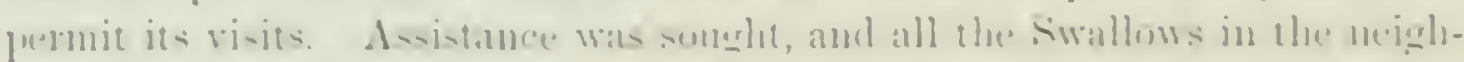

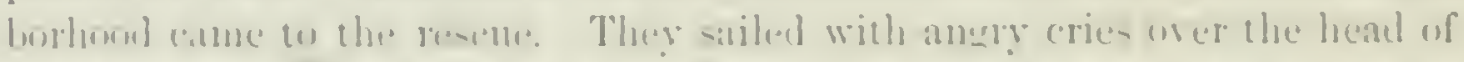

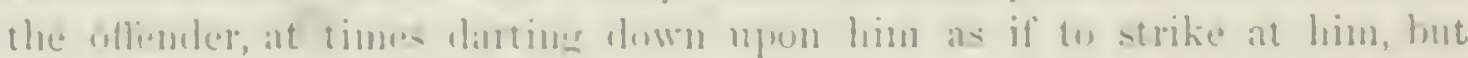

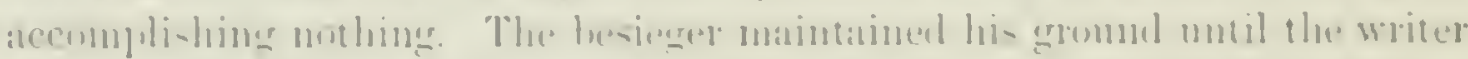

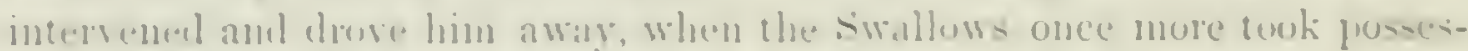

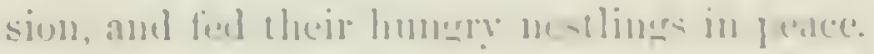

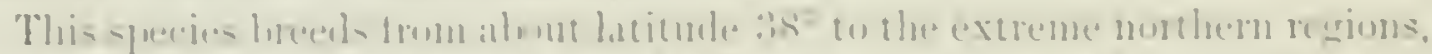

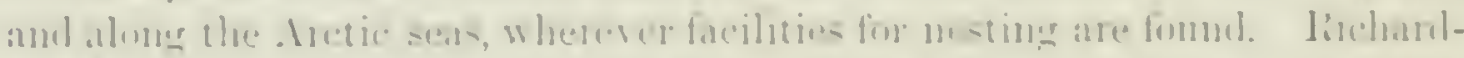

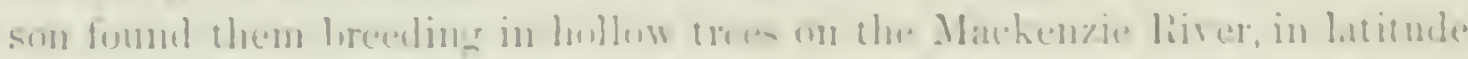

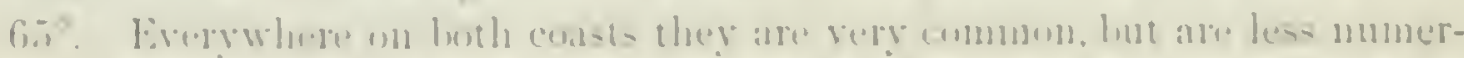

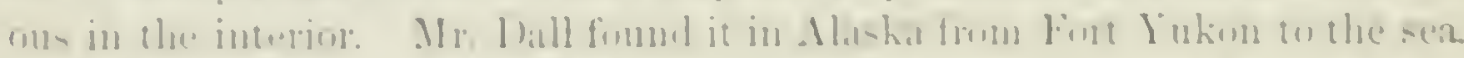

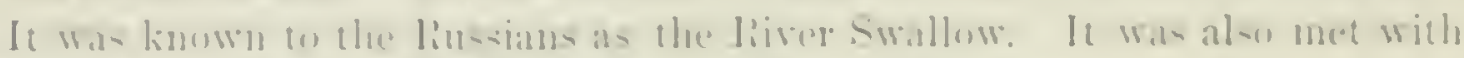

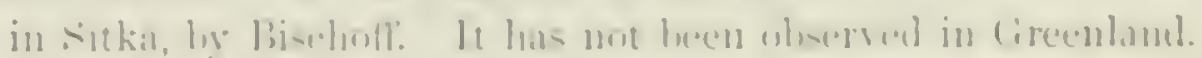

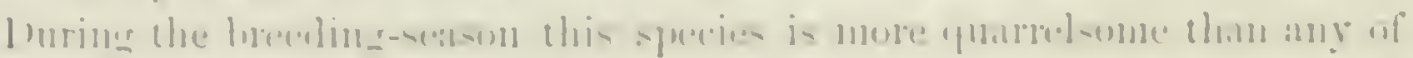

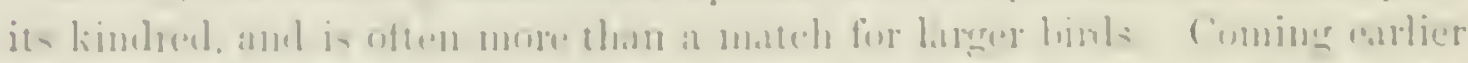

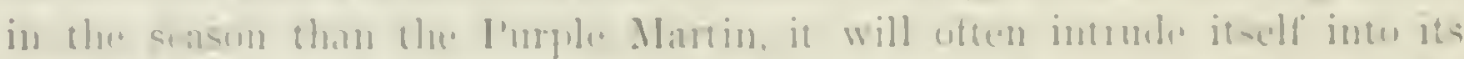

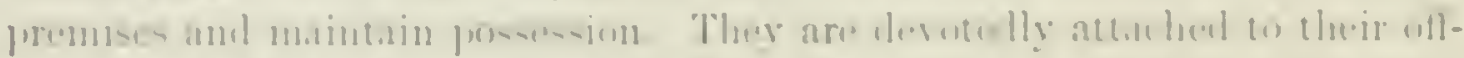

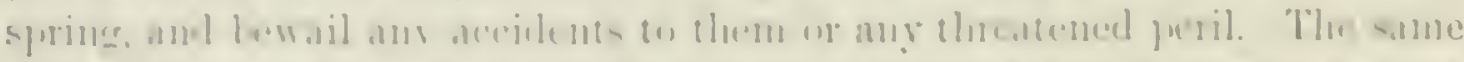

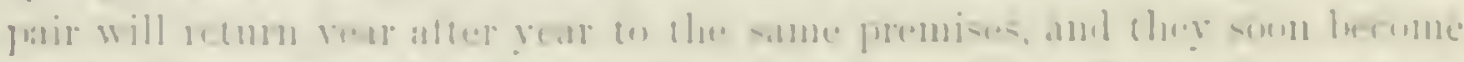

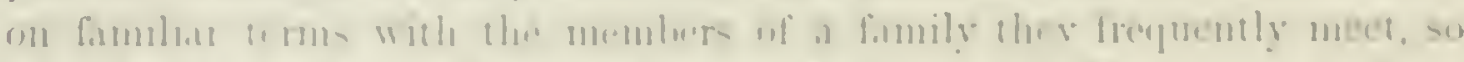

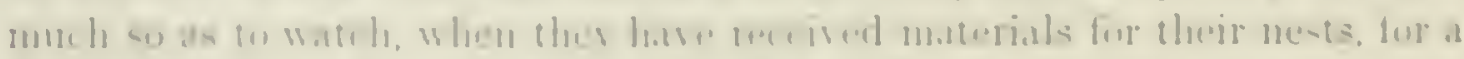

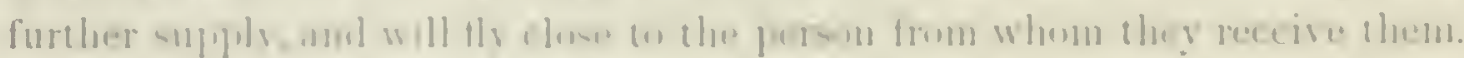

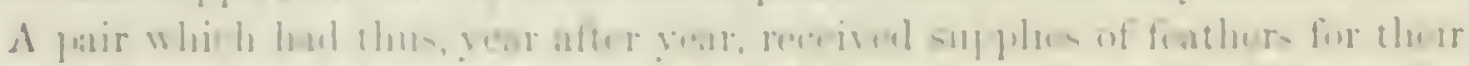

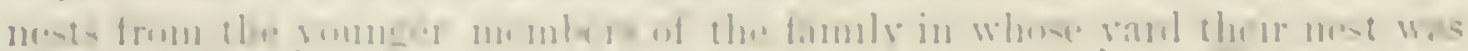

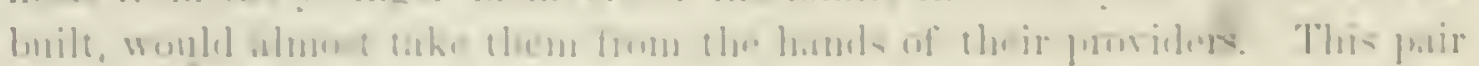

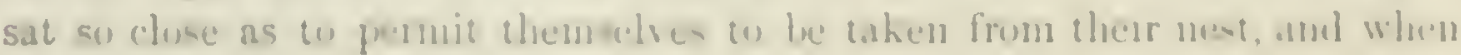


released would at once fly back to their brood. They build a loose, soft, and warm nest of fine soft leaves and hay, abundantly lined with down and feathers, with which the egrgs are not unfrequently covered. The addition of soft and warm materials is often made during incubation, and the nest is thoroughly repaired before it is used for a second brood, of which they usually have two in a season.

The eggrs are of a uniform pure white, and are never spotted. They lave a delicate pinkish shade before they are blown. They are of an oblong-oval shape, one end more pointed than the other, and they vary considerably in size. They vary in length from .75 to .875 of an inch, and in breadth from .50 to .56 .

Mr. Hephurn states that the great mass of these birds leave California in August, lut that a few are resident during the winter. The principal accession to their numbers takes place about the end of Felmuary, and they become quite abundant by the end of March. In Vancouver they are a month later. In 1853 Mrr. Hepburn states that a pair constructed their nest in a piece of canvass at the end of the yard-arm of a store-ship that lay off the levee at Sacramento. He first noticed them on the 28th of $\Lambda_{1}$ rril, when the nest had already made some progress. liy the 19th of May there were seven eggrs in it which were slightly incubated. The nest was a great mass of hay and dried grasses, in the midst of which was a cup-shaped depression very neatly lined with feathers, some of which bent over, forming a slight dome.

\section{Hirundo thalassina, Swatrs.}

\section{VIOLET-GREEN SWALLOW.}

Hirundo thatussina, Swarsox, Phil. Mag. I, 1827, 365 (Mexicol. - Atrd. - Brewer, N. A. Oïl. I, 1857, 102 (the fig. pll. v, fig. lxxiv of egg belongs to another species). B.11n, Birds N. Am. 1858, 311. - Jol:1, Pr. K. A. Inst. Woolwiclu, IV, 186t, 115 (Vinconver Isl.; nests in looles of trees). - Cooper \& Sucklder, P. R. R. Rep. XII, 1I, 185 (W. T.). - Coomer, Orn. CaI. I, 1870, 107. Chelidon thatessine, Bore, Isis, 1844, 171. Tuchycinetu thutussinu, CAB. IIus. IIein. 1850, 48. Mirundo (Tuchyscineta) thalassine, Banid, liev. Am. B. 1864, 299. Petrochelidon thulussine, Sclater \& SaLVix, Ibis, 1859, 13 (Guatemala). - Iв. P. Z. S. 1864, 173 (City of Mex.).

Sp. Cmar. Tail acutely emarginate. Beneath pure white. A hove soft relvety-oreen, with a very faint shade of purplish-violet concentrated on the nape into a transverse hand. Rump rather more vivid green; tail-coserts showing a good deal of purple. Colors of female nuch more obscure. Length, 4.55 ; wing, 4.50 ; tail, 2.00 .

Hab. Western and Middle Provinees of United States, snuth to Guatemala, east to the Upper Missouri. Breeds on Plateau of Mexico (Sumcnr.ısT).

Young birds are of a dull velvety grayish-brown, not unlike the shade of color of Cotyle riparia, but may be distinguished by the absence of the tuft of feathers at base of toes, and the gray (not white) bases of the featliers of under parts. There is only an asliy shade across the brenst, not a pectoral band. 


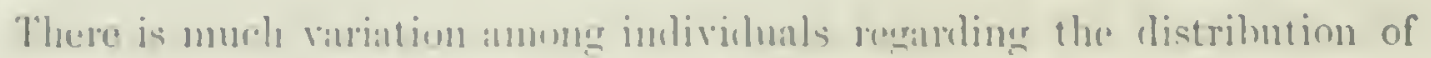

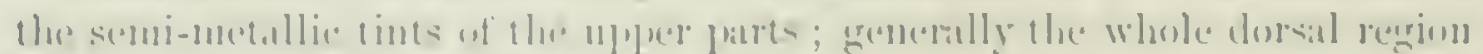

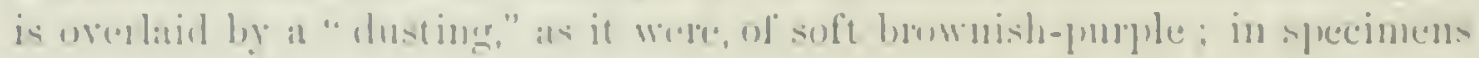

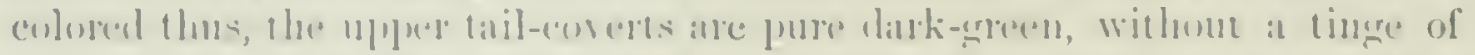

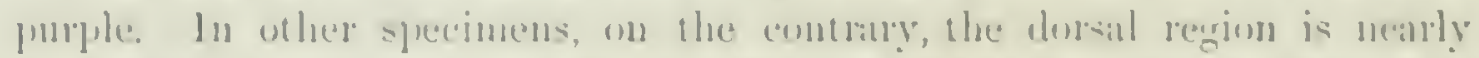
pure green, that of the 11 pere tail-coverts less golden, and mixed with a rery beatutiful ring soft violed.

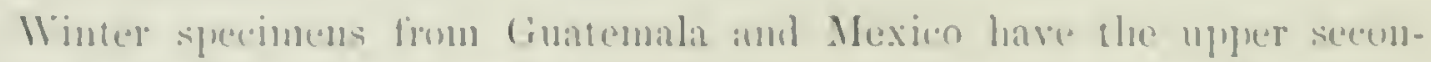

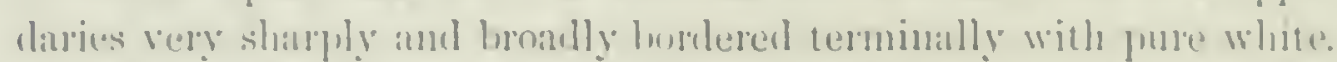

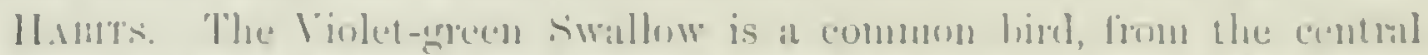

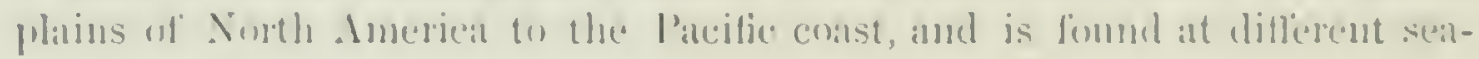

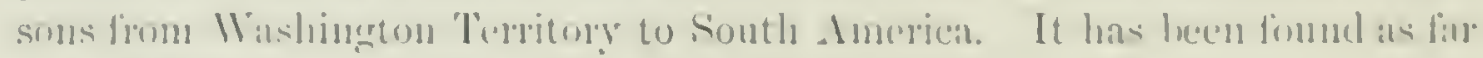

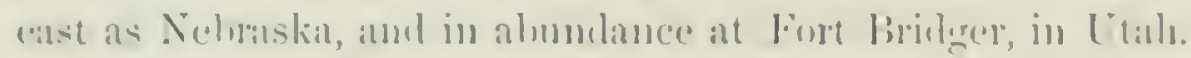

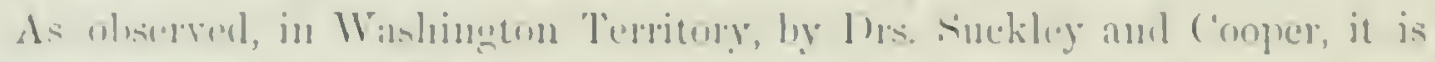

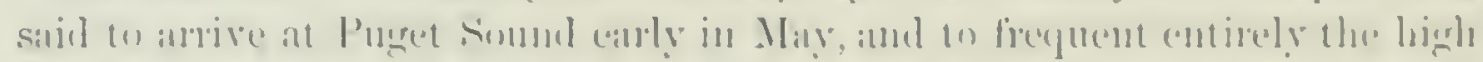
pratries bomlered with oak and uthed decidnous trees, in the kunt-holes of

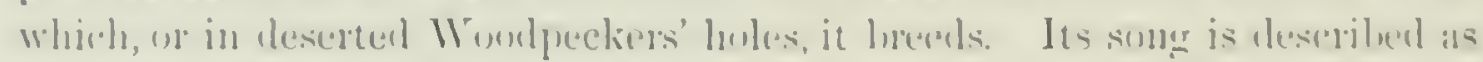

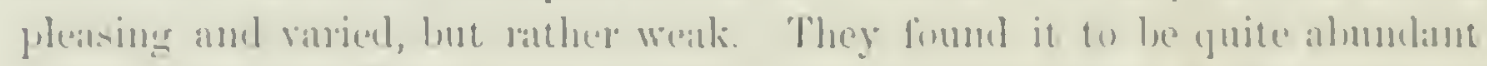

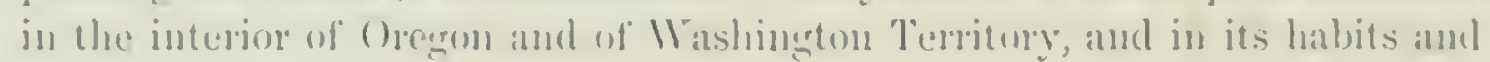
mole of llight havelly distinguishable forn the liculur.

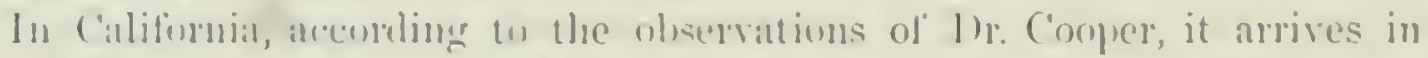

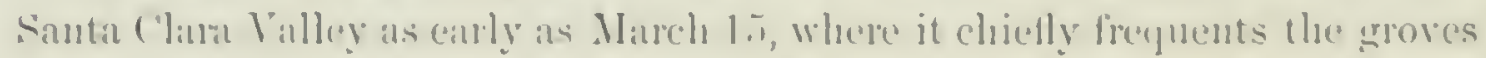

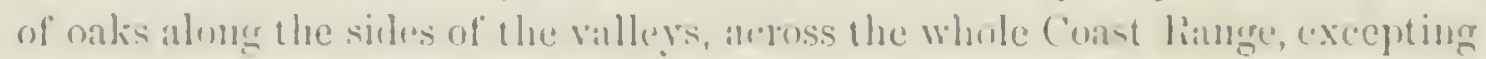

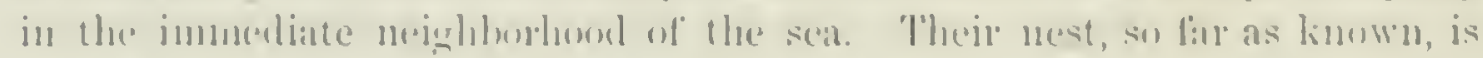

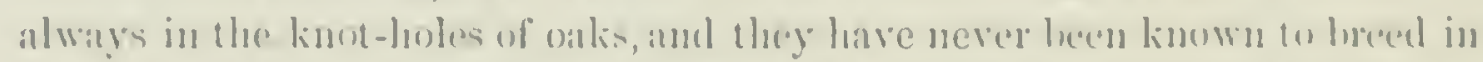

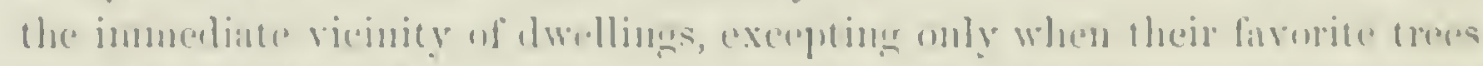

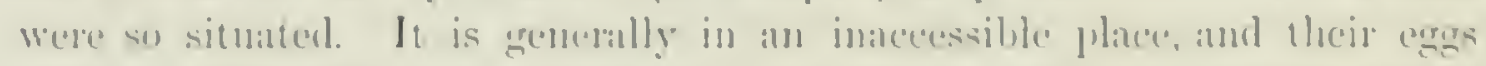

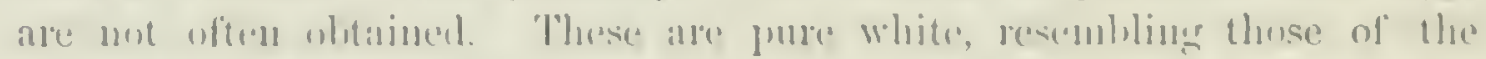

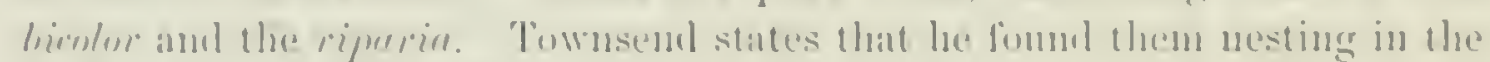

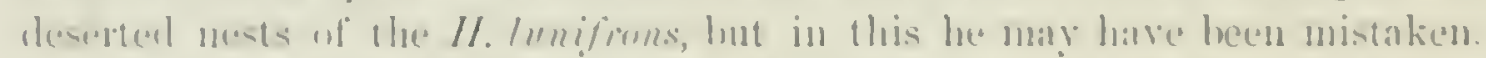

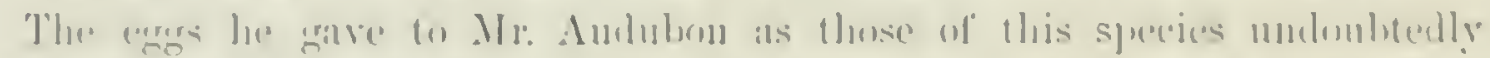

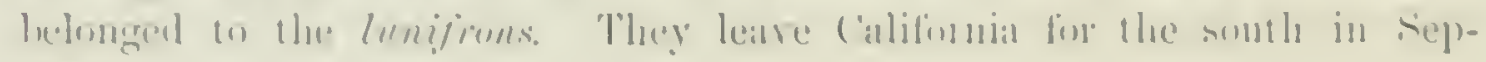
lo.mulued:

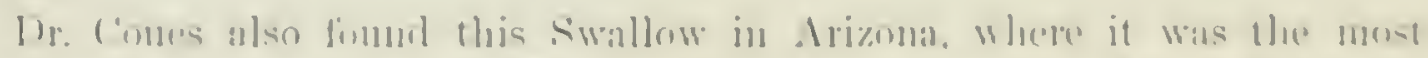

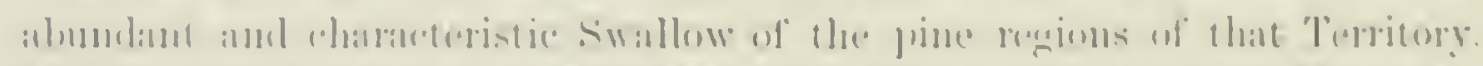

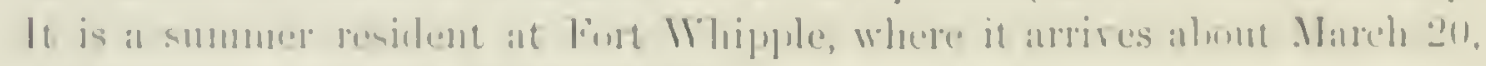

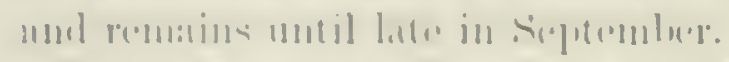

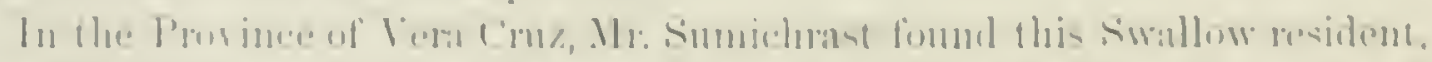

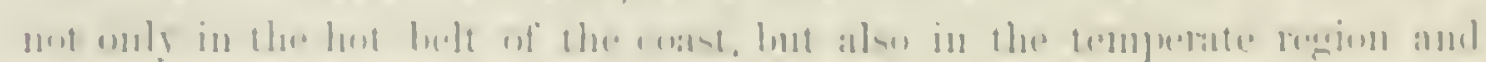

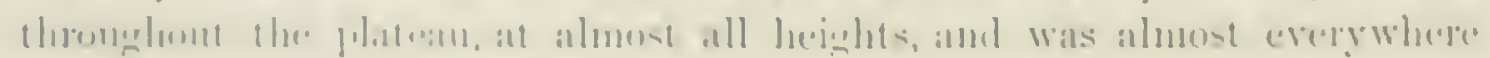

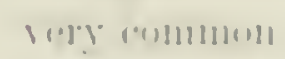

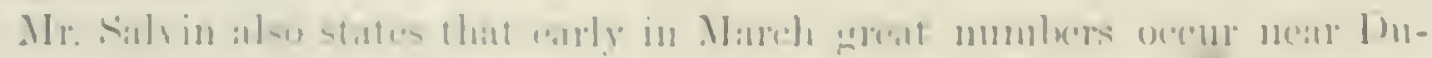

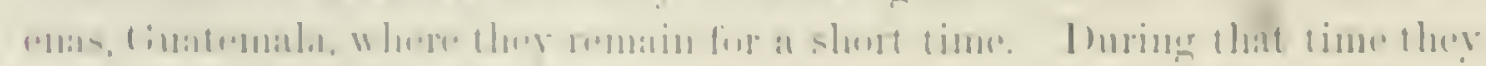

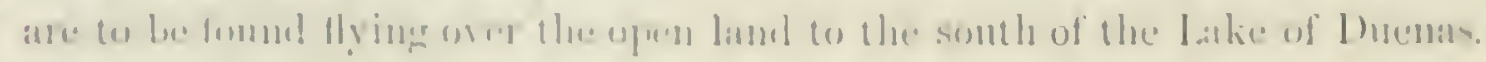


Mr. Hepburn states that this Swallow has quite an extensive mane along the Pacifie coast, but is restricted as to the localities it inhabits. At the Pulgas Ranche, near San Francisco, it is eren more common than the bicolor, while a few miles from thence nut one is to be seen. He has also seen it on the banks of the Fresmo, near its junction with the san Joaquin. River, and again in the Yosemite Valley. without meeting with a single specimen in the interrening conntry. About Victoria this was the prevailing species. These Swallows, so far as Mr. Hepburn observed, alwars build in hules of trees. Their nest, he states, is formed of a few fine dry stems of grass, placed at the bottom of the hole, corered over with a thick malss of feathers. The egrgs, he aduls, are pure white, larye for the size of the bird, measuring .81 of an inch in length by . .0 in breadth. These Swallows have two broods in a season. In $186+$ he noted their arrival in San Mateo County on the 2Sth of Tareh.

Mr. Pidewar writes that he first met with the Violet-green Swallow in Mar, on the islands in Prramid Lake. He there found it rery abuudant among the cliffs of calcareous tufa of which the island was composed. They were seen to enter the fissures of the rock to their nests within, which it was found impossible to reach. Ther were again seen in July among the limestone clift's along the cañons of the East Humboldt Mountains, associated with the White-throated Swift. building like them in the small horizontal crevices or fissures on the face of the precipice. He was not able to get at more than two of their nests, the first in a horizontal fissure just wide enough to admit the hand, and about eight inches from the entrance. It contained five roung. The nest was similar to that of the Bank sirallow, and was composed of sticks, straws, and fenthers. In the other the female was dead on her nest, and the eggs were broken. Ther were white, like those of the H. bicolor:

In its flight this bird is said to greatly resemble the White-bellied Strallow, but is distinguishable by the contust of the three colors of its upper plumage. These two species are rarely to be seen in the same localities, the bicolor preferring wooded, and this species rocky localities.

Mr. Lord states that this beautiful Swallow was common from the coast along the entire course of the boundary line, to the summit of the Rocky Mountains. They were among the earliest risitors at Colville, arriving in small flocks in March, but in greater numbers in Nay and June. Ther build in June, making their nests in holes in dead trees as high as they can get, and lay four or fire eggrs. The nest is made of feathers and soft hair. They assemble in large flocks before migrating in September. Mr. Lord felt pretty sure their nesting-holes rere excarated in the soft mood br themselves, though their soft beak seems ill adapted to perform such labor. 


\section{Fi: STELGIDOPTERYX, HIM!。}

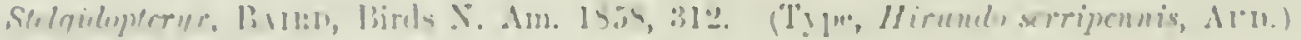

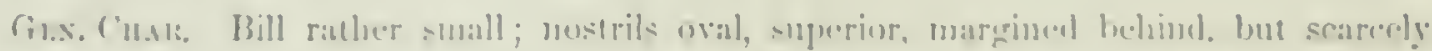

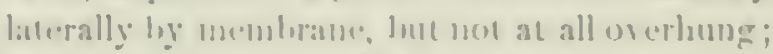

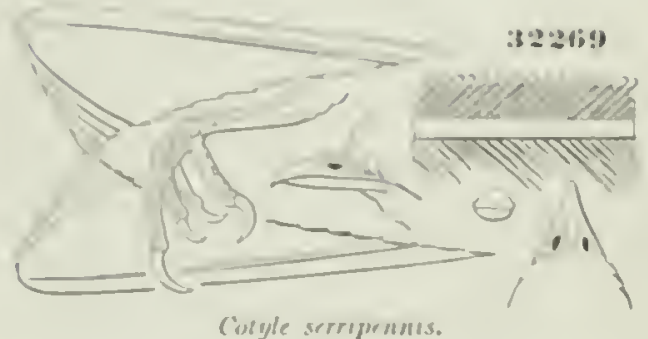

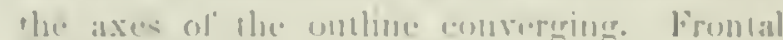

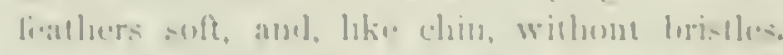

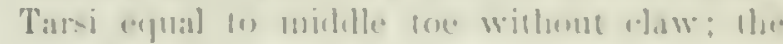

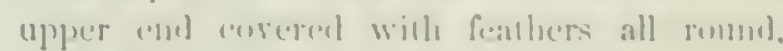

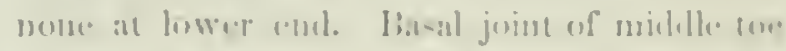

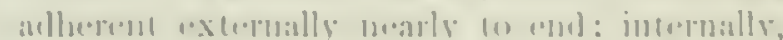

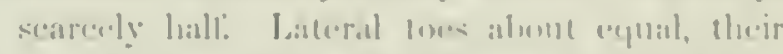

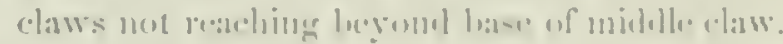

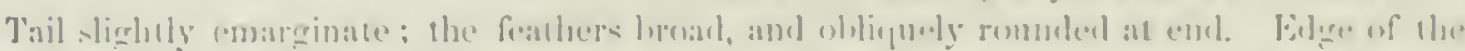

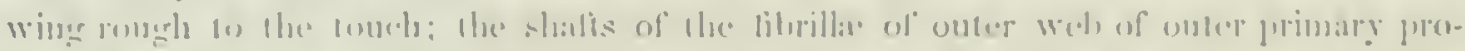

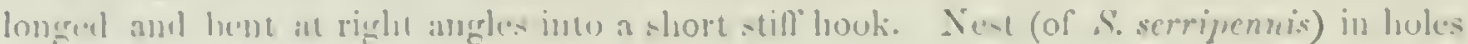
in hankis; erers pures while, unspotced.

colur dull brown alsore.

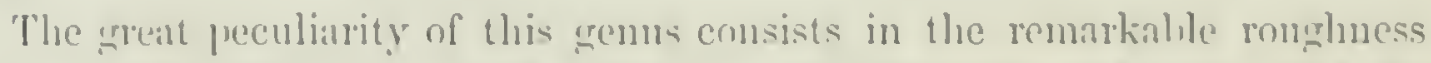

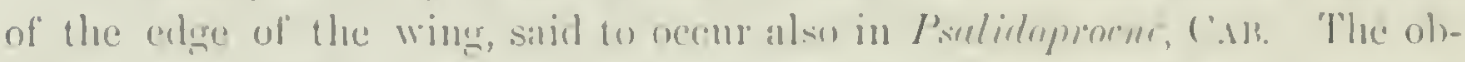

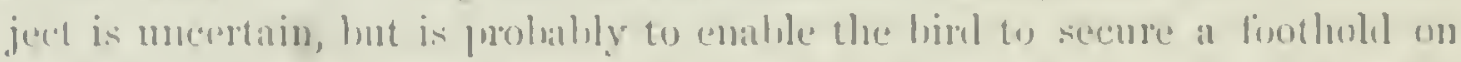

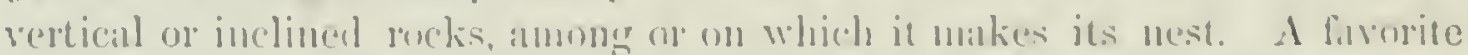

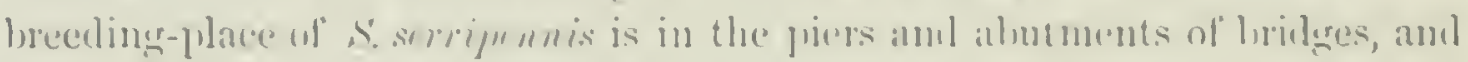
these hooks mirht remler essential ain in entering into therir lobles.

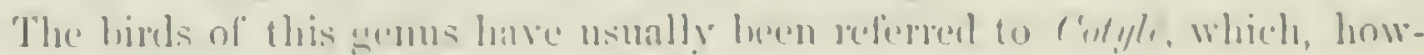

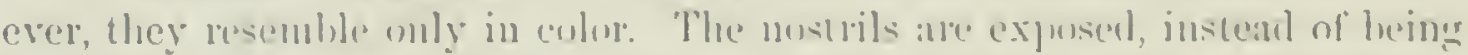

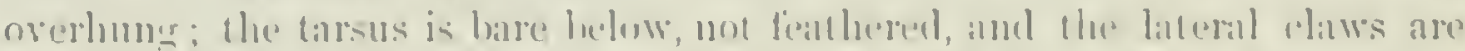

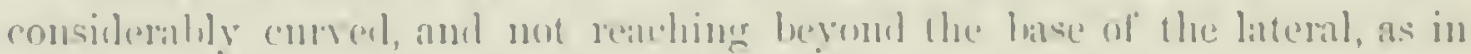
Cotyle. The strueture of the wing is very dillerrent.

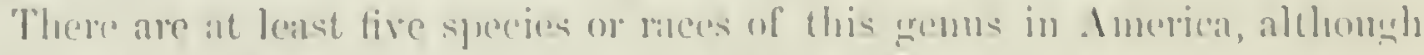

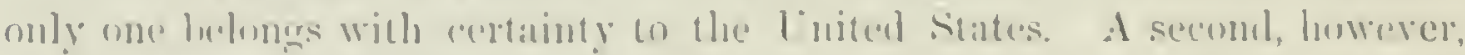

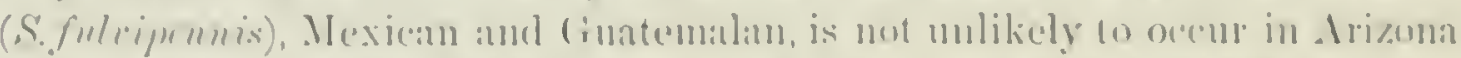

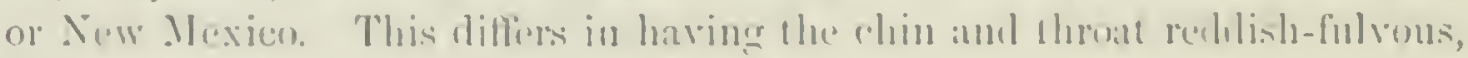
not mustorgaty; the lully tinged with vellow.

Stolgidopteryx serripennis, Bislin. ROUGH-WINGED SWALLOW

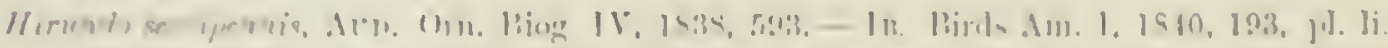

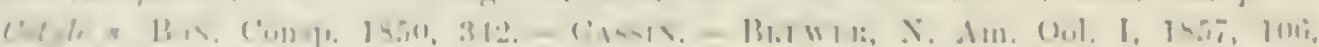

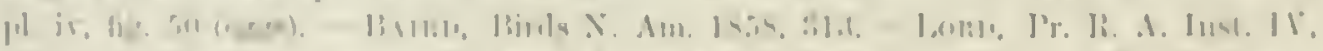

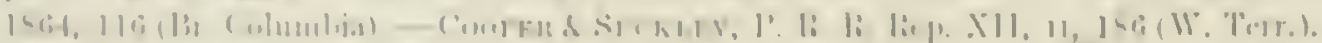

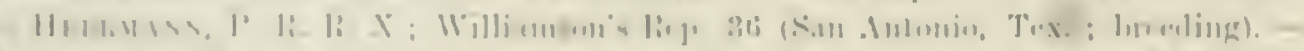

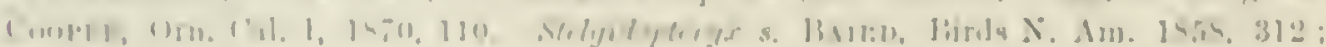
li. $x: 311$ 
Sp. CaAr (No. 32.269 ठ.) Above smoky-brown, rather deeper on the head, perhaps a little paler on the rump. Larger quills and tail-feathers dusky-brown: the secondaries and greater coverts sometimes lighter along their external edges. The under parti for al out half the total length) from bill to and including breast, with the sides of body and lining of wings, mouse-gray, rather lighter alung the throat; the rest of unler parts, including crissum, white, the latter with the shath sometimes dusty, aud very rarely with dnskr blotches at the ends of the longer feathers.

Foung birds (as in 1.120) ditter in a tinge of reddish-fultous on the upper parts: the wing-corerts, secondaries. and inner primaries marined nore or less broadly with a brighter shade of the sane. The gray of the under parts is also washed with this color, especially on the chin and across the breast. The hooks of the edge of the wing have not ret become dereloped.

(No. 32.2199 o. fresh specimen before being skinned.) Total length, 5.40; expanse of wings, 12.20: wing from carpal joint. t.50.

(10. 32.269 8. prepared specimen.) Total length. 5.20: wing. 4.50; tail. 2.2.5, depth of fork. .15; differuce of primaries, 2.2S; length of bill from forehead, .40, from uostril, .24 . along gape, .56 , width of gape, .4.3; tarsus. .45: middle toe and claw, .57 : claw alone, .19 ; hind toe and claw, .t1: claw alone. 16 .

HAB. Whole Cnited States (exclusive of Lortheastern States?) south to Central Mexico.

Habits. The Rough-winged Swallow was first met with by Audubon, in Louiisiana, but describel by him from sjecimens aftermards procured near Charleston, S. C. He knew nothing in regarl to its habits, and its distribution was equally unknown to him. It las since been found, but nowhere very abundanty, in various parts of the Lnited States. It has not been met with on the Atlantic coast farther to the north than New Jerser and Pennsylyania. On the Pacific const it is more common. Dr. Suchley speaks of it as quite abundant both in Oregon and in Washington Territory. Dr. Cooper, in his Zoology of Washington Territory, speaks of it as common about the sandy cliffs of the bays and inlets of that coast, arriving near the Colunbia in May, and remaining only until the midule of Angust, when all these Swallows go southwarls, though their last brool is hardly able to Hy. He sars that they burrow holes in the soft sandy banks near the tops of clifis, and have generilly the same habits as the common Bank Swallow. They have no song, only a few chirping calls.

Dr. Cooper, in his Report on the birds of California, further states that this Swallow, in summer, is found througliout the lower portions of that State. He sam them at Fort Mojare as early as the 2-ith of February, and as he has met with them at San Diego in Norember, ancl also in Januart, he thinks they may winter within the State. He describes their burrows in the sandy banks of rivers as being to the depth of three feet, crowded rery near together, and near the upper edge of the bank, in no wise different from the nesting of the common $C$. riparia. The nests are composed chiefly of dry grasses, with a few feathers, and contain five white eggs. Occasionally, however, they resort to natural clefts in the bank or in buildings, and to knotholes in trees. In the fall they congregate in great numbers about certain farorite spots, and keep much together in flocks. At night they roost in 


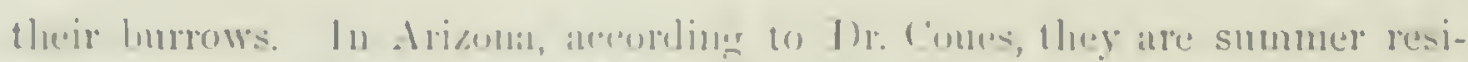

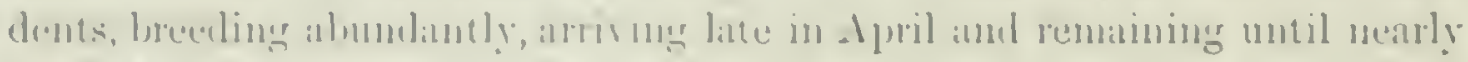
the liat of sepelembluer.

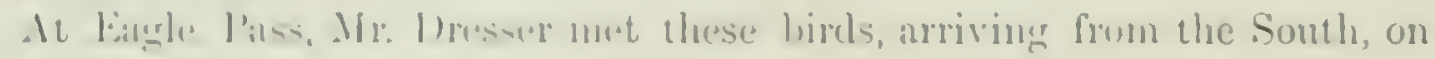

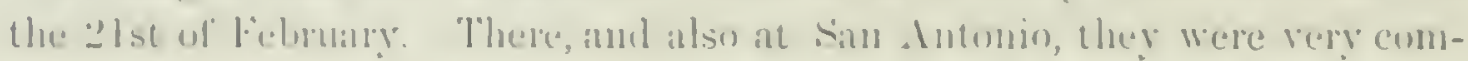

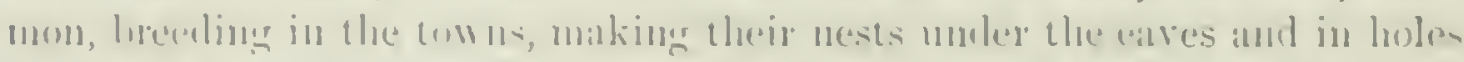

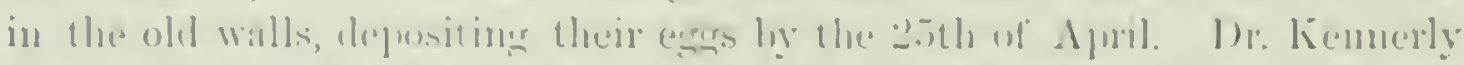

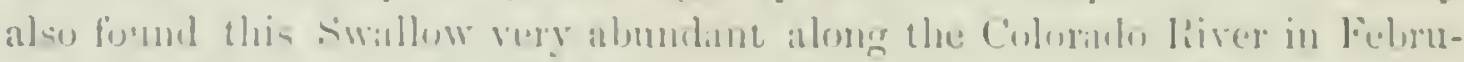

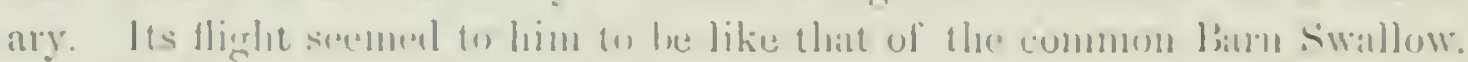

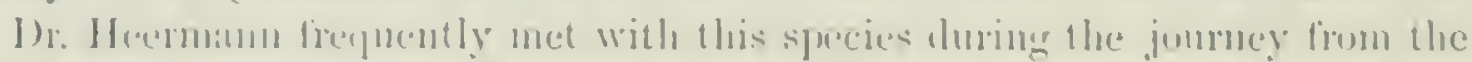

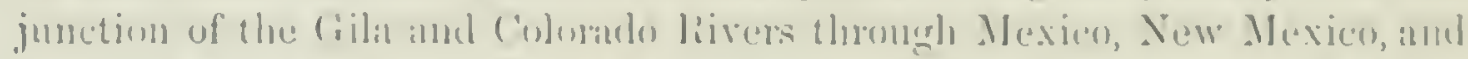

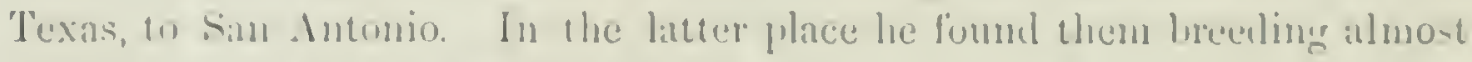
entirely in crestees in the walle of homsess.

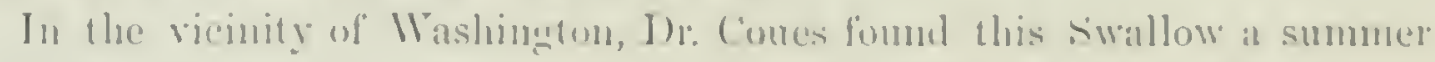
resiclent, but rather rane, arviving in the third week of April, and leaving about the midelle of sepmomber.

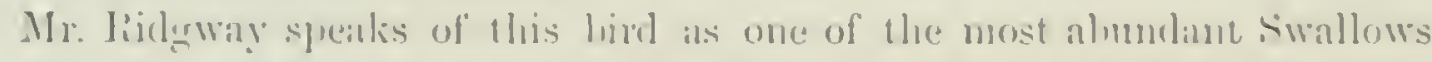

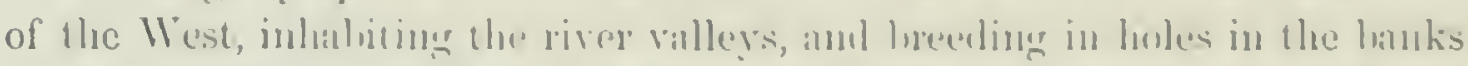
of the rivers. Ile sils that in suntien lllinois it if much more abundant

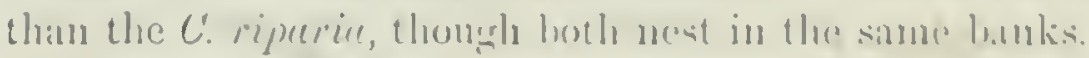

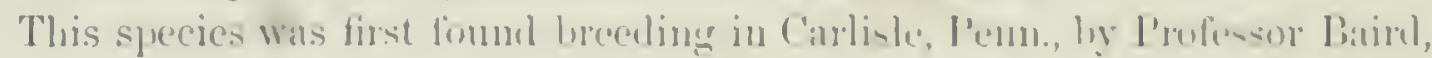

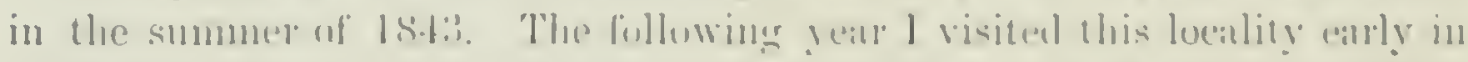

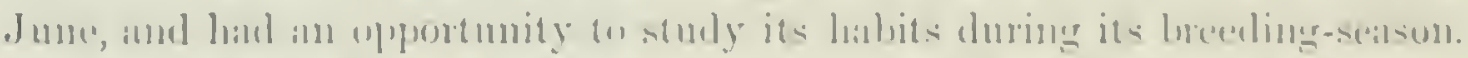

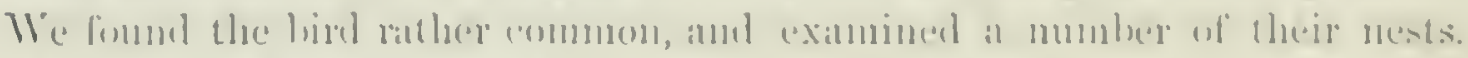

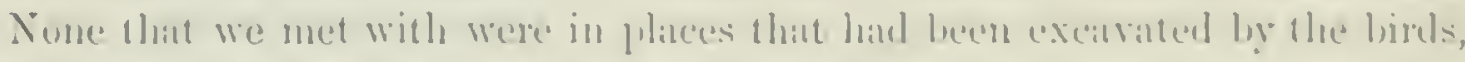

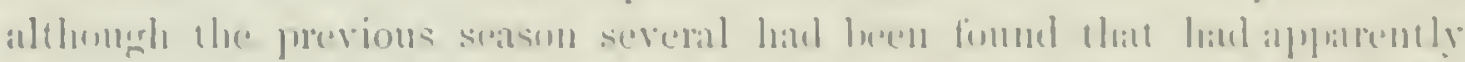

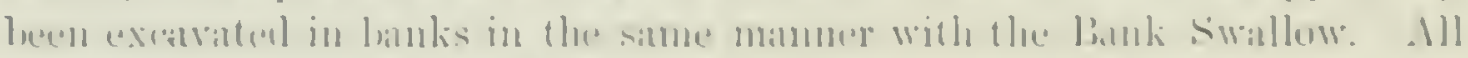
the ments (seven in mumber) thitl we then net with were in situttions aced-

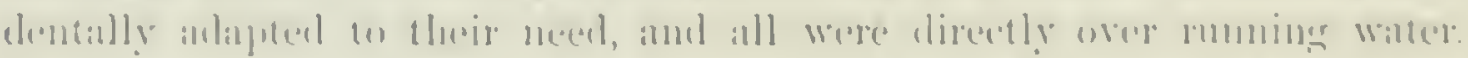

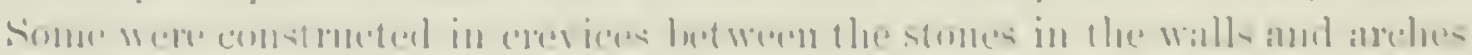

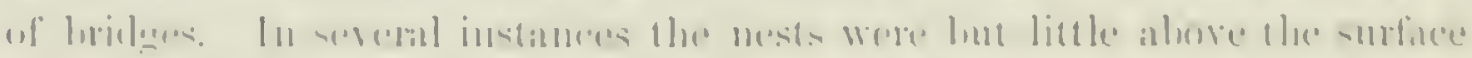

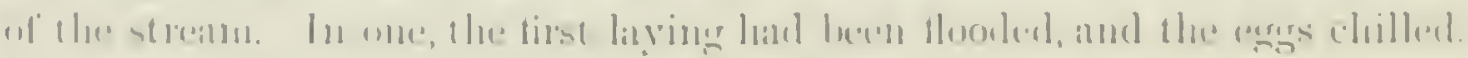

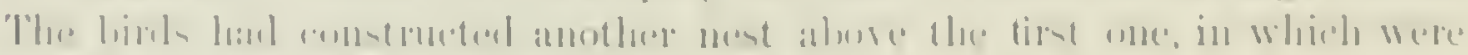

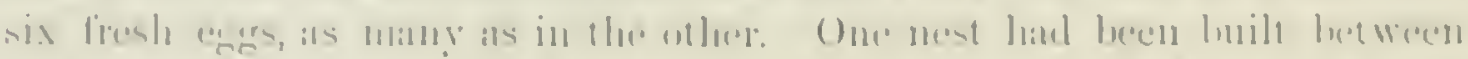
the stouses of the wall that fortured ane of the sides of the flume of a mill.

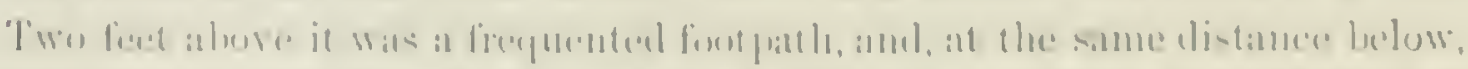

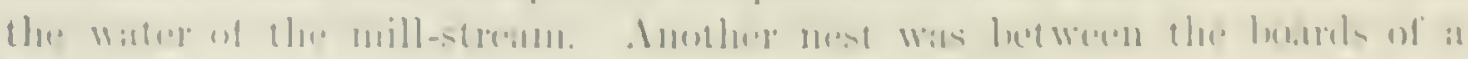

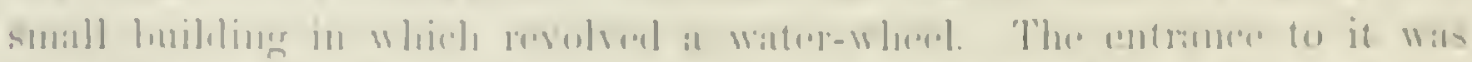

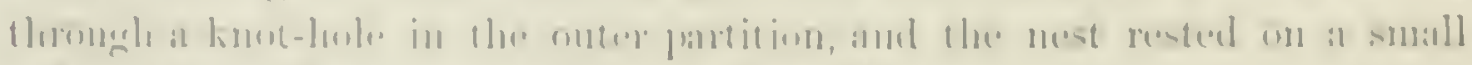

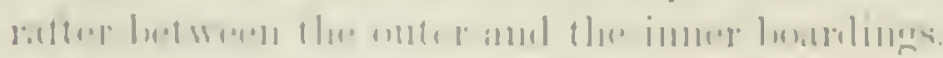

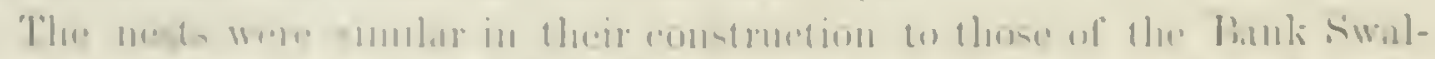

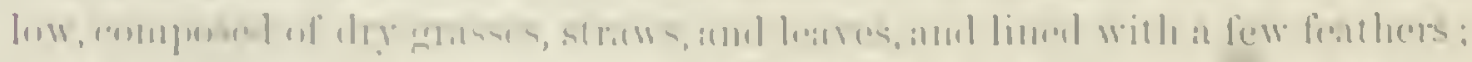

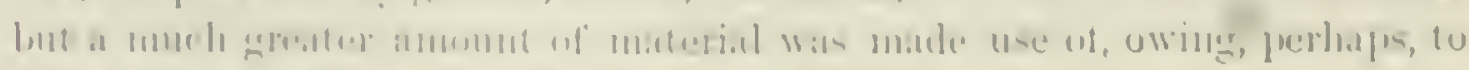

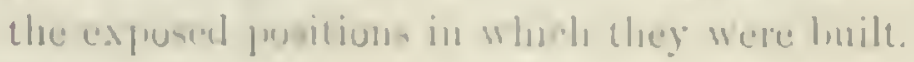


The eggs, six in number, in every instance that we noticed, were pure white, abont the size of those of the ripuriu, but a little more uniformly oblong in shape and pointed at one end. Their length raries from .78 to .69 of an inch, the arerage being.$\overline{5}$. Their arerage breadth is .5. of an inch.

\section{Gest's COTYLE, Bore.}

Colyle, Bolf, Isis, 1\&20, 550. (Trpe, Himulo riparia, L.)

Gex. Char. Bill small : nostrils lateral, orerhung hy a straiglit-edged membrane. Tarsus about equal to middle toe without claw ; feathered at upper end, especially on inner face. and having also a small tuft of feathers attached to posterior edge near the hind toe. Middle toe with basal joint adherent externally to near the end. half-war internally, the claws comparatirely little eurved, the lateral reaching beyond the base of the middle. Tail slightly forked. Color dull lustreless brown above. in riparia white beneath with gray pectoral band. Nests in holes in banks; eggs white.

Many American birds have heen referred to Cotyle, but the only one really belonging to the genus is the cosmopolitan C.riparia. The peculiarity of the genus consists essentially in the tuft of tarsal feathers at the base of the hind toe, and the unusual length of the lateral clars, combined with the lateral nostrils orerhung by mem-

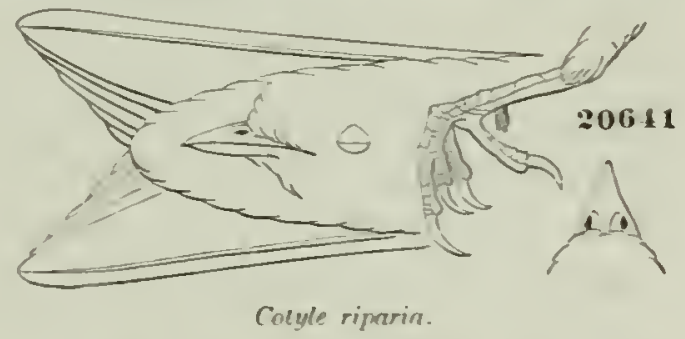
brane. By these characters the genus is rery easily distinguished from Stelgidopteryx.

\section{Cotyle riparia, Bore.}

\section{BANK SWALLOW : SAND MARTIN.}

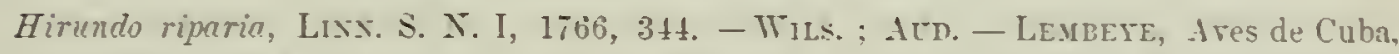
1ミ50, ti, lam. rii, fig. 3. -Joxes, Yat. Hist. Bermula, 34 lotcasional, Aug. and Sept.). Cotyle riparia, Bore, Isis, 1822, 5jo. - CAssis. - Brewer, N. A. Oöl. I, 1\$57, 105, pl. ir, fig. 49 (eggs). - CAB. Jour. 1\$56, 4 (Cuba). - BArrn, Birls X. Am.

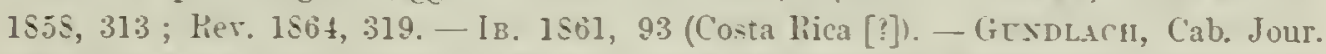

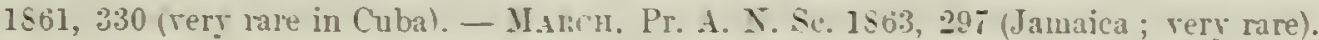

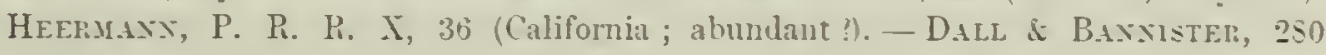
(Alaska). - Cooper, Orn. Cal. I, 1sio, 110. - Sastels, 25S. Hirundo cinerea, VIEILL. Himendo riparia americune, IAx.

Sp. Char. .Idult. Abore grayish-brown, somewhat fuliginous, with a tendeney to paler margins of the feachers. Beneath pure white, with a band across the breast and the sides of the bodr like the back. Length, 4.75 ; $\pi$ ing. $4.00:$ tail. 2.00 .

Young tirds have less emarginate tails, and the feathers of back. rump, and wings edged with whitish.

H.s. The whole of North America: Bermudas; Greater Antilles: Costa Rica; Western Brazil (Pelz.). Also found in the northern parts of the Old World. 
A rritial examination has failanl to reveal any difference Letween Eum.

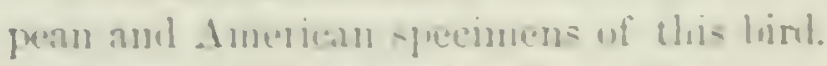

H.nars. The common bank swalluw as we know it, or Sand Martin as

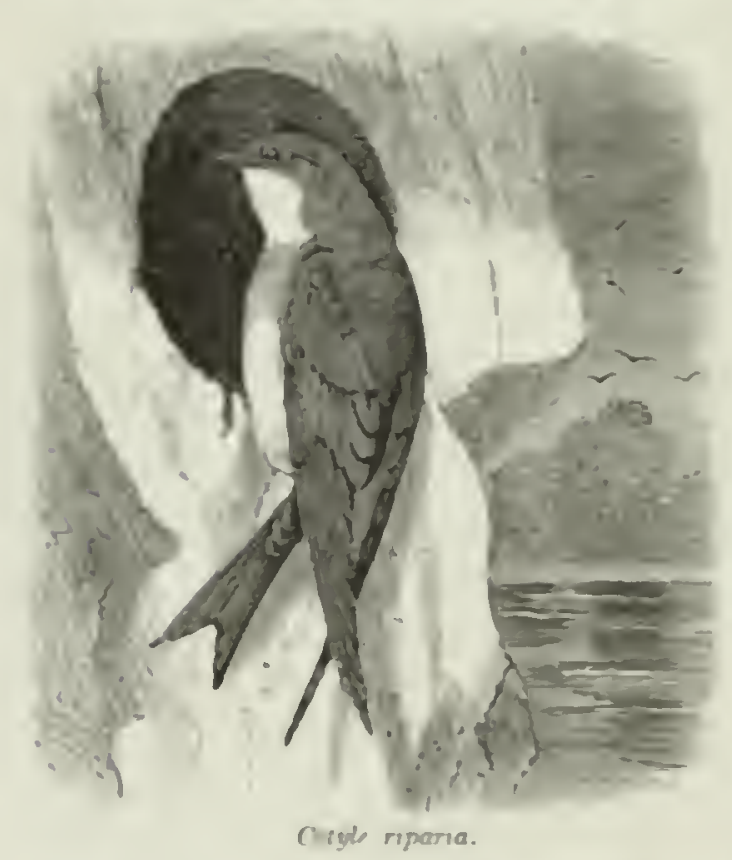
it is called in linglane, is nearly ur yuite cosmopnlitan in its distribution. Funnd throuchunt liurope in the season of repueduction, and in prortins of Afrivat in the winter monthe, it is "pually common thromehout North America in the summer, and protalily wincers in Mexien and in lenmal and sombl America, thombh it is unt mentiunel by sumichrast as a ligrl of lera cruz. It is saill tur orecur in rarious parts of the comtinent of Afrien, and in Furupe it exteuds its migrations to the extreme northeru reeriuns. It las alon been met with in Imlia aml in siberia. Mr.

Salvin nbtained several specimens at Duenas, Guatemala, in Suptember,

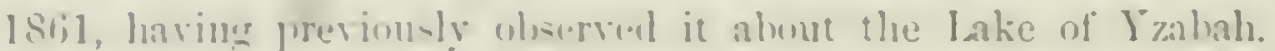

On Imts continents it is sumewhat locil in its distribution, in favomble

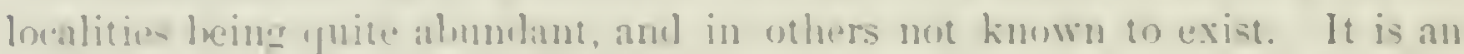

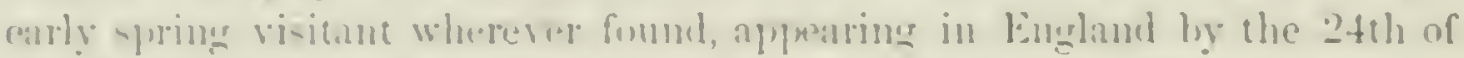

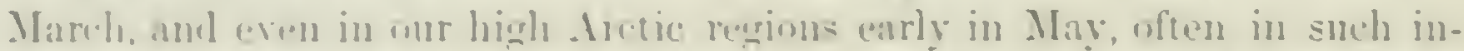

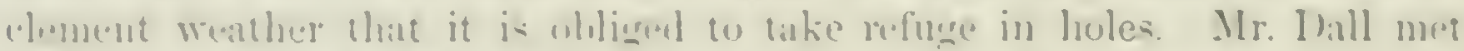

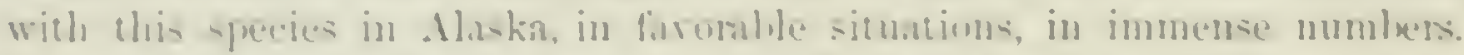

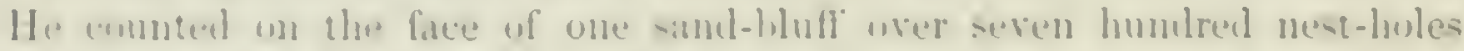

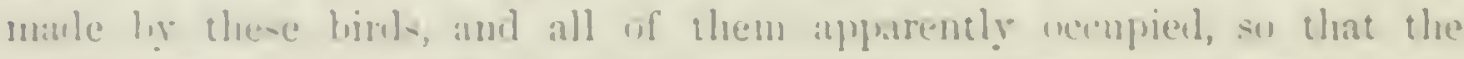

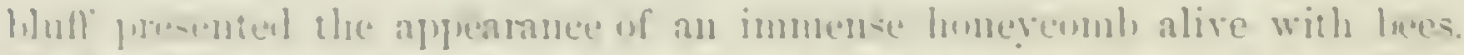

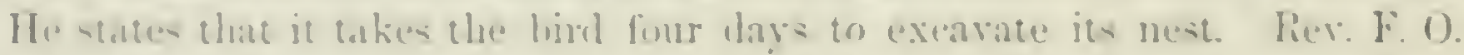

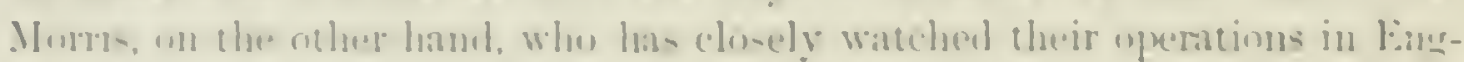
lauml, on - that it ropuires a fortuight, and that the weight of sond a pair

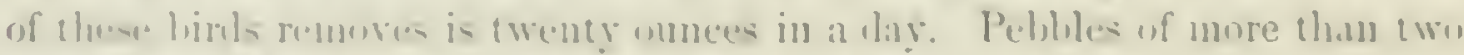

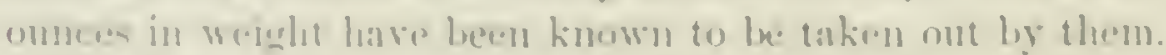

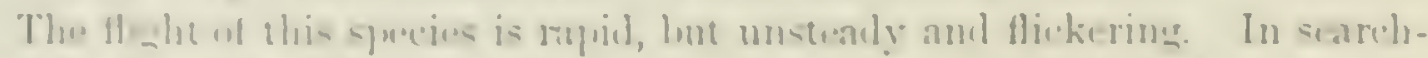

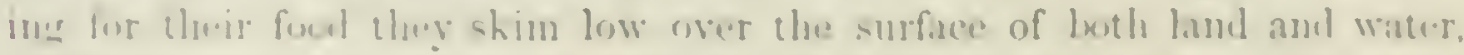

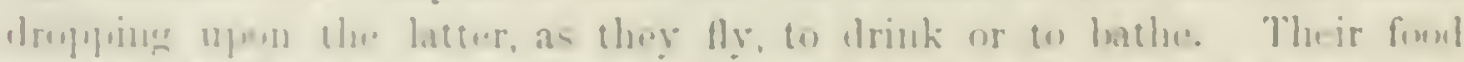

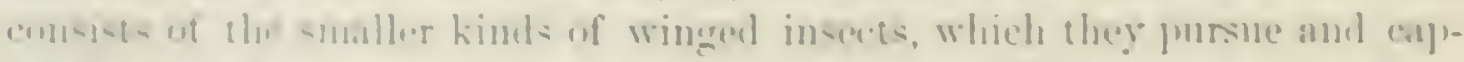

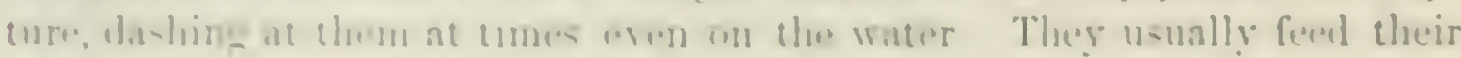

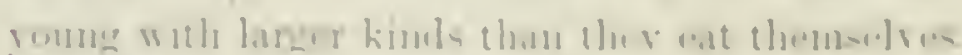

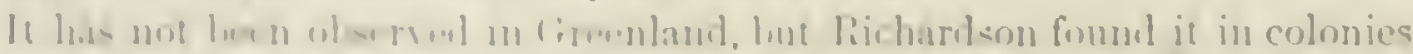

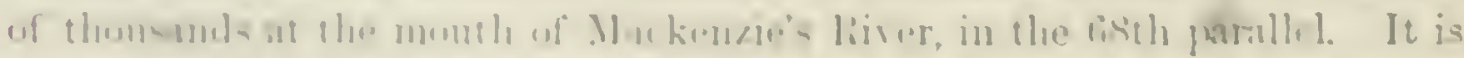

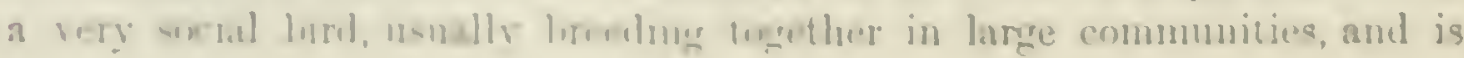


more independent of man than most of its family, owing him no other farors than those incident to excavations through sand-hanlis, of which it avails itself. The nests of these Swallows are placed in excavations male by them in the banks of rivers, cliff's by the sea-shore, and sinilar favorable situations. These are usually as near the surface of the gromd as the nature of the soil permits to be readily penetrated, thongh the bird lias been known to work its way even through hard gravel. Their depth varies from fourteen inches to four feet, though two feet is the usual distance.

Mr. Augustus Fowler mentions a remarkable instance of sagacity and provident forethought in these birds, not easily separable from reasun. In the town of Beverly, in a stratum of sandy loam, he observed each season a colony of some twenty or thirty pairs of these birds. In this place these birds never burrowed more than two or three feet. Within a mile of this place another colony exearated a bank in which the layer of loam was mixed with small stones. In this bank they excavated to the depth of five, seven, and even nine feet. Why was there this extraordinary difference in the length of burrows made by the same species, in situations not more than a mile apart? The reason for this difference, upon examination, became very" obvions. We give the explanation in Mr. Fowler's own words: "In one bank, where the earth was of a fine sandy loam, easily perforated, from the entrance to the extremity the burrows did not exceed three feet in length; while in the other bank, with harkler loam to work in, one burrow was found nine feet in length. After examining six holes of nearly equal length, it appeared that these little birds had sufficient reason for extending their labors so far into the earth. In every instance, where they net with a spot firee from stones they finished their burrows; thus showing great care for the welfare of their eggs or young by aroiding, in the stony soil, a catistrophe so great as would befall their treasures if by accident one of these stones should fall upon thein."

The work of perforation they perform with their closed bill, swaring the body round on the feet, beginning at the centre and working ontwards. This long and often winding gallery gradually expands into a small spherieal apartment, on the floor of which they form a rude nest of straw and feathers. The time occupied in making these excavations varies greatly with the nature of the soil, from four or five days to twice that number.

Their eggs are five in number, pure white, and when unblown have a fine roseate luue. They are oral in slape, larger at one end, and pointed at the smaller. Their average length is .72 of an inch, and their avenge breadtlı .47 . 
Wr.

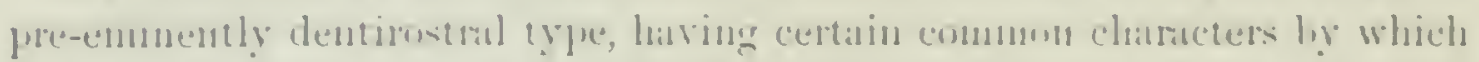
they ane distingui-halile, with but litte dilliculy, from all velers. In their

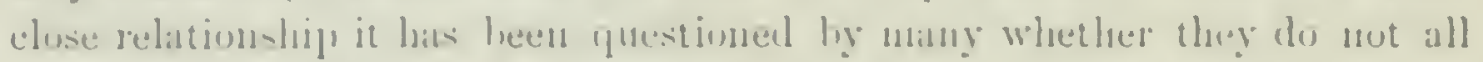

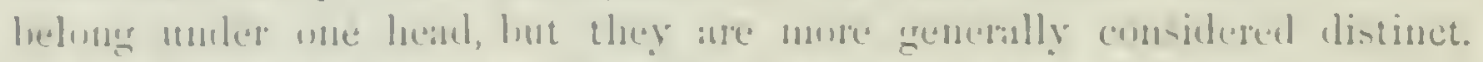
The common chatraters, and hlose preculiar to eath, are as lollows : -

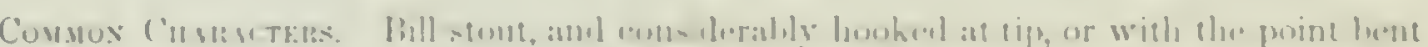

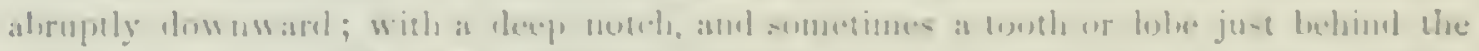

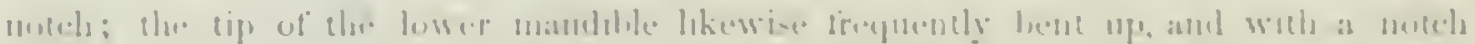

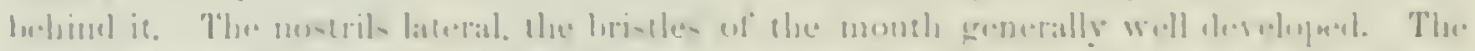

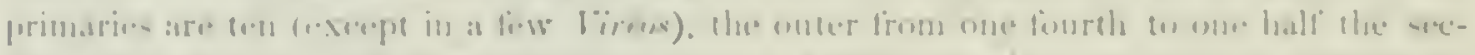

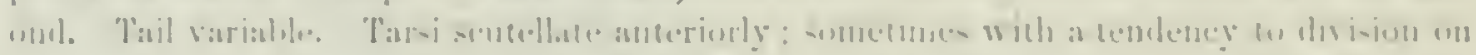

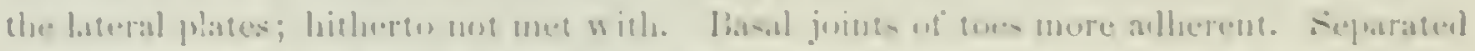

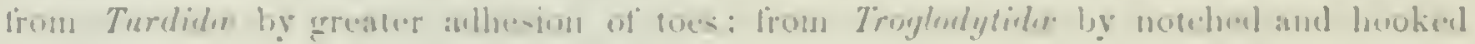
liill, $1 \times 81 \%$

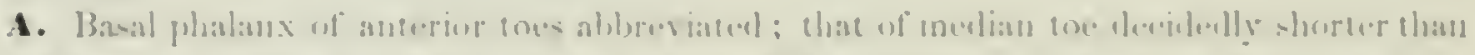

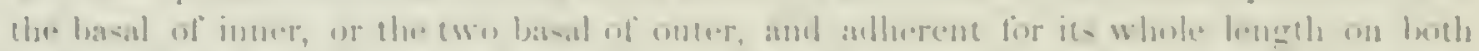
- biles to the laberal (i. e. nut free at all). Latoral plates of tarsus mudwided, excepte at

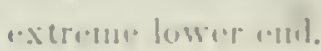

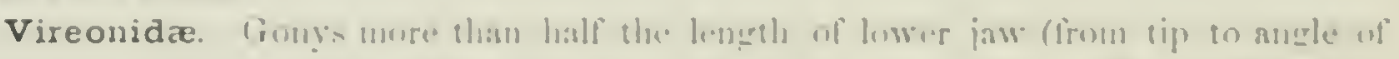

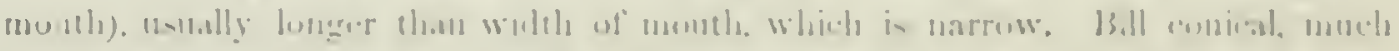

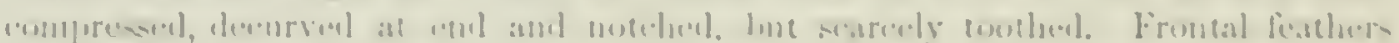

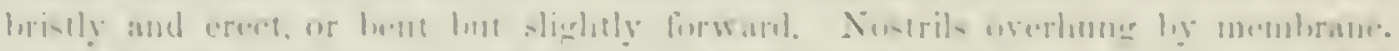

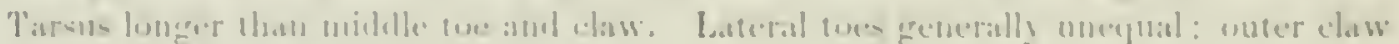

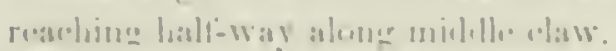

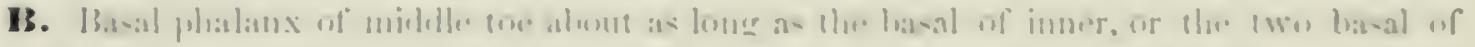

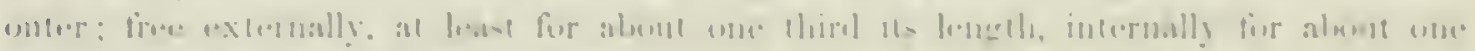

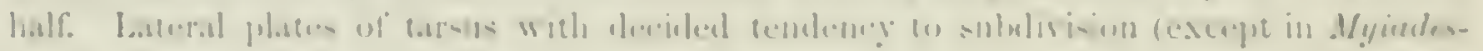
fiili).

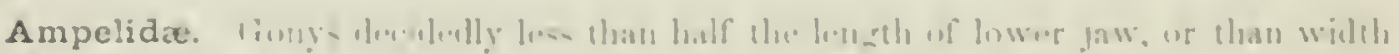

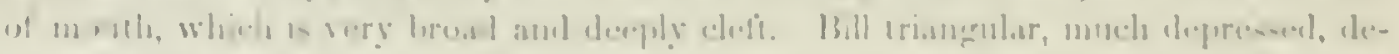

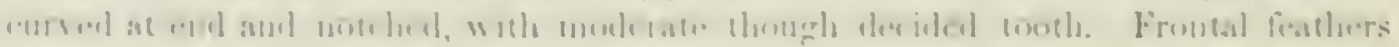

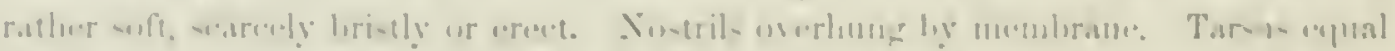

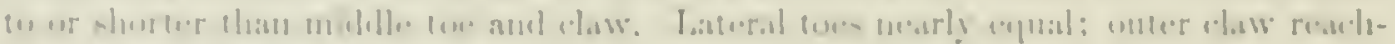

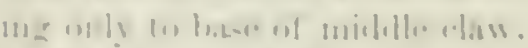

Lanildae. 1: l:|ll 10! fuw

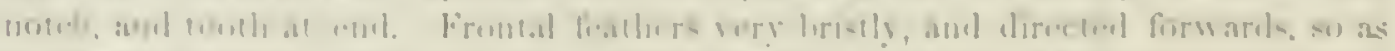

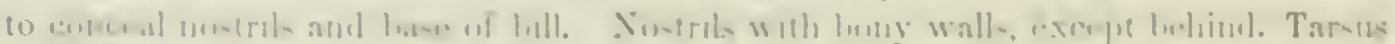

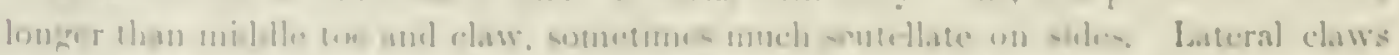

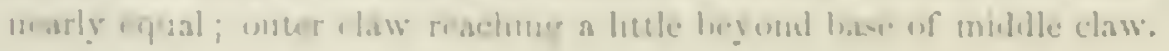




\section{F.MILY VIREONID无. - THE VIREOS}

The essential features of this family appear to consist in the combination of the dentirostral bill, notehed in both mandibles; the ten primaries (except Vircosylria), of which the outer is usually from one fourth to one half the second; the rather short, nearly even tail, with narrow feathers, and the great amount of adhesion of the anterior toes, - the whole basil joint of the middle being generally united on both sides to the adjacent joints, and decidedly shorter than the basal of inner or two basal of onter. The onter lateral toe is generally appreciably longer than the inner, reathing considerably berout the base of the middle claw. The tarsi are alwars distinctiy scutellate anteriorly. The young are never spotted, or streaked as in the Thrushes; nor, indeed, do the adults exhibit such markings.

The Tireonide are peculiar to the New World, and are widely distributed, although but one genus belongs to the L'nited States.

\section{Gexts VIREO, VieILL.}

I'irco, Vietld. Ois. Am. Sept. I, 1S07, \$3. (Trpe, Muscicapa nowlnracensis, G».)

No great violence will be done hy considering all the American Vireos as belonging to one genus, divisible into three subgenera, as, howerer different the extremes of the series may be from each other, the gradation is quite complete.

The North American species take a wide muge during their sonthern winter migration, only pandleled in this respect by the sylvicolilla; they do not visit the West Indies, save as rery liure stragglers to Cuba ( $T$. olizucus, solitarius, flarifrons, and norborecensis.). They all have a melodions song, and, so far as known, make a deep nest, suspended by its upper edge between the forks of a horizontal twig. The eggs are white, generally with a few reddish or lorown blotches.

Quite a number are characterized by having the eyes white, red, or yellow.

\section{Subgenera.}

Vireosylvia. Bill compresecl. narrow: culmen and commisure straight, the tip abruptly curved (or, if this is not the case. there is no trace of light bands on the wing: see section " $b$ "). Superciliary stripe eontinued back to the occiput. No trace of light bands on the wing. No conspicuous ring round the eye.

a. To spurious primart. Bill compressed, its tip abruntly hooked; culmen and commissure straight. Crown decidedly more ashy than the back.

Sp. Alurorividis, barbatulus, olivaceus, philadelphicus. b. An acute spurions primary. Bill depressed, the tip only slightly hooked; culmen slightly curred. Crow scarcely more ashy than back . . Sp. gilms. 


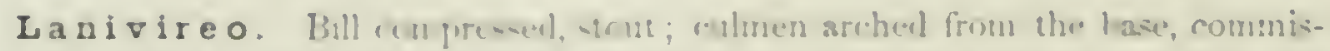

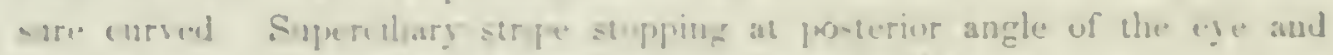

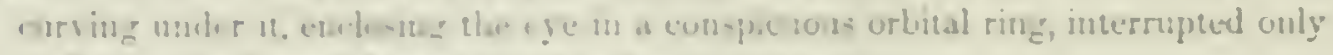

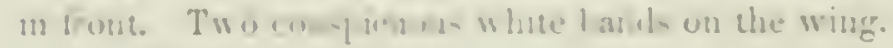

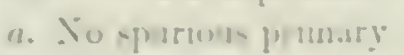

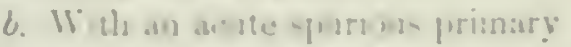

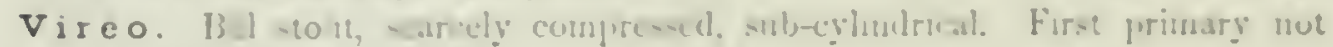
-pursulse, or, if - not aeme.

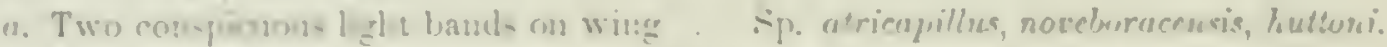

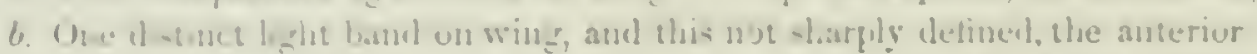

one berng almont ubeulete

Sp. Gelli, pusillus, ticiniur.

\section{SLutivis VIREOSYLVIA, Bos}

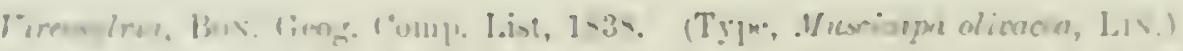

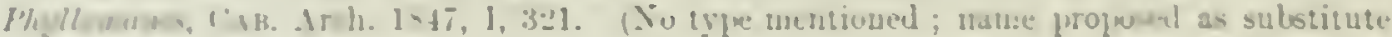
for Rireusylriu.)

Gی: Cusp. Wing long and pointed, one thirl or one fourth longer than the neariy "ron or slighlly robuded tanl. Fir-e quill rery suall (hes than one thinl the second), sometumes apparenty wanting. Servud yutl lunger than the seventh, mush longer than the

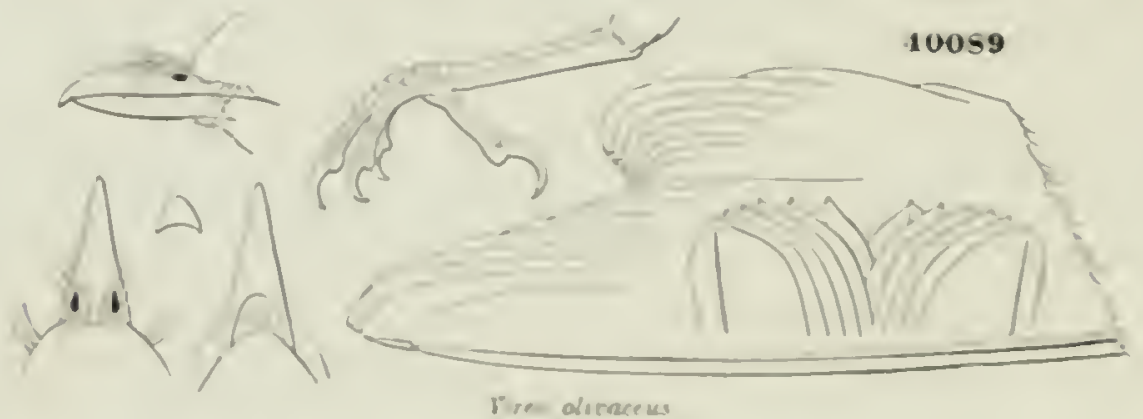

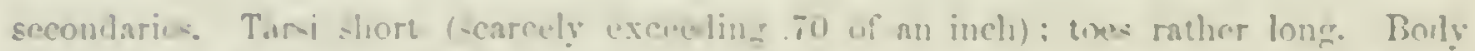

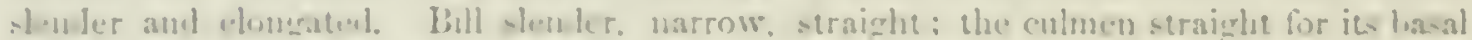

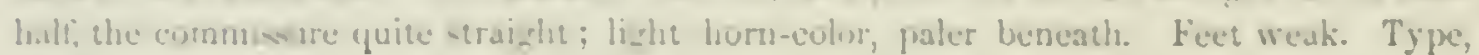
5. ulivacras.

\section{Species and Varietics}

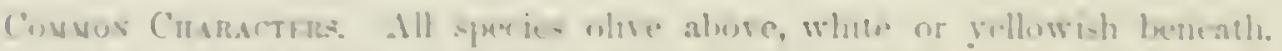

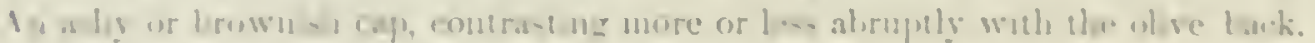

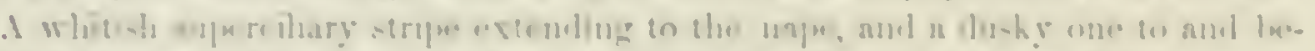

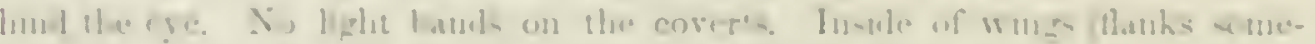
ture) $\rightarrow$ in

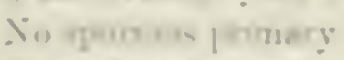

A tquñus provery

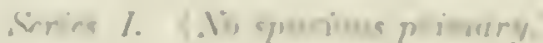

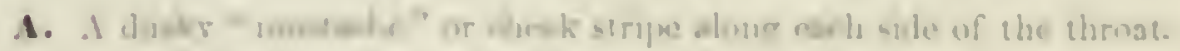

I V. calidris. line r l!

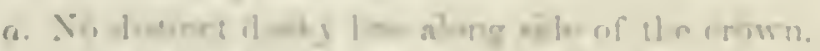

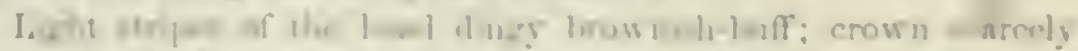

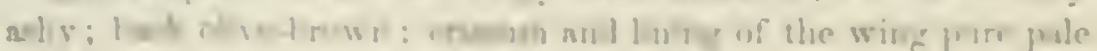


yellow. Wing, 3.20 ; tail, 2.25 ; bill, .42. Hab. Jamaica; Santo Domingo, Porto Rico, Sinta Cruz, St. Thomas, and Sombrero.

Light stripes of the head dingy grayish-white; crown distinetly ashy; back grayish-olire; crissum and lining of the wing scarcely yellow. Wing; 3.20 ; tail, 2.35; bill, .42. Hab. Cuba, Bahamas, and South Florida. . . . . . rar: burbatulus

b. A distinet dusky line along each side of crown.

Colors as in barbatula, but "mustache" broader and more conspicuous, and crown much purer ash. Wing, 3.30 ; tail, 2.50 ; bill, 48. IIab. Barbadoes . . . . var. barbadense.2

B. No "mustache."

a. A dusky line along each side of crown.

2. V. olivaceus. Grayish olive-green above; beneath white, tinged laterally with dull olive; crissum and lining of wing scarcely yellow; inner edges of quills white. Eyes red.

1. Wing, 3.30 ; tail, 2.40 ; bill, .38. IIab. Eastern Province of

North America, south to Northern Sonth America - var. olivaceus.

2. Wing, 2.50 ; tail, 1.80 ; bill, .33. IHab. Eastern South Ameriea.

rar. chivi.

3. V. flavoviridis. Yellowish olire-green above; beneath white medi-

- ally, bright greenish olive-yellow laterally ; crissum, lining of wings, and inner edges of quills, light yellow. Eyes yellow.

1. Wing, 3.15 ; tail, 2.55 ; bill, .41. IJab. Micklle $A$ merica north of

Panama . . . . . . rar.flevorividis.

2. Wing, 2.80; tail, 2.25; bill, 36 . Hab. South America, from

Buenos Ayres northward; Guatemala . . . rar. "gilis."

b. No dusky line on side of erown.

4. V. magister. ${ }^{5}$ Large. Above sooty-olive, more rirescent posteriorly; crown without ashy tinge. Beneath sinular: but lighter, whitish medially. Crissum and lining of wing very faintly yellow; inner edges of quills white. Eyes? Wing, 3.05 ; tail, 2.40 ; bill, .45. Hab. Honduras (Belize).

5. V. philadelphicus. Small. Above grayish-green; crown aslyy. Beneath liglnt yellow, deepest on the jugulum, whitish on belly. Eyes? Wing, 2.70; tail, 1.95; bill, .27. Hab. Eastern Province of North America; in winter south to Costa Rica.

\section{Series II. (i1 spurious primary.)}

C. No dusky line along side of crown. No "mustache."

6. V. gilva. Eyes hazel (in all ?).

a. Crown nearly like the back.

Above olive-gray, rump more vircscent; crown more ashy. Bc-

neath dingy whitish, with a strong tinge of dingy buff from bill

1 Vircosylvia calidris, Banle, Rev. Am. Birds, 1865, 329. (Molacilla calidris, L. Sỵst. Nat. 10th ed. $1758,184$.

${ }^{2} V$. cellidris var. berbadense, Ringway.

${ }^{3} \mathrm{~V}$. olivaccu var. chivi. Vircosylvia chivi, Band, Rev. 32i. (Syllia chivi, Vifild. Nour. Dict. XI, 1817, 174.)

$4 V$. faroriridis val. agilis. Vircosylvia agilis, Barri, Rev. 338. (Lamius agilis, LICut,

Verz. Doubl., 1823, no. 526.)

$5 V$. magistcr, Ball:D. 


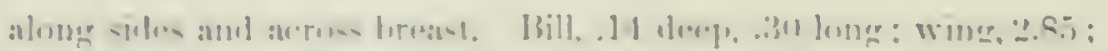

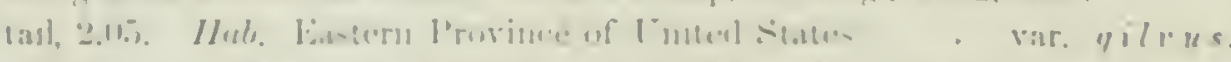

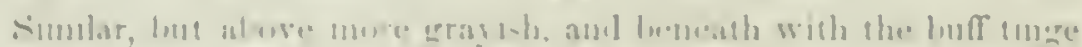

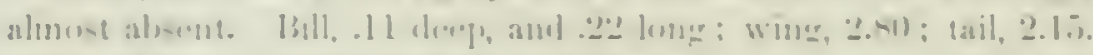

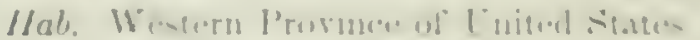

1. Crown very dillierent from the hack (tark lawn).

Alure olise-lorown; rump mere virencent; crown dark smunt-

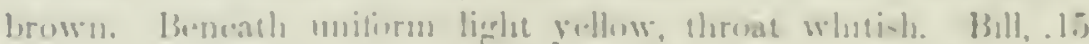

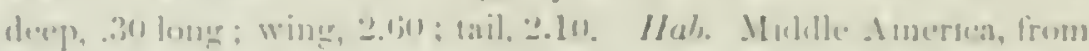
Ecinalor wh Honduras

var. josephu?

Vireosylvia calidris, var. barbatulus, P.akl).

\section{FLORIDA GREENLET.}

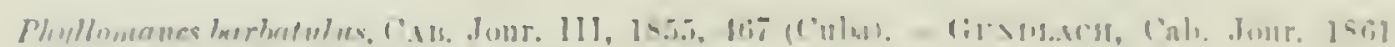

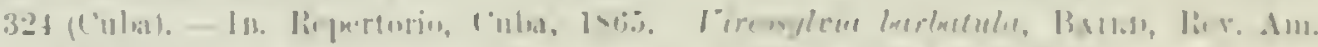

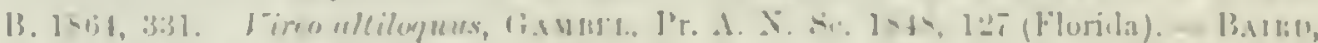

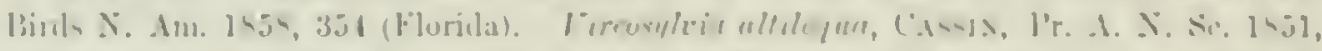

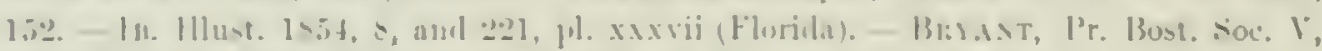

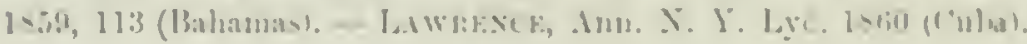

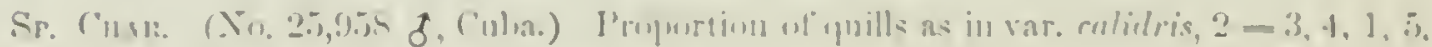

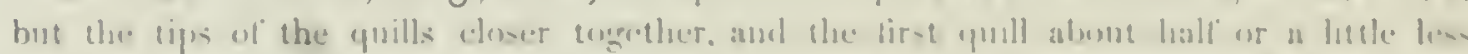

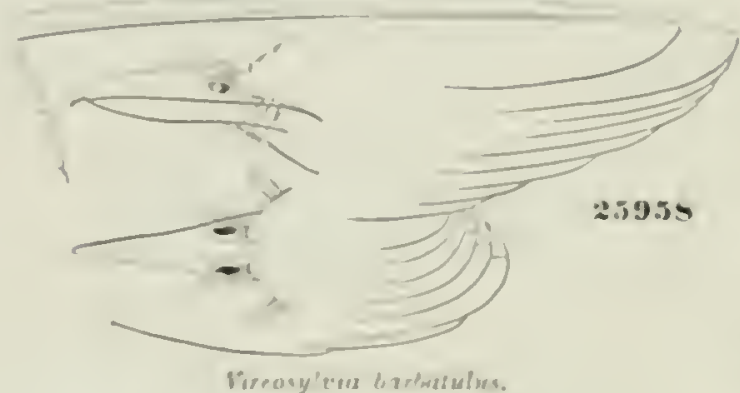
than halt the dhatmere between tifit and finurto: the quull- narrswer.

Colur- -indilar to thene of var. relidris. but of a purer amd paler wlive above:

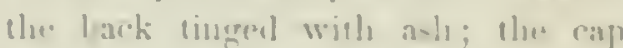

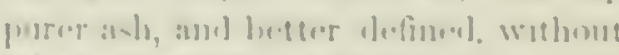

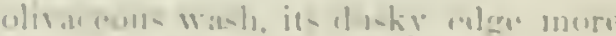
di-\{met. The supere-iliary srije whitish or gravish, with the elecek= paler.

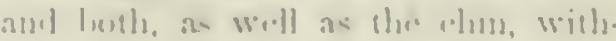

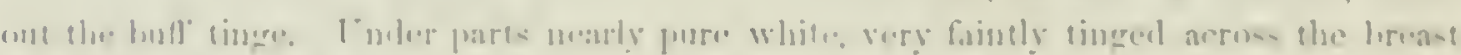

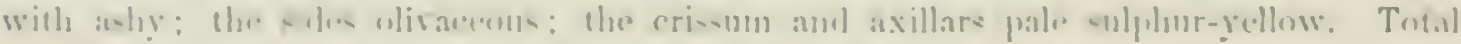

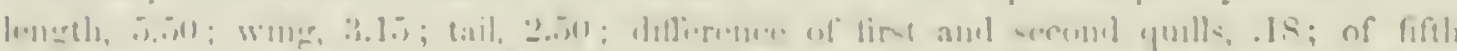

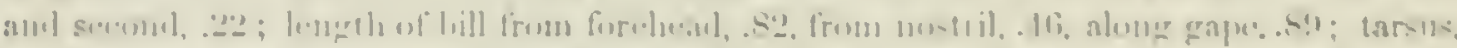

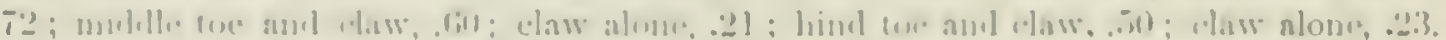

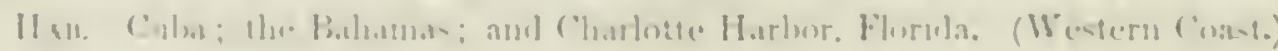

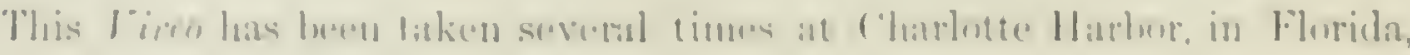

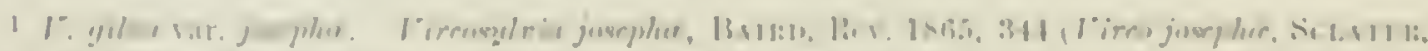

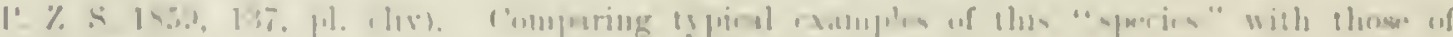

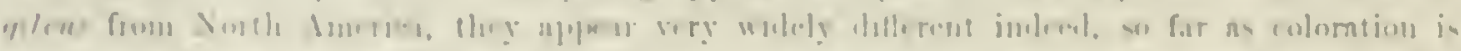

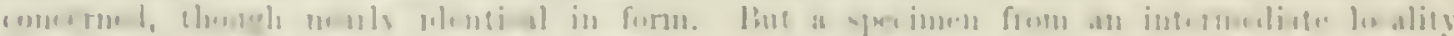

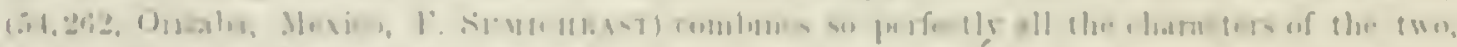

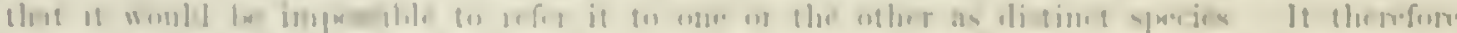

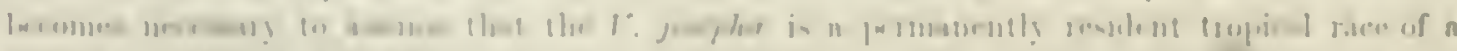

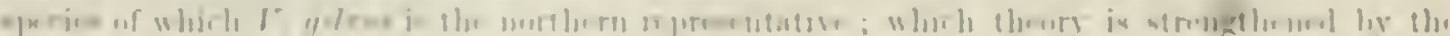

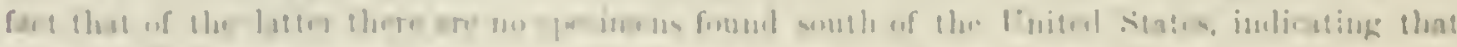

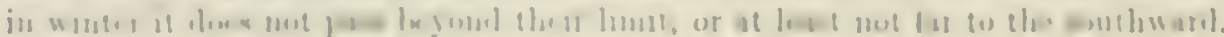


and is thus entitled to a place in our fanna. Its distinction from a closely allied race in Jamaica, Hayti, etc., var. culidris, is shown on page 359.

A specimen belonging to MIr. Salvin ("No. 187 "), from "Isthmus of Pamma," we camnot distinguish satisfactorily from typieal examples of the present race: with which it is to be compared, and not with culdiris. The colors are quite identical with those of burbutulus. In size it is slightly larger, the wing measuring 3.25 instead of 3.15 ; the tail 2.50 , instead of 2.35 (from exposed base of fenthers); the bill is thicker, being .20 instend of .18 deep; the third quill is longest, the second intermediate between it and the fourth; the first intermediate between the fourth and fifth. In barbutulus the second is longest, the third and fourth successively a little slıorter. It is not improbable that other specinens from that locality may show greater differences, as the specimen under examination is in rather worn plumage, and has the tip of the bill broken off.

Habits. This speeies only claims a place in our avifanna on the ground of its presence in Florida. How abundant it is there is not determined, further than it has been observed within a restrieted locality by Dr. Heermann. This was at Charlotte Harbor, on the sonthwestern const. They appeared to be visitors only, from a more southern clime. They reached Florida in their northern migrations, remaining only for a short season, but evidently staying long enough to breed. Dr. Heermann states that this species resembles, in manners and in appearance, the common Red-eyed Vireo of the more northern States. He describes its song as clear and musical, and very distinetly uttered. It was constantly on the searels for inseets, and appeared even more active than any of the northem speeies, darting among the fuliage, peering into crevices and cobwebs, suspended from branches with its back downward, and oceasionally chasing a flying insect in the manner of a tme Flyeatcher. These movements were usually accompanied by a song. This species was not abundant, thongh Dr. Heermam saw it frequently, and obtained several specimens.

Dr. Bryant found this species very aloundant at the Bahamas, arriving there ahout the first of May. All the speeimens he obtained were inales, the females not arriving there until after the 13th of May. The notes of these birds, he states, vary, though the most common one resembles $x$ kip tom kĕlly̆ phexu u, pronouncing the first word distinctly.

This bird, ${ }^{1}$ in Brown's History of Jamaiea, is called "Whip-tom-kelly," from the supposed resemblance of its notes to these articulate sounds, and this popular appellation has been given it by varions other writers. $\mathrm{Mr}$. Gosse, however, in his Birds of Jamaica, calls this bird "Joln-to-whit," and can find no resemblance in its notes to the words referred to. He deseribes its song as uttered with incessant iteration and untiring energy, and as resembling Sucet-John! John to whit! sucet John to whit! After July the

1 The Jamaican bird is $V$. calidris, not barbatulus. In all probability, howerer, they do not differ in habits and notes. $-R$. $R$. 
notes change to fw-whit-tw-uhe, and sonetimes to a soft, simple chirp, whispereel so fently as sareely to ixe audille. The name of Whip-tom-kelly.

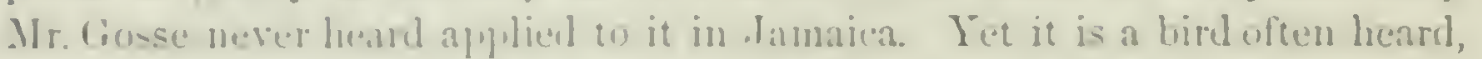

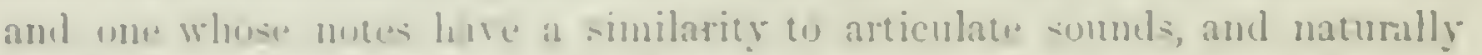

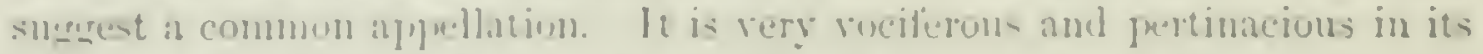

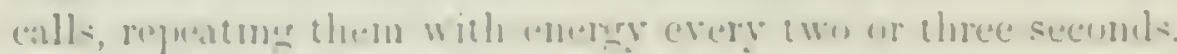

This sprecies, he states, dees mut urlininily sit on a prominent twig, or elart

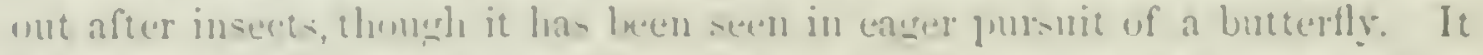
Feems to live in the centre of thick wouds. It does not pass the winter in

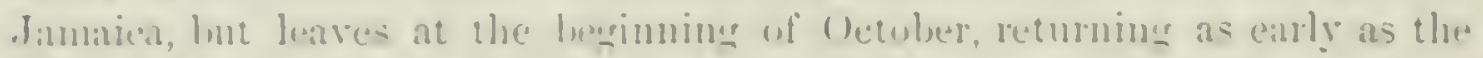

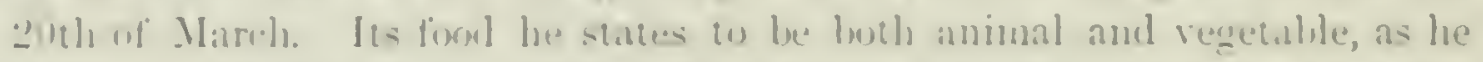
foumd in its stomach the sieds of the tropical plant- and herries. In $\mathrm{Ap}$,ril,

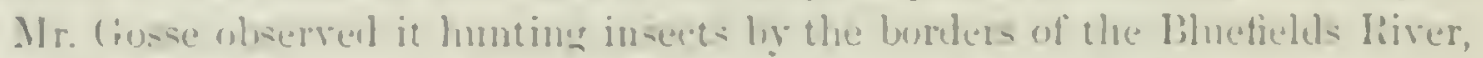
and so intent 1 pon its recujation as to alfow of a very near appruach. It sommht insects anmm the erion and how herhare, perching on the stalks of weeds, and darting unt after luth vagrant and statimary prey. They inculate in June and July

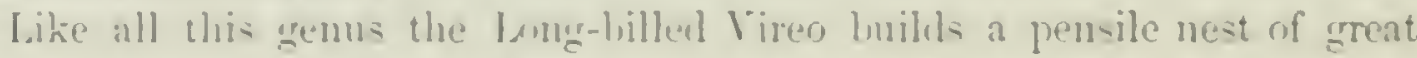

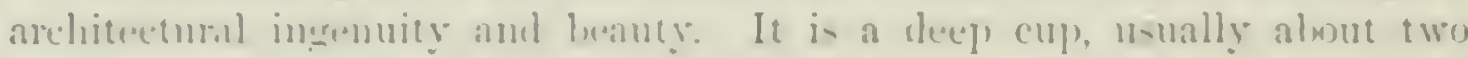
thirds of a sphere in shape, trumented at the top. The materials of which it is male are often somewhat conror. Mr. liowe describes it a.s about as laren as an ordinary teacup, nartoweul at the month, compused of dry grases, silk, cotten, lichens, ant spillers'-weh. It is usually suspemled from the fork of twe twirs, the murin very matly urewusen to embrace them. The materials are well interworen, and the walls firm and elose, though not very thick. The where is smmothly lined with slenter veretalde fibres resembline human hair. One mest hanl it eavity nearly filled with a mase of white entton, interwoven with the wther materials, which, leing picked cotton, hat

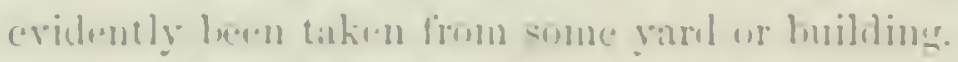

The werge of this spereses are three in number, of a lorilliant white, delicately tinten with pink, and markeal with a lew tine red and red-brown sputs, watilly alwout the larerer and.

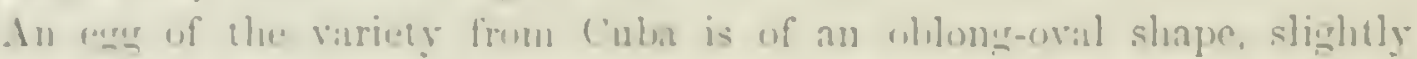

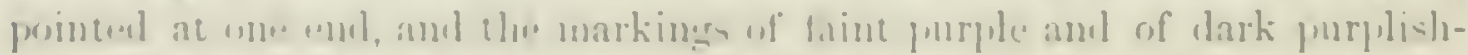

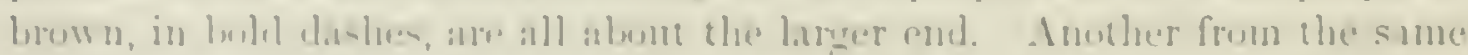

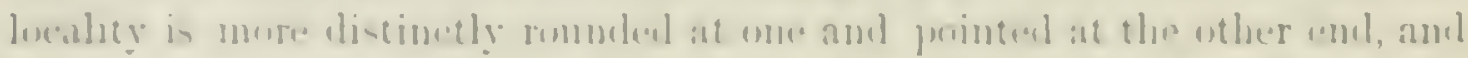

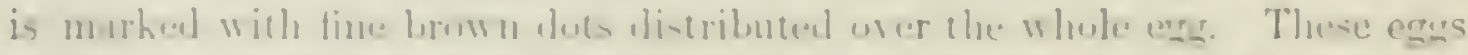

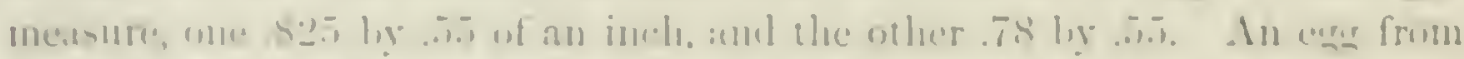

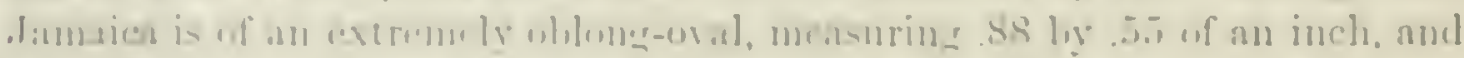

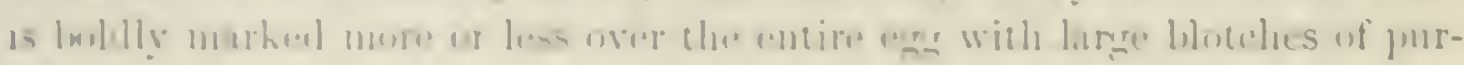
phiste-brow?

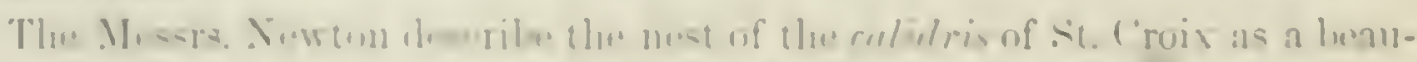

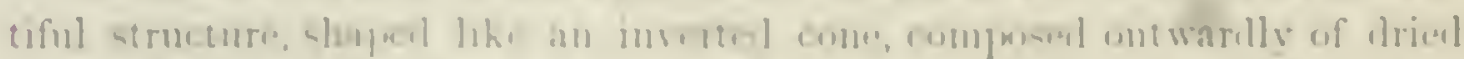

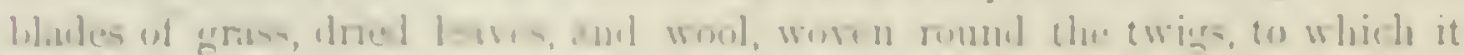


was attached with spiders'-rebs, lined inside with finer blades of grass, and abont three inches and a half in diameter, and five in height. The eggs, three in number, were white, with a few black spots, chiefly disposed about the larger end.

\section{Vireosylvia olivaceus, BoxaP.}

RED-EYED GREENLET.

Muscicape olivacea, Lix. Syst. Fat. 1, 1766, 327 (based on EDwands, tab. 253, and CATEs-

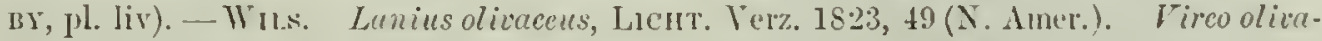

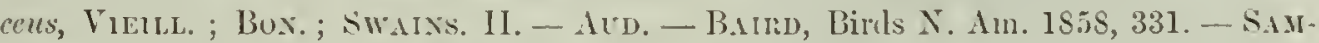
I'LLs, Birds N. Eng. 270. Irireosylvia oliv. Box. Geog. Comp. List, 1838. - I b. Consp. 1850, 329. - lininitidot, Vid. Med. f. 1853, 1854, 82 (Greenland). - I B. Ibis, III, 7. -Sclater, P. Z. S. 1855, 151 (lBogota) ; 1859, 137, 363 (Nalapa). - A. \& E. New'ox, Ibis, 1859, 145. - Sclater \& SALris, Ibis, 1859, 12 (Guatemala). - LawliExce, Anu. N. Y. Lyc. VII, 1\$60, 240 (Cuba). - ? Ibis, 1864, 394 (Derby, Engl. May, 1859). — Barro, Rev. Am. B. 1S64, 333. Phyllomenes olil. CAB. Nlus. Hein. 1850-51, 63. - IB. Jour. 1S60, 404 (Costa Rica). - Grxdu. Cab. Jour. 1861, 324 (Cuba ; rery rare). ? Fireo virescens, Vieill. Ois. Am. Sept. 1, 1807, S\$, pl. liii ('enna.). - ? Ghdy, Genera, I, 267, pl. lxr. Vireo bogotensis, BrY.xт, Pr. Bost. Soc. VII, 1S60, 227 (Bogota). Lawrexce, Ann. N. Y. Lye. 1863 (Birds Panama, IV, No. 378).

Sp. Crar. (No. 1,418 §, Carlisle, Penn., May, 184t.) Ulper parts olire-green. Top of head, from bill to nape, ash-color. A white line from nostrils above and beyond the eye, borlered above by a dusky line forming the edge of the ashy cap, and below by a similar, perhaps paler, loral and post-ocular cheek-stripe. Beneath, including tibire. white, with perhaps a tinge of olivaceous-ash across the breast; the sides of the neck like the

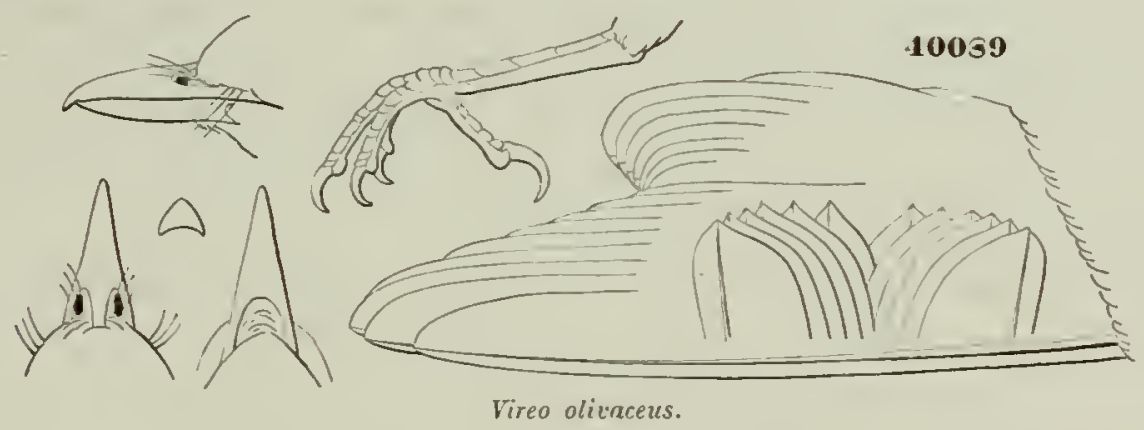

back; sides of the body with a faint wash of olive. Axillars and crissum faintly tinged with sulphur-yellow; lining of wings and its edge, the latter especially, nearly white. Quills blackish-brown, edged extermally, except at ends of primaries, with olive, internally with white. Tail-feathers lighter brown, edged externally like the back, intemally witl pale oliraceous-white. Bill dusky above, pale below; tarsi plumbeous ; iris red. Length, 6.33 ; extent of wings, 10.25 ; wing, 3.33 ; tail, 2.50 .

Female similar, but chuller in plumage.

HAB. Whole of Eastern North Ameriea (Greenland, Halifax, Fort Simpson), west to base of Rocky Mountains, reachirg Fort Bridger; and still farther northward to Bitterroot Mountains and Kootenay; south to Panama and Bogota, in winter (Aalapa only in Mexico); very rare in Cuba (only West Indian locality). Acciclental in England. Trinidad. (Frssch.) 


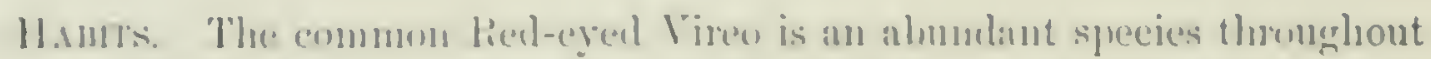

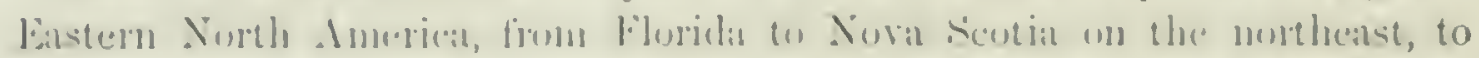

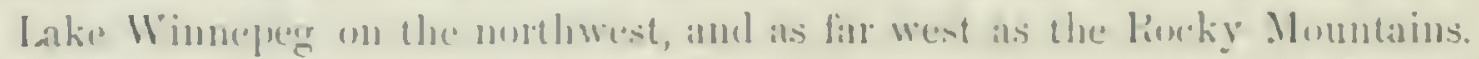

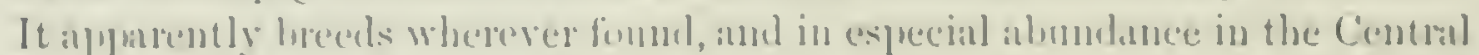
Statces. It is a fomiliar and fearless species, often found, like the Wabling

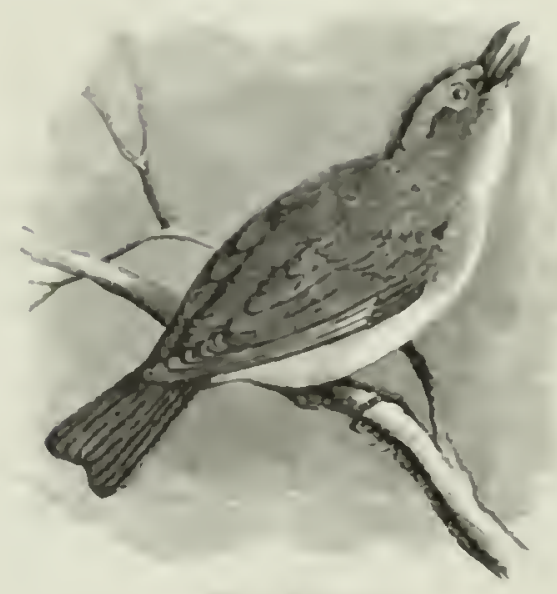

Vireo sireceus.

Vireo, in the very midst of crowded cities, and making its lively aml pleasant notes heard in their pmblic syuates and private equrelens, amiul the ruclel sommls of the neighlmering strects. It loreds in Texas and lonisiana, at the Somthwest, and alsu in almulance, at least as far as Halifilx, in the olymsite direetion. At Fort Resulution, at the ('umberland Honse, and at Furt simplosi, the nests amd enregs of this species were procured ly kenuicott and lioss. A single specimen of the birl has been procured in Grenlind, and another aecirlental sprecinen wis shot in lingland. Sipecimens hare also been juoenreal in central Americal.

This Virew, like all of its peeuliar and well-matked genus, prefers the

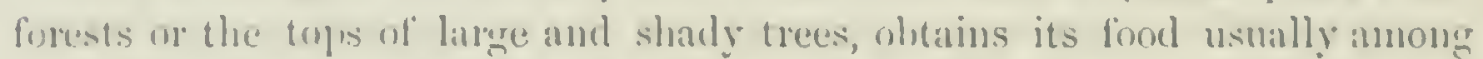

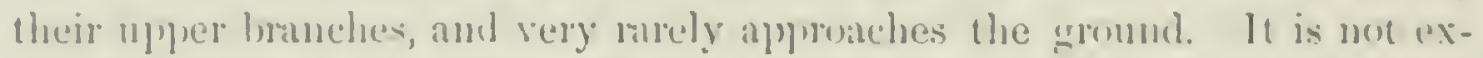

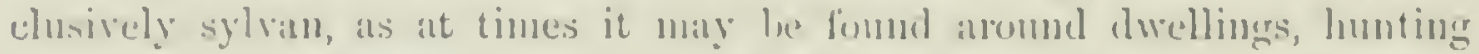

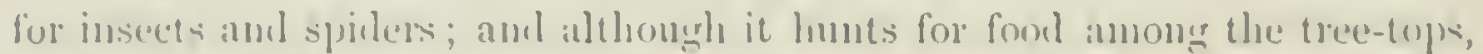
its ne-t is not always in sted high situltions, often not more than four or five fiee from the grommel.

In their mingtions these birds ented the Vuited states anly in Mareh, hut

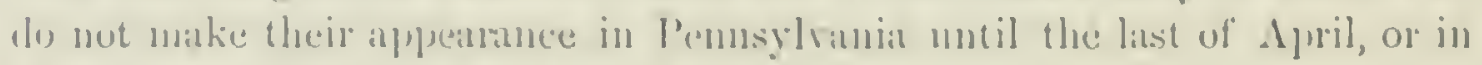

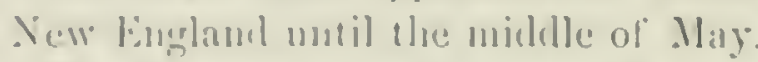

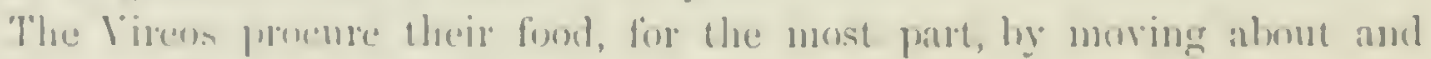

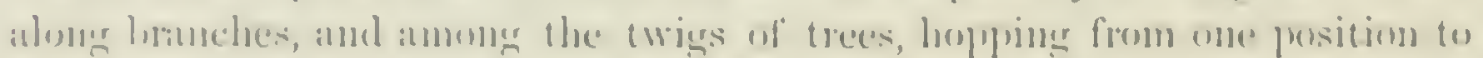

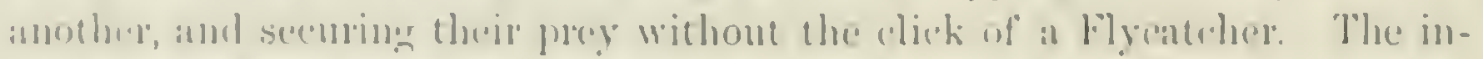

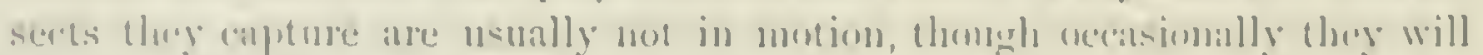
take them on the wing. They also leeel on several kinds of ripe herries in lle atutumun.

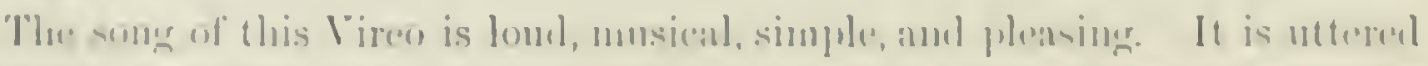

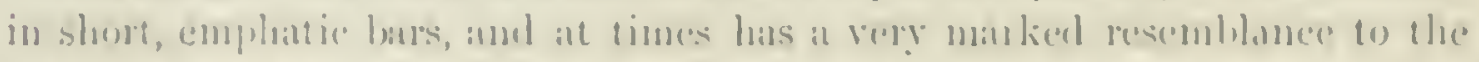

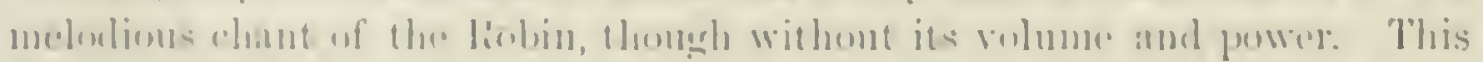

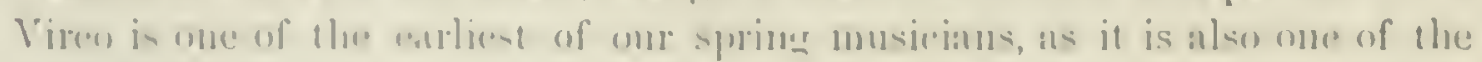

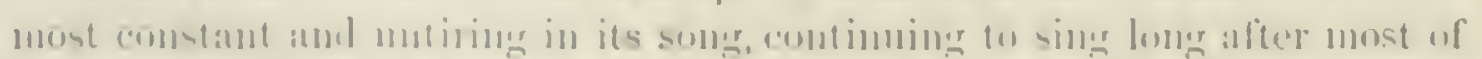

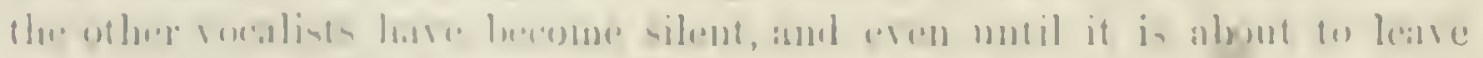

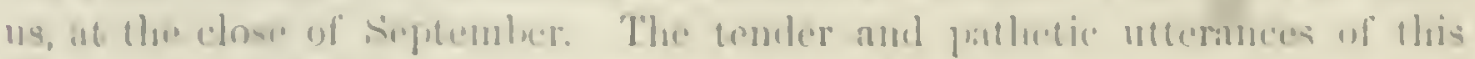

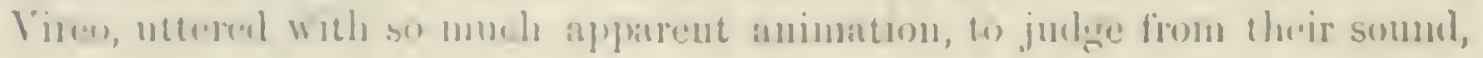


are in striking contrast to the apparent indifference or unconscionsness of the little rocalist who, while thus delighting the ear of the listener, seems to be all the while chiefly bent on procuring its daily supply of food, which it pursues with unabated ardor.

This Vireo builds the neat pensile nest of its race, suspending it from the fork of two or more twigs of a forest tree, at various heights of from five to fifty feet from the ground. It is cup-like in shape, and always dependent from small twigs, around which its upper edges are firmly bound. Externally it is woven of rarious materials, fine strips of bark, the liempen fibres of vegetables, and webs of spiders and of various caterpillars. These are compactly pressed and woren, and, as some suppose, agrglutinated by the saliva of the builder. Sometimes the ummanageable materials give to the outside of the nest a rude and unfinished appearance, at others they are evenly and smoothly wrought. They are very strong, uninjured by the storms of winter, and are often made use of by other birds, by mice, and even by the same bird a second senson.

A nest of this birl (S. I. Coll., 3,353) was obtained at the Cumberland House by $\mathrm{Mr}$. Kennicott. It is pensile, like all others, but is composed almost exclusively of pine-needles, - a dry and hard material, difficult of management in making such a nest. With these are intermingled a few bits of moss, fine strips of bark, and flax-like vegetable fibres. Within this rude basket is an inner nest, made up of fine dry grasses, strips of bark, and pine leares. The external fabric is loosely put together, - an unusual feature, but the inner portion, in the firmmess and strength with which it was made, is in remarkable contrist.

'The Red-eyed Vireo's nest is often chosen by the Cowbird for the deposition of her parasitic eggs, and these foster-parents are singularly cleroted in the care of their alien guests, whom they tenclerly nurture, even to the neglect of their own offspring. In one instance three eggs of a Cowbird were deposited in the nest of the Vireo before any of her own, and, without laying any, the female Vireo proceeded to sit upon and hatel the intruders. In another case, where two of the Tireo's lad been laid, two Cowbird's eggs were added. The Vireo stopped laying, and proceeded to incubate. In each instance the female Vireo seemed to forego her own natural aspirations, and at once conform to the new situation.

The male Vireo often evinces grent comrage and spirit in the defence of his nest, when the young are hatched driving away intruders, and even flying in the face of a man who approaches too near.

Mr. Nuttall states that the young of the Red-eyed Vireo feed eagerly upon the berries of the cornel and the Viburmum dentatum, and other shrubs. A young bird kept in confinement soon beeame very gentle, and readily ate flies and grasshoppers from his hand, and viburnm berries. A tame Kingbird in the same room was very jealous of and tyramnized over him, so as to compel him to seek protection from his captor. The Vircos, like Flycatchers, 
hate the puwer to rengrequtate by the bill pellet of indigestible portions of their fund.

The enes of this Vireo valy sreatly in size, according to the locality; the farther somb the smaller they are finud. One, marked on the shell bast

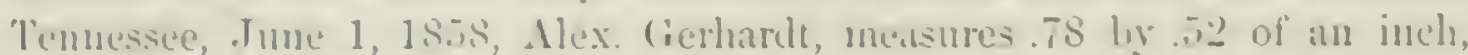

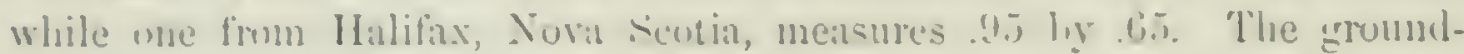
culor of all is a clear erystal-white, and they are marked chichly at the langer end with sprets and fincr dots of red-linown.

Mr. Iinhert Kennicutt, in his notes, speaks of finding a nest of the Peeteyed Virew it the Cumberland House, Sarkatchewan, June 2s. Incuhation lated not yet commenced. The pensile and neatly luilt nest was suspended about four feet from the ground, upon at hazel-hush. The parent, when seared from it, remained neatr until she wits killed.

Vireosylvia flavoviridis, Cassis. YELLOW-GREEN VIREO.

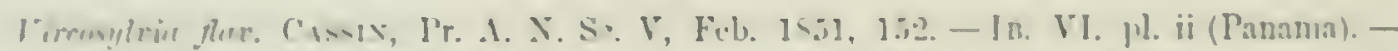

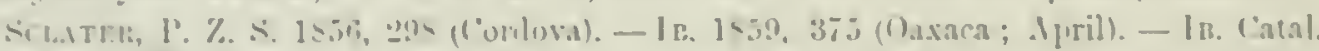

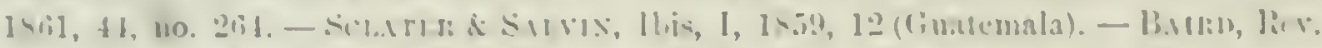

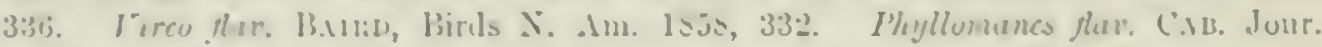
1seil, y3 (lusba líica).

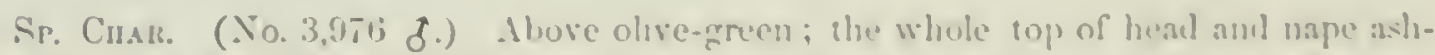

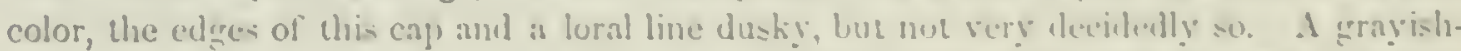

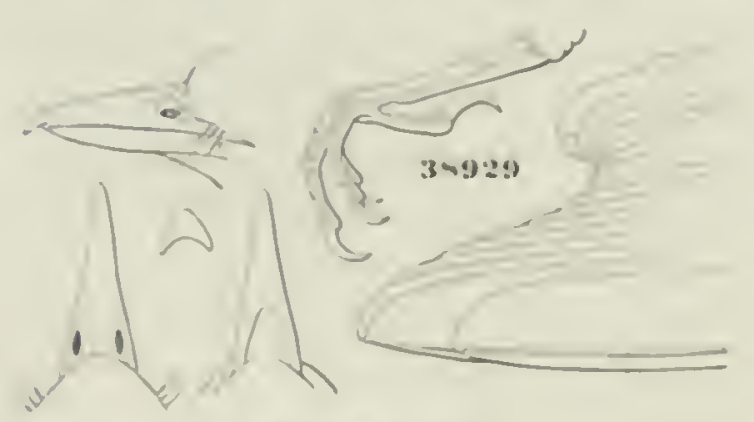

irreo facovirsdes white line from son-trils os cre the "ye. Beneath white, the silen of the suech, lirea-t, and Inely liright olisaneons-yellow; the axillars amel primen riels sulphur-yclluw. On the hrease the gellow "xtemels almose to she" median lime, the

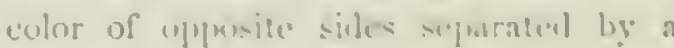
usrow interval. Quills dusy-lurww: mareined extrmalls, cexerept at emols of primaries, with rlise-gren, intermally

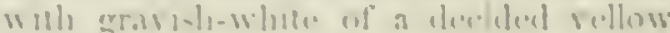

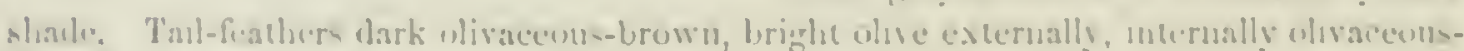
blluw. Iris yellow or "reel."

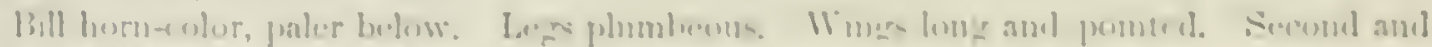

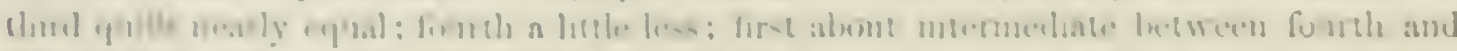

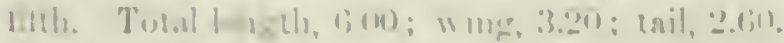

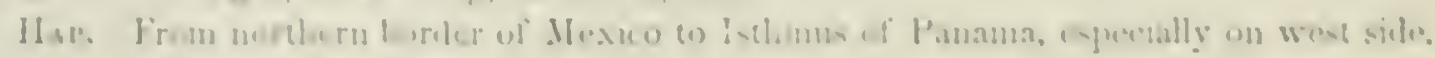

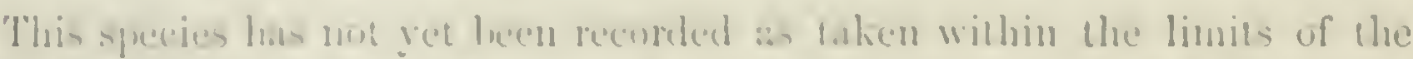

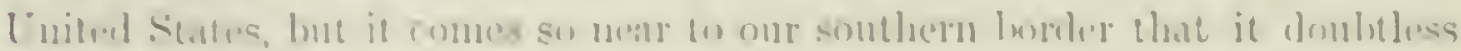

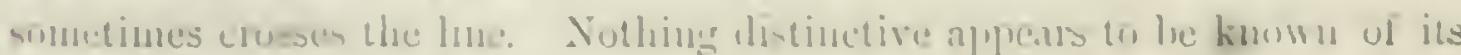
h.oljils. 


\section{Vireosylvia philadelphicus, Cassix. PHILADELPHIA GREENLET.}

Tircosylvia phizadelphica, Cassis, Pr. A. N. Se. T, Feb. 1557, 153. - Iв. VI, pl. i. fig. 1

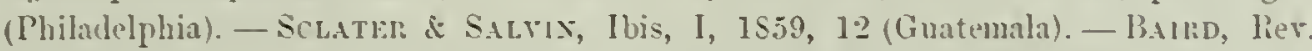
Am. Birds, 340. Tirco philadelphicus, B.turd, Birds X. Am. 1S5s, 335, pl. Ixxviii, fig. 3. Fircosylria cobanensis, Sclater, P. Z. S. 1S60, $40^{3} 3$ (Coban). - In. Amn. Mag. X. H. 1\$61, 32S.

Sr. Cuin. ( cept on the rump; top of head and nape purer plumbeous-ash, not edged with dusky, the line of clemarcation indistinet. Beneath light sulphur-rellow, pale! and almost white on chin and middle of abdomen; sides more oliraceous. A whitish stripe from bill orer eye, as also a patel beneatl it and the eyelids. A dusky loral and post-ocular spot. Quills and rectrices brown, edged externally witls olire, internally with whitish; the larger corerts with pales outer edges. Bill blackish, paler plumbeous

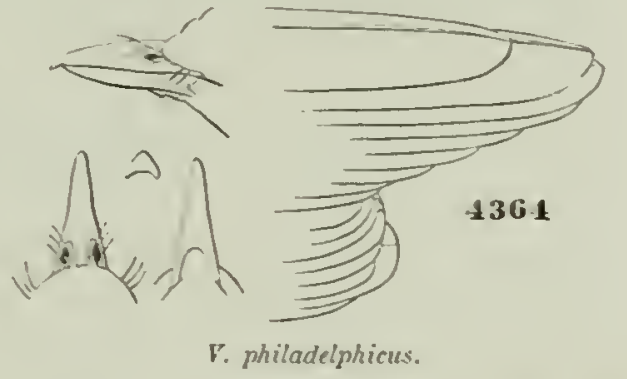

below. Legs plumbeous. Spurious outer or first quill (seen in gilva) wanting: the outer about equal to fifth; third longest; second and fourth not much shorter. Total lengeth; 4.80 ; wing, $2.65 ;$ tail, 2.25 .

H.sB. Eastern Torth America to IIudson's Bay and Maine, soutl (in winter) to Costa Rica and Guatemala. Veragua (S.twis). Not recolded from Mexico or West Indies.

Specimens vary somewhat in purity of tints, and especially in intensity of rellow of under parts, which color is decper in autumnal shins.

Specimens from Costa lica and Guatemala, being merely winter visitors to that region, are quite identical with North American examples.

H.ınits. This but little known species was first described by Mr. C'assin, in 1851, from a specimen shot by him in some woods near Philadelphia nine rears previously, which was then unique, and remained so for some time after. This fact, and its resemblance to $V$. gilıa, led to the impression that it might be only a rariety of that species. Since the publication of the description other specimens hare been procured from different localities, - ILose Factory, Maine, Ohio, Wisconsin, Costa Rica, and Guatemala. But little is as yet known in regard to its habits or its distribution. It is quite abundant in the spring in Sonthern Wisconsin, where it appears only as a migrant passing north, none remaining to breed. As it makes its appearance late in Mar, and usually passes rapidly on, it seems natural to infer that it cannot be far from its breeding-place at the period of its appearance. The specimen obtained by Mr. Cassin was shot in September, on its southward journey. It was in the upper branches of a high tree. capturing insects; and his attention was drawn to it by its slow and deliberate morements.

Mr. Thure Kumlien, of Dane County, Wis., informs me that he has been familiar with this Vireo since $18+9$, and las collected it erery year since 
that period, fincling it hoth in the spring and fall. It appears oceacionally as early ats the 10 th of $\mathrm{May}$, the time varying with the season from the loth to the -1 th. In 155 , when the seasm wats rery lackward and May very culd, they did not arrive until June?2. They were mustally numeroms, ant remained only a diyy or two. So far as he has been alle to ascertain, none stop to lirect. They are very quiet, hase no sner at the time they are passing, and secen only intent on collecting their fool and in proceeding on their way. They are very tame and unsuspueting, and one ean readily get to within a few fect of them. In the fill they are returning south from the 7 th (1) the lith of september.

The nest and engrs remain to be chtained.

\section{Vireosylvia gilvus, cissix. \\ WARBLING GREENLET}

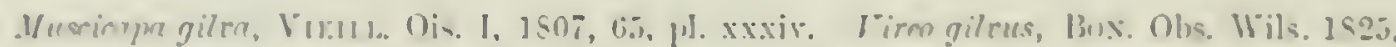

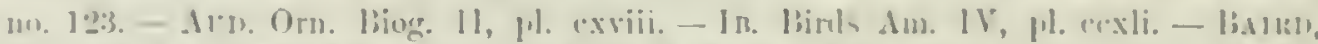

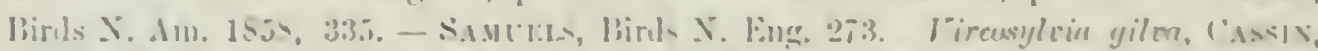

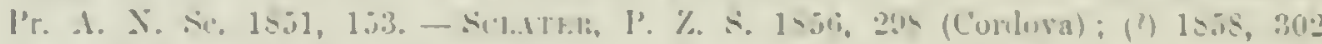

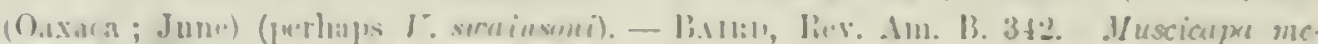

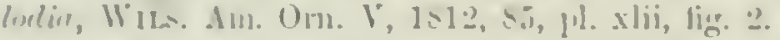

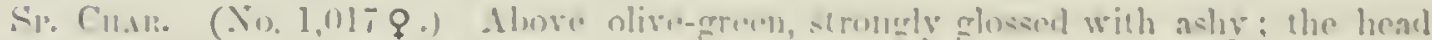

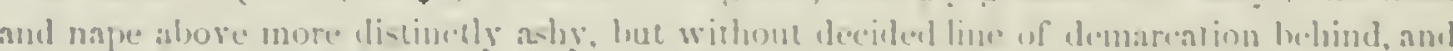

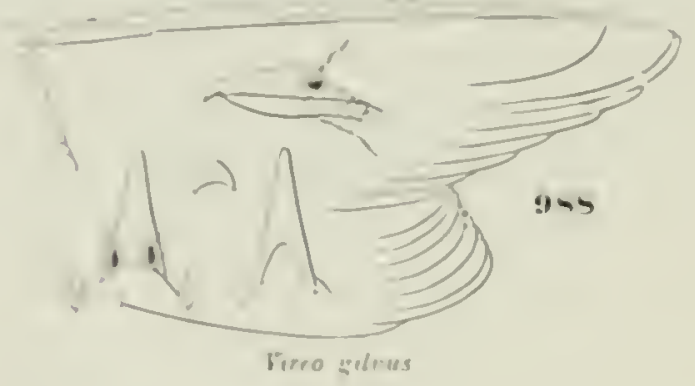
willume duaky emere; rump pure olive. Stripe from nustrits orer are to mape, redids, and -pace helow eye, creanywhile. A rather dukty puat-on'ular sut lural spot. the latter not exleuding (1) the bill. Tucler parts whito, with linger of

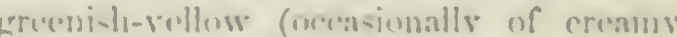

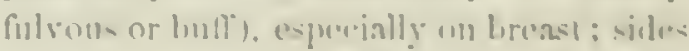

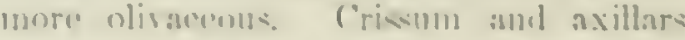
rareng more rellowioh. Guills and rer-

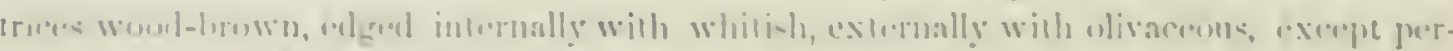

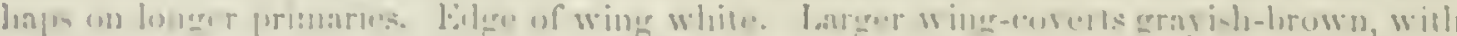

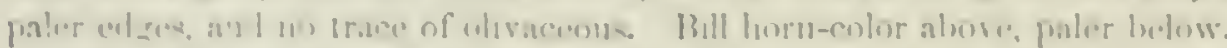

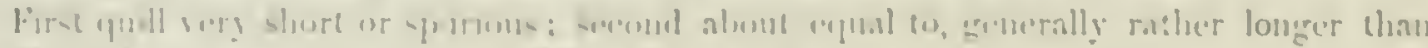

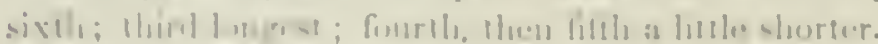

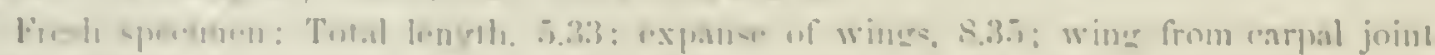

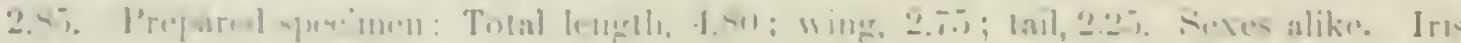
l.ruw!.

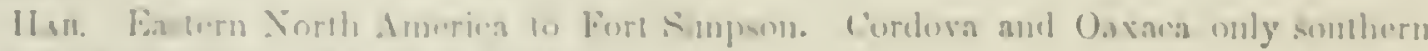

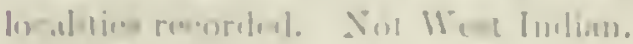

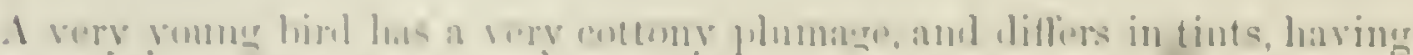

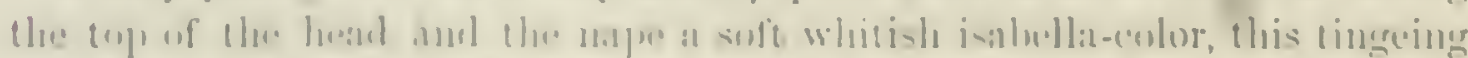

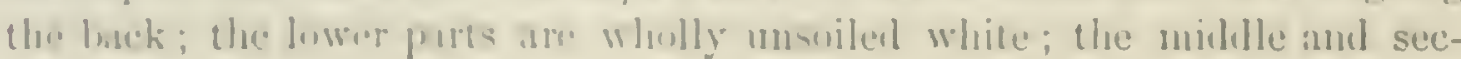


ondary coverts are obscurely tipped with light brown, forming two indistinct bands across the wing.

A specimen (No. 54,262) from Orizaba is, in positively every respect, exactly intermediate between this species and $V$.josepho of Costa lica, Ecuador, etc. (See footnote on page 360.) The erown is brown, decidedly darker than, and different in tint from, the back, but less so than in joscpher; the back is less olive than in the latter, and less gray than in the former. The lower parts are more yellow than in gilurs, and less so than in josephec, the supereiliary stripe whiter and extending farther back than in the former, and less pure white and shorter than in the latter, ete.

Habits. The Warbling Vireo has only a slighttly less extended distribultion than the Red-eyed, being found throughout all Eastern North Anerica, as far north as Fort Simpson and Selkirk Settlement, and west to the Missouri River, and breeding as far sonth as Louisiana. It is stated by Audubon to be found on the Columbia River, but in this lie probably referred to the Western race, $V$. sucainsoni. That writer never observed this species in Louisiana or Kentucky, nor in the maritime part of Georgia, and its manner of entering the United States he was unable to ascertain. Where it moves to in the winter is also unknown, none having been met with in the West Indies, and only at a few points in IJexico, Cordora, Oaxaca, and the State of Yera Cruz. It was, however, found breeding at Caleasien, Lonisiann, by Mr. Wiurdemann.

It breeds abundantly from Virrinia to Nova Scotia, and throughout the Northwestern States. West of the Rocky Mountains it is replaced by a closely allied species, the $Y$. sucainsoni. This Yireo, more than any other of its genus, if not exclusively, is to a large extent a resident of villages, towns, and even cities. It is by far the sweetest singer that rentures within their crowded streets and public squares, - although Mr. Cassin gives his preference to the notes of the Red-eyed, - and the melody of its song is exquisitely soft and beantiful. It is chiefly to be found among the tall trees, in the vicinity of dwellings, where it seems to delight to stay, and from their highest tops to suspend its pensile nest. It is especially abundant among the elms on Boston Common, where at alnost any hour of the day, from early in the month of May until long after summer has gone, may be heard the prolonged notes of this, one of the sweetest and most constant of our singers. Its roice is not powerful, but its melody is flute-like and tender. Throughout the last of May, and in June and July, their charming song may be heard amid the din of the city from earliest dawn till nighttfall, and rarely ceases even in the noontide heat, when all other birds are silent. It is ever in motion, while thus singing; and its sweetest notes are given forth as it moves among the tree-tops in search of insects. It is not only one of our most constant singers, but it remains musical almost until its departure for the South in October.

The Warbling Vireo appears in the Middle States about the 15th of April, 
amb reaches New Fongland early in May. The path of its mortheru migrations, and of its refurn, is somewhat in dombt. It is abmulant in winter,

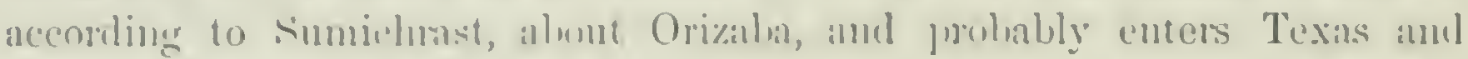
passes uorth and eat alomg the Mississippi and the Oho livers. In certain portious of the commtry this species is evidently on the inerease, hecoming more and more common as the comntry is settled, and towns and villages spring

The Warbling Vireo builds its nest usually in more elevated positions than any others of this family. For the most part in the vicinty of dwellings, often over freplented strects, they suspund their elabomately woren and beautiful little basket-like nest, secume from intrusion from their human neighburs, and frotered ly the near fresence of man from all their more dreaded enemies. Andulwn namates, in an interesting manner, the building of their nest hy a par of these hirds on a proplatretre, menr his window, in Cammlen, X. I. It was suspended between the holy of the tree and a biunch eoming ont at an acute angle. The prair were at work, morning and erening, eight dass, first attaching slender linules of grass to the knots on the branch ambl the bark of the trunk, and thence working dowmand and ontward. They varied their materials, from time to time, mutil at last be traed them, after a prolenged alsenee, to a distant haystack, from which they brought fine, slender, dry grasses, with which they completed and lined their nest.

The nests of the Winhling Vireo, while they resemble elosely those of the other speries in all the chancteristics of this well-mathed family, are yet, as a

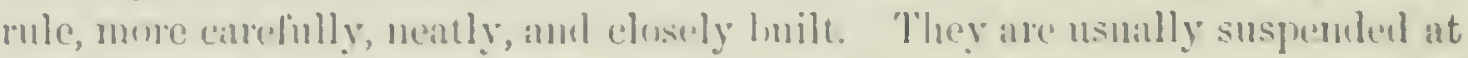
the hejeht of form thing to fifty feet, in the fork of twigs, muler and near the extremity of the tresetep, often an elm, protected from the sum ame storm hy a cimmly of leatres, and quite ont of reach of most enemies. They vary little in size, being almut fwo inches in hejght and thee amb a half in their greatest dhandotor, natrowing, toward their junction with the twigs, to two inclacs. They are all secured in a very firm mamer to the fwigs from which they ane suspended by a felting of various materials, chictly soft, flexible, flax-like strips of regetalle filmes, leaves, stems of plants, amd strips of hark.

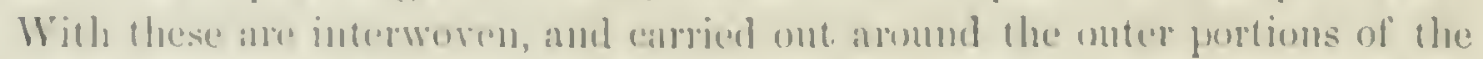
mest, lones strips of soft flexilile bark of decidums trees. They are softly and compunty lilled in and lined with fine stems of plants.

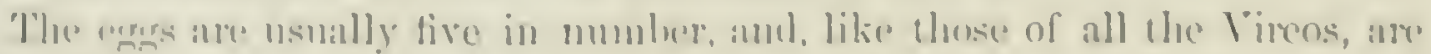

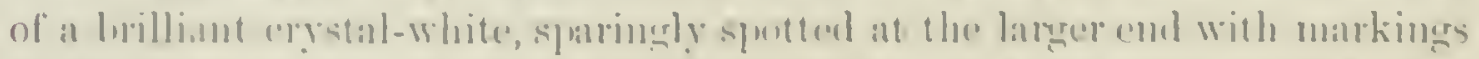

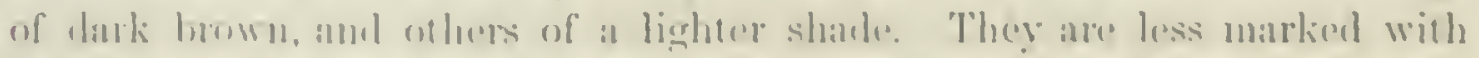

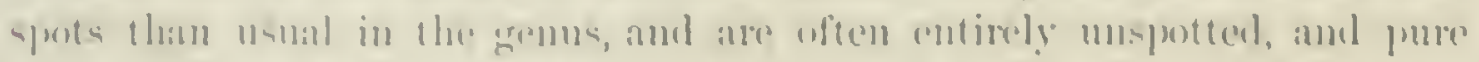

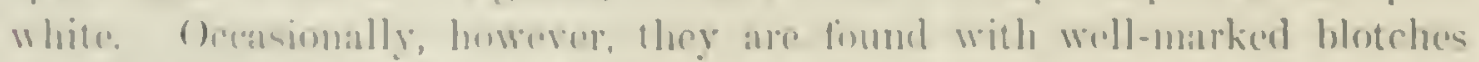

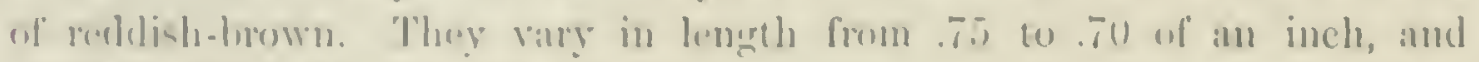
average about .in in their hrealth. 
Vireosylvia gilvus, var. swainsoni, BAIRD.

\section{WESTERN WARBLING GREENLET.}

Virco sicainsoni, B.rmo, Birls X. Am. 1858, 330 (Pacifie coast). - Ellint, lllust. Birds

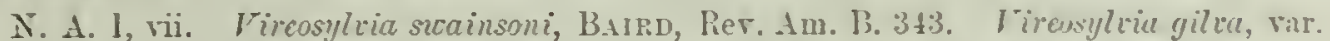
surainsoni, Coopeli, Orn. Cal. I, 1570, 116. V'ireo hertiumii, Swasisus, F. B. A. 11, 1\$31, 235 (in part; spec. from Columbia River ?).

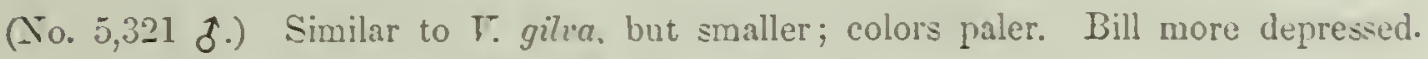
Upper mandible almost black. Second quill much shorter than sixth. Total length, 4.ij; wing, 2.i1; tail, 2.35; difference between tenth quill and lougest, .js; exposed portion of first primary, .5\&, of second, 1.\$2, of longest (measured from exposed base of first primary), 2.10; length of bill from forehead, .56, from nostril, .29, along gape, .65 ; depth of bill, .13; tarsus, .i0; middle toe and claw, .56; hind toe and claw, . 43 .

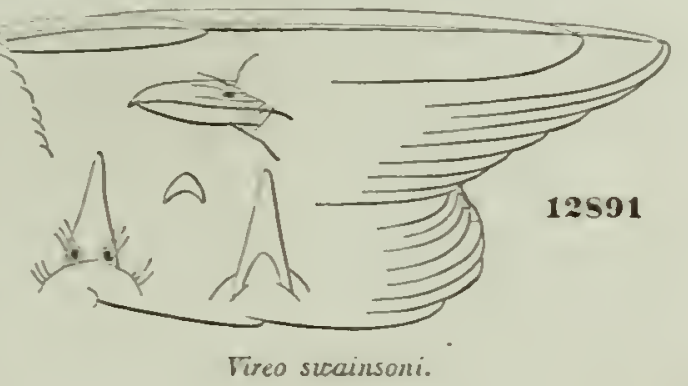

Hab. United States, from Rocky Mountains to Pacific corst.

In the present bird the bill is darker in color, much smaller, and more depressed, the depth at the base being less than the width, instead of being equal to it as in var. gilvus. The wing is more rounded, the second quill much shorter than the sixtl, genemlly shorter or but little longer than the serenth. In var. gilvus, the second quill is about equal to the sixth. The second quill is about .30 of an inch (or more) shorter than the longest in sucainsoni, while in gilus it is only about 20 shorter. The feet of sucainsoni are weaker, and the colors generally paler and grayer. The iris, according to Coues, is dark brown.

Young birds in autumnal plumage have the crown decidedly ash, the sides more greenish; the wing-corerts pass terminally into a light brownish tint, producing an inconspicuous band.

Habits. This Western representative of the Warbling Vireo is found throughout the western portions of our Union, from the Great Plains to the Pacific, and from Arizona to the extreme northern boundary of Washington Territory.

Dr. Cooper characterizes this as a lively and familiar songster. It arrives, he states, at San Diego about April 10, and reaches Puget Sound toward the middle of May, occupying nearly all the intermediate country throughout the summer. It frequents the deciduous trees along the borders of streams and prairies, coming into garrlens and orchards with familiar confidence, wherever cultivation has reclaimed the wilderness. Like its Eastern prototype, its cheerful and varied song is heard all day long until quite late in the autumn. They too build their nests in the shade-trees of the parks of busy cities, singing erer their delightful strains, unconscious of the busy and noisy crowd that throngs the neighboring streets. 
1)r. (ooper statea that ite neets are fremelent firm the forks of a linanch

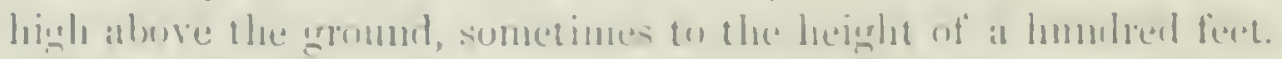

Mr. liblgway, whu olserved the hahits of this species in lath and Ne-

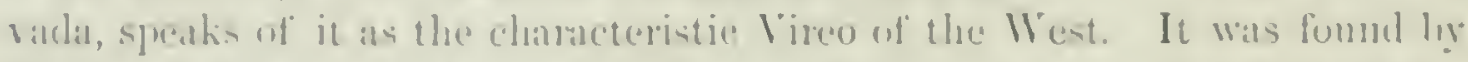
him in all the fertile focalities, and wats ane of the mont common birds in the

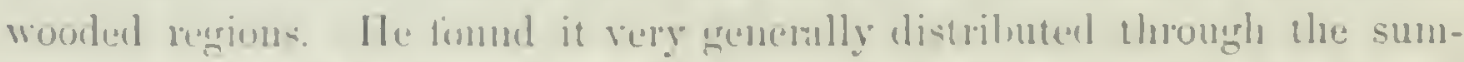

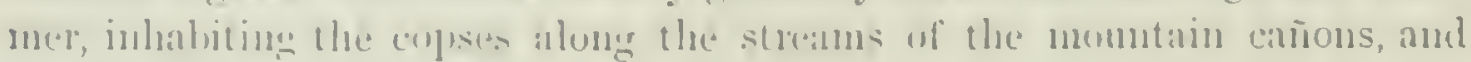
the opren grores of the parks, ats well as the cottonwook and willows of the river villeges. In the fitl the herres of a speceses of the comel that grows along the momatan streams constitute its principal ford. Its notes and manners are inlentical with those of the bisteru species.

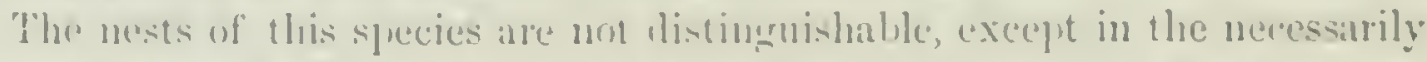
varying matcrials, from those of the Eistern hirds. In pustion, si\%, and shape

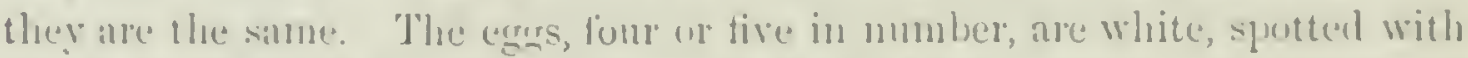
brown and redelish-brum, and measure is by sis af an incle. The spots are somewhat darker than those of the $l$. gilens, and the shape more of an oblong-ovil, in all that I have seen. But this diflerence may disilpear in the

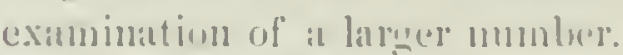

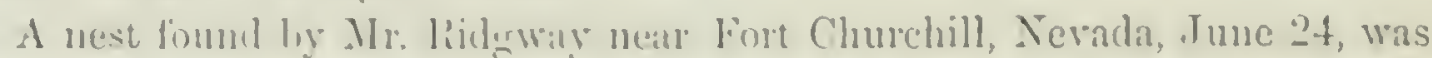
suspremled from the extremity of a twig of a sapling of the cotconwood, in at copse of the same erowing in a river-luttom. It has a height of two amel a half inclese and a diameter of three. It is enmpesed extermally of

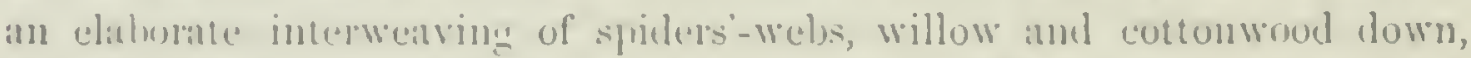
and strong cond-like stripe of finc inner bark. These are strongly bound aroum the twigre fom which the nest is susperuled. It is nue of the most

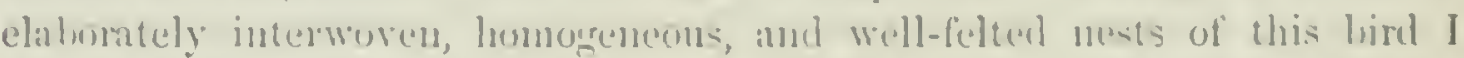
have ever met with. Another nest, from Parley's Park, Vtah, ubtained Jume 2-5, diflers in latsing the cxtemal portion woren alunst explusively of tine

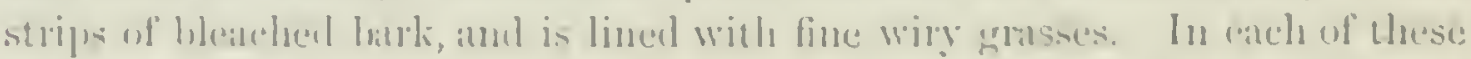

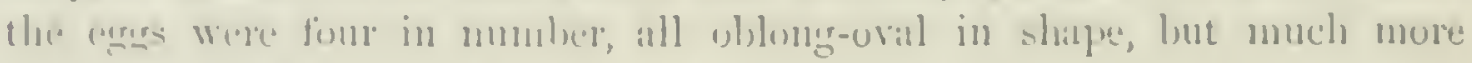
printal at one end in the latter mest.

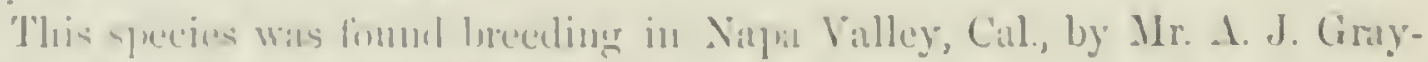
stur, and at fort Tejom by Mr. Santus.

\section{Sirmisis LA N I VIREO, Buแ,}

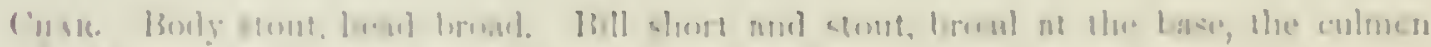

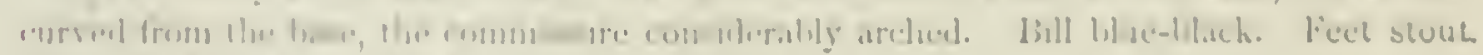

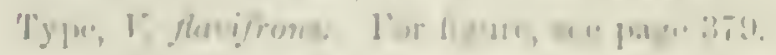

\section{Epccics mind Varictics.}

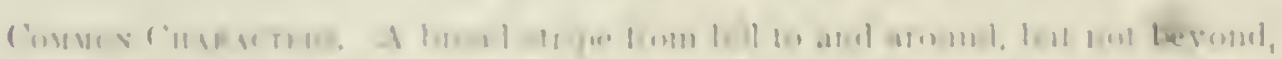

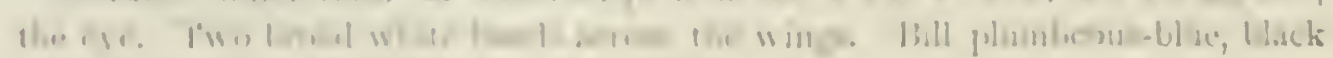

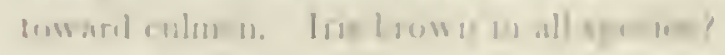


1. L. solitarius. Spurious primary exposed. Throat and orbital ring white. a. Spurious primary well developed, -.60 or more long, .10 broad.

Nape and side of neck plumbeous; upper tail-corerts olive-grcen. Crissum tinged with yellow, but none on side of throat, nor across brenst. Wing, 3.05 ; tail, 2.40 ; bill, from nostril, .27; tarsus, .66. Hab. Eastern Province of United States, straggling westward to the Pacifie Coast, especially in its migration southward into Mexico, where it penctrates in winter as far is Guatemala . . . . . rar. solitarius. Above continuous olive-brown; below ochraceous-white, with a buffy tinge across breast, and deeply olivaceous along sides. Crissum tinged witls ycllow. Wing, 2.80; tail, 2.15; bill, 30 ; tarsus, 66. Hab. Pacific Province of Unitel States, straggling in autumn eastward into the Middle Prorince.

rar. $c$ as s in i.

Above continuous ashy-plumbeous. Beneath pure white, ashy along sides, and rery slightly so across breast. Wing, 3.25 ; tail, 2.50 ; bill, .30 ; tarsus, .66. Hab. Middle Province of United States, south, in winter, through Westem Mexico to Colima . . . . var. plumbeus.

b. Spurious primary very minute, - about .30 long by $.0 t$ wide.

Nape and side of neck olive-green; upper tail-corerts plumbeous. Crissum not tinged with yellow, but sides of the throat and across the breast are. Wing, 3.10 ; tail, 2.20 ; bill, .29; tarsus, .64. Hab. Coban,

- Vera Cruz, Guatemala; resident? . . . . var. propinquus'

2. I. flavifrons. Spurious primary concealed. Throat and orbital ring yellow. Anterior half of body olive-green above, lemon-yellow below; posterior half plumbeous-ash above, white below. Wing, 3.00 ; tail, I.90; bill, .32; tarsus, .70. Hab. Eastern Province of United States, south, in winter, to Costa Rica, and very rare in Cuba.

\section{Lanivireo solitarius, BAIRD.}

BLUE-HEADED VIREO.

Muscicapa solitaria, W1Ls. Am. Orn. II, 1810, 143, pl. xvii, fig. 6. Virco solitarius, V1eıl. -Aun. I. - Cassix, Sc. - Sclater, P. Z.S. 1856, 298 (Corlova); 1859, 363 (Xalapa); 375 (Oaxaca ?). - Sclater \& SAlvix, Ibis, 1860, 31 (Guatemali). - CAB. Jouir. III, $46 \mathrm{~S}$ (Cuba). - Guridach, Cab. Jour. 1S61, 321 (Cuba ; rery lare). - SAMuels, Birds N. Eng. 277. Tireo (Lanivirco) sol. BAIr.s), Birds X. Am. 1S58, 329. Vireosyluia (Lanivireo) solitaria, Balld, Rev. Am. B. $1564,347$.

Sp. Crar. (No. 300 §.) Above olive-green, including upper tail-coverts; the top and sides of head and nape ashy-plumbeous; sides of the neek plumbeous-olive. Broad line from nostrils to and around eye, involving the whole lower eyelid, white. A loral line

1 Vircosylvic propinqua, Bannn, Rev. 1865, p. 34S. This appears to be merely a permanent resident race of soliturizs, which itself visits Guatemala only in winter. Closely resembling the latter, it differs essentially in the respects pointed ont above. The difference in coloration is produecd by a shifting, as it were, toward the head of the yellow and olive, leaving the upper tail-coverts clear ash, and the lower pure white, and encroaching upon the ash anteriorly to the crown and ear-eoverts, and the white alongside of the throat. In the $V$. plumbcus these tints are simply alnost entirely removed, leaving clear ash and pure white, with a tinge, however, of olive on the rump and of ycllow on the sides. In $V$. cassini the tints are darkened and browned by the peculiar influence of the region where found, there being neither clear ash, nor olive-green, nor pure jellow or white, in the plumage. 
involving the edge of the crelit, anul a spare beneath the eye, dusky piumbenus. Beneath white; the sides yollow, overtail with olive, this color not extendung anterior to the

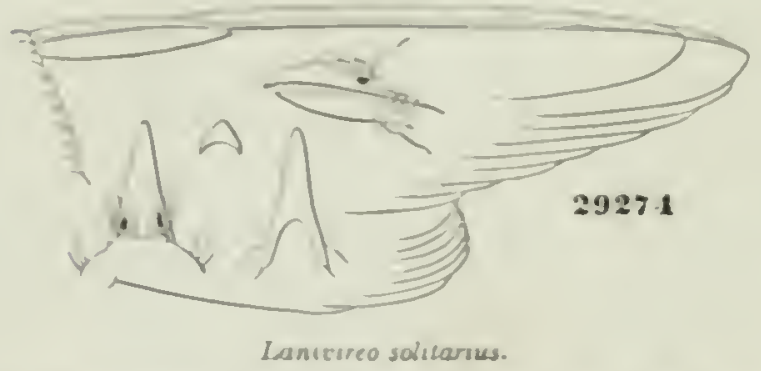
liren-t. Axillar: and lian of crisemm pale anlphur-yellow, the lung feathers of the tatle. numeth palor or neesrly white. Winges with two bands and outer mberes of imuermose secoudarmes olivareou-white; the yquills dark hrown, engerd externally with olivegreen, interually with white: tail-fe:athtrs similarly innoked, except that the lateral fealher is endged externally al oo with white. the central withont internal border. Ibll and lent blankssh-plumbeous. Iris brown.

Fine quill spurious, rather more than one tifih the second, which is intermediate twetween the fifth and sixth: third lougest.

Fresh specinen: Total length, i.t0; expanse of wing, 9.00. l'repared specinen: Total lengeth, 5.2.5; wing, 2.9.3: tail, 2..35.

Hass. Luiteil States, frum Atlantic to Pacific; Cape St. Luscas. Nut recorded from Sousthern lacky Muuntains, where replaceal by Ls plumbeus. South to Ifexicu and Guateuala. Vera Cruz (winter, Sumcurast). Very rare in Cuba.

Spring specimens show sometimes a gloss of plumbeous on the back, chscuring the olive, the cuntrast of colors being greater in the antumnal and young birds. Sometimes the crissum appears nearly white. The length of the spurions primary varies considerably, from t.5 to 75 ot an ineh.

In autumn the colors are sinilar, but slightly duller and less starply definerl, while the back is considerably tinged with ashy.

B.mits. The Solitary lireo appears to be found, irrecallarly, thronghout the United states. Nowlere alundant, so far as I am aware, it seens w be more common in Citlifmina than on the Atlantic, while there are also lamge tracks of intervening territury in which we have no knowledge of its presance. On the Atlantie it hats been met with from (ieorgit to the bay of Fundy. In Massithusetts it has heen found in at fow restricted hocalities; in one or two of them, they are as alumbat as the White-ered. Mr. l)reser found it in Texas, near San Antonin, late in the autum, and early in sprime, hut none remained to lowed. Mr. Boardman gives them its a smmuner visitant at Calais, but not common, and Professor Verrill makes a similar statement for We-tern Maine, where it arrives in the sceond week of May. Accurding (1) Mr. Allen, it reaches Westem Matsalhusetts by May 1 ,

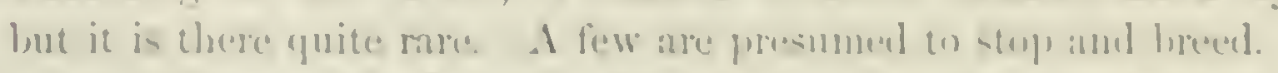

In Califonin, Mr. Gambel states that it is puite alumblant in the latter part of sumber, and thronghont the winter, frewluenting low bushes and

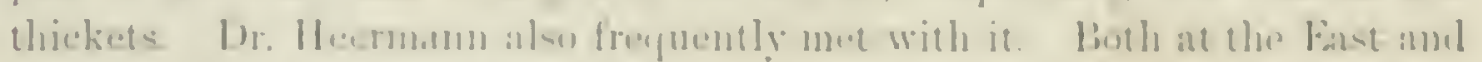

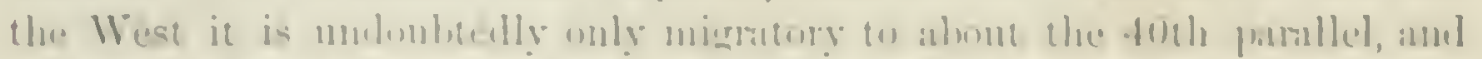

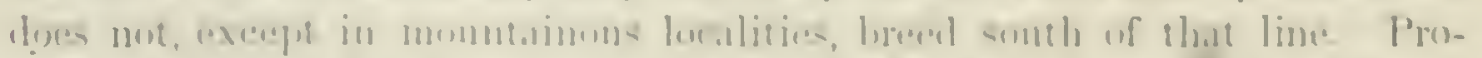

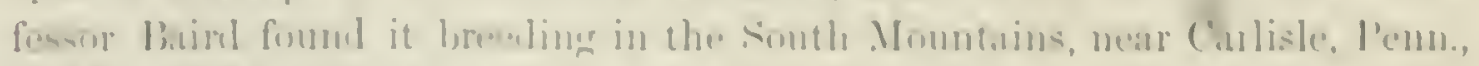
in May, 18\%. It vecurs in Gintemaln in the winter. 
Dr. Cooper states that it reaches Puget Sound by the first of May, and he has also observed it in the Colorado Valley, after the 14 th, where they made themselves conspicnous by their song, but in a few days had all passed northward. He has met them nesting in May at the eastern base of the Coast Range, and has also found them quite common, in summer, on the Columbia River. Their favorite resorts are the deciduous oaks.

These birds were found breeding at Fort Tejon by Mr. Xantus, and at Vancouver by Mr. Hepburn.

Mr. Ridgway met with a few in September, in the thickets along the streams flowing from the Clover Mountains.

This species was taken in winter by Mr. Boucard, at Talew, in the State of Oaxaca, Mexico.

Mr. Audubon's statement that this bird is rather abundant, and that it breeds in Louisiana, is muloubtedly incorrect, and his description of its nest and eggs belongs rather to the Yellow-throated, and agrees with none that I have ever seen of this species. That he found them abundant in Maine, and traced them as far north as Picton, Nora Scotia, is more probable. Dr. Bachman speaks of this species becoming each year more abundant in South Carohina, coming in February and remaining throngh March.

Mr. Nuttall, who met with this species on the Columbin, about the beginning of May, describes its soug as a plaintive, deliberate warble, intermediate between the song of the oliraccus aurd the flarifrons. Mr. Burroughs describes the love-notes of these birds as being inexpressibly sweet and tender in both sexes. The song of the male, as I have heard it, bears no rescmblance to that of any other Vireo. It is a prolonged and very peculiar ditty; repeated at frequent intervals and always identical. It begins with a lively and pleasant warble, of a gradually ascending scale, which at a certain pitch suddenly breaks down into a falsetto note. The song then rises again in a single high note, and ceases. For several summers the same bird has been heard, near my house in Hingham, in a wild pasture, on the edge of a wood, always singing the same singular refrain, during the month of June.

Mr. Nuttall found a nest of this species suspended from the forked twig of a wild crab-tree, about ten feet from the ground. . The chief materials were dead and withered grasses, with some cobwebs agglutinated together, externally partially covered with a few shreds of hypumm, assimilating it to the branch on which it hung, intermingled with a few white paper-like capsules of the spiders' nests, and lined with a few blades of grass and slender root-fibres.

Seven nests of this species, found in Lynn and Hingham, Mass., exhibit peculiarities of structure substantially identical. In comparison with the nests of other Vireos, they are all loosely constructed, and seem to be not so securely fastened to the twigs, from which they are suspended. One of these nests, typical of the general character, obtained in Lynn, May 27, 1859, by Mr. George O. Welch, was suspended from the branches of a young oak, 
ahout twelve fort from the errouml. The external depth of this nest was

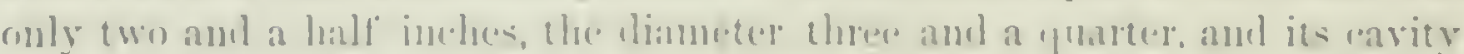
onse and three quarters inches derep, and two inches wite at the rim. It wase constructed externally of stripss of vellow and of apra hirch-bark, intermingrled with hits of woul and dry grasses. The external furtion was quite

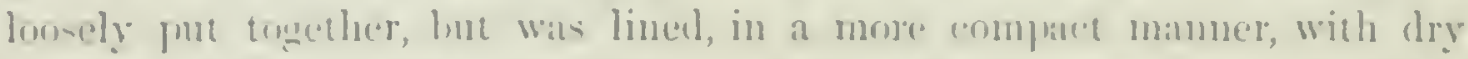
leaves of the white pine, armangel in layers. Another neet. fouml in Ilingham, was lut two feet frem the gromul, on a branch of a hictory saplingr.

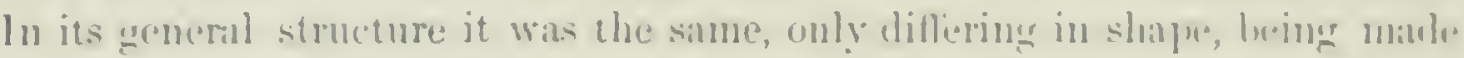
to conform to its position, and lueing twice as long as it was luat. It contained four young, when fomml, ahont the luth of . Ime. ()ne nest alone,

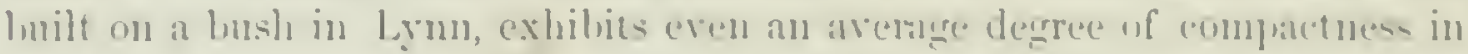
its external structure. This is laterely romument of conouns, which are woren tugether jute a somewhat hunugromeus and cluth-like substance.

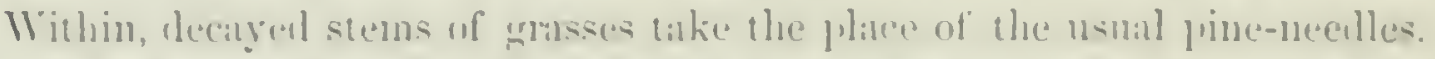

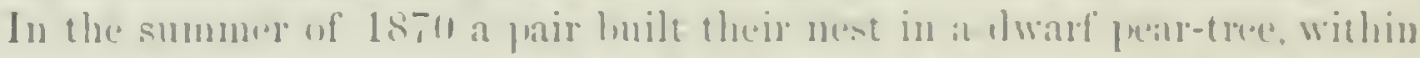
a few rols of my house. They were at tirst rery shy and would not permit themselves to he seen at their work, and suspenderl all lalue when any whe

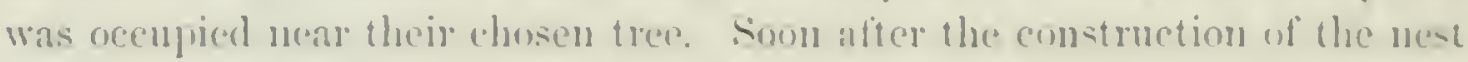

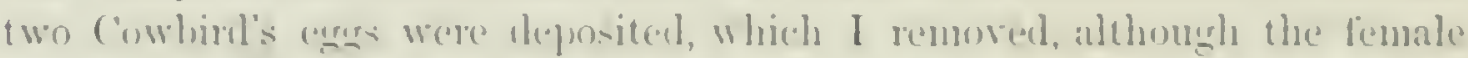

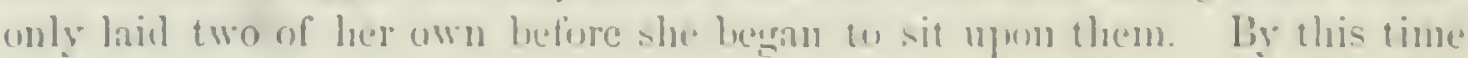

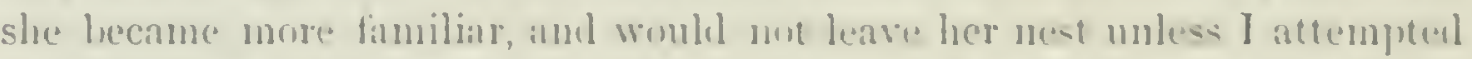
to lay hamds upon her. She mate no complaints in the manner of the

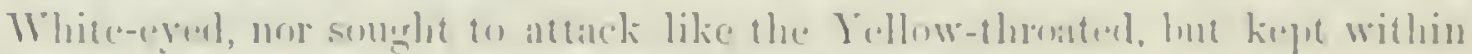

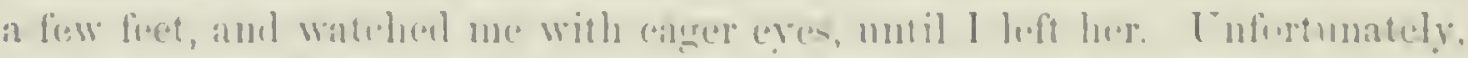

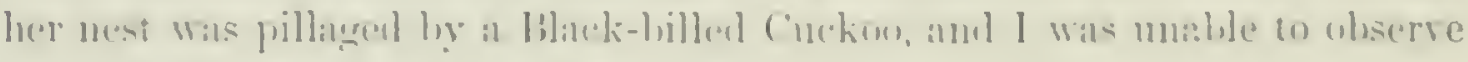

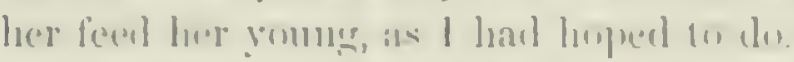

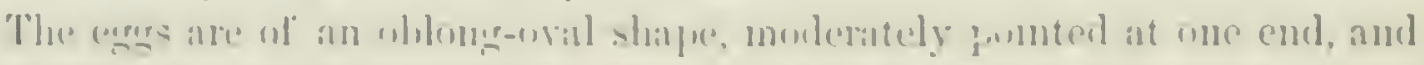

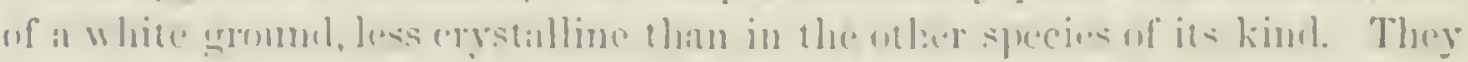

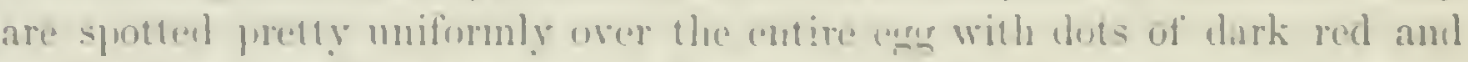

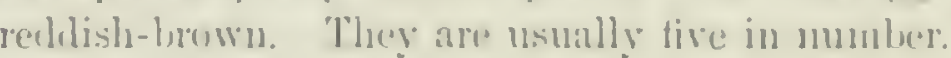

\section{Lanivireo solitarius, vilr. cassini, Pintr.}

\section{CASSIN'S VIREO}

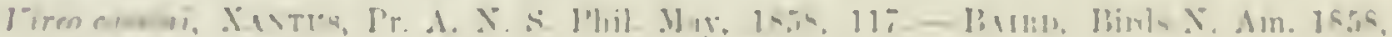

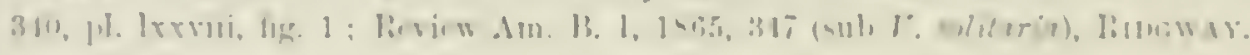

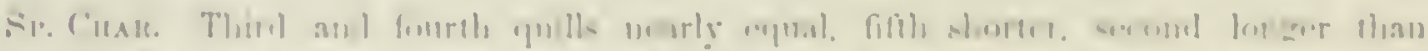

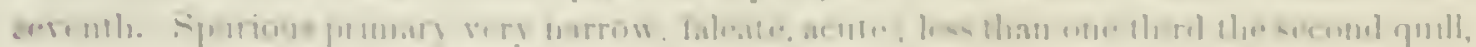

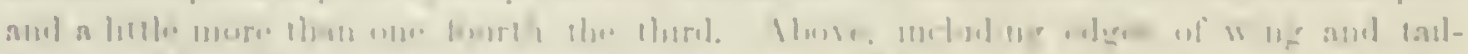

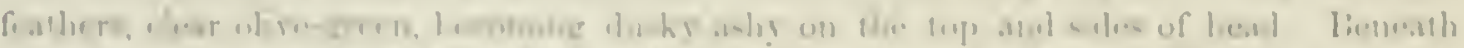

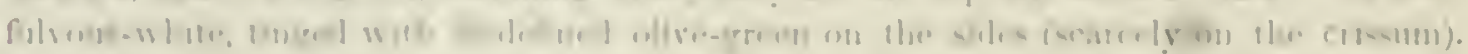

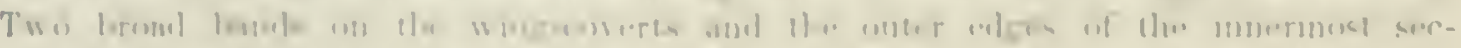

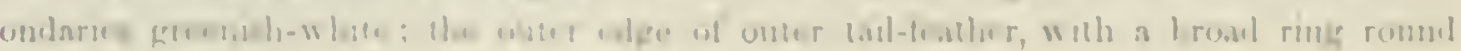


the eje, extending to a frontal band, dull white. Length about 5 inches; wing, 2.75 ; tail, 2.30 .

Hab. Fort Tejon, Cal. (A.stres); West Humboldt Mountains, Nerada (RidG Way).

Since the type of this variety was obtained, two other specimens (Nos. 53,418 \&, and 53,419 8 . September, 1867 ; R. Ridgway) have been secured by the Lnited States Geological Surver of the 40th Parallel, in command of Mr. Clarence King, in the West Humboldt Mountains, Nevada. These specimens are even more different from true soliturius than is the type of this race, showing that it is really distinct, as a variety. In the same thickets at the same season, perfectly typical specimens of $V$. solitcrius were obtained: the latter having, no doubt, come from their more northern summer home on their passige sonthward into Mexico.

In the Humboldt Mountain specimens the crown shows no trace of ash, and is eren darker and more brownish than the back. In fact, the relation of the $V$. cassini to $V$. solitaria is an almost exact parallel to that of $V$. josepha to $V$. gilvus, as far as coloration is concerned, in each case the extreme being widely different, but connected by specimens showing intermediate characters.

Nothing is known of the habits of this race.

\section{Lanivireo solitarius, rar. plumbeus, CouEs. \\ LEAD-COLORED VIREO}

Vireosylvia plumbea, Cores, Pr. A. I. Sc. Phila. $1 \$ 66$ (Fort Thipple, near Prescott, Arizona). - Coopel, Orn. Cal. 1, 1870, 119. - Ellot, Illust. Birds N. A. I, rii. $Y$. (Lanivirco) plumben, Bsind, liev. 349.

Sp. Cuar. (No. 37,011.) Thole upper parts and sides of head uniform plumbeous; the lower part of the baek with a faint wash of oliraceons. I white line from bill to and around ere; a dusky line from corner of eye to bill. Sides of breast and flanks plumbeous, paler than the back; the flanks very slightly tinged with olive-green. Rest of under parts white; the axillars ashy, edged with white. Wings above witl two conspicwous white bands; the innermost quills elged externally and the longer ones internally with white, the latter edged externally with light ash. Bill and legs dark plumbeous. "Iris hazel." Tail-feathers narrowly edged all round witlı white, narrowest internally, and increasing from central to lateral feathers. Upper tail-corerts clear ash.

As the specimen in finest plunuage (described abore) is moulting the quills, the measurements are taken from another $(37,010)$. In this the first quill is not quite one third the second, which equals the sixth, the third and fourtl longest.

(No. 37,010.) Fresh specimen: Total length, 6.10 ; exparse of wings,

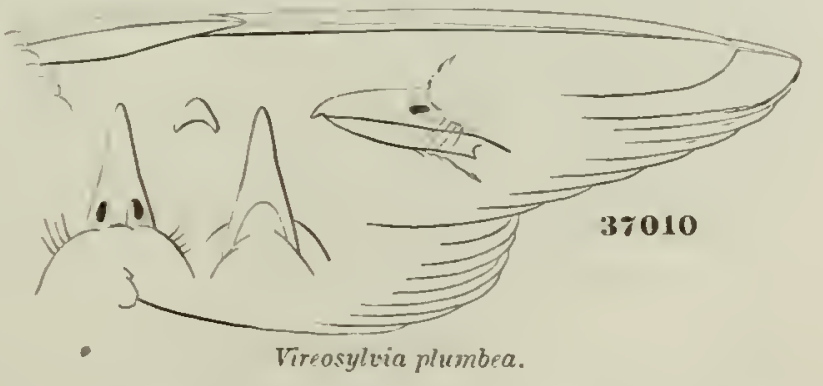
10.80. Prepared specimen : Total length. 5.75; wing, 3.25; tail, 2.70; difference between tenth and longest quill, .95 ; exposed portion of first primary, .75, of second, 2.34 , of lon- 


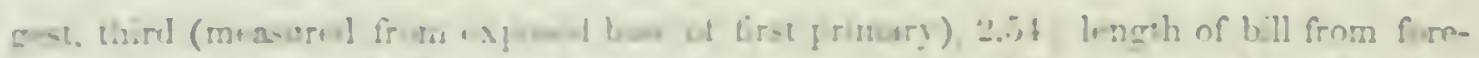

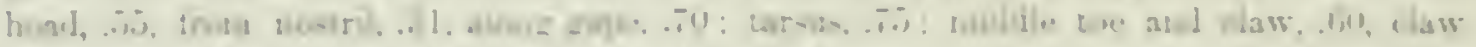

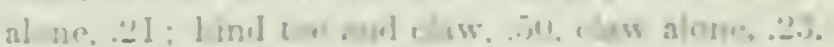

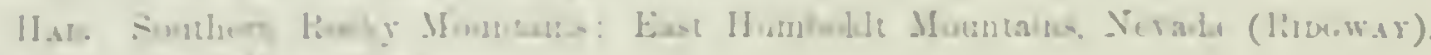
In wisher wo collus. Mexien.

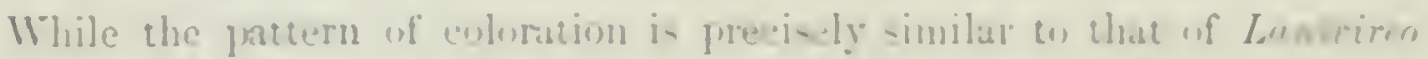

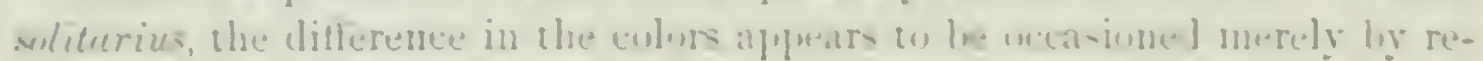
moriug, as it were, the rellow stabin, which on the plumberse produces the

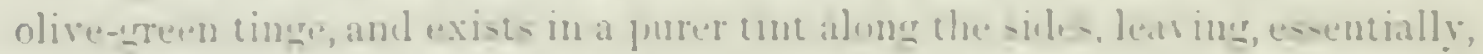

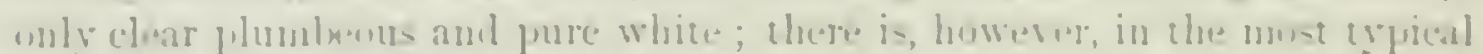
sperimems, always a faint tinge of green on the sumpl, and a statin wi redluw

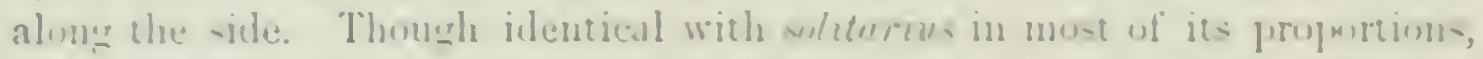
the wing and tail are consilegally homer thon in the aremere of that form.

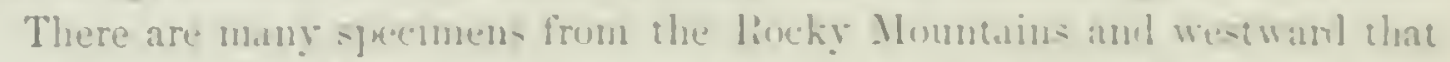

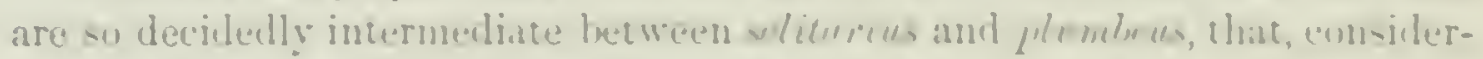
in also the lack of e.ential lifledence in firm and roloration leetween the

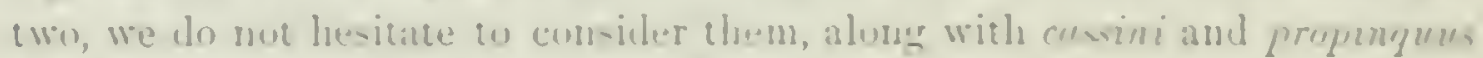

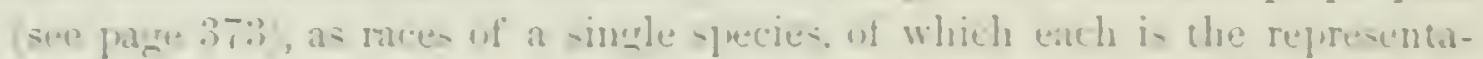

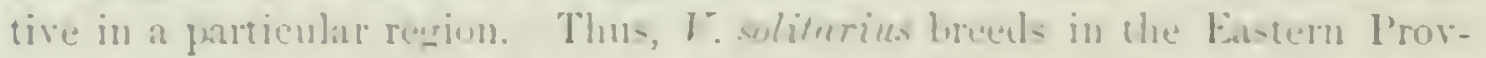
ince of the United stutes and presibly in the IFestern, following the same route fur w the northwarl that many Falsern hink pursue in strangling

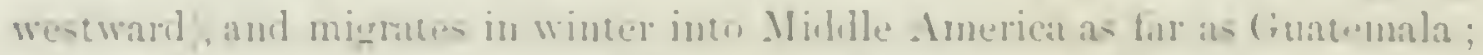

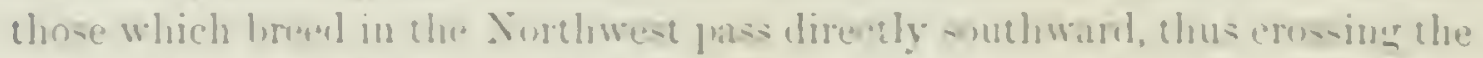

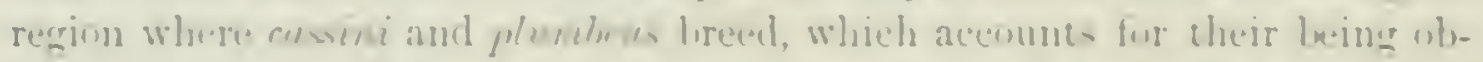

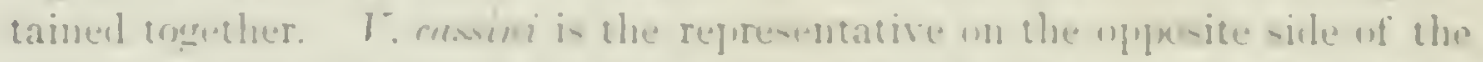

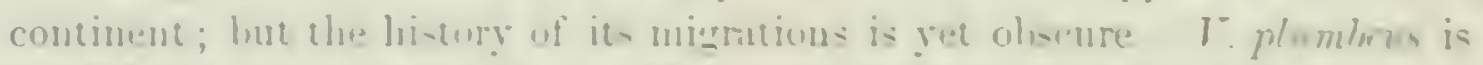

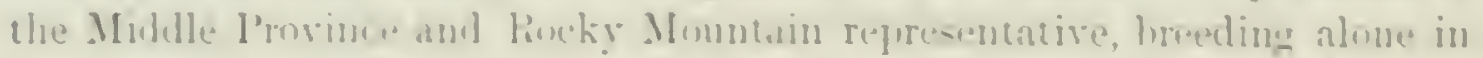

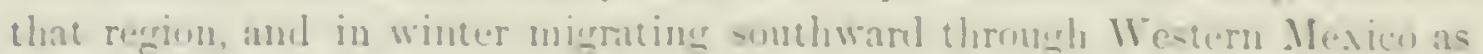

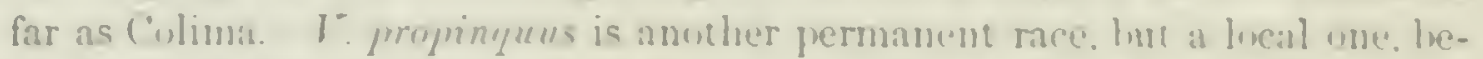
inf revilent in the coumery where foumd, though mixed $\mathrm{in}$ winter with vi-itors of soliturius from the lionth.

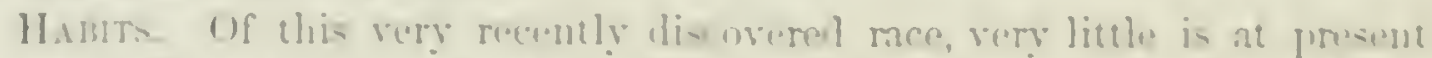
known. It was time leweribel ly l)r. cimes. Whe me with it in Arizun.

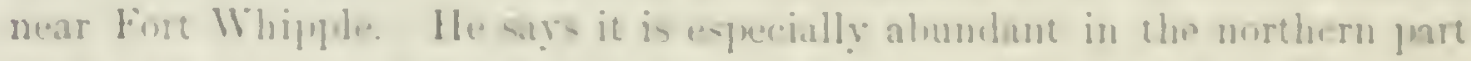
of that Tirritory: It was hy far the must enmmon lireo at Furt Whipple. whe ro it is a summer reoblent, arrisine there alsut the lieh of April aud remamm: umil bequler.

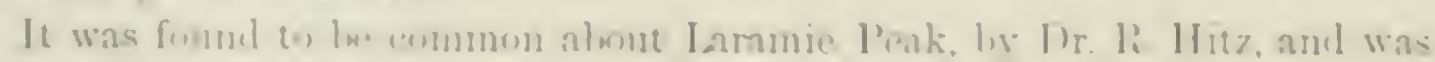

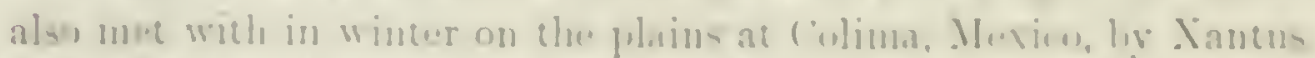

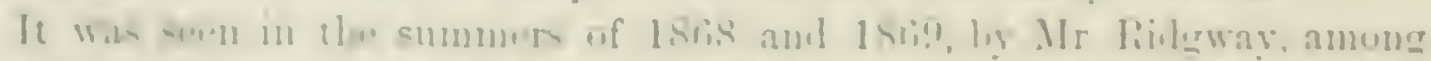

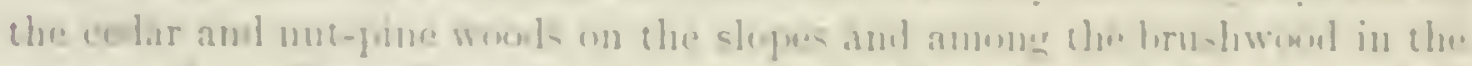

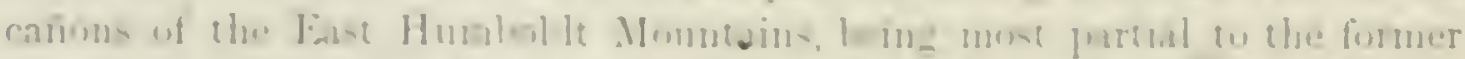

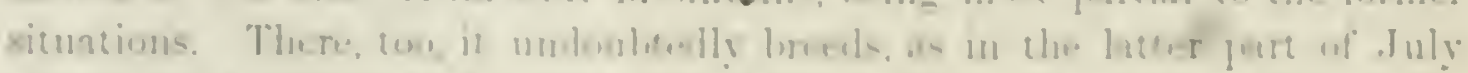

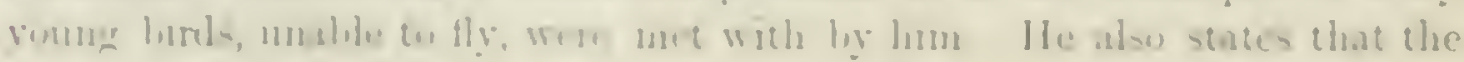


common notes of this Vireo rery closely resemble those of the Western Wood Wren (Troylodytes parlinanni).

\section{Lanivireo flavifrons, BaIRD.}

\section{YELLOW-THROATED VIREO.}

Virco flavifrons, VIEILl. Ois. All. Sept. I, 1807, 85, pl. liv. - Aud. Oru. Biog. II, 1S34, pl. cxis. - i B. Birds. An. IV, pl. cexixriii. - CAssix, P1. A. N. Sc. 1S51, 149. SClater, P. Z. S. 1S57, 227 (Veral Cluz) ; 1S60, 257 (Orizaba). - Sclatel: \& SALvix, Ibis, I, 1S59, 12 (Guatemalis). - CAB. Jour. III, 465 (Cuba : winter). - Gưulacn, Cab. Jour. 1S61, 324 (Cuba; rare). - CAB. Jour. 1860, 405 (Costa lica). Vireo (Lanivircu) flav. BAH1D, Birls N. An. 1858, 341. Vircosylvia (Lanivirca) flarifrons, Balnd, Rev. 316. Jluscicupa syluicolu, WILs. Am. Orn. II, 1S10, 117, pl. vii, f. 3.

Sp. CuAr. (No. 23.390.) Head and neck above and on sides, with interscapular region, bright olive-green. Lower back, rump. tail, and wing-corerts ashy. Wings brown, with two white bands across the coverts, the outer edges of inner seconclaries, and inner edges of all the quills, with inside of wing. wliste. Outer prinaries edged with gray, the inner with olive. Tail-feathers brown, entirely encireled by a narrow erlge of white. Under parts to midelle of body. a line from nostrils over eye, eyelids, and patel beneath the eye (bordered behind by the olive of neck) bright gamboge-yellow; rest of

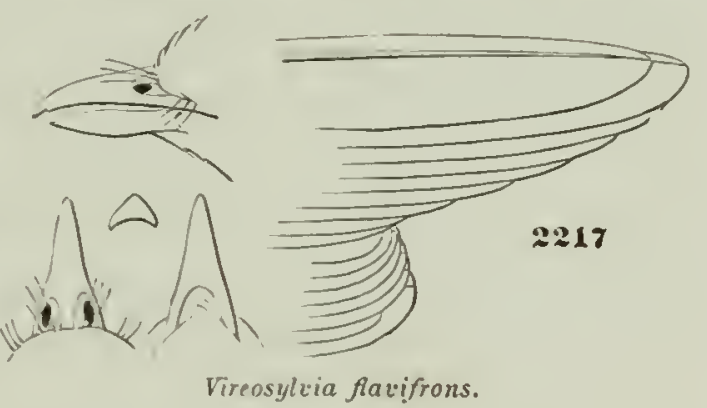
under parts white, the flanks finintly glossed witl ashy. Lores dusky. Bill and legs plumbeous-black.

No spurious primary evident: second quill longest : first a little shorter than third.

Lenğth, 5.80 ; wing, 3.00 ; tail, 2.00 ; difurence of longest and innermost quills. .90 ; tarsus, . . 33 .

HAB. Eastern United States, soutlı to Costa Rica. Veragua (SALFis). Very rare in Cuba.

Autumnal birds, perhaps more especially the young, are more glossed with olivaceous, which invades the ashy portions, and tinges the white.

Habirs. All the older ornithological witers, in speaking of the Yellowthroated Vireo, repeat each other in describing it as peculiarly attraeted to the forest, seeking its solitudes and gleaning its food chiefly among its topmost limnches. Sueh has not been my experience with this interesting and attractive little songster. I have found no one of this genus, not eren the gilva, so common in the vicinity of dwellings, or more familiar and fearless in its intercourse with man. All of its nests that I have ever met with have been built in gardens and orchards, and in close proximity to dwellings, and they have also been exclusively in eomparatively low positions In one of the most recent instances a pair of these birls built one of their beautiful moss-covered nests in a low branch of an apple-tree that overhung the croquet-wround, within a few rods of my house. It was first noticed in conse- 


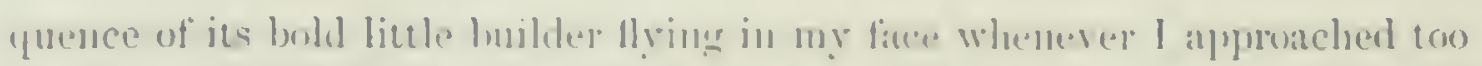

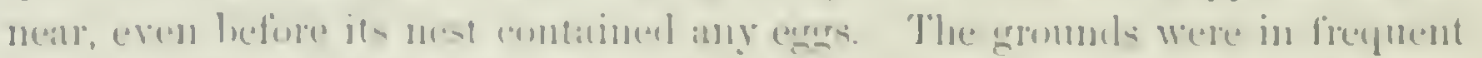

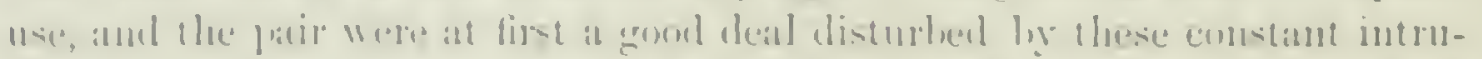

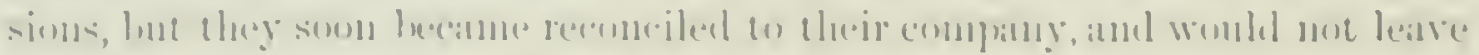

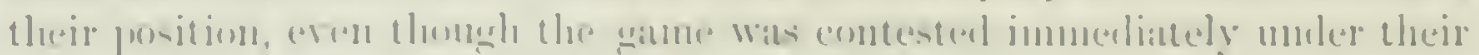

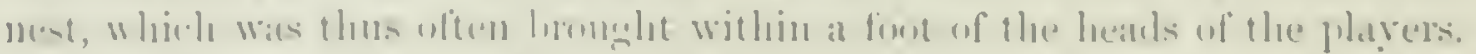

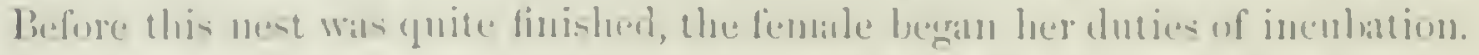

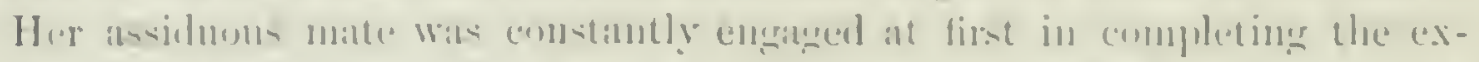
termill ornanentation of the mest with lichens and moses. and then with a

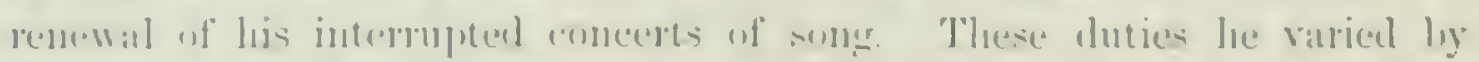

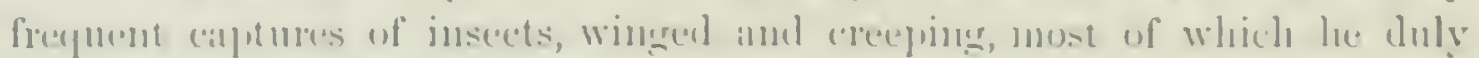

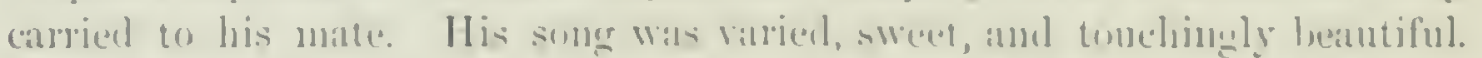

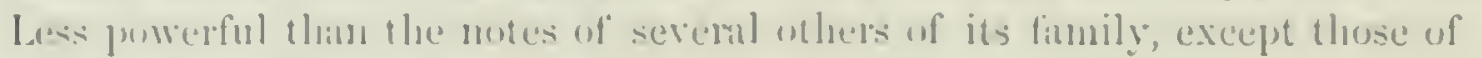
the Worloling, l kuow of mone mole charminge.

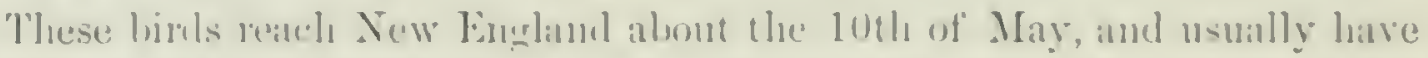

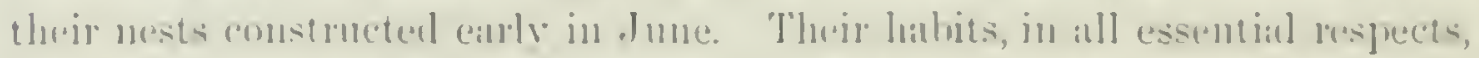

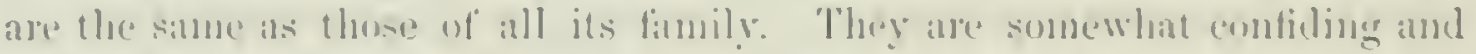

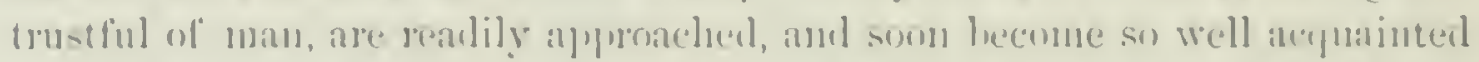
with those among whom they hats a home as to featrles-ly enute to the win-

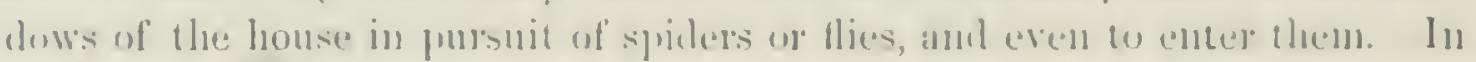

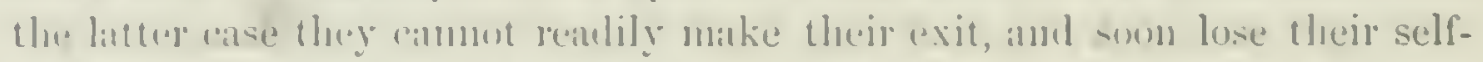

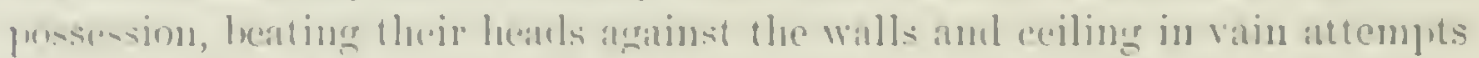

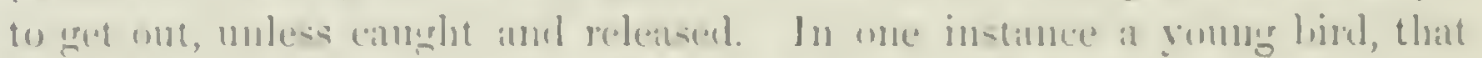

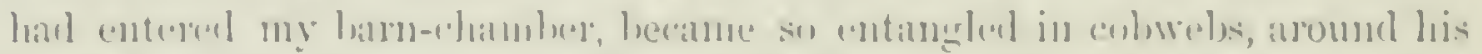

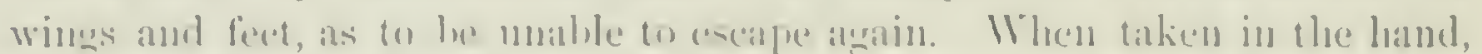

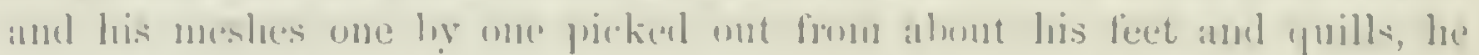

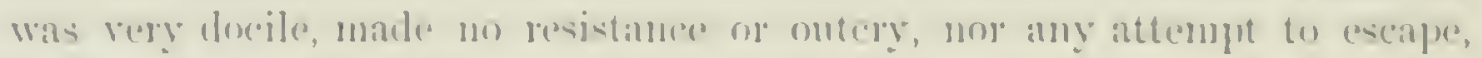

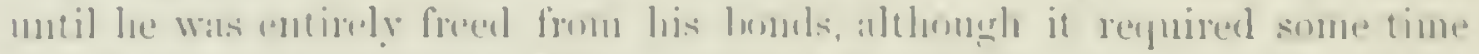

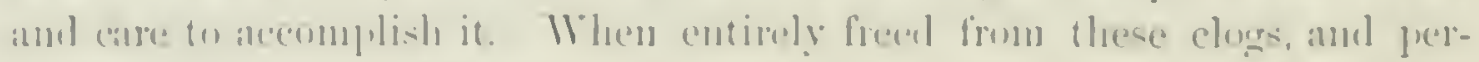

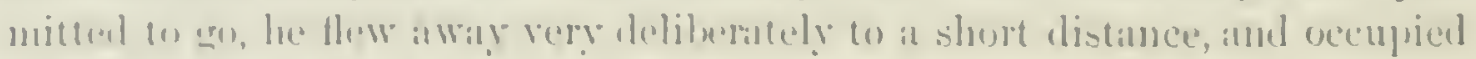

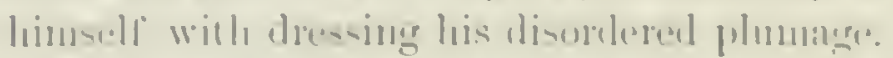

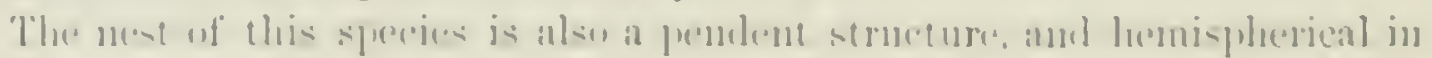

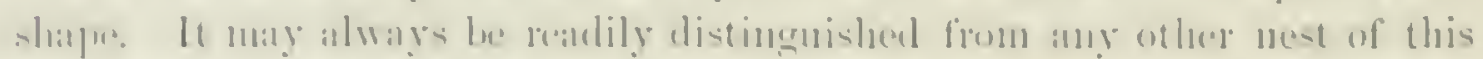

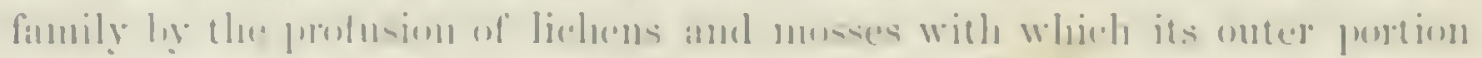

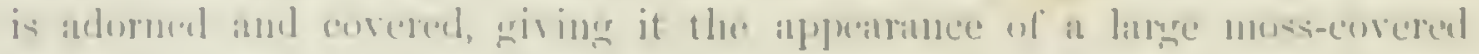
killot.

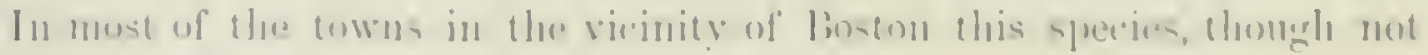

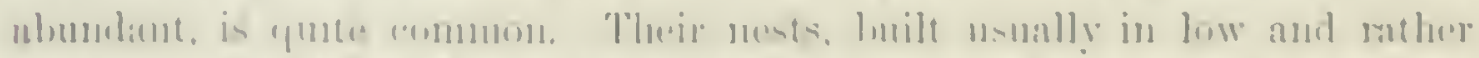

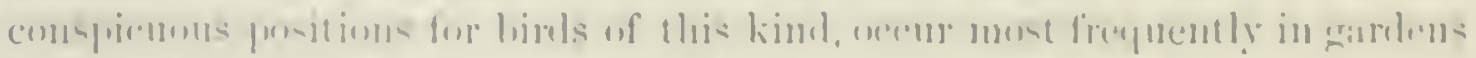

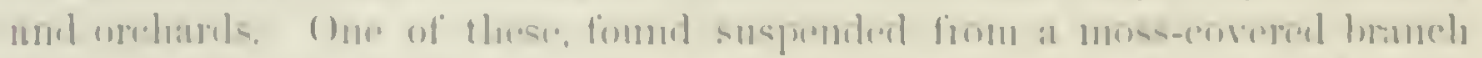

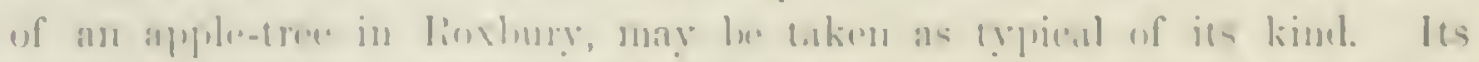

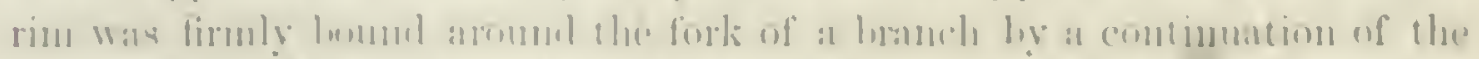

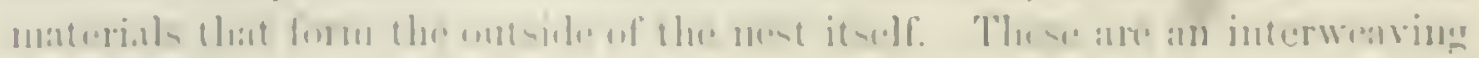

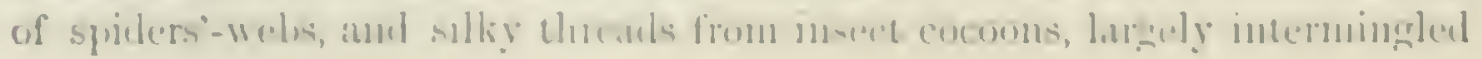


with mosses and lichens, and thus made to conform closely in appearance to the moss-grown bark of the tree. The under portion of the nest is strengthened by long strips of the imner bark of the wild grape. Within is an immer nest made of fine grassy stens and bark. It forms exactly a lalfsphere in shape, is symmetrical, and is very thoroughly made. Its diameter is four, and its height two and one fourth inches.

Mr. Nuttall describes a nest of this bird, found by him suspended from the forked twig of an oak, near a dwelling-house, as coated over with green lichens, attached very artfully by a slemler string of caterpillars' silk, the whole afterwards tied over by almost invisible threads of the same, so nicely done as to appear to be glued on. The whole fabric was thus made to resemble an accidental knot of the tree, grown orer with moss. Another nest, observed by the same writer, was fixed on the depending branches of a wild cherry, and was fifty feet from the ground. So lofty a position as this is probably very unusual. I have never met with any higher than ten feet from the ground.

The food of this Vireo is chiefly insects, and in the breeding-season is altogether so. Later in the season they mingle with these various hinds of small berries.

The egrgs of this species vary from .95 to $.8 S$ of an inch in length, and from .65 to $.60 \mathrm{in}$ breadth. Their ground-color is white, often with a rery perceptible tint of roseate when fresh. In this respect they differ in a very marked manuer from the eggs of any other of this genus, except, perhaps, the bribatula, and may thus alwars be very easily recognized. They are more or less boldly marked with blotehes of a dark roseate-brown, also peculiar to the eggs of this species, though rarying grently in their size and depth of color.

This Tireo winters, in great numbers, in Central Anerica, and was largely represented in the collection of Dr. Tan Patten from Ginatemala. It was also found at Pirico, in Colombia, Sonth America, by Mr. C. W. Myatt. It occurs in abmudance as far to the west as Grinnell, Iowa, where Mr. IV. H. Parker found it to be a rery common summer resident. 
Stoutsils VIREO, Vi1:1.1.

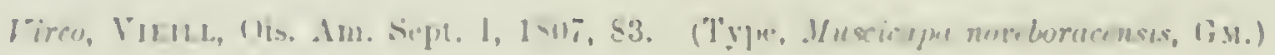

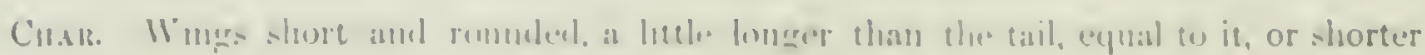

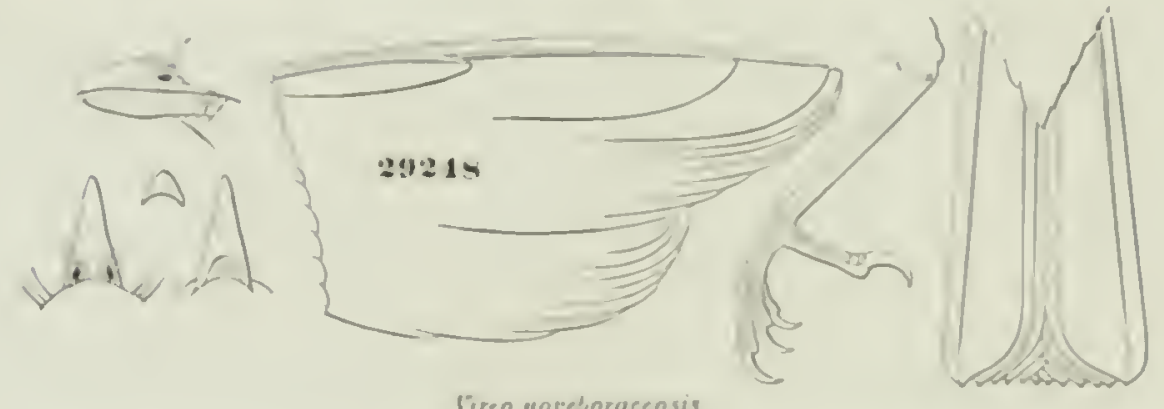

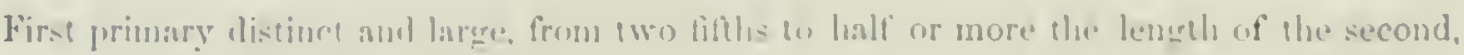
shorler or not lonerer than the eighth.

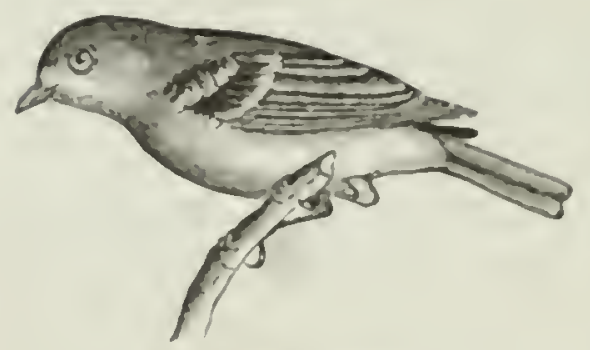

lireo noreburacensis.

The chancters of lirom are essentially those of ritresiglen: the hill, however, is shorter: the first quill always present, better

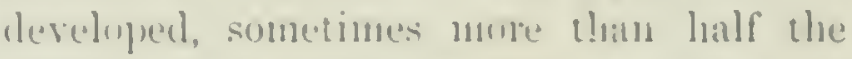
second. The wings are sluoter, and more rouncleal; the titri usuilly longer. The sections ane is follow: : -

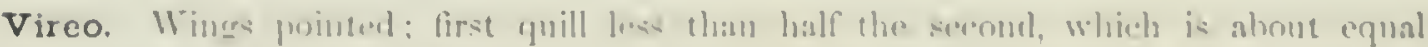

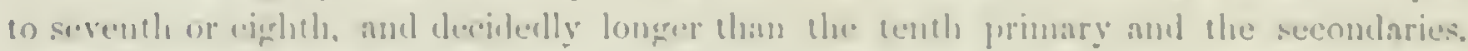

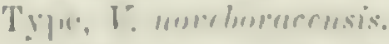

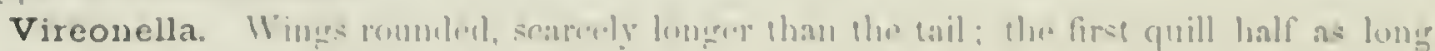

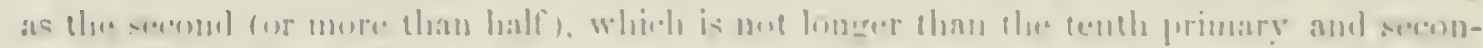

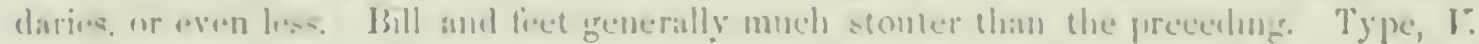
gundluelio

None of the species of Firmmolla are fomml in the L"nited states.

\section{Species}

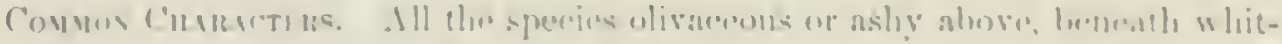

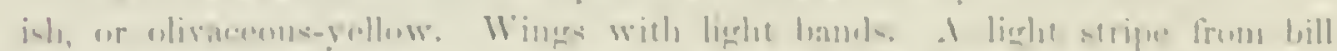

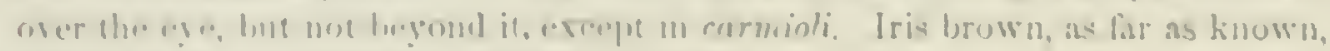

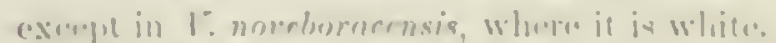

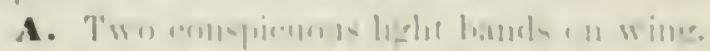

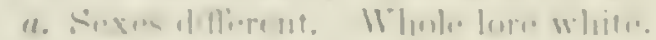

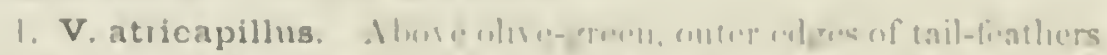

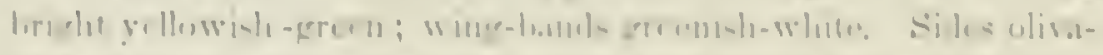

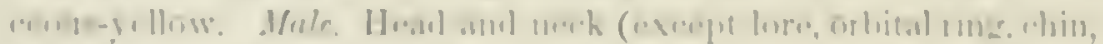

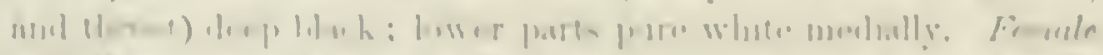

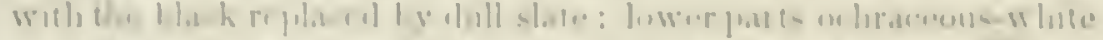

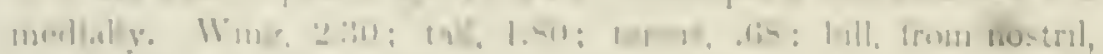

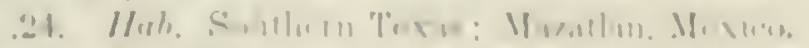

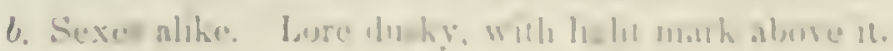


2. V. carmioli. ${ }^{1}$ Above hrownish olive-green. Beneath, with supra-loral stripe, orbital ring, and light markings on the wings, light ochrey-y ellow more whitish on the throat. Wing, 2.55; tail, 2.00; tarsus, .66; bill, .26. Hub. Costa Rica.

3. V. noveboracensis. Above olive-green, ashy across the nape. Supra-loral stripe and orbital riug deep yellow. Beneath asly-white on throat, purer white on abulomen; sides, and a tinge across the breast, light yellow. Iris white. Wing, 2.40 ; tail, 2.00; tarsus, .63: bill, .26. Hab. Eastern Province of United States, south (in winter) to Guatemala (and Bogota?) ; very rare in Cuba; abundant and resident in Bermuda.

4. V. huttoni. Above grayish-olive, more olive-grcen toward tail. Bclow pale grayish-buff. Orbital ring very broad, yellowish-white. Wing, 2.50 ; tail, 2.05 ; tarsus, .67; bill, .24. IIab. California; in winter; Western Mexico to Oaxaca.

B. Only one band on wing, and this indistinct.

5. V. belli. Above ashy-olive, inore rirescent posteriorly. Markings on sicle of had not well definell. Below dull white, with a slight buffy tinge. strongly stained with yellow on sicles and flanks. Upper feathers of midlle row of wing-coverts passing into paler at tip, producing an indication of an anterior band. Wing, 2.20; tail. 1.80 ; tarsus, .69; bill, .25. Hub. I'lains between the Mississippi Falley and the Rocky Mountains, from Dakota to Texas; in winter south to Tehuantepec, Mcxieo.

6. V. pusillus. Above gray ish-ash, very slightly tinged with olive on rump. Below dull white, ashy laterally, the flanks with the slightest possible tinge of yellow. Wing, 2.30 ; tail, 2.20 ; tarsus, .69 ; bill, .24, .13 deep. Hab. Arizona; Cape St. Lucas, Lower California : California north to Sacramento City.

7. V. vicinior. Above bhish-ash, below ashy-white, scarcely more asliy laterally. Lores entirely ashy-white. Wing, 2.60; tail, 2.40 ; tarsus, .67 ; bill, .26, .18 deep. Hab. Fort Whipple, Arizona.

\section{Vireo atricapillus, Woonhorse}

\section{BLACK-CAPPED VIRE0.}

Virco atricnpillus, Toodnot'se, Pr. A. N. Sc. 1S52, 60 (San Pedro, T'ex.). - 1B. Sitgreares's Rep. 1853, 75, pl. i, Birds. - Cassis, llhust. 1854, 153, pl. xxiv. - B.anid, Birds X. Am. 1855s, 337 ; Rer. 353. - Coupeli, Oln. Cal. 1, 1870, 121.

S. Char. (No. 6.818.) Top and sides of lzad and neck black; rest of upper parts oliregreen. Wing and tail feathers almost black on their upper surfacc. the quills and rectrices edged with olirc (paler on the exterior primaries), the wing-coverts with two greenish-white bands on a blackish ground. Broad line from lijil to and around eye (not meeting on forehead) with under parts white; the sides of body olivaceons; the axillars and inner wing-coverts (perhaps crissum)

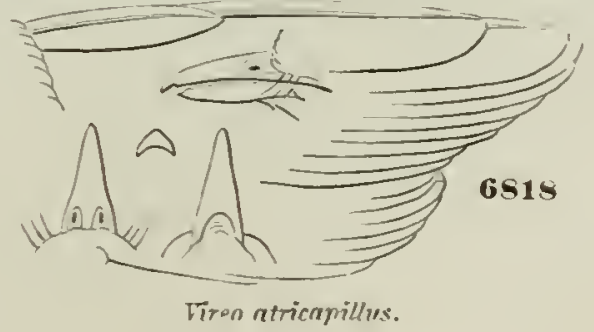

2 Virco carmioli, Ban:D, Review Am. B. I, 1965, p. 356. Hub. Costa Rica. 


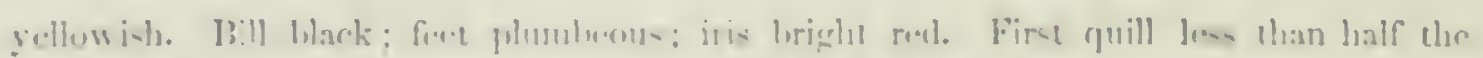

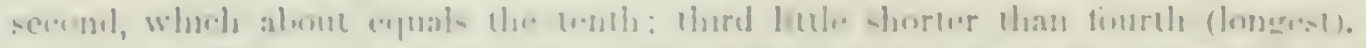

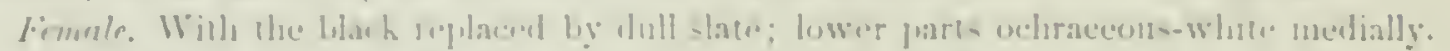

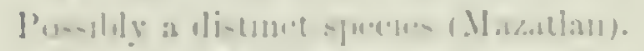

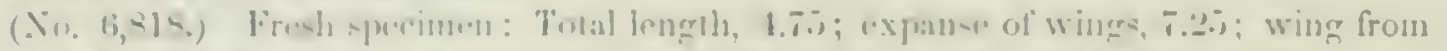

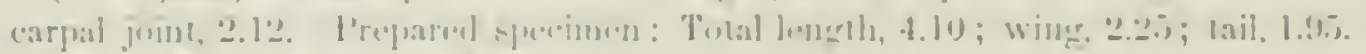

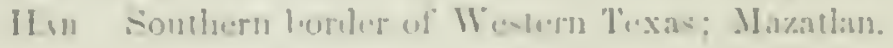

The hack head of this sprecies, as for as kmown, makes it minue in the

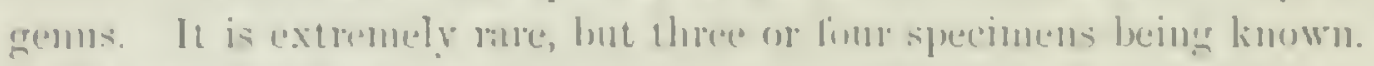

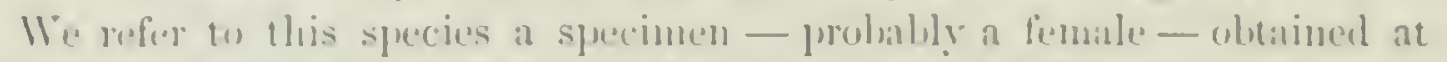

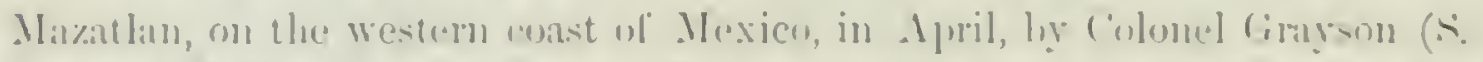

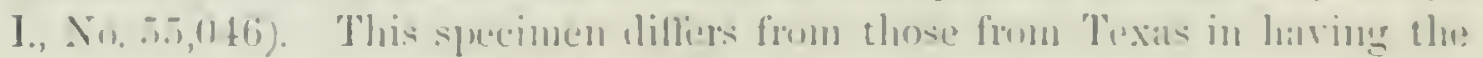

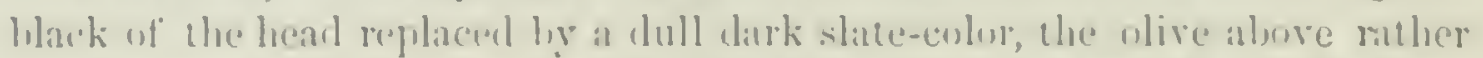

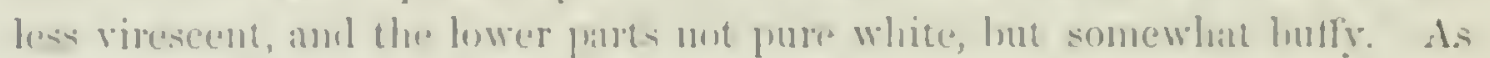
all the other essential chancters are identieal, there leeing in both the

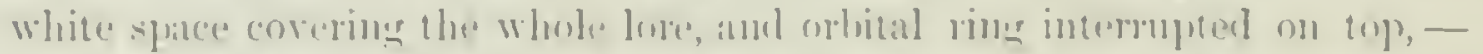
foatures not seen in any other species, - we have little hesitation in eonsillorine them the same species; which opinion is moreover strengthened ly the fact, that anong the Texas specimens, all with black calps, there are nor) liomalus.

Habrs. Of the general history and hahits of this rare species very little is known. It was tir-t wet with ly ly. Woodhomse, un the 2bth of May,

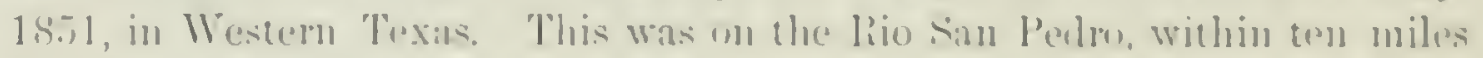
of its sontee. He fomm it ammong some colars and was attracted ly its very

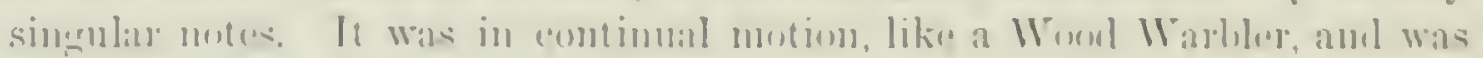
ly him at first suppused to be une of those birls. He obtained two speci-

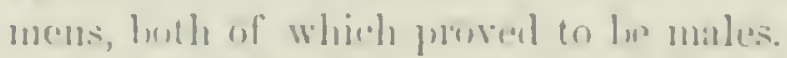

Mr. Juhn II. Clatk, the matmalist of the Mexian Pumblary Commission,

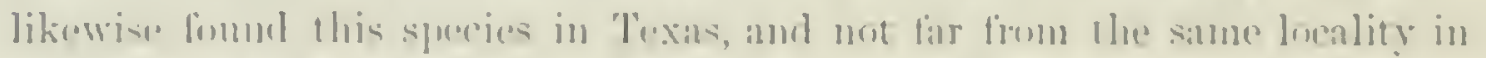

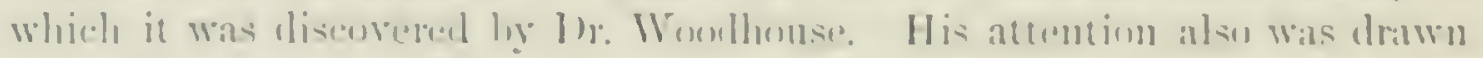

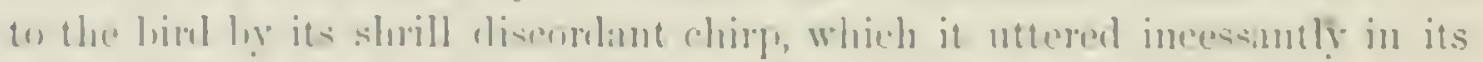

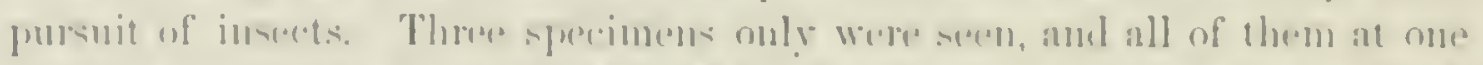

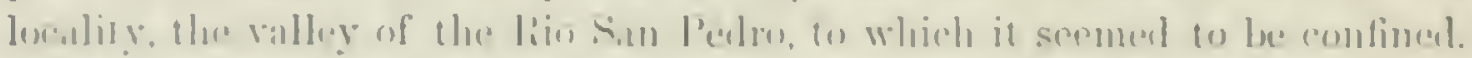

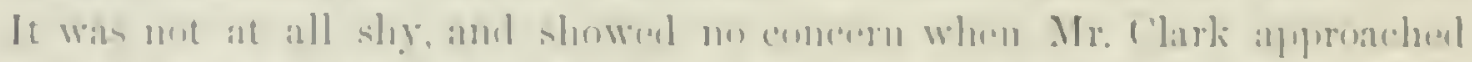

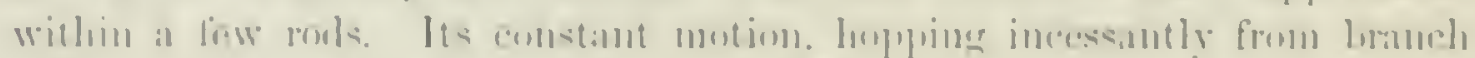

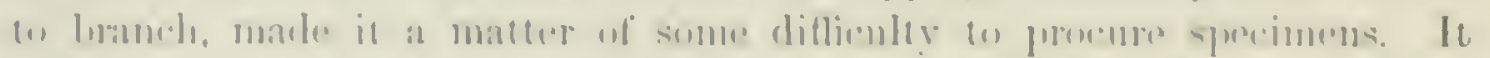

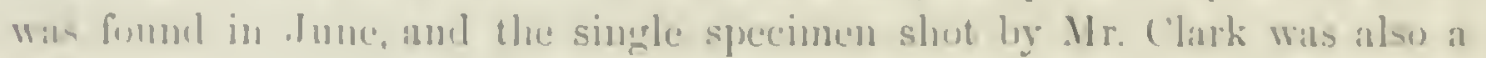
mitlli. 
Vireo noveboracensis, BOxaP.

\section{WHITE-EYED VIREO.}

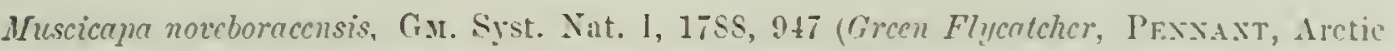

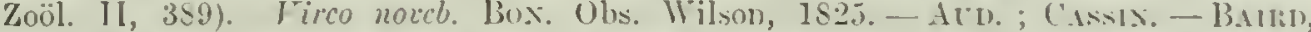

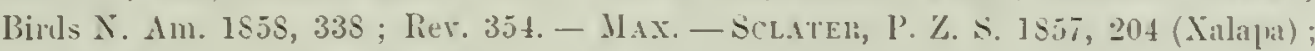

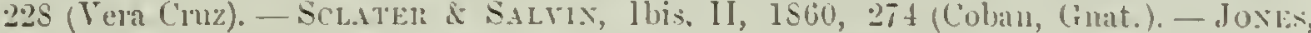

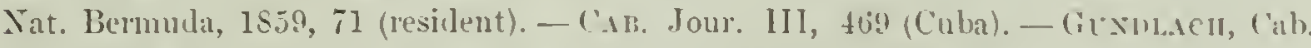

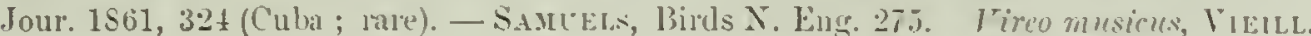
Ois. Am. Sept. I, 1S07, S3, pl. liii. Muscicam contutris, Wirs. II, 1S10, 260, pl. xviii. Figures : AlD. Orn. Biog. pl. Lxiii. - I B. Birds X゙. A. IT, pl. cex!.

Sp. Cusı. (No. 10,193 ठ․ Illinois.) First primary abont half the leucth of second. which is longer than secondaries, and about equal to the eighth: the fourth longest; third and filth little shorter.

Above quite olive-green; sides of neck, and a gloss on its upper surface. ashy. The middle eoneealed portion of feathers of lower back and rump pale sulphur-yellowislz. Beneath white; the chin and lower checks with a gravish tinge; the sides of breast and body, with axillars and base of crissum (more faistly), lright yellow; the inuer wingcoverts and rest of erissum much paler, almost white. A broal yellow line from nostril. to and continuous with a yellow ring round the erc. which is encircled exteriorly ly olivaceous; a dusky loral, but no post-ocular spot. Wings with two corert-bands and inncrmost secondaries cxternally, broadly yellowisly-white; rest of quills erled externally with olive, except the two outer and tips of other primaries. which are grayish. Rectrices elged externally with olive, except ontemost, which is bordered hy gravish. All the long quills bordered internally by whitish. Bill blue-black, maler oid the edges; legs dark plumbeous. Iris white. Total length, 4.90; wing. 2.40: tail. ․․ㅇ.

H.ı. Cnited States, west to base of Rocky Momntains: south to Guatemala; Bogota? Tery rare in Cuba. Abundant and resident in the Bermudas.

Specimens vary slightly in a greater amount of ashy on the head, and less brilliancy of the yellow of head and sides. Sometimes there is a decided ashy shade in the white of throat and jugulum, which again has a very faint tinge of yellowish.

Habits. The White-eyed Vireo is one of the most common and one of the most widely diffused of its renus in all parts of the L'nited States east of the Rocky Mountains. It apparently breeds in all parts of the Lnion, from Texas and the Indian Territory on the southwest to Iowa and Wisconsin, and as far to the northeast as Míassachusetts. In the last-named State it becomes exceedingly rare, and beyond it is apparently not found, none having been met with either hy Messrs: Terrill or Boardman in any part of Maine. In Westem Massachusetts it was not found by Mr. Allen, though it occurs in the eastern part, along the coast. Mr. Dresser found it common in Wrestern Texas, many remaining there to breed, and Dr. Woodhonse also found it abundant in Texas, New Mexico, and the Indian Territory, where it frequented the thickets bordering on the streams. It breeds almundantly in the Northwest States of Illinois, Iowa, and Wisconsin. It also breeds in the islinds of Bermuda. 


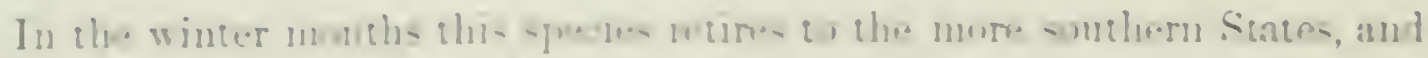

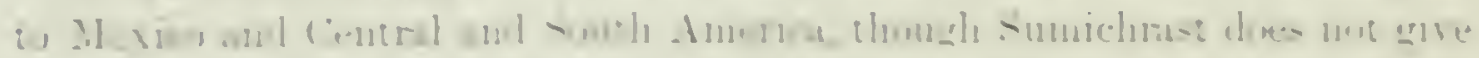

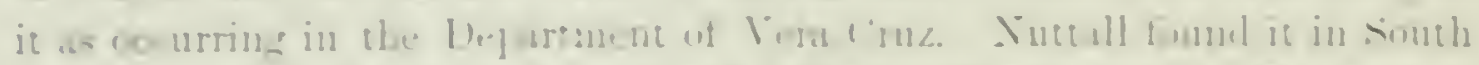

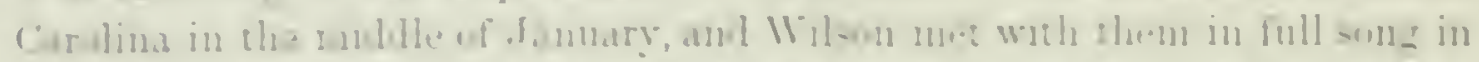

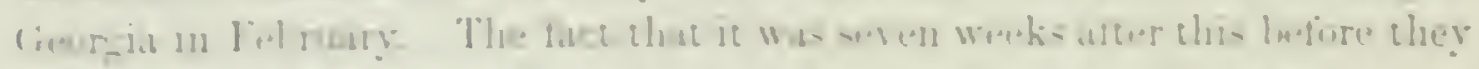

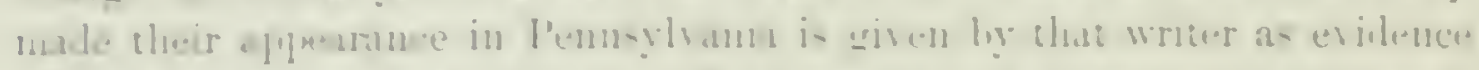

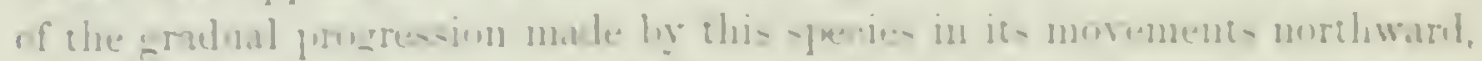

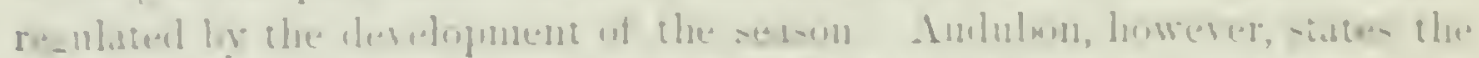

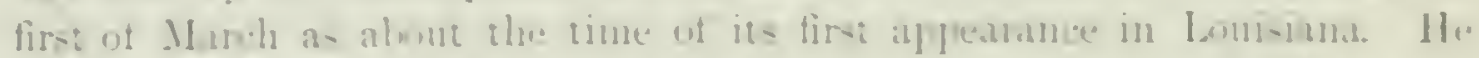

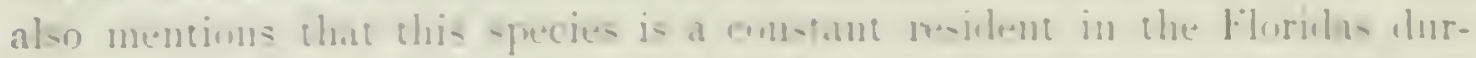

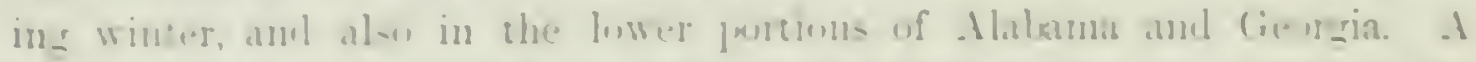

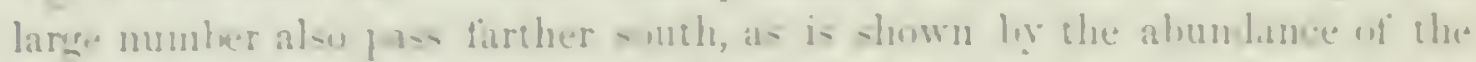

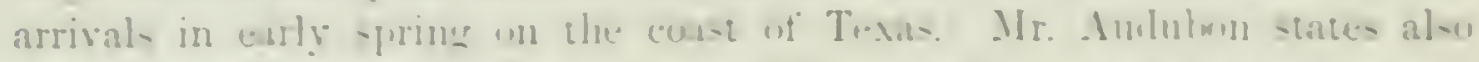

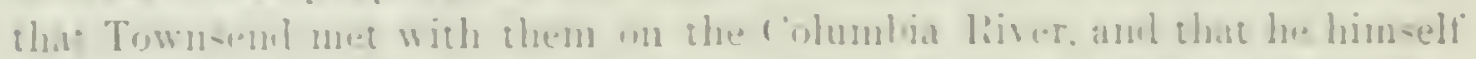

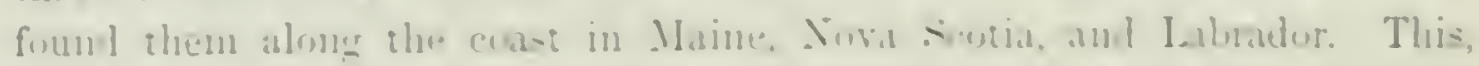

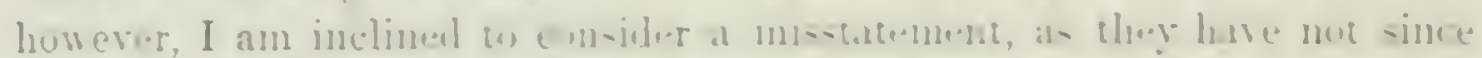

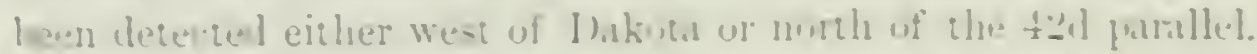

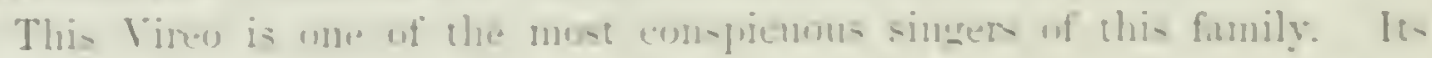

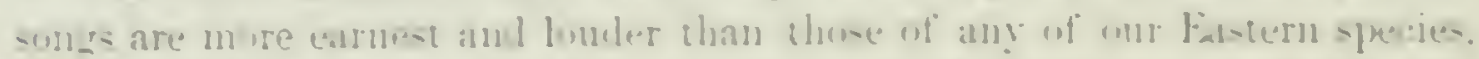

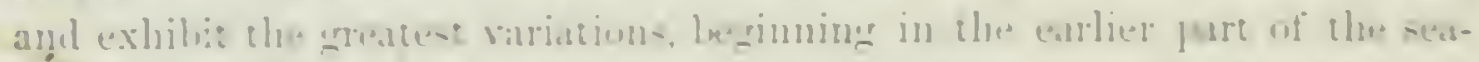

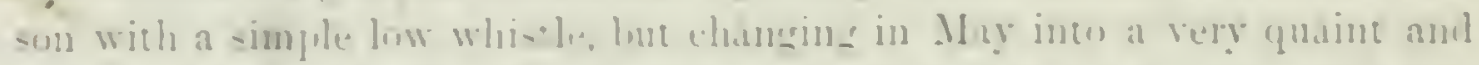

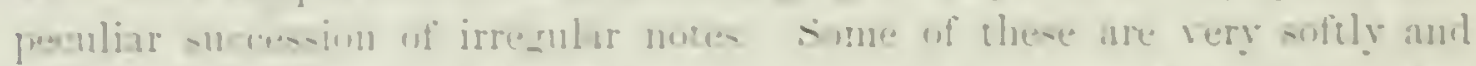

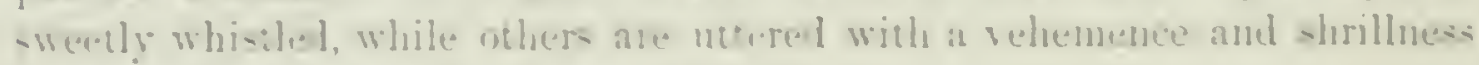

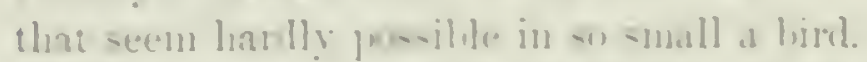

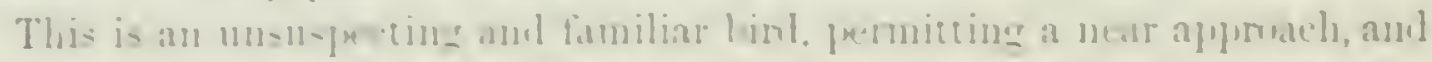

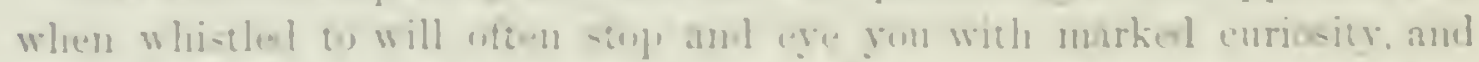

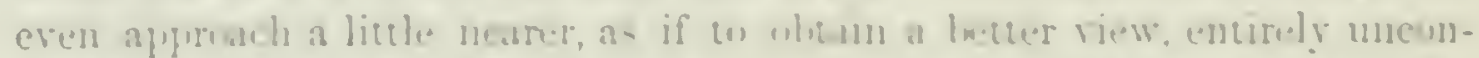

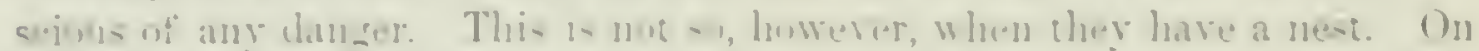

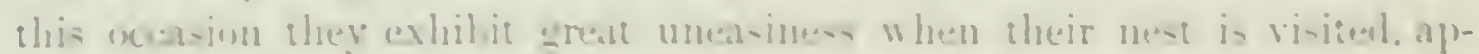

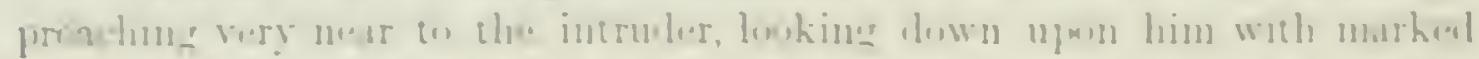

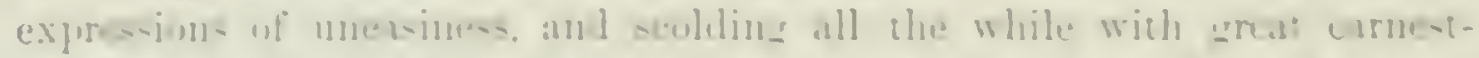

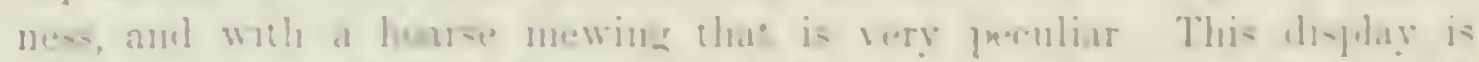

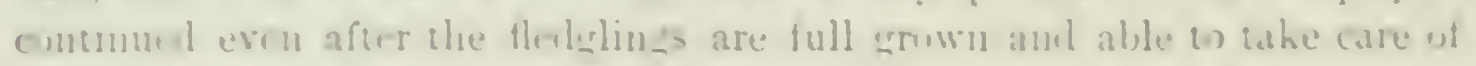
thementin-

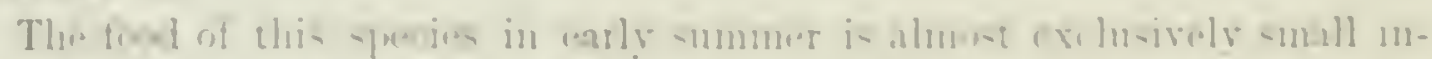

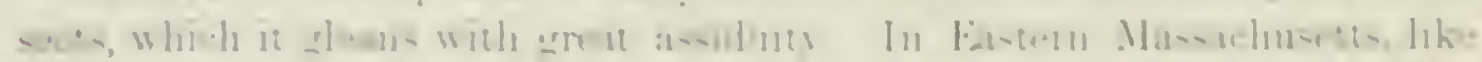

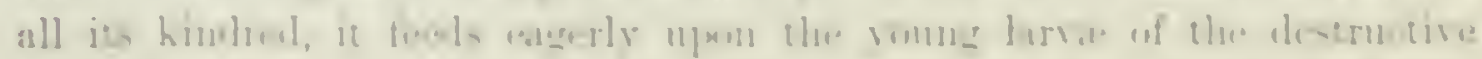

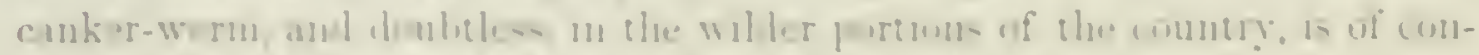

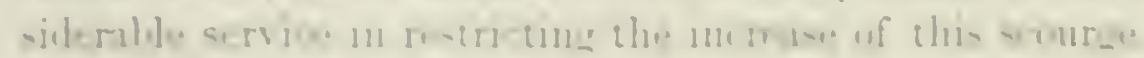

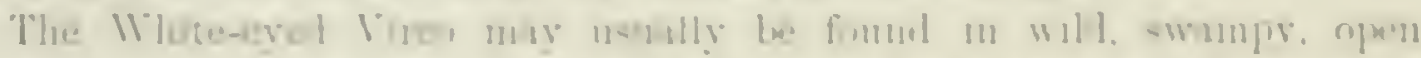

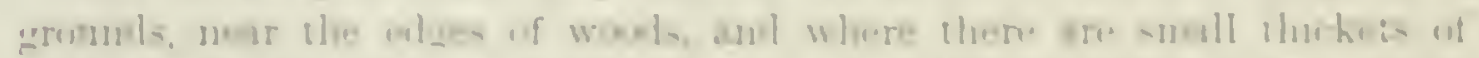

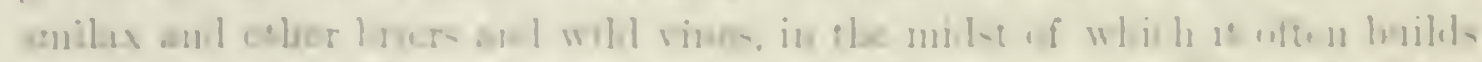

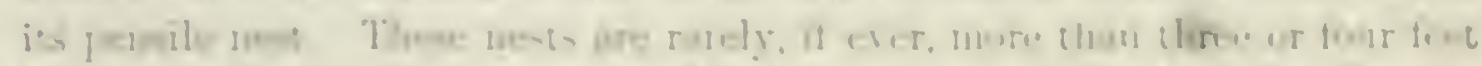

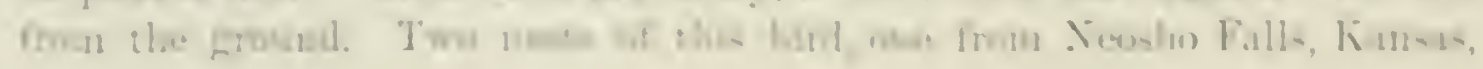


the other from Lymm, Mass, may be taken as characteristic of the species. They are ahmost exactly hemispherical in shape, their height and cliameter being the same, - three inches. They were suspended from low bushes, longing from the extreme ends of the twigs, among which the nests wore fastened by fine inpucted masses of wood-mosses, which are very nicely and elaborately interwoven with the lower portions of the outer covering of the nest. The latter is composed of a singular medley of varions materials, among which may be noticed broken fragments of dry leares, bits of decayed wood and bark, coarse blandes of grass, rarious vegretalble fibres, lichens, fragments of insects, mosses, straws, stems, ete. These are all wripped romul and firmly bound together with strong hempen fibres of regetables. Within this outer envelope is an inner nest, mate of the funer stems of grasses and dry needles of the white pine, firmly interworen. For the size of the bird, these nests are proportionally larger and deeper than any others of the common linds. The carity is two or two and a half inches deep.

The eggs are usually five in number. One from Georgia measures . 77 by .55 of an inch, and is of an oblong-oral shape; another, from Massachusetts, is much more broadly orate, measuriug .80 by .62 . Their greatest breadth is .65. of an inch, and their length . 80 . They have a clear crystal-white ground, spotted about the larger end with fine dark-purple and reddish-brown dots.

This species is one of the most common foster-parents of the Cowbird, the eggs of which are always tenderly cared for, and the offspriug nurtured by them, always to the destruction of their own nestlings.

Vireo huttoni, Cassis.

\section{HUTTON'S VIREO.}

Virco huttoni, C.sssix, Pr. A. X. šc. Phila. 185), 1,50 (Monterey, Cal.). - Iı. 1852, pl. i, fig. 1. - B.1111, Birls N. Am. 1858, 339, pl. 1xxriii, lig. 2; lier. 357. - ScLatri, P. Z. S. 1858, 302 (Oaxaca) : 1862, 19 (La Parada). - In. Catal. 1861, 358, no. 256. - Cuoper, Orn. Cal. I, 1570, 121.

Sp. Cnar. (No. 3,725.) First quill rather less than half second, which ahout equals the tentls; thirel a little longer than serenth; fourth and fifth nearly equal, and longest. Tail slightly ronnded, shorter than wings. Bill vary small.

Above olive-green: brightest hehind, espereially on rump and elging of tail, duller and more aslyy towarels and on top and sides of lorad and neck. Wings with two bands on corerts, and outer edges of innermost secondaries rather broadly oliraceons-white; other quills edged externally with olive-green, paler towards onter

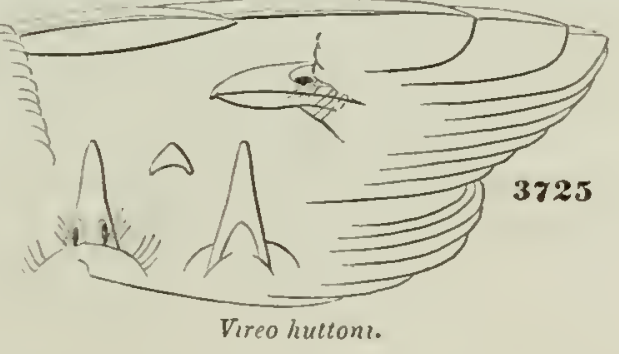
primary; internally with whtısh. Lateral tail-feather edged externally with yellowishwhite. Feathers of rump with much concealed yellowish-gray. 


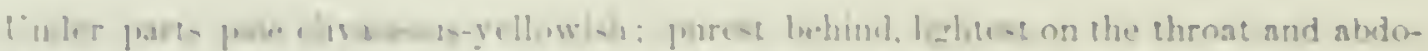

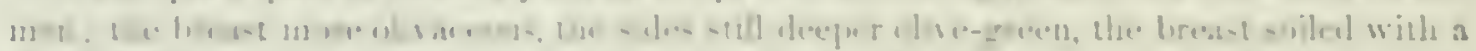

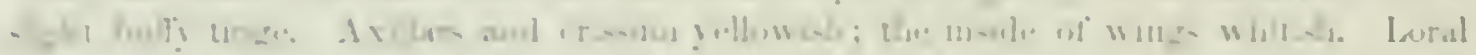

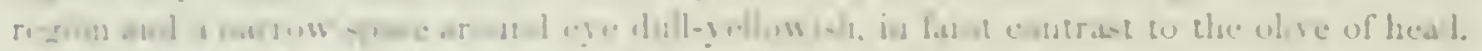

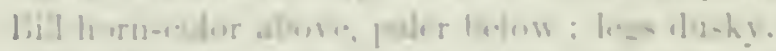

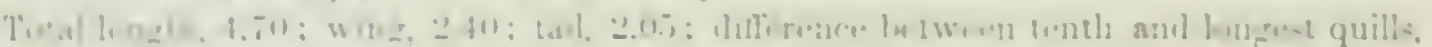

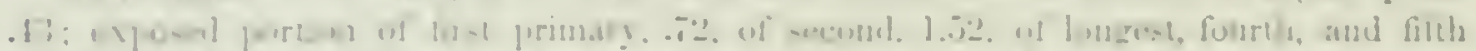

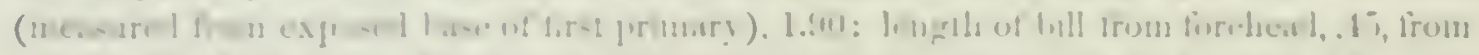

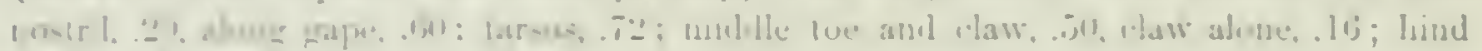

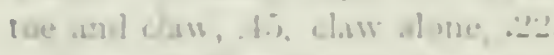

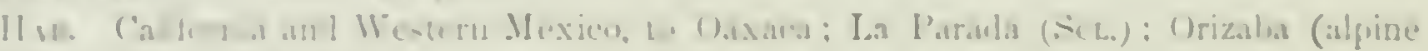

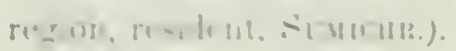

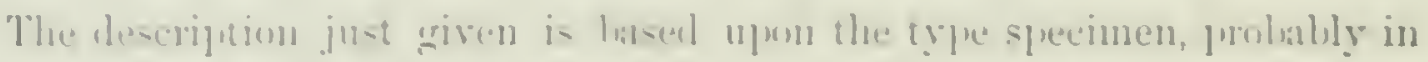

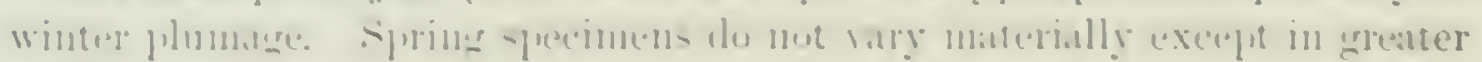

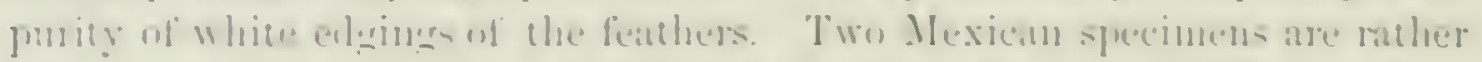

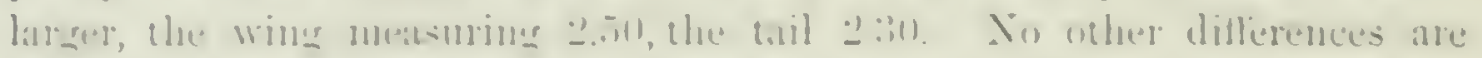

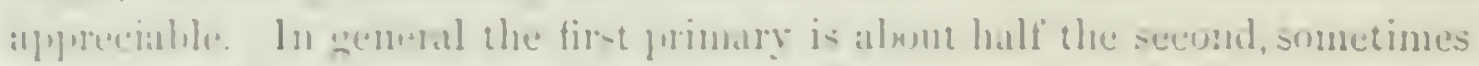
ritlier len.

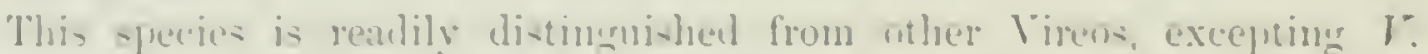

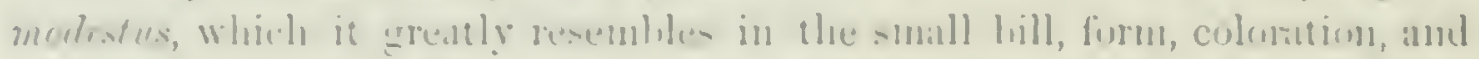

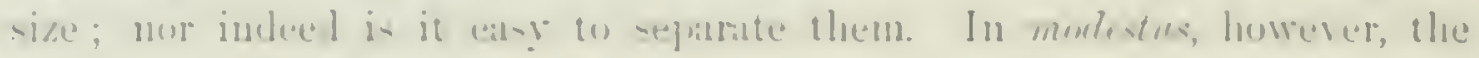

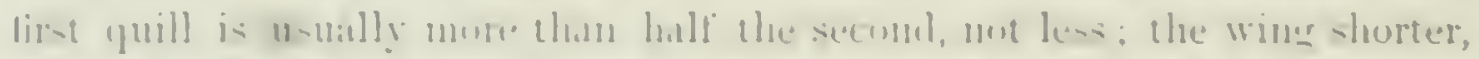

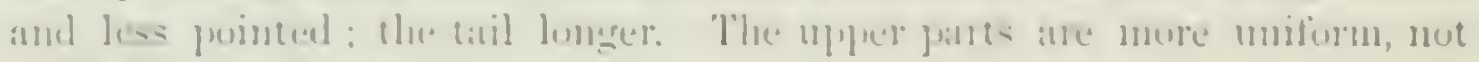

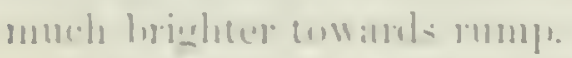

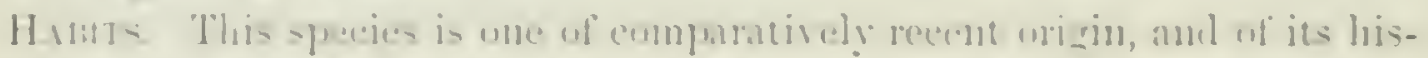

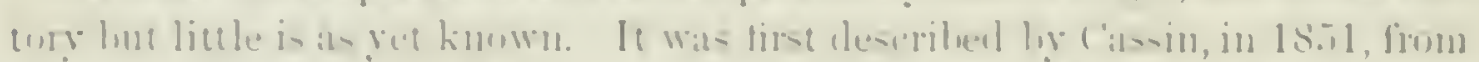

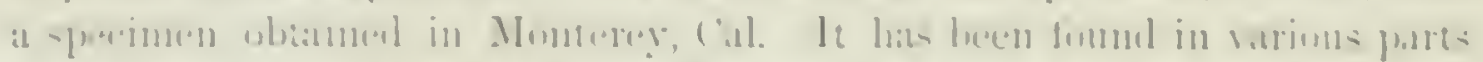

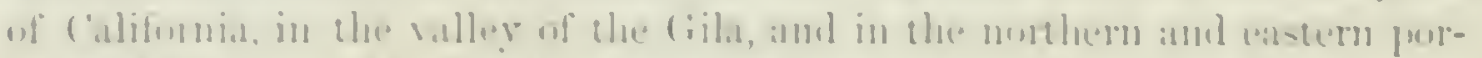

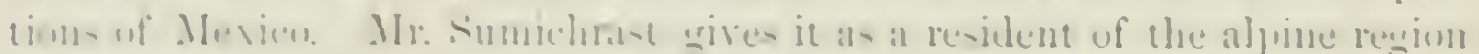

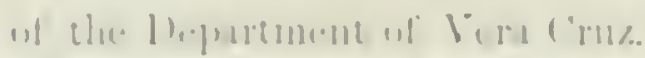

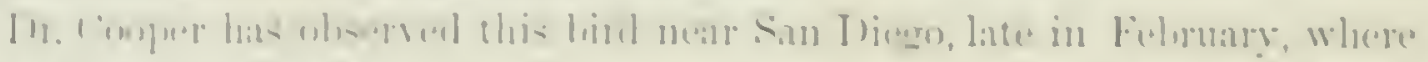

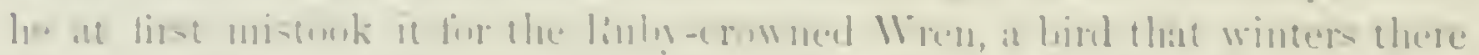

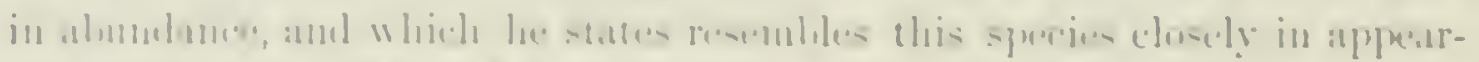

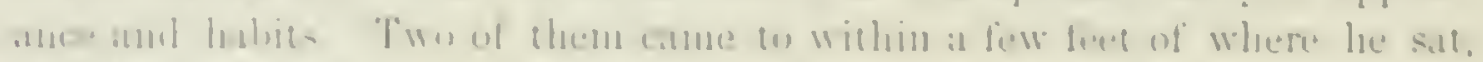

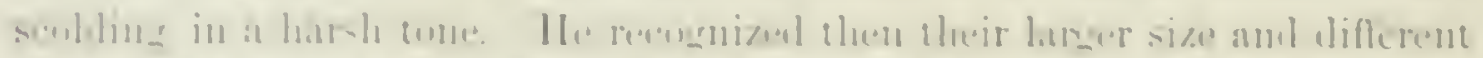

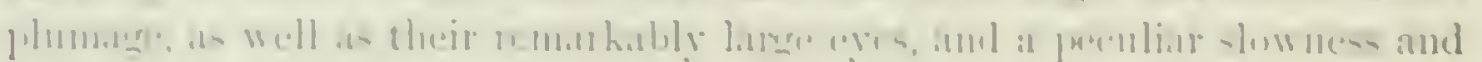

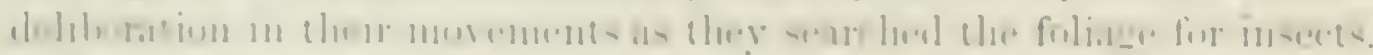

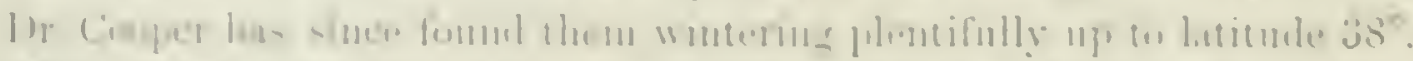

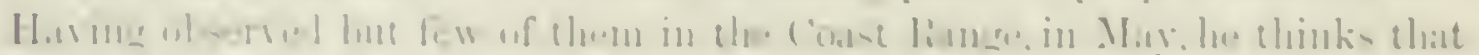

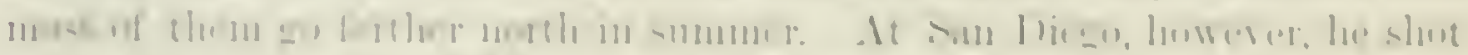

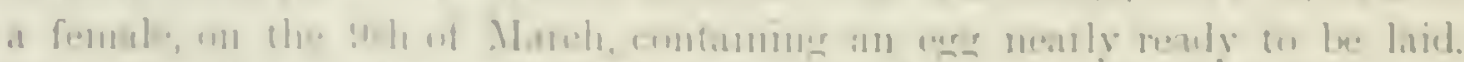

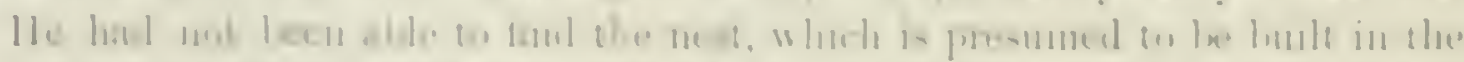

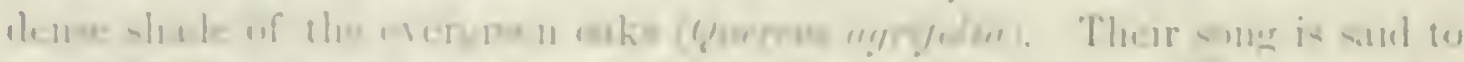

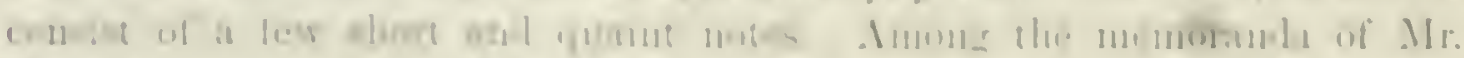

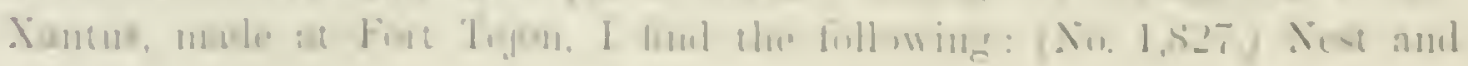


eggs of Vireo huttoni, found May 8, one foot from the ground, under ligh trees, suspended from three high stems of weeds, fastened to them, but very loosely put together. The eggs had been incubated. He furnished no further description of nest or eggs.

Vireo belli, AuD.

BELL'S VIREO.

Vireo belli, Aro. Birds Am. VIl, 1844, 333, pl. cccelxxxy (Missouri River). - Cassix, Pr. A. N. Sc. Phila. 1851, 150. - Batm, Birds N. Am. 1858, 337; liev. 358. Sclater, Catal. 1861, 42, no. 258. - Box. Consp. 1850, 330. - Cuop'si, Orm. C'al. I, $1870,123$.

Sp. Cuar. (No. 1,926.) Above olive-green, brightest on the rump; tinged anteriorly with ashy; the top and sides of head ashy; in faint contrinst. A line from nostriks to cyo (scarcely beyond it), and eyelids very pale yellowish-white; lores dusky. Under parts, including imer wing-eoverts, and cdge of wing, creany-white; the sides, axillars, and crissum pale yellow (sides of lower neck and of breast glossed with olivaceons, faintest on the longer feathers of the latter. Two rather narrow bands on the wing-coverts, and the outer edges of junermost secondaries white; the

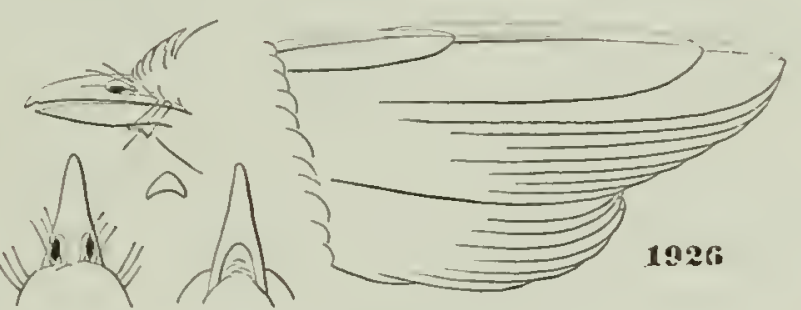

Vireo belli. other quills edged with faded olivaceons. Inner edges of quills whitish. Tail-feathers brown, edged externally with olive; internally finling into paler brown. Meclian portion of rump feathers concealed with pale rellowish. Bill horn-color above, pale below. Legs plumbeous. "Iris brown."

First quill spurious; not quite half the second, which is about equal to the eighth; third and fourth quills longest; fifth scarcely shorter. Tail nearly even, or a little rounded, the feathers narrow.

Total length, 4.20 ; wing, 2.18 ; tail, 1.20 ; tarsus, .75

HAB. United States, from Missouri River to base of Rocky Mountains; Telunantepec, Mexico (October, Sumcirast); Missouri (Hoy); Iowa (Allex); Sonthenst lllimois (RIDGWAY).

The above description is taken from a type specimen received from Mr. Andubon, and represents the average spring plumage. Antumnal slins are rather brighter, and there is occasionally an ocluaceons tinge on the white of the under parts.

This species at first sight appears like a miniature of $V$. gilv"rs, the liead being almost exactly similar. The back is, lowever, much brigliter olive, the sides and crissum deeper yellow. The superciliary light stripe is shorter. The white markings of the wings are wanting in gilurs. 'The wing, tail, and feet are entirely different in their proportions.

Habits. This species was first procured by Mr. Andubon's party in the excursion to the Yellowstone River, in what is now known as Dakota 'Ter- 


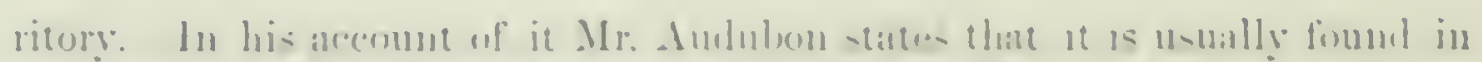

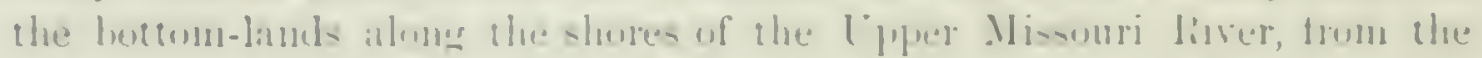

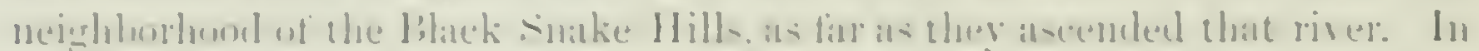

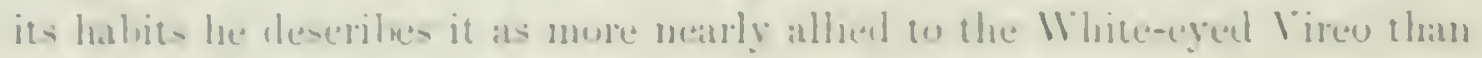

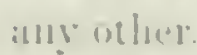

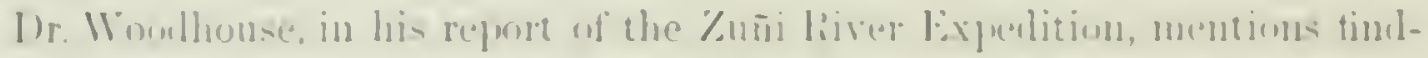

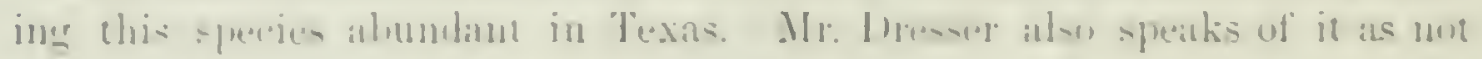

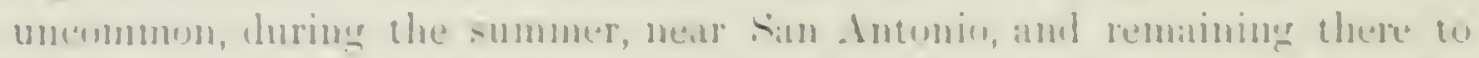

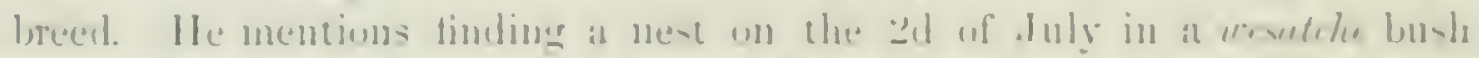

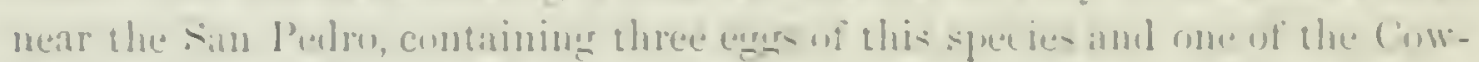

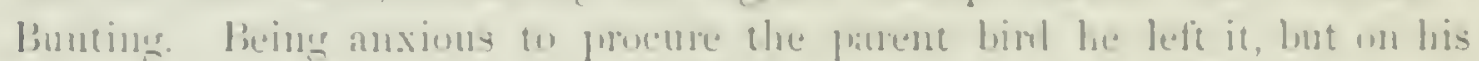

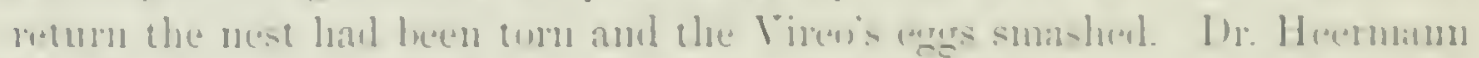

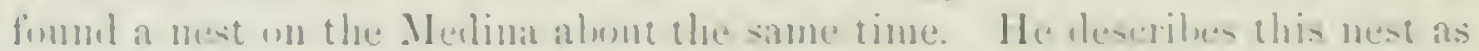

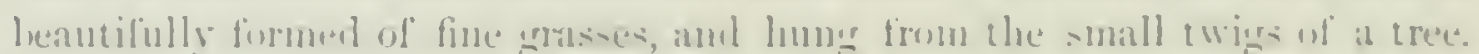

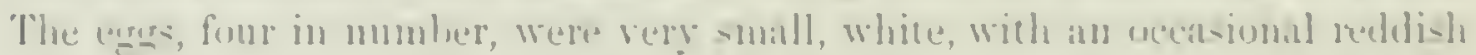

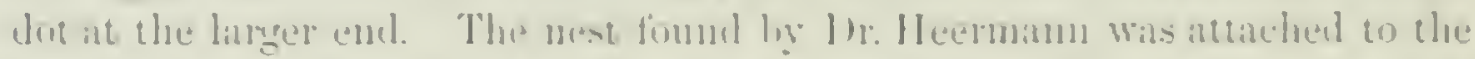

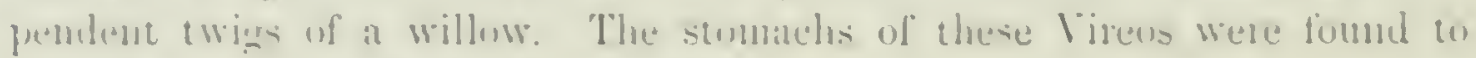
contain sumbll areen raterpillars.

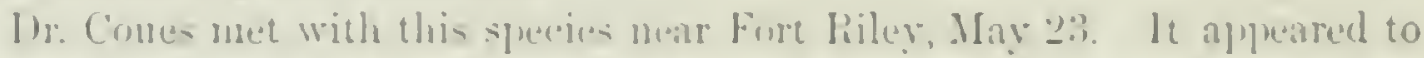

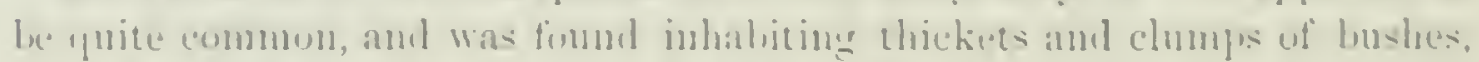

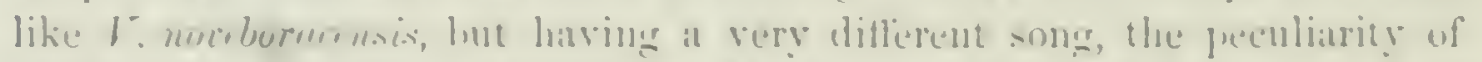

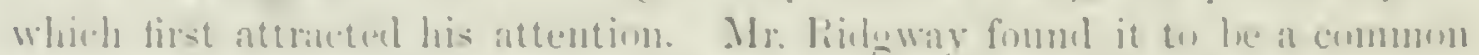

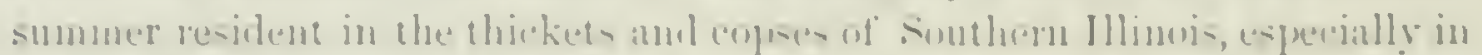

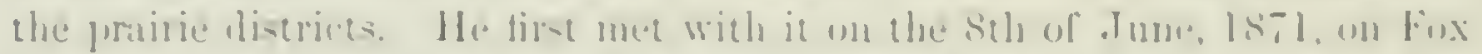

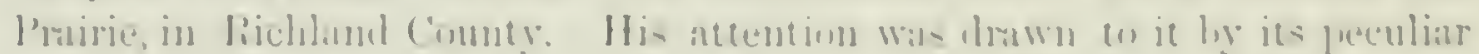

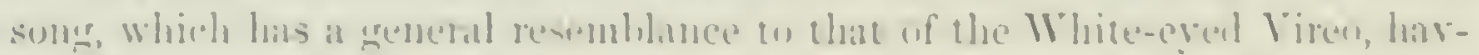

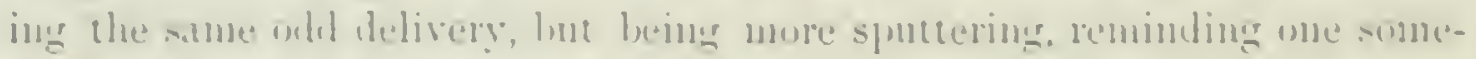
what of the sulls of Truglonlytes arlont

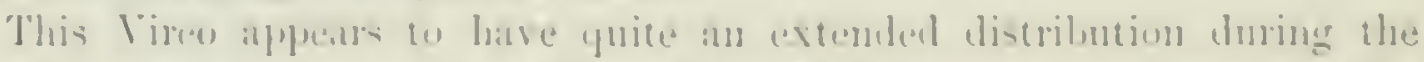

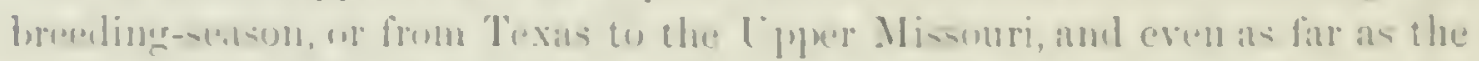

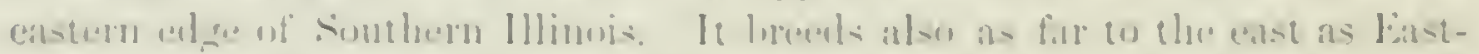

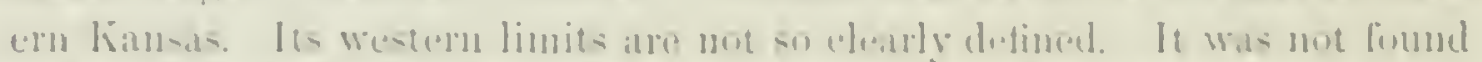

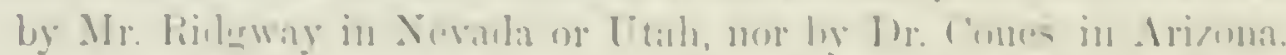

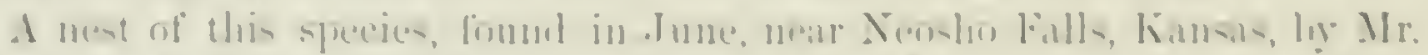

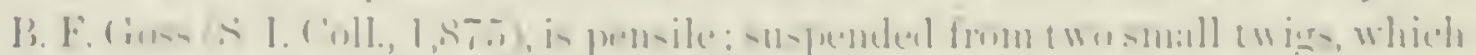

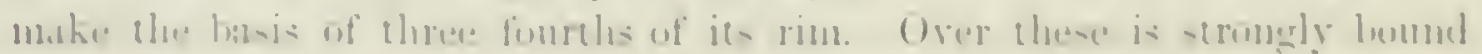

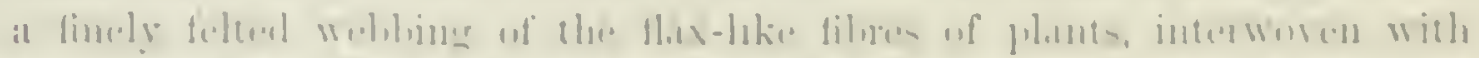

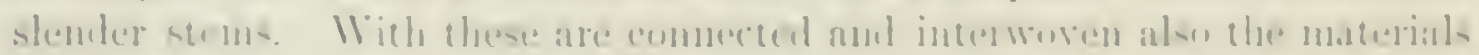

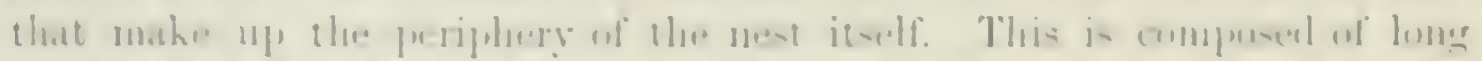

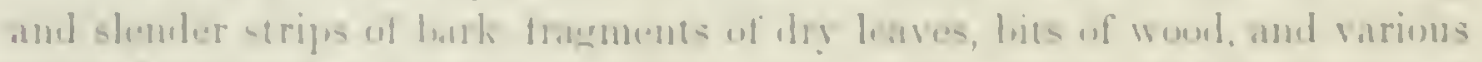

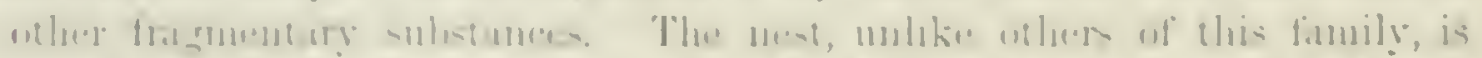

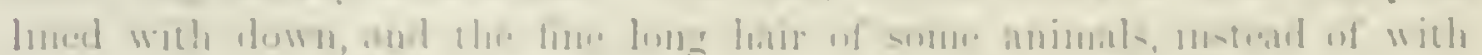

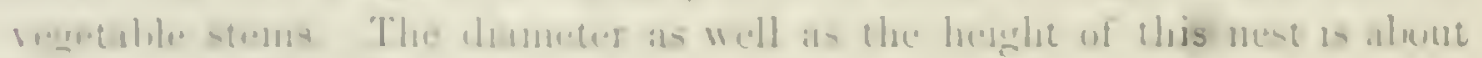
imo and is half Imelis. 
Another nest from West Texas, obtained by Captain Pope, is essentially different in its general characteristics. It is three inches in dianeter, and but one inch and three quarters high. The opening is circnlar, hut only one and a half inches wide. Below the rim the cavity widens until it is two and a half inches in diameter. 'The onter nest is made up of' an interwearing of fine strips of bark and dry leaves, intermixed with and firmly bound around by strong flax-like fibres of different plants. Within, it is lined with fine flexible grasses and stems of plants.

The eggs of this species are from .73 to .76 of an inch in length, and from .52 to .56 in breadth. They are pure white, sparingly spotted with fine red dots distributed around the larger end.

\section{Vireo pusillus, Coues.}

\section{LEAST VIREO.}

Virco pusillus, Coves, Pr. A. N. Se. Phila. 1866. - Bandi, hev. Am. B. 360. - Eulot,

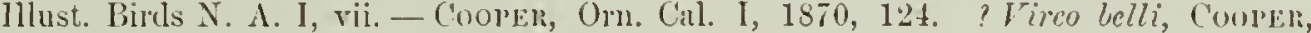
Pr. CaI. Acad. 1561, 122 (Fort Moliave).

Sp. Cuar. Somewhat similar in general appearance to Vireosylvin gilva and swainsoni, but smaller. Bill very small; tarsi lengthenel. Wincrs abont equal to the tail, which is lengthenel, gracluated, and with the feathers narrow and pointed. Exposed part of first primary about hialf that of the second, whel is intermediate between seventh and cightl ; the fourth and fifth longest.

Above gratyish-ash, with a tinge of olive behind. Beneath, including the inside of the wings, white, with : soiled tinge on the sides of the throat and across the breast. Axil-

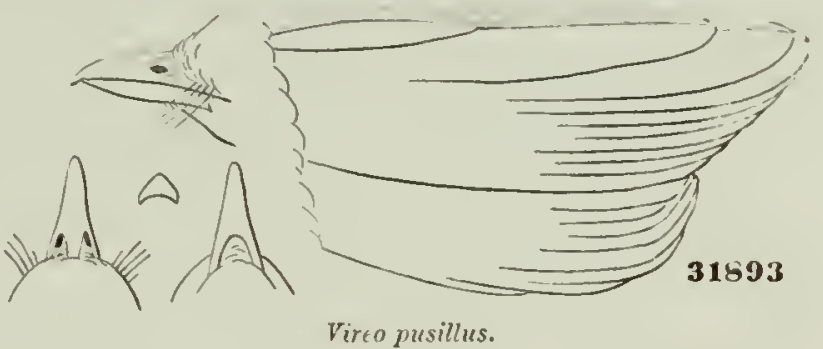

lars and flanks exhibiting a faint trace of greenish-yellow. Eyclids and a short line from the nostrils to the eye whitsh; no other stripe apparent. A dusky loral spot. l'rimary coverts edged indistinetly with whitish, moducing an obscure band (a second on the middle coverts harlly appreciahle). Quills amd tail-feathers edgerl extemally with pale grayisholire, the imemost scondaries with whitish. Bill dusky above, whitish beneath. Lees: plumbeous. Iris of two specimens matred as "light brown," of another as " "ufous."

The detaik of stumeture taken from No. 23,785, of culor from No. 23,788: Length, of $23,785 \pi, 4.80$ when fresh, of skin, 4.25 ; wing, 2.25 ; tail, 2.25 ; bill above. .37; tarsus, .73 ; mirldle toe and claw; .50; hind toe and claw, .42. First quill, .70; sccond, 1.40; longest (fiftli), 1.6t. (Caj)e St. Lucas.)

IIAB. Cape St. Lucas; San Diego; Fort Ilolıve, and Arizona; Sacramento, California (RIDGWar).

This species scarcely needs comparison with any other, except, perhaps, $V$. pallens of Midlle Ameriea, which, however, besides belonging to Virconella, and not Vireo, as restricted, differs in many minor, but no less essential points. The coloration of the two is remarkably similar, but pusillus has 
only one indi-tine band on the wine, instual of two sharply defined ones.

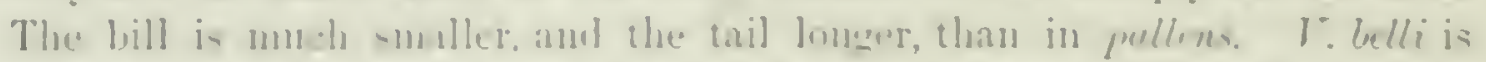

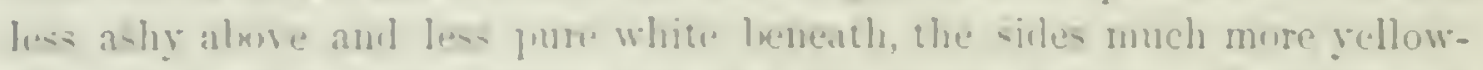
is l, the wine is alse longer, and the tail much shorter. $l$. ririnior is much larer, with the wing longer than the tail, instend of shorter: the ash alove has a bhish imsend of at greenish east; the loses are wholly grayishwhite, e.i.

Homis: The lanst Viren is a recently dereribed species of its gemus, and one in resard to whoe history complaratively little has Ineen ascerained. It

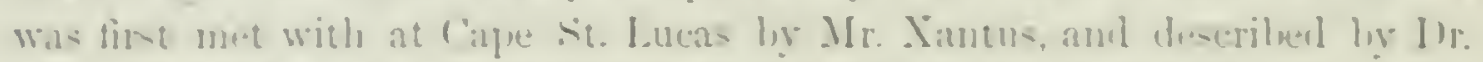

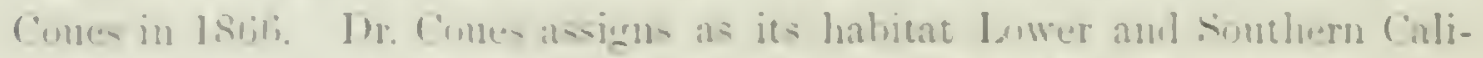

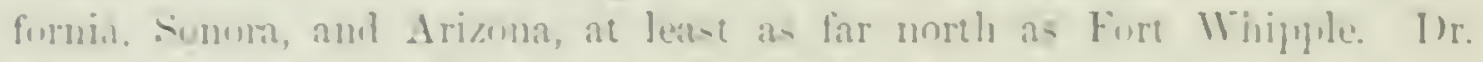
Cooper alow found it at Fort Mnhave. Ir. Cones met with it fifty miles sonth of Fort Whiplle, where he fonnd it lmenline atmulantly. He crives mo information in reand to its habits. Dr. Couper states that he fonnd it mother

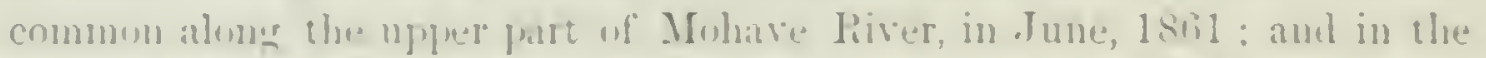

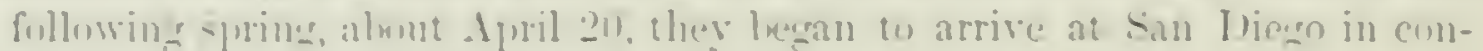

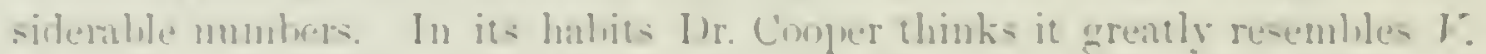

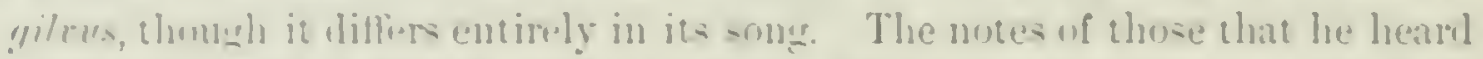

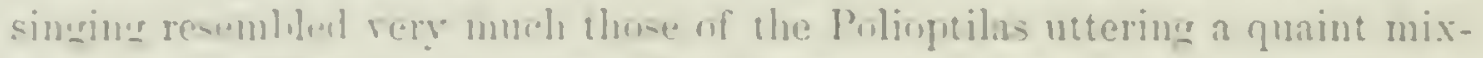

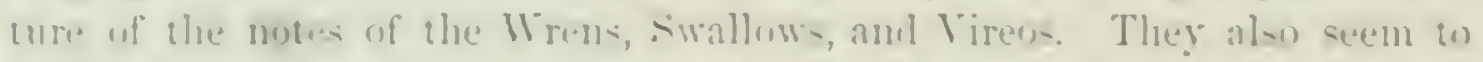
juntess mure ur leas of initative powers. At sacramento he saw and heard,

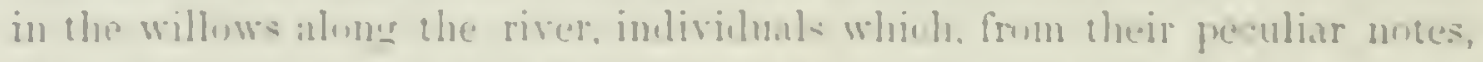

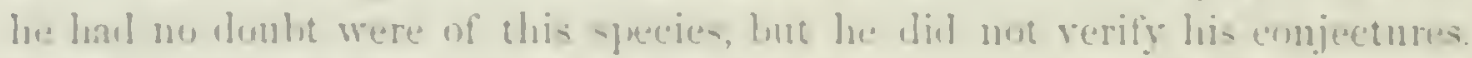

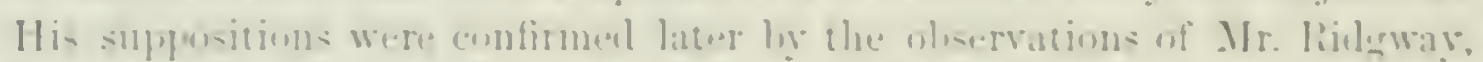
who states that he formd there birls the most almutant as well as the mot

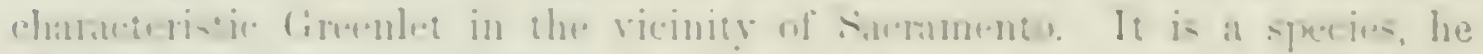

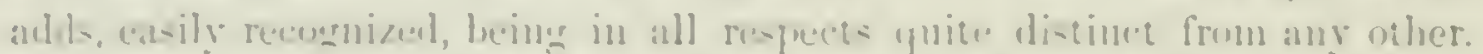

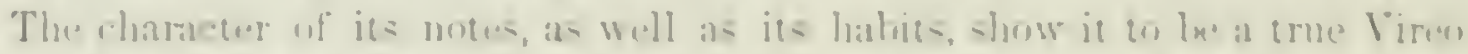

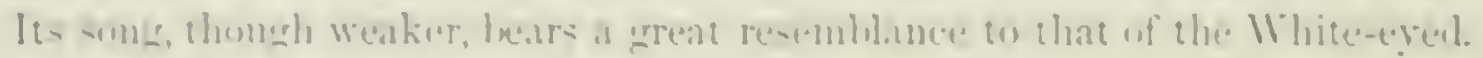

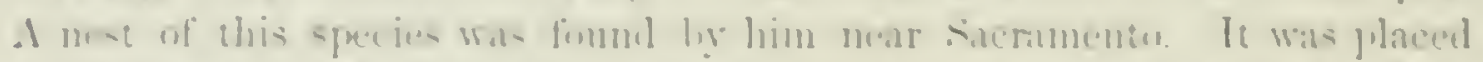

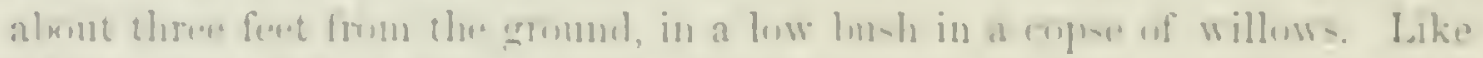

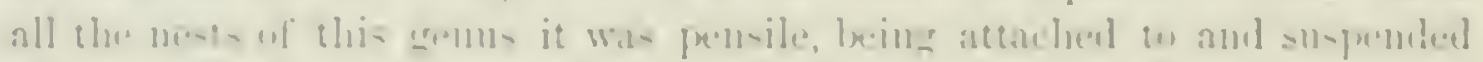
from the twign of a ham h.

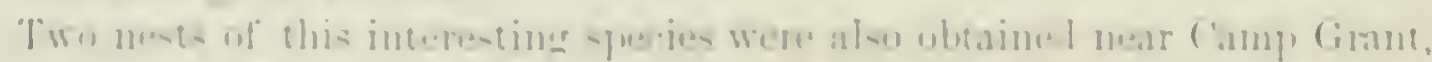

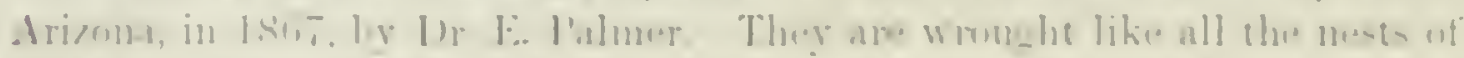

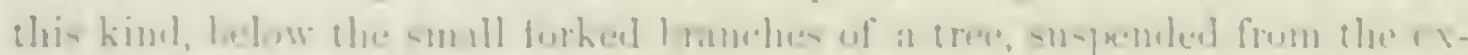

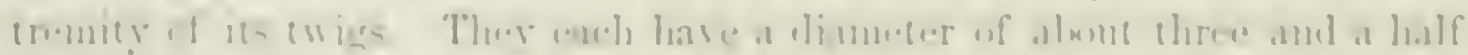

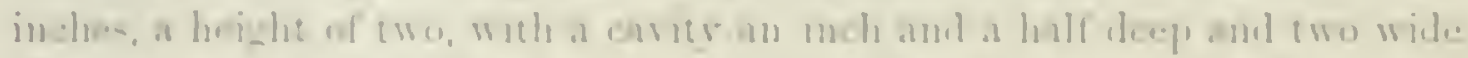

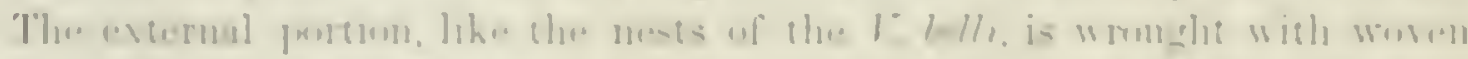

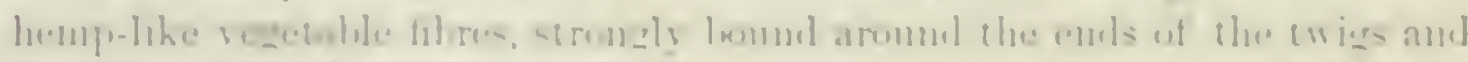

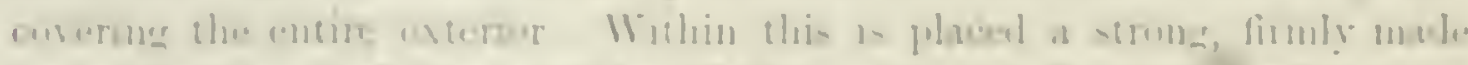

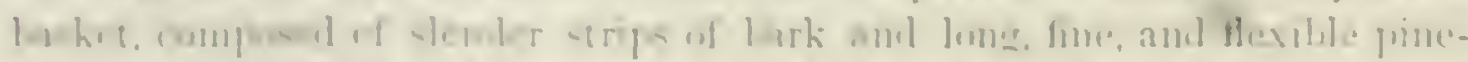

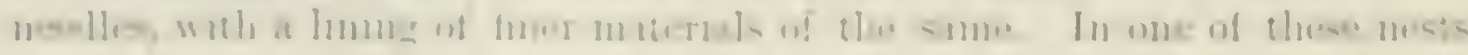


there rere three eggs of the Vireo, and one of a Molothrus (obscurus?). The former were of a bright crystalline whiteness, marked with very minute and hardly discernible spots of red, and measure .69 by .56 of an inch. The egg of the Molothrus, except in its much smaller size, is harlly distinguishable from those of the common $M$. pecoris, and measures .75 by .56 of an inch.

In the other nest were also three egrss of the Vireo. They correspond in size, but are much more distinctly marked with larger spots of a dark red and reddish-brown. In this nest there is a somewhat larger proportion of fine strips of inner bark, and mixed with these are also a few silky insect cocoons, by means of which the nest is firmly bound around the twigs from which the whole is suspended.

\section{Vireo vicinior, Couts.}

\section{ARIZONA VIREO.}

Virco vicinior, Coces, Pr. A. N. Se. Phila. 1866. - Barnd, Rer. Am. B. 361. - Eiluot, -Illust. Birds X. A. I, vii. - Coopris, Orn. Cal. I, $1870,125$.

S. Cпrar. (No. 40,697 §.) Bill stont. considerably compressed and deep. Wings moderately pointed, about equal to tail, which is decidedly graduated; first quill rather more than half the second, which about equals nintls and the secondaries; the fonth and and fifth longest. Tarsus considcrably longer than mirldle toe and claw: lateral toes quite conspicuous for their clisproportion, the inner claw reaehing only to base of outer, and falling short of base of middle; the terminal digit of inner toe reaching only to end of seeond joint of middle tne.

Upper parts, will sides of head and neck, ashy or light plumbeous, faintly olivaceous on rump. Beneath white; slightly ashy on sides of breast. Flanks and inside of wings showing a faint trace of yellow, only appreciahle on raising the wings. An obsolete line from bill to ere, and a more distinct ring round the eye, white.

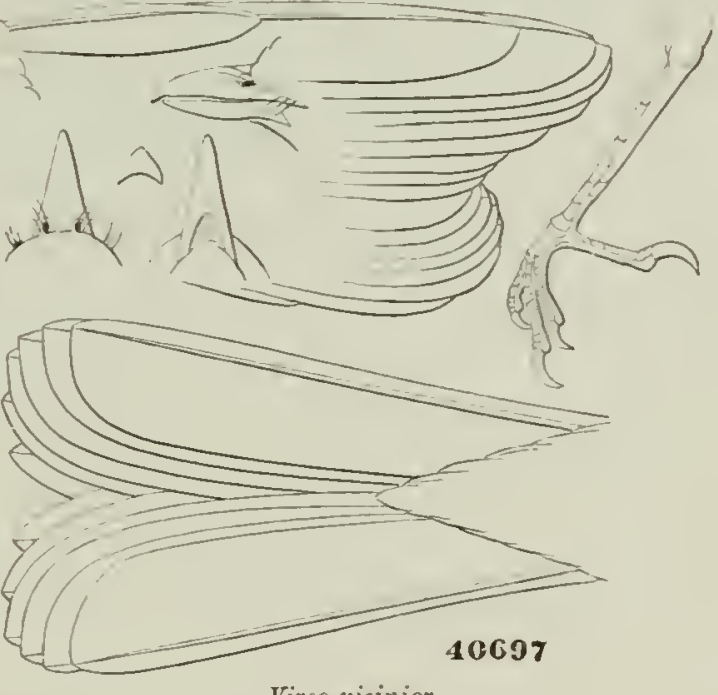

Vireo ricinior

No bands on the wing, exeept a faint edging of whitish on the greater corerts; the quills edged internally with white. Bill and legs plumbeous. "Iris brown. Mouth hivid, bluish-white." (Covrs.)

Fresh specimen: Total length, 5.60; expanse of wings, 8.60. Prepared specimen: Total length, 5.10; wing, 2.50: tail, 2.60, its graduation, .22: difference of tenth and longest quills, .40; exposed portion of first primary, .85, of second, 1.65. of longest (measured from exposed base of first primary), 1.95; length of bill from forelread, .50 , from nostril, .32, along gape, .61; deptl of hill, .18: tarsus, .72; middle toe and claw, .51 , claw alone, .16; hind toe and claw, .40, claw alone, .19.

HАв. Prescott, Arizona. 
This species might at fir-t siolit le alien fir a -mall specimen of 7 . plumbens, the colors, characier of lill, ete., Ineing very simblar, excegi that the whe

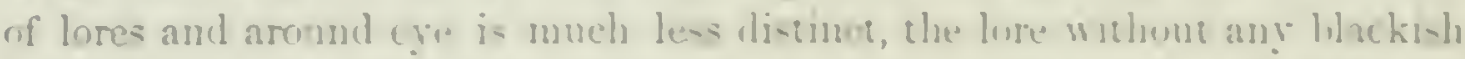

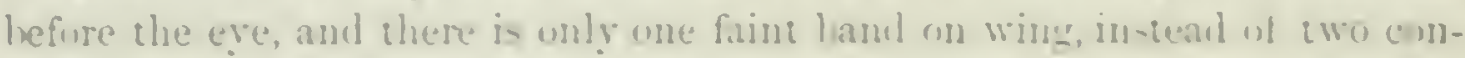

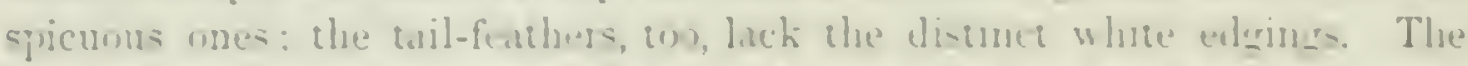

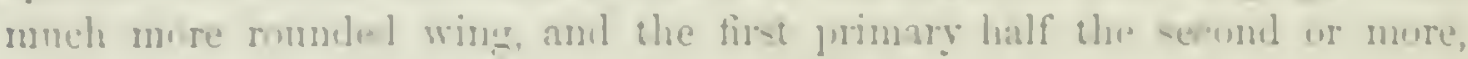
will, however, realily disingui-h them. The form of the him is very mueh

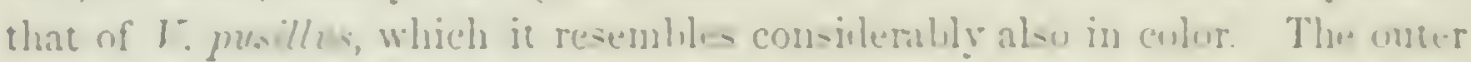
quill is, however, lomger, the bill deejer and more compresed, the inner lateral twe con-illembly -horter, and the size laner. The enlur-are purer, without the olive of the hack or the vellowish of the umber part-; the libll, tens, is entirely durt plumberus, im-teall uf horn-color. Whiti-h lemeath. From I. pullens it is distinguished by a smaller, darker lill ; longer toil and wing: one wing-hand, nut two: and pumer colurs.

HaBITs. In regarl to the habis of this well-marted but very mre specien lut little is as yet knnwn. It was fir-t dererilkel, in lstit, ly. Ir. Contes. from a single specimen olianed by him near Fort Whiple, Arizona. It

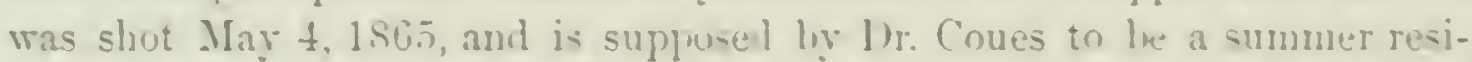
dent of Arizona wintering in the Cila and the Lower Colomdn Valleys, or in Sonor. 


\section{Family AMPELID仺. - The Chatterers.}

The characteristics of the Ampelide have already been presented in the symopsis of allied families; chief among them, the short, broad, depressed, and triangular bill with short gonys, the deeply cleft mouth, the short tarsus, and the tendency to subdivison of its lateral plates.

The South American genus, Dulus, probably torms the type of a subfamily Dulince, characterized by the much arched gape of mouth, the metatarsal scutellæ in two series, and the body streaked beneath, as in young Ampelis. The. two other subfamilies may be defined as follows: -

\section{Subfamilies.}

Commos Characters. Gape of mouth nearly straight. Metatarsal scutellæ in three series. Bacly plain beneath.

Ampelinæ. Wings very long and much pointed, longer than the short, even tail. First primary excessively rudimentary; the outermost about the longest. Gape without bristles. Frontal feathers extending forwarl beyond the nostrils.

Ptilogonatinæ. IIorny appendages like red sealing-twax at end of shaft of secondarie.. Wings rounded, shorter than the graduated tail. First primary nearly half the second. Gape well bristled. Frontal feathers falling short of the nostrils. No red horny appendage to wing-feathers.

\section{SUbFanily A M PELIN 屆。}

Cinar. Legs moderate. Nostrils elongated, linear, with the frontal feathers extending close to the edge and to anterior extremity, concealing them; these featlers sloort, relrety, and erect, witlı few bristles. Wings very long and acute; outer or first primary so much reduced as to he almost inappreciable; the second nearly the longest. Wing nearly twice the length of the short, narrow, even tail. Under corerts of tail reaching almost to its tip. Secondary quills with flat horny appendages at end of shaft like red sealing-wax. Young birds streaked benently as in Dulus. Adults plain.

Of this family as restricted, we have but a single genus in America.

\section{Gexus AMPELis, Lisx.}

Ampelis, Lisx. Syst. Nat. 12th ed. I, 1766, 297. (Type, Lanius garrulus, L. Named Linnæus in 1735.)

Gex. Char. Tail even. Tertials and secondaries with horny appendages like red sealing-wax. A well-dereloped soft crest.

A more elaborate diagnosis of this genus could be readily given (see Rev. Am. Birds, 404), but the above characters, as entirely peculiar, will serve to establish it. 


\section{Species.}

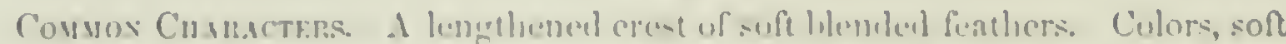

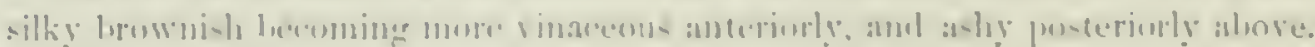

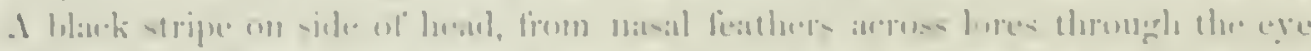

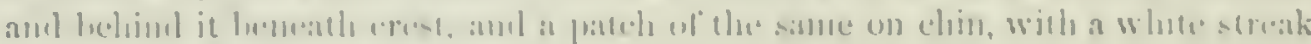

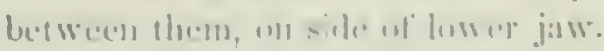

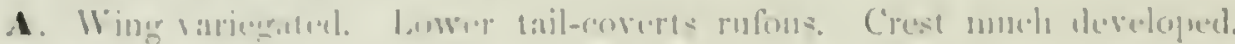

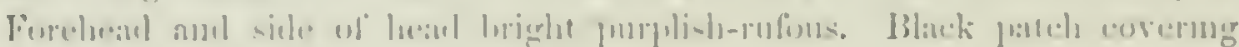

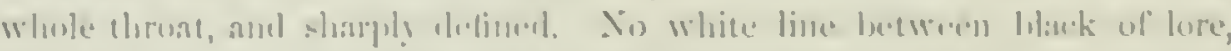
"ete, and brown of forchesul. Inner webs of prinaries tippenl narrowly with white.

a. Terminal band of tail reml.

A. phonicopterum.' liwnter enverk tipped with reel, producing

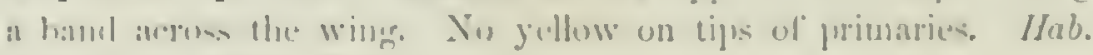

Japnan sut bistern siberia.

b. 'Trominal hame of tail rellow.

A. garrulus. Seromlanive and primary coverts tippeil with white,

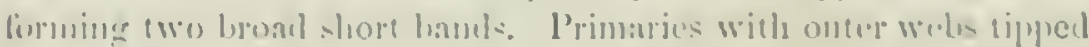

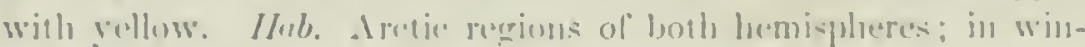

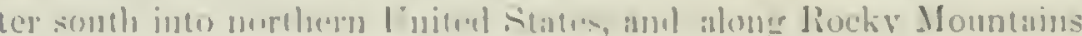

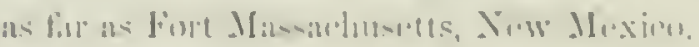

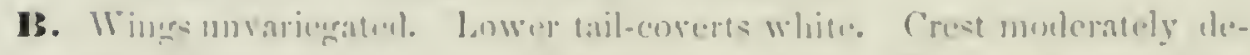

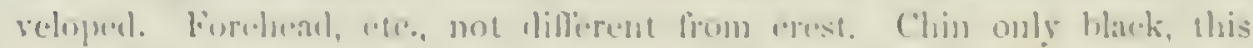

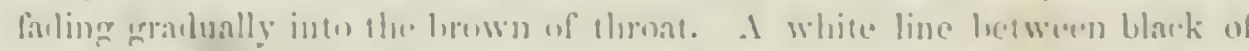
lore, ed.., and bown of foreluanl. Inner webs of primaries not tipped with white.

a. Terminthl hatul of tail yellow.

A. cedrorum. Whing bluish-ashy. IJab. Whote of Xorth Amer-

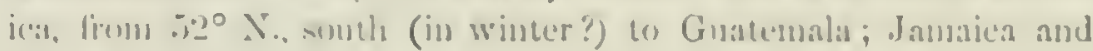
Culat in winter.

\section{Ampelis garrulus, Iox:}

\section{NORTHERN WAXWING; BOHEMIAN CHATTERER.}

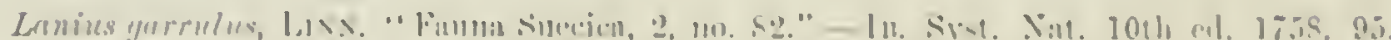

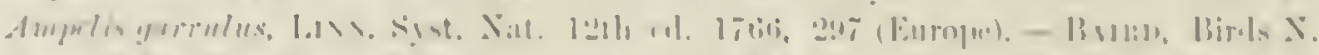

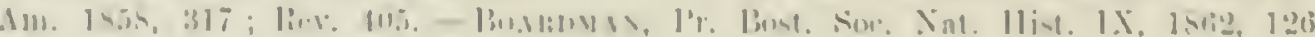

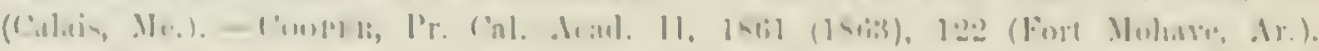

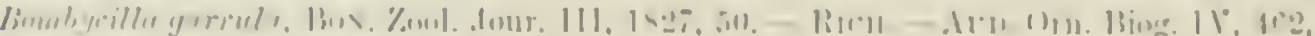

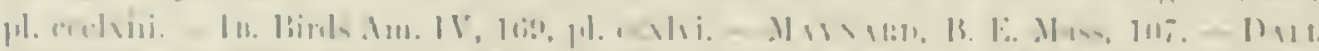

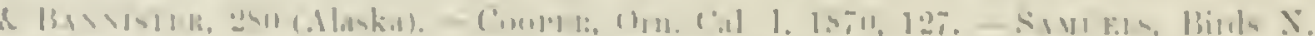

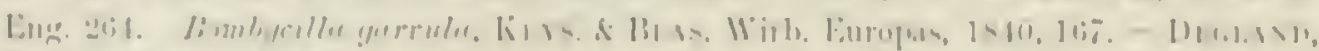

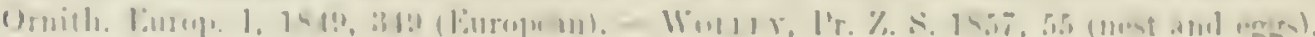

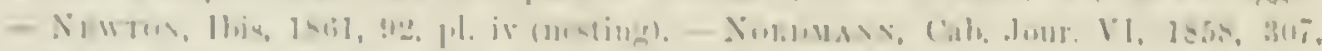

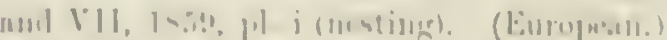

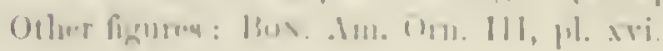

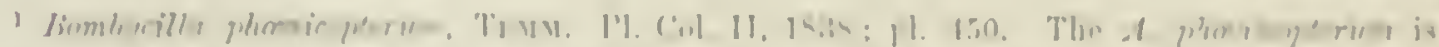

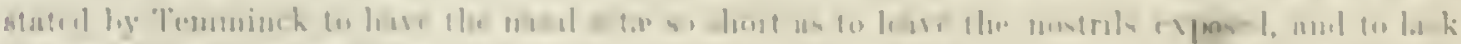

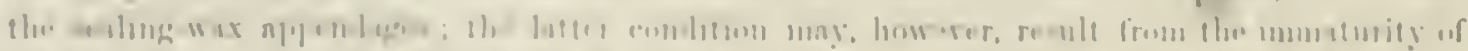

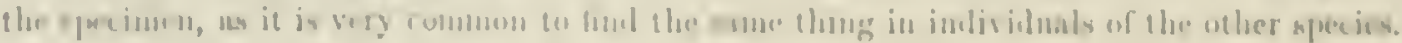


Sp. Cuar. Crest lengthened. Body generally soft, silky brownish-ashy, with a purplish east, the wing-corerts and seapulars more bownish, becoming more redtish anteriorly and ashy posteriorly: the rump and upper tail-coverts. as well as the secondaries, heing vearly pure ash. Interiorly the color frasses gradually into deep vinaceous-chestnut on the foreheal to behind the ere and on the cheeks: abtomen rellowish-white. Lower tail-corerts deep chestnut. I stripe on sile of the head, covering the lores and nasal feathers (scarcelv meeting acros the fordead). involving the eve and eontinued back toward the occiput and beneath the crest, with a large patch covering the chin and throat. deep black; a narrow crescent on lower evelid, and a short stripe between the black of

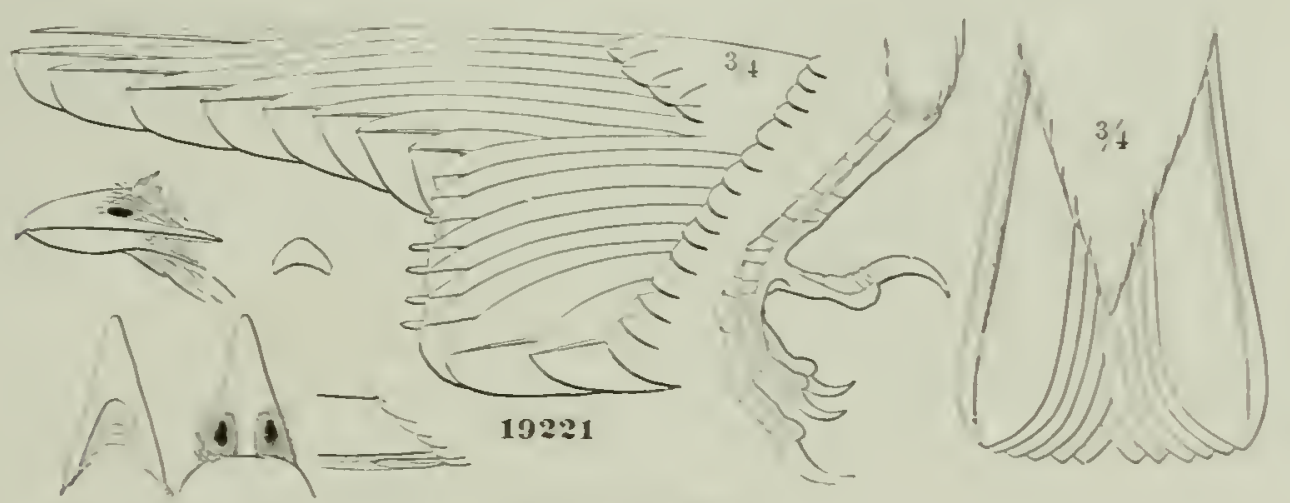

Ampelis garrula.

the throat and that of the chin at the base of the lower manlible. tro rerr broad bars on the wing, one across ends of nrimary coverts, and the other across ends of serondaries (the first occupving both webs. and the latter the onter). white. Primary coverts, primaries. and tail slaty-black. the latter growing gratually ashy bnsally. A brond band across end of tail. and a longitudinal space along end of outer web of primaries. gamboge rellow. the marks on primaries, however, sometimes white. only stained with yellow. Each of the serondaries with an expanded continuarion of the shaft, in form of flattened, rers thin, somewhat elliptical appendages of a bright vermilion-red resembling red sealing-wax. IVale with the white of outer web of primaries continued around ent of inner webs also. Female without white on terminal edge of imer webs of primaries, and with the "sealing-wax" appendages smaller. Foung not seen. Length, T.t0; wing. 4.50; tail, 3.00 .

Hab. Torthern parts of Europe. America. and Asia. In America not hitherto found in the Pacific Province. In winter extending along the Rocky Mountains and the Plains as far sourh as Fort Massachusetts and Fort libley: recular visitor to shores of Labe Michigan and Lake Erie. East of this rarely seen along the Luited States border. Fort Mohave (??) (COOPER).

The specimen seen by Dr. Cooper, at Fort Mohare, if really of this species, fixes the most western locality on record.

For many years authentic egors of the Bohemian Chatterer were greatly sought after, but it was not until 18.56 that any were bronght to the notice of the scientific world, when the late Mr. H. Wolley discovered them in Lapland. Early duplicates from his collection were sold at five guineas each, and although a good many have since been obtained, they are ret considered as great prizes. A nest, with its egrgs, of those collected by $\mathrm{Mr}$. Wolley, has been presented to the Smithsonian Institution by Mr. Alfred Newton. The only instances on record of their discorery in America are of a nest and one egg by Mr. Kemmicott, on the Iukon, in 1861, and a nest and single egg 


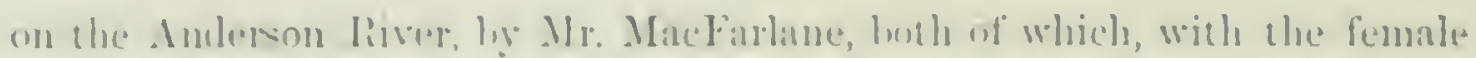

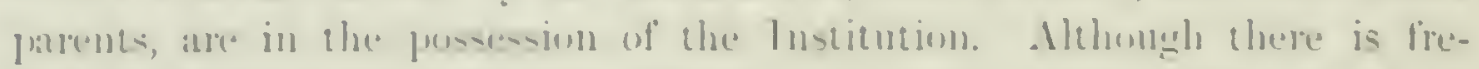

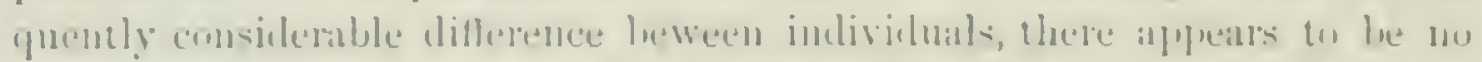
ditlerence lnetwerest those from the two conthents.

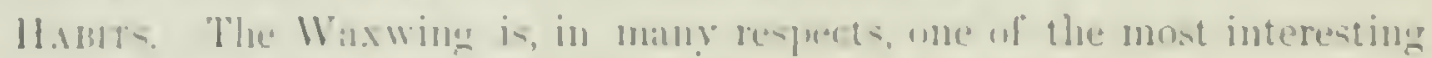

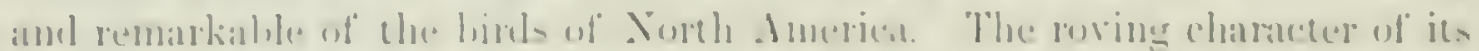

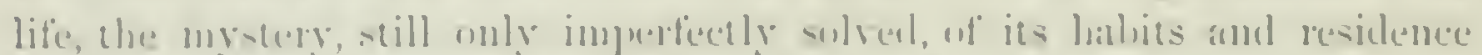

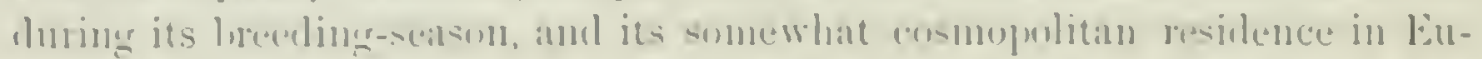
rope, $\lambda$ sist, and America, imprate to it an interes that allaches to hut few

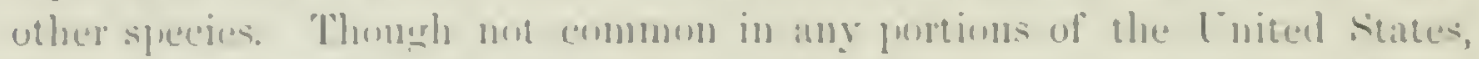
and whly appestring att all huring midwinter, yet in the mone methern states, in which it is oecilsionally fomml, it moves in smeh lame flecks, and is so

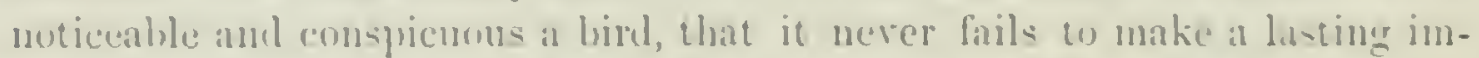
pression, amb harlly secems to 11 so very mos as it undoubtedly is.

In a single instance, in midwinter, somewlere alout 1844 , during a sovere

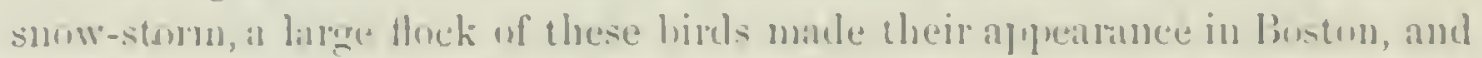
alighteel on a lange horre-chestmut tree that stoml in an open and retired place. There were at least twenty or thirty in the flock; they remainet in

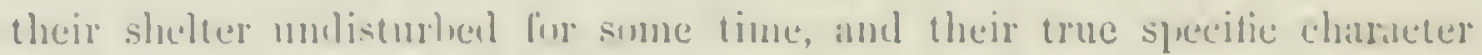
Wats glainly moticable.

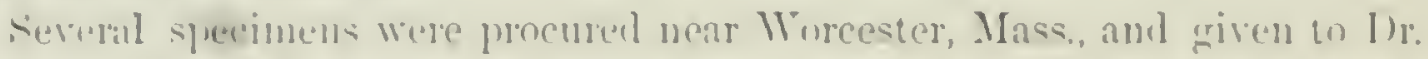

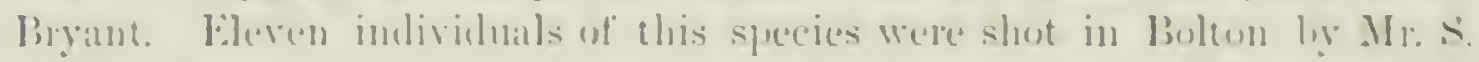

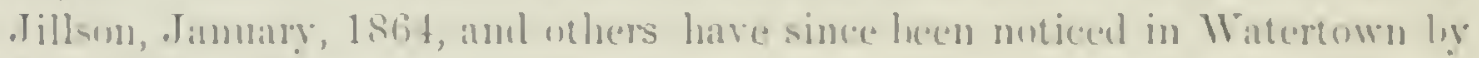

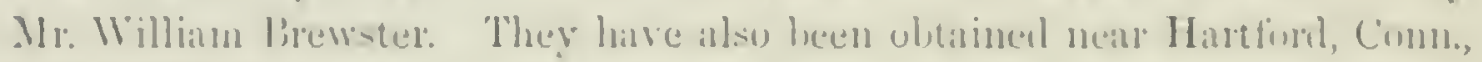
l, Dr. Wroml.

Jrior on this, as Mr. Amhulum states, sperimens land heen procured near

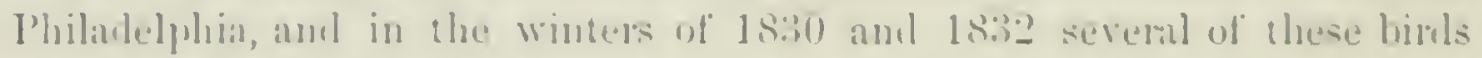

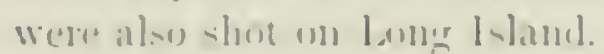

Mr. Inamlunan mentims that they are oceasional, in winter, near Calats : and l'mlenson Verrill, whes diel not neet with it in Norway, Mee, cites it ats alceidental and rare in the statu.

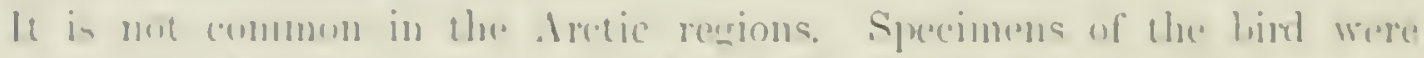

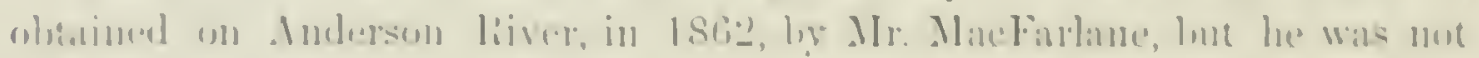

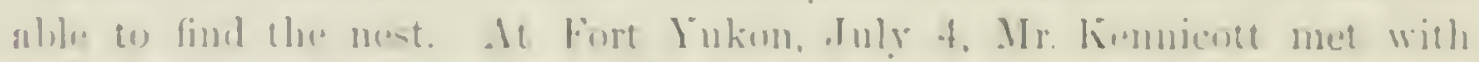

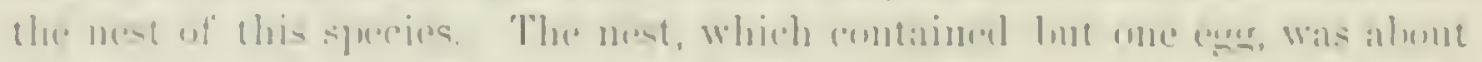

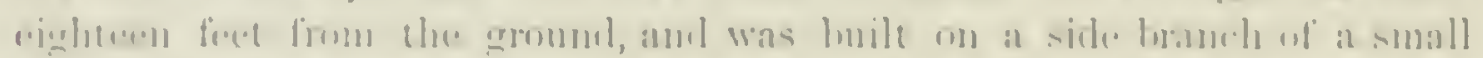

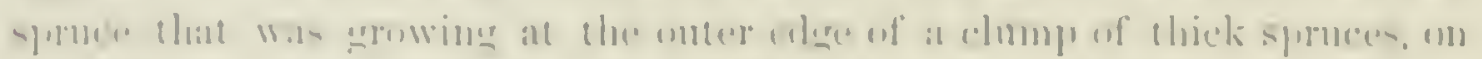

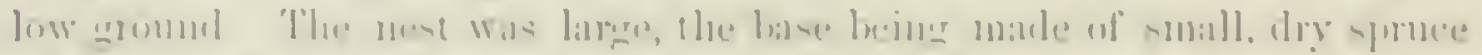

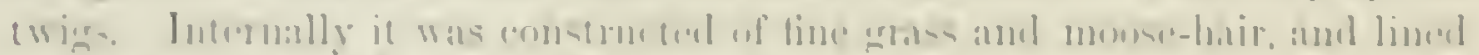

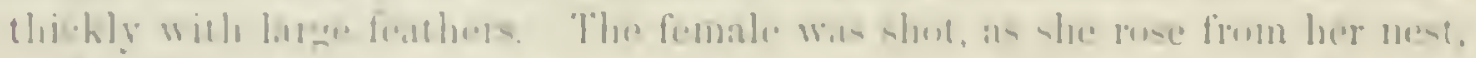

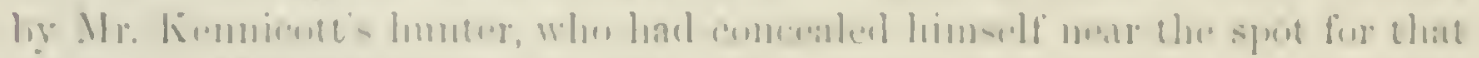

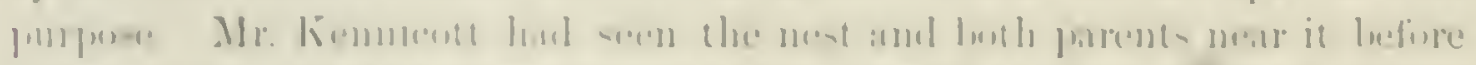

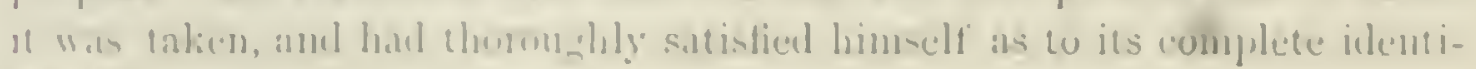
[1r., linl]. 
Ross spealis of them as not rare throughout the district in which they winter, but yet not numerous. He adds that at Great Bear Lake they are very plentiful, and that they are reported to nest there. Mr. Iall states that they were quite common at Nnlato, where they did not arrive before June 10 , or later. He obtained a number of skins from the Indians, talien in his absence. He adds that it breeds, and its egrgs have been obtained at Fort Yulion.

Except in a few instances, where Dr. Cooper noticed this species, in September, at Fort Laramie, and also when he obtained an individual on the Coloralo, none of these birds have been seen west of the Rocky Mommtains. The bird obtained by Dr. Cooper was, in his opinion, a strargler from some neighboring momtain. It made its appeallance January 10, after a period of stormy weather, and was shot while feeding on the berries of the mistletoe.

This bird was first noticed in America, in the spring of 1826 , near the sonrces of the Athabasca River, by Mr. Drummond, and in the same season by Sir John Richardson, at Great Bear Lake, latitnde 65. In the latter region he states that they appeared in flocks about the 24 th of May. At that time the spring thaw had exposed the berries of the Arbutus and the Tucinium, that had been covered during the winter. It stayed only a few days, and none of the Indians knew where it bred, or land ever seen its nest. Afterwards, early in May, 1S2 $\bar{\tau}$, Sir Juhn Richardson saw a large flock of three or four hundred indivirtuals at Cinlton House, on the Saskatchewan. They all alighted in a grove of pophars, on one or two trees, making a lond twittering noise. They stayed only about an hour in the morning, and were too shy to be approacher within gunshot.

In England they have been known to appear as early as August. They are always shy, and not easily approached. In their activity and incessant change of position and place, they are said to resemble the Titnice. They feed on the berries of the mountain-ash, the hawthorn, and the iry. They will also feed on insects, catching them as dexterously as Flycatchers. Their callnote is a single chirp, frequently repeated.

Mr. MeCulloch, writing to Mr. Audubon, gives a touching account of the devotion shown by one of these birds to its wounded mate. The latter had been so crippled that it was hardly able to move. Its mate stationed itself on the top of the tree in which it had songht shelter, and with great rehemence contimually nttered the notes tzes-tze', in alarm and warning, and, when danger approached, flew anainst it and urged it on to flight, and stayed to share its fate, rather than leave its partner.

The nest and eggs of this species remained entirely unknown until the spring of $185 \tilde{6}$, when the late Mrr. Joln Wolley, an enthusiastic English oölogist, first discovered them in Lapland. The season was musually backward and cold, and the nests contained their full complement by the 12th of June. One of the nests, obtained in Finland, June 19, 1861 (S. I., 5,327), 


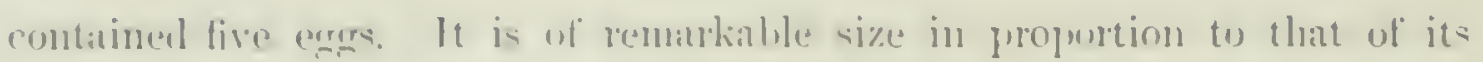

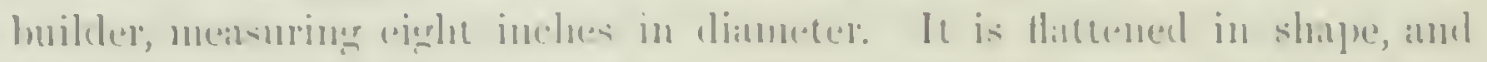

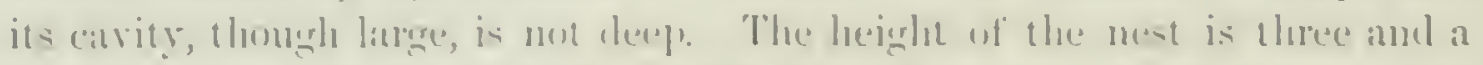
quarter inderes, and the dephth of the lase is fully two and a half inderes. The (avity is less than an inch deeph, and is four inchess in dianneter: The base

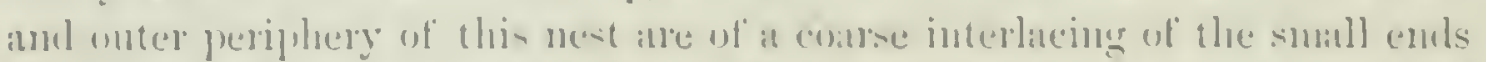

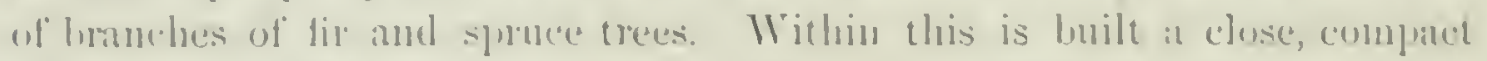

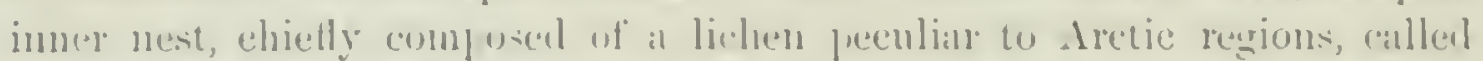
tree-hair, which handes abundantly from the branches of trees in northern

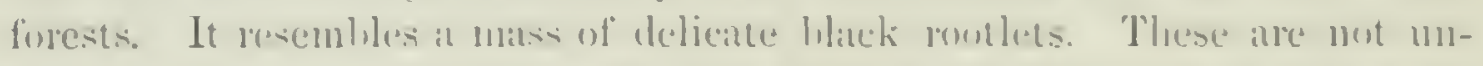

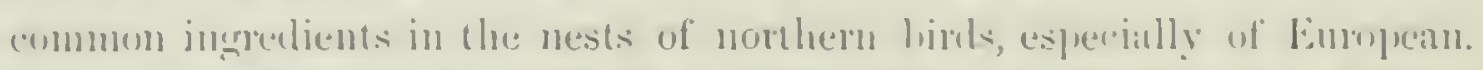

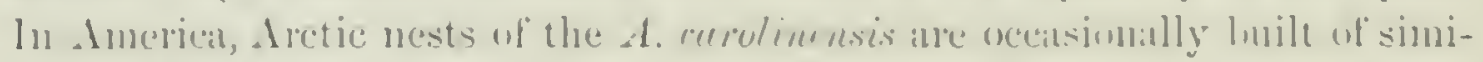
litr materials. With these liehens are also mingled fingments of dry leares amb soft datk-culored musses. The rin of the nest is strungly made, almost pechnsively of these fine dirk-colored lichens. This kind of lichen is men alwilys hlick, but is often hrown, and even whitish. ha some of these neste silvery filmes of grass-leaves are mingled with the lichens, and in one or two there is a slight lining of peathers.

The Laplinul mests were built on the branch of a tree, at a distance from

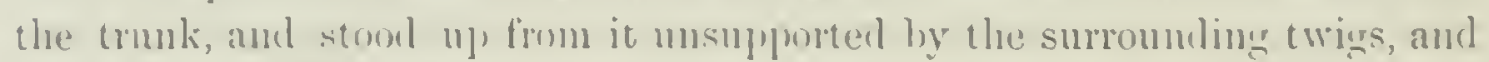
at the height of from six to twelve feet from the grouml. They were gener-' ally much exposed, and were, for the must part, built in the more open prortimis of the forrests. The general number of the egrgs was five, in one instinnce it wis six.

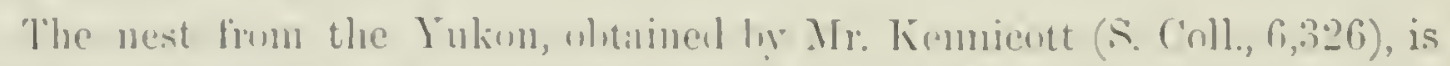

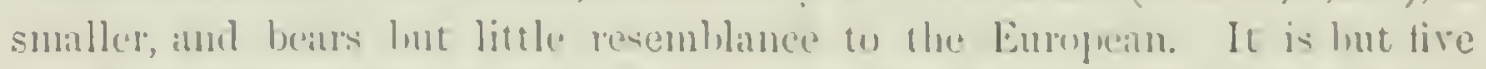

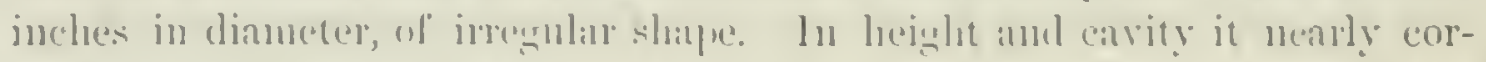
responds. In plice of the lichens of the linroperan, this nest is mate of fine

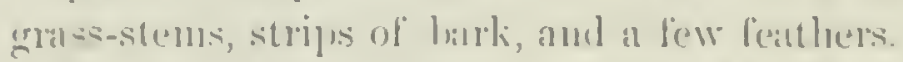

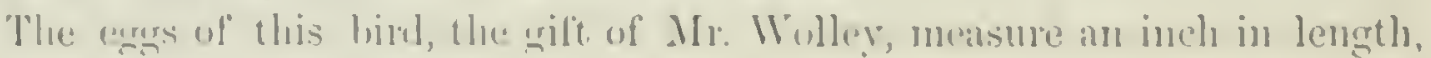

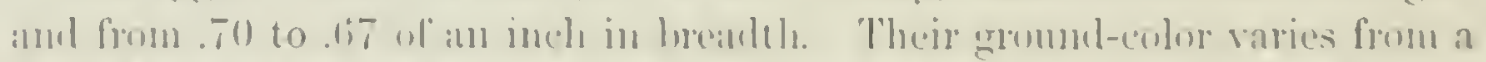

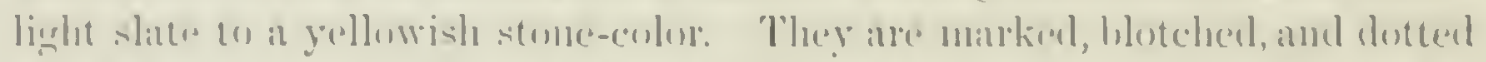

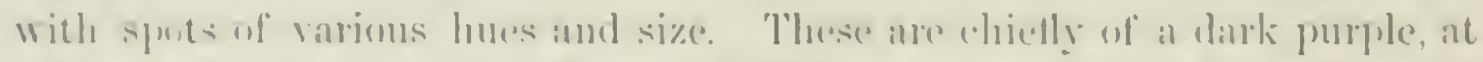

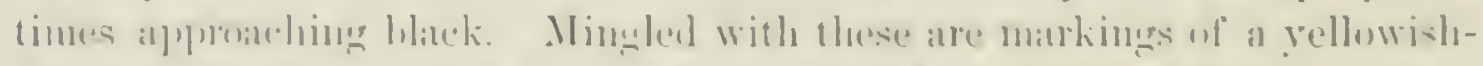

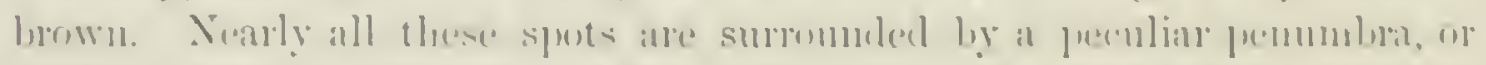

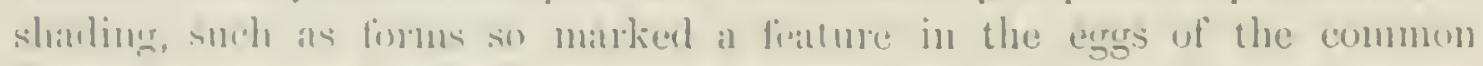
Corlar-liard.

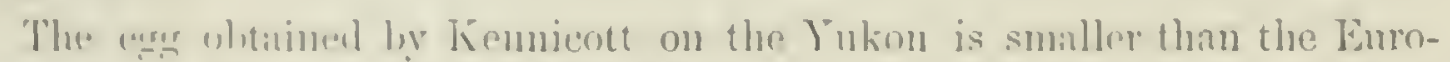

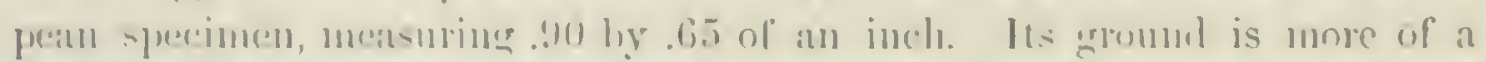

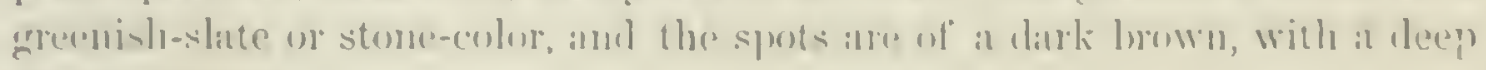
violet shinding. 


\section{Ampelis cedrorum, ScL.}

\section{SOUTHERN WAXWING; CEDAR-BIRD.}

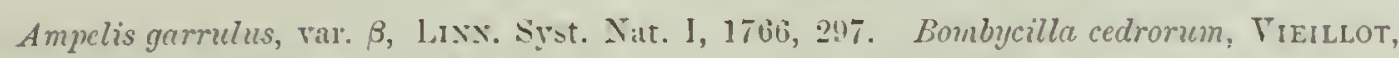
Ois. Am. Sept. I, 1s07, ss, pll. Irii. - IB. Galerie Ois. I, 1\$34, 1S6, pl. cxriii. - CAB. Jour. IV, 1S56, 3 (Cuba). - Gixnlach, Cab. Jour. 1Só1, 32S (Cuba; rare). Ampclis cediorum, Scldter, P. Z. S. 1856, 299 (Cordura); 1858, 302 (Oaxala ; January) ; 1859,

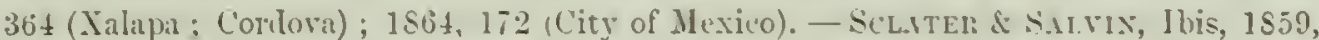

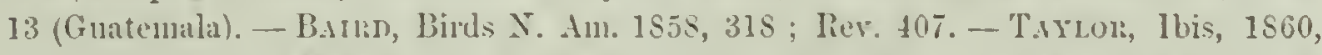

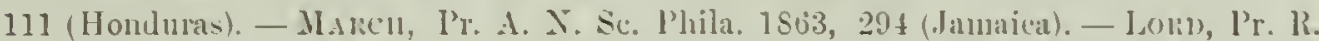
Art. Lnst. Woolwich, IV, $110^{\circ}$ (British Columbia; nesting). - ('nopke \& StCkLEY, P. R. liep. XII, แ, 157 (Wallington Ter.). - Cooreli, Orn. Cal. I, 1870, 129.-

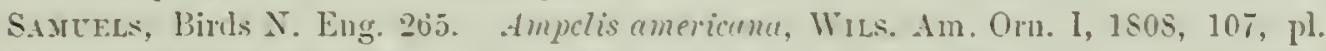
vii. Bombycilla americuna, Josks, Nat. Bermula, 1559, 29 (winter). - lirer. Bom-

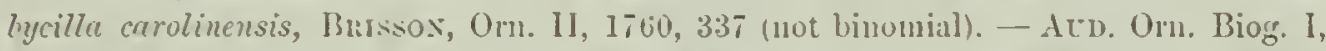
1\$31, 227, pl. xliii. - IB. Birls An. IV, 1\$42, 165, [1. cexlv. - WAgLer. Ampclis

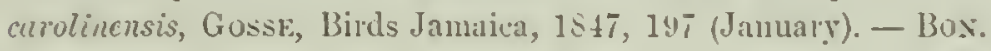

Sp. Crisn. Crest moderate. Creneral culul soft vinaceons-cimamon, derepest anteriorly, more olivaceous on back, scapulars and wiurr-coverts, passing into pure liegt ash on the rump and npper tail-corerts, and into dingry rellow on thanks and abdomen. Lower tail-

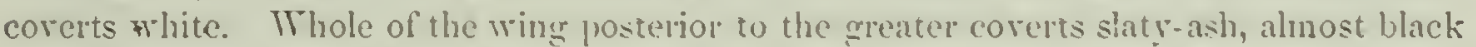
along end of inner webs of primaries, the outer wehs of which are narrowly edged with hoary whitish. Tail slate pasing into hlack terminally, tipper with a broal. sharply defined band of gamboge-rellow. I broad stripe of intense relretr-black on side of head, starting from nostril, passing across lore, and involving the cye, continued from it beneath the erest to the oceiput; elin dull black. blending gladually into the bownish of the throat. A narrow white line across the forehearl and along side of crown, between brown of erown and black of lore, ete., a narrow reserent on lower eyelid and a stripe between black of lore and that of the throat. white. Whle with uach secondary quill terminated by a bright red horny ippendage to the shaft. Female with these very small and few in number, or entirely absent. Tonny. In general appearanee similar to the atult female. Colors mor gravish, with obsulete coneraled whitish stroaks on nape and down back. these stripes becoming rery comspicums on the siles and flamlis and aeross breast. No black on elin. Rump erayish-hown; abromen and flanks diugy whitish. No appendages to secondaries, and the yollow band across end of tail narrower than in arlult.

HaB. Whole of North Aneriea as far north as Lake Winnjueg and Hudson: Bay, south branch of Saskatchewan, latitude $522^{\circ}$ (Rumsusos); south to Guatemala: Jamaica and Cuba in winter.

A specimen from Guatemala (No. j0,455 $\delta$ ) is almost identical with examples from the United States, but differs in having a small spot of yellow at the tip of each primary: also there are red appendages on the tip of a few tail-feathers, as well as the longest feather of the lower tail-coverts. The colors, generally, are softer, the brown more purplish, and the ash finer and more bluish, than in a fine spring male from Washington, I). C.

A specimen (No. 53,396 o , Humboldt River, Nevada, September 10, 1868, C. King, R. Ridgway) from the Middle Province of the United States, differ's considerably from any other in the collection. The color's are much paler, the anterior portions being ahnust ochraceous, the whole abdomen 


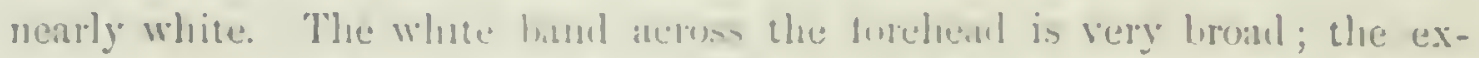

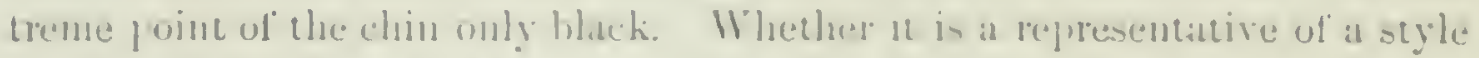

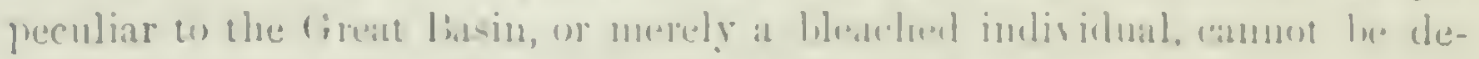

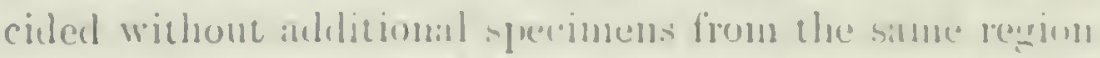

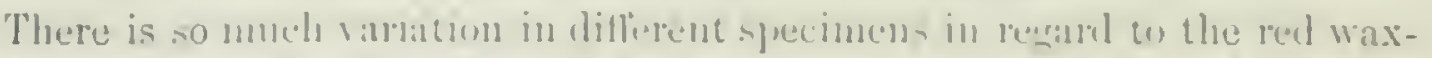

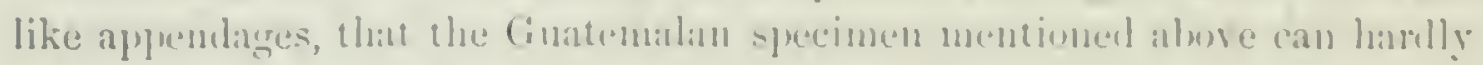

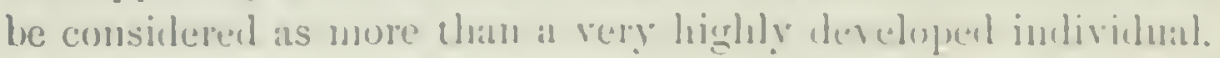

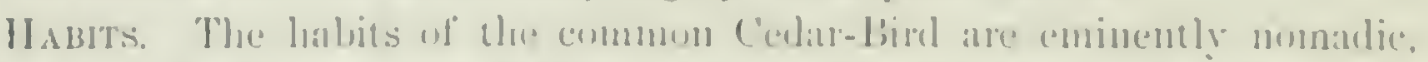

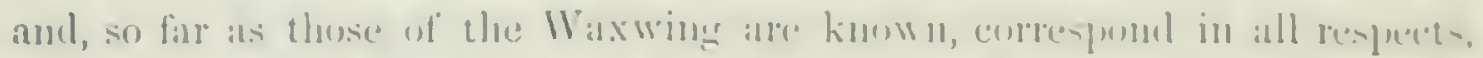
cxcept in the muse general and esjecially the more sumtern distrilution of

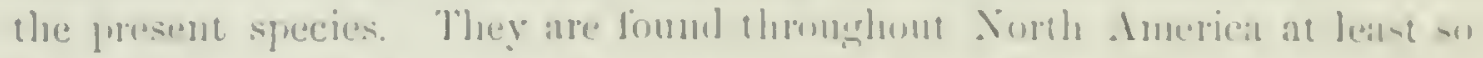

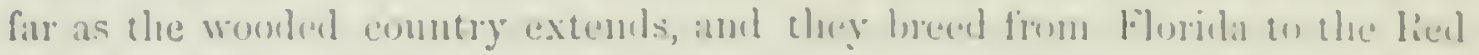
liver comutry. They ane a common lime in Sew linglaml, ambl wombl be

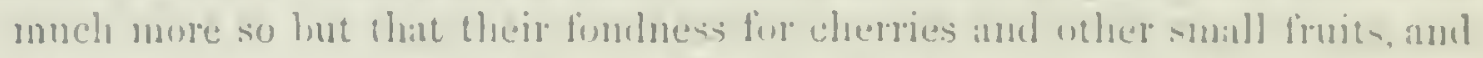

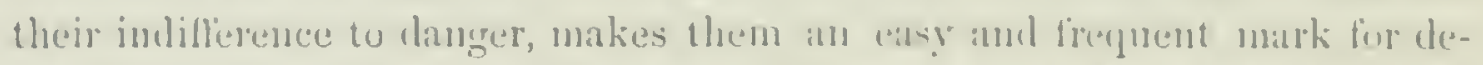
struction. Their mupopularity las cansed their numbers (w) he areatly reduced of late years in the thickly settled fortions of the conmtry.

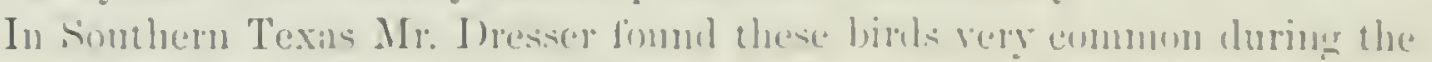
winter at San Antonio and batro l'ass, but he olserved nome lattel than the

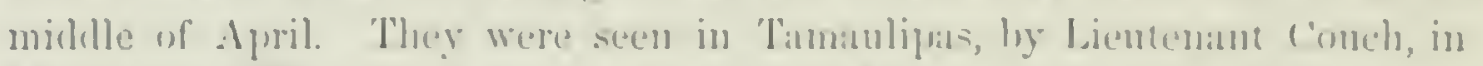

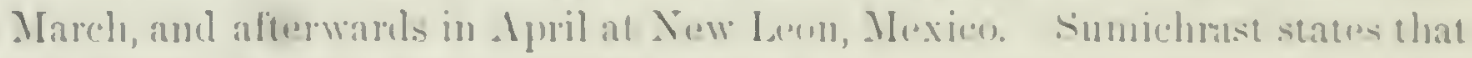

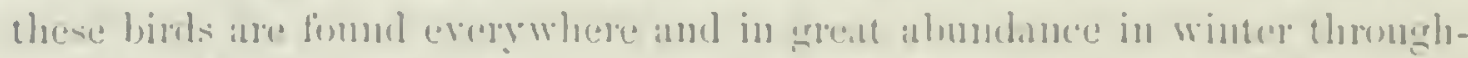

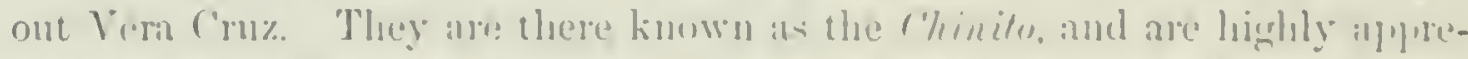

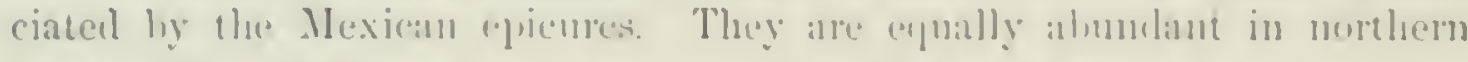

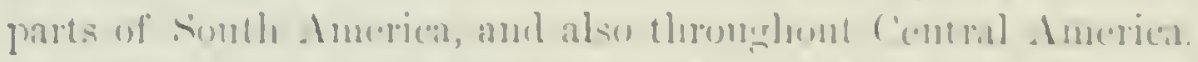

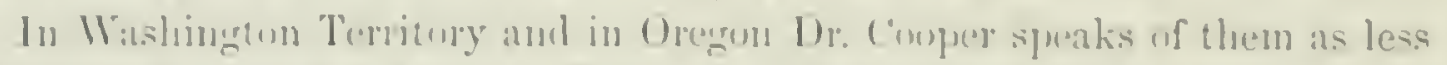

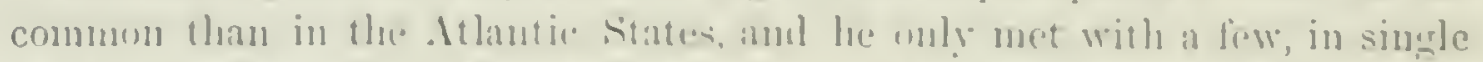

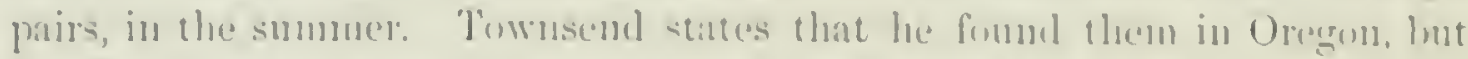

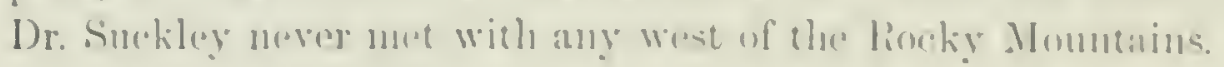

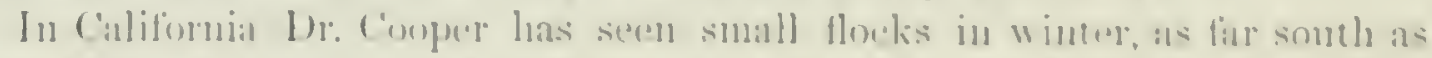

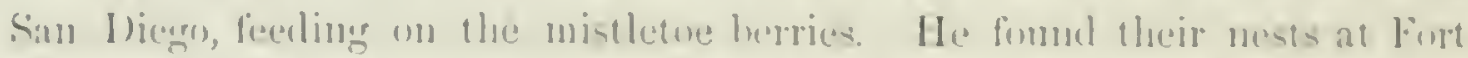

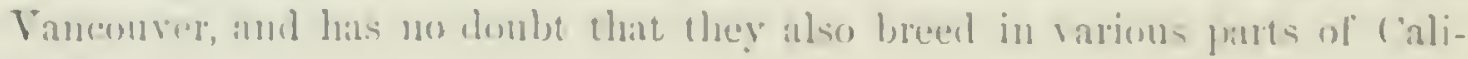
forniat.

Mr. Rohert Kenniont states, among uther memormma of his roule, that, May :I, on an island in Wimniperg River, le saw a large thock of these livele, mumbluerius lifty ur more.

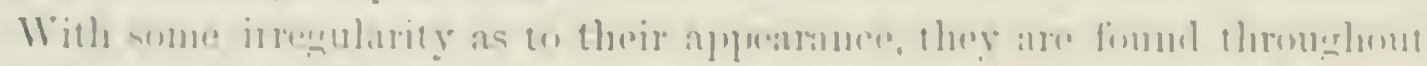

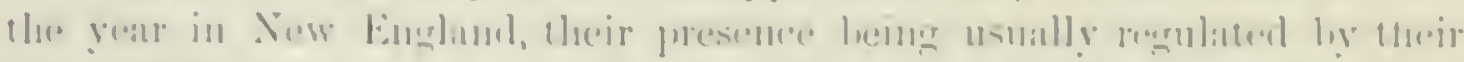

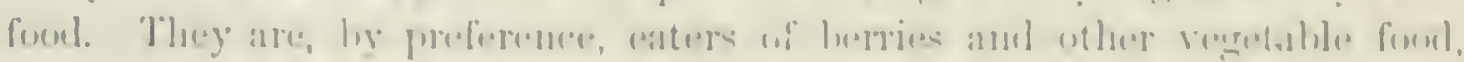

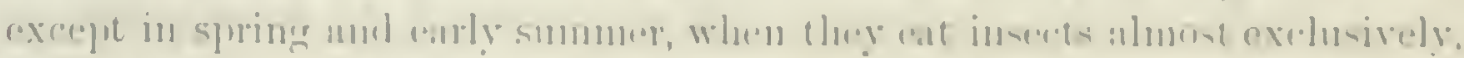

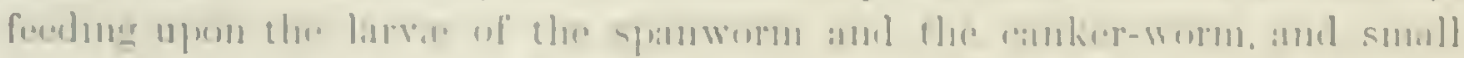

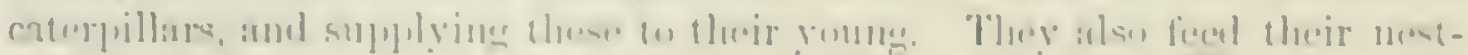

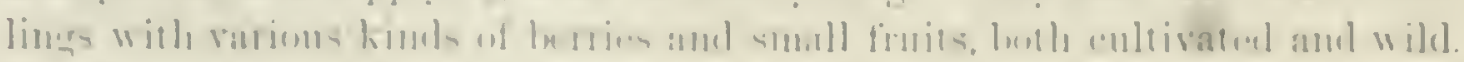

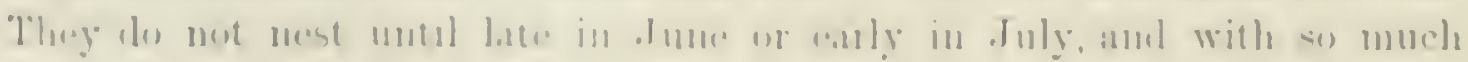


irregularity that I have found them sitting on their unhatched eggs as late as the 1.2th of October. They are a greedy bird, feeding voracionsly where they have an opportunity. They are rery much attached to each other and to their offspring. Once, when one had been taken in a net spread orer strubberries, its mate refused to leave it, suffered itself to be taken ly the hand, in its anxiety to free its mate, and when set at liberty would not leave until its mate had also been released and permitted to go with it. In the summer of $18 \% 0$ a nestling, harlly half fledged, fell from its nest, and was found injured by its fall, taken into the house, and fed. Whenever exposed in its cage its parents came about it, and supplied it with cherries and other fruit, ummindful of the near presence of the family. The young bird lived, and became perfectly tame, feeding from the hand, and preferring to be fed rather than feed itself. Besides its low lisping call, this bird had a regular faint attenipt at a song of several low notes, uttered in so low a tone that it would be almost inandible at even a short distance. It became perfectly contented in confinement, and appeared fond of such members of the family as noticed it.

The noticeable feature of the Cerlar-Bird, its crest, it has the power to erect or depress at will. In confinement it generally keeps this depresserl, only erecting it when excited from any cause, such as alarm, or desire to receive food.

Wilson states that in Pemnsylvania they collect in Angust in large flocks and retire to the mountains, feeding on the fruit of the Vaccinium uliginosum, which grows there in great abundance. Later in the season they descend to the lowlands to feed on the berries of the sour-gum and the redcedar. In confinement they are very fond of apples, bread soaked in mik, and almost any kind of soft food. They are also very fond of flies, and are expert flycatchers, snapping at all that venture within the cage.

In their migrations their flight is graceful, easy, and continned, and is performed at a considerable height.

It is unfortunate for the horticulturist that this bird has done so much to merit his prejudices and reprobation, and that he does not appreciate to the full the immense services it renrlers to him each spring in the destruction of injurions insects. A flock of these birds will, in a short space of time, devour an immense number of the larre of the destructive canker-worms (Phalcone ) that infest the apples and elms of Massachusetts, and, if permitted, wonld soon greatly reduce their numbers. But these prejudices cannot be softened by their good deeds, and the Cherry-Bird is still hunted and destroyed.

Their nests are usually constructed late in June or early in July, and are placed in rarious positions, sometimes in a low bush or tree not more than three or four feet from the ground, and rarely more than twenty. Their nests are large and bulky, but strongly made of varions materials. Generally they build a strong external framework, six or seven inches in diameter, 


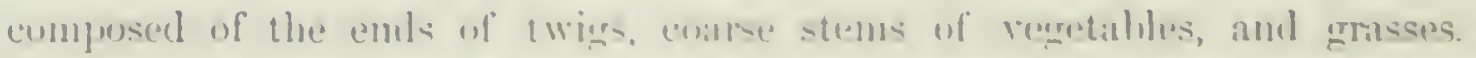

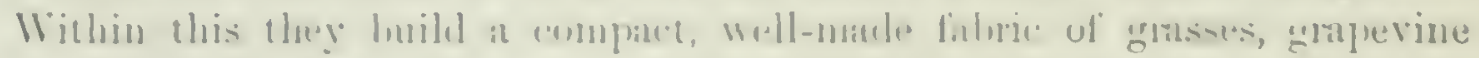
bark, and other liner sulstumen, linine the whole with leaves and fine rout-

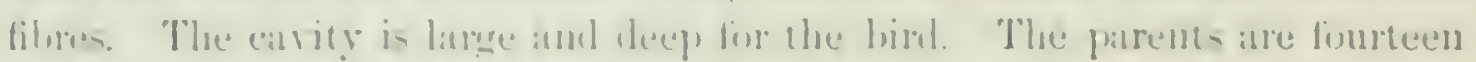

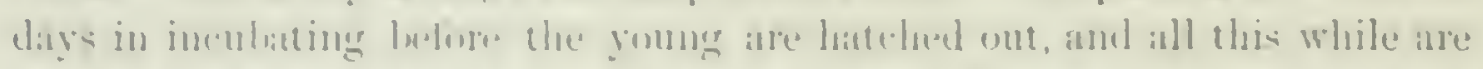
remarkbly vilent, handly utwring a somnd, eren their faintest licping note, when the nent in medhlled with, though they evine great andety hy their

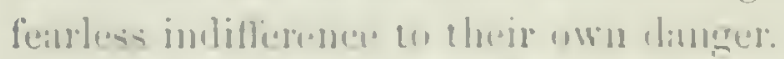

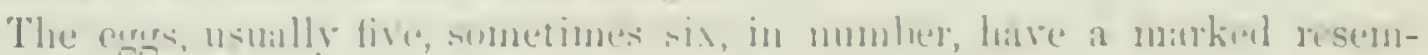

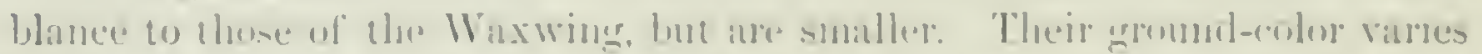

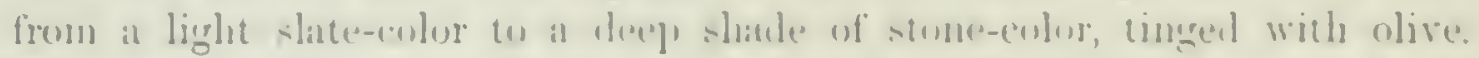
These are markial with bloteles of at dark purplish-brown, almust black, lighter shates of a dark purple, and penumbat of linim pupple, sometimes

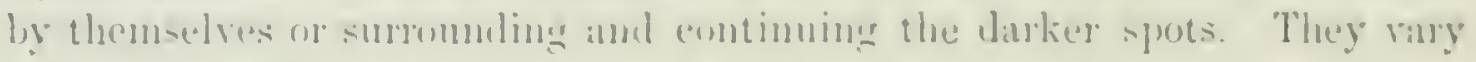

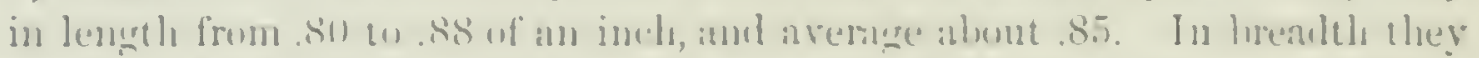

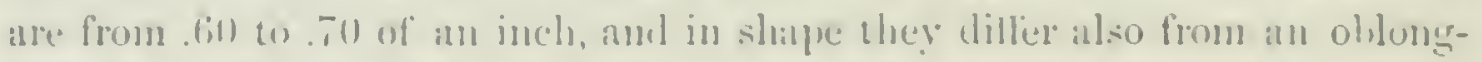

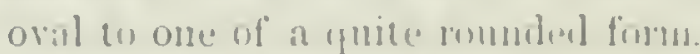

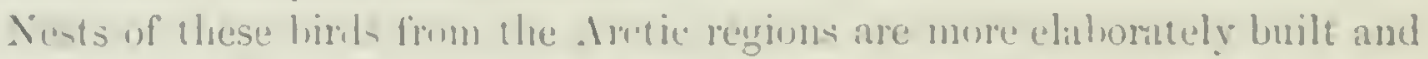
more warmly lined, heing of hen largely mante up of the line dark-culored lichens that cover the forest trees of those reniuns.

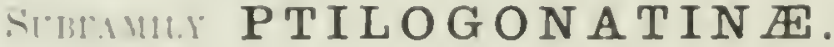

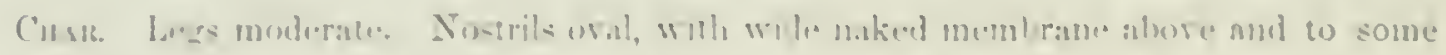

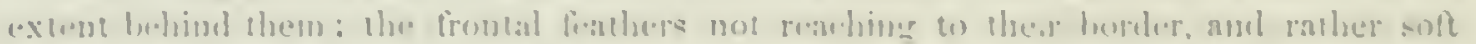

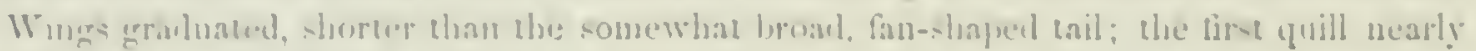
half the renond. Dilulte plain.

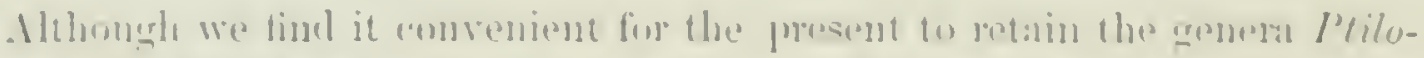

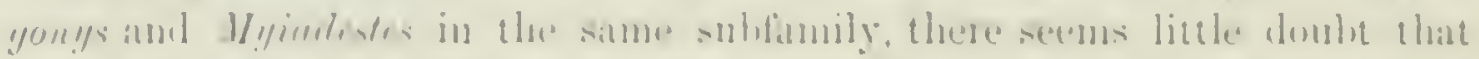

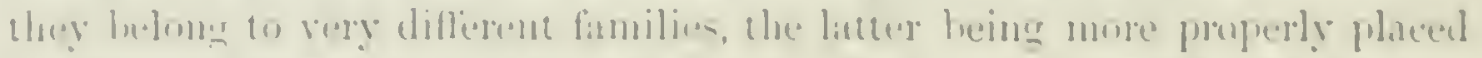

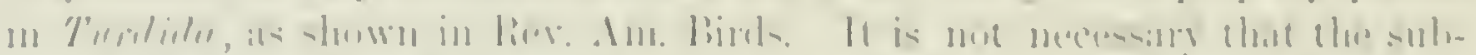

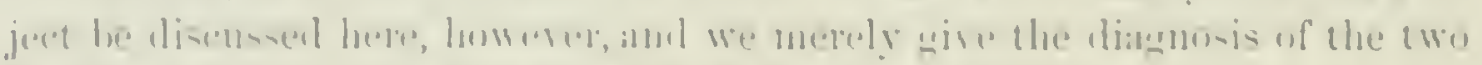

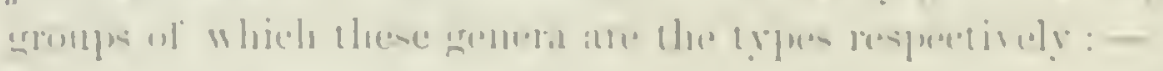

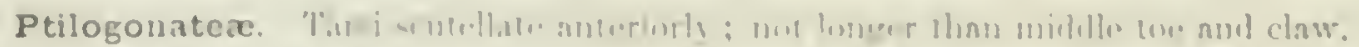

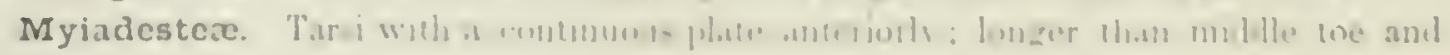
"law

\section{SirTINPTILOGONATEFE.}

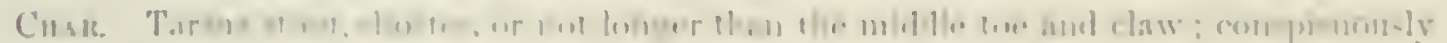

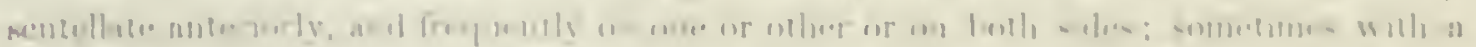

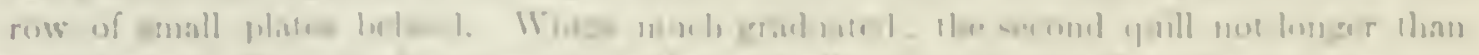

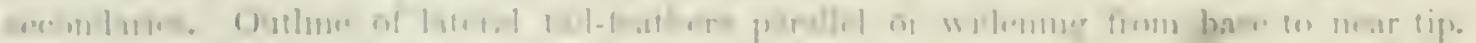

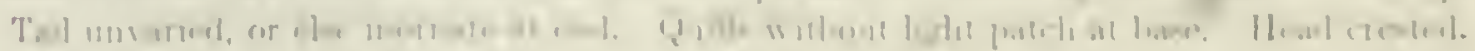

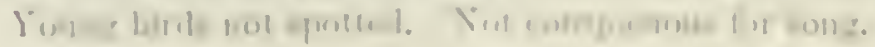


There are two genera of this section having in brief the following character's :-

Crest narrow, pointed, its feathers stiff, their webs compact; ontel primaries

broad. Tail rounded . . . . . . . . Pluenopepla.

Crest broad. decumbent, soft, the feather's loose; onter primaries attenuated.

Tail eren or cuncate

Ptilogonys.

The genus Ptilogonys has two species, one Mexican, the other CostaRican, neither coming within the limits of the United States. The type is P. cincreus, Swanson (Balrd, Rev. Am. Birds, 412), a species of the tablelands of Mexico, which may yet be found within the southern borders of the United States in New Mexico or Arizona.

\section{Gexcs PH平NOPEPLA, Scliter.}

Phanopeplu, Sclater, P. Z. S. IS5S, 543. (Type, Plitiogonys nilens, Swalss.)

Ger. Cirar. Crest narrow, pointed behind. Outer primaries broad, not attenuated nor pointed at end; the first half the second. Tail rounded, fan-shaped; feathers very broad, wider towards end. Bill feeble, rather narrow, well bristled; nostrils somewhat orerhung by frontal feathers. Sexes dissimilar: male black; quills with median white patch on inner webs; tail not varied.

The single known species is glossy black in the male; the female brownish-ash.

\section{Phænopepla nitens, Sclater.}

\section{SHINING-CRESTED FLYCATCHER.}

Ptiliogonys nitens, Sw. An. in Menag. 1S3S, 2S5. - Box. Consp. 1850, 335. - HeErmaxx, Jour. A. N. Sc. Phila. II, 1553, 263. - C.1sisl ; Ill. Birls Texas, etc. 1854, 169, pl. xxix. Cichtopsis nitens, B.Irn, Birts X. Im. 1S58, 320, 923. Phenopeple nitens, Sclater, P. Z. S. 1S5S, 543 ; 1S64, 1 i3 (City of Mexico). - B.tnd, Rer. An. B. 1S64, 416. - Cooperi, Orn. Cal. 1, 1570, 131. "Lepturus yulcatus, Less."

Sp. Curar. (No. 8.27) ठ.) Tail broad. almost fan-shaped: graduated slightly; not at all emarginate, and longer than wing. First quill broad. slightly falcate, searcely attenuated; more than half the second. which about equals the tenth; sixth longest; third equal to serenth. Feathers on nape rather full, with a leugthened, pointed, narrow, occipital crest.

Ifale (No. 8.275) entirely glossy greenish-black; the inner webs of all the primary quills with a large, lengthened patch of white, which does not reach the imner margin; their outer webs rery narrowly edged with ashy, as are also lateral tail-feathers externally.

Female (No. 8,274) brownish-ash, paler below: the white of inner wels of quills obsolete; the greater corerts and quills edged externally with whitish. the anal and crissal feathers edged and tipped with the same; the onter tail-feather with narrow edge of white externally towards end.

Immature birds show every gradation of color between the two extremes described abore. 


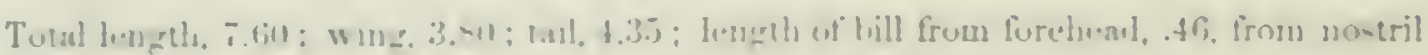
31. along gape, diti : tarm- . ill: mullle lue and claw, ckis.

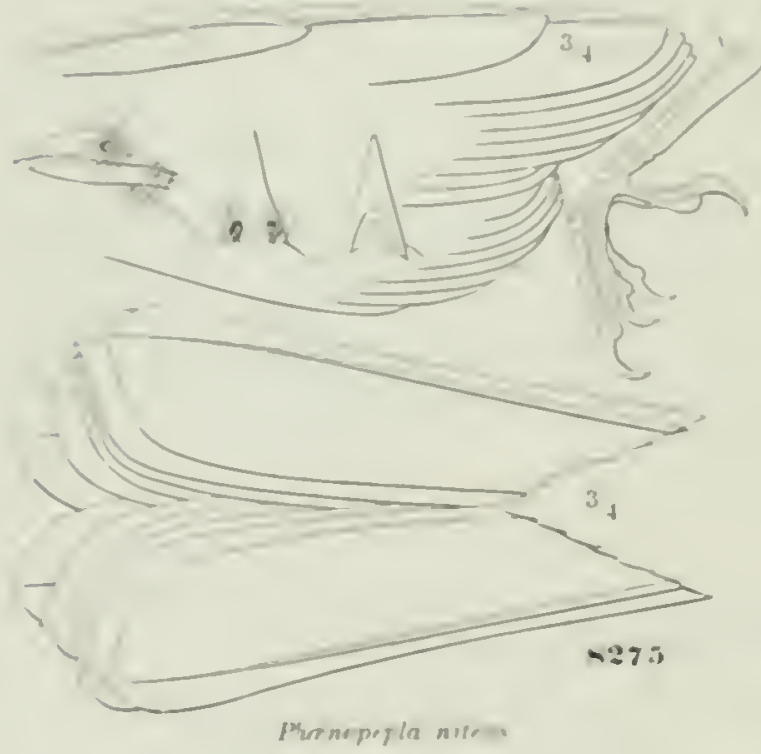

11. MII. Mauntanums region of the

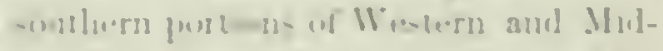

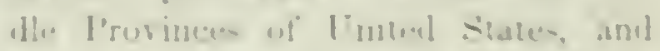

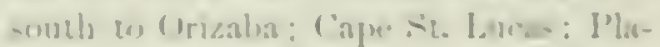

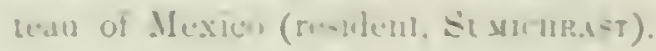

Humts. Sil for as knuwn, this hirel ocems in the mombatmons gertions of the linted situte.

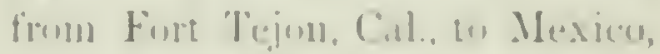
and from the Hin Cirande to san Dimen. It is clunely alliell, in its ilpleatrance, as al-u in mally of its hablits, luth with the Waxwings and the Flycatulieds.

This spercies was first lotected

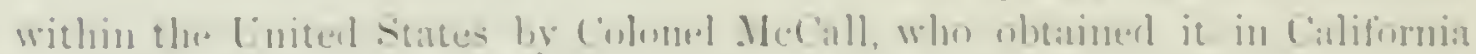

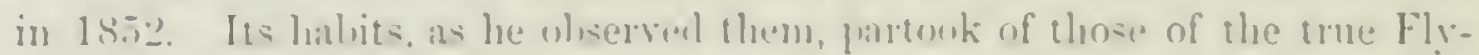
catcher. They are satid to be romarkalle for their slendel, active form, in whels their Inter and ample tail, amd the elomeated forthers of their heat.

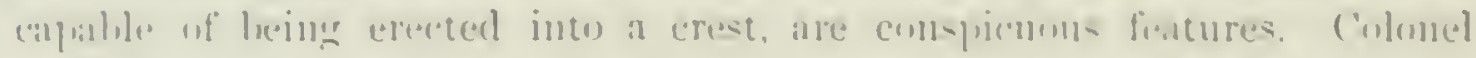
Mreall tiret met with them in a clump nt trees on the Inemler of a mountain

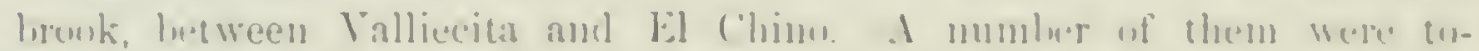

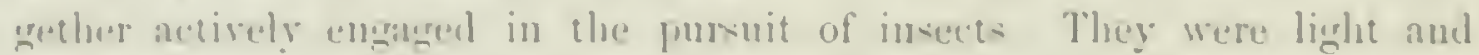
graccoful on the wine, thomeh less swift and decilled in their motions than the true Flycatchere ln thene enolutions the bright white spot on the wing, visil. mbly when the wine

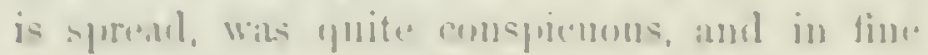
contrat with thre elases black of the eneneral

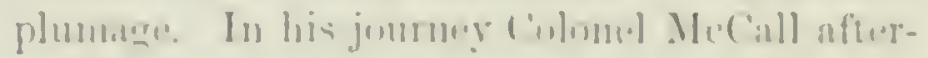

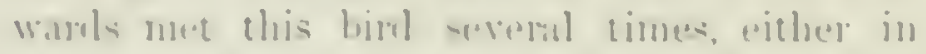

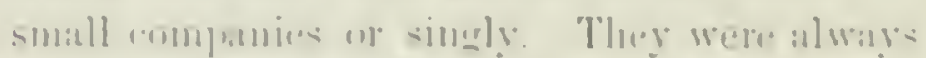
either on monmtain -idles or in the timluerol pemelers of mommlatin stronms

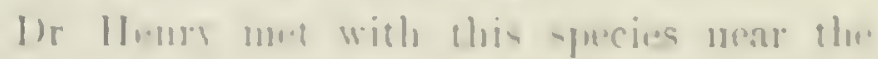

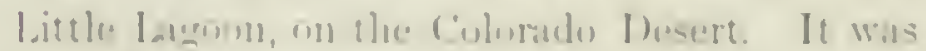

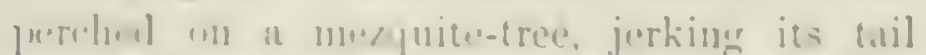

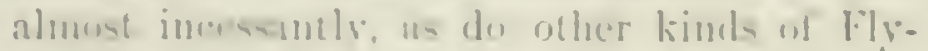

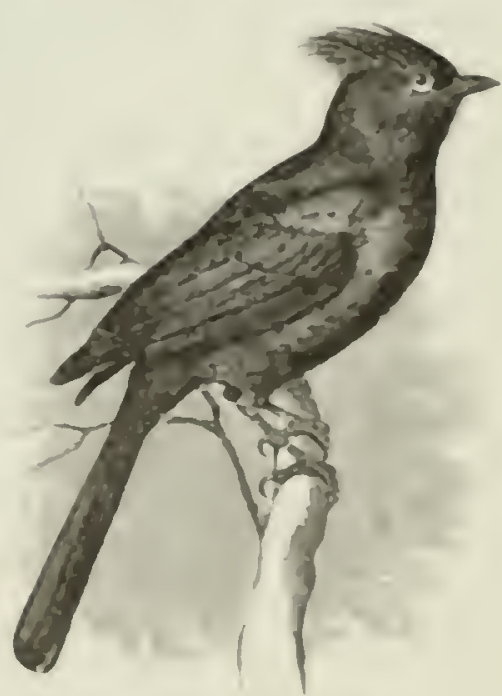

Phomoporia nusew

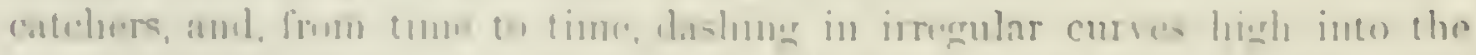

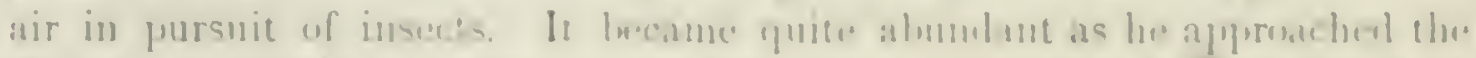

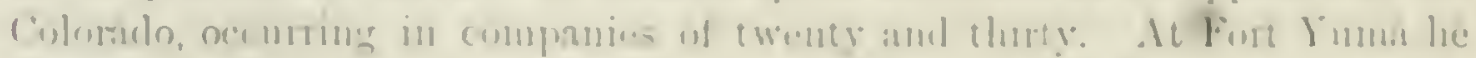
ulso me with them in conshlerahle mumbers hate in Nownder, as they were 
migrating sonthward. Dr. Hemry describes its note as a low, plaintive whistle. He ascertained that it breeds in California by finding specimens of young birds. He likewise met with this species near Fort Webster, in New Mexico; and Dr. Kemerly also noticed it, in February and March, between Big Sandy Creek and the Colorado River.

Mr: Dresser obtained two specinens of this species at Eagle Pass. One of these had its stomach filled with the berries of a species of mistletoe that grows abundantly on the mezquite-trees. He noticed that it carries its crest erect and much recurved, after the mamer of the Enropean Purus cristatus.

Sumichust states that this species, called Reyerito, is well distributed throughout the Plateau of Mexico, but only ranges in the valley of the Orizaba, to the height of about 1,500 metres, rarely coming as far as that. It is also common at Tehamntepec and other places.

Dr. Cooper found them quite numerous, in winter, near the Colorado. He also found them common, in Lecember, about the Molave River, and in simmer, from Los Angeles to San Diego. They were found to prefer the trees in which the mistletoe grows, on the berries of which they largely feed, though they occasionally pursue insects in a zigzag comrse similar to that of the Sayornis nigricans.

They almost constantly utter a loud cry of alarm, and when pursued are very wild. When womded, they conceal themselves so closely in the thick tufts of the mistletoe as to be found with difficulty. Many left the Colorado Talley in April, but a few remained. Their notes Dr. Cooper describes as similar to those of the Crested Flycatchers, but sweeter.

It was found by Feilner, at Fort Crook, in April, 1860, but lias not been met with near the coast so far to the nortl.

A nest of this bird, obtained by Dr. Cooper, on the 27 th of April, was built on a horizontal branch of the mezyuite (Algurobia), twelve feet from the ground. It was found near Fort Mohave, on the Colorado River. The nest is a very flat structure, four inches in diameter, and less than two in height. The carity is less than an inch in depth. The nest is made almost entirely of hempen or flax-like fibres of plants, interworen with fine grasses, stems of plants, and stalks of a larger size. It is lined with a soft downy substance of a regetable character.

The eggs, two in number, are of an oblong-oval shape, nearly equal at either end, and with a ground-color of a light slate, tinged with a yellowishgreen. They are marked and blotched equally orer the entire egg, with spots and blotches of various lines, from a light, faint, obscure purple to deeper tints of purplish-brown, even to black. It is a rery marked eggr, and unique in its appearance. They measure .90 by .60 of an inch.

Dr. Cones found this species a summer resident in Arizona, somewhat rare about Fort Whipple, but found very abundantly a little farther south, and a permanent resident in the sonthem portions of that Territory. It inhabits rather open country in preference to densely wooded regions. He 
describes it is a shy, will, and restless bird, witl a superb song, powerful

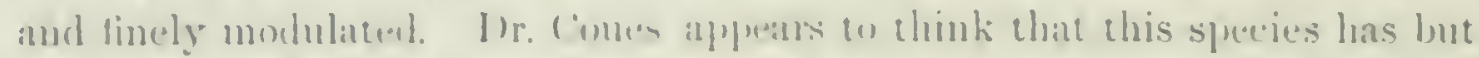
lifte affuity with the forms with which it is usulally grouped.

\section{Sectios MYIADESTEF.}

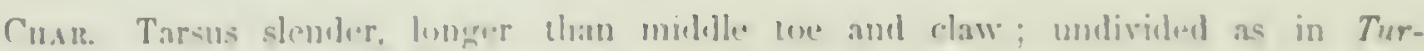

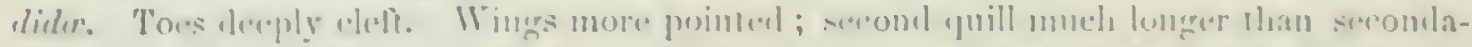

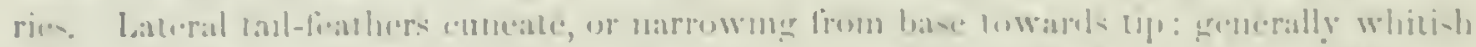

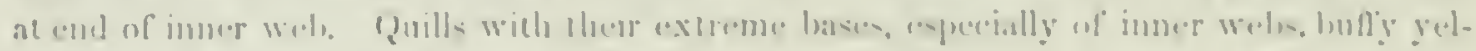

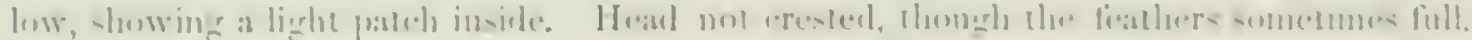

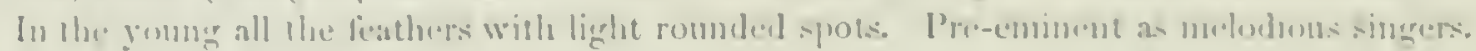

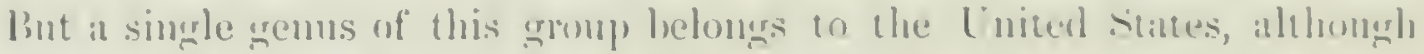

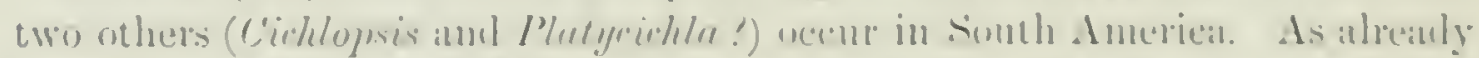
stated, the affinties of Myiuldoter are much closest to Turdide, and this would seem the proper funily for it.

\section{(ilit: MYIADESTES, SWMSOS.}

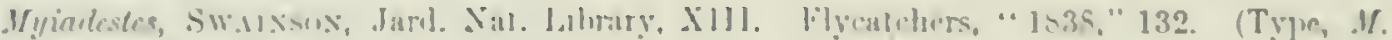
genilurlis.s. sil.)

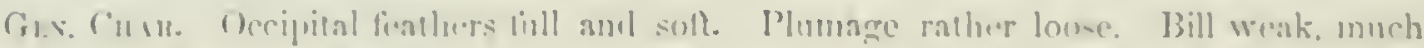

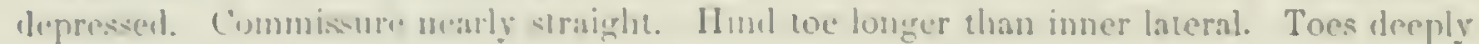

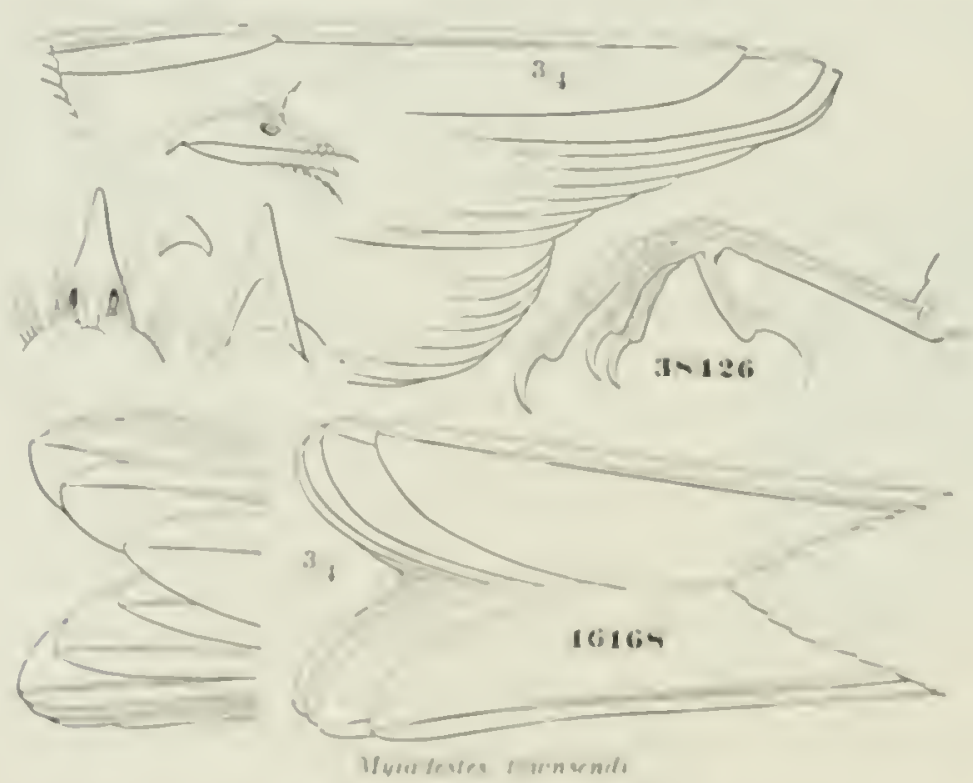

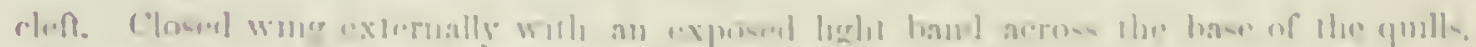

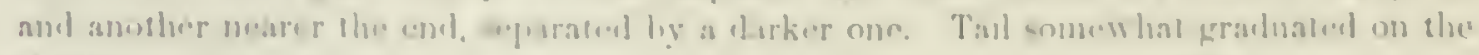
sick.e.

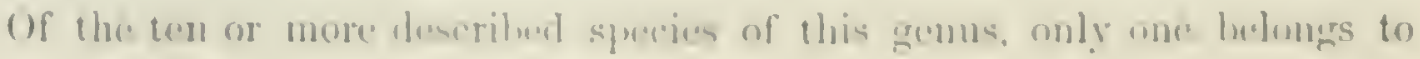


the limits of the Lnited states, althongh several others occupy aljacent territury in Mexico. Sereral are peculiar to islands of the West Indies.

The only two species closely relaterl to the M. tounsindi are the W. unicolor and $M$. obscurus, which belong to Mexico. They maty be distinguished as follows :-

An ochraceous band across base of secondaries and upper primaries. conspicuous on onter surfice.

I. M. townsendi. Gernerally dull ashy, paler beneatl. Throat and abulomen

whitish. Hat. Midule and Paific Provinces of Lnited States only.

To ochraceous on uuter webs of secondaries and primaries.

2. M. obscurus.' Back and wings rusty-olive. Head and beneath asliy. top of head deepest ash. Hab. Jountains of Mexico and Guatemala: Tres Marias Islands.

3. M. unicolor:- Entirely tark bluish slate-color, lighter beneatl. Lores black.

Hab. Central Mexico and Guatemala.

\section{Myiadestes townsendi, ('AB.ז.}

\section{TOWNSEND'S SOLITAIRE.}

Ptiliogonys tounsendi, AtD. Orn. Bing. 1, 1ミ39, 200, pl. cecexix, fig. 2. (For other references see Birls X. Am. 321.) - Newrel:ri, P. R. Rep. VI, Whipple's Rep. Zoül. \$2. Culicirora touns. DE K.11, N. I. Zoul. 11, 1st4, 110. Myindestes touns. CABAsIs,

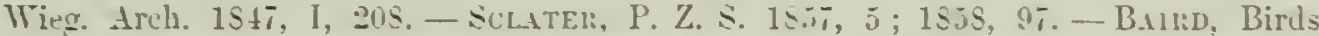

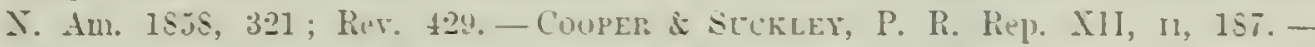
Kexsertr, P. R. Rep. X, Whiprle's Rep. 25. - Lolin, l'r. R. Art. Inst. Woolwich, IV. $110^{\circ}$ (Br. Col.). - Cinoleli, Oru. Cal. I, 1570, 134.

Sp. Cratr. Tail rather deeply forket. Exposed portion of spurious quill less than one third that of the second: fourth quill longest: secomel a little lunger than the sisth. Head not crested. General color bluish-ash. paler beneath; umler wing-coverts white. Quills with a brownisli-yeliow bar at the base of both webs mostly concealed, but showing a little below the greatur coverts and alule: this succeeded by a bar of duskr. and next to it another of brownish-vellow across the onter webs of the central quills only. Tertials tipned with white. Tail-feathers dath brown; the mildle ones nore like the back; the lateral with the onter web and tip. the second with the tip only. white. A white ring rouml the eve. Lemgth, \& incles: wing. 4.50: tail, 3.s.j. (\$.234.)

H.s. Momntainons recrions of Middle and Western Lnited states. (Tot found at Cape St. Lueas nor in Mexico.)

Young birls have a large triangular pale-nchraceons light spot on the end of each feather (rather paler helow), bounded exterually br a narrow border of blackish; the quill and tail feathers as in the adult.

H.sits. The first specimen of this somewlint remarkable hird was shot by Captain Brotclie, at Fort Creorge, Astoria, and presented to Mr. Townsend, and by the latter given to Xr. Audubon. For some time this remained unique,

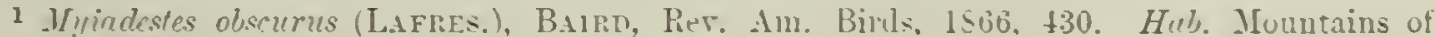
Yexico to Guatemala and Tres Marias Islands.

2. Myiadesics unicolor (Sclater), Barrd, Rev. Am. Birls, 1s6iv, tos. Hab. Central Mexicu and Guatemala. 

Dr. Cooper, in his Birds of California, dwells with much emphasis upon the delightful melody of this species. Maving always found them silent, and with habits like the Flycatchers', he was yuite umprepared to hear them singing in the Sierra Nerada, and, if he had not obtained the bird, would not have beliered that one of this family was capable of singing with such power. Their song, he says, can be compared with nothing nttered by any other bird he has ever heard in the Lnited States; for, he adds, it excels that of the Mocking-Bird in sweetness, besides being entirely original.

He met with only a few of this species among some junipers on the westem slope near the summit, in september, 1863. He las alwars met with them nearly singly. Dr. Henry found them at Fort Webster, New Mexico, in läge numbers, both in fall and in winter. Their home, 1)r. Cooper thinks, seems to be in the ricinity of the great cleserts of the central regions, or the cedar-covereil mountains that intersect them.

Dr. Woodlouse obtained sereral specimens on the Zuñi Mountains in New Mexico, and from there westwark fomd it exceedingly abundant. Its food seemed to be exchusively berries, and chiefly those of the cedar.

Dr. Cones also found these birds rare summer residents in Arizona, and confinns its possession of rare local powers, producing a rich, sweet, and finely modulated song.

Mr. liobert liclgway, in accompanying Mr. King's party of explorations, writes that he found this curious birl only occasionally, most frequently among the pines of the Sierra Nevala, and only once or twice among the mountains east of that range. In July, 186 7 , he found a nest of this bird. It was in a deep ravine on the western slope of the Sierras, at an altitude of five thousand feet. It was placed in a carity of the roeks forming the perpendicular upper bank of a sluice constructed for mining purposes, through which ran the waters of a considerable mountain stream. The nest was about a foot above the water, and was as bulky as that of the Hurporhynchus rufus, and similarly constructed, being composed almost entirely of sticks. It contained four young. When lie approached, the female was much exciter, flying before, or lunning on the ground in the manner of a true Thrush. Mr. Ridgway makes no mention of its song.

Mr. Lord met with these birds only once, and then at Colville, towards the end of Norember. All the leaves lad fallen, the cround was deeply corered with snow; and the cold was intense. His attention was first attracted by liearing a low sweet song, not unlike that of the Song Thrush of Europe, which at that season was a most munsual sound. On looking around he saw about twenty of these birds perched on the top sprays of some white thorm-bushes. In their mode of darting off and returning agnin they reminded him of a Shrike. He shot six, and conld detect no material difference in plumage between males and females. In the stomachs of those he opened were the remains of sinall coleopterous insects and a few haws. 


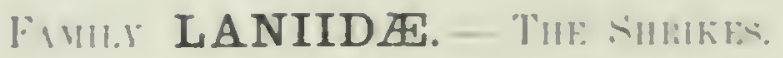

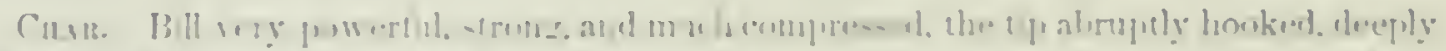

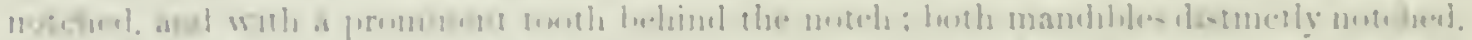

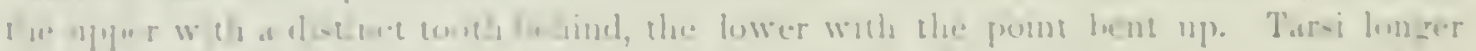

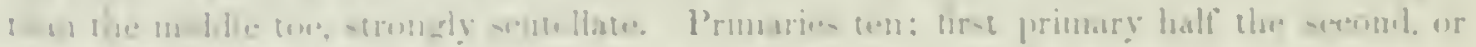

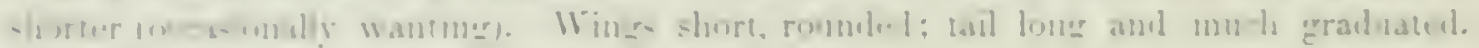

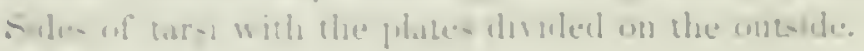

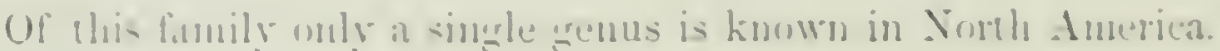

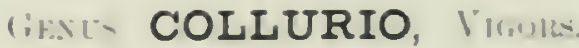

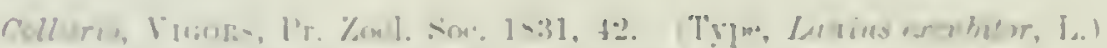

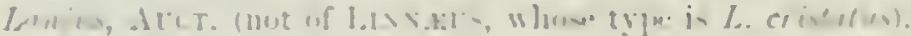

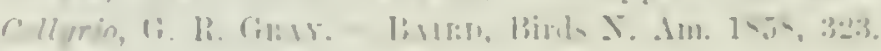

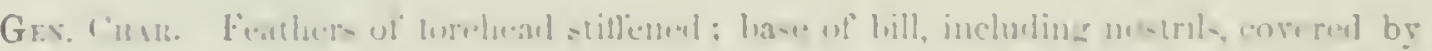

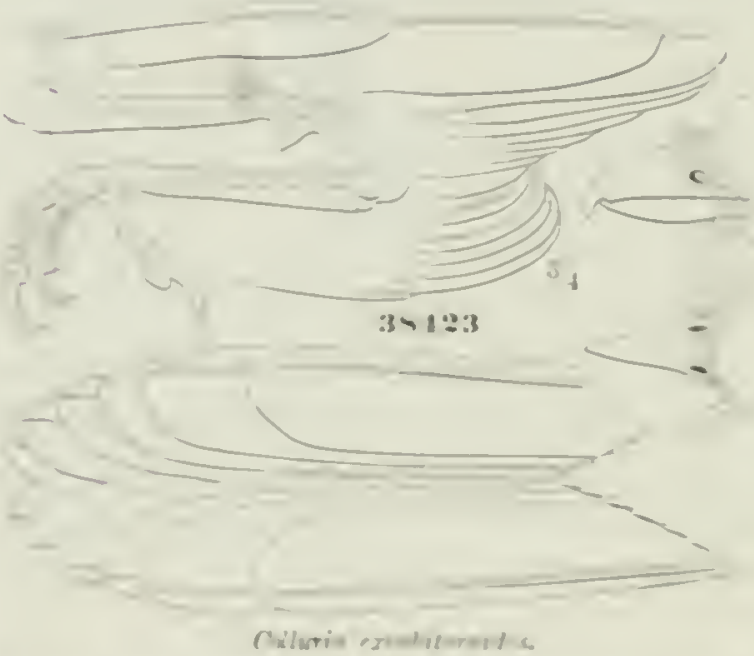
bristle liathers ilirentoml torward. Bill -larker than the heas. much cumpromed, and rery jowerful. Cuhnen

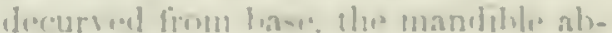
rup.ly Ix-11t duw 11 in a pewertill hook "wh an sente lute mar the lip. Tip of lower mandatle leotut upards in a

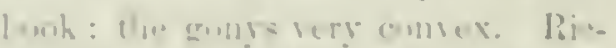

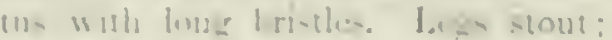

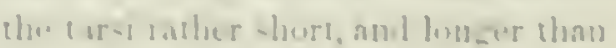
the muthe ton: the lateral equal: the raws = all rery sharp and mued curvel. Winge mumlul: the fir-p primsary almot hali the arwond, which

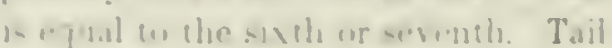

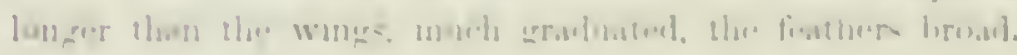

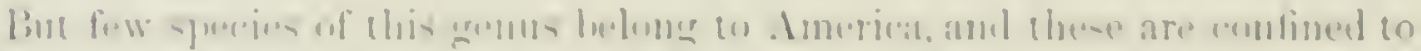

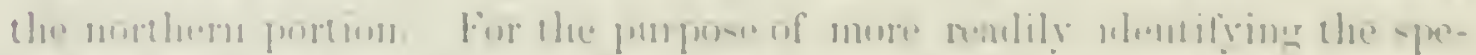

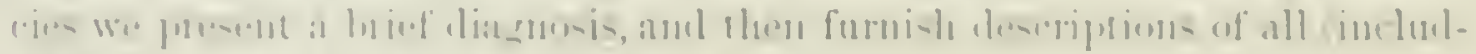

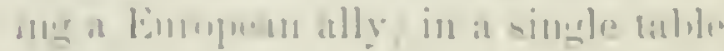

\section{Species.}

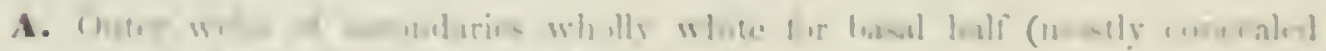

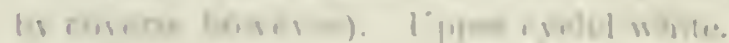

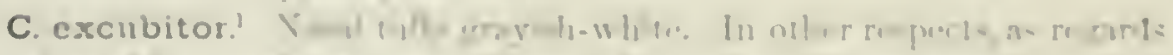

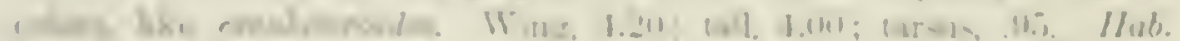
L.t.rip.

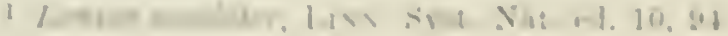


B. Outer webs of secondaries black to the base. Upper "yelirls black.

a. White crescent on lower "yclicl. Beneatl with way bas of dnsky in all stages. Tarsus less than 1.010; wing more than 4.īo.

C. borealis. Lpuer lalf of nasal tufts white: Black spectacle bordereed above the ear-coverts by loary whitish. Scapulars and upler tailcoverts approaching white. Wing, 4.70; tail, 4.70; tarsus, .93. Mab. Arctic America; in winter south into [niterl States, esplecially into the northeru portions.

b. No white elexeent on lower eyelicl. Beneatl witlout bars, exeept in young. Tarsus mole than I.00; wing less than t.50.

C. ludovicianus. Black spectacle not borelerel over ear-coverts with whitish.

White patch on primaries renching nearly as far as end of first quill Sasal tufts entirely black.

Black of lores and nasal tufts borlered above with hoary whitish. Tail white at base; innel webs of secondarics paler towarl mangin, but not abruptly white. Beneatl cutinely white, without asly tinge laterally, or across breast. Axillars whitish. Umper tail-coverts ashy-white, scapulars pure white. Wing, 4.10 ; tail. 4.20); tarsus 1.10; bill, .50. IIab. Western North Ancrica from Pacific Coast east to a little beyond the Mississippi, and to 'Texas. Nearly all of Mexico. . . var. excubitoroides.

Black of lores, ete., not bordered above ly whitish. Tail black at base. Inner wobs of secomlinies pure white to the slatit on basal half. Beneatl tinged witl aslyy laterally and across breast. Scapulars and upper tail-eoverts hardly diflerent from back. Bill, 60. Hab. California and fur comntries . . . var. robustus

White patch on primaries reurleing only alonut half-urely to end of first quill. Fresal tujts houry-yrayish abore.

Black of lores hordered above by hoary-whitish. Tail as in elegans, - secondaries as in ermbitoroides. Beneath rery strongly tinged with plumbeous laterally and across breast. Tpper tail-coverts like the back, posterior scapulars only inclining to white. Axillars plumbeous. Wing, 3.80 : tail, 3.9.); tarsus, 1.00 ; bill, .50. Hab. South Atlantic and Gulf States. . . . var. lu dovicianus.

We now proceed to give a more detailed table of these species, and under the heading of each shall omit any further description :-

Gexeral Color. Bluish or plumbeous aslu above; the ontur edees of scapulars, sometimes the forehearl and rump, palel. Beneatl white, sometim(s witl waved transverse dark lines. A broal black stripe from sicle of upper bill through eye (extending more widely beneath than abore it, sometimes wanting above) to end of ear-coverts. Wings (except lesser eoverts) and tail black; the former witl a white patch across base of primares, sometimes on inner webs of secondaries) ; the secondaries tipped with white; the tail with broul white tips to the lateral feathers, the concealed bases of which ate also usually white.

A. Black check-stripes inrolving eyelicl only on upper border of eye, and not meeting across the forehcarl. A crescentic patel of white in the black below the eye ; mpler elge of black stripe behind the eye bordered by hoary whitish. Brenst and belly always with distinet, transverse waved lines of dusky. Bill, when mature, entirely black. Length about 10 inches. 


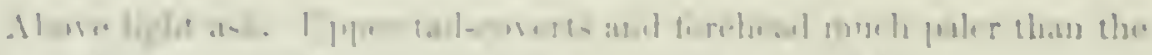

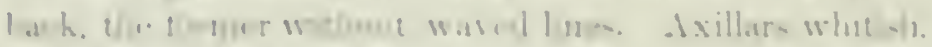

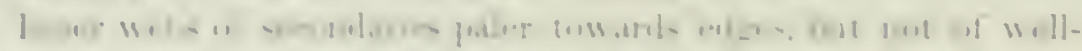

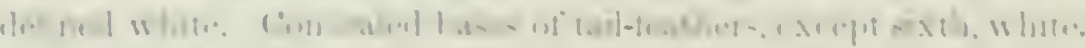

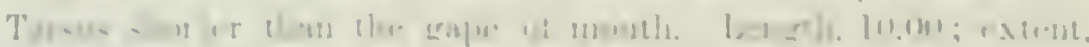

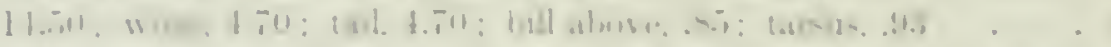

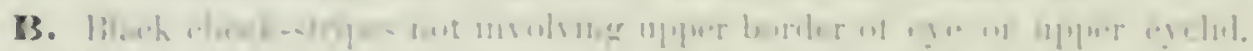

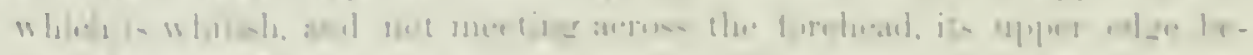

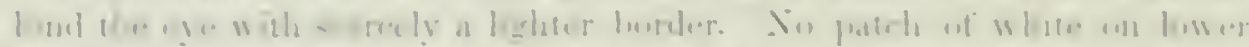

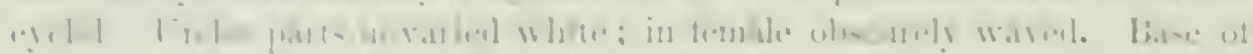

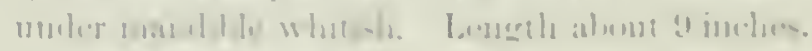

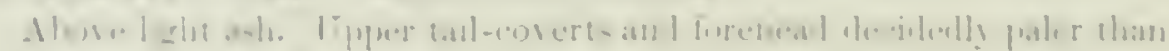
the l.wh. In! : a - whitis.

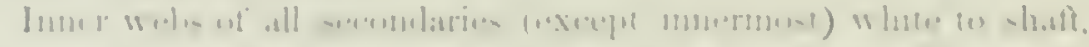

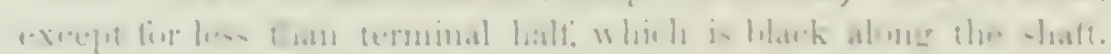
('on

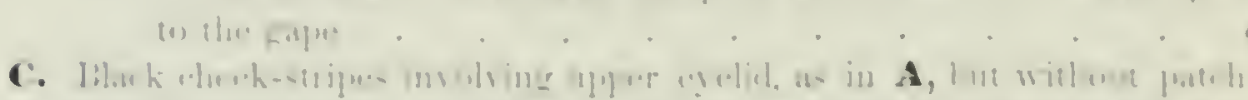
In, in iv revliitur.

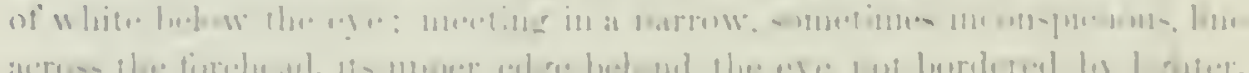

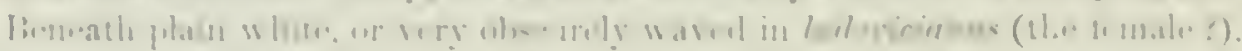

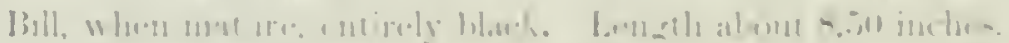

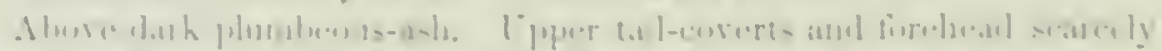

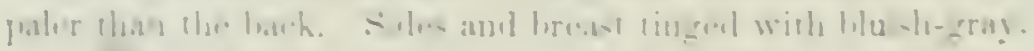

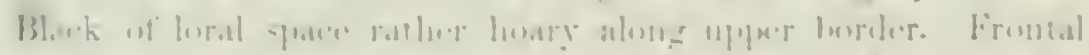

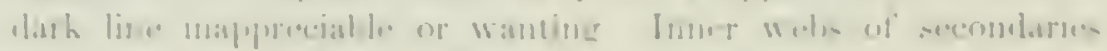

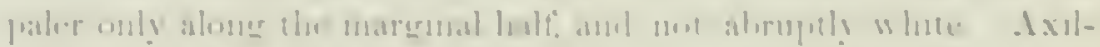

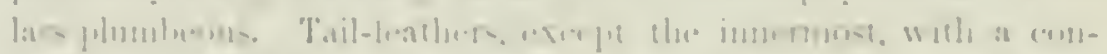

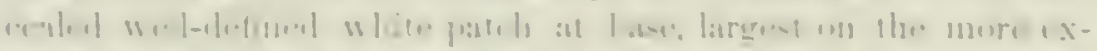

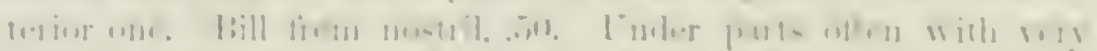

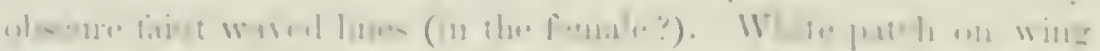

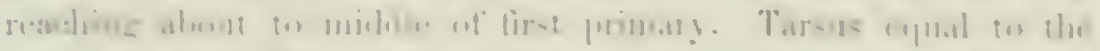

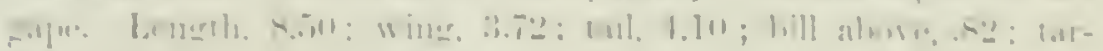

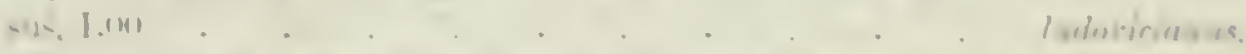

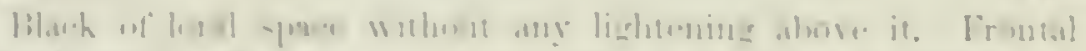

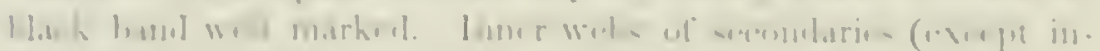

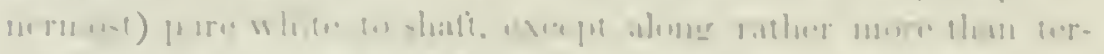

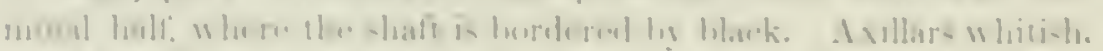

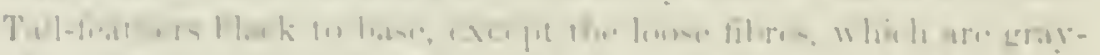

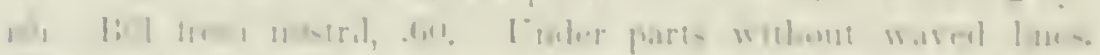

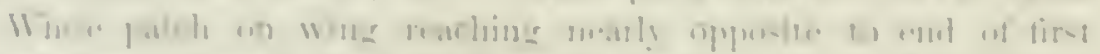

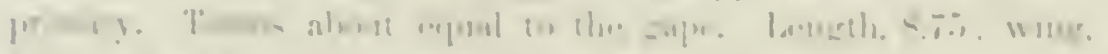

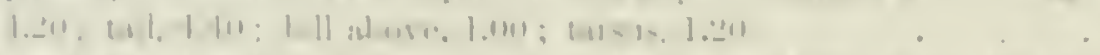

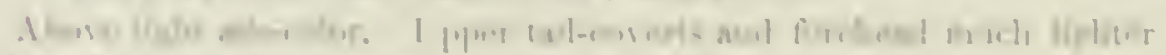

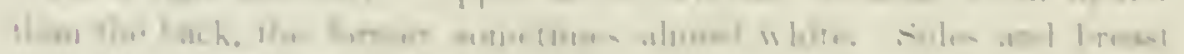

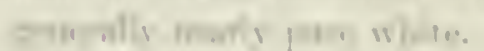

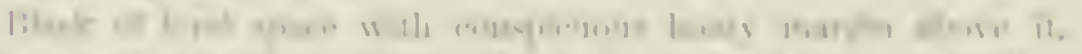

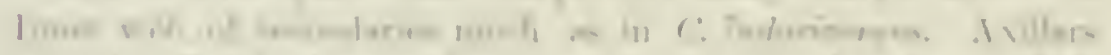

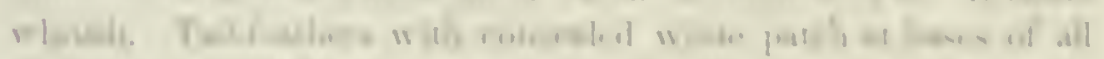

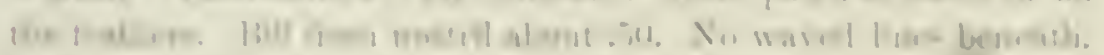

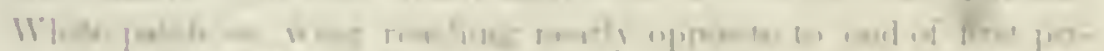

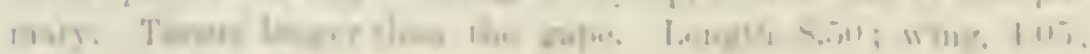

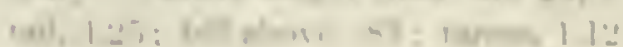


Collurio borealis, lisint)

\section{GREAT NORTHERN SHRIRE, OR BUTCHER-BIRD}

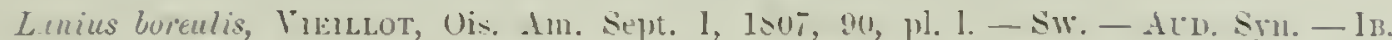

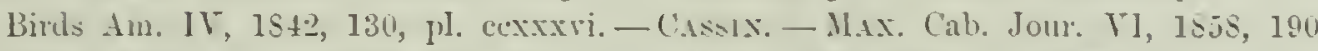

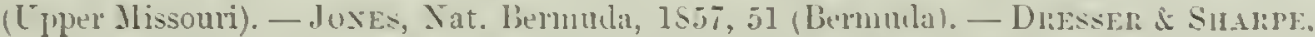

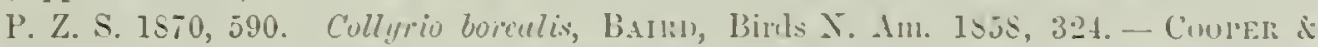

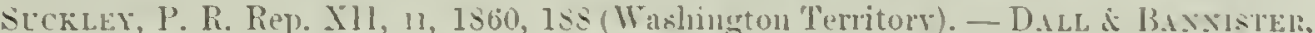

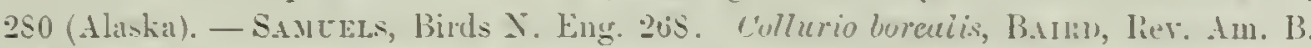

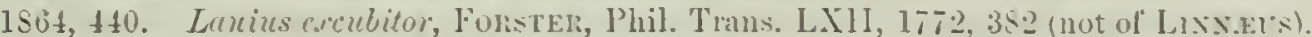

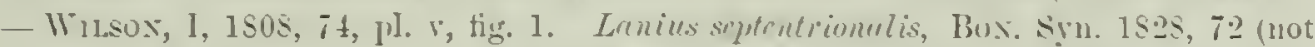
of GMELIx, which cannot le ielentificel as an Anerican species). - ('oulder. Oll1. ('al.

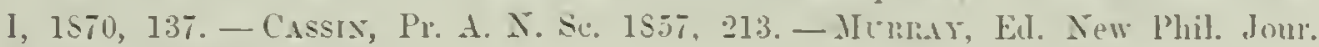
XI, $1559,2-23$ (H. B. T.).

H.tB. Whole of America north of Lnited States; in winter south to Wasington. St. Louis, Prescott (Arizona), and North California: Bermuda (winter, Joses).

The description of this and the succeeding species will be lound on pange 413. In winter, the colors, especially of the immature birds, are quite cliflerent from those described. The plumage of the aulult, in winter, diller's from that of spring as follows: the lores and nasal tults are whitish, instead of pure, sharply defined biuk, with, howerer, some of the hair-like filires blackish. The ash above is a little less clear, the white beneath less pure; the under mandible whitisly at the base. An immature bird, in winter, las the ash above overlaid by a wash of redelishbrown, producing a prevailing uniform light-brown tint; the black on side of head is reduced to an obsolete patch on the ear-curerts. The dull white beneath is everrwhere - sometimes even on the lower tail-coverts - covered with numerous bars of duskr, more sharply defined, and darkel than in the adult.

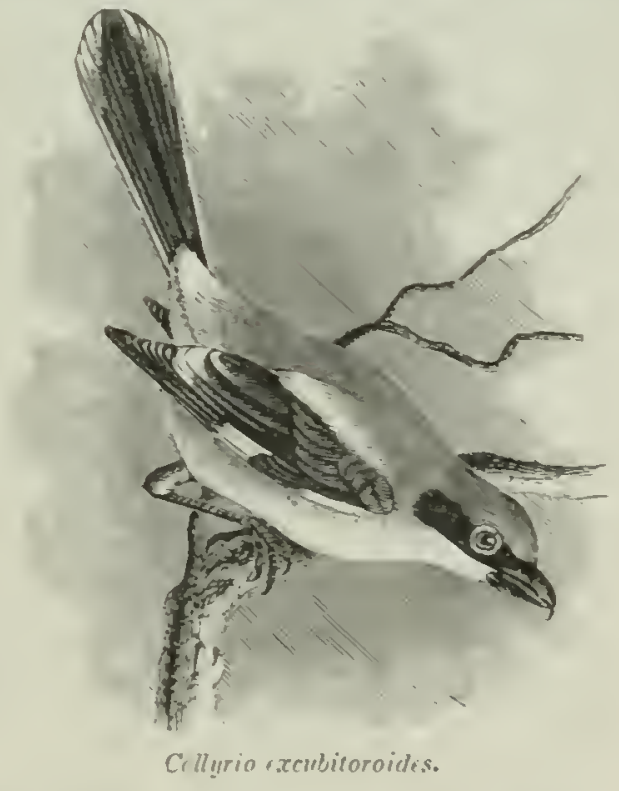

Eastern specimens appear to have as moch white on the l'ump als Western ones.

Habits. In the breeding-senson this species of slnike is found in all North America north of the Cnited States, and is said to breed also within our territory, in momntinous districts. Such, at least, is the statement of Mr. Audubon, and Wilson leaves us to infer the sime thing by giving a minute description of its nest and egos. lint Auduhon may have confounded this species with the errubitoroides, and Wilson, ilpparently helieving our species and the excrbitor of Europe to be idlentical, may lave had the 


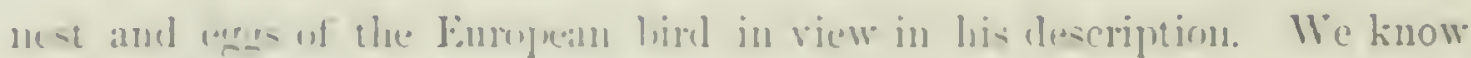

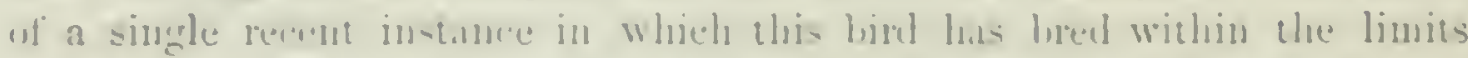

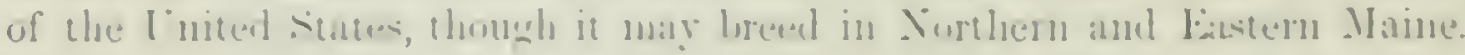

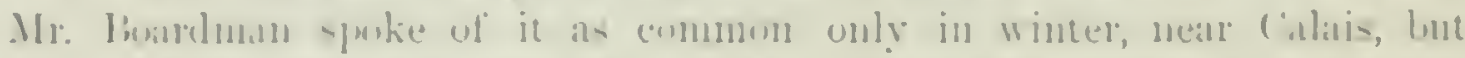

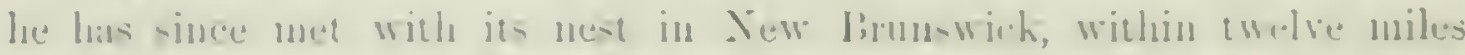

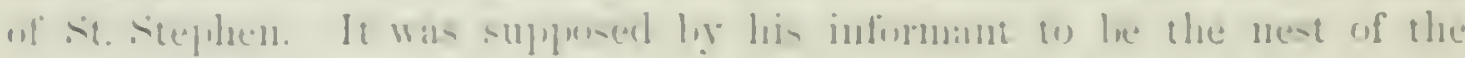

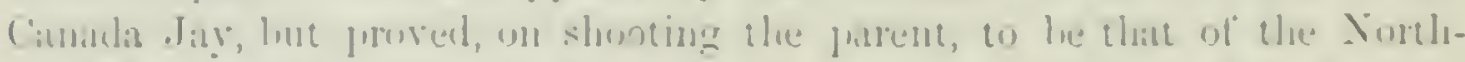

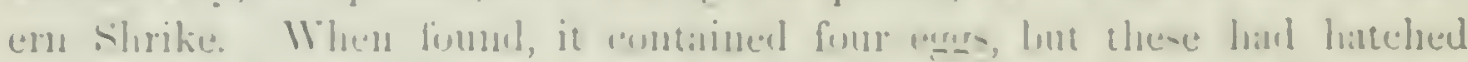

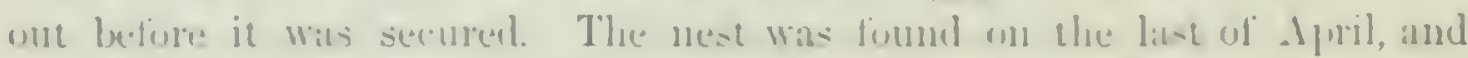

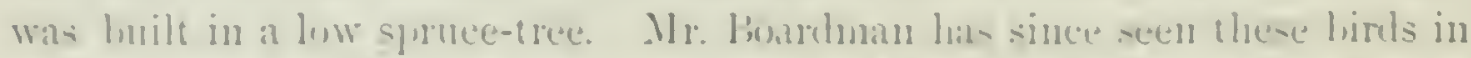

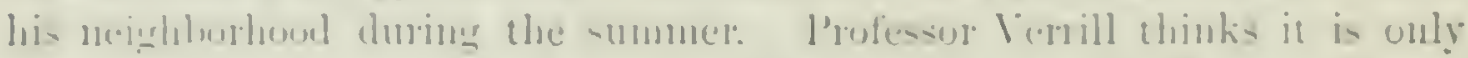
common in the antum and winter in Wentern Maine. In We-tern . Iassachusents, Mr. Allen cites it as mot verg commun, but at reaglat winter visitant, from the late of (betuber an the midelle of April.

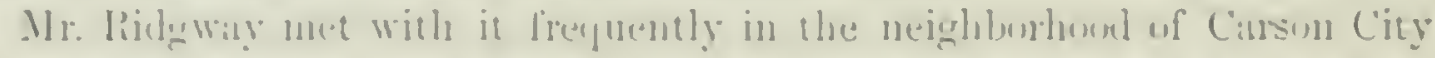
during the winter, among the willows hemblering the streams that flow from

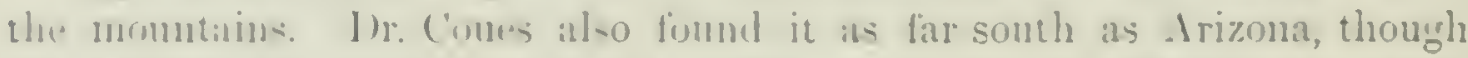

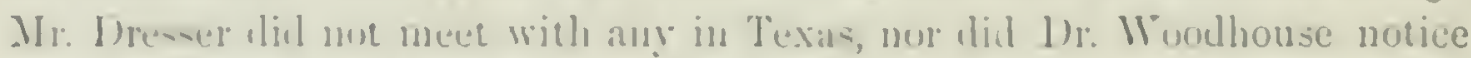

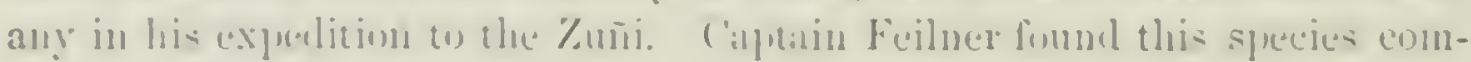

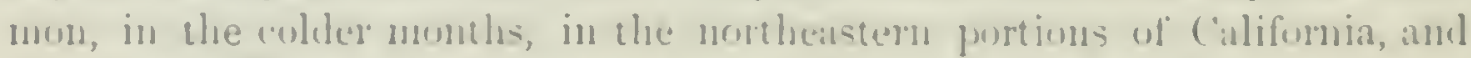

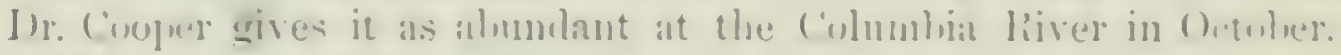

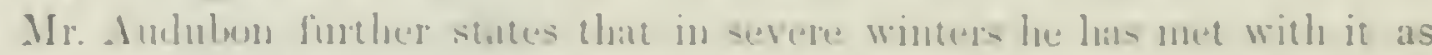

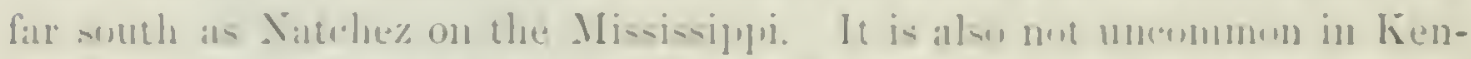

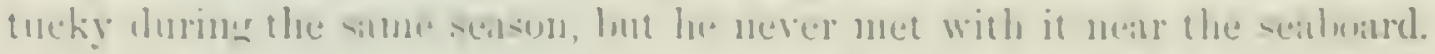

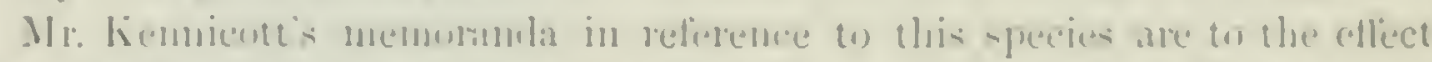

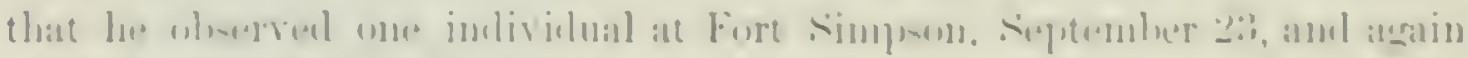

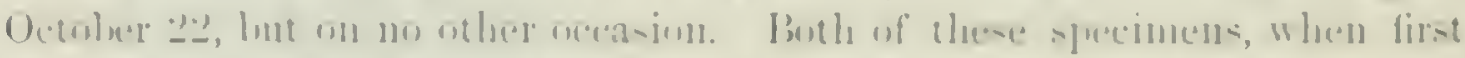

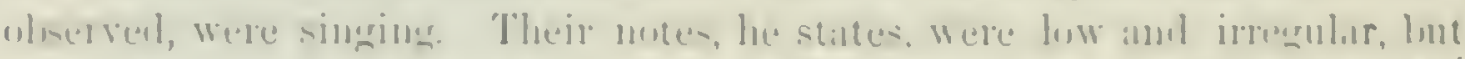

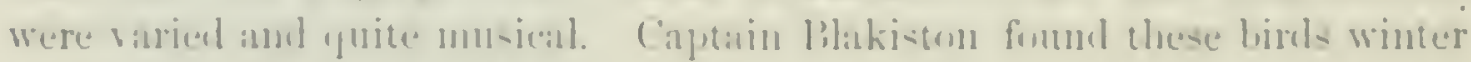

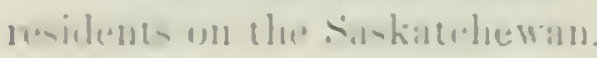

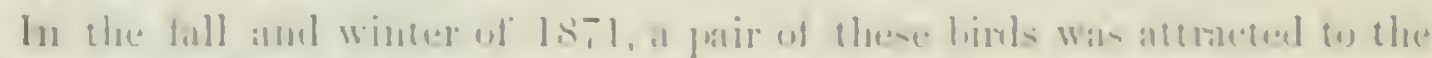

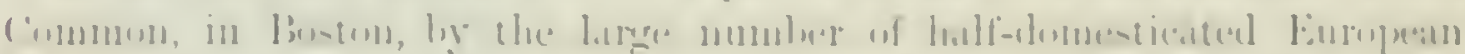

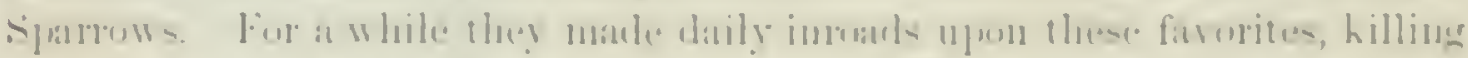

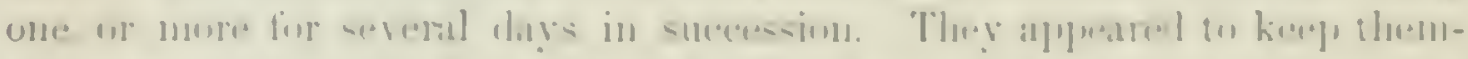

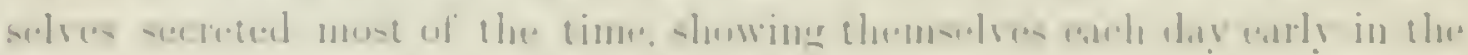

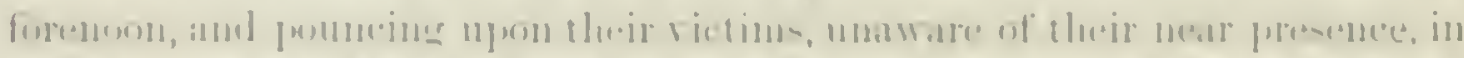

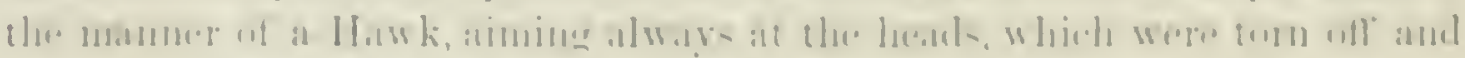

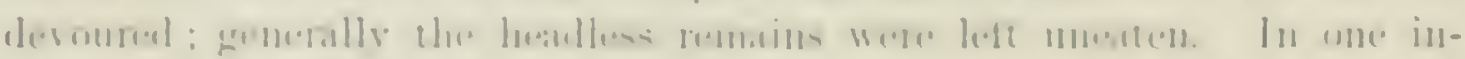

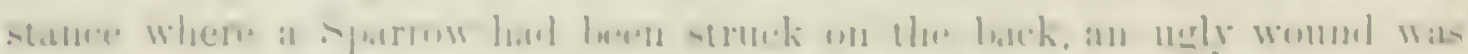

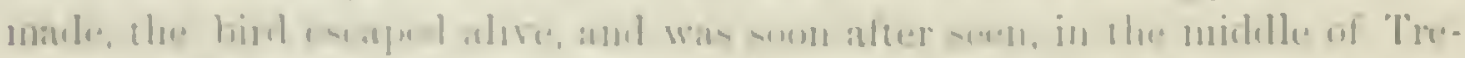

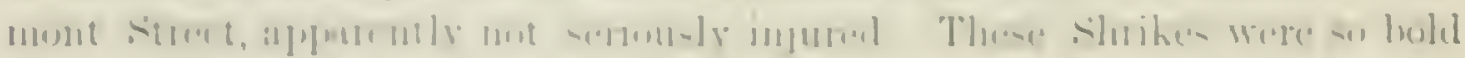

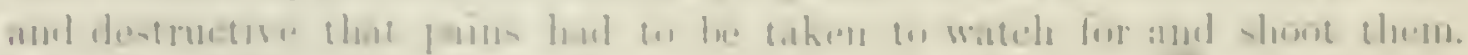

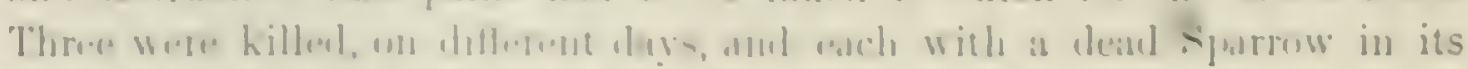

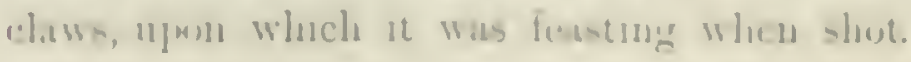


Both Mr. Audubon and Mr. Nuttall refer to this Shrike's imitating the cries of other birds, apparently to decoy them within its reach. The former has heard it utter cries like those of the sparrow screaning in the claws of a Hawk, to induce them to come ont uf their curerts and rescue their sultering fellows, and has seen them dart suddenly into a thicket in pursuit of one, from which would soon issue the real cries of the bird it had seized. Nuttall states that in some parts of New England this Shrike is called a MochingBird, on account of its imitations of the notes of smaller birds. Its more nsual note resembles the discordant creaking of a simboard hinge. He also states that it has been known to mimie the quacking of ducks, so that these would answer to it as to a decoy. He henrl one of these birds, as late as Norember 10, uttering a low and soft warble, resembling that of the Song sparrow, immediately after changing it to the notes of the Catbird.

Ihen in pursuit of small birds, it will dart down with closed wings, in the manner of a Hawk, and seldom fails to obtain the object of its pursuit, following it with rapidity and pertinacity throngh the thickets in which it seeks shelter. When it seizes its prey, it alights on its back, and tears open its head.

Its bold audacity and perserernence are quite remarkable, and are often displayed, in the fall, in the manner in which it will enter an apartment through an open window and attack a Camary, even in the presence of mentbers of the family. It rarely fails, if it gains aceess to the enge, to destroy its inmate before the latter ean be rescued by the intervention of those present, and only by grent promptness in sheltering the eage. In une instance the writer was sitting at a clnsed window lealling, with a Canary lungring above him. Suddenly there was a serere blow struch at the pane of glass near the eage, and the frightened Canary uttered cries of alarm and fell to the bottom of its cage The cause was soon explained. A Shrike had dashed upon the bird, unconscious of the intervening glass, and was stretched upon the snow under the window, stmmed by the blow. He revived when taken up, and lived several days, was sullen, but tame, and ntterly deroid of fear. He refused raw meat, but eagrerly tore in pieces and devoured small birds when given to him. His tameness and indifference to onr presence may lave been occasioned by stupor arising from his injury. In another case a shrike made a similar attack, hut escaped unharmed, and though he remained about the house several days, was too wary to allow himself to be decoyed within gunshot.

A nest of the Northern Shrike, containing six eggs, mas obtained by R. R. McFarlane, at Anderson River Fort, Jume 11, 1863. This is in many respects in striking contrast with the nests of its kindred species of the Southern States, far exceeding them in its relative size, in elaborate finish and warmth. It is altogether a remarkable example of what are known as felted nests, where various materials are most elaborately worked togrether into a homogeneous and symmetrical whole. It is seven inches in diameter 
and three and a hatf in holinht. 'Th" eavity is proportionately large and

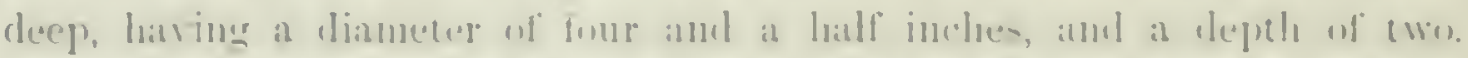
Exrepte the hase, which is enmpused of at liew twigs amel stalks of eodrser

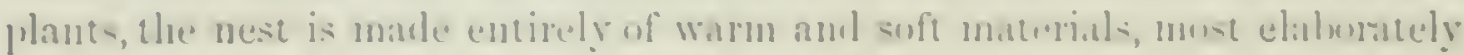

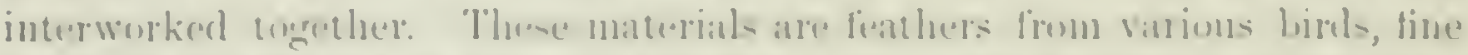

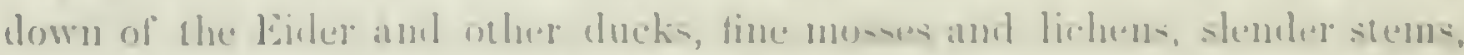

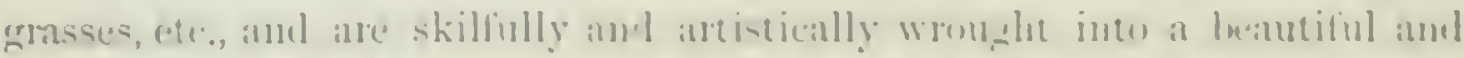

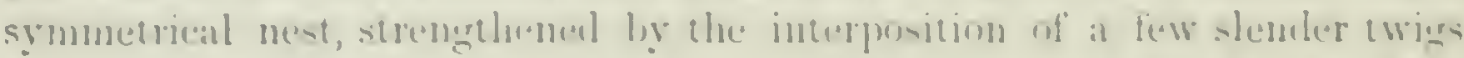

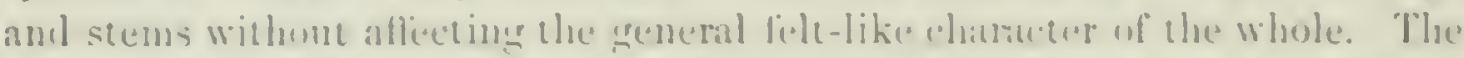

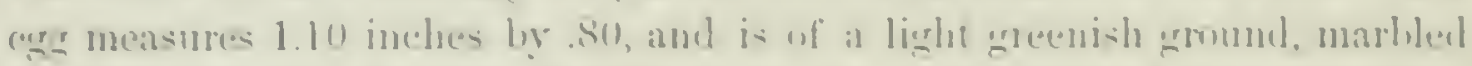

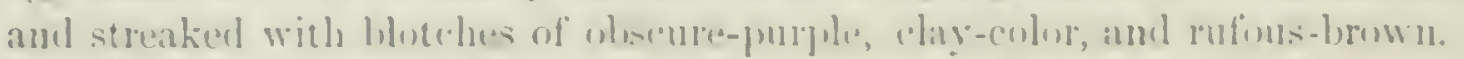

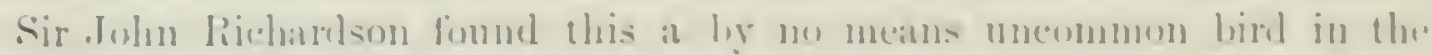

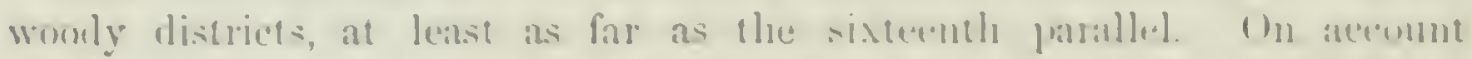

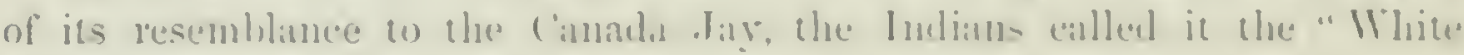

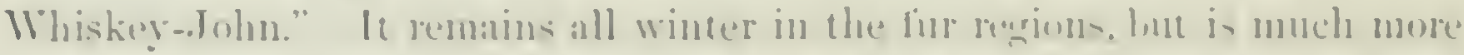
numeromi in smmuner. He -tantes that the nest is built in the fork of a tree, of dry grass and lichens neatly intertwined, and lined with feathers.

\section{Collurio ludovicianus, limin.}

\section{SOUTHERN SHRIKE; LOGGERHEAD.}

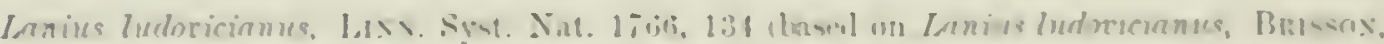

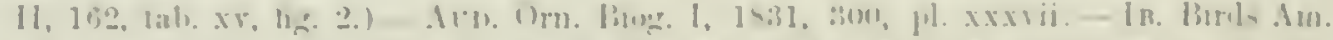

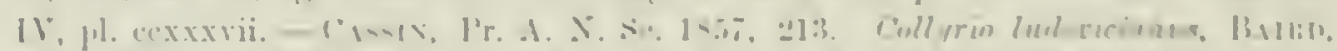

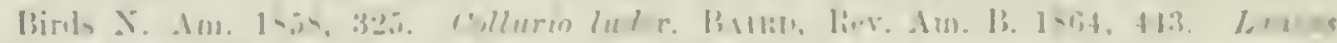

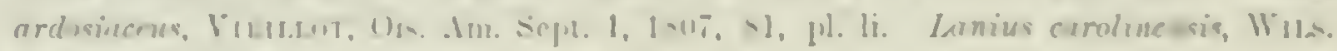

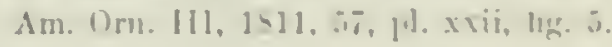

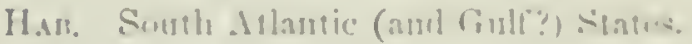

The youms liml is quite dillicent from the arblt, differing as does that of

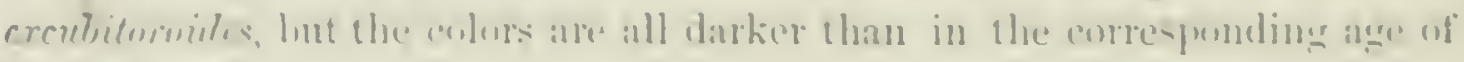
that speedus.

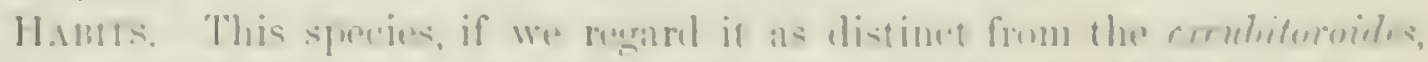

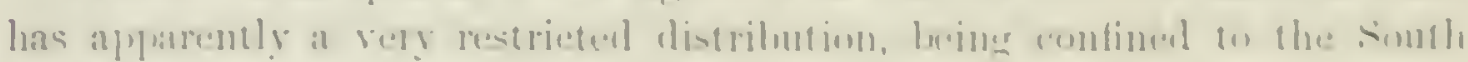

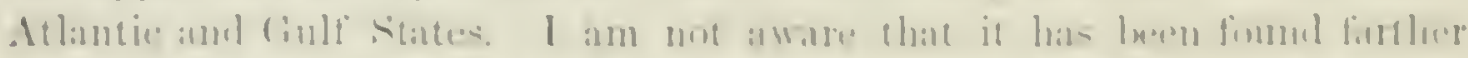

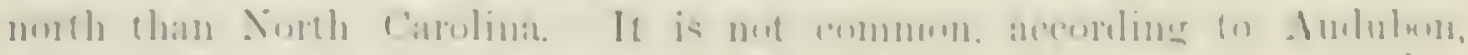

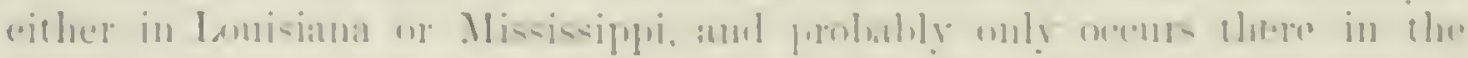

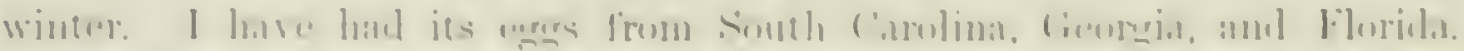

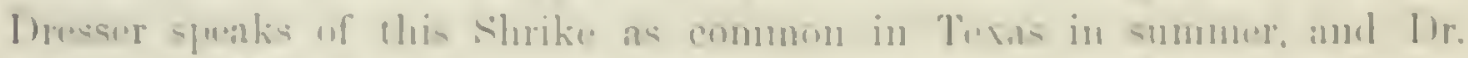

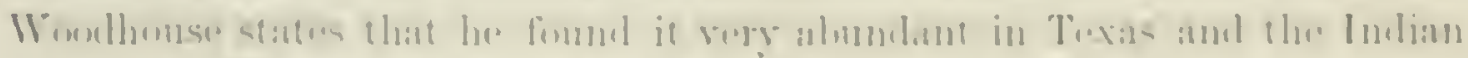

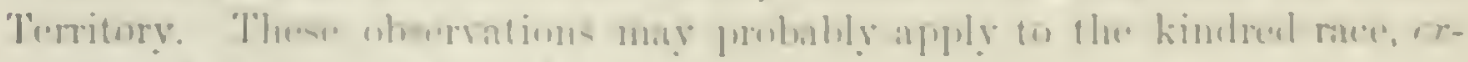

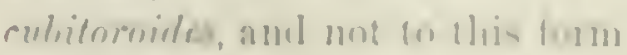

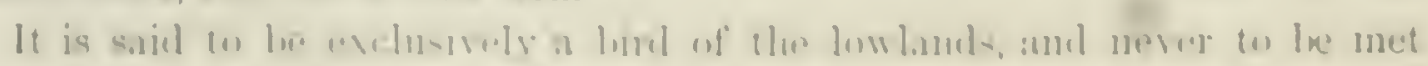

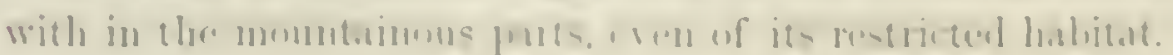


Dr. Coues fonnd this species rery common in the neighborhood of Columbia, S. C., frequenting the wooded streets and waste fields of that city. On one oceasion he observed a Loggerhead busily foraging for insects in the grumuls of the Capitol. From the top of a tall bush it would occasionally sally out, capture a large grasshopper, and carry it to a tree near by, full of sharp twigs. It would then proceed to impale the insect on one of these points, remain awhile watching the result of its performance, and then resume its post on the bush, watching for more grisshoppers, some of which, one by one, it canglit and impaled in like manner, other's it ate on the spot.

This curious habit of impaling insecto, more or less common to the entire family of Shrikes, seems to admit of no satisfactory explanation. In this case the bird thus secured them when apparently lungry, eating some and impaling others. Yet, so far as I know, it never makes any use of those it thus impales.

Mr. Audubon states that in Soutl Carolina it is quite common along the fences and hedges about the rice plantations at all seasons, and that it renders good service to the planters in the destruction of field-mice, as well as of many of the larger insects. He speaks of its song as consisting only of shrill, chlear, creaking, prolonged notes, resembling the grating of a rusty hinge. His account differs, in many respects, from the more minute and exact descriptions of Rer. Dr. Bachman. In pursuing its prey, he states that it invariably strikes it with its bill before seizing it with its claws.

In reference to its song, Dr. Bachman states that it has other notes besides the grating sound mentioned by Audubon. During the breeding-season, and nearly all the summer, the male birl posts itself at the top of some tree and makes an effort at a song, which he compares to the first attempts of a young Brown Thrush. This is a labored effort, and at times the notes are not umpleasing, but very irregular.

Dr. Bachman also claims that the male evinces marked evidences of attachment to lis mate, carrying to her, every now and then, a grasshopper or a cricket, and driving away liawk or crow as they approach the nest.

He also states that he has usually found the nest on the outer limbs of trees, often from fifteen to thirty feet from the gromnd, and only once on a bush so low as ten feet from the ground. He has occasionally seen these birds feeding on mice, and also on hirds that had been apparently wounded by the sportsman. It will sometimes catch young birds and derour them, but its food consists chiefly of grasshoppers, crickets, coleopterous and other insects, including butterflies and moths, which it will pursue and capture on the wing. Dr. Bachman has observed its habit of pinning insects on thorns. In one instance he saw it occupy itself for lours in sticking np, in this way, small fishes thrown on the shore, but he lias never known them to derour anything thus impaled.

This Shrike is partially migratory in South Carolina, as a few may be found all winter, but only one tentl of those seen in summer. It is also 


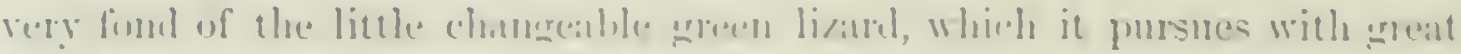

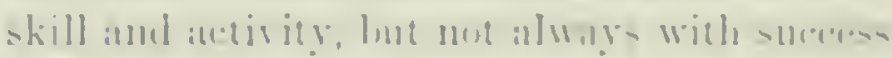

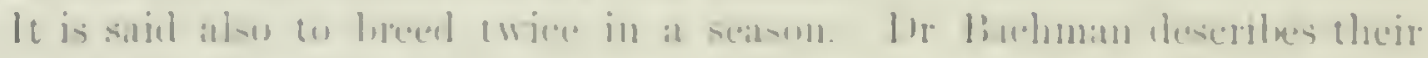

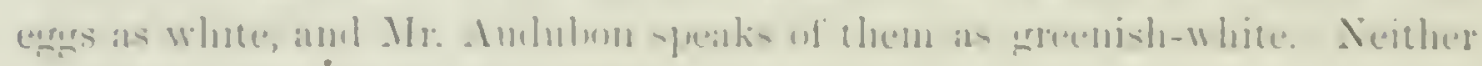
make any reference to their yots.

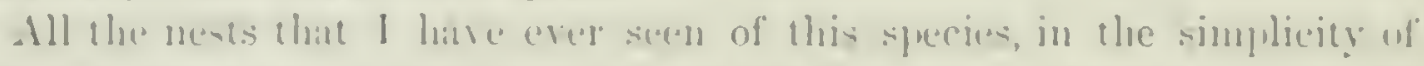

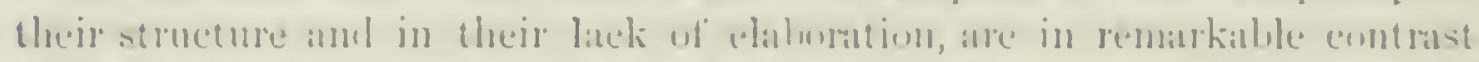

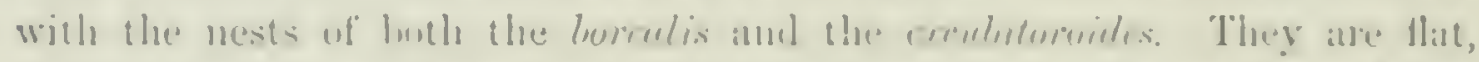
slabllow stmetures, with a height of about two inches and a diameter of five.

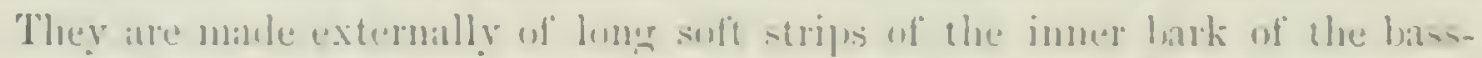

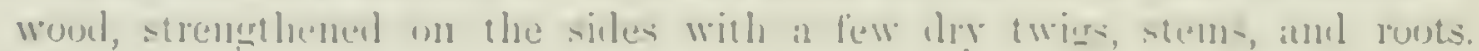

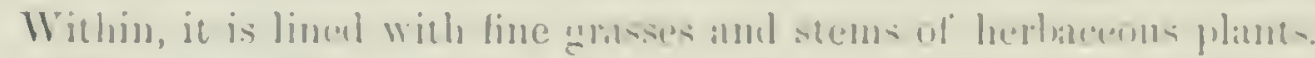

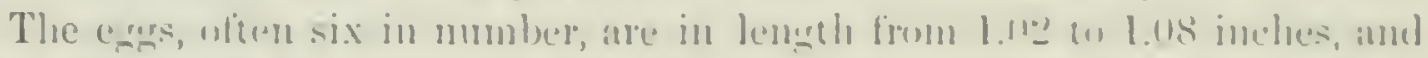

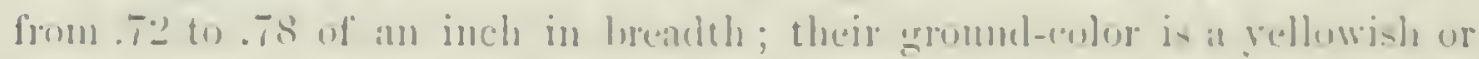

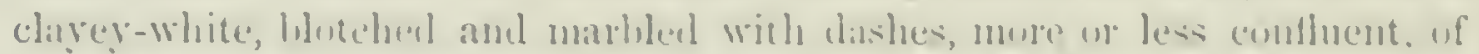
olscure jumple, light hrown, and a purplish-eray. The spots are msmally

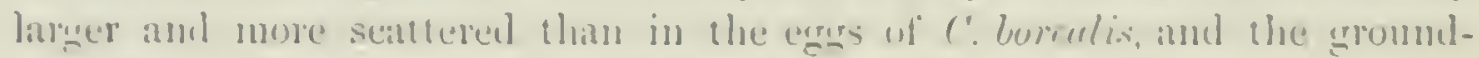

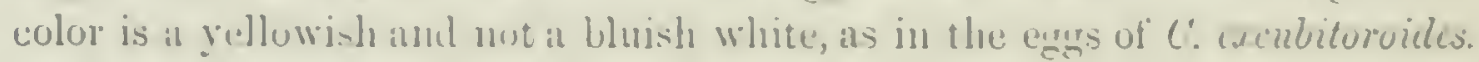

Collurio ludovicianus, var. robustus, li.,llit. WHITE-WINGED SHRIKE.

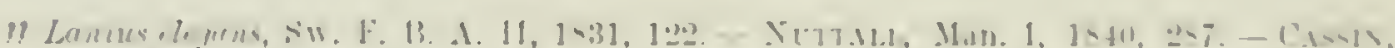

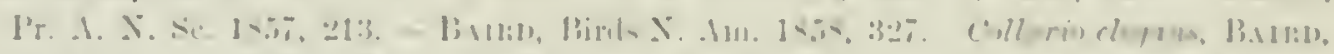

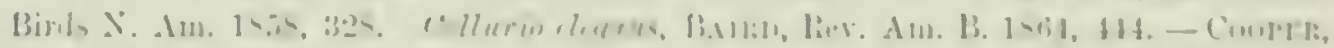

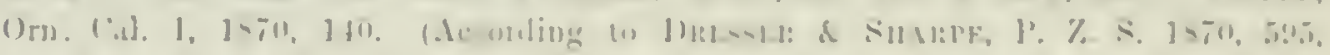

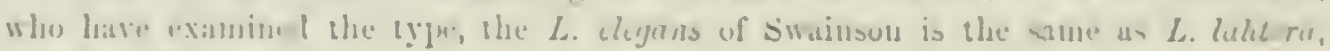
siki., of silntis.)

IIı\&. Cillibruia?

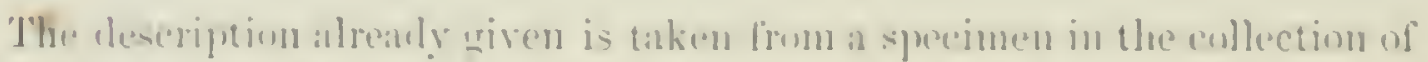

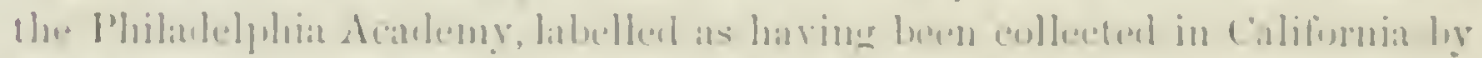

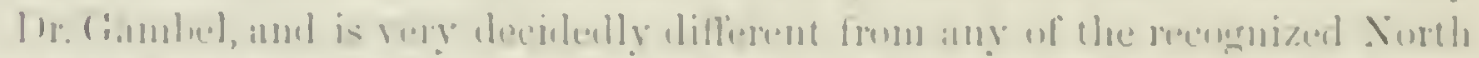

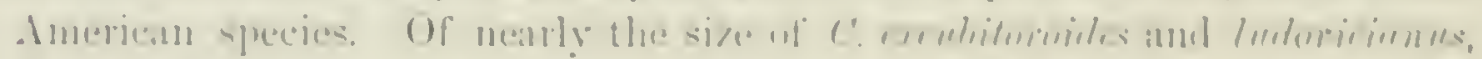

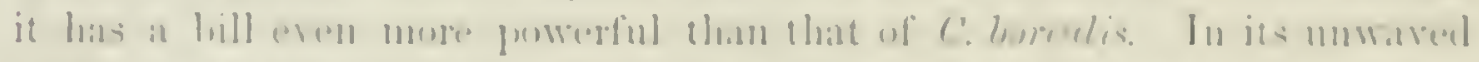

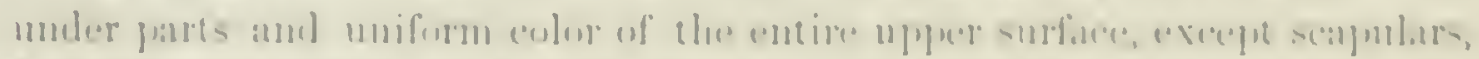

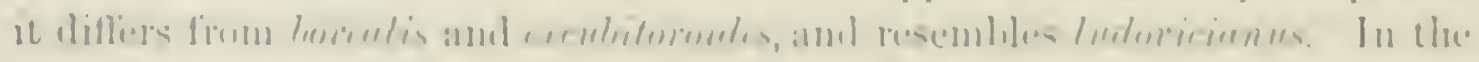

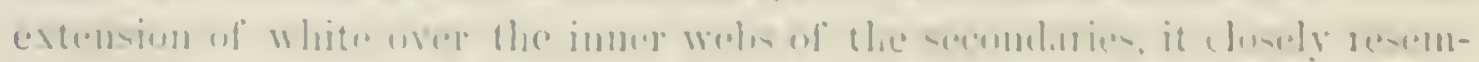

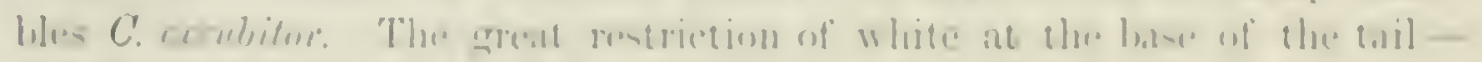

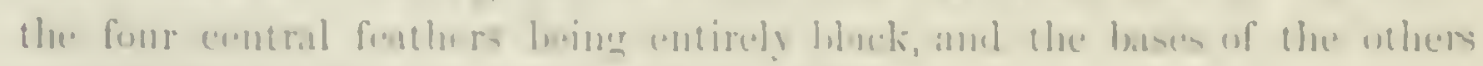

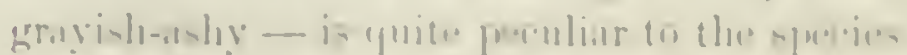

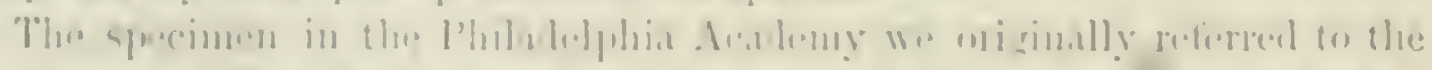

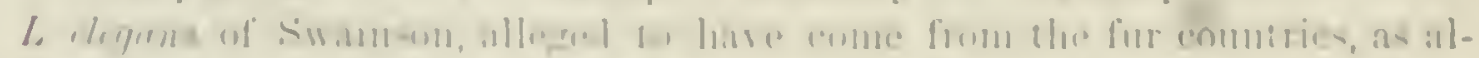

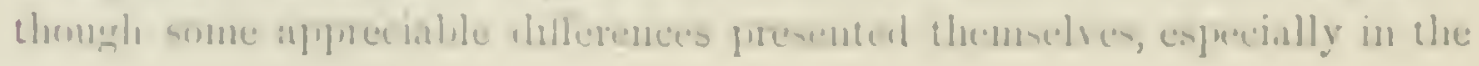


coloration of the tail, these were consilered as resulting from an imperfect description. Messrs. Sharpe and Dresser, however, as quoted above, show that Swainson's type really belongs to L. lahtora, an Old World species. We therefore find it expedient to give a new name to the variety, having no reason to discredit the alleged locality of the specimen.

\section{Collurio Iudovicianus, var. excubitoroides, Barin. WESTERN LOGGERHEAD; WHITE-RUMPED SHRIKE.}

Lanius crcubitoroides, Swarsor, F. B. A. II, 1831, 115 (Saskatchewan). - G.dmen, Pr.

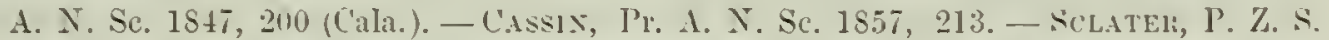

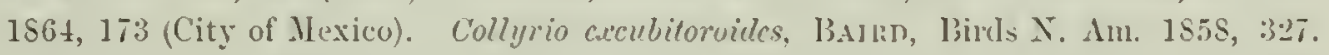
Collurio excub. BAllid, Rev. Am. B. 156t, 4t5. - Couplili, Orn. Cal. I, 1sio, 13s. ? Lanius mexicunus, Brenu, Cab. Jour. I1, 1554, 145. - Sclatril, Catal. 1561, 40 (Hexico). Lanius ludoricinus, Max. Cab. Jour. 185\&, 191 (Ĺpler Missonri). Dresser of SHIliIE, P. Z. S. $1570,595$.

Hab. Western Prorince of North America, as far north as Oregon; Midlle North America, to the Saskatchewan, and east to Wisconsin, Michigan, and Illinois; south to Orizaba and Oaxaca, and City of Mexico; Cape St. Lucas.

The precise boundaries between this species and $C$. hudoricianus are difficult of definition, as the transition is almost insensible.

The young bird is pale fulvous-ash above, everywhere with transverse crescentic bars of dusky. Two bands of mottled pale fulvous across wings, on tips of middle and greater coverts. Tail tipped with ochraceous, the white feathers tinged with the same. Breast and sides with obsolete luars of dusky. Black band on side of head rather olsolete.

In its extreme stage of coloration it differs from ludoricianus in paler and purer color; the ash of back lighter; the under parts brilliant white, not decidedly plumbeous on the sides as in the other, and withont so great a tendeney to the usual obsolete waverl lines (noticed distinctly only in wiater or immature hirds); the axillars bluish-white, not plumbeous. The white of wings and tail is more extended ; the hoary of forehead and whitish of scapulars more distinet. The bristles at base of bill somewhat involving the feathers are black, forming a narrow frontal line, not seen in the other. The most striking difference is in the rump and upper tail-coverts, which are always appreciably and abruptly lighter than the back, sometimes white or only faintly glossed with phunbeous; while in typical specimens of ludovicianus these feather's are scarcely lighter at all, and generally more or less varied with blackish spots at the end. The legs and tail are apparently longer, the latter less graduated. These differences are, lowever, most appreciable in specimens from the Middle and Western Provinces. Those from the Western States, east of the Missouri River, as far north as TVisconsin, are more intermediate between the two, although still nearest to the Rocky Momntain bird 
at descrileal ; the batck darker, the rump and axillars nore plumberus, the sides more lilui-h. There is little dould that the eximination of series from

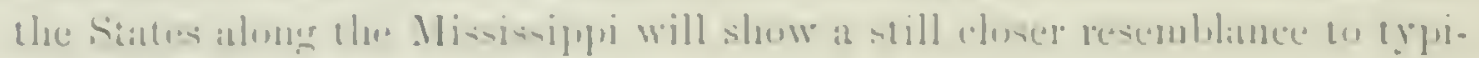

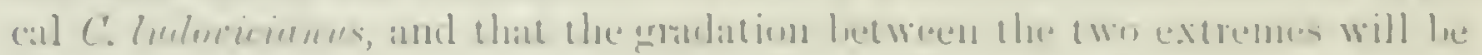

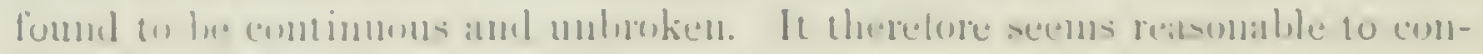

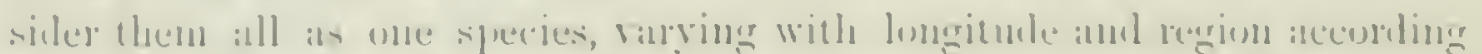

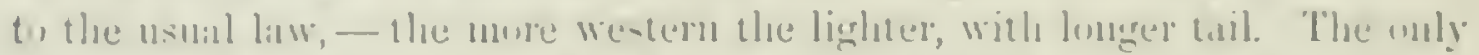

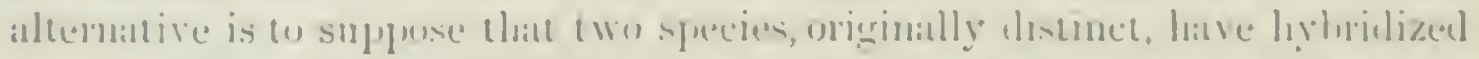

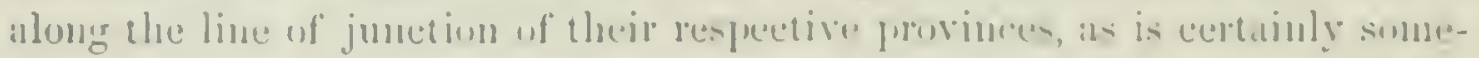
times the tase. The alpheximation in many reserets of colomition of the

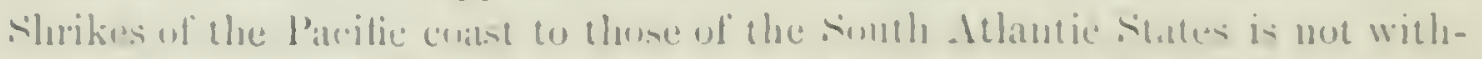
out its inportance in the discenssion of the sulpeet. Howeres it may he, it

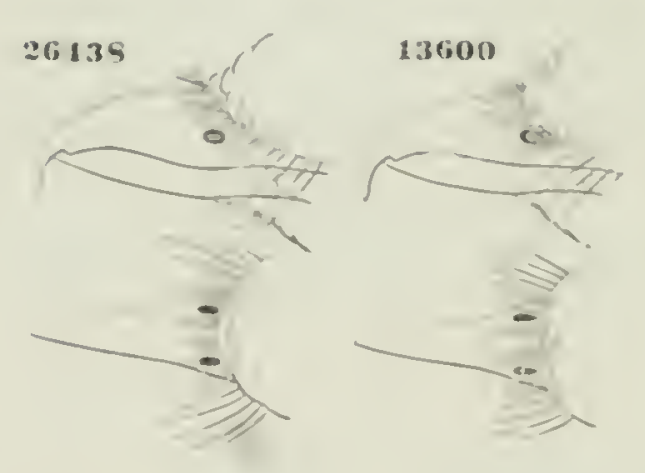
is necessing to retain the name of erenbiturnilis, als repesentutiner, whether it.s species or variety, al pereuliar resindal linm. Which must be kept distinetly in minl. The comparatively greater size of the hill in the (itpe st. Lateils specimens is seen in othere speecien from this Lemality (No, 26, 6 tis of adjacent lignre).

The intensity of the luack front in this species raries considerably, lnemer sometimes very distinct, and again entirely wanting. This may probally.

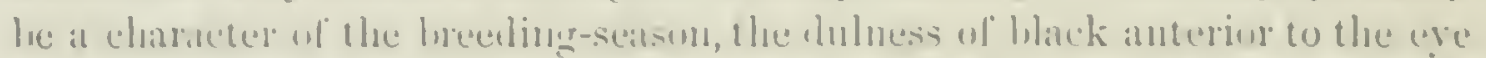

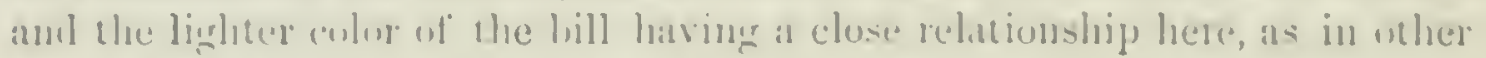
speciles, to maturity, sex, ind se:simn.

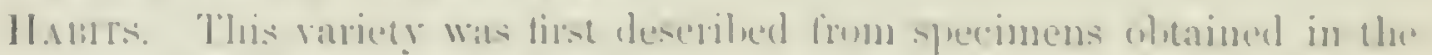

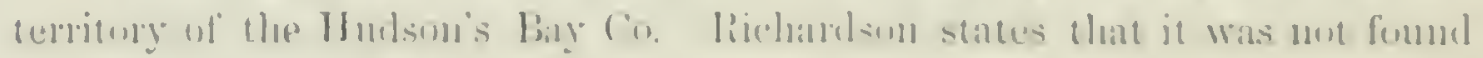

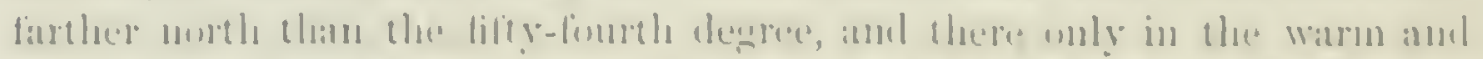

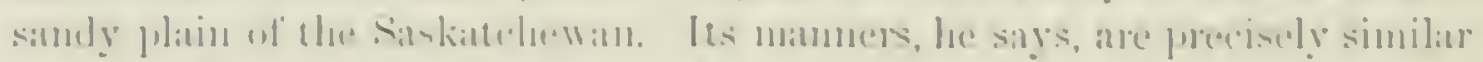

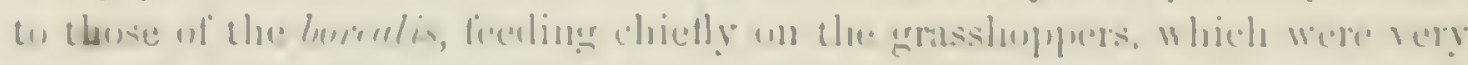

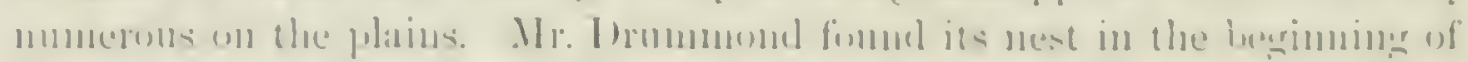

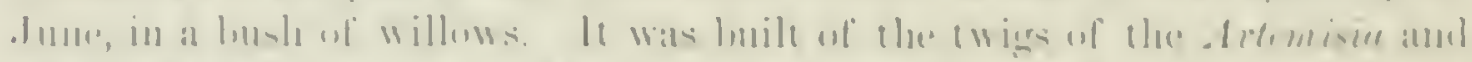

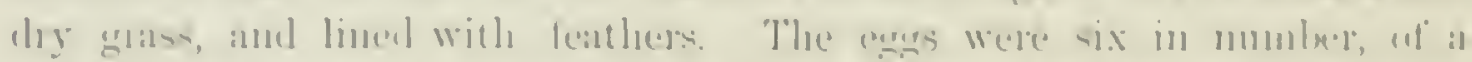

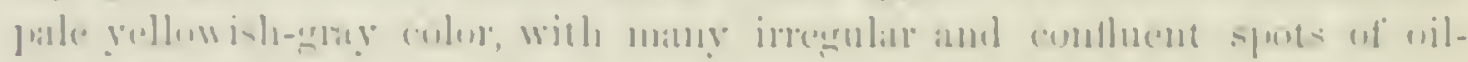

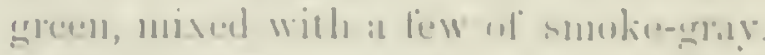

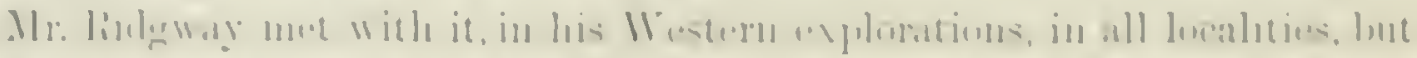

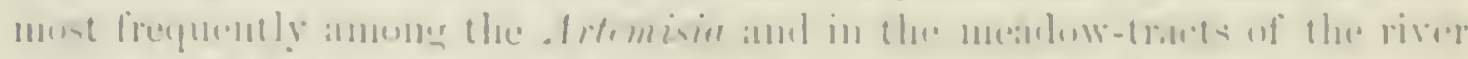

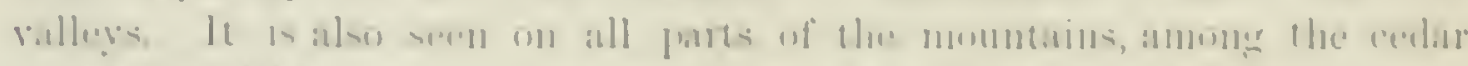

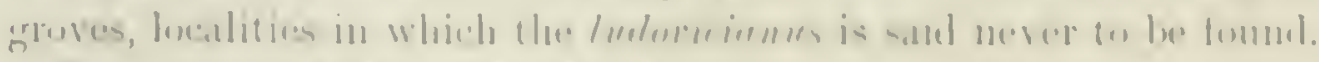

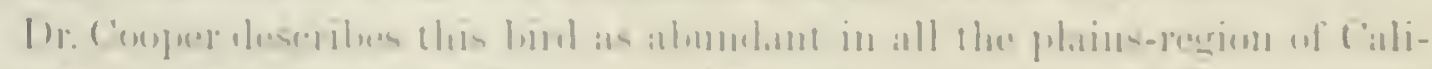

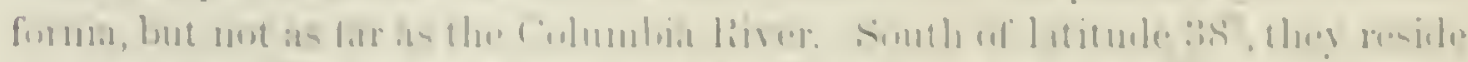

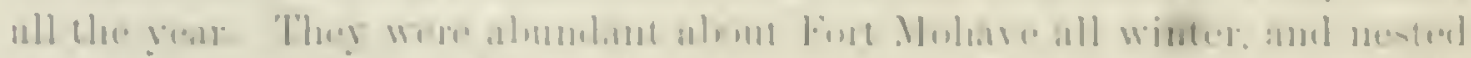

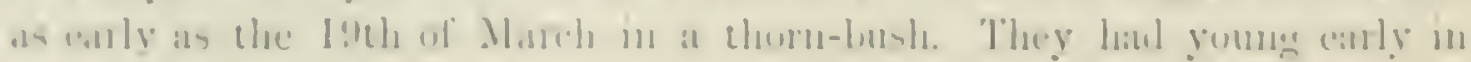


April. At San Diego they nested later, about April 20. He speaks of their singing as an attempt at a song, the notes being hinssh, like those of a Jay, lut not imitative. They catch birds, but do so very rarely, depending upon urusshoppers and other insects.

The nests of the carcubitoroides, so far as I have had any opportunity to examine them, always exhibit a very marked contrast, in the elahorateness of their structure, to any of the ludoricianus that have fallen under my notice. They resemble those of the borealis in their size and the felted nature of their walls, but are more coarsely and rudely put together. They have an extermal diameter of about eiglut inches, and a height of four. The earity is also large and deep. These nests are always constructed with much artistic skill and pains. The base is nsually a closely impacted mass of fine grasses, lichens, mosses, and leares, intermingled with stout dry twigs. Upun this is wrought a strong fabric of fine wood-mosses, flaxen fibres of plants, leares, grasses, fur of quadrupeds, and other substances. Intertwined with these are a sufficient number of slender twigs and stems of plants to give to the whole a remarkable strength and firmmess. This is often still further strengthened by an extemal protection woven of stouter twigs and small ends of branches, stems, etc. The whole is then thoronghly and warmly lined with a soft matting of the fur of several kinds of small animals, vegretable down, and a few feathers.

The eggs, fire or six in number, measure $1.00 \mathrm{hy} .7: 3$ of an inch, and strongly resemble those of both the borectis and the ludoriciunus. Their ground-color is pale greenish-white, orer which are marks and blotehes, more or less confluent, of lilac, purplish-brown, and light umber:

Mr. Rilgway, who is faniliar with this birl in Southern lllinois, informs me that in that section it is a resilent species, being abundant during the summer and by no means rare in the winter. It is there, strangely enough, often called the Mocking-Bird, its similar appearnnce and fondness for the same locality leading some persons to confound these very different birds. In districts where the true Wimus is not common, young birds of this species are frequently taken from their nests and imnocently sold to unsuspecting admirers of that highly appreciated songster.

This bird inhabits, almost exclusirely, open situations, being particularly fond of waste fields where young honey-locusts (Gileditschia triucunthos) have grown up. Among their thorny branches its nests are almost utterly inaccessible, if beyond the reach of poles. In such localities this hird may often be seen perched in an upright position upon some thorn-bush, or a fencestake, quietly watching for its prey, remaining nearly an hour at a time motionless except for an occasional morement of the head.

The flight of this bird, Mr. Ridgway adds, is yuite peculiar, utterly unlike that of any other bird except the Orcoseoptes montenus, which it only slightly resembles. In leaving its perch it sinks nearly to the ground, describing a curve as it descends, and, passing but a few feet above the surface, ascends in 


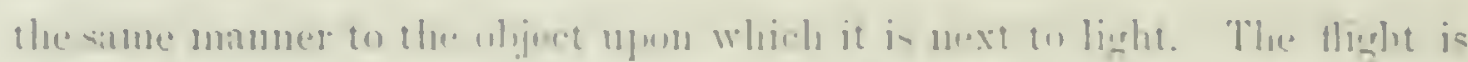

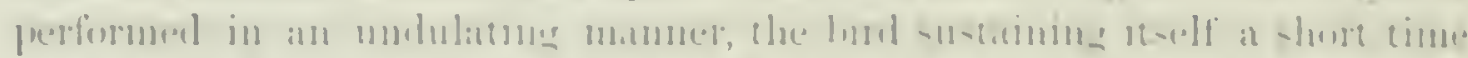

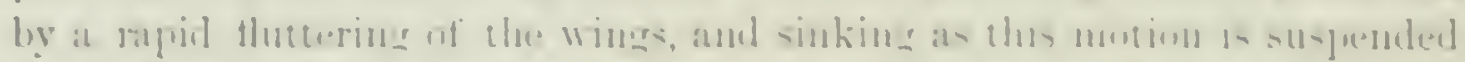

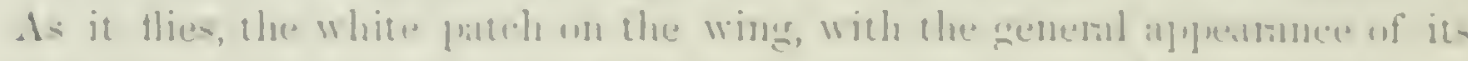

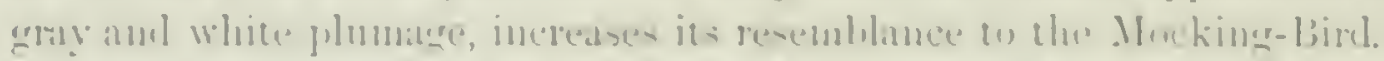

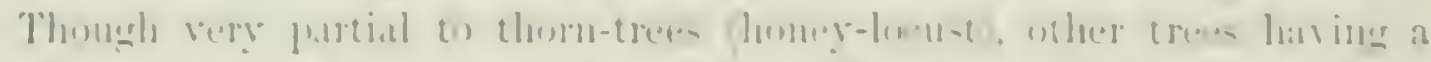

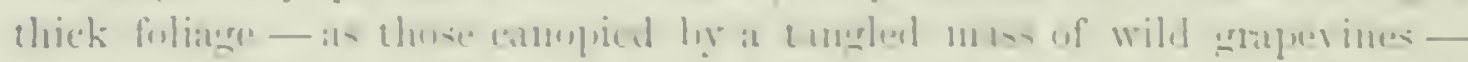

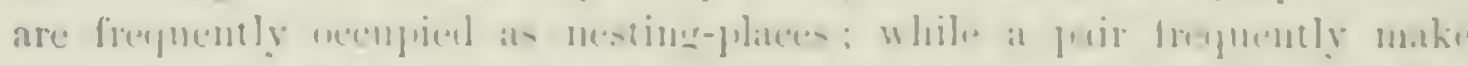

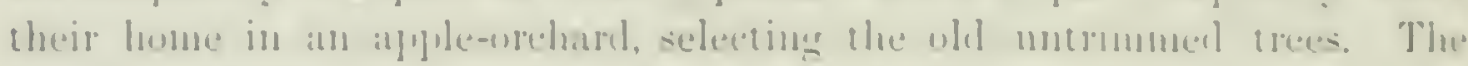

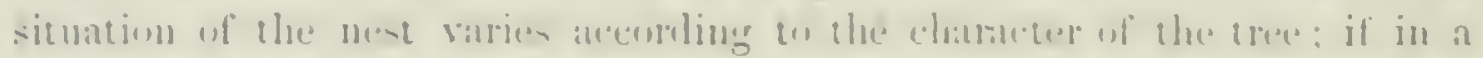

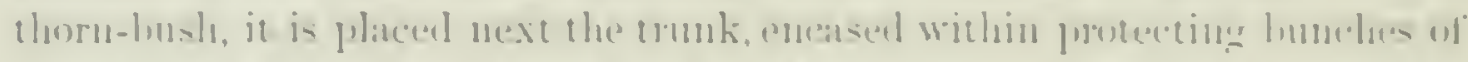

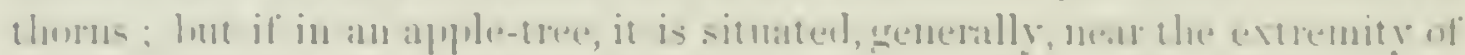

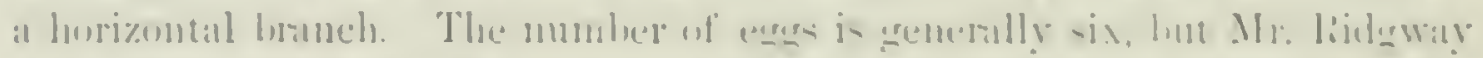

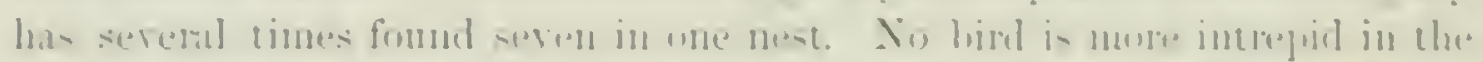

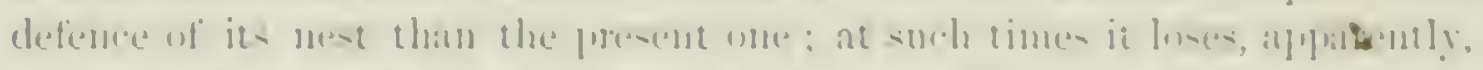

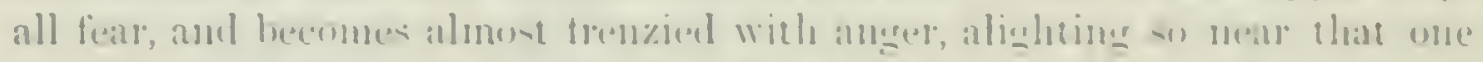

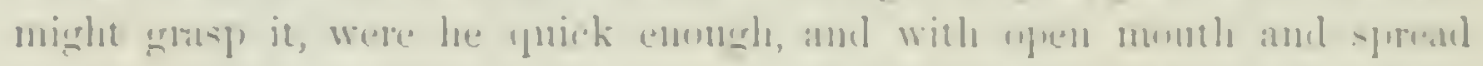

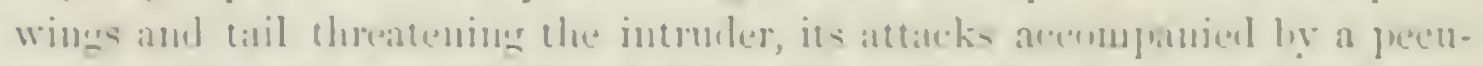

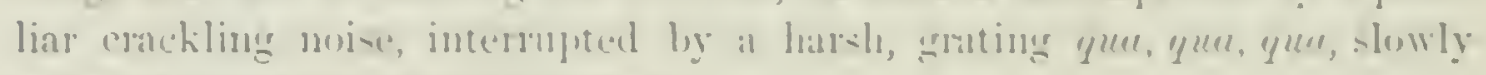
repeated, but comphattically nttereel.

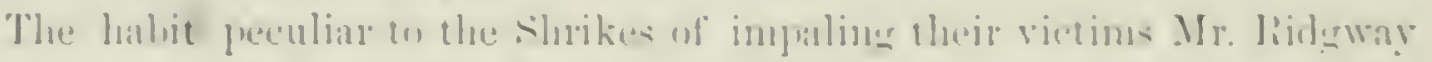

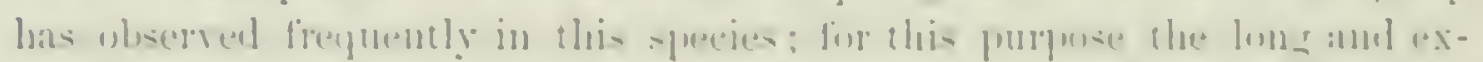

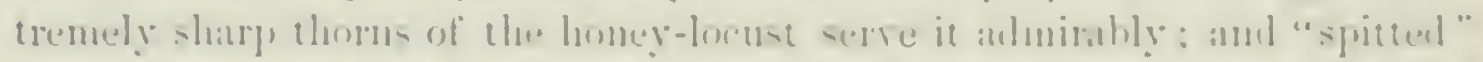

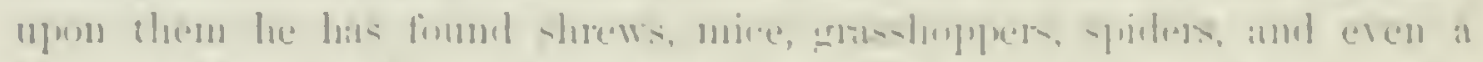

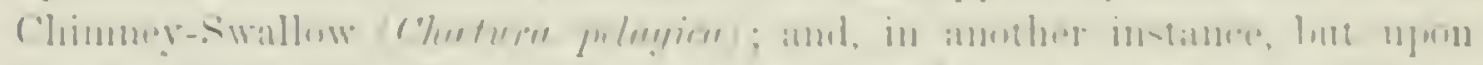

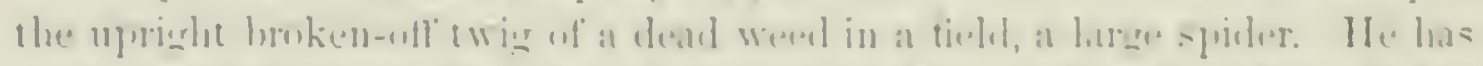

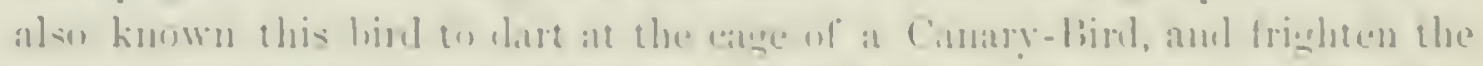

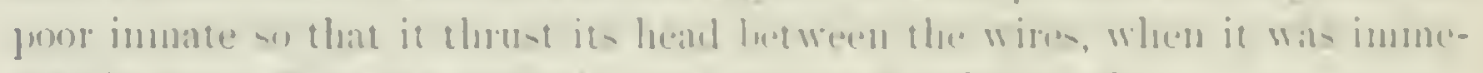
diately torn ofl by the puwertul beat of the binteher-birel.

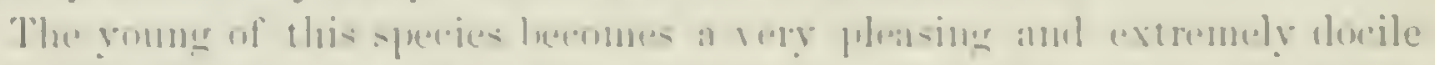

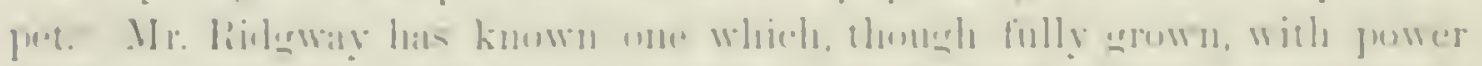

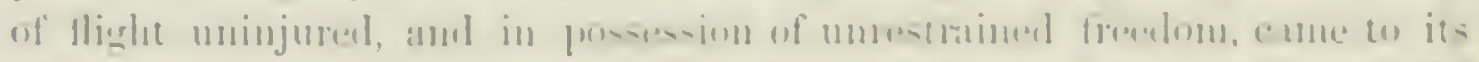

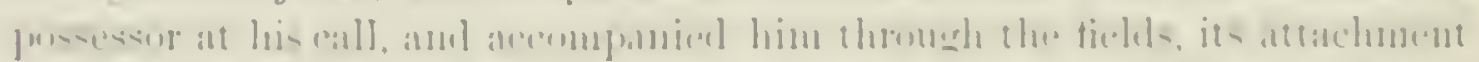

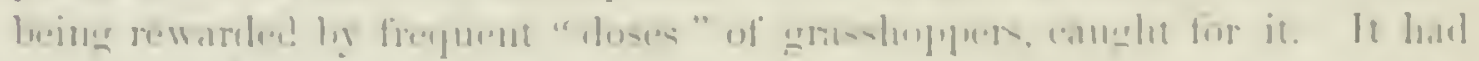

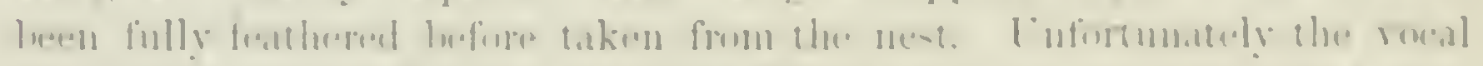

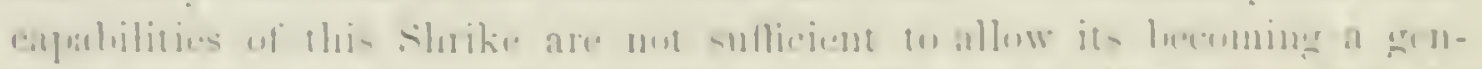

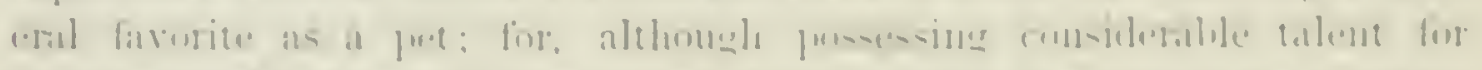

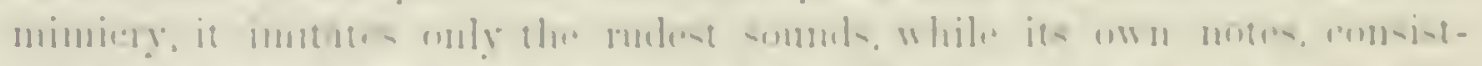

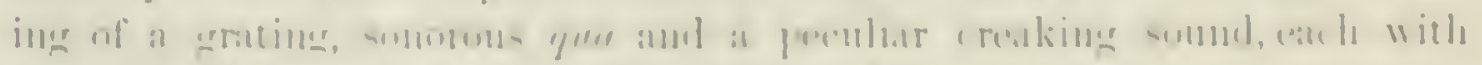

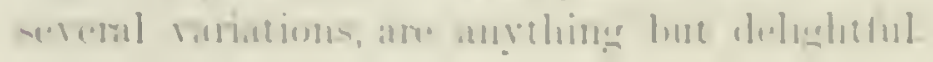




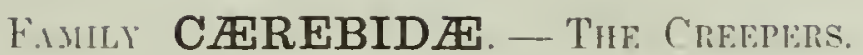

As already stated on linge 177 , there is little to distinguish the Curbida from the Sylicolinla, except by the longer and more protracted tonghe, and by the narrower galle in some of the forms. The genera Corthiola, Corebu, Diglossu, etc., have peculiarities by which they are eisily recognized ; but when we come to such members as Ducuis, Conirostrum, etc., it becomes very difficult to seprarate them from the slender-billed Tanagers, the Wood Warblers, and the Hehminthopluens.

Althongh the family is one widely distributed, in munerous genera, over Midklle and South Anerien, but one, C'crthiolı, belongs to North America, this being represented hy a species, or rather" al race, abundant in the Ballamas, and occasionally met with in the Florida Keys. We shall therefore give oinly the diagnosis of this fimily.

\section{GeNis CERTHIOLA, stromila.}

Certhiolu, Stxpeviu, Vet. Akal. Handl. Stockholm, 1835, 99. (Type, Certhia Aaveola, Lix.)

Gex. Cir.u:. Bill ucarly as long as the heal; as high as broad at hase. clongated, conical, rery acute, aud gently decurved from base to tip. Culmen uniformly convex : gonys concave. No bristles at base of bill. Tail rommled, rather shorter than the wings. Tarsi longer than the niddle tou. Iris brown? Nest pensile and arehed. Egrss with ycllowish ground dotted thickly with rufous spots.

This genus is one of those especially "rlaracterizing the West Indies, alnost erery island as far as known having its peculiar species, differing, it is true, in very slight

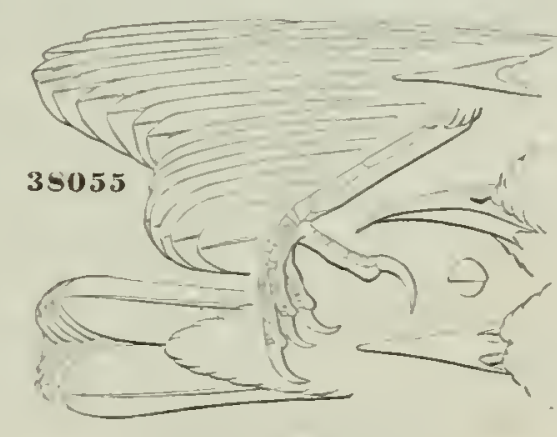

Firlliolu fureola, Sund. eharacter's, but always constant to the nominal type. Cuba alone lias so far furnisled no representative of this wenus, its place being supplied apparently by curdur cyanca. The specimens from St. Thomas I cannot distinguish from thuse of Porto Rico, but this is, so far as the series before me indicates, the only case where one species oceurs on two islands. All the West Indian species, nine or ten in number, agree in having the whole upper part nearly uniformly dusky or blackish; the head and back being: concolored, while of the three or four south Anerican all but one $(C$. lutcola) have the back more olivaceons, the head murh darker. Again, the West Indian species, with a single exception (C. bunanicora), have both webs of lateral tail-feathers broarly and about equally tipped with white; while in all the Sonth American this white is more restrieted on the imner 


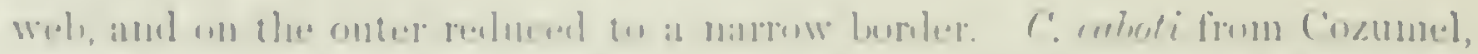

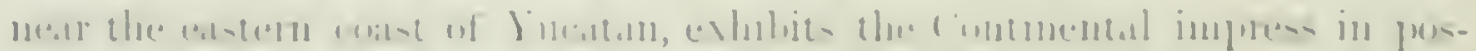

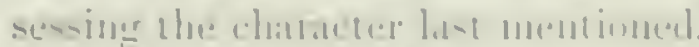

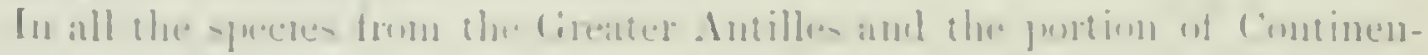

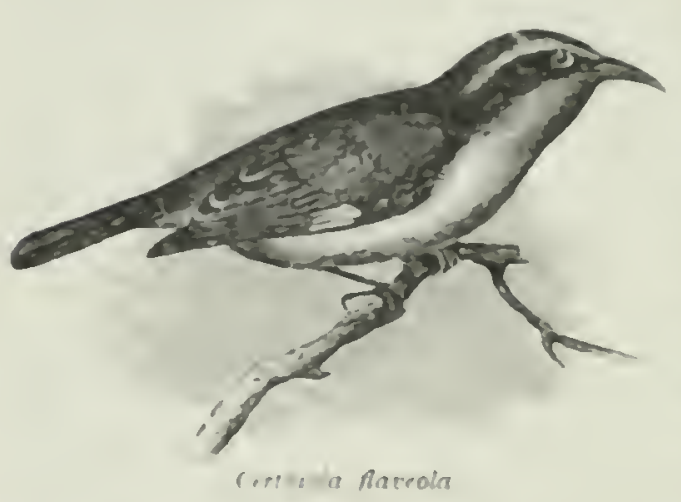

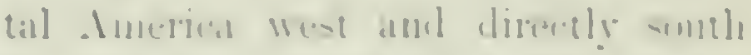

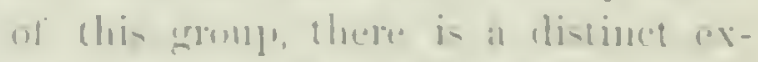

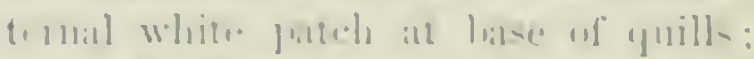

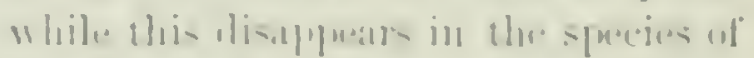

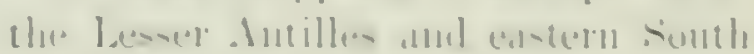

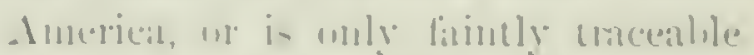

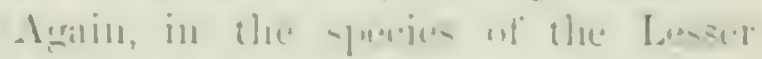
Antilles, with the disalpentance of the white wing-patch, the ereater am mint-

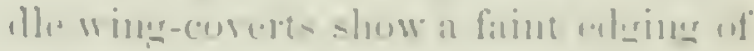

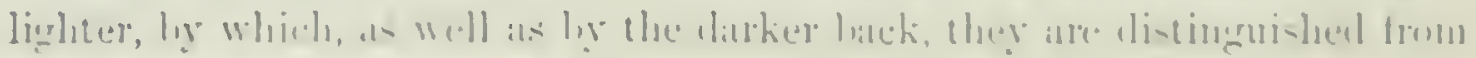
their sumth . Amserican allice.

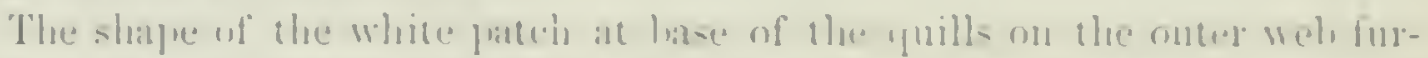

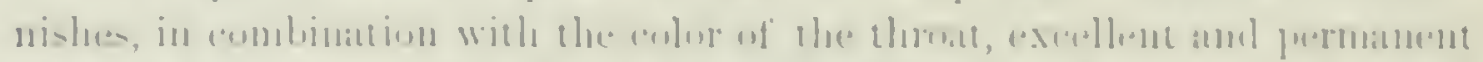

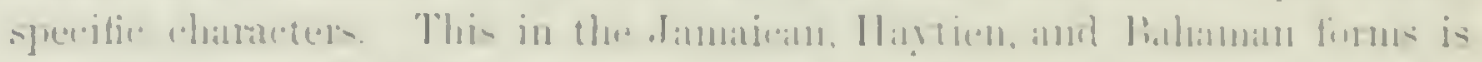

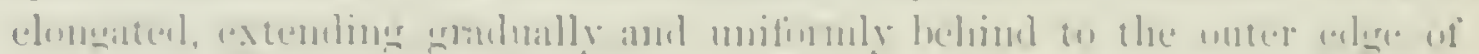

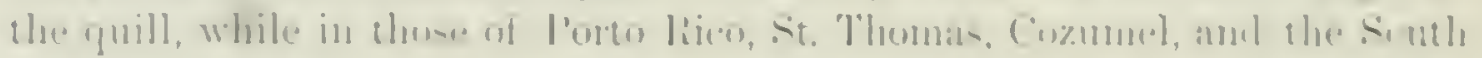

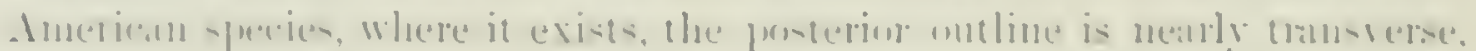

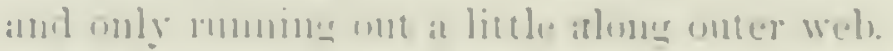

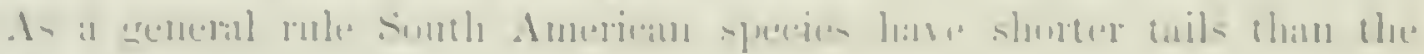
Wind Indiun

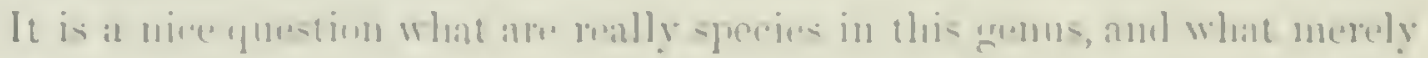

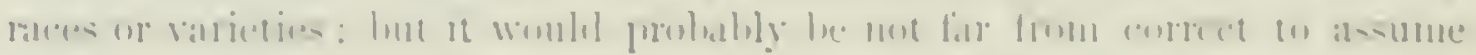

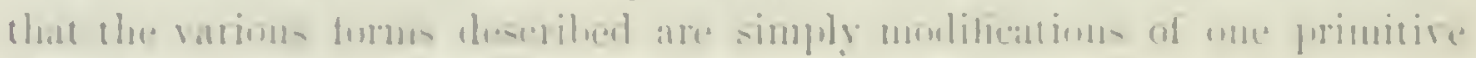

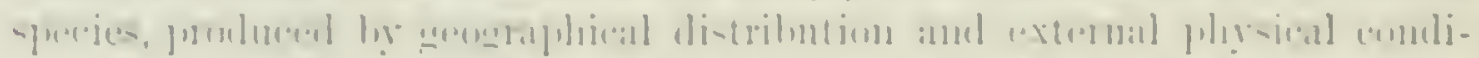

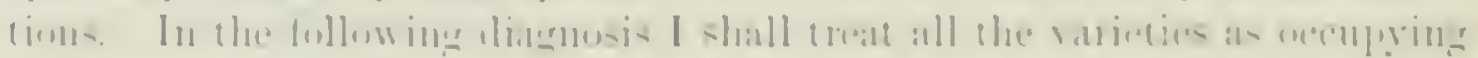

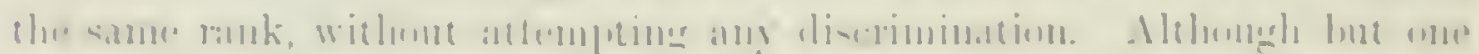

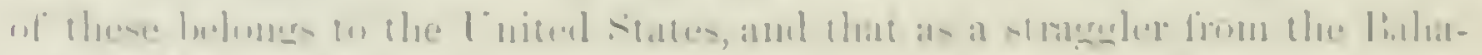

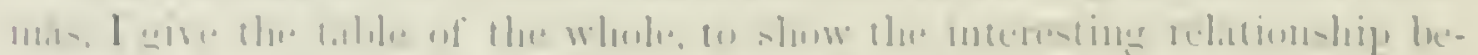
\{111.11 ใ / $1 \mathrm{~L}\} 1$

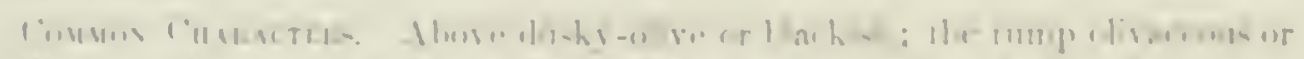

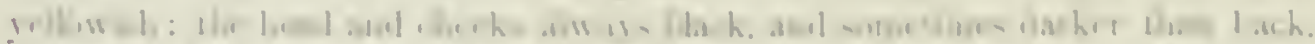

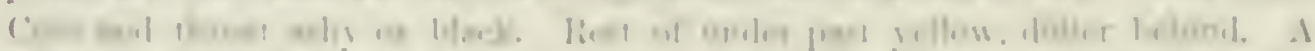

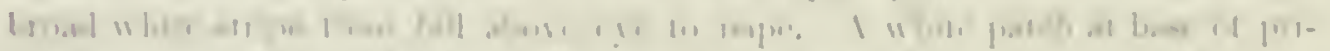

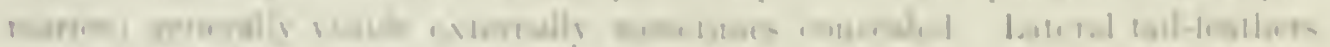

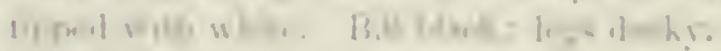

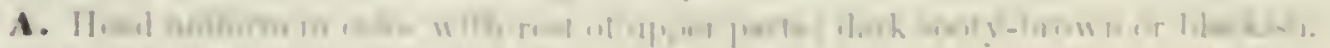

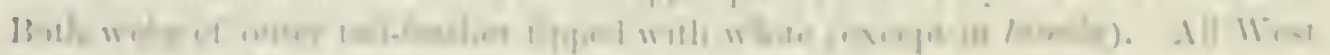

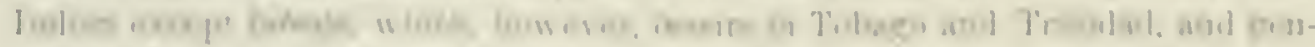

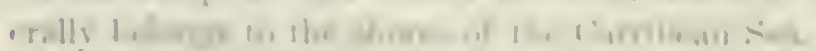

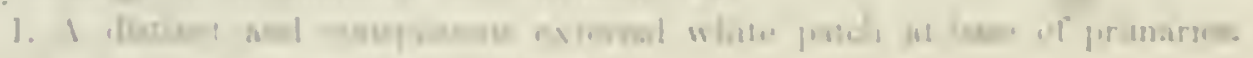

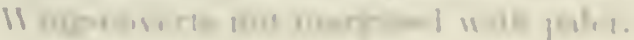


a. Throat unibormly but dercided datk ash-color, rarying in shade, nerer eutirely black, howerer, nor asly-white.

Throat vely dark ash, not contrasting or apprecialuly different liom Whekish of checks.

Wing-spot clongated; the white running out gradually and oblinucly behind to the outer edge of the primaly, renching slatt of outer primary. Fellow of breast decidedly ochraceons. Rump as bright yellow as the belly. Hab. damaica .
White patch of wing more quadrate on each quill; transrerse; not tapering ofl' gradually and unilormly behind; not reaching the shaft on onter primary. Breast without ochriaceons; rmmp olivaceons-yellow; the color different firom that b. Chin and throat lighter ash (but not at all whitish); in clecided and appreciable contrast with blatkish of eheeks. Jugulum yellow, like under parts generally.

Lateral tail-feather broally tipped with white on hoth webs. limmp olivaceons-yellow.

Wing-spot on each primary nearly quanleate, as in nerrtumi.

Hab. Porto Rico and st. Thomas . . . . prortoricensis. ${ }^{3}$

Lateral tail-feather with inner wel) only boatly tipperl with

white. Itump lught yellow like belly. Bill rely small.

White of wing as in jlaceola, but less extended, and matrgining erlgere only of onter primary. Lhtb. Ilayti and St. Domingo . . . . . . . . benenirora.

White of wing as in nevefoni. Sime much larger; darles

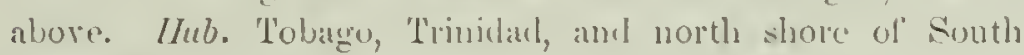
Amerier

luteoln..$^{5}$

c. Chin, throat, and jugnum white, with a tinge of aslyg. Yelluw of under parts meh restricterl.

Depth ol' litl less than half distance from nostril to tip. Sinperciliary stripe reaching to nape. Fellow of under part restrictud to a triangular patch on breast. White spot on wing large, tapering of gradually on cach primary, as in fluveola; on the outer reaching shaft. Both webs of outer tail-feather about equally tipreel. Itwb. Bahlamas and Florida Keys

Depth of bill fully latl" distance from nostril to tip. Suprerciliary stripe reaching the occiput only. Yellow of muler parts more extended. White spot on wing restrictel; more qualrate, as in neutoni; edge only of outer primary involved. Onter web of outer tail-feather scarcely tipped. IIab. Cozumel Island, Fueatan . 2. No external white patch at hase of primary quilk. Wing-coverts obscurcly margined with palter. Both wels of onter tail-feathers tipped about equally with white. Rump olivaceons; this color of but slight extent.

1 Certhin faceola, Lixx. Syst. Nat. ed. 10, 1758, 119.

2 C. farcole, A. \& E. Newtos, 1bis, 1859, 67. IInb. St. Croix. C'. nertoni, Bann.

3 C. Alaveole, var. portoriennsis, Bryast, Pr. Bost. Soc. N. H. Jan. 1866. Hab. Porto Rico.

4 .Motacilla bananivoru, G.Melix, Syst. Nat. I, 1788, 951. (Bananiste, Buffon, St. Domingo.)

${ }^{5}$ Certhiste luteote, CAB. II. H. 1851, 96. C. major, CAB.; C. minor, Bus.

${ }^{6}$ Certhiolu bahemensis, Reicir. IIandb. I, 1853, 253. C'. fleveolu, B.sll, B, B. N. 1. ; C. bairdi, CAB.

i C. culoti, Ballin, MSS. 


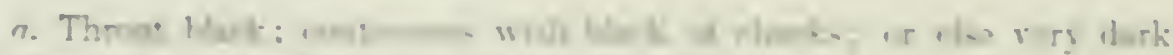

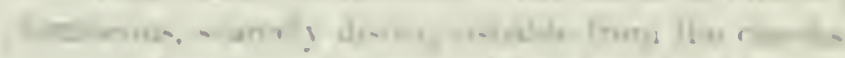

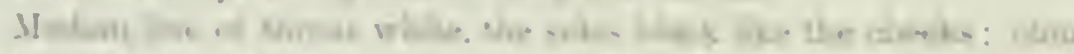

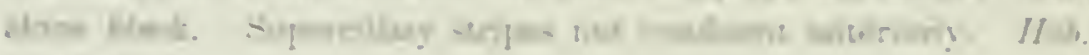

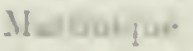

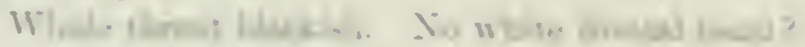

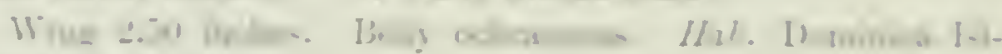

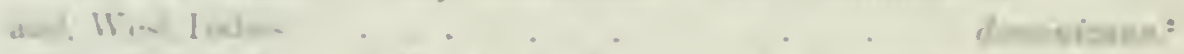

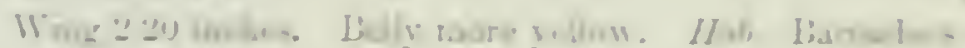

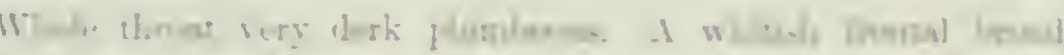

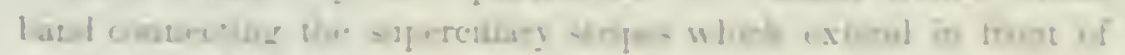

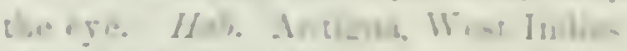

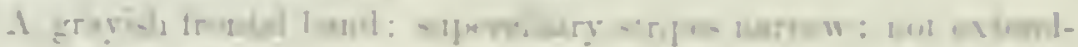

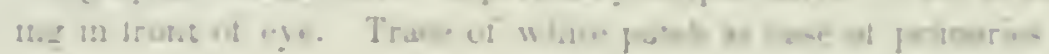

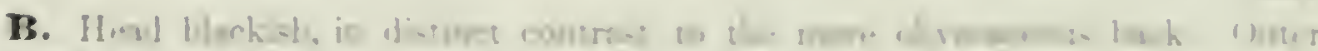
enthe $\sin ^{3}$

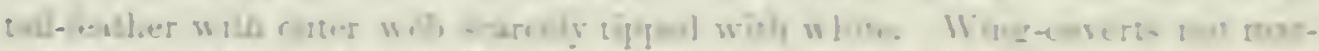

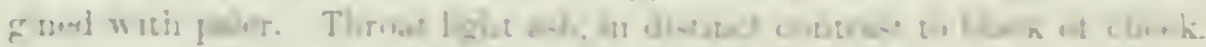

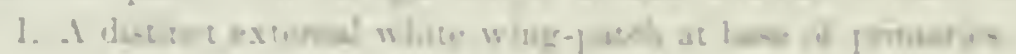

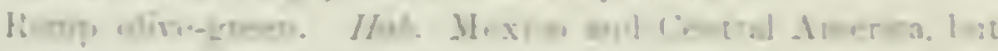

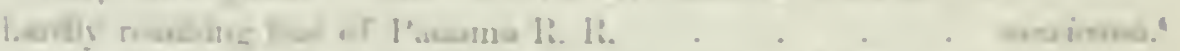

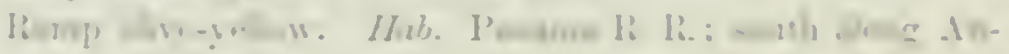
1] 0.5 is, l'ons

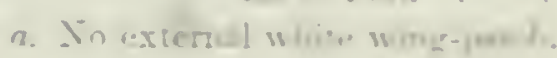

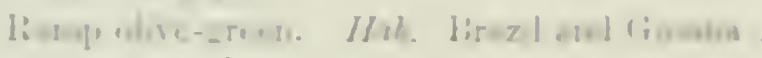

rin $i=0$.

ringmes

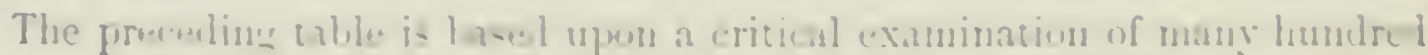

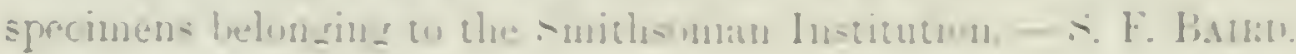

Certhiola bahamensis, lifun.

\section{BAHAYA CREEPER.}

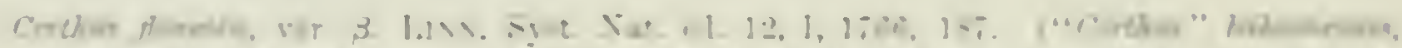

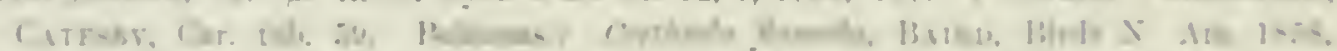

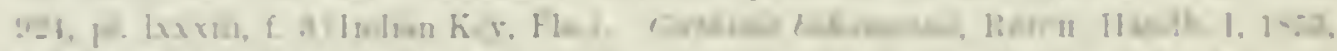

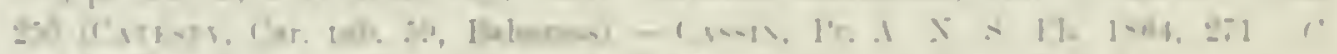

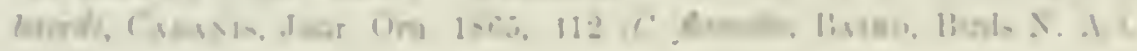

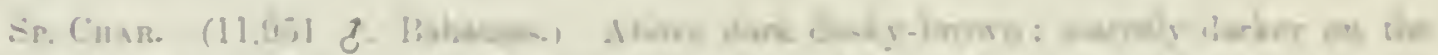
I

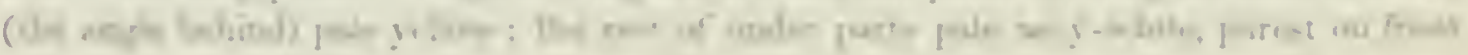

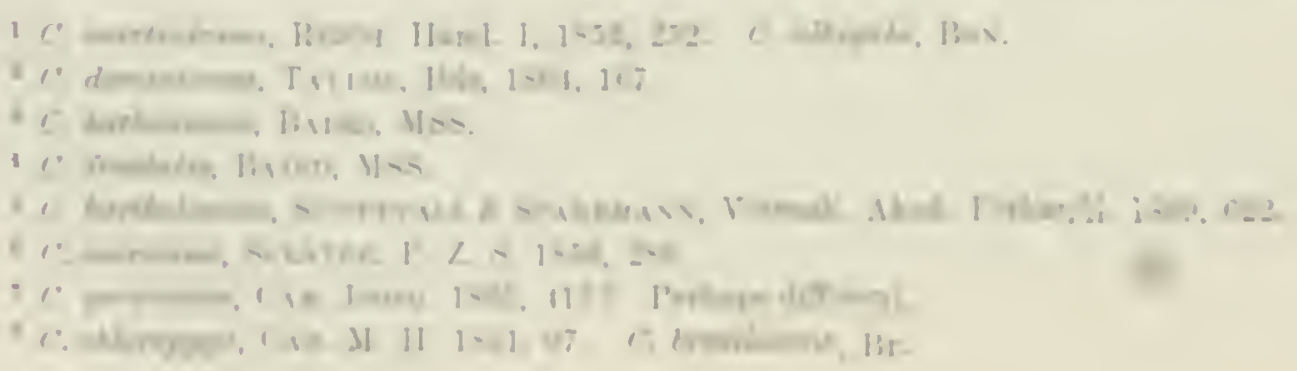


and sides of neck and ou crissum; on Ranks somewhat soiled and rather" darker. A loroal supereiliary white stripe (not crossing the foreheal) from bill to nape, but little lighter than the throat; the line of feathers immediately behind the nostrils, and a small patch at base of lower mandible under the tins, with the usual stripe from bill through the eye, heing blackish. White spot at base of quils rery distinct extemally; the posterior outline on each onter web of the primaries not qualrate, but ruming ont obliquely behincl and on the outermost puill reaching the shaft. Elges of quills narrowly margined with arayish-white: on the seconclaries continned romel the tips. No listinct bands on the coverts. Outer tail-teathers broally tipperl with white; this eren inrolving the innemost, but reducerl to a marrow elge. Total lenerth, 4.40 ; wing, 2.30; tail, 1.80.

13ill: I.engrth from forchearl, .62; from nostril, .t1; along gape, .59; depth at base, .17. Legs: Tarsus, .75; mildle toe and claw, .js; claw alone, .17; hind toe and claw, .45; clatw alone, 20.

Han. Bahamas and Keys of soutleast const of Florida.

A speeinen from the Florida Krys $(10,367)$ is rather darker than those from the Bahamas, the white less extended, and not yuite reaching the shafts in the-outer quills.

Habits. This species, helonging properly to the Baluanan group of the West Indian Islands, was fomd at Indian Key, lla., January :31, 1S58, by Mr. Wirdemam, where it appeared to be not at all rare. Nothing is known of its habits, but they are dountless nearly the same as those of the allied species. The C. Alureole is known in Jamaica as the Bamana Quit, MoneySncker, and Black and Yellow C'reeper. According to the deseription of them given by Mr. Gosse, these birds, scarcely lirger than the llummingBirds, are often seen in company with them, probing the flowers for similar puposes, but in a very different manner. Instead of hovering like the II umming-Bird in front of the blosson, for which its short wings would be incompetent, these birds alight on the tree and proceed in a very lusiness-like mamer. Hopluing from twig to twig in an active manner, they carefully exannine each blossom. In doing this they throw their bodies into a variety of positions, nften clinging by the feet with the back clownards, the hetter to reach the interior of a blossom with their curved bealis and peculiar tongue. The objects of these researches are the small inseets which are always found in the interior of flowers. This bird is unsuspecting and familiar, and rery freely resorts to the blossoming shrubs of the gardens and yards. Mr. Gosse mentions, in evidence of this familiarity, that a large molinga-tree under his window, as he was writing, and which all throngh the year was profusely set with fragrant blossoms, and was a farorite resort of these birds, was being carefully scrutinized by two active little Creepers. Although within a few feet of his window, they pursued their examinations, perfectly undisturbed by his looking on. As they move about they utter a soft sibilant note.

The nests of this little bird are usually built in those low trees and bushes to which are fastened the nests of the brown wasps, and in close contiguity to them. Mr. Gosse regards this singular predilection as a remarkable exercise of instinct, if not of reason, as the evident object of it is the protection 


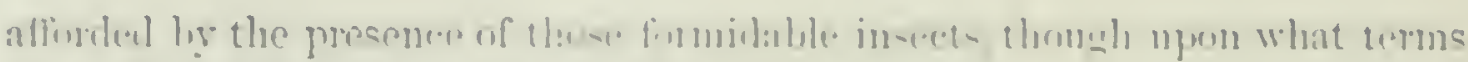

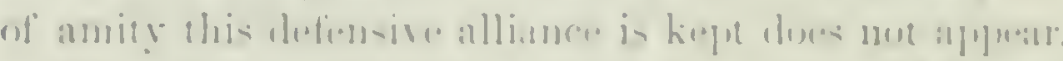

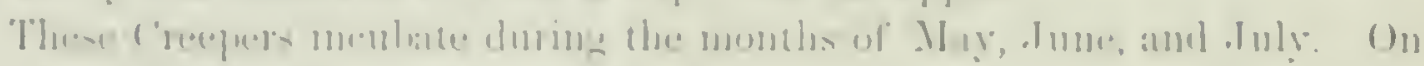

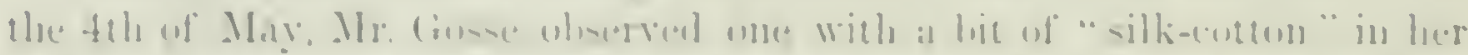

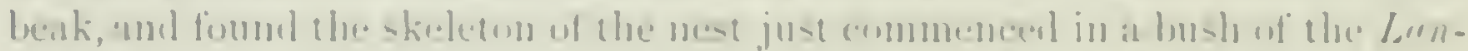

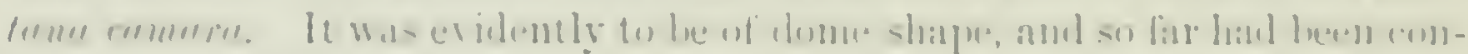
structed entirely of silk-cotton. The rompleted mats are male in the finm

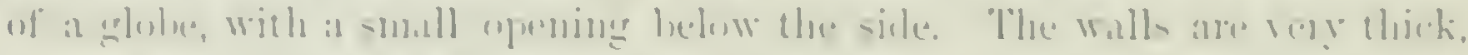

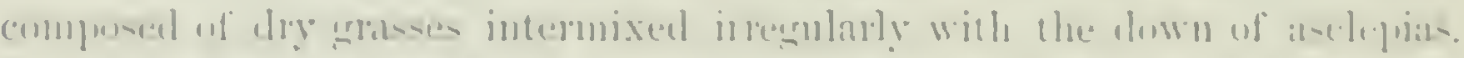

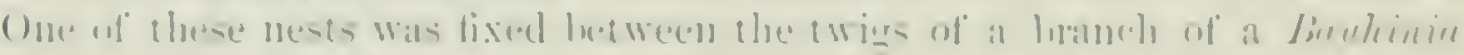

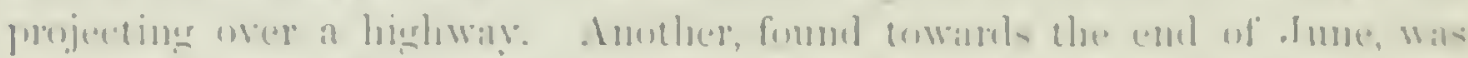

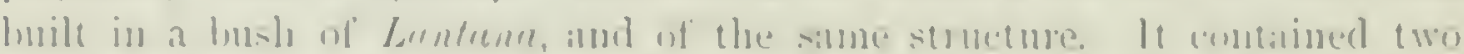

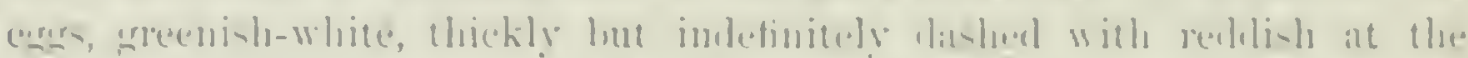

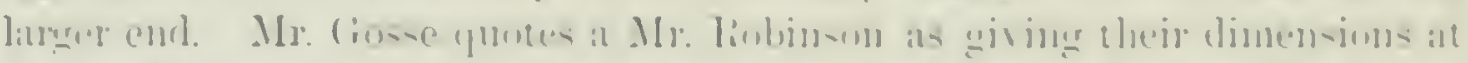

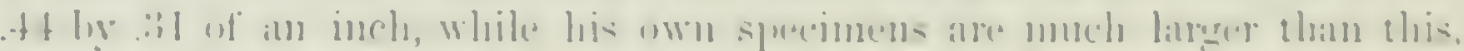

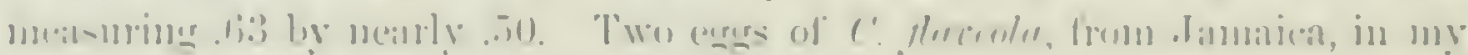

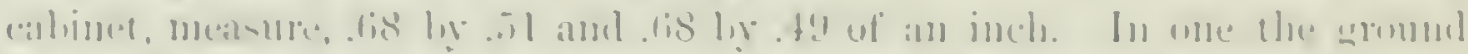

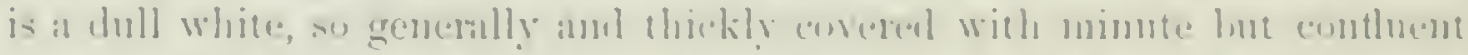

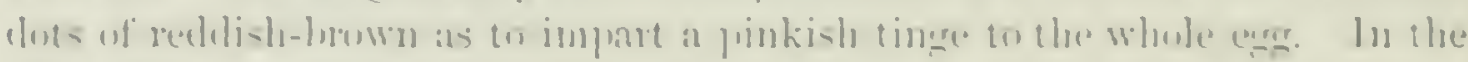

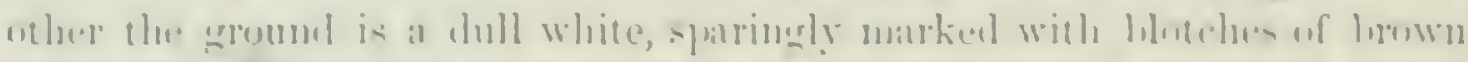

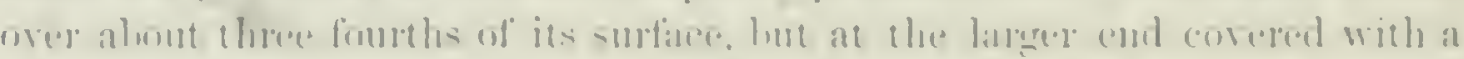

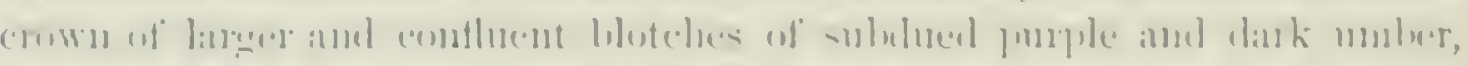

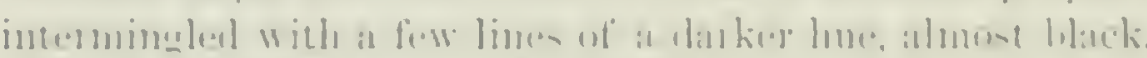

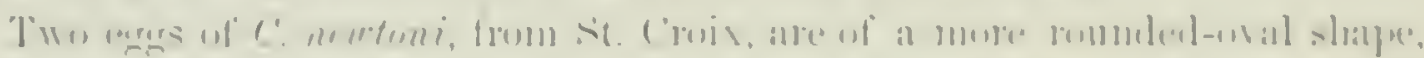
and as a

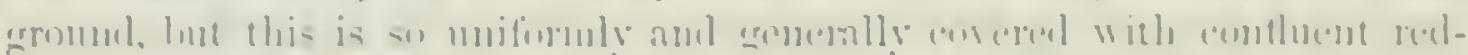

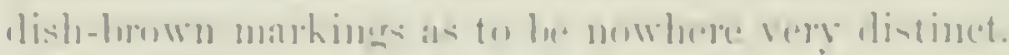

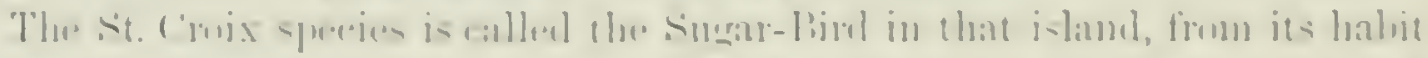

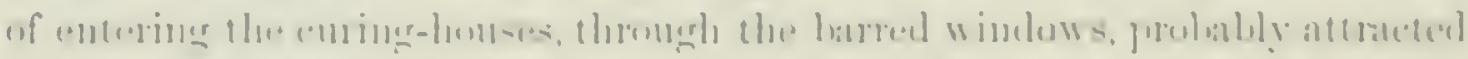

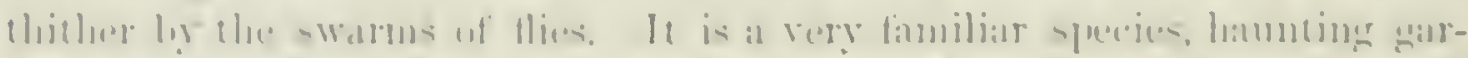

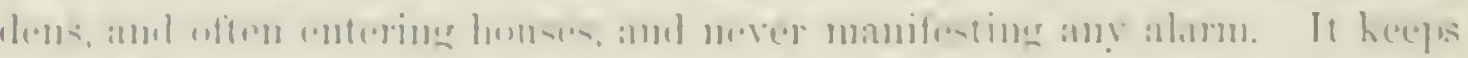

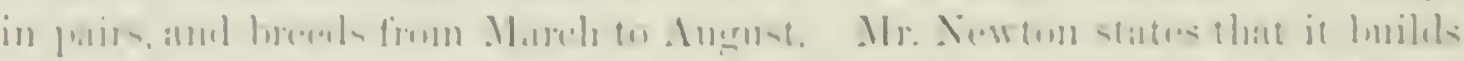

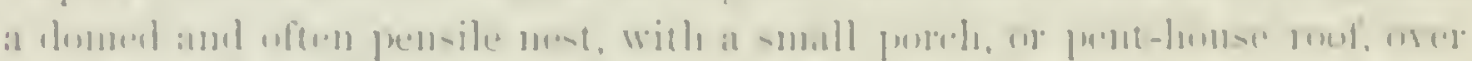

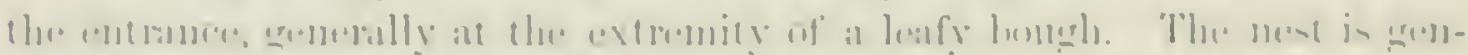

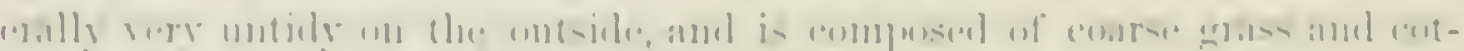

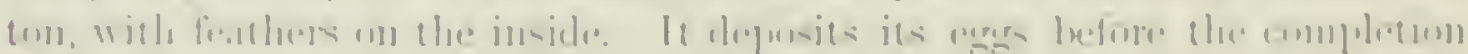

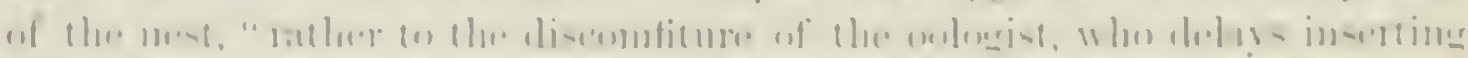

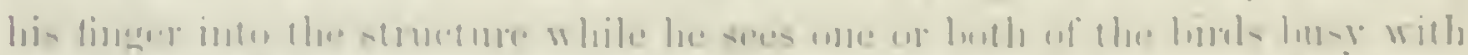

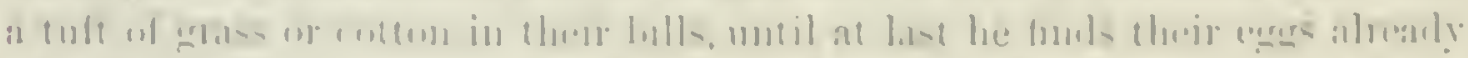

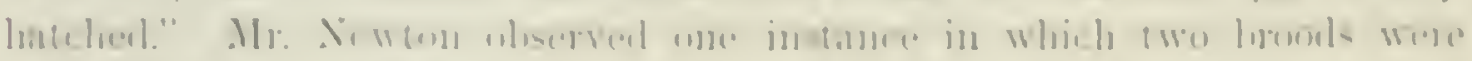

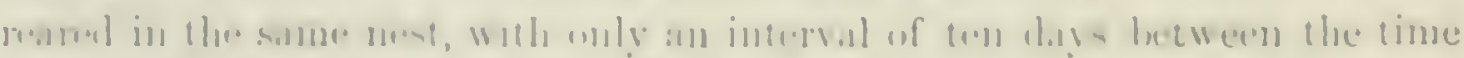

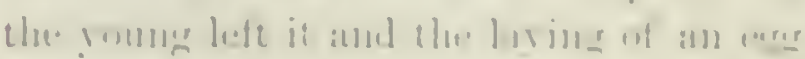


F.Mily TANAGRID止. - The Thiagers.

Cunr. Primaries nine. Bill usually conical, sometimes depresed or attenuated, usually mure or less triangular at base, and with the eutting edges not much inflected; sometimes toothed or notehed. Legs short ; claws eurred : colors mitually brilliant.

We confess our entire inahility to present a diagnosis that shall define and separate satisfacturily by external characters the chosely allied families of Carcbide, sylvicolide, Tunuyride, and Fringillide, agreeing as they do in the main in every respect. The only attempt at distinction is based upon the shape of the bill, and this in what are grenerally called Trencegride presents every variety of shatpe, from the attenuation seen in Dendroim to the stontest form of the Fringillide. The c'ardbila have peculiarities of the tongue, not appreciable, however, in the skin. In view, therefore, of the difficulty: in chestion, we shall copy the conrentional names and unsatisfiactory definitions of other anthors, in wur inability to present a satisfactory arrangement of our own.

Carus and Gerstiecker in Handhuch der Zoolowie, I, 2-T, adopt a classification of the Oscines based on the palatine hones in which Fringillide and Tenengride are distinguisheed from the siglricoliele as follows:-

Suborder OSCINES. Suxprwal.. Of the ten primaries, the first is short. rulimentary, or wanting: the number of seconlaries is racely more than nine. Tirsus entirely booted, or else with an undiviled plate on the sides. Lower trache: completely formed by the help of the trachea and bronchix; generally with tour pairs of nuseles, distributed before and behind.

Grocp I. Spizogratm.e. Outer lamella of the palatine hone dercloned in a rertical plane, with the hinder border more or less cmarginated; the anterior palatine process broad, and united br a truncated border to the high and broad upper mandible.

Famir 1. Ploreidee. Ten primaries.

Fumity 2. Fingillide. Bill encircled by a more or lcse distinct swelling at hase. Frontal feathers not forming lateral angles. Elges of the jaws drawn in as far as the eorner of the mouth; nine primaries; the first three usually longest. Legs with undivided plates belind.

Fumur 3. Tanagrider. Bill more or les triangular at the base. Cumen always nore or less curved. Frequently a tooth or noteh in the upner bill, sometimes fine serrations. Wings moderate: somewhat pointed: primaries nine. Tursus and toes short and stout. Hind toe stont and long. Claws curved.

Groce II. Cor.zogratu.e. Palatine bone broad and rather flat behinil. the external angles prolonged, not extended into a rertical plate. Base of bill generally narrower. Primarics nine or ten. This scction cmbraces, of Yorth Americau forms:-

\begin{tabular}{|c|c|}
\hline $\begin{array}{l}\text { Mniotiltidx, } \\
\text { Motacillidre, } \\
\text { Alautidx, } \\
\text { Sylriidre, }\end{array}$ & $\begin{array}{l}\text { Crelebidie, } \\
\text { IIirundiniex. } \\
\text { Ampelidax, } \\
\text { Laniide. }\end{array}$ \\
\hline
\end{tabular}

Turdidx, Troglodrtille.

all of which have already been described in the present work, with the exception of the last two. 


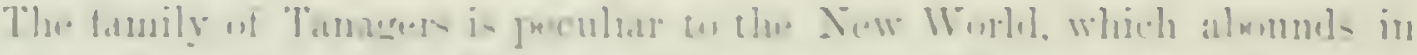

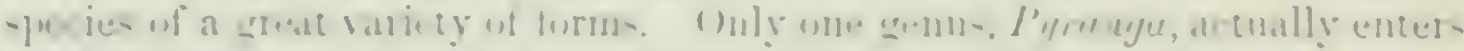

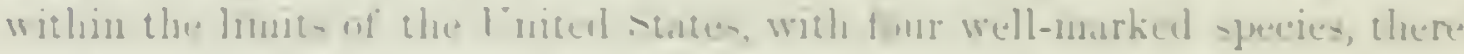

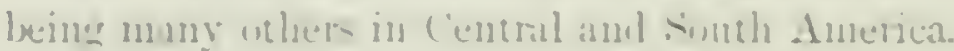

\section{liLIT PYRANGA VIFHA.}

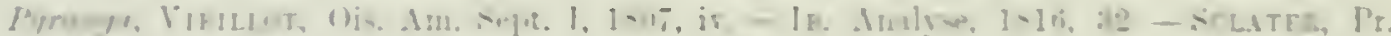
\%ol. $=1-i+1,1: 3$.

1.

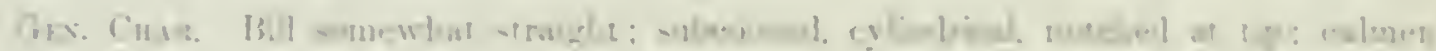

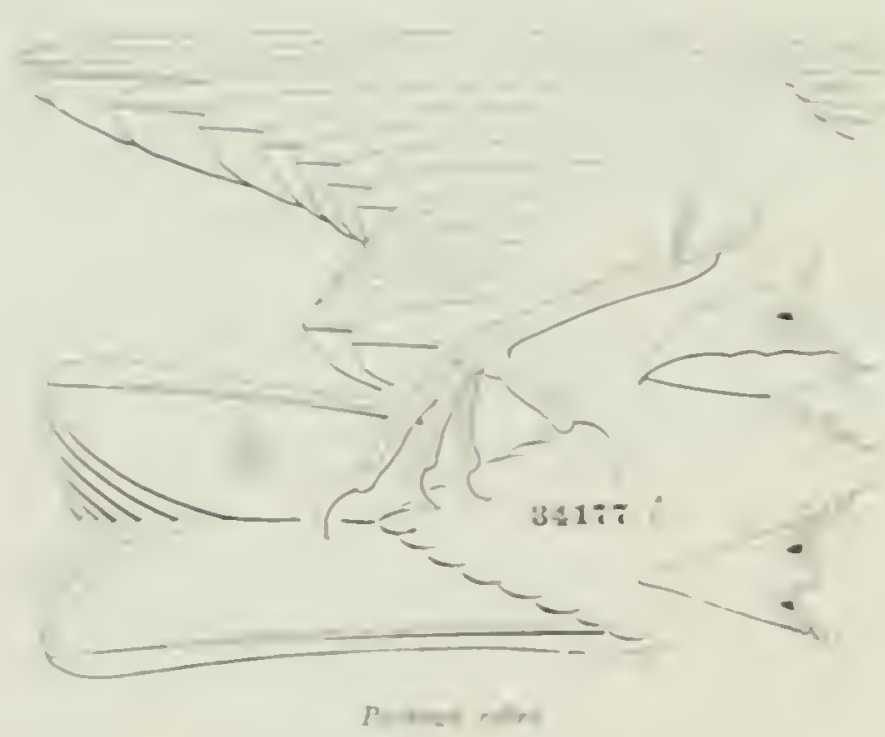

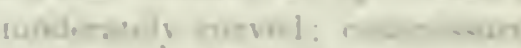

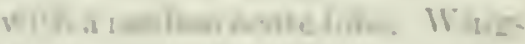

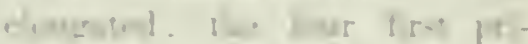

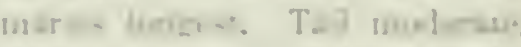

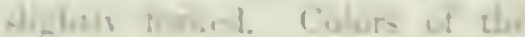

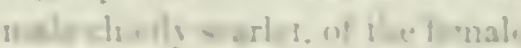
$3,4+1$,

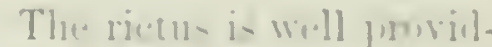
ed with hristles. which Lem

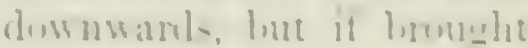
forward wonld reach the murils Then are rumm I-

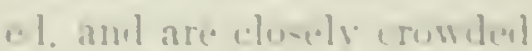
le the fmintal leatluers. The tursis is shrtu.r thin the

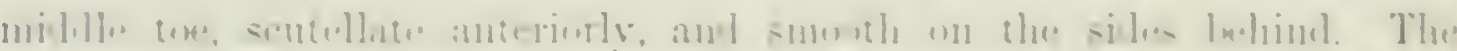

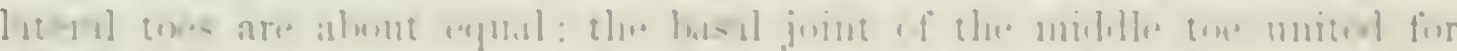

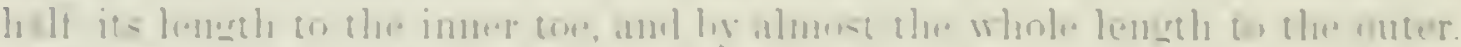

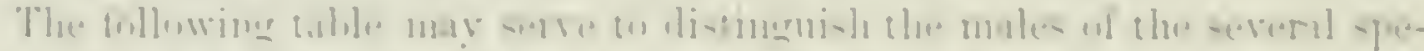

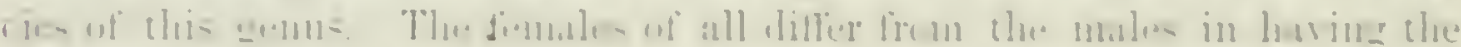

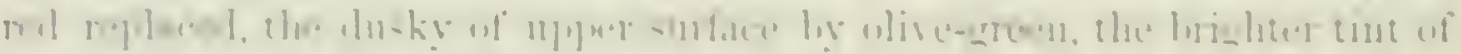

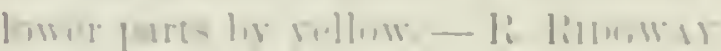

\section{Species and Varieties.}

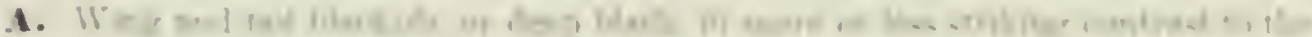

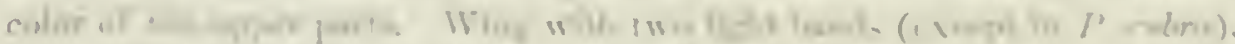

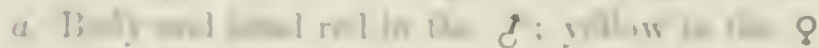

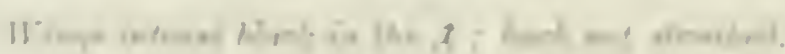

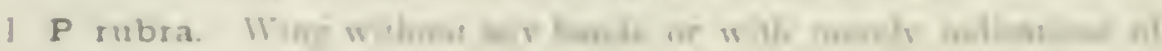

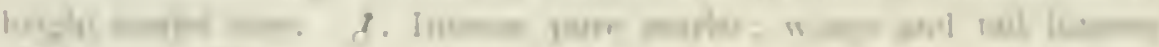

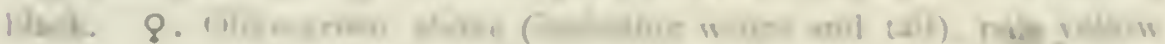

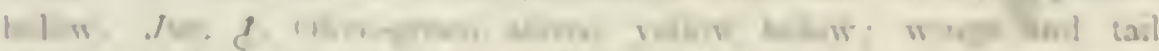

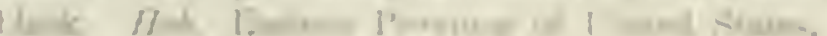


2. P. erythromelæna. Wing with two bands of pure white. $\delta$. Brighlut scarlet: wings, tail, and lores intense black. $\$$. Ulive-erreen abore, yellow beneath; wings and tail slaty.

Forehead. eyelids, and anterion halt of cheeks velvety-black; red of a carmine shade. IIub. Middle Americat, north to Miratlor. var. e ryth romelena.

Forehcad, eyelick, and anterior hall of checks scarlet (lores only blark); red of a scarlet shate. Hub. Northern South America.

val. artens.?

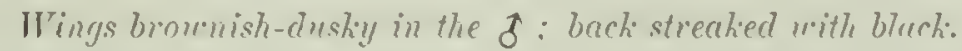

3. P. bidentata. Wing with two bands of pinkisl-white ( $\delta$ ), or yellowish-white ( 9 ). \&. Abore reddish-bown: heal and beneath minimm-searlet. 9 . Alwre olive-rreen: heal and heneath yellow. IInb. Millelle Anerion (both const.) from Costal Rie'a to Mirllle Mexieo.

5. Body always rellow; head real in the $\delta$.

$$
\text { Lessele riny-ronerts blark ne dusky. }
$$

4. P. Indoviciana. Wing with two light yellow hands. §. Back. wings and tail intense hark: hual crimson. 9 . Ahove olive-green, tinged with ashy on the back: beneath pale greenish-yellow: wings and tail dusky olive-green: 110 red on heal. Mab. Western Province of Enited States.

$$
\text { Lesser wing-roverts and middle corerts yellow. }
$$

5. P. rubriceps." Wing without ligght hands. \&. laack and rumpl olive-green: wings and tail black; head crimson. Jlab. Xew Granada.

B. Wing and tail reddish or greenish, of the same geuneral rolor of the upner parts; wing without any light hands.

a. Wing. 3.10. Body always yellow: head red in the of.

6. P. erythrocephala. ibore olive-green, beneath rellow. J. Head

red. Wing, 3.00; tail, 2.70. Hab. Mexim (Temiscaltiper).

b. Wring 3.50 or morc. Body and head red in $\delta$

$$
\text { Commissure with "distinct tronth : bill bluish. }
$$

7. P. hepatica. Bill suall, not swollen laterally : culnen gently eursed terminally, straight basally: commissural tooth small. of. Hhore reddish-ashy, becoming brighter reddish on the head ahow: heneath minium-scarlet medially, much tinged with asly laterally. 9. Ishygreen and greenish-rellow. instead of reddisk. Jui. d. similar, thit throat tinged with orange-red.

1 Pyrang" crythromelane, ScLatrR, P. Z. S. Lousl. 1856. 126. (Tanatern erythromelas, Lichit. Preis. - Yerz. d. Saïg. u. Yög. no. $69 ; 1 \varsigma 31.1$

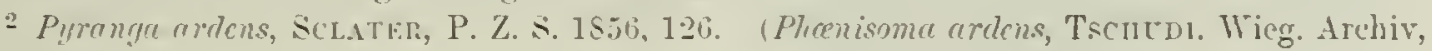
$154+, 207$.

${ }^{3}$ Pyorunga bidentitu, Swarxs. Philos. Mag. 1:27, 420

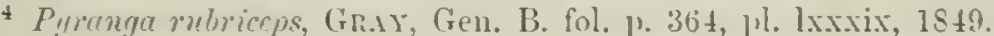

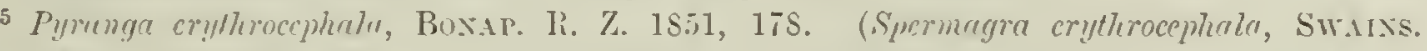
Phil. Jag. 1\&27, 437. Were it not for the suall size, one woult. without secing a speeimen, be inclined to suspect this as being a young male of $P$, restivn, which often occurs in very similar plumage. 


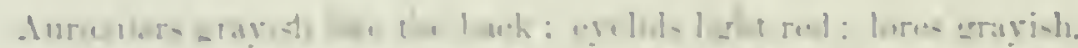

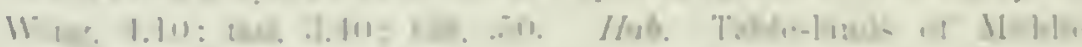

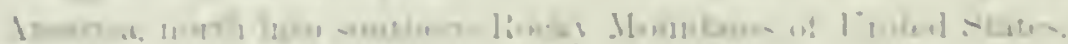

sar. hepulir".

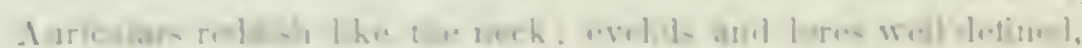

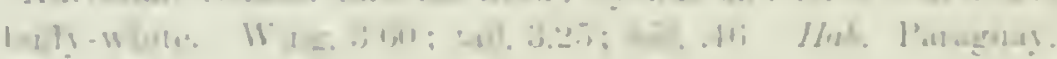

a. $n=11211$

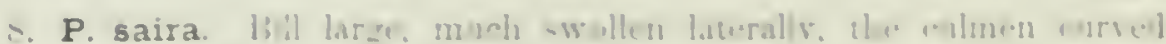

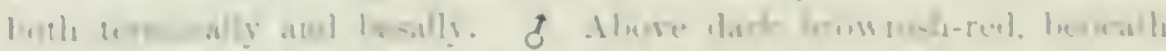

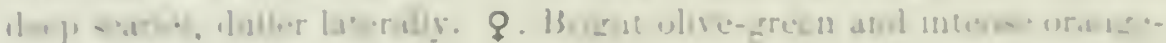

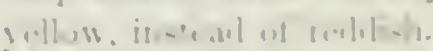

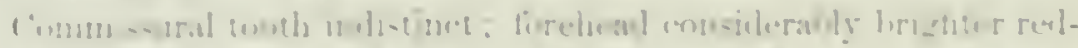

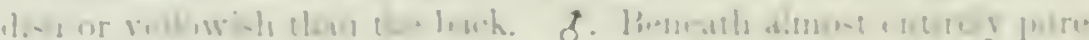

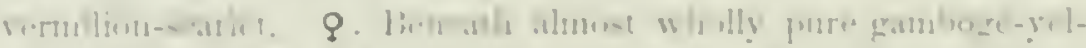

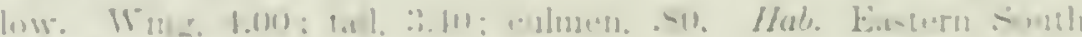

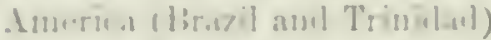

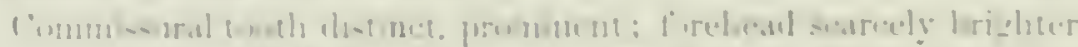

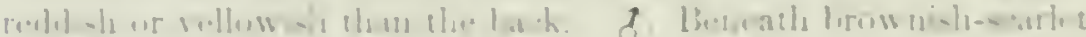

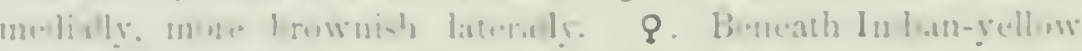

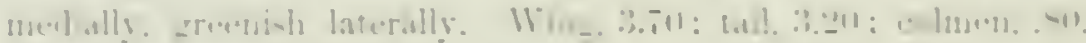

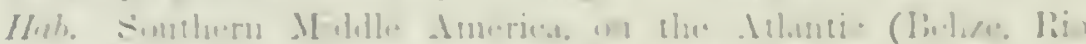

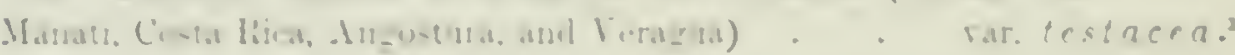

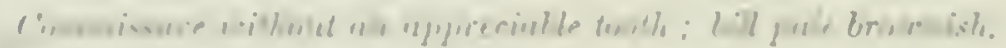

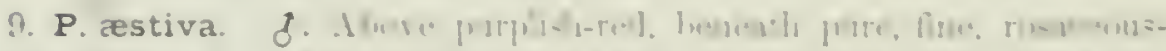

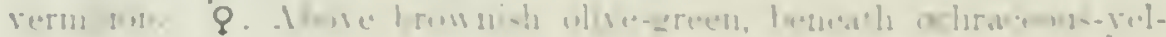
luw.

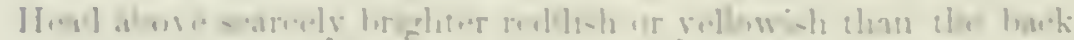

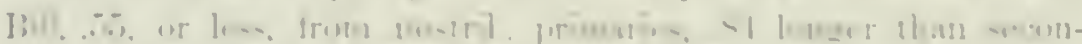

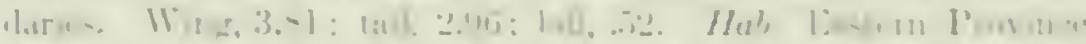

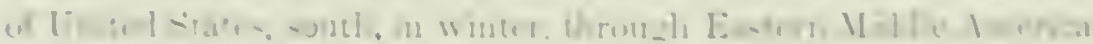
$1, \ln x=1$

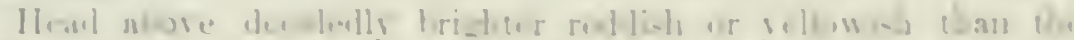

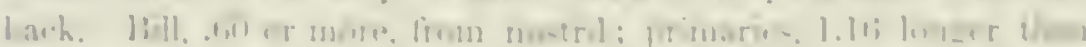

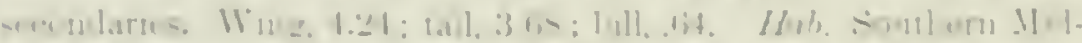

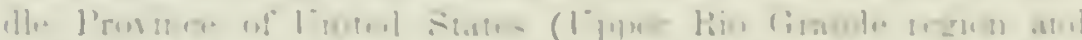

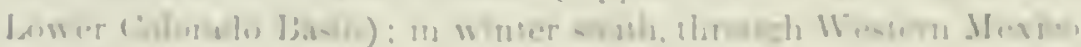
1,1 inthes

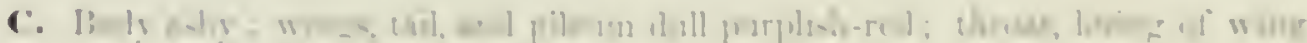

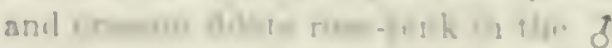

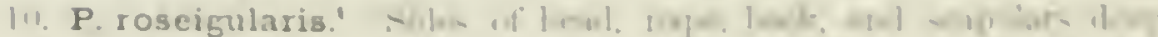
a. . . Und I

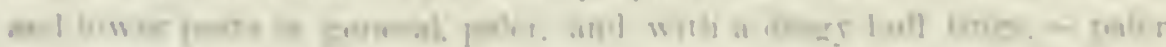

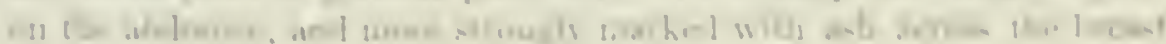

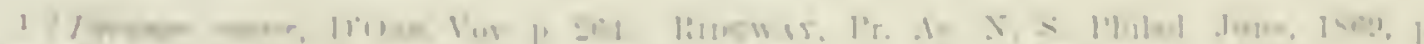
1216.

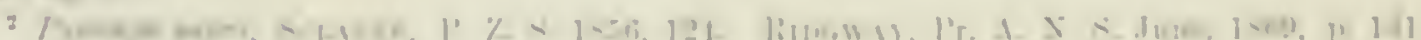
H. I i 7 -

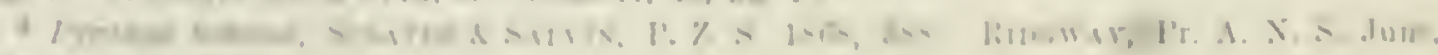
$1=1,1 \%, 8$

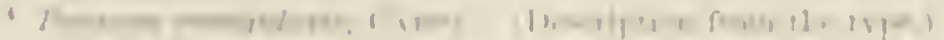


and along sides. Whole pilemm. frem hill to nape ant down to the upper edge of lorer wes, and anrinulars, wings, upper tail-coverts, and

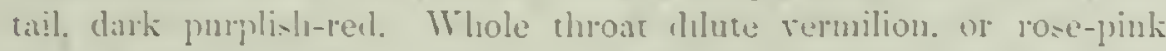
sluarply definesl: crissmm and lining of wings: a paler shate of the same Wing, 3.0.); tail, 2.5.j; bill. from nostril. 45 ; its depeh at the base. 40 . its breadth, .30 ; tarsus. . . . Hab. Yucatan.

\section{Pyranga rubra, Tieill. THE SCARLET TANAGER.}

Tenugru rubru, Lis. I, 1760. 314. - GMELIS, 1, 17Es, ss!. - WILsos, Am. Orn. II,

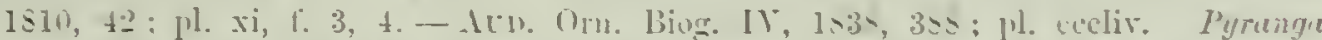

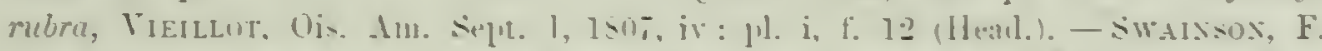

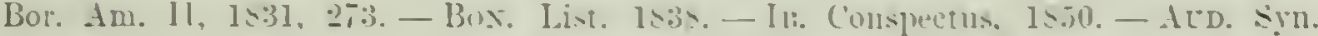

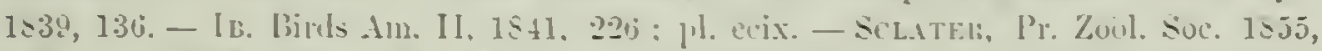

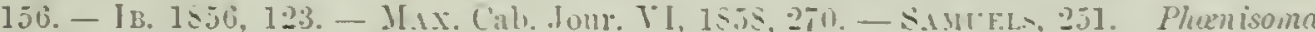

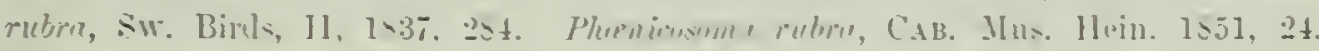

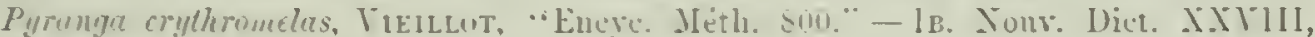
$1517,293$.

Sp. Crup. Bill shorter than the head. Secund tuill longest: hirst amet third a litcle shorter. Tail molerately forkexl. Ifule. Whole luead and huly continuous, pure. intense scarlet. the feathers white heneath the surfare, and grarish at the mots. Wings and tail, with the seapulars. uniform intense black: the midlle-coverts sometnues party real. forming an interrupted band. Lining of wing white. A biekish tinge along sides of the

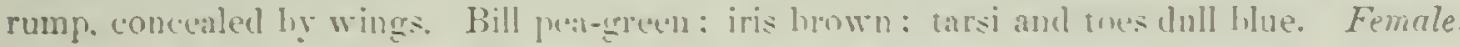
Ulive-green abore, rellowish heneath. Winer and tail fearluers hrown, edged with olivaceous. Length, 7.40: wing. 4.100: t:ill, 3.010.

Hab. Eastern Province Forth Ameriea, 1rorth to Winnepreg (west to Lil T'aso? Hfersuxx). In winter, south to Eimalur (Rio Napo, ScL.). Bogota (ScL.) Cuha (ScL. \& Grant.): Jamaica (ScL. \& Gosse); P'anama (Lawr.); Costa Rica (Lawr.); Tera Cruz (winter, Scmchrast).

At least three rears seem to be required for the assumption of the perfect plumage of the male. In the first year the young male is like the fenale, but has black wings and tail; in the fall red feathers begin to make their appearance, and the following spring the red predominates in patches.

Habits. The Scarlet Tanager is one of the most conspicuons and lnilliant of all our summer risitants. Elegant in its attire, retiring and modest in manners, sweet in song, and useful in its destruction of linrtful insects, it well merits a cordial welcome. This

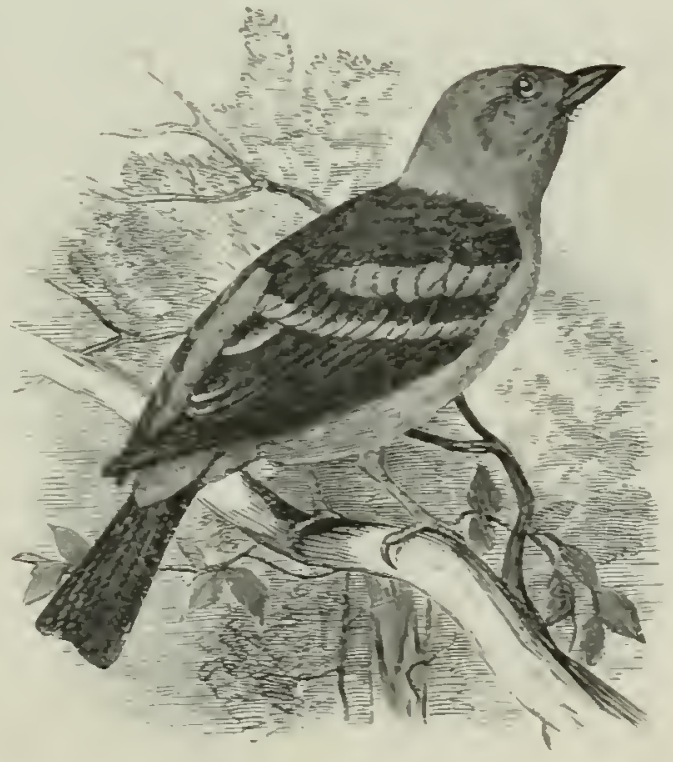

Pytanga ludoriciana. Tanager is distributed over a wide extent of territory, from Texas to Maine, and from South Carolina to the northern shores of Lake Huron, in all which 


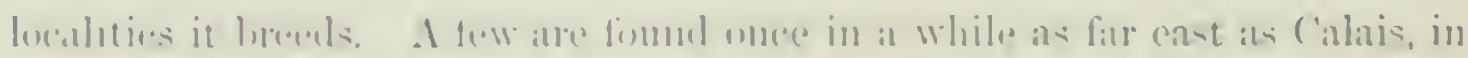

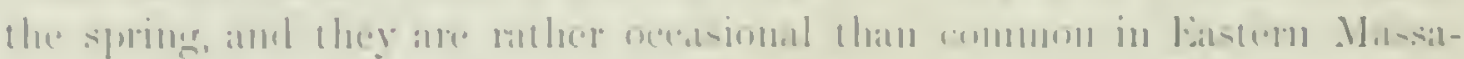

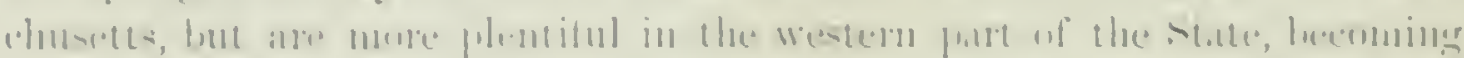

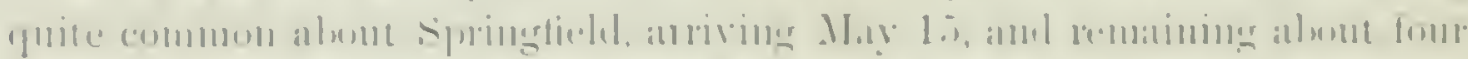

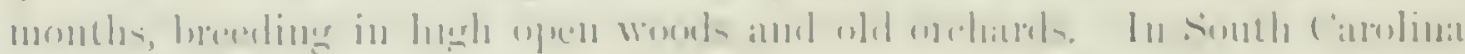

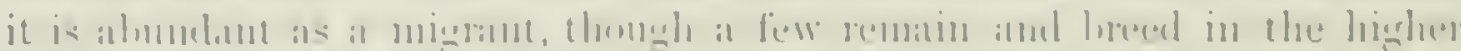

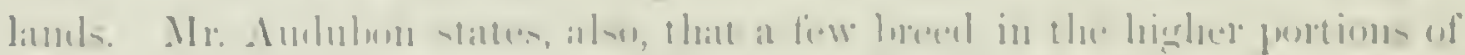

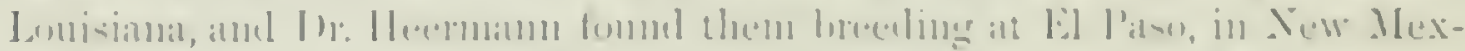

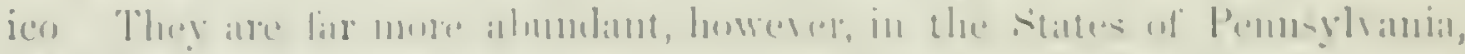

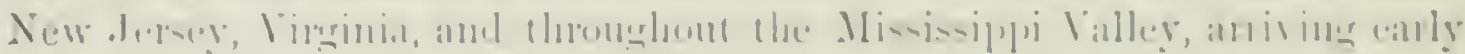

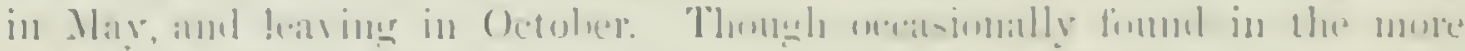

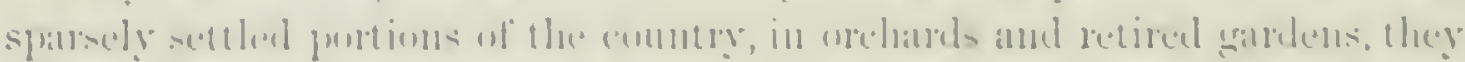

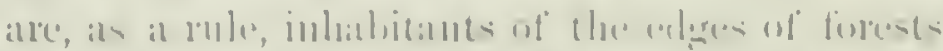

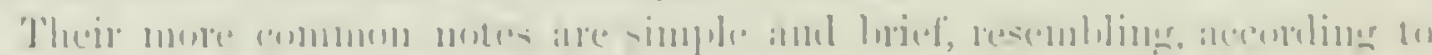

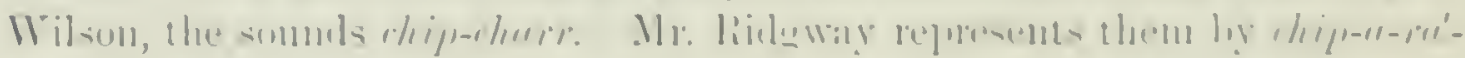

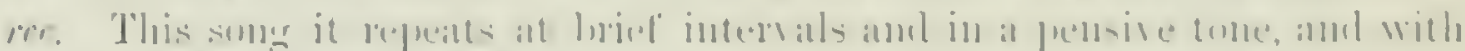

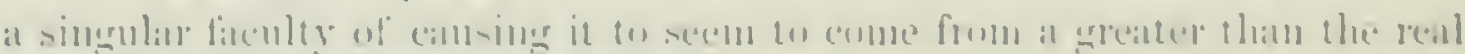

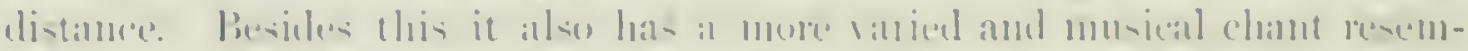

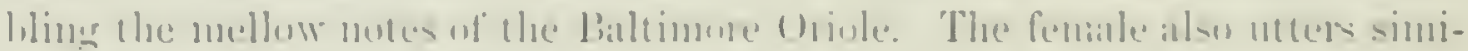

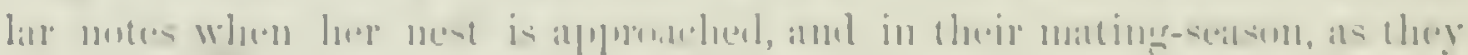

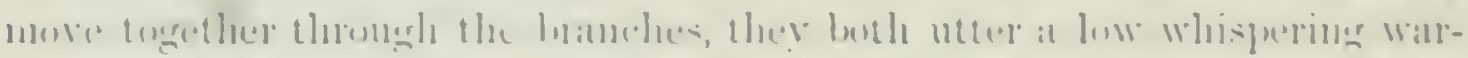

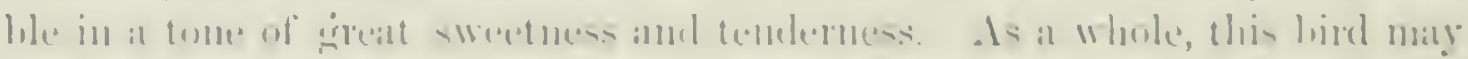

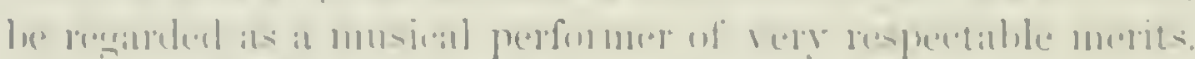

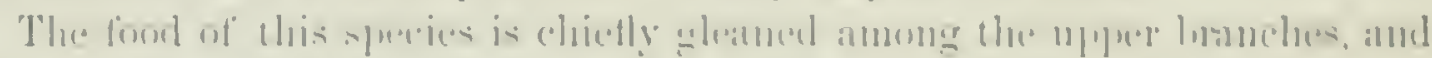

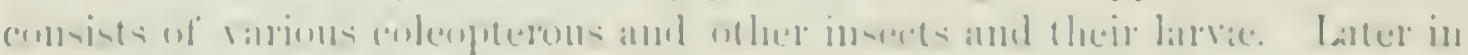

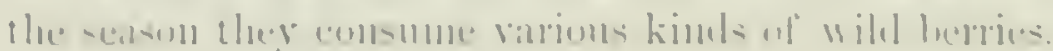

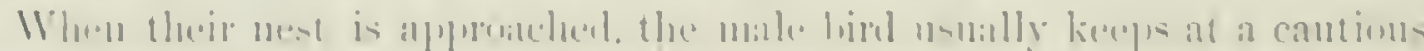

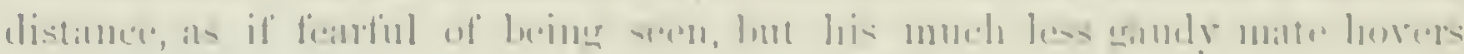

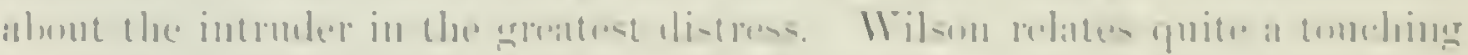

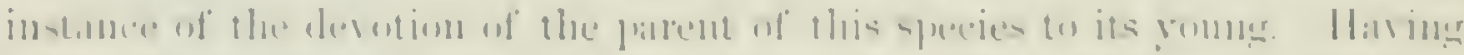

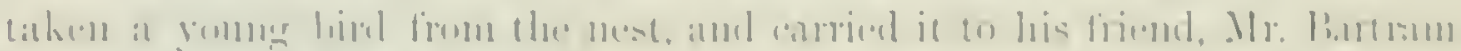

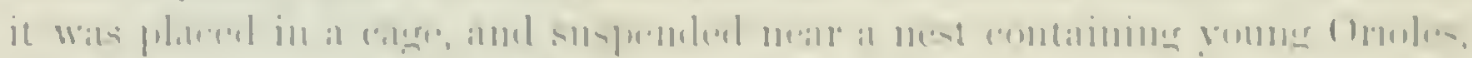

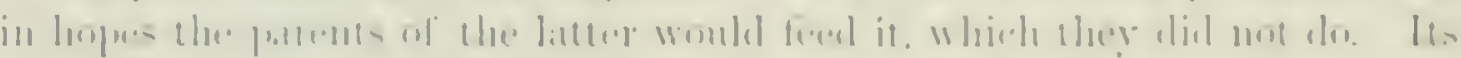

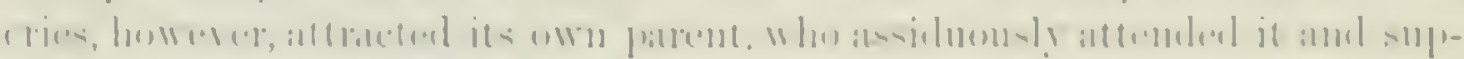

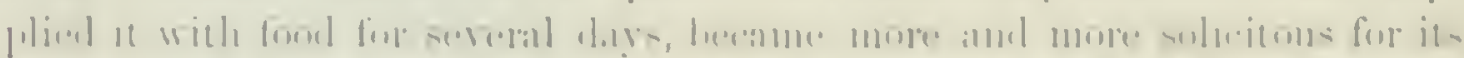

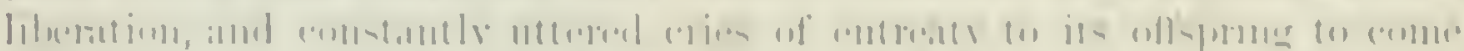

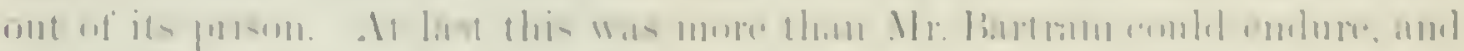

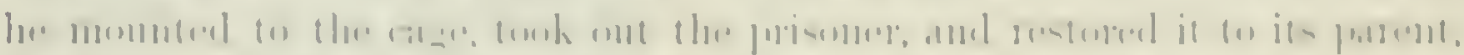

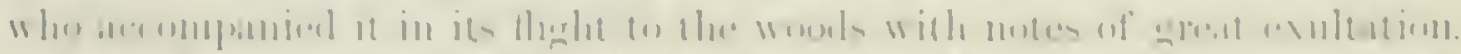

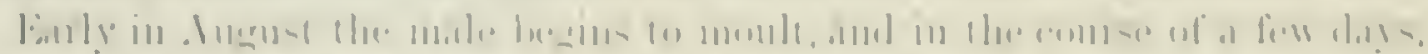

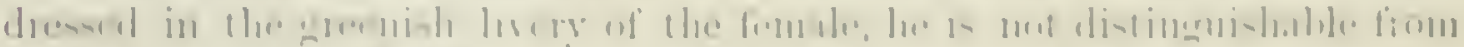

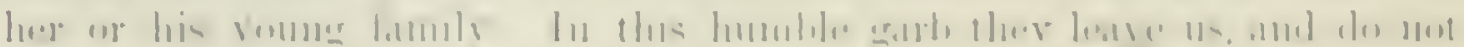

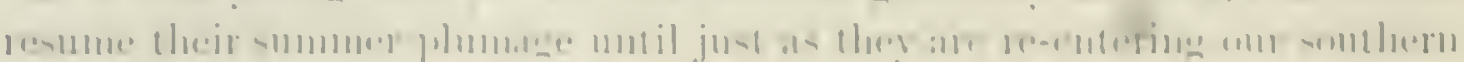

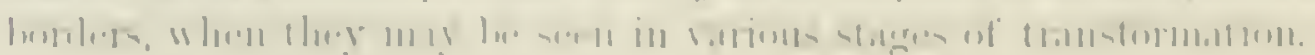


This species is extremely susceptible to cold, and in late and musually chilly seasons linge numbers often perish in their more northern ham as as Massachusetts and Northern New Iork.

The nests of the sicurlet Tanager are built late in May, or early in . June, nu the horizontal branch of a forest tree, usually on the edge of a wood, but occasionally in an orchand. They are nsually very nearly Hat, five or six inches in diameter, and about two in height, with a depression of only abont half an inch. They are of somewhat iregular shape, or not yuite symmetrically circular. Their base is somewhat loosely constructed of coarse stems of regetables, strips of bark, and the rootlets of wooded plants. Upon this is wought, with more compactness and neatness, a frumework, within which is the lining, of long slender fibrons roots, interspersed with which are slender stems of plants and a few strips of fine immer bark.

Mr. Nuttall describes a nest examined by him as composed of rigid stalks of weeds and slender fir-twigs tied tugether with narrow strips of Apocynum and pea-vine lunners, and lined with sleuder wiry stalks of the Holianthemum, the whole so thinly plaited as readily to admit the light through the interstices.

The egrs, fom or fire in number, vary in length from an inch to .90, and have an arerage breadth of .65. Their ground-color raries from a wellmarked shade of greenish-blue, to a dull white with hanlly the least tinge of blue. The spots rary in size, are more or less continent, and are clictly of a reddish or rufous brown, interningled with a few spots of a brownish and obscure purple.

Pyranga ludoviciana, Boxsp.

\section{LOUISIANA TANAGER}

Tanngre ludericimu, Wryns. Am. Orn. 11I, 1:11. 27. pl. xx, f. 1. - Pox. Obs. 1826,

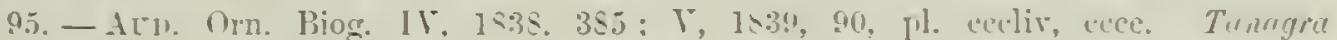

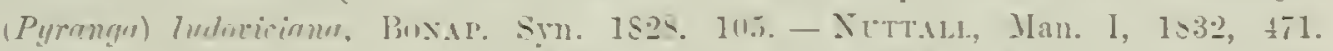

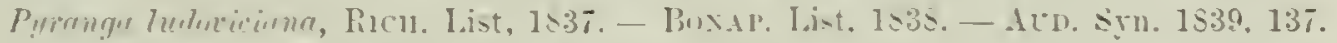

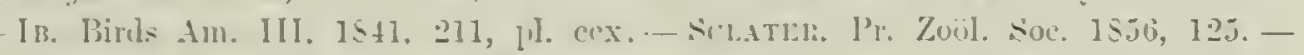

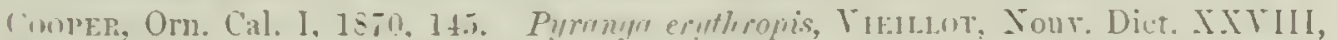

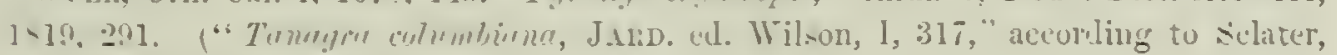
but I cannot fiud such name.)

Sp. Crun. Bill shorter than the heal. Tail slighely forker]: first three quills nearly equal. Male. Lollow: the midhle of the hack, the wings: and the tail black. Head and neck all poum -trongly tinged with renl: least sn on the sirles. A hand of vellow across the midlle corerts. and of yellowish-white aross the greater nues: the tertials more or less coldenl with whitish. Female. Olive-green alove. vellowish heneath: the foathers of the intersapular region dnskr, margined with olire. The wings and tail ralleel dark brown, the former with the same marks as the male. Length. 7.2.5: wing. 3.fol: tail. 2.8.j.

Hab. Western portions of Lnited States. from the Misouri Plains to the Paeific: north to Fort Liarl. sunth to Cape St. Lucas. Oaxaca (ScL.): Guatenala (Ecc.); ()rizaba (ScL.); Tra Cruz (winter. sumchrast). 


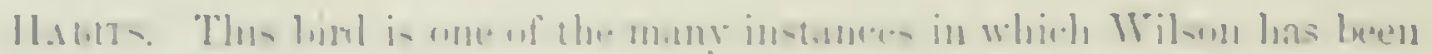

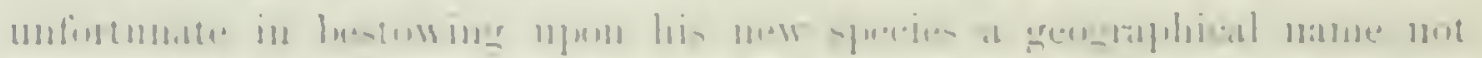

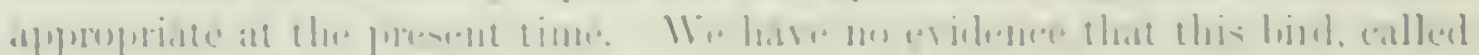

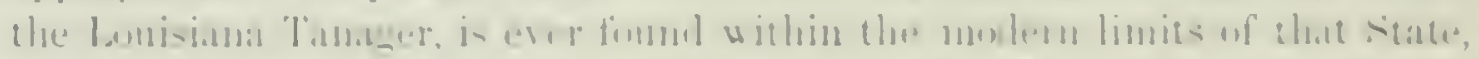

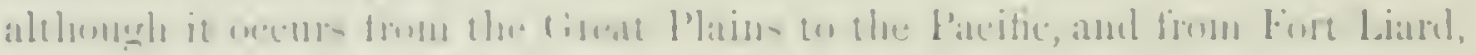

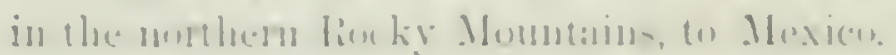

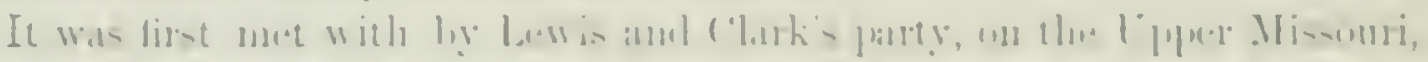

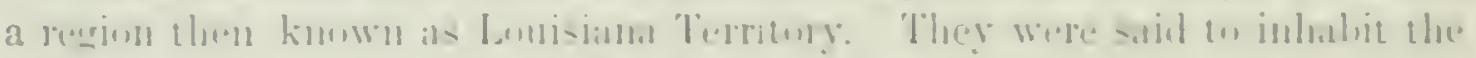

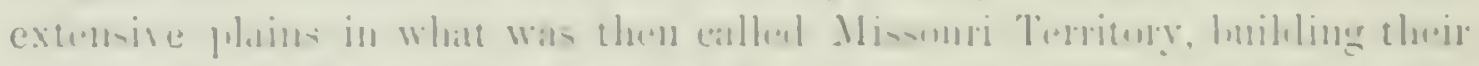

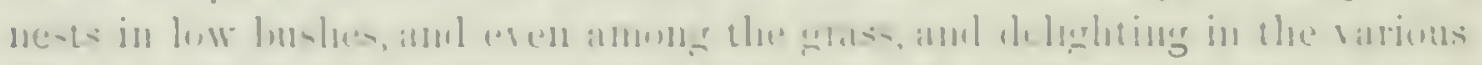

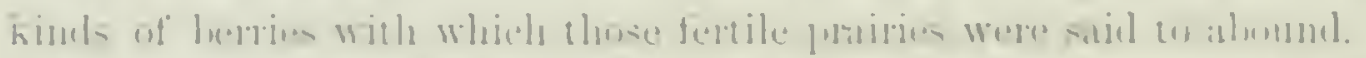

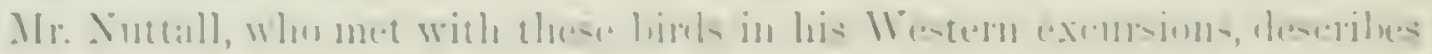

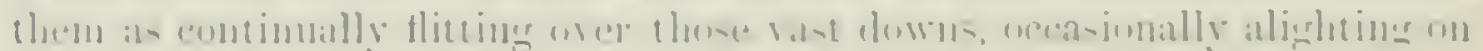

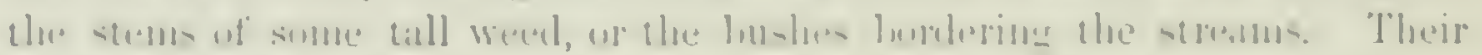

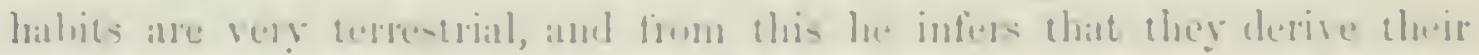

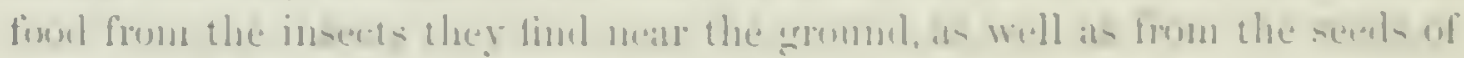

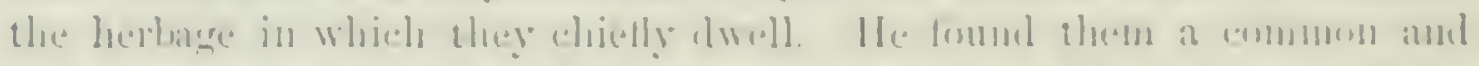

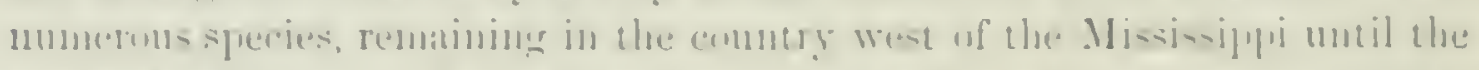

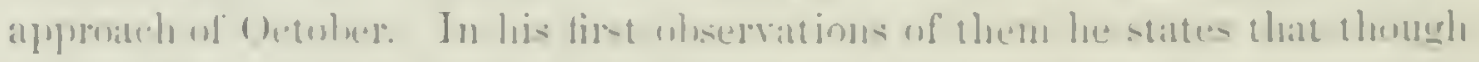

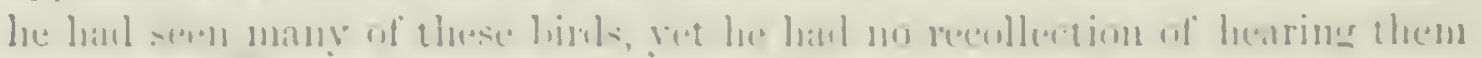
utter an! molulated or musical and almus silemt:

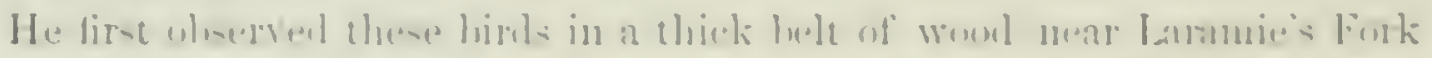

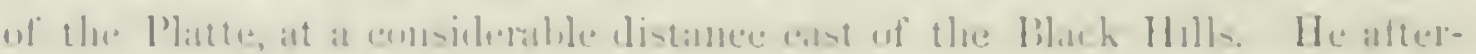

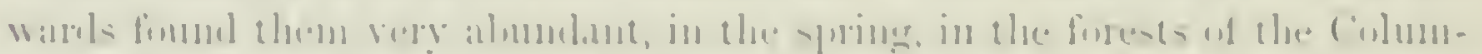

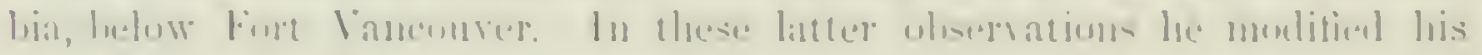

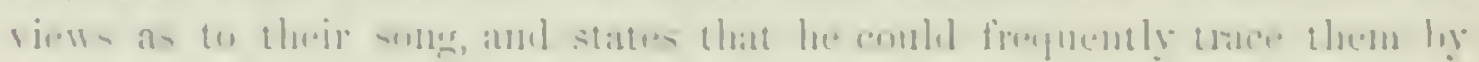

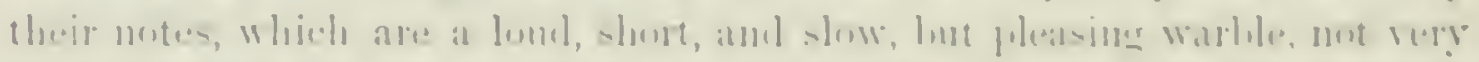
mulike that of the (n)

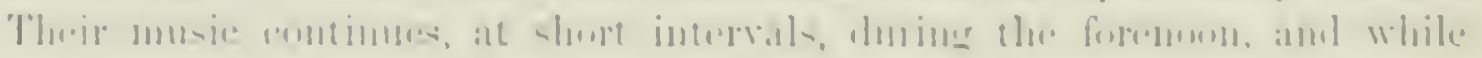

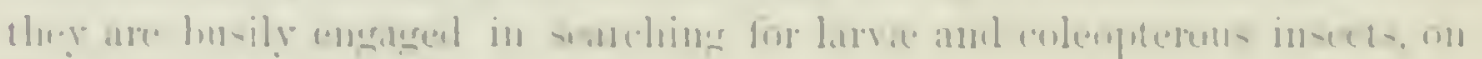

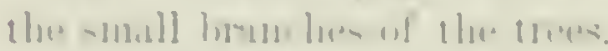

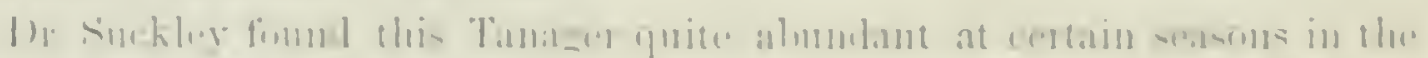

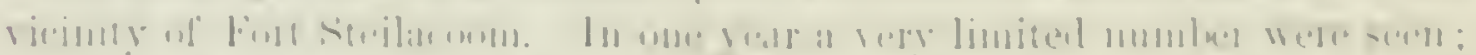

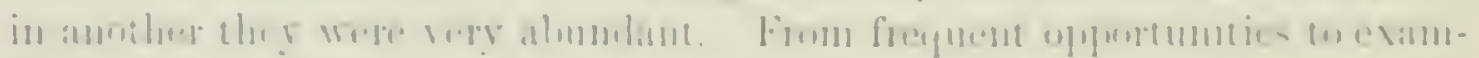

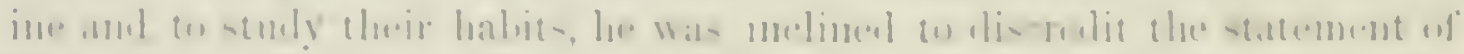

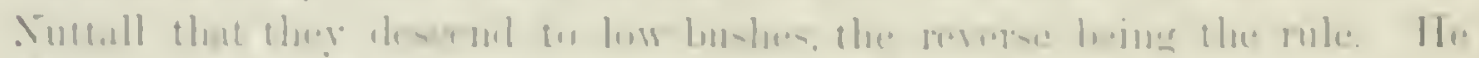

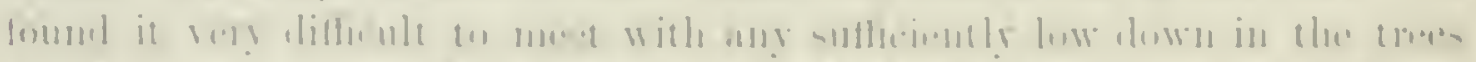

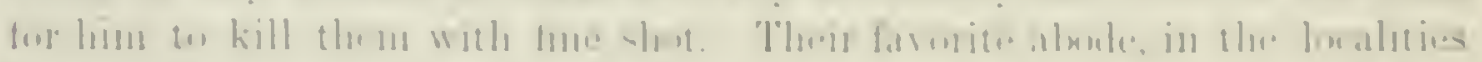

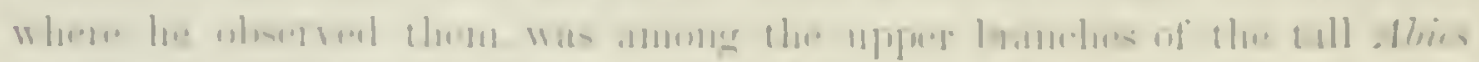

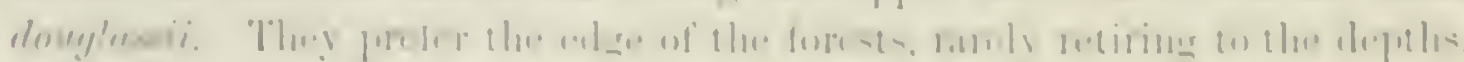

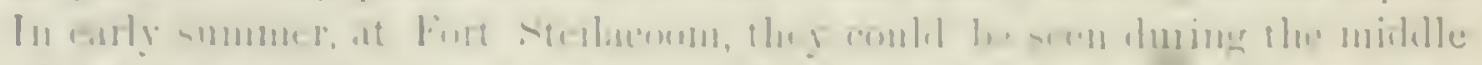

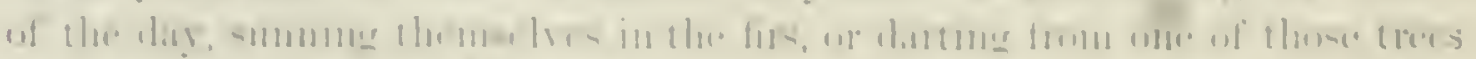

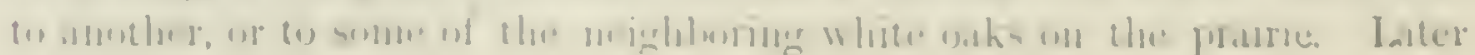


in the season they were to he snen flying rery actirely about in quest of insect food for their young. On the 10th of July he saw one carrying a worm in its month, showing that its young were then hatehed ont. During the breeding-season they are much less shy, the males frequently sitting on some low limb, rendering the neighborhood joyons with their lelightful melody.

'Their stomachs were found filled with insects, eliefly coleoptera; annong these were many fragnents of the linge green Buprestis, found on the I) ouglass fir-trees.

1)r. Cooper adds to this aceomt, that this bird arrives at l'uget sound abont May 1j, and becones al conmon smmmer resident in Washington Territory, especially near the river-banks and among the plinies, on which are found decicluons trees. He compares its song to thit of its black-winged relative $(P$. rubror), being of a few notes only, whistled in the manner of the Robin, and sommling as if the birk were quite distant, when in reality it is rery near. He met with these birls east of the Rocky Mountains and up to the 49 th parallel.

In California the same ohserver noticed their arrival near San l)iegro, in small parties, abont the 2t th of April. The males come in advance of their mates, and are more bold and conspicuons, the females being rarely seen. He saw none of then in the C'oast Range toward Sinta Cruz, or at Sinta Barbara, in summer. He also found them in september, 1860, in the higher liocky Mountains, near the sompes of the Columbia, in latitude $47^{\circ}$. In the fall the young and the old associate in fanilies, all in the same dnll-greenish plumage, feeding on the berries of the elder, and other shrubs, withont the timility they manifest in spuring.

Mr. J. K. Lurd states that he did not once meet with this species west of the Cascarle Momtains. He found them on the spokan Plains and at ('olville, where they arrive in June. Male hirds were the first to be seen. On their anival they perch on the tops of the highest pine-trees, and continually utter a low piercing chirp. They soon alter pair, and clisippear in the forest. Where they breed, Mr. Lord was not alle to discorer, though he sought high and low for their nests. As he never sneceeder in finding them, he conjectured that they must breed on the tops of the loltiest pine-trees. They all leare in September, but do not assemble in Hocks.

These Tamagers breed at least as far to the south as Arizona, Dr. Cones haring found them a summer resident near Fort Whiplle, though rare. They arrive there in the middle of April, and leave late in September.

Mr. Salvin states that this Tanager was found between the volcanoes of Agna and Fuego, at an eleration of about five thousand feet. Syecimens were also received from the Tera Paz.

Specimens of this species were taken near Oaxaca, Mexicn, by Mr. Boneard, where they are winter residents.

Mr. Ridgway writes that he first met with these Tanagers in July, among the pines of the Sierra Nerada. There its sweet song first attracted his 


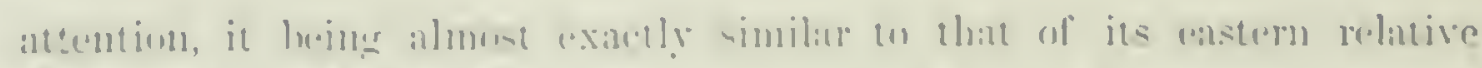

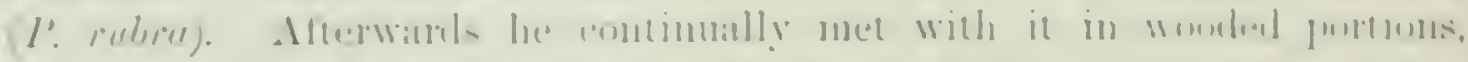

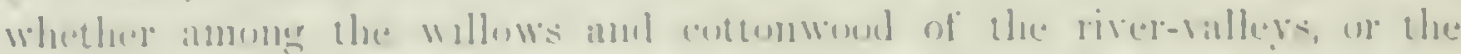

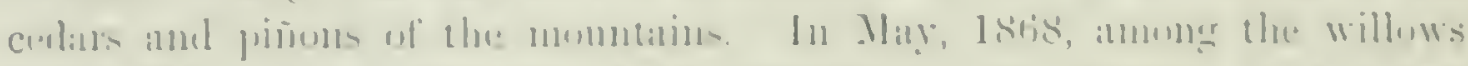

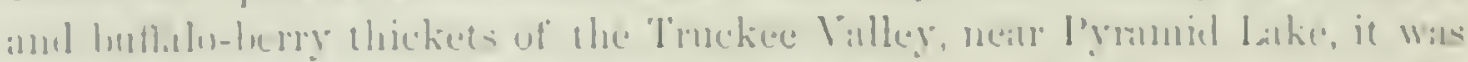

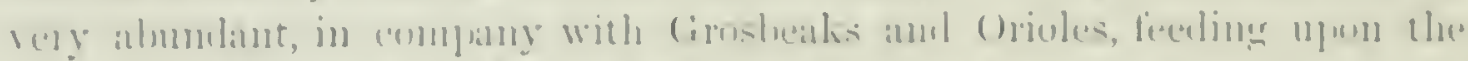

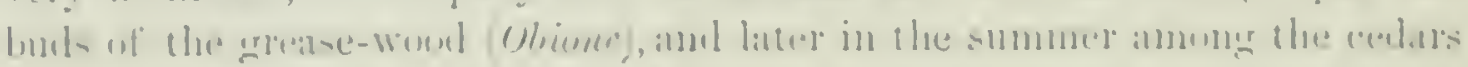

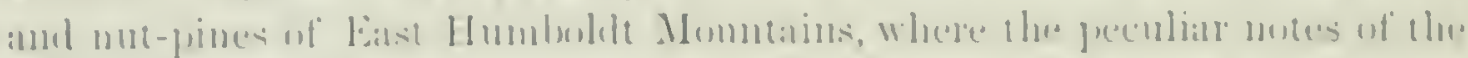

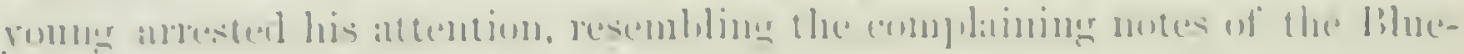

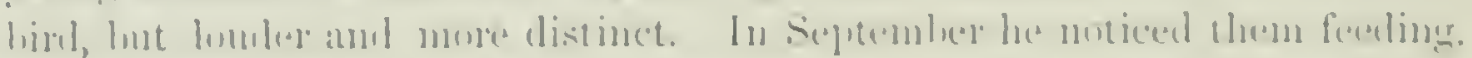

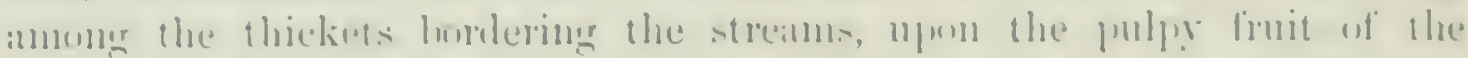

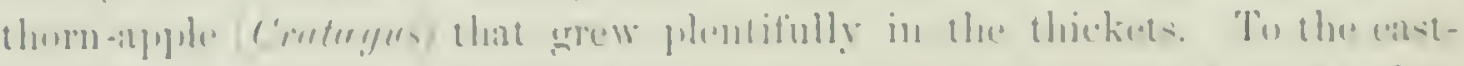

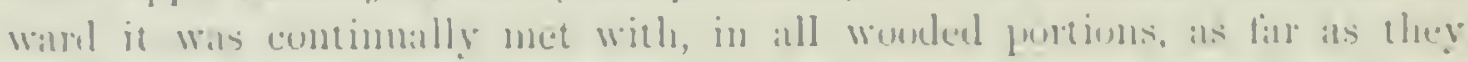
(… pliniml.

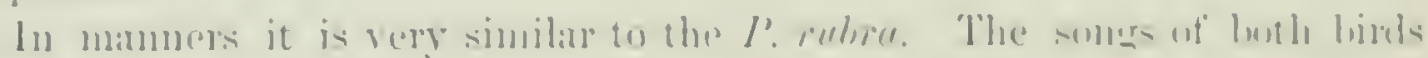

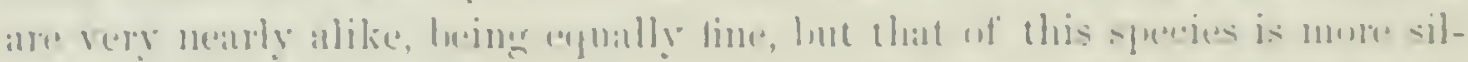

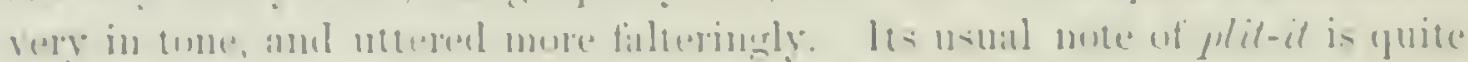

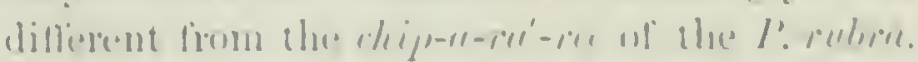

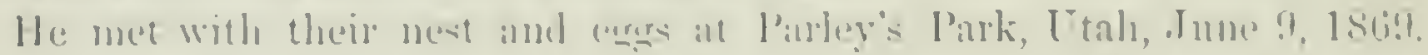

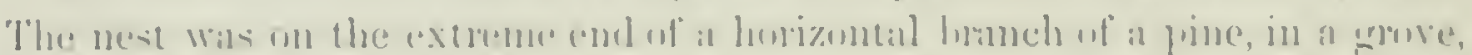

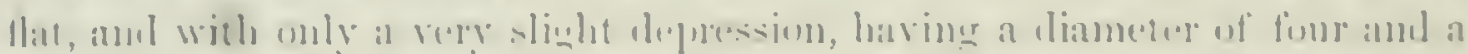

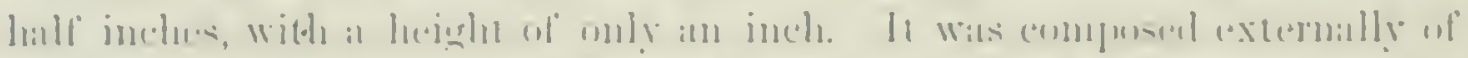

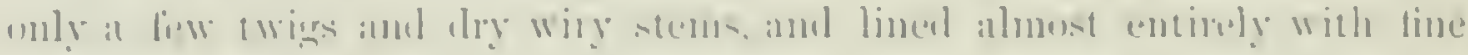
veretialile rentlets.

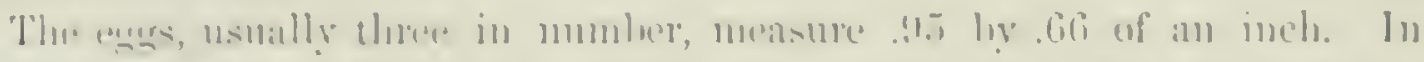

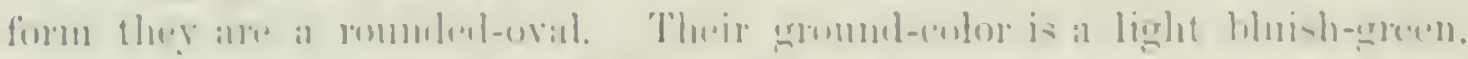

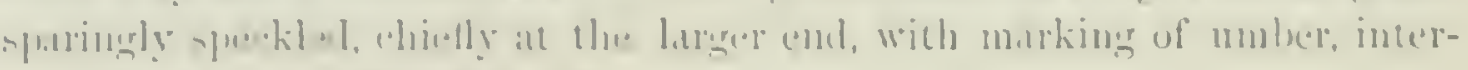
mingled with a len duts of bilate.

\section{Pyranga hepatica, sirirsix.}

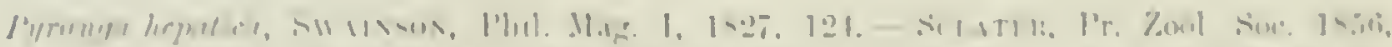

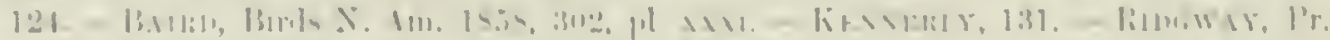

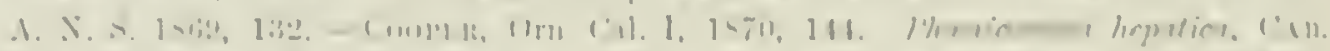

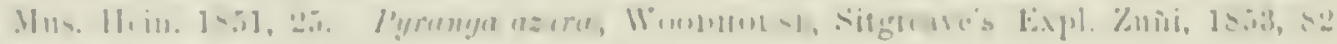

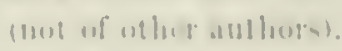

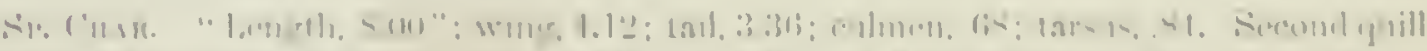

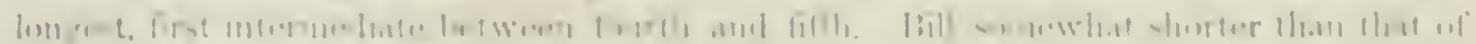

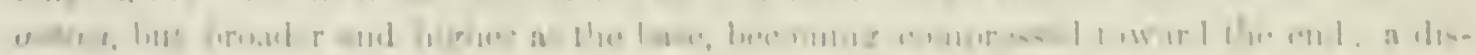

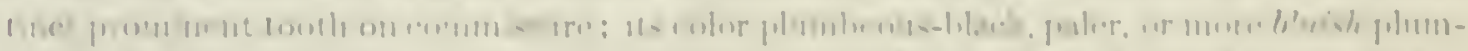
In

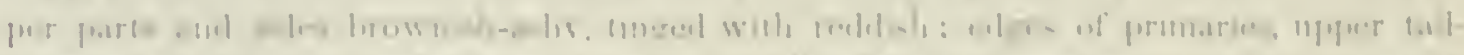

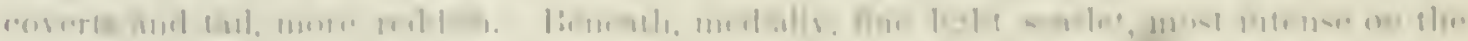

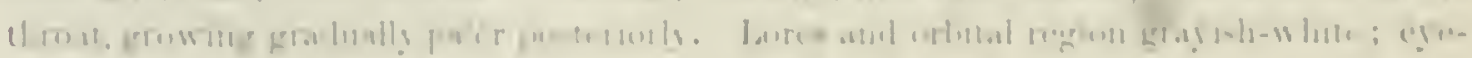

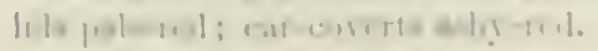


Female. Abore ashy-greenish-olivaceous, brightest on forehead; edges of wingfeathers, upler tail-coverts, and tail more aslyy on the back; beneath nearly uniform olivaceous-yellow; purer medially; lores ashy; a supereiliary stripe of olivaceous-rellow. Young male similar to the female, but forehead and crown olivaceous-orange, brightest anteriorly; supercilhary stripe bright orange, whole throat, abdomen, and breast medially rich rellow, nost intense, and tinged with orange-chrome on throat.

HAB. Mountain regions of Mexico and southern Rocky Mountains of Lnited States. Oaxaca (Oct., Selater); Aulapa (Sez.); Guatemala (Sclater); Vera Cruz (not to alpine regions, StMichrast).

This species differs from all the others in the great restriction of the red; this being confined primcipally to the head above, and median lower surface, the literal and upper parts being quite different reddish-ashy. The shade of red is also peculiar among the North American species, being very fine and light, of a red-lead cast, and most intense anteriorly.

Habits. A single female specimen in full plumage of this beautiful bird was obtained by Dr. Woodhonse in the San Francisco Mountains of New Mexico. It was an adult female, and so far is the only one known to have been foind within the limits of the United States. It is not rare in the highlands of Mexico, whence it probably extends into the mountainous portions of the United States.

Specimens have also been procured from Guatemala, and Mr. Boncard met with it at Choapan, a mountainous district in the State of Oaxaca, Mexico.

Nothing is known of its habits.

\section{Pyranga æstiva, rar. æstiva VieILL. \\ SUMMER REDBIRD.}

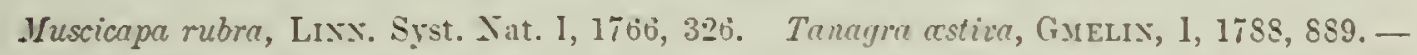
Wilsor, I, 1810, 95, pl. ri, f. 3.-Al゙D. Orn. Biog. I, 1\$31, 232; V, 1\$39, 51s, pl. xlir. Pyranga astiva. Vrerll. Nouv. Dict. XXVIII, 1S19, 291. - Box. List, 1S3S. - IB. Conspectus, 1\$50. - Atrn. Syn. 1839, 136. - IB. Birds Am. III, 1S 4 ,

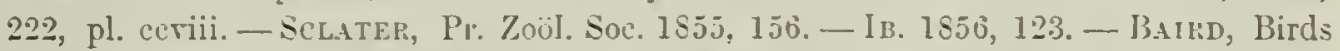
T. Am. 1S5S, 301.-Heermass, P. R. R. I, p. 17.-Ridgwar, Pr. A. X. S. 1569, 130. - Marsard, Birds E. Mass. 1570, 109. Phonisomu wstiru, Sw. Birds, II, 1537, 2S4. Phonicosoma astiva, CABAsrs, Mus. Hein. 15j1, 2j. ? Loxia virginica, GuELIs, I, 17Ss, S49. (Male changing.) ? Tanagra mississippiensis, GuELIx, I, 17£S, S59. Pyranga mississimpiensis, MAx. Cab. Jour. VI, 1S5S, 272. Tanamra variegata, LAth. Ind. Orn. I, 1790, 422. (Male changing.) Tangare du Mississippi, BtFFor, Ois. $\mathrm{r}, 63$, pl. enl. $i \notin 1$.

Sp. Char. Bill nearly as long as the head, nithout any median tooth. Tail nearly eren, or slightly rounded. Male. Vermilion-red; a little darker ahore. and brightest on the head. Quills bromn, the outer webs like the back. Shafts ouly of the tail-feathers brown. Bill light horn-color, more rellowish at the edges. Female. Olive abore, yellow beneath, with a tinge of reddish. Length, 7.20 ; wing, 3.75 ; tail, 3.00 ; culmen, . $\overline{0}$, tarsus, .68.

HAB. Eastern Prorince Lnited States, north to about $10^{\circ}$, though occasionally straring as far as Nora Scotia ; west to borders of the plains. In winter, south through the whole of Middle America (except the Pacific consr) as far as Econalor and Peru. Cuba; Jamaica. 
In the accoupanyine rut we erive outline of the hill of the two varieties

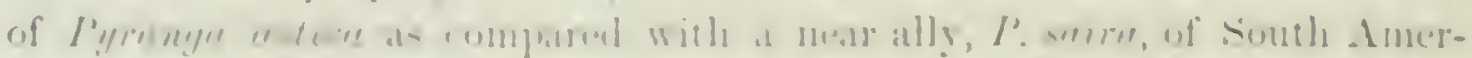

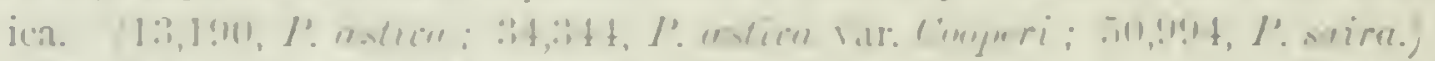

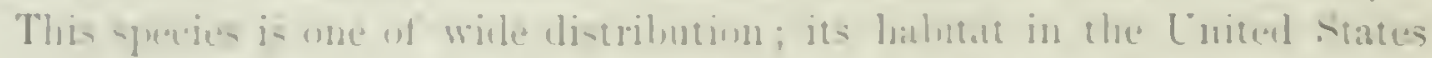
includine the "listern l'rovince", merth

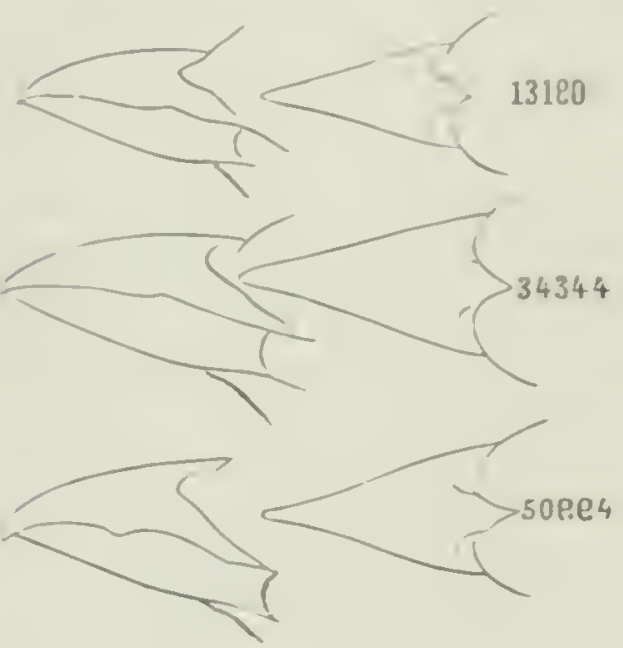
(1) Ciwa sondia, and west tuwarl the limky .lnumtains, along the streans watering the platus, through lexas, intw

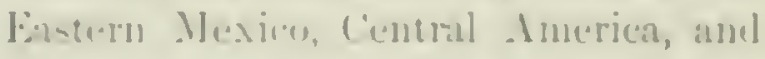

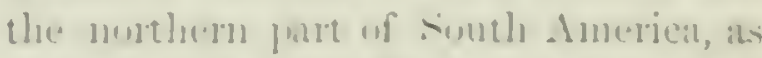
well as sume of the $1 W^{*}$ et Iuelia ialauds.

In the diflerent regrings of its habigtat the species mulergoes ansiderable variations its repands shates of coulur and junnertins. Sinecinens from lexils and bistern Mexien texlibit a deciterl tendesury to buger hill, and more slomeler forms than those of the bastern Luiterl

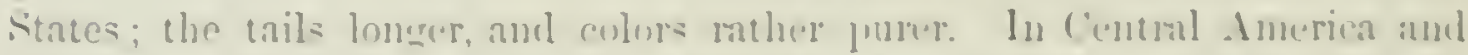

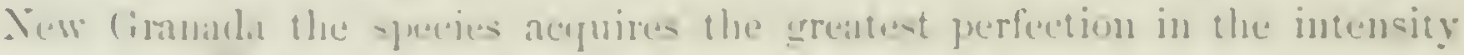

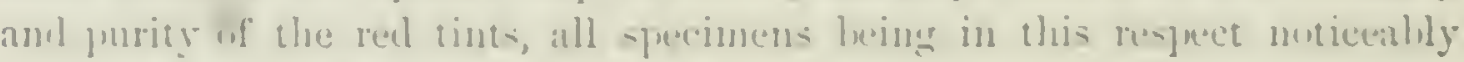

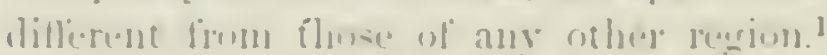

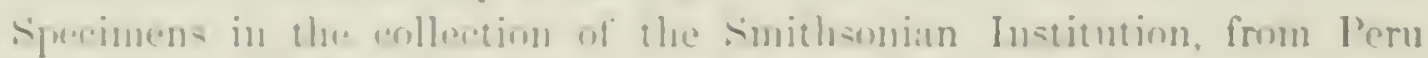

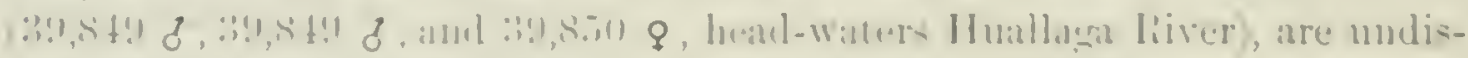

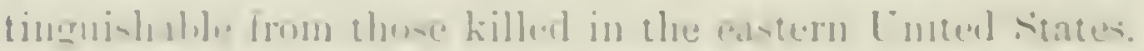

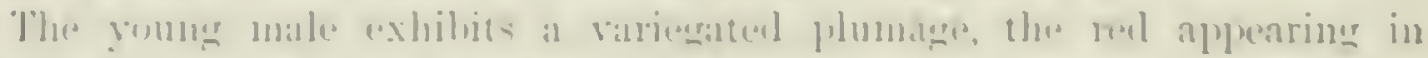

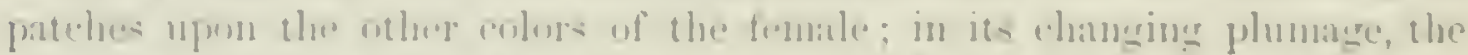

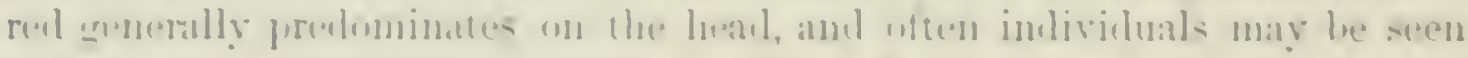

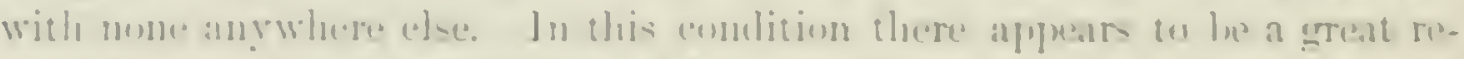

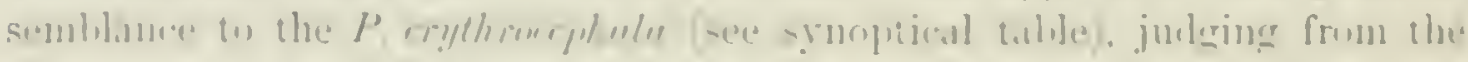

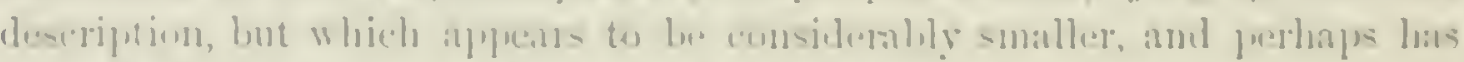

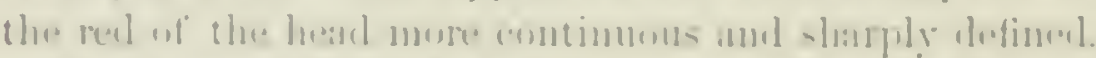

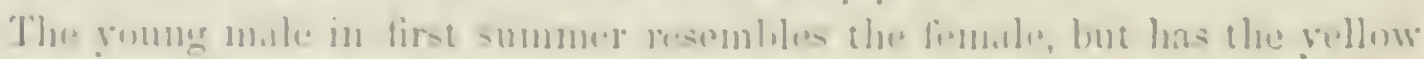

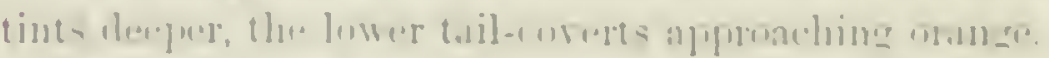

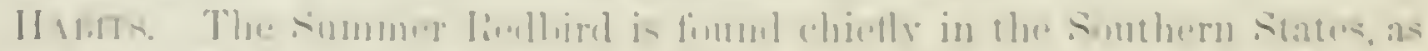

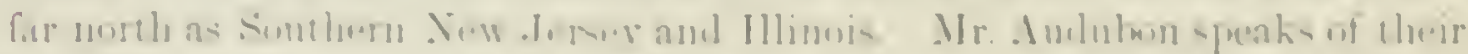

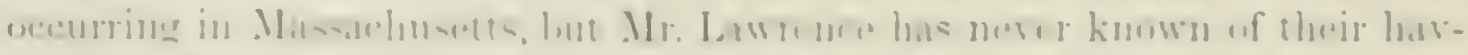

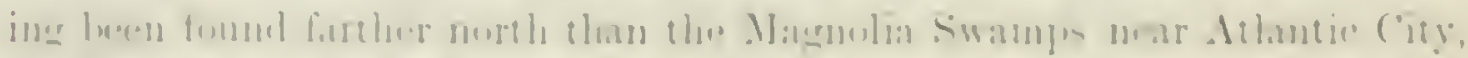

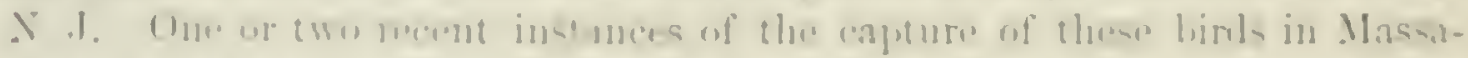

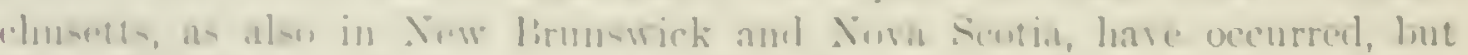

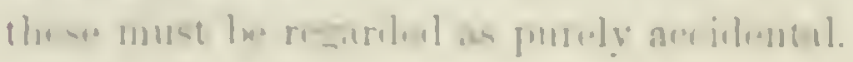

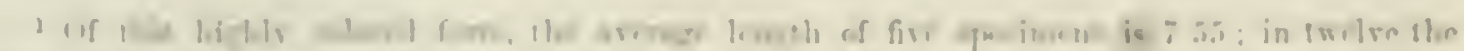

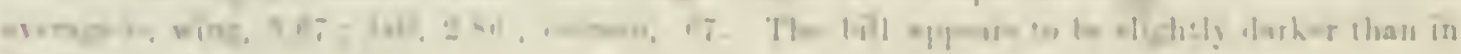

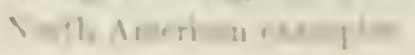


This species is said by Mr. Salvin to enjoy an almost nniversal range throughout Ginatemala. It oceurred in December at the month of the Rio Dulce, in the pine ridges near (unisigna, and along the whole roud from Isabel to Guatemala, a clistince of eighty leagues.

Mr. C. W. Wyatt met with these birds also, in all varieties of plumage, thronghont Colombia, Sonth America, at Herratura, Cocuta Valley, and Canta. Mr. Boncard obtained them at Plaza Yicente, Mexico. I)r. Woodhouse observed this species throughout the Indian Territory, Texas, and New Mexico, where it seemed solitary in its labits, frequenting the thick serubby timber. It has been known to breed at various points in Florida, Georgia, South Carolina, Louisiana, and Texas. To the northward it breeds more or less abundantly, as far as Washington, D. C., on the east, and Southern Inlinois and Kansas on the west, being nunch more common in the Mississippi Valley than in the States on the Atlantic in the same parallel of latitude.

Mr. Dresser found it quite common about San Antonio, Texas, during the summer season, arriving there about the middle of April, which is just about the period at which the three specimens were taken near Boston. It is comparatively rare in Pennsylvania, though abundant in the sonthern comnties of New Jersey, and in Delaware, Eastem Maryland, and Virginia. It is also abundant in the Carolinas, in Creorwia, Florida, and the Gulf States.

Wilson, in describing the nest and eggs of this species, has evidently confounded them and some of their habits with those of the Blue Grosbeak. Their eggs are not light-blue, nor are the nests, so far as I linow, as described by him. Audubon and Nuttall copy substantially his errors.

The food of this species during the spring and early summer is chiefly various kinds of large coleopterous insects, bees, wasps, and others. Later in the season, when whortleberries are ripe, they feed chietly on these and other small fruit. In taking its food it rarely alights on the ground, but prefers to capture its insects while on the wing.

The usual note of this bird, which Mrr. Audubon pronounces numusical, resembles the sounds "chicky-chuchy-ehuck:" The same writer states that during the spring this bird sings pleasantly for nearly half an hour in succession, that its song resembles that of the Red-ered Vireo, and that its notes are sweeter and more varied and nenrly equal to those of the Orehard Oriole.

The late Dr. Gerhardt of Varnell's Station, in Northern Georgia, informed me that these birds are quite common in that section of country. The nest is usually built on one of the lower limbs of a post-oak, or in a pine sapling, at a height of from six to trenty feet. They are usually constructed toward the extremity of the limb, and so far from the trunk as to be rery difficult of access. They are generally built from the middle to the end of May. The egres are four in number.

In Southern Illinois, according to Mr. Ridgway, the Summer Redbird arrives about the 20th of April, staring until the last of September. It is more abundant than the Scarlet Tanager, and much less retiring in its habits, 
frequenting the open grmes insteat of the leeper wooks and the forests of

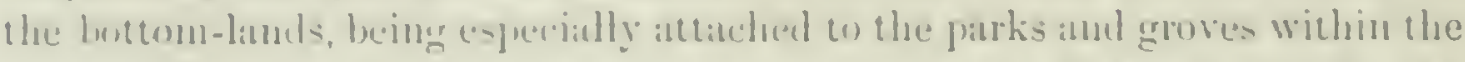

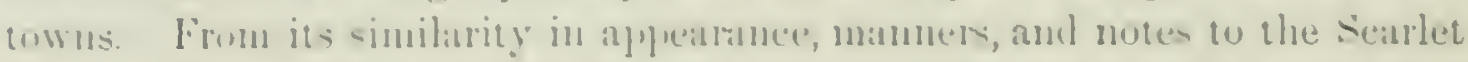

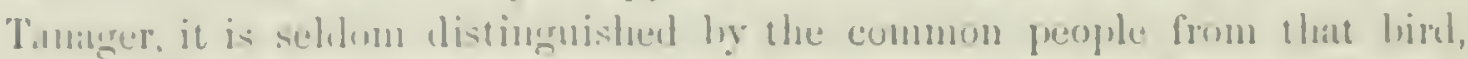

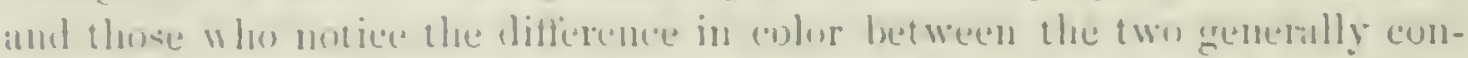

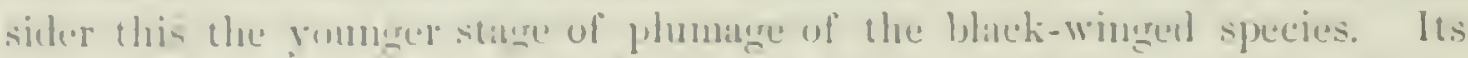
song is said (1) he somewhat after the style of the liubin, hut in at firmer

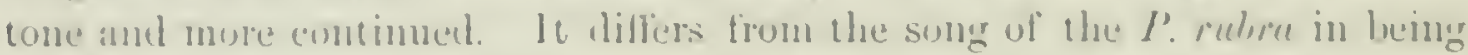
more vigorons, and heliverent in a manner less faltering. Its molinary note of

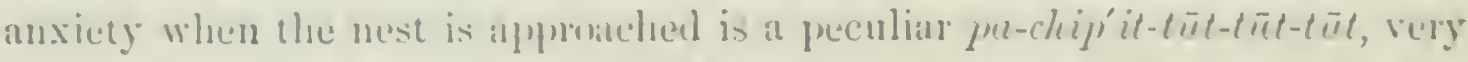

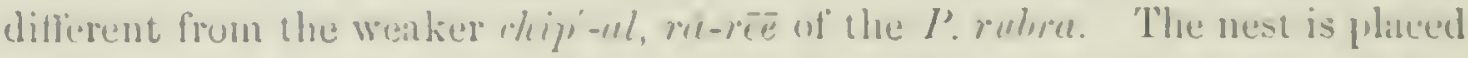
on a low horizontal or dowoping hanch, near its extremity, the tree beng generally an onk, or sometimes a hickury, and sitmated near the rankinte or at the algre of a grove. In its comstruction it is described as rerg thin, thungh by no means fratl, fermitting the engigs to he seen thromgh the interstices from below. Mr. lidinway never found mure than three engers in me nest.

A nest of this species (Smith. ('oll., iss, from Prative Mer lionge, Louisiana, has a dianeder of four inches and a lecight of two. Like all the nests

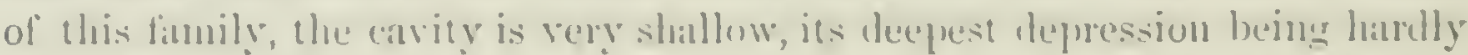
lulf an inch. So far from eorresumeling with the descriptions genterally given of it, this nest is well and even strongly put together, although a portim of the base and some of the external parts are somewhat openly interwoven, als if for ventilation. These materials are fragnents of plants, catt-

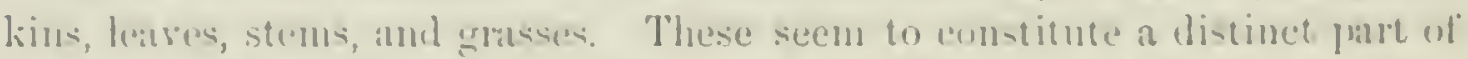

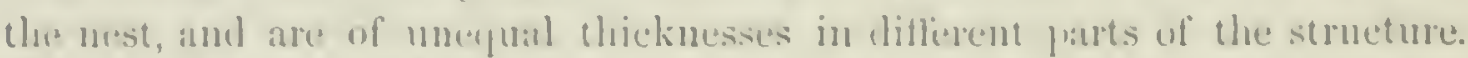
Within this externat frame is a much more at istic and elalumately interwo-

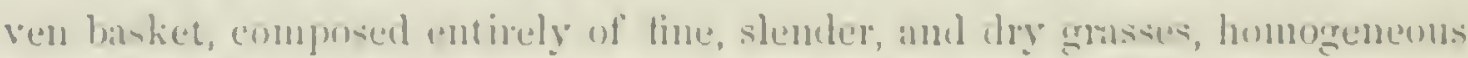

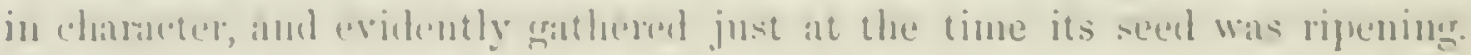
It is of a bringt straw-yellow, and forms the whole internal portion of the IItי)

The curgs vary sumewhit in sime and shipe, from an ohlong to a rommled wisl. Their length is from sill of an inch to an inch, and their brealth

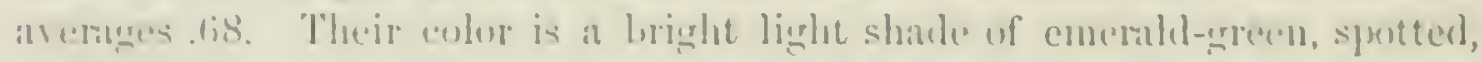
mithled, dothel, and hlotehed with varions shates of lilac, hrownish-purple, anul dark-brown. Thuse are generally well dithsed equally over the entire reng.

Pyranga astiva, var. cooperi, linuilly.

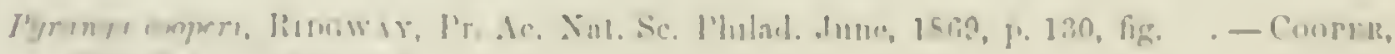
(1) (ㄴ. 1, 1คin, 11!.

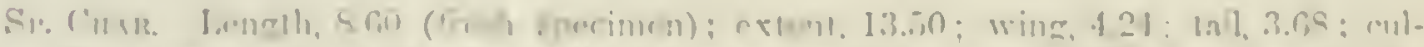

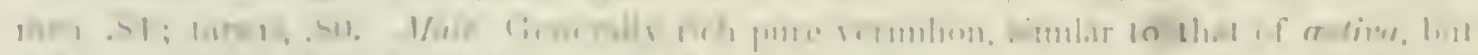

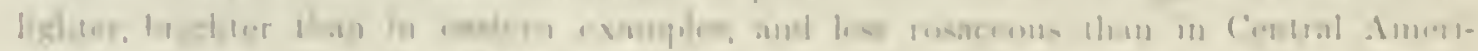

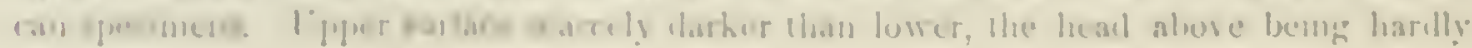


diflerent from the throat, and abruptly lighter than the back, which, with the wings and tail, is of a much lighter dusky-red than in astiva; exposed tips of primaries pure slaty-umber, primaries faintly nargined terminally witl paler (in the type, this character is not apparent, owing to the feathers being somewhat worn; in other specimens, howerer, it is quite a noticeable feature, although possibly not to be entirely relied on). Female. Above orange-olivaceous, beneath more light yellowish, purest medially: erissun richer yellow than other lower parts, being in some individuals (young males?) intense Indian-yellow, with the inner webs of the tail-feathers margined with the same; quite distinct line of orange-yellow orer the lores.

Hab. Upper Rio Grande and Colorado region of Sonthern Middle Province; south, in winter, along Pacifie coast of Mexico as far as Colima.

This bird, quite different from Eastern cestiva, is, however, probably only a representative form of the same species in the Colorado and Upper Rio Grande region, migrating south in winter, through Western Mexico to Colima, as specimens from Texas and Middle Mexico appear to be quite intermediate, at least in form.

HABITS. This is a new form, whose claim to distinctness was first made known-by Mr. Ridgway, in 1869. In appearance, it most resembles the $P$. astiva, but is larger. It has been found in the Middle Province of the United States, from Fort Mohare at the north, to Colima and Mazatlan in Mexico.

Dr. Cooper found this bird quite common near Fort Mohave, after April 25 , in the Colorado Valley, latitude $35^{\circ}$. They cliefly frequented the tall cottonwood, feeding on insects, and occasionally Hew down to the Larrea bushes after a kind of bee found on them. He states also that they have a call-note sounding like the words ke-dik; which, in the language of the Mojave Indians, signifies "come here." They sing in a loud, clear tone, and in a style much like that of the Robin, but with a power of rentriloquism which makes the sound appear much more distant than it really is. The only specimens of this species known to have been obtained in the United States were taken at Los Pinos, New Mexico, by Dr. Coures, and at Fort Mohave by Dr. Cooper. Other specimens have been procured from Western Mexico 


\section{FanLY FRINGILLID无. - THE Finchis.}

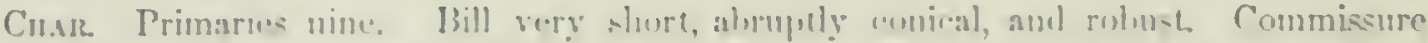

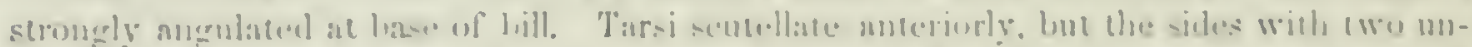

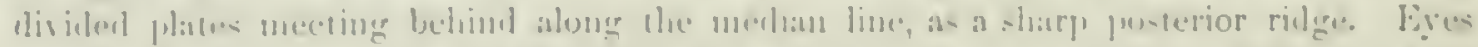

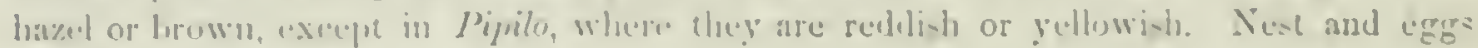
very variable as to dharacter and siluation.

I still lalor under the inalitity expresend in linds of North America (1). 406 ), in 1858 , to satisfactorily define and linit the sublinilies and generat of the Fringillider of North Americat, and catn only lope that hy the aid of the firmes of the present work no material difliculty will be experienced in determining the species. The distinctions from the allied fomilies are also diflicult to draw with precision. This is esprecially the ease with the Timnuritu, where we have much the sane external anatomy, including the lill, nearly all the varying peculiarities of this member in the one being repented in the other. - S. F. P.

All the United states sprecies may be provisionally divided into four subfanilies (the European House-S parrow forming a tifth), brietly chancterizable as follows:-

Coccothraustinze. IBill varialle. from enormous ly large to quite small: the hase

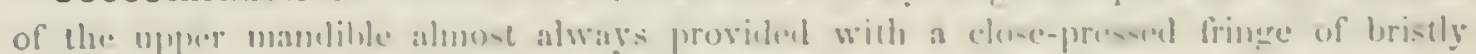

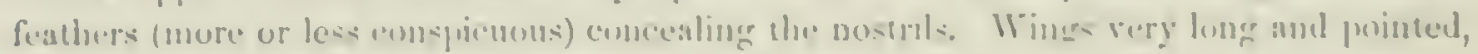

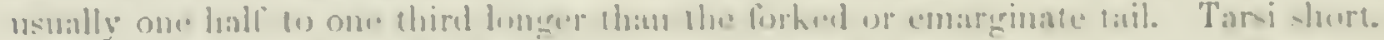

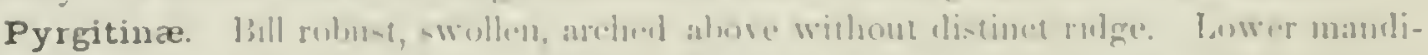

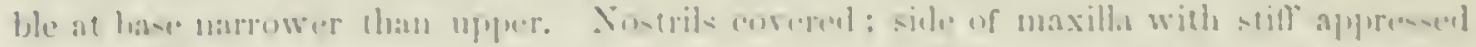

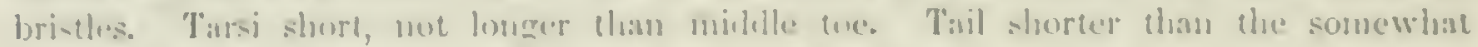

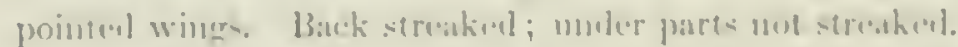

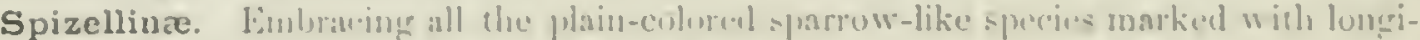

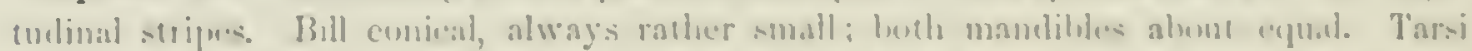

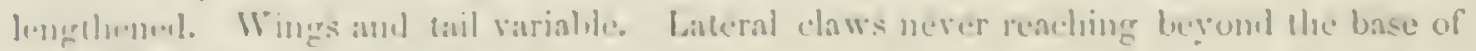

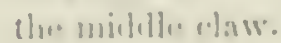

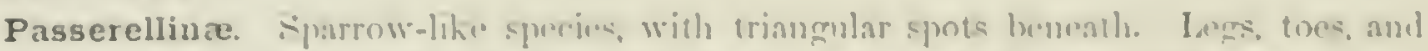

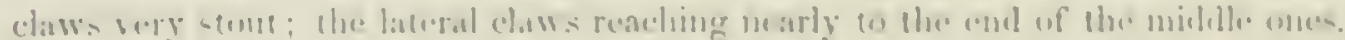

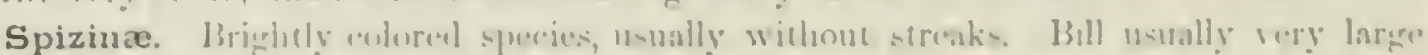

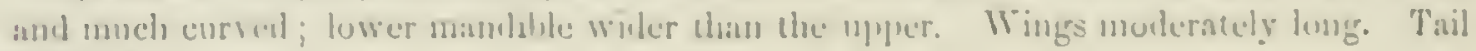
varialle.

\section{Sumpami. COCCOTHR A UST IN}

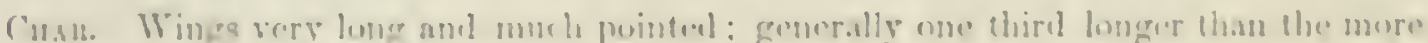

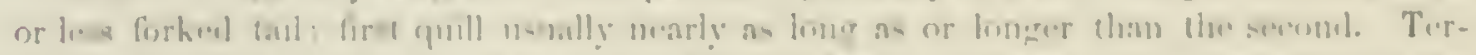

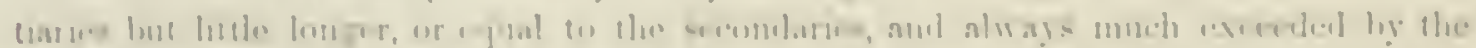

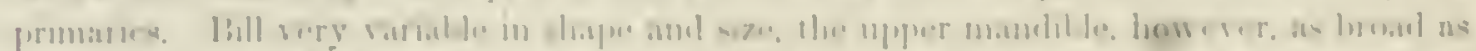

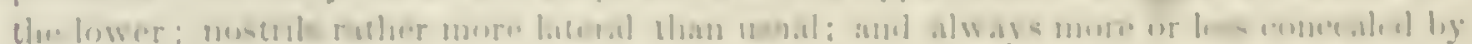

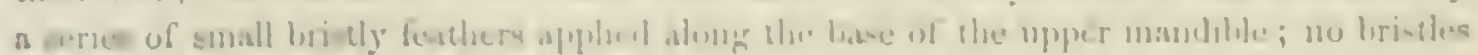


at the base of the bill. Feet short and rather weak. Hind claw usually considerably longer than the middle anterior one; sometines nearly the same size.

In the preceding diagnosis I have combined a number of forms, all agreeing in the lengtl and acuteness of the wing, the bristly feathers along the base of the bill, the absence of conspicuons bristles on the sides of the month, and the shortness of the fect. They are all strongly marked and brightly colored birds, and usually belong to the more northern regions.

The bill is very rariable, eren in the same genus, and its shape is to a considerable extent of specific rather than of generic importance. The fringe of short bristles along the base of the bill, concealing the nostrils, is not appreciable in Plcctrophanes (except in $P$. nivalis), but the other claracteristics given above are all present.

\section{Genera.}

A. Bill enormously large and stout; the lateral outline as long as that of the skull. Culmen gently curred.

$$
\text { Colors green, yellow; and bluck. }
$$

Hesperiphona. First quill equal to the second. Tings one half longer than the tail. Lateral claws equal, reaching to the base of the middle claw.

Claws much curred, obtuse; hinder one but little longer than the middle.

B. Bill smaller, with the culmen more or less curred; the lateral outline not so long as the skull. Wings about one third longer than the tail, or a little more; first quill shorter than the second. Claws considerably curred and thickened; hinder most so, and almost inappreciably longer or eren slorter than the middle anterior one. Tarsus shorter than the inildle toes. Lateral toes unequal.

\section{a. Colors red, gray, and black; never streaked.}

Pyrrhula. Bill excessirely swollen; as broad and as high as long, not half length of head; upper outline much curved. Tail-coverts corering two thirds the tail, which is nearly eren, middle and hinder claws about equal.

\section{b. Colors red and gray, or streaked bron:n and white.}

Pinicola. Bill moderately swollen; longer than high or broad, upper outlines much curred; the tip hooked. Tail-corerts reaching over basal half of tail, which is nearly even. Middle claw longer than linal; outer lateral claw extending beyond base of middle (reaching to it in Pyrrhula and Carpodacus). $\$$ and jur. not streaked.

Carpodacus. Bill variable, always more or less curred and swollen; longer than high or broad; the tip not looked. Tail-corerts seaching orer two thirds the tail, which is decidedly forked. Middle and hind claw about equal. $q$ and juv. streaked.

\section{c. Colors black and yellow.}

Chrysomitris. Bill nearly straight. Hind claw stouter and more curred, but scarcely longer than the middle anterior one. Outer lateral toe reaching a little beyond the base of the mildle claw ; shorter than the hind toe.

Wings longer and more pointed. Tail quite deeply forked.

C. Hind claw considerably longer than the middle anterior one. with about the same currature; claws attenuated towards the point, and acute. Lateral toes about equa]. Wings usually almost one half longer than the tail, which is deeply forked. Tarsus shorter tlian middle toe. 
1. Puiste of monuliblee nrerlnpping.

Curvirostra. Tar-1- hereer than midhlue ine. Bhll much rompressed,

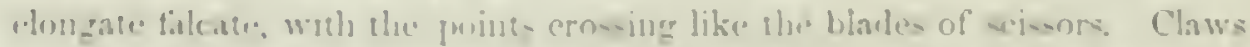
very large; lateral extemding beyoml the base of the middle. Colore red or gray. Streaked in jur.

\section{b. Puints of mandibles wot urerlayjping.}

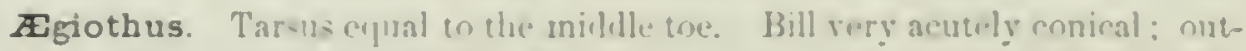

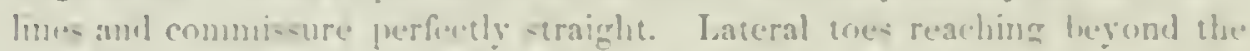
have of the mildle one. No ridge on the side of the lower mandible.

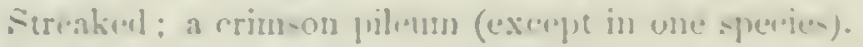

Leucosticte. Culmen sighty decurved: commisanre a little concave. I3.11 whenkly coniral : not sharp-printed. A con-picuns ridge on the side of th. lwwer mandible. Claw large; the lateral not rearhiug beyond the lian of the middle one. Colurs red and hrown.

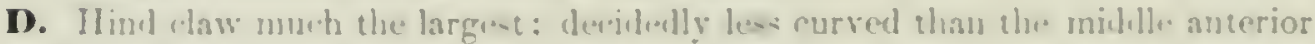

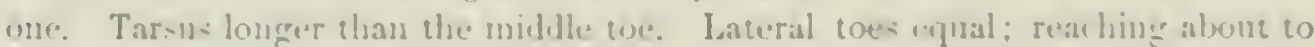
the hase of the midhle claw. Himd tore as loug or longer than the midhlle nue. Bill very varialde; always more or less eurrenl and hluntel. Palate somewhat tuluerculate: margins of lower jaw much inflexend. Tail slighely conarginate or

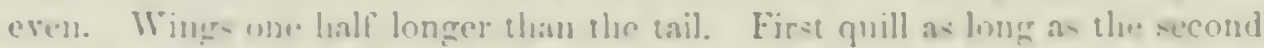

Plectrophanes. Color black and white. With or without rufous nape or (Hhuws. Jluch white on tail.

\section{GEYT: HESPERIPHONA BOXIP.}

Hequriphnn, Busar. Comptes Iendus, XXXI, seje. 1E5n, 424. (Type, Fringilln reepertive.

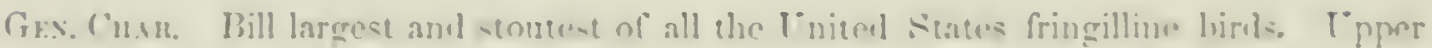

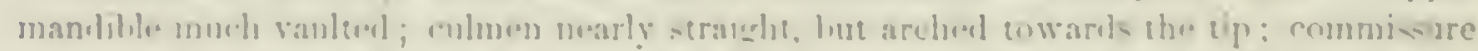

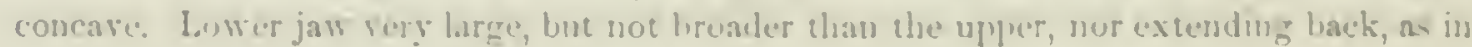

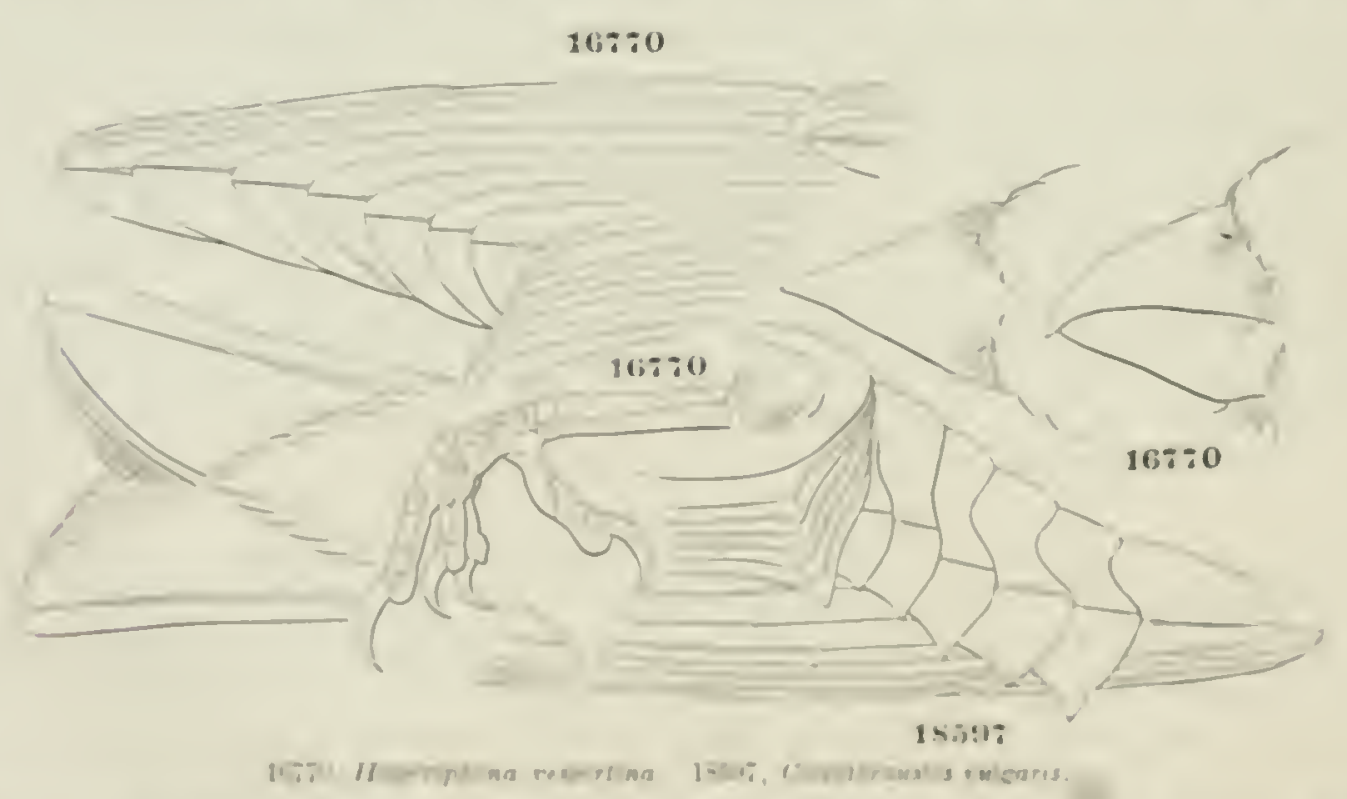

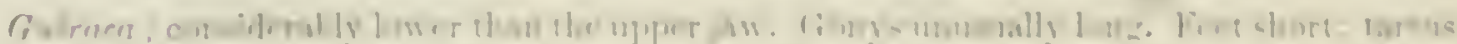

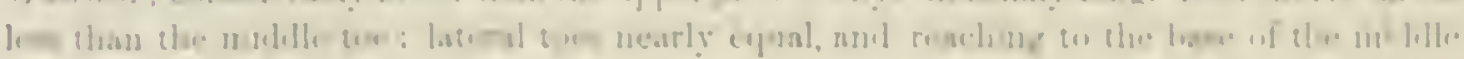




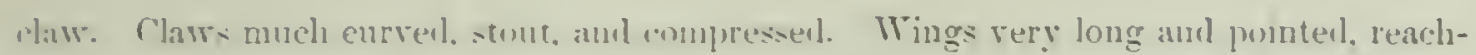
ing heyond the middle of the tail. Primaries much longer than the nearly equal secondaries and tertials: outer two quills longest: the others rapidly graduated. Tail slightly forked; searcely more than two thirds the length of the wings its coverts corering nearly: tluree fourths of its extent. Nest and egrgs unknown.

This gemus is allied to the European C'uccothroustes, but differs in wanting the curious expansion of the immer secondaries, as shown in Fig. 18,597. Species are said to occur in Asia, but we have only two in America, - one peculiar to Mrexico (H. abeillii), the other H. vapertina.

The American species may be thus distingruished:-

\section{Species and Varieties.}

Conmox Chanactrips. Wings and tail black, the tertials with more or less whitikl2 body concolored, with more or less of a vellowish tinge. §. Body yellowish, more oliraceous above: no white at base of primaries. $\$$. Body gray. isl, merely tinged with yellow: a white spot at base of primaries. Nest and egge unknown.

1. H. vespertina. §. Head oliraceous-sepia, with a rellow frontal cresceni and a black occipital patch. 9 . Crown plumbeous-brown; a duskv "bridle" down side of the throat: npper tail-corerts tipped with a white spot.

Yellow frontal trescent loroal, as wide as the black behind it: inner webs of tertials partially black: secondaries and inner webs of tailfeathers tipped with white. Inb. Yorthern mountain regions of Enited States and interior of British America . var. vespertina

Yellow frontal crescent narrow. less than half as wide as the black behind it: inner webs of the tertials without any black: secondaries and inner webs of tail-feathers without white tips. Hab. Southern Rocky Iountains of United States, and mountains of Mexico.

var. $m$ on $\tan a$.

2. H. abeillii. J. Head entirely black, sharply defined. Q. Crown (only) black; no dusky "bridle" on side of throat; upper tail-coverts without white tips. Hab. Mrountains of Guatemala and Southern Mexico.

\section{Hesperiphona vespertina, Boxap.}

\section{EVENING GROSBEAR.}

Fringilla resportinn. Cuoprer, Annals Yer York Lrcenm, X. H. 1, II, 1\$25, 220 (Sanlt St. Marie). - Arr. Orn. Biog. IT, 1\$3\$, 515; T, 235, pl. ceclxxiii, cecexrir. Fringizla (Coccothraustes) respretinn, Bur. Sin. 1E2S, 113. - IB. Am. Orn. II, pl. xr. C'ocrothraustes respertina, Sw. F. Bor. Am. H, 1\$31, 269. - At'D. Birds Am. IIJ, 1\&41, 217. pl. cerii. Hesperiphona respertina, Box. Comptes liendus, XXXI. Sept. 1850, 424.--

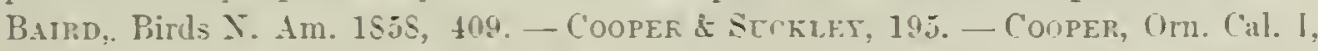
174. Coccothroustes bonrpartii, LEs:os, Illust. de Zoöl. 1\$34, pl. xxxir. 9 (Melville Island1). Lnxin bmampretii, Less. Bull. Se. tab. xars. Hesperiphour vespertine, var. vespertinn, RuJGWY (new rariety from Mexico and the sonthern Rocky Mountains). 


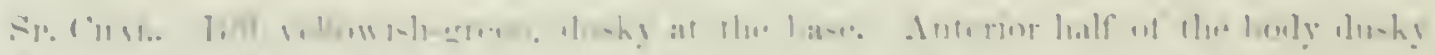

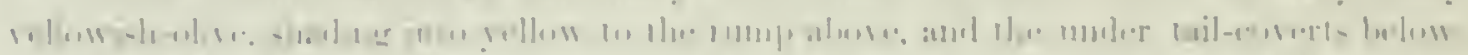

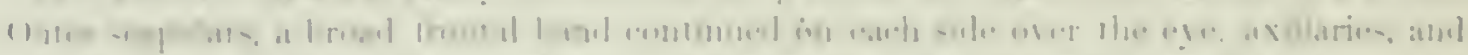

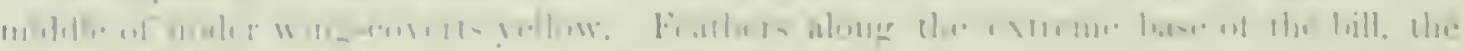

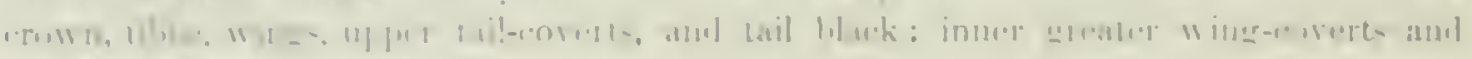

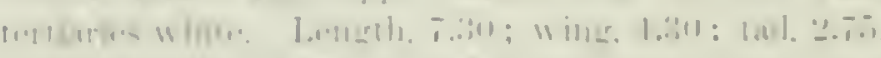

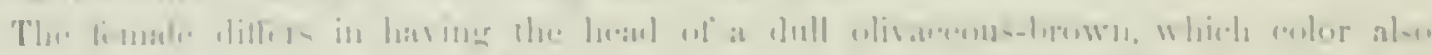

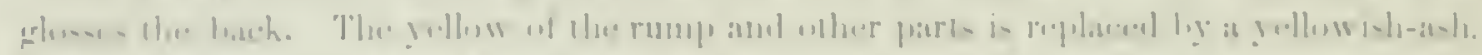

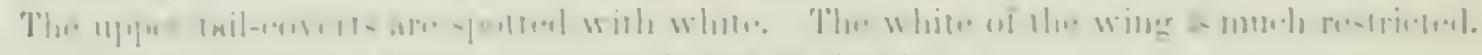

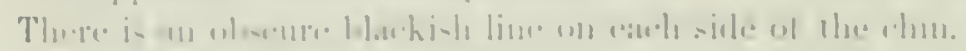

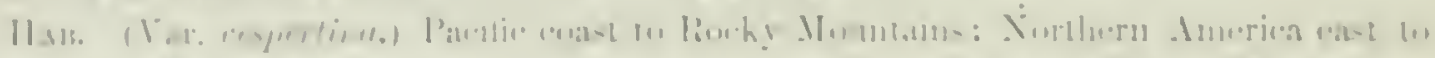

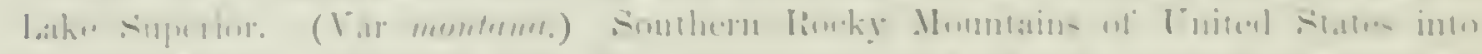

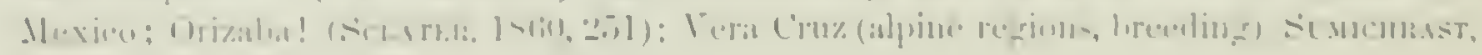

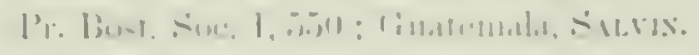

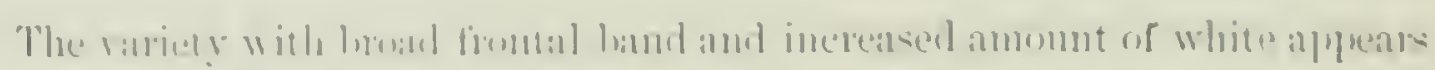

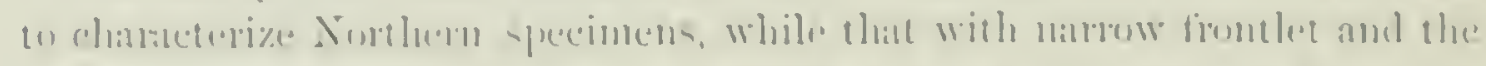

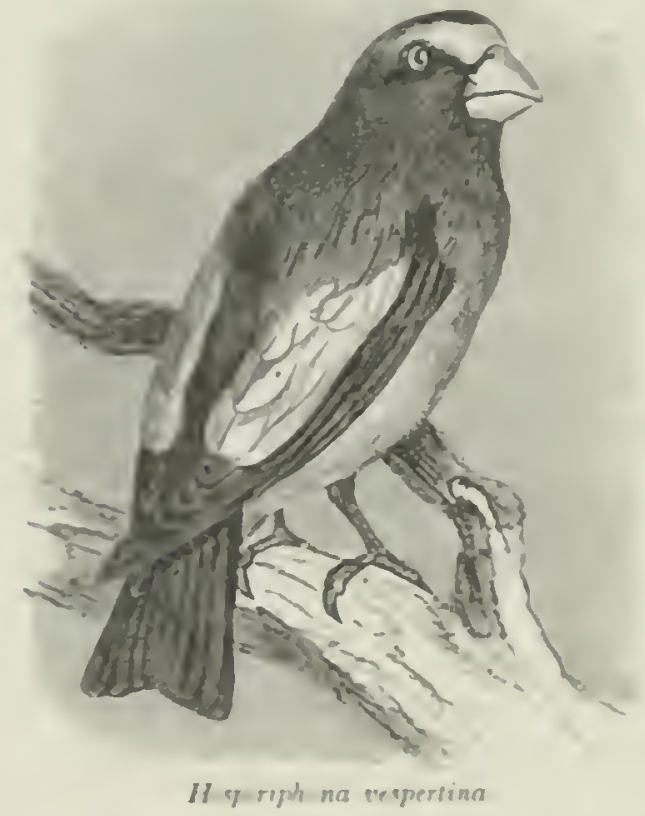

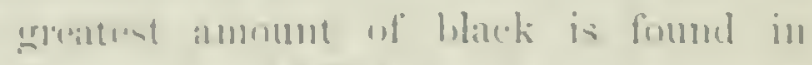
(inatematlat. Mexime and the somthern lincky Mlumbaims, and may be called "1"unlı!"!.

In sime it is also a little smaller. Speci-

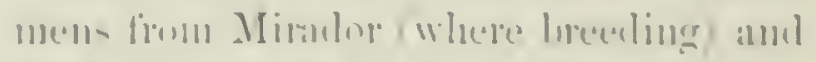

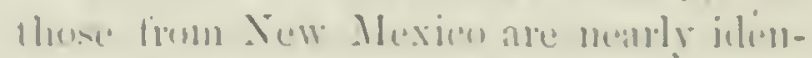

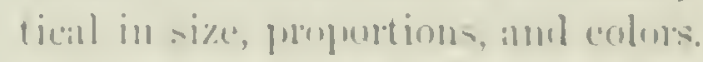

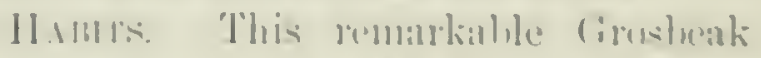

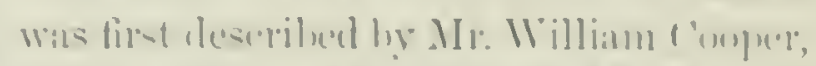

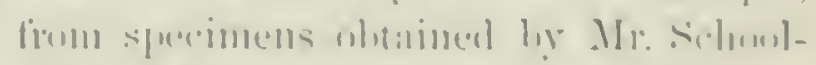

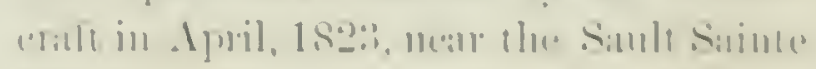

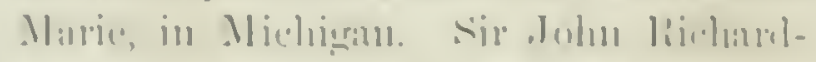

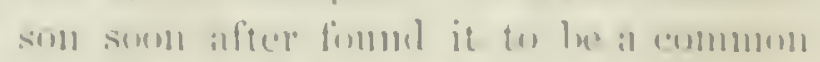

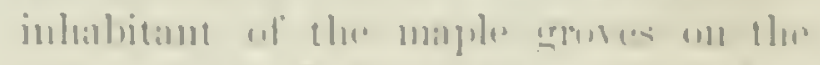

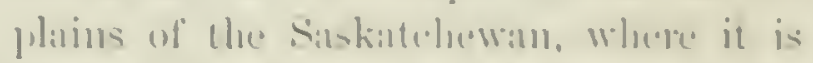

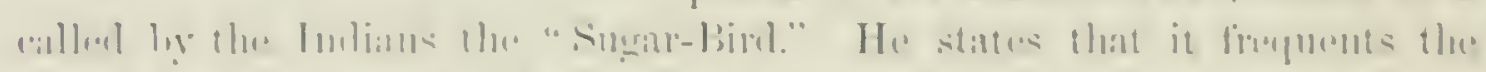

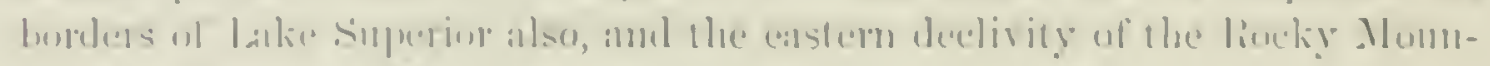
taim, in lallitmle int.

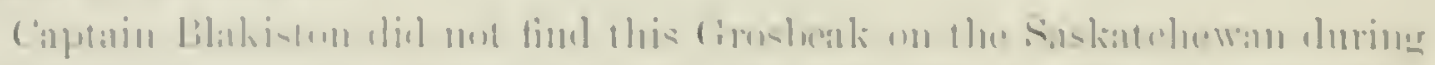

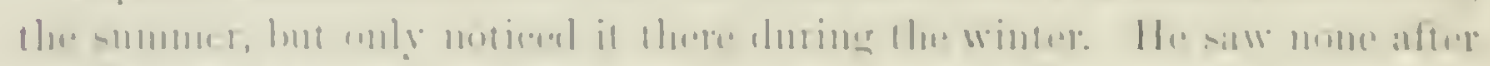

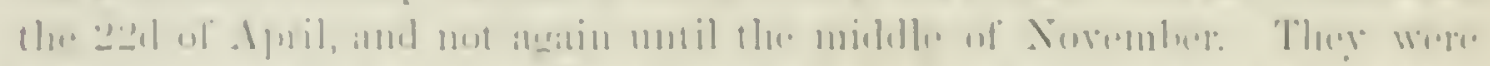

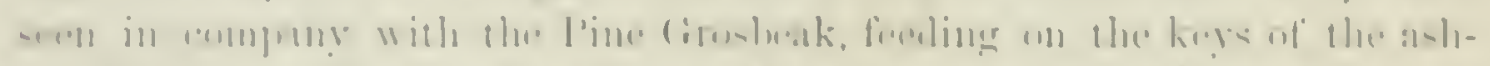

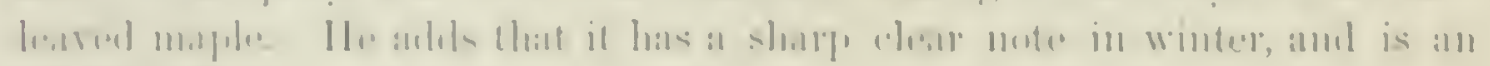

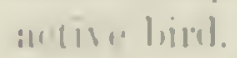

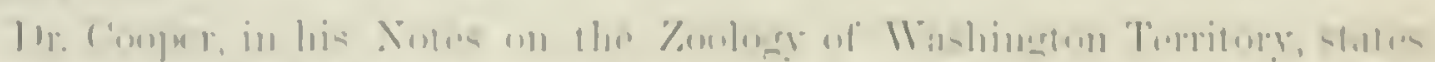

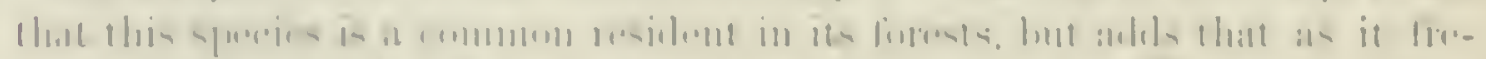

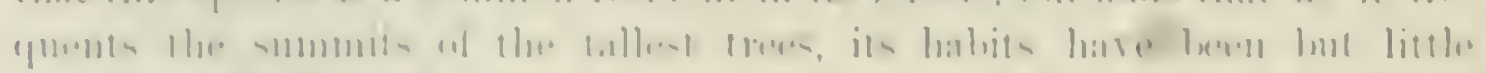

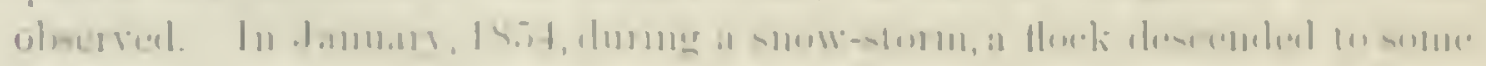


low bushes at Tancouver, and began to eat the seeds. Since then he had only seen them flying high among the tops of the poplars, upon the seeds of which they feed. They were uttering their loud, shrill call-notes as they flew.

The same writer, in his Report on the birls of California, makes mention of the occurrence of this Grosbeak at Aiehigan Bluffs, in Placer County, in about latitude $39^{\circ}$. Specimens were obtained by $\mathrm{AL}$. F. Gruber, and were probably the variety designated as montunc. The same form donbtless occurs along the summits of the sierra Nevada, and they have been traced among the Rocky Mountains to Fort Thorn in New Mexico.

These birds do not come down near the sea-coast even at the mouth of the Columbia, and in Califomia have not been met with in the Coast Riange. They are said to feed ehiefly on the seeds of the pine, spruce, and cottonwood trees, occasionally seeking other seeds near the ground. They are silent when feeding, but utter a loud call-note as they fly from place to place. In spring, I)r. Cooper states, they liare a short but meloclious song, resembling that of the Robin or Black-headed Crosbeak. He afterwards met with a flock in the winter near Sinta Cruz, where they remained until the end of April. Their farorite resort was a small grove of alders and willows, close to the town, where their lond eall-notes cunld be hearl at all times of the day, though he never heard them sing. In the early spring their farorite food was the young leaves of rarious wild plants that grew under the trees. They also fed on the huds of the kignndo, and frequented the large pear-trees in the old mission garden. They were rery tame, and allowed an approach to within a few yards, when feeding. Mr. Townsend, in 1836, found this Grosbeak almundant about the Colunbia Liver. Late in May they were quite numerous in the pine woods. They were very unsuspicious and tame. Under the impression that these birds were only musical towards night, they have been styled the Evening Grosbeak. But this, according to Mr. Townsend, is a misnomer. He also contraverts several other statements made in reference to their habits. He found them remarkably noisy from morning until night, when they quietly retire like other bircls, and are not heard from mintil the next day-dawn. They go in large flocks, and are rarely met with singly. As they feed upon the seeds of the pine and other trees, they proceed by a succession of hops to the extremities of the branches. They also feed largely on the larve of the large black ant, for which object they freunent the tops of the low oaks on the elges of the forests. Their ordinary roice is said to be a single screaming note, uttered while feeding. At times, about milday, the male attempts a song, which Mr. Townsend describes as a miserable failure. It is a single note, a warbling eall like the first note of the Robin, but nut so sweet, and suddenly checked, as if the performer were out of hreath.

Mr. Sumichrast met with the variety of this species designated as montanu, May, 1857, in the pine wonds of Monte Alto, ahout twelve leagues from Mexico; and although le has nerer found it in the alpine region of Tera 


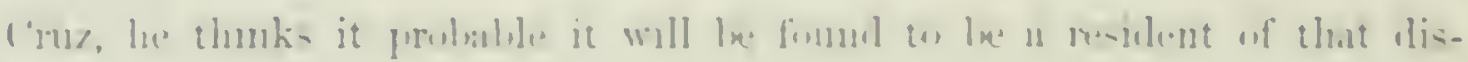
triet

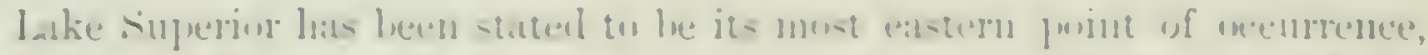

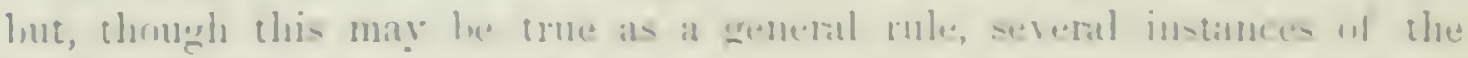

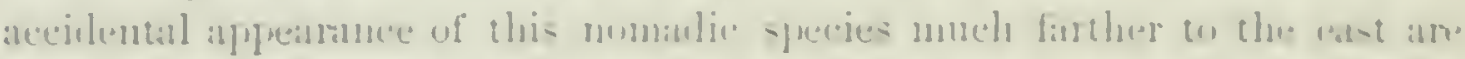

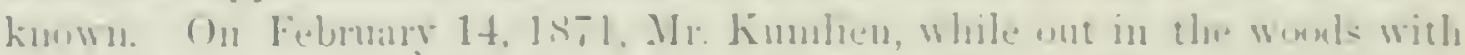

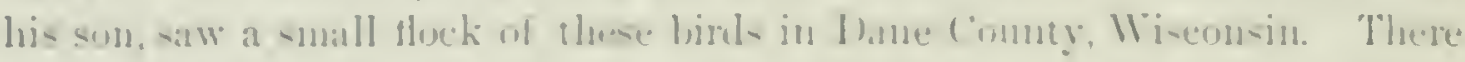

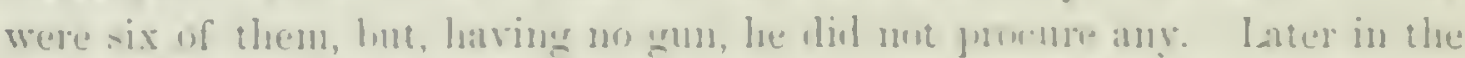

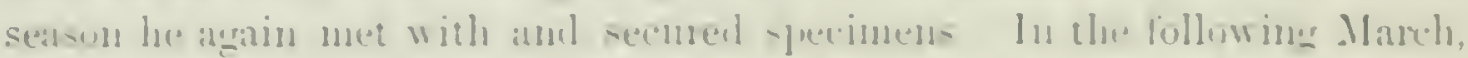

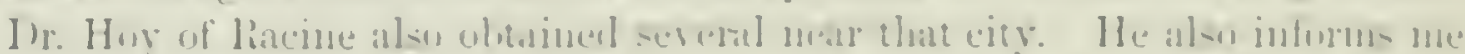

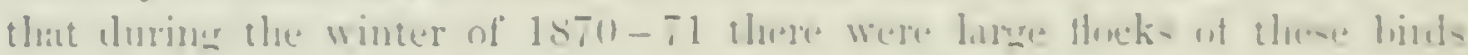

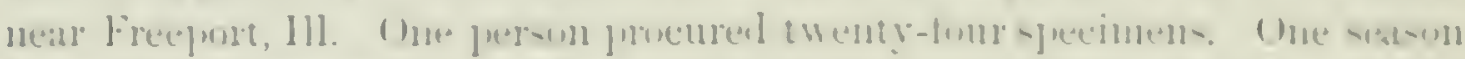

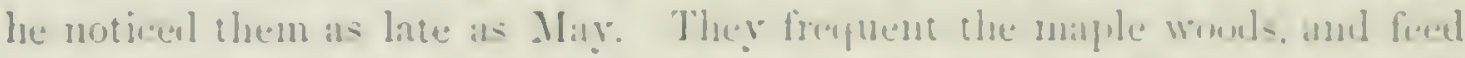

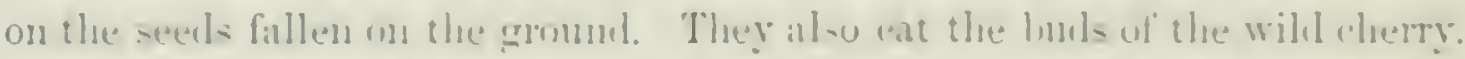
Their visits are male at imenular intervals. In some years nut a sinele imli-

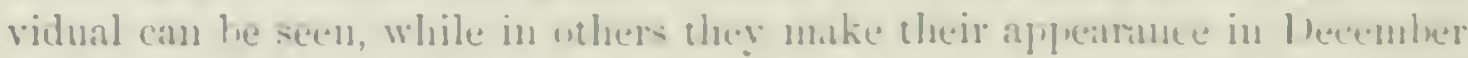
and continne thromels the whole winter.

Specimens have also been ubaiued uear Cleveland, Whio, and at Hanilum,

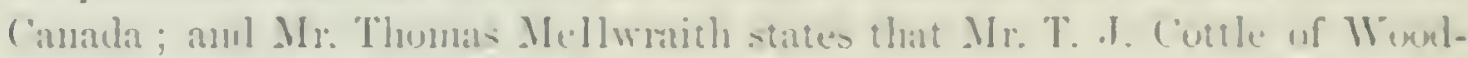

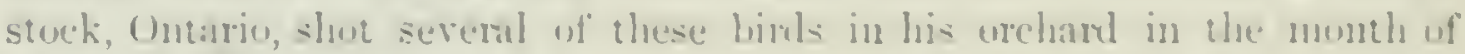
May. They were quite numerous, and remained about the place several days.

\section{GEN"s PINICOLA, Vhiml.}

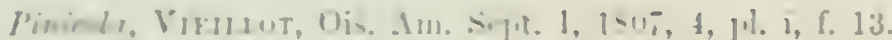

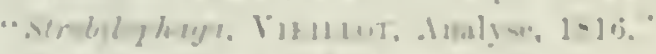

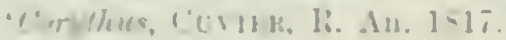

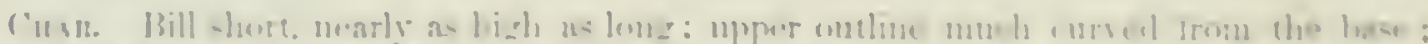

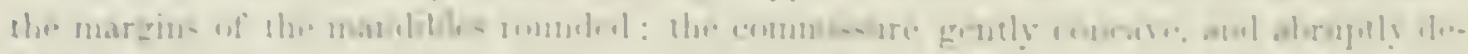

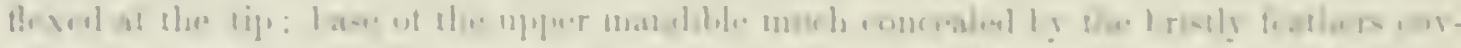

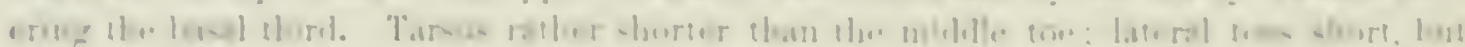

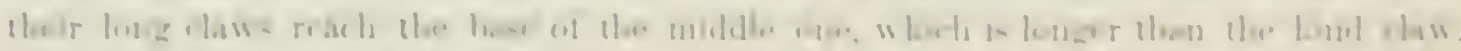

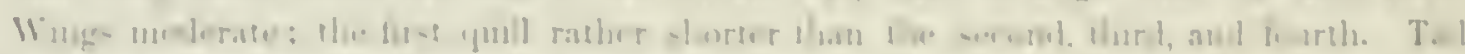

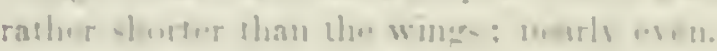

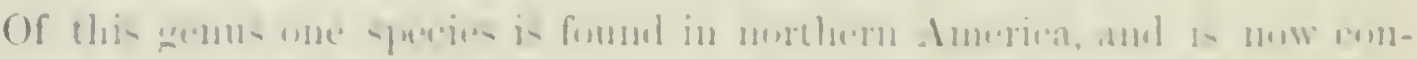

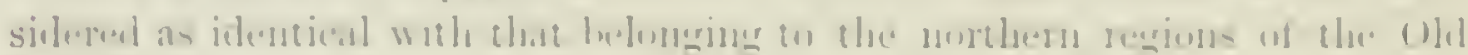
Wull 
Pinicola enucleator, CAB.Lis.

THE PINE GROSBEAK.

Coccothraustes canadensis, B1:1ssos, On'1. 111, 1760, 250, pl. xii, f. 3. "Corythus canalensis,

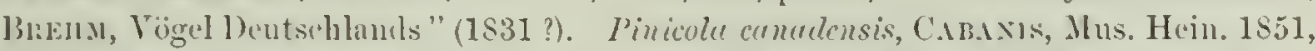

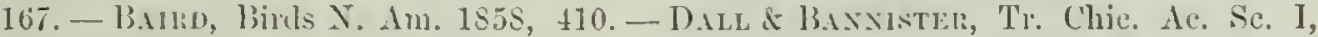

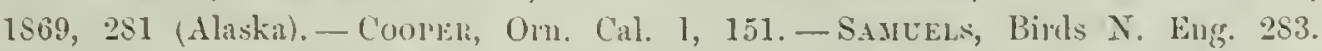
P'inicole americane (C.AB. IlSS.), Bp. Consp. 1550, 528. Loxiu cnucledur, Lixi. Syst. Nat. 1, 299. - Forst. Phil. 'Tlans. 1.XiI, 1772, 3\$3. - Wus. Am. Oru. I, 1\$08,

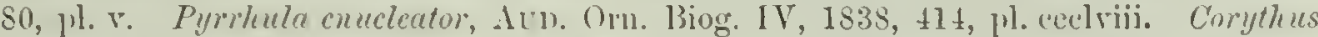
cnucleutor, Buxip. List. 1838. - Avn. sym. 127. - I1: Birls Am. H1, 1841, 179, pl.

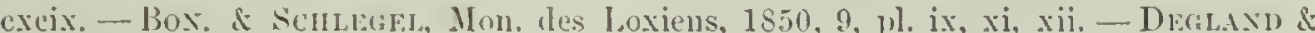

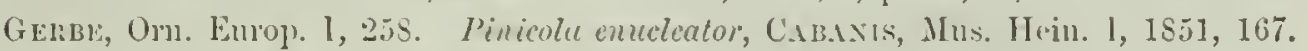

Sr. Cusn. Bill and legs black. Ifule. General color light camnine-red or rose, not continuons above, however, except on the head; the feathers showing brownish centres on the back, where, too, the red is darker. Loral region. base of lower jaw all round, sides (uncter the wing), abdomen, and posterior part of the body, with under tail-corerts, ashy,

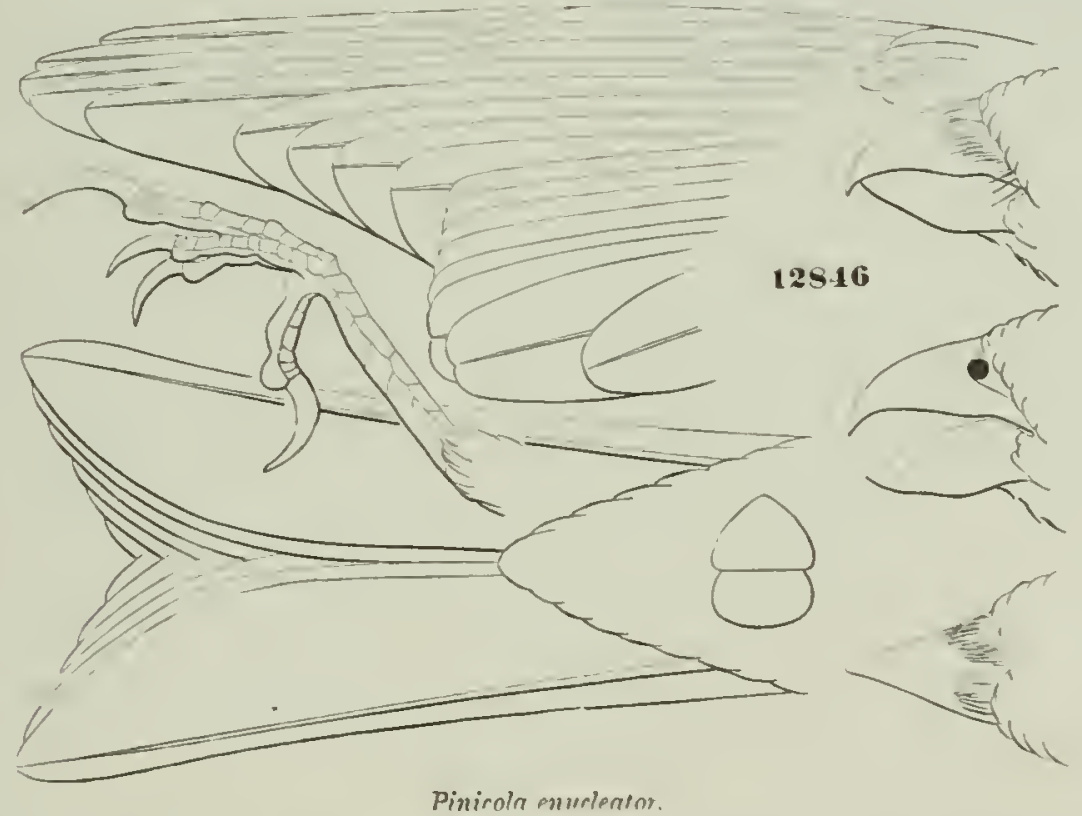

whitest behind. Wing with two white hanks acoss the tips of the greater and millle: coverts; the outer edges of the quills also white. broadest on the turtianies. on secomblatis tinger with red. Femule ashy, brownish above, tinged with greenish-yellow benenth; top of head. rump, and mpper tail-crwerts browms gamboge-rellow. Wings much as in the male. Length about 8.50; wing, 4.50; tail. 4.ou. Joung like fenale, but more ashy.

IIAB. Aretie America, sonth to Cnited States in serere winters.

A careful comparison of American with Emropean specimens of the Tine Grosbeak does not uresent any tangihle point of distinction, and it appears inexpedient to preserve the name of conadensis for the hird of the New World. There is considerable difference in the size, the proportions of the bill, and the color of different specinens, lunt nome of appreciable geographical ralue. 


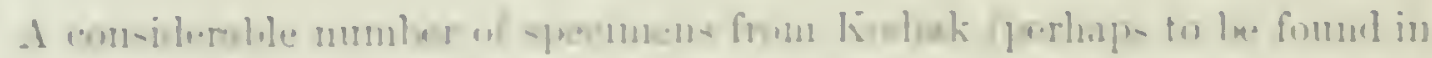

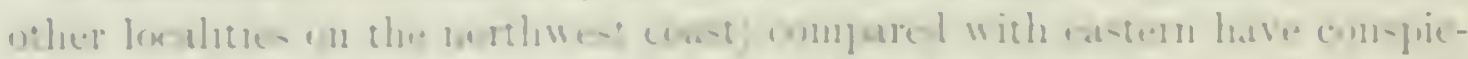

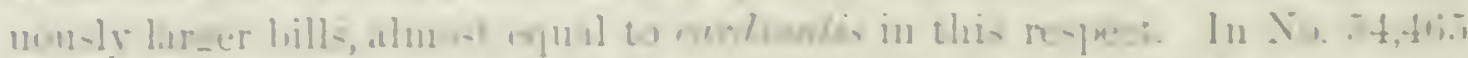

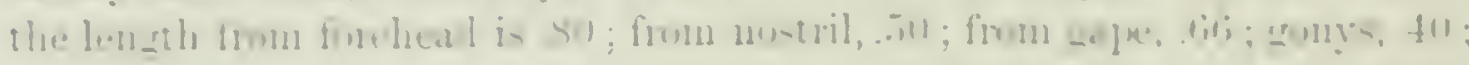

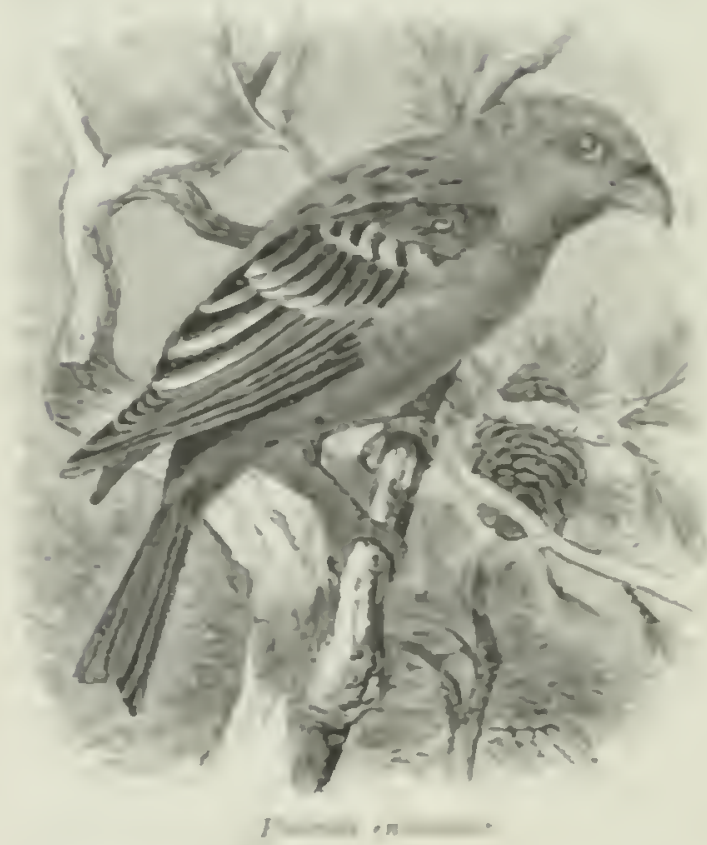
greate- ilepill, il. In at linsthly

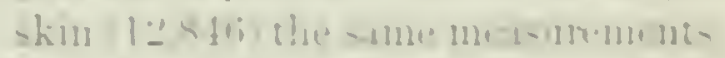

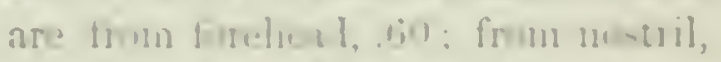

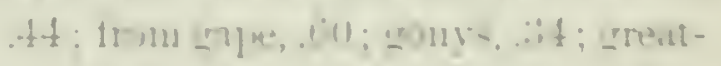

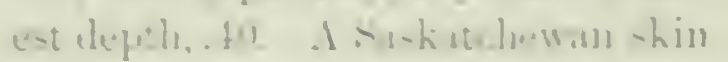

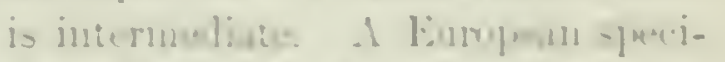
nuen has the hill as lon as that form linliak, lut l, s swollen. A Himn-

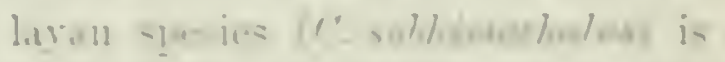

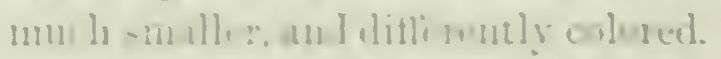

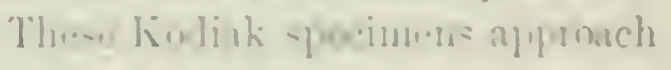
the Eurplan linl mom nesty in form of the libly, is whiols there is a temleney an a mire alomptly lentied "1per matilue than in the birls from the catsorm prortions of listish Ameria. As a gerenal thinge the

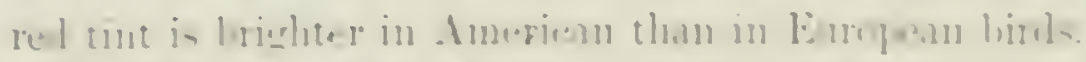

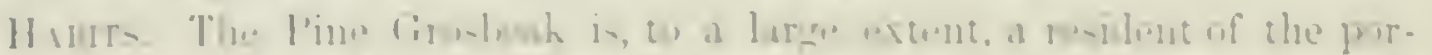

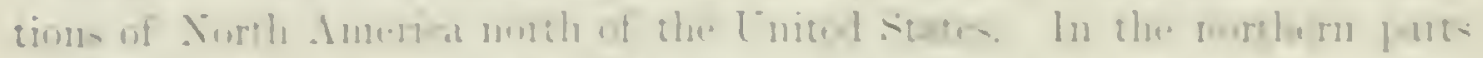

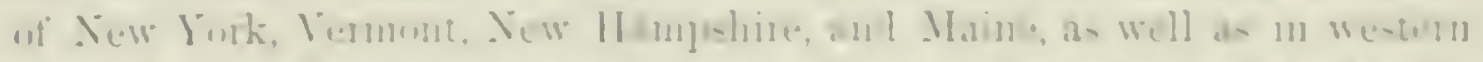

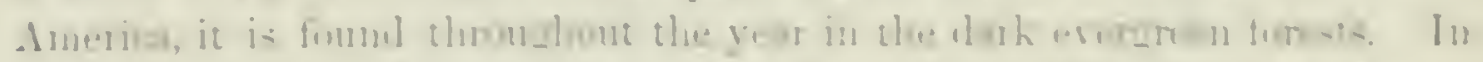

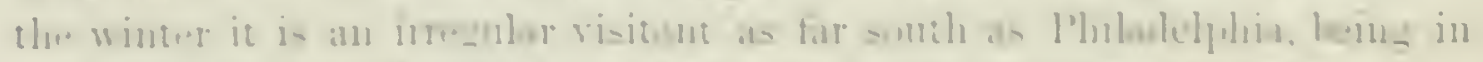

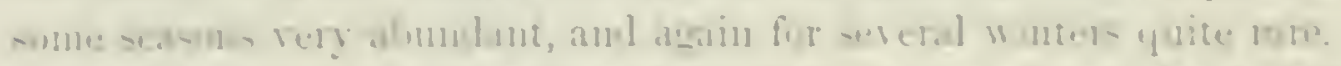

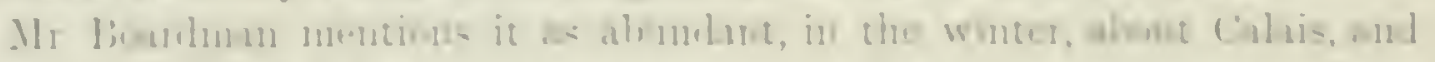

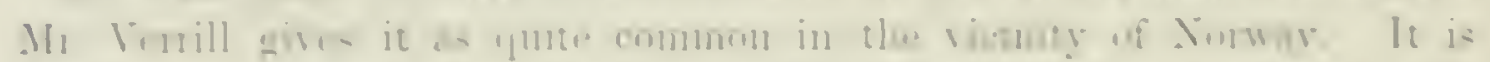

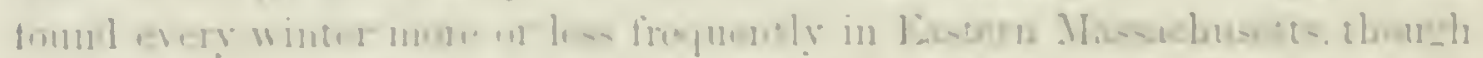

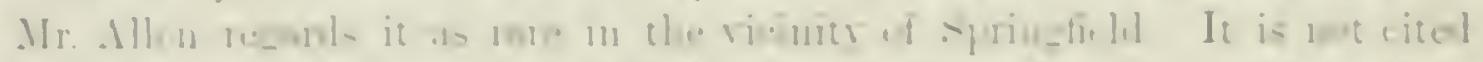

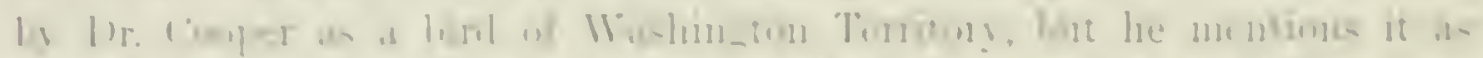

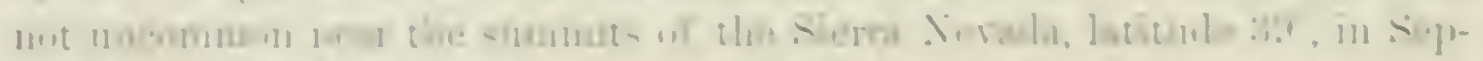

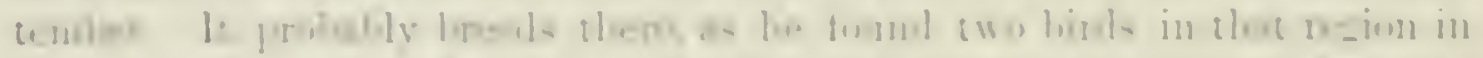

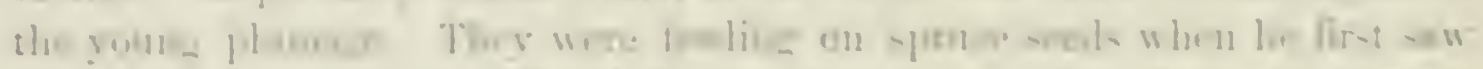

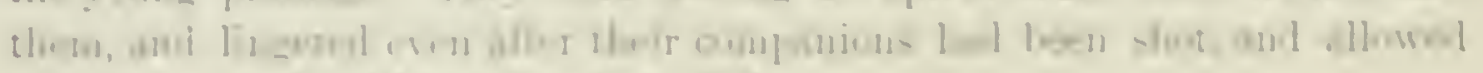

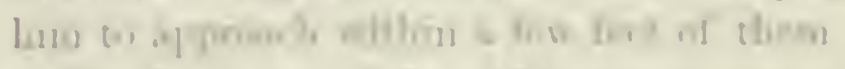

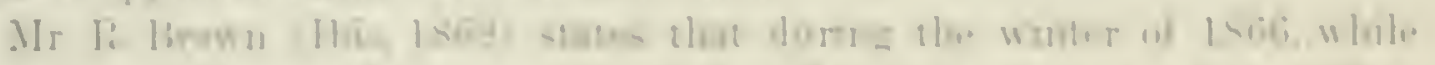

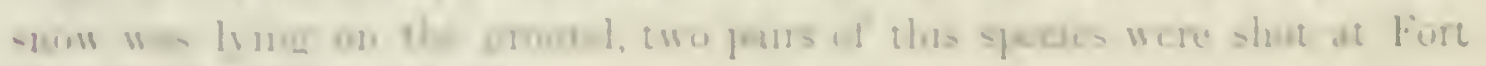

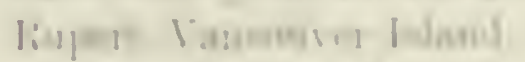

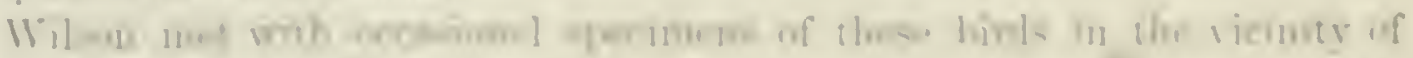

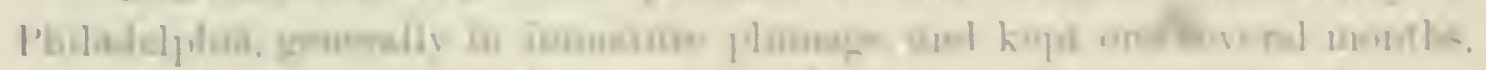

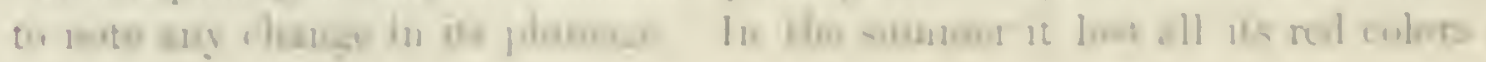


and became of a greenish-yellow. In May and Jume, its song, though not so lond as that of some binds, wak extremely elear, mellow, and sweet. This song it warbled out for the whole morning, and also initated the notes of a Carlinal, that hom near it. It hecame exceedingly tame and familiar, and when in want of food or water, uttered a continual melancholy and anxious note.

In the winter of $18: 3.5$, and for several following seasons, these hirds were exceedingly abmudant in the vicinity of Buston. 'They appenred early in Decenher, and remained until quite late in Mareh, feeding chiefly on the berries of the red celiur. They were so unsuspecting and fimiliar that it was often possible to capture them alive in butterfly-nots, and to knoek them down with poles. Large numbers were restroyed and hronght to market, and many were taken alive and eaged. They were tame, lut unlatpyy in confinement, uttering mommful cries as the wam weather alproalied. In the winter of $1869-70$ they again made their appenance in extratdinary numbers, in a few localities on the sea-const of Massachusetts, where they did eonsiderable damage to the fruit-huls of the alple and pear.

Sir Joln Richardson states that this birl was not observed lyy his expedition higher than the 60th parallel. It lives, for the nost part, a very retired life, in the deepest recusses of the pine forests, where it passes the entire year, having been foumd ly Mr. I)rage, near York Fort, on the enth of January, 17+7. Richurdson adds that it builds its nest on the lower branches of trees, and feeds chiefly on the seeds of the white spruce.

1)r. Cones speaks of it as not at all rare along the coast of Talmador, where he obtained severil specimens. It was confined entirely to the thick woods and patches of serubly juniper. A female remained meoncemedly on a twig after he had slot her mate, uttering continually a low soft shep, like that of the Fox-colored Sparrow. Another note wis a prolonged whining chirrup, uttered in a rather low tone, apparently a note of recognition.

A lady resident in Newfoundland informed Mr. Autubon that she lad kept several of these Grosbealis in confinement, that they soon hecame very familiar, wonld sing during the night, feeding, during the summer, on all kinds of fruit and berries, and in the winter on different seeds. Mr. Audubon also often observed that, when firing at one of their number, the others, instead of flying away, would nove towards him, often to within a few feet, and remain on the lower hanches of the trees, gazing at him in curiosity; entirely unminglerl with any sense of their own danger. MI. Auduhon quotes from Mr. MeCulloch, of Pictou, an interesting account of the habits of one of these hirds, kept in confinement. The winter had been very severe, the storms violent, and, in consequence of the depth of snow, many birds har perished from humger and cold. The Grosbeaks, driven from the woods, songht food around the bans and outhouses, and crowderl the streets of Pictou. One of these, taken in a staring condition, smon becane so tane as to feed from his hand, lived at large in his chamber, and would awaken him 


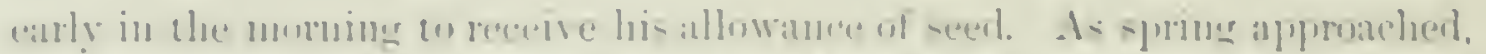

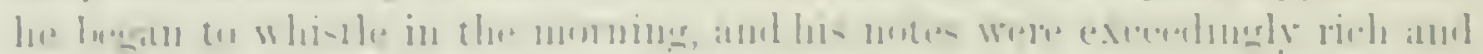

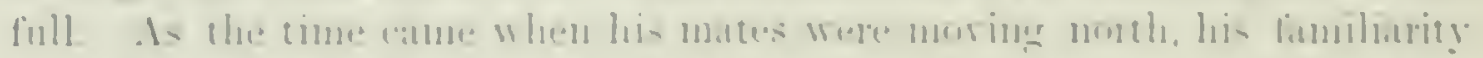

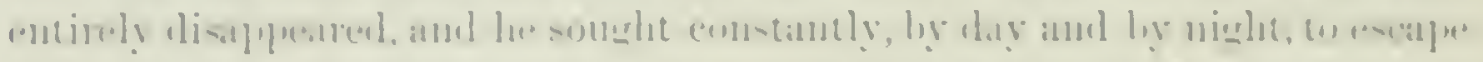

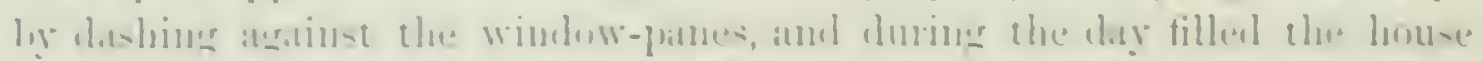

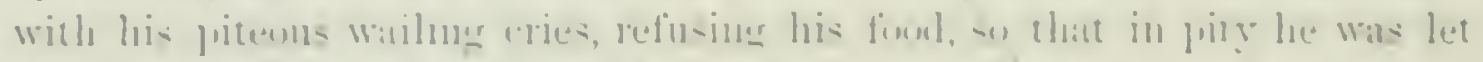

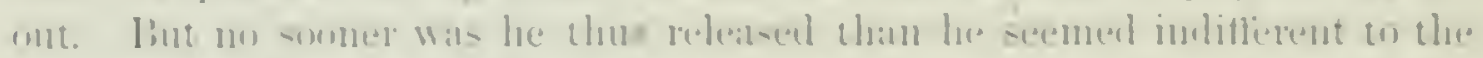

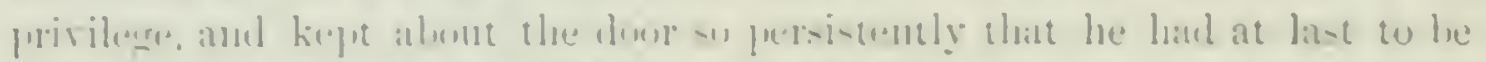

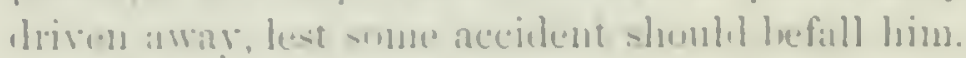

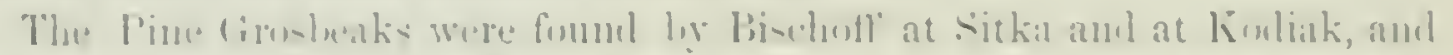

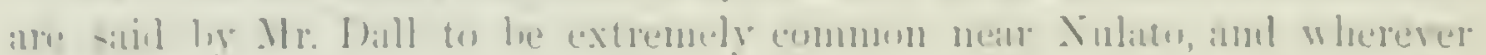

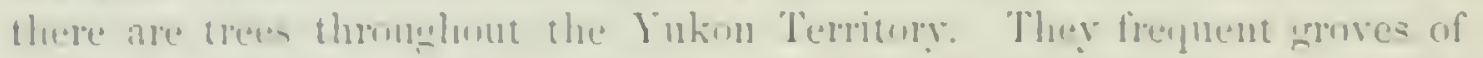

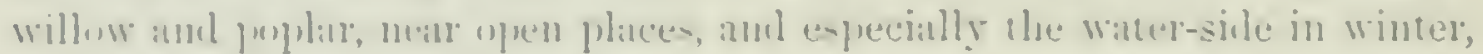

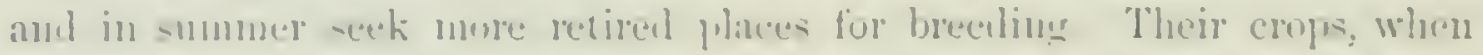

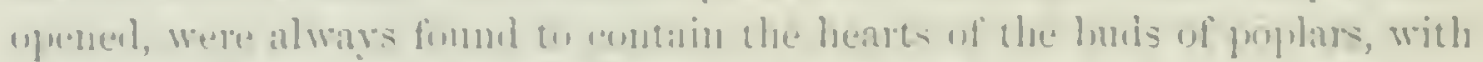

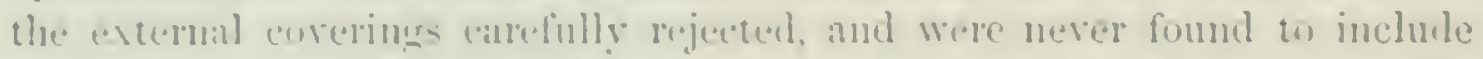

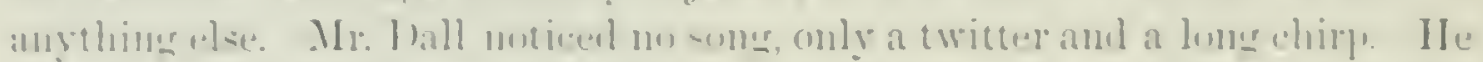

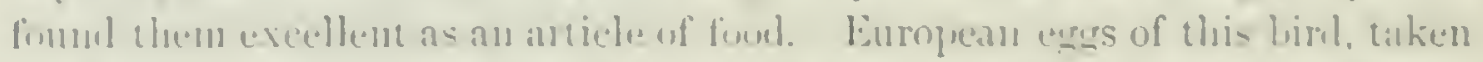

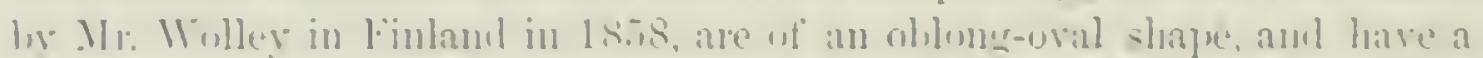

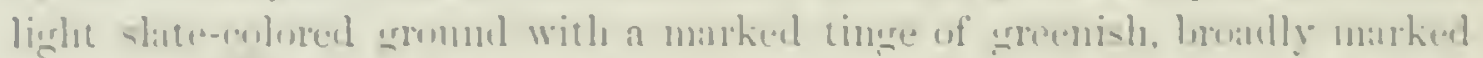

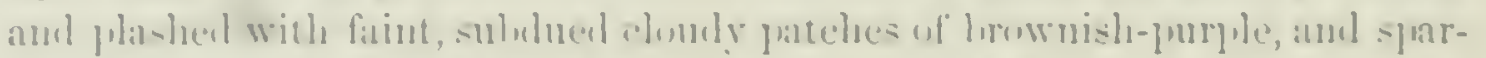

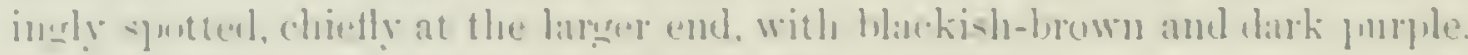

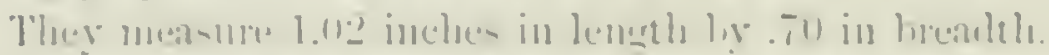

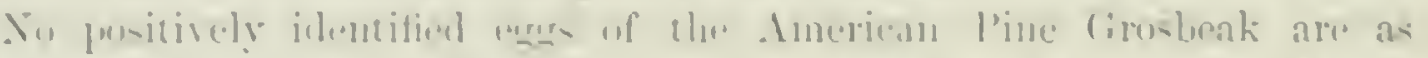

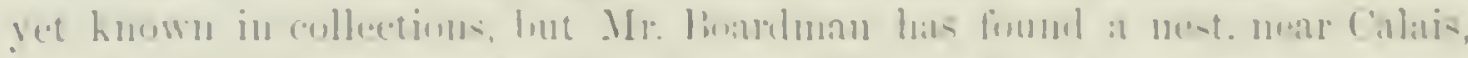

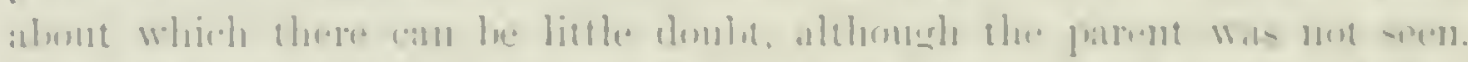

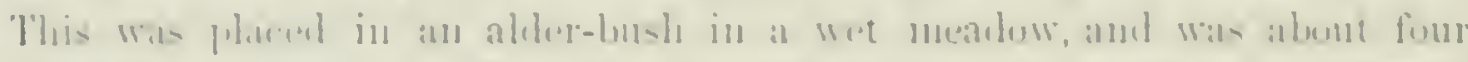

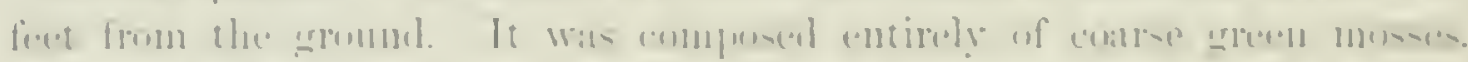

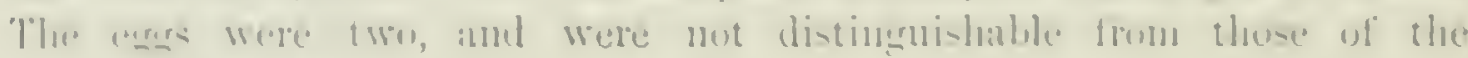
limmeall rnelemin.

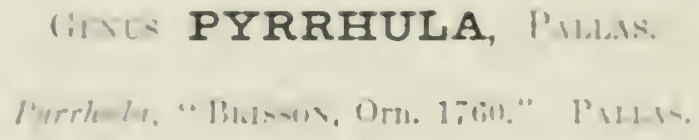

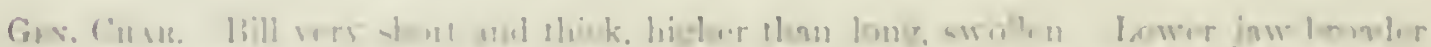

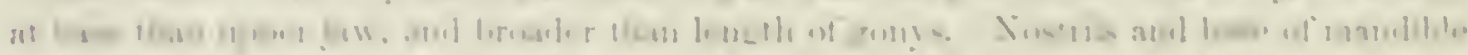

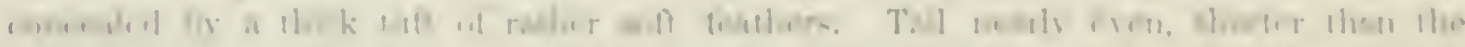

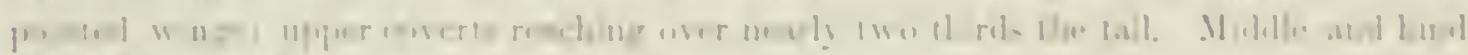

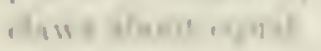

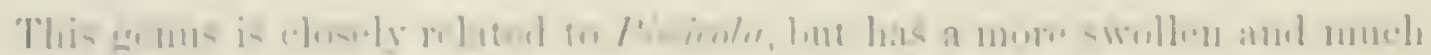

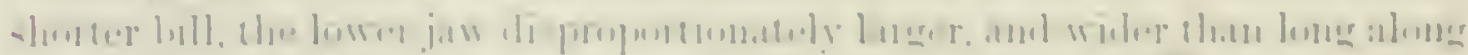

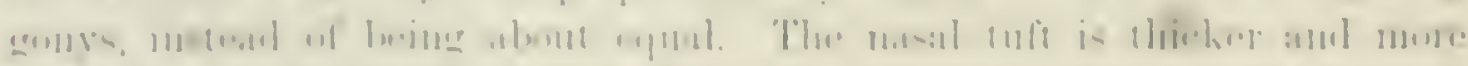

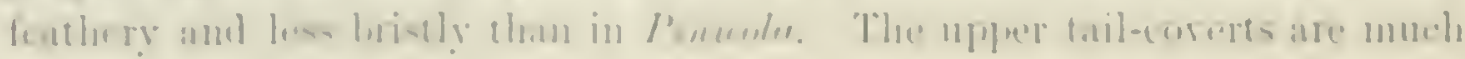


longer, the tail less emarginate. Other differences exist in the grooves and ridges of the palate, which need not be here referred to. The middle claw is about equal to hind claw; not longer, as in Pinicola.

The genus Pymoula is an Old World one; extending across from the Atlantic to the Pacific, six or eight species or varieties being recognized by naturalists. All liave the back ash-colored; the wings and tail, with top of head, lustrous black; the under parts ash, generally with ver-

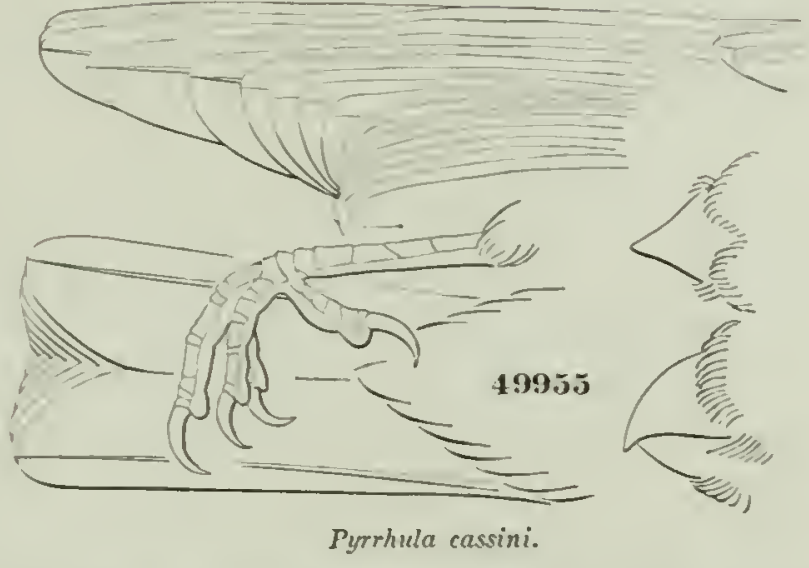
milion on the cheeks and chin, sometimes extending over the whole under surface; the rump and crissum white: the females similar, but lacking the vermilion. Its introduction into the North American fauma rests on the collecting by the naturalists of the Russian Teleguph Expedition in Alaska of a specimen which - if a full-plumaged male, as stated - differs from all of its congeners in the entire absence of any rermilion tint.

\section{Pyrrhula cassini, Barro.}

\section{CASSIN'S BULLFINCH}

P. coccinen, var. cossini, Barnd, Trans. Chicago, Ac. Se. l, 1869, ii, p. 316. - Dall \& B.xxistel, Tr. Chic. Ac. I, 1869, 281 (Alaska). P. cussini, Tristran, Ibis, 18i1, 231. - Fisscu, Omith. X. W. Amerikas, 1872, 54.

Sp. Crtar. Description of specimen No. 49,955: Upper parts clear ash-gray, as are the alula, and the lesser and middle secondary and the primary wing-coverts. Under parts

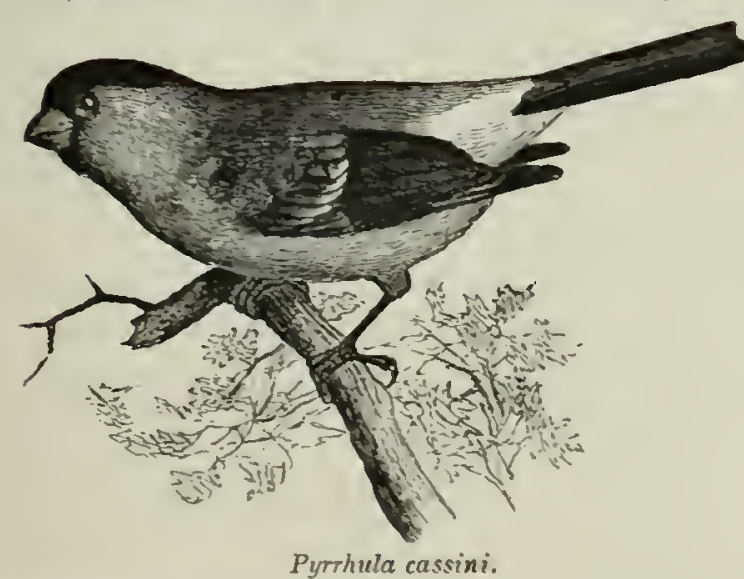

and the silles of heal cinnamon-gray; the inside of wings and axillars, anal region, tibia. crissum, and rump white; wings and tail, including upper tail-corerts, the entire top of head (to level of eves), the base of bill all romd, and the clin, lustrons violet-black. Greater wing-coverts black, with a broal band of ashy-white across the ends; outer primaries, externally, with a narrow border of grarishwhite near the ends; inner edges suffused with the same. Outer tail-feathers with an elongated patch of white in the terminal half, along the shaft, but not reaching the tip. Bill black; feet dusky.

Dimensions (prepared specimen): Total length, 6.50; wing. 3.5.5; tail, 3.25. Exposed portion of first primary, 2.6.5. Bill: Length from forehead, .44; from nostril, .34. Legs: Tarsus, .55; claw alone, .26; hind toe and claw, .45; claw alone, .25. 


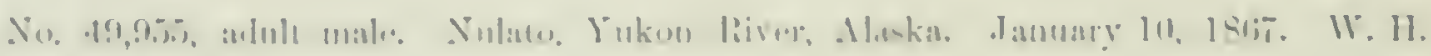

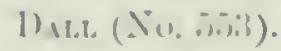

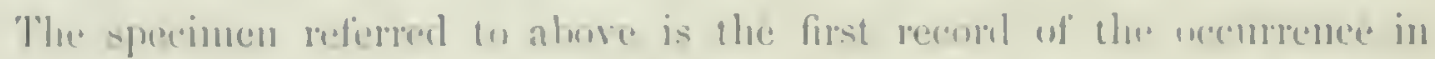

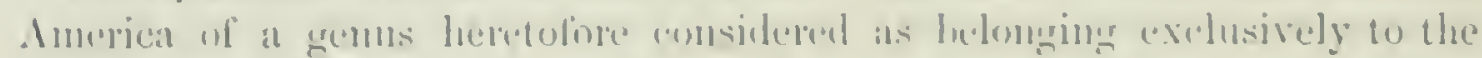
(1). World.

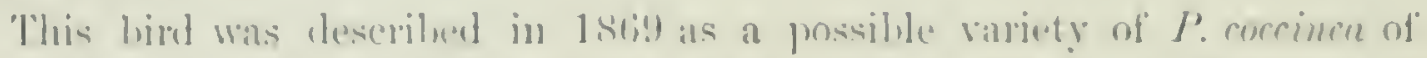

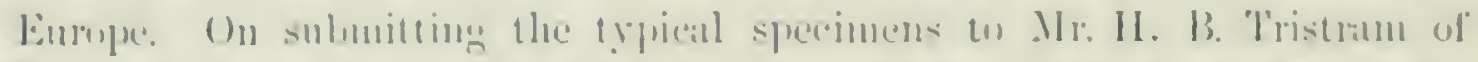

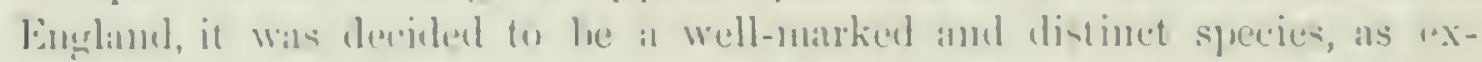

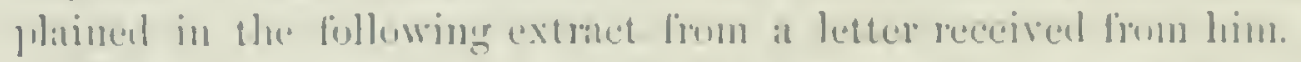

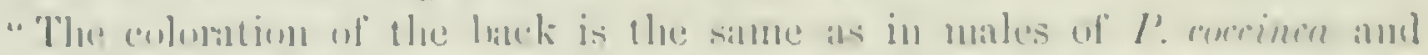

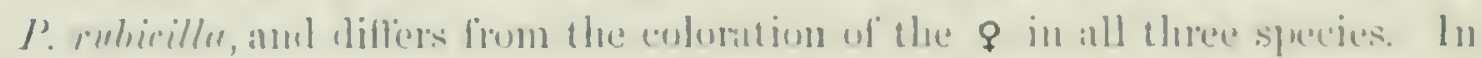

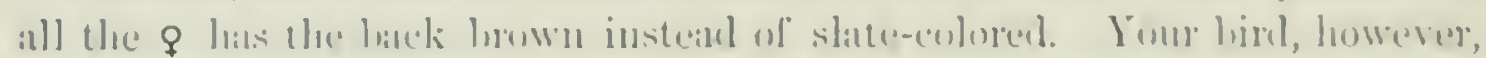

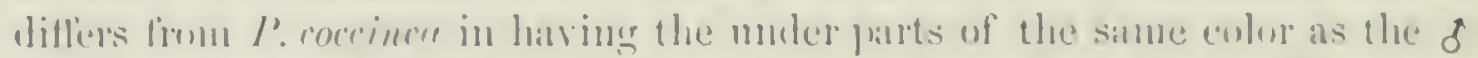

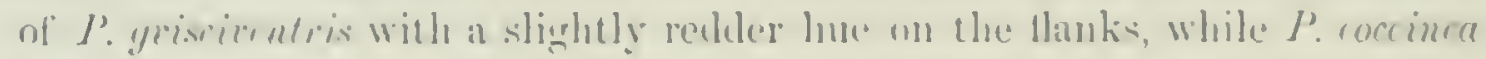
is a hrilliant having red. In this yemr hird is like I'. muring of the Azores, lut that has mu white on the rump).

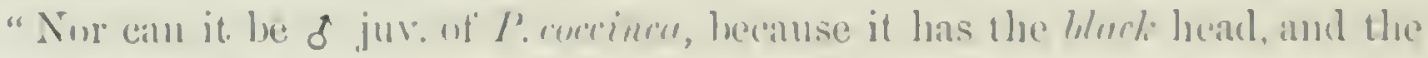

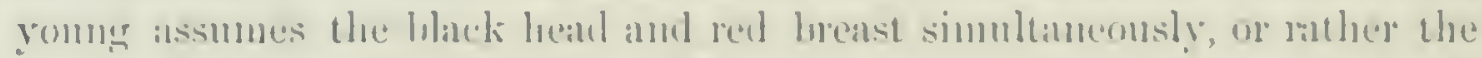
red hergins timet. It dillers form l'. nipulensis in having a hatek head and

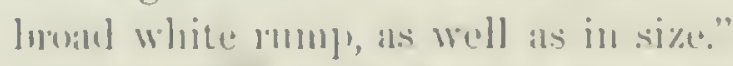

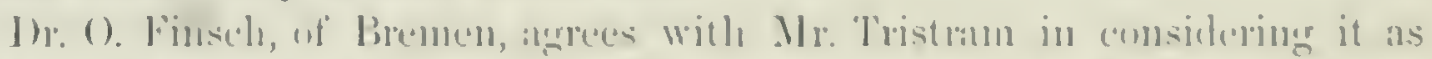

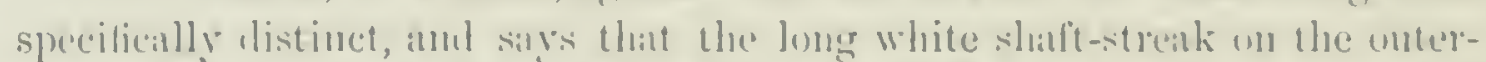

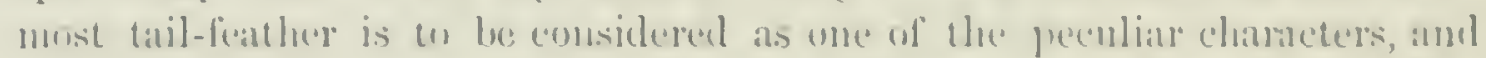

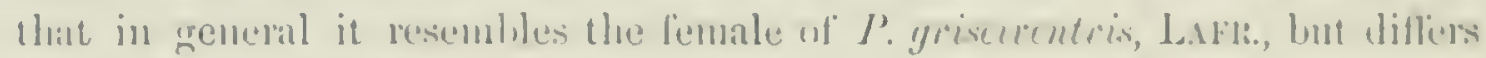
in haviug the hatek heantilul asli-glay.

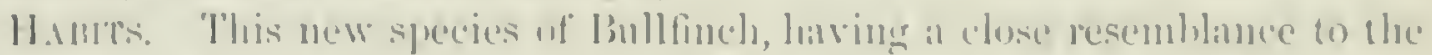

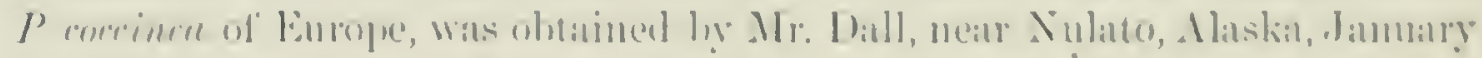

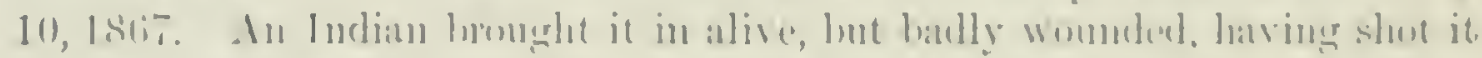

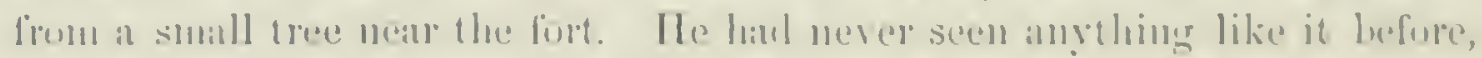

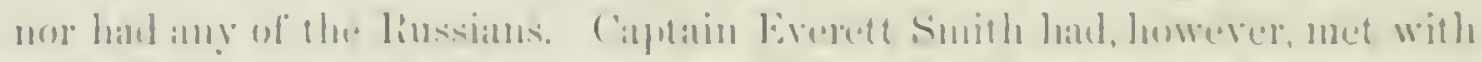

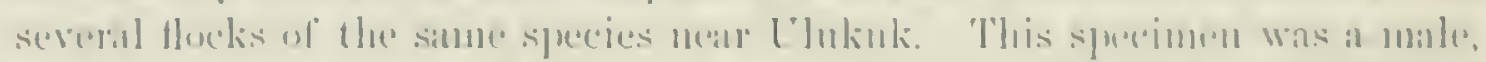
with hlack eges, feet, and hill, and wats the only hird of the kimd met with li. Mi. I I:Ill.

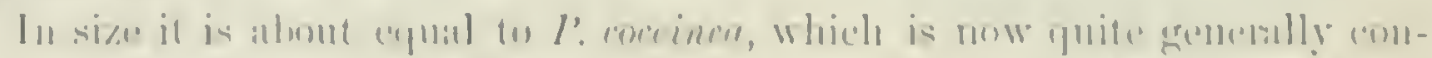

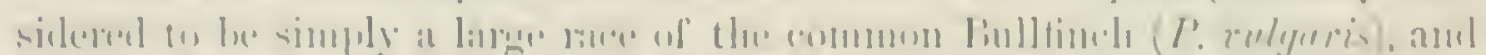

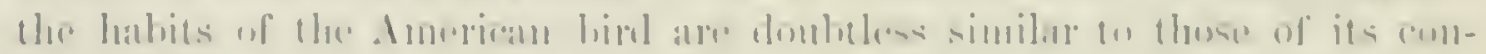

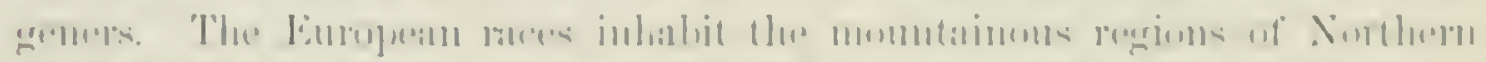

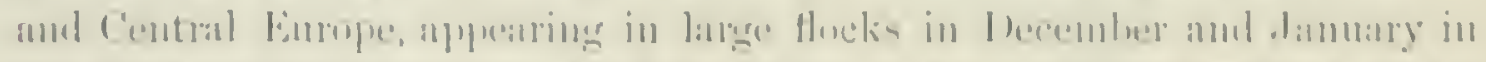

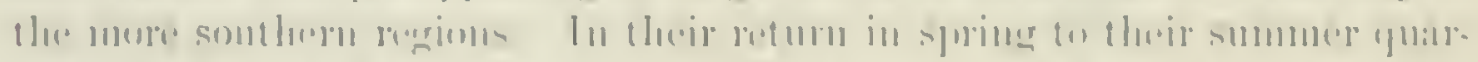

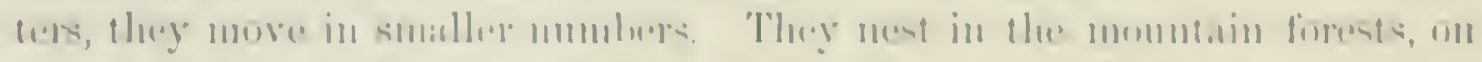

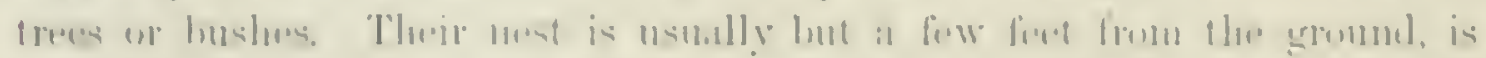
leaturifully wronght in a [1

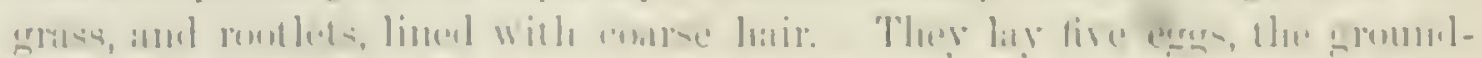

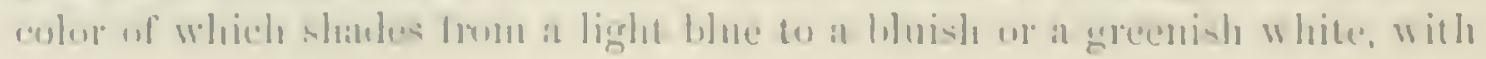


brown and violet-colored spots, that usnally form a ring around the larger cnd. Their food is grain and small seeds, and, in spring, the buds of certain trees.

The Bullfinch is a favorite cage-bird, soon reconciled to confinement, and capable of being taught to whistle whole airs of opera music with wonderful exactness and beauty.

\section{GeNus CARPODACUS, Kinp.}

Carpodacus, Katp, "Entw. Europ. Thierw. 1S29." ('Type, Loxia crythrina, PaLL.)

Erythrospiza, Bosaparite, Saggio di una dist. met. 1831.

Homorrhous, Swansos, Class. Birds, II, 1£3i, 295. (Type, Fringilla purpuren, GMrLis.)

Char. Bill short, stout, raulted; the culmen decurved towards the end; the commissure nearly straight to the slightly decurved end. A slight development of bristly featluers aloug the sides of the hill, concealing the nostrils. Tarsus sliorter than the middle toe; lateral claws reaching to the base of the milldle one. Claw of hind toe much eurred, smaller than the "middle one, and rather less than the digital portion. Wings long and pointed. reaching to the midlle of the tail, which is considerably shorter than the wing, and moderately forked. Colors red, or red and brown. Fiemale with the red replaced by brown.

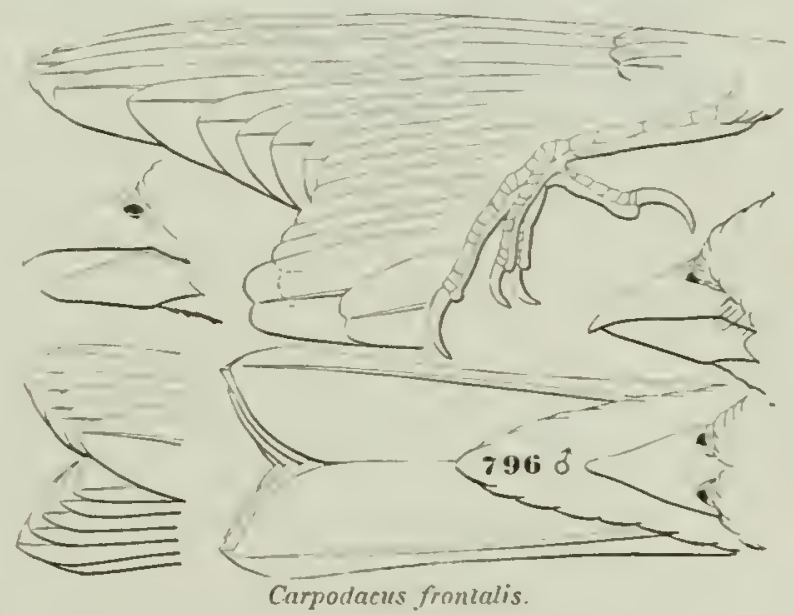

The gemus Carpodacus, including the American Purple Finches, is composed of species the males of which are more or less red in full plumage, while the females are brown-streaked. They are spread over North Americn, and species also occur in considerable numbers in Northern Europe and Asia.

\section{Species and Varieties.}

A. Culmen only slightly curred. Tail and wing feathers edged with reddish in the male.

a. ठ. Crown much brighter purple than the rump or throat. \$. Withont lighter superoral and maxillary stripes, the whole head being pretty uniformly streakell.

1. C. cassini. đ. Crown bright crimson; rest of head, brenst. rump, etc., much lighter purple-pink; lower tail-corerts with a shaft line of dusky. Hab. MLountain regions of the Middle Provinee, sonth, through the table-lands and alpine regions of Mexico, to Miralor.

b. $\delta$. Crown scarcely brighter pupple than the rump or throat. $q$. With conspicuons superoral and maxillary stripes.

2. C. purpureus. Crown purple; rest of head, breast, rump, etc., nearly similar in tint; lower tait-corerts without dusky shaft-lines.

Purple tints of a rosy carmine cast; first quill longer than the

fourth. Hab. Eastern Prorince of North America - var. purpureus. 


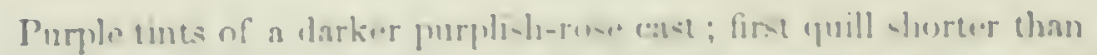

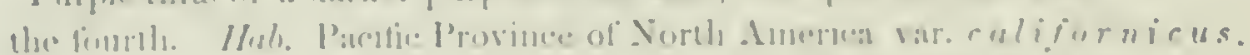

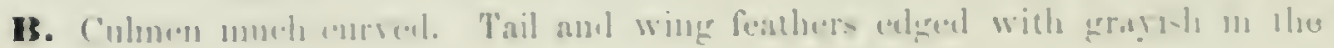
male:

$\therefore$ C. frontalis. \&. I frontal amel supereiliary tamel of erim-on; a

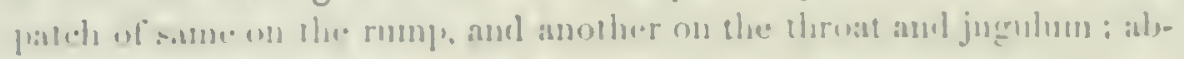

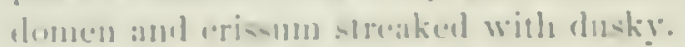

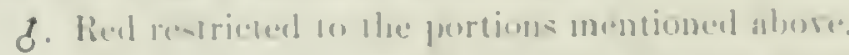

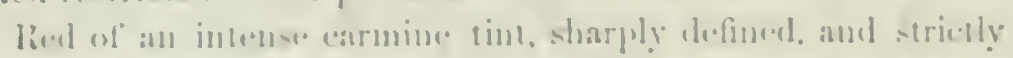

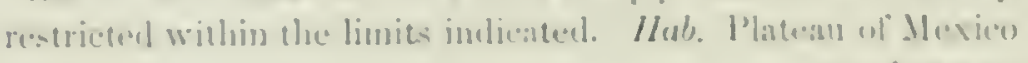
lar. humurrhu us.'

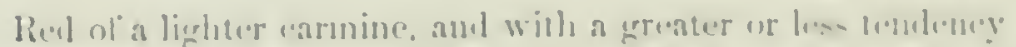

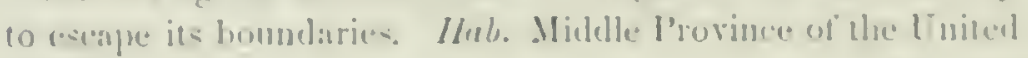
Stales . . . rare frontalis.

8. licel nut restrictent, but spearl orer the crownd, lingering the bark and other portions, "xcepting wings and tail.

Red tint sarving from scarlet to wins-rect. Inb. Pacific Province of Linited states, including the pendissula of lower Califoruia . . . var. rlodocolpus.

\section{Carpodacus cassini, B.ump.}

\section{CASSIN'S PURPLE FINCH.}

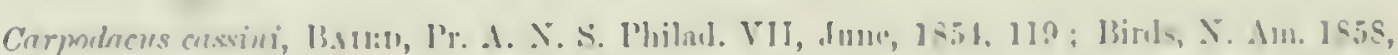

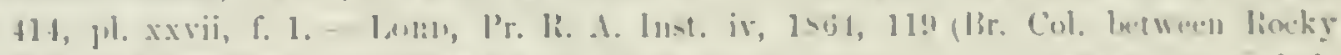

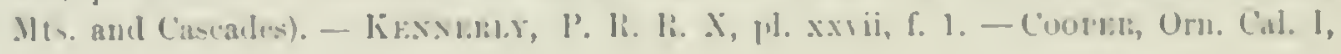
1.5.

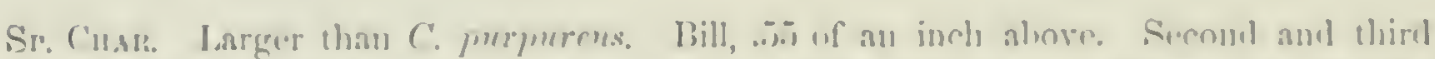

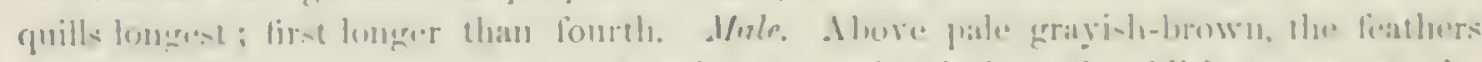

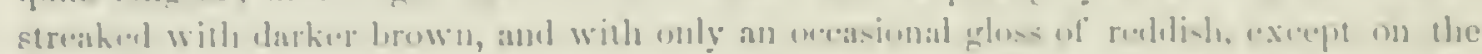

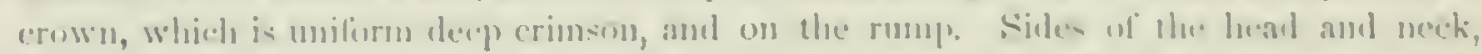

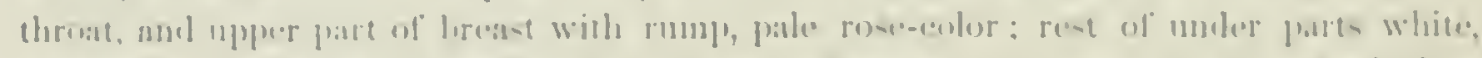

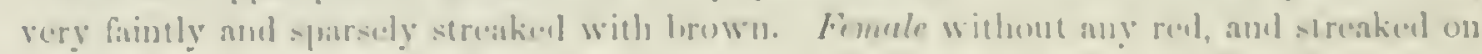

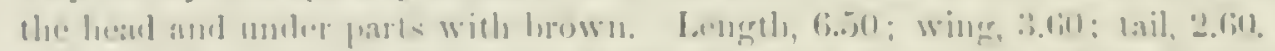

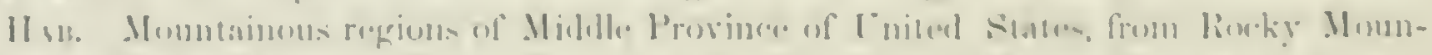

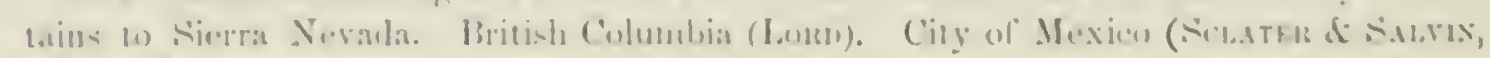

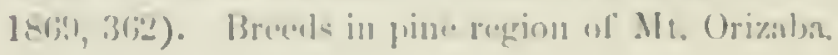

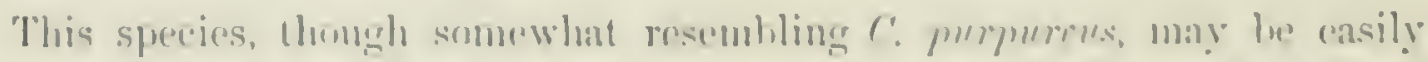

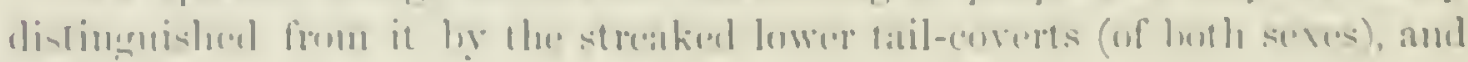

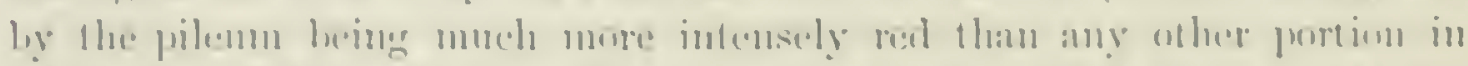

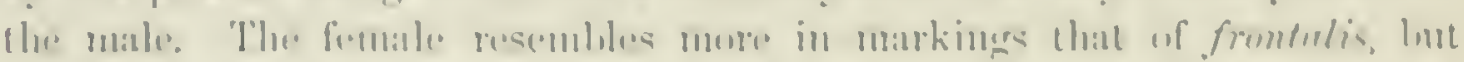

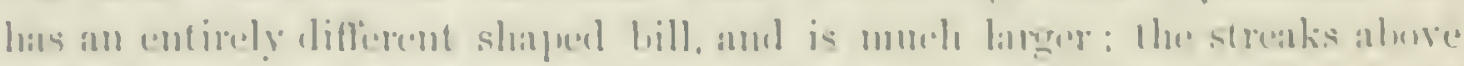

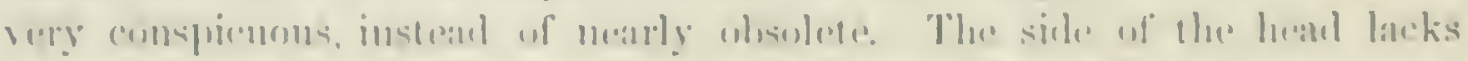

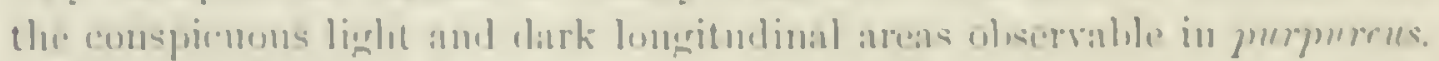

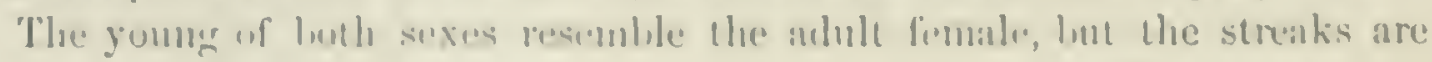

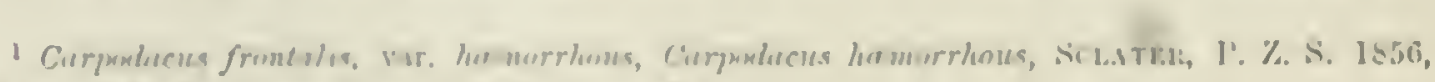

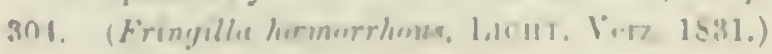


less sharply defined, and the wing-feathers are broadly edged with light earth-brown.

In autumn and winter, as in all the other species, the red tints are softer and more purplish than in spring and summer.

Habits. C'assin's Puple Finch is the largest of the American birds of this genus, and is not only conspicuonsly different from all in size, but also in other respects. It is foumd between the great Central Plains and the coast range of momntains. being one of the common birls of Culorado, Ltah, Nevala, and Eastern California. Dr. Cooper found these birds in large numbers abont Lake Tahoe in California. They were all in their brown plumage, and seemed so much like the $C$. californirus in their habits that he mistook them for that species. He noticed in them a very peculiar call-note as they Hew, reminding him of that of Pyranga, and quite different from the other Carpodaci. The song of these birds, as he afterwards heard it, was mucl louder and finer than that of $C$. californicus, and more original in style. He is not familiar with their other habits, and has never met with them in the Colondo Valley. They have been procured from Fort Thorne, Pueblo Creek, and Alberquerque, New Mexico. Mr. Ridgway met with these birds in the Wahsatch Mountains, June 26, 1869, in Parley's Park, Ltah, where he found them breeding. Their nest was in the top of a cottonwood-tree near the canon stream, abont forty feet from the ground. It is a soft homogeneous structure, flattened in shape, and with only a slight depression. It is composed principally of roots and twigs, lined with softer materials of the same, interspersed with moss, cotton, and other soft substances. It is two inches in height with a width of four and a half inches. The cavity is about an inch deep.

In his Report on the birds of Mr. King's surrey, Mrr. Ridgray states that he found this Limnet in the greatest abundance among the pines of the Sierra Nevada, near Carson City. It was next seen among the cedars and unt-pines of the East Humboldt Mountains, and again in the pine woods and cottonwood-trees along the streams on the Wahsatch Mountains. It breeds in all these localities, and is in its habits essentially, thongh not exclusively, resident among the pines. March 21, 1S6S, Mr. Ridgway observed flocks of these birds near Carson City. They were found in erery portion of the woods, feeding among the branches of the pine-trees. They were all in full song, the females as well as the males. A weck later he again found them common among the isolated pines in the fields at the foot of the Sierras, alighting on the trees in companies. Their notes resemble the song of the $C$. purpurcus, but are finer and more musical. They have a great resemblance 


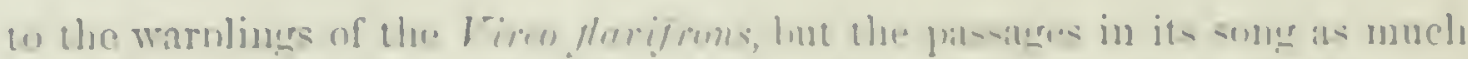

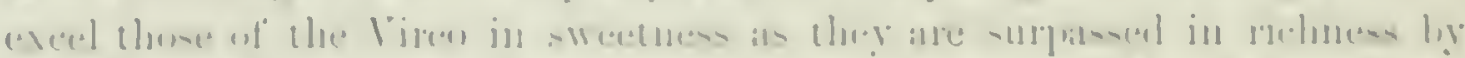

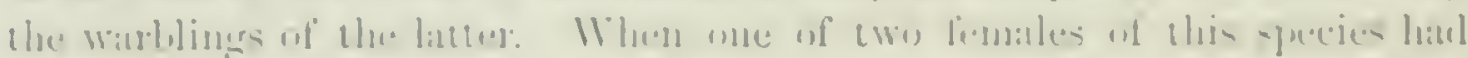

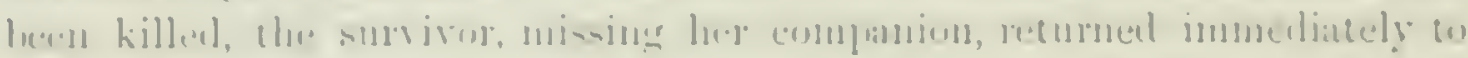

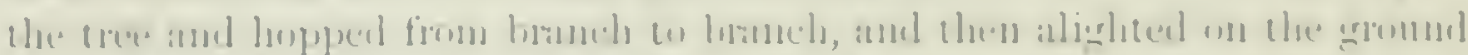

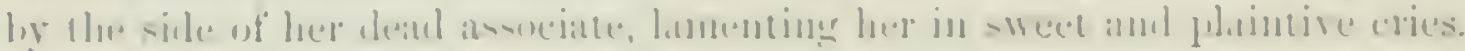

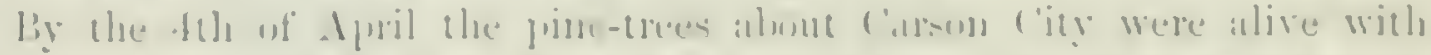

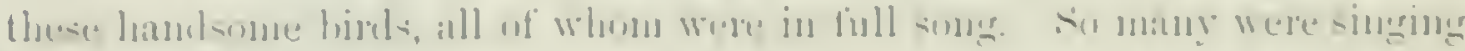

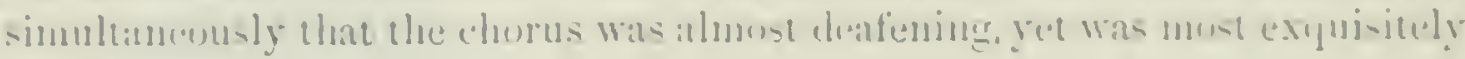
1]:isiug.

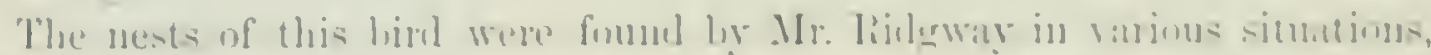
such is a lox-eldeg husle, the (1)

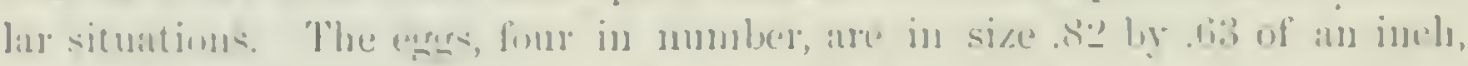

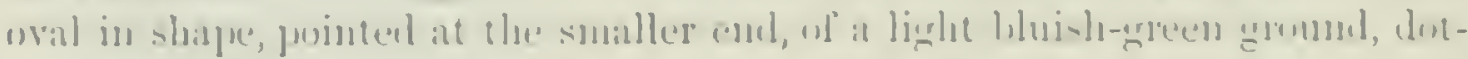

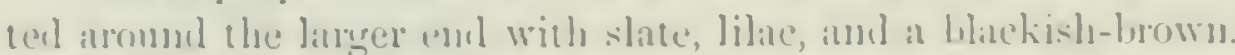

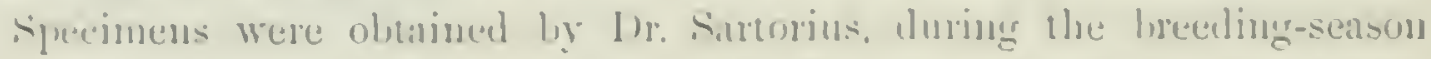

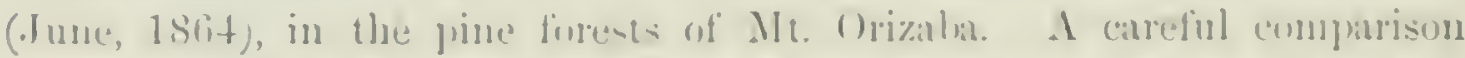
slums no diflerence from birkls procureal in the sinne month in Nerata.

\section{Carpodacus purpureus, Gilil.}

\section{EASTERN PURPLE FINCH.}

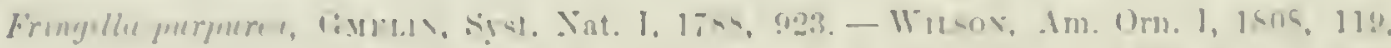

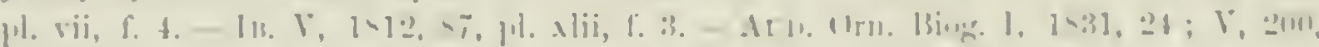

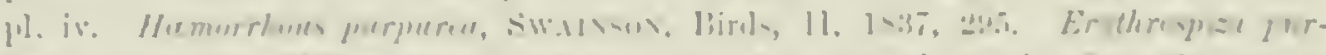

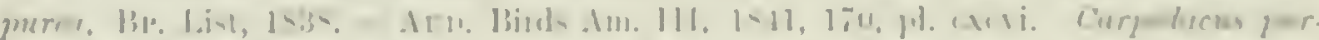

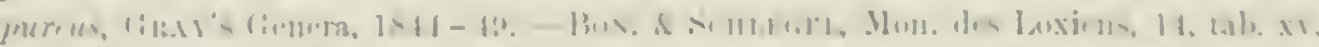

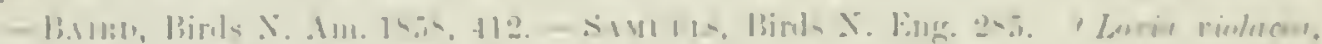

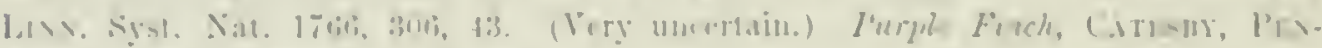

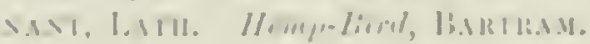

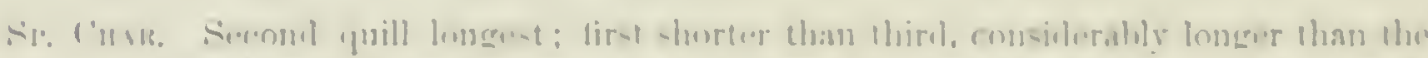

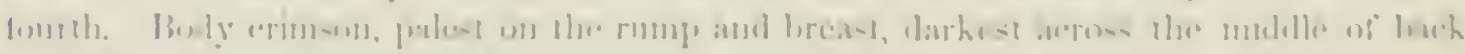

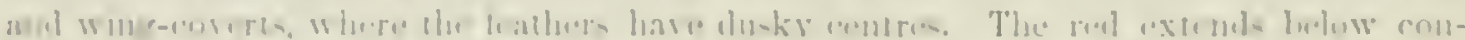

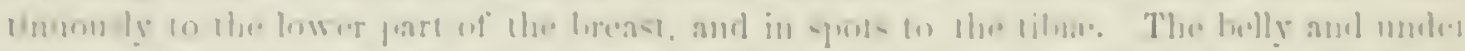

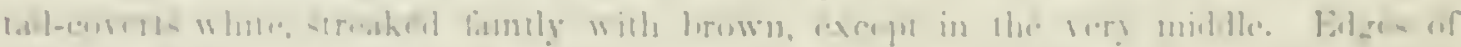

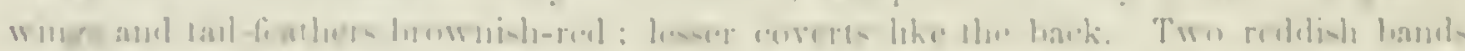

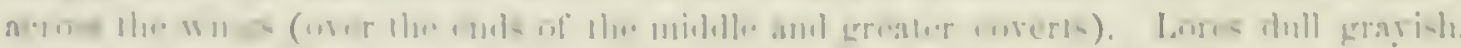

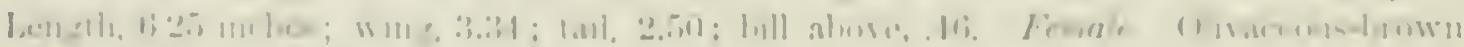

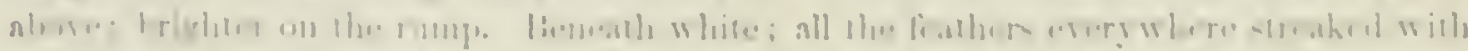

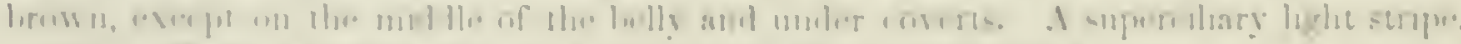

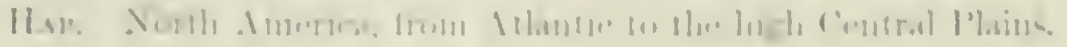

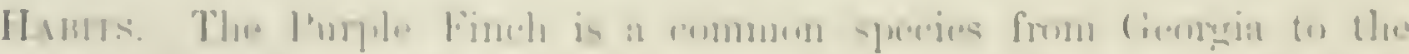

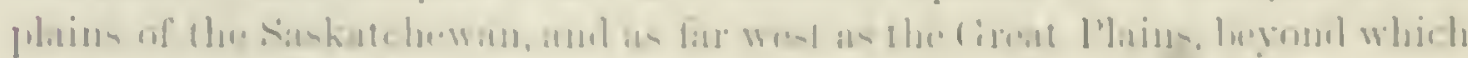

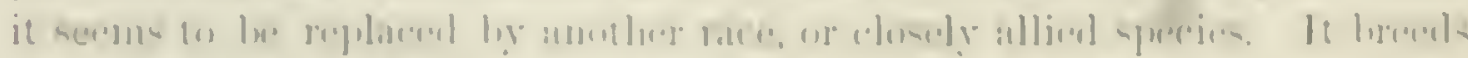

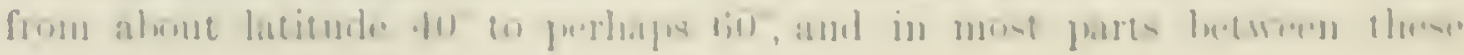


parallels is a rather common hird in suitable localities. A few are oceasionally fumd cluring the winter in Massachnsetts, but nsually they all pass farther south. In the State of south Carrolina they are especially abundant throughont the winter, or from Oetuber until April.

Dr. Coues states that the l'urple Finch is a rery abundant winter resident near. Washington, arriving early in Octoher ind remaining until May, being eminently gregarious. Straggler's were seen until nearly June, but the majority had departed as the leaves expanded. They were most common in high open woods, and were observed to feed chietly on tender young buds of trees. They were in full song before they touk their departure.

They make their first appearance in regular migrations, in Massachusetts, from the 10th to the 20th of May, and ocensionally a few are seen earlier. They are often unwelcome visitors to the fruit-growers, having a great fondness for the blossoms of the peach, cherry, plum, and apple. They will also feed upon other kinds of buds and blossons. They have a great predilection for erergreen trees, especially the fir, the spruce, and the red cedar, and most generully build their nests in these trees. In summer they feed on seeds, insects, and berries of the honeysuckle and other shrubs.

The Purple Finch, or, as it is generally known in New England, the Limnet, is one of our sweetest, best, and most constant sonysters, and is often trapped and sold as cayed birds. They soon become accustomed and partially reconciled to their confinement, but sing only during a small part of the year. Wlien one of these birds, confined in al cage, is hung outside the house, in the country, he is sure to draw around him quite a number of his species, and this furnishes the dealer a ready means of capturing them.

This Finch was once regarded as quite rare in the ritinity of I3oston, so much so that during a four years' residence in Cambridge, when collections of nests and eggs had many votaries, not a single nest of this speeies was obtained by any one. Since then, from some cause, probably the increase of gardens, groves of erergreens, and other localities firvorable for their preservation and reproduction, these graceful little Finches have become quite abundant in places propitions for their residence. No less than seven pairs of these favorite songsters took up their abole in my grounds at lfingham in- a single summer, and two had nests in the same tree, one of which was at least sixty feet from the ground, on the very top of a tall fir. These several pairs, as a general thing, lived together very harmoniously, save unly when one would approach too near the farorite station of another, when the latter would begin to bristle up his crest, and give very evident hints that his near presence was not agreeable. The extreme southern end of the ridge-pole. of the house had been, for several summers, the farorite post fer the patriarch of the flock, from which at morning and at evening he made the neigh borhood rocal with his melody. If in his absence any other of these birls rentured to nceupy his position, there was always sure to be a disturbance on lis retum, if it was not instantly racated. These encounters were frequent, 
and always very amusing. Discretion usunlly took the place of valor on the lart of the intrulex.

The sorm of the Purple finch resembles that of the Canory, ambl thongh

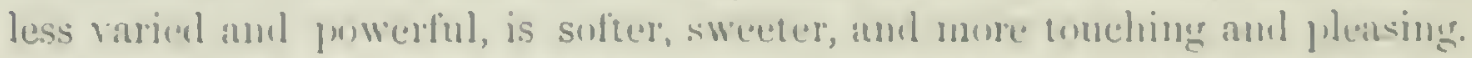

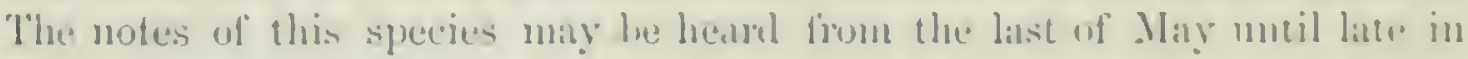
s.pptember, and in the long summer esenings are often comtinned matil alter it is quite dark. Their sumg has all the Inemby and pathos of the Warbling Vireco, and greatly resumbles it, lut is more jowerful and full in tone. It is a very interesting sight to watch one of these little performers in the midst of his somg. He appeam perfectly absombel in his work, his form dilites,

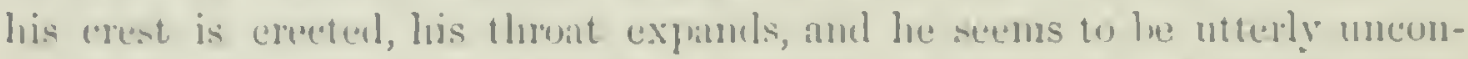
scions of all aromml him. But let an intruter of his own natee aljexar within a fow feet of the singer, and the song instantly ceases, and in a viulent fit of indignation le chases him away.

The flight of the l'urple finch is sibl hy Mr. Aulubon to resemble that of the (ireen finch of Europe. Ther fly in complate thocks, with an undulattug motion, alighting all at once, ant then instantly, ats if sudelenly alinmed, take again to flight only to return to the sinne tree. They then immediately make eateh his sepmate way to the ends of the hamehes, and commence eating the hmls. The ford they tatke to their youm is juicy berries and the soltare portions of the yommer cones of the fir and spruce.

They uest arenerally in tirs, spruces, or cerlan-trees, though accasionally nu

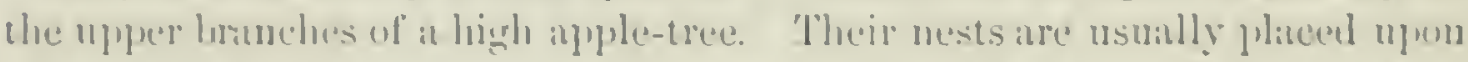
a hranch, rathror than interdaced between its forked twigs. I have known them not nowe than five leet limm the gromed, and at other times on the high-

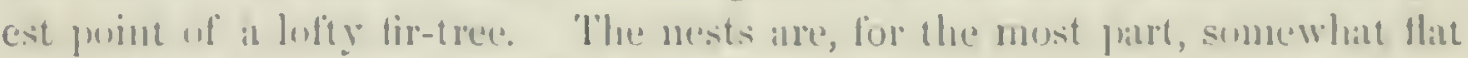

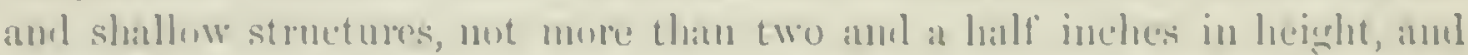
abmut throe amb a hall in hrealth. The walls of the nest averagre less tham

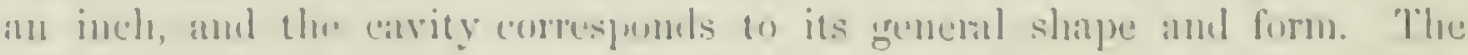

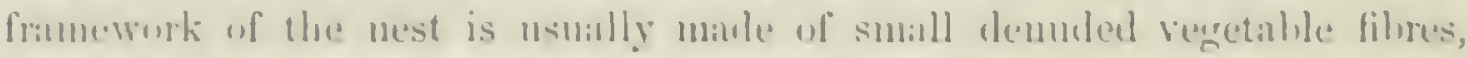

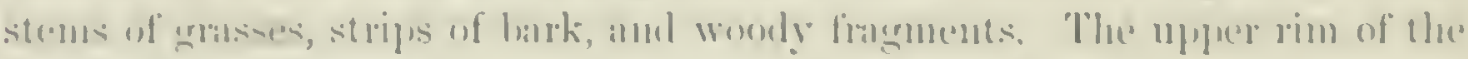

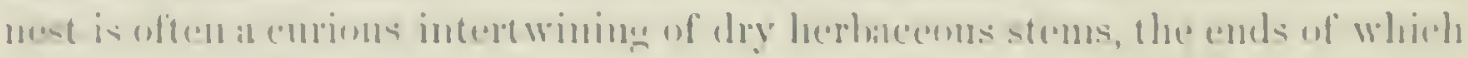

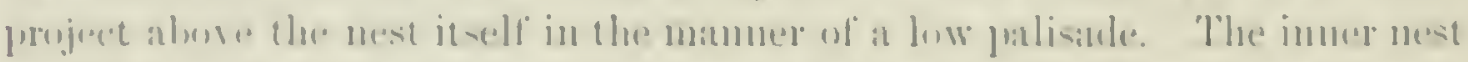

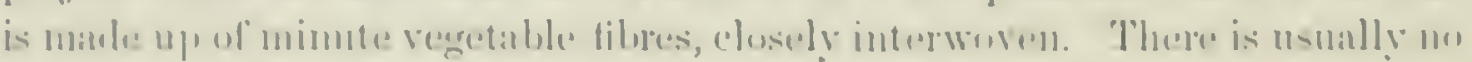

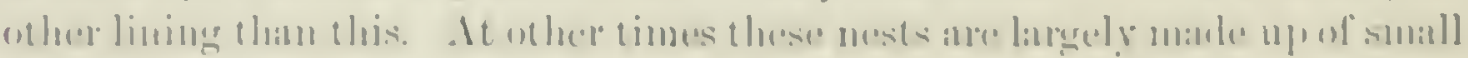

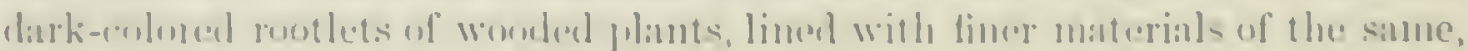

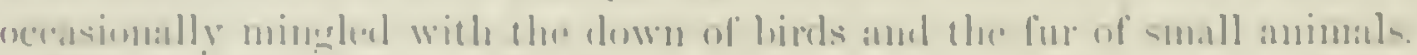

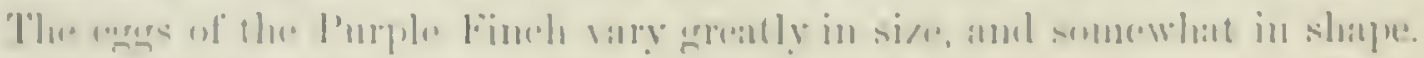

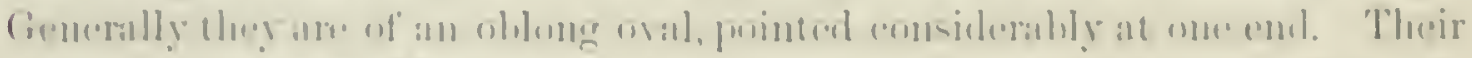

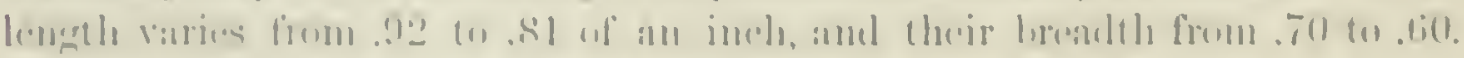

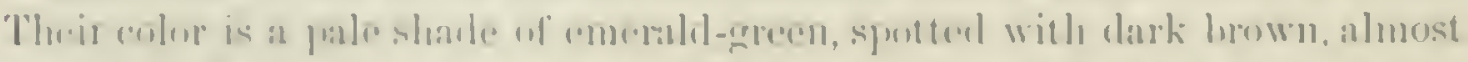

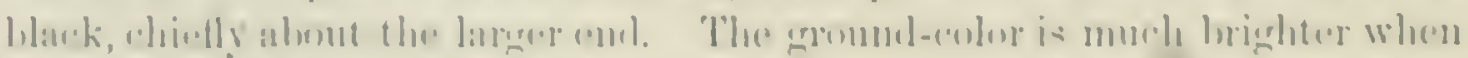

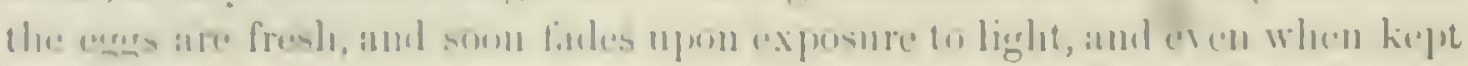
111 a cluse drawer. 
Carpodacus purpureus, rar. californıcus, Bind.

\section{THE CALIFORNIA PURPLE FINCH.}

Cerpodacus califomicus, B.t1:D, Birds X. An. 1s5s, 413, pl. Lxxii, f. 23.-Coopels i SuckLeY, 190. - Cuupeli, Orn. Cal. I, 154.

SP. Cunr. Similar to prepureus. Third quill longest; first shorter than the fourth. Purple of head and rump much darker than in C. purpureus; the heal with a broad supra-orbital lateral band of lighter purple. Length 6.20 ; wing, 3.20; tail, 2.60 .

Hab. Pacifie Province of Linited States.

The female of the western type differs from that of the eastern in being more olivaceous above, and in having the streaks helow rather larger, and not so well defined. There appears to be a difference in the marking of the wings. In eastern $C$. mupurens there is usually a well-marlied whitish band acioss the ends of the midhle coverts, while the greater coverts, though margined externally by paler, have a still lighter har across the posterior extremity, which is not seen in the western bird.

Habits. The Californian I'nuple Finch is found throughout the Pacific coast, from the Straits of Fuca to ('alifornia, as far south as Monterey. 1)r. C'ooper states that this species is rather a northern bird, being common at the Columbia River, and even farther north, while in California it las not heen found south of Monterey on the evast, and Fort Tejon in the Sierra Nevada. In summer they frequent the mountain forests, especially those in part composed of Conifora. In winter they descend to the valleys, where they are found associating with the more common and faniliar $C$. fiuntulis. He met with them in May on the summits of the coast range towad Sinta cruz, but they were not very numerous. They then had nests, though he did not succeed in finding them.

The song of the California Limet is quite lond and raried, often resembling that of other hirds, especially Tripos and Drurlioice, for which I)r. Cooper has often mistaken it. Their food consists of seeds, herries, and the buds of trees. Their nest and eggrs are unknown, but probably resenuble those of $C^{\prime} \cdot$ purpureus.

Carpodacus frontalis, ScLITER.

\section{HOUSE LINNET; CRIMSON-FRONTED FINCH; BURION.}

Fringiulr frontalis, S.AT, Long's Exper. R. MIs. II, 1S24, 40. (For other symonymes see under the different rarieties.)

Sp. Cuır. Bill short, neally as deep as broarl; culmen much curverl. commissure arched ; lower mandible nearly as deep as the upper. Tail more than three fourths as long as wing, slightly emarginated. Wing and tail feathers without reddish edges; lower tail- 


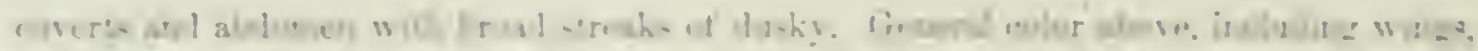

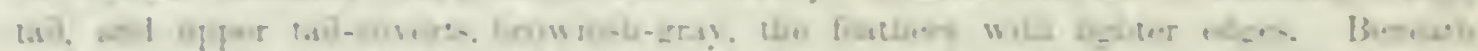

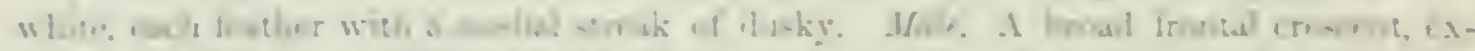

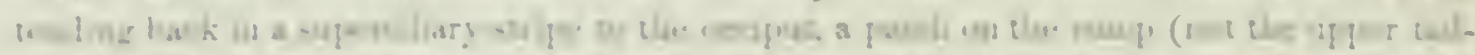

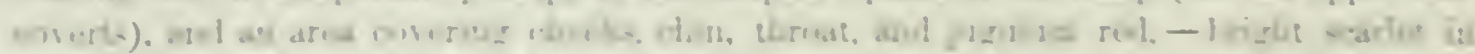

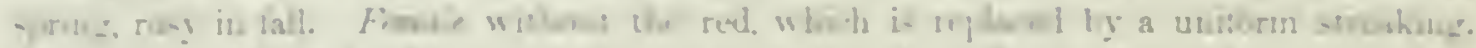

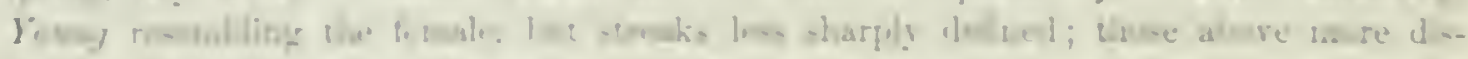

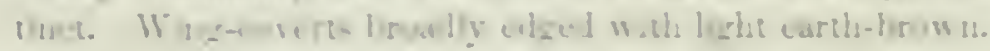

This spreie inluhits the weotern regions of Xurth Aneriea, from the

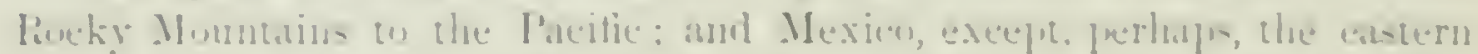

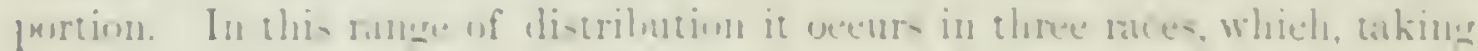
extreme extmplen, an well marked, but when at large series is examined are

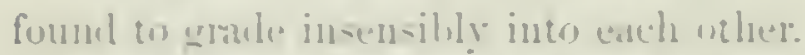

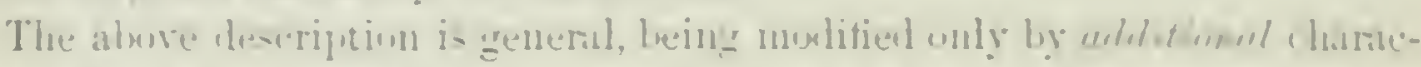

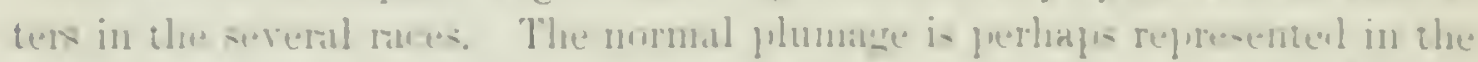

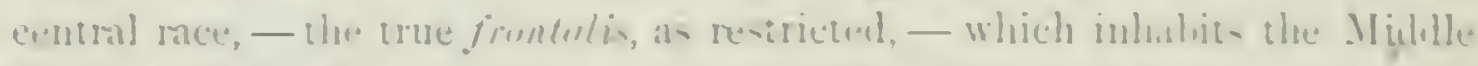

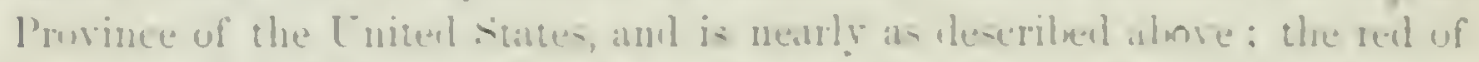
the male of this style is of a hright - antet timt, and in nearly all -pecinens

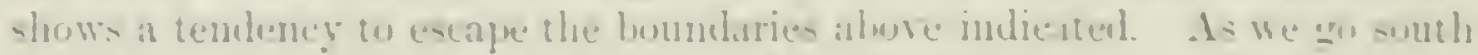

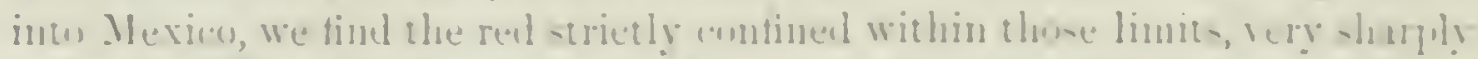
detined; and, unter the tropieal influente, intensitied into at wery bright car-

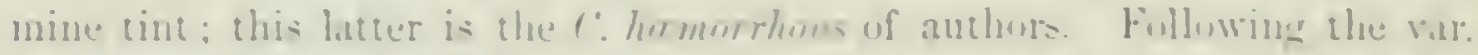

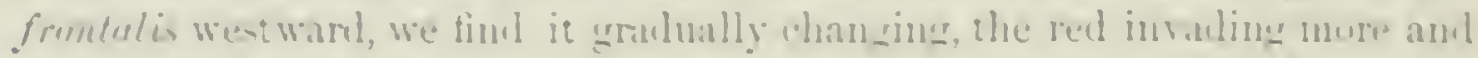

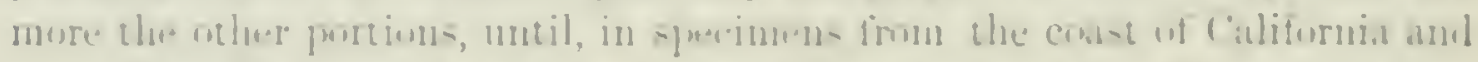

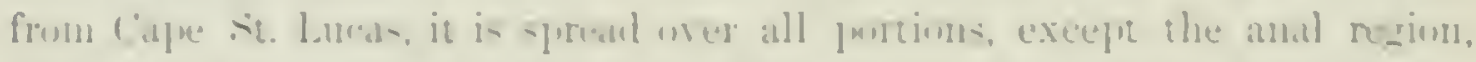
wing, and hal, - thingh always hightert within thise onthines which con-

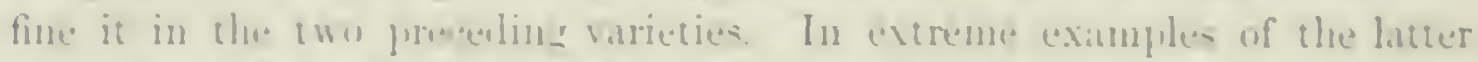

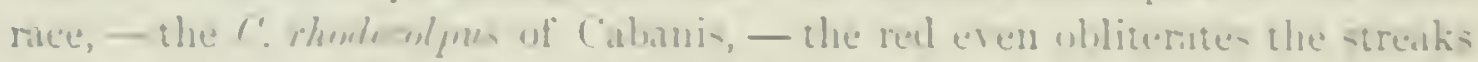

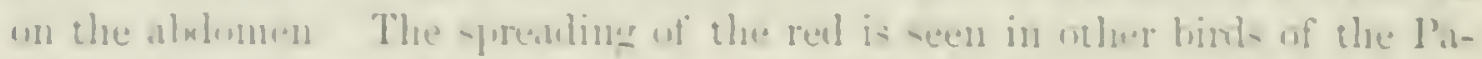

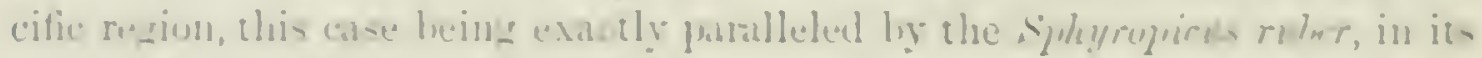

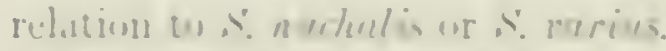

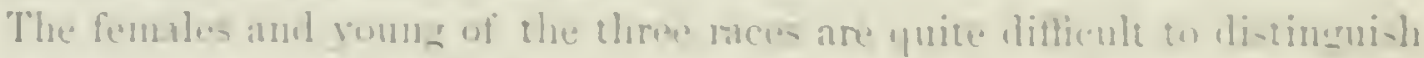

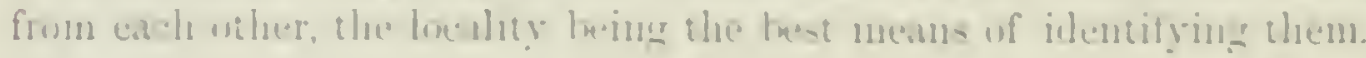

\section{Carpodacus frontalis, ir. frontalis, lipu}

\section{CRIMSON-FRONTED FINCH：BURION.}

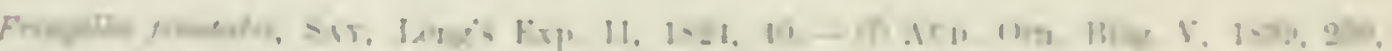

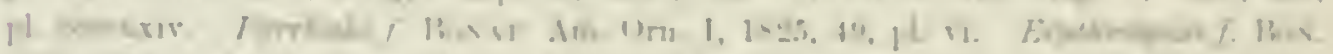

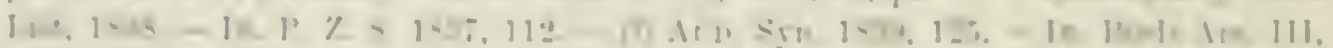

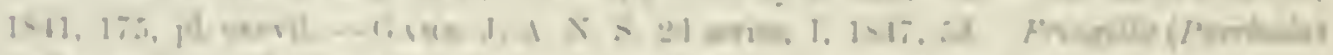

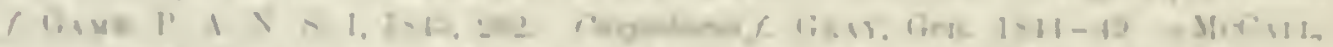

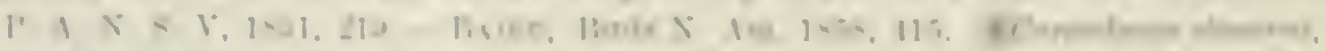

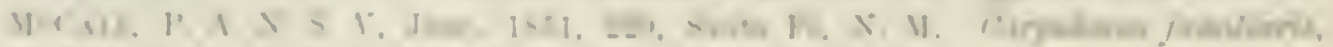

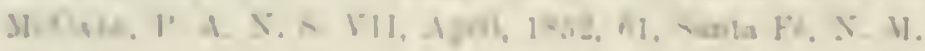


S1. Cunr. (o 58,589, Great Salt Lake City, Utah, June 1, 1869.) Abore brownishgray, faintly glossed with red on the nape and back; wing and tail feathers passing into lighter on their edges, and dorsal feathers with obsolete shaft-streaks of darker. A frontal band, alout as witle as the length of the culmen, continuing back in a superciliary stripe to the orciput, throat, jugulum, and a patch on the lower part of the rump (but not on upper tail-eorerts) carmine-scarlet. Rest of lower parts white, each feather with a medial streak of brown like the baek. Wing, 3.10); tail, 2.60; culmen, .38; tarsus, .6.); midille toe, $.5 \%$.

( 958,590 , Salt Lake City, June 21, 1869.) Similar, but red entirely absent, the throat and jugulum being white streaked with brown, and the front, rmup, ete., crrayish, obsoletely streaked with darker. Wing, 3.00; tail, 2.40.

(Jux. 40, 199 , Fort Whipple, Arizoni, June 5, 1865.) Generally similar to the atl. $\&$, but more brownish, and the wing-feathers passing into dull bufy-ochraceous on their edges; streaks beneath narrower and less distinct.

In winter the red is softer and less sharply defined, and msually of a more purplish tint; the markings. generally more blendecl.

Has. Ifidlle Prorince of the United States, from Roeky Mountains to the interior valleys of Califonian.

Habits. This form of the House Finch appears to be a very common bird throughout the interior region of the United States, extending to New Mexico and Arizona on the south and sontheast, and probably to Mexico. On the l'acific coast it is replaced by another and closely allied variety.

I)1. Woodhouse states that his attention was first called to this interesting little songster while at Sante Fé. It was there known to the American residents as the "Adobe Finch." By the Mexicuns they were called Buriones. IIe foumd them exceedingly tame, building about the dwellings, churches, and other buildings, in every nook and eorner, and even entering the honses to pick up crumbs. They are never disturbed by the inhabitants. He adds that at the first dawn of the morning they commence a very sweet and clear warble, which he was quite mable to clo justice to by any verbal deseription. He has often in the early morning listened with admiration and gratifieation to the song of this bird, which is deservedly a great farorite. He found it throughout New Mexico, and beyond. He did not distingnish it from the const variety.

Dr. Cones also found this bird very abundant in Arizona, where it is a permanent resident, but most abundant in spring and fall. He describes it as eminently gregarious. He found it in all situations, but most common in the spring among the groves of willows and poplars, on the buds of which it feeds. He met with this species all the way from the Rio Grande through New Mexico and Arizona to California. and appears to have noted no differences between this form and the coast rariety. He also mentions finding, during a few days' stay in the New Mexican village of Los Pinos, near Alberquerque, on the Rio Grande, this pretty little Finch the most common and characteristic of the local birds. It was there breeding indifferently in the courtyards, sheds, under porticos or eaves, and also in the forks of trees in the streets. It had sharp conflicts with the Barn Swallows, whose nests it 
often took possesion of, and was a lively amd must anteralile leatme in the

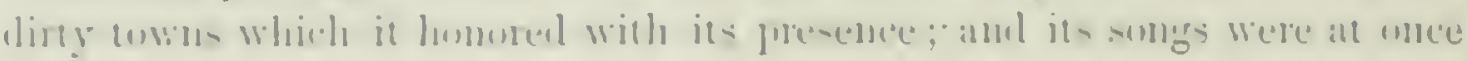

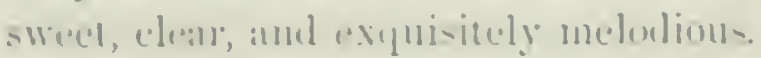

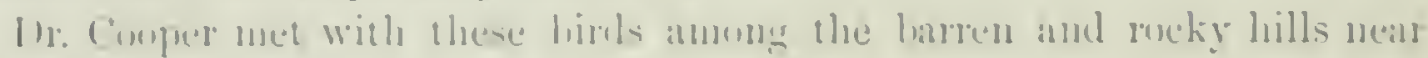
the (in)math.

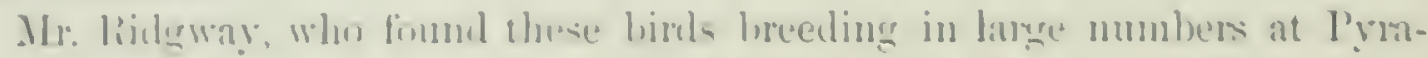

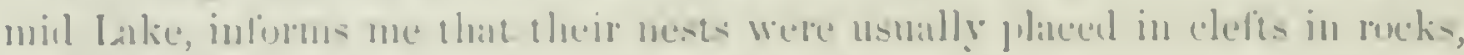

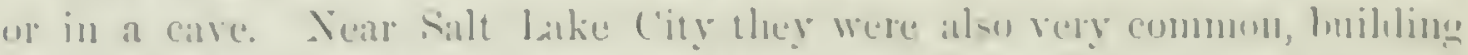

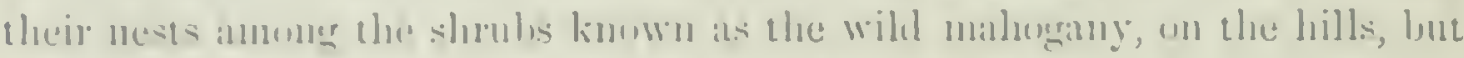
never freplesuting the higher rengins of the mommatios.

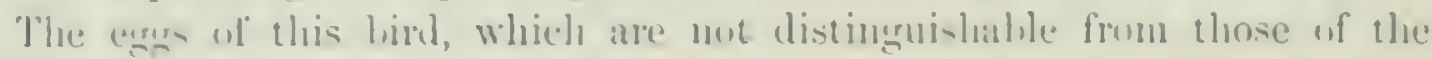

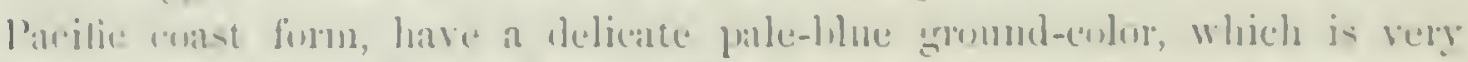

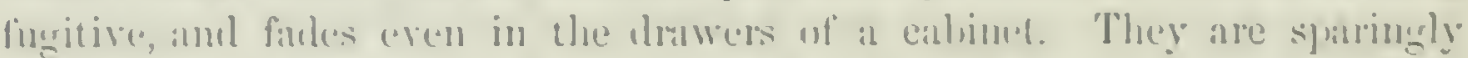

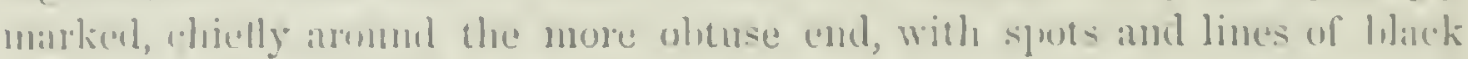
and a latk brown. They are of oval slatpe, clongate and pointed at one cud, and uneasure sill of an inch in lengeh he fol in breadsh.

\section{Carpodacus frontalis, var: rhodocolpus, Ciвı:}

\section{CALIFORNIA HOUSE-FINCH; RED-HEADED LINNET; BURION.}

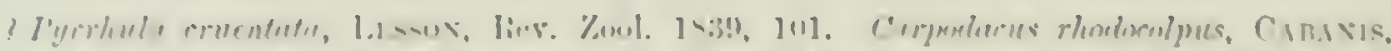

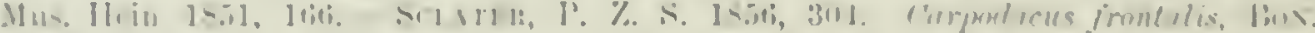

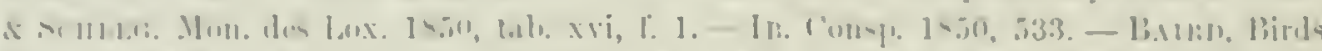

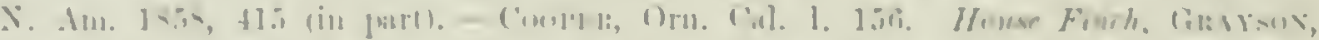

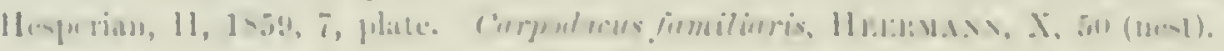

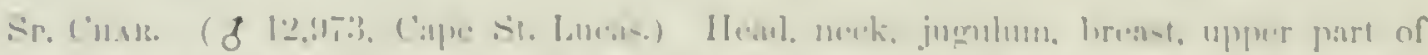

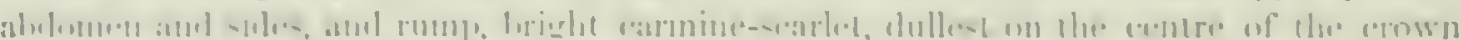

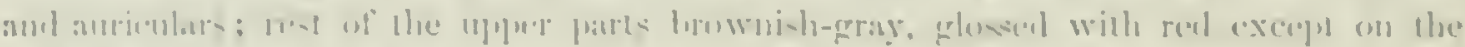

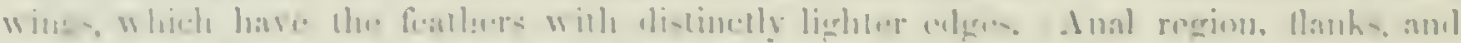

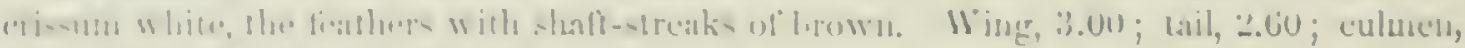

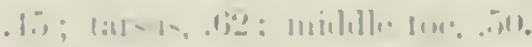

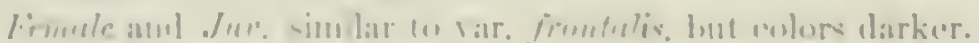

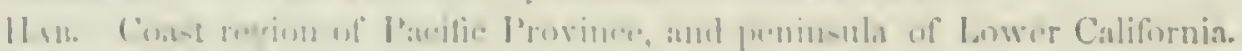

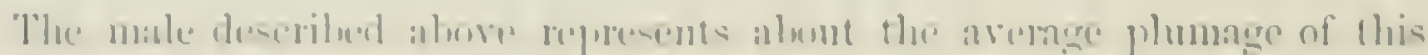

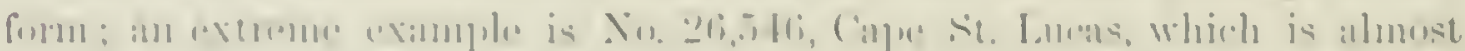

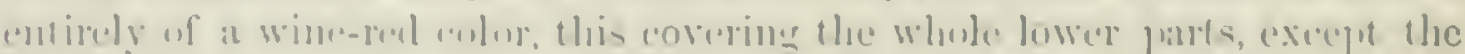

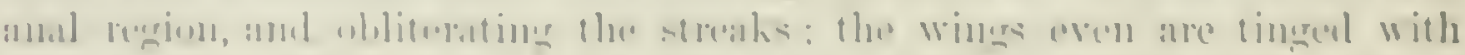

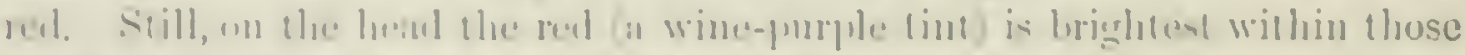

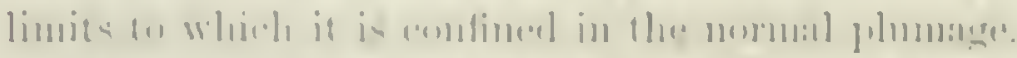

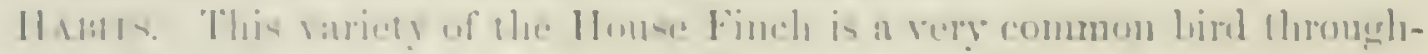

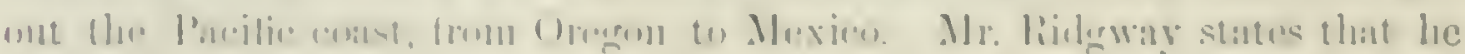

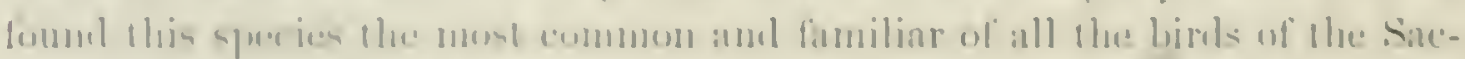

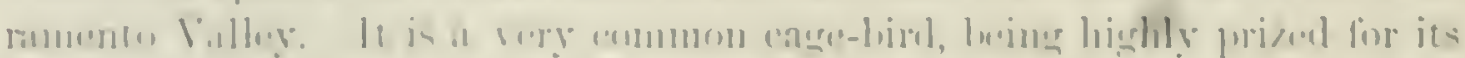

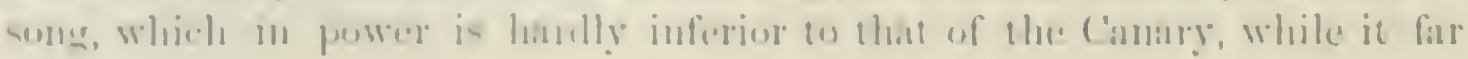


surpasses it in sweetness. Its beautiful plumage also renders it still more attractive. The peculiarly soft and musical twet of this bird is also very similar to that of the Canary, and is rery different from the common note of the Purple Finch. This bird breeds rery numerously among the shade-trees in the streets of Sacramentu, as well as among the oak groves on the ontskirts of that city. The males are very shy, but the females, when their nest is disturbed, keep up a lively chirping in an adjoining tree. The nest is generally situated near the extremity of a horizontal branch of a small oak, usually in a grove, oceasionally in an isulated tree. In one instance it made use of an abandoned nest of a Bullock's Oriole, and in another of that of a Cliff Swallow.

Dr. Cooper speaks of this bird as heing especially abundant in all the southern portions of California, and also, according to 1)r. Newberry, throughout all the valleys northward into Oregon. It is a species that is everywhere peculiar to the vallers, while the others of this genus are equally confined to the wooded mountains. Dr. Cooper also met with this species in the plains near the cuast, where there are no plants higher than the wild mustard, on the seeds of which they feed. They also frequent the groves and the open forests on the summits of the const range, but in small numbers, in company with the $C$. culifomicus. Ther at times feed on buds of trees, and seeds of the cottonwood and other plants. It is most abundant anong ranches and gardens where, I)r. Cooper states, it does mueh mischief by destroying seeds and young plants, fruit and buds. For these depredations even its cheerful and constant song is not regarded as an adequate compensation; and unlike the New-ILexicans in their treatment of its kindred race, the California cultivators wage an unrelenting war upon these hirds.

At San Diego, Dr. Cooper found them building as carly as the 15 th of March, and even a little earlier. Both the sitnation and the materials of their nest vary. He has found them nesting in trees, on logs and rocks, on the top rail of a picket fence, inside a window-shutter, in the holes of walls, mnder tiles, on the thatch of a roof, in barns and haystacks, and even between the interstices in the sticks of which the nest of a Hawk had been made, and once in the old nest of an Oriole. Aloont dwellings they always seek the protection of man, and seem to be quite unconscious of having deserved or incurred his enmity. The materials of their nests are usually coarse grasses and weeds, with a lining of hair and fine roots. They raise two, sometimes three, broods in a season, and in the autumn assemble in large flocks, but migrate very little, if any, to the south.

Dr. Cooper states that their songs are very different from those of the other species. They are very raried and very lively, and are heard throughout the rear. They are easily kept as cage-birds, but soon lose the beanty. of their plumage in confinement, their bright purple colors changing to a dirty yellow.

Nuttall did not observe any of this species in Oregon. 


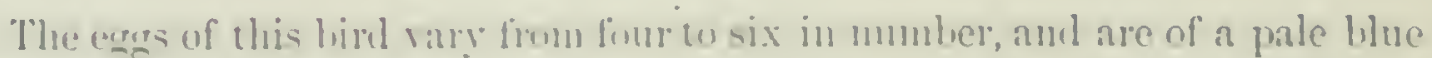

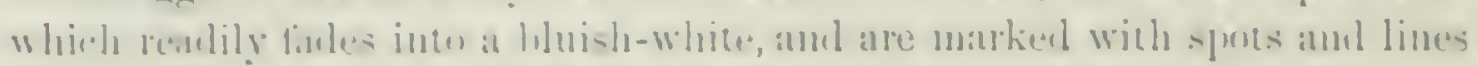
of a dart hrown or hlack. They are of an elongate-olat shape, and menome

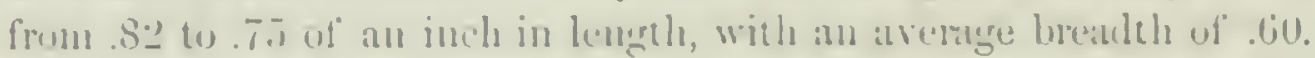

\section{(ini: CHRYSOMITRIS, 13il:}

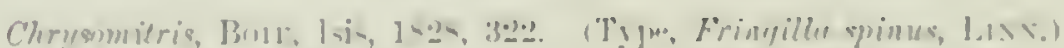

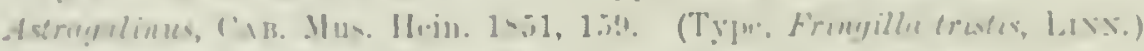

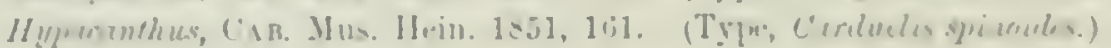

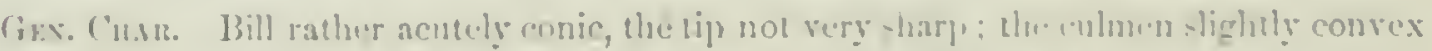

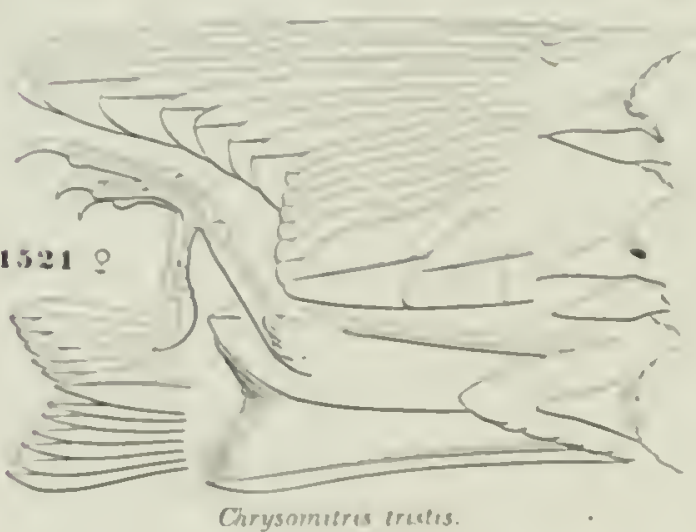

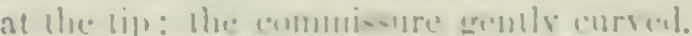

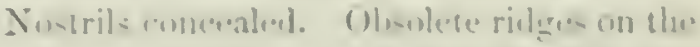
nypur mandilile: Tar-i shorter than the midllle lon; onter lese rather the longer, reathing to the base of the millle onde Claw of hime toe shorler than the digrial purtion. Winers and tail a. in . Eygiothus.

The colors are gemerally yelluw, with black on the erows, throblt, hack, wings, and tail, raried sometimes with white.

Thre limales waut the bright markings of the imale.

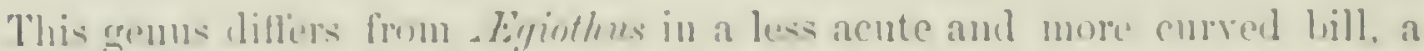
much less derelnpument of the hrivily feathers at the hase of the hill, the claw of the hime toe slorter than its digital purtiun, the claws shorter and les curverl and attenuated, and the onter lateral toes not extemling beyoud the base of the millille elaw.

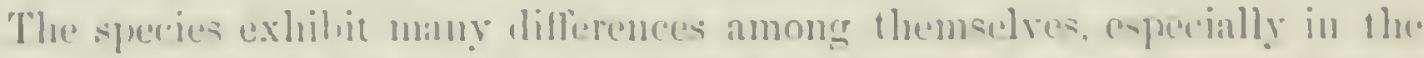
size and shate of the hill, whinh have heen male the basis of generic distinetions. 'They may be dintinguisherl as fulluw: :-

\section{Species and Varicties.}

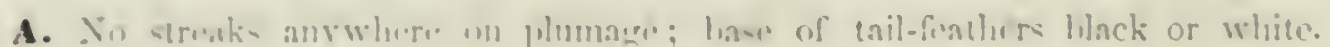

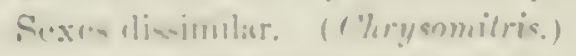

(1. Vi) yelliw un the wines.

1. C. tristis. Inmer watis of Inil-fonthere always whiti-h terminally

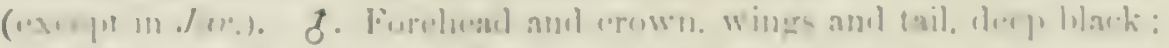

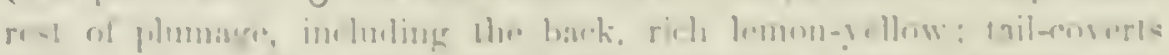

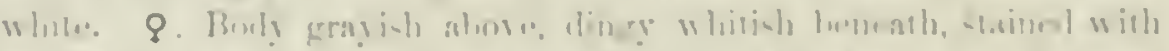

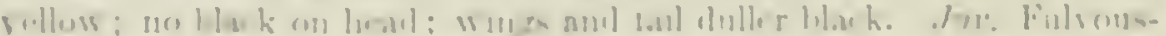

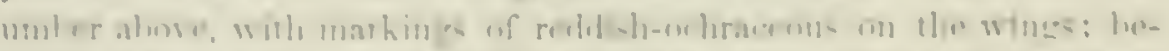

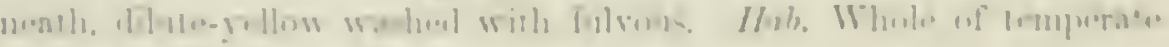

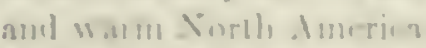

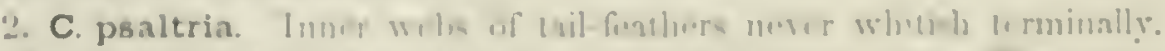

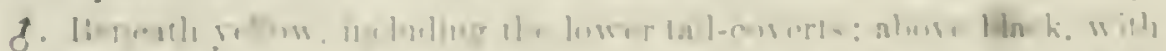

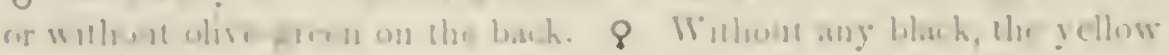
dullir. 
Tail with white on inner webs; tertials with large white spots.

8. Auriculars, mape, back, and rump olive-green. Hab. Rocky Mountains of L"nited States . . . . var. psaltria. ठ. Auriculars black; nape, back, and rump green clonded with

black. Hab. Arizuna . . . . . var a rizona. o. Auriculars, nape, back, and rump entirely black. Hab. Middle America .

rar. mexican $u$.

Tail without any white on inner webs; tertials without white spots.

§. Auriculars, nape, back, and rump wholly black. Hab. Panama and New Granada . . var. columbiana.

b. Terminal half of onter webs of wing-corerts and secondaries rellow.

3. C. lawrencii. Prevailing color ashy, lighter beneath. d. A large pateh on the breast, the rump. and most of the onter surface of the wing, yellow; forehead, crown, lores, all round hase of bill, chin, wings (benteath the yellow), and tail black. 9 . Lacking the black, and with the yellow only indicated. Hab. California and Suutlwestern Arizona.

B. Whole body and head thickly streaked; bases of tail-feathers yellow. Sexes alike. (Astragalinus.)

4. C. pinus. Abore brownish-gray, beneath white, with conspicuous dusky streaks ererywhere; two light bands on the wing; bases of secondaries and primaries yellow. Het. Whole of North America.

Three species of Chrysnmitris, given by Mr. Audubon, are to be erased from the list: C. stanleyi, C. yarrelli, and $C$. magellunica. If, as he states, he killed specimens of the latter in Kientuchy, they must have belonged to the $C$. notata of Dubus, a Mexican species, not since net with in our limits. The other two were given him as coming from California, - a statement we now know to be incorrect, both belonging to South America.

Chrysomitris tristis, BOA.

\section{YELLOW-BIRD ; THISTLE-BIRD}

Fringilla tristis, Lisx. Srst. Nat. I, 1760, 320. - WiLs. An. Om. I, 1808, 20, pl. i, f. 2. - AtD. Orn. Biog. I, 1\$31, 172: T, 510, pl. xxxiii. Curclueles tristis, Pux. Obs. Wils. 1\$25, No. 96. - Aun. Birds An. II, 1841, 129, pl. clxxxi. - Max. Cab. Journ.

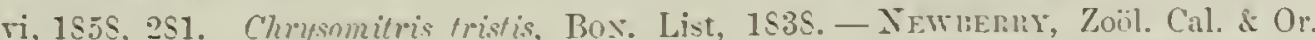
Route: Rep. P. R. R. Surv. YII, w, 185i, \$i.-B.rrn, Birds X. Am. 1\$55, t21.CoOper of StCKLET, 197. - Cnoper, Om. Cal. I, 167. Astragalimus tristis, CABAsis, Mus. Hein. 1851, 159 (trpe). Carduclis ameriana, (Euwards,) Sw. \& Rren. F. B. A. 1I, 1\$31, 26S. Golden Finch, PExist. American Goldfinch, Edwards. Churdonneret juune; Chardonneret du Cunatu; Turin de le Sourlle Forck, Beffos. - Iв. Pl. enl., pl. ceii, f. 2, pl. cexcii, f. 1. - Styltels, Birds I. Eng. 2SS.

Sp. Char. Male. Bright gamboge-yellow : crown, wings, aud tail black. Lesser wing-corerts, hand aeros: the end of greater ones, ends of secondaries and tertiaries, inner magins of tail-feathers. upper and under tail-corerts. and tibia white. Length, 5.25 inelies; wing, 3.00. Female. Fellowish-grar ahore: greenish-rellow below. No black on forehead. Wing and tail much as in the inale. Young. Reddish-olire abore; fulrous- 


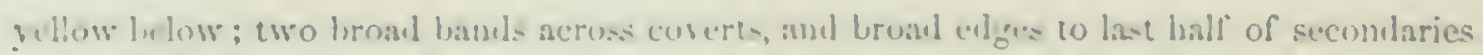
jolle rulum:

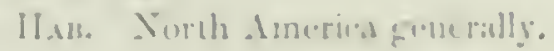

In winter the yellow is replaced by a yellowish-brown; the black of the

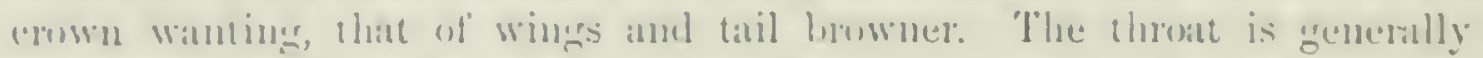

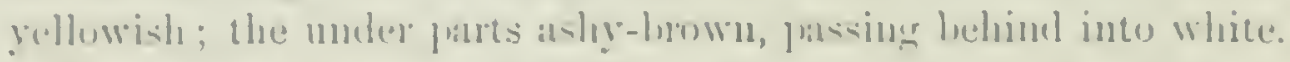

There are no uhervable diflenences between eastem and western specimin'lls.

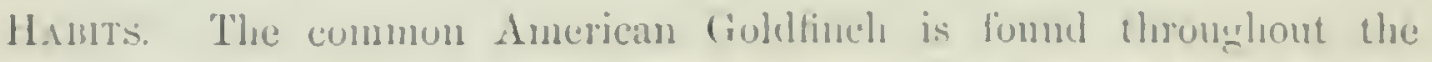

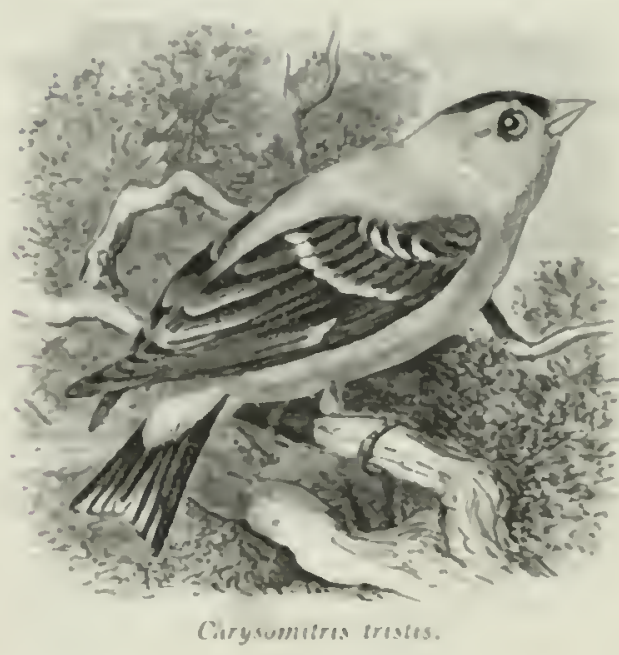
greater pertion of Surth Aneriea, from the Allantic (n the l'acitic. Sir Iolu livehatelson met with it in the fur regrims, where it is one of the tarliest af the smmmer visitors, and whence it departs early in sepuemher. The sjeeriment describerl hy him wats talken .Inue 29). It the extreme south it is mut

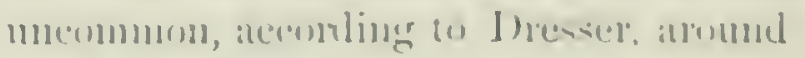
Sinn Antonio, and 1)r: Womblumae fomml it abmulant lorth in Texas and in the Indian Territory. Dr. Cones diel not find it in Aliznna, nor dues sumichnast

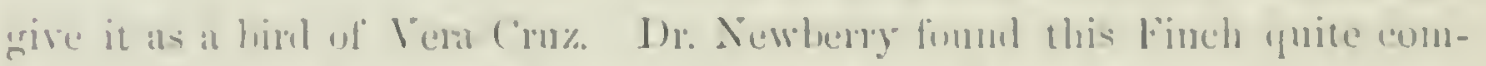

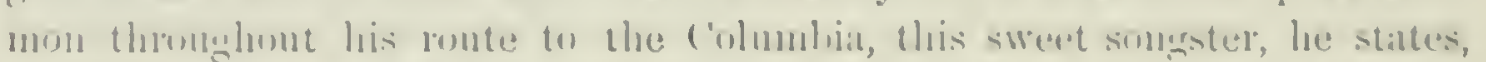

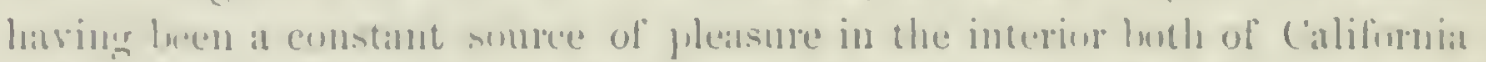

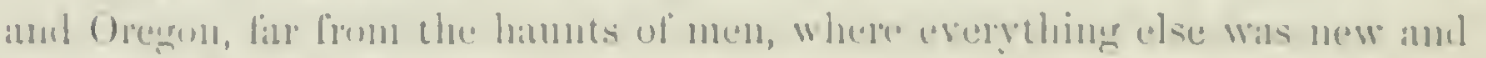

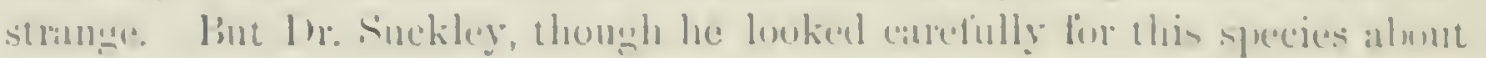

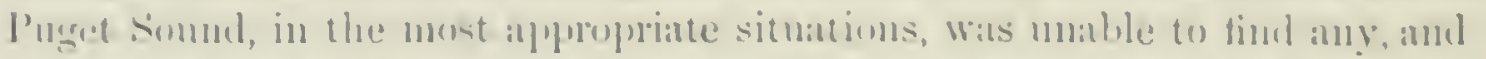

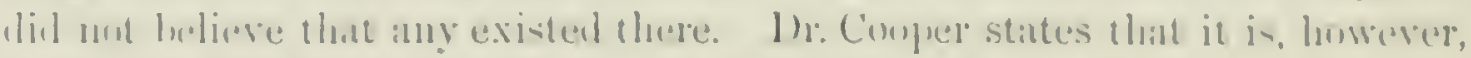

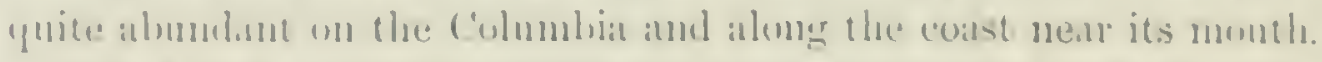

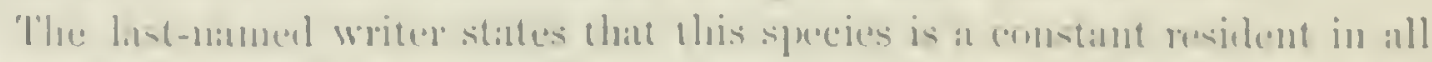

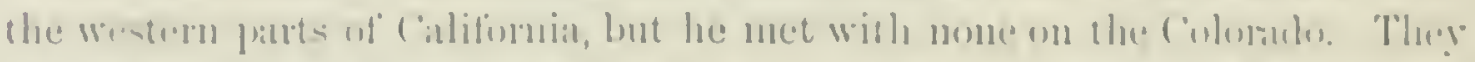

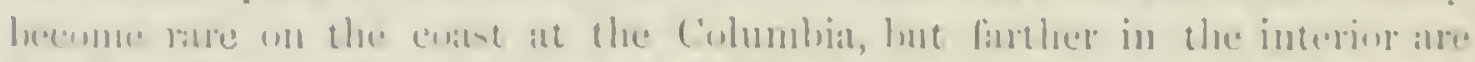

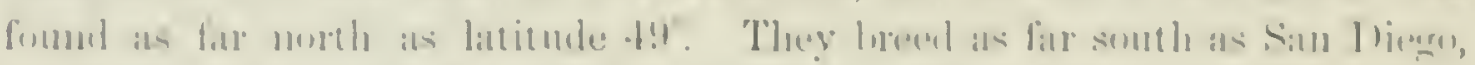

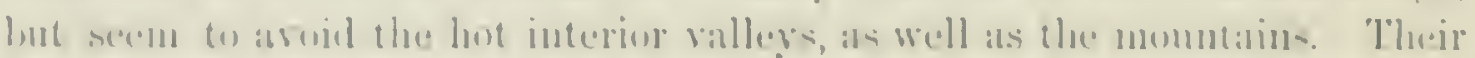

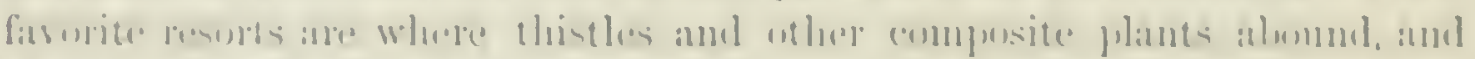

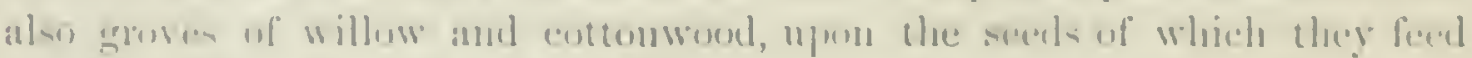

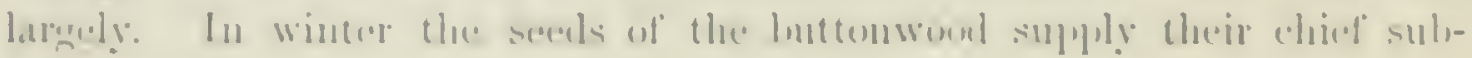
sistence.

The (е)

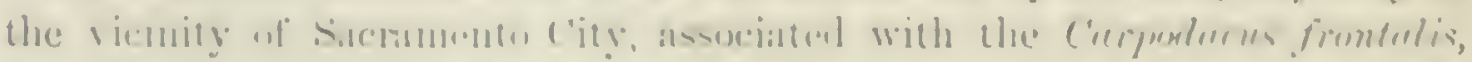

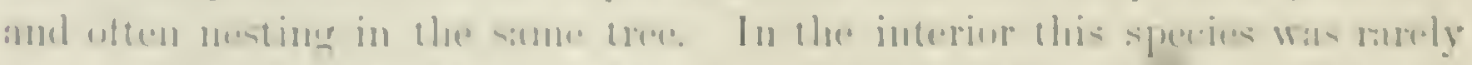

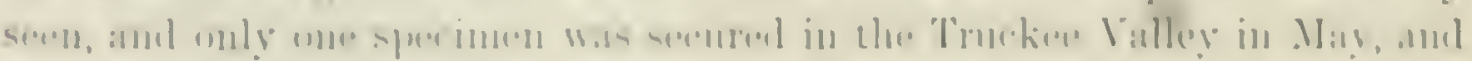

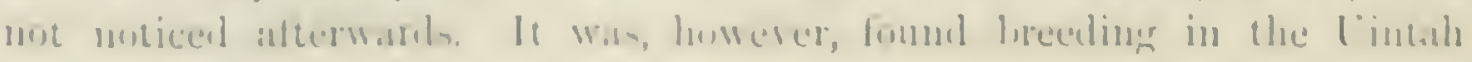


Mountains, where its nest and eggrs were ubtained. The nests procured by Mr. Ridgway were all found abunt June b, except one, ten days later, showing that these birds are fuur or five weeks entier in their breeding on the Pacifie than on the Atlantic coast. In the Uintah Mountains they were breeding, as at the East, in July.

The Goldtinch is to a large extent gregarions and nomalie in its habits, and only for a short portion of the rear do these birds separate into pairs for the purposes of reproduction. Buring at least three fourths of the year they assuciate in small flocks, and wander about in an irregukar and uncertin manner in quest of their fond. They are resident throughout the year in New England, and also throughout the greater portion of the country, their presence or absence being regulated to a linge extent low the abundance, searcity, or atsence of their farorite kinds of food. In the winter, the seeds of the taller weeds are their principal means of subsistence. In the summer, the seeds of the thistle and other plants and weeds are somght out by these interesting and busy gleaners. Ther are abundant in gardens, and as a general thing do very little harm, and a vast amount of benefit in the destruction of the seeds of troublesome weeds. As, howerer, they do not always liscriminate between seets that are troublesome and those that are desirable, the croldtinches are unwelcone risitors to the finmers who seek to raise their own seeds of the lettuee, turnip. and other similar vegetables. They are also very fond of the seeds of the sunflower.

Owing possibly to the scarcity of proper food for their young in the early summer, the Coldfinches are yuite late before they mate and raise their single brood. It is usually past the 1uth of July before their nests are constructed, and often September before their hroods are reaty to $\mathrm{Hl}$.

The song of the Croldfinel - very different from their usual plaintive cry or call-note, uttered as they are Hying or when they are feeding - is very sweet, brilliant, and pleasing; most so, indeed, when giren as a solo, with no other of its kindred within hearing. I know of none of our common singers that excel it in either respect. Its notes are higher and more flute-like, and its song is more prolonged than that of the l'urple Fineh. Where large flocks are found in the spring or early summer, the males often join in a very curions and remarkable coneert, in which the roices of the several performers do not alway's accort. In spite of this frequent want of harmony, these concerts are varied and pleasing, now ringing like the loud roices of the Canary, and now sinking into a low soft warble.

During the warm summer weather the Goldfineh is very fond of bathing, and the sandy shelving margins of bronks are alwars their farorite places of resort for this purpose. I do not think ther ever raise more than a single brood in a season in New England, and are in this somewhat irregular, depositing their eggs from July 10 to September, as it may happen.

They usually select a small upright tree, sueh as a young elm, apple, or pear, or a tall shrub, for their nest, which they rarely place higher than ten 
feet from the aromml. Than the me-t uf our findltinels we have no more heau-

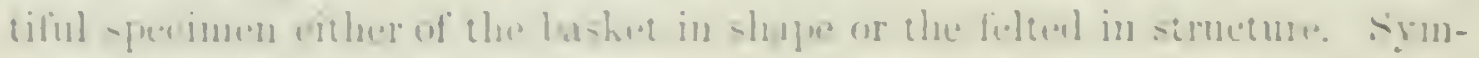

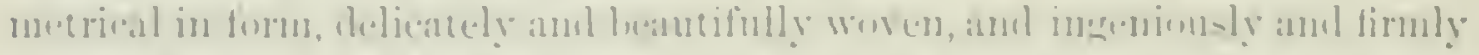

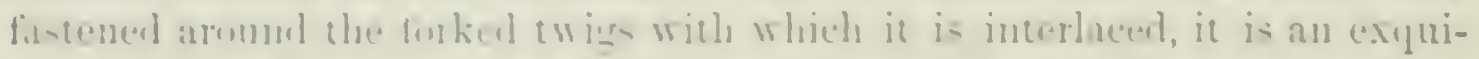

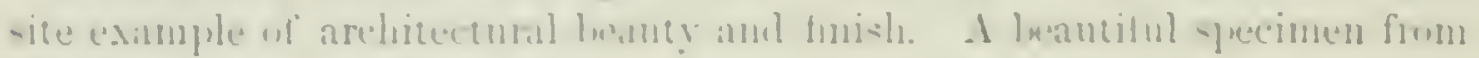

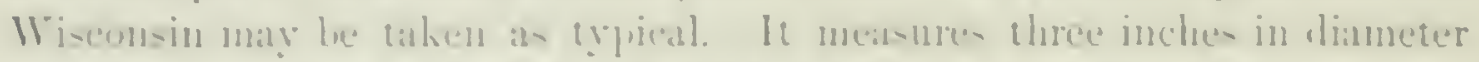

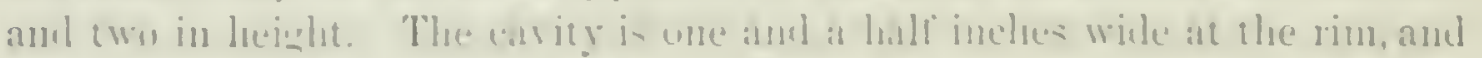

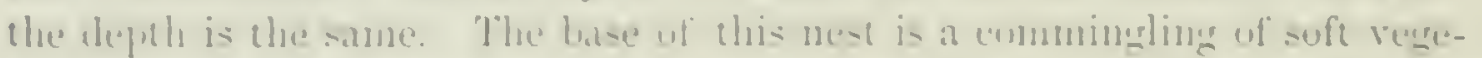

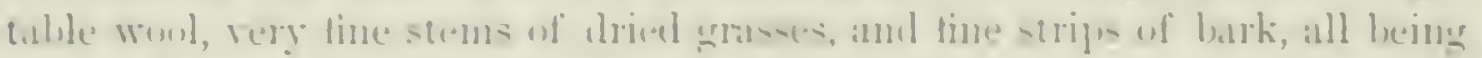

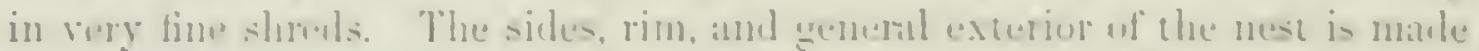

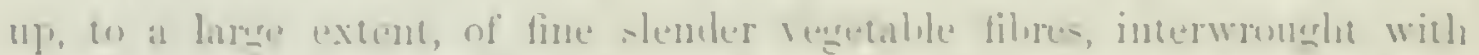

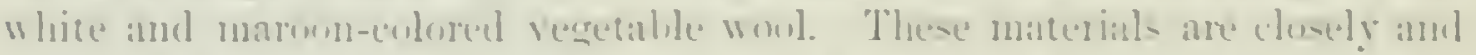

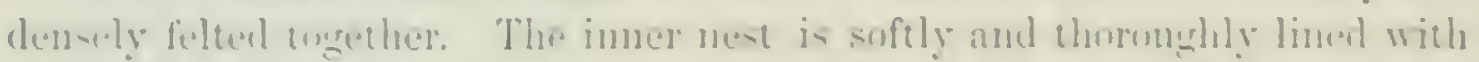

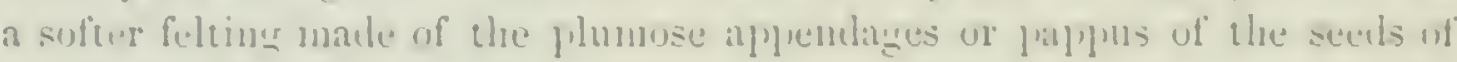
compusite plants.

The curess, usually five, maty six in mumber, are of a uniform bui-li-whites,

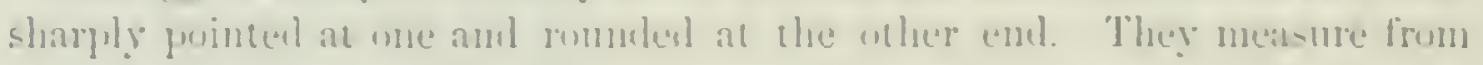

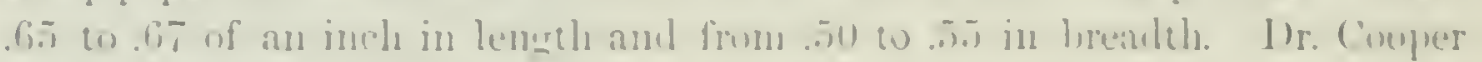

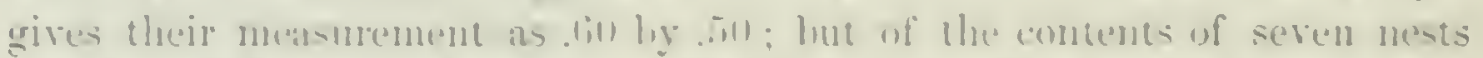

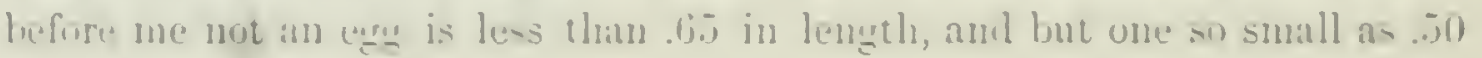
in lireulits.

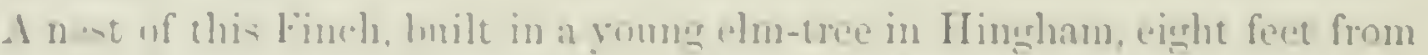

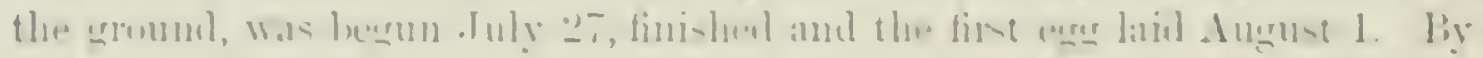

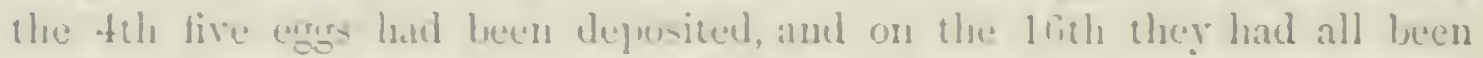
linteinem.

\section{Chrysomitris psaltria, var. psaltria, limap.}

\section{ROCKY MOUNTAIN GOLDFINCH: ARKANSAS GOLDFIXCH.}

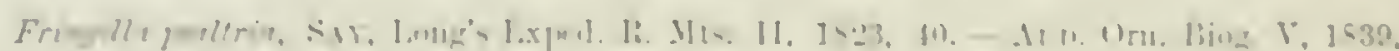

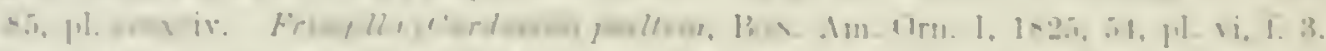

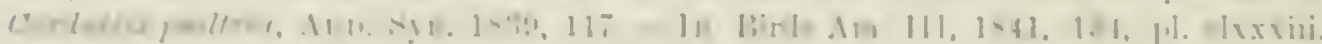
(?)

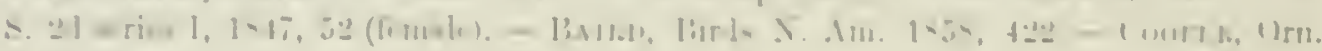
(') 1, 1, 19.

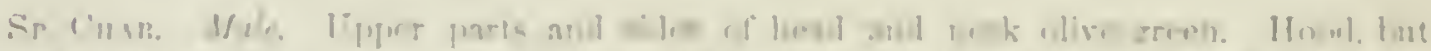

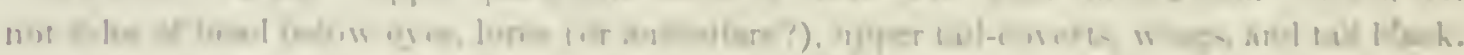

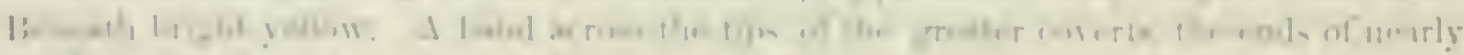

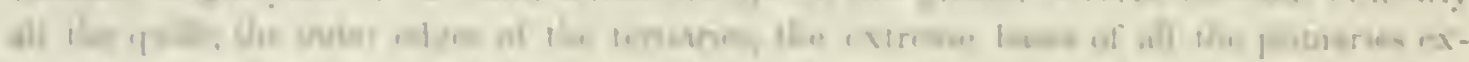

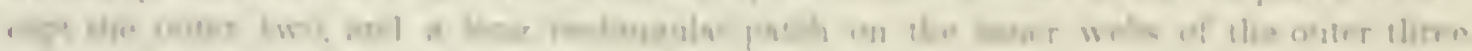

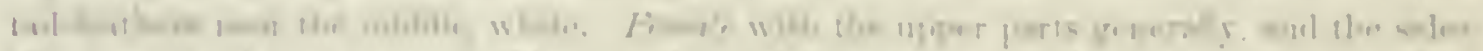

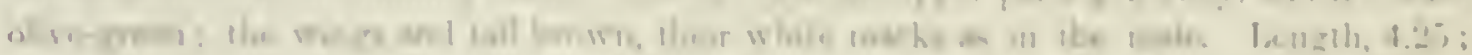

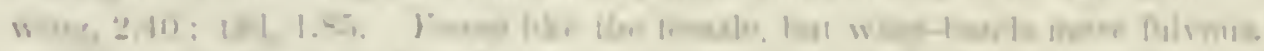

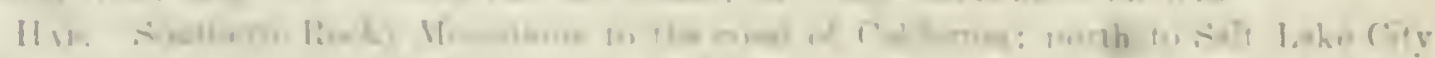

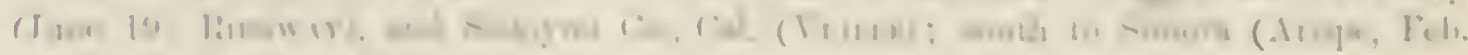
$\because 6 ; 1 .<11,3 x+1,11 \%$. 
With quite a small series of specimens, a perfect transition can be shown from the typical $C$ : psaltria, as abore described, to the $C$. columbianus, the opposite extreme (see table, page $4 \nmid 1$ ). The former is the most northern, the latter the most sonthern form; arizonce and mericunn, intermediate in habitat, are also as strikingly so in phunage. The diflerence is in the quantity of the black, this eolor preclominating orer the olive of the back and the white of wings and tail, in proportion as we go sonthwarl. There cannot, upon the whole, be any doubt that they are all specifically the same. The females can searcely be distinguished.

Habits. The Arkansas Finch was first discovered in Long's expedition to the Rocky Mountains, and described by Say in 1823. It lias since been met with in New Mexico and in various parts of California. Dr. Cooper did not find this species in the Colorado Valley, although Dr. Kennerly met with it along Williams Fork, in New Mexico. Dr. Woochlouse did not see it in his route to the Zuni River, either in New Mexico or the Indian Territory.

Dr. Kemnerly met with these hirds in the month of February. He found them very abundant all along the banks of the Bill Williams Fork. They were feeding on the young buds of the cottonwood trees. A that season they were in small flocks, and the only note he heard from them was a short chirp, as they hopped from twig to twig, or flew from one tree to another.

Dr. Heermann states that he found these Finches abundant in the northern mining regions of California, frequenting and feeding in the same localities with the $C$. lawereneii, and often associated with the Pine Fincli. He adds that, while thus associated, he shot a large number of both species. They seemed to be employed, at the time, in picking out the fine gravel mixed in the mud used as mortar for a chimney, flying away at each discharge of the gun, but returning, in a few minutes, to the same place.

Mr. Audubon regarded this species as acciclental in Louisiana, haring procured individuals a few miles from Bayou Sara.

The Arkansas Goldfinch was found by Mr. Ridgway among the Wahsateh Mountains, his attention being at once drawn to it by its curious notes. $\mathrm{He}$ first met with it in "City-Creek Cañon," near Salt Lake City, where indiriduals of it were frequently found mixed in with flocks of C. pinus. The note of this bird is remarkable for its power and very sad tone. The ordinary note is a plaintive, mellow, whistling call, impossible to describe, and so inflected as to produce a rery mournful effect. When the bird takes to flight, it is changed to a simple cherr, similar to the amxious notes of the male Agclains phenicens, uttered when its nest is disturbed. This species was quite rare, not being so common as either $C$. pinus or $C$. tristis. Its nest was found in Parley's Park, Wahsatch Mountains, June 22, in the top of a willow-bush near a stream.

At San Diego, and along the whole coast border of California, Dr. Cooper thinks that this Finch is rather rare. In the interior valleys they seem to be quite common. They also breed in small numbers in the Coast Range, 


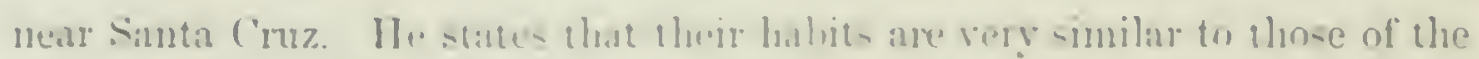

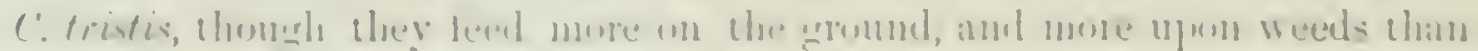

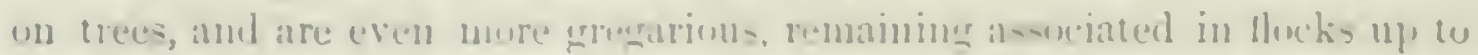

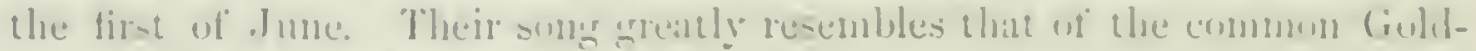
finch, but is much fininter.

In. (noper never met with their nest, nor has he received any dearription of n. Mr. Xintus fomnd one, cuntining four euress, on the branch of an

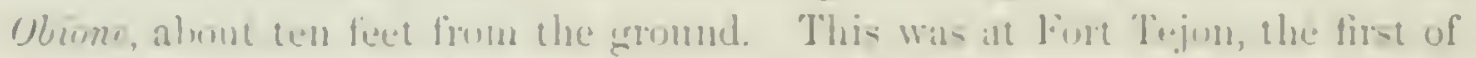

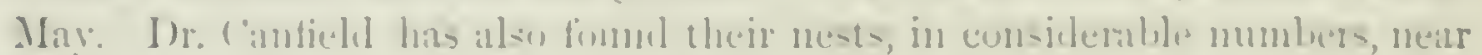
Monteres. Thes are huilt in the forks of trees, in the sine manmere with

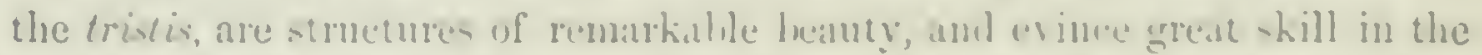

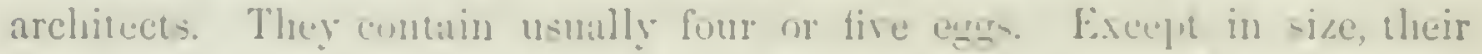

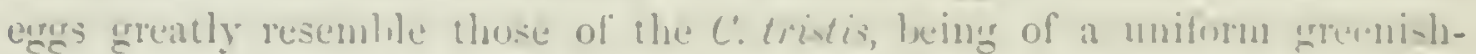
white, unspotteil, of a rounded-ural shape, sharply pointed at one end. They measure .60 by .ju of an inch.

\section{Chrysomitris psaltria, var. arizonæ, Cotes.}

\section{ARIZONA GOLDFINCH.}

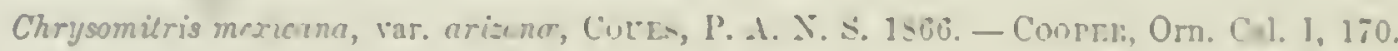

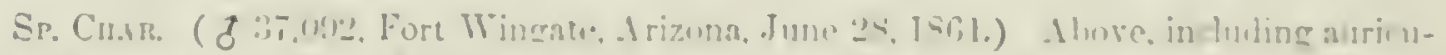

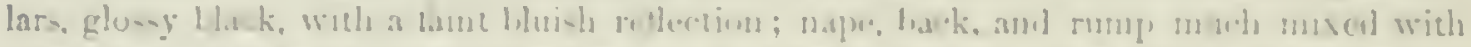

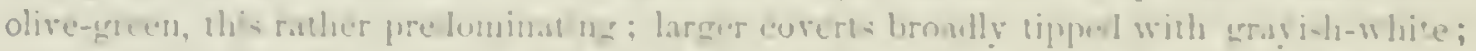

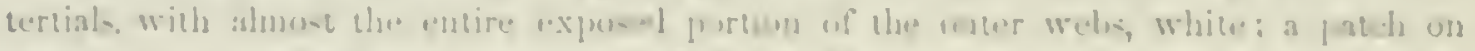

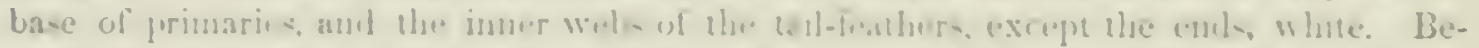

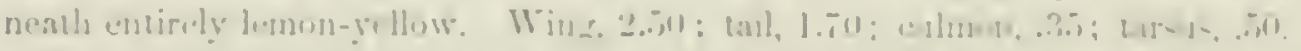

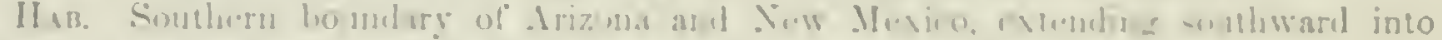
Mlexico, and gradually whaneng me mericum, and nordhward into pederie.

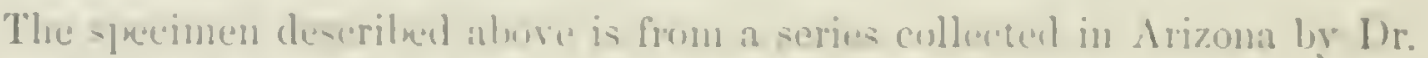

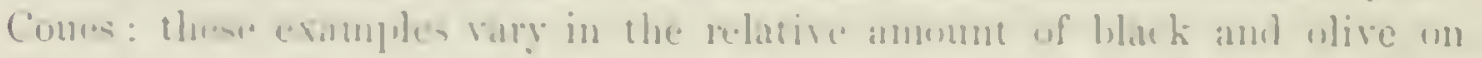

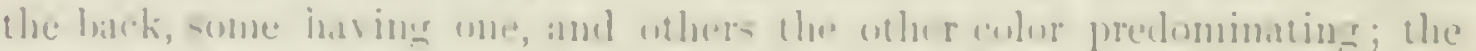
igne selented is one which represents alust the average plumbere of this spereing from Arismil

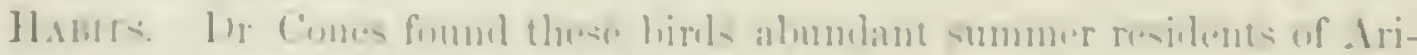

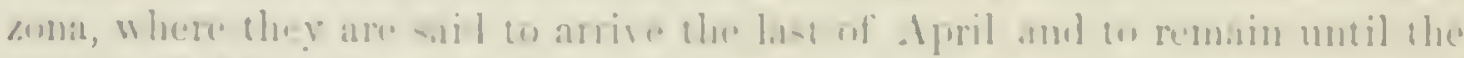

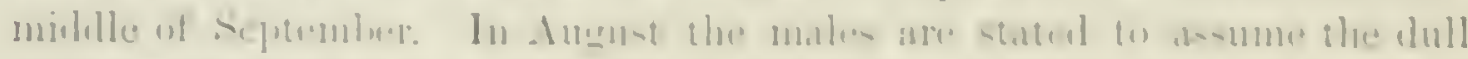

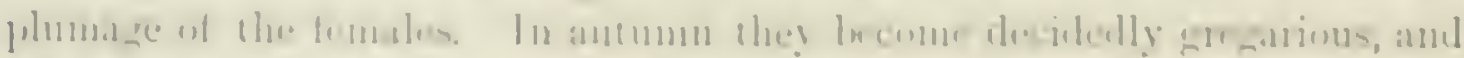

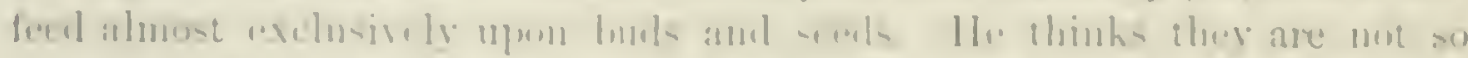

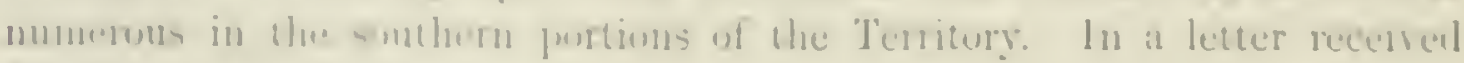
from him loce remath

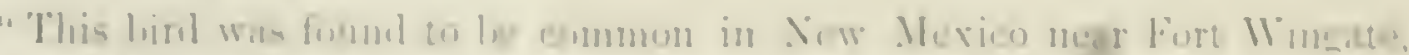

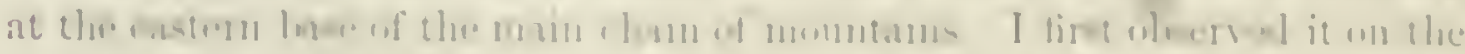

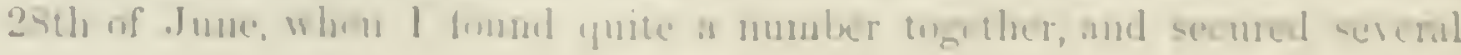


specimens. They were in small troops on a rugged hillside covered with a sparse growth of junipers and stmited pines, feeding in company with the Poospiza bilineutu. Judging from their actions, and from the fact that none but males were taken, I presume they were breeding in the vicinity. I found some difficulty in securiug specimens, partly owing to the broken nature of the locality, and partly to the birds' timidity in the unaccustoned presence of maln. Those that were shot were all found to have the asophagns as well as the gizzand crammed with seeds. They constantly uttered a plaintive lisping whistle as they gathered food, or as they Hew from one tree to another, but their song did not strike my ear as precisely the same as that of the Goldfinch. These specimens were all in what I take to be perfect plumage, although the back was mixed with olive and black in nearly equal proportions, and the black of the pilemm did not reach below the eyes to c'it off the yellow under eyelid from the other yellowish parts of the head; thus closely resembling true psaltria.

"Upon my arrival at Fort Whipple in July, I found birds of this type abundant, and took a good many during the two following months, when they disappeared, and I saw none until about the first of May. A small rarine close by the fort, choked with a rank growth of weeds, was a favorite resort; there the birds conld be fornd at nearly all times in season, in large troops, feeding in company with Chipping ".parrow's, and the Spizella atrignlaris. They were very tame during the latter part of the summer, would only rise when very closely approached, when they flew in a hesitating manner a short distance, and then pitched down again among the weeds to resume their busy search for food. In their undulating flight they utter their peculiar note, generally with each impulse of the wings, and lieep up a continnal chirping when feeding; but I did not hear their true song at this season. Some of the specimens taken were very young birds, and the species unquestionably breeds here, although I never sncceeded in finding a nest.

"I should not omit to add, that whilst at Santa Fé, New Mexico, I saw eaged birds that were thriving well, and apparently reconciled to confinement."

A nest of this bird, obtained near Camp Grant, Arizona, by Dr. Palmer, is a flat and shallow structure, having a diameter of three inches, and a height of one and a quarter. The cavity is only a slight depression. This nest is made of a felting of various materials, chiefly the cotton-like down of the cottonwood-tree and other soft regetable matter, fine stems of grasses, fragments of mosses, and various other similar materials, lined with finer materials of the same. Except in their slightly smaller size, the eggs are not distinguishably different from the preceding. 
Chrysomitris psaltria, var. mexicana, lioxil.

\section{BLACX GOLDFINCH; MIEXICAN GOLDFINCH.}

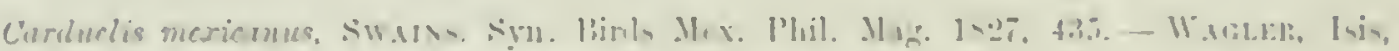

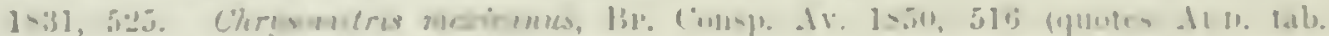

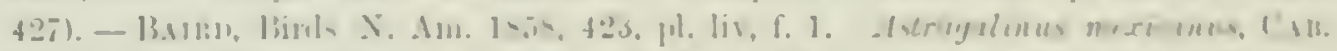

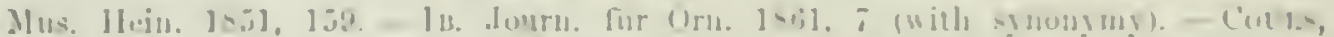

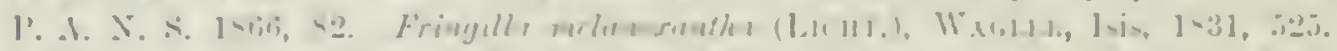

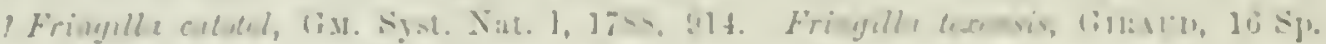

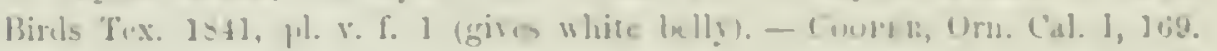

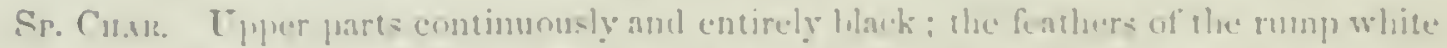
sulferminally, and showing this throngh the hlack: a lew of the leathers with greeni-h-

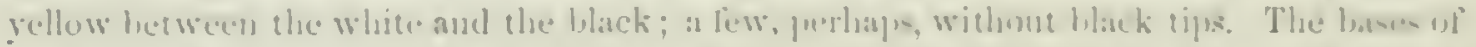
the thiml to seventh primaries, and the ends of the teriaries comernally white. The aail is

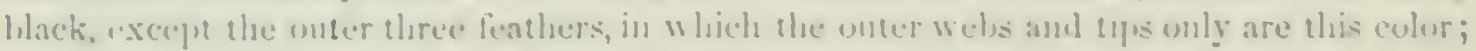

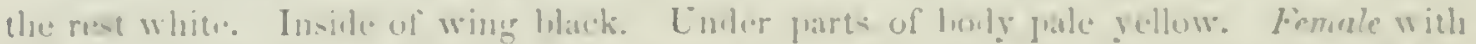

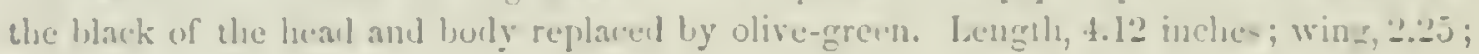
tail. :2.00.

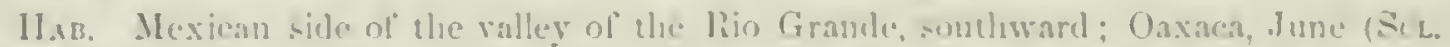

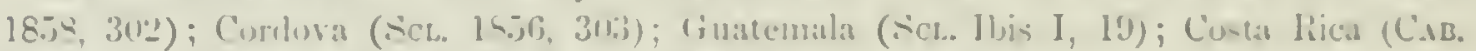

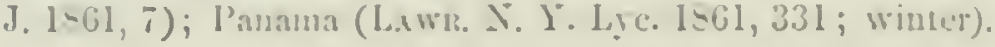

HAnts. The Mexican Goldfinch is distributed from the western side of the liso cirmule, throush Nexico and (entral Ameriea, to liumama. Sunichrast mentions it as found thronghent the state of Vera crum, but most abmulant in the temperate segion. It lireeds in the vicinity of Grizalsa. It was taken in Central America, by . Mr. Skimmer, aul has been reporturl from costit likit, and from I'unama in the winter. Of its distine-

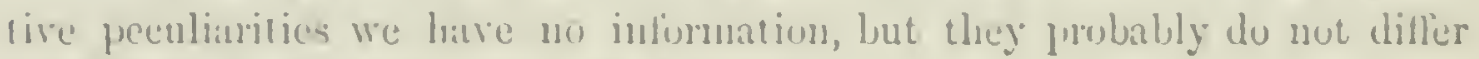
from those of the other forms of c'. prottriet.

\section{Chrysomitris lawrencii, Boxisp.}

\section{LAWRENCE'S GOLDFINCH.}

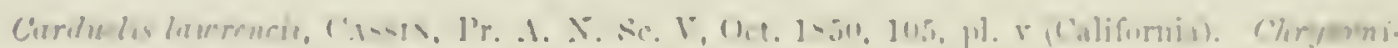

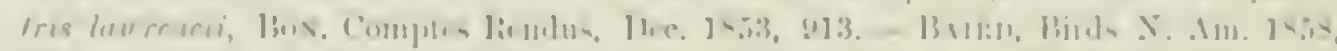

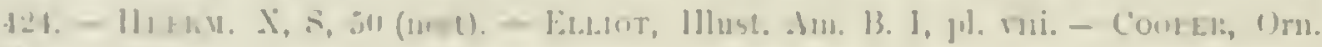
(al. 1, 1\%1.

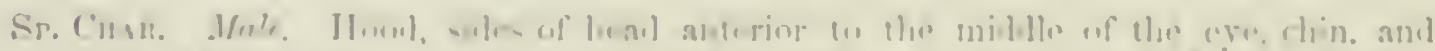

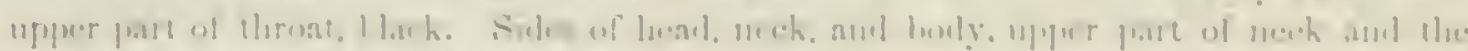

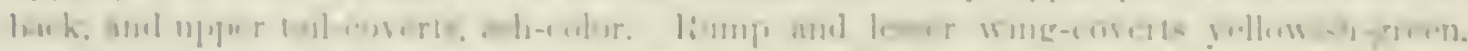

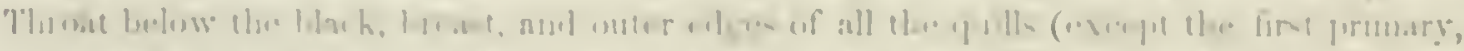
mul pun

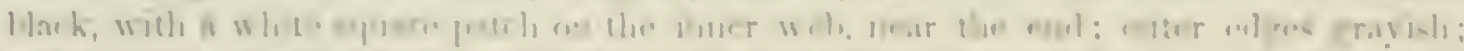

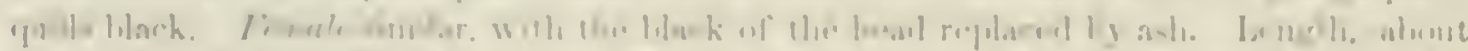

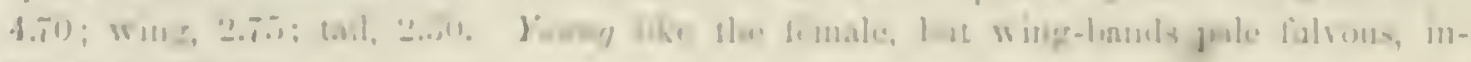

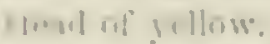

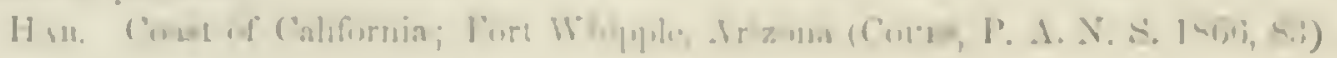


Habits. This speeies, now known to be so common throughout the greater portion of California, was first described by Mr. Cassin in 1850. Dr. Heermam afterwards found them very abundant throughout the northern mining regions of California, frequenting the hillsicles covered with brush, the seeds and buds of which they eat with great aridity. Later in the season he found them at San Diego, in quest of grass-seeds on the level plains. They were in linge flocks, and so closely packed that he shot thirteen at one discharge. Their nests, he states, are built in the fork of a bush or stunted oak, and are composed of fine grasses, lined with hair and feathers. They contain four or five pure white eggrs.

Mr. Ridgway only met with this Goldfinch near the foot of the western slope of the Sierra Nerada.

Dr. Cooper met with a few of this species at Fort Mohave, on the Colorado, but found them more numerous near the coast as far north as San Franciseo, at least, and also in the more northem mining regrions. He has seen them about San l'ranciseo in Decenber, and has no cloubt that they remain all the winter thronghout the lower conntry. They seem to aroid the mountainous regions, and have not been met with in Oregon.

Their habits and their song are, in general respects, similar to those of the Goldfinel (C. tristis), but their roice is mueh weaker, and is higher in its piteh. Their nests, Dr. Cooper thinks, are placed, in preference, on the liveoaks; at least, he has never met with them in any other sitnation. They are built very much in the style of those of the Goldfinch, but are much smaller, the cavity measuring only an ineh in depth and one and a half in breadth. The eggs lie clescribes as four or five in number, pure white, and measuring $.80 \mathrm{by} .+6$ of an inch. He adds that they sometimes feed on the ground, on grass-seeds, as well as on buds and seeds of varions weeds and trees. They were regarded by him as more of a sylvan species than the Goldfuch, and not so fond of willows and other trees growing along streams and in wet places. In the Colorado Valley they feed on the seeds of the artemisia. IIe did not notice any there after the middle of April. Eugs, in my own cabinet, from Monterey, identified by Dr. Canfield, are of a uniform greenishwhite, exactly similar to those of C.pseltrice and tristis, and measure only .58 by .45 of an incli, or less in length by .2.2 than as given by Dr. Cooper.

Three nests of this species obtained at Monterey; Cal., by Dr. Canfield, all exhibit more or less variations as to material and style of make. They are all more or less felted, and beantifully wronght, fully equal in artistic skill to the nests of the Goldfinch. They are about one and a half inches in height and three in diameter, and the eavity is an inch in depth and one and three quarters in diameter. The walls of these nests are soft, warm, and thick, composed of wool, both regetable and animal, fine stems of grasses, down, feathers, and other materials, all elosely matted together, and lined with the long hair of the larger animals. One of these nests is male up entirely of the finer grasses, strongly matted together. 
Chrysomitris pinus, linste. PINE GOLDFINCH.

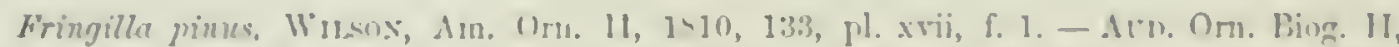

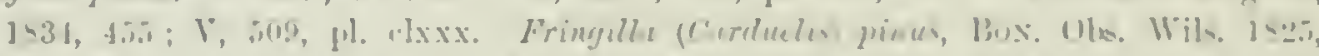

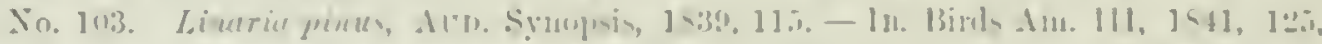

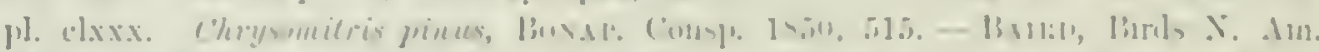

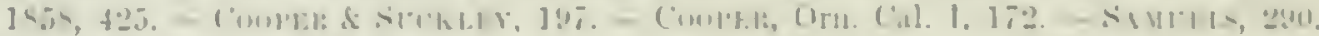

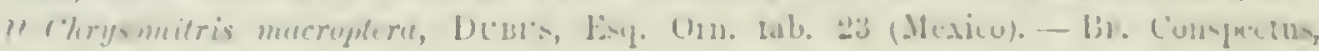
$18,0,515$.

Sr. Curr. Tail dereply forkem. Above hrownith-olive. Beneath whiti h, wery fenther

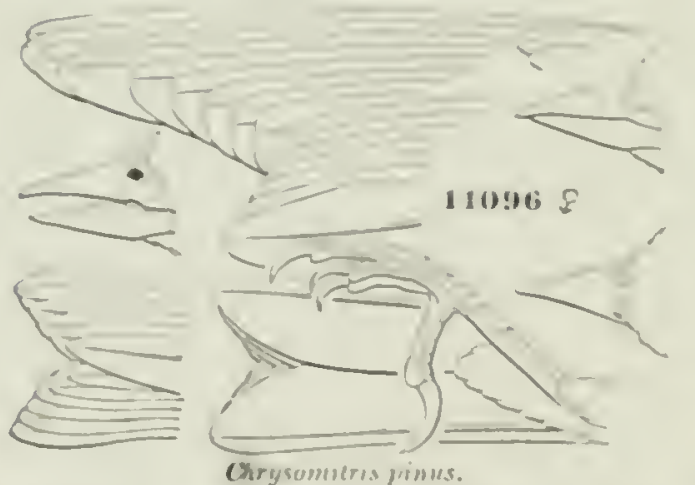
streakient desinetly witl in-hy. Concealed bases of tail-feather* and guills, longed herwith their imer colpes. smplumr-yellow. Gater

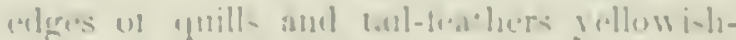
grocen. Two hrown-li-white bauds on the

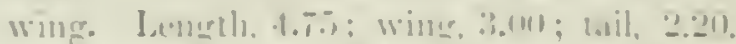

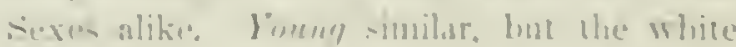
lnelow tmeal with grollew, the ujper pars with rededi-la-lnown, and there are two pale ochararoms baml- un the wing.

H.s1:. Xorlh Amerien from Allantic 10

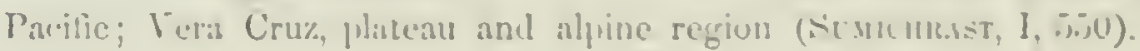

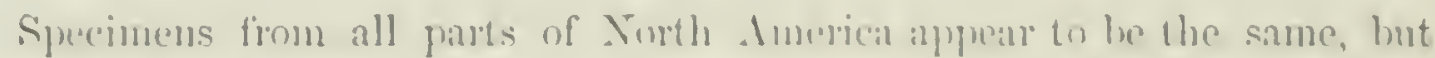

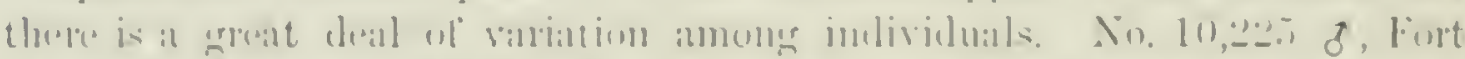

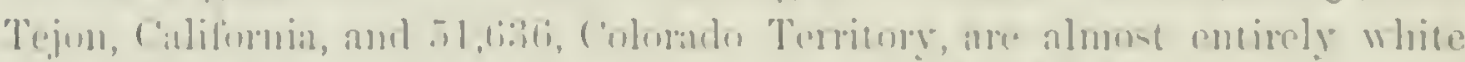

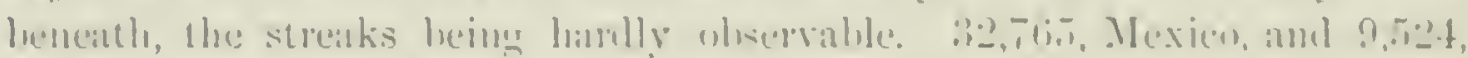

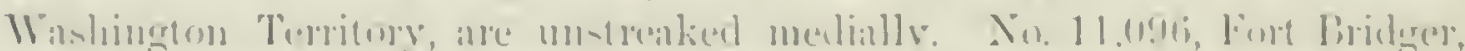

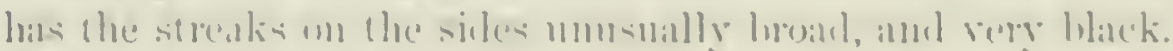

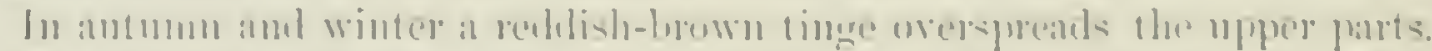

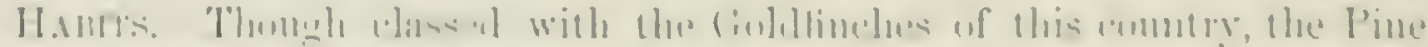

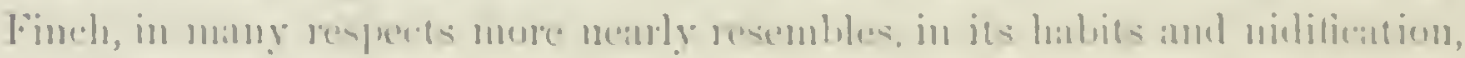

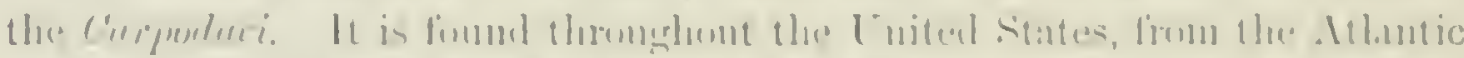

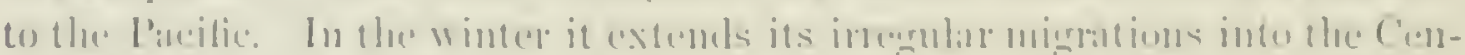

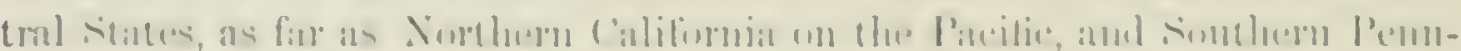

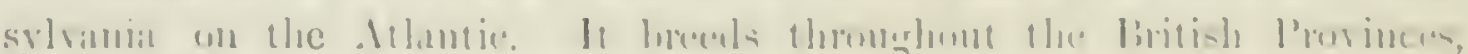

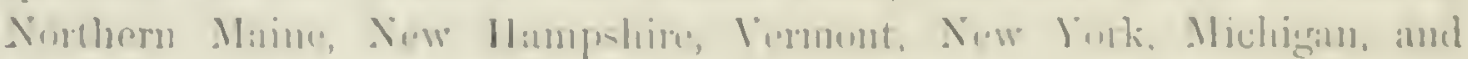

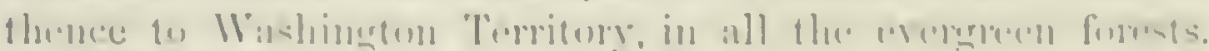

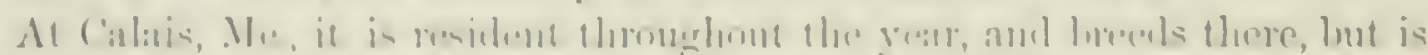

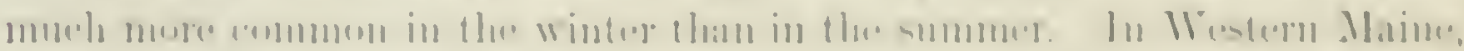

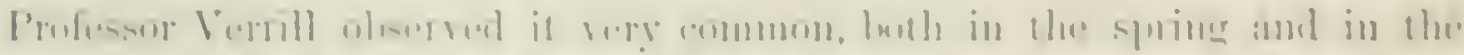

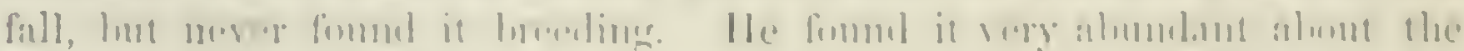

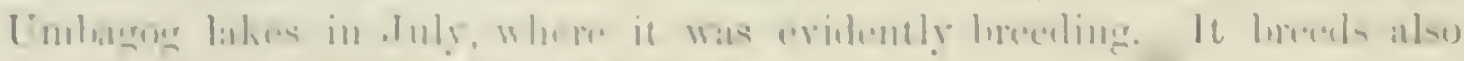

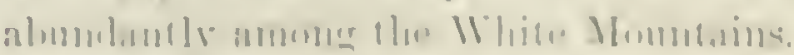

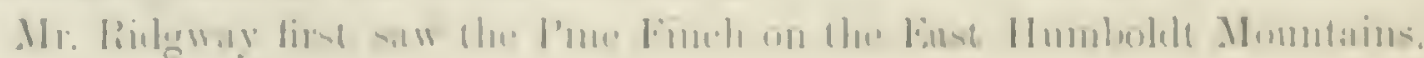


where, through July and August, it was quite common, itud where undoubtedly it breeds, as a young bird mable to fly was obtained. On the Walisateh Monntains it was a rery abundant speeies, inlabiting the pines as well as the groves of aspens in the alpine regions. Is is grecarious at all times, Hying in roving, sereeching flocks. The notes it utters on all occisions resemble

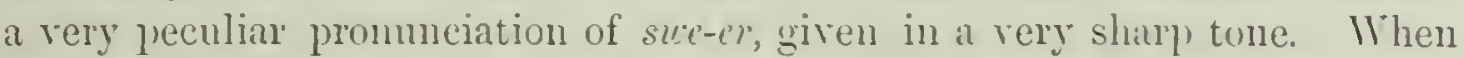
the flock suddenly takes to flight, this is changed to a more mattling outery. A nest, containing no egrgs, was found in an aspentree; and another, containing one egg, similar to those described elsewhere, was found in a fir-tree (Abics) situated near the extremity of a horizontal branch abunt twenty feet from the grround.

The Pine Finch is also a very common and resident hird in the platean of Mexico and in the alpine regions of the state of Veral C'ruz. Its common name there is Dominiguito montero. In the alpine regrons smmichrast states that it is found to the height of six thousand five hundred feet, and does not, to his knowledge, descend below three thousand feet. It nost especially frequents the platean.

Captain Blakiston met witl this speeies on the plains of the Saskatehewan, near the Rocky Mountains, August 6, 18.5 .

In the eastern portion of Massachusetts it is somewhat irregular in its morements and appearnee, which are supposed to be aflected by the abundance or seareity of its food elsewhere. Here it feeds chiefly on seeds of grasses and weeds, probably only after the seeds of the hemlock and other forest trees hare failed it. They are usually most alumdant late in the season and after heary falls of snow farther north have diminished their means of subsistence. Mr. Maynard found it rerr numerous in the winter of $1859-60$, remaining until quite late in the season, and again in the winter of 1S6S-69, remaining until the last week in May. In Western Massachusetts, according to Mr. Allen, it is a regular winter visitant, lut never abundant. It arrives early in October, and may be seen in small flocks from that time to the third week in May. It sometimes frequents the appleorchards, where it feeds on the Aphides. According to Dr. Cones, this species occasionally strays as far to the south as the Carolimas, but it is not common there.

Wilson observed these birds near Philadelphia, where they were leeding on the seeds of the alder. Later in the season they collected in larger flocks and took up their abode among the pine woods. In one particular locality, he states, a flock of two or three hundred of these birds regularly wintered, for many years in succession, where noble avenues of pines furnished them with abundant food throughout the season. Early in Mareh they all disappeared. While there, they were so tame as to allow a person to appronch within a few yards. They fluttered among the branches, frequently hanging from the cones, at the same time uttering notes elosely resembling those of the Goldfinch. 
In severe winters Mr. Andubun his nee with llue Pine [inch as far south

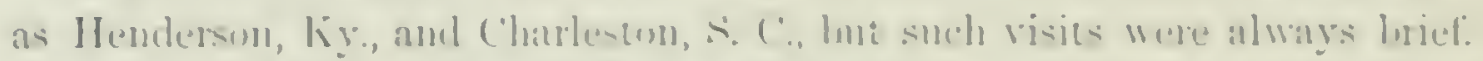

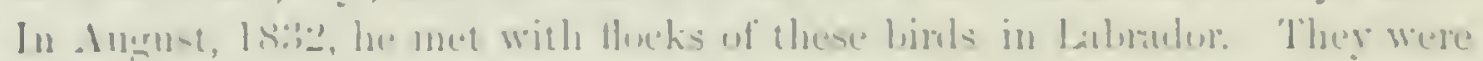

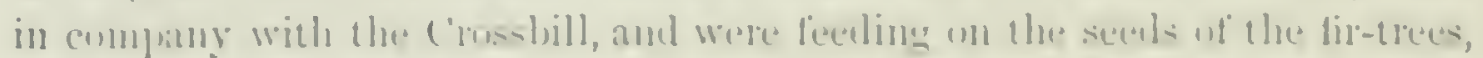

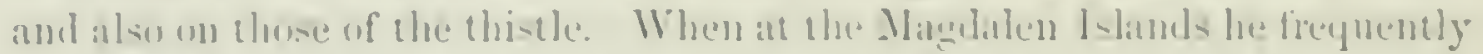

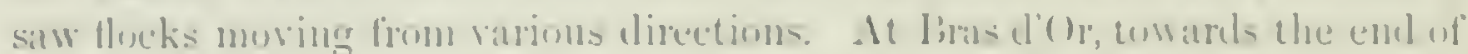
July, they were in aleat mumbers, and the old hinds were atcomplanied hy

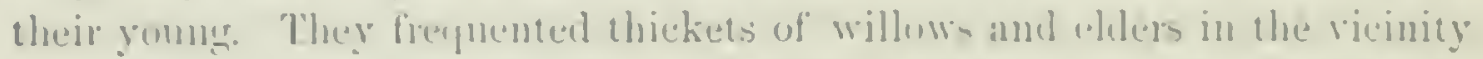

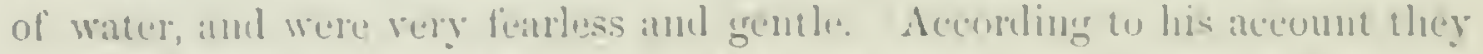
sing while on the wing, and their nutes are sweet, varied, clear, and mellow, and, while sonnewhat resembling the soms of the $C$. tristis, are perfectly distinct from it. Its llight is exnetly simiar, both gliding through the air in graceful and deepl corres.

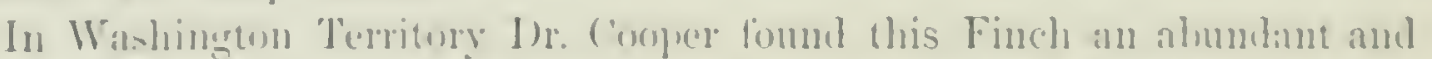
constant resilent, migrating (1) the roat in winter, where it lieels an the seeds

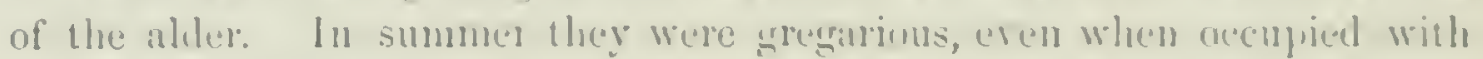
their mels and young. Ile has never met with any in Califinnia, not eren

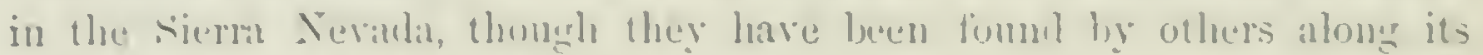

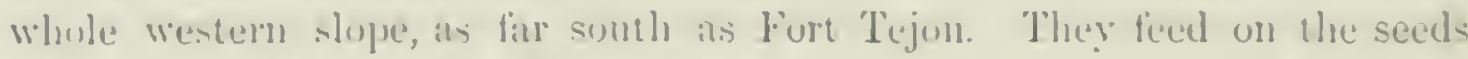
of both emonifomens and decidumes trees.

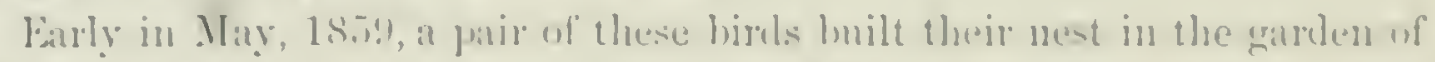
Profiesol Penjamin Peirere, in ('ambridive, Mass, neall the collenes. It was

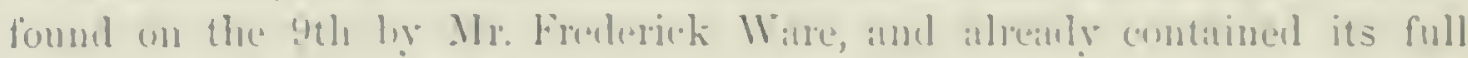

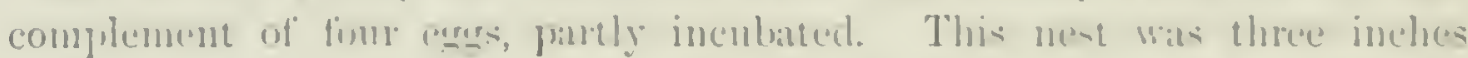
in leciplat and four in dianeter. The elepth of the eavity, als well at its diancher at the rim, was two inches. The have of this mone was a mas

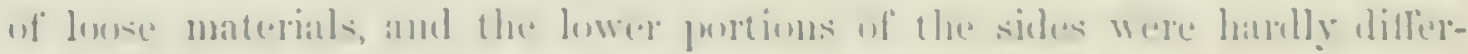

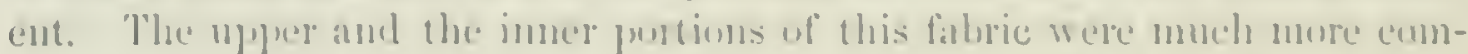

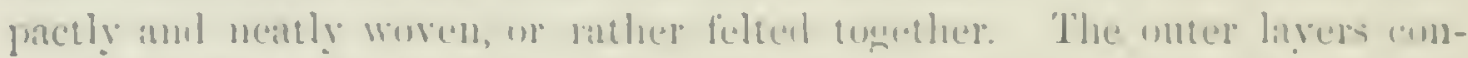

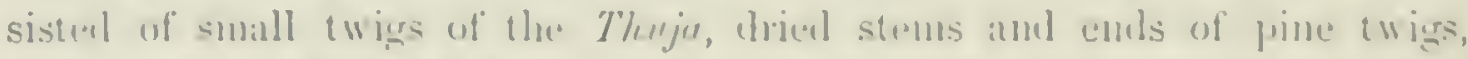

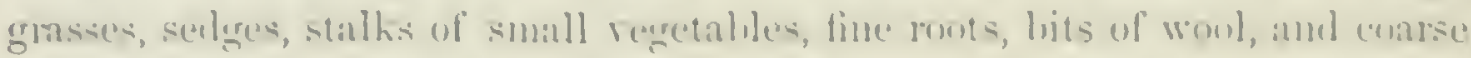

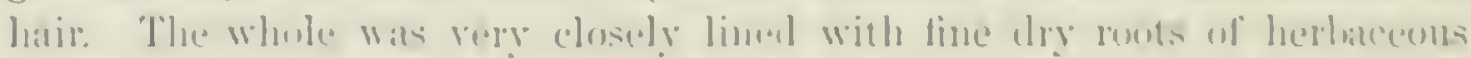
plants amb the latir of smatl quatulrumels.

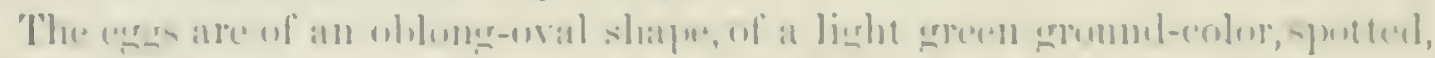

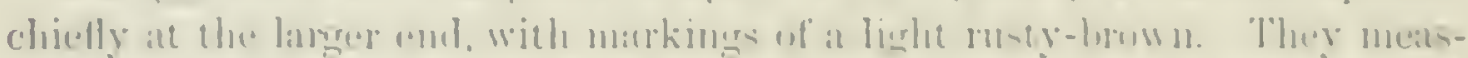

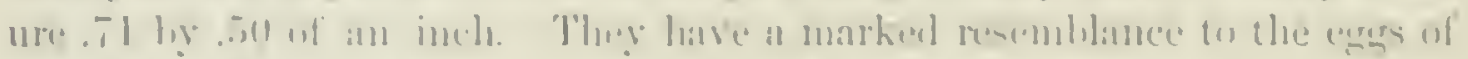

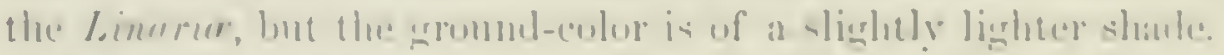

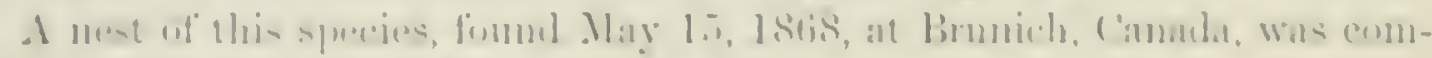

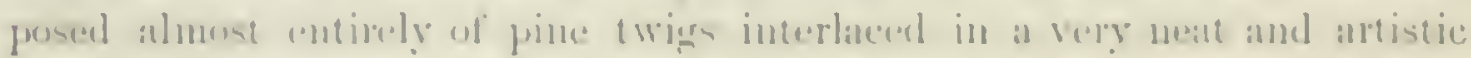

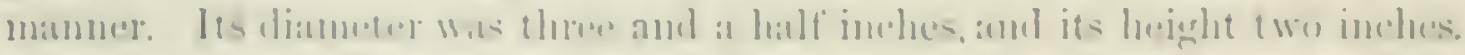

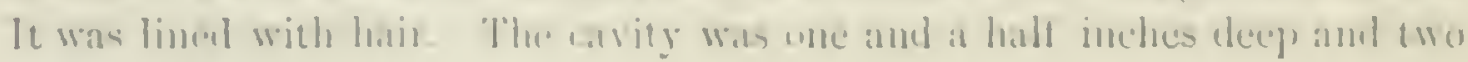
inclees wivle. 


\section{Geves LOXIA, Linxwes.}

Loxia, Lixsaus, Syst. Nat. ed. 10, 75s. ('Type, Loxia curvirostra, L.)

Curirostra, "Scounul, 1777." (Type, L. curvirostru.)

Gex. Cinar. Mandibles much elongated, compressed and attenuated; greatly curved or fulcate, the points crossing or orerlapping to a greater or less degree. Tarsi very short; elaws all very long; the lateral extending beyond the millule of the eentral; hind claw longer than its digit. Wings very long and pointed, renching beyoud the middle of the narrow, forked tail.

Colors redlish in the male.

The elongated, compressed, falcate-curved, and overlap-

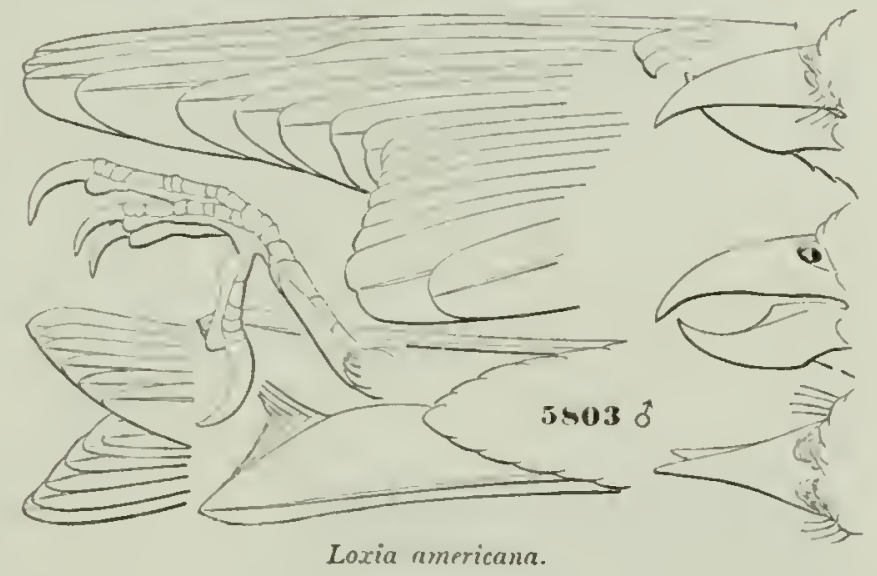
ping mandibles readily characterize this genus amoug birds. This feature, however, only belongs to grown specimens, the young haring a straight bill, as in other Finches.

The United States species of Locice are readily distinguished by the presence of white bands on the wing in leucopterce and their absence in americana. Neither form, however, is to be considered as specifically distinct from their European allies. The differences are as follows :-

\section{Species and Varieties.}

L. curvirostra. Wings dusky, without white bauds.

1. Bill from forehead, .74; wing, 3.90 ; tail, 2.40. Lower mandible much

weaker than the upper. Hab. Europe . . . . var. curvirostra.'

2. Bill from forehead, .80 or more; wing, 4.00 ; tail, 2.50. Lower mandible as strong as the upper. Hab. Rocky Mountains of United States, and mountainous regions of Mexico

var. mexicana.

3. Bill from forehead, 60 or less; wing, 3.30 ; tail, 2.20. Hab. Nortl

Ameriea generally

var. a mericana.

L. Ieucoptera. Wings deep black, with two brond white bands.

1. Body and head pomegranate-red; hlack of scapulars nearly meeting across lower back. Ilab. Nurthern North America; "Himalayas"; "Japan". . . . . . . var, lencopteri. 2. Body, etc., cinnabar-red; back nearly wholly red. Hab. Europe.

$$
\text { var. bifasciata.? }
$$

1 Loxia curvirostra, LinN., Syst. Nat. 299.

2 Loxia bifasciutu, Dn Shiss-Tosigchamps, Faune Belge, 76. Bonar. \& Schlegel, Mon. des Loxiens, 7 . 
Loxia curvirostra rar: americana, Piım, RED CROSSBILL.

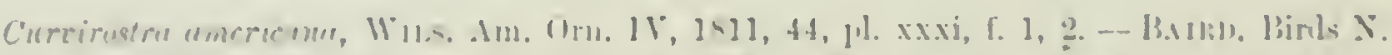

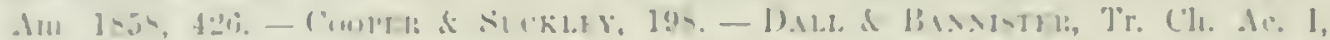

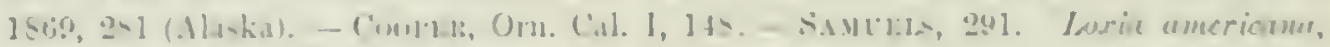

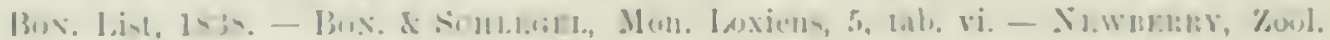

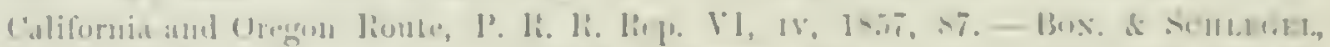

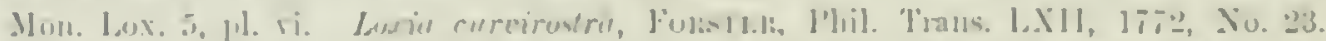

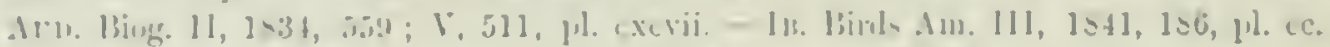

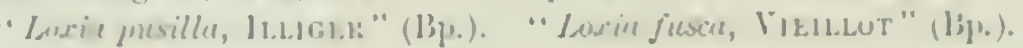

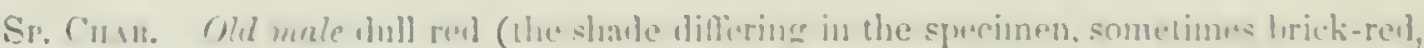
sometines vermiliun, etc.); dartes across the back; wings and tail bark llacki-h-

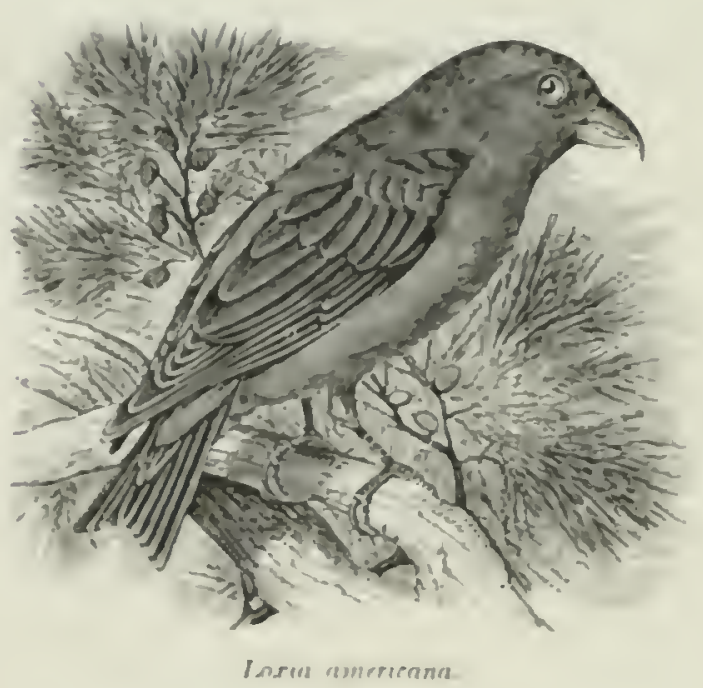
lorown. Fonum male vellowish. Fimule

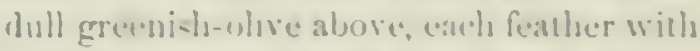
a dusky rentre: rump and arown briglit

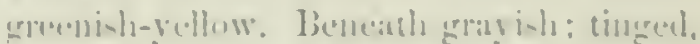
aprodilly on the sides of the berly, with

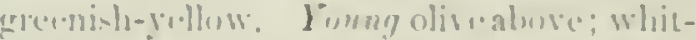

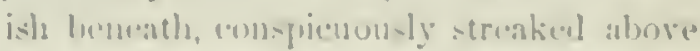

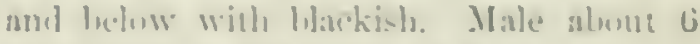
inches; wing, :3.311; lail, 2.2.

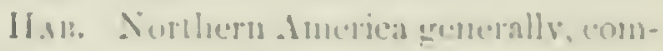

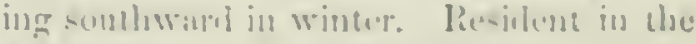
Alleghany and livety . Mountain:

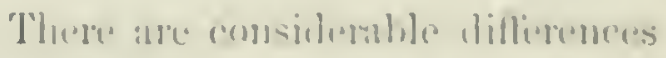
both in colon and sim, mpecially of hill, in sperimmens fom vimions parts

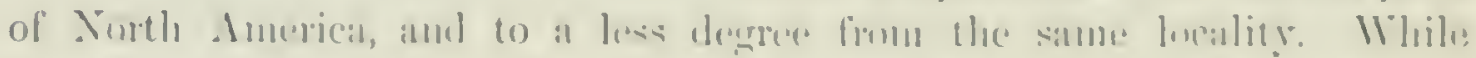

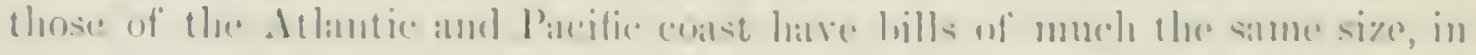

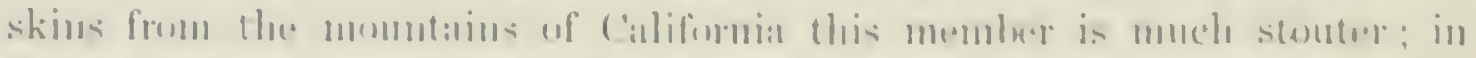

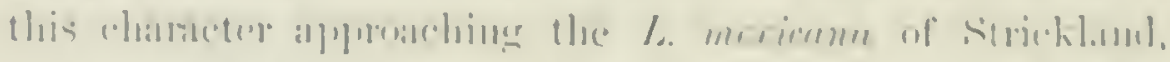

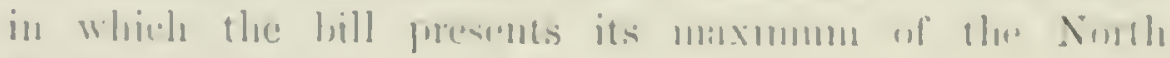
Imirvintal lintus.

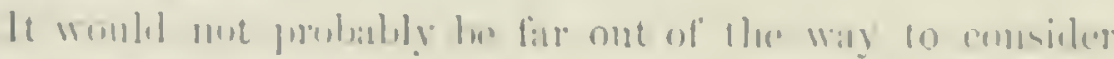

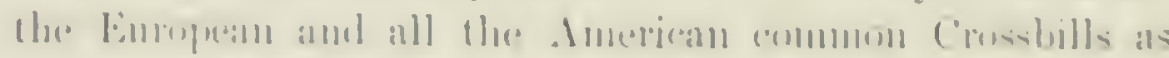

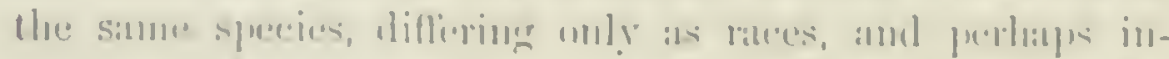

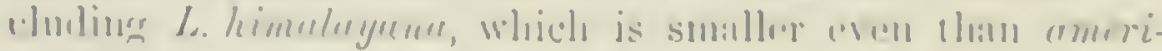
culm.

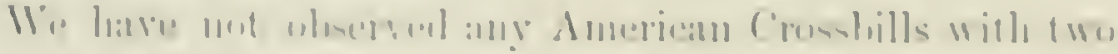

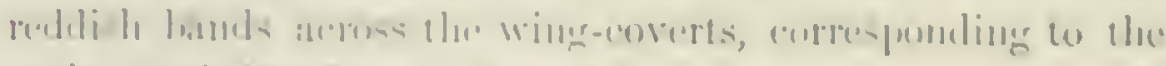

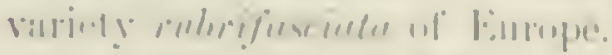

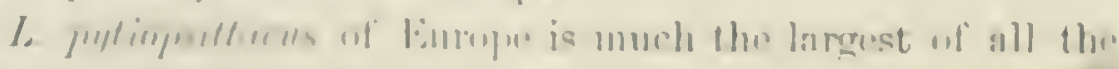

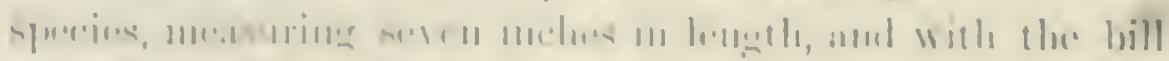

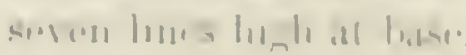

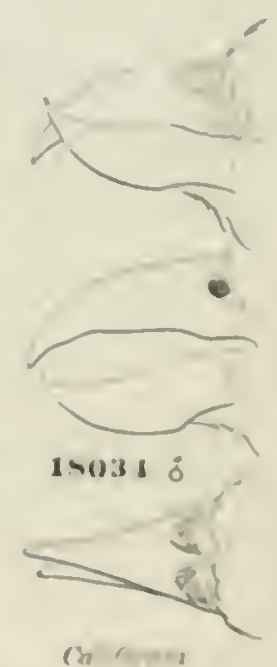


In the intensity, as well as the shate of the red in the males; there is a great range of ramiation. Genemally it is of a tint almost precisely like that of $L$. currirostra, though deeper. The most lighly colored specimen is it,795, Philadelphia (J. H. McIlvine), which is entirely continuous deep tile-red, approaching vermilion on the rump. The abdomen and crissum are light pinkish. In No. 31,459 , Fort liae, April, the reel is of a curiuus and regr unsual purplish wine-red shade.

The average of western specimens, particularly those from the northwest coast of the United States, have bills scarcely larger than in the arerage of eastern examples; thus, 1S,037. Fort Crook, $\mathbf{N}$. Cal., has the bill of the same size as No. 5, S03, Philadelphia, while No. 5̋3,48.2, East Humboldt Mountains, has the bill smaller than any other in the collection.

In color, there are scarcely any tangible differences between the European Loxia curvirostra and the two American varieties, the distinctive character being in the form of the bill and the size; the $C$. merima is the langest of the three, and the bill is quite peculiar in form, the lower mandible almost equalling the upper in length, and exceeding it in thickness. L. curricustia is slightly smaller, and lias the lower mandible mueh smaller and less powerful than the upper, being inferior to it both in length, breadth, and thickness. The colors also appear to be rather less intense than in C'. mevicuna.

The $C$. americana is in every way, the bill especially, smaller than either of the preceding. The lower mandible, although but slightly shorter than the upper, is still much weaker, as in the European bird. The majority of western birds have the bill but slightly larere than eastern, and most of those with large bills are only intermediate between americance and maxicanc. In some specinens the bill, although almost equalling in length that of the latter, has yet the form of the former; on the other hand, there are specimens with the proportions of the mandibles as in mericana, while the size is intermediate.

The following formes will illustrate the differences in the size of the bills of the different races.

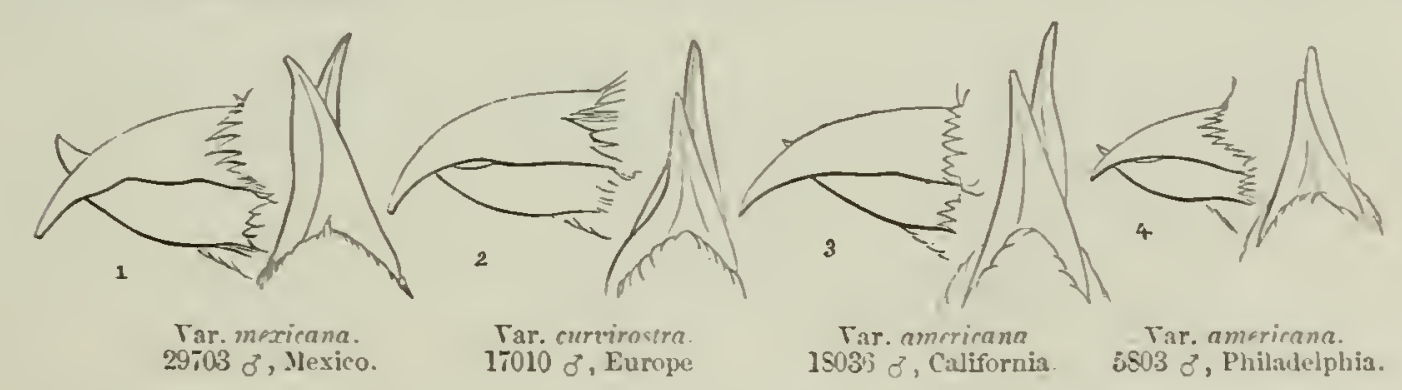

Specimens from the Columbia River region and northwest coast of the United States appear to have the red more rosaceous and the bill more slender than the typical style. One specimen (No. 31,459. Fort Rae) is altogether a very peculiar one: the shade of red is different from that of any other specimen, beinw a dark maroon-carmine, with a clenr ash suffusion on the back. There are two distinct dusky stripes on the cheek, one orer the 


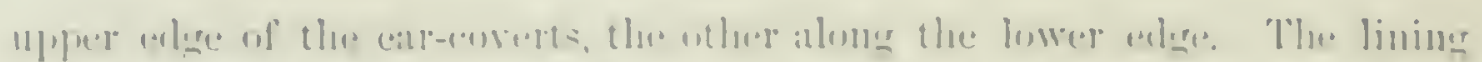

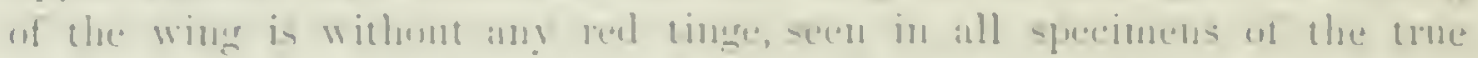

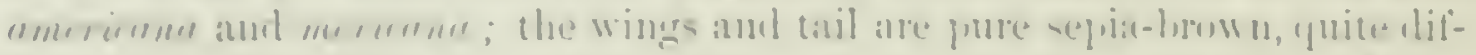

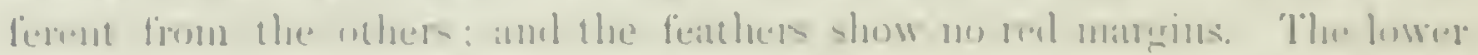

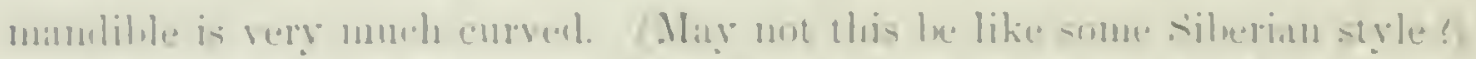

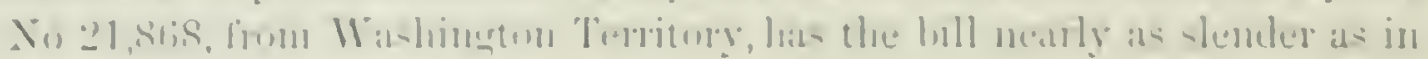

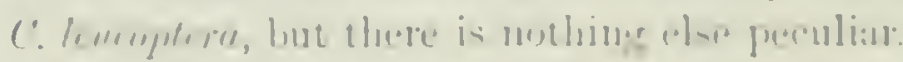

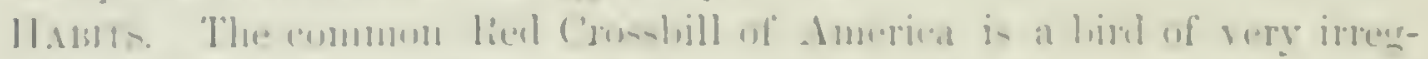

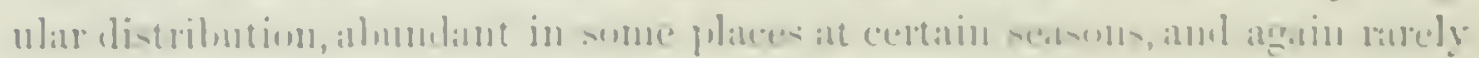

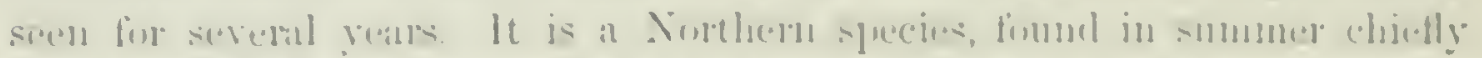

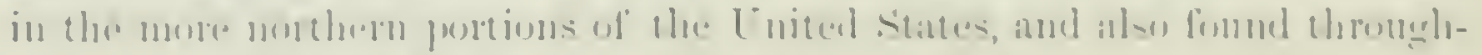

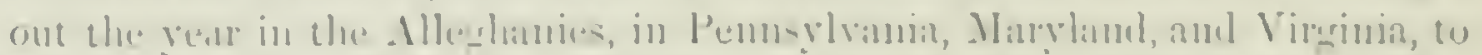

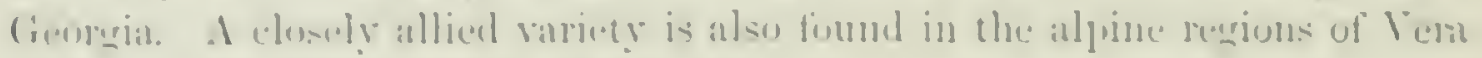

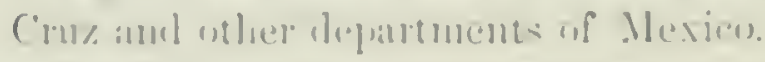

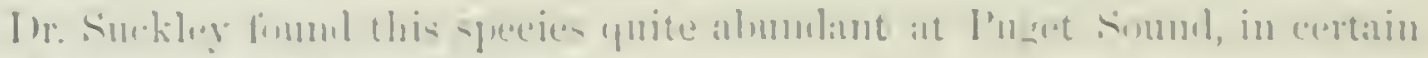

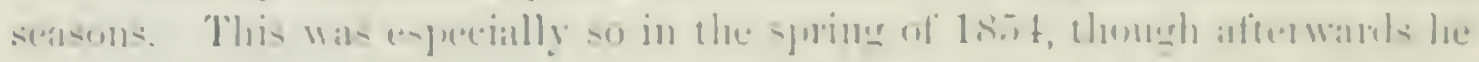

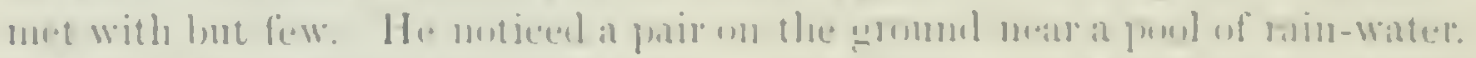

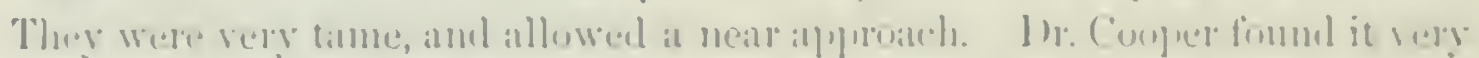

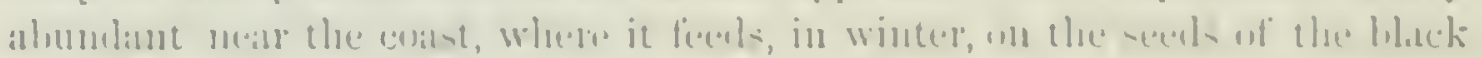

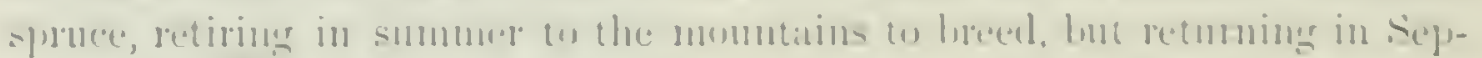

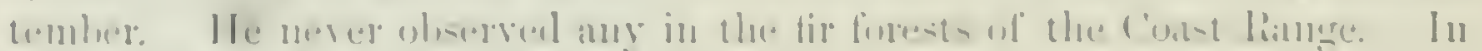

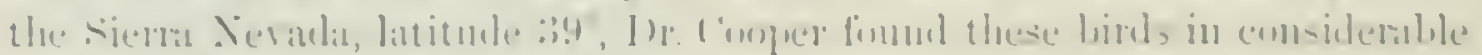

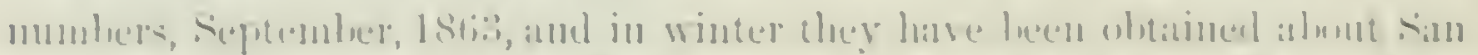

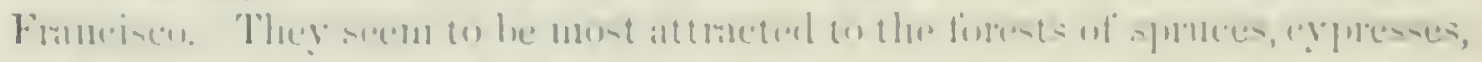

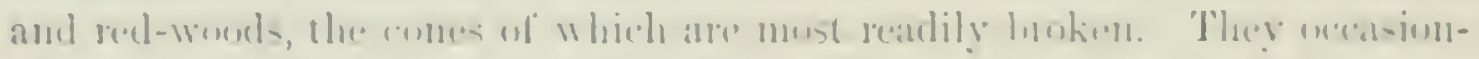

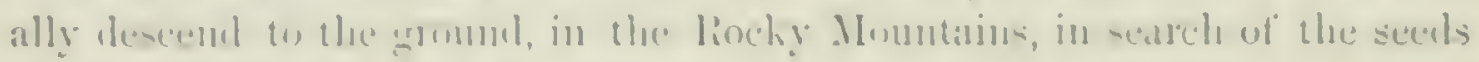
of" sumall plants, amel aloo fim watter.

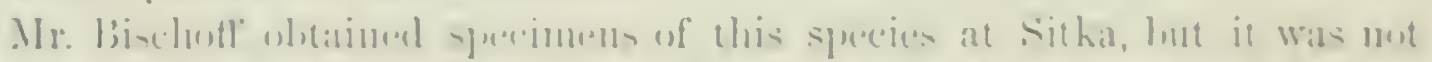

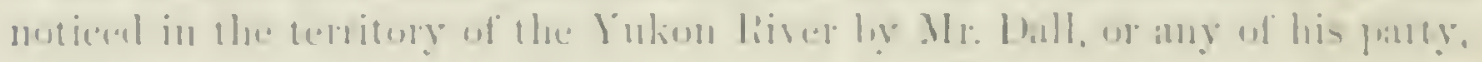

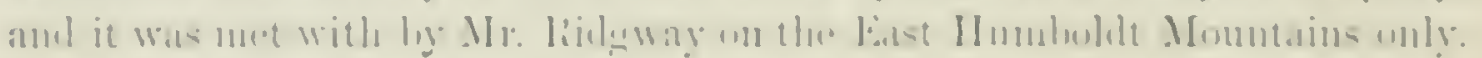

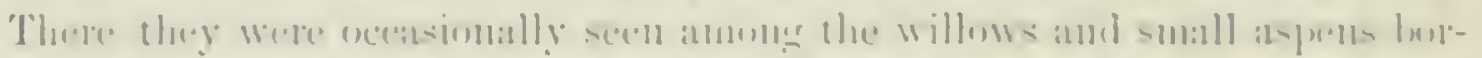

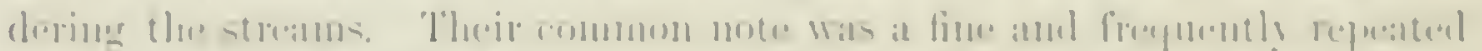

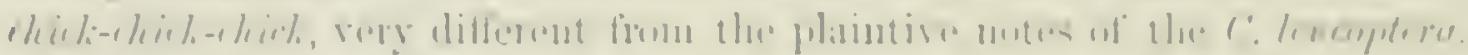

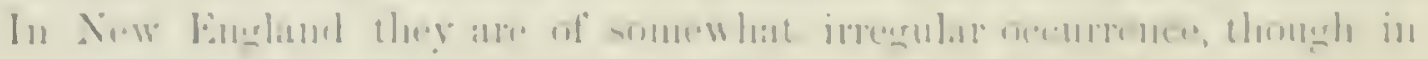

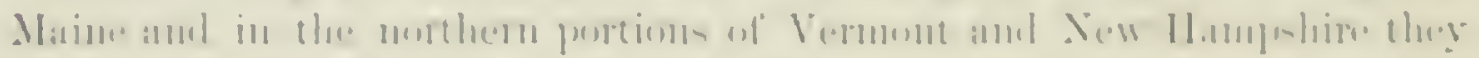

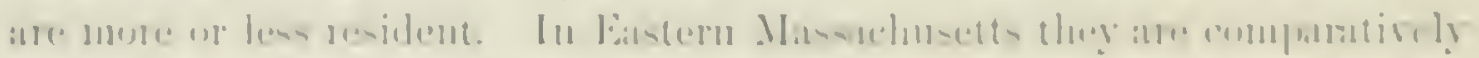

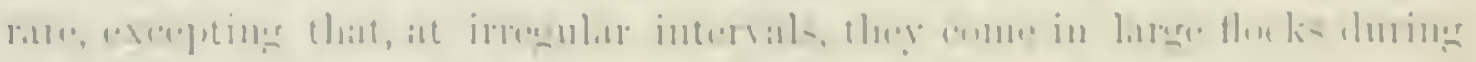

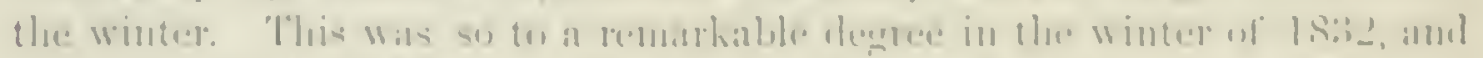

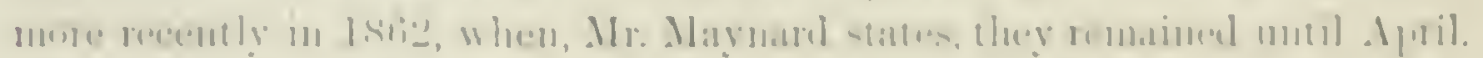

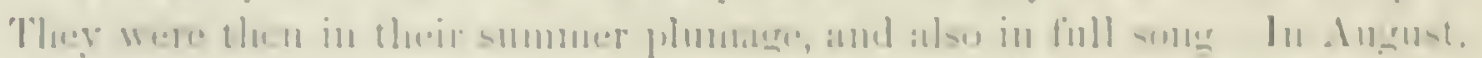

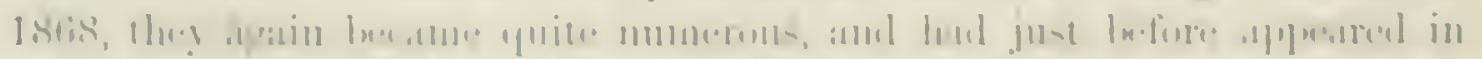

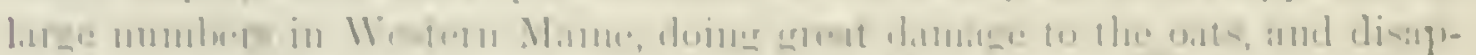
for rime. 14 -

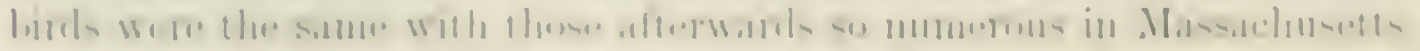


The same peculiarities of irregular aplearance lave been observed by Mr. Allen, in Springfield, where it is often a rery abundant risitor, but generally not so common. In the winter of $1559-60$ the pine woods in the vicinity of that eity abounded with them, and in February they were already in full song. They are at all times gregarions, and are sometimes seen in large flocks.

They have, as they fly, a loul, peculiar, and not mmusical cry. This caltnote they do not utter when at rest or when feeding. Their song in the spring and summer is varied and pleasing, hut is not powerful, or in any respect remarkable. This song is especially noticeable in caged birds, who soon become very tanc, and feed readily from the hand, eren when taken at an adult age. Their mannes in continement are very like thuse of the Parrots, clinging to the top of the wires with their claws, lianging with their heads downard, and, when feeding, holding their food in one claw. On the trees, their habits and manner are also said to be similar to those of I'arrots.

Mr. Audubon has found these birds, in Augnst, in the pine woods of Pennsylvania, and inferred that they breed there. This does not necessarily follow. They breed so early at the north as to give ample time for their migrations, even in midsumner, to remote places. Professor Bain, howcrer, informs me that during a summer spent in the monntains of Schuylkill County, Penn., in the coal regrion, he saw them nearly erely day, moving about or feeding, in pairs.

The Crossbills are extremely gentle and social, are easily approached, caught in traps, and even knocked down with sticlis. Their food is chicfly the seeds of the Conifcre', and also those of plants. Anduhon's statenent that they destroy apples merely to secure the seeds is harlly accurate. They are extraragantly fond of this fruit, and prefer the flesh to its seeds. Their flight is undulating, somewhat in the manner of the Goldfinch, firm, swift, and often protracted. As they fly, they always keep up the utterance of their loud, clear call-notes. They move readily on the gromend, up or down the trumks and limbs of trees, and stand as'readily with their heads downward as upright.

Wilson states that in the interior of Pennsylvania this species appears in large flocks in the winter, and during the prevalence of leep snows they keep about the doors of dwellings, pick off the clay with which these huts are plastered, and are exceedingly tame and not easily driven off.

So far as is known, these Crossbills breed in midwinter, or very early in the spring, when the weather is the most inclement. The nest and eggs of this species were procured by $\mathrm{M}$ r. Charles S. Paine, in East Randolplu, Tt., early in the month of March. The nest was built in an upper branch of an eln, - which, of course, was leafless, - the ground was corered with snow, and the weather severe. The birds were very tame and fearless, refusing to leave their eggs, and had to be several times taken off by the hand. After its nest had been taken, and as Mr. Paine was descending with it in his hand, 


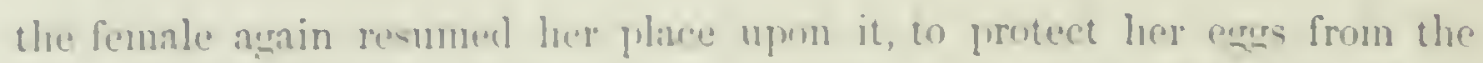

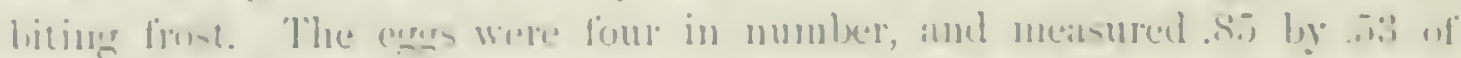

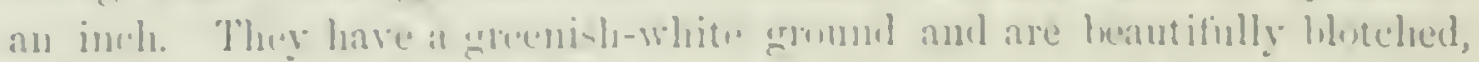
morbled, and doted with ratuns slankes of lilac and pupli-h-brown.

Loxia curvirostra, var. mexicana, Strkkisn.

\section{MEXICAN CROSSBILL.}

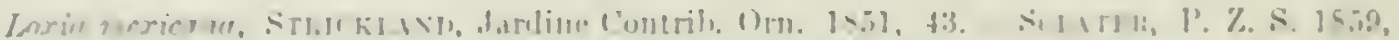

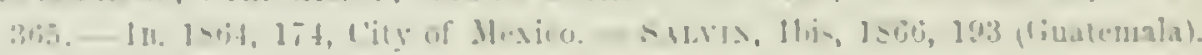

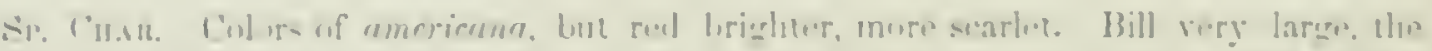

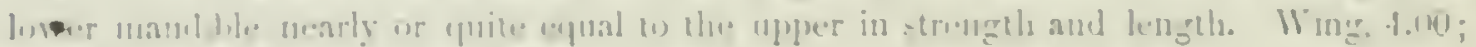
เa1. …

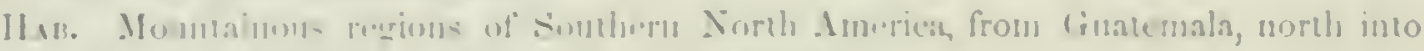

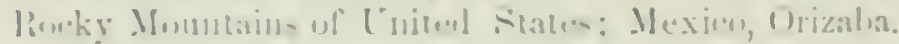

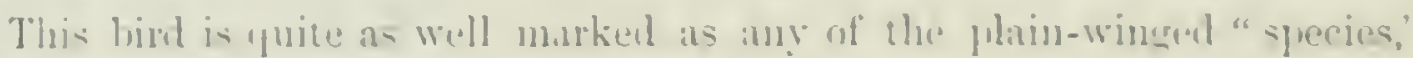

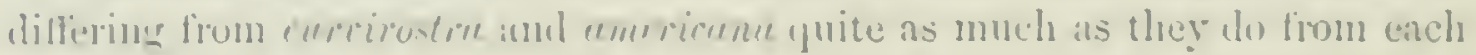
otlle?.

All spreimens from Mexim, as well as from the fentral liocky Mountains

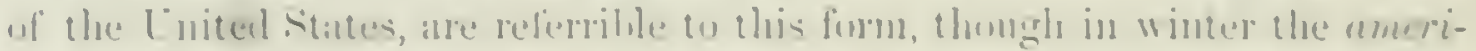

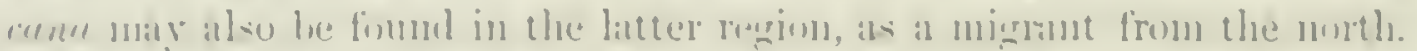

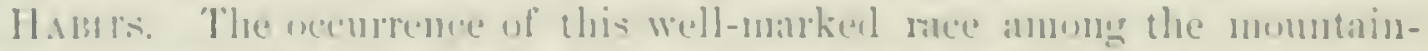
ons distriet of Mexien is a very interesting and sugesestive firet in resarl to the distribution of hirds, demenstratinge, as it denes, the elose connection he-

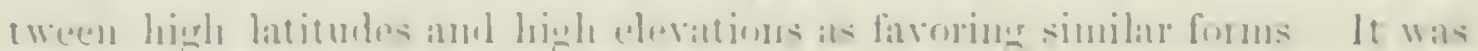

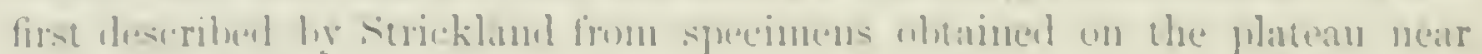
the eity of Mexien. Amother speciness is referred (n) he Mr. Selater als

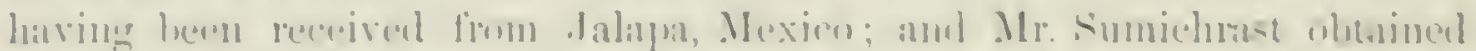

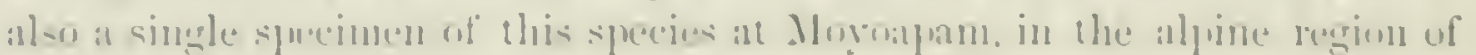

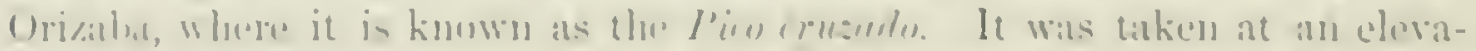

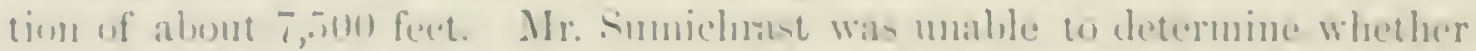

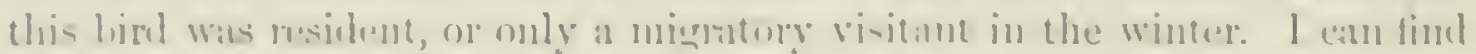

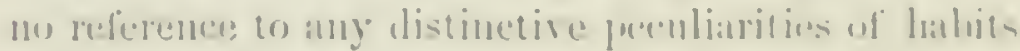

\section{Loxia leucoptera, Gumits}

WHITE.WINGED CROSSBILI.

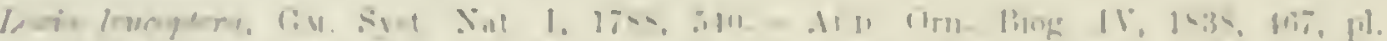

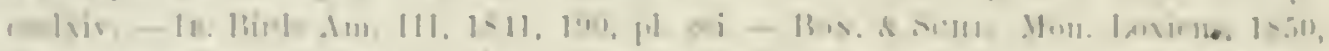

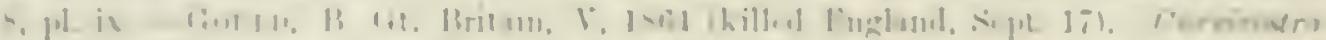

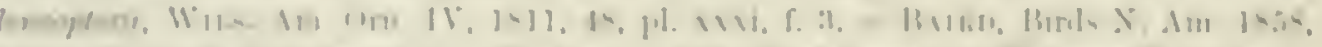

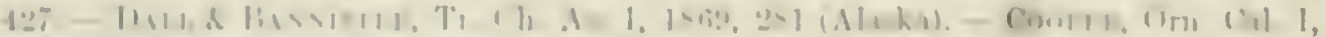
$14: 2$ - s (11) I, f f
} 
Sp. Crar. Bill grently compressed, and acute towalls the point. Male camine red, tinged with dusky across the back: the sides of body under the wings streaked with brown; from the midulle of helly to the tail-corerts whitish, the latter streaked with brown. Seapulars, wings, and tail thack: two hroad bands on the wings across the ends of greater and meelian covert: : white spots on the end of the inner tertiaries. Female brownish, tinged with olive-green in places; feathers of the back and crown with dusky centres; rump bright brownish-rellow. Lengeth aloou 6.25 ; wing. 3.50; tail, 2.60 .

H.ı. Northern parts of North America ceenerally; Greenland (Rewsi. Ibis, III, 1 \&61. S); England, (Eeptember 17, Guctu, Birds Great Britaiu).

The white bands on the wings distinguish this species from the preceding, althongh there are some other differences in form of bill, feet, wing, etc. There is less rariation in form and color among specimens than in the preceding. It diflers from the European analogue, L. bifusciuta, according to authors, in the more slender horly and bill, and in having the body pomegranate-red, with blackish batk, insteal of cimabar-red, as in curvirostra and umericann. Bonaparte and schlegrel quote the American species as occurring in the Himalaya Momntains, and perhaps Japan, but throw doubts on the supposed linropean localities.

Habits. Both the distribution and latbits of this species are probably, in all essential respects, the sime with those of the preceding. It is, if anything, a more northern bird, and it his not been detected anyhere on the Pacific coast south of British Anerica. It was found in the Arctic regrions by Sir John lichardson, where the other species wis not observed. He found it inhabiting the dense white-spruce forests of the fur comntry, feeding principally on the seeds of their cones. Up to the sixty-eighth parallel he found them ranging throngly the whole hrealth of the continent. It is supposed to go as far as these woods extend, thourh it has not been traced farther than the sixty-secund degree. It wis found feeding on the upper branches, clinging to them when wounded, and remaining suspended even after death. In Septemher they collected in small flocks, and flew from tree to tree with a clattering noise. In the leptl of winter they retire from the coast to the thick wooks of the interior.

A few indiriduals of this species are recorded by Professor Reinhardt as having been taken in south Greenland.

In Pemsylrania this species is much more rare than the amcricana, and Wilson only met with a few specimens. Since his day it las been found more abundantly, occasionally in the neighhorhood of Philadelphia.

Mr. Dall states that these birds were not uncommon near Nulato in the winter. Sereml specimens were obtained in February and April. None were found there in the summer. He speaks of their great expertness in opening the spruce cones with their curved bills, and extracting the seeds.

Its appenrance in Eastern Massachusetts is much more irregular both as to mmbers and time than that of the other species. In the fall and winter of 1868 and 1869 they were uneommonly abundant, appearing early in the fall, and remaining until quite late in the spring. Ther were eren more fearless 
and tame than the ameramen, and in one instance a pair were taken ly the hamd, and afterwark kejt in continement. They alpeatred around Boston in lawe Hocks, and remained thromgh . April. One wats shut in Newton by Mr.

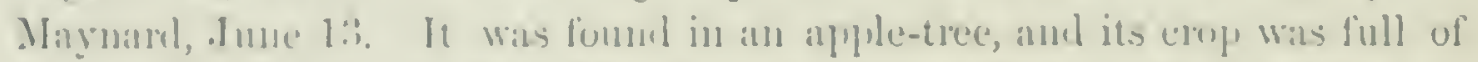
ranker-werms. In Eastern Maine it is resident throughout the year, and, like the uther species, hreeds in winter. In Westem Matine l'rutesson Verrill has finnd it at common winter visitant, but it is not known to be resident.

Near Sumingtield Mr. Allen considered this sprecies a much less freruent rivitor than the precerling. In the winters of 18.54 ind 1860 he found them very alumblan, occurring in larre flocks.

Mr. Andubon, on his way to Iabratur in 189.?, foumd these birels quite comman, in May, anomg the islands of the bay of Fundy, evidently migrating, on their way to more northern regions. 1, howerer, observed none there during my visits in the summers of 18.01 and 18.1 , although a specinen was afterwards ubtained on the Munre Istamk, on the :3ith of . June.

Su far as they are known, the habits of this species are exactly similar to those of the preceding. They feed in the same manner and upon like food. Their flight is moluliting and well sustained, and their movements in the trees are not perceptibly diflerent.

In the spring of 1869, Mr. Jillson, of Huitson, Mars., sent me a pair of these hivels which he hat capturest the precenting antumn. They were very tanne, and were exceedingly interesting little pets. Their movements in the cage were like these of earget parrots in every respect, execept that they were firr more easy and mpid. They rlung to the sides and upper wires of the care with their fect, hung down from them, and secmet to enjoy the

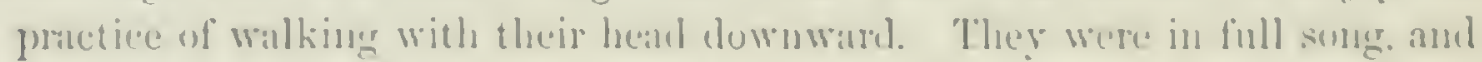

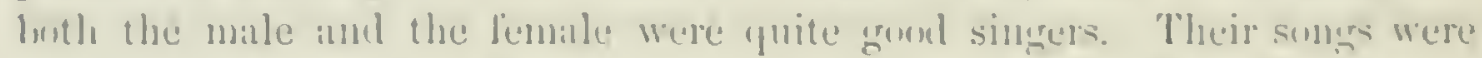

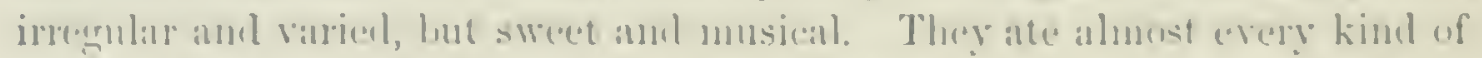
forml, hut were (s) eone was also a great treat to them. Althengh while they lived they were

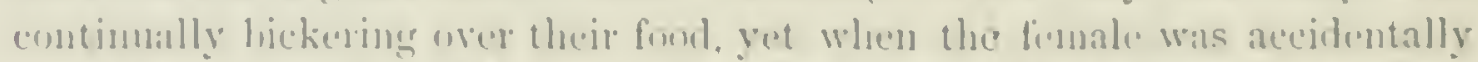

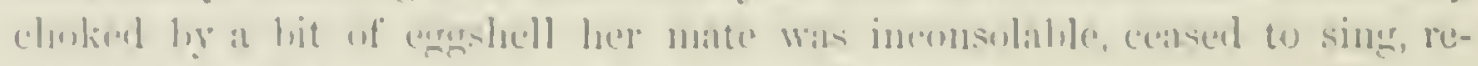
fused his fomel, and diend of grief in a very few dayk

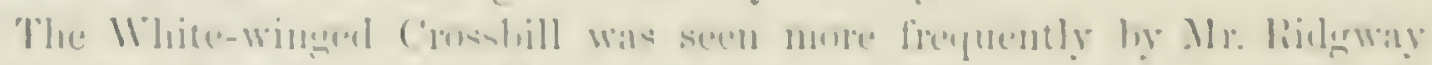

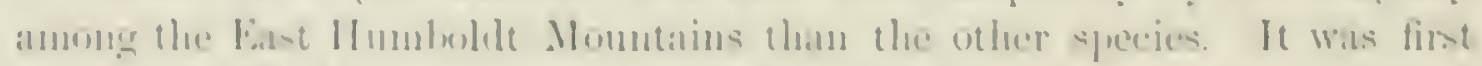

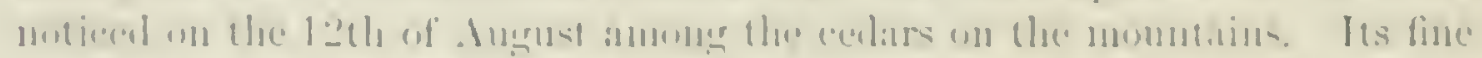

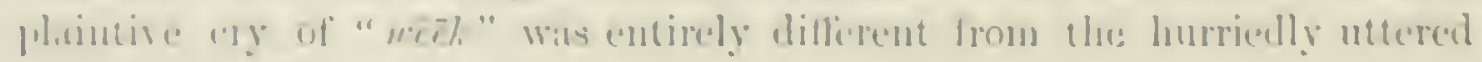

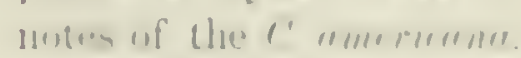

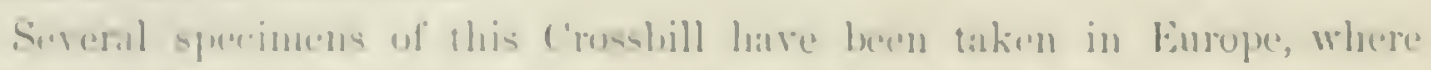

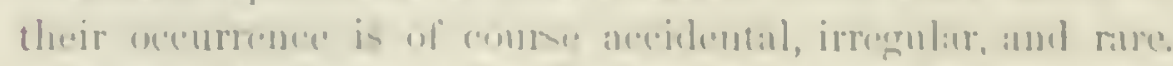

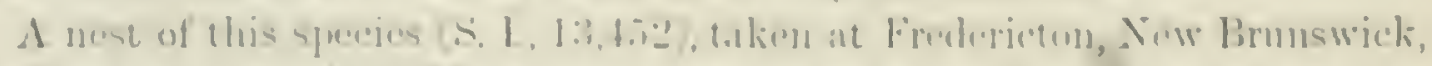

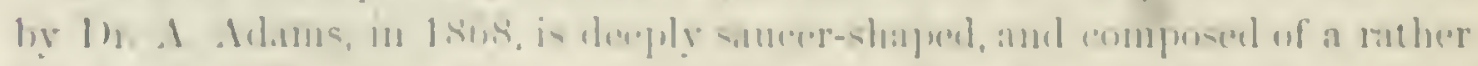

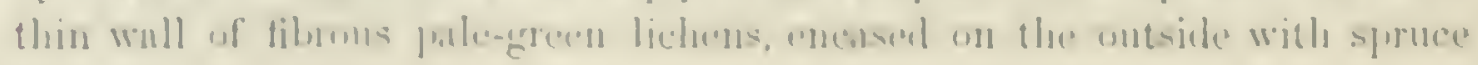


twigs, and thinly lined with coarse hairs and fine shreds of inmer bark. Its external diameter is a little less than four inches, the rim being almost perfectly circular; the carity is an inch and a half deep by two and a half broad.

The one egg is pale blue, the large end rather thickly spattered with fine dots of black and ashy-lilac; is regularly or rather slightly elongate-oral, the small end rather obtuse. It measures . 80 of an inch in length by .56 in breadth.

\section{Gexts \#GIOTHUS, Cabix.}

Acanthis, Boxap. Conspectus, 1850, not of Bechstein, 1802, nor of lieys. \& Blas. 1840. Ágiothus, Cabasis, Mus. Hein. 1S51, 161. (Type, Fringilla linaria, Lisx.) - CorEs, Pr. Acad. Nat. Sf. Pliil. 1S61, 373; 1S63, 40;1S62, 1 S0.

Sp. Cinar. Bill very short, conical, acntely pointed, the ontlines sometimes concare; the commissure straight; the base of the upper mandible and the nostrils conecaled by stiff, appressed bristly featlers; middle of the mandible liaving sereral ridges paralle] with the culmen. Inner lateral toe rather the longer, its claw reaching the middle of the milllle claw; the hind toe rather longer, its claw longer than the digital portion. Wings very long, reaching the millile of the tail; second quill a little longer than the first and third. Tail deeply forked.

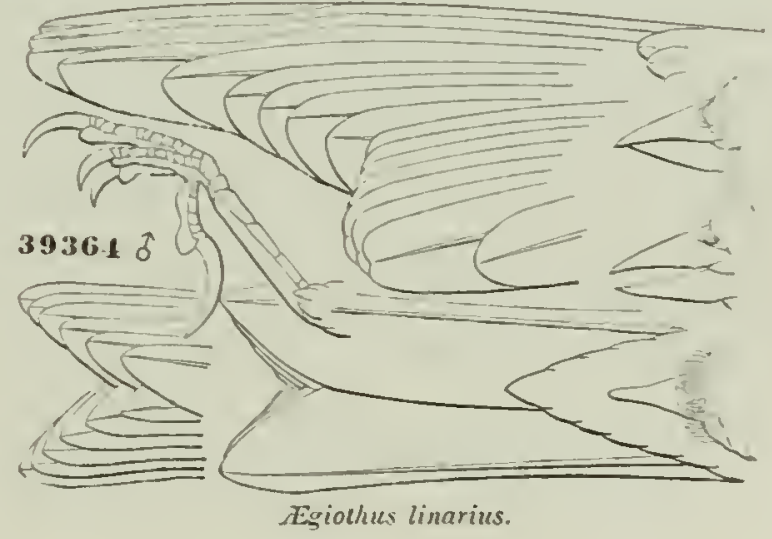

Difficult as it sometimes is to define with precision the characters of closely allied species of birds, there are few genera where this is the case more strikingly than in Egiothus. Leaving out of view the peculiar European species, it has been a mooted question whether North America, including Greenland, possesses one, two, or six species, owing to the strictly boreal

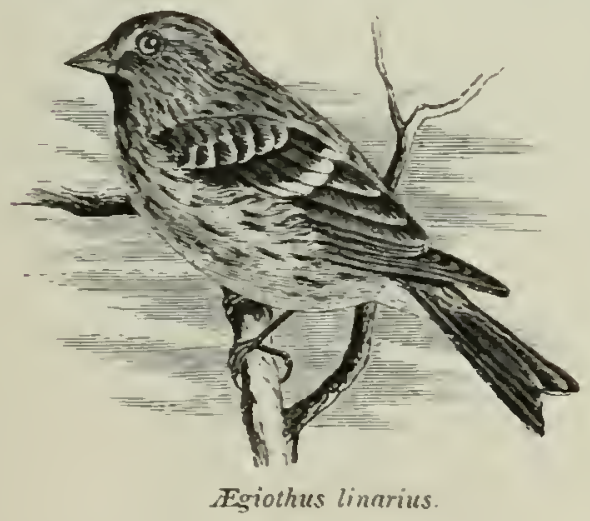
distribution of these birds, and the fact that their summer resorts are seldom invaded by the naturalist. The necessary means of determining the proper distribution of the forms and the rariations with season, locality, and sex, are scarcely to be met with in any public musem, that of the Smithsonian Institution, lowever, being the most complete in this respect.

To Dr. Cones, as quoted above, we owe the most satisfactory indications of the different species and rarieties, his papers in the Proceedings of the Philadelphia Academy of Natural Sciences 


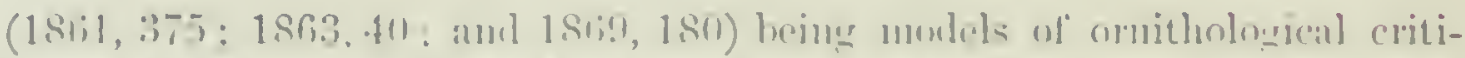

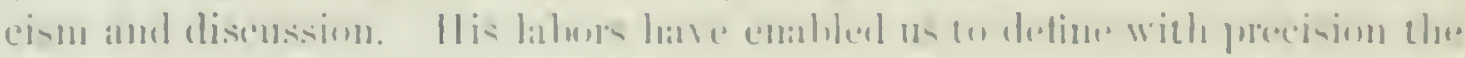

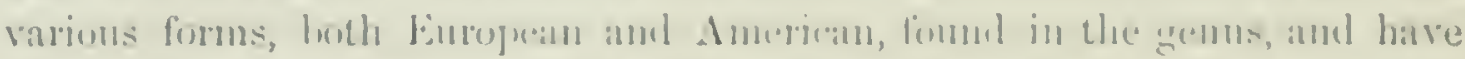

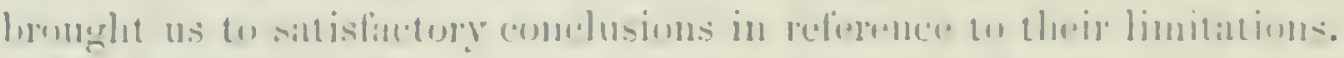

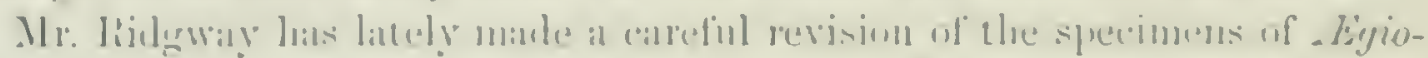

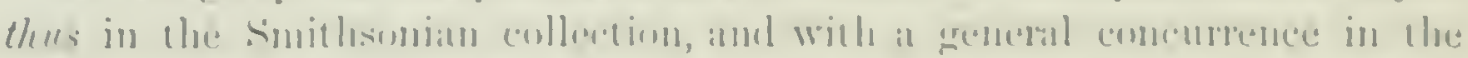

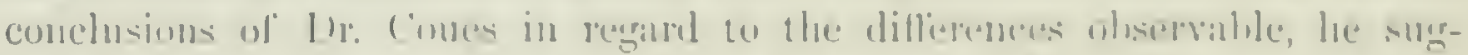

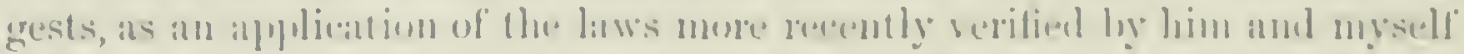

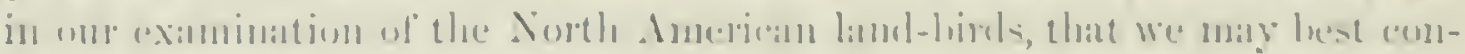

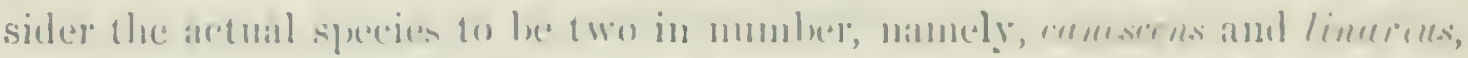

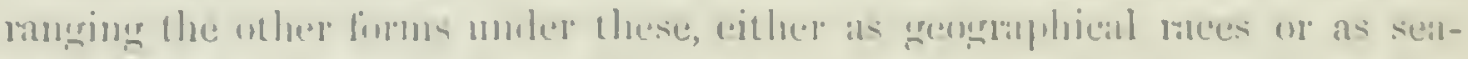

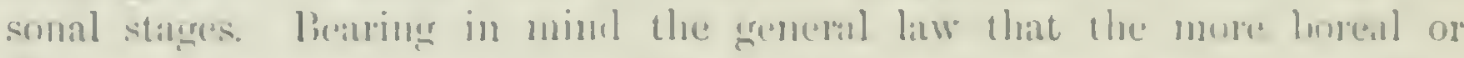

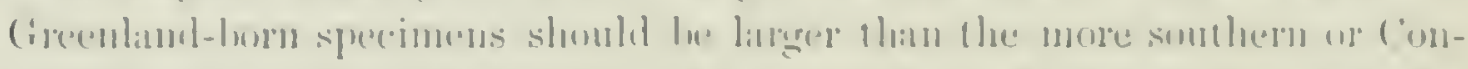

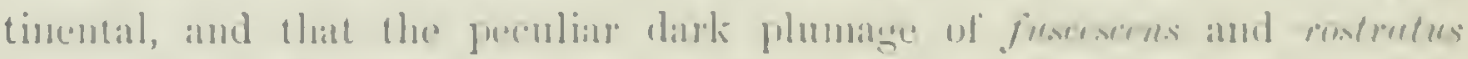

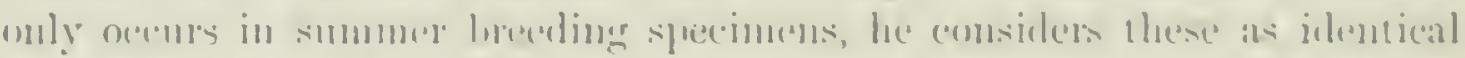

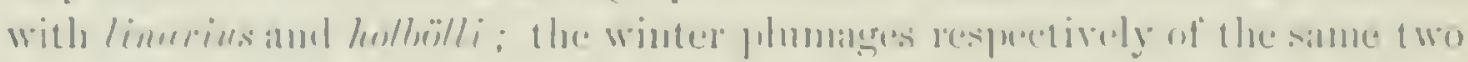

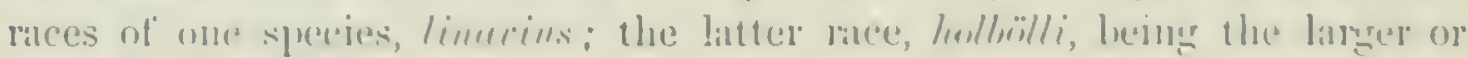

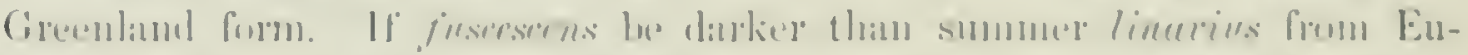

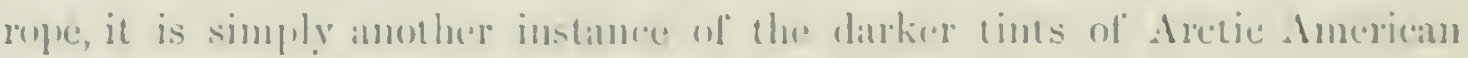

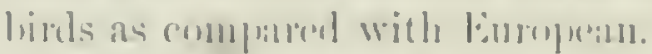

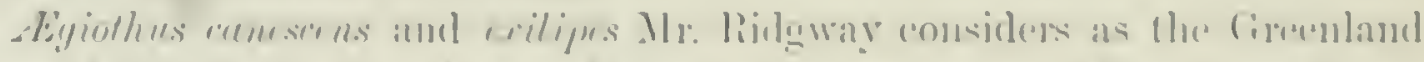

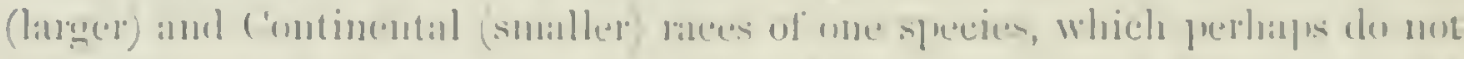

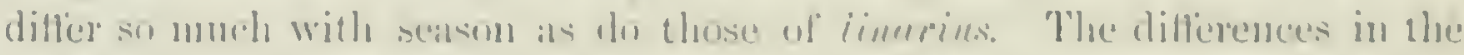

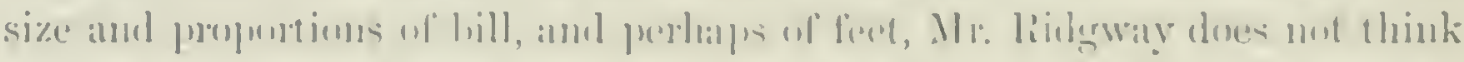

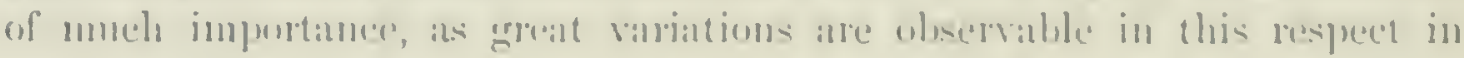

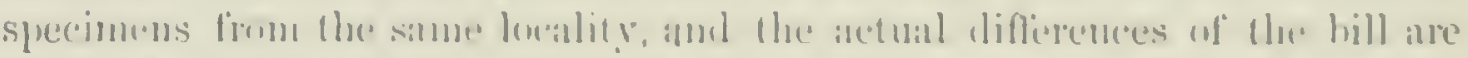

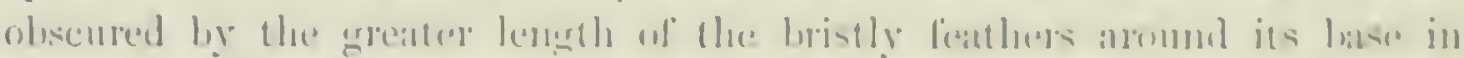

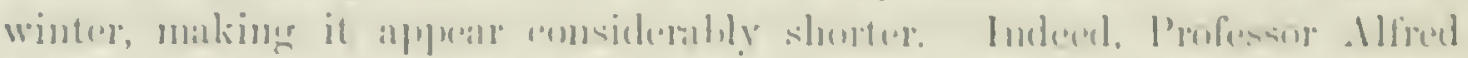

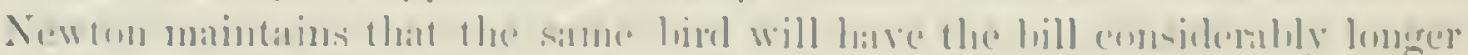

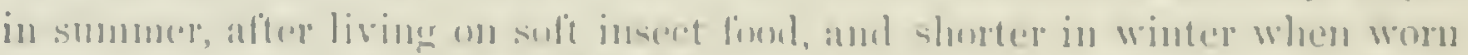

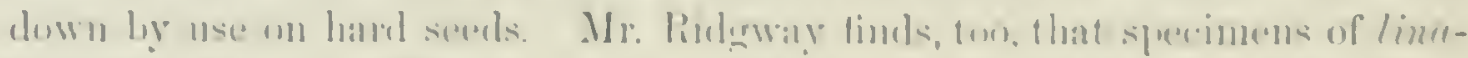

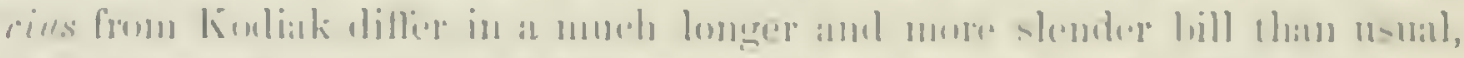

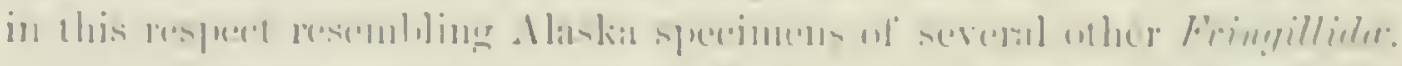

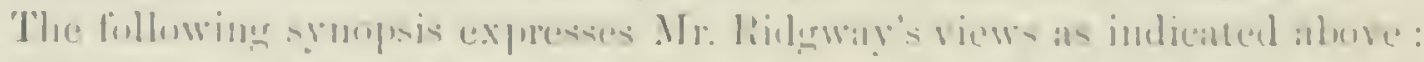

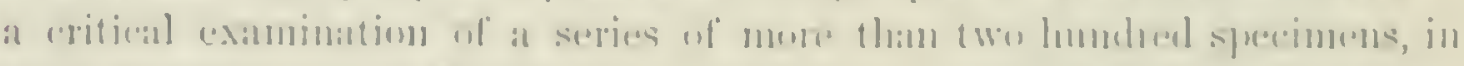

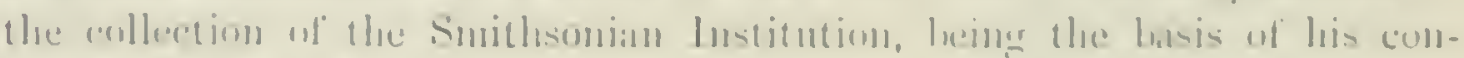

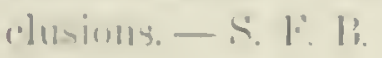

\section{Species nnd Varictics.}

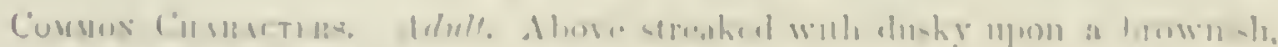

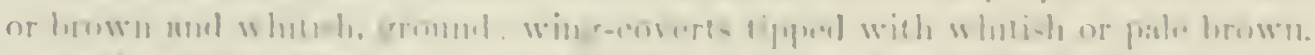

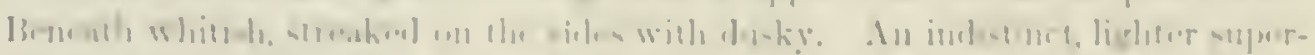

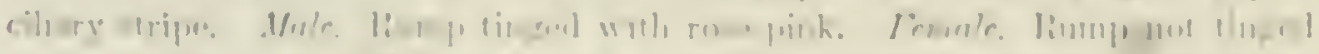

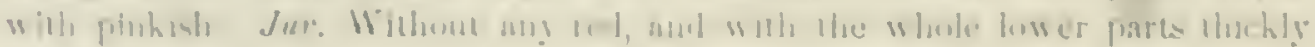
trimhoil. 
A. Crown with a quadrate patch of crimson. in adult; throat and chin with a dusky spot; quills and tail-feathers not edgred conspicuously with white. of with the breast tingerl with red.

1. A. canescens. Rump unstreaked white (both sexes, at all seasons): the lower tail-coverts with white slatts: the red tinge on the breast in the $\delta$, of a delicate pale rosaceous-pink tint.

Bill rery short and thick, its hejght through the base nearly equalling the length of the eulmen. Wing, 3.20 : tail, 2.6.5. Bill: culmen, .35: leight, .30. Hub. Greenland . . var. canescen Bill much smaller, more acute, its height through the base nuch less than the leneth of the culmen. Wing, 3.00; tail, 2.50. Bill: culmen, .30; height, 2.2. Hab. Continental aretic Anteriea

2. A. linarius. Rump always streaked : lower tail-corerts with dusky shati-strealis; the red tinge on the breast of the $\delta$ of a rosaceonscarmine tims.

Bill about .35 in length by .22 in leeight; wing, 2.50: tail, 2.40. IIab. Contineutal aretic and cold temperate North America var. linarius.

Bill about .40, or more. in length, by .30 in height; wing. 3.20 ; tail. 2.60. Hab. Greenlant in summer, antl Continental aretic and cold temperate Sorth America in winter. . . var. holbölli.

B. Crown without any red; throat and chin without any dusky spot : quills and tail-feathers of alult male elged conspicuously with white. \& without red tinge on the breast.

3. A. flavirostris. Rump rose-pink in the $\delta$. hrown streaked with dusky in 9 . No red on crown or breast.

9. Abore umber-browu streaked with dusky: ground-color of rump light brown; throat and jugulum strongly ochraceons-buff. Hab. Europe. . . . . . rar. Alarirostris. ㅇ. Abore olive-brown streaked with dusky; ground-color of rump sulphur-yellow: throat and jugulum faintly silphur-yellow,

tinged with buff. Hab. North America . . var.brewsteri.

\section{Æ̈giothus linarius, CaBasts.}

\section{LESSER RED-POLL.}

Fringitla linaria, Lrsx. Srst. Nat. I, 1766, 322. - Arn. Orn. Biog. IV, 1\$3ৎ, 53\&, pr.

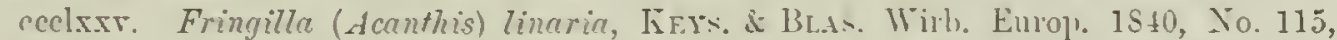
page 161. - Acanthis linariu, Br. Conspectus, 1850, $5 \$ 1$. Elyiothus linarin, Cabasts,

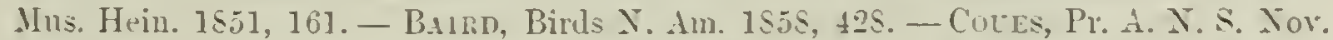

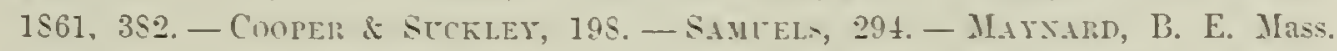
1570, 110. - D.ull \& Busxister, Tr. Chic. Acal. I, 1\$69, 2\$1. - Cooper, On. Cal. I, 159. Linaria minor, Sw. F. Bor. Am. II. 1\$31, 267. - It'D. Syn. 1\$39, 114. - IB. Birds Am. III, 1S41, 122, pl. clxxix. ? Linnrin holbölli, Brens, Vügel DeutschTands. Acrinthis holbölli, Br. \& Schleger, Mon. Loxiens, $1 £ 50$, 50, pl. liii. Egiothus holbölli, Coues, Pr. A. X. \$c. 1\$61, 3\$5. Linaria americann, IIAx. Cab. Journ. V'I,

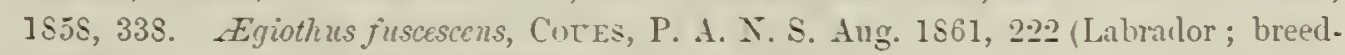
ing dress). - Iв. p. $3 s_{0}$. Egiothus rostratus, ElLiot, Illust. B. Am. I, pl. ix. Cores, P. A. N. S. Nor. 1\$61, 3is (Greenland). - Ell.1ot, Illust. Birds X. A. I, pl. $x$. 


\section{Sigriey and II iser Plunerge}

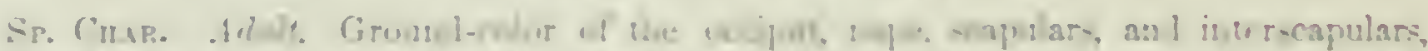

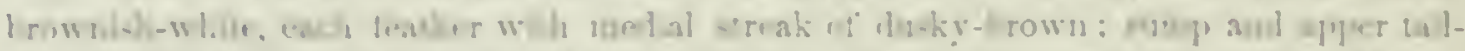

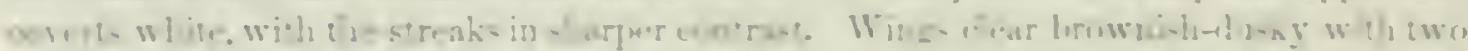

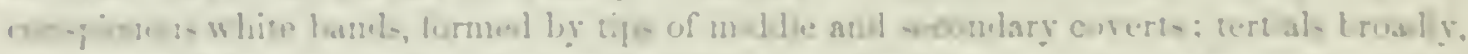

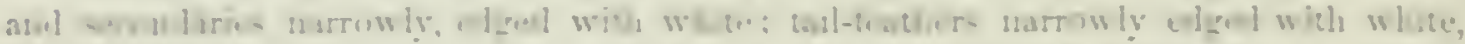

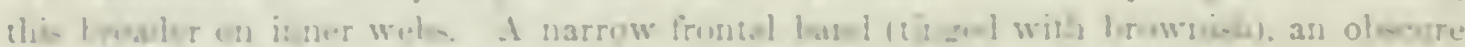

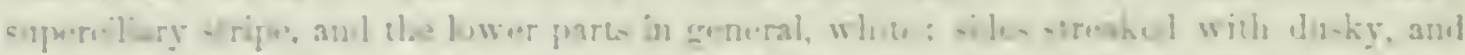

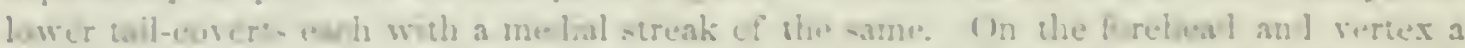

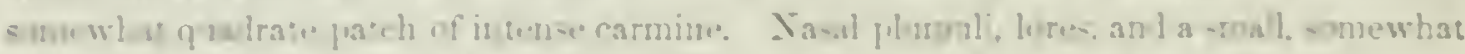

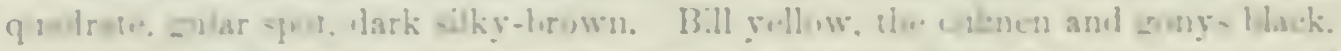

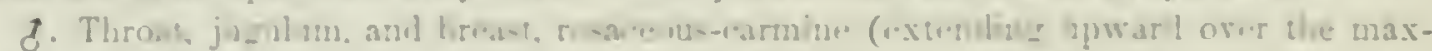

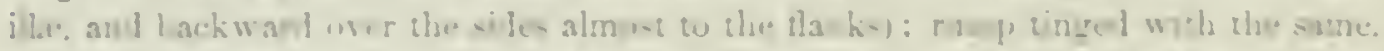

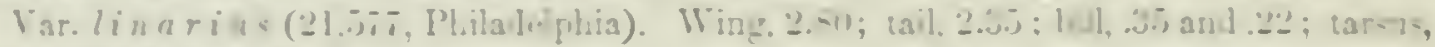

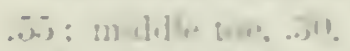

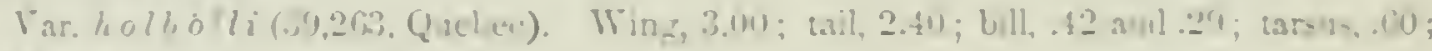

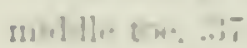

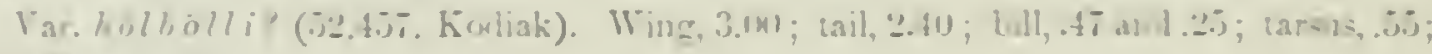

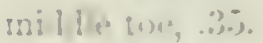

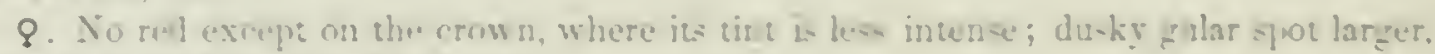

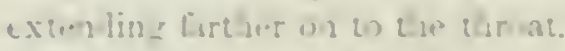

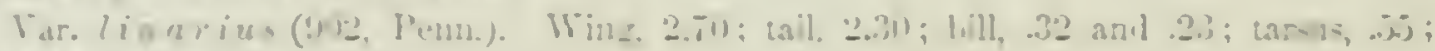

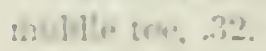

Var. Boll

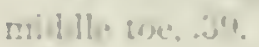

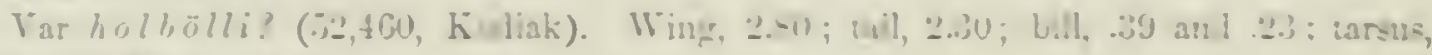

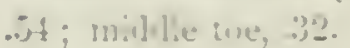

\section{Sunerer or Iireoding Piumane.}

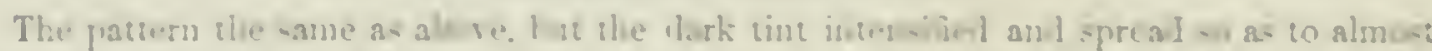

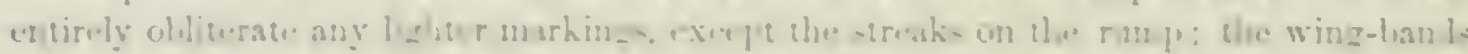

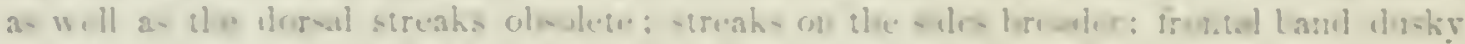

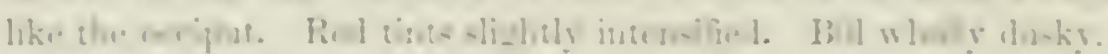

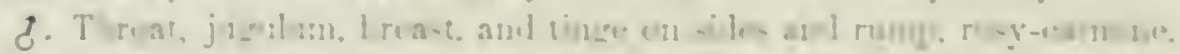

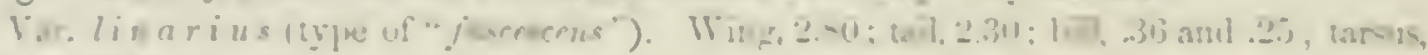

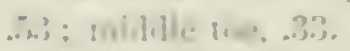

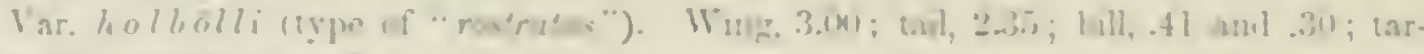

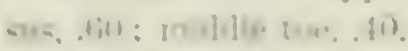

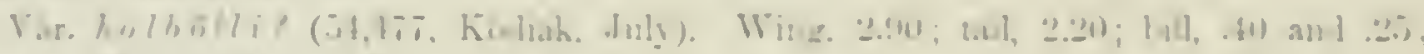

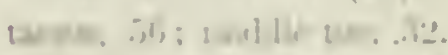

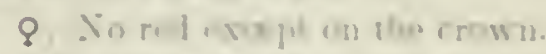

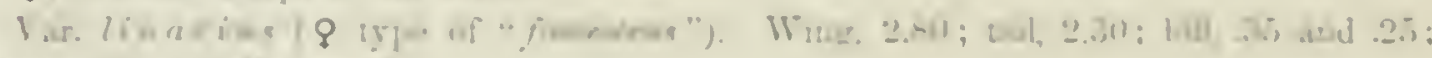

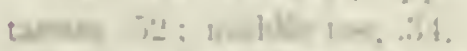

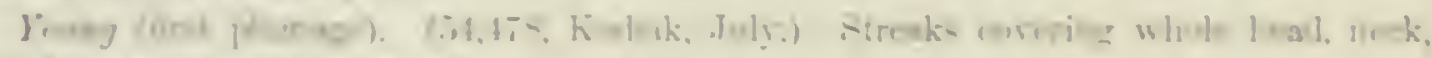

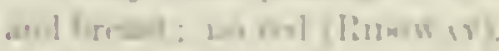

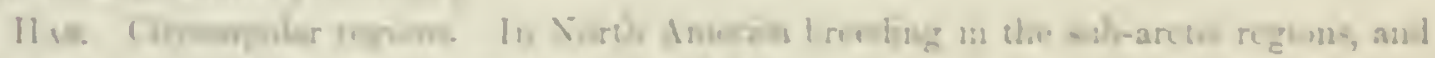

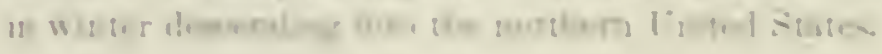

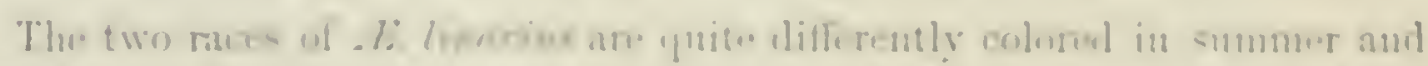
in winter. In the lateer som the plumber is solter aml mose las, and the

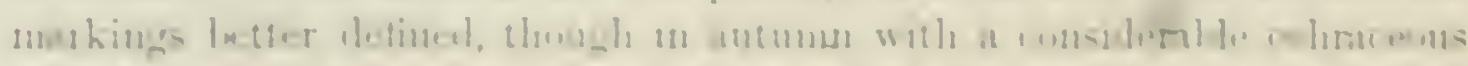

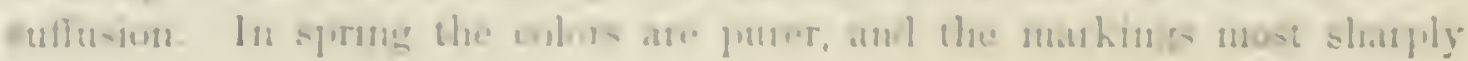


defined; in the breeding-season the plumage assumes a burnt appearance, the dark tints intensify and spread, so that sometimes the upper parts appear almost miformly dusky; the bill appears larger, in eonsequence of the less development of its basal tufts, than in winter. In this dusky summer condition these birls form the AX. fuscescens and AE. rostrutus of Cones, the latter being the summer plumage of var. holböll, the former that of rar. linarins. In the series of orer two hundred examples examined, all miclsummer specimens are in the plumage of fuscescens or rostrutus, while the latter is not seen in any autumnal, winter, or spring birds.

Specimens of the var. holbölli have been received from Quebec, collected by Mr. W. Couper.

HaBiTs. Accepting as variations due either to locality, latitude, or season the differences already referred to in the plumage of this species, it is not necessary to consider the question of races in connection with our story of their labits. We possess but very little information as to their peenliarities as races in these respects. Treating, then, the Lesser lied-Poll, though appearing in four differing phases, as one species, we claim it to be common to the northern portions of both hemispheres.

It is found throughout northern North America from the Atlantic to the Pacific, is abundant in the boreal regions of Europe, and probably of Asia also. On the Pacific coast, I)r. Cooper has obserred it only as far south as Washington Territory. Farther north it is much more abundant. Mr. Bannister found it common at St. Micliaels, both in summer and in winter. At Nulato Mr: Dall found this species rery common in winter, and rery little less so in summer. He states that the nest is usually lined with hair, and covered externally with moss, dry grass, and like materials, built in bushes, near the ground. They begin to build the 15th of May. The eggos are laid abont the 1st of June, and the young are flying near the end of July: The young of the first year are dark, with a snall patch of brown on the breast. After their second year the males increase the amomit of rosecolor on the head and breast, and the very old birds are quite brilliant in the breeding-season. At St. Michaels, where there are no trees and very few bushes, these birds frequently build their nests in the grass.

Mr. Dall states that this bird has no song, but that their eheerful twittering and ehirping, their fearless and sociahle ways, their bright plumage and elegant nests, are quite enough to make them general favorites.

Richardson found this neat and hardy little bird one of the few permanent residents of the fur countries, where it was seen, in the coldest weather, on the banks of lakes and rivers, hopping among the reeds or clinging to their stalks.

$\mathrm{Mr}$. Lord found this species a rare bird in British Columbia. It was found in swampy places, where the alders grew thickly, and where there were large water-plants. To these it clings, pecking at their seed-pods, or, senching the remaining flowers, feeds upon any insects they may contain. Their song he describes as a soft and pretty warble, coming in bursts, the singer perching 


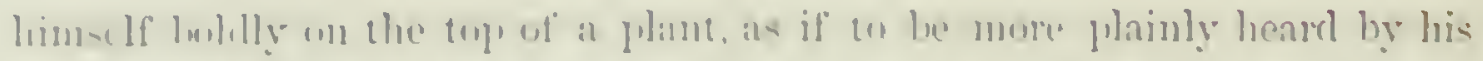

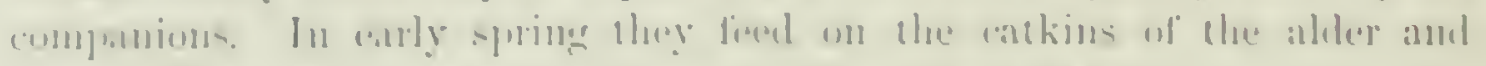

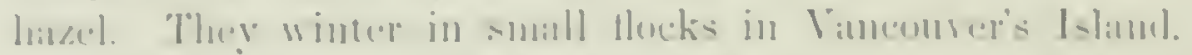

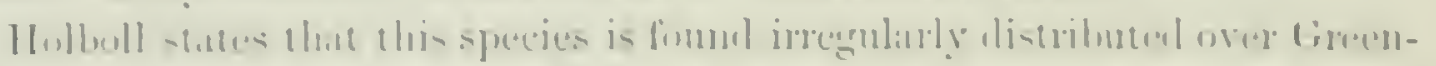

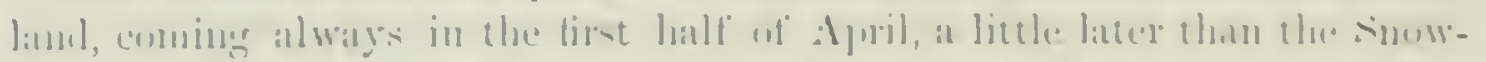

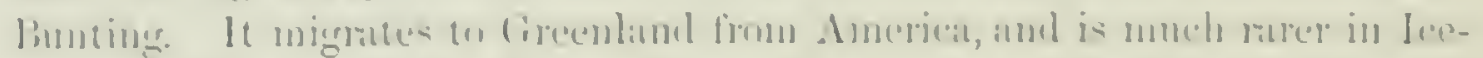

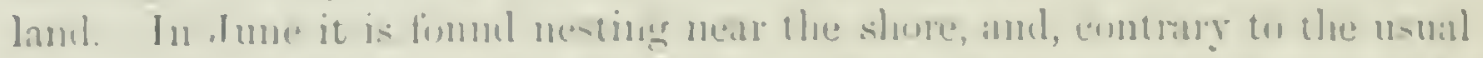

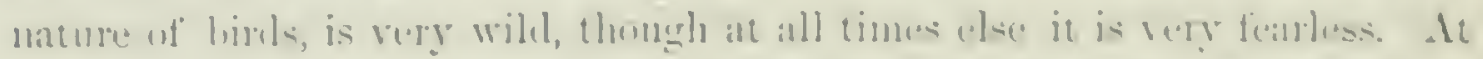

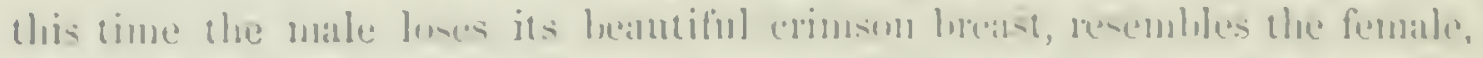

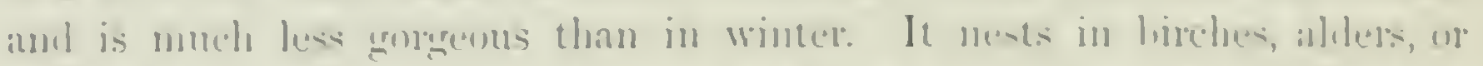

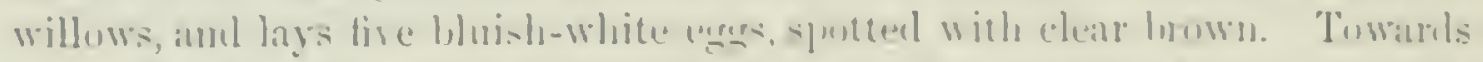

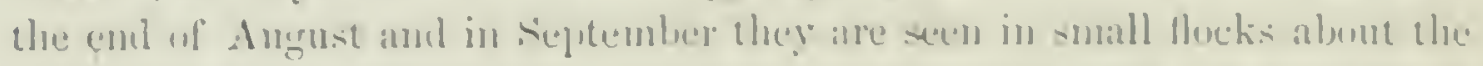

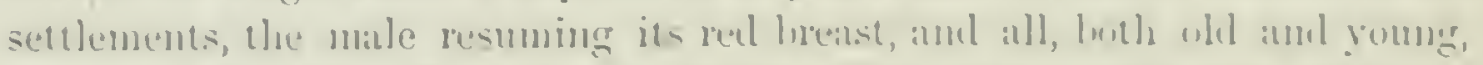
beine very learlens. In continement they som treme very tame, and in a few dars would pereh upon his hamb and strungste with eatch other for the

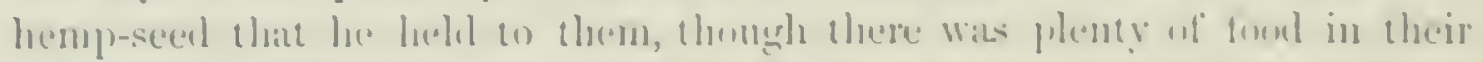

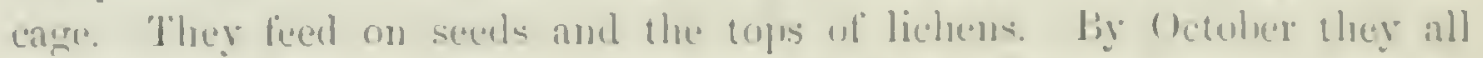
disippear, and are not seen in (irentand in the winter.

IVilson stitles that, in his day, these birls we very common in Sorth-

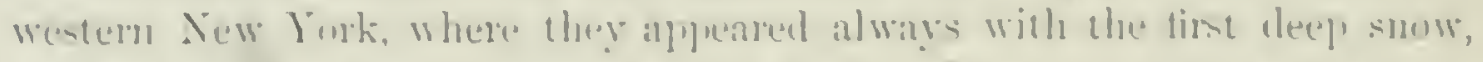

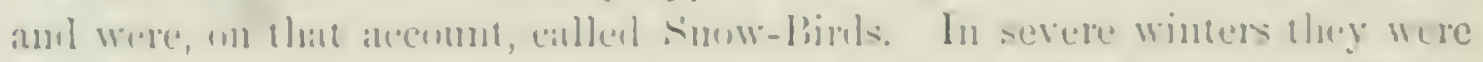

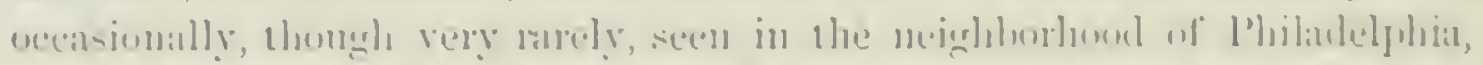

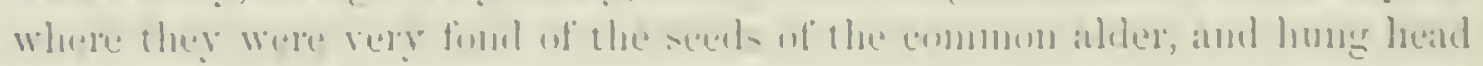
downwats while feeding. in the manner of our lindlinch. Ther were very

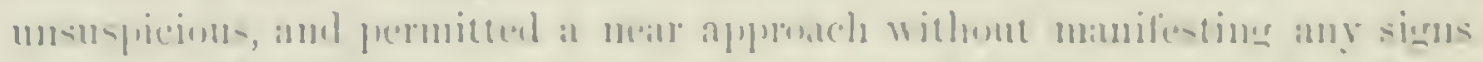

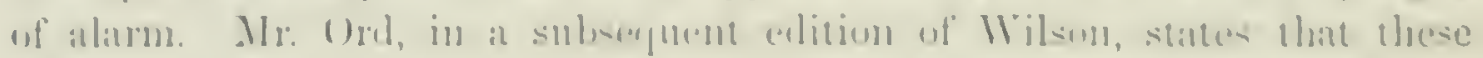

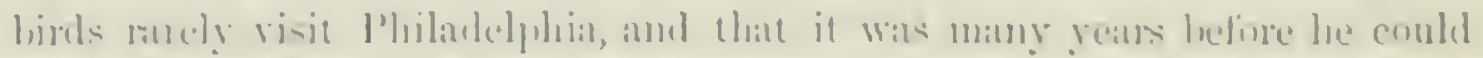

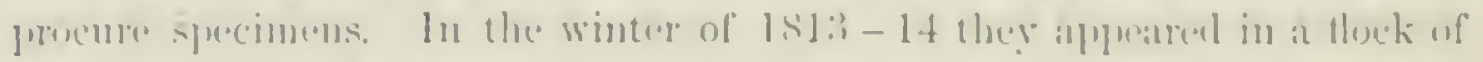

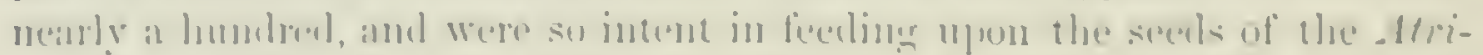

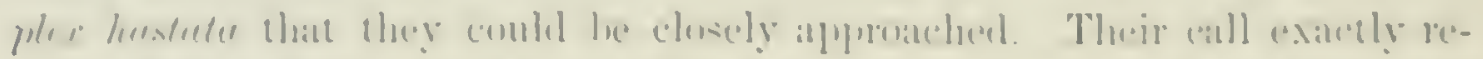

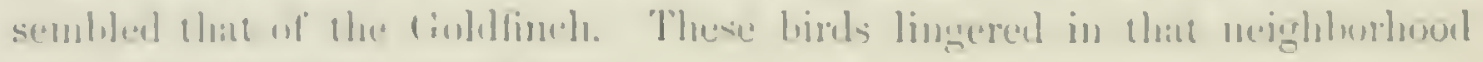
until alnut the mishle of $A_{1}$,ril.

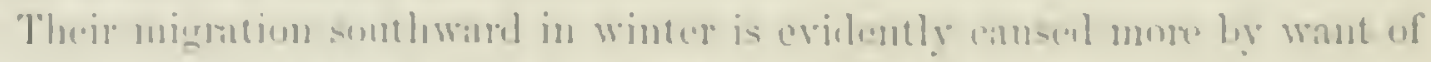

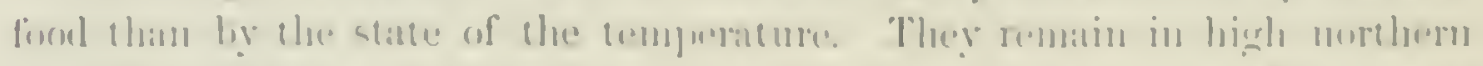

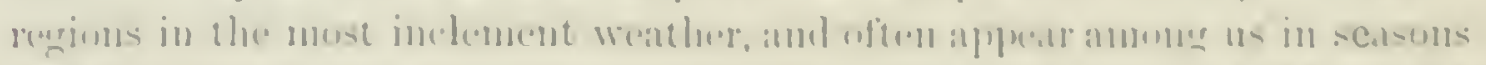

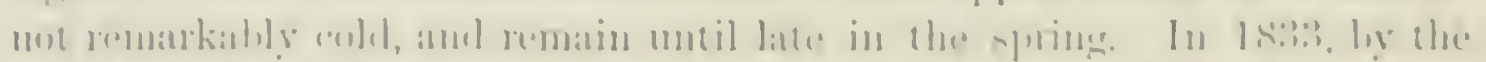

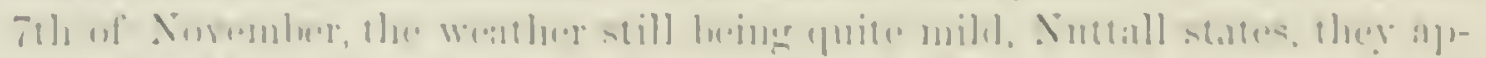

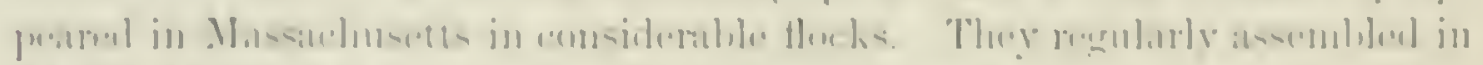

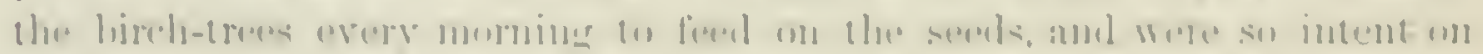

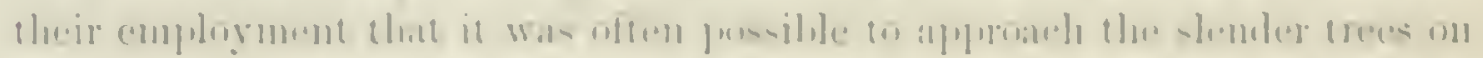

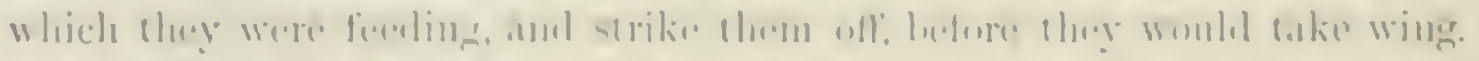

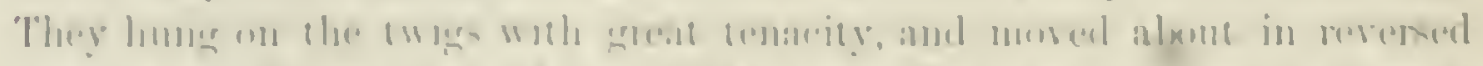

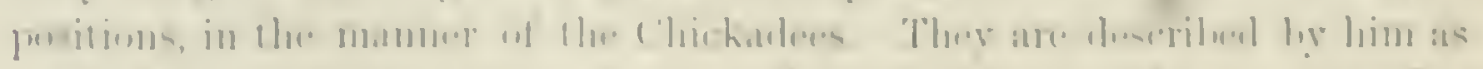

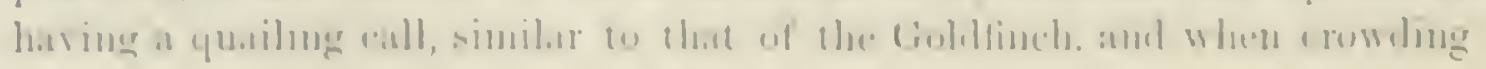


together, in Hight, as making a confused chimping, with a rattling noise, and moving off with a simnltaneons twitter. Ther were attracted to the pines by the Crossbills, and were busily employed in collecting the seeds, dropped from the cones as the Crossbills opened then. They at times fecl on the buds of fruit-trees. They were alwars found to be fat, even on their first amrival, and there were no obrions reasons fur their nurements.

Mr. Boardman speaks of them as common at Calais by the first of the winter. At Norway, Me., Professor Verrill found then very conmon in fall, winter, and spring, and most abundant in Manch and $A$ pril. In Springfield they are, according to Mr. Allen, an irregular and nceasional visitant, coming in very large tlocks one yealr, and again not seen for several years. In a more recent paper (18-0) Mir. Allen states that during the preceling five years these birds have been several times very mumerons in Massachusetts, appearing in quite linge tlocks.

Mr. Audubon met with these birds in Labrador the last of July, and obtained specimens of clifferent ares. He thinks their notes more like those of the Siskin of Europe than of our Goldfinch, uttered both when the birds are on the wing and when they have alighted. They were in small parties of seven or eight, evidently members of the same fanily. They were tame and familiar, and fearlessly returned to the sime spot after having been shot at. They were also remarkably affectionate, and he frequently observed them passing seeds one to the other in the most loving manner.

Dr. Cones also observed this bird in Labrador, and described it as LE. fuscescens. He fonnd it abundinnt along the const, and was struck with its resemblance, in habits, to the Chrysomitris tristis. It was remarkably unsuspicions and familiar, and showed no sims of fear even when rery closely ipproached. It frequented, almost exclusively, the scrubby junipers that grow everywhere in open places in thick impenetrable patches. He describes its flight as irregular, rising and falling in eurres, and seldom protracted to any great distance. While passing overhead, it uttered al peculiar rattling chirp. He thinks it has no song.

Dr. Kirtland informs me that early in the winter of 1868 his grandson picked up a wing-hroken male Red-Poll, and placed it in his greenhouse. It began at onee to feed on crumbs of bread and hay-seed, and rapilly recovered. It soon acquired the habit of leaping from shelf to shelf, among the plants, and was finally seen climbing up some stately Pelargonium shrubs, and suspending itself, parrot-like, by its feet from the limls, capturing aphides. From that time it took no other food, living exclusively on the parasitic insects of the plants. So active was it in capturing these, that for two months it was not necessary to fumigate the greenhouse to destroy them. From day to day a female Red-Poll hovered over the building, and her calls were responded to by the invalid. Later in the season he eseaped from his confinement, and was seen to rejoin his faitlful mate, which had remained near him all the winter. As in Europe, this species in the Aretic regions of America has been found nesting in low trees and bushes, from two to six feet from the ground. 


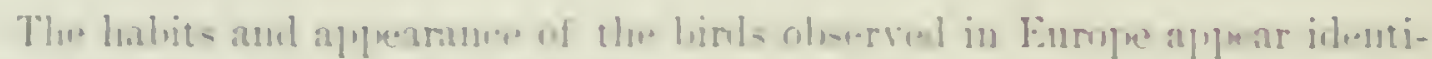

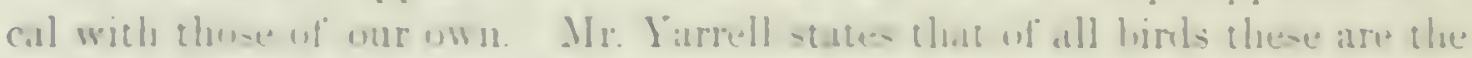
munt

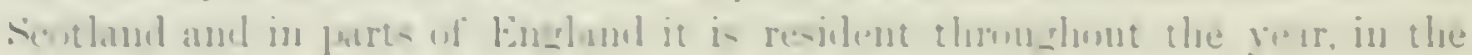
sumuer retiring to the hase- of the momutuins, and there boraling in the un-

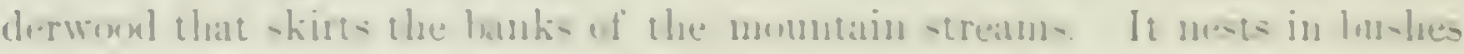
or luw trees, such as the aliler and the willow. There an emo-tructert of

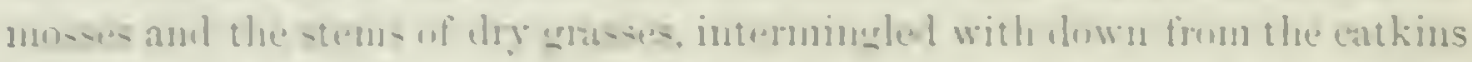
of the willow, and linet with the same, unking them solt and warm. The

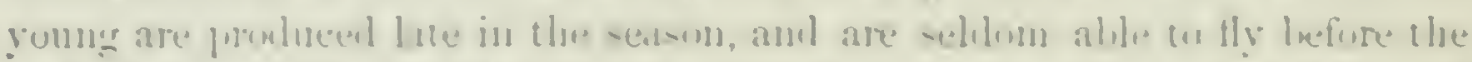
first of .July. The parest himls are devoted in their attaclisuent. P'ennant

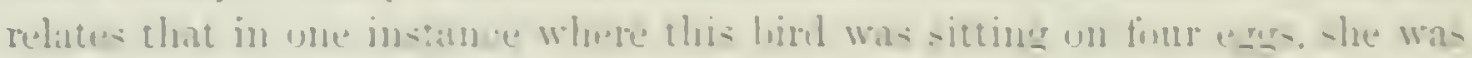

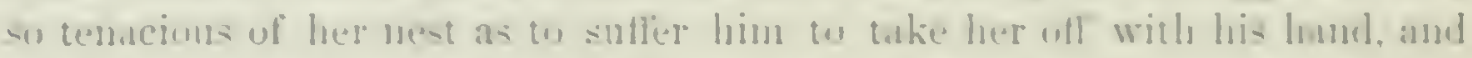
after havine Inen releatsed she still refu-el to leave it. In the winter they

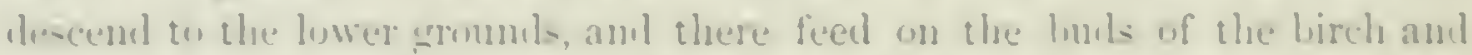

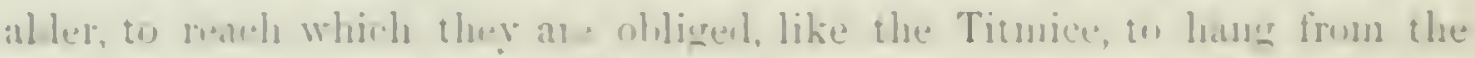

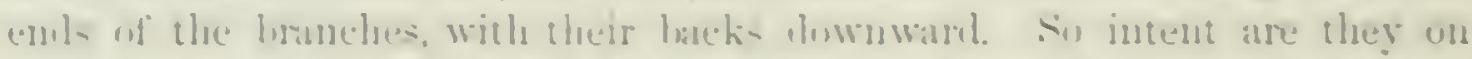
their work that they are es-ily taken allive by mean = of a lom -tiek smeared

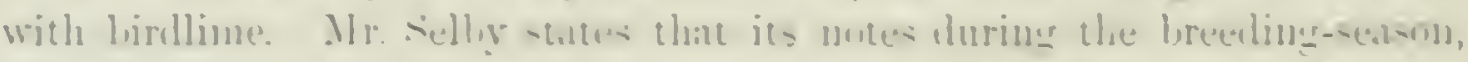

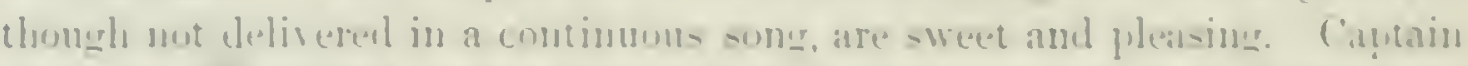

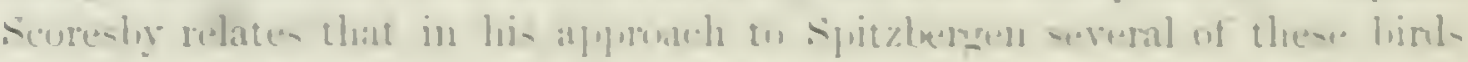

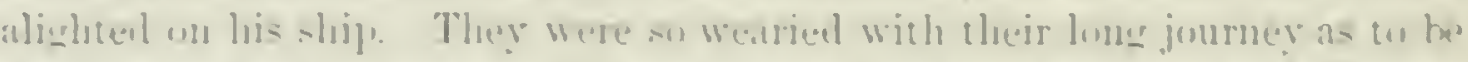

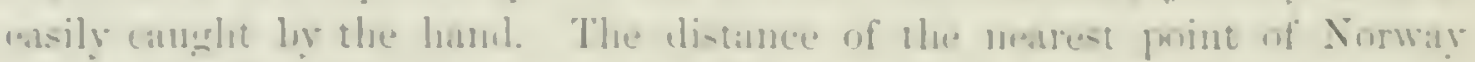

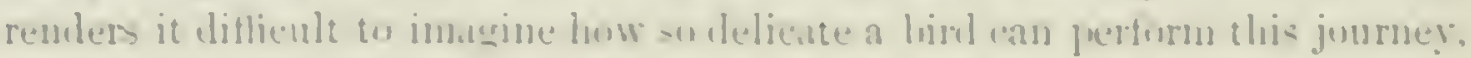

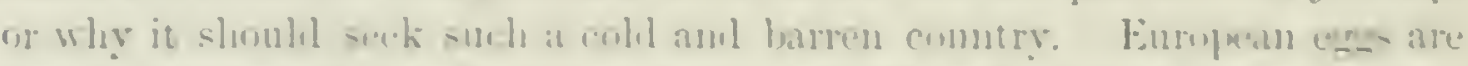

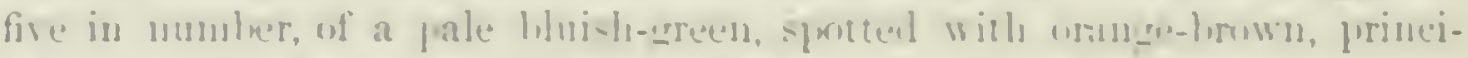

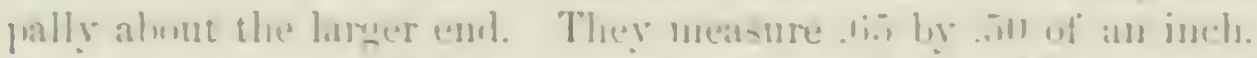

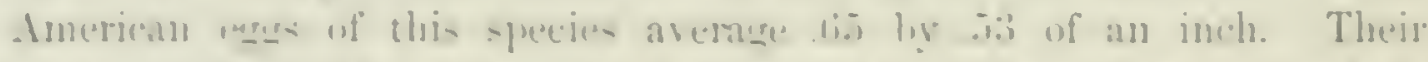
color is a liegth bluish-white, which varies consjlemally in the depth of its

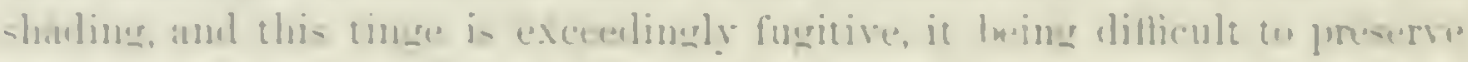
it eren in a cabine:. The exps are generally and fincly doteml with a sustybur, amel are wi a rather mundel oral shipe.

\section{Egiothus canescens, 1'131.11}

\section{MEALY RED-POLL.}

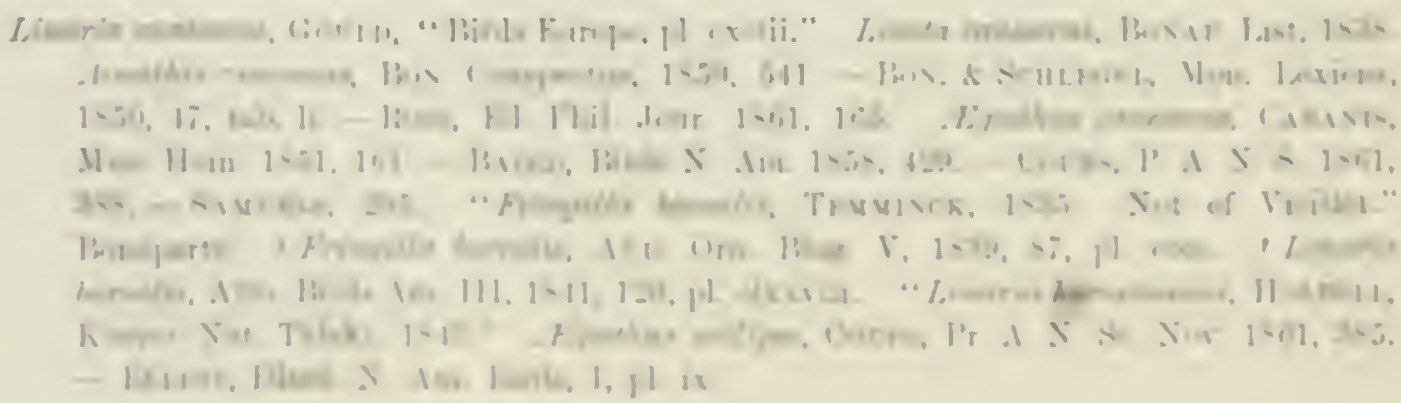


Sp. Cusı. Autumnal femule. Freenland race (canescens). (23,377, Greenland, Univ. Zoül. Mus. Copenhagen.) In general appearance like the corresponding plumage of $A$. linarius, but the whole rump immaculate white; frontal band nore than twiee as wide as in linarius, and better defmed; lower tail-eorerts without streaks, their shafts eren being white. Carmine vertical pateh only a little wider than the whitish frontal patch; hear with a strong ochraceous sulfusion. Wing, 3.30 ; tail, 2.90 ; bill, .35 and 30 ; tarsus, .60 ; middle toc, 32. Wing-formula, 1,2 , and 3.

HAs. Greenland. Variations with season probably as in smaller Continental rare.

Adult of buth sexes in spring. Continental race (exilipes). As leseribel for the Greenland form, but without the ochraceons suffision. Sides rery sparsely streaked.

Male in spring. Breast only tinged with delicate peach-blossom-pink, this extending farther back medially than laterally, - just the reverse of $A$. linarius: a very faint tinge of the same in the white of the rump. Measurements (No. I9,686, Fort Simpson, April 30, 1860 ; B. R. Ross, Couss's (ype) : Wing, 3.00 ; tail. 255 ; bill, .29 and .25; tarsus, .52; middle toe, .30 ; wing-formula, $2,1,3,4$.

Female in spring. Fimilar, but lacking all red except that of the pilem, which is less intense, though not more restricted, than in the male. IIeasurements (No. 19,700, Fort Simpson, April 28; B. R. Ross): Wing, 2.80 ; tail, 2.35 ; bill, 25 and .22; tarsus, .51; middle toe, .30 .

Both sexes in autumn. ( 9 . Fort Rae.) The white of the whole plumage, except on the rump, overspread by a wash of pale ochraceous, this deepest anteriorly; on the anterior upper parts a deep tint of ochraceous entirely replaeing the white; wing-markings broader and more ochraceous than in the spring phumage. Wing, 2.85 ; tail, 2.50 ; bill, .30 and .25; tarsus, .51; midlle toe, . 30 .

Hab. Continental arctic America. In wintel sonth into the United States (as far as Mount Carroll, Illinois).

Though $A$. cancscens is nearly identical with $A$. linarins in size, these two species may always be distinguished from each other by certain well-nurked and constant differences in coloration; the principal of these have been mentioned in the syrnoptical table, but a few other points may be noted here. In spring males of cencscens the delicate rosaceons-pink of the breast does not extend up on to the cheeks, and backward it extends farther medially than laterally, scarcely tingeing the sides at all; while in LE. linurius the intensely rosaceous, almost carmine, tint covers the cheeks, and extends backward much farther laterally than medially, covering nearly the whole sides.

Though the weakness, or shortness, of the toes compared with the tarsus, is a feature distinguishing, upon almost microscopical comparison, the $A$. c c c nescens in its two races from the races of $\mathcal{E}$. linarizes, it will not by any means serve to distinguish concsecns and exilipes, since, as will be seen by the measurements given, the proportion of the toes to the tarsus is a specific, and not a race, character. (RIDGWAY.)

Habits. The history of the Mealy Red-Poll can only be presented with some doubts and uncertainties. We cannot always determine low far the accounts given by others may have belonged to this species, and we can only accept, with some reserve, their statements.

This form, whether species or race, is known to inhabit Greenland, where, according to Dr. Reinhardt, it is constantly resident, and I have received its 


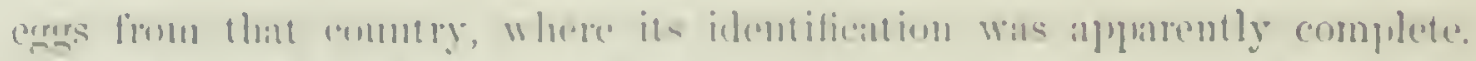

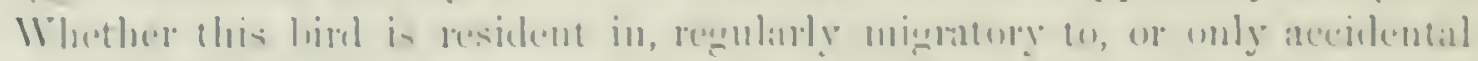

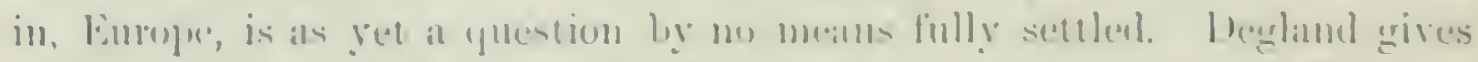

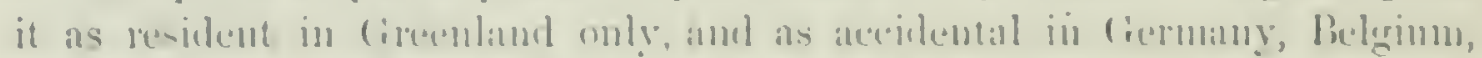

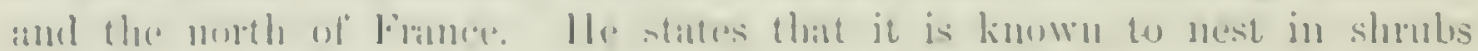
and in low trees, and that, in all essontial resperts, its manmers are identical

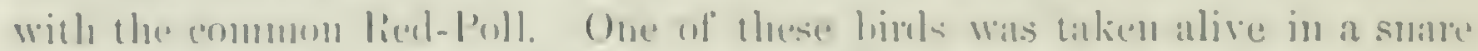
in the vicinity of Abberille, and kept in at cage, malking part of the collecetion of .I. Bitillon.

Farrell thoment that sullicient evidenee existed of its specifie distinctness,

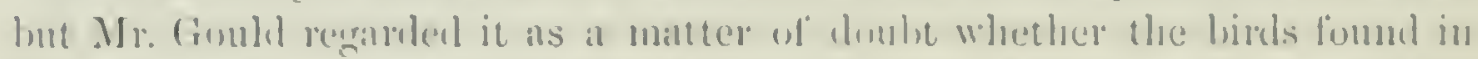
bincope were natives, on only anrivals from northern Ameriea. He states that

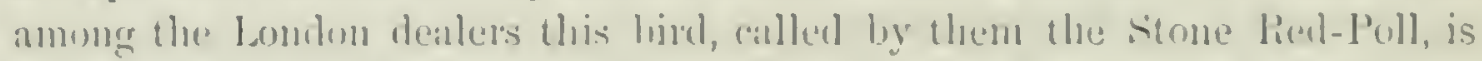

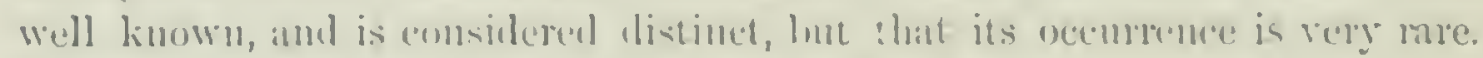

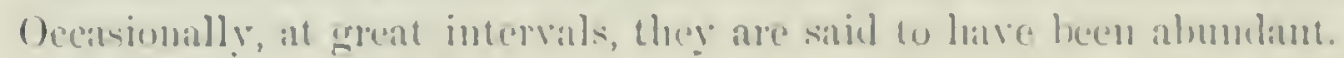

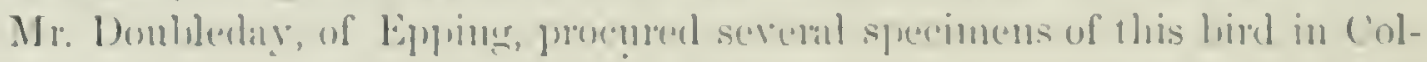

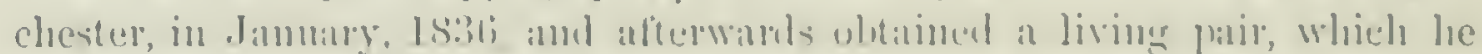

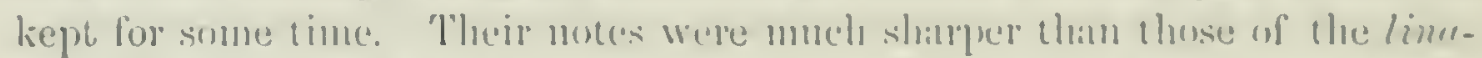
rins. Its werorence was most frephent in winter, many opecinens having

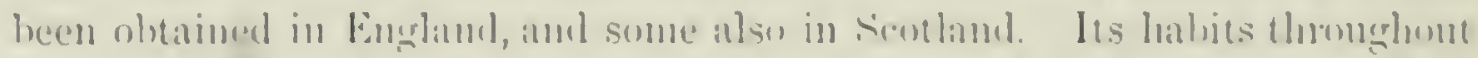

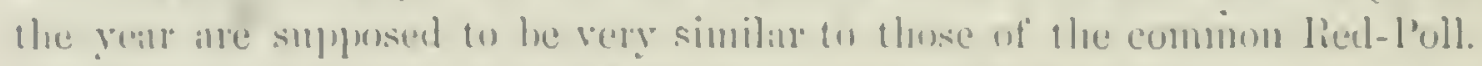

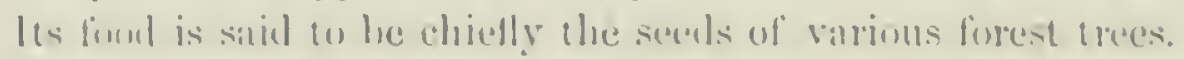

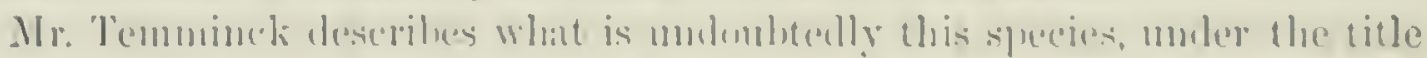

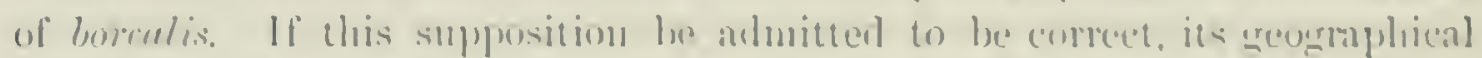

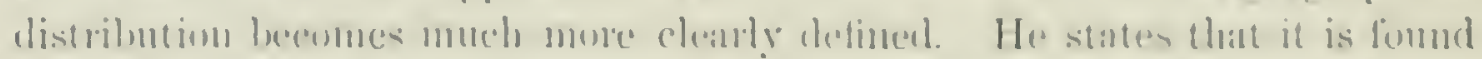
buring the sumner in Yorwaty and sweeten, and is resident of the Aretie

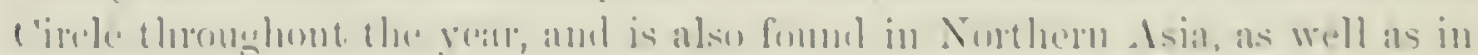

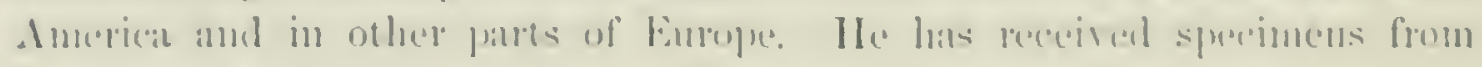

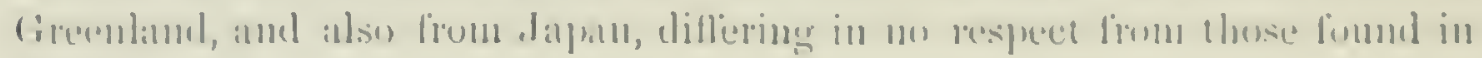
Emme.

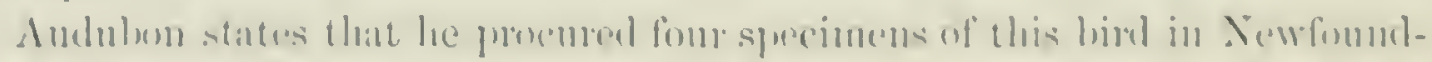

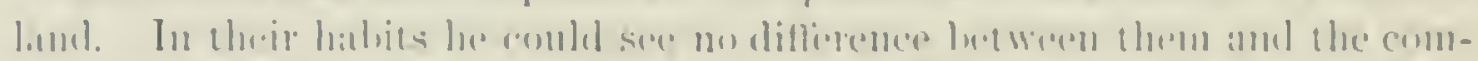

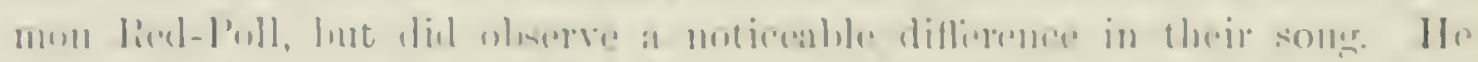

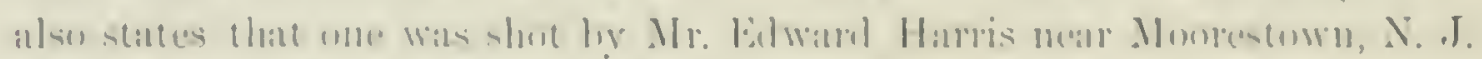

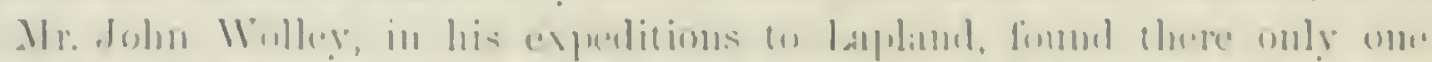

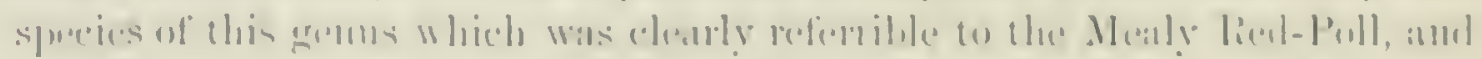

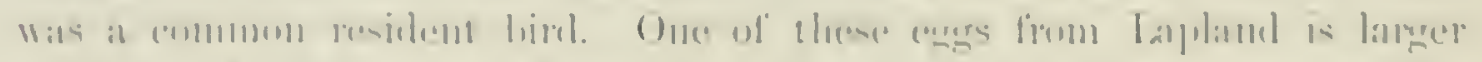

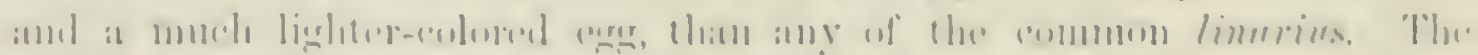

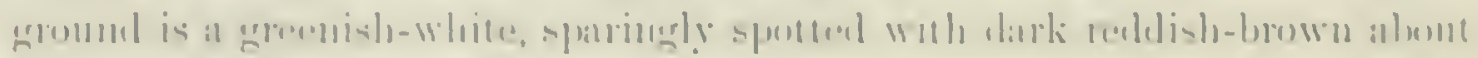

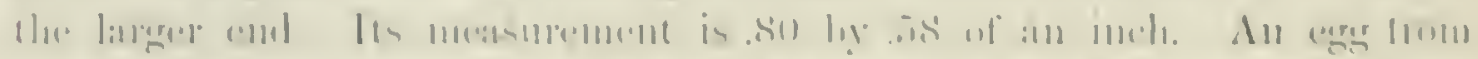

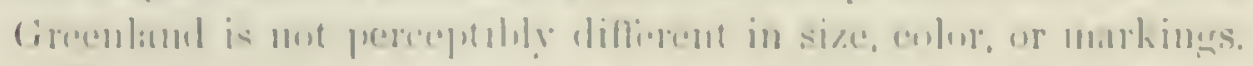

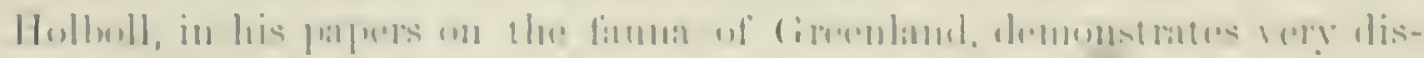

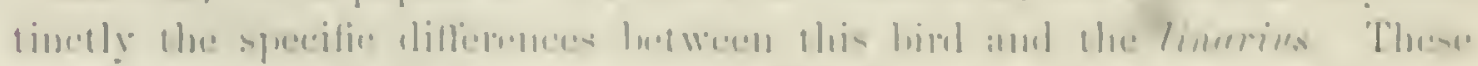

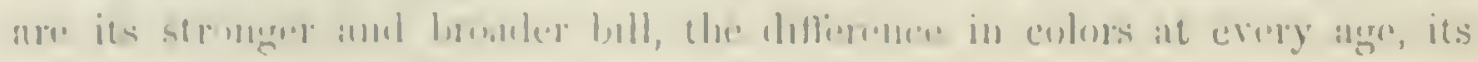


much sreater size, its very different notes, and its quite lifterent modes of life, the cuncums being a strictly resident species, and the linurius being migratory.

In the summer this species is formd to the extreme north of Greenland, and has never been knuwn (o) uest larther south than the 69th parallel. It is more numerons in North Greenland than the linarius, which is rare at the extreme morth, while this is very common even at latitule $73^{\circ}$. This bird builds its nests in bushes in the same manner with linarius, and its egres closely resemble those of that hird. Its notes, he adks, do not at all resemble those of the lied-l'oll, but are like those of the Ampelis garrulus.

It is a resident of Greenland throughout the year, and in the winter lieeps on the montains in the interior, but is much more numerous at latitude $66^{\circ}$ than farther south. In February, 1S26, Holböll saw many Hocks on the momntains between Ritenbank and Omanak, and in the jomrney taken in 18.30 by a merehant from Holsteinborg into the interior of the country a great many flocks were observed. They are also freynently met with by reindeer-hunters, who go far into the interior. It is rarely found in South Greenland at any time, and never in the summer. In mild winters they sometimes come about the settlenents, as happeneul in the winter of $1828-29$, and agnin in $1935-38$. In the intervening winters it was not seen at Crodhanb, and in serere winters it is never to be found near the coast, only single specimens occurring there in spring and autumn.

Mr. MacFarlane thinks this species spends tle winter at Fort Anderson, as he has met with it as late as December and as early as February, and believes it to have been present in the ricinity in the interval. It nests in May. Mr. Harriott found one of its nests on the branch of a tree, about five feet from the ground. It coutained five egrss.

The egg of this species resembles that of the linarins except in size and its lighter ground-color. The ground is a bluish or greenish white, dotted with a tawny-brown. The egg is of a more oral shape, and measures . 75 by 60 of an inch.

झgiothus flavirostris, ${ }^{1}$ var. brewsteri, LInGWA.

\section{BREWSTER'S LINNET}

S. Char. General appearance sometrhat that of . E. linailus, but no red on the erown. and the sides and rump tinged with sulphur-yellow: no bliek gular spor. $q$ ad. Groundcolor abore light umber, hecoming sulphur-rellum on the rump. each feather, even on the crown. with a distinct medial streak of dusky. Beneath white, tingerl with fulrous-yellow anteriorly and along the sides; siles and crissun straked with duskr. Wings anu tail dusky; the former with two pale fulrous bands; the secondaries; primaries, and tail-

1 Fringilth linarin. TFuм. Mass. Orn. 1\$35, 267 (not of Linnæus). "Fringilla rufescens, VIeIll. Fann. France tab. 41, f. 1." Linota montium, Bp. \& Sculegel, Mon. Lox. 1\$50. "Linaria furirostris, Впешм." 


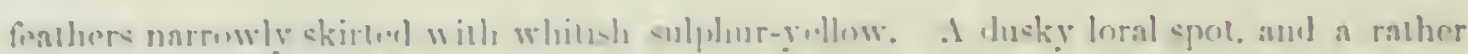

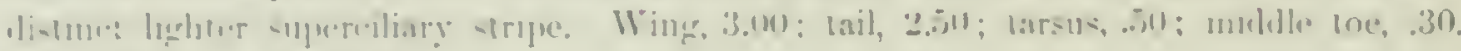
Wing-formulit, 1, 2, 3, 1.1\%:

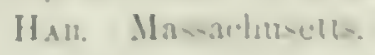

As the present article on bighollus is going lo press, wo have received,

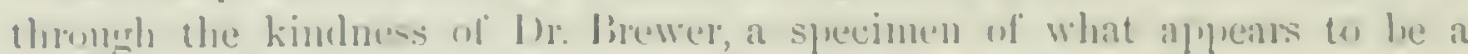

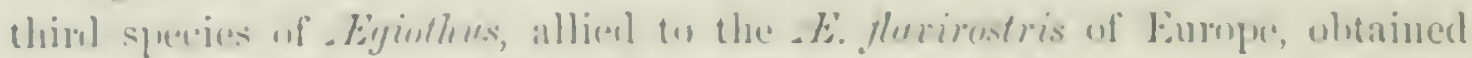
in Walthan, Mass, hy Mr. Willian Brewsted, of ('ambrilgere This hirel was killed in a thock of . E. linnrius, of which five were alsushot at the same dischatere. Sone af the others, nor indeed of any of ninety specimens prepared ly $1 /$. Brewstel during the winter, were at all like the present one, which is entirely diflerent from anything we have crees seen from Surth Amerien.

The relationship uf this himl appeass to be nearest to the E. flarimstris of burope, with the of which it agrees in may respects, as distimsushed from linurius and rourserns. The European lird, luwerer, lacks the sulphur-yellow time (which gives it somewhat the appearance of chrysomitris pinus), has the throat and jugnlum stromgly redelish-lutl, iustead of dingy yellowish-white, and is much brumer alwere; besides which the tail is longer and less deeply forked, with warrower leathers.

llamts. Nothing distinctive was observed by Mr. Brewster in regard to the habits of the specinen killed ly hin.

\section{(:IXI:S LEUCOSTICTE, SWMNON.}

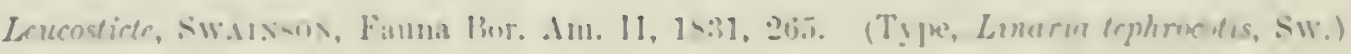

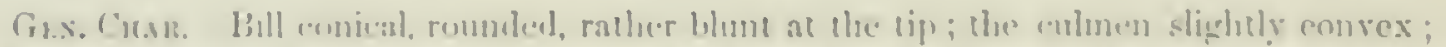

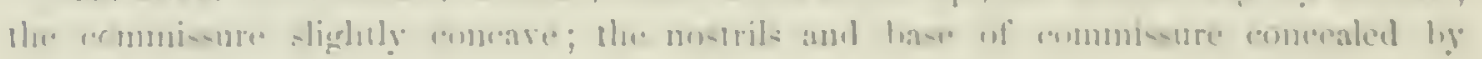

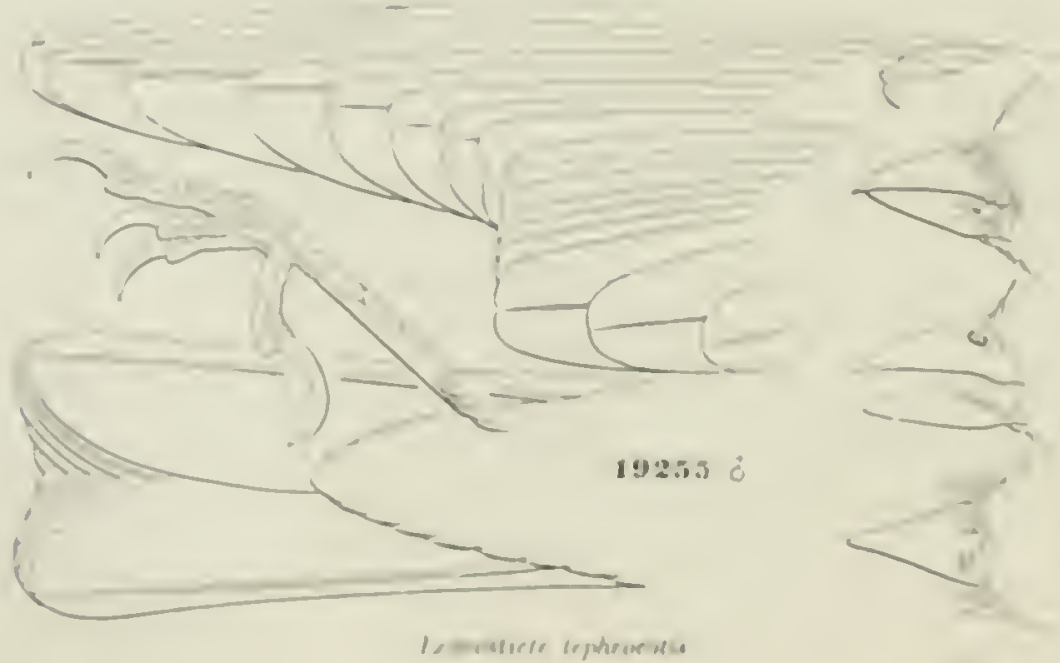

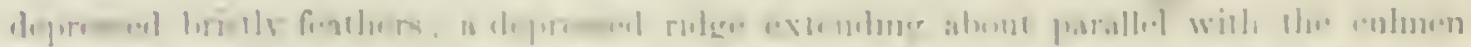

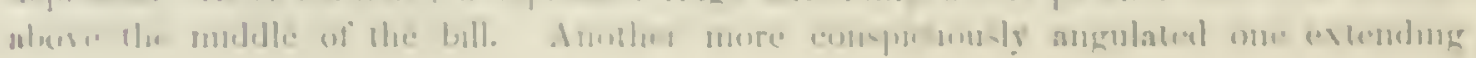


forward from the lower posterior angle of the side of the lower mandible, nearly parallel with the gonys. Tarsus abont equal to the middle toe and claw. Inner toe almost the longer, its claw not reaching beyond the base of the midlle one. Hind toe rather longer, its claw longer than the digital portion. Wings verg long; first quill longest; all the primaries longer than the secondarie.s. Tail forked.

This genus differs from Eigiothus in the more obtuse and curved bill, the less development of bristly fenthers at the base, the ridge on the lower mandible, the lateral toe not reaching berond the base of the middle one, and possibly a longer hind toe. Its relationship to the other allies will be found expressed in the synoptical tahle of Coccothrustino.

The number of Anerican species, or at least races, of this genus has been increased consilerably since the publication of Birds of Tortl Anerica, five now belonging to the American fama, insteat of the three there mentioned. Of the species umually assigned to the grenus, one, L. urctun, is quite different in form, lacking the ridge of the mandible, etc., and in having the ends of the secondaries graduated in the closed wing, instead of being all on the same line. The colors, too, are normally different; in arctoa being disky, with silvery-gray wings and tail, without rose tips to the feathers of the posterior part of body; and in Leucosticte proper, the wings and tail being dark-brown narrowly edged with whitish, or more broadly, like the ends of the feathers of the body behind, with rose-color. For the

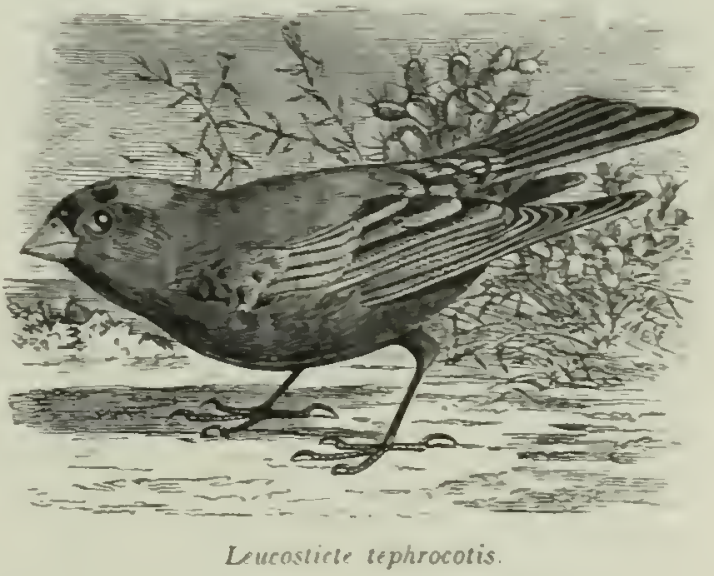
present, howerer, we shall combine the species, not having before us any American specimens of $L$. aretoa.

From the regular gradation of each form into the other - the extremes being thus connected by an unbroken chain of internerliate forms - it seems reasonable to consider all the Torth American forms as referable to one species (L. tephrocotis, Sw., 1S:31) as geographical races. They may he distinguished as follows:-

Commox Charscters. Bodr anteriorly chocolate-brown; posteriorly tinged with rose-red. Wing-corerts (broadly) and quills elged with the same. Head above light ashr or silvery-grar, as are also the featliers aromd the base of upper mandihle; the forehead and a patch on crown blackish. Throat dusky.

Additional Characters. The chocolate-colored feathers and the secondary quills,

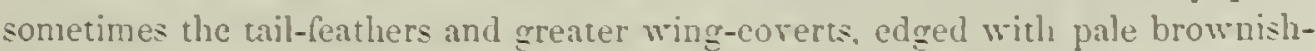
white or fulsous; the interscapulars with darker centres. Rose of rump and upper tail-corerts in form of transrerse bands at end of feathers. that of abdomen more a continnous wash. Lining of wings and axillars white. tinged with rose at ends of feathers Feathers of crissum dark brown, edged with whitish, sometimes tinged with rose. Bill generally reddish or yellowish, with blackish tip. 


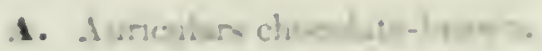

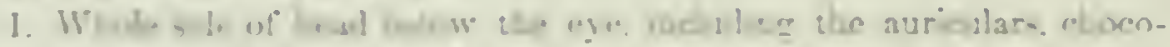

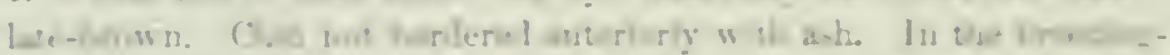

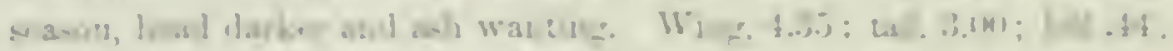

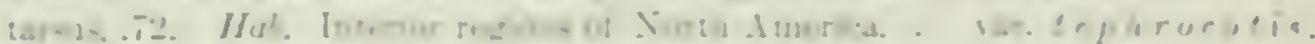

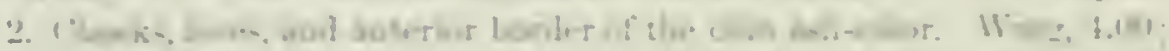

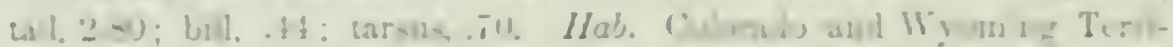
turies

sar. $a+y+s t r i s$

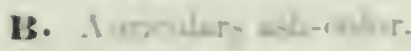

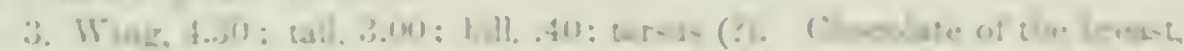

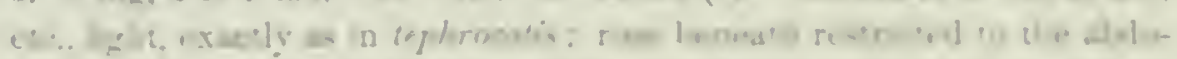

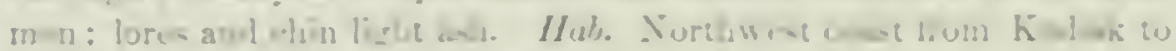

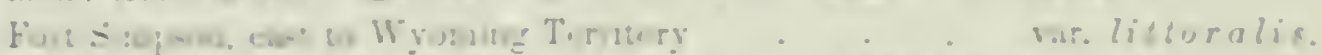

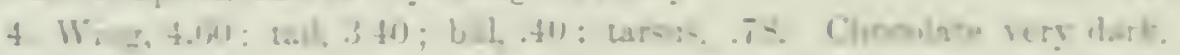

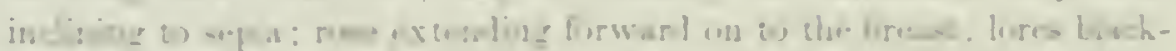

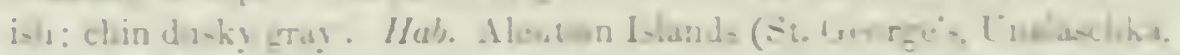
and hishis.)

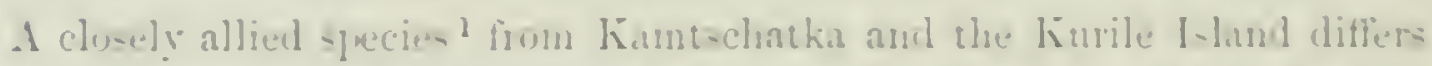
mainly in lasing the nand fenthers as well as the heal blackish. Lut withont disinct pteh on the top, and the nape rusty, in contrast with the back.

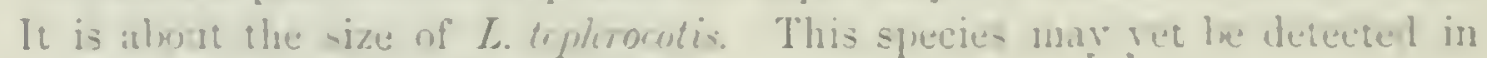
the westermust Aleutian.

\section{Leucosticte tephrocotis," smarsur.}

\section{GRAY-CROWSED FINCH.}

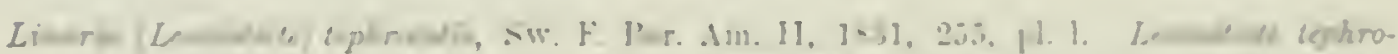

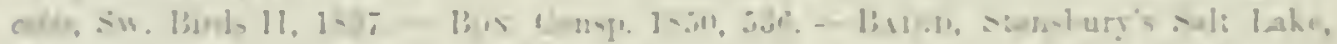

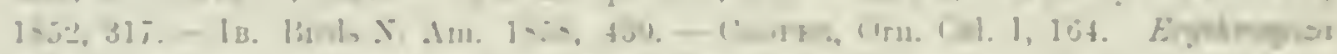

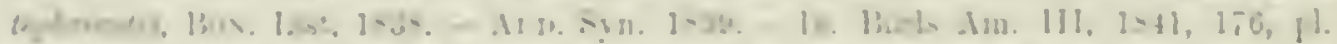

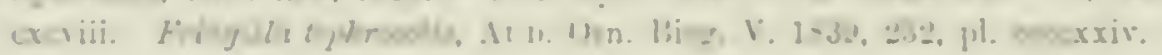

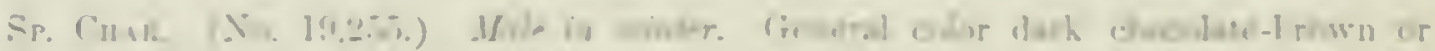

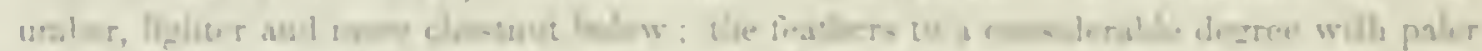

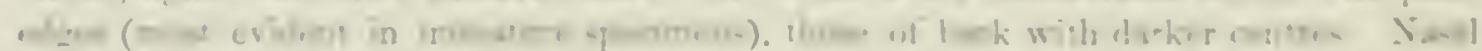

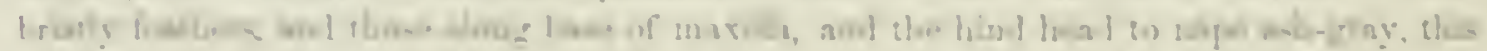

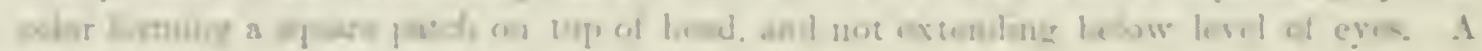

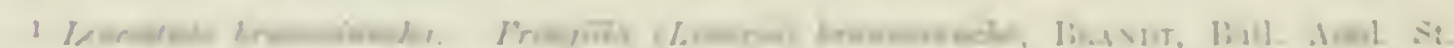

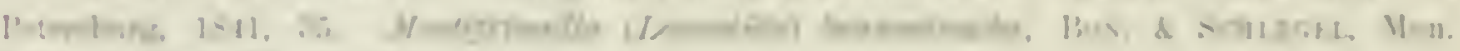

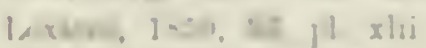

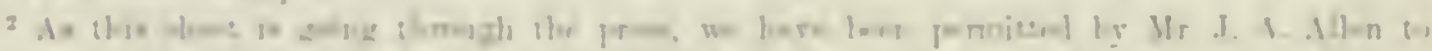

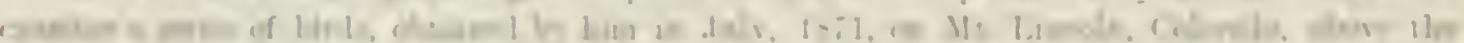

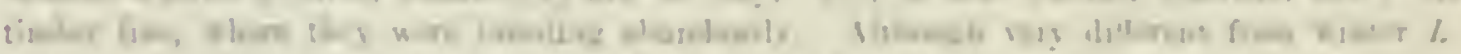

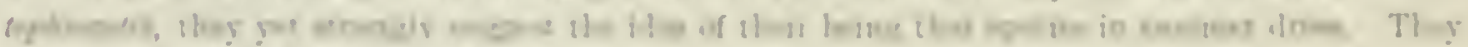

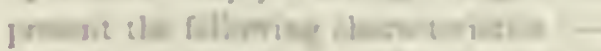

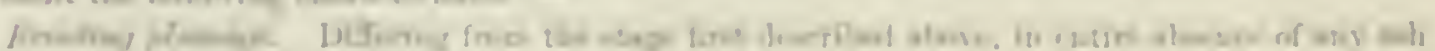

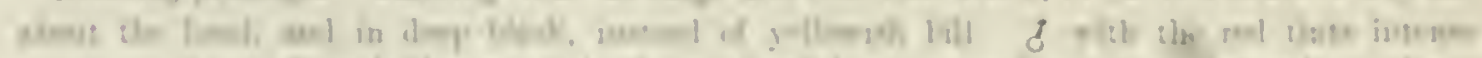

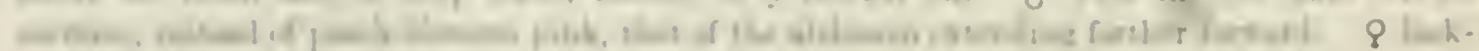

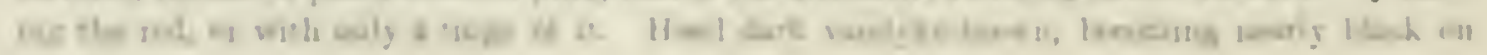


frontal blackish patch extending from base of bill (excepting the bristly feathers immediately adjacent to it), and reaching sonewhat beyond the line of the eyes, with conrex outline behind, and extenaing les: distinctly on the loral region. Chin and throat darker chestnut, not grayish anteriorly. Body behind dusky; the feathers of abdomen and flanks washed, and of crissum, rump, and upper tail-eoverts tipped, with rose-red; wing-coverts, and to some extent quills, edged with the same; otherwise with white. Bill yellowish, with dnsky tip; feet black. Length before shinning, 0.50 ; extent, 11.50 . Skin: Lengtll, 6.50 ; wing, 4.30 ; tail, 3.00 .

Young. Pattern of coloration as in the adult of L. tephrocotis; ash similarly restrieted, but with the black frontal pateh badly defined. The brown of the plumage, howerer, is of an entirely different shade from that of adult specimens of teplirocotis, being of a blackish-sepia cast, much darker, even, than in griseinucha; each feather also broadly bordered terminally with paler, these borders being whitish on the throat and breast, brownish on the nape and back, aid light rose (broadly) on the scapulars. The whole abdomen, flanks, and crissum are nearly continuonsly peach-blossom pink, which, with that of the lesser and middle wing-coverts and rump. is of a finer and brighter tint than in adults. The other edgings to wings are pale ochraceons; under side of wing pure white. Bill dull yellow, dusky toward tip. Wing, 4.20; tail, 3.80. (60,638, Uintal Mountains, Utal, September 20, 1870; Dr. F. Y. HAYDEx.)

The young specimen described was obtained during the summer of 1871 in the Uintah Mountains; and were it not unmistakably a birl of the year, it would be considered almost a distinct species, so different is it from adult specimens of tephrocotis.

Habits. Of the listory and habits of this well-marked and strikingly peculiar bird, but little is known. It was first described by Swainson from a single specimen, obtained on the Saskatchewan Plains, in May, by Dr. Richardson's party. Specimens were afterwards procured in Captain Stansbury's experlition, near Salt Lake City, Utah, in March, 1850. Dr. Hayden found them very abundant on the Laramie Plains during the winter season, and Mr. Pearsall obtained numbers about Fort Bentou. Dr. Cooper has also seen one specimen brought from somewhere east of Lake Tahoe, in Washoe, by Mr. F. Gruber. They were said to be plentiful there in the cold winter of 1S61-62. Dr. Cooper thinks it probable that they risit the similar country east of the northern Sierra Nevada, in Califormia.

A single flock of what is presumed to have been this species was seen by Mr. Ridgway, on the 5th of Jamuary, in the outskirts of Virginia City, Ne-

the forehead; rest of head light chocolate-brown, similar to, but nore faded than, that of the winter plumage; nasal tufts grayish-white.

Ten specimens collected by Mr. Allen all agree in the character's pointed out, by which they difler from the winter plumage of $L$. tephrocotis. Taking into consideration the fact of their black insteal of yellowish bill, nore intense red, and generally more lusky colors, as well as the other points of distinction from the previously known plumages of $L$. tephrocotis, and also that they are identical in size and proportion, while specimens of $L$. tephrocotis in the breeding plumage have not before been seen, it secms very reasonable to suppose that these specimens represent the breeding plumage of that species. There is some resemblance to $L$. brunueinucha, which, from the plate in Bonaparte and Schlegel's monograph of the Coccothranstina, seems to differ mainly in being lighter colored. Mr. Allen says that these birds were breeding abundantly in the locality where they were found. 
vald. The flock wan flitting restlesty orer the sunw in the manner of the Hetiophlentis.

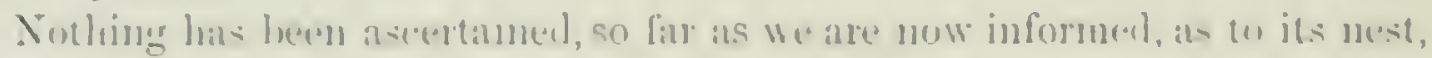

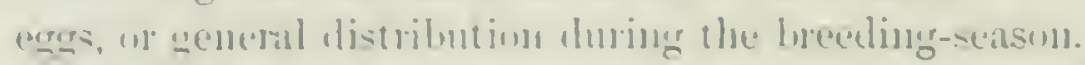

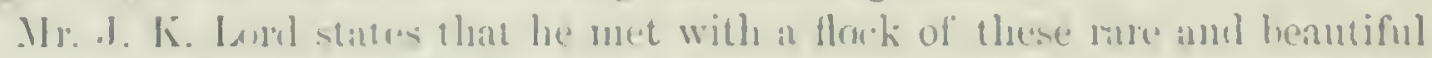
hirels on the smmuni of the Cisscinle Monntains. It was linte in Oetuber, and

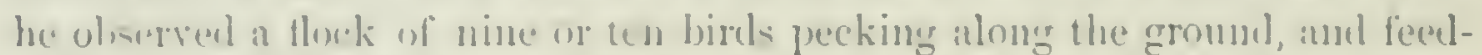
mug somewhat in the manner of larks. P'nzhled to know whin birk they conld be at smoh an aldimbe so litte in thre reate, he fired among them and secureal three, a female amd two mates in fine plumage. (I'erhaps var. littor"lis.?

In July of the fullowing smmmer, nn the smmmit of the liocky Momntans,

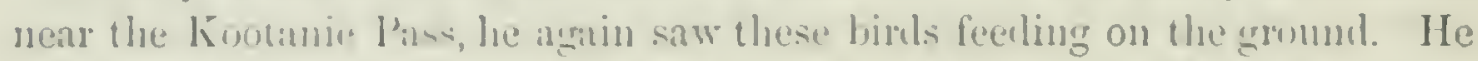
slut several, lut they were all romer libls of the year. It is therefore rendered probalile that these Findes heent on the Ciscate and Rocky Mountaims, in lwhls at about the same altitude, or seven thousand feet. coming into the lowlinds durimg the winter, its it is mot likely that they could endure the cold of the summits, or find there is sufficiency of food, the winter bein. very severe, and the sunw three leet ar more in depth.

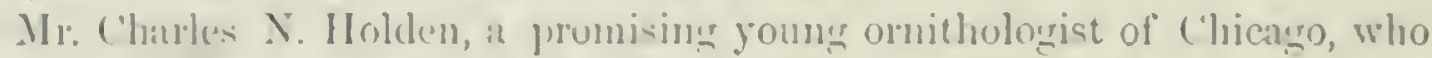

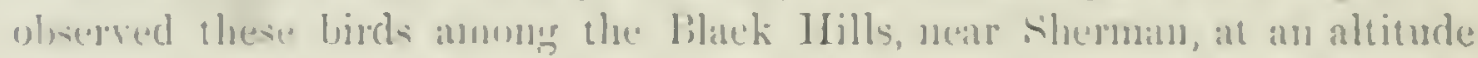
of eiglit thousand linet abore the seat, has furnished me with interesting

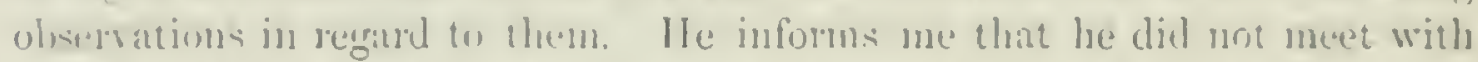

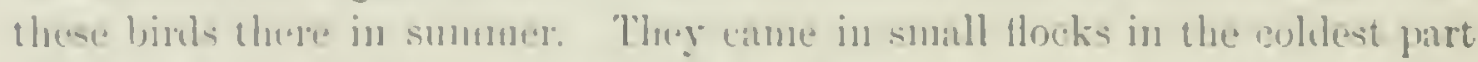

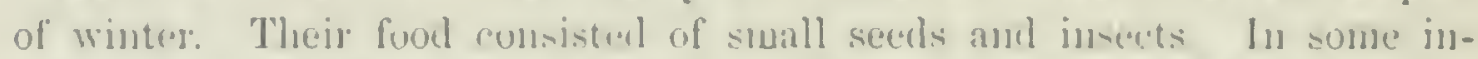
stanem le fomel the arojsis su distenderl with seeds as to distont their shape.

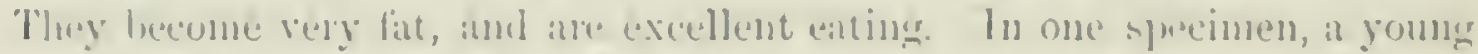

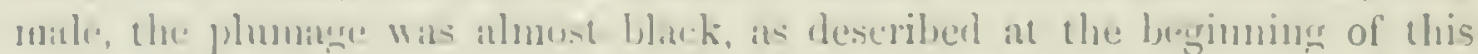
artiche. Thes hirls were ynite munerous, and nearly forty specimens were

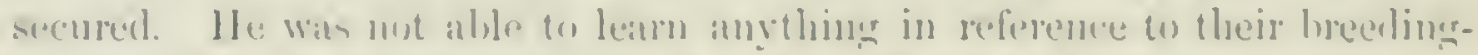

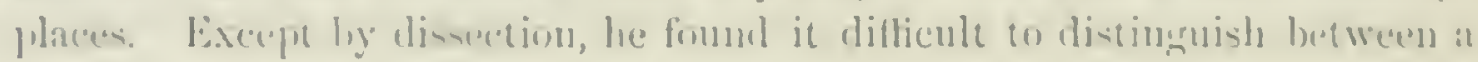

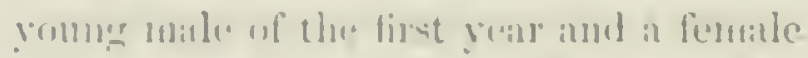

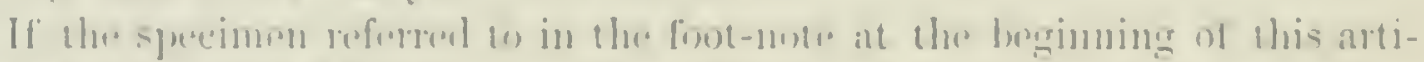

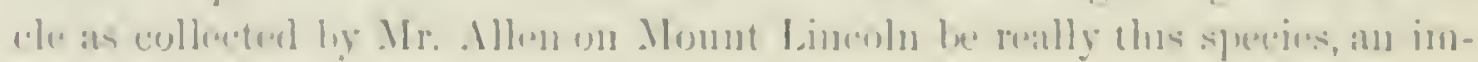

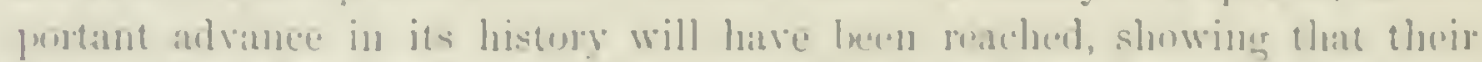

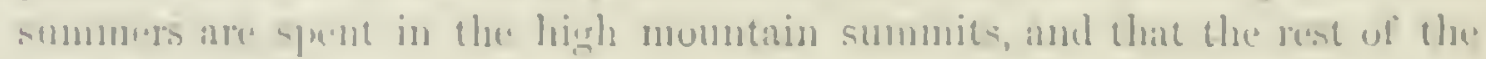
gear is prosud lowre dewn on the plains. 


\section{Leucosticte tephrocotis, var: campestris, B.IRD. THE GRAY-CHEERED FINCH.}

Leucosticte campestris, Bann, Cooper, Orn. CaI. I, 163, 1870.

Sp. Cirar. Body light chocolate-brown, the feathers edged with paler, those of the back with rather darker centres. Featlers of anal region, flanks behind. crissum. rump, and upper tail-corerts, wing-corerts, and primary quills, edged with rose-red; secondary quills and tail-feathers with pale fulrous; little or no trace of rose on under wings. Forehead and patch on crown blackish: the hind head to nape, cheeks immediately under the ere (but not including the auriculars, except, perhaps, the most anterior) and hase of lower mandible all round, ashy-gray. Throat dusky. Bill yellowish, with dusky tip. Legs dusky.

సo. 41,527, near Denver City, Col., January. 1862 (Dr. C. Wfrsigk). Length. T.00; wing, 4.00 ; tail, 300 ; exposed portion of first primary; 3.IU. Bill from forehead. .60; from nostril, :40: tarsus, .75 ; midule toe and claw. .so; claw alone. .24 ; hind toe and claw, . .0 ; claw alone, .37.

HAB. Colorado Territory (Dr. Wersigk): Wyoming Territory (Mr. H. R. Demkes).

This form bears a close resemblance to $L$. tephrocotis, and mar, indeed, be a variety of it: but as it differs in the characters that appear generally to be those most constant in Lcucosticte, and as, in fifty shins of the tephrocotis from one locality, we have seen nothing like it, we are inclined to consider them distinct. The size and general appearance are much the same, the difference being that in tephrorotis the whole cheeks are chocolate below the level of the ere, the chin without any gray; while in compestris the sides of lead below the eve, but not including the ears, with a narrow border of the chin. are of this color.

From littoralis this form may be distinguished by the less extent of ash on the cheeks, which in littorulis covers the whole ears, and extends back farther on the head all round. L. griscinucha is marked like littoralis, and is much larger than either. Possibly it may be well to entertain the idea of its being a hrbrid between tephrocotis and littoralis or giveinucha.

The specimen described was presented to the Smithsonian Institution by Dr. Wernigh, and at the time was supposed to be L. trphrocotis.

Of this form, nothing as to its habits is known with certainty. It probaliy does not differ in any important respect from the allied races.

\section{Leucosticte tephrocotis, var. littoralis, BAlRD.}

\section{HEPBURN'S FINCH.}

Leucostictc griscinucha, Elulot, Illnst. Birds Am. I. Leucosticte littoratis, Batro, Tr. Ch.

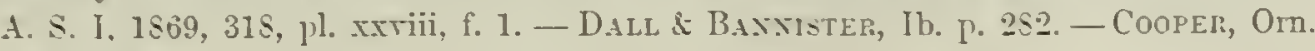
Cal. I, 162.

Sp. Cnar. Body chocolate-brown, the fenthers narrowly margined with paler. those of the back with rather darker centres Abdumen, flanks, crissum, rump, upper tail-corerts, 


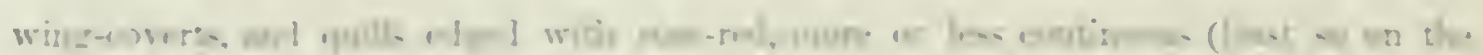

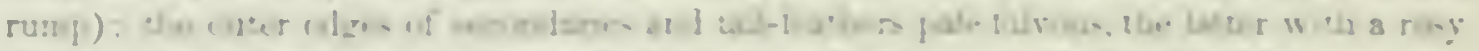

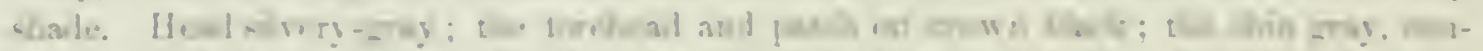

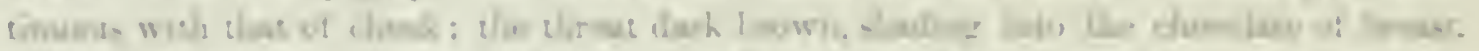

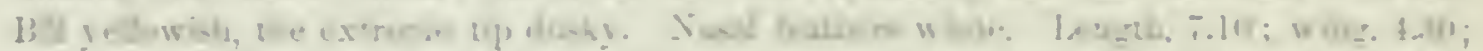

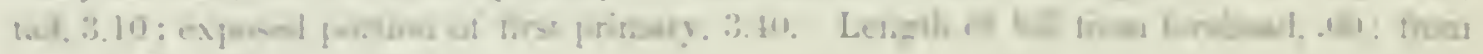

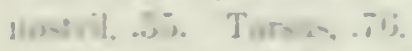

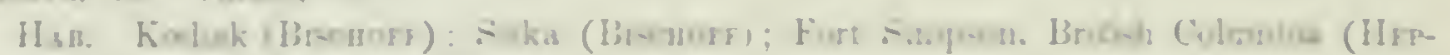

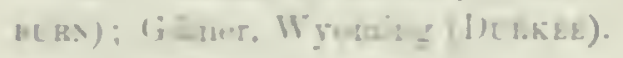

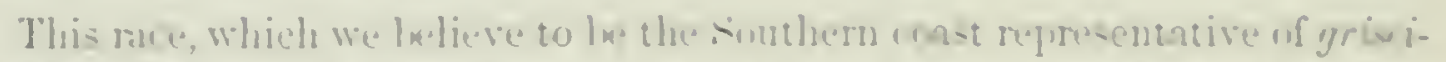

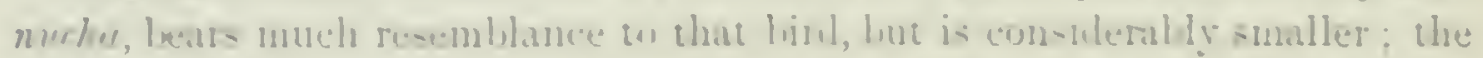

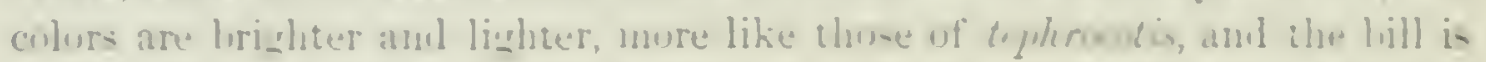

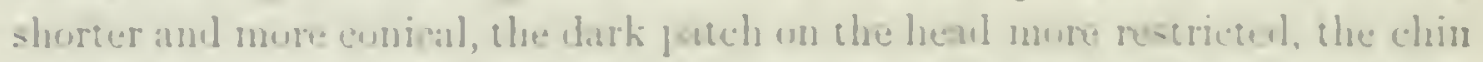

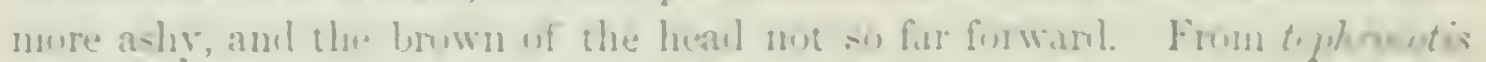

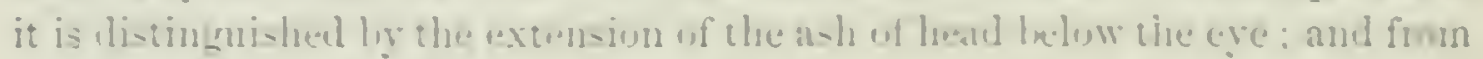

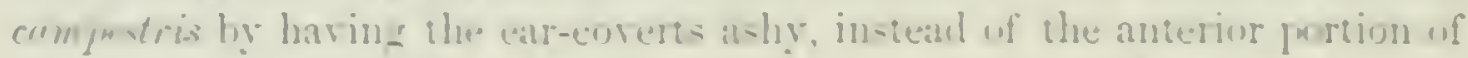

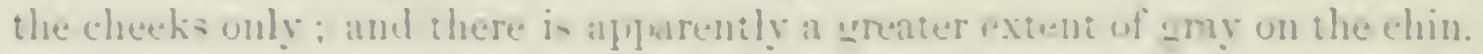

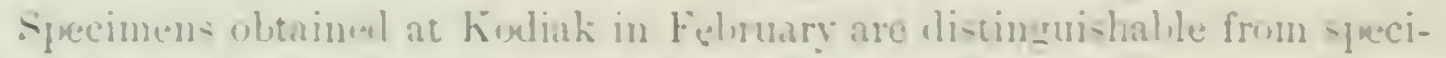

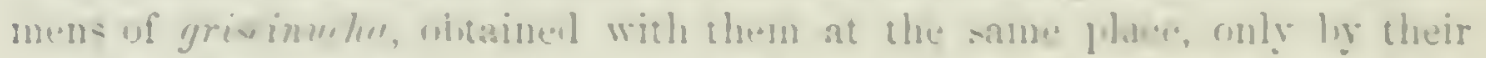
much smaller size, and lighter chomline tinis. The wearrence of Loth these races at the -ame flace, at the sume time, is as -mbject for Fperulntion. A

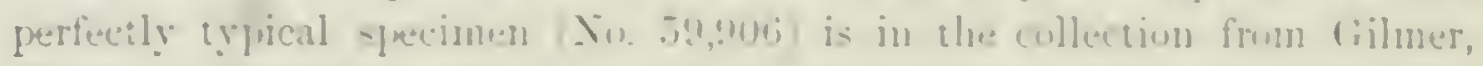

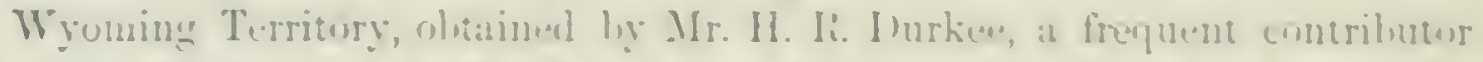

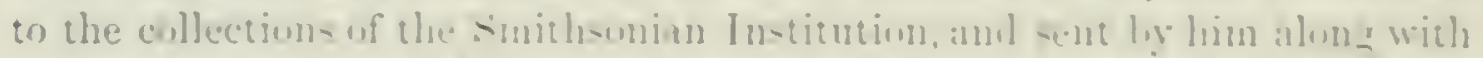

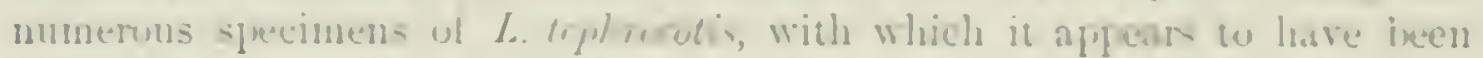
mixed.

\section{Leucosticte tephrocotis, ar griseinucha, li.ı. THE GRAY-EARED EIXCH.}

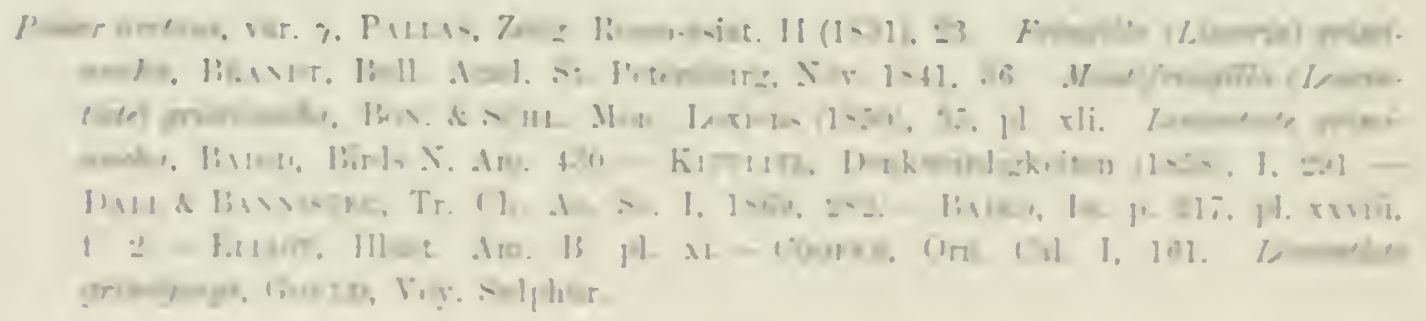

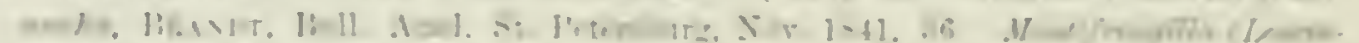

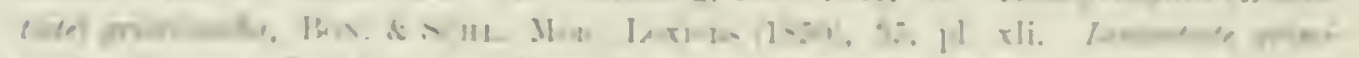

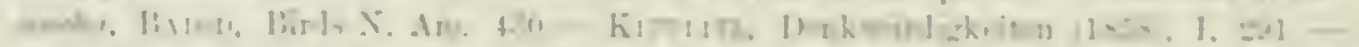

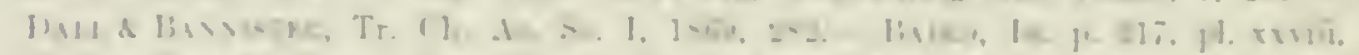

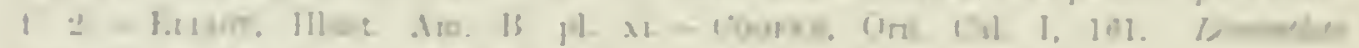

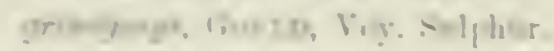

SP. Chsн If

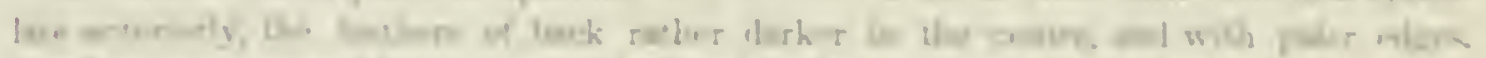

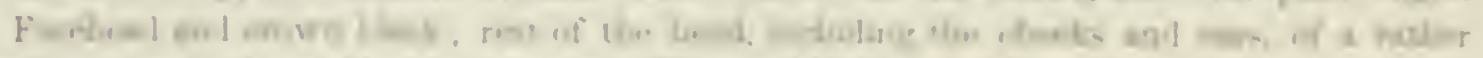

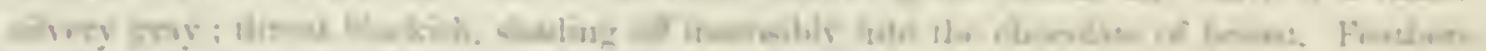

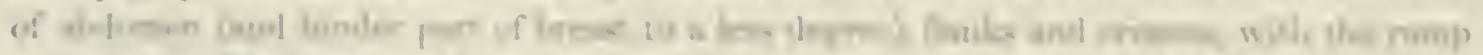

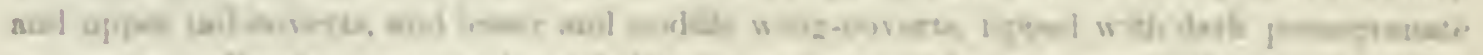

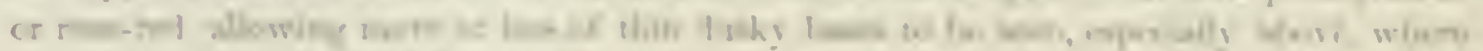

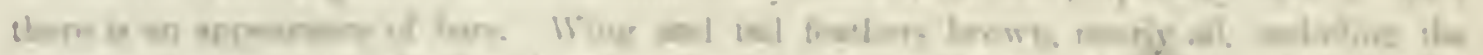

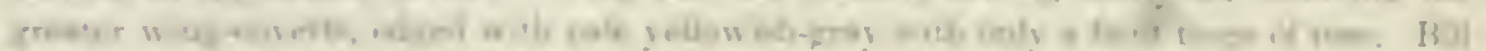

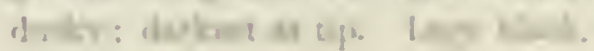


Dimensions: Total length, 7.50; wing, 4.50; tail, 3.50. Exposed portion of first primary, 3.50. Bill, from foreliead, .69; from nostril, .42. Legs: tarsus, .95; middle toe and claw, .92 ; claw alone, .35; lind toe and claw, .69; claw alone, .38 .

Hav. Alentian Islands (St. George's and Unalaschlia).

This is consiclerably the largest of the Anerican species of Lencosticte, and has a longer bill. It also has the chocolate and rose color darker, and the rose extending farther forward on the breast than in other species. It conld only be confouncted with C. litforalis as to color, both having the head above, and on the sides, ashy, covering the whole ear-coverts; but the dusky patch on the crown is more extended, the ash of chin more restricted, and the throat darker. The rose extends farther along the breast, and the tints are different. The size-is much larger.

A specimen, apparently young, perhaps a female, differs in duller tints, and a tinge of ochreous-yellow on the middle of the abdomen and crissum. The lining of the wings is without any rose-color.

Bonaparte and Schlegel describe the young of this species as withont rosecolor.

Specimens of this bird were obtained at St. Genrye's Island, with the eggs (which are white), by $\mathrm{Mr}$. $\mathrm{T}$. H. I)all. Dr. Minor found it at Unalaschka.

Habits. The Gray-eared Finch is the largest species of this remarkable genus known to inhabit North America. Thus far, except in one instance, it has been met with only in the Aleutian Islands and Unalaschka. In the latter place they were met with by I)r. T. T. Minor; and in the former by Mr. I)all.

Mr. T. Brown (Ibis, 1868, p. 432) states that a single specinen of this very rare lird was taken at Fort limpert, Vancouver Island, in June, 1862 , by Mr. I. MI. Compton, the officer in charge of that station. 'This, however, may have belonged to the var. litforalis.

Mr. Dall states that they abound on the Pribylow and the other Alentian Islands. A number of specimens were obtained on the St. George's in August, though at that time they were moulting. At that scason this bird had no song except a clear chirp, sounding like wéet-a wèet-ı-vée-weet. It was on the wing a great part of the time, rarely alighting on the ground, but darting rapidly in a series of descending and ascencling curves. At one time it would swing on the broad top of an umbelliferons plant, and at another alight on some ledge of the perpendicular bluff, jumping from point to point, as if delighting to test its own agility. Mr. Mall adds that its nest is a simple hollow on one of the ledges, provided with a few straws or a bit of moss. They deposit their eggs in May, and these are four in number. In Angust their young were fully fledged.

They feed on the seeds of grasses and other small plants, but in the crop of one Mr. Dall found two or three sinall beetles. They were also receired from Kodiak, through Mr. Bischoff.

Their eggs are of a glayish-white, with a slight tinge of yellowish, and measure 95 by .70 of an inch. 


\section{(H:NL PLECTROPHANES, MHI:}

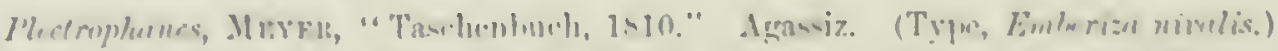

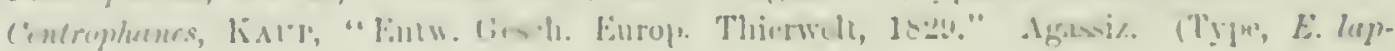
monica.)

Gr.s. Conse. liall sariahle; conisal; the lewer mandible higher than lhe upper; the

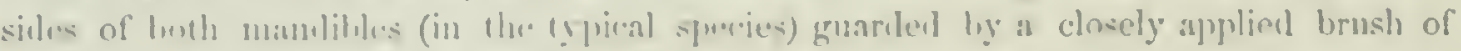

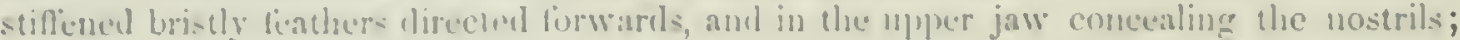

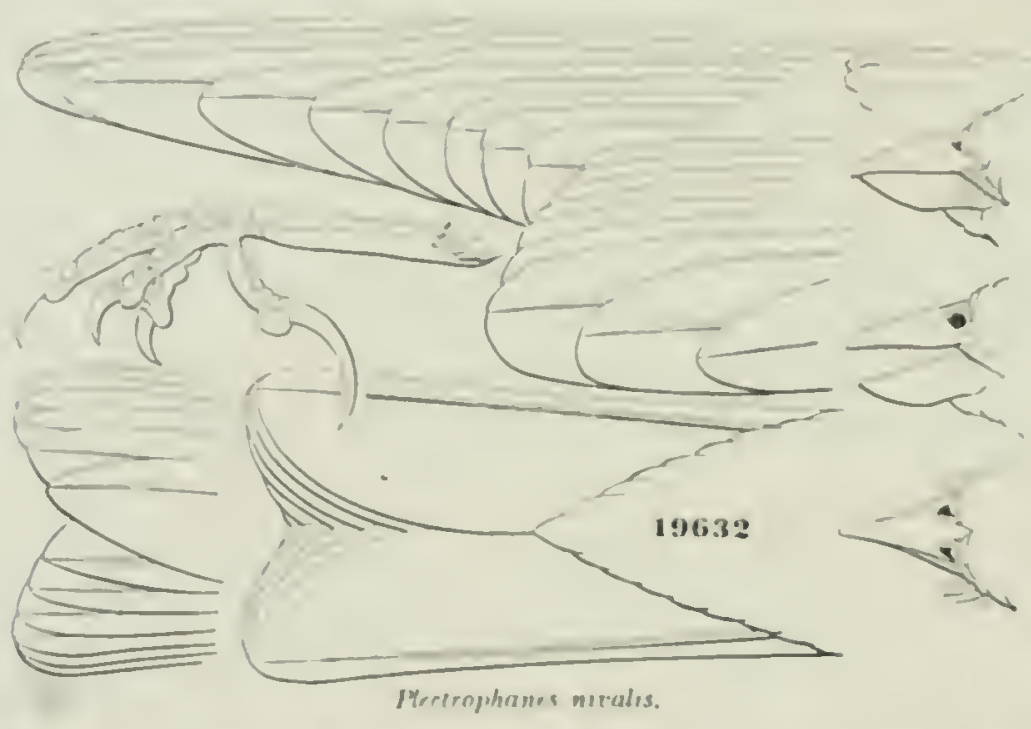

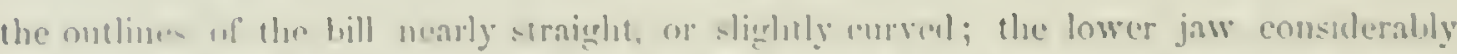

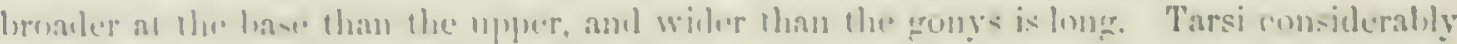

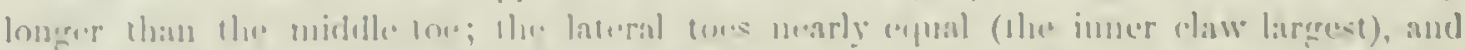

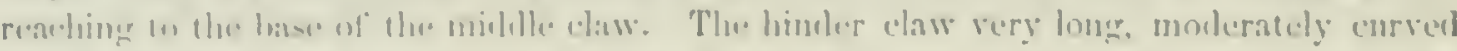

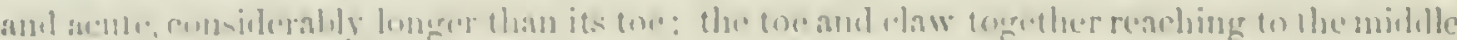

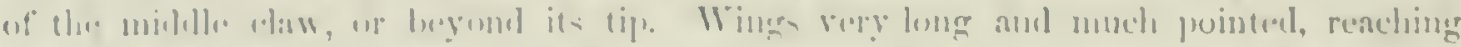

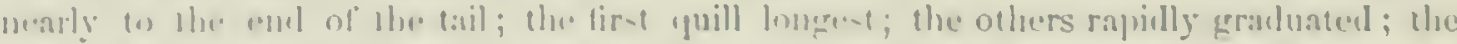

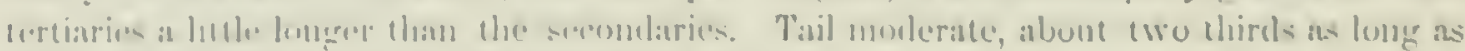

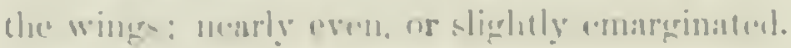

The species of this gentus are essentially foreal and cosmopolitan, allhough

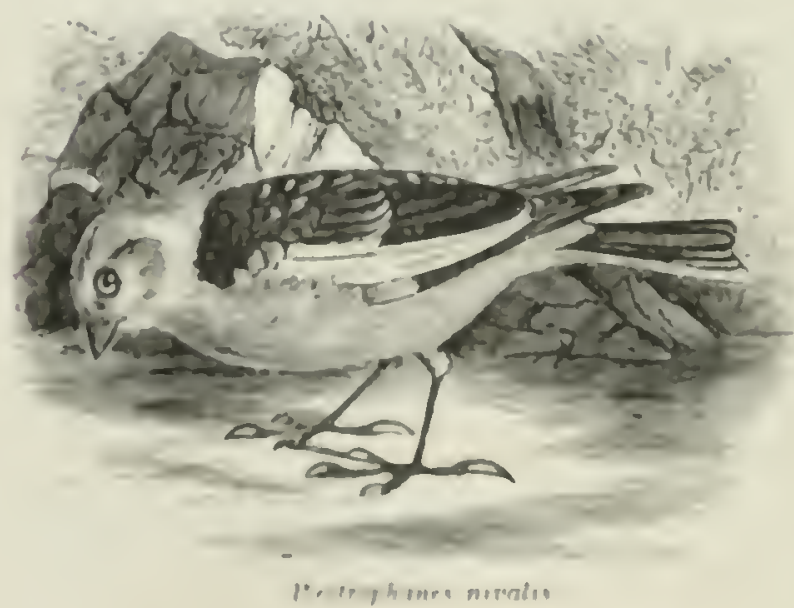

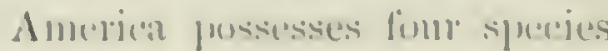
mot fouml, lilic her two others, in the olst World. They are all erromml-himls, collentiug in large fluckis, in antumn anml winfer, an probires and plams, sulle of the sturedes fassimer fat (1) Dhe southward. There is musch vallation in the collor, and in the detaits of structure of hill and line. In I'. nimlis alome is the frimge of hristly

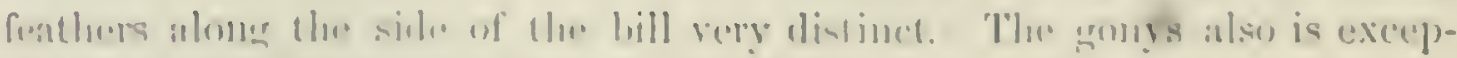

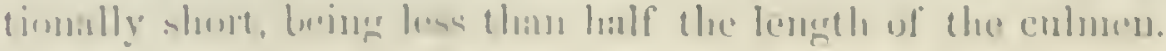


The females are less strongly marked than the males, lacking the distinct patches of black (which, however, are nearly always faintly indicated), and other characters, and are streaked like the Spizellince.

\section{Species and Varieties.}

A. Prerailing color white.

1. P. nivalis. đ. Back, scapulars, ends of tertials, alula, terminal half of primaries and the middle tail-feathers, deep black; otherwise pure white. \&. The black replaced by grayish with black spots; crown grayish spotted with black. Young considerably tinged with ochraceons. Hab. Circumpolal regions: south in winter into the Lnited States.

B. Alore brown, spotted with blaek. of. Crown black.

a. Six to ten middle tail-feathers almost wholly black; the lest withont black encls. \& with a nuchal collar of rufous or buff; and without rufous on the wings.

2. P. lapponicus. J. Ilead, all round, and jugulum, deep black; a post-ocular stripe, ruming downward behind the black jugular pateh, and entire lower parts from the jugulum, white. Nuchal collar chestnutrufous. $q$ with the black areas merely inclicated by a dlusky clouding, and merely a tinge of rufous round the nape. IIub. Circumpolar regions; south in winter into the Lnited States.

3. P. pictus. 3. Head aborc and laterally deep black, borlered anteriorly and below with whitc; a post-ocular stripe, and an orate auricular spot of the sanc. Nuchal collar and ('ntire lower surface bright buff. \%. Pale grayish-buff, darker above; ahore distinctly, and on the jugulum obsoletely, streaked with black. Hub. Interior plains of North America, north to Arctic Ocean.

4. P. ornatus. 8. Head abore, and whole breast and abdomen, black; a superciliary stripe, sicle of heal, chin, throat, anal region and crissum, white; nuchal collar rufous. \& hardly distinguishable from that of $P$. pictus.

a. Lesser wing-corerts brownish-gray; black feathers of breast, etc., withont rufous elges. Hub. Interior plains of L'nited States.

var. or natus.

b. Lesser wing-corerts black; black feathers of breast, etc., with rufous edges. Hub. Southern plains of Xorth America, and tableland of Mexico. . . . . . rar. melanomus.

6. Only two middle tail-feathers almost wholly black; the rest with black ends. \& withont a nuchal collar of rufous or buff, and with rufous on the wings.

5. P. maccowni. §. Crown, and a broad crescent on the jugulum, black; rest of head and neck ashy, appronching white on the throat and over the eye; beneath white, above grayish-brown, streaked with black; middle wing-corerts rufons. \&. Abore yellowish-umber, beneath yellowish-white; thickly streaked abore, unstreaked beneatl. No rufous on wings, and no black on head or jngulum. Hab. Plains, from Texas, northward.

There seems to be no special reason for subdividing this genus, although this has been done, $-P$. nivalis being alone retained in Plectroppanes; $P$. maccouni forming the type and sole member of the genus Rinyncophanes 


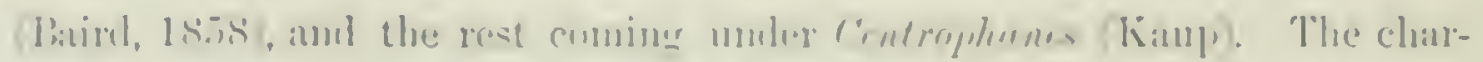

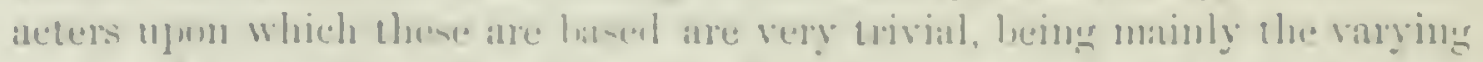

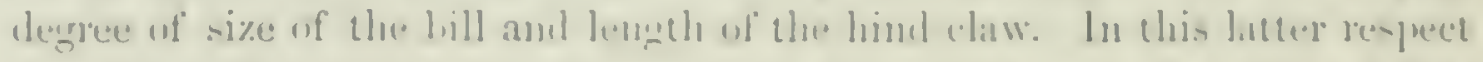
there is too much indivielual variation in the sane species to inlunit of this lecing availahle as a specitic, much less ats a sulngeneric character, while the size of the bill is not of more thin specilie impurtance.

Plectrophanes nivalis, Mryfi.

\section{SNOW-BUNTLNG.}

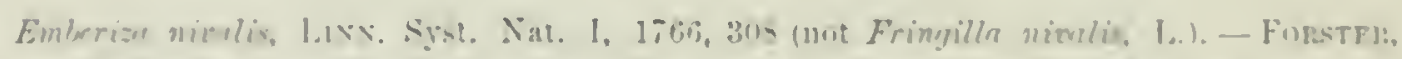

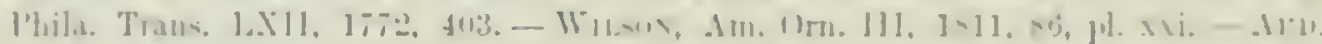

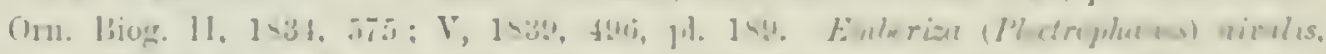

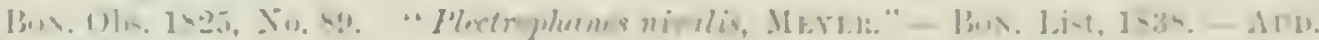

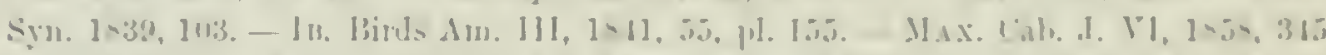

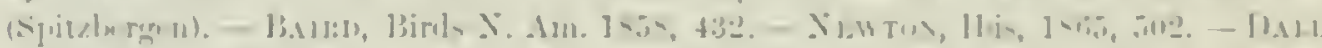

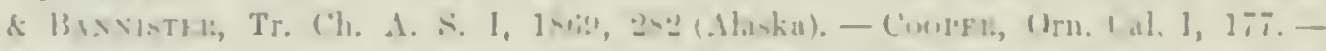

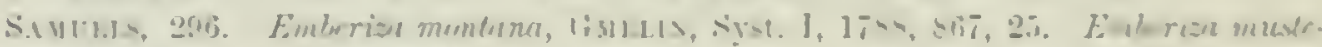

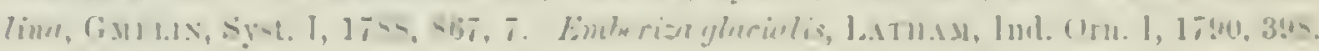

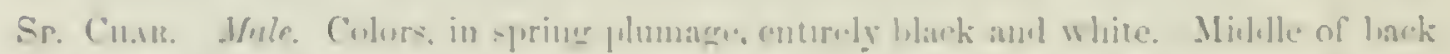

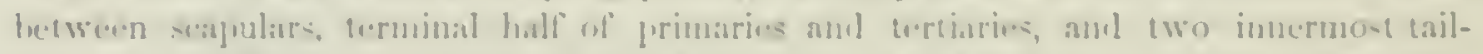

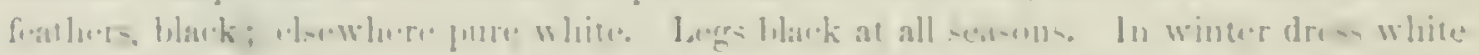

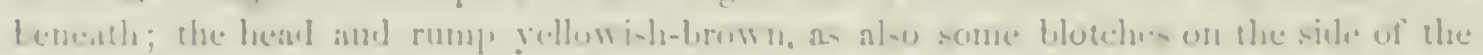

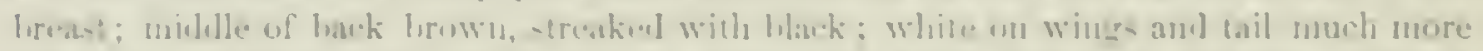

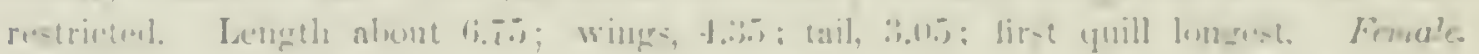

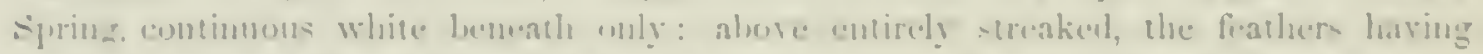

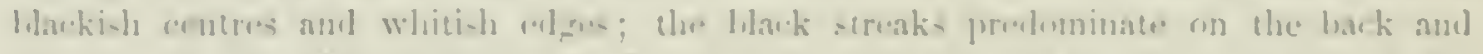

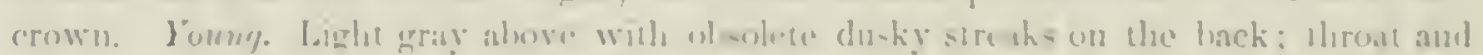

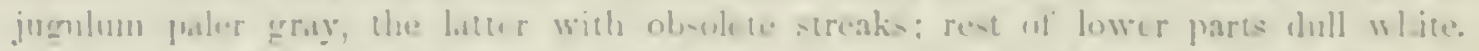

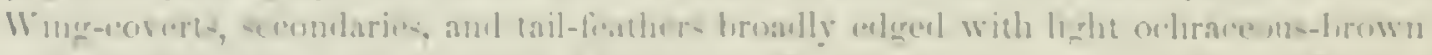

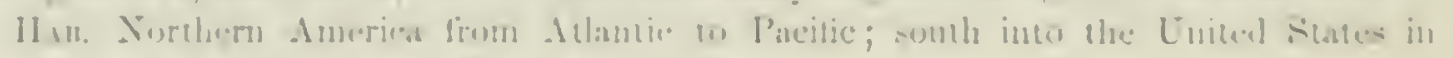

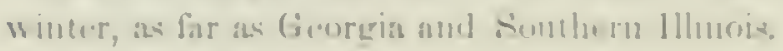

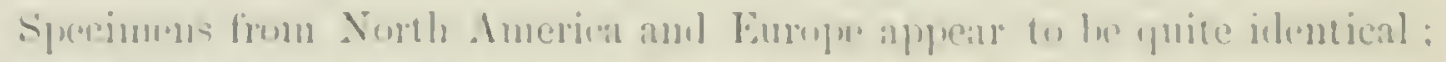

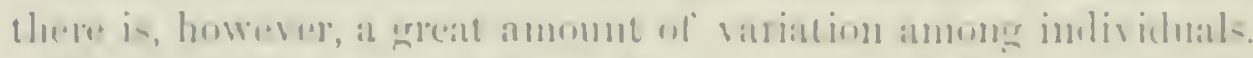

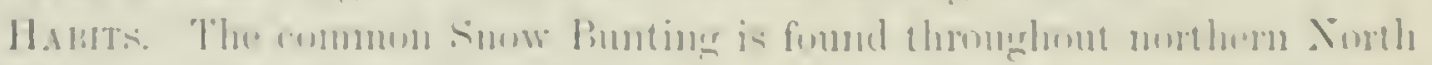

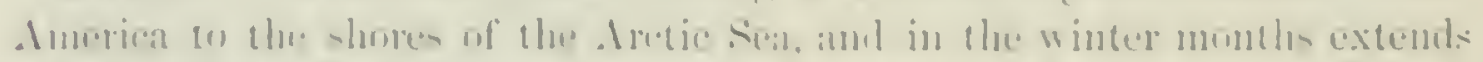

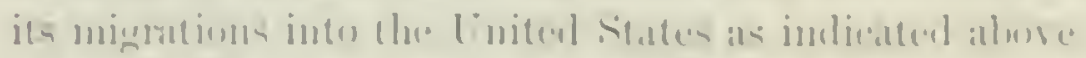

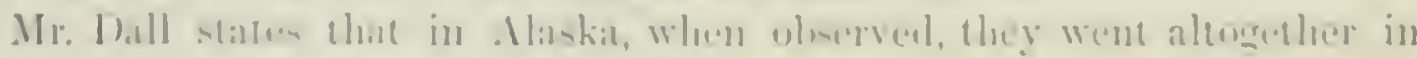

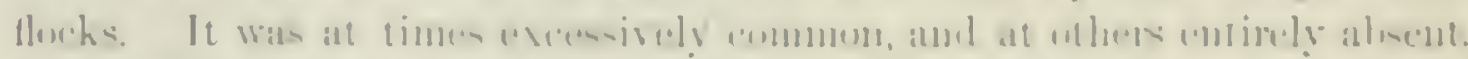

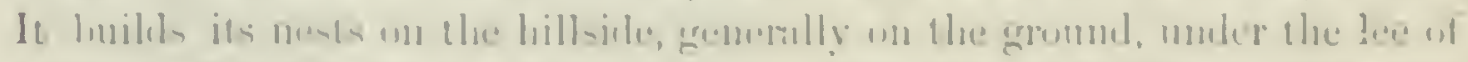

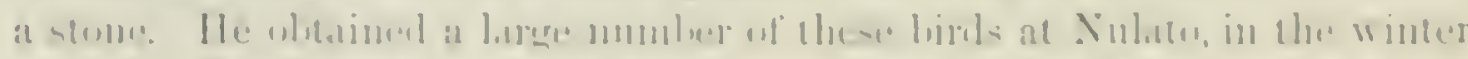

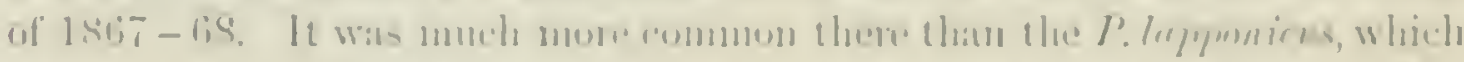

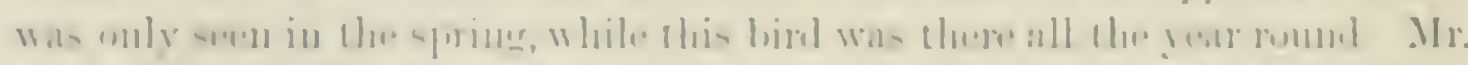

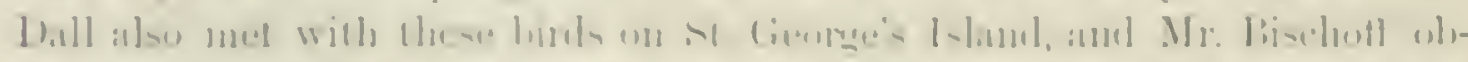

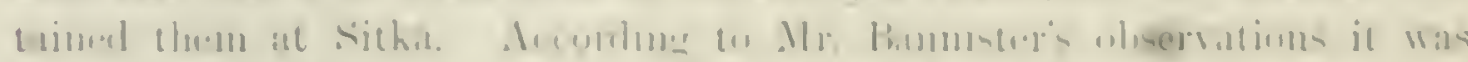

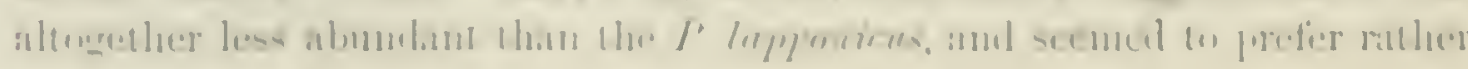


different situations. On St. Michael's Island he never saw one of this species far from the shore, while the other species was abumbunt everywhere in the interior of the island. Imring the smmuer he never saw more than one or two of these birks at once, nor anywhere except on rocky points or on small rocky islands near the shore. These localities they seemed to share with the liavens and l'uftus. In the antumn they are nore gregarious, hut still seem to prefer the ricinity of water. Mr. Bamnister also observed this bird at Unalaklik, where it is common.

Wilson was of the opmion that these hirls derive a considerable part of their food from the seeds of certain aquatic plants, and this he supposed one of the principal reasons why they prefer remote northern regions intersected with streams, ponds, lakes, and arms of the sea, abounling with such plants. On Seneca liver, near Lake Ontario, in Oetober, he met with a large flock feeding on the surfice of the water, supprorted on the close tops of weeds that rose from the botton. They were ruming about with great activity, and the stomachs of those he shot were filled not only with the seels of that plant, but also with minute shell-fish that adhered to the leares.

Richardson states that this species breeds in the most northern of our Aretic islinds, and on all the shores of the continent, from Chesterfield's Inlet to Behring Strait. The most snuthery of its breeding-places known to him was Southampton Island, in the 62 el parallel, where Captain Lrons found a nest on the grave of an Esquimanx child. Its nest was usually male of dry grass, neatly lined with deer's hair and a few feathers, and is generally fixed in the crevice of a rock, or in a loose pile of timbers or stones. The eggs are described as of a greenish-white, with a cirele of irrogular umber-brown spots round the larere end, with numerous blotches of subdued lavender-purple. July 22, in removing some drift timber on a beach at Cape Parry, he discovered a nest on the ground, containing four young Snowbirds. Care was taken not to injure them, and while they were seated at breakfast, at a distance of only two or three feet, the parent birds made frequent visits to their offspring, each time bringing grubs in their bills. The Snowbircls are in no apparent haste to leave for the Sonth on the approach of winter, but linger about the forts and open places, picking up seeds, until the snow becomes too deep. It is not until Decenber or January that they retire to the south of the Saskatchewan. It returns to that river about the middle of February, by April it has reached the 6.5th parallel, and by the beginning of May it is found on the shores of the Polar Sea. At this periork it feeds on the buds of the Scurifraga oppositifolia, one of the earliest of the Arctic plants. The young are fed with insects.

The Snow Bunting is also an inhalitant, during the breeding-season, of the Arctic regions of Emrope and Asia, and the islands of the Aretic Sea. Scoresby states that it resorts in large flocks to the shores of Spitzhergen, and Captain Sabine includes it among the birds of Greenland and the North Georgian Islands, where it is among the earliest arrivals. Mrr. Proctor, who 


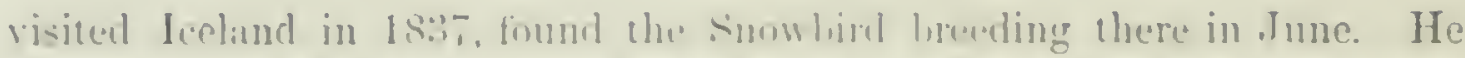

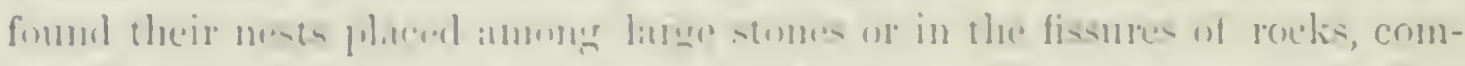

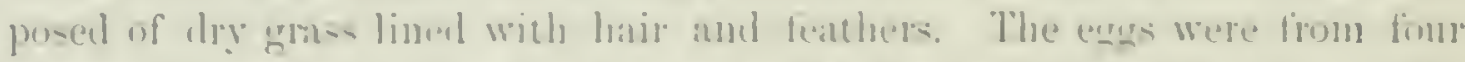
to six in mumlere. The malo attent the female duriun incubation. Mr.

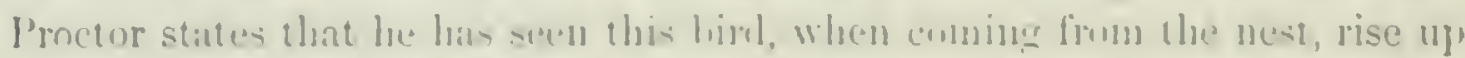

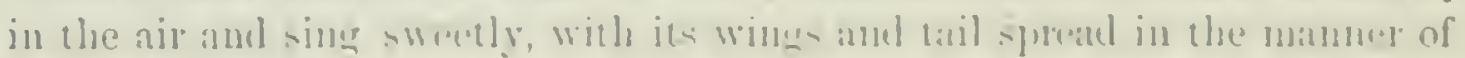

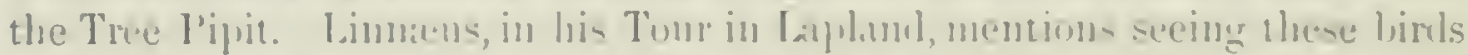

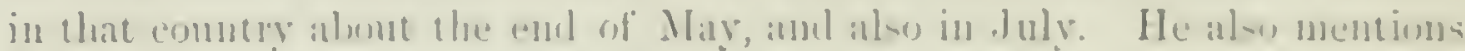

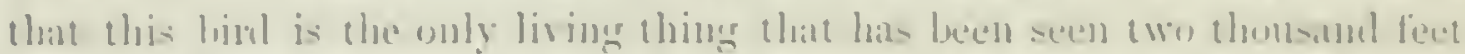

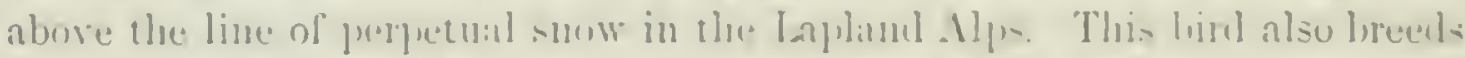

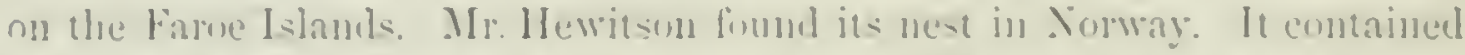
young, and was huilt muler some lonse stones. Young link have also been

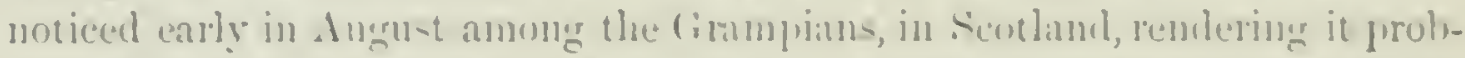
able that they breed in that locality, ant perhapis in comsile ralle mumbers. As the sererity of winter increates, they leave the heaths where they have

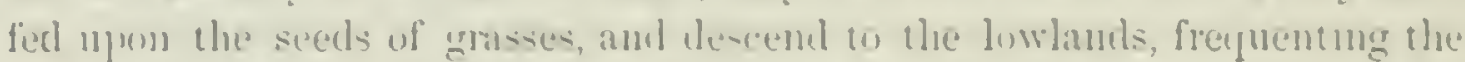
ont-stuhhles, and, when the snow is derpl, alphoaching the coa-t. Their callnote is pleasing, and is often repeated during their flight, which they matke

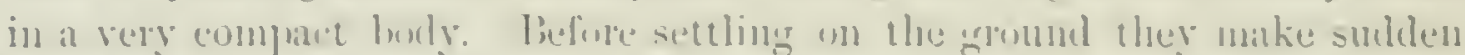
whects, combing almo-t into collision with eatch other, uttering at the same

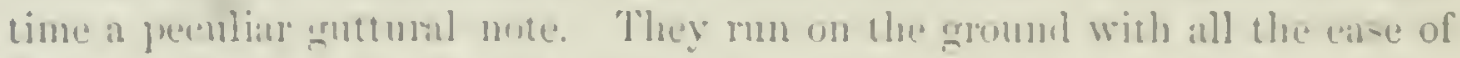

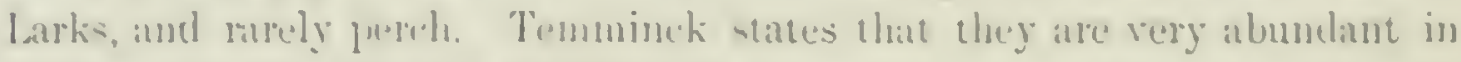

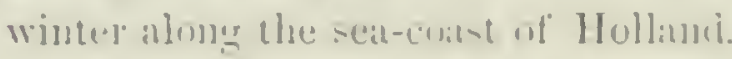

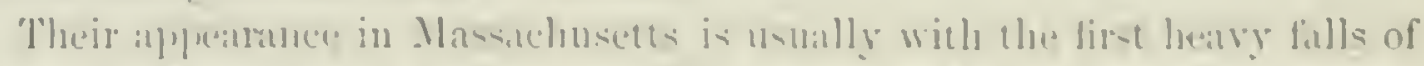

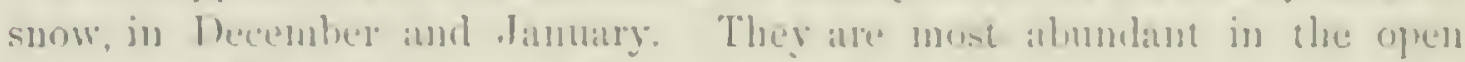

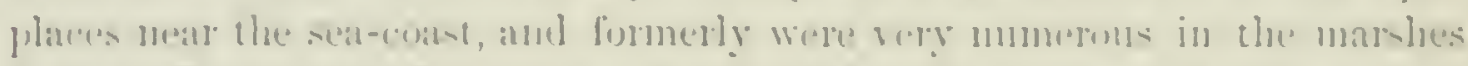

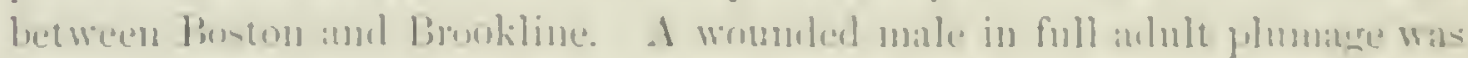
taken ly mm, in 3 s:is, amb liept some time in confinement. It would not

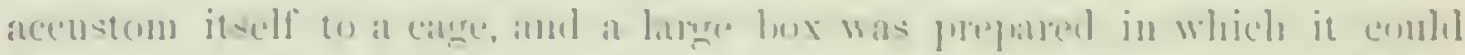

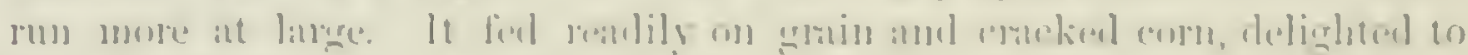

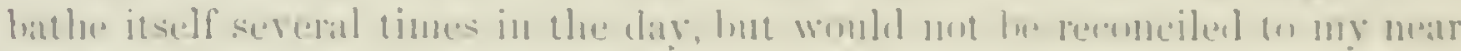

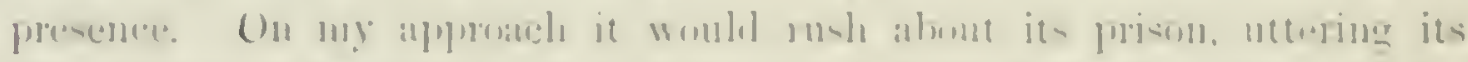

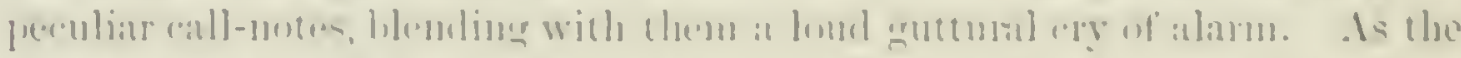

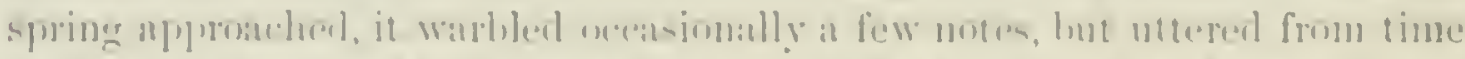

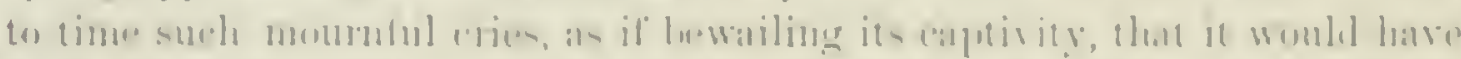

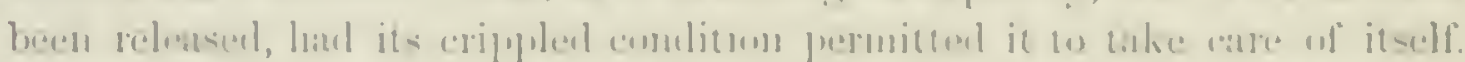

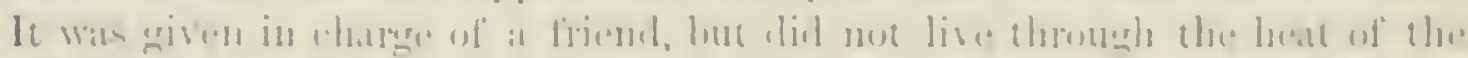
cusming sแmแmer

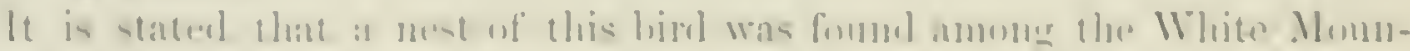

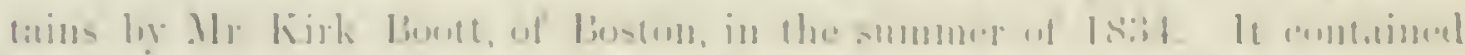

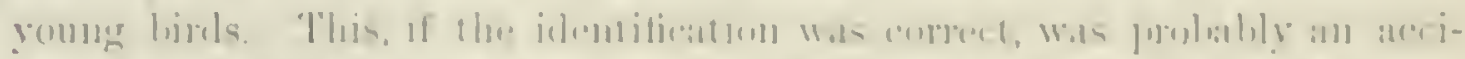

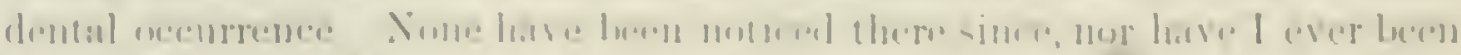

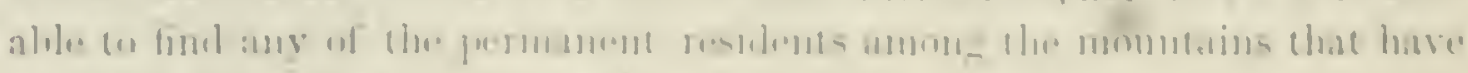

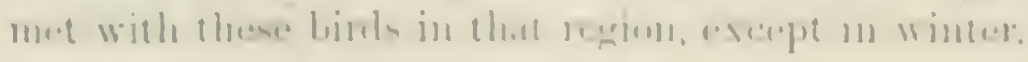


The only authenticated nest and eggrs $(10,4: 33)$ in the Smithsonian collection were received from Mr. R. MacFarlane, with the parent; taken on the Aretic coast east of Fort Anderson, and haring on the label, "Nest situated in a cave in a sand-bank." The nest is deeply santeer-shaped, and composed of wiry grass-stems, with a few feathers in the lining; external diameter 3.75 inches, internal about 3.00 ; depth, 2.50 externally and 1.50 internally. The eggs, five in number, are of a dull white, with perhaps a faint bluish cast, sprinkled and spattered with dilute yellowish-rufous, the markings most numerous towarl the langer end ; they mensure .95 of an inch in length by .64 in breadth.

\section{Plectrophanes lapponicus, Selby. LAPLAND LONGSPUR.}

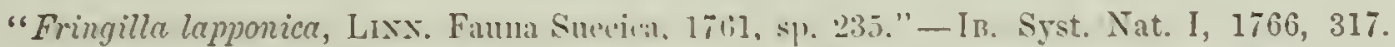
Fonster, Phil. Trans. LXII, 17T2, 4104. Eimberize (Ploctrophenes) lapponica, Sw. F. B. Am. II, 1831, 24S, p]. xlviii. Émberizn lapponica, Atn. On. Biog. IV. 1S39, 473, pl. 365. Plectrophanes lupponicus, “\$1:135," Box. List, 183s. - Avv. Syn. 1539, 9S. - 1B. Birls Am. III, 1\$41, 50, pl. 150.-B.11:n. Birls N. Am. 1858, 433. -

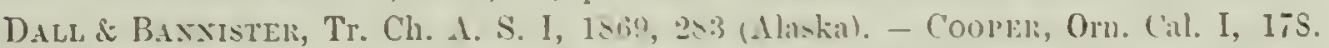

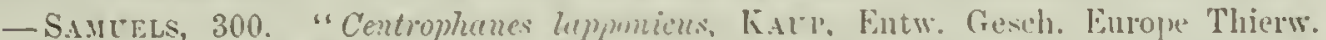

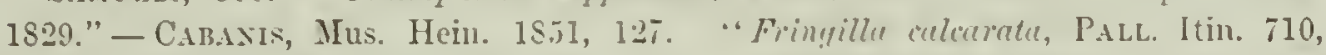

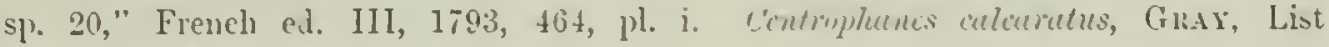
Gell. 1S41, App. 1S42, 11.

Sp. Crar. Male. Heal all round, and neck black, extending on the jugulum in a crescentic patch; a broad line from above and behind the eyc. siles of neck, a patch in the black of hind head, and whole nnder parts, white; the sides of body streaked broally with hlack. A brond half-collar of chestunt on back of neck, separated from the hood narrowly, and from the auriculars and throat broally, by the white stripe from the ere. Above brownish-black, the feather's sharply celged with brownish-yellow. Onter tail-feathers white, except the basal portion of iuner weh, and a sluaft streak at end; next feather with a white streak in end, rest hlark. Leas black: bill yellow, tipped with black. In winter plumage the black and other markings orerlaid by rusty and fulrous; beneath by whitish. Female with the black foathcrs of head edged with rellowish-lusty; the throat white, bordered on the sides and behind hy hlackish ; feathers edgel with gravish-white, the rufous of nape obscure, and streaked with hlackish. Length of male, 6.25 ; wing, 3.90 ; tril, 2.80 .

H.ub. Northern portions of the Old and the Ner World; breeding in arctic and subaretic regions, and

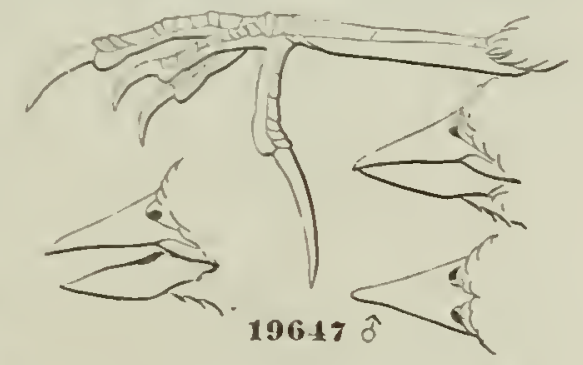
in winter descending southwarl, as far at least as New York, Southern Illinois, and Fort Garland, New Irexico.

Antumnal specimens, of both sexes, differ in having the pattern of coloration obscured by ochraceous borders to the feathers, and a general rusty cast to the plumage.

There appears to be no difference between North American and European specimens of this bird. 


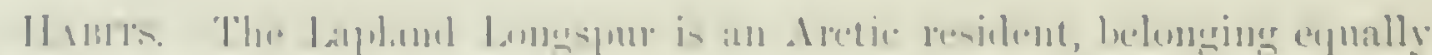

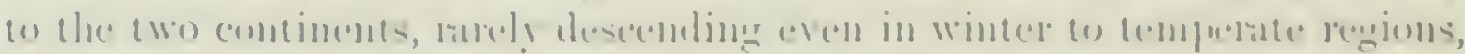

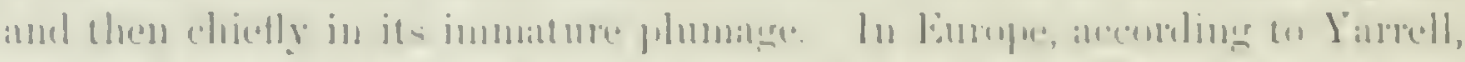

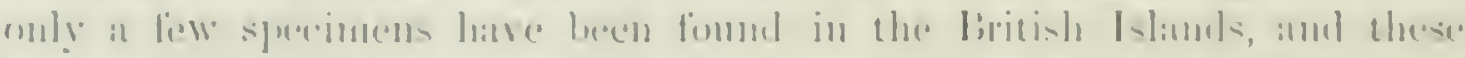

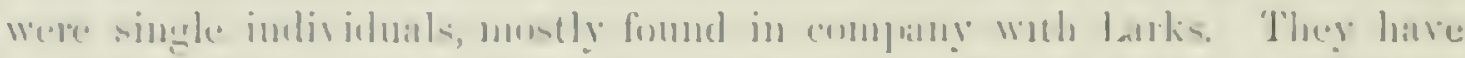

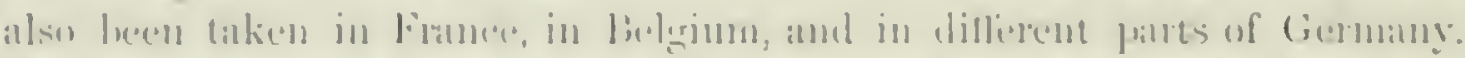

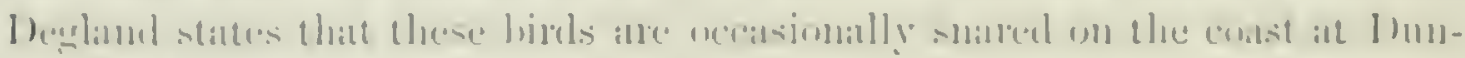

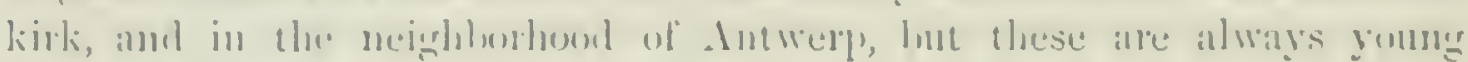
malen in lacise winter plumige.

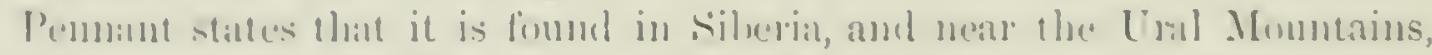

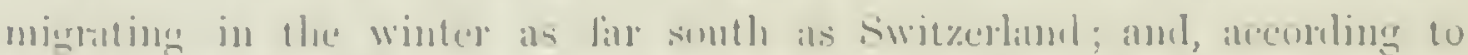

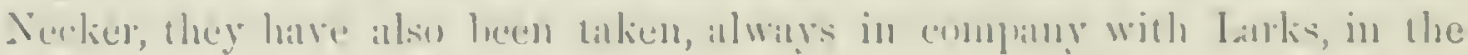

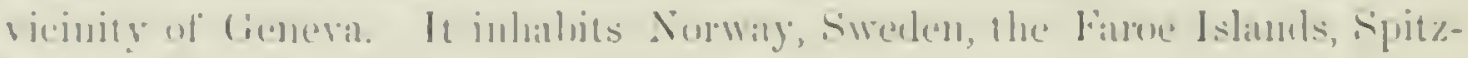

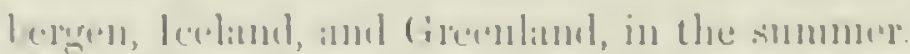

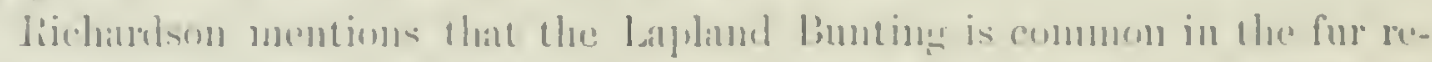
grons, wintering on the colist of Ilutsunts bily. During its staly it fecels un

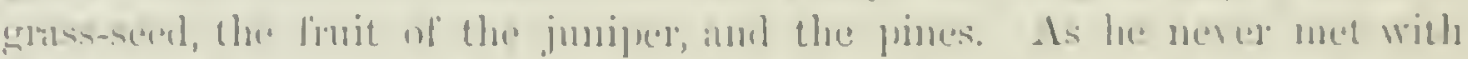

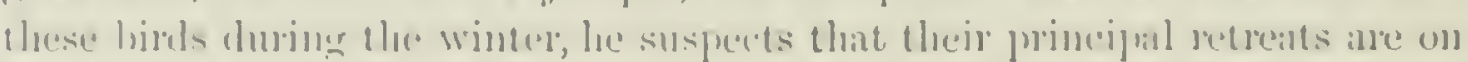

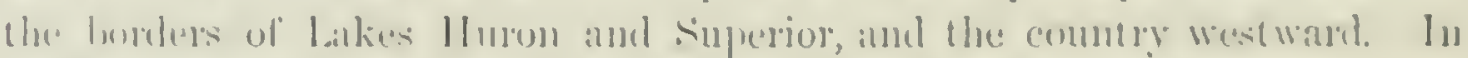

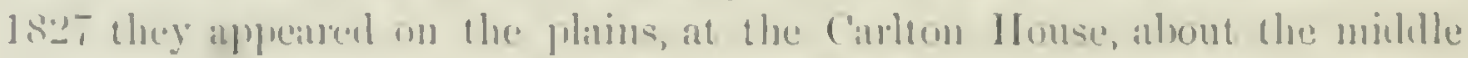

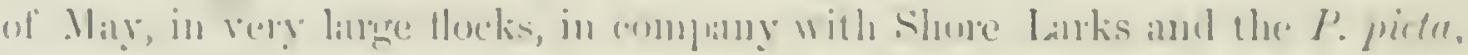

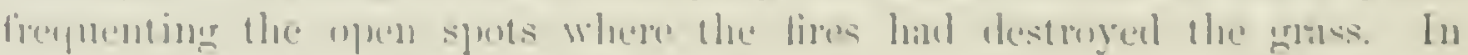

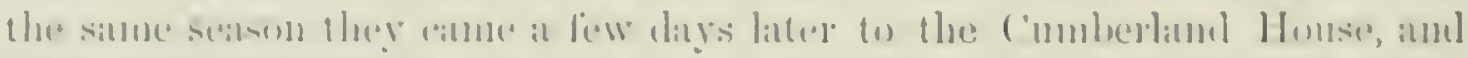

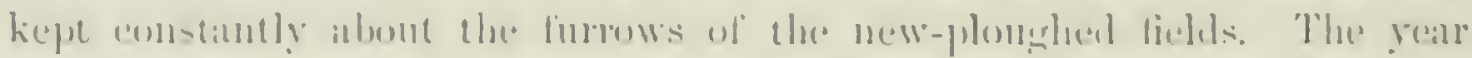

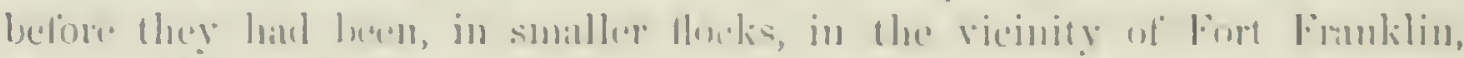

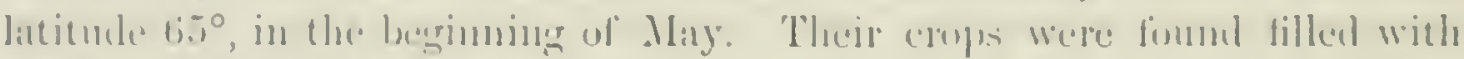
sueds of the alpine allulus.

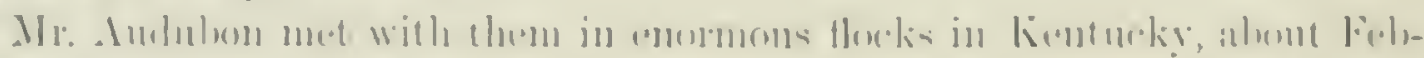

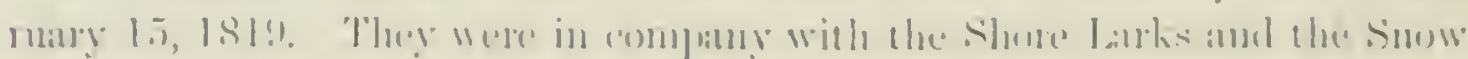

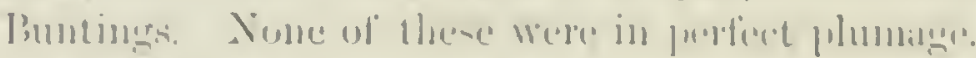

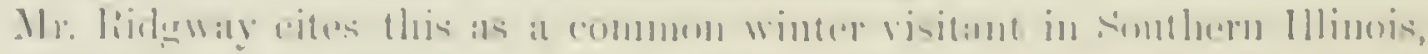

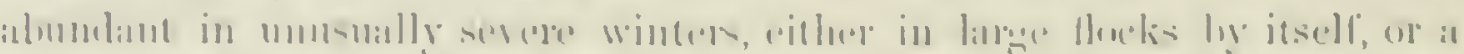

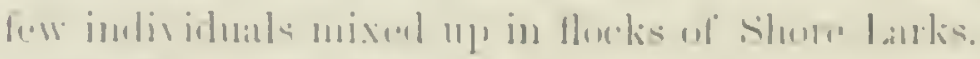

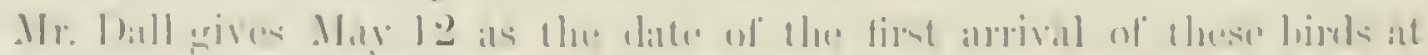

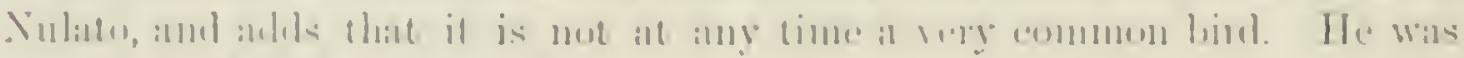

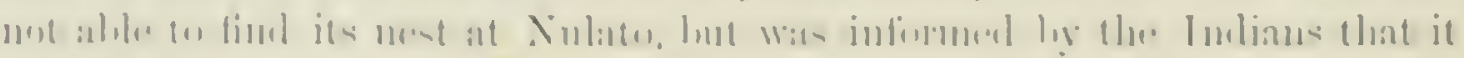

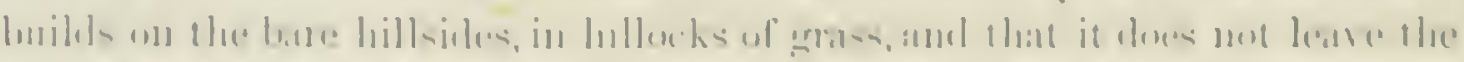
ment whell

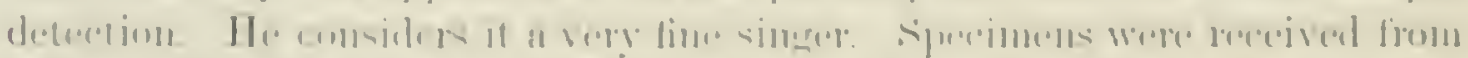

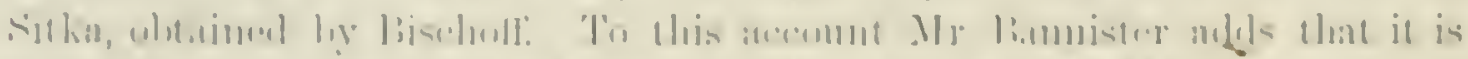

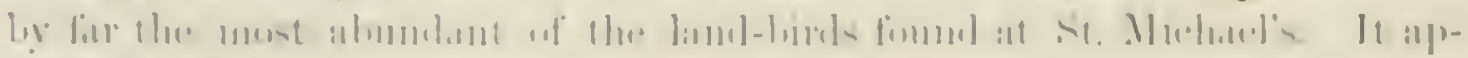
|

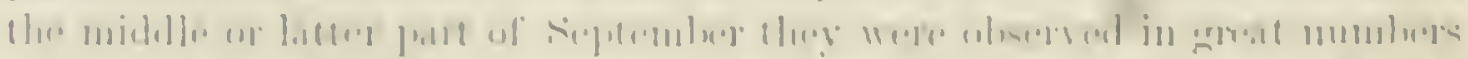

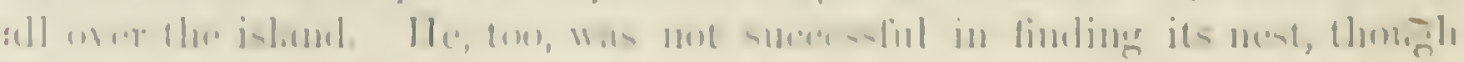


the birls were stanted up by humheds on every walk over the island. From this he infers that they must he very carefully concenled. He often searehed for them, but alwas with the sime result. Mr. Bamnister regarded this species as decidedly the best sungster of its family.

In the far Torth it is an extremely abumlant species from one ocean to the other, in the winter moving finther south, to the United states, in linge Hocks. It has not been fomd in Califorma, but in the central and eastern regions las been obtained as far south as Leavenwortl, Kinn., liacine, Wis., Boston, and New lork. It is stated by ditlerent observers, that, like the Lark, it sings only while in motion in the air, or while suspended, and that its notes are agreeable and melodions.

According to Richardson, they breed in moist meadors on the shores of the Arctic Sea, the nest being placed in a small hilloch, among moss and stones. It is compused extemally of dy stems of "yms, interworen to a considenable thichness, and lined rer neatly and cumpletly with deer's hair. The eggs, seven in number, he descrilues as pale ochre-vellow, spotted with brown. Sir James lioss found them by no means numerous in the higher northern latitudes, and obtained one nest, containing five egors, in July.

According to Hulbull, this lird is common along the shores of both North and South Greenland. They reach Godluab in the beginning of May, and Godhaven a month liter. Their migrations do not take place all at once, but they are constantly arriving during the month. It remains in south Greenland until the begimning of September, and longer if the deep snows do not drive it away. This bind is never met on shipboard until the ressels are in Davis Strait, proving that their migrations must be from Anerica. The Greenlanders call it Narksmmak (inhabitant of the plains), - an appropriate name, as it only lives on the lowhuls near the sen-shore, where it builds its nest in the manner of the Lark, in the grass, or among the lichens. Its five egas, of a lirty olive-color spotted with brown, are smaller than those of $P$. nirulis. The song of the male bird, as it horers in the air or rocts on a swaying twig, is rery clen and melolions. It is even known as the (ireenland Nightingale. Its fool is seels, and it is not known to suek insectlarre on the houses of the Greenlanders, as does the $P$. niculis. In their winter dress they all resemble the female in her summer plumage, only in the male some black is seen in the head-feathers.

Fabricius deseribes its eurs as five or six in numher, of a reddish-gray with brownish spots. I) enland deseribes their ground-eolor as an ashy-gray, corered with spots of light brown, with lines and spots of deep brown, and also of elear black.

Eggs from Anderson River exhibit great rariations in their appearance, more from the difference in the distribution of their spots than from variations in colors. Where distinctly visible, the ground-color appears to be of yellowish-gray, frequently so thickly spotterl as not to be recognizable. The blutehes are of rarions shades of brown, with sliadings of olive, purple, or 


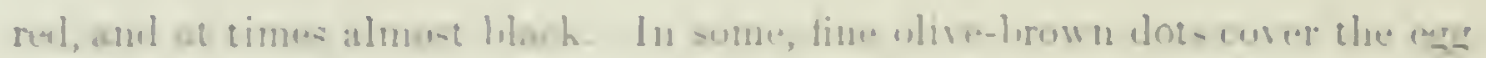

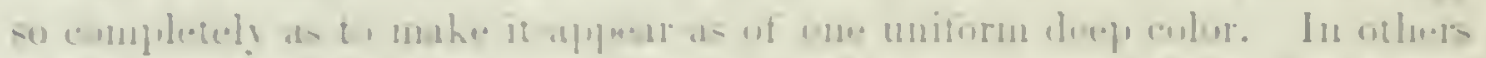

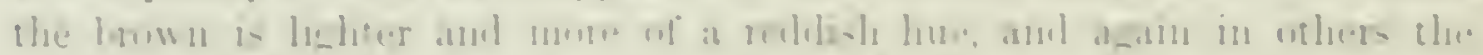

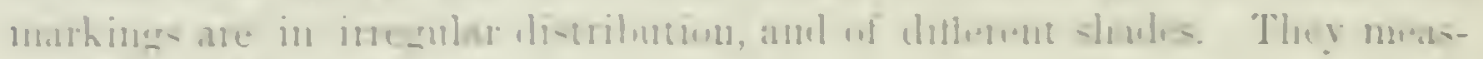
ure Q

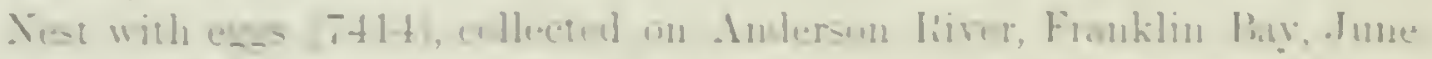

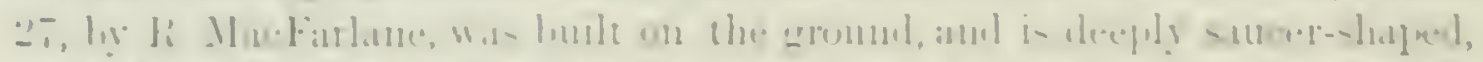

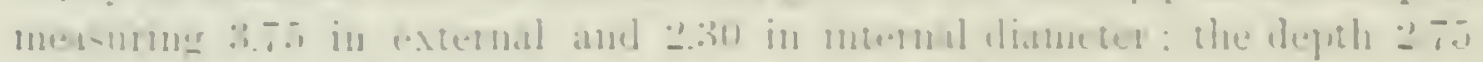

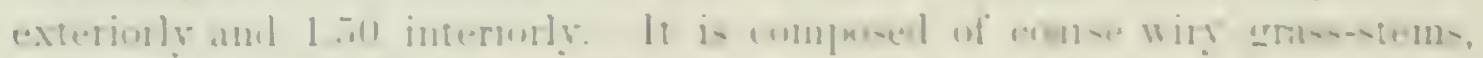

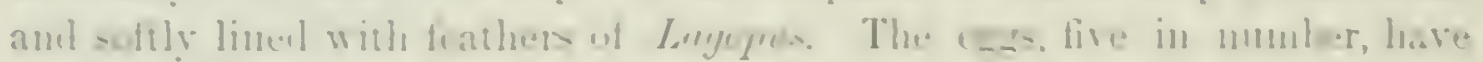

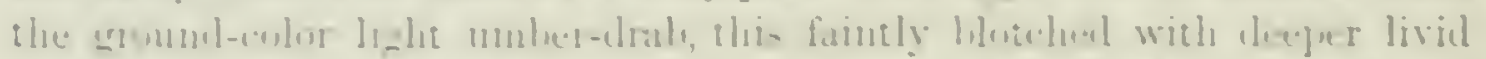

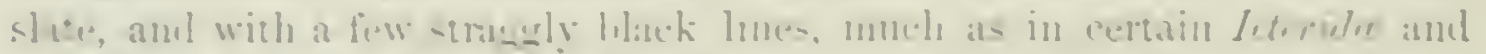

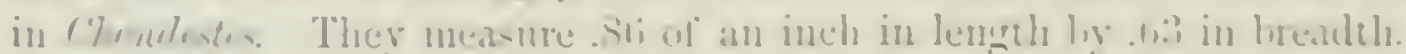

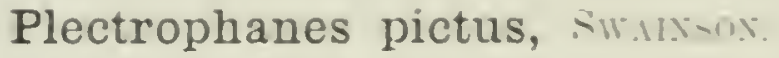 SMITHS BUNIING: PAINTED LONGSPUR.}

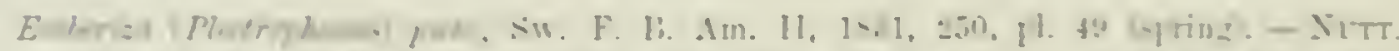

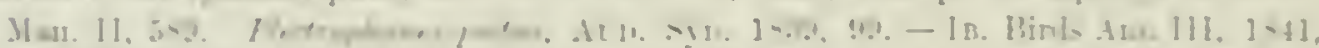

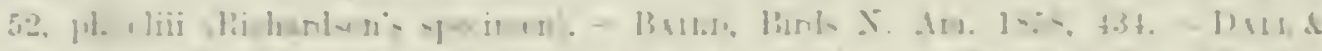

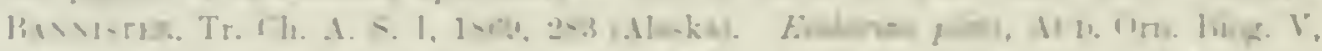

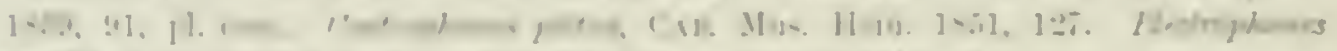

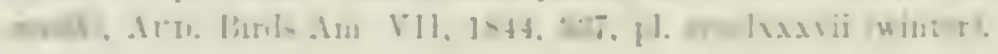

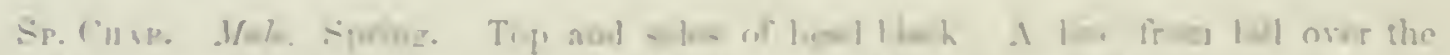

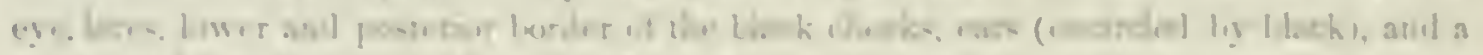

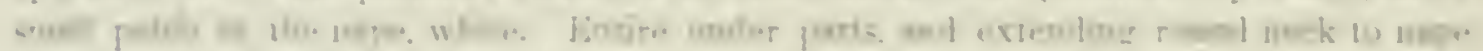

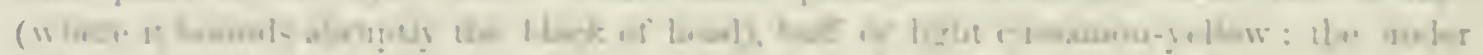

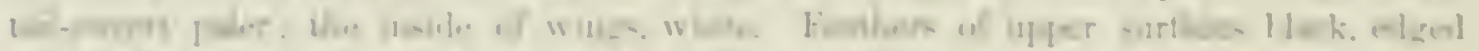

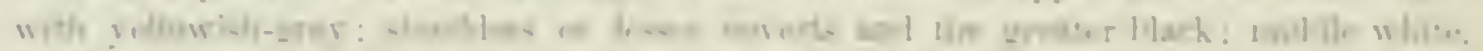

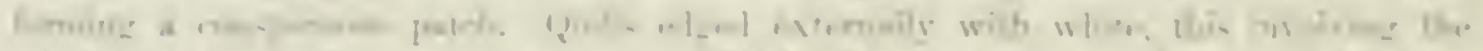

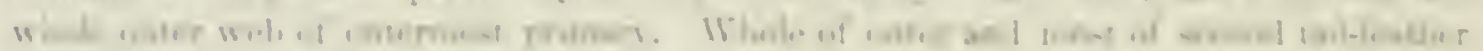

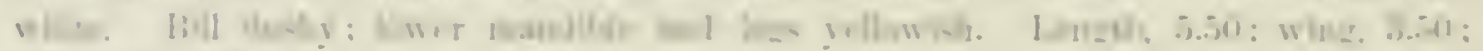

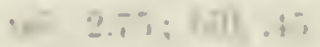

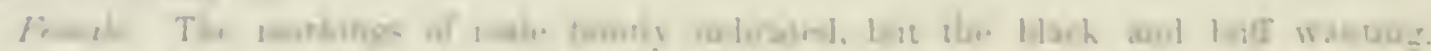

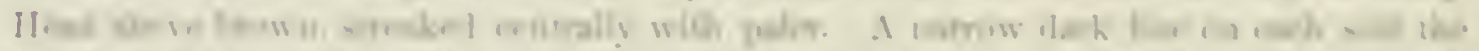

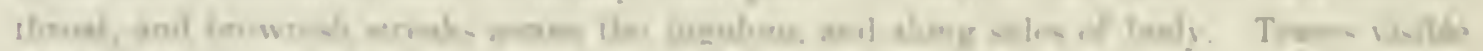

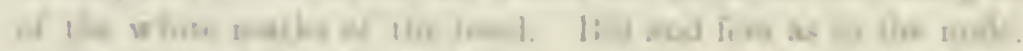

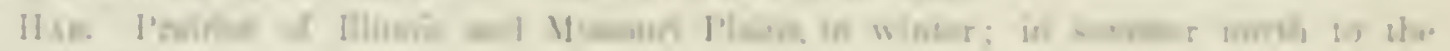
Anin Thensei

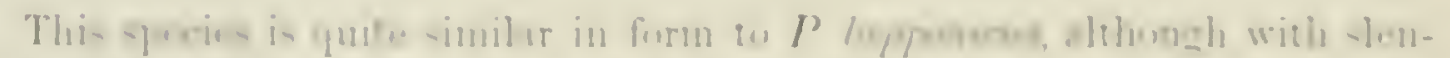

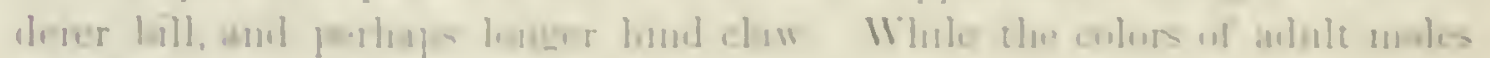

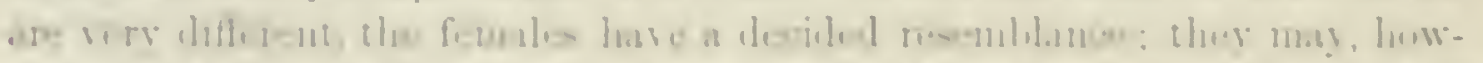

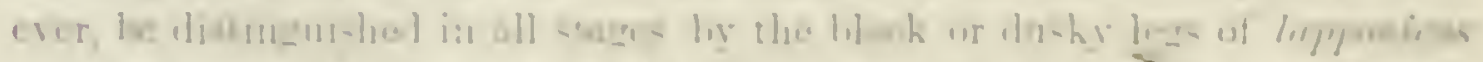

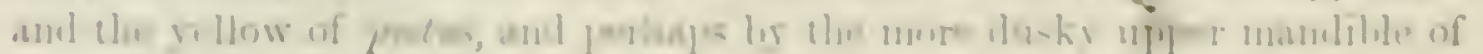
1h. beter 
H.ıbits. This species was first obtainerl by Sir John lichurdson's party, and described hy swainson in the Fenme Bureuli-dmericene. It was observed associating with the Lapland Buntings on the banks of the Saskatchewan, but no information was oltained in regard to its breeding-halbits. No specimens in the mature plumage are known to have been obtained in the United States, but birls in the immatme plumage are not unfrequent, in early spring, thronghont Inlinois. Mr. Audubon, in eonnpany with MIr. Harris and Mr. Bell, obtained specimens of these birds ne:ll kidwardsrille, and deseribed them as an new species. Mr. Bell states, in regard to these birls, that he found them very abundant on the low prinie near a lake, a few miles from Edwardsville. They were gencrally in large floeks, and when once on the ground they began to separate. They ran very nimbly, in a mamer resembling that of the Grass Finch, and when they arose, which they rarely did unless they were nearly alproached, they uttered a sharp click, repeated several times in quiek succession, and noved with an casy undulating motion for a short distance and then alighted very suddenly, seeming to fall perpendicularly several feet to the ground. They preferred the spots where the grass was shortest. When in the air they Hew in eircles, to and fro, for a few minutes, and then alighted, leeping up a constant chirping or eall, somewhat like that of the Red-l'oll.

These birds were observed in large numbers at Fort Anderson, and on the Lower Anderson River, by Mr. MaeFarlane, and a large number of their nests obtained. These were all on the ground, and usually in open spruces, but also in the vicinity of trees. The nsual number of exins fomm in at nest appears to have been four. The nests, for the most part, were censtructed of fine dry grasses, carefully arranged, and lined with down, feithers, or finer materials similar to those of the onter portions. In a few there were no feathers; in others, feathers in different proportions; and in a few the down and feathers composed the chief portion of the nest, with only a few leares as a base to the nest. They were sometimes sunk in excavations made by the birds, or placed in a tussock of grass, and, in one instance, placed in the midst of a bed of Labrador teal.

They were also obtained at Fort Yukon, at the month of Porenpine River, by Strachan Jones. They were much more abundant in the Mackenzie River district.

Specimens of this bird, in the fall plumage, were obtained from Fort Simpson, where Mr. B. R. Iioss states that it appears on its way north in May: They resort to the fields aromut the fort in search of grain. Although these birds keep entirely apart from the $P$. nivalis, Mr. Ross has frequently observed several P. lapponicus associating with them.

When their nests are approached, the female quietly slips off, while the male bird may be seen hopping or flying from tree to tree in the neighborhood of the nest, and will at times do all he can to induce intruders to withdraw from the neighborhood. 


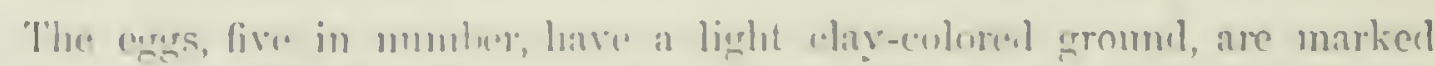

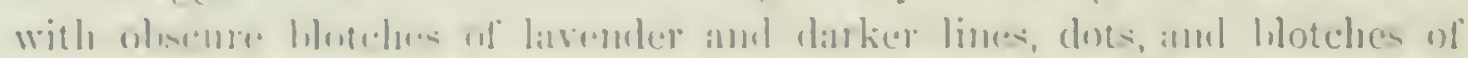

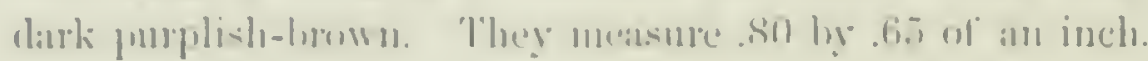

\section{Plectrophanes ornatus, Tows.}

\section{CHESTNUT-COLLARED BUNTING; BLACK-BELLIED LONGSPUR.}

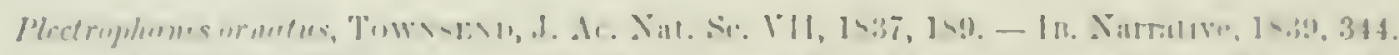

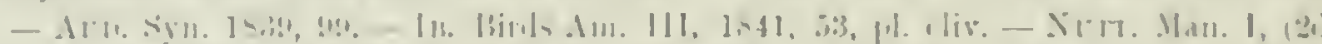

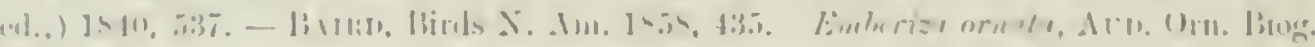

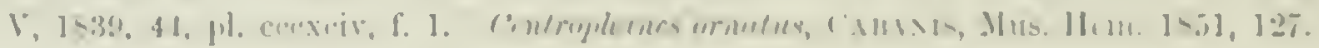

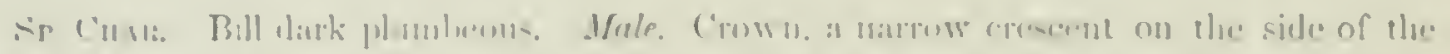

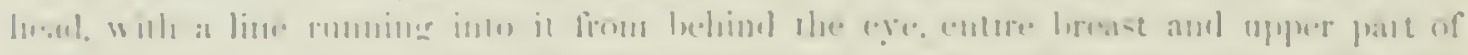

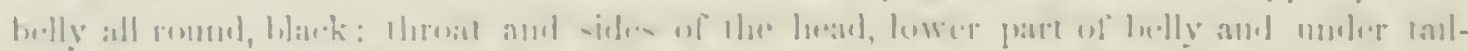

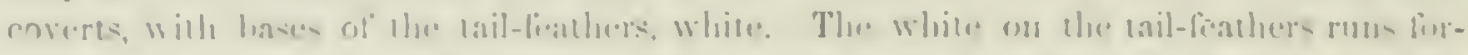

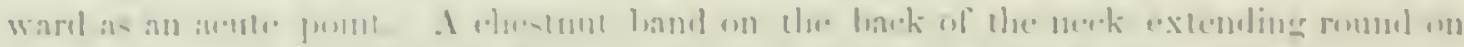

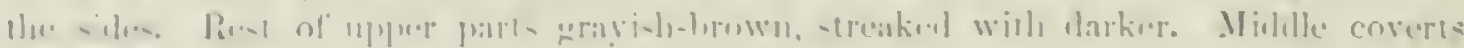

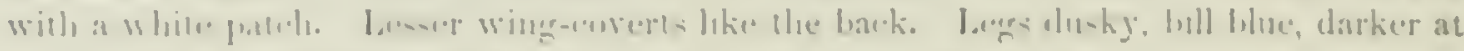

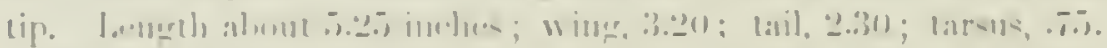

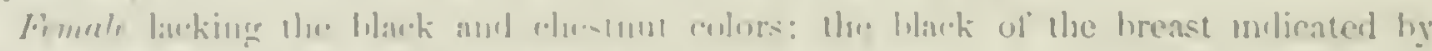

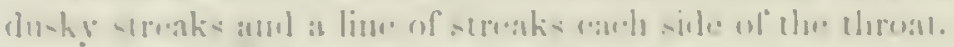

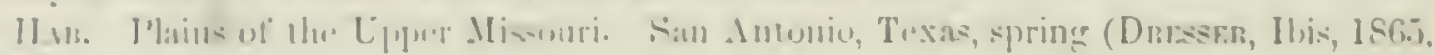
firli).

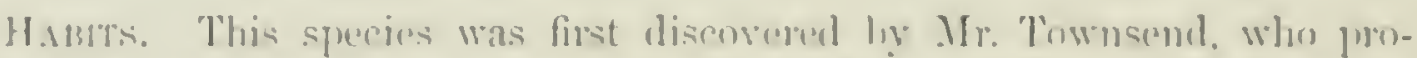

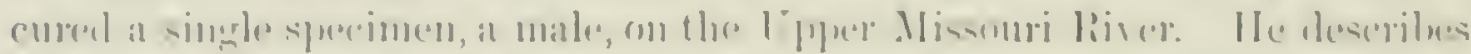
it a

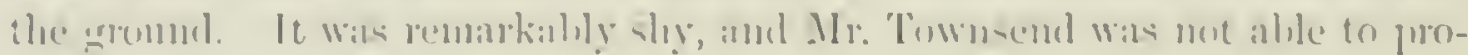
cure more thall al simgle spereimen.

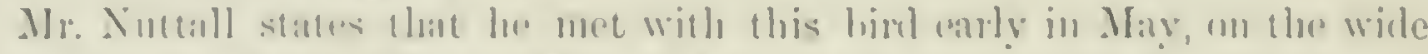

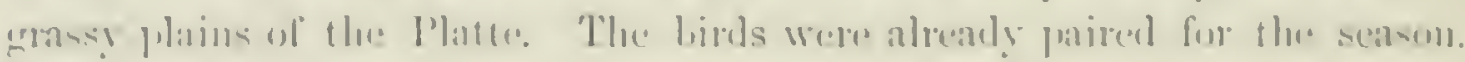

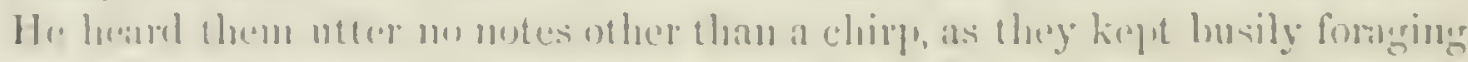
lin Harir milsistence.

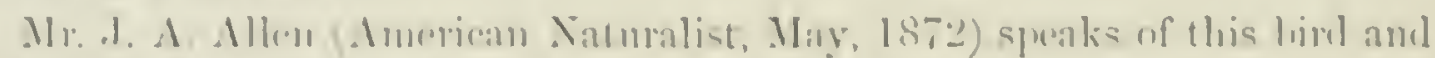

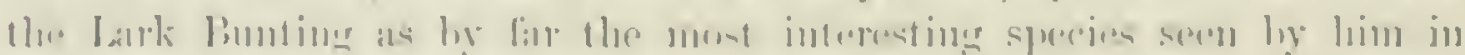

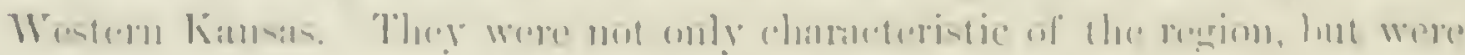

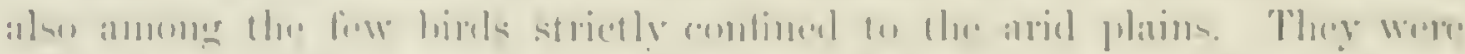

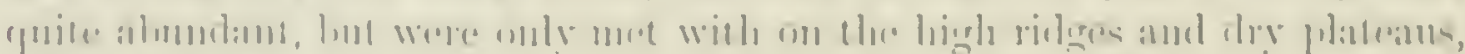

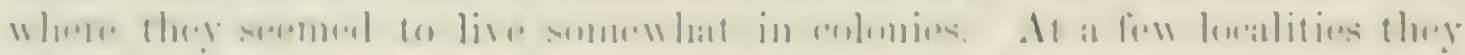

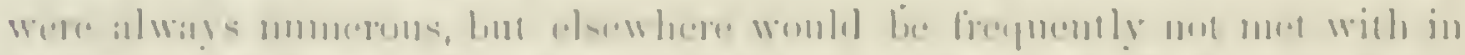

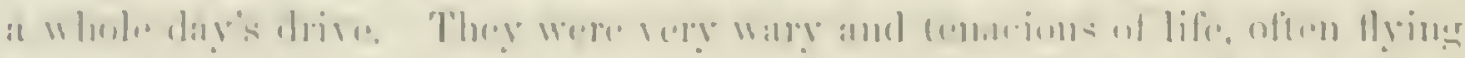

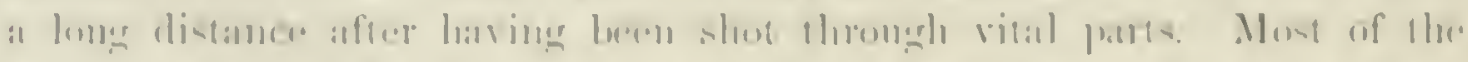

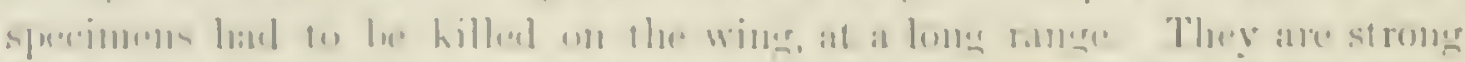

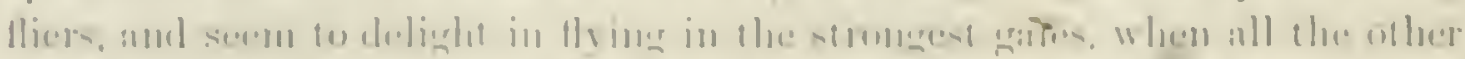

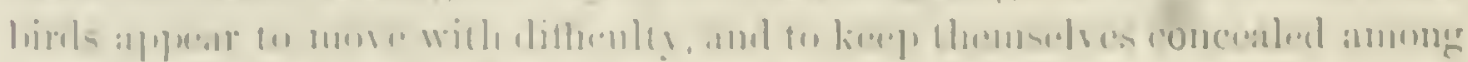

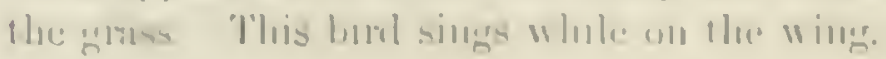


Mr. H. F. Dresser, in his paper on the birls of Southern Texas, mentions finding the Chestnut-collared Bunting in flocks early in the spring, on the prairies near San intonio, but it was not a common bird there.

Dr. Woodhouse found this species quite rare in the Indian Territory, where he was only able to secure a single specimen.

Captain Blakiston met with this species on the Saskatehewan Plains on the 15th of May, 1858, - a higher range than has been noticed by any one else.

Dr. Heermann, while on a trip to the Rocky Mountains in 1843 , met with this species in small tlocks and pairs, scattered over the prairies of the P'latte River, arrl was so fortmnate as to meet with one of its nests. It was built on the ground, and was made of an interwearing of fine grasses and lined with hair. He describes the eggs, which were four in number, as having a white ground, with black lines at the larwer end, and a few faint blotches of a neutral tint scattered over their whole surface.

This description does not quite correspond with the egus colleeted by Mr. Audubon on the Upper Missouri. These have a clay-colored ground with the slightest possible tinge of green, and are marked with fine dots of purplishbrown, and larger minkings, blutehes, and short lines of dark brown. They measure .70 by .55 of an inch, and liave a strong resemblance to the eggs of both P. pietus and P. maccounin.

Five eggrs of this species, obtained at Fort Hars, Kansas, June 1, 1S71, by Mr. J. A. Allen, measure .55 of an inch in length by .j8 in breadth. They are small in proportion to the birl, and are somewhat pointed at one end. Their ground is a gray or grarish-white slade of stone-color, and this is somewhint sparingly marked with blotches of dark brown, almost black, and lighter markings of purplish-brown. The nest wis placed on the ground, and was composed altogether of fine stems of grasses.

\section{Plectrophanes ornatus, var. melanomus, BAIRD.}

\section{BLACK-SHOULDERED LONGSPUR.}

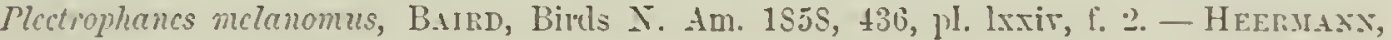
$\mathrm{I}, \mathrm{c}, 13$.

Sp. Cuar. Bill yellowish, dark brown along the culmen. Male. Crown, a short stripe behind the eye, and a short crescent behind the ear-corerts, entive breast as far back as the thighs, and the lesser wing-coverts. black. The black on the breast margined with dark cinnamon. Sides of head, chin. throat, and region behind the black of the belly, white. A broad half-collar of lark cinnamon-brown on the back of the neck. Tailfeathers mostly white; the innermost tipped with dark brown; the white ending in an acute angle. Length. 5.30; wing, 3.40; tail. 2.60. (No. 6,290.)

H.ı. Eastern slope of the Rocky Mountains, Mexico, on the table-lands, north to Upler Missouri. Orizaba (Scliter, 1860, 25l); San Antonio, Texas, spring (Dresskr, Ibis, IS65. 486); Fort Whipple, Arizona (Cotes, P. A. N. S. 1866, S4); Vera Cruz, plateau, breeding (Sincur.ss, I, $55 \mathrm{I}$ ). 


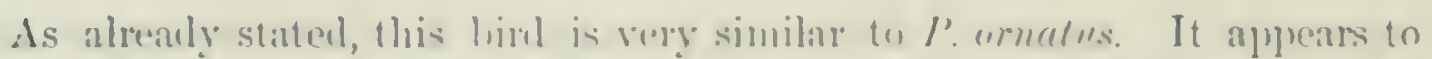
lo a very little langer, or, at any batte, with considerably longer wings.

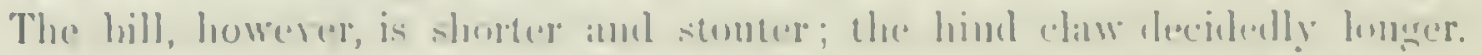

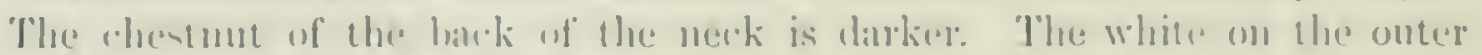

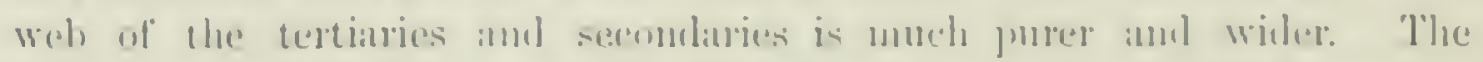

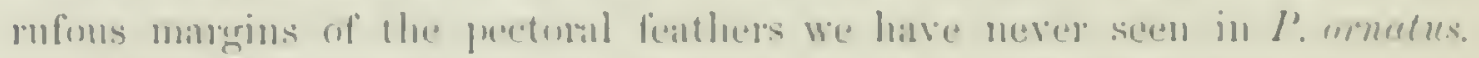

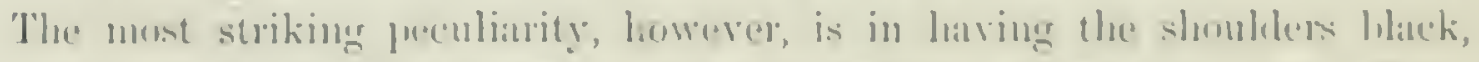
intend at hrown like the rest of the wing-feathers, whed with paller. Ponh have lle white pusterior row af lesere wing-ronerts.

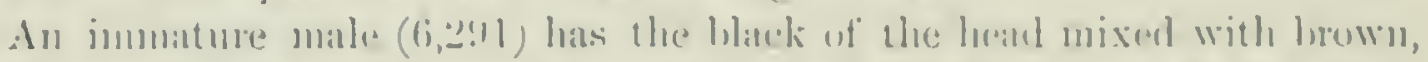
ancl a maxillary series of spots on catch side of the thruit. A female has a

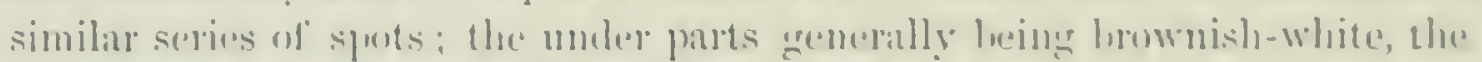
slafts arross the breast and allong the sides streikenl with brown, the conreated pritions of the feathers light hrown, finding ont to the whitish exterion: There is no halek on the shoulder, nur chestnut on the napre.

Fully mature specimens of this hivel and of ormelus atre st bare in collec-

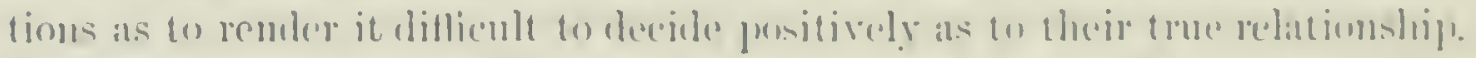
It is by no meins impersible that they meredy represent difterent comelitions

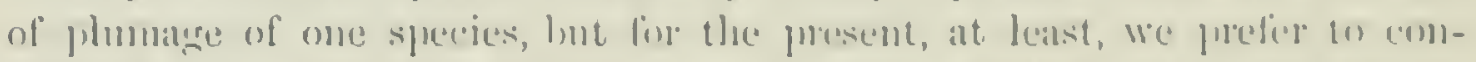
sider them ats distinet. The P. milenomes is resident on the table-lands of Mexim.

Habuts. Of the habits and geneml histury of this species, very little

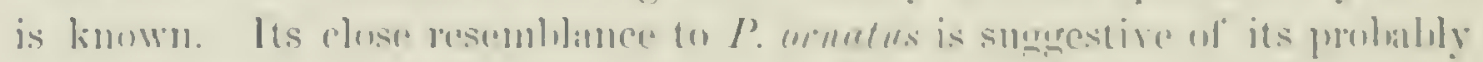

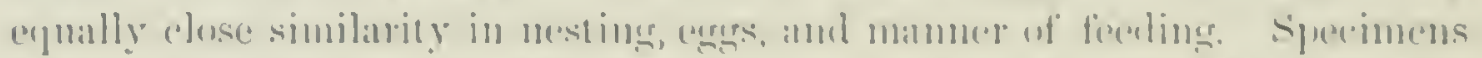

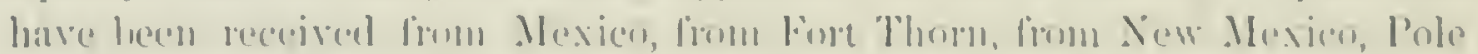

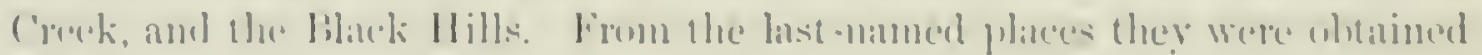

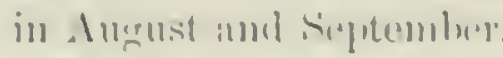

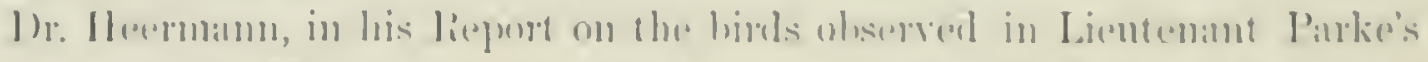

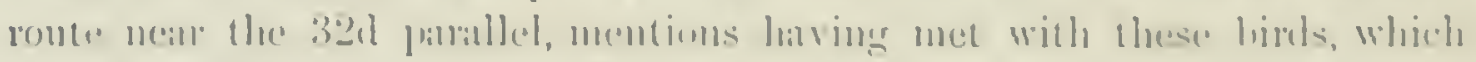

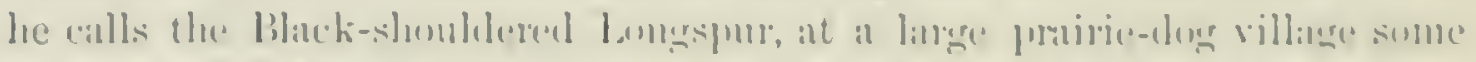

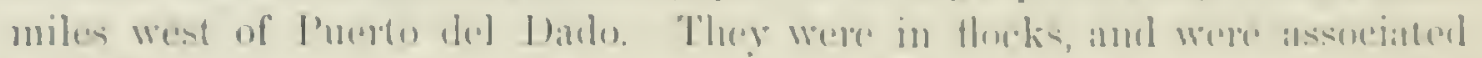

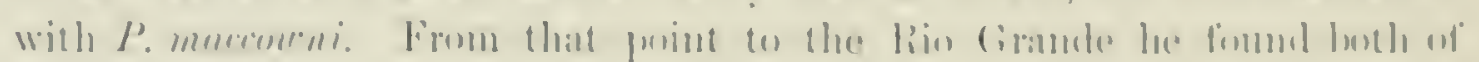

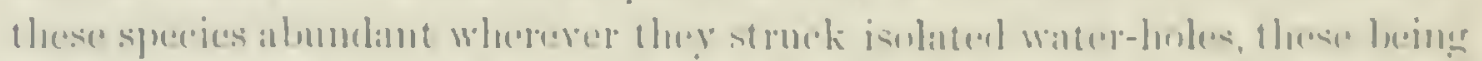

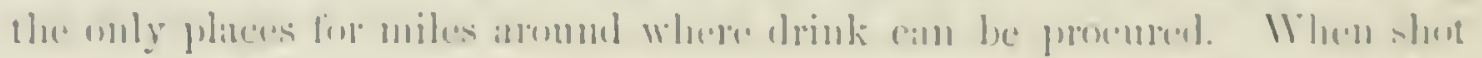

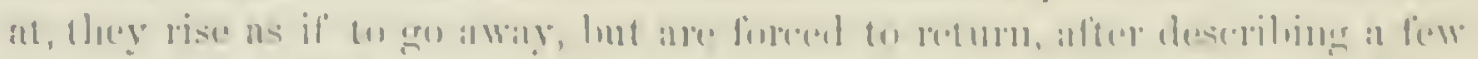

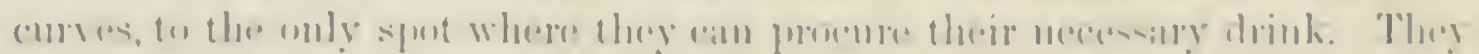

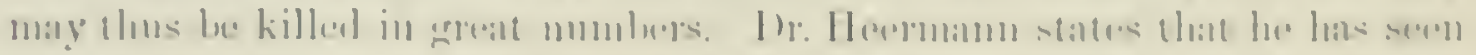

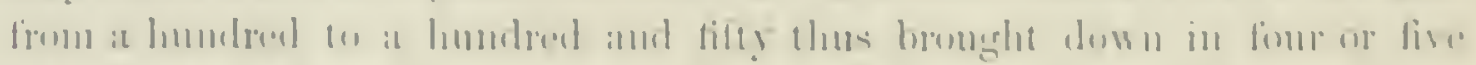

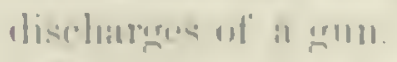

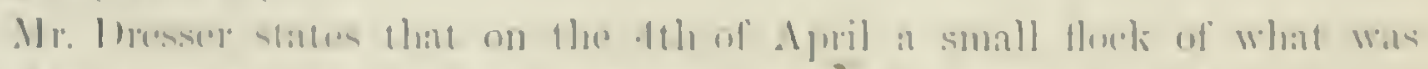

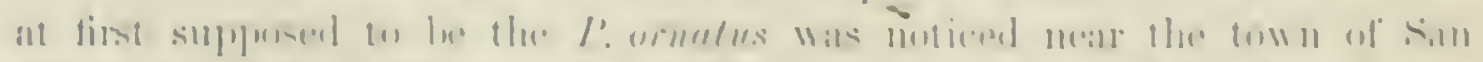

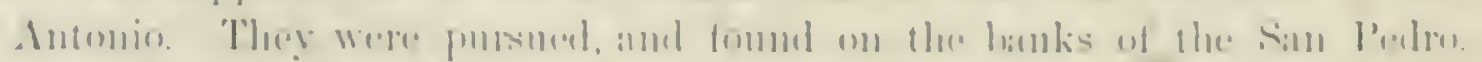

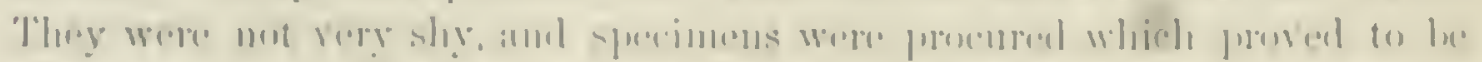

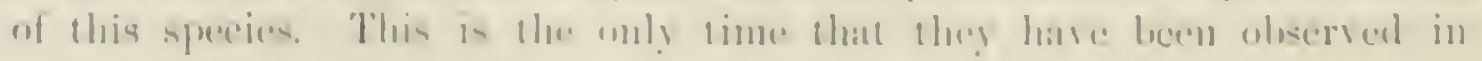


that part of the country, though they may have been mistaken for other species.

Dr. Cones mentions the taking of a single specimen of this species, October 17 , on the open wrassy plains of Arizona.

This species is also given by Mr. Sunichust as a resident throughout the rear of the great plains of the plateau of Mexico. From them it ocrasionally descends to the distant intervals, as far as Orizaba, or at the elevation, above the gulf-level, of $1,2,20$ metres.

\section{Plectrophanes maccowni, LAWREICE.}

\section{CHESTNUT-SHOULDERED LONGSPUR: MACCOWN'S BUNTING.}

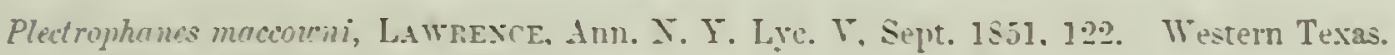

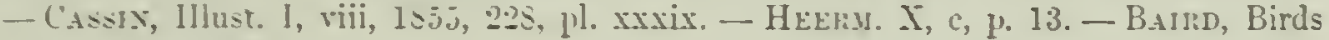
న. $-1 m .1555,437$.

Sp. Curs. Male in spring. Top of head. a broad stripe each side the throat from lower mandible, and a hrual crescent on jugulum, black; side of head including lores and band above the eye. throat, and under parts, ashy-white: earcurerts bordered ahove and behind by blackish, running out at the maxillary stripe. Breast just hehind the black crescent and silles, showing dark bases of feathers. Upper parts ashy. tinged with yellowish on the mandible. and streaked with dusky; least so on nape and rump. Lesser wing-coverts aslyy: median chestnut-brown. with blackish bases sonetimes evident;

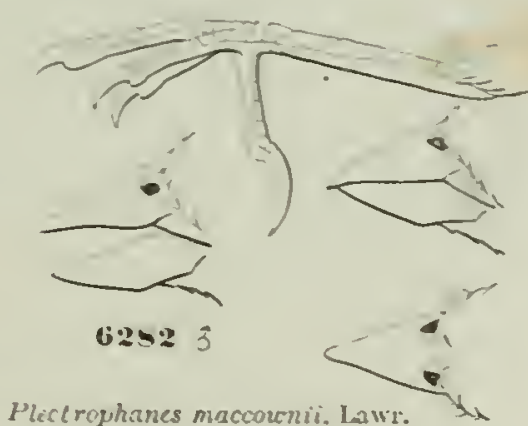
the quills all bordered broadly externally with whitish, becoming more ashy on sccondaries. Tail-feathers white except at the concealed bases and the cuds, which have a transverse (not oblique) lip of blackish: the outermost white to the end; the two central like the back. Bill dark plumbeous; legs blackish. In winter the inarkings more or less obscured; the bill and less more rellowish.

Female lacks the black markinges, which, howercr, are indicated obsoletely as in other Plectrophanes: there is no trace of chesmut on the wings, no streaks on the breast. Length, 5.50: wing. 3.60 : tail. 2.50: bill. . 46 .

Hab. Eastern slopes of Rocky Mountains, from Texas to Lpper Missouri.

This species varies considerably in markings, but is readily recognized among other Plectrophancs in all stages by short hind toe, rery stout bill, and the transverse dark bar at the end of all tail-feathers except the inner and outer.

Habits. Maccown's Lark Bunting is ret another of the rarious species of our birds whose history is rery little known, and in regard to which the most we are able to state, at present, is that they appear in different parts of the interior plains of the United States, between the Pocky Mountains and the Missouri River and the lower tributaries of the Mississippi, extending from New Mexico and Texas northward, during the breeding- 


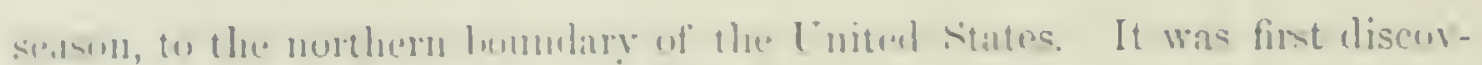

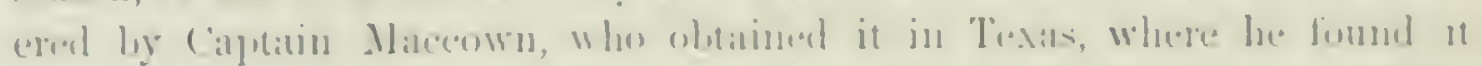

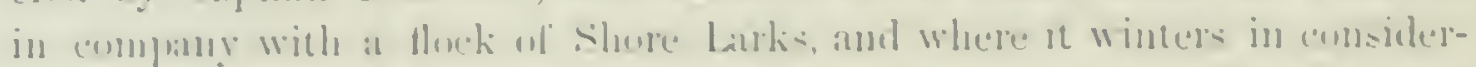

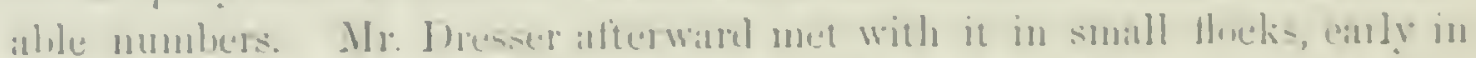

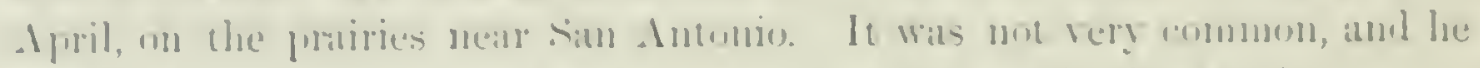

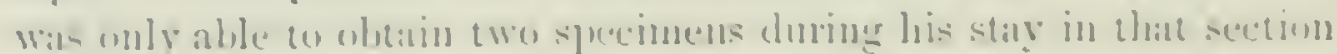

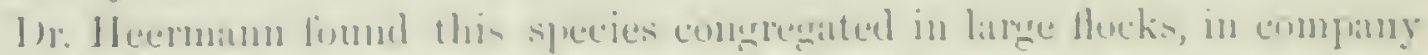

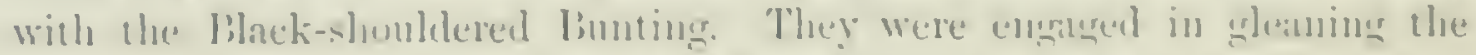

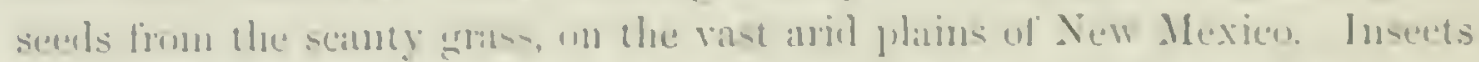

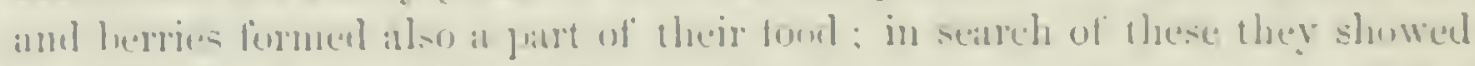

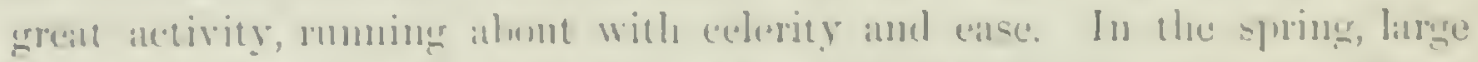
flucks were secu at Fort Thurn, latring migrated thither from the North the previus fall. With the return of mill weather they andin departed

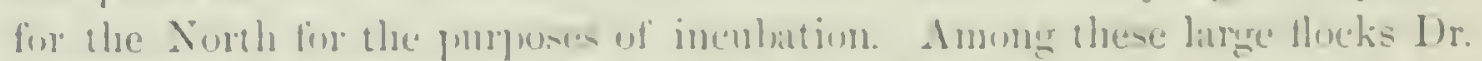
Hecrmann noticed al-e the Shore Latk, but they formed only at small proportion of the whole mumber.

In a letter th Mr. Citsin, Dr. Herrmatum states that he found this species

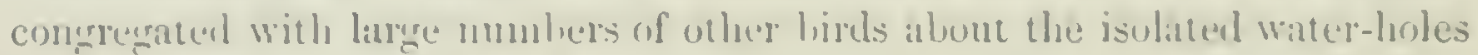
in the barren platins if New Mexieo.

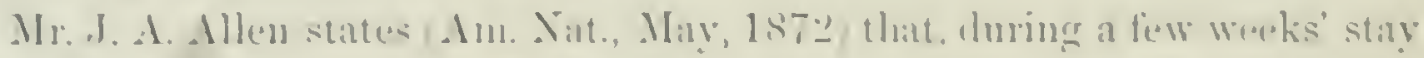

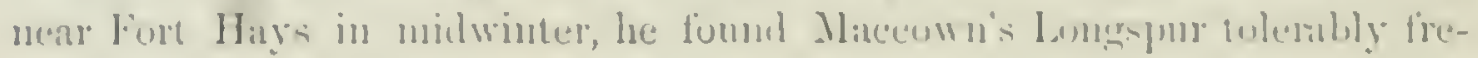
quent in that vilinity

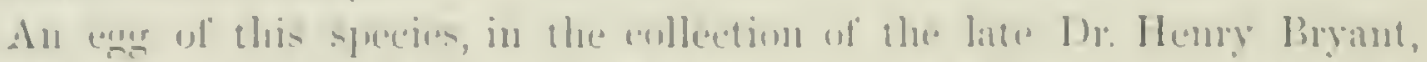

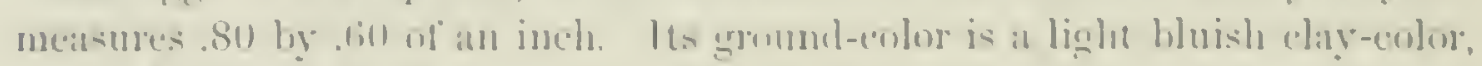

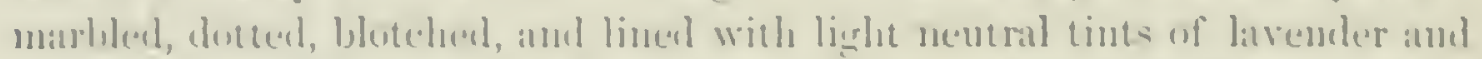

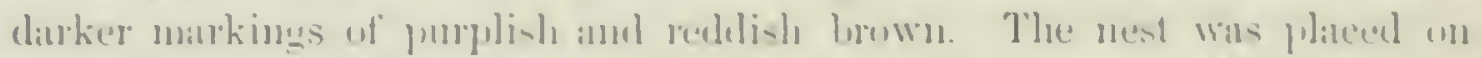

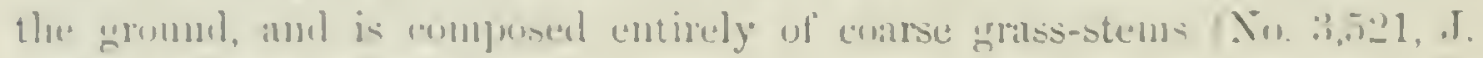
Pearsill, Furt lientun).

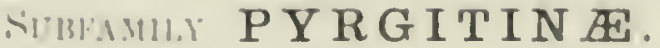

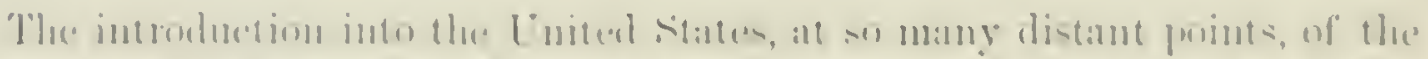

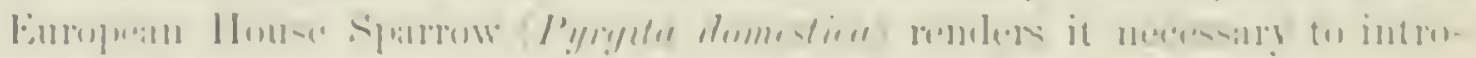

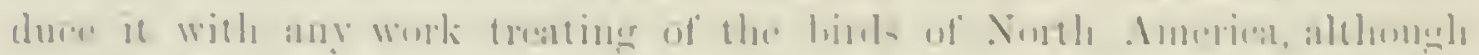

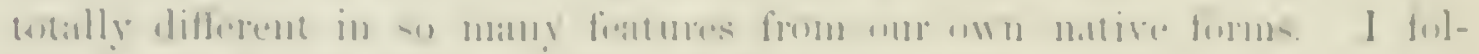

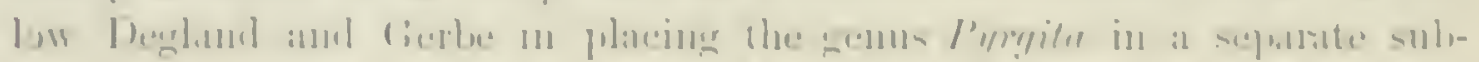

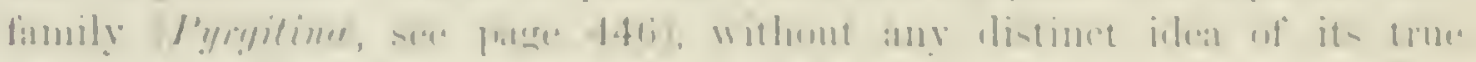

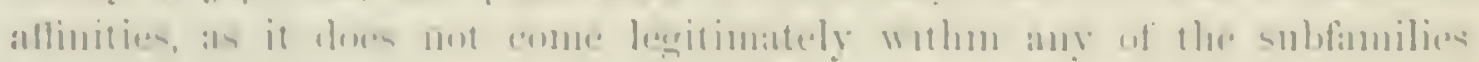

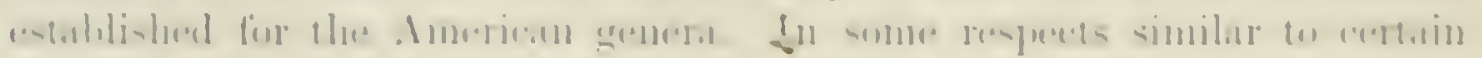

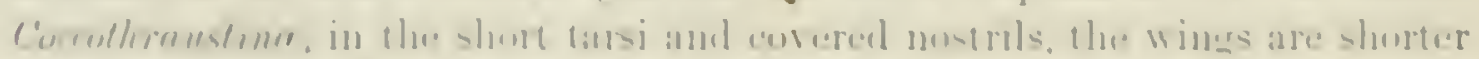

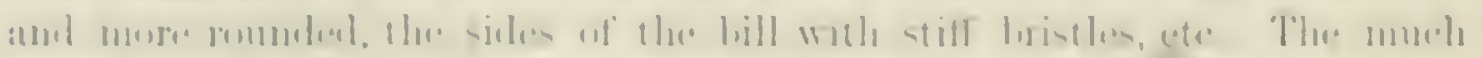

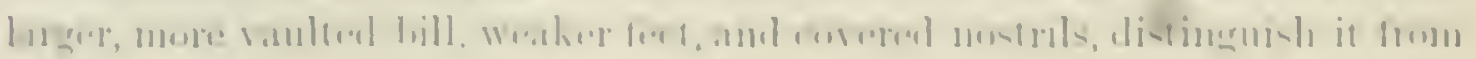

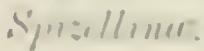


Gexus PYRGITA, Curier.

Pyrgita, Cerier, R. A. 1S17. (Type, Fringillu elomestica, Isזs.)

Pusser, Brissus, Orn. 1760. Sante type. Deglaxd \& GElBb, Orn. Europ. I, 1S67, 239.

Grs. Cuar. Bill robust, swollen, without any distinct ridge; upper and under outlines curred; margins inflexed; palate raulted, without any knob; nostrils corered by sparse, short, incumbent feathers; side of bill with stiff, appressed bristles. Tarsi short and stout. about equal to or shorter than the middle toes; claws short, stout, and considerably curved. Wings longer than tail; somewhat pointed. Tail nearly even, emarginated, and slightly rounded.

\section{Pyrgita domestica, Cuv.}

\section{THE HOUSE SPARROW.}

Fringilla domestica, Liss. Sysst. Nat. 12th ed. 323, 17vov. Pyryita domestice, C'v. Reeg. An. 21 ed. (15:9), I, 439. P'usser domesticies, DEgLavd \& GEibE, Ornith. Europ. 1, $1 \varepsilon 67,2+1$.

SP. Curı. Male. Above chestnut-brown; the interscapular feathers streaked by black on inner webs; the top of head and nape, lower back, rumpl, and tail-corerts plain aslıy; narrow frontal line, lores, chin. throat, and jugulum black; rest of under parts grayisl, nearly white along melian region. I broad chestmut-brown stripe from behind eye, rumning in to the chestmut of back; cheeris and sides of neck white; ontside of closerl wing, pale chestunt-brown, with a broal white hand on the middle corerts, and behind showing the brown quills; the lesser curerts dark chestnut like the licad stripe. Tail clark hrown, edged with pale chestumt. Bill black; feet realdish. Iris brown.

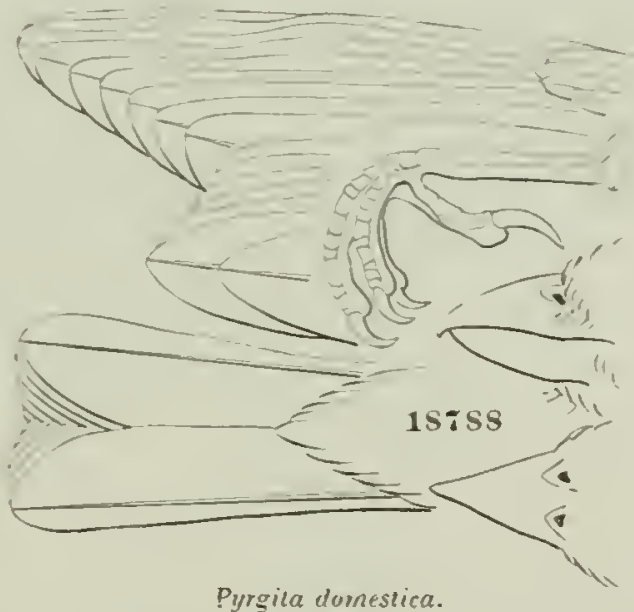

Female. Dnller of color, and lacking the black of face and throat; breast and abdomen reddish-ash; cheeks aslyy; a yellow-ochre band above and behind the cycs, and across the wings. Heal and neck above brownish-ash; body above reddish-asl, streaked longiturlinally with hlack.

Male in winter. The colors generally less distinct. Length, 6.00; wing, 2.85; tail, 2.50 ; tarsus, . 10 ; middle toe and claw, .60.

The House Sparrow of Europe las been introduced into so many parts of the Uniterl States as to render it probable that at no distant day it will have become one of our most familiar species. Brought orer to the New World within a comparatively few years, it lias commenced to multiply about the larger cities, especially in the environs of New York, as also about Portland, Boston, Newark, and Philadelphia. The first effort made to naturalize it about Washington failed in consequence of the death of three hundred individuals imported by the Smithsonian Institntion. A second, 


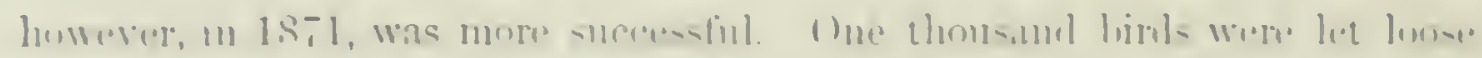

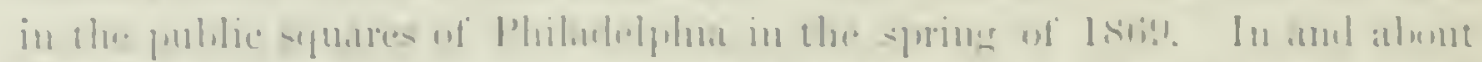

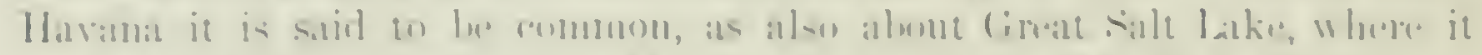

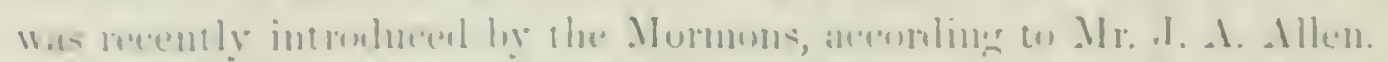

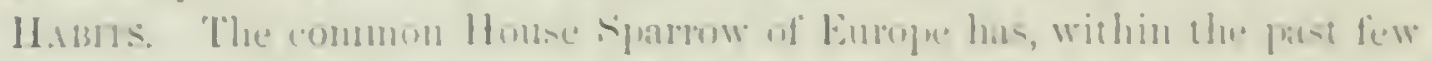

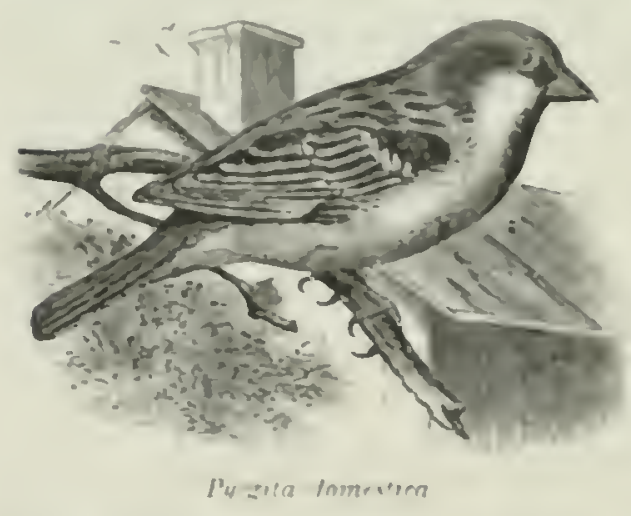

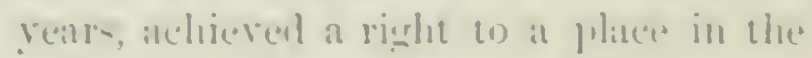
ari-fimna of Sinth Ameriea hy its complete intrulurtion, and its reprulnetion in darge mombers, in rariums parres of the country, limu linetluml, Me., to Wishington ('ity, iks alsu ibbult sillt listio.

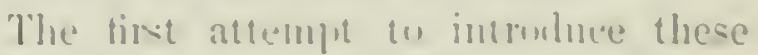
hirds, within my kumsledige, was made

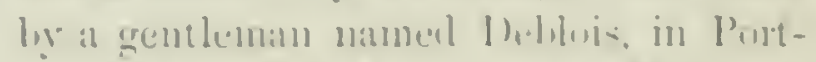
lame, Ne., in the fall of lisis. Six hirds

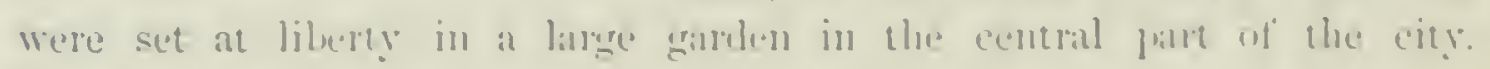

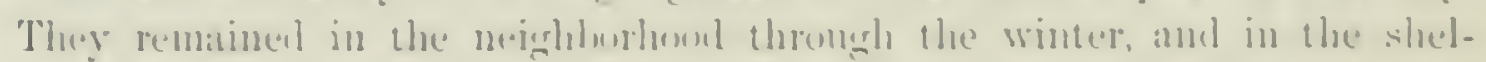

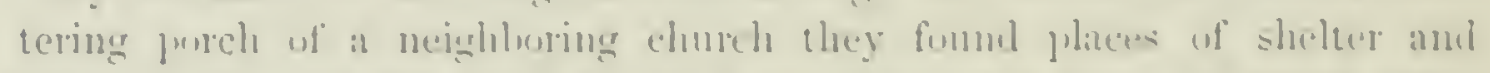
securty. In the following spring thee meste were huilt in dwatr preartress in the grarten in which they were tirst set at liberty. One, at

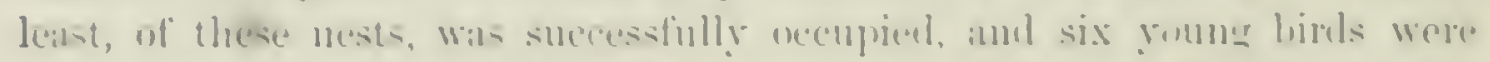

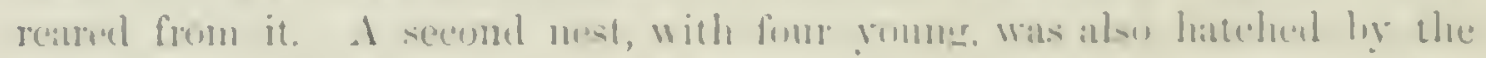

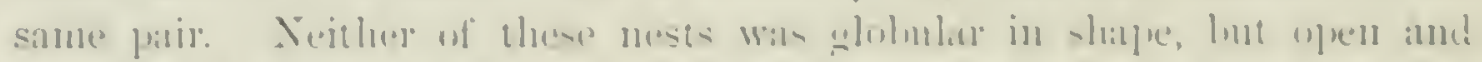

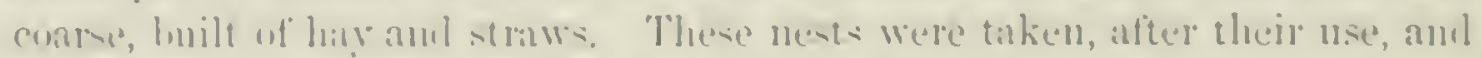

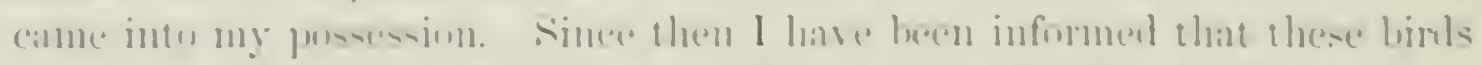

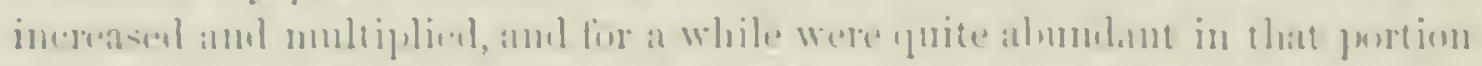

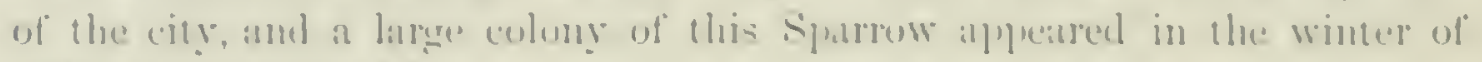
1 st I in linklinml, Me.

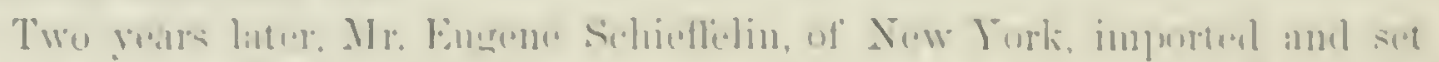

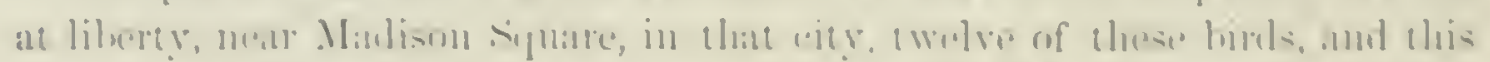

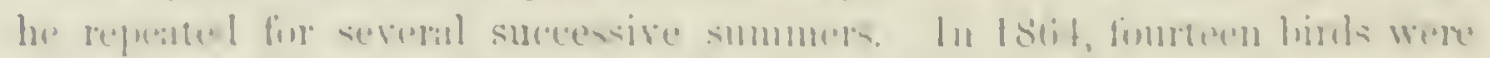

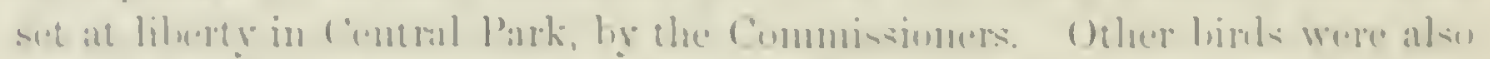

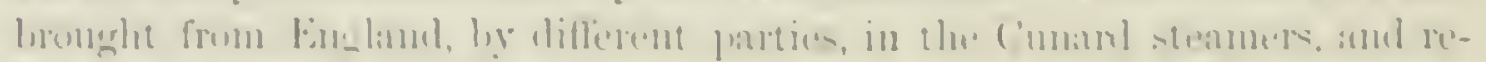

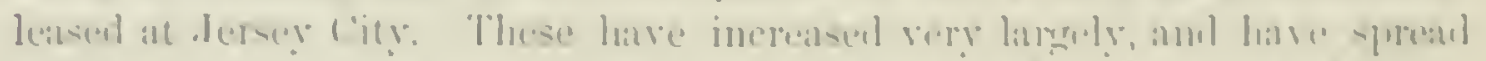

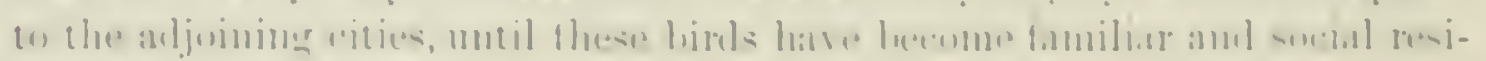

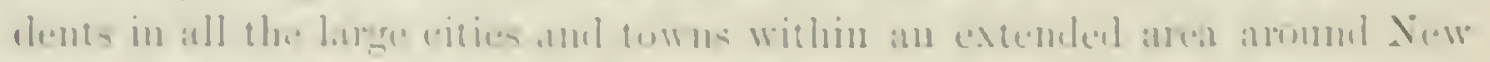

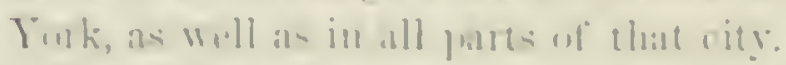

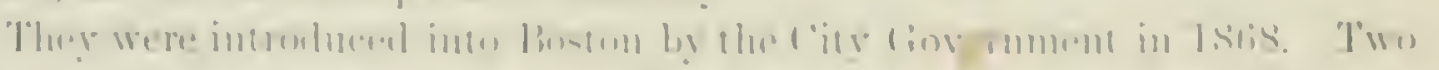

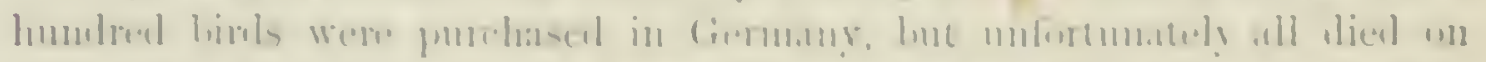

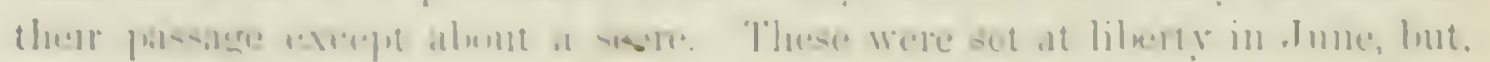

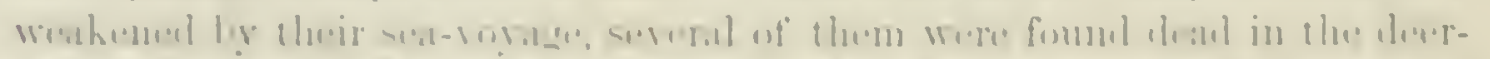

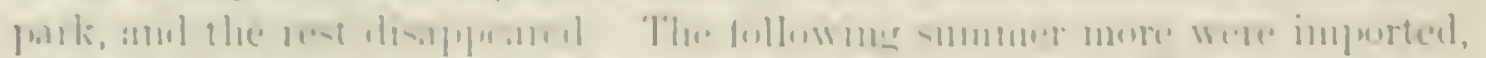

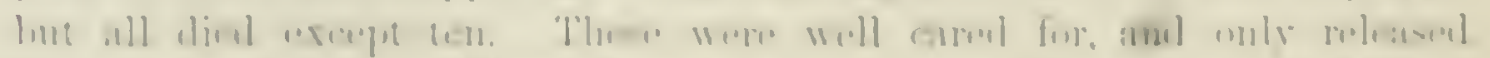

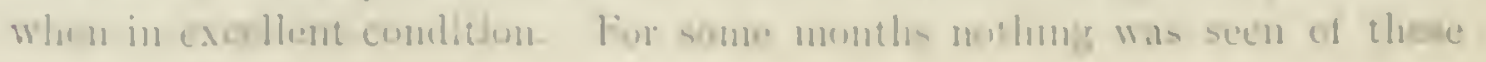


birds, and the experiment was supposed to be a failure, when it was ascertained that they had betiken themselves to the ricinity of stables in the southern part of the city, had increased and multiplied in large numbers, reaplearing in the winter to the number of one humbed and fifty. They were regularly fed by the city forester each day in the deer-park, and ronsted at night in the thatch of the roufs of the huildings. Since then they have rery laryely increased. About twenty, that same summer, were set at liberty in Monmment syurare, Charlestown.

In 1869 about one thousand birds were imported, hy the ('ity Crovernment, into l'hilatelphia. Fortunately they came in good condition, and heing released early in May immediately separated into scattered parties and prepared for themselres new homes. Some appeared in Morristown and other distant towns in New Jersey. Others wandered to (iermantown, ant the remoter suburbs of l'hilidelphia, where they found the cherry-trees in full blossom, and where their exploits in striphing the hloums from the trees gave a not rery favorible first impression of these new-conners.

It has been exeechingly interesting to watch the manners and habits of these strangers in their new homes. Ther have become yute tame, are fearless and gentle, and as they have been verv kindly treated live in a condition of semi-clomestication. It first they built their nests, and passed their winters, in New Jork, among the thick jves that cover the walls of so many ehurehes, in such cases building globular nests. Is soon, howerer, as suitable boxes were prepared for them in suthicient quantities, these were taken possessiun of in preference to anything else.

At the time of their introluction the shate-trees in the parks and squares of New York, Philatelphia, Brooklyn, Newark, and other places, were greatly infested with the larve of the measure-worms that clestroved their foliage. Since then these worma have almost entirely tisappeared. A loubt has been expressed whether the Sparrows destroy these insects. That they eat them in the larve form I lo not know. but to their destruction of the chrrsalis, the moth, and the egors, I can testify, having been eve-witness to the act.

Apprehensions have been expressed lest these new-comers may molest and drive away our own native hirls. How this may be when the suarows become more numerous eannot now he letermined, but so far they manifest no such disposition. Sinee their introduction into Boston the Chipping Sparrows appear to have increased, and to assochate by preference with their European visitors, feeding with them unmolested. I have been unable to deteet a single instance in which ther have been molested, in any manner, hy their larrer companions. Their predatory agressions, however, upon the rights of the common Rohin have been noticed, and deserve mention. The Sparrows appear to be extravigantly fond of eartlworms, but not alile to hunt for them themselves. They have learned to watch the liobin as it forages for these worms, keeping around, at a respeetful distance, and as soon 
as onc, with much toil, has dragereal a worm from it place of concenlanent,

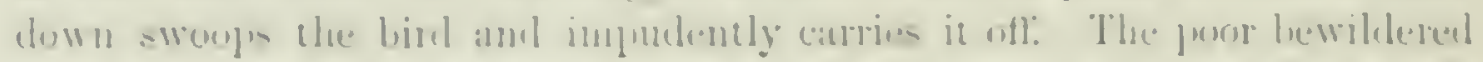

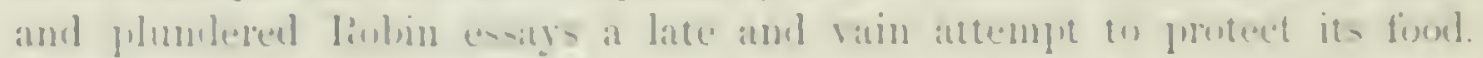

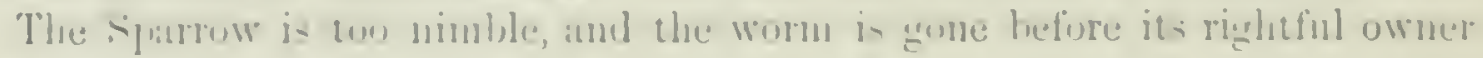
ein turn to face the roblier.

The sparrows emblure the severest of the winter weathor without any

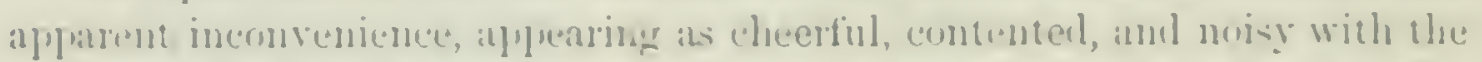

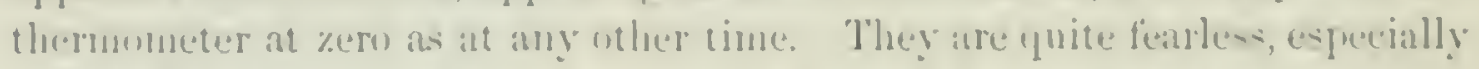

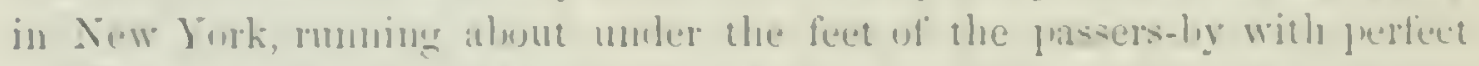

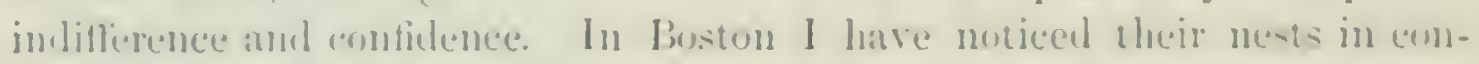
ventent places, a few feet ahove crowded sidewalks. In winter they come

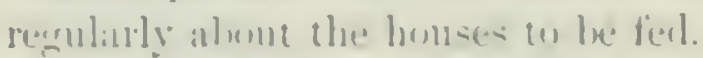

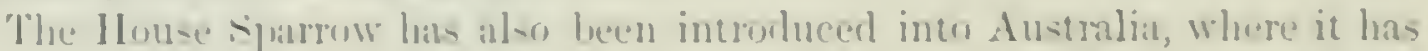

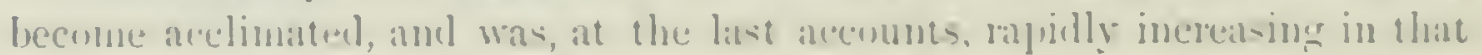
quarter: It is likewise very emmmun about II:sima, l'uha.

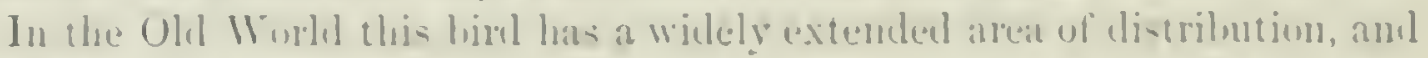

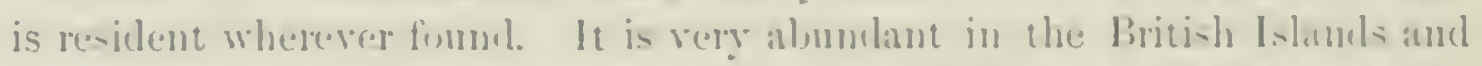

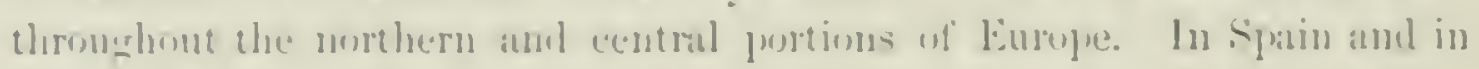

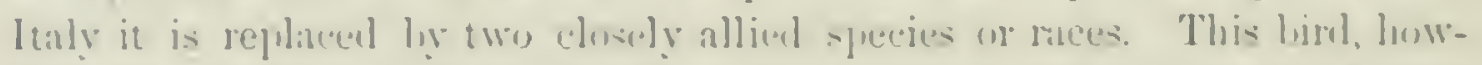

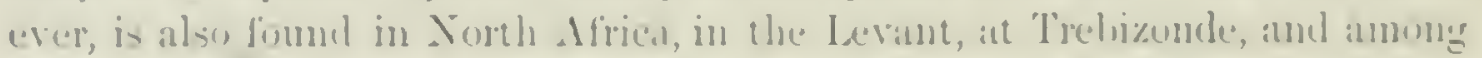

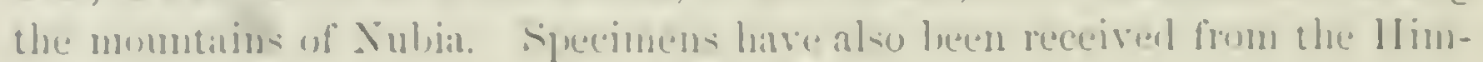
alilys, from Xepaul, and the vieninty of ralentta.

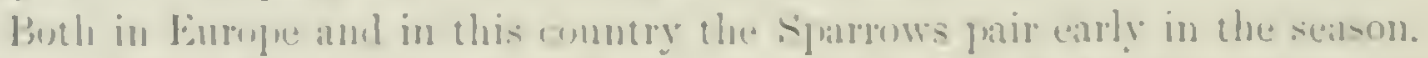

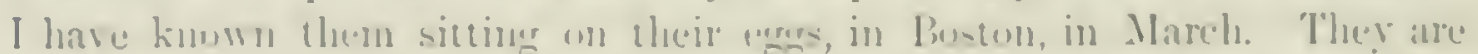
very prolitic, have hrouls of five, six, and even seven at at time, three ur four times in a seasun. They are full of life anl animation, somewhat lispused (1) hrief and molsy ynarrels, which are always h,omlus.

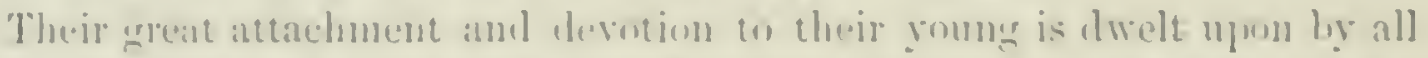
Engli-h writers as quite remarkible. They evinece a great partiality fur

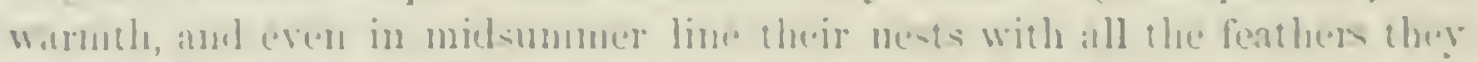

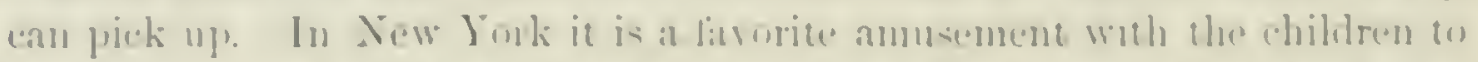

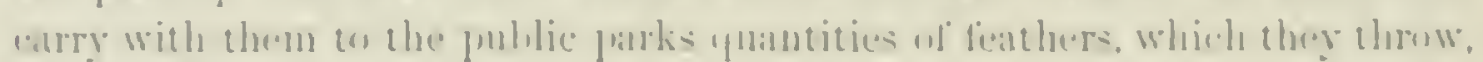

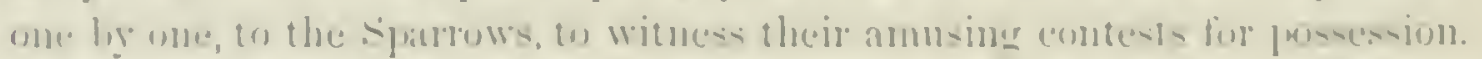

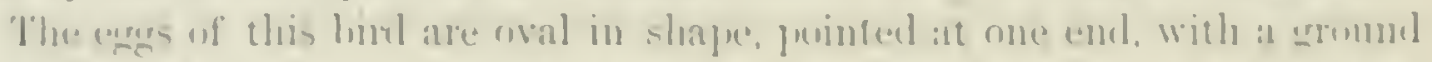

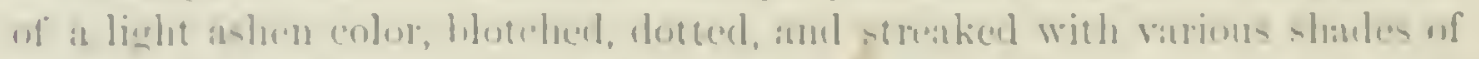

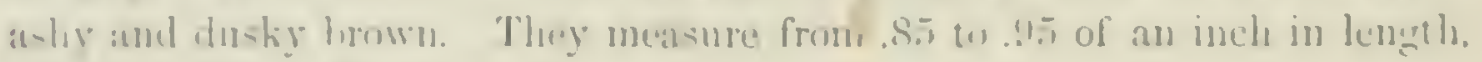
and from dill to li.j in heaslit.

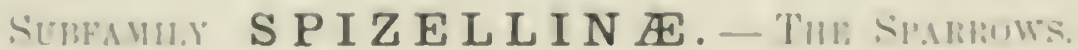

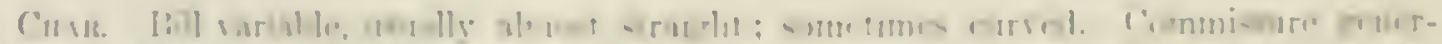

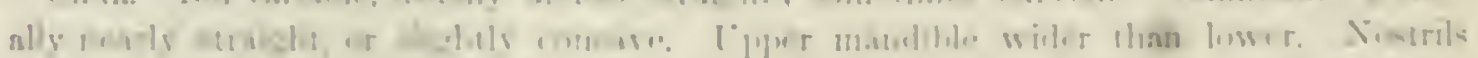

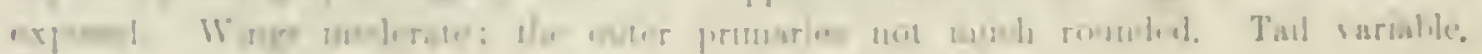

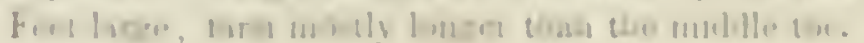


The species are usually small, and of dull color, thongh frequently handsomely marked. Nearly all are streaked on the back and crown, often on the belly. None of the United States speeies have any red, blue, or ormge, and the yellow, when present, is as a supereiliary streak, or on the elbow edge of the wing.

In the arrangement of this subfanily, as of the others belonging to the Fringillide, we do not profess to give anything like a natural system, but merely an attempt at a convenient artificial scheme by which the determination of the genera may be facilitated.

A. Tail small and sluort; considerably or decidedly shorter than the wings, owing either to the elongation of the wing or the shortening of the tail. Lateral tocs shorter than the micllle without its clarr. Species streaked above and bclow. (Passerculeæ.)

a. Thickly streaked ererywhere above, on the sides, and across the breast.

Wing pointed; longest primaries considerably longer than the secondarics.

Tail forked.

Centronyx. Hind claw rery large; rather longer than its digit. The hind toe and claw, together, as long as or longer than the micklle toe and claw. Other toes as in Passerculus. Claws gently curved. Tertials shorter than the scconlaries. Tail forked, but the lateral fenthers shorter.

Passerculus. Ilind claw as long as its digit; the toe equal to the micklle one without its elaw; lateral toes filling consilerably short of the middle claw. Wings very long; first primary longest. Tertials as long as the primaries. Tail forked; feathers acute.

Poocæetes. Hind claw shorter than its digit; the whole toe less than the midclle toe without its elaw. Lateral toes nearly equal to the middle one, without its claw. Tertials but little longer than secondaries. Tail stiffened, forked; feather's acute, outer oncs white.

b. Moderately streaked abore, on the silles, and on the breast, the latter sometimes unstreaked; the dorsal streaks broader, the others fainter than in the last. Wings short, reaching a little beyond the base of the tail. Int much difference between the primaries and secontarics. T'ail short, graduated, and the feathers lanceolate, acute.

Coturniculus. Bill short; thick. Tertials almost equal to the primaries; truncate at the end. Claws small, wcak; hinder one shorter than its digit. Ontstretched feet not reaching the tip of the tail. Tailfeathers not stiffened. (In one spccics tail nearly equal to the wing.)

Ammodromus. Bill slender, small at base, and elongated. Tertials not longer than the secondaries: rounded at the tip. Claw's large, hinder one equal to its digit. Outstretched toes reaching considerably beyond the end of the stiffened, almost scansorial tail.

B. Tail longer and broader; nearly or quite as long as, sometimes a rery little longer than, the wings, which are rather lengthened. The primaries considerably longer than the secondaries. None of the species streaked beneath, and the back alone streakcd above. (Spizelleæ.)

a. Tail rounded or slightly grar!uated.

Chondestes. Tail considerably graduated, not emarginated, Lateral toes considerably shorter than the middle toc, without its claw. Wrings very long, decidedly longer than the tail, reaching the midclle of the 


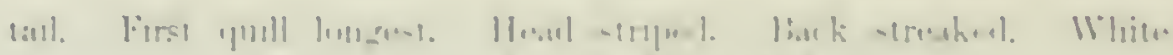

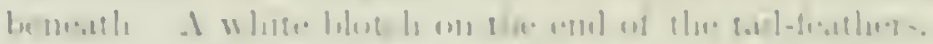

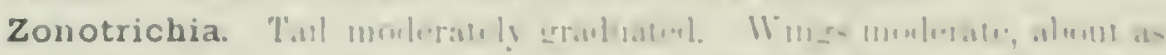

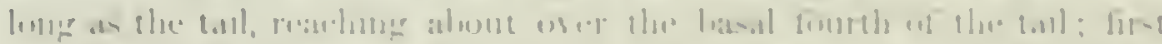

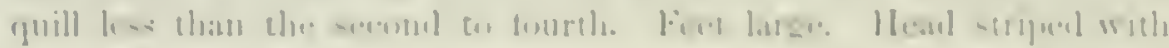

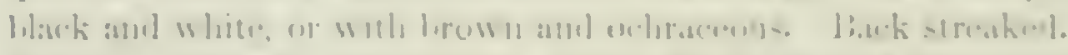

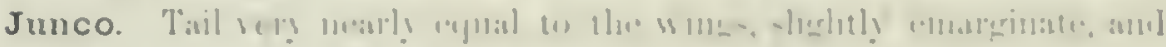

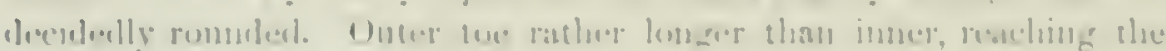

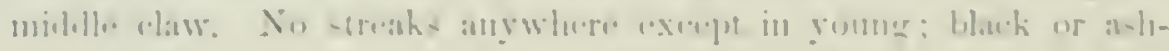

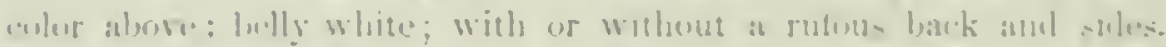
() Muter tail-fintlum - White.

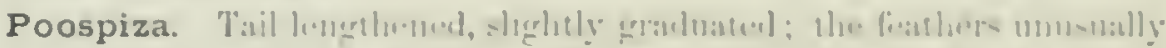

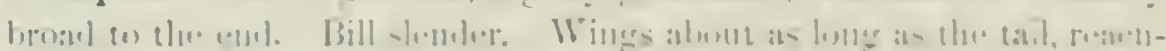

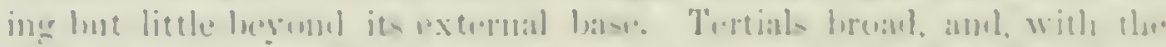

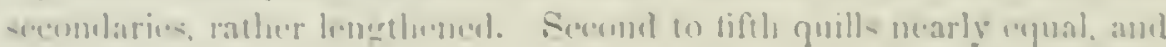

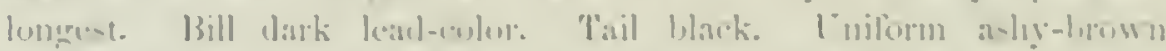

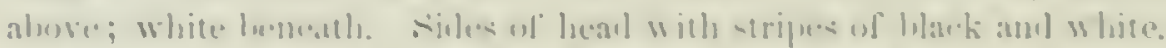

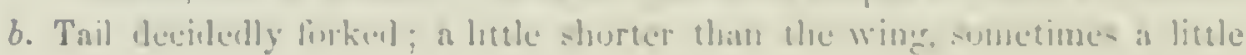
longer.

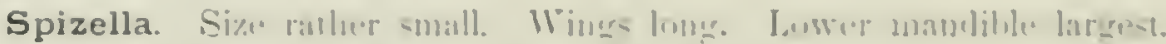

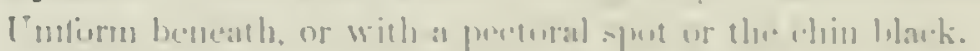

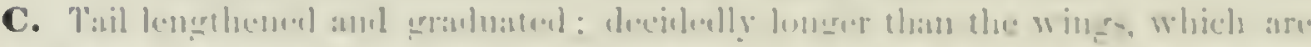

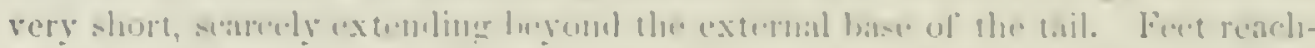

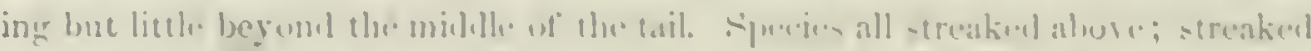

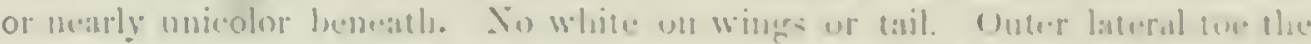

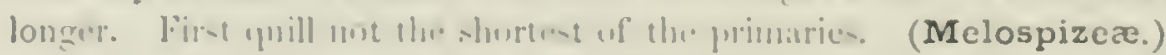

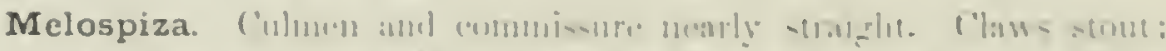

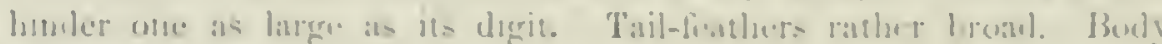
stratikinl liementh.

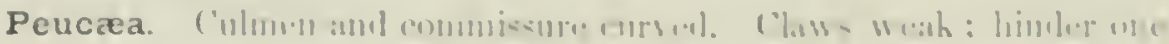

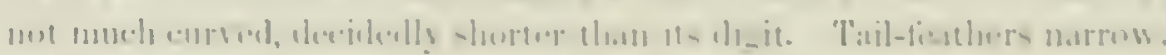

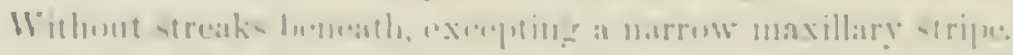

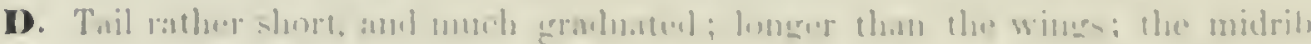

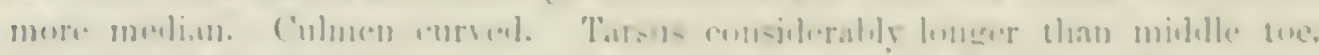

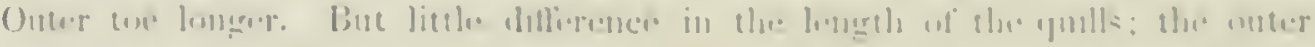

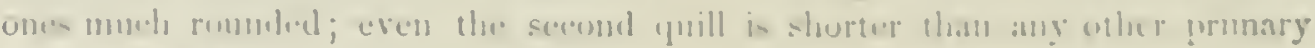
excepet tlu lir-s.

Embernagra. Colon, uhectercen allure.

\section{(i.) CENTRONYX, H,URM}

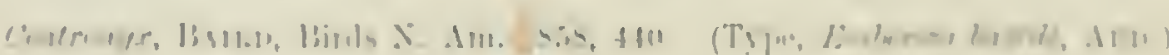

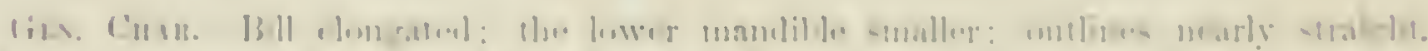

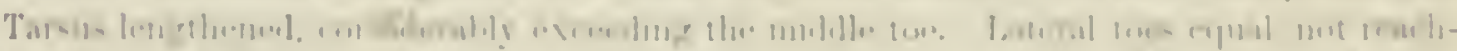

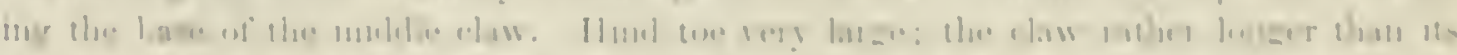

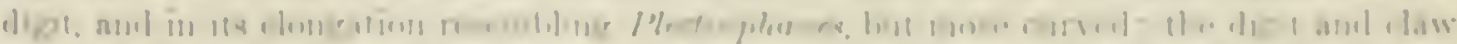

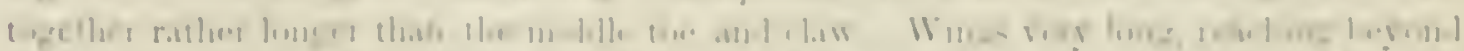

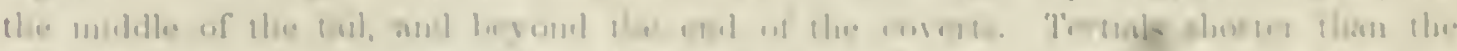

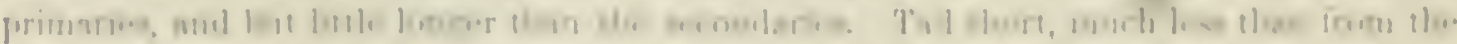

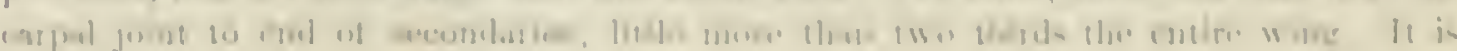


slightly forked, and moderately rounded laterally: the fenthers all acute. Color somewhat as in Passerculus.

This genus differs from Passerculus, as stated in the description of the species farther on. It would be taken for P'lectrophanes on account of its lengthened hind claw, which, howerer, is more curred than in that genus; the tarsi are much longer, the tertials less elongated, and the coloration different, though closely resembling that of the female Plectrophancs. But one species has thus far been recognized.

\section{Centronyx bairdi, B.IRD.}

\section{BAIRD'S BUNTING.}

Emberiza Guirdi, Avd. Birls Am. VII, 1\$ 43,359 , pl. 1. Coturniculus bairdi, Bos. Syn. 1\$50, 4\$1. Centronyx bairdi, B.trid, Birds N. Am. 1S5S, 411.

Sp. Char. Somewhat similar in gumeral appearance to Passerculus savanna. Bael grayish, streaked with dukky. ('rown nearly covered by black streaks, but dirided by a broad median band of brownish-rellow. Eyelids and a faint supereiliary stripe yestlowish-white. Benenth white, with a maxillary blackish stripe and some narrow streaks on the upper part of the breast, and sides of the throat and body. Outer edges and tips of tail-feathers white; the two outer feathers ohsoletely white. Bend of wing white. Length, 4.7.) : wing. 2.50; tail, 2.20 .

Hab. Mouth of the Iellowstone River. One specimen only known.

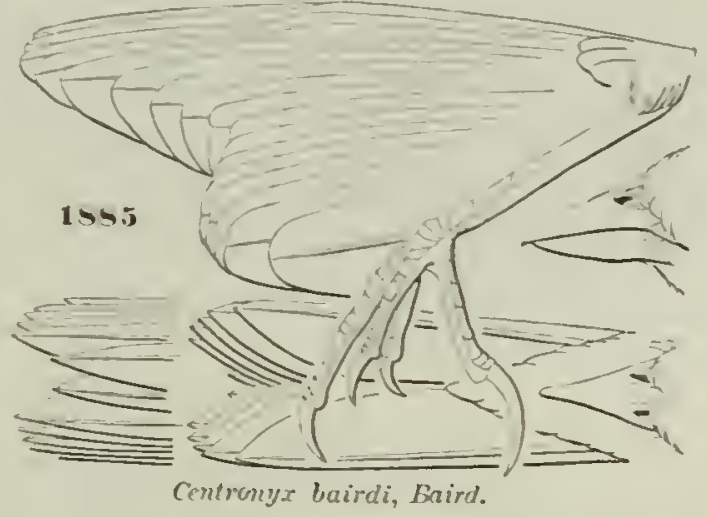

This species has somewhat of the general appearance of Passerpulus sarcenna, but with important differences both of form and culor. The bill is much longer, and more slender in proportion. The wings are quite un-

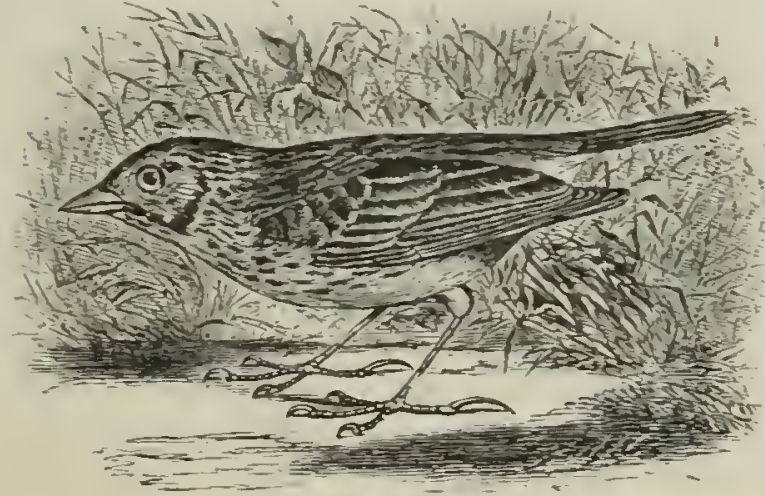

Centronys bairdi. usually lougr; the primaries more than lialf an inch longer than the tertinries; the first quill as long as the fourtl, and lut little less than the second and third. The tail is vely slunt; the fenthers narrow ancl pointed. The feet are large; the hind claw rem long and consillerably curved, as are the other claws generally.

The species was based by Mr. Audubon on a skin brought by him from the mouth of the Yellowstone River, in 18t3, in rather defective and worn plmmage. This has hitherto 


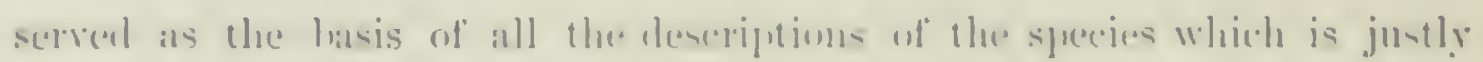

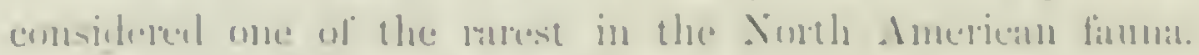

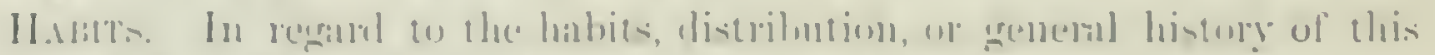

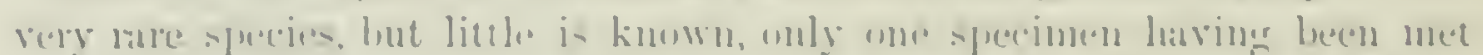

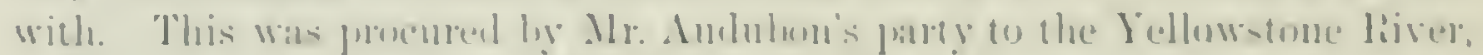

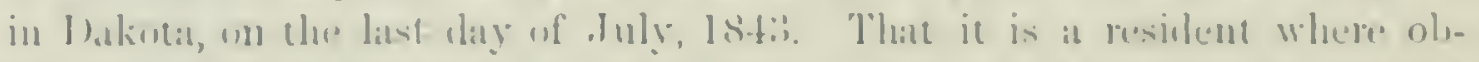

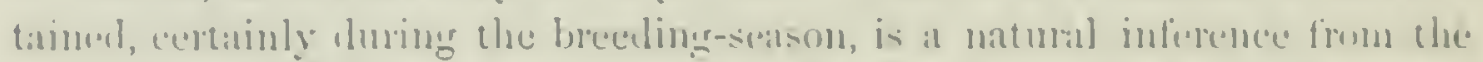

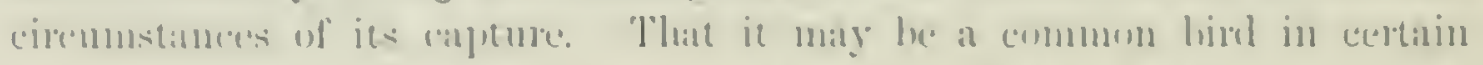

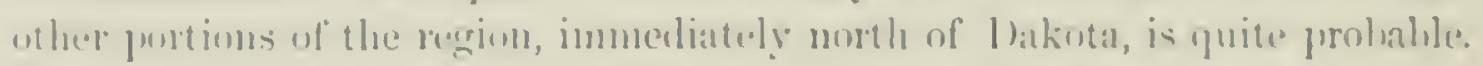

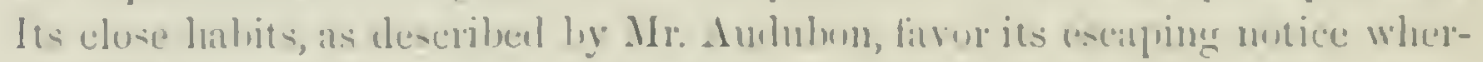
("rol it maty exist.

The sperointen was met with in a wet place, overgrown clnsely he a himl of slemela melh-like ermas, from the midst of which the notes of these birels wore lacarl, and at first mistaken for those of the Marsh Wien. A seareh was immeliatcly in-titnted lin the sinners, which Mr. licell smon ascertained

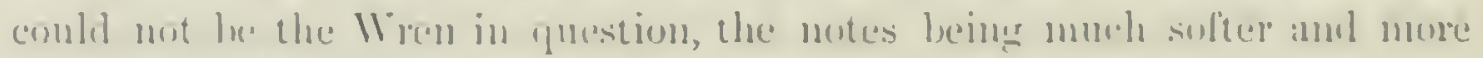

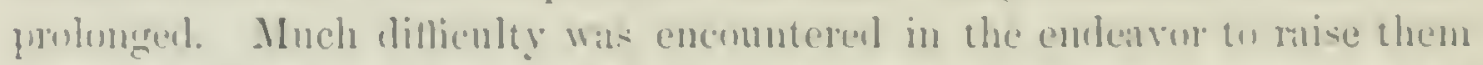

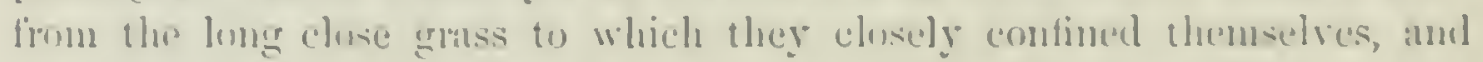

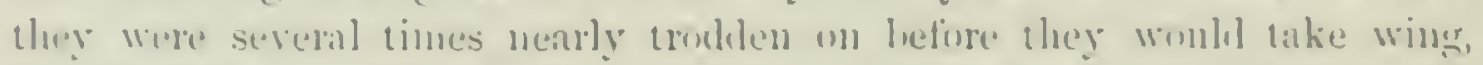
alnost inclantanermsly realighting within a few stepes, and rumbug like miec thromgh the gritss. Alter a while two were shot while un the wing and

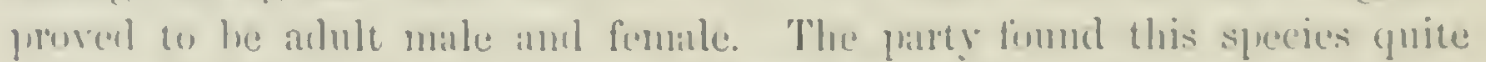
alumblant in all such sitnations, and there seens to have been mo dembe that it was freceliner.

\section{FiNi PASSERCULUS, lix.}

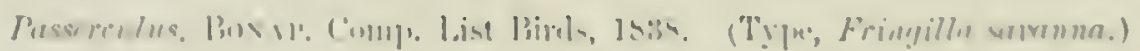

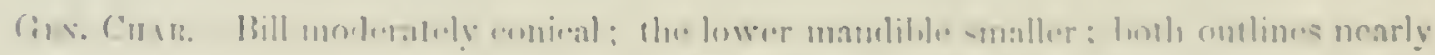

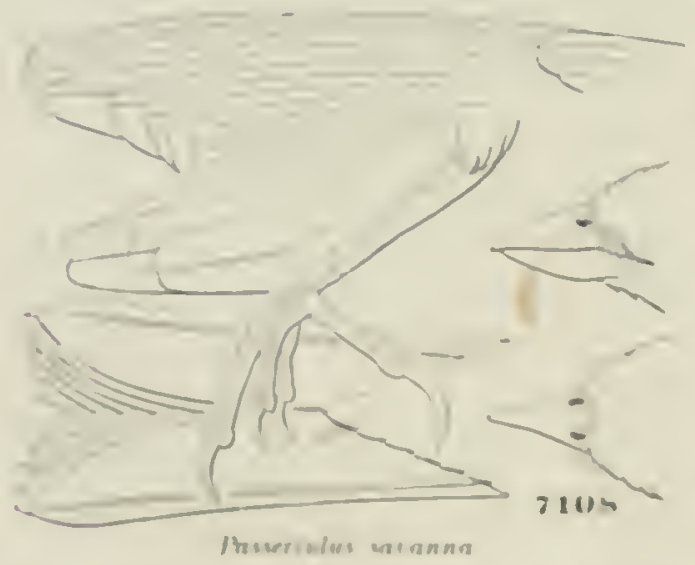

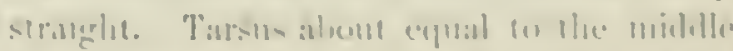

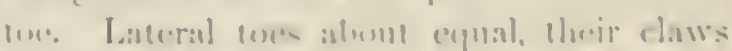

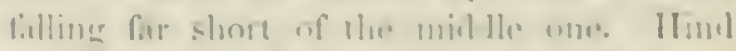

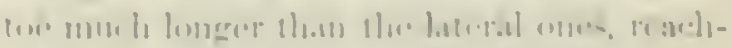

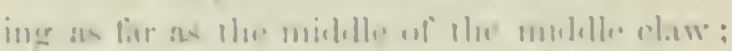

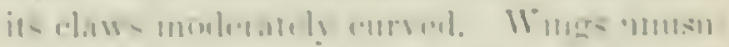

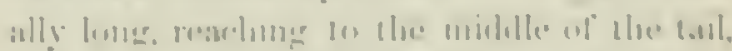

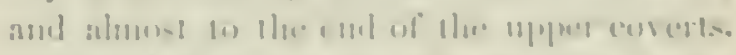

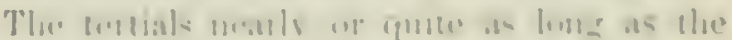

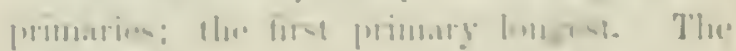

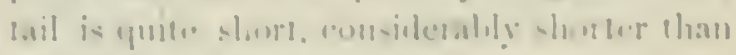

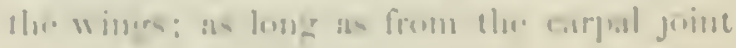

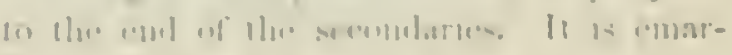

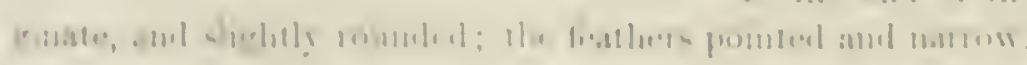

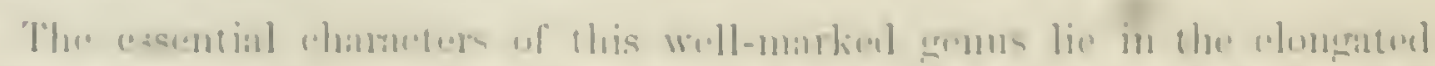

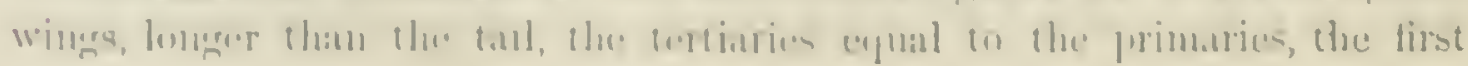


quill almost longest. The legs are long, the outstretched toes reaching to the end of the tail; the lateral toe considembly shorter than the middle, which is not much longer than the hinder. The tail is short, narrow, and emarginate; the feathers acute.

\section{Species and Varieties.}

Commox Cnuractress. Above gravish-brown, beneath white; whole unper surface, as well as the breast and sides. streaked with dusky. 1 light superciliary stripe, and a whitish maxillary one, the latter bordered above and below by stripes of coalesced dusky streaks.

A. Bill small, the culmen slightly concare in the midule portion; a median lights stripe on the crown.

1. P. savauna. Superciliary stripe yellow anteriorly; streaks on the back blackish, sliarply" defined.

Throat und upper part of ubdomen unstreaked; vertex-stripe without yellow tinge.

Bill . $3 \pm$ from foreheal and $.25 \mathrm{in} \mathrm{depth}$ at the base; wing. 2.S5; tail, 2.30. Colors deep; outer surface of wing (in spring) decileelly reddish. Hab. Eastern Prorince of Jorth America - var. $s a x a n n a$. Bill, .32 and .20, or less; wing, 2.75; tail, 2.10. Colors rery pale: onter surface of wing (in spring) pale ashy. Hab. Western Prosince of North America, except coast of California, where replaced br rar. avthinus. . . . var. alaudinus. Bill. .37 and .27, or considerably more; wing, 3.10: tail, 2..40. Colors as in savanua. Hab. Northrest coast of North America

var. $s$ and $u$ ichensis.

Throat and upper part of abdomen streaked: vertex-stripe strongly tinged with yellow.

Bill, .33 and .19: wing, 2.50: tail, 1.90. Colols darker than rar. saranna. the ground-color more uniform, ant the black streaks

hearier and more numerous. Hab. Coast of California. var. anthinus.

2. P. princeps. Superciliary stripe white anteriorly; streaks on the back sandy-brown, bally lefined. Wing, 3.2.5; tail, 2.60; bill, .45 and .23 ; tarsus, .95; middle toe, .80. Hab. Fastern Massachusett: (northern regions in summer?).

B. Bill robust, the culmen arched: no median light stripe on the crown. Supereiliary stripe white anteriorty; streaks on the back sandr-brown. obsolete.

\section{P. rostratus}

Bill, .43 and .30 ; wing. 2.90 ; tail, 2.25. Ground-color abore fulrous-gray, beneath white; the streaks. above and below, sandsbrown. Colors much as in $P$. princeps. Hub. Coast of California, to the mouth of the Colorado Pirer: Cape St. Lucas in winter var. rostrutus. Bill, .33 and .2.) wing. 2.55; tail, 200 . Ground-color abore plumbeous-gray; beneath white: streaks blackish-brown. Hab. Cape St. Lucas (resident?) . . . . var. guttatus.

A careful examination of the rery large series of Passerculus allied to saranna-in the museum of the Smithsonian Institution, recently made, 


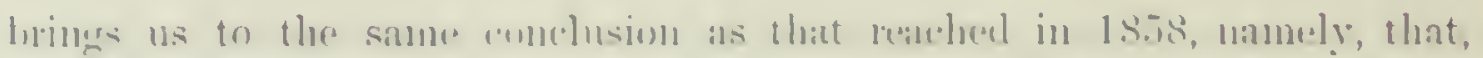

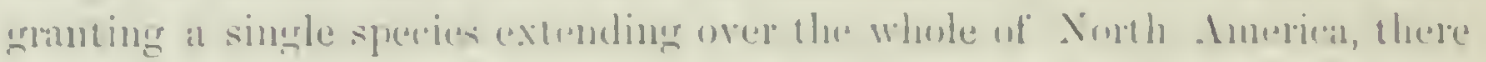

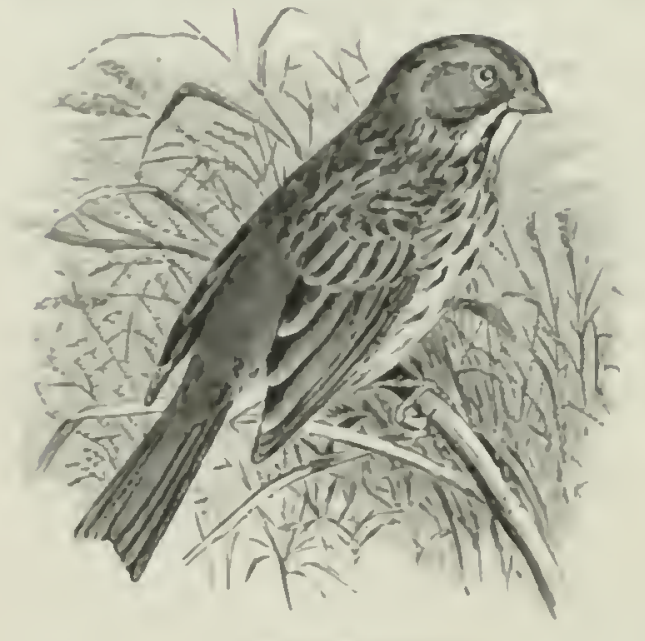

Piocorrulus sanentinn.

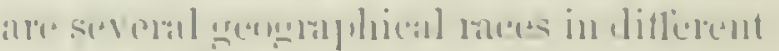

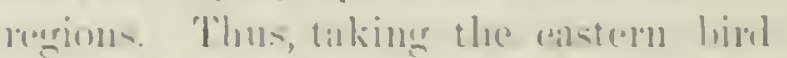

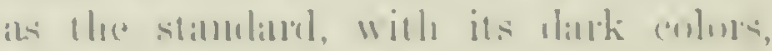

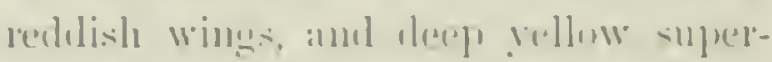
ciliary strije, alul the complarative 111 "ntire absence of sjunt an the luwer part of hreast, we hatre in the millille puresince, amel to sum. "atent in the western,

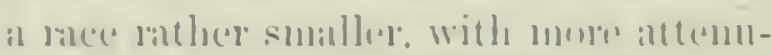
itcel and longer libll, and paler colors; the wing entivish, the vellum of heal

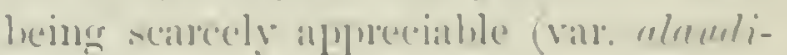
mus). On the ruist of Cillilomiat, int-

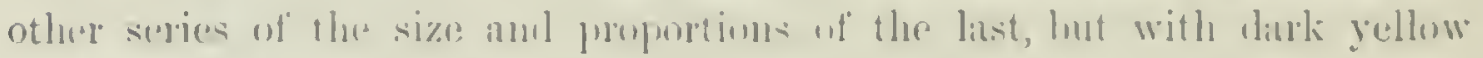

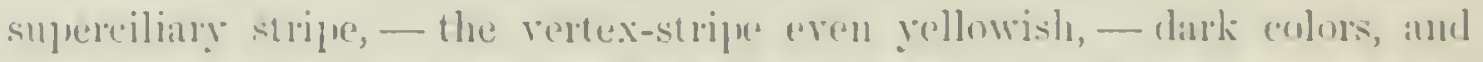
the lower part of breast, as well as the throat, derildelly streaked, as well as the jugnhm var. rnthinns); and finally an the not hwest const, from

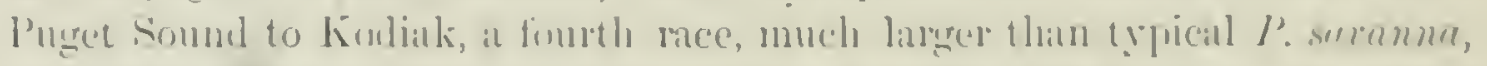

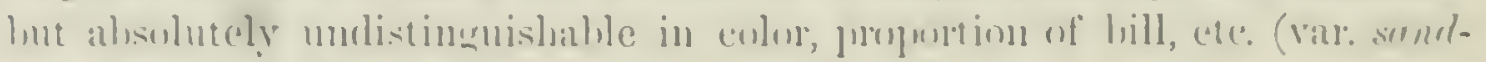

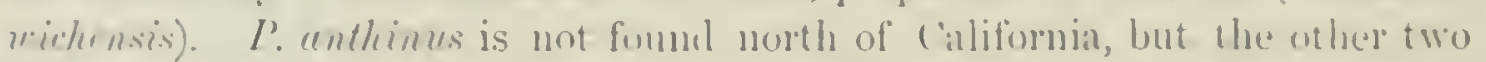

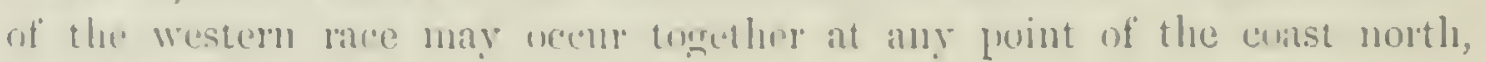
perhilps, nt the columbliat liver.

Passerculus savanna, Bosap.

SAVANNA SPARROW.

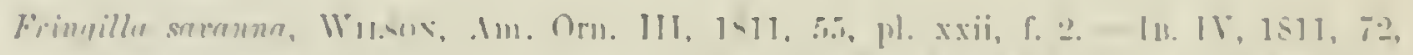

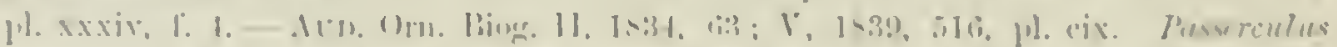

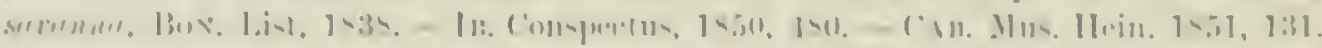

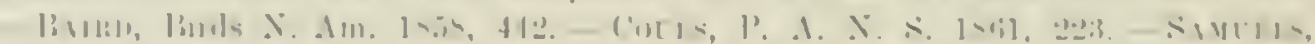

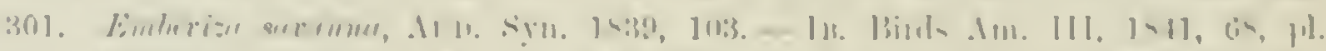

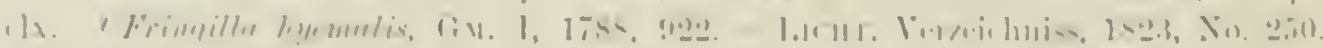

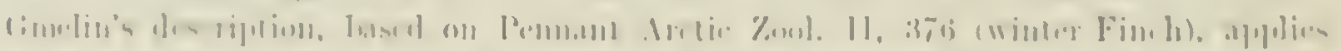

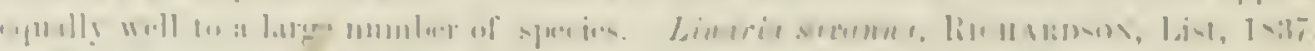

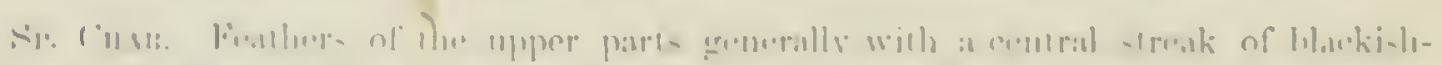

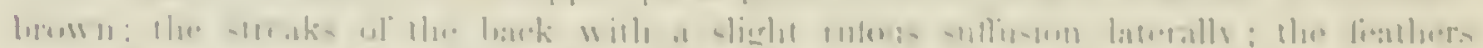

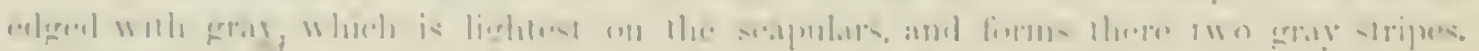

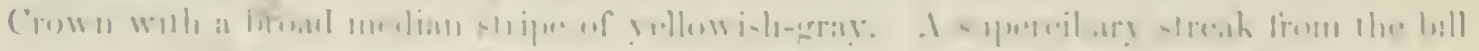

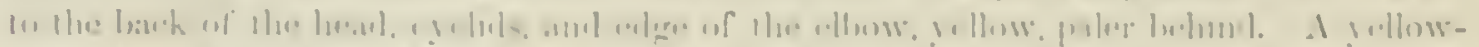
wh-white motulliblat -

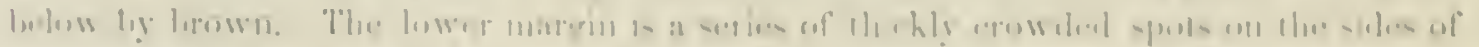

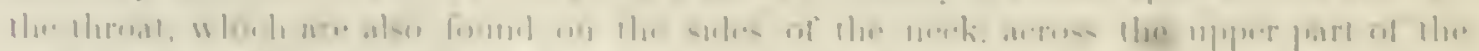

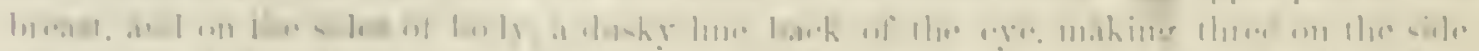

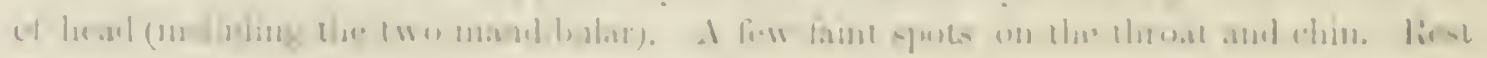


of muler parts white. Onter tail-feathers and prumaries edged with white. Lenerth, 5.50 ; wiun, 2.70; 1:il, 2.111.

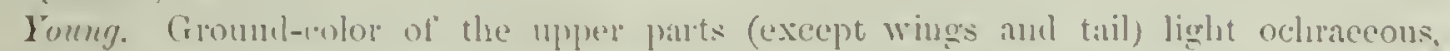

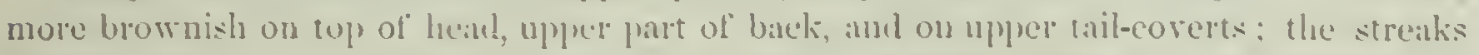
blacker and more conspienoms than in the alult. Bencath with an ochlateous tinge auteriorly. the streaks broaler, and deeper hack, than in the adult, though less sharply. defined. The infra-maxilluy streak expanded into a broal blackish clongated bloted.

H.r. Eastern Xorth America to the Missuni plains, and northwest tu Alaska. Cuba. winler (C.в. Junt. 11, 6).

Specimens vary considerably in size, color, and shape of hill, hut the average is as described. Spring birels liave the malkings sharper and elearer, the clark streaks with little ur no suffusion of l'ufous.

H.sirTs. The savanna Sparrow is an abundant species throughout Nortl Anerica, from the Atlantic sea-board to the Great Plains. It is, howerer, everywhere much less common in the interior than nearer the shore. The Smithsonian specinens are from points als far south as Georoial anl Louisiana, and als far West as the Black Hills of Wyoming. It passes nortl through Massachusetts, from the first to the mildle of $A$ pril, and sume remain to breed in the eastem part of the State. Mr. Maynard spealis of it as a common summer resident. 'This, howerer, is true only of a few restricted maritime localities, but is nut so of the entire eastem portion of the State. It occurs both in the salt marshes of Charles River and in the vicinity of Fresh l'onl, but I conld liever trace it in any of the neighboring tomns. It is oecasionally met with in inlaud situations where we would not naturally look for it. In the summer of 1869, Mr. William lirewstel fommel quite a colony of these birds in an open field near the Glen Honse, at the foot of Ml. Wishimgton. They had nests with egrgs the last of July and the first of Angust.

In Mestern Massachusetts, according to Mr. Allen, it rinely or never stops to lreed. In Western Maine, Mr. Verrill mentions it as a common summer visitant, and as breeling there in the latter part of May. In the vicinity of Eistport, and in all the islands of the (irand Menam group, I fouml these Sparrows very abmudant. They almost invariably built their nests in depressions on the edge or just muler the projecting tops of high bluffs of land near the sea. 'They were by far the most abundant of the land-birds, and it was quite common to find their nests in close proximity one to another. They arive there in April, and leave in September, passing slowly south more in reference to the abmulance of their food than the severity of the season, until the weather becomes very severe, when they all clisappear. They winter in the Sonthern States, from Virginia to Georgia, and are especially abmuclant in the Carolinas. Dr. Coues states that they were rery common abont Colmmbia from October to April, moving in large flocks and assoeiating with other species. Wilson states that he net with this species, from Saramal to Xew York, in all the low comntry, and regarded it as resident in those places, but rurely fouml at a distance from the sen-shore. He found them especially numerous at Great Egrg Harbor, N. J. 


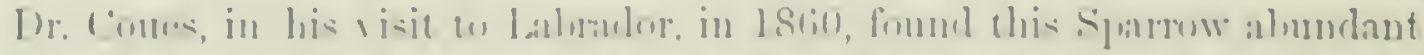

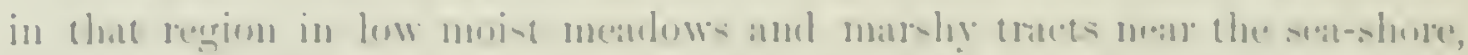

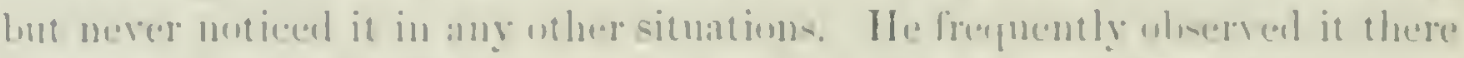

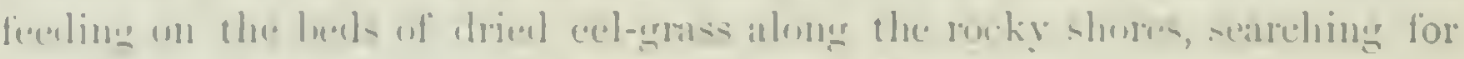

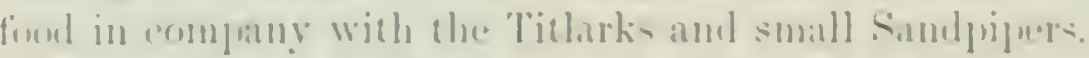

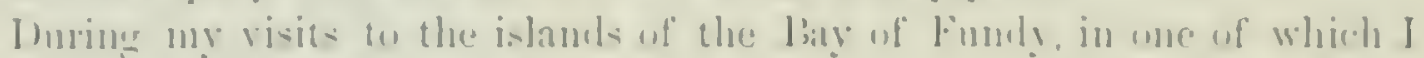

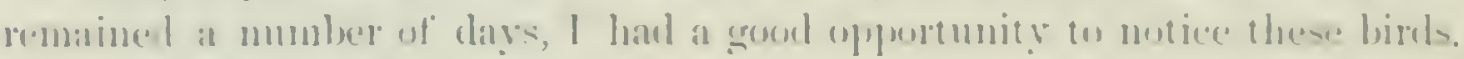

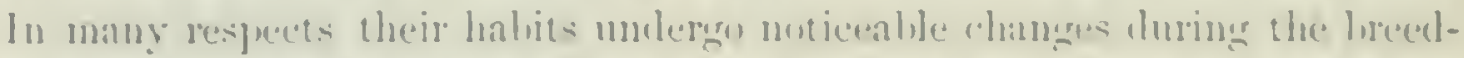

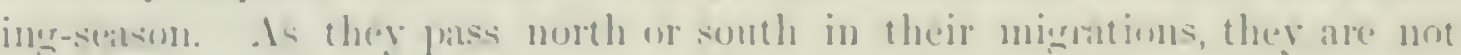

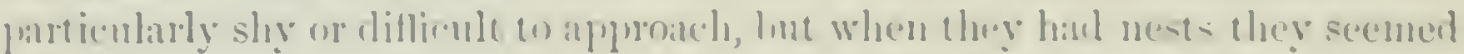

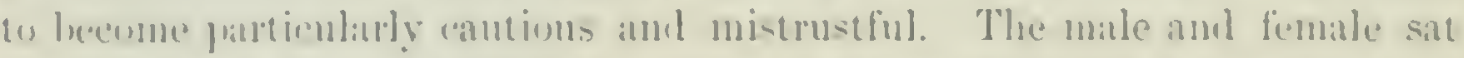

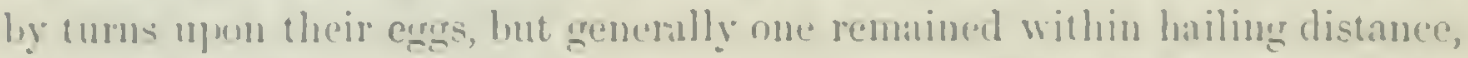

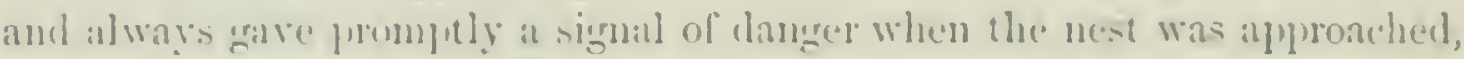
at which the oflece would glicle from the nest, rmuning ofl on the gromud like a monse. I fomml it impurible to inlentify ly slumsiug the parent on the

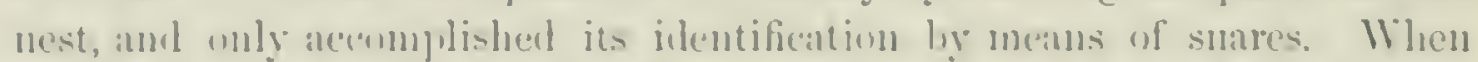
once lon in the tall grass, it wits impussille to find it agrain, or if it reappeirect it was impossible to tell which of the many chimping sparrows, all of them ont of reach of shot, and keeping a sharp lnokent on my movements, hat any connection with the nest. This manchure wis grone thromgh with in every nest I fomml, hut I sum leaned to distinguish them without the meer of :-

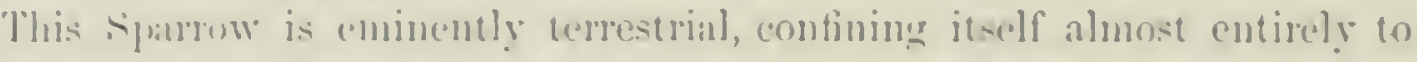
the gromml, and rarely alighting on anything even so high als a fence.

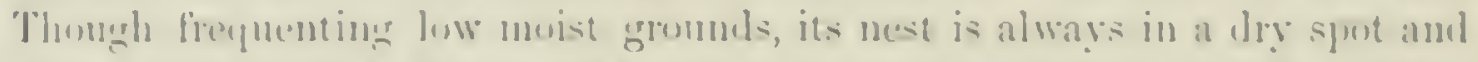

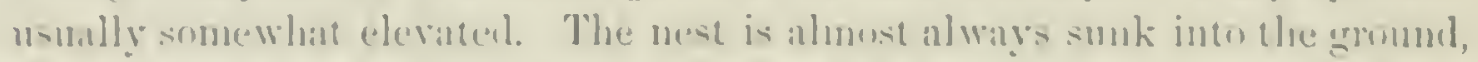
is mille rery simply and lousely of dry graters, with at lining of softer matheriak of the sinne. I have nerop found any other material than this in the

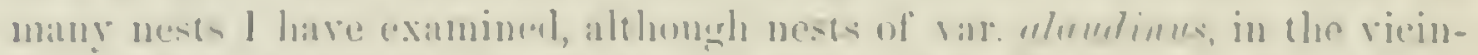

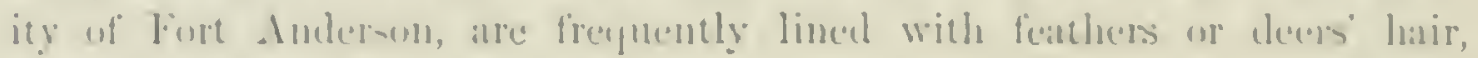

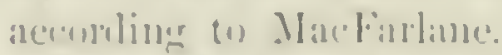

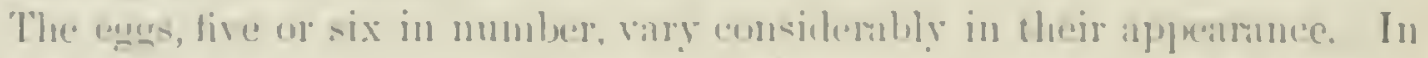

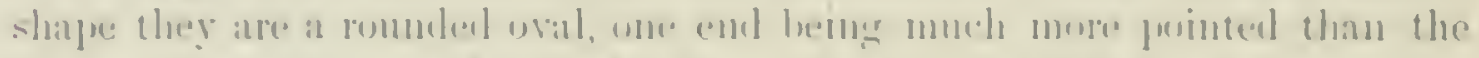

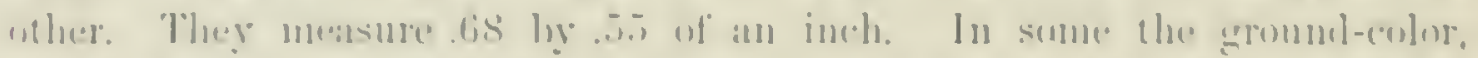

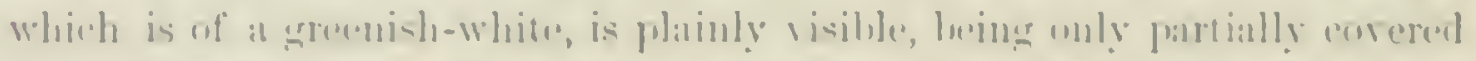

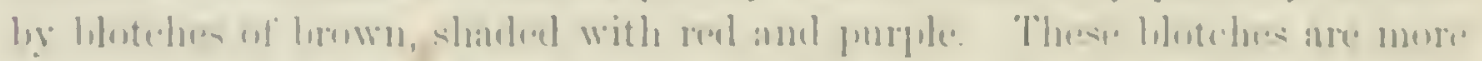

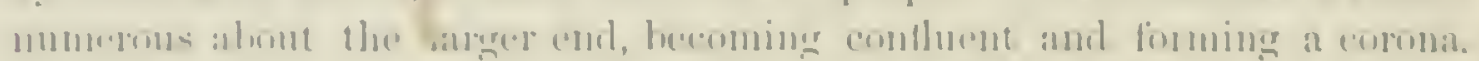

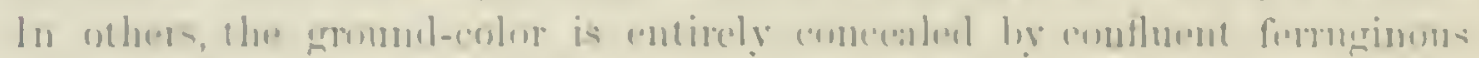

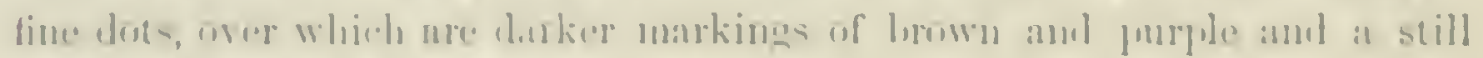

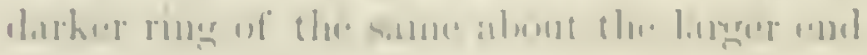




\section{Passerculus savanna, rar. alaudinus, Boxap.}

\section{WESTERN SAVANNA SPARROW.}

Passerculus alaudinus, BP. Comptes Romdus, XXXVII, Dex. 1553, o1s, Califormia. - Iв.

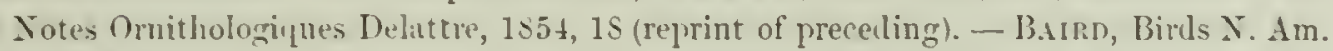

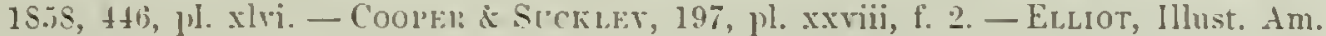

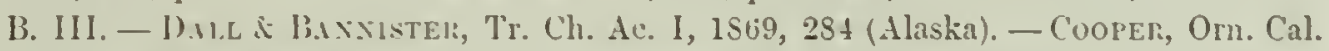

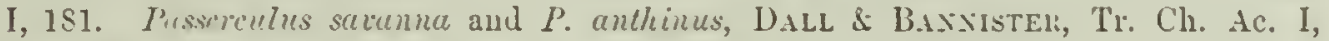
1569, p). $253,2 S 4$.

Sp. Cusı. Similar to P. saranna, but smaller; the bill slenderer and more elongated. Little of yelluw in the superciliay stripe (most distinct antcriorly); the rest of the head without any tinge of the same. General color much palel and grayer than in P. saranna. Breast with only a few spots. Length, 5.25 ; wing, 2.75; tail, 2.30.

II.ıb. Midlle and Western Provinces of North America; south to Orizaba, worth to Aliska (Kodiaki) and the Aretic coast. Oasaca (Scc. Oct.); Tera Cruz (winter, Sty CHRAST).

This westem race of $P$. serenne is smaller, considembly paler in general colors, the supereiliary stripe with little yellow in it, and the bill more slender, and longer. In coloration, some Atlantic coast specimens often exhibit an approximation, especially in the pale tint of the superciliary stripe; but the bill is always decidedly more attenuated in clumtinus.

The Westem Savanna sparrow is a common species throughout the Western Province of North Ameriea, from the plains to California, and from Alaska to Mexicn. In California it appears to be rephaced along the Pacifie const by the variety onthinus, a quite different and very local form. In Alaska, specinens were obtained ly the naturalists of the fiussian Telegrand Expedition at rarions localities, chiefly in the interior, and on the Tukon-it was obtained by Mrr. Lockhart. Dr. Cooper found it at Fort Steilacoom, in Washington Territory, where it was in company with $P$. sendwichensis, in the wet meadows. In California this species inlabits chiefly, according to Dr. Cooper, the dry plains of the interior of the State. The statement of the occurrence of this form anywhere along the coast of California should be received with considerable doubt, since in the large series of these birds all specimens from this region are of the rariety anthinus, an exclusirely littoral trpe.

Habits. The Westem Savama Sparrow was found throughout the Great Basin, by Mrr. Ridgway, in all wet, grassy situations, in which preference it is like its eastem relative. It was very aluundant at Carson City, inhabiting exclusively the meadows. At Salt Lake City it was also very abundant, frequenting the wet meadows near the Jordan.

This bird was also oltained at Sitki ly Bischoff, and was found on the Tukon by Mr. Locklart. It is the only speeies found in the Valley of the Mackenzie, up to the Arctic coast.

Dr. Cooper also met with it amnng the low meadows of Washington Ter- 


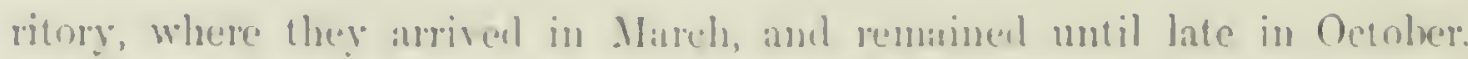

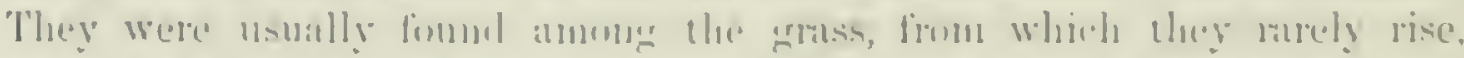

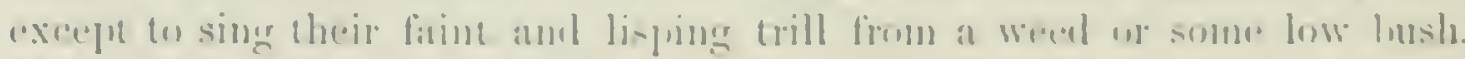

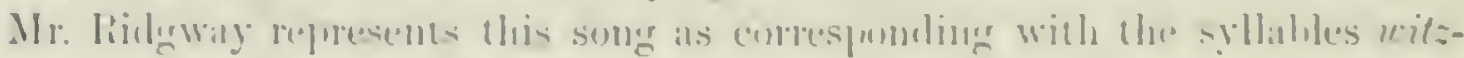

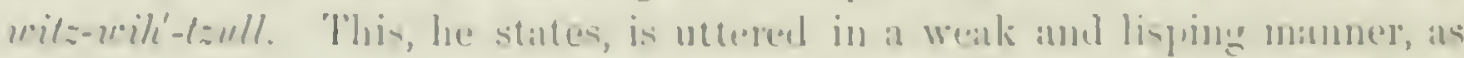

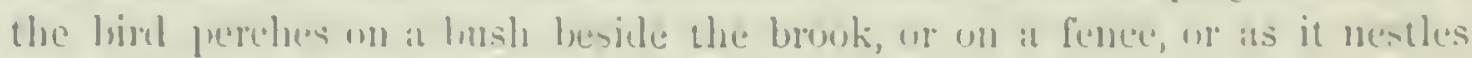
amoner the grass on the around.

1)r. ('ooprer speatis of thems as only winter visitants in Collifirnia, and there resiling only on the dry interior phins, at fitr somb ans Sin Dimo, where they remain in lange llocks mitil April. He has never met with

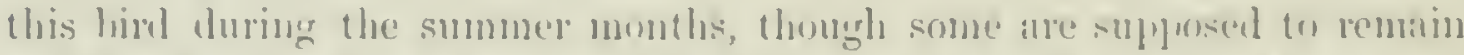
and hreed in the high pribien. He did not mene with any allunt the sum-

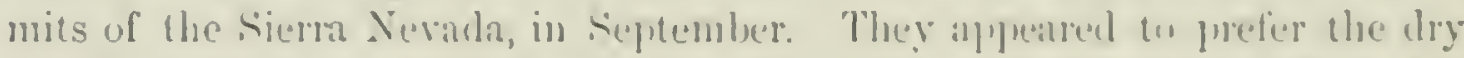
rolling prairies to marshes, though they were oceasiomally found in the littel:

This sprecies is also a mirbatory visitant to the Department of Vera Cru\%, Mexien, where they are sabil hy sumichmst to pass the winter.

Their nests are built npun the eround, and atre composed almost entirely

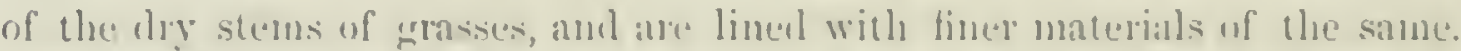

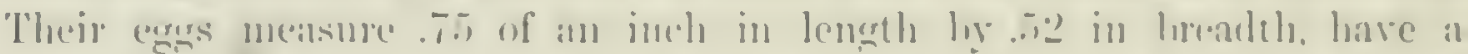
greenish-white ground, over which are distrilmtenl mmmenems matimer, spots,

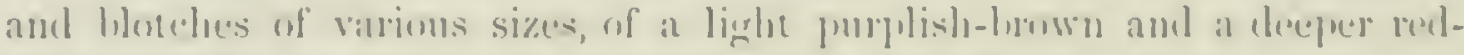

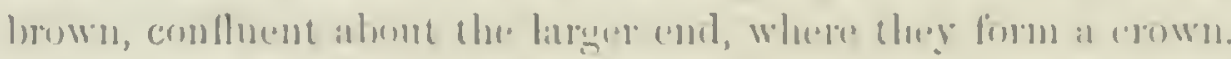

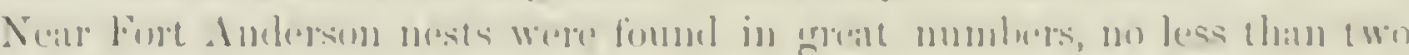

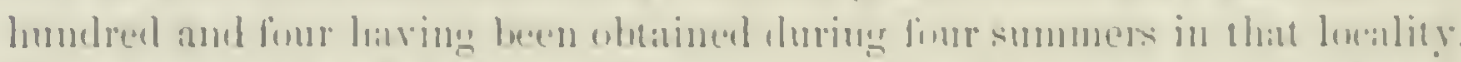

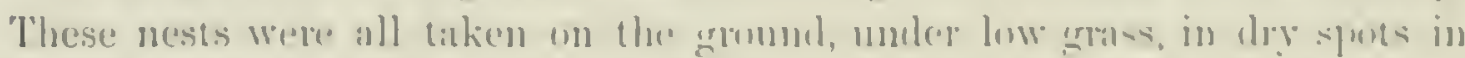
a large marshy prative, and it is stated that they were meser found in any other situation or lonility.

Passerculus savanna, vill: sandwichensis, BaInt.

\section{NORTRIVESTERN SEVANNA SPARROW.}

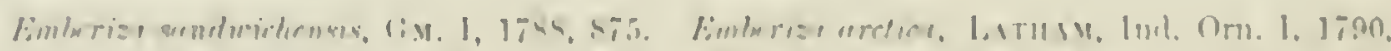

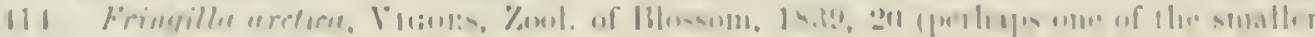

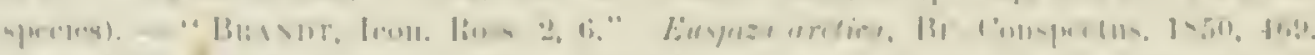

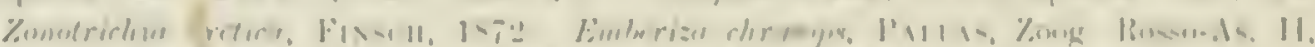

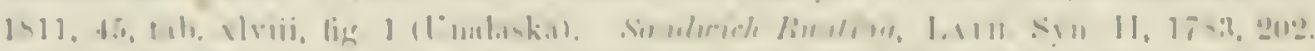

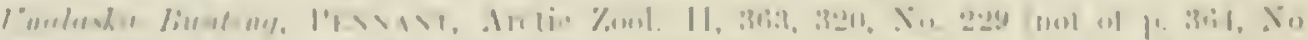

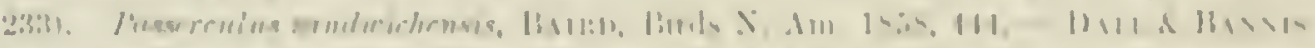

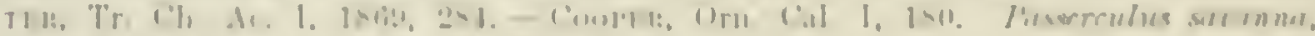

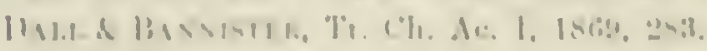

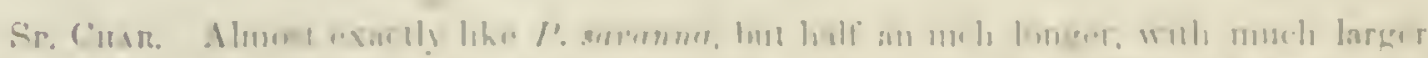

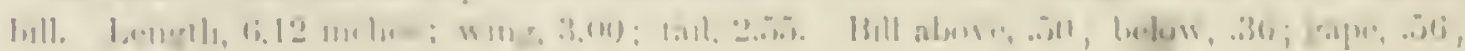
॥,

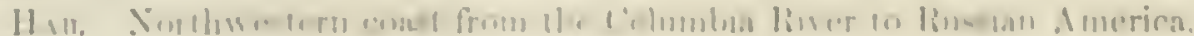


Specimens of this race from Sitka are absolutely undistinguishable from eastem 1 ? sucumu except in size: the color's and proportion of bill being the same. A young bird (from Kodiali) differs from that of saranna in larger size, and a bright reddish-fulvous tinge to upper parts, and a deep yellowish-fulvons tinge on juguhum and along the sicles.

Habits. This variety is the northwest-coast form of the common Saranna Sparrow, and is found during the summer from Oregon to Alaska. Dr. Suckley states that he found this species an abundant spring risitor at Fort Steilacoom. Dr: ('ooper, in his Zoölogy of Washington 'Territory, states it to be only a passenger through that section, migrating northward, at the end of April, in pairs, and not returning until the end of September. They come back in Hocks, and frequent the shores and prairies along the sea-coast. Their plumage seems to be the same at all seasons. Nothing is known of their note. They are supposed to spend their winters in Southern Oregon and California, though their actual presence has not been detected in either State. They do not remain cluring the summer near the Columbia, but pass to the north, or to the interior plains east of the Cascade liange. Dr. Cooper states that their habits closely resemble those of $P$. anthinus.

Mr. Dall states that two specimens of this species were taken at Sitka by Mr. Bischoff.

\section{Passerculus savanna, var. anthinus, Borap.}

\section{CALIFORNIA SHORE SPARROW.}

Passerculus anthinus, 130xAP. Comptes Rendus, XXTIl, Dec. 1853,919, Russian America. ${ }^{2}$ - IB. Sotes Ornitl. Delattre, 1854, 19. - Banid, Birds Y. Am. 1858, p. 445. CuOPer, Oru. C'al. I, 1870, 183.

Sr. Cnar. Similar to P. saranna, but smaller. Beneath tinged with reddish. Breast and upper part of belly thickly spotted with sharply defined sagittate brown spots, exhibiting a tendeney to aggregation on the middle of the belly. Superciliary stripe and one in the middle of the crown decided greenish-yellow, the head generally tinged with the same, as also the back and siles of the neck. Uncler tail-coverts somewhat streaked. Length, 5.00; wing. 2.66; tail, 2.24.

Haв. Coast of California, neal San Francico; "Russian America, Kocliak" (Boxaparte).

This is the most strongly marked of the several races of $P$. sacanna, differing from all the others in several important respects. The markings beneath are more generally dispersed, extending back upon the lower part of the breast, and forwarl over the throat; the lower tail-coverts have distinct medial blackish streaks, though they are somewhat concealed. The median stripe on the crown is clecidedly greenish-yellow, not pale ashy; the whitish edges to the interscapular feather's, so conspicuous in the other races, are more concealed, presenting a more uniformly brown surface above, with broader

I From the fact that this form is not fom I in any part of Alaska, nor, indeed, north of California, it is probable that the localities of anthinus and alaudinus were transposed in Bonaparte's oriçinal descriptions. 
Mack -tripes. The lunal lateml stripes of the crown are deep olive or hair-

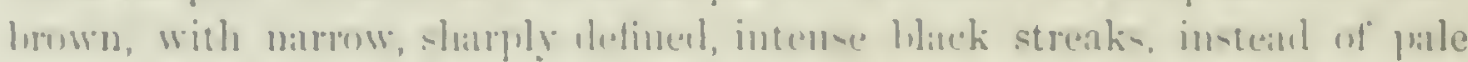

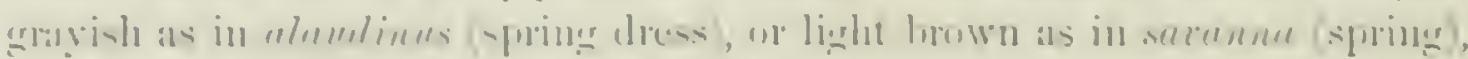

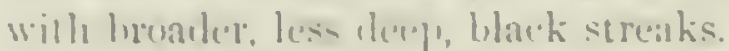

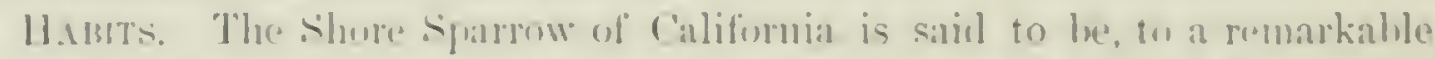

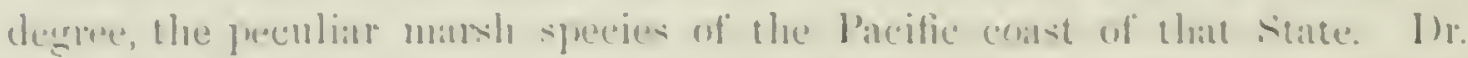

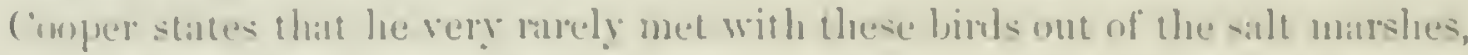
where they lie so chere and rum so stealthily among the weets that they are

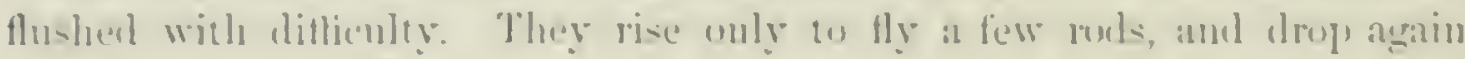

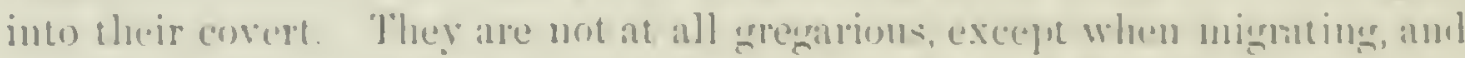

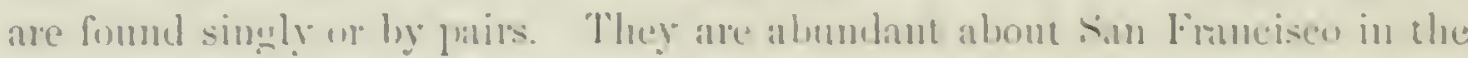

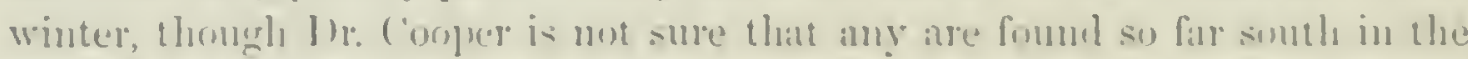

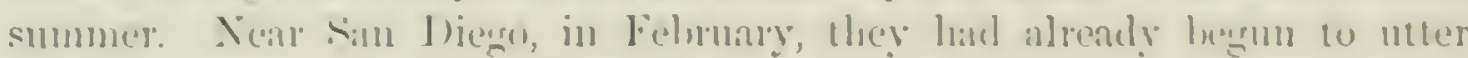

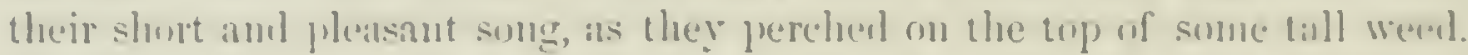

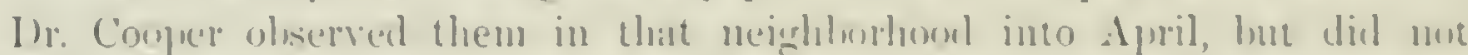
succeed in linding any of their nests, nor was lee ever able to meet with this sprecies at sim l'edro in sumuer.

Dr. ('unes speatis of (1lis, 1S6ti, p. 268) finding three species of the diffi-

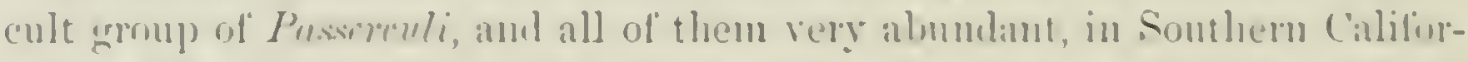
nia in Noresulere. These were I'. rostrutus, I'. ulumlinus, and I'. anthinus.

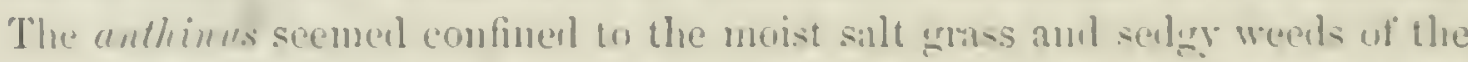
seat-shure itself. It was flusherl will ereat difliculy, and then its flight was

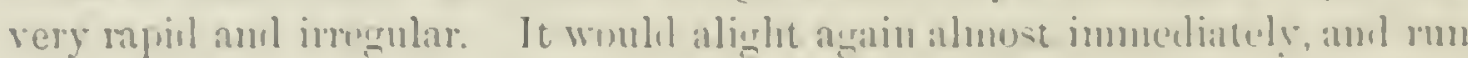

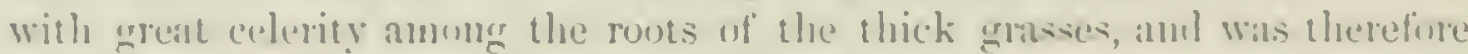
exceedingly diflicult to procure. P. ulmulinus wats common two or lliree miles away from the coast, lut Dr. (ones diel not fund one miximg with I. anthints. It was a bush and weed, mather that at grass, specier, ansuciating with Anthus lueturirinuss and Zonutriehie roronelu.

Passerculus princeps, Mariand.

\section{IPSWICH SPARROW}

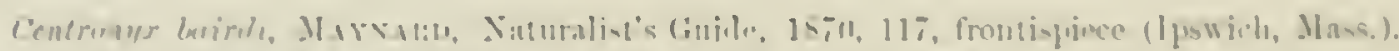

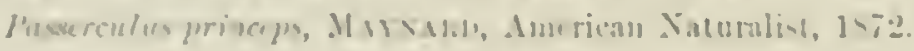

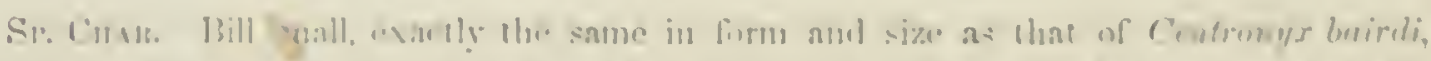

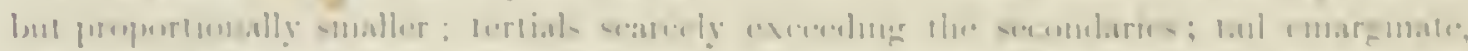

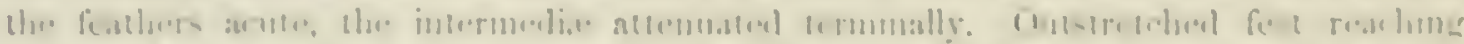

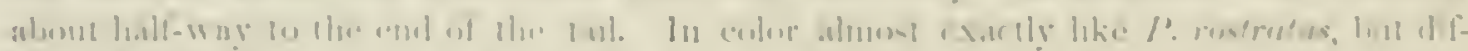

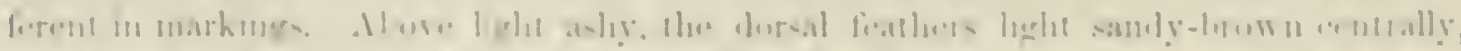

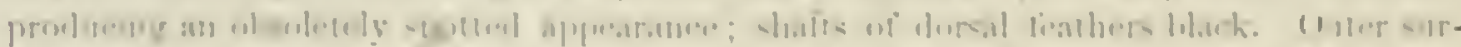

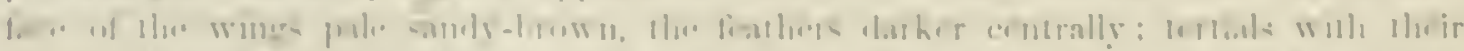

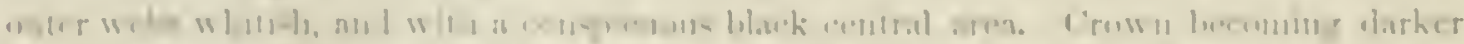
1 |

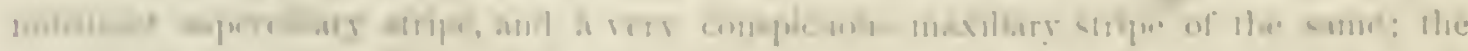

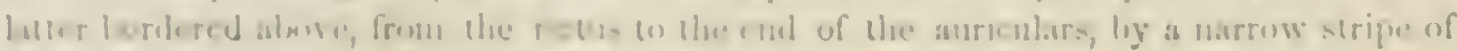


duskr: lores and sub-orbital region like the superciliary stripe; auriculars pale brownish like the crown, borlered along the upper and lower edge with a dusky narow stripe. Beneath white, slightly tinged with ashy on the tlanks: sides of the throat, whole breast. sides, and Ranks, with Jamow strealis of samly-brown, more blackish towarl the shaft; abdomen. erissm, and lininer of the wing, immaculate: throat with a few minute specks, but aloug each side bordereel by a "bridle" of suffizsed streaks.

ঠ. (Collector's To. 1,it4, I pswich, Mass. Dec. 4. 1868; C. J. Maynard.) Wing, 3.2.; tail. 2.60; (mulmen, .45; tarsus. .95; midille toc, .80; hind claw;.40.

․ (Collector's No. 6.245. Ipswich, Oct. 15. 1851: C. J. M.) Wing. 2.90; tail, 2.40: culmen, .jo; tarsus, .S5; miclelle toe. . .5.): hind claw, .30.

(Collector"s No. 6.224. Ipswin. Oct. 14, 18-1: C. J. M.) IIing. 3.00; ‘ail, 2.30: culmen, .50; tarsus, . 55 ; midlle toe. .60; hind claw. .30.

The specimens deseribed above were at first supposed to be C'entronyx baindi, having sereral points of resemblance to that species, a comprison with the trpe in Professor Baird's collecetion at first finling to establish a difference, as it was in faded and nuch worn summer plumane, while the Massachusetts specimens were in perfect, blended fall dress, so that a satisfactory comparison was almost impossible. A more recent examination, lowerer, with the advantage of two ahlitinnal speenuens of the Massachusetts bird, has fully convinced Mr. Maynard that his specinens are not Centronyi bairdi, and that, indeed, they are referrible in all respects to the genus Pressereulus.

In carefully examining the type of contronyz baidi, it is seen that its chameteristic features are the following: Ontstretched fect reaching beyoud the end of the tail ; hind claw as lomer as its digit, and much eurred; - whereas in Mr. Marnard's specimens the ontstretehed feet reach to only abont the middle of the tail, while the hind claw is much shorter than its digit, and only slightly curved. With a wing .11 to .45 of an inch longer, they have the tarsus not any longer, and proportionally more slender. In coloration ther are still more different. The most striking feature in $C$. brivdi is a broad and very conspicuons mediun stripe of oclunceous-buff on the crown, bordered on each side by an aggregation of black streaks, which form the predominating color of the lateral stripes; of this median stripe there is scarcely any trace in the specimens under consideration, while the crown wenerally is grayishbrown, with small dusky strealis; C. baireli lias broad, conspicuous, black stripes on the back, while $P$. maynumli has obsolete sandy-brown ones; in C. bairdi there are only a few small strealis of black across the jugulum and along the sides and flanks, while in $P$. muyncerdi the whole breast, as well as the sides and flanks, are thickly strealied with broader marks of sandy-brown.

In point of coloration, as well as in the feet, there is in reality a much closer resemblance to Passerenlus rostratus; but in this the rery different bill and different arrangement of markings are sufficient distinetive characters.

Epon the whole, therefore, there can be little doubt that the present birds are well entitled to the name which Mr. Maynard has given them; for after 


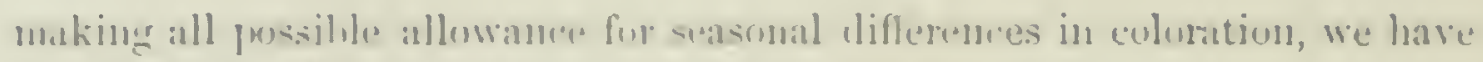

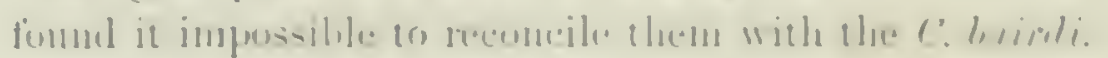

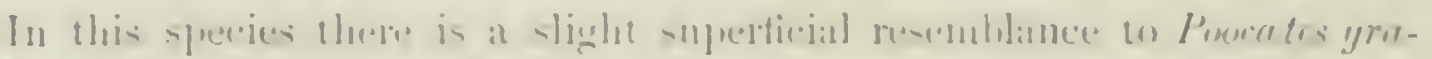

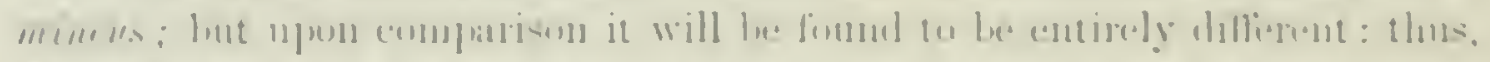

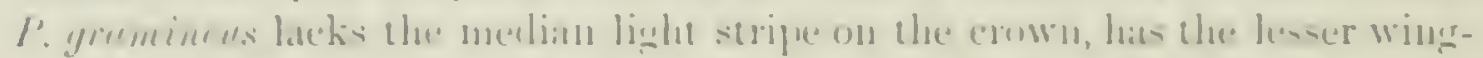

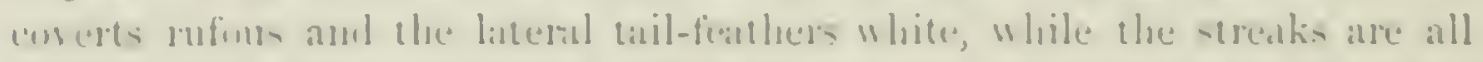

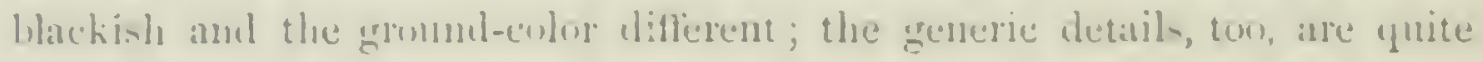
ditliesent.

II.nitr. This species hats been obtainen only in Eastern Mas-achusetts,

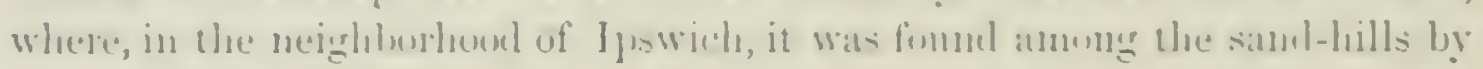
the sea-shere. The place where the individuals tatien were met with is a

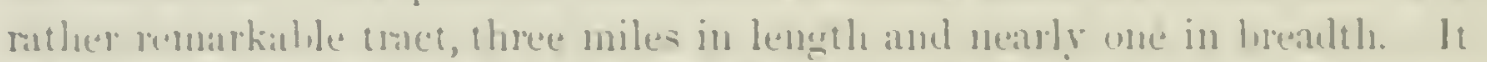
is as treelesis is the (ireat Plains, and as heak ant harren, with no vengetation exceptr a seant growh of enarse grass. Mr. Maymarl obtained his tirst speci-

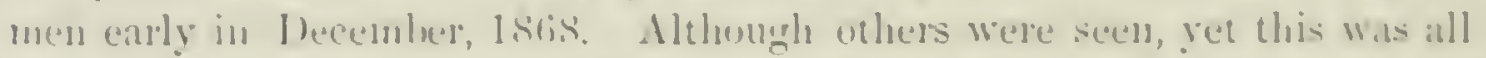
he was then ahle to ohtain. He has since taken others in the same flace and seasun. Nuthing is known ats to its habits. It uttered, as it ruse, a short chirp of alarm.

Passerculus rostratus, B.inn.

SAN DIEGO SPARROW.

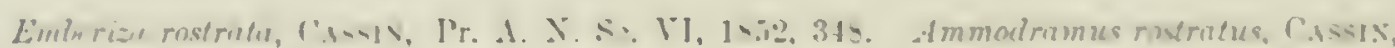

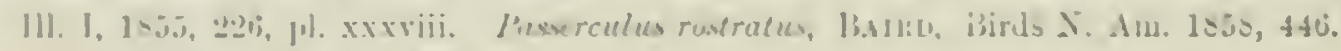

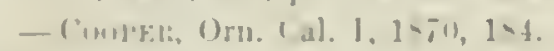

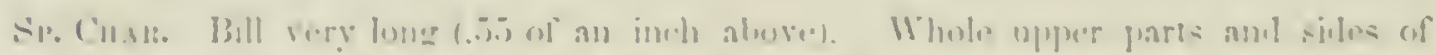

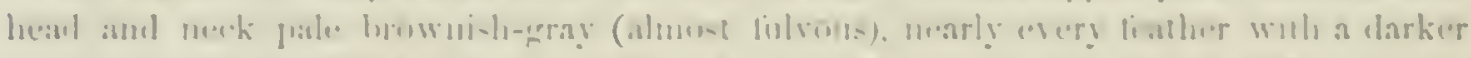

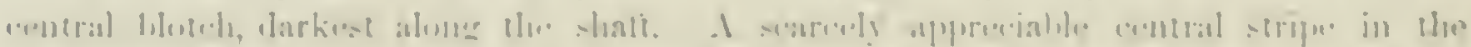

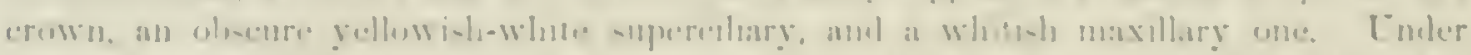

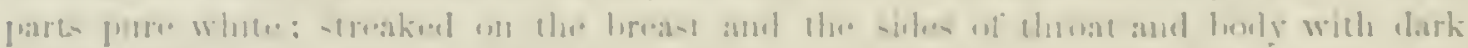

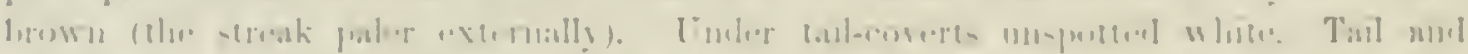

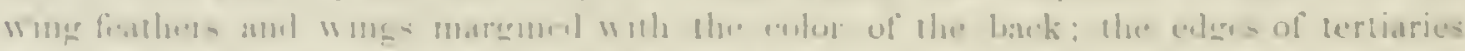

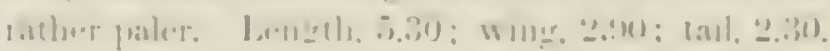

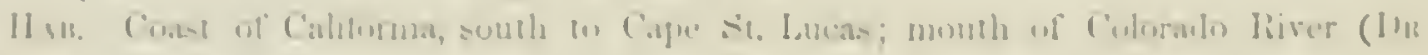
I':14:16.

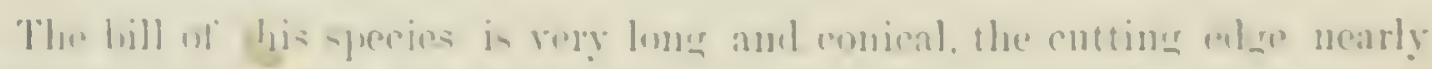

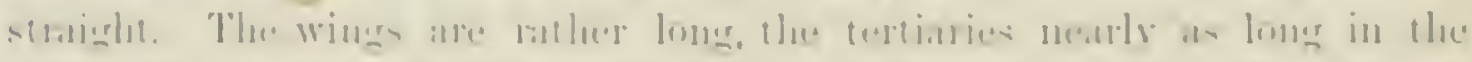

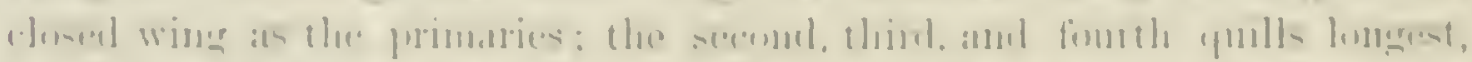

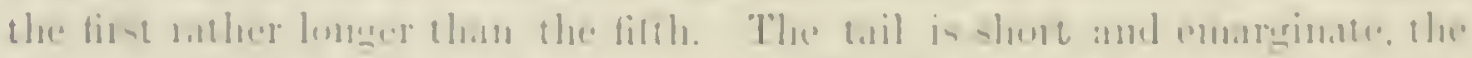

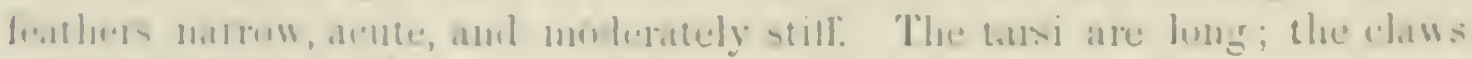
little custul.

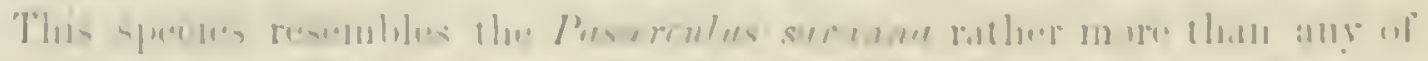

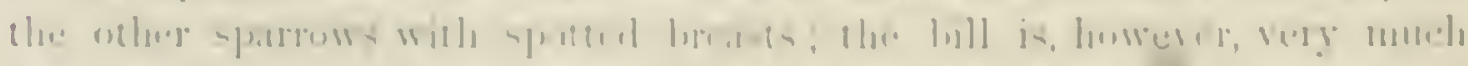

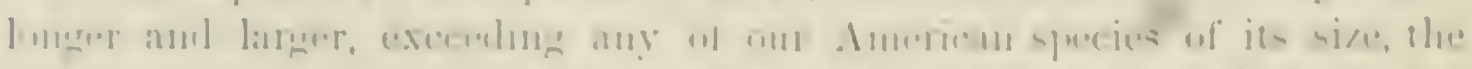

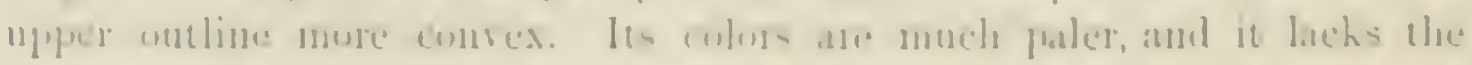


yellow on the heat and wing. The much shorter tail and entire absence of mifons distingrish it from the spotted Melospizas. In shape the bill is like that of Ammodromus cauducutus, but it is larger; the head lacks the yellow, etc.

In some speeimens the streaks on the hack are almost obsolete.

Habirs. So far as is known, this bird seems to have a somewhat restricted habitat, being apparently confined to the sea-coast of Southern Culifornia. There it was first met with by I)r. Heermann, in the neighborhood of San Diego, and was described by Mr. Cassin as an Ammortromus, with which genus of birds it seemed to have many peculiarities in common. Inr. Heerminn first met with this bird in 1851, on the shores of the bay of San Diego, in eompany with other species, apparently in search of grass-seed. Afterwarts, in the Pacifie Railroad Survey, with Lientennt Willianson, he again met with these birds in considerable numbers at Santa Barbara and San P'edro. In all the places in which he met with it he found it frequenting low sandy beaches, and the heary sedge-grass which abounds on the shores. On the former it seemed to be feeding on marine insects and seeds thrown " by the tide, and in the latter to find places for easy and immediate concealment when alarmed or pursued. Naturally it appeared to be a quiet and unsuspicious bird. He heard it utter no other note than a short sharp chirp.

Dr: Cooper thinks this species has a mueh greater affinity to the Ammodrami than to the Passerculi, both in its bill and elaws, as well as in its habits. He found them very abundant, both at San Pedro and San Diego, at all seasons, and he does not think that they migrate at all from those localities. He found them frequenting the shores of the bays and the seabeaches. They also came confidently and familiarly about the buildings near the water, feeding on any seeds or insects they could find. On the beach they rum along the sand, in the rows of drifted sea-weeds, seeking their food, and rarely take to flight mnless surprised, and then only fly a short distance. Dr. Cooper has never known them to alight on any bush, nor does he think that they lave any song. The only note he has ever heard them utter is a short chirp. At San Pedro he saw them, in July, feeding their young, but he las never found a nest that he was certain belonged to this species.

Dr. Cones found this bird abundant in Sonthern California, where it kept among the thick weeds of the dry plain, and was much on the ground, where it ran as easily as a Pipilo, often flying up into the bushes and resting there quietly. They were to be seen also in great numbers sunning themselves and eatching flies on the piles of lumber on the wharf, so tame as to be almost liable to be struck by a cane.

It is a winter resiclent at Cape St. Lueas, where Mr. Xantus found them abundant. They were not seen there in summer, though it is probable they reside on the shores in its neighborhoad. Their nest and eggs remain unknown. 


\section{Passerculus rostratus, var: guttatus, l.twi.}

\section{ST. LUCAS SPARROW.}

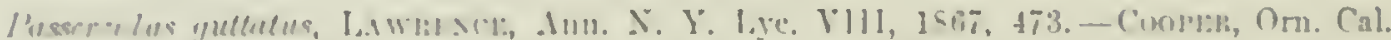
I, 15.

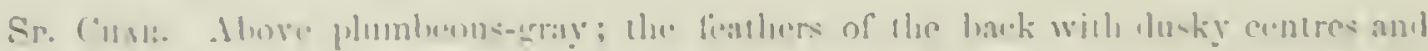

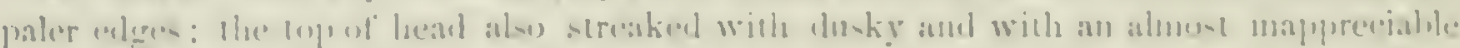

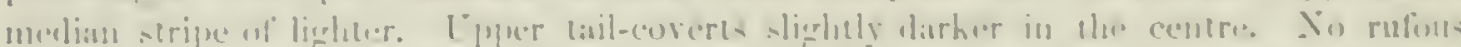

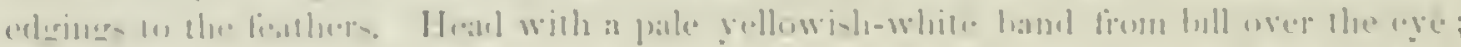

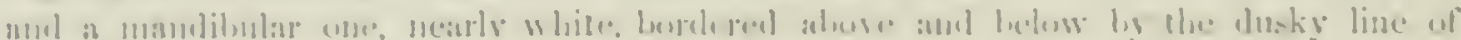

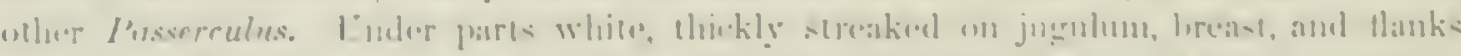

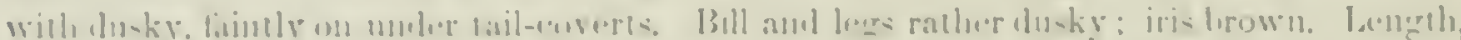

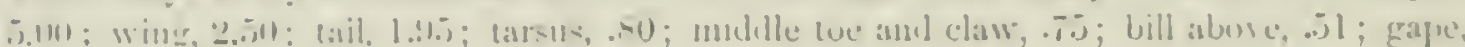

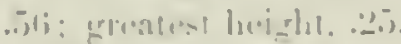

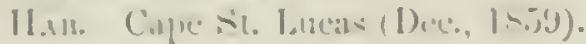

This hirl, of which in single specimen only is so far known, is very closely

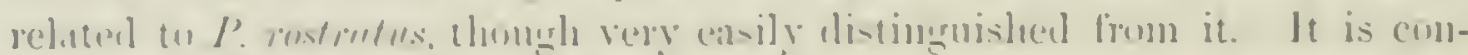

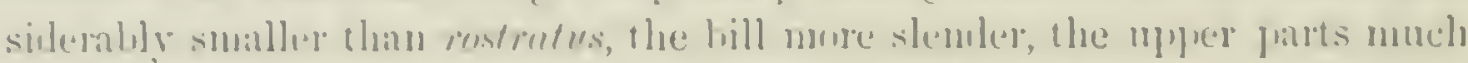

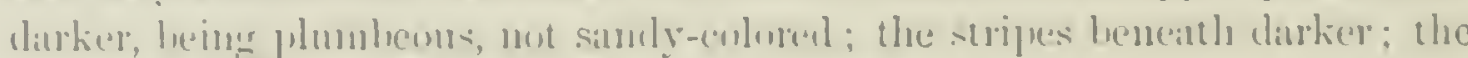

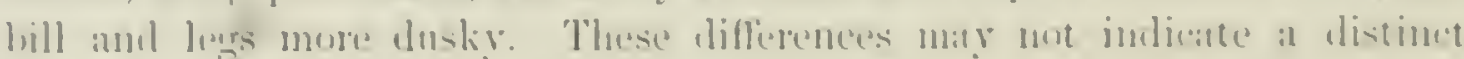

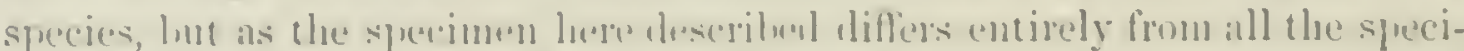
mens of a lithese number of $I$ '. rustrutus, it is yet entitled (1) erousideration as

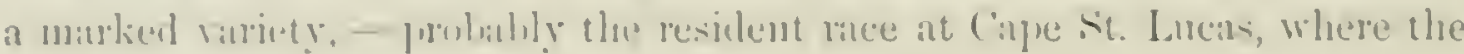
var. imstomfles is merely a winter isitur.

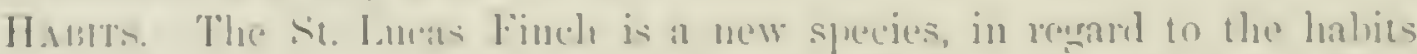

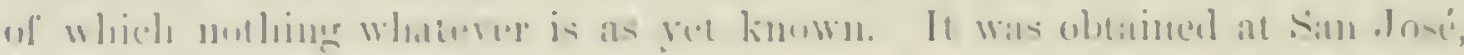

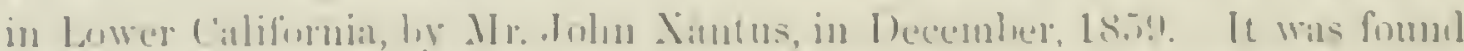

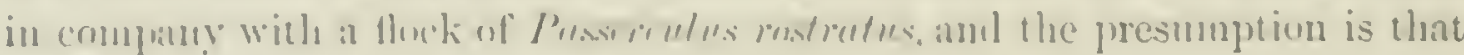
its hablits maty resemble thuse of that little-known species.

\section{(iivit: POOCFETES, B.AHI}

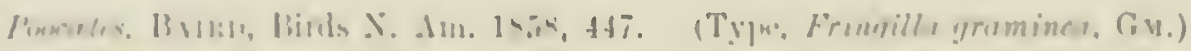

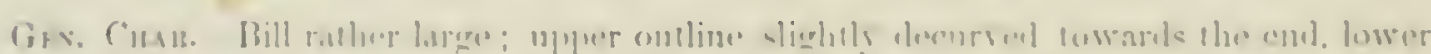

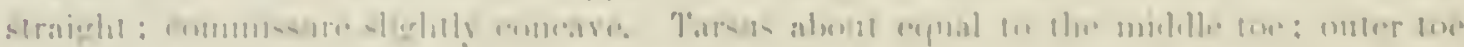

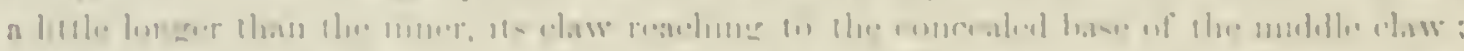

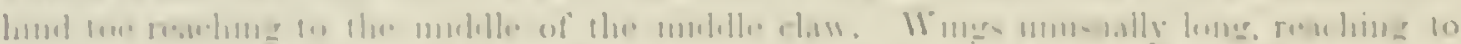

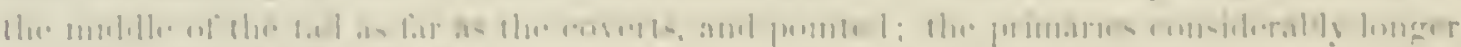

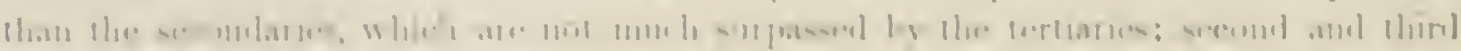

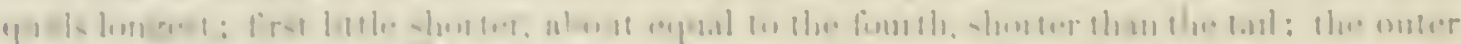

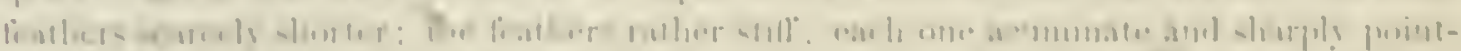

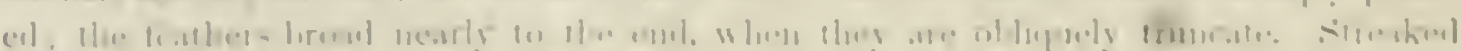

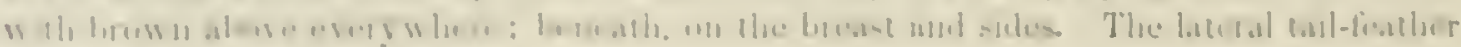
" whate. slusul ler clu loust iown. 
The essential character of the genus consists in the long and pointed wings, longer than the tail and without long tertials; and the rather stiff, forked tail, with its acute feathers. But one species is recognized at present.

\section{Poocætes gramineus, B.IRD.}

\section{GRASS SPARROW; BAY-WINGED BUNTING.}

\section{Tar. sramineus.}

Fringille gramince, G.s. Syst. Jat. 1, 1iss, 92:2. - Av1. Oru. Biog. I, 1S31, 473; V, 502, 11. xc. Emberizu gruminer, Wilsux, Am. Orn. IV, 1S11, j1, pl. xxxi, f. 5. - AโD. Sıu. 1\$39, 102. - IB. Birds Am. III, 1S41, 6j, pl. clix. - IIx. Cab. Jonr. ri, 1S5S, 342. Fringilla (Zonutrichiu) grrminea, swassos, F. B. Am. II, 1\&31, 254. Zonotrichia graminere, Box. List, 1835. - IB. Consprectus, 1550, tis. Puocates gramineus,

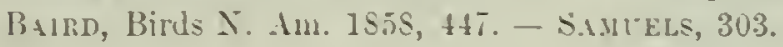

Sr. Cuar. Till-feathers rather acute. Above light yollowish-brown; the fegthers everywhere streaked abruptly with dark brown, eren on the silles of the neck, which are paler. Bencatlı rellowish (sometimes reldish) white; on the jugulum and sides of neck and body streaked with brown. il faint light superciliary and maxillary stripe: the latter margincd above and below with dark brown: the upper stripe continued around the carcorerts. which are darker than the brown color elsewhere. Wings with the shoulder light chestunt-brown,

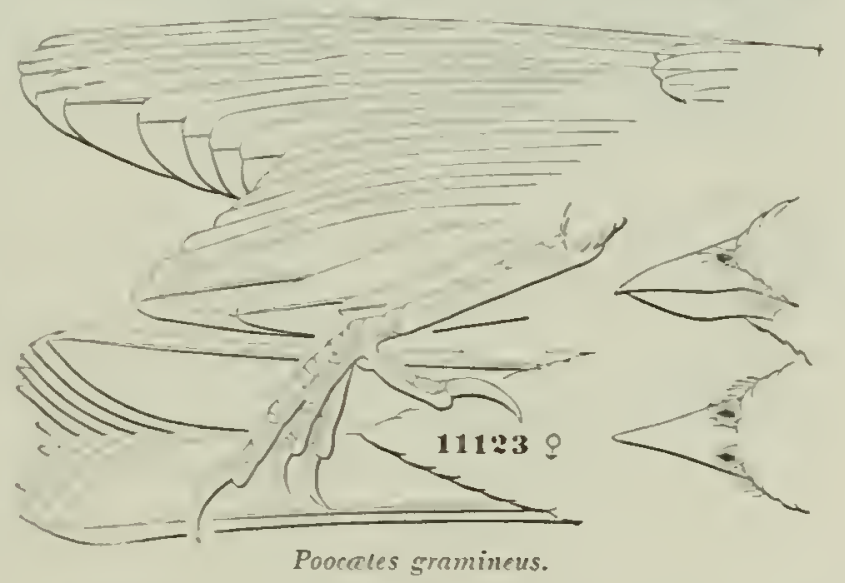
and with two dull whitish bands along the ends of the coverts; the outer cdge of the secondaries also is white. Exposed portion of outer tail-feather. and edge and tip of the sccond, white. Length, about 6.2.5; wing, 3.10; tail, 2..50; bill. 33 from frontal feathers to point, by .33 in lepth at base; tarsus. .72. Bill yellow, dusky abore; legs yellow. (Measurement of $\mathrm{No}$ o. 10,14i d; Washington, D. C.)

Hab. Eastern Province of Lnited States.

\section{Var. confinis.}

Poocates gramineus, rar. confunis, B.illn, Birds X. Am. 1Sjs, p. ItS (in text under P. gramineus). Poocates gramineus, Courfis \& Scroker, 200. - Coorel, Orn. Cal. I, 1ミb.

SP. Cuur. Resembling P. gramineus, but colors paler, the dark streaks narrower. Bill move slender, tarsi longer. (Measurement of $40,803 \mathrm{\delta}$. Fort Whipple, Arizona: Bill, .36 from point of frontal feathers by .25 in depth through base; tarsus, .73 ; wing, 3.35 ; tail, 2.80).

HAB. Western and Middle Prorinces of Tnited States, south into Mexico; Oaxaca (ŚcL. 1859, 379; March).

This species is readily identified by the absence of a median stripe on the head, the chestnut-brown of the shoulder, and the white lateral tail-feathers. The young birds have the ground-color above more whitish, the streaks blacker, in sharper contrast; the streaks on jugulnm, etc., less sharply de- 


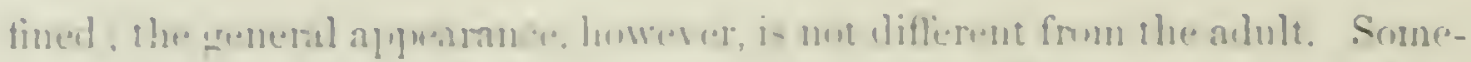

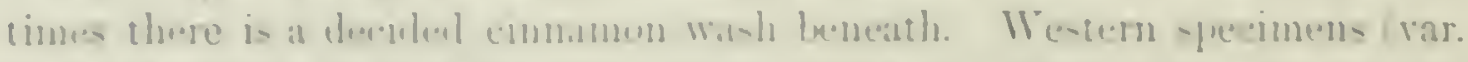

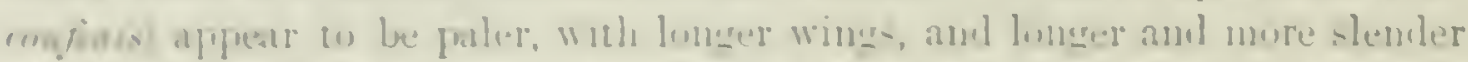

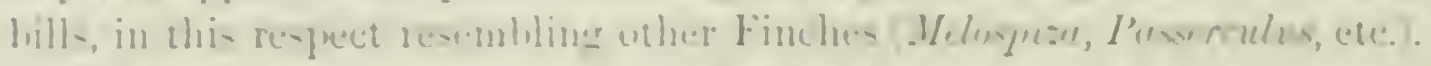

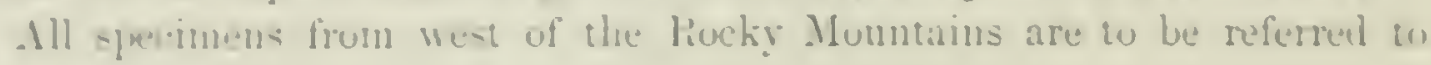
var. rmingus.

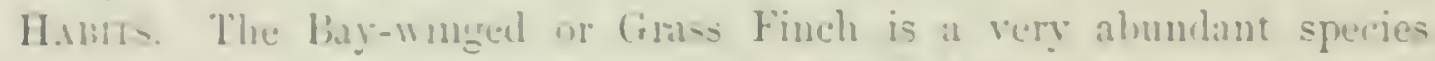

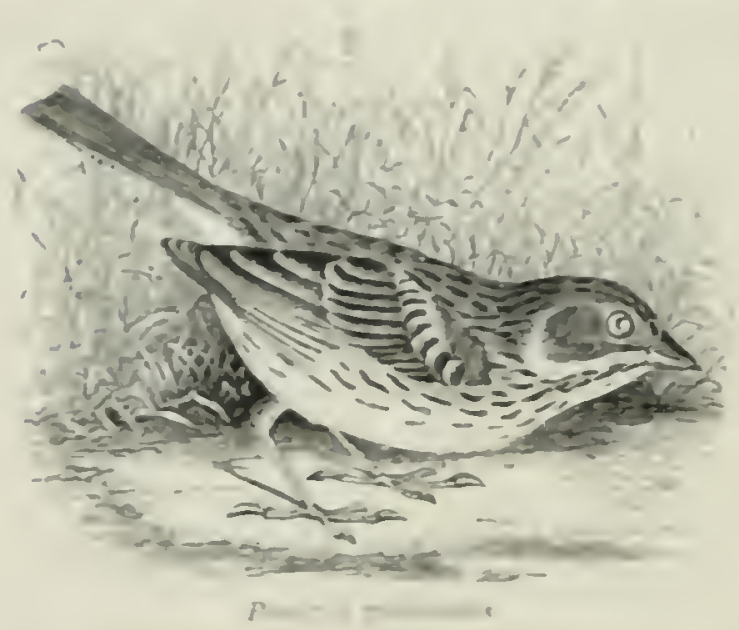
whererey fomml, and has a very extended distribution. Acceptime as one spectes the slightly rariant rances alsove imlieateel, this fird extends from Flurida and Mexico, ou the south, th the itite paralled of latiturle, and from the eastern to the western shores. It wals found by licharblon freyuenting the phans of the Saskatchewan, where it arrives early in May and leares in septemluer, and where it nests abumdantly in the shont witherenl prass of that sterile region. Richamenu

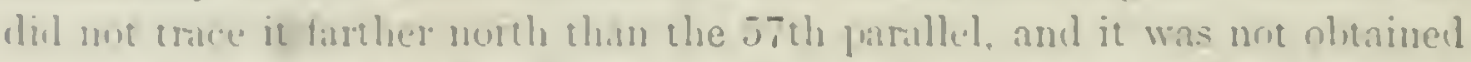

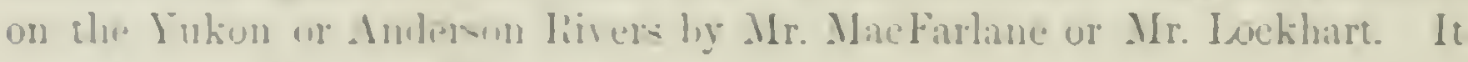

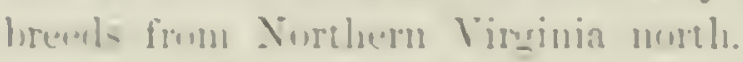

In the Nilllle state it is pattially resident, a portion remaining all the

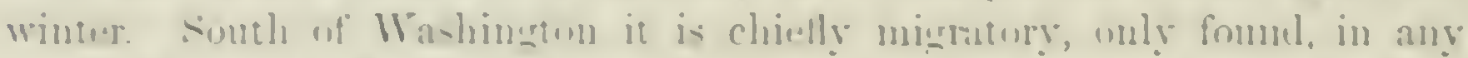

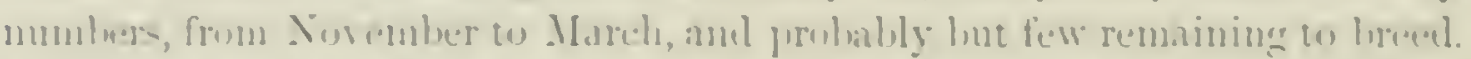

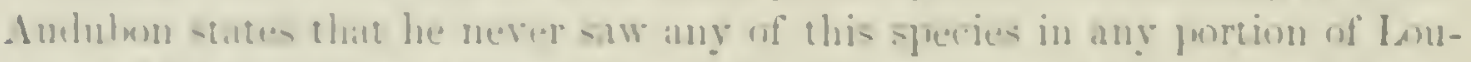

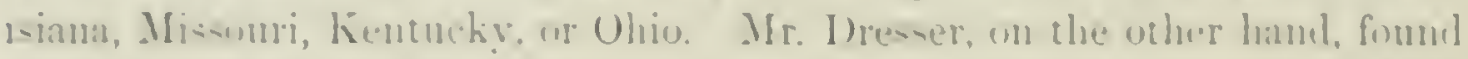

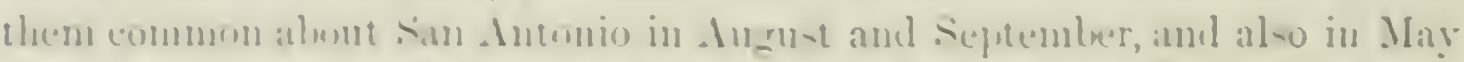

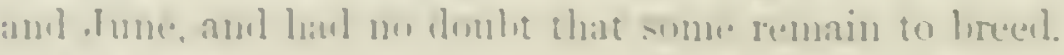

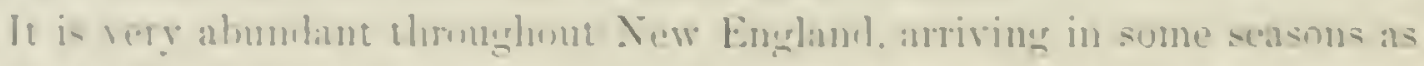

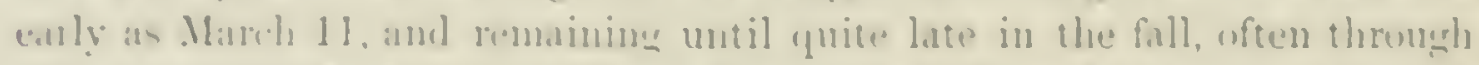
Sorrulxer. It is fomml elicelly in dry opren fields and pastures, where it

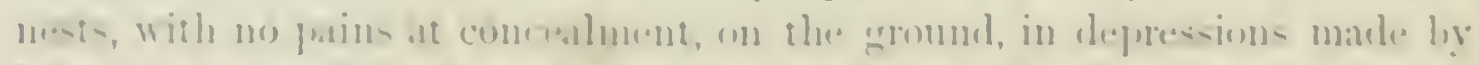

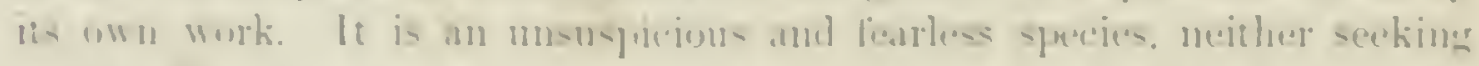

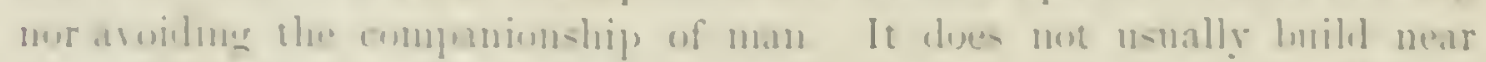

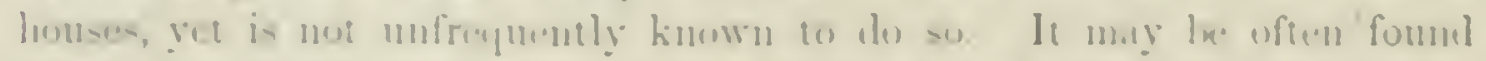

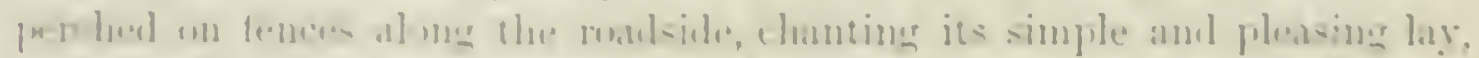

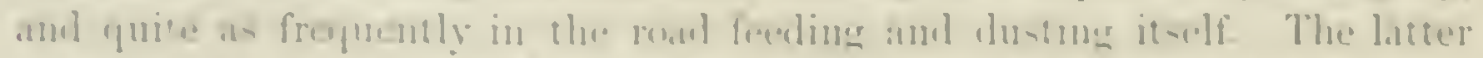

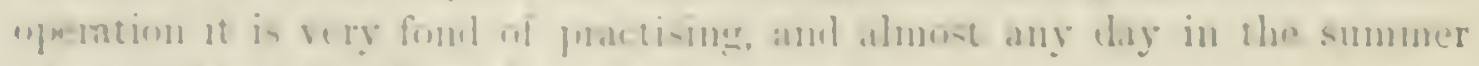

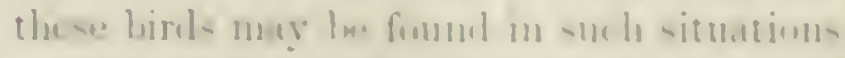

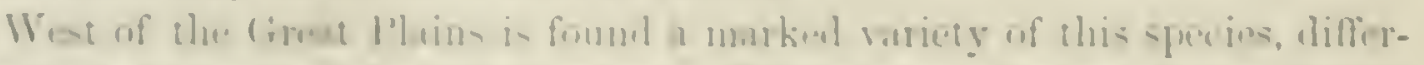

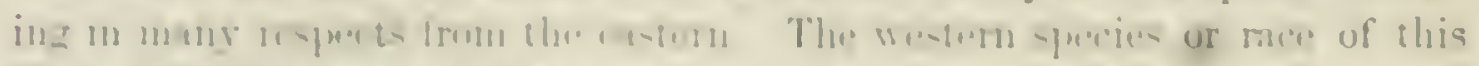

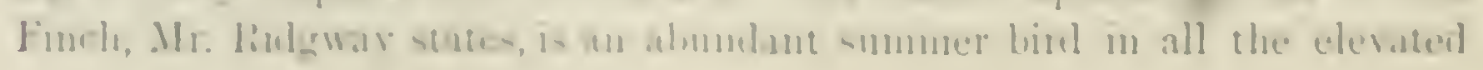


grassy portions of the West. It is especially chancteristic of the higher grassy slopes of the elevated mountains, particularly in the liocky Momntain regions, and its sweet and simple song is one of the pleasant associations of those regions. It descends, in the autumn, to the lower districts, having been observed during September in the greatest abundance among the "rye-grass" meadows of Senot Valley, at the northern end of the East Humboldt liange. It nests on the ground in grassy banks, in various situations.

Dr. Suckley found this bird abundant on the Nisqually Plains, about Puget Sound; and Dr. Cooper says it is common, in summer, on the prairies of the interior of Washington 'Territory. Dr. Cooper also found it wintering in the Colorado Valley, in consiclerable numbers, but all disappenred in April. He thinks they breed in Northern California, though he has never found them doing so. Dr. Newberry states that they are common in the Sacramento Valley, both in the summer and in the fill. It was found by Mr. Boucard, in winter, near Oaxaca, Mexico.

Their song is a very simple and pleasant succession of soft notes, resembling that of the Canary, but thimner and feehler. It is begun early in the morning and contimued a few hours, and then renewed at sunset and liept up often until after clark. It is also not mulike the song of the Song sparrow, but is neither so varied nor so lond and strong. It continues to sing until late in the season.

They feed in the road, eating insects, seeds, and grain. They are fond of searching also in ploughed fields, and keep principally upon the ground, exchivively so when they are searching for their food.

Although as unsuspicious as the Song Sparrow or the Chipping Sparrow, this Finch rarely, like them, comes about the house for crumls of bread, but seems to prefer to forage for itself in the fields and by the roalside. Taken from the nest, these birds may be readily tamed, and soon hecome very interesting and familiar little pets, though Nuttall states that where several are thus kept they become very jealous of each other, and quarrelsome.

Their nest is always placed mpon the gromd, and is very simply constructed of dry stems of grasses, with no other lining than soft fine materials of the same. They have two, and sometimes three, broods in a season. When their nest is approached, they make use of various artifices to draw away the intruder, and often vary their derices in a very striking nanner. In May, 1836, crossing a field within a few rods of my home in Roxbury, I nearly stepped upon a female sitting upon her nest. She immediately tumbled forward towards me, comterfeiting the most extraordinary lameness, so much so that I supposed that I had really stepped upon and severely injured her. I stooped to pick up what I supposed to be a wounded bird, and found her nest and four eggs. Visiting her nest again, as I approached she flew from it quietly and silently, and inmediately began the same manouvres, at some little distance from her nest, which she discontinued as soon as she noticed that I was examining her treasures. These devices she 


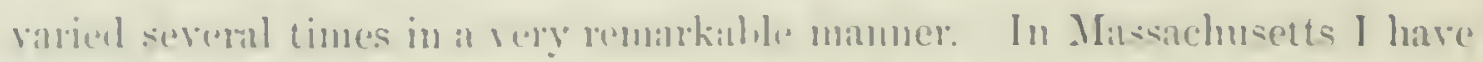

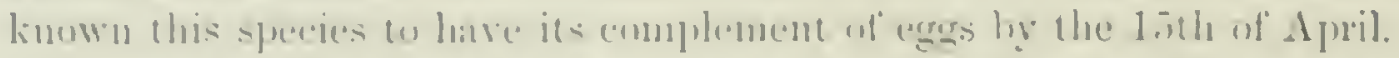

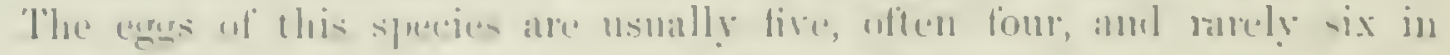

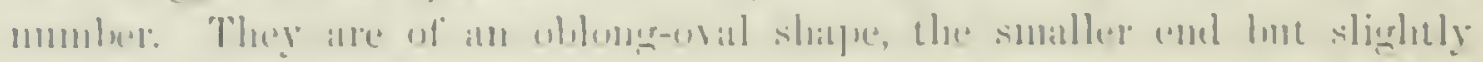

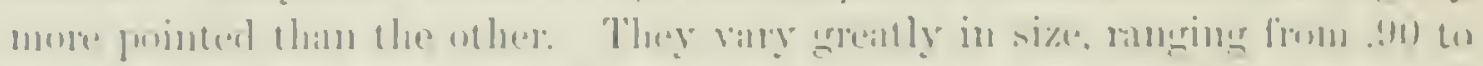

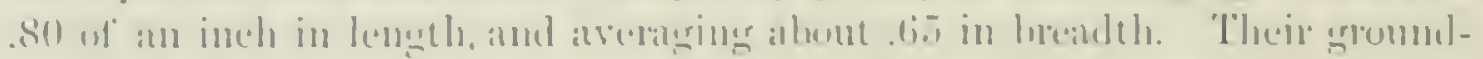

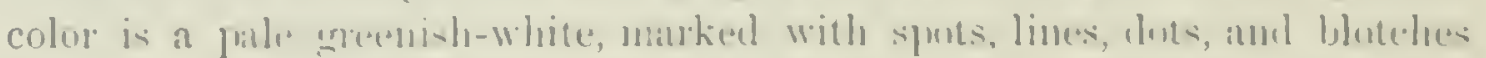

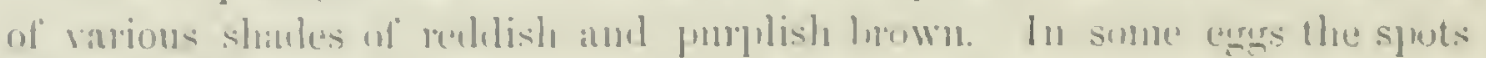

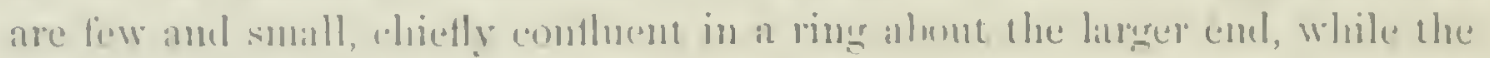

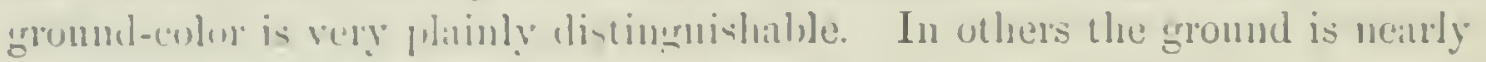
cuncealed by the ahmulance of the spots.

\section{Gi:t: COTURNICULUS, MoxAl.}

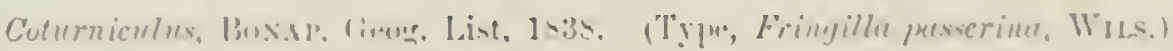

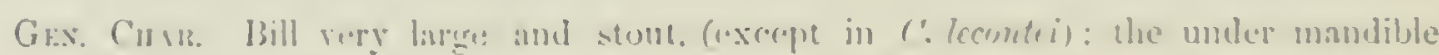

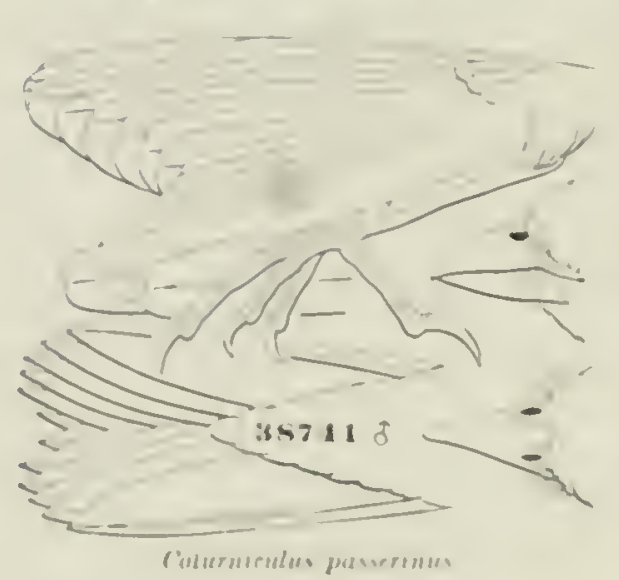
lupouler. Lut lower than the upper, which is deci-

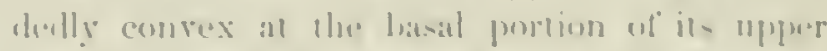

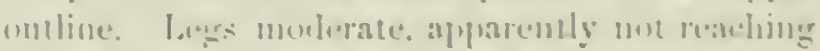
to the cort of the tail. The tar-ils apprectisbly lomger thams the midllle toce the lateral teres equal, and wilh lheir clow = talling kevelelenlly short of the midelle rlaw: Iles limd toe intermediate betweren the [wo. The winge are short and romblod,

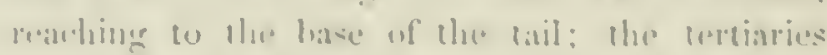

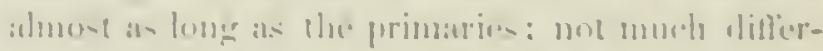

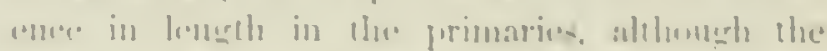

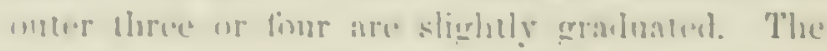

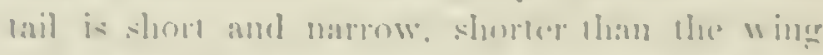

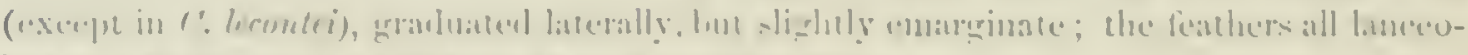

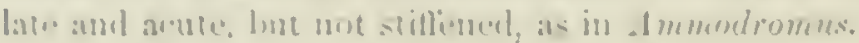

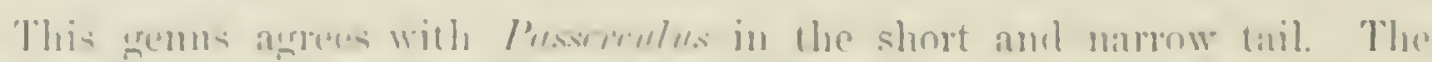

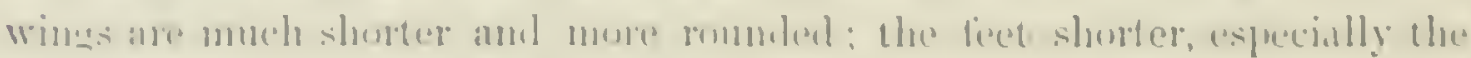

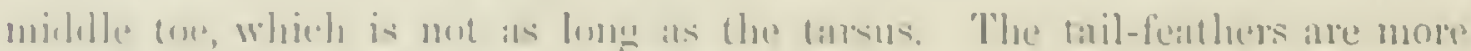

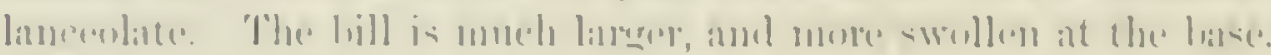

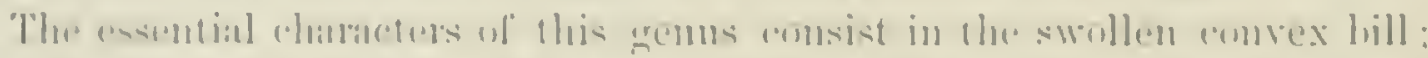

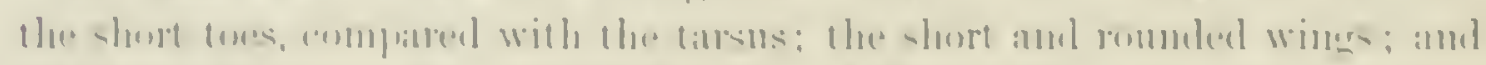

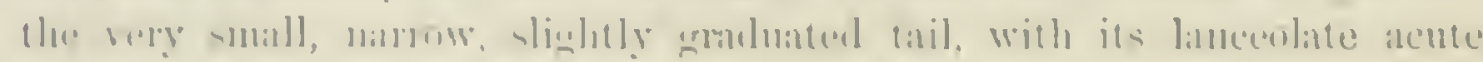

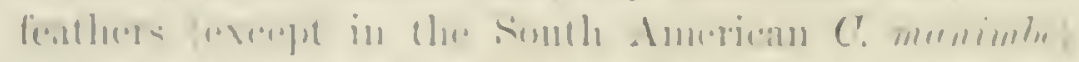

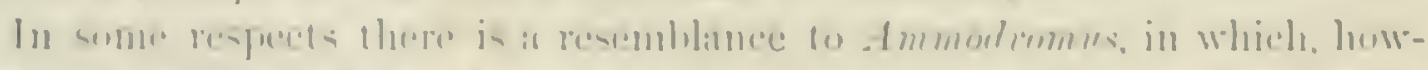

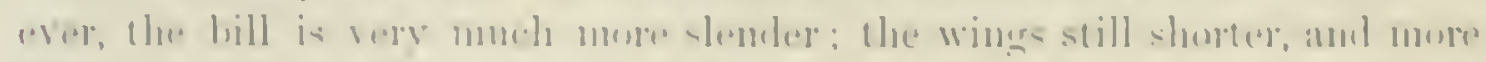

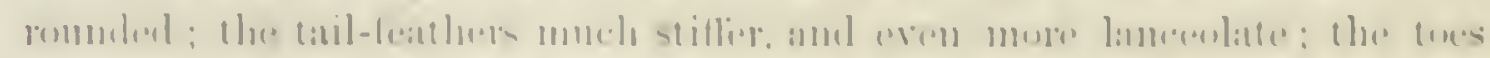

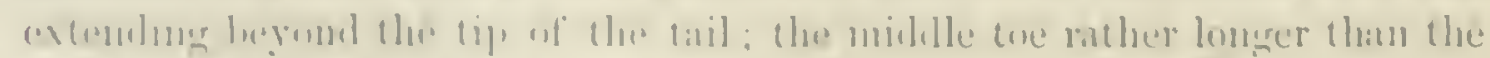

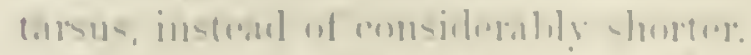

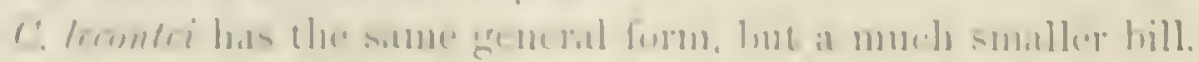




\section{Synopsis of Species.}

Comsos Chrspacters. Crown and hack streaked with black upon an ashy, olive, or chestnut ground: beneath whitish, tinged across the hreast with ochlanevus or ashy, flain, or with hackish streaks on the brease. I light superciliary stripe.

A. Tail-feathers attenuated, acute at ends, much graduated. On the crown a median light stripe.

a. A dusky streak on each side of the throat, and one abore the light ochraceous maxillary stripe.

1. C. henslowi. Bill very robust, .35 along culmen by .30 deep at base Wing. 2.25; tail. 2.20. Heat ochraceous or greenish olive, lighter on the throat; a blackish stripe on each side of the crown. Brease streaked with black at all ages. Hab. Eistern P'rorince of "Lnited States.

b. Co dusky streak on side of throat nor above the maxilla.

2. C. lecontei. Bill very narrow only .16 hroal by 20 deep at base. Median stripe of the cruwn ochraceons for anterior thirel, the remaining part ahy-white: supereiliary stripe wholly ochraceous: edge of wing whit: breast sparsely streaked in the adult. Iring. 2.15: tail. 2.20. Hab. Plains west of the Mlssouri. from Texas to Dakenta.

3. C. passerinus. Bill robust. 23. or mere, hroad, hy 2t, or more. deep at hase. Median stripe of the crown neluraceuns throughout : supereiliary stripe yellow anteriorly, athy posteriorly; edge of wing bright yellow, breast unstreaked in the alult, streaked in the young, in which the head stripes are ashy, with no yellow on wing or over lore.

Colors dark, the black markings predominating above. Id. Anterior lower parts deep buff at all seisuns. Jut. Dusky streaks on breast rery distinct. Bill, .33 and .30: wing, 2.60: tail, 1.90. Hub. Eastern I'rovince of Luinted States, and West Indies . . . . . . rarpasserinus,

Colors pale, the light markings pretominating above. $A d$. Buff of the breast scarcely observable in summer. Jut. Dusky streaks on breast scarcely appreciable. Bill, .33 and .24; wing, 2.60; tail, 1.90. Hab. Western Province of Luited States

var. perpallidus.

B. Tail-feathers broad, rounded at ends; only slightly rounded. Crown not divided by a meilian stripe.

4. C. manimbe. Head elear ashr, whitish on throat; crown uniformly streaked with black. Supra-loral streak and edge of wing bright yellow. No streaks on breast in adult.

Breast tinged with ashy: black strenks on upper parts much narrower than the intervening ones of the ashy grouml-eolor; dorsal feathers rufescent-umber medially, edtred with ashr, and with a shaft-streak of black. Wing. 2.3j: tail. 2.00. Hab. Brazi

var. manimbe.

Breast tinged with ochraceons: black streaks on upper part: much broader than the ashy ones of the ground-eolor; dorsal feathers black, edged with ashy: wing. 2.2.; tail. 1.90. Ilub.

Buenos Ayres and Lruguay. . . . var. dorsalis. 
Coturniculus henslowi, liaxil.

\section{HENSLOW'S BUNTING.}

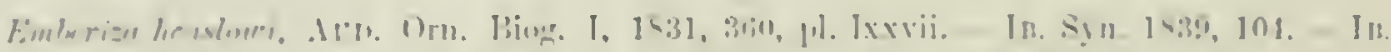

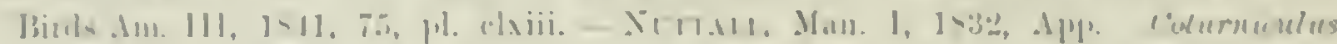

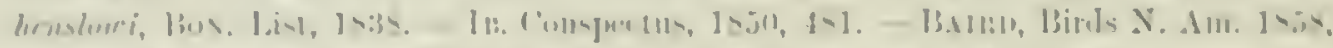

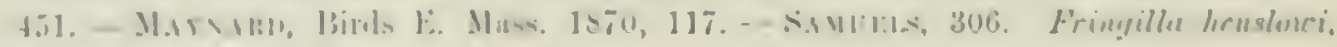

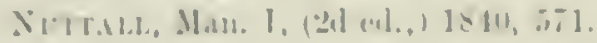

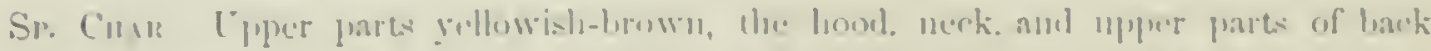

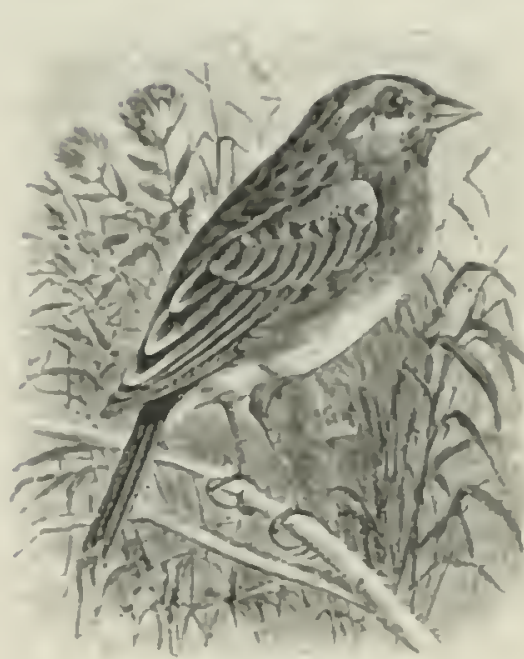

Citurnecu us g ar rinus.

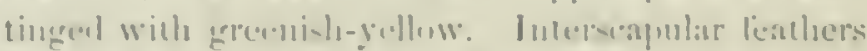

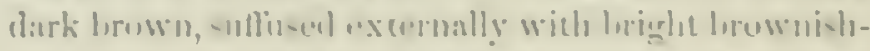

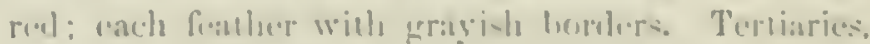

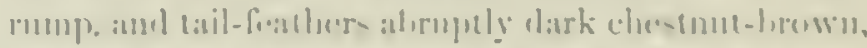

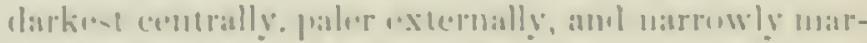
grimel witl gras. (rows wilh a loroml black spolled

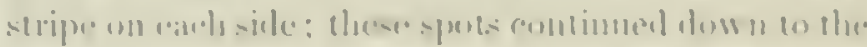

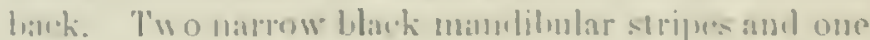

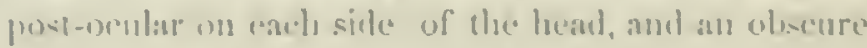

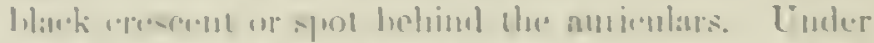

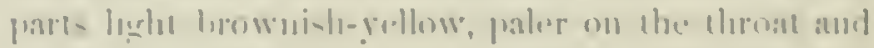

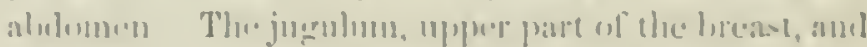

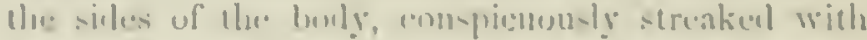
black. Filere of wing yellow. A - trubg tiuger of palde rlantmut on the wines and tail. The median

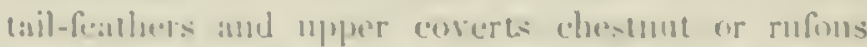

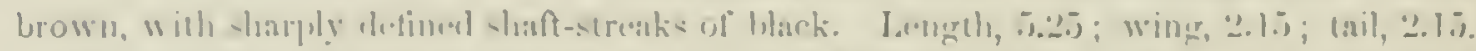

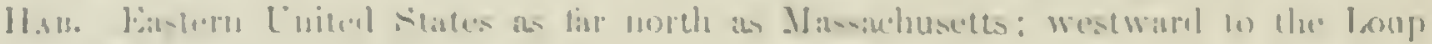
Furk of I'latle.

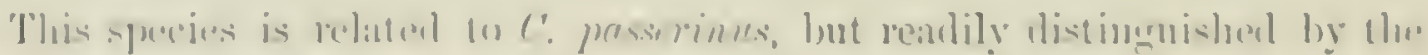

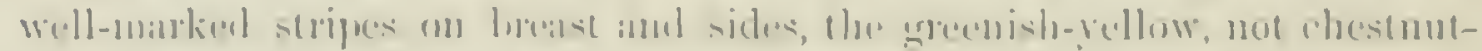

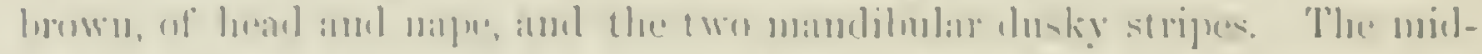

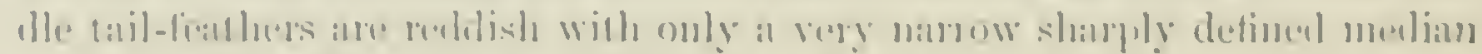

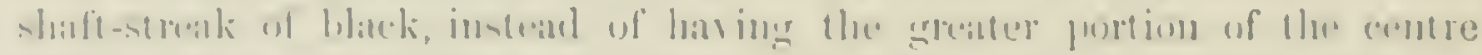

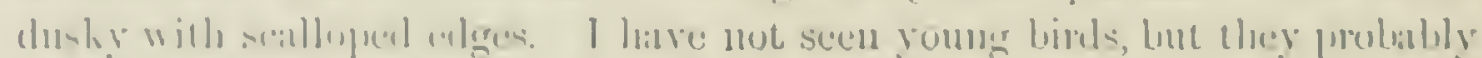
dilli.r litule from the inlults.

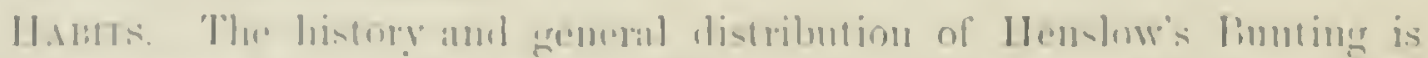

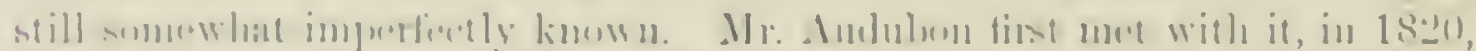

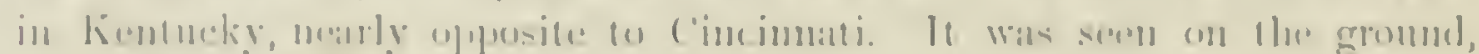

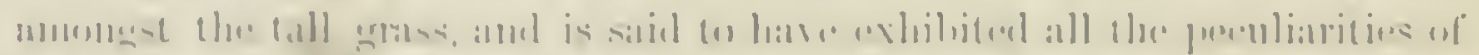

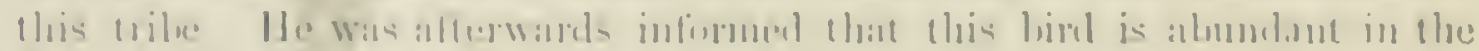

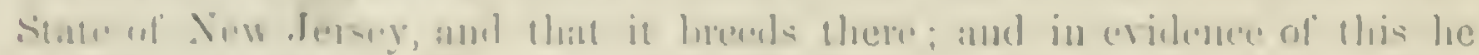

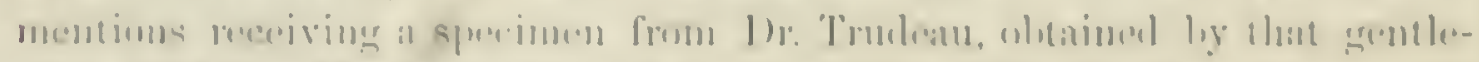

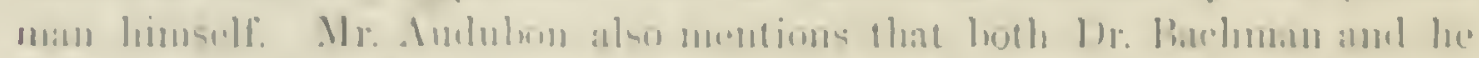

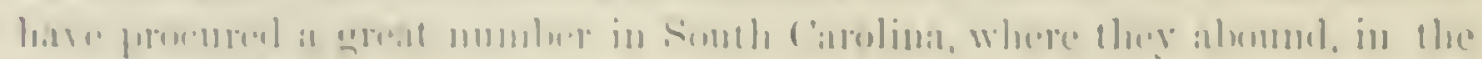

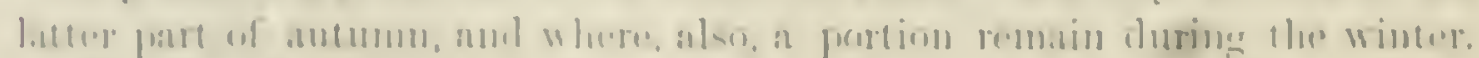

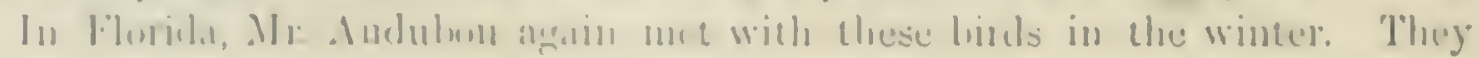


were in great numbers in all the pine barrens of that State, in light and sandy suil, and in woods but thinly overgrown by tall pines. They never alight on trees, but spend their time on the ground, nuning with great rapidity throngh the grass, in the mimner of a mouse.

In New Jersey they were found in plonghed fields, where they are presumed to have been overlouked and mistaken for the Yellow-winged sparrow. Mr. Audubon supposed that they were not found farther eastward than that State.

Specimens in the Smithsonian collection have been procured in Georwia in I)ecember; in Jaryland in July; at Fort Liley, Fansas, Southern Inlinois, and in Vebraskia, in June.

In Massachusetts they are regular summer risitants, though as yet they have been met with in only a few instances and in a somewhat restricted locality. They are now met with nearly every year, and several nests have been taken. Mr. Maynard obtained two specimens, May 10, in a wet meadow in Newton. Their song-note he describes as like the syllables secwick, the first syllable prolonged, the latter given quickly. This birl was first obtained in Berlin, in that State, by Mr. E. S. Wheeler, who discorered its nest and eggs. It was mistaken for Bachman's Finch, and was at first so placed on the record, thongh the error was immediately corrected. Since then, in that town, and in one or two others in its neighborhood, other nests ha: been met with. Mr. Willian Brewster obtained several specimens in Lexington, May 14, 1S72. It is quite probable that it has been confounded with C.passerinus, and it is now supposed to be more common in the eastern part of the State than that bird.

One specimen of this Bunting was taken near Washington, during the summer season, from which circumstance Dr. Cones gives it as an exceedingly rare summer resident of the District of Columbia.

In 1Si1, Mr. Ridgway ascertained that, so far from being rare, Henslow's Bunting is very abundant on the prairies of Southern Illinois, as well as the Yellow-winged species, but far exceeding the latter in numbers. Though entirely similar to that bird in labits and manners, it may be readily distinguished by its note, which is said to be an abrupt pil-lut, much more like the common summer-call of the Shore Lark than the lisped grasshopper-like chirp of the C.passerinus, and to be uttered as the bird perches on the summit of a tall weed, the tail being depressed, and the head thrown back at each utterance. A number of unidentified eggs were sent to me several rears since, by Mr. Kennicott, from near Chicago. They resembled somewhat the eggs of C.passerinus, but were not the eggs of that species. I have now no doubt they belonged to this bird.

The nest is built in the ground, in a depression, or apparently an excaration scratched out by the bird itself, and is a well-made structure of coarse, dry, and soft reeds and grasses, well lined with finer materials of the same description. The egrgs, five or six in number, somewhat resemble those of 


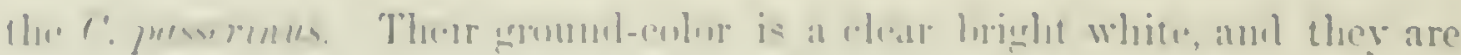

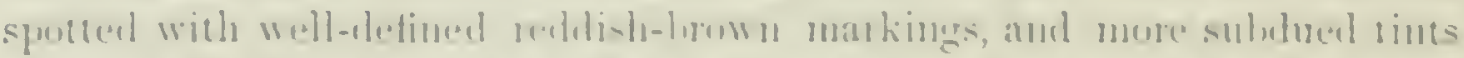

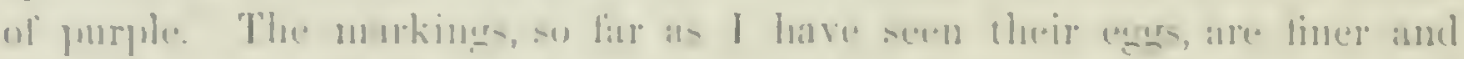

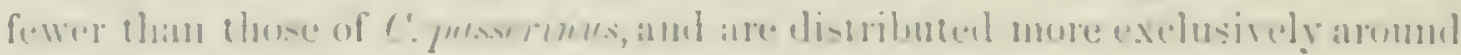

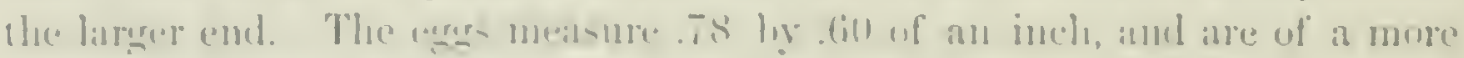
whlume-oval than those of the eommon lelluw-Wing.

Coturniculus lecontei, linsar: LECONTE'S BUNTING.

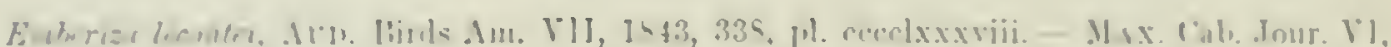

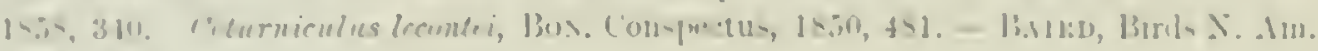
$1-\therefore, 4.2$.

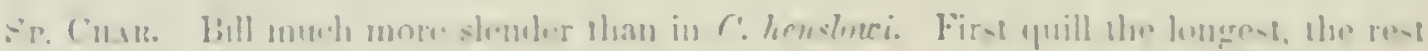

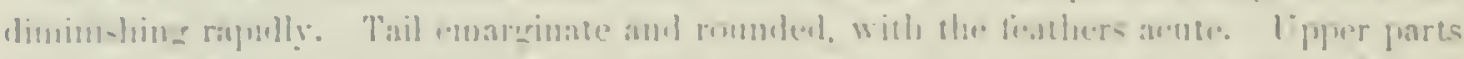

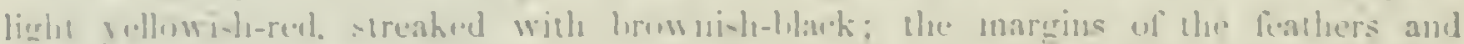

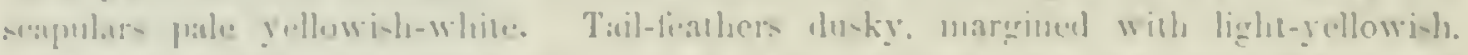

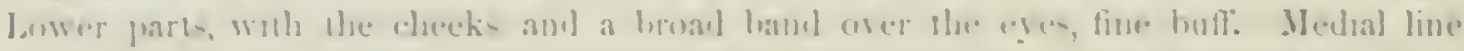

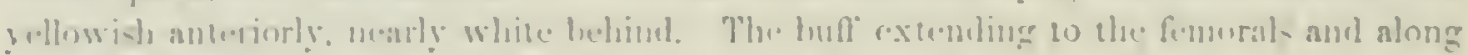

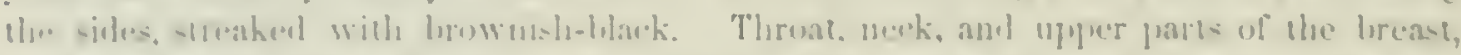

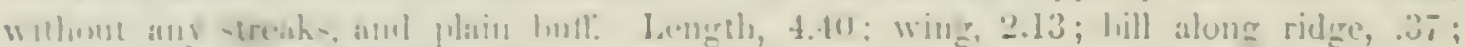
relece.

lls. Month of Yellow-lume, to Texis.

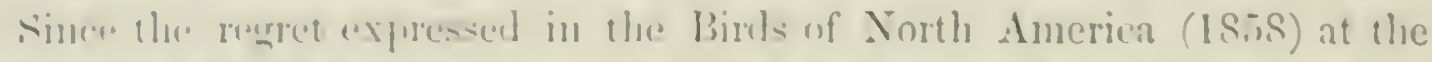

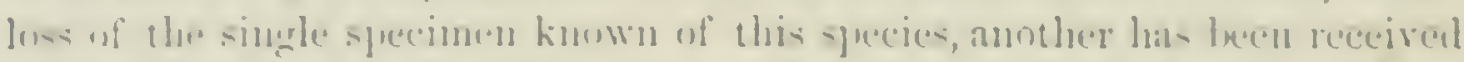

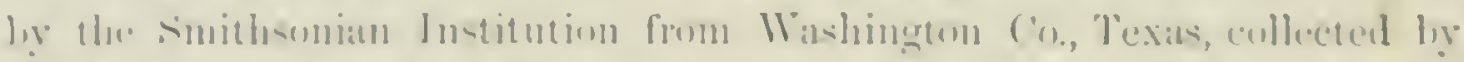

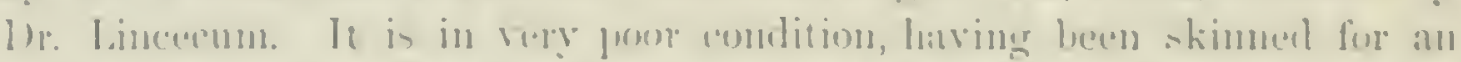

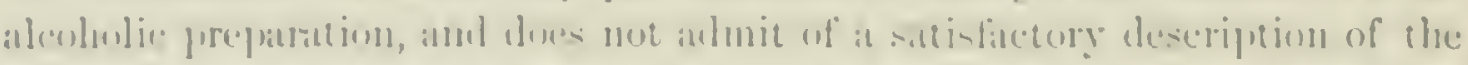

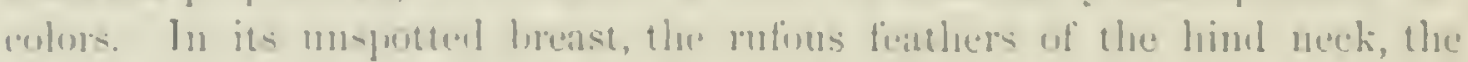

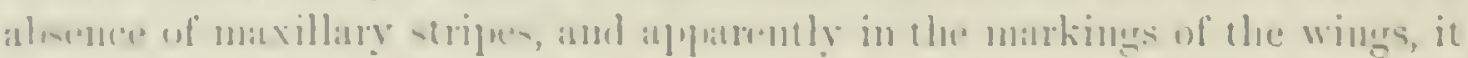

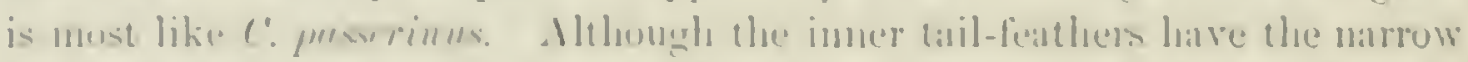

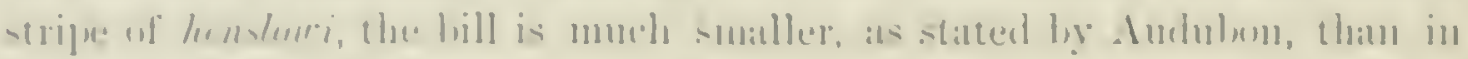

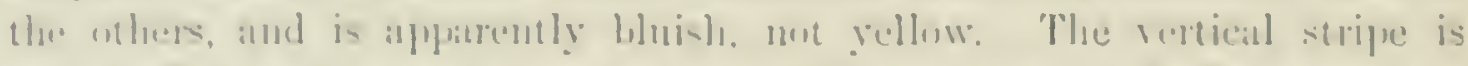

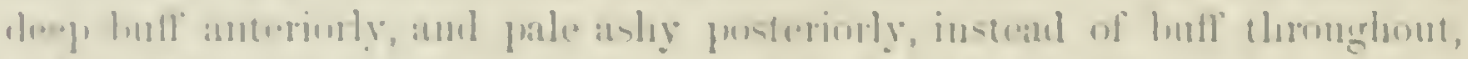

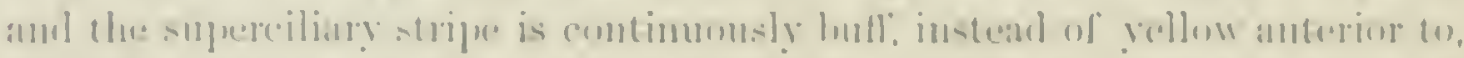

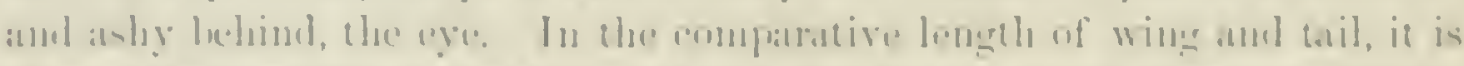

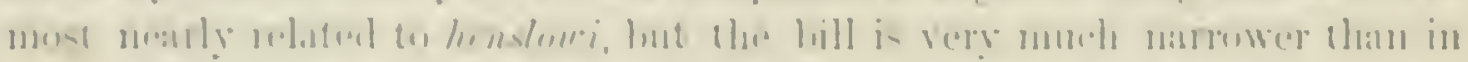

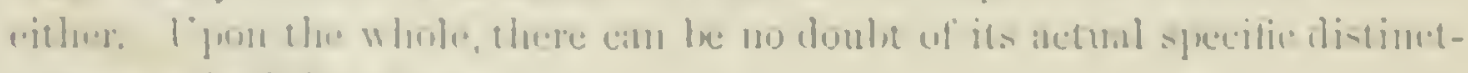
men fum indh it alliw.

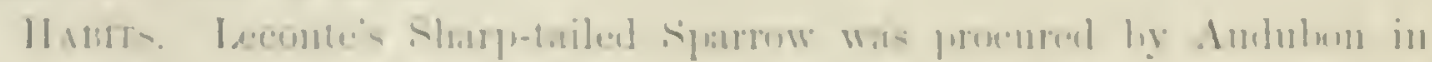

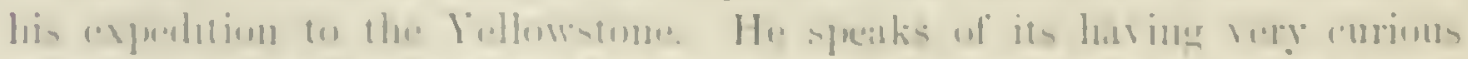

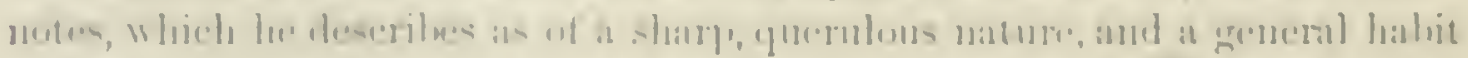

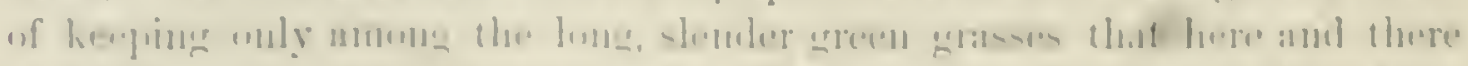

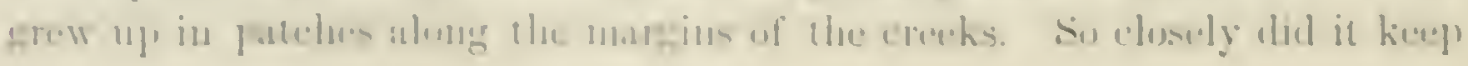


in the coverts to which it resorted, that it was very difficult to force it to rise on the wing, when only it could be proeured. Mr. Audubon did not meet with its nest or young, and they remain unknown.

This type specimen was presented ly Audubon to Professor Baird. A secnnd was sent to the Smithsonian Institution, from Texas, by Dr. Lincecetim.

\section{Coturniculus passerinus, BoraP.} YELLOW-WINGED BUNTING.

Fringilla passerinu, WiLsox, An. Orn. I11, 1811, 7i, pl. xxvi, f. 5. - Aln. Orn. Biog. 11, 1S34, $180 ; \mathrm{V}, 49 \overline{7}$, pl. exxx. Fringillu (s'pizu) pesserina, Box. Obs. Wils. 1S25, No. 111. Coturniculus pusscrine, Box. List, 1838. - Iв. Conspectus, 1850, 4\$1. -

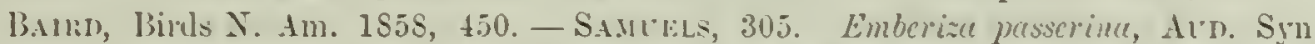

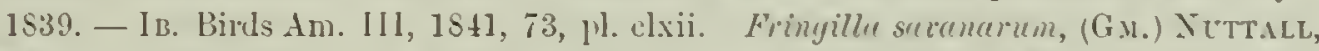

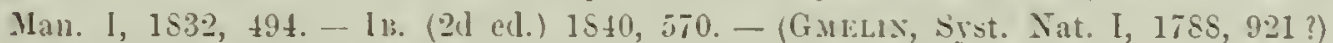

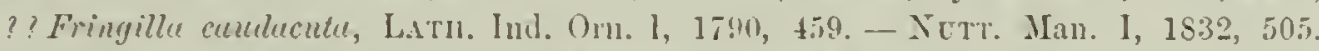
? Passerina pratensis, Vietllot. Coturniculus tivicrus, Gosis.

Loc.nlities: Oaxaca, March (Sec. ]S59, 379). Guatemala (AcL. Ihis, I, 1S). Cuba (winter,

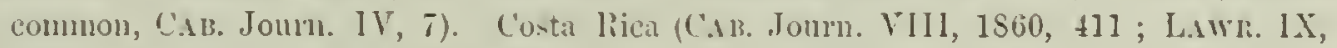
103). Vera Cruz (winter, Sum. Mem. Bost. Soc. 1, 552).

Sp. Cun.r. Feathers of the upper parts brownish-rufous or ehestmut-brown, margined narrowly and abruptly with asli-color; redclest on the lower part of the back and rump? ; the feathers all abruptly black in the ecutral portion; this color visible on the interseapular region, where the rufous is more restricted. Crown blackisls. with a central and superciliary stripe of yellowish tinged with hrown, brightest $n$ front of the eje. Bend of the wing bright yellow; lesser corerts tinged with greenish-rellow. Quills and tail-feathers erlged with whitish; tertiaries much variegated. Lower parts brownish-yellow or buff, nearly white on the middle of the belly, clarkest on the jugntlum. The feathers of the upper breast and sides of the body with ohsoletely darker centres, these sometimes wanting. Silles of breast against bend of wing with a few black streaks, usually concealed. Length about 5 inches; wing, 2.40 ; tail, .2.00.

Haв. Eastern Lnited States; south to Guatemala; Famaica, resident; Porto Rico.

The young of this species lave the jugulum and sides of the breast streaked with black, much more distinct than in the adult, and exhibiting a slight resemblance to $C$. honslouri. The upper parts are less raried.

Specimens from the Far West have the bill more slender, the reddish of the back considerably paler, the dark markings of the back restricted, the light stripe on the head with scarcely any yellow, a decided spot in front of the eye quite yellow, and little or no ochraceous on the breast.

The young bird, with streaked jugulum, may be most readily distinguished from $C$. henslowi by the grayer plumage withont any shade of chestnut or greenish-yellow, the sparseness of streaks on the side, the absence of the two mandibular dusky stripes, and the broad dusky centres of the middle tail-feathers.

Quite a fine series of specimens from Jamaica and other West India Islands affords ample material to judge of the valichty of the C. tixicrus of 


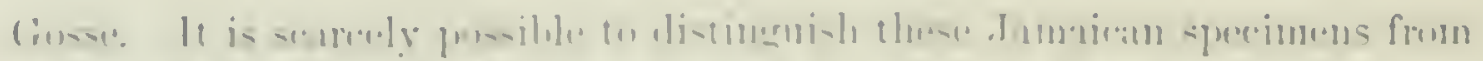

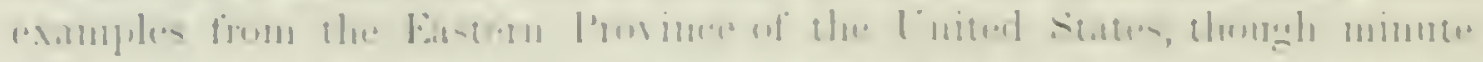

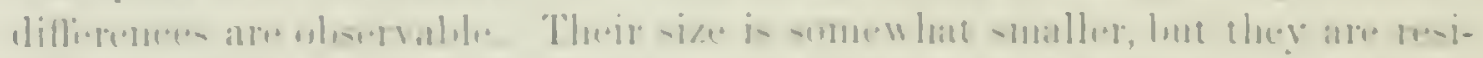

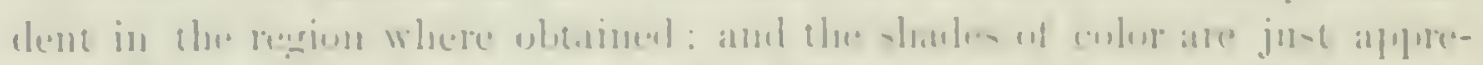

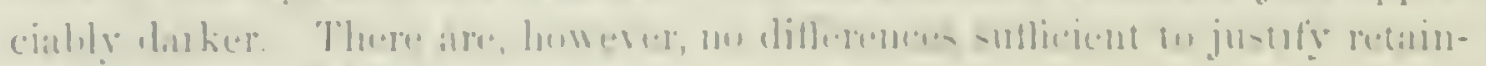

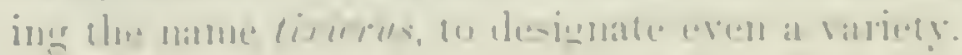

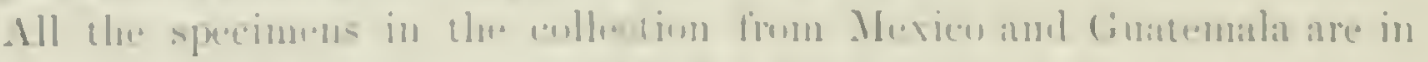

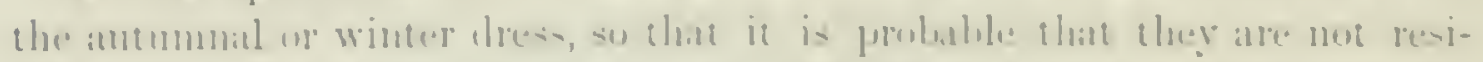

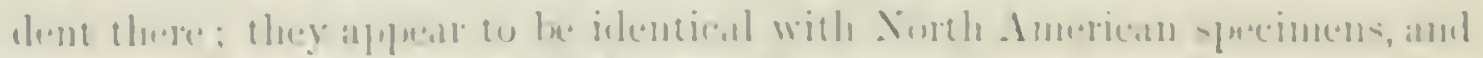

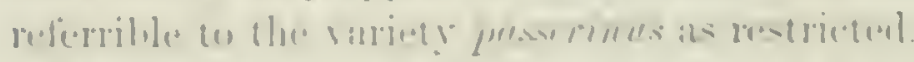

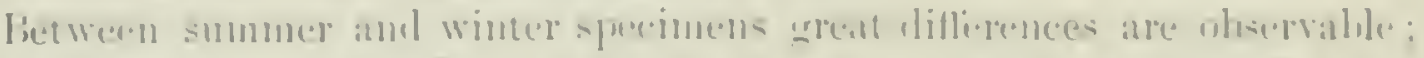

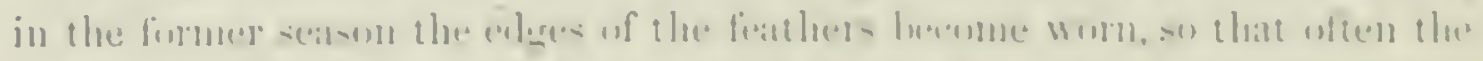

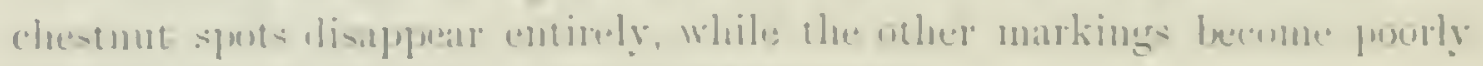

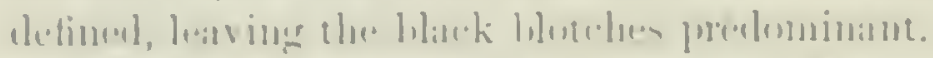

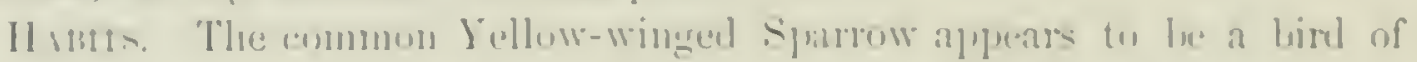

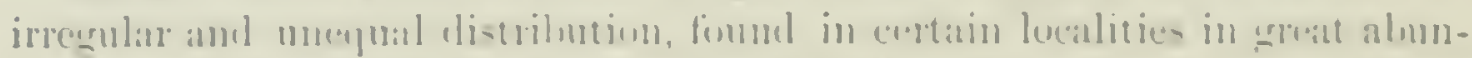
dame, and mot seren in the interventug districts. Acourdine to some writers,

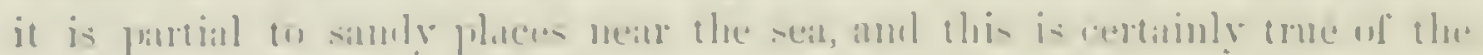

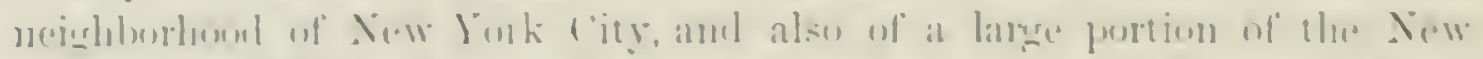

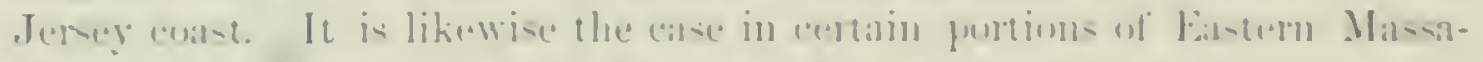

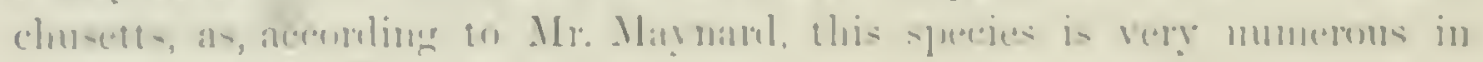

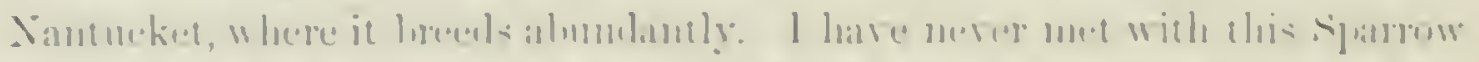

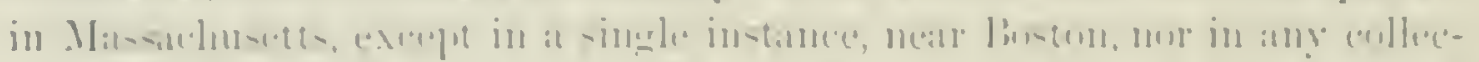

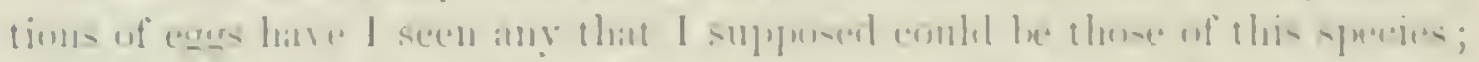

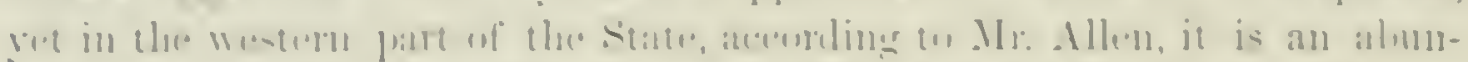

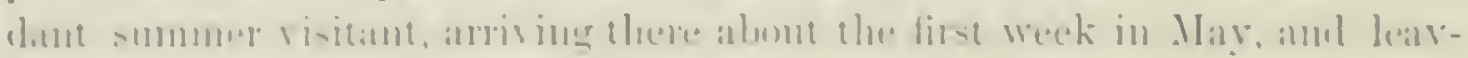

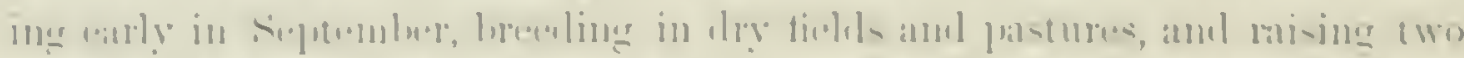

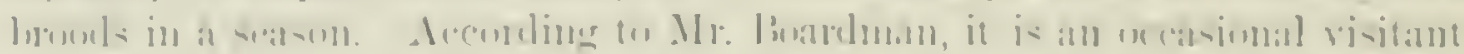

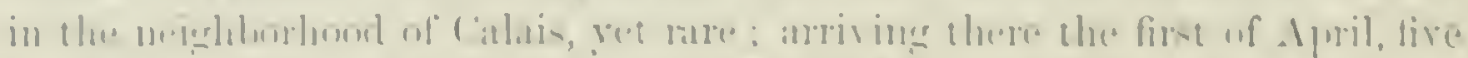

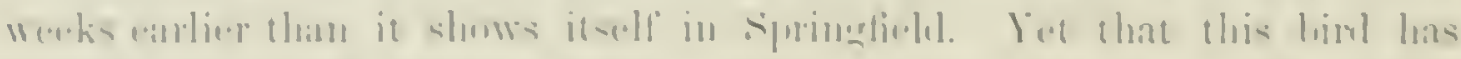

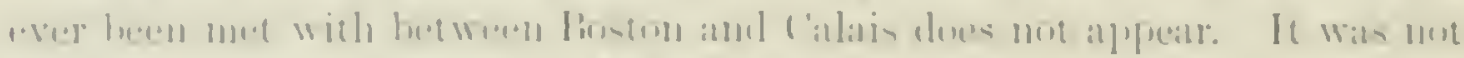

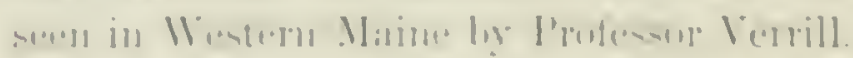

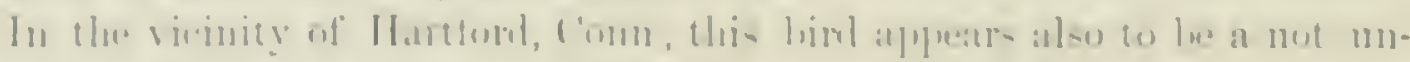

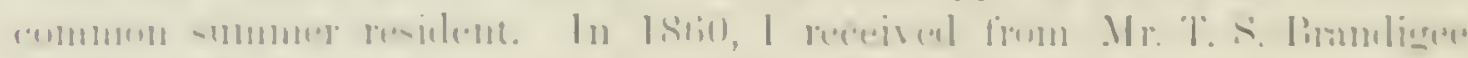

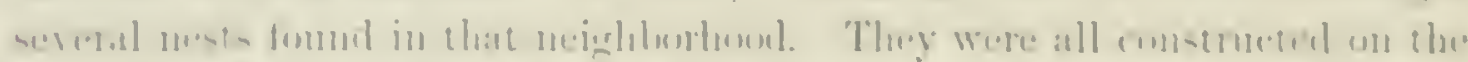

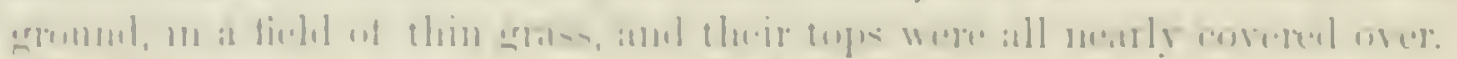

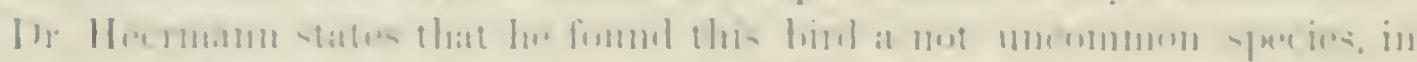

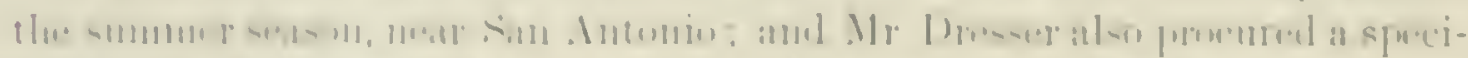

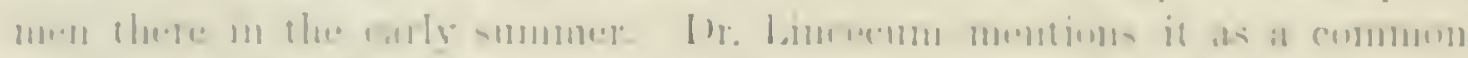

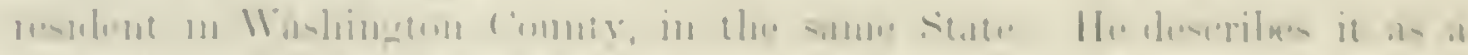

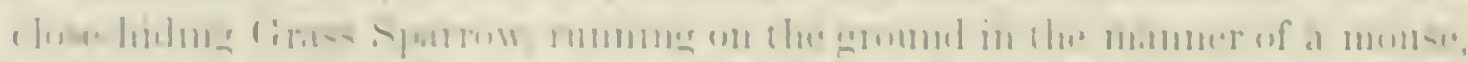

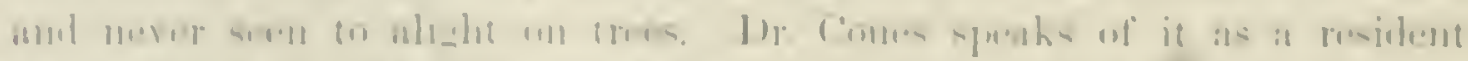

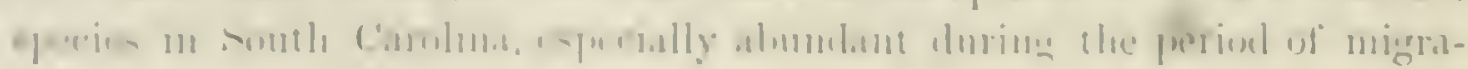
[1,1] 
It has been found quite common, during the winter months, in C'entral Ameriea, specimens laving been procured there by Señor Constancia, Mr. Slinner, and Dr. Van I'atten. It was also found at Oaxaca, Mexico, by Mr. Boncard.

Mr. Nuttall and Mr. Auluhon speak of it as oceurring in Oregon, but Dr. Couper did not meet with it on the l'acific const. 1)r: Kemerly obtained a single specimen on one of the forks of the Colondo, in February. Mr. Ridgway met with the western form of this species, in suitable places, in the Sacrumento Talley and the Great Basin, ind proposes for it the name of perpalliclus.

In the vicinity of Newark, N. .., I have found this species apparently one of the most abmolant in that neighborhood, having obtained there in the month of June more egrgs of this than of any other species.

In Northfield, Ill, near the lake shore, Mrr. Robert Kenuicott met with the nests of these birds in great abmulance. From these facts I infer that it is not necessarily or exclusively a bird of the sea-shore, but that in certain farorable localities it is as abmdant in the interior as on the coast, and that at interrals it may be met with from Texas to Maine, and from the Atlantic to the interior, nearly or yuite to the Pacific coast.

Ir e amaica, Mr. March states, this species is not nucommon in the sarannas and griss lands near spanish Town. It is a resident in that island, and breeds there in considenale numbers, nesting in tufts of grass-roots. It is only common in ecrtain localities.

I have never heard its note to know it. Wilson speaks of it as a short, weak, interrupted chirp. According to Mr. Iidgway, it bears a close resemblance to the note of a grasshopjer. Nuttall says they sing in an agreeable roice, something like that of the Pmple Finch, though less rigoronsly; and Audubon characterizes it as an mmusical ditty, composed of a few notes weakly enunciated at intervals.

It is terrestrial in its hahits, living, nesting, and feeding on or near the ground. It subsists on larrix, insects, and the seeds of grisses and small weerls.

This bird builds its nest on the ground, usually in a small tuft of grass or in a cluster of plants. It is made of dry grasses, and is lined with fine bent and horsehair. The roung are said to follow their parents for a short time, but soon separate, and learn to take care of themselves. This species is not gregarious, and is never seen in flocks, not even when just alont to migrate.

Wilson and Nuttall describe the eggs as gravish-white, sprinkled with brown. Audubon says they are dingy-white, sprinkled with brown spots. This is not accurate. The gromnd-color is a clear crystalline white, beautifully dashed and marbled with bold markings of an almost golden brown. These spots vary in size, are often quite large, and necasionally make a corona ahout the larger end. The egros are of a rounded oval, almost spherical, shape, measuring .75 by .63 of an inch. 
Coturniculus passerinus, ne: perpallidus, limm:1r.

\section{WESTERS YELLOW.WINGED BUSTIYG.}

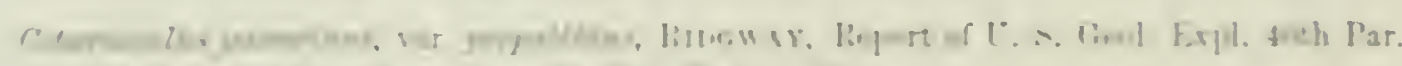

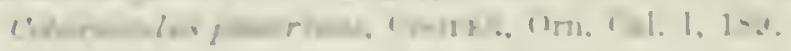

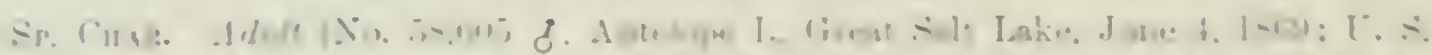

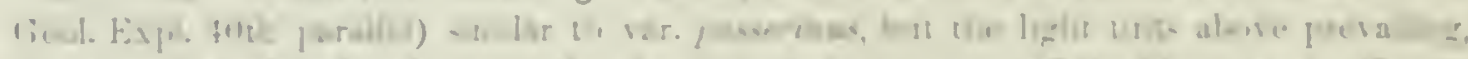

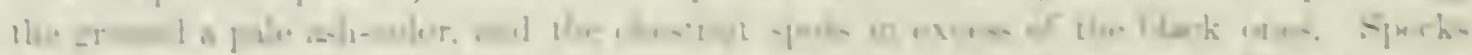

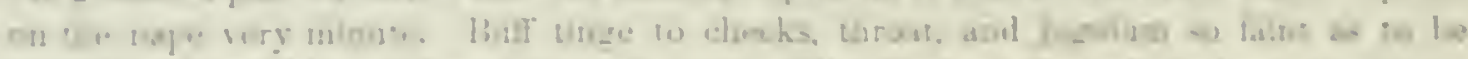

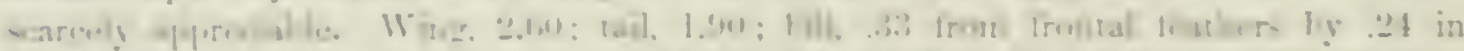

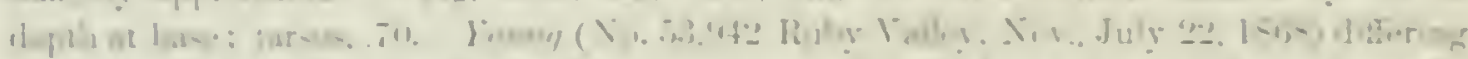

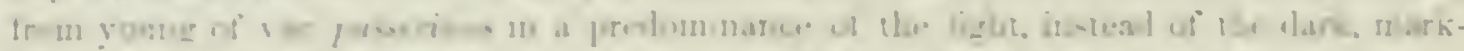

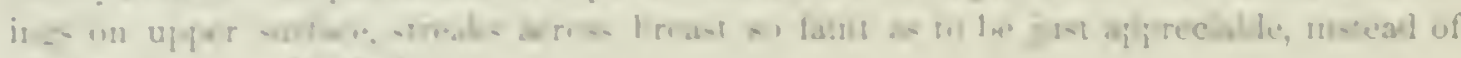

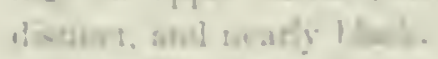

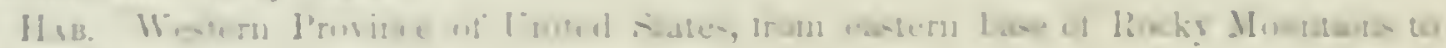
I. I. I. i.

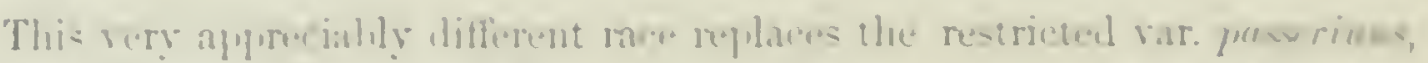

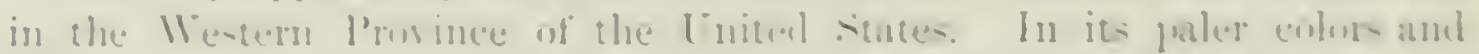

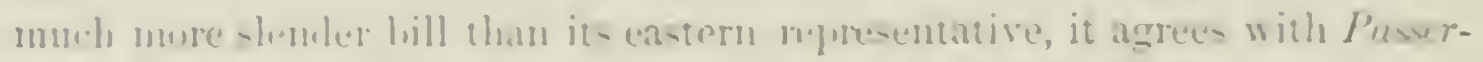

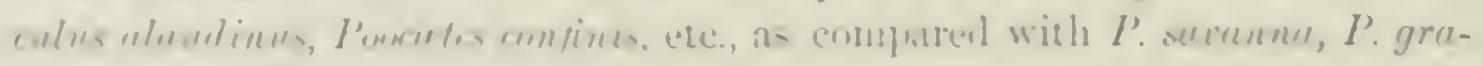

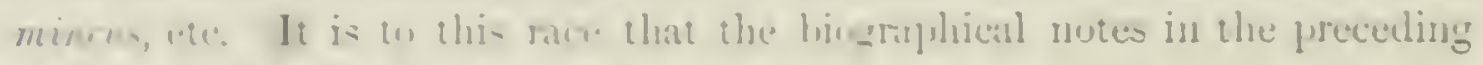
article reter, as fir as lased on western opeecinen-

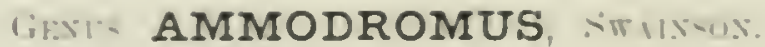

A

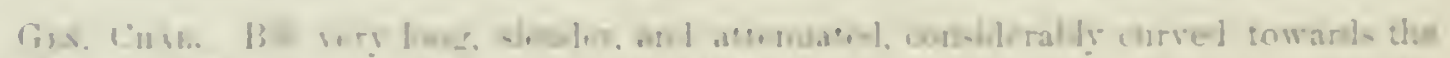

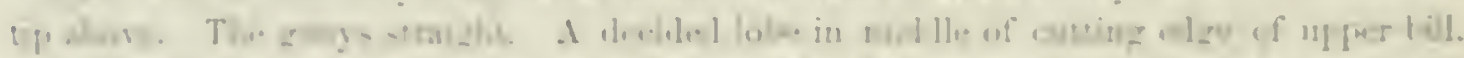

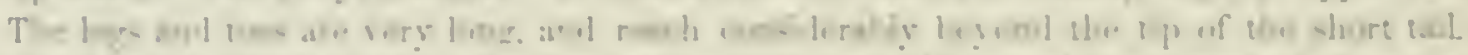

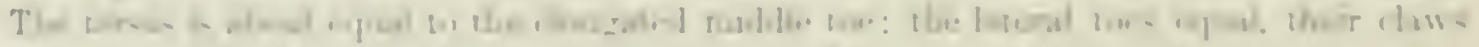

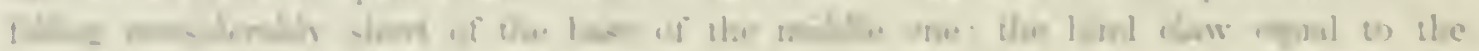

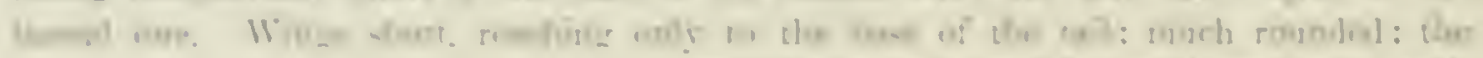

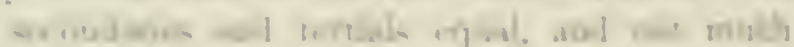

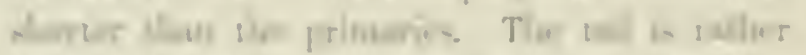

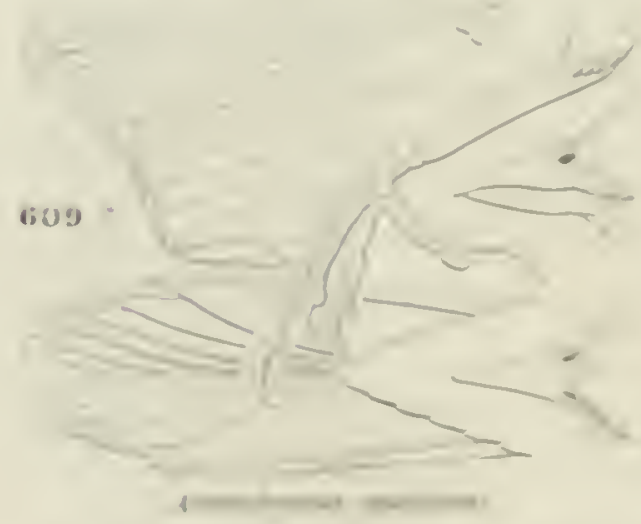

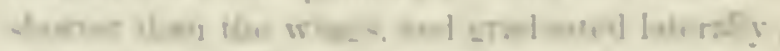

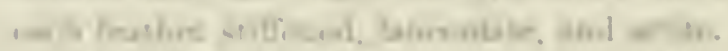

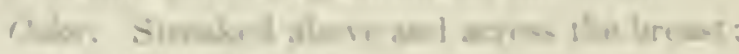

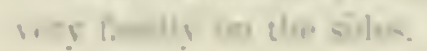

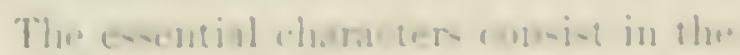

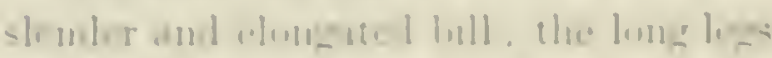
realing omsuteribly lesumel the tail,

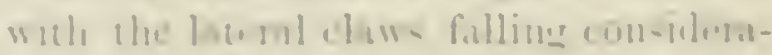
his slean of the sabllle aste: and the

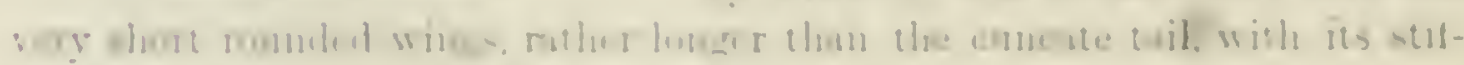

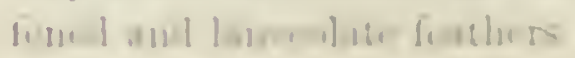


Commox Cnuracters. Above oliraceons or ashy, the crown wisheel with brown laterally, the dorsal feathers darker centrally; beneath white, tinged across the jugulum with ochraceors or ashy; jugulum streaked: a dnsky "bridte" on each side of throat; abore it a maxillary stripe of ocluaceons or white.

1. A. caudacutus. Id. Above olive, the dorsal fenthers dirker and edged with whitish-ochraceous; supereiliary and maxillary stripes deep ochraceons; jugulum and sieles tinged with the same, and sharply streaked with black. Jur. Wholly ochraceous, darker abore; crown and back streaked with black, the former divided medially by a pale-brown stripe; breast and sides streaked with black. IIab. Atlantic const of United States.

2. A. maritimus. Ald Above asly, the dorsal fenthers obsoletely darker centrally; supereiliary stripe yellowish-ashy, bright yellow orer the lores; maxillary stripe white; jugulum and sides tinged with ashy, the former obsoletely streaked with dark ashy. Juv. Above oliraecons, the crown and back streaked witl black, the former not divided by a lighter median line; breast and sides washed with ochuraceous and distinctly strualiond with black.

Hal. Atlantic coast of United States.

\section{Ammodromus caudacutus, Swarsox.}

\section{SHARP-TAILED BUNTING.}

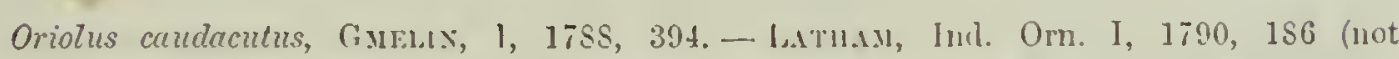
Fringilla caudecuta, Latı.). Fringille ceudecuta, Wnsox, Am. Orı. IV, 1S11, 70, pl. xxxiv, f. 3. - A'v. On. l3iog. 11, 1834, 281; V, 499, pl. cxlix. Fringille (Spize)

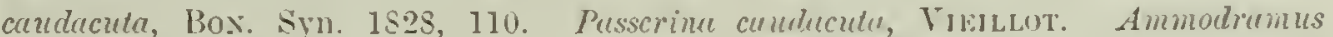

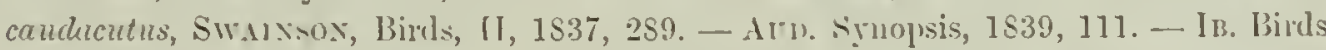
Am. IlI, 1St1, 10S, pl. clxxir. - Boxt1. Conspertus, 15514, 4S2. - B.1m,n, Birds N. Am. 1S5S, 453. - S.1MrELs, 307. Fringillu lillorelis, NitTall, Man. I, 1832, 50t (2d ed. 18 40,590$)$. Sharp-tailed Oriole, PExaxt, Aretic Zoül. II, 261, New York.

Sp. Cirar. Upper parts brownish-oliraceous. Head brownish. streaked with black on the sides, and a broad central stripe of ashy. Back blotched with darker: edges of interscapular feathers and inner secondaries whitisl, just exterior to a blackisls sufusion. A broad superciliary and maxillary stripe, meeting behind the ashy ear-corcrts, and a band across the upper breast, buff-yellow. The sicles of the throat with a brown stripe; the upper part of the breast and the sides of the body strenked with blaek; rest of under parts whitish. Elge of wing ycllowish-white. Bill yellowish below: dusky above. The female appears to lave more buff on the breast than the nuale. Length, 5 inches: wing, 2.30 .

Hab. Atlantic coast of the Lnited States.

The young is of a more yellowish tinge above and below; the streaks on the back more conspicuous; the scapular feathers without the whitish edging.

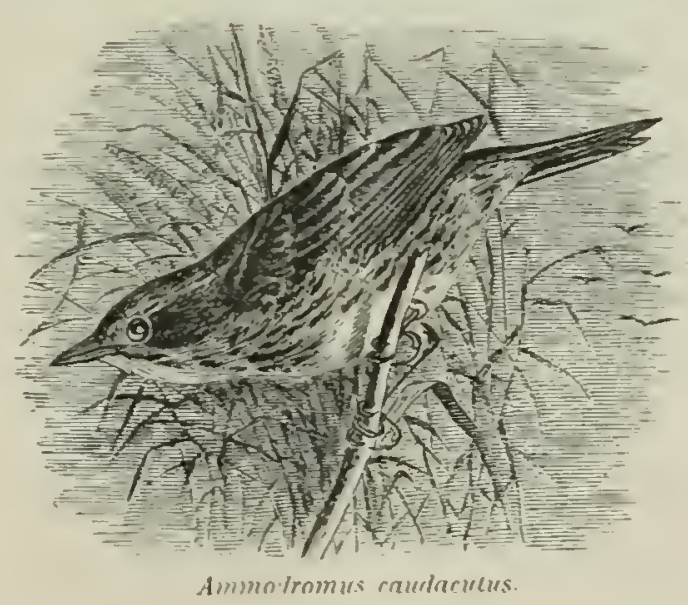

In autumnal and winter specinens the buff tints are much deeper than in 
spring: the side of the crown, is well as the diut markines an the hack, more intensified, and in ereatlen anthast with the lighter ashy and olive tiuts.

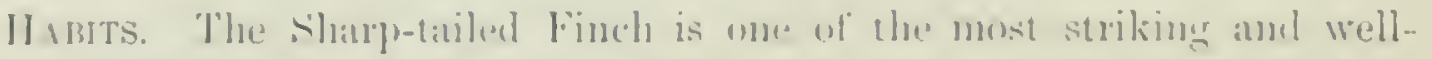
chatreterized of lamb-hibls, and ats peculiar to the seit-shore as the fringu. lu hablits it very closely resembliles the whole fandy of llallers in many striking respects. Like them it feeds nponz small erustacens and minute marine insects, keeping about the water's edere, Walking upon the fluating werts and other substances mised lye the tide, preferring this mode of life to a more inland residence, and only resorting to the uplands to fied mpon the seeds of errassess and sederes when their food fails them at the water's alige.

1)1: ('nnes is of the opinion that this him thes not hreed in the neighborhorml of lieanfort, X. (', and that it leaves for the North in May, having a more northern hahitat than $A$ moritimn. He lenes not coincile with those who detect a resemblance between the actions of the Ammorlimi and of the simpipers. He thinks the manner in which they climb the reeds, slide "p and down, and hang from them in rarions attitudes, is mure like that of Nuthatehes and Titmice. On the ground they seem to him mmistakably sparmu-like.

This Shary-tailed Finch is almulant alnug the coasts of ('ommecticut and lihule Island, and is also fomd in Massichusetts, thongh sparingly, and only in a few congenial locilities. In the marshes of (harkes liver. near liuston, this spectes is occisionally common in the bereding-seatson. In the summer of 1stig, Mr. H. W. Henshatw found quite a numlere of their nests. Mr. Maynand has also taken it amoner the marshes of Ijswich, which is probalily ahent its extreme northern linit. It has not, so fill as I ann awatre been

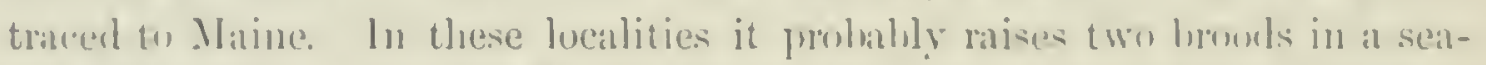

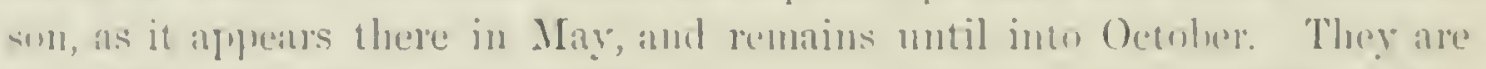

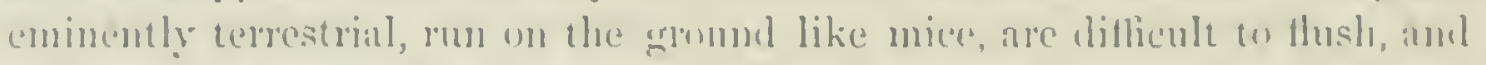

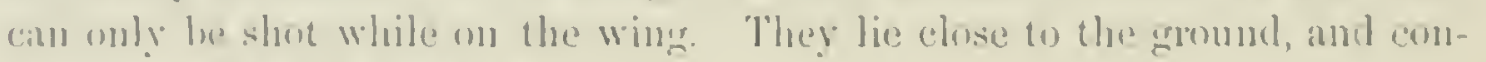
coil thematros in the ansis.

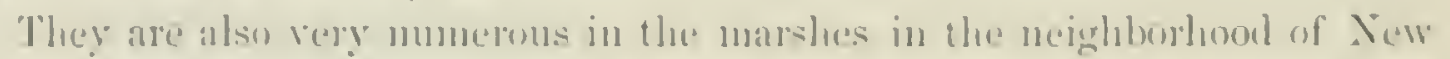

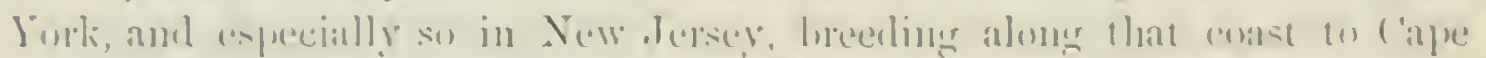

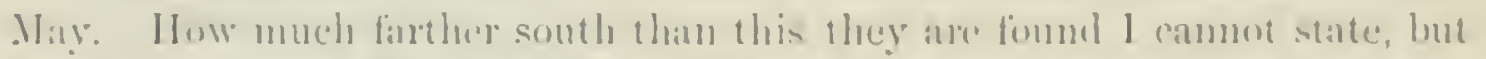

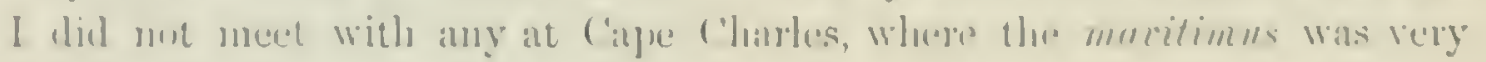
abundant

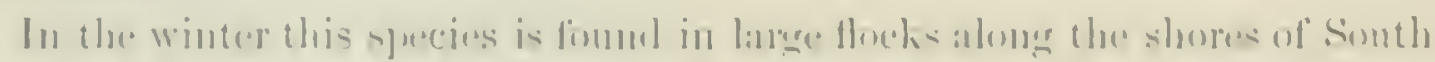

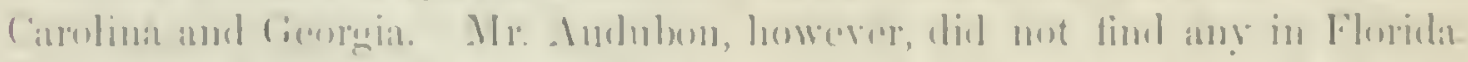

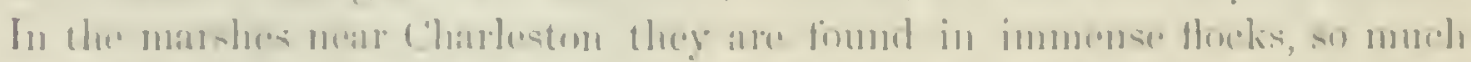

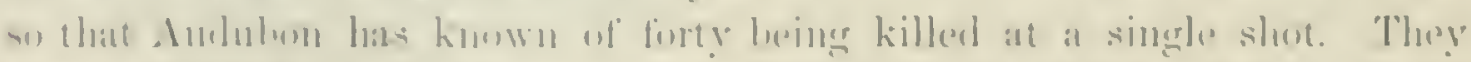

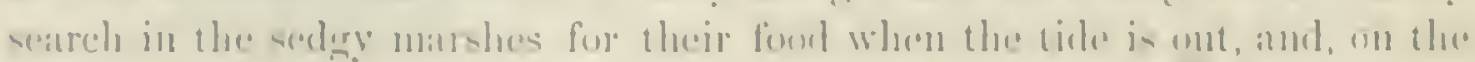

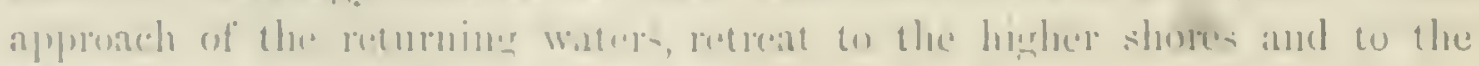
now coubanlinents. 
The flight of this species is quite different from that of any other bird, and by it they may at once be recognized. In flying, they also drop their tails very low.

Mr. Audubon states that during the winter the Sharp-tailed Finch is fumished with an extra quantity of feathers on the rmmp, for which he finds it diflicult to accomnt.

These birds are essentially maritime, are foumd only in the vicinity of the sea, and always kecp immediately about the water, except when the inclenency of the weather drives them to the high grass of the uplands for shelter. They walk and run, or remain feeding on the floating weeds and other sulstances raiserl by the tide, with all the ease and fearlessness with which they move on the land. They are gregarions in the winter, and in the Southern marshes are found feecling in comprnies. Inuring the breeding-season they leep more in pairs, and are found more isolated. At this time they are also shy, and diflicult to detect. Their usual call-note is only a single tucet, and in the love-season their series of twitters Mr. Andubon thinks hardly worthy to be colled a song. They feed indiscriminately on seeds, insects, small crustaceans, and rarious forms of refuse matter floated or thrown up by the tides.

On the coast of New Jersey, where these birds are found in the greatest abundance, they have at least two broods in a season. Their nest is on the ground, in a small tussock of grass or sedges, but little renoved from the reach of the tide, and is placed in a depression apparently excarated for the purpose. They are loosely made of soft and slender grasses, arranged in a circular form. The nest is large for the bird, spacious and deep, and is softly lined with finer and similar materials.

Their egrss, five or six in number, are of a somewhat rounded oval shape, having an average breadth of .59 of an inch, and vary in lengtl from . 58 to 70. Their ground-color is a light green, oecasionally a dull white, with hardly a pereeptible tinge of greenish, thickly sprinkled equally orer the entire egge, with fine rusty-brown dots. These are of various sizes, but all fine. In a few the larger dots are confluent in a ring around the larger end; in others, the finer dots are so small as to be only distingruishable under a glass, concealing the ground-color, and giving to the egg an almost miform rusty color. These eggs rary but little in shape, and are nearly equally rounded at either end, though never entirely so. 


\section{Ammodromus maritimus, S゙แ}

\section{SEASIDE BUNTING.}

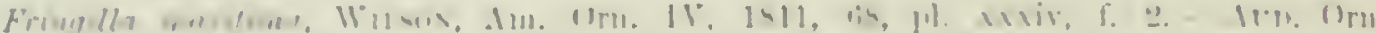

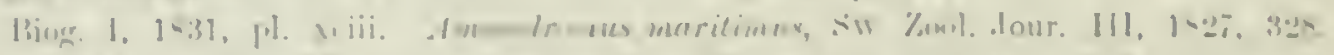

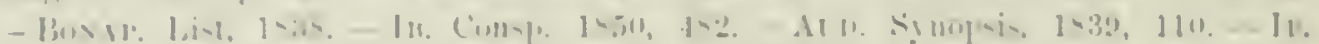

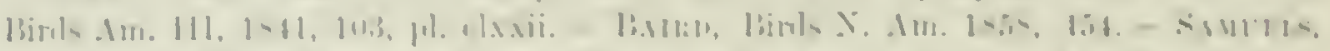

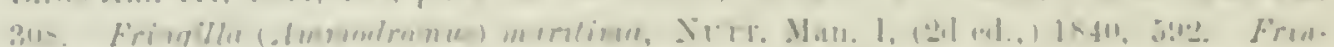

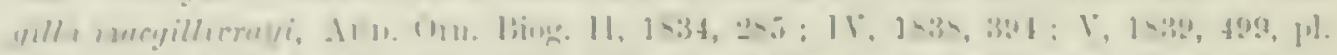

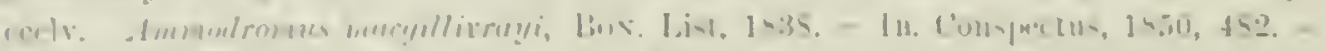

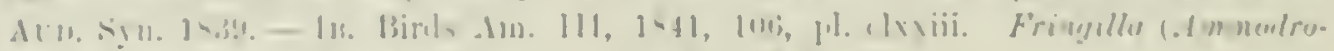

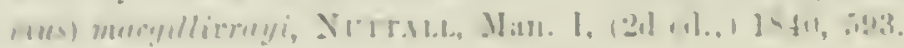

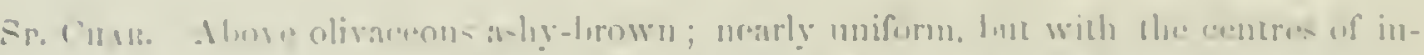

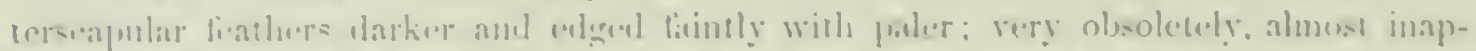

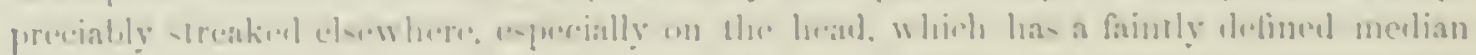

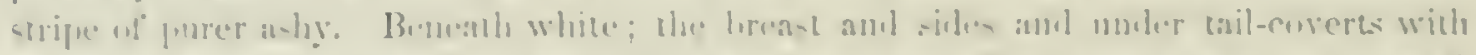

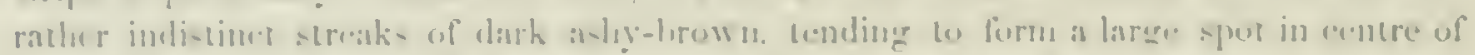

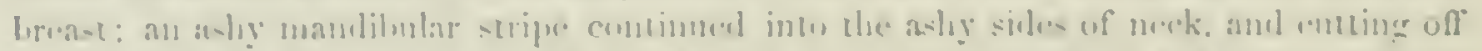

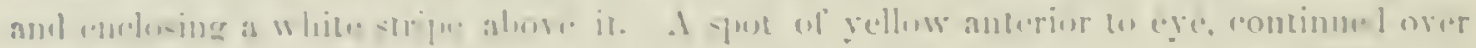

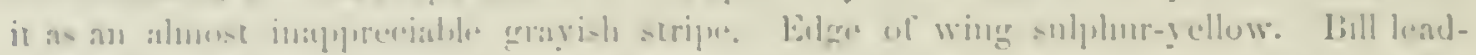

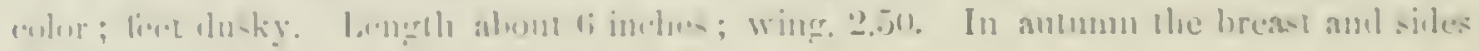

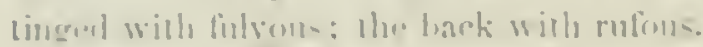

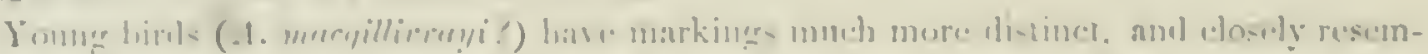

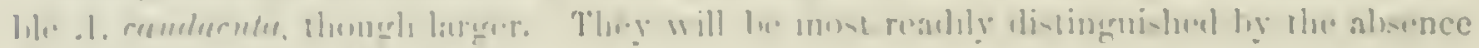

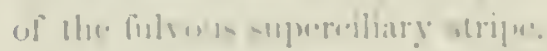

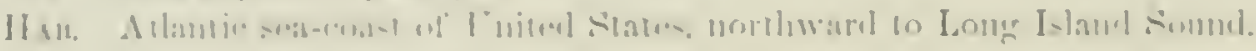

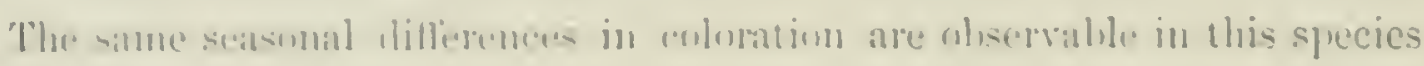
as in .1. renderullus

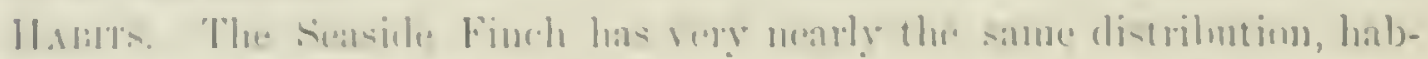

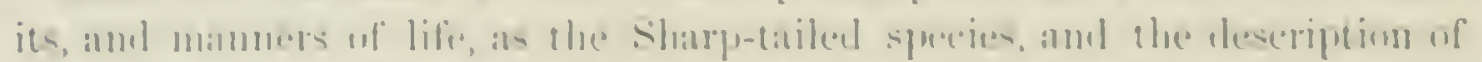
these in one womlel answere alumet mually well fin the other. There are,

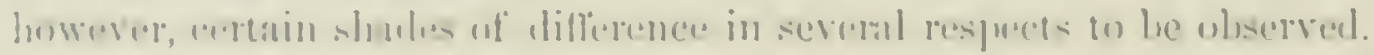

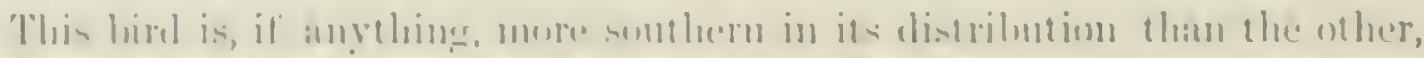

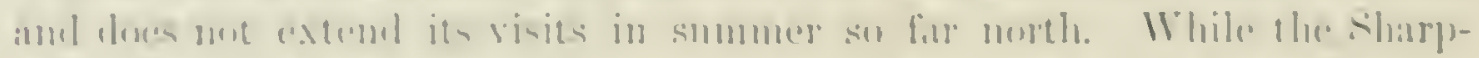

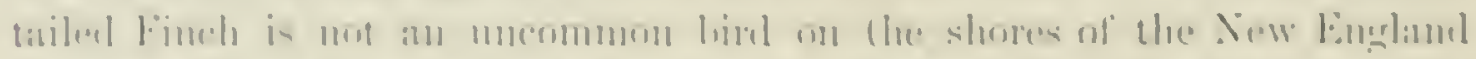

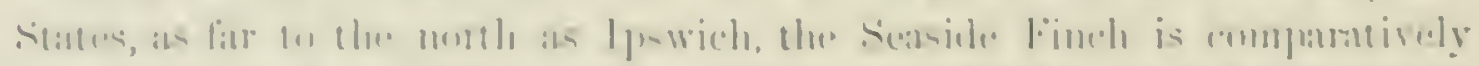

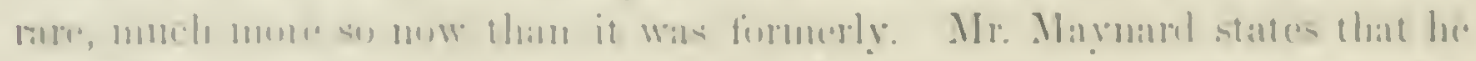

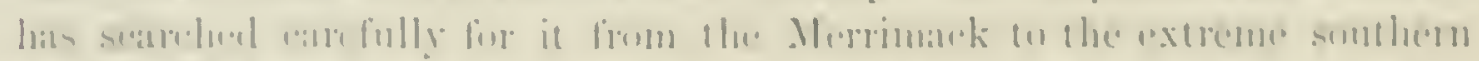

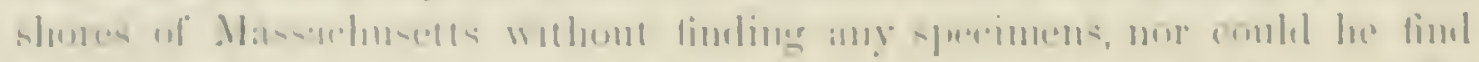

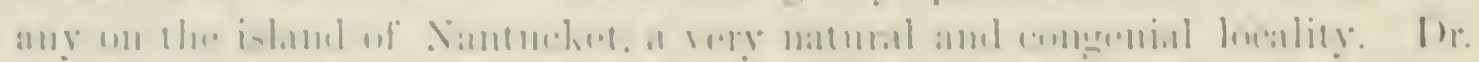

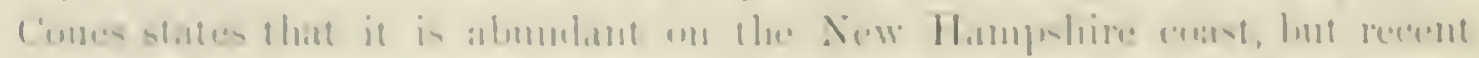

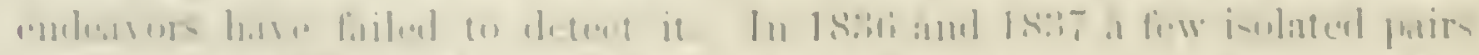

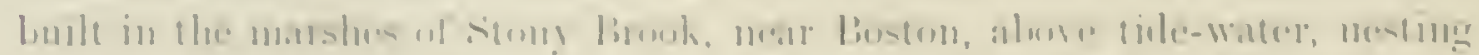

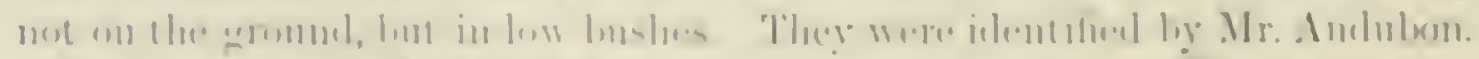

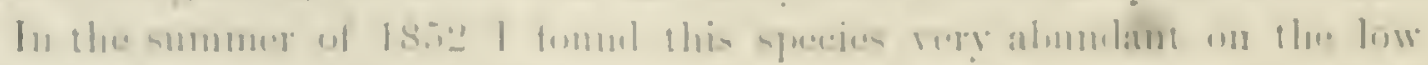

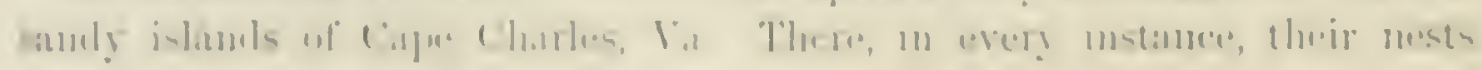


were in low bushes, ahout a fout from the grome. They were the only landbirls found on these islands.

Rev. ('. M. Jones informs me that at Madison, C'omn., on the cuast, the Seaside and the Sharp-tililed Finches ocenr in about eyual numbers in the salt marshes. He was not able to observe any specific difference in their mode of nesting, except that the muritimus seemed to be more common in that part of the minsh nearest the shore, while the caudecutns.s was more alomndant fartlier back towards the highlands, though this was not the invariable rule. He sometines found the nests suspended in the salt grass, the latter being interworen with the other materials. In all such cases the entrance was on the side of the nest, in the mamner of the Marsh Wren. At other times he found the nest placed under a quantity of lodged grass, but resting on a portion still lower. In such cases it is generally open at the top. He has also found them on the ground, and, when thus placed, always much more bulky than when built as above, a considerable quantity of dead grass being laid down to keep the nest ahore the wet, though not always with success. On Cobl's Island, Va., Mr. Jones only found the maritimus, the nests of which were in hushes, from one foot to eightecen inehes from the ground.

The call-note of this species is said to be a monotonous chirj, and its song hardly to deserve that name. The notes of which it is composed are few, and have neither variety, emphasis, nor attractiveness.

Dr. Cones states that this Finch begins to sing when mating, and is afterwards, during the incubating, particularly earnest and perserering about it. Each pair usually chaims some particular copse, and the male usually has his favorite singing-post, to which it continually resorts. He adds that its simple song is something like that of the Yellow-shouldered Sparrow, beginning with a few slow notes, then a rapid trill, finally slurred, till it sounds like the noise made by some of the grasshoppers.

These birds are at all times shy and difficult to be approached. When their nest is visited, the parents leave it and secrete themselves, and cannot be traced without great difficulty. When thus hidden, they will almost suffer themselves to be trudden upon before they will fly up.

Mr. Audubon thinks they have two broods, their first being hatehed out early in June. Their nests, he states, are usually placed next to the ground, but not sunk in it. Their food consists of marine insects, small crabs, and snails, as well as small sand-beetles and seeds. Their flesh has a rank, msavory flaror, so much so that, haring had some made into a pie, he could not eat it. He states also that they are resident in the Southern States, and are found along the Gulf coast as far as Texas.

The nest is strongly but coarsely woren of dry sedges, stems, and grasses, and is lined with similar but finer materials. The eggs are fire in number, have a grayish-white ground, and are spotted and blotched with reddishlnown. The blotches are distributed arer the entire egg, and are mueh 


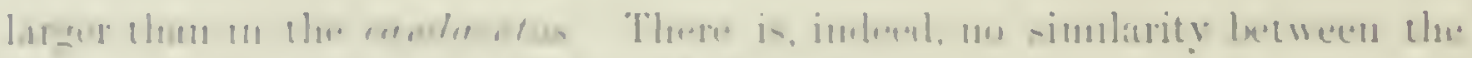

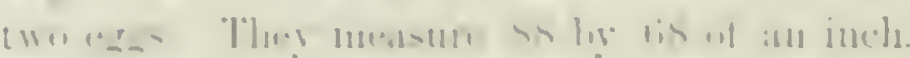

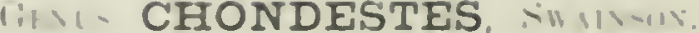

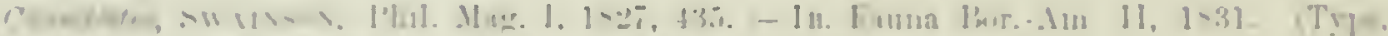

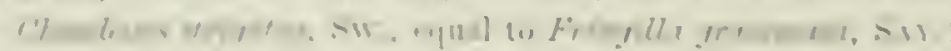

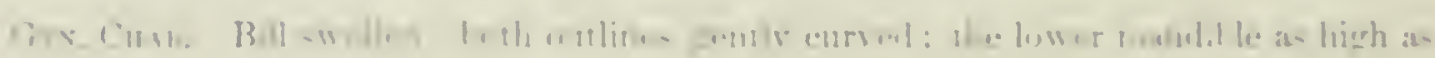

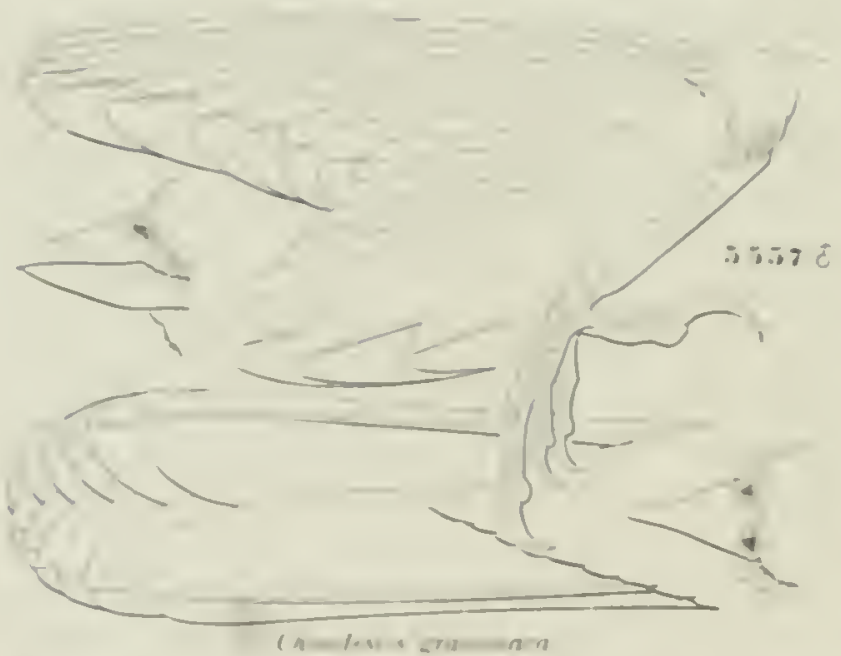

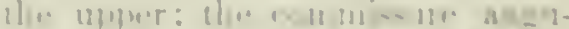

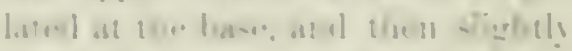

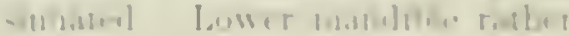

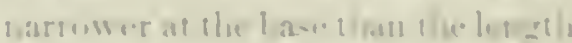

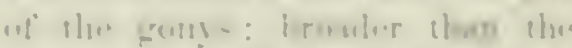

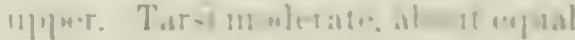

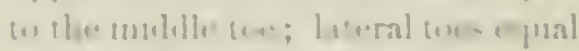

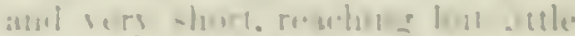

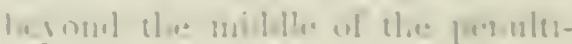

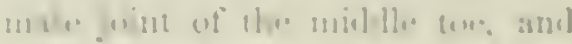

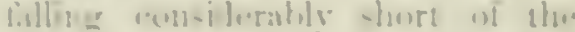

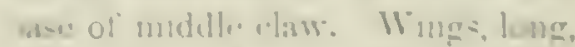

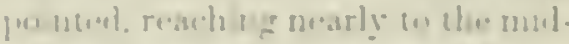

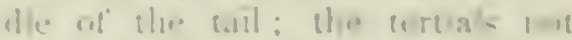
longer than the areundarno: the

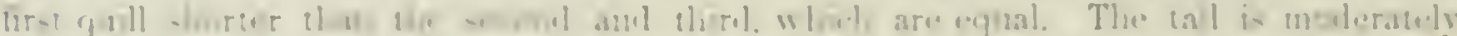

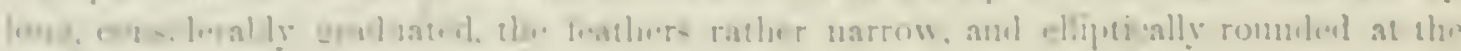
$1 \cdot 1=1$.

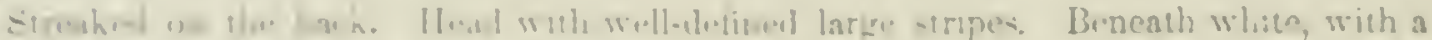

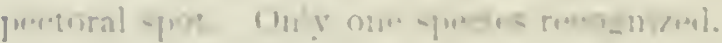

\section{Chondestes grammaca, Hoxap?}

\section{LARK SPARROW.}

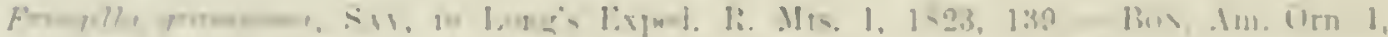

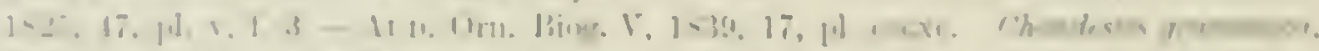

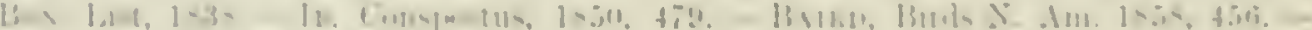

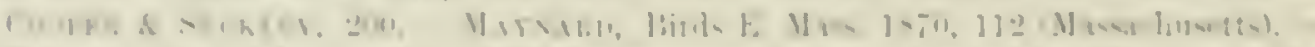

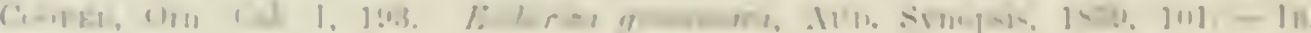

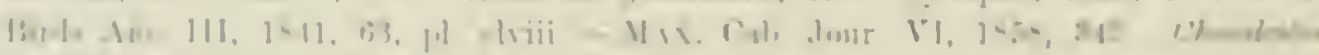

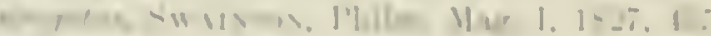

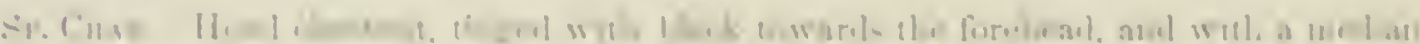

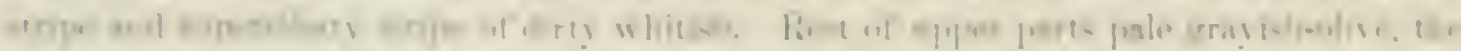

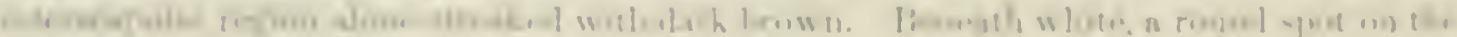

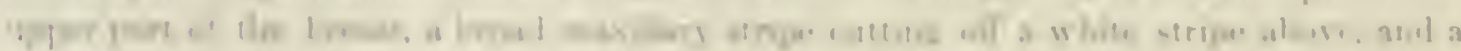

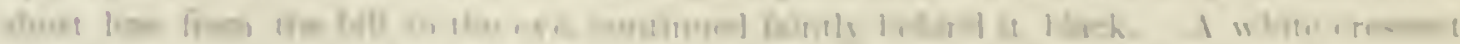

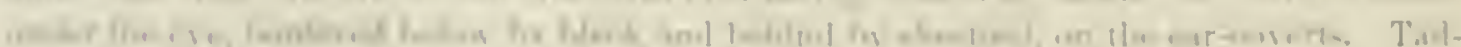

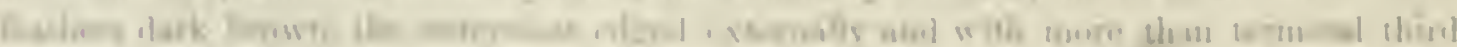

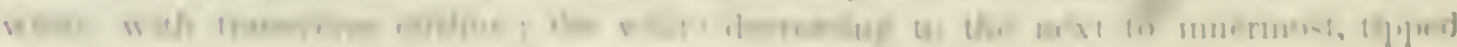

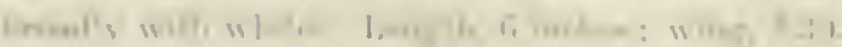


Hab. From Tisconsin and Illinois (also in Michigan and Ohio) to the Pacific coast; Cape St. Lucas, south to Texas aml Mexico. Oaxaca (Scl. 1859, 379); Vera Cluz (winter, Scmuchrast, 552); Eastern Massachusette, accidental (Marian).

The eolors of the female are duller than in the male, the ehestnut less briwht, the black not so intense; the pattern, howerer, is the same.

The roung birl has the breast and throat. with a good many spots of dark brown instead of the single large one on the breast. The other markings are more obseure.

H.rims. The Lark Finch is found from Eastern Illinois to the I'acific, and from Oregon to Texas. Within this wide area of distribution it is everywhere abundant in the open prairies and plains. It is not funnd in wooded re. gions. This bird was described by Say; and was first met with by Long's expe-

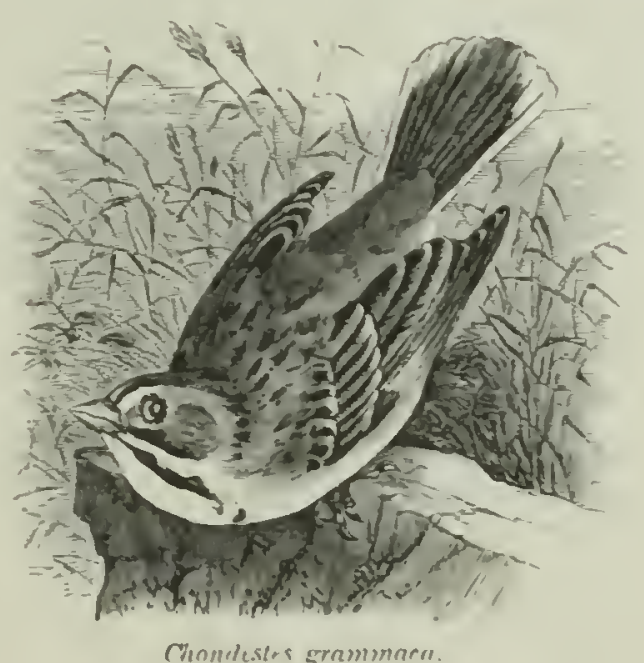

Chonilesers grammaert. dition to the-iissouri River. It was not known to either Milson or Audubon, and its habits were very imperfoetly known to Nuttall.

Mr. I)resser found this bird very abundant in 'Texis thronghont the summer, arriving in the neighborhood of san Antonio in March, and leaving there early in October. He found their nests quite common, and usually built in a mesquite tree or bush, of tine roots and grasses. 1)r. Heprmann also found it abundant in New Mexico. In Arizona, I)r. Cones found it. ehiefly in spring and antumn, a migrant, and, at those seasons, very mmerons. Many remain during the summer to breed, and a few are found in the winter. It was met with near New Lenn, Mexiun, by Lientenant (onch, but was not obtained in Vera C'ruz by Sumichrast. It was taken near Oaxaca, Mexico, by Mr. Boncard. A single specimen was ohtained at Fort lalles in Oreron, by 1)r. Suchley, but it was not met with by lim west of the Cascade Momntains. Irr. Townsend states that he also fouml it in that remion.

Dr. Cooper did not find this species in the Coloralo Valley, thongl it has been obtained at Fort Tuma in Deeember; and, as he has met with them in large flocks in the valleys of San I liegn in Fehnury, he conchudes that they winter in the southern part of California. They lneed from sin Diego throughout California, and as far north as the Columbia, where they arrive early in Mar. Dr. Cooper has never found their nest in C'alifornia, but has frequently met with it in Kansas and Tebraska in May and June. He found them on the around, and their nests were constructed chietly of gl'ass.

He speaks of them as singing rery sweetly, and states that in their song they resemble the Canary more than any other bird. They frequent the open plains, usually in the neighborhood of trees, upnn which they often 


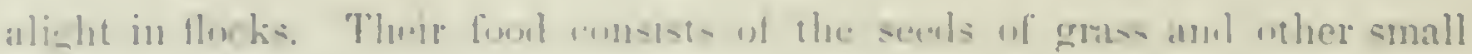

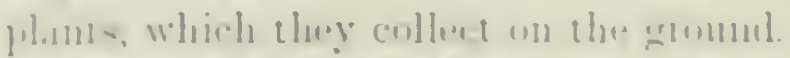

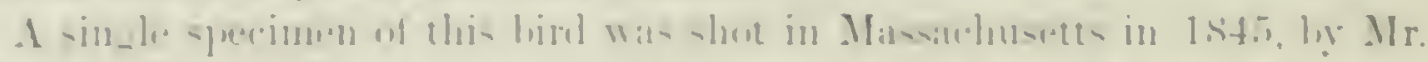

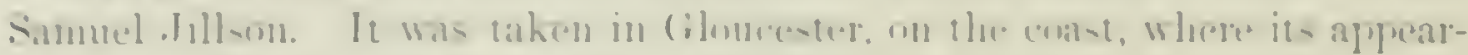
ance was, of coume, furmly accidentat.

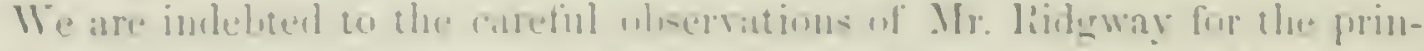

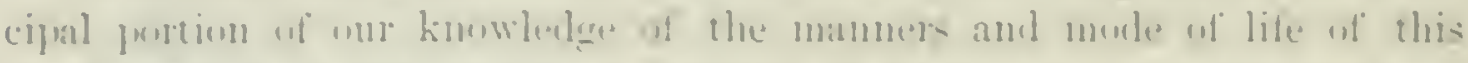

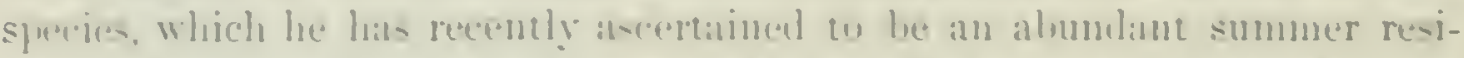

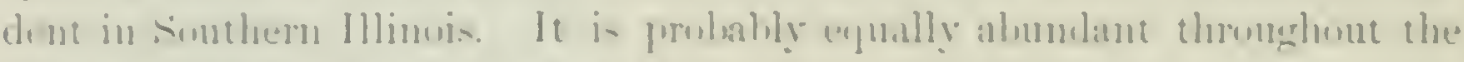

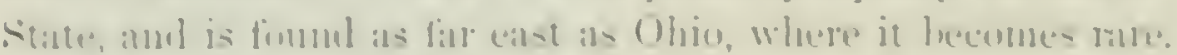

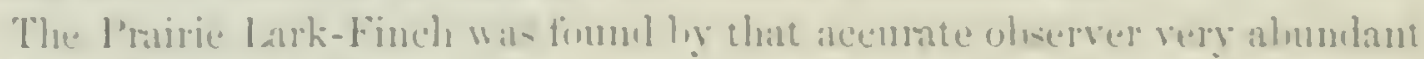

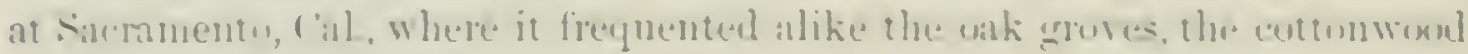

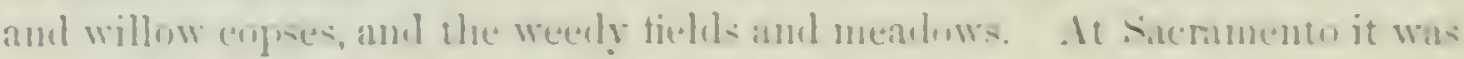

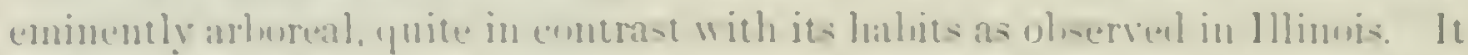
was also met with in the interios, wherever the locality was suterl to it. Sear

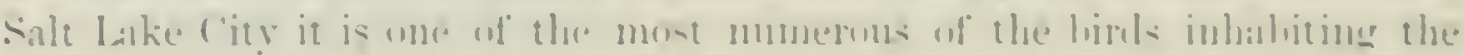

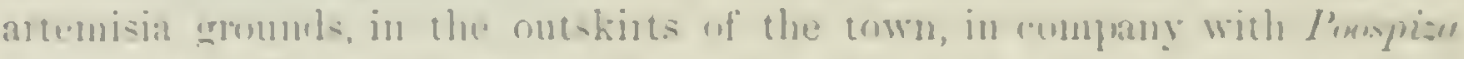

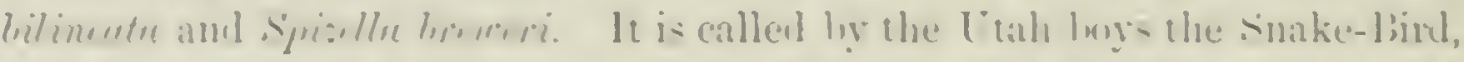
from the supposent deremblanee of its strijued hend to that uf a mithe. It

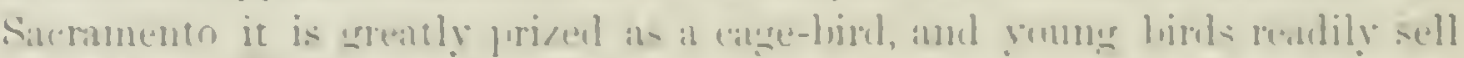

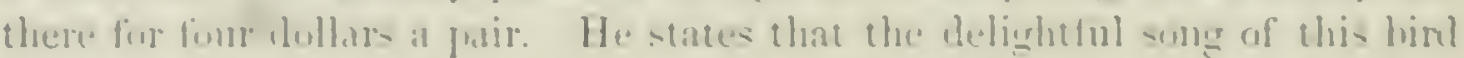

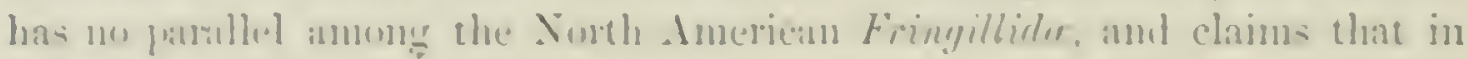
this mepere it is pre-eminemty smperior to that of all the wher members of

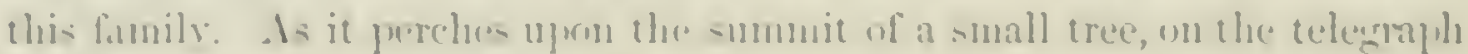

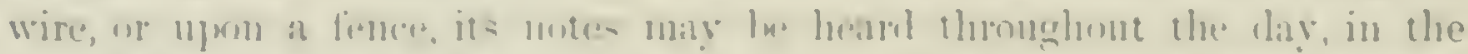

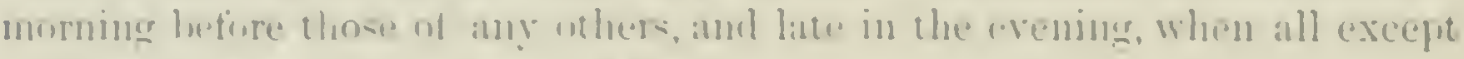

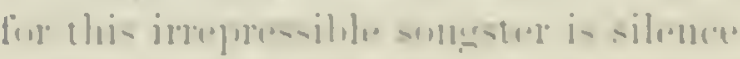

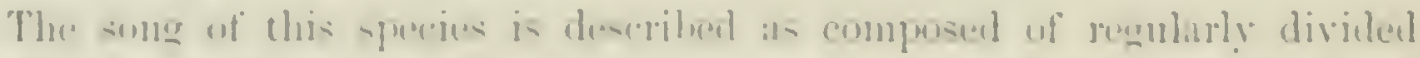

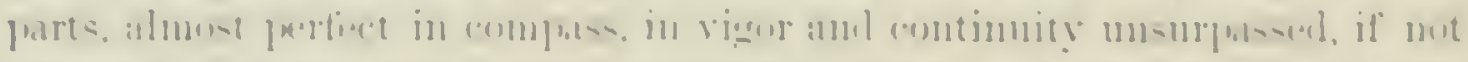

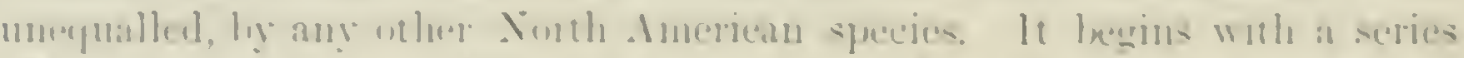

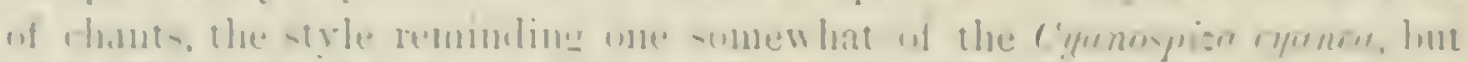

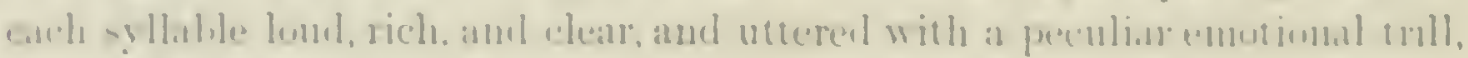

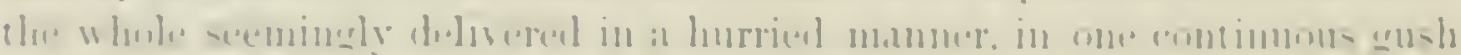

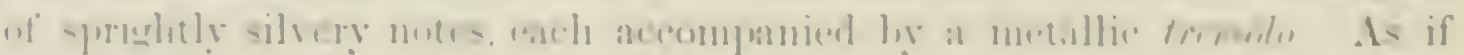

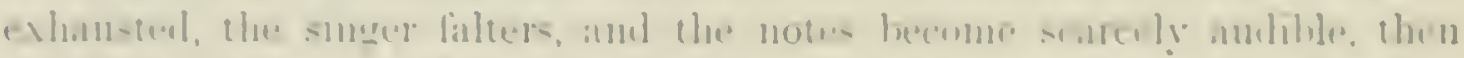

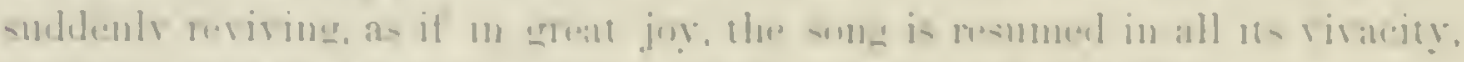

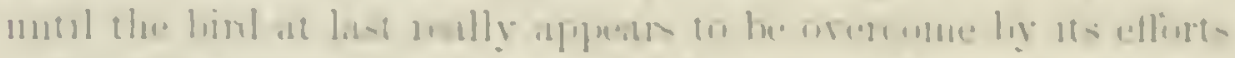

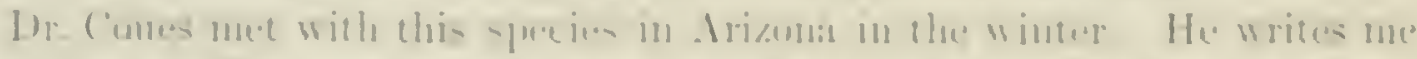

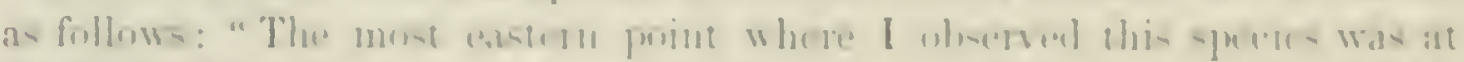

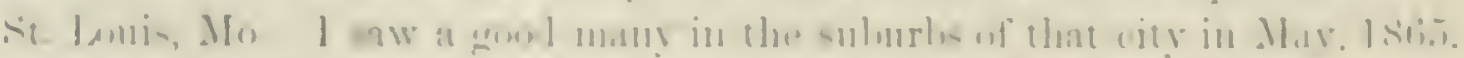

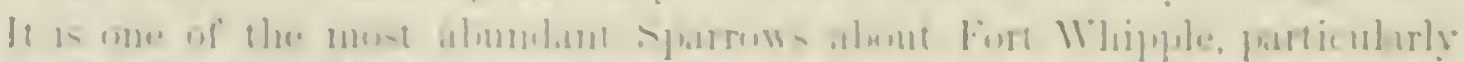

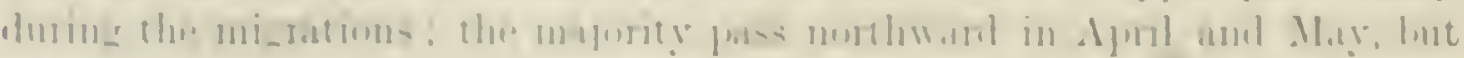

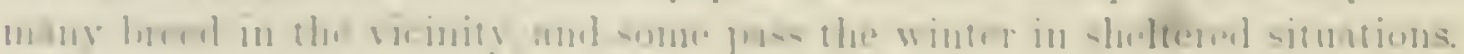

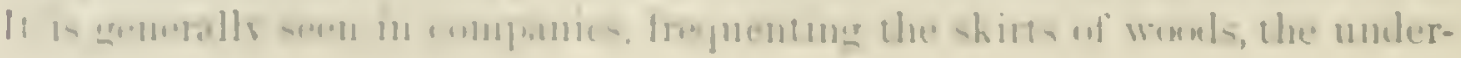


brush along momntain rivulets, and similar sitnations, where the seeds of varions plants are procurable; its general habits resemble those of the species of Zonotrichie."

The nests were found by Mr. Ridgway in varions situations; the larger number were upon the ground, but several were in trees varying in height from six to twenty feet from the ground. They were found from the latter part of May through . June. A nest obtained in Southern Wisconsin by Mr. Thure Kumlien is very homogeneous in structure, consisting entirely of loosely intertwined stems of dry grasses, sedges, and carices. It was built on the gromnd, is nearly flat, and has only a very shallow cavity. Its entire height is less than two inches, and the depth of its depression not half an inch. The diameter of the nest is three and a half inches, and that of the cavity at the rim three inches.

The maximum number of their eggs is five. Their arerage measurement is .85 by .65 of an inch. The ground-color is usually a grayish-white, rarely a light brown, marbled and streaked with waving lines, and a few dots of black or a blackish-lorown.

\section{GENUS ZONOTRICHIA, SW.INSON.}

Zonotrichia, Swalssox, Fauma Bor.-Am. II, 1831. (Type, Emberiza leucophrys.)

Gex. Cirar. Body rather stout. Bill conical, slightly notched, somewhat compressed, exearated inside; the lower mandible rather lower than the mpper; grony's slightly conrex; commissure nearly straight. Feet stout; tarsus rather longer than milllle toe; the lateral toes very nearly equal. Hind toe longel than the lateral ones; their claws just reaching to base of middle one. Inner claw contained twice, in its toe proper; claws all slender and considerably curved. Wings moderate, not reaching to the middle of the tail, but beyond the rump; secondaries and tertials equal and considerably less than longest primaries; second and third quills longest; first about equal to the fifth, much longer than tertials. Tail rather long, noderately rouncled: the fienthers not very hroarl.

Back streaked. Rump and under parts immaculate, except in young. Head black, or with white streaks. entirely different from the back.

This genus embraces some of the most beantiful of American Sparrows, all of the largest size in their subfamily.

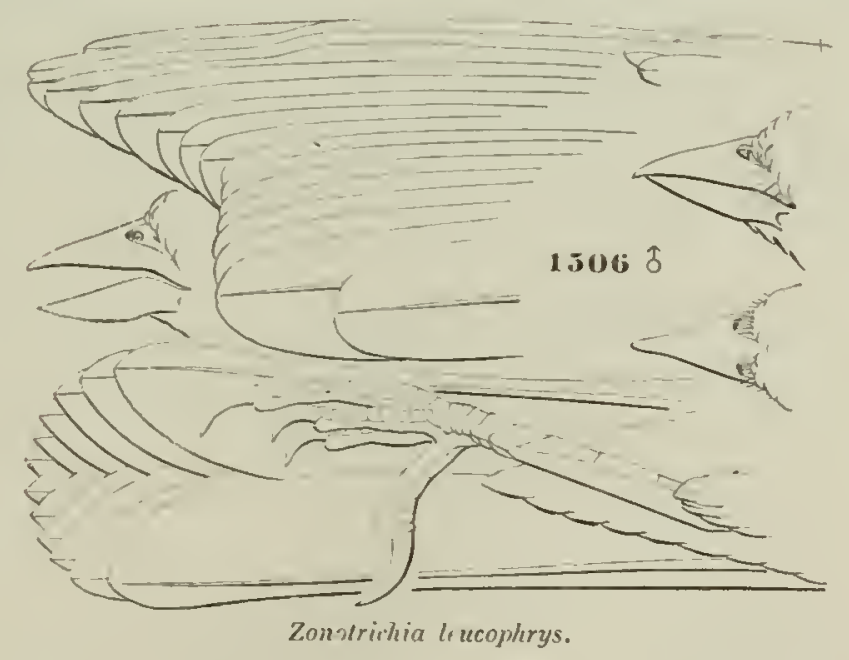

All the species properly belonging to this genus are Nortl American; several South Amcrican species, have, however, been assigned to it; but they are none of them strictly congeneric with those given below. 


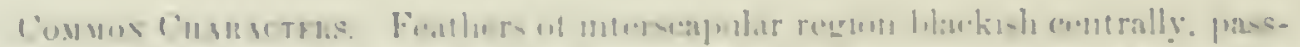

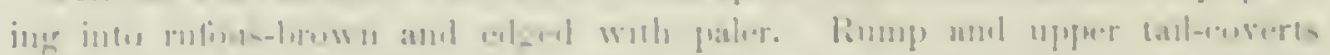

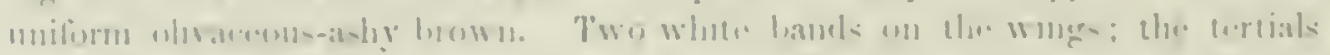

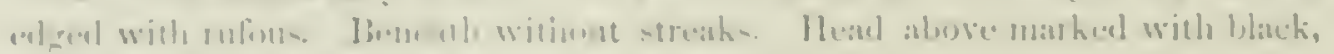

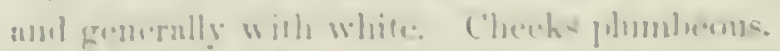

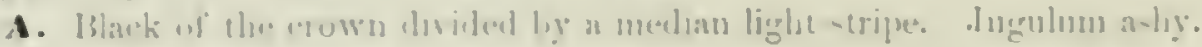

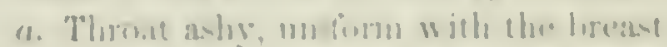

1. Z. lencophrys. Mcolian stripn of the crown white. A luluek

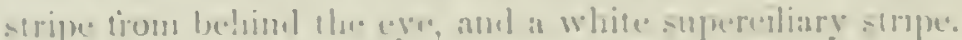

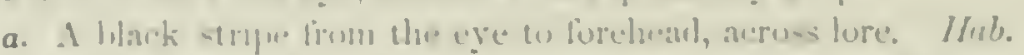

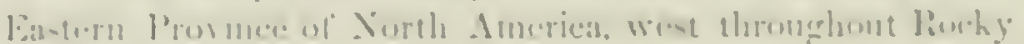

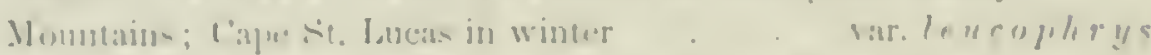

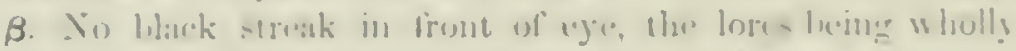

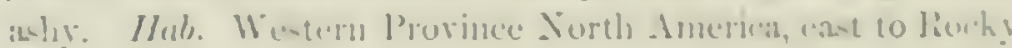
Momminus
v.11. ya mbeli.

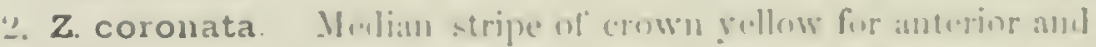

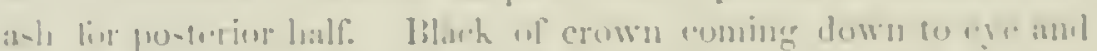

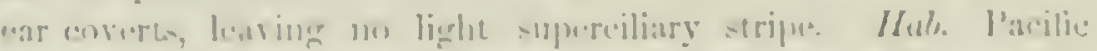

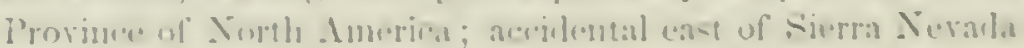

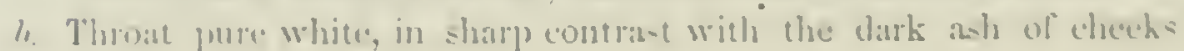
ancl jurpuhm

i. Z. albicollis. Minlian slipe of rown white. A light super-

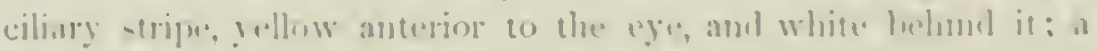

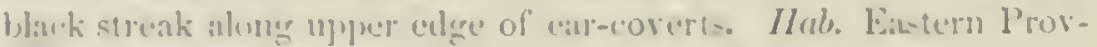
ince of Direls . Amerie:a.

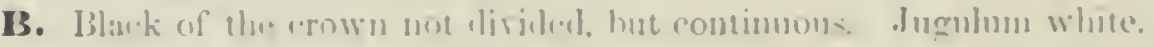

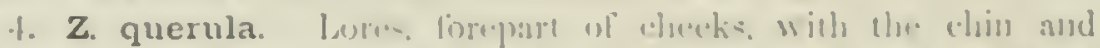

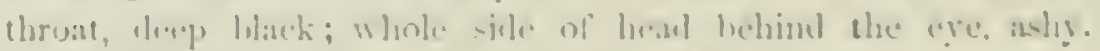

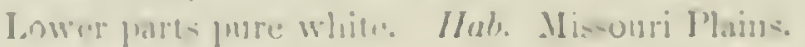

\section{Zonotrichia leucophrys, sirisso:}

\section{WHITE-CROWNED SPARROW.}

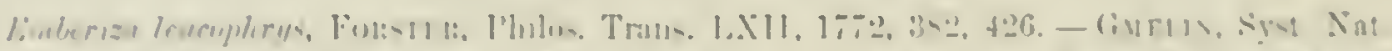

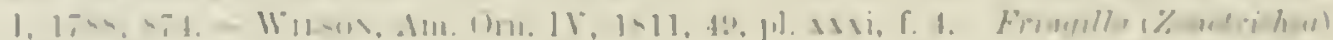

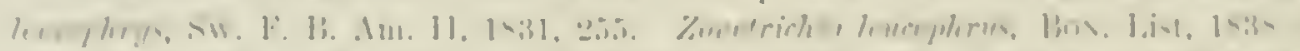

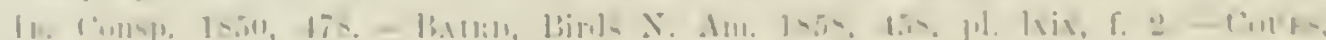

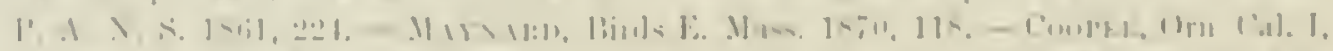
1!10 -

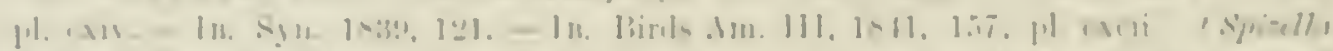

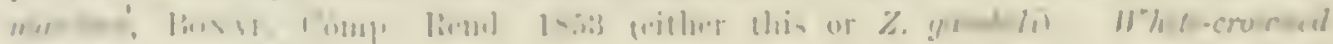

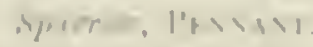

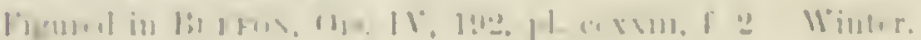

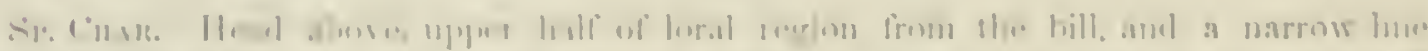

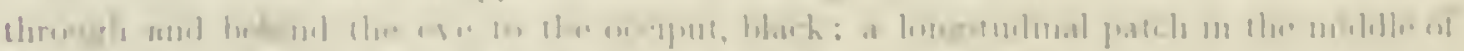

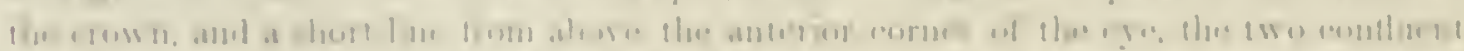

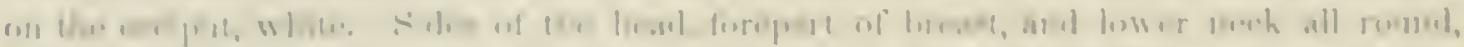

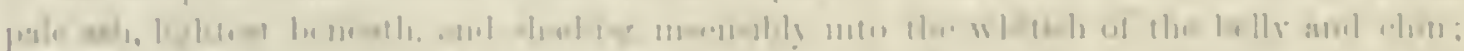

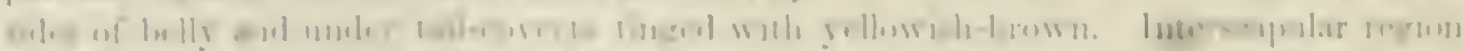

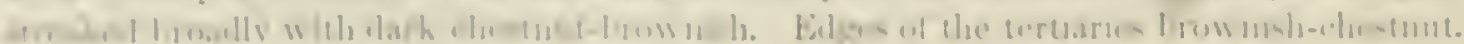

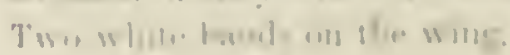


Female similar, hut smaller: immature hirds in fire winter, with the black and white stripes on the crown replaced by dark chestnut-brown and brownish-yellow. Length. -10 inclues; wing, 3.25. Young of the !/ear thickly streaked with dusky on the brenst. The lateral stripes of the crown dull hrown, the median one streaked whitikh.

Hab. Lnited States tiom the Atlantic to the Rocky Jountains, where they hecome associated witl $Z$. gumbeli. Cape St. Lucas; freenland (Reisilard, Ibis, III, i). Breed in Walssatch Ifountains (Rincwir).

The white of the crown seprates two black stripes on either side, rather narrower than itself. The black line hehind the eve is continued anterior to it into the hack at the base of the bill. 'The lower "relid is white. There are some ohscure rloudings of darker on the neck abore. The rump is immaculate. No white on the tail, except very obscure tips. The

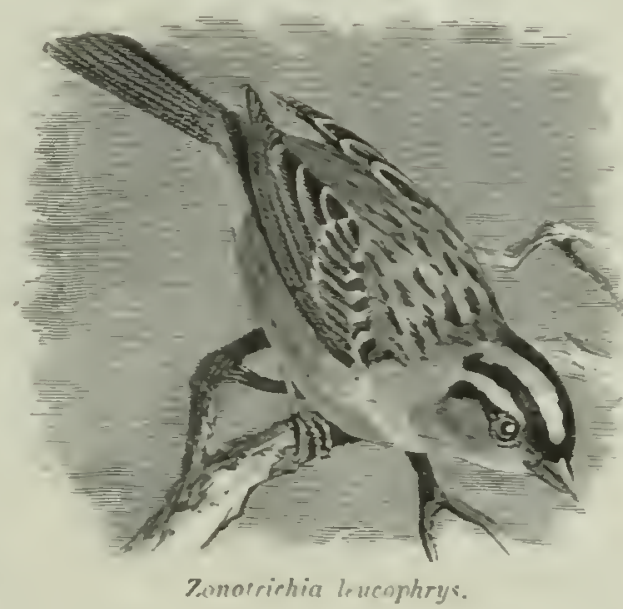
white on the wings crosses the ends of the middle and greater coverts.

The character listinguishing the western representative ( $Z$. grmbeli) of leucophrys is apparently very tritling, but is rerry constant.

HABITs. The White-crowned sparrow is found from the liocky Mountains eastward to the Atlantic, and in all the intervening territory, from the Sonthern States to the Aretic reaions. In the high nuendors of the Wahsatch Momntains, Mrr. Ridgway found this bird rery abundant, and one very characteristic, breeding there quite as mumerously as any other species. In all that region Mr. Tidgway did not meet with a single individual of $Z$. gambcli, its western representative. At the encampment at Parley's Park these birds soon became on rery familiar terms with the party. They were rery sociable, and pair frequent visits to the cook's tent, and picked up, without the slightest signs of fear, the crumbs from the ground. Their sweet morning carol was, he states, delightful to the ear, and they were held in great faror by all. A nest of these birds was found on the ground, at Parley's Park, June 26. It was built in a bunch of Gerenium. speeinens of this species were obtained, in winter, at Cape St. Lncas, Lower California, by MIr. Xantus.

Although an eastem species, passing, in its migrations, through the southern Atlantic States to Labraclor in the spring and returning in the fall, it is a rare species in all New Englaud. Mr. Boardman says that it is not common in Eastern Maine, and Mr. Terrill that it is rare in the western part of that State. In Eastern Massachusetts it is rery rare. Mr. Mayuard mentions obtaining a single specimen, Мay 27 , and regards it as quite a rare migrant. I lave never met with the bird near Boston, and lo not believe that it is found there, except singly and rarely. In the western part of the State, though less rare, it is rery far from being common. It is found there in the spring, from the 2uth to the 30 th of May, and in October from the 1st 


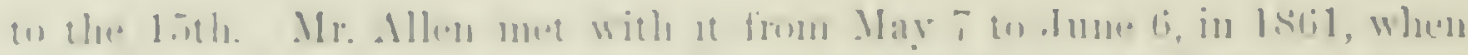

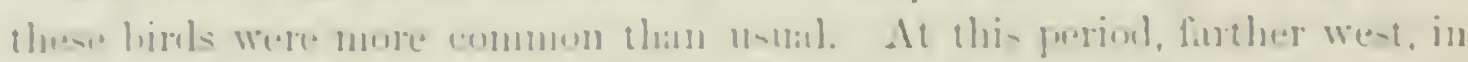

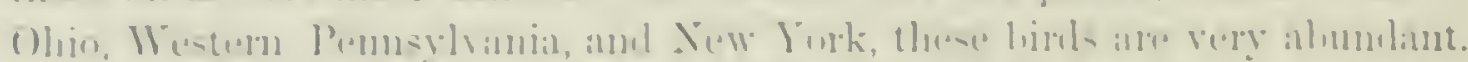

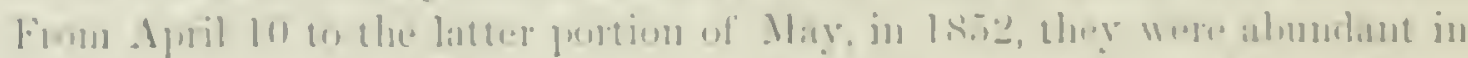

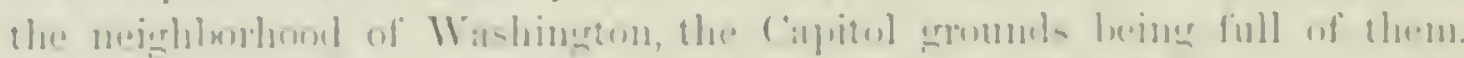

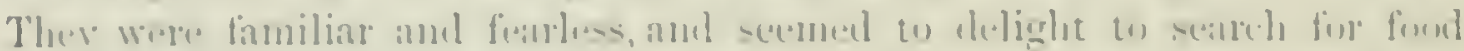

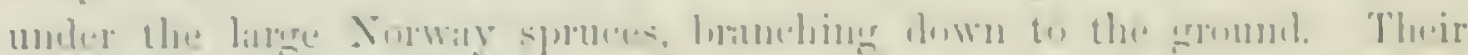

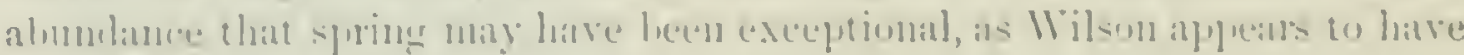
met with hut very fem specimens.

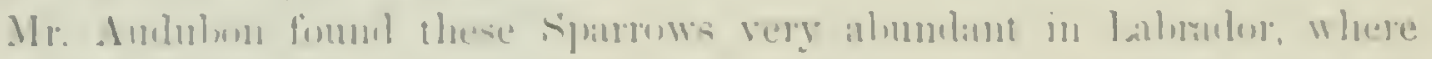

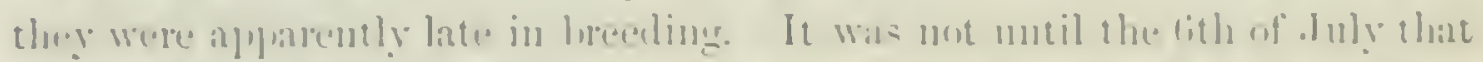

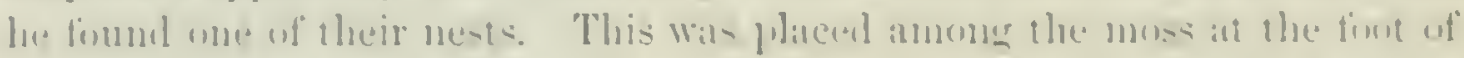

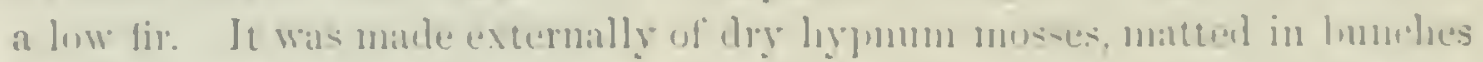

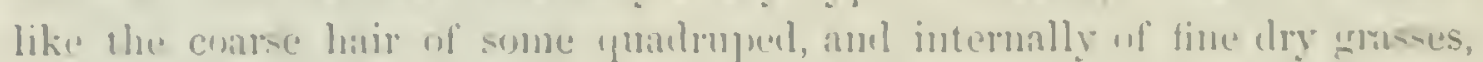

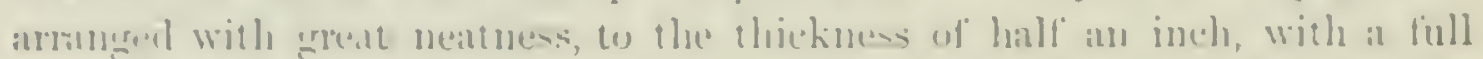

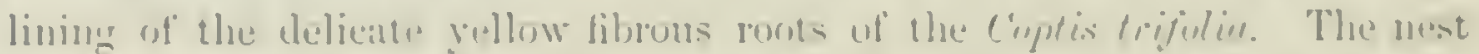
was five jueles in its estermal dianseter, and two in depth, the eavity two and a quater wide and one and three ynartere deep. The exgers, five in mumber,

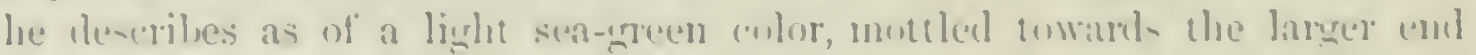
with hownish spots and bluteless, a few spots af a lighter tint heing dis-

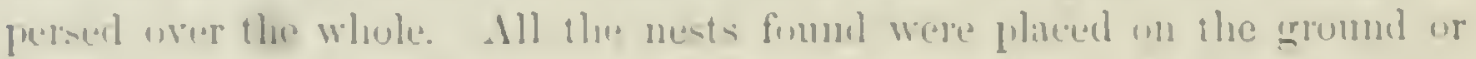
ammon the muss, and all were alike in thejr construction. By the lusimning

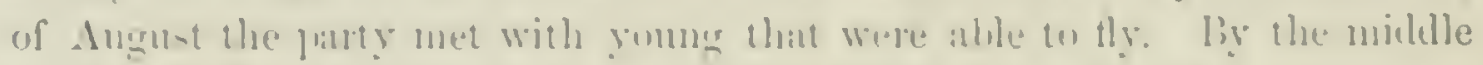
of llatl month they hate enmmented their sonthern miemations.

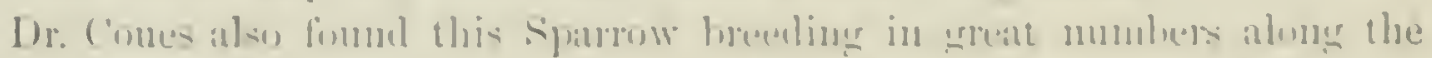

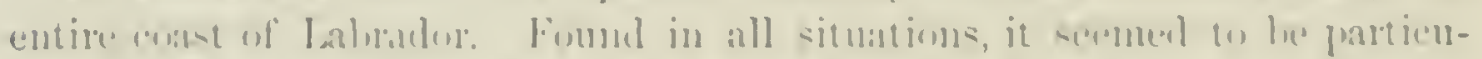

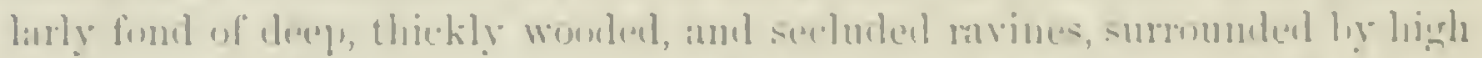

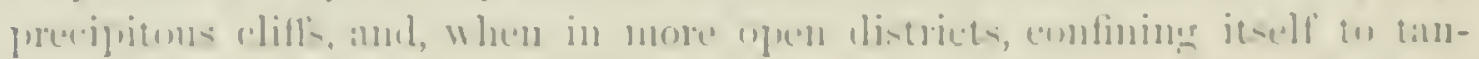

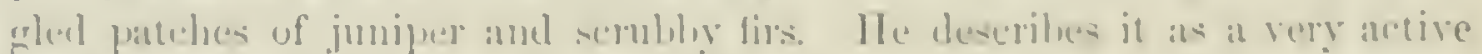

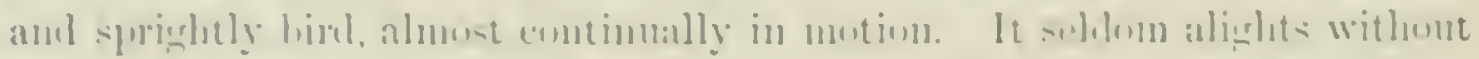
nupilly jorting and flinting its tail, and uttering its lomel chirpings. While

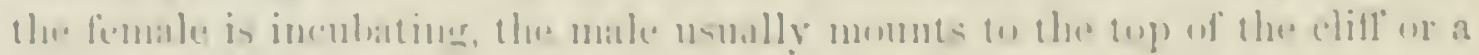

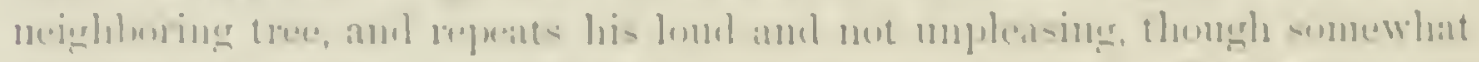

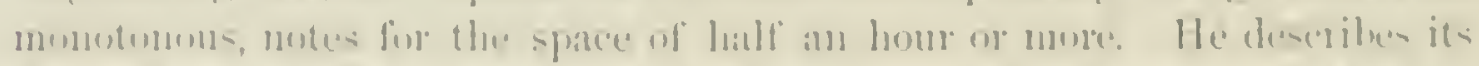

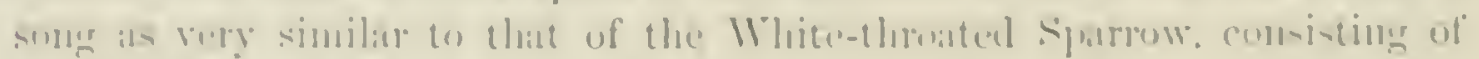

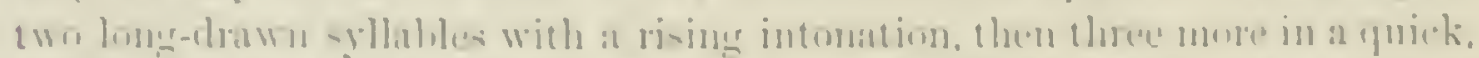

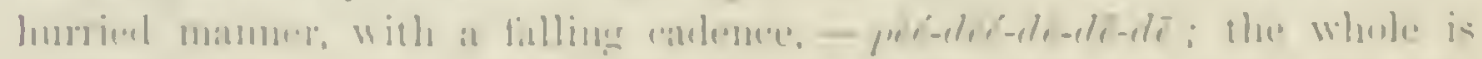

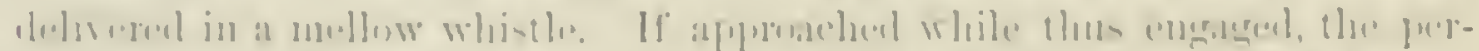

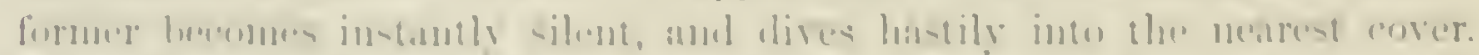

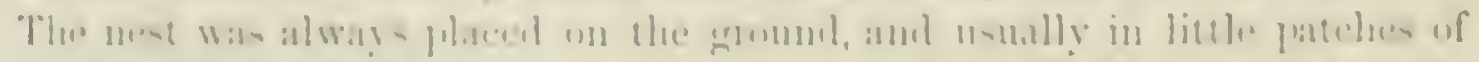

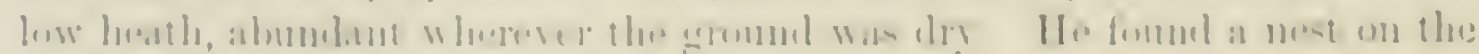

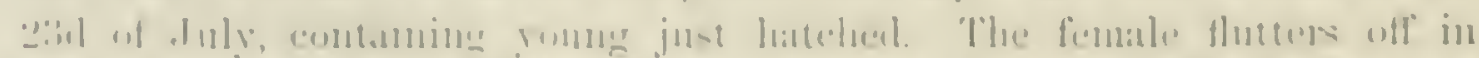

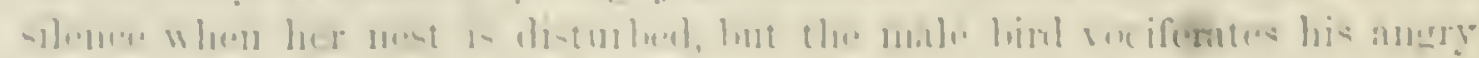

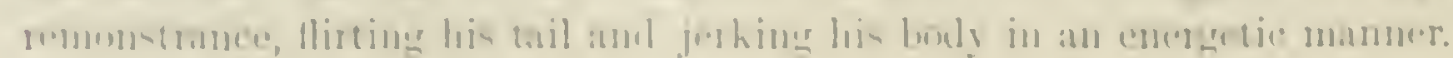


The food of this bird, in Labrador, was found to consist of small coleopterous insects, grass-seeds, a rariety of berries, as well as minute shell-fish, for which they searched the margins of ponds near the sea-shore. They were also seen to pursue insects on the wing. Mr. Audubon speaks of its song as consisting of six or seren notes, and deseribes it as lond, clear, and musical, although of a plaintive nature, diminishing in power to the last note. Its flight he describes as low, swift, and protracted.

Dr. Cous did not find this bird abundant in South Carolina during the winter, and conjectures that it does not go so far to the south. Its migrations do not appear to be well defined, and nowhere is it known to be abundant during this season. Lientenant Conch met with it at Brownille, Texas, and Tamaulipes, Mexico, and at Chareo Escondido, in March, at which time they were in flocks, indicating a more sonthern migration than is generally supposed.

It extends its northern migrations to the extreme northern and northeastern portions of the continent, and also to Greenland. On the Yukon and Anderson River it is replaced by the $Z$. gambeli. It is not abundant in Greenland. Holböll obtained a single specimen only in August, and afterwards met with a flock of young birds. He infers that they breed in the interior, but are restricted to a very narrow strip of territory.

Eggs of this species, from Wyoming Territory, measure from .90 to .95 of an inch in length by $.70 \mathrm{in}$ breadth, and are of an oblong-oral shape. The ground-color is a light greenish-white, thickly marked with reddish-brown and lighter markings of an obscure purplish-brown. The intensity, depth of coloring, and size of the darker brown markings, vary. They are principally disposed about the larger end.

\section{Zonotrichia leucophrys var. gambeli, GaMbeL.}

\section{WESTERN WHITE-CROWNED SPARROW.}

Fringilla gambeli, Nutr. Man. I, (2d ed.,) 1840, 556.-Ganben, Pr. A. N. Sc. Phila. I, 1843, 262. (California.) Zonotrichia gambeli, Ganbel, J. A. N. Se. 2l series, I, Dec. 1847, 50. - Batl:D, Birds I. Am. 1858, 460, pl. lxix, f. 1. - Lond, Pr. R. A. Inst. 1V, 1864, 118 (British Colnmbia). - Couper: \& Suckler, 201. - Dall \& Basister, Tr. Ch. Ae. I, 1869, 284 (Alaska).-Cooper, On1. Cal. I, 195. Zonotrichia leucophrys, Newbernx, Zoöl. Cal. \& Or. lioute; liep. P. R. R. VII, w, 1857, 87.

Sr. Char. Precisely similar to Z. Teucophrys. but rather smaller; the lores are gray throughont, this color continnons with a white superciliary stripe along the side of the head. Length, 6.25; wing, 2.\$3; tail, 3.08 .

Hab. Rocky Mountains to the Pacific coast, north to Nulato and Fort Kenai, east through the valley of the Mackenzie River, and south to Jalisco and Mazatlan. Mexico.

As stated in the previous article, the only appreciable and constant difference between this race and $Z$. levcophrys is found in the character of the black stripe on the side of the crown. In leucophrys the black passes down 


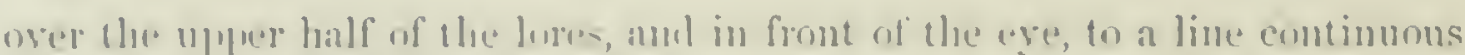

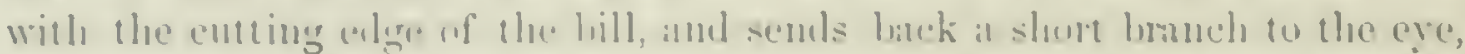
which ents ofl the white supereiliary stripe. In yomluli the supereiliary

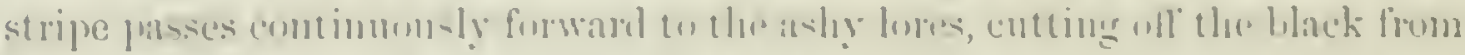
the ere. The lowere enge of the liack anteriorly is much ligher than in

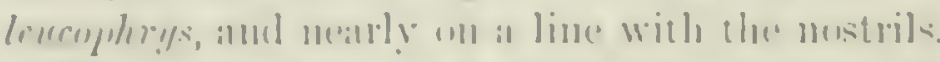

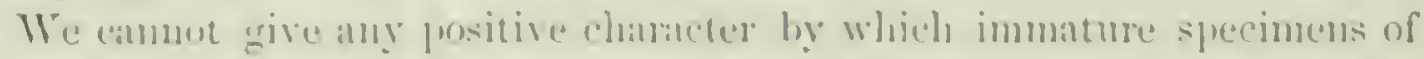

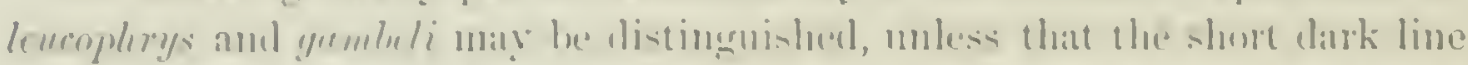

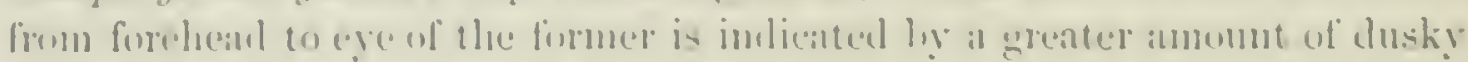
at the hate of the fiathers of that regriont.

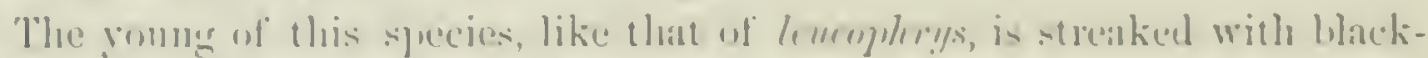
ish on side of the throat, aleross the hreast, and on the siles of benly, insteanl of heing entirely mmorkenl lementh, as in the mlult.

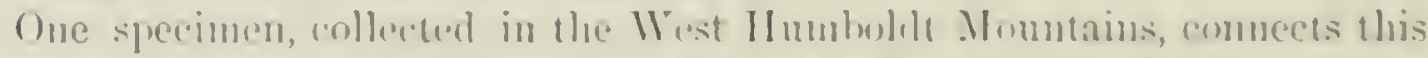

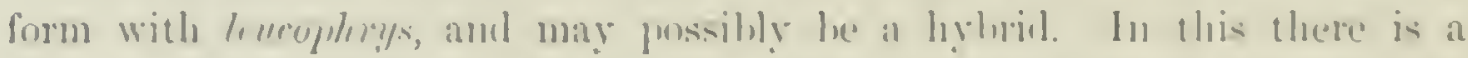
back spot in frout of the eye, but separated fiom the hatek of the crown hy the usual lighe supereilimy striju ut yumlerli.

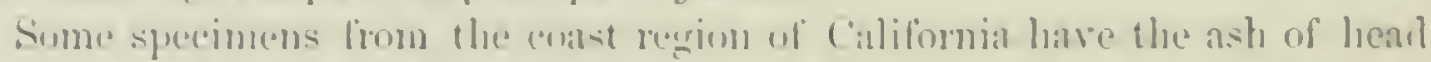

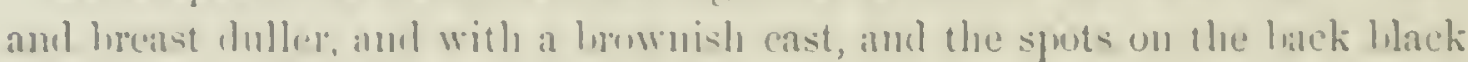
iusteanl of deep dart linows.

Habrts. The Wutern White-crowned starmw is fomml in great alum-

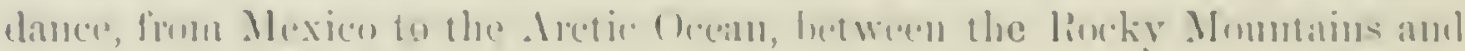

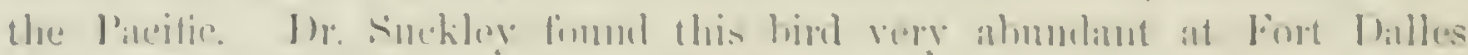

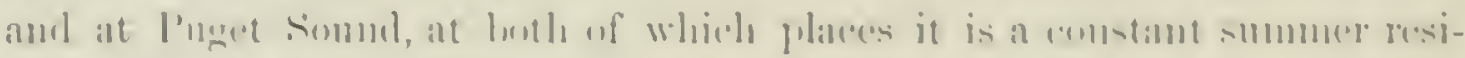

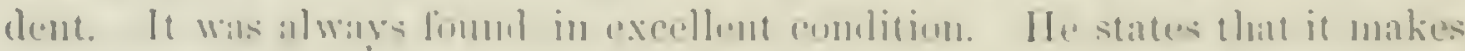

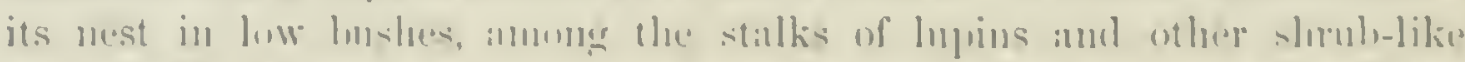

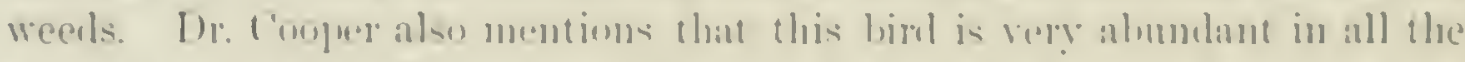

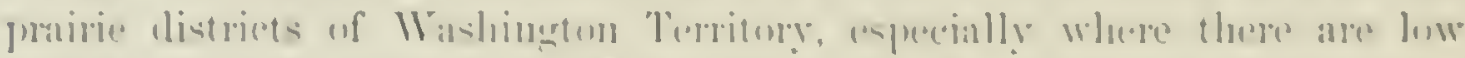

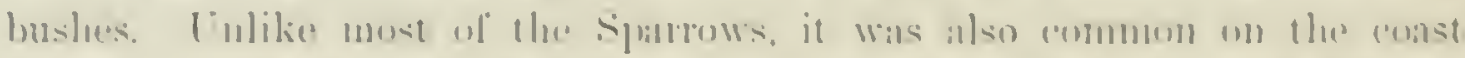

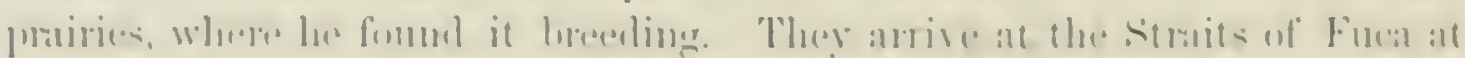

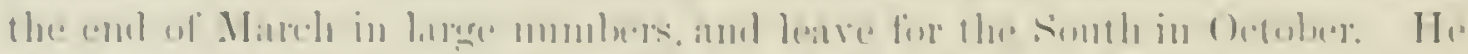

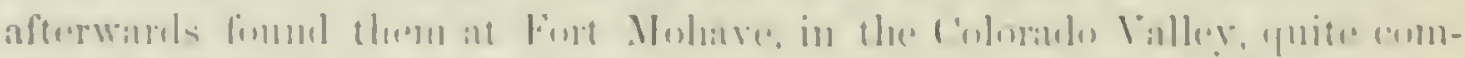

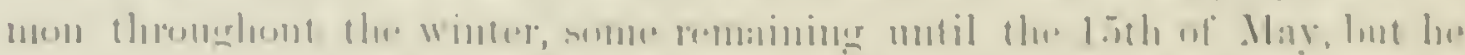

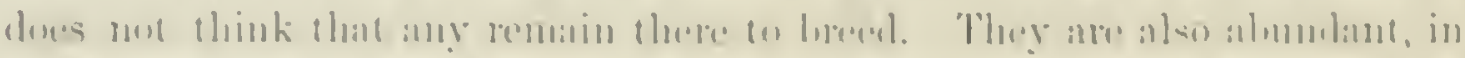

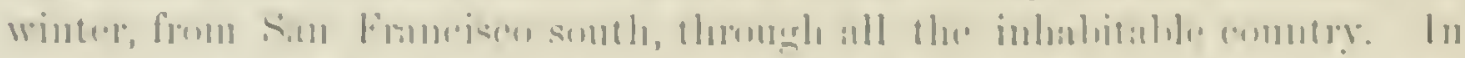

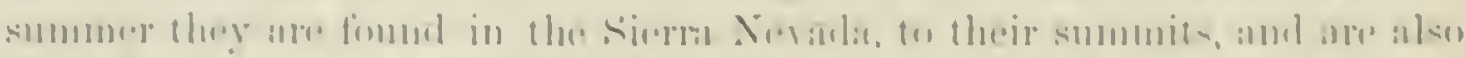

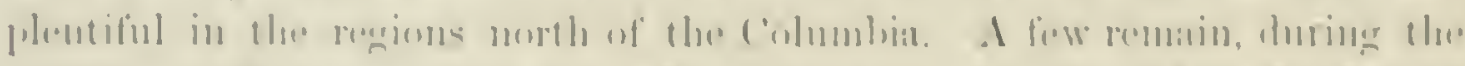

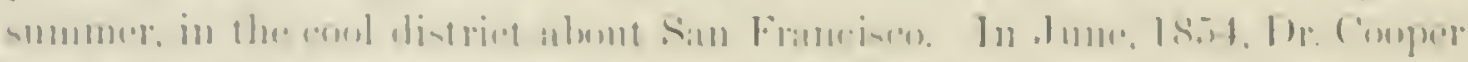

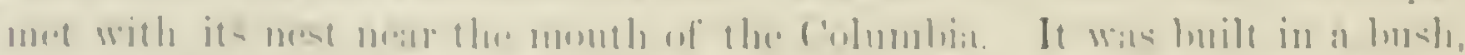

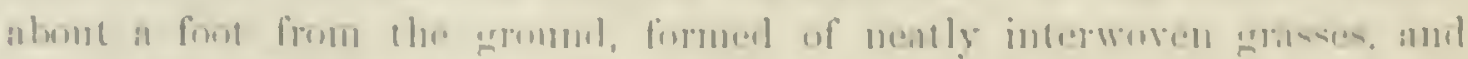

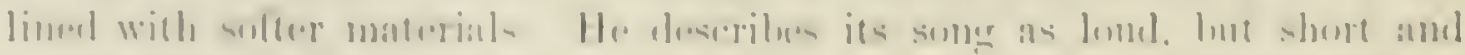

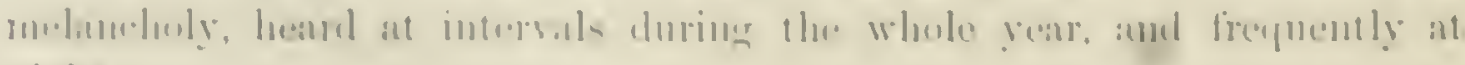
nimlit.

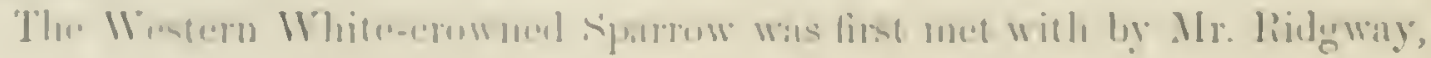


at the Summit Meadows, near the summit of Donner Lake Pass of the Sierra Nevada, at an altitude of about seren thonsand feet. It was there an abundant and characteristic bird. The males were in full song in all parts of the meadow, and were nesting in such numbers that on the evening of July 9 , on halting for the night, in a hurried search no less than twenty-seren of their eggs were obtained within about fifteen minutes. In every instance the nests were embedded under a species of dwarf-willow, with which the ground was covered. The birds were extremely misuspicions, the male often sitting on a bush within a few feet of the collectur, and chanting merrily as the eggs were being blown. In one instance, having occasion to repass a spot from which a nest had been taken, the female was found sitting in the cavity from which its nest had been removed. This species is only a winter risitant of the lower country, but is there universally distribnted, and always found in bushy localities.

Mr. Bamister states that this bird was tolerably abundant among the alder-bushes in certain parts of St. Michael's Island. Mr. Dall found it common at Nulato, and especially so at Fort Yukon. It arrived at Nulato about May 20. Its nests and eggs were obtained from Indians at Nowikakat, on the Yukon River. Dr. Kennerly met with these birds, in February, at White Cliff Creek, New Mexico. They were first observed on approaching the Big Sandy, and from thence to the Colorado they were found in abundance. They were mostly in flocks, and were generally found among the bushes, in the ricinity of water. He also met with it in the valley of the Rio Grande, Corralitos, and Janos Rivers. It seemed to prefer the vicinity of settlements, where it was always seen in greater numbers than elsewhere.

Mr. Dresser found these birds common about San Antonio, Texas, during the winter, arriving late in September. Some may remain and breed, as several were observed there in June. Dr. Cones also found them abundant in Arizona, where he first observed them September 15. After this they became exceedingly numerous, and remained so until January. Later than this only a few stragglers were seen, until April, when they again became abundant. By far the greater part left, and proceeded north to breed.

These Sparrows were found breeding on the Tukon and at Fort Anderson in great numbers by Messrs. MacFarlane, Lockhart, and Ross. Their nests were in nearly all cases found upon the ground, often in tufts of grass, clumps of Labrador tea, or other low bushes. They were composed of hay, and, in nearly every instance, were lined with deer's hair, and in a few with feathers. A few were without any lining. In selecting a situation for their nests, they seemed generally to give the preference to open or thinly wooded tracts. The male bird was usually seen, or its note heard, in the immediate ricinity of the nest. The egoss were oltained from the th of June to the 1st of July. Their maximum number was six; the most common, four.

Mr. B. R. Ross states that this species arrives at the Arctic Cirele from 
about the 15 th to the 20ith of May, and at slate lakke only a few days carlicr. They are then mo longer in flocks, lut late alreanly paired. They comnence nesting almost immediately ujon their arrival at the Yukom and

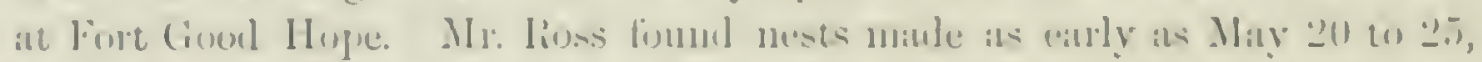
While there was still considerable snow upon the ground. They nostly nest, however, in the first hall of thue, the young nsially hatehing hetween the 1.th and sonh, and leaving the nests when less than at month old. They all lenve the Aretic circle albunt the middle of september. A few were seen at Fort simpsum in the latter part of that month. When stirting, they gather in small flecks. The nest is built on high gromed, among low, open husher, always at the fout uf some shrub or hush, and mure or less protected and concented by grass. It is never fliteed in the edges of

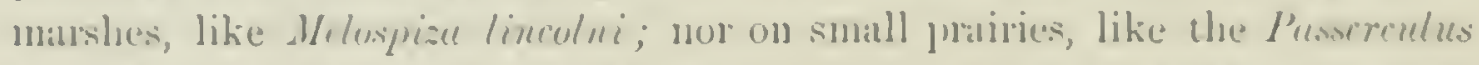
serrenme; nor in thick woods, als does sonetimes the $Z$. ulbioll is. The nest is neatly buih, is more complat and of finer materials than that of the latter. It is lange and deep, formed extermally of coarse grass, and lined with finer materials.

When stanted from her nest, the female flies ofl a few yards and fhutters silently along the ground to divert attention. If unsuccessful, she Hies ahout her nest uttering sharp, harsh nutes of anxiety. The male is less bold on surh necasions. Their firvorite habitat is light open bushes, aflecting neither open flnins nor deep woods and never ferching so high as twenty feet from the ground, and usually, in all their movements, keeping cluse to the eirrth.

Its frool, sin fir as could be olserved, consisted almost wholly of seeds, songht mostly on the gromul. It hatches only a single bromel in a year.

Mr. J3. R. Resse andes that this is the most alundant sparrow throughont the Mackenzic River region, and also the most interesting. Through the spring and summer its melodinus son!r, which strongly alls to mind the

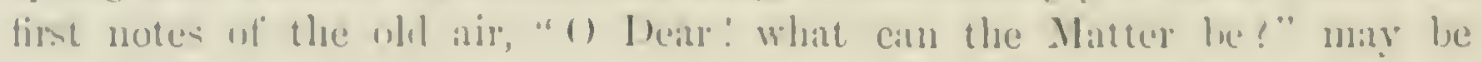
heard from erery thicket, both night and day. When sleeping in the woods, Mr. Finse stattes that he has often heen a watkened by sereral of these hisk singing near him, answering each other, throughent the short nightt, when ill the othere birels were silent. On this ancomnt, lut for the richenes and melody of its song the hird world lase made itself guite disagreeable.

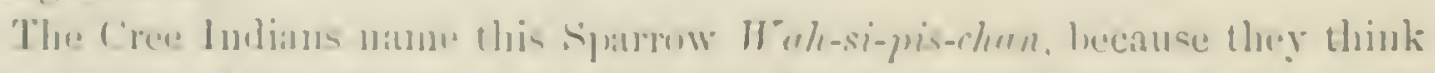

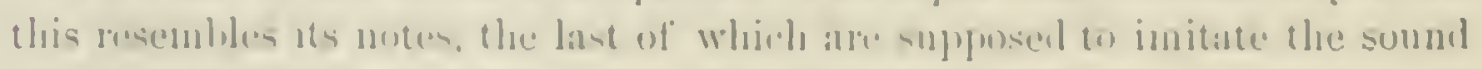

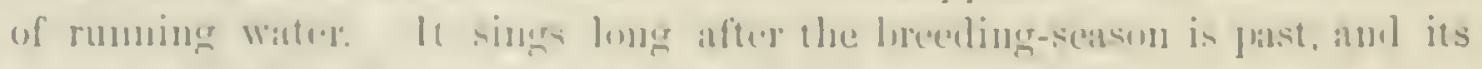

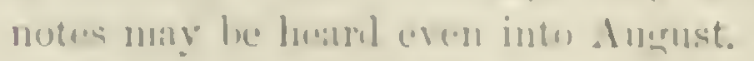

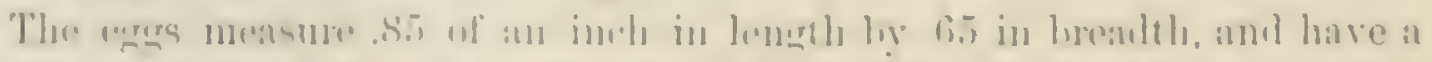
ground of a grenish-white mathed with it runcy-brown. They are of a rounded-urial shate. 


\section{Zonotrichia coronata, BAIRD.}

\section{GOLDEN-CROWNED SPARROW.}

Emberiza coronata, Pallas, Zoüg. Rosso-Asiat. II, 1S11, 4 , plate. Zonotrichia c., BAIRD, Birds N. Am. 1858, tö1. - HeElis. I. S, tS (nest). - CoOpel \& Stchler, 201. -

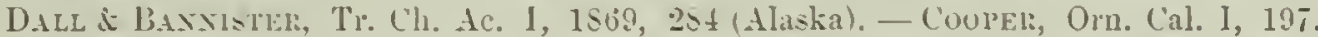

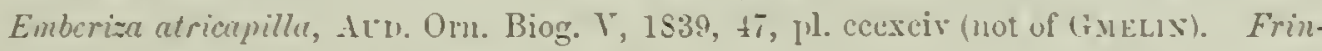
yilla atricapille, A'D. Synopsis, 1\$39, 122. - I B. Birds .1m. III, 1s41, 162, 11. cxciii. Fringilla aurocapillu, Nutrals, Mau. I, (2d. ed..) 1S40, 555. Zonutichio aurocapilla, Bos. Consp. 1550, tis. - Newben:r, Zoul. Cal. E Or. Route, Rep. P. R. R. V1, IY.

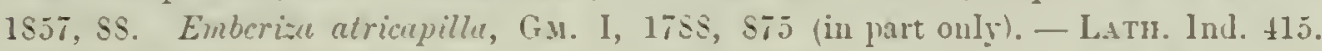
Black-cronned Bunting, I'Fsxist, Arc. Zoöl. 1I, 30t. - LAтH. II, I, 202, 49, tab. Ir.

Sp. Char. Hood, from bill to upper part of mape, pure black, the middle longitudinal third occupied by yellow on the anterior half; and pale ash on the posterior. Sides and under parts of head and nech, with upper part of breast. ash-color, passing insensibly into whitish on the middle of the body; sides and under tail-coverts tinged with brownish. A ycllowish spot above the eye, bounded anteriorly by a short blach line fiom the eye to the black of the foreheal. This yellow spot, howerer, reduced to a few feathers in spring dress. Interscapular region, with the feathers, streaked with dark brown, suffused with dark rufous externally. Two narrow white bands on the wings. Bill dushy abore, paler beneath: legs flesh-color.

Autumnal specimens have more or less of the whole top of head greenish-yellow; the feathers somewhat spotted with dusk ; the black stripe of the hood reduced to a narrow superciliary line, or else to a spot anterior to the eye. Length about $\bar{\imath}$ inches; wing, 3.30 .

HAB. Pacific coast from Russian America to Southern California; West Humboldt Mountains, Ner. Black Hills of Rocky Mountains?

Habits. This species, described and figured by Mr. Audubon as the Fringilla atricapilla, is found in western North America, from Alaska to Southern California and Cape St. Lucas, and is almost entirely confined to the Pacific Prorince, being known east of the Cascade Mountains and Sierm Nerada only as stragglers. In its general habits it is said to greatly resemble the $Z$. gumbeli. In the vicinity of Fort Dalles, and also in the neighborhood of Fort Steilacoom, Dr. Suckley found it quite abundant in the summer.

Dr. Cooper says that it is only a straggler in the forest regions west of the Cascade Mountains, but that it probably migrates more abtundantly to the open plains eastward of them. He met with them but once near Puget Sound, May 10, when they were apparently migrating. Dr. Cooper found a few of this species wintering as far south as San Diego, associating with $Z$. gambeli. They were much less familiar, did not come about the houses, but kept among the dense thickets. They were then silent, nor has he ever heard them utter any song. He met with none near the summit of the Sierra Nevada.

Dr. Newberry found these birds abundant in the vicinity of San Francisco in winter.

Mr. Nuttall met with the young birds of this species on the central table- 


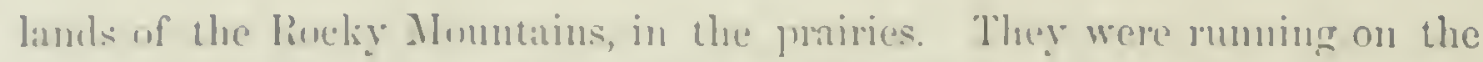

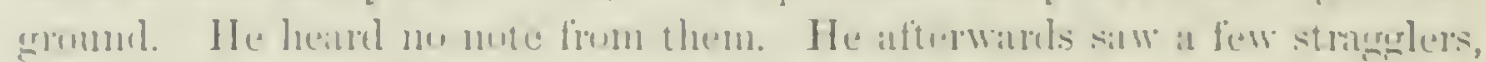
in the early gitlt of winter, in the thichets of the formets of the columbia

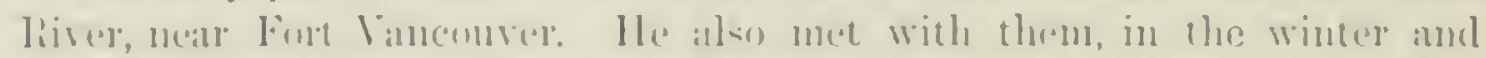
until late in the spring, in the womk and thickets of Calitinnia.

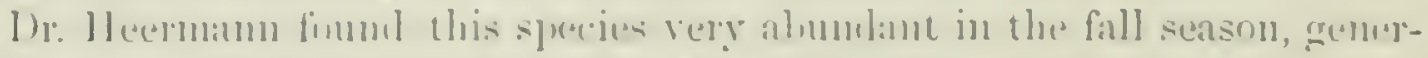

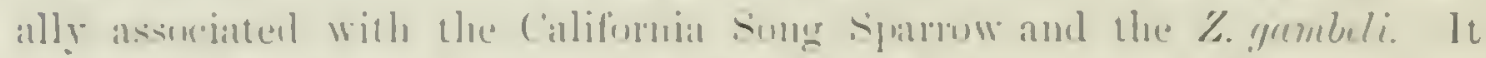

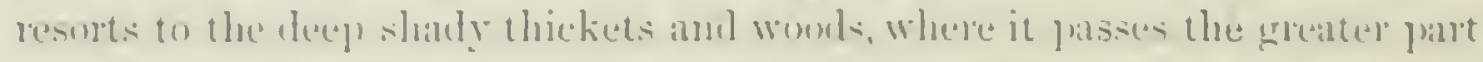
of its time. In the momutainums districts it luefers the hillsides, coremel

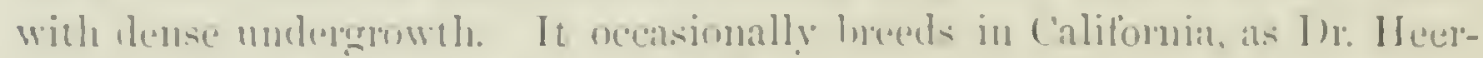

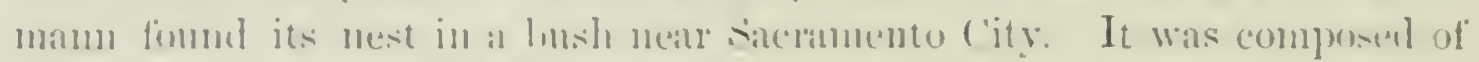

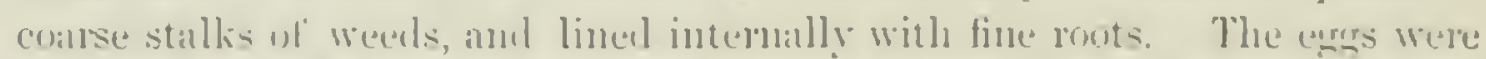

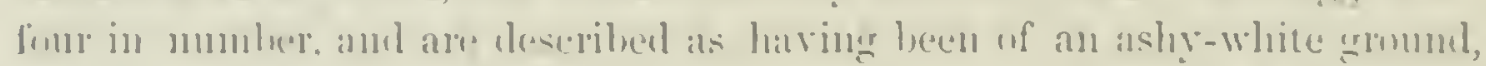
with marlings of bown umber, at times appealling alnost black flom the depth of their shate. They were marked also witle a few spots uf a nentral tint.

Many of these hirks were ritaned in Sitka and in Kollak, ly lisschoff, aml also in biritish (')lumbia ly Ellin.

Only one specimen of this spectes was neet with hy .Mr. Riderway in his

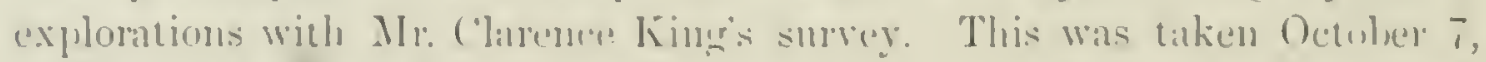
list, in the Wost Humbult Momntains, in company with a flose of $\%$. gumblili.

\section{Zonotrichia albicollis, Puxip.}

\section{WHITE-THROATED SPARROW.}

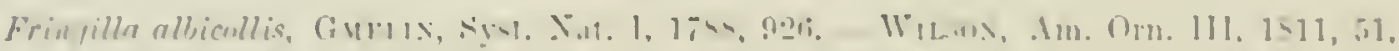

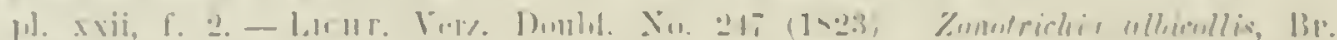

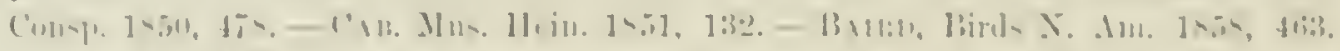

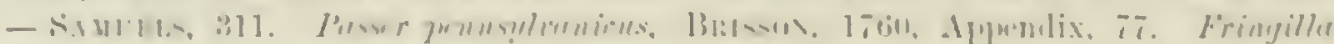

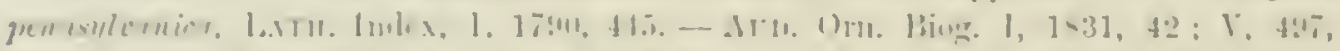

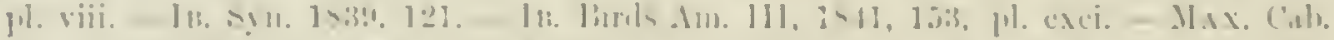

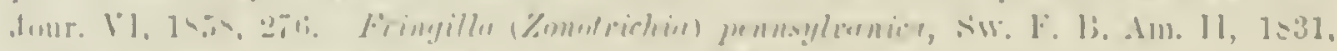

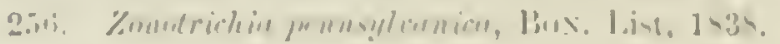

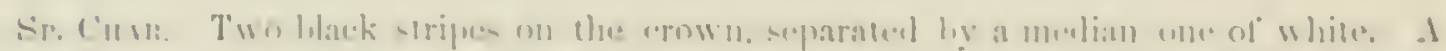

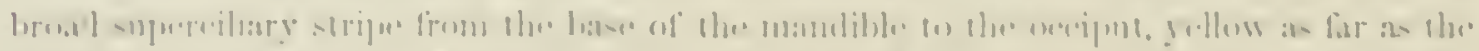

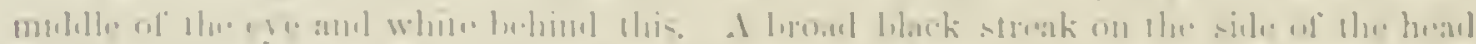

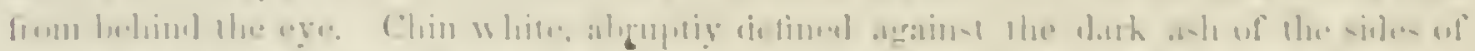

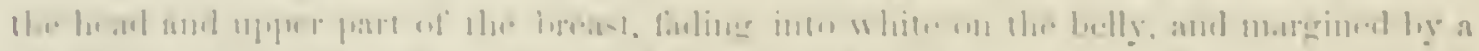

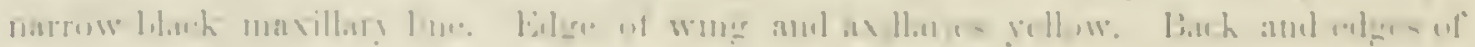

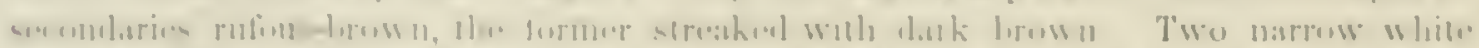

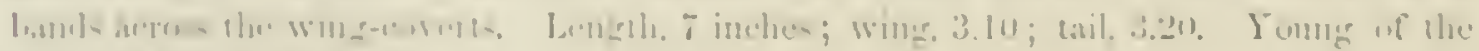

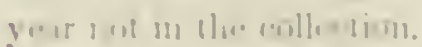

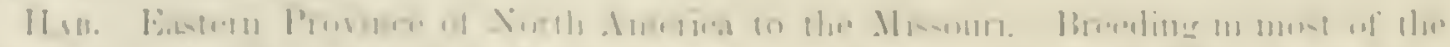

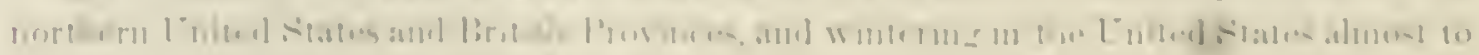

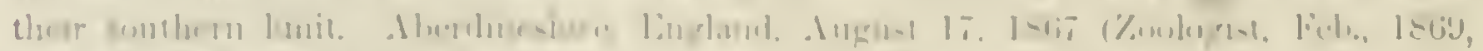

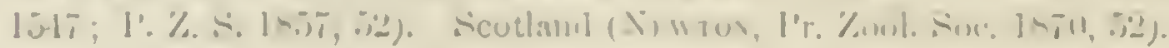


Female smaller, and the colors rather duller. Immature and winter specimens have the white chin-pateh less abmptly lefined, the white markings on the top and sides of the lead tinged with brown. Some specimens, apparently mature, show quite distinct streaks on the breast and sides of throat and hody.

II.unITs. The White-throated Sparrow is, at certain seasons, an abundant bird in all parts of North Ameriea, from the Great Plains to the Atlantic, and from Georoia to the extreme Aretic regions. A few lreed in farorable situations in Massachusetts, especially in the extreme northwestem part of the State. It breeds alurudantly in Vermont, New Hampshire, and Maine, and in all the British I'rovinces.

Nir Johm Richardson states that they reach the Saskatchewan in the middle of May, and spread throughont the fur comntries, as far, at least, as the 6oth parallel, to breed. He states that he saw a female sitting on seven eggs near tle Cumberland House, as early as June t. The nest was placed under a fallen tree, was made of grass, lined with deer's hair and a few feathers. Another, formd at (rreat Bear's Lake, was lined with the sete of the Bryum mliginosum. He describes the eggs as of a pale mountain-yreen, thiekly marhled with reddish-brown. When the female was disturbed, she ran silently off in a cronching manner, like a Iark. He describes the note of this bird as a clear song of two or three notes, utterecl very distinctly, but without variety, - a very incomplete deseription.

Mr. Kennicott states that this species does not extend its migrations as far to the north as $Z$. gumbeli, and is even much less mumerous on the south shores of the Slave Lake, where he dicl not observe half so many of this as of the other. It also nests later, as he found the first nest observed on the 22d of June, with the exgs (puite fresh, incubation not having commenced, and found others after that date. On Euglish liver he found two nests with eggs on the 9th and 17 th of July, and one near the Cumberland House on the 30 th of Jume. Two of these were in low swampy ground among large trees, the other on high ground among small buslies. They were constructed on large bases of moss, and lined with soft grasses. When startled from her nest, the female always crept silently away through the grass.

He met with this speeies in considerable tlocks, accompanied by small numbers of Z. lcucophrys, on the north shore of Lake Superior, on the 11th of May. He saw individuals on the 29th of May, near the Lalie of the Woods, and it doubtless breeds as far sonth as that region. In the fall it was not seen at Fort Simpson later than the last of September. As it is a much more enstern bird than $Z$. gumbcli, it is probably in greater abundance on the eastern end of Slave Lake. Its song he regards as by no means so attractive as that of $Z$. gumbeli or of $Z$. leucophirys. Its general habits are very much like thuse of the former, and though by no means a strictly terrestrial bird, it rarely perches high on trees, and generally flies near the gromd, except in its long migratory flights. 


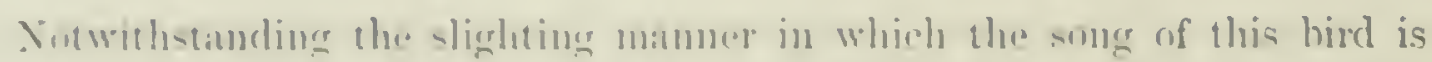

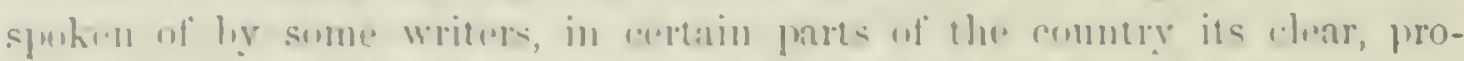

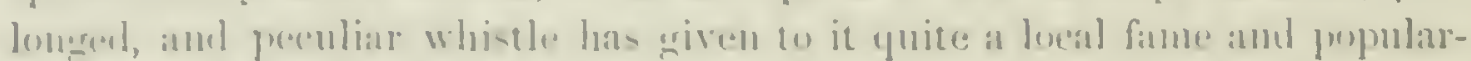

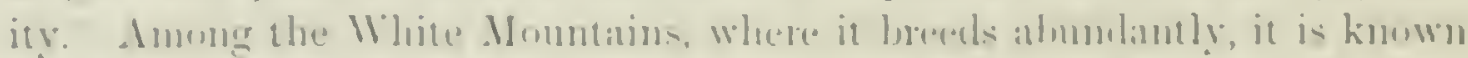

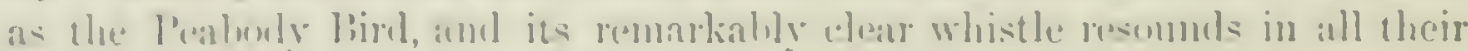

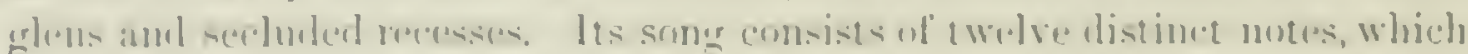

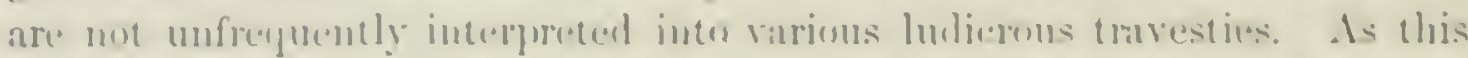

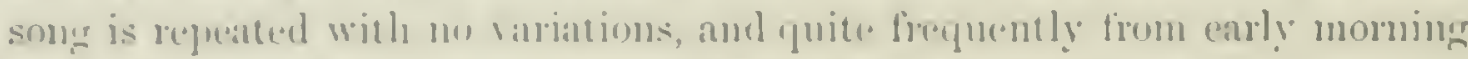

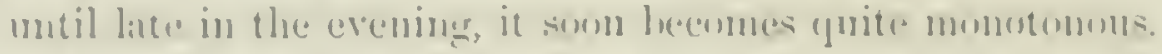

Among the White Mommtans I hare repeatedly fomm its mests. They

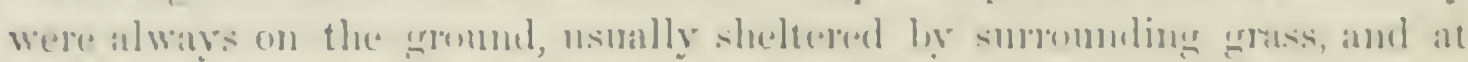
the fent of lushles or a tree, or in the wouds rumder a fillen log. In that

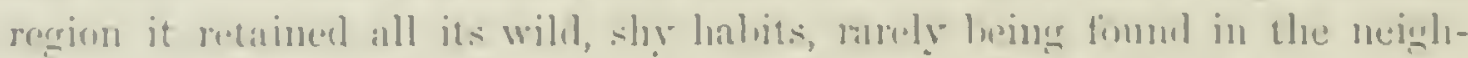

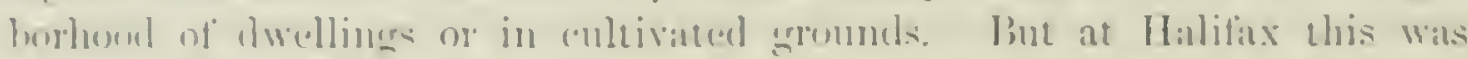

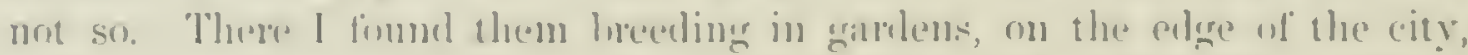

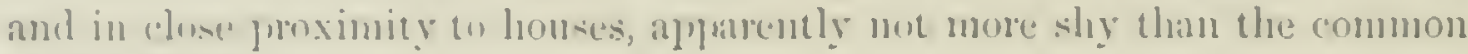
Song silntrow.

Wilson states that these limls winter in most of the states sonth of New

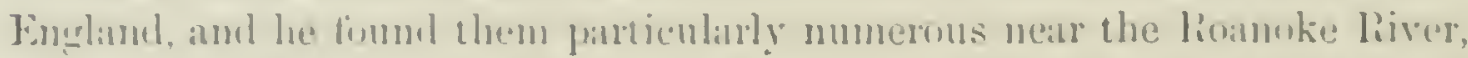
collecting in flocks on the borders of swammy thickets, anmenter lones mank werds, the seeds of which forment their principal foud. He gives the zoth

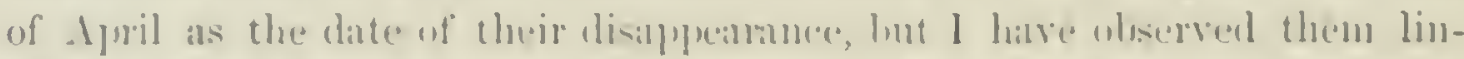

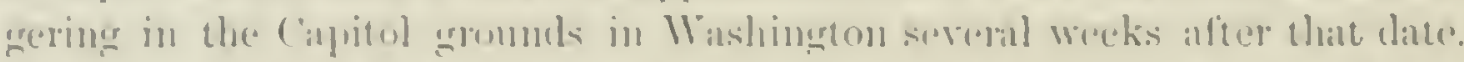

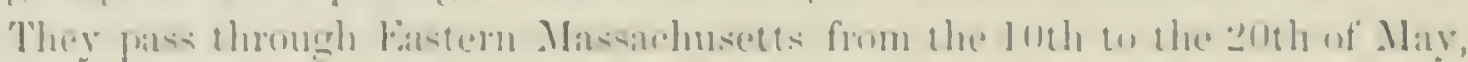

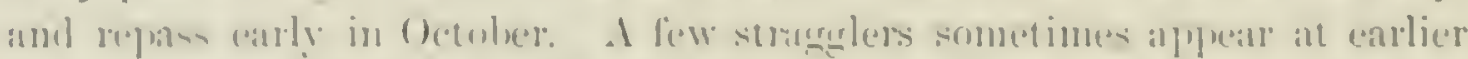

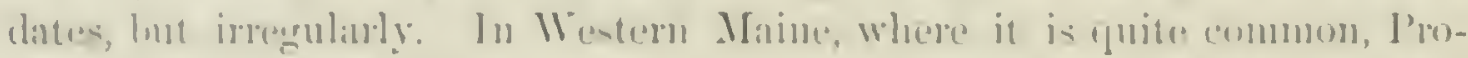

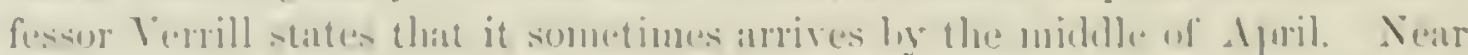

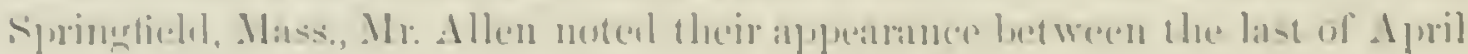

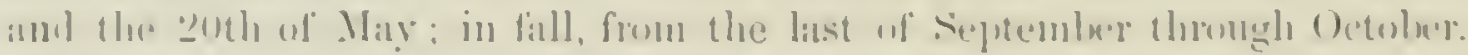

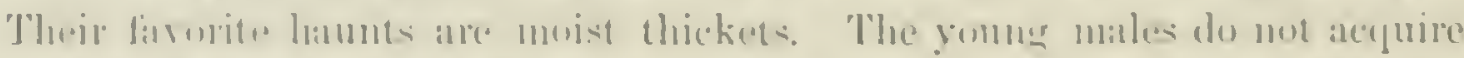

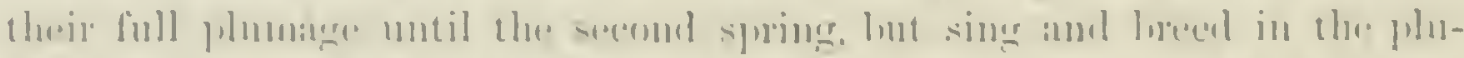

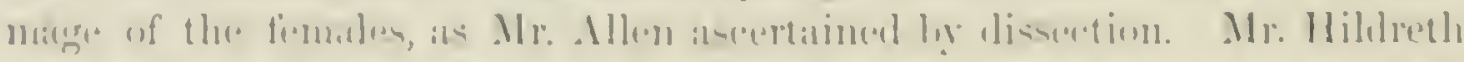

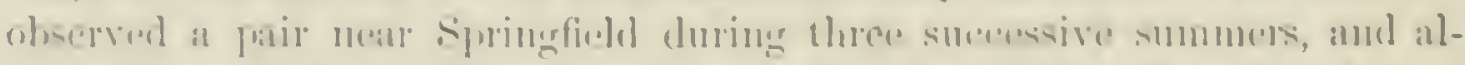

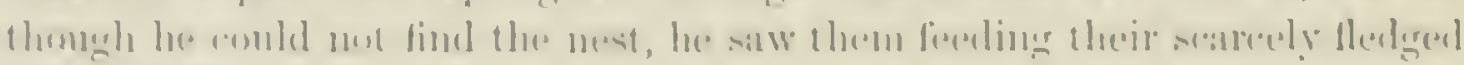
youller lirkls.

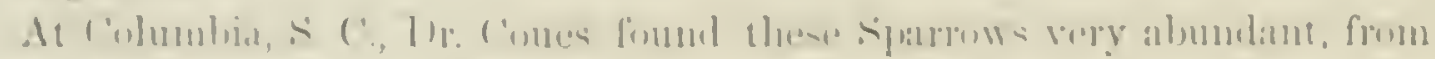
chaber thromele April They -ine, more or less, all winter, and during the

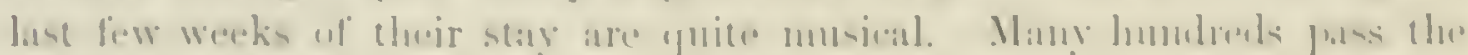

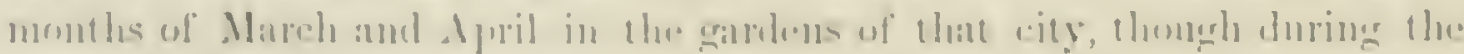

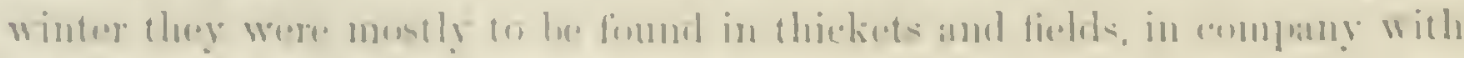

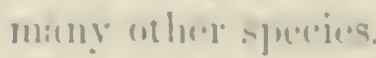

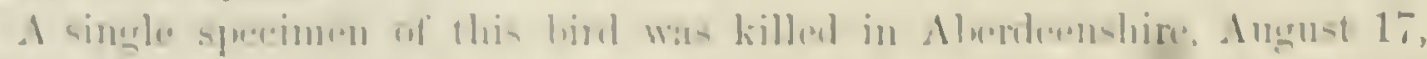

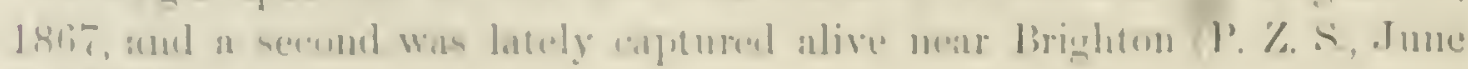
1. $18 \div \div)$ 
Mr. Audubon says that this hird visits Louisiana and all the Southern districts in winter, remaining from Norember to March, in great numbers. They form groups of from thirty to fifty, and live together in great harmony, feeding upon small sechs. At this time they are plump to excess, and are regarded as a great delicacy.

When kept in confinement these birls beeome quite tame, and in the spring will sing at all hours of the day or night.

The nest of this birl is usually, if not alway's, ou the ground, but in rarious situations, as I have foumd them on a hillside, in the milst of low underbrush, in a swampy thicket, at the foot of some large tree in a garden, as at Halifax, by the edge of a small poud, or in a hollow and decaying stump. Their nest is linge, deep, and capacions, with a base of moss or coarse grasses, woven with finer stems above and lined with hair, a few feathers, fine rootlets of plants or soft grasses. The eggs vary from four to seren in number. Their ground-color is of a pale green or a greenishwhite, marked over the entire og with a fox-colored or rusty brown. Ocensionally these markings are sparsely scattered, permitting the ground to be plainly visible, hut generally they are so very abundant as to cover the entire egg so closely as to conceal all uther shade, and give to the whole a deep uniform rufous-brown hue, through which the under color of light green is hardly distinguishable. They measure $.90 \mathrm{by} .68$ of an ineh.

\section{Zonotrichia querula, 'r.smbel.}

\section{HARRIS'S SPARBOW; BLACK-HOODED SPARROW.}

Fringillu querulu, NutTalu, Jan. I, (2) ed.,) 1840, 555 (Westport, Mo.). Zonotrichice querulu, Gondmel, J. A. N. Sc. 2l ser. 1, 1847, 51. - Boxal. Consp. 1850, 478. Batlid, Birls N. Am. 1S5s, 462. - Allex, Amer. Jatumlist, Ilay, 1872. Fringilla harrisi, Acu. Birds An. VII, 1S43, 331, pl. recelxxxir. Fringille comata, P1. Max. Reise II, 1841. - IB. Cab. Jour. VI, 1858, 279. Zonotrichin connete, BP. Consp. 1850, 479.

Sp. Cirar. Hood and nape, sides of head anterior to and including the eyes, cluin, throat, and a fer spots in the middle of the upper part of the breast and on its sides, black. Sicles of head and neck ash-gray. with the trace of a narrow crescent back of the ear-corerts. Interscapular region of back with the feathers reddish-brown streaked with dark brown. Breast and belly clear white. Sides of borly light brownish. streaked. Two narrow white bands across the greater and middle coverts. Length about 7 iuches; wing. 3.40 ; tail, 3.65 .

Hab. Missouri River, above Fort Learenworth. Chillicothe, Mo. (Hor). Tery common in Eastern Kansas (Alles). San Antonio, Texas, spring (Dresser, Ibis, 1865, 4S8).

The bill of this species appears to be yellowish-red. More immature specimens vary in having the black of the head above more restricted, the nape and sides of the head to the bill pale reddish-brown, lighter on the latter region. Others have the feathers of the anterior portion of the hood edged with whitish. In all there is generally a trace of black anterior to the ere. 


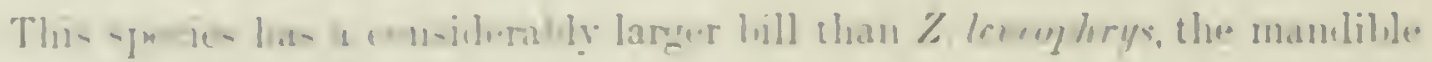
e-jerinll!

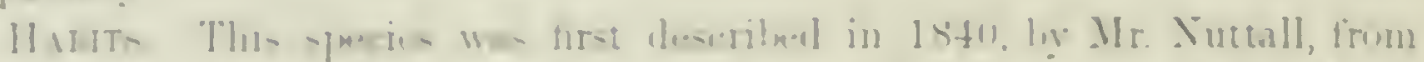

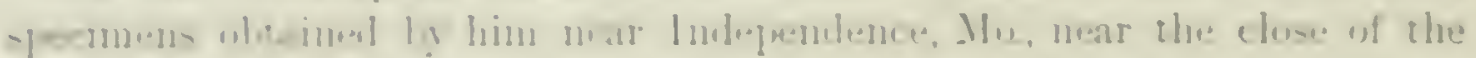

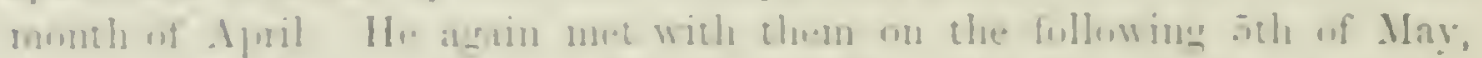

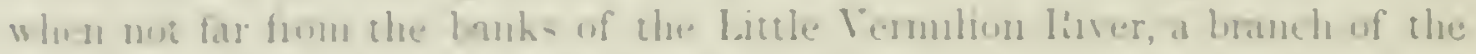

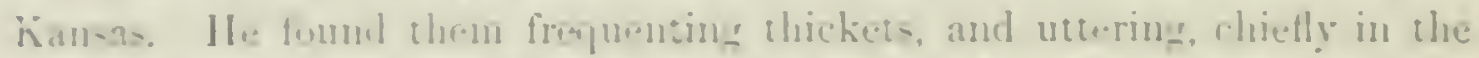

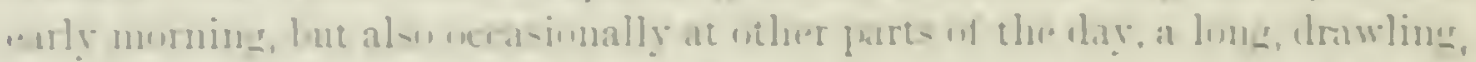

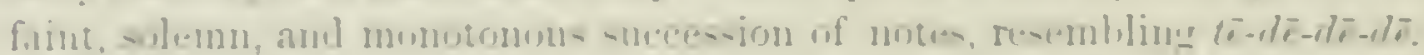

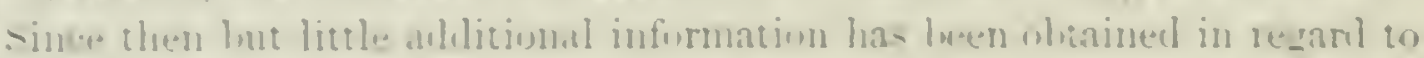

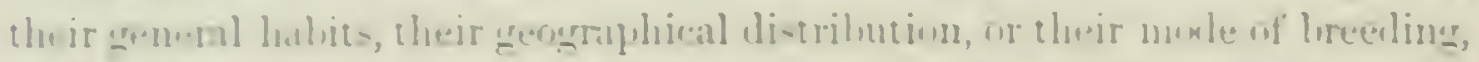

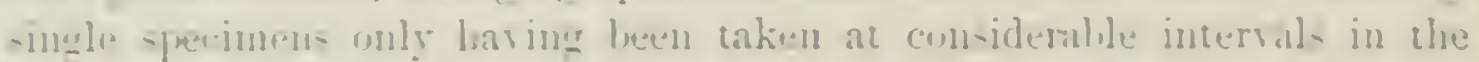
valley of the Mi-wari and elsewhere until 18T:-. Twu specimens were se-

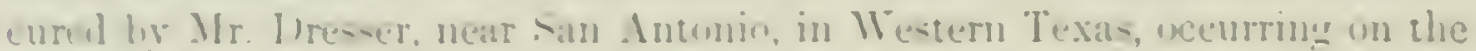

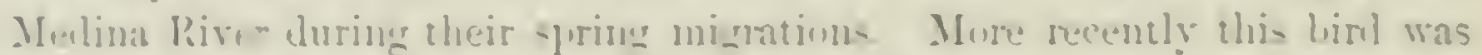
taken twice by Mr 11. W' l'arter, in . Ta-jer County, Iowa. The latest of there was securm! Maly $1 !$.

I'rotesso: I. H. Fum, in lis li-t uf hansas Jirels, published April, 197:2,

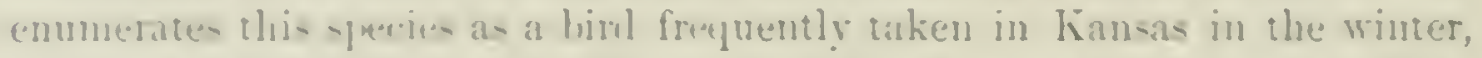

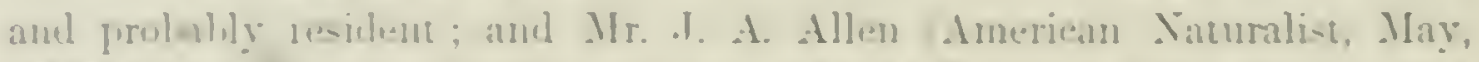

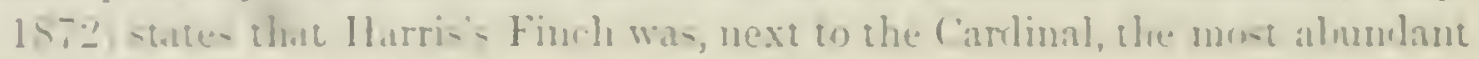

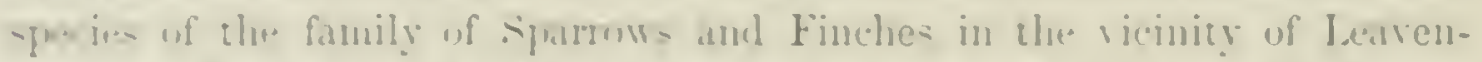

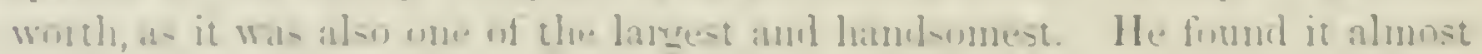

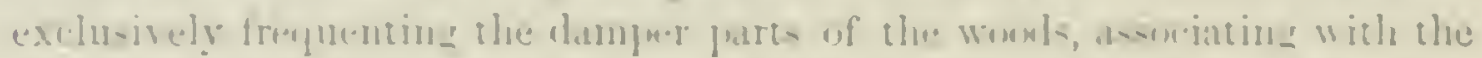

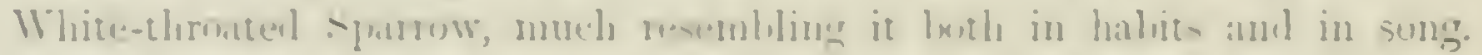

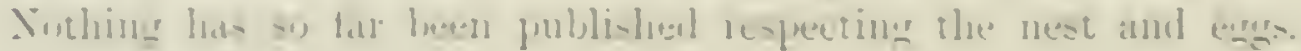

\section{CANL JUNCO,}

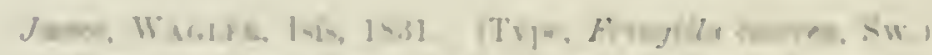

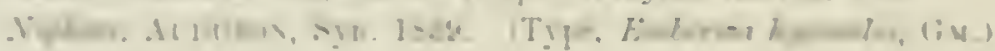

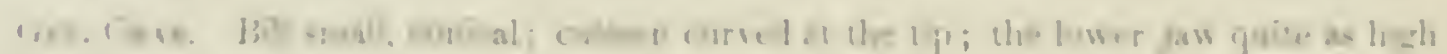

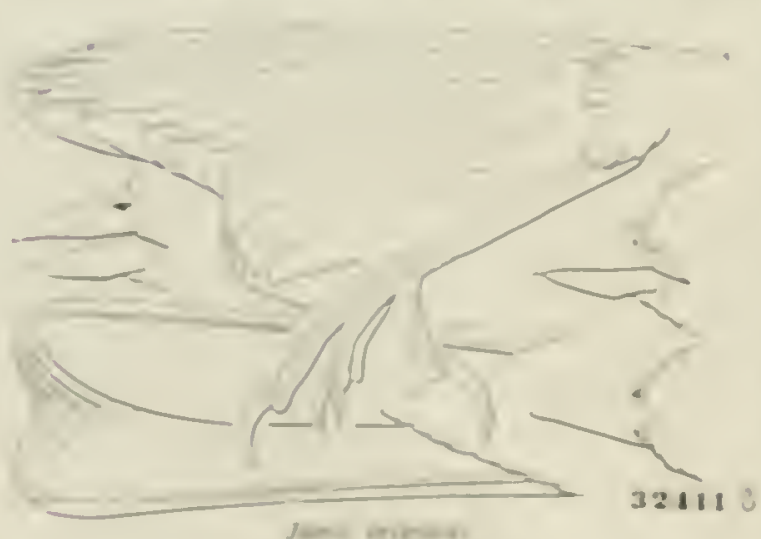

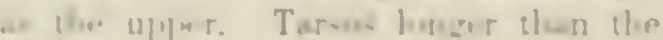

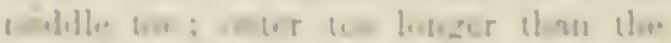

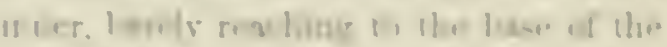

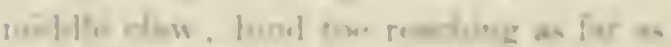

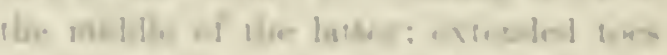
reste the shent th the sillle of the nal.

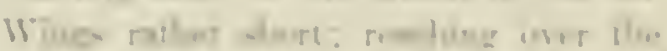

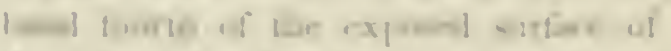

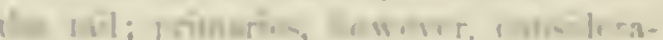
Mr I

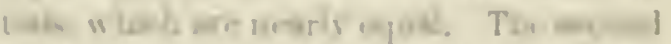

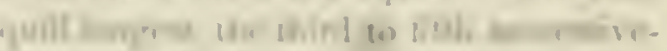

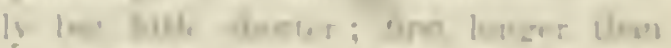

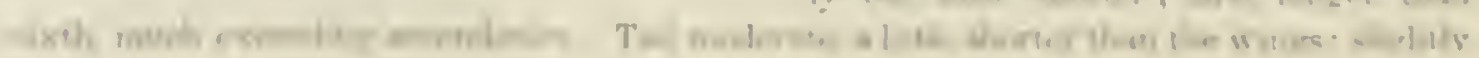


emarginate and rounded. Feathers rather narrow; oval at the cud. No streaks on the hend or body; color above uniform on the head, back, or rump, separately or on all together. Belly white; onter tail-feathers white. Young birds streaked ahove and below.

The essential characters of this genus are the middle toe rither slorter. than the short tarsus; the lateral toes slightly unequal, the outer reaching the base of the midclle claw; the tail a little shorter than the wings, slightly emarginate. In Junco cinereus the claws are longer; the lower mandible a little lower than the upper.

\section{Species and Varieties.}

Commos Characters. Prevailing color plumbenis: almomen, erissmm, and lateral tail-featlier's white.

A. Bill entirely light flesh-colored, dusky only at extreme point. Color of jugulum (deep ash or plumbeous-black) abruptly defines against the pure white of the abdomen.

a. Posterior ontline of the dark color of the jugnlum convex; sides pinkish.

1. J. oregonus. Back and wings more or less tinged with dark rusty, in sharp contrast with the black ( $\delta$ ) or asli ( $q$ ) of the head and neck. Hab. Pacific Province of Nortl America, from Sitka sonthward; cast across the Middle Province of United States, to the Rocky Mountains (where mixed with $J$. eaniceps ${ }^{1}$ ) occasionally to the Plains (where mixed with $J$. hyematis ${ }^{2}$ ).

๖. Posterior outline of the dark color of the jugulum concare; sides ashy.

2. J. hyemalis. Back and wings without rusty tinge.

Wing without any white; three outer tail-feathers only, marked with white. Bill, .40 and .25; wing, 3.10 ; tail. 2.80; tarsus, .80. Hab. Eastern Prorince North America. Straggling west to Arizona (Cotrs); in the northern Rocky Mountains, mixed with $J$ oregonus . . . . var.hyemalis. Wing with two white bands (on tips of middle and greater coverts); four outer tail-feathers marked with white. Bill. .50 and .30 ; wing, 3.40 ; tail, 3.20. Hab. High mountains of Coloralo (El Paso Co, Aikex) . . . var. cikeni.

3. J. caniceps. Back (interscapulars) rufons: scapulars and wings uniform ashy. Hab. Central Rocky Mountains of Lnited States. (Along scuthern boundary mixed with $J$. einereus. ${ }^{3}$ )

1 Hybrid hetween oregonus and coniceps, = "anneetens," Batur, Geol. Surv. Cal. Orn. I, P. 564 .

Cuar. Pinkish sides and convex outline to ash of breast, as in orcyonus, with the bright I'ufous back and ashy head, with black lores of eaniceps; a tendency in the rufous of back to tinge the wings, as in oregonus. Hab. Southern Rocky Mountains. (Fort Whiplple, Arizona, Corrs ; Fort Bridger, Wyoning, Drexler ; Fort Burgwyn, Mountains of Coloralo, Anex.)

2 Hybrid between hyemalis and oregonus.

CHar. Plumbrous back of hyemalis, with pinkish sides of oregonus; or else reddish back of oregonus and plumbeous sides of hycinalis, or colors mixed both above and below. Hab. Sun liver, Dakota ; McKenzie River District? Fort Whilple, Arizona ; and Fort Bridger, Wyoming.

${ }^{3}$ Hy-brid between caniecps and cinerens, $=$ "dorsalis," Hrakr, Pr. Phil. Ac. 1858, 117; Batrid, Birls N. Anı. 1858, 467.

Chap. Rufous restricted to interscapular region, as in the former, with black upper mandible, and pale ash throat of the latter. Hab. Fort Thorn, New Mexico. 
13. Inill with the upger mandible black, the lower yollow. Ash of the

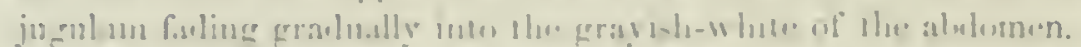

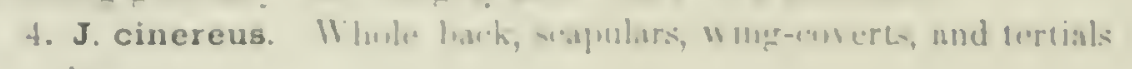
rulius.:

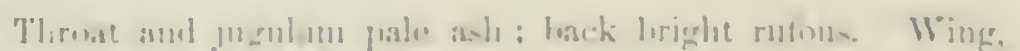

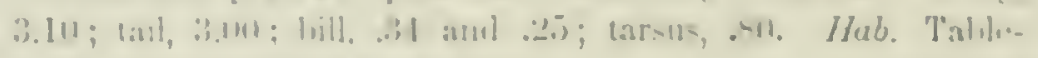

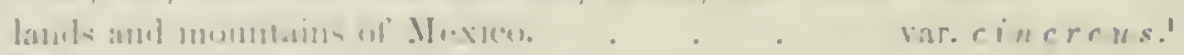

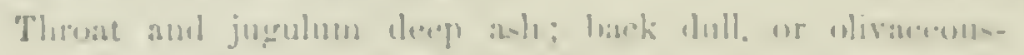

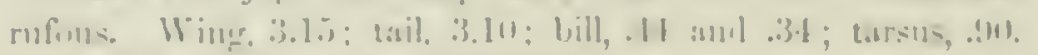

Hab. Hiph momutains of traturmala.

- var. allicula.

\section{Junco hyemalis, silltik.}

\section{SNOWBIRD.}

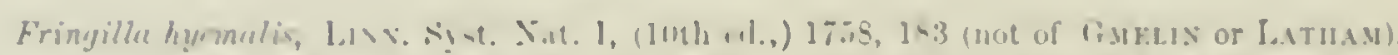

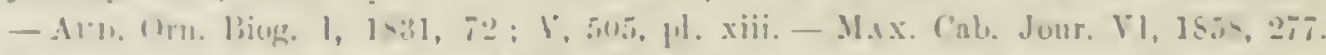

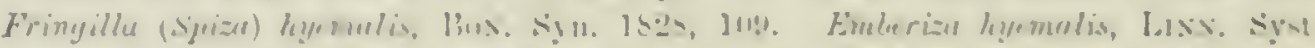

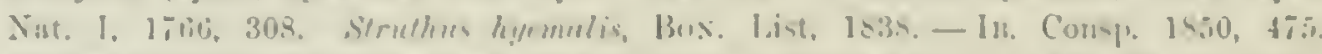

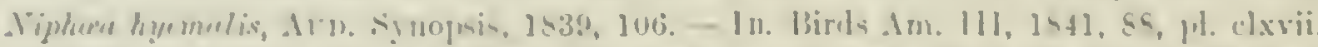

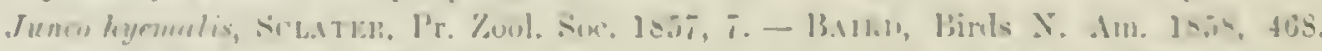

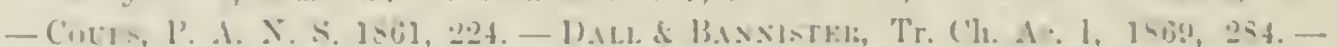

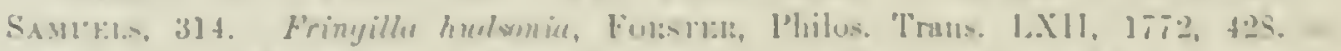

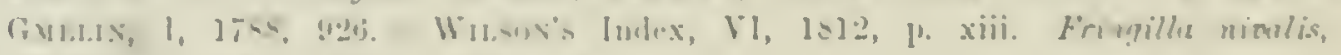

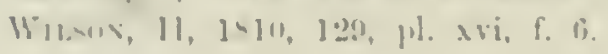

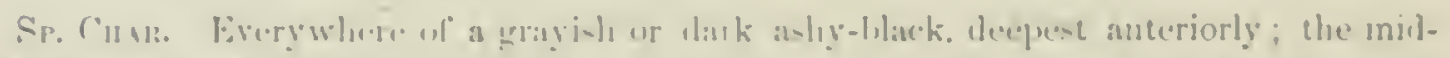

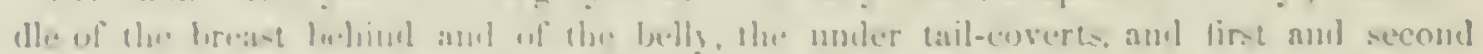

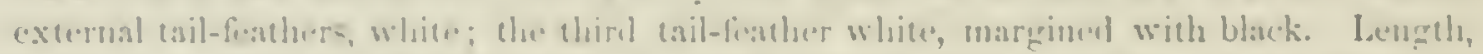

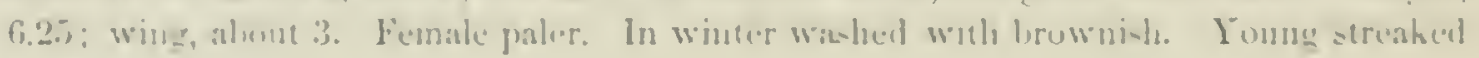

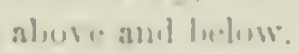

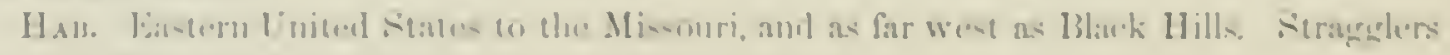
at Fort Whipple, driknsa, aml mumutains of Colurato.

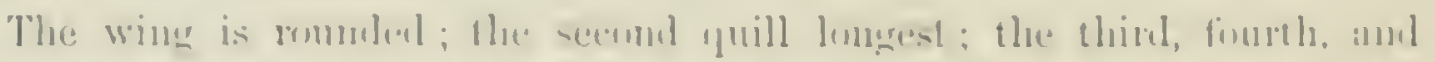
fifth, suremively, a litte shorter; the first lemerer than the sistlo. Tail

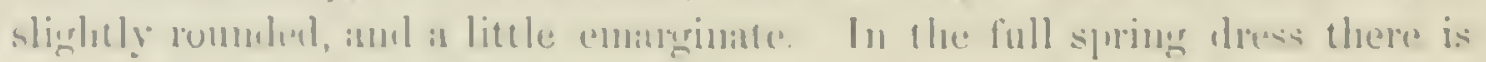

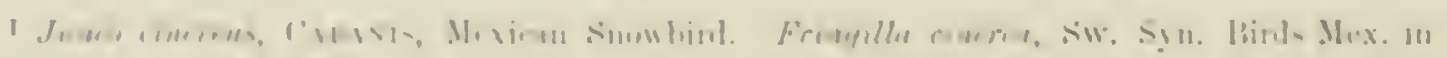

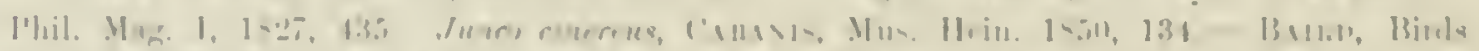

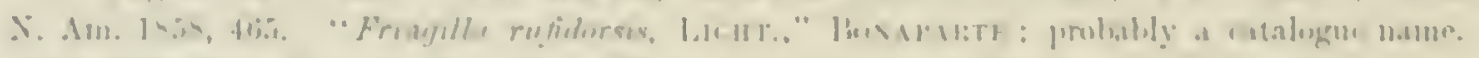

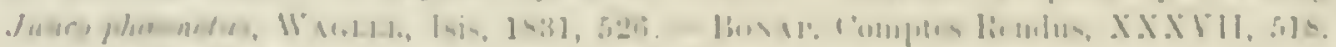

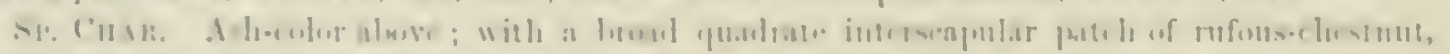

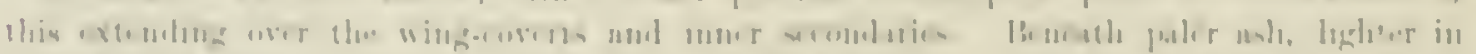

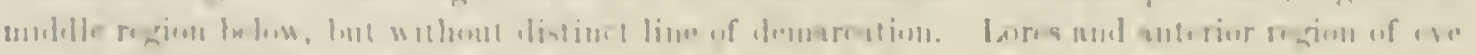

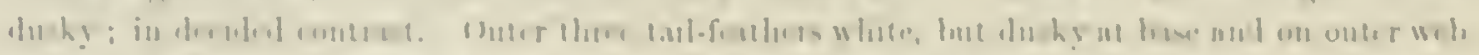

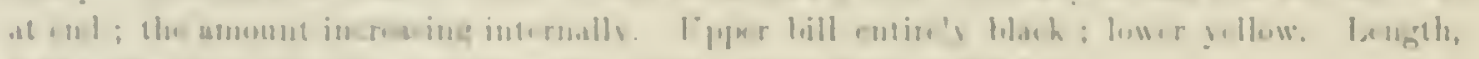

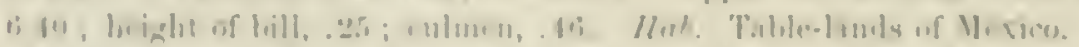

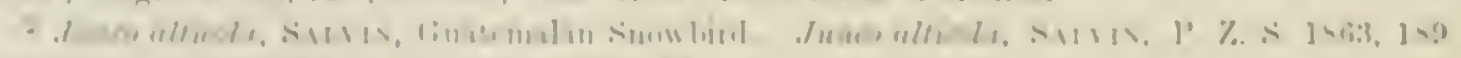

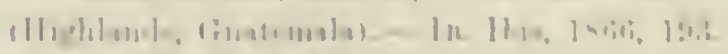

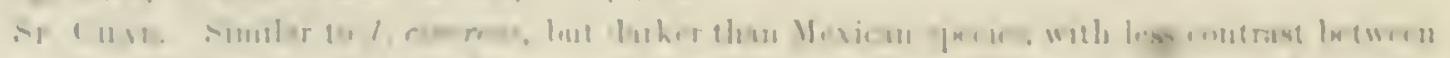

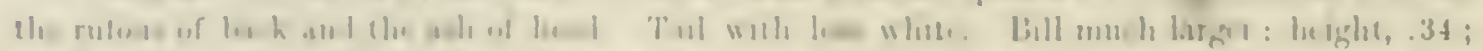

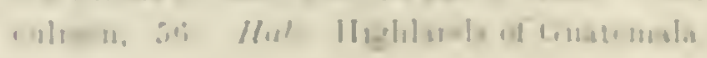


no trace of any second color on the back, except an exceedingly faint and scarcely appreciable wash of dull brownish over the whole upper parts. The markings of the third tail-feather vary somewhat in specimens. Sometimes the whole tip is margined with brown; sometimes the white extends to the end; sometimes both webs are margined with brown; sometimes the outer is white entirely; sometimes the brownish wash on the back is more distinct.

Some specimens (No. 52,702 and 52,701, males) from Sun River, Dakota, appear to be hybrids with oregonus. They have the general appenrance of hyemalis, the back being nearly uniform with the hear (with

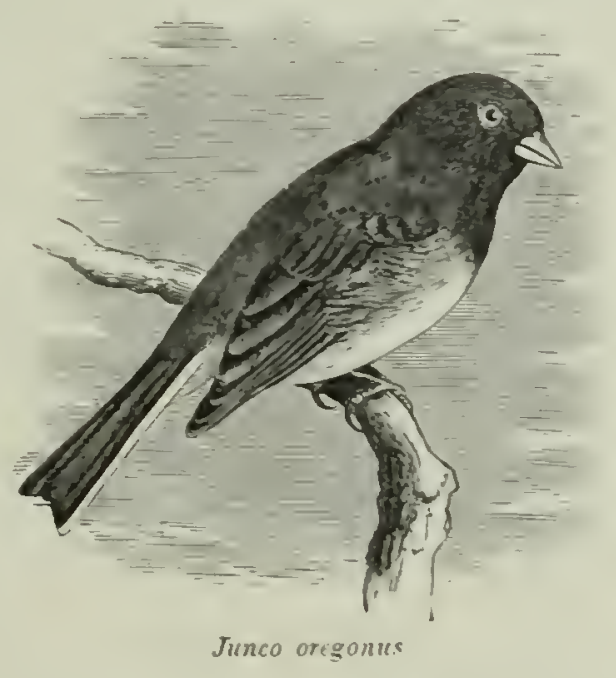
a wash of sepia-brown, however), and the head and neck of the same dark plumbeous; the sides, however, are pinkish, and the plumbeous on the jugulum has its posterior outline convex, as in oregonus. If, as there is every reason to believe, these specimens are really hybrids, then we have the two extreme forms of the genus connected by specimens of such a condition; thus, hycmalis with oregonus, oregonus with caniceps (=annectens, Baird), and cuniceps with cinereus (= lorsalis, Henry). It may perhaps be considered a serious question whether all (including alticola) are not, in reality, geographical races of one species. However, as there is no possibility of ever proving this, it may be best to consider them as representative species, and these specimens of internediate characters as liybricls.

Habits. The common familiar Snowlird of the Eastern States is found throughout all North America, east of the Black Hills, from Texas to the Arctic regions. Wherever found, it is at certain seasons a rery abundant and an equally familiar bird.

It nests as far south, in mountainous regions, as Virginia, and thence to New York and the northern parts of the New England States, lireeding only in the highlands, but descending more and more into the plains as we proceed north. As it is a very hardy bird, its migrations are irregular and uncertain. In some seasons I lave observed but few at irregular intervals; and in others, in which the spring was cold and hackward, I have met with them in every month except July and August.

Mrr. Kennicott found but few birts of this species l,reeding as far south as Fort Resolution or Slave Lake, and was unalle to find any of their nests, though he met with a few birds that were evidently breeding there. He found it afterwards nesting in the greatest abundance about latitude $65^{\circ}$. They were very numerous on the Yukon, and Mr. MacFarlane found them breeding plentifully on the Anderson River, at the etge of the barren-ground region. 
There nests found lye Mr. Kembute were all on the ground, more or lese

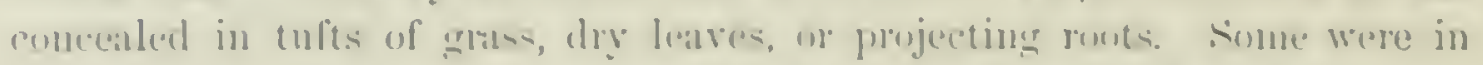

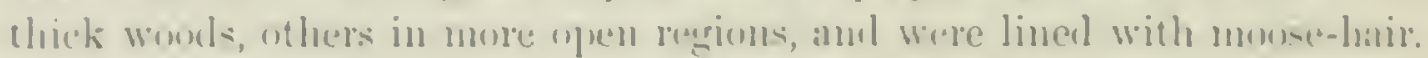

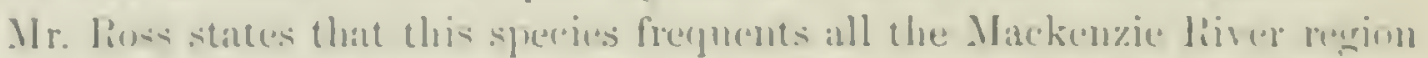
in summer, arriving almut the -2uth of . I pril, and leaving alwout the loth of Octoher. Lemiles its call-mote, on chirp, it has a very pretty sime.

Mr. Dall also remarks that thy were puite common at Nolatn in the spring, not aryiving there, however, nutil about the first of June.

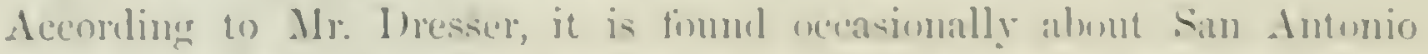
in winter, and Ir. Wowdlouse salys that it is also common in the Indian Territory in fall and winter. Aceording w Mr. Audubum, it makes its appearance in Ionisiana in November, and remains there until early sprims. It is also abundaut in South ('arolina, arriving there in october and leaving in . 1 prit.

This species was observed hy. Mr. Aiken in Colomatn Territory for ahout three weeks following Mareh 201 , after which they were seen no more.

It lareds more or less abundintly in the northeru and castern portions of Matine. Aheut ('alais and in all the islands of the bay of leundy, and througlume New Brunswick and Nova Scotia, I foumd this ly fir the most common and faniliar species, especially at l'icton, where it alumnded in the sardens, in repeated instances coming within the outhuildings to hild its nests. In a worndied connected with the dwelling of Mr. Inawson, ny attention was eallent to the nests of several of these hirds, luilt within reach of the hand, and in flaces where the fannily were passing and repassing

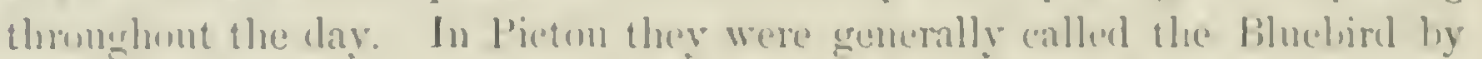
the common perople. On my ride from Ilalifix to l'ietnu, I also found these livis hreeding lye the roadside, often under the shelted of a projecting lank, in the manner of the I'tsestrulus saranm. I afterward found them nesting in similar situations among the White. Inuntains, the roadsides seeming tu

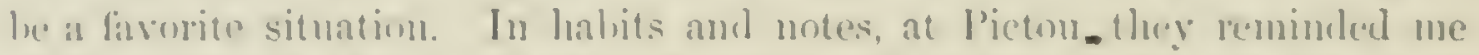

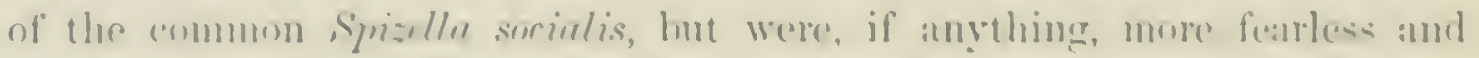
entidinge coming into the rom where the farmily were at their meals, and only flying away when they had securent a crumb of sullecent size.

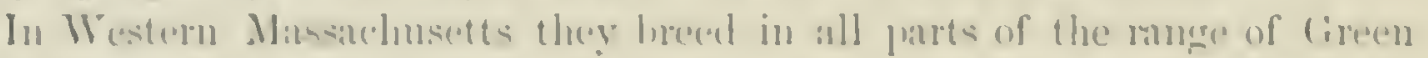

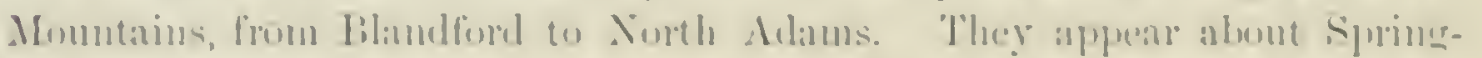

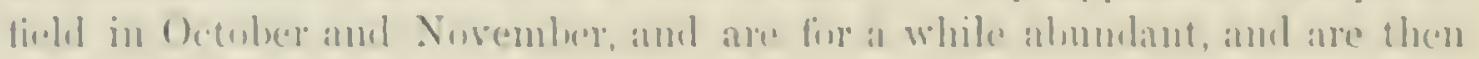

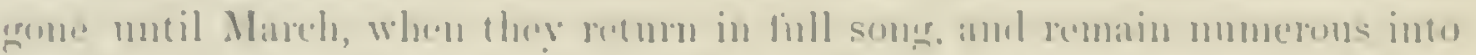
A mil, and less common mutil into May. In the castem pant of the sinte

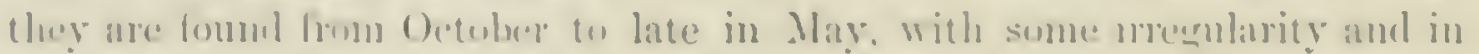
varying mumber. Mr. Amblubum did not ment with any on the colan of

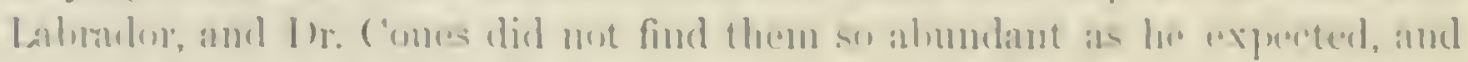

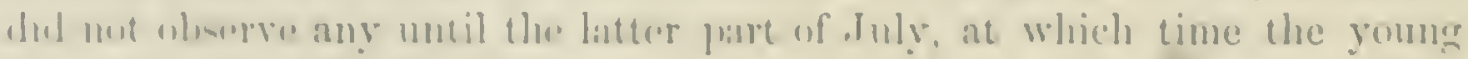

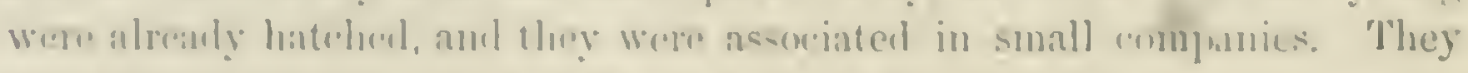

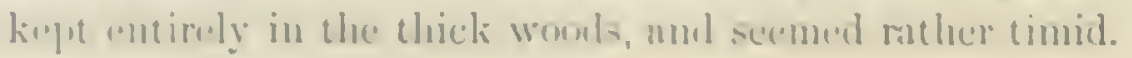


Their food is small berries, seeds of grasses and small plants, insects, and larre. 'They seek the latter on the gromul, and in the winter are said to frequent the poultry-yards, and avail themselves of the services of the fowls in turning up the earth. On the ground they hop about in a peculiar manner, apparently without moving their feet. At night and during storms they shelter themselres in the thick branches of evergreens, and also in stacks of hay and piles of brushwood.

During the winter the Snowbird appears to be ratler more numerous in the Middle and Sonthern States than in New England. In the former they appear late in October, at first on the borders of woods, searehing for food among the fallen and decaying leaves. Later in the season, as the weather becomes colder, and the snow deprives them of this means of feeding, they resort to the roadsides and feed on the seeds of the taller weeds, and to the farm-houses and farm-yards, and even enter within the limits of large cities, where they become very tame and familiar. They are much exposed to attacks from several linds of Hawhs, and the apparent timidity they erince at certain times and places is due to their apprehensions of this danger. The sudden rustle of the wings of a harmless fowl will cause the whole Hock to take at once to flight, returning as soon as their alarm is found to be needless, but repeated again and again when the same dreaded sounds are heard.

Neither Wilson, Nuttall, nor Audubon appear to have ever met with the nests or eggs of this bird, though the first met with them breeding both among the Alleghanies, in Virginia, and the highlands of Pennsylrania and New York. In Otsego County, in the latter State, Mr. Edward Appleton was the first to discover and identify their nest and eorgs, as cited by Mr. Audubon in the third volume of his Birds of America. They were found in considerable numbers in the town of Otsego. Their nests were on the ground in sheltered positions, some of them with covered cntrances. Their complement of eggs was four. One of their nests was sent me, and was characteristic of all I have since seen, having an external diameter of four and a half inclies and a depth of two. The cavity was deep and capacious for the bird. The base and periphery of the nest were made of slender strips of bark, coarse straws, fine roots, and horsehair, lined with fine mosses and the fur of smaller animals. The eggs were of a rounded-oval shape; their ground-color is a creamy yellowish-white, marked with spots and blotches of a reddish-brown confluent around the larger portion of the egg, but rarely covering either end. They measure .75 by .60 of an incl, not varying in size from those of $J$. oregonus. 
Junco hyemalis, r.⿲: aikeni, liın:lir. WHITE-WINGED SNOWBIRD.

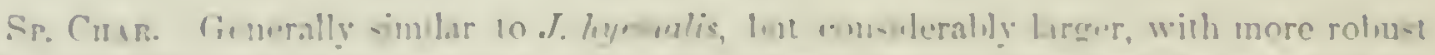

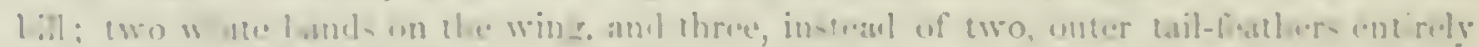

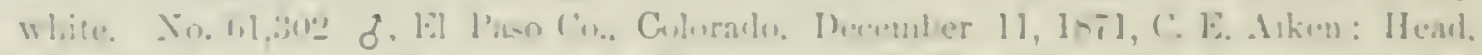

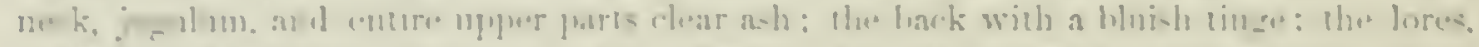

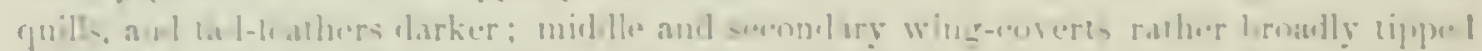

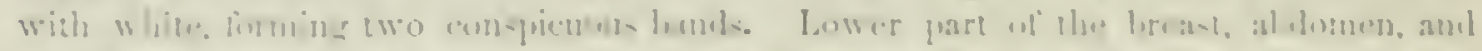

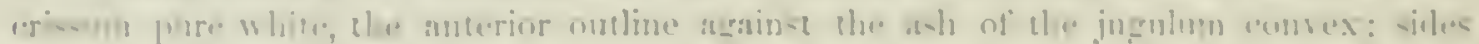

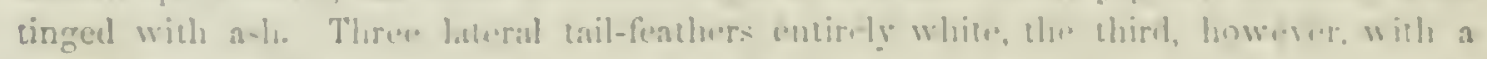

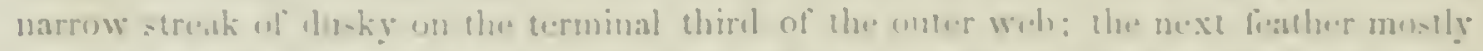

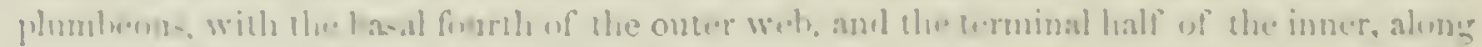

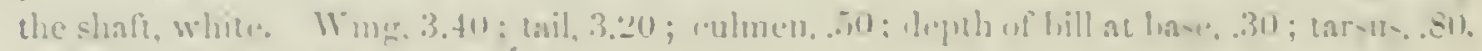

H.sB. El I'a-1 Colubly, Colorado.

It tirst sight, this lird appears to le a very distinet species, Ineing larger

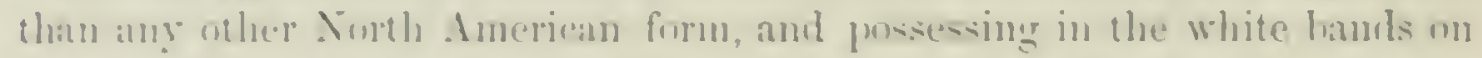

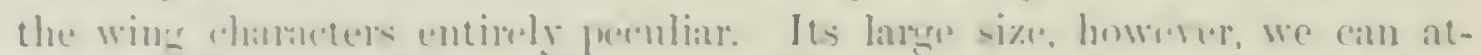

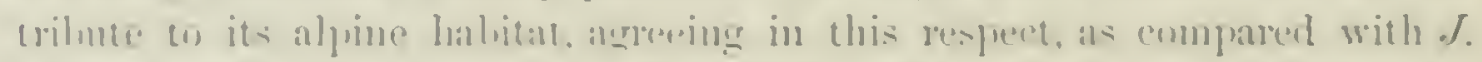

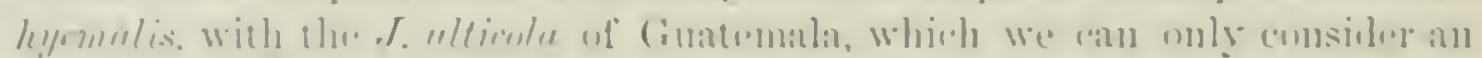

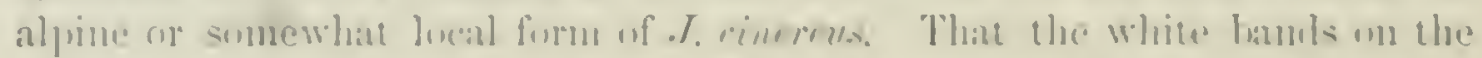

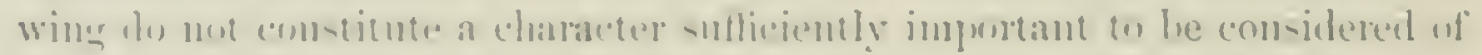

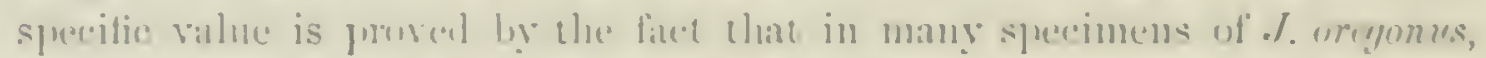

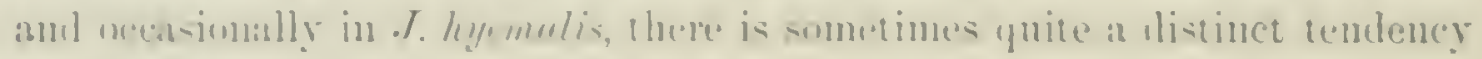

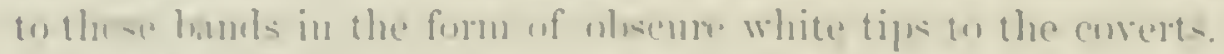

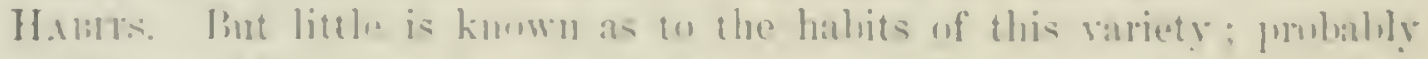
they de mot ditlier from thuse of its ampeners. It was met with hy Mr.

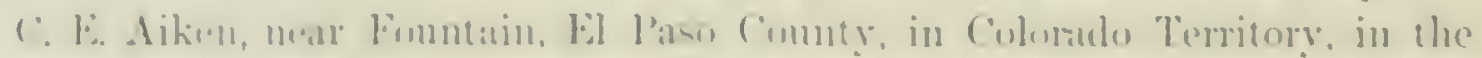

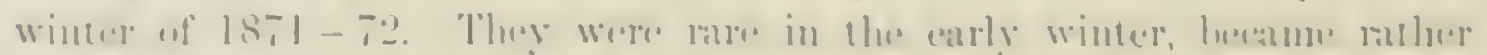

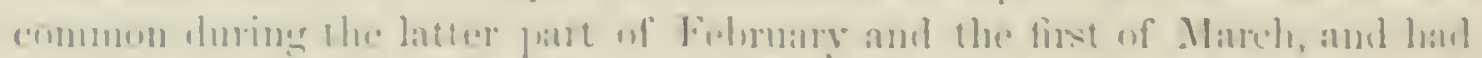

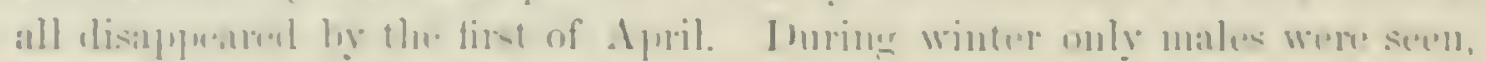

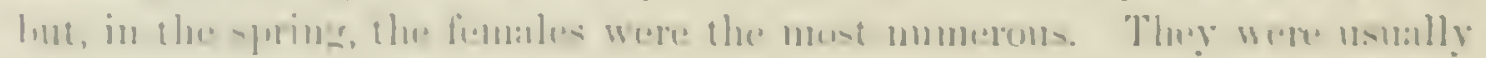

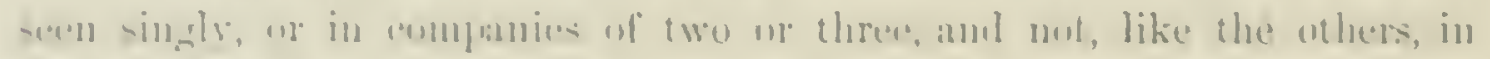
larert lluctis.

\section{Junco oregonus, siatris.}

\section{OREGON SNOWBIRD.}

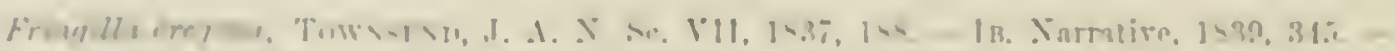

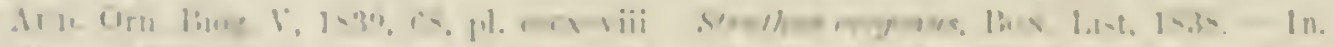

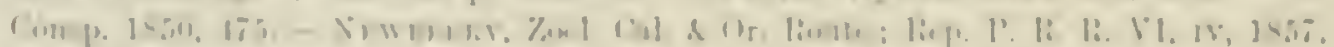

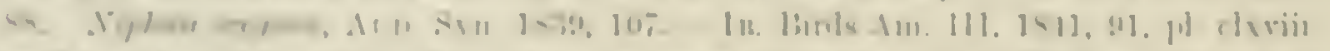

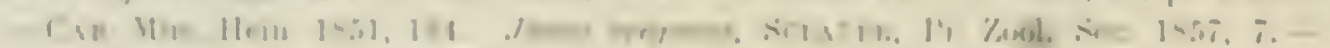

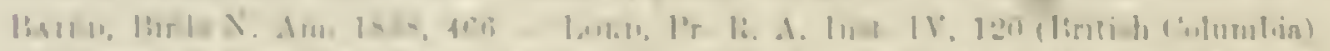

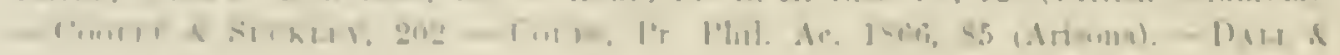


Basxister, Tr. Ch. Ac. I, 1569, 254. - ('m) Per, Orn. ('al. I, 199. Fringilla hudsoniu, Licut. Beit. Fann. Cal. in Alh. Akad. Wiss. Berlin, for 183s, 1539, 424 (not $F$. hudsonia, Forsten). "Fringille alrata, Bravit, Icon. Rosso-As. tah. ii, f. 8 " (CAB.).

Sp. Char. Head and neck all lound sooty-black; this color extending to the upper part of the loreast, but not along the sides undel the wings, and with convex ontline behind. Interscapular region of the back and exposed surface of the wing-corerts and seconlaries dark rnfons-brown, forming a square patch. A lighter, more pinkish tint of" the same on the sides of brenst and belly. Rest of uncler parts clear white. Rump brownish-ash. Lpper tail-coverts dusky. Outer two tail-feathers white; the third with only an obscurc streal of white. Bill flesh-color, dusky at tip. Legs flesh-color. Leugth about 6.50 inches; wing, 3.00 .

Hab. Pacific coast of the United States to the easteru sidr of the liochy Momntains, and north to Alaska. Stragglers as far east as Fort Leavenworth in winter and Great Bend of Missouri.

Sitka and Oregon specimens hare the back of a darker rufous than those from California and the Middle Province, in which this portion of the body, as well as the sides, is paler, and in more ahrupt contrast with the head.

Immature and the majority of winter specimens do not hare the liack of the head and neck so well defined, hut edged above more or less with the color of the back, below with light ashy.

The Oregon Snowbind in full plunage is readily distinguishable from the eastem species by the purer white of the belly; the more slarply defined outline of the black of the head passes directly across the upper part of the breast, and is eren convex in its posterior ontline, without extending down the side of the breast, with its posterior outline strongly concave, as in hyemalis. The absence of black or asliy-lurown under the wings, with the pufous tinge, are highly characteristic of orryonus. The head and neck are considcrably blacker; the rufous of the back and wings does not exist in the other. The wings and quills are more pointed; the second quill usually longest, insteact of the third, etc. The dusky of the throat reaches in J. oreyonus only to the upper part of the breast; to its ruidulle region in hypmulis.

Sonnetines, in adult males, the middle and greater wing-coverts are faintly tipped with white, indicating two inconspicuous bands.

In a large series of Juncos collected at Fort Whipple, Arizona, hy Dr. C'oues, are several specimens so decidedly intermediate between $J$. oregonus and $J$. cuniceps as to suggest the probability of their being hybrids; others, from Fort Burgwrn and Fort Bridger, are exactly like them. With the aslyy head and jugulum, and black lores, as well as bright rufous back, of the latter, the sides are pinkish as in the former; while, as in this too, the posterior ontline of the ash on jugulum is convex, not concare, and the rufous of the hack has a tendency to tinge the wings, instead of being confined to the interscapnlars. (See foot-note to synoptical table, p. 579.)

Habits. Dr. Suckley found this bird extremely abundant in Oregon and Washington Territory, where it holds about the sane position that the hye- 


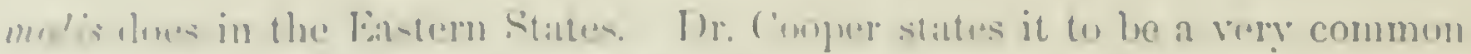

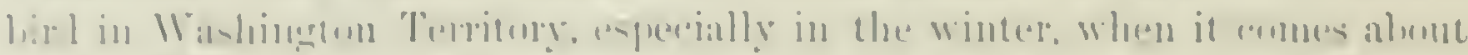

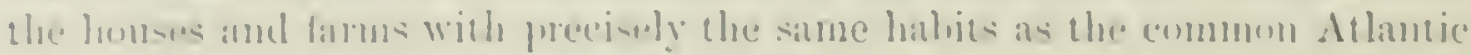

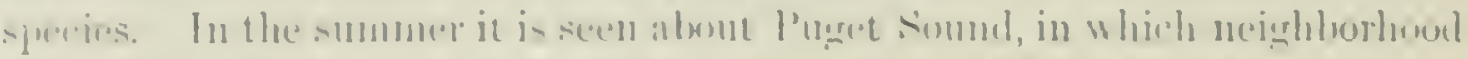

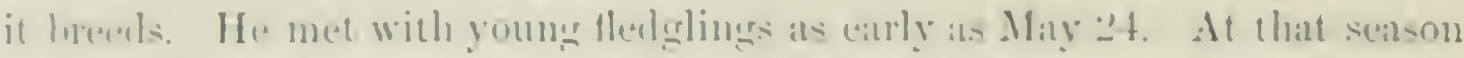

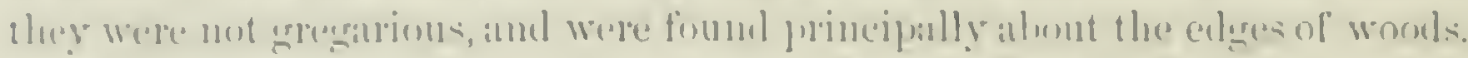

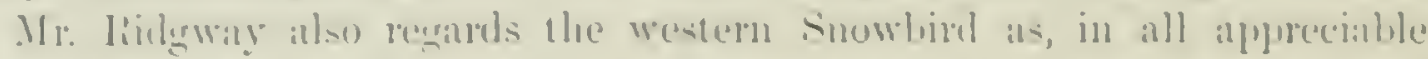

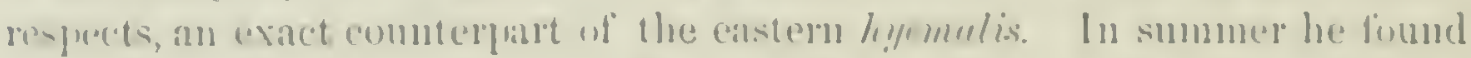
it inhalintine the pine wouls of the mombans, hut in wintor descending to lle lowlands, and entering the towns and gardens in the same mamer with

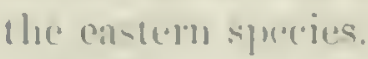

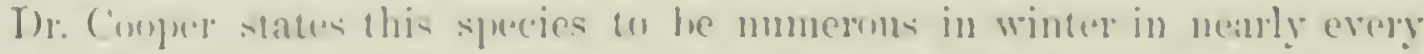

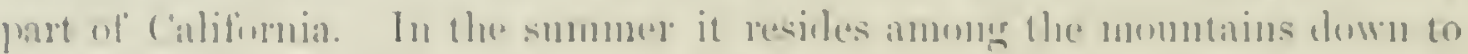

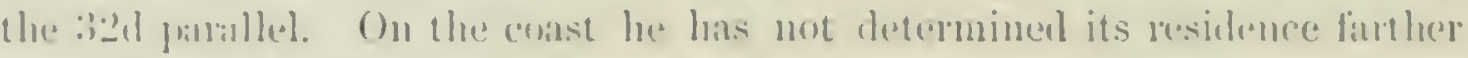

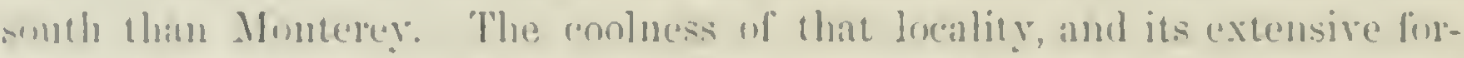
ests of pines extemeting to the eonst, laver the residence of such hirts during the smmmer. At sim bieng he olserved them until the first of April, when

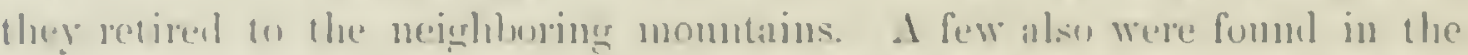
colomelu balley in the winter. On the Cuast Mountains sonth of sinta ('lana he fomml them hreeling in laree munbers in May, listit. One nest enntainer yomm, just realy on 1 ly, as early as May $1:$. This was huilt in a

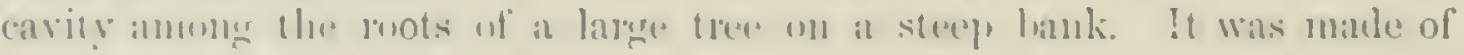

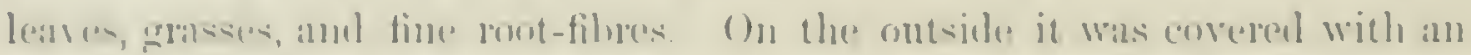

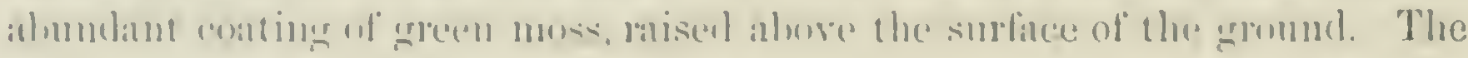

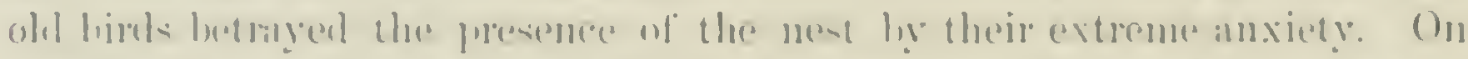

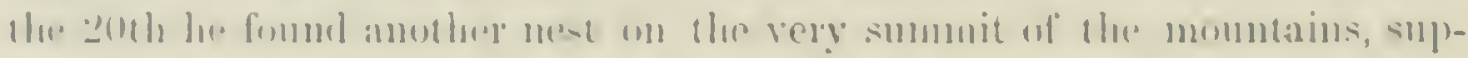

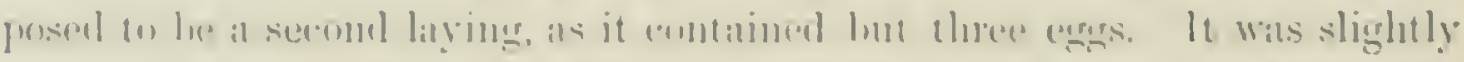

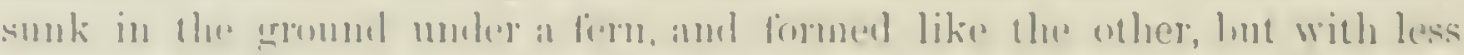

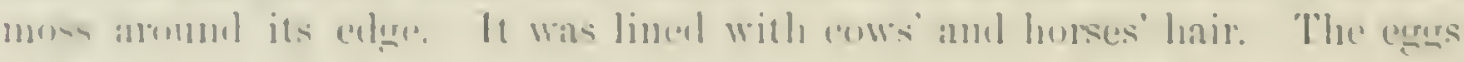

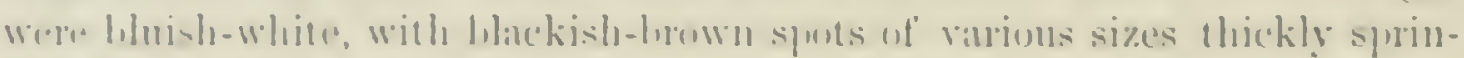

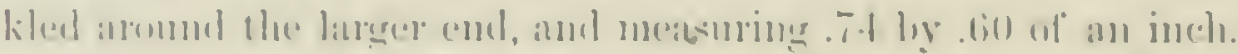

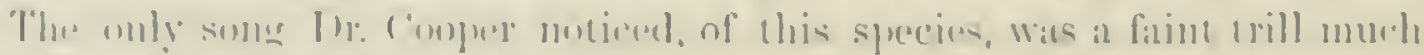

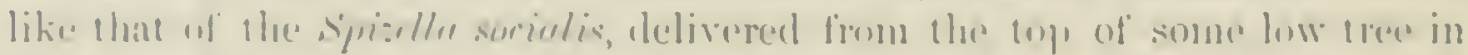

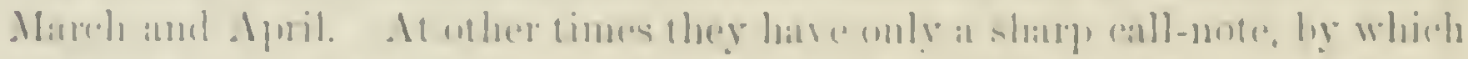

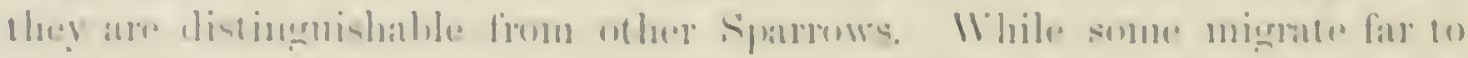

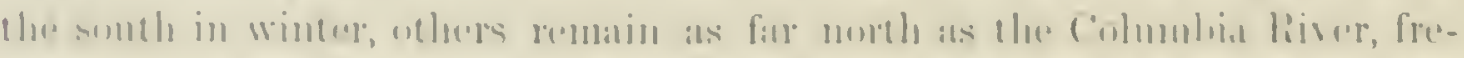

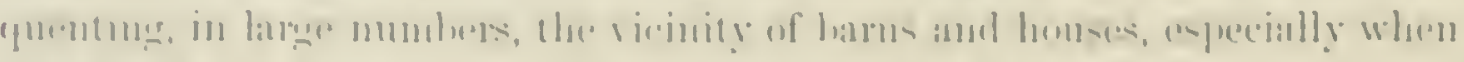

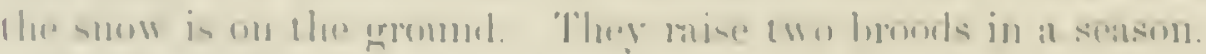

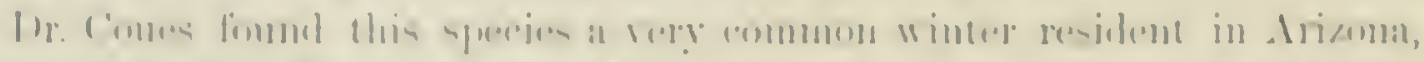

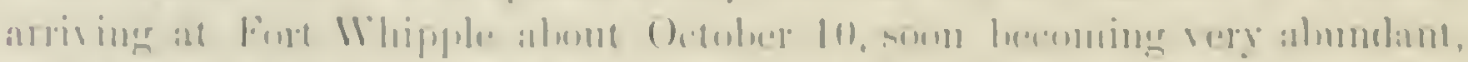

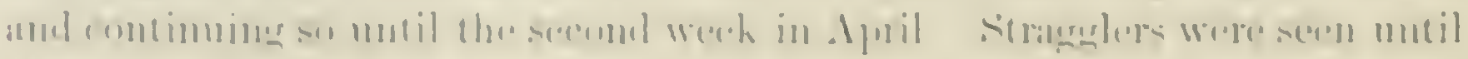
$.11: 111$.

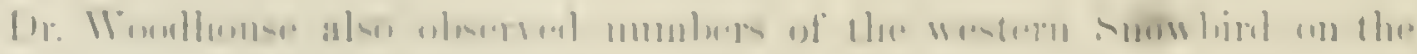

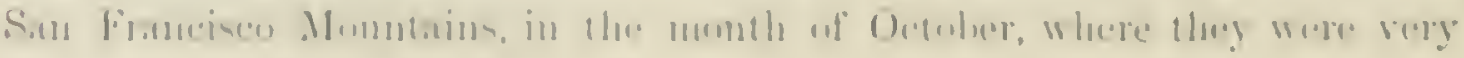


abundant. Many specimens were obtained in Sitka by Mr. Bischoff. None have so far been recorded from the Aleutian Islands.

I)r. Kennerly frequently saw these birds near the Pueblo of Zuñi in New Mexico; in the months of October and Norember they were very abundant among the cedars to the westward of that settlement as far as the Little Colorado. Dr. Heermann also met with them near Fort Yuma in December, having previously noticed them during the fall, nigrating in large Hocks.

Mr. Aiken frequently found this species throughont the winter in Colorado. It was very common during March and the first of April. By May only a few straggling females were seen, and then they all disappeared.

The nests of this species have a greneral resemblance in structure to those of the common hycmalis. They are well constructed and remarkably symmetrical, made externally of mosses and other coarse materials, within which is rery nicely woven an inner nest of fine, bent stems of grasses, linerl with hair. The egres, four or five in number, resemble those of the hycmalis, but are lighter. They have a ground-color of greenish-white, marked abont the larger end with fine dots of reddish-brown. Their measurement is .75 by .60 of an inch.

\section{Junco. caniceps, BiIrD}

RED-BACKED SNOWBIRD.

Struthus caniccps, Woodhotse, Pr. A. X. Ac. Phila. VI, Dee. 1\$52, 202 (New Mexico and Texas). - IB. Sitgreares's Report Zuni \& Colorado, 1853, \$3, pl. iii. Junco caniceps, BAIrd, Birds I. Am. ISjS, 46\$, pl. Lxii, f. 1. - Conper, Orn. Cal. I, 201.

Sp. Chır. Bill yellowish: hlack at the tip. Abore astr (of the sanne shade before and behind); the head and neck all round of this color. which cstends (paling a little) along the sides, leaving the middle of the belly and cris-mm quite abruptly white. Lores conspicuously but not rery abruptly darker. Interseapular region abruptly reddish chestnut-brown, which does not extend on the riugs, aud makes a triangular patch. Two outer tail-feathers entirely white; third with a long white terminal stripe on the inner web. Foung streaked with blackish abore and below; cxcept along midale of belly and behind. Length, 6.00 ; wing. 3.23 ; tail, 3.04 .

HAB. Rocky Mountains; from Black Hills to San Francisco Mouutains, Arizona. Wahsatch and Uintah Mountains (RiDGWAr).

This species is similar to the common $J$. hycmalis in color, though paler; the tint of the under parts and sides is not quite so dark, and is less abruptly defined against the white. The conspicuous chestnut patch on the back and the dusky lores will distinguish them. The edge of the outer web of the third tail-feather is brown, not white. It differs from oregonus and cincreus in haring no chestnut on the wings, especially the tertials, and from the former in the extension of the ash of the neck along the sides and much lighter head.

Young birds are streaked above and below as in other species; they may be distinguished from those of cincreus by the rufous being confined to the interscapular region, the same as in the adult. 


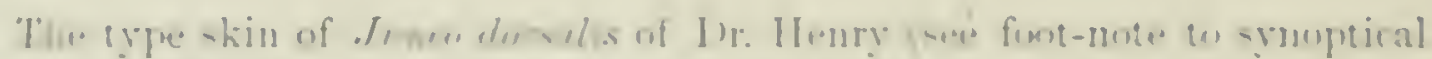

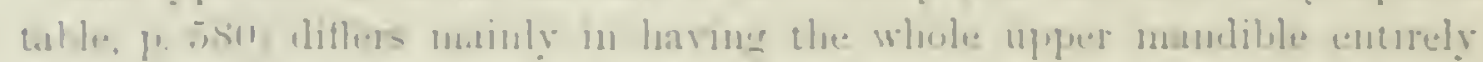

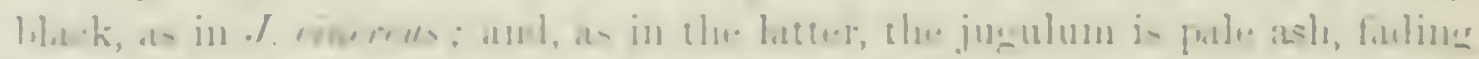

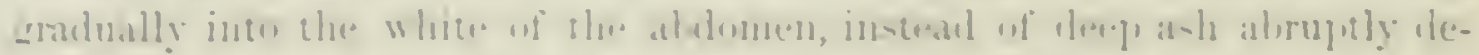

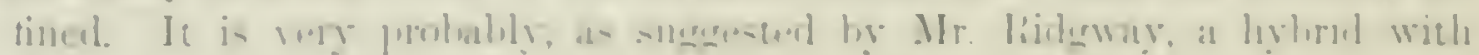
I. rinorrus

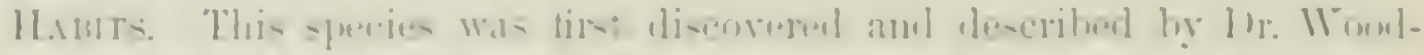

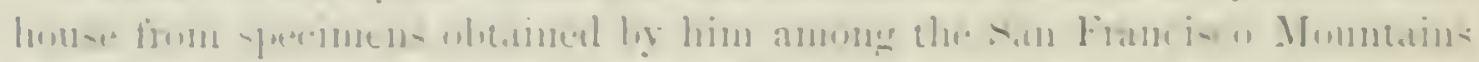

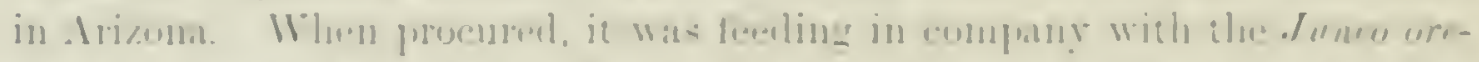

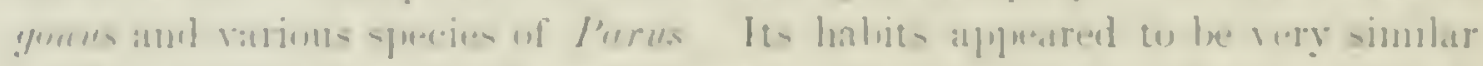

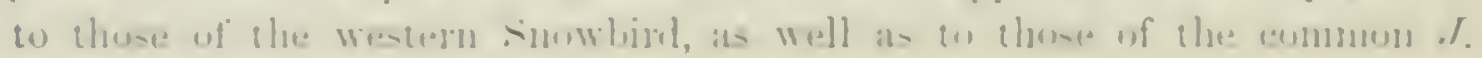
hy. meati.

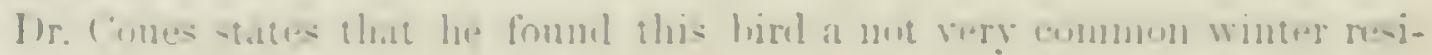
dent a Fore Whiphle, where is times of artinal and leparture, ats well as it:

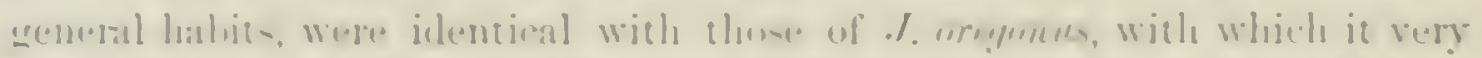

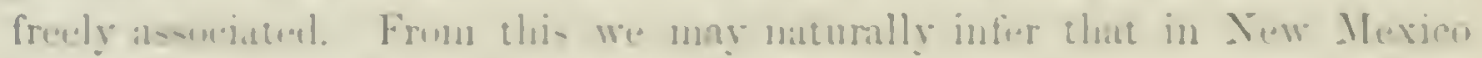

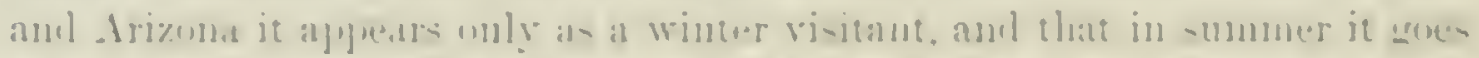

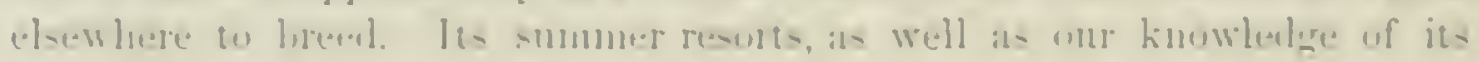

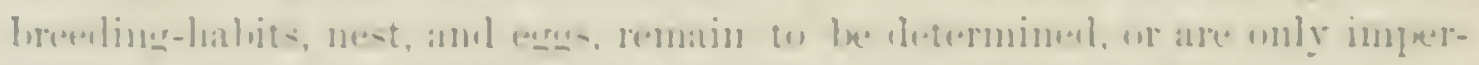

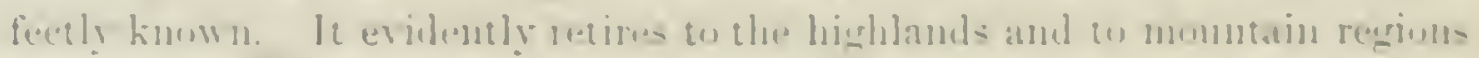

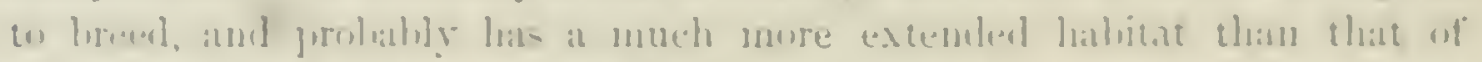

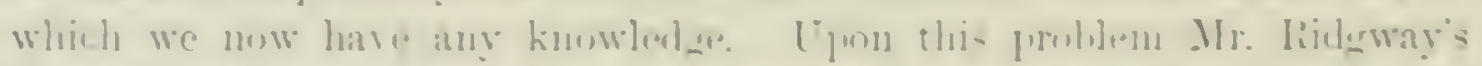

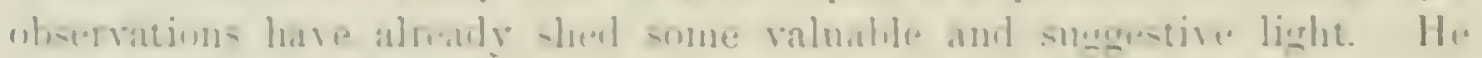

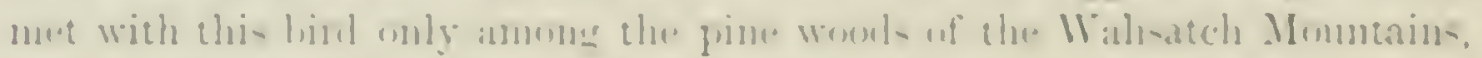

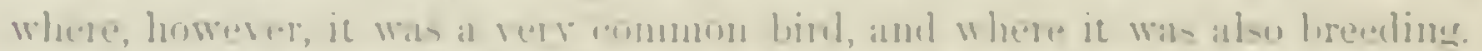

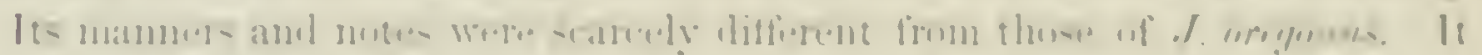
is, hwever, a shrer hird than the lather, and its solle, which is only a simple

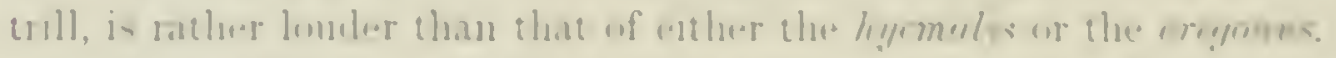

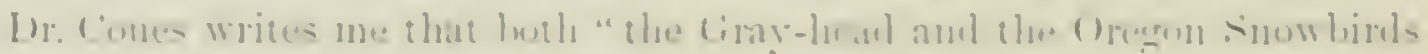

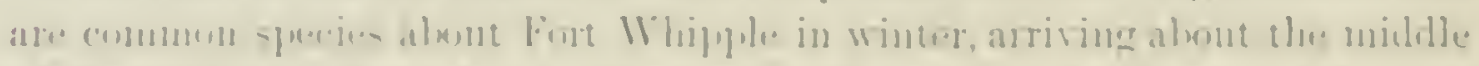

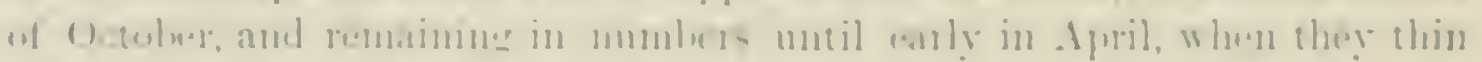

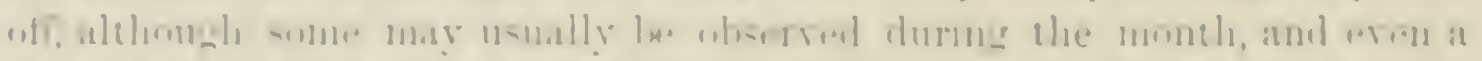

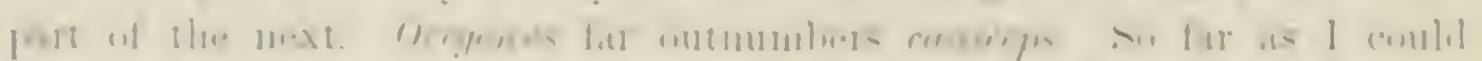

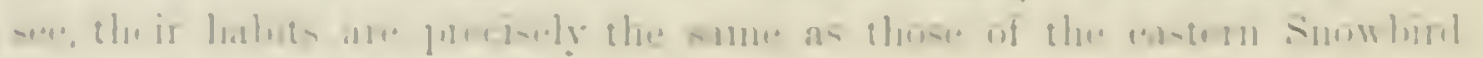

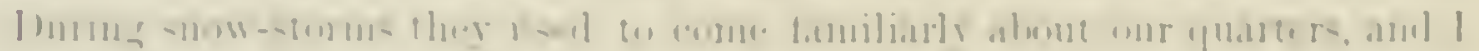

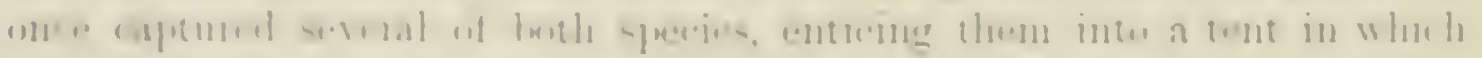
-

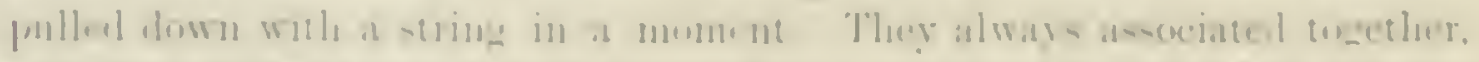

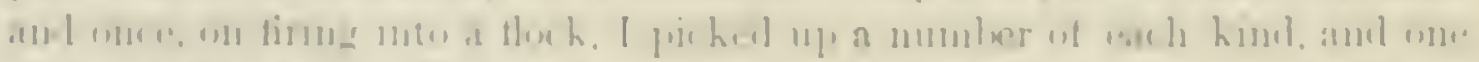

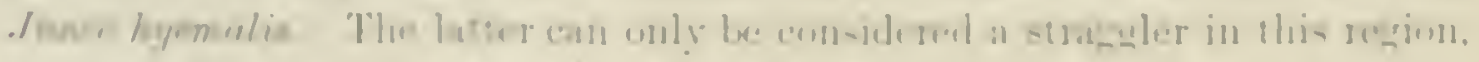

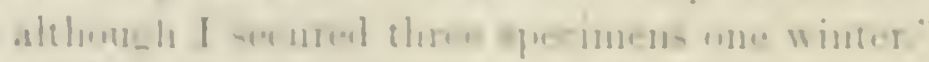

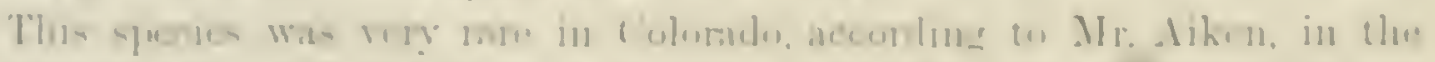
"inter of | -

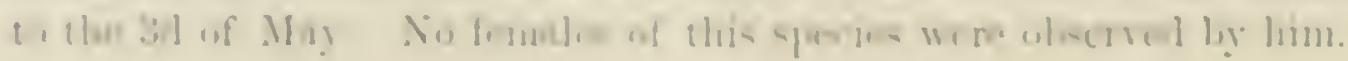


Mr. J. A. Allen mentions first meeting with this species at an elevation of seven thonsand feet, and from that height it was common, on the slopes of Mount Lincoln, to the extreme limit of the timber line.

\section{GEÑES POOSPIZA, CABANIS.}

Puospizu, Cabaxis, Wiegnamu's Archir, 1s $47,1,349$. (Type, Emberizu nigro-rufu, D'Orв., or Pipilo personculu, SW.)

Gex. Curr. Bill slender, conical, both outlines gently emred. Under jaw with the edges considerably inflecterl; not so high as the upper. Tursi elongated. slunder; considerably longer than the milllle toc. 'Toes short, weak; the outer decidedly longer than the inner; but not reaching to the base of the iniddle cliw. IIind toe abont equal to the micldle withont its claw. All the claws compressed and moderately cured. Wings rather long, reaching about over the basal fourth of the exposed portion of the rather long tail. Tertiaries and secondaries about equal, and not much shorter than the lengthened primaries; the second to fifth about equal and longest; the first considerably shorter, and longer than the seventh. Tail long, slightly emarginate, graluated; the outer feather abruptly shorter than the others. Feathers

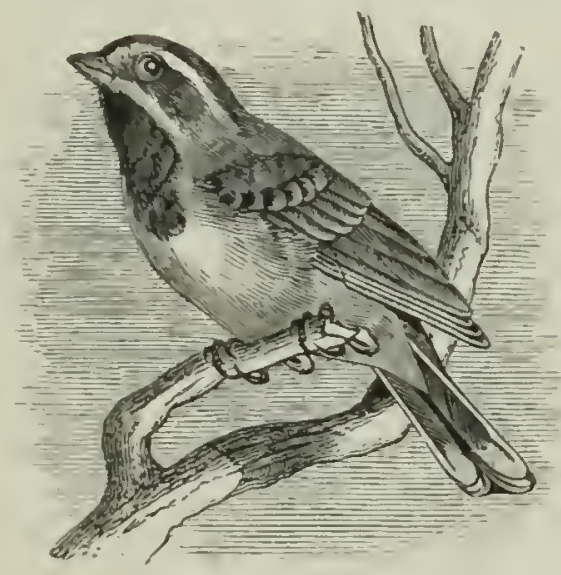

Poospiza bilineala. broad, linear, and rather obliquely truncate at the ends, with the comers romeled.

Color. Uniform above, withont streaks. Beneath white, with or without a black throat. Black and white stripes on the head.

We are by no means sure that the two North American specinens here indicated really belong to the genus Poospiza, but we know no better position for them. They may be distinguished as follows:-

Comson Characters. Lores and beneatl the eyc black, a white orbital ring, white spot above the lore (in bilineatu continued back in a supercilinry stripe); a white maxillary stripe. Lateral tail-feathers, with outer web, and terminal horder of inner, hoary or pure white.

A. Throat black in adult: sides not streaked.

\section{1 continuons white supercitiary stripe.}

1. P. bilineata. Black patch of throat covering jugulum, with a convex outline belind. Crown and back withont streaks, concolored. Wing-eoverts without white bands; lesser coverts ash. Wing, 2.55; tail, 2.8.; bill, from nostril, .37; tarsus, .65.

\section{Io white superciliary stripe.}

2. P. mystacalis. Black patel of throat not extending on jugulum; its posterior outline truncated. Crown and back with distinct hlack streaks. Back scapulars and rump rufous in contrast with the ash of head and neck. Wing-corerts witl two narow, sharply defined white bands; lesser coverts black. Wing, 2.80 ; tail, 3.30 ; bill, .40; tarsus, .80. Hab. Mexico. 


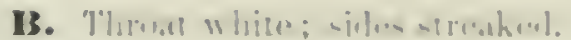

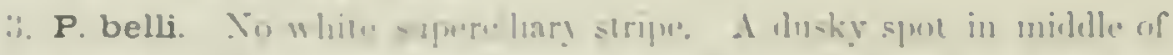

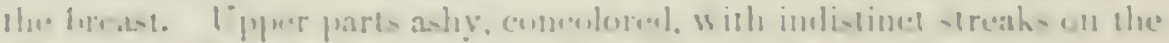

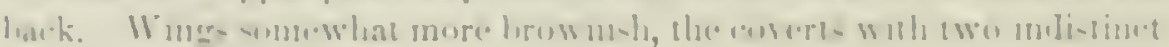
limelat (1101 whlumo) liamls.

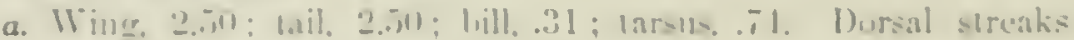

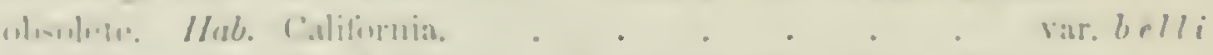

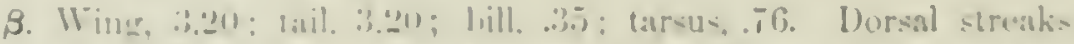

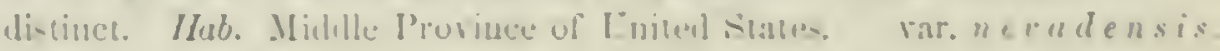

\section{Poospiza bilineata, sistrk. \\ BLACK-THROATED SPARROW.}

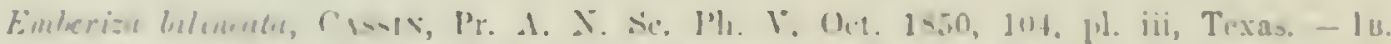

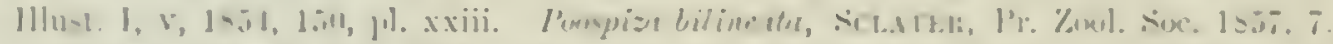

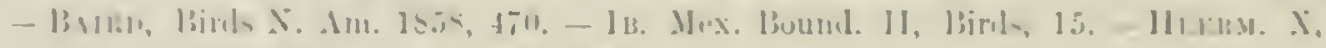

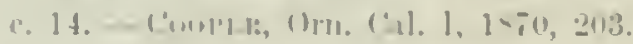

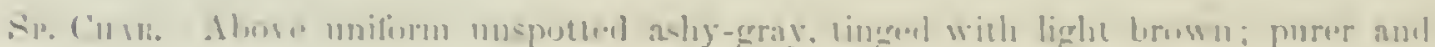

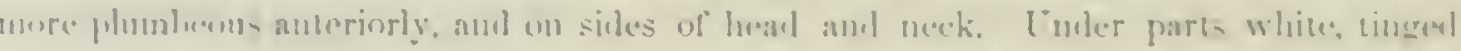

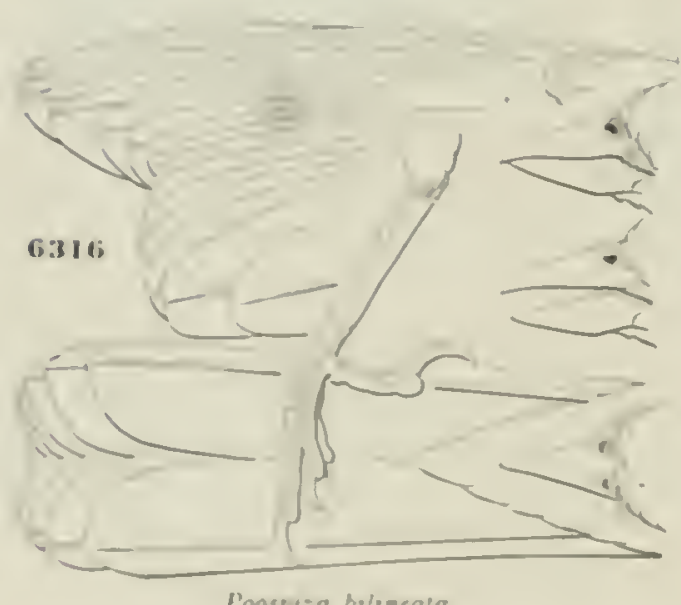

Cloovi=a byingath with phumlenems on the sicles. and with

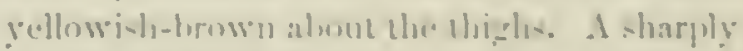

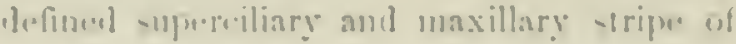

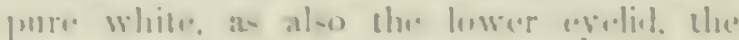
liurmer mar gimel intermally will lifuck. laral region luack, las-ing insensilly inlu dark

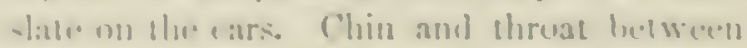
the white maxillary siripes black. emliu: on tho.

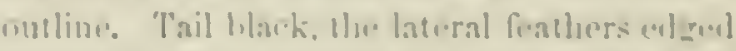

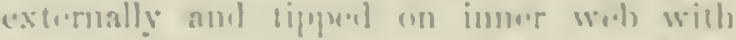

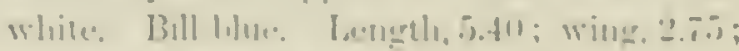
taul. 2.!11. Si.su = alihr.

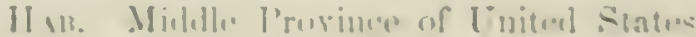

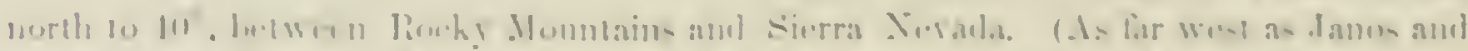

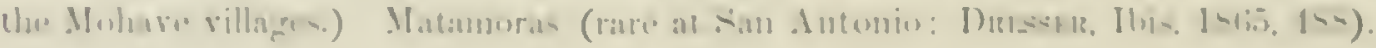

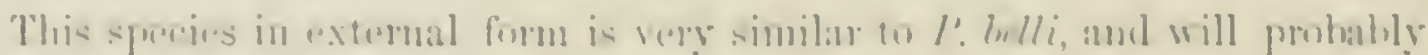

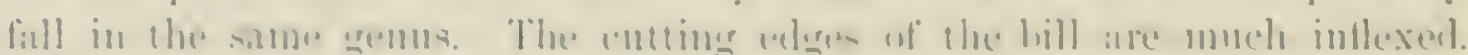

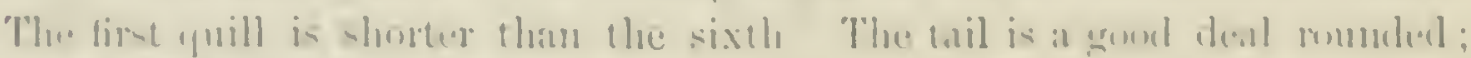

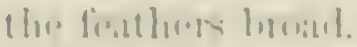

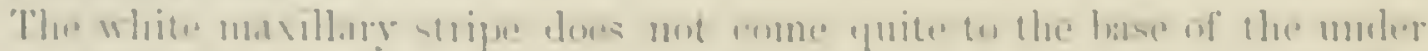

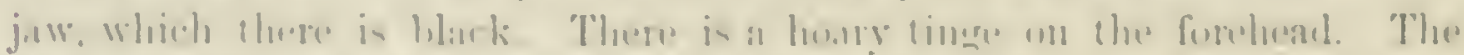

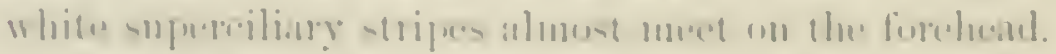

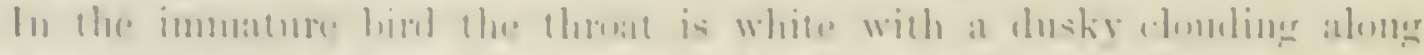

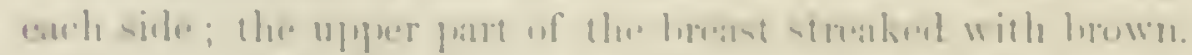

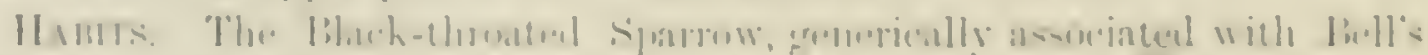

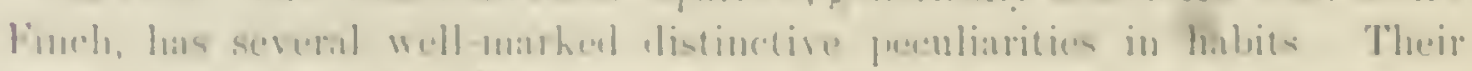

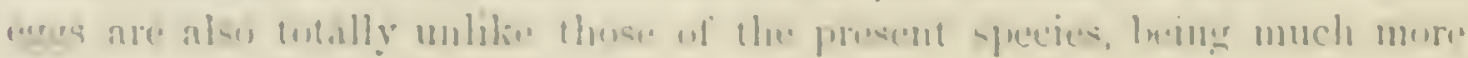


like those of the Pencere and of Lencosticte griseinuchu, and, like them, white and unspotterl.

This species was first described by $\mathrm{Mr}$. Cassin from specimens obtained in Western Texas by John W. Audubon, and its habitat was at first supposed to be restricted to the rallers of the liio Grande and the Gila, but more recent explorations show it to liave a much wider distribution. It is found from Western Texas throngh part of Mexico, New Mexico, the Indian Territory, and Arizona, to Southem C'alifornia, and towards the north throughont the region of the Great Basin to an extent not yet fully determined. In portions at least of this territory it is migratory, and only resident in the summer months.

Mr. Dresser found this Sparrow very abundant during July and August in the mesquite thickets in the town of Matamoras. In I)ecember it was equally common at Lagle l'ass, but at San Antonio it was quite a rare bird. He only observed it on two or three occasions at a rancho on the Medina River, and late in June a nest and four egrgs were obtained. Between Laredo and Matamoras, after crossing the Nueces, he found these birds very numerous, and near Laredo met with several nests, some containing young and some eggs nearly hatched. One taken on the 20th of July contained three fresh eggs, probably indicating a second laying. This nest was in a low bnsh, carefully concealed. It was composed of straws and lined with fine roots. The eggs, when fresh, were nearly white, with a delicate bluish tinge. On his joumey down the river he found many nests, all empty or containing young. Some of these were partially lined with cotton. Though not wild, the birds were so restless that he found it difficult to shoot them. Dr. Woodhonse obtained one specimen on the Rio Pedro, in Texas.

In Mexico this Sparmw was found by Lientenant Conch to be numerous in parts of Tamanlipas, Nueva Leon, Coahuila, and other. States on the Rio Grande, immediately sonth and west of the linnits of the territory of the United States. It was first seen at Santa Rosalio, and specimens obtained, though none were noticed at Brownsville, only twenty miles east, during a month's residence. At Charco Escondido, forty miles farther in the interior, it was very plentiful, and although it was early in March, had already reared a brood of young, one specimen appearing to be a young bird only a few weeks old. Its favorite home appeared to be the scattered mesquite, on the plains east of the Sierra Madre. During the warm hours of the clay it does not seek the shade, but may always be found chirping and hopping from one bush to another. South of Cadoreita the birds disappeared, but after a month's loss of their company he again met with them annong some flowering Leguminosa, between Pesquieria and Rinconada. He thus found it several times entirely absent from districts of considerable extent, but always reappearing again throughout his journey. The usual note of this bird, at the season in which he met with it, was a simple chirp; but on one occasion, haring halted during a norther in Tamanlipas, he heard a "gay little black-throated 
felluw," rewathlless of the bitter wind, from the top of a yellow mimosa then

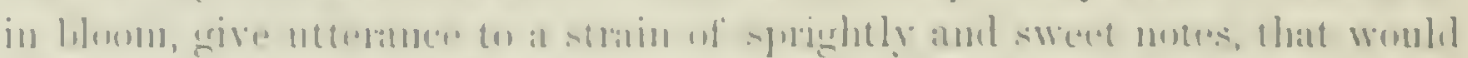

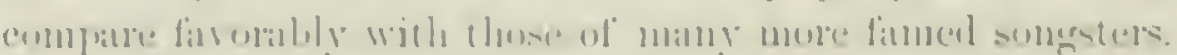

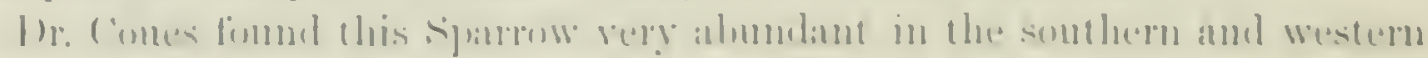

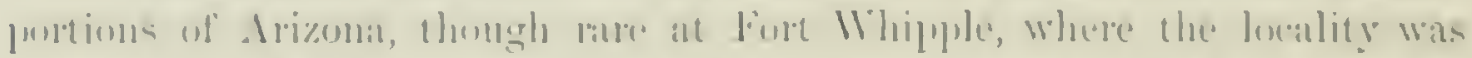

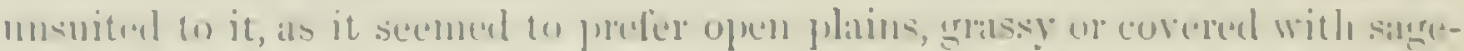
linstis.

Mr. I. II. Clarke, who met with these birks in 'T'mandipas, Tixas, and

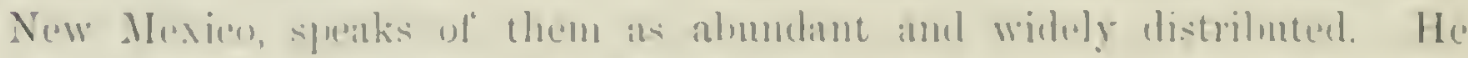

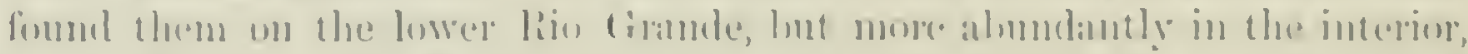

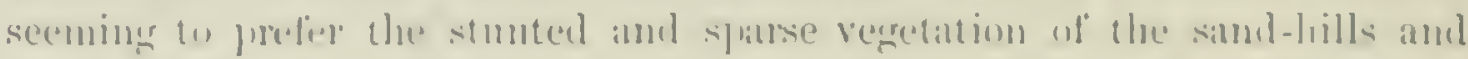
dry plains to the coftonwont groves and willow thekels of the river valleys, "lhere they were mever seen. They would he bery inconspicuous did

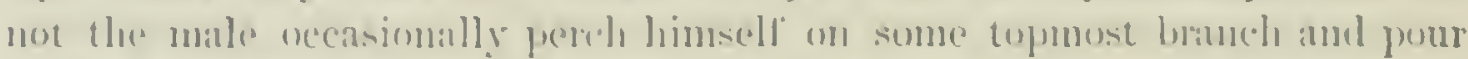
linth a comtimmos stmin at musie. In the more harren rearions they were

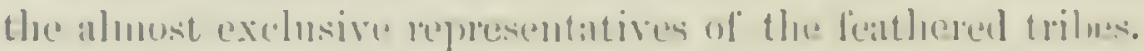

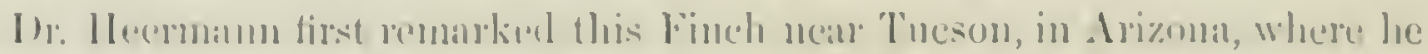

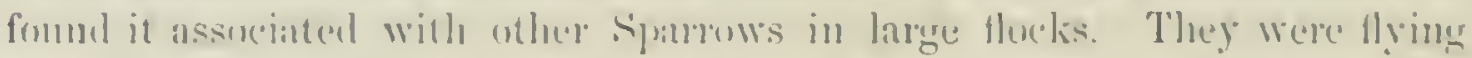
from bush to bush, alighting on the gromel to pick mp grass-seeds and in-

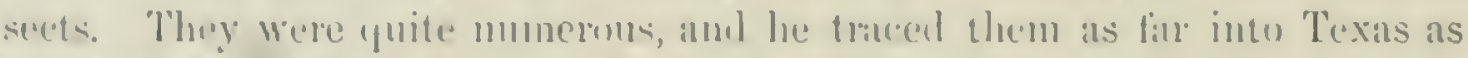

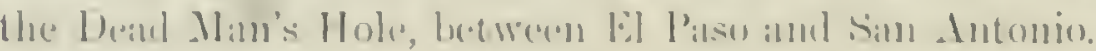

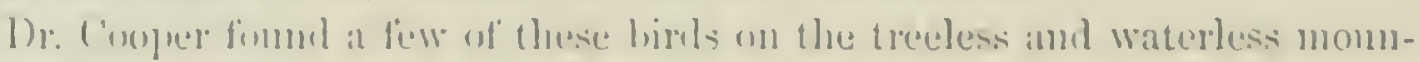

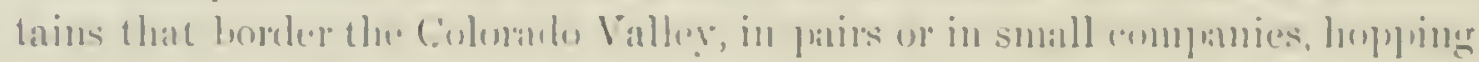

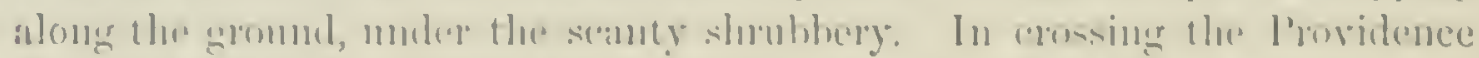

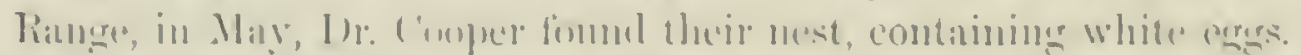

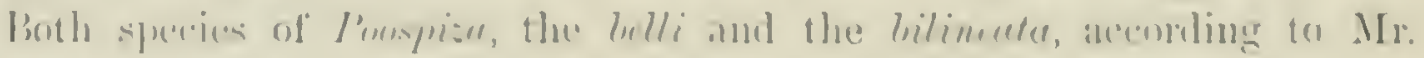

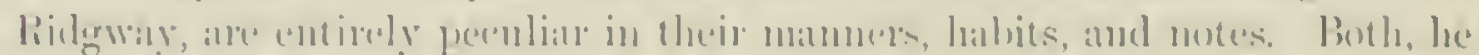

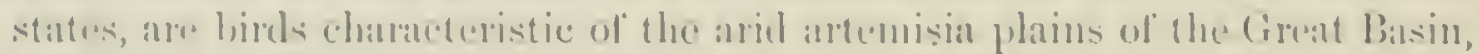

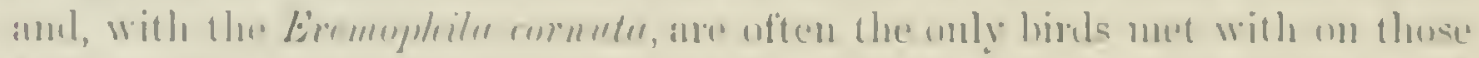

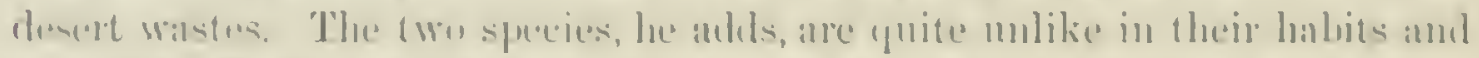

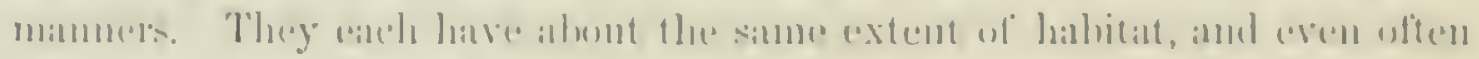

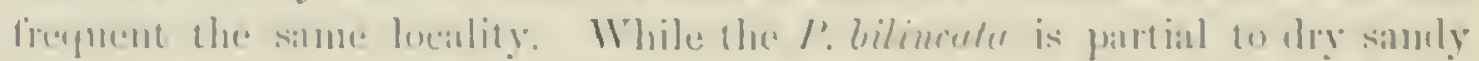

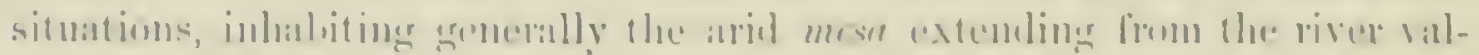

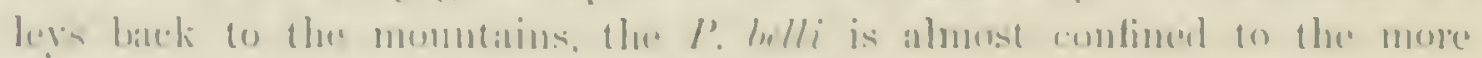

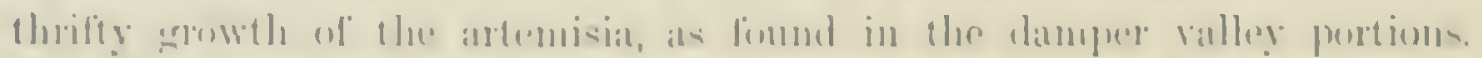

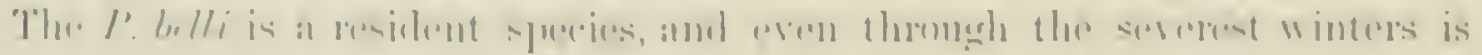

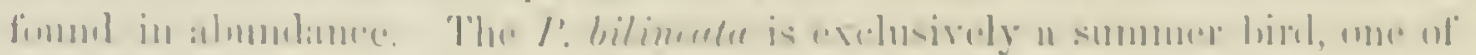

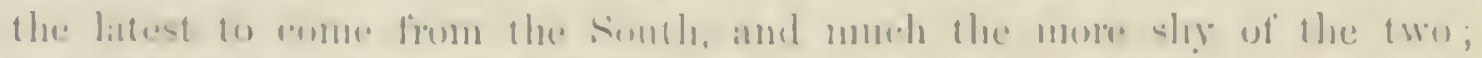

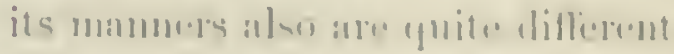

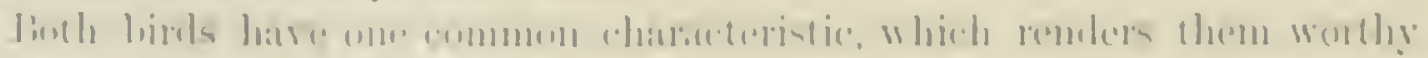

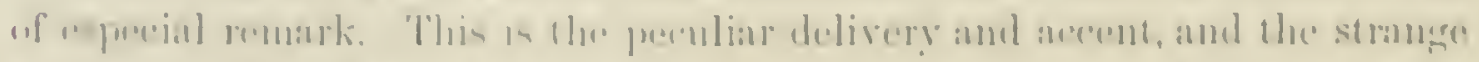

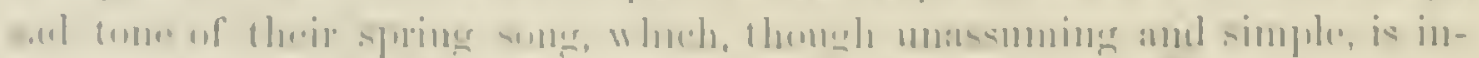

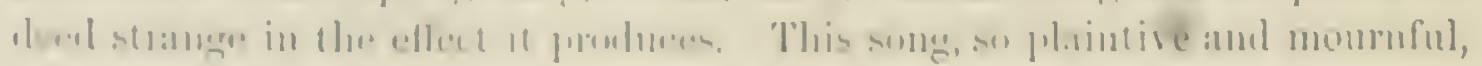

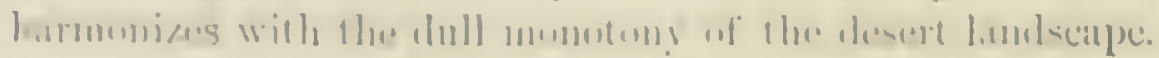


Mr. Ridgway states that the P. Lilincate is not so abundant as the other species, and is more retiring in its habits. It principally frequents the desert tracts and sandy wastes, on which are found only the most stunted forms of sage-brush. Its solyg, though quite simple, is exceedingly fine, its modula-

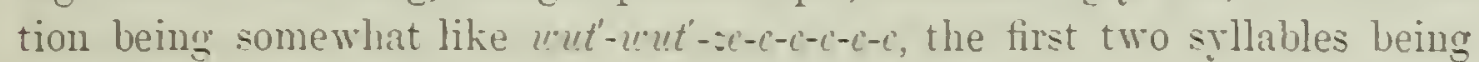
uttered in a rich metallie tone, while the final trill is in a lower key, and of the most liquid and tremulons character inaginable. This simple chant is repeated erery few seconds, the singer being perched upon a bush. He adds that this bird arrives on the Trnckee Reservation about the 1.3th of Mar. The nest is built in sage-bushes, and the eggs are found from the 7 th to the 21st of June. The nests are usually about one foot from the ground, or thereabouts.

The eggs vary in size from .70 by .55 of an inch to .75 by 60 . They are of a rounded-oval shape, and of a pure white with a slight tinge of blue, somewhat resembling the eggs of the Bachnan Finch.

\section{Poospiza belli, Sclater. BELL'S SPARROW.}

Emberiza belli, CAssix, Pr. A. I. Sc. Phila. V, Ost. 1850, 104, pl. ir (San Diego, Cal.).

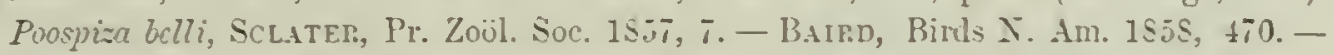
Heers. I, s. p. 46. Zonotrichia belli, Elltot, Illust. Birds I. Am. 1, pl. xir.Cooper, Orn. Cal. I, 204.

SP. Char. Tpper parts generally, with sides of head and neck, uniform bluish-ash. tingel with rellowish-gray on the crown and back, and with a few rery obsolete dusky streaks on the interscapular region. Beneath pure white tinged with yellowish-brown on the sides and under the tail. Erelids. short streak from the bill to abore the eye, and small median spot at the base of culmen. white. A stripe on the sides of the throat and spot on the upper part of the breast. with a few streaks on the sides, with the loral space and region round the eres, plumbeous-black. Tail-feathers black: the outer edged with white. Wing-feathers all broally edged with brownish-yellow; the elbow-joint tinged with rellowish-green. Bill and feet blue. Length, 5.70 ; wing, 2.80; tail, 2.90. (Largest specimen. 6,33s б. Cosunnes Rirer).

Haв. Southern California.

The colors are softer and more blended in the autumn; the young are obsoletely streaked on the breast.

HABITs. Bell's Finch has apparently a more restricted distribution than the Black-throated species, and is resident wherever found. It has been met with at Posa Creek, Cal., by Dr. Heermann, at Fort Thorn by Dr. T. C. Henry, and along the Colorado River by Drs. Kennerly and Möllhausen. It has likewise been found in Southern Cialifornia, as far north as Sacramento Valley, and in the ralley of the Gila.

Dr. Cooper states that all the extensire thickets throughout the sonthern half of California are the farorite resorts of this bird. There theyapparently live upon snill seeds and insects, indifferent as to water, or 
dipending upon what they uhtain from dews or fors. They recide all the

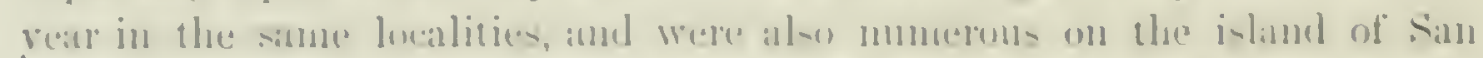

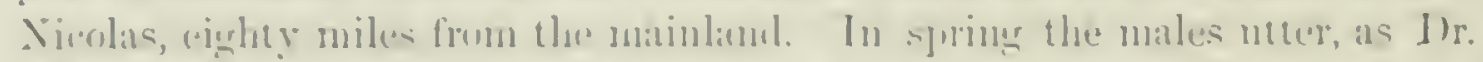

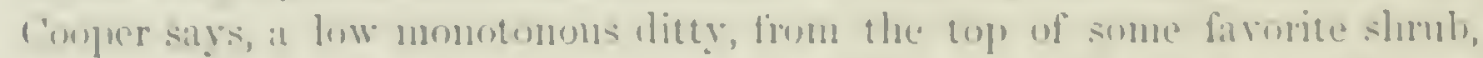

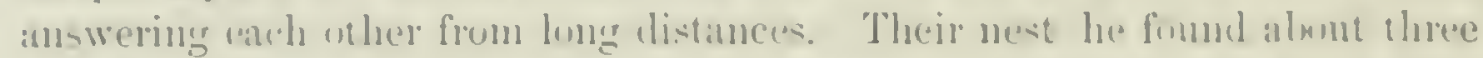
feet from the gromul, comprosed of amsses and slender weeds, lined with lanir and other substances. The engs, four in mumber, he describes at prole

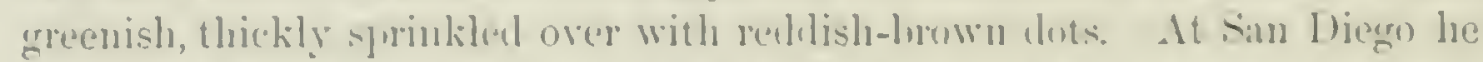

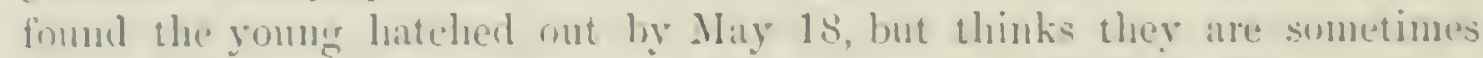
earlier. It is also al common hire in the chaparal of sinta Clasa Valley, and alson, accurling to [or. Heermann, along the (osumnes fiver.

In Arizona, accomline to 1)r. Couses, it is rather uncoummon ahout Fort Whiphle, owing to the monsutalle nature of the locality, hut is ahmulant ammo the sage-lnush of the Gilat Valley, where it keeps mueh on the gromul, and where its movements are very much like those of a I'ipilu.

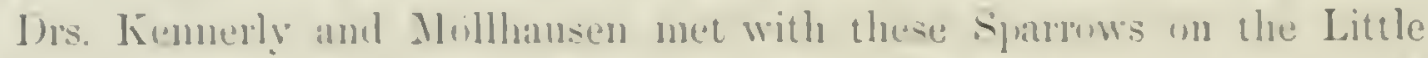
Colenato liver, in (allifornia, December 15. They were found during that month along the banks of the river wherever the weeds and bushes were thick. It was never observed rery far from the water, and its foud, at that season, secmed to consist of the seents of barions kinds of weenls. Its

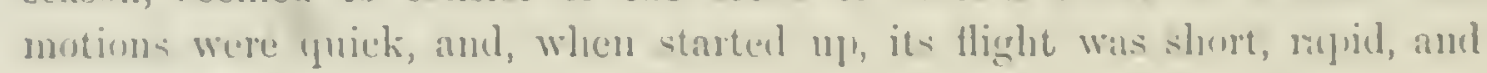
near the carth.

Dr. Heermann states that in the fall of 18.1 he fomml this species in the

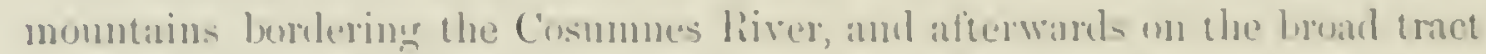

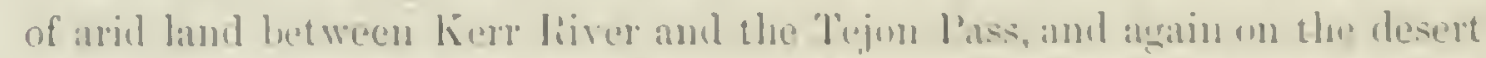
letween that amd the Mollate River. He often foum them wambering to a great distance from water. With only a few exceptions, these were the only hirds inhabiting the desolate plains, where the artenisia is the almest exchnsive reartation. When mulisturbed, it chants merrily from some hush-top,

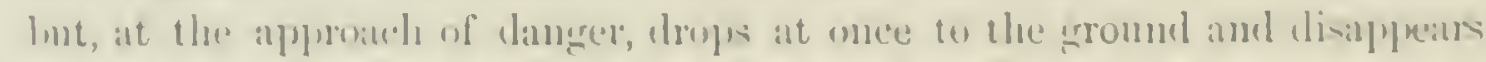

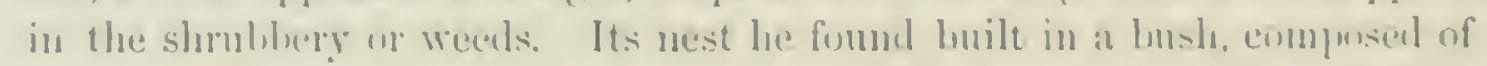
twigs and grasese, and lined with hair. The eress, fimm in mumber, he describes is uf" a light garenish-blue, marked with reddish-purple spots, diffuring in intensity of shinde.

Poospiza belli, ar. novadensis, lingwar.

\section{ARTEMISIA SPARROW.}

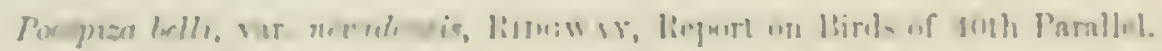

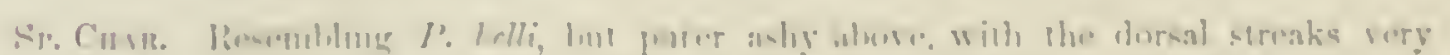

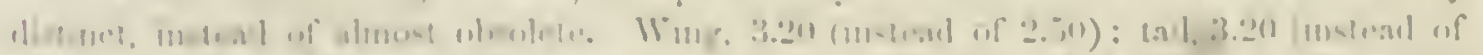

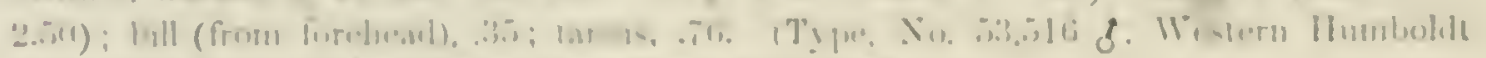

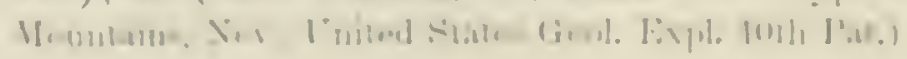


Young. Streaked abore, the crown obsoletetr, the back distinctly. Whole breast and sides with numerous short dusky streaks upon a white ground. Jarkings about the head indistinct, wing-bands more distinct than in the adult.

Hab. Middle Prorince of L'nited States, north to beyond $40^{\circ}$ (resident).

The difference in size between the race of the Great Basin and that of the southern Pacific Province, of this species, is quite remarkable, being much greater than in any other instance within our knowledge. This mar, perhaps, be explained by the fact that the former is not migratory,

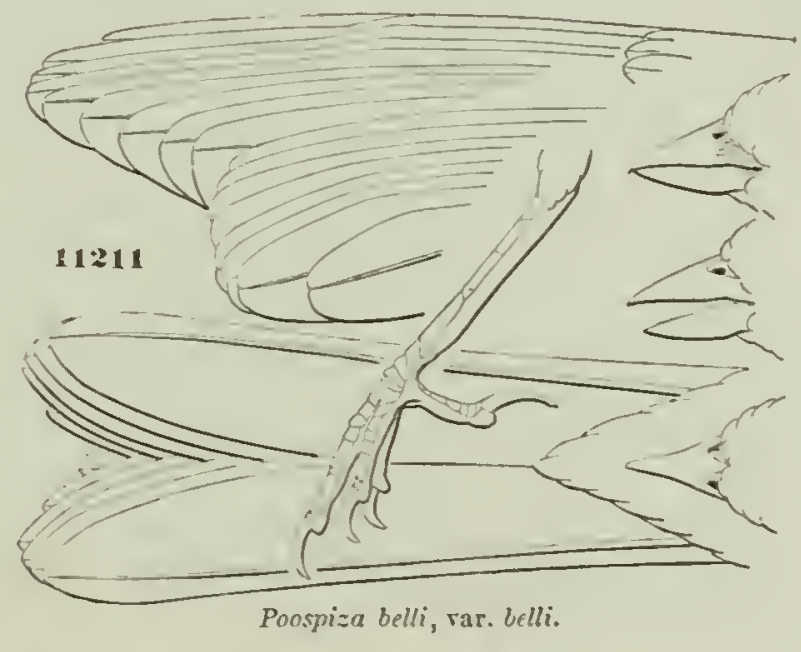
but resident even in the most northern part of its range; while the California one is also resident, and an inhabitant of only the sonthern portion of the coast region, not reaching nearly so far north as the race of the interior.

The coloration of the two races is quite identical, though in all speciunens of var. belli the dorsal streaks are obsolete, sometimes even apparently wanting, while in the rar. nevedensis they are always conspicuous. The former appears to be more brownish abore than the latter.

HABITS. These birds, Mr. Ridgway states, have a very general distribution, extending as far west as the eastern base of the Sierra Nevada. At Carson City, February 27 , he heard for the first time their sweet sad chant. A week later he found the sage-brush full of these birds, the males being in full song and answering one another from all clirections. In walking throngh the sagebrush these Sparrows were seen on every side, some ruming upon the ground with their tails elevated, uttering a chipping twitter, as they sought to conceal themselves behind the shrubs. Some were seen to alight upon the tops of dead stalks, where they sit with their tails expanded almost precisely after the manner of the Kingbird. The song of this bird is feeble, but is unsurpassed for sweetness and sadness of tone. While its effect is rery like the song of a Meadow Lark singing afar off, there is, besides its peculiar sadness, something quite unique in its modulation and delivery. It is a chant, in style somewhat like the spring warbling of the Shore Lark.

On the 24th of March, at Carson City, he found these Sparrows very abundant and ererywhere the predominating species, as it was also the most unsuspicious and familiar. It was even difficult to keep them from under the feet. A pair would often run before him for a distance of several rods with their unexpanded tails elerated, and when too nearly approached would only dodge in among the bushes instead of flying off.

On the 9th of April, walking among the sage-brush near Carson City, Mr. Ridgway found several nests of this Sparrow, the female parent in each 


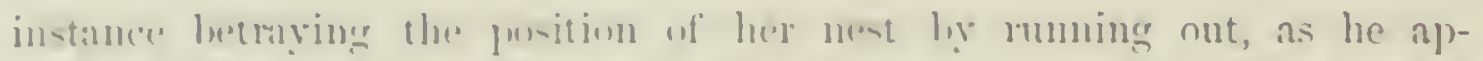

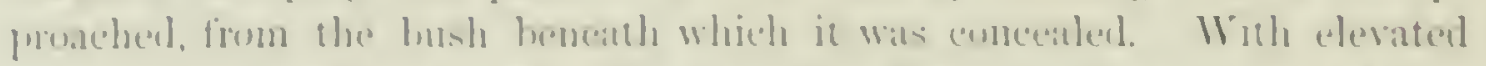

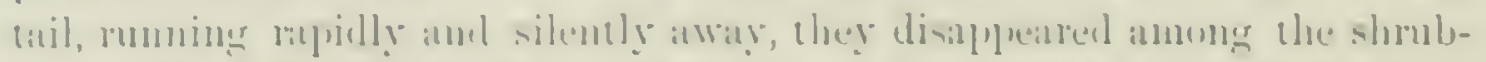

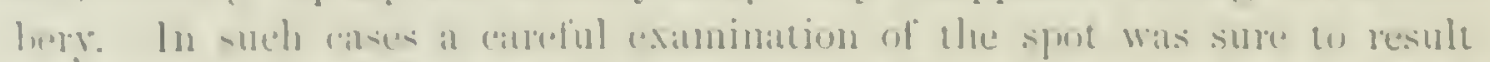

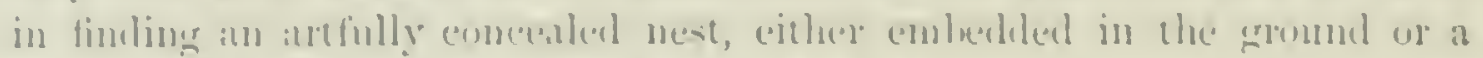

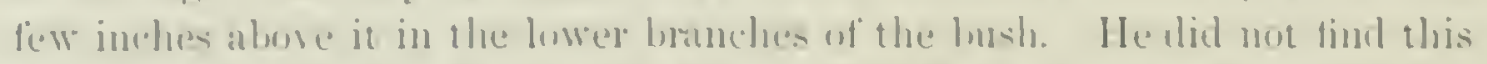

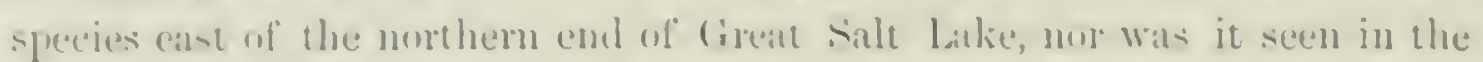

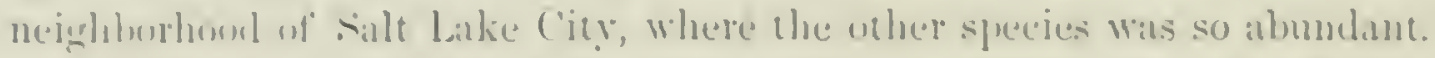

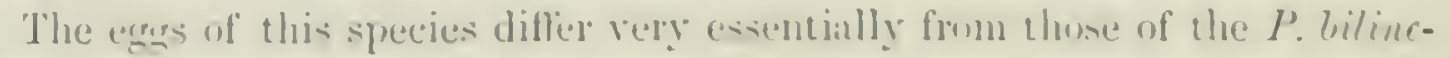

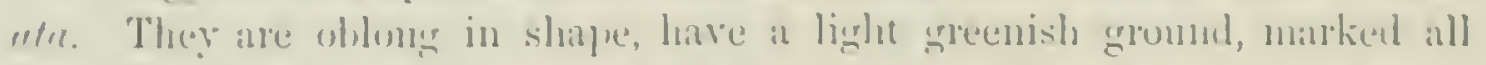

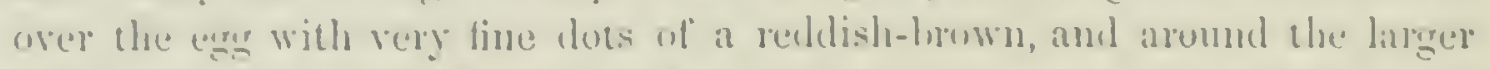

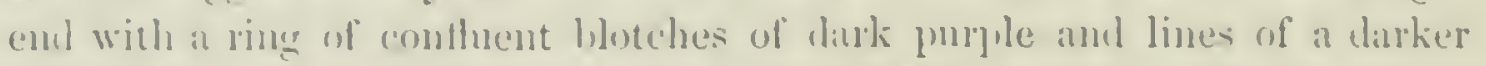
Lrown, almost bitek. 'They meisure 80 hy . 150 of an inels. Theg resemble

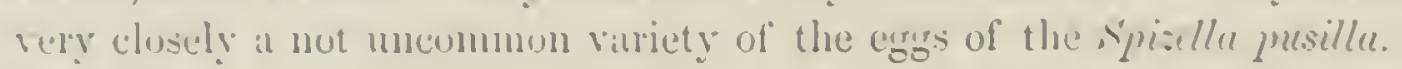




\section{INDEX TO PLATES OF LAND BIRDS.}

Egiothus brewsteri, exilipes, fuscescens,
I. 501, pl. 22, fig. 6 Calamospiza bicolor, б" "49S, " " 2 Callipepla squamata, 8" "493, " " 3 Calypte anlia,
\& II. 61, pl. 29, fig. 3 III. 457, pl. 63, " 6

8 ]l. 454, pl. 47 , " 7 " " 457 " " 8

Agelaius gubernator (shoulder), Campepluilus principalis,

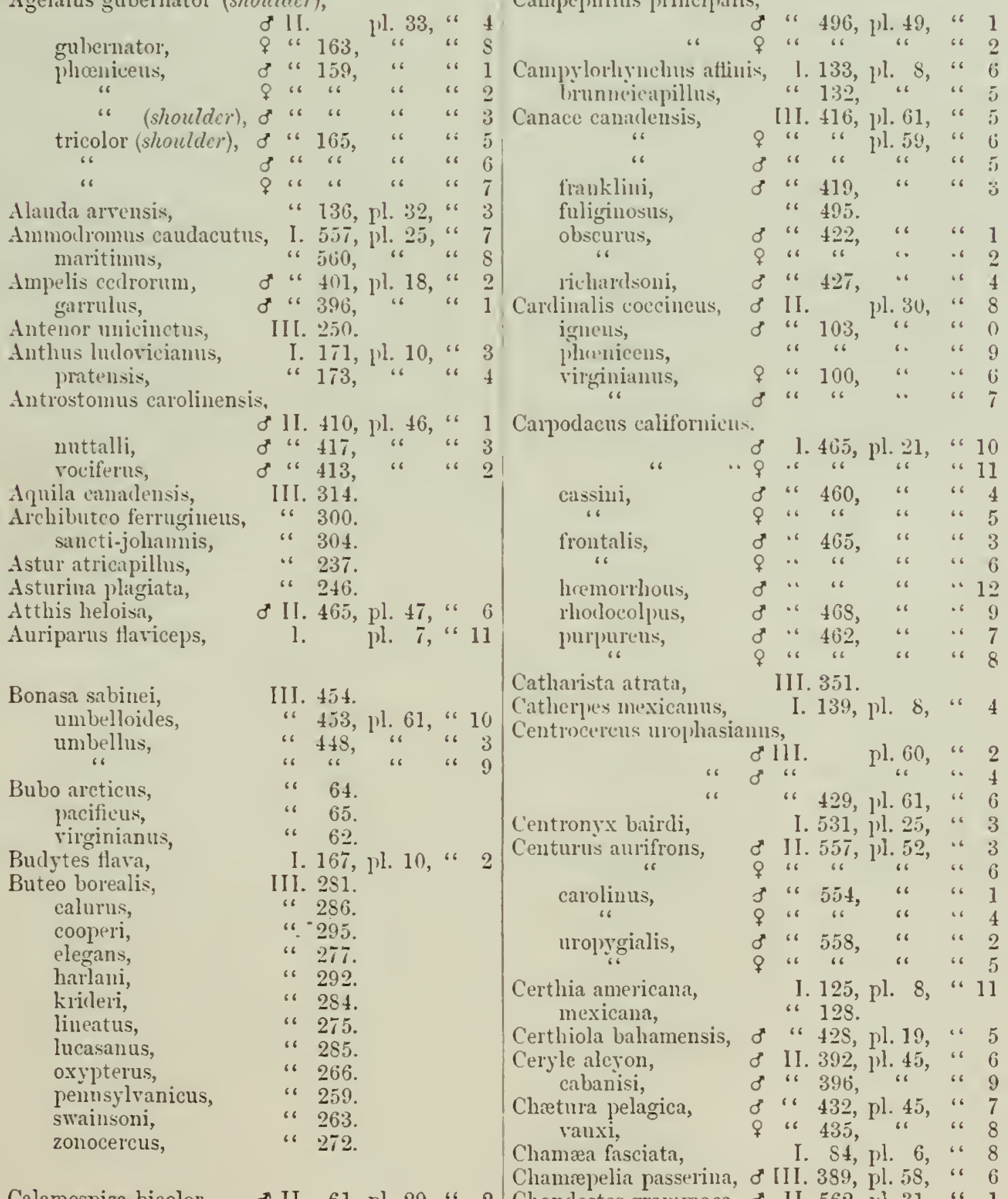

Calamospiza bicolor, đ゙ II. 61, pl. 29, “ 2 Chondestes grammaca, ơ II. 562, )1.31, “ 
(Hor biles lumiri. I (.) $, 1,1,1$

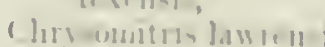

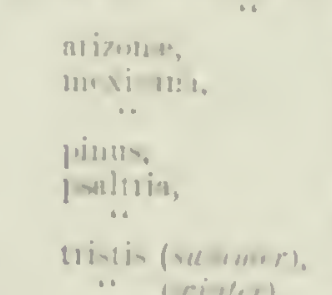

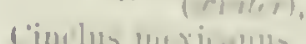

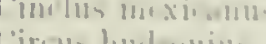

(istothin tus juslusiris, atoll เтіs.

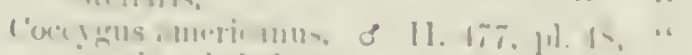
irrilimplithalmur.

mintr,
colaphes auratus,

dirysuilis,

jolitilus,

uir.xicantus,

Collutio lxiritiv, (Jur.

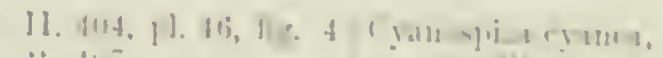
i, inilinis,

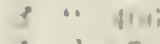

1. $1 \rightarrow \because 11.22$

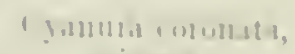

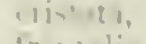

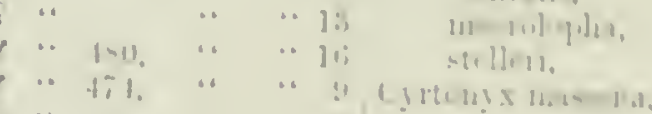

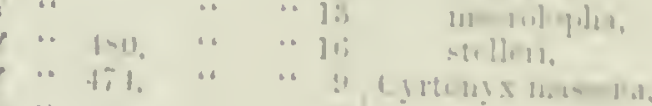

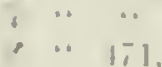

".

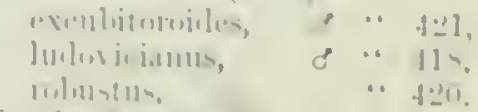

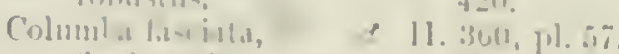

Burimblis

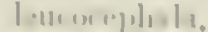

('untepun lontelix. I" timing, [i.lutrl-onui,

birms.

, .

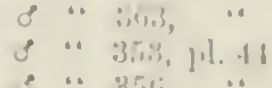

- 8511,

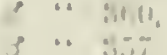

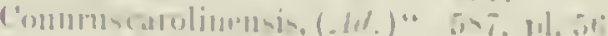

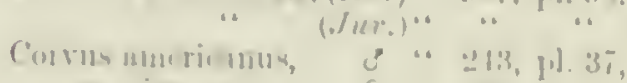
cornisiolls.

outinus.

ervipulemens.

11 i i J.1 11114.

"11 vicmull,

n=-iTr.aplas.

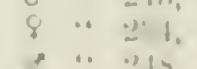

(.) 2100

210

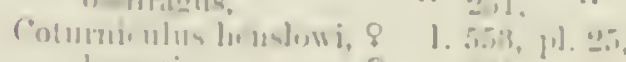

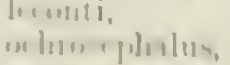

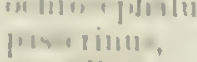

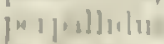

(int) IInuis,

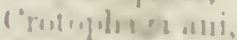

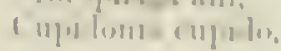

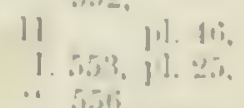

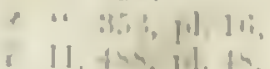

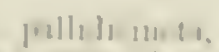

[youm 11:

口lifular,

आ11, lit.

11,1810

andill,

(14)1] li? 11,

V. Ihom 1 ,

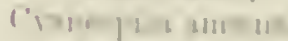

in.

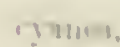

III- IIII, ju, nil

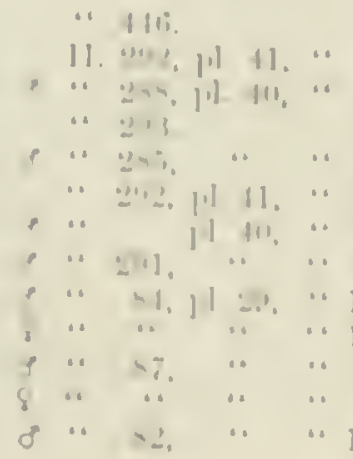

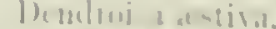 a) ilum. llakhomis.
(เเแ) ส,
(4) $1111+x+11$.

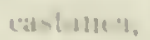
1313:411. i. vorimats.
di nlers,
d) nuni
tring.
firil hili,
ma) low,
III) 1 : $11 \mathrm{~h}$,
11i- Ir = 11 , encilnomliv
wis...,
f

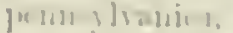
pimu,
silisti.
tw1

11111,

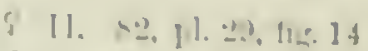

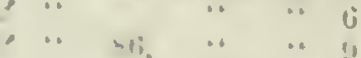
" l11

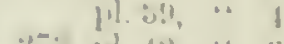
$\because 2,11.4 \div$ "1, Jl. $2: 1$.

, .. 27

111. $4 ! 2,[1$, il

a jl. vil.

I. 222, , 1, ] $4, \cdots$ 2110

ㄴ.?! 1113

$$
\text { .. }
$$$$
25
$$

. II, 1. 1.2

‥1, ․]. 13, ..

“.

..

a

“

․ $\because 13, \quad$.

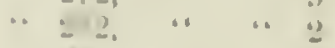

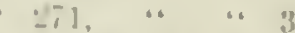

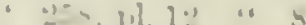

..

$\therefore, 111 \%, \cdots$

ㄴ., !l. 13, ..

..

(11.

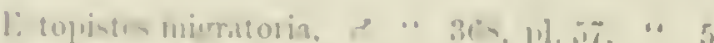

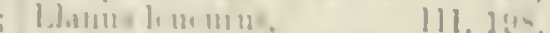

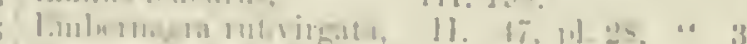

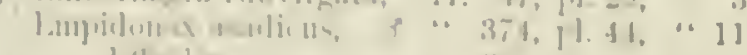

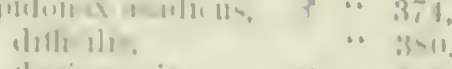

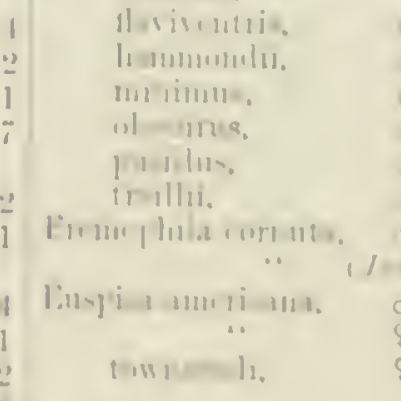

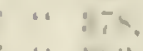

. $\quad$ " 1!

1. $33 \div$

.. : : 1 ,

.. 314

111. 11. 3:\%, 1

$\because \therefore, 11: \cdots, \cdots$

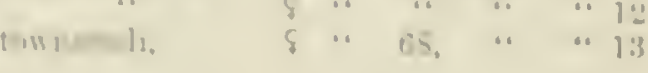

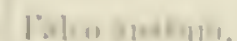

eminlin.

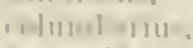

1=i, elis.

111. 1..'

$1=1,1 / \ldots 11$.

$\therefore 111$

“ $1: 5$

. 1,1. 


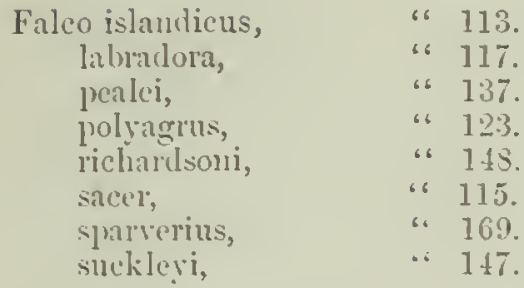

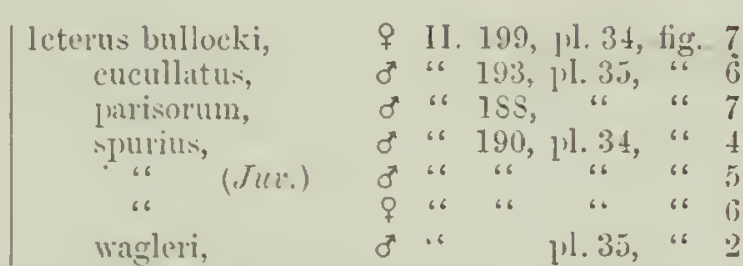

Galeoscoptes carolinensis, 1. 52, pl. 3, fig. 5) Junco aikeni, $\quad$ o 1 1. 5St, pl. 26, “6 6 Geococerx californiamm,

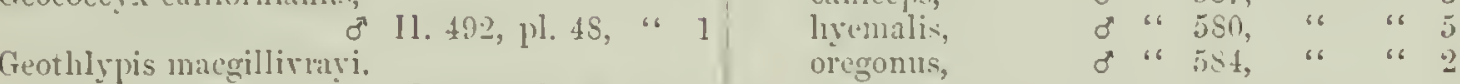
Geothlypis macgillivityi, philatelphin, of " 301 , « trichas, $\quad$ o

Glaucilium californicnm. I1I. S1. ferrucinusum,

Guiratea carule:s, of 11. iT, pl. Gymnokitta cyanocephialit,

Ialiaètus albicilla, III. 32 !. leucocephalus, $\quad$ : 326 .

IIarporlynchus cinereus, I. 10, jl. 4, " * ? crivinlis,

curvirostris, “ $\quad$ " $11,11.3$, ،

“ “ lonerimotris,

jalineri,

relivivus,

rufus,

Iledymeles indoriciamm,

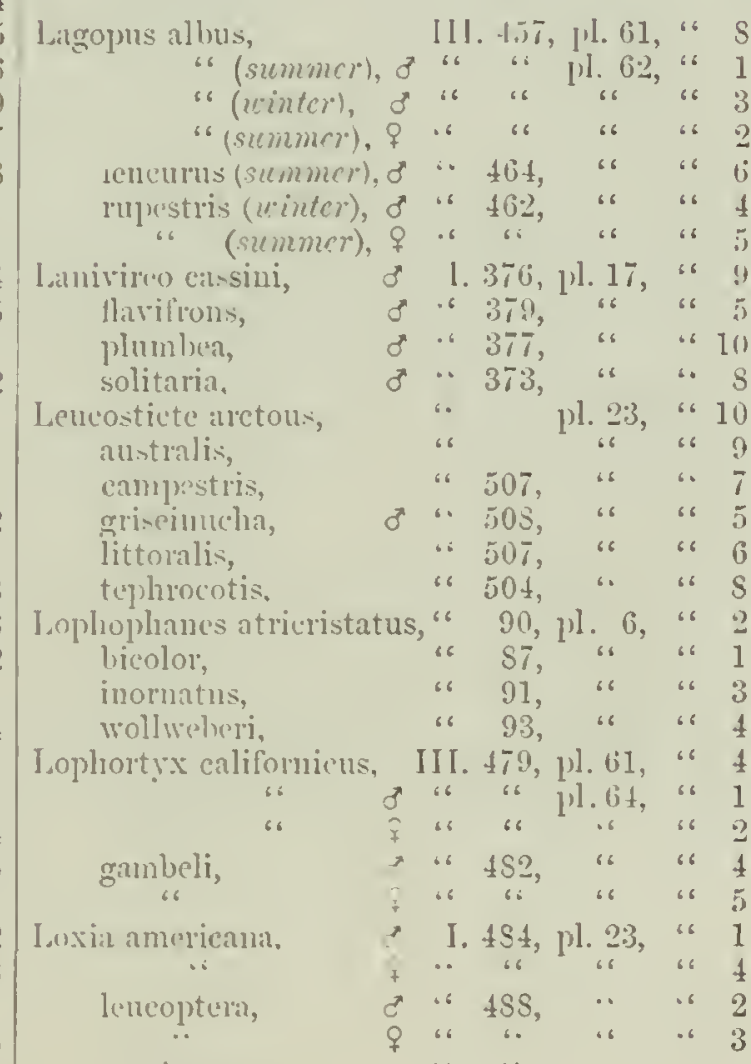

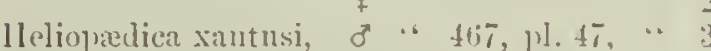
Helminthophaga bachnninit, 124 , 11, .6 celata (car. Cape lancian), I. $204, \quad$ " (var. Rocliy .Its.)

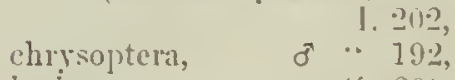
liwix,

peresrina (ms sming), " 205 (iil (t)

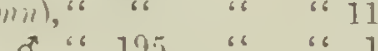
ruficapilla, " " 190 , “ “ 7

mrxicana,

Mrlanernes angustifrons,

nitherus swainsoni, rermivolus,

Hesperipliona montana. respertiua,

Hirundo hor'eorum,

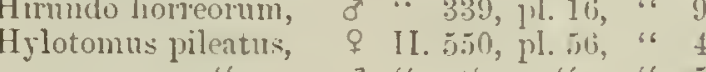
" 199, " 190,1010

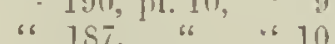
" 449, pl. 22, " " 10

leteria longicauda, virens,

Tcterus auduboni, baltimore, bullochi,
1. 303. sammelis, 307, pl. 15. "12 Mieratlene whitneyi, 8 11. 156 , pl. 35 , “ 1 Mirrulus forficatus, 3. Miums polyglottus,
" 11.573, pl. 33, " 3

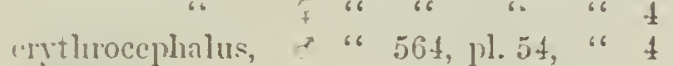
formicivorns, द “ "566, 1). torquatus, of "6 $561,01,54$.

[e]leagris galloparo, III.41)4. mexicana, " 410 Melopucia leuroptera. o “ lospizal fallax, क 11.22 , pl. 27, " 10 snttata, 6 27, "6 " 12 insignis, " " 30 , " " 5 lincolni, “ $31, \quad$ " $\quad$ " 13 meloclia, " " 19, " 19 " 6 palnstris, $\quad$ " " 34 , pl. $2 \mathrm{~S}$, "6 1

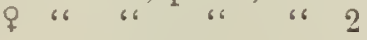
“ 29 , pl. 27, “ 11 III. ST.

\% 11. 311, pl. 43 , " 1 I. 49, 1)]. 3, “ 4 


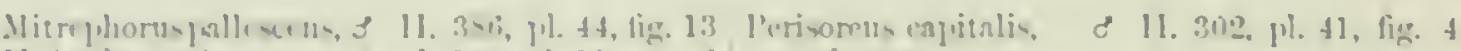

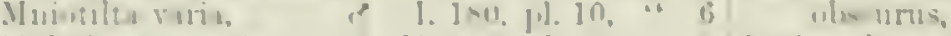

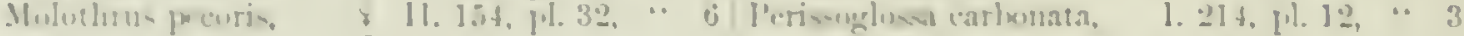

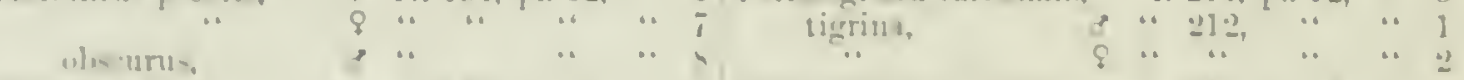

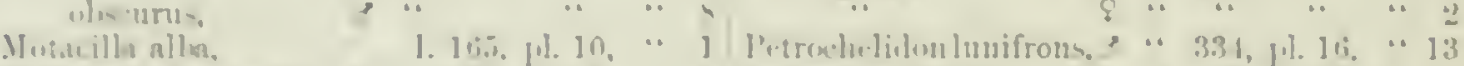

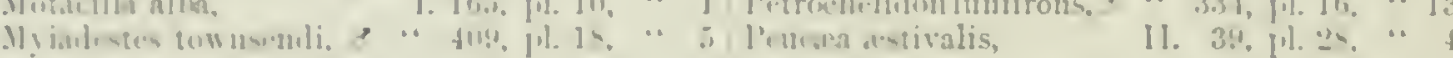

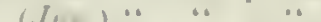

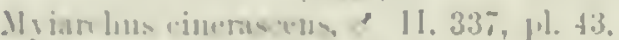

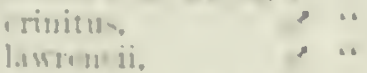

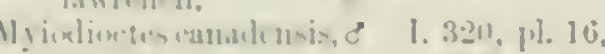
mintutus, $31 \mathrm{i}, \quad,$. mismins,

piloulatus, ju-illus,

“ $31 \%$.

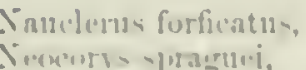

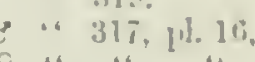

111. 192.

Siplunierom nigers.

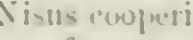

$$
\text { furell. }
$$

mexis:antis.

Pretale di larisuni, a amlis.

1. $7 \div, 0,10] .10$ stricollote ianini. miliceliss, ['haxu)

1'honipara 7.218. “4 41.

1il. fri.

4. 4.,.., is 1. $4(10 \%, 1,1,1, \ldots 3$

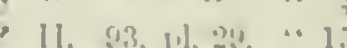
\& $\cdots$

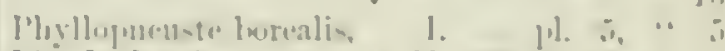

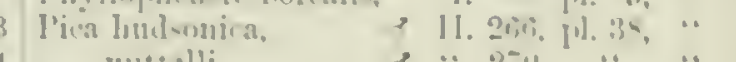

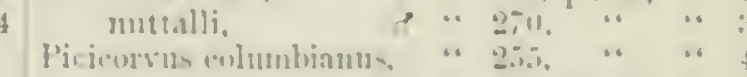

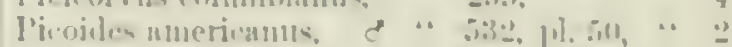
Pieu-uliolarratur, 11. 42!!, 11. 4.) 111. 2311.

.. 204.

Ficted scoullaca,

.. 40.

Onteluetes gruberi,

(1)ororsi- agrili.

firmonas.

Oung le ia matrinian, (1)rot?

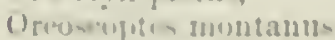
Oraliıla maclli, Ortyx ux:tuts.

virginiาuแะ,

Otus lirathyotu. wilnuाiumus,

$$
\begin{array}{ll}
.13 \\
\therefore \quad 7
\end{array}
$$

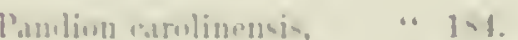

$$
\text { ‥ } 2.04 .
$$

\& 1.200. 11. 10

c. 2303.

2 111.353, 11.5.

- . $17 i, 11.63$ 1. $3:-11.3$ 11. :39, jl. : ร III. 411, II. 133. c... .. \& “ ". $\begin{array}{ll}\cdots & 20 . \\ \cdots & 15 .\end{array}$

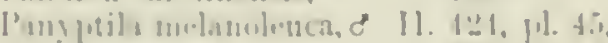

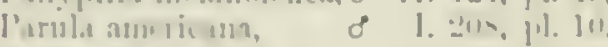

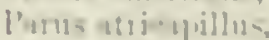

alolime main,

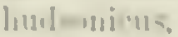

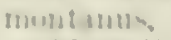

rillontislio.

tuff - jor nirimalia,

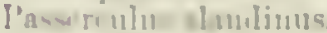
anthimus.

, als ts,

gittusti.

[1]in y.

[u= 21 itus,

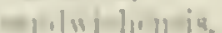

arsumat.

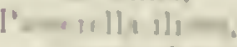

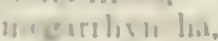

hile m.

!ni. ju. i,

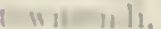

1112:

.6 10:i.

- $\quad 1,1$,

. 101,

1114.

..

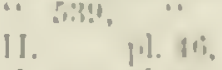

1. 511 . 1.1. :1.

(ill,

il:. N1.:-1.

$\therefore \quad: 15$

II. il. H1. ㄱ.

$\because 11 . .2$ ini.

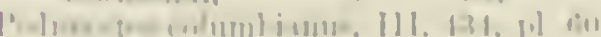

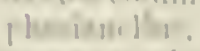
131,

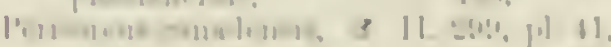
$(.1 \%$.

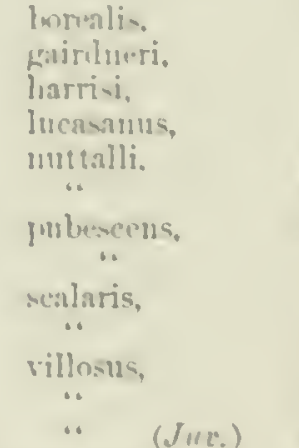

l'inimala inur limtor.

l'ipilo alm rti.

alli:mila,

ulleni,

arrtirus.

(1) lomina,

irimalis,

ersthruphthalnue

megralons $x$.

1310 - cole 110115 .

chrenthis?

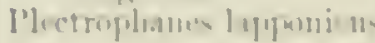

แแมเ .. แก แ.

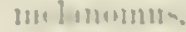

nivilis,

misutilu-

jiitus

loliverilu arulen. 131 lisum.

jhlimlwat.

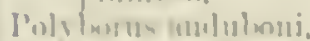

l'ikne?... gmathinems.

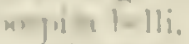

11611-14,

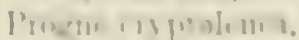
slis.

|'Tufumbarit, ims.
, .

, .

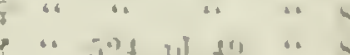

$\because$ 긴.

‥

“泣], pl. 沙, “

“

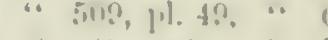

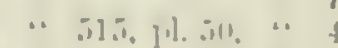

“6

○ 4 .

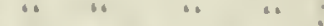

[1. $4.13,[1,21 . \cdots$ ]

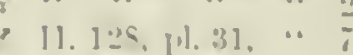

ㄱ. 1

“ 11:.

, 113 .. 110

. $1: 31, \quad \cdots \quad$ ".

, . 1. 1. . .

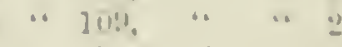

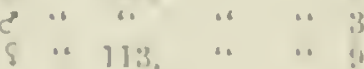

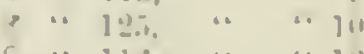

1. .1.1. J.1.21, . -

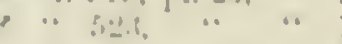

‥

..

, “.

…p. di. .

$\because$ "

$111.1 \%$

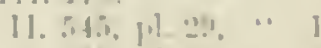

I. $5 ! 1,3,1,1210, \ldots$

(1)

$3: 30$.

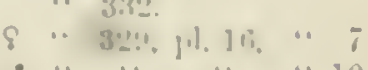

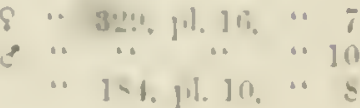


Psaltripuras melanotis,

I. $10 s, \mathrm{pl} .7$, fig. $\&$ Speotyto hypugrea,

III. $\$ 0$. minimus,

" $10 !$,

plumbens,

Pseudogryplutus californinnus,

10 sinrropicus nuchalis,

Psilorhinus morio,

111. 33 s.

Prranga restiva,

cooperi,

hepatica,

ludoriciana.

rubra,

9 11. 304, pl. 42

$\begin{array}{cccccc}o & 1 . & 411,1,1 . & 20, & \cdots & 5 \\ + & 6 & \cdots & \cdots & \cdots & 0\end{array}$

8 “ $\quad 4 t \frac{1}{4}, \cdots \quad$. 1

8 “ $140, \ldots \ldots$

f $\cdots$

c $\therefore 4$. $43 \%$

Prrgita domestica,

Prroceplialus mexicanus,

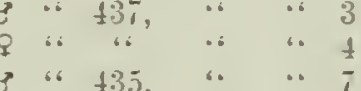

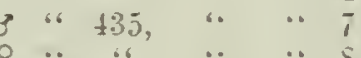

Procephalus mexicanus.

Prrrhula casini.
Pirrhuloxia sinuata,

Z II. $35 \pi,]_{11 .}^{11}$

Quisealus reneus,

agliztls,

macrourus,

major,

purpureus,

Regulns calendula, cuvieli,

sarmpa,

Phinogrvolus anm,

Rostrhamus sociabilis,

salpinetes obsoletus,

sixicula renanthe.

sayomis fusents,

niggricaus, sarus.

Searlafella inea

8 II. $05,11.30$

2
5
0
1
2
6
0
3
7
5
2
2

is 215

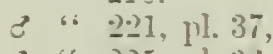

c " 2.25 .41 .30

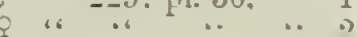

c " 2202, "6

8.. 214, pl. 3i

I. $75, \mathrm{pl} .5$. “

1. $75, \mathrm{pl} .5 ., \ldots$

III. 344 ,

“ 209.

I. $135, p] . \varepsilon$

" 60, pl. 5 ,

1. $343,[1.45$

" $3 \pm n, \cdots \cdots 1$

8. III. 35\%, 01. 55

scolecephalus cyanocephalus.

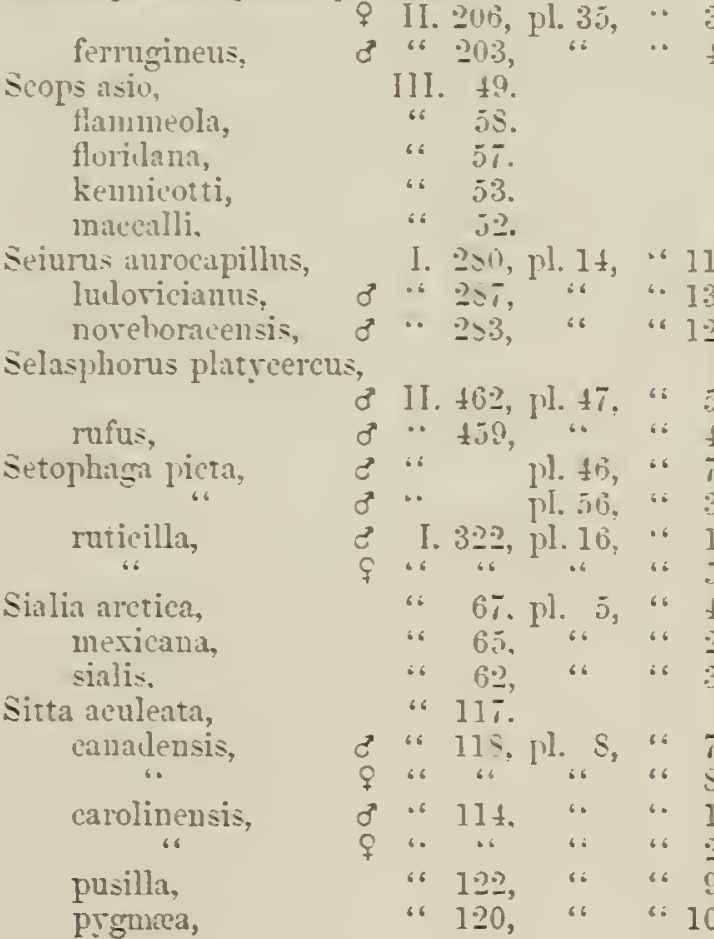

\section{ruber,}

thivroideus,

rarills,

willi:usoni,

silizella arizonr. atrigularis.

lireweri.

monticola,

Inalliıla,

jusilli,

Staricenas cyanocejhala

Stelgidapterrx serripenuis, Stellula calliope,

Strix pratincola

simmelia magra.

llegleeta.

sturnus vulgaris.

Sintuil ululit,

sirniun cinereum,

nebulosun,

Tachrcineta bicolor, $8 \quad 1.34 t, 17.10$, " $\mathrm{s}$ thalassina,

Thammatias limmei

Thrvoihons berlandieri, 1. $1 \pm \frac{1}{4}, 1.9, \ldots$,

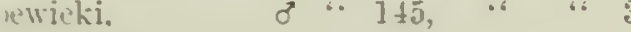

leneogaster, ludoricianus, syilurus,

Troclilus alexandri, colubris.

Troglodites atlon, alasensis,

hyrmalis, bacifieus, larkmanni,

Turdus alici.e, auluboni, confinis.

fuscercens,

iliaem,

migratorius,

mustelinus.

nerins,

กลวนเ,

Jilllasi.

wainsoni,

u- - $u$ littus,

d 1. $350,11.10, \cdots 1$.

II. $4 \frac{14}{4}, 11.4 \bar{i}, \cdots$

3 II. 17t, pl. 3t. “ -2

2 $1,6, \ldots$, 6

iा 2020,

111. 30.

" 34

“6 38.

Trramus cinoliuensis, 8 II. 316 . pl. 43 , “ collehi,

dominicensis,

rerticalis,

rociferum

Vireo atricapillus,

belli.

luttoni,

noret aracensis.

pusillus,
“ $1 \pm \vec{i}$.

. 142,

. 11\%.

11. 4 il, I1] 45, "

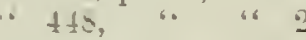

15.

“ 15.), "

“ 153

11, pl. 1, "6

ำ " "

?7, pl. 2, "

1, [1]. 1, “6

23. 11]. 2, “

05 × 63

․, pl. 1. “. 1

20. [1. 2, 202

20. pl. 1, 60 -

“ 329,660

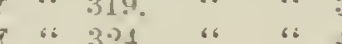

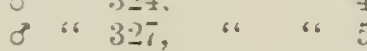

द $1.353, \mathrm{p} 1.17$, " 6

8 " 399, " 613

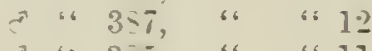

[. $14 \%$, pl. $\Omega, \cdots j$

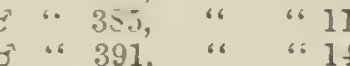




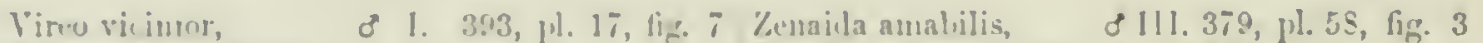

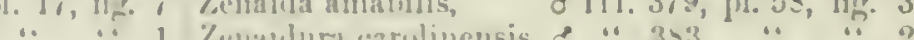

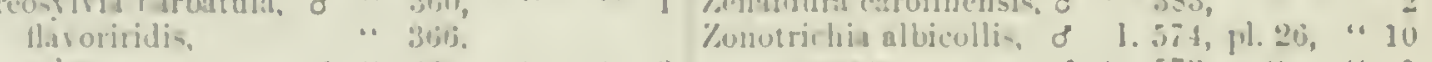
gitlit, olina 8 " istio $\therefore$ : 36.3, Hhathelpilices,

i. $31 \%$, corultats, tram $x \cdot 1$, .. (Jur.) \& $\cdots$ ? slratusulsi,

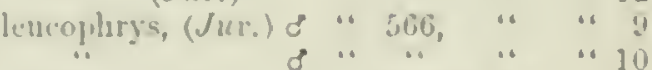

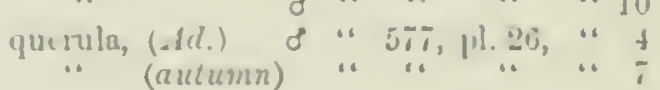

Xanthorephalus icterue fluslus

Xruthomu luxiusal,

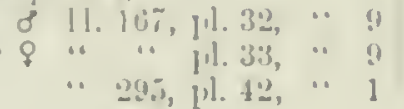



PLATE I.
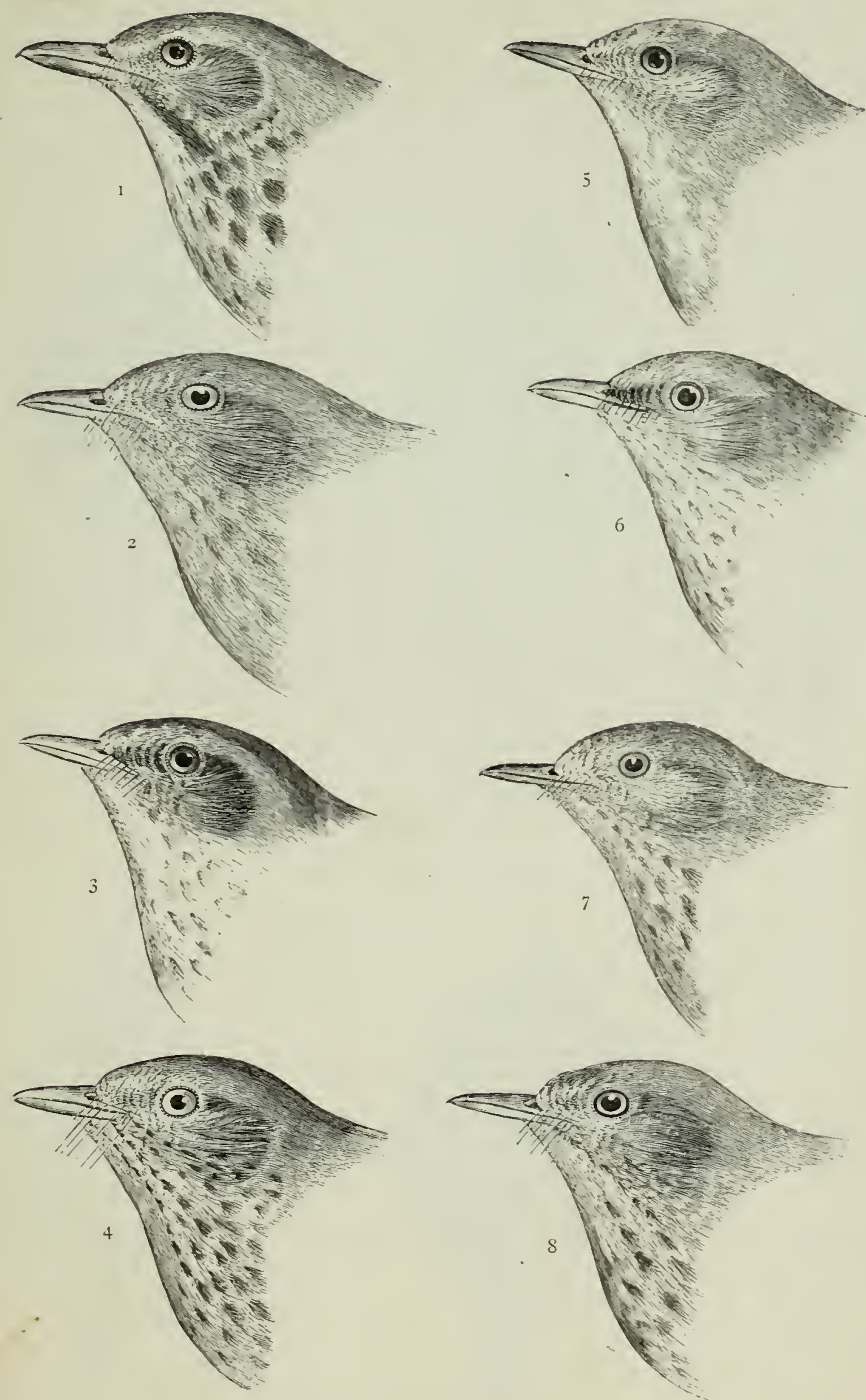

1. Turdus mustelinus, Om. Penn., 157

2. " ustulatus, liutt. Oregon, 204

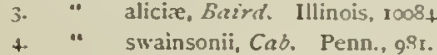

5. Turdus fuscescens, Secph. D C., $2823 x$.

6. ". pallasiti, Cab. Penn., 2146 .

. " nanus, Alut. Cala., 1jg9 
A p

or 
PLATE III.
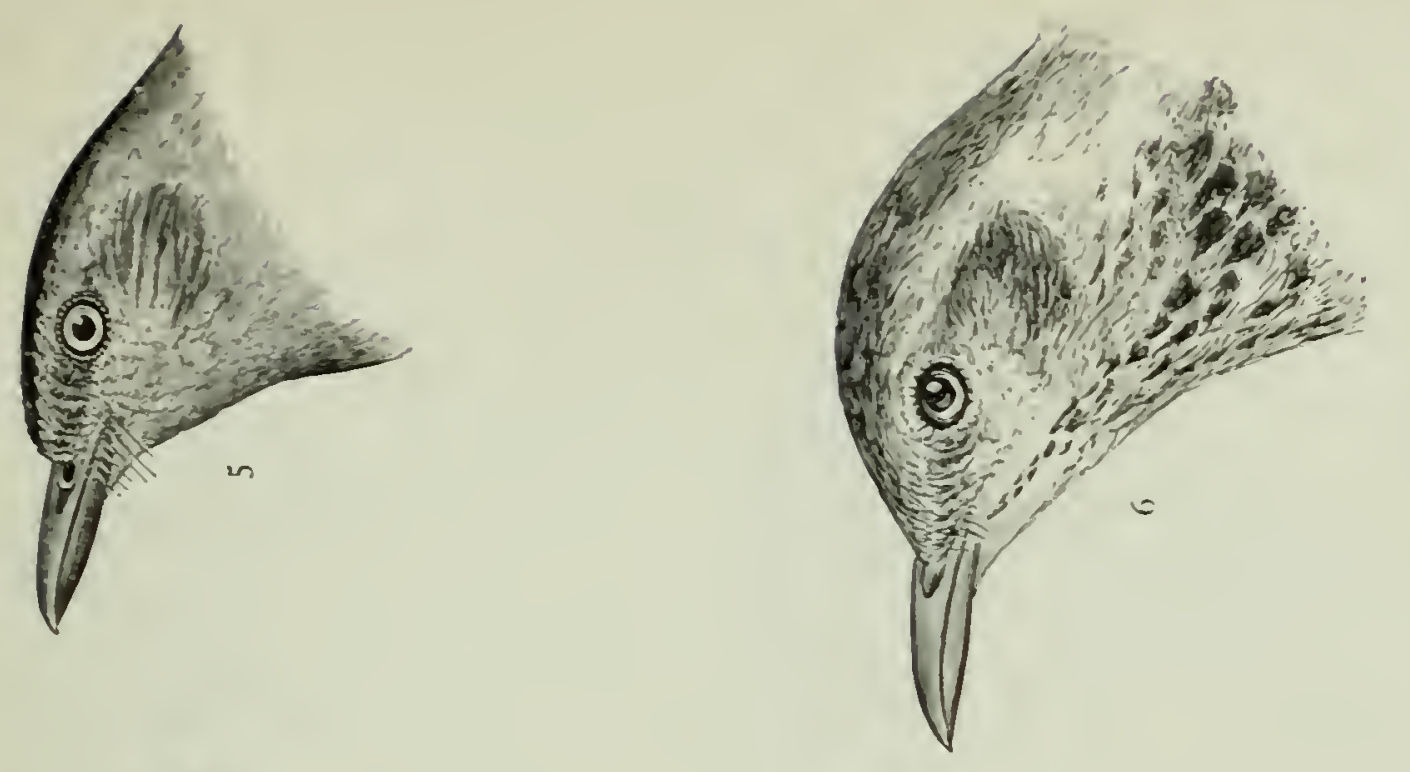

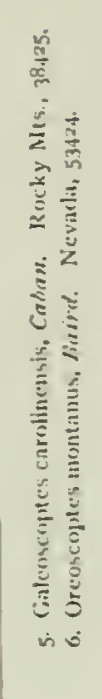
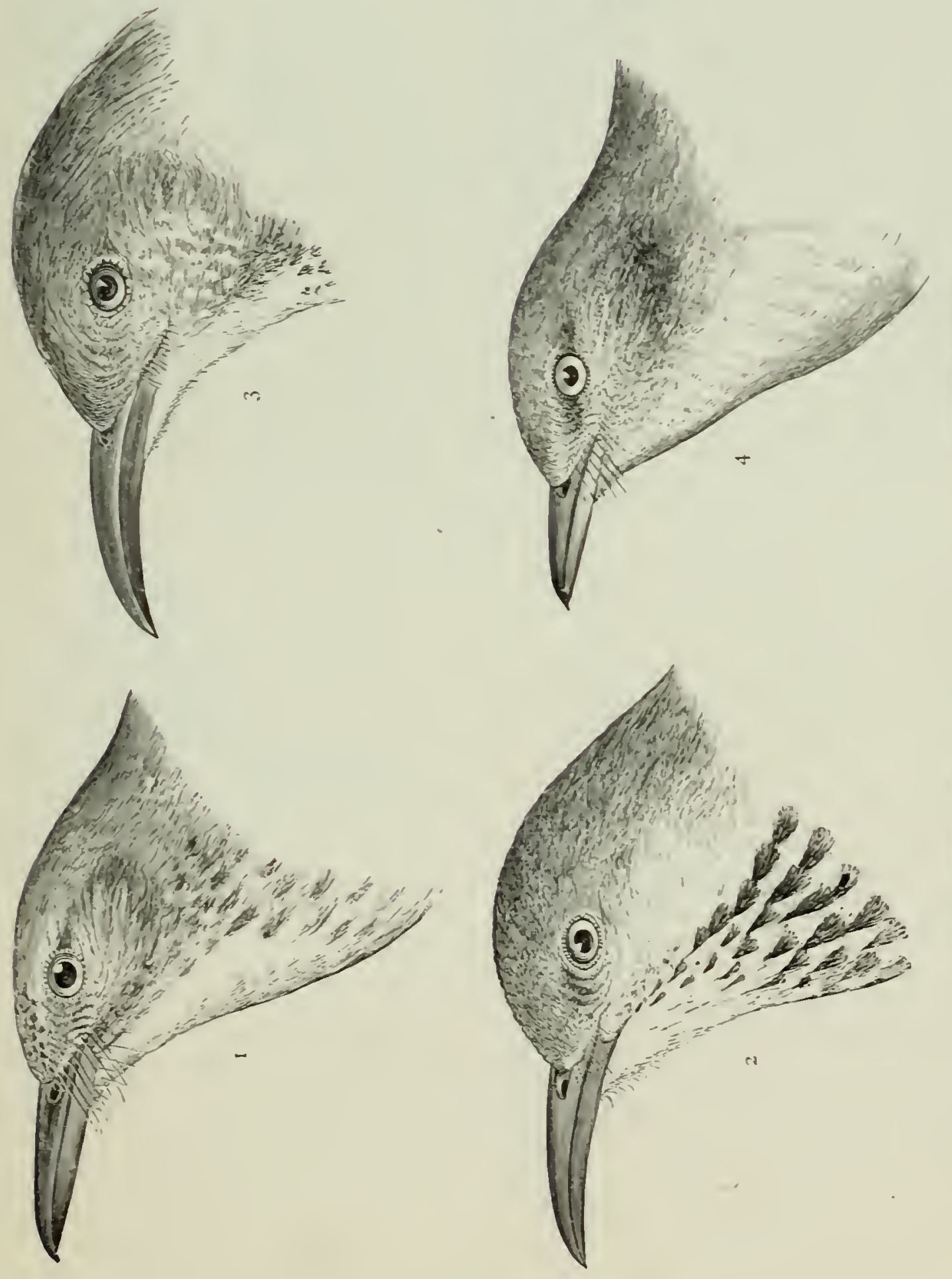

PLATE V.
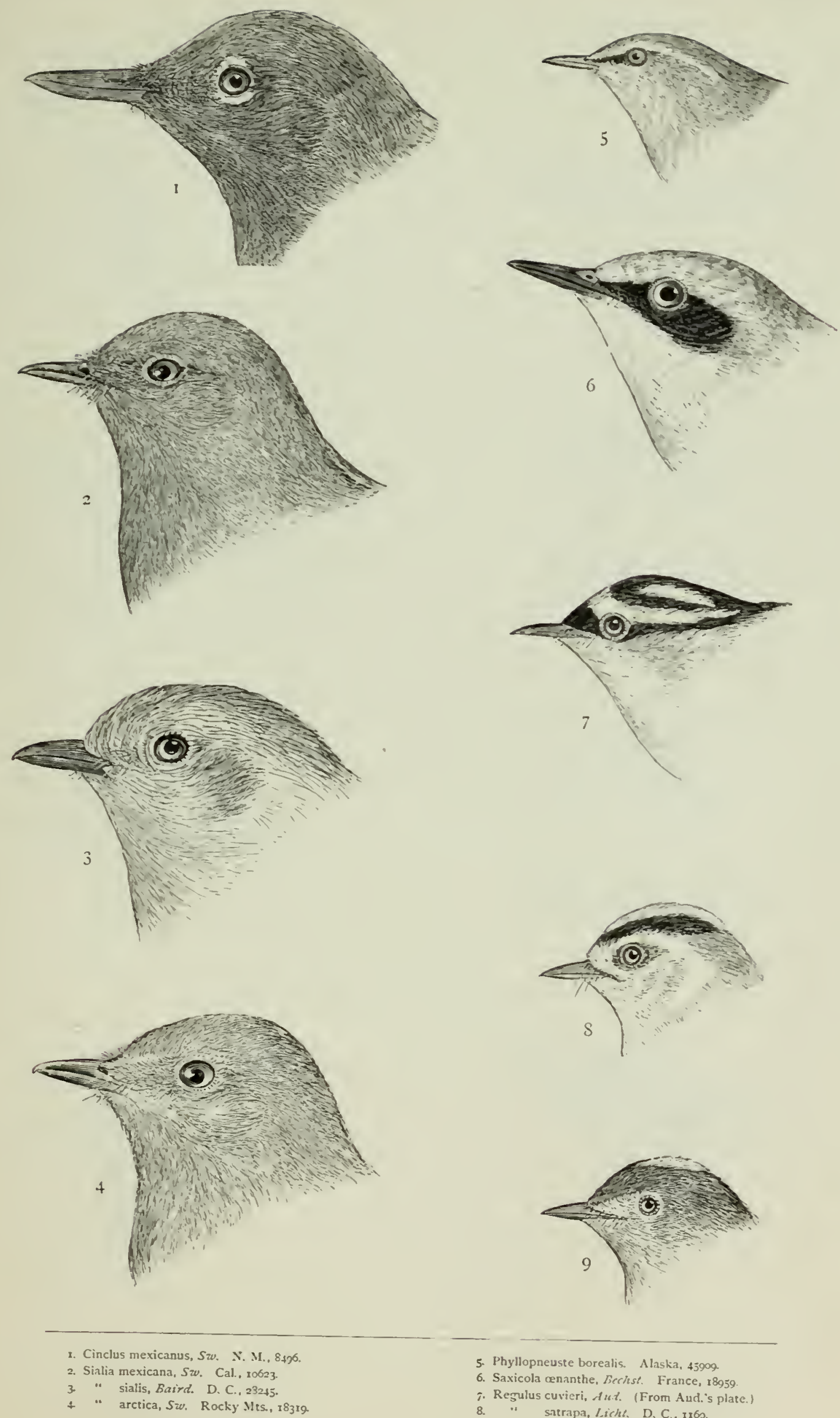

5. Phyllopneuste borealis. Alaska, 45909.
6. Saxicola oenanthe, Bechist. France, 18959 .
7. Regulus cuvieri, A wh. (From Aud."s plate.)
8. ." satrapa, Lich. D. C., I16s.

9. “ calendula, Licht. Penn., $73^{6}$. 
ivite ditar ing 8! Elat 
PLATE VI.
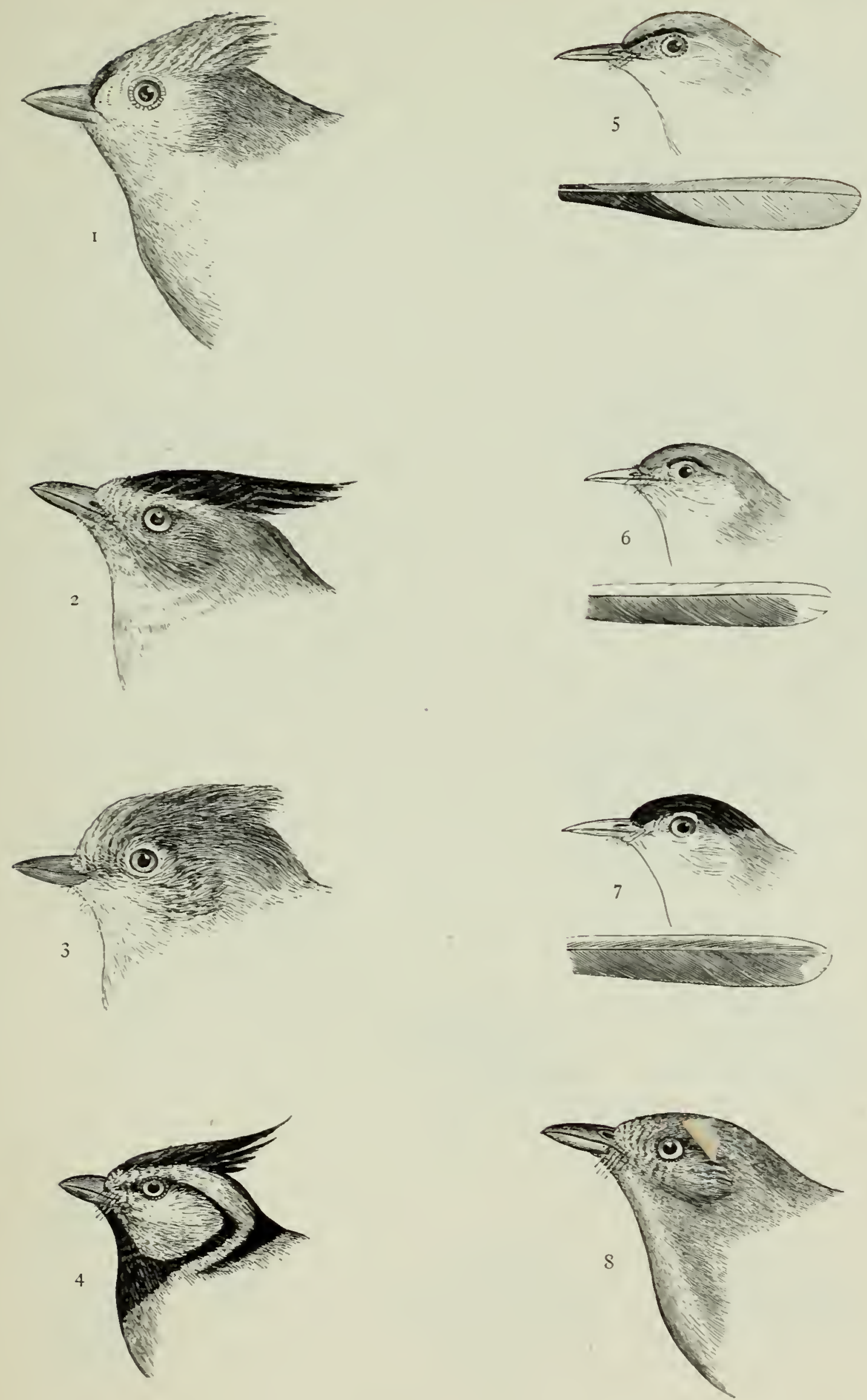

I. Lophophanes bicolor, Bon. III. 29679

atricristatus, Cass. Tcx, 125?

$\begin{array}{lll}2 . & \text { atricristatus, Cass. Tex., 12I } \\ 3 . & . & \text { inornatus, Cass. Cal. } 3705 \mathrm{r} . \\ 4 & . & \text { wollweberi, Bon. Ariz., } 40712\end{array}$

Polioptin cterulea, Scl. IIl, 10213.

6 " plumbea, Baird. Ariz., 31545

7. " melanura, Lazur. Cal., 7 191.

8. Chanzea fasciata, Gamb. Cal, 5924 
inde iliny iitin? III. (?) gik: s.avi Ed 
PLATE TII,
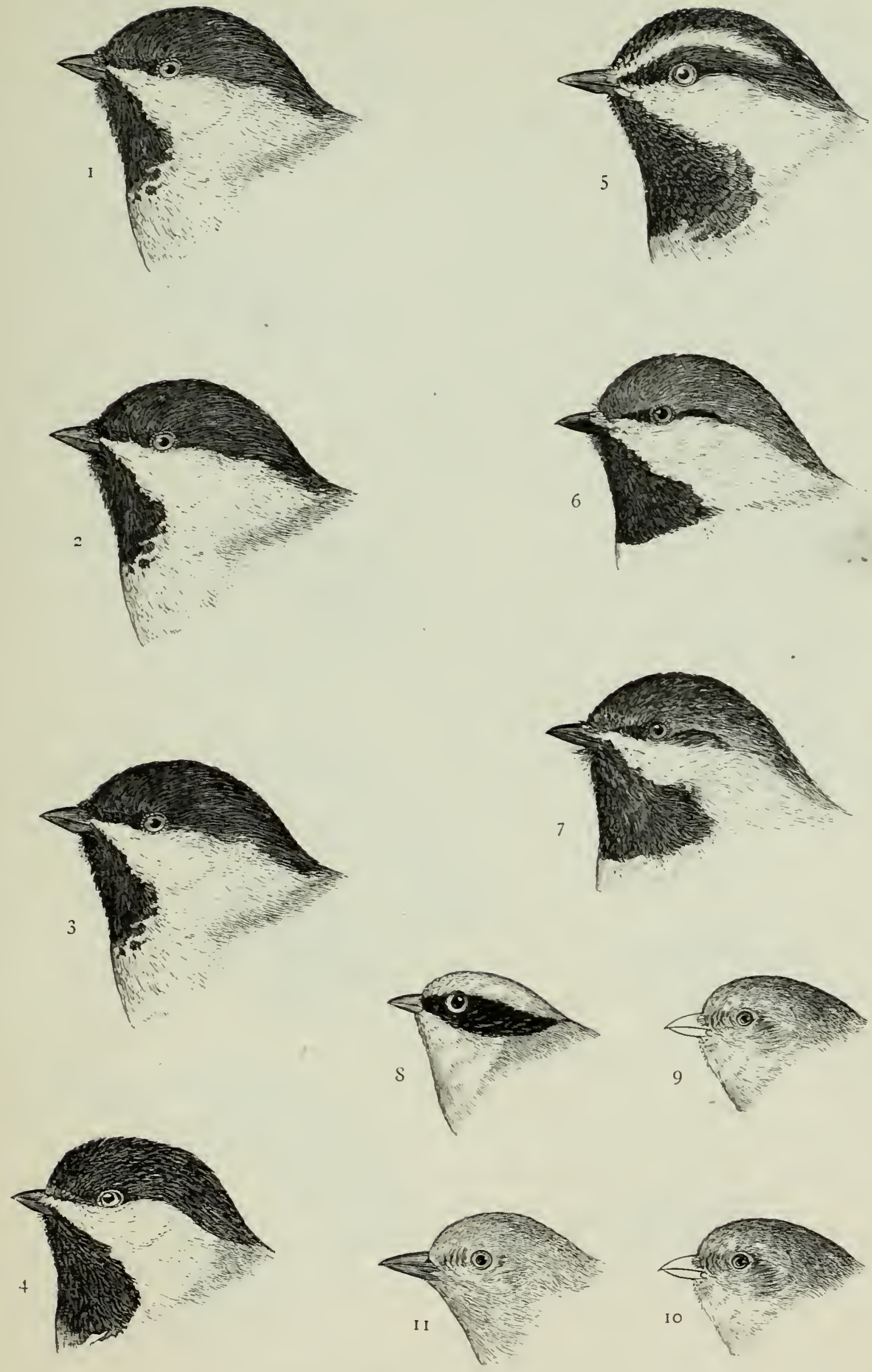

t. Parus atricapillus, Lim o N. York, $1285 \mathrm{I}$.

. var. septentrionalis, Harris. Mission Valley.

. var, occidentalis, Baird. Washinzton Territory.

" carolinensis, Aud. of D. C., , 06.

6. ." rufescens, Tomens, Pacific cosi5. 
PLATE VIII.
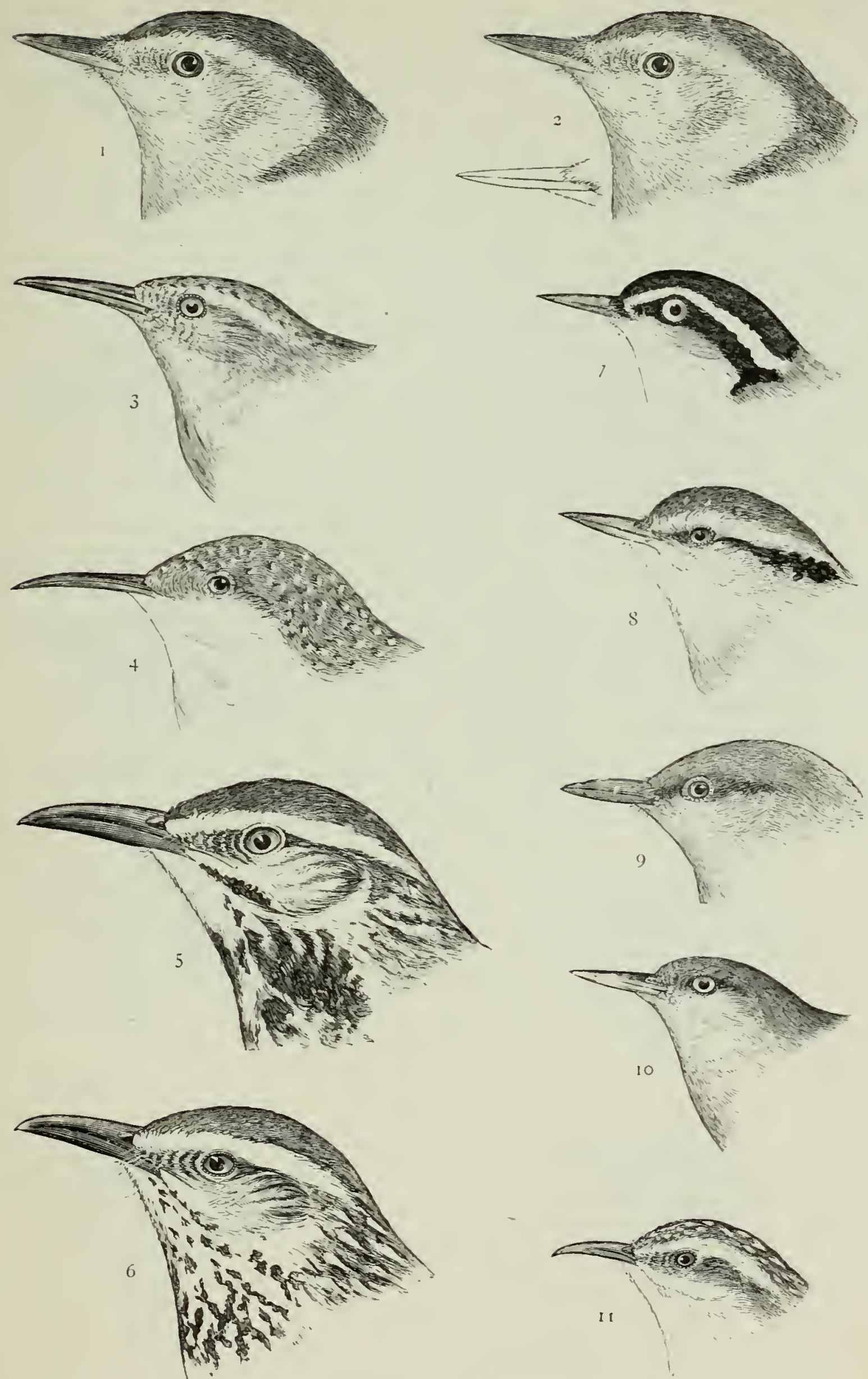

1. Sitta carolinensis, Gm. of Pa. 5932+

3. Silpinctes obsoletus, Say. Cal, 7157.

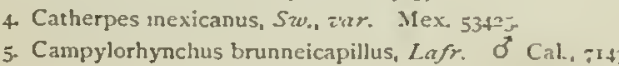

affinis, Pantucs. Oे Carc St, Lucas, 1296 
PLATE IX.
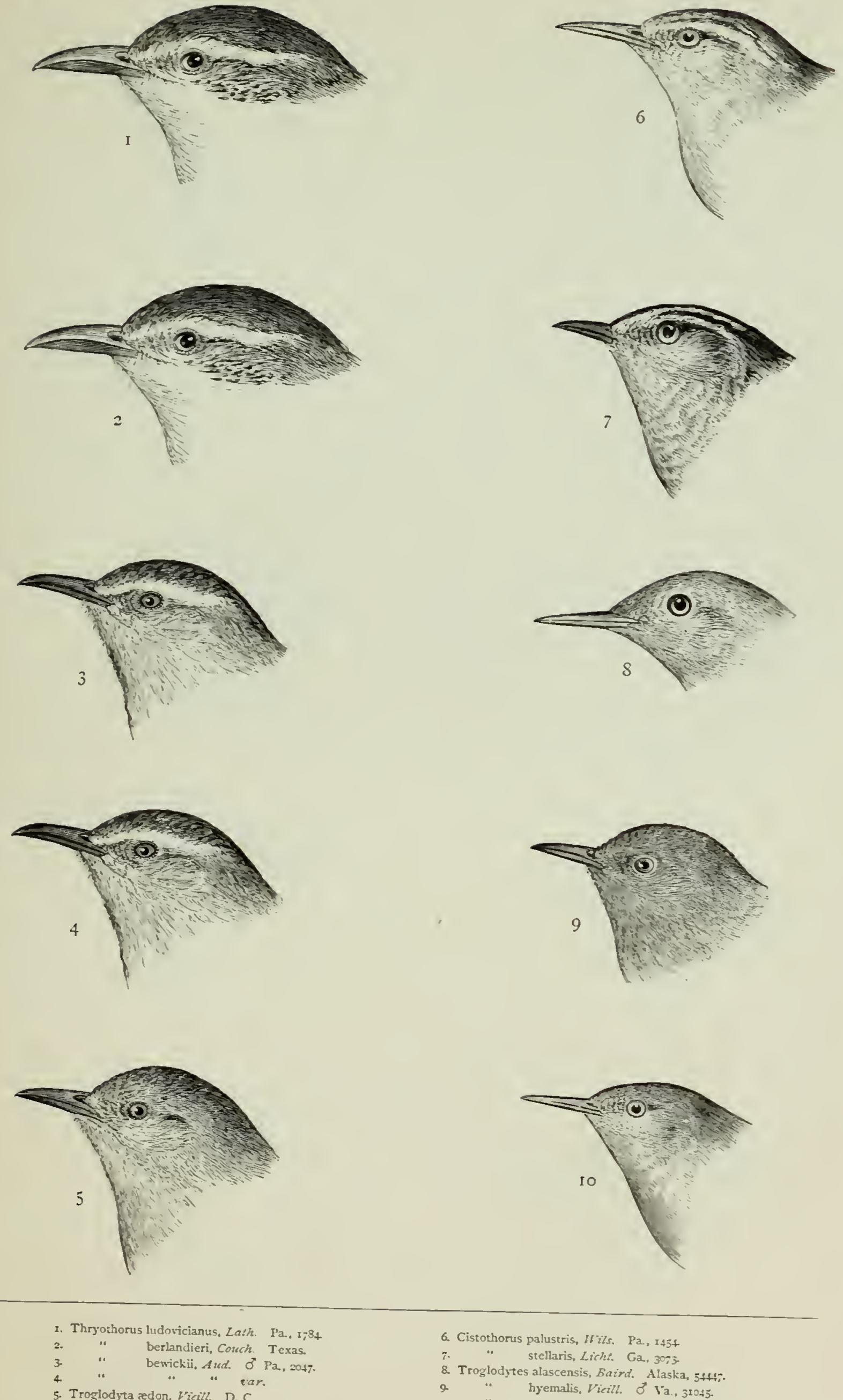

6. Cistothorus palustris, Wils. Pa, $145+$

7. " stellaris, Liche. Ga, $30 ; 5$

8. Troglodytes alascensis, Baird. Alaska, sutit.

5. Troglodyta adon, vicill. D. C

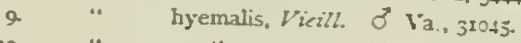


Plate $\mathrm{X}$
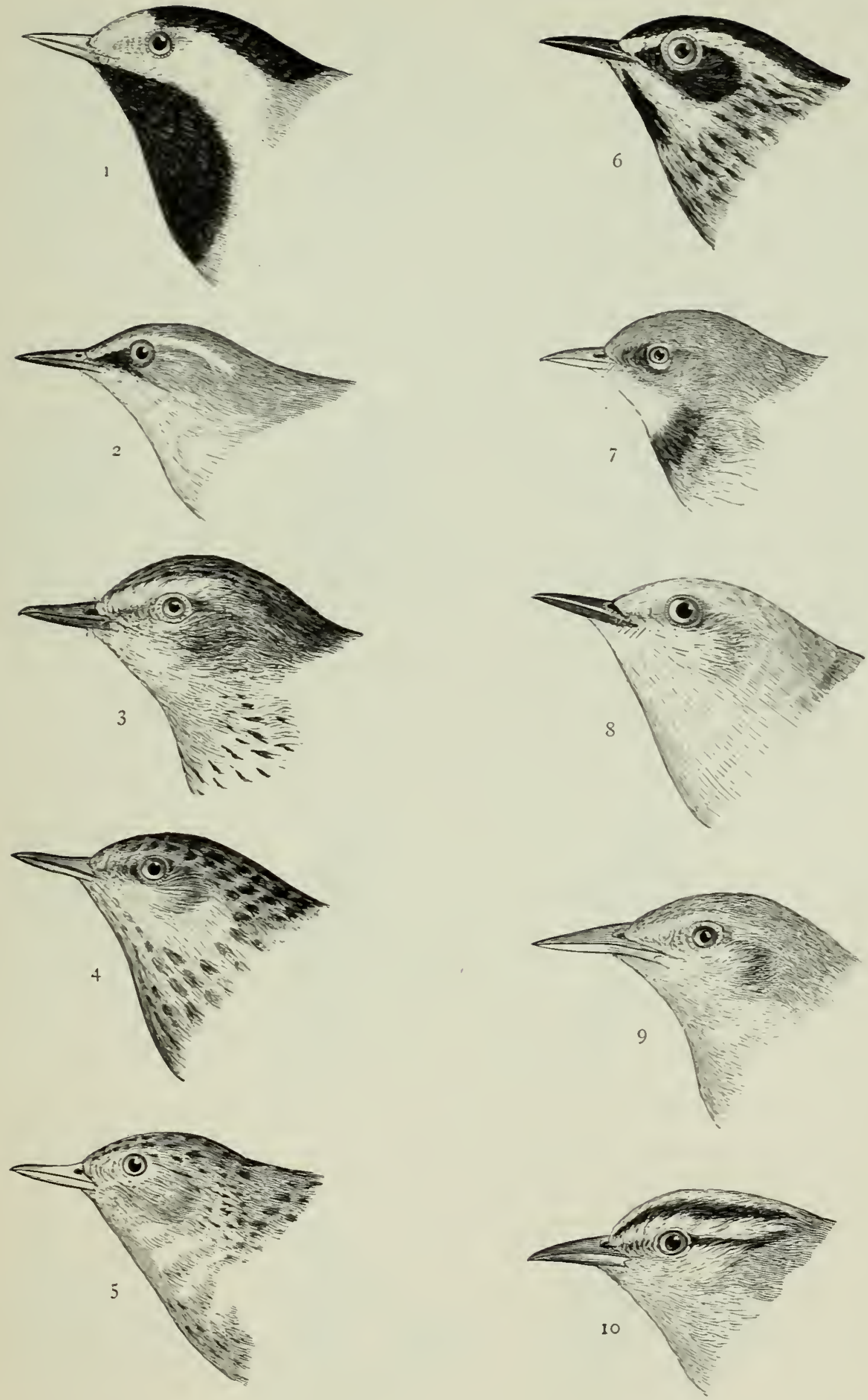

I. Motacilla alba, Lirn. Europe.

2. Budytes flava Lirre. Alaska, 45912.

3. Anthus ludoricianus, Gm. Labrador, r808

4 "“ pratensis, Linn. Europe, 18590.

6. Mniotilta varia, $\operatorname{Lin} n$. O 18685

7. Parula americana, Linn. $\delta \mathrm{Pa}, 5338=$

8. Protonotaria citrea, Bodd. IIL., sosi.

9. Helmitherus swainsoni, Aud. S. C., ro5t

. Ncocorys spraguei, $A$ ud. $f$ Dacota, I88

10. vernivorus, $\mathrm{Gm}$. $\mathrm{Pa}$ at 
PLATE XI
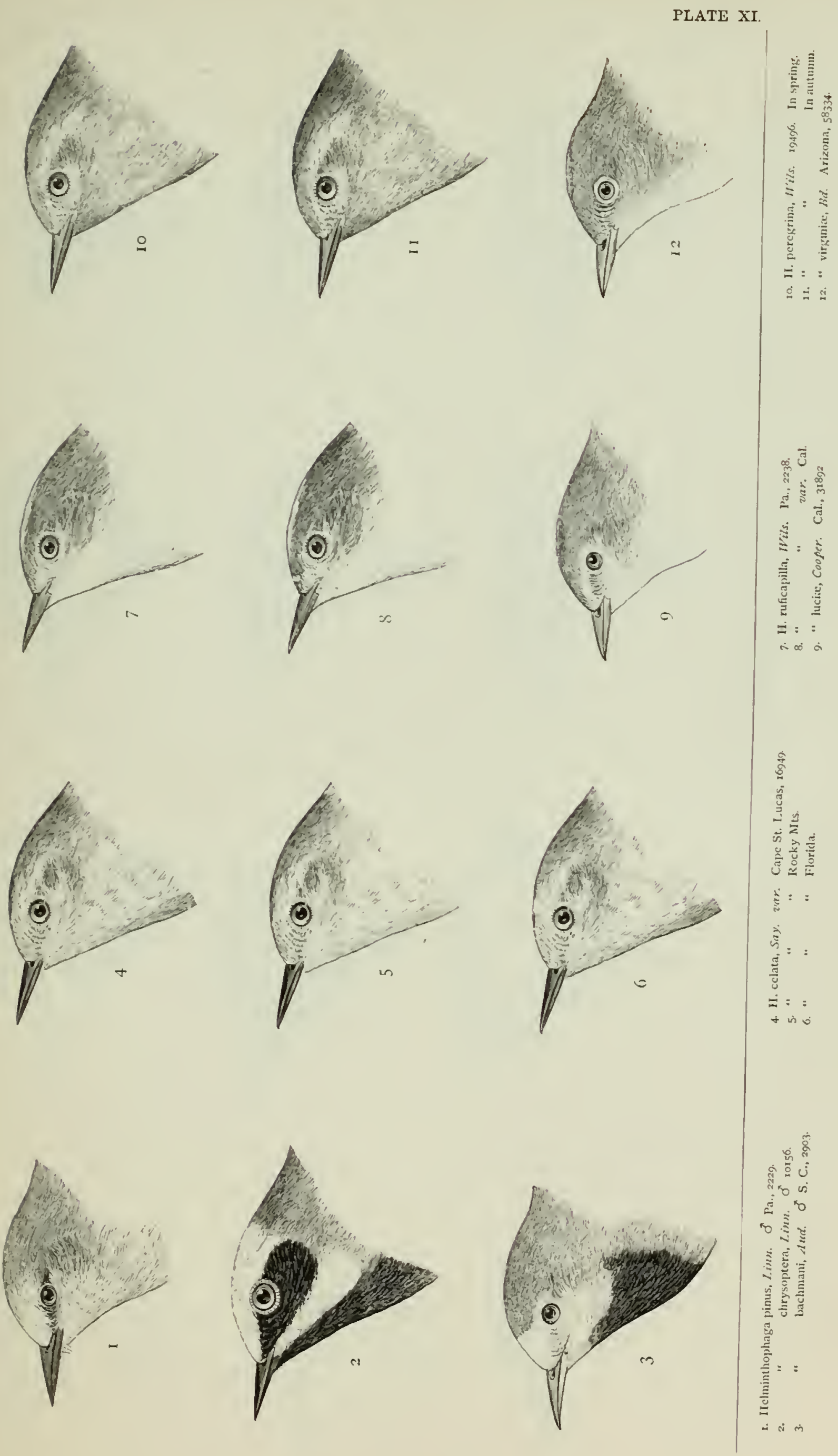
PLATE XII.
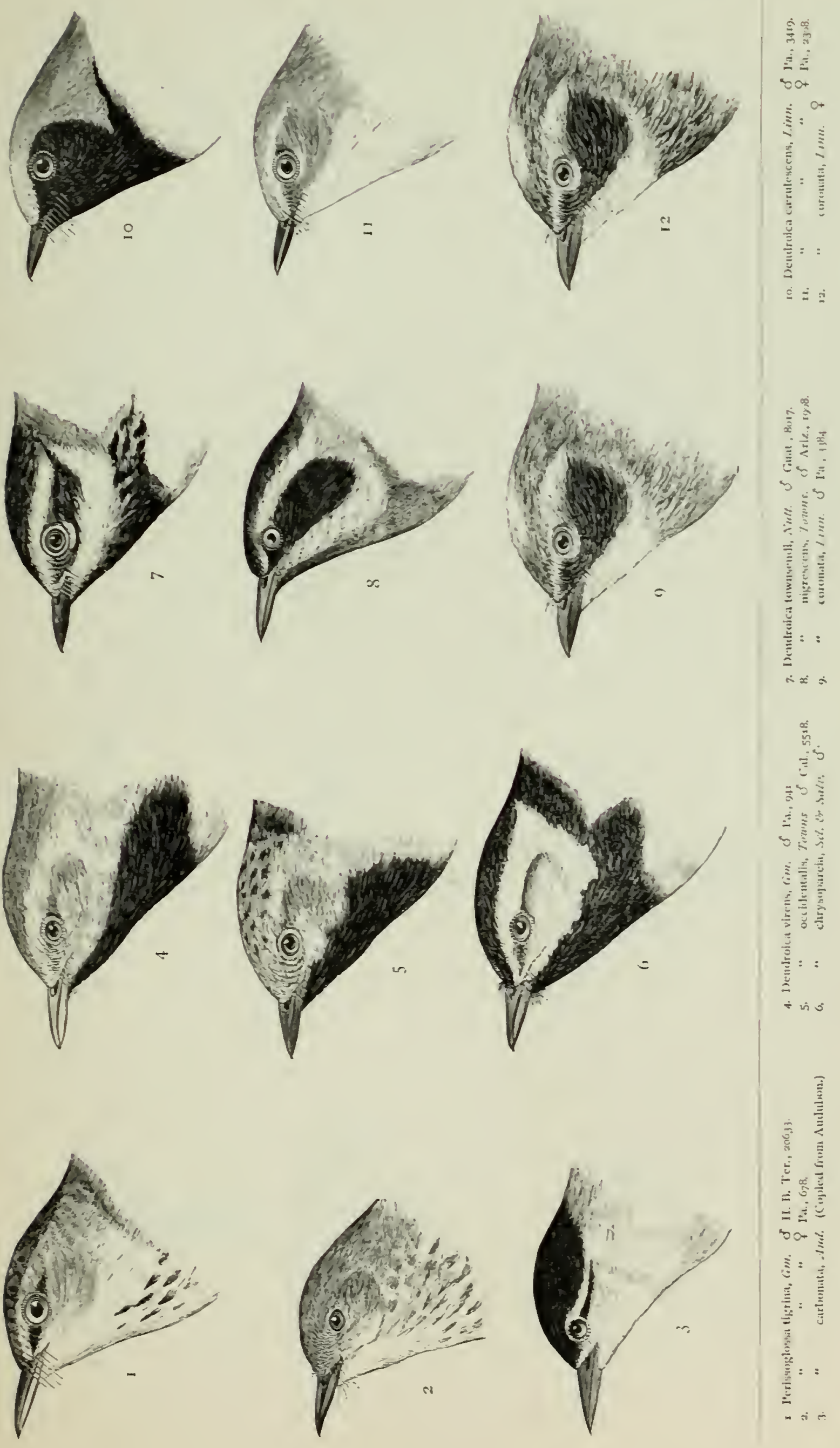
inep ingr iii the 
PLATE XIII.
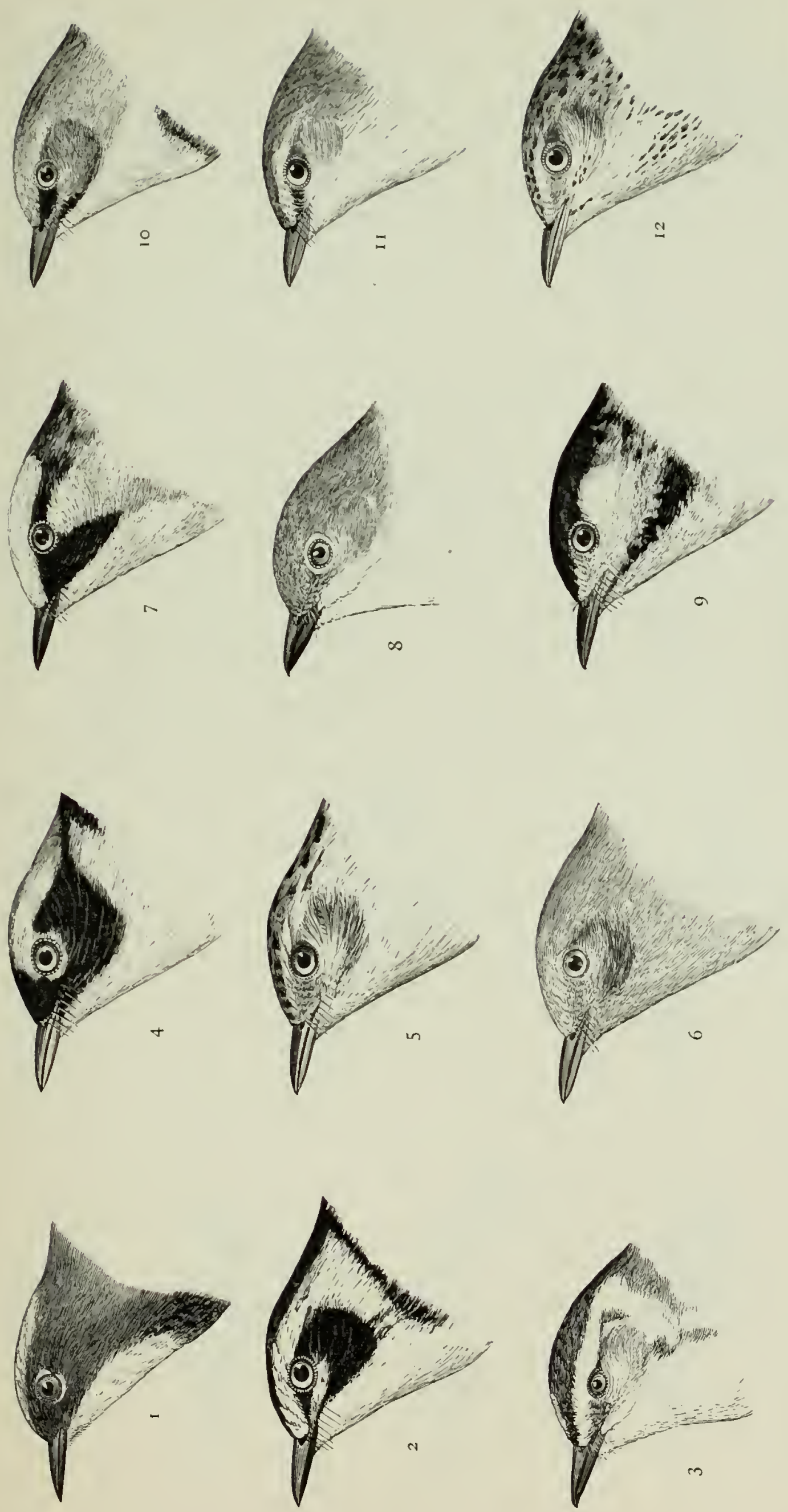

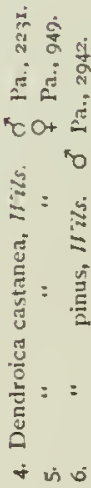

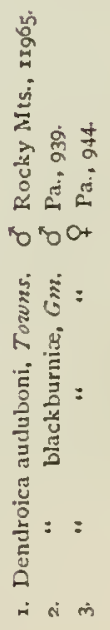


ilite

III Iit: 8i (1): gias Ging Nais $\frac{1}{4} 13$ $\frac{17}{4}$ 

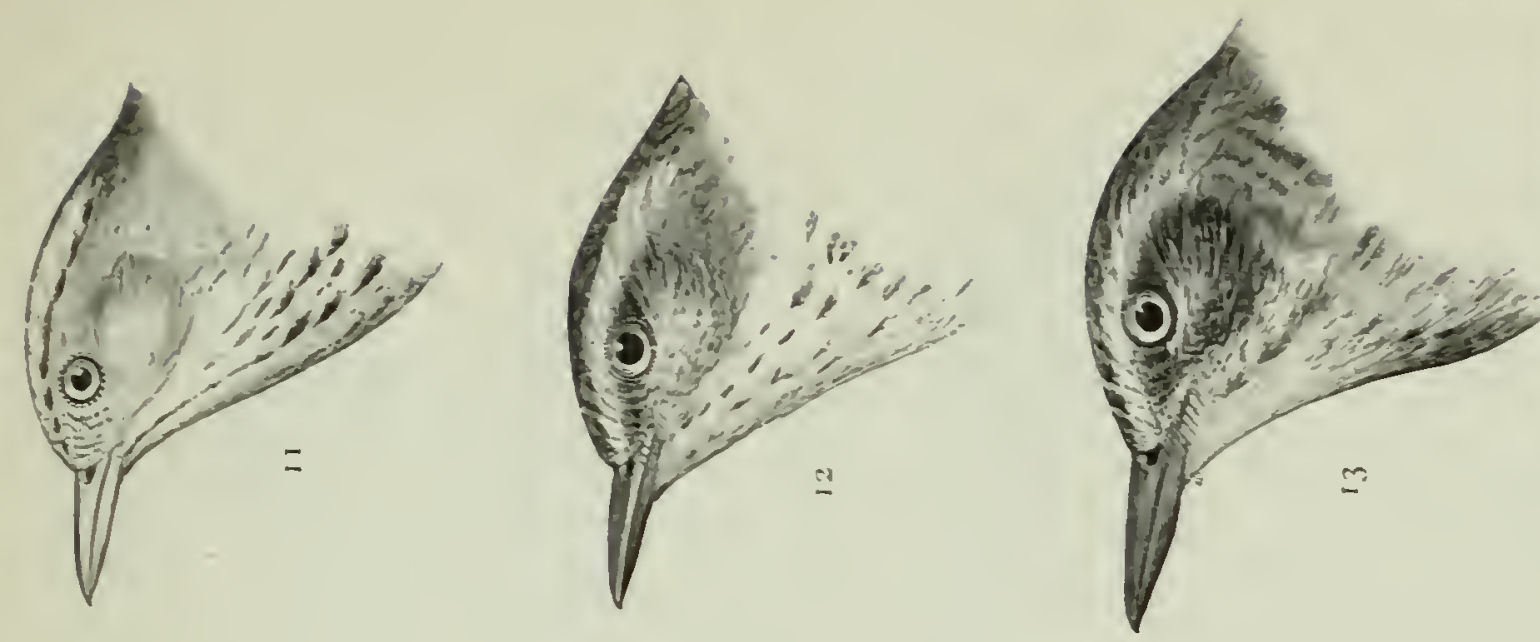

章意

5

突
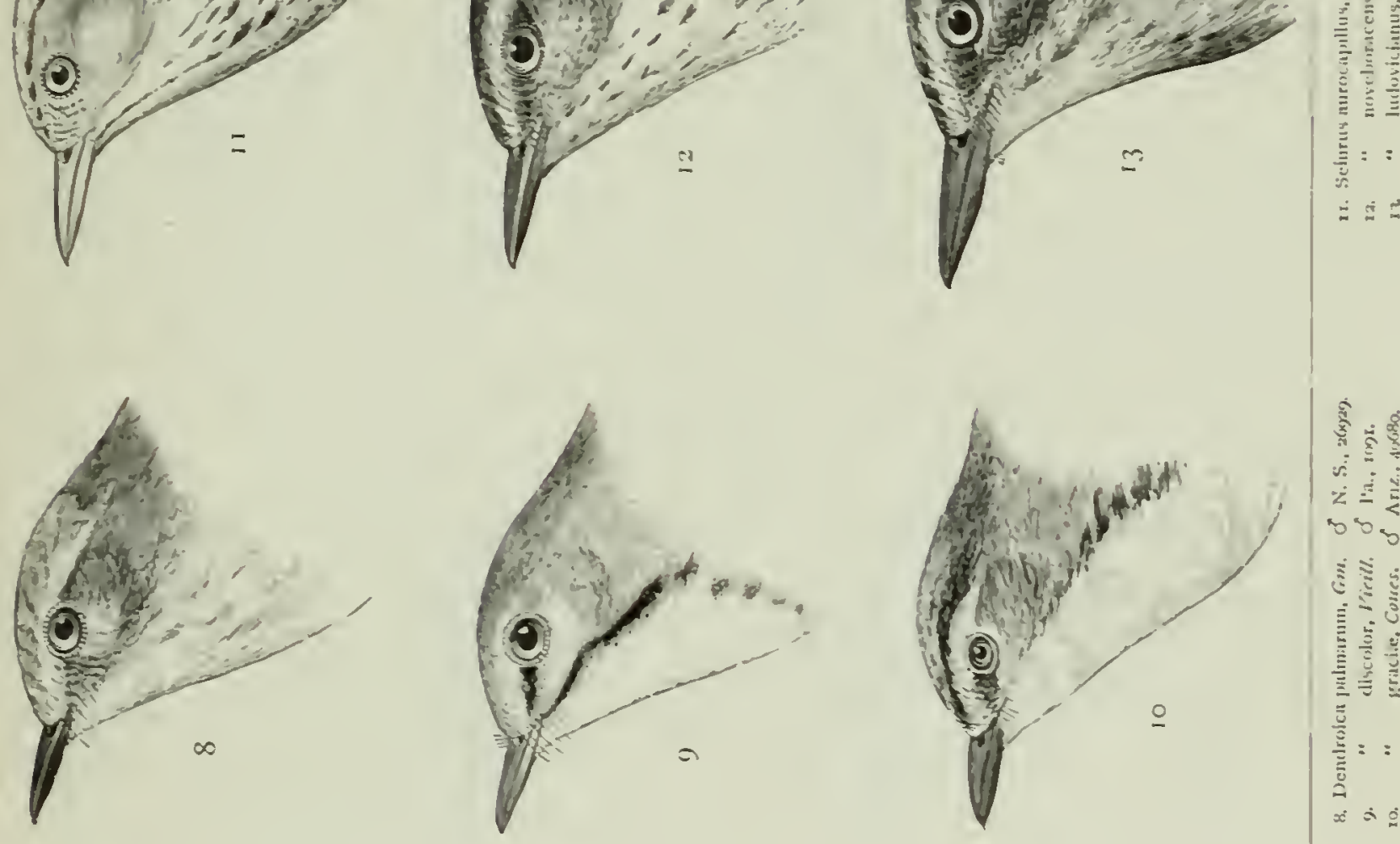

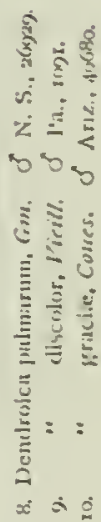
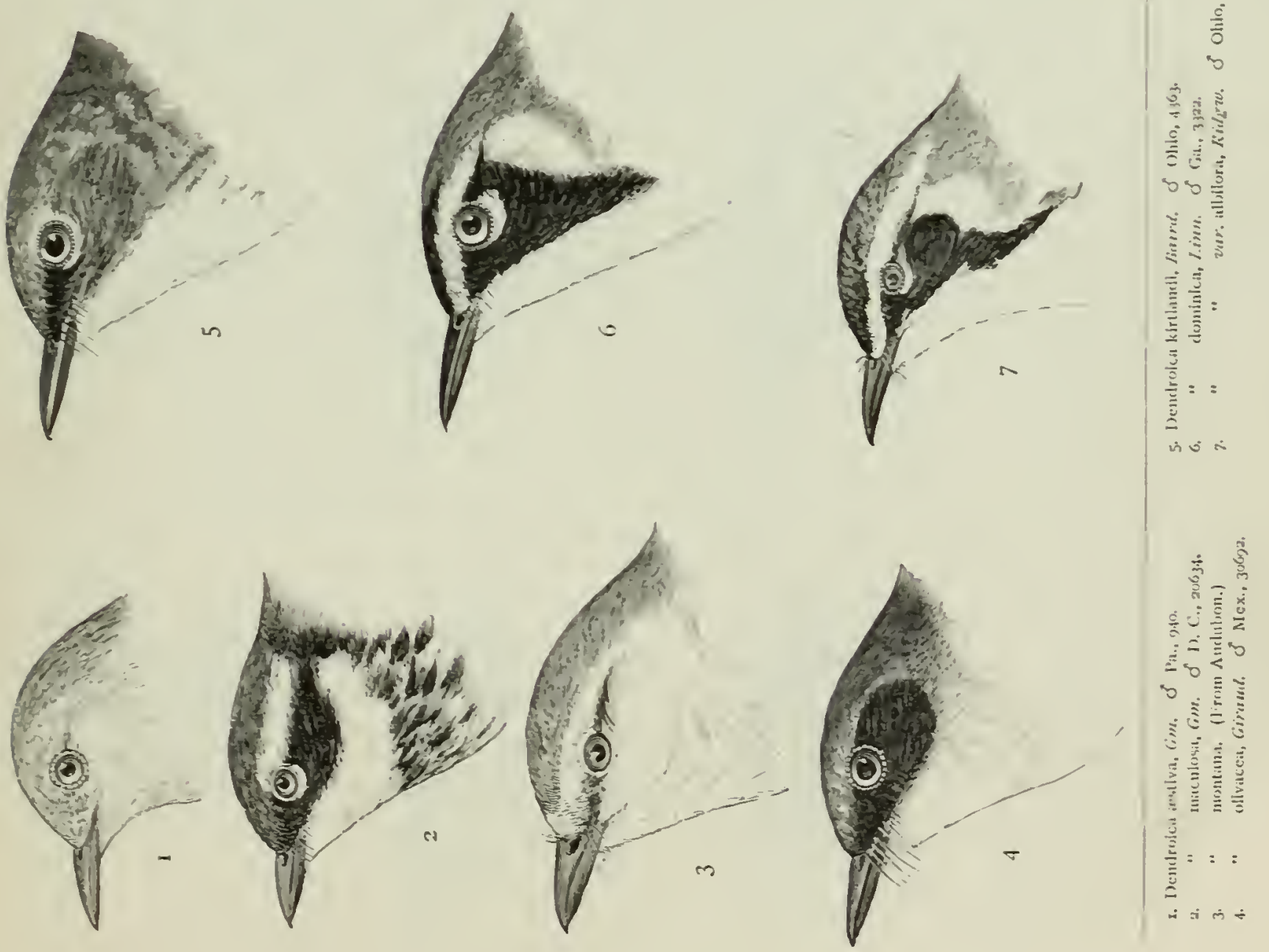
PLATE XV.
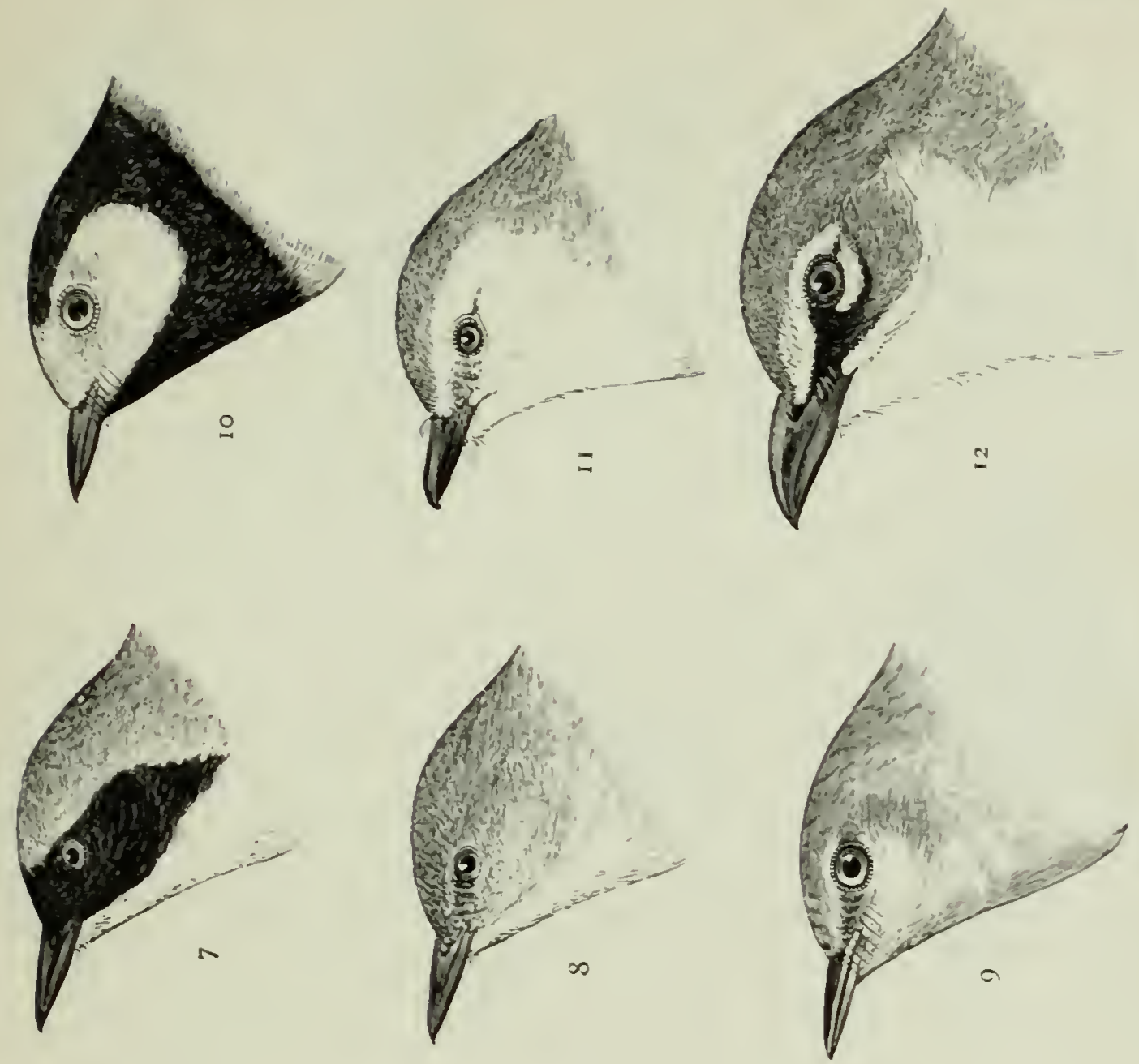

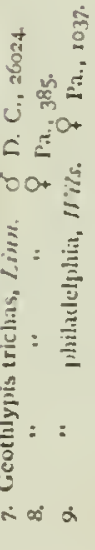
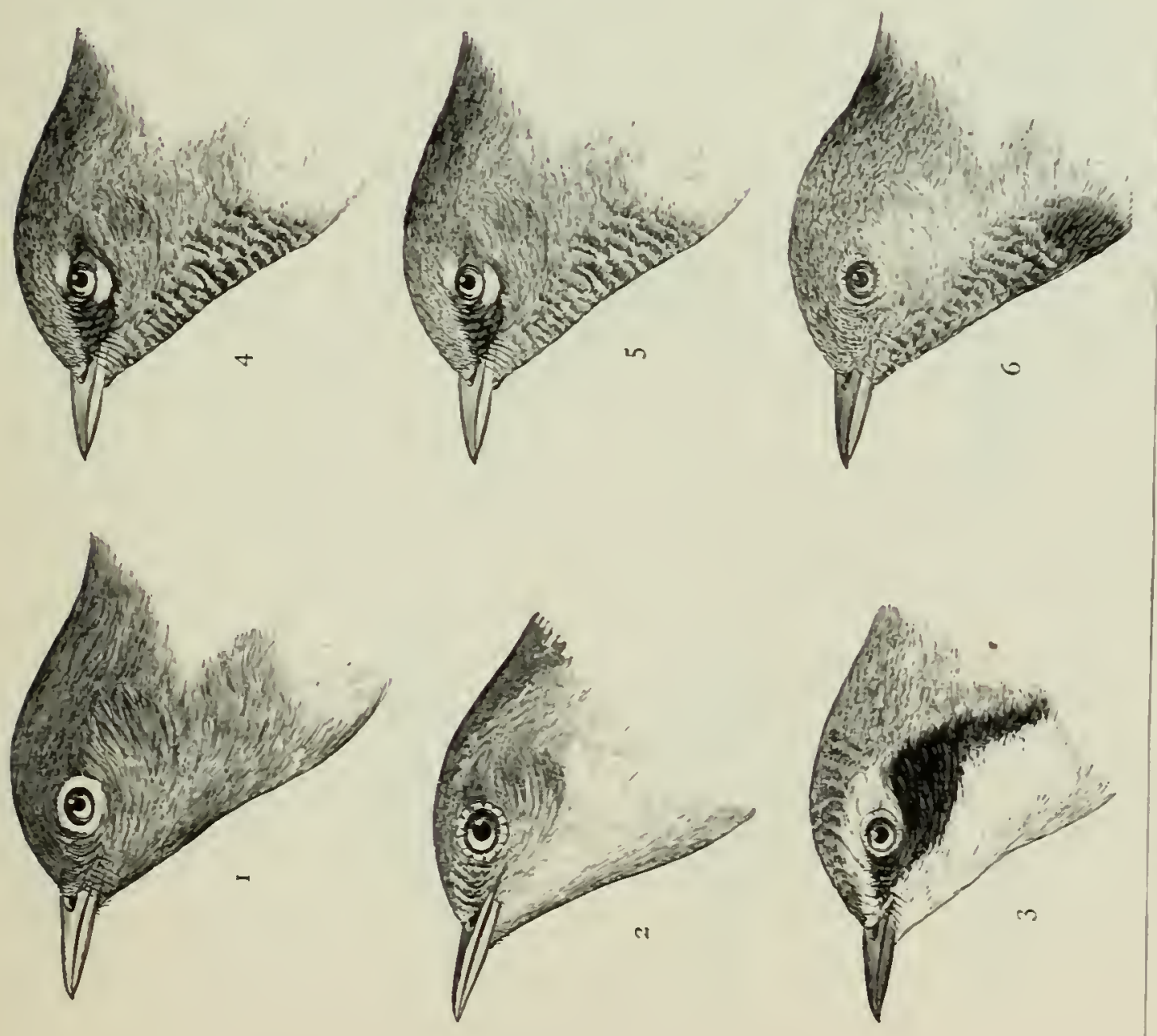

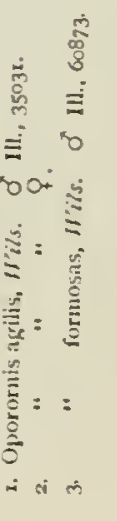


ind

Itty

int?

ing

Uif

vistu

hat

gat

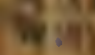

8

th 
PLATE XVI
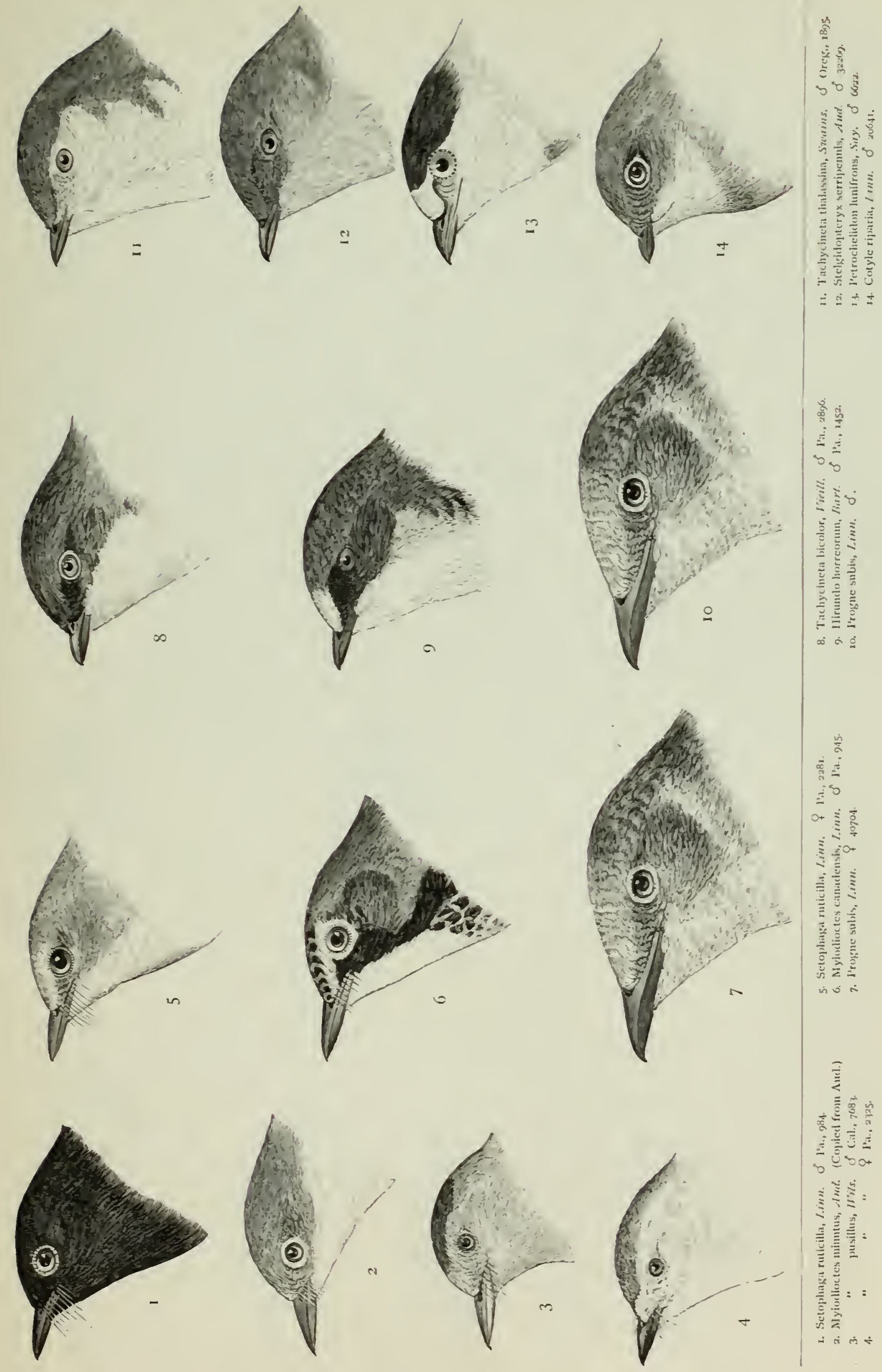
inep IIIy iut Ais 16 



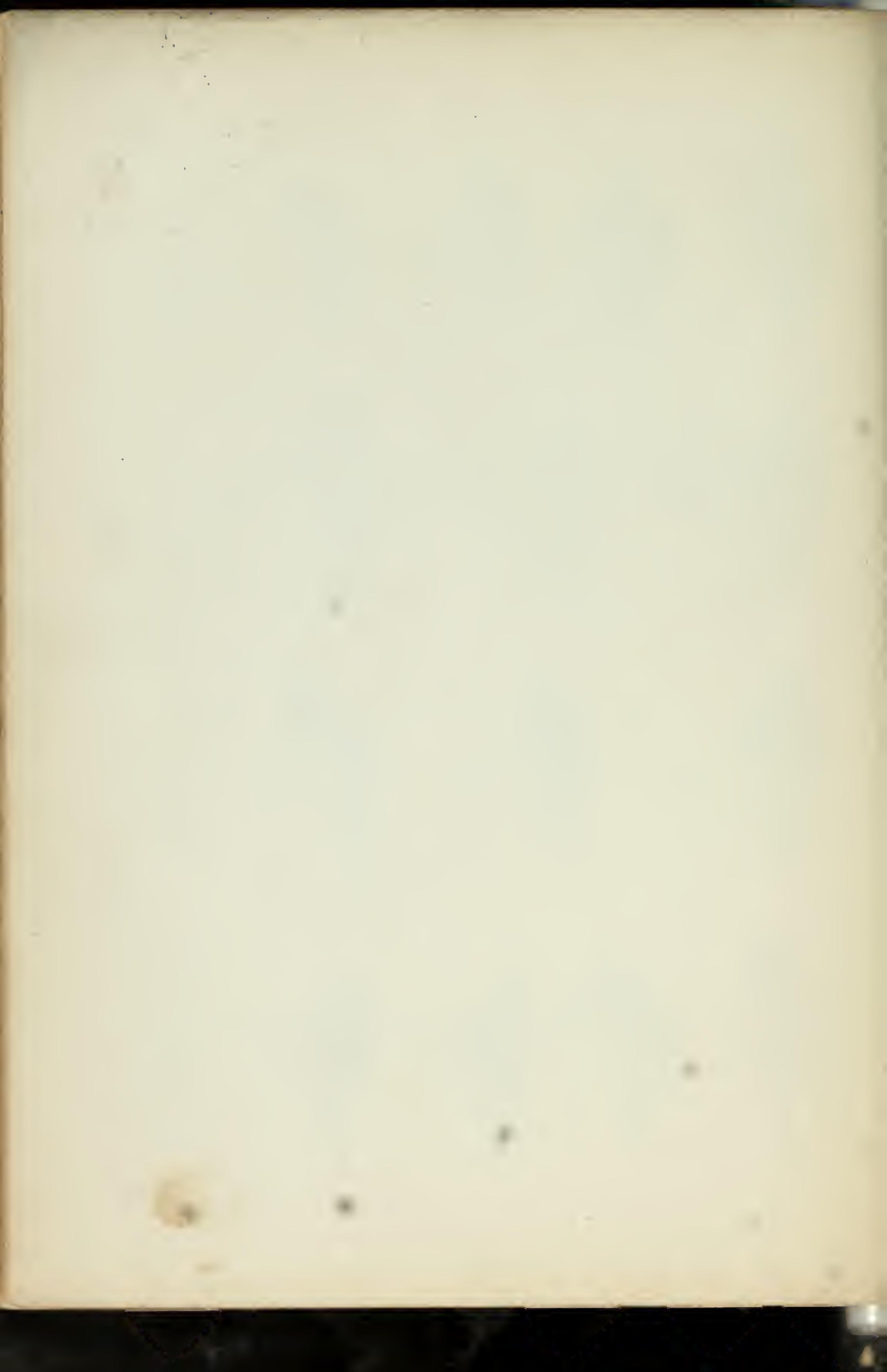




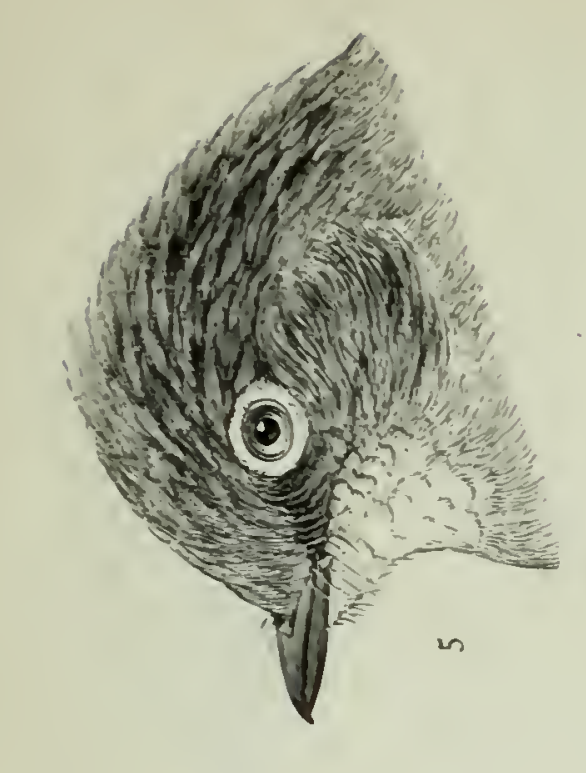

PLATE XIIII.
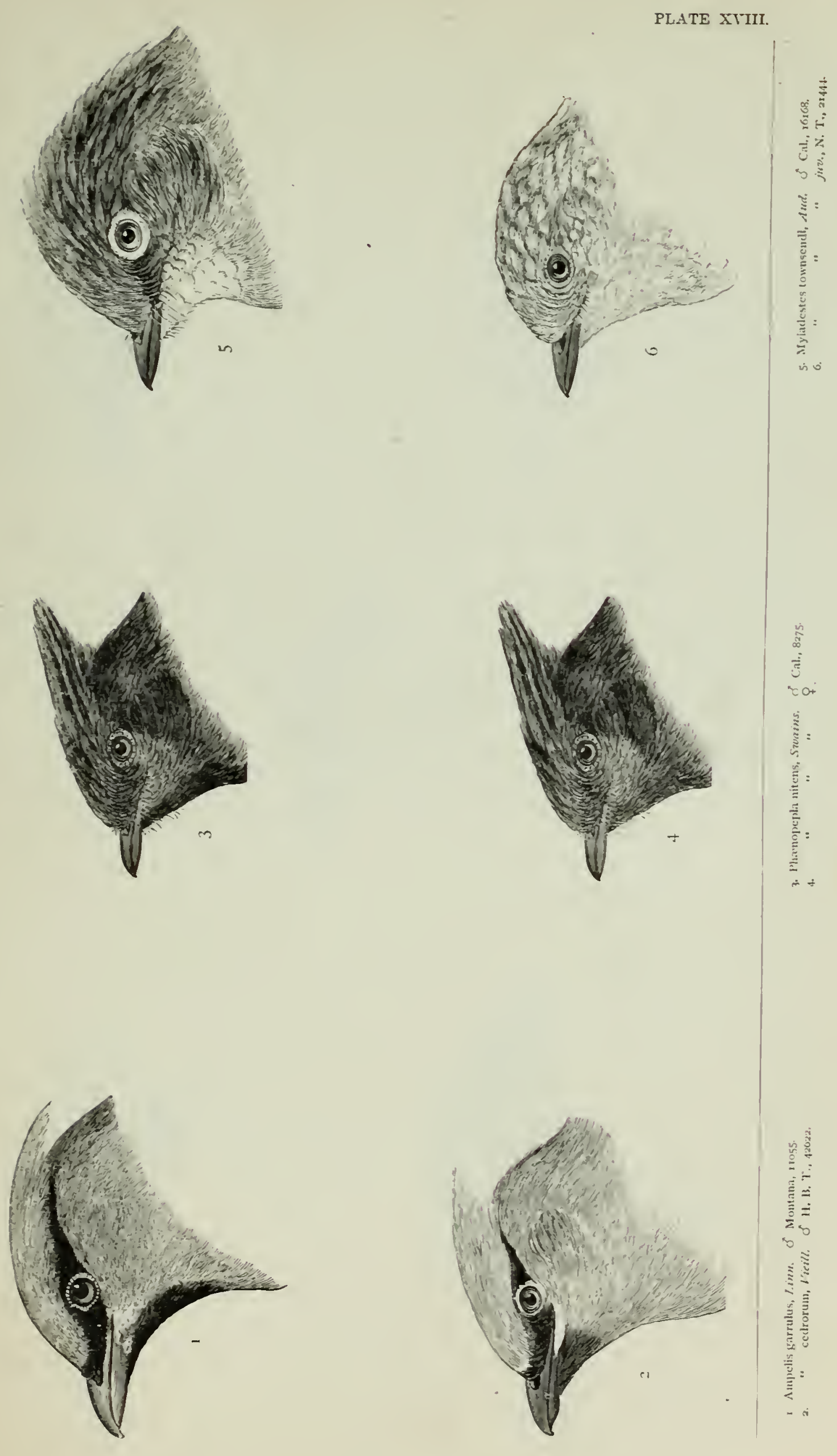


$$
\begin{aligned}
& 84 \\
& 88
\end{aligned}
$$


PLATE XX.

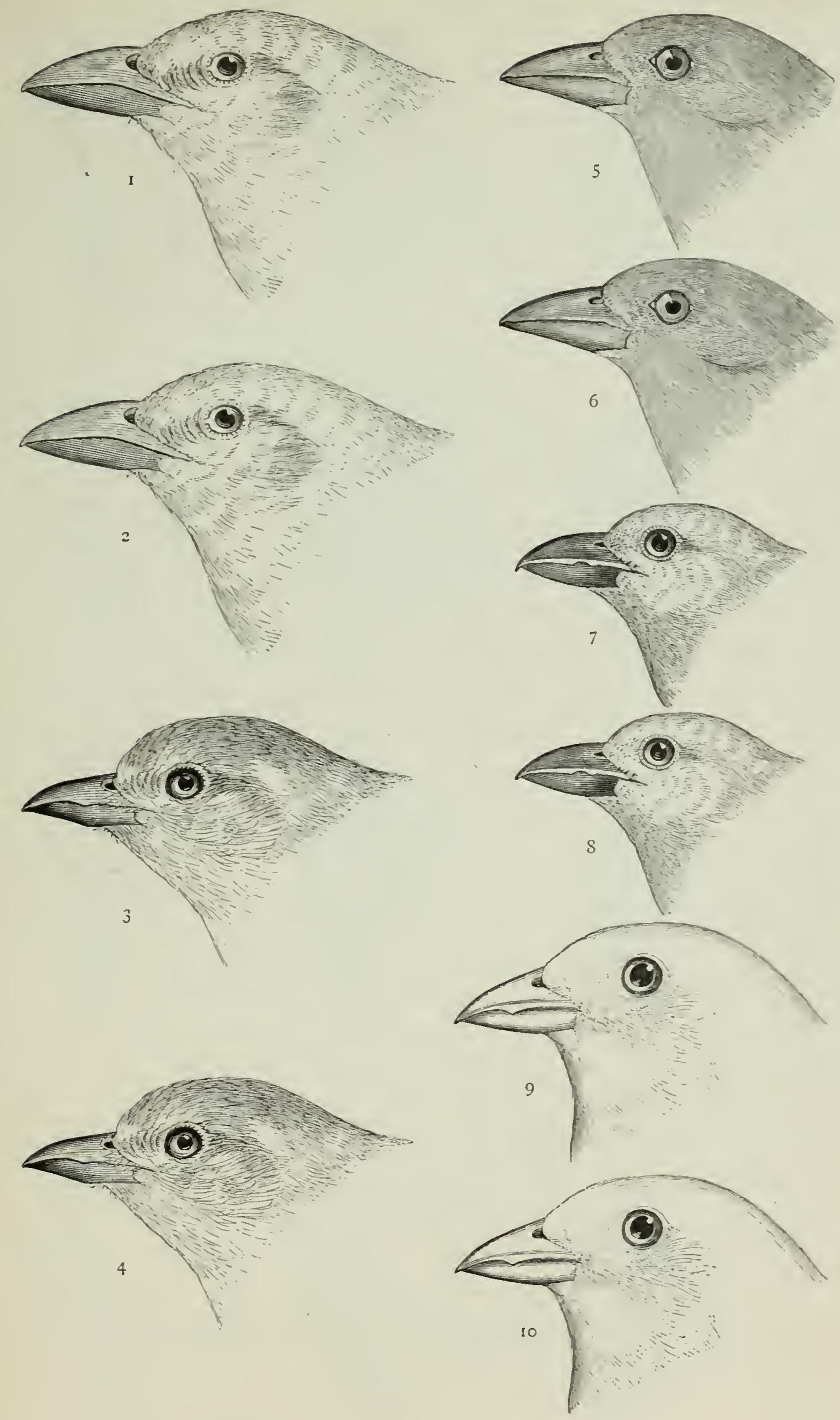

1. Pyranga cooperi, Ridgw. $\sigma^{2} \times$ Mex, $3434+$

3 ". ludoviciana, wils. 8 . Neb., 38393. restiva, $\mathrm{Gm}$. Oै Ga, 1319a

6. Pyrangra aestiva, Gm.

7. " rubra, Linn. Oे Iowa, 34177

9. " hepatica, Swains. Oे Mex, 224r 


$$
\begin{aligned}
& 46 \\
& 86 \\
& A 6 \\
& 6
\end{aligned}
$$


PLATE XXIL.
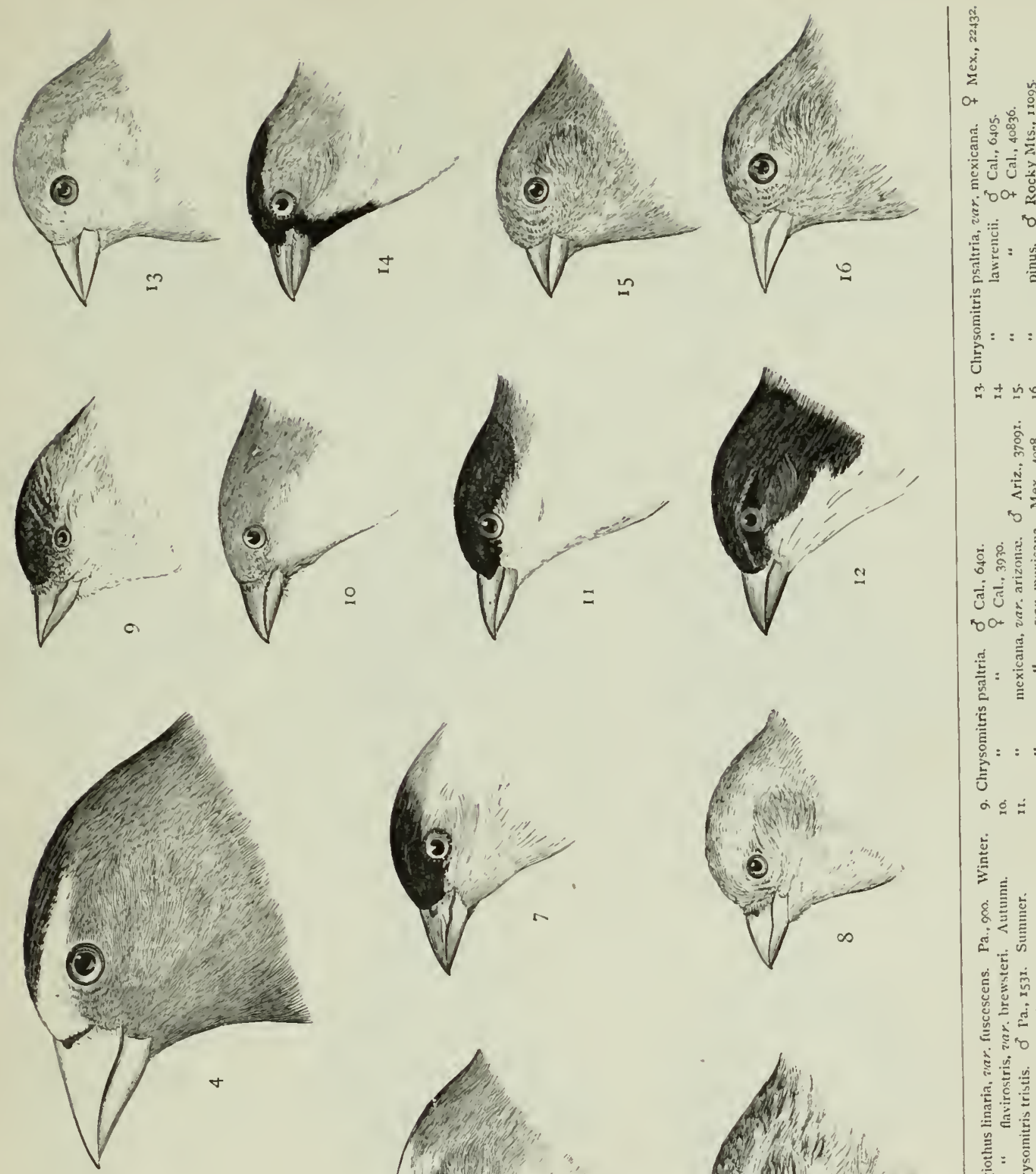

它吉的

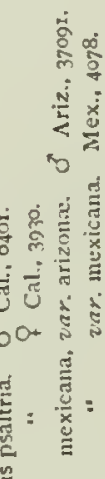

兑
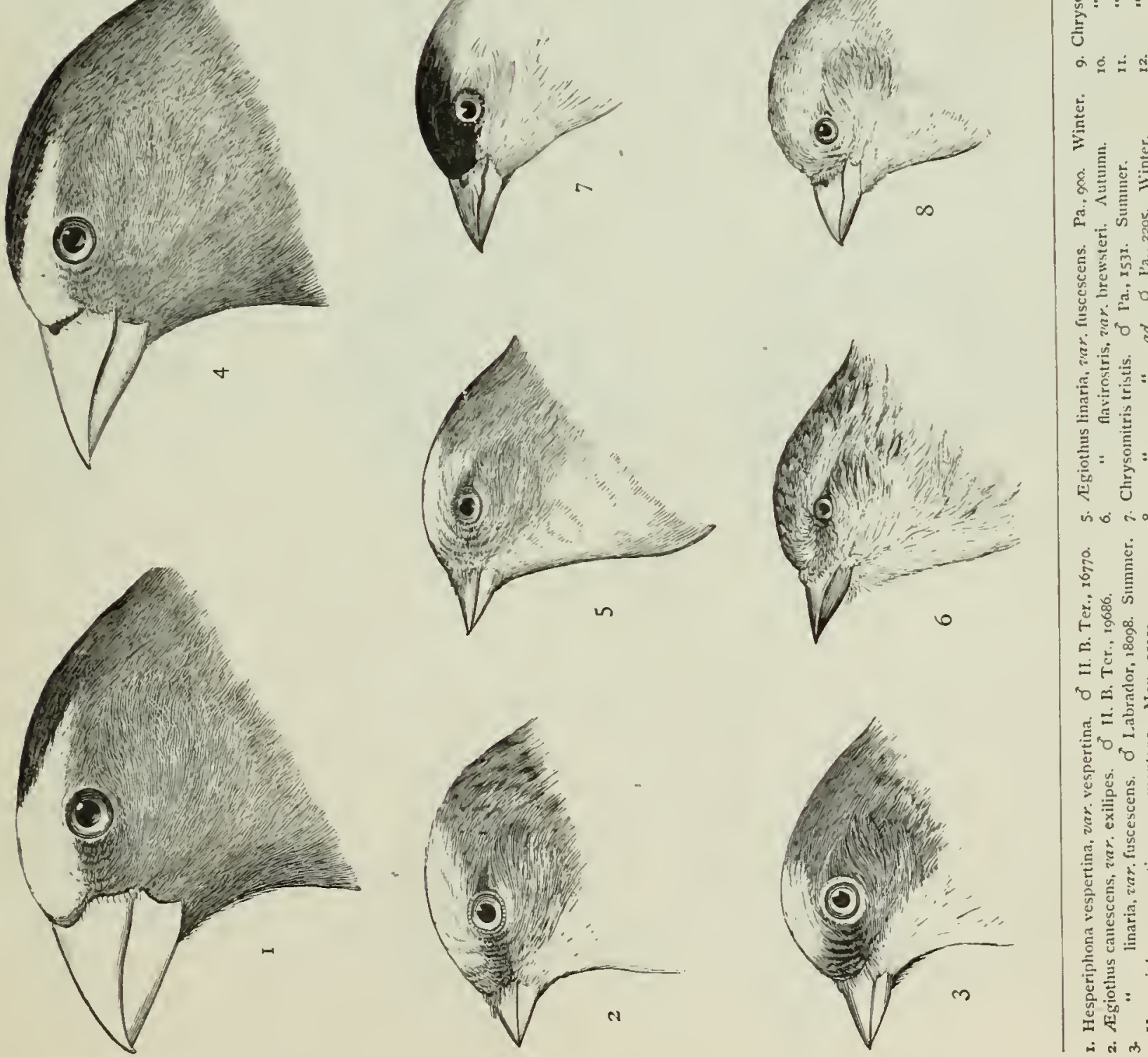

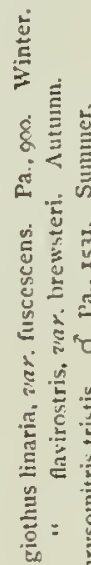

郎

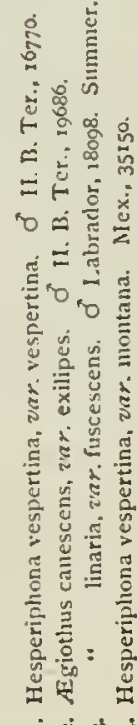


inte Iffer 나요 A. 4 sie is yi) 


$$
\begin{aligned}
& 106 \\
& 101 \\
& 100 \\
& 46
\end{aligned}
$$


PLATE XXIV.
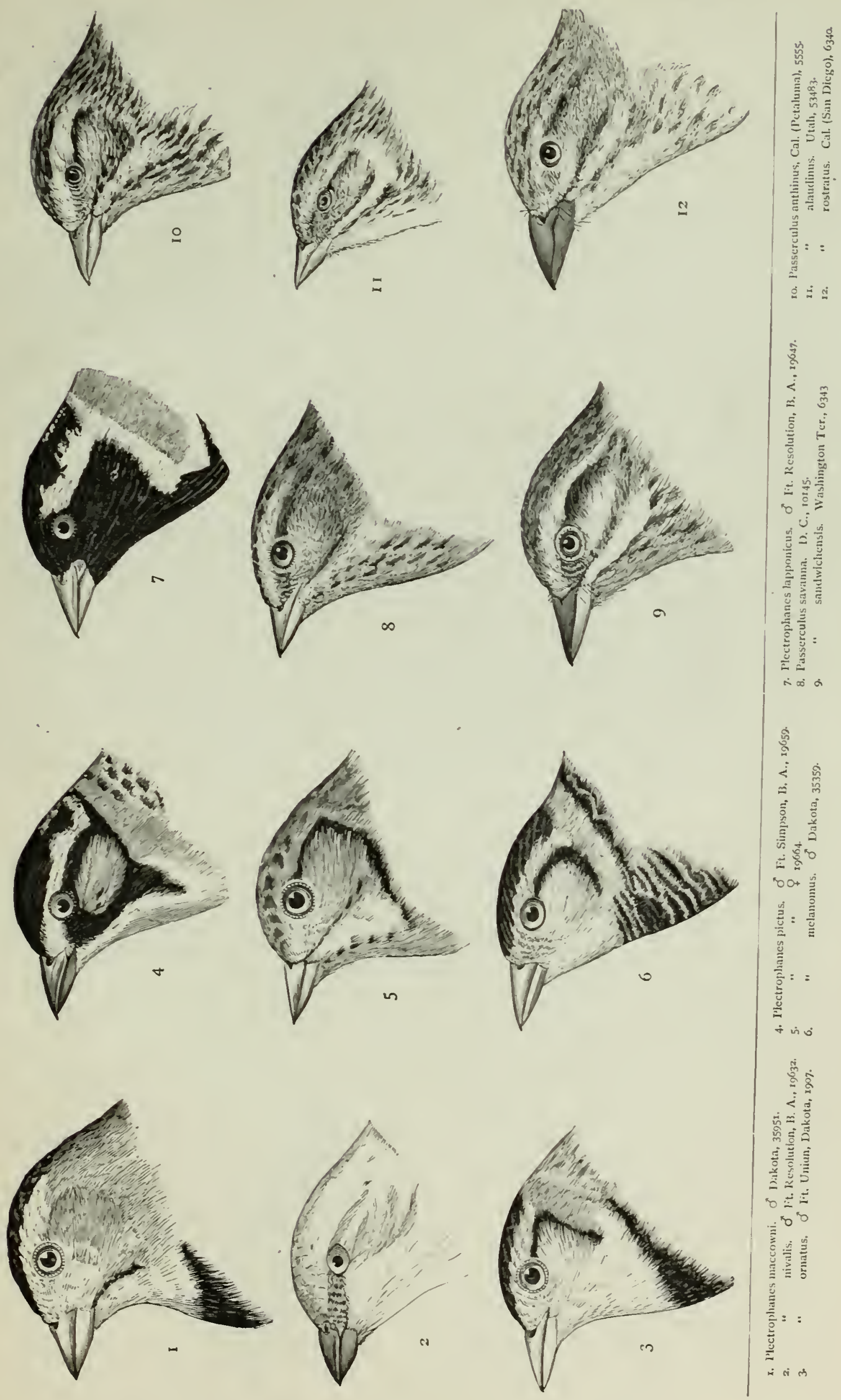
PLATE XXV.
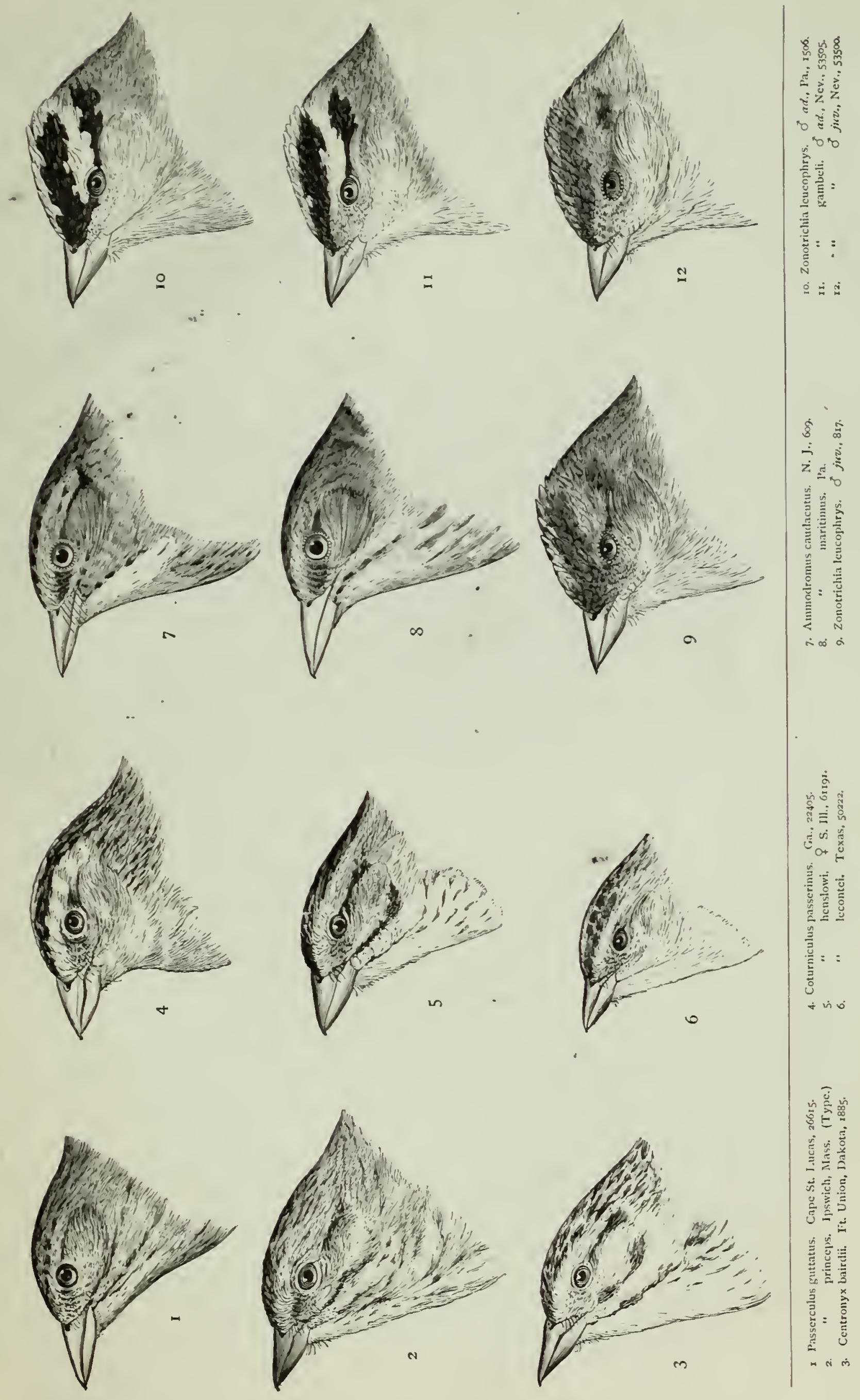

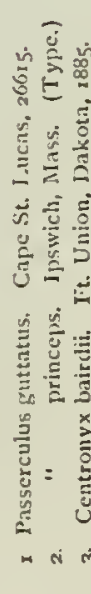




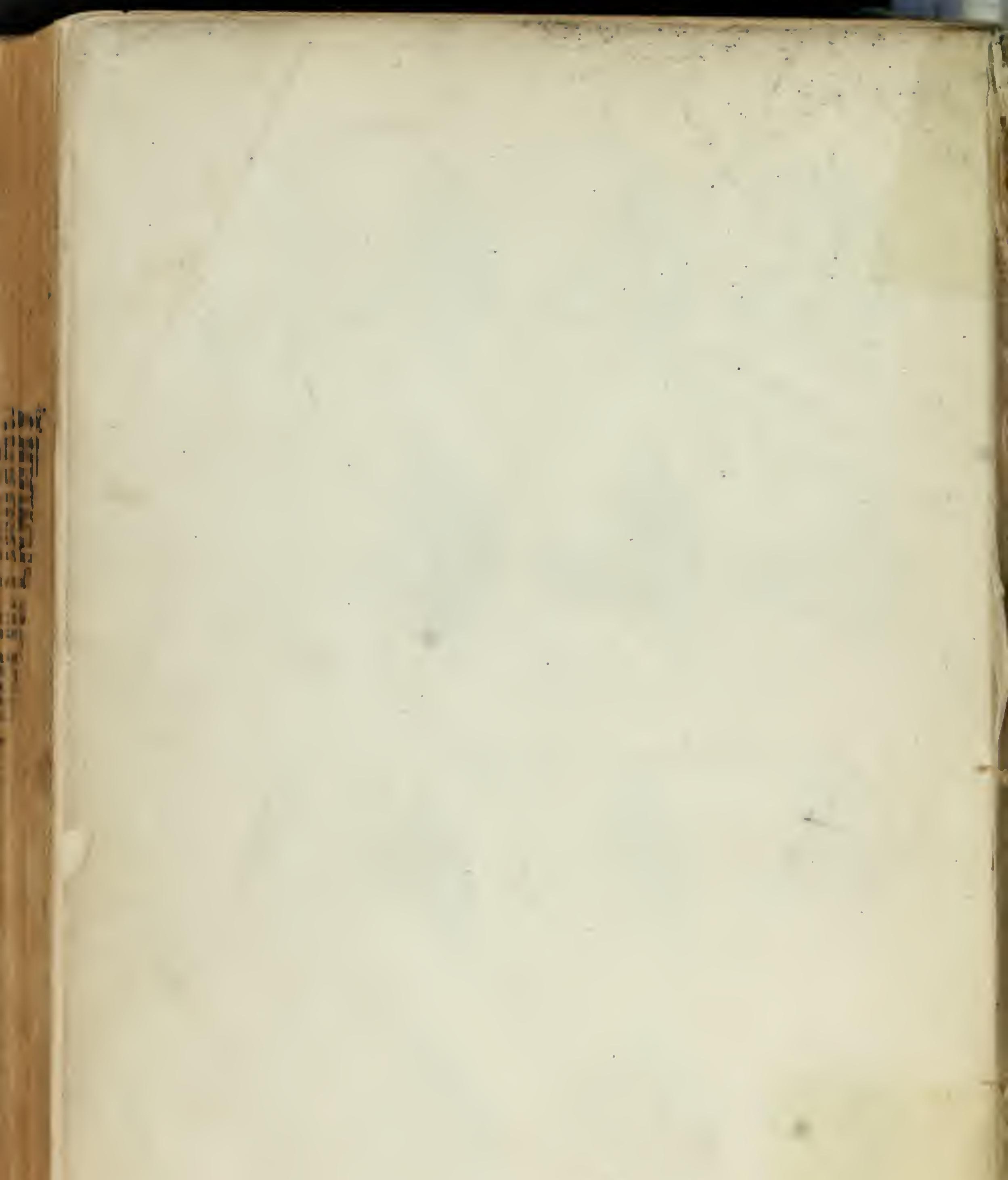




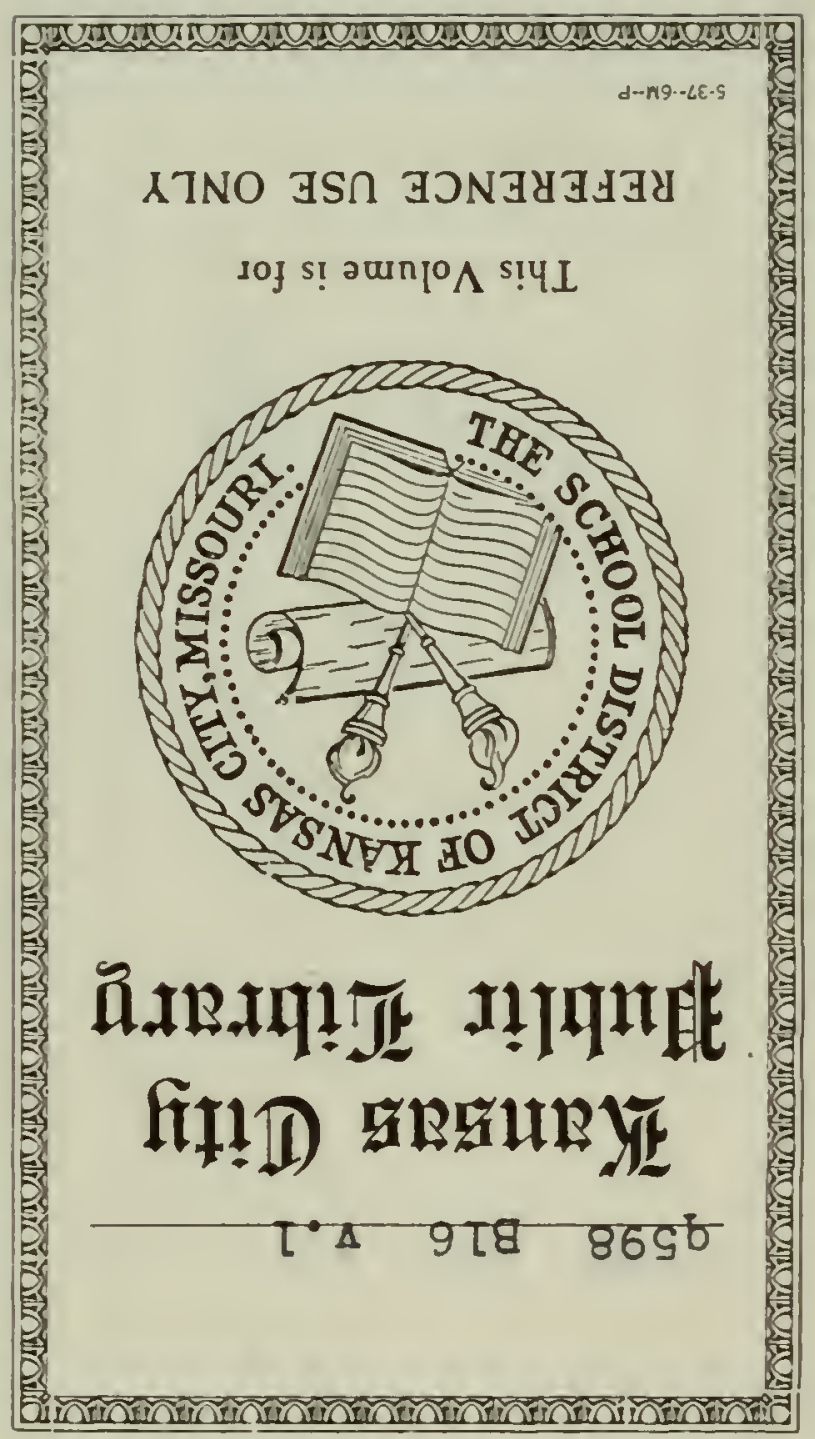


$-1$

$\infty$

the 